\title{
Rechterlijke toetsing aan het gelijkheidsbeginsel
}

Citation for published version (APA):

Gerards, J. H. (2002). Rechterlijke toetsing aan het gelijkheidsbeginsel. [Doctoral Thesis, Maastricht University]. Sdu Uitgevers. https://doi.org/10.26481/dis.20021108jg

Document status and date:

Published: 01/01/2002

DOI:

10.26481/dis.20021108jg

Document Version:

Publisher's PDF, also known as Version of record

\section{Please check the document version of this publication:}

- A submitted manuscript is the version of the article upon submission and before peer-review. There can be important differences between the submitted version and the official published version of record.

People interested in the research are advised to contact the author for the final version of the publication, or visit the DOI to the publisher's website.

- The final author version and the galley proof are versions of the publication after peer review.

- The final published version features the final layout of the paper including the volume, issue and page numbers.

Link to publication

\footnotetext{
General rights rights.

- You may freely distribute the URL identifying the publication in the public portal. please follow below link for the End User Agreement:

www.umlib.nl/taverne-license

Take down policy

If you believe that this document breaches copyright please contact us at:

repository@maastrichtuniversity.nl

providing details and we will investigate your claim.
}

Copyright and moral rights for the publications made accessible in the public portal are retained by the authors and/or other copyright owners and it is a condition of accessing publications that users recognise and abide by the legal requirements associated with these

- Users may download and print one copy of any publication from the public portal for the purpose of private study or research.

- You may not further distribute the material or use it for any profit-making activity or commercial gain

If the publication is distributed under the terms of Article $25 \mathrm{fa}$ of the Dutch Copyright Act, indicated by the "Taverne" license above, 
Rechterlijke toetsing aan het gelijkheidsbeginsel 



\section{Rechterlijke toetsing aan het gelijkheidsbeginsel}

\section{Een rechtsvergelijkend onderzoek naar een algemeen toetsingsmodel}

\section{PROEFSCHRIFT}

ter verkrijging van de graad van doctor aan de Universiteit Maastricht, op gezag van de Rector Magnificus, Prof. dr. A.C. Nieuwenhuijzen Kruseman, volgens het besluit van het College van Decanen, in het openbaar te verdedigen op

vrijdag 8 november 2002 om 14.00 uur

door

JANNEKE HILLIGJE GERARDS 
Promotor:

Prof. mr. A.W. Heringa

Beoordelingscommissie:

Prof. mr. L.F.M. Verhey (voorzitter)

Prof. mr. J.E. Goldschmidt (Universiteit Leiden)

Prof. mr. B.P. Sloot (Open Universiteit Nederland)

Dr. L. Waddington

Prof. mr. B.E.F.M. de Witte

C 2002 Sdu Uitgevers BV, Den Haag

Omslagontwerp: Villa Y, Den Haag

Van deze studie is een handelsuitgave verschenen bij Sdu Uitgevers BV onder ISBN: 9054093536 


\section{Inhoud}

\section{Hoofdstuk 1}

\section{Algemene inleiding: noodzaak van een algemeen toetsingsmodel}

1.1 Toetsing van ongelijke behandeling door de rechter

1.2 Problemen bij de rechterlijke toetsing aan het gelijkheidsbeginsel

1.3 Noodzaak van een goede motivering van uitspraken over ongelijke behandeling 5

1.4 Wenselijkheid van de ontwikkeling van een toetsingsmodel; opzet van het onderzoek 7

\section{Hoofdstuk 2}

\section{Een theoretisch model voor rechterlijke toetsing aan het gelijkheidsbeginsel}

I Begripsbepaling

1.1 Gelijkheid, vergelijkbaarheid, onderscheid en discriminatie

1.1.1 De aristotelische gelijkheidsformule

1.1.2 Onderscheid, ongelijke behandeling, differentiatie, classificatie en discriminatie

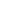


3.3.4 Subsidiariteit $\quad 51$

3.3.5 Proportionaliteit in strikte zin $\quad 53$

4 De vergelijkbaarheidstoets en de eerste fase van de toetsing 57

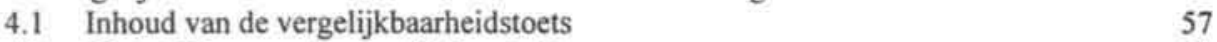

$\begin{array}{lll}4.2 & \text { Vaststelling van de vergelijkbaarheid } & 58\end{array}$

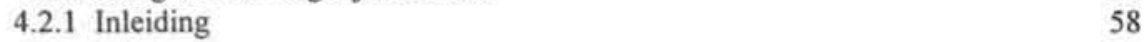

4.2.2 Noodzaak van het vaststellen van de vergelijkingsmaatstaf $\quad 60$

4.2.3 Inhoudelijke beoordeling van de vergelijkingsmaatstaf 63

4.2.4 Rechtvaardigingsmodel en vergelijkbaarheidstoets: over- en underinclusiveness

4.3 De tweede fase van de toetsing: wenselijkheid van de keuze voor het rechtvaardigingsmodel

4.3.1 Inleiding

4.3.2 Wenselijkheid van de keuze voor het rechtvaardigingsmodel

4.3.3 Conclusie: geen toetsing van de vergelijkbaarheid

4.4 De bewijsfunctie van de vergelijkbaarheidstoets; alternatieve toetsingsingangen

4.4.1 Toetsing in de eerste fase: bewijslastverdeling

4.4.2 Eerste alternatief: motief of doelstelling als toetsingsingang

4.4.3 Tweede alternatief: het "but for"-criterium

4.4.4 Derde alternatief: benadeling als toetsingsingang 77

$\begin{array}{ll}\text { 4.4.5 Conclusie } & 79\end{array}$

5 Toetsingsintensiteit $\quad 79$

5.1 Inleiding: noodzaak van differentiatie in de toetsingsintensiteit 79

5.2 Gradaties van toetsingsintensiteit en hun betekenis voor de toetsing 81

5.2.1 Gradaties of "niveaus" van toetsingsintensiteit

5.2.2 Consequenties van de keuze voor een bepaald "niveau" van toetsingsintensiteit

5.3 Factoren die bepalend zijn voor de intensiteit van de toetsing

5.3.1 Inleiding

85

5.3.2 Intensiteitbepalende factoren

85

a. Grond van het onderscheid

b. Indirect en materieel onderscheid

d. Aard van de handeling/regeling waardoor onderscheid is gemaakt; aard en gewicht van de nagestreefde belangen

e. Aard van het betrokken beleidsveld

5.3.3 Afweging van de verschillende factoren en bepaling van de toetsingsintensiteit

6 Korte weergave van het theoretische toetsingsmodel

\section{Hoofdstuk 3}

Toetsing door het Europees Hof voor de Rechten van de Mens aan artikel 14 EVRM

1 Algemeen

1.1 Het accessoire karakter van het discriminatieverbod

1.1.1 Wijze waarop het Hof invulling heeft gegeven aan het accessoire karakter

1.1.2 Nadelen van het accessoire karakter

1.1.3 Consequenties van het accessoire karakter voor de toetsingsmethodiek 
1.2 Inhoud en reikwijdte van het discriminatieverbod

1.2.1 Gronden van onderscheid; vereiste van onderscheid op persoonskenmerk

1.2.2 Inhoudelijke behandeling van beroepen op artikel 14

1.3 Direct en indirect onderscheid; formeel en materieel onderscheid

1.3.1 Direct en indirect onderscheid

1.3.2 Materieel en formeel onderscheid

1.4 Uitsluitend toetsing van tegen de overheid gerichte klachten

1.5 De concrete toetsing door het Hof

118

Het toetsingsmodel

2.1 Ontwikkeling en inhoud van het toetsingsmodel 120

2.2 Vergelijkbaarheid als toetsingsingang

2.2.1 Toetsingsmaatstaven bij de beoordeling van de vergelijkbaarheid

2.2.2 Ontbreken van de vergelijkbaarheidstoets in specifieke gevallen

2.2.3 De benadelingstoets als alternatief voor de vergelijkbaarheidstoets

2.3 Toetsing van het doel

2.3.1 Vaststelling van het doel van het onderscheid

2.3.2 Gerechtvaardigheid van het nagestreefde doel

2.4 Toetsing van de verhouding tussen doel en middel: proportionaliteit in ruime zin $\quad 144$

2.4.1 Inhoud en toepassing van de doel-middeltoets bij artikel $14 \quad 144$

2.4.2 De doel-middeltoets bij substantiële verdragsbepalingen $\quad 148$

2.5 Geschiktheid 151

2.5.1 Toetsing van de geschiktheid bij substantiële verdragsbepalingen $\quad 151$

2.5.2 De geschiktheidstoets bij artikel $14 \quad 152$

2.6 Subsidiariteit en noodzakelijkheid 154

2.6.1 Subsidiariteit en noodzakelijkheid bij de substantiële verdragsbepalingen 154

2.6.2 Subsidiariteit en noodzakelijkheid bij de toetsing aan artikel $14 \quad 156$

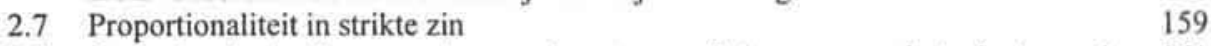

2.8 Ontbrekend criterium: toetsing van de mate van fit (over-en underinclusiveness) 161

2.9 Conclusie 163

3 Toetsingsintensiteit en de margin of appreciation 165

$\begin{array}{ll}3.1 & \text { Inleiding } \\ & 365\end{array}$

3.1.1 Inhoud van de margin of appreciation-doctrine 165

3.1.2 Basis voor de aanvaarding van de margin of appreciation-doctrine $\quad 166$

3.1.3 Betekenis van de margin of appreciation-doctrine voor de toetsingsintensiteit 168

3.2 Factoren ter bepaling van de omvang van de margin of appreciation 169

$\begin{array}{ll}3.2 .1 \text { Inleiding } & 169\end{array}$

3.2.2 De common ground-factor: aanwezigheid van een Europese consensus $\quad 170$

a. Bestaan van overeenstemming op nationaal niveau 173

b. Bestaan van internationale verdragen en soft law 176

c. Aanwezigheid van bijzondere lokale situaties of belangen 177

$\begin{array}{ll}\text { 3.2.3 Het better placed-argument } & 179\end{array}$

3.2.4 De aard en het gewicht van de nagestreefde doelstellingen 181

3.2.5 Context van de getroffen maatregel 184

3.2.6 Het gewicht van het aangetaste recht: fundamentele belangen en kernrechten 186

$\begin{array}{ll}\text { 3.2.7 Aard van de betrokken beperkingsmaatregel } & 191\end{array}$

3.2.8 Afweging van factoren 192

3.3 Toetsingsintensiteit en artikel 14: de "very weighty reasons"-doctrine 197

3.3.1 Vertaling van de margin of appreciation-doctrine in een very
weighty reasons-doctrine 
3.3.2 Criterium voor toepasselijkheid van de very weighty reasons-doctrine: grond van het onderscheid

3.3.3 Conclusie

4 Conclusies

4.1 Conclusies met betrekking tot de toetsingsmethodiek

4.1.1 Inleiding

4.1.2 Toetsing in de eerste fase: de vergelijkbaarheidstoets

4.1.3 De tweede fase van de toetsing: toetsing aan het rechtvaardigingsmodel

4.2 Conclusies met betrekking toetsingsintensiteit

4.2.1 Werkwijze van het Hof, niveaus van toetsingsintensiteit en invloed op de toetsingsmethodiek

4.2.2 Factoren die de toetsingsintensiteit bepalen

\section{Hoofdstuk 4}

\section{Toetsing aan het gelijkheidsbeginsel door het Europees Hof van Justitie}

1 Algemeen

1.1 Inhoud en achtergrond van het gelijkheidsbeginsel in het gemeenschapsrecht

1.1.1 Weerslag van het gelijkheidsbeginsel in het EG-Verdrag

1.1.2 Achtergrond en betekenis van het gelijkheidsbeginsel in het Europese recht

1.2 Direct en indirect onderscheid; formeel en materieel onderscheid

1.2.1 Direct en indirect onderscheid

1.2.2 Formeel en materieel onderscheid

1.3 Horizontale en verticale verhoudingen

1.4 Aard van de procedures waarin het gelijkheidsbeginsel een rol speelt 233

1.5 Opzet van het hoofdstuk 234

2 Het toetsingsmodel 236

2.1 Algemene beschrijving van het toetsingsmodel 236

2.1.1 Het toetsingsmodel bij onderscheid op grond van geslacht 236

2.1.2 Het toetsingsmodel bij onderscheid op het gebied van het landbouwbeleid 238

2.1.3 Het toetsingsmodel bij onderscheid op grond van nationaliteit 243

2.2 De eerste fase van de toetsing: vergelijkbaarheid en benadeling

2.2.1 Vergelijkbaarheid en benadeling bij onderscheid op grond van geslacht $\quad 245$

2.2.2 Vergelijkbaarheid en benadeling op het gebied van de landbouw 251

2.2.3 Vergelijkbaarheid en benadeling bij onderscheid op grond van nationaliteit 258

2.2.4 Toepassingen van de vergelijkbaarheidstoets bij artikel 90 EG 266

2.3 Toetsing van het doel 269

2.3.1 Toetsing van het doel bij onderscheid op grond van geslacht 269

2.3.2 Toetsing van het doel bij onderscheid op het gebied van de landbouw 275

2.3.3 Toetsing van het doel bij onderscheid op grond van nationaliteit 278

2.3.4 Toetsing van het doel bij artikel 90 EG 281

2.3.5 Conclusie 284

2.4 Toetsing van geschiktheid, subsidiariteit en proportionaliteit 286

2.4.1 Toetsing van geschiktheid, subsidiariteit en proportionaliteit bij onderscheid op grond van geslacht

2.4.2 Toetsing van geschiktheid, subsidiariteit en proportionaliteit bij onderscheid op het gebied van de landbouw

2.4.3 Toetsing van geschiktheid, subsidiariteit en proportionaliteit bij onderscheid op grond van nationaliteit 
2.5 Ontbrekend element in de toetsing van het Hof: de mate van fit 304

3 Toetsingsintensiteit $\quad 306$

$\begin{array}{lll}3.1 & \text { Algemeen } & 306\end{array}$

3.2 Toetsingsintensiteit bij onderscheid op grond van geslacht 307

$\begin{array}{ll}3.2 .1 \text { Inleiding } & 307\end{array}$

3.2.2 Factoren die de toetsingsintensiteit bepalen 308

$\begin{array}{ll}3.2 .3 \text { Conclusie } & 318\end{array}$

3.3 Toetsingsintensiteit bij onderscheid op het gebied van de landbouw 319

$\begin{array}{ll}3.3 .1 \text { Inleiding } & 319\end{array}$

3.3.2 Factoren die de toetsingsintensiteit bepalen $\quad 320$

$\begin{array}{ll}3.3 .3 \text { Conclusie } & 328\end{array}$

3.4 Toetsingsintensiteit bij onderscheid op grond van nationaliteit 329

3.4.1 Aard en gewicht van het verbod van onderscheid op grond van nationaliteit 329

3.4.2 Factoren die een verminderde toetsingsintensiteit opleveren 332

$\begin{array}{ll}3.4 .3 \text { Conclusie } & 340\end{array}$

4 Conclusies $\quad 341$

4.1 Conclusies met betrekking tot de toetsingsmethodiek 341

4.1.1 Consequenties van de achtergrond van het verbod van onderscheid 341

4.1.2 Horizontale en verticale verhoudingen: gevolgen voor de toetsingsmethodiek 344

4.1.3 Toetsing in de eerste fase: vergelijkbaarheid en benadeling 345

4.1.4 Het doel van het onderscheid 352

4.1.5 Mate van fit, geschiktheid, noodzakelijkheid en proportionaliteit 355

4.2 Conclusies met betrekking tot de toetsingsintensiteit 357

4.2.1 Gradaties of "niveaus" van toetsingsintensiteit 357

4.2.2 Factoren die een rol spelen bij de bepaling van de toetsingsintensiteit $\quad 358$

\section{Hoofdstuk 5}

\section{De toetsing aan de Equal Protection Clause door het Supreme Court}

1 Inleiding

1.1 Achtergrond en reikwijdte van de Equal Protection Clause 363

1.1.1 Totstandkoming en betekenis van het Veertiende Amendement 363

1.1.2 Uitbreiding van de reikwijdte tot aantasting van alle belangen en rechten 365

1.1.3 Uitbreiding van de reikwijdte naar andere gronden van onderscheid 367

1.1.4 Materiēle of formele gelijkheid; direct en indirect onderscheid 368

1.1.5 Toepasselijkheid van de Equal Protection Clause in alle situaties $\quad 371$

$\begin{array}{lll}1.2 & \text { Federale en statelijke verhoudingen } & 372\end{array}$

1.2.1 Gevolgen van het federale stelsel voor de opstelling van het Supreme Court 372

1.2.2 Toepassing van de Equal Protection Clause op de federale overheid $\quad 373$

$\begin{array}{lll}1.3 & \text { Horizontale werking } & 376\end{array}$

1.3.1 Het Veertiende Amendement en de noodzaak van state action 376

1.3.2 Horizontale werking: de Civil Rights Act $1964 \quad 378$

$\begin{array}{lll}1.4 & \text { Werkwijze van het Supreme Court } & 380\end{array}$

1.5 Toetsingsmethodiek van het Supreme Court en opzet van het hoofdstuk 386

2 Toetsingsmethodiek 387

2.1 Algemeen overzicht van de door het Supreme Court gehanteerde tests 387

$\begin{array}{lll}2.1 .1 & \text { De rational basis-test } & 387\end{array}$

2.1.2 Rational basis "with bite" 391

2.1.3 De strict scrutiny-test 393 
2.1.4 De intermediate scrutiny-test

2.2 Toetsing in de eerste fase: vergelijkbaarheid, benadeling en discriminatoire doelstelling

2.2.1 Vergelijkbaarheid

2.2.2 Direct onderscheid: het bestaan van een classificatie als toetsingsingang 405

2.2.3 Indirect onderscheid: effect en bedoeling als toetsingsingang

2.3 Toetsing van de aanwezigheid van een gerechtvaardigde doelstelling

2.3.1 Wijze van vaststelling van het doel

2.3.2 Pluraliteit van doelstellingen

2.3.3 Toetsing van de gerechtvaardigdheid van het doel

2.4 Toetsing van de verhouding tussen doel en middel

2.4.1 Inleiding

2.4.2 Toetsing van de mate van fit

2.4.3 Toetsing van de geschiktheid

2.4.4 Toetsing van noodzakelijkheid en subsidiariteit

2.4.5 Toetsing van proportionaliteit in strikte zin

3 Toetsingsintensiteit

3.1 Inleiding

3.2 Theoretische onderbouwing van de variatie in toetsingsintensiteit

3.3 Factoren die betrekking hebben op de ongelijke behandeling

3.3.1 Factoren met betrekking tot de benadeelde groep

3.3.2 Factoren met betrekking tot de grond van onderscheid

3.3.3 Afweging van de factoren met betrekking tot het onderscheid als zodanig

3.4 Strict scrutiny bij aantasting van fundamentele rechten

3.4.1 Erkenning van individuele grondrechten als rechtvaardiging voor strict scrutiny

3.4.2 Erkenning van politieke rechten als rechtvaardiging voor strict scrutiny

3.4.3 Verandering van rechtspraak: constitutionele rechten als basis voor intensivering van de toetsing

3.4.4 Ernst van de aantasting

3.5 Overige factoren die de toetsingsintensiteit beïnvloeden

3.5.1 Inleiding

3.5.2 Aanwezigheid van beleidsvrijheid, aard van het beleidsterrein en het better placed-argument

3.5.3 Context van het onderscheid

3.5.4 Verhouding tussen staten en federale overheid; subsidiariteitsargument

3.5.5 Ongewoon karakter van het onderscheid

4.1.1 Inleiding

4.1.2 Toetsing in de eerste fase: vergelijkbaarheid, benadeling en discriminatoire doelstelling

4.1.3 Toetsing van het doel

4.1.4 Beoordeling van de verhouding tussen doel en middel

4.2 Conclusies met betrekking tot de toetsingsintensiteit

4.2.2 De intensiteitbepalende factoren 


\section{Hoofdstuk 6}

\section{Toetsing aan het gelijkheidsbeginsel in Nederland}

1 Algemeen

1.1 Gelijkheidsbepalingen in het Nederlandse recht 513

1.1.1 Inleiding 513

1.1.2 Artikel 1 Grondwet 513

1.1.3 Gelijkheidsbepalingen in internationale verdragen $\quad 514$

1.1.4 Gelijkheidsbepalingen in het Europese recht 519

1.1.5 Gelijkheidsbepalingen in Nederlandse wetgeving 521

1.1.6 Het gelijkheidsbeginsel als algemeen beginsel van behoorlijk bestuur $\quad 523$

$\begin{array}{ll}1.2 & \text { Situaties van onderscheid } \\ 1.326\end{array}$

1.3 Direct en indirect onderscheid; materieel en formeel onderscheid 527

1.3.1 Formeel en materieel onderscheid 527

1.3.2 Direct en indirect onderscheid $\quad 529$

1.4 Horizontale en verticale werking 533

1.5 Verschillen tussen de tot toetsing bevoegde instanties; opzet van het hoofdstuk 535

2 Toetsingsmethodiek $\quad 538$

2.1 Algemene beschrijving van de methodiek van de verschillende instanties 538

2.1.1 Toetsingsmethodiek van de Hoge Raad - civiele en strafkamer 538

2.1.2 Toetsingsmethodiek van de Hoge Raad - belastingkamer 544

2.1.3 Toetsingsmethodiek van de Afdeling Bestuursrechtspraak 552

2.1.4 Toetsingsmethodiek van de Centrale Raad van Beroep $\quad 555$

2.1.5 Toetsingsmethodiek van de Commissie Gelijke Behandeling 560

2.2 Vergelijkbaarheid en benadeling in de Nederlandse rechtspraak 565

$\begin{array}{ll}2.2 .1 & \text { Inleiding } \\ 565\end{array}$

2.2.2 De vergelijkbaarheidstoets als toetsingsingang $\quad 566$

2.2.3 De benadelingstoets als toetsingsingang $\quad 575$

2.3 Toetsing van het doel $\quad 588$

$\begin{array}{ll}2.3 .1 \text { Inleiding } & 588\end{array}$

2.3.2 Vaststelling van het doel $\quad 588$

2.3.3 Toetsing van de gerechtvaardigdheid van het doel 595

2.4 Toetsing van de verhouding tussen doel en onderscheid 610

2.4.1 Mate van fit (over- en underinclusiveness) en toetsing van de relevante proxy 610

2.4.2 Geschiktheid 616

2.4.3 Noodzakelijkheid en subsidiariteit $\quad 619$

2.4.4 Proportionaliteit in strikte zin 625

3 Toetsingsintensiteit 633

3.1 Variatie in de toetsingsintensiteit in Nederland 633

3.2 Factoren die de intensiteit van de toetsing bepalen 638

3.2.1 Inleiding 638

3.2.2 Factoren die verband houden met de bevoegdheidsverdeling 638

3.2.3 Andere factoren die de toetsingsintensiteit kunnen beïnvloeden 643

3.2.4 Afweging van de verschillende factoren 649

4 Conclusies $\quad 650$

4.1 Conclusies met betrekking tot de toetsingsmethodiek 650

4.1.1 Toetsing in de eerste fase: vergelijkbaarheid en benadeling 650

4.1.2 Toetsing in de tweede fase: de rechtvaardigingstoets 654 
4.2 Conclusies met betrekking tot de toetsingsintensiteit

\section{Hoofdstuk 7}

\section{Conclusie: naar een algemeen toetsingsmodel}

1 Inleiding

2 Toetsing in de eerste fase: benadeling als toetsingsingang

2.1 Inleiding

2.2 De vergelijkbaarheidstoets als toetsingsingang

2.3 De doeltoets als toetsingsingang

2.4 De benadelingstoets als toetsingsingang

2.4.1 De benadelingstoets als toetsingsingang voor het algemene toetsingsmodel

2.4.2 Vormgeving van de benadelingstoets

3 Toetsing in de tweede fase: het rechtvaardigingsmodel

3.1.1 Inleiding

3.1.2 Vaststelling van het doel van het onderscheid

3.1.3 Beoordeling van de gerechtvaardigdheid van het doel

3.2 Toetsing van de gehanteerde proxy en de mate van fit

3.2.1 Inleiding

3.2.2 Toetsing van de proxy

3.2.3 Toetsing van de mate van fit

3.3 Geschiktheid

3.4 Subsidiariteit en noodzakelijkheid

3.5 Proportionaliteit

3.5.1 Abstracte of concrete toetsing?

3.5.2 Opbouw van het proportionaliteitsoordeel; vaststelling van belangen

3.5.3 Gewicht van de betrokken belangen

3.5.4 Toetsing van de belangenafweging

4.1 Inleiding: niveaus van toetsingsintensiteit

4.2 De intensiteitbepalende factoren

4.2.1 Groep 1. Factoren die het onderscheid als zodanig betreffen

a. Factoren die betrekking hebben op de grond van onderscheid

4.2.2 Groep 2. Factoren met betrekking tot de belangenaantasting
a. Factoren met betrekking tot de aard en het gewicht van het aangetaste recht
b. Factoren met betrekking tot de aard en de ernst van de belangenaantasting 709

4.2.2 Groep 3. Factoren met betrekking tot het nagestreefde belang, het beleidsveld en de positie van de wederpartij

a. Factoren met betrekking tot de nagestreefde belangen en de aard van het beleidsveld

b. Factoren met betrekking tot de positie van de wederpartij en van de rechter

c. Factoren met betrekking tot de context van het onderscheid 
Summary

Jurisprudentie

Literatuur

Zakenregister

781

Dankwoord

801

Curriculum Vitae

803 



\section{Algemene inleiding: noodzaak van een algemeen toetsingsmodel}

\section{$1.1 \quad$ Toetsing van ongelijke behandeling door de rechter}

Het gelijkheidsbeginsel is een rechtsbeginsel van bijzonder fundamenteel belang: het vormt de basis voor het nastreven van een zo volledig mogelijke persoonlijke ontplooiing en daarmee voor de individuele vrijheid. ${ }^{1}$ Van belang is echter tegelijkertijd dat inbreuken op het gelijkheidsbeginsel onvermijdelijk zijn. In iedere wet die tot stand wordt gebracht zal noodzakelijkerwijze worden gedifferentieerd, ${ }^{2}$ terwijl evenmin kan worden verwacht dat ieder mens alle anderen op precies dezelfde manier behandelt. ${ }^{3}$ Volledige gelijkheid is zelfs niet wenselijk, omdat daardoor geen ruimte meer zou bestaan voor de verschillen in wensen, capaciteiten en behoeften van ieder individu. Niettemin kan worden vastgesteld dat niet ieder verschil in behandeling zonder meer redelijk is: wanneer een groep wordt benadeeld op basis van vooroordelen of vergaan-

1. Vgl. Leibholz 1925, p. 21, Simon 1994, p. 39 en Plamenatz 1969, p. 86. Dit lijkt overigens vanzelfsprekender dan het is: door diverse auteurs is een zekere spanning gesignaleerd tussen gelijkheid en vrijheid (vgl. Alexy 1985, p. 379, voetnoot 66, waarin hij aangeeft dat gelijkheid en vrijheid deels overeenkomsten vertonen, maar ook met elkaar in botsing kunnen komen; zie ook Leibholz 1925, p. 17-19, Burkens 1989 (II), p. 67 en Van der Hoeven 1992, p. 102). Inderdaad beperkt gelijkheid de individuele vrijheid in die zin, dat op grond van het gelijkheidsbeginsel een ieder over een kans op zelfontplooiing moet kunnen beschikken; dit betekent dat de individuele vrijheid niet onbeperkt is, maar begrensd wordt door de ontplooiingsmogelijkheden van anderen. Gesteld kan echter ook worden dat volledige, absolute gelijkheid niet verenigbaar is met het vrijheidsideaal: wanneer er geen enkel verschil in behandeling mogelijk is, kan nooit recht worden gedaan aan de natuurlijke verschillen tussen mensen in capaciteiten, wensen en behoeften en worden mensen juist daardoor belemmerd in het nastreven van hun persoonlijke voorkeuren en ambities (vgl. Blackstone 1969, p. vi en meer in het algemeen de kritiek op het door Bedau als "radical" aangeduide egalitarisme (1967, p. 13/14); deze vorm van egalitarisme lijkt overigens vrijwel door niemand serieus te worden aangehangen). Gelijke behandeling in minder absolute zin kan echter juist een voorwaarde vormen voor vrijheid, zeker wanneer het gelijkheidsbeginsel wordt opgevat als een mogelijkheid om gelijke kansen te creëren en onterechte privileges weg te nemen (vgl. Van der Hoeven 1992, p. 102). Voor groepen die zich in een achterstandssituatie bevinden of door het bestaan van vooroordelen worden belemmerd in hun zelfontplooiing kan de werking van het gelijkheidsbeginsel een grote mate van vrijheid bewerkstelligen. Bovendien betekent het gelijkheidsbeginsel in dit verband dat de kansen en mogelijkheden in de samenleving voor iedereen openstaan, hetgeen eveneens een waarborg voor vrijheid en individuele ontplooiing vormt (vgl. Laski 1969, p. 166-168).

2. De reikwijdte van iedere wettelijke bepaling is noodzakelijkerwijze beperkt tot een bepaalde groep mensen of tot een bepaalde groep gevallen, ook al lijkt deze nog zo breed. Dit betekent dat er in wetgeving altijd onderscheid zal worden gemaakt. Zie o.a. Gunther/Suilivan 1997, p. 628 en Burkens 1982, p. 59.

3. Zo is de benoeming van een bepaalde sollicitant ten nadele van andere geschikte kandidaten te beschouwen als een ongelijke behandeling, net zoals, op meer persoonlijk niveau, de selectie van gasten voor een huwelijksreceptie: het maken van onderscheid is ook op dit niveau onvermijdelijk. Zie Alexy 1985 , p. 360 , Sloot 1986 , p. 21 , Benn/Peters 1969 , p. 57 , Maris 1988 , p. $35 / 36$ en 40 en Tussman/TenBroek 1949, p. 343/344. Ook op verticaal niveau is ongelijke behandeling onvermijdelijk: ook bestuursorganen zullen bij het voeren van beleid onderscheid moeten maken tussen (groepen van) rechtssubjecten. 
de stereotyperingen, of wanneer een ongelijke behandeling de belangen van de benadeelde groep onevenredig zwaar aantast, kan zonder meer worden gesproken van een ontoelaatbaar onderscheid. ${ }^{4}$ Het is dan ook essentieel dat er voor iedere ongelijke behandeling een toereikende motivering of rechtvaardiging bestaat. ${ }^{5}$

In de praktijk blijkt het de rechter te zijn die in belangrijke mate is belast met het toezicht op de naleving van het gelijkheidsbeginsel: wanneer een individu of groep zich door een normatieve classificatie of door een concreet onderscheid ${ }^{6}$ benadeeld voelt, kan hij het onderscheid aan de rechter voorleggen; de rechter zal het onderscheid vervolgens toetsen op zijn verenigbaarheid met het gelijkheidsbeginsel. ${ }^{7}$ Een dergelijke toetsing is in ieder geval mogelijk wanneer de klacht een ongelijke toepassing van een algemene regeling betreft: in vrijwel alle rechtsstelsels is op enigerlei wijze in de wet, in de grondwet of in direct werkende verdragen het vereiste van "gelijkheid voor de wet" neergelegd. In deze vorm vereist het gelijkheidsbeginsel dat een regel wordt toegepast op alle gevallen die voldoen aan de door de regel gestelde voorwaarden. Dit vereiste valt feitelijk samen met dat van een juiste regeltoepassing: uit de idee van de algemeenheid van regelgeving vloeit vanzelf voort dat een regel moet worden toegepast op alle gevallen waarop deze betrekking heeft. ${ }^{8}$ Het is dan ook vanzelfsprekend dat de rechter, die normaal gesproken immers ook beoordeelt of een regel op juiste wijze is toegepast, controle kan uitoefenen op de gelijke toepassing van de wet.

Het is echter niet voldoende dat de rechter kan toetsen of een regel op gelijke wijze is toegepast: ${ }^{9}$ een dergelijke beperking zou ertoe leiden dat iedere classificatie toelaatbaar is, zolang hieraan maar op gelijke wijze toepassing wordt gegeven.$^{10}$ Dit is problematisch in die gevallen waarin door de classificatie als zodanig ten onrechte aan een bepaalde groep een belangrijk voordeel wordt ontzegd of wanneer hierdoor een oneven-

4. Deze spanning tussen het nastreven van gelijkheid en het rekening houden met de verschillen tussen mensen wordt aangeduid als de paradox van de rechtsgelijkheid (bijv. Sloot 1986, p. 19, Loenen 1998, p. 12 en Tussman/TenBroek 1949, p. 344) of het "dilemma of difference" (Minow 1990, p. 20).

5. Vgl. Sloot 1986: de oplossing van de paradox van de rechtsgelijkheid is gelegen in de doctrine van de redelijke classificatie (p. 19) en Ross 1958, p. 269 ("in the demand for equality lies only the requirement that no one, either arbitrarily or without sufficient reason, shall be subjected to treatment that differs from that accorded to any other person").

6. Op de verschillende vormen van ongelijke behandeling zal in hoofdstuk 2 nader worden ingegaan.

7. Vgl. Burkens 1982, p. 60.

8. Leibholz 1925, p. 31, Ross 1958, p. 272 en 273, Perelman 1963, p. 37, Benn/Peters 1969, p. 71, Burkens 1969 , p. 11 en Westen 1982 (I), p. 548

9. Dit is overigens zonder meer een zinvol vereiste, dat kracht bijzet aan de eis van juiste regeltoepassing. Door dit vereiste wordt verduidelijkt dat niet zomaar van de wet mag worden afgeweken en dat rationeel en niet willekeurig moet worden gehandeld (vgl. Ross 1958, p. 281 en Benn/Peters 1969, p. 73). Ook is dit vereiste van belang wanneer een regel onduidelijk is of beleidsruimte laat (Chemerinsky 1983 , p. 579 en Burkens 1969, p. 11): het beginsel verplicht tot goede motivering van een interpretatie van de bepaling die een ongelijke behandeling oplevert. Zie nader Westen 1983 (I), p. 645.

10. Dit wordt duidelijk door de volgende omschrijving van Westen (waarin "FE" staat voor "formal equality"; zie over het begrip formele gelijkheid nader paragraaf 1 van hoofdstuk 2): "FE: Equals ... should be treated ... equally. FE1: Persons who by a given prescriptive rule are all entitled to common treatment ... should be treated ... as all entitled to that common treatment" (1983 (I), p. 1192). Het gelijkheidsbeginsel vereist dus niet meer dan dat een prescriptieve regel (de wet) wordt toegepast op alle gevallen waarop deze betrekking heeft. 
redig hoge last wordt opgelegd of inbreuk wordt gemaakt op een fundamenteel recht. ${ }^{11}$ Zou de rechter de inhoud van een classificatie niet mogen toetsen, dan betekent dit dat de bevoegdheid om onderscheid te maken (en daarmee bepaalde groepen te bevoordelen of te benadelen) volledig en oncontroleerbaar bij de regelgever wordt gelegd. Dit kan misschien nog worden verdedigd in het geval waarin de classificatie is vastgesteld door of met medewerking van een volksvertegenwoordiging, aangezien daarbij het argument van de werking van de democratie en de meerderheidsregel een rol speelt. ${ }^{12}$ Daartegenover staan echter belangrijke en overtuigende argumenten die pleiten vóór een rechterlijke toetsing, zoals het rechtsstatelijke argument dat het de taak van de rechter is om de belangen van de minderheid te beschermen tegen willekeur en onrechtvaardige beslissingen van de meerderheid. ${ }^{13}$ Bovendien kan worden vastgesteld dat het democratieargument in mindere mate geldt in het geval waarin de litigieuze classificatie door een bestuursorgaan is vastgesteld. ${ }^{14}$ In het hiernavolgende zal er dan ook van worden uitgegaan dat de rechter niet alleen de bevoegdheid heeft om de gelijke toepassing van regels te beoordelen, maar ook bevoegd is om een oordeel te geven over de toelaatbaarheid van normatieve, d.w.z. in algemene regels vervatte, classificaties. ${ }^{15}$ Op de discussie over de verenigbaarheid van een dergelijk oordeel met de positie van de rechter in een democratische samenleving zal in hoofdstuk 2 nader worden ingegaan.

\subsection{Problemen bij de rechterlijke toetsing aan het gelijkheidsbeginsel}

Gezien het hiervoor geschetste belang van het gelijkheidsbeginsel voor de individuele vrijheid is het essentieel dat de rechterlijke toetsing aan dit beginsel zo voorspelbaar,

11. Stel bijvoorbeeld dat een wet wordt aangenomen op grond waarvan mensen met rood haar meer belasting moeten betalen dan mensen met een andere haarkleur. Gelijkheid voor de wet betekent dan slechts, dat de hogere belasting aan alle mensen met rood haar moet worden opgelegd, dus dat er niet zomaar een uitzondering kan worden gemaakt voor bepaalde mensen met rood haar. Of haarkleur uberhaupt een redelijk en relevant criterium is om de hoogte van de te betalen belasting vast te stellen is een vraag die bij deze toets niet aan de orde komt. Alleen bij een onderzoek naar de redelijkheid van de wettelijke classificatie als zodanig kan de rechter hierover een oordeel geven.

12. Er bestaat onvermijdelijk een zekere spanning tussen het feit dat wetten tot stand komen door een bij meerderheid beslissend orgaan dat door de bevolking is gekozen en de toetsing van die wetten door een oncontroleerbare en niet verkozen rechter (vgl. Ely 1980, p. 5 en 7). Deze spanning blijft altijd aanwezig, hoe wenselijk rechterlijke toetsing uit rechtsstatelijk oogpunt ook kan zijn.

13. Dit argument is op diverse plaatsen terug te vinden; zie bijv. Leibholz 1925, p. 34 en 38, Ely 1980, p. 103 en Koopmans (Nabeschouwing bij Wiarda) 1999, p. 133/134 en 1989, p. 111. Een bijzonder sterke rechtvaardiging voor de rechterlijke toetsing van wetgeving is te vinden bij Dworkin. Doorslaggevend is volgens hem dat in de samenleving gelijk respect en gelijke zorg voor een ieder worden gegarandeerd; het bestuur van de samenleving moet zodanig worden ingericht dat dit altijd mogelijk is. Zolang de meerderheidsregel deze gelijke zorg en dit gelijke respect kan waarborgen kan deze uitkomst bieden; wanneer dit niet meer het geval is, dan moet een ander orgaan, zoals de rechter, ingrijpen en de gewenste situatie herstellen (Dworkin 1996, m.n. p. 17).

14. Een dergelijke classificatie kan bijvoorbeeld zijn opgenomen in een beleidsregel.

15. Van belang is in dit verband dat de discussie over rechterlijke toetsing aan het gelijkheidsbeginsel niet afwijkt van de discussie over toetsing door de rechter van wetten aan andere grondwettelijke bepalingen. Gesteld kan zelfs worden dat het argument van minderheidsbescherming bij de rechterlijke toetsing aan het gelijkheidsbeginsel nog sterker is dan bij de toetsing aan andere grondrechten, aangezien vooroordelen en vergaande stereotyperingen die bij de meerderheid heersen hun invloed bij uitstek zullen doen gelden bij het definiëren van classificaties. 
objectief en zorgvuldig mogelijk is. ${ }^{16}$ De voorspelbaarheid van de toetsing kan worden gediend door de ontwikkeling van duidelijke, algemene regels, die de rechter kan toepassen zonder dat hij te maken krijgt met ingewikkelde interpretatieproblemen of met complexe vertaalslagen naar de feiten van het individuele geval. ${ }^{17}$ In vrijwel alle rechtsstelsels is het gelijkheidsbeginsel echter uitsluitend voor een specifiek aantal gevallen of voor een beperkt aantal gronden van onderscheid uitgewerkt in wetgeving, waarbij bovendien kan worden vastgesteld dat deze uitwerkingen vaak veel aan duidelijkheid te wensen overlaten. ${ }^{18}$ Dit betekent dat de rechter in een groot aantal gevallen geen duidelijk houvast heeft aan de wet en bij zijn toetsing moet terugvallen op algemeen geformuleerde bepalingen in grondwet of verdragen of op het algemene en ongeschreven gelijkheidsbeginsel. Dit heeft tot gevolg dat de rechter in de praktijk een relatief grote mate van vrijheid heeft bij de interpretatie en de toepassing van het gelijkheidsbeginsel: hij zal van geval tot geval opnieuw invulling moeten geven aan dit beginsel en zal daarbij in beginsel steeds andere maatstaven kunnen hanteren. ${ }^{19}$ Het gelijkheidsbeginsel biedt in zichzelf dus nauwelijks waarborgen voor een goede en voorspelbare toetsing. ${ }^{20}$ Gezien het fundamentele belang van het gelijkheidsbeginsel is een dergelijk gebrek aan voorspelbaarheid en de daaruit resulterende rechtsonzekerheid duidelijk niet wenselijk. ${ }^{21}$

Van belang is verder dat iedere juridische procedure tot op zekere hoogte een "politiek" karakter heeft. Vaak spelen uiteenlopende en tegenstrijdige waarden een rol, en is het aan de rechter om te bepalen welke van de betrokken waarden en belangen voor de uitkomst van het geding doorslaggevend zijn. ${ }^{22}$ Dit politieke karakter is in zaken waarin het gelijkheidsbeginsel een rol speelt bij uitstek aanwezig. De wijze waarop dit beginsel wordt geïnterpreteerd is in belangrijke mate afhankelijk van het tijdgewricht en van de heersende waarden en normen in een bepaald rechtsstelsel: zo was onderscheid op grond van ras in de Verenigde Staten in de $19^{\mathrm{e}}$ eeuw algemeen geaccepteerd, terwijl "ras" tegenwoordig als een zeer afkeurenswaardige grond voor onderscheid

16. Bovendien kan alleen door een dergelijke toetsing de rechtszekerheid voldoende worden gewaarborgd (zie Pels Rijcken 1979, p. 312-314, die uitgebreid ingaat op het belang van het waarborgen van rechtszekerheid en Benn/Peters 1969, p. 76).

17. Vgl. Van den Oord 1994, p. 44 en Kewenig 1972, p. 74. De laatste benadrukt de duidelijkheid van de algemeen geformuleerde discriminatieverboden: hoe groter deze duidelijkheid is, hoe minder ruimte er bestaat voor een willekeurige of subjectieve invulling door de rechter.

18. Vgl. Loenen 1992, p. 210, Mulder 1987, p. 107 en Alkema 1987, p. 66. Deze stelling zal nader worden toegelicht in de rechtsvergelijkende hoofdstukken van dit boek (hoofdstuk 3 tot en met 6).

19. Zie in dit verband Alkema 1987, die het algemene gelijkheidsbeginsel een "zwakke norm" noemt die erg vaag is.

20. Vgl. Burkens 1969, p. 12/13.

21. Vgl. Van Hoof/Jaspers 1986, p. 136/137. Rechtszekerheid kan als een waarde in zichzelf worden beschouwd, die bovendien belangrijker wordt naarmate de betrokken belangen voor het individu zwaarwegender zijn: zie Benn/Peters 1969, p. 78, Van der Hoeven 1989, p. 2, Scheltema 1989 (1), p. 16 en Pels Rijcken 1979, p. 311-313.

22. Burkens 1969, p. 13, Schoordijk 1972, p. 32 en Dworkin 1985, p. 23; vooral ook Van Gerven 1973. De laatste geeft aan dat iedere regel een bepaalde speelruimte heeft waarbinnen een dialoog kan worden aangegaan (p. 130; vgl. ook Ross 1958, p. 284, die spreekt van een marge die bij iedere regel aanwezig is en waarbinnen meerdere beslissingen juist zijn), en waarbinnen de rechter een afweging van belangen en waarden moet maken (p. 137); door het innemen van een standpunt in dit waardendebat doet de rechter volgens hem nolens volens aan "politiek" (p. 138). 
wordt beschouwd; ook bestaan er bijvoorbeeld verschillen in opvatting over ongelijke behandeling van mannen en vrouwen tussen Noord-Amerika en Europa enerzijds en veel islamitische landen anderzijds. ${ }^{23}$ Als gevolg van deze variatie in de inhoud en betekenis van het gelijkheidsbeginsel kenmerken veel gelijke behandelingszaken zich door een controverse over de waarde die in het specifieke geval aan gelijke behandeling moet worden gehecht. De rechter moet in dit soort moeilijke kwesties onvermijdelijk zijn standpunt bepalen en een keuze maken. De moeilijkheid daarbij is dat de rechter altijd vooroordelen jegens bepaalde personen of groepen zal koesteren of zal denken in stereotypen ${ }^{24}$ en dat zijn persoonlijke opvattingen bewust of onbewust, gewild of ongewild, altijd een rol zullen spelen bij zijn interpretatie en toepassing van het gelijkheidsbeginsel. ${ }^{25}$ Het is voor de rechter dan ook bijzonder moeilijk om een objectief oordeel uit te spreken. ${ }^{26}$

\subsection{Noodzaak van een goede motivering van uitspraken over ongelijke behan- deling}

Gezien de hierboven geschetste problemen kan worden gesteld dat het noodzakelijk is om hoge eisen te stellen aan de motivering van het rechterlijk oordeel. Bij de rechtvaardiging en rationalisering van het oordeel dat de rechter wil geven, kan een slechte of onduidelijke motivering namelijk verhullen dat de door de rechter gemaakte keuze subjectief van aard is of anderszins moeilijk is te verantwoorden. ${ }^{27}$ Door specifieke eisen te stellen aan het proces van rationalisering en motivering lijkt het mogelijk de

23. Zie o.a. Benn/Peters 1969 , p. 62 , die aangeven dat er geen sprake is van een ontwikkeling naar meer gelijkheid, maar van een ontwikkeling naar steeds andere vormen van gelijkheid. Dit wordt verklaard doordat de opvattingen over de vraag welke gronden relevant zijn voor het maken van onderscheid steeds veranderen: sommige gronden van onderscheid worden nu niet meer toelaatbaar geacht, en worden vervangen door onderscheid op andere gronden die we nu heel aanvaardbaar en redelijk vinden. In vergelijkbare zin Loenen 1998, p. 13. Een goede illustratie is ook te vinden bij Sloot 1989, p. 4 e.v., die aangeeft dat in Nederland in de 19e eeuw katholieken structureel werden achtergesteld ten opzichte van protestanten; katholicisme wordt tegenwoordig echter nauwelijks nog als relevante grond van onderscheid beschouwd.

24. Zie over de invloed van stereotypen Ely 1980, p. 155-159.

25. Vgl. bijvoorbeeld Loenen 1996, p. 136, die stelt dat de rechter recht spreekt vanuit een bepaald perspectief en andere invalshoeken vaak niet goed zal zien; zie ook Schoordijk 1972, p. 11, Goldschmidt 1993, Minow 1990, p. 61-65, De Jong 1975, p. 545 en De Lange 1991, p. 130 en p. 172. Bezwaarlijk is hierbij niet alleen dat sommige groepen de dupe zullen worden van een door de rechter jegens hen gekoesterd vooroordeel, maar ook dat hierdoor de rechtszekerheid wordt bedreigd: als subjectieve elementen een rol spelen kan immers de uitkomst van een procedure moeilijk worden voorspeld (vgl. Fuss 1959, p. 330).

26. Gesteld kan zelfs worden dat een objectieve toetsing een illusie is die in werkelijkheid niet kan worden bereikt: Minow 1990, p. 61 e.v.

27. Leijten 1981, p. 85. Het is belangrijk om een onderscheid te maken tussen de fase van de rechterlijke rechtsvinding en die van de rationalisering van het oordeel. Tegenwoordig wordt vrijwel algemeen aangenomen dat het rechterlijk oordeel tot stand komt door intuitie (zie daarover Crombag/Cohen/De Wijkerslooth 1977, p. 13) of op basis van algemene juridische kennis en inzichten (De Jong 1975, p. 544); zie hierover uitgebreid Llewellyn 1960, p. 12, Nieuwenhuis 1976, p. 494 en 501 en Van Gerven 1981 , p. 4/5. Pas wanneer het oordeel tot stand gekomen is zal de rechter argumenten zoeken om de uitkomst te rationaliseren en te rechtvaardigen. De motivering hoeft dus niet altijd, en kan waarschijnlijk niet eens, een juiste en exacte weergave vormen van het denkproces van de rechter (De Jong 1975 , p. 545 en 546 ). 
invloed van subjectieve opvattingen op de uitkomst van de procedure enigszins terug te dringen. ${ }^{28}$ Vanzelfsprekend kan objectiviteit hierdoor niet worden gegarandeerd, maar door een goede motivering kan in ieder geval duidelijk worden vanuit welke invalshoek en uit welk persoonlijk perspectief de rechter de zaak heeft bekeken. Dit heeft tot groot voordeel dat de uitspraak controleerbaar wordt voor de partijen, het publiek en eventueel een hogere rechter.

Zichtbaarheid van de redenering vormt ook om een andere reden een belangrijke waarborg voor een goede en zorgvuldige toetsing: omdat de rechter weet dat zijn opinie gelezen en bekritiseerd zal worden, zal hij waarschijnlijk proberen zijn uitspraak met deugdelijke argumenten te onderbouwen. ${ }^{29}$ Het vereiste van een goede motivering dwingt bovendien tot het ordenen van de gedachten, waardoor de zuiverheid en de kwaliteit van het rechterlijk oordeel kunnen worden bevorderd. ${ }^{30}$

Tenslotte is een goede motivering van belang voor de aanvaardbaarheid van de uitspraak. Zoals gezegd is er bij klachten over inbreuken op het gelijkheidsbeginsel vaak sprake van complexe problemen: de invulling van het gelijkheidsbeginsel is afhankelijk van context en tijdperk, in veel gevallen is de fundamentele menselijke waardigheid in het geding en in het geval van ongelijke behandeling door de overheid spelen diverse algemene belangen en beleidsdoelstellingen een rol. Dit betekent dat de rechter bij de beoordeling van de redelijkheid van een ongelijke behandeling voortdurend keuzen moet maken tussen tegenstrijdige waarden en belangen. De uitkomst van zijn keuzen zal noodzakelijkerwijze controversieel zijn: altijd zal worden gesteld dat hij met bepaalde belangen onvoldoende rekening heeft gehouden, of juist ten onrechte voorbij is gegaan aan andere belangen. ${ }^{31}$ Wanneer de rechter zorgvuldig motiveert waaróm hij

28. Vgl. De Lange 1991, p. 17 en 229/230: irrationaliteit, grilligheid, onvoorspelbaarheid en willekeur in rechterlijke uitspraken kunnen volgens hem worden voorkomen door een rationele motivering te vereisen, die bij voorkeur wordt gebaseerd op feitelijke gegevens of op rationele elementen in het rechtssysteem in het algemeen. Zie ook Benn/Peters 1969, p. 77, die stellen dat door een goede motivering een gedeeltelijke verzekering van onpartijdigheid wordt gegeven, en Coffin 1988, p. 25, die aangeeft dat het zorgvuldig formuleren van de verschillende overwegingen en argumenten tot gevolg heeft dat de essentiele subjectiviteit van het oordeel de gewenste objectiviteit zo dicht mogelijk nadert.

29. Llewellyn 1960, p. $26 / 27$ (over het vereiste van inbouwen van bepaalde waarborgen ook p. 17); in deze zin ook Benn/Peters 1969, p. 77, die aangeven dat de wetenschap dat de uitspraak als een precedent zal fungeren een grotere zorgvuldigheid oproept en ertoe zal leiden dat de rechter zich zo min mogelijk op eigen oordelen baseert, en Coffin 1988, p. 24/25. Zie verder De Lange 1991, p. 17, waar hij het belang van een rationeel onderbouwde motivering voor rechtsoordelen baseert op de noodzaak van voorspelbaarheid en "reckonability"; zie verder p. 130/131, p. 215 en vooral p. 229 e.v. Hij gaat ook in op de wijze waarop een beslissing moet worden gerationaliseerd: een motivering kan alleen rationeel zijn wanneer zij berust op feiten (p. 230).

30. Van Male 1988 (I), p. 76. Gesteld kan bovendien worden dat het vereisen van een goede en uitgebreide motivering een stimulans vormt voor wat door Shapiro "judicial candor" is genoemd: de rechter moet in zijn uiteenzetting oprecht zijn, en geen gebruik maken van precedenten of argumenten om de lezer van de uitspraak opzettelijk te misleiden. Alleen dan zijn de uitspraken voldoende betrouwbaar en kan de maatschappij ze aanvaarden (1987, p. 737). Wanneer specifieke eisen worden gesteld aan de motivering zal misleiding moeilijker zijn dan wanneer genoegen wordt genomen met een heel algemene uitspraak, waarin met een vage argumentatie wordt volstaan.

31. Vgl. Schoordijk 1972, p. 49. Drion heeft bovendien gesteld dat rechterlijke beslissingen in dit soort controversièle situaties sneller kunnen afgedwongen dan door de samenleving in haar geheel wordt verdragen; daardoor kunnen belangrijke delen van de samenleving niet de tijd hebben om de nieuwe situatie in hun gedachten- en gevoelswereld te verwerken (1989, p. 105). Een dergelijk bezwaar is nog in sterkere mate geldig wanneer de beslissing niet voldoende met redenen is omkleed. 
heeft gekozen voor een bepaalde oplossing, zal het voor de partijen en voor het algemene publiek gemakkelijker zijn om de uitspraak te begrijpen en te aanvaarden dan wanneer hij morele waardeoordelen en controverses verbergt achter holle frasen en lege zinsneden. ${ }^{32}$

\subsection{Wenselijkheid van de ontwikkeling van een toetsingsmodel; opzet van het onderzoek}

Hiervoor is aangegeven dat het stellen van hoge eisen aan de motivering een belangrijke manier is om de objectiviteit, voorspelbaarheid, controleerbaarheid en aanvaardbaarheid van de rechterlijke toetsing aan het gelijkheidsbeginsel te vergroten." ${ }^{3}$ Tegelijkertijd moet echter worden vastgesteld dat duidelijke richtlijnen voor de rechterlijke toetsing vooralsnog ontbreken: rechters blijken in de praktijk veelal slechts algemene en vage formuleringen van het gelijkheidsbeginsel tot houvast te hebben. ${ }^{4}$ Om die reden is het wenselijk om een toetsingsmodel te creëren dat rechters behulpzaam kan zijn bij de rechtsvinding en dat structuur kan geven aan de rechterlijke motivering. ${ }^{35}$ Beoogd wordt om in dit proefschrift een dergelijk model te ontwikkelen.

In het eerste deel van dit boek zal worden getracht op basis van de theoretische literatuur over het gelijkheidsbeginsel een normatief en hypothetisch toetsingsmodel te ontwikkelen (hoofdstuk 2). Daartoe zal worden onderzocht welke factoren de rechter in zijn toetsing zou moeten betrekken om tot een goede motivering van zijn uitspraak te komen, zonder daarbij de grenzen van de rechterlijke toetsingsbevoegdheid te overschrijden. Daarnaast zal in hoofdstuk 2 aandacht worden besteed aan de intensiteit van

32. Zie Dworkin 1985, p. 329 (“'...] if each judge faces the moral question openly, an informed public will be in a better position to understand and criticize them than if the moral grounds of decision lie hidden under confused arguments [...]"; in deze zin ook Van Male 1988 (1), p. 76.

33. Vgl. Fuss 1959, p. 335, die stelt dat het goed is om te accepteren dat de rechter controle uitoefent op de wetgevende handelingen en deze soms ook corrigeert, maar dat er dan wel theoretische en concrete maatstaven moeten worden geboden die het beroep op het algemene gelijkheidsbeginsel zullen beperken.

34. Voorbeelden laten zien dat de formuleringen zelden helder zijn. Zie bijvoorbeeld de eerste volzin van artikel I van de Nederlandse Grondwet: "Allen die zich in Nederland bevinden, worden in gelijke gevallen gelijk behandeld", het Veertiende Amendement van de Amerikaanse constitutie: "No State shall [...] deny to any person within its jurisdiction the equal protection of the laws", of de eerste volzin van artikel 26 IVBPR "Allen zijn gelijk voor de wet en hebben zonder discriminatie aanspraak op gelijke bescherming door de wet". Alleen de laatste bepaling garandeert uitdrukkelijk gelijke behandeling in wettelijke classificaties, bij de overige bepalingen is dit niet duidelijk. Verder biedt geen van deze bepalingen ook maar enig aanknopingspunt om vast te stellen wanneer gevallen "gelijk" zijn, het punt waarom de gehele rechterlijke toetsing toch eigenlijk draait. Wanneer de rechter met bepalingen als deze wordt geconfronteerd, zal hij dan ook in belangrijke mate zelf moeten bepalen wanneer er sprake is van gelijke gevallen en van gelijke behandeling. Uit hoofdstuk 2 zal blijken dat deze vraag gemakkelijker te beantwoorden lijkt dan in werkelijkheid het geval is.

35. Overigens kan worden opgemerkt dat een dergelijk model niet alleen voor de rechter bruikbaar zal zijn, maar ook voor diegenen die verantwoordelijk zijn voor het maken van onderscheid, zoals de wetgever (vgl. Tussman/TenBroek 1949, p. 365). Wanneer zij bij het tot stand brengen van een onderscheid rekening houden met het model en hun motivering daarop afstemmen, zal het aanzienlijk eenvoudiger zijn om te beoordelen of een onderscheid redelijk is. Niet alleen wordt daardoor het werk van de rechter vergemakkelijkt, maar ook zal het aantal beroepen op de rechter daardoor kunnen worden verminderd. 
de toetsing. Voor de uitkomst van een gelijke behandelingszaak kan het namelijk bepalend zijn of de rechter een marginale, oppervlakkige, toetsing uitvoert of juist zeer nauwkeurig nagaat of de argumenten die ter rechtvaardiging van een onderscheid zijn aangevoerd voldoende hout snijden. Gezien het belang van een goede keuze voor een bepaalde toetsingsintensiteit is het wenselijk om de rechter ook daarvoor enige aanknopingspunten te verschaffen. Nagegaan zal dan ook worden in hoeverre variatie in de toetsingsintensiteit wenselijk en mogelijk is, en bezien zal worden welke factoren bij de bepaling van de intensiteit van de toetsing een rol kunnen spelen.

In het tweede deel zal vervolgens worden ingegaan op de wijze waarop in de praktijk aan het gelijkheidsbeginsel wordt getoetst. In dat verband zal worden onderzocht op welke wijze het Europees Hof voor de Rechten van de Mens (hoofdstuk 3) en het Hof van Justitie van de EG (hoofdstuk 4) aan deze toetsing vorm geven en welke methodiek hierbij wordt gehanteerd in de Verenigde Staten (hoofdstuk 5) en in Nederland (hoofdstuk 6) ${ }^{36}$ Ook zal in deze hoofdstukken aandacht worden besteed aan de mate waarin variatie in de intensiteit van de toetsing zichtbaar is en zal worden nagegaan welke factoren bij deze variatie een rol spelen. Tenslotte zal in ieder hoofdstuk worden beoordeeld in welke mate de toetsing overeenstemt met het in hoofdstuk 2 ontwikkelde, theoretische, toetsingsmodel en op welke punten de gehanteerde methodiek een aanvulling of nuancering van dit model rechtvaardigt.

Tenslotte zal het theoretische toetsingsmodel in hoofdstuk 7 worden geoptimaliseerd met het oog op de eisen die de praktijk aan de toetsing blijkt te stellen. Dit betekent dat aan de hand van de rechtsvergelijkende hoofdstukken zal worden nagegaan met welke problemen rechters bij hun toetsing aan het gelijkheidsbeginsel worden geconfronteerd en welke oplossingen zij daarvoor hebben gevonden. Deze bevindingen zullen worden vergeleken met het theoretische model, dat vervolgens verder zal worden gedifferentieerd en verfijnd om het beter te laten beantwoorden aan de in de praktijk bestaande behoeften; ook zullen elementen of criteria aan het model worden toegevoegd die in de rechterlijke toetsingspraktijk zinvol en bruikbaar zijn gebleken.

36. De rechtspraak van de verschillende instanties is bestudeerd tot en met 31 december 2001; uitspraken die na deze datum zijn gewezen zijn slechts sporadisch in de tekst verwerkt. In dit proefschrift is getracht te werken langs de methodische lijnen zoals die zijn uitgestippeld door Koopmans; zie onder andere Koopmans 1986, p. 350-358; vgl. ook Florijn 1996, p. $91 / 92$ en p. 99 . In verband daarmee is het onderzoek naar de Amerikaanse toetsing aan het gelijkheidsbeginsel zoveel mogelijk in de VS is uitgevoerd, tijdens een verblijf van enkele maanden aan de University of Michigan Law School; daarbij is zoveel mogelijk Amerikaanse literatuur gebruikt en is gesproken met een aantal deskundigen. Daarnaast is, om een goede achtergrond te verkrijgen voor het onderzoek, in de VS onderwijs gevolgd op het terrein van gelijke behandeling en rechterlijke toetsing.

Van belang is verder dat de verschillende rechtsvergelijkende hoofdstukken steeds een inleidende paragraaf bevatten waarin enkele bijzonderheden van het systeem uiteen worden gezet, die nodig zijn voor een goed begrip van de toetsingsmethodiek. Vervolgens wordt in de paragrafen 2 en 3 van de rechtsvergelijkende hoofdstukken een uiteenzetting gegeven van de toetsingsmethodiek en de wijze waarop de toetsingsintensiteit wordt bepaald. Tenslotte wordt in een concluderende paragraaf steeds bezien in hoeverre de methodiek van de onderzochte rechterlijke instantie(s) overeenstemming vertoont met het in hoofdstuk 2 ontwikkelde theoretische toetsingsmodel. 


\section{Een theoretisch model voor rechterlijke toetsing aan het gelijkheidsbeginsel}

\section{$1 \quad$ Begripsbepaling}

\subsection{Gelijkheid, vergelijkbaarheid, onderscheid en discriminatie}

\subsubsection{De aristotelische gelijkheidsformule}

Hoewel algemeen wordt aangenomen dat het gelijkheidsbeginsel een fundamenteel rechtsbeginsel is, bestaat er maar weinig overeenstemming over de precieze betekenis van dit beginsel.' Meestal wordt het gedefinieerd volgens de zogenaamde aristotelische formule: "gelijke gevallen moeten gelijk worden behandeld en ongelijke gevallen ongelijk, naar mate van hun ongelijkheid."' Deze formulering heeft echter een sterk formeel karakter en biedt daardoor maar weinig duidelijkheid over de precieze betekenis van het gelijkheidsbeginsel: onzeker blijft bijvoorbeeld wanneer gevallen gelijk zijn en waaruit een gelijke behandeling zou moeten bestaan. ${ }^{3}$ Belangrijk is echter dat uit deze formule kan worden afgeleid dat gelijkheid een comparatief begrip is dat pluraliteit veronderstelt: er moet sprake zijn van een verschillende behandeling ${ }^{4}$ van twee of meer

1. Zoals O'Fallon aangeeft is gelijkheid een "essentially contested concept": het is een normatief concept waaraan geen betekenis kan worden gegeven waarover iedereen het eens kan worden (1979, p. 22).

2. Deze formulering wordt toegeschreven aan Aristoteles, die het overigens iets ingewikkelder stelt dan meestal wordt weergegeven: "The just [...] involves at least four terms: for the persons for whom it is in fact just are two, and the things in which it is manifested, the things distributed, are two. And the same equality will exist between the persons and between the things concerned; for as the latter - the things concerned - are related, so are the former; if they are not equal, they will not have what is equal, but this is the origin of quarrels and complaints - when either equals have and are awarded unequal shares, or unequals equal shares"; vervolgens koppelt hij deze formule aan het vereiste van proportionaliteit en geeft daarmee aan dat alleen die verdeling gelijk en rechtvaardig kan zijn die ook proportioneel is: ("the just, then, is a species of the proportionate. [...] The conjunction, then, [...] is what is just in distribution") ([Ethica Nicomachea V.3.1131a6-1132a2]).

3. Door diverse auteurs is aangegeven dat dit begrip inhoudsloos is: Ross 1958, p. 272 ("empty formula"), Westen 1982 (I), p. 547 ("equality is an empty vessel with no substantive moral content of its own"), Benn/Peters 1969, p. 62 ("'equality' is an empty framework"). Zie verder Flathman 1967, p. 39/40, Pojman/Westmoreland 1997, p. 2, Sloot 1986, p. 11, Burkens 1982, p. $59 / 60$ en Perelman 1963, p. $81 / 82$. Een afwijkende mening is te vinden bij Loenen 1992, p. 18; zij vindt dat het gelijkheidsbeginsel in ieder geval wordt ingevuld door de premisse dat ieder mens in abstracto een gelijke inherente waarde heeft en gelijk respect verdient; in vergelijkbare zin ook Greenawalt 1983, p. 1169/1170. Deze invulling maakt het gelijkheidsbeginsel echter niet minder leeg, aangezien hierdoor nog steeds niet duidelijk is waardoor gelijk respect wordt gerealiseerd. Overigens doet deze leegheid niet af aan het nut van het concept: het biedt zonder meer een analytisch denkkader en verschaft een nuttige formele leidraad voor de rechtspraktijk. Bovendien kan worden gesteld dat het begrip een belangrijke retorische en morele waarde heeft (zie bijvoorbeeld Chemerinsky 1983, p. 585-587).

4. Pluraliteit van object: er moet sprake zijn van tenminste twee verschillende mogelijke behandelingen (Sloot 1986, p. 15, nader uitgewerkt en toegelicht op p. 28). Sloot lijkt de pluraliteit van object overigens te beschouwen als een schaarsteprobleem. Wanneer er geen sprake is van schaarste kan er ook geen ongelijke behandeling zijn, omdat iedereen dan immers op een andere manier toegang kan krijgen tot de goederen (p. 28). Of dit geheel juist is valt te betwijfelen: ook wanneer er geen schaarste is kan 
verschillende ${ }^{5}$ zaken, handelingen of personen ${ }^{6}$, waarbij eigenschappen of kenmerken van de ene zaak, handeling of persoon vergeleken worden met de andere? ${ }^{7}$ Personen, handelingen of zaken hoeven daarbij niet volledig identiek te zijn om "gelijk" te kunnen worden genoemd: het is voldoende wanneer zij in bepaalde, relevante opzichten vergelijkbaar zijn..$^{8}$ Dit betekent dat het voor een zinvolle vergelijking noodzakelijk is om na te gaan welke kenmerken of eigenschappen van de zaken, personen of handelingen voor de vergelijking van belang zijn.' Bovenstaande formule veronderstelt dan ook de aanwezigheid van een maatstaf ter beoordeling van de relevantie van overeenkomsten en verschillen. ${ }^{10}$

Op deze aristotelische formule, die een belangrijke invloed heeft gehad op het denken over gelijke behandeling, zal in paragraaf 4 van dit hoofdstuk nader worden ingegaan. Met name zal daar aandacht worden besteed aan de vraag of de formule een zinvol aanknopingspunt kan bieden bij de rechterlijke toetsing aan het gelijkheidsbeginsel. Betoogd zal daarbij worden dat het voor het bereiken van een zuivere en doorzichtige

er sprake zijn van ongelijke behandeling, aangezien een bepaalde groep (in ieder geval in theorie) een monopolie kan uitoefenen op de verdeling en daarmee alsnog kan bepalen wie de beschikking over het goed kan hebben (Walzer 1983, p. 11). Beter is het dan ook om de pluraliteit van object betrekking te laten hebben op de verschillende mogelijke behandelingen die het subject ten deel kunnen vallen (vgl. de hiervoor geciteerde passage uit de Ethica Nicomachea).

5. Westen 1990, p. 12: er moet altijd sprake zijn van verschillende dingen, anders zou er sprake zijn van een en hetzelfde goed of een en dezelfde persoon: "[...] simple equalities [...] all involve a relationship between things that are distinguishable in one or more respects."

6. Pluraliteit van subject (Sloot 1986, p. 15, nader uitgewerkt en toegelicht op p. 27 en Westen 1990, p. 12).

7. Dit blijkt reeds uit de eerder geciteerde passage uit de Ethica Nicomachea van Aristoteles. Vgl. ook Ruiter 1985, p. 21 , die benadrukt dat gelijkheid geen rechtstreekse betrekking is tussen mensen, dingen, toestanden of gebeurtenissen, maar een betrekking tussen eigenschappen van mensen, dingen, toestanden of gebeurtenissen. Zie ook Alexy 1985, p. 362, die aangeeft dat gelijkheidsoordelen oordelen zijn over een drieledige verhouding ( $a$ is ten opzichte van $b$ gelijk wat betreft eigenschap E). Zoals Westen aangeeft is pluraliteit overigens niet alleen vereist bij gelijke behandeling, maar bij alle comparatieve rechten (1982 (I), p. 552/553); in die zin ook Simons 1985, p. 389.

8. Volledige gelijkheid is feitelijk niet eens mogelijk: zelfs twee voor het oog identieke pingpongballetjes zijn samengesteld uit verschillende moleculen en nemen een verschillende ruimte in beslag (Pojman/Westmoreland 1997, p. 2; vgl. ook Westen 1990, p. 23 en Burkens 1982, p. 60). Twee zaken kunnen dus feitelijk niet identiek zijn, anders zouden zij één en hetzeifde voorwerp zijn (Westen 1983 (II), p. 610 en 1991, p. 25; idem Bedau 1967, p. 8). Gesteld kan worden dat er een verschil bestaat tussen "gelijkheid" en "vergelijkbaarheid", in die zin dat gelijkheid duidt op een grotere mate van overeenstemming dan vergelijkbaarheid. Westen formuleert dit verschil tussen de begrippen als volgt: "[...] just as "similar" differs from "equal" in its lack of sufficient identity, so, too, "equal" differs from "same" in its lack of complete identity; and just as "dissimilar" differs from "unequal" in its lack of sufficient nonidentity, "unequal" differs from "different" in its lack of complete nonidentity" (1983 (II), p. 610 ; in deze zin ook Bedau 1967, p. 7). Hieruit concludeert Westen dat vergelijkbaarheid betekent dat gevallen die in een beperkt aantal relevante opzichten identiek zijn "vergelijkbaar" kunnen worden genoemd; "gelijkheid" betekent dat de gevallen in alle relevante opzichten (dus niet in alle opzichten) identiek zijn (p. 611; in vergelijkbare zin ook Perelman 1963, p. 80). Zie over deze en andere begrippen, zoals "sameness" en "uniformity" ook Thomson 1969, p. 3 en Kewenig 1972, p. 73.

9. Dit wordt in de literatuur algemeen aanvaard. Zie bijvoorbeeld Westen 1982 (I), p. 552/553 en Ross 1958 , p. 270; vgl. ook Maris 1988, p. 53.

10. Vgl. Westen 1983 (II), p. 611 en Ruiter 1985, p. 22. Zie verder paragraaf 4.2. 
motivering noodzakelijk is om juist het comparatieve, door velen als essentieel beschouwde, element van deze formule bij de rechterlijke toetsing achterwege te laten.

\subsubsection{Onderscheid, ongelijke behandeling, differentiatie, classificatie, discriminatie}

De begrippen "onderscheid", "classificatie" en "differentiatie" hebben vrijwel dezelfde betekenis als het hiervoor kort besproken begrip "ongelijke behandeling" en zijn even waardeneutraal en inhoudsloos: door gebruik te maken van deze begrippen wordt niets gezegd over de toelaatbaarheid of wenselijkheid van de ongelijke behandeling." Ook het begrip "discriminatie" betekent van oorsprong niets anders dan "ongelijke behandeling" of "onderscheid", ${ }^{12}$ maar dit specifieke begrip heeft in de loop van de tijd een negatieve bijklank gekregen: meestal wordt het gehanteerd om onderscheid op een als ontoelaatbaar beschouwde grond aan te duiden of om aan te geven dat het onderscheid om andere redenen niet door de beugel kan. ${ }^{13}$ Dit betekent dat het begrip in die gevallen wordt gebruikt om de uitkomst van een toetsing aan het gelijkheidsbeginsel aan te duiden: discriminatie is dan hetzelfde als ongerechtvaardigd onderscheid. ${ }^{14}$ Daarnaast wordt het begrip soms gebruikt om aan te geven of, of in welke mate, een rechtvaardiging voor het onderscheid mogelijk is. Volgens sommige auteurs is discriminatie namelijk moeilijk of zelfs in het geheel niet te rechtvaardigen, terwijl een rechtvaardiging bij ongelijke behandeling wel steeds mogelijk is. ${ }^{15}$

Door deze onduidelijkheid over de precieze juridische betekenis en door de negatieve connotatie is het begrip "discriminatie" als juridisch concept minder bruikbaar dan begrippen als onderscheid, classificatie en ongelijke behandeling. ${ }^{16} \mathrm{Om}$ die reden zal het begrip discriminatie in het hiernavolgende zoveel mogelijk worden vermeden en zal vooral gebruik worden gemaakt van de eerdergenoemde neutrale begrippen. ${ }^{17}$

11. Er kleeft dus geen negatieve connotatie aan de begrippen, zoals het geval is bij het hiema te bespreken begrip discriminatie. Om die reden kunnen de verschillende begrippen elkaar heen worden gebruikt, hoewel met het aan het Engels ontleende begrip "classificatie" vrijwel steeds wordt geduid op onderscheid in regelgeving. Om dit te verduidelijken zal in het hiernavolgende meestal worden gesproken over "normatieve classificaties".

12. Dit is met name het geval in het Engels; vgl. Kewenig 1972, p. 25.

13. Vgl. Burkens 1982 , p. 61 , Wiggers 1991, p. 6-7, Kewenig 1972, p. $25 / 26$ en Loenen 1992, p. 218 ("discriminatie doet zich alleen voor als er sprake is van een structurele achterstelling, en/of als er sprake is van een maatschappelijk patroon van benadeling van een bepaalde groep"); zie ook p. 244.

14. Vgl. Maris 1985, p. 1295, Sloot 1986, p. 10/11, Loenen 1998, p. 34 en Van der Grinten 1984, p. 2. Sloot werkt dit concept op fraaie wijze verder uit; zie daarvoor m.n. p. 27-29. Vgl. ook Kewenig 1972, p. 51 .

15. Zie Mulder 1987, p. 108. Deze gevolgtrekking lijkt ongelukkig: zoals hiema zal blijken moet iedere ongelijke behandeling aan de hand van dezelfde criteria worden beoordeeld op zijn toelaatbaarheid, of er nu sprake is van een discriminatie of van een ongelijke behandeling (zie ook Wentholt 1990, p. 46). Het is ook moeilijk vast te stellen wanneer er nu precies sprake is van een discriminatie en wanneer van een "gewone" ongelijke behandeling. Waarschijnlijk spelen daarbij factoren een rol als de verdachtheid van een bepaalde grond van onderscheid of het gewicht van het aangetaste belang. Zoals nog zal blijken kunnen dergelijke factoren wel een rol spelen bij de toetsing aan het gelijkheidsbeginsel, maar vooral wanneer het gaat om de vaststelling van de intensiteit van de toetsing.

16. Van Maarseveen 1990, p. 5 ("hoekpunten zijn: onderscheid, achterstelling en onrechtvaardigheid"); hij geeft aan dat het begrip door zijn bijklank nauwelijks bruikbaar is als juridisch-operationeel begrip, maar een juridisch concept is dat inhoudelijk verwijst naar een moreel concept.

17. Van deze algemene lijn zal soms worden afgeweken in het rechtsvergelijkende gedeelte: in de praktijk wordt niet altijd scherp onderscheid gemaakt tussen de verschillende begrippen en wordt vaak op een 


\subsection{Formeel en materieel onderscheid; direct en indirect onderscheid}

\subsubsection{Formeel en materieel onderscheid}

Het maken van formeel onderscheid betekent dat vergelijkbare gevallen ongelijk worden behandeld, het maken van materieel onderscheid dat onvergelijkbare gevallen gelijk worden behandeld. Hoewel er in het tweede geval geen onderscheid gemaakt lijkt te worden - er is immers juist sprake van een gelijke behandeling - wordt ook daarbij vaak gesproken van ongelijke behandeling. Een op het eerste gezicht gelijk lijkende behandeling kan namelijk wel degelijk een ongelijkheid opleveren: een ongelijkheid in resultaat, veroorzaakt door het feit dat er onvoldoende rekening wordt gehouden met feitelijk bestaande verschillen tussen groepen of personen. ${ }^{\text {is }}$

Ter verheldering van dit begrippenpaar kan gebruik worden gemaakt van het voorbeeld van een bedrijf dat verschillende producten op de markt brengt. Daarbij kan ervan worden uitgegaan dat voor het maken van bepaalde producten een specialistische opleiding en een zekere mate van ervaring nodig is, terwijl andere producten zonder bijzondere kennis en vaardigheid kunnen worden gefabriceerd. Het verschil tussen formeel en materieel onderscheid wordt duidelijk wanneer binnen dit bedrijf een salarisregeling geldt op grond waarvan alle medewerkers beloond worden op basis van een identiek stukloon. Dit betekent dat voor ieder afgeleverd product, ongeacht de eisen die het fabriceren ervan stelt, hetzelfde bedrag wordt toegekend. Een dergelijke salarisregeling heeft een formeel gelijk karakter: iedere medewerker ontvangt immers een salaris op grond van dezelfde voet van berekening. Tegelijkertijd kan echter worden gesteld dat de salarisregeling materieel gezien leidt tot een ongelijkheid in behandeling, omdat geen rekening wordt gehouden met de specifieke eisen die het fabriceren van de producten aan de kennis en ervaring van de medewerkers stelt.

Uit dit voorbeeld blijkt dat bij formeel onderscheid uitsluitend wordt gekeken naar de classificatie zelf, terwijl de praktische consequenties van deze classificatie minder aandacht krijgen. Bij materieel onderscheid is daarentegen juist het feitelijke gevolg van de classificatie doorslaggevend en is de classificatie zelf minder van belang. ${ }^{190}$

min of meer neutrale manier gebruik gemaakt van het begrip discriminatie; dit is met name het geval wanneer er gesproken wordt over direct of indirect onderscheid (zie hierna) of over voorkeursbehandeling ("positieve discriminatie").

18. Zie o.a. Wentholt 1990 , p. 50 (die overigens om niet geheel duidelijke redenen onderscheid maakt tussen de visie dat materieel onderscheid een bepaald resultaat is, en de visie dat materieel onderscheid voortvloeit uit de aard van de behandeling) en Minow 1990, p. 20 e.v. Zie over dit onderscheid, dat voortvloeit uit een erkenning van de bestaande verschillen van individuen, verder Wiggers 1990, die stelt dat er een ontwikkeling heeft plaatsgevonden van een klassiek-liberale opvatting naar een meer maatschappelijke opvatting van gelijkheid (p. 3). De ontwikkeling van het begrip materieel onderscheid lijkt met deze ontwikkeling parallel te lopen. Zie hierover ook Sloot, die een vergelijkbare ontwikkeling signaleert (1986, p. 17-19).

19. Vgl. Sloot 1986, p. 31. Met het gebruik van begrippen als formeel en materieel onderscheid is overigens nog niets gezegd over de bedoeling die aan het onderscheid ten grondslag ligt, hoewel het erop zou kunnen lijken dat formeel onderscheid altijd bedoeld is, terwijl materieel onderscheid een onbedoeld effect is van een bepaald formeel onderscheid. Dit hoeft echter niet het geval te zijn: een regelgever kan soms de bedoeling hebben om met een bepaalde (formeel gelijke) regeling een materiële ongelijkheid te bewerkstelligen. Een onsympathiek voorbeeld is een aantal wetten dat in de jaren 50 in een aantal Amerikaanse staten werd ingevoerd en het stemrecht beperkten tot mensen die konden lezen; het beoogde resultaat van deze regeling was dat zwarte burgers, waarvan een grote meerderheid 


\subsubsection{Direct en indirect onderscheid - verhouding van deze begrippen tot materieel en formeel onderscheid}

Het begrippenpaar direct en indirect onderscheid heeft vooral een functie wanneer de wetgever onderscheid op een aantal specifieke, limitatief opgesomde, gronden heeft verboden. Er is sprake van direct onderscheid wanneer het onderscheid daadwerkelijk op een van deze verboden gronden is gebaseerd. Van indirect onderscheid kan worden gesproken als een onderscheid op een andere, niet in de wettelijke opsomming genoemde grond tot effect heeft dat er onderscheid wordt gemaakt op één van de verboden gronden..$^{21}$

Een voorbeeld kan dit verduidelijken. Wettelijke regelingen verbieden dikwijls expliciet dat er onderscheid wordt gemaakt op grond van geslacht; andere mogelijke differentiatiegronden, zoals de omvang van het dienstverband, worden zelden met zoveel woorden genoemd. Een dergelijke wettelijke bepaling maakt het voor een werkgever mogelijk om een interne regeling vast te stellen waardoor deeltijdwerkers worden benadeeld ten opzichte van voltijdwerkers: nu dit onderscheid niet direct is gebaseerd op geslacht, maar op een niet expliciet verboden differentiatiecriterium, is een dergelijke regeling niet in strijd met het wettelijke verbod. ${ }^{22} \mathrm{Nu}$ in de huidige samenleving het aantal in deeltijd werkende vrouwen aanzienlijk groter is dan het aantal mannen dat in deeltijd werkt, zal het feitelijke effect van dit soort maatregelen echter zijn dat er veel meer vrouwen dan mannen worden benadeeld. Indirect wordt er dan ook wel degelijk onderscheid gemaakt op grond van geslacht.

Tussen de begrippen formeel en materieel onderscheid enerzijds en direct en indirect onderscheid anderzijds bestaat een nauwe samenhang. Het concept van indirect onderscheid impliceert immers een erkenning van het feit dat een formeel gelijke behandeling een materiële, feitelijke, ongelijkheid tot gevolg kan hebben. ${ }^{23}$ Van belang is echter dat het begrippenpaar direct/indirect onderscheid uitsluitend wordt gehanteerd in de gevallen waarin door een wet, grondwet of verdrag een verbod wordt gesteld op onderscheid op een limitatief opgesomd aantal gronden. Wanneer een beroep wordt gedaan op het algemene, niet tot bepaalde gronden beperkte, gelijkheidsbeginsel is het niet nodig om gebruik te maken van de terminologie van direct en indirect onderscheid. In die gevallen kan immers iedere vorm van onderscheid, ongeacht het differentiatiecrite-

analfabeet was, het kiesrecht werd ontzegd; zie over deze wetgeving en de rechtspraak daarover hoofdstuk 5.

20. Gesteld kan worden dat formele en materièle gelijkheid betrekking hebben op andere "niveaus" van gelijkheid: formele gelijkheid richt zich op het wegwerken van oppervlakkige, duidelijk zichtbare ongelijkheden (bijvoorbeeld rechtstreeks zichtbare onderscheidingen op grond van ras of geslacht), terwijl materięle gelijkheid zich richt op een feitelijk gelijk resultaat, d.w.z. dat ervoor wordt gezorgd dat mensen, ongeacht de tussen hen bestaande verschillen, zoveel mogelijk kans krijgen op zelfontplooiing (vgl. bijvoorbeeld Sloot 1986, p. 16, Maris 1988, p. 17 en Loenen 1992, p. 23 en 260).

21. Het begrip indirect onderscheid is op diverse plaatsen beschreven. Zie o.a. Loenen 1999, p. 198.

22. Zie voor voorbeelden uit de praktijk vooral het hoofdstuk over de toetsing door het Europees Hof van Justitie (hoofdstuk 4).

23. Immers, in het voorbeeld van onderscheid op grond van werktijd worden mannen en vrouwen weliswaar formeel gelijk behandeld, maar bij nadere beschouwing wordt duidelijk dat deze formeel gelijke behandeling materieel gezien tot gevolg heeft dat vrouwen worden benadeeld, doordat zij zich feitelijk in een andere positie bevinden dan mannen. 
rium, voor de rechter worden aangevochten, zodat ieder onderscheid feitelijk kan worden aangemerkt als direct onderscheid. ${ }^{24}$ Wel kan in dit soort gevallen nog altijd onderscheid worden gemaakt tussen materieel en formeel ongelijke behandeling: gesproken kan worden van direct materieel en direct formeel onderscheid. In het hiervoor gegeven voorbeeld kan bijvoorbeeld worden gesteld dat er sprake is van direct formeel onderscheid op grond van de omvang van het dienstverband. Van direct materieel onderscheid op grond van de omvang van het dienstverband zou in dit voorbeeld sprake zijn wanneer bij de berekening van het maandsalaris geen rekening wordt gehouden met de omvang van het dienstverband: deeltijd- en voltijdwerkers ontvangen dan weliswaar een formeel gelijk salaris, maar materieel gezien worden voltijdwerkers hierdoor benadeeld.

\subsubsection{Andere begrippen}

Naast de begrippenparen materieel/formeel onderscheid en direct/indirect onderscheid zijn er in de literatuur nog verschillende andere begrippenparen terug te vinden, zoals absoluut en relatief onderscheid ${ }^{25}$, feitelijk en juridisch onderscheid ${ }^{26}$ en kwantitatief en kwalitatief onderscheid. ${ }^{27}$ Deze begrippenparen worden in de praktijk echter nauwelijks gehanteerd; de verschillen in betekenis tussen deze begrippen en de begrippen materieel en formeel onderscheid zijn ook niet van zodanige betekenis dat dit nodig is. ${ }^{28}$ In het hiernavolgende zal van deze begrippenparen dan ook geen gebruik worden gemakkt.

Van belang is wel nog het begrip "procedurele gelijkheid", nu dit een verdere differentiatie binnen de onderverdeling in materiële en formele gelijkheid mogelijk maakt. Met procedurele gelijkheid wordt gedoeld op de situatie waarin gestreefd wordt naar het creëren van gelijke kansen. ${ }^{29}$ Anders dan bij formele gelijkheid wordt er bij procedurele gelijkheid tot op zekere hoogte rekening gehouden met de tussen individuen bestaande verschillen (namelijk met verschillen in de uitgangspositie waarin mensen verkeren),

24. Zo kan in dat geval een onderscheid op grond van werktijd rechtstreeks worden aangevochten; vgl. Wentholt 1990, p. 51. Zie over de verhouding tussen indirect en materieel onderscheid ook Loenen 1999 , p. $198 / 199$ en $204 / 205$.

25. 'Als absolute Gleichbehandlung ist das zu bezeichnen, was [...] als 'formell-egalitäre', als 'schematische' Gleichheit angesprochen, als relative Gleichbehandlung dagegen das, was [...] als 'materielldifferenzierende', als 'proportionale' Gleichheit gekenzeichnet wurde”; Kewenig 1972, p. 187.

26. Zie bijvoorbeeld Alexy 1985, p. 377/378: "Die Begriffe der Gleich- und Ungleichbehandlung [...] kőnnen sowohl akt- als auch folgenbezogen gedeutet werden. De aktbezogene Deutung stellt ausschlieBlich auf die zu beurteilende staatliche Handlung als solche ab [later aangeduid als rechtliche Gleichheit, JHG]. Für die folgenbezogene Deutung sind demgegenüber die faktische Konsequenzen der staatlichen Handlung entscheidend [later aangeduid als faktische Gleichheit, JHG]." Vgl. ook Tribe 1988 , p. 1439, die aangeeft dat juridische gelijkheid hetzelfde is als formele gelijkheid, terwijl feitelijke gelijkheid hetzelfde is als materiele gelijkheid.

27. Vgl. de beschrijving door Wentholt 1990, p. 58: "Gaat het om kwantitatieve verschillen, dan impliceert het discriminatieverbod een verplichting tot differentiëren. Een voorbeeld levert deeltijdarbeid op. Deeltijdarbeid is vergelijkbaar met voltijdarbeid; gelijke behandeling moet plaatsvinden naar rato van de kwantitatieve verschillen. Een kwalitatief verschil [...] behelst een gebod tot differente behandeling. De verboden discriminatie ligt dan in de gelijke behandeling van ongelijken."

28. Zie ook Wentholt 1990 , p. 56-58.

29. Procedurele gelijkheid is dan ook wel bekend onder de Engelse term "equality of opportunity". 
maar anders dan bij materiële gelijkheid wordt er niet gestreefd naar een volledige gelijkheid in resultaat: zelfs als mensen zich in een gelijke uitgangspositie bevinden kan het uiteindelijke resultaat dat zij bereiken verschillen. ${ }^{30}$

Het verschil tussen de drie vormen van gelijkheid kan worden verduidelijkt door een schaatswedstrijd tot voorbeeld te nemen. De deelnemers aan een dergelijke wedstrijd kunnen in allerlei opzichten verschillen: niet alleen zullen sommige schaatsers van nature meer getalenteerd en sneller zijn dan andere, maar ook is het mogelijk dat sommige van hen een betere training hebben gekregen of over beter materiaal beschikken. Een formeel gelijke behandeling betekent in dit verband niet meer dan dat alle deelnemers aan de start mogen verschijnen en dat gelijke spelregels op hen van toepassing zijn; de verschillen in kwaliteit van de sporters en het verschil in training of materiaal zijn niet van belang voor de kwalificatie van de behandeling van de deelnemers als "gelijk". Om te kunnen spreken van procedurele gelijkheid moet daarentegen wel waarde worden gehecht aan enkele verschillen tussen de schaatsers, aangezien deze vorm van gelijkheid vereist dat de kans om te winnen voor alle deelnemers gelijk is. Dit zou bijvoorbeeld betekenen dat de deelnemers een training krijgen van een vergelijkbaar niveau, afgestemd op hun specifieke capaciteiten, en dat de kwaliteit van het gebruikte materiaal vergelijkbaar is. Ook wanneer daardoor een gelijkheid in kansen wordt gecreëerd zal er echter nog een winnaar kunnen worden aangewezen: de verschillen in talent en snelheid van de deelnemers blijven immers bestaan." Wanneer een materieel gelijkheidsbeginsel tot uitgangspunt wordt genomen zal ook dit door de natuurlijke kwaliteiten en talenten ontstane verschil moeten worden geminimaliseerd, bijvoorbeeld door de van nature langzamere deelnemers een zekere voorsprong te geven. Het gaat er immers om een gelijk resultaat te bereiken, hetgeen in dit voorbeeld inhoudt dat alle deelnemers in een gelijke tijd aan de finish verschijnen.

Theoretisch gezien is deze indeling in drie vormen van gelijkheid zuiverder dan de meer gebruikelijke indeling in materieel en formeel onderscheid. Bovendien biedt deze indeling de mogelijkheid om genuanceerd over gelijke behandeling na te denken en kunnen bepaalde ontwikkelingen over het denken over gelijke behandeling door middel van de driedeling beter worden verklaard. ${ }^{12}$ Voor de rechterlijke toepassing van het

30. Sloot 1986, p. 16. Door de meeste auteurs worden de procedurele en materiële gelijkheid niet gezien als aparte begrippen, maar worden ze samengenomen onder het begrip materiele gelijkheid. Sommigen zien echter een andere scheidslijn: zo stelt Kewenig een onderscheid tussen juridische en feitelijke gelijkheid vast, waarbij juridische gelijkheid de formele en procedurele gelijkheid van Sloot omvat, terwijl feitelijke gelijkheid alleen op de materiele gelijkheid ziet (p. 187 e.v.).

31. Het doorslaggevende verschil tussen materieel en procedureel gelijkheid is gelegen in de aard en de mate van de verschillen die moeten worden weggenomen. Om procedurele gelijkheid te verwezenlijken hoeven alleen de niet natuurlijk aangeboren, maar maatschappelijk bestaande verschillen te worden weggenomen, zoals verschillen in inkomen of kwaliteit van opleiding. Om materiele gelijkheid te bereiken moeten er ook aanpassingen worden verricht om de onveranderlijk en onvermijdelijk bestaande natuurlijke verschillen tussen mensen weg te nemen. Omdat dit niet mogelijk is door verandering van de eigenschappen van mensen zelf moet dit door middel van compensatie plaatsvinden. Zie nader Dworkin 1986, p. 207/208, Bedau 1967, p. 14/15 en Laski 1969, p. 166 en 168 . Het zal duidelijk zijn dat gelijkheid in deze laatste zin in een maatschappij waarin de goederen schaars zijn feitelijk nooit kan worden bereikt, zelfs als er al overeenstemming zou kunnen worden bereikt over de wenselijkheid van een dergelijke volledig egalitaire samenleving.

32. De waarde is vooral gelegen in de verklaring die door deze begrippen kan worden gegeven voor be- 
gelijkheidsbeginsel lijkt deze nadere differentiatie echter weinig betekenis te hebben. In concrete gevallen wordt met het begrip materiële gelijkheid slechts zelden daadwerkelijk gedoeld op een volledige gelijkheid in resultaat, maar wordt daarbij eerder gedacht aan gelijkheid in kansen. Het begrip procedureel onderscheid heeft daardoor te weinig onderscheidend vermogen om een zinvol aanknopingspunt te bieden voor de rechterlijke toetsing. In het verband van dit boek zal dan ook uitsluitend worden gewerkt met de onderverdelingen materieel/formeel onderscheid en direct/indirect onderscheid.

\section{Toepassingsbereik van het toetsingsmodel}

\section{$2.1 \quad$ Inleiding}

De bedoeling van dit hoofdstuk is om een toetsingsmodel te ontwikkelen voor de beoordeling van de toelaatbaarheid van ongelijke behandeling door de rechter. Daarbij zal worden getracht criteria te vinden die in het oordeel van de rechter betrokken moeten worden om een goede motivering te garanderen. In hoofdstuk 1 is al gesteld dat een dergelijk model vooral bijzonder nuttig zal zijn in die gevallen waarin de rechter over een grote mate van autonomie beschikt: er zijn enkele gevallen waarin een toetsingsmodel minder noodzakelijk of zelfs overbodig is. Alvorens uiteen te zetten hoe het toetsingsmodel er feitelijk uit zou moeten zien zal in deze paragraaf dan ook eerst worden ingegaan op het toepassingsbereik van dit model. In paragraaf 3 en 4 zal vervolgens aandacht worden besteed aan de inhoud van het toetsingsmodel, waarbij de verschillende beoordelingscriteria en de rechterlijke bevoegdheid om daaraan te toetsen nader zullen worden besproken. Tenslotte zal in paragraaf 5 worden ingegaan op de intensiteit van de toetsing en op de factoren die bij de bepaling daarvan een rol zouden moeten spelen.

\subsection{Open en gesloten modellen}

Zoals al is aangegeven is het toetsingsmodel vooral bedoeld voor de gevallen waarin de rechter over een grote mate van autonomie beschikt bij het bepalen van zijn toetsingsmethodiek. Een (beperkt) deel van de gelijke behandelingsbepalingen die in wetgeving of verdragen zijn neergelegd heeft echter een "gesloten" karakter, in die zin dat door de betrokken bepalingen nauwelijks ruimte wordt gelaten voor de ontwikkeling van een eigen stelsel van toetsingsmaatstaven door de rechter. ${ }^{33}$ Dit soort bepalingen bevat meestal een absoluut verbod van onderscheid op een aantal limitatief opgesomde gronden, waarbij een beperkt aantal uitzonderingsmogelijkheden wordt genoemd. ${ }^{34} \mathrm{De}$

paalde maatschappelijke en historische ontwikkelingen in het denken over gelijkheid. De driedeling heeft bovendien een belangrijke sociologische waarde. Zie daarover uitgebreid Sloot 1986, p. 16-19.

33. Zie voor een nadere omschrijving van de begrippen "gesloten" en "open model" Heringa 1999, p. 27.

34. Een voorbeeld is te vinden in artikel 2 lid 2-5 van de Nederlandse Algemene wet gelijke behandeling (Awgb) en in het communautaire recht (met name in richtlijnen met betrekking tot onderscheid op grond van geslacht; zie nader hoofdstuk 4, paragraaf 1.2.1). Enkele voorbeelden uit het internationale recht worden gegeven door Kewenig 1972, p. 76-78. 
rechter kan dan volstaan met de (feitelijke) vaststelling of er in het voorgelegde geval onderscheid is gemaakt op één van de verboden gronden, waarna hij alleen nog hoeft te beoordelen of één van de uitzonderingen van toepassing is. ${ }^{35}$ In dit soort omstandigheden bestaat er veelal minder behoefte aan een motiveringsmodel. De wettelijke bepaling bevat (in de meeste gevallen) immers al zodanig scherp geformuleerde toetsingsmaatstaven dat de rechter over voldoende aanknopingspunten beschikt om een goed gemotiveerd oordeel te geven. ${ }^{36}$

Dit is vanzelfsprekend anders in die gevallen waarin een duidelijk (grond)wettelijk houvast ontbreekt. Dit is bijvoorbeeld het geval voor bepalingen waarin ongelijke behandeling is verboden "behoudens de mogelijkheid van objectieve en redelijke rechtvaardiging". De rechter zal in dit soort gevallen zelf moeten vaststellen wanneer een rechtvaardiging aanwezig is en wanneer deze als objectief en redelijk kan worden beschouwd; de rechterlijke vrijheid is hierbij dus relatief groot. ${ }^{37}$ Hetzelfde geldt voor veel bepalingen waarin ongelijke behandeling op een bepaalde grond is verboden, zonder dat er in een duidelijke uitzonderingsmogelijkheid is voorzien. Hoewel daarbij sprake lijkt te zijn van een gesloten formulering die geen ruimte laat voor een rechtvaardiging, wordt vrij algemeen aangenomen dat het niet de bedoeling van dit soort bepalingen kan zijn om iedere ongelijke behandeling ontoelaatbaar te achten. Bij dergelijke "absolute" verboden van ongelijke behandeling wordt dan ook vaak een impliciete en inherente rechtvaardigingsmogelijkheid aanwezig geacht. ${ }^{3 .}$ De beantwoording van de vraag aan welke eisen een dergelijke rechtvaardiging moet voldoen wordt daarbij volledig aan de rechter overgelaten.

35. Overigens is ook hierbij de rechterlijke vrijheid soms aanzienlijk, met name wanneer de uitzonderingsgronden niet nauwkeurig zijn omschreven. Bovendien heeft de rechter zich in een aantal gevallen meer vrijheid toegeěigend dan de bepalingen op het eerste gezicht toelaten, bijvoorbeeld door, ten aanzien van bepalingen die direct onderscheid verbieden, te erkennen dat ook indirect onderscheid niet toelaatbaar is. Nu een dergelijke invulling door de wetgever niet is voorzien ontbreken hierbij duidelijke aanknopingspunten voor de wijze van beoordeling. De rechter heeft daardoor, zelfs binnen het kader van een "gesloten" model, een aanzienlijke vrijheid om een eigen toetsingsmethodiek te ontwikkelen.

36. Dit zal niet altijd het geval zijn: het is mogelijk dat ook gesloten geformuleerde gelijkheidsbepalingen ruimte laten voor rechterlijke oordeelsvorming, bijvoorbeeld doordat de rechter zelf nog moet beoordelen of het gemaakte onderscheid in een redelijke verhouding staat tot een specifiek in de bepaling neergelegde doelstelling. Ook in die gevallen kunnen elementen uit het toetsingsmodel bruikbaar zijn, met name voor zover daarmee nader invulling wordt gegeven aan de vage toetsingscriteria uit de gesloten bepalingen.

37. Zie bijv. artikel 2 lid 1 Algemene wet gelijke behandeling: "Het in deze wet neergelegde verbod van onderscheid geldt niet ten aanzien van indirect onderscheid dat objectief gerechtvaardigd is."

38. Dit is niet meer dan redelijk: zelfs ongelijke behandeling op grond van een op het eerste gezicht irrelevante grond als huidskleur kan toelaatbaar zijn, bijvoorbeeld in het geval waarin testpersonen worden gezocht voor cosmetica die speciaal voor een bepaalde kleur huid bedoeld is. Het verbaast dan ook niet dat rechters in veel gevalien hebben aangenomen dat dit soort "gesloten" bepalingen toch een open karakter hebben. Voorbeelden van verboden waarbij impliciet een rechtvaardigingsmogelijkheid mogelijk wordt geacht zijn te vinden in het EG-recht (bijvoorbeeld artikel $12 \mathrm{EG}$, eerste volzin: "Binnen de werkingssfeer van dit Verdrag en onverminderd de bijzondere bepalingen, daarin gesteld, is elke discriminatie op grond van nationaliteit verboden", en artikel 39 lid 2 EG). Op deze voorbeelden zal in hoofdstuk 4 nader worden ingegaan. Daarbij zal ook aandacht worden besteed aan een bijzonder geval waarin het Europees Hof van Justitie juist geen impliciete rechtvaardigingsmogelijkheid heeft aanvaard (namelijk bij artikel 90 lid I EG). 
Van een grote mate van rechterlijke autonomie is tenslotte sprake bij volledig "open" gelijke behandelingsbepalingen. In dergelijke bepalingen wordt meestal zeer in het algemeen gesteld dat gelijke gevallen gelijk moeten worden behandeld of dat discriminatie is verboden, zonder dat er een limitatief aantal differentiatiecriteria wordt genoemd en zonder dat er een beperking wordt gesteld aan de mogelijkheid van rechtvaardiging. ${ }^{39}$ In dit soort gevallen heeft de rechter een vrijwel onbegrensde vrijheid om te beoordelen of een bepaald onderscheid toelaatbaar is.

In de hiervoor besproken (relatief) "open" modellen heeft de rechter steeds de mogelijkheid om de gerechtvaardigdheid van een onderscheid te beoordelen, zonder dat hem nadere aanknopingspunten voor de te hanteren toetsingsmethodiek worden verschaft. Door het ontbreken van toetsingsmaatstaven bestaat in deze gevallen steeds het in hoofdstuk 1 gesignaleerde risico van onvoorspelbaarheid en ondoorzichtigheid en van de (onuitgesproken) invloed van subjectieve overwegingen op de uitkomst van de procedure. Het hierna te ontwikkelen toetsingsmodel is bedoeld om juist voor deze situaties een richtlijn voor de rechter te vormen.

\subsection{Situaties waarin kan worden geklaagd over ongelijke behandeling}

\subsubsection{Situaties van onderscheid}

Ongelijke behandeling kan zich in een groot aantal verschillende situaties voordoen. Voor de toepassingsmogelijkheden van het toetsingsmodel is het van belang om deze situaties zorgvuldig van elkaar te onderscheiden. Daarbij kan de volgende driedeling worden gemaakt.

\section{Situatie 1: normatieve classificaties}

Zoals in hoofdstuk 1 is aangegeven kan de rechter allereerst worden geconfronteerd met onderscheid dat in een algemene regeling is opgenomen, dat wil zeggen met een "normatieve classificatie". ${ }^{\text {to }}$ Normatieve classificaties zijn inherent aan de idee van regelgeving: het is niet mogelijk om een regel vast te stellen zonder de reikwijdte ervan te bepalen. ${ }^{4}$ Er kunnen dan ook talloze voorbeelden van normatieve classificaties worden gegeven, variërend van de Nederlandse grondwet die het recht op gelijke behandeling beperkt tot "allen die zich in Nederland bevinden", ${ }^{42}$ of een wettelijke regeling op grond waarvan alleen subsidie wordt verleend aan varkenshouders die minder dan 200 varkens hebben, tot een bedrijfspensioenregeling waardoor de mogelijkheid van pensioenopbouw aan deeltijdwerkers worden onthouden. In deze voorbeelden heeft de classificatie steeds betrekking op de definitie van de groep van personen waarvoor de regeling geldt. Het onderscheid kan echter ook zijn gelegen in de groep van gevallen

39. Hiervan zijn talrijke voorbeelden te vinden, zoals artikel 14 EVRM (zie hoofdstuk 3), artikel 1 van de Nederlandse Grondwet (zie hoofdstuk 6) en de Equal Protection Clause in het Veertiende Amendement van de Amerikaanse Constitutie (zie hoofdstuk 5).

40. Het gaat dan om ongelijke behandeling "in" de wet; zie over de bevoegdheid van de rechter om dergelijke classificaties te toetsen hoofdstuk 1.

41. Vgl. Tussman/TenBroek 1949, p. 344.

42. Artikel 1 eerste volzin van de Nederlandse Grondwet. 
waarop de regeling betrekking heeft. Zo is in artikel 7 van de Nederlandse grondwet het volgende vastgelegd: "Niemand heeft voorafgaand verlof nodig om door de drukpers gedachten of gevoelens te openbaren, behoudens ieders verantwoordelijkheid volgens de wet". ${ }^{3}$ Deze bepaling kent door zijn formulering geen beperking tot een bepaalde groep van personen, zodat er in dat opzicht niet van een classificatie kan worden gesproken. In de bepaling is echter wel degelijk een onderscheid opgenomen, namelijk een onderscheid naar de aard van de uitingen die door de bepaling worden beschermd: zoals blijkt uit de formulering beperkt de bescherming zich tot uitingen door middel van drukpers. ${ }^{4}$ Ook dit soort onderscheidingen kan aan een toetsing aan het gelijkheidsbeginsel worden onderworpen, hoewel dit in de praktijk minder gebruikelijk lijkt te zijn."s

$\mathrm{Bij}$ de rechterlijke beoordeling van normatieve classificaties kan worden onderscheiden tussen abstracte en concrete toetsing. ${ }^{46}$ Wanneer de rechter een abstracte toetsing uitvoert zal hij de normatieve classificatie als zodanig, dus los van het concrete geval dat aan hem is voorgelegd, op zijn gerechtvaardigdheid beoordelen. Bij een concrete toetsing staat daarentegen de toepassing van de classificatie in het individuele geval centraal. Het kan immers zo zijn dat een normatieve classificatie op zichzelf (dus in abstracto) voldoende gerechtvaardigd is, maar dat zich in het concrete geval zodanige omstandigheden voordoen dat een strikte toepassing van de classificatie tot een onredelijke ongelijkheid leidt. ${ }^{47}$ Dit onderscheid tussen de abstracte toetsing van de classificatie en de toetsing van de concrete toepassing daarvan kan consequenties hebben voor de uitkomst van de procedure, zoals in paragraaf 2.3 .2 nog zal blijken. ${ }^{4 *}$

\section{Situatie 2: concrete ongelijke behandeling door bevoegdheidsuitoefening}

In de tweede plaats is het mogelijk dat er voor de rechter wordt geklaagd over de wijze waarop een bepaalde bevoegdheid of verantwoordelijkheid in een concreet geval is uitgeoefend. ${ }^{4 "}$ Deze situatie zal zich vooral voordoen wanneer de bevoegdheid tot toe-

\section{Cursief toegevoegd.}

44. Hierdoor is het mogelijk dat andere uitingen, bijvoorbeeld via de ether, buiten het toepassingsbereik blijven. Een ander voorbeeld is een beleidsregel op grond waarvan alleen voor bouwplannen die aan bepaalde voorwaarden voldoen een bouwvergunning kan worden verleend. Ook daarbij is de classificatie niet gelegen in de personele sfeer, maar heeft deze betrekking op de groep van gevallen waarop de regeling ziet.

45. In sommige rechtsstelsels wordt een toetsing van de tweede groep van classificaties zelfs volledig afgewezen, zoals in het rechtsstelsel dat door het EVRM in het leven is geroepen: het EHRM toetst alleen onderscheid op grond van persoonsgebonden kenmerken. Zie daarover nader hoofdstuk 3, paragraaf 1.2 .

46. Vgl. Simon 1994, p. 42 en Heringa 1984, p. 782.

47. Zo kan een onderscheid op grond van nationaliteit in het immigratierecht in abstracto heel redelijk zijn, maar kan een concreet geval van uitzetting zodanig zwaarwegende gevolgen hebben voor het individu dat de toepassing van de betrokken regeling achterwege moet blijven. Zie nader Loenen 1992, p. 172.

48. Zie paragraaf 2.3.2. Zie over het onderscheid tussen abstracte en concrete toetsing nader De Lange, p. $42 / 43$ en Stroink 1987, p. 34 e.v.; de laatste geeft overigens aan dat de toetsing in beide gevallen vrijwel identiek is en dat het eigenlijk niet denkbaar is dat toepassing van een regel in een concrete situatie leidt tot een onrechtvaardige situatie zonder dat er in abstracto aan de regel zelf iets schort (p. 43; vgl. ook Loenen 1996, p. 130).

49. Gesteld zou kunnen worden dat de situaties 1 en 2 elkaar kunnen overlappen, namelijk wanneer de bevoegdheidsgrondslag zelf een classificatie bevat, die door een bestuursorgaan moet worden toege- 
passing in individuele gevallen is toegekend aan een bestuursorgaan. ${ }^{50}$ Dit bestuursorgaan beschikt meestal over een zekere mate van discretie om te kunnen beoordelen of, of op welke manier, de regeling in een concreet geval moet worden toegepast. Daarbij is het mogelijk dat het bestuursorgaan een zodanig gebruik van zijn discretie maakt dat er een ongelijke behandeling ontstaat, bijvoorbeeld doordat in een bepaald geval een vergunning is afgegeven, terwijl dit in een vergelijkbaar geval is geweigerd, of doordat de waarde van vergelijkbare panden ten behoeve van de onroerende zaakbelasting verschillend is getaxeerd. In dergelijke gevallen is het niet zozeer de regeling zelf die de ongelijkheid veroorzaakt, maar de wijze waarop daaraan in het concrete geval invulling is gegeven. Ook voor dergelijke gevallen van ongelijke behandeling geldt dat zij alleen toelaatbaar zijn wanneer hiervoor een toereikende rechtvaardiging bestaat. ${ }^{\text {ti }}$ Onderzocht zal dan ook worden of in deze situatie hetzelfde toetsingsmodel kan worden gebruikt als in de gevallen waarin een normatieve classificatie wordt beoordeeld.

\section{Situatie 3: bloot onderscheid}

Een derde situatie waarin onderscheid kan worden gemaakt is de situatie van "bloot" onderscheid. Daarbij gaat het - anders dan in situatie 2 - om onderscheid waaraan geen algemene regel ten grondslag ligt. Deze vorm van onderscheid zal vooral op horizontaal niveau, dus op het niveau van particulieren onderling, zichtbaar zijn, zoals bij de afwijzing van een sollicitante wegens zwangerschap of de weigering van een portier om mensen met een donkere huidskleur toe te laten tot een horecagelegenheid. Het is bovendien denkbaar dat bestuursorganen zodanig handelen dat er van bloot onderscheid gesproken kan worden, bijvoorbeeld wanneer een onderscheid het gevolg is van bestuurshandelen zonder duidelijke bevoegdheidsgrondslag (feitelijk handelen) of zelfs wanneer het bestuursorgaan heeft gehandeld op basis van een zeer algemeen omschreven, niet nader genormeerde bevoegdheid.

\subsubsection{Consequenties voor de toetsingsmethodiek}

Het is van belang om de hierboven beschreven situaties scherp van elkaar te onderscheiden. In de eerste plaats is dit nodig omdat de uitkomst van de toetsing per situatie zal verschillen: in situatie 1 kan de rechter de regeling onverbindend verklaren of kan

past. In die gevallen moet echter worden gesproken van een situatie 1-onderscheid: het bestuursorgaan is dan immers niet zelf voor het gemaakte onderscheid verantwoordelijk, maar past het slechts toe. Alleen wanneer de concrete ongelijke behandeling het directe gevolg is van een ongelijke uitoefening van een bevoegdheid (zodat niet de regelgever, maar het bestuursorgaan verantwoordelijk is) kan van een situatie 2-onderscheid worden gesproken. Vgl. ook Stroink 1987, p. 34, die een vergelijkbaar onderscheid maakt voor de toetsing aan artikel 10 EVRM.

50. De situatie kan zich ook in horizontale verhoudingen, dus in de verhouding tussen burgers onderling, voordoen. Zo is het mogelijk dat een personeelsfunctionaris in een bedrijf bepaalde verantwoordelijkheden heeft en deze zodanig uitoefent dat er op de werkvloer ongelijkheden ontstaan.

51. Dat ook deze vorm van onderscheid steeds om een rechtvaardiging vraagt is treffend geillustreerd door Ely 1970, p. 1286: "There is no reason why a tax assessor, when asked why he assessed one house higher than all the rest on the block, should be able to get away with explaining that the dice happened to roll that way, or that he simply felt that assessing the one house higher would promote the general welfare. There is, in other words, no excuse here for suspending the disadvantageous distinction model [zie daarover nader par. 4.6, JHG]; a difference in valuation should call for proof of a difference in value $[. .] .$. 
hij, in het geval van een concrete toetsing, oordelen dat de regeling in het voorgelegde geval buiten toepassing moet blijven ${ }^{52}$, in situatie 2 kan hij het bestuursbesluit vernietigen, en in situatie 3 kan hij diverse maatregelen treffen, zoals het opleggen van een verplichting tot het alsnog toekennen van een bepaald voordeel, het opleggen van een verbod of het toekennen van een schadevergoeding. ${ }^{53}$

Het is verder van belang om tussen de verschillende situaties te onderscheiden, omdat de toetsingsmethodiek voor iedere situatie enigszins anders zal zijn. Het hierna te ontwikkelen toetsingsmodel is in beginsel bedoeld om toegepast te worden in alle situaties, maar het is primair gericht op de abstracte toetsing van normatieve classificaties. In de beide andere situaties kan het model weliswaar als uitgangspunt dienen, maar zal hieraan een iets verschillende uitwerking moeten worden gegeven om rekening te houden met de bijzondere kenmerken van de specifieke situatie. Zo is er in de tweede situatie steeds sprake van een concreet geval van ongelijke behandeling, waarbij dus ook een concrete toetsing moet worden uitgevoerd. Dit betekent bijvoorbeeld dat de rechter moet beoordelen of de belangen die bij het nemen van het litigieuze besluit zijn betrokken in het concrete geval op een redelijke manier tegen elkaar zijn afgewogen, terwijl het toetsingsmodel eigenlijk uitgaat van een abstracte evenredigheidstoets. ${ }^{54}$ Ook verder geldt dat een toetsing aan het volledige toetsingsmodel bij de beoordeling van concreet onderscheid niet altijd mogelijk is; zo zal in het hiernavolgende nog blijken dat de toetsing aan het vereiste van een voldoende mate van fit uitsluitend relevant is bij de beoordeling van normatieve classificaties. In paragraaf 3 , waarin het toetsingsmodel wordt beschreven, zal aan dergelijke afwijkingen nader aandacht worden besteed.

Ook bij bloot onderscheid lijkt het model van toepassing te kunnen zijn, al moet ook daarbij een formulering worden ontwikkeld die meer is toegesneden op het specifieke karakter van de situatie. Een belangrijk verschil met normatieve classificaties is immers ook hier dat de toetsing niet abstract, maar concreet van aard zal zijn, waardoor het model niet volledig kan worden toegepast. Van belang is echter dat de bewijsproblematiek in de situatie van bloot onderscheid sterk verschilt van die bij normatieve classificaties. Zo zal bij een klacht over ontslag wegens zwangerschap de aandacht niet zozeer gericht zijn op de mogelijke rechtvaardiging daarvan (zoals het geval is bij nor-

52. En zal het individuele besluit dat uit de concrete toepassing voortvloeide worden vernietigd. Zoals Stroink aangeeft zal het praktisch effect van onverbindend verklaren en buiten toepassing laten in het algemeen hetzelfde zijn, (1987, p. 51); niettemin is het verschil belangrijk, nu bij onverbindendverklaring de geldigheid van de regeling wordt aangetast, terwijl dit bij buiten toepassing laten niet het geval is. Vgl. ook Loenen 1996, p. 130/131.

53. Vanzelfsprekend is in situatie 3 het gevolg van de uitspraak over de toelaatbaarheid van de ongelijke behandeling afhankelijk van de specifieke omstandigheden van het geval. Zie verder De Lange p. $83 / 84$.

54. Dit geldt overigens ook voor de concrete toetsing van een normatieve classificatie. Zoals eerder is opgemerkt kan een op zichzelf gerechtvaardigde classificatie in een concreet geval zodanig vergaande en belastende consequenties hebben dat de toepassing ervan onredelijk moet worden geacht. In die gevallen moet dus, aan de hand van het toetsingsmodel, een abstracte toetsing van de classificatie worden uitgevoerd, maar vervolgens moet ook nog worden gecontroleerd of er in het concrete geval een juiste afweging is gemaakt van (enerzijds) het belang bij een juiste toepassing van de classificatie tegen (anderzijds) de aangetaste belangen van het individu. Het uitvoeren van een abstracte toets, voorafgaand aan een concrete toetsing van de belangenafweging, is in dit soort gevallen noodzakelijk: de rechter kan niet volstaan met een uitsluitend concrete toetsing (vgl. Loenen 1996, p. 129-132). 
matief onderscheid), maar vooral op de vraag of kan worden aangetoond dat de zwangerschap de enige of belangrijkste reden voor ontslag vormde. Om die reden wordt er in het hiernavolgende weliswaar van uitgegaan dat het model in beginsel (en althans gedeeltelijk) op bloot onderscheid kan worden toegepast, maar zal aan deze situatie geen bijzondere aandacht worden besteed: de bewijsproblematiek bij direct onderscheid vormt als zodanig geen voorwerp van onderzoek. ${ }^{35}$

\subsection{Verschijningsvormen van onderscheid: formeel of materieel, direct of indirect, bedoeld of onbedoeld}

Het is de bedoeling dat het toetsingsmodel bruikbaar is in alle gevallen van onderscheid, ongeacht hun verschijningsvorm. Dat betekent dat het model zal moeten gelden voor alle vormen van onderscheid zoals die in paragraaf 1.2 zijn omschreven, dus zowel voor formeel en direct onderscheid als voor materieel en indirect onderscheid. Hoewel het idee dat ook materieel onderscheid op zijn toelaatbaarheid kan (en zelfs moet) worden beoordeeld niet algemeen geaccepteerd lijkt te zijn, bestaan er goede redenen om ook deze vorm van onderscheid aan een inhoudelijke toetsing te onderwerpen. ${ }^{56} \mathrm{Zo}$ kan worden gesteld dat materieel onderscheid, net zo goed als formeel onderscheid, een rem kan plaatsen op de persoonlijke vrijheid en de individuele ontplooiingsmogelijkheden. Ieder mens is anders en heeft andere behoeften en wensen. Een ideale maatschappij zou zoveel mogelijk recht moeten doen aan die individuele wensen en behoeften en zou niet zonder meer iedereen op dezelfde manier mogen behandelen. ${ }^{57}$ De vergaande mate van differentiatie die dit uitgangspunt zou vereisen is in de praktijk

\section{Zie daarover vooral Leenders 1997.}

56. Er wordt met name bezwaar gemaakt tegen een toetsing van materieel onderscheid vanwege de potentieel vergaande maatschappelijke consequenties die dit kan hebben: zo zullen de maatschappelijke kosten die zijn verbonden aan de verplichting om rekening te houden met de individuele verschillen tussen gevallen aanzienlijk kunnen zijn (Wentholt 1990, p. 56). In Amerika lijkt dit zelfs de belangrijkste reden te zijn geweest om indirect onderscheid (hetgeen in feite een vorm van materieel onderscheid is; zie par. 1.2.2) niet onder de bescherming van het Veertiende Amendement te brengen; zie Loenen 1999 , p. 200 en verder hoofdstuk 5. Het toetsingsmodel is echter voldoende flexibel om het hoofd te bieden aan dit soort problemen, aangezien het de mogelijkheid biedt om een materieel onderscheid in stand te houden wanneer ter rechtvaardiging voldoende zwaarwegende algemene belangen zijn aangevoerd; hiertoe kunnen ook dwingende economische overwegingen behoren.

57. In de rechtsfilosofische en rechtstheoretische literatuur bestaat hierover al vrij lang eenstemmigheid. In de meeste gevallen wordt er dan in plaats van over materiële of substantiele gelijkheid gesproken over "proportionele" gelijkheid, waarmee gedoeld wordt op een distributie van goederen of rechten die in overeenstemming is met het bepalende criterium, zoals behoefte of verdienste. Zoals in paragraaf 1.1 is aangegeven was Aristoteles al van oordeel dat rechtvaardigheid vrijwel synoniem is met proportionele gelijkheid (Ethica Nicomachea [1131a6-1132a2]). Ook Perelman stelt in de beschrijving van zijn concepten voor rechtvaardigheid vast dat concepten als "to each according to his merits, works or needs" een proportionele gelijkheid noodzakelijk maken $(1963$, p. 7 e.v., maar meer in het bijzonder ook p. $32 / 33$ en p. 70); vgl. op dit punt ook Walzer 1983, p. 20-25, Van Maarseveen 1990, p. 31 en Benn/Peters 1969, p. 55. Voor het feit dat het in de praktijk minder algemeen aanvaard is dat ook materieel onderscheid getoetst moet worden op zijn aanvaardbaarheid is volgens Sloot een sociologische verklaring te geven: de terughoudendheid vloeit voort uit de weerstand om een positieve overheidsplicht te erkennen om ongelijkheden te redresseren die niet door de overheid zelf zijn veroorzaakt. Formeel onderscheid wordt daarentegen direct en herkenbaar door de overheid veroorzaakt, zodat het daarbij redelijker lijkt om te verwachten dat dit onderscheid wordt opgeheven (Sloot 1986, p. 25; in dezelfde zin Tribe 1988, p. 1439, noot 21). 
vanzelfsprekend ondenkbaar: generalisaties zijn noodzakelijk om het bestuur van een samenleving werkbaar te houden. Gekeken zal echter steeds moeten worden of een bepaalde generalisatie de belangen van het individu niet te zwaar aantast, in verhouding tot de doelstellingen die ermee worden nagestreefd.

Het is dus niet wenselijk om bij het ontwikkelen van een toetsingsmodel tot uitgangspunt te nemen dat (formeel) gelijke behandeling de ideale situatie is, zoals door enkele auteurs wel is verondersteld. Dit uitgangspunt heeft immers tot consequentie dat gelijke behandeling als zodanig niet hoeft te worden gerechtvaardigd ${ }^{58}$ Ideaal is echter niet een gelijke behandeling, maar een zodanige behandeling van ieder individu dat zoveel mogelijk recht wordt gedaan aan zijn capaciteiten en behoeften. Zoals is aangegeven kan dit ideaal niet alleen worden doorkruist door differentiatie (de situatie waarin onderscheid wordt gemaakt tussen op relevante punten vergelijkbare groepen), maar ook door generalisatie (de situatie waarin juist geen onderscheid wordt gemaakt tussen groepen die op relevante punten verschillen). ${ }^{.9}$ Bij het ontwikkelen van het toetsingsmodel is dan ook tot uitgangspunt genomen dat gelijke en ongelijke behandeling in gelijke mate om een rechtvaardiging vragen. ${ }^{60}$

Van belang is verder dat het voor het vereiste van een rechtvaardiging geen verschil maakt of een ongelijke behandeling slechts een onbedoeld effect is van een maatregel, of dat er daadwerkelijk sprake is van een bewust en beoogd onderscheid. De vraag of het onderscheid al dan niet beoogd is lijkt op het eerste gezicht samen te vallen met het verschil tussen formeel en materieel onderscheid. Bij formeel onderscheid zal er immers meestal sprake zijn van een uitdrukkelijke bedoeling, terwijl materieel onder-

58. Zoals is gesteld door Berlin 1969, p. 16/17 ("The assumption is that equality needs no reasons, only unequality does so; that uniformity, regularity, similarity, symmetry $[\ldots]$ need not be specially accounted for, whereas differences, unsystematic behaviour, change in conduct, need explanation, and, as a rule, justification"), Chemerinsky 1983, p. 588 ("The concept of equality [...] [creates] a presumption that people should be treated alike, and puts the burden of proof on those who wish to impose differences in treatment"), Greenawalt 1983, p. 1175-1176 en Maris 1985, p. 1295; meer impliciet ook Benn/Peters 1969, p. 58. De onhoudbaarheid van deze voorkeur voor gelijke behandeling wordt theoretisch aangetoond door Westen; een lang citaat is dan ook de moeite waard. In het citaat betekent "PE" "prescriptive equality", dit ter onderscheiding van feitelijke gelijkheid ("descriptive equality"). "To say that rules prescribing equal treatment are presumptively better than rules prescribing unequal treatment presupposes a prescriptive standard for distinguishing between equal and unequal treatment. The standard cannot be found in the structure of the rules themselves, because, structurally, all rules treat people equally in some respects and unequally in other respects [...]. Nor can the standard underlying PE be found in the structure of the classifications themselves, because, structurally, all classifications, too, treat people equally in some respects and unequally in other respects [...]. It therefore follows that PE cannot distinguish equal treatment from unequal treatment without positing anterior judgments that particular classifications (and the particular equalities they entail) are presumptively invalid. Yet given such anterior judgments, PE does nothing but give the particular presumptions the content they have already been determined to possess" (1983 (II), p. 1205/1206; voetnoten zijn weggelaten). Dit betekent dat het gelijkheidsbeginsel zelf geen "voorkeur" kan hebben voor gelijke of ongelijke behandeling: of een gelijke of ongelijke behandeling redelijk is, wordt niet bepaald door het gelijkheidsbeginsel, maar door een anterieur waardeoordeel. Zie ook Leibholz 1925, p. 40.

59. Zie nader Minow 1990, p. 20 e.v., Loenen 1992, p. 247 en p. $262 / 263$ en Wentholt 1999 (I), p. 58.

60. Het toetsingsmodel zal verder zowel bruikbaar moeten zijn voor direct als voor indirect onderscheid. Voor direct onderscheid ligt het voor de hand dat het model van toepassing is: deze term ziet, zoals in par. 1.2.2 is aangegeven, op alle gevallen van ongelijke behandeling, hetzij formeel, hetzij materieel. 
scheid in veel gevallen een effect is waarmee de regelgever geen rekening had gehouden. Van een volledig samenvallen is echter zeker geen sprake, aangezien ook een materieel of indirect onderscheid uitdrukkelijk beoogd kan zijn. ${ }^{61}$

Het is niet algemeen aanvaard dat ook een onbedoelde ongelijke behandeling moet worden gerechtvaardigd, zelfs niet wanneer deze redelijkerwijze voorzienbaar was. ${ }^{62}$ Niettemin moet worden aangenomen dat het niet wenselijk is om de inhoudelijke beoordeling te beperken tot die ongelijke behandelingen die daadwerkelijk beoogd zijn. Het gaat er bij procedures over ongelijke behandeling immers niet om de verantwoordelijke te "straffen" voor zijn ongerechtvaardigde en discriminatoire bedoelingen: van belang is vooral dat ongelijkheden worden weggenomen waardoor mensen worden belemmerd in hun ontplooiingsmogelijkheden. ${ }^{63}$ Vanuit deze gedachte kan worden aangenomen dat er soms een positieve verplichting bestaat om ongelijkheden uit de weg te ruimen die het gevolg zijn van een regeling of handeling, zelfs wanneer zij een volledig onbedoeld of zelfs onvoorzienbaar effect zijn van een overigens volstrekt redelijke maatregel. ${ }^{64}$ Of een dergelijke positieve verplichting in een concreet geval inderdaad aanwezig is, moet voor ieder afzonderlijk geval worden beoordeeld, waarbij rekening moet worden gehouden met alle omstandigheden van het geval. ${ }^{65}$ Dat is echter

61. Meestal zijn de voorbeelden van dit soort uitdrukkelijk bedoelde materiële of indirecte onderscheidingen minder sympathiek: vaak is daarbij sprake van het verhullen van onderscheidingen op gronden die eigenlijk niet toelaatbaar zijn door de keuze voor een op het eerste gezicht neutrale grond van onderscheid. Een voorbeeld uit de Amerikaanse rechtspraktijk kan dit illustreren. Veel Amerikaanse staten waren aanvankelijk gekant tegen de politiek van desegregatie die in de jaren 50/60 werd opgelegd en probeerden deze zoveel mogelijk te ontwijken. Om te voorkomen dat hun op raciale gronden gebaseerde classificaties door een federale rechter werden vemietigd, probeerden zij hun werkelijke bedoelingen vaak te verhullen. Zo werden in verschillende Amerikaanse staten regelingen vastgesteld, op grond waarvan analfabeten werden uitgesloten van het kiesrecht. Indirect had deze regeling het (zonder meer beoogde) effect dat met name Afro-Amerikanen van het kiesrecht werden uitgesloten: een groot percentage van hen had nooit gelegenheid gekregen om een opleiding te volgen en was daardoor analfabeet. Zie nader hoofdstuk 5 .

62. Met name in Amerika zijn de eisen die worden gesteld aan de bedoeling zeer hoog. Het enkele bestaan van een ongelijk effect is niet voldoende om een inhoudelijke toetsing van het onderscheid uit te lokken: in de meeste gevallen moet worden aangetoond dat er daadwerkelijk sprake was van een op het onderscheid gerichte doelstelling. Hierop zal in hoofdstuk 5 nader worden ingegaan.

63. Zie Binion 1983, p. 421 en 443.

64. Vgl. Brest 1971, p. 105. Zie hierover nader Ely 1970, p. 1255; hij noemt dit de "affirmative duty of accommodation". Tegen deze benadering heeft hij grote bezwaren, vooral wanneer hieruit zou voortvloeien dat er een positieve verplichting bestaat om een evenwichtige situatie te bereiken (p. 12561260). Het centrale idee lijkt daardoor echter niet juist te worden geformuleerd: het gaat er niet om een volledig evenwicht tussen groepen te bereiken, zodat de wetgever voortdurend met alle individuele verschillen en alle mogelijke gevolgen voor iedere denkbare groep rekening moet houden. Relevant is slechts dat in bepaalde omstandigheden de effecten voor een bepaalde groep zodanig onredelijk zijn dat er een verplichting moet bestaan om deze effecten uit de weg te ruimen.

65. Dit geldt overigens ook voor een bijzondere groep van gevallen, namelijk die gevallen waarin niet één persoon, orgaan of lichaam verantwoordelijk is voor het gemaakte onderscheid. Soms ontstaat een ongelijke behandeling immers doordat twee bestuursorganen, bijvoorbeeld gemeenten, in vergelijkbare gevallen een ander besluit nemen, of doordat door een latere wetswijziging een bepaalde groep nog onder een oud wettelijk regime valt, terwijl een andere groep onder het nieuwe, andere regime valt. Het kan niet zonder meer worden aangenomen dat dit soort gevallen van onbedoelde ongelijke behandeling altijd toelaatbaar zijn: ook hier geldt de regel dat in ieder specifiek geval moet worden bekeken of er een positieve verplichting bestaat om de ontstane ongelijkheden uit de wereld te helpen. 
alleen mogelijk wanneer wordt aangenomen dat ook onbedoelde ongelijke behandelingen inhoudelijk moeten worden beoordeeld door de rechter.

\subsection{Grond van onderscheid}

Voor de toepassing van het algemene toetsingsmodel is het niet relevant op welke grond het onderscheid is gebaseerd: of er nu sprake is van onderscheid op grond van ras of godsdienst of op grond van het aantal kippen dat een pluimveehouder in zijn bezit heeft, een inhoudelijke beoordeling van de toelaatbaarheid van het onderscheid is steeds vereist. ${ }^{66} \mathrm{De}$ in de literatuur sporadisch naar voren gebrachte stelling dat een ongelijke behandeling alleen hoeft te worden gerechtvaardigd wanneer een (wettelijke) regel de grond van onderscheid expliciet verbiedt moet worden verworpen. ${ }^{67}$ Een dergelijk standpunt heeft immers de onwenselijke consequentie dat bepaalde, arbitraire onderscheidingen niet aan een inhoudelijke beoordeling kunnen onderworpen, omdat een regelgever deze niet met zoveel woorden heeft verboden. ${ }^{68}$ Ook de stelling dat onderscheid op bepaalde gronden nooit toelaatbaar is, en dus niet inhoudelijk op zijn redelijkheid hoeft te worden beoordeeld, is onjuist. ${ }^{69}$ Allereerst is het buitengewoon moeilijk om vast te stellen om welke gronden het hierbij zou moeten gaan en welke criteria bij de bepaling daarvan zouden moeten worden gehanteerd. ${ }^{70}$ Bovendien is het, ook bij gronden waarvan de onaanvaardbaarheid algemeen is geaccepteerd - zoals bijvoorbeeld het geval is bij huidskleur -, niet wenselijk om ieder onderscheid op een dergelijke grond te verbieden. Zelfs onderscheid op "verdachte" gronden kan in bepaalde gevallen toelaatbaar worden geacht; een bekend voorbeeld is het selecteren van modellen voor een fotoreportage over cosmetica voor mensen met een lichte huid."

66. Dit geldt vanzelfsprekend niet wanneer er sprake is van een in een algemene regeling uitdrukkelijk neergelegd verbod van onderscheid op bepaalde gronden. In dat geval zal voor een toetsing van het onderscheid zijn vereist dat het onderscheid (direct of indirect) is terug te voeren tot deze grond.

67. Dit standpunt wordt, voor zover mij bekend, alleen verdedigd door Asscher-Vonk: "[...] objective justification is linked to the non-discrimination rule: if there is not an explicit or implicit rule that forbids discrimination, there is no need to justify the differentiation. For instance, differentiation on the ground of beauty seems at this moment not to be part of even the most general non-discrimination rule: a preference on that ground does not have to be justified [...]" (1999, p. 40).

68. Diverse voorbeelden zijn denkbaar waaruit kan blijken dat de rechter in dit soort gevallen wel degelijk naar de rechtvaardiging van een onderscheid zal moeten kijken. Te denken valt aan de afwijzing van een zeer gekwalificeerde sollicitant voor de functie van archivaris vanwege een ontsierende wrat op zijn neus, of aan het uitsluiten van een ziektekostenverzekering van mensen die besmet zijn met HIV.

69. Door sommige auteurs is wel gesteld, dat onderscheid op grond van "onveranderlijke" kenmerken zoals huidskleur nooit aanvaardbaar is: vgl. Wiggers 1991, p. 5 en p. 172 e.v. en Wentholt 1990, p. 81. Zie ook Eisenberg 1977, p. 69, die de ontoelaatbaarheid echter beperkt tot die gevallen waarin bewust en bedoeld onderscheid op de betrokken grond is gemaakt. Een rechtvaardiging voor onderscheid op die gronden is dan ook niet mogelijk.

70. Vgl. Tussman/TenBroek 1949, p. 355. Hierop zal in paragraaf 5.3.1, waarin de toetsingsintensiteit aan de orde komt, nader worden ingegaan. Hier kan worden volstaan met de opmerking dat onveranderlijkheid van het betrokken persoonskenmerk (dat door de voorstanders van deze stelling als bepalend criterium naar voren wordt gebracht) niet altijd geschikt is: sommige persoonskenmerken zijn in beginsel veranderlijk, zoals nationaliteit (naturalisatie!) of godsdienst, maar vormen lang niet altijd een aanvaardbare grond van onderscheid. Daartegenover staat dat bepaalde onveranderlijke kenmerken, zoals intelligentie of talent, in de huidige maatschappij in het algemeen als redelijke gronden voor onderscheid worden gekwalificeerd.

71. Een groot aantal rechtvaardigingen voor onderscheid op schijnbaar ontoelaatbare gronden is te vinden 
Daarnaast wordt vrij algemeen aanvaard dat onderscheid op grond van "verdachte" criteria toelaatbaar kan zijn wanneer er sprake is van positieve actie of voorkeursbehandeling. ${ }^{12}$ Ook onderscheid op schijnbaar ontoelaatbare gronden moet dan ook steeds inhoudelijk op zijn toelaatbaarheid worden beoordeeld. ${ }^{n}$

\subsection{Toepasselijkheid in horizontale verhoudingen}

Over de vraag of het gelijkheidsbeginsel werking heeft in horizontale verhoudingen, dus in de verhouding tussen burgers onderling, is in de loop van de tijd veel discussie gevoerd. Hoewel veel specifieke regelgeving tot stand is gebracht die betrekking heeft op horizontale vormen van onderscheid (met name op het gebied van het arbeids- en contractenrecht en het strafrecht ${ }^{74}$ ), lijkt het niet algemeen geaccepteerd te zijn dat het algemene gelijkheidsbeginsel horizontale werking heeft. ${ }^{75}$ Vaak wordt gesteld dat individuele burgers, anders dan de overheid, niet de plicht hebben om "gelijke gevallen gelijk te behandelen", maar hun eigen voorkeuren mogen bepalen en hun eigen keuzen mogen maken. ${ }^{76}$ Bovendien wordt aangenomen dat individuen normaal gesproken weinig rekening hoeven te houden met de externe effecten van hun handelingen en keuzen. ${ }^{77}$ Door het gelijkheidsbeginsel ook op horizontaal niveau te laten gelden wordt volgens tegenstanders een te grote inbreuk gemaakt op deze individuele vrijheid. ${ }^{78}$

Zelfs door de tegenstanders van horizontale werking wordt echter aangenomen dat niet iedere ongelijke behandeling in de verhouding tussen burgers toelaatbaar is. ${ }^{79}$ Wanneer

in het Nederlandse Besluit gelijke behandeling van 18 augustus 1994, Staatsblad 1994, 657, dat een uitwerking vormt van de Algemene wet gelijke behandeling.

72. Positieve actie of voorkeursbehandeling is erop gericht een feitelijk bestaande situatie van structurele achterstand of achterstelling van een bepaalde groep, zoals in de VS mensen met een donkere huidskleur of in Nederland vrouwen, zoveel mogelijk te redresseren.

73. Wel kan, om recht te doen aan de emst van onderscheid op dit soort gronden, worden vereist dat de rechter een zeer strenge toetsing van de rechtvaardiging uitvoert. Op deze mogelijkheid zal in paragraaf 5 van dit hoofdstuk nader worden ingegaan.

74. Zie voor Nederland bijvoorbeeld artikel 7:646 BW en artikelen 137g en 429quater Wetboek van Strafrecht. In het rechtsvergelijkende gedeelte van dit boek zal op enkele van deze specifieke bepalingen nader worden ingegaan, met name wanneer zij ruimte bieden voor een verdergaande rechterlijke toetsing; dit is in het bijzonder het geval voor de horizontale bepalingen in het Europese recht.

75. Vgl. Schiek 1999, p. 77/78.

76. Burkens 1982, p. 65

77. Bennett 1979, p. 1066/1067

78. Van der Grinten 1984, p. 4: "In privaatrechtelijke verhoudingen is het m.i. als regel geoorloofd discriminatie, in de zin van onderscheid maken, voorkeur geven zonder dat hiervoor zakelijke gronden aanwezig zijn. De vrijheid van de menselijke persoon en van organisaties die als rechtspersoon aan het maatschappelijk verkeer deelnemen brengt dit mede." Vgl. ook Schiek 1999, p. 85 en Bezzenberger 1996, p. 401/402.

79. Zo maakt Van der Grinten, een overtuigd tegenstander van horizontale werking, onderscheid tussen de verhouding tussen particulieren in het gewone dagelijkse leven en particulieren in bedrijfs-en beroepsuitoefening. In dit laatste geval neemt hij aan dat bepaalde voorkeuren (bijvoorbeeld de weigering van een advocaat om kleurlingen en niet-Nederlanders rechtsbijstand te verlenen) onbehoorlijk kan zijn (1984, p. 3). Zie voor een enigszins vergelijkbare benadering Simon 1994, p. 43 (de "sfeer" waarin het horizontale onderscheid wordt gemaakt is bepalend voor de wijze waarop het gelijkheidsbeginsel door kan werken). Door anderen wordt wel gesteld dat het gelijkheidsbeginsel in ieder geval kan doorwerken in de algemene beginselen en regels van privaatrecht, ook al erkennen zij geen rechtstreekse hori- 
iemand schade lijdt of anderszins meetbaar nadeel ondervindt van een door een particulier gemaakt onderscheid is het niet onredelijk om van deze particulier te verwachten dat hij voor het maken van dit onderscheid goede redenen aanvoert. ${ }^{w_{0}}$ Bovendien wordt de werking van het gelijkheidsbeginsel vaak wél geaccepteerd wanneer de ongelijke behandeling is veroorzaakt door een groot bedrijf of wanneer er sprake is van een andere horizontale verhouding waarin een machtsevenwicht tussen de partijen ontbreekt. Om die reden lijkt het niet onredelijk om te stellen dat de rechter ook in horizontale verhoudingen van geval tot geval mag nagaan of er sprake is van een ongerechtvaardigde ongelijke behandeling.

In de gevallen waarin het gelijkheidsbeginsel horizontale werking toekomt, kan in beginsel gebruik worden gemaakt van hetzelfde toetsingsmodel als kan worden gehanteerd bij verticale gevallen van onderscheid. In dat verband is van belang dat alle in paragraaf 2.3 beschreven situaties van onderscheid zowel op verticaal als op horizontaal niveau kunnen voorkomen. Veel ondernemingen kennen bijvoorbeeld algemene regelingen voor beloning en arbeidsvoorwaarden. Daarin zullen net zo goed normatieve classificaties voorkomen als het geval is bij formeel wettelijke regelingen (situatie 1). Ook in horizontale verhoudingen kan bovendien gelden dat een benadeling het gevolg is van een ongelijke uitoefening van verantwoordelijkheden (situatie 2). ${ }^{\mathrm{si}}$ Aangezien horizontale ongelijke behandelingen nauwelijks verschillen van de verticale gevallen van onderscheid, kan de rechter hierbij zonder meer gebruik maken van het toetsingsmodel. $^{\mathrm{x} 2}$

Zoals eerder al is opgemerkt zal er echter juist in horizontale gevallen sprake kunnen zijn van bloot onderscheid (situatie 3 ), bijvoorbeeld in het geval van een arts die islamitische patiënten weigert of in het geval van een café-eigenaar die alleen vrouwelijke

zontale werking (Bezzenberger 1996, p. 402).

80. In de theoretische discussie wordt door tegenstanders van horizontale werking steeds weer gewezen op de mogelijkheid om persoonlijke voorkeuren uit te spreken of keuzen te maken zonder dat daardoor schade wordt aangericht; door een volstrekt horizontale werking te aanvaarden zou op deze onschadelijke uitoefening van de individuele keuzevrijheid inbreuk worden gemaakt, omdat burgers dan iedere persoonlijke keuze moeten rechtvaardigen. Deze stelling is misschien wel juist, maar is als argument in de discussie over de noodzaak van rechtvaardiging eigenlijk niet zo interessant. In de praktijk zal het aantal gevallen waarin een burger voor de rechter een door hem gemaakt, maar voor niemand nadelig onderscheid moet verdedigen minimaal zijn: als er al iemand naar de rechter stapt, moet hij nog de horde nemen van het aantonen van voldoende belang, hetgeen in deze gevallen vrijwel ondoenlijk zal zijn. Vgl. in dit verband Simon 1994, p. 43. Zie verder Alexander 1992, m.n. vanaf p. 190.

81. In paragraaf 2.3 .1 is al het voorbeeld gegeven van een personeelsfunctionaris in een groot bedrijf die verantwoordelijk is voor het uitvoeren van een beloningsregeling. Als zijn verantwoordelijkheden in de regeling ruim zijn geformuleerd kan er ook op dit niveau sprake zijn van een zekere mate van discretie. Wanneer bij de uitoefening van de verantwoordelijkheden een ongelijke behandeling wordt gecreěerd is er dan ook zeker sprake van een situatie 2-onderscheid.

82. Het idee van horizontale werking wordt voor dit soort verhoudingen ook veel gemakkelijker erkend, omdat zich daarbij vaak een, voor verticale verhoudingen eveneens typerende, machtsongelijkheid voordoet (vgl. bijvoorbeeld de individuele medewerker die zich teweer moet stellen tegen een ongelijke behandeling door een grote multinational); bovendien is het verschil tussen als private rechtspersonen optredende overheidsorganen en werkelijk private organisaties niet altijd even duidelijk (vgl. bijvoorbeeld een ministerie als werkgever met een advocatenkantoor als werkgever). Het is daarom niet redelijk om alleen overheidsorganen aan het gelijkheidsbeginsel te binden. Vgl. Bezzenberger 1996, p. 406-408 en Simon 1994, p. 42. 
bediendes in dienst neemt. Ook in dit soort gevallen kan tot uitgangspunt worden genomen dat degene die verantwoordelijk is voor het onderscheid redenen moet aanvoeren om het onderscheid te rechtvaardigen; bij de beoordeling van deze rechtvaardiging kan gebruik worden gemaakt van (een iets aangepaste versie van) het toetsingsmodel. ${ }^{\mathrm{k}}{ }^{3}$ Daarbij zal rekening moeten worden gehouden met de beschikkings- en contractsvrijheid van het betrokken individu: deze zal altijd moeten worden afgewogen tegen het belang dat de benadeelde heeft bij een gelijke behandeling. ${ }^{4}{ }^{4}$ Zoals in paragraaf 2.3 .2 al is aangegeven spelen bij bloot onderscheid in het algemeen echter vooral bewijstechnische problemen een rol, waardoor zelden zal worden toegekomen aan een zuivere toepassing van het toetsingsmodel. Om die reden zal aan de situatie van bloot onderscheid geen bijzondere aandacht worden besteed: de aandacht zal worden geconcentreerd op normatieve classificaties en gevallen van concrete bevoegdheidsuitoefening waardoor onderscheid wordt veroorzaakt.

\section{Inhoud van het toetsingsmodel}

\subsection{Algemene opmerkingen}

\subsubsection{Inleiding}

Uit het voorgaande is gebleken dat het wenselijk en noodzakelijk is om de rechter een toetsingsmodel aan te reiken dat bruikbaar is in (relatief) open modellen van onderscheid, ongeacht de situatie waarin onderscheid wordt gemaakt, ongeacht de verschijningsvorm van het onderscheid, ongeacht het differentiatiecriterium en ongeacht de aard van de betrokken rechtsverhouding. Dit betekent dat een goed toetsingsmodel aan twee belangrijke, maar tegelijkertijd tegenstrijdige eisen moet voldoen: enerzijds moet het de rechter voldoende houvast bieden bij zijn toetsing, maar anderzijds moet het voldoende flexibel en open zijn om ruimte te kunnen bieden aan de veelheid van verschijningsvormen van ongelijke behandeling waarmee de rechter wordt geconfronteerd. In deze paragraaf zal worden geprobeerd een dergelijk model tot stand te brengen, op basis van theoretische veronderstellingen en ideeën over de noodzaak van toetsing aan bepaalde criteria.

\subsubsection{Fasen van toetsing}

Voor een goed begrip van de betekenis en de inhoud van het toetsingsmodel is het van belang dat een toetsing aan het gelijkheidsbeginsel in drie fasen verloopt. In de eerste fase gaat de rechter na of de eisende partij, die stelt dat hij slachtoffer is van een ongelijke behandeling, voldoende recht van klagen heeft. Anders gezegd: in deze fase wordt vastgesteld of er daadwerkelijk sprake is van een onderscheid dat rechtvaardiging behoeft. Dit is slechts een feitelijke vaststelling, waarbij nog geen oordeel wordt gegeven over de redelijkheid van het gemaakte onderscheid. ${ }^{85}$ Pas wanneer duidelijk is dat er

83. Vgl. in dit opzicht Benn/Peters 1969, p. 75.

84. Vgl. Bezzenberger 409/410, Simon 1994, p. 40 en Alkema 1987, p. 81.

85. Het is van belang om dit goed in het oog te houden: vaak ontstaat er een conceptuele verwarring tussen 
daadwerkelijk sprake is van onderscheid, zal de rechter overgaan tot een inhoudelijke beoordeling van de toelaatbaarheid daarvan: de tweede fase van de toetsing. Wanneer in deze fase is vastgesteld dat het onderscheid niet kan worden gerechtvaardigd, bepaalt de rechter in de derde fase welke gevolgen er aan deze conclusie moeten worden verbonden: zo kan hij de betrokken regeling zodanig proberen uit te leggen dat het onderscheid wordt weggenomen, maar hij kan bijvoorbeeld ook een schadevergoeding toekennen of de regeling als zodanig onverbindend verklaren. ${ }^{\mathrm{N}}$

In het kader van dit proefschrift zal uitsluitend aandacht worden besteed aan de eerste en de tweede fase van de toetsing, nu alleen deze fasen daadwerkelijk betrekking hebben op de inhoudelijke beoordeling van het onderscheid. Aan de eerste fase zal pas in de volgende paragraaf aandacht worden besteed: voor een goed begrip van de daarin te hanteren toetsingsmethodiek en de onderlinge verhouding tussen de eerste en de tweede fase is het nodig om kennis te hebben van het algemene toetsingsmodel. In deze paragraaf zal daarom uitsluitend aandacht worden besteed aan de tweede fase: ingegaan zal worden op de wijze van beoordeling van de toelaatbaarheid van het onderscheid en het daarbij te hanteren toetsings- of rechtvaardigingsmodel.

\subsubsection{Opzet van het toetsings- of rechtvaardigingsmodel}

Om een duidelijke en doorzichtige motivering te realiseren moet de rechter ieder onderscheid bij voorkeur toetsen aan de volgende vijf criteria:

1. Ligt er aan het onderscheid een gerechtvaardigde bedoeling of reden ten grondslag, of heeft de maatregel maatschappelijk wenselijke effecten (doeltoets)?

2. Is de classificatie nauwkeurig genoeg geformuleerd in verhouding tot het doel dat met de regeling wordt nagestreefd (toets van de mate van fit, of van over- of underinclusiveness)?

het begrip gelijkheid en de notie van rechtvaardigheid die tot een bijzonder troebele toetsing kan leiden. Van belang is dat het begrip gelijke behandeling, zoals al gesteld in paragraaf 1.1.1, een leeg begrip is: het kan slechts helpen bij de vaststelling of twee gevallen in relevante opzichten gelijk zijn of juist van elkaar verschillen, en of deze gevallen al dan niet verschillend zijn behandeld. De vraag of de verschillende behandeling van de vergelijkbare of onvergelijkbare gevallen ook gerechtvaardigd is, wordt door het waardeneutrale gelijkheidsbeginsel niet beantwoord: om dit te bepalen moet het beginsel gekoppeld worden aan een notie van rechtvaardigheid (vgl. Bedau 1967, p. 9/10). Dat is wat bij het toetsen aan het rechtvaardigingsmodel gebeurt in de tweede fase van de toetsing. Op deze problematiek zal verder worden ingegaan bij de bespreking van de eerste fase van de toetsing (paragraaf 4 ).

86. Het wegnemen van een ongelijke behandeling kan op verschillende manieren plaatsvinden, bijvoorbeeld door het voordeel waarom het gaat tot alle betrokken groepen uit te breiden of door het voordeel aan alle betrokken groepen te ontnemen (vgl. Simons 1985, p. 392). De keuze van de rechtsgevolgen is sterk afhankelijk van het specifieke geval en van de opvattingen van de rechter over zijn eigen taken en bevoegdheden. Zo geeft de Hoge Raad er soms de voorkeur aan om de wetgever zelf gevolgen te laten verbinden aan de conclusie dat de classificatie in strijd is met het gelijkheidsbeginsel (bijv. HR 23 september 1988, NJ 1989/740 (Naamrecht)); de Centrale Raad van Beroep kent wat dit betreft minder scrupules en geeft zelf vaak een zodanige uitleg aan een wettelijke regeling dat het daarin gemaakte ontoelaatbare onderscheid wordt weggenomen (bijv. CRvB 7 december 1988, RSV 1988/67 (AWW)). Wanneer de rechter het onderscheid niet wil wegnemen zijn er bovendien diverse mogelijkheden denkbaar, zeker wanneer het gaat om een onderscheid op horizontaal niveau: te denken valt aan financiele compensatie, ontbinding van een contract of herstel van een dienstverband. 
3. Kan het doel door het gemaakte onderscheid inderdaad worden bereikt (geschiktheidstoets)?

4. Kon de doelstelling niet met andere, de getroffen belangen minder ernstig aantastende, middelen worden bereikt (subsidiariteitstoets)?

5. Bestaat er een evenredige verhouding tussen het nagestreefde doel en de aangetaste belangen (proportionaliteitstoets in strikte zin)?

Dit model is zo opgebouwd dat de rechter allereerst moet beoordelen of de reden voor (of de doelstelling van) het maken van onderscheid gerechtvaardigd is. Daarbij wordt ervan uitgegaan dat mensen en organen altijd een bepaalde reden zullen hebben voor hun handelen, ook al wordt deze niet altijd geëxpliciteerd. ${ }^{87}$ Zoals eerder is aangegeven kan het echter ook zo zijn dat een ongelijke behandeling niet uitdrukkelijk is beoogd, maar veeleer een onbedoeld effect is van een bepaalde handeling of maatregel. In dat geval zal de rechter moeten bekijken of met de regeling of handeling die dit effect teweeg heeft gebracht als zodanig een gerechtvaardigd doel wordt nagestreefd. Blijkt dit inderdaad het geval te zijn, dan moet hij vervolgens aan de hand van de overige criteria van het toetsingsmodel bepalen of deze doelstelling een voldoende rechtvaardiging kan vormen voor het effect van de maatregel. ${ }^{\mathrm{s}}$

In dit verband moet verder worden gewezen op het feit dat de doelstelling of reden voor de toelaatbaarheid van het onderscheid niet altijd doorslaggevend mag zijn voor de uitkomst van de toetsing. Wanneer er een onoorbare doelstelling wordt nagestreefd, maar de maatregel maatschappelijk wenselijke effecten blijkt te sorteren, lijkt het niet nodig om de betrokken regeling te invalideren. ${ }^{80}$ Wanneer een dergelijke regeling ontoelaatbaar wordt verklaard, heeft dit immers tot gevolg dat belangrijke voordelen worden weggenomen als gevolg van een rechterlijk oordeel over de nagestreefde doelstelling; dit is een consequentie die zelfs bij een ruime opvatting over rechterlijke bevoegdheden niet aanvaardbaar lijkt. ${ }^{\text {xo }}$ Dit probleem van een discrepantie tussen doel-

87. Dit geldt in ieder geval voor algemene regelgeving: zoals Sloot aangeeft maakt de overheid altijd classificaties voor het bereiken van bepaalde doeleinden, hoe vaag die ook zijn omschreven (1986, p. 24; zie ook Brest 1971, p. 104: "Every explicit or implicit distinction made by law may have objectives"). Hetzelfde geldt voor de toepassing van regelgeving door administratieve organen en voor bloot onderscheid: ook deze ongelijke behandelingen zullen altijd zijn ingegeven door bepaalde overwegingen en doelstellingen, ook al blijven deze in het merendeel van de gevallen onuitgesproken (zeker bij bloot onderscheid, zoals in het voorbeeld van de selectie van gasten voor een feestje). Zie ook Brest 1971 , p. $111 / 112$.

88. De noodzaak om deze volgorde te hanteren is uitstekend beargumenteerd door Tribe: "without [...] a requirement of legitimate public purpose, it would seem useless to demand even the most perfect congruence between means and ends, for each law would supply its own indisputable - and indeed tautological - fit: if the means chosen burdens one group and benefits another, then the means perfectly fits the end of burdening just those whom the law disadvantages and benefiting just those whom it assists" (1988, p. 1440).

89. "Note" 1970, p. 1891, Tussman/TenBroek 1949, p. 360 en Leibholz 1925, p. 92. Zie in dit verband ook het door Ely aangehaalde citaat van de Amerikaanse rechter Warren: "the Lord's work should not be thwarted simply because Satan helped it along" (1970, p. 1215).

90. "Note" 1970 , p. 1891; zie verder paragraaf 3.2.4. Een probleem is overigens dat ook het oordeel over de wenselijkheid van de effecten door de rechter zal worden uitgesproken, hetgeen eveneens een grote mate van rechterlijke activiteit oplevert. Voorop moet dan ook worden gesteld dat de rechter zich in situaties waarin de keuze zich voordoet tussen het doel van de regeling of de effecten daarvan terughoudend moet opstellen. 
stelling en effect zal zich in de praktijk slechts zelden voordoen: in veruit de meeste gevallen zal een ongerechtvaardigde bedoeling samengaan met onaanvaardbare of op zijn minst problematische effecten." Voor zaken over gelijke behandeling geldt dit nog in het bijzonder. Het is immers duidelijk dat er bij zaken over ongelijke behandeling altijd wordt geklaagd door een individu of een groep van individuen die door een regeling wordt benadeeld, hetgeen impliceert dat de maatregel zeker niet alleen positieve effecten genereert. ${ }^{2 / 2}$ Niettemin is het denkbaar dat in sommige gevallen meer waarde moet worden gehecht aan de wenselijke effecten van een ongelijke behandeling dan aan het bestaan van een ongerechtvaardigd doel. ${ }^{93}$ Om die reden zal de rechter niet alleen moeten beoordelen of er een gerechtvaardigd doel bestaat, maar zal hij, in het kader van de toetsing van het doel, soms ook moeten nagaan welke effecten de regeling sorteert. ${ }^{94}$ Mocht het doel niet gerechtvaardigd zijn, maar de effecten wel, dan mag de rechter aan de toetsing aan het eerste toetsingscriterium niet zonder meer de conclusie verbinden dat het onderscheid ontoelaatbaar is: een toetsing aan de overige criteria van het model is in een dergelijk geval noodzakelijk." Wanneer in het hiernavolgende gesproken wordt over de gerechtvaardigdheid van het doel, wordt hiermee dan ook altijd impliciet gedoeld op de effecten van de regeling.

Wanneer de rechter heeft vastgesteld dat de aan een ongelijke behandeling ten grondslag liggende bedoeling niet gerechtvaardigd is, is het niet meer nodig dat hij nagaat of de ongelijke behandeling een redelijk middel vormt om de nagestreefde doelstelling te bereiken. Dit betekent dat de rechter alleen hoeft te beoordelen of de keuze voor de middelen om het gestelde doel te bereiken een redelijke was, als de toetsing van het doel een positief resultaat heeft opgeleverd. Het tweede deel van de rechtvaardigings-

\section{Leibholz 1925 , p. 92}

92. Dit geldt zeker wanneer wordt bedacht dat ook het creèren van een gevoel van inferioriteit bij een bepaalde groep of het bevestigen of benadrukken van reeds bestaande stigma's en vooroordelen als effect van een maatregel kunnen worden beschouwd; een dergelijk (neven)effect zal regelmatig voorkomen bij maatregelen waarmee een ontoelaatbare doelstelling wordt nagestreefd, ook al worden daarmee tegelijkertijd maatschappelijk wenselijke effecten bereikt. Vgl. Clark 1978, p. 964.

93. Een voorbeeld is te vinden in het Amerikaanse recht. In de zaak Palmore v. Sidoti (466 U.S. 429 (1984)) moest het Amerikaanse Supreme Court een oordeel geven over de beslissing van een lagere rechter om een kind na echtscheiding toe te wijzen aan de moeder. Reden hiervoor was het feit dat de vader een donkere huidskleur had; het kind zou daarvan in de toekomst nadeel kunnen ondervinden, gezien de ernstige vooroordelen die er in de betrokken staat tegenover donkere mensen bestonden. Het Supreme Court oordeelde, zonder dit overigens nader te motiveren, dat dit rechterlijk oordeel door inherent discriminatoire overwegingen was ingegeven en dat het daarom niet toelaatbaar was (466 U.S., 433). De vraag is echter of een dergelijke snelle conclusie wel aangewezen was: het is zeker verdedigbaar dat de rechterlijke beslissing, gezien de omstandigheden in de staat, voor het kind wenselijke effecten had.

94. Pas in het kader van de toetsing van de verhouding tussen doel en middel, en met name bij de beoordeling van de proportionaliteit, mag de rechter een oordeel geven over de vraag of deze maatschappelijk wenselijke effecten de ongelijke behandeling inderdaad kunnen rechtvaardigen, ondanks de ontoelaatbaarheid van de doelstelling.

95. In dit soort gevallen zal de toetsing aan het model bovendien een iets andere inhoud krijgen: bij de beoordeling zal steeds moeten worden bekeken of de gemaakte onderscheiding t.a.v. het bereikte effect geschikt, subsidiair en proportioneel is. Ook voor de toetsing van de over- en underinclusiveness, hierna nog te bespreken, geldt dat zal moeten worden nagegaan of de definitie van de classificatie voldoende aansluit bij het bereikte effect van de regeling. 
toets, dat nader is uitgesplitst in de criteria twee tot en met vijf, is bedoeld om de rechter houvast te bieden bij de beoordeling van deze verhouding tussen doel en middel.

In het hiernavolgende zullen de verschillende criteria van het rechtvaardigingsmodel nader worden toegelicht en uitgewerkt. Daarbij zal niet alleen aandacht worden besteed aan de inhoud van de criteria en aan de noodzaak om deze te betrekken bij de beoordeling van een ongelijke behandeling, maar ook aan de vraag of en in hoeverre de rechter bevoegd en in staat is om een toetsing aan deze criteria uit te voeren.

\subsubsection{Voorkeursbehandeling}

Een laatste opmerking die moet worden gemaakt alvorens kan worden ingegaan op de inhoud van het toetsingsmodel betreft de rechtvaardiging van de diverse vormen van voorkeursbehandeling. ${ }^{\%}$ Aan deze problematiek zal geen bijzondere aandacht worden besteed, hoewel het hierbij zonder meer gaat om een belangrijke en controversiële kwestie. Waar het de manier van toetsing door de rechter betreft, bestaat er weinig reden om onderscheid te maken tussen voorkeursbehandeling en andere vormen van ongelijke behandeling: het hiervoor beschreven toetsingsmodel biedt zonder meer mogelijkheden voor de rechtvaardiging van voorkeursbehandeling. Zo lijkt het waarschijnlijk dat de meest genoemde doelstellingen van voorkeursbehandeling - het wegwerken van een maatschappelijke achterstand van een bepaalde groepering of het compenseren van een dergelijke groepering voor in het verleden aangedaan onrecht - gerechtvaardigd kunnen worden geacht." Voor het overige kan aan de hand van de geschiktheidstoets, de subsidiariteitstoets en de proportionaliteitstoets worden bezien of het gemaakte onderscheid redelijk is in verhouding tot de belangen die hierdoor worden aangetast. Het model biedt daardoor ruimte voor het ontoelaatbaar achten van te vergaande of onredelijke vormen van voorkeursbehandeling. Een verschil met "gewone" ongelijke behandeling kan hoogstens worden gevonden in de intensiteit waarmee voorkeursbehandeling moet worden getoetst; daarop zal in paragraaf 5 van dit hoofdstuk nader worden ingegaan.

\subsection{Het vereiste van een gerechtvaardigd doel}

\subsection{Inleiding: noodzaak van de toetsing van het doel}

De rechterlijke toetsing van de doelstelling van een algemene regeling of van een administratieve beschikking wordt in de literatuur veelal met argwaan bekeken en soms zelfs volledig afgewezen. ${ }^{98}$ Opvallend is echter dat auteurs die normaal gesproken van

96. Zie voor een beschrijving van de modaliteiten van voorkeursbehandeling Sloot 1989, p. 34.

97. Loenen 1992, p. 252

98. Zie bijvoorbeeld de door Bickel geciteerde auteurs (1962, p. 208/209); vgl. ook Bhagwat 1997, p. 321. Een fervent tegenstander is ook Scalia, die zijn bezwaren als volgt formuleert: "[...] it is simply incompatible with democratic government, or indeed, with fair government, to have the meaning of a law determined by what the lawgiver meant, rather than by what the lawgiver promulgated. That seems to me one step worse than the trick the emperor Nero was said to engage in: posting edicts high up on the pillars, so that they could not easily be read. Government by unexpressed intent is similarly tyrannical. It is the law that governs, not the intent of the lawgiver" (1997, p. 17). Daar staat tegenover dat door 
mening zijn dat de rechter niet hoort te zoeken naar de bedoeling van een regel, daarover in het geval van ongelijke behandeling anders blijken te denken." Dit is ook niet verrassend, nu het vrijwel onmogelijk is om een zinvol oordeel over de toelaatbaarheid van een ongelijke behandeling te geven zonder rekening te houden met de doelstelling ervan. ${ }^{100}$ Dit kan worden verklaard vanuit het bijzondere karakter van gelijke behandelingskwesties. Bij "normale" grondrechtenschendingen, zoals bij een schending van het verbod op foltering, is het lang niet altijd nodig om te kijken naar de redenen voor de schending. Om vast te kunnen stellen dat er sprake is van een schending is het in beginsel voldoende dat een regeling een inbreuk op een grondrecht tot gevolg heeft. ${ }^{101}$ Hetzelfde geldt voor het tegenovergestelde geval: heeft een regeling geen illegitieme gevolgen, dan is het wat artificieel om na te gaan of de maatregel dan misschien wel ille-

veel auteurs terecht is gewezen op het feit dat de rechter tot op zekere hoogte altijd rekening moet houden met het doel van een regeling: wanneer de rechter een uitleg of toepassing geeft aan een wettelijke regeling die niet met het doel in overeenstemming is, zal zijn uitspraak in het algemeen onbevredigend worden geacht; zie bijvoorbeeld Leijten 1981, p. 112.

Verder is gewezen op de specifieke problemen die de op de doelstelling gerichte toetsing met zich meeneemt. Zo zou er een risico bestaan dat het gemaakte onderscheid gewoon weer opnieuw wordt ingevoerd, maar dan met een andere bedoeling die de feitelijke, ontoelaatbare doelstelling kan verhullen; ook zal meer moeite worden gedaan om die doelstelling te verbergen (Brest 1971, p. 125/126). Juist om die reden is een redelijk vergaande mogelijkheid voor de rechter om onderzoek te doen naar de werkelijke bedoelingen van het onderscheid noodzakelijk. Zie daarover de volgende paragraaf.

99. Vgl. Bickel 1962, die zeer negatief is over de mogelijkheid de doelstelling van regelgeving te achterhalen (m.n. p. 215-221), maar niettemin aangeeft dat de vraag of een gelijke behandeling toelaatbaar is afhankelijk is van de rationaliteit van de verhouding tussen het gemaakte onderseheid en het nagestreefde doel (p. 224). Ook Ely is negatief over het zoeken naar en beoordelen van doelstellingen als het gaat om interpretatie van wetgeving of de constitutie ("The problem is that the more one tries to specify a way in which the Court might participate in forcing articulation, the clearer it seems to become that none exists whose costs will not exceed the benefits"; 1980, p. 125); wanneer hij komt te spreken over ongelijke behandeling blijkt echter dat hij het zoeken naar de bedoeling van het onderscheid veel minder problematisch en zelfs noodzakelijk vindt ("[...] there are real-world cases where an unconstitutional motivation, even on the part of a legislature, can quite confidently be inferred, and [...] there will be cases your intuition tells you involve unconstitutional action that cannot responsibly rationalized on anything but a motivation theory"; 1980, p. 139; zie in dit verband ook Ely 1972, m.n. p. $1261 / 1262$ ). Verder wordt in de literatuur waarin wordt gepleit voor een toetsing van het doel door de rechter bij interpretatie van regelgeving meestal verwezen naar rechtspraak over gelijke behandeling (bijv. "Note" 1970, p. 1893 e.v.))

100. Vgl. Tussman/TenBroek 1949 , p. 366 (" $[$....] it is impossible to judge the reasonableness of the law without relating it to the purpose of the law").

101. Zie Alexander 1978, p. 927 en de opinie van Chief Justice Warren in het Amerikaanse arrest United States v. O'Brien, 391 U.S. $367,383 / 384$. Overigens verdient deze stelling wel enige nuancering. In bepaalde omstandigheden zal de bedoeling van een inbreuk ook bij "gewone" grondrechten (mede) bepalend zijn voor de uitkomst van de procedure, namelijk in het kader de beoordeling of het effect (de inbreuk) op een of andere manier kan worden gerechtvaardigd; vgl. Brownstein 1994, p. 867/868. De tweede leden van de artikelen 8-11 van het Europees Verdrag voor de Rechten van de Mens en de Fundamentele Vrijheden zijn daarvoor illustratief: deze leden, die een rechtvaardigingsmogelijkheid geven voor een inbreuk op het betreffende grondrecht, geven steeds aan dat voor een rechtvaardiging vereist is dat met de inbreuk tenminste één van de in de artikelen opgesomde doelstellingen wordt nagestreefd. Feitelijk verschilt deze situatie dan ook niet bijzonder van die van gelijke behandeling, omdat ook daarbij de vraag of er echt sprake is van een ontoelaatbare inbreuk afhankelijk is van het doel. De situatie is echter anders bij de grondrechten waarop geen uitzonderingen worden toegelaten, zoals het verbod op foltering; ongeacht de doelstellingen van de verantwoordelijke is het effect van de handeling bepalend voor het oordeel van een schending. Voor die groep gaat de stelling dat bij grondrechten het effect bepalend is dus wel steeds op. 
gitieme doelstellingen had. ${ }^{102} \mathrm{Bij}$ zaken over ongelijke behandeling gaat deze redenering echter niet op: als een maatregel resulteert in een ongelijke behandeling hoeft dit er lang niet altijd op te duiden dat deze ontoelaatbaar is. ${ }^{103}$ Eerder is bovendien al aangegeven dat ook een op het eerste gezicht gelijke behandeling niet altijd gerechtvaardigd is. ${ }^{104} \mathrm{Om}$ te kunnen beoordelen of een ongelijke (of juist gelijke) behandeling toelaatbaar is kan dan ook niet worden volstaan met de enkele constatering van die ongelijke behandeling: steeds moet worden gekeken naar de reden waarom er onderscheid wordt gemaakt. ${ }^{105}{ }^{106}$ Het onderscheid kan alleen gerechtvaardigd worden geacht wanneer die reden inhoudelijk is te verantwoorden. ${ }^{107}$

102. Vgl. in dit verband Binion 1983, p. 444/445, die stelt dat door een dergelijke focus op de doelstellingen in plaats van op de effecten het accent teveel wordt gelegd op het zoeken naar fouten in het proces van besluitvorming, terwijl het daadwerkelijke probleem niet daarin is gelegen, maar in de consequenties van de besluitvorming voor de rechten van de betrokkenen.

103. Zoals eerder is opgemerkt is het maken van onderscheid inherent aan het vaststellen van regelgeving: alleen al door de bepaling van de reikwijdte van een regeling wordt onderscheid gemaakt. Zou in al dit soort gevallen worden gesteld dat een ongelijk effect ontoelaatbaar is, dan zou iedere vorm van regelgeving onmogelijk worden.

104. Het gaat hierbij om gevallen van materieel ongelijke behandeling, waarbij groepen of mensen een zelfde behandeling ten deel valt, terwijl zij zich in een verschillende situatie bevinden; zie hierover nader de paragrafen 1.2.1 en 2.4. Een goed voorbeeld van een geval waarin een gelijke behandeling tot onredelijke resultaten zou leiden is het vaststellen van belastingwetgeving waarin iedereen, ongeacht zijn inkomen, eenzelfde absolute hoeveelheid belasting zou moeten betalen.

105. Het nut van het zoeken naar een doelstelling of motief wordt voor gevallen van normatief onderscheid wel eens ontkracht door de stelling dat de regelgever een bepaling na vernietiging weer gewoon zal kunnen aannemen, maar dan met een betere motivering (Ely 1970, p. 1214/1215 en Ely 1980, p. 138). Dit argument is echter niet bijzonder sterk, aangezien dit alleen mogelijk is wanneer er een andere, plausibele motivering voor de classificatie kan worden bedacht. Als dit al het geval is, blijft het altijd de vraag waarom dit doel niet eerder is aangevoerd. In de meeste gevallen zal een dergelijke wettelijke regeling bij een nieuwe rechterlijke toetsing dan ook opnieuw sneuvelen (zie ook Ely 1980, p. I38/139). Bovendien kan worden gesteld dat in de zeldzame gevallen waarin een classificatie opnieuw wordt ingevoerd op grond van argumenten die voldoende draagkrachtig en overtuigend zijn, hiertegen nauwelijks bezwaar kan bestaan: het gaat dan vooral om de hiervoor reeds besproken, vrijwel theoretische, gevallen waarin wetgeving is vastgesteld die, ondanks ontoelaatbare doelstellingen, maatschappelijk wenselijke gevolgen sorteert. In dergelijke gevallen kan de wetgeving opnieuw worden vastgesteld, ditmaal met een motivering die is afgestemd op deze wenselijke effecten. Het is dan onredelijk om de wet opnieuw te invalideren met een beroep op de eerdere, onoirbare doelstellingen.

106. Een heel ander soort argument voor de beoordeling van de motieven en doelstellingen van een classificatie is gegeven door Clark, die na een uitgebreide analyse concludeert dat "[...] laws motivated by prejudice produce feelings of anger, devaluation, and breach of the social contract demanding fair representation" (1978, p. 968). Een dergelijke redenering is wel door meer auteurs aangedragen om een doeltoets te rechtvaardigen. Weliswaar kan dit een belangrijke reden zijn om inhoudelijk naar een doelstelling te willen kijken, maar het zal zeker niet de enige kunnen zijn. Ook doelstellingen die een heel andere basis hebben dan vooroordelen jegens bepaalde groepen kunnen immers ongerechtvaardigd zijn, bijvoorbeeld wanneer het gaat om een specifiek doel dat in strijd is met een hogere rechtsregel (een voorbeeld is een regeling waarin een classificatie wordt opgenomen met het doel de mededinging te beperken, terwijl een hogere regeling het beoogde soort mededingingsbeperkingen verbiedt). Bovendien geldt de genoemde rationale alleen voor onderscheid dat door de overheid wordt gemaakt, terwijl het model ook betrekking heeft op door particulieren gemaakt onderscheid.

107. Zoals wordt gesteld door Tussman en TenBroek: "[...] the prohibition against discriminatory legislation is a demand for purity of motive" (1949, p. 358); vgl. ook Leibholz, die stelt dat het in het kader van een toetsing op willekeur altijd nodig is om te beoordelen of er aan de ongelijke behandeling een "sachfremden Motivation" ten grondslag ligt; hij ziet "Motivation" daarbij als een correlatief ten opzichte van het "Zweck" van de ongelijke behandeling (1925, p. 89). Zie verder Eisenberg 1977, p. 100. 


\subsubsection{Het achterhalen van de doelstelling van een ongelijke behandeling}

\section{Gesteld of "werkelijk" doel van het onderscheid}

Om te kunnen beoordelen of een onderscheid (of een regeling die daarin resulteert) een gerechtvaardigd doel heeft zal de rechter allereerst moeten achterhalen welke redenen er aan het maken van onderscheid ten grondslag lagen. Hoewel dit tot de normale taken van de rechter behoort (ook bij gewone wetsinterpretatie en -toepassing zal de rechter immers proberen een uitkomst te zoeken die in overeenstemming is met de doelstellingen van de wet), zal het duidelijk zijn dat dit in de praktijk bijzonder lastig kan zijn.

Tot uitgangspunt kan worden genomen dat de rechter bij de vaststelling van het doel af moet gaan op de doelstellingen zoals die door de verdedigende partij naar voren zijn gebracht: degene die verantwoordelijk is voor het gemaakte onderscheid zal immers het beste kunnen oordelen over de doelstellingen die hieraan ten grondslag lagen. Soms kan het echter zo zijn dat er nog andere redenen bestonden om onderscheid te maken, maar dat deze door de wederpartij niet expliciet worden genoemd. Van een dergelijk verhullen van doelstellingen zal met name sprake zijn wanneer deze minder gemakkelijk te rechtvaardigen zijn. ${ }^{10 \mathrm{x}}$ Vanuit het gezichtspunt van een goede bescherming van de individuele klager tegen arbitraire vormen van ongelijke behandeling is het dan ook van belang dat de rechter niet alleen afgaat op de doelstellingen zoals die door de betrokken partij naar voren worden gebracht, maar actief op zoek gaat naar het bestaan van eventuele achterliggende, minder edele doelstellingen.

Problematisch bij een dergelijk onderzoek naar de niet genoemde, "werkelijke" bedoelingen van het onderscheid is de mate waarin en de wijze waarop de rechter dit onderzoek moet uitvoeren. ${ }^{109}$ Wanneer een overtuigende en gerechtvaardigde doelstelling is

Gesteld zou kunnen worden dat door het vereisen van een gerechtvaardigd doel, en meer in het algemeen van een rechtvaardiging, de notie van gelijkheid gekoppeld wordt aan de notie van rechtvaardigheid. Anders dan soms wel wordt verondersteld is gelijkheid zelf een waardeneutraal begrip: het kan alleen helpen bij het vaststellen of twee gevallen in relevante opzichten gelijk zijn, niet bij de beantwoording van de vraag of het redelijk is om deze gevallen al dan niet gelijk te behandelen. Deze conclusie kan alleen worden bereikt door in de tweede fase van de toetsing een rechtvaardigheidstoets uit te voeren (vgl. Goldschmidt 1989, p. 88). Aan deze problematiek zal wel aandacht worden besteed in paragraaf 4 , waar de eerste fase van de toetsing wordt behandeld.

108. Vooral in de VS zijn hiervan voorbeelden te vinden; soms wordt een bedoeling om Afro-Amerikanen te benadelen daar verhuld achter allerlei objectieve doelstellingen, zoals in het al eerder genoemde voorbeeld van wetgeving waardoor het kiesrecht beperkt werd tot alfabeten. De gestelde reden daarvoor was, dat alleen alfabeten voldoende in staat zijn om zich te informeren en daardoor een zinvolle stem uit te brengen. De werkelijke achtergrond bleek te zijn dat de wetgever probeerde AfroAmerikanen, waarvan het grootste gedeelte in de relevante periode geen goed onderwijs had kunnen genieten, hun mogelijkheid tot politieke participatie te ontzeggen. Ook in minder evidente gevallen van onoorbaarheid kan er echter reden bestaan om bepaalde doelstellingen te verhullen. $\mathrm{Z}_{0}$ is het duidelijk dat financièle of administratieve doelstellingen niet altijd als een overtuigende rechtvaardiging voor het maken van onderscheid worden aanvaard; uit een oogpunt van verdediging van het gemaakte onderscheid is het dan voor de hand liggend dat dergelijke doelstellingen zullen worden verdoezeld en eventueel worden verborgen achter doelstellingen waarvan duidelijk is dat zij wel zwaarwegend zijn.

109. Dit geldt meer in het algemeen als een bijzonder punt van kritiek op de verplichting voor de rechter om het doel van het onderscheid vast te stellen: met name in de VS, waar het aantonen van een ontoelaatbare bedoeling door de eiser wordt gezien als een voorwaarde voor een toepassing van de rechtvaardigingstoets, wordt steeds opnieuw gewezen op de aan het vaststellen van het doel verbonden problemen (bijv. Scalia 1997, p. 30 en Ely 1980, p. 125). Helaas bieden deze auteurs geen goed alternatief voor de 
aangevoerd, zal een rechterlijk onderzoek naar de werkelijke bedoeling impliceren dat er twijfel bestaat over de integriteit van de bedoelingen van de verdedigende partij; tot een dergelijk onderzoek mag dan ook alleen worden overgegaan als daarvoor voldoende reden bestaat. ${ }^{110}$ Van belang is bovendien dat het vaak moeilijk is om de werkelijke bedoeling van het onderscheid te achterhalen, nu dit een inhoudelijk onderzoek verlangt naar de overwegingen en motieven die aan het maken van het onderscheid ten grondslag hebben gelegen."' Dit is vooral lastig wanneer er sprake is van een classificatie die is vastgesteld door het parlement of een ander wetgevend lichaam: zelfs wanneer in de parlementaire stukken een relatief duidelijke bedoeling is terug te vinden blijft het de vraag in hoeverre de daarin omschreven doelstelling de opvattingen van de verschillende individuele parlementariërs representeert. ${ }^{112}$ Een groter probleem is nog aanwezig wanneer de werkelijke doelstelling niet gemakkelijk uit documenten als de preambule of de wetsgeschiedenis kan worden afgeleid. De rechter moet dan al snel terugvallen op vage bronnen als de "collectieve overtuiging", hetgeen betekent dat de

toetsing: hoewel het niet nodig is om de doeltoets tot toetsingsingang in de eerste fase te nemen (zie daarover paragraaf 4.7 .1 ), is het onvermijdelijk om het doel te toetsen in het kader van de beoordeling van de rechtvaardiging. Hoewel de moeilijkheden bij het zoeken naar het doel zonder meer groot zijn, kan dus niet worden volstaan met de stelling dat de doeltoets achterwege moet worden gelaten; er zal daadwerkelijk een oplossing moeten worden gevonden voor de gesignaleerde problemen.

110. Vgl. Tussman/TenBroek 1949, p. 359 en 366/367 en Binion 1983, p. 442; de laatste wijst op het gevaar van een "process, necessarily characterized by innuendo, gossip and suspicion". Dit risico bestaat vooral wanneer de rechter de wederpartij ervan verdenkt een werkelijk onoirbare (bijvoorbeeld een duidelijk discriminatoire) doelstelling na te streven.

111. Bickel 1962, p. 214. Zie ook "Note" 1972, p. 141, waar deze moeilijkheid nog eens wordt benadrukt: "Since in each case both the "real", intended goal and the unintended goal are suggested by the same statutory terms and involve the same social or economic consequences, the Court's special knowledge could not have come merely from examining the statute or its consequences. The Court would have had to know or to conjecture what prompted the majority of the legislators to enact the legislation, using something like a motive test [...]".

112. Zie over deze problematiek diverse auteurs, m.n. Tussman/TenBroek 1949, p. 359, MacCallum 1966, p. 765 , Clark 1978, p. 974, Scalia 1997, p. 30 e.v. en Vogenauer 1997, p. 238/239. Zie specifiek over gelijke behandeling bijv. Alexander 1978, p. $937 / 938$ en Ely 1980, p. 125 e.v.; de laatste lijkt bij toetsing van gewone regels meer moeite te hebben met het zoeken van het doel in de wetsgeschiedenis dan bij ongelijke behandeling, zie p. 144.

Van belang is overigens dat in de literatuur de vraag is gesteld of de rechter alleen mag kijken naar de doelstelling van de regeling, of ook rekening mag houden met de motieven die hieraan ten grondslag liggen; zie voor een uitvoerige beschrijving van deze discussie Farrell 1992, p. 1-20; vgl. ook Bickel 1962 , p. 62. Met name wordt gesteld dat doelstellingen aangeven wat de wetgever beoogde te bereiken, maar niet waarom hij dit wilde; de "waarom"-vraag betreft het motief van de regeling (vgl. Clark 1978, p. 958: "One [...] can speak of having a purpose to do something because of a given motivation"). Gesteld is wel dat het weliswaar niet mogelijk is om de motieven van de wetgever te achterhalen, nu daarbij de problemen van het concept van de collectieve bedoeling een rol spelen, maar wel gekeken kan worden naar de objectieve doelstelling die door de wetgever werd nagestreefd (vgl. bijv. "Developments" 1969, p. 1091). Deze aanpak biedt echter geen oplossing. Weliswaar kan op een algemeen niveau worden gesteld dat er een verschil in abstractieniveau en objectiviteit bestaat (doelstellingen zijn concreter dan motieven en minder subjectief van aard), maar als het aankomt op de beoordeling van dit verschil in een concreet geval blijkt dat er sprake van een continuüm waarbij het omslagpunt van motieven naar doelstellingen niet duidelijk kan worden vastgesteld (vgl. Eisenberg 1977, p. 41 en Clark 1978, p. 958). Ook motieven kunnen immers worden beschouwd als doelstellingen, zij het dat het gaat om een soort onderliggende, meer individuele doelstellingen (Ely p. 1218-1221; vgl. in dit verband ook Leibholz 1924, p. 89). Het is daardoor erg gemakkelijk om motieven te vertalen in doelstellingen en andersom (vgl. "Note" 1970, p. 1887, voetnoot 1 en Clark 1978, p. 961). 
bedoeling van de wetgever moet worden afgeleid uit een combinatie van de diverse opvattingen van individuele parlementariërs. ${ }^{13}$ Vanzelfsprekend is dit een lastige methode om de precieze doelstelling van een regeling te achterhalen: in veel gevallen weten de parlementariërs zelf niet eens waarvoor zij precies stemmen, terwijl hun motieven om een wet aan te nemen divers en subjectief zullen zijn. ${ }^{14}$

Gezien deze moeilijkheden moet voorop worden gesteld dat het alleen noodzakelijk is om een onderzoek naar de "werkelijke" bedoeling van het onderscheid uit te voeren, wanneer het waarschijnlijk is dat er andere redenen voor het onderscheid bestaan dan door de wederpartij naar voren zijn gebracht. Een aanleiding tot het uitvoeren van een dergelijk onderzoek kan bijvoorbeeld aanwezig zijn wanneer de benadeelde partij op grond van feiten en omstandigheden aannemelijk heeft gemaakt dat er andere doelstellingen aan het onderscheid ten grondslag lagen dan is gesteld, of wanneer het bestaan hiervan uit de feiten van het voorliggende geval kan worden afgeleid. Daarbij kan worden aangenomen dat er bij een intensieve toetsing eerder aanleiding bestaat voor een nader onderzoek dan bij een marginale toetsing: rechterlijke terughoudendheid kan juist zijn uitdrukking vinden in het feit dat de rechter een rechtvaardigingstoets uitvoert aan de hand van de doelstellingen zoals die door de verdedigende partij naar voren zijn gebracht. ${ }^{113}$

\section{Wijze waarop het onderzoek naar het werkelijk doel plaats kan vinden}

Als de rechter heeft vastgesteld dat een nader onderzoek naar de doelstellingen van het onderscheid noodzakelijk is, rijst de vraag hoe aan een dergelijk onderzoek vorm moet worden gegeven. Bij normatieve classificaties kan daarbij, zoals hiervoor al is aangegeven, tot uitgangspunt worden genomen dat de rechter moet zoeken naar doelstellingen die tot uitdrukking komen in de tekst van de wet zelf, in de preambule of in de totstandkomingsgeschiedenis van de wet. Nu dergelijke teksten algemeen toegankelijk zijn verschaft een dergelijke werkwijze een zekere waarborg voor de objectiviteit en de controleerbaarheid van het rechterlijk onderzoek. ${ }^{116}$ Opgemerkt moet echter worden dat het zoeken van de doelstelling van het onderscheid in de formulering van de classificatie als zodanig, een mogelijkheid die in de literatuur soms is genoemd, niet wenselijk is. ${ }^{117}$ In een wettelijke regeling kan bijvoorbeeld zijn vastgelegd dat aan eigenaars van

113. Dworkin 1985 , p. 322

114. "Note" 1972 p. 141: "A major difficulty [...] is [...] that the motivations behind voting for a statute are as varied as all the possible consequences of the statute's enactment"; vgl. ook Bickel 1962, p. 62. Zoals Dworkin aangeeft wordt het bovendien moeilijker om via deze methode de bedoeling van een regeling te achterhalen naarmate het langer geleden is dat een regeling is aangenomen (1985, p. 322).

115. Zie over de verschillende vormen van toetsingsintensiteit en de wijze waarop deze kan worden bepaald paragraaf 5 van dit hoofdstuk.

116. Het gaat hierbij om de zogenaamde "geĩnstitutionaliseerde bedoeling"; vgl. Dworkin 1985, p. 320. Wanneer dit de gebruikelijke methode is of wordt om de doelstelling van een regeling te achterhalen, kan de wetgever hierdoor ook worden gestimuleerd om zijn doelstellingen duidelijker tot uitdrukking te brengen. Dit lijkt in ieder geval in de Verenigde Staten een gevolg te zijn geweest van een grotere rechterlijke aandacht voor de wettelijke doelstellingen in de jaren 30; zie daarover Cox 1966, p. 105.

117. "Note" 1972, p. 131, Scalia 1997, p. 17 (die stelt dat de bedoeling van de wetgever altijd in de tekst tot uitdrukking zal komen) en Tribe 1997, p. 65. Deze benadering houdt verband met de overtuiging dat de wetgever in de tekst van de wet meestal zal proberen zijn bedoeling zo goed mogelijk tot uitdrukking te laten komen; dit veronderstelt dat de wet een vorm van communicatic is, waarbij de doelstel- 
zware voertuigen een hogere motorrijtuigenbelasting wordt opgelegd dan aan eigenaars van lichte voertuigen. Uit een dergelijke regeling kan worden afgeleid dat het de bedoeling van de wetgever was om onderscheid te maken tussen zware en lichte voertuigen." ${ }^{\prime \prime}$ Een dergelijke "semantische" benadering levert op zichzelf duidelijkheid op over de meest directe doelstellingen van een ongelijke behandeling. ${ }^{119}$ Problematisch is echter dat juist deze meest directe doelstelling geen goed uitgangspunt biedt voor de toetsing van de redelijkheid van de classificatie. Met de enkele vaststelling dat het de bedoeling is om onderscheid te maken op grond van het gewicht van voertuigen is immers geen antwoord gegeven op de relevante vraag of de classificatie gerechtvaardigd is: daarvoor moet worden onderzocht waarom juist gewicht als onderscheidend criterium is gekozen. Voor een beoordeling van de gerechtvaardigdheid van het doel moet dus altijd worden gezocht naar de achterliggende reden voor de keuze van een bepaald onderscheidingscriterium. ${ }^{120}$

Wanneer het niet mogelijk is om de doelstelling op deze "institutionele" manier vast te stellen, dient de rechter de doelstelling op andere wijze te achterhalen. ${ }^{12}$ Zoals hiervoor al is aangegeven is het daarbij weinig zinvol om te kijken naar de "collectieve bedoeling" van de parlementariërs, nu die methode zelden duidelijkheid verschaft over de precieze redenen voor het maken van onderscheid. In de literatuur zijn echter diverse alternatieven naar voren gebracht die een vaststelling van het doel mogelijk maken. ${ }^{122}$ Door verschillende auteurs is gesteld dat de rechter in dit soort gevallen zelf de bedoeling van de bepaling kan (re)construeren aan de hand van de tekst van de wet, de wetsgeschiedenis, en de maatschappelijke omstandigheden en het politieke klimaat waarin de regeling tot stand is gekomen. ${ }^{123}$ Interessant is ook de wetsystematische methode, die inhoudt dat de rechter moet proberen de doelstelling van de regeling te achterhalen door deze in de context van andere regelgeving te plaatsen; uit de samenhang van wet-

lingen kunnen worden afgeleid uit datgene dat wordt gezegd. Zie kritisch over deze wijze van interpretatie ("semantic intent") Dworkin 1997, p. 11.

118. Vgl. "Note" 1972

119. Ely 1980 , p. $145-147$ ("naturally you suspect [...] that the law's motivation was that most naturally suggested by its terms [...]" (p. 147)). Zie ook Brest 1971, p. 121.

120. Vgl. Farrell 1992, p. 15 en "Note" 1978, p. 798. Een bijkomend probleem van deze benadering is dat deze de toetsing aan de hierna nog te bespreken vereisten van over- en underinclusiveness en van de geschiktheid vrijwel overbodig maakt. Zoals nog zal blijken betreffen de criteria van over-en underinclusiveness de aansluiting tussen het doel van de classificatie en de definitie van de groep waarop de classificatie betrekking heeft. Wanneer de definitie zelf als doel wordt gekozen zal deze aansluiting altijd perfect zijn. Hetzelfde geldt voor de geschiktheid: uit het gegeven voorbeeld wordt meteen al duidelijk dat het te bereiken doel (maken van onderscheid naar gewicht) altijd zal worden bereikt door de classificatie (lagere belasting voor lichte voertuigen dan voor zwaardere). Vgl. Tribe 1988, p. 1440, Loenen 1992, p. 222 en meer in het algemeen "Note" 1972, p. 128 en 131.

121. Het probleem van het ontbreken van een geìnstitutionaliseerde bedoeling kan worden opgelost door de wetgever te verplichten om in de betrokken wet of preambule aan te geven welke doelstellingen worden nagestreefd. Een nadeel hiervan is dat dit niet altijd tot concrete en heldere doelstellingen zal leiden, maar eerder tot vaag en algemeen geformuleerde doelen (Ely 1980, p. 129).

122. Zie o.a. "Note" 1972, p. 141 en Dworkin 1985, p. 322.

123. Deze methodiek is verdedigd door Dworkin, die het de "coherence theory" noemt (1985, p. 327). In vergelijkbare zin ook Brest 1971, p. 120/121; hij stelt bovendien dat veel informatie over het doel kan worden verkregen door te kijken naar andere regelgeving of juridische en politieke gebeurtenissen die plaatsvonden rond het tijdstip waarop de classificatie werd vastgesteld (p. 123). 
geving kan dan worden afgeleid wat de bedoeling van een specifieke regeling zal zijn geweest. ${ }^{124}$ Beide methoden, zeker wanneer zij in combinatie worden gebruikt, lijken voor de praktijk zeer bruikbaar. Een nadeel is echter dat zij een vrij vergaande mate van rechterlijke activiteit vergen. Het is dan ook alleen wenselijk om gebruik te maken van deze methoden wanneer de werkelijke doelstelling echt niet uit de tekst of de totstandkomingsgeschiedenis van de regeling zelf is af te leiden.

Tenslotte is in de literatuur gesteld dat voor het achterhalen van de doelstelling van een onderscheid moet worden gekeken naar de effecten van de regeling, nu de bedoeling van de wetgever meestal op het realiseren van deze effecten gericht zal zijn. ${ }^{125}$ Deze methode staat echter niet garant voor een juiste conclusie over de doelstellingen van een regeling. Er kan immers lang niet altijd worden vertrouwd op de vaardigheid van de wetgever om de gevolgen van zijn handelen te voorspellen: in een groot aantal gevallen zullen de door de wetgever gewenste gevolgen niet of in mindere mate worden gerealiseerd, zeker nu ook andere factoren dan alleen wetgeving het handelen van mensen bepalen. Bovendien wordt deze techniek minder betrouwbaar naarmate een wet al langer bestaat: in dat geval is het niet altijd meer vast te stellen of bepaalde omstandigheden inderdaad een direct effect waren van de wet. Wanneer met dergelijke restricties voldoende rekening wordt gehouden lijkt deze methode echter toch wel bruikbaar te zijn, zeker wanneer deze met de hiervoor besproken methode zou worden gecombineerd. ${ }^{126}$

Samenvattend kan dan ook worden gesteld dat de rechter zich bij het bepalen van het doel van het onderscheid in principe moet baseren op de doelstellingen zoals die door de wederpartij naar voren zijn gebracht. Zijn er goede redenen om te veronderstellen dat er daarnaast nog andere doelstellingen bestaan die voor de beoordeling van de gerechtvaardigdheid van de classificatie relevant zijn, dan kan de rechter een nader onderzoek instellen. Hij zal daarbij primair moeten kijken naar controleerbare bronnen waaruit de doelstelling van het onderscheid kan blijken, zoals de tekst van de regeling of de toelichting daarop. Levert dit onderzoek geen duidelijke resultaten op, dan zal hij het doel van het onderscheid moeten reconstrueren. Daarbij kan hij rekening houden met de wetssystematiek, de totstandkomingsgeschiedenis, de politieke en sociale omstandigheden waarin de regeling tot stand is gekomen en, onder bepaalde voorwaarden, de effecten die de regeling bewerkstelligd heeft. ${ }^{127}$

124. Vgl. Perelman 1963, p. 65.

125. "Note" 1970, met name p. 1893 en Farrell 1992, p. 33.

126. Dit is ook wat de auteur van de "Note" (1970) op het oog had: hij stelt dat er steeds moet worden gekeken naar een wisselwerking van de doelstelling zoals die tot uitdrukking komt in bijvoorbeeld wetsgeschiedenis en de effecten van de regeling. Zie de voorbeelden op p. 1894/1895.

127. Hiervoor is steeds gesproken over het achterhalen van de bedoeling bij normatieve classificaties (situatie 1). Ook in de situatie van concreet onderscheid zal de rechter echter moeten onderzoeken welke redenen of doelstellingen er aan de ongelijke behandeling ten grondslag lagen. In veel gevallen zal dit nog lastiger zijn dan bij normatief onderscheid: documenten waaruit de bedoeling met enige zekerheid kan worden afgeleid zullen hierbij vaak ontbreken, hoewel van bestuursorganen mag worden verwacht dat zij hun besluiten motiveren. Ook in dit soort gevallen zal de rechter voornamelijk af moeten gaan op de stellingen van de partijen. Wanneer hij zich genoodzaakt voeit een nader onderzoek naar het nagestreefde doel uit te voeren, zal hij zich vooral moeten baseren op de indicaties die de omstandighe- 


\subsubsection{Het gelijktijdig nastreven van verschillende doelstellingen (pluraliteit van doelstellingen)}

In het voorgaande is er steeds van uitgegaan dat er één duidelijke reden voor het maken van onderscheid kan worden vastgesteld. In de grote meerderheid van de gevallen, zeker wanneer het gaat om regelgeving, zullen er echter meerdere doelstellingen tegelijkertijd worden nagestreefd. In dit verband zijn er twee verschillende situaties denkbaar: het kan zijn dat de regeling is gericht op het verwezenlijken van verschillende doelstellingen met een min of meer gelijke waarde ${ }^{128}$, maar het is ook mogelijk dat de doelstellingen een verschillend gewicht hebben. ${ }^{129}$ In deze laatste situatie wordt er vaak een zeer algemeen doel vooropgesteld, zoals het verzekeren van openbare veiligheid, terwijl er tegelijkertijd enkele specifieke subdoelstellingen worden geformuleerd die aan dit doel onderschikt zijn; er bestaat dan een zeker hiërarchisch verband tussen de doelstellingen. ${ }^{130}$

In de meeste gevallen zal de rechter de verschillende doelstellingen in hun onderlinge samenhang bestuderen: het is immers het samenstel van doeleinden dat heeft geleid tot het aannemen van een maatregel, niet de afzonderlijke doelstellingen als zodanig. ${ }^{131} \mathrm{Bij}$ pluraliteit van doelstellingen kunnen zich echter problemen voordoen, bijvoorbeeld

den van het geval geven en op zijn eigen ervaring. Vgl. Bezzenberger 1996, p. 431 en 432, die benadrukt dat de ervaring in een groot aantal gevallen heeft geleerd wanneer het waarschijnlijk is dat er een onoorbare bedoeling aan een bepaalde handeling ten grondslag heeft gelegen. Dit geldt met name in standaardgevallen van onderscheid op grond van geslacht of ras, nationaliteit, etnische afkomst of huidskleur. Vgl. ook Leenders 1997, p. 254. Bovendien kan ook in dit soort gevallen gebruik worden gemaakt van de methode van (re)constructie van de doelstellingen.

128. Een voorbeeld wordt gegeven door Farrell, die wijst op de Amerikaanse Foot Stamp Act of 1964 (1992, p. 17/18). Op basis van deze wet werden een soort voedselbonnen aan minvermogenden verstrekt, om op die manier de voeding van gezinnen met lage inkomens te verbeteren en tegelijkertijd de landbouweconomie te bevorderen door de distributie van overschotten van bepaalde producten. Geen van beide doelstellingen leek daarbij belangrijker te zijn dan de andere.

129. Zie Sundberg-Weitman 1980, p. 49 e.v.; vgl. ook Green 1998, p. 444, die stelt dat er bij regelgeving sprake zal zijn van een soort "concentrische cirkels" van doelstellingen, waarbij de ruimste cirkel de meest algemene doelstelling is die dan vervolgens wordt ingevuld door smallere cirkels die nauwkeurigere doelstellingen representeren.

130. Een goed voorbeeld is gegeven door Sundberg-Weitman, die wijst op een regeling die de taalkwestie op Belgische scholen beoogde op te lossen door in sommige gebieden alle scholen Nederlandstalig te laten zijn en in andere gebieden Franstalig. Zij onderscheidt daarvoor de volgende doelstellingen, die in een hiërarchisch verband staan: "a) Secure peace and order; b) Ensure a state of equilibrium between the two linguistic groups (means in relationship to a)); c) Ensure that, apart from the existing Frenchspeaking élite, there would also be a Flemish-speaking élite (means in relationship to a) and b)); d) Encourage Flemish-speaking education and discourage French-speaking education in certain regions (means in relationship to a), b) and c))" (1980, p. 49). In dit geval wordt de ongelijke behandeling dus zowel gesteund door een heel specifieke doelstelling, maar ook door ruimere, met de specifieke doelstelling verband houdende doelstellingen. Zie nader Green 1998, p. 445, die stelt dat de keuze voor het juiste "level of generality" door de rechter ook van belang is in een ander verband: hij geeft aan dat het in het algemeen gemakkelijker zal zijn om een redelijke verhouding tussen doelstelling en onderscheid aan te tonen naarmate de doelstelling specifieker is geformuleerd. Het is bij ruimere doelstellingen namelijk niet altijd gemakkelijk om aan te tonen dat voldaan is aan het subsidiariteitsvereiste. Ook om die reden is het van belang dat de rechter zorgvuldig vaststelt welke doelstellingen er met een bepaald onderscheid worden nagestreefd en dat hij zich bewust is van het "level of generality" waarop deze doelstelling zich bevindt (Green 1998, p. 449); zie ook Gottlieb 1988, p. 963.

131. Vgl. Nagel 1972, p. 126/127. 
wanneer één of meer van de vastgestelde doelstellingen ongerechtvaardigd moeten worden geacht, terwijl de andere doelstellingen heel redelijk zijn. In dit soort gevallen is het de vraag wanneer de rechter de conclusie kan bereiken dat het onderscheid ontoelaatbaar is.

$\mathrm{Bij}$ de beantwoording van deze vraag moet volgens de literatuur onderscheid worden gemaakt tussen de situatie waarin er verschillende doelstellingen met gelijk gewicht worden nagestreefd en de situatie waarin er sprake is van hoofd- en subdoelstellingen. In het eerste, in de praktijk vrij zeldzame, geval is het volgens de betreffende auteurs niet problematisch als één of meer van de doelstellingen ongerechtvaardigd zijn: de overige doelstellingen kunnen het onderscheid dan immers dragen, ook wanneer de ongerechtvaardigde doelstelling weg zou vallen. ${ }^{132}$ Deze stelling is echter niet vanzelfsprekend. Aangenomen kan immers worden dat juist de combinatie van doelstellingen vaak een doorslaggevend argument vormde voor het maken van onderscheid, terwijl de individuele doelstellingen als zodanig geen voldoende rechtvaardiging voor het onderscheid zouden vormen. Bovendien is het de vraag of de stelling ook op zou gaan wanneer (bijvoorbeeld) drie van vier gelijkwaardige doelstellingen ongerechtvaardigd zouden worden geacht. Gesteld moet dan ook worden dat de rechter in deze situatie nauwkeurig moet kijken naar de omstandigheden van het geval. Vormen de verschillende doelstellingen, ook bij het wegvallen van één of minder ongerechtvaardigde doeleinden, nog steeds een overtuigende rechtvaardiging, dan is het onderscheid toelaatbaar. Kunnen de overblijvende doelstellingen het onderscheid onvoldoende dragen, dan moet het onderscheid ongerechtvaardigd worden geacht. ${ }^{13}$

In de literatuur is aangegeven dat er een andere methodiek zou moeten worden gekozen in de tweede situatie, waarin er sprake is van een hiërarchisch verband tussen de verschillende doelstellingen. Zo is betoogd dat in dat geval niet alleen het hoofddoel, maar ook alle subdoelstellingen gerechtvaardigd moeten zijn. Zou een andere opvatting worden aangehangen, dan zou het te gemakkelijk zijn om een ongerechtvaardigde bedoeling te verbergen achter een algemeen geformuleerde hogere doelstelling: in de meeste gevallen geldt dat een algemene of abstracte doelstelling minder moeilijk is te rechtvaardigen dan een specifieke, eng geformuleerde, doelstelling. ${ }^{134}$ Hoewel dit laatste zeker juist is lijkt het niet wenselijk om deze daaraan verbonden conclusie over te nemen. Er zijn immers gevallen denkbaar waarin de gerechtvaardigde doelstellingen van

132. Vgl. Ely 1980 , p. 146. Green suggereert echter dat het soms denkbaar is dat een belang zo duidelijk ongerechtvaardigd is dat het een regeling ontoelaatbaar maakt, al zijn er ook andere doelstellingen die wel gerechtvaardigd zijn (1998, p. 471). Inderdaad is dit denkbaar, maar in de praktijk zal dit niet vaak voorkomen, zoals Green zelf ook toegeeft.

133. Overigens is dit een beoordeling die pas plaats kan vinden na de toetsing van de proportionaliteit, omdat hierbij het gewicht van de nagestreefde belangen een belangrijke rol speelt. In de praktijk zal eerst moeten worden nagegaan of er sprake is van een redelijke verhouding tussen het gekozen middel (het gemaakte onderscheid) en de resterende, gerechtvaardigde doelstellingen; pas als dit het geval is kan worden beoordeeld of het onderscheid gerechtvaardigd is.

134. Zo zal iedereen het er in het hiervoor gegeven voorbeeld van de taalwetgeving in Belgiè over eens zijn dat het nastreven van vrede en het voorkomen van wanordelijkheden een wenselijke en nastrevenswaardige doelstelling is. Over de toelaatbaarheid van de wens om naast een Franstalige elite ook een Nederlandstalige elite te hebben is al heel wat meer discussie mogelijk, al is het maar omdat de redelijkheid van een dergelijke wens veel moeilijker is vast te stellen dan die van algemeen geaccepteerde doelstellingen als "veiligheid en het voorkomen van wanordelijkheden". 
een regeling zo belangrijk zijn dat de regeling in stand moet worden gehouden, ook al worden er tegelijkertijd ontoelaatbare, aan dit doel ondergeschikte, doelstellingen nagestreefd. ${ }^{115}$ Het is dan ook beter om in deze situatie dezelfde methodiek te hanteren als bij de doelstellingen van vergelijkbaar gewicht, hetgeen betekent dat de rechter per geval moet onderzoeken of de maatregel ook gerechtvaardigd zou zijn wanneer de ontoelaatbare doelstelling zou wegvallen. ${ }^{136}$

\subsubsection{Inhoudelijke beoordeling van de gerechtvaardigdheid van het doel}

\section{Inleiding}

Wanneer de rechter eenmaal heeft vastgesteld welke doelstellingen er aan het litigieuze onderscheid ten grondslag liggen, zal hij de vraag moeten beantwoorden of deze ook daadwerkelijk gerechtvaardigd zijn. Dit is vooral bij normatieve classificaties een beoordeling die de grenzen van de rechterlijke bevoegdheid dicht nadert. Feitelijk wordt hierbij immers van de rechter verwacht dat hij een inhoudelijk oordeel uitspreekt over de legitimiteit en redelijkheid van de doelstellingen die door de wetgever zijn vastgesteld. ${ }^{137}$ Ook in de andere situaties van onderscheid is het echter niet zonder meer aanvaardbaar dat de rechter een oordeel geeft over de toelaatbaarheid van de nagestreefde doelstellingen. Wanneer er sprake is van een ongelijkheid bij een administratieve bevoegdheidsuitoefening komt de rechter door een dergelijke toetsing al snel terecht in het vaarwater van het betrokken bestuursorgaan (hetgeen vooral problematisch is wanneer dit orgaan over een ruimte mate van bestuurlijke discretie beschikt), terwijl hij bij de toetsing van onderscheid in horizontale verhoudingen terdege rekening zal moeten houden met de individuele beslissingsvrijheid. ${ }^{138}$ In deze paragraaf zal aandacht worden besteed aan de vraag op welke manier de rechter een inhoudelijke toetsing van het doel kan uitvoeren, zonder daarbij de grenzen van zijn bevoegdheden te overschrijden.

\section{Toetsing aan het geschreven recht; afwijking hiervan in bijzondere gevallen}

Het is van belang om vast te stellen dat niet iedere toetsing van het doel bijzondere problemen zal opleveren vanuit het oogpunt van de rechterlijke bevoegdheid. Binnen de grenzen van de bevoegdheid valt in ieder geval duidelijk de beoordeling of een doelstelling in strijd is met het geschreven recht, zoals formele wetgeving, de Grondwet en verdragsbepalingen: het is algemeen aanvaard dat een dergelijke toetsing be-

135. Vgl. "Note" 1970, p. 1890/1891.

136. Deze methodiek komt ook voldoende tegemoet aan het door Sundberg-Weitman gesignaleerde probleem, omdat immers moet worden nagegaan of de doelen die overblijven na het wegstrepen van de ontoelaatbare doelstellingen het onderscheid voldoende kunnen rechtvaardigen. De criteria twee tot en met vijf (die vorm geven aan de toetsing van de verhouding tussen doel en onderscheid) bieden voldoende aanknopingspunten om deze draagkracht te testen, zodat het gevaar dat een maatregel op ontoereikende gronden in stand wordt gehouden in de praktijk nauwelijks aanwezig zal zijn.

137. Brest 1971, p. 129/130. Dit wordt vooral problematisch geacht vanuit de democratische gedachte: het is de volksvertegenwoordiging die de wetgeving, en daarmee de doelstellingen daarvan, heeft vastgesteld, en deze wetgeving mag inhoudelijk niet zomaar op zijn redelijkheid worden beoordeeld door de niet democratisch gelegitimeerde rechter. Ook wordt wel gesteld dat hierdoor inbreuk wordt gemaakt op het politieke proces dat aan de besluitvorming ten grondslag ligt, terwijl dat veel beter in staat zou zijn tot het bepalen van de wenselijkheid van bepaalde regelgeving dan de rechter. Zie o.a. Bickel 1962, p. 16.

138. Brest 1971, p. 128/129 
hoort tot de normale taak van de rechter. ${ }^{139}$ Zeker wanneer wordt aangenomen dat het geschreven recht kan worden uitgelegd aan de hand van algemene en ongeschreven rechtsbeginselen of fundamentele waarden kan dit bovendien worden beschouwd als een vrij ruime toetsingsgrond. In de meeste gevallen zal de rechter dan ook kunnen volstaan met een toetsing van het onderscheid aan het geschreven recht.

Het is echter de vraag of de rechter verder mag gaan en, los van het positieve recht, mag oordelen dat bepaalde doelstellingen ongerechtvaardigd zijn. Op zichzelf is dit niet wenselijk: niet alleen is dit problematisch in het licht van de verhouding van de rechter tot de democratisch gelegitimeerde wetgever, maar ook is het beter wanneer de rechter zijn oordeel baseert op de duidelijke maatstaven en regels die in het geschreven recht zijn neergelegd dan dat hij geheel zelfstandig nagaat of een doelstelling volgens hem wenselijk en redelijk is. ${ }^{140}$

Een volledige beperking tot een toetsing aan het geschreven recht is in sommige omstandigheden echter te beperkt. Van belang is namelijk dat de rechter rekening zal moeten houden met veranderingen in opvattingen die zich in de samenleving voordoen. Wanneer er een duidelijke consensus is gegroeid over de afwijsbaarheid van een bepaalde doelstelling, is het wenselijk dat de rechter zich daaraan conformeert, ook al was de doelstelling op het moment waarop de maatregel tot stand kwam volledig in overeenstemming met het geldende recht. ${ }^{1+1}$ Een verdergaande opvatting luidt dat er in

139. Scheltema 1989 (II), p. 86; zie ook De Lange 1991, p. 31 en Perelman 1963, p. 82. In sommige gevallen wordt hierop een uitzondering gemaakt: zo verbiedt artikel 120 van de Nederlandse grondwet de nationale rechter na te gaan of wetgeving in overeenstemming is met de grondwet: het wordt aan de wetgever overgelaten om te bepalen of een inbreuk op de door de grondwet beschermde rechten (binnen de door de grondwet gestelde grenzen) al of niet toelaatbaar is. In de VS wordt daarentegen tot algemeen uitgangspunt genomen dat de grondwet nu juist bedoeld is om de allerbelangrijkste rechten te beschermen, en dat ook de wetgever hierop geen inbreuk mag maken; het wordt aan de rechter overgelaten om als onafhankelijke instantie na te gaan of daarvan sprake is (zie bijv. Berrett: "[...] we have long agreed that the only way to protect those interests is to require that the special justification for legislative burdens be made in the courts" (1980, p. 847)).

140. Leijten 1981, p. 108; vgl. ook Bickel 1962, p. 55, De Lange 1991, p. 102 en Dworkin 1985, p. 16. In de richting van vrije rechtsvinding wijzen de opvattingen van Schoordijk: hij stelt dat de enige grens voor de rechter is gelegen in de mogelijkheid van het inpassen van zijn waardeoordelen in een open systeem, hetgeen betekent dat de rechter zijn waardeoordeel in overeenstemming zal moeten brengen met de eerder al door de praktijk of de theorie gegeven waardeoordelen; dit betekent dat hij nauwelijks gebonden is aan de wet en zelfs niet aan de systematiek daarvan (1972, p. 15 en p. 27). Een dermate vergaande vrijheid voor de rechter is echter moeilijk in overeenstemming te brengen met het toch zeer valide argument dat hij niet beschikt over een democratische legitimatie. Zelfs de hierna nog te bespreken theorie waarin het democratieargument niet op de voorgrond staat, maar eerder wordt uitgegaan van een theorie van checks en balances, laat weinig ruimte voor een dergelijke vergaande redenering.

141. Zie bijvoorbeeld Leijten 1981, p. 71 en ook Schoordijk 1972, p. 41. Deze problematiek doet zich in de praktijk met enige regelmaat voor. Zo hebben rechters vooral in de jaren 80 en 90 een flinke klus gehad aan het verwijderen uit het familierecht van ongelijke behandelingen van onwettig geboren kinderen en ongehuwd samenwonenden, die er in dezelfde eeuw nog vol overtuiging over de redelijkheid van dit soort onderscheid waren ingezet. Daarbij moet wel worden aangetekend dat het voor de rechter bijzonder moeilijk zal zijn om nieuwe maatschappelijke ontwikkelingen te signaleren, met name omdat hij in mindere mate dan de wetgever beschikt over maatschappelijke "voelhoorns"; Ely 1980, p. 63-69. Ook Schoordijk, normaal gesproken een aanhanger van vergaande autonomie voor de rechter, signaleert dit probleem: hij stelt dat de pluriformiteit van waardeoordelen in de samenleving steeds meer toeneemt, zodat het voor de rechter bijzonder moeilijk is om een juiste keuze te maken (1972, p. 41). 
sommige omstandigheden ook een taak voor de rechter kan bestaan om in te grijpen wanneer nog geen sprake is van een "nieuwe" maatschappelijke consensus. Hoewel het in het laatste geval aangewezen lijkt om de democratisch gelegitimeerde instellingen de kans te geven om te reageren op de maatschappelijke veranderingen en ontwikkelingen, blijkt het politieke proces, door pressie van invloedrijke groeperingen of door andere oorzaken, soms onvoldoende in staat om op adequate wijze op te treden. ${ }^{142}$ In die omstandigheden kan redelijk zijn dat de rechter zowel het geschreven recht als de maatschappelijke consensus terzijde schuift. Van belang is namelijk dat de rechter weliswaar rekening moet houden met zijn positie ten opzichte van de democratisch gelegitimeerde instellingen, maar dat hij daarnaast een plicht heeft om rechtsstatelijke belangen te beschermen. ${ }^{143}$ Op basis van die verplichting zal hij mogen afwijken van het geschreven recht als het democratisch proces niet voldoende in staat blijkt te zijn de rechtsstatelijke belangen voldoende te beschermen.

Een situatie waarin het voor de rechter toelaatbaar is om in te grijpen was duidelijk zichtbaar in de Verenigde Staten halverwege de twintigste eeuw. Op dat moment waren de meeste publieke voorzieningen gesegregeerd overeenkomstig de "separate but equal"-doctrine, die inhield dat er geen sprake was van een schending van het gelijkheidsbeginsel door het instellen van aparte, maar gelijkwaardige, voorzieningen voor blanken en Afro-Amerikanen. ${ }^{14}$ Hoewel in de loop van de twintigste eeuw steeds duidelijker werd dat de rechten en belangen van Afro-Amerikanen door het gesegregeerde systeem ernstig werden aangetast en dat er bovendien van een gelijke kwaliteit van voorzieningen geen sprake was, bestond er gedurende lange tijd grote verdeeldheid over de afschaffing van de segregatie. Met name de zuidelijke staten en bepaalde pressiegroepen verzetten zich hevig tegen ieder voornemen tot desegregatie, zodat er op

\section{Schoordijk 1972 , p. 45}

143. Zoals is aangegeven door Tussman en TenBroek bestaat er een belangrijk verschil van opvatting over de verhouding tussen rechter en wetgever (1949, p. 365/366). Enerzijds is er de functionele opvatting, die radicaal verschil in taakstelling tussen rechter en wetgever ziet; wanneer de rechter zich met dezelfde vraagstukken gaat bezighouden als waarop de wetgever zijn pijlen heeft gericht, is er in die opvatting sprake van een ernstige doorkruising. Een fervent aanhanger van deze opvatting is Scalia (zie bijv. 1997, op p. 20: "Congress can enact foolish statutes as well as wise ones, and it is not for the courts to decide which is which and rewrite the former", zie ook p. 23); vgl. verder Perelman 1963, p. 63 en Bickel 1962, p. 16/17 (" [...] when the Supreme Court declares unconstitutional a legislative act or the action of an elected executive, it thwarts the will of the representatives of the actual people of the here and now; it exercises control, not in behalf of the prevailing majority, but against it. That, without mystic overtones, is what actually happens [...] [...] [1]t is the reason the charge can be made that judicial review is undemocratic"). Daartegenover staat een andere opvatting, die de verhouding tussen rechter en wetgever vooral ziet als een systeem van checks en balances. In deze opvatting is de doelstelling van iedere democratie dat de overheid een ieder behandelt met gelijk respect en gelijke zorg. Deze doelstelling kan worden gegarandeerd door eenieder die daartoe het best in staat is. Daarbij geldt bijvoorbeeld dat de instellingen die bij meerderheid besluiten nemen, zoals het parlement, dit mogen doen zolang ze de democratische doelstelling proberen te realiseren; doen zij dit niet, dan kan er vanuit deze opvatting van democratie geen bezwaar zijn tegen andere procedures of instellingen die de democratische basisvoorwaarden beter respecteren en waarborgen. Deze theorie is ontwikkeld en beschreven door Dworkin (1996, p. 16/17; de rol van de rechter wordt beschreven op p. 32/33). Zie voor vergelijkbare opvattingen over de "rechtsstatelijke" rol van de rechter 0. a. Koopmans in zijn nabeschouwing bij Wiarda 1999, p. 134, Ely 1980, p. 77, Bezzenberger 1996, p. 397 e.v. en Leibholz 1925, p. 124.

144. Deze doctrine was door het Amerikaanse Supreme Court in 1896 uitdrukkelijk grondwettig verklaard in de uitspraak Plessy v. Ferguson, 163 U.S. 537 (1896). 
politiek niveau zeker op korte termijn geen oplossingen te verwachten waren. Uiteindelijk greep het Supreme Court in door te oordelen dat segregatie van bepaalde openbare voorzieningen in strijd was met het in de Amerikaanse constitutie neergelegde gelijkheidsbeginsel. De belangrijkste reden hiervoor was dat de voorzieningen waarom het hier ging, zoals onderwijs, van fundamenteel belang voor het individu werden geacht. Op dit fundamentele belang werd door segregatie een ontoelaatbare inbreuk gemaakt, nu de voorzieningen voor Afro-Amerikanen in het algemeen inferieur waren en, in het geval van onderwijs, aan kinderen het belangrijke voorrecht werd ontnomen om gezamenlijk naar school te gaan. ${ }^{\text {is }}$

Het risico van meerderheidsopvattingen die zijn ingegeven door vooroordelen of stereotypen, of door een gebrek aan respect voor de rechten van minderheden, is op het gebied van gelijke behandeling zeer duidelijk aanwezig: gewezen kan niet alleen worden op het voorbeeld van de achterstelling van Afro-Amerikanen in de VS, maar ook op de vooroordelen en stereotypen die de positie van groepen als homoseksuelen, onwettige kinderen en vrouwen in veel landen nog steeds bepalen. Om die reden moet het wenselijk worden geacht dat de rechter bij de toetsing van de doelstelling van een discriminatoire regeling niet alleen rekening houdt met het geschreven recht, maar ook met ongeschreven fundamentele waarden en beginselen ${ }^{146}$ en met de ontoelaatbaarheid van de wens tot de uitsluiting van bepaalde groepen van een volwaardige maatschappelijke en politieke participatie. ${ }^{147}$

Concluderend kan worden gesteld dat de rechter het doel van het onderscheid primair zal moeten toetsen aan het geschreven recht. Wanneer echter duidelijk is dat er een

145. Brown v. Board of Education, 347 U.S. 483 (1954); overigens kwam deze uitspraak iets minder onverwacht dan vaak wel werd gesteld: het Supreme Court had in enkele eerdere zaken al uitspraken gedaan waaruit bleek dat segregatie in bepaalde omstandigheden tot een zodanige benadeling van zwarte studenten kan leiden dat de segregatie moet worden doorbroken. In de rechtspraak waren dus al duidelijke aanwijzingen zichtbaar dat de "separate but equal"-doctrine enigszins aan gezag begon in te boeten. Zie nader Missouri ex rel. Gaines v. Canada, 305 U.S. 337 (1938), Sipuel v. Board of Regents, 332 U.S. 631 (1948) en Sweatt v. Painter, 339 U.S. 629 (1950).

146. Zie Wright 1980, p. 17 en 18; hij geeft aan dat het juist om deze reden in het algemeen redelijker is om bij ongelijke behandeling verdergaande vrijheid aan de rechter te laten dan bij andere grondrechten.

147. Wel moet er een relativerende kanttekening worden geplaatst bij de rol die de rechter kan spelen bij de bescherming van minderheden en grondrechten: ook bij een grote rechterlijke vrijheid zullen onredelijke en willekeurige ongelijke behandelingen niet kunnen worden vermeden. Weliswaar kan door de rechterlijke controle het risico worden verminderd dat de meerderheid de minderheid op een ongerechtvaardigde manier benadeeit, maar andersom bestaat evenzeer het risico dat de rechter een verkeerde en gecorrumpeerde beslissing neemt door een goede en rechtvaardige wet buiten toepassing te laten. Dit betekent dat noch een vergaand autonome, noch een sterk aan de wet gebonden vorm van toetsing altijd een waarborg vormt voor een goede en rechtvaardige uitkomst. Dit geldt zeker wanneer het waardensysteem in een land volkomen gecorrumpeerd is geraakt, bijvoorbeeld door overheersing van een ideologie als het nationaal-socialisme: Leijten 1981, p. 117. Eenzelfde gedachte komt naar voren in de uitspraak van Schoordijk dat "het [...] een nairef misverstand omtrent functie en mogelijkheden van een juridische methodologie [is], te veronderstellen dat deze het gerechtigheidsgehalte van uitspraken op hun waarde zou kunnen beoordelen" (1972, p. 28). Van belang is bovendien dat een rechtstreekse toetsing aan fundamentele beginselen en waarden bijzonder lastig is, al is het maar omdat het soms moeilijk is om vast te stellen wanneer een beginsel zodanig fundamenteel is dat het moet prevaleren boven het positieve recht en boven de opvattingen van de meerderheid. Zo is het alleen al moeilijk om te bepalen wanneer er een fundamenteel beginsel aanwezig is: tegen veel bronnen van fundamentele rechten (traditie, het natuurrecht, de rede) zijn bezwaren in te brengen (zie daarover uitgebreid Ely 1980, p. 43 e.v.). 
maatschappelijke consensus is ontstaan waaruit blijkt dat de doelstelling, ook buiten het positieve recht om, niet meer als toelaatbaar kan worden aangemerkt, zal de rechter over de bevoegdheid moeten beschikken om het geschreven recht buiten beschouwing te laten en de doelstelling ontoelaatbaar te bevinden. In uitzonderlijke gevallen kan tenslotte worden gesteld dat hij deze bevoegdheid zelfs heeft wanneer een duidelijke maatschappelijke consensus ontbreekt, namelijk in het geval waarin door het nastreven van bepaalde doelstellingen inbreuk wordt gemaakt op fundamentele rechten of beginselen, of wanneer wordt gestreefd naar een uitsluiting van bepaalde groepen van een volwaardige maatschappelijke en politieke participatie. Het zal echter duidelijk zijn dat het aantal gevallen waarin de rechter van het geschreven recht mag afwijken niet bijzonder groot is. Gesteld moet bovendien worden dat in die gevallen hoge eisen moeten worden gesteld aan de zorgvuldigheid en overtuigingskracht van de motivering. ${ }^{\text {14s }}$

\subsection{Toetsing van de verhouding tussen doel en middel}

\subsubsection{Inleiding}

Wanneer de rechter heeft vastgesteld dat er sprake is van een gerechtvaardigd doel zal hij vervolgens moeten nagaan of het redelijk is om dit doel te bereiken door middel van het maken van onderscheid. De elementen 2 tot en met 5 van het model (over- en underinclusiveness, geschiktheid, subsidiariteit en proportionaliteit) hebben op deze verhouding tussen doel en middel betrekking. Het model is daarbij zodanig opgebouwd dat het onderscheid ontoelaatbaar moet worden geacht, zodra de rechter bij de toetsing aan een van de criteria tot de conclusie komt dat daaraan niet is voldaan. Kan een onderscheid de toetsing aan een specifiek criterium wel doorstaan, dan betekent dit echter nog niet dat het onderscheid ook gerechtvaardigd is: die conclusie kan pas worden getrokken wanneer aan alle criteria is getoetst.

In de hiernavolgende paragrafen zullen de verschillende toetsingscriteria worden besproken, waarbij bovendien zal worden nagegaan op welke manier de rechter hieraan zou moeten toetsen en in hoeverre hij daartoe de bevoegdheid heeft.

\subsubsection{Over-en underinclusiveness of de toetsing van de mate van fit}

\section{Inhoud van het toetsingscriterium}

De toetsing van de over- of underinclusiveness van het onderscheid (ook vaak omschreven als de mate van fit) heeft betrekking op de mate van aansluiting van de definitie van de classificatie op het doel van een maatregel. ${ }^{149} \mathrm{Zo}$ is het mogelijk dat de groep aan wie door de maatregel bepaalde lasten worden opgelegd of waaraan bepaalde voordelen worden toegekend te ruim is gedefinieerd om het nagestreefde doel te berei-

148. Vanzelfsprekend geldt dat er eerder ruimte zal bestaan voor een toepassing van deze theorie wanneer er een strikte toetsing wordt uitgevoerd (bijvoorbeeld omdat er onderscheid is gemaakt op een verdachte grond of omdat er een fundamenteel recht is aangetast; zie daarover paragraaf 5 van dit hoofdstuk), dan wanneer er marginaal wordt getoetst.

149. Zie voor een uitstekende uitleg van deze begrippen en een fraai schematisch overzicht Tussman/TenBroek 1949, p. 346-348. In het hiernavolgende zal gebruik worden gemaakt van de Amerikaanse terminologie, aangezien voor de begrippen over- en underinclusiveness geen goed Nederlands equivalent bestaat dat net zo kort en duidelijk aangeeft waar het om gaat. 
ken (overinclusiveness). ${ }^{150}$ Een voorbeeld is een regeling die zware lichamelijke arbeid voor vrouwen verbiedt ten behoeve van de bescherming van de volksgezondheid. Deze maatregel is overinclusive, nu er een groot aantal vrouwen zal bestaan wier gezondheid niet onder zware lichamelijke arbeid zal lijden. Om het doel, bescherming van de volksgezondheid, te bereiken is de maatregel dus te ruim geformuleerd: de reikwijdte had beperkt kunnen worden tot die vrouwen die niet zonder gevaar voor hun gezondheid in staat zijn tot het verrichten van zware lichamelijke arbeid.

Een dergelijke, te ruime formulering van de classificatie kan voor de betrokken groep benadelend werken; zo wordt het in het gegeven voorbeeld voor een groot aantal vrouwen onmogelijk gemaakt de arbeid van hun keuze te verrichten. Overinclusiveness is vooral problematisch wanneer een maatregel een nadeel of beperking oplegt; wanneer een voordeel wordt toegekend aan een te grote groep zal er wel sprake zijn van een gebrek in de definitie, maar hierover zal in de meeste gevallen niet snel worden geklaagd. ${ }^{151}$

Aan de andere kant is het mogelijk dat een classificatie te eng is gedefinieerd, zodat er sprake is van underinclusiveness. ${ }^{132}$ In dat geval is de reikwijdte van een maatregel beperkt tot een bepaalde groep van gevallen of personen, terwijl een andere, ten opzichte van het nagestreefde doel vergelijkbare, groep buiten de reikwijdte van de regeling valt. ${ }^{133}$ Ook hierbij kan de regeling die zware lichamelijke arbeid voor vrouwen verbiedt als voorbeeld dienen. Door deze maatregel worden alle mannen van de bescherming uitgesloten, ook wanneer zij lichamelijk niet in staat zijn tot het verrichten van zware lichamelijke arbeid. Uit dit voorbeeld blijkt dat underinclusiveness vooral problematisch zal zijn wanneer de betrokken maatregel een voordeel verschaft; het is niet waarschijnlijk dat er snel zal worden geklaagd wanneer een nadeel aan een te eng gedefinieerde groep wordt opgelegd.

Hoewel er verschillen zijn in de specifieke aard van de tekortkoming en in de omstandigheden waarin hierover zal worden geklaagd, zien overinclusiveness en underinclusiveness op een vergelijkbaar defect: een tekortkoming in de nauwkeurigheid van de definitie van de classificatie ten opzichte van het nagestreefde doel. Het komt dan ook in een zeer groot aantal gevallen voor, zoals ook in het gegeven voorbeeld, dat een

150. Feitelijk ontstaat daardoor een materieel ongelijke behandeling; zie daarover nader paragraaf 4.3 .

151. Een voorbeeld van een dergelijke regeling wordt gegeven door Bennett (1980, p. 1062/1063): wanneer de overheid besluit dat er fluor moet worden toegevoegd aan het drinkwater omdat dit de meest gemakkelijke manier is om ervoor te zorgen dat kinderen voldoende fluor binnenkrijgen, terwijl oudere mensen noch behoefte, noch hinder van fluor zullen ondervinden, dan is er weliswaar sprake van overinclusiveness (een groep die voor zijn gezondheid geen fluor nodig heeft zal dit door het drinken van kraanwater onvermijdelijk toch binnenkrijgen), maar omdat de nadelen hiervan minimaal zijn zal een klacht hierover niet in de rede liggen; zou dit wel het geval zijn, dan is het onwaarschijnlijk dat de klager de eerste fase van de toetsing (waarin wordt vastgesteld of er voldoende reden tot klagen bestaat) zal doorstaan.

152. Door Tribe zeer helder als volgt geformuleerd: "Underinclusive classifications do not include all who are similarly situated with respect to a rule, and thereby burden less than would be logical to achieve the intended government end" (1988, p. 1447).

153. Hierbij is feitelijk dus sprake van formeel ongelijke behandeling; zie voor een nadere uitwerking paragraaf 4.3 . 
maatregel beide defecten gelijktijdig vertoont, dat wil zeggen zowel over- als underinclusive is. ${ }^{\text {s4 }}$

Het is van groot belang dat de formulering van iedere classificatie zo goed mogelijk aansluit op het nagestreefde doel, dus dat de mate van over- en underinclusiveness minimaal is: alleen daardoor kan worden voorkomen dat mensen bepaalde voordelen ten onrechte niet ontvangen of dat zij ten onrechte worden belast of achtergesteld. ${ }^{\text {iss }}$ Het bestaan van onzorgvuldigheden in de definitie zal in de meeste gevallen zelfs de aanleiding zijn voor het aanspannen van een gerechtelijke procedure: juist door underof overinclusiveness bestaat er een nadeel voor een bepaalde persoon of groep. Opgemerkt moet echter worden dat de aansluiting tussen de gekozen classificatie en het nagestreefde doel nooit geheel perfect kan zijn: er zullen in de praktijk altijd individuele gevallen zijn die ten onrechte onder de reikwijdte van de classificatie vallen of daar juist buiten blijven. ${ }^{156}$ De enkele conclusie van onnauwkeurigheid van de definitie kan voor de uitkomst van de rechtvaardigheidstoets dan ook nooit bepalend zijn: alleen een mate van zorgvuldigheid die in het gegeven geval onaanvaardbaar is kan leiden tot een ontoelaatbaarverklaring van het gemaakte onderscheid. De precieze eisen die in een concreet geval kunnen worden gesteld aan de zorgvuldigheid zullen van geval tot geval verschillen. Deze eisen zullen vooral worden bepaald door de intensiteit van de toetsing die wordt uitgevoerd: zo kan een rechter bij een marginale toets al tevreden zijn met een redelijke mate van aansluiting, terwijl de te stellen eisen bij een intensieve toetsing aanzienlijk hoger kunnen zijn. ${ }^{157}$

\section{Gevallen waarin de over- en underinclusiveness kunnen worden getoetst}

Van belang is dat een toetsing van de zorgvuldigheid van de definitie niet altijd mogelijk is: voor deze toetsing bestaat uitsluitend ruimte bij de beoordeling van een normatieve classificatie. ${ }^{158}$ Er kan namelijk alleen een oordeel over de mate van fit worden gegeven wanneer er een bepaalde groep is uitgezonderd voor een bijzondere behandeling. In een dergelijk geval is het voor de beoordeling van de redelijkheid van deze

154. Vgl. Tussman/TenBroek 1949, p. 352.

155. Iedere classificatie verschaft immers voor een bepaalde groep een voordeel of nadeel dat een andere groep niet ten deel zal vallen; zie Minow 1990, p. 21 e.v.

156. Loenen 1992, p. 216; zie ook O'Fallon 1979, p. 52. Gesteld kan zelfs worden dat een "perfect fit" lang niet altijd wenselijk is: om goed beleid te kunnen voeren heeft de wetgever enige ruimte nodig. Zo kan een regeling die underinclusive is worden gerechtvaardigd door de stelling dat de wetgever de doelstelling niet in één keer wilde bereiken, maar dit in verschillende stappen beoogde te doen; daardoor kan een tijdelijke ongelijkheid optreden (vgl. Tussman/TenBroek 1949, p. 348). Zoals Tussman en TenBroek aangeven kan echter niet iedere underinclusiveness op deze manier worden gerechtvaardigd: hoewel de rechter oog moet houden voor het experimentele karakter van bepaalde regelgeving en voor de ruimte die een wetgever nodig heeft om goede regelgeving vast te stellen, moet gewaakt worden voor "an overconcern for mere "convenience"" (1949, p. 351).

157. Op de toetsingsintensiteit en de factoren die daarvoor bepalend zijn zal in paragraaf 5 van dit hoofdstuk worden ingegaan.

158. Zoals eerder is aangegeven is de groep van normatieve classificaties zeker niet beperkt tot classificaties in wetgeving: ook een algemene regeling op horizontaal niveau (bijvoorbeeld een bedrijfspensioenregeling of een regeling met betrekking tot functioneringsgesprekken in een onderneming) zal normatieve classificaties bevatten, net zoals algemene regelingen op administratief niveau, zoals in het geval van beleidsregels of uitvoeringsmaatregelen. 
uitzondering noodzakelijk dat de rechter nagaat of deze groep voldoende zorgvuldig is gedefinieerd in relatie tot het nagestreefde doel. Bij een ongelijke behandeling die is veroorzaakt door een concrete bevoegdheidstoepassing zal er nooit sprake zijn van een uitzondering van een groep: het gaat daarbij steeds om de nadelige behandeling van één enkel individu. Een beoordeling van de reikwijdte van de classificatie is daarbij vanzelfsprekend niet mogelijk.

Het voorgaande betekent dat het theoretische model niet in alle situaties van onderscheid volledig kan worden toegepast: een toetsing van de mate van fit is alleen bij de beoordeling van normatieve classificaties nodig. In gevallen van concrete bevoegdheidsuitoefening moet na de beoordeling van de gerechtvaardigdheid van het nagestreefde doel meteen worden getoetst aan het derde criterium van het toetsingsmodel: het geschiktheidsvereiste.

\subsubsection{Geschiktheid}

\section{Inhoud van de geschiktheidstoets en verhouding tot andere toetsingscriteria}

De toetsing van de geschiktheid van een ongelijke behandeling vereist een onderzoek naar de causaliteit tussen het nagestreefde doel en het middel dat is gekozen om dit doel te bereiken, namelijk het gemaakte onderscheid. Het lijkt redelijk om te stellen dat een onderscheid ontoelaatbaar is wanneer een voldoende mate van causaliteit ontbreekt, dat wil zeggen wanneer het nagestreefde doel met het gemaakte onderscheid niet kan worden bereikt. Een klacht over ongelijke behandeling zal immers alleen aan de rechter worden voorgelegd wanneer hierdoor belangen of rechten van een bepaald individu of een bepaalde groep zijn aangetast. Zoals al is aangegeven kan een dergelijke aantasting redelijk zijn wanneer met het onderscheid een voldoende zwaarwegend en gerechtvaardigd doel wordt nagestreefd. Wanneer echter blijkt dat deze doelstelling door middel van het maken van onderscheid helemaal niet bereikt kan worden, zal de maatregel feitelijk uitsluitend een belangenaantasting tot gevolg hebben. ${ }^{159}$ In dat geval kan er nooit een redelijk evenwicht bestaan tussen het nagestreefde doel en het gemaakte onderscheid, zodat in die gevallen het onderscheid ontoelaatbaar moet worden geacht. ${ }^{160}$

Juist vanwege het feit dat het geschiktheidsvereiste betrekking heeft op het evenwicht tussen het nagestreefde doel en de door het onderscheid aangetaste belangen wordt het in de literatuur vaak genoemd als een onderdeel van het vereiste van proportionaliteit,

159. Een dergelijke toetsing is met name nuttig omdat de rechterlijke toetsing pas zal plaatsvinden op het moment dat de classificatie al langer bestaat; vaak kon de verantwoordelijke op het moment van de inwerkingtreding nog niet voorspellen of het beoogde doel met het onderscheid inderdaad wel bereikt kon worden, terwijl op het moment van de rechterlijke toetsing kan blijken dat er sprake was van een miscalculatie; vgl. Bennett 1979, p. 1066.

160. Een voorbeeld is een regeling waarmee wordt geprobeerd het parkeerprobleem binnen een kleine studentenstad op te lossen. Omdat de gemeente vermoedt dat studenten de belangrijkste oorzaak zijn van dit probleem (zij gaan immers vaak met de auto naar college) wordt studenten verboden om overdag hun auto in de stad te parkeren; andere mensen mogen dit wel doen. Wanneer na een jaar blijkt dat het parkeerprobleem nog net zo groot is, kan worden gesteld dat de getroffen maatregel ongeschikt was om het beoogde doel te bereiken. In een dergelijk geval is het niet redelijk om studenten nog langer de mogelijkheid van parkeren te ontzeggen. 
net als het hierna te bespreken subsidiariteitsvereiste en het vereiste van proportionaliteit in strikte zin. Het is echter waardevol om geschiktheid, subsidiariteit en proportionaliteit in strikte zin als afzonderlijke toetsingsmaatstaven te beschouwen. ${ }^{161}$ Daardoor worden nauwkeuriger gedefinieerde aanknopingspunten geboden voor de rechterlijke toetsing, hetgeen de duidelijkheid en doorzichtigheid van de motivering ten goede zal komen: de uitsplitsing biedt de rechter de mogelijkheid om preciezer te kunnen aangeven op welke punten het onderscheid tekortschiet. ${ }^{162}$ Daarnaast kan worden gesteld dat het niet logisch is om criteria als geschiktheid en subsidiariteit onder de algemene noemer van evenredigheid te schuiven, nu het gaat om zelfstandige toetsingselementen met een eigen waarde en karakter. De toetsing van de oorzaak-gevolgrelatie zoals die plaatsvindt bij de toetsing aan het vereiste van geschiktheid verschilt bijvoorbeeld duidelijk van de hierna nog te bespreken proportionaliteitstoets in strikte zin, waarbij niet wordt gekeken naar het causale verband tussen doel en middel, maar wordt beoordeeld of er een redelijk evenwicht bestaat tussen de verschillende belangen die bij de besluitvorming een rol hebben gespeeld.

\section{Bevoegdheid van de rechter om de geschiktheid te beoordelen}

Net als bij de toetsing van het doel van een onderscheid kan ook bij de toetsing van de geschiktheid de vraag worden gesteld in hoeverre de rechter bevoegd moet worden geacht om deze toetsing uit te voeren. Door verschillende auteurs is aangegeven dat het beoordelen van geschiktheid uit oogpunt van de rechterlijke bevoegdheidsomvang nauwelijks problematisch is. De reden die daarvoor wordt genoemd is dat dit toetsingscriterium niet bijzonder veel rechterlijke oordeelsvorming zou vergen: de geschiktheid van een maatregel om het beoogde doel te bereiken zou eenvoudig kunnen worden vastgesteld op grond van maatstaven die zijn ontleend aan wetenschappelijke inzichten over oorzaak en gevolg. ${ }^{163}$ Door één auteur wordt zelfs aangegeven dat de "judicial performance will be improved by more sensitive determination of the effects of an act". ${ }^{164}$ Vermoedelijk is het echter zo dat het geven van een oordeel over de geschiktheid in theorie gemakkelijker lijkt dan in de praktijk het geval zal zijn. Zo is het voor een rechter waarschijnlijk lastig om te beoordelen of er een toereikende oorzaakgevolgrelatie bestaat wanneer hij wordt geconfronteerd met complexe economische situaties of met een beleidsterrein waarbij een groot aantal factoren bepalend is voor de effecten van een bepaalde maatregel. Meestal zal de rechter in dergelijke gevallen niet

161. Zo ook De Lange 1991, p. 179.

162. Dit heeft niet alleen voordelen voor de begrijpelijkheid van het oordeel en voor de aanvaardbaarheid ervan, maar kan ook verder nuttig zijn: het feit dat een onderscheid ontoelaatbaar is verklaard vanwege zijn ongeschiktheid of vanwege het bestaan van andere, minder vergaande middelen (subsidiariteit, zie hierover de volgende paragraaf), kan de regelgever belangrijke aanwijzingen geven voor de wijze waarop hij alsnog kan proberen zijn gerechtvaardigde doelstellingen te realiseren. In het geval van gebrek aan subsidiariteit zal hij kunnen volstaan met het treffen van een maatregel die de belangen minder vergaand aantast, bij ongeschiktheid zal hij daadwerkelijk onderzoek moeten doen naar bron van de ongeschiktheid en zal hij moeten nagaan of er andere maatregelen mogelijk zijn die wel geschikt zijn om het doel te bereiken.

163. In deze zin De Lange 1991, p. 156

164. "Note" 1970 , p. 1893 
beschikken over de voor een goede beoordeling benodigde maatschappelijke voelhoorns en mist hij de hiervoor noodzakelijke beleidsmatige achtergrond en kennis. ${ }^{165}$ Gesteld kan echter worden dat ook hier de juiste opstelling in belangrijke mate kan worden bepaald aan de hand van de intensiteit van de toetsing. Bij een intensieve toetsing kan van de rechter een verdergaand onderzoek naar de geschiktheid worden vereist (en kunnen er bovendien hogere eisen aan de causaliteit worden gesteld) dan bij een marginale toetsing. Bij het uitvoeren van een terughoudende toetsing kan bijvoorbeeld tot uitgangspunt worden genomen dat de rechter alleen op de causaliteitseis hoeft in te gaan als duidelijk uit de feiten naar voren komt, of voldoende aannemelijk is gemaakt, dat het onderscheid geen geschikt middel is om het gestelde doel te bereiken.

\subsubsection{Subsidiariteit}

\section{Inhoud van het criterium; bevoegdheid tot rechterlijke toetsing}

Het criterium van subsidiariteit vereist dat de rechter nagaat of de doelstellingen die door het onderscheid worden nagestreefd niet ook konden worden bereikt door gebruik te maken van een ander, minder belastend of benadelend, middel dan het litigieuze onderscheid. Als dit het geval is kan worden gesteld dat de keuze voor het gemaakte onderscheid niet redelijk is, nu daardoor de belangen van het individu zwaarder zijn aangetast dan noodzakelijk is. Een onderscheid moet dan ook als ongerechtvaardigd worden aangemerkt wanneer het niet voldoet aan het vereiste van subsidiariteit. ${ }^{166}$

Volgens verschillende auteurs is de toetsing aan dit criterium problematisch tegen de achtergrond van de omvang van de rechterlijke bevoegdheid. De subsidiariteitstoets vereist dat de rechter min of meer zelfstandig nagaat of er alternatieven beschikbaar waren en vergt bovendien een waardering van deze alternatieven: gecontroleerd moet immers worden of deze inderdaad een minder ernstige belangenaantasting zouden opleveren, terwijl tevens duidelijk moet zijn dat het nagestreefde doel door de keuze voor één van de alternatieven voldoende zou kunnen worden bereikt. ${ }^{167} \mathrm{Bij}$ een dergelijke toetsing moet de rechter een beoordeling van de doelmatigheid geven en moet hij in vrij vergaande mate treden in de keuzevrijheid van de wetgever.

Ook bij de andere vormen van onderscheid kan een subsidiariteitstoets onwenselijk worden geacht. Bij onderscheid dat is veroorzaakt door een administratieve bevoegdheidsuitoefening is rechterlijke toetsing van de subsidiariteit bijvoorbeeld problematisch, omdat de rechter hierdoor in de discretie van het betrokken bestuursorgaan zou treden: wanneer een bestuursorgaan verschillende mogelijkheden tot zijn beschikking heeft om het beoogde doel te bereiken is het aan het bestuursorgaan om hiertussen een keuze te maken, niet aan de rechter.

165. Het feit dat reeds vaststaat welke doelstellingen en effecten worden nagestreefd maakt het voor de rechter overigens gemakkelijker om te bekijken of de beoogde effecten zijn bereikt: in ieder geval weet hij daardoor waarnaar hij in een complexe feitelijke situatie moet zoeken ("Note" 1970, p. 1896).

166. Vgl. Bennett 1979, p. 1062 en Gottlieb 1988, p. 968: de achterliggende gedachte is dat altijd het minst belastende middel moet worden gekozen om maatschappelijk wenselijke doelstellingen te bereiken, om op die manier belangenaantastingen te minimaliseren. In het voorbeeld van het oplossen van een parkeerprobleem in een studentenstad door studenten te verbieden om overdag in het centrum te parkeren, kan als minder vergaand alternatief bijvoorbeeld worden gekozen voor cen vergunningenstelsel.

167. Zie hierover Bhagwat 1997, p. 322. 
Tegen deze bezwaren kan worden ingebracht dat de vrijheid van regelgevers, bestuursorganen en individuen niet zover strekt dat zij naar believen inbreuk kunnen maken op het fundamentele recht op gelijke behandeling. In het geval van een ongelijke bevoegdheidsuitoefening kan bovendien worden gesteld dat de rechter de bevoegdheid heeft om controle uit te oefenen op de legitimiteit van het administratieve handelen, hetgeen ook inhoudt dat de rechter kan controleren of individuele rechten en belangen niet onredelijk zwaar zijn aangetast. In dit verband is van belang dat subsidiariteit een aspect vormt van het proportionaliteitsbeginsel in ruime zin, nu het hierbij gaat om een aspect van de vraag of er een redelijk evenwicht bestond tussen, enerzijds, de nagestreefde belangen en doelstellingen en, anderzijds, de belangen en rechten die door de keuze voor een bepaald middel zijn aangetast: wanneer de beoogde doelstellingen ook bereikt konden worden door een ander, minder vergaand middel, is dit noodzakelijke evenwicht niet bereikt. Wanneer wordt geaccepteerd dat de rechter de bevoegdheid heeft om een oordeel te geven over de proportionaliteit in ruime zin, wordt daarmee ook geaccepteerd dat er een subsidiariteitstoets kan worden uitgevoerd.

\section{Verhouding tot andere toetsingscriteria}

De toetsing aan het vereiste van subsidiariteit lijkt in bepaalde opzichten sterk op de toetsing van de hiervoor beschreven toetsing van de mate van fit (over- en underinclusiveness) en wordt daarmee ook nogal eens verward. ${ }^{168} \mathrm{Zo}$ wordt soms gesteld dat er bij een regeling die over- en/of underinclusive is steeds een minder bezwaarlijk alternatief voorhanden is. ${ }^{169}$ In het in paragraaf 3.3.2 gegeven voorbeeld zou bijvoorbeeld kunnen worden volstaan met een regeling die alleen zware lichamelijke arbeid verbiedt voor die mensen die daartoe aantoonbaar niet in staat zijn zonder hun gezondheid in gevaar te brengen. De criteria van over- en underinclusiveness en van subsidiariteit vertonen echter belangrijke verschillen. De overinclusiveness van een maatregel betekent dat het doel had kunnen worden bereikt door het geven van een zorgvuldigere of meer genuanceerde definitie. Hetzelfde geldt voor underinclusiveness: ook daarbij kon het doel door een andere, in dit geval ruimere, definitie worden bereikt. Het subsidiariteitsvereiste ziet echter niet zozeer op de wijze waarop de classificatie is gedefinieerd, maar op de keuze van een classificatie als middel om het beoogde doel te bereiken. Bij de toetsing aan dit criterium is de vraag dus vooral of het eigenlijk wel nodig was om onderscheid te maken, los van de vraag hoe dit onderscheid vervolgens wordt gedefinieerd.

Het verschil tussen de beide vereisten kan worden verduidelijkt aan de hand van een zaak die in de jaren 40 in New York speelde. Er bestond in deze stad een verbod op het maken van reclame door middel van het laten rondrijden van vrachtwagens met teksten aan de zijkant. De relevante regeling maakte op dit verbod een uitzondering voor bedrijven die advertenties voor hun eigen bedrijf op hun vrachtwagens aanbrachten. Volgens het stadsbestuur was deze regeling ingesteld ten behoeve van de verkeersveiligheid: deze was volgens het bestuur in gevaar, nu verkeersdeelnemers door de reclames op de auto's zouden worden afgeleid. Het is duidelijk dat de regeling in het licht van deze doelstelling underinclusive is: het gevaar van afleiding wordt immers net zo goed veroorzaakt door vrachtwagens waarop de eigenaar zijn eigen bedrijf of product aan-

168. In die zin ook Simons 1985 , p. 451.

169. Tribe 1988, p. 1450 en Baker 1980, p. 1037; zie ook Ely 1980, p. 149. 
prijst. Gezien zijn doelstelling had de classificatie dan ook ruimer moeten worden geformuleerd. Gesteld kan echter ook worden dat deze maatregel niet voldeed aan het vereiste van subsidiariteit: het was zeker mogelijk geweest om het beoogde doel door andere middelen te bereiken, bijvoorbeeld door eisen te stellen aan het kleurgebruik, de grootte van de gebruikte letters of de omvang van de reclame zelf. Het maken van onderscheid tussen verschillende groepen adverteerders, los van de definitie van dit onderscheid, was in ieder geval niet noodzakelijk om het gestelde doel te bereiken. ${ }^{170}$

Ook om een andere reden is het wenselijk en nuttig om de criteria van de mate van fit en van subsidiariteit afzonderlijk in het model op te nemen. Zoals eerder is aangegeven is het vereiste van een voldoende mate van fit alleen bruikbaar voor gevallen van normatief onderscheid. In gevallen van ongelijke bevoegdheidsuitoefening is er van een duidelijk gedefinieerde classificatie nooit sprake, zodat dit criterium voor de beoordeling van de ongelijke behandeling niet bruikbaar is. In die gevallen is het echter wel degelijk denkbaar dat de doelstelling die de betrokkene voor ogen had kon worden bereikt door de keuze voor een andere oplossing dan ongelijke behandeling: het subsidiariteitsvereiste heeft voor die gevallen dan ook een bijzondere toegevoegde waarde.

\subsubsection{Proportionaliteit in strikte zin}

\section{Inhoud van de proportionaliteitstoets}

Bij de bespreking van de vereisten van geschiktheid en subsidiariteit is aangegeven dat het hierbij gaat om aspecten van de toetsing van de evenredigheid tussen de nagestreefde doelstelling en het middel dat is gekozen om dit doel te bereiken. Een derde aspect van de proportionaliteitstoets wordt gevormd door de eigenlijke toetsing van de evenredigheid tussen doel en middel. Bij de toetsing van dit specifieke aspect van proportionaliteit kan worden gesproken van "proportionaliteit in strikte zin", ter onderscheiding van het ruime proportionaliteitsbegrip dat alledrie de aspecten (geschiktheid, subsidiariteit en proportionaliteit in strikte zin) omvat. De noodzaak tot het uitvoeren van een dergelijke toets vloeit voort uit het karakter van het gelijkheidsbeginsel: dit is geen rechtsregel, maar een rechtsbeginsel. Juist bij beginselen kan niet zonder meer van iedere inbreuk of beperking worden gesteld dat deze ongeldig is, zoals het geval is bij een rechtsregel. ${ }^{171}$ Typisch voor een rechtsbeginsel is dat dit "states a reason that argues in one direction, but does not necessitate a particular decision". ${ }^{12}$ Met rechtsbeginselen moet bij de besluitvorming dan ook zeker rekening worden gehouden, maar in voorkomende gevallen kunnen zij in hun werking worden geremd of beperkt door tegengestelde beginselen of belangen. ${ }^{173}$ Wel is het in dit soort gevallen noodzakelijk dat er

170. Vgl. Justice Jacksons dissenting opinion bij de uitspraak van het Amerikaanse Supreme Court in de zaak Railway Express Agency, Inc. v. New York, 336 U.S. 106, 113 (1949).

171. Dworkin 1977, m.n. p. 23-28. Overigens bestaat er nogal wat discussie over de vraag waar de grens tussen rechtsbeginselen en rechtsregels moet worden getrokken: Dworkin stelt dat deze grens vrij strak en duidelijk is, terwijl De Lange aangeeft dat het verschil gradueel is en gezien moet worden op een schaal die van duidelijke regels via vage normen verloopt naar rechtsbeginselen (De Lange 1990, p. 99-101). De precieze grensbepaling is in het kader van het onderzoek echter niet zo interessant, nu algemeen wordt aangenomen dat het gelijkheidsbeginsel geen regel maar een beginsel is.

172. Dworkin 1977 , p. 26

173. "There may be other principles or policies [met policies duidt Dworkin op "that kind of standard that 
goede afweging plaatsvindt van de verschillende in aanmerking komende rechten of belangen. ${ }^{174}$ Het vereiste van proportionaliteit in strikte zin wordt in dit verband vaak gezien als een bij uitstek rechtsstatelijk vereiste dat beschermt tegen het opleggen van ongerechtvaardigde lasten door de overheid. ${ }^{175}$

Ook bij de toetsing aan het gelijkheidsbeginsel speelt het proportionaliteitsvereiste een belangrijke rol. In bepaalde gevallen kunnen maatregelen nodig en wenselijk zijn om maatschappelijk belangrijk geachte doelstellingen te bereiken, maar staat daar de aantasting van een individueel recht of belang tegenover. Hoewel het in een dergelijk geval op zichzelf gerechtvaardigd is om het beoogde doel na te streven, mag het gekozen middel (de classificatie) daar niet altijd voor worden gebruikt. ${ }^{176}$ Van belang is daarbij dat in het kader van de proportionaliteitstoets niet alleen direct meetbare belangen moeten worden meegewogen, maar ook meer abstracte belangen, zoals het belang van een individu om niet te worden achtergesteld bij andere personen of groepen (dat nog in het bijzonder geldt als dat op een kwetsende grond of wijze gebeurt). ${ }^{17}$ Gesteld kan immers worden dat mensen, in het algemeen gesproken, recht hebben op een gelijke mate van individuele vrijheid en dat er op gelijke wijze rekening moet worden gehouden met hun behoeften en hun verdiensten; gebeurt dit in een individueel geval door het maken van een bepaald onderscheid niet, dan kan het zijn dat de betrokkene daardoor ten opzichte van de anderen een ongerechtvaardigd hoge last draagt die moet worden vermeden of eventueel moet worden gecompenseerd. ${ }^{178}$

\section{Verhouding tot andere toetsingscriteria}

Door sommigen is wel gesteld dat de proportionaliteitstoets in strikte zin kan worden uitgevoerd in het kader van de toetsing van de gerechtvaardigdheid van het nagestreefde doel; vereist wordt dan bijvoorbeeld dat wordt aangetoond dat het doel voldoende zwaarwegend is. ${ }^{179}$ Door een dergelijke benadering is echter een risico aanwezig dat een toetsing aan de andere criteria van het model achterwege blijft. ${ }^{180}$ Inhoudelijk gezien hoeft dit niet erg te zijn, zeker niet als de regeling duidelijk disproportioneel is, maar bezwaarlijk is dat hierdoor afbreuk wordt gedaan aan de duidelijkheid en overzichtelijkheid die met de uitsplitsing in verschillende criteria nu juist wordt beoogd.

sets out a goal to be reached, generally an improvement in some economic, political feature of the community", 1997, p. 22] arguing in the other direction [...]. If so, our principle may not prevail" (Dworkin 1977, p. 26). In vergelijkbare zin ook Karst 1977, p. 42.

174. Vgl. De Lange 1991, p. 108 en 114 en - in een iets ander verband-Alexy 1985, p. 384. Er zijn nog diverse andere redenen die pleiten voor een belangenafweging bij constitutionele toetsing (en dus ook bij toetsing aan het gelijkheidsbeginsel), zoals de gedachte dat alleen door een dergelijke afweging voldoende recht kan worden gedaan aan het recht als instrument in een veranderende samenleving waarin tegenstrijdige belangen een rol spelen. Zie voor de betekenis van het concept van belangenafweging Aleinikoff 1987, p. 953-963.

175. De Lange 1991, p. 134; vgl. ook Simon 1994, p. 42.

176. Zie Loenen 1992, p. 224.

177. Vgl. Dworkin 1977, p. 227: “An individual's right to be treated as an equal means that his potential loss must be treated as a matter of concern, but that loss may nevertheless be outweighed by the gain to the community as a whole." Meegewogen moet dus altijd worden het recht op gelijk respect, ofwel het recht om als een gelijke te worden behandeld.

178. Wiggers 1991, p. $177 / 178$

179. Bijvoorbeeld Wentholt 1991, p. 87-88.

180. Loenen 1992, p. 224 
Van belang is bovendien dat vrij algemeen wordt aangenomen dat de proportionaliteitstoets een vergaande rechterlijke activiteit vergt. Het lijkt dan ook beter om de overige toetsingscriteria eerst en afzonderlijk aan de orde te laten komen: bij een goede toetsing zullen veel ondeugdelijke onderscheidingen hierbij reeds sneuvelen. ${ }^{1 \times 1}$ In die gevallen is het niet meer nodig om een proportionaliteitstoets uit te voeren.

\section{Bevoegdheid van de rechter tot toetsing aan het vereiste van proportionaliteit}

Ten aanzien van het vereiste van proportionaliteit in strikte zin wordt vaak de kritiek geuit dat de rechter zich bij de toetsing hieraan te zeer zou begeven op het terrein van de doelmatigheid, dus op het vlak van de inhoudelijke waardering van een regeling, terwijl hij alleen bevoegd zou zijn tot een toetsing van de rechtmatigheid. ${ }^{112}$ Dit bezwaar kan echter niet doorslaggevend worden geacht. Doelmatigheid en rechtmatigheid zijn niet altijd tegengestelden en zijn in de praktijk vaak moeilijk van elkaar zijn te onderscheiden. ${ }^{183}$ Zwaarwegender is het bezwaar dat de beoordeling van het afwegingsproces vaak het geven van een waardeoordeel impliceert en daardoor ruimte biedt voor een subjectieve rechterlijke toetsing: een "externe", objectieve weegschaal voor de afweging van belangen is eenvoudigweg niet te vinden. ${ }^{14}$ Het lijkt echter mogelijk om aan dit bezwaar enigszins tegemoet te komen door objectieve factoren vast te stellen die bij het afwegingsproces behulpzaam kunnen zijn. Zo kan worden gesteld dat de rechter bij zijn afweging rekening moet houden met de over de kwestie bestaande maatschappelijke opvattingen, geschiedenis en traditie ${ }^{185}$ en dat hij, bij de toetsing van een ongelijke behandeling die het resultaat is van een ongelijke bevoegdheidsuitoefening, de wettelijke grondslag tot richtsnoer moet nemen. ${ }^{.86}$

181. Vgl. Loenen 1992, p. 224.

182. Vgl. Kewenig 1972, p. 106, waar hij stelt dat door de beoordeling van de doelmatigheid van het onderscheid, waartoe een rechtvaardigingstoets onvermijdelijk leidt, de rechterlijke bevoegdheden worden overschreden en een te grote inbreuk wordt gemaakt op de vrijheid van de wetgever om besluiten te nemen. Om deze reden wijst Kewenig de mogelijkheid van een rechtvaardigingstoets zelfs volledig af. Vgl. ook O'Fallon 1979, p. 43; hij wijst verder op het probleem van het identificeren van de verschillende betrokken belangen.

Overigens is vooral in Amerika vrij algemeen aanvaard dat het toetsen van de verhouding tussen doel en middel een zeer wenselijke benadering is bij het beoordelen van gelijke behandeling; zie bijvoorbeeld Bhagwat 1997, p. 321. De onderliggende gedachte is dat rechters in het algemeen goed in staat zijn om zonder al teveel subjectiviteit en zonder een te grote inbreuk te maken op de vrijheid van wetgever of administratic te beoordelen of er een redelijke verhouding bestaat tussen doel en middel. Zoals Aleinikoff stelt: er wordt vaak van uitgegaan dat de rechter in staat is om de belangen af te wegen zoals ook een winkelier in staat is om een bepaalde hoeveelheid van iets af te wegen, d.w.z. zonder waarde te hechten aan de aard van hetgeen er toevallig in de weegschaal ligt (1987, p. 963).

183. De Lange 1991, p. 180. Van belang is in dit verband ook de stelling van Alexy dat het lang niet altijd nodig is om een subjectief waardeoordeel over de doelmatigheid te geven: hij geeft aan dat het goed mogelijk is om dit oordeel rationeel te motiveren (1985, p. 376 en 377).

184. Aleinikoff 1987, p. 973

185. Zie Aleinikoff 1987, p. 974 , die echter onmiddellijk waarschuwt dat dergelijke factoren nooit een volledige oplossing kunnen bieden voor het probleem van de subjectieve weegschaal.

186. Bovendien kan worden gewezen op de door Schoordijk geformuleerde stelling dat het weliswaar in veel gevallen mogelijk is om verschillend te denken over belangen en het gewicht daarvan, maar dat in een minstens zo groot aantal gevallen met zekerheid kan worden gesteld dat een bepaalde afweging niet juist kán zijn (Schoordijk 1972, p. 56). 


\section{Wijze van toetsing aan het proportionaliteitsbeginsel}

De precieze manier waarop de toetsing van de proportionaliteit kan worden uitgevoerd is afhankelijk van de aard van de voorgelegde ongelijke behandeling. Zoals eerder is uiteengezet kan worden geklaagd over een normatief onderscheid of over de concrete toepassing daarvan, maar ook over een ongelijke bevoegdheidsuitoefening.

In het geval van een normatieve classificatie ligt het in de rede dat er een volledig abstracte toetsing wordt uitgevoerd: gekeken dient te worden of de wetgever in abstracto de verschillende belangen op een redelijke manier tegen elkaar heeft afgewogen. ${ }^{187}$ Deze situatie roept verder weinig vragen op, net zomin als de situatie van concrete bevoegdheidsuitoefening: daarbij is het vanzelfsprekend dat de rechter in concreto beoordeelt of er sprake is van een redelijke afweging tussen de nagestreefde doelstelling en het gemaakte onderscheid.

De toetsing van de toepassing van een normatieve regeling in een individueel geval vereist een iets gecompliceerdere benadering. Voor deze situatie geldt dat pas kan worden overgegaan tot een concrete toetsing van de individuele toepassing, wanneer uit de abstracte toetsing van de classificatie is gebleken dat deze als zodanig deugdelijk is. Vervolgens dient de rechter vast te stellen of bij de toepassing van de classificatie in het concrete geval voldoende rekening is gehouden met de individuele belangen van de benadeelde en moet hij beoordelen of er sprake is van een redelijke afweging van deze belangen tegen de andere belangen die in de zaak een rol spelen. In deze situatie moet de rechter in het bijzonder rekening houden met de belangen die gediend worden door een onverkorte toepassing van de regeling. Dit laatste is van belang in het licht van de discussie over de contra legem-werking van het gelijkheidsbeginsel, waarbij de vraag speelt of een beroep op het gelijkheidsbeginsel mag leiden tot een individuele beslissing die in strijd is met de wet. Dit mag niet zonder meer worden afgewezen, maar in gevallen waarin contra legem-werking de consequentie is van een geslaagd beroep op het gelijkheidsbeginsel zal wel steeds een extra zorgvuldige afweging moet worden gemaakt tussen het belang van de eiser bij het honoreren van het beroep op het gelijkheidsbeginsel, het belang van de overheid bij een onverkorte toepassing van de wet (daarbij ook rekening houdend met eventuele precedentwerking) en de belangen van eventuele derden die door de contra legem-werking worden aangetast. ${ }^{188}$

\section{Belangen die bij de proportionaliteitstoets mogen worden betrokken}

Een laatste probleem dat bij de toepassing van de proportionaliteitstoets in strikte zin een rol speelt betreft de bepaling van de belangen die bij de afweging kunnen worden betrokken. Dit is met name lastig, nu niet alle betrokken belangen altijd even concreet

187. Dit betekent dus dat de rechter niet specifiek rekening zal houden met de individuele belangen van de benadeelde partij, maar in het algemeen moet bezien of de verantwoordelijke voldoende rekening heeft gehouden met de belangen die in abstracto door de classificatie worden aangetast; de individuele belangen van de benadeelde worden dus veralgemeniseerd tot abstracte belangen van de groep van individuen waarvan de benadeelde deel uitmaakt (vgl. Aleinikoff 1987, p. 981). Overigens betekent dit zeker niet dat de rechter in een vacuùm opereert en volledig moet loskoppelen van de omstandigheden van het geval: daaruit kunnen immers wel aanwijzingen worden afgeleid voor de abstracte belangen die zijn aangetast. Zie nader Clark 1978, p. 982.

188. Zie hierover met name Versteden 1985, p. 67 en 68 . Ook in het rechtsvergelijkend deel zal hieraan aandacht worden besteed: vooral in Nederland is de contra legem-werking regelmatig voorwerp van rechtspraak geweest; zie nader hoofdstuk 6. 
zijn: ook het abstracte belang om niet te worden bevestigd in een achtergestelde positie moet bijvoorbeeld in aanmerking worden genomen. ${ }^{\text {Isy }}$ Bovendien kan het noodzakelijk zijn om, naast de direct betrokken individuele belangen en de nagestreefde doelstellingen, ook andere belangen mee te wegen, zoals bijvoorbeeld in het geval waarin een regeling effecten heeft waardoor belangen worden aangetast of nagestreefd die voor het rechtsgeding niet rechtstreeks van belang zijn. ${ }^{190}$ Aan dit probleem van de bepaling van de betrokken belangen en het relatieve gewicht daarvan wordt in de literatuur over het gelijkheidsbeginsel in het algemeen slechts in beperkte mate aandacht besteed: gesteld wordt meestal slechts dat bij een abstracte toetsing op objectieve wijze een afweging moet worden gemaakt tussen het algemene belang enerzijds en het aangetaste belang van de betrokken individuen anderzijds. Het is dan ook van bijzonder belang om na te gaan op welke manier rechters in de praktijk met het proportionaliteitsvereiste omgaan en welke belangen zij in hun afweging betrekken; wellicht kunnen daaruit criteria worden gedestilleerd waardoor nader invulling aan het proportionaliteitsvereiste kan worden gegeven.

\section{De vergelijkbaarheidstoets en de eerste fase van de toetsing}

\subsection{Inhoud van de vergelijkbaarheidstoets}

"Gelijke gevallen moeten gelijk worden behandeld, ongelijke gevallen ongelijk naar mate van hun ongelijkheid". Zoals in paragraaf 1.1 van dit hoofdstuk is aangegeven wordt deze formule in veel gevallen tot uitgangspunt van de rechterlijke toetsing aan het gelijkheidsbeginsel genomen. $\mathrm{Er}$ is dan geen sprake van een rechtvaardigingstoets zoals die in paragraaf 3 is beschreven, maar van een "vergelijkbaarheidstoets". Inderdaad is het mogelijk dat de rechter niet toetst aan het rechtvaardigingsmodel, maar bij de beoordeling van de redelijkheid van een ongelijke behandeling gebruik maakt van een vergelijkbaarheidstoets. Ook in dat geval zal er sprake zijn van een toetsing die in drie fasen verloopt, maar de invulling die aan de toetsing wordt gegeven is een andere dan bij de toetsing aan het rechtvaardigingsmodel. ${ }^{191}$ Belangrijk is vooral dat de rechter bij een toepassing van de vergelijkbaarheidstoets zal moeten vaststellen of de voorgelegde gevallen al dan niet vergelijkbaar zijn: dit vormt de eerste fase van de toetsing. Vervolgens zal hij, in de tweede fase, moeten aangegeven wat de consequenties van de geconstateerde vergelijkbaarheid of onvergelijkbaarheid zijn, hetgeen betekent dat hij $\mathrm{zal}$ moeten aangeven of het gemaakte onderscheid al of niet toelaatbaar is. ${ }^{192}$ De derde

189. Dworkin 1977, p. 227 (recht op behandeling als een gelijke moet worden meegewogen) en Loenen 1992, p. 244; vgl. ook Clark 1978, p. 980.

190. Wiggers 1991 , p. 5

191. Zie daarvoor paragraaf 3.1.2.

192. De consequenties zijn afhankelijk van de opvatting die de rechter daarover heeft. In paragraaf $4.3 \mathrm{zal}$ duidelijk worden dat er vier mogelijke benaderingen zijn die bij de keuze voor een vergelijkbaarheidstoets in de tweede fase kunnen worden gevolgd. Afhankelijk van de gekozen benadering kan het oordeel over de vergelijkbaarheid van de voorgelegde gevallen direct doorslaggevend zijn voor de uitkomst van de toetsing, maar het kan ook nodig zijn dat er nog een rechtvaardigingstoets wordt uitgevoerd. 
fase bestaat ook bij de vergelijkbaarheidstoets uit het vinden van een passende remedie om het door de ongelijke behandeling veroorzaakte nadeel te weg te nemen of te compenseren.

In de rechtstheoretische literatuur wordt vaak als voordeel van de vergelijkbaarheidstoets genoemd dat deze feitelijker zou zijn dan de rechtvaardigingstoets en daardoor een minder actieve opstelling van de rechter zou vergen. Om die reden wordt wel gesteld dat deze toets moet worden verkozen boven de rechtvaardigingstoets, of wordt aangegeven dat een toetsing aan het rechtvaardigingsmodel moet worden gecombineerd met elementen van de vergelijkbaarheidstoets. Met name een combinatie van de eerste fase van de vergelijkbaarheidstoets met een toetsing aan het rechtvaardigingsmodel in de tweede fase wordt in de literatuur veel genoemd als ideale toetsingsmethodiek. In het hiernavolgende zal echter worden betoogd dat het niet wenselijk of nodig is om in het kader van een toetsing aan het gelijkheidsbeginsel na te gaan of er sprake is van vergelijkbare gevallen en zal worden gesteld dat ook een combinatie vąn vergelijkbaarheids- en rechtvaardigingstoets niet nodig of wenselijk is.

Om deze stellingen te onderbouwen zal allereerst aandacht worden besteed aan de inhoud van de vergelijkbaarheidstoets en aan de overlappingen tussen deze toets en het rechtvaardigingsmodel (paragraaf 4.2). Vervolgens zal worden ingegaan op de toetsingsmethodiek in de tweede fase van de vergelijkbaarheidstoets en zal worden aangegeven waarom een toetsing aan het rechtvaardigingsmodel te prefereren is (paragraaf 4.3). Tenslotte zal aandacht worden besteed aan de bewijsrechtelijke waarde van de vergelijkbaarheidstoets voor de eerste fase van de toetsing en zullen enkele alternatieven voor deze toets worden besproken (paragraaf 4.4).

\subsection{Vaststelling van de vergelijkbaarheid}

\subsubsection{Inleiding}

Zoals hiervoor kort is aangegeven is een belangrijke reden om de voorkeur te geven aan de vergelijkbaarheidstoets boven de toetsing aan het rechtvaardigingsmodel voor veel auteurs gelegen in de gepercipieerde eenvoud en objectiviteit van deze toets en in de beperkte mate van rechterlijke activiteit die deze toets zou vereisen. Immers, zo stellen deze auteurs, om te kunnen beoordelen of twee gevallen vergelijkbaar zijn zal de rechter kunnen volstaan met een vaststelling van de feiten: daaruit blijkt in het algemeen vanzelf of twee gevallen te vergelijken zijn. ${ }^{193}$ Als vervolgens de consequenties

193. Zie bijv. Blackstone, die aangeeft dat "questions of relevance [van het onderscheidingscriterium dat de vergelijkbaarheid helpt vast te stellen, JHG] are factual or descriptive claims, straightforwardly verifiable or falsifiable" (1969, p. 117). Overigens geeft Blackstone aan dat er naast deze gemakkelijk te bepalen descriptieve of feitelijke vergelijkbaarheid ook nog een moeilijker bepaalbaar prescriptief element bestaat: de bepaling van de vraag of bepaalde kenmerken en eigenschappen ook relevant behoren te zijn. De beantwoording van deze normatieve vraag hoort echter niet tot de eerste fase van de rechterlijke toetsing, maar tot de tweede: het gaat hierbij om een beantwoording van de vraag welke conclusie er aan het bestaan van de feitelijk relevante ongelijkheden moet worden verbonden. Vgl. verder Van Dijk/Van Hoof 1990, p. 543: "[...] The question of whether an inequality in treatment results in a factual equality or inequality leaves much more scope for an independent inquiry [...] than does the question of whether a given measure does or does not serve the general interest of the State [...]". 
van de geconstateerde (on)vergelijkbaarheid moeten worden vastgesteld zal de rechter zich iets actiever moeten opstellen, maar ook dan is de rol van de rechter nog relatief beperkt. ${ }^{194}$

Een tweede reden die in de literatuur is genoemd om de vergelijkbaarheidstoets te verkiezen boven de toetsing aan het rechtvaardigingsmodel, is gelegen in de veronderstelling dat de vergelijkbaarheidstoets een grote mate van zuiverheid en duidelijkheid aan de beoordeling van het onderscheid zou verschaffen. Het uitvoeren van een rechtvaardigingstoets zou daarentegen kunnen leiden tot een ondoorzichtige en niet te doorgronden brei, waarin het afzonderlijke karakter van de verschillende rechten en belangen nauwelijks een rol speelt; om die reden is het uitvoeren van een dergelijke toets niet wenselijk. ${ }^{195}$

Verder verdient de vergelijkbaarheidstoets volgens sommigen de voorkeur, omdat deze toets een verdergaand en nauwkeuriger onderzoek naar de grondslagen van het onderscheid mogelijk maakt. De vraag of er een redelijke grond bestaat voor het onderscheid is een andere dan de vraag of er voldoende rekening is gehouden met de achterliggende feitelijke gelijkheid of ongelijkheid tussen mensen. ${ }^{1 \%}$ De rechtvaardigingstoets laat geen ruimte om deze achtergronden te onderzoeken, terwijl de vergelijkbaarheidstoets die mogelijkheid wel verschaft.

Verband met de voorgaande stelling houdt tenslotte de opvatting dat er voor iedere ongelijke behandeling wel een objectieve rechtvaardiging kan worden gevonden, terwijl het veel moeilijker is om de bewering te ontkrachten dat er sprake is van een gelijke behandeling van ongelijke gevallen of een ongelijke behandeling van gelijke gevallen: hoewel de verdedigende partij allerlei argumenten kan bedenken om een onderscheid redelijk te laten lijken, kunnen de feitelijke verschillen en overeenkomsten tussen situaties en personen niet worden ontkend. ${ }^{197}$

De eenvoud en objectiviteit van de vergelijkbaarheidstoets zijn echter bedrieglijk. Bovendien maakt een goede beoordeling van de vergelijkbaarheid van de voorgelegde gevallen wel degelijk een vergaande rechterlijke toetsing noodzakelijk. Van belang is verder dat de nauwkeurigheid en zuiverheid van de toetsing van de vergelijkbaarheid vaak te wensen overlaten: de vergelijkbaarheidstoets resulteert zeker niet noodzakelijkerwijze in een goede en doorzichtige motivering. ${ }^{198}$ Tenslotte kan worden vastgesteld dat het niet gemakkelijker is om de vergelijkbaarheid vast te stellen dan om een objectieve rechtvaardiging voor een onderscheid te vinden. Dit wordt duidelijk wanneer meer specifiek wordt nagegaan wat een toetsing van de vergelijkbaarheid precies inhoudt.

194. Zie daarover nader paragraaf 4.3 , waarin de verschillende mogelijkheden om invulling te geven aan deze tweede toetsingsfase zullen worden besproken.

195. Alexy 1985 , p. 364

196. Mulder 1987 , p. 116

197. Kewenig 1972, p. 106: "Mit der Hinweis, der Zweck der gesetzlichen Regelung sei vemünftig und die Ungleichbehandlung deshalb gerechtfertigt, laßt sich praktisch jede Maßnahmen halten; denn welche Gesetzgeber oder welche Verwaltung wäre so einfallslos, daß inhnen nicht ein vernünftiger, ein plausibeler Grund für ihr diskriminierendes Verhalten einfiehle?" Vgl. ook Van Hoof/Jaspers 1986, p. 146.

198. Eerder is het tegenovergestelde het geval: doordat de vergelijkbaarheidstoets onvoldoende duidelijke aanknopingspunten voor de rechterlijke toetsing biedt, zal de motivering in veel gevallen aan duidelijkheid te wensen overlaten. 


\subsubsection{Noodzaak van het vaststellen van de vergelijkingsmaatstaf}

Voorop moet worden gesteld dat het niet mogelijk is om tot een oordeel over de vergelijkbaarheid te komen door louter en alleen naar de feiten van het voorgelegde geval te kijken. Deze feiten zullen immers altijd zowel overeenkomsten als verschillen laten zien: personen, handelingen en dingen zijn nooit geheel gelijk, terwijl zij altijd bepaalde overeenkomsten vertonen. Paradoxaal genoeg zijn gevallen dus altijd zowel vergelijkbaar als onvergelijkbaar. ${ }^{199} \mathrm{Om}$ vast te kunnen stellen of er sprake is van een ongelijke behandeling van vergelijkbare gevallen zal de rechter dan ook altijd moeten nagaan welke verschillen en overeenkomsten voor de vergelijking van belang zijn. ${ }^{200} \mathrm{Om}$ dit te kunnen doen moet hij zoeken naar een geschikte vergelijkingsmaatstaf: een inhoudelijke, prescriptieve regel aan de hand waarvan hij de relevantie van overeenkomsten en verschillen tussen gevallen kan vaststellen. ${ }^{201}$ Deze stelling kan worden toegelicht door het voorbeeld van het vaststellen van de prijzen van bepaalde producten. Zo kunnen de prijzen van citrusfruit in de winkel sterk verschillen: citrusvruchten die voortkomen uit bijzondere kruising of die moeilijk verkrijgbaar zijn zullen in het algemeen duurder zijn dan gewone sinaasappelen. In dit voorbeeld betreft het verschil in prijs vruchten die zekere overeenkomsten vertonen, maar waartussen duidelijk ook verschillen bestaan. Het gaat immers steeds om citrusvruchten, die zich kenmerken door een hoog gehalte aan sap en vitamines. Tegelijkertijd kan echter worden vastgesteld dat de vruchten verschillen in de wijze van teelt en hun verkrijgbaarheid op de markt. De vraag of er in dit geval sprake is van vergelijkbare vruchten kan met de feitelijke vaststelling van de verschillen en overeenkomsten niet worden beantwoord: het is immers niet duidelijk welke van de gesignaleerde overeenkomsten en verschillen voor de beoordeling van de vergelijkbaarheid relevant moeten worden geacht. Dit kan alleen worden bepaald door te kijken naar de inhoudelijke regel die wordt toegepast bij het bepalen van de fruitprijzen. Als de regel wordt gehanteerd dat de verkrijgbaarheid en de teeltmethode van een vrucht bepalend zijn voor de prijs, dan kan worden geconcludeerd dat er inderdaad relevante verschillen bestaan tussen de verschillende vruchten. In dat geval kan de conclusie worden getrokken dat er door het ongelijk prijzen van de vruchten sprake is van een ongelijke behandeling van onvergelijkbare gevallen. ${ }^{202}$ Wordt echter gesteld dat het sapgehalte van een vrucht de prijs bepaalt, dan is het duidelijk dat het prijsverschil een ongelijke behandeling van vergelijkbare gevallen oplevert.

199. Anders gezegd: gevallen zullen altijd in bepaalde opzichten identiek zijn; zie Westen 1983 (II), p. 610 en Pojman/Westmoreland 1997, p. 2. Zie ook Berlin en zijn kritiek op de vergelijkbaarheidsformule: 1969, p. 16. Verder in deze zin Perelman 1963, p. 16, Alexy 1985, p. 362, Koopmans 1972, p. 226, Loenen 1992, p. 213 en Ruiter 1985, p. 13/14.

200. In dit verband kan worden gewezen op de stelling van Westen dat het gelijkheidsbeginsel zoals dat wordt omschreven door het imperatief "gelijke gevallen moeten gelijk worden behandeld" in wezen tautologisch en leeg is. Het krijgt pas inhoud wanneer het wordt gekoppeld aan een inhoudelijke, prescriptieve regel, die een maatstaf geeft om twee gevallen met elkaar te vergelijken: Westen 1982 (I), p. 548/549 en p. 557. Vgl. ook Alexy 1985, p. 363, Van Hoof/Jaspers 1986, p. 141/142 en Wiggers 1991, p. $173 / 174$.

201. Westen 1990, p. 30; zie ook Flathman 1967, p. 38.

202. Daaruit kan overigens nog niet automatisch worden geconcludeerd dat het prijsverschil ook inderdaad redelijk is: deze vaststelling komt pas in de tweede fase van de toetsing aan de orde. 
Uit dit voorbeeld blijkt dat de rechter niet kan volstaan met de eenvoudige vaststelling van feitelijk bestaande verschillen en overeenkomsten tussen de gevallen: aan de hand van een inhoudelijke regel, de vergelijkingsmaatstaf, zal hij steeds moeten nagaan welke verschillen en overeenkomsten relevant zijn. ${ }^{203}$ Laat de rechter deze stap achterwege, dan zal zijn oordeel bij uitstek ondoorzichtig en oncontroleerbaar zijn: de betekenis van bepaalde overeenkomsten en verschillen voor het rechterlijk oordeel kan dan immers niet worden achterhaald. Het risico is echter aanzienlijk dat het vergelijkingscriterium niet uitdrukkelijk wordt geformuleerd. In veel gevallen acht de rechter de keuze voor een bepaalde maatstaf voor de hand liggend of is hij van mening dat er sprake is van een evidente onvergelijkbaarheid, hetgeen al snel tot gevolg heeft dat hij zijn oordeel hierover nauwelijks nader motiveert. ${ }^{204}$ Juist in dit soort gevallen krijgen subjectieve opvattingen of ongefundeerde stereotyperingen de kans om een rol te spelen bij de oordeelsvorming, zonder dat dit naar buiten toe blijkt. Dit is vooral het geval wanneer er onderscheid wordt gemaakt op grond van een maatschappelijk breed aanvaard criterium, of op grond van een criterium dat niet altijd irrelevant is. Dit is lange tijd bijvoorbeeld het geval geweest in zaken over ongelijke behandeling op grond van geslacht. Vaak werd dit soort zaken afgedaan met een eenvoudig beroep op de maatschappelijke of biologische verschillen tussen man en vrouw, zonder dat werd nagegaan of deze verschillen voor het voorgelegde geval daadwerkelijk relevant waren. Hoewel het waarschijnlijk is dat dergelijke vormen van ongelijke behandeling ook via een rechtvaardigingstoets in stand zouden zijn gehouden ${ }^{203}$, bestaat er een belangrijk verschil tussen de beide toetsen. In gevallen waarin geklaagd zou worden over het feit dat alleen voor mannen een onderhoudsverplichting geldt, of over het feit dat nachtarbeid alleen voor vrouwen verboden is, kan bij een toepassing van de vergelijkbaarheidstoets gemakkelijk worden volstaan met het enkele oordeel dat er geen sprake is van vergelijkbaarheid. $\mathrm{Bij}$ een toetsing aan het rechtvaardigingsmodel is een verdergaande motivering echter noodzakelijk: de rechter moet daarbij daadwerkelijk nagaan en uitleggen waaróm het eigenlijk zo is dat mannen wel en vrouwen geen onderhoudsverplichting hebben, en waaróm vrouwen geen nachtarbeid mogen verrichten en mannen wel. Dit betekent dat de rechter bij een toepassing van het rechtvaardigingsmodel wordt gedwongen tot een goede motivering van zijn oordeel, waardoor het voor de partijen in het geding en voor het grotere publiek mogelijk wordt om na te gaan welke

203. Vgl. Van Hoof/Jaspers 1986, p. 144 en Burkens 1982, p. 59.

204. Vgl. Minow 1990 , p. $22 / 23$ en 56. Diverse voorbeelden van een dergelijke gemakzuchtige motivering, waarbij vaak zonder meer wordt gesteld dat gevallen "evident" verschillen, of dat het toch algemeen bekend is dat bepaalde groepen zich niet in een vergelijkbare positie bevinden, zullen worden gegeven in het rechtsvergelijkende gedeelte. Hier kan worden volstaan met een voorbeeld uit de rechtspraktijk van het Europees Hof van de Rechten van de Mens. De betreffende zaak had betrekking op een verschil in behandeling tussen advocaten en rechters: terwijl advocaten niet betaald werden voor pro deozaken, ontvingen rechters voor hun behandeling van dit soort zaken wel een vergoeding. In dit geval kunnen duidelijk relevante verschillen worden vastgesteld, maar er bestaan zeker ook overeenkomsten tussen rechters en advocaten. Het was dan ook nodig om hierbij een vergelijkingsmaatstaf vast te stellen. Dit gebeurde echter niet: het Hof volstond met de enkele stelling dat " [...] [t] he evidence before the Court does not disclose any similarity between the disparate situations in question: each one is characterised by a corpus of rights and obligations of which it would be artificial to isolate one specific aspect" (EHRM 23 november 1983, Van der Mussele, Series A, vol. 70, $\S 46$ ). Door dit oordeel wordt feitelijk alleen bevestigd dát er verschillen bestaan, maar niet waarom die relevant zouden moeten zijn.

205. Vgl. Benn/Peters 1969, p. 65. 
factoren en criteria de uitkomst van het geding hebben beïnvloed. Belangrijk is daarbij ook dat door een dergelijke motivering goed kan worden nagegaan in hoeverre persoonlijke opvattingen van de rechter of stereotypen een rol hebben gespeeld. Weliswaar vormt dit geen volledige waarborg voor objectiviteit, maar in ieder geval wordt het hierdoor mogelijk om controle op het rechterlijk oordeel uit te oefenen.

Gesteld kan worden dat dit verschil in de kwaliteit van de motivering kan worden opgeheven door de rechter ook bij de vergelijkbaarheidstoets te verplichten om aan te geven welke vergelijkingsmaatstaf hij hanteert en te motiveren waarom hij de gevallen in het licht van die maatstaf vergelijkbaar acht. Ook dan geldt echter dat de vergelijkbaarheidstoets geen aanwijsbaar gemakkelijkere en objectievere toetsing oplevert dan de rechtvaardigingstoets. De reden daarvoor is nu juist gelegen in de noodzaak om een goede vergelijkingsmaatstaf te kiezen. Het zal duidelijk zijn dat de rechter niet iedere willekeurige maatstaf als uitgangspunt van de vergelijking zal kunnen hanteren: juist dan bestaat er risico voor het binnensluipen van persoonlijke vooroordelen of stereotypen. ${ }^{206}$ Gesteld kan dan ook worden dat de rechter zich bij de keuze voor een vergelijkingsmaatstaf zoveel mogelijk moet laten leiden door de directe context van de ongelijke behandeling. In gevallen van normatief onderscheid betekent dit bijvoorbeeld dat de doelstelling van de betrokken regeling moet dienen als vergelijkingsmaatstaf, terwijl ook voor de andere situaties van onderscheid kan worden gesteld dat de redenen om onderscheid te maken tot uitgangspunt moeten worden gekozen. ${ }^{207}$ Dit betekent dat het,

206. Zo zou het in het hiervoor gegeven voorbeeld van de citrusvruchten onwenselijk zijn als de rechter zijn opvattingen over de sociale of politieke toestand in het land van herkomst van de vruchten als vergelijkingsmaatstaf zou hanteren, en op die grond zou oordelen dat er geen sprake is van vergelijkbaarheid. Vgl. ook Baker: "Similarity depends on perspective, on the values or objectives of the observer. And if the Court chooses the perspective, it imposes its values on the law" (1980, p. 1033/1034).

207. Vgl. Baker 1980, p. 1034 ("[...] [T]he only value-neutral perspective from which the court can determine similarity of circumstances is the perspective of the legislative purpose or end"); zie ook Burkens 1982 , p. 60 . Theoretisch gezien kan worden gesteld dat het niet nodig is om te kijken naar de doelstelling van het onderscheid om de vergelijkingsmaatstaf te bepalen: de rechter kan immers ook zelf een vergelijkingsmaatstaf vaststellen. Wanneer in het citrusvruchtenvoorbeeld de bedoeling van het prijsbeleid zou zijn geweest om prijzen te bepalen op grond van de zeldzaamheid van een bepaald product, zou de rechter in plaats daarvan kunnen vaststellen dat niet dat, maar de smaak van de vrucht doorslaggevend moet zijn voor de prijs. Zoals al gezegd is dat niet wenselijk, aangezien de rechter dan volledig zelf bepaalt welke kenmerken relevant zijn. Zijn taak is niet om zelf vast te stellen wat het relevante onderscheidende criterium zou moeten zijn, maar alleen om na te gaan of de keuze voor een bepaald criterium door de verdedigende partij onredelijk is. Zou een andere opvatting worden aangehangen, dan zou dit betekenen dat de vergelijkbaarheidstoets een nog veel grotere mate van rechterlijke activiteit vereist dan de toetsing aan het rechtvaardigingsmodel (waarbij alleen een toetsing op redelijkheid van het door de verdedigende partij aangevoerde doel wordt uitgevoerd). Zie over dit onderwerp verder Nieuwenhuis 1976, p. 503, Sloot 1986, p. 26 en "Note" 1978, p. 781; vgl. ook Loenen 1992, p. 213, Loenen 1998, p. 20 en Wentholt 1990, p. 65/67. Kritisch over het hanteren van de doelstelling als vergelijkingscriterium is Ruiters, die stelt dat ook niet-teleologische maatstaven kunnen worden gehanteerd $(1985$, p. $22 / 23)$. Zoals echter is aangegeven kan meer in zijn algemeenheid worden gekeken naar de reden waarom onderscheid wordt gemaakt, dus naar de motieven die aan het onderscheid ten grondslag liggen. Hierdoor wordt ook ruimte geboden voor overwegingen die niet direct als doelstelling zijn te beschouwen, maar misschien eerder als motief (zie voor het onderscheid tussen motieven en doelstellingen de voetnoten in paragraaf 3.2). Belangrijk is wel dat in sommige omstandigheden een duidelijke doelstelling ontbreekt. Dit is bijvoorbeeld het geval wanneer de ongelijke behandeling het gevolg is van de toepassing van een regel die een grote mate van beleids- of beoordelingsvrijheid laat: in dat 
ook in het kader van de vergelijkbaarheidstoets, nodig is om het doel van het onderscheid vast te stellen, waarbij alle aan die vaststelling inherente problemen gelden die hiervoor in paragraaf 3.2.2 en 3.2.3 zijn besproken. ${ }^{20 s}$

\subsubsection{Inhoudelijke beoordeling van de vergelijkingsmaatstaf}

Hiervoor is aandacht besteed aan de vaststelling van de vergelijkbaarheid aan de hand van een inhoudelijke vergelijkingsmaatstaf, waarbij is vastgesteld dat het doel van het onderscheid in beginsel als vergelijkingsmaatstaf moet worden gehanteerd. Nu dit betekent dat de rechter ook bij de vergelijkbaarheidstoets onderzoek moet verrichten naar het doel van het onderscheid, kan worden gesteld dat het verschil tussen beide toetsen minimaal is. Toch is wel betoogd dat er op een ander punt een belangrijk verschil bestaat: terwijl het rechtvaardigingsmodel vereist dat het doel van de regeling inhoudelijk op zijn redelijkheid wordt getoetst, lijken sommige voorstanders van de vergelijkbaarheidstoets ervan uit te gaan dat een dergelijke redelijkheidstoets daarbij niet nodig is. ${ }^{209}$ Deze veronderstelling vormt voor hen een overtuigend argument voor het gebruik van de vergelijkbaarheidstoets: doordat een onderzoek naar de gerechtvaardigdheid niet nodig is, is er immers sprake van een minder vergaande rechterlijke activiteit. ${ }^{210}$

Gesteld moet echter worden dat ook bij de vergelijkbaarheidstoets een beoordeling van de legitimiteit en redelijkheid van de vergelijkingsmaatstaf (dus van het doel van het onderscheid) wenselijk is. ${ }^{211}$ Het voorbeeld van het entreebeleid van een discotheekei-

geval schrijft de regel immers niet automatisch cen bepaalde behandeling voor en kan het doel van de regeling niet gebruikt worden als vergelijkingsmaatstaf. Ook dan geldt echter dat aan de ongelijke behandeling (bijvoorbeeld wel verlening van een vrijstelling aan X, maar niet aan $\mathrm{Y}$ ) een bepaalde reden ten grondslag zal liggen. Deze reden zal dan kunnen gelden als vergelijkingsmaatstaf.

208. In veel theoretische literatuur wordt niet zozeer het concrete doel van de maatregel als vergelijkingsmaatstaf gekozen, maar wordt vooral gewerkt met abstracte en theoretische toetsingsmaatstaven. Zo spreekt Aristoteles over verdienste als bepalend criterium ("all men agree that what is just in distribution must be according to merit in some sense" [Ethica Nicomachaea V.3.113la]), terwijl Walzer en Perelman wijzen op criteria als behoefte en rang: zie Walzer 1983, p. 23-25 en Perelman 1963, p. 7, met nadere uitwerking op p. 17-28). Het is voor de rechter bijzonder moeilijk om met dit soort abstracte criteria te werken, hoe verhelderend en waardevol deze in theoretisch opzicht ook zijn: maatstaven als behoefte, rang of verdienste zullen de rechter weinig duidelijkheid bieden wanneer hij de redelijkheid van een prijsverschil tussen citrusvruchten moet bepalen.

209. Zo stelt Kewenig dat een belangrijk nadeel van het rechtvaardigingsmodel is, dat dit alleen een gerechtvaardigd doel en een redelijke verhouding tussen doel en middel vereist (daarbij neemt hij het, qua toetsingsmethodiek niet het meest fraaie en uitgebreide, model van het Europees Hof voor de Rechten van de Mens tot uitgangspunt; zie daarover nader hoofdstuk 3). Bezwaarlijk aan de doorslaggevende betekenis die in dit model wordt toegekend aan de aanwezigheid van een gerechtvaardigd doel vindt hij, dat via dit model eigenlijk iedere ongelijke behandeling kan worden gerechtvaardigd, omdat er altijd wel argumenten zijn te bedenken die voor het maken van onderscheid pleiten (1972, p. 106). Lijkt deze kritiek meer in het algemeen al wat overtrokken (zie in dat verband nader paragraaf 3 ), in ieder geval is dit geen goed argument voor een keuze voor de vergelijkbaarheidstoets.

210. Kewenig 1972, p. 106; hij stelt dat de rechtvaardigingstoets juist door de noodzaak van een onderzoek van het doel op ontoelaatbare wijze treedt in de discretie van de wetgever.

211. Nodig is dit overigens zeker niet; conceptueel gezien is het zelfs zuiverder om een dergelijke inhoudelijke toetsing niet uit te voeren. Het gelijkheidsbeginsel is zelf immers waardeneutraal: het vergt weliswaar een onderzoek naar de relevante verschillen tussen de gevallen, maar geen beoordeling van de redelijkheid van de gekozen toetsingsmaatstaf (zie daarover Bedau 1967, p. 9 en 10). De redelijkheid of de gerechtvaardigdheid van een gelijke of ongelijke behandeling kan dan ook niet uitsluitend 
genaar kan dit verduidelijken. Wanneer deze eigenaar tot doel heeft om kleurlingen te ontmoedigen in zijn discotheek te komen, kan hij proberen om dit doel te bereiken door van kleurlingen een aanzienlijk hogere entree te vragen dan van blanken. Een dergelijk verschil in behandeling is gebaseerd op een verschil in huidskleur dat, in het licht van het doel van het entreebeleid, zonder meer relevant is. Wanneer een zuivere vergelijkbaarheidstoets wordt uitgevoerd, kan de rechter in dit geval zonder veel moeite tot de conclusie komen dat blanken en kleurlingen niet vergelijkbaar zijn. Of het doel van de regeling, en daarmee de gehanteerde vergelijkingsmaatstaf, eigenlijk wel redelijk is, is een vraag die hierbij in het geheel niet aan de orde is.

Wanneer de rechter de vraag wordt voorgelegd of er sprake is van een ongerechtvaardigde ongelijke behandeling zal hij echter niet kunnen volstaan met de beoordeling of de verschillen in het licht van het doel van de regeling relevant zijn, maar zal hij ook moeten beoordelen of de maatstaf zelf wel deugdelijk is. ${ }^{212}$ In het bovenstaande voorbeeld betekent dit dat de rechter niet alleen moet beoordelen of huidskleur een in het licht van het gestelde doel relevant verschil vormt, maar ook of het toelaatbaar is om een entreebeleid te voeren waardoor kleurlingen worden ontmoedigd een bepaalde discotheek te bezoeken. ${ }^{213}$ Een inhoudelijke beoordeling van het gemaakte onderscheid in relatie tot de gekozen vergelijkingsmaatstaf komt dan ook onvermijdelijk neer op een beoordeling van de gerechtvaardigdheid van het doel. ${ }^{214}$

Wanneer ervan wordt uitgegaan dat ook de vergelijkingsmaatstaf moet worden beoordeeld op zijn redelijkheid, is het duidelijk dat er geen bijzonder grote verschillen bestaan tussen de vergelijkbaarheidstoets en de rechtvaardigingstoets. ${ }^{215}$ In beide gevallen

aan de hand van het gelijkheidsbeginsel worden bepaald: daarvoor is het nodig om een expliciete koppeling te leggen met de notie van rechtvaardigheid, zoals dit gebeurt bij de toetsing aan het rechtvaardigingsmodel. Om die reden is het feitelijk beter om in de eerste fase van de vergelijkbaarheidstoets te volstaan met een feitelijke vaststelling van de vergelijkbaarheid, om pas in de tweede fase van de toetsing de gerechtvaardigdheid te beoordelen. Door de aanhangers van de vergelijkbaarheid wordt een dergelijke verdeling echter nooit gemaakt, waarschijnlijk omdat dit tot onwenselijke consequenties zou leiden (zie in dat verband paragraaf 4.3, over de benaderingen 1-3: deze vereisen in bepaalde omstandigheden geen rechtvaardigingstoets, zodat het niet beoordelen van de redelijkheid van de toetsingsmaatstaf in de eerste fase voor die, veelgevolgde, benaderingen leidt tot de onmogelijkheid om de gerechtvaardigdheid van de toetsingsmaatstaf te beoordelen). Overigens kan worden vastgesteld dat het vaststellen van de vergelijkbaarheid zelfs in de meest zuivere benadering (benadering 4 ) geen bijzondere toegevoegde waarde heeft en de toetsing zelfs ondoorzichtig kan maken. Zie daarover nader paragrafen 4.3.2 en 4.3.3.

212. Vgl. Burkens 1982 , p. 60 , Simons 1985 , p. 391 , Ruiters 1986, p. $24 / 25$, Benn/Peters 1969 , p. 59 en Sloot 1986, p. 26.

213. Dworkin vat dit compact samen voor het geval waarin het niet zou gaan om een horizontale verhouding, maar om een normatieve classificatie in wetgeving: "[...] compliance with the rule book is plainly not sufficient for justice; full compliance will achieve very great injustice if the rules are unjust" (1985, p. 12).

214. Het nalaten van een inhoudelijke toets zou nog te billijken zijn wanneer gevraagd wordt om een toetsing aan algemene beginselen of ander ongeschreven recht: zoals eerder al is opgemerkt zou de verhouding tussen rechter en wetgever hieraan in de weg kunnen staan. Eerder is echter ook reeds aangegeven dat er overtuigende argumenten kunnen worden aangevoerd ter ontkrachting van deze stelling. Duidelijk is bovendien dat er niets in de weg staat aan een inhoudelijke toetsing wanneer de maatstaf in strijd is met hoger geschreven recht; sterker nog, in het geval van strijd met een hogere regel zal de rechter vrijwel verplicht zijn om zich uit te spreken over de geldigheid van de vergelijkingsmaatstaf.

215. Zie ook Loenen 1992, p. 212; ook Wentholt is van mening dat de toetsen overlappen (1990, p. 74-76). 
is het uitgangspunt van de toetsing immers dat de rechter onderzoek moet verrichten naar de bedoeling van het onderscheid. Zowel bij de vergelijkbaarheidstoets als bij de toepassing van het rechtvaardigingsmodel moet de rechter bovendien nagaan of de doelstelling van het onderscheid voldoende gerechtvaardigd is. Duidelijk is dan ook dat de veronderstelde objectiviteit en de eenvoud van de vergelijkbaarheidstoets bedrieglijk zijn: deze toets vergt een beoordeling die in sterke mate overeenkomt met de toetsing die door het eerste criterium van het rechtvaardigingsmodel wordt vereist. De vergelijkbaarheidstoets kan dan ook zeker niet zonder meer worden verkozen boven het rechtvaardigingsmodel. Op de redenen waarom een toetsing aan het rechtvaardigingsmodel dan wel moet worden verkozen boven de vergelijkbaarheidstoets zal in het hiernavolgende nader worden ingegaan (zie paragraaf 4.3).

\subsubsection{Rechtvaardigingsmodel en vergelijkbaarheidstoets: over- en under- inclusiveness}

Niet alleen ten aanzien van de doeltoets zijn er sterke overeenkomsten zichtbaar tussen de vergelijkbaarheidstoets en de toetsing aan het rechtvaardigingsmodel: van belang is ook dat in beide gevallen een oordeel moet worden uitgesproken over de mate van fit. ${ }^{216}$ Voor de vergelijkbaarheidstoets ligt dit misschien niet voor de hand. Als wordt bezien wanneer er sprake is van een ongelijke behandeling van vergelijkbare gevallen en wanneer er sprake is van over- en underinclusiveness, blijkt echter dat er op dit punt van een inhoudelijk vergelijkbare toetsing sprake is.

Zoals eerder is aangegeven wordt met de begrippen over- en underinclusiveness geduid op de aansluiting tussen de definitie van een normatieve classificatie en de nagestreefde doelstelling. Wanneer de definitie onvoldoende zorgvuldig is kan dit, afhankelijk van de mate van fit die wordt vereist, leiden tot het oordeel dat het onderscheid ontoelaatbaar is. Het vaststellen van vergelijkbaarheid en onvergelijkbaarheid komt feitelijk op een zelfde toetsing neer. Wanneer een regeling een classificatie bevat die twee in relevante opzichten verschillende gevallen gelijk behandelt, zal deze classificatie altijd overinclusive zijn: de definitie van de classificatie is dan immers te ruim in verhouding tot het nagestreefde doel. Andersom is er bij een ongelijke behandeling van relevant gelijke gevallen steeds sprake van underinclusiveness: in dat geval is de definitie kennelijk te eng in verhouding tot het nagestreefde doel. ${ }^{217}$ Als voorbeeld kan opnieuw de regeling dienen die vrouwen verbiedt om zwaar lichamelijke arbeid te verrichten, om op die manier de volksgezondheid te beschermen. Zoals in paragraaf 3.3 .2 al is aangegeven is deze regeling zowel over-als underinclusive: ook vrouwen die heel goed in staat zijn om zonder gevaar voor hun gezondheid zwaar werk te doen vallen immers onder de reikwijdte van het verbod, terwijl mannen die dit niet kunnen van bescherming worden uitgesloten.

Bij een toepassing van de vergelijkbaarheidstoets vindt de beoordeling langs dezelfde lijnen plaats. In dat verband kan allereerst worden vastgesteld dat, in het licht van het

216. Zie over dit begrip en over de toepassing van dit element in het kader van de rechtvaardigingstoets par. 3.3.2.

217. Zie in deze zin Barents 1994, p. 332 en 333, hoewel hij geen gebruik maakt van de terminologie van over- en underinclusiveness. Zie verder "Note" 1978, p. 783. 
doel van de regeling, het kunnen verrichten van zwaar werk zonder gevaar voor de volksgezondheid het relevante kenmerk is voor de bepaling van de vergelijkbaarheid. Uit die vaststelling blijkt meteen al dat de regeling ongelijke gevallen gelijk behandelt: vrouwen die wel in staat zijn om zware arbeid te verrichten worden door de regeling op dezelfde manier behandeld als vrouwen die hier niet toe in staat zijn, ondanks het feit dat zij relevante verschillen vertonen. De ongelijke behandeling van gelijke gevallen komt dus overeen met overinclusiveness van de normatieve classificatie. Tegelijkertijd is er in deze regeling sprake van een ongelijke behandeling van gelijke gevallen: mannen die onvoldoende in staat zijn om zonder gevaar voor hun gezondheid zwaar werk te verrichten bevinden zich in een positie die relevant vergelijkbaar is met die van vrouwen die dit niet kunnen, maar worden door de regeling niet beschermd. Gelijke behandeling van ongelijke gevallen is dus feitelijk hetzelfde als de underinclusiveness van een normatief onderscheid.

Ook in dit opzicht levert de toetsing aan het rechtvaardigingsmodel dus geen bijzonder grote verschillen op met een toepassing van de vergelijkbaarheidstoets. Een voordeel van het rechtvaardigingsmodel is echter dat de mate van aansluiting tussen doel en classificatie door de rechter uitdrukkelijk moet worden getoetst: het is niet zo dat iedere over- of underinclusiveness meteen leidt tot een ontoelaatbaarverklaring van het onderscheid. Daardoor biedt deze toetsing een aanzienlijke mate van flexibiliteit, waardoor de rechter ruimte heeft om rekening te houden met de beoordelingsvrijheid van de regelgever. Bij de uitvoering van een vergelijkbaarheidstoets is deze flexibiliteit afwezig: daar bestaat slechts ruimte voor de enkele vaststelling of er sprake is van een gelijke behandeling van ongelijke gevallen of een ongelijke behandeling van gelijke gevallen. ${ }^{218} \mathrm{Om}$ die reden lijkt het beter om een rechtvaardigingstoets dan een vergelijkbaarheidstoets tot uitgangspunt van de rechterlijke toetsing te maken.

\subsection{De tweede fase van de toetsing: wenselijkheid van de keuze voor het rechtvaardigingsmodel}

\subsubsection{Inleiding}

In paragraaf 4.1 is reeds angegeven dat de vaststelling van de vergelijkbaarheid als zodanig de eerste fase van de vergelijkbaarheidstoets vormt. Terwijl over deze fase relatief veel eenduidigheid bestaat, is het verre van duidelijk hoe vervolgens vorm moet worden gegeven aan de tweede fase van deze toetsing. Grofweg kan worden gesteld dat er op vier verschillende manieren invulling aan de tweede fase kan worden gegeven:

1. De uitkomst van de vergelijkbaarheidstoets is automatisch beslissend voor de uitkomst van de procedure: zijn de gevallen vergelijkbaar, dan kan geen enkele vorm van ongelijke behandeling door de beugel; zijn de gevallen verschillend, dan is een ongelijke behandeling zonder meer toelaatbaar. ${ }^{219}$

218. Wel kan er in de tweede fase soms rekening worden gehouden met de mate van ongelijkheid of gelijkheid van de gevallen. De mate waarin dit mogelijk is, is afhankelijk van de gekozen benadering; zie paragraaf 4.3 .

219. Een belangrijke voorstander van deze opvatting is Kewenig: “[...] bei der Feststellung des Vergleich- 
2. Wanneer er relevante verschillen zijn gesignaleerd moet de rechter bekijken of deze verschillen in een redelijke verhouding staan tot de ongelijke behandeling. Anders gezegd: de rechter zal steeds moeten onderzoeken of de relevante verschillen evenredig zijn ten opzichte van het verschil in behandeling. Wanneer in de eerste fase geconcludeerd wordt dat de gevallen vergelijkbaar zijn, is iedere ongelijke behandeling echter ontoelaatbaar. ${ }^{220}$

3. Als de gevallen relevant verschillen is het maken van onderscheid toelaatbaar; een proportionaliteitstoets is niet nodig. Zijn de gevallen vergelijkbaar, dan moet de rechter beoordelen of het gemaakte onderscheid op basis van objectieve en redelijke argumenten kan worden gerechtvaardigd. ${ }^{221}$

4. Bij ongelijke gevallen moet er een proportionaliteitstoets worden uitgevoerd (waarbij wordt beoordeeld of de gesignaleerde verschillen in een redelijke verhouding staan tot het nagestreefde doel), bij gelijke gevallen een rechtvaardigingstoets (waarbij wordt beoordeeld of het gemaakte onderscheid kan worden gerechtvaardigd op basis van objectieve en redelijke argumenten). Noch vergelijkbaarheid,

statbestandes [wird] im Grunde nichts anderes unternommen [...] als der Versuch einer Antwort auf die Frage, ob eine - auf sachlichen Unterschieden beruhende und damit - sachlich gerechtfertigte Ungleichbehandlung vorliegt oder nicht. Unter diese Umständen erscheint es deshalb weder erforderlich noch zulăssig, die Frage der Sachwidrigkeit noch einmal aufzuwerfen, nachdem die Erörterungen zum Vergleichstatbestand abgeschlossen sind" (1972, p. 101; zie ook p. 135/136). Kewenig is dus van mening dat al bij de vaststelling van de gelijkheid van de gevallen een maatstaf wordt gekozen en beoordeeld, waardoor ook al antwoord is gegeven op de vraag of de ongelijke behandeling objectief gerechtvaardigd is. Wanneer na de vaststelling van de vergelijkbaarheid nog een aparte rechtvaardigingstoets zou worden uitgevoerd, leidt dit volgens hem tot een doublure (p. 100/101). Flathman 1967, p. 45 e.v., gaat uit van een vergelijkbare benadering; weliswaar laat hij enige ruimte voor het als ontoelaatbaar beschouwen van een ongelijke behandeling van onvergelijkbare gevallen, maar daarbij maakt hij geen gebruik van een proportionaliteitstoets: "If the policy of giving $\mathrm{X}$ to $\mathrm{A}$ but not to $\mathrm{B}, \mathrm{C}, \mathrm{D}, \ldots \mathrm{N}$ is not wrong for $\mathrm{B}, \mathrm{C}, \mathrm{D}, \ldots \mathrm{N}$, a permissible classification has been made and it is right to give $\mathrm{X}$ to $\mathrm{A} .[\ldots]$ If giving $\mathrm{X}$ to $\mathrm{A}$ but not to $\mathrm{B}, \mathrm{C}, \mathrm{D}, \ldots \mathrm{N}$ wrongs $\mathrm{B}, \mathrm{C}, \mathrm{D}, \ldots \mathrm{N}$, the classification is not permissible and the policy must be abandoned". De nadruk ligt hierbij dus op de vraag of B door de ongelijke behandeling, ook al bevond hij zich in een verschillende situatie, al of niet is benadeeld: is dit niet het ge$\mathrm{val}$, dan is er geen probleem, is dit wel zo, dan is het gemaakte onderscheid niet toelaatbaar. Voor een proportionaliteitstoets bestaat in deze benadering geen ruimte: het gaat slechts om de vraag of het "verkeerd" is dat A een behandeling kreeg die B niet ten deel viel, niet om de vraag of de behandeling die A en B hebben gekregen in een redelijke verhouding staat tot de tussen A en B bestaande verschillen.

220. Zie Aristoteles (ongelijke gevallen moeten ongelijk worden behandeld naar mate van hun ongelijkheid; zie Politics, vertaling in het Engels door Jowett, met name III.12.1283a.2; in deze zin ook Leibholz 1925, p. 45 en Benn/Peters 1969, bijv. op p. 57, 60/61 en 75. Deze benadering wordt ook besproken door Bedau 1967, p. 19.

221. Zie bijv. Timmermans 1982, p. 442. Een overtuigd aanhanger van deze benadering is ook Happé; zie bijvoorbeeld Happé 1991, p. 300: "Het tweede vereiste [dat van een objectieve rechtvaardiging] komt eerst aan de orde als de rechter heeft geconstateerd dat er sprake is van een ongelijke behandeling van gelijke gevallen", in samenhang met noot 5: "Als de rechter vaststelt dat er sprake is van een ongelijke behandeling van ongelijke gevallen, dan is daarmee tevens komen vast te staan dat het gelijkheidsbeginsel is geschonden." Ook bij Alexy (1985) kan deze gedachte impliciet worden teruggevonden: doordat hij uitsluitend aandacht besteedt aan de vraag of een ongelijke behandeling van vergelijkbare gevallen kan worden gerechtvaardigd, kan ervan worden uitgegaan dat in zijn visie een ongelijke behandeling van onvergelijkbare gevallen niet nader op zijn redelijkheid hoeft te worden beoordeeld. De aandacht voor de rechtvaardigingsmogelijkheid van een ongelijke behandeling van vergelijkbare gevallen is het duidelijkste terug te vinden op p. 370 . 
noch onvergelijkbaarheid leidt bij deze benadering automatisch tot de conclusie van toelaatbaarheid of ontoelaatbaarheid van de ongelijke behandeling. ${ }^{22}$

De eerste benadering wordt slechts door een zeer beperkt aantal auteurs verdedigd. Dit is ook niet verbazend, aangezien een dergelijke eenvoudige gevolgtrekking uit het bestaan van vergelijkbare of onvergelijkbare gevallen tot onverantwoorde en onwenselijke resultaten kan leiden. ${ }^{223}$ Dit kan worden verduidelijkt aan de hand van het theoretische voorbeeld van een strafwet waarin, vanuit de gedachte dat misdrijven moeten worden bestraft in overeenstemming met hun ernst, een andere strafmaat is vastgelegd voor moord dan voor doodslag. De straf op doodslag is in deze wet vastgesteld op een maximale gevangenisstraf van twee jaar, terwijl moord moet worden bestraft met minimaal twintig jaar gevangenisstraf. Geredeneerd vanuit de doelstellingen en achtergrond van de strafwet kan worden opgemerkt dat er relevante verschillen tussen moord en doodslag bestaan. Bepalend is immers de ernst van het misdrijf, terwijl het feitelijk niet moeilijk is om vast te stellen dat moord een ernstiger misdrijf is dan doodslag. Wordt de eerste benadering gevolgd, dan vloeit uit dit verschil automatisch voort dat de ongelijke strafmaat toelaatbaar is. Dit betekent echter ook dat er geen enkele ruimte bestaat voor de beoordeling van de redelijkheid van het extreme verschil in strafmaat waarvan in het gegeven voorbeeld sprake is. ${ }^{224}$

222. Een voorbeeld van deze benadering is, in uitgewerkte vorm, te vinden bij Loenen 1992, p. 212-215.

223. Bovendien kan in het algemeen worden gesteld dat deze benadering voorbij gaat aan het conceptuele verschil tussen gelijkheid en billijkheid. Dit wordt duidelijk aan de hand van een door Bedau gegeven voorbeeld waarin twee mensen een ongelijke hoeveelheid krijgen van iets, maar ook duidelijk verschillen in hun behoeften. Daarover merkt hij het volgende op: "One could certainly not say, 'The stuff has been fairly distributed, though of course one got twice as much as the other; and thus the stuff was equally distributed after all.' Once we know that the shares were not the same, we know that they were not equal; and even if the distribution was fair, we know too much to countenance the inference. To think otherwise is to rely on some such principle as 'Fairness implies equality' [...]. But there is no such principle [...]" (1967, p. 9). Toch probeert de eerste benadering uit de gelijkheid van de gevallen de rechtvaardigheid, en daarmee de toelaatbaarheid, van de ongelijke behandeling af te leiden. Dit is conceptueel gezien niet mogelijk: het gelijkheidsbeginsel is zelf waardeneutraal en kan alleen worden gebruikt om vast te stellen of twee gevallen feitelijk relevant gelijk zijn. Of het vervolgens ook redelijk is dat een bepaald onderscheid wordt gemaakt, kan alleen worden beoordeeld expliciet te toetsen aan een rechtvaardigheidsnotie. Dit is precies wat het hiervoor in paragraaf 3 beschreven rechtvaardigingsmodel doet: daarbij is het aan de rechter om te beantwoorden in hoeverre een in de eerste toetsingsfase feitelijk vastgestelde ongelijke behandeling kan worden gerechtvaardigd. Overigens geldt deze kritiek in mindere mate wanneer wordt aangenomen dat in het kader van de vaststelling van de vergelijkbaarheid reeds een oordeel mag worden gegeven over de rechtvaardigheid van de gehanteerde toetsingsmaatstaf; in dat geval wordt er immers al een soort rechtvaardigheidselement in de toetsing van de vergelijkbaarheid zelf is ingebouwd. Zoals in voetnoot 211 al bleek is dit de enige manier waarop de eerste benadering redelijkerwijze kan worden verdedigd: er is dan sprake van een soort fusie van de eerste en de tweede fase van de toetsing.

224. Gesteld kan echter worden dat in dit soort gevallen een onwenselijke uitkomst van de toetsing kan worden voorkomen door een goede vergelijkingsmaatstaf te kiezen: daardoor ontstaat op zichzelf voldoende ruimte om ethische of maatschappelijke overwegingen mee te nemen in de vergelijking. In het gegeven voorbeeld kan bijvoorbeeld worden gesteld dat de bestraffing van misdrijven moet worden bepaald in verhouding met de gepercipieerde ernst van het misdrijf, relevant is dan niet alleen de objectieve ernst van het misdrijf, maar ook de perceptic daarvan. In dat geval kan tot de conclusie worden gekomen dat er geen relevante verschillen bestaan die het gegeven verschil in behandeling kunnen rechtvaardigen (vgl. Kewenig 1972, p. 135). Door een dergelijke methode komt alle nadruk te liggen op de zoektocht naar een juiste vergelijkingsmaatstaf en is het niet nodig om verder te kijken naar de 
De meeste voorstanders van de vergelijkbaarheidstoets geven dan ook aan dat de rechter zijn oordeel over de toelaatbaarheid van een ongelijke behandeling niet uitsluitend mag laten afhangen van zijn oordeel over de vergelijkbaarheid. Ook dan zijn er echter nog verschillen in opvatting mogelijk over de mate waarin en de wijze waarop de vergelijkbaarheid of onvergelijkbaarheid de uitkomst van de toetsing kan bepalen, zoals blijkt uit de benaderingen twee tot en met vier. Terwijl de tweede en vierde theorie in het voorbeeld van de strafwet een oordeel vereisen over de redelijkheid van het verschil in strafmaat in verhouding tot de gesignaleerde relevante verschillen, is dit in de derde opvatting niet nodig. De derde theorie vereist alleen een verdergaande toets in het theoretische geval waarin de rechter concludeert dat moord en doodslag vergelijkbaar zijn (bijvoorbeeld omdat het misdrijf in beide gevallen resulteert in het overlijden van het slachtoffer). Volgens deze theorie, en overigens ook volgens de vierde, is het in dat geval nodig om te beoordelen of er een objectieve rechtvaardiging bestaat voor het gesignaleerde verschil in strafmaat.

Uit het voorgaande blijkt dat bij de laatste drie benaderingen, en met name bij de vierde, een rechterlijke toetsing is vereist die tot op zekere hoogte vergelijkbaar is met die in het rechtvaardigingsmodel. Vereist is immers steeds dat de rechter in de eerste fase van de toetsing onderzoekt welke doelstelling door het onderscheid wordt nagestreefd en een oordeel uitspreekt over de gerechtvaardigdheid van deze doelstelling. Vervolgens vereisen alle benaderingen - zij het niet voor alle gevallen - een beoordeling van de redelijkheid van het gemaakte onderscheid in het licht van de tussen de gevallen bestaande verschillen, waardoor feitelijk van de rechter wordt gevergd dat hij een doelmiddeltoets uitvoert. Gezien deze grote mate van overeenkomst tussen de vergelijkbaarheidstoets en het rechtvaardigingsmodel is de vraag gerechtvaardigd waarom het rechtvaardigingsmodel dan toch moet worden verkozen boven de vergelijkbaarheidstoets.

\subsubsection{Wenselijkheid van de keuze voor het rechtvaardigingsmodel}

Ter motivering van de keuze voor het rechtvaardigingsmodel kan allereerst worden gesteld dat dit model het voordeel biedt van duidelijkheid. Voor de vergelijkbaarheidstoets geldt immers dat er tenminste vier benaderingen mogelijk zijn, die zeer verschillende consequenties hebben voor de uitkomst van de procedure. Als over het hiervoor gegeven voorbeeld van het verschil in strafmaat zou worden geklaagd bij een rechter die de tweede of de vierde benadering volgt, dan zou dit waarschijnlijk tot gevolg hebben dat de klager in het gelijk wordt gesteld: in beide gevallen moet de rechter namelijk aandacht besteden aan de proportionaliteit van de verschillen ten opzichte van de ongelijkheid in de strafmaat. ${ }^{22}$ Zou dezelfde klager echter naar een rechter stappen

rechtvaardigheid van de uitkomst van de vergelijkingstoets. Feitelijk betekent deze benadering echter niet veel meer dan het samenvoegen van verschillende stappen in één enkel toetsingscriterium. De rechterlijke activiteit wordt hierdoor zeker niet verminderd, terwijl de toetsing moeilijk controleerbaar en ondoorzichtig wordt. Het is dan ook niet wenselijk om van een dergelijke benadering gebruik te maken.

225. Tenzij de rechter toch nog tot de conclusie zou komen dat het verschil in strafmaat gezien de bestaande verschillen tussen doodslag en moord gerechtvaardigd is. 
die de voorkeur geeft aan de eerste of de derde benadering, dan zou zijn beroep zonder twijfel worden afgewezen: uit het bestaan van relevante verschillen kan de rechter immers zonder meer afleiden dat de ongelijke behandeling toelaatbaar is.

Door dit soort verschillen ontstaat een grote mate van rechtsonzekerheid en rechtsongelijkheid, hetgeen een consequentie is die, gelet op het belang van een voorspelbare toetsing bij een zo belangrijk beginsel als het gelijkheidsbeginsel, moet worden vermeden. Bij een toepassing van het rechtvaardigingsmodel zoals dat in paragraaf 3 is uitgewerkt ontbreekt de onzekerheid over de manier waarop de rechter een voorgelegde ongelijke behandeling zal benaderen: de te volgen toetsingsmethodiek is daarbij duidelijk voorgeschreven.

Gesteld kan echter worden dat het gevaar voor rechtsonzekerheid en rechtsongelijkheid gemakkelijk kan worden vermeden door één van de hierboven beschreven benaderingen dwingend voor te schrijven. Vanzelfsprekend moet daarbij worden gekozen voor die benadering die de betrokken partijen, dus zowel de eisende als de verdedigende partij, de meeste voordelen biedt. ${ }^{226}$ Een keuze voor de eerste, tweede of derde benadering ligt in dit verband niet voor de hand. Bij de eerste en tweede benadering bestaat er immers een duidelijk nadeel voor de verwerende partij: zelfs als er goede en gerechtvaardigde argumenten bestaan om het onderscheid toelaatbaar te achten laat deze benadering daarvoor geen ruimte. Een belangrijk probleem bij deze keuze is dan ook dat maatschappelijk wenselijk onderscheid niet op zijn merites kan worden beoordeeld. ${ }^{27}$

226. Door de keuze voor een bepaalde benadering moet recht worden gedaan aan de belangen van degene die door het onderscheid is benadeeld, maar anderzijds moet ook niet uit het oog worden verloren dat degene die verantwoordelijk is voor het onderscheid in veel gevallen goede redenen had om dit onderscheid te maken. Dit geldt vooral bij wetgeving, waarbij door een classificatie vaak wordt geprobeerd om maatschappelijk wenselijke doelstellingen te verwezenlijken. Het gaat dus niet aan om bij de rechterlijke toetsing eenzijdig alle aandacht te richten op de bescherming van het individu tegen ongelijke behandeling: er moet ook ruimte worden gelaten voor de wens algemene belangen na te streven.

227. Het nadeel van deze keuze is vooral zichtbaar bij de problematiek van voorkeursbehandeling. Een goed voorbeeld is te vinden in de toelatingsprocedures voor Amerikaanse universiteiten. In het algemeen wordt aangenomen dat voor de toelating tot een universiteit de kwaliteit en het talent van de potentielle studenten bepalend zijn; een criterium als huidskleur is in dit verband niet relevant. Dit betekent dat gekleurde en blanke studenten zich in het algemeen in een vergelijkbare positie zullen bevinden. Wanneer de tweede benadering wordt gekozen zal dit betekenen dat zij volstrekt gelijk moeten worden behandeld. Sommige universiteiten bekommeren zich echter om het feit dat gekleurde studenten sociaal en historisch gezien consequent achtergesteld zijn, waardoor zij binnen de studentenpopulatie een ondervertegenwoordigde groep vormen. Om deze ondervertegenwoordiging enigszins op te heffen hechten zij bij de toelating toch waarde aan de huidskleur van de kandidaten. Door velen wordt dit als een maatschappelijk gezien wenselijke vorm van onderscheid beschouwd. Binnen de tweede benadering bestaat er echter geen ruimte om met een dergelijke externe, maatschappelijke rechtvaardiging rekening te houden: deze verandert immers niets in de situatie dat er geen relevante verschillen tussen gekleurde en blanke studenten bestaan.

Een ander voorbeeld, dat in de praktijk veel voor zal komen, is het geval waarin een bepaald onderscheid gemaakt wordt uit overwegingen van administratieve aard, bijvoorbeeld ten behoeve van de vergemakkelijking van registratie, of ter voorkoming van fraude. Dergelijke overwegingen kunnen nauwelijks als vergelijkbaarheidsmaatstaf worden gehanteerd, omdat zij niet kunnen worden geformuleerd als typische kenmerken of eigenschappen van een bepaalde groep, en dus ook geen relevante verschillen tussen de betrokken groepen kunnen opleveren. Toch kan het de moeite waard zijn om na te gaan of dergelijke overwegingen een bepaald onderscheid kunnen rechtvaardigen; vanzelfsprekend 
Ook de keuze voor de derde benadering is problematisch, zoals eerder ook al is aangegeven. Volgens deze benadering is het immers altijd toelaatbaar dat onvergelijkbare gevallen ongelijk worden behandeld. Door de keuze voor deze benadering wordt miskend dat niet iedere ongelijke behandeling even redelijk is en dat het wenselijk is om een oordeel te geven over de proportionaliteit van de verhouding tussen het onderscheid en het nagestreefde doel. Vanzelfsprekend geldt dit bezwaar in gelijke mate voor de eerste benadering, die immers op hetzelfde uitgangspunt is gebaseerd. ${ }^{228}$

Alleen door een keuze voor de vierde benadering wordt optimaal recht gedaan aan alle betrokken belangen. Deze benadering vereist immers zowel een beoordeling van de rechtvaardiging bij een ongelijke behandeling van vergelijkbare gevallen, als een toetsing van de proportionaliteit bij een ongelijke behandeling van onvergelijkbare gevallen. Om een goede motivering te waarborgen zou bij de keuze voor deze benadering kunnen worden gesteld dat de redelijkheid van de ongelijke behandeling moet worden beoordeeld aan de hand van het rechtvaardigingsmodel. Daardoor zou de situatie ontstaan dat de eerste fase van de toetsing bestaat uit het vaststellen van de vergelijkbaarheid, terwijl de tweede fase een toetsing aan het rechtvaardigingsmodel omvat.

Tegen deze combinatie van de vergelijkbaarheidstoets met het rechtvaardigingsmodel kan als bezwaar worden ingebracht dat deze een verwarrende en sterk overlappende toetsing tot gevolg heeft. $\mathrm{Al}$ in het kader van de vergelijkbaarheidstoets moet immers worden beoordeeld welke doelstelling met het onderscheid wordt nagestreefd, terwijl ook de mate van fit en de gerechtvaardigdheid van het doel al aan de orde zouden komen. In het kader van de rechtvaardigingstoets moet aan deze vereisten opnieuw worden getoetst: nu er in de eerste en tweede fase sprake is van een verschillende context en een andere bewijslastverdeling, kan de toetsing aan deze vereisten niet goed worden

moet daarbij vooral rekening worden gehouden met de proportionaliteit tussen doel (administratief gemak) en aangetast belang.

Van belang is tenslotte dat er ook voor de eisende partij bij de keuze voor de tweede benadering een nadeel bestaat ten opzichte van het rechtvaardigingsmodel. Een ongelijke behandeling zal namelijk alleen heel in het algemeen op zijn evenredigheid worden beoordeeld, hetgeen betekent dat criteria die de toetsing en de motivering kunnen verduidelijken, zoals over- en underinclusiveness, geschiktheid en subsidiariteit niet met zoveel woorden aan de orde zullen komen.

228. Gesteld zou bovendien kunnen worden, zoals eerder al opgemerkt (voetnoot 223), dat er bij de benaderingen 1, 2 en 3 verwarring bestaat tussen gelijkheid en billijkheid, nu uit het bestaan van feitelijke gelijkheid of ongelijkheid meteen de conclusie van onrechtvaardigheid of rechtvaardigheid wordt getrokken. Een dergelijke gelijkstelling is conceptueel gezien onjuist, aangezien het gelijkheidsbeginsel zelf waardeneutraal is en op basis hiervan geen oordelen over de rechtvaardigheid van een bepaalde distributie of classificatie kunnen worden geveld. Hoewel benadering 1 in dit opzicht het minst zuiver is, geldt dit bezwaar ook voor de benaderingen 2 en 3, waarbij hetzij uit de feitelijke vergelijkbaarheid, hetzij uit de feitelijke onvergelijkbaarheid onmiddellijk conclusies over de gerechtvaardigdheid voortvloeien. Alleen benadering 4 doet recht aan het verschil tussen gelijkheid en rechtvaardigheid door, nadat is vastgesteld dat de gevallen feitelijk verschillen, de conclusie over de toelaatbaarheid ervan afhankelijk te maken van een aparte toetsing aan de notie van rechtvaardigheid. Zie nader Bedau 1967, p. $9 / 10$. Zoals al is aangegeven wordt een deel van deze kritiek verzacht doordat al in het kader van de eerste fase van de vergelijkbaarheidstoets een toetsing van de gerechtvaardigdheid van het doel wordt uitgevoerd. Zoals echter uit het voorbeeld van de gevangenisstraf blijkt, geeft het bestaan van een gerechtvaardigd doel voor onderscheid echter nog geen garantie voor daadwerkelijke rechtvaardigheid: daarvoor is ook een proportionaliteitstoets vereist. 
samengevoegd. De doelstelling van het rechtvaardigingsmodel, een zuivere en doorzichtige toetsing, kan door deze combinatie dan ook onvoldoende worden bereikt.

Van belang is echter vooral dat bij toepassing van deze combinatie de feitelijke vaststelling van de vergelijkbaarheid van de gevallen overbodig is. Nagegaan moet immers niet alleen worden of er een rechtvaardiging bestaat voor een ongelijke behandeling van vergelijkbare gevallen, maar de eis van een objectieve en redelijke rechtvaardiging moet ook worden gesteld bij een ongelijke behandeling van onvergelijkbare gevallen. In dat licht kan worden vastgesteld dat het weinig nut heeft om van de rechter te vergen dat hij vaststelt of er sprake is van een ongelijke behandeling van vergelijkbare of onvergelijkbare gevallen: een rechtvaardiging is altijd nodig. ${ }^{229}$

\subsubsection{Conclusie: geen toetsing van de vergelijkbaarheid}

Uit het voorgaande is gebleken dat het niet zinvol is om te vereisen dat de rechter vaststelt of twee aan hem voorgelegde gevallen voldoende vergelijkbaar zijn: in de tweede fase van de toetsing zal iedere ongelijke behandeling moeten worden gerechtvaardigd, of er nu sprake is van vergelijkbare gevallen of niet. Gebeurt dit niet, dan kan dit leiden tot een uitkomst die voor beide partijen en vanuit het oogpunt van het algemeen belang onwenselijk is. Uit het feit dat de vergelijkbaarheidstoets en de toetsing aan het rechtvaardigingsmodel een grote mate van overlap vertonen kan bovendien worden afgeleid dat de kwaliteit van de toetsing niet in gevaar wordt gebracht wanneer alleen een toetsing aan het rechtvaardigingsmodel wordt uitgevoerd.

Gebleken is verder dat een toetsing aan het rechtvaardigingsmodel geen complexere of intensievere toetsing oplevert dan een toepassing van de vergelijkbaarheidstoets. ${ }^{230}$ Aangegeven is dat de vaststelling van de vergelijkbaarheid minstens zo complex is en net zoveel, zo niet meer, ruimte laat voor een subjectieve invulling als de toetsing aan het rechtvaardigingsmodel. Ook voor de tweede fase van de toetsing geldt dat er nauwelijks verschil bestaat in complexiteit en rechterlijke activiteit: wanneer in het kader van de vergelijkbaarheidstoets de vierde benadering wordt gekozen, waarvan is aangegeven dat deze de enige is die recht doet aan alle betrokken belangen, is een minstens zo grote mate van rechterlijke activiteit vereist als bij een toetsing aan het rechtvaardigingsmodel.

Uit één en ander kan blijken dat het de voorkeur verdient om in de eerste fase geen gebruik te maken van de vergelijkbaarheidstoets.

229. Vgl. ook Van den Berge 2000, p. 895.

230. Als dit al een factor van doorslaggevend belang zou mogen worden genoemd. Gekeken moet immers ook worden naar het belang dat tegenover dat van een minimaal rechterlijk activisme staat, namelijk het individuele belang van de burger bij een gedegen toetsing van maatregelen die hem kansen en mogelijkheden ontzeggen of die zelfs zijn menselijk waardigheid aantasten. Het lijkt vanzelfsprekend dat maatregelen en handelingen die voor de individuele burger een zo belangrijke invloed hebben zo zorgvuldig mogelijk worden getoetst, hetgeen een goede rechtvaardiging vormt voor een actievere rechterlijke toetsing. 


\subsection{De bewijsfunctie van de vergelijkbaarheidstoets; alternatieve toetsingsin- gangen}

\subsubsection{Toetsing in de eerste fase: bewijslastverdeling}

Zoals hiervoor is aangegeven is het rechtvaardigingsmodel bedoeld om invulling te geven aan de tweede fase van de toetsing: voordat wordt beoordeeld of de ongelijke behandeling gerechtvaardigd is dient te worden vastgesteld of de eiser die het onderscheid voor de rechter heeft gebracht eigenlijk wel recht van klagen heeft.

Op zichzelf is het niet nodig om in deze eerste fase van de toetsing hoge eisen te stellen aan de bewijslast van de eisende partij. Door verschillende auteurs is aangegeven dat het voldoende is dat de eiser stelt dat er sprake is van een ongelijke behandeling, waarna van de verwerende partij meteen kan worden verwacht dat deze een objectieve rechtvaardiging aandraagt. ${ }^{211}$ Op zichzelf lijkt de keuze voor een dergelijke, eenvoudige toetsingsingang ook niet problematisch: een zaak zal meestal pas voor de rechter worden gebracht wanneer bij de eiser (en zijn raadsman) de overtuiging bestaat dat er sprake is van een onrechtvaardig onderscheid. ${ }^{232}$ Dit is echter een risicovolle veronderstelling, die te zeer uitgaat van de overtuiging dat mensen alleen procederen wanneer zij daartoe een objectief verdedigbare reden hebben. Een gevoel van aangedaan onrecht zal echter vaak subjectief van aard zijn, terwijl bij nader onderzoek ook kan blijken dat de betrokkene (bijvoorbeeld door het bestaan van compensatieregelingen) feitelijk helemaal niet is benadeeld. In dergelijke gevallen is het niet redelijk om van de verwerende partij te vergen dat deze redenen en argumenten aanvoert om het onderscheid te rechtvaardigen en om de rechter te belasten met een uitgebreid onderzoek.

Een bijkomend probleem is dat door een toetsingsingang als hiervoor omschreven een redelijk evenwicht in de bewijslast van de procespartijen ontbreekt. De eisende partij hoeft immers uitsluitend te stellen dat er sprake is van onderscheid, terwijl de verwerende partij gehouden is om redenen aan te voeren (en bewijsmateriaal aan te dragen) waaruit kan blijken dat het onderscheid gerechtvaardigd is. Dit kan misschien nog redelijk zijn wanneer het onderscheid is veroorzaakt door een overheidsorgaan (dat waarschijnlijk beschikt over meer middelen om bewijs te vergaren), maar is dit zeker niet in een horizontale verhouding waarin grote machtsverschillen ontbreken.

Een combinatie tussen de vergelijkbaarheidstoets en het rechtvaardigingsmodel, zoals in paragraaf 4.3 is afgewezen, vormt op het eerste gezicht een goede oplossing voor dit probleem. Bij deze combinatie moet de eiser aannemelijk maken dat er sprake is van vergelijkbare gevallen en is het vervolgens aan de verweerder om het gemaakte onderscheid te rechtvaardigen; daardoor zou automatisch een redelijke bewijslastverdeling worden gecreëerd. Zoals eerder is aangegeven is het aantonen van vergelijkbaarheid voor het vereisen van een rechtvaardiging echter niet relevant: zowel een ongelijke behandeling van vergelijkbare gevallen als een ongelijke behandeling van onvergelijkbare gevallen moet immers aan het rechtvaardigingsmodel worden getoetst. ${ }^{23}$ Het lijkt

231. Zie vooral Ely 1970, p. 1254 e.v., die stelt dat dit in de VS een gebruikelijke toetsingsingang is.

232. Sjerps 1999 , p. 241 en 243

233. Zie paragraaf 4.3.2 en 4.3.3: een ongelijke behandeling van onvergelijkbare gevallen moet inhoudelijk worden getoetst om te kunnen beoordelen of er wellicht sprake is van een bepaalde mate van dispro- 
weinig zinvol om een partij te belasten met het aanvoeren van bewijs dat voor de procedure verder niet interessant is.

Om te komen tot een goed evenwicht in de bewijslastverdeling zal moeten worden gezocht naar een alternatieve toetsingsingang. Deze toetsingsingang mag geen overlappingen met het toetsingsmodel opleveren en moet bovendien leiden tot een duidelijke en voorspelbare rechterlijke toetsing.

\subsubsection{Eerste alternatief: motief of doelstelling als toetsingsingang}

In de eerste plaats is het mogelijk om, in plaats van de vergelijkbaarheid, de bedoeling van degene die voor het onderscheid verantwoordelijk is tot uitgangspunt te nemen. Dit betekent dat het voor een inhoudelijke toetsing van de aangevoerde rechtvaardiging noodzakelijk is dat de klager aantoont dat de verdedigende partij met het onderscheid een specifieke, op de benadeling van een bepaalde groep gerichte, doelstelling nastreefde. ${ }^{23}$ Een dergelijke toetsingsingang heeft bijvoorbeeld tot gevolg dat een maatregel die een bijzonder nadeel oplevert voor een raciale minderheid, maar niet op die benadeling is gericht, niet gerechtvaardigd hoeft te worden: het is alleen vereist om een rechtvaardiging aan te voeren wanneer kan worden aangetoond dat de regeling door raciale overwegingen is ingegeven. ${ }^{235}$

Het is echter niet wenselijk is om de doelstelling van de regeling tot toetsingsingang te nemen. Allereerst is van belang dat hierdoor onvoldoende tegemoet zou worden gekomen aan de uitgangspunten die in paragraaf 2.4 voor de toetsing van ongelijke behandeling zijn vastgesteld. Gesteld is daar dat niet alleen bedoeld, maar ook onbedoeld onderscheid aan een inhoudelijke toetsing moet kunnen worden onderworpen: door beide vormen van ongelijke behandeling kunnen mensen worden beperkt in hun indivi-

portionaliteit, zoals in het geval van het grote verschil in strafmaat in het gegeven voorbeeld van de bestraffing van moord en doodslag. Een ongelijke behandeling van vergelijkbare gevallen moet eveneens aan een toetsing aan het model worden onderworpen, omdat er wellicht externe algemene belangen kunnen worden gevonden die de ongelijke behandeling kunnen rechtvaardigen.

234. Het is van belang om in te zien dat de toetsing van het doel in de eerste fase een heel andere inhoud en functie heeft dan de doeltoets zoals die plaats vindt in het kader van de toetsing aan het rechtvaardigingsmodel. Aangetoond moet worden dat de verdedigende partij een discriminatoire bedoeling had met het onderscheid, terwijl bij het rechtvaardigingsmodel in het algemeen wordt onderzocht welke doelstellingen met de regeling werden nagestreefd. Het persoonlijke verantwoordelijkheidsaspect en de subjectiviteit van de overwegingen die een rol speelden bij het instellen van een bepaalde regeling zijn bij de toetsing aan het rechtvaardigingsmodel dus van veel minder belang dan bij het hanteren van het doel als toetsingsingang. Een tweede belangrijk verschil betreft de bewijslast: deze berust bij de klager in het geval waarin het doel als toetsingsingang wordt gehanteerd, terwijl het bij de toetsing aan het rechtvaardigingsmodel aan de verdedigende partij is om aan te tonen dat hij met het onderscheid een gerechtvaardigd doel nastreefde.

235. Zie met name de zaak Washington v. Davis, 426 U.S. 229, 242 (1976), in samenhang met Personnel Administrator of Massachusetts v. Feeney, 442 U.S. 256, 279 (1979); in hoofdstuk 5 zal hierop nader worden ingegaan. Deze toetsingsingang betekent overigens niet dat al in de eerste fase moet worden aangetoond dat de motieven of redenen als zodanig ontoelaatbaar zijn; aan die toetsing wordt pas toegekomen in het kader van de rechtvaardigingstoets. 
duele vrijheid en het nastreven van hun persoonlijke ambities. ${ }^{236}$ Verder kan worden gewezen op de onredelijkheid van de bewijslast die deze toetsingsingang met zich meebrengt: zeker wanneer een overheidsorgaan of een groot bedrijf voor de disproportionele benadeling verantwoordelijk is, is het voor individuele eisers bijzonder moeilijk om een op deze benadeling gerichte bedoeling aan te tonen. ${ }^{27}$ Aangezien gestreefd wordt naar een zo evenwichtig mogelijke bewijslast kan dit alternatief niet geschikt worden geacht. ${ }^{238}$ Tenslotte is een belangrijk nadeel dat deze toetsingsingang tot gevolg kan hebben dat onwenselijke ongelijkheden gemakkelijk in stand kunnen blijven. ${ }^{29}$ Deze toetsingsingang heeft immers tot gevolg dat er, in alle gevallen waarin wordt vastgesteld dat er geen discriminatoir doel wordt nagestreefd, sprake is van een geoorloofd onderscheid. In die gevallen kan de rechter dan ook niet meer nagaan of het onderscheid voldoende gerechtvaardigd is, hetgeen tot gevolg heeft dat onderscheid dat duidelijk niet geschikt is om het gestelde doel te bereiken of dat een onevenredige belangenaantasting oplevert gewoon in stand kan blijven. ${ }^{240}$

\subsubsection{Tweede alternatief: het "but for"-criterium}

Als alternatief voor de vergelijkbaarheid als toetsingsingang kan verder worden gewezen op een vooral in de Engelse en Amerikaanse literatuur en rechtspraak vaak genoemd criterium: het "but for"-criterium. ${ }^{211}$ Dit criterium houdt in dat de eiser aannemelijk moet maken dat hem een behandeling ten deel is gevallen die hij niet zou hebben ontvangen wanneer hij niet een specifiek kenmerk zou hebben bezeten. ${ }^{242}$ Bewezen moet dus worden dat er een direct causaal verband bestaat tussen een aantoonbare benadeling en een bepaalde grond van onderscheid. Dit betekent dat dit criterium, anders dan de hiervoor besproken toetsingsingang, geen verband houdt met de subjectieve bedoeling van degene die verantwoordelijk is voor het onderscheid. ${ }^{243}$

236. Zoals eerder is gezegd (zie paragraaf 2.4) gaat het er bij gelijke behandeling niet om de verantwoordelijke te bestraffen voor wat hij gedaan heeft, maar om degene die daardoor is benadeeld te beschermen. Ook wanneer wel zou worden gedacht in termen van verantwoordelijkheid, is het bovendien merkwaardig om iemand alleen verantwoordelijk te houden voor zijn bedoelingen en niet voor de resultaten van zijn handelen. In de woorden van Binion: "Perhaps the most profound consequence of intent theory is that it shifts constitutional law away from its focal attention on state responsibility for state actions. It distorts the law by holding states constitutionally responsible for what they intended to do and not for what they have done" (1983, p. 443). Een bijkomend argument tegen de doeltoets als toetsingsingang kan worden gevonden in het feit dat er door ongelijke behandeling vaak individuele rechten worden aangetast. Normaal gesproken is een dergelijke aantasting voldoende om een rechtvaardiging te vereisen, maar in het geval van aantasting in het kader van gelijke behandeling moet bovendien nog worden aangetoond dat de aantasting ook daadwerkelijk beoogd was. Het is niet duidelijk welke rechtvaardiging er voor een dergelijk vereiste bestaat.

237. Issacharoff 1982, p. 341 en Nelson 1988, p. 344. Dit is alleen al het geval omdat het vaak moeilijk is na te gaan wie er nu precies voor een ongelijke behandeling verantwoordelijk was, zeker wanneer het gaat om regelingen die al langere tijd bestaan: Binion 1983, p. 426 e.v.

238. Een belangrijk nadeel van dit alternatief is bovendien dat het overlappingen zou vertonen met het rechtvaardigingsmodel, nu reeds in de eerste fase moet worden onderzocht welke bedoeling er aan het onderscheid ten grondslag lag.

239. Vgl. Nelson 1988, p. 336.

240. Vgl. "Note" 1981, p. 923.

241. Zie bijvoorbeeld Eisenberg 1977, p. 58/59.

242. Banton 1999 , p. 110

243. Er bestaat een verschil tussen de vraag of iemand dezelfde behandeling ten deel zou zijn gevallen als 
Het "but for"-criterium vormt op zichzelf een geschikte toetsingsingang en kan ook een redelijke bewijslast opleveren. Een voordeel is vooral dat deze toetsingsingang niet alleen bij formeel, maar ook bij materieel onderscheid bruikbaar is: aan het criterium is ook voldaan wanneer iemand kan aantonen dat een regeling tot effect heeft dat hij wordt benadeeld, "but for" de aanwezigheid van een bepaald kenmerk. Een voorbeeld kan worden gegeven aan de hand van een wettelijke regeling die onderscheid op grond van geslacht verbiedt. Om te kunnen spreken van verboden onderscheid moet in dat geval worden aangetoond dat er een rechtstreeks verband bestaat tussen een bepaalde maatregel of handeling en een voor vrouwen ${ }^{2+4}$ benadelend effect. Dit is mogelijk wanneer er sprake is van een benadeling van vrouwen die bijzonder duidelijk en ernstig is. Wanneer een werkgever bijvoorbeeld deeltijdwerkers benadeelt ten opzichte van voltijdwerkers, terwijl $97 \%$ van de deeltijdwerkers vrouw is, dan kan worden gesteld dat er een vrijwel direct causaal verband bestaat tussen de gekozen grond van onderscheid en de benadeling van vrouwen. Aangetoond is dan ook meteen dat vrouwen een benadeling ontvangen die hen niet ten deel zou zijn gevallen als zij geen vrouw waren geweest.

Hoewel deze toetsingsingang op zichzelf zeer bruikbaar lijkt moet worden vastgesteld dat de praktische relevantie ervan relatief beperkt is. Het "but for"-criterium is alleen goed bruikbaar wanneer van tevoren is vastgesteld dat bepaalde gronden van onderscheid niet toelaatbaar zijn, zoals in het gegeven voorbeeld van de wettelijke regeling die onderscheid op grond van geslacht verbiedt. In gevallen waarin geen limitatief aantal "verboden" gronden bestaat valt het criterium samen met het hierna te bespreken criterium van benadeling: in dat geval is iedere aantoonbare benadeling (op welke grond dan ook) voldoende om een inhoudelijke toetsing uit te voeren. ${ }^{245}$ Zo kan in het gegeven voorbeeld worden gesteld dat er een causaal verband bestaat tussen de benadeling en het criterium waarop de benadeling is gebaseerd: als het verrichten van deeltijdwerk als differentiatiecriterium geldt, zal het altijd zo zijn dat deeltijdwerkers worden achtergesteld op de enkele grond van de omvang van hun dienstverband. Het aantonen van een rechtstreeks verband met een andere onderscheidingsgrond, zoals geslacht, is in dit soort omstandigheden dus niet nodig. Nu het toetsingsmodel juist be-

hij een bepaald kenmerk niet zou hebben bezeten (causaliteit tussen kenmerk en behandeling), en de vraag of hem dezelfde behandeling ten deel zou zijn gevallen als de verantwoordelijke andere motieven zou hebben gehad (causaliteit tussen motieven en behandeling). Zo zal er bij een regeling die een disproportioneel effect heeft voor een bepaalde groep een rechtstreeks causaal verband bestaan tussen dit effect en een kenmerk van de betrokken groep, maar hoeft de regeling niet op het bereiken van dit effect gericht te zijn. Zie ook Selmi 1997, p. 289.

244. Of mannen.

245. Dit kan worden toegelicht aan de hand van een regeling die alleen melkquota toekent aan producenten die in de afgelopen twee jaar een bepaalde kwantiteit aan melk hebben geproduceerd. Een dergelijke regeling is benadelend voor die producenten die door onvoorziene omstandigheden (bijv. ziekte onder de veestapel) minder geproduceerd hebben dan gebruikelijk, of die net op de markt zijn gekomen en nog een kleine veestapel hebben. Net zo gemakkelijk als de benadeelde producenten in dit geval kunnen aantonen dat zij door de regeling zijn benadeeld ten opzichte van producenten die wel aan het productievereiste voldoen, zullen zij ook kunnen aantonen dat deze benadeling zich niet zou hebben voorgedaan wanneer ("but for") zij zouden hebben voldaan aan het vereiste van een bepaalde productie. 
doeld is voor de (relatief) open gelijkheidsbepalingen ${ }^{246}$ heeft het "but for"-criterium als toetsingsingang geen bijzondere zelfstandige waarde.

\subsubsection{Derde alternatief: benadeling als toetsingsingang}

Het spreekt vanzelf dat een ongelijke behandeling alleen hoeft te worden gerechtvaardigd wanneer aannemelijk is dat een bepaalde groep of persoon daadwerkelijk nadeel van een ongelijke behandeling ondervindt. Wanneer dit niet het geval is bestaat er weinig reden tot klagen: het is juist de benadeling of achterstelling die tot gevolg heeft dat een bepaalde persoon of groep minder kansen of mogelijkheden heeft om zichzelf te ontplooien en zijn wensen en ambities waar te maken dan anderen. ${ }^{247}$ Het "benadelingscriterium" lijkt om die reden een bijzonder geschikte toetsingsingang te vormen. Gebruik van dit criterium zou inhouden dat de eisende partij in de eerste fase van de toetsing moet kunnen aantonen dat hij door een regeling of behandeling daadwerkelijk is benadeeld ten opzichte van een andere persoon of groep. Wanneer hij aan dit vereiste heeft voldaan kan worden gesproken van een ongelijke behandeling die door de wederpartij moet worden gerechtvaardigd. ${ }^{24}$

Het gebruik van deze toetsingsingang heeft diverse voordelen. Allereerst levert de benadelingstoets een redelijke bewijslastverdeling op. Aangezien de eisende partij aan de hand van feiten en omstandigheden moet aantonen dat hij daadwerkelijk nadeel van

246. Zie voor deze term paragraaf 2.1 .

247. Vgl. Kewenig, die stelt dat het gelijkheidsbeginsel beschermt tegen uit ongelijke behandeling voortvloeiend nadeel (1972, p. 151). Zie ook Simons, die aan de hand van voorbeelden duidelijk maakt dat het juist de benadeling is die een gevoel van onrecht oplevert en dus moet worden gerechtvaardigd (1985, p. 391). Een theoretische onderbouwing is ook gegeven door Benn/Peters 1969, p. 57.

248. Een comparatief element blijft dus aanwezig (er moet immers een benadeling ten opzichte van een ander geval worden aangetoond), maar het accent verschuift van het subject van de ongelijke behandeling naar het object ervan: het is niet nodig om aan te tonen of de groepen van gevallen die een bepaalde behandeling ten deel is gevallen (het subject) als zodanig vergelijkbaar zijn, het gaat er slechts om dat wordt aangetoond dat de behandeling (het object) verschilt. Doordat er toch een comparatief element aanwezig is, heeft het gelijkheidsbeginsel toch waarde ten opzichte van andere juridische concepten (vgl. Simons 1985, p. 390/391). In dit verband is de volgende passage van Ely van belang: “[...] any case, indeed any challenge, can be put in an equal protection framework by competent counsel. If you wish to challenge the fact that you are not getting good $\mathrm{X}$ (or are getting deprivation $\mathrm{Y}$ ) it is extremely probable that you will be able to identify someone who is getting good $\mathrm{X}$ (or is not getting deprivation $\mathrm{Y}$ ). What's more [...], the odds are good that the reasons adduced for giving $\mathrm{X}$ to the other person but not to you are much the same as would be produced if you simply, without reference to the other person, challenged the fact that you weren't getting X. [...] Because the limitation to cases involving differential treatment turns out to be no significant limitation at all, the Equal Protection Clause has to amount to [...] a rather sweeping mandate to judge of the validity of governmental choices" (1980, p. 32). Inderdaad kunnen mensen die het slachtoffer zijn van een regeling die, bijvoorbeeld, inbreuk maakt op vrijheid van meningsuiting, deze regeling op twee manieren aanvechten: ofwel door rechtstreeks een beroep te doen op vrijheid van meningsuiting, ofwel door de classificatic in de regeling aan te vallen. Dit laatste zal vooral gebeuren wanneer niet zozeer de regeling zelf onredelijk lijkt, maar vooral de beperking van het toekennen van nadelen of voordelen tot een bepaalde groep. Dit betekent meteen ook dat lang niet in alle gevalien een beroep op het gelijkheidsbeginsel zal worden gedaan: hoewel het mogelijk is om nagenoeg alle klachten in termen van ongelijke behandeling te formuleren, zal dit meestal niet gebeuren. Bovendien illustreert dit meteen dat het gelijkheidsbeginsel als structurerend beginsel een belangrijke toegevoegde waarde heeft, nu hierdoor andere aspecten van benadeling kunnen worden getoetst dan door een rechtstreekse toetsing van een bepaling aan hoger recht. 
een bepaalde behandeling heeft ondervonden, is een rechtvaardiging alleen vereist in die gevallen waarin dit echt nodig is. De toetsingsingang heeft daardoor veel meer onderscheidende waarde dan de vergelijkbaarheidstoets, waarbij immers steeds een rechtvaardigingstoets is vereist. ${ }^{249}$ Anderzijds worden door het vereiste van benadeling, anders dan bij de keuze voor het doel van het onderscheid als toetsingsingang, geen onredelijk hoge eisen aan de bewijslast van de eisende partij gesteld: het zal waarschijnlijk relatief gemakkelijk zijn om aan de hand van cijfermatige of feitelijke gegevens een benadeling aan te tonen. Een voordeel van deze toetsingsingang is verder dat het begrip "benadeling" op verschillende manieren kan worden uitgelegd. Een benadeling kan bestaan in een rechtstreeks voelbaar en materieel nadeel, bijvoorbeeld een verlies aan inkomsten of het niet ontvangen van een vergunning of subsidie, maar ook in een meer immaterieel nadeel, zoals de versterking van een vooroordeel of het stigmatiseren van een bepaalde groep. ${ }^{250}$ Belangrijk is ook dat de toetsingsingang voldoende ruimte laat voor een toepassing van het concept van materieel onderscheid. Een feitelijk nadeel kan immers niet alleen ontstaan doordat twee vergelijkbare personen of gevallen ongelijk worden behandeld, maar net zozeer door een gelijke behandeling van twee onvergelijkbare personen. Gesteld kan zelfs worden dat het concept van materieel onderscheid door gebruik van deze toetsingsingang voor de rechterlijke toetsingspraktijk overbodig wordt. ${ }^{251}$ Een laatste groot voordeel van deze toetsingsingang is dat de vergelijkbaarheid van de gevallen hierbij geen rol speelt. Vereist is slechts dat de be-

249. Het gewicht van de bewijslast die deze toetsingsingang meebrengt is met name afhankelijk van de eisen die worden gesteld aan de aan te tonen benadeling. Wanneer wordt vereist dat deze door feitelijke, bijvoorbeeld statistische of anderszins cijfermatige, gegevens moet worden aangetoond is de bewijslast bijvoorbeeld zwaarder dan wanneer wordt gesteld dat kan worden volstaan met het aantonen van de waarschijnlijkheid van benadeling.

250. Zo wordt door Simons het voorbeeld gegeven van een beloningsregeling die mensen met een donkere huidskleur een lager salaris toekent dan blanken. Wanneer er vervolgens alleen mensen in dienst blijken te zijn met een donkere huidskleur, kan deze regeling niet leiden tot een materięle benadeling: iedere medewerker ontvangt immers een gelijk salaris. Niettemin kan worden gesteld dat door deze regeling een bestaande achterstelling, die is gebaseerd op vooroordelen en stigma's, wordt benadrukt. Daardoor levert een dergelijke regeling toch een benadeling op (Simons 1985, p. 419, vooral noot 65). Het nut van het aannemen van een immateriěle benadeling kan ook worden aangetoond door te wijzen op de segregatieproblematiek. In Amerika werd segregatie goedgekeurd met een beroep op de "separate but equal"-doctrine: hoewel veel voorzieningen gescheiden waren, hadden zij een gelijke kwaliteit en was er dus ook geen sprake van een benadeling. Met deze doctrine werd echter (los van het feit dat er in werkelijkheid geen sprake was van voorzieningen van gelijke kwaliteit) over het hoofd gezien dat door de segregatie de achterstelling van en vooroordelen jegens een kwetsbare groep werden benadrukt. Via een concept van benadeling dat ruimte laat voor een erkenning van een dergelijke achterstelling kan in dit soort gevallen toch een objectieve rechtvaardiging worden vereist.

251. Het accent bij deze toetsingsingang verschuift immers van de vergelijking tussen de betrokken groepen, personen of gevallen naar de aard van de behandeling zelf: wanneer deze voor een bepaalde groep nadelig is bestaat er voldoende reden om een rechtvaardiging te vereisen, ongeacht de vraag of de gevallen die die verschillende behandeling hebben uitgelokt vergelijkbaar waren of niet. Dit betekent dat het niet meer nodig is om na te gaan of de benadeling van een bepaalde persoon of groep is ontstaan door een gelijke behandeling van ongelijke gevallen of door een ongelijke behandeling van gelijke gevallen. Vanzelfsprekend geldt dat het concept indirect onderscheid, een gekwalificeerde vorm van materieel onderscheid, met de keuze voor deze toetsingsingang niet overbodig wordt. Wanneer in een regeling alleen onderscheid op bepaalde gronden is verboden, moet het concept van benadeling inhouden dat moet worden aangetoond dat de benadeling herleidbaar is tot een van de verboden gronden; in dat geval is er dus eigenlijk sprake van een toepassing van het hiervoor besproken "but for"-criterium. 
trokkene aantoont dat hij door een specifieke behandeling nadeel heeft ondervonden ten opzichte van een andere groep; het is verder niet van belang of die andere groep zich al dan niet in een vergelijkbare positie bevindt. Dit kan problematisch lijken vanuit het evenwicht van de bewijslastverdeling, nu het vrij gemakkelijk zal om in een geval van evident verschillende gevallen aan te tonen dat er sprake is van een benadeling; dit zou betekenen dat de bewijslast al snel naar de verdedigende partij verschuift. Deze onevenwichtigheid zal in de praktijk echter minder groot zijn dan op het eerste gezicht het geval is. Allereerst kunnen er namelijk, ook los van de vergelijkbaarheid, zodanige eisen worden gesteld aan het bewijs van benadeling dat lang niet in alle gevallen een rechtvaardiging vereist is. Bovendien zal het in gevallen van evidente onvergelijkbaarheid in het algemeen heel gemakkelijk zijn om objectieve argumenten aan te voeren die de benadeling kunnen rechtvaardigen, zodat de bewijslast van de verdedigende partij minder groot zal zijn dan kan worden verondersteld. ${ }^{252}$

\subsubsection{Conclusie}

Uit het voorgaande is gebleken dat het niet noodzakelijk is om de vergelijkbaarheidstoets te gebruiken als toetsingsingang, dat wil zeggen als toetsingscriterium voor de invulling van de eerste fase van de toetsing. Duidelijk is bovendien geworden dat er geen overtuigende redenen bestaan om de vergelijkbaarheidstoets te hanteren als alternatief voor het rechtvaardigingsmodel. Beter is het om in de tweede fase te toetsen aan het rechtvaardigingsmodel en voor de eerste toetsingsfase te zoeken naar een bruikbaar alternatief, dat een doorzichtige motivering mogelijk maakt, geen overlappingen vertoont met het rechtvaardigingsmodel en een redelijke bewijslastverdeling oplevert. Uit de bespreking van verschillende mogelijke alternatieven is gebleken dat vooral de benadelingstoets een zinvolle invulling kan vormen voor de toetsing in de eerste fase. Deze toetsingsingang is dan ook tot uitgangspunt van het theoretische toetsingsmodel gekozen. ${ }^{23}$

\section{$5 \quad$ Toetsingsintensiteit}

\subsection{Inleiding: noodzaak van differentiatie in de toetsingsintensiteit}

Bij de toetsing van ongelijke behandeling bevindt de rechter zich in een lastige positie: bij de beoordeling van wettelijke classificaties moet hij rekening houden met de verhouding ten opzichte van de democratisch gelegitimeerde wetgever, bij administratieve toepassing moet hij ruimte laten voor de discretie van het bestuursorgaan en bij horizontale vormen van onderscheid moet hij rekening houden met de beslissings- en keuzevrijheid van het individu. Er zijn dan ook bijna altijd goede redenen aanwezig om

252. En wanneer het toch onverhoopt lastig mocht zijn om een rechtvaardiging te bedenken, pleit dit wel weer voor de wenselijkheid van het uitvoeren van een inhoudelijke toetsing.

253. Zie voor een korte uiteenzetting daarvan nader paragraaf 6 van dit hoofdstuk. 
aan te nemen dat de rechter zich bij de beoordeling van de toelaatbaarheid van een ongelijke behandeling terughoudend moet opstellen. ${ }^{2 s 4}$

Het aantal mogelijke vormen van ongelijke behandeling is echter eindeloos, net als het aantal mogelijke gronden voor onderscheid. Een ongelijke behandeling kan zich voordoen in de situatie waarin aan Afro-Amerikanen wordt verboden met een blanke te huwen of in de situatie waarin vrouwen het kiesrecht wordt ontzegd, maar is ook aanwezig bij een regeling die de inkomstenbelasting proportioneel laat stijgen naar gelang de grootte van het inkomen, of bij een regeling die andere vergunningsvoorwaarden stelt voor de exploitatie van chemische bedrijven dan voor het opstarten van een biologische groentekwekerij. Het zal duidelijk zijn dat deze vormen van ongelijke behandeling niet alleen verschillen naar de grond van onderscheid, de belangen die worden getroffen en de doelstellingen die worden nagestreefd, maar dat er ook verschillend zal worden gedacht over hun wenselijkheid of redelijkheid. ${ }^{2 s s}$

Hoewel er goede redenen aanwezig zijn voor het uitvoeren van een terughoudende rechterlijke toetsing lijkt het, vanwege het grote verschil in vormen en soorten van onderscheid en in de gepercipieerde aanvaardbaarheid daarvan, niet redelijk wanneer de rechter bij de beoordeling van ieder onderscheid dezelfde mate van terughoudendheid zou betrachten. Door een dergelijke benadering wordt weliswaar rekening gehouden met de positie van de rechter en met de belangen van degene die voor het onderscheid verantwoordelijk is, maar veel minder met de rechten en belangen van degene die door het onderscheid is benadeeld. ${ }^{256} \mathrm{Bij}$ sommige wettelijke classificaties, zoals bij het hierboven genoemde verbod op interraciale huwelijken, bestaat duidelijk het vermoeden dat de wetgever onvoldoende rekening heeft gehouden met het individuele recht op gelijkwaardigheid, gelijk respect en zelfbeschikking. In een dergelijk geval is het redelijk om strengere eisen te stellen aan de rechtvaardiging van een onderscheid dan gebruikelijk, juist vanwege de verdenking dat de voor het onderscheid verantwoordelijke geen goed gebruik heeft gemaakt van de hem toegekende vrijheid en de belangen van de betrokkene onevenredig zwaar heeft aangetast. ${ }^{257}$ Een marginale toetsing

254. Vgl. Leibholz 1925, p. 77/78 en 89 en Loenen 1998, p. 42; door Fallon is deze reden voor terughoudendheid aangeduid als de "comparative competence difficulty" (1993, p. 376).

255. Zoals in het eerste hoofdstuk al is aangegeven wordt het denken over de toelaatbaarheid van gelijke en ongelijke behandeling sterk bepaald door ideeèn over rechtvaardigheid en door cultureel en historisch gegroeide waarden en normen. Sommige vormen van onderscheid zullen daardoor sneller als gerechtvaardigd worden geaccepteerd dan andere. Een en ander is fraai samengevat door Plamenatz: "There are three kinds of identities and differences of ability or right: the kind that engages our attention so little that we never call them equalities or inequalities; the kind that we sometimes attend to and call by these names, although we do not feel strongly about them; and the kind that excites us" (1967, p. 82). In belangrijke mate is deze perceptie van "ernst" gevoelsmatig van aard en wordt deze bepaald door onbewuste waarden en normen: vgl. Alexander 1992, p. 151. Op de factoren die de "ernst" of de verdachtheid van een onderscheid beïnvloeden zal nader worden ingegaan in paragraaf 5.3.2, onder a.

256. In vergelijkbare zin Tussman/TenBroek 1949, p. 366.

257. Zie Eisenberg 1977, p. 102, Fallon 1993, p. 380, Bhagwat 1997, p. 339, Karst 1977, p. $41 / 42$ en Sunstein (verkort gepubliceerd in Garvey/Aleinikoff 1999), p. 60/61. De laatste geeft aan dat in dit soort gevallen de verdenking bestaat dat de verantwoordelijke overheid zich heeft laten leiden door "naked preferences" jegens een bepaalde groep, in plaats van door algemene en publieke belangen. Ook geeft hij aan dat in gevallen waarin het waarschijnlijk lijkt dat het onderscheid wél is gebaseerd op algemene belangen en waarden, een vermoeden kan bestaan dat de overheid zich naar behoren heeft gedragen, zodat een marginale toets voldoende is. Vanzelfsprekend betekent dit niet dat er in alle gevallen van "naked preferences" sprake is van een ontoelaatbaar onderscheid: het kan altijd zo zijn dat er omstan- 
biedt voor het stellen van hoge eisen aan de rechtvaardiging echter niet veel ruimte, zodat een striktere toetsing in dit soort gevallen noodzakelijk is. ${ }^{2.5}$

Het is dan ook wenselijk om enige variatie mogelijk te maken in de intensiteit waarmee een rechter een aan hem voorgelegd onderscheid beoordeelt: hoewel soms een marginale toetsing redelijk is, kan in andere gevallen worden gesteld dat een zorgvuldigere beoordeling van het onderscheid is aangewezen. Vanzelfsprekend roept een dergelijke stelling vragen op. Zo is het interessant om na te gaan welke verschillende gradaties van toetsingsintensiteit mogelijk zijn, welk effect de variatie in toetsingsintensiteit heeft voor de rechterlijke toetsing en welke factoren bij de bepaling van de intensiteit bepalend moeten zijn. In deze laatste paragraaf zal worden getracht op deze vragen een antwoord te formuleren.

\subsection{Gradaties van toetsingsintensiteit en hun betekenis voor de toetsing}

\subsubsection{Gradaties of "niveaus" van toetsingsintensiteit}

Bij de gedachte aan een mogelijke variatie in toetsingsintensiteit kan allereerst de vraag worden gesteld op welke manier een dergelijke differentiatie tot uitdrukking komt. Van belang is daarbij dat er in theorie diverse gradaties van toetsingsintensiteit denkbaar zijn. Gesteld zou zelfs kunnen worden dat er bij de intensiteit van de rechterlijke toetsing sprake is van een glijdende schaal, die loopt van zeer marginaal tot zeer intensief. ${ }^{259}$ Voor de ontwikkeling van een toetsingsmodel is het echte het beste om met niet

digheden zijn die het gemaakte onderscheid toch kunnen rechtvaardigen; zoals O'Fallon stelt: "Sometimes, despite a high antecedent likelihood of corruption, the result of the legislative process clearly negates the presupposition of corruption" (1979, p. 48). Zie over deze rationale voor differentiatie in toetsingsintensiteit ook Baker 1978, p. 1039.

258. Hoewel het aannemelijk is dat de rechter een onderscheid dat werkelijk niet door de beugel kan ook ontoelaatbaar zal achten bij een marginale toetsing of een toetsing op willekeur (in dit soort situaties is er immers sprake van willekeur; vgl. Leibholz 1925, p. 80), wijst de praktijk uit dat dit niet altijd het geval is. Het probleem is vooral gelegen in het feit dat een terughoudende toetsing slechts een heel marginale beoordeling van de gerechtvaardigdheid van het doel toelaat: voor een rechtvaardiging wordt het vaak al voldoende geacht dat het voorstelbaar is dat er een gerechtvaardigd doel wordt nagestreefd. Er zijn diverse "verdachte" ongelijke behandelingen denkbaar waarin de doeltoets zelf nauwelijks een belemmering oplevert. Gewezen kan worden op het al enkele malen genoemde voorbeeld van een wettelijke regeling die voor het uitbrengen van een stem bij de verkiezingen vereist dat iemand met goed gevolg een test op alfabetisme heeft afgelegd, zodat hij voldoende geïnformeerd is over de betrokken politieke items, maar waarmee verhuld wordt nagestreefd dat een door historische omstandigheden veelal ongeletterde en bovendien verafschuwde groep van het kiesrecht wordt uitgesloten. Dit soort regelingen zou heel goed gerechtvaardigd kunnen worden geacht bij een terughoudende toets, omdat daarbij slechts weinig ruimte zal bestaan voor een rechterlijk onderzoek naar de werkelijke bedoelingen van het onderscheid. Zie over de noodzaak van differentiatie in de toetsingsintensiteit verder Ely 1980, p. 31 en Loenen 1998, p. 42.

259. Vgl. Rutten 1997, p. 634; hij stelt dat een dergelijk "glijdende schaalmodel" ook wel als theoretische leidraad voor de rechter bruikbaar is, maar dat hieraan bijzondere bezwaren zijn verbonden. Allereerst biedt dit model de rechter maar weinig houvast, hetgeen gezien het belang van de toetsingsintensiteit voor de uitkomst van de toetsing een bedreiging kan betekenen voor de rechtszekerheid en de duidelijkheid van de rechtspraak. Daamaast ontstaat hierdoor volgens Rutten zoveel ruimte voor de rechter om zijn eigen toetsing vorm te geven, dat het risico voor het ongemerkt invoegen van eigen waardeoordelen en subjectieve elementen bijzonder groot is. Aangezien beide bezwaren een belangrijke reden vormen voor het creêren van een toetsingsmodel en een model voor het vaststellen van de toetsingsintensiteit, is het niet wenselijk om een dergelijk glijdende schaalmodel als uitgangspunt te hanteren. 
meer dan drie of vier "niveaus" van toetsingsintensiteit te werken. Zou gekozen worden voor meer niveaus, dan zouden deze al snel hun onderscheidend vermogen verliezen en is het bovendien moeilijk om hieraan praktische consequenties voor de toetsingsmethodiek te verbinden. Problematisch is bovendien dat het bij een keuze voor meer niveaus moeilijk zal zijn om te bepalen welk niveau in een bepaald geval moet worden toegepast, hetgeen de duidelijkheid van de uitspraak niet ten goede zou komen. Uitgegaan moet dan ook worden van een onderverdeling in een zeer marginale, een marginale, een tamelijk intensieve en een zeer intensieve toets, of in een marginale, een "neutrale" en een intensieve toets. Essentieel is vervolgens dat de rechter uitdrukkelijk aangeeft welke van deze drie of vier niveaus hij tot uitgangspunt neemt en vervolgens toetst op een wijze die met zijn keuze in overeenstemming is. Dat de neutrale toets de ene keer iets intensiever uitvalt dan de andere, of dat een intensieve toets soms iets minder intensief lijkt, is daarbij onvermijdelijk; de rechtszekerheid of duidelijkheid van de motivering wordt daardoor ook niet meteen negatief beïnvloed.

\subsubsection{Consequenties van de keuze voor een bepaald "niveau" van toetsings- intensiteit}

Zoals hiervoor is aangegeven moet de rechter een oordeel uitspreken over de intensiteit van zijn toetsing voordat hij kan beoordelen of er sprake is van een ongelijke behandeling en voordat hij de toelaatbaarheid hiervan kan toetsen; de vaststelling van de toetsingsintensiteit gaat dus nog vooraf aan de eerste fase van de toetsing. Vervolgens moet hij de gekozen toetsingsintensiteit consequent toepassen: aan alle criteria van het model moet met dezelfde intensiteit worden getoetst. Interessant is daarbij de vraag wat er nu precies onder een (zeer) marginale, neutrale of (zeer) intensieve toets moet worden verstaan, dat wil zeggen wat de keuze voor een van deze niveaus concreet betekent voor, bijvoorbeeld, de toetsing van de subsidiariteit of van de mate van fit. In de literatuur zijn daarvoor helaas slechts weinig aanwijzingen terug te vinden. Bij de beschrijving van de rechterlijke toetsing aan de verschillende criteria van het rechtvaardigingsmodel (paragraaf 3 ) is echter al een indruk gegeven van de mogelijke consequenties die een bepaalde toetsingsintensiteit voor de toetsingsmethodiek kan hebben.

Het verschil in toetsingsintensiteit zal zich vooral kunnen manifesteren in de mate waarin de rechter zich actief opstelt en in de verdeling van de bewijslast. Zo kan bij een intensieve toetsing van de rechter worden verwacht dat hij nagaat of met het onderscheid nog andere dan de aangevoerde doelstellingen worden nagestreefd, terwijl bij een werkelijk marginale toetsing veel sneller met de stellingen van de verdedigende partij genoegen kan worden genomen. ${ }^{260}$ Een neutrale toetsing zou dan inhouden dat de

260. Een andere mogelijke, nog marginalere, benadering is beschreven door Tussman/TenBroek: "The Court can simply infer or discover the legislative view or assumption about the relation between the classes from the general context of the problem or from legislative sources and records, and having done so, may refuse to challenge it on the ground that the determination of fact is peculiarly a legislative function. The Court's reluctance openly to challenge legislative belief is true or false, but whether this belief is 'reasonable' or 'entertainable' or such that a reasonable man might well hold it" (1949, p. 367). In een dergelijk geval hoeft van de wederpartij niet eens te worden verwacht dat hij goede doelstellingen aanvoert. Zoals in hoofdstuk 5 nog zal blijken is dit in Amerika een gebruikelijke benadering, maar zijn hierbij enige vraagtekens te plaatsen. Vooralsnog kan er in ieder geval vanuit worden 
rechter in beginsel uitgaat van de aangevoerde doelstellingen, maar een nader onderzoek kan uitvoeren als de benadeelde partij overtuigend aannemelijk heeft gemaakt dat er (ook) andere, minder gemakkelijk te rechtvaardigen doelstellingen voor het onderscheid bestonden.

Een vergelijkbaar verschil in rechterlijke activiteit kan tot uitdrukking komen bij de toetsing aan de vereisten van geschiktheid en subsidiariteit. Zo kan de rechter bij een intensieve toetsing zelfstandig nagaan of er geen andere maatregelen of middelen beschikbaar waren om het gestelde doel te bereiken en mag hij bij een dergelijke toetsing niet tevreden zijn met de stelling van de verdedigende partij dat hij, op het moment waarop de regeling tot stand werd gebracht, redelijkerwijze kon verwachten dat de classificatie een geschikt middel was. Bij een marginale toetsing kan een dergelijke onderzoeksverplichting bij de subsidiariteitstoets afwezig worden geacht, terwijl de rechter bij de beoordeling van de geschiktheid genoegen kan nemen met vermoedens over de causaliteit van de classificatie. Bij een neutrale toetsing kan ook hierbij worden gesteld dat de mate waarin de rechter aandacht moet schenken aan alternatieven of aan de causaliteit afhankelijk is van de stellingen van de benadeelde partij. Iets vergelijkbaars geldt ook bij de toetsing van de aan het onderscheid ten grondslag liggende belangenafweging: bij een marginale toetsing hoeft slechts te worden nagegaan of er sprake was van aperte onredelijkheid of van een evidente onevenwichtigheid, terwijl de rechter bij een intensieve toetsing de mogelijkheid heeft om de belangenafweging vergaand te beoordelen op zijn redelijkheid. ${ }^{261}$ De neutrale toetsing vraagt ook hierbij om een middenweg.

Een verschil in toetsingsintensiteit kan verder tot uitdrukking komen in de eisen die worden gesteld aan de vormgeving van het onderscheid. Eerder is al gesteld dat er bij een intensieve toetsing veel hogere eisen kunnen worden gesteld aan de zorgvuldigheid van de definitie van een classificatie dan bij een marginale toetsing.

Tenslotte kan het verschil in toetsingsintensiteit zijn weerslag vinden in de eerste fase van de toetsing, dat wil zeggen bij de beoordeling of er eigenlijk wel sprake is van een ongelijke behandeling. Een marginale toetsing leidt in dit geval tot hogere eisen aan het door de benadeelde te leveren bewijs; zo kan worden gevergd dat hij overtuigende statistische gegevens of ander wetenschappelijk of cijfermatig bewijs aanvoert om aan te tonen dat het onderscheid voor hem een daadwerkelijke benadeling tot gevolg heeft. Worden in deze fase hoge eisen gesteld aan de bewijslast van de benadeelde, dan betekent dit dat de rechter zelf weinig actief hoeft te zijn bij de beoordeling van de benadeling, terwijl evenmin snel een rechtvaardiging hoeft te worden verlangd. Bij een intensieve toetsing kan daarentegen worden volstaan met het vereiste dat het voorstelbaar moet zijn dat een maatregel benadelende effecten voor een bepaalde groep heeft: bij deze toetsingsintensiteit is het sneller noodzakelijk te achten dat de wederpartij een

gegaan dat de rechter ook bij een marginale toets in beginsel uit moet gaan van de door de verdedigende partij aangevoerde doelstellingen.

261. Volgens Bhagwat kan de toetsingsintensiteit ook een iets andere betekenis hebben voor de proportionaliteitstoets, namelijk in de vorm van een "thumb on the scale": bij het vinden van evenwicht tussen het aangetaste individuele belang en het door de overheid met een ongelijke behandeling nagestreefde belang kan door de rechter bij verhoogde toetsingsintensiteit een groter gewicht worden toegekend aan het individuele belang, waardoor het overheidsbelang corresponderend zwaarwegend moet zijn om het gemaakte onderscheid te kunnen rechtvaardigen (1997, p. 311). 
toereikende rechtvaardiging voor het onderscheid aanvoert en dat de rechter een goed onderzoek van die rechtvaardiging kan uitvoeren.

De effecten van de intensiteitsverschillen voor de toetsingsmethodiek zijn in het voorgaande slechts schetsmatig weergegeven en bieden de rechter nog niet bijzonder veel helderheid. Het is echter waarschijnlijk dat het effect op de toetsingsmethodiek duidelijker naar voren zal komen bij het onderzoek naar de wijze waarop rechters in de praktijk gebruik maken van een gedifferentieerde benadering. Ook ligt het in de lijn der verwachting dat uit een dergelijk onderzoek enkele praktisch bruikbare aanknopingspunten voor de rechterlijke toetsing kunnen worden afgeleid. In het concluderende hoofdstuk van dit boek (hoofdstuk 7) zal aan de hand van de resultaten van het rechtsvergelijkende onderzoek nader worden ingegaan op deze problematiek.

\subsection{Factoren die bepalend zijn voor de intensiteit van de toetsing}

\subsubsection{Inleiding}

Hoewel het duidelijk is dat een zekere mate van differentiatie in de intensiteit van de rechterlijke toetsing wenselijk is kan de vraag worden gesteld welke omstandigheden de keuze voor een bepaald niveau van toetsingsintensiteit bepalen. In het hiernavolgende zullen enkele factoren worden besproken die theoretisch gezien bij iedere vaststelling van de toetsingsintensiteit een rol zouden moeten spelen. Deze factoren zijn in beginsel neutraal van aard, in die zin dat zij zowel kunnen leiden tot een intensivering als tot een afzwakking van de toetsing. Zo zal de factor "gewicht van de aangetaste belangen" tot een intensievere toetsing kunnen leiden wanneer de aangetaste belangen bijzonder zwaarwegend zijn, maar zal het ontbreken van gewichtige individuele belangen juist een ondersteuning kunnen vormen voor de keuze voor een marginale toetsing. ${ }^{262}$

Een belangrijk probleem bij het vaststellen van de toetsingsintensiteit betreft daarnaast de afweging van de verschillende factoren. Wanneer voor iedere factor als zodanig is vastgesteld of deze aanleiding geeft tot het uitvoeren van een intensieve of juist marginale toets, zal vrijwel steeds blijken dat er zowel argumenten voor als tegen de keuze voor een bepaalde toetsingsintensiteit bestaan. De rechter zal, nadat hij heeft vastgesteld welke betekenis en welk gewicht de verschillende factoren in het concrete geval hebben, de verschillende factoren tegen elkaar moeten afwegen om te kunnen bepalen welke toetsingsintensiteit in het concrete geval is aangewezen.

In het hiernavolgende zullen eerst de factoren worden besproken waarvan het theoretisch gezien wenselijk is dat de rechter ze betrekt bij het vaststellen van zijn toetsingsintensiteit (paragraaf 5.3.2). Vervolgens zal nader worden ingegaan op de bij de afweging van de verschillende factoren te volgen methodiek (paragraaf 5.3.3).

262. Aangezien de toetsingsintensiteit al moet worden vastgesteld voordat wordt ingegaan op de vraag of er sprake is van een benadeling, betekent dit overigens wel dat af en toe vooruit moet worden gelopen op de inhoudelijke toetsing. Dit is niet in alle omstandigheden problematisch: voor de vaststelling van de toetsingsintensiteit kan meestal worden volstaan met een vluchtige bestudering van de voorliggende feiten die zelden diepgaander zal zijn dan een marginale toetsing. 


\subsubsection{Intensiteitbepalende factoren}

\section{a. Grond van het onderscheid}

Een zeer belangrijke intensiteitbepalende factor is de grond van onderscheid: het kenmerk of de eigenschap van een groep, geval of persoon waarop het onderscheid is gebaseerd. ${ }^{263}$ Algemeen wordt aangenomen dat het maken van onderscheid op bepaalde gronden maatschappelijk gezien laakbaar of in ieder geval twijfelachtig is. Wanneer er onderscheid op een dergelijke "verdachte" grond is gemaakt kan worden vermoed dat degene die voor het onderscheid verantwoordelijk heeft gehandeld vanuit ontoelaatbare motieven. ${ }^{264}$ Een algemeen aanvaard voorbeeld van een verdacht differentiatiecriterium is bijvoorbeeld huidskleur. Wanneer iemand onderscheid maakt op die grond (zoals in het eerder gegeven voorbeeld van de discotheekeigenaar die een hogere entreeprijs vraagt van kleurlingen dan van blanken) rijst de verdenking dat er geen gerechtvaardigd doel wordt nagestreefd en dat er bij de besluitvorming onvoldoende rekening is gehouden met het essentiële recht op gelijkwaardigheid en gelijk respect. Het bestaan van een dergelijke verdenking geeft de rechter de bevoegdheid om met meer zorgvuldigheid en activiteit dan gebruikelijk na te gaan of de betrokken persoon of groep niet ten onrechte in zijn vrijheden en belangen is aangetast. Degene die verantwoordelijk is voor het onderscheid op de "verdachte" grond zal in dit soort gevallen bijzonder goede redenen aan moeten voeren om het onderscheid te kunnen rechtvaardigen. ${ }^{205}$

Van belang is tegelijkertijd dat er ook gronden zijn die in het algemeen als een volstrekt redelijke basis voor onderscheid worden beschouwd, zoals in het geval van het maken van onderscheid op grond van leeftijd bij de vaststelling van bepaalde rechten en bevoegdheden of in het geval van onderscheid op grond van inkomen bij de bepaling van de hoogte van de inkomstenbelasting. ${ }^{266}$ In dergelijke gevallen is het vermoe-

263. Hierbij wordt meestal gedacht aan specifieke persoonsgebonden kenmerken, zoals ras, geslacht, nationaliteit en religie. Het is echter van belang om in te zien dat onderscheid op vrijwel iedere denkbare grond kan worden gemaakt, variërend van het aantal huizen dat iemand in zijn bezit heeft tot het voldoen aan de voorwaarden voor het exploiteren van een olieplatform, en van het hebben van twee of meer kinderen tot het beschikken over bepaalde diploma's. Ook hierbij gaat het steeds om "kenmerken" of "eigenschappen" van een bepaalde (rechts)persoon, alleen moeten deze begrippen dan in ruimere zin worden opgevat: het gaat om die kenmerken waardoor een bepaalde (rechts)persoon of groep zich onderscheidt van anderen. Belangrijk is overigens dat deze factor vereist dat de rechter al iets vooruitloopt op zijn inhoudelijke toetsing, omdat hij moet vaststellen op welke grond het beweerde onderscheid is gebaseerd. Dit is echter in de meeste gevallen vrij gemakkelijk.

264. Vgl. Sunstein (opnieuw gepubliceerd in Garvey/Aleinikoff 1999), p. 63 en "Developments" 1969, p. 1125 ,

265. O'Fallon beschrijft dit tamelijk formeel als de "[...] legislative actions in which there is a high antecedent likelihood of corruption of the legislative process through the influence of external preferences" (1979, p. 44).

266. Voorbeeiden van algemeen geaccepteerd onderscheid op grond van leeftijd zijn het kiesrecht, de bevoegdheid een auto te besturen en om alcohol te kopen; ook weinig verdacht is het feit dat er voor jonge kinderen meestal een ander strafrechtelijk regime geldt en dat zij ook in het civiele recht soms andere rechten hebben dan volwassenen. Hierbij blijkt overigens meteen dat de grond van onderscheid niet de enige intensiteitbepalende factor is: de toetsingsintensiteit wordt daarnaast in belangrijke mate bepaald door de aard van de aangetaste belangen. Wanneer er bijzonder zwaarwegende of fundamentele belangen worden aangetast, zoals in het theoretische geval waarin jongeren onder de 30 jaar verboden wordt om hun mening in de media naar voren te brengen, maar ook al in het praktische voorbeeld van de vaststelling van de kiesgerechtigde leeftijd, zal een intensieve toets redelijk kunnen zijn. 
den meestal gerechtvaardigd dat de verantwoordelijke binnen de grenzen van zijn bevoegdheden is gebleven en de rechten en vrijheden van de benadeelde niet op willekeurige wijze heeft aangetast. Een terughoudende toetsing is in dergelijke gevallen op zijn plaats. ${ }^{267}$

\section{Maatschappelijke opvattingen als factor bij de bepaling van de "verdachtheid"}

Hoewel het redelijk lijkt om de toetsingsintensiteit te laten bepalen door de verdachtheid van het differentiatiecriterium, zal het in de praktijk niet altijd gemakkelijk zijn om vast te stellen wanneer er van een verdachte grond sprake is. ${ }^{268}$ Op het eerste gezicht lijken vooral algemene rechtsopvattingen doorslaggevend te zijn bij de bepaling van de verdachtheid: wanneer er een algemene consensus bestaat die onderscheid op een bepaalde grond goed- of afkeurt kan de rechter zich daardoor bij het bepalen van zijn toetsingsintensiteit laten leiden. Opgemerkt moet echter worden dat de opvattingen over de verdachtheid van een bepaalde grond van onderscheid sterk afhankelijk zullen zijn van tijd en plaats en bijzonder vatbaar zijn voor veranderingen. ${ }^{269}$ Terwijl in literatuur uit de jaren zestig bijvoorbeeld nog werd gewezen op relevante en vanzelfsprekende verschillen tussen man en vrouw als het gaat om hun rol in het huishouden en bij het opvoeden van kinderen, ${ }^{270}$ wordt over de verdachtheid van geslacht als differentiatiekenmerk tegenwoordig volkomen anders gedacht. Hoewel de maatschappelijke consensus zeker relevant is bij het bepalen van de verdachtheid, moet hiermee dus op een voorzichtige manier worden omgesprongen: het is vaak moeilijk om de precieze consensus op een bepaald moment te bepalen, zeker wanneer de opvattingen over een bepaald differentiatiecriterium sterk in beweging zijn.

Op dit samenspel van de grond van onderscheid en het gewicht van de aangetaste belangen zal hierna nog worden ingegaan.

267. Hetgeen overigens niet impliceert dat er in deze gevallen altijd een terughoudende toetsing moet worden toegepast: of dat het geval is hangt ook af van de beoordeling van de andere, hierna nog te bespreken, intensiteitbepalende factoren. Er zijn zeker omstandigheden denkbaar waarin een weinig verdachte grond van onderscheid toch vraagt om een intensieve toetsing, bijvoorbeeld wanneer er door het onderscheid fundamentele individuele belangen worden aangetast.

268. Te denken valt bijvoorbeeld aan de grond "geslacht". Enerzijds kan dit in een groot aantal gevallen een relevante grond van onderscheid vormen en hoeft het maken van onderscheid op deze grond niet te wijzen op het bestaan van onedele motieven en gedachten. Anderzijds is geslacht een grond die gemakkelijk wordt ingeroepen om onwenselijk onderscheid te rechtvaardigen en waardoor vaak vooroordelen en stereotypen worden bevestigd; daardoor zou juist aanleiding kunnen bestaan voor het uitvoeren van een strengere toetsing. In dit soort gevallen is een middenweg op zijn plaats: zoals gezegd is het niet noodzakelijk of wenselijk is om slechts twee toetsingsniveaus te hanteren, maar kan beter worden gewerkt met drie of zelfs vier niveaus.

269. Vgl. Alexander 1992, p. 153. Dit blijkt ook uit een onderzoek naar de verandering van opvattingen over toelaatbaar onderscheid dat is uitgevoerd door Groenendijk (1988, p. 621/622). Hij geeft aan dat in Nederland in 1978 nog $40 \%$ van de bevolking vond dat nationaliteit een rol mag spelen bij ontslag en $50 \%$ dat vrouwen mogen worden ontslagen op grond van hun geslacht, terwijl in 1988 maar liefst $80 \%$ stelde dat het betrekken van nationaliteit of geslacht bij ontslag onaanvaardbaar is.

270. Benn/Peters 1969, p. 64/65: "There are admittedly biological and psychological differences between men and women that can properly support a difference in function within the family. A mother is expected to occupy herself with house and children, a father with earning the family living. [...] Where, as in family life, sex differences are held to be relevant, the egalitarian is usually ready to accept differences in rights. [...] These distinctions are not called 'inequalities' because they are held to be justified". 
Ook om een andere reden is het niet altijd wenselijk om voor de bepaling van de verdachtheid van een differentiatiecriterium aansluiting te zoeken bij de heersende consensus. Wanneer in een samenleving algemeen aanvaard wordt dat het redelijk is om onderscheid te maken op grond van criteria als ras of godsdienst, is het van belang dat de rechter zich niet alleen richt naar de maatschappelijke opvattingen, maar ook rekening houdt met abstracte en morele normen met betrekking tot de toelaatbaarheid van dit soort gronden als basis voor achterstelling. ${ }^{271} \mathrm{Om}$ die reden is het wenselijk om de rechter enkele meer abstracte en objectieve factoren aan te reiken als aanknopingspunt voor de vaststelling van zijn toetsingsintensiteit.

\section{Onderscheid op grond van onveranderlijke en irrelevante persoonskenmerken}

Belangrijk is allereerst dat er enkele abstracte criteria kunnen worden geformuleerd die verband houden met de aard van het onderscheidingscriterium. Gesteld kan bijvoorbeeld worden dat er sprake is van verdacht onderscheid wanneer dit is gebaseerd op typisch persoonsgebonden kenmerken of op grond van kenmerken waaraan de betrokkene niets kan veranderen; welbekende voorbeelden hiervan zijn gronden als geslacht, etnische afkomst of huidskleur. ${ }^{272}$ Ook de irrelevantie van een bepaald onderscheidend kenmerk voor het maatschappelijk functioneren kan worden gezien als een reden om kritischer naar het gemaakte onderscheid te kijken; ook daarbij biedt huidskleur een uitstekend voorbeeld.

Van belang is echter dat de praktische betekenis van deze factoren voor de bepaling van de verdachtheid van een bepaald differentiatiecriterium enigszins moet worden gerelativeerd. Zo moet worden vastgesteld dat het bij veel gronden waarvan de verdachtheid algemeen is geaccepteerd niet gaat om onveranderlijke kenmerken: nationaliteit wordt bijvoorbeeld vaak genoemd als een verdachte grond van onderscheid, terwijl hieraan relatief gemakkelijk iets is te veranderen door naturalisatie; ook bij religie en politieke voorkeur gaat het om persoonsgebonden kenmerken die voor verandering vatbaar zijn. ${ }^{273}$ Anderzijds is er niet altijd reden aanwezig om onderscheid op grond van strikt persoonsgebonden en onveranderlijke kenmerken als verdacht aan te merken: te denken valt aan onderscheid op grond van intelligentie en talent (bijvoorbeeld bij de toelating tot een bepaald schooltype, zoals een conservatorium of een universiteit) of op grond van het al dan niet hebben van een geestelijke stoornis. ${ }^{274}$ Tenslotte kan wor-

271. Zie bijv. Bezzenberger 1996, p. 397-399. Hieraan is ook aandacht besteed bij de bespreking van de bevoegdheid van de rechter om af te wijken van de heersende opinie bij het beoordelen van de gerechtvaardigdheid van de doelstelling van een onderscheid. In de context van het bepalen van de toetsingsintensiteit kunnen vergelijkbare overwegingen gelden. Ter rechtvaardiging van de stelling dat de rechter soms kan afwijken van de heersende opvattingen kan dan ook volstaan worden met een verwijzing naar paragraaf 3.2 .3 en 3.2.4.

272. Vgl. Mulder 1987, p. 111 en Burkens 1982, p. 63/64.

273. Ely 1980, p. 150 en Alexander 1992, p. 151. Aan dit bezwaar kan tegemoet worden gekomen door de factor preciezer te formuleren, bijvoorbeeld door te stellen dat het gaat om kenmerken die niet kunnen worden veranderd zonder af te doen aan de strikt eigen individualiteit; in deze zin Heringa 1992, p. $13 / 14$.

274. Ely 1980, p. 150. In vergelijkbare zin ook Wiggers 1991, p. 173, Alexander 1992, p. 151 en Tribe 1980 , p. 1073 (voetnoot 51). Wel is het mogelijk om zin te geven aan dit criterium door het enger te formuleren, bijvoorbeeld door te stellen dat het moet gaan om een onveranderlijk kenmerk dat niets zegt over iemands fysieke of mentale capaciteiten (vgl. Perry 1979, p. 1066); daarmee komt de formulering dicht in de buurt van een combinatie van de onveranderlijkheid en de irrelevantie van een be- 
den opgemerkt dat ook de relevantie voor het maatschappelijk functioneren niet altijd bruikbaar is als bepalende factor. Problematisch is met name dat het bij sommige kenmerken of eigenschappen moeilijk is vast te stellen of zij in hun algemeenheid relevant zijn voor iemands functioneren. Een voorbeeld is het inkomen dat iemand heeft: weliswaar wordt dit kenmerk tot aanknopingspunt genomen bij veel maatschappelijk belangrijke vormen van onderscheid (het vaststellen van de hoogte van de belasting, het bepalen van de premies voor sociale verzekeringen), maar het is moeilijk te zeggen of het hierbij gaat om een eigenschap is die daadwerkelijk relevant is voor het maatschappelijk functioneren.

Het voorgaande betekent zeker niet dat factoren als persoonsgebondenheid, onveranderlijkheid en maatschappelijke irrelevantie in het geheel niet in het oordeel over de verdachtheid van een grond mogen worden betrokken. Wel betekent het dat aan deze factoren nooit absolute conclusies mogen worden verbonden: de rechter zal nooit uitsluitend op basis van de onveranderlijkheid of persoonsgebondenheid van een kenmerk mogen vaststellen dat er sprake is van een verdacht onderscheidingscriterium. Bij de bepaling van de verdachtheid zal altijd rekening moeten worden gehouden met een samenstel van factoren.

\section{Stigmatisering en vooroordelen als bepalende factor voor de verdachtheid}

Van belang is dat het bij verdachte differentiatiecriteria meestal gaat om kenmerken waardoor specifieke, duidelijk definieerbare groepen zich in de samenleving onderscheiden van anderen. ${ }^{275}$ Onderscheid dat is gebaseerd op dergelijke kenmerken moet vooral met extra zorgvuldigheid worden bekeken wanneer het onderscheid tot gevolg heeft dat de inferioriteit van de betrokken groep wordt benadrukt (stigmatisering) ${ }^{276}$, of wanneer het onderscheid een uitdrukking vormt van vooroordelen of onjuiste en ver-

paald kenmerk. Inderdaad lijkt een dergelijke combinatie een goede manier om te bepalen of een kenmerk "verdacht" is en tot een striktere toetsing moet leiden.

275. Daarbij hoeft de term "groep" niet te betekenen dat mensen zich met deze groep identificeren of dat de groep zichzelf daadwerkelijk als groep beschouwt. Eerder duidt het begrip hier op een bepaalde hoeveelheid mensen met een specifiek kenmerk dat hen onderscheidt van andere mensen. Vgl. in deze zin ook Tribe 1980, p. 1074/1075. Het feit dat er een groepskenmerk wordt gesignaleerd betekent dus niet noodzakelijkerwijze dat de focus van het gelijkheidsbeginsel wordt verplaatst van een recht voor het individu naar een groepsrecht, zoals soms wordt verondersteld (vgl. bijv. Fried 1990, p. 108/109). Ook moet worden opgemerkt dat de duidelijke definieerbaarheid van een groep niet altijd samengaat met de duidelijke zichtbaarheid van of de identificatie met het onderscheidende kenmerk. Ook groepen als homoseksuelen of onvermogenden kunnen immers duidelijk worden gedefinieerd, terwijl de zichtbaarheid van deze groepen niet bijzonder groot is en niet alle leden zich met de groep zullen identificeren. Zie daarover nader Ackerman 1985, m.n. p. 729-731.

276. Vgl. bijvoorbeeld Sloot 1986, p. 29: sommige gronden van onderscheid, zoals ras, kunnen worden beschouwd als "een rechtstreekse uitdrukking van uitsluiting, achterstelling en denigratie van de ene groep, kortom van tweederangs (of nulde-rangs) burgerschap". De mate waarin en de wijze waarop aan de inferioriteit uitdrukking wordt gegeven kan verschillen. Zo geven Benn en Peters aan dat de inferioriteit van een groep kan worden benadrukt door eenvoudig te weigeren de idee van gelijke consideratie uit te strekken tot de betrokken groep, net zoals deze idee zich ook niet uitstrekt tot dieren. Inferioriteit kan echter ook worden benadrukt door het leveren van twijfelachtig biologisch en etnologisch bewijs waardoor wordt aangetoond dat een groep daadwerkelijk inferieur is en dat er op die grond reden is om de groep uit te zonderen van bepaalde behandelingen (1969, p. 63/64). Zie verder "Developments" 1969, p. $1126 / 1127$ en Perry 1979, p. 1051. 
gaande stereotyperingen. ${ }^{2 m}$ Wanneer dat het geval is wordt door het onderscheid het zelfrespect van een individu dat deel uitmaakt van de benadeelde groep op een ernstige manier aangetast. Bovendien kan het benadrukken van vooroordelen tot gevolg hebben dat groepen van daadwerkelijke deelname aan het maatschappelijk leven worden uitgesloten. ${ }^{27 x}$ In dit soort gevallen bestaat er steeds reden om een strikte toetsing toe te passen.

Om te achterhalen of er sprake is van een op vooroordelen of stigma's gebaseerd onderscheid, moet de rechter op zoek gaan naar de achtergrond of de "psychologie" een bepaalde benadeling. ${ }^{230}$ Dit lijkt wellicht moeilijk, maar zal dit niet altijd zijn: het bestaan van vooroordelen kan vaak redelijk gemakkelijk en objectief worden afgeleid uit de omstandigheden van het voorliggende geval. ${ }^{281} \mathrm{Zo}$ kan worden gesteld dat de

277. Ely 1980, p. 151 e.v.; ook Dworkin lijkt het bestaan van vooroordelen - en het tegenovergestelde: favoritisme - reden te achten voor een intensieve toetsing (Dworkin 1996, p. 159). Deze factor wordt in het algemeen overigens bepalend geacht: classificaties kunnen vrijwel steeds als verdacht worden aangemerkt wanneer zij groepen benadelen waarvan bekend is dat zij het slachtoffer zijn van een wijdverspreide laster en vijandigheid en waarvan bekend is dat zij regelmatig door andere groepen worden benadeeld; zie Ely 1980, p. 153 en vgl. ook Wiggers, die stelt dat er sprake moet zijn van een objectief bepaalbare minachting jegens een bepaalde groep, hetgeen wil zeggen dat iemand op een maatschappelijk gezien identiteitsbeschadigende en vernederende wijze wordt behandeld (1991, p. 175 en 197), en Mulder, die spreekt van een grillig en redeloos gedragspatroon dat voortkomt uit de heersende, consistente moraal van een bepaalde maatschappij of groep (1987, p. 111). Tribe acht tenslotte niet zozeer vooroordelen, maar de heersende inhoudelijke visie over normen en waarden doorslaggevend (1980, p. 1076); het begrip "vooroordeel" lijkt echter meteen al in te houden dat er een heersende, niet nader gemotiveerde, opvatting bestaat over wat al dan niet normaal of "juist" is. Vooroordelen zijn overigens zeker niet alleen reden voor een intensievere toetsing wanneer zij uitdrukking geven aan de vijandigheid jegens een bepaalde groep. Vooroordelen kunnen ook basis zijn voor een overdreven paternalisme waardoor een groep gehinderd wordt in het maken van eigen keuzes; "bescherming" van vrouwen als kwetsbare groep is hiervan een voorbeeld (Clark 1978, p. 965). In de meeste gevallen van paternalisme is er overigens niet zozeer sprake is van vooroordelen, maar eerder van onredelijke of te vergaande stereotypering. Het begrip "stereotypering" is door Sloot omschreven als een eenzijdige beeldvorming, waarbij de negatieve of positieve kenmerken van een of meer personen van toepassing worden verklaard op een hele groep (1986, p. 28). Zoals Ely aangeeft zijn stereotyperingen niet te vermijden; voor het dagelijks leven zijn dergelijke veralgemeniseringen zelfs bijzonder nuttig (1980, p. 155). Problematisch worden zij echter wanneer het duidelijk is dat in een meerderheid van de gevallen de feiten de stereotypering tegenspreken. Wanneer dat het geval is bestaat er aanleiding tot het uitvoeren van een intensievere toets (Ely 1980, p. 157).

278. Karst 1977 , p. $6 / 7$ en p. 48 : "[...] [T] he harms resulting from stigma may take two separate forms. Most obvious is the harm to the primary self-respect. In addition, a legislator may be systematically inattentive to inequities that fall on members of a stigmatized group." Clark heeft aangegeven dat een dergelijke basis voor onderscheid ook om een andere reden bezwaarlijk is: "[...] the resulting sense of unfairness necessarily has bred a deep cynicism about the very legitimacy of government itself" (1978, p. 967).

279. Ely 1980 , p. 151

280. Vgl. O'Fallon, die aangeeft dat het aan de rechter is om na te gaan of er redenen zijn om te veronderstellen dat het besluitvormingsproces of beleid is beïnvloed door opvattingen die duiden op een gebrek aan respect of zorg voor bepaalde personen (1979, p. 45).

281. Dit geldt in het bijzonder wanneer het duidelijk de bedoeling was om een bepaalde groep te stigmatiseren of te benadelen. In veel gevallen zal dit echter niet het geval zijn, maar vloeit het stigma eerder voort uit handelingen en redeneringen die zijn gebaseerd op maatschappelijk breed aanvaarde, maar niet altijd duidelijk zichtbare, vooroordelen en stereotypen; zie Karst 1977, p. 51. Ook in die gevallen bestaat er reden voor aanscherping van de toetsing: het enkele bevestigen of verdiepen van een stigma is daarvoor voldoende, nu ook daardoor sprake zal zijn van een emstige belangenaantasting. In derge- 
historische achterstelling van een specifieke groep of een duidelijk patroon van benadeling een belangrijke indicatie vormt voor het bestaan van vooroordelen jegens deze groep. ${ }^{2 \times 2}$ Verder kan de uitsluiting van een groep van belangrijke maatschappelijke voordelen hiervoor een aanwijzing vormen, zoals in het geval waarin de mogelijkheid van politieke en sociale participatie wordt beperkt. ${ }^{283}$ De kans op het bestaan van vooroordelen jegens een bepaalde groep is tenslotte aanzienlijk wanneer deze groep omwille van maatschappelijke opvattingen in de verborgenheid blijft, zoals in veel samenlevingen zichtbaar is bij homoseksuelen, of wanneer het contact tussen bevolkingsgroepen minimaal is en de benadeelde groep feitelijk wordt geïsoleerd, zoals bij sommige etnische of religieuze groeperingen het geval is. In dit soort omstandigheden kan een gebrek aan communicatie leiden tot het ontstaan van vreemde, onrealistische en onredelijke ideeën over de betrokken groep, hetgeen een voedingsbodem kan vormen voor achterstelling en stigmatisering. ${ }^{28+}$

\section{Gebruik van factoren die de verdachtheid bepalen}

De factoren die hiervoor zijn genoemd vormen vooral een basis voor een intensivering van de toetsing: wanneer zij in combinatie aanwezig zijn, kan er al snel een vermoeden ontstaan van een onderscheid op onredelijke gronden, waardoor een verhoogde toetsingsintensiteit wordt gerechtvaardigd. Belangrijk is echter dat deze factoren ook aanknopingspunten kunnen verschaffen voor het vaststellen van een minder vergaande toetsing. Als voorbeeld kan worden gewezen op geslacht als differentiatiegrond: langzaamaan neemt de betekenis van geslachtsgebaseerde stereotyperingen en vooroordelen af, terwijl ook kan worden opgemerkt dat de maatschappelijke participatie van de van oudsher benadeelde groep, vrouwen, sterk is verbeterd. Hoewel in dit geval een "second look approach" nog steeds aangewezen is - het gaat immers om een onveranderlijk criterium en er bestaan nog steeds veel stereotypen die de positie van vrouwen bemoeilijken - lijkt een zeer intensieve en drastische toets hierbij in mindere mate nodig. In dit soort omstandigheden kan worden gekozen voor een tussenliggend niveau

lijke gevallen mag in ieder geval sneller van de verantwoordelijke worden verlangd dat hij met de consequenties van zijn handelen meer rekening had gehouden of dat hij alsnog zorgt voor het wegnemen daarvan.

282. Loenen 1992, p. 218 en 243; zie ook O'Fallon 1979, p. 47 en Clark 1978, p. 969/970. Gesteld kan worden dat de historische uitsluiting van een bepaalde groep vanwege een onderscheidend kenmerk zelfstandig aanleiding kan geven tot een intensievere toetsing. Betoogd is namelijk wel dat een historische achterstelling negatieve effecten kan hebben op de politieke participatie van een groep, waardoor deze niet voldoende in staat is om zich te verzetten tegen negatieve regelgeving. Het risico voor fouten in het democratisch proces, een belangrijke reden voor verhoging van de toetsingsintensiteit, is in een dergelijk geval duidelijk aanwezig. Vgl. Baker 1980, p. 1053/1054.

283. Wanneer dit het gevolg is van onderscheid op bepaalde gronden is er vooral reden voor een intensievere toetsing omdat in die gevallen de mogelijkheid van minderheden om zelf hun achtergestelde positie te verbeteren door middel van het gebruik van de politieke organen vergaand wordt beperkt. Zie Sunstein (opnieuw gepubliceerd in Garvey/Aleinikoff 1999), p. 62.

284. Ely 1980 , p. 161 e.v. Overigens hangt het bestaan van vooroordelen en stereotypen nauw samen met de eerste reeds genoemde factor: de aard van het kenmerk waardoor een bepaalde groep zich onderscheidt. Met name wanneer groepskenmerken duidelijk zichtbaar en onveranderlijk zijn is de kans op het ontstaan van vooroordelen en stereotypen groot. Vgl. Karst 1977, p. 23. De rechter zal daarmee dan ook in het bijzonder rekening moeten houden. 
van toetsingsintensiteit. ${ }^{2 s s}$ In omstandigheden waarin een gevaar voor stigmatisering volledig afwezig is en waarin ook verder geen reden bestaat om het onderscheid als verdacht te kenmerken kan deze factor bovendien een belangrijk argument vormen voor de keuze voor een terughoudende toetsing.

Verder is het van belang om op te merken dat een bepaalde grond van onderscheid in sommige gevallen verdacht zal zijn, terwijl dit in andere gevallen niet het geval is. Voor veel westerse landen kan bijvoorbeeld betoogd worden dat een benadeling van blanken minder aanleiding geeft tot een strikte toetsing dan een benadeling van een raciale minderheidsgroep. Weliswaar wordt er ook in een dergelijk geval onderscheid gemaakt op grond van een onveranderlijk persoonskenmerk dat voor het maatschappelijk functioneren niet relevant is, maar enkele belangrijke factoren voor verdachtheid ontbreken: er is geen sprake van stigmatisering vanwege het hebben van een blanke huidskleur, noch van diepgewortelde vooroordelen of een geschiedenis van achterstelling. ${ }^{2 \times 6}$ Een vermoeden dat er onderscheid wordt gemaakt op een manier die doet twijfelen aan het respect van de meerderheid voor de minderheid is in dit soort gevallen vrijwel steeds afwezig, zodat de belangrijkste rechtvaardiging voor een intensivering van de toetsing ontbreekt. ${ }^{207}$ De rechter zal er dan ook niet zonder meer vanuit mogen gaan dat een bepaalde grond van onderscheid "inherent" verdacht is, maar moet aan de hand van de hiervoor genoemde factoren in ieder concreet geval opnieuw vaststellen of er gesproken kan worden van een verdachte grond van onderscheid. ${ }^{2 \mathrm{xa}}$

285. Vgl. Ely 1980, p. 168-169; zie ook O'Fallon 1979, p. 49, die stelt dat het risico op corruptie van het besluitvormingsproces als gevolg van de ontkenning van het recht van mensen op gelijke consideratie en gelijk respect zal verschillen. Hij geeft verder aan dat de rechterlijke activiteit minder groot zal kunnen zijn wanneer het risico voor corruptic beperkt is.

286. Gesteld kan zelfs worden dat ras in deze specifieke context wel een relevant kenmerk is: het is immers juist vanwege hun ras dat bepaalde groepen problemen ondervinden in hun maatschappelijk functioneren (zie "Developments" 1969, p. 1108 en 1112). Daarmee kan het argument worden bestreden dat gelijke behandeling door de keuze voor deze benadering te zeer wordt gezien als een groepsrecht in plaats van als individueel recht, een bezwaar dat vooral in de VS naar voren is gebracht. Zie daarover nader hoofdstuk 5 . Het voorgaande is vooral van belang voor de toetsing van voorkeursbehandeling. Door deze "omgekeerde discriminatie", zoals deze vorm van onderscheid vaak wel genoemd wordt, worden veelal de normaal gesproken bevoordeelde groepen, zoals blanken of mannen, benadeeld. Wanneer ras of geslacht worden gezien als inherent verdachte gronden van onderscheid, moet dit soort vormen van onderscheid steeds aan een strikte toetsing worden onderworpen. Hoewel het ook dan mogelijk lijkt om voorkeursbehandeling te rechtvaardigen, is het niet onredelijk om in dit soort gevallen een iets terughoudender toetsing uit te voeren. Vooral in de VS bestaat hierover veel discussie, nu daar wel wordt gesteld dat ras een absoluut verdacht kenmerk is, ongeacht de groep die hierdoor wordt aangetast (zie bijv. Fried 1990, p. 111). Op deze discussie zal in hoofdstuk 5 nader worden ingegaan.

287. Vgl. "Developments" 1969 , p. 1108 . Een bijkomende reden voor terughoudendheid bij voorkeursbehandeling kan worden gevonden in het nog steeds ontbreken van een consensus over de wenselijkheid van positieve discriminatie en het bestaan van onzekerheid over de lange termijneffecten. In een dergelijke situatie is het beter om het voeren van beleid zoveel mogelijk over te laten aan het politieke proces (vgl. "Developments" 1969, p. 1114-1115); dergelijke specifieke factoren die de toetsingsintensiteit kunnen beïnvloeden zullen verderop nader worden besproken.

288. Dit maakt het overbodig om te werken met de in de literatuur wel genoemde factor "aard van het onderscheid". Met name door Van Maarseveen is betoogd dat de rechter moet nagaan of het gemaakte onderscheid in overeenstemming is met het in de maatschappij meest zichtbare patroon van ongelijke behandeling (congruent onderscheid), dan wel of er sprake is van een afwijking van dit patroon (discongruent onderscheid). Volgens hem geldt dat "hoe meer congruent een bepaalde discriminatie is, hoe 


\section{b. Indirect en materieel onderscheid}

Een intensieve toetsing wegens onderscheid op een verdachte grond kan relatief gemakkelijk worden omzeild door een indirect onderscheid te construeren. Voorbeelden hiervan waren (en zijn overigens nog steeds) vooral zichtbaar in de Verenigde Staten, waar overheidsorganen vooral in de jaren vijftig en zestig actie ondernamen om AfroAmerikanen hun recentelijk verworven burgerrechten te ontnemen. Zo kan worden gewezen op pogingen om via het aanpassen van de grenzen van een kiesdistrict AfroAmerikanen van plaatselijke verkiezingen uit te sluiten ${ }^{289}$ en op pogingen om ditzelfde doel te bereiken door het instellen van een "poll tax"200. ${ }^{291}$ In deze gevallen is er geen sprake van onderscheid dat rechtstreeks is gebaseerd op een verdachte grond, maar van onderscheid op "neutrale", op het eerste gezicht toelaatbare gronden. Het is dan moei-

meer rechtvaardiging zij behoeft" (1990, p. 28). Zo is het in de huidige samenleving gebruikelijk dat onderscheid op grond van geslacht leidt tot een benadeling van vrouwen ten opzichte van mannen, en dat onderscheid op grond van seksuele geaardheid leidt tot een achterstelling van homoseksuelen. In de gevallen waarin toevallig een man of een heteroseksueel door een classificatie of onderscheid wordt benadeeld, is er volgens Van Maarseveen sprake van een maatschappelijk gezien minder "ernstig" onderscheid en is het niet nodig om een strikte toetsing uit te voeren. Zie in vergelijkbare zin Loenen, die spreekt over symmetrische en asymmetrische discriminatie (1998, p. 244 e.v.; 1999, p. 205 en 206) en stelt dat asymmetrische discriminatie minder streng kan worden getoetst dan symmetrische discriminatie. Een belangrijk nadeel van de congruentie/discongruentie- of de symmetrie/asymmetriebenadering is dat deze praktisch niet echt bruikbaar is. De benadering vergt van de rechter immers de lastige vaststelling van een "gebruikelijk" discriminatiepatroon. Dit zal nog niet zoveel moeilijkheden opleveren bij gronden als geslacht, ras en seksuele geaardheid, omdat het daarbij relatief duidelijk is welk patroon er bestaat. Ook dan bestaan er echter al bepaalde problemen: zo is het bijvoorbeeld de vraag of moet worden gekeken naar het patroon van achterstelling in een gehele cultuur of samenleving of bijvoorbeeld alleen in een bepaalde bedrijfstak of regio (vgl. Minow 1990, p. 22, voetnoot 5). In andere gevallen is de situatie nog veel moeilijker, zoals in het geval van onderscheid op grond van leeftijd: het zal duidelijk zijn dat het daarbij niet mogelijk is om een groep te onderkennen die structureel wordt achtergesteld bij een andere. Jongeren worden soms achtergesteld ten opzichte van ouderen, zoals wanneer het gaat om het kiesrecht, de mogelijkheid om een auto te besturen of het recht om zelf financiële handelingen te verrichten. Hoewel ouderen in dergelijke gevallen worden bevoordeeld en ook in andere omstandigheden soms voor bijzondere voordelen in aanmerking komen (te denken valt aan bepaalde kortingsregelingen en het recht op een betaald pensioen), worden zij soms ook benadeeld (zoals tot uitdrukking komt bij de verplichte pensionering, waaraan ook mensen worden onderworpen die nog graag zouden blijven werken). Een duidelijk patroon van bevoordeling en benadeling van bepaalde groepen is in ieder geval nauwelijks terug te vinden (Van Maarseveen zelf oordeelt hierover echter duidelijk anders; zie 1990, p. 28). Dit bezwaar weegt nog zwaarder wanneer ook wordt gekeken naar de talrijke onderscheidingen die niet rechtstreeks zijn terug te voeren op een typisch persoonskenmerk, zoals in het voorbeeld waarin er andere vergunningsvoorwaarden worden gesteld in het geval van exploitatie van een chemische fabriek dan bij het opstarten van een biologische groentekwekerij. Het zal duidelijk zijn dat het onderscheid congruent/discongruent voor dit soort gevallen onvoldoende aanknopingspunten biedt. Verder kan worden gesteld dat het niet nodig is om van deze factor gebruik te maken om ervoor te zorgen dat benadeling van kwetsbare groepen aan een striktere toetsing wordt onderworpen. In gevallen van discongruent onderscheid zal de verdachtheid van bepaalde onderscheidingsgronden minder groot zijn: in dergelijke gevallen zal er weliswaar sprake zijn van onderscheid op grond van onveranderlijke kenmerken als ras of geslacht, maar zal er meestal geen sprake zijn van stigmatisering of van een langdurige geschiedenis van achterstelling. De aard van het onderscheid heeft als intensiteitbepalende factor dan ook geen bijzondere waarde naast de al genoemde factoren.

289. Zie bijvoorbeeld Gomillion v. Lightfoot, 364 U.S. 339 (1960).

290. Zie Harperv. Virginia, 383 U.S. 663 (1966).

291. In een iets minder ernstige vorm is dit zichtbaar bij onderscheid op grond van geslacht dat wordt veroorzaakt doordat criteria als deeltijdwerk of kostwinnerschap tot uitgangspunt van het onderscheid worden genomen. 
lijk om te beredeneren dat er vanwege de grond van onderscheid een intensieve toetsing moet worden uitgevoerd, ook al lijkt er voor een dergelijke toetsing alle reden te bestaan vanwege de effecten of verborgen bedoelingen van het onderscheid.

Dit probleem kan volgens sommigen worden opgelost door gebruik te maken van een andere intensiteitbepalende factor: de bedoeling van het onderscheid. In deze benadering is een intensieve toetsing op zijn plaats in die gevallen waarin er op het eerste gezicht sprake is van onderscheid op een neutrale grond, maar aannemelijk is dat het eigenlijk de bedoeling was om onderscheid te maken op een verdachte grond. ${ }^{292} \mathrm{Om}$ te voorkomen dat de rechter in dit soort gevallen al bij de vaststelling van de toetsingsintensiteit (dus nog vóór de eerste fase van de toetsing van het onderscheid) een oordeel moet geven over de doelstelling van het onderscheid, kan volgens voorstanders van deze benadering worden gewerkt met een "vermoeden van onderscheid op verdachte gronden". Van een dergelijk vermoeden kan sprake zijn wanneer het duidelijk voorzienbaar of algemeen bekend is dat het gemaakte onderscheid leidt tot onderscheid op een verdachte grond. ${ }^{293}$

Het is echter onwenselijk om (alleen) de bedoeling van het onderscheid als uitgangspunt te nemen bij de bepaling of er sprake is van een onderscheid op een verdachte grond, niet in het minst vanwege het al genoemde bezwaar dat daardoor wordt vooruitgelopen op de inhoudelijke beoordeling van het onderscheid. Problematisch is vooral dat het al dan niet uitvoeren van een strikte toetsing door het volgen van deze benadering volledig afhankelijk zou worden gesteld van de bedoelingen van degene die voor het onderscheid verantwoordelijk is. Gesteld is dat het bij de keuze voor een verhoogde toetsingsintensiteit bepalend is of er een vermoeden bestaat dat de belangen van de benadeelde op ongerechtvaardigde wijze door het onderscheid zijn aangetast. Een dergelijk vermoeden zal niet alleen kunnen rijzen wanneer er sprake is van een bedoeld onderscheid op een verdachte grond, maar ook wanneer er een onderscheid wordt gemaakt dat een benadeling van een bepaalde groep tot onbedoeld effect heeft. ${ }^{24}$ Het lijkt redelijk om niet alleen bij beoogd onderscheid op verdachte gronden een verhoogde toetsingsintensiteit aan te nemen, maar dit ook te doen bij maatregelen die een dergelijk onderscheid tot effect hebben. Alleen op die manier kan recht worden gedaan aan de belangen van de betrokken partijen en kan effectief worden voorkomen dat wordt geprobeerd om de verhoogde toetsingsintensiteit te omzeilen door onderscheid te maken op een neutrale grond.

292. Dit is met name in de Verenigde Staten de heersende leer; zie nader hoofdstuk 5.

293. Vgl. Loenen 1992, p. 256.

294. Zie voor deze rationale Alexander 1978, p. 939. Gesteld zou kunnen worden dat het kiezen van een verhoogde toetsingsintensiteit in dit soort gevallen tot gevolg heeft dat ook volkomen redelijke regelingen aan een strikte toetsing moeten worden onderworpen, omdat zij bij toeval een disproportioneel nadeel voor een groep als Afro-Amerikanen of vrouwen opleveren. Dit is geen bijzonder sterk argument: het is immers ook bij een strikte toetsing mogelijk om het onderscheid te rechtvaardigen. Wanneer een regeling inderdaad op goede gronden tot stand is gebracht en er geen reden bestaat om het de verantwoordelijke kwalijk te nemen dat hij onvoldoende heeft gedaan om het disproportionele effect te vermijden of te voorkomen, is er geen enkele reden om een dergelijk onderscheid ontoelaatbaar te achten. 


\section{c. Gewicht van het aangetaste belang}

Het is verder redelijk om een intensievere toetsing uit te voeren wanneer een onderscheid een fundamenteel recht aantast dan wanneer er een minder gewichtig belang in het geding is. In het eerste geval wordt door een classificatie immers niet alleen iemands recht op gelijke behandeling aangetast, maar ook nog een ander, eveneens fundamenteel belang. ${ }^{295}$ Het is noodzakelijk dat de rechter een dergelijke ongelijke behandeling met een bijzondere mate van zorgvuldigheid beoordeelt. Zo kan worden gesteld dat een intensieve toets op zijn plaats is wanneer het kiesrecht afhankelijk wordt gesteld van het hebben van een bepaald inkomen, of wanneer de overheid zichzelf de bevoegdheid heeft toegeëigend om op een beperkt aantal kranten censuur uit te oefenen. ${ }^{2 \%}$

Gesteld is wel dat het niet juist is om de vraag welk gewicht er aan bepaalde rechten en belangen toekomt ter beantwoording aan de rechter over te laten. ${ }^{297}$ Het is echter juist de rechter die is aangewezen om fundamentele rechten te beschermen tegen willekeurige aantastingen door overheidsorganen. ${ }^{298} \mathrm{Om}$ die reden moet hij ook bevoegd worden geacht om vast te stellen of er daadwerkelijk van een fundamenteel recht sprake is: zijn toetsingsbevoegdheid zou anders inhoudsloos zijn. Bovendien is van belang dat het hier slechts gaat om de vraag of er redenen aanwezig zijn om met extra zorgvuldigheid te kijken naar de argumenten die ter rechtvaardiging van een onderscheid zijn aangevoerd. Het is dus zeker niet zo dat een ongelijke behandeling ontoelaatbaar is in alle gevallen waarin de rechter een aantasting van een fundamenteel recht signaleert: dit kan alleen worden beoordeeld aan de hand van het in hoofdstuk 3 beschreven toetsingsmodel.

Hoewel het variëren van de toetsingsintensiteit naar gelang het gewicht van het aangetaste belang redelijk en wenselijk is, moet worden vastgesteld dat het hierbij gaat om een praktisch lastig bruikbare factor. Allereerst is het moeilijk te bepalen of de rechter bij zijn beoordeling moet kijken naar de objectieve waarde van een belang of recht of

295. "Developments" 1969, p. 1121

296. Zie hierover Ely; hij stelt zelfs dat de redenen voor ongelijke behandeling niet hoeven te worden onderzocht wanneer een fundamenteel, door de grondwet beschermd recht wordt aangetast: volgens hem moeten alle fundamentele rechten gelijkelijk worden toegekend en kan er geen enkele goede reden worden bedacht om dit niet te doen. Dit soort ongelijke behandeling kan dan ook niet worden gerechtvaardigd (1980, p. 141). Jammer is dat Ely op dit punt niet nader specificeert welke rechten hij als fundamenteel beschouwt, terwijl juist dat bij een vergaande stelling als deze van groot belang is. Bovendien kan worden gesteld dat ook op een "regel" als deze uitzonderingen denkbaar zijn, al zullen deze heel goed moeten worden gemotiveerd. Een voorbeeld is bijvoorbeeld het uitsluiten van jongeren tot 18 jaar van het kiesrecht; hoewel het hierbij gaat om een fundamenteel, grondwettelijk beschermd recht, zal algemeen worden aangenomen dat het stellen van een leeftijdsgrens redelijk is (al is er natuurlijk discussie mogelijk over de vraag waar de leeftijdsgrens dan precies moet worden getrokken).

297. Vgl. Barrett 1980, p. 855. Deze mening is ook naar voren gebracht door een Amerikaanse rechter in de Supreme Court, Justice Harlan, die stelde: "[...] 1 know of nothing which entitles this Court to pick out particular human activities, characterize them as 'fundamental', and give them added protection under an unusually stringent equal protection test" (Shapiro v. Thompson, 394 U.S. 618, 662 (1969) (dissenting opinion)).

298. Zie hierover met name paragraaf 3.2.4, waarin de rol van de rechter bij de beoordeling van de gerechtvaardigdheid van het doel is besproken; daarbij spelen vergelijkbare argumenten een rol als bij het bepalen van de toetsingsintensiteit aan de hand van fundamentele rechten. 
juist naar het subjectieve gewicht dat dit belang in het specifieke geval voor de betrokkene heeft. Voor een willekeurige melkveehouder zal het kiesrecht misschien van minder direct belang zijn dan zijn aanspraak op een bepaald productiequotum, terwijl vanuit een objectief perspectief kan worden vastgesteld dat het grondwettelijk beschermde kiesrecht fundamenteler is. ${ }^{299}$ Uitgangspunt moet echter zijn dat zoveel mogelijk wordt gekeken naar de objectief bepaalbare waarde van een belang of recht, dat wil zeggen naar de waarde die een redelijk denkend mens aan het belang zou toekennen. Het vasthouden aan de subjectieve waarde van het belang kan er te gemakkelijk toe leiden dat er in iedere zaak een strikte toetsing wordt uitgevoerd: waarschijnlijk zal iedere klager ervan uitgaan dat zijn persoonlijke belangen van bijzonder gewicht zijn. Door de keuze voor een dergelijke benadering zou de mogelijkheid van differentiatie in de toetsingsintensiteit illusoir worden. Daarnaast kan worden gesteld dat het voor de rechter altijd nog iets gemakkelijker is om de objectieve dan de subjectieve waarde van een recht te bepalen, aangezien hij in het eerste geval houvast heeft aan factoren zoals die hierna zullen worden beschreven. Bij het bepalen van de subjectieve waarde worden bovendien hoge eisen gesteld aan het inzicht van de rechter in de persoonlijke opvattingen en belangen van iedere individuele klager. Een dergelijk psychologisch inzicht kan redelijkerwijze niet van de rechter worden gevergd.

Zoals gezegd zijn er verschillende factoren die de rechter behulpzaam kunnen zijn bij de objectieve vaststelling van de waarde van een bepaald fundamenteel recht of belang. Een belangrijke factor is allereerst de waarde van een recht voor de politieke en maatschappelijke participatie van het individu. Deze participatie is van essentieel belang, omdat deze ertoe bijdraagt dat ieder individu tot op zekere hoogte invloed kan uitoefenen op de hem rechtstreeks rakende overheidsbesluiten. Daaraan kan nog worden toegevoegd dat juist deze mogelijkheid tot participatie burgers het gevoel geeft volwaardig deel uit te maken van de samenleving, hetgeen van groot belang is voor het bereiken van een gevoel van gelijkwaardigheid en zelfrespect. ${ }^{300}$ Een voorbeeld van rechten die een rechtstreeks verband vertonen met de mogelijkheid van politieke participatie zijn de vrijheid van meningsuiting, de demonstratievrijheid en, vanzelfsprekend, het kiesrecht. Gesteld kan worden dat een aantasting van die rechten in ieder geval moet leiden tot een zeer strenge toetsing.

Andere rechten hebben een minder politiek-procedurele rol, maar hebben een belang dat is gelegen op een ander vlak: zij beschermen de persoonlijke, individuele vrijheid van ieder mens tegen vergaand ingrijpen door de overheid en dragen daardoor bij tot een zo optimaal mogelijke zelfontplooiing. Typische voorbeelden van dit soort rechten zijn het recht op privacy en de vrijheid van godsdienst. ${ }^{301}$

299. Vgl. Loenen 1992, p. 243.

300. Karst 1977 , p. $28 / 29$ : "Voting is the preeminent symbol of participation in the society as a respected member. [...] To be a citizen is to belong, to know oneself to be a valued part of the community's common venture. [...] Equality in the electoral process is a crucial affirmation of the equal worth of citizens."

301. Vgl. O'Fallon 1979, die deze rechten als aspecten van een meer algemeen "right to personal autonomy" beschouwt. Ook Karst geeft een fraai argument voor het beschouwen van deze rechten als fundamenteel: "The choice to be a spouse or a parent is, among other things, a choice of a social role and of self-concept. For the state to deny such a choice is for the organized society to deny an individual so 
Aangenomen kan worden dat rechten en belangen die in rechtstreeks verband staan tot het uitoefenen van de hierboven genoemde categorieën van fundamentele rechten en belangen eveneens om de bijzondere aandacht van de rechter vragen. ${ }^{302}$ Zo kan worden gesteld dat het belang bij een goed onderwijssysteem rechtstreeks verband houdt met de uitoefening van belangrijke politieke rechten als het kiesrecht en de vrijheid van meningsuiting, of dat het belang bij het kennen van de identiteit van de ouders nauw verbonden is met het fundamentele recht op het hebben van een eigen identiteit. ${ }^{303} \mathrm{Ge}-$ steld kan worden dat, hoe verder het verband tussen de duidelijk fundamentele rechten en deze "afgeleide" rechten verwijderd is, hoe minder reden er bestaat voor een intensieve toetsing.

Toegegeven moet worden dat de hierboven beschreven factoren nog steeds weinig helder zijn en de rechter niet bijzonder veel steun zullen bieden. Om die reden zal in het rechtsvergelijkende gedeelte van dit proefschrift bijzondere aandacht worden besteed aan de rol die fundamentele rechten bij de vaststelling van de toetsingsintensiteit in de praktijk blijken te spelen. Wellicht kunnen daaruit enkele praktisch beter bruikbare criteria worden afgeleid.

\section{Samenspel van de factoren a en c: het gewicht van het aangetaste belang}

Er lijkt een lastige situatie te ontstaan wanneer de hierboven genoemde factoren a en c aanleiding geven tot een verschillend oordeel over de toetsingsintensiteit, zoals in het geval waarin er wel een fundamenteel belang in het geding is, maar er onderscheid wordt gemaakt op een grond waarbij een marginale toetsing aangewezen lijkt (zoals in het geval waarin het kiesrecht afhankelijk wordt gesteld van het hebben van een bepaald inkomen), of in het geval waarin er juist onderscheid wordt gemaakt op een verdachte grond, maar hierdoor geen bijzonder fundamentele rechten worden aangetast (bijvoorbeeld in het geval waarin aan mensen met een donkere huidskleur de mogelijkheid wordt ontnomen om naar de bioscoop te gaan).

Opgemerkt kan echter worden dat de twee factoren minder verschillend zijn dan op het eerste gezicht het geval is. In beide gevallen is er immers sprake van een omschrijving van de belangen die door het onderscheid worden aangetast. De formulering van de grond van onderscheid als verdacht is bijvoorbeeld ingegeven door het abstracte belang van ieder individu om niet te worden achtergesteld op grond van irrelevante kenmerken of eigenschappen. ${ }^{304} \mathrm{Bij}$ de factor van de fundamentele rechten en belangen is er sprake

incapacitated of the presumptive right to be treated as a person, one of equal worth among citizens" (1977 (I), p. 32).

302. Zie in dit verband Sloot 1989 , p. $221 / 222$, die onderscheid maakt tussen substantięle en intermediaire goederen. Vgl. ook Walzer, die stelt dat er in een maatschappij altijd een beperkt aantal "dominante", bijzonder fundamentele, goederen zal bestaan, die bepalend zijn voor het kunnen hebben van andere goederen. Er bestaat volgens hem dus een soort hiërarchie van goederen, waarbij aan degene die een dominant goed bezit, de andere goederen vaak min of meer vanzelf toevallen (1983, p. 10). Op die manier kan ook een hiërarchische verhouding worden gezien tussen de fundamentele rechten of belangen en daaruit afgeleide, ondergeschikte rechten of belangen.

303. Zie voor het tweede voorbeeld het Nederlandse arrest Valkenhorst, dat overigens ook een uitstekende illustratie geeft van een fundamenteel recht dat in Nederland geen grondwettelijke bescherming geniet. Zie HR 15 april 1994, NJ 1994/608 (Valkenhorst).

304. Vgl. Karst 1977, p. 33: "The main reason that race is a suspect classification is that racial discrimination invades the most fundamental interest of all, the interest in being treated by the organized society 
van een concretere formulering van de aangetaste belangen: het gaat hierbij om duidelijk bepaalbare, individuele belangen bij het kunnen uitoefenen van bijvoorbeeld het kiesrecht of de vrijheid van meningsuiting. Op deze manier beschouwd bestaat er nauwelijks een tegenstelling tussen de grond van het onderscheid en de aanwezigheid van een fundamenteel belang, maar is er slechts sprake van een verschil in abstractiegraad van de aangetaste belangen.

Het voorgaande betekent dat de rechter bij de keuze voor een bepaalde toetsingsintensiteit globaal zal kunnen vaststellen hoe groot het belang van de betrokkene is bij het wegnemen van de ongelijke behandeling; daarbij kan zowel het abstracte belang bij het voorkomen van achterstelling op bepaalde gronden als het meer concrete belang bij het niet aantasten van een specifiek recht worden meegewogen. Een combinatie van beide kan dan uiteindelijk leiden tot een waardering van het betrokken belang en op die manier tot de keuze voor een bepaalde toetsingsintensiteit. ${ }^{305}$

\section{d. Aard van de handeling/regeling waardoor onderscheid is gemaakt; aard en gewicht van de nagestreefde belangen}

Een belangrijke factor voor de vaststelling van de toetsingsintensiteit is verder de aard van de regeling of handeling waardoor onderscheid wordt gemaakt. In het licht van de opvatting dat de rechter in beginsel ${ }^{306}$ gebonden is aan de wet en de redelijkheid daarvan moet accepteren, lijkt het redelijk dat hij bij de toetsing van wetgeving in beginsel kiest voor een terughoudende opstelling. Hetzelfde geldt voor strikt horizontale verhoudingen: in dat geval zal de rechter immers ruimte moeten laten voor de contractvrijheid en de individuele handelingsvrijheid. Tenslotte zal ook een onderscheid dat is gemaakt in het kader van een toepassing van een beleidsvrije bepaling in principe een minder intensieve toetsing opleveren. ${ }^{307}$ Belangrijk is echter dat deze factoren nooit in isolatie bezien mogen worden: wanneer in een wettelijke bepaling of door het gebruik van een beleidsvrije bevoegdheid onderscheid wordt gemaakt op een verdachte grond, dan zal een striktere toetsing toch vereist zijn. Op de afweging die in dat verband tussen de verschillende intensiteitbepalende factoren moet worden gemaakt zal nader worden ingegaan in paragraaf 5.3.3 van dit hoofdstuk.

Daarnaast kunnen de aard en het gewicht van de bij het maken van onderscheid betrokken belangen aanleiding vormen voor een minder intensieve toetsing. Illustratief daarvoor is het voorbeeld van de ongelijke behandeling van vreemdelingen. Nationaliteit kan op zichzelf worden beschouwd als een verdachte grond van onderscheid: er bestaan over het algemeen veel vooroordelen jegens "buitenlanders" en de betrokken groep is bij gebrek aan mogelijkheden tot politieke participatie vaak moeilijk in staat om benadelingen te verhinderen. ${ }^{30 s}$ Het aan deze groep onthouden van bepaalde voor-

as a respected and participating member."

305. Het is overigens niet steeds nodig om de verschillende belangen in combinatie te bezien: in sommige gevallen kan uit het feit dat er onderscheid is gemaakt op een verdachte grond of uit het feit dat er een fundamenteel belang is aangetast al meteen worden afgeleid dat een strikte toetsing vereist is.

306. Zie paragraaf 3.2 .3 en 3.2 .4 .

307. "In principe", omdat de toetsingsintensiteit ook afhankelijk zal zijn van de mate van discretie die de bepaling aan het betrokken administratieve orgaan toekent.

308. Vgl. O'Fallon 1979, p. 56/57. 
delen die de eigen onderdanen wel ten deel vallen, zoals uitkeringen of de mogelijkheid van een goede gezondheidszorg, zal dan ook strikt moeten worden getoetst. Wanneer er echter sprake is van het voeren van een vreemdelingen- of asielbeleid is het algemeen aanvaard dat er geen noodzaak is voor een strikte toetsing. ${ }^{309}$ Zo zal het feit dat vreemdelingen aan een visum- en asielbeleid kunnen onderworpen en het land uit kunnen worden gezet, terwijl ditzelfde niet het geval is voor de eigen onderdanen, in het algemeen voorwerp kunnen zijn van een marginale toetsing. De reden daarvoor is vooral gelegen in het feit dat hierbij de soevereine belangen van de staat een rol spelen. Deze belangen worden zo zwaarwegend geacht dat een marginale toetsing op zijn plaats is, ook al is er sprake van een verdachte grond van onderscheid.

Nauw verband met de aard van het belang dat is betrokken bij het maken van onderscheid houdt een in de literatuur vaak genoemde andere factor, namelijk het gewicht van het met het onderscheid nagestreefde doel. Zo wordt regelmatig gesteld dat er bij voorkeursbehandeling een minder strenge toetsing kan worden uitgevoerd omdat het daarbij niet gaat om een schadelijke ongelijke behandeling, maar eerder om een vorm van onderscheid die een "hogere" vorm van gelijkheid - materiële gelijkheid - tot doelstelling heeft. ${ }^{300}$ Meer in het algemeen zou kunnen worden gesteld dat een minder intensieve toetsing op zijn plaats is wanneer er een maatschappelijk gezien belangrijke doelstelling wordt nagestreefd. Een groot bezwaar tegen een dergelijk algemeen gebruik van deze factor is echter dat de keuze voor de toetsingsintensiteit hierdoor te zeer wordt gekoppeld aan een inhoudelijke waardering van de nagestreefde doelstelling door de rechter, hetgeen een duidelijke doorkruising van het toetsingsmodel oplevert. Normaal gesproken zal de rechter immers pas toekomen aan een inhoudelijke beoordeling van de doelstelling van het onderscheid en de waarde ervan wanneer de toetsingsintensiteit al is vastgesteld. Juist door die volgorde wordt verzekerd dat de rechter niet overgaat tot een vergaande beoordeling van het doel, wanneer er goede redenen zijn om te kiezen voor een terughoudende toetsing. Het is dan ook niet wenselijk om van de rechter te verwachten dat hij het gewicht van het nagestreefde doel al beoordeelt bij de vaststelling van de toetsingsintensiteit, los van de vraag of er zwaarwegende belangen zijn betrokken bij het maken van onderscheid. Hoogstens kan worden gesteld dat in gevallen waarin de waarde van de betrokken belangen objectief en los van de voorgelegde zaak vaststelbaar is, zoals in het geval van voorkeursbehandeling, met deze factor rekening mag worden gehouden.

\section{e. Aard van het betrokken beleidsveld}

Een laatste factor die bepalend kan zijn voor de toetsingsintensiteit is de aard van het betrokken beleidsveld. Op sommige beleidsterreinen zal er voor de overheid meer speelruimte bestaan dan op andere, terwijl de toetsingsintensiteit bovendien kan worden beïnvloed door de aanwezigheid of juist het ontbreken van de noodzakelijke kennis van de rechter over het betrokken beleidsveld. Met name wanneer het onderscheid is ingebed in een ingewikkelde economische context of wanneer er sprake is van een onoverzichtelijk beleidsveld als de sociale zekerheid zal er reden bestaan voor een

310. Vgl. Loenen 1992, p. 244 e.v. en vooral p. 251 e.v.; zie ook Wentholt 1999 (1), p. 60. 
terughoudende opstelling van de rechter." Ook wanneer er sprake is van zeer controversiële onderwerpen, zoals de bescherming van de goede zeden, zijn redenen aanwezig om de keuzen die worden gemaakt door wetgever, administratie of individu eerder te accepteren en dus te kiezen voor een terughoudende opstelling.

\subsubsection{Afweging van de verschillende factoren en bepaling van de toetsingsintensiteit}

Zoals gezegd moet van de rechter verwacht worden dat hij in ieder aan hem voorgelegd geval nagaat welke betekenis de hiervoor besproken factoren voor het concrete geval hebben. Zo zal hij steeds moeten beoordelen of er sprake is van een grond van onderscheid waarbij er reden bestaat voor het uitvoeren van een intensievere toetsing en of het betrokken beleidsveld aanleiding geeft tot een marginalere toets. Een loutere opsomming van deze factoren biedt echter nog niet veel duidelijkheid over de vraag met welke intensiteit een ongelijke behandeling moet worden beoordeeld. Slechts in een beperkt aantal gevallen zal het zonder meer duidelijk zijn dat een bepaald toetsingsniveau moet worden gekozen, doordat alle genoemde factoren wijzen in de richting van een marginale, neutrale of intensieve toetsing. In de meeste gevallen is de situatie lastiger. De vraag is bijvoorbeeld of de rechter intensief mag toetsen als er sprake is van een onderscheid op een verdachte grond, terwijl er sprake is van vergaande beleidsvrijheid en het onderscheid betrekking heeft op een complex terrein als de sociale zekerheid. Lastig is ook of de rechter marginaal mag toetsen als er sprake is van een voorkeursbehandeling waardoor fundamentele belangen worden aangetast.

In dit soort gevallen moet de rechter een afweging maken tussen de verschillende betrokken factoren, waarbij hij voldoende aandacht besteedt aan hun relatieve gewicht. Daarbij kan worden gesteld dat een neutrale toetsing (noch marginaal, noch intensief) het uitgangspunt van deze afweging vormt en dat moet worden nagegaan of er overtuigende redenen bestaan om deze te intensiveren of juist af te zwakken. Op die manier wordt recht gedaan aan de keuzevrijheid van de voor het onderscheid verantwoordelijke, maar ook aan de belangen van degene die door het onderscheid wordt aangetast. Zo kan de rechter nagaan of er in het voorliggende geval bijzondere redenen aanwezig zijn die voor een terughoudende toetsing pleiten, zoals het feit dat er sprake is van onderscheid op een complex sociaal-economisch beleidsterrein of het feit dat een bestuursorgaan in een bepaald geval bijzonder veel vrijheid toekwam; is daarvan sprake en zijn er geen bijzondere redenen aanwezig voor een intensieve toetsing, dan is een marginale (in plaats van een neutrale) toetsing op zijn plaats. In de meeste gevallen zullen de abstracte of concrete belangen van de benadeelde echter doorslaggevend zijn voor de uiteindelijke vaststelling van de toetsingsintensiteit. Zelfs wanneer er goede redenen bestaan voor een terughoudende toetsing, moet er een intensieve toetsing worden uitgevoerd wanneer er sprake is van een ernstige belangenaantasting (bijvoorbeeld doordat er onderscheid wordt gemaakt op een verdachte grond of doordat er een fundamenteel recht of belang is aangetast). In dergelijke gevallen is er immers steeds sprake van het vermoeden dat het onderscheid op onjuiste en ontoelaatbare gronden is geba-

311. Deze rationale kan ook worden gebruikt om een intensievere toetsing in andere omstandigheden, zoals de beperking van rechten van verdachten, te verdedigen: soms is het juist zo dat de rechter beter in staat is om bepaalde rechten op hun waarde te beoordelen dan de wetgever; zie "Developments" 1969, p. 1128 . 
seerd, een situatie waarin een terughoudende toetsing onvoldoende recht zou doen aan de belangen van de benadeelde partij.

\section{6}

\section{Korte weergave van het theoretische toetsingsmodel}

In het voorgaande is gebleken dat de rechter ieder aan hem voorgelegd geval van ongelijke behandeling moet onderwerpen aan een zorgvuldige toetsing en dat hij een overtuigende en uitgebreide motivering moet geven voor zijn oordeel over de toelaatbaarheid van het onderscheid. Gesteld is daarbij dat een acceptabele en redelijke toetsingsuitkomst alleen kan worden bereikt wanneer alle relevante aspecten van de ongelijke behandeling worden getoetst. In dat verband is van belang dat er twee toetsingsfasen kunnen worden onderscheiden: een eerste fase waarin de eisende partij moet aantonen dat er daadwerkelijk sprake is van een ongelijke behandeling, en een tweede fase waarin de wederpartij moet aantonen dat er voor het onderscheid een toereikende rechtvaardiging bestaat. Voordat de rechter kan toekomen aan de toetsing in de beide fasen moet de rechter echter allereerst vaststellen hoe intensief zijn toetsing zal zijn; de gekozen toetsingsintensiteit dient hij gedurende de gehele toetsing consequent vol te houden.

Rekening houdend met het voorgaande kan het theoretische toetsingmodel beknopt worden weergegeven als volgt:

\section{Voorfase: vaststelling van de toetsingsintensiteit}

In paragraaf 5 is gebleken dat de rechter zijn toetsingsintensiteit zal moeten bepalen aan de hand van drie of vier ijkpunten - de "niveaus" van toetsingsintensiteit. Dit betekent dat de toetsing marginaal, neutraal en intensief kan zijn of, bij de keuze voor vier niveaus, zeer marginaal, neutraal, intensief of zeer intensief. Bij de bepaling van de toetsingsintensiteit kan een neutrale toets tot uitgangspunt worden genomen, waarna vervolgens kan worden bepaald of er zodanige factoren aanwezig zijn dat deze toets moet worden afgezwakt of juist verder moet worden aangescherpt. De rechter kan hierbij rekening houden met de volgende intensiteitbepalende factoren:

a. De grond van onderscheid: bij verdacht onderscheid zal eerder een intensieve toetsing kunnen worden uitgevoerd dan bij onderscheid dat op een niet-verdacht differentiatiecriterium is gebaseerd. De verdachtheid kan worden bepaald aan de hand van de volgende factoren:

- het bestaan van maatschappelijke consensus over de verwerpelijkheid van onderscheid op een bepaalde grond;

- $\quad$ onveranderlijkheid van het betrokken onderscheidingskenmerk en irrelevantie van dit kenmerk voor het maatschappelijk functioneren;

- het bestaan van vooroordelen of stigma's ten aanzien van de benadeelde groep;

b. Het gewicht van het aangetaste belang: wanneer er fundamentele rechten of belangen zijn aangetast zal de keuze voor een intensieve toetsing voor de hand liggen, 
terwijl in andere gevallen een neutrale of zelfs een marginale toets gerechtvaardigd kan zijn;

c. Aard en gewicht van de maatregel of handeling waardoor onderscheid is gemaakt; aard en gewicht van de nagestreefde belangen. In hoeverre deze factoren een intensieve of juist een marginale toetsing rechtvaardigen wordt in sterke mate bepaald door de omstandigheden van het geval; zie daarvoor de bespreking van deze factor in paragraaf 5.3.2.

d. Aard van het betrokken beleidsveld: wanneer het beleidsveld een grote mate van beleidsvrijheid voor de wederpartij impliceert, zal de rechter in beginsel voor een terughoudende opstelling moeten kiezen.

De genoemde factoren hebben een sterk theoretisch karakter. Het is niet geheel duidelijk of een afwegingsmodel aan de hand van deze factoren in de praktijk voor een rechter bruikbaar is: het is mogelijk dat bepaalde, praktisch relevante factoren hierin ontbreken of dat er in de praktijk een bijzonder model wordt gehanteerd voor de afweging van deze factoren. Om die reden zal in het rechtsvergelijkende gedeelte van dit boek worden nagegaan op welke manier rechters hun toetsingsintensiteit bepalen in de aan hen voorgelegde zaken over gelijke behandeling. Bekeken zal worden of daaruit afwijkende of aanvullende factoren blijken die in een algemeen afwegingsmodel kunnen worden opgenomen. Ook zal worden nagegaan op welke wijze in de praktijk de afweging van tegengestelde factoren plaatsvindt; wellicht kunnen ook daaruit nadere criteria worden afgeleid die voor een algemeen bruikbaar model bruikbaar zijn.

\section{Eerste fase: vaststelling van ongelijke behandeling}

In paragraaf 4 is aangegeven dat er goede redenen bestaan om in de eerste toetsingsfase geen vergelijkbaarheidstoets uit te voeren. Dit betekent dat de rechter volgens het theoretische model niet na zal hoeven te gaan of er sprake is van een ongelijke behandeling van vergelijkbare gevallen of van een gelijke behandeling van onvergelijkbare gevallen. In plaats daarvan kan hij gebruik maken van één van de volgende toetsingsmethodes:

1. Doelstelling of motief als toetsingsingang: de rechter moet beoordelen of de verdedigende partij met zijn handeling of maatregel een op benadeling nastreefde van de klager of van de groep waarvan de klager deel uitmaakt;

2. "But for"-test als toetsingsingang: de rechter moet vaststellen of de klager een behandeling ten deel is gevallen die hij niet zou hebben ontvangen wanneer hij niet een specifiek kenmerk zou hebben bezeten;

3. Benadelingstoets als toetsingingang: de rechter moet bepalen of de klager door de regeling of behandeling is benadeeld ten opzichte van een andere persoon of groep.

In paragraaf 4.4 is angegeven dat de keuze voor het eerste of het tweede alternatief minder wenselijk is, omdat hierdoor een te zware bewijslast aan de klager wordt opgelegd (alternatief 1), of omdat het alternatief alleen bruikbaar is bij gelijkheidsbepalingen die alleen onderscheid op bepaalde gronden verbieden (alternatief 2 ). In theorie gaat de voorkeur dan ook uit naar het derde alternatief, dat een redelijke bewijslast oplevert en in alle gevallen van onderscheid goed bruikbaar is. Voor de ontwikkeling 
van een algemeen toetsingsmodel kan het echter interessant zijn om na te gaan op welke manier rechterlijke instanties in de praktijk bepalen of er sprake is van een zodanige ongelijke behandeling dat een rechtvaardiging kan worden vereist. Het is namelijk denkbaar dat rechterlijke instanties in de praktijk op overtuigende wijze gebruik maken van de vergelijkbaarheidstoets of van de eerste twee alternatieven, of dat er nog een vierde alternatieve toetsingsingang bestaat die goed bruikbaar is. In de rechtsvergelijkende hoofdstukken zal dan ook uitgebreid aandacht worden besteed aan de keuze voor een toetsingscriterium in de eerste fase.

\section{Tweede fase: beoordeling van de aangevoerde rechtvaardiging}

Wanneer de rechter eenmaal heeft vastgesteld dat er sprake is van een ongelijke behandeling, zal hij moeten nagaan of daarvoor een toereikende rechtvaardiging bestaat. Om dit te kunnen beoordelen zal hij de door de wederpartij aangevoerde argumenten moeten toetsen aan de volgende vijf criteria:

1. Ligt er aan het onderscheid een gerechtvaardigde bedoeling of reden ten grondslag, of heeft de maatregel maatschappelijk wenselijke effecten (doeltoets)?

2. Is de classificatie nauwkeurig genoeg geformuleerd in verhouding tot het doel dat met de regeling wordt nagestreefd (toetsing van de mate van fit)?

3. Kan het doel door het gemaakte onderscheid daadwerkelijk worden bereikt (geschiktheidstoets?)

4. Kon het doel niet met andere, de getroffen belangen minder ernstig aantastende, middelen worden bereikt (subsidiariteitstoets)?

5. Bestaat er een evenredige verhouding tussen het nagestreefde doel en de aangetaste belangen (proportionaliteitstoets in strikte zin)?

Zoals in paragraaf 3 is gebleken bestaat er ten aanzien van de invulling en de praktische toepasbaarheid van enkele van deze theoretische toetsingscriteria nog enige onduidelijkheid. Zo kan de vaststelling van het doel in sommige gevallen problemen opleveren en is het theoretisch gezien moeilijk vast te stellen op welke manier de rechter de gerechtvaardigdheid van het doel kan bepalen. Verder is ten aanzien van vereisten als die van subsidiariteit en proportionaliteit opgemerkt dat een toetsing hieraan kan leiden tot een overschrijding van de rechterlijke taakomvang, met name wanneer de rechter zelf slechts ruimte ziet voor een marginale toetsing. Om die reden zal in de verschillende rechtsvergelijkende hoofdstukken uitgebreid worden ingegaan op de wijze waarop rechters in de praktijk aan hun rechtvaardigingstoets vorm geven en zal worden nagegaan welke criteria zij in hun oordeel betrekken. Op basis van de resultaten van dit onderzoek kan vervolgens worden beoordeeld of een aanpassing of nuancering van het theoretische model op bepaalde punten gewenst is. 


\section{Toetsing door het Europees Hof voor de Rechten van de Mens aan artikel 14 EVRM}

\section{Algemeen}

\subsection{Het accessoire karakter van het discriminatieverbod}

\subsubsection{Wijze waarop het Hof invulling heeft gegeven aan het accessoire karakter}

Het verbod van discriminatie zoals dat is neergelegd in artikel 14 EVRM luidt als volgt:

"The enjoyment of the rights and freedoms set forth in this Convention shall be secured without any discrimination on any ground such as sex, race, colour, language, religion, political or other opinion, national or social origin, association with a national minority, property, birth or other status."

Uit deze formulering blijkt dat het niet de bedoeling van de opstellers van het Verdrag was om een algemeen gelijkheidsbeginsel neer te leggen waarop een zelfstandig beroep kan worden gedaan. Het artikel heeft een accessoir karakter en is vooral bedoeld als middel om een effectieve uitoefening van de door de Conventie beschermde grondrechten te waarborgen. ${ }^{2}$ Het accessoire karakter betekent dat een beroep op artikel 14 alleen ontvankelijk is als er een zeker verband bestaat tussen de litigieuze ongelijke behandeling en een door één van de substantiële verdragsbepalingen' ${ }^{3}$ beschermd recht. Voor de klager betekent dit dat hij altijd een koppeling zal moeten vinden met een materiële bepaling van het Verdrag of een van de Protocollen om een beroep te kunnen doen op het discriminatieverbod.

Aanvankelijk waren de eisen die aan deze koppeling werden gesteld zeer streng. De Europese Commissie voor de Rechten van de Mens ${ }^{4}$ koos in de eerste jaren van haar bestaan voor een benadering waardoor een beroep alleen ontvankelijk was als was

1. In dit hoofdstuk zal ten behoeve van de toegankelijkheid voor de lezer steeds de Engelse tekst van het Verdrag en van de rechtspraak worden geciteerd, tenzij een bepaalde uitspraak alleen in het Frans beschikbaar is.

2. Vgl. Robertson/Merrills 1993, p. 177.

3. Dit zijn in ieder geval de rechten die zijn neergelegd in artikelen 2 tot en met 12 van het Verdrag en een aantal in de Protocollen neergelegde rechten, zoals het in artikel 1 Eerste Protocol neergelegde eigendomsrecht.

4. Deze Commissie fungeerde voor de inwerkingtreding van het Elfde Protocol als een soort "voorportaal" van het Europese Hof en was bevoegd om uitspraak te doen over de ontvankelijkheid van door individuele klagers ingediende zaken (zie artikel 25 en 27 EVRM (oud)). Daarbij kon zij een zaak ook niet-ontvankelijk verklaren wanneer het beroep "manifestly ill-founded" was (artikel 27 lid 2 EVRM (oud)). Dit betekende voor de praktijk dat zij de feiten kon vaststellen en ook kon beoordelen of het Verdrag door een bepaalde maatregel of handeling was geschonden. Daardoor speelde de Commissie lange tijd een belangrijke rol bij de interpretatie en toepassing van het Verdrag. 
gebleken dat de materiële verdragsbepaling was geschonden. ${ }^{5}$ De rol en de effectiviteit van het discriminatieverbod waren daardoor zeer beperkt: een beroep op artikel 14 had vrijwel geen kans van slagen. ${ }^{6}$ Op den duur zag ook de Commissie dit in, hetgeen tot resultaat had dat zij in haar rapport in de Belgische Taalzaak koos voor een nieuwe benadering:

"the applicability of Article 14 is not limited to cases in which there is an accompanying violation of another Article. Such a restriction would deprive Article 14 of any practical value."”

In dezelfde Belgische Taalzaak was het Hof ook in de gelegenheid om uitspraak te doen over artikel $14 .^{8}$ Het Hof stelde in zijn arrest dat deze bepaling weliswaar een accessoir karakter heeft, zodat een zelfstandig beroep niet mogelijk is, maar dat het artikel toch een zekere autonome functie heeft:

\begin{abstract}
"While it is true that this guarantee has no independent existence in the sense that under the terms of Article 14 it relates solely to 'rights and freedoms set forth in the Convention', a measure which in itself is in conformity with the requirements of the Article enshrining the right or freedom in question may however infringe this Article when read in conjunction with Article 14 for the reason that it is of a discriminatory nature."'
\end{abstract}

Uit deze overweging blijkt dat een beroep op artikel 14 ook kan worden gedaan wanneer het Hof tot de conclusie is gekomen dat de materiële verdragsbepaling niet is geschonden. ${ }^{10}$ Uit een tweetal voorbeelden dat het Hof in deze zaak gaf kan bovendien

5. Zie bijvoorbeeld Application 16/808 van 8 maart 1960, Isop v. Austria, Yearbook of the European Convention on Human Rights 5 (1962), p. 108 e.v.: "Whereas, in regard to the complaint that the said refusal constituted a violation of Article 14 of the Convention, it is to be observed that this Article, by its express terms, forbids discrimination only with regard to the enjoyment of the rights and freedoms guaranteed in the Convention; and whereas the Commission has already held above that such right is not violated in the present case; whereas it follows that Article 14 of the Convention has no application in the circumstances of the present case."

6. Partsch 1993, p. 577. Matscher stelt dat een geslaagd beroep op artikel 14 in deze interpretatie slechts zou leiden tot een verzwarende omstandigheid bij de reeds vastgestelde verdragsinbreuk (1980, p. 630).

7. Rapport van de Commissie in de Belgische Taalzaak, rapport van 24 juni 1965, Series B, vol. 3, p. 305. Overigens was de opvatting van de Commissie over het accessoire karakter al eerder verruimd, zoals overtuigend wordt aangetoond door Eissen 1968, p. 122 e.v. Een goed voorbeeld van deze verruiming is het rapport van de Commissie in Grandrath, waarin de Commissie stelde, dat "Article 14 may be violated in a field dealt with by another Article of the Convention, although there is otherwise no violation of that Article" (Appl. 2299/64, Grandrath v. Austria, Yearbook of the European Convention on Human Rights 10 (1967), p. 697). Zie ook McKean 1985, p. 216.

8. Dit was de eerste keer dat het Hof over dit onderwerp uitspraak deed. Voor de inwerkingtreding van het Elfde Protocol kon het Hof slechts uitspraak kon doen over een klacht als deze door de Commissie of een lidstaat was voorgelegd (zie artikel 44 EVRM (oud)). Dit gebeurde niet als de Commissie de klacht niet-ontvankelijk had verklaard: door deze uitspraak was de zaak beëindigd (Klerk 1995, p. 112). Voor het Hof was het daardoor niet mogelijk om uitspraak te doen over de koppeling tussen artikel 14 en een substantiële verdragsbepaling, zolang de Commissie daarover geen zaak voorlegde. Vgl. Matscher 1980, p. 630 (in voetnoot 10).

9. EHRM 23 juli 1968, Belgische Taal, Series A, vol. 6, $\$ 9$

10. Een bekend voorbeeld van een geval waarin de materiële bepaling niet is geschonden, maar wel sprake is van een ongelijke behandeling, is een gemeenteverordening die klokgelui verbiedt in de nacht en de vroege ochtend. Deze regeling is waarschijnlijk wel te verenigen met artikel 9 EVRM, maar als de regeling zich alleen tot bepaalde geloofsgemeenschappen zou richten, dan kan de regeling wel in strijd 
worden afgeleid dat zelfs wanneer de nationale autoriteiten een verdergaande bescherming van bepaalde rechten hebben geboden dan volgens het verdrag is vereist, een daarbij opgetreden ongelijke behandeling onder artikel 14 kan worden beoordeeld."

Deze verruiming van de betekenis van artikel 14 kan de vraag oproepen naar de betekenis die het Hof dan nog wel aan het accessoire karakter toekent. Het Hof beantwoordde deze vraag in het arrest Abdulaziz $^{12}$ als volgt:

"According to the Court's established case-law, Article 14 complements the other substantive provisions of the Convention and the Protocols. It has no independent existence, since it has effect solely in relation to 'the enjoyment of the rights and freedoms' safeguarded by those provisions. Although the application of Article 14 does not necessarily presuppose a breach of those provisions - and to this extent it is autonomous - there can be no room for its application unless the facts at issue fall within the ambit of one or more of the latter," ${ }^{13}$

Voldoende is dus dat de feitenconstellatie waarop de klacht over ongelijke behandeling is gebaseerd op de een of andere manier ook onder de reikwijdte van een substantiële bepaling kan worden gebracht. ${ }^{14}$ Een mooi voorbeeld van toepassing van dit vereiste is

zijn met artikel 14. Vgl. Matscher 1980, p. 635.

11. EHRM 23 juli 1968, Belgische Taal, Series A, vol. 6, $\$ 9$, tweede en derde alinea; zie ook Frowein/Peukert 1996, p. 445 en Harris/O'Boyle/Warbrick 1995, p. 466. Gesteld zou kunnen worden dat het dan gaat om een recht dat niet door de Conventie beschermd wordt, zodat niet voldaan is aan het vereiste dat het gaat om een van de "rights and freedoms set forth in this Convention". Vooral Judge Fitzmaurice was een grote aanhanger van deze beperktere opvatting, zoals blijkt uit zijn dissenting opinion bij het arrest National Union of Belgian Police (EHRM 27 oktober 1975, Series A, vol. 19, dissenting opinion Judge Sir Gerald Fitzmaurice, $\S 18$ ). Zie verder Fitzmaurice 1983, p. 218 en Sundberg-Weitman 1980, p. 33.

12. EHRM 28 mei 1985 , Series A, vol. 94

13. $\$ 71$; cursief toegevoegd. Overigens heeft Partsch opgemerkt dat de eis in dit arrest minder streng is dan in eerdere arresten. In de eerdere zaak Schmidt and Dahlström eiste het Hof nog dat er sprake moest zijn van een discriminatie die is "linked to the exercise of a right guaranteed" (EHRM 6 februari 1976, Series A, vol. 21). In Marckx leek de het Hof deze eis al wat af te zwakken: voor ontvankelijkheid was toen nog slechts vereist dat de discriminatie "comes within the sphere" van een materiele bepaling (EHRM 13 juni 1979, Series A, vol. 31). Pas in 1983 hanteerde het Hof voor het eerst de geciteerde formule, namelijk in Van der Mussele (EHRM 23 november 1983, Series A, vol. 70); dit is sindsdien vaste rechtspraak (zie bijvoorbeeld ook EHRM 27 juni 2000, Jewish Liturgical Association Cha'are Shalom Ve Tsedek, EHRC 2000/66, § 86). Zie Partsch 1993, p. 582-583 en in gelijke zin Heringa 1998, p. 3.14-2.

14. Erg duidelijk is dit criterium niet; het Hof heeft verder ook geen aanknopingspunten voor de toepassing hiervan geformuleerd. Wel bleek lange tijd uit de rechtspraak dat snel aan het criterium zal zijn voldaan: er zijn maar weinig gevallen waarin het Hof het beroep op artikel 14 niet op de een of andere manier onder de reikwijdte van het Verdrag heeft weten te brengen. Het leek er dan ook op dat een koppeling alleen geacht werd te ontbreken als er sprake was van onderscheid bij een grondrecht dat beschermd wordt door een door de betrokken staat niet ondertekend Protocol of door een bepaling waarbij de staat uitdrukkelijk een voorbehoud heeft gemaakt (Matscher 1980, p. 637). Verder ontbreekt een koppelingsmogelijkheid als er sprake is van een recht dat duidelijk niet door het Verdrag beschermo wordt, zoals het recht op toegang tot de arbeidsmarkt of het recht op gezondheidszorg. Recente rechtspraak lijkt duidelijk te maken dat het Hof weer iets hogere eisen stelt aan het koppelingsvereiste. Een voorbeeld is Prince Hans-Adam II of Liechtenstein v. Germany (EHRM 12 juli 2001, EHRC 2001/64). Bij de inhoudelijke beoordeling van de klacht over het in het geding zijnde eigendomsrecht (beschermd door artikel 1 Eerste Protocol) had het Hof gezegd dat dit recht niet geschonden kon worden geacht. Voor toepasselijkheid van artikel 14 is een dergelijke schending ook niet nodig. Het Hof oordeelde echter dat "[...] the facts of which the applicant complained under Article 1 of Protocol No. 1 [...] did 
te vinden in het arrest National Union of Belgian Police. ${ }^{15}$ Volgens de klager in deze zaak werd er in een regeling over de consultatie van werknemersverenigingen bij $\mathrm{CAO}$-onderhandelingen ten onrechte onderscheid gemaakt naar de grootte van deze verenigingen. Het Hof oordeelde dat door de regeling geen inbreuk werd gemaakt op de door artikel 11 beschermde verenigingsvrijheid, omdat het recht om geconsulteerd te worden daardoor niet uitdrukkelijk wordt beschermd. ${ }^{16}$ Ten aanzien van de klacht over artikel 14 in combinatie met artikel 11 stelde het Hof echter het volgende:

"the subject-matter of the disadvantage [...] constitutes one of the modalities of the exercise of a right guaranteed by Article $11 \S 1 ., 17$

Hierdoor was de ongelijke behandelingsklacht ontvankelijk en kon het Hof een oordeel uitspreken over de redelijkheid van het onderscheid naar grootte van de werknemersverenigingen.

\subsubsection{Nadelen van het accessoire karakter}

Hoewel het door de soepele benadering van het Hof relatief gemakkelijk is om een verband met een materiële bepaling aan te tonen, blijkt het accessoire karakter van artikel 14 soms toch nog problemen op te leveren..$^{18}$ Vaak moet het Hof een vrij technische constructie bedenken om een ongelijke behandeling onder de reikwijdte van artikel 14 te kunnen brengen. Een goed voorbeeld daarvan is het arrest Thlimmenos ${ }^{19}$, dat betrekking had op de weigering om klager tot accountant te benoemen omdat hij in het verleden was veroordeeld voor een misdrijf. Feitelijk was deze klacht gebaseerd op het feit dat er onderscheid werd gemaakt op grond van klagers status als veroordeelde.

not amount to an interference with any of his rights under that provision. He cannot therefore claim that in these respects he had been discriminated against in the enjoyment of his property rights" $(\$ 92)$. In het licht van de eerdere rechtspraak is deze overweging moeilijk te begrijpen: artikel 1 Eerste Protocol was in dit geval weliswaar niet geschonden, maar wel degelijk van toepassing. Beoordeeld had slechts moeten worden of de klacht over artikel 14 op een feitencomplex betrekking had dat ook onder de reikwijdte van artikel 1 Eerste Protocol kon worden gebracht. Afgewacht zal moeten worden hoe het Hof in de toekomst met zijn eerdere, soepele benadering zal omgaan. Het lijkt namelijk goed denkbaar dat het Hof in dit geval om "beleidsmatige" redenen niet in wilde gaan op de lastige klacht over ongelijke behandeling, maar in verdere rechtspraak de oude lijn weer gewoon zal volgen. Dit lijkt inmiddels bevestigd te worden door een soepele toepassing van het koppelingsvereiste in arresten als Wessels-Bergervoet (EHRM 4 juni 2002, EHRC 2002/60) en Willis (EHRM 11 juni 2002, EHRC 2002/62).

15. EHRM 27 oktober 1975 , National Union of Belgian Police, Series A, vol. 19

16. Zie nader $\S 38$.

17. $\$ 45$. Zie nader Alkema 1978 , p. $37 / 38$.

18. Hierbij kan overigens worden opgemerkt dat op 1 februari 1998 het Kaderverdrag inzake de bescherming van nationale minderheden in werking is getreden (Trb. 1995, 97). In dit Kaderverdrag is een bepaling opgenomen die de staten verplicht tot het garanderen van het recht van gelijkheid voor de wet en van gelijke bescherming door de wet aan personen die tot nationale minderheden behoren. Het gaat hierbij dus om een zelfstandig gelijkheidsbeginsel, dat het accessoire karakter van artikel 14 mist (Zwart 1999, p. 348). Dit betekent dat de hierna aan te geven beperkingen in principe niet gelden voor ongelijke behandeling wegens het behoren tot een minderheidsgroepering. Het Kaderverdrag kent echter geen individueel klachtrecht, maar slechts een rapportageverplichting (zie artikel 25). Het Hof is dan ook niet bevoegd is om een toetsing aan dit Verdrag uit te voeren en de toetsingsmethodiek zal door de afwijkende bepaling niet worden beînvloed. 
Omdat het moeilijk is om een dergelijk onderscheid onder de reikwijdte van een van de materiële verdragsbepalingen te brengen, maar het Hof toch van mening was dat een toetsing aan artikel 14 wenselijk was, koos het voor een kunstgreep: in zijn uitspraak stelde het vast dat de betrokkene destijds werd veroordeeld omdat hij om godsdienstige redenen geweigerd had een legeruniform te dragen. In essentie kon er volgens het Hof dan ook worden gesproken van materieel onderscheid op grond van religie: bij de benoemingseisen voor accountants zou onvoldoende onderscheid worden gemaakt tussen mensen die veroordeeld zijn in verband met hun godsdienst en mensen die om andere redenen veroordeeld zijn. ${ }^{20} \mathrm{Nu}$ het recht op vrijheid van godsdienst wordt beschermd door artikel 9 van het Verdrag, was een koppeling met een materiële verdragsbepaling aanwezig: het Hof had dan ook ruimte om een inhoudelijk oordeel over het onderscheid te geven.

Van het toepassen van dit soort kunstgrepen om een onderscheid onder de reikwijdte van het Verdrag te brengen kan nog worden gezegd dat zij weinig bezwaarlijk zijn. Een groter nadeel van het accessoire karakter van artikel 14 is echter dat bepaalde ongelijke behandelingen hierdoor in het geheel niet bij het Hof kunnen worden aangevochten. Dit geldt met name voor onderscheid waardoor sociale grondrechten worden geraakt, nu deze rechten slechts in beperkte mate door het EVRM worden gegarandeerd. ${ }^{21}$ Dit betekent dat gevallen van ongelijke behandeling bij de toegang tot de arbeidsmarkt of in de sociale zekerheid niet altijd door het Hof beoordeeld kunnen worden. ${ }^{22}$ Wel heeft het Hof vooral recentelijk moeite gedaan om dergelijke vormen van ongelijke behandeling toch binnen de reikwijdte van het Verdrag te brengen. Zo heeft het Hof in een aantal zaken geoordeeld dat het recht op sociale zekerheidsuitkeringen onder de reikwijdte valt van het eigendomsrecht, dat wordt beschermd door artikel 1 Eerste Protocol. ${ }^{23}$ Ook blijken bepaalde sociale grondrechten in de bepalingen van het Verdrag te worden ingelezen, bijvoorbeeld door middel van het construeren van positieve verplichtingen: het Hof heeft uitdrukkelijk erkend dat het voor de bescherming van een klassiek grondrecht soms nodig kan zijn dat de overheid maatregelen treft die eigenlijk een sociaaleconomisch karakter hebben. ${ }^{24}$ Deze erkenning is vooral van belang omdat het verbod van discriminatie ook geldt voor het nalaten van het treffen van positieve verplichtingen: als er een ongelijkheid bestaat en de overheid treft geen maatregelen om deze te

\section{0. $\$ \$ 41$ en 42}

21. Ook voor andere dan sociale rechten kan het accessoire karakter beperkend werken. Zie daarover nader Kerdel 2001, p. 43, die wijst op de mogelijkheid van ongelijke behandeling bij de vereisten om tot het rechterlijk ambt te worden toegelaten.

22. Vgl. Harris/O'Boyle/Warbrick 1995, p. 464 en 486 en Strasser 1996, p. 41 . Ook in andere gevallen zijn beperkingen aanwezig. Zo stelde het Hof in de zaak Botta dat het recht van een gehandicapte om tijdens zijn vakantie toegang tot het strand te hebben betrekking heeft op zeer brede en onbepaalde interpersoonlijke relaties en daardoor niet onder de reikwijdte van artikel 8 valt. Hieraan verbond het Hof ook de conclusie dat artikel 14 niet van toepassing is (EHRM 24 februari 1998, Reports 1998-I, $\$ \S 35$, 39 en 40).

23. Zie bijvoorbeeld Gaygusuz (16 september 1996, Reports 1996-IV), Van Raalte (EHRM 21 februari 1997, Reports 1997-I), Petrovic (EHRM 27 maart 1998, Reports, 1998-II), Wessels-Bergervoet (EHRM 4 juni 2002, EHRC 2002/60) en Willis (EHRM 11 juni 2002, EHRC 2002/62). Zie hierover uitgebreid Heringa/Woltjer 1997, p. 1712.

24. EHRM 9 oktober 1979, Airey, Series A, vol. 32, §26. Vgl. ook Heringa 1989, p. 294 en Viljanen 1994 , p. 59. 
beëindigen, blijkt dit een schending van artikel 14 op te kunnen leveren. ${ }^{25}$ Op deze manier is het in beginsel mogelijk om een onderscheid op het gebied van de sociale grondrechten aan een toetsing aan het discriminatieverbod te onderwerpen. In de praktijk is het aantal voorbeelden hiervan echter uiterst beperkt.

\subsubsection{Consequenties van het accessoire karakter voor de toetsingsmethodiek}

Het accessoire karakter van artikel 14 is verder van belang voor de wijze waarop het Hof omgaat met de toetsing aan deze bepaling. Volgens zijn vaste werkwijze zal het Hof altijd beginnen met het beoordelen van de klacht over de aantasting van het materiële verdragsrecht. Aangezien het Hof bij de toetsing van ongelijke behandeling vergelijkbare toetsingscriteria hanteert als bij de toetsing van een aantasting van een materieel verdragsrecht, ${ }^{26}$ komt het veelvuldig voor dat het Hof over een bepaald toetsingselement, zoals de noodzakelijkheid of het doel, al een uitgebreid gemotiveerd oordeel heeft gegeven bij de toetsing aan de materiële bepaling. Bij de toetsing aan artikel 14 wordt daarnaar dan ook vaak impliciet of expliciet verwezen, zonder dat er een nieuwe, specifiek op de ongelijke behandeling gerichte beoordeling wordt uitgevoerd. ${ }^{27}$ Zo stelde het Hof in het arrest Spadea and Scalabrino ${ }^{28}$ dat de omvang van de margin of appreciation zoals die was vastgesteld bij de toetsing aan de materiële bepaling ook gold voor de toetsing aan artikel $14^{29}$, in de zaak Building Societies ${ }^{30}$ refereerde het Hof aan zijn bij de toetsing aan artikel 1 Eerste Protocol gegeven beoordeling van het doel van het onderscheid en in Sheffield and Horsham ${ }^{31}$ gaf het Hof aan dat het oordeel over de proportionaliteit zoals dat was gegeven bij de toetsing aan artikel 8 lid 2 ook gold voor de beoordeling onder artikel $14 .^{32}$

De verwijzingen naar het oordeel over de aantasting van een materiële verdragsbepaling zijn niet altijd even expliciet. Ook in gevallen waarin een uitdrukkelijke verwijzing ontbreekt kan uit de motivering echter regelmatig worden afgeleid dat de toetsing aan artikel 14 door de eerdere beoordeling is geïnspireerd. Een voorbeeld hiervan is het arrest Ireland $v$. UK (de IRA-zaak) ${ }^{33}$, dat betrekking had op verschillende maatregelen

25. Zie Frowein/Peukert 1996, p. 441. Een voorbeeld hiervan (waarbij het overigens niet ging om sociale grondrechten) is het arrest Vermeire (EHRM 29 november 1991, Series A, vol. 214-C, m.n. § 25).

26. Zie daarover nader paragraaf 2 .

27. Het Hof toetst altijd eerst aan het materiële artikel en pas daarna aan artikel 14. Vgl. Gomien/Harris/Zwaak 1996, p. 351, Robertson/Merrills 1993, p. 179 en Partsch 1993, p. 589. Meestal wordt terugverwezen naar artikel 1 Eerste Protocol, maar soms ook naar de artikelen 8-11 lid 2 of naar artikel 6 (bijv. EHRM 16 december 1997, Canea Catholic Church, Reports 1997, VIII).

28. EHRM 28 september 1995 , Series A, vol. 315-B

29. Met name $\$ \S 29$ en 46 . Ook in James werd voor de vaststelling van de omvang van de margin terugverwezen naar de beoordeling onder artikel 1 Eerste Protocol: EHRM 21 februari 1986, James and Others, Series A, vol. 98, met name $\$ \$ 46$ en 77 (vgl. Merrills 1993, p. 169).

30. EHRM 23 oktober 1997, Building Societies, Reports 1997 VIII, $\$ 81$

31. EHRM 30 juni 1998, European Human Rights Reports 1998, 163, §76

32. Andere voorbeelden zijn Lithgow, waarin het Hof verwees naar zijn eerdere oordeel over de redelijkheid van een discriminatoire regeling (EHRM 8 juli 1986, Series A, vol. 102, § 183), Gillow, waarin werd gerefereerd aan het bij de toetsing aan artikel 8 lid 2 gegeven oordeel over de legitimiteit van het doel (EHRM 24 november 1986, Series A, vol. 109, § 65) en Handyside, waarin werd verwezen naar de toetsing aan artikel 10 lid 2 voor een antwoord op de vraag of er van vergelijkbare gevallen sprake was (EHRM 12 december 1976, Series A, vol. 24, §66).

33. EHRM 18 januari 1978, Series A, vol. 25 , m.n. $\$ \$ 207$ en 229 ; zoals Merrills stelt: "the resonance of 
die de Engelse regering had getroffen om een einde te maken aan de gewelddadigheden in Noord-Ierland. Omdat er sprake was van een noodsituatie als bedoeld in artikel 15 EVRM had het Hof het VK een ruime margin of appreciation toegekend. ${ }^{34} \mathrm{Bij}$ de toetsing van de maatregelen aan artikel 14 werd niet uitdrukkelijk op de margin of appreciation ingegaan, terwijl evenmin werd terugverwezen naar de eerdere vaststelling daarvan. Het is echter niet mogelijk om de uitspraak van het Hof over de verenigbaarheid van de ongelijke behandeling met het discriminatieverbod goed te begrijpen zonder naar het oordeel over de toepasselijkheid van artikel 15 te kijken.

In een beperkt aantal gevallen blijkt het Hof zelfs nog verder te gaan dan het geven van een impliciete of expliciete verwijzing naar een eerder gegeven beoordeling en wordt de toetsing aan het substantiële artikel volledig in de toetsing aan artikel 14 geîncorporeerd. Een voorbeeld van die werkwijze is te vinden in het arrest Hoffmann. ${ }^{35}$ Dit arrest had zowel betrekking op een inbreuk op het door artikel 8 gewaarborgde recht op "family life" als op een ongelijke behandeling. In zijn arrest stelde het Hof allereerst vast dat inderdaad sprake was van een inbreuk op artikel 8. Volgens zijn gebruikelijke methodiek zou het Hof vervolgens in moeten gaan op de mogelijke rechtvaardiging van deze inbreuk en zou pas daarna een beoordeling van de ongelijke behandeling moeten volgen. Het Hof koos in deze uitspraak echter voor een soort fusie van de beoordeling van beide klachten: de toetsing aan het substantiële artikel werd overgeslagen en vervangen door een toetsing aan artikel 14, waarin echter wel een aantal elementen uit artikel 8 lid 2 (waarin de rechtvaardigingsmogelijkheid is vastgelegd) werd ingevoegd. ${ }^{36}$

Voor een goede beoordeling van de toetsingsmethodiek van het Hof bij de toetsing aan het gelijkheidsbeginsel betekent het voorgaande dat het nodig is om niet alleen aandacht te besteden aan de rechtspraak waarin expliciet uitspraak is gedaan over het discriminatieverbod, maar ook om in te gaan op de rechtspraak over de substantiële verdragsbepalingen. In het vervolg van dit hoofdstuk zal dan ook uitgebreid aandacht worden besteed aan deze jurisprudentie, waarbij het accent zal liggen op de toetsing van de rechtvaardiging en op de wijze waarop de omvang van de margin of appreciation wordt vastgesteld. ${ }^{37}$

the Court's earlier comments on Article 15 and in particular the scope of the respondent's margin of appreciation are clearly audible here" (1993, p. 171).

34. Aan dit begrip zal in paragraaf 3 uitgebreid aandacht worden besteed.

35. EHRM 23 juni 1993, Series A, vol. 255-C

36. "[I]n view of the nature of the allegations made, the Court [...] considers it appropriate to examine the present case under Article 8 taken in conjunction with Article 14" $(\$ 30)$ en "[...] the Court does not consider it necessary to rule on the allegation of a violation of Article 8 taken alone; the arguments advanced in this respect are in any case the same as those examined in respect of Article 8 taken in conjunction with Article 14" ( $\$ 37$ ). Hoewel de uitspraak maar door 5 van de 9 rechters werd gesteund, maakte geen van de dissenters bezwaar tegen de keuze om de toetsing aan artikel 8 lid 2 te incorporeren in de toetsing aan artikel 14; vgl. Partsch 1995, p. 1053-1054. Een min of meer vergelijkbare constructie is te vinden in het arrest Salgueiro da Silva Mouta, EHRM 21 december 2000, EHRC 2000/16.

37. Dit is met name van belang omdat de toetsingsmethodiek die bij de substantiele bepalingen gevolgd wordit in bepaalde opzichten verschilt van de bij artikel 14 uitgevoerde toetsing. Ook is de toetsing aan substantiěle artikelen soms intensiever dan die aan artikel 14 (vgl. Warbrick 1989, p. 710). 


\subsubsection{Betekenis van het Twaalfde Protocol}

Opmerking verdient tenslotte dat de lidstaten van de Raad van Europa inmiddels een Twaalfde Protocol bij het EVRM hebben ondertekend, waarin een zelfstandig verbod van discriminatie is opgenomen en de verplichte koppeling aan een substantiële verdragsbepaling is vervallen. ${ }^{3 \mathrm{x}}$ Wanneer dit Protocol, na ratificatie door voldoende lidstaten, in werking treedt zal dit belangrijke consequenties hebben voor de mogelijkheid om ongelijke behandelingen aan te vechten voor het Hof. Ongelijke behandelingen waardoor sociale, economische of culturele grondrechten worden aangetast komen daardoor onder de reikwijdte van het discriminatieverbod te vallen, terwijl het Protocol bovendien tot gevolg kan hebben dat het discriminatieverbod een belangrijkere, zelfstandige betekenis krijgt in de rechtspraak van het Hof. ${ }^{39}$ Hierdoor zal een belangrijke tendens die de laatste jaren in de rechtspraak van het Hof zichtbaar is verdwijnen. Op dit moment wordt er eigenlijk alleen nog aan artikel 14 getoetst wanneer een klacht feitelijk uitsluitend betrekking heeft op een ongelijke behandeling of wanneer de klacht een duidelijk ander aspect van een recht betreft dan de beweerde schending van het substantiële artikel. ${ }^{40}$ Wanneer het zelfstandige discriminatieverbod in werking treedt zal de klacht over een ongelijke behandeling niet per se vergelijkbaar zijn met de "hoofdklacht" over de aantasting van een materieel verdragsrecht. Een toetsing aan het gelijkheidsbeginsel zal dan zeker niet zonder meer achterwege kunnen worden gelaten of kunnen worden geîncorporeerd in de toetsing aan het substantiële artikel. Of deze verandering ook consequenties zal hebben voor de toetsingsmethodiek moet worden afgewacht. Het ligt echter voor de hand dat dit niet het geval zal zijn, nu de toetsingsmethodiek van het Hof inmiddels al is uitgekristalliseerd. Wel zullen de verwijzingen naar de toetsing aan substantiële artikelen aanzienlijk minder frequent voorkomen.

38. Dit verbod luidt als volgt: "1. The enjoyment of any right set forth by law shall be secured without discrimination on any ground such as sex, race, colour, language, religion, political or other opinion, national or social origin, association with a national minority, property, birth or other status. 2 . No one shall be discriminated against by any public authority on any ground such as those mentioned in paragraph 1." De tekst van het protocol en de toelichting zijn te vinden via http://conventions.coe.int (laatstelijk bezocht 9 juli 2002); het Protocol is in november 2000 opengesteld voor ratificatie en zal in werking treden wanneer het door tien landen is geratificeerd. Op 9 juli 2002 was het verbod overigens pas door twee lidstaten (Georgië en Cyprus) geratificeerd.

39. Vgl. Kerdel 2001, p. 44/45.

40. Zie over de waarde van artikel 14 voor het EVRM ook Heringa 1998, p. 3.14-2/3. Aanvankelijk had artikel 14 belangrijke betekenis in gevallen waarin het feitencomplex wel onder de reikwijdte van een substantiële bepaling viel, maar geen inbreuk op deze bepaling aanwezig werd geacht. Het Hof heeft echter in het arrest Jewish Liturgical Association Cha'are Shalom Ve Tsedek echter aangenomen dat in dat geval kan worden gesteld dat de ongelijke behandeling een beperkte omvang heeft (EHRM 27 juni 2000 , EHRC 2000/66, $\S 86$ ). Hoewel dit op zichzelf niet bepalend is voor de reikwijdte en toepasselijkheid van artikel 14 wordt de betekenis van dit artikel hierdoor wel verminderd, nu dit zal betekenen dat een beroep op het discriminatieverbod in deze situatie zelden zal worden gehonoreerd. 


\subsection{Inhoud en reikwijdte van het discriminatieverbod}

\subsubsection{Gronden van onderscheid; vereiste van onderscheid op persoonskenmerk}

Uit de formulering van artikel 14 blijkt dat de hierin gegeven opsomming van gronden van onderscheid niet limitatief bedoeld is. Het Hof heeft dit uitdrukkelijk bevestigd in het arrest Engel ${ }^{41}$, waarin het stelde dat

"the list set out in that provision [artikel 14, JHG] is illustrative and not exhaustive, as is shown by the words 'any grounds such as' (in French 'notamment'). ${ }^{.22}$

Dit betekent dat iedere mogelijke ongelijke behandeling door het Hof getoetst kan worden: voor een klager is het niet nodig om aan te tonen dat het litigieuze onderscheid berust op één van de in artikel 14 expliciet genoemde gronden. Dat dit ook lang niet altijd gebeurt blijkt bijvoorbeeld uit het arrest Rasmussen. ${ }^{3}$ In dit arrest was een verschil in het geding in de vereisten voor het instellen van een procedure tot ontkenning van het vaderschap: de "vader" kon alleen gedurende een bepaalde termijn een ontkenningsprocedure starten, terwijl voor de moeder een dergelijke termijn niet gold. Hoewel dit onderscheid eenvoudig te kwalificeren is als onderscheid op grond van geslacht, stelde het Hof het volgende:

"For the purposes of Article 14, the Court [...] finds that there was a difference of treatment as between Mr. Rasmussen and his former wife as regards the possibility of instituting proceedings to contest the former's paternity. There is no call to determine on what ground this difference was based, the list of grounds appearing in Article 14 not being exhaustive."

Omdat de grond van een ongelijke behandeling lang niet altijd zo duidelijk kwalificeerbaar is als in Rasmussen is dit voor klagers een groot voordeel: vrijwel iedere ongelijke behandeling kan hierdoor, mits aan het koppelingsvereiste is voldaan, voor het Hof worden gebracht. Uit het arrest Kjeldsen ${ }^{45}$ blijkt echter dat het aantal mogelijke ongelijke behandelingen waarbij een beroep op artikel 14 mogelijk is toch niet onbeperkt is: het Hof stelde in deze zaak dat er niet alleen sprake moet zijn van een ongelijke behandeling, maar ook dat deze zijn oorzaak moet vinden in

\footnotetext{
"a personal characteristic by which persons or groups of persons are distinguishable from each other." ${ }^{16}$
}

Dit betekent dat het Hof alleen aan artikel 14 kan toetsen als er onderscheid is gemaakt op grond van persoons- of groepsgebonden kenmerken; geheel "open" is de bepaling kennelijk niet. Uit latere rechtspraak blijkt echter dat het vereiste uit Kjeldsen ruim wordt uitgelegd en dat het bovendien lang niet altijd wordt toegepast. Zo werd er in de

41. EHRM 23 november 1976 , Series A, vol. 22

42. \$72. Vgl. ook EHRM 21 december 1999, Salgueiro da Silva Mouta, EHRC 2000/16, § 16.

43. EHRM 28 november 1984 , Series A, vol. 87

44. EHRM 28 november 1984, Rasmussen, Series A, vol. 87, \$34. Wel geldt natuurlijk altijd de eis dat de beweerde ongelijke behandeling een recht moet aantasten dat onder de reikwijdte van een substantieel verdragsartikel valt.

45. EHRM 7 december 1976 , Series A, vol. 23

46. $§ 56$ 
zaak Lithgow ${ }^{\text {t7 }}$ geklaagd over een ongelijke behandeling bij het verlenen van compensatie bij nationalisatie: voor de vaststelling van het compensatiebedrag werd bij sommige bedrijven gekeken naar het totale vermogen, terwijl bij andere bedrijven uitsluitend werd gekeken naar hun omzet. Deze ongelijke behandeling is moeilijk te beschouwen als gebaseerd op een "personal characteristic", zelfs als een heel ruime uitleg aan dit begrip zou worden gegeven. Ook in verschillende andere zaken bleek het feit dat het onderscheid geen basis vond in een duidelijk persoonlijk kenmerk geen belemmering te zijn voor beoordeling van de klacht. ${ }^{4 s}$

Toch kan niet worden gesteld dat het Hof in de loop van de tijd volledig afstand heeft gedaan van dit vereiste, zoals blijkt uit enkele recente zaken tegen Turkije. In deze zaken werd gesteld dat de bescherming van het Turkse strafprocesrecht bij sommige delicten minder vergaand zou zijn dan bij andere. Ten aanzien van deze ongelijke behandeling stelde het Hof het volgende:

"The Court notes that in principle the aim [van de ongelijke regels van procesrecht, JHG] is to penalise peopie who commit terrorist offences and that anyone convicted under that law will be treated less favourably with regard to automatic parole than persons convicted under the ordinary law. It deduces from that fact that the distinction is made not between different groups of people, but between different types of offence, according to the legislature's view of their gravity. The Court sees no ground for concluding that that practice amounts to a form of 'discrimination' that is contrary to the Convention."

Voor toepasselijkheid van artikel 14 blijft het kennelijk vereist dat er enig verband kan worden gelegd tussen de grond van onderscheid en de betrokken persoon of groep.

\subsubsection{Inhoudelijke behandeling van beroepen op artikel 14}

Hierboven is gebleken dat het voor de ontvankelijkheid van een beroep op artikel 14 nodig is dat er een koppeling met een substantieel artikel is aangetoond en dat er een verband kan worden gelegd tussen de grond van onderscheid en de betrokken persoon of groep. Aangezien aan beide vereisten een ruime uitleg wordt gegeven, is de reikwijdte van artikel 14 aanzienlijk en zullen de meeste klachten ontvankelijk kunnen worden verklaard. Dit betekent echter nog niet dat een in principe ontvankelijk beroep ook altijd inhoudelijk wordt behandeld. In het arrest Airey ${ }^{s_{0}}$ stelde het Hof namelijk, dat:

47. EHRM 22 mei 1984 , Series A, vol. 102

48. Zie bijvoorbeeld Fredin, waarin klagers stelden dat hun vergunning tot exploitatie van een gravelmijn ten onrechte werd ingetrokken op grond van milieuoverwegingen; ook daarbij lijkt geen enkel persoonsgebonden kenmerk een rol te spelen (EHRM 18 februari 1991, Series A, vol. 192). Zie ook Building Societies, waarin onderscheid werd gemaakt tussen "building societies" die al in een vroeg stadium bezwaar hadden gemaakt tegen een bepaalde regeling en "societies" die dit niet hadden gedaan (EHRM 23 oktober 1997, Reports 1997-VII).

49. EHRM 8 juli 1999, Gerger, nog niet gepubliceerd, $\$ 69$. Zie ook EHRM 17 oktober 2000, Mutlu and Yildiz, nog niet gepubliceerd. Ook wanneer het onderscheid voort blijkt te komen uit regionale of geografische verschillen wordt er volgens het Hof geen onderscheid gemaakt op grond van persoonskenmerken en kan artikel 14 niet toepasselijk worden geacht; zie EHRM 6 juni 2000, Magee, EHRC $2000 / 63, \S 19$.

50. EHRM 9 oktober 1979, Series A, vol. 32 
"If the Court does not find a separate breach of one of those Articles [materiële verdragsbepalingen, JHG] that has been invoked both on its own and together with Article 14, it must also examine the case under the latter Article. On the other hand, such an examination is not generally required when the Court finds a violation of the former Article taken alone. The position is otherwise if a clear inequality of treatment in the enjoyment of the right in question is a fundamental aspect of the case [...]."

In de praktijk blijkt het Hof een klacht over schending van artikel 14 alleen in behandeling te nemen als de klacht onder het substantiële artikel ongegrond is verklaard, als de klacht ziet op een ander aspect van de zaak dan de specifieke klacht over het substantiële artikel of als de klacht weliswaar ziet op een zelfde aspect van een grondrecht, maar wel betrekking heeft op een juridisch gezien interessante vraag. ${ }^{52}$

\subsection{Direct en indirect onderscheid; formeel en materieel onderscheid}

\subsubsection{Direct en indirect onderscheid}

Zoals eerder is aangegeven is de opsomming van gronden van onderscheid in artikel 14 niet limitatief. Dit betekent dat er in beginsel geen noodzaak bestaat voor het gebruik van een concept van indirect onderscheid: iedere ongelijke behandeling kan rechtstreeks worden aangevochten. Niettemin kan het voor klagers nuttig zijn om een beroep te doen op dit concept, nu het Hof voor sommige gronden van onderscheid een striktere toetsing heeft aanvaard dan voor andere. Een klacht makt bijvoorbeeld meer kans van slagen wanneer kan worden aangetoond dat er indirect onderscheid wordt gemaakt op een verdachte grond (waarbij een strikte toetsing wordt uitgevoerd) dan wanneer een onderscheid op een neutrale grond rechtstreeks wordt aangevochten (zodat er een terughoudende toetsing wordt uitgevoerd). Het Hof erkende aanvankelijk echter niet dat een beroep op het concept van indirect onderscheid mogelijk is. ${ }^{53}$ Hoogstens stelde het dat bij de beoordeling van een klacht over direct onderscheid ook met de effecten van deze ongelijkheid rekening kan worden gehouden. Zo oordeelde het in de Belgische Taalzaak ${ }^{44}$, dat:

"[...] the principle of equality of treatment is violated if the distinction has no objective and reasonable justification. The existence of such a justification must be assessed in relation to the aim and effects of the measure under consideration [...].",ss

51. $\S 30$. Dit is vaste rechtspraak van het Hof.

52 Overigens is het niet erg duidelijk wanneer het Hof van mening is dat een klacht over artikel 14 een fundamenteel aspect van de zaak vormt. Het Hof lijkt dit argument vooral goed te kunnen gebruiken als het er weinig voor voelt in een toetsing van de ongelijke behandeling uit te voeren, bijvoorbeeld omdat het dan een oordeel moet uitspreken over gevoelig liggende kwesties (zoals in de zaken over ongelijke behandeling van homoseksuelen; bijv. EHRM 22 oktober 1981, Dudgeon, Series A, vol. 45, $\$ 69$ ), of omdat het dan te maken krijgt met moeilijke rechtvaardigingsproblemen (zoals in het geval waarin een onderscheid gevoelsmatig gerechtvaardigd lijkt, maar het moeilijk is om de rechtvaardiging met rationele argumenten te ondersteunen). Zie hierover ook Harris/O'Boyle/Warbrick 1995, p. $468 / 469$ en Matscher 1980, p. 638.

53. Vgl. Harris/O'Boyle/Warbrick 1995, p. 477.

54. EHRM 23 juni 1968 , Series A, vol. 6

55. $\$ 10$; cursief toegevoegd. 
De terughoudendheid van het Hof om het concept van indirect onderscheid te aanvaarden blijkt ook uit zijn oordeel in de zaak Abdulaziz. ${ }^{56}$ Deze zaak had betrekking op een Engelse wet die scherpe regels stelde op het gebied van immigratie en gezinshereniging en die gelijkelijk gold voor alle immigranten. Het overgrote deel van de buitenlanders die zich als immigrant in Engeland wilden vestigen bleek echter afkomstig te zijn uit de New Commonwealth of uit Pakistan, waardoor de immigratieregeling tot feitelijk effect had dat er veel meer kleurlingen dan blanken werden benadeeld. De klaagsters stelden dan ook dat er sprake was van indirect onderscheid op grond van ras: een evident verdachte grond waarbij een strikte toetsing gerechtvaardigd zou zijn. Het Hof was echter een andere mening toegedaan:

"That the mass immigration against which the rules were directed consisted mainly of would-be immigrants from the New Commonwealth and Pakistan, and that as a result they affected at the material time fewer white people than others, is not a sufficient reason to consider them as racist in character: it is an effect which derives not from the content of the 1980 Rules but from the effect that, amongst those wishing to immigrate, some ethnic groups outnumbered others." ${ }^{\text {? }}$

Deze redenering impliceert dat het vrijwel onmogelijk is om een geslaagd beroep te doen op het concept van indirect onderscheid. Dit concept is immers juist gebaseerd op de gedachte dat regelgeving door de verschillen in maatschappelijke positie van bepaalde groepen ongelijke effecten kan opleveren. Wanneer een maatregel belastende effecten heeft voor bepaalde kwetsbare groeperingen (zoals etnische of raciale groepen) kan van de wetgever worden verwacht dat hij hiermee rekening houdt, zeker wanneer er sprake is van indirect onderscheid op verdachte gronden. Wanneer de wetgever een regeling, ondanks dit soort effecten, doorvoert en in stand houdt, lijkt het dan ook redelijk dat de rechter verlangt dat hiervoor een voldoende rechtvaardiging bestaat: wanneer een dergelijke rechtvaardiging niet zou worden vereist kan dit leiden tot een sterk verminderde bescherming van individuele belangen tegen het optreden door de overheid.

Recentelijk lijkt het Hof deze bezwaren tegen zijn redenering te hebben erkend, hetgeen heeft geleid tot een andere benadering. Dit kan blijken uit het arrest Kelly ${ }^{\mathrm{ss}}$, dat betrekking had op de gewelddadigheden in Noord-Ierland. Klagers stelden dat de overgrote meerderheid van de mensen die waren omgekomen als gevolg van het optreden van "security forces" katholiek was; protestanten bleken daarentegen vrijwel nooit slachtoffer te zijn van dit optreden. Volgens klagers leverde het gebruik van geweld dan ook indirect onderscheid op grond van godsdienst op. Het Hof oordeelde als volgt:

\footnotetext{
"Where a general policy or measure has disproportionately prejudicial effects on a particular group, it is not excluded that this may be considered as discriminatory notwithstanding that it is not specifically aimed or directed at that group. However, even though statistically it appears that the majority of people shot by the security forces were from the Catholic or nationalist community, the Court does not consider that statistics can in themselves disclose a practice which could be classified as discriminatory within the meaning of Article 14 .

56. EHRM 25 mei 1985, Abdulaziz, Cabales and Balkandali, Series A, vol. 94

57. $\$ 85$. Zie hierover en over een ander aspect van dezelfde zaak waarbij ook sprake was van een door het Hof niet erkend indirect onderscheid Harris/O'Boyle/Warbrick 1995, p. 478.

58. EHRM 4 mei 2001, EHRC 2001/40
} 
There is no evidence before the Court which could entitle it to conclude that any of those killings [...] involved the unlawful or excessive use of force by members of the security forces."

Blijkens deze overweging acht het Hof het in beginsel denkbaar dat er een geslaagd beroep wordt gedaan op het concept van indirect onderscheid. In dat opzicht betekent deze uitspraak een grote vooruitgang in vergelijking tot Abdulaziz. Uit de overweging blijkt echter ook dat het aantal geslaagde beroepen minimaal zal zijn, nu de eisen die worden gesteld aan het bewijs van indirect onderscheid bijzonder hoog zijn. Zo blijkt het niet voldoende te zijn dat er een duidelijk disproportioneel effect wordt aangetoond: enig bijkomend bewijs is noodzakelijk. Jammer genoeg geeft het Hof geen antwoord op de vraag waarin dit bijkomend bewijs dan zou moeten worden gevonden. Uit de overweging kan hoogstens blijken dat het, om te kunnen spreken van een "toetsbaar" indirect onderscheid, nodig is dat de bevoegdheidsuitoefening waarvan het indirecte onderscheid het resultaat is zelf niet legitiem is. Dit betekent feitelijk dat alleen maatregelen die daadwerkelijk gericht zijn op het bereiken van discriminatoire effecten aan een inhoudelijke toetsing kunnen worden onderworpen. Onbedoelde effecten zijn in die lezing niet problematisch, ook al zijn zij voor de betrokken groep bijzonder nadelig. ${ }^{\omega}$ Duidelijk is de uitspraak op dit punt echter niet; om werkelijk conclusies te kunnen bereiken over de nieuwe benadering bij indirect onderscheid zal nadere jurisprudentie moeten worden afgewacht.

\subsubsection{Formeel en materieel onderscheid}

Een andere belangrijke kwestie betreft het verschil tussen materieel en formeel onderscheid. ${ }^{1}$ Het is lange tijd onduidelijk geweest welk standpunt het Hof hierover innam, ook doordat het Hof slechts in een zeer beperkt aantal gevallen werd geconfronteerd met een klacht over gelijke behandeling van ongelijke gevallen (materieel onderscheid). Uit een arrest uit 1996, Stubbings, kan worden afgeleid dat het Hof aanvankelijk niet bereid was het concept van materieel onderscheid te erkennen. ${ }^{62}$ Het Hof moest zich in deze zaak uitspreken over een klacht van enkele Engelse vrouwen die in hun jeugd het slachtoffer waren van seksueel misbruik. Zij hadden daardoor op latere leeftijd psychische klachten gekregen en hadden zich pas geruime tijd na het ontstaan van deze klachten gerealiseerd dat de oorzaak daarvan in het seksuele misbruik was gelegen. In Engeland gold voor een claim tot schadevergoeding wegens opzettelijk toegebracht leed echter een verjaringstermijn van zes jaar, die begon te lopen vanaf de achttiende verjaardag van het slachtoffer. Door deze termijn was de eis van klaagsters verjaard, zodat zij naar Engels recht geen schadevergoeding meer konden eisen. Klaagsters stelden voor het Hof dat door de eenvormigheid van deze verjaringsregeling inbreuk was gemaakt op artikel 14: zij waren van mening dat er duidelijk verschil be-

59. $§ 148$

60. Wanneer dit inderdaad het geval is, is dit geen wenselijke benadering. Deze wordt ook gevolgd door het Amerikaanse Supreme Court en resulteert daar in een zware bewijslast en in de onmogelijkheid maatschappelijke effecten van regelgeving effectief aan te vechten. Zie daarover hoofdstuk 5 , m.n. paragraaf 2.2.3.

61. Zie voor de begripsbepaling nader hoofdstuk 2, paragraaf 1.2.1.

62. EHRM 22 oktober 1996, Stubbings and Others, Reports 1996-IV 
stond tussen het specifieke psychische leed dat zij ondervonden en andere gevallen van opzettelijk toegebracht leed. Volgens hen was er dan ook sprake van een materieel onderscheid. Het Hof oordeelde anders:

"The Court observes [...] that as between the applicant and victims of other forms of deliberate wrongdoing with different psychological after-effects, there was no disparity in treatment, because the same rules of limitation are applied to each group." ${ }^{\prime 63}$

Met deze overweging gaf het Hof duidelijk te kennen geen oog te hebben voor het concept van materieel onderscheid. Recentelijk, met het in 2000 gewezen arrest Thlimmenos $^{64}$, is het Hof echter teruggekomen van deze benadering en heeft het uitdrukkelijk erkend dat ook materiële ongelijkheid onder de reikwijdte van artikel 14 valt. In deze zaak was een wettelijke regeling aan de orde op grond waarvan mensen die in het verleden waren veroordeeld wegens een misdrijf niet tot accountant konden worden benoemd. Klager stelde dat de wettelijke regeling onvoldoende rekening hield met het zeer uiteenlopende karakter van misdrijven; daardoor was er volgens hem sprake van een materieel onderscheid waardoor inbreuk werd gemaakt op artikel 14. Het Hof gaf hierover het volgende oordeel:

"The Court has so far considered that the right under Article 14 not to be discriminated against in the enjoyment of the rights guaranteed under the Convention is violated when States treat differently persons in analogous situations without providing an objective and reasonable justification. However, the Court considers that this is not the only facet of the prohibition of discrimination under Article 14. The right not to be discriminated against in the enjoyment of the rights guaranteed under the Convention is also violated when States without an objective and reasonable justification fail to treat differently persons whose situations are significantly different." ${ }^{\text {"6s }}$

Vervolgens voerde het Hof een rechtvaardigingstoets uit aan de hand van het model dat normaal gesproken bij formeel onderscheid wordt gehanteerd. ${ }^{66}$ In het hiernavolgende zal dan ook tot uitgangspunt worden genomen dat het toetsingsmodel van het Hof zowel bij formeel onderscheid als bij materieel onderscheid kan worden toegepast.

\subsection{Uitsluitend toetsing van tegen de overheid gerichte klachten}

Op grond van artikel 34 EVRM kan het Hof slechts klachten in behandeling nemen die afkomstig zijn van individuele personen, non-gouvernementele organisaties en groepen van personen die beweren het slachtoffer te zijn van een schending van één van de door het EVRM beschermde rechten. Vereist is daarbij dat de schending moet kunnen worden gerekend tot de verantwoordelijkheid van de betrokken lidstaat. ${ }^{67}$ Dit betekent dat het Hof alleen uitspraak kan doen in verticale verhoudingen. De reikwijdte van het begrip 'verticale verhouding' blijkt echter ruim te worden geïnterpreteerd: hieronder

\section{3. $\$ 73$}

64. EHRM 6 april 2000, EHRC 2000/45

65. $§ 44$. Het Hof bevestigde dit oordeel in EHRM 18 januari 2001, Jane Smith, EHRC 2001/19, $\$ 138$.

66. Zie daarover paragraaf 2 .

67. Dit vloeit bovendien voort uit artikel I EVRM, waaruit blijkt dat het Verdrag zich alleen richt tot de staten: "The High Contracting Parties shall secure to everyone within their jurisdiction the rights and freedoms defined in Section I of this Convention." 
valt blijkens de rechtspraak van het Hof niet alleen de situatie waarin een overheidsinstantie rechtstreeks inbreuk maakt op het recht van een individuele burger, maar ook de situatie waarin de overheid heeft nagelaten een positieve maatregel te treffen om een bestaande verdragsschending te beëindigen, zelfs als deze verdragsschending feitelijk door een particulier is veroorzaakt. ${ }^{68}$ Van belang is echter dat in de toelichting bij het Twaalfde Protocol (waarin een zelfstandig gelijkheidsbeginsel is opgenomen) uitdrukkelijk is aangegeven dat uit deze rechtspraak van het Hof niet mag worden afgeleid dat het discriminatieverbod daadwerkelijk horizontale werking heeft: een beroep op de positieve verplichtingen zal volgens deze toelichting alleen mogen worden gehonoreerd, wanneer het niet nakomen van dergelijke verplichtingen voldoende duidelijk en ernstig is. Dit zal meestal alleen het geval zijn in gevallen waarin het gaat om horizontale relaties in de openbare sfeer waarvoor de staat een zekere verantwoordelijkheid heeft, zoals bij medische voorzieningen of bij de toegang tot de arbeid. ${ }^{69}$ Hoewel het Twaalfde Protocol nog niet in werking is getreden, kan worden aangenomen dat soortgelijke overwegingen ook nu reeds een rol spelen; de mogelijkheid van horizontale werking van artikel 14 moet daarom relatief beperkt worden geacht.

Van belang is verder dat het Hof een ruime uitleg heeft gegeven aan het begrip "overheidsinstantie". Onder dit begrip worden alle overheidslichamen en -organen begrepen, inclusief de rechterlijke macht. Dit betekent dat er ook sprake is van een verticale verhouding als een rechter in een geschil tussen particulieren (bijvoorbeeld in een rechtszaak over de toewijzing van een kind aan één van de ouders) een uitspraak doet waardoor inbreuk wordt gemaakt op een door het EVRM beschermd recht: het bij het EHRM ingestelde beroep is dan immers gericht tegen de rechterlijke uitspraak en daarmee tegen de overheid. ${ }^{70}$ Voor de bevoegdheid van het Hof om over een klacht te oordelen maakt het verder geen verschil of de overheid optreedt "als zodanig" of in een andere hoedanigheid, bijvoorbeeld in die van werkgever of van verhuurder van onroerend goed. Het Hof lijkt dit vanzelfsprekend te vinden en is maar in enkele gevallen uitdrukkelijk op deze kwestie ingegaan. Een voorbeeld daarvan is het arrest Schmidt

68. Zo was in de zaak Young, James and Webster een closed shop-agreement in het geding tussen private partijen, namelijk een geprivatiseerd bedrijf en een aantal vakbonden. Door deze afspraak werd inbreuk gemaakt op het door artikel 11 EVRM beschermde recht op vakbondsvrijheid van de klagers. Het is duidelijk dat het hierbij gaat om een horizontale situatie, waarin het Hof eigenlijk geen bevoegdheid toekomt. I.c. aanvaardde het Hof de klacht echter wel, met de stelling dat de staten verantwoordelijk zijn te achten voor schendingen van het Verdrag die het gevolg zijn van een niet-nakoming door de staat van de door artikel 1 EVRM opgelegde verplichting om de in het Verdrag neergelegde rechten en vrijheden aan iedereen te garanderen (EHRM 13 augustus I981, Series A, vol. 44, $\S 48$ ). Ook via de constructie van het niet-nakomen van de positieve verplichting om een horizontale grondrechtenschending te beëindigen heeft het Hof zich soms bevoegd verklaard om een oordeel uit te spreken in feitelijk horizontale verhoudingen. Een voorbeeld is te vinden in $X$ and $Y v$. The Netherlands. Het Hof stelde hierin expliciet, dat "[...] there may be positive obligations inherent in an effective respect for private or family life [...]. These obligations may involve the adoption of measures designed to secure respect for private life even in the sphere of the relations of individuals between themselves" (EHRM 26 maart 1985, Series A, vol. 91, \$22). Zie nader Alkema 1978, p. 33.

69. De toelichting bij artikel 1 van het Twaalfde Protocol is te vinden via http://conventions.coe.int (laatstelijk bezocht op 9 juli 2002).

70. Zie bijvoorbeeld EHRM 23 juni 1993, Hoffmann, Series A, vol. 255-C en EHRM 21 december 1999, Salgueiro da Silva Mouta, EHRC 2000/16. 
and Dahlström ${ }^{71}$, een zaak waarin geklaagd werd over een inbreuk op artikel 11 die door de staat in zijn hoedanigheid als werkgever werd veroorzaakt. Het Hof stelde in zijn uitspraak, dat

" $[t]$ he Convention nowhere makes an express distinction between the functions of a Contracting State as holder of public power and its responsibilities as employer. In this respect, Article 11 is no exception. Article 11 is accordingly binding upon the 'State as employer', whether the latter's relations with its employees is governed by public or by private law."'"

In de meeste gevallen laat het Hof zich niet uitdrukkelijk uit over de vraag of het Verdrag van toepassing is op de betrokken rechtsverhouding, maar wordt dit als vanzelfsprekend aangenomen. ${ }^{3}$

Het voorgaande heeft voor de beoordeling van de toetsingsmethodiek tot gevolg dat er in de rechtspraak van het Hof geen aanwijzingen kunnen worden gevonden over de mogelijkheid van toepassing van het toetsingsmodel op gevallen van ongelijke behandeling in horizontale verhoudingen.

\subsection{De concrete toetsing door het Hof}

De arresten van het Hof hebben geen erga omnes werking: ze hebben slechts rechtsgevolgen voor de bij het geschil betrokken partijen. ${ }^{74}$ Deze beperkte reikwijdte van de uitspraken heeft geleid tot een toetsingspraktijk waarbij de uitleg van de verdragsbepalingen in hoge mate wordt bepaald door de concrete omstandigheden van het geval. ${ }^{\text {s }}$

71. EHRM 6 februari 1976, Series A, vol. 21

72. $§ 33$

73. Voorbeelden van klachten over de overheid als werkgever zijn de arresten National Union of Belgian Police (EHRM 27 oktober 1975, Series A, vol. 19) en Swedish Engine Drivers' Union (EHRM 6 februari 1976, Series A, vol. 20). De overheid trad als verhuurder van onroerend goed op in Larkos (EHRM 18 februari 1999, Reports 1999-I).

74. Wel is het volgens het Hof zelf soms onvermijdelijk dat een uitspraak effecten heeft die de begrenzingen van het specifieke geval te buiten gaan: zie EHRM 13 juni 1979, Marckx, Series A, vol. 31 , 58 . Dit is met name het geval als de schending van het verdragsartikel direct is veroorzaakt door een algemeen verbindend voorschrift in plaats van door een op het individu gerichte maatregel (zie ook Schokkenbroek 1995, p. 156 en Loucaides 1995, p. 215).

75. Dit blijkt bijvoorbeeld uit de toetsingspraktijk bij de beperkingsclausules van de artikelen 8-11 tweede lid, met name als het gaat om de vraag of de inbreuk voldoet aan een van de limitatief opgesomde doelcriteria. Het Hof blijkt een abstracte interpretatie van deze doelcriteria zoveel mogelijk te vermijden, hetgeen een sterk "zaakgebonden" toepassing oplevert (Schokkenbroek 1996, p. 184; zie ook expliciet EHRM 31 juli 2000, A.D.T. v. UK, EHRC 2000/69, §36). Voor het Hof heeft dit het grote voordeel van flexibiliteit van het toetsingsbeleid: als een uitspraak erg omstreden is of als er nationale gevoeligheden in het spel zijn kan het Hof eenvoudig stellen dat een eerdere uitspraak niet van toepassing is, omdat deze werd ingegeven door de specifieke omstandigheden van het geval (vgl. Callewaert 1993, p. 728 en Alkema 1985, p. 18). Warbrick verklaart de keuze voor een casuïstische benadering vanuit het grote aantal rechters dat soms over een zaak heeft te beslissen: als onder het oude Verdrag het voltallige Hof een beslissing nam, oordeelden er 21 rechters over de zaak. Hierdoor is het volgens hem lastig om een algemene benadering te vinden voor de verschillende artikelen (Warbrick 1989, p. 710). Onder het nieuwe Verdrag is dit probleem minder groot, nu het Hof meestal beslist in kamers van zeven rechters. Alleen wanneer uitspraak wordt gedaan door de Grand Chamber beslissen er zeventien rechters over de zaak (zie artikel 27 lid 1 EVRM). 
Dit heeft tot consequentie dat het Hof zelden een abstracte uitspraak doet over de toelaatbaarheid van normatieve classificaties: het zal vrijwel steeds de toepassing in het individuele geval zijn die wordt getoetst. ${ }^{76}$ Dit concrete karakter van de toetsing komt vooral tot uitdrukking bij de beoordeling van de verhouding tussen doel en middel: over de gerechtvaardigdheid van het doel zal meestal wel een abstract oordeel worden gegeven.

Het concrete karakter van de toetsing heeft er verder toe geleid dat de jurisprudentie van het Hof bijzonder casuïstisch van aard is. ${ }^{n}$ Voor de beoordeling van de toetsingsmethodiek van het Hof betekent dit dat het niet altijd gemakkelijk is om algemene conclusies te trekken over de interpretatie van een verdragsbepaling of over de toepassing van doctrines als de, in paragraaf 3 nader te bespreken, margin of appreciationdoctrine. $^{78} \mathrm{Bij}$ de beoordeling van de verschillende elementen van de toetsing aan artikel 14 moet dan ook voortdurend rekening worden gehouden met het feit dat aan de uitspraken van het Hof slechts beperkte waarde worden kan toegekend. Zo betekent een van de normale lijn afwijkende benadering nog niet dat het Hof zijn benadering daadwerkelijk heeft aangepast: de afwijking kan heel goed zijn ingegeven door bijzondere omstandigheden van het voorliggende geval. Het is daardoor niet altijd mogelijk om door analyse van de rechtspraak te komen tot vergaande en algemene conclusies over de factoren die bepalend zijn voor de omvang en de inhoud van de toetsing aan het gelijkheidsbeginsel. Van belang is echter dat bepaalde elementen wel degelijk tot vaste rechtspraak zijn verworden, zoals bijvoorbeeld het geval is bij het toetsingsmodel dat het Hof hanteert bij de beoordeling van een beweerde ongelijke behandeling en bij het

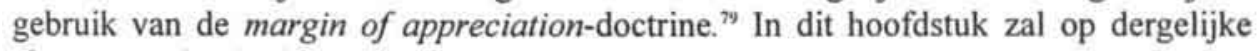
elementen uitgebreid worden ingegaan.

76. Vgl. Klerk 1995, p. 216. Dat dit de hoofdregel is blijkt ook uit het eerste Sunday Times-arrest: "[...] the Court has to be satisfied that the interference was necessary having regard to the facts and circumstances prevailing in the specific case before it" (EHRM 29 maart 1979, Series A, vol. 30, $\$ 65$ ). Een uitzondering is het arrest Gillow. Hierin toetste het Hof niet alleen of door de toepassing van de regeling een disproportionele inbreuk was gemaakt op de belangen van klagers, maar werd ook nagegaan of de regeling als zodanig voldeed aan het vereiste van evenredigheid (EHRM 24 november 1986, Series A, vol. 109, $\$ \$ 56$ en 57). Zie ook Schokkenbroek 1995, p. 157, die een verklaring geeft voor de gevallen waarin wel een abstracte toetsing wordt uitgevoerd: als de nationale maatregel veel ruimte laat voor variaties bij de toepassing is het voor de proportionaliteitstoets zinvol om te kijken naar de toepassing; laat de maatregel weinig ruimte en is er dus sprake van een soort "mechanische" toepassing, dan verschuift de aandacht van het Hof bij de proportionaliteitstoets naar de maatregel als zodanig.

77. Zie Weidmann 1985, p. 131, Matscher 1993, p. 63 en Heringa 1998, p. 3.14-6.

78. Hierop is veel kritiek geleverd; het Hof heeft bovendien ook zelf aangegeven dat een van de doelstellingen van zijn uitspraken is "not only to decide those cases brought before the Court but, more generally, to elucidate, safeguard and develop the rules instituted by the Convention" (EHRM 18 januari 1978, Ireland v. United Kingdom, Series A, vol. 25, $\$ 154$ ). Het zou wenselijk zijn als het Hof soms een meer abstracte interpretatie zou geven; niet alleen zou dit leiden tot meer rechtszekerheid en duidelijkheid, maar ook zouden de nationale autoriteiten, vooral de rechters, hierdoor over betere richtlijnen beschikken voor de interpretatie van het verdrag. Vgl. Ress 1983, p. 722.

79. Zie ook Heringa 1998 , p. 3.14-9. Hierbij moet overigens de kanttekening worden geplaatst dat de elementen van het toetsingsmodel lang niet altijd op dezelfde manier worden ingevuld; ook de invulling van de margin of appreciation verschilt van geval tot geval. De elementen zelf vormen echter steeds een vast onderdeel van de toetsing en kunnen daardoor als houvast fungeren. 
Ook buiten de door het Hof zelf erkende vaste toetsingselementen kunnen uit de jurisprudentie soms criteria voor de toepassing van artikel 14 en voor de vaststelling van de toetsingsintensiteit worden afgeleid. Hoewel het Hof, zoals gezegd, zijn toetsing tot het concrete geval beperkt en hierdoor veel afwijkingen en uitzonderingen mogelijk zijn, volgt het namelijk in het merendeel van de gevallen wel zijn eigen precedenten. ${ }^{80}$ Daarbij geldt dat het, naarmate er meer uitspraken zijn waarin het Hof teruggrijpt naar een eerder gebruikt criterium, gemakkelijker is om dit criterium als vast toetsingsvereiste aan te merken. ${ }^{81}$ Aangezien het Hof inmiddels in een relatief groot aantal zaken inhoudelijk is ingegaan op een beweerde schending van artikel 14 is het daardoor redelijk goed mogelijk om uit de rechtspraak enkele algemeen toepasbare criteria te destilleren. In de loop van dit hoofdstuk zullen verschillende van deze criteria nader worden besproken. Daarbij zal allereerst worden ingegaan op de toetsingsmethodiek van het Hof. $\mathrm{Na}$ een algemene uiteenzetting over de ontwikkeling en de inhoud van het door het Hof gehanteerde toetsingsmodel (paragraaf 2.1) zal daarbij uitgebreid aandacht worden besteed aan de afzonderlijke toetsingscriteria (paragraaf 2.2-2.9). In paragraaf $3 \mathrm{zal}$ vervolgens worden ingegaan op de intensiteit van de toetsing van het Hof, die vooral blijkt te worden bepaald door de margin of appreciation-doctrine (paragraaf 3.1 ) en door de grond van onderscheid (paragraaf 3.3). In deze paragraaf zal in het bijzonder ook worden nagegaan welke factoren de intensiteit van de toetsing van het Hof bepalen (paragraaf 3.2). Tenslotte zal in paragraaf 4 worden beoordeeld in hoeverre de toetsingsmethodiek van het Hof overeenstemt met het theoretische toetsingsmodel zoals dat in hoofdstuk 2 uiteen is gezet en zal worden bekeken in welk opzicht er uit de toetsingspraktijk van het Hof aanvullingen en nuanceringen van dit model kunnen worden afgeleid.

\section{$2 \quad$ Het toetsingsmodel}

\subsection{Ontwikkeling en inhoud van het toetsingsmodel}

In het eerste arrest dat over artikel 14 werd gewezen, de Belgische Taalzaak ${ }^{{ }^{2}}$, ging het Hof uitgebreid in op een aantal fundamentele aspecten van de toetsing aan dit artikel. Het Hof sprak zich daarbij niet alleen uit over het karakter van het discriminatieverbod (waaraan in de vorige paragraaf aandacht is besteed) maar ook over de toetsingsmetho-

80. In Cossey stelde het Hof dit expliciet vast: "It is true that [...] the Court is not bound by its previous judgments [...]. However, it usually follows and applies its own precedents, such a course being in the interests of legal certainty and the orderly development of the Convention case-law" (EHRM 27 september 1990, Series A, vol. 184, §35); zie recentelijk ook EHRM 18 januari 2001, Jane Smith, EHRC $2001 / 19, \S 77$. Volgens Ress zal het Hof slechts zelden van zijn precedenten afwijken, omdat de nationale staten op grond van eerdere jurisprudentie vaak veranderingen in hun wetgeving of rechtspraak hebben aangebracht: het Hof zal proberen te voorkomen dat door wijziging van de interpretatie aanpassingsproblemen in de lidstaten worden veroorzaakt (Ress 1983, p. 732); vgl. ook Merrills 1993, p. 13/14 en Alkema 1978, p. 18.

81. Vgl. Matscher, die stelt dat wanneer de hoeveelheid jurisprudentie groter wordt, het voor het Hof beter mogelijk wordt om stellingen te poneren die vatbaar zijn voor algemene toepassing.

82. EHRM 23 juli 1968 , Series A, vol. 6 
diek die gevolgd moet worden bij de beoordeling van klachten over ongelijke behandeling. Het Hof ontwikkelde in dit arrest een toetsingsmodel waarvan het in alle latere zaken over het discriminatieverbod gebruik is blijven maken. Om die reden is het de moeite waard om de belangrijkste overwegingen van het Hof volledig weer te geven:

"It is important [...] to look for the criteria which enable a determination to be made as to whether or not a given difference in treatment, concerning of course one of the rights and freedoms set forth in the Convention, contravenes Article 14. On this question the Court, following the principles which may be extracted from the legal practice of a large number of democratic States, holds that the principle of equality of treatment is violated if the distinction has no objective and reasonable justification. The existence of such a justification must be assessed in relation to the aim and effects of the measure under consideration, regard being had to the principles which normally prevail in democratic societies. A difference of treatment in the exercise of a right laid down in the Convention must not only pursue a legitimate aim: Article 14 is likewise violated when it is clearly established that there is no reasonable relationship of proportionality between the means employed and the aim sought to be realised."

Opvallend is dat in deze overweging geen aandacht wordt besteed aan de toetsing in de eerste fase: uit het weergegeven citaat zijn slechts aanwijzingen af te leiden voor het uitvoeren van een rechtvaardigingstoets. ${ }^{84}$ Ook uit andere uitspraken uit de beginperiode van de toetsing aan artikel 14 blijkt dat het Hof aanvankelijk niet goed wist hoe het aan deze eerste fase invulling zou moeten geven. Weliswaar is in sommige arresten een soort vergelijkbaarheidstoets zichtbaar, maar het Hof bleek deze niet te hanteren als toetsingsingang: eerder werd deze toets gezien als een manier om te beoordelen of het onderscheid inhoudelijk gerechtvaardigd is. Een toetsing in de eerste fase bleef in de meeste gevallen eenvoudigweg achterwege. Een illustratie van deze benadering vormt het arrest Engel ${ }^{\text {ss }}$, een zaak die onder andere betrekking had op een onderscheid tussen militairen van verschillende rang bij de uitvoering van disciplinaire straffen. Nadat het

\section{P. 34}

84. Zie voor de onderverdeling in toetsingsfasen hoofdstuk 2, paragraaf 3.1.2. In hoofdstuk 2 is ook ingegaan op verschillende manieren waarop inhoud kan worden gegeven aan deze eerste fase; zie daarvoor vooral paragraaf 4.4. Het is niet geheel duidelijk waarom het Hof in deze zaak geen aandacht aan de toetsing in de eerste fase besteedt. In uitspraken van de Europese Commissie voor de Rechten van de Mens, die onder de oude versie van het Verdrag bevoegd was om een inhoudelijke beoordeling van de zaak te geven alvorens deze aan het Hof werd voorgelegd en waarvan de oordelen vaak een belangrijke inspiratiebron voor het Hof vormden, is een toetsing in de eerste fase wel steeds terug te vinden; daarbij werd deze fase ingevuld door een vergelijkbaarheidstoets. Zie bijv. Grandrath, waarin de Commissie stelde dat "the notion of discrimination between individuals implies a comparison between two or more different groups or categories of individuals and the finding that one group is treated differently from - and less favourably than - another group or category" (Appl. 2299/64, Grandrath v. Austria, Yearbook of the European Convention on Human Rights 10 (1967), p. 694); vgl. Partsch 1993, p. 585. Een dergelijke vergelijkbaarheidstoets komt ook in de Belgische Taalzaak even aan de orde als het Hof de specifieke klachten behandelt. Bij de beoordeling van de eerste van de zes klachten over artikel 14 stelt het Hof namelijk dat "Article 14 does not prohibit distinctions in treatment which are founded on an objective assessment of essentially different factual circumstances [...]" (p. 44). Dit oordeel heeft echter geen invloed op de toetsingsmethodiek: het Hof behandelt de klacht op de manier waarop dit in het weergegeven citaat werd aangekondigd, dus aan de hand van doel en proportionaliteit.

85. EHRM 23 november 1976, Engel and Others, Series A, vol. 22 
Hof had vastgesteld dat er werd geklaagd over een onderscheid op grond van rang, gaf het hierover het volgende oordeel:

"The hierarchical structure inherent in armies entails differentiation according to rank. Corresponding to the various ranks are differing responsibilities which in their turn justify certain inequalities of treatment." ${ }^{\text {" } 6 ~}$

In deze overweging is er sprake van een soort fusie van de eerste en tweede fase van de toetsing, doordat de onvergelijkbaarheid van de gevallen als rechtvaardiging voor het onderscheid wordt aangemerkt. ${ }^{87}$ Pas in 1979, met het arrest Marckx ${ }^{88}$, aanvaardde het Hof dat de vergelijkbaarheid van de voorgelegde gevallen een voorwaarde vormt voor de toepassing van het beslissingsmodel. De vergelijkbaarheidstoets fungeerde daardoor niet meer als onderdeel van of als vervanging voor het rechtvaardigingsmodel, maar als toetsingscriterium in de eerste toetsingsfase:

"Article 14 safeguards individuals, placed in similar situations, from any discrimination in the enjoyment of the rights and freedoms set forth in the other provisions."

Uit de rechtspraak na Marckx blijkt dat het Hof de vergelijkbaarheidstoets beschouwt als een vast element van de toetsing in de eerste fase. Het toetsingsmodel van het Hof zoals ontwikkeld in de Belgische Taalzaak kan, met toevoeging van de eerste fase-toets van Marckx, dan ook als volgt worden weergegeven:"\%

86. $\$ 72$. In deze overweging wordt de afwezigheid van vergelijkbare gevallen duidelijk gezien als een rechtvaardiging voor een verschil in behandeling, niet als een toetsingsingang. Een vergelijkbare benadering is zichtbaar in een aantal andere arresten, zoals EHRM 12 december 1976, Handyside, Series A, vol. $24, \S \S 56$ en 66 en EHRM 18 januari 1978, Ireland $v$. UK, Series A, vol. 25, $\$ 228$. Zie verder het vlak na Engel gewezen arrest Kjeldsen, dat betrekking had op een onderscheid tussen godsdienstonderwijs en seksuele voorlichting. Het Hof stelde hierover: "[...] the Court finds that there is a difference between religious instruction and the sex education concerned in this case. Accordingly, the distinction objected to by the applicants is founded on dissimilar factual circumstances and is consistent with the requirements of Article 14" (EHRM 7 december 1976, Series A, vol. 23, § 56). In andere zaken ontbreekt de vergelijkbaarheidstoets en wordt er meteen een toetsing aan het rechtvaardigingsmodel van de Belgische Taalzaak uitgevoerd. Zie bijvoorbeeld EHRM 27 oktober 1975, National Union of Belgian Police, Series A, vol. 19, $\$$ 46-49, EHRM 6 februari 1976, Swedish Engine Driver's Union, Series A, Vol. 20, $\$ \$ 46-48$ en EHRM 6 februari 1976, Schmidt and Dahlström, Series A, vol. $21, \S 40$.

87. Vanuit bewijstechnisch oogpunt is deze fusie lastig, omdat juist een heldere scheiding van de eerste en tweede fase het mogelijk maakt om de bewijslast evenwichtig te verdelen. Aangenomen zou dan kunnen worden dat de verdedigende staat slechts argumenten ter rechtvaardiging hoeft aan te tonen wanneer de klager voldoende duidelijk heeft gemaakt dat daarvoor aanleiding bestaat. Bij een benadering als in Engel is het onduidelijk welke bewijsvereisten er voor de partijen gelden.

88. EHRM 13 juni 1979, Marckx, Series A, vol, 31

89. $\$ 32$; cursief toegevoegd. De beslissing om vergelijkbaarheid nu opeens als een bepalend element in de toetsing aan artikel 14 te beschouwen wordt overigens niet toegelicht; wel past de uitspraak in de in noot 86 genoemde jurisprudentie van het Hof, waarin groeiend belang wordt gehecht aan de vergelijkbaarheid.

90. Dit is vaste rechtspraak. Zie bijvoorbeeld EHRM 18 februari 1991, Fredin, Series A, vol. $192, \$ 60$, EHRM 23 juni 1993, Hoffmann, Series A, vol. 255-C, EHRM 22 oktober 1996, Stubbings, Reports 1996-IV, § 72, EHRM 23 oktober 1997, Building Societies, Reports 1997-VII, EHRM 29 april 1999, Chassagnou, 1999-III, §91, EHRM 21 december 1999, Salgueiro da Silva Mouta, EHRC 2000/16, § 26, EHRM 1 februari 2000, Mazurek, EHRC 2000/25, § 46, EHRM 6 april 2000, Thlimmenos, EHRC 2000/45, $\$ 19$, EHRM 11 januari 2001, P.M. v. Italy, nog niet gepubliceerd, $\$ 53$, EHRM 18 januari 2001, Chapman, nog niet gepubliceerd, \$129, EHRM 28 juni 2001, VGT Verein gegen Tierfabriken, EHRC 2001/55, § 86, EHRM 11 oktober 2001, Sahin, EHRC 2001/81, § 56 en EHRM 16 oktober 
1. Is er sprake van vergelijkbare gevallen?

Zo nee: het onderscheid is toelaatbaar;

Zo ja:

2. Heeft het onderscheid een objectieve en redelijke rechtvaardiging, d.w.z.

- Heeft het onderscheid een gerechtvaardigd doel?

- Is er sprake van een redelijke mate van evenredigheid tussen het gehanteerde middel en het nagestreefde doel?"

Uit deze weergave van het model blijkt dat het Hof het alleen noodzakelijk vindt om te bekijken of er een rechtvaardiging voor het onderscheid bestaat als blijkt dat de betrokken gevallen voldoende vergelijkbaar zijn. Is dit niet het geval, dan zal het Hof niet nader ingaan op de vraag of het onderscheid om andere redenen niet toch ongerechtvaardigd moet worden geacht, bijvoorbeeld omdat de ongelijke behandeling niet in een redelijke verhouding staat tot de tussen de gevallen bestaande verschillen., ${ }^{12}$ Komt het Hof daarentegen wél tot de conclusie dat de gevallen voldoende vergelijkbaar zijn, dan zal het steeds een toetsing van de hiervoor aangedragen rechtvaardiging uitvoeren.",

Het tweede onderdeel van het model bevat een tweetal criteria, die dienen als invulling van de rechtvaardigingstoets. Deze criteria hebben een cumulatief karakter: het onderscheid kan slechts gerechtvaardigd zijn als er zowel sprake is van een gerechtvaardigd doel als van een redelijke (in de terminologie van het Hof: proportionele) verhouding tussen doel en middel. ${ }^{94}$ Wanneer is vastgesteld dat er een gerechtvaardigd doel met het onderscheid wordt nagestreefd, dan betekent dit dus nog niet dat het onderscheid toelaatbaar is: om dit te kunnen beoordelen is ook een toetsing van de redelijkheid van het gekozen middel (het gemaakte onderscheid) noodzakelijk.

Het voorgaande lijkt duidelijk uit de weergegeven uitspraken voort te vloeien, maar uit de toetsingspraktijk van het Hof blijkt dat van een vanzelfsprekendheid zeker geen sprake is. Zo blijkt het geregeld voor te komen dat het Hof niet onderzoekt of voldaan

\section{1, Eliazer, EHRC 2001/82, \$40.}

91. Door sommige auteurs is het door het Hof in de Belgische Taalzaak ontwikkelde model anders geînterpreteerd. Zo stelt Heringa dat het vereiste van objectieve en redelijke rechtvaardiging een apart vereiste is naast de eisen van legitimiteit van het doel en proportionaliteit (Heringa 1998, p. 3.14-5; zo ook McKean 1995, p. 221). Gomien, Harris en Zwaak geven een nog andere interpretatie: zij stellen dat het onderscheid niet toelaatbaar is, als "the distinction does not have an aim, that is, it has no objective and reasonable justification having regard to the aim and effects of the measure under consideration" (1996, p. 350). De interpretatie waarin een objectieve en redelijke rechtvaardiging aanwezig wordt geacht als er een gerechtvaardigd doel is en als er sprake is van proportionaliteit komt echter het beste overeen met de rechtspraak van het Hof.

92. Zie voor een toepassing EHRM 18 december 1986, Johnston, Series A, vol. 112.

93. Deze benadering correspondeert met de in paragraaf 4.3 .1 van hoofdstuk 2 weergegeven derde benadering van de vergelijkbaarheidstoets. Zoals in hoofdstuk 2 is aangetoond is deze benadering vanuit een theoretisch oogpunt onwenselijk, nu hierdoor ongelijke behandelingen in stand kunnen blijven die duidelijk overbodig of disproportioneel belastend zijn. De rechtspraak van het Hof illustreert dat deze benadering ook in de praktijk tot problematische consequenties leidt; het is opmerkelijk dat het Hof hiervoor zo weinig oog heeft. In paragraaf 4.1.2 zal worden ingegaan op enkele voorbeelden die de onwenselijkheid van deze toets kunnen illustreren.

94. Zie voor een toepassing EHRM 23 oktober 1990, Darby, Series A, vol. 187, $\$ \S 33 / 34$. Vgl. ook Partsch 1993, p. 590 en Helfer 1990, p. 1067. 
is aan de proportionaliteitseis, terwijl het wel een legitiem doel aanwezig heeft geacht." ${ }^{\text {95 }}$ In andere gevallen besteedt het Hof zelfs in het geheel geen aandacht aan de aanwezigheid van een gerechtvaardigd doel en aan de verhouding tussen doel en middel, maar beoordeelt het slechts in zijn algemeenheid of er een objectieve rechtvaardiging voor het onderscheid bestaat. ${ }^{\% 6}$ Tenslotte blijft de functie van de vergelijkbaarheidstoets, ondanks de verduidelijking in het Marckx-arrest, onduidelijk: een beoordeling van de vergelijkbaarheid in de eerste fase van de toetsing, zoals volgens het model is vereist, blijft in veel gevallen achterwege ${ }^{n \text {, }}$, terwijl in andere gevallen van vergelijkbaarheidsargumenten gebruik wordt gemaakt bij de beoordeling van de rechtvaardiging"s.

Een typerend voorbeeld van het voorgaande is het arrest Spadea and Scalabrino. ${ }^{99}$ Dit arrest had betrekking op door de Italiaanse regering getroffen maatregelen waardoor het verhuurders onmogelijk werd gemaakt om hun huurders de huur op te zeggen. Volgens klagers leverden deze maatregelen een schending van artikel $14 \mathrm{op}$, omdat huurders werden beschermd ten nadele van verhuurders; bovendien trof de regeling

95. Zie bijvoorbeeld EHRM 21 februari 1986, James and others, Series A, vol. 98; zie vooral $\$ 77$ laatste zin, waarin een oordeel wordt gegeven over de klacht dat eigenaren van eigendom met een lagere waarde worden benadeeld. Het Hof geeft daarbij geen oordeel over het doel van de regeling, maar stelt zonder meer dat de regeling objectief en redelijk gerechtvaardigd is. Zie verder EHRM 22 mei 1986, Lithgow, Series A, vol. 102 ( $\$ 181$ : het Hof geeft aan dat door de regeling rekening kan worden gehouden met feitelijke verschillen tussen de gevallen en dat daardoor de verschillen bij de toepassing van deze regeling gerechtvaardigd worden; het Hof bekijkt echter niet of door de toepassing een disproportionele inbreuk op het recht van klager werd gemaakt) en EHRM 2 maart 1987, Monnell and Morris, Series A, vol. 115 ( $\$ \$ 73$ en 75: het Hof acht het doel gerechtvaardigd, maar besteedt geen aandacht aan het proportionaliteitselement).

96. In Kamasinski stelde het Hof: "in so far as any difference exists between defendants in civil actions and defendants to civil claims in criminal proceedings, the interests of the proper administration of justice provide an objective and reasonable justification [...]" (EHRM 19 december 1989, Series A, vol. $168, \S 93$; ook $\$ 100$ geeft een voorbeeld). Weliswaar kan uit de geciteerde overweging worden afgeleid dat het Hof van mening is dat een gerechtvaardigd doel en een voldoende mate van evenredigheid tussen doel en middel aanwezig zijn, maar er wordt niet expliciet aan deze elementen getoetst. Toch zou dit vanuit de noodzaak van een goede motivering wenselijk zijn. Hetzelfde geldt voor het arrest Moustaquim, waarin het Hof eveneens zonder nadere toetsing aan de verschillende elementen aangaf dat er een objectieve en redelijke rechtvaardiging aanwezig was (EHRM 18 februari 1991, Series A, vol. 193). Alleen wanneer het Hof voor de inhoudelijke rechtvaardiging terugverwijst naar de beoordeling onder het substantiële verdragsartikel kan deze korte motivering redelijk zijn; zie voor een voorbeeld van die benadering EHRM 18 januari 2001, Jane Smith, EHRC 2001/19, $\$ 138$.

97. Zie bijvoorbeeld EHRM 29 november 1991, Pine Valley Developments, Series A, vol. 222, $\$ 64$, EHRM 21 november 1994, The Holy Monasteries, Series A, vol. 301-A, § 92 en EHRM 29 april 1999, Chassagnou, Reports 1999-III, $\$ 92$. Ook in de vaste definitie van de criteria waaraan het Hof toetst ontbreekt de vergelijkbaarheidstoets af en toe, zonder dat de reden daarvoor duidelijk wordt; zie bijvoorbeeld EHRM 3 oktober 2000, Camp and Bourimi, EHRC 2000/82, $\S 13$. Opmerkelijk zijn ook de uitspraken waarin niet wordt nagegaan of de gevallen relevante verschillen vertonen, maar of de behandeling verschilt; zie bijvoorbeeld EHRM 23 juni 1993, Hoffmann, Series A, vol. 255-C, $\$ \$ 31-33$ en EHRM 21 december 1999, Salgueiro da Silva Mouta, EHRC 2000/16, \$ 26-28. Op enkele specifieke omstandigheden waarin de vergelijkbaarheidstoets consequent afwezig is zal worden ingegaan in paragraaf 2.2.2.

98. Zie bijvoorbeeld EHRM 29 februari 1988, Bouamar, Series A, vol. 129: "[...][A difference of treatment] stems from the protective - not punitive - nature of the procedure applicable to juveniles in Belgium. In the Court's view, there is accordingly an objective and reasonable justification for the difference in treatment" ( $\$ 67$, cursief toegevoegd). Een vergelijkbare benadering werd gevolgd in EHRM 18 februari 1991, Moustaquim, Series A, vol. 193, $\$ 49$.

99. EHRM 28 september 1995, Spadea and Scalabrino, Series A, vol. 315-B 
volgens hen ten onrechte alleen eigenaren van woonhuizen en niet van bijvoorbeeld kantoorpanden. Het Hof overwoog hierover het volgende:

"The Court points out in the first place that, according to its case-law, Article 14 will be breached where, without objective and reasonable justification, persons in 'relevantly' similar situations are treated differently. For a claim of violation of this Article to succeed, it has therefore to be established, inter alia, that the situation of the alleged victim can be considered similar to that of persons who have been better treated.

With regard to the first part of the complaint, the Court notes that it raises the question whether the emergency measures complained of were proportionate to their aim, a point already considered in connection with Article 1 of Protocol No. 1.

As for the difference in treatment vis-à-vis the owners of non-residential property, the Court considers that the distinction drawn between these two classes of persons for the purpose of enforcing evictions was objective and reasonable given the aim of the legislation and the use made of the properties, one category being let as housing and the other used mainly as commercial premises."

Het Hof geeft in deze overwegingen aan dat voor de verschillende klachten moet worden vastgesteld of aan het vereiste van vergelijkbaarheid is voldaan. Dit duidt op het gebruik van de vergelijkbaarheidstoets als toetsingsingang, hetgeen in overeenstemming is met het hiervoor beschreven model. Zowel bij de klacht met betrekking tot de noodmaatregelen als bij de klacht over de verschillende behandeling van particuliere en commerciële eigenaars ontbreekt een daadwerkelijke vaststelling van de vergelijkbaarheid echter volledig: in plaats daarvan gaat het Hof onmiddellijk over tot een inhoudelijke beoordeling van de aangedragen rechtvaardiging. ${ }^{101}$ Ten aanzien van het tweede onderdeel van de klacht oordeelt het Hof bovendien dat er geen strijd bestaat met artikel 14 , niet zozeer omdat niet is voldaan aan het vereiste van een gerechtvaardigd doel of aan dat van proportionaliteit, maar omdat de gevallen onvoldoende vergelijkbaar zijn. Anders dan volgens het model is vereist wordt de vergelijkbaarheidstoets hierbij dus niet als toetsingsingang, maar als rechtvaardigingstoets gehanteerd.

Ook de beoordeling van de eerste klacht vertoont onduidelijkheden: weliswaar voert het Hof hierbij een toetsing aan het rechtvaardigingsmodel uit, maar daarbij geeft het, zonder aandacht te besteden aan het doel van de regeling, meteen een beoordeling van de proportionaliteit. De werkwijze van het Hof bij de eerste klacht kan op zichzelf nog wel worden verklaard door het feit dat het Hof bij de toetsing aan artikel 1 Eerste Protocol reeds een vrij uitgebreide toetsing had uitgevoerd van het doel van de regeling, terwijl bij artikel 14 vrijwel dezelfde argumenten ter rechtvaardiging waren aangevoerd. Een werkelijke noodzaak om de doelstelling opnieuw te beoordelen ontbrak daardoor. Niettemin kan, wanneer naar de overwegingen als geheel wordt gekeken, worden opgemerkt dat de toetsing in dit arrest buitengewoon slordig is: het Hof houdt onvoldoende vast aan zijn zelfontwikkelde toetsingsmodel en gaat bovendien op een onduidelijke manier om met de vergelijkbaarheidstoets.

100. $\$ \S 45$ en 46 . Een vergelijkbare overweging is terug te vinden in EHRM 11 januari 2001, P.M. v. Italy, nog niet gepubliceerd, $\$ 54 / 55$.

101. Zie ook Van Dijk/Van Hoof 1997, p. 722 in noot 106. 
In de jurisprudentie van het Hof zijn diverse andere gevallen te vinden waarin de vergelijkbaarheidstoets (en daarmee de toetsing in de eerste fase) volledig ontbreekt, waarin toetsingselementen van het rechtvaardigingsmodel ten onrechte ontbreken of waarin een soort vermenging van de verschillende toetsingscriteria te zien is. ${ }^{102}$ Toch kan worden vastgesteld dat het Hof in een groot aantal gevallen blijkt vast te houden aan het hiervoor weergegeven model en zelfs vrij nauwkeurig nagaat of aan de verschillende vereisten is voldaan. Het is dan ook de moeite waard om uitgebreider in te gaan op de manier waarop het Hof omgaat met de toetsing aan de verschillende criteria, waarna nadere conclusies kunnen worden getrokken over de wenselijkheid of noodzakelijkheid van de toepassing van deze criteria. In de hiernavolgende paragrafen zal achtereenvolgens aandacht worden besteed aan de vergelijkbaarheidstoets (paragraaf 2.2), de toetsing van het doel (paragraaf 2.3) en de verhouding tussen doel en onderscheid (paragrafen 2.4-2.7). Tenslotte zal worden ingegaan op een criterium dat niet in het beslissingsmodel van het Hof voorkomt, maar waaraan het Hof in de praktijk soms wel blijkt te toetsen: het vereiste van een voldoende mate van fit (paragraaf 2.8). Deze paragraaf zal worden afgesloten met een korte tussenconclusie (paragraaf 2.9).

\subsection{Vergelijkbaarheid als toetsingsingang}

\subsection{Toetsingsmaatstaven bij de beoordeling van de vergelijkbaarheid}

Zoals in paragraaf 2.1 is opgemerkt heeft het Hof de vergelijkbaarheidstoets in de zaak Marckx ${ }^{103}$ voor het eerst expliciet als toetsingsingang aangewezen. Volgens dit arrest is een beoordeling van de rechtvaardiging voor een ongelijke behandeling slechts vereist als de betrokken personen of groepen van personen waartussen onderscheid wordt gemaakt zich in een gelijke ("analogous") of vergelijkbare ("similar") situatie bevinden. ${ }^{104}$ In Marckx werd echter geen aandacht besteed aan de wijze waarop aan deze vergelijkbaarheidstoets inhoud moet worden gegeven. ${ }^{105}$ Ook in latere rechtspraak heeft het Hof maar weinig bereidheid getoond om de nationale instanties meer aanknopingspunten te geven voor de wijze waarop zij in de eerste fase aan artikel 14 zouden moeten toetsen: de rechtspraak heeft steeds een bijzonder casuïstisch karakter.

Een typisch voorbeeld van de benadering van het Hof is het arrest Van der Mussele. ${ }^{106}$ De klager in deze zaak was een Belgische advocaat in opleiding. In die hoedanigheid moest hij veel pro deo-zaken behandelen, een activiteit waarvoor hij geen vergoeding ontving. Hij voelde zich hierdoor benadeeld, nu rechters die pro deo-zaken behandelen of tolken die in dergelijke zaken optreden wel degelijk voor hun inspanningen beloond worden. Bovendien was klager van mening dat hij door de verplichting om gratis rechtsbijstand te verlenen nadeliger werd behandeld dan bijvoorbeeld artsen, die wel

102. Aan deze arresten zal nader aandacht worden besteed waar het gaat om de toepassing van de vergelijkbaarheidsvraag en de toepassing van het toetsingsmodel voor de beoordeling van de rechtvaardiging.

103. EHRM 13 juni 1979 , Series A, vol. 31

104. Er lijkt overigens geen inhoudelijk verschil te bestaan tussen de termen "analogous" en "similar"; het Hof gebruikt ze door elkaar heen.

105. Verderop zal nader worden ingegaan op het weglaten van een inhoudelijke toepassing van de vergelijkbaarheidstoets bij bepaalde differentiatiecriteria.

106. EHRM 23 november 1983, Series A, vol. 70 
betaald worden voor het verlenen van hun diensten aan minvermogenden. Het Hof was echter van oordeel dat het gemaakte onderscheid niet in strijd was met artikel 14:

"Article 14 safeguards individuals, placed in analogous situations, from discrimination. Yet between the Bar and the various professions cited by the applicant, including even the judicial and parajudicial professions, there exist fundamental differences [...], namely differences as to legal status, conditions for entry to the profession, the nature of the functions involved, the manner of exercise of those functions, etc. The evidence before the Court does not disclose any similarity between the disparate situations in question: each one is characterised by a corpus of rights and obligations of which it would be artificial to isolate one specific aspect."

Hoewel het feitencomplex in deze zaak goede mogelijkheden bood voor het ontwikkelen van criteria voor de toetsing van vergelijkbaarheid, maakte het Hof daarvan nauwelijks gebruik: het stelde uitsluitend vast dat de door klager aangevoerde gevallen werden beheerst door een complex van rechten en verplichtingen dat op belangrijke punten verschilde van het geval van pro deo-advocaten. ${ }^{108}$ Een dergelijke benadering is problematisch, nu deze het in potentie mogelijk maakt om ieder geval van ongelijke behandeling met artikel 14 in overeenstemming te verklaren. Zoals in hoofdstuk 2 reeds werd aangegeven zullen er immers altijd bepaalde verschillen bestaan tussen de personen, gevallen of situaties die aan een rechter worden voorgelegd: wanneer gevallen niet in bepaalde opzichten verschillen gaat het feitelijk om één en hetzelfde geval. De vraag is dan ook niet zozeer of de voorgelegde gevallen verschillen vertonen, maar of deze verschillen voor het maken van onderscheid daadwerkelijk relevant zijn. Een dergelijke oordeel kan alleen worden gegeven wanneer de rechter duidelijk vaststelt welke verschillen het voor de vergelijking van belang acht en als hij voldoende motiveert waarin dit belang is gelegen. Het vaststellen van een vergelijkingsmaatstaf is daarbij noodzakelijk, waarbij geldt dat de keuze voor de maatstaf zelf voldoende gerechtvaardigd moet zijn. In het weergegeven citaat is een dergelijke, zorgvuldige vaststelling niet terug te vinden. Weliswaar noemt het Hof een aantal opzichten waarin de gevallen van elkaar verschillen, zoals verschillen in juridische status en in de toegang tot de genoemde beroepen, maar het geeft niet aan waarom deze punten relevant zijn voor de beoordeling van het onderscheid. ${ }^{109}$ Bovendien blijkt uit de uitspraak niet welke bron

107. $\$ 46$

108. Zie ook Harris/O'Boyle/Warbrick 1995, p. 474: zij stellen dat de motivering van het Hof te vluchtig is. Vooral de, in het citaat zelf overigens niet opgenomen, verwijzing van het Hof naar de beoordeling van het bewijs door de Commissie stelt weinig voor, nu de Commissie nauwelijks inhoudelijk aandacht had besteed aan dit bewijs.

109. Dit is een regelmatig terugkerend gebrek in de rechtspraak van het Hof. Zie bijvoorbeeld ook EHRM 18 februari 1991, Fredin, Series A, vol. 192. Het Hof werd in deze zaak gevraagd zich uit te spreken over de sluiting van een grindgroeve, die beweerdelijk was ingegeven door overwegingen van natuurbescherming. Fredin merkte op dat alleen zijn groeve was gesloten, hoewel andere groeves in vergelijkbare mate een aantasting van het milieu opleverden. Hierdoor zou een met artikel 14 onverenigbaar onderscheid zijn gemaakt. Het Hof gaf het volgende oordeel: "[...] the Court has to presume that the applicants' pit is the only one to have been closed [...]. However, this is not sufficient to support a finding that the applicants' situation can be considered similar to that of other ongoing businesses which have not been closed. The Court perceives no reason why it should assess the evidence otherwise than did the Commission and accordingly holds that no issue of discrimination contrary to Article 14 arises" (\$61). Het oordeel van de Commissie was echter zeer summier: zij stelde slechts vast dat uit een door 
het Hof voor de vaststelling van deze vergelijkingsmaatstaven heeft gehanteerd. Ook dat is problematisch: zoals in hoofdstuk 2 is aangegeven biedt juist het niet expliciteren van de bron van een vergelijkingsmaatstaf ruimte voor het invoegen van subjectieve en moeilijk controleerbare elementen.

Zoals is aangegeven kan het Van der Mussele-arrest niet als een uitzondering worden beschouwd. Ook in andere uitspraken van het Hof is de motivering bij de vaststelling van de vergelijkbaarheid uiterst summier: het Hof geeft regelmatig aan dat twee gevallen al of niet vergelijkbaar zijn, maar waarom dat zo is wordt zelden duidelijk. ${ }^{\text {1to }}$

klagers aangedragen rapport bleek dat klagers groeve de enige was waarvan de vergunning ingetrokken werd. Klager had volgens de Commissie onvoldoende bewijs geleverd van vergelijkbaarheid, zodat deze geacht moest worden te ontbreken (zie ECRM 6 november 1989, Fredin, Series B, vol. 182, $\$ \$ 75$ en 77). Een duidelijke vergelijkingsmaatstaf werd door de Commissie niet vastgesteld, zodat het Hof voor een goede beoordeling van de vergelijkbaarheid eigenlijk niet met het gegeven oordeel kon volstaan.

110. Zo volstond het Hof in Moustaquim, waarin het ging om ongelijke behandeling van Belgen en nietBelgen bij uitzetting wegens criminele activiteiten, met de enkele stelling, dat "in the instant case the applicant cannot be compared to Belgian juvenile delinquents" (EHRM 18 februari 1991, Series A, vol. 193, $\$ 49$ ). Ook in Observer and Guardian ontbrak een goede motivering. In deze zaak was een publicatieverbod in het geding van artikelen over een bepaalde rechtszaak. Klagers hadden beroep tegen dit verbod ingesteld, omdat zij vonden dat zij hierdoor ten onrechte nadeliger werden behandeld dan buitenlandse kranten: daaraan kon bij gebrek aan jurisdictie geen publicatieverbod worden opgelegd. Het Hof stelde: "If and in so far as foreign newspapers were subject to the same restrictions as Observer and Guardian, there was no difference of treatment. If and in so far as they were not, this was because they were not subject to the jurisdiction of the English courts and hence were not in a situation similar to that of Observer and Guardian" (EHRM 26 november 1991, Series A, vol. 216, § 73). Deze motivering schiet in het bijzonder tekort, nu klagers erkend hadden dat er geen jurisdictie was: dat was nu juist de reden om over het verbod te klagen. Ook het oordeel dat gevallen wél vergelijkbaar zijn wordt overigens meestal niet nader gemotiveerd; zie bijvoorbeeld EHRM 23 oktober 1990, Darby, Series $\mathrm{A}$, vol. 187, $\$ 32$.

In recentere rechtspraak is de motivering soms iets beter. Zo werd in het arrest Building Societies vrij veel aandacht besteed aan de feitelijke omstandigheden die aanleiding gaven tot het oordeel dat de klagers zich in een andere positie bevonden dan degene met wie zij zich vergeleken (EHRM 23 oktober 1997, Building Societies, Reports 1997-VII, § 89). Een betere motivering wordt soms ook bereikt doordat voor de beoordeling van de vergelijkingsmaatstaf wordt terugverwezen naar de beoordeling onder het substantięle verdragsartikel (zie bijvoorbeeld EHRM 16 oktober 2001, Eliazer, EHRC 2001/82, § 41). Van een bijzondere zorgvuldigheid getuigen verder EHRM 22 oktober 1996, Stubbings, Reports 1996-IV, § 73 en EHRM 18 februari 1999, Larkos, Reports 1999-1, § 30. Van een daadwerkelijke nieuwe lijn die door deze rechtspraak is ingezet is echter zeker geen sprake: ook in recente uitspraken wordt regelmatig zonder goede toelichting gesteld dat er geen sprake is van vergelijkbaarheid. Een voorbeeld is EHRM 28 juni 2001, VGT Verein gegen Tierfabriken, EHRC 2001/55. In geschil was een verbod op een reclamespotje tegen de bio-industrie dat verboden werd vanwege zijn politieke karakter; reclame door de vleesverwerkende industrie werd echter niet verboden. Het Hof stelde hierover, dat "[i]n the present case, the Court notes the decision of the Federal Court of $20 \mathrm{Au}$ gust 1997 according to which promotions of the meat industry were economic in nature in that they aimed at increasing the turnover, whereas the applicant association's commercial, exhorting reduced meat consumption, was directed against industrial animal production and related to animal protection. As a result, the applicant association and the meat industry cannot be considered to be "placed in comparable situations' as their commercials differed in their aims" ( $\$ \$ 87$ en 88 ). Het Hof stelde in dit arrest weliswaar vast dat er verschillen bestonden tussen de reclamespotjes wat betreft hun doelstellingen, maar het gaf niet aan waarom deze verschillen in het licht van de zaak relevant moesten worden geacht. Zie verder EHRM 29 april 1999, Chassagnou, Reports 1999-III, § 120 en EHRM 11 januari 2001, P.M. v. Italy, nog niet gepubliceerd, $\$ 54$. 
Evenmin is duidelijk welke eisen er precies worden gesteld aan het bewijs van vergelijkbaarheid. Hoewel het Hof verschillende keren heeft aangegeven dat er in een zaak onvoldoende bewijs door de klager is aangedragen om zijn beroep op het gelijkheidsbeginsel te ondersteunen, heeft het nooit precies aangegeven welk bewijs dan wél zou volstaan. ${ }^{\text {"I }}$

Een benadering zoals die van het Hof is vanuit het oogpunt van rechtszekerheid en de controleerbaarheid van de uitspraak niet wenselijk. Het zou dan ook goed zijn wanneer het Hof betere en specifiekere toetsingscriteria voor de toepassing van de vergelijkbaarheidstoets zou ontwikkelen. ${ }^{112}$ Op zijn minst mag worden verwacht dat het in iedere zaak duidelijk maakt welke vergelijkingsmaatstaf het hanteert en waarom het voor deze maatstaf heeft gekozen.

\subsubsection{Ontbreken van de vergelijkbaarheidstoets in specifieke gevallen}

\section{Inleiding}

Het Hof heeft niet alleen nauwelijks criteria ontwikkeld voor de beoordeling van de vergelijkbaarheid, het blijkt ook weinig consequent te zijn in de toepassing van de vergelijkbaarheidstoets. Hoewel de toets volgens vaste jurisprudentie van het Hof een belangrijk onderdeel van het toetsingsmodel zou moeten vormen, besteedt het in een relatief groot aantal zaken in het geheel geen aandacht aan dit toetsingselement. ${ }^{113}$ Bovendien komt het regelmatig voor dat het Hof de vergelijkbaarheidstoets weliswaar uitdrukkelijk noemt, maar hieraan vervolgens niet toetst. In dit soort gevallen stelt het Hof zonder nadere motivering vast dat er sprake is van vergelijkbare gevallen, waarna het meteen overgaat tot een beoordeling van de rechtvaardiging. Voor de beoordeling van de noodzaak en wenselijkheid van het vaststellen van de vergelijkbaarheid in de eerste fase van de toetsing is het interessant om na te gaan in welke gevallen deze toetsing achterwege wordt gelaten en om te bezien welke verklaring daarvoor kan worden gegeven.

\section{Veronderstellen van vergelijkbaarheid bij verdachte classificaties}

Volgens vaste rechtspraak van het Hof moeten onderscheidingen die zijn gebaseerd op bepaalde differentiatiecriteria, zoals nationaliteit of geslacht, als "verdacht" worden gekwalificeerd. Bij classificaties op dergelijke gronden voert het Hof een veel intensievere toetsing uit dan gebruikelijk en zal het een rechtvaardiging niet snel accepteren. ${ }^{114}$ Het is opmerkelijk dat het Hof bij dit soort classificaties vrijwel nooit expliciet aan-

111. Zie bijvoorbeeld het hiervoor al geciteerde arrest Fredin, EHRM 18 februari 1991, Series A, vol. 192, $\S 61$; vgl. ook EHRM 23 september 1982, Sporrong and Lönnroth, Series A, vol. 52, § 77.

112. Zie ook Kewenig 1972, p. 74 en Sundberg-Weitman 1980, p. 34. De laatste stelt dat het ook uit respect voor de soevereiniteit van de nationale staten wenselijk zou zijn als het Hof duidelijker zou maken aan de hand van welke criteria het te werk gaat bij het vaststellen van vergelijkbaarheid.

113. Ook in de vaste formulering van het toetsingsmodel, zoals die in vrijwel iedere uitspraak terugkomt, ontbreekt de vergelijkbaarheidstoets af en toe, zonder dat de reden daarvoor duidelijk wordt. Zie bijvoorbeeld EHRM 29 november 1991, Pine Valley Developments, Series A, vol, 222, §64 en EHRM 3 oktober 2000, Camp and Bourimi, EHRC 2000/82, \$13.

114. Op deze "verdachte" classificaties zal worden ingegaan in de paragraaf over toetsingsintensiteit (paragraaf 3), waarin ook aandacht zal worden besteed aan de vraag in welke gevallen het Hof een classificatie als verdacht bestempelt. 
dacht besteedt aan de vergelijkbaarheidstoets. In sommige uitspraken wordt deze toets wel genoemd, maar een inhoudelijk onderzoek naar de vergelijkbaarheid ontbreekt vrijwel steeds: in de meeste gevallen lijkt het Hof eenvoudigweg te veronderstellen dat de voorgelegde gevallen vergelijkbaar zijn. ${ }^{115}$ Hoewel het Hof zelf nooit een reden heeft gegeven voor deze veronderstelling van vergelijkbaarheid, kan hiervoor waarschijnlijk een verklaring worden gevonden in de aard van de differentiatiecriteria die in deze gevallen in het geding zijn. ${ }^{116}$ Zoals in paragraaf 3.3 nog nader zal blijken heeft het Hof slechts een aantal gronden als verdacht gekwalificeerd, namelijk nationaliteit, ${ }^{1{ }^{17}}$ wettige geboorte, ${ }^{118}$ godsdienst, ${ }^{119}$ geslacht ${ }^{120}$ en seksuele geaardheid ${ }^{121}$. Het betreft hier steeds persoonlijke kenmerken die (meestal) geen invloed hebben op iemands maatschappelijk functioneren en die voor het maken van onderscheid hoogst zelden relevant zullen zijn. ${ }^{122}$ Vanuit die achtergrond lijkt het niet onredelijk dat het Hof veronderstelt dat er

115. Verder blijkt de afwijkende benadering uit de wijze waarop het toetsingsmodel wordt geformuleerd. Hiervoor is aangegeven dat in de definitie van het bij artikel 14 toe te passen model normaal gesproken melding gemaakt wordt van het vereiste van vergelijkbaarheid. Bij verdachte classificaties ontbreekt dit vergelijkbaarheidselement, zoals blijkt uit het hierboven weergegeven citaat uit Abdulaziz. Zie bijvoorbeeld ook EHRM 11 oktober 2001, Sahin, EHRC 2001/81, $\$ 56$.

116. Kewenig heeft nog een andere verklaring gegeven: hij stelt dat als de grond waarop de gegeven ongelijke behandeling is gebaseerd uitdrukkelijk verboden wordt door een gelijkheidsbepaling, dit een sterke aanwijzing geeft voor de vergelijkbaarheid van de gevallen (1972, p. 75). Op het moment dat een regeling onderscheid op grond van geslacht uitdrukkelijk verbiedt, geeft dit in zijn visie dus een indicatie van de vergelijkbaarheid van man en vrouw. Voor het EVRM lijkt dit als verklaring echter minder zinvol, nu artikel 14 slechts een aantal voorbeelden geeft van verboden onderscheidingscriteria: aan de opgesomde gronden kan niet meer gewicht worden toegekend dan aan niet-opgesomde differentiatiecriteria. Dit wordt geillustreerd door het feit dat het Hof onderscheid op grond van seksuele geaardheid als verdacht heeft aangemerkt, terwijl deze grond niet uitdrukkelijk in artikel 14 is opgenomen (zie EHRM 21 december 1999, Salgueiro da Silva Mouta, EHRC 2000/16 en, hierna, paragraaf 3.3.3).

117. EHRM 16 september 1996, Gaygusuz, Reports 1996-IV

118. EHRM 13 juni 1979, Marckx, Series A, vol. 31 (nog niet met gebruik van de "very weighty reasons"formule, maar wel al met een duidelijk intensievere toetsing), EHRM 28 oktober 1986, Inze, Series A, vol. 126, EHRM I februari 2000, Mazurek, EHRC 2000/25, §49, EHRM 3 oktober 2000, Camp and Bourimi, EHRC 2000/82 en EHRM 11 oktober 2001, Sahin, EHRC 2001/81.

119. EHRM 23 juni 1993, Hoffmann, Series A, vol. 255-C en EHRM 21 december 1999, Salgueiro da Silva Mouta, EHRC 2000/16; hierin werd geen gebruik gemaakt van de "very weighty reasons"-formule, maar is, zoals verderop nog zal blijken, de toetsing wel erg streng. In beide arresten valt op dat het Hof weliswaar lijkt in te willen gaan op de vergelijkbaarheid ( $\$ 31$ resp. $\$ 28)$, maar de toetsing vooral neerkomt op een beoordeling van de vraag of er sprake is van een nadelige behandeling die is ingegeven door de godsdienst van klaagster resp. door klagers homoseksualiteit. Ook in het arrest Thlimmenos (EHRM 6 april 2000, EHRC 2000/45), dat eveneens betrekking had op onderscheid naar godsdienst, komt de vergelijkbaarheidsvraag niet terug. Het weglaten van een inhoudelijke toepassing van de vergelijkbaarheidstoets is in dit arrest des te opvallender, omdat het Hof geen very weighty reasons als rechtvaardiging vereiste. Bovendien was er sprake van materiéle ongelijkheid, een situatie waarin het Hof vereist dat de situaties "significantly different" zijn. Verwacht zou dan toch kunnen worden dat aan de vergelijkbaarheid op zijn minst enkele woorden zouden worden gewijd.

120. EHRM 28 mei 1985, Abdulaziz, Cabales and Balkandali, Series A, vol. 94, EHRM 24 juni 1993, Schuler-Zgraggen, Series A, vol. 263, EHRM 22 februari 1994, Burghartz, Series A, vol. 280-B, EHRM 18 juli 1994, Karlheinz Schmidt, Series A, vol. 291-B, EHRM 21 februari 1997, Van Raalte, Reports 1997-I en EHRM 27 maart 1998, Petrovic, Reports 1998-II.

121. EHRM 21 december 1999, Salgueiro da Silva Mouta, EHRC 2000/16

122. Overigens geeft dit geen goede verklaring voor de keuze om bepaalde gronden als verdacht te beschouwen en andere niet. Zo is ook transseksualiteit een persoonskenmerk dat het functioneren niet beïnvloedt, maar onderscheid op grond daarvan wordt door het Hof niet als verdacht aangemerkt (vgl. EHRM 30 juni 1998, Sheffield and Horsham, European Human Rights Reports 1998, 163). Het ken- 
bij onderscheid op een van deze gronden altijd sprake is van vergelijkbaarheid: van maatschappelijk relevante verschillen zal immers vrijwel nooit sprake zijn.

Soms kunnen de verschillen tussen de betrokken groepen, ook bij verdachte onderscheidingscriteria, echter wel degelijk relevant zijn. Zo kunnen bepaalde biologische verschillen, zoals zwangerschap, bij onderscheid op grond van geslacht soms tot gevolg hebben dat mannen en vrouwen onvergelijkbaar moeten worden geacht. Evenzeer kunnen de verschillen tussen bepaalde religies soms relevant zijn, bijvoorbeeld als het gaat om het stellen van gezondheidsvoorschriften voor de bereiding van voedsel. Juist in dit soort gevallen blijkt het Hof meer aandacht te besteden aan de vergelijkbaarheid. Illustratief in dit verband is het arrest Van Raalte. ${ }^{12}$ Deze uitspraak had betrekking op de verplichting tot betaling van bepaalde sociale zekerheidspremies in Nederland. Voor de betaling van premies onder de Algemene Kinderbijslagwet was een vrijstelling opgenomen voor ongehuwde, kinderloze vrouwen ouder dan 45 jaar: vanaf deze leeftijd is het voor vrouwen zeer onwaarschijnlijk dat zij nog kinderen krijgen, zodat de wetgever het niet redelijk achtte dat zij nog zouden moeten bijdragen aan de kosten van kinderbijslag. Voor kinderloze mannen gold een dergelijke uitzondering niet, nu zij tot op hoge leeftijd in staat zijn om kinderen te verwekken. Er was in dit geval dus sprake van een situatie waarin het verschil in geslacht redelijkerwijze relevant kon worden geacht. Het Hof ging in dit geval dan ook uitdrukkelijk in op de vergelijkbaarheid:
"At the time of the events complained of contributions under the general Child Care Benefits Act were levied from unmarried childless men aged 45 or over but not from unmarried childless women of the same age. This undoubtedly constitutes a 'difference in treatment' between persons in similar situations, based on gender. The factual difference between the two categories relied on by the Government, namely their respective biological possibilities to procreate, does not lead the Court to a different conclusion. It is precisely this difference which is at heart of the question whether the difference in treatment complained of can be justified." ${ }^{24}$

Ook de specifieke context van het onderscheid blijkt het Hof ertoe te kunnen bewegen om meer aandacht te besteden aan de vergelijkbaarheidstoets. Een voorbeeld daarvan is het arrest Gaygusuz ${ }^{125}$, dat betrekking had op onderscheid op grond van nationaliteit. Normaal gesproken voert het Hof bij deze grond een zeer marginale toetsing uit, nu het

merken van een onderscheiding als verdacht lijkt dan ook voornamelijk te zijn ingegeven door andere redenen, zoals het bestaan van een Europese consensus over de verdachtheid. Hierop zal in paragraaf 3 nader worden ingegaan (zie m.n. paragraaf 3.3.2).

123. EHRM 21 februari 1997, Reports 1997-1

124. $\$ 40$. Ook in Petrovic, een zaak die eveneens betrekking had op onderscheid op grond van geslacht, besteedde het Hof aandacht aan de vergelijkbaarheid. In deze zaak werd geklaagd over het feit dat alleen aan de vrouw een uitkering gedurende ouderschapsverlof kon worden toegekend. Omdat het Hof van mening was dat er biologisch bepaalde verschillen tussen man en vrouw zou kunnen bestaan als het gaat om de relatie met hun kinderen, achtte het het nodig om uitdrukkelijk in te gaan op de vraag of de ouders zich in een vergelijkbare situatie bevonden: "While aware of the differences which may exist between mother and father in their relationship with the child, the Court starts from the premise that so far as taking care of the child during this period is concerned, both parents are 'similarly placed"' (EHRM 27 maart 1998, Petrovic, Reports 1998-II, § 36).

125. EHRM 16 september 1996, Gaygusuz, Reports 1996-IV 
daarbij meestal gaat om zaken waarbij het immigratiebeleid in het geding is. ${ }^{126}$ In dergelijke gevallen komt de nationale autoriteiten een grote mate van beleidsvrijheid toe waarop het Hof geen inbreuk wil maken. In dit geval was de context echter een andere: het ging om een ongelijke behandeling bij de toepassing van een sociale zekerheidsregeling. Volgens deze regeling hadden Oostenrijkse werknemers recht op een bepaalde uitkering, terwijl buitenlandse werknemers dit recht niet toekwam. In deze context achtte het Hof nationaliteit een persoonlijk kenmerk dat geen invloed zou mogen hebben bij het vaststellen van regelgeving. Het onderscheid op deze grond werd dan ook als verdacht aangemerkt. Gezien de vaste rechtspraak zou het Hof er dan zonder meer van uit mogen gaan dat er sprake was van vergelijkbaarheid tussen Oostenrijkers en werknemers van een andere nationaliteit. Het Hof besteedde in deze zaak echter toch expliciet aandacht aan de vraag of er sprake was van een vergelijkbare situatie ${ }^{127}$, waarschijnlijk omdat dit tegen de achtergrond van de immigratiezaken, waarin nationaliteit wel een rol mag spelen, niet geheel vanzelfsprekend was.

Samenvattend kan worden gesteld dat het Hof er bij verdachte classificaties vrijwel steeds vanuit gaat dat de gevallen voldoende vergelijkbaar zijn. Alleen wanneer er reden bestaat voor twijfel, hetzij doordat het waarschijnlijk is dat er relevante verschillen tussen de gevallen of groepen bestaan, hetzij doordat de context van het onderscheid hierover onzekerheid creëert, besteedt het Hof expliciet aandacht aan de vergelijkbaarheid. ${ }^{128}$

\section{Andere gevallen waarin vergelijkbaarheid wordt verondersteld}

Zoals is aangegeven is het waarschijnlijk dat het achterwege laten van een expliciet oordeel over de vergelijkbaarheid bij verdachte classificaties is ingegeven door het specifieke karakter van de betrokken onderscheidingskenmerken. Ook in gevallen waarin het niet gaat om verdachte classificaties komt het echter regelmatig voor dat het Hof de vergelijkbaarheidstoets weglaat en meteen overgaat tot een beoordeling van de aangevoerde rechtvaardiging.

In een aantal gevallen kan deze weglating worden verklaard door het feit dat bij een beoordeling van de vergelijkbaarheid dezelfde argumenten en overwegingen een rol spelen als bij de toetsing aan het rechtvaardigingsmodel; het geven van een afzonderlijk oordeel over de vergelijkbaarheid is dan niet erg zinvol. Op deze wijze motiveerde

126. Zie nader paragraaf 3.2 .5 .

127. In $\S 46$ merkt het Hof op dat Gaygusuz legaal in Oostenrijk verbleef en daar ook werkte, waarbij hij premies voor de sociale verzekering betaalde in dezelfde mate en op dezelfde voet als Oostenrijkse werknemers. In $\S 48$ stelde het Hof dat verder niet was gebleken dat hij niet voldeed aan de eisen voor de toekenning van de uitkering in kwestie en dat "he was accordingly in a like situation to Austrian nationals as regards his entitlement thereto".

128. De rechtspraak van het Hof is ook in dit opzicht echter niet geheel consistent: soms gaat het Hof ook bij verdachte classificaties in op de vergelijkbaarheid, zonder dat daarvoor een duidelijke reden bestaat; zie bijvoorbeeld EHRM 1 februari 2000, Mazurek, EHRC 2000/25, \$ 44-47 (onderscheid op grond van onwettige geboorte). Uit het arrest Camp and Bourimi kan blijken dat Mazurek eerder gezien moet worden als een onverklaarbare uitzondering dan als een nieuwe hoofdregel: in dit arrest werd bij onderscheid op grond van wettige geboorte de vergelijkbaarheid, net als in eerdere rechtspraak, verondersteld (EHRM 3 oktober 2000, EHRC 2000/82, §14). 
het Hof het achterwege laten van een vergelijkbaarheidstoets bijvoorbeeld in het arrest Rasmussen: ${ }^{129}$

"The Government supported the conclusion of the minority of the Commission that husband and wife were not placed in analogous situations [...]. The Court does not consider that it has to resolve this issue, especially as the positions and interests referred to are also of relevance in determining whether the difference of treatment was justified. It will proceed on the assumption that the difference was made between persons placed in analogous situations." 130

In andere gevallen lijkt de verklaring voor het achterwege blijven van een expliciete vergelijkbaarheidstoets gelegen te zijn in overwegingen van proceseconomie. Een typisch voorbeeld is het oordeel van het Hof in het arrest Monnell and Morris. ${ }^{13}$ In deze zaak was een regeling van strafprocesrecht in het geding die bedoeld was om te voorkomen dat in zinloze gevallen hoger beroep werd ingesteld. Volgens de Engelse wetgeving werd de tijd die een gevangene gedurende de behandeling van zijn hoger beroep in voorlopige hechtenis had doorgebracht in beginsel afgetrokken van de uiteindelijk opgelegde gevangenisstraf. Volgens de regeling kon de hoger beroepsinstantie echter beslissen om de verstreken tijd niet te verrekenen als er onvoldoende reden bestond voor het instellen van het hoger beroep. De klagers waren van mening dat hierdoor een ongerechtvaardigd onderscheid ontstond tussen gedetineerde en niet-gedetineerde veroordeelden: voor niet-gedetineerden bleek geen vergelijkbare sanctie te bestaan. Volgens het door het Hof gehanteerde toetsingsmodel zou bij de beoordeling van dit onderscheid eerst een oordeel moeten worden uitgesproken over de vergelijkbaarheid; pas als zou blijken dat er sprake was van een vergelijkbare situatie zou gekeken kunnen worden naar de rechtvaardiging. In dit geval koos het Hof echter voor een andere benadering:

"[...] even assuming that the situation of Mr. Monnell and Mr. Morris was comparable to that of convicted persons at liberty - which the Government disputed -, the difference in treatment complained of had, in the Court's view, an objective and reasonable justification."132

De reden waarom het Hof een uitgebreide beoordeling van de vergelijkbaarheid achterwege liet is waarschijnlijk gelegen in het feit dat het in dit geval relatief eenvoudig was om vast te stellen dat het onderscheid gerechtvaardigd was; het vaststellen van vergelijkbaarheid had in dit geval wellicht een lastiger en omslachtiger onderzoek vereist.

In een derde groep van gevallen kan een verklaring voor het veronderstellen van vergelijkbaarheid worden gevonden in het feit dat het vaststellen van vergelijkbaarheid

129. EHRM 28 november 1984 , Series A, vol. 87

130. \$37. Opgemerkt moet worden dat het hier eigenlijk ging om onderscheid naar geslacht, een verdacht differentiatiecriterium, maar dat het Hof het onderscheid niet als zodanig kwalificeerde. De verdachtheid van het onderscheid oefende dus in ieder geval geen invloed uit op de beslissing om de vergelijkbaarheidstoets weg te laten.

131. EHRM 2 maart 1987, Monnell and Morris, Series A, vol. 115

132. $\$ 73$ 
een vergaand onderzoek zou vergen naar het nationale recht. ${ }^{133}$ Dit kan worden geîllustreerd aan de hand van het arrest Kamasinski. ${ }^{134}$ Naar Oostenrijks recht was het mogelijk om een civiele actie tot schadevergoeding in te voegen in een strafrechtelijke procedure. Klager was echter van mening dat hij hierdoor over minder goede processuele waarborgen beschikte dan het geval zou zijn als zijn schadevergoedingsactie door een civiele rechter zou worden behandeld. Het geven van een oordeel over de vergelijkbaarheid van de waarborgen bij schadevergoedingsacties voor de civiele rechter en bij vergelijkbare acties in een strafproces zou in dit geval een uitgebreid onderzoek naar het nationale recht hebben gevergd, terwijl het redelijk gemakkelijk bleek te zijn om een objectieve en redelijke rechtvaardiging voor het verschil te vinden. ${ }^{135}$ De keuze voor het achterwege laten van een uitdrukkelijke vergelijkbaarheidstoets lag in dit geval dan ook voor de hand.

In de hierboven genoemde gevallen veronderstelde het Hof weliswaar dat de betrokken gevallen vergelijkbaar waren, maar besteedde het in ieder geval nog impliciet aandacht aan de vergelijkbaarheidstoets. In de rechtspraak van het Hof zijn echter ook voorbeelden te vinden van uitspraken waarin volledig aan de vergelijkbaarheidstoets voorbij wordt gegaan. Dit gebeurde bijvoorbeeld in het in paragraaf 2.1 reeds besproken arrest Spadea and Scalabrino, ${ }^{136}$ waarin het Hof weliswaar stelde dat het nodig was om de vergelijkbaarheid van de voorgelegde gevallen te bepalen, maar dit vervolgens in het geheel niet bleek te doen. ${ }^{137}$ Ook in verschillende andere arresten ontbreekt een vaststelling van de vergelijkbaarheid. ${ }^{138}$ Hoewel het lastig is om hiervoor een verklaring te vinden, is het waarschijnlijk dat deze is gelegen in het gemak waarmee de aanwezigheid van een objectieve rechtvaardiging kan worden vastgesteld.

\subsubsection{De benadelingstoets als alternatief voor de vergelijkbaarheidstoets}

Uit de in paragraaf 2.2.2 en 2.2.3 besproken rechtspraak zou kunnen worden afgeleid dat het Hof alleen een expliciet oordeel over de vergelijkbaarheid geeft wanneer er

133. Het Hof heeft als supranationale rechter een subsidiaire functie: de verantwoordelijkheid om te beantwoorden aan de eisen die het EVRM stelt is allereerst gelegen bij de nationale overheid. Het Hof oefent hier weliswaar toezicht over uit, maar is daarbij gebonden aan bepaalde grenzen. Zie hierover Petzold 1993, p. 49 en 50. Op de subsidiaire rol van het Hof en de daaraan verbonden consequenties voor de intensiteit van de toetsing zal in paragraaf 3 nader worden ingegaan.

134. EHRM 19 december, Series A, vol. 168

135. Bovendien geldt dat het Hof de Staten in het algemeen nogal wat vrijheid geeft als het gaat om de keuze tussen middelen om te verzekeren dat het rechtssysteem in overeenstemming is met artikel 6. Het Hof zal in dit soort gevallen niet al te intensief toetsen en geen uitgebreid onderzoek naar de feiten en de specifieke procedurele regels uitvoeren. Hierdoor kan verklaard worden dat het Hof in dit geval niet beoordeelde of er sprake was van vergelijkbaarheid. Zie Schokkenbroek 1998, p. 32 en EHRM 12 februari 1985, Colozza, Series A, vol. 89, $\$ 30$ en EHRM 24 mei 1991, Quaranta, Series A, vol. 205, $\S$ 30.

136. EHRM 28 september 1995, Series A, vol. 315-B

137. $\$ 46$; idem in EHRM 11 januari 2000, P.M. v. Italy, nog niet gepubliceerd, $\$ \$ 53$ en 55 . Vgl. ook Van Dijk/Van Hoof 1997, p. 722, in noot 106.

138. Bijvoorbeeld EHRM 21 februari 1986, James and Others, Series A, vol. 98 (waarbij de vergelijkbaarheidstoets in ieder geval niet aan de orde kwam bij de twee laatste onderdelen van de drieledige klacht), EHRM 24 november 1986, Gillow, Series A, vol. 109 en EHRM 30 juli 1998, Sheffield and Horsham, 27 European Human Rights Reports 163 (1998). 
daadwerkelijk reden bestaat om aan de aanwezigheid hiervan te twijfelen of wanneer een dergelijk oordeel goed past in de motivering van de uitkomst die het Hof wil bereiken. In sommige gevallen, met name bij klachten over onderscheid op verdachte gronden, kan het achterwege blijven van een vergelijkbaarheidstoets echter problematische consequenties hebben voor de evenwichtigheid van de bewijslastverdeling. Het volledig ontbreken van een toetsing in de eerste fase heeft immers tot consequentie dat de staat bij iedere klacht over een onderscheid op een verdachte grond een overtuigende en zwaarwegende rechtvaardiging moet aanvoeren. Een dergelijke verplichting zou zelfs bestaan wanneer duidelijk is dat de belangen van de betrokken klager door de betrokken handeling of maatregel in het geheel niet werden aangetast. Om deze consequentie te vermijden kiest het Hof in veel gevallen van verdacht onderscheid dan ook voor een alternatieve toetsing in de eerste fase: de hoge bewijslast blijkt in het algemeen alleen aan de staat te worden opgelegd wanneer voldoende duidelijk is dat de klager daadwerkelijk is benadeeld en wanneer vaststaat dat deze benadeling ook echt berust op de beweerde verdachte grond. De vergelijkbaarheidstoets wordt in dit soort gevallen dus vervangen door een benadelingstoets. ${ }^{139}$

Een duidelijk voorbeeld van een toepassing van de benadelingstoets is het arrest Buckley. ${ }^{1+0} \mathrm{Klaagster}$, een zigeunerin, mocht volgens een wettelijke regeling geen woonwagen neerzetten op een stuk grond dat zij in eigendom had, maar alleen op speciaal door de overheid aangewezen terreinen. Volgens haar werd door deze regeling onderscheid gemaakt op grond van ras, een grond die zeker kan worden gezien als verdacht. In de praktijk bleek klaagster echter maar weinig nadeel te ondervinden van het feit dat zij handelde in strijd met de wettelijke regeling: in de periode dat haar woonwagen op haar stukje grond stond kreeg ze slechts twee kleine boetes en werd nooit gedreigd met verwijdering. Het Hof stelde dan ook het volgende:

"[...][I]t does not appear that the applicant was at any time penalised or subjected to any detrimental treatment for attempting to follow a traditional Gypsy lifestyle. In fact, it appears that the relevant national policy was aimed at enabling Gypsies to cater for their own needs."

Nu er geen sprake was van een duidelijke benadeling die was ingegeven door het ras van klaagster was het volgens het Hof niet nodig om na te gaan of er sprake was van een objectieve rechtvaardiging. In dit geval werd de benadelingstoets dan ook duidelijk gebruikt als toetsingsingang.

139. Het tweede vereiste komt naar voren in een tweetal arresten waarin een rechterlijke uitspraak over de toekenning van een kind aan één van de ouders in het geding was. In beide arresten werd door klagers gesteld dat de rechter bij zijn oordeel doorslaggevende betekenis had toegekend aan een verdacht differentiatiecriterium; voor het Hof was het noodzakelijk om na te gaan of deze grond daadwerkelijk bepalend was geweest. Zie EHRM 23 juni 1993, Hoffmann, Series A, vol. 255-C, $\$ 33$ en EHRM 21 december 1999, Salgueiro da Silva Mouta, EHRC 2000/16, $\$ 28$. Ook wanneer geklaagd wordt over materieel onderscheid op een verdachte grond wordt een nauwkeurig onderzoek uitgevoerd naar de benadeling en de grond waarop deze is gebaseerd; zie bijvoorbeeld EHRM 6 april 2000, Thlimmenos, EHRC 2000/45, $\$ \$ 16 / 17$.

140. EHRM 25 september 1996, Reports 1996-IV

141. $\$ 88$ 
Ook in verschillende andere arresten over verdachte classificaties heeft het Hof van de benadelingstoets gebruik gemaakt. ${ }^{142}$ Daarbij is het opvallend dat het nadeelsvereiste meestal vrij ruim lijkt te worden geïnterpreteerd. Er hoeft bijvoorbeeld geen aantoonbare schade aan de kant van de benadeelde partij te bestaan. ${ }^{143}$ Ook blijkt het Hof een benadeling te aanvaarden wanneer een bepaalde groep of persoon weliswaar niet direct wordt beperkt in het genot van een door het Verdrag beschermd recht, maar duidelijk is dat hij niet in aanmerking komt voor een voordelige behandeling die aan een andere groep of persoon is toegekend:

"The notion of discrimination within the meaning of Article 14 includes in general cases where a person or a group is treated, without proper justification, less favourably than another, even though the more favourable treatment is not called for by the Convention."144

142. Zie bijvoorbeeld EHRM 25 mei 1985, Abdulaziz, Cabales and Balkandali, Series A, vol. 94, $\$ 74$ (onderscheid op grond van geslacht), EHRM 28 oktober 1987, Inze, Series A, vol. 126, $\$ 39$ (onderscheid op grond van onwettige geboorte), EHRM 25 november 1994, Stjerna, Series A, vol. 299-B, § 51 (onderscheid op grond van onwettige geboorte), EHRM 24 februari 1995, McMichael, Series A, vol. 307-B, $\$ 96$ (onderscheiding op grond van wettig vaderschap; hierbij werd geen very weighty reasons-toets toegepast, maar het gaat duidelijk om een verdachte grond), EHRM 16 december 1997, $\mathrm{Ca}$ nea Catholic Church, Reports 1997-VII, $\$ 46$ (onderscheid op grond van religie; net als bij McMichael paste het Hof hierop geen very weighty reasons-toets toe, maar is het duidelijk dat het gaat om een grond die in andere zaken als verdacht is aangemerkt), EHRM 1 februari 2000, Mazurek, EHRC $2000 / 25, \S 45$ (onderscheid op grond van onwettige geboorte; overigens voerde het Hof in deze zaak ook nog een vergelijkbaarheidstoets uit), EHRM 6 april 2000, Thlimmenos, EHRC 2000/45, $\$ \$ 16 / 17$ (onderscheid op grond van religie; een uitgebreid onderzoek was in dit geval vooral nodig omdat er geklaagd werd over materieel onderscheid dat op deze grond was gebaseerd: formeel gezien was er sprake van een gelijke behandeling en dus niet van een duidelijke benadeling), EHRM 13 juli 2000, Elsholz, EHRC 2000/73, $\$ \$ 59-61$, EHRM 3 oktober 2000, Camp and Bourimi, EHRC 2000/82, $\$ 12$, EHRM 11 oktober 2001, Sahin, EHRC 2001/81, § 55 en EHRM 21 november 2001, Fogarty, EHRC 2002/4, $\S 42$ (waarin het Hof om volstrekt ontoereikende redenen geen benadeling aanwezig achtte: zie daarover mijn noot bij dit arrest in EHRC 2002/4). Overigens wordt lang niet in alle gevallen uitdrukkelijk op de benadeling ingegaan: vaak veronderstelt het Hof eenvoudigweg dat door de getroffen regeling sprake is van een benadeling van een kwetsbare groep (zie bijvoorbeeld EHRM 24 juni 1993, Schuler-Zgraggen, Series A, vol. 263 en EHRM 22 februari 1994, Burghartz, Series A, vol. 280-B). Opmerkelijk is verder dat het Hof een toetsing van de benadeling een enkele keer uitvoert buiten de context van verdachte classificaties, namelijk wanneer niet geheel duidelijk is of er daadwerkelijk sprake is van een ongelijke behandeling; zie bijvoorbeeld EHRM 2 maart 1987, Monnell and Morris, Series A, vol. $115, \S 75$. Ook daarbij is de motivering van de benadelingstoets minimaal; hoogstens blijkt hieruit dat de benadeling voldoende ernstig moet zijn. Illustratief is in dit verband het arrest Boyle \& Rice, dat betrekking had op een verschil in gevangenisregimes. Hoewel het Hof zich kon voorstellen dat het voor gevangenen moeilijk is om van een gevangenis met een vrij soepel regime overgeplaatst te worden naar een gevangenis met een strikt regime, was het van mening dat "[...] it [is] evident that in principle the difference in treatment complained of does not raise an arguable issue of discrimination under Article 14" (EHRM 27 april 1988, Series A, vol. 131, $\$ 86$ ).

143. Frowein/Peukert 1996, p. 447. Het Hof lijkt wel hoge eisen te stellen aan het bewijs dat de benadeling daadwerkelijk is terug te voeren op de verdachte grond van onderscheid. Zo vereiste het Hof in Velikova (EHRM 18 mei 2000, EHRC 2000/57), waarin geklaagd werd over onderscheid op grond van etnische afkomst, dat "beyond reasonable doubt" werd aangetoond dat de benadeling die klaagster ten deel was gevallen inderdaad was gebaseerd op haar etnische afkomst. Het Hof motiveerde dit oordeel verder niet, en gaf niet duidelijk aan waarom dergelijk bewijs in dit geval ontbrak. Verdere rechtspraak zal dan ook moeten worden afgewacht om te kunnen bepalen of dit bewijsvereiste van toepassing is bij alle vormen van benadeling op verdachte gronden.

144. EHRM 28 mei 1985, Abdulaziz, Cabales and Balkandali, Series A, vol. $94, \S 82$ 
Voor het overige heeft het Hof echter relatief weinig invulling gegeven aan het benadelingscriterium. Zo is het niet volledig duidelijk of ook een immateriële benadeling voldoende zou kunnen zijn voor het uitlokken van een inhoudelijke rechtvaardigingstoets en heeft het Hof nog niet aangegeven welke eisen er precies kunnen worden gesteld aan het bewijs van benadeling. Hoewel uit de rechtspraak dan ook zeker kan worden afgeleid dat de benadelingstoets een bruikbare en soms zelfs noodzakelijke invulling vormt voor de eerste toetsingsfase, kunnen hierin slechts weinig concrete aanknopingspunten of criteria worden gevonden die een zinvolle invulling geven aan het algemene toetsingsmodel.

\subsection{Toetsing van het doel}

\subsubsection{Vaststelling van het doel van het onderscheid}

Wanneer eenmaal is vastgesteld dat er sprake is van vergelijkbare gevallen (of wanneer een benadeling voldoende vaststaat) zal het Hof overgaan tot een beoordeling van de voor de ongelijke behandeling aangevoerde rechtvaardiging. Daarbij zal het Hof, volgens het in paragraaf 2.1 weergegeven model, allereerst moeten vaststellen of met het onderscheid een "legitimate aim" wordt nagestreefd. Het is daarbij van belang dat het Hof niet uitsluitend zou mogen kijken naar het doel zoals dat door de verdedigende staat naar voren is gebracht, maar soms ook moet nagaan of er nog andere doelstellingen aan het onderscheid ten grondslag lagen. Dit is noodzakelijk, nu het Hof in het algemeen zeer ruime doelstellingen als gerechtvaardigd blijkt te accepteren, zoals de bescherming van de belangen van het kind of de bescherming van de volksgezondheid. ${ }^{145}$ Voor een staat is het relatief gemakkelijk om met een beroep op dergelijke, volstrekt redelijke, doelstellingen te verhullen dat er tegelijkertijd nog andere, minder gemakkelijk te rechtvaardigen, overwegingen aan het onderscheid ten grondslag lagen. ${ }^{1+6}$ Een effectieve bescherming van de aangetaste individuele belangen kan een verdergaand onderzoek naar het bestaan van dit soort verhulde bedoelingen in dit soort gevallen rechtvaardigen.

In de eerste arresten waarin het Hof uitspraak deed over artikel 14 leek het inderdaad aandacht te besteden aan de vraag of er met het onderscheid, naast het gestelde doel,

145. Zie daarover nader paragraaf 2.3.2, waarin nader zal worden ingegaan op de gerechtvaardigdheid van het doel. Zie ook Sundberg-Weitman, die stelt dat uit het in het internationale recht geldende bona fidebeginsel voortvloeit dat alle doelstellingen gerechtvaardigd moeten zijn om onredelijk onderscheid uit te sluiten (1980, p. 50/51). Verder wijst zij op een ander probleem rondom de doelstellingen van het onderscheid, namelijk "killing two birds with the same stone". Daarvan is sprake als er meerdere doelstellingen op hetzelfde hiêrarchische niveau bestaan. Ter rechtvaardiging van een onderscheid is het volgens haar voldoende als tenminste een van deze doelstellingen gerechtvaardigd is en het onderscheid voldoende kan dragen (p. 52). Zie voor een beschrijving van deze problematiek nader hoofdstuk 2, paragraaf 3.2.3.

146. Vgl. Harris/O'Boyle/Warbrick 1995, p. 479. Dit probleem doet zich vooral voor bij de toetsing aan lid 2 van de artikelen 8-11: omdat het erg gemakkelijk is om een maatregel te rechtvaardigen onder een van de doelstellingen die in deze artikelen zijn opgesomd, stellen klagers regelmatig dat het gestelde doel niet het werkelijke doel van de maatregel was. Het Hof lijkt echter niet snel bereid te zijn om uitgebreid te onderzoeken of een dergelijke klacht gerechtvaardigd is. Zie Harris/O'Boyle/Warbrick 1995, p. 290 en 344. 
ook nog een ander, niet uitgesproken, doel werd nagestreefd. ${ }^{147}$ Een daarbij veel gehanteerde formulering is te vinden in het arrest National Union of Belgian Police. ${ }^{148}$ In deze zaak klaagde een kleine vakbond over het feit dat zij niet bij een CAO-overleg met de Belgische overheid betrokken werd: alleen de grotere vakbonden waren voor dit overleg uitgenodigd. De regering stelde dat het gemaakte onderscheid voortkwam uit de wens om alleen voldoende representatieve vakbonden te laten onderhandelen en daardoor "vakbondsanarchie" te voorkomen. Het Hof oordeelde hierover het volgende:

"The Government has urged, that it wished to avoid 'trade union anarchy' [...]. This is a legitimate aim in itself and the Court has no reason to think that the Government had other and ill-intentioned designs."149

Uit deze overweging kan blijken dat het Hof zich realiseert dat de gestelde bedoeling van het onderscheid niet altijd de werkelijke bedoeling is, maar ook dat het Hof niet snel bereid is om actief naar die werkelijke bedoeling op zoek te gaan. Dit is jammer, nu de "voorkoming van vakbondsanarchie" een wel zeer vage doelstelling is, die andere doelstellingen goed kan verhullen. De beperking van het aantal in het CAO-overleg deelnemende kleinere vakbonden zou bijvoorbeeld ook kunnen zijn ingegeven door de wens een voordeel in onderhandelingspositie te creëren, bijvoorbeeld omdat bij de regering bekend was dat juist kleinere vakbonden bijzonder actief en hardnekkig zijn in het vertegenwoordigen van de belangen van hun achterban. Een dergelijke doelstelling is als rechtvaardiging voor een inbreuk op de verenigingsvrijheid en het recht op gelijke behandeling veel minder gemakkelijk te rechtvaardigen dan het door de overheid in dit geval aangevoerde doel. ${ }^{150}$

Opmerkelijk is dat het Hof na $1976^{151}$ nog slechts in zeldzame gevallen gebruik heeft gemaakt van de formule van National Union of Belgian Police en bijzonder weinig interesse toont voor de mogelijkheid van een discrepantie tussen de gestelde en de werkelijke bedoeling van een onderscheid..$^{152}$ Alleen wanneer klagers de door de staat

147. Dit geldt niet voor de Belgische Taalzaak, waarin geklaagd werd over Belgische wetgeving die ervoor zorgde dat in Vlaamse regio's alleen nederlandstalige scholen konden bestaan en in Waalse regio's alleen franstalige. De regering stelde dat het de bedoeling was "to exercise 'the grave national crises' caused by 'Flemish seperatism' and Flemish and Walloon seperatism, to rehabilitate 'Flemish language and Flemish culture by developing an intelligentsia with a good knowledge of Dutch', able to play a formative role and, in a more general sense, to give the country a stable structure based mainly on two large homogeneous regions and a bilingual capital." Het Hof accepteerde deze doelstellingen zonder meer als werkelijke bedoeling, terwijl de klagers hadden gesteld, dat "the present purpose of the legislation consists in 'assimilating part of the population by compulsion' and especially in 'liquidating the French-speaking minorities' in Flanders by obliging their members to become 'flemicised' or to 'move away"'."

148. EHRM 27 oktober 1975, National Union of Belgian Police, Series A, vol. 19

149. \$48. Een vrijwel identieke formulering komt voor in EHRM 6 februari 1976, Swedish Engine Drivers Union, Series A, vol. $20, \S 46$ (waarbij het Hof overigens een iets uitgebreidere motivering gaf dan in NUBP) en in EHRM 6 februari 1976, Schmidt and Dahlström, Series A, vol. 21, $\$ 40$.

150. Vgl. Sundberg-Weitman 1980 , p. 40.

151. EHRM 6 februari 1976, Schmidt and Dahlström, Series A, vol. 21

152. Voorbeelden waarin het Hof deze formule wel nog hanteerde zijn EHRM 24 november 1986, Gillow, Series A, vol. 109, waarin het Hof bij de toetsing aan artikel 8 lid 2 over het doel oordeelde dat het gerechtvaardigd was en vervolgens stelde: "The Court does not find it to be established that the legislation pursued any other purpose" (\$54) en EHRM 27 april 2000, L.Finland, nog niet gepubliceerd, 
aangevoerde bedoeling uitdrukkelijk betwisten blijkt het Hof soms bereid te zijn om nadere aandacht te besteden aan de vaststelling van het doel. Een voorbeeld hiervan is het arrest James. ${ }^{153}$ De klachten in deze zaak vloeiden voort uit een Engelse regeling met betrekking tot zogenaamde "long leases". Het ging daarbij om een soort pachtregeling voor lange termijn, waarbij de pachter alle kosten van onderhoud en reparaties moest betalen. Aan het einde van de pachttermijn kwamen alle gebouwen, inclusief verbeteringen en reparaties, toe aan de verpachter. De regering wilde deze voor pachters bijzonder nadelige situatie opheffen: volgens een nieuwe regeling zou de pachter met een "long lease"-contract het eigendom aan het einde van de pachttermijn tegen de grondwaarde kunnen overnemen. De verpachters van eigendommen met een "long lease"-overeenkomst voelden zich door deze nieuwe regeling ernstig benadeeld en stelden dat hun door artikel 1 Eerste Protocol beschermde eigendomsrecht hierdoor werd aangetast. $\mathrm{Zij}$ voerden in hun klacht onder andere aan dat de door de regering naar voren gebrachte motieven voor het treffen van de regeling daarvoor niet de werkelijke reden vormden: de regeling zou vooral door politiek gewin zijn ingegeven. Het Hof ging op deze stelling uitdrukkelijk in:

"The applicants suggested, that the 1967 Act was in reality motivated by purely political considerations. The Court notes, however, that leasehold reform in England and Wales has been a matter of public concern for almost a century and that, when the 1967 Act was passed, enfranchisement was accepted as a principle by all the major political parties. The Court does not find that such political considerations as may have influenced the political process, socio-economic legislation being bound to reflect political attitudes to a greater or lesser degree, precluded the objective pursued by the 1967 Act from being a legitimate one 'in the public interest'. Similar reasoning applies to the applicants' claim that the amendment introduced by the Conservative Government in 1974 was 'born of political expedience alone'."154

Uit deze overweging kan worden afgeleid dat het Hof bereid is om aandacht te besteden aan de "werkelijke" bedoeling van het onderscheid, wanneer de klagers voldoende aannemelijk hebben gemaakt dat het onderscheid een ander doel dient dan door de staat gesteld is. ${ }^{155}$ Dit lijkt geen onredelijke benadering te zijn: zelfs als het Hof al voldoende middelen zou hebben om steeds uit eigen beweging op zoek zou te gaan naar eventuele

waarin het Hof stelde, dat "[t]here is nothing to suggest that it was applied for any other purpose in the present case" (\$108); idem in EHRM 27 april 2000, K. and T./Finland, EHRC 2000/49, $\$ 134$. Vgl. Zwart 1999, p. 340.

153. EHRM 21 februari 1986, James and Others, Series A, vol. 98

154. $\S 48$. Naar deze beoordeling van het doel van de regeling verwees het Hof verderop in zijn uitspraak uitdrukkelijk terug, waar het ging om de gerechtvaardigdheid van een onderscheid dat de regeling maakte tussen eigenaars van huizen die onderworpen waren aan een "long lease"-contract en eigenaars van andere woningen. Het Hof stelde over het doel van dit onderscheid in $\S 76$, dat "[t]he aim pursued by the legislation had been held by the Court to be a legitimate one in the public interest". Dit betekent dat niet alleen het oordeel over het gestelde doel van overeenkomstige toepassing is bij de beoordeling van art. 14, maar ook het oordeel over het "werkelijk doel".

155. Dit wordt ondersteund door een arrest van het Hof dat betrekking heeft op artikel 8 EVRM, namelijk B. v. UK. Het Hof stelde in dit arrest, dat: "[there is no] evidence that the measures taken were not designed to achieve a legitimate purpose, namely the protection of health or of the rights and freedoms of others" (EHRM 26 mei 1987, Series A, vol. 121-B, § 62). Uit deze overweging blijkt dat de bewijslast voor het aantonen van een andere bedoeling dan de gestelde bij de klagers rust. 
verborgen bedoelingen, dan zou het hierdoor de omvang van zijn rechterlijke taak al snel te buiten gaan. ${ }^{156}$ Ook is een dergelijke actieve benadering moeilijk te verenigen met de subsidiaire functie van het Hof: het Hof is een internationale instelling en zal daarom enige terughoudendheid moeten betrachten als het gaat om de beoordeling van nationale maatregelen. ${ }^{157}$ Niettemin zou het, vanuit het oogpunt van een goede individuele rechtsbescherming, wenselijk zijn als het Hof zich, zeker bij een intensievere toetsing, actiever zou tonen, wanneer door de verwerende staat alleen een zeer abstract doel is aangegeven, zoals het "belang van een goede rechtsbedeling"15s of "het voorkomen van administratieve lasten"15\% ${ }^{160}$

\subsubsection{Gerechtvaardigdheid van het nagestreefde doel}

\section{Algemene vereisten voor toetsing van het doel}

Eerder is aangegeven dat het Hof een ongelijke behandeling van vergelijkbare gevallen slechts toelaatbaar acht, wanneer hiermee een "legitimate aim" wordt nagestreefd. In artikel 14 zijn, anders dan bij een aantal substantiële bepalingen van het EVRM het geval is (met name de artikelen 8-11 EVRM), geen nadere aanwijzingen te vinden voor de beantwoording van de vraag wanneer er van een dergelijk "legitimate aim" sprake is. ${ }^{161}$ Het aantal mogelijke gerechtvaardigde doelstellingen is daardoor vrijwel onbeperkt, waardoor het Hof veel ruimte heeft om zelf criteria vast te stellen voor de beoordeling van de aangevoerde doelstellingen.

Van deze ruimte heeft het Hof nauwelijks op een goede manier gebruik gemaakt. Alleen in de Belgische taalzaak $k^{162}$ heeft het een algemeen bruikbaar criterium voor toetsing vastgesteld, door aan te geven dat bij de beoordeling van de gerechtvaardigdheid

156. Vgl. Kewenig 1972, p. 106.

157. Zie over deze redenen voor terughoudendheid nader paragraaf 3.

158. EHRM 19 december 1989, Kamasinski, Series A, vol. $168, \S 93$

159. EHRM 21 februari 1986, James and Others, Series A, vol. $98, \S 68$

160. Vgl. Helfer 1990 , p. 1066.

161. Dit betekent echter niet dat artikel 14 veel meer ruimte laat dan bepalingen als de artikelen 8-11: de daarin opgesomde doelcriteria zijn zo ruim geformuleerd dat vrijwel alle mogelijke doelstellingen daar wel onder zijn te brengen. Zie Loucaides 1995, p. 189 en Harris/O'Boyle/Warbrick 1995, p. 290. Velaers wijst erop dat de ruime formulering kan zijn ingegeven door de bewuste keuze van de opstellers van het Verdrag om alleen die rechtsgoederen als doelstelling op te nemen die inderdaad door de uitoefening van een grondrecht in het gedrang kunnen worden gebracht (1991, p. 347). Vgl. verder Schokkenbroek 1996, p. 184, die erop wijst dat het vereiste van een legitiem doel niet snel een doorslaggevend element zal zijn bij de beoordeling van de rechtvaardiging: het Hof benadert de toets nogal pragmatisch, duidt het doelcriterium losjes aan en doet dit meestal zonder nadere argumentatie. Volgens hem is de belangrijkste functie van de doeltoets vooral om een richtpunt te geven voor de toetsing van de proportionaliteit. De motivering bij de toetsing aan de substantielle verdragsartikelen is in het algemeen zorgvuldiger en uitgebreider dan bij de toetsing aan artikel 14, iets dat overigens lijkt te gelden voor de gehele rechtvaardigingstoets. Een goed voorbeeld van de betere toetsing bij substantiěle verdragsbepalingen is Gillow, waarin het doel weliswaar gerechtvaardigd werd geacht, maar een vrij uitgebreide motivering werd gegeven voor dit oordeel (EHRM 24 november 1986, Series A, vol. 109). De toetsing van het doel is met name uitgebreid en zorgvuldig als het niet gaat om toetsing aan de artikelen 8-11, maar aan artikel I Eerste Protocol. Zie met name James (EHRM 21 februari 1986, Series A, vol. 98, $\$ \$ 47-49$ ) en Building Societies (EHRM 23 oktober 1997, Reports 1997-VII, § 81).

161. EHRM 23 juli 1968, Belgische Taalzaak, Series A, vol. 6

162. EHRM 23 juli 1968, Belgische Taalzaak, Series A, vol. 6 
van een ongelijke behandeling moet worden gekeken naar de beginselen die normaal gesproken in een democratische samenleving gelden. ${ }^{163}$ Dit vereiste is echter bijzonder abstract: om een zinvol aanknopingspunt voor toetsing te kunnen bieden zou dit eerst preciezer en vooral concreter moeten worden uitgewerkt. Een dergelijke uitwerking in algemene en praktisch hanteerbare toetsingscriteria ontbreekt echter. In plaats daarvan beoordeelt het Hof voor iedere zaak afzonderlijk of er een gerechtvaardigd doel aanwezig is. Opvallend is daarbij dat het Hof vrijwel iedere doelstelling gerechtvaardigd acht en ook een beroep op zeer algemene doelstellingen en beweegredenen accepteert: er lijken geen bijzondere eisen te worden gesteld aan de specificiteit van het doel. ${ }^{164}$ Dit kan geïllustreerd worden aan de hand van een - zeker niet volledig - overzicht van doelstellingen die door het Hof als gerechtvaardigd zijn aanvaard:

- voorkoming van "trade union anarchy"; ${ }^{\circ}$

- voorkoming van een excessief groot aantal onderhandelingspartners bij caoonderhandelingen om daardoor gemakkelijker tot een concreet onderhandelingsresultaat te komen; ${ }^{166}$

- het bewaren van discipline in het leger; ${ }^{167}$

- mensen die op een bepaalde plaats geboren zijn hebben daarmee een speciale band, zodat er sterke sociale redenen zijn om hen met voorkeur te behandelen boven mensen die op die plaats niet geboren zijn; ${ }^{168}$

- het wegnemen van sociale onrechtvaardigheid; ${ }^{169}$

- voorkoming van onzekerheid, gerechtelijke procedures, hoge kosten en vertraging; ;70

- beperking van de tijd die wordt besteed aan de behandeling van zinloze beroepen; ${ }^{171}$

- belangen van een goede rechtsbedeling; ${ }^{172}$

- het behoren van de verdedigende staat tot de EU en daarmee tot een bijzondere rechtsorde; ${ }^{13}$

- voorkomen van sociale spanningen en ordeverstoringen; ${ }^{174}$

163. Zie ook Robertson/Merrills 1993, p. 181; dit aanknopingspunt lijkt bovendien beter geschikt om de toetsingsintensiteit te bepalen dan om de rechtvaardigheid van een doelstelling vast te stellen. Zie daarover paragraaf 3 .

164. Er is eigenlijk maar één geval waarin het Hof geen rechtvaardiging aanwezig achtte, terwijl er geen sprake was van een verdachte classificatie. Het ging daarbij om een zaak waarin de regering voor het Hof in het geheel geen rechtvaardiging naar voren had gebracht, zodat dit oordeel ook wel evident was (EHRM 23 oktober 1990, Darby, Series A, vol. 187, $\$ 33$ en 34).

165. EHRM 27 oktober 1975, National Union of Belgian Police, Series A, vol. 19, $\$ 48$

166. EHRM 6 februari 1976, Swedish Engine Drivers' Union, Series A, vol. 20, $\$ 46$

167. EHRM 23 november 1976, Engel and Others, Series A, vol. 22, $\$ 72$

168. EHRM 25 mei 1985, Abdulaziz, Cabalez and Balkandali, Series A, vol. 94, \$88 en EHRM 24 november 1986, Gillow, Series A, vol. 109, $§ 54$

169. EHRM 21 februari 1986, James and Others, Series A, vol. $98, \S 47$

170. EHRM 21 februari 1986, James and Others, Series A, vol. $98, \S 68$

171. EHRM 2 maart 1987, Monnell and Morris, Series A, vol. $115, \$ 73$

172. EHRM 19 december 1989 , Kamasinski, Series A, vol. $168, \S 93$

173. EHRM 18 februari 1991, Moustaquim, Series A, vol. 193, $\$ 49$ en EHRM 7 augustus 1996, C. $v$. Belgium, Reports 1996-III, $\$ 38$

174. EHRM 28 september 1995, Spadea and Scalabrino, Series A, vol. 315-B, §31 
- waarborgen van rechtszekerheid; ${ }^{175}$

- bescherming van de belangen en de gezondheid van een kind. ${ }^{176}$

Deze voorbeelden maken duidelijk dat de rechtvaardiging meestal is gelegen in het nastreven van algemene en abstracte belangen. ${ }^{177}$

\section{Toetsing van het doel bij verdachte classificaties; de "very weighty reasons"-test}

Uit deze terughoudende toetsing van het doel kan echter niet worden afgeleid dat artikel 14 een tandeloze bepaling is, zoals in de literatuur op sommige plaatsen wel is beweerd. ${ }^{178}$ Met name als het gaat om verdachte classificaties blijkt het Hof aanzienlijk strengere eisen te stellen: in dat geval is zelfs vereist dat ter rechtvaardiging van het onderscheid "very weighty reasons" worden aangedragen..$^{179}$ De betekenis van dit vereiste heeft echter niet zozeer betrekking op de redelijkheid van het doel als zodanig, als wel op het gewicht ervan: in veel gevallen acht het Hof het doel dat met een verdachte classificatie wordt nagestreefd op zichzelf wel gerechtvaardigd, maar geeft het aan dat dit niet zwaarwegend genoeg is om de verdachte classificatie te kunnen rechtvaardigen. Een voorbeeld is het al eerder genoemde arrest Abdulaziz. ${ }^{180}$ Dit arrest had betrekking op een Engelse regeling (de "1980 Rules"), op grond waarvan het voor een in Engeland gevestigde buitenlandse man gemakkelijker was om toestemming te krijgen voor gezinshereniging dan voor een in dezelfde situatie verkerende vrouw. Volgens de regering was deze maatregel bedoeld om de arbeidsmarkt te beschermen: statistisch gezien zochten mannen vaker naar werk dan vrouwen, zodat er door gezinshereniging met geïmmigreerde vrouwen een grote toevloed van mannelijke werkzoekenden zou ontstaan. Het Hof merkte hierover het volgende op:

"Whilst the $[\ldots]$ aim was without doubt legitimate, this does not in itself establish the legitimacy of the difference made in the 1980 Rules [...]. [T] he Court is not convinced that the difference that may exist between the restrictive impact of men and of women on the domestic labour market is sufficiently important to justify the difference of treatment, complained of by the applicants, as to the possibility for a person settled in the United Kingdom, as the case may be, his wife or her husband." ${ }^{81}$

175. EHRM 22 oktober 1996, Stubbings and Others, Reports 1996-IV, $\$ 51$

176. EHRM 21 december 1999, Salgueiro da Silva Mouta, EHRC 2000/16, $\$ 30$

177. Vgl. Van Dijk/Van Hoof 1997, p. 726 en Partsch 1993, p. 588 en 589.

178. Kewenig 1996, p. 106

179. Zie ook Helfer 1990, p. 1067 en Van Dijk/Van Hoof 1997, p. 727. Er zijn overigens ook voorbeelden van arresten te vinden waarin er weliswaar sprake was van een verdachte classificatie, maar waarin het doel toch gerechtvaardigd werd geacht. Dit was het geval in McMichael (EHRM 24 februari 1995, Series A, vol. 307-B) (waarin dit kan worden verklaard vanuit de specifieke omstandigheden van het geval, waarin het belang van het kind inderdaad zwaarwegend was) en in Petrovic (EHRM 27 maart 1998, Reports 1998-II). Op dit laatste arrest zal verderop nader worden ingegaan, nu daarin de margin of appreciation-doctrine op een wat merkwaardige manier werd toegepast. Daarin kan een verklaring worden gevonden voor het feit dat de toetsing van het doel minder uitgebreid was.

180. EHRM 28 mei 1985, Series A, vol. 94

181. $\$ \$ 78$ en 79. Een ander voorbeeld is het arrest Hoffmann, waarin het Hof eveneens stelde dat het doel (bescherming van de belangen en de gezondheid van het kind), op zichzelf legitiem was, maar zelfs een dergelijk legitiem doel een uitsluitend op godsdienst gebaseerd onderscheid niet kan dragen (EHRM 23 juni 1993, Series A, vol. 255-C, \$§ 34 en 36); idem in EHRM 21 december 1999, Salgueiro da Silva Mouta, EHRC 2000/16, $\$ 30$ en 36. Vgl. ook Partsch 1995, p. 1054. 
Deze overweging impliceert dat het Hof in het kader van de toetsing van het doel een soort proportionaliteitstoets uitvoert. Van belang is immers niet zozeer of het doel als zodanig gerechtvaardigd is, maar vooral of het voldoende zwaarwegend is in verhouding tot de door de classificatie aangetaste belangen. Op deze benadering zal nader worden ingegaan bij de bespreking van de proportionaliteitstoets in paragraaf 2.4.

Verder hanteert het Hof bij verdachte classificaties dezelfde sterk casuïstische benadering als bij "gewone" classificaties, zodat het ook hier lastig is om een antwoord te vinden op de vraag in welke omstandigheden het Hof een doelstelling nu precies gerechtvaardigd acht. In het arrest Inze heeft het Hof echter toch een drietal criteria neergelegd die voor een meer algemene toepassing vatbaar zijn. ${ }^{182}$ Deze zaak had betrekking op een aantal Oostenrijkse regels over de vererving van boerderijen en landerijen. Om opdeling en versnippering van het grondgebied van een boerderij te voorkomen was het volgens de Oostenrijkse wetgever van belang dat alle eigendommen op één erfgenaam zouden overgaan. Voor het geval waarin er meer erfgenamen waren en zij geen onderlinge overeenstemming over de erfenis konden bereiken had de wetgever dan ook een voorrangsregeling getroffen, waardoor alle eigendommen toch in één hand zouden blijven. Volgens deze regeling hadden wettige geboren erfgenamen voorrang boven onwettige kinderen. Volgens de Oostenrijkse regering was dit onderscheid op grond van onwettige geboorte gebaseerd op objectieve gronden. De automatische voorrang voor de wettig geboren erfgenaam zou beantwoorden aan de veronderstelde voorkeur van de overledene. Bovendien gaf de voorrangsregel uitdrukking aan de opvattingen van de rurale bevolking en beantwoordde deze aan de sociaal-economische situatie van de boeren: onwettige kinderen werden volgens de regering meestal niet op de boerderij opgevoed en hadden daardoor geen mogelijkheid om nauwe banden met het boerenbedrijf te ontwikkelen. Het Hof oordeelde over deze rechtvaardiging als volgt:

"[...] [T]he Court is not persuaded by the Government's arguments. Most of them are based on general and abstract considerations which may sometimes not reflect the real situation.

[...] Those considerations cannot justify a rule of this kind. [...]

The Court also considers that the argument relating to the convictions of the rural population merely reflects the traditional outlook." "163

Uit deze overweging kan allereerst worden afgeleid dat het Hof bij verdachte classificaties vereist dat het doel voldoende specifiek is: algemene en abstracte overwegingen kunnen niet als gerechtvaardigd worden aangemerkt. Bovendien mogen overwegingen die aan de classificatie ten grondslag liggen niet uitsluitend uitdrukking vormen van traditionele opvattingen. De reden voor dit oordeel zal waarschijnlijk zijn dat dit soort opvattingen in veel gevallen is gebaseerd op stereotypen of vooroordelen jegens een groep die maatschappelijk niet volledig is geaccepteerd. ${ }^{184}$ Tenslotte blijkt uit de geci-

182. EHRM 28 oktober 1987, Inze, Series A, vol. 126

183. $\$ \S 43$ en 44

184. Het Hof had al eerder twijfels uitgesproken over de bruikbaarheid van traditionele opvattingen als rechtvaardiging, namelijk in het arrest Marckx. Deze uitspraak had betrekking op een regeling, als gevolg waarvan niet onmiddellijk een familierechtelijke band ontstond tussen een moeder en haar niet binnen een huwelijk geboren kind. Het doel van deze regeling was de bescherming van het traditionele gezin. Het Hof achtte dit doel op zich niet ongerechtvaardigd, maar vond het niet redelijk dat de rege- 
teerde overweging dat het doel moet beantwoorden aan een reële situatie, hetgeen betekent dat het onderscheid een voldoende feitelijke grondslag moet hebben. Aan die eis was in dit geval niet voldaan: het uitgangspunt van de regering was dat onwettige kinderen meestal niet op de boerderij werden opgevoed en dat zij daardoor onvoldoende voeling met het boerenbedrijf zouden hebben. In het geval van klager was dit echter niet juist, nu hij tot hij 23 jaar oud was op de boerderij had gewoond en er grote affiniteit mee had. iss

Deze drie criteria lijken, hoewel zij door het Hof verder niet vaak worden genoemd, zeker voor een meer algemene toepassing vatbaar en kunnen een nuttige invulling vormen van het algemene toetsingsmodel.

\subsection{Toetsing van de verhouding tussen doel en middel: proportionaliteit in ruime zin}

\subsubsection{Inhoud en toepassing van de doel-middeltoets bij artikel 14}

\section{Inhoud van de doel-middeltoets}

De aanwezigheid van een gerechtvaardigd doel is volgens het beslissingsmodel van het Hof nog niet voldoende om te kunnen spreken van een gerechtvaardigd onderscheid: daarvoor moet er bovendien sprake zijn van een redelijke mate van proportionaliteit tussen het belang dat door het onderscheid wordt aangetast en het doel dat hiermee wordt nagestreefd. Het Hof heeft dit proportionaliteitsvereiste in de Belgische Taalzaak als volgt geformuleerd:

"[...] Article 14 is [...] violated when it is clearly established that there is no reasonable relationship of proportionality between the means employed and the aim sought to be realised." "в6

Een zorgvuldige toetsing aan dit proportionaliteitsvereiste is van groot belang voor een goede beoordeling van een ongelijke behandeling, zeker nu, zoals hiervoor is gebleken,

ring trachtte dit doel te bereiken door een onwettig gezin te benadelen (EHRM 13 juni 1979, Series A, vol. $31, \S 40$ ). In latere rechtspraak werd een iets andere benadering gekozen, waarbij het doel om de traditionele familie te beschermen wel gerechtvaardigd werd geacht, maar het Hof vervolgens stelde dat deze doelstelling niet voldoende gewichtig was om het onderscheid te kunnen dragen; zie EHRM I februari 2000, Mazurek, EHRC 2000/25, $\$ 50$.

185. De eis dat het doel een reèle situatie weergeeft komt ook tot uitdrukking in het arrest Karlheinz Schmidt (EHRM 18 juli 1994, Series A, vol. 291-B). Deze zaak had betrekking op de betaling van een bijdrage voor de brandweer. Deze bijdrage diende als een financiele compensatie voor de feitelijke verplichting om te helpen bij het blussen van branden. Vrouwen waren van deze feitelijke verplichting uitgesloten en hoefden als compensatie dus ook geen financiële bijdrage te leveren. Het doel van de uitsluiting van vrouwen bij de verplichting tot het verrichten van brandweerdiensten was de bescherming van hun gezondheid: de regering baseerde het onderscheid op lichamelijke en mentale verschillen die vrouwen minder geschikt maken voor het verrichten van bluswerkzaamheden. Het Hof stelde dat "[...] what is finally decisive in the present case is that the obligation to perform such service is exclusively one of law and theory. In view of the continuing existence of a sufficient number of volunteers, no male person is in fact obliged to serve in a fire brigade. The financial contribution has - not in law but in fact - lost its compensatory character and has become the only effective duty. In the imposition of a financial burden such as this, a difference of treatment on the ground of sex can hardly be justified" (\$ 28).

186. EHRM 23 juli 1968, Series A, vol. 6 
de doeltoets een relatief zwak onderdeel van de toetsing vormt. ${ }^{187}$ Het Hof is echter bijzonder terughoudend geweest in het geven van nadere invulling aan het vereiste van "a reasonable relationship of proportionality". Het is daardoor niet geheel helder of met deze formule gedoeld wordt op een proportionaliteitstoets in strikte zin, waarbij alleen de belangenafweging mag worden getoetst, of een proportionaliteitstoets in ruime zin, waarbij bijvoorbeeld ook de geschiktheid of de subsidiariteit in het oordeel kunnen worden betrokken. De tweede uitleg lijkt het meest waarschijnlijk, nu het Hof in het kader van zijn proportionaliteitstoets regelmatig een beoordeling uitvoert die uitsluitend kan worden beschreven in termen van noodzakelijkheid, geschiktheid of subsidiariteit. Voor de duidelijkheid zal de proportionaliteitstoets van het Hof in het hiernavolgende dan ook worden beschreven als een doel-middeltoets, nu dit een ruimer begrip is dat ook betrekking heeft op de vereisten van geschiktheid, noodzakelijkheid en subsidiariteit. Het begrip "proportionaliteitstoets" zal alleen worden gehanteerd wanneer gedoeld wordt op proportionaliteit in de strikte zin van het woord, dus op de redelijkheid van de belangenafweging die aan het onderscheid ten grondslag heeft gelegen.

\section{Toepassing van de doel-middeltoets}

Zoals in paragraaf 3 nog zal blijken zijn er variaties mogelijk in de intensiteit waarmee het Hof de redelijkheid van de verhouding tussen doel en middel beoordeelt. In beginsel lijkt het Hof te kiezen voor een terughoudende opstelling: zoals uit de geciteerde overweging blijkt moet het ontbreken van proportionaliteit duidelijk vaststaan en is als rechtvaardiging slechts een redelijke mate van proportionaliteit vereist. ${ }^{1 \mathrm{kx}}$ Deze terughoudendheid is ook nodig, omdat de bevoegdheid tot het maken van een belangenafweging primair berust bij de nationale instanties. Het Hof oefent hier weliswaar toezicht over uit, maar zal steeds een zekere afstand houden, zeker als het gaat om toetsing van algemene regels die door een nationale wetgever zijn vastgesteld. ${ }^{189}$ Hoewel het Hof in een beperkt aantal gevallen (namelijk bij een strikte toetsing) zeer zorgvuldig nagaat of er sprake is van een redelijke verhouding tussen doel en middel ${ }^{100}$ is deze toetsing in de meeste gevallen marginaal. Dit marginale karakter komt vooral tot uitdrukking in een zeer algemene redelijkheidstoets. Een goed voorbeeld daarvan is het al eerder genoemde arrest Monnell en Morris ${ }^{19}$, dat betrekking had op een regeling die beoogde het aantal hogere beroepen in strafzaken te verminderen. Als de hoger be-

187. Proportionaliteit en noodzakelijkheid worden in het algemeen zelfs gezien als de belangrijkste toetsingsvereisten die in het Verdrag zijn terug te vinden. Zie Velaers 1991, p. 312.

188. Zie Schokkenbroek 1996, p. 37.

189. Frowein/Peukert 1996, p. 452. Volgens Sundberg-Weitman wordt door een proportionaliteitstoetsing altijd een te vergaande inbreuk gemaakt op de soevereiniteit van de staat. Een dergelijke test mag volgens haar dan ook niet worden uitgevoerd $(1980$, p. 53). Dit is echter een te extreme stelling. Op het moment dat de rechter niet kan beoordelen of een regeling de betrokken belangen te vergaand heeft aangetast verliest het gelijkheidsbeginsel veel van zijn kracht. Bovendien moet het Hof, nu het de hoogste tot interpretatie van het Verdrag bevoegde instantie is, de mogelijkheid hebben om zelf na te gaan welke belangen een rol mogen spelen bij de afwijking van een verdragsbepaling (Burke 1981, p. 1133). Wel moet het Hof steeds de nodige terughoudendheid in acht moet nemen, zeker als het gaat om een toetsing van nationale wetgeving. Zoals Bossuyt uiteen heeft gezet geldt daarbij een soort "dubbele subsidiariteit": niet alleen geldt dan de terughoudendheid van een internationale rechter tegenover nationaal recht, maar ook nog de terughoudendheid van een rechter tegenover de wetgever (1976, p. 83).

190. Bijvoorbeeld EHRM 27 oktober 1975, National Union of Belgian Police, Series A, vol. 19, $\$ 49$.

191. EHRM 2 maart 1987, Monnell and Morris, Series A, vol. 115 
roepsinstantie oordeelde dat het hoger beroep zinloos was, dan was hij volgens deze regeling bevoegd om de voorlopige hechtenis niet in mindering te brengen op de opgelegde straf. Hierdoor werd onderscheid gemaakt tussen appellanten die in voorlopige hechtenis zaten en appellanten die in vrijheid beroep konden instellen: voor de laatsten was deze feitelijke strafverhoging niet mogelijk. Het Hof stelde hierover het volgende:

\footnotetext{
"The aim pursued by the Court of Appeal's power to order loss of time, as it is exercised, is to expedite the process of hearing applications and so to reduce the period spent in custody by an applicant with a meritorious appeal. The great majority of applications for leave of appeal are lodged by those in custody. This being so [...] the difference in treatment complained of had in the Court's view, an objective and reasonable justification."192
}

Blijkens deze overweging achtte het Hof een gerechtvaardigd doel voldoende aangetoond, zodat een goede beoordeling van de verhouding tussen doel en middel volgens het in paragraaf 2.1 weergegeven model noodzakelijk was. Een dergelijke toetsing is in de geciteerde overweging echter niet terug te vinden: het Hof stelt slechts dat de overgrote meerderheid van de appellanten in voorlopige hechtenis zat, zonder dit argument nader te kwalificeren. Het wordt hierdoor aan de lezer van de uitspraak overgelaten om te bepalen of dit argument betrekking heeft op de mate van fit (d.w.z. op de vraag of de classificatie voldoende zorgvuldig is gedefinieerd, zodat alleen die groep wordt uitgezonderd die in het licht van het doel uitgezonderd zou moeten worden) of op de geschiktheid (wanneer een grote groep mensen niet in hechtenis zou zitten, dan zou het minder waarschijnlijk zijn dat het gestelde doel door de regeling kon worden bereikt). Bovendien ontbreekt in het citaat iedere toetsing van de belangenafweging die aan de regeling ten grondslag lag, terwijl een dergelijke toetsing volgens het toetsingsmodel van het Hof nodig zou zijn geweest om tot de conclusie te kunnen komen dat het onderscheid gerechtvaardigd is. ${ }^{193}$

Wordt er in veel gevallen nog een zeer algemene redelijkheidstoets uitgevoerd, het komt ook voor dat een doel-middeltoets volledig ontbreekt. Een voorbeeld daarvan is het arrest Stubbings. ${ }^{194}$ De klaagsters in deze zaak waren als kinderen seksueel misbruikt en ondervonden daarvan op latere leeftijd psychische schade. Toen zij een bijzondere actie tot schadevergoeding instelden bij de civiele rechter werden zij echter geconfronteerd met een verstreken verjaringstermijn. Voor andere, meer gebruikelijke, acties uit onrechtmatige daad was de verjaringstermijn veel flexibeler, hetgeen volgens klaagsters een met artikel 14 strijdig onderscheid opleverde. Het Hof oordeelde hierover als volgt:

192. $\$ 73$

193. Kwalijk is dat dit arrest niet het enige voorbeeld vormt van de tekortschietende motivering van het Hof: ook in een groot aantal andere gevallen worden de verschillende onderdelen van de toetsing niet duidelijk genoemd of ontbreken essentiële elementen van de toetsing van de verhouding tussen doel en middel. Zie bijvoorbeeld Lithgow (EHRM 8 juli 1986, Series A, vol. 102, $\S 181$ en 183), Kamasinski (EHRM 19 december 1989, Series A, vol. 168, $\$ \$ 93$ en 100), Moustaquim (EHRM 18 februari 1991, Series A, vol. 193, § 49), C. v. Belgium (7 augustus 1996, Reports 1996-III) en Building Societies (EHRM 23 oktober 1997, Reports 1997-VII, § 90). In deze uitspraken stelde het Hof eerst vast dat er sprake was van een gerechtvaardigd doel en concludeerde het vervolgens zonder meer dat er een objectieve en redelijke rechtvaardiging aanwezig was.

194. EHRM 22 oktober 1996, Reports 1996-IV 
"[...] the difference in treatment may be reasonably and objectively justified [...]. It is quite reasonable, and falls within the margin of appreciation afforded to the Contracting States in these matters to create separate regimes for the limitation of actions based on deliberately inflicted harm and negligence, since, for example, the existence of a civil claim might be less obvious to victims of the latter type of injury."19s

Het ontbreken van een uitgebreidere beoordeling van de verhouding tussen doel en middel is in deze specifieke zaak op zichzelf wel verklaarbaar: het Hof was bij de toepassing van artikel 6 al uitgebreid ingegaan op de proportionaliteit van de regeling en was daar tot de conclusie gekomen dat de verjaringstermijn de toegang van klaagsters tot de rechter niet disproportioneel beperkte. ${ }^{196}$ Dit vormt echter onvoldoende rechtvaardiging voor een volledige weglating van een doel-middeltoets bij de toepassing van artikel 14: zeker als er wezenlijke individuele belangen zijn aangetast is het van belang om niet alleen te bezien of de regeling zelf redelijk is, maar ook of het onderscheid dat daarin is gemaakt in een redelijke verhouding staat tot het nagestreefde doel. Hoewel het instellen van verjaringstermijnen op zichzelf redelijk is, kan immers de vraag worden gesteld of het ook redelijk is dat voor bepaalde schadeclaims veel kortere verjaringstermijnen gelden dan voor andere.

Tenslotte wordt in een aantal arresten over artikel 14 weliswaar expliciet aandacht besteed aan de doel-middeltoets, maar ontbreekt een goede inhoudelijke motivering. Zo had het arrest Engel ${ }^{197}$ betrekking op disciplinaire maatregelen in het leger, waarbij de aard en de wijze van uitvoering van deze maatregelen afhankelijk waren van de rang van degene die de regels had overtreden: soldaten werden bij "zwaar arrest" in een cel geplaatst, terwijl officieren deze straf thuis konden uitzitten; verder konden alleen gewone soldaten aan de zwaarste straf (plaatsing in een tuchtklasse) worden onderworpen. De klagers stelden dat artikel 14 door deze verschillen geschonden was. Het Hof oordeelde hier echter anders over:

"Based on an element objective in itself, that is rank, these distinctions could have been dictated by a legitimate aim, namely the preservation of discipline by methods suited to each category of servicemen. [...] On the whole, the legislator does not seem in the circumstances to have abused the latitude left to him by the Convention. Furthermore, the Court does not consider that the principle of proportionality has been offended in the present case." ${ }^{\prime \prime}$

Het Hof volstond in deze zaak dus met de ongemotiveerde stelling dat er een redelijke verhouding bestond tussen doel en middel. Het ging hier echter om maatregelen die strekten tot vrijheidsberoving, zodat gezegd kan worden dat klagers er een aanzienlijk

195. $\$ 73$

196. $\mathrm{Bij}$ de beoordeling van het recht op toegang tot de rechter hanteerde het Hof een ruime margin of appreciation. Het Hof oordeelde in deze zaak dat er over verjaringstermijnen maar weinig consensus bestaat tussen de Europese staten, zodat daarin geen reden kon worden gevonden voor een intensievere toets. Van belang achtte het Hof verder dat er in het parlement uitgebreid was gesproken over de verandering van de verjaringstermijnen, waarna uiteindelijk was besloten tot de huidige regeling. Hoewel het Hof stelde dat gezien de bijzondere situatie van mensen zoals klaagsters in de toekomst nog eens goed gekeken zou moeten worden naar de termijnen, achtte het de regeling op het moment van de uitspraak niet disproportioneel. Zie $\S \S 50-55$ van het arrest.

197. EHRM 23 november 1976, Engel and Others, Series A, vol. 22

198. $\S 72$ 
belang bij hadden om op dezelfde manier behandeld te worden als (bijvoorbeeld) officieren. Een uitgebreidere motivering zou dan ook geen overbodige luxe zijn geweest. ${ }^{19}$

Uit het weglaten van de doel-middeltoets en uit het gebrek aan motivering zou wellicht kunnen worden afgeleid dat het Hof de toetsing van de redelijkheid van onderscheid niet bijzonder serieus neemt. Dit is problematisch, nu hiervoor is vastgesteld dat door de (vaak) terughoudende en oppervlakkige toetsing van het doel het accent volledig op de doel-middeltoets is komen te liggen. Doordat die toetsing in de praktijk vaak achterwege blijft, ontbreekt een goede bescherming tegen ongelijke behandeling. Artikel 14 kan daarom als een krachteloze waarborg worden aangemerkt. Zoals eerder al is aangegeven zijn er echter verschillende omstandigheden waarin het Hof overgaat tot een intensievere en zorgvuldigere toetsing. Het gaat dan vooral om de situatie waarin er sprake is van verdachte classificaties en om die arresten waarin voor de beoordeling van de verhouding tussen doel en middel wordt terugverwezen naar de toetsing aan het substantiële artikel: in die gevallen blijkt de movering van het Hof vaak aanzienlijk uitgebreider en zorgvuldiger te zijn.

In het hiernavolgende zal eerst kort worden ingegaan op de wijze waarop de verhouding tussen doel en middel wordt beoordeeld bij de toetsing aan enkele substantiële bepalingen (paragraaf 2.4.2). Vervolgens zal aandacht worden besteed aan enkele specifieke elementen van de doel-middeltoets die in de toetsing aan artikel 14 (met name bij verdachte classificaties) en in de toepassing van de substantiële verdragsbepalingen kunnen worden onderscheiden (paragraaf $2.5,2.6$ en 2.7). Tenslotte zal nog worden ingegaan op een criterium dat in het theoretische model is genoemd en waaraan ook door het Hof soms getoetst is, zonder dat dit echter een vast onderdeel lijkt te vormen van de toetsing (paragraaf 2.8). Deze paragraaf zal worden afgesloten met een korte tussenconclusie (paragraaf 2.9).

\subsubsection{De doel-middeltoets bij substantiële verdragsbepalingen}

In een vrij groot aantal gevallen verwijst het Hof voor de beoordeling van de verhouding tussen doel en middel terug naar de beoordeling die het heeft gegeven bij de toetsing aan het substantiële artikel; dit gebeurt vooral wanneer het beroep op artikel 14 is gekoppeld aan een beroep op een van de artikelen 8-11. ${ }^{200}$ Volgens de rechtvaardigingsclausules van deze artikelen is het voor toelaatbaarheid van een inbreuk op het grondrecht vereist dat deze "necessary in a democratic society" is. Volgens vaste rechtspraak van het Hof moet aan dit vereiste de volgende invulling worden gegeven:

199. Een ander voorbeeld is het arrest Swedish Engine Drivers' Union, waarin het Hof volstond met de stelling, dat: "[...] the Court does not consider that the principle of proportionality has been offended in the present case" (EHRM 6 februari 1976, Series A, vol. 20, $\S 48$ ). Precies dezelfde formulering komt voor in het arrest Schmidt and Dahlström (EHRM 6 februari 1976, Series A, vol. 21, $\$ 42$ ).

200. EHRM 30 juli 1998, Sheffield and Horsham, 27 European Human Rights Reports 163 (1998), \$ 76 (verwijzing naar artikel 8 lid 2), EHRM 21 februari 1986, James and Others, Series A, vol. 98, $\$ 76$ (verwijzing naar artikel 1 Eerste Protocol (vgl. ook Merrills 1993, p. 170)), EHRM 28 september 1995 , Spadea and Scalabrino, Series A, vol. 315-B, $\$ 46$ (verwijzing naar artikel 1 Eerste Protocol) en EHRM 23 oktober 1997, Building Societies, Reports 1997-VII, $\$ 90$ (verwijzing naar artikel 1 Eerste Protocol). 
"The test of 'necessity in a democratic society' requires the Court to determine whether the 'interference' complained of corresponded to a 'pressing social need', whether it was proportionate to the legitimate aim pursued and whether the reasons given by the national authorities to justify it are relevant and sufficient."201

Een inbreuk op deze artikelen is blijkens deze overweging alleen gerechtvaardigd wanneer deze voldoet aan een drietal eisen: de aangevoerde argumenten moeten relevant en toereikend zijn, er moet sprake zijn van een "pressing social need" en er moet sprake zijn van een evenredige verhouding tussen doel en middel. ${ }^{202}$ Het Hof heeft in de loop van de tijd nader invulling gegeven aan deze verschillende toetsingsmaatstaven: door de toepassing in een groot aantal arresten zijn de criteria nader verfijnd en is de verhouding van de verschillende maatstaven ten opzichte van elkaar duidelijker geworden. Opmerkelijk is daarbij vooral dat de toetsing aan deze vereisten aanzienlijk nauwkeuriger en beter gemotiveerd is dan de toetsing aan het proportionaliteitsvereiste (in ruime zin) dat bij de toetsing aan artikel 14 wordt gehanteerd.

Interessant voor de beoordeling van de toetsingsmethodiek is verder nog de wijze waarop het Hof artikel 1 van het Eerste Protocol (eigendomsrecht) heeft toegepast: een beroep op artikel 14 wordt zeer regelmatig aan deze bepaling gekoppeld. Hoewel in artikel 1 Eerste Protocol, anders dan bij de artikelen 8-11, geen uitdrukkelijke uitzonderingsbepaling is opgenomen, heeft het Hof consequent aangenomen dat hierbij een rechtvaardigingsmogelijkheid geldt. De wijze waarop het Hof bij artikel 1 Eerste Protocol vorm heeft gegeven aan deze rechtvaardigingsmogelijkheid komt goed tot uitdrukking in het arrest James: ${ }^{203}$

"Not only must a measure depriving a person of his property pursue a legitimate aim 'in the public interest', but there must also be a reasonable relationship between the means employed and the aim sought to be realised. This was expressed in other terms in the Sporrong and Lönnroth judgment ${ }^{204}$ by the notion of the 'fair balance' that must be struck between the demands of the general interest of the community and the requirements of the

201. EHRM 25 november 1999, Nilsen and Johnsen, EHRC 2000/10, $\$ 43$. Deze overweging behoort tot de "algemene beginselen" voor interpretatie van de verdragsbepalingen die het Hof in ieder geval opnieuw aanhaalt. In vrijwel alle rechtspraak over de artikelen 8-11 EVRM is een vergelijkbare overweging dan ook terug te vinden. De verschillende criteria zijn vooral ontwikkeld in de jaren 70 . De basis hiervoor vormen de arresten Handyside (18 januari 1978, Series A, vol. 24, m.n. § 48/49) en Sunday Times (I) (EHRM 26 april 1979, Series A, vol. 30). Zie voor voorbeelden van het toetsingsmodel bij andere bepalingen EHRM 27 september 1999, Lustig-Prean en Beckett, EHRC 1999/2 (artikel 8, bescherming van privacy), EHRM 14 december 1999, Serif, EHRC 2000/14 (artikel 9, vrijheid van godsdienst) en EHRM 8 december 1999, Freedom and Democracy Party of Turkey (OZDEP), EHRC $2000 / 12, \S 28$ (artikel 11 , vrijheid van vereniging). In een aantal arresten, met name met betrekking tot de bescherming van "family life" of bij uitspraken over positieve verplichtingen, wordt een iets andere formule gekozen: gesteld wordt dan dat er sprake moet zijn van een "fair balance" tussen het aangetaste en het nagestreefde belang (zie bijvoorbeeld EHRM 16 november 1999, E.P. v. Italy, EHRC $2000 / 9, \$ 62$ ). Uit de toetsing die in deze gevallen wordt uitgevoerd blijkt dat het verschil in formulering van de toets niet leidt tot grote inhoudelijke verschillen in toetsingsmethodiek.

202. Zie Schokkenbroek 1996, p. 194

203. EHRM 21 februari 1986, Series A, vol. 98

204. EHRM 23 september 1982, Series A, vol. 52, $\$ 69$. Ook de eis van een "individual and excessive burden" komt in dit arrest voor (zie $\$ 73$ ), maar in James is de proportionaliteitseis voor het eerst helder en kort uiteengezet. 
protection of the individual's fundamental rights. The requisite balance will not be found if the person concerned has had to bear 'an individual and excessive burden'."20s

Zoals blijkt uit deze overweging is de rechtvaardigingsmogelijkheid die het Hof bij artikel 1 Eerste Protocol heeft erkend sterk vergelijkbaar met het vereiste van een "pressing social need" bij de artikelen 8-11, maar wijkt deze hiervan op een belangrijk punt ook af: anders dan bij de artikelen 8-11 het geval is zal er alleen sprake zijn van disproportionaliteit wanneer de litigieuze maatregel voor de klager een individuele en excessieve last tot gevolg heeft. ${ }^{206}$ Dit betekent dat er aanzienlijk hogere eisen worden gesteld aan het gewicht van het aangetaste belang dan het geval is bij de artikelen 8-11. Dit verschil lijkt echter niet zozeer de toetsingsmethodiek te betreffen (in beide gevallen wordt er immers een proportionaliteitstoets uitgevoerd), maar houdt vooral verband met de intensiteit van de toetsing: door hogere eisen te stellen aan het aangetaste belang zal immers minder snel tot de conclusie kunnen worden gekomen dat de staat zijn beleidsvrijheid op een té belastende manier heeft aangewend. ${ }^{207}$

Zoals al is aangegeven zal in het hiernavolgende aan enkele van de door het Hof ontwikkelde vereisten nader aandacht worden besteed: juist omdat het Hof bij de beoordeling van de redelijkheid van een classificatie vaak terugverwijst naar de toetsing aan de substantiële verdragsbepalingen is de interpretatie van deze vereisten bijzonder interessant. Daarbij zal echter uitsluitend worden ingegaan op die toetsingselementen die bij de toetsing aan artikel 14 én de substantiële bepalingen zijn terug te vinden. Dit betekent dat geen aandacht zal worden besteed aan het specifieke vereiste dat de aangevoerde redenen "relevant and sufficient" moeten zijn, nu dit vereiste in geen enkel arrest over artikel 14 expliciet of impliciet is terug te vinden. ${ }^{208}$

205. $\$ 50$. Deze formule maakt, met een paar tekstuele variaties, deel uit van de vaste rechtspraak van het Hof over artikel 1 Eerste Protocol: zie EHRM 23 september 1982, Sporrong and Lönnroth, Series A, vol. $52, \S 73$, EHRM 8 juli 1986, Lithgow, Series A, vol. 102, $\$ 120$, EHRM 9 december 1994, Holy Monasteries, Series A, vol. 301-A, $\$ 70$ (waarin gesproken wordt van een "considerable burden"), EHRM 23 oktober 1997, Building Societies, Reports 1997-VII, \$ 81, EHRM 29 april 1999, Chassag. nou, Reports 1999-III, $\$ 85$ (waarin gesproken wordt van een "disproportionate burden") en EHRM 28 juli 1999, Immobiliare Saffi, Reports 1999-V, $§ 59$. In een aantal arresten over artikel 1 komt het vereiste van een "individual and excessive burden" niet terug; bijvoorbeeld EHRM I8 februari 1991, Fredin, Series A, vol. 192, $\$ 51$ en EHRM 28 september 1995, Spadea and Scalabrino, Series A, vol. 315 $\mathrm{B}, \S 33$. Het Hof volstaat dan met de stelling dat er een "fair balance" moet bestaan. Deze afwijking kan worden verklaard vanuit het feit dat het in deze arresten ging om een minder vergaande mate van beperking van de eigendom; dit kan de intensiteit van de toetsing en de eisen die aan de evenredigheid worden gesteld beīnvloeden. Zie daarover paragraaf 3 .

206. Zie ook Frowein/Peukert 1996, p. 798.

207. Er wordt dan ook relatief zelden tot een schending van het proportionaliteitsvereiste geconcludeerd: in de gevallen waarin dit wel gebeurt is er sprake van een maatregel of een overheidsoptreden dat een grote mate van willekeur vertoont (zie voor enkele recentere voorbeelden EHRM 29 april 1999, Chassagnou, Reports 1999-III, EHRM 5 januari 2000, Beyeler, EHRC 2000/18, EHRM 11 januari 2000, Almeida Garrett, EHRC 2000/20, EHRM 30 mei 2000, A.O. v. Italy, EHRC 2000/58), van een maatregel die een extreem zware inbreuk maakt op individuele belangen zonder daarmee een overeenstemmend algemeen belang te dienen (EHRM 23 september 1982, Sporrong and Lönnroth, Series A, vol. 52, EHRM 28 juli 1999, Immobiliare Saffi, Reports 1999-V, EHRM 3 augustus 2000, G.L. v. Italy. EHRC 2000/76) of van een onteigeningsregeling waarin geen enkele compensatie is voorzien (EHRM 21 november 1994, Holy Monasteries, Series A, vol. 301-A).

208. Van belang is bovendien dat de precieze betekenis van dit vereiste voor de rechtspraak over de sub- 


\subsection{Geschiktheid}

\subsubsection{Toetsing van de geschiktheid bij substantiële verdragsbepalingen}

Als een maatregel ongeschikt is om het nagestreefde doel te bereiken, terwijl door deze maatregel wel individuele belangen worden aangetast, is het niet wenselijk om hem in stand te laten: in dergelijke gevallen mag van de nationale regelgever worden verwacht dat hij de regeling aanpast of vervangt door een effectievere regeling. ${ }^{209}$ Toch maakt de geschiktheidstoets blijkens de rechtspraak van het Hof over de artikelen 8-11 EVRM niet officieel deel uit van de toetsing van de verhouding tussen doel en middel: vereist is daarbij uitsluitend een "pressing social need" en een voldoende mate van proportionaliteit. Opmerkelijk is echter dat in andere formuleringen van de rechtvaardigingstoets, zoals in de bij artikel 1 Eerste Protocol gehanteerde toets, soms wel een geschiktheidsvereiste voorkomt. Een goed voorbeeld daarvan is het arrest James ${ }^{210}$, waarin het Hof stelde dat het voor een rechtvaardiging van de inbreuk nodig is, dat

"[...] a measure must both be appropriate for achieving its aim and not disproportionate thereto."211

stantielle bepalingen niet bijzonder duidelijk is: niet alleen is het onduidelijk wat er met de begrippencombinatie wordt bedoeld, maar ook is niet helemaal helder wat de verhouding is van het vereiste van "toereikendheid" ten opzichte van de vereisten van noodzakelijkheid en proportionaliteit. De betekenis van het vereiste van "relevantie" is iets duidelijker: uit een door Schokkenbroek gemaakte analyse van de rechtspraak blijkt dat het Hof alleen de noodzakelijkheid en proportionaliteit zal vaststellen van argumenten en redenen die het in het licht van de toetsing voldoende relevant vindt (1996, p. 194/195). Bij de toetsing van het doel worden, zoals eerder al is aangegeven, vrijwel alle argumenten van de nationale overheid geaccepteerd; het is niet erg efficiênt om voor ieder van die doelstellingen na te gaan of er ook sprake is van een redelijke verhouding tussen doel en middel. Door een toepassing van de relevantietoets is het mogelijk om alleen die doelstellingen te kiezen die interessant en relevant zijn. Schokkenbroek geeft echter aan dat het vereiste in veel arresten achterwege wordt gelaten: het accent is duidelijk gelegen op de toetsing van de noodzakelijkheid en de proportionaliteit (1996, p. 193). Een illustratie van de benadering van het Hof is te vinden in het arrest News Verlags GmbH and Co. KG (EHRM 11 januari 2000, EHRC 2000/21), waarin het Hof de redenen die het eerder als gerechtvaardigd doel accepteerde vervolgens ook beschouwde als "relevant" in het kader van de noodzakelijkheidstoets (zie $\$ 58$ ); idem in Wabl, EHRM 21 maart 2000, EHRC 2000/36, $\S 8$. Ook het vereiste dat de argumenten "sufficient" moeten zijn wordt meestal met een beoordeling van de proportionaliteit en noodzakelijkheid verweven. Een mooi voorbeeld daarvan is te vinden in het arrest Sunday Times, waarin het Hof na een zeer uitgebreide beschrijving van de verschillende betrokken belangen en een nauwkeurige analyse van het gewicht daarvan het volgende overwoog: "Having regard to all the circumstances of the case [...] the Court concludes that the interference complained of did not correspond to a social need sufficiently pressing to outweigh the public interest in freedom of expression within the meaning of the Convention. The Court therefore finds the reasons for the restraint imposed on the applicants not to be sufficient under Article 10 (2). That restraint proves not to be proportionate to the legitimate aim pursued; it was not necessary in a democratic society for maintaining the authority of the judiciary" (EHRM 26 april 1979, Series A, vol. 30, \$67). Het Franse equivalent van het "sufficiency"-vereiste werd recentelijk ook genoemd in de context van de toetsing aan artikel 14: in het arrest Mazurek stelde het dat het litigieuze onderscheid "apparait proportionnée et adéquate par rapport au but poursuivi” (EHRM 1 februari 2000, EHRC 2000/25, $\S 51$, cursief toegevoegd). Net als bij de toetsing aan de substantielle verdragsbepalingen heeft dit vereiste echter vooral retorische waarde: aan de toetsing zelf voegt het weinig toe.

209. Zie nader hoofdstuk 2, paragraaf 3.3.3.

210. EHRM 21 februari 1986, Series A, vol. 98

211. $\$ 50$, cursief toegevoegd. 
Het Hof ging in het vervolg van zijn uitspraak echter niet in op de vraag of de litigieuze inbreuk ook daadwerkelijk aan dit geschiktheidsvereiste voldeed. Het aantal voorbeelden van uitspraken over substantiële verdragsbepalingen waarin de geschiktheid expliciet wordt getoetst is bovendien bijzonder klein. In veruit de meeste uitspraken worden geschiktheidsargumenten ingebed in de noodzakelijkheidstoets, hetgeen ook gemakkelijk mogelijk is: een maatregel die niet geschikt is om een doelstelling te bereiken zal immers ook niet noodzakelijk kunnen zijn ter bereiking van dit doel. ${ }^{212}$ Vanzelfsprekend maakt een dergelijke benadering de motivering niet doorzichtiger.

\subsubsection{De geschiktheidstoets bij artikel 14}

De doel-middeltoets die het Hof voor artikel 14 heeft ontwikkeld is in beginsel ruimer dan de voor substantiële bepalingen vastgestelde toets: nu hierin geen specifieke eisen worden gesteld aan de rechtvaardiging is het mogelijk dat het Hof zelf een aantal factoren en criteria vaststelt. Bij de toetsing aan de substantiële bepalingen moeten vergelijkbare factoren steeds worden ingepast in de beoordeling van de aanwezigheid van een "pressing social need" of van de proportionaliteit. Dat het Hof van deze relatieve vrijheid inderdaad gebruik heeft gemaakt komt tot uitdrukking in het feit dat in verschillende zaken een meer of minder expliciete geschiktheidstoets is terug te vinden. Een goede illustratie van de methodiek van het Hof is het arrest National Union of Belgian Police. ${ }^{213}$ Zoals eerder is aangegeven had dit arrest betrekking op de beslissing van de Belgische regering om alleen grotere vakbonden uit te nodigen voor het voeren van CAO-onderhandelingen. In het kader van de beoordeling van de verhouding tussen doel en middel merkte het Hof het volgende op:

"It remains to be seen whether the disadvantages to which members of the applicant union are put in compared with members of the trade unions consulted is justified not only in principle, but also in scope. The answer seems clear insofar as consultation covers questions

212. Vooral in de jurisprudentie over artikel 10 wordt met enige regelmaat een beroep gedaan op het ontbreken van geschiktheid in het kader van de noodzakelijkheidstoets, met name als het gaat om het verbieden van het openbaren van informatie die inmiddels algemeen bekend is: in dergelijke gevallen kan een publicatieverbod het gestelde doel (geheimhouding, bescherming van de openbare orde, bescherming van de goede zeden of welke andere doelstelling ook) niet meer bereiken, zodat het zeker niet aan het geschiktheidsvereiste voldoet. Een voorbeeld hiervan biedt het arrest Vereniging Weekblad "BLUF!". Geklaagd werd over een verbod op de verspreiding van een uitgave van het blad BLUF!, dat was ingegeven door het feit dat in deze uitgave geheime informatie openbaar zou worden gemaakt. Ten tijde van het verbod was echter al een groot aantal bladen verspreid en was de informatie door andere media overgenomen. Het Hof stelde dan ook het volgende: "[...][T]he information in question was made accessible to a large number of people, who were able in their tum to communicate it to others. Furthermore, the events were commented upon by the media. That being so, the protection of the information as a State secret was no longer justified and the withdrawal of issue no. 267 of Bluf? no longer appeared necessary to achieve the legitimate aim pursued" (EHRM 9 februari 1995, Vereniging Weekblad BLUF!, Series A, vol. 306-A, § 45). Zie verder EHRM 26 november 1991, Observer and Guardian (Spycatcher), Series A, vol. 216, $\$ \$ 68-69$ en EHRM 29 oktober 1992, Open Door, Series A, vol. $246-A, \S 76$. In ieder geval worden, zoals Schokkenbroek opmerkt, eventuele twijfels aan de geschiktheid steeds zwaar meegewogen in de toetsing van de proportionaliteit in strikte zin (1996, p. 199).

213. EHRM 27 oktober 1975 , Series A, vol. 19 
of a general nature which are of interest to all provincial or municipal staff; in this regard, the measure is a proper means of attaining the legitimate aim sought to be realised."214

Een voorbeeld van een arrest waarin een regeling waarin onderscheid wordt gemaakt daadwerkelijk sneuvelde wegens haar ongeschiktheid is het al verschillende malen genoemde arrest $A b d u l a z i z^{215}$, waarin een Engelse regeling over gezinshereniging (de "1980 Rules") in het geding was. Door deze regeling werd onderscheid gemaakt naar geslacht, doordat het voor een in Engeland woonachtige buitenlandse vrouw veel moeilijker was om gezinshereniging aan te vragen dan voor een in dezelfde situatie verkerende man. Het Hof stelde in deze zaak het volgende:

"The Court accepts that the 1980 Rules [...] had, as the Government stated, the aim of advancing public tranquillity. However, it is not persuaded that this aim was served by the distinction drawn in those rules between husbands and wives."216

Opmerkelijk is dat in deze overweging een goede motivering van het geschiktheidsoordeel ontbreekt: het Hof lijkt bij zijn oordeel over de causaliteit tussen doel en middel louter af te gaan op veronderstellingen en evidentie. Kennelijk acht het Hof het niet nodig om het oordeel over de geschiktheid te baseren op empirische of wetenschappelijke gegevens die door de partijen zijn aangevoerd.

Net als bij de toetsing aan de substantiële bepalingen is het Hof ook bij de toetsing aan artikel 14 regelmatig geneigd de geschiktheidstoets niet apart te noemen, maar deze onder te brengen bij een algemene beoordeling van de noodzakelijkheid. Een goed voorbeeld van dit gebruik van het geschiktheidsvereiste is te vinden in het arrest Chassagnou. ${ }^{217}$ Deze zaak had betrekking op een Franse regeling die tot doel had de jacht beter te organiseren, zodat de wildstand in evenwicht zou blijven en er op een meer verantwoorde manier zou worden gejaagd. Om dit doel te bereiken waren in verschillende gemeenten jachtverenigingen opgericht (ACCA's), waarvan alle eigenaren van grond binnen het door een ACCA beheerd gebied verplicht lid waren; bovendien waren de eigenaren verplicht om de jacht op hun terrein toe te staan. Slechts eigenaren van een stuk grond dat groter was dan een bepaald aantal hectaren konden zich aan het verplichte lidmaatschap onttrekken. Het lidmaatschap was onder meer verplicht gesteld om de jacht enigszins te "democratiseren": de jacht was normaal gesproken voorbehouden aan de eigenaar van de grond, maar door de nieuwe regeling zouden meer mensen op zijn grondgebied kunnen jagen. Klagers stelden onder andere de vraag aan de orde of het gerechtvaardigd was om bij het verplichte lidmaatschap onderscheid te maken tussen eigenaars van grote en kleinere stukken grond. Het Hof vond dat dit niet het geval was:

"With respect to the need to protect the rights and freedoms of others to ensure democratic participation in hunting, an obligation to join an ACCA which is imposed on landowners in only one municipality in four in France cannot be regarded as proportionate to the legitimate aim pursued. Nor can the Court see why it might be necessary to pool only small properties

214. $\$ 49$, cursief toegevoegd.

215. EHRM 25 mei 1985, Series A, vol. 94

216. $\$ 81$

217. EHRM 29 april 1999, Reports 1999-III 
while large estates, both public and private, are protected from democratic participation in hunting." ${ }^{218}$

Hoewel deze overweging is geformuleerd in termen van noodzakelijkheid, kan hierin zeker ook een geschiktheidselement gelezen worden. Het is immers merkwaardig om het lidmaatschap voor kleine eigenaars verplicht te stellen, terwijl grotere grondeigenaars die verplichting niet hebben. Grotere grondeigenaars kunnen zich hierdoor gemakkelijk onttrekken aan de verplichting hun grondgebied voor de jacht door anderen open te stellen, waardoor de doelstelling (democratisering van de jacht) niet bereikt zal kunnen worden.

\subsection{Subsidiariteit en noodzakelijkheid}

\subsubsection{Subsidiariteit en noodzakelijkheid bij de substantiële verdragsbepalingen}

In zijn rechtspraak over de substantiële verdragsbepalingen blijkt het Hof onderscheid te maken tussen een vereiste van noodzakelijkheid en een vereiste van subsidiariteit. Het verschil hiertussen blijkt vooral gelegen te zijn in de abstractiegraad van de toetsing: terwijl bij een toepassing van de subsidiariteitstoets daadwerkelijk onderzoek wordt uitgevoerd naar het bestaan van alternatieve mogelijkheden waardoor het doel op een minder belastende wijze zou kunnen worden gerealiseerd, gaat het Hof bij de noodzakelijkheidstoets meer in het algemeen na of de maatregel "nodig" was om het doel te bereiken. Wat precies onder het vereiste van noodzakelijkheid moet worden verstaan is door het Hof uitgelegd in het arrest Handyside ${ }^{219}$ :

"The Court notes at this juncture that, whilst the adjective 'necessary', within the meaning of Article 10 para. 2, is not synonymous with 'indispensable' [...], the words 'absolutely necessary' and 'strictly necessary' and $[\ldots]$ the phrase 'to the extent strictly required by the exigencies of the situation', neither has it the flexibility of such expressions as 'admissible', 'ordinary' [...], 'useful' [...], 'reasonable' [...] or 'desirable'..'220

In beginsel is de noodzakelijkheidstoets dus relatief soepel: aangetoond hoeft bijvoorbeeld niet te worden dat de inbreuk op het grondrecht onmisbaar was om het beoogde doel te bereiken. Evenmin is het echter voldoende dat de maatregel alleen maar een handige manier was om bepaalde doelstellingen te realiseren: nu er door de maatregel individuele grondrechten zijn aangetast zal de staat toch voor een voldoende overtuigende en sterke argumentatie moeten zorgen. Uit het, hierboven niet geciteerde, vervolg van de uitspraak in Handyside blijkt preciezer welke eisen het Hof dan wél stelt: de maatregel moet beantwoorden aan een "pressing social need". Dit vereiste is in de loop van de tijd talrijke malen toegepast en blijkt in de praktijk een combinatie in te houden van noodzakelijkheid en proportionaliteit in strikte zin.

De precieze eisen die aan de noodzakelijkheid worden gesteld zijn afhankelijk van de omvang van de margin of appreciation die het Hof aan de betrokken staat toekent: bij een smalle margin gaat het Hof veelal nauwkeurig na of de maatregel onmisbaar is 
voor het bereiken van het nagestreefde doel, ook al is dit volgens de geciteerde overweging niet nodig, en zal het bovendien zorgvuldig controleren of het doel inderdaad zodanig zwaarwegend is dat het fundamentele recht hiervoor moet wijken. ${ }^{221} \mathrm{Bij}$ een ruime margin zal het Hof daarentegen uitsluitend een relatief oppervlakkige redelijkheidstoets uitvoeren, waarbij het vooral nagaat of het nationale oordeel over de noodzakelijkheid willekeurig of apert onredelijk is. ${ }^{22}$

In de context van deze noodzakelijkheidstoets blijkt soms ook een subsidiariteitstoets te worden uitgevoerd. Dit zal bij een terughoudende toetsing echter niet snel gebeuren, zoals bijvoorbeeld blijkt uit de volgende overweging uit het arrest James ${ }^{23}$ :

"The availability of other solutions does not in itself render the [...] legislation unjustified; it constitutes one factor, along with others, relevant for determining whether the means chosen could be regarded as reasonable and suited to achieving the legitimate aim being pursued, having regard to the need to strike a fair balance. It is not for the Court to say whether the legislation represented the best solution for dealing with the problem or whether the legislative discretion should have been exercised in another way."

Om een bepaald doel te bereiken is het vrijwel altijd mogelijk om te kiezen uit verschillende oplossingen en maatregelen. Blijkens uitspraken als James laat het Hof de keuze tussen deze verschillende mogelijkheden in beginsel over aan de nationale overheid en gaat het slechts na of de gekozen maatregel in strijd is met één van de bepalingen van het Verdrag. Dit betekent dat een keuze die het Hof weliswaar niet de beste of de minst belastende acht, maar die op zichzelf wel verenigbaar is met het Verdrag, meestal toelaatbaar zal worden geacht. ${ }^{225} \mathrm{Bij}$ een smalle margin zal het veel minder gemakkelijk zijn om te voldoen aan het vereiste van subsidiariteit. Het komt daarbij echter zelden voor dat het Hof een rechtvaardiging afwezig acht om de expliciete reden dat er andere, minder belastende middelen bestonden waardoor het doel kon worden bereikt. Veel gebruikelijker is dat het Hof weliswaar vaststelt dat er alternatieven denkbaar waren, maar dat deze stelling alleen dient als argument om het onderscheid niet noodzakelijk of disproportioneel te bevinden. ${ }^{226}$ Hoewel de motivering daardoor niet

221. Een voorbeeld van een zorgvuldige toetsing is te vinden in EHRM 27 september 1999, Lustig-Prean and Beckett, EHRC 1999/2, waarin het Hof in het kader van een inbreuk op het privé-leven van homoseksuelen in het Engelse leger nauwkeurig naging of deze inbreuk noodzakelijk was. Daarbij werd vooral aandacht besteed aan het gewicht van de aangetaste belangen en de ernst van de aantasting, maar ook aan het gewicht van het nagestreefde doel. Ook ging het Hof na of de maatregel, gezien het bestaan van allerlei andere beleidsinstrumenten die werden gehanteerd om het doel te bereiken, daadwerkelijk nodig was.

$222 \mathrm{Vgl}$. Alkema 1978, p. 42.

223 EHRM 21 februari 1986, James and Others, Series A, vol. 98

$224 \S 51$

225 Vgl. Mahoney 1990, p. 78 en 87.

226. Een voorbeeld van deze benadering is te vinden in het arrest Lustig-Prean and Beckett (EHRM 27 september 1999, EHRC 1999/2), waarin geklaagd werd over het feit dat de ontdekking van homoseksualiteit bij iemand die in het Engelse leger diende onmiddellijk leidde tot ontslag. De reden voor deze inbreuk op de privacy was gelegen in de bescherming van het moraal in het leger, die zou worden aangetast door de aanwezigheid van homoseksuelen; bovendien zouden homoseksuelen zelf hinder ondervinden van discriminatie. Volgens het Hof kon het moraal echter ook beschermd worden door andere maatregelen dan ontslag, bijvoorbeeld door een gedragscode in te stellen en door meer informatic over homoseksualiteit te verschaffen. De aanwezigheid van dit soort mogelijkheden was in deze zaak 
geheel zuiver is, leidt deze benadering wel tot goede resultaten. Aan een expliciete subsidiariteitstoets kleeft namelijk het bezwaar dat het Hof in ieder geval daadwerkelijk zal moeten onderzoeken of er voldoende bruikbare alternatieven bestonden. Daarvan zal lang niet altijd sprake zijn, ook niet wanneer er op zichzelf wel twijfel mogelijk is over de noodzakelijkheid van de maatregel. Een noodzakelijkheidstoets kan in dergelijke gevallen leiden tot een ontoelaatbaarverklaring van het onderscheid, terwijl dit bij een toepassing van de subsidiariteitstoets anders kan zijn: uit het feit dat er geen geschikte alternatieven bestonden zou dan immers moeten worden afgeleid dat de gekozen maatregel toelaatbaar is. In dat opzicht kan de benadering van het Hof de individuele klager in sommige gevallen een betere bescherming bieden.

Een tweede voordeel van de benadering van het Hof houdt verband met het feit dat de subsidiariteitstoets vergt dat de rechter niet alleen onderzoek doet naar het bestaan van alternatieven, maar ook naar hun effectiviteit om het gestelde doel te bereiken. Dit vergt een aanzienlijke mate van rechterlijke activiteit, terwijl een internationale rechter als het Hof niet altijd over de juiste middelen beschikt om een dergelijk onderzoek goed uit te voeren. Wanneer de subsidiariteitstoets wordt ingevoegd in de noodzakelijkheidstoets is een onderzoek naar de bruikbaarheid van de alternatieven niet per se nodig. Door de werkwijze van het Hof is het immers mogelijk om het bestaan van alternatieven in de beoordeling van de rechtvaardiging mee te wegen, zonder dat hun geschiktheid een bepalend element vormt. Om die reden kan het wenselijk worden geacht om een noodzakelijkheidstoets als alternatief voor of als aanvulling op de subsidiariteitstoets toe te voegen aan het algemene toetsingsmodel.

\subsubsection{Subsidiariteit en noodzakelijkheid bij de toetsing aan artikel 14}

Bij de toetsing aan het gelijkheidsbeginsel maakt het Hof geen gebruik van het vereiste van een "pressing social need": zoals eerder is aangegeven gaat het Hof alleen in het algemeen na of er sprake is van een redelijke verhouding tussen doel en middel, zonder expliciet onderscheid te maken tussen de vereisten van noodzakelijkheid, subsidiariteit en proportionaliteit. Uit de wijze waarop de doel-middeltoets wordt uitgevoerd blijkt echter dat de benadering die bij artikel 14 wordt gevolgd in veel gevallen vergelijkbaar is met de bij de substantiële bepalingen gehanteerde toetsingsmethodiek. Wanneer er een intensievere toetsing wordt uitgevoerd blijkt het Hof bijvoorbeeld vaak na te gaan of de maatregel in het algemeen "nodig" kon worden geacht voor het bereiken van het nagestreefde doel. Een voorbeeld daarvan biedt het arrest Camp and Bourimi. ${ }^{227}$ Deze zaak had betrekking op een erfrechtelijk probleem dat ontstond doordat de natuurlijke vader van een onwettig kind overleed, nog voordat het kind was geboren en hij het had erkend. Door brieven van wettiging konden alsnog familierechtelijke betrekkingen tussen vader en kind tot stand worden gebracht, maar volgens de geldende regelgeving kon het kind in deze omstandigheden niet als wettige erfgenaam worden beschouwd. De regering stelde dat deze regeling bedoeld was om de belangen en de rechtszekerheid

weliswaar geen doorslaggevend argument, maar opgeteld bij een aantal andere argumenten die twijfel opriepen over de noodzaak van ontslag en de proportionaliteit daarvan leidde het tot het oordeel dat een voldoende rechtvaardiging ontbrak.

227. EHRM 3 oktober 2000 , EHRC $2000 / 82$ 
van andere erfgenamen te beschermen tegen het plotseling opduiken van een onbekende erfgenaam. Het Hof oordeelde hierover als volgt:

"[...][W]hen it comes to the question of the proportionality of the means chosen to achieve this aim the Court observes that Sofian [het kind in kwestie, JHG] was not a descendant of whose existence the other heirs were unaware. Here, there is no indication that the exigencies of the situation required the level of protection that was afforded to [...] [applicant's] parents and siblings to the detriment of his son. The Court considers that in these circumstances Sofian's exclusion from his father's inheritance was disproportionate."22s

Deze argumentatie is niet anders te kwalificeren dan als een noodzakelijkheidstoets, waarbij het Hof voor het concrete geval naging of de ongelijke behandeling inderdaad was vereist voor het bereiken van het gestelde doel.

Net als bij de substantiële bepalingen maakt een toetsing van de subsidiariteit soms expliciet deel uit van de toetsing van de verhouding tussen doel en middel. Een voorbeeld hiervan is het arrest Rasmussen ${ }^{229}$, dat betrekking had op de Deense regelgeving over procedures met betrekking tot de ontkenning van het vaderschap van een binnen een huwelijk geboren kind. In het belang van de rechtszekerheid en ter bescherming van de belangen van het kind kon de man slechts een ontkenningsprocedure instellen tot vijf jaar na de geboorte van het kind; voor de vrouw gold een dergelijke tijdslimiet niet. In de jurisprudentie was echter een "doctrine of acknowledgement" ontwikkeld die inhield dat het recht om een ontkenningsprocedure te starten verloren ging wanneer één van de echtgenoten na de geboorte van het kind uitdrukkelijk of stilzwijgend erkend had dat de echtgenoot ook inderdaad de vader van het kind was. Deze doctrine gold zowel voor de vader als voor de moeder en had, net als de wetgeving, tot doel het kind te beschermen tegen de lasten die een na jaren ingestelde ontkenningsprocedure met zich meeneemt. Deze doctrine illustreerde dat het doel van de regeling ook bereikt kon worden zonder onderscheid te maken op grond van geslacht. Het Hof gaf het volgende oordeel:

"It is true that an equivalent result might have been obtained through the doctrine of acknowledgement, but $[\ldots]$ the competent authorities were entitled to think that as regards the husband the aim sought to be realised would be the most satisfactorily achieved by the enactment of a statutory rule, where as regards the mother it was sufficient to leave the matter to be decided by the Courts on a case-by-case basis. Accordingly, $[\ldots]$ the authorities [...] did not transgress the principle of proportionality." 230

In deze overweging is een subsidiariteitsoverweging vervat, nu het Hof uitdrukkelijk inging op de vraag of het doel van het onderscheid even goed kon worden bereikt door een alternatieve, minder discriminatoire, mogelijkheid. ${ }^{21}$ Aanleiding voor het uitvoeren

228. $\$ 15$

229. EHRM 28 november 1984, Series A, vol. 87; vgl. ook Schokkenbroek 1996, p. 200.

230. $\$ 41$

231. Vgl. Harris/O'Boyle/Warbrick 1995, p. 483. Ook bij de beoordeling van inbreuken op substantiele artikelen wordt soms aandacht besteed aan de subsidiariteitseis. Een voorbeeld daarvan is te vinden in het arrest Informationsverein Lentia, dat betrekking had op het handhaven van een monopolie op uitzendrechten. De verwerende staat had zich ter rechtvaardiging hiervan onder andere beroepen op het 
van deze toets was waarschijnlijk dat de "doctrine of acknowledgement" door klager expliciet als alternatief was aangevoerd, zodat een onderzoek naar de eventuele andere mogelijkheden erg gemakkelijk was. Bovendien was er in dit geval sprake van onderscheid op grond van geslacht, hetgeen door het Hof als een verdachte grond wordt beschouwd. Zoals eerder is aangegeven wordt in een dergelijk gevallen een intensieve toets uitgevoerd, waarbij een verdergaand onderzoek naar de redelijkheid van de door de overheid gemaakte keuzes in de rede ligt.

Een tweede zaak waarin het Hof een toetsing uitvoerde aan het subsidiariteitsvereiste is het arrest Inze. ${ }^{232}$ Zoals eerder is uiteengezet had deze zaak betrekking op de vererving van grote boerderijen, waarbij een wettig geboren erfgenaam automatisch voorrang kreeg boven een onwettig geboren erfgenaam. Volgens de regering was deze voorrangsregeling bedoeld om tegemoet te komen aan de onuitgesproken wens van de overledene en aan de opvattingen van de rurale bevolking. De regering gaf verder aan dat er inmiddels een nieuwe regeling was voorgesteld, waarin de vererving zou worden bepaald aan de hand van meer objectieve criteria. Het Hof kwam op grond van deze omstandigheden tot het volgende oordeel:

"The Court wishes to make it clear that these proposed amendments cannot in themselves be taken as demonstrating that the previous rules were contrary to the Convention. They do however show that the aim of the legislation in question could also have been reached by applying criteria other than that based on birth in or out of wedlock." ${ }^{233}$

Uit deze overweging blijkt dat het Hof het onderscheid ontoelaatbaar achtte omdat er andere, minder vergaande mogelijkheden voorhanden waren om het gestelde doel te bereiken. Opmerkelijk is dat het Hof in dit geval, anders dan in het hiervoor besproken arrest Rasmussen, niet op aandringen van de klager, maar uit eigen beweging een oordeel over de subsidiariteit gaf. Een verklaring hiervoor kan gelegen zijn in het feit dat voor de vaststelling van alternatieven een vergaand eigen onderzoek niet nodig was: het bestaan daarvan kon eenvoudigweg uit de voorgestelde regelgeving worden afgeleid. Deze uitspraak lijkt te bevestigen dat het Hof bij verdachte classificaties soms reden ziet voor een onderzoek naar alternatieve, minder belastende maatregelen; een dergelijk onderzoek wordt echter alleen uitgevoerd als het bestaan van alternatieve mogelijkheden duidelijk uit de feiten of uit de stellingen van partijen naar voren komt. ${ }^{24}$

Het bovenstaande citaat uit Inze is ook in een ander opzicht van belang. Het is duidelijk dat het Hof voor het oordeel over de noodzakelijkheid relevant achtte dat er inmiddels

feit dat het alleen door een monopolie mogelijk was om te zorgen voor een objectieve berichtgeving, uitgebalanceerde programmering en onafhankelijke medewerkers. Het Hof was echter van mening dat uit de ervaringen van andere staten bleek dat er wel degelijk andere mogelijkheden bestonden om dit doel te bereiken. De maatregel was dan ook disproportioneel (zie $\$ \S 39$ en 42). Ook in het arrest Fuentes Bobo gaf het Hof met zoveel woorden aan dat er minder vergaande mogelijkheden voorhanden waren dan in het voorgelegde geval waren gekozen (EHRM 29 februari 2000, EHRC 2000/34, § 49).

232. EHRM 28 oktober 1987 , Series A, vol. 126

233. \$44. Idem in EHRM 11 oktober 2001, Sahin, EHRC 2001/81, § 60.

234. Vgl. Harris/O’Boyle/Warbrick 1995, p. 483. 
een nieuwe regeling tot stand was gekomen, waarin het litigieuze onderscheid op grond van onwettige geboorte bleek te ontbreken. De benadering van het Hof is erg voorzichtig: het bestaande voornemen om een nieuwe, niet discriminatoire regeling tot stand te brengen is geen doorslaggevend gegeven, maar vormt slechts een aanwijzing voor het ontbreken van noodzakelijkheid. Deze voorzichtigheid lijkt zonder meer terecht, nu niet iedere wetswijziging zal impliceert dat het onderscheid in de eerdere regeling niet noodzakelijk was. Wanneer er bijvoorbeeld sprake is van een wijziging van een wet die al lang bestaat en waarin een onderscheid is opgenomen dat lange tijd redelijk werd geacht, zal vaak kunnen worden vastgesteld dat deze wet ten tijde van zijn inwerkingtreding voldeed aan het vereiste van noodzakelijkheid. De voorzichtige benadering van het Hof, waarin wetswijziging slechts wordt gezien als een indicatie van een gebrek aan noodzaak, kan worden beschouwd als een zinvolle aanvulling op het algemene toetsingsmodel.

\subsection{Proportionaliteit in strikte zin}

De proportionaliteitstoets in strikte zin is bij de toetsing aan de substantiële verdragsbepalingen een belangrijk element. In de meeste gevallen is een toetsing van de belangenafweging, zeker wanneer er een striktere toetsing wordt uitgevoerd, zelfs bepalend voor de uitkomst van de procedure. Dit is anders voor de toetsing aan artikel 14: bij de beoordeling van ongelijke behandeling wordt zelden een duidelijk oordeel gegeven over de belangenafweging die aan een normatieve classificatie ten grondslag heeft gelegen. De reden hiervoor lijkt dezelfde te zijn als die genoemd is bij de bespreking van de subsidiariteitstoets: het Hof stelt zich in de meeste gevallen terughoudend op en laat de beoordeling van de redelijkheid van een belangenafweging graag over aan de nationale instanties. Ook hier geldt echter dat een andere benadering wordt gekozen wanneer de toetsing wordt geïntensiveerd, bijvoorbeeld omdat er onderscheid is gemaakt op verdachte gronden. Zoals eerder is aangegeven wordt in dat geval van de nationale overheid verlangd dat deze very weighty reasons aanvoert ter rechtvaardiging van zijn classificatie, hetgeen niet alleen betekent dat er legitieme en objectieve argumenten moeten worden aangevoerd, maar ook dat moet worden aangetoond dat deze het gemaakte onderscheid voldoende kunnen dragen. Om te beoordelen of er van een toereikende rechtvaardiging sprake is zal het Hof het door het onderscheid gediende belang af moeten zetten tegen het belang dat door het onderscheid is geraakt: in feite is er daardoor sprake van een proportionaliteitstoets.

Opmerkelijk is dat de proportionaliteitstoets die wordt uitgevoerd bij de uitvoering van de very weighty reasons-toets iets verschilt van de proportionaliteitstoets bij "gewone" classificaties. In het laatste geval maakt het Hof een afweging tussen het algemene belang dat wordt nagestreefd en het individuele belang dat daardoor in het concrete geval wordt aangetast. Als het gaat om een verdachte classificatie lijken de in het concrete geval betrokken belangen veel minder belangrijk te zijn: het Hof kiest in die gevallen veeleer voor een afweging van het nagestreefde doel tegen een abstract individueel belang, namelijk het zwaarwegende belang om niet te worden achtergesteld op grond van een irrelevant criterium, zoals ras of geslacht. Bij deze toetsing blijkt er 
vrijwel nooit sprake te zijn van evenredigheid, zelfs niet wanneer er in het concreet voorliggende geval geen sprake is van een aantasting van zwaarwegende concrete belangen. Deze benadering is zeker te rechtvaardigen, nu het maken van onderscheid op grond van een verdacht criterium de betrokkenen een gevoel van inferioriteit kan geven en zelfs kan leiden tot stigmatisering van een bepaalde groep. Het gevaar van het creëren van een dergelijk stigma zal niet minder groot zijn wanneer de direct aangetaste belangen niet bijzonder gewichtig zijn. ${ }^{235}$

Een voorbeeld van een zaak waarin het Hof het nagestreefde doel niet voldoende zwaarwegend achtte om een onderscheid op een verdachte grond te kunnen rechtvaardigen is het al meermalen genoemde arrest Abdulaziz. ${ }^{236}$ Dit arrest had betrekking op een onderscheid tussen mannelijke en vrouwelijke immigranten, dat werd ingegeven door de wens de Engelse arbeidsmarkt te beschermen. In deze uitspraak overwoog het Hof het volgende:

"[...] the Court is not convinced that the difference that may exist between the respective impact of men and of women on the domestic labour market is sufficiently important to justify the difference of treatment, complained of by the applicants."217

Een ander, jets extremer voorbeeld is te vinden in het arrest Hoffmann ${ }^{238}$ In deze zaak werd het Hof gevraagd om te oordelen over een rechterlijke uitspraak in een geschil over de toewijzing van kinderen na een echtscheiding. De moeder van de kinderen, een Jehova's getuige, leek op zichzelf de meest aangewezen persoon te zijn om de kinderen op te voeden. De vader stelde echter dat haar godsdienstige overtuiging gevaar zou opleveren voor de sociale ontwikkeling van de kinderen en voor hun gezondheid. De nationale rechter had bij zijn belangenafweging de balans door laten slaan naar de vader, waarbij hij vooral rekening had gehouden met godsdienstige argumenten; daardoor was er volgens het Hof sprake van een verschil in behandeling dat in essentie was gebaseerd op godsdienst. In het kader van zijn beoordeling van de gerechtvaardigdheid van dit onderscheid stelde het Hof het volgende:

"The aim pursued by the judgment of the Supreme Court was a legitimate one, namely the protection of the health and rights of the children; it must now be examined whether the second requirement [de proportionaliteitseis, JHG] was also satisfied. [...] Notwithstanding any possible arguments to the contrary, a distinction based essentially on a difference in religion alone is not acceptable. The Court therefore cannot find that a reasonable relationship of proportionality existed between the means employed and the aim pursued."239

Uit deze overweging kan worden afgeleid dat een onderscheid dat uitsluitend is gebaseerd op een verdachte grond weliswaar een gerechtvaardigd doel kan dienen, maar dat een dergelijk doel nooit zwaarwegend genoeg kan zijn om het onderscheid te recht-

235. Vgl. Heringa 1992, p. 12. Zie ook hoofdstuk 2, paragraaf 5.3.2.

236. EHRM 25 mei 1985, Series A, vol. 94

237. $\$ 79$, cursief toegevoegd.

238. EHRM 23 juni 1993, Series A, vol. 255-C

239. $\$ \$ 34$ en 36 , cursief toegevoegd. 
vaardigen: een proportionele verhouding tussen doel en aangetast belang zal bij een dergelijk onderscheid steeds ontbreken. ${ }^{240}$

Overigens moet worden opgemerkt dat er niet veel voorbeelden zijn te vinden van arresten over verdachte classificatie waarin het Hof uitgebreid ingaat op de proportionaliteit. In veel gevallen is het Hof erg kort en volstaat het met de ongemotiveerde mededeling dat er geen objectieve en redelijke rechtvaardiging voor het onderscheid bestaat. Typerend is een overweging als de volgende, afkomstig uit het arrest SchulerZgraggen ${ }^{211}$ :

"[...] very weighty reasons have to be put forward before [...] a difference of treatment could be regarded as compatible with the Convention. The Court discerns no such reason in the instant case. It therefore concludes that for want of any reasonable and objective justification, there has been a breach of Article $14 .^{\text {n212 }}$

Een dergelijke, buitengewoon summiere motivering komt zeker niet ten goede aan de controleerbaarheid van de rechtspraak en de doorzichtigheid van de overwegingen die aan een bepaalde conclusie ten grondslag hebben gelegen. De inbreuk op de rechtszekerheid die door een dergelijke onzorgvuldige motivering kan worden veroorzaakt lijkt hoogstens enigszins te worden opgevangen door het feit dat de voorspelbaarheid van de uitkomst van de very weighty reasons-toets bijzonder groot is: in vrijwel geen enkel geval waarin het Hof deze toets heeft toegepast is het tot het oordeel gekomen dat het onderscheid met artikel 14 verenigbaar is. Wanneer er onderscheid is gemaakt op verdachte gronden staat dus in ieder geval vast dat het onderscheid ongeoorloofd is, ongeacht de aangevoerde rechtvaardiging; daardoor wordt toch een vrij grote mate van duidelijkheid en voorspelbaarheid gecreëerd. Het accent van de toetsing verschuift hierdoor van de inhoudelijke beoordeling van het onderscheid naar bepaling van de toepasselijkheid van de very weighty reasons-test. In paragraaf $3 \mathrm{zal}$ dan ook uitgebreid worden ingegaan op de vraag welke factoren daarbij een rol spelen.

\subsection{Ontbrekend criterium: toetsing van de mate van fit (over- en under- inclusiveness)}

Van over- of underinclusiveness zal sprake kunnen zijn als een regeling ertoe strekt een bepaalde groep een voordeel toe te kennen of een bepaalde bescherming te bieden, terwijl deze aan andere groepen wordt ontzegd. Bij dergelijke maatregelen is het zaak om de bevoordeelde groep nauwkeurig te definiëren. Gebeurt dit niet, dan zullen er al snel mensen van een voordeel worden uitgesloten, terwijl deze daar gezien het doel van de regeling wel recht op hebben (underinclusiveness); andersom kan een onzorgvuldige definitie tot gevolg hebben dat mensen ten onrechte worden gerekend tot de groep die voor een nadelige behandeling wordt uitgezonderd (overinclusiveness).

240. Een vergelijkbare redenering is te vinden in het arrest Salgueira da Silva Mouta, dat betrekking had op onderscheid op grond van seksuele geaardheid (EHRM 21 december 1999, EHRC 2000/16, \$36).

241. EHRM 24 juni 1993, Series A, vol. 263

242. $\$ 67$. Een vergelijkbare overweging is te vinden in Gaygusuz (EHRM 16 september 1996, Reports 1996-IV). 
De toetsing van over-en underinclusiveness wordt door het Hof niet als afzonderlijk element van zijn toetsing gezien. Geheel verwonderlijk is dit niet, nu het Hof een vergelijkbaarheidstoets als toetsingsingang hanteert. Zoals in hoofdstuk $2 \mathrm{al}$ is aangegeven vertonen beide tests een zekere mate van verwantschap: overinclusiveness is ook te omschrijven als een gelijke behandeling van onvergelijkbare gevallen, terwijl underinclusiveness kan worden gezien als een ongelijke behandeling van vergelijkbare gevallen. ${ }^{233}$ Het belangrijkste verschil is dat het Hof de vergelijkbaarheidstoets ziet als een toetsingsingang, waardoor het aan de klager is om aan te tonen dat de gevallen vergelijkbaar of juist, in het geval van materieel onderscheid, onvergelijkbaar zijn. De toetsing van de mate van fit, zoals de beoordeling van over- of underinclusiveness kortheidshalve kan worden omschreven, maakt daarentegen deel uit van het rechtvaardigingsmodel, waardoor het aan de verantwoordelijke staat is om aan te tonen dat de definitie van de uitgezonderde groep voldoende aansluit op de nagestreefde doelstellingen. Het is echter duidelijk dat, wanneer in de eerste fase al een oordeel is gegeven over de vergelijkbaarheid, een toetsing van de mate van fit in de tweede fase zou leiden tot overlappingen. Het is dan ook niet verrassend dat deze toets geen vast onderdeel vormt van de toetsing van het Hof.

Bij de toepassing van de doel-middeltoets maakt het Hof echter wel degelijk soms gebruik van een argumentatie die niet anders kan worden beschreven dan als een toetsing van de mate van fit. Het duidelijkste voorbeeld hiervan is terug te vinden in het arrest Van Raalte. ${ }^{24}$ Deze zaak had betrekking op een Nederlandse uitzonderingsregeling voor de betaling van een bijdrage voor de Kinderbijslagwet. Ongehuwde, kinderloze vrouwen ouder dan 45 jaar waren volgens deze regeling niet verplicht tot het betalen van de premies; voor mannen gold deze uitzondering niet. De redering trachtte dit onderscheid op grond van geslacht te rechtvaardigen met het argument dat het door biologische verschillen voor vrouwen boven een bepaalde leeftijd veel moeilijker is om nog kinderen te krijgen dan voor mannen. Verondersteld werd bovendien dat kinderloze vrouwen lijden onder het idee dat zij geen kinderen meer kunnen krijgen, zodat de verplichting om premies te betalen voor de kinderbijslag zou kunnen leiden tot een zware emotionele belasting. Het Hof gaf over deze redenatie het volgende oordeel:

"In this context it must be borne in mind that just as women over $\mathbf{4 5}$ may give birth to children, there are on the other hand men of 45 or younger who may be unable to procreate. The Court further observes that an unmarried childless woman aged 45 or over may well become eligible for benefits under the Act in question; she may, for example, marry a man who already has children from a previous marriage. In addition, the argument that to levy contributions under a child care benefits scheme from unmarried childless women would impose an unfair emotional burden on them might equally well apply to unmarried childless men or to childless couples."2as

De regeling was volgens het Hof dus zowel over-als underinclusive. Allereerst kwam de groep vrouwen die weliswaar ouder zijn dan 45 , maar biologisch nog in staat zijn om kinderen te krijgen, door de definitie ten onrechte in aanmerking voor een vrijstel-

243. Zie paragraaf 4.2 .4 .

244. EHRM 21 februari 1997, Series A, vol. 1997-I

245. $\S 43$ 
ling. Op zichzelf is dit niet zo erg, omdat het enige gevolg daarvan is dat zij een financieel voordeel hebben: van een voor mannen benadelend effect is hierdoor geen sprake. Problematischer was dat de regeling zich niet uitstrekte tot mannen die niet in staat zijn om kinderen te krijgen: zij moesten de premies gewoon betalen en konden daardoor onderhevig zijn aan de daaraan eventueel gepaard gaande emotionele belasting. Bovendien bevatte de regeling nog een tweede underinclusiveness, doordat deze niet zag op enkele andere gevallen waarin de premieplicht een emotionele belasting zou kunnen opleveren. Duidelijk was in ieder geval dat de regeling zodanig slordig was geformuleerd dat deze de toetsing aan artikel 14 niet kon doorstaan.

Er zijn geen andere zaken waarin het Hof zo duidelijk aandacht heeft besteed aan de mate van fit. ${ }^{246}$ Hoogstens blijkt het Hof in zijn doel-middeltoets soms een argument te verwerken dat hierop betrekking heeft. Dit blijkt vooral te gebeuren bij verdachte classificaties, waarbij geen vergelijkbaarheidstoets wordt uitgevoerd. ${ }^{247}$ Uit die jurisprudentie blijkt dat de toets in de praktijk wel degelijk een nuttige functie kan hebben.

\subsection{Conclusie}

In het voorgaande is duidelijk geworden dat het Hof bij de toetsing aan artikel 14 weliswaar gebruik maakt van een op zichzelf mooi en helder toetsingsmodel, maar dat de toetsing daaraan nogal wat gebreken vertoont. Allereerst is het Hof weinig consequent in het toepassen van het model. Gebleken is dat het Hof lang niet altijd ingaat op de vergelijkbaarheid, terwijl dit volgens het model een voorwaarde is om een recht-

246. De verklaring voor het feit dat dit argument in Van Raalte zo uitdrukkelijk is terug te vinden is waarschijnlijk gelegen in het feit dat de auteur van de opinie zich heeft laten inspireren door de Amerikaanse rechtspraak over gelijke behandeling (vgl. Heringa/Woltjer 1997, p. 1713): de toetsing van de mate van fit vormt in de gelijke behandelingsrechtspraak van het Amerikaanse Supreme Court een belangrijk element. De Amerikaanse inspiratie wordt ook op andere punten van de uitspraak duidelijk, bijvoorbeeld doordat, anders dan gebruikelijk, wordt vereist dat de doelstellingen die worden aangevoerd "compelling" zijn; in de VS is het vereisen van een "compelling governmental interest" gebruikelijk bij het toepassen van de meest intensieve toets, de strict scrutiny-test. De Amerikaanse inspiratie lijkt echter eenmalig te zijn: noch een zo duidelijke toetsing van de mate van fit, noch het vereiste van "compelling reasons" is in de latere rechtspraak over artikel 14 terug te vinden.

247. Een voorbeeld is het arrest Thlimmenos (EHRM 6 april 2000, EHRC 2000/45). In dit arrest werd geklaagd over het verbod om mensen die in het verleden strafrechtelijk waren veroordeeld te benoemen tot accountant. Daarbij werd echter geen onderscheid gemaakt naar de aard van het misdrijf waarvoor iemand was veroordeeld. Het Hof oordeelde hierover, in het kader van de toetsing van de verhouding tussen doel en middel, het volgende: "The Court considers that, as a matter of principle, States have a legitimate interest to exclude some offenders from the profession of chartered accountant. However, the Court also considers that, unlike other convictions for serious criminal offences, a conviction for refusing on religious or philosophical grounds to wear a military uniform cannot imply any dishonesty or moral turpitude likely to undermine the offender's ability to exercise his profession. Excluding the applicant on the ground that he was an unfit person was not, therefore, justified" $(\$ 22)$. Het Hof interpreteerde in dit geval zelf de doelstelling van de regeling als het uitsluiten van een bepaald beroep van mensen die hiervoor in moreel opzicht niet geschikt zijn. In het licht van die doelstelling is, zo blijkt uit de overweging, de groep van mensen die van het accountantsberoep wordt uitgesloten onvoldoende specifiek gedefinieerd: er worden ook mensen uitgesloten die weliswaar een misdrijf hebben begaan, maar geen blijk geven van morele ongeschiktheid. Dit betekent dat in de motivering van het Hof in essentie een toetsing van de mate van fit kan worden gezien, waarbij het Hof tot de conclusie komt dat de maatregel een ontoelaatbare mate van overinclusiveness vertoont. 
vaardigingstoets te kunnen uitvoeren. Ook bij de uitvoering van de rechtvaardigingstoets zelf worden vaak criteria overgeslagen of verwisseld: soms gaat het Hof, zonder aandacht te besteden aan de legitimiteit van het doel, over tot de uitvoering van een proportionaliteitstoets, en in andere gevallen laat het de proportionaliteitstoets volledig achterwege, terwijl het wel een gerechtvaardigd doel aanwezig acht.

Bij de toetsing aan de verschillende criteria van het model zelf ontbreekt eveneens vaak de nodige zorgvuldigheid. Het Hof is snel tevreden met de aangevoerde doelstellingen en zoekt slechts zelden naar het werkelijke doel van een onderscheid, zelfs niet wanneer daarvoor, gezien de omstandigheden van het geval, wel aanleiding zou bestaan. Ook de doel-middeltoets is in veel gevallen oppervlakkig en wordt lang niet altijd goed gemotiveerd. Weliswaar is in de uitspraken soms een toetsing aan criteria als geschiktheid, noodzakelijkheid, subsidiariteit of proportionaliteit terug te vinden, maar van een consequent toetsingsbeleid is geen sprake. In dat opzicht is de rechtspraak met betrekking tot de substantiële bepalingen aanzienlijk beter uitgewerkt: niet alleen is daarbij door middel van de vaststelling van specifieke toetsingscriteria beter uitwerking gegeven aan de doel-middeltoets, maar ook geeft de toetsing aan deze criteria in de meeste gevallen blijk van een grote mate van zorgvuldigheid. Door de betere motivering bij de substantiële artikelen is de controleerbaarheid van deze rechtspraak veel groter dan die over artikel 14. Bovendien wordt door de uitgebreidheid van de motivering meer recht gedaan aan de bij de lidstaten bestaande behoefte om duidelijkheid te krijgen over de wijze waarop zij het Verdrag moeten toepassen.

Uit het voorgaande is verder naar voren gekomen dat de toetsing aan het gelijkheidsbeginsel in veel gevallen beter en intensiever is in gevallen waarin er sprake is van verdachte classificaties. In die gevallen wordt veelal nauwkeurig gekeken naar de aangevoerde argumenten en is de motivering iets uitgebreider. Bovendien is het daarbij zo dat, zelfs als een inhoudelijke toetsing ontbreekt, de rechtszekerheid minder ernstig wordt aangetast: de uitkomst van de very weighty reasons-toets is zo voorspelbaar dat een uitgebreide inhoudelijke toetsing nauwelijks nog aan een verhoging van de rechtszekerheid bijdraagt. ${ }^{248}$ Dit kan de vraag oproepen in welke gevallen het Hof voor deze intensievere toetsing kiest en welke factoren bepalend zijn voor de typering van een onderscheidingsgrond als verdacht. Aan deze onderwerpen zal in de volgende paragraaf uitgebreid aandacht worden besteed.

248. Overigens moet daarbij worden opgemerkt dat voorspelbaarheid van de uitkomst wel een ander probleem oplevert. Dit leidt er namelijk toe dat de uitkomst van de toetsing niet zozeer wordt bepaald door een inhoudelijke toetsing van het onderscheid, maar door de vaststelling van de toetsingsintensiteit. De factoren die daarbij een rol spelen zijn lang niet altijd geschikt als vervanging voor een inhoudelijke toetsing van de aangevoerde rechtvaardiging. Op deze problematiek zal worden ingegaan in hoofdstuk 5, waarin de Amerikaanse rechtspraak wordt besproken: deze rechtspraak kenmerkt zich door een uitgesproken grote voorspelbaarheid van bepaalde gelijkheidstoetsen, een eigenschap die in de praktijk regeimatig tot problemen leidt. 


\section{Toetsingsintensiteit en de margin of appreciation}

\subsection{Inleiding}

\subsubsection{Inhoud van de margin of appreciation-doctrine}

De toetsingsintensiteit van het Hof wordt in belangrijke mate bepaald door de doctrine van de margin of appreciation. Het eerste arrest waarin het Hof refereerde aan deze doctrine is de al eerder vermelde Belgische Taalzaak, waarin het Hof aangaf welke criteria en factoren een rol spelen bij de beantwoording van de vraag of een onderscheid gerechtvaardigd is. ${ }^{249}$ Het Hof gebruikte in dit arrest overigens nog niet expliciet het begrip margin of appreciation ${ }^{20}$, maar uit de uitspraak kan worden afgeleid dat het Hof de doctrine wel al erkende. Ook blijkt hieruit wat hiervan de betekenis is:

"In attempting to find out in a given case, whether or not there has been an arbitrary distinction, the Court cannot disregard those legal and factual features which characterise the life of the society in the State which, as a Contracting Party, has to answer for the measure in dispute. In so doing it cannot assume the role of the competent national authorities, for it would thereby lose sight of the subsidiary nature of the international machinery of collective enforcement established by the Convention. The national authorities remain free to choose the measures which they consider appropriate in those matters which are governed by the Convention. Review by the Court concerns only the conformity of these measures with the requirements of the Convention."251

Uit deze overweging blijkt dat het Hof een zekere mate van terughoudendheid zal betrachten bij het beoordelen van door de staten genomen maatregelen op het door het Verdrag beheerste gebied. Deze terughoudendheid komt tot uitdrukking in het verschaffen van een bepaalde ruimte aan de staten, waarbinnen zij zelf kunnen bepalen welke maatregelen nodig en geschikt zijn om een bepaald doel te bereiken. Pas als de staten de grens van deze ruimte hebben overschreden zal het Hof concluderen dat zij het Verdrag hebben geschonden. Deze aan de staten gelaten beslissingsruimte wordt in latere rechtspraak consequent aangeduid als de margin of appreciation.

De omvang van de ruimte die de staten hebben om beslissingen te nemen is niet steeds hetzelfde: in sommige gevallen zal het Hof de staten meer vrijheid laten dan in andere. De intensiteit van de toetsing blijkt in de praktijk nauw verbonden te zijn met de omvang van de margin of appreciation die aan de staten wordt toegekend. In het licht van het voorwerp van het onderzoek is het dan ook interessant is om te bezien welke factoren een rol spelen bij de vaststelling van de margin. Alvorens in te gaan op deze factoren lijkt het echter zinvol om enige aandacht te besteden aan de rechtvaardiging die het Hof voor de doctrine heeft gegeven en aan de precieze betekenis die deze doctrine heeft voor de toetsingsmethodiek van het Hof.

249. EHRM 23 juli 1968, Series A, vol. 6

250. Dit gebeurde pas in het arrest Ireland v. UK (EHRM 18 januari 1978, Series A, vol. 25). Verschillende auteurs stellen dat het concept in de arresten over artikel 15 voor het eerst is toegepast en dat het van daaruit verder is toegepast op andere bepalingen (bijv. Burke 1981, p. 1132 en O'Donnell 1982, p. 477). Uit de geciteerde passage blijkt echter dat het Hof al in 1968 aandacht besteedde aan de beoorde251. $\$ 10$ lingsruimte van de staten bij de toepassing van artikel 14 EVRM; in deze zin ook Alkema 1975, p. 9. 


\subsubsection{Basis voor de aanvaarding van de margin of appreciation-doctrine}

Uit het hiervoor weergegeven citaat uit de Belgische Taalzaak blijkt dat de margin of appreciation-doctrine in belangrijke mate is gebaseerd op het in het internationale recht algemeen geldende principe van de subsidiariteit. ${ }^{252}$ Dit principe houdt in dat een internationale organisatie alleen mag optreden als de nationale staten niet of onvoldoende in staat blijken te zijn om zelf tot actie over te gaan: de verantwoordelijkheid om aan de vereisten van het Verdrag te voldoen berust in de eerste plaats bij de staten. ${ }^{253}$ Wanneer er verschillende manieren zijn om aan de verdragsverplichtingen te voldoen is het dan ook primair aan de staat is om hiertussen een keuze te maken. De internationale rechter mag vervolgens slechts nagaan of de gemaakte keuze niet in strijd is met het Verdrag. ${ }^{24}$ Zoals hiervoor is aangegeven heeft het Hof, om de ruimte af te bakenen waarbinnen de staten de vrijheid hebben om keuzen te maken, gebruik gemaakt van margin of appreciation-doctrine. Aangegeven is reeds dat het uitgangspunt van deze doctrine is dat de staten pas in strijd handelen met het Verdrag als zij de grenzen van de door het Hof aanvaardbaar geachte beoordelingsruimte hebben overschreden. ${ }^{25 s}$

Naast deze door het internationale recht geïnspireerde onderbouwing heeft het Hof ook een meer praktische reden gegeven voor het hanteren van de margin of appreciationdoctrine. Het Hof is van mening dat de staten in het algemeen beter uitgerust zijn dan de internationale rechter om de nationale situatie te beoordelen en in te schatten welke maatregelen er op een bepaald moment nodig zijn. ${ }^{256}$ Dit argument speelt met name een rol bij de beantwoording van de vraag of een maatregel noodzakelijk is. Om dit te bepalen moet vaak worden vastgesteld of de genomen maatregel in de feitelijke situatie daadwerkelijk vereist was. In het algemeen is de internationale rechter minder goed in staat om hierover een oordeel te geven dan de nationale instanties, zodat het redelijk is

252. Vgl. EHRM 12 december 1976, Handyside, Series A, vol. 24, $§ 48$ : "The Court points out that the machinery of protection established by the Convention is subsidiary to the national systems safeguarding human rights [...]. The Convention leaves to each Contracting State, in the first place, the task of securing the rights and liberties it enshrines. The institutions created by it make their own contribution to this task but they become involved only through contentious proceedings and once all domestic remedies have been exhausted (Article 26)." Velaers geeft zelfs aan dat het subsidiariteitsbeginsel het wezen van het Europese waarborgsysteem vormt (1991, p. 349).

253. Vgl. Petzold 1993, p. 41: "The principle of subsidiarity is generally understood to mean that in a community of societal "pluralism" the larger social unit should assume responsibility for functions only insofar as the smaller social unit is unable to do so."

254. Mahoney 1990 , p. 78

255. Hierdoor ontstaat voldoende flexibiliteit om de moeilijke balans tussen nationale soevereiniteit en internationale controle te vinden (Mahoney 1990, p. 81). Zo kan het Hof door de margin of appreciation-doctrine rekening houden met bijzondere feiten en omstandigheden die in een bepaalde staat een rol spelen. Dit betekent dat de staten soms de vrijheid hebben om enigszins af te wijken van een verdragsbepaling omdat nationale bijzonderheden dit noodzakelijk maken. Ook hierbij geldt echter dat het Hof het laatste woord heeft en kan vaststellen wanneer het beroep op dergelijke omstandigheden een inbreuk niet kan rechtvaardigen. Vgl. Burke 1981, p. 1136 en Heringa 1996, p. 112/113.

256. Zie EHRM 18 januari 1978, Ireland v. UK (IRA-case), Series A, vol. 25, $\S 207$ : "By reason of their direct and continuous contact with the pressing needs of the moment, the national authorities are in principle in a better position than the international judge to decide both on the presence of such an emergency and on the nature and scope of derogations necessary to avert it. In this matter Article $15 \S$ 1 leaves those authorities a wide margin of appreciation." Vgl. ook EHRM 12 december 1976, Handyside, Series A, vol. 24, $\$ 48$ en, meer recent, EHRM 18 januari 2001, Jane Smith, EHRC 2001/19, §98. 
om de staten hierbij iets meer ruimte te geven. ${ }^{257}$ Dit argument speelt echter niet altijd een even grote rol. In veel gevallen acht het Hof zichzelf minstens zo goed als de nationale instanties in staat om een oordeel te geven. Dit is met name het geval als een zaak niet zozeer vraagt om het beoordelen van een feitelijke situatie, maar om het geven van een waardeoordeel. In dergelijke gevallen blijkt het Hof dan ook sneller bereid om een minder ruime margin of appreciation toe te kennen.

Het gebruik van de margin of appreciation-doctrine is door verschillende auteurs bekritiseerd. De kritiek luidt vooral dat de doctrine de staten te veel ruimte biedt om rekening te houden met lokale belangen en praktijken, hetgeen tot gevolg zou hebben dat de positie van het toch al minder sterk staande individu nog verder wordt verzwakt. ${ }^{258}$ Ook uit een andere hoek is er kritiek mogelijk: diegenen die grote waarde hechten aan de soevereiniteit van de staten zullen al snel vinden dat het Hof hierop een inbreuk maakt door een beperking van de omvang van de margin of appreciation.

Niettegenstaande deze kritiek is het gebruik van de margin of appreciation-doctrine goed te rechtvaardigen. ${ }^{259}$ De door het Hof hiervoor gegeven motivering - de subsidiaire functie van de internationale rechter en de betere geschiktheid van nationale autoriteiten om te beoordelen welke maatregelen in een bepaald geval noodzakelijk zijn - is op zichzelf al toereikend om het gunnen van enige vrijheid aan de staten te billijken. Naast deze rechtvaardiging zijn er bovendien nog andere argumenten te vinden voor het gebruik van de doctrine. Zo is van belang dat een goede bescherming van grondrechten vaak op verschillende manieren kan worden bereikt, zodat het zeker niet noodzakelijk is de interpretatie van het Hof als de enige juiste voor te schrijven en de staten geen ruimte te geven voor een eigen invulling. Het is bovendien maar de vraag of het wenselijk is om, in een samenstel van staten met een verschillende cultuur en met uiteenlopende problemen, te streven naar volledige uniformiteit bij de bescherming van grondrechten ${ }^{260}$ Het lijkt beter om de grondrechten te garanderen op een manier die bij deze verschillen aansluit en die ervoor zorgt dat diversiteit en culturele verscheidenheid blijven bestaan. ${ }^{261}$ Tegelijkertijd moet het Hof er echter op toezien dat de grondrechten op een goed niveau worden gegarandeerd en moet cultureel relativisme worden vermeden. ${ }^{262} \mathrm{Om}$ in dit spanningsveld een evenwicht te vinden is de margin of appreciationdoctrine een zinvol instrument: de doctrine biedt immers de mogelijkheid om staten de ruimte te geven, maar ook om in te grijpen als een staat te ver is gegaan.

Ook om een andere reden is het toekennen van een margin of appreciation wenselijk. Het Hof bevindt zich, zoals al is aangegeven, in een subsidiaire positie ten aanzien van

257. Wiarda 1986, p. 15. Zie hierover ook paragraaf 3.2 .3 , waarin aandacht zal worden besteed aan de invloed van dit argument op de toetsingsintensiteit van het Hof.

258. Vgl. Wiarda 1986, p. 19. Verder is wel gesteld dat door het verschaffen van de mogelijkheid van variatie het risico bestaat dat het "acquis conventionnel" over de grondrechtenbescherming wordt aangetast: Lord Lester of Herne Hill 1995, p. 236-237

259. Daarmee is overigens nog niets gezegd over de toepassing van de doctrine in concrete gevallen: daarop is soms kritiek mogelijk, zoals uit het vervolg van deze paragraaf nog zal blijken.

260. Vgl. Velaers 1991 , p. 360 en 361.

261. Zie Matscher 1993, p. 75 en 76 . Met Velaers kan worden opgemerkt dat, naarmate er een meer uniforme Europese consensus groeit, de mate van Europese controle en van een verdragsautonome begripsbepaling kan stijgen (Velaers 1991, p. 360).

262. Vgl. Bleckmann 1979, p. 487 en Mahoney 1998, p. 3. 
de staten; alleen al om die reden zal het af en toe terughoudend moeten zijn. Daarnaast geldt dat het Hof een rechterlijke instantie is en rekening moet houden met de plaats die een rechter in een democratische samenleving toekomt. ${ }^{263}$ Het is primair de taak van de nationale, democratisch gekozen organen om vast te stellen welke maatregelen in een staat noodzakelijk zijn. De internationale rechter zal, net als de nationale rechter, dan ook enige afstand moeten nemen van de door wetgever en regering gemaakte beleidskeuzen. Het is echter lastig om een lijn te trekken tussen datgene dat nog door de nationale wetgever kan en mag worden beslist en datgene dat als zo essentieel en belangrijk wordt ervaren dat het door een rechterlijke instantie als het Hof mag worden opgelegd. Door de margin of appreciation-doctrine heeft het Hof een instrument voor zichzelf gecreěerd dat het trekken van een dergelijke grens vergemakkelijkt.

\subsubsection{Betekenis van de margin of appreciation voor de toetsingsintensiteit}

Het Hof heeft uitdrukkelijk gesteld dat het toekennen van een margin of appreciation niet gelijk mag worden gesteld aan het creëren van een vermoeden dat de staat heeft gehandeld in overeenstemming met het Verdrag, zodat de toetsing zou moeten worden beperkt tot de vaststelling of de staat "reasonably, carefully and in good faith" heeft gehandeld. ${ }^{26}$ Het is dus zeker niet zo dat een staat zonder meer het voordeel van de twijfel heeft zodra er een ruime beoordelingsruimte wordt toegekend. De doctrine moet vooral worden beschouwd als een instrument waarmee het Hof kan bepalen hoe terughoudend het zal zijn bij de beoordeling van nationale handelingen en maatregelen. ${ }^{265} \mathrm{De}$ ruimte die het Hof aan de nationale overheid laat is dan ook te beschouwen als een inperking van zijn toetsingsmogelijkheden: op die punten waar het het nodig oordeelt om enige ruimte te laten zal het Hof zich onthouden van een intensief onderzoek naar details. ${ }^{266}$ Dit vertaalt zich in de toetsing van het Hof vooral naar de eisen die worden gesteld aan de redenen die de verwerende staat heeft aangevoerd ter rechtvaardiging van een beperking. Is de omvang van de margin of appreciation ruim, dan eist het Hof slechts dat de regering "voldoende redenen" heeft voor de inbreuk. Is er daarentegen een smalle beoordelingsruimte, dan zullen de redenen "grondig" of "pertinent" moeten zijn. ${ }^{267}$ De margin of appreciation-doctrine kan daardoor worden gezien als een instrument voor differentiatie in toetsingsintensiteit: als de margin ruim is, dan zal de toetsing van de nationale maatregel marginaal zijn; is de omvang van de beoordelingsruimte beperkt, dan zal er een intensievere toetsing worden uitgevoerd. ${ }^{268}$ In het licht

\section{Mahoney 1998, p. 2}

264. EHRM 29 maart 1979, Sunday Times, Series A, vol. 30, \$ 59; zie ook Schokkenbroek 1996, p. 203. In het arrest Olsson heeft het Hof hiervoor de reden aangegeven: het vaststellen of een staat "reasonably, carefully and in good faith" heeft gehandeld gaat in sterke mate uit van de subjectieve waardering door de staat zelf, terwijl het Hof een meer objectieve maatstaf wil aanleggen (EHRM 24 maart 1988, Series A, vol. $130, \S 82$ ).

265. Burke 1981, p. 1132 en Schokkenbroek 1996, p. 203

266. Zie Alkema 1975, p. 8.

267. Velaers 1991, p. 355

268. Macdonald 1993, p. 84 en 85 : "The margin of appreciation is really just the other side of the scope of review coin; it is the amount of latitude left to national authorities once the appropriate level of review has been decided on by the Court." Zie ook O'Donnell 1982, p. 477. Schokkenbroek geeft aan dat het niet geheel mogelijk is om de margin of appreciation en de toetsingsintensiteit als twee zijden van dezelfde medaille te zien, met name omdat de margin of appreciation-doctrine in sommige gevallen geen 
van dit onderzoek is het dan ook interessant om te bekijken op welke manier het Hof te werk gaat bij het bepalen van de omvang van de margin of appreciation. De vraag welke factoren beslissend zijn voor de omvang van de margin of appreciation zullen in deze paragraaf centraal staan.

\subsection{Factoren ter bepaling van de omvang van de margin of appreciation}

\subsubsection{Inleiding}

Zoals hiervoor is aangegeven is er een zekere differentiatie mogelijk in de omvang van de margin of appreciation en daarmee in de intensiteit van de toetsing: in sommige gevallen beschikken de staten over een "wide"269 of een "considerable" ${ }^{\text {"270 }}$ margin of appreciation, terwijl er in andere gevallen sprake is van een "less discretionary" 271 margin of appreciation. Het Hof heeft verschillende malen in meer algemene termen aangegeven welke factoren bepalend zijn voor het vaststellen van de omvang van de beoordelingsruimte. Heel duidelijk gebeurde dit in het arrest Rasmussen ${ }^{272}$, waarin het Hof stelde, dat:

"[...] [t]he scope of the margin of appreciation will vary according to the circumstances, the subject-matter and its background; in this respect, one of the relevant factors may be the existence or non-existence of common ground between the laws of the Contracting States."273

In latere arresten noemde het Hof nog enkele andere relevante factoren. In Gillow ${ }^{274}$ stelde het Hof bijvoorbeeld, dat

"[...] the scope of the margin of appreciation enjoyed by the national authorities will depend not only on the nature of the aim of the restriction but also on the nature of the right involved." 275

In Leander ${ }^{276}$ voegde het hieraan nog toe dat

"[...] the national authorities enjoy a margin of appreciation, the scope of which will depend not only on the nature of the legitimate aim pursued but also on the particular nature of the interference involved $[\ldots] .{ }^{27}$

verklaring kan geven voor feitelijk bestaande verschillen in intensiteit (1996, p. 211). Inderdaad is het zo dat in bepaalde arresten een ruime margin wordt gelaten, maar vervolgens toch een intensieve toetsing wordt uitgevoerd. Dit betekent echter nog niet dat beoordelingsruimte en toetsingsintensiteit twee verschillende dingen zijn. Eerder lijkt dit te duiden op slordigheid en inconsistentie in toetsingsmethodiek, hetgeen - zoals ook in paragraaf 2 al is gebleken - in de rechtspraak van het Hof niet ongebruikelijk is.

269. EHRM 21 februari 1986, James and Others, Series A, vol. $98, \S 46$

270. EHRM 23 november 1976, Engel and Others, Series A, vol. 22, §72. Er lijkt geen duidelijk verschil in toetsingsintensiteit te zijn tussen zaken waarin de margin of appreciation door het Hof als "wide" wordt aangemerkt en de zaken waarin de margin als "considerable" wordt aangeduid.

271. EHRM 29 maart 1979, Sunday Times, Series A, vol. 30, $\$ 59$

272. EHRM 28 november 1984 , Series A, vol. 87

273. $\S 40$

274. EHRM 23 oktober 1986, Series A, vol. 109

275. $\S 55$

276. EHRM 26 maart 1987, Series A, vol. 116

277. $\S 52$ 


\title{
Tenslotte overwoog het Hof in Buckley:278
}

\begin{abstract}
"The scope of this margin of appreciation is not identical in each case but will vary according to the context. Relevant factors include the nature of the Convention right in issue, its importance for the individual and the nature of the activities concerned." ${ }^{279}$
\end{abstract}

Deze citaten verschaffen echter nog maar weinig duidelijkheid over de betekenis van de genoemde factoren: ze zijn erg ruim en vaag geformuleerd, terwijl bovendien onduidelijk is welke omstandigheden of onderwerpen leiden tot een ruime margin en welke tot een smallere. In het hiernavolgende zal worden getracht om, door middel van een analyse van de jurisprudentie over dit onderwerp, een duidelijker antwoord te geven op de vraag welke betekenis er aan deze factoren moet worden toegekend. Daarbij moet worden opgemerkt dat er grote overeenkomsten bestaan tussen de factoren die een rol spelen bij de bepaling van de toetsingsintensiteit bij artikel 14 en de factoren die de margin beïnvloeden bij de toetsing aan de substantiële bepalingen van het Verdrag. Vooral omdat er bij de toetsing aan artikel 14 vaak impliciet of expliciet wordt gerefereerd aan de margin die geldt bij de toetsing aan een substantieel artikel zal hierna dan ook eerst in zijn algemeenheid worden ingegaan op de verschillende intensiteitbepalende factoren (paragraaf 3.2.2 tot en met 3.2.7); daarbij zal ook worden bezien hoe de factoren op elkaar inwerken en op welke manier zij de omvang van de margin of appreciation bepalen (paragraaf 3.2.8). Daarna zal in een afzonderlijke paragraaf aandacht worden besteed aan de bijzondere vertaling die bij de beoordeling van klachten over ongelijke behandeling vaak aan de margin of appreciation wordt gegeven (paragraaf 3.3).

\subsubsection{De "common ground"-factor: aanwezigheid van een Europese consensus}

Een van de belangrijkste factoren die een rol spelen bij de bepaling van de omvang van de margin of appreciation is de aanwezigheid van een common ground. In een groot aantal arresten onderzoekt het Hof of er tussen de verschillende lidstaten van de Raad van Europa een consensus bestaat ten aanzien van het onderwerp waarover het Hof uitspraak moet doen. ${ }^{280}$ De reden voor het uitvoeren van een dergelijke rechtsvergelijking is in belangrijke mate gelegen in het feit dat de nationale autoriteiten uiteindelijk verantwoordelijk zijn voor de implementatie van het Verdrag. Als het Hof onvoldoende rekening zou houden met de bestaande regelgeving en jurisprudentie op nationaal niveau, dan zou het animo van de staten om de uitspraken na te leven sterk verminde-

278. EHRM 25 september 1996, Reports 1996-IV

279. $\$ 75$

280. Het concept van de Europese consensus wordt overigens niet alleen gebruikt ter vaststelling van de toetsingsintensiteit, maar wordt ook gehanteerd als interpretatiemechanisme. Dit is vooral nuttig als het Hof een nieuwe, verdergaande uitleg aan een verdragsartikel wil geven en daarvoor legitimatie zoekt, of wanneer de uitleg van een verdragsbepaling op een bepaald punt eenvoudigweg niet duidelijk is. Voorbeelden van deze benadering zijn EHRM 30 juni 1993, Sigurdur A. Sigurjónsson, Series A, vol. 264, EHRM 24 juni 1993, Schuler-Zgraggen, Series A, vol. 263 en EHRM 16 december 1999, $v, v$. UK, EHRC 2000/15, \$\$ 73-77. In deze paragraaf zal aan het gebruik van de common ground als interpretatiemechanisme geen aandacht worden besteed, hetgeen betekent dat ook niet zal worden ingegaan op de verenigbaarheid van het consensus-principe als interpretatiemechanisme met andere interpretatiemechanismen, zoals de autonome en evolutieve interpretatie; zie daarover uitgebreid Heringa 1996, p. 108 e.v. en Brems 1996, p. 304 e.v. 
ren. ${ }^{2 \mathrm{is}}$ Bovendien kan een beroep op een Europese consensus voor het Hof een waardevolle legitimatie opleveren voor controversiële uitspraken of zaken waarin nationale waarden en gevoeligheden een belangrijke rol spelen, zoals bij zaken met betrekking tot homoseksualiteit of abortus. ${ }^{282}$

Voor de intensiteit van de toetsing betekent het gebruik van de common ground-factor dat het Hof een minder strenge toetsing uitvoert als er geen of nauwelijks overeenstemming bestaat tussen de verschillende landen. Is een Europese consensus wel aanwezig, dan is de intensiteit van de toetsing afhankelijk van de aard van de overeenstemming. Wordt de inbreuk door de meerderheid van de Europese staten goedgekeurd, dan zal de toetsing in het algemeen marginaal zijn. Lijkt een bepaalde praktijk of handelwijze in Europa echter algemeen te worden veroordeeld, dan zal het Hof een indringende toetsing uitvoeren. ${ }^{283}$ Een drietal voorbeelden kan dit verduidelijken.

In het arrest Stjerna ${ }^{234}$ vormde het ontbreken van een common ground voor het Hof aanleiding om een ruime margin of appreciation toe te kennen. De klager in deze zaak had gevraagd om een wijziging van zijn achternaam. Dit was hem door de Finse autoriteiten geweigerd, omdat zijn huidige naam niet voldeed aan een van de voorwaarden voor wijziging. Hij was van mening dat door het stellen van voorwaarden een inbreuk was gemaakt op zijn door artikel 8 EVRM beschermde privé-leven. Bij de beoordeling of de gestelde voorwaarden noodzakelijk waren in een democratische samenleving, stelde het Hof het volgende voorop:

"[...] [I]t is to be noted that in a number of Contracting States a request to change one's name must be supported by convincing or specific reasons whereas in other States any reasons may be invoked and in one State there are in principle no restrictions. There is little common ground between the domestic systems of the Convention countries as to the conditions on which a change of name may be legally effected. The Court deduces that in the particular sphere under consideration the Contracting States enjoy a wide margin of appreciation."2zss

In dit geval voerde het Hof dus vooral een soepele toetsing uit omdat er weinig overeenstemming bestond over de voorwaarden voor naamsverandering.

Een aanzienlijke mate van beoordelingsruimte werd ook toegekend in het arrest En$\mathrm{ge}^{P^{\mathrm{s}},}$, maar de reden daarvoor was een andere. In deze zaak werd geklaagd over het feit dat bij disciplinaire straffen in het leger de aard en de zwaarte van de straf (mede) af-

281. Als reden is in de literatuur ook wel aangevoerd dat de in het Verdrag opgenomen grondrechten logisch voortvloeien uit de gemeenschappelijke erfenis van de verschillende staten: hierdoor is het moeilijk om de bepalingen van het Verdrag goed te begrijpen zonder aandacht te besteden aan de nationale rechtssystemen (Brems 1996, p. 300, Carozza 1998, p. 1226 en Heringa 1996, p. 110; zie ook Tomuschat 1992, p. 135). Hoewel dit kan verklaren waarom de common ground-factor wordt gebruikt bij de uitleg van bepalingen, kan dit argument slechts in beperkte mate dienen als verklaring voor het gebruik van de factor bij de vaststelling van de omvang van de margin of appreciation.

282. Harris/O'Boyle/Warbrick 1995, p. 296

283. Vgl. Heringa 1996, p. 110.

284. EHRM 24 oktober 1994, Series A, vol. 299-B

285. $\$ 39$

286. EHRM 23 november 1976, Series A, vol. 22 
hankelijk waren van de rang van de betrokkene. Bij de beantwoording van de vraag of een dergelijk verschil toelaatbaar is nam het Hof het volgende in aanmerking:

"The hierarchical structure inherent in armies entails differentiation according to rank. Corresponding to the various ranks are differing responsibilities which in their turn justify certain inequalities of treatment in the disciplinary sphere. Such inequalities are traditionally encountered in the Contracting States and are tolerated by international humanitarian law. In this respect, the European Convention allows the competent national authorities a considerable margin of appreciation."237

Het litigieuze onderscheid werd in de verschillende staten dus niet afgekeurd, maar juist algemeen aanvaard. Het bestaan van een dergelijke consensus leidt dan tot de toekenning van een ruime margin of appreciation. Dit is anders in gevallen waarin de consensus afwijzend is ten aanzien van bepaalde praktijken. Buiten de, in paragraaf 3.3 nader te bespreken, klachten met betrekking tot artikel 14 heeft het Hof slechts zelden een strengere toetsing uitgevoerd wegens het bestaan van een "afwijzende" common ground $^{2 \mathrm{2s}}$ Een uitzondering is het arrest Dudgeon ${ }^{280}$, een arrest dat betrekking had op een Noord-Ierse wet die bepaalde homoseksuele handelingen strafbaar stelde. In het kader van de beoordeling van de rechtvaardiging voor deze wet overwoog het Hof het volgende:

"[...] [T]here is now a better understanding, and in consequence an increased tolerance, of homosexual behaviour to the extent that in the great majority of the member States of the Council of Europe it is no longer deemed necessary or appropriate to treat homosexual practices of the kind now in question as in themselves a matter to which the sanctions of criminal law should be applied; the Court cannot overlook the marked changes which have occurred in this regard in the domestic laws of the member States. [...] It cannot be maintained in these circumstances that there is a 'pressing social need' to make such acts criminal offences [...].".200

Hoewel in deze overweging een uitdrukkelijke verwijzing naar de margin of appreciation ontbreekt, blijkt hieruit duidelijk dat het bestaan van een Europese consensus over de onwenselijkheid van het strafbaar stellen van homoseksuele handelingen de belangrijkste reden vormde voor het afwijzen van de rechtvaardiging.

Hoewel het principe van een common ground een mooi en objectief criterium lijkt voor de bepaling van de toetsingsintensiteit, kan bij het gebruik hiervan een aantal vragen rijzen. ${ }^{291}$ Belangrijk is allereerst de vraag wanneer er eigenlijk kan worden gesproken

\section{7. $\$ 72$}

288. Dit kan niet geheel worden verklaard door de door Carozza aangevoerde reden dat zaken bij een volledige overeenstemming niet zo vaak aan het Hof zullen worden voorgelegd (1998, p. 1228). Vaak zal er wel een sterke mate van overeenstemming bestaan, maar conformeert een enkele staat zich hier niet aan; de zaak Dudgeon is daarvan een uitstekend voorbeeld. Het ligt in de lijn der verwachting dat juist dit soort zaken voor het Hof zal worden gebracht, omdat de grondrechtenschending dan wel heel onrechtvaardig lijkt.

289. EHRM 22 oktober 1981, Series A, vol. 45

290. $\$ 60$

291. Bovendien is kritiek mogelijk op het gebruik van een Europese consensus voor de bepaling van de omvang van de toetsingsintensiteit: dit kan gemakkelijk leiden tot het hanteren van een minimum beschermingsstandaard. De grondrechten worden hierdoor immers niet verdergaand beschermd dan in 
van een Europese consensus: de vraag is of het voor het aanvaarden daarvan nodig is dat alle Europese staten een bepaalde opvatting zijn toegedaan, of dat het al voldoende is wanneer slechts een meerderheid een bepaald beleid nastreeft. Verder kan de vraag rijzen in hoeverre rekening mag worden gehouden met bijzondere omstandigheden die in een bepaald land gelden, met name wanneer het gaat om controversiële kwesties waarbij gevoelige waarden en normen in het geding zijn. Het Hof heeft tot nu toe geen uitdrukkelijk antwoord gegeven op deze vragen, maar heeft zich beperkt tot het per geval vaststellen van het bestaan van een Europese consensus; een zuivere en doorzichtige doctrine ontbreekt daardoor. ${ }^{292}$ Gezien de grote hoeveelheid arresten waarin gebruik is gemaakt van het concept lijkt het echter goed mogelijk om enkele algemene lijnen in de rechtspraak aan te geven.

\section{a. Bestaan van overeenstemming op nationaal niveau}

De belangrijkste aanwijzing voor het bestaan (of de afwezigheid) van een Europese consensus kan worden gevonden in de overeenstemming van de nationale wetgeving van de verschillende staten. Het Hof maakt slechts zelden gebruik van dit argument om een intensievere toetsing uit te voeren. Een voorbeeld is echter het hiervoor geciteerde arrest Dudgeon: het Hof leidde in dit arrest het bestaan van een common ground af uit het feit dat wetgeving die homoseksuele handelingen strafbaar stelde in de grote meerderheid van staten was afgeschaft en dat deze handelingen volgens de regelgeving in veel andere staten niet meer konden worden vervolgd. ${ }^{293}$

In een groter aantal gevallen heeft het Hof een beroep op de nationale wetgeving gedaan om aan te tonen dat een Europese consensus ontbreekt. Deze benadering is zichtbaar in het arrest Petrovic ${ }^{24}$, dat betrekking had op het toekennen van een uitkering tijdens ouderschapsverlof. In Oostenrijk werd een dergelijke uitkering wel toegekend aan de moeder, maar niet aan de vader. De vraag rees met welke intensiteit de rechtvaardiging voor dit onderscheid moest worden beoordeeld. Het Hof oordeelde daarover als volgt:

"[...] Only gradually, as society has moved towards a more equal sharing between men and women of responsibilities for the bringing up of their children, have the Contracting States introduced measures extending to fathers, like entitlement for parental leave. [...] There still remains a very great disparity between the legal systems of the Contracting States in this field. While measures to give fathers an entitlement to parental leave have now been taken by a large number of States, the same is not true of the parental leave allowance, which only a very few States grant to fathers. The Austrian authorities' refusal to grant the applicant a

een meerderheid van de Europese staten gebruikelijk is, zelfs als een dergelijke verdergaande bescherming wel wenselijk zou zijn. Dit kan worden geillustreerd aan de hand van de zaken over transseksualiteit, die hierna nog aan de orde zullen komen. Zie ook Carozza 1998, p. 1218 en 1228.

292. Vgl. Helfer 1993, p. 140

293. Andere voorbeelden van uitspraken over substantiele bepalingen waarin een consensus tussen de nationale wetgeving leidt tot een beperkte beoordelingsruimte zijn EHRM 13 juni 1979, Marckx, Series $\mathrm{A}$, vol. $21, \S 41$ (waarbij het Hof overigens vooral een consensus aannam vanwege het bestaan van twee regionale verdragen), EHRM 25 april 1978, Tyrer, Series A, vol. 26, §31, EHRM 29 maart 1979 , Sunday Times I, Series A, vol. 30, $\$ 59$, EHRM 29 september 1988, Norris, Series A, vol. 142, $\$ 46$ en EHRM 28 oktober 1993, Lentia, Series A, vol. 276, $\$ 41$.

294. EHRM 27 maart 1998, Petrovic, Reports 1998-II 
parental leave allowance has not, therefore, exceeded the margin of appreciation allowed to them."29s

Hoewel uit arresten als het hiervoor geciteerde blijkt dat de wetgeving van de staten een belangrijke rol speelt bij de vaststelling van de margin of appreciation heeft het Hof nog geen antwoord gegeven op de vraag in welke mate de wetgeving van de staten moet overeenstemmen om te kunnen spreken van een Europese consensus. Opvallend is ook het ontbreken van een grondige analyse van de wetgeving en rechtspraak in de verschillende staten, waardoor het moeilijk is om vast te stellen op welke gronden het Hof tot het bestaan of juist de afwezigheid van een consensus concludeert. ${ }^{2 \%}$ Uit het zeer kleine aantal zaken waarin het Hof oordeelt dat een overeenstemming tussen nationale wetgeving aanwezig was, kan echter worden afgeleid dat het Hof hoge eisen stelt: het lijkt in ieder geval zo te moeten zijn dat de grote meerderheid van staten een vergelijkbaar beleid voert. Deze conclusie wordt ondersteund door de jurisprudentie over transseksualiteit. In het in 1986 gewezen arrest Rees ${ }^{297}$ ging het Hof uitgebreid in op de vraag of er in de verschillende Europese staten eenstemmig werd gereageerd op de juridische problemen (zoals die kunnen rijzen bij huwelijkswetgeving of naamwetgeving) die verbonden zijn aan geslachtsveranderingen. Het Hof concludeerde dat de wetgeving hierover sterk uiteenliep en er dus een ruime beoordelingsmarge moest worden toegekend. Wel stelde het dat in de loop van de tijd wijzigingen in de wetgeving zouden kunnen optreden die in de toekomst tot een ander oordeel zouden kunnen leiden. ${ }^{208}$ Vier jaar later werd er opnieuw een zaak aan het Hof voorgelegd die betrekking had op transseksualiteit. ${ }^{29}$ Het Hof erkende in zijn arrest dat er bepaalde veranderingen waren opgetreden in de nationale wetgeving over dit onderwerp, maar stelde vast dat er nog steeds een aanzienlijke diversiteit bestond: ook in deze zaak werd een ruime margin of appreciation toegekend. ${ }^{300}$ Ook uit het meest recente arrest van het Hof over dit onderwerp, Sheffield and Horsham, ${ }^{301}$ blijkt dat het Hof niet snel geneigd is om het

295. $\$ \S 22,24$ en 25 . Zie voor een ander voorbeeld, waarin niet expliciet een verband werd gelegd tussen het bestaan van consensus en een beperkte margin, maar de beleidsruimte uit de overwegingen van het Hof wel kan worden afgeleid, EHRM 28 september 2000, Messina (No. 2), EHRC 2000/80, $\$ 66$.

296. Vgl. Helfer 1993, p. 154, Brems 1996, p. 285 en Carozza 1998, p. 1224. Opvallend is dat het Hof nooit aangeeft welke landen het heeft onderzocht en dat het evenmin aangeeft welke methode van rechtsvergelijking het hanteert.

297. EHRM 17 oktober 1986 , Series A, vol. 106

298. "[...] [T]here is at present little common ground between the Contracting States in this area and [...] generally speaking, the law appears to be in a transitional stage. Accordingly, this is an area in which the Contracting Parties enjoy a wide margin of appreciation ( $\$ 37)$. [...] That being so, it must for the time being be left to the respondent State to determine to what extent it can meet the remaining demands of transsexuals. However, the Court is conscious of the seriousness of the problems affecting these persons and the distress they suffer. The Convention has always to be interpreted and applied in the light of the current circumstances. The need for appropriate legal measures should therefore be kept under review having regard particularly to scientific and societal developments ( $\$ 47) . "$

299. EHRM 29 augustus 1990, Cossey, Series A, vol. 184

300. $\$ 40$. Opmerkelijk is dat vier dissenters erop wijzen dat al in veertien lidstaten van de Raad van Europa een regeling was getroffen voor de juridische erkenning van een nieuw geslacht; enige reden om te stellen dat er van een groeiende consensus sprake was, was dus al in 1990 aanwezig. Zie EHRM 29 augustus 1990, Cossey, Series A, vol. 184, dissenting opinion Judge Martens, punt 5.5 en 5.6.2, en joint dissenting opinion Judges Palm, Foighel en Pekkanen, punt 3.

301. EHRM 30 juli 1998, European Human Rights Reports 1998, 163 
bestaan van een common ground wegens overeenstemming van regelgeving te aanvaarden. Volgens een onderzoek dat door een amicus curiae was verricht was er inmiddels sprake van een sterk toegenomen convergentie tussen de nationale wetgeving op het gebied van transseksualiteit; uit dit onderzoek bleek bijvoorbeeld dat het in slechts 4 van de 37 onderzochte staten niet was toegestaan om het geboorteregister te wijzingen na een geslachtsverandering. Voor het Hof was dit echter niet voldoende:

"[...] [T] he Court is not fully satisfied that the legislative trends outlined by amicus suffice to establish the existence of any common European approach to the problems created by the recognition in law of post-operative gender status. In particular, the survey does not indicate that there is as yet any common approach as to how to address the repercussions which the legal recognition of a change of sex may entail for other areas of law such as marriage, filiation, privacy or data protection, or the circumstances in which a transsexual may be compelled by law to reveal his or her pre-operative gender. [...] For the Court, it continues to be the case that transsexualism raises complex scientific, legal, moral and social issues, in respect of which there is no generally shared approach among the Contracting States." ${ }^{302}$

Het Hof kiest blijkens deze jurisprudentie voor een strikte benadering: de intensiteit van de toetsing zal pas worden verhoogd als vrijwel alle staten maatregelen hebben genomen waardoor ieder aspect van een recht volledig wordt gedekt. ${ }^{303}$ Het is de vraag of met een dergelijke terughoudendheid voldoende recht wordt gedaan aan de bescherming van grondrechten. De uitspraken van het Hof vormen voor veel staten een belangrijke aanleiding om de bescherming van grondrechten in hun eigen land te verbeteren. ${ }^{304}$ Als het Hof pas een smallere margin accepteert wanneer er een zeer vergaande mate van Europese consensus bestaat zal er slechts een beperkte prikkel tot vernieuwing van de uitspraken uitgaan. Staten die een behoudende wetgeving hebben zullen door dit soort jurisprudentie eerder worden bevestigd in hun opvattingen dan dat zij worden geïnspireerd tot het aanvaarden van regelgeving waardoor de grondrechten op een meer voortvarende manier worden beschermd. Het risico bestaat dan dat het EVRM wordt gedegradeerd tot een minimumbeschermingsniveau, een kleinste gemene deler van grondrechtenbescherming. ${ }^{305} \mathrm{Om}$ een daadwerkelijke en vooruitstrevende bescherming van grondrechten te verzekeren zou het Hof een voortrekkersrol moeten vervullen. ${ }^{306}$ Het laten van een grote beoordelingsruimte, zelfs als zich al een sterke

\section{2. $\$ \S 57$ en 58}

303. Helfer 1993 , p. 142

304. Vgl. Tomuschat 1992 , p. 136 e.v., die diverse voorbeelden geeft van wijzigingen die staten hebben aangebracht in hun wetgeving en uitvoeringspraktijk naar aanleiding van arresten van het EHRM.

305. Velaers 1991, p. 365 en Carozza 1998, p. 1218 en 1228. Ovey stelt dat het laten van een ruime beoordelingsmarge in dit soort gevallen redelijk is, omdat een divergentie in nationale regelgeving kan betekenen dat de aard en het belang van het individuele recht nog steeds onderhevig is aan een proces van begrip, erkenning en acceptatie (1998, p. 11). Wellicht is dit een goede verklaring, maar het is zeker geen rechtvaardiging: het Hof zou juist een bijdrage kunnen leveren aan de erkenning en acceptatie van een bepaald recht door het belang hiervan gemotiveerd te benadrukken en door staten aan te sporen het recht voldoende te beschermen.

306. Wellicht is dit zelfs te beschouwen als een rechtsstatelijke taak van de rechter: het is zijn taak om grondrechten te beschermen, zelfs als een parlementaire meerderheid of, zoals in dit geval, een meerderheid van staten een dergelijke bescherming van grondrechten niet accepteert (vgl. Koopmans' nabeschouwing bij Wiarda 1999, p. 134). 
ontwikkeling in de richting van een Europese consensus voordoet, is hiermee niet in overeenstemming.

\section{b. Bestaan van internationale verdragen en soft law}

Bij het zoeken naar een common ground besteedt het Hof regelmatig aandacht aan het bestaan van internationale of regionale verdragen. Ook wijst het Hof nogal eens op resoluties en aanbevelingen die door het Comité van Ministers, door de Parlementaire Vergadering van de Raad van Europa of door andere internationale instanties zijn aangenomen. ${ }^{307}$ Zeker als er op het niveau van de nationale wetgeving diversiteit bestaat kan dit een nuttig aanknopingspunt vormen: het bestaan van een internationaal verdrag kan immers aantonen dat er, ondanks de variatie in wetgeving, duidelijke aanwijzingen bestaan in de richting van een Europese consensus. Ook hierbij is echter vaak onduidelijk in welke mate het bestaan van een verdrag of van "soft law" aanleiding kan geven tot het aanvaarden van een smallere margin. Zo kan de vraag rijzen of het nodig is dat alle staten van de Raad van Europa partij zijn bij een verdrag, terwijl het eveneens van belang is te weten of het voldoende is als een groot aantal staten een verdrag heeft ondertekend, maar een aantal van hen het verdrag nog niet heeft geratificeerd.

Het Hof lijkt bij het gebruik van dit criterium minder hoge eisen te stellen dan bij het zoeken naar overeenstemming tussen nationale wetgeving. Een goed voorbeeld van de benadering van het Hof is te vinden in het arrest Marckx. ${ }^{308}$ In deze zaak werd geklaagd over een Belgische wet, die voor het ontstaan van familierechtelijke banden tussen de moeder en haar natuurlijke kind vereiste dat het kind door de moeder uitdrukkelijk werd erkend. Een dergelijke regeling is in strijd met het beginsel "mater semper certa est", dat het uitgangspunt vormt van de Brussels Convention on the Establishment of Maternal Affiliation of Natural Children en de European Convention on the Legal Status of Children born out of Wedlock. Het eerste verdrag was echter door slechts acht van de tien onderhandelende staten ondertekend en was ten tijde van het arrest pas door vier staten geratificeerd. Het tweede verdrag was door tien staten ondertekend, waarvan eveneens maar vier staten het verdrag hadden geratificeerd; verder waren er drie voorbehouden gemaakt bij de regel "mater semper certa est" ${ }^{309}$ Niettemin stelde het Hof het volgende:

"[...] [T]his state of affairs cannot be relied on in opposition to the evolution noted above. Both the relevant Conventions are in force and there is no reason to attribute the current

307. Een goed voorbeeld hiervan is het arrest Sigurjónsson (EHRM 30 juni 1993, Series A, vol. 264). In zijn arrest zocht het Hof naar een Europese consensus om steun te vinden voor de opvatting dat ook het negatieve recht op vakbondsvrijheid door artikel 11 wordt beschermd, maar ook om de omvang van de beoordelingsruimte te bepalen. In dit arrest verwees het Hof naar diverse verschillende internationale regelingen en resoluties, zoals een aanbeveling van de parlementaire Vergadering van de Raad van Europa, uitlatingen van het Committee of Independent Experts dat toeziet op de naleving van het ESH, en de praktijk van het Freedom of Association Committee of the Governing Body of the ILO (\$ 35; zie hierover uitgebreid Heringa 1996, p. 119 e.v.). De duidelijke common ground inspireerde het Hof tot de toekenning van een zeer smalle margin of appreciation: het Hof stelde zelfs dat, nu de klager was onderworpen aan een vorm van dwang die zeer zeldzaam is in de Lidstaten, de inbreuk op het eerste gezicht als ontoelaatbaar moet worden aangemerkt $(\$ 41)$. Er moeten dan wel zeer goede argumenten worden aangedragen om dit vermoeden van schending te ontkrachten.

308. EHRM 13 juni 1979, Series A, vol. 31

309. Zie $\$ 41$ van het arrest. 
small number of Contracting States to a refusal to admit equality between 'illegitimate' and 'legitimate' children on the point under consideration. In fact, the existence of these two treaties denotes that there is a clear measure of common ground in this area amongst modern societies." $" 310$

Uit deze overweging zou kunnen worden afgeleid dat het enkele bestaan van een verdrag over een bepaald onderwerp voldoende is om tot het bestaan van een Europese consensus te concluderen. ${ }^{311}$ Hoewel dit een wenselijke benadering is vanuit de gedachte dat het Hof een voortrekkersrol moet vervullen bij de bescherming van grondrechten, staat deze in opvallend contrast met de hoge eisen die aan de overeenstemming van nationale wetgeving worden gesteld. Het is moeilijk om dit verschil te verklaren, anders dan uit strikt casusgebonden overwegingen. ${ }^{312}$

\section{c. Aanwezigheid van bijzondere lokale situaties of belangen}

Tenslotte heeft het Hof in sommige gevallen gesteld dat er weliswaar sprake was van een Europese consensus, maar gaf het tegelijkertijd aan dat de betrokken lokale of nationale belangen zo zwaarwegend waren dat een ruime margin of appreciation (en daarmee een minder intensieve toetsing) werd gerechtvaardigd. Een voorbeeld bij uitstek is het arrest $F . v$. Switzerland. ${ }^{313}$ Dit arrest had betrekking op de bevoegdheid van de Zwitserse rechter om één van de partijen bij een echtscheidingsprocedure een termijn op te leggen waarbinnen hij of zij niet in het huwelijk zou mogen treden. Het Hof stelde hierover het volgende:

"The Court notes that a waiting period no longer exists under the laws of other Contracting States. [...] However, the fact that, at the end of a gradual evolution, a country finds itself in an isolated position as regards one aspect of its legislation does not necessarily imply that that aspect offends the Convention, particularly in a field - matrimony - which is so closely

310. $\$ 41$

311. Hierbij moet overigens worden opgemerkt dat het Hof recentelijk heeft aangegeven dat niet uit ieder sluiten van een verdrag een zodanige consensus blijkt dat een intensievere toetsing moet worden verkozen: de consensus moet daarvoor voldoende concreet zijn en relevante betekenis hebben voor het voorgelegde geschil. In het arrest Jane Smith oordeelde het Hof bijvoorbeeld dat er weliswaar een verdrag bestond over het betrokken onderwerp, maar dat "the consensus is not sufficiently concrete for it [het Hof, JHG] to derive any guidance as to the conduct or standards which Contracting States consider desirable in any particular situation" (EHRM 18 januari 2001, EHRC 2001/19, $\S 101$ ). Kennelijk is het dus niet van groot belang hoeveel staten een verdrag hebben ondertekend of geratificeerd, maar is wel de inhoud van het verdrag zelf relevant.

312. Het lijkt erop dat bij het vaststellen van de margin ook niet duidelijk gearticuleerde omstandigheden een rol kunnen spelen, zoals de politieke aanvaardbaarheid van een bepaalde beslissing. Zowel Schokkenbroek (1996, p. 234) als Alkema (1995, p. 40) geven overtuigende voorbeelden van zaken waarin het Hof politieke argumenten heeft laten meespelen in zijn beslissing. De motivering van het Hof wordt vervolgens op de op deze wijze vastgestelde margin afgestemd, waarbij argumenten als de common ground-factor naar believen een rol kunnen spelen; vgl. O'Donnell 1982, p. 482 en Harris/O'Boyle/Warbrick 1995, p. 297. Een dergelijke benadering lijkt onvermijdelijk (rechters zullen in het algemeen geneigd zijn om naar een bepaalde, gewenste uitkomst toe redeneren), maar de motivering kan worden verbeterd: in ieder geval is het wenselijk dat het Hof meer inzicht geeft in de wijze waarop en de mate waarin bepaalde intensiteitbepalende factoren als de common ground-factor een rol spelen.

313. EHRM 27 november 1987 , Series A, vol. 128 
bound up with the cultural and historical traditions of each society and its deep-rooted ideas about the family unit."

Ook het vaststellen van het curriculum van scholen ${ }^{315}$ en van regels voor het uitoefenen van juridische beroepen ${ }^{316}$ zijn volgens het Hof typisch nationale aangelegenheden, waarbij de staten de nodige vrijheid moeten hebben. ${ }^{317}$

Op zichzelf lijkt het inderdaad redelijk om rekening te houden met nationale eigenaardigheden: wanneer een traditie in een land diepgeworteld is, is het belangrijk om de opvattingen van een meerderheid van staten niet te snel aan dit land op te dringen. Dit geldt vooral als het gaat om een inbreuk die is ingegeven door een specifieke waardenopvatting of wanneer een zaak betrekking heeft op controversiële aangelegenheden. ${ }^{31}$ Zoals in hoofdstuk 2 reeds is aangegeven hebben rechters een belangrijke, rechtsstatelijke taak waar het gaat om de bescherming van minderheden tegen de opvattingen van de meerderheid. Dit geldt ook voor een internationale rechterlijke instantie als het Hof, zodat verwacht mag worden dat het Hof ruimte laat voor specifieke opvattingen en waardensystemen en deze niet automatisch ondergeschikt maakt aan de Europese consensus. Anderzijds kan worden gesteld dat het, juist als een staat zich in een geïsoleerde positie bevindt, wenselijk is om de positie van deze staat kritisch te bekijken en zorgvuldig te bezien of de inbreuk die is gemaakt op een individueel grondrecht voldoende gerechtvaardigd en proportioneel is. Het uitvoeren van een strengere toetsing lijkt in dit soort situaties dan ook niet onterecht. ${ }^{119}$

Het Hof heeft de spanning tussen de bescherming van nationale waarden en het belang van de grondrechtenbescherming onderkend en heeft gezocht naar een oplossing. Zo oordeelde het Hof in de zaak Campbell and Cosans ${ }^{320}$ dat het feit dat het slaan op scholen in het Verenigd Koninkrijk een erkende traditie is die slechts door weinig ouders wordt afgekeurd niet voldoende is om een ruime margin toe te kennen. ${ }^{321}$ Kennelijk ligt de grens van het respect voor culturele en historische eigenheden bij schendingen waarvan het Hof vindt dat ze het betrokken grondrecht op een essentiële manier aantasten. ${ }^{32}$ Dit lijkt een redelijk compromis, waardoor zowel wordt tegemoetgekomen

\section{4. $\$ 33$}

315. EHRM 7 december 1976, Kjeldsen, Busk Madsen and Pedersen, Series A, vol. 23, § 53: "[...] the setting and planning of the curriculum fall in principle within the competence of the Contracting Sates. This mainly involves questions of expediency on which it is not for the Court to rule and whose solution may legitimately vary according to the country and the era."

316. EHRM 26 januari 1994, Casado Coca, Series A, vol. 285-A, §54: "[...] the rules governing the profession, particularly in the sphere of advertising, vary from one country to another according to cultural tradition" en $\S 55:$ " [...] Because of their direct, continuous contact with their members, the Bar authorities and the country's courts are in a better position than an international court to determine how, at a given time, the right balance can be struck between the various interests involved [...]".

317. Brems 1996, p. 291

318. Vgl. Brems 1996, p. 309.

319. Anders: Schokkenbroek 1996, p. 226 en Brems 1996, p. 285.

320. EHRM 29 januari 1982, Series A, vol. 48

321. \$29: "Corporal chastisement is traditional in Scottish schools and, indeed, appears to be favoured by a large majority of parents. Of itself, this is not conclusive of the issue before the Court for the threat of a particular measure is not excluded from the category of 'degrading', within the meaning of Article 3, simply because the measure has been in use for a long time or even meets with general approvement." Vgl. ook EHRM 25 april 1978, Tyrer, Series A, vol. 26, § 31

322. Vgl. Brems 1996, p. 292. 
aan de kritiek dat het Hof zich schuldig maakt aan cultureel relativisme als aan de kritiek dat het Hof te weinig oog heeft voor nationale waarden.

\subsubsection{Het better placed-argument}

In veel gevallen wordt een ruime margin of appreciation gerechtvaardigd door het feit dat het Hof zichzelf minder goed in staat acht om een besluit te nemen over een bepaalde situatie dan de nationale autoriteiten. ${ }^{323}$ Zo blijkt uit verschillende uitspraken dat het Hof zich terughoudend op zal stellen als er wordt geklaagd over door de nationale rechter opgelegde sancties. Zo oordeelde het Hof in het arrest Weeks ${ }^{324}$ dat het niet de geschikte instantie is om te beoordelen of een sanctie in een concreet geval de meest geëigende is of om te bepalen of het noodzakelijk en wenselijk is om een voorlopig vrijgelatene weer opnieuw gevangen te zetten: de bevoegde nationale autoriteiten zijn veel beter uitgerust om het voorliggende bewijs en feitenmateriaal te waarderen dan het Hof. ${ }^{325}$ In het betrokken arrest voerde het Hof dan ook een toetsing op willekeur uit:

"[t]he Minister's decision [...] remained within the bounds of the margin of appreciation available to the responsible national authorities; it cannot be regarded as arbitrary or unreasonable $[\ldots]]^{.326}$

Verder wordt meestal een ruime margin of appreciation gelaten bij de beantwoording van de vraag welke maatregelen in een concreet geval nodig zijn om de belangen van een kind te beschermen. Voor het Hof is het bijvoorbeeld bijzonder lastig om te beoordelen of de situatie inderdaad vereiste dat een kind bij (een van) de ouders werd weggehaald en in een pleeggezin of tehuis werd geplaatst; de bevoegde nationale instellingen zijn volgens het Hof veel beter in staat tot een goede waardering van de omstandigheden en van de noodzaak tot het nemen van bepaalde beslissingen. Tegelijkertijd heeft het Hof erkend dat het nodig is om grondig na te gaan of de gevolgde procedure wel zorgvuldig was, juist omdat door dit soort besluiten zwaarwegende individuele belangen worden aangetast en de genomen beslissingen vaak onomkeerbaar zijn. ${ }^{\text {mp }}$ Het

323. Deze factor wordt door het Hof ook als algemene rechtvaardiging gehanteerd voor het toepassen van de margin of appreciation-doctrine; zie daarover supra paragraaf 3.1.2.

324. EHRM 27 januari 1987, Series A, vol. 114

325. $\$ 50$. Dit wordt in het algemeen opgevat als een weigering van het Hof om als een soort "vierde instantie" op te treden. Deze terughoudendheid geldt meer in het algemeen in gevallen waarin een oordeel van het Hof een interpretatie van het nationale recht zou bevatten, zodat het als een soort cassatierechter zou gaan optreden. In die gevallen spreekt het Hof wel een oordeel uit, maar alleen over de verenigbaarheid van de inbreuk met het Verdrag: over de interpretatie van het nationale recht wordt geen uitspraak gedaan. Zie voor enkele recentere voorbeelden EHRM 15 februari 2000, Garcia Manibardo, EHRC 2000/30, §36, EHRM 28 maart 2000, Baranowski, EHRC 2000/38, EHRM 14 november 2000, Annoni di Gussola, EHRC 2001/4, §48.

326. $\S 51$

327. Dit blijkt uit het arrest W. v. UK: "The Court recognises that, in reaching decisions in so sensitive an area, local authorities are faced with a task that is extremely difficult. To require them to follow on each occasion an inflexible procedure would only add to their problems. They must therefore be allowed a measure of discretion in this respect. On the other hand, predominantly in any consideration of this aspect of the present case must be the fact that the decisions may well prove to be irreversible: thus, when a child has been taken away from his parents and placed with alternative carers, he may in the course of time establish with them new bonds which it might not be in his interests to disturb or interrupt by reversing a previous decision to restrict or terminate parental access to him. This is accor- 
Hof heeft hierin een evenwicht gevonden door een redelijkheidstoets uit te voeren, maar tegelijkertijd de feiten nauwkeurig te bestuderen en vooral na te gaan of de betrokken autoriteiten zorgvuldig hebben gehandeld. ${ }^{32 x}$

Tenslotte speelt het better placed-argument een belangrijke rol in de jurisprudentie over artikel 1 Eerste Protocol. De rechten waar het in deze jurisprudentie om draait zijn meestal sociaal-economisch van karakter. Het Hof heeft verschillende malen aangegeven dat het juist in dit soort zaken nodig is om een ruime margin of appreciation te laten. Een voorbeeld hiervan is het arrest James ${ }^{329}$, dat betrekking had op de beslissing om bepaalde pachters het recht te geven om aan het einde van de pachttermijn het gepachte tegen de grondprijs over te nemen. Het Hof oordeelde met betrekking tot de omvang van de margin of appreciation in deze zaak het volgende:

"The national authorities are in principle better placed than the international judge to appreciate what is 'in the public interest'. The national authorities accordingly enjoy a certain margin of appreciation. The notion of 'public interest' is necessarily extensive. The decision to enact laws expropriating property will commonly involve consideration of political, economic and social issues on which opinions within a democratic society may reasonably differ widely. The Court, finding it natural that the margin of appreciation available to the legislature in implementing social and economic policies should be a wide one, will respect the legislature's judgment to what is 'in the public interest' unless that judgment is manifestly without a reasonable foundation." 330

Het is volgens het Hof dus op nationaal niveau al lastig om vast te stellen welke beslissingen nodig zijn om tot een goed sociaal-economisch beleid te komen, zodat het wel

dingly a domain in which there is an even greater call than usual for protection against arbitrary interferences" (EHRM 25 mei 1987, Series A, vol. 121-A; idem in EHRM 26 mei 1987, B. v. UK, Series A, vol. 121-B, § 63 en EHRM 26 mei 1987, R. v. UK, Series A, vol. 121-C, §67).

328. Uit het arrest B. v. UK (EHRM 26 mei 1987, Series A, vol. 121-B) blijkt welke criteria het Hof hierbij zal betrekken: "The local authority's decision-making process clearly cannot be devoid of influence on the substance of the decision, notably by ensuring that it is based on the relevant considerations and is not one-sided and, hence, neither is nor appears to be arbitrary. Accordingly, the Court is entitled to have regard to that process to determine whether it has been concluded in a manner that, in all the circumstances, is fair and affords due respect to the interests protected by Article 8 " (\$ 63). Idem in EHRM 26 mei 1987, W. v. UK, Series A, vol. 121-A, \$ 63 en EHRM 26 mei 1987, R. v. UK, Series A, vol. 121-C, $\$ 67$. Recentelijk is het Hof nog meer waarde gaan hechten aan de procedurele waarborgen: in de afgelopen twee jaar zijn er verschillende arresten gewezen die specifiek zijn gericht op een beoordeling van de procedure, niet zozeer op de schending van het recht op gezinsleven als zodanig. Zie bijvoorbeeld EHRM 13 juli 2000, Elsholz, EHRC 2000/73 en EHRM 11 oktober 2001, Sahin, EHRC 2001/81. Uit het arrest Olsson kan blijken dat het Hof zich niet wil beperken tot het bekijken of de staat bij het uitoefenen van zijn discretionaire bevoegdheid "reasonably, carefully and in good faith" heeft gehandeld; wel is ook hier de toetsing marginaal: "[...] having regard to their margin of appreciation, the Swedish authorities were reasonably entitled to think that it was necessary to take the children into care [...]" (EHRM 24 maart 1988, Series A, vol. 130, § 74). Zie ook Ovey 1998, p. 12. Uit $K$ and T. $v$. Finland (EHRM 27 april 2000, EHRC 2000/49, \$ 135) blijkt bovendien dat de toetsingsintensiteit wordt verhoogd als er niet zozeer sprake is van het plaatsen van het kind in "public care", maar van andere maatregelen, zoals beperkingen van de toegang tot het kind; hieruit kan worden afgeleid dat ook de ernst van de inbreuk (het Hof stelt dat door dit soort maatregelen het gevaar bestaat dat "the family relations between the parents and a young child are effectively curtailed") een rol speelt bij de bepaling van de omvang van de margin of appreciation. Op deze factor zal in paragraaf 3.2.7 nader worden ingegaan.

329. EHRM 21 februari 1986, Series A, vol. 98

330. $\$ 46$ 
heel moeilijk is om van de internationale rechter te verwachten dat hij hierover vergaande uitspraken doet. De nationale overheid komt dan ook een zeer grote vrijheid toe, waarmee een bijzonder marginale toetsing door het Hof correspondeert. Dit is het algemeen geldende uitgangspunt in zaken op sociaal-economische terrein, met name als het gaat om controle op het gebruik van eigendom ${ }^{331}$, ruimtelijke ordening ${ }^{332}$ en huisvestingsbeleid. ${ }^{33}$ Slechts in bijzondere omstandigheden zal deze margin of appreciation smaller kunnen worden.

\subsubsection{De aard en het gewicht van de nagestreefde doelstellingen}

Het Hof heeft verschillende malen expliciet aangegeven dat ook de aard en het gewicht van het nagestreefde doelstelling invloed kunnen hebben op de omvang van de margin of appreciation. ${ }^{34} \mathrm{Zo} \mathrm{zal}$ het Hof enige terughoudendheid betrachten als een grondrechtbeperkende maatregel is genomen in het belang van de nationale veiligheid of wanneer de maatregel bedoeld is om de goede zeden of bepaalde morele waarden en normen te beschermen. In het eerste geval zal het Hof zich vooral terughoudend opstellen vanwege het feit dat de staten zelf het beste in staat zijn om in te schatten welke eisen de nationale veiligheid op een bepaald moment stelt. ${ }^{335}$ In het tweede geval is de reden voor het laten van ruimte gelegen in het feit dat het erg moeilijk is om objectief vast te stellen wat de heersende waarden en normen in een bepaald land op een bepaald tijdstip zijn. Hieruit blijkt al, dat bij de vaststelling van de aard van het doel de hiervoor besproken common ground- en better placed-argumenten een belangrijke rol spelen; gesteld kan zelfs worden, dat de factor "aard van het nagestreefde doel" beschouwd

331. EHRM 18 februari 1991, Fredin, Series A, vol. 192, $\$ 51$

332. EHRM 25 september 1996, Buckley, Reports 1996-IV, $\$ 75$ en EHRM 18 januari 2001, Jane Smith, EHRC 2001/19, §99

333. EHRM 19 december 1989, Mellacher, Series A, vol. 169, $\$ 45$, EHRM 28 september 1995, Spadea and Scalabrino, Series A, vol. 315-B, § 29 en EHRM 28 juli 1999, Immobiliare Saffi, Reports 1999-V, $\$ 49$. Zie ook Ovey 1998, p. 12.

334. EHRM 26 april 1979, Sunday Times I, Series A, vol. 30, §59. Zie ook EHRM 23 oktober 1986, Gillow, Series A, vol. 109, $\$ 55$ en EHRM 26 maart 1987, Leander, Series A, vol. 116, $\$ 59$

335. Zie bijv. het Klass-arrest, dat betrekking had op het aftappen van telefoons in het kader van de opsporing. Het Hof stelde in zijn arrest voorop dat artikel 8 lid 2 strikt moet worden geìnterpreteerd. "Secret surveillance", het controleren van telefoongesprekken, post etc. zonder dat de betrokkene daarvan op de hoogte is gesteld, is alleen toegestaan als dit strikt noodzakelijk is om de democratische instellingen te behouden. Dit duidt op een intensieve toetsing. Niettemin was het Hof van mening dat de staten gezien de huidige vormen van spionage en terrorisme die de democratische samenleving bedreigen de vrijheid moeten hebben om effectief op te treden. De toetsing die werd uitgevoerd was dan ook marginaal: het Hof beperkte zich tot een toetsing of er voldoende waarborgen tegen misbruik bestonden en stelde daaraan niet eens erg hoge eisen (EHRM 6 september 1978, Series A, vol. 28, $\$ \S 42,48$ en 49; zie ook Schokkenbroek 1996, p. 94/95). Ook in de recente arresten over inbreuken op de vrijheid van meningsuiting in Turkije levert het feit dat deze inbreuken zijn gemaakt om geweld te voorkomen en zo de nationale veiligheid te beschermen een iets ruimere margin of appreciation op: "[...] where such remarks incite to violence against an individual, a public official or a sector of the population, the State authorities enjoy a wider margin of appreciation when examining the need for an interference with the freedom of expression" (EHRM 8 juli 1999, Ceylan, Reports 1999-IV, $\$ 34$; idem in EHRM 2 oktober 2001, Stankov, EHRC 2001/84, \$90); vgl. verder, buiten de specifieke Turkse context, EHRM 27 september 1999, Lustig-Prean and Beckett, EHRC 1999/2, § 82. Zie ook Ovey 1998, p. 12. 
moet worden als een specialis van deze factoren. Deze stelling wordt ondersteund door de rechtspraak van het Hof. Zo stelde het in het arrest Handyside ${ }^{336}$, dat

\begin{abstract}
"[...] it is not possible to find in the domestic law of the various Contracting States a uniform European conception of morals. The view taken by their respective laws of the requirements of morals varies from time to time and from place to place, especially in our era which is characterised by a rapid and far-reaching evolution of opinions on the subject. By reason of their direct and continuous contact with the vital forces of their countries, State authorities are in principle in a better position than the international judge to give an opinion on the exact content of these requirements as well as on the 'necessity' of a 'restriction' or 'penalty' intended to meet them."'317
\end{abstract}

Deze argumentatie keert ook terug in de gevallen waarin het Hof van mening is dat een nauwere margin of appreciation op zijn plaats. Een voorbeeld daarvan is het arrest Sunday Times I ${ }^{338}$, dat betrekking had op een geplande publicatie in de Sunday Times over het thalidomide-schandaal. Dit schandaal ontstond nadat een aantal vrouwen, als gevolg van het innemen van het kalmeringsmiddel thalidomide tijdens de zwangerschap, zwaar gehandicapte kinderen had gekregen. Tijdens de gerechtelijke procedure tot schadevergoeding die door een aantal van deze vrouwen was aangespannen werd getracht tot een schikking te komen over het bedrag van de vergoeding. De Sunday Times kondigde daarop aan dat het een artikel zou publiceren over het schandaal en de schikking. Publicatie van dit artikel werd echter verboden, omdat dit zou leiden tot "contempt of court": de nationale autoriteiten achtten een risico aanwezig dat het artikel de rechters bedoeld of onbedoeld zou beïnvloeden, zodat zij niet meer onbevooroordeeld over de zaak zouden kunnen oordelen. Deze argumentatie stemt overeen met het in artikel 10 lid 2 opgenomen doelcriterium "maintaining the authority and impartiality of the judiciary". In zijn uitspraak herhaalde het Hof de hiervoor geciteerde overweging uit het Handyside-arrest, waaruit bleek dat er in de Europese staten weinig eenduidigheid bestond over de invulling van de doelstelling "bescherming van de goede zeden". Vervolgens stelde het Hof, dat

"[p]recisely the same cannot be said of the far more objective notion of the 'authority' of the judiciary. The domestic law and practice of the Contracting States reveal a fairly substantial measure of common ground in this area. This is reflected in a number of provisions of the Convention, including Article 6, which have no equivalent as far as 'morals' are concerned. Accordingly, here a more extensive European supervision corresponds to a less discretionary power of appreciation."1339

Uit deze overweging blijkt dat het voor de vaststelling van de toetsingsintensiteit van belang is dat de betekenis van de doelstelling objectief bepaalbaar is, bijvoorbeeld aan

336. EHRM 12 december 1976, Handyside, Series A, vol. 24

337. \$47. Zie ook EHRM 28 april 1988, Müller and Others, Series A, vol. 133, §35; uit Otto Preminger blijkt dat dit ook opgaat voor de vraag welke betekenis aan religieuze gevoelens moet worden toegekend (EHRM 20 september 1994, Series A, vol. 295-A, § 50; zie ook EHRM 22 oktober 1996, Wingrove, Reports 1996-V, § 58).

338. EHRM 26 april 1979 , Series A, vol. 30

339. $\$ 59$ 
de hand van de mate van consensus over de waarde van deze doelstelling en aan de hand van de inhoud van het Verdrag. ${ }^{3+0}$

Tot de in de beperkingsclausules opgesomde legitieme doelstellingen hoort ook de bescherming van de rechten en vrijheden van anderen. Op deze grond wordt door de staten regelmatig beroep gedaan, bijvoorbeeld in arresten die betrekking hebben op klachten van ouders over maatregelen die door de overheid in het belang van hun kinderen genomen zijn of in zaken over smaad of belediging. Het gebeurt echter zelden dat het Hof deze doelstelling bepalend acht voor de omvang van de margin of appreciation; meestal beroept het Hof zich in dit soort gevallen op de better placed-factor of op het belang van het door de Conventie beschermde recht. Toch heeft het Hof aangegeven dat het belang van de doelstelling "bescherming van rechten van anderen" wel degelijk invloed kan hebben op de omvang van de margin of appreciation. In het arrest Chassagnou ${ }^{31}$ overwoog het Hof het volgende:

"In the present case the only aim invoked by the Government to justify the interference complained of was 'protection of the rights and freedoms of others'. Where these 'rights and freedoms' are themselves among those guaranteed by the Convention or its Protocols, it must be accepted that the need to protect them may lead States to restrict other rights and freedoms likewise set forth in the Convention. [...] The balancing of individual interests that may well be contradictory is a difficult matter, and Contracting States must have a broad margin of appreciation in this respect, since the national authorities are in principle better placed that the European Court to assess whether or not there is a 'pressing social need' capable of justifying interference with one of the rights guaranteed by the Convention.

It is a different matter where restrictions are imposed on a right or freedom guaranteed by the Convention in order to protect 'rights and freedoms' not, as such, enunciated therein. In such a case only indisputable imperatives can justify interference with enjoyment of a Convention right." ${ }^{\prime 42}$

Uit deze passage kan worden afgeleid dat er een ruime margin of appreciation zal worden toegekend wanneer een staat met zijn inbreuk op een verdragsrecht een ander door het EVRM beschermd recht beoogt te beschermen. ${ }^{3.3}$ In alle andere gevallen geldt in beginsel een uiterst beperkte beoordelingsruimte en is de toetsing van het Hof zeer intensief.

340. Er bestond echter grote verdeeldheid binnen het Hof over de margin of appreciation: met een minimale meerderheid (elf tegen negen) werd geaccepteerd dat er sprake was van een schending van artikel 10. Zeven dissenters gaven aan dat zij het niet eens waren met de argumentatie van het Hof ten aanzien van de omvang van de margin of appreciation: zij waren van mening dat er helemaal geen common ground bestond over de interpretatie van het gestelde doel.

341. EHRM 29 april 1999, Reports 1999-III

342. $\$ 113$

343. Dit is in overeenstemming met de eerdere jurisprudentie over dit onderwerp. Zo gaf het Hof in het arrest Otto Preminger aan dat artikel 9 EVRM voor staten een verplichting meeneemt om gelovigen te beschermen tegen vergaande beledigingen; staten mogen zelfs inbreuk maken op artikel $10 \mathrm{om} \mathrm{dit} \mathrm{te}$ kunnen doen. Het Hof kent de staten daarbij een ruime margin of appreciation toe (EHRM 20 september 1994, Series A, vol. 295-A, $\$ \$ 47$ en 49 ; vgl. Jacobs/White 1996, p. 306). Iets dergelijks blijkt uit een andere blasfemiezaak, Wingrove (EHRM 25 november 1996, Reports 1996-V). 


\subsubsection{Context van de getroffen maatregel}

In een beperkt aantal gevallen wordt de omvang van de margin of appreciation bepaald door de context waarbinnen de grondrechtbeperkende maatregel is getroffen. Deze factor is in ieder geval van belang voor de rechtspraak met betrekking tot het vreemdelingenbeleid. Als het gaat om uitzetting is het primair aan de staten om te beoordelen of daartoe de noodzaak bestaat, zoals blijkt uit het arrest $C$. v. Belgium: ${ }^{34}$

"It is for the Contracting States to maintain public order, in particular by exercising their right, as a matter of well-established international law and subject to their treaty obligations, to control the entry and residence of aliens and notably to order the expulsion of aliens convicted of criminal offences." ${ }^{\text {34 }}$

Aan deze ruime margin is een zeer marginale toetsing verbonden, zoals eveneens kan blijken uit $C$. $v$. Belgium:

"[...] there is nothing to indicate that in the circumstances of the case the Belgian authorities acted in an arbitrary or unreasonable way, or failed to fulfil their obligation to strike a fair balance between the relevant interests. ${ }^{1346}$

Een verklaring voor deze terughoudendheid is gelegen in het feit dat het Verdrag niet verbiedt dat de staten maatregelen treffen ter regulering en beperking van de instroom van vreemdelingen; op dat gebied heeft een staat dus een relatief grote handelingsvrijheid. ${ }^{37}$ Verder geldt dat het hier bij uitstek om een onderwerp gaat dat nauw is verbonden met de soevereiniteit van de staten. Omdat het Hof daarop een niet al te grote inbreuk wil maken zal het geneigd zijn de staat een ruime beoordelingsruimte toe te kennen.

Het Hof heeft echter een veel smallere margin of appreciation aan de staten toegekend wanneer maatregelen ten nadele van allochtonen niet worden genomen binnen de context van het immigratiebeleid, maar bijvoorbeeld op het gebied van sociale zekerheid. De specifieke omstandigheden die een terughoudende toetsing bij het immigratiebeleid rechtvaardigen doen zich op die gebieden niet voor, zodat de rechtvaardiging voor het toekennen van een aanzienlijke beoordelingsruimte niet meer aanwezig is. Dit blijkt duidelijk uit het arrest Gaygusuz ${ }^{\text {us }}$, waarin het Hof hoge eisen stelde aan een onderscheid in een sociale zekerheidsregeling waardoor vreemdelingen werden benadeeld. ${ }^{39}$

344. EHRM 7 augustus 1996, Reports 1996-III

345. $\$ 31$; dit is vaste rechtspraak van het Hof. Zie bijvoorbeeld ook EHRM 26 februari 1992, Beljoudi, Series A, vol. 234-A, $\$ 74$.

346. $\$ 36$

347. Zo stelde het Hof in Berrehab, dat: "In determining whether an interference was 'necessary in a democratic society', the Court makes allowance for the margin of appreciation that is left to the Contracting States. In this connection, it accepts that the Convention does not in principle prohibit the Contracting States from regulating the entry and the length of stay of aliens" (EHRM 21 juni 1988, Series A, vol. 138, $\$ 28$; zie ook EHRM 28 mei 1985, Abdulaziz, Cabales and Balkandali, Series A, vol. 94, $\$ 67)$. Idem in EHRM 11 juli 2000, Ciliz, EHRC 2000/72, §66, waaruit overigens blijkt dat de ruime margin weliswaar geldt voor het voeren van een vreemdelingenbeleid, maar dat dit niet wegneemt dat de juridische procedures voor uitzetting zorgvuldig moeten zijn. De toetsing van dergelijke procedures zal, anders dan de beoordeling van het beleid als zodanig, dan ook vrij nauwkeurig zijn, zoals uit het arrest Ciliz duidelijk blijkt.

348. EHRM 16 september 1996, Reports 1996-IV

349. $\$ 42$ 
Het Hof zal in het algemeen ook een ruimere margin of appreciation toekennen, wanneer de inbreuk is gemaakt door maatregelen ten behoeve van het leger of in een gevangenissituatie: voor beide gevallen heeft het Hof erkend dat er sprake is van een bijzondere context waarin andere en vaak verdergaande maatregelen mogelijk zijn dan in het "normale" leven. Zo werd de omvang van de margin in het arrest Hadjianastassiou beïnvloed door het feit dat klager, die militaire gegevens had doorverkocht, deel uitmaakte van de luchtmacht:

"It is [...] necessary to take into account the special conditions attaching to military life and the specific 'duties' and 'responsibilities' incumbent on the members of the armed forces." 350

Het arrest Silver ${ }^{351}$ had betrekking op een klacht over het tegenhouden van brieven die een gevangene had geschreven aan zijn familie en zijn advocaat. Bij de beantwoording van de vraag of een dergelijke inbreuk op het privé-leven toelaatbaar is overwoog het Hof het volgende:

"[...] in assessing whether an interference with the exercise of the right of a convicted prisoner to respect for his correspondence was 'necessary' for one of the aims set out in Article $8 \S 2$, regard has to be paid to the ordinary and reasonable requirements of imprisonment. Indeed, the Court recognises that some measure of control over prisoners' correspondence is called for and is not of itself incompatible with the Convention."

Tenslotte heeft het Hof nog aangegeven dat er een ruimere margin of appreciation geldt wanneer de benadeelde werkzaam is in de openbare dienst, bij de politie of in het leger. Voor de vrijheid van meningsuiting werd dit door het Hof duidelijk aangegeven in het arrest Rekvényi ${ }^{333}$ :

"[...] the Court will bear in mind that whenever civil servants' right to freedom of expression is in issue the 'duties and responsibilities' referred to in Article $10 \$ 2$ assume a special significance, which justifies leaving to the national authorities a certain margin of

350. EHRM 23 november 1992, Series A, vol. 252, § 46. In dit arrest was voor de omvang van de margin of appreciation bovendien van belang dat de inbreuk tot doel had de nationale veiligheid te beschermen; zie $\$ \$ 43$ en 47 .

351. EHRM 25 februari 1983, Series A, vol. 61

352. $\$ 98$. Het Hof had dit al eerder overwogen, namelijk in Golder (EHRM 21 februari 1975, Series A, vol. $18, \S 45)$. Uit het arrest Boyle \& Rice blijkt dat dit ook geldt als het gaat om bezoek aan de gevangenis en contact met de familie (EHRM 27 april 1988, Series A, vol. 131). In Campbell heeft het Hof geoordeeld dat de margin smaller is als het gaat om correspondentie tussen de gevangene en zijn advocaat: het belang om een persoonlijke, niet gecensureerde, correspondentie te onderhouden is zeer groot, niet alleen voor de gevangene (voor wie het vaak de enige manier is om contact te onderhouden), maar ook voor de samenleving als zodanig. Er mogen dan ook hogere eisen worden gesteld aan het aantonen van de noodzakelijkheid van een inbreuk (EHRM 28 februari 1992, Series A, vol. 233, $\$ \S 45,46$ en 53; idem in EHRM 5 juli 2001, Erdem, EHRC 2001/62, § 61). In het laatstgenoemde arrest waren de gestelde eisen overigens weer iets minder hoog, dit in verband met de specifieke omstandigheden van het geval (de zaak had betrekking op de correspondentie van een man die werd verdacht van lidmaatschap van een terroristische organisatie) (zie $\$ 66 / 67$ ). Overigens is het zowel in Campbell als in Erdem opvallend dat de inhoudelijke toetsing en de vaststelling van de omvang van de margin of appreciation niet scherp van elkaar worden onderscheiden.

353. EHRM 20 mei 1999, Reports 1999-III 
appreciation in determining whether the impugned interference is proportionate to the above aim. Such considerations apply equally to military personnel and police officers." ${ }^{354}$

\subsubsection{Het gewicht van het aangetaste recht: fundamentele belangen en kernrechten}

Een andere factor die blijkens de rechtspraak van het Hof van groot belang is bij de bepaling van de intensiteit van de toetsing betreft de aard en het gewicht van het recht dat in het specifieke geval is aangetast:

"The scope of the margin of appreciation is not identical in each case but will vary according to the context. Relevant factors include the nature of the Convention right in issue, its importance for the individual and the nature of the activities involved." 355

Als het betrokken recht of belang een fundamenteel karakter heeft zal het Hof in beginsel een strenge toetsing uitvoeren. ${ }^{356} \mathrm{Bij}$ de bepaling of van een fundamenteel karakter sprake is lijkt het Hof uit te gaan van een objectieve notie van het gewicht van het betrokken recht of belang: gekeken wordt of het recht als zodanig grote waarde heeft en of het objectief gezien voor de individuele burger van bijzonder belang is. Niet relevant is dus of het betrokken recht in het concrete geval vanuit het oogpunt van de betrokken burger van zwaarwegend belang is; dit is een kwestie die pas aan de orde zal komen bij de inhoudelijke beoordeling, namelijk in het kader van de concrete toetsing van de proportionaliteit. ${ }^{357}$

Het Hof heeft in verschillende arresten een smallere margin of appreciation toegekend vanwege de betrokkenheid van een fundamenteel recht. De jurisprudentie over artikel 10 geeft daarvan de meest uitgesproken voorbeelden. ${ }^{358}$ Het is vaste rechtspraak van het Hof dat de vrijheid van meningsuiting voor een democratische samenleving uiterst belangrijk is:

"[...] the freedom of expression enshrined in Article 10 constitutes one of the essential foundations of a democratic society and one of the basic conditions for its progress and each individual's self-fulfilment. [...] [I]t is applicable not only to 'information' or 'ideas' that are favourably received or regarded as inoffensive or as a matter of indifference, but also to

354. $\S 43$. Blijkens het arrest Wille geldt dit ook voor leden van de rechterlijke macht (EHRM 28 oktober 1999, EHRC 1999/7, § 64). Zie verder EHRM 26 september 1995, Vogt, Series A, vol. 323, § 53 en EHRM 2 september 1998, Ahmed and Others, Reports 1998-VI, $\$ 61$.

355. EHRM 25 september 1996, Buckley, Reports 1996-IV, $\$ 74$

356. Overigens zegt dit nog niet zoveel over de uitkomst van de toetsing: in veel gevallen waarin een smalle margin of appreciation is toegekend omdat er een fundamenteel recht in het geding is, wordt een beperking toch toelaatbaar geacht. Vgl. O'Donnell 1982, p. 484.

357. In uitzonderingsgevallen houdt het Hof wel rekening met het belang van het recht voor de betrokken klager; zie EHRM 26 maart 1987, Leander, Series A, vol. 116.

358. Vgl. Velaers 1991, p. 320. Hierbij moet worden opgemerkt dat de jurisprudentie over artikel 10 niet consistent is als het gaat om de toetsingsintensiteit. Terwijl in bepaalde arresten het fundamentele karakter van het recht duidelijk aanwezig is, wordt er vaak geen intensieve toetsing uitgevoerd. Dit is niet altijd te verklaren uit de aanwezigheid van tegengestelde factoren; vaak zijn de omstandigheden van het geval doorslaggevend of hebben politieke of persoonlijke overwegingen van de rechters meegespeeld. Aan deze gevallen zal hier geen aandacht worden besteed, nu het gaat om uitzonderingen. Op de arresten waarin tegengestelde factoren een rol spelen zal wel worden ingegaan; zie paragraaf 3.2.8. 
those that offend, shock or disturb; such are the demands of pluralism, tolerance and broadmindedness without which there is no "democratic society'."159

De toetsing van inbreuken op dit recht zal dan ook bijzonder streng zijn:

"Where [...] there has been an interference with the exercise of the rights and freedoms guaranteed in paragraph 1 of Article 10, the supervision must be strict, because of the importance of the rights in question; the importance of these rights has been stressed by the Court many times. The necessity for restricting them must be convincingly established." ${ }^{m}$.

Uit de jurisprudentie over artikel 10 blijkt echter ook dat het belang van een bepaald recht kan verschillen naar gelang de persoon of groep door wie het recht wordt uitgeoefend: voor sommige groepen kan een bepaald recht van een nog groter gewicht zijn dan voor andere. In dergelijke gevallen zal de toetsing door het Hof dan ook intensiever zijn:

"While precious to all, freedom of expression is particularly important for political parties and their active members. Accordingly, interferences with the freedom of expression of a politician who is a member of an opposition party, like the applicant, call for the closest scrutiny on the Court's part." 361

Anderzijds zal de margin of appreciation bij de beperking van de vrijheid van meningsuiting van ambtenaren in het algemeen iets ruimer zijn:

"[...] the Court will bear in mind that whenever a civil servants' right to freedom of expression is in issue the 'duties and responsibilities' referred to in Article 10 par. 2 assume a special significance, which justifies leaving to the national authorities a certain margin of appreciation [...]., ${ }^{, 362}$

Daarnaast acht het Hof het van belang of er bij de uiting sprake is van public of van private speech. $^{363}$ Uit diverse arresten blijkt dat de toetsing wordt geïntensiveerd wanneer een uiting betrekking heeft op een publiek belang of wanneer deze gericht is tegen een politiek belangrijk figuur. ${ }^{364}$ Daartegenover is er een ruimere margin of appreciati-

359. EHRM 9 juni 1998, Incal, Reports 1998-IV, $\S 46$

360. EHRM 24 april 1990, Autronic AG, Series A, vol. 178, $\S 61$; idem in EHRM 28 oktober 1993, Informationsverein Lentia, Series A, vol. 276, $\$ 35$ en (in het bijzonder voor de persvrijheid) EHRM 11 januari 2000, News Verlags GmbH, EHRC 2000/21, § 55/56. Het gebeurt overigens zelden dat het Hof zo expliciet aangeeft dat er een strikte toetsing zal worden uitgevoerd; meestal volstaan het Hof met een aanduiding van de omvang van de margin of appreciation. Zie ook Schokkenbroek 1996, p. 146.

361. EHRM 9 juni 1998, Incal, Reports 1998-IV, § 46. Zie bijvoorbeeld ook EHRM 26 maart 1992, Castells, Series A, vol. 236, $\S 42$, waarin de margin of appreciation sterk werd beperkt vanwege het feit dat de klager een parlementslid was; in dat geval moet het Hof met de "closest scrutiny" onderzoeken of de inbreuk is te rechtvaardigen. Idem in EHRM 27 februari 2001, Jerusalem, EHRC 2001/27, \$36; in deze uitspraak ging het om een meningsuiting van een gemeenteraadslid.

362. EHRM 28 oktober 1999, Wille, EHRC 1999/7, § 62; zie overigens ook $\$ 64$ van dit arrest, waarin het Hof zonder veel nadere motivering aangaf dat in dit geval toch sprake moest zijn van "close scrutiny". Zie verder EHRM 2 september 1998, Ahmed and Others, Reports 1998-VI, § 56.

363. Dit onderscheid is afkomstig uit de Amerikaanse literatuur en heeft grote invloed gehad op de Amerikaanse en Europese rechtspraak. In Nederland is het onderscheid geinntroduceerd en verder uitgewerkt door Peters 1981, m.n. p. 87 e.v..

364. Zie bijvoorbeeld EHRM 8 juli 1986, Lingens, Series A, vol. 103, $\$ 42$ (waarin het ging om een meningsuiting in de context van een politiek debat), de diverse arresten over persvrijheid (onder andere EHRM 12 december 1976, Handyside, Series A, vol. 24, EHRM 29 maart 1979, Sunday Times I, Se- 
on wanneer er sprake is van commerciële uitingen of van "fighting words". ${ }^{365}$ De verklaring hiervoor is opnieuw te vinden in het belang dat de vrijheid van meningsuiting objectief gezien heeft: politieke uitingen zijn voor het goed functioneren van een democratische samenleving of voor een zo volledig mogelijke individuele ontplooiing aanzienlijk groter dan commerciële uitingen of een scheldpartij.

In de jurisprudentie met betrekking tot artikel 11 EVRM heeft het Hof eveneens veel waarde gehecht aan het belang dat door dit artikel beschermd wordt. Vooral wanneer er sprake is van een inbreuk op het recht om een politieke partij te vormen is de margin of appreciation minimaal. Het Hof heeft dit onder andere uitgebreid gemotiveerd in het arrest Freedom and Democracy Party (ÖZDEP). ${ }^{366}$ Deze politieke partij was door het Turkse Constitutionele Hof meteen na haar oprichting ontbonden, omdat door haar programma de territoriale integriteit van de staat en de eenheid van de natie zouden worden ondermijnd. In zijn arrest benadrukte het Hof dat democratie een fundamenteel kenmerk is van de Europese rechtsordes en dat het Verdrag mede is bedoeld om de waarden en idealen van een democratische samenleving te behouden en te bevorderen. ${ }^{367}$ De conclusie van het Hof luidde dan ook als volgt:

"In view of the essential role played by political parties in the proper functioning of democracy [...], the exceptions set out in Article 11 are, where political parties are concerned, to be construed strictly; only convincing and compelling reasons can justify restrictions on such parties' freedom of association." ${ }^{368}$

In de hierboven gegeven voorbeelden werden grondrechten steeds fundamenteel en zwaarwegend geacht vanwege hun betekenis voor het functioneren van de democratische samenleving. ${ }^{369}$ Ook als de democratie niet direct in het geding is blijkt het ge-

ries A, vol. 30, EHRM 26 november 1991, Spycatcher, Series A, vol. 216, EHRM 2 mei 2000, Bergens Tidende, EHRC 2000/52 en EHRM 6 februari 2001, Tammer, EHRC 2001/20, § 62) en de rechtspraak over aanvallen op publieke figuren (onder andere EHRM 21 maart 2000, Andreas Wabl, EHRC 2000/36). Ook het feit dat de uiting heeft bijgedragen aan een publiek debat over politiek of maatschappelijk gezien belangrijke onderwerpen kan een intensiteitverhogende factor zijn; zie bijvoorbeeld EHRM 25 november 1999, Nilsen and Johnsen, EHRC 2000/10, \$ 46, EHRM 27 februari 2001, Jerusalem, EHRC 2001/27, \$38 en EHRM 28 juni 2001, VGT Verein gegen Tierfabriken, EHRC $2001 / 55, \S 70$. Andersom blijkt het feit dat de uiting geen betrekking heeft op een publiek persoon of een maatschappelijk belangrijk debat te kunnen leiden tot een ruimere margin voor de staat en dus tot een minder strenge toetsing van de inbreuk op de vrijheid van meningsuiting; zie (vrij impliciet) EHRM 6 februari 2001, Tammer, EHRC 2001/20, \$66-68. Kritisch over de grenzen die het Hof trekt tussen "private" en "public" speech is Heringa in zijn noot bij Tammer: hij geeft aan dat het onderscheid soms nogal arbitrair aandoet en niet altijd even overtuigend wordt gemotiveerd.

365. Voorbeelden hiervan zijn EHRM 25 oktober 1989, markt intern Verlang GmbH, Series A, vol. 165 (commerciele uitingen), EHRM 21 januari 1999, Janowski, JB 1999/40 (fighting words) en EHRM 21 maart 2000, Wabl, EHRC 2000/36 (fighting words). Er zijn ook duidelijke twijfelgevallen, zoals Hertel (EHRM 25 augustus 1998, Reports 1998-V1).

366. EHRM 8 december 1999, EHRC 2000/12

367. $\$ 44$. Zie ook een eerder arrest, waarop het Hof zijn oordeel in OZDEP baseerde: EHRM 30 januari 1998, United Communist Party of Turkey, Reports 1998-1, $\$ 45$.

368. $\$ 44$

369. Zoals Weidmann stelt, is de "democratische samenleving" alfa en omega van het systeem van het Verdrag: de verzekering van een pluralistische democratie is het hoogste doel. Dit doel kan slechts verwezenlijkt worden door een goede bescherming van de grondrechten $(1985$, p. 267). Dit geldt overigens ook bij artikel 9 EVRM. Het Hof stelde hierover, dat: "[...] freedom of thought, conscience and 
wicht van een recht echter van invloed te kunnen zijn op de omvang van de margin of appreciation. Vooral in de jurisprudentie over artikel 8 EVRM zijn daarvan verschillende voorbeelden te vinden. Zo had het arrest $Z v$. Finland ${ }^{370}$ betrekking op een Finse strafrechtelijke procedure tegen $\mathrm{X}$. X werd verdacht van poging tot doodslag omdat hij verschillende vrouwen had verkracht, terwijl hij zich bewust was van zijn besmetting met het HIV-virus. Voor de bewijsvoering achtte de nationale rechter het in deze zaak van belang dat een aantal medische gegevens over de echtgenote van $\mathrm{X}$ werd achterhaald. Haar volledige naam en haar medische gegevens werden, hoewel zij zich daar uitdrukkelijk tegen verzette, opgenomen in het vonnis en daardoor openbaar gemaakt. Alvorens te beoordelen of een dergelijke openbaring in strijd is met het recht op privacy benadrukte het Hof het belang van het recht op geheimhouding van medische gegevens:

"[...] the Court will take into account that the protection of personal data, not at least medical data, is of fundamental importance to a person's enjoyment of his or her right to respect for private and family life [...]. [This consideration is] especially valid as regards protection of the confidentiality of information about a person's HIV infection. The disclosure of such data may dramatically affect his or her private and family life, as well as social and employment situation [...]. In view of the highly intimate and sensitive nature of information concerning a person's HIV status, any State measures compelling communication or disclosure of such information without the consent of the patient call for the most careful scrutiny on the part of the Court [...]."

Het Hof geeft in deze overweging aan dat voor de keuze van een striktere toetsing vooral de aard van de betrokken activiteiten van belang is. Het is echter gemakkelijk om deze reden te herleiden tot de betrokkenheid van een fundamenteel belang voor de klager: in feite is doorslaggevend dat de wetgeving een zeer intiem aspect van het privé-leven raakt. Juist vanwege het belang van het privé-leven voor het individu is een intensievere toetsing daarbij op zijn plaats.

religion is one of the foundations of a "democratic society" within the meaning of the Convention. It is, in its religious dimension, one of the most vital elements that go to make up the identity of believers and their conception of life, but it is also a precious asset for atheists, agnostics, sceptics and the unconcerned. The pluralism indissociable from a democratic society, which has been dearly won over the centuries, depends on it" (EHRM 25 mei 1993, Kokkinakis, Series A, vol. 260-A, §31). In Manoussa$k i s$ bevestigde het Hof dit en voegde het eraan toe, dat "[t]he restrictions imposed on the freedom to manifest religion [...] call for very strict scrutiny by the Court" (EHRM 26 september 1996, Reports 1996-IV, § 44). Zie ook EHRM 14 december 1999, Serif, EHRC 2000/14.

370. EHRM 25 februari 1997, Reports 1997-I

371. $\$ \$ 95$ en 96 . Een ander voorbeeld is Gillow. In deze zaak werd geklaagd over maatregelen die op Guernsey waren getroffen om de huisvestingsproblematiek op te heffen; in het concrete geval hadden deze ertoe geleid dat de eigenaren van een huis niet meer in hun eigen huis konden wonen. Het Hof merkte in dit arrest het volgende op: "In the instant case, the economic well-being of Guersey must be balanced against the applicants' right to respect for their 'home', a right which is pertinent to their own personal security and well-being. The importance of such a right to the individual must be taken into account in determining the scope of the margin of appreciation allowed to the Government" (EHRM 23 oktober 1986, Series A, vol. 109, §55). Zie verder EHRM 25 september 1999, Buckley, Reports 1996-IV, EHRM 26 maart 1985, $X$ and $Y v$. The Netherlands, Series A, vol. 91 , $\$ \$ 24$ en 27, EHRM 27 september 1999, Lustig-Prean and Beckett, EHRC 1999/2, §83 en EHRM 31 juli 2000, A.D.T. v. UK, EHRC 2000/69, §37). 
In de literatuur is soms kritiek geleverd op het feit dat het belang van het betrokken recht een rol speelt bij de vaststelling van de omvang van de beoordelingsruimte: ieder in het EVRM opgenomen grondrecht is van groot belang voor het individu, zodat er op die grond altijd sprake zou moeten zijn van een beperkte margin of appreciation." ${ }^{\text {m }}$ Deze kritiek lijkt niet geheel terecht. Ieder grondrecht heeft deelaspecten, waarvan sommige als "kernrechten" kunnen worden beschouwd. Deze kernrechten zijn voor het individu van een groter belang dan andere, meer perifere, aspecten van het grondrecht. Dat bij een schending van kernrechten een intensievere toetsing wordt gehanteerd dan bij inbreuken op perifere aspecten is zeker niet onredelijk. Wel is het buitengewoon lastig om te bepalen welke aspecten van een recht als kernrechten moeten worden gekwalificeerd. ${ }^{3 n}$ Het Hof heeft daarover wel enige duidelijkheid gegeven. Zo heeft het, zoals hierboven is gebleken, vooral die aspecten van de vrijheid van meningsuiting als kernrechten gekwalificeerd die essentieel zijn voor een goed functioneren van de pluralistische en democratische samenleving. ${ }^{314} \mathrm{Bij}$ beperkingen van meningsuitingen met een commercieel karakter is er daarentegen geen sprake van een kernrecht, maar van een aspect van de vrijheid van meningsuiting dat een minder groot belang heeft voor het individu: in zaken die dergelijke uitingen tot voorwerp hebben ontbreekt de passage waarin het belang van de vrijheid van meningsuiting wordt onderstreept en wordt er een marginale toetsing uitgevoerd. ${ }^{375}$ Ook als het gaat om uitingen waarvan de kans bestaat dat zij persoonlijke gevoelens of opvattingen op het moreel of religieus gebied krenken kent het Hof een ruimere margin of appreciation toe. Ook daarbij gaat het kennelijk om aspecten van de uitingsvrijheid die het Hof niet tot de kern van deze vrijheid rekent. ${ }^{376}$

Voor artikel 11 geldt dat de kern van het recht wordt gevormd door de mogelijkheid tot oprichting van politieke partijen en het lidmaatschap daarvan. Ook het recht op vakbondsvrijheid, zowel positief als negatief, is volgens het Hof een recht dat "strikes at the very substance of the freedom of association guaranteed by Article 11". ${ }^{3 n}$ Het door

372. Zie Schokkenbroek 1996, p. 129 en Velaers 1991, p. 334; de laatste stelt dat er niet zoiets bestaat als "het wezen van het recht op vrijheid van meningsuiting". Volgens hem zetten de begrippen "kem" en "wezen" weinig zoden aan de dijk als het gaat om het stellen van een beperkingsgrens.

373. Vgl. Burkens 1989 (I), p. 95.

374. Dit is ook bij artikel 9 het geval. Zie EHRM 25 mei 1993, Kokkinakis, Series A, vol. 260-A, $\$ 31$, EHRM 26 september 1996, Manoussakis, Reports 1996-I, § 44 en (meer impliciet) EHRM 14 december 1999, Serif, EHRC 2000/14, $\$ 49$.

375. Zo stelde het Hof in markt intern Verlag het volgende: "[...] the Contracting States have a certain margin of appreciation in assessing the existence and extent of the necessity of an interference [...]. Such a margin of appreciation is essential in commercial matters and, in particular, in an area as complex and fluctuating as that of unfair competition. Otherwise, the European Court of Human Rights would have to undertake a re-examination of the facts and all the circumstances of each case. The Court must confine its review to the question whether the measures taken on the national level are justifiable in principle and proportionate" (EHRM 25 oktober 1989, Series A, vol. 165, $\S 33$ ); opgemerkt moet wel worden dat dit arrest met de kleinst mogelijke meerderheid werd gewezen en dat alle dissenting opinions zijn gericht tegen de geciteerde overweging. In een later arrest nuanceerde het Hof zijn uitspraak door aan te geven dat, als door de commerciele uiting wordt bijgedragen aan een debat dat het algemeen belang betreft, de margin of appreciation beperkter is en een zorgvuldige toetsing zal worden uitgevoerd (EHRM 25 augustus 1998, Hertel, Reports 1998-VI, § 47).

376. EHRM 22 oktober 1996, Wingrove, Reports 1996-V, $§ 58$

377. EHRM 25 april 1996, Gustafsson, Reports 1996-II, $\$ 45$. Het negatieve recht op vakbondsvrijheid makt echter alleen deel uit van de kern van artikel 11 als het echt gaat om een gedwongen lidmaat- 
artikel 11 beschermde recht van vakbonden om hun belangen na te streven, gehoord te worden en te staken kan daarentegen beschouwd worden als een perifeer recht, waarbij de staat een ruime beoordelingsruimte heeft. ${ }^{378}$ Tenslotte kan ook bij het door artikel 8 beschermde recht op privacy een kern worden geformuleerd: volgens de rechtspraak is vooral de bescherming van de zeer intieme aspecten van het privé-leven essentieel.

Hieruit kan dus worden afgeleid dat vooral politieke rechten en rechten die rechtstreeks in verband staan tot de individuele ontplooiing en de menselijke waardigheid tot de kern van de door het EVRM beschermde rechten behoren.

\subsubsection{Aard van de betrokken beperkingsmaatregel}

Tenslotte kan de aard van de inbreuk volgens de rechtspraak van het Hof van invloed zijn op de omvang van de margin of appreciation. Dit blijkt duidelijk uit het arrest Leander: $:^{379}$

"[...] the Court recognises that the national authorities enjoy a margin of appreciation, the scope of which will depend not only on the nature of the legitimate aim pursued but also on the particular nature of the interference involved."

Het Hof heeft in verschillende uitspraken rekening gehouden met deze factor. Zo achtte het Hof het in het al genoemde arrest Sunday Times I ${ }^{\text {sit }}$ van belang dat het verbod dat aan de krant was opgelegd er niet alleen voor zorgde dat een specifiek artikel niet kon worden gepubliceerd, maar ook dat er geen verder onderzoek naar het schandaal kon worden gedaan, dat de resultaten van eerdere onderzoeken niet aan parlementariërs konden worden doorgegeven en dat de plannen voor het publiceren van een boek over dit onderwerp werden vertraagd. Het Hof stelde:

"In fact, the injunction was couched in terms wide enough to cover such items; its very breadth calls for a particularly close scrutiny of its 'necessity'."'nz

Verder blijkt uit de rechtspraak dat de omvang van de margin of appreciation bij beperkingen van de vrijheid van meningsuiting wordt beïnvloed door het verschil tussen voorafgaande beperkingen en maatregelen die achteraf worden genomen. Voorafgaande beperkingen leveren in het algemeen een ernstige aantasting van de vrijheid van meningsuiting op: door een voorafgaand verbod wordt het volstrekt onmogelijk gemaakt om op de gewenste manier uitdrukking te geven aan een mening. Een boete of strafrechtelijke veroordeling achteraf heeft het (relatieve) voordeel dat het publiek in ieder geval kennis heeft kunnen nemen van de uiting. Het is dan ook redelijk om aan de rechtvaardiging van censuur nog hogere eisen te stellen dan aan de rechtvaardiging van

schap: zie EHRM 20 april 1993, Sibson, Series A, vol. 258-A. Uit Gustafsson blijkt overigens dat het feit dat het gaat om een kernrecht nog lang niet altijd wil zeggen dat er een strengere toetsing wordt uitgevoerd: in een concreet geval kunnen andere factoren zwaarder wegen. Zie nader paragraaf 3.2.8.

378. Zie bijvoorbeeld EHRM 6 februari 1976, Swedish Engine Drivers' Union, Series A, vol. $20, \S 40$ en EHRM 6 februari 1976, Schmidt and Dahlström, Series A, vol. 21, §36. Vgl. ook Prebensen 1998, p. 17.

379. EHRM 26 maart 1987, Series A, vol. 116

380. $\$ 59$, cursief toegevoegd.

381. EHRM 26 april 1979, Series A, vol, 30

382. $\S 63$ 
een repressieve maatregel. Zoals blijkt uit de volgende overweging uit het arrest $O b$ server and Guardian ${ }^{3 \times 3}$ is het Hof ook zeker gevoelig voor dit argument:
"[...] Article 10 of the Convention does not in terms prohibit the imposition of prior restraints on publication, as such. [...] On the other hand, the dangers inherent in prior restraints are such that they call for the most careful scrutiny on the part of the Court. This is especially so as far as the press is concerned, for news is a perishable commodity and to delay its publication, even for a short period, may well deprive it of all its value and interest." 384

Ook buiten het kader van de preventieve beperkingen blijkt het Hof soms rekening te houden met de aard van de inbreuk, waarbij dan vooral de ernst van de belangenaantasting van belang blijkt te zijn. Een voorbeeld daarvan is te vinden in het arrest LustigPrean and Beckett ${ }^{3 \mathrm{ss}}$, waarin geklaagd werd over het feit dat ontdekking van homoseksualiteit in het leger leidde tot ontslag; bezwaarlijk achtten de klagers vooral dat de betrokken autoriteiten soms vergaand inbreuk maakten op de privacy van betrokkenen om bewijs van de homoseksuele voorkeur te vergaren. Het Hof stelde in het kader van de vaststelling van de margin of appreciation het volgende:
"Concerning as it [het ontslag en het onderzoek naar aanleiding van verdenking van homoseksualiteit, JHG] did a most intimate aspect of an individual's private life, particularly serious reasons by way of justification were required. In the case of the present applicants, the Court finds the interferences to have been especially grave for the following reasons. In the first place, the investigation process [...] was of an exceptionally intrusive character. [...] Secondly, the administrative discharge of the applicants had [...] a profound effect on their careers and prospects. [...] Thirdly, the absolute and general character of the policy which led to the interferences in question is striking."

In dit geval werd de strikte toetsing niet eens zozeer ingegeven door het feit dat er een fundamenteel kernrecht werd aangetast, hoewel dat zeker ook een rol speelde, maar vooral door de ernst en het karakter van de inbreuk die hierop werd gemaakt. ${ }^{387}$ Dit lijkt dan ook als een zelfstandige factor binnen de rechtspraak van het Hof over de margin of appreciation te kunnen worden beschouwd.

\subsubsection{Afweging van factoren}

In de meeste gevallen die ter beoordeling aan het Hof worden voorgelegd zullen verschillende van de hierboven beschreven factoren een rol spelen. Als deze factoren in

383. EHRM 26 november 1991, Series A, vol. 216

384. $\$ 60$; cursief toegevoegd. Zie ook EHRM 25 november 1996, Wingrove, Reports 1996-V, $\$ 58$ in fine, EHRM 9 juni 1998, Incal, Reports 1998-IV, § 56 en EHRM 17 juli 2001, Association Ekin, EHRC $2001 / 66, \$ 57$ in fine. Overigens lijkt dit niet alleen te gelden voor voorafgaande beperkingen op de vrijheid van meningsuiting, maar ook voor voorafgaande beperkingen op de vrijheid van godsdienst, bijvoorbeeld door het vereisen van registratie door de regering voordat een kerkgenootschap in de praktijk kan functioneren. Hoewel het Hof dit niet met zoveel woorden heeft gesteld kan uit EHRM 13 december 2001, Eglise Métropolitaine de Bessarabie, EHRC 2002/9 worden afgeleid dat in dit soort gevallen hoge eisen aan de rechtvaardiging worden gesteld.

385. EHRM 27 september 1999, EHRC 1999/2

386. $\$ \$ 83,84,85,86$ en 98

387. Zie voor een vergelijkbaar oordeel EHRM 8 december 1999, Freedom and Democracy Party (ÖZDEP), EHRC 2000/12, $\$ 45$ ("such drastic measures may be taken only in the most serious cases"). 
dezelfde richting wijzen is dat niet problematisch: de factoren versterken elkaar dan slechts. Daarvan is bijvoorbeeld sprake als er een Europese consensus bestaat die wijst in de richting van een strengere toetsing en er een fundamenteel belang van betrokkene wordt aangetast, terwijl er geen bijzondere beleidsvrijheid bestaat en het Hof voldoende in staat is om de belangenaantasting te beoordelen: in een dergelijk geval bestaat er alle reden voor een beperking van de margin of appreciation en de toepassing van een zeer strikte toetsing. ${ }^{38 s}$ Problemen kunnen echter rijzen als de verschillende factoren elkaar tegenspreken. Zo kan het gebeuren dat de aard van het nagestreefde doel een ruime margin of appreciation noodzakelijk maakt, terwijl er door het nationale optreden een fundamenteel belang wordt aangetast, of dat er sprake is van een zeer vergaande en ernstige aantasting van een grondrecht op een gebied waarop het Hof eigenlijk onvoldoende tot oordeelsvorming in staat is. In dergelijke situaties zal het Hof bij het bepalen van de omvang van de margin een afweging moeten maken, waarbij het rekening zal moeten houden met het relatieve gewicht dat aan de verschillende factoren moet worden toegekend.

In de praktijk blijkt het Hof met deze problematiek minder zorgvuldig om te gaan dan verwacht zou mogen worden: in veel gevallen stelt het Hof weliswaar vast welke intensiteitbepalende factoren in de zaak een rol spelen, maar geeft het niet aan waarom een afweging van deze factoren tot de conclusie van een bepaalde toetsingsintensiteit leidt. ${ }^{389}$ Een typisch voorbeeld van de benadering die door het Hof wordt gevolgd is het arrest Gillow. ${ }^{390}$ In deze zaak werd geklaagd over een maatregel die door de regering van Guernsey getroffen was om de huisvesting te reguleren op dit erg kleine, maar door belastingvoordelen aantrekkelijke eiland. Door deze maatregelen was het voor de klagers, die na lange tijd op het eiland te hebben gewoond enige tijd in het buitenland hadden verbleven, onmogelijk geworden om terug te keren naar hun eigen huis. Zij stelden dat daardoor een inbreuk werd gemaakt op hun door artikel 8 beschermde recht om in hun eigen woning te verblijven. Met betrekking tot de intensiteit van de toetsing die in dit geval zou moeten worden uitgevoerd oordeelde het Hof als volgt:

388. Een voorbeeld waarin alle factoren in een vergelijkbare richting (namelijk in die van een ruime margin of appreciation) wezen is EHRM 18 januari 2001, Jane Smith, EHRC 2001/19: hierin was sprake van een beleidsterrein waarop de staten een grote vrijheid tot besluitvorming moest worden toegekend $(\$$ 99), terwijl tegelijkertijd uit een onderzoek van het Hof bleek dat er een relatief beperkte consensus bestond over de vraag hoe met problemen als het in geding zijnde moet worden omgegaan $(\$ 100 / 101)$. Ook stelde het Hof vast dat de inbreuk op de rechten en belangen van klaagster niet bijzonder emstig was $(\$ 104$ en 110$)$.

389. Soms kan juist uit het feit dat er een afweging moet worden gemaakt een ruimere margin of appreciation wordt afgeleid. Een voorbeeld is het eerder genoemde arrest $Z v$. Finland (EHRM 25 februari 1997, Reports 1997-I). Het Hof gaf hierin aan dat de aard van het aangetaste recht een intensieve toetsing vergde. Vervolgens stelde het daartegenover dat de belangen van de betrokkene moesten worden afgewogen tegen het belang dat door de staat met de inbreuk werd nagestreefd. Uit het feit dat een dergelijke afweging moet worden gemaakt leidde het Hof vervolgens toch een zekere margin of appreciation af voor de staat. Dit is een onwenselijke methodiek, omdat op deze manier altijd een ruime margin of appreciation kan worden toegekend: bij iedere inbreuk zullen immers verschillende belangen tegen elkaar moeten worden afgewogen. Het is weliswaar aan de staat om deze afweging te verrichten, maar het is aan het Hof om te bepalen hoe intensief deze zal worden beoordeeld. Een zelfstandige beoordeling van het gewicht van de factoren die in een bepaald geval een rol spelen is daarbij onontbeerlijk.

390. EHRM 23 oktober 1986, Series A, vol. 109 
"In the instant case, the economic well-being of Guernsey must be balanced against the applicant's right to respect for their 'home', a right which is pertinent to their own personal security and well-being. The importance of such a right to the individual must be taken into account in determining the scope of the margin of appreciation allowed to the Government." 391

Uit deze overweging blijkt dat het Hof zich er voldoende van had vergewist dat tegenstrijdige factoren een rol speelden en dat het onderkende dat hiertussen een afweging moet worden gemaakt om de toetsingsintensiteit te kunnen bepalen. Opmerkelijk is echter dat het Hof niet duidelijk maakte hoe deze afweging plaats zou moeten vinden; evenmin gaf het Hof precies aan tot welke mate van toetsingsintensiteit de afweging in dit specifieke geval leidde. ${ }^{32}$

Op zichzelf is het ook niet altijd nodig om veel woorden vuil te maken aan het proces van afweging, omdat in veel gevallen de uitkomst voor de hand ligt. Dit is zeker het geval als er verschillende sterke factoren zijn die wijzen in de richting van een smalle margin, terwijl daar slechts één intensiteitverminderende factor tegenover staat. Een illustratie daarvan is het arrest Dudgeon ${ }^{393}$, waarin geklaagd werd over een regeling waardoor het verrichten van homoseksuele activiteiten strafbaar werd gesteld. Het doel van de strafbaarstelling was volgens de regering de bescherming van de goede zeden, een doelstelling die, zoals eerder is aangegeven, een ruime beoordelingsmarge rechtvaardigt vanwege het gebrek aan common ground dat er op dit gebied bestaat. Daartegenover stond echter het feit dat de maatregel een fundamenteel belang aantastte én dat er in dit geval een Europese consensus bestond die strafbaarstelling van homoseksuele activiteiten veroordeelde. ${ }^{34}$ In een dergelijk geval zijn de intensiteitverhogende factoren zo zwaarwegend dat het niet meer dan logisch is dat het Hof kiest voor een beperkte margin. $^{395}$

Wanneer de tegenstrijdige factoren een sterk vergelijkbaar gewicht hebben is het maken van een afweging beduidend lastiger. Gezien het belang van de intensiteit van de toetsing voor de inhoudelijke beoordeling is het in dergelijke gevallen wenselijk dat het Hof zijn afweging expliciteert en aangeeft welke relatieve waarde in het concrete geval aan de verschillende factoren moet worden toegekend. In de meeste gevallen gebeurt dit echter niet: het Hof kiest meestal zonder nadere argumentatie voor die toetsingsintensiteit die het in een gegeven geval kennelijk het meest geschikt acht. ${ }^{3 \%}$ Soms lijkt het Hof zich bovendien niet goed raad te weten met gevallen waarin zowel intensiteitverhogende als intensiteitverminderende factoren een rol spelen, zoals wordt geïllustreerd door het arrest Otto Preminger..$^{377}$ Dit arrest had betrekking op de vertoning van een

391. $\$ 55$

392. Wel kan dit worden afgeleid uit de toetsing van de concrete toepassing van de litigieuze maatregelen: het Hof betrekt daarbij alle omstandigheden en toetst de genomen beslissing integraal.

393. EHRM 22 oktober 1981, Series A, vol. 45

394. Zie over het bestaan van een common ground in dit specifieke geval supra paragraaf 3.2 .2 onder a. Zie verder $\$ 52$ van het arrest.

395. Hoewel moet worden opgemerkt dat ook in dergelijke, zeer duidelijke gevallen een nadere motivering van de belangenafweging verduidelijkend en verhelderend kan werken.

396. Vgl. Harris/O'Boyle/Warbrick 1995, p. 297 en O’Donnell 1982, p. 479.

397. EHRM 20 september 1994, Series A, vol. 295-A 
film die beledigend zou kunnen zijn voor mensen met religieuze opvattingen. De film was in beslag genomen en er was een strafrechtelijke procedure ingesteld tegen het instituut dat verantwoordelijk was voor de vertoning. Het Hof werd geconfronteerd met de vraag of de vrijheid van meningsuiting terecht beperkt was om de religieuze gevoelens te beschermen. Het Hof overwoog dat de vrijheid van meningsuiting een essentieel recht is in een democratische samenleving en dat door artikel 10 ook schokkende of beledigende uitingen worden beschermd. Vervolgens stelde het echter dat er in Europa nauwelijks consensus bestaat over de betekenis van godsdienst in een samenleving; de opvattingen daarover kunnen zelfs al binnen een bepaald land verschillen. Het Hof stelde dat het om die reden bijzonder lastig is om eenduidig vast te stellen in welke omstandigheden de bescherming van godsdienstige opvattingen een inbreuk op de vrijheid van meningsuiting toelaatbaar kan maken. Het Hof kende daarom "a certain" margin of appreciation toe om de noodzakelijkheid van de inbreuk te beoordelen. Daaraan voegde het het volgende toe:

"The authorities' margin of appreciation, however, is not unlimited. It goes hand in hand with Convention supervision, the scope of which will vary according to the circumstances. In cases such as the present one, where there has been an interference with the exercise of the freedoms guaranteed in paragraph 1 of Article 10, the supervision must be strict because of the importance of the freedoms in question. The necessity for any restriction must be convincingly established."398

Deze overweging impliceert dat de staat wel enige vrijheid heeft tot beperking van de vrijheid van meningsuiting vanwege het ontbreken van een Europese consensus, maar dat het toezicht dat wordt uitgeoefend op het gebruik van deze vrijheid toch relatief streng zal zijn. Hoewel dit een aardig compromis lijkt, is het moeilijk voorstelbaar op welke manier een dergelijke toetsing dan vorm zou moeten krijgen. Het Hof leek daar in Otto Preminger ook duidelijk moeite mee te hebben: weliswaar besteedde het enige aandacht aan de in het conflict betrokken belangen en de omstandigheden van de schending, maar van een zorgvuldige toetsing, zoals door de geciteerde overweging wordt geïmpliceerd, is geen sprake..$^{399}$

398. $§ 50 . \mathrm{Vgl}$. in dit opzicht ook VGT Verein gegen Tierfabriken, waarin geklaagd werd over een verbod van een politiek getint reclamespotje. In beginsel zal het Hof zich bij beperkingen van commerciele uitingen terughoudend opstellen, maar bij een aantasting van politieke uitingen kiest het, zoals eerder is aangegeven, juist voor een zeer intensieve toetsing. Het Hof oordeelde in dit geval dan ook, dat "[a]s a result, in the present case the extent of the margin of appreciation is reduced, since what is at stake is not a given individual's purely "commercial" interests, but his participation in a debate affecting the general interest. The Court will consequently carefully examine whether the measures in issue were proportionate to the aim pursued. [...]" (EHRM 28 juni 2001, EHRC 2001/55, $\$ \$ 71$ en 72).

399. Het Hof beperkte zich zelfs tot een zeer marginale toetsing, waarbij werd verwezen naar de redelijkheid van de uitspraken van de nationale rechters; zie $\$ 56$ van het arrest. Dit was anders in het arrest Wingrove (EHRM 22 oktober 1996, Reports 1996-V), dat eveneens betrekking had op een uiting die de christelijke gevoelens zou kunnen schokken. In dit arrest werd een ruime margin of appreciation toegekend omdat er geen uniforme Europese opvatting bestaat over de vraag wat een ernstige belediging van religieuze opvattingen is $(\$ 58)$. Het Hof stelde echter ook in dit arrest dat er een goed Europees toezicht nodig is, met name omdat er een risico bestaat voor willekeurige en als bestrijding van blasfemie vermomde beperkingen van de vrijheid van meningsuiting en omdat het in deze gevallen om een voorafgaande beperking gaat $(\S 59)$. De toetsing die vervolgens werd uitgevoerd is meer uitgebalanceerd en intensiever dan die in Otto Preminger. 
Uit het voorgaande kan blijken dat het Hof zich maar zelden uitspreekt over de wijze waarop intensiteitbepalende factoren tegen elkaar moeten worden afgewogen. Uit een analyse van de verschillende arresten kan echter blijken dat er in dit opzicht toch enig patroon zichtbaar is. Van belang is dat bij de vaststelling van de toetsingsintensiteit het gewicht van het aangetaste recht het uitgangspunt vormt. Is dit recht niet bijzonder zwaarwegend of fundamenteel, dan wordt er meestal een ruime margin of appreciation worden toegekend en is de toetsing in principe marginaal; alleen wanneer er factoren aanwezig zijn die een verhoogde toetsingsintensiteit overtuigend kunnen rechtvaardigen zal daarvoor worden gekozen. ${ }^{400}$ Als er daarentegen wordt geklaagd over de aantasting van een kernrecht zal de toetsing in beginsel zeer streng zijn. In dat geval zullen alleen overtuigende intensiteitverminderende factoren tot een ruimere margin leiden. Van de tweede situatie blijkt in de rechtspraak het vaakst sprake te zijn. Een duidelijk voorbeeld is het arrest Ceylan. ${ }^{401}$ De klager in deze zaak was voorzitter van een Turkse vakbond en had een zeer kritisch artikel geschreven over het optreden van de Turkse regering tegen de Koerden in het zuidoosten van het land. Hij werd vervolgd en tot een zware straf veroordeeld, omdat hij met dit artikel de toch al breekbare rust onder de bevolking zou verstoren. De regering beriep zich voor het Hof op de bescherming van de openbare orde en de nationale veiligheid, doelstellingen die zeker gezien de omstandigheden van het geval tot een ruime beoordelingsmarge hadden moeten leiden. In het geding was echter een politieke meningsuiting die gericht was tegen de regering; dergelijke uitingen zijn volgens de vaste rechtspraak van het Hof essentieel voor het goed functioneren van een democratische samenleving. Het Hof stelde dan ook voorop dat de ruimte voor een staat om beperkingen te stellen bij dergelijke uitingen minimaal is ${ }^{402}$, waarna het het volgende overwoog:

"The Court recalls [...] that there is little scope under Article $10 \S 2$ of the Convention for restrictions on political speech or on debate on matters of public interest. Furthermore, the limits of permissible criticism are wider with regard to the government than in relation to a private citizen or even a politician. [...] Nevertheless, it certainly remains open to the competent State authorities to adopt, in their capacity as guarantors of public order, measures, even of a criminal-law nature, intended to react appropriately and without excess to such remarks. [...] [W] here such remarks incite to violence against an individual, a public official or a sector of the population, the State authorities enjoy a wider margin of appreciation when examining the need for an interference with the freedom of expression." ${ }^{\text {403 }}$

In deze zaak was sprake van een aantasting van een kernrecht en, om die reden, van een zeer smalle margin of appreciation. Volgens het Hof waren er echter ook belangrijke intensiteitverminderende factoren aanwezig: de situatie in Turkije was zeer explosief, zodat de staat snel en flexibel moest kunnen optreden. Bovendien gold dat de nationale autoriteiten beter dan het Hof in staat zijn te kunnen beoordelen welke maatregelen nodig zijn ter bescherming van openbare orde en veiligheid, een zeer zwaarwegend

400. Vgl. O'Donnell 1982, p. 492-493. Ook de conclusies van Prebensen wijzen in deze richting (1998, p. 17).

401. EHRM 8 juli 1999, Reports 1999-IV

402. $\S 32$ onder (i); zie supra paragraaf 3.2.6.

403. $\$ 34$ 
openbaar belang. ${ }^{404}$ Het samenstel van factoren dat in deze zaak een rol speelde (het better placed-argument, de aard en het gewicht van het nagestreefde doel en de context waarin de inbreuk moest worden geplaatst) pleitte op een overtuigende manier voor een terughoudende toetsing. In een dergelijk geval acht het Hof dan ook, ondanks het feit dat er een kernrecht werd aangetast, een ruimere margin of appreciation op zijn plaats. ${ }^{\text {us }}$

Een voorbeeld van de tegenovergestelde situatie is het arrest Rees. ${ }^{406}$ De klager in deze zaak stelde dat zijn door artikel 8 beschermde recht op privacy een positieve verplichting voor de staat meebracht om na een geslachtswijziging het nieuwe geslacht in het geboorteregister te vermelden. Het is moeilijk om het aan deze verplichting gekoppelde recht te beschouwen als een kernrecht. Daarvan zou misschien nog sprake zijn als geslachtsverandering als zodanig verboden wordt of als het niet mogelijk is om de naam te wijzigen of het nieuwe geslacht te vermelden op gangbare identiteitspapieren, maar in casu was een dergelijk zwaarwegend belang niet in het geding. Het Hof gaf uitdrukkelijk aan dat er ook verder geen factoren aanwezig waren die een intensieve toetsing zouden kunnen rechtvaardigen: zo oordeelde het dat er geen sprake was van een duidelijke common ground op het gebied van de juridische consequenties van geslachtsverandering en dat er geen sprake was van een vergaande aantasting van het betrokken belang. ${ }^{407}$ Dit arrest past dan ook uitstekend in het weergegeven patroon: een marginale toetsing is redelijk zolang er geen kernrecht in het geding is. Pas als er voldoende zwaarwegende factoren kunnen worden gevonden die een intensievere toetsing kunnen rechtvaardigen, bestaat er aanleiding tot een intensivering van de toetsing.

\subsection{Toetsingsintensiteit en artikel 14: de "very weighty reasons"-doctrine}

\subsection{Vertaling van de margin of appreciation-doctrine in een very weighty reasons- doctrine}

$\mathrm{Al}$ in de Belgische Taalzaak stelde het Hof dat de margin of appreciation-doctrine ook van toepassing is op klachten over ongelijke behandeling; het was zelfs in het kader van de toetsing aan artikel 14 dat het Hof voor het eerst oordeelde dat de staten een zekere ruimte moeten hebben om op het gebied van het Verdrag keuzes te maken en maatregelen te treffen. ${ }^{408}$ Ook in latere arresten waarin aan artikel 14 werd getoetst is het Hof steeds zonder meer uitgegaan van de toepasselijkheid van de margin of appreciation-doctrine. Inhoudelijk gezien hanteert het Hof daarbij dezelfde factoren als bij

404. Dit argument speelde ook een belangrijke rol bij de beoordeling van de proportionaliteit van de inbreuk; zie $\$ 35$ van het arrest.

405. Overigens is het opvallend dat het Hof, ondanks de ruime margin of appreciation, een vrij volledige proportionaliteitstoets uitvoerde: van een werkelijk marginale toetsing was geen sprake. Waarschijnlijk hebben vooral de politieke aanvaardbaarheid van de beslissing en zijn precedentwaarde het Hof ertoe aangezet om zo uitdrukkelijk aan te geven dat de verwerende staat hier een ruimere margin heeft.

406. EHRM 17 oktober 1986 , Series A, vol. 106

407. Deze argumenten zijn verspreid door het arrest aan te treffen en zijn vooral verbonden met de inhoudelijke beoordeling; in dat opzicht is de argumentatie niet geheel zuiver. Vergelijkbare argumenten als zijn gegeven ten aanzien van de noodzakelijkheid zullen normaal gesproken vooral bij de vaststelling van de omvang van de margin of appreciation worden gehanteerd. Zie $\$ \$ 37,39$ en 42.

408. EHRM 23 juli 1968, Series A, vol. 6, $\$ 10$; zie ook het citaat in paragraaf 3.1.1. 
de beoordeling van klachten over substantiële artikelen. Deze factoren zijn hiervoor uitgebreid besproken, zodat de rechtspraak over artikel 14 in dat opzicht geen afzonderlijke uiteenzetting behoeft. ${ }^{499}$ Interessant is echter dat het Hof in zijn jurisprudentie over artikel 14 een bijzondere uitwerking heeft gegeven aan de margin of appreciationdoctrine. De aanzet voor deze uitwerking werd gegeven in het arrest Abdulaziz. ${ }^{10}$ In deze zaak werd geklaagd over een Engelse wet die betrekking had op gezinshereniging. Deze wet maakte het voor buitenlandse gezinnen waarvan de man al in Engeland woonachtig was veel gemakkelijker om herenigd te worden dan voor gezinnen waarvan alleen de vrouw in Engeland woonde. Reden voor dit onderscheid was het feit dat in Engeland een grote werkloosheid heerste en statistisch was vastgesteld dat mannen een grotere belasting vormen voor de arbeidsmarkt dan vrouwen. Door de beperking van de hereniging van gezinnen waarvan de vrouw in Engeland woonde werd overbelasting vermeden. Normaal gesproken komt de staten op het gebied van werkgelegenheid en immigratiebeleid een ruime margin of appreciation toe, zodat in dit geval een marginale toetsing op zijn plaats zou zijn geweest. In het onderhavige geval achtte het Hof voor de intensiteit van zijn toetsing echter doorslaggevend dat er onderscheid op grond van geslacht werd gemaakt:

"Although the Contracting States enjoy a certain 'margin of appreciation' in assessing whether and to what extent differences in otherwise similar situations justify a different treatment, the scope of this margin will vary according to the circumstances, the subjectmatter and its background. As to the present matter, it can be said that the advancement of the sexes is today a major goal in the member States of the Council of Europe. This means that very weighty reasons would have to be advanced before a difference of treatment on the ground of sex could be regarded as compatible with the Convention."

Zoals uit deze overweging blijkt was de aanwezigheid van een common ground voor het Hof bepalend bij de vaststelling van de intensiteit van de toetsing. Eerder is gebleken dat deze factor ook bij de toetsing aan de substantiële verdragsbepalingen een belangrijke rol speelt en ook daar kan resulteren in een intensieve toetsing. Blijkens bovenstaande overweging verbindt het Hof aan deze factor nog verdergaande gevolgen wanneer er een ongelijke behandeling in het geding is: in dat geval kan de ongelijke behandeling alleen gerechtvaardigd worden door zeer gewichtige redenen. In de praktijk blijkt dit te betekenen dat het Hof de door de regering aangevoerde argumenten bijzonder streng toetst en nauwkeurig nagaat of deze sterk genoeg zijn om het gemaakte onderscheid te kunnen dragen. Dit blijkt slechts zelden het geval te zijn: als het Hof gebruik maakt van de very weighty reasons-formulering zal dit in het algemeen betekenen dat het onderscheid niet toelaatbaar is. Met name zal een dergelijk onderscheid in de meeste gevallen de proportionaliteitstoets niet doorstaan, zoals al naar voren is gekomen in paragraaf 2.7.

409. Zie bijvoorbeeld EHRM 6 februari 1976, Swedish Engine Drivers' Union, Series A, vol. 20, $\$ 47$, EHRM 23 november 1976, Engel and Others, Series A, vol. 22, $§ 72$ en EHRM 28 november 1984, Rasmussen, Series A, vol. $87, \S 40$. In dit laatste arrest besteedde het Hof expliciet aandacht aan de factoren die een rol kunnen spelen bij de omvang van de margin of appreciation, zoals de omstandigheden, het onderwerp en de achtergronden van de inbreuk. Hieruit blijkt dat de reeds besproken factoren ook een rol kunnen spelen als het gaat om artikel 14.

410. EHRM 25 mei 1985 , Series A, vol. 94

411. $\$ 78$ 
Opgemerkt moet worden dat deze bijzondere uitwerking niet betekent dat aan de eigenlijke margin of appreciation-doctrine bij artikel 14 geen betekenis meer toekomt: als het Hof geen gebruik maakt van de very weighty reasons-formulering wordt zeker niet per definitie een marginale toetsing uitgevoerd. Gesteld is al dat bij gelijke behandeling in de meeste gevallen gewoon gebruik wordt gemaakt van de factoren die in het algemeen de toetsingsintensiteit bepalen. Ook als er geen very weighty reasons worden vereist kan de toetsing dus intensief zijn, bijvoorbeeld als door het onderscheid een fundamenteel recht zoals de vrijheid van meningsuiting of het recht op een woning wordt aangetast. ${ }^{412}$

\subsubsection{Criterium voor toepasselijkheid van de very weighty reasons-doctrine: grond van het onderscheid}

Doorslaggevend voor de toepasselijkheid van de very weighty reasons-doctrine blijkt de grond van het onderscheid te zijn. Het maken van onderscheid op grond van bepaalde persoons- of groepskenmerken moet volgens het Hof als "verdacht" worden aangemerkt. ${ }^{413}$ Een ongelijke behandeling die op een dergelijke grond is gebaseerd kan alleen in heel bijzondere omstandigheden worden gerechtvaardigd. Het Hof heeft tot nu toe geen algemene criteria aangereikt aan de hand waarvan kan worden bepaald welke gronden van onderscheid als verdacht moeten worden aangemerkt. Wel blijkt uit de jurisprudentie dat het Hof de doctrine bij een beperkt aantal gronden consequent toepast, namelijk bij onderscheid op grond van geslacht, onwettige geboorte, godsdienst, nationaliteit en seksuele geaardheid. ${ }^{414}$

\section{Onderscheid op grond van geslacht}

Blijkens het hiervoor al geciteerde arrest Abdulaziz is de very weighty reasons-doctrine in ieder geval van toepassing op onderscheid op grond van geslacht. ${ }^{415}$ Ook uit de latere jurisprudentie blijkt dat de very weighty reasons-doctrine bij deze grond consequent

412. Zie bijvoorbeeld EHRM 24 november 1986, Gillow, Series A, vol. 109.

413. Overigens maakt het Hof zelf geen gebruik van de term "suspect classifications"; de term wordt hier alleen gebruikt ter verheldering van de rechtspraak.

414. Bij de grond "nationaliteit" moet wel de kanttekening worden geplaatst dat deze alleen als verdacht wordt aangemerkt indien deze zich in een bepaalde context voordoet. Hierop zal verderop nog nader worden ingegaan.

415. Opvallend is dat het Hof in het vlak voor Abdulaziz gewezen arrest Rasmussen (EHRM 28 november 1984, Series A, vol. 87), dat eveneens betrekking had op onderscheid op grond van geslacht, in het midden liet op welke grond het onderscheid berustte en daarmee de vraag vermeed of een strengere toetsing moet worden uitgevoerd. Het is moeilijk daarvoor een verklaring te geven, maar deze zou kunnen gevonden in het feit dat het Hof er weinig voor voelde om op het gebied van vaderschapsacties (waarover weinig consensus bestaat) een vergaande uitspraak te doen (zie Heringa 1998, p. 3.14-11 en Merrills 1993, p. 172). Verder is het interessant om te signaleren dat het Hof geen rekening houdt met de congruentie van het onderscheid. Van Maarseveen heeft wel betoogd dat congruent onderscheid (d.w.z. onderscheid dat overeenstemt met het normale discriminatiepatroon) strenger moet worden beoordeeld dan discongruent onderscheid. Nu bij onderscheid naar geslacht meestal de vrouw de benadeelde is, zou dit betekenen dat daarbij een strengere toetsing zou moeten worden uitgevoerd (1990, p. 28 en 31). Uit arresten als Karlheinz Schmidt (EHRM 18 juli 1994, Series A, vol. 291-B), Burghartz (EHRM 22 februari 1994, Series A, vol. 280-B) en Van Raalte (EHRM 21 februari 1997, Reports 1997-1) blijkt echter dat het Hof aan dit criterium geen aandacht besteedt. Vgl. ook Schokkenbroek 1998, p. 22. 
wordt toegepast. ${ }^{416}$ Het Hof heeft steeds uitdrukkelijk aangegeven waarom juist bij deze grond de toetsing zo intensief moet zijn. Doorslaggevend is het feit dat er in alle landen die lid zijn van de Raad van Europa gestreefd wordt naar gelijkberechtiging van mannen en vrouwen. De aanwezigheid van een zeer sterke common ground op dit gebied is dus bepalend voor de intensiteit van de toetsing. Het is opmerkelijk dat de common ground-factor het enige argument is dat ter rechtvaardiging van de toepasselijkheid van de very weighty reasons-doctrine is aangevoerd: een meer inhoudelijke of fundamentele rechtvaardiging ontbreekt. Geen enkele aandacht wordt bijvoorbeeld besteed aan het feit dat geslacht een persoonlijk kenmerk is dat de betrokkene zelf niet kan veranderen, noch aan het feit dat het geslacht in veel gevallen irrelevant is voor het maatschappelijk functioneren van een bepaald individu. Evenmin lijkt waarde te worden gehecht aan het feit dat onderscheid op grond van geslacht vaak is gebaseerd op stereotypen en traditionele opvattingen over rolpatronen en het juist daarom aan een zorgvuldig rechterlijk onderzoek moet worden onderworpen. Het ontbreken van een dergelijke onderbouwing is als een gemis te beschouwen. De reden daarvoor is al bij de bespreking van de common ground-factor gegeven: wanneer het Hof alleen intensief toetst bij het bestaan van een Europese consensus ontneemt het zichzelf de mogelijkheid om een voortrekkersrol te vervullen en zelf actief bij te dragen aan de ontwikkeling van een dergelijke consensus. ${ }^{417}$

Zoals is aangegeven wordt de very weighty reasons-doctrine bij onderscheid op grond van geslacht consequent toegepast. In een tweetal recente arresten heeft het Hof echter een toepassing aan de doctrine gegeven die afwijkt van de gebruikelijke lijn. Van belang is allereerst het arrest Van Raalte, ${ }^{418}$ waarin het Hof koos voor een iets andere, op het eerste gezicht scherpere, formulering van de doctrine. Dit arrest had betrekking op de te betalen bijdragen onder de Nederlandse Kinderbijslagwet. Betaling van bijdragen was volgens deze wet voor iedereen verplicht, ongeacht de vraag of degenen die bijdroegen zelf gebruik zouden maken van de uit de wet voortvloeiende voordelen. Alleen ongetrouwde, kinderloze vrouwen ouder dan 45 jaar werden van deze verplichting uitgezonderd. ${ }^{419}$ Het Hof overwoog dat er very weighty reasons moesten worden aangevoerd ter rechtvaardiging van het hieruit voortvloeiende onderscheid op grond van geslacht. Vervolgens stelde het echter, dat

"[w]hile Contracting States enjoy a certain margin of appreciation under the Convention as regards the introduction of exemptions to such contributory obligations, Article 14 requires that any such measure, in principle, applies even-handedly to both men and women unless compelling reasons have been adduced to justify a difference in treatment." ${ }^{\text {"No }}$

416. Zie EHRM 24 juni 1993, Schuler-Zgraggen, Series A, vol. 263, $§ 67$, EHRM 22 februari 1994, Burghartz, Series A, vol. 280-B, $\$ 27$ en EHRM 18 juli 1994, Karlheinz Schmidt, Series A, vol. 291-B, § 27.

417. Strikt theoretisch gezien kan bovendien de vraag rijzen wat de consequentie zou zijn van het verdwijnen van de common ground. Een dergelijke verdwijning zou niet afdoen aan de inhoudelijke factoren die de intensivering van de toetsing bij deze grond ondersteunen. Wanneer het Hof desondanks zou besluiten tot een minder strikte toetsing wegens het ontbreken van een Europese consensus, zou dit geen wenselijke ontwikkeling zijn.

418. EHRM 21 februari 1997, Reports 1997-1

419. Zie voor een nadere bespreking van de inhoudelijke redenering die het Hof ten aanzien van dit onderscheid volgde paragraaf 2.8 .

420. $\$ \$ 41$ en 42 , cursief toegevoegd. 
Volgens het Hof waren in dit geval dus niet slechts very weighty, maar zelfs compelling reasons vereist ter rechtvaardiging van het gemaakte onderscheid. Uit deze formulering zou kunnen blijken dat het Hof zijn doctrine heeft aangescherpt. Vooralsnog is echter niet duidelijk of het Hof deze nieuwe formulering ook inderdaad als een aanscherping bedoeld heeft. ${ }^{421}$ Dit lijkt niet erg waarschijnlijk, vooral omdat het praktisch effect van een dergelijke aanscherping buitengewoon beperkt zal zijn: ook als gebruik wordt gemakt van de very weighty reasons-formulering betekent dit meestal dat het onderscheid niet toelaatbaar is. ${ }^{422}$ Verdere rechtspraak zal dan ook uit moeten wijzen wat de betekenis van het arrest op dit punt precies is.

Een tweede afwijking van het normale patroon is terug te vinden in de uitspraak die het Hof in 1998 deed in de zaak Petrovic. ${ }^{423}$ Dit arrest had betrekking op een regeling van ouderschapsverlof in Oostenrijk. Volgens deze regeling konden zowel mannen als vrouwen een dergelijk verlof opnemen, maar kwamen alleen vrouwen gedurende het ouderschapsverlof in aanmerking voor een speciale uitkering. Volgens de geldende doctrine zou een dergelijk onderscheid op grond van geslacht verdacht zijn en zou het slechts door het aanvoeren van very weighty reasons kunnen worden gerechtvaardigd. Het Hof overwoog in zijn uitspraak echter het volgende:

"It is true that the advancement of the equality of the sexes is today a major goal in the member States of the Council of Europe and very weighty reasons would be needed for such a difference in treatment to be regarded as compatible with the Convention. However, the Contracting States enjoy a certain margin of appreciation in assessing whether and to what extent differences in otherwise similar situations justify a different treatment in law. The scope of the margin of appreciation will vary according to the circumstances, the subjectmatter and its background; in this respect, one of the relevant factors may be the existence or non-existence of common ground between the laws of the Contracting States. It is clear that at the material time, that is at the end of the 1980 s, there was no common standard in this field, as the majority of the Contracting States did not provide for parental leave allowances to be paid to fathers."

Het lijkt erop dat het Hof met dit arrest een differentiatie in toetsingsintensiteit mogelijk heeft willen maken bij ongelijke behandeling op grond van geslacht. Uitgangspunt is dan weliswaar dat er very weighty reasons moeten worden aangevoerd, maar in sommige omstandigheden kan er een zekere ruimte worden gelaten aan de staten. Dit zou betekenen dat het Hof is afgestapt van de, tot nu toe kennelijk geldende, opvatting dat onderscheid op grond van geslacht per definitie een verdacht karakter heeft en om die reden altijd strikt moet worden getoetst. Op zichzelf is er veel te zeggen voor een dergelijke soepele benadering. Van belang is namelijk dat de verdachtheid van een bepaalde grond van onderscheid niet in zijn algemeenheid, maar per geval moet wor-

421. Vgl. Heringa/Woltjer 1997, p. 1713.

422. Zoals in paragraaf 2.8 al werd opgemerkt wijkt dit arrest ook in andere opzichten af van de gebruikelijke benadering en terminologie van het Hof: er werd in dit arrest gebruik gemaakt van een over- en underinclusiveness-redenering, terwijl dit in geen enkele andere uitspraak expliciet gebeurt. Het is dan ook waarschijnlijk dat er sprake is van een uitzondering waaraan geen bijzondere betekenis moet worden toegekend.

423. EHRM 27 maart 1998, Reports 1998-II

424. $\$ \$ 37-39$ 
den vastgesteld. Met name wanneer bij de bepaling van de toetsingsintensiteit rekening wordt gehouden met inhoudelijke factoren, zoals de vraag of het onderscheid is gebaseerd op stereotypering of traditionele opvattingen, bestaat er voor een dergelijke variatie reden: wanneer duidelijk is dat deze factoren in een concreet geval geen rol hebben gespeeld, bestaat er in beginsel geen aanleiding voor een intensivering van de toetsing. ${ }^{425}$

Bij de door het Hof gekozen benadering wreekt zich het gebrek aan een inhoudelijke motivering van de keuze voor een intensieve toetsing. In de opvatting van het Hof is uitsluitend het bestaan van Europese consensus bepalend, niet de vraag of het gaat om een onderscheid dat is gebaseerd op een onveranderlijk, irrelevant kenmerk of dat is ingegeven door traditionele opvattingen of vergaande en onjuiste stereotyperingen. Op het gebied van ouderschapsuitkeringen, maar ongetwijfeld ook op andere beleidsterreinen, geldt kennelijk dat in een groot aantal staten alleen vrouwen voor een uitkering in aanmerking komen en gelijke behandeling niet de regel is. De kans is aanzienlijk dat deze regel is gebaseerd op de opvatting dat het meestal de vrouw is die na de geboorte van het kind van ouderschapsverlof gebruik maakt, terwijl de man aan het werk gaat. Het is de vraag of het wenselijk is dat een dergelijke stereotiepe opvatting een rechtvaardiging vormt voor een marginale toetsing, zeker wanneer het gaat om toetsing door een op het gebied van individuele grondrechtenbescherming toonaangevende rechterlijke instantie. Het valt dan ook te hopen dat het Hof zich in de toekomst nader zal bezinnen op de wenselijkheid om alleen de Europese consensus als uitgangspunt te nemen voor de bepaling van de intensiteit van de toetsing.

\section{Onderscheid op grond van onwettige geboorte}

In het arrest $M a r c k x^{136}$ gaf het Hof al aan dat er een Europese consensus bestaat ten aanzien van de wenselijkheid van gelijkberechtiging van wettige en onwettige kinderen en hun ouders. Hoewel er in dit arrest een intensieve toetsing aan artikel 14 werd uitgevoerd maakte het Hof echter nog geen melding van de margin of appreciation of van de noodzaak van het aanvoeren van very weighty reasons. Dit gebeurde wel in het arrest Inze. ${ }^{427}$ De klager in deze zaak, een onwettig kind, kwam niet in aanmerking voor het erven van een boerderij, omdat het Oostenrijkse recht daarbij voorrang gaf an wettig geboren kinderen. Het Hof stelde daarover het volgende:

"The question of equality between children born in and born out of wedlock as regards their civil rights is today given importance in the member States of the Council of Europe. This is shown by the 1975 European Convention on the Legal Status of Children born out of Wedlock, which is presently in force in respect of nine member States of the Council of Europe. It was ratified by the Republic of Austria on 28 May 1980 [...]. Very weighty reasons would accordingly have to be advanced before a difference of treatment could be regarded as compatible with the Convention." ${ }^{\text {ndx }}$

425. Vanzelfsprekend is ook in dit soort gevallen steeds een afweging van de verschillende factoren vereist: ook wanneer een onderscheid niet verdacht is, is het immers mogelijk dat andere factoren (zoals het feit dat er een fundamenteel kernrecht is aangetast) tot een intensivering van de toetsing nopen.

426. EHRM 13 juni 1979 , Series A, vol. $31, \S 41$

427. EHRM 28 oktober 1987 , Series A, vol. 126

428. $§ 41$; cursief toegevoegd. 
Net als bij onderscheid op grond van geslacht is ook hier het bestaan van een common ground kennelijk doorslaggevend voor de keuze voor een intensieve toetsing. Hiervoor gelden dan ook vergelijkbare opmerkingen als hierboven zijn gemaakt met betrekking tot onderscheid op grond van geslacht. ${ }^{40}$

\section{Onderscheid op grond van nationaliteit}

Ook bij onderscheid op grond van nationaliteit heeft het Hof erkend dat ter rechtvaardiging very weighty reasons moeten worden aangevoerd. Dit gebeurde voor het eerst in het arrest Gaygusuz. ${ }^{430}$ De klager in deze zaak woonde en werkte in Oostenrijk, maar had de Turkse nationaliteit. Nadat hij gedurende een bepaalde periode arbeidsongeschikt was geweest vroeg hij, als een soort noodvoorziening, een voorschot op zijn pensioen aan. Zijn verzoek werd echter geweigerd, omdat hij niet de Oostenrijkse nationaliteit had. Ten aanzien van de intensiteit van de toetsing stelde het Hof het volgende:

"[...] [T] he Contracting States enjoy a certain margin of appreciation in assessing whether and to what extent differences in otherwise similar situations justify a different treatment. However, very weighty reasons would have to be put forward before the Court could regard a difference of treatment based exclusively on the ground of nationality as compatible with the Convention."

Bijzonder is, dat een goede en inhoudelijke motivering in deze overweging ontbreekt: het Hof legt niet uit waarom bij onderscheid op grond van nationaliteit een intensieve toetsing moet worden uitgevoerd en verwijst zelfs niet, zoals bij de hiervoor behandelde verdachte gronden, naar het bestaan van een Europese consensus. Dit gebrek aan motivering is des te opvallender, nu nationaliteit niet altijd een verdacht criterium blijkt te zijn. De context van het onderscheid is voor deze kwalificatie van bijzonder belang:

429. Voor onderscheid op grond van onwettige geboorte geldt dat het Hof consequent heeft gekozen voor een toepassing van de very weighty reasons-test; zie bijvoorbeeld EHRM 1 februari 2000. Mazurek, EHRC 2000/25, $\$ 49$, EHRM 3 oktober 2000, Camp and Bourimi, EHRC 2000/82 en EHRM 11 oktober 2001, Sahin, EHRC 2001/81, $\S 81$. Er is slechts één afwijking van deze lijn zichtbaar, namelijk het arrest McMichael (EHRM 24 februari 1995, Series A, vol. 307-B). Naar Schots recht kreeg de vader van een kind meteen allerlei ouderlijke rechten wanneer hij op het moment van de geboorte met de moeder was getrouwd; natuurlijke vaders konden dergelijke rechten alleen verkrijgen door daartoe bij de rechtbank een verzoek in te dienen. Er is hierbij sprake van een verschil in behandeling tussen wettige en onwettige vaders, waarbij het Hof normaal gesproken een intensieve toetsing zou uitvoeren. In dit geval ontbrak echter iedere verwijzing naar de margin of appreciation en werd na een marginale toetsing gesteld dat het gemaakte onderscheid gerechtvaardigd was. Hoogstens zou deze benadering kunnen worden verklaard door te wijzen op het feit dat het in McMichael niet, zoals in eerdere uitspraken, ging om een benadeling van onwettige kinderen, maar om een benadeling van onwettige vaders. Bij kinderen is onwettigheid een onveranderlijke eigenschap, waarvoor zij zelf in het geheel niet verantwoordelijk kunnen worden geacht (een factor waaraan het Hof in het hierboven genoemde arrest Mazurek uitdrukkelijk waarde hechtte). Bij onwettige vaders is dit anders: zij kunnen hun status gemakkelijk aanpassen, bijvoorbeeld door het kind officieel te erkennen. Het is denkbaar dat het Hof aan dit verschil waarde heeft willen toekennen, waardoor het impliciet zou aanvaarden dat de veranderlijkheid van het onderscheidingskenmerk van belang is voor de kwalificatie hiervan als verdacht. Uit een latere uitspraak blijkt echter dat, als het Hof in McMichael al bepalende waarde aan deze argumentatie toekende, het deze nu niet meer van belang acht: in het arrest Sahin was eveneens een benadeling van natuurlijke vaders in het geding, maar paste het Hof toch een very weighty reasons-test toe (EHRM II oktober 2001, EHRC 2001/81, §57).

430. EHRM 16 september 1996, Gaygusuz, Reports 1996-IV
431. $\$ 42$ 
zoals eerder is opgemerkt wordt bij zaken die het immigratiebeleid betreffen geen groot gewicht toegekend aan het feit dat uitwerkingen van dit beleid een ongelijke behandeling op grond van nationaliteit tot gevolg kunnen hebben. ${ }^{432}$

\section{Onderscheid op grond van godsdienst}

Ook bij onderscheid op grond van godsdienst voert het Hof een zeer intensieve toetsing uit. Opvallend is daarbij dat in het belangrijkste arrest dat op deze grond betrekking heeft, Hoffmann ${ }^{43}$, geen gebruik wordt gemaakt van de very weighty reasons-doctrine, maar van een andere formulering. In dit arrest stelde het Hof namelijk, dat

"[n]otwithstanding any arguments to the contrary, a distinction based essentially on a difference in religion alone is not acceptable."

Uit deze overweging zou wellicht kunnen worden afgeleid dat voor de rechtvaardiging van onderscheid op grond van godsdienst very weighty reasons niet voldoende zijn: het Hof lijkt onderscheidingen die uitsluitend gebaseerd zijn op een verschil in godsdienst zelfs in het geheel niet acceptabel te achten. ${ }^{33}$ Het Hof motiveert deze stelling verder niet, zodat het niet eenvoudig is om uit te vinden waarom het Hof onderscheid op grond van godsdienst als zodanig ernstig beschouwt dat dit altijd, ongeacht de rechtvaardiging, in strijd met artikel 14 zou zijn. Het is ook niet waarschijnlijk dat het daadwerkelijk de bedoeling van het Hof was om binnen de categorie van verdachte onderscheidingen nog een nadere onderverdeling te maken tussen tamelijk verdachte en zeer verdachte gronden. Een dergelijke onderverdeling zou veronderstellen dat het Hof onderscheidingen die uitsluitend zijn gebaseerd op godsdienst inherent ontoelaatbaar acht, terwijl dit bijvoorbeeld niet het geval is bij onderscheid dat uitsluitend is gebaseerd op grond van wettige geboorte. Het is onwaarschijnlijk dat het Hof een dergelijk belangrijk waardeoordeel in zijn algemeenheid uit zou spreken, zonder dit nader te motiveren.

In de recente zaak Thlimmenos ${ }^{436}$ kreeg het Hof een kans om meer duidelijkheid te scheppen over de toetsingsintensiteit bij onderscheid op grond van godsdienst. In deze zaak werd geklaagd over een Grieks verbod om mensen tot accountant te benoemen die in het verleden waren veroordeeld wegens een misdrijf. De klager stelde dat er hierdoor sprake was van materieel onderscheid op grond van godsdienst: volgens hem was het onredelijk dat het verbod ook gold voor veroordelingen wegens een vergrijp dat rechtstreeks verband hield met iemands godsdienstige overtuiging. Hoewel het Hof in deze

432. Eerder is aangegeven dat deze benadering zeker redelijk kan zijn: de intensiteit van de toetsing moet per geval worden bepaald. De verdachtheid van de grond van onderscheid is slechts éen (zij het een zeer belangrijke) factor bij de bepaling van de intensiteit van de toetsing; ook andere factoren kunnen hierbij nog een rol spelen. Dit betekent dat de rechter een afweging kan maken van de ernst van het onderscheid (gezien de grond daarvan of gezien het belang dat hierdoor is aangetast) tegen intensiteitverlagende factoren als de context van het onderscheid. Problematisch is echter dat in de rechtspraak van het Hof een goede motivering van de keuze voor een bepaalde toetsingsintensiteit ontbreekt; daardoor is het niet te achterhalen of de afweging die in een concreet geval is gemaakt voldoende is gerechtvaardigd.

433. EHRM 23 juni 1993, Series A, vol. 255-C

434. $\$ 36$

435. Vgl. Heringa 1998, p. 3.14-12.

436. EHRM 6 april 2000, EHRC 2000/45 
zaak een rechtvaardigingstoets uitvoerde maakte het, merkwaardig genoeg, geen melding van de very weighty reasons-doctrine. Voor dit verschil tussen Hoffmann en Thlimmenos kan hoogstens als verklaring worden aangenomen dat het in dit geval niet ging om een formeel, maar om een materieel onderscheid: het is mogelijk dat het Hof daarbij meer ruimte wil laten aan de nationale wetgever. ${ }^{477}$ Het Hof heeft dit echter zeker niet met zoveel woorden gezegd; verdere rechtspraak zal moeten worden afgewacht om over dit onderwerp meer duidelijkheid te verkrijgen.

\section{Onderscheid op grond van seksuele geaardheid}

In het arrest Salgueiro da Silva Mouta ${ }^{\mathrm{ji}}$ heeft het Hof voor het eerst een oordeel uitgesproken over een ongelijke behandeling gebaseerd op seksuele geaardheid. Deze uitspraak had betrekking op de toewijzing van een kind aan een van zijn ouders na echtscheiding. De feitenrechter had vastgesteld dat de moeder en de vader gelijkelijk geschikte ouders waren en had op grond van genuanceerde overwegingen het kind aan de vader toegewezen. De appèlrechter betrok nagenoeg dezelfde feiten in zijn oordeel, maar kwam tot een andere conclusie. In zijn oordeel besteedde hij veel aandacht aan het feit dat de vader inmiddels samenwoonde met een man, waarmee hij ook een homoseksuele relatie onderhield. Het Hof oordeelde dat de overwegingen omtrent de homoseksuele relatie van de vader in hoger beroep beslissend waren geweest voor de uitkomst van de zaak en dat er daardoor sprake was van een ongelijke behandeling op grond van homoseksualiteit. Omtrent de proportionaliteit hiervan oordeelde het Hof als volgt:

"Force est donc de constater, au vu de ce qui précède, que la cour d'appel a opéré une distinction dictée par des considerations tenant à l'orientation sexuelle du réquerant, distinction qu'on ne saurait tolérer d'après la Convention.

Dès lors, la Cour ne peut conclure à l'existence d'un rapport raisonnable de proportionnalité entre les moyens employés et le but visés [...]."3.39

Deze formulering lijkt sterk op die in het hierboven besproken arrest Hoffmann, dat betrekking had op onderscheid op grond van godsdienst. Jammer genoeg ontbreekt een nadere toelichting van de keuze voor de gehanteerde formulering, zodat het niet duidelijk is welke factoren het Hof ertoe hebben gebracht om seksuele geaardheid als een verdachte grond aan te merken en zelfs te oordelen dat onderscheid dat uitsluitend op deze grond is gebaseerd in het geheel niet toelaatbaar kan worden geacht.

\subsubsection{Conclusie}

In het voorgaande is een opsomming gegeven van de verschillende gronden van onderscheid die door het Hof als verdacht zijn gekwalificeerd. Bij al deze gronden van onderscheid past het Hof een zeer strikte toetsing toe, die in de meeste gevallen tot gevolg heeft dat het onderscheid ontoelaatbaar wordt geacht. Opvallende afwezige in het rijtje is onderscheid op grond van ras, etniciteit en huidskleur; kennelijk zijn daarover tot nu toe nog geen zaken voorgelegd aan het Hof. Het ligt echter in de lijn der verwachting

437. Zie voor mogelijke redenen daarvoor nader hoofdstuk 2, paragraaf 5.3.2, onder b.

438. EHRM 21 december 1999, EHRC 2000/16

439. $\$ 36$ 
dat het Hof ook bij deze onderscheidingsgronden gebruik zal maken van de very weighty reasons-doctrine. ${ }^{400}$

Op zichzelf is het een wenselijke situatie dat het Hof bepaalde gronden als verdacht kwalificeert: in paragraaf 2 is al gebleken dat juist deze kwalificatie vaak een zorgvuldige en uitgebreide toetsing tot gevolg heeft. Problematisch is echter dat iedere onderbouwing ontbreekt bij de kwalificatie van nationaliteit, godsdienst en seksuele geaardheid als verdachte onderscheidingsgronden. Hierdoor is het moeilijk voorspelbaar of er nog andere gronden van onderscheid als verdacht zullen worden toegevoegd. Bovendien wordt de controleerbaarheid van de uitspraken hierdoor belemmerd: het is in arresten als Gaygusuz, ${ }^{41}$ Hoffmann $^{42}$ en Salgueiro da Silva Mouta ${ }^{43}$ moeilijk na te gaan of de keuze voor een strikte toetsing is ingegeven door objectieve criteria of door persoonlijke opvattingen van de rechters.

Wanneer de keuze voor de toepassing van de very weighty reasons-doctrine wél wordt gemotiveerd, zoals bij onderscheid op grond van geslacht en onwettige geboorte, is deze motivering beperkt tot een beroep op het common ground-argument. Het gebruik van dit argument voor de bepaling van de "verdachtheid" van een bepaalde grond heeft zeker voordelen: het vaststellen van een Europese consensus is relatief gemakkelijk en kan op een objectieve manier plaatsvinden. Het vellen van een waardeoordeel over de "ernst" van een bepaald onderscheid of het gewicht van een aangetast belang kan door deze benadering worden vermeden. Toch kleeft er, zoals eerder al is aangegeven, een aantal nadelen aan het uitsluitende gebruik van de common ground bij de bepaling van differentiatiecriteria als verdacht. Een probleem is allereerst dat bij een eventueel wegvallen van consensus de toetsing gemakkelijk kan worden afgezwakt. Het wegvallen van een Europese common ground hoeft echter nog niet te betekenen dat de classificatie geen betrekking meer heeft op een voor het maatschappelijk functioneren irrelevante eigenschap die iemand niet kan veranderen, of dat het onderscheid niet meer is ingegeven door vooroordelen jegens een kwetsbare minderheid. ${ }^{44}$ Een tweede belangrijk bezwaar is reeds genoemd. Hoewel het Hof vanzelfsprekend rekening moet houden met zijn subsidiaire positie ten opzichte van de staten, kan worden gesteld dat het een voortrekkersrol dient te vervullen op het gebied van de bescherming van de individuele grondrechten. Dit betekent dat het soms wenselijk is dat het hoge eisen stelt aan de rechtvaardiging van inbreuken, ook in gevallen waarin een Europese consensus op het gebied van de wenselijkheid van bepaalde ontwikkelingen nog ontbreekt. Een duidelijke illustratie van dit bezwaar kan worden gevonden in het eerder besproken arrest $\mathrm{Pe}$ -

440. Vgl. Schokkenbroek 1998, p. 22.

441. EHRM 16 september 1996, Reports 1996-IV

442. EHRM 23 juni 1993, Series A, vol. 255-C

443 EHRM 21 december 1999, EHRC 2000/16

444. Een sprekend voorbeeld hiervan is onderscheid op grond van seksuele geaardheid. Dit is een sterk persoonsgebonden kenmerk, dat iemand niet kan veranderen en dat voor het maatschappelijk functioneren meestal niet relevant is. Achterstelling levert bovendien een gevoel van inferioriteit en nietgeaccepteerd zijn op bij de betrokkene. Het moet dan ook wenselijk worden geacht om onderscheidingen die op deze grond zijn gebaseerd streng te beoordelen. Dit zal echter niet gebeuren als het Hof zijn huidige lijn blijft aanhangen: juist over onderscheid op grond van seksuele geaardheid bestaat maar weinig consensus. 
trovic. ${ }^{\text {ts }}$ In dit arrest beriep het Hof zich op het ontbreken van een Europese consensus als rechtvaardiging voor een marginale toetsing, maar het ontbreken van deze consensus lijkt zelf vooral verband te houden met verouderde opvattingen over rolpatronen en stereotiepe opvattingen over kinderzorg door mannen en vrouwen. Sommige staten zouden in de terughoudende benadering van het Hof een rechtvaardiging kunnen zien van hun eigen, uit oogpunt van gelijkberechtiging ongewenste, opstelling. Het zal duidelijk zijn dat dit geen wenselijke consequentie is.

Concluderend kan worden gesteld dat het niet wenselijk is om de verdachtheid van een bepaalde grond volledig afhankelijk te stellen van de aanwezigheid van een bepaalde consensus. Het lijkt beter te zijn dat van deze factor gebruik wordt gemaakt in combinatie met een aantal andere, meer inhoudelijke factoren zoals de vraag of het onderscheid is ingegeven door vooroordelen of stereotypen, de onveranderlijkheid van het betrokken onderscheidingskenmerk of de irrelevantie van het kenmerk voor het dagelijks functioneren. In dat geval worden de nadelen van deze factor voldoende gecompenseerd, terwijl toch kan worden geprofiteerd van de objectivering van de toetsing die het gebruik van de common ground-factor kan opleveren.

\section{Conclusies}

\subsection{Conclusies met betrekking tot de toetsingsmethodiek}

\subsubsection{Inleiding}

In het voorafgaande is uiteengezet op welke manier het Hof vorm heeft gegeven aan zijn toetsingsmodel voor artikel 14 . Volgens dit model is het noodzakelijk dat het Hof nagaat of de voorgelegde gevallen voldoende vergelijkbaar zijn. Als dit niet het geval is, dan is er geen sprake van een ongelijke behandeling en is artikel 14 niet geschonden. Zijn de voorgelegde gevallen wel vergelijkbaar, dan zal het Hof toetsen aan een rechtvaardigingsmodel dat twee cumulatieve elementen bestaat uit. Allereerst moet volgens dit model worden beoordeeld of met het gemaakte onderscheid een gerechtvaardigd doel wordt nagestreefd. Als het Hof daarvan voldoende overtuigd is zal het vervolgens nagaan of er sprake is van een redelijke mate van evenredigheid tussen het gehanteerde middel en het nagestreefde doel, waarmee gedoeld wordt op de evenredigheid in ruime zin. Hoewel het model van het Hof hierdoor in grote lijnen overeenkomt met het theoretische model, wijkt het hiervan op een aantal belangrijke punten af. Een eerste verschil is dat het Hof in de eerste fase van de toetsing gebruik maakt van een vergelijkbaarheidstoets: als vergelijkbaarheid ontbreekt, is het volgens het Hof niet nodig om te beoordelen of het gemaakte onderscheid objectief en redelijk gerechtvaardigd is. Een tweede verschil is dat het Hof de vereisten van een voldoende mate van fit, geschiktheid, subsidiariteit en proportionaliteit niet uitdrukkelijk onderscheidt als afzonderlijke toetsingselementen: in de meeste gevallen geeft het slechts een meer algemene beoor- 
deling van de redelijkheid van de verhouding tussen doel en middel of brengt het deze toetsingselementen onder bij de toetsing van het doel.

In deze laatste paragraaf zal worden ingegaan op de vraag of deze afwijkingen aanleiding vormen voor het aanvullen of wijzigen van het theoretische model.

\subsubsection{Toetsing in de eerste fase: de vergelijkbaarheidstoets}

\section{De vergelijkbaarheidstoets levert soms een minder aanvaardbaar resultaat op}

Zoals in hoofdstuk 2 is aangegeven levert het gebruik van de vergelijkbaarheidstoets als toetsingsingang een aantal problemen op. ${ }^{46}$ Bezwaren tegen deze toetsingsingang rijzen met name wanneer de uitkomst van de vergelijkbaarheidstoets bepalend is voor de uitkomst van de procedure. Wanneer een ongelijke behandeling van onvergelijkbare gevallen niet hoeft te worden gerechtvaardigd, bestaat er immers geen ruimte om een oordeel te geven over de geschiktheid, noodzakelijkheid en vooral de proportionaliteit van het onderscheid. Problematisch is verder dat het gebruik van de vergelijkbaarheidstoets gemakkelijk kan leiden tot een onzuivere toetsing: hoewel het voor een goede toetsing noodzakelijk is om expliciet na te gaan welke vergelijkingsmaatstaf wordt gehanteerd en om te beoordelen of deze als zodanig voldoende gerechtvaardigd is, blijken beide toetsingselementen vaak achterwege te blijven. Deze bezwaren kunnen aanleiding vormen tot de conclusie dat de toepassing van de vergelijkbaarheidstoets tot een minder goede resultaten leidt dan de toetsing aan het rechtvaardigingsmodel, gecombineerd met een benadelingstoets als toetsingsingang.

In de rechtspraak van het Hof kunnen diverse voorbeelden worden teruggevonden van de bezwaren die verbonden zijn aan het hanteren van de vergelijkbaarheidstoets als toetsingsingang. Illustratief is het arrest Observer and Guardian ${ }^{447}$, dat betrekking had op een verbod voor Engelse kranten om te publiceren over het boek Spycatcher. Dit boek was geschreven door een voormalig medewerker van de Britse geheime dienst (MI5) en had betrekking op zijn ervaringen bij deze dienst. De Engelse overheid had grote bezwaren tegen publicatie van het boek omdat de auteur hierin vertrouwelijke informatie zou hebben verwerkt; met name had zij moeite met de beschrijving van enkele illegale activiteiten die door MI5 zouden zijn verricht. De Engelse Attorney General had daarom een rechtszaak tegen de schrijver aangespannen om te voorkomen dat het boek zou worden verspreid. Nog voordat de nationale rechter uitspraak in deze zaak deed werd er echter een aantal artikelen gepubliceerd in twee Engelse kranten - de Observer en de Guardian - waarin passages uit het boek werden geciteerd. Om het gevaar voor het nog verder uitlekken van vertrouwelijke informatie zoveel mogelijk te beperken werd beide kranten verboden om nog verder over het boek te publiceren. De kranten waren van mening dat door dit verbod de persvrijheid ernstig werd aangetast en dat hierdoor bovendien inbreuk was gemaakt op het gelijkheidsbeginsel: buitenlandse kranten, die in Engeland vrij verkrijgbaar zijn, werden immers niet door het verbod geraakt en konden gewoon over het boek publiceren. Het Hof stelde hierover het volgende: 
"Article 14 affords protection against different treatment, without an objective and reasonable justification, of persons in similar situations. If and in so far as foreign newspapers were subject to the same restrictions as Observer and Guardian, there was no difference of treatment. If and in so far as they were not, this was because they were not subject to the jurisdiction of the English courts and hence were not in a situation similar to that of Observer and Guardian."

Doorslaggevend voor het Hof was dus het feit dat buitenlandse kranten niet onder de jurisdictie van de Britse rechtbanken vallen, zodat er geen sprake was van vergelijkbare gevallen. Hoewel dit oordeel op het eerste gezicht aanvaardbaar lijkt, zou door toetsing an het rechtvaardigingsmodel een andere, redelijkere, conclusie kunnen worden bereikt. Bij een toetsing aan dit model zou in de eerste fase bijvoorbeeld kunnen worden nagegaan of er sprake is van een benadeling (hetgeen in dit geval duidelijk is), waarna kan worden bekeken of door het onderscheid een gerechtvaardigd doel werd nagestreefd en of er een redelijke verhouding tussen doel en middel bestond. Een voor de casus belangrijk vereiste is daarbij dat de getroffen maatregel geschikt moet zijn om het gestelde doel te bereiken. De vraag is of daaraan in dit geval is voldaan. Een publicatieverbod lijkt op het eerste gezicht erg effectief wanneer het is bedoeld om de verspreiding van geheime informatie te voorkomen, maar is dat alleen wanneer een dergelijk verbod daadwerkelijk aan alle media wordt opgelegd. Als uitsluitend aan Britse kranten wordt verboden om over het boek te publiceren, terwijl andere Engelstalige kranten vrij op de markt verkrijgbaar zijn, is het zeer de vraag of kan worden voorkomen dat de informatie toch bekend wordt gemaakt. Het feit dat de Engelse regering juridisch gezien niet in staat was om het verbod te laten gelden voor buitenlandse kranten doet aan deze ongeschiktheid verder niet af. ${ }^{49}$ Hierdoor lijkt de door het verschil in behandeling veroorzaakte belangenaantasting veel minder acceptabel. Ook bij een ongelijke behandeling van schijnbaar onvergelijkbare gevallen is het dan ook redelijk en wenselijk om na te gaan of het verschil in behandeling voldoende gerechtvaardigd is.

\section{Gebruik van de vergelijkbaarheidstoets levert geen beter resultaat op}

Hiervoor is aangegeven dat er in de rechtspraak van het Hof voorbeelden te vinden zijn van gevallen waarin de toetsing aan het rechtvaardigingsmodel aanvaardbaardere resultaten oplevert dan een toetsing van de vergelijkbaarheid. Dit hoeft echter nog geen reden zijn voor het weglaten van de vergelijkbaarheidstoets, wanneer zou blijken dat deze toets in een groot aantal gevallen leidt tot betere conclusies. In de literatuur over artikel 14 is met enige regelmaat betoogd dat dit het geval is, terwijl kan worden vastgesteld dat de toetsing aan het rechtvaardigingsmodel inderdaad een aantal moeilijkheden oplevert, ${ }^{40}$ Door te vereisen dat een onderscheid een gerechtvaardigd doel heeft, wordt van de rechter verwacht dat hij vaststelt welk doel een wetgever of regering met

448. $\S 74$

449. Overigens kan ook worden gesteld dat het verbod in onaanvaardbare mate underinclusive is: slechts een klein gedeelte van de groep waarvoor het verbod relevant zou moeten zijn valt onder de reikwijdte van het verbod.

450. Zie met name Van Dijk en Van Hoof 1998, p. 722-727. Zij stellen onder andere dat de benadering van het Hof om de vergelijkbaarheidstoets in bepaalde gevallen weg te laten "would seem to water down the significance of Article 14 to the bare minimum" (p. 727). 
het betrokken onderscheid wil bereiken; daarnaast zal hij zich moeten begeven in de lastige beoordeling van de gerechtvaardigdheid van dit doel. Uit respect voor de bestaande machtsverdeling zal de rechter veelal enige afstand willen houden van het oordeel van wetgever en bestuursorganen; in ieder geval zal hij niet snel geneigd zijn om de innerlijke waarde van een regeling te beoordelen. Deze terughoudende opstelling heeft tot gevolg dat de rechter in veel gevallen genoegen zal nemen met een nogal algemene doelstelling. ${ }^{451}$ Voor de wetgever is het gemakkelijk genoeg om een dergelijk doel te bedenken, terwijl het bovendien niet erg waarschijnlijk is dat een doelstelling zo zal worden geformuleerd dat deze ook bij oppervlakkige bestudering inherent discriminatoir of anderszins onaanvaardbaar blijkt te zijn. Dit heeft tot gevolg dat een ongelijke behandeling al snel als geoorloofd zal worden aangemerkt, ook wanneer een nauwkeurig onderzoek zou uitwijzen dat er wel degelijk reden bestaat om aan de redelijkheid van het onderscheid te twijfelen.

Bij de vergelijkbaarheidstoets heeft de rechter volgens critici van de rechtvaardigingstoets meer ruimte voor een goede beoordeling van het onderscheid. De rechter kan hierbij immers volstaan met de beantwoording van de vraag of er objectief gezien sprake is van een vergelijkbare situatie. Hiertoe hoeft hij alleen de feitelijke verschillen en overeenkomsten te beoordelen, zodat het niet nodig is om het doel van het onderscheid vast te stellen en de waarde ervan te beoordelen. ${ }^{42}$ Aan de hand van een voorbeeld uit de rechtspraak van het Hof kan echter aannemelijk worden gemaakt dat dit niet automatisch tot een betere uitkomst en een geringere belasting van de rechter leidt. In het al genoemde arrest $A b d u l a z i z^{453}$ moest het Hof uitspraak doen over de toelaatbaarheid van een Engelse regeling voor gezinshereniging die het voor buitenlandse vrouwen die in Engeland woonden moeilijk maakte om hun gezin naar Engeland te halen. Eén van de stellingen van de klaagsters luidde dat het niet redelijk was dat Engelse vrouwen altijd samen mogen wonen met hun buitenlandse man, terwijl veel geëmigreerde vrouwen als gevolg van de regeling uit Engeland weg moeten gaan om met hun echtgenoot samen te kunnen leven. Dit onderscheid leek klaagsters met name niet gerechtvaardigd, nu een geëmigreerde vrouw die al jaren in Engeland woont minstens zoveel binding met dit land zal hebben als een Engelse die vrijwel steeds in het buitenland woont en werkt. Met toepassing van zijn rechtvaardigingsmodel overwoog het Hof hierover het volgende:

"It is true that a person who [...] has been settled in a country for several years may also have formed close ties with it, even if he or she was not born there. Nevertheless, there are in general persuasive social reasons for giving special treatment to those whose link with a country stems from birth within it." ${ }^{\text {s4 }}$

451. Vgl. Khol 1970, p. 292.

452. Kewenig 1972, p. 106. Ook dit kan een nogal arbitraire toetsing opleveren, omdat het nooit zal voorkomen dat twee gevallen volledig identiek zijn. Enig verschil is altijd wel aan te wijzen, zodat bij de beoordeling van de vraag welke verschillen wel en welke niet van belang zijn afhankelijk is van de persoonlijke opvattingen van de rechter. Een objectieve toetsing zal door de vergelijkbaarheidstoets dus niet in veel sterkere mate dan bij de rechtvaardigingstoets kunnen worden bereikt. Vgl. SundbergWeitman 1982, p. 35 en 39.

453. EHRM 28 mei 1985, Series A, vol. 94

454. $\$ 88$ 
In de literatuur is gesteld dat in dit geval een toepassing van de vergelijkbaarheidstoets tot een andere conclusie zou hebben geleid: vrouwen die al dertig jaar in Engeland wonen hebben waarschijnlijk een net zo sterke band met het land als vrouwen die daar geboren zijn, zodat zij zich in een vergelijkbare situatie bevinden. ${ }^{455}$ De maatstaf die dan wordt aangelegd is de feitelijke binding die iemand heeft met het land waar hij of zij woont; met het oog daarop bestaan er inderdaad geen relevante verschillen tussen de aan het Hof voorgelegde gevallen. Uit het arrest blijkt echter dat dit kennelijk niet de enige maatstaf was die de wetgever hanteerde: er zijn ook nog andere - sociale - redenen die van belang kunnen zijn bij het bepalen van de rechten of plichten van allochtonen en autochtonen, met name wanneer het gaat om gezinshereniging. Als met dergelijke redenen rekening zou zijn gehouden bij het vaststellen van de vergelijkbaarheid, dan zou waarschijnlijk zijn gebleken dat de betrokken gevallen wel degelijk relevante verschillen vertonen. De toepassing van de vergelijkbaarheidstoets zou in dit geval dan ook niet tot een ander resultaat hebben geleid dan de toetsing aan het rechtvaardigingsmodel.

Uit dit voorbeeld blijkt dat het ook bij de vergelijkbaarheidstoets van belang is om het precieze doel van de regeling vast te stellen: dit is noodzakelijk om te kunnen bepalen of de voorgelegde gevallen relevante verschillen en overeenkomsten vertonen. In casu gold dat de voorgelegde gevallen met het oog op de ene maatstaf (feitelijke binding met het land) belangrijke overeenkomsten vertoonden, maar dat er met het oog op een andere, zorgvuldiger geformuleerde maatstaf (waarin ook rekening zou worden gehouden met bepaalde, helaas niet geëxpliciteerde, sociale factoren) wel degelijk relevante verschillen zichtbaar waren. Door de noodzaak van het zuiver vaststellen van het doel wordt het verschil met de rechtvaardigingstoets bijzonder marginaal: dit verschil bestaat dan eigenlijk alleen nog in de beoordeling van de legitimiteit van de maatstaf. Het zou echter merkwaardig zijn wanneer een rechter wel bevoegd wordt geacht om het doel van het onderscheid te bepalen, maar zich vervolgens niet mag uitspreken over de aanvaardbaarheid daarvan. Dit is met name vreemd als duidelijk blijkt dat het doel willekeurig of inherent discriminatoir is, of wanneer zou blijken dat de doelstelling in strijd is met de door het Verdrag beschermde grondrechten of met algemene rechtsbeginselen. Dit betekent dat ook in de praktijk de vergelijkbaarheidstoets geen minder grote belasting voor de rechter oplevert dan de rechtvaardigingstoets en evenmin tot betere resultaten leidt. ${ }^{\text {s6 }}$

\section{Vergelijkbaarheid wordt door het Hof regelmatig verondersteld}

Van belang is verder dat het Hof niet consequent is in het toepassen van de vergelijkbaarheidstoets. Hoewel de vraag of de voorgelegde gevallen voldoende vergelijkbaar zijn een essentieel onderdeel van het toetsingsmodel vormt, wordt in een groot aantal arresten een inhoudelijke beantwoording van deze vraag achterwege gelaten. In deze gevallen veronderstelt het Hof kennelijk dat de gevallen voldoende vergelijkbaar zijn en gaat het meteen over tot een beoordeling van de aangevoerde rechtvaardiging. Bij de

455. Zie Van Dijk/Van Hoof 1990 , p. 544.

456. Zie ook Sundberg-Weitman, die vaststelt dat zowel bij de vergelijkbaarheidstoets als bij de rechtvaardigingstoets een waardeoordeel moet worden geveld om tot een aanvaardbare uitkomst te komen. In zoverre verschillen de twee toetsen nauwelijks van elkaar (1980, p. 35). 
door het Hof als verdacht aangemerkte classificaties (onderscheid op grond van geslacht, nationaliteit, godsdienst, onwettige geboorte en seksuele geaardheid) wordt zelfs alleen in uitzonderingsgevallen aandacht besteed aan de vergelijkbaarheidstoets. Zoals eerder is aangegeven ligt dit bij deze gronden van onderscheid ook wel voor de hand. Het gaat hierbij steeds om onderscheid op grond van persoonlijke eigenschappen die in het algemeen niet relevant zijn voor het maatschappelijk functioneren van de betrokkene. Als een ongelijke behandeling op een dergelijke grond is gebaseerd impliceert dit vrijwel automatisch dat de voorliggende gevallen vergelijkbaar zijn. ${ }^{47}$

Opmerkelijk is echter dat het Hof de beoordeling van de vergelijkbaarheid ook bij nietverdachte classificaties geregeld achterwege blijkt te laten. Het is moeilijk hiervoor een verklaring te geven, zeker nu het Hof het belang van de vergelijkbaarheidstoets steeds voorop stelt. Slechts in een enkel geval heeft het Hof een expliciete motivering gegeven voor het weglaten van de toets. In deze zaken overwoog het Hof dat het weinig toegevoegde waarde zou hebben om op de vergelijkbaarheid in te gaan, nu de vragen die daarbij aan de orde zouden komen net zo goed konden worden beantwoord bij de toetsing aan het rechtvaardigingsmodel. ${ }^{4 s 8}$ Uit deze motivering en uit het frequente wegblijven van een beoordeling van de vergelijkbaarheid kan een belangrijke relativering van de noodzaak van het gebruik ervan worden afgeleid: kennelijk vindt het Hof het zelf in ieder geval niet problematisch om in bepaalde gevallen de vergelijkbaarheidstoets achterwege te laten en in plaats daarvan meteen een rechtvaardigingstoets uit te voeren. Meer in het bijzonder kan worden gesteld dat het meestal niet nodig is om in te gaan op de vergelijkbaarheid als het gaat om verdachte classificaties.

\section{Vergelijkbaarheidstoets leidt niet tot een betere motivering}

$\mathrm{Bij}$ de beoordeling van de rechtvaardiging moet het Hof volgens zijn eigen toetsingsmodel expliciet aandacht besteden aan het doel van de maatregel en aan het vereiste van een redelijke verhouding tussen doel en middel. Het Hof blijkt zich door het bestaan van dit model echter lang niet altijd genoodzaakt te voelen tot het geven van een goede motivering: in paragraaf 2 zijn verschillende voorbeelden gegeven van gevallen waarin het Hof zonder enige inhoudelijke onderbouwing en zonder aan de verschillende criteria afzonderlijk te toetsen een oordeel uitsprak over de aanwezigheid van een objectieve en redelijke rechtvaardiging. Een dergelijke werkwijze is problematisch, omdat de rechtspraak hierdoor moeilijk controleerbaar is en het voor de staten lastig is om te bepalen hoe zij zich moeten gedragen om toekomstige verdragsschendingen te voorkomen. Als de toepassing van de vergelijkbaarheidstoets, hetzij als toetsingsingang, hetzij als inhoudelijk model, meer waarborgen zou bieden voor een zorgvuldige motivering, zou het wenselijk kunnen zijn om deze toets toch als afzonderlijk element in het normatieve model op te nemen. Uit de toetsingspraktijk van het Hof blijkt echter dat ook de vergelijkbaarheidstoets geenszins noodzaakt tot een inhoudelijke motivering. In veruit de meeste gevallen geeft het Hof slechts met enkele woorden aan waar-

457. Een nadere nuancering van deze stelling is nodig, omdat sommige verdachte gronden van onderscheid wel degelijk in bepaalde omstandigheden een relevant verschil kunnen opleveren. Zie daarvoor supra paragraaf 2.2.2.

458. Zie EHRM 28 november 1984, Rasmussen, Series A, vol. 87, \$37 en EHRM 21 februari 1997, Van Raalte, Reports 1997-1, §40. 
om twee gevallen verschillen; het hiervoor geciteerde arrest Observer and Guardian (Spycatcher) vormt daarvan een duidelijk voorbeeld. Zeker nu het rechtvaardigingsmodel in beginsel een grotere noodzaak tot motivering oplevert - er moet immers aan meer elementen inhoudelijk worden getoetst - kan worden geconcludeerd dat de toetsingspraktijk van het Hof ook in dit opzicht geen overtuigend argument verschaft om de vergelijkbaarheidstoets aan het model toe te voegen.

\subsubsection{De tweede fase van de toetsing: toetsing aan het rechtvaardigingsmodel}

Toetsing van het doel van het onderscheid

Zoals hiervoor is aangegeven kan de beoordeling van het doel van het onderscheid theoretisch gezien problemen opleveren. Het is voor een rechter niet eenvoudig om te achterhalen welke doelstelling een overheidsorgaan met een bepaalde maatregel beoogt na te streven. Iets als "de wil van de regelgever" is in de praktijk moeilijk vast te stellen en het is voor de rechter lastig om te bepalen in welke mate hij moet zoeken naar de "werkelijke bedoeling" van een bepaalde maatregel. Een tweede belangrijk probleem is dat de rechter moet vaststellen of het nagestreefde doel voldoende gerechtvaardigd is. Daarbij moet hij een inhoudelijk oordeel uitspreken over de waarde van het doel, waardoor hij al snel in het vaarwater van het besluitvormende orgaan terechtkomt en waardoor bovendien een risico bestaat voor een subjectief gekleurd oordeel.

In de jurisprudentie van het Hof kan voor deze problemen helaas nauwelijks een oplossing worden gevonden, met name door het zeer casuïstische karakter van de toetsing. Uit de rechtspraak kan slechts blijken dat het Hof al snel genoegen neemt met de doelstelling zoals die door de regering naar voren wordt gebracht, zelfs als deze nogal algemeen van aard is. Het Hof blijkt bovendien geen bijzonder hoge eisen te stellen aan de gerechtvaardigdheid: vrijwel ieder aangevoerd doel wordt door het Hof aanvaardbaar geacht, zolang het enigszins aansluit bij de in het Verdrag genoemde doelcriteria. Niettemin kunnen er in de rechtspraak van het Hof, met name in de uitspraken met betrekking tot ongelijke behandeling op verdachte gronden, enkele criteria voor de beoordeling van het doel worden gevonden die voor een meer algemene toepassing bruikbaar lijken te zijn. Belangrijk is allereerst dat het Hof eisen heeft gesteld aan de specificiteit: te algemene en zeer abstracte overwegingen kunnen in het algemeen niet dienen als rechtvaardiging voor een verdachte classificatie. Relevant is ook een tweede criterium, dat inhoudt dat de overwegingen die aan een classificatie ten grondslag liggen niet uitsluitend een uitdrukking mogen vormen van traditionele opvattingen of van vooroordelen jegens een bepaalde groep. Voor invoeging in het algemene toetsingsmodel bruikbaar is ook het vereiste dat het doel moet beantwoorden aan een reële situatie: wanneer blijkt dat het onderscheid alleen is ingegeven door de wens om een theoretisch of puur hypothetisch probleem te bestrijden, kan het in het algemeen niet gerechtvaardigd worden geacht. Meer twijfel is mogelijk over de bruikbaarheid van het laatste criterium dat door het Hof is ontwikkeld: vaste rechtspraak is dat een ongelijke behandeling op een verdachte grond alleen gerechtvaardigd kan worden geacht wanneer hiervoor very weighty reasons kunnen worden aangevoerd. Een toetsing aan dit vereiste van zwaarwegendheid zou ertoe leiden dat er al in het kader van de doeltoets een oordeel moet worden uitgesproken over het gewicht van deze doelstelling, waardoor er feitelijk al uitspraak wordt gedaan over de evenredigheid van de ongelijke behandeling. 
Een dergelijke uitspraak zal noodzakelijkerwijze onvolledig zijn, omdat bij de toetsing van het doel nog geen goed oordeel kan worden gegeven over het gewicht van het aangetaste belang, noch over de redelijkheid van de gemaakte belangenafweging. Het komt de zuiverheid en de duidelijkheid van de motivering ten goede wanneer niet al bij de toetsing van het doel, maar pas bij de beoordeling van de proportionaliteit in strikte zin uitspraak wordt gedaan over het gewicht van het nagestreefde doel.

Van belang is tenslotte dat het Hof bereid is om een verdergaand onderzoek naar het doel uit te voeren als de klagende partij steekhoudende argumenten aanvoert voor de stelling dat de gestelde bedoeling niet de werkelijke bedoeling van het onderscheid is. Door bij de klager de last te leggen om aannemelijk te maken dat er nog een andere bedoeling is, wordt aan de rechter de lastige en tijdrovende taak ontnomen om in iedere zaak ambtshalve na te gaan of de gestelde bedoeling overeenstemt met de werkelijke bedoeling. Deze benadering is voor de praktijk zeer bruikbaar, zij het dat deze alleen redelijk is in gevallen waarin een terughoudende toetsing is uitgevoerd: bij een intensieve toetsing kan het redelijk zijn om in alle gevallen een zorgvuldig onderzoek naar de werkelijke bedoeling van het onderscheid uit te voeren.

\section{Toetsing van de mate van fit, de geschiktheid en van de subsidiariteit}

Aangegeven is al dat de vereisten van een voldoende mate van fit, geschiktheid en subsidiariteit bij de toetsing aan artikel 14 niet als afzonderlijke toetsingscriteria worden gezien. Ten aanzien van het subsidiariteitsvereiste heeft het Hof zelfs uitdrukkelijk aangegeven dat het dit niet in zijn toetsing wil betrekken. De beoordeling van subsidiariteit impliceert dat er een keuze mogelijk is tussen verschillende maatregelen die geschikt zijn om het gestelde doel te bereiken. Het maken van deze keuze moet in de visie van het Hof aan de nationale overheden worden overgelaten: als de rechter een oordeel uit zou moeten spreken over de wenselijkheid van de gemaakte keuze, zou de nationale soevereiniteit te zeer worden aangetast.

In de praktijk blijkt het Hof zich minder te beperken dan het zelf stelt: in paragraaf 2.6 is een aantal voorbeelden gegeven van arresten waarin het Hof wel degelijk een uitspraak doet over de subsidiariteit van de getroffen maatregel. De bezwaren tegen de toetsing aan het subsidiariteitsvereiste worden hierdoor enigszins gerelativeerd. Er bestaat dan ook geen aanleiding om het element volledig uit het algemene model te schrappen. Wel kan naar aanleiding van de verschillende uitspraken van het Hof worden gesteld dat een uitgebreide toetsing van de subsidiariteit in het geval van een marginale toetsing alleen nodig is als de klager aannemelijk heeft gemaakt dat er in het concrete geval andere, minder vergaande mogelijkheden bestonden om het gestelde doel te bereiken. Bovendien kan als alternatief voor de subsidiariteitstoets soms de minder vergaande noodzakelijkheidstoets worden gehanteerd: daarbij is het mogelijk om te beoordelen of het echt nodig was om onderscheid te maken, zonder dat precies hoeft te worden nagegaan welke alternatieven er bestonden en zonder dat hoeft te worden beoordeeld of door het gebruik van die alternatieven het gestelde doel voldoende zou kunnen worden bereikt. 
Tegen de toetsing van de mate van fit en van de geschiktheid heeft het Hof geen expliciete bezwaren aangevoerd. Uit de rechtspraak blijkt bovendien dat het Hof soms inderdaad aan deze elementen toetst, vooral in gevallen waarin toetsing van het doel en van de proportionaliteit in strikte zin geen uitkomst bieden. ${ }^{459}$ Van belang is verder dat er verschillende arresten zijn te vinden die kunnen illustreren dat het weglaten van een toetsing aan deze criteria leidt tot een minder acceptabele conclusie of tot een weinig overtuigende motivering. Hiervoor is al het voorbeeld gegeven van het arrest Spycatcher, waarin geklaagd werd over een maatregel die een ongelijke behandeling tot gevolg had, maar die duidelijk niet geschikt was om het doel van de maatregel te bereiken. Aangezien het Hof in dit geval alleen op de vergelijkbaarheid inging werd deze geschiktheid niet beoordeeld; het onderscheid werd daardoor ten onrechte toelaatbaar geacht. Een voorbeeld waaruit kan blijken dat het wenselijk is om een afzonderlijke toetsing aan het vereiste van een voldoende mate van fit uit te voeren is het al meermalen genoemde arrest Thlimmenos. ${ }^{+60}$ Het probleem in deze zaak was dat het ingevolge een wettelijke regeling verboden was om mensen tot accountant te benoemen die in het verleden waren veroordeeld wegens het plegen van een misdrijf. De klager had gesteld dat hierdoor materieel onderscheid op grond van godsdienst werd gemaakt, nu er geen rekening werd gehouden met het feit dat sommige misdrijven rechtstreeks verband houden met iemands godsdienstige overtuiging. Zelf was klager in het verleden veroordeeld voor het feit dat hij vanuit zijn geloofsovertuiging geweigerd had een militair uniform te dragen ten tijde van algehele mobilisatie. Het Hof stelde hierover het volgende:

"The Court considers that, as a matter of principle, States have a legitimate interest to exclude some offenders from the profession of registered accountant. However, the Court concludes that, unlike other convictions for serious criminal offenders, a conviction for refusing on religious or philosophical grounds to wear the military uniform cannot imply any dishonesty or moral turpitude likely to undermine the offender's ability to exercise this profession. Excluding the applicant on the ground that he was an unfit person was not, therefore, justified."

Deze redenering komt neer op een argument van overinclusiveness: een wettelijke regeling die mensen van het accountantsberoep uitsluit is weliswaar redelijk, maar alleen wanneer slechts die mensen worden uitgesloten die moreel ongeschikt zijn voor het beroep. De gekozen regeling was volgens het Hof te algemeen en sloot ook mensen uit die wel een voldoende mate van morele geschiktheid vertoonden. Het Hof leidde hieruit de conclusie af dat de regeling geen gerechtvaardigd doel diende. Dit is merkwaardig, nu aan de gerechtvaardigdheid van het doel (benoeming van accountants die voldoen aan de eisen van morele geschiktheid en integriteit) op zichzelf geen twijfel kon bestaan. Het was dan ook niet zozeer het doel van de regeling, maar vooral de manier waarop de classificatie was gedefinieerd, waardoor de maatregel in strijd was met artikel 14. Het zou dan ook zuiverder zijn geweest wanneer het Hof in een geval als dit een aparte toets van de mate van fit zou hebben uitgevoerd.

459. Zie paragraaf 2.5 .1 en 2.5 .2 .

460. EHRM 6 april 2000, EHRC 2000/45

461. $\S 47$ 


\section{Toetsing van de proportionaliteit in strikte zin}

In paragraaf 2 is opgemerkt dat de beoordeling van de redelijkheid van de verhouding tussen doel en middel bij de toetsing aan artikel 14 nogal wat te wensen overlaat: in een groot aantal gevallen laat het Hof deze toetsing volledig achterwege, stelt het slechts zonder nadere motivering dat een redelijke doel-middelverhouding aanwezig is of voert het alleen een zeer marginale toetsing van de proportionaliteit uit. Ook bij verdachte classificaties (waarbij normaal gesproken een intensievere en zorgvuldigere toetsing wordt uitgevoerd) is de motivering niet altijd even overtuigend. Het is duidelijk dat een dergelijke benadering geen navolging verdient.

Bij de substantiële verdragsartikelen is de proportionaliteitstoets aanzienlijk beter ontwikkeld. Bij de beoordeling van inbreuken op deze artikelen gaat het Hof meestal vrij uitgebreid en zorgvuldig na welke belangen bij de besluitvorming een rol hebben gespeeld en welke rechten en belangen van de klagende partij daardoor zijn aangetast; vervolgens wordt bepaald of er sprake is van voldoende evenwicht tussen deze belangen. Het is wenselijk dat het Hof een dergelijke zorgvuldige en uitgebreide toetsing ook meer consequent uitvoert bij het gelijkheidsbeginsel.

\subsection{Conclusies met betrekking tot de toetsingsintensiteit}

\subsection{Werkwijze van het Hof, niveaus van toetsingsintensiteit en invloed op de toetsingsmethodiek}

In paragraaf 3 van dit hoofdstuk is uitgebreid aandacht besteed aan de verschillende factoren die een rol spelen bij de vaststelling van de omvang van de margin of appreciation en, daarmee, bij de bepaling van de intensiteit van de toetsing. Genoemd zijn de aanwezigheid van een Europese consensus (het common ground-argument), het better placed-argument, de context van de genomen maatregel, de aard van het nagestreefde doel, de aard van de betrokken beperkingsmaatregel, het gewicht van het betrokken recht of belang en de grond van het onderscheid. Duidelijk is geworden dat de verschillende factoren vaak gelijktijdig een rol spelen in de aan het Hof voorgelegde zaken. Het is dan nodig om, nadat het relatieve gewicht van de verschillende factoren is vastgesteld, hiertussen een afweging te maken. Bij klachten over artikel $14 \mathrm{zal}$ het Hof daarbij in de eerste plaats kijken naar de grond van het onderscheid. Als deze als verdacht kan worden aangemerkt zal de toetsing intensief zijn: de andere factoren zullen in een dergelijk geval nog maar weinig invloed hebben. ${ }^{462}$ Als er geen sprake is van een verdachte classificatie gaat het Hof anders te werk. In dat geval zal het allereerst beoordelen of de aantasting een fundamenteel kernrecht of juist een meer als perifeer te beschouwen recht betreft. Is er een kernrecht aangetast, dan kunnen alleen zwaarwegende factoren die in de richting van een marginale toetsing wijzen de keuze voor een ruime margin of appreciation rechtvaardigen. Is er geen fundamenteel recht aangetast,

462. Het Hof leek deze opvatting in Petrovic (EHRM 27 maart 1998, Reports 1998-II) te willen nuanceren: hoewel er sprake was van een verdachte classificatie, werd hierin toch een marginale toetsing toegepast, omdat het onderscheid betrekking had op een beleidsveld waarover in Europa weinig overeenstemming bestaat. Het is nog niet duidelijk of het Hof van plan is om deze lijn voort te zetten en deze ook bij andere gronden dan geslacht toe te passen. Nadere jurisprudentie daarover zal moeten worden afgewacht. 
dan zal de toetsing in beginsel marginaal zijn; intensiteitverhogende factoren kunnen in dat geval echter aanleiding zijn voor de keuze voor een striktere toetsing. Met name kan de aan- of afwezigheid van een Europese consensus over het onderscheid worden gezien als een zwaarwegende intensiteitbepalende factor; ook het beleidsveld en het better placed-argument kunnen een belangrijke rol spelen.

De jurisprudentie van het Hof over de margin of appreciation is van groot belang voor de ontwikkeling van een model voor de bepaling van de toetsingsintensiteit. Allereerst is het belangrijk dat het Hof in vrijwel alle gevallen eerst de omvang van de margin of appreciation (en daarmee de intensiteit van de toetsing) vaststelt en pas daarna overgaat tot een inhoudelijke beoordeling van het onderscheid. Hieruit kan blijken dat een scheiding van de vaststelling van de toetsingsintensiteit en de inhoudelijke beoordeling praktisch mogelijk is en leidt tot een overzichtelijke en heldere toetsingsmethodiek. Uit de rechtspraak van het Hof blijkt verder dat het in de praktijk goed mogelijk is om variatie aan te brengen in de intensiteit van de toetsing. Aangegeven is verder dat het effect op de toetsingsmethodiek bij het Hof meestal duidelijk zichtbaar is: een smalle margin, of een very weighty reasons-test, leidt tot een indringende toetsing van de aangedragen motivering, waardoor de inbreuk meestal in strijd met het Verdrag wordt geacht. Een ruime margin brengt daarentegen een soort willekeurstoets mee, die leidt tot een terughoudende opstelling bij de beoordeling van de noodzakelijkheid en proportionaliteit.

De vaststelling van de toetsingsintensiteit door het Hof wijkt anderzijds ook af van het theoretische model, in die zin dat er geen duidelijkheid bestaat over de verschillende gradaties of "niveaus" van toetsingsintensiteit. Hoewel de twee uitersten (een zeer intensieve en een zeer marginale toetsing) in de rechtspraak duidelijk zijn te herkennen, blijken daartussen talrijke tussenvormen zichtbaar te zijn. De benadering van het Hof is daarmee het beste te beschrijven als een glijdende schaal, waarbij de omslagpunten tussen verschillende niveaus van toetsingsintensiteit niet duidelijk herkenbaar zijn. Deze benadering heeft het voordeel van flexibiliteit: de intensiteit kan precies worden afgestemd op de omstandigheden van het voorliggende geval. Een belangrijk nadeel is echter de onduidelijkheid die erdoor wordt gecreëerd: het is zelden duidelijk welk effect de aanwezigheid van bepaalde factoren nu precies heeft op de toetsingsintensiteit, terwijl ook het effect van een bepaalde intensiteit op de methodiek niet altijd helder kan worden vastgesteld. Het is dan ook de vraag of een dergelijke "glijdende schaal"benadering navolging verdient en bij de ontwikkeling van een algemeen toetsingsmodel moet worden overgenomen. Op deze, vooralsnog lastig te beantwoorden, vraag zal in hoofdstuk 7 worden teruggekomen, waarbij ook zal worden gekeken naar de werkwijze van de andere rechterlijke instanties die in het kader van dit proefschrift zijn onderzocht.

\subsubsection{Factoren die de toetsingsintensiteit bepalen}

In paragraaf 3.3 is duidelijk geworden dat het Hof verschillende gronden van onderscheid als verdacht heeft gekwalificeerd. Jammer is dat het Hof niet in het algemeen heeft aangegeven welke overwegingen precies tot deze kwalificatie hebben geleid. Bij twee van de vijf als verdacht aangemerkte classificaties (namelijk geslacht en onwetti- 
ge geboorte) heeft het Hof het bestaan van een common ground als bepalend aangemerkt; bij de andere drie gronden (godsdienst, seksuele geaardheid en nationaliteit) ontbreekt een inhoudelijke motivering zelfs volledig. Hierdoor kan uit de rechtspraak van het Hof weliswaar worden afgeleid dat bepaalde gronden van onderscheid eerder een intensievere toetsing rechtvaardigen dan andere, maar is het moeilijk om te bepalen welke factoren daarvoor bepalend zijn.

Van belang is echter dat het Hof, zowel bij de toetsing aan de substantiële verdragsbepalingen als bij de toetsing aan artikel 14 , gebruik maakt van een aantal factoren waarvan al in hoofdstuk 2 is vastgesteld dat het wenselijk zou zijn om ze te betrekken bij de vaststelling van de toetsingsintensiteit. Zo bevestigt de rechtspraak van het Hof dat factoren als de grond van onderscheid en het gewicht van het aangetaste belang een bepalende rol spelen bij de keuze voor een intensieve of juist een meer marginale toetsing. Het Hof heeft bovendien een aantal criteria ontwikkeld die behulpzaam kunnen zijn bij de beoordeling van het gewicht van een bepaald recht of belang. In de visie van het Hof is een intensivering van de toetsing in ieder geval op zijn plaats als het betrokken belang of recht van groot belang is voor het goede functioneren van een democratische samenleving of als het raakt aan een zeer intiem aspect van het privé-leven. Deze criteria kunnen worden gezien als een nuttige aanvulling op de in het normatieve gedeelte behandelde criteria.

Van de in het hoofdstuk 2 niet genoemde factoren is vooral de common ground-factor interessant. Voor het Hof vormt het bestaan van een consensus tussen de lidstaten een belangrijke rechtvaardiging voor een intensievere toetsing: ontbreekt een dergelijke consensus, dan zal het de keuzevrijheid van de staten in veel verdergaande mate moeten respecteren. Het gebruik van deze factor is in belangrijke mate ingegeven door het internationale beginsel van de subsidiariteit. Omdat dit beginsel op nationaal niveau geen rol speelt lijkt het belang van deze factor voor de nationale rechter kleiner te zijn dan voor een internationale rechter als het Hof. Beredeneerd kan echter wel worden dat het bestaan van een common ground ook op nationaal niveau een rol kan spelen. Net als de internationale rechter zal ook een intensief toetsende nationale rechter immers een rechtvaardiging moeten vinden voor zijn vergaande ingreep in de vrijheid van regering of wetgever. Het op rechtsvergelijking gebaseerde argument dat in andere staten een bepaald onderscheid niet toelaatbaar wordt geacht zou zijn keuze voor een intensieve toetsing zeker kunnen ondersteunen.

Voor de wijze waarop een dergelijke rechtsvergelijking kan worden uitgevoerd heeft het Hof een tweetal aanknopingspunten aangereikt. Gekeken kan worden naar de mate waarin wetgeving en uitvoeringspraktijk van verschillende staten overeenstemmen en naar de aanwezigheid van verdragen of andere internationale regelingen. Vooral het bestaan van verdragen blijkt te worden gezien als een belangrijke rechtvaardiging voor een intensieve toetsing, zelfs al is een verdrag niet door de betrokken lidstaat ondertekend of geratificeerd. Verder is duidelijk dat het voor een intensieve toetsing niet vereist is dat een bepaalde praktijk door alle staten wordt gevolgd. In welke mate overeenstemming wel nodig is, wordt door het Hof niet gepreciseerd; de steun die door de criteria wordt geboden is daardoor relatief gering. Niettemin kan de common ground- 
factor een belangrijke toevoeging vormen op de in het theoretische gedeelte reeds genoemde criteria, met name omdat de factor een grote mate van objectiviteit in zich draagt. Wel moet daarbij worden opgemerkt dat de factor niet zelfstandig gehanteerd mag worden, zeker niet als het gaat om de kwalificatie van bepaalde gronden als verdacht: de jurisprudentie van het Hof laat zien dat het daarbij wenselijk is om gebruik te maken van een aantal meer inhoudelijke factoren. ${ }^{463}$

Tenslotte kan worden gesteld dat, net als de common ground-factor, ook de better placed-factor zowel op internationaal als op nationaal niveau bruikbaar is: in de kern houdt deze factor in dat de rechter afstand zal moeten houden voor zover er een ander orgaan is dat beter in staat is om besluiten te nemen dan hij. Bij de beoordeling van beslissingen op beleidsvelden als werkgelegenheid, ruimtelijke ordening en sociaaleconomisch beleid geldt niet alleen voor de internationale rechter, maar ook voor de nationale rechter dat hij zich in beginsel terughoudend op moet stellen.

463. Zie daarover nader paragraaf 3.3 . 



\section{Toetsing aan het gelijkheidsbeginsel door het Europees Hof van Justitie}

Algemeen
1.1 Inhoud en achtergrond van het gelijkheidsbeginsel in het gemeenschaps- recht

\subsection{Weerslag van het gelijkheidsbeginsel in het EG-Verdrag}

Het gelijkheidsbeginsel is een van de belangrijkste beginselen in het Europese recht. Het beginsel is dan ook op verschillende plaatsen in het Verdrag terug te vinden, zij het dat het meestal is geformuleerd als een discriminatieverbod.' In artikel 12 EG is bijvoorbeeld een algemeen verbod op discriminatie op grond van nationaliteit opgenomen, terwijl artikel 13 EG de Europese instellingen de mogelijkheid biedt om maatregelen te treffen met betrekking tot ongelijke behandeling op andere gronden. Het gelijkheidsbeginsel heeft bovendien op diverse plaatsen in het Verdrag en in het secundaire gemeenschapsrecht een meer specifieke uitwerking gekregen. ${ }^{2}$ Zo verbiedt artikel 34 lid 2 EG iedere discriminatie tussen producenten en verbruikers op het gebied van het gemeenschappelijk landbouwbeleid, terwijl de bepalingen over de verschillende "vrijheden" - soms impliciet - discriminatie op grond van nationaliteit verbieden. ${ }^{3}$ Een expliciet verbod van discriminatie is verder neergelegd in artikel $141 \mathrm{EG}$, waardoor een gelijke beloning van mannen en vrouwen bij gelijke of gelijkwaardige arbeid wordt voorgeschreven. Als uitwerking van deze bepaling is bovendien een groot aantal richtlijnen en verordeningen vastgesteld, waardoor de reikwijdte van dit gelijkheidsbeginsel

1. Met het begrip discriminatie wordt in het Europese recht gedoeld op een ongerechtvaardigde ongelijke behandeling. In het hiernavolgende zal zoveel mogelijk worden vastgehouden aan de terminologie zoals die in hoofdstuk 2 is gekozen. Dit betekent dat vooral gesproken zal worden over ongelijke behandeling en onderscheid. Wanneer specifiek wordt verwezen naar een formulering in Europese regelgeving of in de rechtspraak van het Hof zal echter soms gebruik worden gemaakt van de term "discriminatie" in de Europeesrechtelijke betekenis.

2. Er wordt dan ook slechts zelden een beroep op het algemene gelijkheidsbeginsel gehonoreerd. Dit gebeurt hoogstens in situaties waarin het Hof van mening is dat de ongelijke behandeling niet toelaatbaar is, maar er geen specifieke bepalingen bestaan om dit op te baseren: zie bijvoorbeeld EHvJ 18 mei 1982, zaak 293/83, Gravier, Jurispr. 1985, 593 en EHvJ 2 februari 1989, zaak 186/87, Cowan, Jurispr. 1989, 195. Interessant is ook de zaak Weiser, waarin het Hof een bepaling van gemeenschapsrecht toetste aan het algemene gelijkheidsbeginsel (EHvJ 14 juni 1990, zaak C-37/89, Jurispr. 1990, 1-2395, m.n. punt 13 en 14). Zie nader De Búrca 1997, p. 15-20; vgl. ook Schwarze 1992, p. 561, p. 3.

3. Artikel 39 verbiedt discriminatie bij het vrij verkeer van werknemers, artikel 43 (in ieder geval in de uitleg van het EHvJ) discriminatie bij de vrijheid van vestiging en artikelen 49 en 50 bij het vrij verkeer van diensten. Ook artikel 28 , dat betrekking heeft op het vrij verkeer van goederen, omvat een verbod van discriminatie, al is dat nogal eens betwist; eerder kan worden gesteld dat in dit artikel een verbod op handelsbelemmeringen is opgenomen (vgl. EHvJ 11 juli 1974, zaak 8/74, Dassonville, Jurispr. 1974, 837, punt 5). Verder is het gelijkheidsbeginsel terug te vinden in de bepalingen over het mededingingsrecht (artikelen 81 en 82 EG; vgl. Timmermans 1982, voetnoot 16) en in artikel 90 EG (binnenlandse belastingen). 
aanzienlijk is verruimd en zich bijvoorbeeld ook uitstrekt tot ongelijke behandeling op het gebied van de sociale zekerheid. ${ }^{4}$

Opmerkelijk genoeg blijkt een werkelijk algemeen gelijkheidsbeginsel in het Verdrag te ontbreken: de relevante bepalingen verbieden steeds een specifiek soort ongelijke behandeling (bijvoorbeeld ongelijke behandeling van producenten of verbruikers) of ongelijke behandeling op een bepaalde grond (bijvoorbeeld nationaliteit of geslacht). In theorie kan dit tot gevolg hebben dat de toetsingsmethodiek van het Europees Hof van Justitie per discriminatieverbod verschilt. In het licht van de doelstellingen van dit onderzoek is de jurisprudentie van het Hof dan ook bijzonder interessant: als blijkt dat het Hof bij de verschillende verboden een vergelijkbare toetsingsmethodiek volgt, kan dit een belangrijke ondersteuning vormen voor de stelling dat het mogelijk is om een algemeen toepasbaar model op te stellen.

\subsubsection{Achtergrond en betekenis van het gelijkheidsbeginsel in het Europese recht}

Voor een goed begrip van de door het Hof gehanteerde toetsingsmethodiek is het van belang enig inzicht te verkrijgen in de functie van het gelijkheidsbeginsel in het Europese recht. ${ }^{5}$ Bepalend voor de toepassing van het gelijkheidsbeginsel door het Hof zijn de ideeën en doelstellingen die aan de opstelling van het EG-Verdrag ten grondslag hebben gelegen. Het was de bedoeling van de oprichters om een Europese interne markt tot stand te brengen waarin sprake zou zijn van een - in ieder geval economische - integratie van de markten van de verschillende lidstaten. Om deze doelstelling te verwezenlijken werd middels het EEG-Verdrag in diverse integratiemechanismen voorzien, waarbij het gelijkheidsbeginsel werd beschouwd als een belangrijk instrument om het protectionistische gedrag van de lidstaten te beperken en de markten van de verschillende lidstaten toegankelijk te maken voor vrije vestiging en een vrij verkeer van personen, goederen en diensten. ${ }^{6}$ Tegen deze achtergrond is het verklaarbaar dat in het Verdrag vrijwel uitsluitend ongelijke behandeling op grond van nationaliteit wordt verboden en dat een gelijkheidsbeginsel als fundamenteel recht ontbreekt: het Verdrag had niet tot doel om grondrechten te beschermen, maar om een economische ordening tot stand te brengen.?

4. Vgl. Craig/De Búrca 1998, p. 802/803. Dit wil overigens niet zeggen dat er sprake is van een algemeen verbod van discriminatie op grond van geslacht: in het arrest Defrenne III overwoog het Hof dat artikel 119 (nu artikel 141, de artikelen 117-120 EG-Verdrag zijn vervangen door de artikelen 136 EG-143 EG) weliswaar uitdrukking vormt van een fundamenteel beginsel van gelijke behandeling op grond van geslacht, maar in hetzelfde arrest stelde het dat uitsluitend aan dit beginsel kan worden getoetst voor zover het is neergelegd in een bepaling van het Verdrag of een secundaire gemeenschapsregeling (EHvJ 15 juni 1978, zaak 149/77, Jurispr. 1978, 1365, punt 27 en 30).

5. Het belang van dit verschil in functie is groot, omdat vaak juist in de context waarin het gelijkheidsbeginsel een rol speelt een verklaring kan worden gevonden voor een bepaalde toetsingsmethodiek of de keuze voor een intensieve of juist marginale toetsing; vgl. Jacqué 1985, p. 136.

6. More noemt dit de "market-unifying role" van het gelijkheidsbeginsel (1999, p. 522); De Bủrca spreekt van een "instrumental role" (1997, p. 24 e.v.). Zie ook Jacobs 1997, p. 1, Watson 1995, p. 33 en Sundberg-Weitman 1977, p. 10.

7. Een bescherming van fundamentele rechten blijkt vooral te ontbreken omdat pogingen een politieke Unie tot stand te brengen waren mislukt en bovendien een apart mensenrechtenverdrag was opgericht - het EVRM - om in een bescherming van deze rechten te voorzien. Een werkelijke noodzaak voor een bescherming van fundamentele rechten leek daardoor afwezig te zijn, terwijl een economisch verdrag 
In dit licht zou het kunnen verbazen dat in artikel 141 een bepaling is opgenomen die discriminatie op grond van geslacht verbiedt: een dergelijk verbod lijkt eerder uitdrukking te vormen van een opvatting van gelijkheid als fundamenteel grondrecht dan van gelijke behandeling als instrument voor integratie en economische eenwording. Uit de totstandkomingsgeschiedenis van het Verdrag kan echter worden afgeleid dat de directe aanleiding voor het opnemen van dit artikel ook hier economisch van aard was: de bepaling blijkt vooral ingegeven te zijn door de vrees dat verschillen in de wetgeving over gelijke beloning tussen de lidstaten zouden leiden tot sociale dumping en daardoor tot een competitief nadeel voor de staten die gelijke beloning en gelijke arbeidsomstandigheden tegen een hoge prijs garanderen. Alleen door harmonisatie zou dit soort negatieve consequenties voldoende kunnen worden vermeden. ${ }^{8}$

Uit het voorgaande mag echter niet zonder meer de conclusie worden getrokken dat het gelijkheidsbeginsel in het gemeenschapsrecht uitsluitend een economische en sterk instrumentele functie heeft. Vooral de laatste jaren is er een duidelijke ontwikkeling zichtbaar in de richting van een betere bescherming van grondrechten en is het werkterrein van de Gemeenschap uitgebreid naar minder economisch getinte beleidsvelden, zoals de sociale zekerheid en de bescherming van het milieu.' Het past in deze ontwikkeling dat het Hof zich de laatste jaren bereid heeft getoond om een meer constitutionele betekenis toe te kennen aan het verbod van ongelijke behandeling op grond van geslacht. ${ }^{10}$ Heel duidelijk komt dit tot uitdrukking in het arrest Schröder ${ }^{11}$, waarin het

ook eigenlijk het enige haalbare was. Vgl. Craig/De Búrca 1998, p. 297.

8. Zie Barnard 1996 (II), p. 322-327 en Ellis 1991, p. 38-42

9. Zie bijvoorbeeld het tijdens de Europese Raad te Nice aangenomen Grondrechtenhandvest (Handvest van de Grondrechten van de EU, Pb. EG 2000 C 364/1) en de invoeging van artikel 6 in het UnieVerdrag bij het Verdrag van Amsterdam. De uitbreiding naar andere beleidsvelden blijkt uit de verruiming van de taakstelling en de uitbreiding van de activiteiten zoals die zijn uiteengezet in de artikelen 2 en 3 van het Verdrag: ten tijde van de oprichting waren beide artikelen aanzienlijk minder ruim geformuleerd dan tegenwoordig (zoals blijkt uit een beschrijving van Sundberg-Weitman (1977, p. 5)). De consequenties van deze veranderingen voor het verbod van discriminatie zijn zichtbaar in het bij het Verdrag van Amsterdam ingevoegde artikel 13, dat de besluitvormende instellingen de mogelijkheid biedt om maatregelen te treffen om discriminatie op diverse gronden te bestrijden; zie hierover Bell 1999, p. 5 e.v. en Flynn 1999, p. 1127 e.v. Recentelijk is op grond van deze bepaling een tweetal richtlijnen tot stand gekomen, namelijk een richtlijn die discriminatie op grond van ras of etnische afstamming, geslacht, godsdienst of overtuiging, handicap, leeftijd en seksuele geaardheid bij de arbeid verbiedt (RI. 2000/78/EG van de Raad van 27 november 2000 tot instelling van een algemeen kader voor gelijke behandeling in arbeid en beroep, Pb. EG $2000 \mathrm{~L}$ 303/16) en een richtlijn die discriminatie op grond van ras en etnische afstamming verbiedt op een groot aantal terreinen (RI. 2000/43/EG van de Raad van 29 juni 2000 houdende toepassing van het beginsel van gelijke behandeling van personen ongeacht ras of etnische afstamming, Pb. EG $2000 \mathrm{~L} \mathrm{180/22).}$

10. Een veelgenoemd voorbeeld hiervan is het arrest $P . v$. S., waarin het Hof zich bereid verklaarde het verbod van discriminatie op grond van geslacht ruim te interpreteren en dit ook van toepassing te verklaren op transseksuelen (EHvJ 30 april 1996, zaak C-13/94, Jurispr. 1996, I-2143). In het later gewezen arrest Grant bleek de reikwijdte van het discriminatieverbod (en van de bereidheid van het Hof om een meer constitutionele functie van het gelijkheidsbeginsel te accepteren) echter toch beperkt te zijn: een uitbreiding van het verbod naar onderscheid op grond van homoseksuele geaardheid achtte het Hof niet mogelijk binnen de formulering van de huidige bepalingen (EHvJ 17 februari 1998, zaak C249/96, Jurispr. 1998, 621); recentelijk herhaalde het Hof dit oordeel in D./Raad (EHvJ 31 mei 2001, gevoegde zaken C-122/99 P en C-125/99 P, Jurispr. 2001, I-4319, punt 46/47). Hierover is een grote hoeveelheid literatuur verschenen, waarin een uitgebreide discussie gevoerd wordt over de vraag of er 
Hof zich uitsprak over het karakter van artikel 141 EG. In deze uitspraak wees het Hof allereerst op de oorspronkelijke doelstelling van dit discriminatieverbod, namelijk te voorkomen dat ondernemingen in een ongunstige mededingingspositie terechtkomen doordat zij in hun sociale wetgeving hebben voorzien in een gelijkwaardige positie van mannen en vrouwen. Vervolgens stelde het Hof echter dat de bepaling ook uitdrukking vormt van de sociale doelstellingen van de Gemeenschap, waarna het het volgende overwoog:

"In latere arresten heeft het Hof [...] herhaaldelijk vastgesteld, dat het recht om niet op grond van zijn geslacht te worden gediscrimineerd, een van de fundamentele rechten van de mens is, waarvan het Hof de eerbiediging dient te verzekeren [...]. Gelet op deze rechtspraak moet worden geoordeeld, dat het economische doel van artikel 119 [141 nieuw, $\mathrm{JHG}$, namelijk opheffing van mededingingsverstoringen tussen in verschillende lidstaten gevestigde ondernemingen, een ondergeschikte betekenis heeft ten opzichte van het sociale doel van deze bepaling, dat de uitdrukking vormt van een fundamenteel mensenrecht."'2

Uit deze overweging blijkt niet alleen dat het Hof erkent dat het verbod van ongelijke behandeling op grond van geslacht een fundamenteel-grondrechtelijk karakter heeft, maar zelfs dat dit karakter tegenwoordig zwaarder weegt dan de economische kant van het verbod. ${ }^{13}$

In de rechtspraak over de andere discriminatieverboden die in het Verdrag zijn neergelegd is een dergelijke functieverandering in mindere mate zichtbaar. Het streven naar economische eenwording en de wens het vrije verkeer tussen de lidstaten te bevorderen blijken voor de interpretatie van deze verboden van onverminderde betekenis te zijn." Gaandeweg is er binnen het gemeenschapsrecht dan ook een verschil ontstaan in rol en karakter van de verschillende discriminatieverboden: op een aantal terreinen blijft het een verbod dat er vooral toe dient om de oorspronkelijke doelstellingen van het Verdrag te verwezenlijken, maar op andere gebieden heeft het gelijkheidsbeginsel een meer constitutioneel karakter gekregen en heeft het primair tot functie de belangen van

nu wel of niet gesproken kan worden van een fundamenteel grondrechtelijk gelijkheidsbeginsel; zie o.a. Craig/De Búrca 1998, p. 366, Barnard 1998, m.n. p. 352 e.v., De Búrca 1997, p. 31 e.v., Mancini/O'Leary 1999, p. 332-335 en p. 348-353. Opmerkelijk is dat ook de in de vorige noot genoemde richtlijnen niet voorzien in een algemeen discriminatieverbod: de reikwijdte is ofwel beperkt tot een bepaald gebied (de arbeid) of tot een bepaalde grond (ras of etnische afstamming).

11. EHvJ 10 februari 2000 , zaak C-50/96, Jurispr. 2000, I-743

12. Punt 56 en 57. Het ambivalente karakter van artikel 141 was al in 1976 door het Hof erkend (EHvJ 8 april 1976, zaak 43/75, Defrenne II, Jurispr. 1976, 455, punt 8-10; zie Hervey 1993, p. 38-40), maar de geciteerde overweging is geheel nieuw. Een aanloop hiertoe kan wel al worden gezien in EHvJ 17 juni 1998, zaak C-243/95, Hill en Stapleton, Jurispr. 1998, 1-3739, punt 42; zie ook Ellis 2000, p. 1407.

13. Afgewacht moet worden in hoeverre dit zal doorwerken in de toetsingspraktijk van het Hof. Op dit moment wordt vooral op het gebied van de sociale zekerheid een toetsing uitgevoerd die lang niet zo streng is als de geciteerde uitspraak van het Hof zou doen verwachten (vgl. Hepple 1997, p. 148 en Ellis 1997, p. 175-177).

14. Vgl. voor het landbouwrecht, waarin het gelijkheidsbeginsel nog steeds van groot belang is en waarin bij de toepassing van dit beginsel grote waarde wordt gehecht aan de oorspronkelijke doelstellingen van het Verdrag, Barents 1997, p. 842. De toepassing van het gelijkheidsbeginsel blijkt in de landbouw in belangrijke mate te worden geïnspireerd door het verbod van verstoringen van de mededinging, eveneens een van de primaire doelstellingen van het EG-Verdrag, en het verwezenlijken van een goed functionerende interne markt (vgl. Tridimas 1999 (I), p. 45-47). 
het individu te beschermen tegen arbitrair optreden door de overheid. Het is noodzakelijk om dit verschil in functie bij de bestudering van de rechtspraak van het Hof in het oog te houden, nu de context en achtergrond van een verbod van ongelijke behandeling bepalend kunnen zijn voor de toetsingsmethodiek. ${ }^{\text {is }}$

\subsection{Direct en indirect onderscheid; formeel en materieel onderscheid}

\subsubsection{Direct en indirect onderscheid}

\section{Verbod van direct onderscheid}

De hiervoor genoemde verdragsbepalingen houden steeds een verbod van direct onderscheid in. Het is vaste rechtspraak van het Hof dat deze vorm van onderscheid alleen toelaatbaar is wanneer voldaan is aan één van de uitdrukkelijk in het Verdrag opgenomen uitzonderingsbepalingen. ${ }^{16}$ Hoewel hiervoor verschillende malen is gepleit, heeft het Hof tot nu toe niet willen accepteren dat ook buiten deze uitzonderingsbepalingen een objectieve rechtvaardiging mogelijk is. ${ }^{17}$ Door deze beperking lijkt er voor het Hof maar weinig ruimte te bestaan om bij de toepassing van de diverse discriminatieverboden een eigen toetsingsmodel te ontwikkelen en toe te passen. ${ }^{18}$ In de praktijk blijkt de omvang van de rechterlijke vrijheid echter vooral te worden bepaald door de specifieke formulering van de betreffende bepaling. Zo heeft het Hof zeer veel vrijheid bij de toepassing van artikel 34 lid 2, derde alinea, dat betrekking heeft op onderscheid op het gebied van het gemeenschappelijk landbouwbeleid. In het ontbreken van uitzonderingsbepalingen bij dit artikel heeft het Hof een uitnodiging gezien om zelf een aantal criteria te ontwikkelen ter beoordeling van de toelaatbaarheid van ongelijke behandeling. ${ }^{19}$ Hetzelfde geldt voor het algemene verbod van ongelijke behandeling op grond

15. Het gaat hier vooral om de vaststelling van de toetsingsintensiteit en de acceptatie van bepaalde doelstellingen. Vgl. Barnard 1996 (I), p. 73 en Bernard 1996 (I), p. 77 en 87.

16. Voor het vrij verkeer van personen is deze uitzonderingsbepaling neergelegd in artikel 39 lid 3, aanhef, voor het recht van vestiging in artikel 46 lid 1 en voor het vrij verkeer van diensten in artikel 55 jo. 46 lid 1. Artikel 141 (gelijke beloning) bevat alleen een heel beperkte uitzonderingsbepaling in het vierde lid, dat is ingevoegd bij het Verdrag van Amsterdam; voor het overige is iedere ongelijke behandeling verboden. In artikel 34 , dat betrekking heeft op de landbouw, is geen uitdrukkelijke uitzonderingsbepaling opgenomen, net zomin als in artikel 90; op deze bijzondere situatie zal verderop worden ingegaan.

17. Vooral A-G Van Gerven heeft hiervoor verschillende malen gepleit, hoofdzakelijk omdat het verschil tussen direct en indirect onderscheid niet groot genoeg zou zijn om te rechtvaardigen dat alleen bij indirect onderscheid steeds een rechtvaardiging mogelijk is (zie zijn conclusie bij SPUC/Grogan, EHvJ 4 oktober 1991, zaak C-159/90, Jurispr. 1991, I-4685, punt 23 en bij Birds Eye Walls, EHvJ 9 november 1993, zaak C-132/92, Jurispr. 1993, I-5579, punt 12-14). Ook A-G Lenz heeft zich voor de mogelijkheid van rechtvaardiging uitgesproken (conclusie bij EHvJ 27 oktober 1993, zaak C-127/92, Enderby, Jurispr. 1993, I-5535, punt 26). Zie hierover Ellis 1996, p. 18 en Watson 1995, p. 41. Opmerkelijk is overigens dat het Hof bij direct onderscheid enkele malen een rechtvaardigingsmogelijkheid heeft geaccepteerd zonder dit uitdrukkelijk te stellen en zonder hiervoor een motivering te geven; zie Tobler 2001 , p. 123/124. Een officięle erkenning van een rechtvaardigingsmogelijkheid ontbreekt vooralsnog.

18. Wel kan het Hof zichzelf enige ruimte geven door het toepassen van de vergelijkbaarheidstoets: door een creatieve zoektocht naar relevante verschillen tussen de voorgelegde gevallen kan het Hof vaak een wenselijk geacht onderscheid billijken (vgl. Drijber/Prechal 1997, p. 133). Het is echter de vraag of dit een wenselijke werkwijze is, omdat hierdoor de limitatief opgesomde uitzonderingsgronden worden omzeild (Tobler 2001, p. 126).

19. Zie bijv. EHvJ 6 december 1984, zaak 59/83, Jurispr. 1984, 4057, punt 19 en 20. De ogenschijnlijk 
van nationaliteit dat is neergelegd in artikel 12: ook daarbij is geen uitzonderingsbepaling opgenomen, maar heeft het Hof consequent geoordeeld dat een ongelijke behandeling toelaatbaar is als deze voldoet aan bepaalde, door het Hof zelf vastgestelde vereisten. ${ }^{20}$

Voor de uitzonderingsbepalingen bij de discriminatieverboden op het gebied van het vrij verkeer is de situatie iets anders. In deze bepalingen is steeds aangegeven dat het verbod van ongelijke behandeling niet in de weg staat aan wettelijke of bestuursrechtelijke bepalingen "welke [...] uit hoofde van de openbare orde, de openbare veiligheid en de volksgezondheid gerechtvaardigd zijn". ${ }^{21}$ Door deze formulering ontbreekt de mogelijkheid om de toetsing volledig zelf vorm te geven. Niettemin heeft het Hof hierbij relatief veel ruimte voor het ontwikkelen van een eigen toetsingsmethodiek: niet alleen zijn de genoemde doelstellingen bijzonder vaag geformuleerd, maar ook zal het Hof zelf moeten bepalen wanneer een bepaling "gerechtvaardigd" is. Het ligt voor de hand dat ter invulling daarvan bepaalde criteria worden vastgesteld die overeenkomsten vertonen met elementen van het theoretische toetsingsmodel, zoals vereisten van geschiktheid, noodzakelijkheid en proportionaliteit.

Bij een derde groep van discriminatieverboden zijn de uitzonderingsgronden zodanig geformuleerd dat er voor het Hof vrijwel geen ruimte bestaat om een eigen toetsingsmodel te ontwikkelen. Zowel de uitzondering bij artikel $141 \mathrm{EG}$, opgenomen in lid vier van dit artikel ${ }^{22}$, als de uitzonderingsbepalingen in de belangrijkste richtlijnen op het gebied van onderscheid op grond van geslacht zijn zeer precies geformuleerd, waardoor de vrijheid van het Hof beperkt is tot de interpretatie van vage begrippen die daarin zijn opgenomen. ${ }^{23}$

logische conclusie van het Hof is overigens niet zo voor de hand liggend: evengoed had kunnen worden gesteld dat het artikel kennelijk geen ruimte biedt voor een rechtvaardiging, en alle vormen van direct onderscheid volledig verbiedt; vgl. ook Tobler 2001, p. 124. Een dergelijke conclusie heeft het Hof wel bereikt bij het hierna nog te bespreken artikel 90 . Daarbij moet echter worden opgemerkt dat deze laatste bepaling ook iets scherper is geformuleerd.

20. Zie bijvoorbeeld EHvJ 20 maart 1993, zaak C-323/95, Hayes, Jurispr. 1997, 1-1711, punt 19 en 24.

21. Het citaat is afkomstig uit artikel 46 EG. De uitzonderingsbepaling bij artikel 28 (artikel 30) bevat een groter aantal toelaatbare doelstellingen en is ook iets anders geformuleerd. Op artikel $30 \mathrm{zal}$ echter niet in het bijzonder worden ingegaan, omdat bij het vrij verkeer van goederen al vanaf het begin is betwist dat het gaat om een discriminatieverbod (vgl. bijv. Barnard 1996, p. 64 en de door haar genoemde literatuur). Hierdoor ontbreekt in de rechtspraak een aantal elementen die juist in het kader van het onderzoek van groot belang zijn, zoals een toepassing van de vergelijkbaarheidstoets.

22. Deze uitzondering is overigens pas door het Verdrag van Amsterdam ingevoegd; daarvoor was geen enkele uitzondering mogelijk (vgl. Ellis 1991, p. 68 en Hervey 1993, p. 50).

23. Zie bijv. artikel 2, lid 2, 3 en 4 van RI. 76/207/EEG (Richtlijn van de Raad van 9 februari 1976, Pb. 1976, L 39/40) en artikel 4 lid 2 en artikel 7 van RI. 79/7/EEG (Richtlijn van de Raad van 19 december 1978, Pb. 1979, L 6/24). RI. 75/117/EEG (Richtlijn van de Raad van 19 februari 1975, Pb. 1975, L 45/19) makt geen enkele uitzondering mogelijk. De beperkte mogelijkheid tot het aannemen van een rechtvaardiging blijkt uit het arrest Johnston, waarin het Hof aangaf dat er geen algemene uitzondering op het discriminatieverbod kan worden aangenomen; uitzonderingen zijn alleen mogelijk als ze zijn in te passen in de desbetreffende artikelen van de richtlijn (EHvJ 15 mei 1986, zaak 222/84, Jurispr. 1986, 1651, punt 26 en 27); zie hierover ook Ellis 1991, p. 162. Overigens moet worden opgemerkt dat het Hof ook bij deze uitzonderingen nog wel enige ruimte heeft gevonden voor eigen invulling, bijvoorbeeld door het inlezen van een vereiste van proportionaliteit (zie het reeds aangehaalde arrest Johnston, punt 38). Opmerkelijk is bovendien dat het verschil tussen direct en indirect onderscheid in de rechtspraak van het Hof niet altijd even duidelijk is. Zo oordeelde het Hof in Brunnhofer (EHvJ 26 juni 2001, zaak C-381/99, Jurispr. 2001, I-4961), dat "[...] het fundamentele beginsel dat in artikel 119 van 
Tenslotte is iedere ruimte voor het Hof om een toetsingsmodel te ontwikkelen geheel afwezig wanneer het gaat om schendingen van het in artikel 90 EG neergelegde verbod van ongelijke behandeling: het is vaste rechtspraak dat een direct onderscheid dat onder de reikwijdte van deze bepaling valt onder geen enkele omstandigheid gerechtvaardigd kan zijn. ${ }^{24}$

\section{Verbod van indirect onderscheid}

Het Hof heeft al in een vroeg stadium het concept van indirect onderscheid erkend voor alle hierboven beschreven verboden van ongelijke behandeling. ${ }^{25}$ Het is vaste rechtspraak dat maatregelen ook zijn verboden wanneer zij, bedoeld of onbedoeld, een ongelijke behandeling op een verboden onderscheidingsgrond tot effect hebben. ${ }^{26} \mathrm{Het} \mathrm{Hof}$ heeft daarbij echter consequent gesteld dat een uitzondering op dit verbod kan worden gemaakt wanneer er een toereikende rechtvaardiging voor het indirecte onderscheid wordt aangedragen. ${ }^{27} \mathrm{Nu}$ het Verdrag niet voorziet in specifiek voor indirect onderscheid opgestelde uitzonderingsbepalingen is het Hof volledig vrij bij de vaststelling van criteria voor de beoordeling van een dergelijke rechtvaardiging. Dit heeft tot ge-

het Verdrag is geformuleerd en in de richtlijn nader is uitgewerkt, zich tegen iedere ongelijkheid in beloning tussen vrouwelijke en mannelijke werknemers voor eenzelfde functie of gelijkwaardige arbeid, ongeacht het stelsel waarvan deze ongelijkheid het gevolg is, tenzij het verschil in beloning zijn rechtvaardiging vindt in objectieve factoren die niets van doen hebben met discriminatie op grond van geslacht" (punt 30). Het Hof maakte echter niet duidelijk of het met deze overweging doelde op direct of indirect onderscheid. Uit het vervolg van het arrest lijkt voort te vloeien dat deze overwegingen ook gelden voor direct onderscheid, maar in de overweging zelf wordt uitsluitend verwezen naar arresten waarin indirect onderscheid aan de orde was. Verdere rechtspraak zal moeten worden afgewacht voordat kan worden geconcludeerd dat het Hof een rechtvaardigingsmogelijkheid voor direct onderscheid openlaat. Zie over eventuele rechtvaardigingsmogelijkheden voor direct onderscheid nader Vegter 2000 (II), p. 119.

24. Dit komt bijvoorbeeld tot uitdrukking in het arrest Hansen \& Balle, EHvJ 10 oktober 1978, zaak 148/77, Jurispr. 1978, 1787, punt 17.

25. Wel bestaat er veel discussie over de terminologie, met name wanneer het gaat om de vrijheden. Een beperkt aantal juristen is van mening dat daarbij geen onderscheid moet worden gemaakt tussen direct en indirect onderscheid, maar tussen ongelijke behandeling enerzijds en niet-discriminatoire belemmeringen van het vrije verkeer anderzijds. In deze visie kan ook indirect onderscheid alleen worden gerechtvaardigd op basis van de in het Verdrag opgesomde uitzonderingen. Dit lijkt echter niet de heersende gedachte te zijn; ook het Hof is deze mening niet toegedaan. Het algemene uitgangspunt is dat er onderscheid moet worden gemaakt tussen direct onderscheid, indirect onderscheid en overige belemmeringen. Alleen bij de eerste gelden de limitatieve uitzonderingsbepalingen; in het geval van indirect onderscheid of non-discriminatoire belemmeringen geldt een door het Hof zelf ontwikkeld toetsingsmodel. Zie Drijber/Prechal 1997, p. 124/125 en Hilson 1999, p. 449/450.

26. Zie EHvJ 8 april 1976, zaak 43/75, Defrenne II, Jurispr. 1976, 455, punt 18 (geslacht), EHvJ 29 oktober 1980, zaak 22/80, Boussac, Jurispr. 1980, 3427 (artikel 12 (voorheen 6 resp. 7)), EHvJ 15 oktober 1969, zaak 15/69, Ugliola, Jurispr. 1969, 363, punt 6 (vrij verkeer van werknemers), EHvJ 5 december 1989, zaak C-3/88, Commissie/Italië (overheidsopdrachten informatisering), Jurispr. 1989, 4035, punt 10 (vrije vestiging) en EHvJ 3 december 1974, zaak 33/74, Van Binsbergen, Jurispr. 1974, 1299 (vrij verkeer van diensten). Voor artikel 90 is het concept niet met zoveel woorden erkend, maar het Hof blijkt er wel vanuit te gaan dat indirect onderscheid tot op zekere hoogte te rechtvaardigen is (vgl. bijvoorbeeid EHvJ 14 januari 1981, zaak 140/79, Chemial Farmaceutici, Jurispr. 1981, 1, punt 14). Vgl. ook Schwarze 1992, p. 617 e.v.

27. Voor onderscheid op grond van geslacht wordt dit bevestigd door de definitie van indirect onderscheid in de Richtlijn inzake de bewijslast in gevallen van onderscheid op grond van het geslacht (RI. 97/80/EG van de Raad van 15 december 1997, Pb. EG 1998 L 14/6, in artikel 2 lid 2). 
volg dat het Hof voor het verbod van indirect onderscheid een eigen toetsingsmodel heeft kunnen ontwikkelen. Dit maakt deze rechtspraak van het Hof bijzonder interessant voor de ontwikkeling van een algemeen toetsingsmodel. Met name kunnen op basis hiervan conclusies worden getrokken over de toepasbaarheid van een algemeen toetsingsmodel op ongelijke behandelingen met een verschillende achtergrond, zonder daarbij te worden afgeleid door een door het Verdrag geschapen toetsingskader.

Om die reden zal bij de bespreking van de toetsingsmethodiek van het Hof vrijwel uitsluitend aandacht worden besteed aan de rechtspraak over indirect onderscheid." Een uitzondering zal hierbij worden gemaakt voor het verbod van ongelijke behandeling op het gebied van het gemeenschappelijk landbouwbeleid en voor het discriminatieverbod van artikel 12 EG. Zoals gezegd heeft het Hof voor beide verboden aangenomen dat er ook een objectieve rechtvaardiging mogelijk is bij direct onderscheid, zonder dat het Verdrag daarbij enig toetsingskader biedt. Bovendien geldt voor het verbod van ongelijke behandeling in de landbouw dat dit een "open" verbod van ongelijke behandeling is, in die zin dat de reikwijdte ervan niet beperkt is tot bepaalde, limitatief opgesomde gronden van onderscheid. De noodzaak om te werken met het concept van indirect onderscheid is daardoor nagenoeg afwezig, hetgeen verklaart dat dit concept in de rechtspraak over het landbouwbeleid niet is terug te vinden.

\subsubsection{Formeel en materieel onderscheid}

In de rechtspraak van het Hof wordt zelden uitdrukkelijk melding gemaakt van het concept van materieel onderscheid. ${ }^{29}$ Een verklaring daarvoor is deels te vinden in het feit dat een groot deel van de rechtspraak van het Hof betrekking heeft op indirect onderscheid. Het gaat daarbij om de situatie waarin een maatregel die op het eerste gezicht niet discriminatoir lijkt een ongelijke behandeling tot effect heeft. Het hanteren van een notie van materieel onderscheid heeft in dat soort gevallen weinig toegevoegde waarde, nu dit concept inhoudt dat ongelijke gevallen niet gelijk behandeld mogen worden. Ook daarbij zal er dus steeds sprake van een formeel gelijke behandeling, die een ongelijk effect teweegbrengt. Indirect onderscheid kan zelfs worden beschouwd als een soort specialis van materieel onderscheid, zodat het vanzelfsprekend is dat het concept van materieel onderscheid als zodanig niet vaak is terug te vinden.

Een tweede verklaring voor het feit dat er slechts sporadisch gebruik wordt gemaakt van het concept van materieel onderscheid is te vinden in de door het Hof gehanteerde toetsing in de eerste fase. Wanneer de vergelijkbaarheidstoets in deze fase als toetsingscriterium wordt gehanteerd, is het verschil tussen materieel en formeel onderscheid van wezenlijk belang voor de wijze waarop de toetsing zal worden uitgevoerd. Bij formeel onderscheid zal dan immers moeten worden gekeken naar relevante overeenkomsten tussen de voorgelegde gevallen, terwijl bij materieel onderscheid nu juist naar verschillen moet worden gezocht. Bij de beoordeling van indirect onderscheid, maar soms ook bij de toetsing van direct onderscheid, blijkt het Hof echter te kiezen

28. Bij de bestudering van de intensiteit van de toetsing zal ook aan direct onderscheid en aan de nondiscriminatoire beperkingen aandacht worden besteed: in deze rechtspraak wordt, anders dan in veel rechtspraak over indirect onderscheid, uitgebreid aandacht besteed aan de toetsingsintensiteit.

Vgl. Drijber/Prechal 1997, p. 124. 
voor een andere toetsingsingang, namelijk voor een benadelingstoets. ${ }^{30} \mathrm{Bij}$ deze toets zal de appellant aan moeten tonen dat hij door een maatregel daadwerkelijk is benadeeld ten opzichte van een andere groep of persoon. ${ }^{31}$ Daarbij is het niet relevant of deze benadeling voortvloeit uit een gelijke behandeling van onvergelijkbare gevallen of uit een ongelijke behandeling van vergelijkbare gevallen, zodat er geen verschil hoeft te worden gemaakt tussen formeel en materieel onderscheid.

Wanneer het Hof wél gebruik maakt van de vergelijkbaarheidstoets, hetgeen vooral in de rechtspraak over het landbouwbeleid en bij de toepassing van artikel 12 EG het geval blijkt te zijn, is het onderscheid tussen formeel en materieel onderscheid wel in de rechtspraak terug te vinden. ${ }^{32}$ Dit blijkt al uit het arrest Italië/Commissie (koelkasten), daterend uit $1963 .{ }^{33}$ Deze uitspraak had betrekking op een door de Commissie aan Frankrijk verleende machtiging om een bijzondere belasting te heffen op uit Italië ingevoerde koelkasten. Dit was volgens de Commissie gebeurd omdat de Italiaanse koelkasten door hun lage prijs de Franse, net vrijgemaakte, markt dreigden te overspoelen. Italië was van mening dat het niet redelijk was om de heffing alleen op te leggen bij de import van Italiaanse koelkasten: volgens haar moesten alle landen hetzelfde worden behandeld. Het Hof was hier kort over:

"[...] [D]e verschillende behandeling van niet vergelijkbare gevallen [wijst] niet zonder meer [...] op discriminatie. [...] [D]aarom [hoeft] in gevallen, die formeel de schijn van discriminatie wekken, materieel nog geen sprake [...] te zijn van discriminatie. [...] [Er zou] sprake [...] zijn geweest van discriminatie in materiêle zin, indien hetzij vergelijkbare gevallen op verschillende wijze, hetzij verschillende gevallen op gelijke wijze waren behandeld." ${ }^{34}$

Voorbeelden van zaken waarin een uitspraak wordt gedaan over materieel onderscheid zijn echter relatief zeldzaam. ${ }^{35}$ De meest waarschijnlijke verklaring hiervoor is gelegen in het feit dat klachten over gelijke behandeling van ongelijke gevallen door het Hof niet snel worden aanvaard. Zeker op het gebied van de landbouw is het Hof van mening dat de gemeenschapsinstellingen de ruimte moeten hebben om algemene regelingen vast te stellen, ook al worden eventuele verschillen tussen producenten of producten daarbij niet volledig in acht genomen. ${ }^{36}$ Een klacht over materieel onderscheid lijkt

30. Zie bijv. EHvJ 8 mei 1990, zaak C-175/88, Biehl, Jurispr. 1990, 1-1779, punt 14 (werknemers) en (meer impliciet) EHvJ 31 maart 1981, zaak 96/80, Jenkins, Jurispr. 1981, 911. Overigens wordt ook bij direct onderscheid soms gebruik gemaakt van het benadelingscriterium. Zie daarover paragraaf 2.2.2.

31. Op de aan de benadeling gestelde eisen zal in het vervolg van dit hoofdstuk nader worden ingegaan.

32. Vgl. Barents 1994 (II), p. 528. Dit ligt ook voor de hand: bij de landbouw is er meestal sprake van direct onderscheid. Anders dan bij indirect onderscheid kan het concept van materiële gelijkheid daarbij dienstig zijn: van direct onderscheid zal niet alleen sprake zijn als er formeel onderscheid gemaakt wordt, maar ook als vergelijkbare gevallen verschillend zijn behandeld.

33. EHvJ 17 juli 1963 , zaak $13 / 63$, Jurispr. 1963 , p. 352

34. De hier gebruikte terminologie kan wellicht enige verwarring oproepen. Kennelijk bedoelt het Hof met "formeel" dat er op het eerste gezicht sprake is van onderscheid, maar dat dit in werkelijkheid eerst nog moet worden aangetoond (dus op "materiele" wijze): aan deze begrippen wordt dus niet de gebruikelijke betekenis toegekend (vgl. Lenaerts 1991, p. 8). Niettemin blijkt uit de laatste volzin van deze overweging de erkenning van het concept van materieel onderscheid (vgl. Drijber/Prechal 1997, p. 124).

35. Timmermans 1982, p. 430

36. Dit komt bijvoorbeeld tot uitdrukking in het arrest Hierl (EHvJ 19 maart 1992, zaak C-311/90, Jurispr. 
dan ook alleen kans van slagen te hebben als er sprake is van een duidelijk willekeurige regeling. Nu dit slechts zelden het geval blijkt te zijn, zal ook het aantal beroepen dat wordt ingesteld tegen een materieel onderscheid relatief beperkt zijn. ${ }^{37}$

\subsection{Horizontale en verticale verhoudingen}

In zijn rechtspraak over ongelijke behandeling op grond van geslacht heeft het Hof al in 1976, in het tweede Defrenne-arrest ${ }^{38}$, erkend dat artikel 141 (119 oud) ook van toepassing is in horizontale verhoudingen:

"[...] artikel 119 [is] dwingend recht [...], zodat het verbod van discriminatie tussen mannelijke en vrouwelijke werknemers niet slechts geldt voor overheidshandelen, doch eveneens van toepassing is op alle overeenkomsten die een collectieve regeling van arbeid in loondienst inhouden, alsmede op contracten tussen particulieren."

Deze erkenning van de horizontale werking van het gemeenschapsrecht vloeit logisch voort uit de opvatting van het Hof dat ongelijke behandeling bij de beloning net zozeer door particuliere organisaties als door de wetgever kan worden veroorzaakt. ${ }^{40}$

Dat ook het op verschillende plaatsen neergelegde verbod van discriminatie op grond van nationaliteit horizontale werking heeft blijkt uit het arrest Walrave en Koch waarin het Hof stelde, dat:

"[...] de artikelen 7, 48 en 59 [nu 12, 39 en 49, JHG] in hun onderscheidene toepassingsgebieden alle discriminaties op grond van nationaliteit verbieden. $[\mathrm{H}]$ et verbod van deze discriminaties [geldt] niet alleen [...] voor het optreden van het openbaar gezag, maar

1992, 1-2061, punt 19). Andere zaken waarin een geval van materieel onderscheid aan het Hof werd voorgelegd zijn EHvJ 5 juli 1977, zaak 114/76, Bela-Mühle, Jurispr. 1977, 1211, EHvJ 24 januari 1991, zaak C-27/90, SITPA tegen Oniflhor, Jurispr. 1991, I-133, EHvJ 5 oktober 1994, gev. zaken C133/93, C-300/93 en C-362/93, Crispoltoni e.a., Jurispr. 1994, 1-4863, EHvJ 17 juli 1997, gev. zaken C-248 en 249/95, SAM Schiffahrt, Jurispr. 1997, I-4475 en EHvJ 8 januari 2002, zaak C-507/99, Denkavit Nederland BV (II), nog niet gepubliceerd. Vgl. Tridimas 1997, p. 231 en Tridimas 1999 (I), p. 59; enkele andere voorbeelden worden nog gegeven door Schwarze 1992, p. 572. Ook buiten het kader van de landbouw wordt soms melding gemaakt van het concept van materieel onderscheid, zoals bijv. in EHvJ 13 februari 1996, zaak C-342/93, Gillespie e.a., Jurispr. 1996, 1-475, punt 16; dit arrest had betrekking op een direct onderscheid op grond van geslacht.

37. Uit het hierboven geciteerde arrest en ook uit andere uitspraken van het Hof valt overigens af te leiden dat het rechtvaardigingsmodel dat bij materieel onderscheid wordt gehanteerd identiek is aan het bij formeel onderscheid toegepaste model; zie p. 376 en 377 van het arrest. Vgl. ook EHvJ 19 maart 1992 , zaak C-311/90, Hierl, Jurispr. 1992, 1-2061, waarin het Hof stelde dat een materieel onderscheid "[...] niet als discriminatie kan worden aangemerkt, wanneer die maatregel is gebaseerd op objectieve criteria [...]" (punt 19), en EHvJ 3 oktober 2000, zaak C-411/98, Ferlini, Jurispr. 2000, I-8081, punt 51 ("volgens vaste rechtspraak is er slechts sprake van discriminatie, indien hetzij verschillende regels worden toegepast op vergelijkbare situaties, hetzij dezelfde regel wordt toegepast op verschillende situaties").

38. EHvJ 8 april 1976, zaak 43/75, Jurispr. 1976, 455; vgl. Drijber/Prechal 1997, p. 127.

39. Punt 39. Zie ook EHvJ 26 juni 2001, zaak C-381/99, Brunnhofer, Jurispr. 2001, 1-4961, punt 32.

40. Zie met name punt 21 en 22 . Ook een overweging van A-G Trabucchi in zijn conclusie bij deze uitspraak zal van belang zijn geweest: hij stelde, dat het niet accepteren van horizontale werking een onaanvaardbaar onderscheid tussen de publieke en de private sector op zou leveren; zie p. 488 van zijn conclusie.

41. EHvJ 12 december 1974, zaak 36/74, Jurispr. 1974, 1405 
[strekt] zich ook [uit] tot bepalingen van andere aard, strekkende tot collectieve regeling van arbeid in loondienst en dienstverrichtingen. [...] [D]e opheffing tussen de Lid-Staten van belemmeringen voor het vrij verkeer van personen en het vrij verrichten van diensten [...] [zou immers] in gevaar [...] worden gebracht, indien de opheffing van de door de staten gestelde belemmeringen kan worden ontkracht door belemmeringen voortvloeiend uit krachtens hun eigen rechtsbevoegdheid door niet onder het publiekrecht vallende verenigingen of lichamen verrichte handelingen."

Gezien de doelstellingen van het Verdrag is het ook niet onlogisch dat het Hof horizontale werking toekent aan de diverse discriminatieverboden: de integratie van de markten, het vrije verkeer tussen de verschillende lidstaten en het wegnemen van ongelijke behandeling op grond van geslacht op het gebied van gelijke beloning en arbeidsomstandigheden kunnen evenzeer of soms zelfs meer worden belemmerd door particuliere ondernemingen en werkgevers dan door de nationale overheid. ${ }^{43}$ Bovendien past de erkenning van horizontale werking goed in de opvatting dat uit het gemeenschapsrecht rechtstreeks rechten en verplichtingen voor burgers kunnen voortvloeien. ${ }^{4}$ Alleen het verbod van ongelijke behandeling in de landbouw lijkt een uitzondering te vormen op deze algemene erkenning van horizontale werking. De bepaling waarin dit verbod is opgenomen richt zich specifiek tot de instellingen en organen die bevoegd zijn maatregelen vast te stellen op het gebied van de gemeenschappelijke ordening van de landbouwmarkten. Dit discriminatieverbod kan daarmee worden gezien als een algemeen beginsel van behoorlijk bestuur, dat zich minder goed leent voor een toepassing in horizontale verhoudingen.

Interessant is tenslotte dat het Hof horizontale werking voor de meeste gelijkheidsbepalingen niet alleen uitdrukkelijk heeft erkend, maar dat het het toetsingsmodel voor de beoordeling van indirect onderscheid op grond van geslacht zelfs heeft ontwikkeld voor toepassing in een horizontale verhouding. Pas in een later stadium is dit verbod ook in verticale situaties gehanteerd. ${ }^{45}$ Hoe vanzelfsprekend de toepassing van het verbod op

42. Punt 16-18. Recentelijk heeft het Hof dit nader geëxpliciteerd en uitgewerkt: zie EHvJ 6 juni 2000 , zaak C-281/98, Angonese, Jurispr. 2000, 1-4139, punt 36, waarin het Hof na een herhaling van de stellingen uit Walrave en Koch concludeerde dat het verbod van onderscheid op grond van nationaliteit ook van toepassing is op particulieren (dus niet alleen op particuliere organisaties); zie hierover de annotatie van Luijendijk en Mortelmans bij dit arrest in Ars Aequi 49 (2000) 11, 801 e.v. Ook uit het arrest Ferlini (EHvJ 3 oktober 2000, zaak C-411/98, Jurispr. 2000, I-8081, punt 50) blijkt dat aan artikel 12 EG rechtstreekse werking toekomt. Zie nader Tridimas 1999 (I), p. 44, Craig/De Búrca 1998, p. 667 en Van der Steen 2001, p. 4 en 6.

43. Hartley 1998, p. 206, Devroe/Wouters 1996, p. 601 en Tridimas 1999 (I), p. 44. Er is vanzelfsprekend geen sprake van directe werking van nog niet of onjuist omgezette richtlijnen in horizontale verhoudingen. Voor het onderhavige hoofdstuk geldt echter dat de meeste uit het oogpunt van ongelijke behandeling belangrijke richtlijnen in nationaal recht zijn omgezet en uit dien hoofde ook horizontale werking hebben.

44. EHvJ 5 februari 1963, zaak 26/62, Van Gend \& Loos, Jurispr. 1963, 1. Overigens moet worden opgemerkt dat dit niet automatisch horizontale werking impliceert: weliswaar kunnen burgers op basis van dit arrest rechtstreeks rechten en verplichtingen hebben, maar het is geenszins duidelijk jegens wie zij deze geldig kunnen maken: het is goed mogelijk dat dit alleen kan is tegenover de overheid. Zie voor een uitgebreide bespreking van deze problematiek Sundberg-Weitman 1977, p. 32-38.

45. Zie vooral 31 maart 1981, zaak 96/90, Jenkins, Jurispr. 1981, 911 en EHvJ 13 mei 1986, zaak 170/84, Jurispr. 1986, 1607. In een verticale verhouding heeft het Hof zich voor het eerst uitgesproken in het arrest Teuling, dat betrekking had op een klacht over een door de WAO veroorzaakt indirect onder- 
horizontale verhoudingen is wordt geïllustreerd door de volgende passage uit de conclusie van A-G Darmon bij het arrest Rinner-Kühn ${ }^{46}$, een van de eerste zaken waarin het Hof zich diende uit te spreken over een in een verticale verhouding veroorzaakt indirect onderscheid op grond van geslacht:

"In de onderhavige zaak heeft het Hof zich [...] uit te spreken over de verenigbaarheid van een wettelijke bepaling met de gemeenschapsbeginselen. Het gaat er dus om, of het in het arrest Bilka ${ }^{47}$ geformuleerde vermoeden van onverenigbaarheid behalve voor contractuele, ook voor overheidsnormen geldt, en ook in dat geval alleen kan worden weerlegd door het bewijs, dat de rechtvaardigingsgronden van de bedoelde maatregelen als 'objectief gerechtvaardigde economische redenen' kunnen worden beschouwd.

Past men die jurisprudentie integraal toe op overheidsnormen, dan zou, wanneer aan bepaalde voorwaarden is voldaan, de verenigbaarheid of onverenigbaarheid van een nationale wettelijke bepaling alleen afhangen van de beweegredenen voor die bepaling. [...] Bestaat er geen gevaar voor de rechtszekerheid, wanneer men de verenigbaarheid van een nationale regeling met het gemeenschapsrecht enkel van de gronden voor haar vaststelling laat afhangen? Mij lijkt het niet verstandig, subjectieve overwegingen ten aanzien van de meer of minder duidelijke, meer of minder uitgesproken motieven die bij de vaststelling van een algemene regel een rol hebben gespeeld, doorslaggevend te laten zijn., ${ }^{48}$

Niet alleen blijkt uit deze passage dat er kennelijk geen bezwaar bestaat tegen het toepassen van het toetsingsmodel in een horizontale verhouding, maar er kan zelfs uit worden afgeleid dat een toepassing van dit model in verticale verhoudingen - normaal gesproken de meest aanvaarde situatie - niet vanzelfsprekend is. Het Hof zelf bleek de bezwaren van Darmon overigens niet te delen en paste in zijn uitspraak, zonder nadere motivering, het rechtvaardigingsmodel toe dat het eerder steeds in horizontale verhoudingen had gehanteerd. ${ }^{\text {" }}$ Hoogstens kan worden opgemerkt dat de interpretatie en de toepassing van dit model enigszins verschillen naar gelang de betrokken rechtsverhouding: in horizontale verhoudingen worden er iets andere criteria gehanteerd bij de beoordeling of er een gerechtvaardigd doel wordt nagestreefd en de toetsing blijkt bij verticale verhoudingen vaak minder intensief te zijn. ${ }^{50}$ Op dit soort verschillen zal verderop in dit hoofdstuk nader worden ingegaan.

scheid (EHvJ 11 juni 1987, zaak 30/85, Jurispr. 1987, 2497, met name punt 14-18). Zie hierover ook Anderman 1996, p. 106.

46. EHvJ 13 juli 1989, zaak 171/88, Jurispr. 1989, 2743

47. Dit arrest zal aan de orde komen in paragraaf 2.1.1 en is het eerste arrest waarin het Hof aangaf welke elementen in de toetsing aan het beginsel van gelijke behandeling op grond van geslacht betrokken moeten worden.

48. Punt 25 en 26 conclusie; origineel cursief. Hij herhaalde deze opvatting in zijn conclusie bij RuziusWilbrink, EHvJ 13 december 1989, zaak C-102/88, Jurispr. 1989, 4311, punt 18.

49. Punt 12

50. Zie voor het vereiste van een objectief gerechtvaardigde economische reden bijvoorbeeld Jenkins (EHvJ 31 maart 1981, zaak 96/80, Jurispr. 1981, 911, punt 12) en Bilka (EHvJ 13 mei 1986, zaak $170 / 84$, Jurispr. 1986, 1607, punt 36); een minder zware toetsingsintensiteit komt tot uitdrukking in Commissie/Belgiē (werkloosheidsuitkeringen) (EHvJ 7 mei 1991, zaak C-229/89, Jurispr. 1991, I2205). Deze verschillen zijn verklaarbaar vanuit de door Darmon in zijn conclusie naar voren gebrachte overweging (zie citaat) dat de overheid meer verschillende belangen moet afwegen bij de besluitvorming, waarbij economische overwegingen niet altijd doorslaggevend mogen zijn. De toetsingsintensiteit wordt door soortgelijke overwegingen bepaald. Met name wanneer de betrokken maatregelen deel uitmaken van het sociaal beleid van de lidstaat is het noodzakelijk dat de staat zelf keuzes 
Gevallen van ongelijke behandeling kunnen in verschillende omstandigheden aan het Hof worden voorgelegd: niet alleen is het mogelijk om direct beroep in te stellen, zoals door middel van de niet-nakomingsprocedure (artikel $226 \mathrm{EG}$ ) en het beroep tot nietigverklaring (artikel $230 \mathrm{EG}$ ), maar ook kan een ongelijke behandeling aan het Hof worden voorgelegd in het kader van een prejudiciële procedure (artikel $234 \mathrm{EG).} \mathrm{Voor} \mathrm{het}$ zoeken naar algemene lijnen in de rechtspraak van het Hof is het van belang om rekening te houden met deze procedurele context, nu deze van invloed kan zijn op de wijze waarop het gelijkheidsbeginsel wordt toegepast.".1

In het landbouwrecht is er in een groot deel van de gevallen sprake van een "gewone" gerechtelijke procedure in de vorm van een niet-nakomingsprocedure of een nietigheidsberoep. Het Hof (of, in bepaalde gevallen, het Gerecht) is in dergelijke procedures rechter in eerste aanleg en heeft daardoor alle ruimte om te bezien of voldaan is aan de verschillende in het toetsingsmodel opgenomen vereisten. Deze rechtspraak is bijzonder interessant, omdat daaruit niet alleen kan worden afgeleid hoe het Hof het toetsingsmodel formuleert, maar ook hoe dit wordt toegepast in een concrete situatie.

Dit laatste is aanzienlijk lastiger bij de rechtspraak over ongelijke behandeling op grond van geslacht en nationaliteit, waarbij in het merendeel van de gevallen sprake is van een prejudiciële procedure. In een dergelijke procedure zal het Hof zich bij zijn beoordeling van de ongelijke behandeling meestal beperken tot een beantwoording van de door de nationale rechter gestelde vragen. Het Hof ziet zelden aanleiding om het gehele toetsingsmodel toe te passen wanneer er uitsluitend een vraag is gesteld over een specifiek onderdeel daarvan. Hierdoor is het soms moeilijk om een integraal beeld te krijgen van de toepassing van het model door het Hof. Daarbij komt nog dat het Hof zich in het kader van een prejudiciële procedure in het algemeen terughoudend opstelt waar het gaat om een beoordeling van de feiten: in veel gevallen zet het Hof wel uiteen aan welke elementen moet worden getoetst, maar wordt de feitelijke toepassing van vereisten als die van geschiktheid en subsidiariteit overgelaten aan de nationale rechter. ${ }^{52}$ Daarnaast zal het Hof in bepaalde gevallen de vaststelling door de nationale rechter van het doel of de aanwezigheid van een benadeling tot uitgangspunt van zijn be-

kan maken en belangen kan afwegen; daarvoor heeft de overheid in het algemeen redelijk veel ruimte nodig. Nu bij werkgevers meestal minder algemene belangen een rol spelen, kan de toetsing daarbij intensiever zijn.

51. Vgl. Lenaerts 1991 , p. 35 .

52. Artikel 234 EG geeft het Hof slechts de bevoegdheid om het Europese recht te interpreteren, de toepassing dient aan de staten te worden overgelaten: zie EHvJ 17 juni 1975 , zaak $7 / 75$, Echtelieden $F$., Jurispr. 1975, 679, punt 10. Vgl. verder Lenaerts 1991, p. 35, Craig/De Búrca 1998, p. 449 en Hartley 1998 , p. 259 . Voorbeelden van zaken waarin de toepassing aan de nationale rechter wordt overgelaten zijn: Bilka (EHvJ 13 mei 1986, zaak 170/84, Jurispr. 1986, 1607), Kowalska (EHvJ 27 juni 1990, zaak C-33/89, Jurispr. 1990, 1-2591, Nimz (EHvJ 7 februari 1991, zaak C-184/89, Jurispr. 1991, I-297), Enderby (EHvJ 27 oktober 1993, zaak C-127/92, Jurispr. 1993, I-5535), Lewark (EHvJ6 februari 1996, zaak C-457/93, Jurispr. 1996, I-243) en Freers en Speckmann (EHvJ 7 maart 1996, zaak C-278/93, Jurispr. 1996, I-1165). Overigens steit het Hof zich in de rechtspraak over onderscheid op grond van nationaliteit meestal minder terughoudend op als het gaat om de toepassing op de feiten (zie echter EHvJ 12 december 1974, zaak 36/74, Walrave en Koch, Jurispr. 1974, 1405). 
oordeling nemen, zonder zelf nog na te gaan of deze vaststelling wel juist is. ${ }^{51}$ Uit de uitspraken in prejudiciële procedures kan de precieze methodiek van het Hof dan ook niet altijd even gemakkelijk worden afgeleid. In veel gevallen blijken nationale rechters hun vragen echter zo te formuleren dat een beantwoording zeer veel informatie verschaft over de wijze waarop door de nationale rechter toepassing moet worden gegeven aan het model; het onderscheid tussen interpretatie en toepassing is dan nauwelijks nog aanwezig. ${ }^{54}$ Daarnaast lijkt het Hof soms bereid te zijn om aanwijzingen te geven over de toepassing wanneer dat voor de uniforme toepassing van het gemeenschapsrecht van belang is of wanneer het Hof dit noodzakelijk acht vanuit het oogpunt van een goede rechtsbedeling. Aan de hand van dergelijke uitspraken en op basis van de diverse uitspraken waarin bepaalde specifieke criteria worden toegepast lijkt het dan ook goed mogelijk om een aantal algemene conclusies te trekken over de inhoud en toepassing van het toetsingsmodel van het Hof.

\subsection{Opzet van het hoofdstuk}

Zoals in paragraaf 1.1 is aangegeven is het gelijkheidsbeginsel in het Verdrag op verschillende plaatsen op een specifieke manier uitgewerkt. Vanwege de grote verschillen in achtergrond en inhoud van deze discriminatieverboden kan in het gemeenschapsrecht moeilijk worden gesproken van een "algemeen" gelijkheidsbeginsel. ${ }^{55} \mathrm{Om}$ voldoende rekening te kunnen houden met de verschillen tussen de diverse bepalingen en om te kunnen beoordelen welke invloed zij hebben op de toetsingsmethodiek zal in dit hoofdstuk afzonderlijk aandacht worden besteed aan de verschillende gelijkheidsbepalingen. Aan drie specifieke discriminatieverboden zal daarbij in het bijzonder aandacht worden besteed.

In de eerste plaats zal worden ingegaan op het verbod van ongelijke behandeling op grond van geslacht. Zoals al is aangegeven heeft dit verbod een fundamenteel grondrechtelijk karakter, waardoor het zich onderscheidt van de andere, meer economisch getinte discriminatieverboden. Door uitdrukkelijk aandacht te besteden aan dit verbod is het mogelijk om conclusies te trekken over de gevolgen van de achtergrond van een gelijkheidsbepaling voor de inhoud van het toetsingsmodel en voor de intensiteit van de toetsing. Bovendien is juist over ongelijke behandeling op grond van geslacht een zeer groot aantal uitspraken gedaan waarin het Hof de kans heeft gekregen het toetsingsmodel verder uit te werken en te verfijnen, zodat het ook om die reden van belang is deze rechtspraak in het onderzoek te betrekken.

Een tweede gelijkheidsbepaling die besproken zal worden is het verbod van ongelijke behandeling van producenten en verbruikers op het gebied van de landbouw. Dit verbod is met name interessant omdat dit juist geen fundamenteel grondrechtelijk karakter heeft: de interpretatie en toepassing worden veeleer bepaald door de oorspronkelijke doelstellingen van het gemeenschapsrecht. Van belang is verder dat de rechtspraak

53. Zie Drijber/Prechal 1997, p. 139.

54. Vgl. Hartley 1998, p. 290.

55. Al kan worden gesteld dat de verboden daarvan steeds uitdrukking vormen: het Hof heeft dit in landbouwzaken regelmatig vastgesteld. Zie bijv. EHvJ 19 oktober 1977, gev. zaken 117/76 en 16/77, Ruckdeschel, Jurispr. 1977, 1753, punt 7. 
over dit onderwerp veel bruikbare informatie kan opleveren over de toetsingsmethodiek, omdat in het landbouwrecht een groot aantal uitspraken is gedaan in het kader van een rechtstreeks beroep. Zoals al is aangegeven heeft het Hof daarbij de mogelijkheid om volledig zelf invulling te geven aan de toetsing en kan het zijn toetsingsmodel daadwerkelijk toepassen op het voorgelegde feitencomplex.

Tenslotte zal uitgebreid aandacht worden besteed aan het verbod van ongelijke behandeling op grond van nationaliteit, zoals (en voor zover) ${ }^{56}$ dit tot uitdrukking komt in de verschillende bepalingen over het vrije verkeer en in artikel $12 \mathrm{EG}$. Dit verbod is met name interessant omdat het daarbij gehanteerde toetsingsmodel bijzonder uitgebreid is en de toetsing meestal zorgvuldig wordt gemotiveerd. Bovendien is deze rechtspraak in het algemeen sterk geïnspireerd door de economische doelstellingen van het Verdrag, waardoor een vergelijking mogelijk is met het meer fundamenteelrechtelijke verbod van onderscheid op grond van geslacht.

Het voorgaande betekent dat de rechtspraak over ongelijke behandeling bij binnenlandse belastingen (artikel $90 \mathrm{EG}$ ) in dit hoofdstuk niet integraal aan de orde zal komen. Aan de discriminatieverboden die tot uitdrukking komen in de bepalingen over het mededingingsrecht (artikelen 81 en 82 EG) zal zelfs in het geheel geen aandacht worden besteed. Voor deze beperkingen is gekozen vanwege het zeer eigen karakter van deze bepalingen en de daarover bestaande rechtspraak. Nu de discriminatieverboden in de artikelen 81, 82 en 90 op een bijzondere manier zijn vormgegeven is het Hof hierbij aan een duidelijk toetsingskader gebonden, waardoor de rechtspraak voor het doel van het onderzoek minder relevant is. De rechtspraak over artikel 90 blijkt echter, binnen de beperkingen van het door deze bepaling gecreëerde toetsingskader, een aantal interessante aspecten te vertonen. Zo kan de manier waarop hierin wordt omgegaan met de vergelijkbaarheidstoets inzicht geven in de bruikbaarheid en wenselijkheid van deze toets voor het algemene toetsingsmodel en kunnen uit de toetsing van het doel bij indirect onderscheid elementen worden afgeleid die voor de ontwikkeling van een algemeen toetsingsmodel van belang zijn. Aan deze aspecten zal in het hiernavolgende dan ook de nodige aandacht worden besteed. Anders dan bij de eerder genoemde verboden van ongelijke behandeling zal hierbij echter niet de gehele toetsingsmethodiek worden besproken, maar zullen alleen de punten aan de orde komen die voor de ontwikkeling van een algemeen toetsingsmodel interessant zijn.

Gezien de grote verschillen in achtergrond en toetsingskader tussen de verboden van ongelijke behandeling is ervoor gekozen om deze in het hiernavolgende steeds afzonderlijk te behandelen. Daarbij zal eerst in het algemeen worden nagegaan op welke manier het toetsingsmodel bij de verschillende verboden is geformuleerd en hoe de toetsingselementen zich tot elkaar verhouden (paragraaf 2.1). Vervolgens zal aan de

56. Zoals in paragraaf 1.1 al duidelijk is geworden, speelt het verbod van ongelijke behandeling lang niet altijd een rol bij deze bepalingen. Om die reden zal niet uitdrukkelijk aandacht worden besteed aan het vrij verkeer van goederen, waarbij de betekenis van het discriminatieverbod al vanaf het begin marginaal was, en zal ook bij de andere vrijheden slechts worden ingegaan op de rechtspraak waarbij daadwerkelijk sprake is van (indirect) onderscheid op grond van nationaliteit. Aan de rechtspraak over nondiscriminatoire beperkingen van het vrije verkeer zal slechts beperkt aandacht worden besteed: alleen in paragraaf $3 \mathrm{zal}$ hierop worden ingegaan. 
hand van de elementen van het theoretische model worden nagegaan hoe daarmee bij de onderscheiden verboden van ongelijke behandeling wordt omgegaan en zal aandacht worden besteed aan de toetsingsintensiteit die daarbij door het Hof wordt gehanteerd (paragraaf 2.2-2.5 en paragraaf 3). Tenslotte zal worden getracht enkele algemene lijnen te ontdekken in de rechtspraak van het Hof over de verschillende verboden en zal worden bezien welke conclusies hieruit kunnen worden getrokken voor de inhoud en de toepassing van het theoretische model (paragraaf 4).

\section{Het toetsingsmodel}

\subsection{Algemene beschrijving van het toetsingsmodel}

\subsubsection{Het toetsingsmodel bij onderscheid op grond van geslacht}

Zoals reeds is aangegeven bestaat er bij het verbod van direct onderscheid op grond van geslacht slechts een beperkte vrijheid voor het Hof om zelf vorm te geven aan zijn toetsing. ${ }^{57} \mathrm{Bij}$ indirect onderscheid is de situatie heel anders. $\mathrm{Al}$ in een vroeg stadium heeft het Hof aangenomen dat onderscheid op grond van geslacht ook is verboden wanneer dit slechts een (on)bedoeld effect is van een door de werkgever of de wetgever getroffen maatregel. ${ }^{58}$ Tegelijkertijd heeft het Hof aangegeven dat dit verbod niet absoluut is: een indirect onderscheid kan toelaatbaar worden geacht als daarvoor een objectieve en redelijke rechtvaardiging bestaat. ${ }^{39} \mathrm{Nu}$ het concept van indirect onderscheid en de noodzaak van een rechtvaardiging daarvoor in het Verdrag niet met zoveel woorden worden genoemd, heeft het Hof alle ruimte om zelf te bepalen welke toetsingscriteria bij de beoordeling daarvan een rol kunnen spelen.

57. Zie paragraaf 1.2.1.

58. Voor het eerst, maar nog niet zo duidelijk, stelde het Hof dit in het arrest Jenkins, waarin het aangaf dat "[...] een verschil in beloning tussen voltijd- en deeltijdwerknemers [...] slechts dan een door artikel 119 verboden discriminatie [is], wanneer het in werkelijkheid enkel een indirect middel is om het loonpeil van deeltijdwerknemers te verlagen wegens de omstandigheid dat deze groep werknemers uitsluitend dan wel voomamelijk uit vrouwen bestaat" (EHvJ 31 maart 1981, zaak 96/80, Jurispr. 1981, 911, punt 15). Voor het aantonen van een indirect onderscheid is het niet nodig dat wordt aangetoond dat een dergelijk onderscheid door de werkgever of de overheid beoogd was: nodig is slechts een duidelijk causaal verband en een aantoonbare benadeling (vgl. Ellis 1996, p. 22). Opgemerkt moet worden dat direct en indirect onderscheid soms dicht bij elkaar liggen: het kan mogelijk zijn dat er onderscheid wordt gemaakt op een neutrale grond, die zo nauw is verbonden met geslacht dat er toch sprake is van direct onderscheid; daarvan is bijvoorbeeld sprake bij onderscheid op grond van zwangerschap. Het Hof is daarop nooit uitgebreid ingegaan: in de meeste gevallen wordt er vanuit gegaan dat, wanneer er geen sprake is van expliciet onderscheid op grond van geslacht of een biologisch gezien noodzakelijkerwijze met geslacht verbonden eigenschap, er sprake zal moeten zijn van indirect onderscheid (zie bijv. EHvJ 7 december 2000, zaak C-79/99, Schnorbus, Jurispr. 2000, 1-10997, punt 33; vgl. ook de conclusie van A-G Jacobs bij deze zaak, die stelt dat het bepalend is of het onderscheidingskenmerk puur juridisch is ofwel fysiek met het geslacht te maken heeft, punt 40). Op de wijze waarop het Hof indirect onderscheid vaststelt zal worden ingegaan in paragraaf 2.2.1.

59. Zie het in de vorige noot genoemde arrest Jenkins, m.n. punt 11 en 12. 
In het arrest Bilka ${ }^{60}$ heeft het Hof voor het eerst duidelijk invulling gegeven aan de toetsing van indirect onderscheid. Dit arrest had betrekking op een bedrijfspensioenregeling, op grond waarvan werknemers alleen voor een aanvullend pensioen in aanmerking kwamen als zij tenminste 20 jaar in een volledige betrekking bij het bedrijf werkzaam waren geweest; deeltijdwerkers kwamen voor dit voordeel dus niet in aanmerking. Volgens één van de werknemers in het bedrijf leverde deze regeling, die op het eerste gezicht geen onderscheid maakt tussen mannelijke en vrouwelijke werknemers, een indirect onderscheid op grond van geslacht op: nu het percentage vrouwelijke deeltijdwerkers aanzienlijk groter was dan het percentage mannelijke deeltijdwerkers had de regeling tot praktisch effect dat vrouwen veel minder snel recht hadden op een aanvullend pensioen dan mannen. Het Hof stelde dat een dergelijke regeling in principe in strijd is met artikel 119 (nu 141), maar voegde daar het volgende aan toe:

"Wanneer de onderneming evenwel kan aantonen, dat haar loonpraktijk kan worden verklaard op grond van factoren die objectief gerechtvaardigd zijn en niets van doen hebben met discriminatie op grond van geslacht, wordt artikel 119 niet geschonden. [...] Het staat aan de nationale rechterlijke instantie, die bij uitsluiting bevoegd is om de feiten te beoordelen, om uit te maken of en, zo ja, in welke mate de redenen die door de werkgever zijn angevoerd ter verklaring van het salarisbeleid dat ongeacht het salaris van een werknemer van toepassing is maar in feite meer vrouwen dan mannen treft, als objectief gerechtvaardigde economische redenen kunnen worden beschouwd. Stelt de nationale rechterlijke instantie vast, dat de door verzoekster in het hoofdgeding gekozen middelen aan een werkelijke behoefte van de onderneming beantwoorden, geschikt zijn om het door haar beoogde doel te bereiken en daarvoor ook noodzakelijk zijn, dan is de omstandigheid dat de betrokken maatregel veel meer vrouwelijke dan mannelijke werknemers treft geen voldoende grond om te concluderen dat artikel 119 is geschonden." ${ }^{61}$

Uit deze overwegingen, en uit enkele nuanceringen en verfijningen die hierin door latere rechtspraak zijn aangebracht, kan worden afgeleid dat het Hof bij de toetsing van indirect onderscheid het volgende toetsingsmodel hanteert:

1. Is er sprake van een maatregel die vrouwen in feite onevenredig veel zwaarder raakt dan mannen, of mannen onevenredig veel zwaarder treft dan vrouwen? ? $^{22}$

2. Bestaat er een objectief gerechtvaardigde reden voor het onderscheid? D.w.z.:

2.1 Heeft het doel van het onderscheid niets van doen met onderscheid op grond van geslacht en

2.2 a. Is de rechtvaardiging economisch van aard en beantwoordt de regeling aan een werkelijke behoefte van de onderneming (bij onderscheid gemaakt door een particuliere werkgever ${ }^{63}$ of

b. Maakt de regeling een integrerend onderdeel uit van het sociale beleid van de lidstaat (bij onderscheid gemaakt door de overheid)? ${ }^{\text {at }}$,

60. EHvJ 13 mei 1986, zaak 170/84, Bilka-Kaufhaus, Jurispr. 1986, 1607

61. Punt 30 en 36

62. Deze voorwaarde blijkt al uit het reeds aangehaalde arrest Jenkins (zie noot 58), punt 13, maar ook uit Bilka (zie noot 60 ), punt 29 ; in latere rechtspraak is deze opnieuw terug te vinden.

63. Dit criterium blijkt uit Bilka, punt 36, maar bijvoorbeeld ook uit EHvJ 1 juli 1986, zaak 237/85, Rummler, Jurispr. 1986, 2101, punt 24 en EHvJ 27 oktober 1993, zaak C-127/92, Enderby, Jurispr. 1993, 1-5535, punt 25. 


\section{Zijn de gekozen middelen geschikt om het doel te bereiken?}

4. Zijn de gekozen middelen noodzakelijk om het doel te bereiken?

Voor dit model geldt dat een bevestigend antwoord op één van deze vragen nog geen eindoordeel oplevert: daarvoor is ook steeds een bevestigend antwoord op alle daarop volgende vragen vereist. Wanneer daarentegen bij de beantwoording van één van deze vragen een ontkennend antwoord is bereikt, dan is het niet meer nodig om aandacht te besteden aan de overige toetsingselementen: het onderscheid kan dan meteen in strijd met het verbod van ongelijke behandeling worden geacht. ${ }^{66}$ Dit model komt daardoor in grote lijnen overeen met het theoretische rechtvaardigingsmodel. Van belang is vooral dat de vergelijkbaarheidstoets in dit model ontbreekt, en dat in plaats daarvan wordt vereist dat er sprake is van een (onevenredig zware) benadeling van de ene groep ten opzichte van de andere. Een opmerkelijke afwijking van het theoretische model is dat het Hof niet expliciet aandacht besteedt aan de proportionaliteit in strikte zin, dus aan de vraag of de door het onderscheid aangetaste belangen in een redelijke verhouding staan tot de te dienen doelen. ${ }^{67}$ Aan deze bijzonderheden zal in het vervolg van dit hoofdstuk nader aandacht worden besteed.

\subsubsection{Het toetsingsmodel bij onderscheid op het gebied van het landbouwbeleid}

In de algemene inleiding bij dit hoofdstuk is aangegeven dat het beginsel van gelijke behandeling zoals dat is neergelegd in artikel 34 lid 2 EG (artikel 40 lid 3, tweede alinea oud) en zoals het wordt geïnterpreteerd door het Hof, zich in belangrijke opzichten onderscheidt van de overige discriminatieverboden in het Verdrag. In de eerste plaats

64. Zie voor dit criterium EHvJ 11 juni 1987, zaak 30/85, Teuling, Jurispr. 1987, 2497 en EHvJ 7 mei 1991, zaak C-229/89, Commissie tegen België (werkloosheidsuitkeringen), Jurispr. 1991, 1-2205, punt 21. In latere rechtspraak is dit criterium geherformuleerd: nu stelt het Hof meestal dat er sprake moet zijn van een legitieme doelstelling van sociaal beleid (zie bijv. EHvJ 24 februari 1994, zaak C-343/92, Roks, Jurispr. 1994, I-571). Beide formuleringen hebben echter dezelfde strekking.

65. Het is belangrijk om onderscheid te maken tussen het vereiste van een economische en een sociale rechtvaardiging, zoals uiteen wordt gezet in de conclusie van A-G Jacobs bij het arrest Lewark (EHvJ 6 februari 1996, zaak C-457/93, Jurispr. 1996, I-243). Wanneer er sprake moet zijn van een economische rechtvaardiging, dan impliceert dat volgens hem een beoordeling van de specifieke omstandigheden van het geval. Het Hof zal zich in een dergelijke situatie terughoudend moeten opstellen ten opzichte van de nationale wetgever. Dit is volgens Jacobs niet het geval bij een situatie waarin het sociale beleid een rol speelt (punt 38 conclusie). In de praktijk blijkt het tegenovergestelde het geval te zijn: het Hof toetst economische redenen aanzienlijk intensiever dan sociale redenen (zie daarover paragraaf 3.2.2). Overigens is in de literatuur nog een derde "categorie" van rechtvaardigingen onderscheiden, namelijk "job related justifications" (Hervey 1993, p. 68 en Bourn 1996, p. 39). Nu het Hof dit onderscheid zelf niet expliciet maakt en deze vorm van rechtvaardiging nauw samenhangt met het vereiste dat de doelstelling noodzakelijk is voor het goed functioneren van het bedrijf, zal hieraan verder geen aandacht worden besteed. Zie verder paragraaf 2.3.1.

66. Het is niet eenvoudig om na te gaan of het Hof in de praktijk vasthoudt aan de volgorde van het model en aan alle verschillende elementen toetst als dat nodig is. Aangegeven is al dat het Hof bij onderscheid op grond van geslacht vooral te maken krijgt met prejudiciele vragen. De nationale rechter zal vaak slechts vragen naar de wijze van toepassing van een specifiek element, zodat het voor het Hof niet nodig is om op de verenigbaarheid van het onderscheid met de overige toetsingselementen in te gaan. Bovendien laat het Hof de toetsing van bepaalde elementen vaak over aan de nationale rechter als een waardering van de feiten nodig is.

67. Vgl. Anderman 1996, p. 105 en 109. 
sluit dit artikel in zijn algemeenheid iedere ongerechtvaardigde ongelijke behandeling tussen producenten en verbruikers binnen de Gemeenschap uit. Het artikel bevat dus geen beperking naar differentiatiecriteria: op grond van dit artikel kan ongelijke behandeling op grond van nationaliteit worden aangevochten, maar er kan evengoed een beroep op het verbod worden gedaan als aan een bepaalde groep producenten een heffing is opgelegd, terwijl een andere groep daarvan is vrijgesteld, of wanneer een specifiek product wel onder een steunregeling valt, maar een gelijkwaardig product niet. ${ }^{6 s}$ Het gevolg van dit "open" karakter is een tweede opvallend verschil met de andere discriminatieverboden, namelijk het ontbreken van rechtspraak over indirect onderscheid: wanneer er geen sprake is van een limitatieve opsomming van onderscheidingsgronden is het niet nodig om van dit concept gebruik te maken. Bijzonder is tenslotte dat het Hof aanneemt dat er een rechtvaardigingsmogelijkheid bestaat voor ongelijke behandeling in de landbouw, ondanks het feit dat artikel 34 lid 2 daarin niet uitdrukkelijk voorziet. Dit kan worden verklaard vanuit het feit dat de rechtspraak over de landbouw vooral in het begin sterk is geïnspireerd door de rechtspraak over het verbod van ongelijke behandeling zoals dat is neergelegd in het EGKS-Verdrag. ${ }^{69}$ In die rechtspraak had het Hof al vroeg aangenomen dat niet ieder onderscheid met dit verbod in strijd is, zoals blijkt uit de volgende overweging uit een arrest uit 1958:

"Volgens een in het recht der deelnemende Staten erkend beginsel belet de gelijkheid der justitiabelen inzake de economische wetgeving geenszins, dat verschillende prijzen worden vastgesteld naar gelang van de bijzondere omstandigheden waarin de verbruikers of groepen van verbruikers verkeren, mits de verschillende wijzen van behandeling overeenstemmen met het feit dat de betrokkenen niet in dezelfde omstandigheden verkeren; zou daarbij een objectief vastgestelde basis ontbreken, dan zouden de verschillen in behandeling inderdaad van willekeurige en discriminatoire aard zijn en daardoor in strijd met het Verdrag." ${ }^{\text {iu }}$

Niet alleen blijkt uit deze overweging dat niet iedere ongelijke behandeling zonder meer verboden is, maar ook wordt hierin een aanzet gegeven voor de door het Hof in

68. Wel is de reikwijdte van het artikel in een ander opzicht beperkt: onderscheid tussen producenten en verbruikers dat wordt veroorzaakt door reeds bestaande natuurlijke, sociale of economische verschillen wordt door de bepaling niet gedekt, net zomin als onderscheid dat het gevolg is van dispariteiten tussen nationale wetgevingen en beleid. Zie Barents 1994 (II), p. 529 en Schwarze 1992, p. 606 e.v. en o.a. EHvJ 13 november 1973, gev. zaken 63-69/72, Willem Werhahn Hansamühle, Jurispr. 1973, 1229. punt $16 / 17$.

69. Ook in het EGKS-Verdrag komt het discriminatieverbod op diverse plaatsen tot uitdrukking. Een algemeen verbod, dat overeenkomsten vertoont met artikel 34 lid 2, is neergelegd in artikel 4 , aanhef en onder b, luidende "als zijnde onverenigbaar met de gemeenschappelijke markt voor kolen en staal worden afgeschaft en zijn verboden binnen de Gemeenschap overeenkomstig de bepalingen van dit Verdrag: [...] b. maatregelen of praktijken, die een discriminatie tussen producenten, tussen kopers, of tussen verbruikers inhouden, met name die, welke betrekking hebben op prijzen of leveringsvoorwaarden en vervoerstarieven [...]." Net als bij artikel 34 lid 2 geldt ook hier dat geen opsomming is gegeven van verboden differentiatiecriteria en dat er geen uitdrukkelijke rechtvaardigingsmogelijkheid is geformuleerd. Zie over de functie van het algemene discriminatieverbod in het EGKS-Verdrag nader EHvJ 23 april 1956, gev. zaken 7/54 en 9/54, Groupement des Industries Siégurgiques Luxemburgeoises, Jurispr. 1954-56, 86, op p. 95/96.

70. EHvJ 21 juni 1958, zaak 13/57, Wirtschaftsvereinigung Eisen- und Stahlindustrie e.a., Jurispr. 195758,285 . Het Hof had zich in vergelijkbare zin, maar iets minder duidelijk, ook al uitgesproken in 1956: zie EHvJ 29 november 1956, zaak 9/55, Naamloze Vennootschap Kolenmijnen van Beeringen, Jurispr. $1954-56,311$; vgl. Schwarze 1992, p. 568. 
latere rechtspraak ontwikkelde toetsingsmethodiek: er is volgens het Hof slechts sprake van een toelaatbare, want niet willekeurige en discriminatoire, ongelijke behandeling wanneer er sprake is van objectief vaststelbare verschillen in omstandigheden. Hieruit komt een element van vergelijkbaarheid naar voren, dat in de rechtspraak over het EGKS-Verdrag en over het landbouwrecht vaak een doorslaggevende rol blijkt te spelen; daarnaast blijkt hieruit een vereiste van objectiviteit en een verbod van willekeur." Beide elementen komen ook tot uitdrukking in de eerste arresten over artikel 34 lid 2. Zo stelde het Hof in 1971 in het arrest Rheinmühlen Düsseldorf ${ }^{72}$, dat

"[...] [d]e non-discriminatieregel [...] slechts [wordt] geschonden als is komen vast te staan dat de communautaire wetgever vergelijkbare situaties op verschillende wijze heeft geregeld; $[\ldots]$ de vergelijkbaarheid $[\ldots]$ moet worden beoordeeld aan de hand van de doelstellingen van de communautaire landbouwregeling."”3

Twee jaar later overwoog het Hof in het arrest Merkur-Außenhandels-GmbH ${ }^{4}$, dat

"de door verzoekster gewraakte ongelijkheid van behandeling slechts dan een inbreuk op het non-discriminatiebeginsel [zou] vormen wanneer daaruit van willekeur zou blijken." ${ }^{7 s}$

In de rechtspraak op het gebied van de landbouw is het echter aanzienlijk moeilijker om een eenduidig en expliciet toetsingsmodel te ontwaren dan bij indirect onderscheid op grond van geslacht: de verschillende relevante arresten kenmerken zich door een inconsistente en sterk casuïstische toetsingsmethodiek en een summiere motivering." Met name is het lastig om in deze jurisprudentie duidelijkheid te vinden over de vraag hoe het Hof aankijkt tegen de verhouding tussen de vergelijkbaarheidstoets en het rechtvaardigingsmodel." In theorie kan op verschillende manieren van een vergelijkbaarheidstoets gebruik worden gemaakt: de gebleken vergelijkbaarheid of onvergelijkbaarheid kan doorslaggevend worden geacht voor de uitkomst van de procedure, maar het is ook mogelijk om deze toets slechts als een toetsingsingang te beschouwen. ${ }^{7}$ in

71. Beide elementen komen in de rechtspraak over het EGKS-Verdrag regelmatig terug. Zie bijv. EHvJ 14 december 1959, zaak 14/59, Société des Fonderies de Pont-à-Mousson, Jurispr. 1959, 215, waarin de vergelijkbaarheidsvraag een doorslaggevende rol speelde, en EHvJ 13 juli 1962, gev. zaken 17 en 20/61, Klöckner-Werke $A G$ en Hoesch $A G$, Jurispr. 1962, 643, waarin ook de objectiviteit en het gewicht van de verschillen aan bod kwam.

72. EHvJ 27 oktober 1971 , zaak $6 / 71$, Jurispr. 1971, 823

73. Punt 14. Een vergelijkbare benadering werd gevolgd in EHvJ 28 oktober 1982, gev. zaken 292 en 293/81, Loiret \& Haentjens, Jurispr. 1982, 3887, punt 24, EHvJ 10 januari 1992, zaak C-177/90, Kühn, Jurispr. 1992, I-35, punt 18 en EHvJ 23 oktober 1997, zaak C-150/95, Portugal/Commissie, Jurispr. 1997, 1-5863, punt 48 .

74. EHvJ 24 oktober 1973, zaak 43/72, Jurispr. 1973, 1055

75. Punt 22

76. Vgl. Bronkhorst 1987 (1), p. 32. Soms is het zelfs zo dat het Hof binnen één uitspraak gebruik maakt van verschillende toetsingsmethodes om verschillende klachten over ongelijke behandeling te beoordelen. Zie bijvoorbeeld EHvJ 17 juli 1997, gev. zaken C-248 en 249/95, SAM Schiffahrt, Jurispr. 1997, $1-4475$, waar het Hof spreekt over objectief verschillende situaties, maar waarin ook een overweging voorkomt waarin de rechtvaardigingstoets een rol lijkt te spelen (zie punt 55,58 en 60 ). Waarschijnlijk houdt de casuistische en onduidelijke toetsing verband met de marginale toetsing die op het gebied van de landbouw wordt uitgevoerd. Daarop zal in paragraaf 3 van dit hoofdstuk nader worden ingegaan.

77. Vgl. Tridimas 1997, p. 220 en Schwarze 1992, p. 563/564.

78. Bovendien is een combinatie van deze mogelijkheden denkbaar; zie hoofdstuk 2, paragraaf 4.3.1, waarin de verschillende mogelijkheden en de consequenties van de keuze daarvoor zijn besproken. 
het tweede geval zal bij gebleken vergelijkbaarheid meestal nog een rechtvaardigingstoets worden uitgevoerd. In de jurisprudentie van het Hof over het landbouwbeleid wordt gebruik gemaakt van beide varianten, een situatie die de doorzichtigheid van de rechtspraak bepaald niet vergroot. Zoals uit de bovengeciteerde arresten al blijkt komt bovendien nog de situatie voor dat het Hof uitsluitend bekijkt of de ongelijke behandeling niet objectief gerechtvaardigd of willekeurig is, zodat de vergelijkbaarheid bij de toetsing geen enkele rol speelt. ${ }^{79}$ Tenslotte vindt er in een aantal arresten een soort versmelting plaats van de vergelijkbaarheidstoets en de rechtvaardigingstoets." Een voorbeeld daarvan is te vinden in het arrest Biovilac. ${ }^{\text {st }}$ Dit arrest had betrekking op een verschil in behandeling van wei en magere-melkpoeder als basis voor dierenvoer: aan magere-melkpoeder werd op grond van een gemeenschappelijke regeling steun verleend, terwijl een vergelijkbaar voordeel niet voor wei gold. Het Hof stelde hierover het volgende:

"Volgens vaste rechtspraak van het Hof staat het in artikel 40, lid 3, sub b [artikel 34 lid 2 nieuw, JHG] neergelegde discriminatieverbod niet eraan in de weg dat vergelijkbare situaties verschillend worden behandeld, wanneer dit verschil objectief gerechtvaardigd is. De toekenning van directe of indirecte steun voor magere-melkpoeder is objectief gerechtvaardigd wegens de aard van dit product en de plaats die het daarom in de gemeenschappelijke ordening der markten in de sector melk en zuivelproducten inneemt als marktondersteunend element, terwijl wei niet dezelfde kenmerken vertoont. Dit is namelijk een bij de kaasbereiding verkregen afvalproduct [...]. Het verschil in behandeling [...] vindt dus zijn grond in objectieve verschillen die voortvloeien uit de economische situatie die ten grondslag ligt aan de gemeenschappelijke marktordening voor melk en zuivelproducten, en kan dus niet discriminerend worden geacht." ${ }^{\text {"12 }}$

De gehanteerde toetsingsmethodiek lijkt in de praktijk sterk te worden bepaald door de door het Hof gewenste uitkomst van de zaak, die in het algemeen gelijk te stellen is met

79. Zie bijv. ook EHvJ 11 juli 1974, zaak 11/74, Union des Minotiers de la Champagne, Jurispr. 1974, 877, punt 22, EHvJ 12 juli 1977, zaak 2/77, Hoffmann's Stärkefabriken, Jurispr. 1977, 1375, EHvJ 15 september 1982, zaak 106/81, Julius Kind, Jurispr. 1982, 2885, punt 22, EHvJ 26 juni 1995, zaak C56/94, SCAC, Jurispr. 1995, 1-1769, EHvJ 5 juli 2001, zaak C-100/99, Italië/Raad en Commissie (agromonetair stelsel voor euro), Jurispr. 2001, I-5217, punt 36/37 en EHvJ 8 januari 2002, zaak C$507 / 99$, Denkavit Nederland BV (II), nog niet gepubliceerd, punt $44 / 45$. Overigens wordt soms als vervangende toetsingsingang gebruik gemaakt van het criterium van benadeling; vgl. Schwarze 1992, p. 575 en Timmermans 1982, p. 433 en zie nader paragraaf 2.2.3.

80. Zie bijv. EHvJ 2 juli 1974, Holtz \& Willemse, Jurispr. 1974, 675, punt 13, EHvJ 27 september 1979. zaak 230/78, Eridania, Jurispr. 1979, 2749, EHvJ 11 maart 1987, gev. zaken 279, 280, 285 en 286/84, Walter Rau Lebensmittelwerke, Jurispr. 1987, 1069, punt 32, EHvJ 19 maart 1992, zaak C-311/90, Hierl, Jurispr. 1992, I-2061, punt 19, EHvJ 6 juli 2000, zaak C-289/97, Eridania II, Jurispr. 2000, I5409 , punt 95 en EHvJ 13 juli 2000, zaak C-117/99, Unilet, Jurispr. 2000, 1-6077, punt 25-27; in vrijwel al deze arresten stelde het Hof dat het verschil in behandeling berustte op objectieve verschillen.

81. EHvJ 6 december 1984 , zaak 59/83, Jurispr. 1984, 4057

82. Punt 19 en 20; cursief toegevoegd. Zie ook Wagner/BALM, waarin zich een vergelijkbare situatie voordeed (EHvJ 23 februari 1983, zaak 8/82, Jurispr. 1983, 371, punt 18 en 19) en EHvJ 12 juli 2001, zaak 189/01, Jippes, Jurispr. 2001, 1-5689, punt 131/132 (zij het minder expliciet). Van een iets andere situatie was sprake in het arrest Denkavit Futtermittel $\mathrm{GmbH}$ : hierin stelde het Hof dat ter beoordeling van de ongelijke behandeling moest worden beoordeeld of er sprake was van willekeur (punt 15); bij de toepassing van dit vereiste op het voorliggende feitencomplex bleek echter doorslaggevend te zijn dat er objectieve verschillen tussen de voorgelegde gevallen bestonden (EHvJ 13 juni 1978, zaak 139/77, Jurispr. 1978, 1317). 
de uitkomst die het meest bevorderlijk is voor de verwezenlijking van de interne landbouwmarkt en die het meeste recht doet aan de gewenste concurrentieverhoudingen. ${ }^{\circ}$ Zo lijkt het Hof vooral gebruik te maken van de vergelijkbaarheidstoets wanneer deze een eenvoudige mogelijkheid biedt om te oordelen dat een wenselijk geachte ongelijke behandeling toelaatbaar is. ${ }^{\text {st }}$ Wanneer het onderzoeken van de vergelijkbaarheid lastig is, maar het Hof toch van mening is dat de ongelijke behandeling toelaatbaar moet worden geacht, zal daarentegen veelal geen aandacht worden besteed aan de vergelijkbaarheid: in dat geval wordt meestal gekozen voor het uitsluitend uitvoeren van een rechtvaardigingstoets. ${ }^{85}$ Een volledige toets (waarbij zowel de vergelijkbaarheid als de rechtvaardiging worden beoordeeld) wordt bij een door de gemeenschapsinstellingen veroorzaakte ongelijke behandeling vrijwel uitsluitend toegepast in de vrij zeldzame gevallen waarin het Hof van mening is dat het onderscheid ontoelaatbaar is. ${ }^{86}$ Bovendien geeft de rechtspraak aanleiding om te veronderstellen dat het Hof bij onderscheid dat door de lidstaten is veroorzaakt vrijwel steeds een volledige toetsing van zowel vergelijkbaarheid als de aangedragen rechtvaardiging toepast, terwijl bij onderscheid dat is gemaakt door de instellingen vaak wordt volstaan met een oppervlakkige vergelijkbaarheidstoets of een marginale willekeurstoets. ${ }^{\text {n }}$ Ook hieraan liggen waarschijnlijk rechtspolitieke overwegingen ten grondslag: het door de lidstaten veroorzaakte onderscheid is in het algemeen veel schadelijker voor het verwezenlijken van de doelstellingen van het gemeenschappelijke landbouwbeleid dan de classificaties in gemeenschapsregelingen, die in het algemeen juist de totstandkoming van een interne landbouwmarkt beogen te bevorderen.

Ondanks het feit dat de toetsingsmethodiek van het Hof pragmatisch en weinig consistent is, kan in de uitgebreide rechtspraak van het Hof wel enige lijn worden onderscheiden. De basis van dit toetsingsschema is te vinden in het hierboven weergegeven citaat uit het arrest Biovilac: vergelijkbare situaties mogen alleen verschillend worden behandeld wanneer daarvoor een objectieve rechtvaardiging aanwezig is.$^{\mathrm{sx}}$ Dit vereiste

83. Hiermee is niet gezegd dat het Hof niet objectief is en de regelingen op het gebied van het gemeenschapsrecht vanuit een politiek gekleurde opstelling en zonder enige kritiek accepteert: de terughoudendheid houdt vooral verband met het feit dat de bevoegdheden van de gemeenschapsinstellingen op het gebied van de landbouw zeer ruim zijn geformuleerd en deze ruimte moet worden gerespecteerd om de bevoegdheidsverdeling niet te zeer te doorkruisen (Barents 1997, p. 835). De terughoudende opstelling van het Hof valt dan ook niet als zodanig af te keuren (zie vooral paragraaf 3.2). Wel is kritiek mogelijk op de inconsequente en pragmatische toetsingsmethodiek, met name vanuit overwegingen van rechtszekerheid en doorzichtigheid van de toetsing.

84. Zie hierover paragraaf 2.2 .2 en vgl. Tuytenschaever 1999, p. 111.

85. Deze komt meestal neer op een willekeurstoets, hoewel het Hof zich niet altijd even kritiekloos opstelt tegenover het door de instellingen gevoerde beleid: wanneer het Hof een ongelijke behandeling echt ontoelaatbaar en onnodig vindt, zal dit in de uitkomst van de toets ook wel naar voren komen. Zie EHvJ 5 juli 1977, zaak 114/76, Bela-Mühle, Jurispr. 1977, 1211 , punt 7.

86. Bijv. EHvJ 18 mei 1994, zaak C-309/89, Codorniu, Jurispr. 1994, 1-1853, punt 28-35.

87. Zie voor een strenge toets bij een afwijkende regeling door de lidstaten bijvoorbeeld EHvJ 14 januari 1993, zaak C-190/91, Lante, Jurispr. 1993, I-67 en EHvJ 13 april 2000, zaak C-292/97, Karlsson e.a, Jurispr. 2000, I-2737.

88. Zie voor een toepassing hiervan bijv. ook EHvJ 19 december 1977, gev. zaken 117/76 en 16/77, Ruckdeschel, Jurispr. 1977, 1753, EHvJ 15 juli 1982, zaak 245/81, Edeka Zentrale, Jurispr. 1982, 2745, punt 11, EHvJ 21 februari 1990, gev. zaken C-267-285/88, Wuidart, Jurispr. 1990, 1-435, punt 13, EHvJ 22 oktober 1998, gev. zaken C-9/97 en C-118/97, Jokela en Pitkäranta, Jurispr. 1998, I-6267, 
van een objectieve rechtvaardiging is in enkele andere uitspraken verder uitgewerkt, waardoor het volgende beslissingsmodel als "basismodel" naar voren komt:

\section{Is er sprake van vergelijkbaarheid?}

2. Is er sprake van een objectieve rechtvaardiging, d.w.z.

2.1 Is er een gerechtvaardigd doel? Meer specifiek: beantwoordt de regeling (daadwerkelijk) aan de eisen en behoeften van de gemeenschappelijke markt?

2.2 Zijn er redenen om aan te nemen dat bij de totstandbrenging van de regeling kennelijk onjuist of willekeurig is gehandeld?"

Zoals uit dit toetsingsmodel blijkt komt een beoordeling van de rechtvaardiging van een ongelijke behandeling neer op een willekeurstoets, waaraan een meer expliciete toetsing van het doel van de regeling vooraf gaat., In het vervolg van paragraaf $2 \mathrm{zal}$ de wijze waarop het Hof de elementen van bovenstaand model in zijn rechtspraak toepast nader worden bestudeerd. Daarbij zal bovendien worden ingegaan op de toetsing aan enkele elementen die in het bovenstaande model ontbreken, maar die in een beperkt aantal arresten impliciet of expliciet wel degelijk een rol blijken te spelen, zoals het vereiste van benadeling, de geschiktheidseis, het vereiste van noodzakelijkheid en het vereiste van proportionaliteit in strikte zin.

\subsubsection{Het toetsingsmodel bij onderscheid op grond van nationaliteit}

Voor de bepalingen over ongelijke behandeling op grond van nationaliteit geldt steeds dat direct onderscheid is verboden, tenzij een geslaagd beroep op een nauwkeurig omschreven uitzonderingsbepaling kan worden gedaan. ${ }^{n}$ Hoewel de uitzonderingsgronden

punt 45 en GvEA 20 maart 2001, zaak T-52/99, T. Port, Jurispr. 2001, II-981, punt 81. Een fraaie toepassing van dit model is terug te vinden in EHvJ 18 mei 1994, zaak C-309/89, Codorniu, Jurispr. 1994, I-1853. Zie ook Barents 1997, p. 840 en Tridimas 1997, p. 220.

89. In een groot aantal arresten wordt ook wel het benadelingscriterium als toetsingsingang gebruikt, zoals het geval lijkt te zijn in EHvJ 13 juli 1978, zaak 8/78, Milac II, Jurispr. 1978, 1721, EHvJ 18 maart 1986, zaak 244/83, Meggle, Jurispr. 1986, 1101, punt 27 en EHvJ 13 april 2000, Karlsson, Jurispr. 2000, 1-2737, punt 42 en 48 . Dit lijkt echter minder gebruikelijk dan de toepassing van het vergelijkbaarheidscriterium.

90. Zie voor deze formulering EHvJ 14 januari 1981, zaak 35/80, Denkavit Nederland BV, Jurispr. 1981, 45, punt 10, EHvJ 15 juli 1982, zaak 245/81, Edeka Zentrale, Jurispr. 1982, 2745, punt 13 en 20, EHvJ 18 maart 1986, zaak 179/84, Bozzetti, Jurispr. 1986, 2301, punt 34, EHvJ 18 maart 1986, zaak 244/83, Meggle, Jurispr. 1986, 1101, punt 29, EHvJ 26 juni 1995, zaak C-56/94, SCAC, Jurispr. 1995, 1-1769, punt 28 en EHvJ 13 april 2000, zaak C-292/97, Karlsson e.a., Jurispr. 2000, 1-2737, punt 45.

91. Vgl. GvEA 20 maart 2001, zaak T-52/99, T. Port, Jurispr. 2001, II-981, waarin het Hof hieraan zelfs nog iets verder uitwerking gaf: een ongelijke behandeling is willekeurig wanneer deze niet objectief gerechtvaardigd is en niet berust op objectieve criteria (punt 82 ).

92. Vgl. Boest 1984 , p. 125 en 131 e.v.

93. Zoals in de inleiding is gesteld is het in ieder geval mogelijk om een beroep te doen op een uitzonderingsbepaling bij de vrijheden. Artikel 12 bevat in het geheel geen uitzonderingsbepaling, maar daarbij is aangenomen dat ook direct onderscheid kan worden gerechtvaardigd (zie EHvJ 20 maart 1997, zaak C-323/95, Hayes, Jurispr. 1997, I-1711, punt 19 en 24). Bij andere gelijkheidsbepalingen, zoals artikel 3 lid 1 van Verordening 1408/71 van de Raad van 14 juni 1971 (betreffende de toepassing van sociale zekerheidsregelingen op werknemers en zelfstandigen), Pb. 1972 L 74/1 en artikel 7 lid 2 van Verordening 1612/68 van de Raad van 15 oktober 1968 (betreffende het vrij verkeer van werknemers binnen de Gemeenschap), Pb. 1968 L 257/2, hangt de mogelijkheid van rechtvaardiging van de formulering 
zoals die zijn neergelegd in het Verdrag en in het secundaire gemeenschapsrecht nog relatief veel ruimte voor interpretatie bieden, is het Hof niet geheel vrij om zijn eigen toetsing vorm te geven. Dit is - net als bij onderscheid op grond van geslacht - anders bij het verbod van indirect onderscheid. ${ }^{94}$ Anders dan bij onderscheid op grond van geslacht heeft het Hof in zijn rechtspraak over ongelijke behandeling op grond van nationaliteit nooit met zoveel woorden vastgesteld aan welke vereisten een dergelijke objectieve rechtvaardiging zou moeten voldoen. Het is echter goed mogelijk om in de uitgebreide rechtspraak over dit onderwerp een algemeen toetsingsmodel te ontwaren dat bestaat uit de volgende onderdelen:"

1. Is er sprake van een criterium dat feitelijk in het nadeel werkt van onderdanen van andere lidstaten?"

2. Wordt door het onderscheid een (objectief) gerechtvaardigd doel nagestreefd? In enkele gevallen werd dit vereiste nog nader gespecificeerd:

2.1. Wordt de regeling objectief gerechtvaardigd door redenen van algemeen belang?"7

2.2. Staat de doelstelling los van de nationaliteit van de betrokkene?"s

3. Is de regeling geschikt om het doel te bereiken?

van de betrokken bepalingen af.

94. Zie voor het vrij verkeer van personen EHvJ 12 februari 1974, zaak 152/73, Sotgiu, Jurispr. 1974, 153, punt 11, voor de vrijheid van vestiging (impliciet) EHvJ 12 februari 1987, zaak 221/85, Commissie/België (laboratoriumverstrekkingen) en meer expliciet EHvJ 5 december 1987, zaak C-3/88, Commissie/Italië (overheidsaanbesteding gegevensbestanden), Jurispr. 1989, 4035, en voor het vrije dienstenverkeer expliciet EHvJ 3 februari 1982, gev. zaken 62-63/81, Seco en Desquenne \& Giral, Jurispt. 1982,223 . Bij de rechtspraak over artikel 12 is dit toetsingsmodel minder duidelijk terug te vinden, hoewel ook daar consequent wordt aangenomen dat een er een objectieve rechtvaardiging voor het onderscheid moet bestaan (zie bijv. EHvJ 29 oktober 1980, zaak 22/80, Boussac, Jurispr. 1980, 3427, punt $11-14)$.

95. In rechtstreekse procedures past het Hof dit model niet altijd volledig toe: in verschillende gevallen waarin sprake was van een rechtstreeks beroep, bijvoorbeeld een niet-nakomingsprocedure, stelde het Hof slechts vast dat er sprake was van een benadeling, zonder dat het daarna naging of voor het vastge. stelde onderscheid een rechtvaardiging bestond. Zie bijv. EHvJ 16 juni 1987, zaak 225/85, Commissie/ltalie, Jurispr. 1987, 2625, EHvJ 17 november 1992, zaak C-279/89, Commissie/VK (visvergunningen), Jurispr. 1992, I-5785 en EHvJ 12 september 1996, zaak C-278/94, Commissie/België (wachtuilkeringen jongeren), Jurispr. 1996, I-4307.

96. Dit criterium komt in vrijwel iedere uitspraak terug. Zie voor het vrij verkeer van personen bijvoorbeeld EHvJ 12 februari 1974, zaak 152/73, Sotgiu, Jurispr. 1974, 153, punt 11, EHvJ 8 mei 1990, zaak C-175/88, Biehl, Jurispr. 1990, I-1779, punt 13 en EHvJ 14 februari 1995, zaak C-279/93, Schumacker, Jurispr. 1995, I-225, punt 28; zie voor de vestigingsvrijheid bijv. EHvJ 12 februari 1987, zaak 221/85, Commissie/België (laboratoriumverstrekkingen), punt 10 en EHvJ 13 juli 1993, zaak C-330/91, Commerzbank $A G$, Jurispr. 1993, 1-4017, punt 15. In een beperkt aantal arresten wordt gebruik gemaakt van een vergelijkbaarheidselement: zie bijvoorbeeld het hiervoor aangehaalde arrest Sotgiu in punt 12, het eveneens al genoemde arrest Schumacker in punt 30, EHvJ 12 juli 1979, zaak 237/78, CRAM, Jurispr. 1979, 2645, punt 14 en 17 en EHvJ 20 november 1997, zaak C-90/96, Petrie, Jurispr. 1997, 1-6529. Op dit gebruik van de vergelijkbaarheidsvraag en het criterium van benadeling zal in paragraaf 2.2 .3 nader worden ingegaan.

97. Zie bijv. EHvJ 3 februari 1982, gevoegde zaken 62 en 63/81, Seco, Jurispr. 1982, 223, punt 10, EHvJ 28 januari 1992, zaak C-204/90, Bachmann, Jurispr. 1992, 1-249, punt 14, EHvJ 28 januari 1992, zaak C-300/90, Commissie/Belgiē, Jurispr. 1992, 1-305, punt 10.

98. EHvJ 23 mei 1996, zaak C-237/94, O'Flynn, Jurispr. 1996, I-2617, punt 19 
4. Is de regeling noodzakelijk om het doel te kunnen dienen?"

$\mathrm{Bij}$ indirect onderscheid op het gebied van het vrij verkeer van diensten worden hierbij nog de volgende specificaties aangebracht:

4.1. Is de eis waardoor het indirecte onderscheid is veroorzaakt algemeen toepasselijk, d.w.z. geldt deze voor iedereen die op het grondgebied van de lidstaat werkzaam is?

4.2. Zijn er geen vergelijkbare eisen voorzien in de staat waar de dienstverrichter is gevestigd, op het voldoen waaraan voldoende toezicht wordt uitgeoefend? ${ }^{100}$

5. Staat het onderscheid in een evenredige verhouding ten opzichte van het doel? ${ }^{101}$

Dit opvallend goed uitgewerkte model bevat vrijwel alle elementen die in het theoretische toetsingsmodel zijn opgenomen. Interessant is bovendien de aanwezigheid van een uitdrukkelijk vereiste van evenredigheid: zowel bij onderscheid op grond van geslacht als bij discriminatie op het gebied van de landbouw ontbreekt dit onderdeel. Opmerkelijk is verder dat het vereiste van subsidiariteit in dit model lijkt te zijn vervangen door een algemeen vereiste van noodzakelijkheid, dat in sommige gevallen bovendien een bijzondere uitwerking blijkt te krijgen. Op de wijze waarop het Hof in de praktijk met de toetsing aan deze criteria omgaat zal in het hiernavolgende uitgebreid worden ingegaan.

\subsection{De eerste fase van de toetsing: vergelijkbaarheid en benadeling}

\subsubsection{Vergelijkbaarheid en benadeling bij onderscheid op grond van geslacht \\ Inleiding}

Bij indirect onderscheid op grond van geslacht bestaat de door het Hof te verrichten toetsing uit twee fasen. In de eerste plaats dient het te beoordelen of een regeling die op het eerste gezicht differentieert tussen personen op grond van een neutraal criterium, toch een onderscheid op grond van geslacht tot gevolg heeft; het gaat daarbij dus om het vaststellen van de aanwezigheid van een indirect onderscheid (fase 1). Pas wanneer is aangetoond dat van een indirect onderscheid sprake is kan worden toegekomen aan de tweede fase van de toetsing: de beoordeling van de toelaatbaarheid of van de rechtvaardiging van het indirecte onderscheid. ${ }^{102}$

In deze paragraaf zal worden onderzocht op welke manier het Hof invulling geeft aan de eerste fase van de toetsing. Daarbij zal uitgebreid worden ingegaan op het door het Hof gehanteerde criterium voor de invulling van deze fase (de benadelingstoets) en op de rol die de vergelijkbaarheidstoets binnen deze toetsing soms nog blijkt te spelen.

99. Zie bijv. EHvJ 27 november 1997, zaak C-57/96, Meints, Jurispr. 1997, I-6689, punt 45 en 48, EHvJ 7 mei 1998, zaak C-350/96, Clean Car Autoservices, Jurispr. 1998, 1-3739, punt 31 en 34 . Zie verder EHvJ 3 februari 1982, gevoegde zaken 62 en 63/81, Seco, Jurispr. 1982, 223, punt 14.

100. Zie bijv. EHvJ 18 januari 1979, gev. zaken 110 en $117 / 78$, Van Wesemael, Jurispr. 1979, 35, punt 29 en EHvJ 18 maart 1980, zaak 52/79, Debauve, Jurispr. 1980, 833, punt 12

101. Zie bijv. EHvJ 28 november 1990, zaak C-379/87, Groener, Jurispr. 1989, 3967 en EHvJ 23 mei 1996, zaak C-237/94, O' Flynn, Jurispr. 1996, I-2617, punt 19 en 20.

102. Vgl. Prechal 1988, p. 88 . 
Benadeling als criterium voor de vaststelling van indirect onderscheid Het Hof heeft voor onderscheid op grond van geslacht een bijzonder criterium ontwik. keld voor het vaststellen van de aanwezigheid van indirect onderscheid: het criterium van benadeling. De inhoud van dit criterium en de mogelijkheden die het gebruik hiervan biedt komen goed tot uitdrukking in de volgende overweging uit het arrest Jørgensen: ${ }^{103}$

"Volgens vaste rechtspraak van het Hof betreffende zowel de beloningen of de socialezekerheidsuitkeringen als de toegang tot het arbeidsproces en de arbeidsvoorwaarden, houdt een nationale bepaling of regeling een indirecte discriminatie jegens vrouwelijke werknemers in wanneer zij, hoewel in neutrale bewoordingen gesteld, feitelijk veel meer vrouwen dan mannen benadeelt, tenzij dit verschil in behandeling wordt gerechtvaardigd door objectieve factoren die niets van doen hebben met discriminatie op grond van geslacht."

Voor het vaststellen van de aanwezigheid van indirect onderscheid is het blijkens deze overweging voldoende dat vaststaat dat een op zichzelf geslachtsneutrale regeling leidt tot de feitelijke situatie dat vrouwen worden benadeeld ten opzichte van mannen of andersom. Uit de geciteerde overweging blijkt bovendien dat het benadelingsvereiste bedoeld is als vervanging voor de vergelijkbaarheidstoets in de eerste fase van de toetsing: wanneer eenmaal is vastgesteld dat er sprake is van een benadeling zal het $\mathrm{Hof}$ (in de tweede toetsingsfase) nagaan of hiervoor een objectieve en redelijke rechtvaardiging bestaat.

Zoals in hoofdstuk 2 is aangegeven kan het benadelingsvereiste een interessant alternatief vormen voor de vergelijkbaarheidstoets; het is dan ook waardevol om nader aandacht te besteden aan de manier waarop het Hof in zijn rechtspraak aan dit vereiste vorm heeft gegeven.

\section{Inhoud van het benadelingscriterium}

Allereerst is van belang dat het Hof steeds vereist dat er sprake is van een feitelijke benadeling. De eiser kan dus niet volstaan met het opperen van veronderstellingen of het aanvoeren van algemeenheden, maar zal daadwerkelijk harde (liefst statistische) gegevens naar voren moeten brengen die zijn stelling ondersteunen. ${ }^{105}$ Het Hof heeft het

103. EHvJ 6 april 2000, zaak C-226/98, Jurispr. 2000, 1-2447

104. Punt 29; cursief toegevoegd. Dit is vaste rechtspraak, in die zin dat deze formulering in vrijwel ieder arrest over indirect onderscheid terugkeert. Een benadelingsvereiste kan zelfs al worden herkend in het eerste arrest waarin het Hof aannam dat er sprake was van indirect onderscheid, namelijk Jenkins (EHvJ 31 maart 1981, zaak 96/80, Jurispr. 1981, 911, punt 13). Inmiddels heeft er een codificatie van deze rechtspraak van het Hof plaatsgevonden: in Richtlijn 97/80/EG van de Raad van 15 december 1997 (Pb. EG 1998 L 14/6) inzake de bewijslast in gevallen van discriminatie op grond van het geslacht is in artikel 2 lid 2 vastgesteld, dat van ontoelaatbaar indirect onderscheid sprake is "wanneet een ogenschijnlijk neutrale bepaling, maatstaf of handelwijze een wezenlijk groter gedeelte van de leden van een geslacht benadeelt, tenzij die bepaling, maatstaf of handelwijze passend en noodzakelijk is en kan worden gerechtvaardigd door objectieve factoren die geen verband houden met het geslacht van de betrokkenen" (cursief toegevoegd).

105. Prechal 1993, p. 85; vgl. ook de codificatie van dit vereiste in artikel 4 van de in de vorige noot genoemde Bewijsrichtlijn. Het Hof lijkt hierin overigens niet altijd even streng te zijn: wanneer duidelijk is dat er sprake is van indirect onderscheid wordt er nauwelijks aandacht besteed aan het bewijs daar- 
vereiste van feitelijke benadeling in verschillende arresten nader uitgewerkt. Een handzame samenvatting van de rechtspraak op dit punt is te vinden in de volgende overweging uit het hierboven reeds geciteerde arrest Jørgensen: ${ }^{106}$

"[...] er [kan] slechts sprake van een indirecte discriminatie [...] zijn, indien de gegevens die op een dergelijke situatie wijzen, valabel zijn. Daartoe moeten die gegevens betrekking hebben op een voldoende groot aantal personen, mogen er geen zuiver toevallige of conjuncturele verschijnselen in tot uitdrukking komen, en moeten zij in het algemeen significant lijken." 107

Uit de rechtspraak van het Hof kan verder worden afgeleid dat cijfermatig bewijs niet altijd voldoende is om te kunnen spreken van indirect onderscheid: de aangetoonde benadeling moet bovendien daadwerkelijk relevant zijn in het licht van de inhoud van de regeling waarover wordt geklaagd. Een voorbeeld kan dit verduidelijken. In het arrest Kirsammer-Hack ${ }^{108}$ was een nationale regeling voor ontslagbescherming in het geding, die alleen gold voor bedrijven of kantoren waar meer dan vijf werknemers in dienst waren. Het probleem was dat bij het bepalen van het aantal werknemers alleen rekening werd gehouden met mensen die meer dan 10 uur per week of 45 uur per maand werkten. Volgens de verwijzende rechter werden vrouwen door deze regeling benadeeld bij het verkrijgen van een ontslagvergoeding: statistisch gezien kon worden aangetoond dat meer vrouwen dan mannen in deeltijd werkten. Het Hof overwoog naar aanleiding van deze stelling het volgende:

"De regeling leidt niet tot een verschil in behandeling tussen deeltijdwerknemers en andere werknemers, maar tussen enerzijds alle werknemers bij kleine ondernemingen die buiten de beschermingsregeling vallen en anderzijds alle werknemers die werkzaam zijn bij ondernemingen waarvoor deze regeling wel geldt omdat zij een groter aantal werknemers in dienst hebben. [...] Het door de verwijzende rechter genoemde percentage vrouwelijke deeltijdwerkers in Duitsland laat derhalve niet de conclusie toe, dat de betrokken bepaling een indirecte discriminatie van vrouwelijke werknemers bevat. Van een dergelijke discriminatie zou alleen sprake zijn als zou blijken dat kleine ondernemingen veel meer vrouwen dan mannen in dienst hadden. In casu moet worden vastgesteld, dat een dergelijke wanverhouding niet uit de aan het Hof verschafte gegevens blijkt."

Van belang is verder dat het Hof voor een specifiek aantal gevallen een nuancering heeft aangebracht in de aan het benadelingscriterium verbonden bewijslast, in die zin dat in bepaalde omstandigheden de aan het aantonen van een benadeling gestelde eisen iets worden afgezwakt. De noodzaak voor een dergelijke vermindering van de bewijslast is volgens het Hof aanwezig wanneer een werkgever een zodanig ondoorzichtig

van. Een voorbeeld is het arrest Schnorbus, dat betrekking had op een toelatingsregeling voor een voorbereidende juridische opleiding. In deze regeling was een bepaling opgenomen die ertoe strekte dat mensen die hun verplichte of vervangende dienstplicht hadden vervuld voorrang konden krijgen bij de toelating tot de opleiding. Nu de dienstplicht alleen gold voor mannen, stelde het Hof dat deze voorrangsbepaling indirect onderscheid op grond van geslacht opleverde, aangezien alleen mannen hierdoor voor het voordeel in aanmerking kwamen (EHvJ 7 december 2000, zaak C-79/99, Jurispr. 2000, I10997, punt 38).

106. EHvJ 6 april 2000, zaak C-226/98, Jurispr. 2000, 1-2447

107. Punt 33. Zie ook EHvJ 27 oktober 1993, zaak C-127/92, Enderby, Jurispr. 1993, 1-5535, punt 16 en 17.

108. EHvJ 30 november 1993, zaak C-189/91, Jurispr. 1993, I-6185

109. Punt 26, 29, 30 en 31 
beloningsstelsel heeft vastgesteld, dat het niet mogelijk is om te achterhalen welke criteria er aan de geconstateerde verschillen in beloning precies ten grondslag hebben gelegen. In zulke omstandigheden is het voor een werknemer bijzonder moeilijk om te bewijzen dat het beloningsverschil feitelijk is terug te voeren op het geslacht van de benadeelde groep. Voor deze situatie heeft het Hof de volgende bewijsregeling aangenomen:

"[...] wanneer een onderneming een stelsel van beloning toepast dat wordt gekenmerkt door een volstrekt gebrek aan doorzichtigheid, dient de werkgever te bewijzen dat zijn beloningspraktijk niet discriminerend is, wanneer de vrouwelijke werknemer met betrekking tot een relatief groot aantal loontrekkenden aantoont, dat de gemiddelde beloning voor vrouwelijke werknemers lager is dan die voor mannelijke werknemers."

Uit deze verschuiving van de bewijslast blijkt dat het benadelingsvereiste voldoende flexibiliteit biedt om rekening te houden met de individuele omstandigheden van het geval. In dat opzicht vormt het benadelingsvereiste een goed alternatief voor de vergelijkbaarheidstoets, waarbij een dergelijke verschuiving eveneens denkbaar is.

Tenslotte is van belang dat het Hof steeds heeft vereist dat er een veel groter of wezenlijk groter aantal vrouwen dan mannen (of, vanzelfsprekend, een veel groter aantal mannen dan vrouwen) door de litigieuze regeling wordt geraakt."' Hoewel dit criterium voldoende ruimte laat om bijzondere omstandigheden bij de beoordeling te betrekken, heeft het als nadeel dat het de nationale rechter weinig houvast biedt. Helaas heeft het Hof dit criterium niet nader gespecificeerd: de waardering van het aangevoerde bewijs wordt vrijwel per definitie aan de nationale rechter overgelaten. ${ }^{112}$ Wel heeft het Hof dit criterium in het recente arrest Seymour-Smith in een belangrijk opzicht genuanceerd: blijkens deze uitspraak is het ook voldoende als de statistische gegevens over een langere periode een minder groot, maar aanhoudend en vrij constant verschil in behandeling aantonen. ${ }^{13}$

\section{Gebruik van de vergelijkbaarheidstoets bij toepassing van het benadelingsvereiste}

Ter afsluiting van deze paragraaf is het van belang om aandacht te besteden aan het arrest Gruber ${ }^{114}$, waarin het Hof, afwijkend van zijn eerdere rechtspraak, een aspect van

110. EHvJ 27 oktober 1993, zaak C-127/92, Enderby, Jurispr. 1993, 5535, punt 14. Deze benadering werd al eerder gekozen in EHvJ 17 oktober 1989, zaak 109/88, Danfoss, Jurispr. 1989, 3199, punt 10, 13, 15 en 16. Doorslaggevend voor deze verzachting van de bewijslast lijkt voor het Hof vooral te zijn dat het nuttige effect van het gelijkheidsbeginsel zou worden ondermijnd als werknemers bij dit soort ondoorzichtige systemen zelf moeten aangeven welke criteria hebben geleid tot een benadeling. Zie voor een toepassing ook EHvJ 26 juni 2001, zaak C-381/99, Brunnhofer, Jurispr. 2001, I-4961, punt 54-56.

111. Zie uitgebreid Herbert 1994, p. 120-122. Zie ook artikel 2 lid 2 van de Bewijsrichtlijn (RI. 97/80/EG), waarin gesproken wordt van een benadeling van een "wezenlijk groter gedeelte" van de leden van eén geslacht. Van belang is overigens dat in de inmiddels aangenomen, maar nog niet in werking getreden Rassenrichtlijn (RI. 2000/43/EG van de Raad van 29 juni 2000) een minder strenge eis wordt gesteld aan de mate van benadeling: voldoende is daar volgens artikel 2 lid 2 sub b dat de betrokken groep "bijzonder" wordt benadeeld. Zie over dit verschil nader Waddington/Bell 2001, p. 593/594.

112. Vgl. Herbert 1994, p. 122-123, Prechal 1993, p. 85, Burkens/Kummeling 1991, p. 8 en Drijber/Prechal 1997, p. $138 / 139$.

113. EHvJ 9 februari 1999, zaak C-167/97, Jurispr. 1999, I-623, punt 61

114. EHvJ 14 september 1999, zaak C-249/97, Jurispr. 1999, I-5295. Vgl. ook Drijber/Prechal, die al in 
vergelijkbaarheid aan de toetsing aan het benadelingscriterium toevoegde. In de betrokken zaak werd geklaagd over een Oostenrijkse regeling voor ontslagvergoeding waarin onderscheid werd gemaakt tussen drie situaties van ontslag: ontslag wegens dringende redenen, verband houdend met arbeidsomstandigheden en -voorwaarden, ontslag wegens kinderzorg, en ontslag zonder dringende redenen (vrijwillig ontslag). Volgens de betrokken regeling werd in het eerste geval een volledige ontslagvergoeding toegekend, in de tweede situatie werd deze vergoeding gehalveerd en in het derde geval werd in het geheel geen ontslagvergoeding toegekend. Gruber stelde dat door deze regeling een indirect onderscheid op grond van geslacht werd veroorzaakt. Door de regeling werden mensen die hun contract opzeggen wegens de noodzaak om voor hun kinderen te zorgen immers benadeeld ten opzichte van de mensen die om andere dringende redenen hun contract opzeggen. Doordat de groep mensen die ontslag nemen omwille van de opvoeding van de kinderen grotendeels uit vrouwen bestaat, had de regeling volgens Gruber tot gevolg dat zij feitelijk werd benadeeld ten opzichte van mannen. De Oostenrijkse regering stelde daarentegen dat er helemaal geen sprake was van een benadeling op grond van geslacht. Volgens haar zou in dit geval niet moeten worden gerefereerd aan de groep mensen die wegens dringende redenen ontslag neemt, maar aan de groep die zonder dringende redenen zijn contract opzegt. In dat licht bezien werden vrouwen door de regeling zelfs in overwegende mate bevoordeeld. Het Hof gaf in deze zaak het volgende oordeel:

"Welke van deze redeneringen [die van Gruber dan wel die van de Oostenrijkse regering, JHG] juist is, hangt ervan af of de situatie van werknemers die ontslag nemen om voor hun kinderen te zorgen qua opzet en oorzaak vergelijkbaar is met die van werknemers die ontslag nemen om dringende redenen [...]. Uit de gegeven voorbeelden komt naar voren, dat de daarin [in de limitatieve opsomming van dringende redenen, JHG] bedoelde situaties gemeen hebben dat zij verband houden met de arbeidsvoorwaarden binnen de onderneming of met het gedrag van de werkgever, waardoor voortzetting van de arbeid volstrekt onmogelijk wordt, zodat van de werknemer niet kan worden verlangd dat hij zijn arbeidsverhouding voortzet, zelfs niet gedurende de normale opzeggingstermijn. Deze situaties verschillen dan ook qua opzet en oorzaak van die van een werknemer als Gruber. Bijgevolg is de uitsluiting van een werknemer als Gruber geen indirect discriminerende maatregel." 115

Blijkens deze overwegingen maakte het Hof gebruik van een soort vergelijkbaarheidstoets: voordat werd nagegaan of er daadwerkelijk sprake was van een benadeling controleerde het of de groep ten opzichte van wie Gruber zich benadeeld voelde zich wel in een vergelijkbare positie bevond. ${ }^{116}$ Gezien het feit dat het Hof een dergelijke

1997 betoogden dat dit aspect in de rechtspraak van het Hof zou moeten worden opgenomen en impliciet ook al zichtbaar was (p. 137). In andere arresten lijkt het Hof wel gebruik te maken van een vergelijkbaarheidstoets, maar komt deze in wezen neer op een toetsing aan het benadelingscriterium. Zie bijv. het arrest Bötel, waarin het Hof sprak over een "andere" behandeling van deeltijdwerkers dan van voltijdwerkers (EHvJ 4 juni 1992, zaak C-360/90, Jurispr. 1992, 1-3589, punt 16 en 17).

115. Punt $31-34$

116. Van dezelfde methodiek maakt het Hof, hoewel in minder vergaande mate, ook gebruik in andere situaties. Zo werd in de zaak Enderby geklaagd over een situatie waarin logopedisten minder goed werden betaald dan bij hetzelfde bedrijf werkzame apothekers. Nu de groep apothekers voomamelijk uit mannen bestond en de groep logopedisten voomamelijk uit vrouwen, meende eiseres dat zij op grond van haar geslacht werd benadeeld. Het Hof voerde ook in deze zaak een soort vergelijkbaar- 
vergelijkbaarheidstoets niet eerder zo expliciet in zijn rechtspraak heeft verwerkt kan een verklaring voor deze benadering waarschijnlijk alleen worden gevonden in de typische feitenconstellatie: hierin kon zowel een benadeling als een bevoordeling aannemelijk worden gemaakt. Gezien deze achtergrond is het nog maar de vraag of het de bedoeling van het Hof is om in de toekomst vaker van deze methodiek gebruik te maken.

In ieder geval kan uit deze uitspraak blijken dat het invoegen van het vergelijkbaarheidsaspect niet zonder meer wenselijk is. Het gevolg hiervan is namelijk dat de aan de vergelijkbaarheidstoets verbonden nadelen, die worden vermeden door het benadelingscriterium tot toetsingsingang te kiezen, toch weer in de toetsing worden ingevoerd. ${ }^{1{ }^{17}}$ Zo blijkt uit de geciteerde overwegingen dat het vinden en goed toepassen van een geschikt vergelijkingscriterium bijzonder lastig is en dat de toepassing van de vergelijkbaarheidstoets overlappingen vertoont met de beoordeling van de rechtmatigheid van het doel in het kader van de rechtvaardigingstoets. Daarnaast is het bezwaarlijk dat belangrijke toetsingselementen als de beoordeling van het doel, de geschiktheid en de noodzakelijkheid niet aan de orde komen, wanneer een regeling toelaatbaar wordt geacht zodra er geen vergelijkbaarheid kan worden aangetoond. ${ }^{118}$ Het Hof had er dan ook beter aan gedaan om het bewijs van benadeling door Gruber te accepteren en pas in het kader van de beoordeling van de toelaatbaarheid van het onderscheid aandacht te besteden aan de door de regering aangevoerde argumenten. ${ }^{119}$

\section{Conclusie}

Uit het voorgaande kan worden afgeleid dat het Hof bij de toetsing van onderscheid op grond van geslacht vrijwel nooit gebruik maakt van het vergelijkbaarheidscriterium: in

heidstoets uit: beoordeeld werd of de functies van logopediste en apotheker wel gelijkwaardig zijn (EHvJ 27 oktober 1993, zaak C-127/92, Jurispr. 1993, I-5535). Deze toetsing lijkt voor de hand liggend, maar is strikt genomen niet nodig: de aspecten die bij de vergelijkbaarheid aan de orde komen (zoals de inhoud van de functie en de daarbij behorende verantwoordelijkheid), kunnen even goed ook in de rechtvaardigingstoets worden betrokken, met name bij de beoordeling van de redelijkheid van het nagestreefde doel.

117. Zie voor de bespreking van deze nadelen nader hoofdstuk 2, paragraaf 4.3.1 en 4.3.2. Problematisch is vooral dat het Hof aan het ontbreken van de vergelijkbaarheid direct de conclusie verbindt dat het onderscheid toelaatbaar is en alleen een rechtvaardigingstoets uitvoert wanneer geconstateerd wordt dat de gevallen relevante overeenkomsten vertonen (benadering drie). Daardoor is het niet mogelijk om na te gaan of er, ondanks de verschillen tussen de gevallen, niet toch sprake is van een onredelijke ongelijkheid, bijvoorbeeld door ongeschiktheid of onevenredigheid van de gekozen classificatie.

118. Dat het toch belangrijk kan zijn om aan deze elementen te toetsen blijkt uit de conclusie van A-G Léger bij deze uitspraak. Léger had, op grond van een redenering waarop die van het Hof deels gebaseerd lijkt te zijn, aangenomen dat er wel sprake was van vergelijkbaarheid en dat op basis van statistische gegevens een benadeling van vrouwen ten opzichte van mannen was aangetoond. Vervolgens moest hij dan ook de vraag beantwoorden of de indirecte discriminatie gerechtvaardigd was. Léger kwam tot de conclusie dat dit niet zo was, omdat een gerechtvaardigd doel zou ontbreken: door de regering was weliswaar aangevoerd dat de vergoeding voor mensen die ontslag nemen wegens het opvoeden van kinderen als een vriendelijke tegemoetkoming is bedoeld, maar daarmee was volgens $L t$ ger onvoldoende gerechtvaardigd waarom slechts de helft van de vergoeding werd verleend als het ontslag feitelijk werd ingegeven door de onmogelijkheid om kinderopvang te regelen (punt 60 van de conclusie). Wanneer het Hof geen gebruik had gemaakt van de vergelijkbaarheidsvraag had het zich in ieder geval ook over dit punt moeten uitspreken.

119. Zie ook Ellis 2000, p. 1411/1412. 
de meeste gevallen volstaat het Hof met een toetsing aan het vereiste van benadeling. Uit de verschillende hiervoor weergegeven vereisten blijkt dat een dergelijke benadeling kan en moet worden aangetoond op grond van statistische of duidelijke feitelijke gegevens. De vaststelling van de benadeling heeft daardoor een objectief karakter: de rechter heeft weinig ruimte om zijn eigen opvattingen mee te laten wegen in zijn oordeel.

Met het oog op de rechtspraak van het Hof kan bovendien niet worden volgehouden dat het ontbreken van het vergelijkbaarheidscriterium in de toetsing van het Hof leidt tot een duidelijk gemis of dat dit resulteert in slechtere toetsingsuitkomsten. Zoals hiervoor al is opgemerkt kan uit een arrest als Gruber, waarin expliciet gebruik wordt gemaakt van de vergelijkbaarheidstoets, eerder worden afgeleid dat deze toets onwenselijke consequenties heeft: vooral het feit dat hierdoor niet meer kan worden getoetst aan voor de toetsingsuitkomst belangrijke elementen als geschiktheid, noodzakelijkheid en proportionaliteit is bijzonder problematisch. Voorlopig kan dan ook worden geconcludeerd dat de vaststelling van een benadeling een geschikte vervanging oplevert voor de vergelijkbaarheidstoets.

\subsubsection{Vergelijkbaarheid en benadeling op het gebied van de landbouw}

\section{De vergelijkbaarheidstoets in de rechtspraak over het landbouwbeleid}

Zoals in paragraaf 2.1.2 is aangegeven vormt de vergelijkbaarheidstoets in de meeste arresten over de landbouw een belangrijk onderdeel van de toetsing. Dit blijkt vooral uit de wijze waarop het $\mathrm{Hof}$ in het overgrote deel van zijn uitspraken uitdrukking heeft gegeven aan het gelijkheidsbeginsel:

"Artikel 40, lid 3, tweede alinea [nu artikel 34 lid 2, JHG], van het Verdrag, dat in het kader van het gemeenschappelijk landbouwbeleid betrekking heeft op het verbod van discriminatie, is slechts de specifieke uitdrukking van het algemene gelijkheidsbeginsel dat verlangt, dat vergelijkbare situaties niet verschillend en verschillende situaties niet gelijk worden behandeld, tenzij een dergelijke behandeling objectief gerechtvaardigd is," ${ }^{120}$

In zijn rechtspraak blijkt het Hof verschillende criteria te hebben ontwikkeld die behulpzaam kunnen zijn bij de beoordeling van de vergelijkbaarheid. Sommige van deze criteria zijn zo algemeen dat zij in vrijwel alle uitspraken impliciet of expliciet terugkomen, terwijl enkele andere specifieker zijn en alleen zullen worden toegepast als dat mogelijk en passend is in de omstandigheden van het geval. In het hiernavolgende zullen eerst drie samenhangende criteria worden besproken die worden gehanteerd bij een specifieke vorm van onderscheid, namelijk ongelijke behandeling van (producenten van) landbouwproducten. ${ }^{121}$ Vervolgens zal aandacht worden besteed aan de meer algemene beoordelingscriteria.

\section{Vergelijkbaarheid bij ongelijke behandeling van landbouwproducten}

Een regelmatig toegepast criterium bij klachten over ongelijke behandeling van landbouwproducten houdt in dat de te vergelijken producten onderling uitwisselbaar of

120. EHvJ 13 april 2000, zaak C-292/97, Karlsson e.a., Jurispr. 2000, 1-2737, punt 39

121. Vgl. Boest 1984, p. 123: het gelijkheidsbeginsel richt zich op de ongelijke behandeling van producten, niet op de persoon van de producent daarvan. 
vervangbaar moeten zijn of op zijn minst met elkaar moeten concurreren. ${ }^{12}$ Een voorbeeld van een toepassing van dit criterium is te vinden in de Isoglucosezaken. ${ }^{12}$ Deze zaken hadden betrekking op een productierestitutie voor zetmeelproducten, die was ingesteld om ervoor te zorgen dat producenten van zetmeel konden concurreren met chemisch gefabriceerde producten met vergelijkbare toepassingsmogelijkheden. Na een bepaalde periode werden de restituties verhoogd voor alle zetmeelproducten, behalve voor isoglucose, een uit zetmeel vervaardigd vervangingsproduct voor suiker. De isoglucoseproducenten achtten dit onderscheid onverenigbaar met artikel 34 lid 2. Het Hof overwoog dienaangaande, dat

"[...] moet worden nagegaan of isoglucose zich in een met andere produkten van de zetmeelindustrie vergelijkbare situatie bevindt in dier voege dat deze produkten kunnen worden vervangen door isoglucose bij het specifieke gebruik dat normaal van dit produkt wordt gemaakt. [...] [V] aststaat dat er geen enkele concurrentie is tussen zetmeel en isoglucose of tussen isoglucose en de andere zetmeelprodukten, tenzij eventueel glucose. [...] [U]it de stukken blijkt, dat door de aanzienlijke verschillen in zoetkracht tussen isoglucose enerzijds en glucose anderzijds deze twee producten een verschillende toepassing vinden, hetgeen uitsluit dat zij zich in een situatie van wederzijdse concurrentie en vergelijkbaarheid bevinden." 124

Het Hof achtte de ongelijke behandeling van de producenten van isoglucose en andere zetmeelproducten dan ook toelaatbaar.

De onderlinge concurrentie of zelfs vervangbaarheid van de producten blijkt echter nog niet voldoende te zijn om te kunnen spreken van een relevante vergelijkbaarheid. Een tweede belangrijk criterium is dat de te vergelijken producten in dezelfde marktordening moeten zijn ondergebracht. ${ }^{125}$ Dit blijkt uit de Kerstboterzaken, waarin een verordening in het geding was op grond waarvan in de kerstperiode overtollige voorraden boter tegen de halve prijs op de markt moesten worden aangeboden. ${ }^{126}$ Voor margarine, bij het normale gebruik in de keuken duidelijk een vervangingsproduct voor boter, was

122. Boest 1984, p. 126, Barents 1994 (II), p. 530 en Tridimas 1999 (I), p. 51 ; de laatste geeft aan dat bij de toepassing dit criterium geen al te hoge eisen worden gesteld; in de meeste gevallen is het voldoende wanneer de producten potentieel in een mededingingsverhouding staan.

123. EHvJ 25 oktober 1978, gev. zaken 103 en 145/77, Royal Scholten-Honig, Jurispr. 1978, 2037

124. Punt 28-30. Het Hof kwam in dezelfde zaak wel tot de conclusie dat isoglucose en suiker vergelijkbart producten zijn, zodat de verschillende behandeling van deze producten een ongelijke behandeling opleverde die gerechtvaardigd moest worden. Het geciteerde criterium is ook in eerdere zaken toegepast, zoals in EHvJ 19 december 1977, gev. zaken $117 / 76$ en 16/77, Ruckdeschel, Jurispr. 1977, 1753, punt 8 en EHvJ 13 juli 1978, zaak 8/78, Milac II, Jurispr. 1978, 1721, punt 26. Zie verder EHvJ 14 januarí 1981 , zaak 35/80, Denkavit Nederland BV , Jurispr. 1981, 45, punt 10 (waaruit blijkt dat de onderlinge vervangbaarheid ook afhankelijk is van de context, zoals de "gebruiksfase" van het product), EHvJ II maart 1987, gev. zaken 279, 280, 285 en 286/84, Walter Rau Lebensmittelwerke ("Kerstboterzaken"), Jurispr. 1987, 1069, punt 27 en EHvJ 26 juni 1995, zaak C-56/94, SCAC, Jurispr. 1995, I-1769, punt 30 (waaruit blijkt dat ook een verschil in gebruiksmogelijkheden van één en hetzelfde product kan leiden tot onvergelijkbaarheid). Bovendien kan vergelijkbaarheid komen te ontbreken als er sprake is van een ander gebruik van een product dan gebruikelijk zou zijn (EHvJ 28 maart 1979, zaak 90/78, Granaria, Jurispr. 1979, 1081, punt 9); vgl. Tridimas 1999 (I), p. 52.

125. Vgl. Barents 1994 (ii), p. 539 en Boest 1984, p. 124.

126. EHvJ 11 maart 1987, gev. zaken 279, 280, 285 en 286/84, Walter Rau Lebensmittelwerke ("Kerstboterzaken"), Jurispr. 1987, 1069 
in de verordening geen compensatie voorzien, hetgeen leidde tot een aanzienlijk verlies aan inkomsten voor de margarineproducenten. Het Hof gaf toe dat de producten onderling vergelijkbaar waren, maar stelde vervolgens dat:

"[...] de door de Raad vastgestelde gemeenschappelijke ordening der markten in de sector zuivel en zuivelprodukten, waaronder boter valt, in een heel andere context is ontworpen dan die in de sector plantaardige vetten." 127

Alleen al door het verschil in de betrokken marktordeningen was het dus niet meer mogelijk om te spreken van relevante vergelijkbaarheid, zodat de ongelijke behandeling toelaatbaar kon worden geacht.

Een derde vereiste in deze specifieke groep gevallen blijkt tenslotte te zijn dat de producten binnen de marktordening een vergelijkbare functie moeten hebben. Dit blijkt bijvoorbeeld uit het al genoemde arrest Biovilac ${ }^{128}$, dat betrekking had op de productie van diervoeders. Zowel wei, een afvalproduct bij het maken van kaas, als magere melkpoeder kunnen dienen als grondstof voor bepaalde diervoeders. Door een aantal verordeningen van de Raad en de Commissie werd echter alleen steun verleend aan magere melkpoeder als grondstof. Het Hof stelde ten aanzien van deze ongelijke behandeling het volgende:

"[...] De toekenning van directe of indirecte steun voor magere-melkpoeder is objectief gerechtvaardigd wegens de aard van dit produkt en de plaats die het daarom in de gemeenschappelijke ordening der markten in de sector melk en zuivelprodukten inneemt als marktondersteunend element, terwijl wei niet dezelfde kenmerken vertoont. Dit is namelijk een bij de kaasbereiding verkregen afvalprodukt, dat in beginsel door de betrokken kaasproducenten wordt verwijderd." ${ }^{\prime 29}$

Het Hof is niet altijd consequent in de toepassing van deze criteria. In een groot aantal gevallen wordt er door partijen getwist over de onderlinge vervangbaarheid van de producten, maar besteedt het Hof hieraan in het geheel geen aandacht. ${ }^{130}$ In andere gevallen acht het Hof niet zozeer de gebruiksmogelijkheden van de producten doorslaggevend, maar eerder het bestaan van verschillen in economische omstandigheden. ${ }^{131}$ Verder blijkt dat bij de toepassing van de vergelijkbaarheidstoets soms niet wordt gekeken naar de vergelijkbaarheid van het eindproduct, maar alleen naar de gebruikte

127. Punt 29. Een vergelijkbare opvatting is te vinden in EHvJ 13 juni 1978, zaak 139/77, Dekavit Futtermittel GmbH, Jurispr. 1978, 1317, punt 15 en EHvJ 28 oktober 1982, gev. zaken 292 en 293/8, Loiret \& Haentjens e.a., Jurispr. 1982, punt 24 . Het betreft hierbij dus niet zozeer een feitelijk, maar eerder een juridisch vergelijkingscriterium; zie Timmermans 1982, p. 435.

128. EHvJ 6 december 1984, zaak 59/83, Biovilac, Jurispr. 1984, 4057

129. Punt 19. Zie voor een vergelijkbare overweging de al eerder genoemde Kerstboterzaken (EHvJ 11 maart 1987, gev. zaken 279, 280, 285 en 286/84, Jurispr. 1987, 1069), punt 30 . Het Hof stelde in deze zaak dat margarine binnen de gemeenschappelijke ordening voor oliēn en vetten geen ondersteunende plaats inneemt, terwijl dit wel het geval is voor boter binnen de sector zuivelproducten.

130. Bijv. EHvJ 24 oktober 1973, zaak 43/72, Merkur-Außenhandels GmbH, Jurispr. 1973, 1055, waarin partijen discussieerden over de vraag of er relevante verschillen bestaan tussen op basis van gerst en op basis van andere granen verwerkte producten (zie Conclusie A-G Mayras, p. 1089), maar het Hof een rechtvaardigingstoets toepaste.

131. Bijv. EHvJ 12 juli 1979, zaak 166/78, Italië/Raad, Jurispr. 1979, 2575, punt 20 
grondstoffen. ${ }^{132}$ Niettemin blijkt het Hof in het merendeel van de gevallen gebruik te maken van de hiervoor besproken criteria.

Het gebruik van de hierboven genoemde, opvallend strenge criteria kan worden verklaard vanuit de achtergrond van het gelijkheidsbeginsel in de landbouw. In het gemeenschappelijk landbouwbeleid bestaat een bijzondere situatie, in die zin dat ieder ingrijpen in een bepaalde landbouwsector vergaande consequenties kan hebben voor producenten die in andere landbouwsectoren werkzaam zijn; bovendien kunnen landbouwmaatregelen leiden tot veranderingen in de mededingingsverhoudingen tussen zeer uiteenlopende producten. ${ }^{13}$ Vooral met dit laatste aspect zal het Hof bij zijn toetsing voortdurend rekening moeten houden. Wanneer door een gemeenschapsinstelling wordt ingegrepen in een verhouding tussen concurrerende producten, zal de concurrentiepositie van het ene product al snel sterker worden dan die van het andere. Zou het Hof in een dergelijk geval stellen dat het gelijkheidsbeginsel aan de ingreep in de weg staat, dan is het verbod van ongelijke behandeling vrijwel gelijk te stellen aan een verbod om de mededinging te verstoren. ${ }^{134}$ Het ingrijpen in de normale concurrentieverhoudingen is bij het voeren van een intensief landbouwbeleid echter veelal onvermijdelijk. Een strikte toepassing van het gelijkheidsbeginsel zou dan ook tot gevolg hebben dat de doelstellingen van de gemeenschapsinstellingen voortdurend zouden worden doorkruist en dat de goede werking van de interne landbouwmarkt zouden worden bemoeilijkt. Het Hof stelt zich daarom terughoudend op als het gaat om het beoordelen van de toelaatbaarheid van ingrepen in het landbouwbeleid. Een gebruik van de vergelijkbaarheidstoets als hierboven beschreven vormt een duidelijke illustratie van deze terughoudendheid: gezien de inhoud van de door het Hof opgestelde criteria zal het bijna nooit tot de conclusie kunnen komen dat producten op relevante punten vergelijkbaar zijn, zodat een toepassing van de vergelijkbaarheidstoets vrijwel steeds leidt tot toelaatbaarheid van de litigieuze classificatie. De uitkomst van de toetsing aan het gelijkheidsbeginsel staat door de keuze voor het toepassen van de vergelijkbaarheidstoets dan ook al bijna op voorhand vast.

Een dergelijk gebruik van de vergelijkbaarheidstoets leent zich duidelijk niet voor een meer algemene toepassing. Van belang is dat het Hof zichzelf hierdoor in veel gevallen de mogelijkheid ontneemt om een oordeel uit te spreken over de doelstellingen van het onderscheid of over de redelijkheid van de keuze van een bepaalde classificatie om dit doel te bereiken. Juist een (marginale) toetsing van die elementen kan echter heel belangrijk zijn, niet alleen omdat hierdoor meer bescherming wordt geboden aan degenen die door de classificatie worden benadeeld, maar ook omdat het Hof hierdoor in de

132. Zie EHvJ 8 april 1992, zaak C-256/90, Mignini, Jurispr. 1992, I-2651, waarin sprake was van een verschillende behandeling van diervoeders en olie, twee op gebruiksniveau duidelijk niet vergelijkbare producten, die echter gemaakt werden uit dezelfde grondstof: sojabonen. Vgl. Boest 1984, p. 127.

133. Barents 1994 (II), p. $532 / 533$

134. De nauwe samenhang tussen het verbod op mededingingsverstoringen en het gelijkheidsbeginsel is ook door het Hof erkend. Zie bijv. EHvJ 17 juli 1959, gev. zaken 32 en 33/58, SNUPAT, Jurispr. 1958-59, 305 , waarin het Hof stelde, "[...] dat elke bemoeiing waarvan het doel of gevolg is, dat de concurrentic op kunstmatige wijze en in belangrijke mate wordt vervalst, als discriminatoir en strijdig met het Ver. drag moet worden beschouwd [...]" (p. 328). In deze zin ook A-G Reischl in zijn conclusie bij EHv] 12 juli 1979, zaak 166/78, Ltalie/Raad, Jurispr. 1979, 2575, op p. 2616, en EHvJ 10 maart 1998, zask C-122/95, Duitsland/Raad (Bananen II), Jurispr. 1998, I-973, punt 62. 
gelegenheid is om, op een afstand, na te gaan of de communautaire doelstellingen wel kunnen worden bereikt.

\section{Vergelijkbaarheid bij andere gevallen van ongelijke behandeling in de landbouw}

De uitspraken over ongelijke behandeling van landbouwproducten maken echter slechts een relatief klein deel uit van alle rechtspraak over het gelijkheidsbeginsel in de landbouw. Er zijn daarnaast talrijke uitspraken gedaan over ongelijke behandeling van producenten (zoals onderscheid tussen melkveehouders op basis van de omvang van hun productie) ${ }^{135}$, over ongelijkheden in importvoorwaarden voor verschillende landen $^{136}$, over differentiaties in regelingen naar gelang de lidstaat of regio waarin de productie plaatsvindt ${ }^{137}$ en over verschillen in wisselkoersen die leidden tot een benadeling van producenten in bepaalde lidstaten ${ }^{138}$. Ook bij deze zaken blijkt de vergelijkbaarheidstoets steeds een belangrijke rol te spelen. Gezien het grote verschil in karakter van de verschillende situaties waarin een beroep op het gelijkheidsbeginsel mogelijk is, heeft het Hof voor de beoordeling van de vergelijkbaarheid enkele algemene criteria geformuleerd. Zo acht het Hof het van belang dat bij deze beoordeling geen rekening wordt gehouden met alle omstandigheden waarin de betrokken ondernemingen, producenten, fabrikanten, et cetera, zich bevinden:

"[d]e opvatting, dat bij elke vergelijking tussen verschillende ondernemingen rekening moet worden gehouden met alle omstandigheden waarin deze zich bevinden, heeft tot resultaat dat elke onderneming alleen met zichzelf kan worden vergeleken [...]."139

De gevallen hoeven dus slechts vergelijkbaar te zijn in bepaalde opzichten. Om te bepalen of dit het geval is heeft het Hof al in 1971 het volgende criterium vastgesteld: ${ }^{140}$

“[...] De vergelijkbaarheid [...] moet worden beoordeeld aan de hand van de doelstellingen van de communautaire landbouwregeling." ${ }^{\prime \prime 1}$

135. Bijv. EHvJ 17 mei 1988, zaak 84/87, Erpelding, Jurispr. 1988, 2665, EHvJ 10 januari 1992, zaak C177/90, Kühn, Jurispr. 1992, 1-35, EHvJ 19 maart 1992, zaak C-311/90, Hierl, Jurispr. 1992, 1-2061 en EHvJ 13 april 2000, zaak C-292/97, Karlsson e.a., Jurispr. 2000, I-2737

136. Bijv. EHvJ 15 juli 1982, Edeka Zentrale AG, Jurispr. 1982, 2745.

137. Bijv. EHvJ II juli 1974, zaak 11/74, Union des Minotiers de la Champagne, Jurispr. 1974, 877, EHvJ 27 september 1979, zaak 230/78, Eridania, Jurispr. 1979, 2749, EHvJ 15 september 1982, zaak 106/81, Julius Kind, Jurispr. 1982, 2885 en EHvJ 13 december 1984, zaak 106/83, Sermide, Jurispr. 1984, 4209

138. Bijv. EHvJ 21 februari 1979, zaak 138/78, Stölting, Jurispr. 1979, 713

139. EHvJ 10 mei 1960, gev. zaken 3-18, 25 en 26/58, Barbara Erzbergbau AG e.a. tegen Hoge Autoriteit van de EGKS, Jurispr. 1960,381 , op p. $411 / 412$

140. Het Hof sprak al in 1956 een soortgelijk, maar minder duidelijk oordeel uit: het Hof stelde dat het criterium van vergelijkbaarheid een betrekkelijk en wisselend karakter heeft en de betekenis afhankelijk is van het gebied waarop het wordt toegepast. Met het oog daarop vond het Hof dat het criterium moest worden verduidelijkt door het resultaat te toetsen aan hetgeen door het Verdrag is gewild (EHvJ 23 april 1956, gev. zaken 7 en 9/54, Groupement des Industries Siégurgiques Luxemburgeoises, Jurispr. 1945-56, 86, op p. 96). Zie hierover Sundberg-Weitman 1977, p. 58 en 59.

141. EHvJ 27 oktober 1971, zaak 6/71, Rheinmühlen Dïsseldorf, Jurispr. 1971, 823, punt 14; vgl. ook reeds EHvJ 10 mei 1960, gev. zaken 3-18, 25 en 26/58, Barbara Erzbergbau AG e.a., Jurispr. 1960, 381, op p. 413. Ook de verschillende Advocaten-Generaal hebben van dit criterium gebruik gemaakt: zie bijv. A-G Lagrange in zijn conclusie bij de Koelkastenzaak, EHvJ 17 juli 1963, zaak 13/63, Italiē/Commissie, Jurispr. 1963, 375, op p. 400 en A-G Capotorti in zijn conclusie bij het arrest Ruckde- 
Door deze uitspraak wordt de in hoofdstuk 2 reeds geopperde gedachte bevestigd dat het vaststellen van een vergelijkingsmaatstaf en het bepalen van het doel van de regeling grotendeels overeenkomen.

Van belang is verder dat het Hof lijkt te accepteren dat ook in het kader van de verge. lijkbaarheidstoets aandacht moet worden geschonken aan de vraag of het doel van de regeling, de vergelijkingsmaatstaf, wel gerechtvaardigd is. ${ }^{142}$ Dit blijkt bijvoorbeeld uit een vroege uitspraak van het Hof over het EGKS-Verdrag, waarin de redelijkheid van het hanteren van een bepaald vergelijkingscriterium in een door de Hoge Autoriteit vastgestelde regeling werd aangevochten. ${ }^{13}$ Het Hof stelde daarover,

"dat het [...] slechts dan bezwaar kan maken tegen deze keuze indien blijkt, dat de Hoge Autoriteit de objectieve grenzen heeft overschreden die het Verdrag aan haar optreden stelt." "14

Nadat het had vastgesteld dat aan deze voorwaarde in deze zaak niet was voldaan formuleerde het Hof de volgende conclusie:

"[...] verzoeksters [hebben] bijgevolg niet [...] bewezen, dat het in de basisbeschikkingen gekozen criterium onjuist of willekeurig is of op zichzelf tot discriminaties leidt." ${ }^{\text {.14 }}$

Vergelijkbaarheid en objectieve rechtvaardiging komen door dergelijke bewoordingen wel heel dicht bij elkaar te liggen.

\section{Het benadelingsvereiste in de rechtspraak over het landbouwbeleid}

Ook op het gebied van de landbouw heeft het Hof in een enkel arrest gebruik gemaakt van het in de vorige paragraaf beschreven criterium van benadeling als alternatief voor de vergelijkbaarheidstoets. ${ }^{146}$ Een goed voorbeeld van deze benadering is te vinden in

schel, EHvJ 19 december 1977, gev. zaken $117 / 76$ en 16/77, Jurispr. 1977, 1753, op p. 1778. Vgl. ook Tuytenschaever, die stelt dat de beoordeling van de vergelijkbaarheid bij het Hof vooral een feitelijke aangelegenheid is, waarbij het doel van de betrokken maatregel een belangrijke rol speelt (1999, $p$. 108). In de praktijk blijkt vooral van belang te zijn dat door een gemeenschapsrechtelijke regeling de concurrentieverhoudingen niet te zeer mogen worden verstoord: zoals gezegd is het bevorderen van een goede mededinging op het gebied van de landbouw één van de belangrijkste doelstellingen van het gemeenschappelijk landbouwbeleid; vgl. Tridimas p. 49 en Manolkidis 1997, p. 88. Veel uitspraken zijn alleen tegen deze achtergrond goed verklaarbaar; vgl. More 1999, p. 531, waar hij stelt dat het Hof juist de bevoegdheid tot oordelen heeft gekregen om te controleren of door de interventionistische gemeenschapshandelingen niet te vergaand wordt ingegrepen in de mededingingsverhoudingen.

142. Bijv. EHvJ 27 september 1979, zaak 230/78, Eridania, Jurispr. 1979, 2749, punt 19: de bij de vergelijking gehanteerde criteria moeten een objectief karakter hebben. Vgl. Schwarze 1992, p. 575 en 581.

143. EHvJ 13 juli 1962, gev. zaken 17 en 20/61, Klöckner-Werke $A G$ en Hoesch AG, Jurispr. 1962, 643. Zoals in paragraaf 2.1.2 al werd aangegeven is de landbouwrechtspraak geïnspireerd door de rechtspraak over het EGKS-Verdrag. Uit deze rechtspraak blijkt dat de vergelijkbaarheidstoets steeds een belangrijke rol speelt bij de bepaling van de toelaatbaarheid van ongelijke behandeling. Zie bijv. EHvJ 21 december 1954, zaak 1/54, Frankrijk tegen Hoge Autoriteit van de EGKS, Jurispr. 1954/55, 6, op 21. Zie verder Tuytenschaever 1999, p. 107, Sundberg-Weitman 1977, p. 56 en More 1999, p. 532.

144. P. 683 van het arrest. Een vergelijkbaar oordeel is terug te vinden in EHvJ 12 juli 1962, zaak $16 / 61$, Accaierie Ferriere e Fonderie di Modena, Jurispr. 1962, 579, op p. 607; zie hierover ook Sundberg. Weitman 1977, p. 57.

145. P. 683

146. Zie hiervoor, naast het hierna te bespreken arrest Karlsson, bijv. ook EHvJ 13 maart 1986, zalk 244/83, Meggle, Jurispr. 1986, 1101; hierin werd overigens gebruik gemaakt van een iets andere terminologie: het Hof stelde dat er sprake moest zijn van "distorsies" en "dispariteiten" (punt 26/27). 
het arrest Karlsson e.a. ${ }^{147}$, dat betrekking had op een Zweedse regeling ter uitvoering van een gemeenschapsverordening op het gebied van melkquota. In deze regeling was bij het toekennen van de quota een verminderingspercentage toegepast dat in hoogte afhankelijk was van de groep waartoe de betreffende melkveehouder behoorde. Daarbij gold onder andere dat de vermindering voor producenten die pas recentelijk als veehouder begonnen waren in bepaalde gevallen minder groot was dan voor producenten die al langer actief waren en een toenemende productie hadden. Het Hof stelde hierover het volgende:

\begin{abstract}
"Binnen de groep van de door een vermindering van hun melkquota getroffen producenten worden de nieuwe producenten gunstiger behandeld dan de producenten met een toenemende productie. De Zweedse regering heeft er in de loop van de procedure evenwel op gewezen, dat dit verschil in behandeling gerechtvaardigd is door de landbouwdoelstellingen die het Koninkrijk Zweden in de zuivelsector nastreeft en die de grenzen van de discretionaire bevoegdheid van het Koninkrijk Zweden niet overschrijden. De rechtmatigheid van dergelijke doelstellingen wordt in het gemeenschapsrecht erkend."148
\end{abstract}

De vergelijkbaarheidstoets komt in deze overweging in het geheel niet aan de orde: nadat een benadeling is vastgesteld gaat het Hof meteen over tot een beoordeling van de aangevoerde rechtvaardiging. Deze benadering ligt zeker niet voor de hand, nu het Hof ook had kunnen volstaan met de eenvoudige en voor het Hof meer gebruikelijke stelling dat de betrokken groepen producenten zich niet in vergelijkbare omstandigheden bevonden. ${ }^{199}$

\title{
Conclusie
}

Anders dan bij onderscheid op grond van geslacht speelt de vergelijkbaarheidstoets bij ongelijke behandeling op het gebied van de landbouw een belangrijke rol: in een groot aantal arresten is de uitkomst van de toetsing aan dit criterium doorslaggevend voor de uitkomst van de procedure. De door het Hof uitgevoerde vergelijking is daarbij in het algemeen zorgvuldig te noemen: slechts zelden wordt zonder nadere motivering gesteld dat de voorgelegde gevallen niet vergelijkbaar zijn. ${ }^{150}$ Deze zorgvuldigheid komt ook tot uitdrukking in het grote aantal maatstaven dat door het Hof is ontwikkeld om de vergelijkbaarheid te beoordelen. Deze criteria zijn grotendeels sterk verbonden met de specifieke doelstellingen van het gemeenschappelijk landbouwbeleid: criteria als de onderlinge uitwisselbaarheid van producten en het behoren tot een gemeenschappelijke marktordening lenen zich duidelijk niet voor een toepassing op andere terreinen of op

147. EHvJ 13 april 2000 , zaak C-292/97, 1-2737

148. Punt 48, cursief toegevoegd. Zie in hetzelfde arrest ook punt 43 en 44 , waar sprake is van benadeling. Een aspect van benadeling is ook terug te vinden in EHvJ 13 december 1989, gev. zaken C-181/88, C182/88 en C-218/88, Deschamps, Jurispr. 1989, 4381, punt 24.

149. Van belang hierbij is overigens dat in het geciteerde arrest al eerder was gesteld dat de verschillende producenten zich in een vergelijkbare situatie bevonden. Dit gebeurde zelfs in het kader van de vaststelling van benadeling bij de beoordeling van een ander aspect van de regeling: het Hof had gesteld dat "de nieuwe producenten en de producenten met een toenemende productie [...] [worden] benadeeld ten opzichte van de reguliere producenten [...], ook al bevinden zij zich in een overeenkomstige situatie" (punt 43; cursief toegevoegd). Hierbij is sprake van een benadering die vergelijkbaar is aan die in het arrest Gruber (EHvJ 14 september 1999, zaak C-249/97, Jurispr. 1999, 1-5295). Hierbij gelden dan ook dezelfde bezwaren, waarvoor verwezen kan worden naar paragraaf 2.2.1.

150. Soms ook wel: zie EHvJ 7 juli 1993, zaak C-217/91, Spanje/Commissie, Jurispr. 1991, 1-3923, punt 38. 
andere vormen van onderscheid. Interessanter is de stelling van het Hof dat de doelstellingen van het gemeenschappelijk landbouwbeleid of van de specifieke regeling die in het geding is bij het beoordelen van vergelijkbaarheid tot vergelijkingsmaatstaf moeten worden gekozen. Van belang is daarbij dat het Hof heeft laten doorschemeren dat de doelstelling zelf voldoende objectief en redelijk moet zijn. De verschillen tussen de vergelijkbaarheidstoets en de rechtvaardigingstoets worden daardoor minimaal. ${ }^{1 s i}$ Uit de rechtspraak van het Hof mag echter zeker niet worden afgeleid dat een zorgvul. dige toepassing van de vergelijkbaarheidstoets de toetsing aan het rechtvaardigingsmo. del overbodig maakt. Een groot nadeel, ook in de toepassing van het Hof, blijft immers dat bij het constateren van onvergelijkbaarheid niet meer wordt toegekomen aan een toetsing aan belangrijke elementen als noodzakelijkheid of proportionaliteit. Hierdoor ontbreekt een belangrijke bescherming van de belangen van de benadeelden. Van belang is bovendien dat het Hof soms heeft aangegeven dat de vergelijkbaarheidstoets kan worden vervangen door een toetsing aan het benadelingscriterium: het feit dat het bij landbouwzaken steeds gaat om direct onderscheid vormt daarvoor kennelijk geen belemmering. ${ }^{152}$ De rechtspraak van het Hof over ongelijke behandeling op het gebied van de landbouw vormt dan ook geen aanleiding om de vergelijkbaarheid alsnog in het algemene toetsingsmodel op te nemen: veeleer kan hierin een bevestiging worden gevonden van de overbodigheid van dit onderdeel van de toetsing. ${ }^{133}$

\subsubsection{Vergelijkbaarheid en benadeling bij onderscheid op grond van nationaliteit}

\section{Inleiding}

$\mathrm{Bij}$ indirect onderscheid op grond van nationaliteit wordt, net als bij indirect onderscheid op grond van geslacht, nauwelijks gebruik gemaakt van de vergelijkbaarheidstoets: ook hier wordt deze toets vervangen door het benadelingsvereiste. Daarbij wordt op dezelfde manier te werk gegaan als bij indirect onderscheid op grond van geslacht: de benadelingstoets wordt gezien als invulling van de eerste fase en daarmee als bepalend criterium bij de vaststelling van de aanwezigheid van een indirect onderscheid. ${ }^{154}$ Dit kan bijvoorbeeld worden afgeleid uit het volgende citaat uit het arrest O'Flynn: ${ }^{195}$

151. Hetgeen ook blijkt uit een aantal arresten waarbij de Advocaat-Generaal constateerde dat de gevallen relevant verschilden, zodat het onderscheid toelaatbaar was, en het Hof vervolgens aan de hand van vergelijkbare argumenten tot het oordeel kwam dat er sprake was van een objectief gerechtvaardigde ongelijke behandeling. Zie EHvJ 12 juli 1977, zaak 2/77, Hoffmann's Stärkefabriken, Jurispr. 1977, 1375, punt 19-21 en de conclusie van A-G Mayras bij dit arrest op p. 1409; zie hierover ook Barents 1994 (I), p. 338-339. Een ander voorbeeld is EHvJ 15 juli 1982, zaak 245/81, Edeka, Jurispr. 1982, 2745, punt 13-20 en de conclusie van A-G Sir Gordon Slynn hierbij op p. 2766.

152. Uit de rechtspraak van het Hof kunnen in dit opzicht geen vergaande conclusies worden afgeleid: het aantal gevallen waarin getoetst wordt aan het benadelingscriterium is daarvoor te beperkt en het Hof heeft geen duidelijke criteria ontwikkeld voor de wijze waarop in het landbouwrecht een benadeling moet worden aangetoond.

153. Zie hierover de conclusie in paragraaf 4 .

154. De verklaring voor deze overeenstemming is gelegen in het feit dat de toetsingsmethodiek zoals die wordt gevolgd bij onderscheid op grond van geslacht is geînspireerd op die bij onderscheid op grond van nationaliteit: het Hof heeft daarbij al in 1974 vastgesteld er sprake moet zijn van een benadeling (zie EHvJ 12 februari 1974, zaak 152/73, Sotgiu, Jurispr. 1974, 153, punt 12 en 13).

155. EHvJ 23 mei 1996, zaak C-237/94, Jurispr. 1996, 1-2617 
"[...] een bepaling van nationaal recht [moet] als discriminerend [...] worden beschouwd, wanneer zij door haar aard zelf migrerende werknemers eerder kan treffen dan nationale werknemers en derhalve de eerste categorie van werknemers meer in het bijzonder dreigt te benadelen, tenzij zij objectief is gerechtvaardigd en evenredig is aan het nagestreefde doel."136

De benadering waarvan deze overweging uitdrukking vormt is sterk vergelijkbaar met die bij onderscheid op grond van geslacht. Afwijkend lijkt slechts te zijn dat er iets minder hoge eisen worden gesteld aan het bewijs van benadeling. Opvallend is verder dat het Hof ook bij indirect onderscheid op grond van nationaliteit soms melding maakt van de vergelijkbaarheid. Aan beide onderwerpen zal in het hiernavolgende aandacht worden besteed.

\section{Het aantonen van benadeling bij onderscheid op grond van nationaliteit}

Anders dan bij onderscheid op grond van geslacht blijkt het Hof bij indirect onderscheid op grond van nationaliteit geen hoge eisen te stellen aan het bewijs van benadeling en zijn de criteria die zijn ontwikkeld voor de vaststelling van benadeling minder zorgvuldig uitgewerkt. ${ }^{157}$ Zo vereist het Hof in geen enkel arrest feitelijk of cijfermatig bewijs; weliswaar wordt in een aantal uitspraken verwezen naar statistische gegevens, maar dit lijkt eerder te gebeuren omdat deze gegevens toevallig voorhanden waren dan omdat het Hof daar uitdrukkelijk om had gevraagd. ${ }^{158}$ Illustratief voor de werkwijze van het Hof is de volgende overweging uit het arrest Commissie/België (wachtuitkeringen jongeren): ${ }^{159}$

"[...] Er behoeft niet te worden vastgesteld, dat de betrokken bepaling in de praktijk een aanzienlijk groter percentage migrerende werknemers treft, doch het volstaat vast te stellen, dat die bepaling een dergelijk effect kan hebben."160

In een groot aantal gevallen neemt het Hof zelfs genoegen met algemene verwachtingen over het ontstaan van een nadelig effect, zoals blijkt uit een overweging uit het arrest Biehl. ${ }^{161}$ Dit arrest had betrekking op een woonplaatsvereiste in een regeling tot terugbetaling van teveel betaalde belasting; volgens het Hof werd daardoor indirect onderscheid op grond van nationaliteit gemaakt, want:

156. Punt 18 en 19; dit is vaste rechtspraak van het Hof en komt in vrijwel alle arresten terug.

157. Zie More 1999, p. 523 en Drijber/Prechal 1997, p. 126. Zeer voor de hand liggend is de overweging in Angonese, waarin het Hof aangaf dat het voor het aantonen van een benadeling niet nodig is dat de betrokken maatregel tot gevolg heeft dat alle werknemers van het eigen land worden begunstigd of dat alleen werknemers die onderdaan zijn van een andere lidstaat worden benadeeld (EHvJ 6 juni 2000, zaak C-281/98, Jurispr. 2000, I-4139, punt 41).

158. Zie bijv. EHvJ 30 mei 1989, zaak 33/88, Allué I, Jurispr. 1989, 1591, punt 12, EHvJ 2 augustus 1993, gev. zaken C-259/91, C-331/91 en C-332/91, Allué II, Jurispr. 1993, 1-4309, punt 12/13 en EHvJ 26 juni 2001, zaak C-212/99, Commissie/ltalie (lectoren), Jurispr. 2001, 1-4923, punt 23 (in beide laatste arresten werd overigens gebruik gemaakt van dezelfde gegevens als bij Allué $I$ ).

159. EHvJ 12 september 1996, zaak C-278/94, Jurispr. 1996, I-4307

160. Punt 20; zie ook de conclusie van A-G Ruiz-Jarabodo Colomer bij deze uitspraak, met name punt 39 42 en de eerder geciteerde uitspraak $O^{\prime}$ Flynn, waarin deze regel voor het eerst werd neergelegd (EHvJ 23 mei 1996, zaak C-237/94, Jurispr. 1996, 1-2617, punt 21).

161. EHvJ 8 mei 1990, zaak C-175/88, Jurispr. 1990, 1-1779 
"[h]et criterium van de vaste woonplaats in het binnenland [...] dreigt [...] in het nadeel te werken van in het bijzonder die belastingplichtigen die onderdaan van andere lidstaten zijn."162

Ook wordt vaak teruggevallen op veronderstellingen of feiten van algemene bekendheid:

"[...] een nationale bepaling die onderscheid makt op basis van het woonplaatscriterium, [dreigt] hoofdzakelijk ten nadele van onderdanen van andere lidstaten te werken. Niet ingezetenen zijn immers in de meeste gevallen buitenlanders." ${ }^{263}$

Tenslotte blijkt het Hof soms bereid te zijn om zelf vrij actief te onderzoeken of een bepaalde groep door een regeling is benadeeld. Dit blijkt bijvoorbeeld uit het arrest Commissie/Italië (lectoren) ${ }^{164}$, waarin het Hof na moest gaan of een beloningsregeling voor lectoren een indirect onderscheid op grond van nationaliteit opleverde. Strikt juridisch gezien leek dit niet het geval te zijn, maar het Hof oordeelde het volgende:

"Een beoordeling van de administratieve en contractuele praktijken van bepaalde Italiaanse openbare universiteiten wettigt [...] de conclusie, dat er discriminerende situaties bestaan."16s

Vervolgens gaf het Hof enkele voorbeelden waaruit bleek dat de lectoren wel degelijk door de regeling werden benadeeld.

Opvallend in arresten als de hiervoor geciteerde is niet alleen dat er geen hoge eisen worden gesteld aan het bewijs van benadeling, maar ook dat het Hof een bijzondere bewijslast hanteert. Wanneer het Hof het aannemelijk acht dat er sprake is van een benadeling wordt de aanwezigheid daarvan tot uitgangspunt van de toetsing gekozen, tenzij deze aanname met goede argumenten wordt betwist door de verwerende partij." Ook op dit punt is een afwijking van de rechtspraak over onderscheid op grond van

162. Punt 14, cursief toegevoegd. Idem in EHvJ 13 juli 1993, zaak C-330/91, Commerzbank AG, Jurispr. 1993, 1-4017, punt 15. Vgl. Jørgensen 1996, p. 201 en 202, die aangeeft dat de zeer marginale eis die wordt gesteld in Biehl maar in een beperkt aantal zaken voorkomt: meestal wordt verwezen naar feitelijke gegevens die een benadeling aannemelijk maken.

163. EHvJ 7 mei 1998, zaak C-350/96, Clean Car Autoservices, Jurispr. 1998, 1-2521, punt 29, cursief toegevoegd. Zie voor een vergelijkbare benadering EHvJ 4 oktober 1991, zaak C-349/87, Paraschi, Jurispr. 1991, I-4501, punt 24 (waarin het Hof ervan uitgaat dat migrerende werknemers bij ziekte of werkloosheid geneigd zijn om naar hun land van herkomst terug te keren), EHvJ 28 januari 1992, zakk C-204/90, Bachmann, Jurispr. 1992, I-249, punt 9 en EHvJ 28 januari 1992, zaak C-300/90, Commis sie/België (levensverzekeringen), Jurispr. 1992, 1-305, punt 7. Ook stelt het Hof soms dat een maatregel naar haar aard meer migrerende dan nationale werknemers treft en daardoor nadelig dreigt te zjo (EHvJ 12 maart 1998, Commissie/Griekenland (anciënniteit musici), Jurispr. 1998, 1-1095, punt 19) of in wezen nationale ondememingen begunstigt (EHvJ 5 december 1989, zaak C-3/88, Commissie/ltatie (overheidsopdrachten informatisering), Jurispr. 1989, 4035, punt 10). Soms is het Hof nog stelliger. in het arrest Borawitz stelde het dat een pensioenregeling die in het buitenland woonachtige rechthebbenden benadeelt vooral onderdanen van andere lidstaten zal treffen, aangezien deze uiteraard een grotet aandeel van de pensioentrekkers buiten Duitsland vormen dan van de pensioentrekkers in die stast; overigens wordt deze stelling gevolgd door een vrij degelijke onderbouwing (EHvJ 21 september 2000. zaak C-124/99, Jurispr. 2000, 1-7293, punt 29).

164. EHvJ 26 juni 2001 , zaak C-212/99, Jurispr. 2001, 1-4923

165. Punt 31

166. Zie bijv. EHvJ 23 januari 1997, zaak C-29/95, Pastoors en Transcap, Jurispr. 1997, 1-285, punt 17/18. 
geslacht zichtbaar. Daarbij vereist het Hof immers dat de eisende partij voldoende feitelijk en statistisch materiaal aandraagt, waarna het in principe de verantwoordelijkheid van de nationale rechter is om op grond daarvan vast te stellen of er van indirect onderscheid sprake is. ${ }^{167}$

Het ontbreken van duidelijke bewijsregels bij indirect onderscheid op grond van nationaliteit is problematisch, met name omdat de toetsing hierdoor aan voorspelbaarheid zou kunnen inboeten en het resultaat moeilijk controleerbaar is. ${ }^{168}$ Dit blijkt vooral uit het feit dat er verschillende uitspraken zijn waarin een benadeling op grond van het voorliggende feitencomplex aannemelijk is, maar deze door het Hof toch niet werd aanvaard. ${ }^{169}$ Wanneer het benadelingscriterium wordt gekozen als toetsingsingang is het in ieder geval nodig om duidelijke regels vast te leggen voor het aantonen van de benadeling.

\section{Vergelijkbaarheid bij indirect onderscheid op grond van nationaliteit}

Net als bij indirect onderscheid op grond van geslacht maakt het Hof ook bij indirect onderscheid op grond van nationaliteit niet uitsluitend gebruik van de benadelingstoets: in een aantal arresten wordt in het kader van de toetsing van de benadeling verwezen naar elementen van vergelijkbaarheid. Een voorbeeld van een uitspraak waarin het Hof gebruik maakte van de vergelijkbaarheidsterminologie is het arrest Sotgiu. ${ }^{170}$ In deze zaak was een Duitse regeling in het geding op grond waarvan een ontheemdingstoelage werd toegekend aan in Duitsland woonachtige werknemers die in een andere plaats te werk waren gesteld dan de woonplaats van hun gezin; aan het recht op deze toelage was een verhuisplicht gekoppeld. Voor werknemers als Sotgiu, die in Duitsland werkte, maar wiens gezin in Italië woonde, gold een $25 \%$ lagere ontheemdingstoelage, waaraan echter geen verhuisplicht was gekoppeld. Het Hof stelde dat een dergelijke regeling in beginsel een ongelijke behandeling op grond van nationaliteit oplevert, maar overwoog daarna het volgende:

"[...] Dit [is] echter niet het geval met een ontheemdingstoelage waarbij in de toekenningsvoorwaarden en de betalingsmodaliteiten rekening wordt gehouden met objectieve verschillen die kunnen voortvloeien uit de situatie van de werknemers naar gelang zij bij de aanvaarding van een bepaalde betrekking hun woonplaats in het land zelf of

167. Vgl. Watson 1995, p. 43/44. Dit neemt overigens niet weg dat het Hof ook bij onderscheid op grond van geslacht soms vaststelt dat er sprake is van indirect onderscheid, omdat deze vaststelling nodig is voor het beantwoorden van de verdere prejudiciele vragen. Bij deze vaststelling gaat het Hof echter uit van de door de partijen in het hoofdgeding naar voren gebrachte gegevens en van de voorlopige vaststelling door de nationale rechter, terwijl bij indirect onderscheid op grond van nationaliteit de benadeling volledig zelfstandig lijkt te worden vastgesteld.

168. Bovendien is dit vanuit het oogpunt van Europees recht onwenselijk, omdat hierdoor inconsistenties tussen de verschillende rechters in de lidstaten kunnen ontstaan; dit zou een uniforme toepassing van het gemeenschapsrecht in gevaar kunnen brengen. Vgl. Tridimas 1999 (I), p. 162.

169. Voorbeelden zijn vooral terug te vinden in de vroege rechtspraak over het vrije verkeer: hoewel een benadeling op grond van nationaliteit daarbij soms heel aannemelijk leek, stelde het Hof toch steeds vast dat de bepalingen niet discriminatoir waren (zie bijv. EHvJ 6 november 1984, zaak 182/83, Fearon, Jurispr. 1984, 3677, EHvJ 12 februari 1987, zaak 221/85, Commissie/België (laboratoriumverstrekkingen), Jurispr. 1987, 719, EHvJ 7 juli 1988, gev. zaken 154 en 155/87, Wolf, Jurispr. 1988, 3897 en EHvJ 7 juli 1988, zaak 143/87, Stanton, Jurispr. 1988, 3877). Ook bij artikel 12 komt dit wel voor; zie bijv. EHvJ 13 december 1984, zaak 251/83, Haug-Adrion, Jurispr. 1984, 4277.

170. EHvJ 12 februari 1974 , zaak $152 / 73$, Jurispr. 1974,153 
in het buitenland hebben. [...] [T] e dien aanzien [kan] de omstandigheid dat de ontheemdingstoelage voor de in het land zelf woonachtige functionarissen slechts tijdelijk is en gekoppeld aan de verplichting hun woonplaats naar de plaats van arbeid over te brengen, terwijl deze toelage van onbeperkte duur en zonder een dergelijke verplichting wordt betaald aan werknemers die, ongeacht hun nationaliteit, hun woonplaats in het buitenland hebben, een gegronde reden voor de differentiatie van het betaalde bedrag [ ...] vormen. [...] []]n elk geval [kan] niet [...] worden gesproken van een met het Verdrag en de verordening strijdige discriminatie, indien uit een vergelijking van de twee toelageregelingen in hun geheel zou blijken dat de werknemers die hun woonplaats in het buitenland handhaven, zich niet in een nadelige positie bevinden ten opzichte van hen wier woonplaats in het land zelf is gelegen."171

Een indirect onderscheid kon volgens het Hof dus niet worden vastgesteld, omdat Sotgiu zich in een andere positie bevond dan degene ten opzichte van wie hij zichzelf benadeeld voelde. Deze benadering lijkt op het eerste gezicht identiek te zijn aan de in het (in paragraaf 2.2 .1 besproken) arrest $\mathrm{Gruber}^{172}$ gevolgde methodiek, maar blijkt daarvan in een belangrijk opzicht te verschillen. De getroffen vergelijking heeft in Sotgiu alleen tot functie om een volledige beoordeling van de gestelde benadeling mo. gelijk te maken: de nadelen en voordelen van de ontheemdingstoelage van Sotgiu moeten bij elkaar worden opgeteld, net als de voor- en nadelen van de regeling voor de in Duitsland woonachtige werknemers. Pas wanneer dit is gebeurd kan objectief worden vastgesteld of er sprake is van indirect onderscheid op grond van nationaliteit. Strikt genomen kan hier dus niet worden gesproken van een toepassing van de vergelijkbaarheidstoets zoals in het arrest Gruber; de door het Hof gehanteerde terminologie is dan ook niet geheel zuiver. ${ }^{13}$

Wat er van deze terminologie ook zij, het door het Hof in dit arrest aan het licht gebrachte punt is zeker van belang. Inderdaad lijkt het niet meer dan redelijk dat bij het beoordelen van de aanwezigheid van een benadeling rekening wordt gehouden met alle omstandigheden van het geval, waarbij niet alleen wordt gekeken naar de nadelen die een regeling voor een bepaalde groep heeft, maar ook naar eventueel aanwezige voordelen die daarvoor een compensatie kunnen vormen.

In een zeer beperkt aantal arresten heeft het Hof daadwerkelijk gebruik gemaakt van de vergelijkbaarheidstoets bij de vaststelling van een benadeling. Een voorbeeld hiervan is te vinden in het arrest Commissie/Italië (effectenbemiddelaars) ${ }^{174}$, waarin het Hof over artikel 52 (oud), dat betrekking heeft op beperkingen van de vrije vestiging, stelde dat dit betrekking heeft op

171. Punt 12; zie ook punt 13 , waarin het Hof duidelijk, zij het ten onrechte, gebruik maakte van de vergelijkbaarheidsterminologie.

172. EHvJ 14 september 1999, zaak C-249/97, Jurispr. 1999, I-5295, m.n. punt 31-34.

173. Een tegengestelde opvatting hierover is verkondigd door Arnull $(1990$, p. 40) en door Jørgensen (1996, p. 207): zij stellen beiden dat hierbij wel degelijk een vergelijkbaarheidsaspect is verwerkt in de redenering van het Hof en dat uit het arrest kan worden geconcludeerd dat onvergelijkbaarheid een rechlvaardiging voor onderscheid kan inhouden.

174. EHvJ 6 juni 1996, zaak C-101/94, Jurispr. 1996, 1-269 
"alle nationale voorschriften die de onderdanen van andere Lid-Staten in een feitelijke of juridische situatie kunnen plaatsen die ongunstig is vergeleken bij die van een onderdaan in die Lid-Staat in dezelfde omstandigheden."175

Anders dan in het arrest Gruber kwam het Hof in deze zaak echter niet tot de conclusie dat er geen sprake was van vergelijkbare omstandigheden: het Hof accepteerde de vergelijkbaarheid zelfs zonder enige nadere motivering. ${ }^{176}$ Niettemin kan het gebruik van dit criterium tot gevolg hebben dat er geen benadeling wordt vastgesteld omdat vergelijkbaarheid ontbreekt. Zoals eerder is aangegeven is dit met name bezwaarlijk omdat hierdoor niet kan worden toegekomen aan essentiële toetsingselementen als geschiktheid of subsidiariteit.

\section{Afwijkende benadering in rechtspraak over directe belastingen}

Hiervoor is gebleken dat het Hof bij de toetsing van indirect onderscheid normaal gesproken nagaat of een classificatie een disproportionele benadeling van een bepaalde groep tot gevolg heeft, waarna het vervolgens onderzoekt of er een rechtvaardiging voor dit benadelende effect bestaat. Opvallend genoeg heeft het Hof in de rechtspraak over ongelijke behandeling bij directe belastingen, zoals inkomstenbelasting of vermogensbelasting, een afwijkende benadering gekozen, waarbij de vergelijkbaarheidstoets een prominente rol speelt. In directe belastingregelingen wordt vaak onderscheid gemaakt tussen ingezetenen en niet-ingezetenen, hetgeen ook in het internationale belastingrecht een veel voorkomend onderscheidingscriterium is. In veel zaken wordt erover geklaagd dat dit onderscheidingscriterium een indirect onderscheid op grond van nationaliteit oplevert, nu niet-ingezetenen voornamelijk mensen van een andere nationaliteit zullen zijn. Wanneer het Hof zijn gebruikelijke methodiek zou volgen, dan zou het volgens zijn vaste toetsingsmodel moeten nagaan of er voor dit indirecte onderscheid op grond van nationaliteit een objectieve en redelijke rechtvaardiging bestaat. In de praktijk blijkt het Hof echter te kiezen voor een andere insteek. Een typisch voorbeeld van de door het Hof gevolgde benadering is te vinden in het arrest Schumacker ${ }^{17}$, dat betrekking had op een Duitse wet over inkomstenbelasting waarin een aantal belastingvoordelen uitsluitend werd toegekend aan Duitse ingezetenen. Het Hof stelde hierover het volgende:

\footnotetext{
"Een nationale regeling van dit type $[\ldots]$ kan $[\ldots]$ in het nadeel werken van hoofdzakelijk onderdanen van andere lidstaten: de niet-ingezetenen zijn immers in de meeste gevallen buitenlanders. Het voorbehouden van fiscale voordelen aan uitsluitend de ingezetenen van een Lid-Staat, kan derhalve een indirecte discriminatie op grond van nationaliteit opleveren.
}

175. Punt 13. Idem in EHvJ 30 maart 1993, zaak C-168/91, Konstantinidis, Jurispr. 1993, I-1191, punt 13. Een voorbeeld is ook te vinden in het arrest Schöning-Kogebetopoulou, waarin het Hof vaststelde dat voor de vaststelling van benadeling in dat geval niet bepalend was dat er verschillen tussen de gevallen bestonden, waarop (in het kader van de rechtvaardigingstoets) was gewezen door A-G Jacobs (EHvJ 15 januari 1998, zaak C-15/96, Jurispr. 1998, 1-47, punt 24 en conclusie bij dit arrest, punt 16-32). Ook in het arrest Ferlini ging het Hof zorgvuldig en vrij uitgebreid na of er sprake was van vergelijkbaarheid voordat werd ingegaan op de vraag of er sprake was van een indirect onderscheid (EHvJ 3 oktober 2000 , zaak C-411/98, Jurispr. 2000, I-8081, punt 51-58).

176. Dit geldt ook voor het in de vorige noot genoemde arrest Konstantinidis en voor het arrest Ferlini, hoewel in dit laatste arrest vrij uitgebreid op de vergelijkbaarheíd werd ingegaan.

177. EHvJ 14 februari 1995, zaak C-279/93, Jurispr. 1995, 1-225 
Volgens vaste rechtspraak is er slechts sprake van discriminatie, wanneer verschillende regels worden toegepast op vergelijkbare situaties of wanneer dezelfde regel wordt toegepast op verschillende situaties. Bij de directe belastingen nu is de situatie van ingezetenen en die van niet-ingezetenen in het algemeen niet vergelijkbaar. [...] Wanneer derhalve een Lid-Staat een niet-ingezetene niet in aanmerking brengt voor bepaalde belastingvoordelen die hij aan de ingezetene verleent, dan is dat in de regel niet discriminerend, aangezien de twee categorieên belastingplichtigen zich niet in een vergelijkbare situatie bevinden." 178

In latere rechtspraak heeft het Hof hieraan nog toegevoegd dat er wel sprake is van vergelijkbaarheid wanneer een groot deel van het inkomen van de niet-ingezetene in het betrokken land is verworven. ${ }^{179}$

Opvallend in deze rechtspraak is dat het Hof weliswaar vaststelt dat er sprake is van indirect onderscheid op grond van nationaliteit, maar vervolgens uitsluitend een toetsing uitvoert van het directe onderscheid tussen ingezetenen en niet-ingezetenen. Getoetst wordt dus niet zozeer de rechtvaardiging voor het benadelende effect van de regeling, maar de redelijkheid van de in de regeling zelf opgenomen classificatie. Daarbij wordt echter eerst de vergelijkbaarheid beoordeeld, waardoor er eigenlijk twee keer een toetsing in de eerste fase wordt uitgevoerd: het Hof gaat niet alleen na of er sprake is van een benadelend effect, maar ook of de gevallen waartussen rechtstreeks onderscheid wordt gemaakt voldoende vergelijkbaar zijn. Het is niet duidelijk waarom het Hof gebruik maakt van deze benadering, zeker niet nu het relatief gemakkelijk zal zijn om een rechtvaardiging voor het gebruik van het criterium van ingezetenschap te vinden. Evenmin is duidelijk waarom het Hof alleen bij de binnenlandse belastingen gebruik maakt van deze redenering, die immers ook bij alle andere vormen van indirect onderscheid op grond van nationaliteit gebruikt zou kunnen worden..$^{180}$

Wat hiervan ook zij: uit deze rechtspraak kan in ieder geval blijken dat het weliswaar mogelijk is om ook bij indirect onderscheid een vergelijkbaarheidstoets uit te voeren, maar dat het zeker niet noodzakelijk is om dit te doen.

\section{Vergelijkbaarheid bij direct onderscheid op grond van nationaliteit}

Ter afsluiting van deze subparagraaf is het zinvol om enige aandacht te besteden an het beperkte aantal arresten dat het Hof heeft gewezen met betrekking tot het verbod van direct onderscheid op grond van nationaliteit zoals dat is vervat in artikel $12 \mathrm{EG}$ :

178. Punt 28-31 en 34. Zie voor een vergelijkbare benadering EHvJ 11 augustus 1995, zaak C-80/94, Wielockx, Jurispr. 1995, 1-2493, punt 18-19, EHvJ 27 juni 1996, zaak C-107/94, Asscher, Jurispr. 1996, 13089, punt 41 en EHvJ 16 mei 2000, zaak C-87/99, Zurstrassen, Jurispr. 2000, 1-3337, punt 21.

179. Zie m.n. de in de vorige noot aangehaalde arresten Wielockx, punt 20,Asscher, punt 43 en Zurstrassen, punt $22 / 23$.

180. Advocaten-Generaal hebben soms gebruik gemaakt van dit criterium, maar het Hof heeft hun aanwij: zingen nooit overgenomen: zie A-G Tesauro bij EHvJ 23 januari 1997, zaak C-29/95, Pastoors en Trans-Cap, Jurispr. 1997, 1-285 in punt 9 en 11. Tesauro was in deze zaak overigens niet consequent in zijn benadering: hoewel hij eerst concludeerde dat ingezetenen en niet-ingezetenen gezien het doel van de regeling niet vergelijkbaar zijn, ging hij vervolgens na of er een objectieve rechtvaardiging voor het onderscheid bestaat. Tesauro had al eerder voor deze benadering gepleit: zie EHvJ 10 februari 1994 , Mund \& Fester, zaak C-398/92, Jurispr. 1994, I-467, punt 12 conclusie. In een eerdere zaak komt hel vergelijkbaarheidscriterium overigens wel voor, hoewel het niet ging om belastingen: zie EHvJ 12 juli 1979, zaak 237/78, CRAM/Toia, Jurispr. 1979, 2645, met name punt 14. Het gaat hierbij echter om een geïsoleerd geval. 
hoewel dit verbod geen uitdrukkelijke opsomming van uitzonderingsgronden bevat, heeft het Hof aangenomen dat hierbij steeds moet worden onderzocht of er een objectieve rechtvaardiging voor het onderscheid bestaat. Het is opvallend dat het Hof bij de toetsing aan deze bepaling de vergelijkbaarheidstoets als toetsingsingang gebruikt en een toetsing aan het benadelingscriterium achterwege laat. Een voorbeeld van de benadering van het Hof is te vinden in het arrest Hochstrass ${ }^{181}$, dat betrekking had op een extra vergoeding voor gemeenschapsambtenaren die in een ander land werken dan waar zij vandaan komen en normaal gesproken wonen. Klager was van mening dat door deze regeling een ongerechtvaardigd onderscheid werd gemaakt op grond van nationaliteit. Het Hof oordeelde als volgt:

"Op grond van dit beginsel [het gelijkheidsbeginsel, JHG] mogen vergelijkbare situaties niet verschillend worden behandeld, tenzij een onderscheid objectief gerechtvaardigd is. Het vereist uiteraard dat personeelsleden die zich in volkomen gelijke situaties bevinden, aan dezelfde bepalingen worden onderworpen, maar het verbiedt de gemeenschapswetgever niet rekening te houden met objectieve verschillen in de omstandigheden of de positie waarin de betrokkenen zich bevinden." ${ }^{\prime 82}$

Net als bij direct onderscheid op het gebied van de landbouw voert het Hof echter lang niet in alle gevallen een vergelijkbaarheidstoets uit, maar maakt het soms gebruik van een soort oppervlakkige benadelingstoets. Zo was er in het arrest Hayes ${ }^{133}$ een Duitse regeling in het geding, op grond waarvan bij een gerechtelijke procedure wel een zekerheidstelling voor de proceskosten kon worden verlangd van buitenlanders, maar niet van Duitsers. Het Hof stelde daarover het volgende:

"Het is duidelijk, dat een bepaling als in het hoofdgeding aan de orde is, een rechtstreekse discriminatie op grond van nationaliteit oplevert. Volgens deze bepaling verlangt een LidStaat namelijk geen zekerheidstelling van eigen onderdanen, ook al hebben zij in deze staat geen vermogen of woonplaats." ${ }^{\prime \prime 4}$

Vervolgens gaf het Hof een oordeel over de aangevoerde rechtvaardiging. Het is niet duidelijk waarom het Hof het in dit geval als vanzelfsprekend aanvaardde dat er sprake was van een vergelijkbare situatie: gesteld zou immers kunnen worden dat er wel degelijk verschillen bestaan tussen buitenlanders en Duitse onderdanen wanneer het gaat om problemen bij de invordering van proceskostenvergoedingen. Net als bij direct onderscheid op het gebied van de landbouw lijkt het waarschijnlijk dat de verklaring voor de verschillen in toetsingsmethodiek eerder moet worden gezocht in pragmatisme dan in een fundamentele en weloverwogen keuze. Nu het Hof het onderscheid in Hayes ontoelaatbaar achtte was het niet erg praktisch om de vergelijkbaarheidstoets toe te passen: in dat geval had het Hof immers moeten toelichten waarom buitenlanders en Duitse ingezetenen vergelijkbaar waren, of waarom de verschillen tussen buitenlanders

181. EHvJ 16 oktober 1980 , zaak $147 / 79$, Jurispr. 1980,3005

182. Punt 7. Vervolgens oordeelde het Hof dat, gezien het doel van de regeling, nationaliteit een relevant onderscheidingscriterium is. Het is daarbij opvallend dat de geschiktheid van nationaliteit als onderscheidend criterium uitgebreid wordt gemotiveerd en dat daarbij veel aandacht wordt besteed aan het doel van de regeling (zie vooral punt 12 en 13).

183. EHvJ 20 maart 1997, zaak C-323/95, Jurispr. 1997, I-1711

184. Punt 19. Zie voor een zelfde benadering EHvJ 26 september 1996, zaak C-43/95, Data Delecta, Jurispr. 1996, 1-4661, punt 16-17. 
en Duitse ingezetenen voor dit geval niet relevant waren. Door gebruik te maken van het rechtvaardigingsmodel kon de gewenste conclusie met een eenvoudiger redenering worden bereikt.

\section{Conclusie}

Uit het voorgaande is gebleken dat het Hof bij indirect onderscheid op grond van nationaliteit het criterium van benadeling tot uitgangspunt van zijn toetsing neemt. Doorslaggevend is daarbij steeds of een benadelende maatregel naar zijn aard mensen uit andere lidstaten eerder kan treffen dan nationale staatsburgers. Eerder is al aangegeven dat dit criterium ook bij indirect onderscheid op grond van geslacht wordt gehanteerd, maar dat daarbij aanzienlijk hogere eisen aan het bewijs worden gesteld: terwijl het Hof bij onderscheid op grond van nationaliteit meestal genoegen neemt met algemene veronderstellingen, moeten bij onderscheid op grond van geslacht steeds feitelijke en statistische gegevens worden aangedragen om een benadeling te bewijzen. Op de vraag welke benadering in het algemene toetsingsmodel zou moeten worden gekozen zal in de algemene conclusie bij dit hoofdstuk (paragraaf 4) nader worden ingegaan.

Van belang is verder dat het Hof in een vrij groot aantal gevallen gebruik maakt van het vergelijkbaarheidscriterium. Dit gebruik is niet altijd overtuigend of voor de hand liggend: zo verhult de vergelijkbaarheidsterminologie in Sotgiu slechts een uitgebreide benadelingstoets, en bestaat er geen duidelijke reden voor het feit dat het Hof bij directe belastingen zowel kijkt naar het benadelend effect, als naar de vergelijkbaarheid van de gevallen waartussen rechtstreeks onderscheid wordt gemaakt. In beide gevallen blijkt de vergelijkbaarheidstoets zeker niet onmisbaar te zijn: deze kon gemakkelijk worden vervangen door een rechtvaardigingstoets, zonder dat dit zou leiden tot een minder goede toetsingsuitkomst.

Voor de gevallen waarin in het kader van de benadelingstoets wordt bekeken of er sprake is van vergelijkbare situaties en voor het gebruik van de vergelijkbaarheidstoets bij direct onderscheid geldt opnieuw dat het problematisch is dat hierbij niet meer wordt toegekomen aan een oordeel over de noodzakelijkheid of proportionaliteit, wanneer eenmaal is vastgesteld dat vergelijkbaarheid ontbreekt. Nu de toepassing van de vergelijkbaarheidsvraag in de beschreven arresten geen duidelijke voordelen oplevert boven een toetsing aan het rechtvaardigingsmodel, kan uit de rechtspraak van het Hof niet worden afgeleid dat het wenselijk zou zijn de vergelijkbaarheidstoets als element op te nemen in het algemene toetsingsmodel. In paragraaf 4 van dit hoofdstuk zal daarop nader worden ingegaan.

\subsubsection{Toepassingen van de vergelijkbaarheidstoets bij artikel 90 EG}

Bij artikel 90, dat betrekking heeft op ongelijke behandeling bij binnenlandse belastingen, speelt de vergelijkbaarheidstoets een belangrijke rol. De eerste alinea van dit artikel stelt dat op producten uit andere lidstaten geen hogere binnenlandse belastingen mogen worden geheven dan op gelijksoortige nationale producten. Daarnaast vloeit uit het tweede lid van dit artikel voort dat ook concurrentie tussen bepaalde producten een 
belemmering kan vormen voor het opleggen van verschillende belastingen. ${ }^{185}$ De eerste alinea laat door zijn formulering geen ruimte voor een rechtvaardiging: zijn de producten gelijksoortig, dan is ook geen enkel verschil in belasting toegestaan, ook al zouden daarvoor overigens goede gronden bestaan. ${ }^{186}$ De beoordeling van de gelijksoortigheid is hierdoor een belangrijk element in de toetsing door het Hof: alleen door te beredeneren dat producten in relevante opzichten verschillen kan de ontoelaatbaarheid van een verschil in belasting worden vermeden. In de praktijk heeft het Hof dan ook veel aandacht besteed aan de interpretatie van het gelijksoortigheidsvereiste, waarbij het een aantal interessante criteria heeft gedefinieerd. ${ }^{187}$ Zo stelde het Hof in het arrest $R e w e^{18 x}$ dat in het kader van de vaststelling van de toepasselijkheid van de eerste alinea van artikel 90 ,

"[...] de belasting moet worden vergeleken die produkten treft die - in hetzelfde stadium van produktie of verhandeling - uit verbruikersoogpunt soortgelijke eigenschappen vertonen en aan dezelfde behoeften voldoen. In zoverre kan voor de beoordeling van veel belang zijn of het nationale en het ingevoerde product in dezelfde post van het gemeenschappelijk douanetarief zijn ondergebracht."189

Deze criteria zijn inhoudelijk enigszins te vergelijken met de criteria zoals die worden gehanteerd op het gebied van de landbouw, maar de toepassing ervan blijkt anders te zijn: waar het Hof op het gebied van de landbouw vrijwel nooit tot de conclusie komt dat er sprake is van vergelijkbaarheid, is bij artikel 90 eerder het tegenovergestelde het geval. Dit verschil is verklaarbaar vanuit de doelstellingen van de betrokken bepalingen. Zoals eerder is opgemerkt kan het in het landbouwrecht wenselijk zijn om ongelijke behandelingen in stand te houden, omdat de doelstellingen van het gemeenschapsrecht vaak alleen op die manier kunnen worden bereikt. Bij de binnenlandse belastingen is de situatie een heel andere: als staten hogere belastingen heffen op geïmporteer-

185. Zie EHvJ 27 februari 1980, zaak 168/78, Commissie/Frankrijk (belasting voor gedistilleerd), Jurispr. 1980, 347, waarin het Hof aangaf dat er een gradatieverschil bestaat tussen gelijksoortigheid en concurrentie: producten kunnen ook met elkaar concurreren wanneer zij niet gelijksoortig zijn (zie punt 6). In de praktijk blijkt het Hof overigens niet altijd even scherp onderscheid te maken tussen de eerste en de tweede alinea.

186. Zie EHvJ 10 oktober 1978, zaak 148/77, Hansen \& Balle, Jurispr. 1978, 1787, punt 17 en EHvJ 8 januari 1980, zaak 21/79, Commissie/ltalië (geregenereerde olie), Jurispr. 1980, 1, punt 15; vgl. Denusso/Denton 1990, p. 76.

187. Zie daarover in het bijzonder Denusso/Denton 1990, p. 73-74.

188. EHvJ 17 februari 1976, zaak 45/75, Jurispr. 1976, 181

189. Punt 12. Aan het criterium van de douane-indeling heeft het Hof later minder belang toegekend (zie de conclusie van A-G VerLoren van Themaat bij EHvJ 4 maart 1986, zaak 106/84, Commissie/Denemarken (belasting vruchtenwijnen), Jurispr. 1986, 833 en EHvJ 4 maart 1986, zaak 234/84, John Walker, Jurispr. 1986, 875 , op p. 855 ; in deze arresten is meer waarde toegekend aan criteria als smaak en alcoholgehalte). Van belang is dat door dit soort criteria een "politieke" invulling aan het vergelijkbaarheidscriterium kan worden voorkomen (hoewel niet volledig, zie verderop). Dit blijkt uit een arrest als EHvJ 8 januari 1980, zaak 21/79, Commissie/ltalië (geregenereerde olie), Jurispr. 1980, $\mathrm{I}$, waarin een verschillende belasting op nieuwe en op geregenereerde olie was opgelegd omdat dit het enige middel was om fraude aan de grens te voorkomen; beide soorten olie zijn uit verbruikersoogpunt volkomen vergelijkbaar. Bij een ruime interpretatie van het vergelijkbaarheidscriterium zou kunnen worden gesteld, dat de producten misschien wel vergelijkbaar zijn uit verbruikersoogpunt, maar relevante verschillen vertonen waar het gaat om de bestrijding van fraude. Een dergelijke ruime interpretatie is gezien de criteria van het Hof niet mogelijk. Zie hierover ook Barents 1983, p. 447. 
de producten dan op nationale producten, kan dit een ernstige verstoring van de handel op de interne markt opleveren. ${ }^{100}$ Dergelijke ongelijkheden moeten dan ook zoveel mogelijk worden bestreden.

De manier waarop het Hof omgaat met de gelijksoortigheidstoets bij binnenlandse belastingen komt fraai tot uitdrukking in het arrest Commissie/VK (belastingregeling voor wijn), waarin met behulp van de hiervoor aangegeven criteria moest worden na. gegaan of er sprake was van gelijksoortigheid of in ieder geval van concurrentie tussen wijn en bier. ${ }^{191}$ Op zichzelf ligt een dergelijke gelijksoortigheid niet direct voor de hand, maar door een creatieve redenering wist het Hof toch tot de conclusie te komen dat de producten vergelijkbaar zijn. Het Hof maakte bij deze vergelijking gebruik van de volgende argumentatie:

"Gezien de verschillen in kwaliteit, en dus in prijs, die men bij wijn aantreft, dient bij de bepaling van de beslissende mededingingsverhouding tussen bier - een populaire en veel verbruikte drank - en wijn te worden uitgegaan van de wijnen die bij het grote publiek het meest in trek zijn, en dat zijn in het algemeen de lichtste en goedkoopste soorten." ${ }^{\prime 12}$

Hieruit blijkt dat het oordeel over de vergelijkbaarheid sterk wordt beïnvloed door de definitie van de groepen of producten die met elkaar worden vergeleken. ${ }^{193}$ Dit is van bijzonder belang, omdat deze definitie vaak ongemerkt plaatsvindt en subjectieve elementen hierbij een belangrijke rol kunnen spelen. Een vergelijkbare problematiek kan zich ook voordoen bij benadeling, nu daarbij moet worden vastgesteld of een groep wordt benadeeld ten opzichte van een andere groep en het zaak is de beide groepen goed te definiëren. Om die reden is het van groot belang om duidelijke aan te geven welke overwegingen bij de definitie van de groepen een rol hebben gespeeld. Een daartoe strekkend vereiste dient dan ook in het algemene toetsingsmodel te worden opgenomen.

190. Het Hof zelf formuleerde de doelstelling als volgt: "Artikel 95 [nu artikel 90, JHG] heeft in zijn gehel beschouwd ten doel, het vrije verkeer van goederen tussen de lidstaten onder normale concurrentiever. houdingen te verzekeren, door elke vorm van bescherming uit te buiten die het gevolg kan zijn van de toepassing van binnenlandse belastingen die discriminerend zijn ten opzichte van producten uit andert lidstaten [...]" (EHv] 4 maart 1986, zaak 106/84, Commissie/Denemarken (belasting vnuchtemvijnen), Jurispr. 1986, 833, punt 10).

191. EHvJ 12 juli 1983, zaak 170/78, Jurispr. 1983, 2265; het Hof maakte in dit arrest geen scherp onderscheid tussen gelijksoortigheid en concurrentie, maar bekeek meer in het algemeen of de producten voldoende vergelijkbaar waren.

192. Punt 12. In arresten waarin uitsluitend de gelijksoortigheid aan de orde is lijkt het Hof strenger te zije: dan moeten ook de "organoleptische" eigenschappen van de producten, zoals smaak, watergehaite en alcoholgehalte, voldoende overeenstemmen (vgl. EHvJ 7 mei 1987, zaak 184/85, Commissie/ltalit (belasting op bananen), Jurispr. 1987, 2013, punt 10). Dat was in het arrest John Walker, waarin hel Hof de gelijksoortigheid van whisky en vruchtenlikeur moest beoordelen, niet het geval, hoewel beide dranken zich lenen als aperitief en minstens zo vergelijkbaar zijn als bier en wijn (EHvJ 4 maart 1986, zaak 234/84, John Walker, Jurispr. 1986, 875, punt 12). Ook hieruit blijkt dat de vergelijkbaarheids. toets geen minder arbitraire toets oplevert dan een toepassing van het rechtvaardigingsmodel.

193. Zie voor een ander voorbeeld EHvJ 16 december 1986, zaak 200/85, Commissie/ltalië (huxebelasting dieselauto's), Jurispr. 1986, 3953, met name punt 16: het Hof gaf hierin (waarschijnlijk geînspireend door A-G Mischo, conclusie p. 3967/3968) aan dat voor de beoordeling van de redelijkheid van taricf. verschillen niet alleen moet worden gekeken naar de markt voor dieselauto's, maar naar de gehele attomarkt. 


\subsubsection{Toetsing van het doel bij onderscheid op grond van geslacht}

De rechtspraak over onderscheid op grond van geslacht biedt veel interessante aanknopingspunten als het gaat om de toetsingsmethodiek: omdat het de nationale rechter is die uiteindelijk moet beoordelen of een onderscheid gerechtvaardigd is, heeft het Hof nauwgezette aanwijzingen gegeven voor de wijze waarop hij dat zou moeten doen. Doordat het Hof zelf niet verantwoordelijk is voor het toepassen van het toetsingsmodel op het voorliggende feitencomplex is de benadering van het Hof bovendien minder casuïstisch dan bij, bijvoorbeeld, het landbouwrecht. De ontwikkelde criteria lenen zich dan ook uitstekend voor een meer algemene toepassing en kunnen een interessante aanvulling en nuancering van het theoretische toetsingsmodel opleveren. Dit geldt in het bijzonder voor de criteria die door het Hof ontwikkeld zijn ter invulling van het vereiste van een gerechtvaardigd doel. Juist omdat dit vereiste vaak centraal staat in de toetsing en het voor de rechter in het algemeen lastig is om hierover een goed oordeel te geven zijn er talrijke prejudiciële vragen gesteld die hierop specifiek betrekking hebben.

Uit de rechtspraak van het Hof kunnen verschillende criteria voor de invulling van het vereiste van een gerechtvaardigd doel worden afgeleid; deze zullen hierna kort worden besproken. ${ }^{194}$

\section{Discriminatoire overwegingen vormen nooit een gerechtvaardigd doel}

In het arrest Jenkins ${ }^{195}$ stelde het Hof dat ongelijke behandeling is toegestaan,

\section{"[...] zolang [het] [...] zijn verklaring vindt in objectief gerechtvaardigde factoren die geen verband houden met discriminatie op grond van geslacht."}

Wanneer een classificatie op grond van een geslachtsneutraal criterium (zoals flexibiliteit of het aantal werkuren) tot effect heeft dat er meer vrouwen dan mannen ${ }^{197}$ worden benadeeld, mag deze classificatie blijkens de geciteerde overweging niet zijn ingegeven door discriminatoire overwegingen. Dit lijkt een heel redelijk criterium te zijn. Door het gebruik ervan kan namelijk worden bestreden dat een onderscheid wordt gerechtvaardigd door overwegingen die bewust of onbewust uitdrukking vormen van stereotypen of vooroordelen over een bepaalde groep. Van belang is bovendien dat bestaande ongelijkheden door het accepteren van discriminatoire overwegingen gemakkelijk in stand kunnen worden gehouden; ook om die reden is het van belang om inherent discriminatoire doelstellingen ongerechtvaardigd te achten.

194. Ook buiten deze criteria om heeft het Hof bepaalde doelstellingen als gerechtvaardigd geaccepteerd. In deze paragraaf zal echter alleen aandacht worden besteed aan de criteria die zich lenen voor een algemene toepassing, d.w.z. die een minder specifiek op de casus toegesneden karakter hebben en zich na enige herformulering ook lenen voor toepassing bij andere differentiatiecriteria. Dit is niet het geval bij een rechtvaardiging als het afzonderlijk voeren van cao-onderhandelingen (vgl. EHvJ 27 oktober 1993 , zaak C-127/92, Enderby, Jurispr. 1993, I-5535, punt 45 en EHvJ 31 mei 1995, zaak C-400/93, Royal Copenhagen, Jurispr. 1995, 1-1275, punt 46).

195. EHvJ 31 maart 1981, zaak $96 / 80$, Jurispr. 1981, 911

196. Punt 11, cursief toegevoegd.

197. Of, vanzelfsprekend, wanneer meer mannen dan vrouwen door het nadeel worden getroffen. 
Hoewel het zeker wenselijk is om dit criterium in te voegen in het algemene toetsingsmodel, moet worden opgemerkt dat het in de praktijk niet altijd even gemakkelijk zal zijn om hieraan toepassing te geven. In veel gevallen zal het immers niet zonder meer duidelijk zijn dat er aan een regeling overwegingen ten grondslag liggen die rechtstreeks verband houden met geslacht. Zeker wanneer er sprake is van een bewuste benadeling zal de opsteller van de litigieuze regeling zijn discriminatoire bedoelingen zoveel mogelijk proberen te verhullen. Ook als dit niet het geval is en te goeder trouw een beroep wordt gedaan op demografische omstandigheden of typische vrouwelijke of mannelijke eigenschappen, zal het voor de rechter niet eenvoudig zijn om vast te stellen of een rechtvaardiging is terug te voeren op discriminatoire motieven: in de meeste gevallen zal de aangevoerde rechtvaardiging uit meerdere argumenten zijn opgebouwd, die zeker niet allemaal op overwegingen betreffende het geslacht berusten. In dat geval zal de rechter moeten bepalen welke doelstelling volgens hem doorslaggevend is geweest en zal hij moeten nagaan of de niet-discriminatoire doelstellingen het onderscheid voldoende kunnen dragen.

Een concrete toepassing van het criterium van de discriminatoire doelstelling is in de rechtspraak van het Hof overigens betrekkelijk zeldzaam: meestal wordt het an de nationale rechter overgelaten om te beoordelen of de aangevoerde doelstelling in overwegende mate discriminatoir is. ${ }^{198}$ Het is daardoor niet gemakkelijk te achterhalen op welke manier in de praktijk met de aan het criterium verbonden problemen moet worden omgegaan. Een voorbeeld waarin het Hof zelf toepassing heeft gegeven aan het criterium is hoogstens te vinden in het arrest Commissie/België (werkloosheidsuitkerirgen). ${ }^{199}$ Dit arrest had betrekking op een Belgische werkloosheidswet waarin de hoogte van de uitkering afhankelijk was gesteld van de gezinssituatie: mensen die samenwoonden met een partner zonder beroepsinkomen ontvingen een hogere uitkering dan alleenstaanden, die op hun beurt weer voor een hogere uitkering in aanmerking kwamen dan mensen die samenleefden met een partner met een eigen inkomen. De groep die de laagste uitkering ontving bestond grotendeels uit vrouwen, terwijl de groep met de hoogste uitkering voornamelijk uit mannen bestond. De Belgische regering had hiervoor als rechtvaardiging aangevoerd dat deze verdeling een afspiegeling vormde van een maatschappelijk fenomeen. Het Hof oordeelde hierover als volgt:

"Uit dergelijke overwegingen betreffende de verschillende plaats die mannen en vrouwen op de Belgische arbeidsmarkt innemen kunnen [...] geen objectieve criteria worden afgeleid die geen verband houden met discriminatie op grond van geslacht."20x

198. Vgl. bijv. het gestelde in de conclusie van A-G Lenz bij het arrest Nolte, waarin hij aangaf dat door de regering weliswaar gesteld werd dat een bepaalde doelstelling ten grondslag lag aan een regeling, max waarin hij ook aangaf dat nagegaan zou moeten worden of dit daadwerkelijk het geval was (EHvJ I4 december 1995, zaak C-317/93, Jurispr. 1995, 1-4625, punt 73 conclusie). Een dergelijke beoordeling kan ook door de nationale rechter plaatsvinden.

199. EHvJ 7 mei 1991, zaak C-229/89, Jurispr. 1991, 1-2205

200. Punt 18. Overigens werd de regeling wel toelaatbaar geacht: er waren volgens het Hof voldoende andere doelstellingen die niet rechtstreeks verband hielden met het geslacht en die het onderscheid vol doende konden rechtvaardigen. Hieruit blijkt dat het enkele bestaan van een doelstelling met en discriminatoir karakter de ongelijke behandeling niet zonder meer ontoelaatbaar maakt. Een ander voor beeld is EHvJ 19 november 1998, zaak C-66/96, Hoy Pedersen e.a., Jurispr. 1998, 1-7327: de Deense regering had hierin ter rechtvaardiging van een voor (zwangere) vrouwen nadelige regeling gesteld dal 
De regeling werd vervolgens echter toch toelaatbaar geacht, nu de Belgische regering ter rechtvaardiging hiervan nog een aantal andere, voldoende overtuigende en nietdiscriminatoire, argumenten had aangevoerd. Hierdoor wordt bevestigd dat het niet in ieder geval zo zal zijn dat discriminatoire overwegingen tot ontoelaatbaarheid van het onderscheid leiden. Tevens wordt hierdoor duidelijk dat het niet noodzakelijk is dat de overwegingen daadwerkelijk op het maken van onderscheid op grond van geslacht zijn gericht: om inherent discriminatoir te zijn is het al voldoende dat er onderscheid wordt gemaakt op grond van een criterium dat noodzakelijkerwijze onderscheid op grond van geslacht tot gevolg heeft.

Gezien de moeilijkheden die zijn verbonden aan het criterium van de discriminatoire doelstelling zal van de rechter moeten worden verwacht dat hij een toepassing hiervan terdege motiveert. Van belang is vooral dat hij voldoende toelicht waarom hij een bepaald argument discriminatoir van aard acht en dat hij, wanneer er als rechtvaardiging nog andere argumenten zijn aangevoerd, op overtuigende wijze aangeeft welk argument naar zijn mening doorslaggevend moet worden geacht. ${ }^{201}$

Van belang is tenslotte dat het Hof in een aantal gevallen een bijzondere uitwerking heeft gegeven aan dit criterium, waardoor het voor de praktijk beter bruikbaar lijkt te zijn. ${ }^{202}$ Een voorbeeld van een dergelijke uitwerking is te vinden in het arrest Rinner$K u ̈ h n,{ }^{203}$ dat betrekking had op een Duitse wettelijke regeling op grond waarvan werknemers die minder dan 45 uur per maand of 10 uur per week werkten geen recht hadden op doorbetaling van loon bij ziekte. De Duitse regering had ter rechtvaardiging van deze regeling aangevoerd dat dergelijke werknemers minder goed in een bedrijf zijn geïntegreerd en ook minder van dit bedrijf afhankelijk zijn dan andere. Het Hof stelde daarover het volgende:

"Deze overwegingen zijn [...] niet meer dan generaliserende uitspraken ten aanzien van bepaalde categorieěn werknemers. Er kunnen geen objectieve criteria uit worden afgeleid die geen verband houden met discriminatie op grond van geslacht."

Hieruit kan worden afgeleid dat de rechtvaardiging moet berusten op specifieke en houdbare stellingen over de betrokken groep. Gesteld kan worden dat dit criterium een verplichting voor de wederpartij inhoudt om voldoende onderzoek te verrichten naar de

het met deze regeling een redelijke verdeling van risico's tussen de zwangere werkneemsters, de werkgever en de samenleving tot stand wilde brengen. Het Hof oordeelde hierover dat een dergelijke overweging niet los staat van onderscheid op grond van geslacht (punt 40).

201. Deze motiveringsplicht geldt vanzelfsprekend nog sterker wanneer de rechter van mening is dat er discriminatoire bedoelingen aanwezig zijn, maar deze door de verwerende partij worden verhuld. Dit hoeft hij overigens niet in iedere zaak na te gaan: alleen wanneer er op basis van de feiten of op grond van stellingen van partijen redenen zijn om te veronderstellen dat dergelijke verborgen bedoelingen aanwezig zijn, zal daartoe aanleiding bestaan.

202. Zie bijv. EHvJ 19 november 1992, zaak C-226/91, Molenbroek, Jurispr. 1992, 1-5943, punt 19.

203. EHvJ 13 juli 1989 , zaak $171 / 88$, Jurispr. 1989, 2741

204. Punt 14. Idem in EHvJ 7 februari 1991, zaak C-184/89, Nimz, Jurispr. 1991, 1-297, punt 14 (waarin was aangevoerd dat voltijdwerkers sneller bepaalde vaardigheden verwerven en ervaring opbouwen), EHvJ 2 oktober 1997, zaak C-1/95, Gerster, Jurispr. 1997, I-5253 (waarin was aangevoerd dat er een verband bestaat tussen anciênniteit en het verwerven van kennis en ervaring) en EHvJ 17 juni 1998, zaak C-243/95, Hill en Stapleton, Jurispr. 1998, 1-3739, punt 38. Zie ook Ellis 2000, p. 1407. 
vraag of de veronderstellingen die hij aan zijn classificatie ten grondslag wil leggen voldoende met de werkelijkheid overeenstemmen. Dit criterium is iets concreter en daardoor bruikbaarder dan het hiervoor genoemde algemene verbod op discriminatoire overwegingen. Een goede toepassing hiervan kan ertoe bijdragen dat ongelijke behandeling niet wordt gebaseerd op overdreven stereotypen of vooroordelen, nu die in de meeste gevallen juist tot uitdrukking zullen komen in generalisaties met betrekking tot bepaalde groepen. Het lijkt dan ook zeker wenselijk om dit criterium in het algemene toetsingsmodel op te nemen.

\section{Doelstelling moet voldoende specifiek zijn}

Een tweede interessant toetsingscriterium is terug te vinden in het arrest SeymourSmith. ${ }^{205}$ In deze uitspraak, die betrekking had op een onderscheid in een regeling met betrekking tot ontslagbescherming, oordeelde het Hof als volgt:

"Eenvoudige algemene beschouwingen ten betoge dat een bepaalde maatregel de aanwerving van arbeidskrachten bevordert, volstaan niet om aan te tonen dat het doel van de litigieuze bepaling niets van doen heeft met discriminatie op grond van geslacht en verschaffen evenmin gegevens op grond waarvan redelijkerwijs kan worden geoordeeld, dat de gekozen middelen geschikt waren ter bereiking van dat doel." 2060

Uit deze overweging kan worden afgeleid dat ter rechtvaardiging van een indirect onderscheid niet kan worden volstaan met te algemene doelstellingen of overwegingen: een voldoende mate van specificiteit is vereist. Ook dit criterium, dat nauw aansluit bij het hiervoor genoemde vereiste dat een doelstelling niet mag berusten op generalisaties, kan uitstekend worden toegepast bij andere vormen en gronden van onderscheid.

\section{Werkelijke behoefte van de onderneming}

Als een maatregel in een horizontale verhouding, bijvoorbeeld de verhouding werkgever-werknemer, een indirect onderscheid tot effect heeft, moet de werkgever blijkens het arrest Bilka ${ }^{207}$ aantonen dat de regeling voorziet in een werkelijke behoefte van de onderneming. ${ }^{20 x}$ In de praktijk blijkt dit te betekenen dat de werkgever met feitelijke gegevens moet aantonen dat zijn bedrijfsvoering door de maatregel daadwerkelijk gediend wordt. ${ }^{200} \mathrm{Zo}$ stelde het Hof in het arrest Danfoss ${ }^{210}$ dat de werkgever het gebruik van een eigenschap als flexibiliteit (die per definitie leidt tot een benadeling van vrouwen) alleen als onderscheidingscriterium kan rechtvaardigen,

"[...] door aan te tonen dat die eigenschap voor de uitvoering van de aan de werknemers opgedragen specifieke werkzaamheden van belang is."211

\section{EHvJ 9 februari 1999, zaak C-167/97, Jurispr. 1999, 1-623}

206. Punt 76

207. EHvJ 13 mei 1986, zaak 170/84, Jurispr. 1986, 1607

208. Het Hof heeft bovendien een tweetal keer gesteld dat er sprake moet zijn van economische redenen (namelijk in EHvJ 31 maart 1981, zaak 96/80, Jenkins, Jurispr. 1981, 911, punt 12 en in Bilka (zie vorige noot), punt 36). In hoeverre dit iets toevoegt aan het vereiste van een werkelijke behoefte van de onderneming is niet geheel duidelijk; het criterium komt in latere rechtspraak ook niet terug. Zie ook Drijber/Prechal 1997, p. 139.

209. Zie het reeds eerder aangehaalde arrest Bilka, punt 36; vgl. Hervey 1993, p. 68.

210. EHvJ 17 oktober 1989, zaak 109/88, Jurispr. 1989, 3199

211. Punt 22. Daarnaast kan uit het arrest Rummler worden afgeleid dat, zelfs als dit het geval is, ook geke- 
Hetzelfde geldt voor het vereisen van een bepaalde opleiding ${ }^{212}$, het betrekken in de beloningsregeling van een criterium als lichamelijke inspanning of belasting ${ }^{213}$, het vermogen zich aan te passen aan werktijden en arbeidsplaatsen ${ }^{214}$ of de persoonlijke arbeidscapaciteit ${ }^{215}$, en voor het vereisen van een bepaalde beroepservaring of anciënniteit. $^{216}$

Door deze invulling van het criterium van de werkelijke behoefte heeft het Hof een duidelijke beperking gesteld aan het doel van een regeling met disproportioneel benadelende effecten: kennelijk mag een werkgever slechts regelingen vaststellen die direct tot doel hebben de bedrijfsvoering te optimaliseren. Het is de vraag of een dergelijke uitwerking zich goed leent voor een algemene toepassing: gesteld kan zeker worden dat optimalisering van de bedrijfsvoering niet altijd het enige gerechtvaardigde doel is. Beter bruikbaar is dan het algemene criterium dat in Bilka is geformuleerd: op grond daarvan hoeft de verwerende partij slechts aan te tonen dat de door hem getroffen maatregel voorziet in een concrete en aantoonbare behoefte, van welke aard dan ook.

\section{Noodzakelijke doelstelling van sociaal beleid}

Voor onderscheid in verticale verhoudingen, zoals bij sociale zekerheidsregelgeving, heeft het Hof eveneens een specifiek vereiste geformuleerd voor de toetsing van het doel. In het arrest Teuling ${ }^{217}$ stelde het Hof dat de getroffen maatregel een integrerend onderdeel moet uitmaken van het sociaal beleid van de lidstaten. ${ }^{218}$ Een nadeel van deze formulering is zijn breedte: geïmpliceerd lijkt te worden dat een doelstelling altijd

ken moet worden naar de regeling als geheel, vooral als er verschillende classificaties in deze regeling zijn opgenomen. In een dergelijk geval moet niet alleen de classificatie voldoen aan een werkelijke behoefte van de onderneming, maar moet er ook voor worden gezorgd dat een criterium waaraan mannen gemakkelijker kunnen voldoen dan vrouwen wordt gecompenseerd door een regeling waaraan vrouwen gemakkelijker kunnen voldoen dan mannen (EHvJ 1 juli 1986, zaak 237/85, Jurispr. 1986, 2101, punt 15; vgl. ook Drijber/Prechal 1997, p. 140).

212. Zie eveneens het arrest Danfoss, punt 23.

213. EHvJ 1 juli 1986, zaak 237/85, Rummler, Jurispr. 1986, 2101, punt 24

214. EHvJ 27 oktober 1993, zaak C-127/92, Enderby, Jurispr. 1993, 1-5535, punt 25

215. EHvJ 26 juni 2001, zaak C-381/99, Brunnhofer, Jurispr. 2001, I-4961, punt 72. Van belang is dat het Hof bij dit criterium aangaf dat hiermee op een zo objectief mogelijke manier moet worden omgegaan. Zo mag een verschil in beloning alleen worden gebaseerd op persoonlijke productiviteit of individuele en concrete resultaten wanneer de betrokken werknemer al binnen het bedrijf werkzaam is. Voorspellingen over de persoonlijke productiviteit mogen bij de aanstelling in ieder geval geen rol spelen; op dat moment is deze factor te subjectief en variabel om een ongelijke beloning te kunnen rechtvaardigen. Zie nader punt $75-78$ van het genoemde arrest.

216. Bij dit laatste is nog interessant dat het Hof aanvankelijk stelde dat het belang van ancienniteit en beroepservaring voor de werkzaamheden binnen een bedrijf zodanig evident is, dat de werkgever op grond hiervan onderscheid kan maken zonder het belang aan te tonen voor de werkzaamheden van de betrokken werknemer (zie opnieuw Danfoss, punt 24). In latere rechtspraak is het Hof hiervan teruggekomen (EHvJ 7 februari 1991, zaak C-184/89, Nimz, Jurispr. 1991, 1-297, punt 14).

217. EHvJ 11 juni 1987, zaak 30/85, Teuling, Jurispr. 1987, 2497

218. Punt 16; het ging hierin om een regeling die tot doel had een sociaal minimum te garanderen. Idem in EHvJ 7 mei 1991, zaak C-229/89, Commissie/België (werkloosheidsuitkeringen), Jurispr. 1991, 1-2205, punt 21 en EHvJ 19 november 1992, zaak C-226/91, Molenbroek, Jurispr. 1992, 1-5943, punt 15; het Hof makte hierin overigens ook melding van het vereiste van een legitieme doelstelling van sociaal beleid (punt 13). Vgl. Hervey 1993, p. 73, Steiner 1996, p. 124 en Craig/De Búrca 1998, p. 817; zij wijzen er alle op dat het verschil in formulering is aangebracht om voldoende ruimte te scheppen voor de verschillen in doelstelling en benadering tussen regelingen op horizontaal en verticaal niveau. 
gerechtvaardigd is, zolang deze maar past in het door de lidstaat gevoerde sociale beleid. Ook dan kan er echter sprake zijn van een gerechtvaardigde doelstelling: het sociale beleid zelf kan immers gebaseerd zijn op ingeslepen vooroordelen jegens bepaalde groepen, terwijl het bovendien mogelijk is dat binnen een op zichzelf redelijk beleid maatregelen worden getroffen met minder aanvaardbare doelstellingen. Het Hof lijks zich dit te hebben gerealiseerd: in 1994 koos het voor een iets andere formulering, die meer ruimte biedt voor een inhoudelijke beoordeling van de doelstellingen en het daaraan ten grondslag liggende beleid. ${ }^{219}$ Het Hof stelde in dit arrest dat een indirect discriminerende wettelijke regeling slechts kan worden gerechtvaardigd,

"[...] wanneer de gekozen middelen beantwoorden aan een legitieme doelstelling van het sociaal beleid van de lidstaat waarvan de wettelijke regeling in het geding is."

In deze beperktere formulering leent het criterium zich goed voor een meer algemene toepassing: het is zonder meer redelijk dat de overheid als regelgever doelstellingen moet formuleren die passen in het gevoerde beleid en die bovendien legitiem zijn. Opmerkelijk is overigens dat het Hof geen nadere invulling heeft gegeven aan het vereiste van legitimiteit. Er kan echter vanuit worden gegaan dat dit vereiste in ieder geval betekent dat het doel in overeenstemming moet zijn met het positieve recht.

\section{Niet toelaatbaar als doelstelling: budgettaire overwegingen}

In de rechtspraak over ongelijke behandeling in de sociale zekerheid heeft het Hof tenslotte een specifieke uitwerking gegeven aan het vereiste dat er steeds een noodza. kelijke doelstelling van sociaal beleid moet worden nagestreefd. ${ }^{22 t}$ In het arrest Roks stelde het Hof het volgende:

"Ofschoon budgettaire overwegingen ten grondslag kunnen liggen aan de sociale beleidskeuzen van een lidstaat en de aard of de omvang van de sociale beschermingsmaatregelen die de Lid-Staat wenst vast te stellen, kunnen beïnvloeden, vormen zij evenwel niet een doelstelling van dat beleid en kunnen zij dus ook niet een discriminatie ten nadele van een der geslachten rechtvaardigen. ${ }^{223}$

Volgens het Hof is de reden voor het vaststellen van dit criterium dat de toepassing van een zo fundamenteel beginsel als dat van gelijke behandeling van mannen en vrouwen niet afhankelijk mag worden gesteld van de stand van de openbare financiën in de lidstaten op een bepaald moment. ${ }^{24}$ Het is echter de vraag of het wenselijk is om een budgettaire doelstelling in alle gevallen ontoelaatbaar te achten. Overwegingen van

219. EHvJ 24 februari 1994, Roks, zaak C-343/92, Jurispr. 1994, 1-571

220. Punt 34. Idem in EHvJ 1 februari 1996, zaak C-280/94, Posthuma, Jurispr. 1996, 1-179, punt 27, EHv] 7 maart 1996, zaak C-278/93, Freers en Speckmann, Jurispr. 1996, I-1165, punt 27, EHvJ 9 februari 1999, zaak C-167/97, Seymour-Smith en Perez, Jurispr. 1999, 1-623, punt 71 en EHvJ 6 april 2000, zaak C-226/98, Jorgensen, Jurispr. 2000, 1-2447, punt 41 . In andere arresten wordt de eis dat het moet gaan om een legitieme doelstelling niet gesteld; de reden daarvoor is onduidelijk (zie bijv. EHvJ 8 fobruari 1996, zaak C-8/94, Laperre, Jurispr. 1996, 1-273, punt 18-19).

221. Ook in de rechtspraak over horizontale gevallen van onderscheid is melding gemaakt van dit criterium: zie EHvJ 17 juni 1998, Hill en Stapleton, Jurispr. 1998, 1-3739, punt 40 (waarbij de grens tussen horizontaal en verticaal onderscheid overigens niet bijzonder scherp kon worden getrokken).

222. EHvJ 24 februari 1994, zaak C-343/92, Jurispr. 1994, I-571

223. Punt 35

224. Zie het arrest Roks, punt 36 . 
economische, financiële en zelfs puur budgettaire aard kunnen in bepaalde gevallen immers wel degelijk een redelijke rechtvaardiging vormen, bijvoorbeeld als er sprake is van een regeling die nauw raakt aan het economisch beleid of aan het belastingrecht. ${ }^{235}$ Bovendien heeft het Hof recentelijk aangenomen dat de noodzaak om overheidsgelden te beheren die bestemd zijn voor publieke goederen een legitieme reden van sociaal beleid kan vormen: geheel absoluut is het verbod dus niet. ${ }^{26}$

Wel kan worden gesteld dat in gevallen waarin budgettaire of financiêle overwegingen worden geaccepteerd als gerechtvaardigde doelstelling, het noodzakelijk is om een extra zorgvuldige toetsing van de noodzaak en de proportionaliteit van het gemaakte onderscheid uit te voeren: op die manier kan worden voorkomen dat individuele belangen te snel of onnodig zwaar worden aangetast.

\subsubsection{Toetsing van het doel bij onderscheid op het gebied van de landbouw}

\section{De doelstellingen van het gemeenschappelijk landbouwbeleid}

Voor de interpretatie en toepassing van het verbod van ongelijke behandeling op het gebied van de landbouw is het van bijzonder belang dat de verschillende doelstellingen van het gemeenschappelijke landbouwbeleid uitdrukkelijk zijn opgesomd in het EGVerdrag; het gaat daarbij om doelstellingen als het doen toenemen van de productiviteit van de landbouw, het verzekeren van een redelijke levensstandaard voor producenten, het stabiliseren van de markten en het verzekeren van redelijke prijzen. ${ }^{27}$ Het Hof heeft al vroeg aangegeven dat er een duidelijk samenhang bestaat tussen deze opsomming en het verbod van ongelijke behandeling:

"[...] al veroorlooft artikel 39 [nu artikel 33, JHG] bij het uitzetten van het gemeenschappelijk landbouwbeleid een ruime keuze van oriěntatic- en interventiemaatregelen, niettemin [moet] volgens artikel 40, lid 3, tweede alinea [nu artikel 34 lid 2, JHG] de gemeenschappelijke ordening van de landbouwmarkten zich [...] beperken tot het nastreven van de [...] genoemde doelen. [...] [A] rtikel 40, lid 3, tweede alinea [bepaalt] bovendien $[\ldots]$ dat de gemeenschappelijke marktordening 'elke discriminatie tussen producenten of verbruikers van de Gemeenschap (moet) uitsluiten'. [...] [A]ldus [verschaft] de formulering van de doelstellingen in artikel 39, tezamen met de bepalingen van artikel 40 , lid 3 , tweede alinea, positieve zowel als negatieve criteria [...] waaraan de wettigheid van de ter zake genomen maatregelen kan worden getoetst."22z

Ook in latere rechtspraak komt een dergelijk verband tot uitdrukking. Zo stelde het Hof in het arrest Denkavit Nederland $B V^{229}$, dat betrekking had op een verschil in subsidiëring van vloeibare magere melk en magere melkpoeder, het volgende:

225. Vgl. Drijber/Prechal 1997, p. 140: zij stellen dat economische of financiēle rechtvaardigingsgronden soms indirect een sociaal doel kunnen dienen. Zie ook de conclusie van A-G Darmon bij het bovengeciteerde arrest Roks, m.n. punt 54 .

226. EHvJ 6 april 2000, zaak C-226/98, Jorgensen, Jurispr. 2000, I-2447, punt 40. Zie ook Lenaerts/Foubert 2001, blz. 274/275.

227. Zie artikel 33 EG. Vgl. Barents 1994 (I), p. 346 en (II), p. 547

228. EHvJ 5 juli 1977, zaak 114/76, Bela-Mühle, Jurispr. 1977, 1211, punt 6. Zie ook EHvJ 11 mei 2000, zaak C-56/99, Gascogne, Jurispr. 2000, 1-3079, punt 39, waarin het Hof uitdrukkelijk aangaf dat de discriminatoire regeling was gericht op een in artikel 39 (oud) opgenomen doelstelling.

229. EHvJ 14 januari 1981, zaak 35/80, Jurispr. 1981, 45 
"[...] de omstandigheid dat bij de vaststelling van de steun voor magere-melkpoeder die voor voederdoeleinden is gebruikt, rekening moet worden gehouden met tal van elementen betreffende de marktsituatie, sluit op zichzelf al uit dat een relatief hogere steun voor magere melk als discriminerend voor magere-melkpoeder kan worden beschouwd, wanneer het verschil tussen de twee steunbedragen beantwoordt aan de behoeften van de betrokken markten en aan de eisen van de gemeenschappelijke marktordening waaronder die produkten vallen."

Hierdoor is er bij het gemeenschappelijk landbouwbeleid een bijzondere invulling gegeven aan het vereiste dat door de ongelijke behandeling een gerechtvaardigd doel moet worden nagestreefd. Bij de beoordeling van de toelaatbaarheid van een ongelijke behandeling van producenten of verbruikers zal het Hof immers steeds moeten nagaan of er een doelstelling wordt nagestreefd die past binnen de in artikel 33 gegeven opsomming. ${ }^{211}$ Het zal duidelijk zijn dat deze interpretatie zich niet of nauwelijks leent voor een toepassing op andere gebieden: de genoemde doelstellingen zijn uitsluitend vastgesteld voor het landbouwbeleid en laten zich niet eenvoudig verplaatsen naar andere beleidsvelden. Ook een aantal meer specifieke criteria dat in dit verband is vastgesteld (zoals het vereiste dat niet in territoriale zin mag worden onderscheiden, maar alleen op basis van productie- en verbruikscondities en op basis van verschillen in streek $^{232}$ en het criterium dat rekening moet worden gehouden met doelstellingen van mededingingsbeleid ${ }^{233}$ ) zijn minder bruikbaar voor ongelijke behandeling op andere terreinen. Deze constatering is van belang, nu daaruit blijkt dat het wenselijk kan zijn om bijzondere criteria te hanteren binnen het kader van het algemene toetsingsmodel, $\mathrm{Bij}$ de uiteindelijke formulering van dit model moet daarvoor voldoende ruimte worden gelaten.

230. Punt 17; zie ook EHvJ 15 juli 1982, zaak 245/81, Edeka, Jurispr. 1982, 2745, punt 13, EHvJ 15 september 1982, zaak 106/81, Julius Kind, Jurispr. 1982, 2885, punt 24, EHvJ 24 januari 1991, zaak C. 27/90, SITPA, Jurispr. 1991, 1-133, punt 32, EHvJ 13 april 2000, zaak C-292/97, Karlsson e.a., Jurispr 2000, 1-2737, punt 45 en EHvJ 11 mei 2000, zaak C-56/99, Gascogne, Jurispr. 2000, I-3079, punt 44.

231. Vgl. Boest 1984, p. 137. In de meeste gevallen wordt afzonderlijk vastgesteld of door de litigieure maatregel inderdaad een van de opgesomde doelstellingen wordt nagestreefd. Pas wanneer dit vaststat wordt nagegaan of het discriminatieverbod is geschonden. Een toetsing van de legitimiteit van het mi gestreefde doel komt bij de toetsing aan artikel 34 lid 2 dan ook nauwelijks voor.

232. Bijvoorbeeld EHvJ 2 juli 1974 , zaak $153 / 73$, Holtz \& Willemse, Jurispr. 1974, 675, punt 13 en EHvJ 13 december 1984, zaak 106/83, Sermide, Jurispr. 1984, 4209, punt 28

233. Zie EHvJ 13 december 1989 , zaak C-204/88, Paris, Jurispr. 1989, 4361, punt 14 . Het verzekeren van goede mededingingsvoorwaarden is in het landbouwrecht van groot belang: zoals al eerder is aangege ven leidt vrijwel iedere ingreep op het gebied van de landbouw tot veranderingen in de mededingings. verhoudingen. Het criterium dat rekening moet worden gehouden met de consequenties van de getroffen maatregelen voor de concurrentie kan dan ook op verschillende manieren worden ingevuld: $z 0 \mathrm{kan}$ de doelstelling om de concurrentie kunstmatig en emstig te vervalsen volgens het Hof nooit toelaatbar zijn (EHvJ 17 juli 1959, gevoegde zaken $32 / 58$ en 33/58, SNUPAT, Jurispr. 1958-59, 305), terwijl het aan de andere kant wel gerechtvaardigd is om maatregelen te treffen waardoor weliswaar een ongelijke behandeling wordt veroorzaakt, maar waardoor de mededingingsverhoudingen worden hersteld (zis EHvJ 10 maart 1998, zaak C-122/95, Duitsland/Raad, Jurispr. 1998, 1-973, punt 62). Ook uit het arrest Maizena (EHvJ 29 oktober 1980, zaak 139/79, Jurispr. 1980, 1-3393) blijkt dat binnen het gemeentschappelijk landbouwbeleid de vaststelling en beïnvloeding van concurrentieverhoudingen zeer be langrijk is. Zie Barents 1994 (I), p. 335 en 336 en Tridimas 1999 (I), p. 49. 


\section{Voorkomen van ernstiger, meer algemene of duidelijkere discriminaties}

In een beperkt aantal arresten heeft het Hof gebruik gemaakt van andere criteria dan rechtstreeks uit artikel 33 EG voortvloeien; het gaat daarbij om criteria die minder specifiek zijn gericht op het gemeenschappelijk landbouwbeleid. Eén van deze criteria is te vinden in het arrest Stölting ${ }^{24}$, waarin een medeverantwoordelijkheidsheffing voor melk in het geding was. ${ }^{235} \mathrm{Bij}$ het vaststellen van het bedrag van deze heffing in nationale valuta werd gebruik gemaakt van zogenaamde "representatieve" of "groene" wisselkoersen, en dus niet van de normale wisselkoersen zoals die tussen de lidstaten golden. ${ }^{26}$ Dit zou door de feitelijke verschillen in de monetaire situatie van de lidstaten tot ongelijke lasten voor de betrokken producenten kunnen leiden: in bepaalde gevallen was de representatieve wisselkoers minder gunstig dan de normale wisselkoers. Het Hof stelde hierover het volgende:

"Ook al kan bij sommige verrichtingen de toepassing van deze wisselkoersen in voorkomend geval voordelen of nadelen opleveren die op discriminaties kunnen lijken, dit neemt niet weg dat in het algemeen daarmee monetaire situaties kunnen worden opgevangen die, bij het ontbreken van een maatregel als in het geding, tot veel ernstiger, duidelijker en meer algemene discriminaties zouden leiden."237

Het door het Hof in dit arrest vastgestelde criterium leent zich uitstekend voor algemene toepassing. ${ }^{238}$

\section{Rechtszekerheid}

Een tweede criterium dat zich goed leent voor een meer algemene toepassing is terug te vinden in enkele arresten van het Hof over de berekening van referentiehoeveelheden bij de productie van melk. Referentiehoeveelheden dienen vaak als berekeningsgrondslag voor quota of heffingen en zijn gebaseerd op de hoeveelheid melk die een veehouder in een bepaalde periode produceert. In de betreffende gemeenschapsregelingen is

234. EHvJ 21 februari 1979, zaak 138/78, Jurispr. 1979, 713

235. Een dergelijke heffing wordt vaak opgelegd wanneer er sprake is van kostbare overschotten en overproductie (zoals bijvoorbeeld bij melk of graan); de opbrengst van de heffing wordt gebruikt om de markt en de afzetmogelijkheden voor het product te verbeteren. Alle producenten, ongeacht de kwaliteit en de bestemming van hun producten, moeten een dergelijke heffing opbrengen. Zie over de werking van de medeverantwoordelijkheidsheffing in het bijzonder EHvJ 18 maart 1986, zaak 179/84, Bozzetti, Jurispr. 1985, 2301.

236. Bij de vaststelling van de hoogte van heffingen of subsidiebedragen werd in het verleden gebruik gemaakt van zogenaamde rekeneenheden. Om het daadwerkelijk te betalen of te verkrijgen bedrag vast te stellen voor een bepaald land moesten deze rekeneenheden worden omgezet naar de betrokken nationale valuta. De geldende wisselkoersen waren daarbij dus van groot belang. Er rees dan ook een probleem toen als gevolg van bepaalde monetaire besluiten begin jaren zeventig de valutakoersen "zwevend" werden ten opzichte van de dollar: de fluctuaties in de hoogte van de wisselkoersen namen daardoor sterk toe. Om de landbouwpolitiek niet te zeer van deze nationale fluctuaties afhankelijk te maken namen de gemeenschapsinstellingen een aantal besluiten, waaronder het gebruik van vaste, representatieve wisselkoersen om de rekeneenheden om te zetten naar bedragen in nationale valuta. Zie nader de conclusie van A-G VerLoren van Themaat bij EHvJ 28 oktober 1982, gev. zaken 292 en 293/81, Loiret \& Haentjens, Jurispr. 1982,3887 , p. 3913 e.v.

237. Punt 10, cursief toegevoegd.

238. Vervolgens moet natuurlijk wel nog worden bekeken of ook aan de overige vereisten is voldaan: van belang blijft bijvoorbeeld of er ter bereiking van het doel niet kon worden volstaan met minder vergaande maatregelen. 
meestal duidelijk vastgelegd welke periode geldt als referentieperiode, hetgeen nadelig kan zijn voor veehouders die gedurende die periode door buitengewone omstandighe. den een niet-representatieve hoeveelheid melk hebben geproduceerd. Dit soort producenten wordt dan benadeeld tegenover producenten die in de referentieperiode wel een representatieve productie hebben gehad. Over de verenigbaarheid van de keuze van een bepaalde referentieperiode met het verbod van ongelijke behandeling stelde het Hof in de zaak Erpelding ${ }^{239}$ het volgende:

"Dit gevolg [de benadeling van bepaalde producenten, JHG] vindt [...] zijn rechtvaardiging in de noodzaak om in het belang van de rechtszekerheid en omwille van de goede werking van het stelsel [...] het aantal jaren dat als referentiejaar kan worden genomen, te beperken."210

Vastgesteld kan worden dat het nastreven van rechtszekerheid ook in andere gevallen van ongelijke behandeling een gerechtvaardigde doelstelling zal zijn. ${ }^{241}$ Het lijkt dan ook wenselijk om een criterium als dit op enigerlei wijze in het algemene toetsingsmodel te verwerken.

\subsubsection{Toetsing van het doel bij onderscheid op grond van nationaliteit}

\section{Inleiding}

Ook bij ongelijke behandeling op grond van nationaliteit vormt de toetsing van het doel een belangrijk onderdeel van het rechtvaardigingsmodel. De rechtspraak op dit punt is echter sterk casuïstisch van aard: het Hof gaat van geval tot geval na of de specifiek aangevoerde doelstellingen al dan niet toelaatbaar zijn, zonder daarbij duidelijk herkenbare criteria te hanteren. Hierdoor kunnen uit de rechtspraak slechts enkele algemene maatstaven worden afgeleid, die hierna kort zullen worden besproken.

\section{Redenen van algemeen belang}

Wanneer een indirect onderscheid op grond van nationaliteit is veroorzaakt door de overheid, zoals meestal het geval blijkt te zijn, vereist het Hof vrijwel steeds dat de discriminatoire regeling is ingegeven door redenen van algemeen belang. ${ }^{22}$ Hoewel er geen twijfel over kan bestaan dat dit een redelijk criterium is dat zich goed leent voor een algemene toepassing op het gebied van regelgeving en beleidsvorming, is het de vraag of het bijzonder zinvol is om dit in het algemene toetsingsmodel op te nemen: het criterium is zodanig ruim geformuleerd dat het slechts een zeer beperkt houvast zal bieden bij het beoordelen van de toelaatbaarheid van het nagestreefde doel. ${ }^{243}$

239. EHvJ 17 mei 1988, zaak 84/87, Jurispr. 1988, 2665

240. Punt 30, cursief toegevoegd. Zie ook EHvJ 10 januari 1992, zaak C-177/90, Kühn, Jurispr. 1992, 1.35, punt 18 en EHvJ 24 oktober 1973, zaak 5/73, Balkan-Import-Export, Jurispr. 1973, 1091, punt 22.

241. Wel zal het duidelijk zijn dat rechtszekerheid alleen niet altijd een ongelijke behandeling zal kunnen rechtvaardigen. Dit is echter een aspect dat pas bij de beoordeling van de evenredigheid tussen doel en middel aan de orde zal komen.

242. Zie bijv. EHvJ 3 februari 1982, gev, zaken 62 en 63/81, Seco, Jurispr. 1982, 223, punt 10, EHvJ 28 januari 1992, zaak C-204/90, Bachmann, Jurispr. 1992, 1-249, punt 14 en EHvJ 28 januari 1992, zasi C-300/92, Commissie/België (levensverzekeringen), Jurispr. 1992, I-305, punt 10. Opvallend is dat dî. niet met zoveel woorden door het Hof als vereiste wordt gesteld, maar dat het wel steeds aangeeft des bepaalde argumenten door de verweerder als "redenen van algemeen belang" naar voren zijn gebracht.

243. Een meer specifieke uitwerking van dit criterium is gegeven in het arrest Mac Quen, dat betrekking 


\section{Geen discriminatoire overwegingen}

In het reeds eerder genoemde arrest $O^{\prime} \mathrm{Flynn}^{2+4}$ stelde het Hof dat bepalingen die een benadeling op grond van nationaliteit teweeg brengen ontoelaatbaar zijn, tenzij

"[...] die bepalingen worden gerechtvaardigd door objectieve overwegingen die los staan van de nationaliteit van de betrokken werknemers en zij evenredig zijn aan het rechtmatig door het nationale recht nagestreefde doel."21s

Net als bij onderscheid op grond van geslacht geldt ook bij nationaliteit dat een maatregel die uitsluitend of in overwegende mate is ingegeven door discriminatoire overwegingen niet gerechtvaardigd kan worden geacht. Deze constatering is met name interessant, nu hieruit blijkt dat het goed mogelijk is om dit criterium bij verschillende gronden van onderscheid toe te passen. Helaas heeft het Hof in zijn rechtspraak over onderscheid op grond van nationaliteit slechts zelden toepassing gegeven aan dit criterium. Het is dan ook niet mogelijk om uit deze rechtspraak conclusies te trekken over de wijze waarop kan worden vastgesteld dat er sprake is van discriminatoire overwegingen en over de mate waarin het Hof in staat en bereid is om eventuele verhulde doelstellingen te traceren.

\section{Niet toelaatbaar: overwegingen van administratieve aard}

In het arrest Terhoeve ${ }^{246}$ was een Nederlandse wet in het geding, op grond waarvan een werknemer die een deel van het jaar in het buitenland werkte voor dat deel van het jaar verplicht verzekerd bleef uit hoofde van de Nederlandse volksverzekeringen. Bij de bepaling van de hoogte van de premies werd daarbij uitgegaan van de maximumgrondslag voor de premieheffing volksverzekeringen, hetgeen soms een hogere premie tot gevolg had dan wanneer de gebruikelijke berekeningswijze zou zijn gehanteerd. De Nederlandse regering had als rechtvaardiging voor deze regeling gesteld dat aan andere heffingsmethoden uitvoeringstechnische bezwaren waren verbonden. Het Hof deed deze rechtvaardiging eenvoudig af met de volgende stelling:

"Overwegingen van administratieve aard kunnen [...] een afwijking door een lidstaat van de regels van gemeenschapsrecht niet rechtvaardigen."247

had op een belemmering van het interstatelijk verkeer. Daarbij verwees het EHvJ in het kader van de rechtvaardiging naar een bepaling van gemeenschapsrecht (artikel 46 lid 1 EG) waarin een aantal toelaatbare rechtvaardigingen voor direct onderscheid opgesomd staan. Wordt én van die doelstellingen aangevoerd in het geval van maatregelen zonder onderscheid (of indirect onderscheid), dan betekent dit volgens het EHvJ dat deze "in beginsel ook nationale maatregelen [kunnen] rechtvaardigen" (EHvJ I februari 2001, Mac Quen, Jurispr. 2001, 1-837, punt 28). Voor het algemene toetsingsmodel is deze benadering niet echt bruikbaar, hoewel kan worden gesteld dat bij de beoordeling van ongelijke behandeling in het geval van open gelijkheidsbepalingen ook gekeken kan worden naar de uitzonderingsbepalingen bij andere, meer specifieke verboden van ongelijke behandeling.

244. EHvJ 23 mei 1996, zaak C-237/94, Jurispr. 1996, 1-2617

245. Punt 19; idem in EHvJ 6 juni 2000, zaak C-281/98, Angonese, Jurispr. 2000, 1-4139, punt 42 . Vgl., in iets andere bewoordingen, ook EHvJ 3 februari 1982, gev. zaken 62 en 63/81, Seco, Jurispr. 1982, 223.

246. EHvJ 26 januari 1999, zaak C-18/95, Jurispr. 1999, 1-345. Van belang is dat het Hof in dit arrest geen gebruik maakte van de gelijke behandelingsterminologie, maar volstond met de stelling dat werknemers door de regeling konden worden weerhouden van migratie. Vervolgens werd wel gebruik gemaakt van de gebruikelijke rechtvaardigingstoets.

247. Punt 45. Idem in EHvJ 3 oktober 2000, zaak C-58/98, Corsten, Jurispr. 2000, 1-7919, punt 42 en EHvJ 
Deze weigering om administratieve overwegingen als gerechtvaardigde doelstelling te accepteren lijkt een soort complement te vormen van het bij onderscheid op grond van geslacht vastgestelde criterium dat budgettaire overwegingen een onderscheid op grond van geslacht nooit kunnen rechtvaardigen ${ }^{248}$ Waar bij dit laatste al de nodige bedenkin. gen zijn te plaatsen (zie daarover paragraaf 2.3.1) geldt dit voor administratieve overwegingen nog in het bijzonder: zeker wanneer er sprake is van onderscheid op minder verdachte gronden of op een gebied waarop de overheid over veel beleidsvrijheid beschikt kunnen administratieve overwegingen wel degelijk gerechtvaardigd worden geacht. ${ }^{249}$ Net als bij budgettaire en financiële overwegingen is het bij deze doelstelling vanzelfsprekend wel van belang om voldoende aandacht te besteden aan de toetsing van de verhouding tussen doel en middel..$^{250}$

\section{Vrij verkeer van diensten: bescherming van gebruikers als gerechtvaardigd doel}

Een laatste interessant criterium komt naar voren in de rechtspraak van het Hof over het vrije verkeer van diensten. De overheden van de verschillende lidstaten stellen aan dienstverleners, zoals advocaten of accountants, vaak allerlei eisen, zoals het bezit van

25 oktober 2001, zaak C-493/99, Commissie/Duitsland (bouwondernemingen), Jurispr. 2001, 1-8163, punt 21; vgl. Jørgensen 1990, p. 211.

248. Kostenoverwegingen lijken een onderscheid op grond van nationaliteit overigens wel te kunnen recht. vaardigen, hoewel dan wel de eis wordt gesteld dat de kosten daadwerkelijk bestaan en niet kunnen worden vermeden. Zie EHvJ 21 september 2000, zaak C-124/99, Borawitz, Jurispr. 2000, 1-7293, punt 32. Dit blijkt echter niet algemeen te gelden: voor het vrij verkeer van diensten geldt dat economische overwegingen niet kunnen dienen als rechtvaardiging (zie bijv. EHvJ 25 oktober 2001, gev. zaken C. 49/98, C-50/98, C-52/98 t/m C-54/98 en C-68/98 t/m C-71/98, Finalarte, Jurispr. 2001, I-7831, punt 39), net zoals voor het vrij verkeer van goederen (bijv. EHvJ 28 april 1998, zaak C-120/95, Decker, Jurispr. 1998, I-1831, punt 39); voor het vrij verkeer heeft het Hof in Decker wel gesteld dat "[...] een ernstige aantasting van het financiele evenwicht van het socialezekerheidsstelsel [niettemin] een dwis. gende reden van algemeen belang kan vormen waardoor een [...] belemmering gerechtvaardigd kan zijn" (punt 39). Van belang is overigens dat het Hof in Finalarte ook oordeelde dat, wanneer in de totstandkomingsgeschiedenis van een regeling alleen economische doelstellingen zijn aangevoerd, de nationale rechter kan nagaan of de regeling in de praktijk nog een andere, wel door het Hof toegelaten, doelstelling dient (zie punt 40 en 41 ). Daarmee laat het Hof niet alleen ruimte voor het verrichten van onderzoek naar het werkelijk doel van de regeling, maar ook naar de eventuele wenselijke effecten van een maatregel; in hoofdstuk 2, paragraaf 3.1.3 is daarvoor al gepleit. Door een dergelijke benadering kunnen de negatieve consequenties van het niet aanvaarden van budgettaire doelstellingen worden vermeden. Een nadeel van deze benadering is echter dat deze een actieve rechterlijke toetsing impliceert, nu het feitelijk de rechter, en niet de wetgever, is die vaststelt welke doelstellingen met de regeling mogen worden nagestreefd.

249. Dit blijkt ook uit de rechtspraak van het Hof zelf: met name op het gebied van de landbouw heeft het Hof administratieve overwegingen wel degelijk gerechtvaardigd geacht. Dit blijkt bijvoorbeeld uit EHvJ 23 februari 1983, zaak 8/82, Wagner/BALM, Jurispr. 1983, 371. Deze zaak had betrekking op een regeling voor de vergoeding van opslagkosten voor suiker, waarbij deze werd verleend voor de op: slagkosten van suiker die op de eerste dag van de maand om 0:00u binnen een lidstaat onderweg was van de ene naar de andere opslagplaats, maar niet als de suiker op dat moment onderweg was naar een opslagplaats in een andere lidstaat. Het Hof stelde hierover: "De controles die noodzakelijk zouden zjp indien de opslagkostenvergoeding ook voor grensoverschrijdende transportkosten worden toegekend, zouden onevenredig veel inspanning van de administratie vergen" (punt 20). Vgl. hierover Boest 1984 p. 134-135.

250. Ook dit blijkt uit de rechtspraak over de landbouw: in de Isoglucosezaken stelde het Hof dat praktische moeilijkheden die worden veroorzaakt door het hanteren van bepaalde quotasystemen geen rechtvals diging op kunnen leveren voor een kennelijk onbillijke last (EHvJ 25 oktober 1978, gev. zaken $103 \mathrm{en}$ 145/77, Royal Scholten-Honig, Jurispr. 1978, 2037, punt 81 en 82). 
vergunningen, het gevolgd hebben van een bepaalde opleiding en het voldoen aan ethische beroepsregels. In veel gevallen worden dergelijke eisen ook gesteld aan buitenlandse dienstverleners, hetgeen benadelend kan werken als deze dienstverleners tegelijkertijd ook moeten voldoen aan eisen die worden gesteld in de staat waar zij gevestigd zijn: er kan dan gemakkelijk sprake zijn van een dubbele en overbodige belasting. Vanwege de specifieke aard van dit indirecte onderscheid op grond van nationaliteit heeft het Hof hiervoor enkele bijzondere toetsingscriteria vastgesteld, waarbij voorop staat dat het door de beroepseisen nagestreefde doel gerechtvaardigd moet zijn. In de regel betekent dit dat alleen die vereisten toelaatbaar zijn die ervoor kunnen zorgen dat het beroep op een verantwoorde wijze wordt uitgeoefend en daardoor de gebruikers van diensten beschermen tegen slechte dienstverlening. ${ }^{251}$ In de rechtspraak zijn hiervan diverse voorbeelden terug te vinden: zo kunnen volgens het Hof bij juristen speciale eisen worden gesteld betreffende de beroepsethiek en als garantie voor een goede rechtsbedeling, ${ }^{252}$ bij impresario's kunnen beroepseisen worden gesteld ter bescherming van de artiesten die van hun diensten gebruik maken ${ }^{233}$ en bij vakantiegidsen is het toegestaan om eisen te stellen die ervoor kunnen zorgen dat historische rijkdommen optimaal worden uitgebaat en dat kennis van de kunst en cultuur van het land op een verantwoorde wijze wordt verspreid. ${ }^{254}$

Voor zover dergelijke toepassingen impliceren dat een gerechtvaardigd doel wordt nagestreefd wanneer door een regeling een goede en verantwoorde beroepsuitoefening wordt gewaarborgd, is het zeker bruikbaar voor een toepassing buiten het specifieke kader van de dubbele belasting bij het vrij verkeer van diensten. Het zal echter duidelijk zijn dat het criterium ook dan slechts toepassing kan krijgen in een specifieke context. Deze rechtspraak van het Hof pleit dan ook voor een vormgeving van het algemene toetsingsmodel waarin voldoende ruimte wordt gelaten om bij de beoordeling van de rechtvaardiging rekening te houden met specifieke omstandigheden.

\subsubsection{Toetsing van het doel bij artikel 90 EG}

Tenslotte kan ook bij de toetsing aan artikel 90 in bepaalde gevallen worden beoordeeld of door een belastingregeling een gerechtvaardigd doel wordt nagestreefd. Hoewel de formulering van het artikel daarvoor op het eerste gezicht geen ruimte laat, blijkt het Hof ook bij deze bepaling namelijk gebruik te maken van het concept van indirect onderscheid. ${ }^{\text {ss }}$ Dit concept blijkt met name bruikbaar te zijn wanneer er sprake is van een regeling van binnenlandse belasting die gelijkelijk geldt voor buitenlandse

251. Vgl. Jørgensen 1996, p. 210.

252. EHvJ 3 december 1974, zaak 33/74, Van Binsbergen, Jurispr. 1974, 1299, punt 12 en 14

253. EHvJ 18 januari 1979, gev. zaken 110 en $111 / 78$, Van Wesemael, Jurispr. 1979, 35

254. EHvJ 26 februari 1991, zaak C-154/89, Commissie/Frankrijk (toeristengidsen), Jurispr. 1991, I-659, punt 17 en EHvJ 26 februari 1991, zaak C-198/89, Commissie/Griekenland (toeristengidsen), Jurispr. $1991,1-727$

255. Zie daarover paragraaf 2.2.4, waarin is aangegeven dat normaal gesproken alleen een beoordeling van de vergelijkbaarheid wordt uitgevoerd. Wanneer er inderdaad sprake is van gelijksoortigheid is ieder verschil in belasting uitgesloten. Er bestaat bij belastingregelingen meestal ook minder ruimte om bepaalde beleidsdoelstellingen na te streven, omdat in het algemeen de voornaamste doelstelling van fiscale maatregelen het verkrijgen van staatsinkomsten is (Barents 1983, p. 455). Vgl. ook Craig/De Búrca 1998, p. 562. 
en binnenlandse producten, maar waardoor de buitenlandse import zwaarder wordt geraakt. Een goed voorbeeld van een dergelijke situatie is te vinden in het arrest Hum. blot. $^{236}$ Deze uitspraak had betrekking op een Franse regeling voor motorrijtuigenbelasting, waarin een indeling in tariefschalen was gemaakt op basis van fiscaal vermogen: voertuigen met een fiscaal vermogen van minder dan $16 \mathrm{pk}$ werden onderworpen aan een differentiële en progressieve belasting, terwijl voertuigen met een hoger fiscaal vermogen niet alleen aan de gewone belasting, maar ook nog aan een zeer hoge bijzondere belasting werden onderworpen. Door deze indeling werd geen direct onderscheid gemaakt op grond van nationaliteit: Franse en buitenlandse auto's werden immers op dezelfde manier ingeschaald. In de praktijk bleek echter dat in Frankrijk geen personenauto's met een fiscaal vermogen hoger dan $16 \mathrm{pk}$ werden geproduceerd, terwijl er wel veel auto's met een dergelijk fiscaal vermogen uit het buitenland werden geïmporteerd. Door de gekozen indeling van de belastingschalen was er dan ook duidelijk sprake van een benadeling van in het buitenland geproduceerde auto's en dus van indirect onderscheid op grond van nationaliteit.

Bij de beoordeling van de toelaatbaarheid van dit soort indirect onderscheid neemt het Hof tot uitgangspunt dat artikel 90 op zichzelf niet in de weg staat aan een differentiatie in belastingtarieven. Het Hof heeft daarbij echter wel een aantal voorwaarden gesteld, die bijvoorbeeld zijn terug te vinden in het arrest Chemial Farmaceutici. ${ }^{237}$ Hierin stelde het Hof dat

"het gemeenschapsrecht niet in de weg [staat] aan de vrijheid van de verschillende LidStaten om met behulp van objectieve criteria [...] een systeem van gedifferentieerde belastingen vast te stellen. Zulke differentiaties verdragen zich met het gemeenschapsrecht, wanneer zij gericht zijn op de verwezenlijking van economische beleidsoogmerken die, op hun beurt, met de in het Verdrag en in het afgeleide recht gestelde eisen verenigbaar zijn en wanneer in de uitvoeringsbepalingen alle mogelijke, rechtstreekse of indirecte discriminatie jegens importen uit derde landen en/of iedere bescherming van concurrerende nationale producten wordt vermeden."2ss

Uit de rechtspraak waarin deze voorwaarden worden toegepast kan worden afgeleid dat in de meeste gevallen eerst wordt onderzocht of voldaan is aan het laatste vereiste: er mag geen sprake zijn van een protectionistische bedoeling. ${ }^{259}$ Wanneer het Hof aannemelijk acht dat een dergelijke bedoeling aanwezig is, zal het de belastingregeling per definitie ontoelaatbaar achten: het aanvoeren van andere legitieme beleidsdoelstellin-

256. EHvJ 9 mei 1985, zaak 112/84, Jurispr. 1985, 1367. Een vergelijkbare situatie, hoewel sprake was van een subtielere regeling, is te vinden in een vervolg op deze zaak: EHvJ 17 september 1987, zaak 433/85, Feldain, Jurispr. 1987, 3536.

257. EHvJ 14 januari 1981 , zaak 140/79, Jurispr. 1981, 1

258. Punt 14; idem in EHvJ 14 januari 1981, zaak 46/80, Vinal/Orbat, Jurispr. 1981, 77 en bijv. EHvJ 4 maart 1986, zaak 106/84, Commissie/Denemarken (belasting vruchtenwijnen), Jurispr. 1986, 833, punt 20. Zoals Barents aangeeft is hierdoor een rule of reason tot stand gebracht die lijkt op die bij de bepalingen over onderscheid op grond van nationaliteit (1983, p. 457).

259. Vgl. Denusso/Denton 1990, p. 86/87 e.v., waar zij een uitgebreide analyse maken van de verschillende relevante arresten, waaruit zij de toetsingsmethodiek van het Hof trachten te destilleren. Zij stellen vast dat het Hof altijd begint met een onderzoek naar de bedoelingen van de regeling; het daadwerkelijke effect van de maatregel is niet van doorslaggevend belang. 
gen zal de regeling niet meer kunnen redden. ${ }^{260}$ In het licht van het voorwerp van onderzoek is deze benadering bijzonder interessant, nu uit de rechtspraak hieromtrent wellicht aanknopingspunten kunnen worden afgeleid voor de wijze waarop het onderzoek naar de werkelijke bedoeling van een ongelijke behandeling kan worden uitgevoerd: feitelijk komt het onderzoek naar een protectionistische bedoeling immers op een dergelijk onderzoek neer. Helaas lijkt het Hof in zijn rechtspraak op dit punt echter vooral gevoelsmatig te werk te gaan en motiveert het zijn conclusies over het protectionistische karakter van het doel niet altijd even duidelijk. De jurisprudentie over artikel 90 is bovendien bijzonder onvoorspelbaar en ondoorzichtig, waardoor het moeilijk is om hieruit zuivere conclusies af te leiden. ${ }^{261}$ In de meeste gevallen blijkt vooral te worden onderzocht of de zwaarst belaste producten naar hun aard ingevoerde producten zijn; wanneer dit het geval is, wordt een protectionistische bedoeling vrijwel steeds aanwezig geacht. ${ }^{262}$ Andersom blijkt uit het arrest John Walker ${ }^{263}$ dat een protectionistische doelstelling geacht moet worden te ontbreken, wanneer elke categorie waartussen gedifferentieerd wordt zowel een aandeel geïmporteerde producten als een aandeel binnenlandse producten omvat. ${ }^{264}$

Een dergelijke wijze van vaststelling van de werkelijke bedoeling van het onderscheid is sterk verbonden met de specifieke problematiek van discriminatoire belastingen in het gemeenschapsrecht; in het kader van dit hoofdstuk zal hierop dan ook niet verder

260. Zie voor een voorbeeld van deze toetsing EHvJ 27 februari 1987, zaak 168/78, Commissie/Frankrijk (belasting voor gedistilleerd), Jurispr. 1980, 347 en EHvJ 7 mei 1987, zaak 184/85, Commissie/Italiē (belasting op bananen), Jurispr. 1987, 2013, punt 13.

261. De ondoorgrondelijkheid van de arresten wordt ook in de literatuur regelmatig bekritiseerd: zie bijv. Barents 1983, p. 461. Een voorbeeld van deze ondoorzichtigheid is te vinden in een tweetal arresten, Commissie/ltalië (nuxebelasting op mousserende wijnen) (EHvJ 11 juli 1985, zaak 278/83, Jurispr. 1985, 2503) en Chemial Farmaceutici (EHvJ 14 januari 1981, zaak 140/79, Jurispr. 1981, 1). In het eerste arrest achtte het Hof een indeling in BTW-tarieven in strijd met artikel 95 (nu artikel 90), omdat door de omschrijving van de categorieën uitsluitend geïmporteerde mousserende wijnen onder het hoogste tarief vielen; de omschrijving strekte er daardoor volgens het Hof toe de nationale mousserende wijnen te beschermen. In het tweede arrest kwam het Hof tot de conclusie dat er geen sprake was van een beschermend effect, terwijl er sprake was van een differentiatie in accijnzen waardoor gedenatureerde alcohol, in Italiê op grote schaal geproduceerd, veel lager werd belast dan synthetische alcohol, een vergelijkbaar product dat in Italie slechts in zeer beperkte mate wordt geproduceerd.

262. EHvJ 4 maart 1986, zaak 106/84, Commissie/Denemarken (belasting vruchtenwijnen), Jurispr. 1986, 833, punt 21. Zie Denusso/Denton 1990, p. 71.

263. EHvJ 4 maart 1986, zaak 243/84, Jurispr. 1986, 875, punt 23. Uit EHvJ 5 april 1990, zaak C-132/88, Commissie/Griekenland (motorrijtuigenbelasting), Jurispr. 1990, I-1567 blijkt echter dat het Hof van mening is dat het feit dat alleen ingevoerde producten tot de zwaarder belaste categorie behoren nog niet betekent dat er een discriminatoire bedoeling is (punt 18): kennelijk kunnen ook dan nog redenen worden aangevoerd waaruit blijkt dat een dergelijke bedoeling afwezig is.

264. Bij de vaststelling van het aandeel van de buitenlandse producten in verschillende categorieèn komen echter diverse problemen naar voren. Dit blijkt bijvoorbeeld uit het arrest Commissie/Italië (luxebelasting dieselauto's) (EHvJ 16 december 1986, zaak 200/85, Jurispr. 1986, 3953), dat betrekking had op een indeling in tariefgroepen waardoor bepaalde dieselauto's zwaarder werden belast dan andere. Opvallend genoeg bleken juist in de hoogste tariefgroep geen Italiaanse auto's te vallen, hetgeen zou kunnen wijzen op protectionisme. Bij nadere beschouwing bleek echter dat bij gewone benzineauto's wel een groot aantal Italiaanse auto's in de hoogste klasse viel, terwijl daarbij ook een groot aantal buitenlandse auto's in de lagere belastingklasse was ondergebracht: gezien tegen de achtergrond van de gehele autobranche was de maatregel dus niet protectionistisch (zie hiervoor ook Denusso/Denton 1990, p. 85/86). Ook andere factoren blijken een rol te kunnen spelen bij het bepalen van het protectionistische karakter, zoals de grootte van het verschil in belastingtarief; zie hierover Barents 1986, p. 650. 
worden ingegaan. Wel lijkt op grond van het voorgaande de conclusie gerechtvaardigd dat het in bepaalde zaken van groot belang is dat een rechter verder kijkt dan alleen naar de doelstellingen die door de regering als rechtvaardiging zijn aangevoerd. Bovendien is van belang dat uit deze rechtspraak kan worden afgeleid dat het zoeken naar de werkelijke bedoeling, hoewel lastig, praktisch wél mogelijk is. ${ }^{265}$

Ook de overige eisen die het Hof blijkens het hiervoor geciteerde arrest Chemial Farmaceutici aan de doelstellingen van een indirect discriminatoire belastingregeling stelt zijn in het kader van het onderzoek interessant. Allereerst blijkt het Hof te vereisen dat de nagestreefde doelstellingen van economische aard zijn. Dit is duidelijk een eis die als zodanig niet voor algemene toepassing vatbaar is: zeker op andere terreinen dan het belastingrecht kunnen niet-economische doelstellingen wel degelijk toelaatbaar zijn." Van groter belang is het tweede vereiste, waaruit blijkt dat de overwegingen die tot het vaststellen van de regeling geleid hebben niet zelf discriminatoir mogen zijn. Hierdoor wordt de reeds eerder geopperde veronderstelling bevestigd dat dit criterium bij alle ongelijke behandelingen, van welke aard en op welke grond dan ook, kan worden toegepast. Helaas is het Hof er ook bij artikel 90 niet aan toegekomen om dit vereiste toe te passen: in de meeste gevallen blijkt dit samen te worden getrokken met het eerder besproken criterium van de protectionistische bedoeling. Tenslotte is het derde vereiste, dat inhoudt dat de doelstellingen van de belastingregeling zelf niet in strijd mogen zijn met het Europese recht, te beschouwen als een specifieke uitwerking van het in het theoretische toetsingsmodel opgenomen vereiste dat de aangevoerde doelstelling in overeenstemming moet zijn met het positieve recht. Praktische toepassingen van dit criterium ontbreken echter.

\subsubsection{Conclusie}

Uit het voorgaande is gebleken dat verschillende van de door het Hof ontwikkelde criteria voor de beoordeling van de gerechtvaardigdheid van het nagestreefde doel zich goed lenen voor een meer algemene toepassing. Het gaat daarbij allereerst om het criterium dat de doelstelling van de maatregel niet inherent discriminatoir mag zijn: dit vereiste komt bij alle bestudeerde vormen van ongelijke behandeling naar voren. Het criterium lijkt echter niet altijd even gemakkelijk toepasbaar te zijn: het is vaak moeilijk vast te stellen of een doelstelling daadwerkelijk discriminatoir van aard is. Een

265. Denusso en Denton geven zelfs aan dat deze test binnen het door artikel 90 geschapen toetsingskader beter werkbaar is dan andere testen om de toelaatbaarheid van een ongelijke behandeling vast te stellen: daarbij moeten vaak ingewikkelde economische berekeningen en inschattingen worden gemaakt, terwijl dit bij het onderzoek naar de bedoeling van de regering niet nodig is; deze is in de meeste gevallen aan de hand van objectieve criteria vast te stellen (1990, p. 117/118). Dit geldt echter in mindere mate voor andere vormen van onderscheid, waar vaak eenvoudiger mechanismen voorhanden zijn (z0als het veronderstellen dat de aangevoerde bedoeling ook de werkelijke bedoeling is).

266. Dit blijkt duidelijk uit de rechtspraak op het gebied van de sociale zekerheid: daar wordt immers vereist dat de doelstelling van een indirect discriminatoire regeling inherent moet zijn aan het sociale beleid van de lidstaat; hierdoor lijkt het erop alsof economische doelstellingen die niet in een dergelijk beleid zijn onder te brengen uit den boze zijn. Zie hiervoor paragraaf 2.3.1. Het vereiste van een economisch doel kan echter worden gezien als een variatie op het verbod van détournement de pouvoir. alleen die doelstellingen mogen worden nagestreefd die voor het betrokken onderwerp relevant zijn Deze algemene basis voor het vereiste van het nastreven van economische doelstellingen is vanzelfsprekend wel voor een bredere toepassing vatbaar. 
bijkomend probleem is daarbij dat er in sommige gevallen weliswaar sprake zal zijn van een discriminatoire doelstelling, maar dat deze door de verwerende partij veelal zorgvuldig zal worden verhuld. Wanneer het discriminatoir karakter eenmaal vaststaat moet bovendien worden nagegaan of er nog andere overwegingen zijn die wél een voldoende rechtvaardiging kunnen opleveren. Een onderzoek naar het discriminatoir karakter van de bedoeling vergt in de meeste gevallen dan ook een aanzienlijke mate van rechterlijke activiteit. Jammer genoeg heeft het Hof tot nu toe nauwelijks toepassing aan dit criterium gegeven, zodat uit de rechtspraak niet goed kan worden afgeleid hoe hiermee moet worden omgegaan.

Praktisch bruikbaar is in ieder geval wel het vereiste dat degene die verantwoordelijk is voor een regeling aantoont dat deze regeling voorziet in een concrete behoefte. Voor onderscheid dat is gemaakt in een verticale verhouding geldt in dat verband het vereiste dat duidelijke, concrete en legitieme beleidsdoelstellingen moeten worden aangevoerd. Dit vereiste kan worden beschouwd als een praktisch bruikbare verbijzondering van het vereiste dat een door de overheid veroorzaakte ongelijke behandeling moet worden gerechtvaardigd door redenen van algemeen belang.

Interessant is verder dat het voorkómen van ernstigere of duidelijkere vormen van ongelijke behandeling steeds een gerechtvaardigd doel zal opleveren, net als het waarborgen van fundamentele rechtsbeginselen als de rechtszekerheid. Daarnaast kan aan het algemene toetsingsmodel zeker als criterium worden toegevoegd dat een doelstelling die op (te) algemene generalisaties is gebaseerd niet gerechtvaardigd kan zijn. Hetzelfde geldt voor het vereiste dat de aangevoerde doelstelling in overeenstemming moet zijn met het positieve recht.

Zoals eerder is aangegeven kunnen er enige kanttekeningen worden geplaatst bij de opvatting van het Hof dat overwegingen van budgettaire aard en administratieve overwegingen geen objectieve rechtvaardiging op kunnen leveren: het is zeker denkbaar dat dergelijke overwegingen in bepaalde omstandigheden een gerechtvaardigde doelstelling vormen. Wel zal bij dergelijke doelstellingen de toetsing aan de vereisten van geschiktheid, noodzakelijkheid en proportionaliteit een belangrijke rol spelen: het zal zelfs bij een marginale toets niet eenvoudig zijn om aan te tonen dat administratieve of budgettaire overwegingen zwaarder wegen dan de belangen die door het onderscheid worden aangetast.

Tenslotte is van belang dat er voor alle besproken vormen van ongelijke behandeling criteria zijn ontwikkeld die vrijwel alleen kunnen worden toegepast in een specifieke context of in een beperkte groep van gevallen. Te denken valt bijvoorbeeld aan het bij vrij verkeer van diensten geldende criterium dat een onderscheid alleen toelaatbaar is als dit ervoor kan zorgen dat de betrokken dienst op een verantwoorde wijze zal worden uitgevoerd, en aan het bij artikel 90 ontwikkelde vereiste dat de doelstellingen niet mogen getuigen van protectionisme. Hoewel dergelijke criteria vanwege hun beperkte bruikbaarheid niet als zodanig in het algemene toetsingsmodel kunnen worden opgenomen, moet hierin in ieder geval ruimte worden geboden om in specifieke gevallen van dit soort maatstaven gebruik te maken. 


\subsection{Toetsing van geschiktheid, subsidiariteit en proportionaliteit}

\subsubsection{Toetsing van geschiktheid, subsidiariteit en proportionaliteit bij onderscheid op grond van geslacht}

\section{Geschiktheid}

In paragraaf 2.1.1 is al aangegeven dat het Hof vereist dat een regeling waardoor indirect onderscheid wordt gemaakt geschikt is om het beoogde doel te bereiken ${ }^{267}$ Het Hof zelf heeft echter slechts zelden een goede uitleg of toepassing aan dit vereiste gegeven. Het ontbreken van een dergelijke inhoudelijke beoordeling van de geschiktheid is redelijk in het relatief grote aantal gevallen waarin het Hof tot de conclusie komt dat een gerechtvaardigd doel ontbreekt: gezien de wijze waarop het toetsingsschema van het Hof is opgebouwd, is het dan immers niet meer nodig om nog te toetsen aan de andere elementen van het model. In de gevallen waarin een gerechtvaardigd doel wel aanwezig wordt geacht kan een verklaring voor de terughoudendheid van het Hof worden gevonden in het sterk feitelijke karakter van de toetsing aan het geschiktheidsvereiste, samenhangend met het feit dat het grootste deel van de arresten over indirect onderscheid op grond van geslacht wordt gewezen in het kader van een prejudiciële procedure. Nu het Hof zich in een dergelijke procedure in het algemeen niet bevoegd acht om de geformuleerde criteria toe te passen op het voorliggende feitencomplex, is het niet onredelijk dat de toepassing van het geschiktheidsvereiste in de meeste gevallen wordt overgelaten aan de nationale rechter. ${ }^{26 s}$

Opmerkelijker is dat het Hof in arresten waarin het wel zelf aan dit vereiste toetst vrijwel steeds zonder nadere motivering vaststelt dat aan dit vereiste is voldaan. ${ }^{209} \mathrm{Hetzelf}$ de geldt wanneer aan het geschiktheidsvereiste wordt getoetst in het kader van een rechtstreeks beroep, zoals een procedure wegens niet-nakoming. ${ }^{270}$ In sommige gevallen kan het ontbreken van een goed gemotiveerde toetsing hoogstens worden verklaard vanuit het feit dat de procedure betrekking heeft op de toelaatbaarheid van een regeling

267. Zie het in paragraaf 2.1.1 geciteerde arrest Bilka (EHvJ 13 mei 1986, zaak 170/84, Jurispr. 1986, 1607, punt 36); vgl. Drijber/Prechal 1997, p. 142-143.

268. Vgl. Prechal 1993, p. 90 en Herbert 1994, p. 129; zie bijv. EHvJ 11 juni 1987, zaak 30/85, Teuling, Jurispr. 1987, 2497, punt 18, EHvJ 6 februari 1996, zaak C-457/93, Lewark, Jurispr. 1996, I-243, punt 38 en EHvJ 7 maart 1996, zaak C-278/93, Freers en Speckmann, Jurispr. 1996, I-1165. In de laatste twee arresten was een goede reden voor het Hof om deze beoordeling aan de nationale rechter over te laten ook gelegen in het feit dat de problematiek die in het geding was op nationaal niveau gevoelig lag en een harde uitspraak van het Hof over de geschiktheid en noodzakelijkheid waarschijnlijk op veel verzet zou stuiten; door in dit geval ruimte te laten voor een eigen beoordeling door de nationale rechter werd de aanvaardbaarheid van de uitspraak vergroot.

269. Dit gebeurt vooral in arresten die betrekking hebben op regelingen van sociale zekerheid, waarbij het Hof de lidstaten een grote beleidsruimte toekent. Zie bijv. EHvJ 19 november 1992, zaak C-22691, Molenbroek, Jurispr. 1992, 1-5953, EHvJ 14 december 1995, zaak C-317/93, Nolte, Jurispr. 1995, 14625, punt 33 en EHvJ I februari 1996, zaak C-280/94, Posthuma, Jurispr. 1996, I-179, punt 27. Zie nader Drijber/Prechal 1997, p. 144 en Stoter 1996, p. 1814; zij geven terecht aan dat dit geen wenselijke ontwikkeling is: het is in deze omstandigheden voor de nationale rechter erg lastig om zich strenger op te stellen en de maatregel alsnog ongeschikt te bevinden.

270. Overigens is het aantal rechtstreekse beroepen over onderscheid op grond van geslacht beperkt. In de gevallen waarin daarvan wel sprake is wordt zonder motivering vastgesteld dat aan het vereiste van geschiktheid is voldaan. Zie bijv. EHvJ 7 mei 1991, Commissie/België (werkloosheidsuitkeringen), zask C-229/89, Jurispr. 1991, 1-2205. 
van sociale zekerheid, een onderwerp waarbij het Hof zich zeer terughoudend pleegt op te stellen. Vastgesteld dient echter te worden dat dit het volledig achterwege laten van een inhoudelijke geschiktheidstoets niet kan rechtvaardigen. ${ }^{271}$

\section{Noodzakelijkheid}

Uit het arrest $B i l k a^{2 n}$ blijkt dat de noodzakelijkheid van de litigieuze maatregel om het gestelde doel te bereiken een belangrijk onderdeel is van het door het Hof ontwikkelde toetsingsmodel. Een nadere toelichting op de precieze betekenis van dit vereiste is in de rechtspraak van het Hof niet terug te vinden: in het grootste deel van de gevallen wordt de toepassing van dit vereiste op de feiten overgelaten aan de nationale rechter. ${ }^{273}$ Weliswaar is er een aantal arresten te vinden waarin het Hof wel aan dit vereiste toetst, maar daarin wordt het oordeel vaak nauwelijks onderbouwd aan de hand van de feiten die aan het geschil ten grondslag liggen. Een voorbeeld daarvan is te vinden in de volgende overweging uit het arrest Nolte: ${ }^{274}$

"[...] de doelstelling van sociaal en werkgelegenheidsbeleid waarop de Duitse rechter zich heeft beroepen, [heeft] objectief gezien niets van doen [...] met discriminatie op grond van geslacht, en [...] de nationale wetgever [kon] er bij de uitoefening van zijn bevoegdheid in redelijkheid vanuit $[\ldots]$ gaan dat de betrokken regeling voor de verwezenlijking van die doelstelling noodzakelijk was." ${ }^{\text {27t }}$

Deze summiere motivering is vooral zichtbaar bij ongelijke behandeling op het gebied van de sociale zekerheid, een gebied waarbij het Hof de lidstaten bewust veel ruimte heeft toegekend om een eigen beleid te voeren. Door de gehanteerde formulering wordt die ruimte zorgvuldig in stand gehouden: de nationale rechter wordt hierdoor de mogelijkheid ontnomen om een eigen, wellicht strenger, oordeel te vellen over de noodzakelijkheid van de getroffen maatregel. ${ }^{276}$ Hoewel dit op zichzelf begrijpelijk is, kan deze benadering in zijn algemeenheid problematisch worden geacht. Door het gebrek aan motivering is het namelijk lastig om na te gaan welke overwegingen ten grondslag hebben gelegen aan het oordeel van het Hof, zodat de rechters van de lidstaten geen

271. Vgl. Prechal 1993, p. 90.

272. EHvJ 13 mei 1986, zaak 170/84, Jurispr. 1986, 1607

273. Zie bijv. het genoemde arrest Bilka, maar ook EHvJ 11 juni 1987, zaak 30/85, Teuling, Jurispr. 1987, 2497, punt 18, EHvJ 6 februari 1996, zaak C-457/93, Lewark, Jurispr. 1996, I-243, punt 38 en EHvJ 7 maart 1996, zaak C-278/93, Freers en Speckmann, Jurispr. 1996, 1-1165, punt 29. Ook ontbreekt een toetsing in veel gevallen, omdat in de prejudiciele vraag die aan het Hof werd gesteld niet aan dit vereiste is gerefereerd; het Hof voelt zich dan niet geroepen om zelfstandig een toetsing uit te voeren.

274. EHvJ 14 december 1995, zaak C-317/93, Jurispr. 1995, 1-4625

275. Punt 34. Zie voor een vergelijkbare benadering EHvJ 1 februari 1996, zaak C-280/94, Posthuma, Jurispr. 1996, I-179, punt 27 en EHvJ 8 februari 1996, zaak C-8/94, Laperre, Jurispr. 1996, 1-273, punt 19. Een zeldzame uitzondering is EHvJ 19 november 1992, zaak C-226/91, Molenbroek, Jurispr. 1992, 1-5943, punt 17 en 18; zoals Prechal (1993, p. 90) aangeeft wordt het uitvoeren van een noodzakelijkheidstoets in dit arrest verklaard door het feit dat de verwijzende rechter daar uitdrukkelijk om gevraagd had.

276. Zie hierover kritisch Stoter 1996, p. 1814 en Manolkidis 1996, p. 101; de laatste geeft aan dat deze benadering neerkomt op een willekeurstoets. Op de vrijheid voor de staten en de terughoudende toetsing bij sociale zekerheid zal in paragraaf 3 van dit hoofdstuk nader worden ingegaan. 
aanknopingspunten hebben om een goede en consistente rechtspraak op het gebied van de sociale zekerheid tot stand te brengen. ${ }^{2 m}$

\section{Proportionaliteit}

In het toetsingsmodel van het Hof wordt geen melding gemaakt van het vereiste dat er een redelijke verhouding dient te bestaan tussen het door de maatregel nagestreefde doel en de belangen die door het indirecte onderscheid zijn aangetast. In de meeste gevallen blijft een dergelijke toetsing van de gemaakte belangenafweging dan ook achterwege. ${ }^{27 \pi}$ Niettemin heeft het Hof de nationale rechter in een beperkt aantal arresten aanwijzingen gegeven die wijzen in de richting van een proportionaliteitstoets in strikte zin. Een goed voorbeeld daarvan is te vinden in het arrest Freers en Speck$m a n n^{279}$, dat betrekking had op het vrijstellen van de arbeid met behoud van loon van werknemers die lid waren van de ondernemingsraad en die voor een goede uitoefening van deze functie cursussen moesten volgen. Het probleem was dat deeltijdwerkers een deel van deze (voltijdse) cursussen buiten hun normale werktijd moesten volgen, terwijl zij slechts compensatie ontvingen voor het aantal uren waarvoor zij waren aangesteld. Het Hof overwoog het volgende:

"Het is aan de verwijzende rechter om na te gaan, rekening houdend met alle relevante gegevens en met de mogelijkheid om de betrokken doelstelling van sociaal beleid met andere middelen te verwezenlijken, of het gewraakte verschil in behandeling een geschikt en noodzakelijk middel is ter bereiking van deze doelstelling. De verwijzende rechter mag daarbij niet uit het oog verliezen, dat een wettelijke regeling als de onderhavige van dien aard is, dat zij de groep van deeltijdwerkers, die ontegenzeglijk grotendeels uit vrouwen bestaat, ontmoedigt om de functie van lid van de personeelsraad te vervullen of om de voor de vervulling van die functie noodzakelijke kennis te verwerven." 230

Hoewel het Hof het aan de nationale rechter overliet om zijn conclusies te trekken over de toelaatbaarheid van de regeling, kan uit deze overweging blijken dat het Hof de aangetaste belangen bijzonder zwaarwegend achtte. De nationale rechter kon er dan ook vrijwel niet aan ontsnappen om bij zijn toetsing een oordeel te geven over de gemaakte belangenafweging en daarbij in het bijzonder rekening te houden met de door het Hof gegeven beoordeling.

Ook in het arrest Enderby ${ }^{281}$ gaf het Hof een aanwijzing die voor de nationale rechtet aanleiding zou moeten vormen om een evenredigheidstoets uit te voeren. In dit arrest was de vraag aan de orde of de situatie op de arbeidsmarkt een rechtvaardiging kan opleveren voor een hogere beloning van functies waarin in het algemeen mannen werkzaam zijn:

277. Zie in deze zin ook Drijber/Prechal 1997 p. 143 en 144 en Manolkidis 1996, p. 103; de laatste stelt dat de nu gekozen benadering resulteert in "rough justice" en onvermijdelijk onvoldoende zal blijken te zijn.

278. Vgl. Bernard 1996 (I), p. 85 en Anderman 1996, p. 105.

279. EHvJ 7 maart 1996, zaak C-278/93, Jurispr. 1993, I-1165

280. Punt 29 en 30. Zie ook EHvJ 4 juni 1992, zaak C-360/90, Bötel, Jurispr. 1992, 1-3589, punt 26 en EHv] 6 februari 1996, zaak C-457/93, Lewark, Jurispr. 1996, 1-243, punt 37. Merkwaardig is dan ook de soms geuite kritiek dat het Hof zich in dit arrest overmatig terughoudend opstelde (bijv. Ellis 1996, p. 177).

28I. EHvJ 27 oktober 1993, zaak C-127/92, Jurispr. 1993, 1-5535 
"[...] de nationale rechter [dient] te beoordelen of de factor marktsituatie bij de vaststelling van de hoogte van de beloning voldoende gewicht in de schaal heeft gelegd om het gehele verschil of een gedeelte daarvan objectief te rechtvaardigen." ${ }^{282}$

Hoewel het Hof in de geciteerde overwegingen niet expliciet melding maakte van het vereiste van proportionaliteit, kan hieruit blijken dat het waarde hechtte aan het vinden van een juiste verhouding tussen de betrokken belangen. ${ }^{23}$ Bovendien kan uit deze overwegingen worden afgeleid dat de toetsing van de gemaakte belangenafweging soms zelfs van doorslaggevend belang kan zijn voor de uitkomst van de procedure. In het feit dat het proportionaliteitsvereiste geen vast onderdeel vormt van de toetsing door het Hof kan dan ook zeker geen reden worden gevonden om dit onderdeel weg te laten uit het algemene toetsingsmodel: de uitspraken van het Hof laten zien dat dit criterium in bepaalde gevallen daadwerkelijk toegevoegde waarde heeft en dat het praktisch mogelijk is om een oordeel uit te spreken over de belangenafweging.

\subsubsection{Toetsing van de geschiktheid, noodzakelijkheid en proportionaliteit bij onder- scheid op het gebied van de landbouw}

\section{Inleiding}

Bij de beoordeling van ongelijke behandeling op het gebied van het gemeenschappelijk landbouwbeleid blijkt het Hof nauwelijks gebruik te maken van een afzonderlijke toetsing aan het vereiste van geschiktheid, subsidiariteit en proportionaliteit. De belangrijkste oorzaak hiervoor is gelegen in het feit dat in een groot aantal zaken wordt vastgesteld dat er geen sprake is van vergelijkbaarheid: daardoor komt het Hof vanzelfsprekend niet meer toe aan een toetsing aan het rechtvaardigingsmodel. Ook wanneer het Hof kiest voor een rechtvaardigingstoets wordt een toetsing van geschiktheid, noodzakelijkheid en proportionaliteit echter regelmatig achterwege gelaten: meestal voert het Hof alleen een algemene willekeurstoets uit, waarbij slechts gekeken wordt of er een gerechtvaardigd doel aanwezig is en of er in zijn algemeenheid redenen zijn om aan te nemen dat de betrokken lidstaat of gemeenschapsinstelling kennelijk onjuist heeft gehandeld. ${ }^{2 s}$

282. Punt 28

283. Heel duidelijk blijkt dit uit het arrest Schnorbus, waarin het Hof stelde dat "[...] het voordeel voor de betrokkenen [...] niet onevenredig [is]" (EHv] 7 december 2000, zaak C-79/99, Jurispr. 2000, I-10997, punt 46).

284. Hiervan zijn talrijke voorbeelden in de rechtspraak te vinden. Zie bijv. EHvJ 24 oktober 1973, zaak 43/72, Merkur-Außenhandels-GmbH, Jurispr. 1973, 1055, EHvJ 11 juli 1974, zaak 11/74, Union des Minotiers de la Champagne, Jurispr. 1974, 877, punt 22, EHvJ 13 juni 1978, zaak 139/77, Denkavit Futtermittel GmbH, Jurispr. 1978, 1317, punt 15, EHvJ 21 februari 1990, gev. zaken C-267 t/m 285/88, Wuidart, Jurispr. 1990, 1-435, punt 14. Vgl. ook de heldere conclusie van A-G Lenz bij EHvJ 24 januari 1991, zaak C-27/90, SITPA, Jurispr. 1991, 1-133; zie verder Boest 1984, p. 115 en 131 en Tridimas 1999 (I), p. 54. Barents (1994 (I), p. 337) geeft aan dat deze toets wel degelijk is te beschouwen als een proportionaliteitstoets in ruime zin, nu hierbij steeds zal worden gekeken naar de verhouding tussen doel en middel. Dit is juist, maar het blijft een feit dat er geen nauwkeurig onderscheid wordt gemaakt tussen de verschillende elementen die deze toets zou moeten bevatten. Op p. 339/340 geeft ook Barents bovendien aan dat de proportionaliteitstoets in veel gevallen slechts een willekeurstoets inhoudt. Herdegen (1985, p. 685) concludeert dat bij het discriminatieverbod het vereiste van proportionaliteit (in ruime zin) in het geheel geen rol speelt, maar dat alleen het effect van de maatregel 
Een verklaring voor deze benadering kan worden gevonden in het feit dat het Hof in de meeste landbouwzaken niet alleen heeft te oordelen over de klacht over de ongelijke behandeling, maar meer in het algemeen een oordeel moet uitspreken over de geldig. heid van een bepaalde landbouwregeling. ${ }^{2 \times 5}$ In het kader van deze toetsing gaat het Hof meestal eerst na of de maatregel als zodanig wel geschikt en noodzakelijk is om een van de in artikel 33 opgenomen doelstellingen van het gemeenschappelijke landbouwbeleid te bereiken ${ }^{2 \times 6}$ en voert het vervolgens vrijwel steeds een toetsing aan het evenredigheidsbeginsel uit. De toetsing aan dit afzonderlijke evenredigheidsbeginsel is voor het landbouwrecht van groot belang, nu het Hof hieraan een ruime uitleg heeft gege. ven. Zo stelde het Hof in het arrest Schräder ${ }^{287}$ het volgende:

"Volgens het evenredigheidsbeginsel zijn maatregelen waarbij de deelnemers aan het economische verkeer financiële lasten worden opgelegd slechts rechtmatig, wanneer zij geschikt en noodzakelijk zijn voor de verwezenlijking van de legitieme doelstellingen die met de betrokken regeling worden nagestreefd. Daarbij geldt, dat wanneer een keuze mogelijk is tussen meerdere geschikte maatregelen, die maatregel moet worden gekozen die de minste belasting met zich brengt; voorts mogen de op te leggen lasten niet onevenredig zijn aan het nagestreefde doel."28s

Volgens het Hof betekent evenredigheid dus niet alleen dat er een evenredige verhouding bestaat tussen doel en middel; ook de vereisten van geschiktheid, noodzakelijkheid en subsidiariteit vallen onder de reikwijdte van dit beginsel. 2 .

$\mathrm{Nu}$ het Hof in het kader van de toetsing aan artikel 33 en aan het evenredigheidsbeginsel zorgvuldig nagaat of er is voldaan aan de eisen van geschiktheid, subsidiariteit en proportionaliteit in strikte zin, zou het nogmaals uitvoeren van een dergelijke toetsing

op de mededingingsverhoudingen wordt gecontroleerd; ook dat is niet geheel juist, zoals uit deze paragraaf zal blijken.

285. Dit is anders bij de meeste zaken over onderscheid op grond van geslacht en nationaliteit, waarbij het Hof, daartoe meestal geinspireerd door de verwijzende rechter, zijn oordeel toespitst op de klacht over ongelijke behandeling.

286. Zie voor een uitvoering van een geschiktheidstoets in dit verband bijv. EHvJ 21 februari 1979, zaaks 138/78, Stölting, Jurispr. 1979, 713, punt 7 en EHvJ 6 december 1984, zaak 59/83, Biovilac, Jurispr. 1984,4057 , punt 17 .

287. EHvJ 11 juli 1989, zaak 265/87, Jurispr. 1989, 2237

288. Punt 21. Zie ook EHvJ 17 december 1970, zaak 11/70, Internationale Handelsgesellschaft, Jurispt. 1970, 1125, m.n. punt 12, EHvJ 30 november 1990, zaak C-331/88, Fedesa, Jurispr. 1990, 1-4023, EHvJ 5 oktober 1994, zaak C-280/93, Duitsland/Raad (bananen I), Jurispr. 1994, I-4973 en EHvJ 12 juli 2001, zaak 189/01, Jippes, Jurispr. 2001, 1-5689, punt 81.

289. Het Hof heeft in een enkel geval ook aangegeven, dat het evenredigheidsbeginsel en het gelijkheidsbeginsel op het gebied van de landbouw grote verwantschap vertonen, zodat het mogelijk is om een gezamenlijke toetsing aan deze beginselen uit te voeren: zie EHvJ 8 april 1992, zaak C-256/90, Mignini, Jurispr. 1992, 1-2651. Het Hof voerde in dit arrest dan ook geen afzonderlijke toetsing aan de beide beginselen uit, maar behandelde deze gezamenlijk. Dit lijkt echter een unieke situatie te zijn: in arresten van latere datum wordt weer onderscheid gemaakt tussen beide toetsen. Van belang is verder dat bij de toetsing aan het evenredigheidsbeginsel vaak geen scherp onderscheid wordt gemaakt tussen geschiktheid en noodzakelijkheid: in veel gevallen wordt alleen gekeken naar de noodzakelijkheid, terwijl het ook regelmatig voorkomt dat het Hof een algemene willekeurstoets uitvoert (vgl. Tridimas 1999 (1), P 97). Opmerkelijk is tenslotte dat het Hof bij een marginale toetsing weliswaar stelt dat alle genoende elementen in de toetsing moeten worden betrokken, maar dat het in de praktijk niet altijd bereid is on aandacht te besteden aan andere elementen dan het geschiktheidselement. Zie bijv. EHvJ 12 juli 2001. zaak 189/01, Jippes, Jurispr. 2001, 1-5689, punt 82/83. 
bij het gelijkheidsbeginsel in veel gevallen leiden tot overlappingen. Van belang is echter dat er belangrijke verschillen kunnen bestaan tussen de toetsing aan artikel 33 en het evenredigheidsbeginsel enerzijds en aan het gelijkheidsbeginsel anderzijds. ${ }^{200} \mathrm{Bij}$ de toetsing aan het evenredigheidsbeginsel en aan artikel 33 wordt immers een oordeel gegeven over de regeling als geheel, terwijl bij de toetsing aan het gelijkheidsbeginsel specifiek wordt gekeken naar een ongelijke behandeling die in de regeling is opgenomen of hierdoor is veroorzaakt. ${ }^{291}$ Dit verschil kan essentieel zijn, nu een bepaalde regeling weliswaar als zodanig geschikt en noodzakelijk kan zijn om een bepaald doel te bereiken, maar tegelijkertijd een overbodige of disproportionele classificatie kan bevatten. Een dergelijke regeling kan een toetsing aan het algemene evenredigheidsbeginsel misschien nog wel doorstaan, maar moet in strijd worden geacht met het gelijkheidsbeginsel. ${ }^{22}$ Het is dan ook van groot belang dat ook bij het verbod van ongelijke behandeling wordt getoetst aan de afzonderlijke elementen van het rechtvaardigingsmodel. ${ }^{203}$

Een bevestiging van het voorgaande kan overigens worden gevonden in de rechtspraak van het Hof: hoewel een beoordeling van de verhouding tussen doel en middel bij de toetsing aan het verbod van ongelijke behandeling meestal achterwege blijft, blijkt het Hof hieraan wel te toetsen wanneer het evident is dat het onderscheid ondeugdelijk is. Hierdoor, en ook doordat het Hof soms aandacht aan deze toetsingselementen moet besteden omdat hierop uitdrukkelijk de aandacht is gevestigd door één van de partijen, is het toch mogelijk om in de rechtspraak van het Hof voorbeelden te vinden van toepassingen van de afzonderlijke toetsingsvereisten.

\section{Geschiktheid}

Een goed voorbeeld van een toepassing van de geschiktheidstoets in het kader van een toetsing aan artikel 34 lid 2 is te vinden in het arrest Bozzetti ${ }^{24}$, dat betrekking had op een medeverantwoordelijkheidsheffing op melk. ${ }^{205}$ Deze heffing had tot doel het door

290. Vgl. Emiliou 1996, p. 151-152 en p. 159.

291. Herdegen 1985, p. 688 , stelt dat de beginselen in het geheel niet te vergelijken zijn en nauwkeurig van elkaar moeten worden onderscheiden. Een dergelijk vergaand onderscheid is niet nodig: het is voldoende als de rechter zich goed realiseert dat bij de proportionaliteitstoets in het kader van de toetsing aan het gelijkheidsbeginsel een andersoortige belangenafweging moet worden getoetst dan bij de toetsing aan het evenredigheidsbeginsel. Vgl. Tuytenschaever 1999, p. 111.

292. Dit blijkt bijvoorbeeld uit het arrest Balkan-Import-Export, waarin alleen naar het evenredigheidsbeginsel werd gekeken (EHvJ 24 oktober 1973, zaak 5/73, Jurispr. 1973, 1091). Daarbij stelde het Hof dat weliswaar geen zwaardere lasten aan deelnemers aan het economisch verkeer mogen worden opgelegd dan strikt noodzakelijk zijn, maar het voegde hieraan toe dat "[...] daaruit niet volgt, dat deze verplichting moet worden afgemeten aan de bijzondere situatie van een bepaalde groep deelnemers; [...] een zodanige benadering [is], gezien de menigvuldige en ingewikkelde economische situaties, niet slechts onuitvoerbaar [...], maar [zou] bovendien een eeuwige bron van rechtsonzekerheid [...] vormen" (punt 22). In het kader van een toetsing aan het gelijkheidsbeginsel zou het bijzondere karakter van deze groep juist van bijzonder belang zijn en zou moeten worden bekeken de maatregel niet overmatig overinclusive was, en zou moeten worden onderzocht of er minder vergaande maatregelen denkbaar waren.

293. Zoals Emiliou stelt wordt, wanneer er onvoldoende onderscheid wordt gemaakt tussen het gelijkheidsbeginsel en het afzonderlijke proportionaliteitsbeginsel, de klager bovendien een afzonderlijke mogelijkheid om te klagen ontnomen (1996, p. 158).

294. EHvJ 18 maart 1986, zaak 179/84, Jurispr. 1985, 2301

295. Zie voor een uitleg over het instrument van de medeverantwoordelijkheidsheffing paragraaf 2.3 .2 . 
overproductie verstoorde evenwicht tussen vraag en aanbod op de zuivelmarkt te beïnvloeden en melkproducenten bewust te maken van de problematische situatie van overproductie. Om die reden had de Raad ervoor gekozen om de heffing op te leggen aan alle melkproducenten. Volgens Bozzetti was dit niet redelijk, omdat de overproductie alleen werd veroorzaakt door producenten van melk met een hoog vetgehalte; door de heffing ook aan producenten van melk met een laag vetgehalte op te leggen werden zij ten onrechte benadeeld. Het Hof stelde hierover het volgende:
"Bij de invoering van de heffing en de vaststelling van de betrokken uitvoeringsmaatregelen heeft de Raad uit verschillende mogelijkheden de formule gekozen die hem het meest geschikt leek voor het nagestreefde doel [...]. [...] Dat de invoering van de medeverant- woordelijkheidsheffing in het kader van de gemeenschappelijke marktordening verschil- lende gevolgen kan hebben voor bepaalde producten, al naar gelang hun individuele productie of de plaatselijke omstandigheden, kan niet worden beschouwd als een [...] verboden discriminatie, nu de berekening van de heffing is gebaseerd op objectieve criteria, die zijn aangepast aan de behoeften van de algemene werking van de gemeenschappelijke marktordening, voor alle daaronder vallende producten." ${ }^{12 \%}$

Uit de formulering van deze overweging blijkt duidelijk dat het Hof in dit arrest een geschiktheidstoets uitvoerde. Er bestaan echter maar weinig uitspraken waarin het Hof in het kader van een toetsing aan het verbod van ongelijke behandeling melding maakt van het geschiktheidsvereiste. Opmerkelijk is dat ook bij de toetsing aan het afzonderlijke evenredigheidsbeginsel vrijwel nooit aan dit vereiste wordt getoetst. ${ }^{29}$ Een verklaring hiervoor kan misschien gevonden worden in het feit dat het Hof bij zijn toetsing rekening houdt met de bijzondere aard van de maatregelen op het gebied van het gemeenschappelijke landbouwbeleid. Een toetsing van de geschiktheid van een maatregel impliceert een sterk feitelijke toetsing, waarbij het Hof een inschatting moet geven van de uitwerking van de maatregel. Zeker nu de meeste landbouwmaatregelen bijzonder complex zijn en het beoordelen ervan een diepgaande kennis vergt van de betrokken sectoren en de werking van bepaalde maatregelen, zal het Hof zich niet vaak tot een toetsing van de geschiktheid geroepen voelen.

Uit het beperkte aantal arresten waarin - in het kader van de toetsing aan het proportionaliteitsbeginsel of het verbod van ongelijke behandeling - wél aan het geschiktheidsvereiste wordt getoetst, kan echter een belangrijk uitgangspunt voor de toetsing van het Hof worden afgeleid. Het Hof blijkt namelijk aan te nemen dat er bij de beoordeling van de geschiktheid van de maatregel moet worden gekeken naar de stand van het recht en de feiten op het tijdstip waarop de maatregel werd getroffen. Wanneer in een later stadium is gebleken dat de gestelde doelen niet of onvoldoende zijn bereikt kan daaruit volgens het Hof niet worden afgeleid dat de maatregel ontoelaatbaar is. Dit blijkt duidelijk uit de volgende overweging uit het arrest Crispoltoni ${ }^{208}$, waarin het Hof de ge-

296. Punt 34 (cursief toegevoegd). Ook in andere arresten wordt melding van het geschiktheidsverciste gemaakt, maar daarbij ontbreekt in het algemeen een inhoudelijke beoordeling. Zie bijv. EHvJ 15 september 1982, zaak 106/81, Julius Kind, Jurispr. 1982, 2885, punt 24 en EHvJ 8 april 1992, zaak C. 256/90, Mignini, Jurispr. 1992, 1-2651, punt 16 en 31.

297. Vgl. Schwarze 1992, p. 856.

298. EHvJ 5 oktober 1994, gev, zaken C-133/93, C-300/93 en C-362/93, Jurispr. 1994, I-4863 
schiktheid beoordeelde in het kader van een afzonderlijke toetsing aan het proportionaliteitsbeginsel:

"De wettigheid van een gemeenschapshandeling kan niet afhangen van overwegingen die men achteraf met betrekking tot de doeltreffendheid van zodanige handeling kan doen gelden. Wanneer de gemeenschapswetgever met het oog op de vaststelling van de regeling de toekomstige gevolgen ervan dient te beoordelen en die gevolgen niet met zekerheid zijn te voorzien, kan zijn beoordeling slechts worden afgekeurd indien zij, gelet op de gegevens waarover de wetgever ten tijde van de vaststelling van de regeling beschikte, kennelijk onjuist is.",

Deze toetsingsmethodiek lijkt vooral te zijn ingegeven door de terughoudende opstelling van het Hof. In het feit dat de gestelde doelen niet zijn bereikt zou bij een intensievere toetsing immers juist aanleiding kunnen worden gevonden om de geschiktheid nader te onderzoeken. Het ontbreken van geschiktheid impliceert namelijk dat er spra$\mathrm{ke}$ is van een aantasting van individuele belangen, waardoor een gerechtvaardigd doel in feite niet kan worden bereikt. In die omstandigheden zou kunnen worden gesteld dat er een positieve verplichting bestaat voor de betrokken instantie om de gekozen regeling te herzien. Dat er aanvankelijk wel sprake was van een vermoeden van geschiktheid is dan verder niet relevant.

\section{Subsidiariteit}

Bij de beoordeling van onderscheid op het gebied van de landbouw heeft het Hof slechts in een beperkt aantal arresten gebruik gemaakt van de subsidiariteitstoets. ${ }^{300}$ Het Hof blijkt eigenlijk alleen aan dit vereiste te toetsen wanneer de eisende partij voldoende aannemelijk heeft gemaakt dat ter bereiking van het beoogde doel met minder vergaande maatregelen had kunnen worden volstaan. Een goed voorbeeld hiervan is te vinden in het arrest Wilhelm Werhahn Hansamühle, ${ }^{301}$ dat betrekking had op een steunregeling voor de productie van griesmeel uit het zogenaamde durumtarwe. Als gevolg van de wijze waarop aan deze steunvoorziening vorm was gegeven waren de productiekosten van griesmeel voor Franse producenten bijzonder laag. Duitse producenten bevonden zich daarentegen in andere omstandigheden, waardoor zij een concurrentie-

299. Punt 43. Vgl, ook EHvJ 24 oktober 1973, zaak 43/72, Merkur, Jurispr. 1973, 1055, punt 24, EHvJ 6 december 1984, zaak 59/83, Biovilac, Jurispr. 1984, 4057, EHvJ 21 februari 1990, gev. zaken C-267 Vm C-285/88, Wuidart e.a., Jurispr. 1990, I-435, punt 15 en 16, EHvJ 5 oktober 1994, zaak C-280/93, Duitsland/Raad (Bananen I), Jurispr. 1994, I-4973, punt 90 en EHvJ 12 juli 2001, zaak 189/01, Jippes, Jurispr. 2001, 1-5689, punt 84 . Zie verder de conclusie van A-G Lenz bij het arrest SITPA/Onifhlor, EHvJ 24 januari 1991, zaak C-27/90, Jurispr. 1991, I-133, punt 41.

300. In het kader van de beoordeling van de evenredigheid buiten het kader van gelijke behandeling weigerde het Hof in één arrest zelfs expliciet om na te gaan of een maatregel voldeed aan het subsidiariteitsof noodzakelijkheidsvereiste: in het arrest Jippes stelde het Hof dat "[h]et [...] er [...] niet om [gaat], of de door de wetgever vastgestelde maatregel de enige mogelijke of best mogelijke maatregel was, doch of hij kennelijk ongeschikt was" (EHvJ 12 juli 2001, zaak C-189/01, Jurispr. 2001, 1-5689, punt 83). Opmerkelijk genoeg beoordeelde het in het kader van de beoordeling van de evenredigheid van een ander aspect van dezelfde zaak wel degelijk of er sprake was van een maatregel die "niet verder ging dan [ter verwezenlijking van het beoogde doel] nodig was" (punt 122). Een verklaring voor deze discrepantie is hoogstens te geven door te stellen dat er een verschil bestaat tussen de "best mogelijke" en de "minst belastende" regeling; dit verschil is echter bijzonder subtiel.

301. EHvj 13 november 1973, gev. zaken 63-69/72, Jurispr. 1973, 1229 
achterstand hadden ten opzichte van de Fransen. De Raad achtte het echter niet nodig om maatregelen te treffen waardoor gezorgd kon worden voor gelijke mededingings. voorwaarden. De verzoeksters in het hoofdgeding hadden enkele mogelijkheden aangedragen waardoor dit wél zou kunnen worden bewerkstelligd. Het Hof stelde dienaangaande, dat:

"[...] niet blijkt, dat de Raad bij zijn beoordeling [...] verder is gegaan dan ter verwezenlijking van de doelstellingen van de steunregeling voor durumtarwe noodzakelijk kon worden geacht." ${ }^{302}$

Vervolgens gaf het gemotiveerd aan waarom de verschillende alternatieven niet deugdelijk waren, hetgeen voor het Hof zeer ongebruikelijk is: als het Hof al ingaat op het subsidiariteitsvereiste stelt het in de regel zonder veel omhaal vast dat hieraan niet is voldaan. ${ }^{303}$

In hoofdstuk 3 is reeds aangegeven dat het redelijk lijkt om alleen aan het subsidiariteitsvereiste te toetsen bij een intensieve toetsing, nu deze toets een, voor de rechter vaak lastige, beoordeling vergt van de verschillende alternatieven. Daarbij is echter gesteld dat dit niet impliceert dat bij een marginale toetsing in het geheel niet aan dit vereiste hoeft te worden getoetst: dit zou immers kunnen leiden tot een vergaande vermindering van de bescherming tegen ongeoorloofd onderscheid. ${ }^{304}$ De hiervoor besproken jurisprudentie verschaft een werkbare oplossing voor dit probleem. In de gevallen waarin een marginale toetsing wordt uitgevoerd is het blijkens deze rechtspraak alleen nodig om een subsidiariteitstoets uit te voeren wanneer uit de feiten van de voorliggende zaak duidelijk blijkt dat er geschikte alternatieven voorhanden waren of wanneer door de eisende partij aannemelijk is gemaakt dat dit het geval is. Het lijkt zinvol om een nuancering van deze strekking in het algemene toetsingsmodel op te nemen.

\section{Proportionaliteit}

In een aantal arresten heeft het Hof bij de toetsing aan artikel 24 lid 2 impliciet, en soms ook meer expliciet, gebruik gemaakt van het vereiste van proportionaliteit in strikte zin. Daarbij is het opvallend dat dit vereiste vrijwel alleen wordt genoemd in de zaken waarin het Hof een maatregel ontoelaatbaar acht omdat er duidelijk sprake is van een onevenredig zware belasting. Een voorbeeld hiervan is te vinden in het arrest Bela-

302. Punt 20. Een duidelijke toepassing van de noodzakelijkheidstoets komt ook naar voren in EHvJ 11 mei 2000, zaak C-56/99, Gascogne, Jurispr. 2000, I-3079, punt 43.

303. Zie bijv. EHvJ 8 april 1992, zaak C-156/90, Mignini, Jurispr. 1992, I-2651, punt 30, waarin het Hof stelde dat de doelstellingen met "minder drastische middelen dan het nu vastgestelde middel" konden worden bereikt. Het is opvallend dat de Advocaten-Generaal in dit opzicht vaak zorgvuldiger te werk gaan. Zie bijv. A-G Capotorti in zijn conclusie bij EHvJ 5 juli 1977, zaak 114/76, Bela-Mühle, Jurispr. 1977 , 1211, op p. 1230-1231, de conclusie van A-G Jacobs bij EHvJ 19 maart 1992, zaak C-311/90, Hierl, Jurispr. 1992, 1-2061 en de uitgebreid gemotiveerde conclusie van A-G Lenz bij EHvJ 29 februari 1996, gev. zaken C-296/93 en C-307/93, Frankrijk en lerland/Commissie, Jurispr. 1996, 1-795; in alle gevallen besteedde het Hof in het geheel geen aandacht aan de noodzakelijkheidstoets in het kader van het gelijkheidsbeginsel, maar uitsluitend in het kader van de toetsing aan het evenredigheidsbeginsel.

304. Zie hoofdstuk 3, paragraaf 2.6 . 
Mühle ${ }^{\text {jos }}$, dat betrekking had op een regeling om overschotten van magere-melkpoeder weg te werken. Op grond van deze regeling waren bepaalde groepen producenten van diervoeders verplicht om magere melkpoeder aan te kopen tegen een prijs die overeenkwam met ongeveer drie keer de voederwaarde. De producenten van diervoeders konden de verhogingen van de lasten die deze regeling tot gevolg had doorberekenen aan hun afnemers; op hun beurt konden de afnemers de verhogingen echter niet doorberekenen in de prijzen van hun producten. Hierdoor werden vooral kippen- en varkensfokkers ernstig benadeeld, terwijl voederproducenten nauwelijks last hadden van de maatregel; de zuivelproducenten profiteerden zelfs van de regeling. Het Hof stelde over de hierdoor ontstane ongelijkheid het volgende:

"Een aankoopverplichting tegen een zo onevenredig hoge prijs komt neer op een discriminerende verdeling van lasten over de verschillende landbouwsectoren; zodanige verplichting was bovendien niet noodzakelijk ter bereiking van het beoogde doel, te weten de afzet van de voorraden magere melkpoeder. Derhalve was zij in het kader van de verwezenlijking van het gemeenschappelijk landbouwbeleid niet gerechtvaardigd." ${ }^{\text {"306 }}$

Het Hof was dus van mening dat de regeling niet gerechtvaardigd was, omdat deze een disproportioneel hoge last oplegde aan een groep producenten die werkzaam was binnen een heel andere sector van de landbouw dan waar de overschotten waren veroorzaakt. ${ }^{307}$ In andere arresten heeft het Hof om vergelijkbare redenen classificaties ontoelaatbaar verklaard: een voorbeeld is te vinden in de eerder besproken Isoglucosezaken, waarin volgens het Hof sprake was van een kennelijk onbillijke last doordat voor isoglucose een veel nadeliger regeling van productieheffingen en exportrestituties gold dan voor suiker. ${ }^{\text {us }}$

\section{Proportionaliteit buiten het kader van ongelijke behandeling}

Zoals hiervoor al is aangegeven toetst het Hof, behalve aan het verbod van ongelijke behandeling, in een groot aantal gevallen ook aan een algemeen en ongeschreven evenredigheidsbeginsel. Deze proportionaliteitstoets heeft een iets ander karakter dan de in het kader van de toetsing aan het verbod van ongelijke behandeling uitgevoerde beoordeling, met name doordat de regeling als zodanig (en niet een daarin opgenomen classificatie) aan de toetsing wordt onderworpen. Het is waardevol om hieraan in de context van deze paragraaf afzonderlijk aandacht te besteden, zeker nu uit het eerder geciteerde arrest Schräder ${ }^{309}$ is gebleken dat het Hof in het kader van de toetsing aan dit beginsel

305. EHvJ 5 juli 1977, zaak 114/76, Jurispr. 1977, 1211

306. Punt 7; cursief toegevoegd. Zie hierover uitgebreid Schmitthof 1977, p. 329 e.v. en Tridimas 1999 (I), p. $100 / 101$

307. Vgl. Manolkidis 1996, p. 88. Deze benadering is wel bekritiseerd, omdat hierin geen duidelijk onderscheid wordt gemaakt tussen de toetsing aan het proportionaliteitsvereiste als zelfstandig beginsel en het specifiek op het gelijkheidsbeginsel toegesneden proportionaliteitsvereiste (zie bijv. Emiliou 1994, p. 152 en 155). Inderdaad is de door het Hof gekozen benadering niet zuiver, hetgeen vooral wordt veroorzaakt door het feit dat het door het Hof gehanteerde toetsingsmodel voor gelijke behandeling geen ruimte laat voor een proportionaliteitstoets in strikte zin. Wel illustreert dit dat het voor een goede uitkomst van de procedure wenselijk kan zijn om een proportionaliteitsvereiste in het toetsingsmodel op te nemen.

308. EHvJ 25 oktober 1978, gevoegde zaken 103 en 145/77, Royal Scholten-Honig, Jurispr. 1978, 2037, punt 82

309. EHvJ II juli 1989, zaak 265/87, Jurispr. 1989, 2237 
een aantal deeltoetsen uitvoert: het Hof ziet het geschiktheidsvereiste en het vereiste van noodzakelijkheid als vaste onderdelen van de proportionaliteitstoets. Een proportionaliteitstoets in strikte zin, waarbij de aan een algemene maatregel ten grondslag lig. gende belangenafweging wordt beoordeeld, lijkt in de meeste gevallen te ontbreken.10 Weliswaar heeft het Hof in een beperkt aantal zaken van de evenredigheid in strikte zin melding gemaakt, maar ook daarin wordt slechts zelden een feitelijke toepassing aan dit vereiste gegeven: meestal wordt volstaan met een beoordeling van de geschiktheid en de noodzakelijkheid." ${ }^{31}$ Het Hof blijkt feitelijk alleen bereid te zijn om een daadwerkelijke proportionaliteitstoets uit te voeren in zaken waarin geklaagd wordt over een aantasting van een fundamenteel recht: in dat geval moet volgens het Hof worden nagegaan of dit recht niet wezenlijk is aangetast en of er een redelijke verhouding bestaat tussen het nagestreefde doel en de getroffen maatregelen. ${ }^{312}$ Het is in dat licht overigens verwonderlijk te noemen dat het Hof een vergelijkbare toetsing niet toepast bij ongelijke behandeling: kennelijk ziet het Hof het gelijkheidsbeginsel op het gebied van de landbouw wel als een algemeen, maar niet als een fundamenteel beginsel van het gemeenschapsrecht. ${ }^{31}$

Opvallend is verder dat het Hof bij de toetsing aan het algemene evenredigheidsbeginsel in het algemeen alleen kijkt naar de abstracte verhouding tussen doel en middel, niet naar de vraag of in het individuele geval de belangen onevenredig zwaar zijn aangetast. $^{31}$ Vooral wanneer het Hof de rechtmatigheid van een algemene regeling dient te

310. Zie Boest 1984, p. 157. In een beperkt aantal arresten komt een dergelijke toetsing wel voor. Zie bijv. EHvJ 28 maart 1996, zaak C-299/94, Anglo Irish Beef Processors, Jurispr. 1996, 1-1925 en EHvJ 12 juli 2001, zaak 189/01, Jippes, Jurispr. 2001, 1-5689, punt 87-94. In dit laatste arrest volgde het Hof overigens een merkwaardige benadering: nadat het uitgebreid uiteen had gezet welke belangen er an beide zijden van het conflict speelden, woog het deze niet expliciet tegen elkaar af, maar oordeelde het dat het beleid niet kennelijk ongeschikt was om het beoogde doel te bereiken. Het is niet duidelijk waarom deze afwijkende benadering werd gekozen.

311. EHvJ 29 februari 1996, gev. zaken C-296/93 en C-307/93, Jurispr. 1996, 1-795, punt 30 en EHvJ 5 oktober 1994, Crispoltoni, gev. zaken C-133/93, C-300/93 en C362/93, Jurispr. 1994, 1-4863, punt 41

312. Zie EHvJ 13 december 1979, zaak 44/79, Hauer, Jurispr. 1979, 3727, punt 23 en EHvJ 13 juli 1989, zaak 5/88, Wachauf, Jurispr. 1989, 2609.

313. Het is vaste rechtspraak dat het gelijkheidsbeginsel een algemeen beginsel van het landbouwrecht vormt: zie bijv. EHvJ 11 mei 2000, zaak C-56/99, Gascogne, Jurispr. 2000, I-3079, punt 37. Interes. sant is in dit verband dat het Hof in een recent arrest wel gebruik heeft gemaakt van de formulering van de in de vorige noot genoemde arresten Hauer en Wachauf, het lijkt echter om een gelsoleerd geval te gaan, waarvan het nog niet duidelijk is of het Hof het als precedent zal beschouwen (EHvJ 13 april 2000, zaak C-292/97, Karlsson e.a., Jurispr. 2000, 1-2737).

314. Vgl. Tridimas 1999 (I), p. 92, die bovendien aangeeft dat het Hof deze individuele beoordeling tot nu toe met succes heeft weten te vermijden. Zie over de verschillende manieren waarop een proportiona. liteitstoets kan worden uitgevoerd ook De Búrca 1993, p. 106/107. Zij onderscheidt tussen de traditionele proportionaliteitstoets, waarbij gekeken wordt naar de aantasting van wettelijk beschermde rech. ten en belangen, en een proportionaliteitstoets waarbij een afweging moet worden gemaakt tussen verschillende beleidsdoelstellingen: vaak kan door een keuze voor een bepaalde maatregel een andere (economische of sociale) doelstelling niet meer worden bereikt. Met name dit laatste levert problemen op in verband met de omvang van de rechterlijke bevoegdheid. Deze situatie doet zich in het gemeenschapsrecht vrij regelmatig voor, zodat het redelijk is dat het Hof zich terughoudend opstelt. Dit betekent echter niet dat het Hof zich in het geheel nooit aan een dergelijke beoordeling zou mogen wagen. Bovendien is het merkwaardig dat het Hof zich in de praktijk ook lijkt te onthouden van een traditio- 
beoordelen zal het over de evenredigheid van de concrete belangenaantasting geen oordeel vellen:

[...] de instellingen [moeten] in de uitoefening van hun bevoegdheden weliswaar ervoor [...] waken aan de deelnemers van het economisch verkeer zwaardere lasten op te leggen dan nodig om de door de overheid te realiseren doeleinden te bereiken, doch [...] daaruit [volgt] niet [...] dat deze verplichting moet worden afgemeten aan de bijzondere situatie van een bepaalde groep deelnemers; [...] een zodanige benadering [is], gezien de menigvuldige en ingewikkelde economische situaties, niet slechts onuitvoerbaar [...], maar [zou] bovendien een eeuwige bron van rechtsonzekerheid $[\ldots]$ vormen $[\ldots] . "$ is

Aan de door het Hof in het bovenstaande citaat aangevoerde bezwaren tegen een concrete proportionaliteitstoets kan echter slechts beperkte waarde worden gehecht. De bezwaren kunnen in belangrijke mate worden verzacht door de keuze voor een geschikte toetsingsintensiteit. Juist op beleidsgebieden als de landbouw kan vaak worden volstaan met een marginale toets, waarbij er sprake moet zijn van een zeer ernstige belangenaantasting om te kunnen spreken van disproportionaliteit. Wanneer een dergelijke belangenaantasting kan worden aangetoond is het nog maar de vraag of aan het door het Hof aangedragen rechtszekerheidsargument meer waarde moet worden gehecht dan aan de bescherming van de belangen van het individu. In de tweede plaats is het onwaarschijnlijk dat een beoordeling van de proportionaliteit in het concrete geval grotere problemen voor de toetsingsmethodiek zal opleveren dan een abstract oordeel over de geschiktheid of noodzakelijkheid van de betrokken maatregel: ook een dergelijk oordeel is vaak bijzonder lastig, omdat de rechter vaak niet over voldoende mogelijkheden beschikt om de alternatieven voldoende in te schatten of om een voorspelling te doen over de mogelijkheid om met een maatregel een bepaald doel te bereiken. ${ }^{36}$ Tenslotte is het in dit verband van belang dat er een belangrijke categorie van gevallen bestaat waarin het Hof wel degelijk een concrete proportionaliteitstoets uitvoert. Het gaat daarbij om zaken waarin het Hof geen algemeen oordeel hoeft uit te spreken over de rechtmatigheid van een landbouwmaatregel, maar uitsluitend over de wijze waarop deze maatregel in het individuele geval is toegepast. In dergelijke situaties gaat het Hof steeds zorgvuldig na of de aan de toepassing ten grondslag liggende belangenafweging redelijk is. ${ }^{317}$

nele proportionaliteitstoets, ook al is de rechter in het algemeen wel degelijk in staat om een dergelijke toets uit te voeren.

315. EHvJ 24 oktober 1973, zaak 5/73, Balkan-Import-Export, Jurispr. 1973, 1091, punt 22. Ongetwijfeld is hierbij ook van belang dat het Hof vreest voor de politieke en beleidsmatige consequenties van het oordeel dat proportionaliteit in het concrete geval ontbreekt: wanneer vervolgens een groot aantal zaken wordt aangebracht door eisers die zich in dezelfde situatie bevinden zal uiteindelijk een wijziging van de regeling onvermijdelijk zijn, zelfs als deze als zodanig niet ondeugdelijk is.

316. Vgl. Tridimas 1999 (1), p. 140.

317. Dit blijkt vooral uit arresten die betrekking hebben op sancties, zoals het verbeuren van een waarborgsom bij het niet naleven van bepaalde verplichtingen; met name wanneer slechts ondergeschikte verplichtingen niet zijn nagekomen of wanneer de niet-nakoming gezien het doel van de regeling niet bijzonder ernstig was, kan er volgens het Hof sprake zijn van een schending van het evenredigheidsbeginsel (zie bijv. EHvJ 20 februari 1979, zaak 122/78, Buitoni, Jurispr. 1979, 677 en EHvJ 27 november 1986, zaak 21/85, Maas, Jurispr. 1986, 3537). Uit het arrest Atalanta blijkt bovendien dat een algemene regeling altijd voldoende ruimte moet bieden om individuele omstandigheden mee te wegen; wanneer een regeling daarvoor geen ruimte laat is deze automatisch in strijd met het evenredigheidsbe- 
Het bovenstaande is van belang voor de toetsing aan het proportionaliteitsvereiste in het kader van de toetsing aan het gelijkheidsbeginsel. Ook daarbij kan immers in zijn algemeenheid worden nagegaan of de maatregel de belangen van een specifieke groep onevenredig zwaar aantast, terwijl daarnaast kan worden onderzocht of er in het concrete geval sprake is van een disproportionele belasting. Gezien het bovenstaande kan worden gesteld dat tegen geen van beide vormen van toetsing overwegende bezwaren bestaan, zodat er geen reden is de toetsing aan het proportionaliteitsvereiste in het algemene model te beperken tot een abstracte toets.

\section{Conclusie}

Zoals eerder is aangegeven gaat het Hof bij ongelijke behandeling op het gebied van het gemeenschappelijk landbouwbeleid op een pragmatische en terughoudende manier met de rechtvaardigingstoets om: in de meeste gevallen ontbreekt een toetsing aan de vereisten van geschiktheid, noodzakelijkheid en proportionaliteit volledig en wordt er slechts een algemene willekeurstoets toegepast. Dit is alleen anders wanneer het Hof van mening is dat het voorliggende onderscheid echt niet toelaatbaar is of als de partijen of de verwijzende rechter de aandacht op een van deze vereisten hebben gevestigd. Juist uit het feit dat het Hof in die gevallen wel degelijk aan de afzonderlijke vereisten toetst kan worden afgeleid dat in veel gevallen alleen hierdoor een overtuigende motivering kan worden bereikt.

Tenslotte is het interessant om op te merken dat het Hof in een recent arrest een nieuwe benadering lijkt te hebben gekozen voor de beoordeling van ongelijke behandeling, waarbij wordt teruggegrepen op de formulering van het algemene evenredigheidsbeginsel zoals dat is ontwikkeld in de rechtspraak over fundamentele beginselen van gemeenschapsrecht ${ }^{318}$ :

"[...] de uitoefening van deze rechten [op gelijke behandeling, JHG] [kan], met name in het kader van een gemeenschappelijke marktordening, [...] aan beperkingen worden onderworpen, voor zover die beperkingen werkelijk beantwoorden aan de doeleinden van algemeen belang die de Gemeenschap nastreeft, en, het nagestreefde doel in aanmerking genomen, niet zijn te beschouwen als een evenredige en onduldbare ingreep, waardoor de gewaarborgde rechten in hun kern worden aangetast." 119

Het is wenselijk dat het Hof in de toekomst vaker van een dergelijke formulering gebruik maakt. De toepassing van een belangrijke vereiste als proportionaliteit wordt hierdoor immers minder afhankelijk gesteld van de aanwezigheid van een evidente schending, terwijl de motivering door deze, aanzienlijk zorgvuldigere benadering doorzichtiger kan worden.

ginsel (EHvJ 21 juni 1979, zaak 240/78, Jurispr. 1979, 2137, punt 45). Dit geldt ook wanneer een regeling te rigide is, in de zin dat er geen vermindering van een sanctie mogelijk is als er echt sprake is van een geringe overschrijding waardoor het realiseren van het gestelde doel niet in gevaar wordt gebracht (EHvJ 6 juli 2000, zaak C-356/97, Mölkereigenossenschaft Wiedergeltingen, Jurispr. 2000, 15461.). Vgl. ook Tridimas 1999 (I), p. 104 en De Moor-van Vlugt 1995, p. 114.

318. Zie m.n. EHvJ 13 december 1979, zaak 44/79, Hauer, Jurispr. 1979, 3727 en EHvJ 13 juli 1989, zask 5/88, Wachauf, Jurispr. 1989, 2609, punt 18.

319. EHvJ 13 april 2000, zaak C-292/97, Karlsson e.a., Jurispr. 2000, 1-2737, punt 45 


\subsubsection{Geschiktheid, subsidiariteit en proportionaliteit bij onderscheid op grond van nationaliteit}

\section{Inleiding}

Het Hof besteedt in zijn rechtspraak over onderscheid op grond van nationaliteit veel aandacht aan de aanwezigheid van een objectieve rechtvaardiging. Anders dan bij onderscheid op grond van geslacht wordt daarbij in de meeste gevallen nauwkeurig nagegaan of de door de verweerder aangevoerde argumenten voldoende overtuigend zijn, zelfs in de gevallen waarin er sprake is van een prejudiciële procedure. ${ }^{320}$ De rechtspraak op dit punt is sterk casuïstisch van aard: doordat het Hof steeds zelf nagaat of er sprake is van een objectieve rechtvaardiging hoeft het de nationale rechter nauwelijks criteria aan te reiken die hem behulpzaam kunnen zijn bij de toepassing van het toetsingsmodel. Het is door de grote hoeveelheid uitspraken op dit terrein en de uitgebreide motivering hiervan goed mogelijk om vast te stellen op welke wijze het Hof te werk gaat bij beoordeling van een aangevoerde objectieve rechtvaardiging. In het hiernavolgende zal worden nagegaan of er uit de rechtspraak algemeen bruikbare criteria voor de toepassing van de vereisten van geschiktheid, noodzakelijkheid en proportionaliteit kunnen worden afgeleid.

\section{Geschiktheid}

Een voorbeeld waaruit de aanpak van het Hof bij de toetsing aan het geschiktheidsvereiste duidelijk naar voren komt is te vinden in het arrest Clean Car Autoservice. ${ }^{321}$ Dit arrest had betrekking op een Oostenrijkse regeling op grond waarvan het voor rechtspersonen en andere vennootschappen verplicht was om een bedrijfsleider aan te stellen. Deze bedrijfsleider moest volgens de betreffende wettelijke regeling zijn woonplaats in Oostenrijk hebben, een vereiste waardoor duidelijk indirect onderscheid op grond van nationaliteit werd gemaakt. De regering trachtte dit woonplaatsvereiste te rechtvaardigen door te stellen dat hierdoor kon worden verzekerd dat voldaan werd aan een ander wettelijk vereiste, namelijk de eis dat de bedrijfsleider daadwerkelijk in het bedrijf werkzaam zou zijn. Het Hof stelde ten aanzien van de geschiktheid van het woonplaatsvereiste om dit doel te bereiken het volgende:

"[...] de omstandigheid dat de bedrijfsleider woonachtig is in de lidstaat waar de onderneming gevestigd is en haar activiteit uitoefent, [vormt] niet noodzakelijkerwijs een waarborg dat hij daadwerkelijk in het bedrijf werkzaam zal kunnen zijn. Immers, voor een bedrijfsleider die in die staat woont, doch op grote afstand van de onderneming, zou het normalerwijze moeilijker moeten zijn om daadwerkelijk in het bedrijf werkzaam te zijn dan voor iemand wiens woonplaats, ook al ligt die in een andere lidstaat, niet ver verwijderd is van de plaats waar de onderneming haar activiteiten uitoefent."

320. En zelfs als daarover niets is gevraagd. De verklaring gaf het Hof in het arrest $O^{\prime}$ Flynn (EHvJ 23 mei 1996, zaak C-237/94, Jurispr. 1996, I-2617): het Hof hecht er waarde aan om de nationale rechter een $z 0$ volledig en nuttig mogelijk antwoord te geven (punt 25 ). Helaas gaf het Hof niet aan waarom het dit wel nuttig acht in het geval van onderscheid op grond van nationaliteit en niet als het gaat om onderscheid op grond van geslacht. Overigens blijkt een inhoudelijke motivering in bepaalde gevallen te ontbreken, zonder dat daarvoor een aanwijsbare reden bestaat; zie bijv. EHvJ 27 november 1997, zaak C-57/96, Meints, Jurispr. 1997, 1-6689, punt 48.

321. EHvJ 7 mei 1998, zaak C-350/96, Jurispr. 1998, I-2521

322. Punt 35. Zie bijv. ook 3 februari 1982, gev, zaken 62 en $63 / 81$, Seco, Jurispr. 1982, 223, punt 14 
Uit deze overweging blijkt dat het toetsen van geschiktheid een sterk feitelijke beoordeling vereist, waarbij met name gezond verstand en inzicht in de werking van regelgeving bepalend zijn voor de uitkomst. Gezien het feitelijke karakter van de geschiktheidstoets lijkt het niet goed mogelijk om duidelijke en vastomlijnde criteria te ontwik. kelen die de rechter bij zijn toetsing kunnen helpen. Dergelijke criteria zijn in de rechtspraak van het Hof in ieder geval niet terug te vinden.

\title{
Noodzakelijkheid en subsidiariteit
}

Noodzakelijkheid blijkt in de rechtspraak van het Hof over discriminatie op grond van nationaliteit een breder begrip te zijn dan subsidiariteit. Zoals eerder is aangegeven ziet het begrip subsidiariteit op het bestaan van alternatieve mogelijkheden waardoor het doel eveneens kan worden bereikt, maar waardoor de belangen van de benadeelde groep in mindere mate worden aangetast. Volgens het Hof is het echter niet altijd nodig om reëel bestaande alternatieven aan te tonen, zoals bijvoorbeeld blijkt uit het arrest Allué $I^{322}$ Dit arrest had betrekking op een Italiaanse regeling op grond waarvan lectoren vreemde talen slechts voor één jaar bij een universiteit konden worden aangesteld en hun contract maar vijf keer verlengd kon worden; het overige wetenschappelijke personeel kon wel een vaste aanstelling krijgen. De regering gaf als argument voor dit onderscheid dat alleen op deze manier kon worden gewaarborgd dat de lectoren over voldoende bijdetijdse theoretische en praktische kennis van de te doceren taal zouden beschikken. Het Hof oordeelde hierover als volgt:

\begin{abstract}
"Dienaangaande moet erop worden gewezen dat het gevaar dat men het contact met de moedertaal verliest kleiner is geworden door de intensieve culturele uitwisseling en de vele communicatiemogelijkheden, en dat de universiteiten verder in elk geval de mogelijkheid hebben het kennisniveau van hun lectoren te controleren. [...] De beperking van de duur van de werkzaamheid kan dus niet gerechtvaardigd zijn op de grond die de Italiaanse regering aanvoert." $\$ 24$
\end{abstract}

Het Hof onderzocht in deze overweging dus niet zozeer of er alternatieven voor de betrokken regeling bestaan, maar ging eerder na of de getroffen maatregel in zijn algemeenheid noodzakelijk was om het gestelde doel te bereiken.

Het grote voordeel van een dergelijke algemene noodzakelijkheidstoets is dat de rechter niet expliciet hoeft aan te geven welke eventuele alternatieven er bestaan en evenmin hoeft na te gaan of deze alternatieven geschikt zijn om het nagestreefde doel te bereiken. Problematisch is dat de inhoud van het noodzakelijkheidsvereiste niet bijzonder duidelijk is: de vraag blijft welke omstandigheden het oordeel dat een maatregel

(waarin opvallend genoeg en met een minimale motivering ("een dergelijke maatregel is naar haar aard ongeschikt") werd geconcludeerd dat een objectieve rechtvaardiging ontbrak) en EHvJ I0 maart 1993, zaak C-111/91, Commissie/Luxemburg (geboortetoelagen), Jurispr. 1993, I-817, punt 12 (waarin het Hof juist wel tot de conclusie kwam dat de maatregel geschikt was om het gestelde doel te bereiken).

323. EHvJ 30 mei 1989 , zaak 33/88, Jurispr. 1989, 1591

324. Punt 14. Idem in EHvJ 20 oktober 1993, zaak C-272/92, Spotti, Jurispr. 1993, I-5185, punt 20. Andere voorbeelden zijn EHvJ 29 oktober 1980, zaak 22/80, Boussac, Jurispr. 1980, 1-3427, punt 12, EHvJ 14 februari 1995, zaak C-279/93, Schumacker, Jurispr. 1995, 1-225, punt 40 e.v. en EHvJ 15 januari 1998, zaak C-15/96, Schöning-Kogebetopoulou, Jurispr. 1998, 1-47, punt 27 (impliciet). Een voorbeeld waarin het Hof de maatregel wel noodzakelijk achtte is EHvJ 16 oktober 1980, zaak 147/79, Hoch. strass, Jurispr. 3005, I-13. 
niet noodzakelijk was toelaten. Het Hof heeft slechts weinig aanknopingspunten geboden voor de beantwoording van deze vraag. Wel zijn soms aanwijzingen terug te vinden die verband houden met een specifieke situatie. Wanneer wordt betoogd dat een regeling is ingesteld "om de goede werking van het belastingstelsel te verzekeren", maar vervolgens wordt ingetrokken kan daaruit volgens het Hof worden afgeleid dat de maatregel kennelijk niet onmisbaar was om deze doelstelling te bereiken. ${ }^{325}$ Of het altijd zo is dat het intrekken van een regeling wijst op een gebrek aan noodzakelijkheid is overigens nog maar de vraag: ook andere beleidsoverwegingen en belangenafwegingen kunnen hierbij immers een rol spelen. ${ }^{320}$

Van belang is verder dat uit de rechtspraak van het Hof blijkt dat in sommige gevallen wel degelijk gebruik wordt gemaakt van het subsidiariteitsvereiste. De subsidiariteitstoets lijkt daarbij te worden gezien als een verbijzondering van de noodzakelijkheidstoets: door op minder vergaande alternatieven te wijzen kan worden aangetoond dat de maatregel niet noodzakelijk was om het gestelde doel te bereiken. Het hiervoor al besproken arrest Clean Car Autoservice ${ }^{327}$ kan hierbij opnieuw als illustratie dienen. De regering had in deze zaak niet alleen gesteld dat het woonplaatsvereiste verzekerde dat de bedrijfsleider daadwerkelijk in het bedrijf werkzaam was, maar ook dat dit de enige mogelijkheid was om, in het geval van onvoldoende nakoming van zijn wettelijke verantwoordelijkheden en verplichtingen, geldstraffen aan hem te betekenen en jegens hem ten uitvoer te leggen. Het Hof overwoog hieromtrent, dat

"[...] met andere, minder beperkende maatregelen, zoals betekening van de straf aan de zetel van de onderneming die de bedrijfsleider in dienst heeft en het waarborgen van betaling doordat vooraf een zekerheid wordt gesteld, [zou] kunnen worden verzekerd dat de an de bedrijfsleider opgelegde geldstraffen hem kunnen worden betekend en jegens hem ten uitvoer kunnen worden gelegd." ${ }^{328}$

Het Hof maakt echter veel minder vaak gebruik van een subsidiariteitstoets dan van het algemene noodzakelijkheidsvereiste: het lijkt erop dat het Hof alleen op het vereiste van subsidiariteit ingaat wanneer alternatieve maatregelen zeer voor de hand liggen, zoals in het bovenstaande arrest het geval was, of als door de eiser in het hoofdgeding bruikbare alternatieven zijn aangevoerd. ${ }^{329}$

325. Bijv. EHvJ 8 maart 2001, Metallgesellschaft Ltd. e.a., Jurispr. 2001, 1-1727, punt 74

326. Zie voor enkele bezwaren tegen het automatisch afleiden van een gebrek aan noodzakelijkheid uit het intrekken van een wettelijke regeling bovendien hoofdstuk 3, paragraaf 3.6.2.

327. EHvJ 7 mei 1998, zaak C-350/96, Jurispr. 1998, 1-2521

328. Punt 36. Vgl. ook EHvJ 10 maart 1993, zaak C-111/91, Commissie/Luxemburg (geboortetoelagen), Jurispr. 1993, 1-817

329. Zie bijv. EHvJ 28 januari 1992, zaak C-300/90, Commissie/België (levensverzekeringen), Jurispr. 1992, 1-305, punt 20. In dit arrest had de regering uitdrukkelijk gesteld dat de door haar getroffen maatregelen noodzakelijk waren om het betrokken doel te bereiken en dat dit doel ook niet met andere maatregelen bereikt kon worden. Verder zijn voorbeelden te vinden in EHvJ 5 december 1989, zaak C. 3/88, Commissie/ltalië (overheidsaanbestedingen automatisering), Jurispr. 1989, 4035, punt 12 en EHvJ 28 januari 1992, zaak C-204/90, Bachmann, Jurispr. 1992, I-249, punt 17 e.v. Ook hier geldt overigens dat het moeilijk is om specifieke criteria af te leiden uit de rechtspraak van het Hof, nu de beoordeling van subsidiariteit (en van noodzakelijkheid) sterk casuistisch is; zie Jørgensen 1996, p. 211. Zij geeft wel aan dat er in de rechtspraak algemene lijnen zijn te ontdekken: zo neemt het Hof volgens haar vrijwel steeds aan dat een woonplaatsvereiste niet noodzakelijk is. 
Interessant is tenslotte de interpretatie die het Hof aan het noodzakelijkheidsvereiste heeft gegeven in het kadet van het vrij verkeer van diensten. Al eerder is aangegeven dat lidstaten vaak eisen stellen aan dienstverleners om te waarborgen dat diensten op verantwoorde wijze worden verleend; op die manier wordt bescherming geboden aan degenen die gebruik maken van deze diensten. Bij grensoverschrijdende dienstverlening kan door het stellen van dergelijke eisen echter een dubbele belasting voor de dienstverlener ontstaan, nu hij in het algemeen niet alleen is onderworpen aan de regels van het land waar de dienst wordt verleend, maar ook aan de regels in het land waar hij is gevestigd. De beoordeling van noodzakelijkheid is in deze situatie van groot belang, nu een extra bescherming door het land van dienstverlening in veel gevallen overbodig is. Het Hof heeft voor de beoordeling van dit soort klachten een bijzondere benadering gekozen, waarvan een voorbeeld is te vinden in het arrest Van Wesemael. ${ }^{30}$ Hierin was een Belgische regeling in het geding, op grond waarvan buitenlandse bemiddelingsbureaus alleen mochten bemiddelen voor artiesten door tussenkomst van een Belgisch bemiddelingsbureau dat over een vergunning beschikte. Het spreekt vanzelf dat dit voor buitenlandse bemiddelingsbureaus de dienstverlening aanzienlijk bemoeilijkte. Het Hof stelde hierover het volgende:

"Dit vereiste blijkt niet objectief noodzakelijk te zijn wanneer de werkzaamheid wordt
verricht door een officieel bureau voor arbeidsbemiddeling in een Lid-Staat of de in een
andere Lid-Staat gevestigde dienstverrichter aldaar houder is van een vergunning afgegeven
onder voorwaarden welke vergelijkbaar zijn met die gesteld door de staat waar de dienst
wordt verricht, en in de eerste staat op elke vorm van arbeidsbemiddeling gepast toezicht
wordt gehouden, ongeacht voor welke Lid-Staat de dienstverrichting is bestemd."

Als de bescherming van de belangen van de betrokkenen al voldoende wordt gegarandeerd door een regeling in het land van vestiging, is het toepassen van de eisen van het land waar de dienst wordt verricht blijkens deze overweging niet noodzakelijk. ${ }^{m} 0 \mathrm{p}$ zichzelf kan een dergelijk vereiste ook bij de overige vormen van onderscheid op grond van nationaliteit een rol spelen: zo kunnen vestigingsvereisten of diplomavereisten bij het vrij verkeer van personen en bij de vrije vestiging overbodig zijn, omdat aan vergelijkbare eisen al in het land van herkomst is voldaan. ${ }^{333}$ Het zal echter duidelijk zijn dat dit criterium minder bruikbaar is wanneer er sprake is van andere gronden van onderscheid dan nationaliteit, of wanneer er een situatie in het geding is waarin grensoverschrijding en het risico van dubbele belasting geen rol spelen. Een volledige veralgemenisering van dit criterium is dus zeker niet mogelijk.

\section{Proportionaliteit}

Anders dan bij onderscheid op grond van geslacht vormt de beoordeling van proportionaliteit een vast onderdeel van de toetsing van indirect onderscheid op grond van natio-

330. EHvJ 18 januari 1979, gev. zaken 110 en $111 / 78$, Jurispr. 1979, 35

331. Punt 30

332. Vgl. Hilson 1999, p. 458.

333. Voorbeelden hiervan zijn vooral te vinden in de recentere rechtspraak van het Hof met betrekking tof non-discriminatoire belemmeringen van het vrije verkeer. Zie bijv. voor de vrije vestiging EHvJ 7 mel 1991, zaak C-340/89, Vlassopoulou, Jurispr. 1991, 1-2357, punt 15 en 16. Zie verder Craig/De Büral 1998, p. 736 e.v. en Tridimas 1999 (1), p. 142-144. 
naliteit. ${ }^{34}$ In de praktijk blijkt een inhoudelijke beoordeling van de evenredigheid in veel arresten echter achterwege te blijven. Vaak is een dergelijke beoordeling ook niet nodig, nu het Hof in het overgrote deel van de gevallen al tot de conclusie komt dat de ongelijke behandeling niet gerechtvaardigd is wegens het ontbreken van geschiktheid of noodzakelijkheid. Er is echter ook een vrij groot aantal arresten waarin een beoordeling van de proportionaliteit ontbreekt, terwijl het Hof tot de conclusie was gekomen dat de maatregel geschikt en noodzakelijk was om het gestelde doel te bereiken. ${ }^{335} \mathrm{De}$ toetsing van de evenredigheid lijkt vooral te worden ingegeven door pragmatische overwegingen; aan dit vereiste wordt alleen getoetst wanneer dit voor de uitkomst van de procedure relevant is.

Een duidelijk voorbeeld van de benadering van het Hof bij de toetsing van de proportionaliteit is te vinden in het arrest Pastoors en Trans-Cap ${ }^{336}$, waarin een Belgische regeling in het geding was die betrekking had op bekeuringen voor het schenden van regels op het gebied van het wegverkeer. Wanneer bij controle werd geconstateerd dat een bestuurder bepaalde voorwaarden niet had nageleefd, kon hij kiezen uit een onmiddellijke betaling van een boete of uit het toepassen van een strafvervolging. Koos de overtreder voor dit laatste en had hij geen vaste woon- of verblijfplaats in België, dan moest hij per overtreding een bedrag betalen dat aanzienlijk hoger was dan de boete zelf. Dit bedrag was bedoeld als dekking van de gerechtelijke kosten en de eventueel op te leggen geldboete. Ten aanzien van deze verplichting stelde het Hof het volgende:

"[...] Dit bedrag, dat $50 \%$ hoger is dan het bedrag dat moet worden betaald indien de overtreder kiest voor de onmiddellijke betaling waardoor de strafvervolging vervalt, is verschuldigd voor elke aan de betrokkene ten laste gelegde overtreding afzonderlijk. Wanneer in hetzelfde proces-verbaal diverse overtredingen tegelijkertijd worden vastgesteld, wordt evenwel tegen de overtreder niet voor elke overtreding een afzonderlijke strafprocedure, doch voor alle overtredingen één enkele strafprocedure ingesteld. Een nationale regeling zoals die welke in het hoofdgeding aan de orde is, waarbij in geval van overtreding door niet-ingezetenen de betaling wordt verlangd van dergelijke bedragen, op straffe van inhouding van hun voertuig, lijkt derhalve buitensporig. Een nationale regeling

334. Zie EHvJ 28 november 1989, zaak C-379/87, Groener, Jurispr. 1989, 3967, punt 19, EHvJ 23 mei 1996, zaak C-237/94, O Flynn, Jurispr. 1996, 1-2617, punt 19, EHvJ 27 november 1997, zaak C-57/96, Meints, Jurispr. 1997, I-6689, punt 45, EHvJ 15 januari 1998, zaak C-15/96. SchöningKogebelopoulou, Jurispr. 1998, I-47, EHvJ 12 maart 1998, zaak C-187/96, Commissie/Griekenland (anciënniteit musici), Jurispr. 1998, I-1095, punt 19, EHvJ 7 mei 1998, zaak C-350/96, Clean Car Autoservices, Jurispr. 1998, 1-2521 en EHvJ 3 oktober 2000, zaak C-411/98, Ferlini, Jurispr. 2000, I8081, punt 59; zie in deze zin ook A-G Van Gerven in zijn conclusie bij het arrest SPUC/Grogan, EHvJ 4 oktober 1991, zaak C-159/90, Jurispr. 1991, 1-4685, punt 27. De rechtspraak is op dit punt echter niet geheel duidelijk: in een aantal arresten wordt weliswaar verwezen naar het proportionaliteitsvereiste, maar beschouwt het Hof dit, net als in de rechtspraak over onderscheid op het gebied van de landbouw, als een overkoepelende term voor de toetsing van geschiktheid en noodzakelijkheid (zie bijv. EHvJ 2 augustus 1993, gev. zaken C-259, C-331 en C-332/91, Allué I, Jurispr. 1993, 1-4309, punt 15). Ook de literatuur is hierover niet eenduidig: zie De Búrca (1993, p. 113), die concludeert dat er een proportionaliteitstoets in strikte zin in de rechtspraak is terug te vinden tegenover Tridimas, die aanneemt dat de proportionaliteitstoets een toets van geschiktheid en noodzakelijkheid inhoudt (1999,

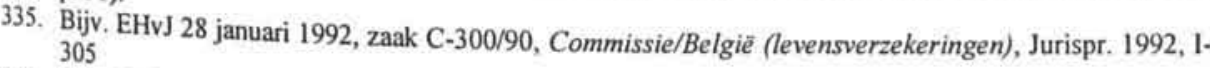

336. EHvJ 23 januari 1997, zaak C-29/95, Jurispr. 1997, I-285 
als bedoeld in het hoofdgeding, is derhalve kennelijk onevenredig, en dus in strijd met artikel 6 van het Verdrag [tegenwoordig artikel 12, JHG]." 337

Op zichzelf is het niet problematisch om alleen aan het proportionaliteitsvereiste te toetsen en te impliceren dat is voldaan aan de andere vereisten: hoewel dit nadelige gevolgen heeft voor de duidelijkheid en de doorzichtigheid van de motivering, heeft dit verder geen invloed op de uitkomst van de toetsing. Kritischer moet worden gekeken naar de praktijk om de proportionaliteitstoets weg te laten als tot de conclusie wordt gekomen dat de maatregel geschikt en noodzakelijk is ter bereiking van het gestelde doel. Hierdoor valt de mogelijkheid weg om na te gaan of de maatregel in het concrete geval een onevenredige aantasting van belangen tot gevolg heeft, hetgeen nadelig is voor de positie van de individuele klager. De weglating moet in die gevallen onwenselijk worden geacht.

\subsection{Ontbrekend element in de toetsing van het Hof: de mate van fit}

Zoals hierboven is gebleken stemt het door het Hof gehanteerde model bij onderscheid op grond van nationaliteit vrijwel volledig overeen met het theoretische toetsingsmodel en bevat het zelfs een element dat nog niet in het model is opgenomen: de beoordeling van noodzakelijkheid in de zin van onmisbaarheid. Ook de toetsing bij onderscheid op grond van geslacht is vrij uitgebreid, hoewel daarbij een toetsing van de proportionaliteit in strikte zin meestal ontbreekt. Het toetsingsmodel zoals dat bij ongelijke behandeling op het gebied van de landbouw wordt uitgevoerd schiet tenslotte tekort als het gaat om de duidelijkheid en doorzichtigheid van de gevolgde toetsingsmethodiek: in de rechtspraak zijn daarbij slechts met moeite elementen als geschiktheid en noodzakelijkheid te onderscheiden, terwijl een proportionaliteitstoets meestal volledig ontbreekt. In de drie toetsingsmodellen, hoe volledig of onvolledig ook, ontbreekt echter steeds één element: de beoordeling van de mate van fit van de maatregel. Ook in de feitelijke toepassing van de toetsingsmodellen wordt vrijwel nooit een oordeel gegeven over de under- of overinclusiveness van het gemaakte onderscheid. Bij onderscheid op grond van nationaliteit en geslacht kan hiervoor een verklaring worden gevonden in het feit dat vrijwel alleen uitspraken over indirect onderscheid in het onderzoek zijn betrokken. Bij het onderzoek van een dergelijk onderscheid wordt uitsluitend nagegaan of het discriminatoire effect van de maatregel is gerechtvaardigd. Het is moeilijk voor te stellen hoe de toetsing van de mate van fit, dus het beoordelen van de wijze waarop een classificatie is gedefinieerd in het licht van de doelstelling van de regeling, daarbij een rol zou kunnen spelen. Dit aspect zou alleen aan de orde kunnen komen als het directe onderscheid (dat het disproportioneel benadelende effect tot gevolg heeft) als zodanig op zijn toelaatbaarheid zou worden onderzocht. ${ }^{31 s}$

337. Punt 25 en 26 , cursief toegevoegd. Zie ook Jacobs 1999 , p. $9 / 10$.

338. Zie ook hoofdstuk 2, paragraaf 3.3.2. Overigens is in paragraaf 2.2 .3 verwezen naar de rechtsprakk over directe belastingen, waarin inderdaad sprake is van een inhoudelijke toetsing van het directe onderscheid in het geval waarin ook een indirect onderscheid op grond van nationaliteit is gesignaleerd. In die gevallen wordt echter een vergelijkbaarheidstoets uitgevoerd, waardoor het nogmaals toetsen van de mate van fit van het onderscheid niet meer relevant is. 
Het is moeilijk te bepalen in hoeverre het Hof wel gebruik maakt van het verbod van over- en underinclusiveness bij direct onderscheid. Gebleken is al dat de toetsing op het gebied van de landbouw vaak zodanig ondoorzichtig en onduidelijk is dat daaruit moeilijk een bepaalde toetsingsmethodiek kan worden afgeleid. Bovendien zal in deze rechtspraak slechts zelden een oordeel over de over- en underinclusiveness worden gegeven, omdat er vrijwel steeds een vergelijkbaarheidstoets wordt uitgevoerd. Zoals in hoofdstuk 2 is aangegeven vertonen de beide toetsen belangrijke raakvlakken. ${ }^{39}$ Gesteld is daar reeds dat bij een ongelijke behandeling van vergelijkbare gevallen per definitie kan worden gesproken van underinclusiveness: een deel van de gevallen die eigenlijk door een maatregel zouden moeten worden geraakt valt daarbij immers ten onrechte buiten de reikwijdte van de regeling. Andersom kan bij het gelijk behandelen van onvergelijkbare gevallen steeds worden gesproken van overinclusiveness: in verhouding tot de doelstelling van de regeling is de reikwijdte ervan te ruim geformuleerd. Als het Hof al een uitgebreide beoordeling heeft gegeven van de vergelijkbaarheid, zoals dat bij de arresten op het gebied van het landbouwrecht meestal het geval is, zal een toetsing van de over- en underinclusiveness in het licht van de beoordeling van de rechtvaardiging dan ook overbodig zijn.

Naast artikel 34 lid 2 is artikel 12 de enige bepaling in het Verdrag waarbij een direct onderscheid aan een rechtvaardigingstoets kan worden onderworpen en waarbij het Hof volledige vrijheid heeft om zijn eigen toetsingsmethodiek vast te stellen. Hoewel het aantal arresten dat over deze bepaling is gewezen vrij beperkt is, kan hierin een aantal voorbeelden worden gevonden van een toetsing van de mate van fit. ${ }^{30}$ Interessant is vooral het arrest Hayes ${ }^{34}$, dat betrekking had op de verplichting voor niet-Duitsers om, wanneer zij voor een Duitse rechter als eiser optraden, een zekerheid te stellen voor de proceskosten. De Duitse regering had ter rechtvaardiging van dit vereiste gesteld dat hierdoor het risico werd bestreden dat zou bestaan bij vertrek van de buitenlandse eiser naar het land van herkomst: de tenuitvoerlegging van een eventuele veroordeling tot de proceskosten zou in dat geval moeilijker en in ieder geval duurder zijn. Ten aanzien van dit argument overwoog het Hof als volgt:

"[...] [] $\mathrm{n}$ casu [kan] [...] worden volstaan met de opmerking dat de bestreden bepaling, doordat zij een verschil in behandeling op grond van nationaliteit van de eiser inhoudt, het

339. Zie hoofdstuk 2, paragraaf 4.2.4. Zie ook Barents 1994 (I), p. 332-333.

340. Naast het, hiema te bespreken, arrest Hayes, kan nog worden verwezen naar het arrest Codorniu, hoewel dat iets minder duidelijk is (EHvJ 18 mei 1994, zaak C-309/89, Jurispr. 1994, 1-1853). In dit arrest werd een maatregel ontoelaatbaar geacht die betrekking had op etikettering van mousserende wijnen. De bedoeling van de in de regeling neergelegde benamingen was om aanduidingen te beschermen die in bepaalde landen al van oudsher golden om producten van een bepaalde herkost aan te duiden. In dat verband waren alleen Frankrijk en Luxemburg aangewezen als landen die de benaming "crémant" mochten gebruiken. Codomiu, een Spaanse producent van mousserende wijnen, maakte hiertegen bezwaar: ook hij produceerde als sinds 1924 wijnen onder de benaming "crémant". Het Hof overwoog het volgende: "Onder deze omstandigheden kan het feit dat de vermelding "crémant" wordt voorbehouden aan in Frankrijk of Luxemburg bereide v.m.q.p.r.d. [een bepaald type mousserende wijn, JHG] niet rechtsgeldig worden gerechtvaardigd uit hoofde van een traditioneel gebruik, aangezien hiermee een eveneens traditioneel gebruik door Codorniu niet wordt erkend" (punt 34). Deze regeling was dus duidelijk underinclusive.

341. EHvJ 30 maart 1997, zaak C-323/95, Jurispr. 1997, 1-1711 
evenredigheidsbeginsel niet in acht neemt. In de eerste plaats kan zij niet in iedere grens. overschrijdende zaak de terugbetaling van de proceskosten garanderen, aangezien geen zekerheid kan worden verlangd van een Duitse eiser die niet in Duitsland woont en aldaar geen vermogen bezit. In de tweede plaats is zij onevenredig aangezien van een niet-Duitser die in Duitsland woont en er vermogen heeft, ook een zekerheidstelling kan worden verlangd." ${ }^{342}$

Hoewel het Hof blijkens deze overweging een evenredigheidstoets uitvoerde, achtte het de regeling feitelijk ontoelaatbaar vanwege haar over- en underinclusiveness: niet in Duitsland wonende Duitsers hoefden immers ten onrechte geen zekerheid te stellen, terwijl in Duitsland wonende niet-Duitsers deze verplichting juist wel hadden, hetgeen gezien het doel eveneens onterecht was.

Hoewel uit de rechtspraak van het Hof geen duidelijke argumenten kunnen worden afgeleid voor een toetsing aan het vereiste van een voldoende mate van fit, kan evenmin worden gesteld dat er overwegende bezwaren tegen het gebruik van dit criterium bestaan: het niet hanteren van het vereiste komt niet zozeer voort uit overwegingen van fundamentele aard, als wel uit de bijzondere toetsingsmethodiek die wordt gehanteerd bij indirect onderscheid op grond van geslacht en nationaliteit en bij direct onderscheid op het gebied van de landbouw.

\section{Toetsingsintensiteit}

\subsection{Algemeen}

In de intensiteit waarmee het Hof ongelijke behandelingen op hun toelaatbaarheid beoordeelt is een duidelijke variatie zichtbaar: in bepaalde gevallen blijkt het Hof een zeer strikte toetsing uit te voeren, terwijl in andere gevallen wordt volstaan met een uiterst marginale toets. Dit kan worden geilllustreerd aan de hand van een tweetal arresten. In het eerste arrest, Adoui en Cornuaille ${ }^{34}$, diende het Hof zich uit te spreken over een Belgische weigering om een verblijfsvergunning toe te kennen aan twee Franse prostituées. Weliswaar is een dergelijke weigering niet te beschouwen als een ongelijke behandeling, maar hierdoor werd wel inbreuk gemaakt op het vrij verkeer van personen zoals dat door artikel 39 EG wordt gewaarborgd. Ter rechtvaardiging van deze inbreuk deed de regering een beroep op de zogenaamde openbare orde-clausule die is neergelegd in artikel 39 lid 3. Het Hof stelde dienaangaande het volgende:

"[...] een nationaal overheidsorgaan [mag] de openbare orde alleen [...] inroepen wanneer er sprake is van een werkelijke, voldoende ernstige bedreiging, die een wezenlijk belang van de samenleving raakt $[\ldots] .{ }^{.344}$

Uit deze overweging kan worden afgeleid dat het Hof bij de toetsing aan artikel 39 lid 3 een strikte toetsing uitvoert, zodat het slechts in bijzondere omstandigheden tot het oordeel zal komen dat de inbreuk is gerechtvaardigd.

343. EHvJ 18 mei 1982, gevoegde zaken 115 en 116/81, Jurispr. 1982, 1665

344. Punt 8 
Uit het arrest SAM Schiffahrt ${ }^{\text {Hs }}$, waarin het Hof de rechtmatigheid van een door de Raad vastgestelde sloopregeling voor binnenvaartschepen diende te beoordelen, kan blijken dat het Hof soms ook bereid is tot het uitvoeren van een zeer marginale toetsing:

"Aangezien de Raad zich op globale vaststellingen mag baseren, kan [...] niet worden gesteld, dat de basisverordening op kennelijke dwaling berust of dat de Raad de grenzen van zijn beoordelingsbevoegdheid kennelijk heeft overschreden, door een sloopactie vast te stellen om de structuren van de binnenvaart te saneren." 346

Het is interessant om in de rechtspraak van het Hof na te gaan welke factoren bepalend zijn voor de keuze voor een bepaalde toetsingsintensiteit. Het blijkt niet altijd eenvoudig te zijn om dit te achterhalen: met name bij onderscheid op grond van nationaliteit heeft het Hof zich zelden met zoveel woorden uitgelaten over de toetsingsintensiteit en de factoren die bij de bepaling daarvan een rol spelen. Het is dan ook vrijwel alleen mogelijk om een oordeel te geven over de intensiteit van de toetsing op basis van een analyse van de rechtspraak, waarbij aan de hand van bepaalde ijkpunten wordt vastgesteld of de toetsing in een bepaalde uitspraak marginaal, neutraal of juist strikt is.

In het kader van dit hoofdstuk zal niet in detail worden nagegaan hoe intensief de toetsing in de diverse arresten nu precies is en welke factoren bij de bepaling daarvan (impliciet) een rol hebben gespeeld: een dergelijke analyse voert te ver en is bovendien onvermijdelijk gebaseerd op een subjectieve interpretatie van de overwegingen van het Hof. In plaats daarvan zal voornamelijk aandacht worden besteed aan de arresten waarbij het Hof uitdrukkelijk een motivering heeft gegeven voor zijn keuze en op die rechtspraak waarin het Hof door het gebruik van formuleringen als in de bovengeciteerde voorbeelden duidelijk uitdrukking geeft aan een bepaalde toetsingsintensiteit. Bij de beoordeling van de gehanteerde toetsingsintensiteit zal bovendien gebruik worden gemaakt van de conclusies van de Advocaten-Generaal, aangezien daarin regelmatig aandacht wordt besteed aan de intensiteit van de toetsing.

Net als in de voorafgaande paragrafen zal ook in deze paragraaf onderscheid worden gemaakt tussen de verschillende verboden van ongelijke behandeling, waarbij voor elk van deze verboden afzonderlijk zal worden nagegaan welke factoren bij de bepaling van de toetsingsintensiteit een rol spelen. Nu er bij de bepaling van de toetsingsintensiteit, anders dan bij de toetsingsmethodiek, nauwelijks verschillen blijken te bestaan tussen gevallen van direct en indirect onderscheid, zullen in deze paragraaf soms ook factoren worden genoemd die in de rechtspraak over direct onderscheid een rol blijken te spelen.

Toetsingsintensiteit bij onderscheid op grond van geslacht

\subsubsection{Inleiding}

Bij het zoeken naar factoren die een rol spelen bij de vaststelling van de toetsingsintensiteit bij onderscheid op grond van geslacht moet rekening worden gehouden met het

345. EHvJ 17 juli 1997, gevoegde zaken C-248 en 249/95, Jurispr. 1997, 1-4475
346. Punt 69 
feit dat de meeste van de uitspraken op dit gebied worden gedaan in het kader van een prejudiciële procedure. Zoals eerder is aangegeven laat het Hof de feitelijke toepassing van elementen als geschiktheid en noodzakelijkheid in een dergelijke procedure meestal over aan de nationale rechter. Het gevolg van deze benadering is dat de intensiteit van de toetsing vaak pas door de nationale rechter zal worden vastgesteld: het is juist bij de feitelijke toepassing van elementen als geschiktheid en noodzakelijkheid dat het verschil tussen een intensieve en een marginale toetsing goed zichtbaar is, zodat het daarbij van belang is om expliciet uitspraak te doen over de intensiteit van de toetsing. Juist doordat de verantwoordelijkheid bij het vaststellen van de toetsingsintensiteit meestal bij de nationale rechter is gelegen is het niet altijd eenvoudig om in de rechtspraak van het Hof aanwijzingen te vinden over de intensiteit van de toetsing. Opgemerkt moet echter worden dat er vooral in de jurisprudentie over direct onderscheid verschillende arresten zijn te vinden waarin het Hof vrij expliciet een oordeel over de toetsingsintensiteit heeft gegeven. Op basis daarvan lijkt het mogelijk om enige conclusies te trekken over de factoren die bij de vaststelling hiervan een rol spelen. In het hiernavolgende zullen enkele van deze factoren worden besproken.

\subsubsection{Factoren die de toetsingsintensiteit bepalen}

\section{Betrokkenheid van een fundamenteel belang; grond van het onderscheid}

Het uitgangspunt van het Hof bij de beoordeling van onderscheid op grond van geslacht lijkt een intensieve toetsing te zijn. ${ }^{377}$ Dit kan onder andere worden afgeleid uit het arrest Thomas, ${ }^{348}$ dat betrekking had op een benadeling van mannen bij de toekenning van bepaalde, aan het pensioen gerelateerde uitkeringen. Een dergelijke benadeling wordt door Richtlijn $79 / 7^{\text {sw }}$ verboden, tenzij er een geslaagd beroep kan worden gedaan op een daarin opgenomen uitzonderingsbepaling. Het Hof overwoog in dit arrest het volgende:

"Gelet op het herhaaldelijk door het Hof beklemtoonde fundamentele belang van het beginsel van gelijke behandeling moet de in de betrokken richtlijn voorziene afwijking van het verbod van discriminatie op grond van geslacht strikt worden uitgelegd." 350

Het Hof lijkt geslacht dus als een "verdachte" grond van onderscheid te beschouwen, omdat gelijke behandeling op grond van geslacht een fundamenteel recht is. In deze

347. Dit geldt zowel voor direct als voor indirect onderscheid; vgl. Hervey 1991, p. 814. Zie ook Somek 1999, p. 246.

348. EHvJ 30 maart 1993, zaak C-328/91, Thomas, Jurispr. 1993, 1-1247

349. Richtlijn van de Raad van 19 december 1978 betreffende de geleidelijke tenuitvoerlegging van het beginsel van gelijke behandeling van mannen en vrouwen op het gebied van de sociale zekerheid, Pb. EG 1979 L $6 / 24$.

350. Punt 8. Ook uit andere rechtspraak kan blijken dat het Hof een intensieve toetsing uitvoert vanwege het fundamentele belang van het verbod van onderscheid op grond van geslacht: "[...] het recht om niet op grond van zijn geslacht te worden gediscrimineerd, [is] een van de fundamentele rechten van de mens [...], waarvan het Hof de eerbiediging dient te verzekeren" (EHvJ 10 februari 2000, zaak C-5096, Schröder, Jurispr. 2000, 1-743, punt 56). Zie daarnaast EHvJ 28 februari 1994, zaak C-343/92, Roks, Jurispr. 1994, I-571, punt 36 en EHvJ 6 april 2000, zaak C-226/98, Jorgensen, Jurispr. 2000, 1-2447, punt 39 , waarin het Hof aangaf dat het bij het verbod van onderscheid op grond van geslacht gat om een fundamenteel gemeenschapsrechtelijk beginsel. Vgl. ook Bieback 1994, p. 45 en 46. 
redenering vloeien twee intensiteitbepalende factoren, de grond van het onderscheid en de aantasting van een fundamenteel belang, feitelijk samen. ${ }^{351}$

In dit licht is verder het arrest $P . v . S .^{332}$ van belang, nu het Hof daarin aangaf waaróm er bij onderscheid op grond van geslacht gesproken moet worden van een schending van een fundamenteel recht. In dit arrest, dat betrekking had op de toepassing van Richtlijn 207/76 $6^{33}$ op transseksuelen, stelde het Hof het volgende:

"Door een dergelijke discriminatie te gedogen, zou afbreuk worden gedaan aan het respect voor de waardigheid en de vrijheid, waarop de betrokkene recht heeft en dat het Hof dient te beschermen." 134

Anders dan het Europees Hof voor de Rechten van de Mens lijkt het Hof zich bij het karakteriseren van een onderscheidingsgrond als "verdacht" dus niet zozeer te baseren op de aanwezigheid van een common ground, maar eerder op overwegingen met betrekking tot de aard en het gewicht van de belangen die door deze vorm van onderscheid worden aangetast: een ongerechtvaardigde ongelijke behandeling op grond van geslacht tast de menselijke waardigheid aan en levert een inbreuk op de persoonlijke vrijheid op.

Criteria als hierboven besproken kunnen ook meer in het algemeen bruikbaar worden geacht bij de vaststelling of er sprake is van een verdachte grond van onderscheid. Met name het oordeel dat de menselijke waardigheid wordt aangetast door onderscheid te maken op een bepaalde grond kan in de praktijk dienstig zijn. ${ }^{355}$

\section{Aard van het betrokken beleidsveld}

In verschillende arresten heeft het Hof aangegeven dat de intensieve toets die bij onderscheid op grond van geslacht het uitgangspunt vormt in bepaalde omstandigheden kan worden afgezwakt. Dit is met name het geval in zaken die een gevoelig beleidsgebied betreffen, zoals kan blijken uit het in 1984 gewezen arrest Hofmann. ${ }^{366}$ Dit arrest had betrekking op een regeling voor zwangerschaps- en moederschapsverlof, op grond waarvan alleen vrouwen voor een dergelijk verlof in aanmerking kwamen. Dit leek in strijd te zijn met het in Richtlijn 76/207 opgenomen verbod van discriminatie op grond van geslacht. Het Hof stelde echter het volgende:

"De richtlijn ruimt de Lid-Staten discretionaire bevoegdheden in ten aanzien van de sociale maatregelen welke zij nemen om, in het door de richtlijn getrokken kader, in verband met de zwangerschap en moederschap voor bescherming van de vrouw te zorgen en compensatie te bieden voor de feitelijke nadelen waarvoor de vrouw zich, wat behoud van haar betrekking betreft, met mannen vergeleken, gesteld ziet. Derhalve dient te worden vastgesteld, dat er

351. In hoofdstuk 2 is al gesproken over de mogelijkheid daarvan: zie het "intermezzo" in paragraaf 5.3.2.

352. EHvJ 30 april 1996, zaak C-14/94, Jurispr. 1996, 1-2143

353. Richtlijn van de Raad van 9 februari 1976 betreffende de tenuitvoerlegging van het beginsel van gelijke behandeling van mannen en vrouwen ten aanzien van de toegang tot het arbeidsproces, de beroepsopleiding en de promotiekansen en ten aanzien van de arbeidsvoorwaarden, $\mathrm{Pb}$. EG $1976 \mathrm{~L} \mathrm{39/40.}$

354. Punt 22

355. Vanzelfsprekend is dit praktisch nut relatief: het zal duidelijk zijn dat de vraag of door een bepaald onderscheid de menselijke waardigheid wordt aangetast niet veel eenvoudiger is te beantwoorden dan de vraag of er sprake is van een verdachte grond van onderscheid. Een dergelijk criterium moet dan ook altijd worden gecombineerd met andere criteria, zoals het common ground-criterium.

356. EHvJ 12 juli 1984, zaak 184/83, Jurispr. 1984, 3047 
aan de Lid-Staten, wat de aard van de beschermende maatregelen en de voor hun doorvoering te kiezen modaliteiten betreft, een redelijke beleidsmarge is gelaten. ${ }^{n 35}$

In de bovengeciteerde zaak is de verklaring voor de terughoudende opstelling van het Hof vooral gelegen in het feit dat de klacht betrekking had op het lastige terrein van de aan zwangerschap en ouderschap gerelateerde rechten en voordelen. ${ }^{3 s s}$ Juist op dit ge. bied liepen en lopen de opvattingen van de lidstaten over de wenselijkheid en de noodzaak van gelijke behandeling van mannen en vrouwen sterk uiteen, terwijl ook in de Europese regelgeving op dit gebied een grote mate van keuzevrijheid voor de staten blijkt te bestaan. ${ }^{359}$ De aard van het betrokken beleidsveld, in samenhang met het be. staan (of het ontbreken) van een zekere mate van common ground, blijkt in de rechtspraak van het Hof dus een rol te spelen bij de bepaling van de toetsingsintensiteit. ${ }^{3 \omega}$

In de rechtspraak over indirect onderscheid op andere gebieden van de sociale zekerheid, zoals werkloosheidsuitkeringen en ouderdomspensioenen, lijkt het Hof minder waarde te hechten aan de common ground-factor; wellicht is de overeenstemming tussen de lidstaten over de onwenselijkheid van onderscheid op grond van geslacht op dit gebied ook iets groter. De verklaring voor de terughoudendheid van het Hof moet hierbij dan ook in andere overwegingen worden gezocht. Ongetwijfeld is van belang dat er bij de sociale zekerheid sprake is van een politiek en beleidsmatig bijzonder gecompliceerd terrein, waarbij de regelgevende instanties over een grote mate van vrijheid dienen te beschikken om een goed en samenhangend beleid te kunnen voeren. ${ }^{361}$ Om deze

357. Punt 27, cursief toegevoegd. In latere arresten heeft het Hof het aantal gebieden waarvoor deze ruime discretionaire bevoegdheid bestaat enigszins beperkt; zie daarover de conclusie van A-G Léger bij het arrest Gillespie, EHvJ 13 februari 1996, zaak C-342/93, Jurispr. 1996, I-475, punt 39-43. Dat op bepaalde gebieden een discretionaire bevoegdheid nog steeds bestaat wordt echter aangetoond door EHv! 30 april 1998, zaak C-136/95, Thibault, Jurispr. 1998, 1-2011, punt 30.

358. Dit komt ook tot uitdrukking in het arrest Reed (EHvJ 17 april 1986, zaak 59/85, Jurispr. 1986, 1283), dat weliswaar niet rechtstreeks betrekking had op onderscheid op grond van geslacht, maar wel op de uitleg van het begrip "echtgenoot" in een van de richtlijnen. Volgens Reed zou daaraan een extensieve uitleg moeten worden gegeven, in die zin dat hieronder ook ongehuwde partners moesten worden begrepen. Het Hof stelde dat een dergelijke ruime interpretatie moet worden gebaseerd op onderzock van het recht en de opvattingen in de verschillende lidstaten. Nu aanwijzingen over een algemene maatschappelijke ontwikkeling in de richting van een extensieve interpretatie ontbraken, oordeelde het Hof dat voor een dergelijke ruime interpretatie geen ruimte bestond (punt 13 en 15; vgl. Koopmans 1989, p. 2). Dit oordeel is dus in belangrijke mate ingegeven door het ontbreken van een common ground op het betrokken beleidsterrein.

359. Dit blijkt bijvoorbeeld uit de uitgebreide analyse van de achtergronden en bedoelingen van artikel 2 van richtlijn 76/207 die door A-G Darmon in zijn conclusie bij het bovengeciteerde arrest Hofmann werd uitgevoerd. Hij gaf daarbij aan dat uit de betrokken bepalingen een omzichtig beleid van de communautaire wetgever sprak, waaruit zou blijken dat deze niet op de ontwikkeling van zedelijke opvattingen vooruit wilde lopen (p. 3083 conclusie). Vgl. ook Craig/De Búrca 1998, p. 854.

360. Vgl. Herbert 1994, p. 132, die aangeeft dat dit meer in het algemeen voor de sociale zekerheid geldh, nu daarbij steeds de moeilijke vraag aan de orde is welke rol aan mannen en vrouwen in familie- en werkverband moet worden toegekend. Ook het "better placed-argument" lijkt hierbij een rol te spelen: op dit soort gevoelige gebieden staat het Hof wellicht te ver van de nationale behoeften en opvattinget af om een goed oordeel te kunnen vellen over de noodzaak van bepaalde maatregelen. Zie ook De Bürca 1993, p. 126.

361. Vgl. Prechal 1993, p. 90. Door verschillende auteurs is bovendien aangegeven dat het Hof enigszins is teruggeschrokken voor de financiěle implicaties die zijn uitspraken op het gebied van de sociale zekerheid voor de lidstaten hebben; het kan zijn dat het Hof zich op basis van klachten van de lidstaten te- 
vrijheid niet te zeer te doorkruisen zal de rechter zich op dit soort beleidsterreinen terughoudend opstellen als hem gevraagd wordt een oordeel te geven over de rechtmatigheid van een algemene regeling. ${ }^{362}$ Een reden daarvoor is temeer aanwezig, nu de consequenties van een strenge toetsing niet altijd goed zijn te overzien en een dergelijke toetsing daarom niet altijd even wenselijk is. ${ }^{363}$

Het Hof blijkt verder veel aandacht aan de beleidsvrijheid van de wetgever te besteden wanneer er geen regeling van een lidstaat in het geding is, maar er beroep is ingesteld tegen een door de gemeenschapsinstellingen vastgestelde maatregel. Zo overwoog het Hof in het arrest Verenigd Koninkrijk/Raad, ${ }^{364}$ dat betrekking had op een richtlijn over maximale werktijden, het volgende:

"Wat de rechterlijke toetsing van bovengenoemde omstandigheden betreft, moet de Raad [...] een ruime beoordelingsbevoegdheid worden gelaten op een gebied waarop van de wetgever, zoals in casu, sociale beleidskeuzen en complexe beoordelingen worden verlangd. Derhalve dient de rechterlijke toetsing van de uitoefening van die bevoegdheid zich te beperken tot de vraag, of er geen sprake is van een kennelijke dwaling of misbruik van bevoegdheid dan wel of de betrokken instelling de grenzen van haar beoordelingsbevoegdheid niet klaarblijkelijk heeft overschreden." ${ }^{36 s}$

De intensiteit van de toetsing lijkt dan ook in belangrijke mate te worden bepaald door de aard van het betrokken beleidsterrein, in samenhang met het argument dat de wetgever beter dan de rechter in staat is om een oordeel te geven over de gemaakte beleidskeuzen. Dit laatste argument kan worden gezien als een variant op het in hoofdstuk 3 al besproken better placed-argument. ${ }^{366}$

rughoudender is gaan opstellen. Zie bijvoorbeeld Hervey 1998, p. 212, Hepple 1997, p. 149 en Stoter 1996, p. 1815.

362. Het ligt in de lijn der verwachting dat een rechter zich minder terughoudend opstelt wanneer geklaagd wordt over de schending van het evenredigheidsbeginsel of het gelijkheidsbeginsel in een individueel geval, bijvoorbeeld wanneer er geklaagd wordt over de rechtmatigheid van een concrete beschikking. De toepassing van het recht op individuele gevallen wordt algemeen beschouwd als de kern van de rechterlijke taak. Pas bij het beoordelen van de rechtmatigheid van algemene regelingen of beleidsdoelstellingen komen problemen kijken als de legitimatie van de rechter om te oordelen over democratisch tot stand gekomen regelingen of de geschiktheid van het rechterlijke mechanisme om onderzoek te doen naar de doelstellingen en de diverse betrokken belangen.

363. Zie Prechal/Burrows 1990 , p. 196, die een voorbeeld geven van een geval waarin een strikte toetsing weliswaar tot een gelijke behandeling van mannen en vrouwen zou leiden, maar waardoor in zijn algemeenheid een ongunstige sociale situatie zou worden gecreëerd. Daarnaast moet worden opgemerkt dat het Hof niet altijd over geschikte middelen beschikt om een ongelijke behandeling op een bevredigende manier op te heffen: vaak zijn er zoveel verschillende mogelijkheden beschikbaar dat er rechtens meer dan én juiste keuze mogelijk is. Het lijkt redelijk om in een dergelijke situatie meer ruimte te laten aan de lidstaten om die keuze zelf te maken en alleen in te grijpen wanneer het evident is dat de gemaakte keuze in strijd is met het recht. Vgl. in dit opzicht ook Manolkidis 1997, p. 102-103.

364. EHvJ 12 november 1996, zaak C-84/94, Jurispr. 1996, 1-5755

365. Punt 58. Opgemerkt moet worden dat er in dit arrest niet werd geklaagd over een inbreuk op het gelijkheidsbeginsel, maar over het algemene evenredigheidsbeginsel. Dit kan van belang zijn, omdat daarbij geen sprake is van een fundamenteel grondrecht. Nu er tot nu toe, voor zover uit het onderzoek is gebleken, nog geen uitspraken zijn gedaan op het gebied van de sociale zekerheid waarin sprake is van een beroep tegen de instellingen, is het moeilijk te voorspellen of dit inderdaad een verschil zal

366. Zie nader hoofdstuk 3, paragraaf 3.2 .3 . 


\section{Het beginsel van subsidiariteit}

De bevoegdheid om op het gebied van de sociale zekerheid beleid vast te stellen en besluiten te nemen berust in belangrijke mate bij de lidstaten. ${ }^{367}$ Het Hof lijkt van me. ning te zijn dat het zich om die reden terughoudend moet opstellen wanneer het natio. nale maatregelen van sociale zekerheid toetst aan het gelijkheidsbeginsel. Dit blijkt bijvoorbeeld uit de volgende overweging uit het arrest Nolte: ${ }^{368}$

"Vastgesteld moet worden, dat het sociale beleid in de huidige stand van het gemeenschapsrecht tot de bevoegdheid van de Lid-Staten behoort. Derhalve staat het aan de Lid-Staten om de maatregelen te kiezen die geschikt zijn voor de verwezenlijking van hun doelstellingen van sociaal beleid en werkgelegenheidsbeleid. Bij de uitoefening van deze bevoegdheid beschikken de Lid-Staten over een ruime beoordelingsmarge."

De beoordelingsmarge lijkt hierbij nog ruimer te zijn dan in het geval van het ontbreken van een common ground of in het geval waarin er wordt geklaagd over het optreden van één van de gemeenschapsinstellingen: het Hof spreekt in bovenstaande overweging niet van een "redelijke", maar zelfs van een "ruime" beoordelingsmarge." Uit deze formulering kan worden afgeleid dat het Hof alleen zal ingrijpen in de beleidsvrijheid van de lidstaten wanneer er sprake is van een evident ongerechtvaardigde of willekeurige ongelijke behandeling op grond van geslacht. ${ }^{37} \mathrm{Net}$ als in de rechtspraak van het Europees Hof voor de Rechten van de Mens is een vorm van het internationaalrechtelijke subsidiariteitsbeginsel van betekenis voor de bepaling van de toetsingsintensiteit. $^{3 n}$

367. Vgl. Hervey 1998, p. 213 en Biedock 1994, p. 47. Dit heeft vooral te maken met het feit dat het Hof nog nauwelijks harmoniserende regelingen op het gebied van de sociale zekerheid tot stand heeft gobracht, maar uitsluitend richtlijnen heeft vastgesteld op grond waarvan onderscheid op grond van geslacht en nationaliteit wordt bestreden en waardoor ervoor wordt gezorgd dat migranten in aanmerking komen voor een behandeling die tenminste vergelijkbaar is met die van de eigen onderdanen. De ruimte voor de lidstaten om zelf maatregelen vast te stellen is daardoor vooralsnog aanzienlijk.

368. EHvJ 14 december 1995, zaak C-317/93, Jurispr. 1995, 1-4625

369. Punt 33. Zie voor een vergelijkbare overweging EHvJ 1 februari 1996, zaak C-280/94, Posthuma, Jurispr. 1996, 1-179, punt 27 en EHvJ 7 mei 1991, zaak C-229/89, Commissie/België, Jurispr. 1991,12205, punt 22. Vgl. ook de conclusie van A-G Léger bij het geciteerde arrest in punt 69 en de conclusie van A-G Fennelly bij EHvJ het hiervoor genoemde arrest Posthuma.

370. Vgl. Stoter 1996, p. 1814. In hoeverre dit verschil consequenties heeft voor de intensiteit van de toetsing is niet geheel duidelijk. Bovendien maakt het Hof ook in arresten betreffende het sociale beleid soms melding van het bestaan van een "redelijke" beleidsmarge (EHvJ 6 april 2000, zaak C-22698, Jorgensen, Jurispr. 2000, 1-2447, punt 4I), zodat het verschil voor de praktijk niet bijzonder groot kan worden geacht.

371. Zie bijvoorbeeld de conclusie van A-G Darmon bij EHvJ 7 mei 1991, zaak C-229/89, Commis. sie/België, Jurispr. 1991, 1-2205, punt 20-22. Vgl. ook Drijber/Prechal 1997, p. 141 en De Búrca 1993, p. 112. Het Hof zelf gaf aan dat de beoordelingsbevoegdheid niet tot gevolg mag hebben dat de tenuitvoerlegging van een fundamenteel beginsel als dat van de gelijke beloning van mannen en vrouwen van haar inhoud wordt beroofd. Wanneer dit als criterium wordt gehanteerd is er inderdaad sprake van een zeer marginale toetsing; vgl. EHvJ 9 februari 1999, zaak C-167/97, Seymour-Smith, Jurispr. 1999, Jurispr. 1999, I-623, punt 75 .

372. Het subsidiariteitsbeginsel is in het Verdrag gecodificeerd, zij het in weinig duidelijke bewoordingen: zie artikel 5 EG. Volgens deze bepaling mag de Gemeenschap alleen optreden wanneer de doelstellingen van het Verdrag niet voldoende door de lidstaten kunnen worden verwezenlijkt en de Gemetn. schap daartoe beter in staat is. Het is moeilijk aan te geven in hoeverre dit beginsel ook geldt voor het Hof en wat de invloed van dit beginsel is voor de bepaling van de toetsingsintensiteit (vgl. De Bürta 1998 , p. 228-229 en Koopmans 1994, p. 50). Het Hof heeft zich daarover tot nu toe nog niet expliciel 
Samenspel van de factoren subsidiariteit, het better placed-argument en het betrokken beleidsveld

Dat er een nauw verband bestaat tussen de aard van het beleidsveld, het better placedargument en het internationaalrechtelijke vereiste van subsidiariteit blijkt duidelijk uit een recent arrest van het Hof, Kreil. ${ }^{33}$ Dit arrest had betrekking had op een ongelijke behandeling die was ingegeven door de wens de nationale veiligheid te beschermen: het Hof moest zich uitspreken over een regeling op grond waarvan vrouwen in het Duitse leger waren uitgesloten van functies waarbij wapens werden gehanteerd. Het Hof oordeelde als volgt:

"Ingevolge artikel 2 lid 2 van de Richtlijn [76/207, JHG] hebben de Lidstaten de bevoegdheid om beroepsactiviteiten van de toepassing van de richtlijn uit te sluiten waarvoor vanwege hun aard of de voorwaarden, voor de uitoefening ervan, het geslacht een bepalende factor is. Hierbij moet evenwel worden bedacht, dat deze bepaling, die een afwijking behelst van een in de richtlijn neergelegd individueel recht, strikt moet worden uitgelegd. [...] De nationale autoriteiten beschikken evenwel, afhankelijk van de omstandigheden, over een zekere beoordelingsmarge bij de vaststelling van de maatregelen die zij ter bescherming van de openbare veiligheid van een Lidstaat noodzakelijk achten." ${ }^{374}$

Hoewel het Hof niet nader motiveert waarom er op het gebied van de nationale veiligheid een ruimere beoordelingsmarge zou moeten gelden, kan worden aangenomen dat hierbij vergelijkbare factoren een rol spelen als bij onderscheid op het gebied van de sociale zekerheid. ${ }^{375}$ Ten aanzien van de bescherming van de nationale veiligheid geldt immers dat de rechter in het algemeen niet voldoende is uitgerust om een goede beoordeling te geven van de noodzaak en de geschiktheid van bepaalde maatregelen. ${ }^{376}$ Verder geldt op dit terrein bij uitstek dat de nationale autoriteiten, en niet zozeer de gemeenschapsinstellingen, bevoegd zijn om maatregelen vast te stellen, terwijl er bovendien maar weinig eenduidigheid bestaat over de manier waarop gelijke behandeling van mannen en vrouwen in de krijgsmacht kan of moet worden doorgevoerd. Het lijkt dan ook redelijk dat het Hof op dit gebied een ruime beoordelingsmarge laat. ${ }^{37}$

uitgelaten. Het ligt echter in de lijn der verwachting dat het Hof, wanneer het gaat om typisch nationale aangelegenheden waarbij het gemeenschapsbelang een minder grote rol speelt, zich tegen de achtergrond van deze bepaling sneller terughoudend zal opstellen. Vgl. ook Craig/De Búrca 1998, p. 129.

373. EHvJ 11 januari 2000, zaak C-285/98, Jurispr. 2000, 1-69

374. Punt 20 en 24; overigens bevestigt deze uitspraak dat door ongelijke behandeling op grond van geslacht sprake is van een aantasting van een fundamenteel recht. Vgl. verder het oordeel van het Hof in de zaak Sirdar, die eveneens betrekking had op de uitsluiting van vrouwen; in die zaak vond het Hof het onderscheid wel aanvaardbaar, juist vanwege de toegekende beoordelingsruimte (zie EHvJ 26 oktober 1999, zaak C-273/97, Jurispr. 1999, 1-7403, punt 27-31). In een eerdere zaak waarin er sprake was van een onderscheid op het gebied van de nationale veiligheid maakte het Hof geen melding van een ruimere beoordelingsmarge, maar werd slechts gesteld dat bij de beoordeling van de rechtvaardiging rekening moest worden gehouden met de nagestreefde belangen. Ook in deze uitspraak lijkt echter al een minder intensieve toetsing te worden uitgevoerd; zie EHvJ 15 mei 1986, zaak 222/84, Johnston, Jurispr. 1986, 1651, punt 34 e.v.

375. Een nadere motivering werd wel gegeven in het arrest Leifer (EHvJ 17 oktober 1995, zaak C-83/94, Jurispr. 1995, I-3231); zie vooral ook de conclusie van A-G Jacobs bij dit arrest (en bij het arrest Wer-

376. Zie daarover nader, 1-3189). Op deze argumenten zal in paragraaf 3.4 nader worden ingegaan.

377. Hetzelfde arrester paragraaf 3.4.2.

vond de uitsluitingreil illustreert overigens dat zelfs een marginale toetsing fataal kan zijn: het Hof vond de uitsluitingsregeling voor vrouwen veel te absoluut gezien de doelstellingen die door de rege- 


\section{Aard van de rechtsverhouding}

De intensiteit van de toetsing van maatregelen op het gebied van de sociale zekerheid lijkt ook te worden verminderd door het feit dat het hierbij vrijwel steeds gaat om een verticale verhouding. Hoewel het Hof heeft aangenomen dat ook in die verhouding het beginsel van gelijke behandeling ten volle geldt, kan worden verondersteld dat het Hof rekening houdt met de bezwaren die tegen de verticale werking van het gelijkheidsbeginsel kunnen bestaan. Zoals in paragraaf 1.1 van dit hoofdstuk is aangegeven zijn deze bezwaren vooral naar voren gebracht door A-G Darmon in zijn conclusies bij de eerste arresten over indirect onderscheid in een verticale verhouding ${ }^{378}$ Volgens Darmon is het problematisch om het door het Hof ontwikkelde toetsingsmodel zonder meer toe te passen op overheidsmaatregelen waardoor indirect onderscheid wordt gemaakt, met name omdat bij het vaststellen van overheidsmaatregelen met diverse sociale, economische en politieke belangen rekening moet worden gehouden. Het is lastig om de exacte achterliggende motivering voor een dergelijke maatregel te achterhalen, temeer daar deze in de totstandkomingsgeschiedenis van de regeling lang niet altijd even duidelijk wordt gearticuleerd. Om die reden moet volgens Darmon de bewijslast in verticale verhoudingen eigenlijk worden omgekeerd. Het Hof zelf heeft deze vrij radicale benadering nooit willen overnemen: zoals eerder al is aangegeven hanteert het bij verticale verhoudingen hetzelfde toetsingsmodel en dezelfde bewijslastverdeling als in horizontale situaties. Aangenomen kan echter worden dat argumenten als die van Darmon, die nauw samenhangen met eerder genoemde factoren als het better placed-argument en de aard van het betrokken beleidsveld, wel degelijk een rol spelen bij de keuze voor de hiervoor geschetste, beduidend minder strenge toetsing van sociale zekerheidsmaatregelen. ${ }^{379}$

\section{Direct of indirect onderscheid}

Zoals eerder in deze paragraaf is aangegeven gaat het Hof ervan uit dat uitzonderingen op het gelijkheidsbeginsel in principe strikt moeten worden getoetst. Van dit uitgangspunt wordt echter uitsluitend gebruik gemaakt wanneer er een direct onderscheid in het geding is: in de rechtspraak over indirect onderscheid wordt nergens verband gelegd tussen het fundamentele belang van het gelijkheidsbeginsel en de intensiteit van de toetsing. Opmerkelijk is verder dat het Hof vooral bij indirect onderscheid bereid is om sociale zekerheidsmaatregelen marginaal te toetsen. ${ }^{380}$ Dit zou erop kunnen wijzen dat het $\mathrm{Hof}$ bereid is om direct onderscheid strenger te toetsen dan indirect onderscheid.

ling werden nagestreefd.

378. Zie zijn conclusie bij het arrest Rinner-Kühn (EHvJ I3 juli 1989, zaak 171/88, Jurispr. 1989, 2743, met name op p. 2753-2755) en bij het arrest Ruzius-Wilbrink (EHvJ 13 december 1989, Jurispr. 1989, 4311, punt 18).

379. Ellis geeft overigens aan dat in dit verband ook de aard en het gewicht van de betrokken belangen een rol kunnen spelen: in verticale verhoudingen, met name in de sociale zekerheid, worden duidelijk waarneembare algemene belangen gediend, terwijl er bij onderscheid door de werkgever vask uitsluitend economische belangen in het geding zijn (1996, p. 26). Doordat de betrokken belangen in verticale verhoudingen zo zwaarwegend zijn kan een minder strikte toetsing in de rede liggen. Zoals Her. bert aangeeft kan dit argument echter niet doorslaggevend zijn, nu ook bij ongelijke behandeling buiten de sociale zekerheid zwaarwegende belangen een rol kunnen spelen (1994, p. 132).

380. Zo is het opvallend dat het Hof in arresten over Richtlijn $79 / 7$, die specifiek betrekking heeft op de sociale zekerheid, heeft aangegeven dat de uitzonderingsbepalingen strikt moeten worden geinterpre" 
Het is echter onwaarschijnlijk dat een dergelijk verschil in toetsingsintensiteit daadwerkelijk beoogd is. Bij indirect onderscheid wordt de beoordeling van een aantal elementen waarvoor de toetsingsintensiteit van wezenlijk belang is, zoals geschiktheid en noodzakelijkheid, vrijwel steeds overgelaten aan de nationale rechter. Hierdoor bestaat er voor het Hof nauwelijks reden om zich expliciet uit te laten over de intensiteit van de toetsing en is het bovendien niet goed mogelijk om conclusies over de toetsingsintensiteit af te leiden uit de toepassing van het toetsingsmodel. Daarnaast is eerder in dit hoofdstuk gebleken dat het Hof vaak strenge eisen stelt aan de rechtvaardiging die door werkgevers naar voren wordt gebracht en de aangevoerde doelstellingen lang niet altijd accepteert: dit wijst zeker niet op een bewuste keuze om bij indirect onderscheid een marginale toetsing uit te voeren. ${ }^{381}$

Er bestaat ook maar weinig reden om bij de toetsing van direct en indirect onderscheid een verschillende toetsingsintensiteit te kiezen. Op het eerste gezicht lijkt een directe ongelijke behandeling inderdaad "ernstiger" te zijn dan een indirect onderscheid op grond van geslacht: waar indirect onderscheid vaak het onbedoelde effect is van een verder heel redelijke regeling, zal er bij direct onderscheid altijd sprake zijn van een bewust onderscheid op een verdachte grond. In dat licht kan het redelijk lijken om direct onderscheid strenger te beoordelen. Het grote bezwaar daartegen is echter dat er geen scherpe grens kan worden getrokken tussen de twee vormen van onderscheid. Zo vergt het in het algemeen niet bijzonder veel moeite om een direct onderscheid op grond van geslacht te verbergen achter een onderscheid op grond van een minder verdacht differentiatiecriterium, zoals arbeidsduur of anciënniteit. ${ }^{3 \times 2}$ Juist om die reden is het verstandig om bij beide vormen van onderscheid een vergelijkbare toetsingsintensiteit te hanteren.

\section{Aard van de nagestreefde doelstellingen: voorkeursbehandeling}

Het Hof heeft zich inmiddels verschillende keren uitgesproken over artikel 2 lid 4 van Richtlijn 76/207, waarin een bijzondere uitzondering is opgenomen op het verbod van onderscheid op grond van geslacht. Volgens deze uitzonderingsbepaling belemmert het verbod van ongelijke behandeling de lidstaten niet in het vaststellen van maatregelen "die beogen te bevorderen dat mannen en vrouwen gelijke kansen krijgen, in het bijzonder door feitelijke ongelijkheden op te heffen welke de kansen van de vrouwen op [het gebied van de werkingssfeer van de richtlijn] nadelig beïnvloeden." Het gaat hierbij om voorkeursbehandeling, dat wil zeggen om (formeel) discriminatoire maatregelen waarmee wordt geprobeerd om een grotere mate van (materiële) gelijkheid te realiseren. Zoals in hoofdstuk 2 is aangegeven zijn er zeker redenen aanwezig om bij een dergelijke doelstelling een minder strikte toetsing uit te voeren. ${ }^{363}$ Het is dan ook op-

teerd: zie bijvoorbeeld EHvJ 30 maart 1993, zaak C-328/91, Thomas, Jurispr. 1993, 1-1247, punt 8.

381. Zie nader paragraaf 2.3.1.

382. Vgl. A-G Van Gerven in zijn conclusies bij de arresten Grogan (EHvJ 4 oktober 1991, zaak C-159/90, Jurispr. 1991, I-4685, punt 22) en Birds Eye Walls (EHvJ 9 november 1993, zaak C-132/92, Jurispr, 1993, I-5579, punt 12-14) en A-G Tesauro in zijn conclusie bij het arrest Enderby (EHvJ 27 oktober 1993, zaak C-127/92, Jurispr. 1993, 1-5535, punt 14). Opmerkelijk is dat het Hof in recente rechtspraak ook niet altijd scherp onderscheid maakt tussen direct en indirect onderscheid; zie vooral EHvJ 26 juni 2001, zaak C-381/99, Brunnhofer, Jurispr. 2001, 1-4961, m.n. punt 30.

383. Zie hoofdstuk 2, paragraaf 5.2 .3 . 
vallend dat de door het Hof gehanteerde toetsingsintensiteit nauwelijks lijkt te worden beïnvloed door het specifieke karakter van de door voorkeursbehandeling nagestreefde belangen, noch door het feit dat bij deze vorm van ongelijke behandeling enkele specifieke, intensiteitverhogende factoren ontbreken. Dit blijkt met name uit een van de eerste arresten waarin het Hof zich diende uit te spreken over een voorkeursbehandeling: Kalanke. ${ }^{334}$ In dit arrest was een Duitse maatregel aan de orde, op grond waarvan vrouwen met gelijke kwalificaties als mannen bij promotie naar een hogere salarisgroep met voorrang in aanmerking werden genomen. Ten aanzien van de vraag of een dergelijke regeling gerechtvaardigd kon worden met een beroep op artikel 2 lid 4 van de richtlijn stelde het Hof het volgende:

"[...] [D]eze bepaling [heeft] een nauwkeurig bepaald en beperkt doel [...], te weten het toestaan van maatregelen die, hoewel schijnbaar discriminerend, in werkelijkheid de in de realiteit van het maatschappelijk leven bestaande feitelijke ongelijkheden beogen op te heffen of te verminderen. [...] Daarbij moet echter worden opgemerkt, dat artikel 2, lid 4, dat een afwijking behelst van een in de richtlijn neergelegd individueel recht, strikt moet worden uitgelegd. Een nationale regeling die vrouwen bij aanstellingen of promoties absoluut en onvoorwaardelijk voorrang verleent, gaat verder dan een bevordering van gelijke kansen en overschrijdt de grenzen van de in artikel 2, lid 4, van de richtlijn voorziene uitzondering." ${ }^{\text {sss }}$

Uit deze overweging blijkt dat het Hof in het bijzondere karakter van voorkeursbehandeling geen reden ziet om een minder strenge toetsing uit te voeren of om de lidstaten de ruimte te geven om dit te doen: het Hof geeft slechts aan dat door het voeren van een voorkeursbeleid wordt afgeweken van het beginsel van formele gelijke behandeling van mannen en vrouwen en dat een dergelijke afwijking per definitie tot een strenge toetsing moet leiden. ${ }^{336}$ Deze benadering heeft geleid tot veel academische en politieke kritiek, waarbij met name de sterk formele benadering van het gelijkheidsbeginsel is aangevallen. ${ }^{37}$ In het in 1997 gewezen arrest Marschall ${ }^{38 x}$ heeft het Hof, waarschijnlijk om tegemoet te komen aan deze kritiek, voor een meer genuanceerde benadering gekozen. ${ }^{389}$ In deze uitspraak stelde het Hof onder meer dat,

"[...] waar artikel 2, lid 4, een afwijking behelst op een in de richtlijn neergelegd individueel recht, deze nationale maatregel die in het bijzonder vrouwelijke kandidaten begunstigt, vrouwen bij een bevordering geen absolute en onvoorwaardelijke voorrang mag garanderen, daar zij anders de grenzen van de in deze bepaling voorziene uitzondering zou overschrijden." ${ }^{30}$

384. EHvJ 17 oktober 1995, zaak C-450/93, Jurispr. 1995, I-3051

385. Punt 18,21 en 22

386. Vgl. Bernard 1998, p. 367-368, Schiek 1998, p. 160 en Somek 1999, p. 246-247.

387. Met name werd gesteld dat gelijke behandeling niet alleen het realiseren van gelijke uitgangsposities betekent (formele gelijkheid), maar ook het verwezenlijken van gelijke resultaten, zoals het bereiken van een evenredige vertegenwoordiging van mannen en vrouwen in hogere functies (matericle gelijk. heid). Door de gekozen benadering van het Hof werd de nationale overheden volgens critici te weinis ruimte gegeven om een dergelijke materiele gelijkheid te bereiken. Zie o.a. Schiek 1998, p. 162/163 en Charpentier 1998, p. 179-181.

388. EHvJ 11 november 1997, zaak C-409/95, Jurispr. 1997, I-6363

389. Vgl. Bernard 1998, p. 369.
390. Punt 32. In het recente arrest Badeck ontbreekt zelfs deze overweging (EHvJ 28 maart 2000, zaak C. 
Hoewel het Hof door deze formulering iets meer ruimte lijkt te verschaffen voor het treffen van nationale voorkeursregelingen, kan zeker niet worden gezegd dat de staten hierdoor beschikken over een ruime beoordelingsvrijheid. Hoogstens kan worden gesteld dat de toetsingsintensiteit ergens tussen een intensieve en een marginale toetsing in ligt. Helaas motiveerde het Hof in dit arrest nauwelijks waarom het voor deze, nog altijd vrij strenge, toetsing had gekozen: het Hof verwijst weliswaar naar het fundamentele belang van het gelijkheidsbeginsel in de zin van gelijkheid van kansen, maar gaat opnieuw voorbij aan het feit dat er daarnaast ook kan worden gestreefd naar gelijkheid van resultaat. ${ }^{311}$ Aangenomen kan echter worden dat de nu gekozen tussenweg tussen de strikte benadering in het Kalanke-arrest en de bijzonder marginale toetsing op het gebied van de sociale zekerheid vooral is ingegeven door een interne discussie over de wenselijkheid van voorkeursbehandeling als middel om een meer evenredige vertegenwoordiging van vrouwen te creëren of door de aard en de ernst van de in het geding zijnde belangenaantasting ${ }^{392}$ Afgewacht moet worden of het Hof in toekomstige rechtspraak een minder strenge toetsing uit zal voeren: wanneer blijkt dat het Hof, zelfs aan de hand van de nu gekozen formule, steeds weer zijn goedkeuring blijkt te hechten aan

158/97, Jurispr. 2000, 1-1875): in deze uitspraak wordt alleen gebruik gemaakt van het uit het arrest Marschall voortvloeiende, specifiek voor positieve discriminatie ontwikkelde toetsingsmodel. Volgens dit model is een nationale regeling "op grond waarvan, bij gelijke kwalificaties van kandidaten van verschillend geslacht wat hun geschiktheid, bekwaamheid en arbeidsprestatie betreft, in openbare diensten waarin een te bekleden hoger ambt van een loopbaan minder vrouwen dan mannen werkzaam zijn, vrouwelijke kandidaten bij voorrang moeten worden bevorderd, voor zover met de persoon van een mannelijke kandidaat verband houdende redenen de balans niet in diens voordeel doen doorslaan, op voorwaarde dat de regeling mannelijke kandidaten met gelijke kwalificaties als vrouwelijke kandidaten in elk individueel geval waarborgt, dat de sollicitaties worden onderworpen aan een objectieve beoordeling, die rekening houdt met alle criteria betreffende de persoon van de kandidaten en de aan vrouwelijke kandidaten toegekende voorrang buiten toepassing laat, wanneer één of meer van die criteria de balans in het voordeel van de mannelijke kandidaat doen doorslaan, en dergelijke criteria niet discriminerend zijn ten opzichte van vrouwelijke kandidaten" toelaatbaar (punt 35). Overigens is een dergelijk specifiek toetsingsmodel niet echt nodig: volstaan kan worden met een toepassing van het algemene model. Feitelijk stelt het Hof immers alleen dat een regeling aanvaardbaar is die voldoende ruimte biedt om op een objectieve manier rekening te houden met de concreet in een bepaald geval betrokken belangen (proportionaliteit in strikte zin) en waarin geen inherent discriminatoire criteria zijn opgenomen. De door het Hof gekozen formulering lijkt vooral uit het oogpunt van politieke aanvaardbaarheid te zijn gekozen.

391. Overigens moet worden toegegeven dat het Hof daarvoor in het arrest Marschall meer aandacht toont (vgl. Bernard 1998, p. 371). In de uitspraak wordt echter voorbij gegaan aan een andere reden voor een minder intensieve toetsing, namelijk dat juist bij voorkeursbehandeling sprake zal zijn van het ontbreken van onderscheid dat is ingegeven door overduidelijke stereotypering of vooroordelen jegens een bepaalde groep.

392. Vgl. Ellis 1998, p. 405. Daarnaast is door Fenwick en Hervey gesignaleerd dat het Hof zich meer in het algemeen in zijn rechtspraak over onderscheid op grond van geslacht lijkt te richten op het verwezenlijken van formele gelijkheid en niet zozeer op het bereiken van gelijke resultaten (materiêle gelijkheid): het Hof hecht daarvoor teveel waarde aan de economische bezwaren die tegen een dergelijke vorm van gelijkheid zijn in te brengen (1995, m.n. p. 448 en 468). Zelfs bij indirect onderscheid signaleren zij een tendens in de rechtspraak die wijst in de richting van een sterke gevoeligheid voor economische rechtvaardigingen, waardoor het verwezenlijken van materiële gelijkheid in de weg wordt gestaan. Nu voorkeursbeleid zeker kan worden gezien als een mechanisme waardoor materiële gelijkheid kan worden gecreěerd, maar waardoor anderzijds een inbreuk wordt gemaakt op de normale werking van de markt, nemen zij aan dat het Hof om die reden een strikte toetsing uitvoert bij voorkeursbehandeling. Vgl. ook Charpentier 1998, p. 181 
voorkeursbeleid, kan worden aangenomen dat de toetsing minder streng is dan de formulering van het Hof doet vermoeden. ${ }^{393}$

\subsubsection{Conclusie}

Zoals hierboven is aangegeven is de door het Hof bij onderscheid op grond van geslacht uitgevoerde toetsing in het algemeen vrij intensief: het Hof hecht grote waarde aan het fundamentele belang dat het verbod van ongelijke behandeling vertegenwoordigt en beschouwt geslacht impliciet als een verdachte grond van onderscheid. Anderzijds kan uit de rechtspraak over de sociale zekerheid en de nationale veiligheid worden afgeleid dat het Hof het in bepaalde omstandigheden redelijk acht om een minder strenge toetsing uit te voeren. Aangegeven is dat de terughoudende opstelling van het Hof soms verklaard kan worden vanuit het ontbreken van een eenduidige opvatting in de lidstaten over het betrokken onderwerp van regelgeving; het bestaan (of het ontbreken) van een common ground blijkt ook in de rechtspraak van het Hof een zekere rol te spelen. Daarnaast is aangegeven dat het better placed-argument en de aard van het betreffende beleidsterrein eveneens belangrijke factoren zijn voor de vaststelling van de intensiteit van de toetsing: juist op het gevoelige en complexe terrein van de sociale zekerheid blijkt het Hof zich terughoudend op te stellen, terwijl op andere gebieden een intensievere toetsing wordt uitgevoerd. Ook het beginsel van subsidiariteit lijkt bij de keuze voor een bepaalde toetsingsintensiteit een rol te spelen: wanneer het nemen van besluiten en het vormen van beleid op een bepaald gebied primair tot de bevoegdheid van de lidstaten behoort, is het waarschijnlijk dat het Hof zich bij zijn toetsing terug. houdend opstelt. Verder is aangegeven dat het Hof meer in het algemeen voor een terughoudende toetsing lijkt te kiezen als er sprake is van een verticale verhouding; een intensieve toetsing is hierbij moeilijk denkbaar, alleen al omdat het lastig is om de benodigde informatie over de achterliggende doelstellingen, de betrokken belangen en de noodzaak en geschiktheid van de maatregel te achterhalen. De vorm van onderscheid (direct of indirect) lijkt voor de toetsingsintensiteit van het Hof wel enige rol te

393. Tot nu toe is het niet goed mogelijk om dergelijke conclusies te trekken. In veel recente rechtspraak over voorkeursbeleid sprak het Hof zich in het geheel niet uit over de toetsingsintensiteit; zie bijv. EHvJ 28 maart 2000, zaak C-158/97, Badeck, Jurispr. 2000, 1-1875 en EHvJ 6 juli 2000, zask C. 407/98, Fogelqvist, Jurispr. 2000, I-5539. Belangrijk is wel EHvJ 19 maart 2002, zaak C-47699, Lommers, nog niet gepubliceerd, waarin het Hof zich moest uitspreken over een milde vorm van voorkeursbehandeling: in het geding was een regeling op grond waarvan in beginsel alleen vrouwelijke werknemers in aanmerking kwamen voor kinderopvangplaatsen. Deze regeling doorstond de evenre. digheidstoets van het Hof met gemak, vooral doordat het Hof minder scherp toetste dan in de eerdere rechtspraak het geval was. Van belang is dat het Hof bij zijn toetsing expliciet aandacht besteedde aan het belang van dit soort maatregelen voor de bevordering van de arbeidsparticipatie van vrouwen. Vervolgens vereiste het Hof slechts dat "zoveel mogelijk een evenwicht tot stand moet worden gebracht tussen het beginsel van gelijke behandeling en de eisen van het aldus beoogde doel" (punt 39, cursief toegevoegd), een vereiste dat aanzienlijk soepeler lijkt te zijn dan de hierboven geciteerde criteria uit Kalanke en Marschall. Uit Lommers kan dan ook worden afgeleid dat het Hof wel degelijk bereid is om bij de bepaling van de toetsingsintensiteit rekening te houden met aard en doel van de relevante maatregelen, mits de aangetaste belangen niet al te zwaarwegend zijn (de eerdere zaken hadden betrekking op toegang tot de arbeid of bevordering naar een hogere functie) en mits de belangenaantasting niet al te ernstig is (de regeling in Lommers voorzag in een uitzonderingsmogelijkheid, waardoor ook mannen nog voor een plaats in aanmerking konden komen). Of deze criteria daadwerkelijk een fol spelen, zal uit latere rechtspraak moeten blijken. 
spelen, maar het Hof heeft zich hierover nooit duidelijk uitgelaten. Gesteld is echter dat er nauwelijks reden bestaat om deze factor bij de bepaling van de toetsingsintensiteit te betrekken, zodat kan worden aangenomen dat deze factor niet in het algemene model hoeft te worden opgenomen. Tenslotte is aangegeven dat de aard van het nagestreefde doel, bijvoorbeeld het verwezenlijken van een meer evenredige vertegenwoordiging van vrouwen op de arbeidsmarkt, tot nu toe niet wordt beschouwd als een intensiteitverminderende factor: het uitgangspunt van het Hof is dat ook bij voorkeursbeleid een strikte toetsing moet worden uitgevoerd.

In zijn algemeenheid kan worden gesteld dat de bovengenoemde factoren overeenstemmen met de factoren zoals die in hoofdstuk 2 zijn genoemd. Daarnaast is interessant dat enkele factoren die het Europees Hof voor de Rechten van de Mens bij de vaststelling van de omvang van de margin of appreciation van belang acht, ook in de rechtspraak van het Hof weer terugkomen; daarbij gaat het vooral om het better placedargument en de common ground-factor.

Bij een bestudering van de rechtspraak valt het op dat het Hof weliswaar enkele belangrijke factoren heeft genoemd die invloed hebben op de toetsingsintensiteit, maar dat het niet heeft aangegeven in welke mate factoren als subsidiariteit en het ontbreken van een common ground kunnen leiden tot een afzwakking van de in beginsel strenge toetsing. Evenmin heeft het Hof ooit een uitdrukkelijke afweging van de verschillende intensiteitbepalende factoren gemaakt, zelfs niet in de gevallen waarin het expliciet aangeeft dat er factoren aanwezig zijn die in een tegengestelde richting wijzen, zoals in het bovengeciteerde arrest Kreil. Uit de algemene lijn in de rechtspraak kan worden afgeleid dat het Hof kiest voor een grotere mate van terughoudendheid zodra een intensiteitverminderende factor aanwezig is: de "afweging" valt vrijwel steeds uit in het voordeel van een marginale toetsing. Het is de vraag of een dergelijk automatisme wenselijk is: in concrete gevallen kan het zeker van belang zijn om te onderzoeken of een intensieve toetsing, ondanks de aanwezigheid van intensiteitverminderende factoren, misschien toch in de rede ligt. Door de rechtspraak van het Hof wordt dan ook bevestigd dat het wenselijk is dat rechters hun keuze voor een bepaalde toetsingsintensiteit beter en duidelijker motiveren en daarbij niet alleen aandacht besteden aan de verschillende intensiteitbepalende factoren, maar ook aan de wijze waarop zij deze tegen elkaar afwegen.

\subsection{Toetsingsintensiteit bij onderscheid op het gebied van de landbouw}

\subsubsection{Inleiding}

Het Hof heeft in zijn rechtspraak steeds aangegeven grote waarde te hechten aan het verwezenlijken van de doelstellingen van het gemeenschapsrecht, met name aan het streven naar een interne markt en een grotere mate van bewegingsvrijheid voor individuen en ondernemingen die in de verschillende lidstaten wonen en gevestigd zijn. Het was vanaf het begin duidelijk dat deze integratie vooral op het gebied van de landbouw kon en moest worden bewerkstelligd, waarbij het de bedoeling was om de nationale 
landbouwmarkten te vervangen door één Europese marktordening. ${ }^{34}$ Voor het realiseren van dit doel waren vergaande bevoegdheden voor de Europese instellingen vereist: om een eenvormig en goed functionerend landbouwbeleid te kunnen verwezenlijken, moest de mogelijkheid bestaan om snel en efficiënt besluiten te nemen en om in te grijpen in bepaalde rechten of in concurrentieverhoudingen. ${ }^{395}$ In de rechtspraak over het gemeenschappelijke landbouwbeleid is goed zichtbaar welke invloed deze achtergrond heeft op de intensiteit van de toetsing aan het gelijkheidsbeginsel. In het hierna. volgende zal op deze rechtspraak nader worden ingegaan.

\subsubsection{Factoren die de toetsingsintensiteit bepalen}

\section{Beleidsvrijheid van de wetgever}

Zoals is aangegeven kent het EG-Verdrag ruime bevoegdheden toe aan de gemeenschapsinstellingen om besluiten te nemen op het gebied van het gemeenschappelijk landbouwbeleid: zonder een redelijke mate van beslissingsruimte is het op een gecompliceerd en zich snel ontwikkelend gebied als de landbouw vrijwel onmogelijk om een goed beleid te voeren. ${ }^{366}$ Het Hof heeft zich steeds bereid getoond om deze beslissingsruimte te respecteren en zich bij de beoordeling van beslissingen van de gemeenschapsinstellingen terughoudend op te stellen. ${ }^{377}$ Eén van de eerste arresten waarin het Hof hiervan blijk gaf is het arrest Merkur. ${ }^{398}$ Dit arrest had betrekking op een compen. satieregeling die (aanvankelijk) alleen gold voor graanproducten en niet voor gerstproducten. Volgens Merkur, die dergelijke gerstproducten verhandelde, was hierdoor sprake van een ontoelaatbaar onderscheid. Het Hof oordeelde in deze zaak als volgt:

"Ten aanzien van de vergelijking met de Duitse exporteurs van producten waarop de bedoelde compensatieregeling van de aanvang af van toepassing is geweest zou de door verzoekster gewraakte ongelijkheid van behandeling slechts dan een inbreuk op het nondiscriminatiebeginsel vormen wanneer daaruit van willekeur zou blijken. [...] [O]pgemerkt [moet worden] dat de Commissie bij de toepassing van de Verordening over een ruime waarderingsbevoegdheid beschikt [...]. [...] Nu de Commissie bij haar beoordeling noodza. kelijkerwijs globaal te werk heeft moeten gaan, vormt de mogelijkheid dat enkele van de gedane keuzen achteraf economisch gezien aanvechtbaar voorkwamen dan wel moesten worden herzien, op zichzelf geen voldoende aanwijzing voor schending van het nondiscriminatiebeginsel, wanneer althans vaststaat dat de Commissie zich klaarblijkelijk niet door onjuiste overwegingen heeft laten leiden." ${ }^{3 \%}$

394. Vgl. Schwarze 1993, p. 395 en 397.

395. Zie voor de zeer ruime toekenning van bevoegdheden aan de gemeenschapsinstellingen artikel 34 lid 1 en 2, eerste alinea en artikel 37, m.n. derde lid. De noodzaak van dergelijke ruime bevoegdheden voor een goed functionerende landbouwmarkt wordt verduidelijkt door Boest 1985, p. 51.

396. Vgl. Dewost 1987, p. 166 en De Moor-van Vlugt 1995, p. 113. Zie voor de wijze waarop aan deze discretionaire bevoegdheden vorm is gegeven o.a. Priebe 1988, p. 22 e.v. (specifiek over bevoegdheden op het gebied van de structuurpolitiek).

397. Vgl. Barents 1994 (1), p. 341 .

398. EHvJ 24 oktober 1973, zaak 43/72, Jurispr. 1973, 1055

399. Punt 22-24. In latere rechtspraak is deze overweging ook wel iets anders geformuleerd. Zo oordeelde het Hof in Italië/Raad en Commissie (agromonetair stelsel voor euro) dat het "[...] alleen mag nagani, of [bij de uitoefening van de beleidsvrije bevoegdheid] [...] geen kennelijke dwaling of misbruik is begaan en of het betrokken gezagsorgaan zich niet kennelijk buiten de grenzen van zijn beoordelingsbevoegdheid heeft begeven" (EHvJ 5 juli 2001, zaak C-100/99, Jurispr. 2001, 1-5217, punt 36). 
Uit deze overweging blijkt dat het Hof zich terughoudend zal opstellen als er sprake is van een ongelijke behandeling op een terrein waarop de gemeenschapsinstellingen beschikken over ruime discretionaire bevoegdheden. ${ }^{400}$ Opmerking verdient echter dat er in het geciteerde arrest geklaagd werd over noodmaatregelen die onder grote tijdsdruk tot stand waren gebracht, waardoor de Commissie geen gelegenheid had om uitgebreid na te gaan welke producten al dan niet onder de regeling moesten vallen. In een dergelijk geval bestaat er een bijzondere noodzaak voor het uitvoeren van een marginale toets. ${ }^{401}$ De toepassing van een marginale toetsing is echter zeker niet tot dit soort bijzondere omstandigheden beperkt. Al eerder in dit hoofdstuk is aangegeven dat het Hof zich bij ongelijke behandeling op het gebied van de landbouw vrijwel steeds beperkt tot een toetsing op willekeur. Een standaardformulering van het Hof bij de toetsing aan de vereisten van geschiktheid en noodzakelijkheid is de volgende:

"Met betrekking tot de vraag $[\ldots]$ in hoeverre [de betrokken bepalingen] voor rechterlijke toetsing vatbaar zijn, moet voor ogen worden gehouden dat de gemeenschapswetgever op het gebied van het gemeenschappelijk landbouwbeleid over een discretionaire bevoegdheid beschikt, in overeenstemming met de hem toegekende politieke verantwoordelijkheid. Derhalve kan aan de wettigheid van de op dit gebied vastgestelde maatregelen slechts afbreuk worden gedaan, wanneer de maatregel kennelijk ongeschikt is ter bereiking van het door de bevoegde instelling nagestreefde doel. ${ }^{\text {"02 }}$

Het Hof zal in het algemeen dus alleen een schending van artikel 34 lid 2 constateren wanneer de communautaire classificatie evident onredelijk is ${ }^{403}$ Dit blijkt maar zelden het geval te zijn; hoewel er veel klachten over ongelijke behandeling worden ingediend, heeft het Hof maar in een beperkt aantal gevallen een schending aangenomen. In deze gevallen ging het inderdaad om gevallen van onderscheid die, gezien de omstandigheden en doelstellingen, duidelijk onredelijk waren. ${ }^{404}$

400. Zie ook Boest 1984, p. 115-116.

401. Deze rechtvaardiging voor een marginale toetsing is ook in latere arresten nog wel aangevoerd. Zie bijv. EHvJ 24 oktober 1973, zaak 5/73, Balkan-Import-Export, Jurispr. 1973, 1091, punt 21. Zie ook Tridimas 1999 (I), p. 123, waar hij aangeeft dat de tijdelijke aard van de maatregelen effect kan hebben op de intensiteit van de toetsing.

402. EHvJ 13 november 1990, zaak C-331/88, Fedesa, Jurispr. 1990, I-4023, punt 14; deze overweging had weliswaar geen betrekking op ongelijke behandeling, maar op een schending van het evenredigheidsbeginsel; vergelijkbare overwegingen zijn echter te vinden in de rechtspraak over artikel 34 lid 2 .

403. Dit betekent vooral dat het Hof slechts in beperkte mate kan oordelen over de opportuniteit van de maatregelen, hetgeen betekent dat het geen oordeel zal uitspreken over de juistheid en wenselijkheid van de aan het besluit ten grondslag liggende beleidsoverwegingen en over de juistheid van de economische prognoses die tot het besluit hebben geleid (De Moor-van Vlugt 1995, p. 113). Deze beperkingen komen vooral tot uitdrukking in een zeer marginale toetsing van de geschiktheid en de noodzakelijkheid van de betrokken maatregelen.

404. Zie bijv. het arrest Bela-Mühle, waarin sprake was van een onevenredig benadelende maatregel (EHvJ 5 juli 1977, zaak 114/76, Jurispr. 1977, 1211; zie verder de bespreking in paragraaf 2.4.2), de Isoglucose-arresten, waarin eveneens sprake was van een onnodig ernstige ongelijke behandeling (EHvJ 25 oktober 1978, gev, zaken 103 en $145 / 77$, Jurispr. 1978, 2037) en het tweede bananenarrest (EHvJ 10 maart 1998, zaak C-122/95, Duitsland/Raad (bananen II), Jurispr. 1998, I-973). Het is frappant dat vooral in dit laatste arrest cen schending werd gevonden, nu het ging om gevoelige materie op een bijzonder gecompliceerd beleidsterrein. Een schending van het evenredigheidsbeginsel wordt vaker aangenomen. Dit ligt ook voor de hand, omdat daarbij minder risico bestaat voor een doorkruising van concurrentieverhoudingen. Het element van een benadeling ten opzichte van een ander ontbreekt daarbij immers, zodat het constateren van een schending niet snel zal leiden tot de aanpassing van de ver- 
Een belangrijk praktisch gevolg van de terughoudende opstelling van het Hof is een (feitelijke) omkering van de bewijslast. Normaal gesproken is het, nadat is vastgesteld dat er van een ongelijke behandeling sprake is, de taak van de verwerende partij om argumenten aan te voeren ter rechtvaardiging hiervan, waarbij aannemelijk moet worden gemaakt dat de maatregel geschikt en noodzakelijk was om het gestelde doel te bereiken. Uit de volgende overweging van het Hof kan echter worden afgeleid dat de bewijslast op het gebied van de landbouw geheel bij de eiser ligt, ook wanneer in de eerste fase is vastgesteld dat er van een ongelijke behandeling sprake is:
"[...] [Volgens eiser] had de nagestreefde doelstelling bereikt kunnen worden met minder ingrijpende maatregelen. Weliswaar valt niet uit te sluiten, dat andere middelen denkbaar zijn om tot het nagestreefde resultaat te komen, maar met betrekking tot de vraag of de door de gemeenschapswetgever gekozen maatregelen al dan niet adequaat zijn, kan het Hof zijn oordeel niet in de plaats stellen van dat van de Raad, waar niet is bewezen, dat zijn maatregelen kennelijk ongeschikt waren om het nagestreefde doel te bereiken. Verzoekster heeft derhalve niet aangetoond, dat de Raad kennelijk ongeschikte maatregelen heeft getroffen dan wel dat hij de gegevens kennelijk onjuist heeft beoordeeld." ${ }^{\text {was }}$

Een dergelijke omkering van de bewijslast vormt de ultieme uitdrukking van terughoudendheid: de rechter noch de verdedigende partij hoeven in dit soort zaken een bijzondere mate van activiteit te betonen. Een nadeel is echter dat de bewijslast hierdoor eenzijdig op de eisende partij komt te rusten. Zeker wanneer het gaat om klacht van een individu dat door een ongelijke behandeling ernstig in zijn belangen is geraakt, is een dergelijke bewijslast niet geheel redelijk. Voor de betrokkene zal vrijwel onmogelijk zijn om feiten en omstandigheden aan te dragen waaruit kan blijken dat het onderscheid niet gerechtvaardigd is: de relevante gegevens zullen vaak wel voorhanden zijn bij de gemeenschapsinstellingen, maar het individu zal hier zelden over beschikken. De beschermende werking van het gelijkheidsbeginsel tegen willekeurig of onredelijk optreden van de gemeenschapsinstellingen wordt door een dergelijke benadering in emstige mate aangetast. Het is dan ook wenselijk dat het Hof de normale bewijslastverdeling tot uitgangspunt neemt en zijn terughoudendheid vooral tot uitdrukking laat komen in een marginale beoordeling van de aangevoerde rechtvaardiging. Hoogstens kan van de eisende partij kunnen worden verwacht dat deze aannemelijk maakt (maar niet hoeft te bewijzen) dat de maatregel niet geschikt is om het beoogde doel te bereiken of dat et minder belastende alternatieven ter beschikking staan.

houdingen tussen twee groepen producenten of verbruikers. Ook bij de toetsing aan dit beginsel blijkt het Hof zich echter terughoudend op te stellen; wanneer een schending wordt geconstateerd gaat het meestal om gevallen die al bij oppervlakkige beschouwing als onevenredig kunnen worden gekwalificeerd.

405. EHvJ 5 oktober 1994, zaak C-280/93, Duitsland/Raad (bananen I), Jurispr. 1994, 1-4973, punt 93-95; vgl. ook Schwarze 1993, p. 426 en Barents 1997, p. 816. Het Hof is overigens niet geheel consequent: Duitsland/Raad (bananen II) had betrekking op dezelfde problematiek als het geciteerde arrest, zodat het voor de hand zou liggen dat voor een vergelijkbare toetsingsintensiteit werd gekozen. Het Hof oordeelde echter dat "[...] de Raad ter rechtvaardiging van een maatregen als die welke in casu aan de ofde is, had moeten aantonen dat het evenwicht [...] slechts kon worden hersteld door aan de marktdeclnemers [...] een wezenlijk voordeel toe te kennen" (EHvJ 10 maart 1998, zaak C-122/95, Jurisps. 1998, 1-973, punt 68). Deze overweging getuigt van een aanzienlijk striktere toetsing, hetgeen gezien de omstandigheden van het geval moeilijk aan de hand van één van de in deze paragraaf besproker factoren kan worden verklaard. 


\section{Het better placed-argument}

Een tweede factor die bepalend is voor de intensiteit van de toetsing hangt nauw samen met de aard van het betrokken beleidsterrein. Het gemeenschappelijk landbouwbeleid is, zoals eerder is opgemerkt, een bijzonder gecompliceerd beleidsterrein. Bij iedere beslissing moet rekening worden gehouden met talrijke (economische) factoren: nagegaan moet worden welke gevolgen een maatregel heeft voor landbouwproducten die niet onder de reikwijdte vallen en onderzocht moet worden hoe de handel met derde landen zal worden beïnvloed, welke invloed de maatregel zal hebben op de werking van andere landbouwmaatregelen, welke consequenties de maatregel op lange termijn zal hebben, enzovoort. ${ }^{406}$ Het zal duidelijk zijn dat een rechterlijke instantie als het Hof niet voldoende is toegerust om maatregelen van een dergelijke complexiteit tot in detail te beoordelen. ${ }^{407}$ Het Hof is dan ook geneigd om zich terughoudend op te stellen en alleen maatregelen af te keuren waarvan het al bij oppervlakkige bestudering duidelijk is dat zij een ongerechtvaardigd zware inbreuk maken op het verbod van ongelijke behandeling. ${ }^{40 \mathrm{~B}}$ Een enkele maal heeft het Hof dit expliciet aangegeven, zoals in een aantal uitspraken over het politiek zeer gevoelig liggende bananenconflict. ${ }^{409}$ In het arrest Duitsland/Raad (bananen I) ${ }^{400}$ oordeelde het Hof als volgt:

406. Vgl. De Búrca 1993, p. 116 e.v., waar zij verschillende voorbeelden van arresten geeft waarin complexe afwegingen van uiteenlopende belangen moesten worden getoetst. Ook het Hof zelf heeft verschillende malen aangegeven dat de discretie die aan de gemeenschapsinstellingen moet worden toegekend in belangrijke mate verband houdt met de grote moeilijkheden bij het vergaren van alle voor de besluitvorming relevante economische factoren en gegevens en met de noodzaak het beleid voortdurend aan te passen aan wijzigingen van de economische situatie. Zie ook EHvJ 12 juli 1979, zaak 166/78, Italië/Raad (premie voor aardappelzetmeel), Jurispr. 1979, 2575, punt 14, GvEA 20 maart 2001, zaak T-52/99, T. Port, Jurispr. 2001, II-981, punt 99/100. Zie verder Schwarze 1993, p. 412 en 413 en Tridimas 1999 (I), p. 49.

407. Zo het daartoe al bevoegd is: het Hof is als rechterlijke instantie zeker niet competent om een oordeel te geven over de doelmatigheid van de beslissingen die door de gemeenschapsinstellingen worden genomen (vgl. A-G Capotorti in zijn conclusie bij het arrest Bela-Mühle, EHvJ 5 juli 1977, zaak 114/76, Jurispr. 1977, 1211, op p. 1226). Vgl. ook het oordeel van het Hof in EHvJ 24 oktober 1973, zaak 5/73, Balkan-Import-Export, Jurispr. 1973, 1091 en zie Tridimas 1999 (I), p. 140-141.

408. Vgl. Boest 1984, p. $118-120$ en 149. Daarbij komt nog, zoals eerder uiteen is gezet, dat een geslaagd beroep op het gelijkheidsbeginsel vrijwel per definitie grote gevolgen heeft voor producten die tot elkaar in een mededingingsverhouding staan. Deze gevolgen zullen niet altijd goed zijn te overzien, hetgeen voor het Hof een extra reden vormt om te kiezen voor een terughoudende opstelling. Vgl. Barents 1994 (II), p. 532 en 533

409. Dit conflict had betrekking op de instelling van een gemeenschappelijke marktordening in de sector bananen. Een dergelijke marktordening impliceert een soort harmonisatie van het beleid op een bepaald onderdeel van het landbouwbeleid, als gevolg waarvan de gemeenschapsinstellingen de bevoegdheid verkrijgen om prijzen vast te stellen, importbeperkingen te stellen e.d. Politiek gezien lag de besluitvorming in deze marktordening erg gevoelig, met name omdat er in deze sector zeer grote verschillen bestaan tussen de lidstaten: enkele lidstaten verkopen vooral bananen uit binnenlandse productie, terwijl andere staten vooral bananen uit derde landen importeren. Een aantal maatregelen dat binnen de gemeenschappelijke marktordening werd getroffen en enkele afspraken die in het kader van het GATT-verdrag werden gemaakt hadden een bemoeilijking van de import van bananen uit derde landen tot gevolg, hetgeen een sterke prijsverhoging opleverde in landen die traditioneel hun bananen uit deze derde landen importeren, zoals Duitsland. Deze landen waren dan ook zeer kritisch over de gang van zaken, waardoor er tal van conflicten ontstonden tussen de lidstaten onderling en tussen de lidstaten en de gemeenschap. Vanwege de enorme politieke impact van de conflicten en vanwege het bemoeilijkende feit dat ook de WTO een rol was gaan spelen in de hele problematiek, is het begrijpelijk dat het Hof zich niet geroepen voelde om ingewikkelde compromissen te doorkruisen door een 
"[...] wanneer de gemeenschapswetgever met het oog op de vaststelling van een regeling de toekomstige gevolgen ervan dient te beoordelen en die gevolgen niet met zekerheid zijn te voorzien, kan zijn beoordeling slechts worden afgekeurd indien zij, gelet op de gegevens waarover de wetgever ten tijde van de vaststelling van de regeling beschikte, kennelijk onjuist was. Deze beperking van de toetsing door het Hof is in het bijzonder geboden, wanneer de Raad zich genoopt ziet, bij de totstandkoming van een gemeenschappelijke marktordening uiteenlopende belangen tegen elkaar af te wegen en aldus in het kader van de onder zijn eigen verantwoordelijkheid vallende politieke beslissingen een keuze te maken."

Ook uit andere uitspraken blijkt dat het Hof rekening houdt met het better placedargument, zelfs als niet de gemeenschapsinstellingen, maar de lidstaten bevoegd zijn. Zo diende het Hof zich in het arrest Wuidart ${ }^{412}$ uit te spreken over een in een verordening aan de lidstaten gelaten keuze om hun grondgebied voor het doel van de regeling als één enkel gebied te beschouwen of het op te splitsen in verschillende delen. Bij deze keuze mochten zij rekening houden met verschillende criteria, zoals natuurlijke omstandigheden en het rendement van de grond. Het Hof overwoog in dit arrest het volgende:

"Daar hierbij criteria moeten worden beoordeeld die op een ingewikkelde economische realiteit betrekking hebben, beschikken de Lid-Staten over een ruime beoordelingsbevoegdheid waarvan de grenzen enkel worden overschreden, indien de beoordeling waartoe zij zijn gekomen kennelijk onjuist is." ${ }^{\text {113 }}$

Aard van de nagestreefde doelstellingen; verantwoordelijkheid voor de besluitvorming Zoals in paragraaf 2.3.2 is aangegeven houdt het Hof bij zijn toetsing van landbouwmaatregelen rekening met de doelstellingen van het gemeenschappelijk landbouwbeleid, zoals het verwezenlijken van een goed functionerende landbouwmarkt, het realiseren van redelijke prijzen voor de consumenten en het stabiliseren van de nationale landbouwmarkten. In de praktijk blijkt het Hof al snel bereid om maatregelen goed te keuren die tot een verwezenlijking van deze doelstellingen kunnen bijdragen en staat het vooral afkeurend tegenover maatregelen waarvan de bijdrage aan de totstandkoming van de gemeenschappelijke marktordening beperkt is of waardoor de doelstellingen van het landbouwbeleid worden doorkruist. ${ }^{414}$ Tegen deze achtergrond is het verklaarbaar dat het Hof zich aanzienlijk terughoudender opstelt wanneer het de rechtmatigheid van een maatregel van een gemeenschapsinstelling moet beoordelen, dan wanneer er geklaagd wordt over een maatregel van een lidstaat. ${ }^{.15}$ Juist maatregelen van de

vergaand oordeel uit te spreken. Vgl. Tridimas 1999 (I), p. 56.

410. EHvJ 5 oktober 1994, zaak C-280/93, Jurispr. 1994, 1-4973

411. Punt 90 en 91

412. EHvJ 21 februari 1990, gev. zaken C-267/88 tot en met C-285/88, Jurispr. 1990, 1-435

413. Punt 35

414. Vgl. Barents 1994 (I), p. 347 en More 1999, p. 534.

415. Hierdoor lijkt overigens geen inbreuk te worden gemaakt op het communautaire subsidiariteitsbeginsel, zoals dat in artikel 5 EG is neergelegd. Dit beginsel impliceert alleen dat het Hof zich ten anziet van de lidstaten terughoudend moet opstellen wanneer de bevoegdheid om op een bepaald gebied te beslissen nog bij de lidstaten en niet bij de gemeenschapsinstellingen berust. Hoewel het vaak moeilijy is om vast te stellen bij wie een bevoegdheid nu precies berust, zeker bij een zo uitgebreid en ingewil- 
lidstaten kunnen immers een bedreiging vormen voor het voeren van een gemeenschappelijk landbouwbeleid, vooral als zij gemeenschapsmaatregelen doorkruisen of daarvan afwijken. ${ }^{416}$

Een voorbeeld van de benadering van het Hof bij de beoordeling van maatregelen van lidstaten is te zien in het arrest Lante. ${ }^{41}$ In dit arrest was een Italiaanse uitvoeringsmaatregel van een communautaire steunregeling in het geding, die bedoeld was om de veehouderij te extensiveren en op die manier het rundvleesoverschot op de gemeenschappelijke markt te verminderen. De Italiaanse wetgever had in zijn uitvoeringsregeling echter een niet in de gemeenschapsverordening opgenomen criterium vastgesteld, waardoor minder veehouders voor steun in aanmerking kwamen dan de bedoeling was. Het Hof overwoog hierover het volgende:

"Hoewel er, zowel economisch als juridisch gezien, andere mogelijkheden zijn om tot een vermindering van de vleesoverschotten te komen, heeft de gemeenschapswetgever [...] enkel gekozen voor extensivering van de vleesproductie als instrument om die vermindering te bewerkstelligen. In casu zou derhalve een bevoegdheid van de Lid-Staten om de kring van begunstigden te beperken, onverenigbaar zijn met de keuze van de wetgever. Daarbij komt, dat zo de Lid-Staten over een discretionaire bevoegdheid beschikken om de categorieën van begunstigden te omschrijven, dit zou kunnen leiden tot ongerechtvaardigde discriminatie tussen de producenten in de verschillende Lid-Staten, wat in strijd zou zijn met artikel 40, lid 3, van het Verdrag [nu artikel 34 lid 2, JHG]." ${ }^{\text {IIx }}$

Hoewel het Hof in deze overweging niet uitdrukkelijk inging op de intensiteit van de toetsing, blijkt hieruit dat de lidstaten slechts een beperkte ruimte hebben voor het treffen van maatregelen die afwijken van gemeenschapsrechtelijke maatregelen. ${ }^{41}$

keld gebied als de landbouw, kan in zijn algemeenheid worden gesteld dat de meeste bevoegdheden bij de gemeenschapsinstellingen berusten. Weliswaar zijn de staten vrij om wetgeving tot stand te brengen op het gebied van het gemeenschappelijk landbouwbeleid, maar de ruimte voor afwijkingen van de communautaire doelstellingen is minimaal. In de praktijk blijken de lidstaten vooral uitvoering te geven aan de op communautair niveau vastgestelde maatregelen en kunnen zij alleen eigen regels vaststellen op het beperkte aantal gebieden waarop de gemeenschapsinstellingen nog niet zijn opgetreden. Vgl. Bernard 1996 (II), p. 663, Barents 1989, p. 399 en Bronkhorst 1987 (II), p. $121-122$.

416. Vgl. Tridimas 1999 (I), p. 124.

417. EHvJ 14 januari 1993, zaak C-190/91, Jurispr. 1993, 1-67

418. Punt 15 en 16

419. Dit blijkt ook uit verschillende arresten van het Hof waarin werd geklaagd over uitvoeringsbepalingen van de lidstaten, die niet geheel in overeenstemming zouden zijn met een gemeenschapsregeling. Hoewel het Hof dit niet expliciet stelt, blijkt uit deze arresten dat het Hof niet snel bereid is om een afwijking te accepteren wanneer deze niet strookt met de doelstellingen van de gemeenschapsregeling. Zie bijv. EHvJ 6 juni 1972, zaak 94/71, Schlüter \& Maack, Jurispr. 1972, 307, EHvJ 28 juni 1979, gev. zaken 233-235/78, Lentes, Jurispr. 1979, 2305 en EHvJ 17 december 1970, zaak 34/70, Syndicat National Céréales, Jurispr. 1970, 1233. De situatie ligt anders in gevallen waarin de lidstaten door een gemeenschapsregeling juist ruime discretionaire bevoegdheden toegekend hebben gekregen en voor het uitoefenen van deze bevoegdheden een goede kennis van het betrokken terrein en de nationale omstandigheden noodzakelijk is, zoals in het arrest Wuidart (EHvJ 21 februari 1990, gev. zaken C-267-88 t/m C-285/88, Jurispr. 1990, 1-435). In een dergelijke situatie is het risico voor een doorkruising van de belangen en doelstellingen van het gemeenschapsrecht echter ook minimaal, zodat er niets in de weg staat aan het toekennen van ruime bevoegdheden. 


\section{Aard en ernst van de inbreuk}

Met name bij de toetsing aan het algemene evenredigheidsbeginsel lijkt de intensiteit van de toetsing ook te worden beïnvloed door de aard en ernst van de inbreuk. ${ }^{.00}$ Wan. neer er sprake is van een maatregel met een punitief karakter blijkt het Hof bijvoorbeeld bereid te zijn om een aanzienlijk strengere toetsing uit te voeren dan gebruike. lijk. ${ }^{221}$ Hetzelfde geldt voor regelingen waarbij een waarborgsom wordt verbeurd als niet aan bepaalde voorwaarden is voldaan of wanneer (per ongeluk) een bepaalde referentiehoeveelheid wordt overschreden. ${ }^{42}$ De belangen van de individuele producent worden door dit soort maatregelen onmiddellijk en vrij hard geraakt, terwijl de rechtstreekse invloed op de individuele belangen minder duidelijk voelbaar is wanneer het gaat om algemene beleidsmaatregelen of vaststellingen van prijzen. ${ }^{43}$

Verder kan worden vastgesteld dat het Hof sneller bereid is om een intensieve toetsing uit te voeren wanneer een klacht betrekking heeft op de rechtmatigheid van een individuele beschikking dan wanneer de geldigheid van gemeenschapsmaatregel als zodanig wordt betwist. ${ }^{24}$ De exacte reden daarvoor wordt in de rechtspraak niet geëxpliciteerd, maar is ongetwijfeld gelegen in het feit dat de consequenties van het onverbindend verklaren van een algemene regeling aanzienlijk groter zijn dan de gevolgen van de vernietiging van een individueel besluit.

420. Vgl. De Búrca 1993, p. 120, Tridimas 1999 (1), p. 122 en Jacobs 1999, p. 3.

421. Zie bijv. EHvJ 21 juni 1979, zaak 240/78, Atalanta, Jurispr. 1979, 2137, waarin het Hof met een zelfs voor landbouwzaken wel heel summiere motivering aangaf dat het evenredigheidsbeginsel was geschonden (punt 45). Het aantal zaken waarin het Hof zich heeft uitgesproken over een punitieve masregel is overigens beperkt, omdat de mogelijkheid om sancties op te leggen in de meeste gevallen tockomt aan de lidstaten. Niettemin zijn sommige van de maatregelen van de gemeenschap zodanig van aard dat zij als punitief kunnen worden aangemerkt. Zie hierover Boest 1984, p. 154; ook zekerheden kunnen soms als punitieve sancties worden aangemerkt (De Moor-van Vlugt 1995, p. 96-98).

422. Zie bijvoorbeeld EHvJ 4 juli 1996, zaak C-295/94, Hüpeden, Jurispr. 1996, I-3375, punt 26 en EHvJ 4 juli 1996, zaak C-296/94, Pietsch, Jurispr. 3409, punt 34 en de conclusie van A-G Jacobs bij deze arresten in punt 29-31. Van belang is bovendien dat in deze arresten steeds sprake was van een beperking van de commerciêle vrijheid; ook dit zal waarschijnlijk van invloed zijn geweest op de toetsingsintensiteit: vgl. Tridimas 1999 (I), p. 111 en Jacobs 1999, p. 3. Anderzijds geeft Barents aan dat, juist bij maatregelen waarbij een zekerheid is gesteld, de voorwaarden voor het terugkrijgen van het bedrag strikt moeten worden geìnterpreteerd om de doelstellingen van de maatregelen te beschermen $(1989, \mathrm{p}$. 415 en 1997, p. 830). Dit verschil is verklaarbaar vanuit de rechtspraak van het Hof: wanneer een waarborg wordt verbeurd wegens het niet nakomen van hoofdverplichtingen die voor het functioneren van de maatregel echt noodzakelijk zijn, kan een terughoudende toetsing worden uitgevoerd. Gaat het om minder belangrijke nevenverplichtingen (zoals administratieve voorschriften) dan zal de maatregel aan een striktere toetsing worden onderworpen. Zie bijv. EHvJ 2 augustus 1993, zaak C-87/92, Hocke, Jurispr. 1993, I-4623, punt 24 en 26. De functie en de aard van waarborgen worden besproken door Gótz 1986, p. 41, Barents 1985, p. 241-243 en De Moor-van Vlugt 1995, p. 94-102.

423. Tridimas geeft aan dat de ruimte nog groter is wanneer er sprake is van agro-monetaire maatregelen: een schending van het gelijkheidsbeginsel zal dan alleen in zeer uitzonderlijke omstandigheden kunnen soort maatregelen, de sterk uiteenlopende monetaire situaties van de lidstaten en de grote tijdsdruk waaronder zij meestal tot stand worden gebracht. Zie in vergelijkbare zin Barents 1994 (I), p. 343 en De Moor-van Vlugt 1995, p. 139.

424. Tridimas 1999 (I), p. 104 en De Moor-van Vlugt 1995, p. 114. Zie bijv. EHvJ 27 november 1986, zask 21/85, Maas, Jurispr. 1986, 3537. 
Afwezigheid van een fundamenteel belang en een verdachte grond van onderscheid Hoewel het Hof verschillende malen heeft vastgesteld dat het gelijkheidsbeginsel ook in het landbouwrecht moet worden gezien als een fundamenteel rechtsbeginsel, lijkt het hiermee bij de bepaling van de toetsingsintensiteit nauwelijks rekening te houden. Hoogstwaarschijnlijk houdt dit verband met het feit dat er bij de landbouw zelden spra$k e$ is van onderscheid op een verdachte grond of van een ongelijke behandeling waardoor de menselijke waardigheid wordt aangetast: hoogstens zal er bij classificaties op het gebied van de landbouw sprake zijn van een inbreuk op de economische vrijheid of van financieel nadeel. Het is waarschijnlijk dat dit voor het Hof een bijkomende, impliciete, reden vormt om een marginale toetsing aan artikel 34 lid 2 uit te voeren. ${ }^{42}$ Het valt te hopen dat het Hof de toetsing zal intensiveren in een geval waarin wel fundamentele individuele belangen zijn betrokken of waarin onderscheid wordt gemaakt op een meer verdachte grond. Gebeurt dit niet, dan dreigen bepaalde beleidsgebieden immuun te worden voor toetsing door het Hof en wordt de bescherming van de individuele rechten tegen het handelen door de gemeenschapsinstellingen sterk beperkt. ${ }^{426}$

Van belang is in dit verband dat het Hof een intensievere toetsing dan gebruikelijk lijkt uit te voeren wanneer door een landbouwmaatregel niet het gelijkheidsbeginsel, maar een ander door het gemeenschapsrecht beschermd grondrecht wordt aangetast. In een dergelijk geval blijken er vooral hogere eisen te worden gesteld aan de evenredigheid van de inbreuk. Dit kan bijvoorbeeld blijken uit de volgende overweging uit het arrest Wachauf, ${ }^{227}$ dat betrekking had op een inbreuk op het eigendomsrecht:

"De door het Hof erkende fundamentele rechten hebben [...] geen absolute gelding, maar moeten in relatie tot hun sociale functie worden beschouwd. Het genot van het eigendomsrecht en de vrijheid van beroepsuitoefening kunnen dus met name in het kader van een gemeenschappelijke marktordening aan beperkingen worden onderworpen, voor zover zulke beperkingen werkelijk beantwoorden aan de doeleinden van algemeen belang die de Gemeenschap nastreeft en, het nagestreefde doel in aanmerking genomen, niet zijn te beschouwen als een onevenredige en onduldbare ingreep, waardoor de gewaarborgde rechten in hun kern worden aangetast." $\$ 2 x$

425. Vgl. Barents 1997, p. 834. Niet geheel juist lijkt de conclusie van De Búrca (1993, p. 122/123) dat het Hof een striktere toetsing toepast wanneer er een duidelijk zichtbaar recht wordt aangetast waar een minder belangrijk gemeenschapsrecht tegenover staat en de intensiteit van de toetsing dus kennelijk wordt bepaald door het gewicht van het aangetaste belang. Inderdaad heeft het Hof in een beperkt aantal arresten maatregelen ongeldig verklaard omdat er duidelijke individuele belangen werden aangetast, terwijl daar veel minder zwaarwegende communautaire belangen tegenover stonden. Voor deze arresten is echter duidelijk dat, zelfs bij een terughoudende toetsing, een schending van het evenredigheidsbeginsel zou zijn geconstateerd. In een aantal andere (ook door De Búrca genoemde) arresten was er sprake van de toetsing van een punitieve maatregel. In die gevallen moet de aard van de inbreuk en niet het gewicht van het aangetaste belang doorslaggevend worden geacht voor de toetsingsintensiteit, hoewel moet worden toegegeven dat de grens tussen deze twee factoren niet altijd scherp valt te trek-

426. Vgl. Priebe 1988, p. 29, Schwarze 1993, p. 419, Barents 1994 (II), p. 537 en Barents 1997, p. 841.

427. EHvJ 13 juli 1989, zaak 5/88, Jurispr. 1989, 2609

428. Punt 18. Overigens kan hieruit niet zonder meer worden afgeleid dat de toetsing noodzakelijkerwijze intensiever is. Verschillende auteurs hebben aangegeven dat ook in de jurisprudentie waarin een grondrecht in het geding is de beoordelingsruimte van de gemeenschapsinstellingen wordt gerespecteerd (bijv. Barents 1997, p. 835). Niettemin lijkt de geciteerde formulering iets meer ruimte te bieden voor 
Zoals eerder is aangegeven heeft het Hof van deze formulering sporadisch ook gebruik gemaakt bij de toetsing aan het gelijkheidsbeginsel. ${ }^{42}$ Betwijfeld kan echter worden of het Hof daarmee de bedoeling had om in het vervolg daadwerkelijk meer waarde toe te kennen aan het gelijkheidsbeginsel: in latere arresten op het gebied van ongelijke be handeling op het gebied van de landbouw komt deze overweging niet terug. Uit een overweging als de geciteerde kan echter wel worden afgeleid dat het fundamentele karakter van het aangetaste belang van doorslaggevende invloed kan zijn op de intensiteit van de toetsing, zelfs op een gevoelig terrein als de landbouw.

\subsubsection{Conclusie}

Bij de vaststelling van de toetsingsintensiteit in het landbouwrecht blijken ongeveer dezelfde factoren een rol te spelen als bij onderscheid op grond van geslacht. Zo zijn ook hier de aanwezigheid van sterk discretionaire bevoegdheden, het better placed. argument en de aard van het betrokken beleidsveld van grote betekenis voor de striktheid waarmee onderscheid op zijn redelijkheid wordt beoordeeld. Verder is gebleken dat ook de aard en de ernst van de belangenaantasting van invloed kunnen zijn op de intensiteit van de toetsing.

Ondanks de vergelijkbaarheid van de factoren die bij onderscheid op grond van geslacht en op het gebied van de landbouw een rol spelen, bestaan er belangrijke verschillen in de op beide gebieden feitelijk toegepaste toetsingsintensiteit. Een afwijking is met name zichtbaar waar het gaat om de "basisintensiteit" van de toetsing en het resultaat van de afweging van de verschillende intensiteitbepalende factoren. Bij onderscheid op grond van geslacht kan worden vastgesteld dat het Hof een in beginsel strikte toetsing toepast, die slechts in bepaalde omstandigheden zal worden afgezwakt. Van belang is bovendien dat de waarde die wordt gehecht aan gelijke behandeling op grond van geslacht bepalend is voor de gekozen basisintensiteit. Op het gebied van de landbouw wordt juist een tegenovergesteld uitgangspunt gehanteerd: zoals is aangegeven wordt daarbij in de meeste gevallen een zeer marginale toetsing uitgevoerd, die slechts in zeldzame gevallen wordt aangescherpt. Bepalend is daarbij dat het bij het landbouwbeleid gaat om een zeer complex terrein, waarbij de bevoegde instellingen over rume discretionaire bevoegdheden beschikken om de doelstellingen van het Verdrag te kunnen verwezenlijken. Van groot belang is bovendien dat het Hof in artikel 34 lid 2 neergelegde verbod van ongelijke behandeling niet beschouwt als een fundamenteel en individueel grondrecht: weliswaar worden door de classificaties regelmatig economische en bedrijfsbelangen aangetast, maar de menselijke waardigheid is tot nu toe ongeschonden gebleven. Hieruit blijkt dat de context van een ongelijke behandeling in sterke mate bepalend kan zijn voor de intensiteit van de toetsing en de afweging die tussen de verschillende intensiteitbepalende factoren wordt gemaakt. Met die factor zal bij het opstellen van een algemeen afwegingsmodel in het bijzonder rekening moeten worden gehouden.

een strikte toetsing dan de formuleringen die normaal gesproken op het terrein van de landbouw worden gehanteerd.

429. EHvJ 13 april 2000, zaak C-292/97, Karlsson e.a., Jurispr. 2000, 1-2737, punt 45 
Opmerkelijk in de rechtspraak over de gemeenschappelijke landbouwpolitiek is tenslotte het feit dat er meestal een intensieve toetsing wordt uitgevoerd wanneer niet de Raad of de Commissie, maar een lidstaat voor de ongelijke behandeling verantwoordelijk is. Deze benadering is zeker niet gebruikelijk en vormt een afwijking van het internationale en gemeenschapsrechtelijke beginsel van subsidiariteit. Normaal gesproken is het subsidiariteitsbeginsel van bijzonder belang wanneer er sprake is van een toetsing van nationale maatregelen door een internationale of supranationale rechterlijke instantie: hiervoor is al gebleken dat zowel het Europees Hof van Justitie als het Europees Hof voor de Rechten van de Mens tegen de achtergrond van dit beginsel vaak kiezen voor een terughoudende toetsing van nationale maatregelen. Een verklaring voor de afwijkende benadering van het Hof in landbouwzaken kan worden gevonden in het feit dat aan het beginsel van subsidiariteit op het gebied van de landbouw minder betekenis toekomt dan bij andere beleidsterreinen. De bevoegdheid om op het gebied van de landbouw besluiten te nemen en beleid vast te stellen is grotendeels overgedragen aan de gemeenschapsinstellingen, zodat de taak van de nationale overheid in veruit de meeste gevallen beperkt is tot het uitvoeren van de communautaire regelgeving. ${ }^{430} \mathrm{Bo}-$ vendien wordt de intensievere toetsing van nationale maatregelen vooral ook ingegeven door het gevaar dat de doelstellingen van het landbouwbeleid worden doorkruist door verschillen in de besluitvorming in de lidstaten en door de bedreiging die de decentrale uitvoering oplevert voor de uniforme toepassing van het gemeenschapsrecht. Dergelijke risico's zijn op andere gebieden dan het gemeenschappelijk landbouwbeleid in veel mindere mate aanwezig. Gezien de zeer specifieke omstandigheden waarin het "omgekeerde subsidiariteitsargument" een rol speelt, kan worden aangenomen dat het niet zinvol is om deze factor in het algemene toetsingsmodel op te nemen.

\subsection{Toetsingsintensiteit bij onderscheid op grond van nationaliteit}

\subsubsection{Aard en gewicht van het verbod van onderscheid op grond van nationaliteit}

Ook bij onderscheid op grond van nationaliteit blijkt tenslotte een zekere variatie in toetsingsintensiteit mogelijk te zijn. Het uitgangspunt van het Hof is daarbij een strikte toetsing, hetgeen vooral blijkt uit de rechtspraak met betrekking tot direct onderscheid. ${ }^{31}$ Een strikte toetsing wordt verder uitgevoerd wanneer er sprake is van nondiscriminatoire belemmeringen van het vrije verkeer. Weliswaar vallen dergelijke belemmeringen niet rechtstreeks onder de in het Verdrag neergelegde discriminatieverboden (er is immers geen sprake van ongelijke behandeling), maar niettemin worden zij

430. Er is overigens geen sprake van een volledige bevoegdheidsoverdracht: met name voor de administratieve vormgeving van de besluiten is de gemeenschapswetgever afhankelijk van het nationale recht (zie Götz 1986, p. 29), terwijl bovendien een "renationalisering" zichtbaar lijkt te zijn (zie daarover Kuiper 1987, p. 615). De lidstaten wordt bovendien veel ruimte toegekend bij het vaststellen van regelingen op het gebied van de landbouw, zolang zij de doelstellingen van de gemeenschappelijke landbouwpolitiek maar niet doorkruisen (Bronkhorst 1987 (II), p. 122-123 en Barents 1989, p. 398). Er zijn echter grote gebieden van het landbouwrecht waarbij de overdracht van bevoegdheden als compleet kan worden beschouwd en waar de ruime voor de lidstaten minimaal is (vgl. Bernard 1996 (II), p. 660). Zie in die zin ook EHvJ 8 januari 2002, zaak C-507/99, Denkavit Nederland BV (II), n.n.g., punt 32.

431. Zie bijv. EHvJ I8 juni 1991, zaak C-260/89, ERT, Jurispr. 1991, 1-2925, punt 24. Vgl. ook De Búrca 1993, p. 126, Timmermans 1982, p. 442, Wilkinson 1995, p. 422 en 430 en Watson 1995, p. 43. 
uitsluitend toelaatbaar geacht wanneer zij worden gerechtvaardigd door "dwingende redenen van algemeen belang". ${ }^{32}$ Deze formulering duidt zonder enige twijfel op een intensieve toetsing.

In zijn rechtspraak over indirect onderscheid heeft het Hof zich veel minder expliciet uitgesproken over de te hanteren toetsingsintensiteit. Dat het ook in deze gevallen een strikte toetsing uitvoert kan echter worden afgeleid uit een aantal kenmerken waaraan al eerder in dit hoofdstuk aandacht is besteed. Zo is in paragraaf 2.2.3 gebleken dat het Hof geen hoge eisen stelt aan het bewijs van benadeling. Dit betekent dat de verweerder al vlug zal moeten aantonen dat de getroffen maatregel gerechtvaardigd is, ook al is er geen sprake van een evident geval van indirect onderscheid. Ook het feit dat het Hof zich in een groot aantal arresten actief opstelt bij het onderzoek naar alternatieve, min. der belastende maatregelen wijst op een intensieve toetsing: bij een marginale toetsing zal een rechter zich juist bij de beoordeling van geschiktheid en subsidiariteit terughoudend opstellen, zodat de door de verwerende partij op dit punt aangevoerde verdediging vaak zonder nader onderzoek zal worden geaccepteerd. ${ }^{43}$ Tenslotte duidt ook het feit dat een objectieve rechtvaardiging slechts zelden de toetsing doorstaat op een strikte benadering van het Hof.

Zoals al is aangegeven heeft het Hof zich vrijwel nooit uitgesproken over de redenen die aan deze intensieve toetsing ten grondslag liggen..$^{34}$ Net als bij onderscheid op grond van geslacht lijkt het er echter op dat het Hof vooral kiest voor deze toetsingsintensiteit vanwege het gewicht dat aan dit verbod van ongelijke behandeling toekomt: ${ }^{\text {ts }}$ in veel gevallen verwijst het Hof naar het fundamentele karakter van dit verbod, om

432. Zie EHvJ 4 december 1986, zaak 205/84, Commissie/Duitsland (verzekeringsmaatschappijen), Jurispt. 1986, 3755: uit dit arrest blijkt niet alleen dat er een strikte toetsing wordt gekozen omdat gebruik wordt gemaakt van de term "dwingende redenen van algemeen belang" (punt 29), maar ook doordat het Hof vereist dat de maatregelen niet verder gaan dan "strikt noodzakelijk" is (punt 33) en zelfs dat vast moet staan dat het belemmerende vereiste "onmisbaar" is om het beoogde doel te kunnen bereiken (punt 52). Zie verder bijv. EHvJ 25 juli 1991, zaak C-288/89, Gouda, Jurispr. 1991, 1-4007, punt 14 en EHvJ 6 juni 2000, zaak C-35/98, Verkooijen, Jurispr. 2000, I-4071, punt 48.

433. Zie hierover paragraaf 2.4.3; voorbeelden van rechtspraak waarin het Hof een dergelijke actieve toetsing uitvoert zijn EHvJ 5 december 1989, zaak C-3/88, Commissie/ltalië (aanbesteding computersys. temen), Jurispr. 1989, 4035, EHvJ 28 januari 1992, zaak C-204/90, Bachmann, Jurispr. 1992, 1-249, EHvJ 10 maart 1993, zaak C-11/91, Commissie/Luxemburg (geboortetoelagen), Jurispr. 1993, 1-817, EHvJ 7 mei 1998, zaak C-350/96, Clean Car Autoservices, Jurispr. 1998, 1-2521.

434. In bepaalde arresten wordt wel verwezen naar de doelstelling van de verdragsbepalingen, maar daaram wordt nooit rechtstreeks de conclusie verbonden dat er een strikte toetsing moet worden uitgevoerd. Zie bijv. de arresten Wolf en Stanton, waarin het Hof stelde, dat "de verdragsbepalingen inzake het vrije verkeer van personen [...] het de gemeenschapsonderdanen [beogen] gemakkelijker te maken om het even welk beroep uit te oefenen op het gehele grondgebied van de gemeenschap en [...] in de weg [staan] aan een nationale regeling die deze onderdanen minder gunstig behandelt wanneer zij op hef grondgebied van meer dan één Lid-Staat werkzaam willen zijn" (EHvJ 7 juli 1988, gev. zaken 154 en 155/87, Wolf, Jurispr. 1988, 3897, punt 9 en EHvJ juli 1988, zaak 143/87, Stanton, Jurispr. 1988, 3877). In andere arresten waarin sprake is van non-discriminatoire belemmeringen zijn soortgelijke overwegingen te vinden. De Advocaten-Generaal hebben in hun conclusies overigens vaker vervezen naar de te hanteren toetsingsintensiteit, zoals blijkt uit het hiervoor weergegeven citaat uit een condlvsie van Jacobs; zie verder bijv. de conclusie van A-G Lenz bij de Toeristengidsenzaken (bij EHvJ 26 februari, zaak C-154/89, Commissie/Frankrijk, Jurispr. 1991, 1-659), waarin hij stelde dat de nood22kelijkheid "grondig" moest worden getoetst (punt 38).

435. Vgl. Tridimas 1999 (l), p. 124. 
vervolgens te stellen dat uitzonderingen hierop strikt moeten worden uitgelegd. ${ }^{436}$ De precieze reden om het verbod van ongelijke behandeling van fundamenteel belang te achten wordt zelden nader gearticuleerd. Het lijkt er daardoor op dat het Hof het fundamentele karakter van dit verbod zo vanzelfsprekend vindt, dat het het niet de moeite waard vindt om daaraan nader aandacht te besteden. Verondersteld kan echter worden dat het Hof voor het toekennen van een bijzonder gewicht aan het verbod van ongelijke behandeling op grond van nationaliteit andere redenen heeft dan een rol spelen bij onderscheid op grond van geslacht. De overwegingen die bij nationaliteit bepalend zijn kunnen worden afgeleid uit de volgende passage uit de conclusie van A-G Jacobs bij het arrest Phil Collins: ${ }^{437}$

"Het verbod van discriminatie op grond van nationaliteit is het belangrijkste beginsel van het gemeenschapsrecht. Het is het leitmotiv van het EEG-Verdrag. [...] Het is niet moeilijk in te zien, waarom de auteurs van het Verdrag zoveel belang aan het discriminatieverbod hebben gehecht. De voornaamste doelstelling van het Verdrag is het verwezenlijken van een geintegreerde economie, waarin de produktiefactoren evenals de vruchten van de produktie vrij en zonder belemmeringen kunnen circuleren, waardoor een doeltreffender spreiding van middelen en een betere arbeidsdeling mogelijk wordt. De grootste hindernis bij het verwezenlijken van deze doelstelling was het bestaan van discriminerende regelingen en praktijken, waarmee de nationale regeringen traditioneel hun eigen producenten en werknemers tegenover de buitenlandse concurrentie beschermden. Ofschoon de afschaffing van discriminerende regelingen en praktijken op zich onvoldoende is om het door het Verdrag beoogde, hoge peil van economische integratie te bereiken, is het onmiskenbaar een eerste, noodzakelijke voorwaarde. Het verbod van discriminatie op grond van nationaliteit heeft eveneens een grote symbolische betekenis, dat het duidelijk maakt, dat de Gemeenschap niet enkel een handelsovereenkomst tussen de regeringen van de Lid-Staten is, maar een gemeenschappelijke onderneming waaraan alle burgers van Europa individueel deel kunnen hebben."

In deze gedachtegang speelt het feit dat door onderscheid op grond van nationaliteit fundamentele individuele grondrechten worden aangetast slechts een ondergeschikte rol: het verwezenlijken van de doelstellingen van het gemeenschapsrecht, met name het bereiken van een grotere economische eenheid door het vergemakkelijken van het verplaatsen van productiemiddelen, is van veel groter belang. ${ }^{439}$ Dit zou betekenen dat een

436. Dit is in diverse arresten terug te vinden, zoals in EHvJ 28 november 1989, zaak C-379/87, Groener, Jurispr. 1989, 3967, waarin het Hof sprak over een "aantasting van een fundamentele vrijheid als het vrije verkeer van werknemers" (punt 19), EHvJ 14 juni 1990, zaak C-37/89, Weiser, Jurispr. 1990, I2395, punt 13, EHvJ 26 januari 1999, zaak C-18/95, Terhoeve, Jurispr. 1999, I-345, punt 44 en EHvJ 13 april 2000, zaak C-251/98, Baars, Jurispr. 2000, I-2787, punt 37 . Ook ten aanzien van het vrij verkeer van goederen heeft het Hof gesteld dat het hierbij gaat om een van de fundamentele vrijheden van het gemeenschapsrecht en om een grondbeginsel van het Verdrag (EHvJ 3 oktober 2000, zaak C-58/98, Corsten, Jurispr. 2000, 1-7919, punt 42 en 46).

437. EHvJ 20 oktober 1993, gev. zaken C-92/92 en C-326/92, Jurispr. 1993, I-5145

438. Punt 9-11 van de conclusie. Zie over deze doelstellingen ook Sundberg-Weitman 1977, p. 128-131.

439. Dat ook het Hof dergelijke overwegingen aan zijn toetsing ten grondslag legt blijkt bijvoorbeeld uit EHvJ 4 december 1986, zaak 205/84, Commissie/Duitsland (verzekeringen), Jurispr. 1986, 3755. In deze zaak was een regeling in het geding waarin voor het verrichten van bepaalde diensten door buitenlandse bedrijven in Duitsland niet alleen werd vereist dat zij over een vergunning beschikten, maar ver dat zij een vaste inrichting in Duitsland hadden. Het Hof is uiterst streng in zijn toetsing van deze vereisten en voert daarvoor de volgende redenen aan; "Terwijl het vergunningsvereiste een beperking 
fundamenteel belang kennelijk niet alleen uit de waarde van een recht voor het individu kan worden afgeleid, maar soms ook uit het belang dat een bepaald recht heeft voor de gemeenschap als zodanig.

\subsubsection{Factoren die een verminderde toetsingsintensiteit opleveren}

\section{Inleiding}

Ook bij onderscheid op grond van nationaliteit blijkt de aanwezigheid van bepaalde factoren te kunnen leiden tot een minder intensieve toetsing. Met name in de rechtspraak over de uitzonderingsbepalingen voor de verschillende vrijheden, waarin het Hof zich meestal vrij duidelijk uitlaat over de intensiteit van de toetsing, kunnen interessante voorbeelden worden gevonden van een marginalere toetsing. De belangrijkste uitzonderingsmogelijkheden zijn de openbare orde en zedelijkheid, de nationale veilig. heid en de volksgezondheid. ${ }^{40}$ Aan de hand van de hierover bestaande rechtspraak zal in het hiernavolgende een overzicht worden gegeven van de verschillende factoren die aanleiding kunnen vormen voor het verminderen van de toetsingsintensiteit.

\section{Afwezigheid van een common ground}

In de rechtspraak over de uitzonderingen bij de bepalingen over het vrije verkeer blijkt op verschillende plaatsen dat het Hof bij de vaststelling van de toetsingsintensiteit rekening houdt met het ontbreken van voldoende consensus over het betrokken onderwerp, dus met de afwezigheid van een common ground. Een duidelijk voorbeeld daarvan is te zien in de rechtspraak over de openbare orde-clausule van artikel 39 lid 3 EG (artikel 48 lid 3 oud), zoals in het arrest Van Duyn. ${ }^{41}$ Dit arrest had betrekking op de weigering om Van Duyn tot het Verenigd Koninkrijk toe te laten, omdat zij daar als secretaresse voor de Church of Scientology wilde gaan werken. Nu deze organisatie door de Engelse regering als een gevaar voor de samenleving werd beschouwd, beriep de Engelse regering zich, ter rechtvaardiging van deze beperking van het vrije verkeer van personen, op de openbare orde-clausule. Het Hof stelde in zijn arrest het volgende:

"[...] het begrip openbare orde [moet] in communautair verband en met name als rechtvaardiging van een uitzondering op het grondbeginsel van het vrije verkeer van werknemers, strikt [...] worden opgevat, zodat de strekking ervan niet eenzijdig door elk der Lid-Staten zonder controle van de gemeenschapsinstellingen kan worden bepaald; [...]

op het vrij verrichten van diensten vormt, is het vereiste van een vaste inrichting in feite de ontkenning van die vrijheid. Het leidt ertoe dat aan artikel 59 [nu artikel 49, JHG], dat juist strekt tot opheffing van de beperkingen op het vrij verrichten van diensten door personen die niet zijn gevestigd in de staat waar de dienst moet worden verricht, ieder nuttig effect wordt ontnomen" (punt 52). Dit lijkt erop te wijzen dat het Hof zich strenger op zal stellen naarmate de vrijheden ernstiger zijn aangetast. Vgl. velder Emiliou 1996, p. 228.

440. Deze uitzonderingsgronden zijn neergelegd in artikel $30 \mathrm{EG}$ (vrij verkeer van goederen), artikel 39 lid 3 EG (vrij verkeer van werknemers) en artikel 46 EG (vrije vestiging en, via artikel 55 , vrij verkeer van diensten). In artikel 30 worden ook nog andere uitzonderingsgronden genoemd, zoals de bescherming van dieren of planten, de bescherming van historisch en archeologisch bezit en de bescherming van industriële en economische eigendom. Het voert in het kader van dit hoofdstuk echter te ver om ook an deze uitzonderingsgronden, die specifiek gelden voor het verder niet besproken vrij verkeer van goede ren, uitgebreid te bespreken. Gekozen is dan ook voor een beperking tot de uitzonderingsgronden waarop het vaakst een beroep wordt gedaan.

441. EHvJ 4 december 1974, zaak 41/74, Jurispr. 1974, 1337 
niettemin [kunnen] de specifieke omstandigheden die een beroep op het begrip openbare orde zouden kunnen rechtvaardigen, naar land en tijd [...] verschillen en [moet] mitsdien ten deze aan de bevoegde nationale autoriteiten een beoordelingsmarge, binnen de door het Verdrag gestelde grenzen, [...] worden toegekend."

Uit deze overweging blijkt dat het voor het toekennen van een ruimere beleidsmarge, en daarmee voor een minder strikte toetsing, doorslaggevend was dat een duidelijke consensus tussen de lidstaten over de inhoud van het begrip openbare orde ontbrak. ${ }^{43}$

Vergelijkbare overwegingen blijken een rol te spelen bij de uitzonderingsgrond "bescherming van de openbare zedelijkheid" zoals die is opgenomen in artikel 30 EG (36 oud). ${ }^{4+4}$ In het arrest Henn en Darby, ${ }^{4+5}$ waarin een importverbod voor pornografie aan de orde was, stelde het Hof over deze uitzonderingsgrond het volgende:

"In beginsel staat het aan elke Lid-Staat om de vereisten van de openbare zedelijkheid op zijn grondgebied te bepalen overeenkomstig zijn eigen waardensysteem en in de door hem gekozen vorm." ${ }^{446}$

Hoewel in dit arrest geen expliciete motivering werd gegeven voor de toekenning van een dergelijke ruime beoordelingsmarge, kan worden aangenomen dat het ontbreken van een common ground over de wenselijkheid van het verbieden van pornografie hierbij een belangrijke rol speelde. ${ }^{47}$

442. Punt 18. Zie in gelijke zin de conclusie van A-G Mayras in deze zaak, op p. 1358. In een later arrest, Rutili, werd de overweging uit Van Duyn herhaald, maar voegde het Hof hieraan nog toe, dat "mitsdien [...] slechts beperkingen mogen worden gesteld wanneer hun aanwezigheid of hun gedrag een werkelijke of genoegzaam emstige bedreiging voor de openbare orde oplevert" (EHvJ 28 oktober 1975, zaak 36/75, Jurispr. 1975, 1219, punt 28; vgl. ook EHvJ 18 mei 1982, Adoui en Cormuaille, Jurispr. 1982, 1665, punt 8). Verderop in Van Duyn legde het Hof bovendien een aantal voorwaarden neer waaraan moet worden voldaan, wil een beperking van het vrij verkeer op deze grond toelaatbaar zijn. De beantwoording van de vraag of aan deze voorwaarden is voldaan lijkt echter te worden overgelaten aan de nationale instanties, zodat hieruit niet automatisch kan worden afgeleid dat er sprake is van een striktere toetsing door het Hof. Soortgelijke beperkingen zijn terug te vinden in de arresten Commissie/Duitsland (huisvestingsvereiste) (EHvJ 18 mei 1989, zaak 249/86, Jurispr. 1989, 1263) en Roux (EHvJ 5 februari 1991, zaak C-363/89, Jurispr. 1991, 1-273); in beide arresten werd aangegeven dat bepaalde doelstellingen niet onder de reikwijdte van het verbod vallen. Zie over de ontwikkeling en nuancering van de rechtspraak na Van Duyn ook Hall 1991, m.n. p. 483-487; hij is van mening dat de nationale beoordelingsruimte door deze rechtspraak sterk is ingeperkt. Aangenomen kan echter worden dat deze beperking vooral de bepaling van de reikwijdte van de clausule betreft en niet zozeer de beoordeling van de noodzaak van de maatregel.

443. Zie ook EHvJ 16 juni 1997, gev, zaken C-65/95 en C-111/95, Shingara en Radiom, Jurispr. 1997, 13343 , punt 30 , waarin het Hof opnieuw stelt dat het verschil tussen de omstandigheden die een beroep op het begrip openbare orde kunnen rechtvaardigen pleit voor de toekenning van een ruime beoordelingsvrijheid. Vgl. Wilkinson 1995, p. 423.

444. Vgl. De Búrca 1993, p. 128; deze bepaling heeft betrekking op het vrij verkeer van goederen.

445. EHvJ 14 december 1979, zaak 34/79, Jurispr. 1979, 3795

446. Punt 15. Idem in EHvJ 11 maart 1986, zaak 121/85, Conegate, Jurispr. 1986, 1007, punt 14. Wel geldt dat de beperkingen die aan buitenlanders of aan buitenlandse producten worden opgelegd niet duidelijk zwaarder mogen wegen dan de aan vergelijkbare nationale producten of aan eigen onderdanen opgelegde beperkingen; zie het arrest Conegate en Craig/De Búrca 1998, p. 597.

447. Dergelijke overwegingen komen wel naar voren in de conclusie van A-G Warner bij het geciteerde arrest, waarin hij ook verwijst naar de benadering die door het Europees Hof voor de Rechten van de Mens wordt gehanteerd bij uitzonderingen op basis van de goede zeden (zie daarover uitgebreid paragraaf 3.2.2 van het vorige hoofdstuk). Het is jammer dat het Hof niet preciezer aangeeft wat nu de in- 
Tenslotte blijkt het consensusargument soms een rol te spelen in de rechtspraak over de bescherming van de volksgezondheid. In de praktijk wordt op deze uitzonderingsgrond vooral een beroep gedaan bij beperkingen van het vrij verkeer van goederen. Het komt regelmatig voor dat het vrije verkeer van levensmiddelen wordt belemmerd doordat sommige lidstaten bepaalde additieven in voedingsmiddelen verbieden, terwijl deze in andere lidstaten wel toelaatbaar zijn. Het Hof heeft zich bereid getoond om de lidstaten een ruime beoordelingsmarge toe te kennen wanneer een dergelijke beperking op het vrij verkeer van goederen wordt gerechtvaardigd met een beroep op de volksgezond. heid. Dit kan bijvoorbeeld blijken uit de volgende overweging uit het arrest Sandoz"t, dat betrekking had op een verbod om vitaminen aan voedingsmiddelen toe te voegen:

"[...] de gemeenschapswetgever [gaat uit] [...] van het beginsel, dat het gebruik van additieven in levensmiddelen dient te worden beperkt tot de limitatief opgesomde stoffen, waarbij de Lid-Staten echter een zekere discretionaire bevoegdheid behouden om strengere regelingen vast te stellen. Die handelingen getuigen dus van een grote voorzichtigheid ten aanzien van de potentiële schadelijkheid van additieven waarvan nog niet vaststaat in hoeverre zij schadelijk kunnen zijn, en laten de Lid-Staten met betrekking tot die additieven een ruime beoordelingsvrijheid. [...] [Het] staat aan de Lid-Staten om, bij ontbreken van harmonisatie en wanneer bij de huidige stand van het wetenschappelijk onderzock onzekerheden blijven bestaan, te beslissen over de mate waarin zij de bescherming van de gezondheid en het leven van personen willen waarborgen, waarbij zij echter rekening dienen te houden met de vereisten van het vrije goederenverkeer binnen de Gemeenschap."

Opmerkelijk in deze overweging is dat voor de toekenning van beoordelingsruimte niet zozeer het ontbreken van een consensus tussen de lidstaten bepalend is, zoals bij een toepassing van het common ground-argument meestal het geval is, maar vooral het ontbreken van wetenschappelijke eenduidigheid over het gevaar dat bepaalde additie-

houd van het gehanteerde common ground-begrip is; anders dan het Straatsburgse Hof, dat vaak een uitgebreid rechtsvergelijkend onderzoek uitvoert of aandacht besteedt aan internationale overeenkomsten, lijkt het Hof vooral uit te gaan van algemene veronderstellingen. Daarbij is het overigens warkschijnlijk dat deze soms worden ontleend aan de rechtspraak van het Straatsburgse Hof; zie daarover ook Hall 1991, p. 481.

448. EHvJ 14 juli 1883, zaak 174/82, Jurispr. 1983, 2445

449. Punt 15 en 16. Gezien de formulering heeft in deze uitspraak ook het toekennen van een beoordelingsmarge door de gemeenschapswetgever een rol gespeeid bij de bepaling van de toetsingsintensiteil Een vergelijkbaar oordeel werd uitgesproken in de arresten De Peijper (EHvJ 20 mei 1976, 2avk 104/75, Jurispr. 1976, 613, m.n. punt 15; dit arrest had betrekking op controles), Koninklijke Kaas/abriek Eyssen (EHvJ 5 februari 1981, zaak 53/80, Jurispr. 1981, 409, punt 10 en 130) en Melkunie (EHvJ 6 juni 1984, zaak 97/83, Jurispr. 1983, 2367, punt 18). In het arrest Koninklijke Kaasfabriek Eyssen werd bij de toekenning van een ruime beoordelingsmarge vooral rekening gehouden met het feit dat de regels omtrent het toevoegen van een bepaald additief in de verschillende lidstaten sterk uileenliepen; het common ground-argument speelde hierbij dus een belangrijke rol.

De intensiteit van de toetsing die bij arresten over dit onderwerp wordt gehanteerd verschilt overigens per geval. Het Hof blijkt vooral uiteenlopende eisen te stellen aan het bewijs van noodzakelijkheid van de maatregel: in het arrest Sandoz vereiste het Hof slechts dat de lidstaten geen verbod zouden instellen als bepaalde additieven aan een werkelijke behoefte van de bevolking voldeden, terwijl in latere rechlspraak, zoals in het arrest Van Bennekom (EHvJ 30 november 1983, zaak 227/82, Jurispr. 1983, 3883) en het arrest Melkunie werd vereist dat de lidstaat zou aantonen dat de betrokken additieven een emstít gevaar voor de volksgezondheid opleveren. In 1986 werd dan weer van de Sandoz-formulering gebrulk
gemaakt (EHvJ 6 mei 1986, zaak 304/84, Muller, Jurispr, 1986, 1511). Zie hierover uitgebreid Sedemund 1987 , m.n. p. 32 en 34. 
ven opleveren voor de volksgezondheid. ${ }^{450}$ Hierdoor krijgt het common ground- of consensusargument een ruimere inhoud, waardoor het ook op nationaal niveau een functie kan hebben bij het vaststellen van de toetsingsintensiteit. ${ }^{451}$ In paragraaf $4.2 \mathrm{zal}$ daarop nader worden ingegaan.

\section{Het better placed-argument}

Uit de rechtspraak van het Europees Hof voor de Rechten van de Mens is gebleken dat het zich terughoudend opstelt wanneer het zich onvoldoende kan verplaatsen in de omstandigheden en opvattingen die aanleiding waren om een bepaalde maatregel te treffen. Dit better placed-argument blijkt ook in de rechtspraak van het Hof van Justitie een rol te spelen, hoewel de jurisprudentie op dit punt minder duidelijk is dan die van het Straatsburgse Hof.452

Een goed voorbeeld van een toepassing van het better placed-argument is te vinden in de rechtspraak over de openbare orde. Op deze uitzonderingsgrond wordt regelmatig een beroep gedaan wanneer een staat voornemens is om een Unieburger uit te zetten wegens het plegen van strafbare feiten. ${ }^{453}$ In dit soort gevallen, waarin een inbreuk wordt gemaakt op het vrij verkeer van personen, stelt het Hof zich meestal terughoudend op. Een illustratie van deze terughoudendheid komt naar voren uit een overweging uit het arrest Bouchereau. ${ }^{454}$ Dit arrest had betrekking op de voorgenomen uitzetting van een man die reeds verschillende malen voor drugsdelicten was veroordeeld:

"[...] het bestaan van een strafrechtelijke veroordeling [doet] slechts ter zake [...] voor zover uit de omstandigheden die tot deze veroordeling hebben geleid, blijkt van het bestaan van een persoonlijk gedrag dat een actuele bedreiging van de openbare orde vormt; $[\ldots]$ het [staat] aan de nationale autoriteiten en eventueel aan de nationale rechterlijke instanties [...] in elk afzonderlijk geval daarover te oordelen, gelet op de bijzondere rechtspositie van de onder het gemeenschapsrecht vallende personen en op het fundamentele karakter van het beginsel van het vrij verkeer van personen." ${ }^{\text {ss }}$

450. Volgens Sir Gordon Slynn is ook het better placed-argument hierbij een factor van betekenis: de autoriteiten van de verschillende lidstaten kennen de nationale voedingsgewoonten en omstandigheden en kunnen daardoor beter dan het Hof beoordelen of het verbieden van bepaalde additieven nodig is om overschrijding van maximale hoeveelheden te voorkomen (1987, p. 22). Dit argument lijkt ook naar voren te komen uit de jurisprudentie, bijv. uit het arrest Muller (EHvJ 6 mei 1986, zaak 304/84, Jurispr. 1986, 1511, punt 20). Zie ook Sedeman 1987, p. 30.

451. Daarover kan bij de "enge" uitleg enige twijfel bestaan: in die uitleg moet aan de hand van de opvattingen in de verschillende lidstaten worden vastgesteld of er voldoende consensus bestaat om een striktere toetsing toe te passen. Op nationaal niveau is het uitvoeren van een dergelijk onderzoek soms moeilijk en ook niet altijd zinvol. Het bovengeciteerde arrest illustreert dat de factor bij een ruimere uitleg ook op nationaal niveau een bijzondere toegevoegde waarde kan hebben.

452. Vgl. De Búrca 1993, p. 127.

453. De mogelijkheid hiertoe is echter sterk beperkt door RI. 64/221/EEG van de Raad van 25 februari 1964 betreffende de coördinatie van de voor vreemdelingen geldende bijzondere maatregelen ten aanzien van verplaatsing en verblijf, die gerechtvaardigd zij uit hoofde van de openbare orde, de openbare veiligheid en de volksgezondheid, Pb. EG (bijzondere editie) 1963-1964, 117. In deze richtlijn is de uitzonderingsbepaling van artikel 39 lid 3 verder uitgewerkt, vooral voor beperkingen bij immigratic en dreiging met uitzetting.

454. EHvJ 27 oktober 1977, zaak 30/77, Jurispr. 1977, 1999

455. Punt 28 en 30 
Het werd in deze zaak dus aan de nationale instanties overgelaten om te beoordelen of voldaan was aan de verschillende voorwaarden die de gemeenschapswetgever voor beperking van het vrije personenverkeer heeft gesteld, hetgeen duidt op een terughoudende opstelling van het Hof. Hoewel het Hof zich in Bouchereau niet expliciet uitliet over de redenen die aan deze benadering te grondslag lagen, kan hiervoor een verkla. ring worden gevonden in het better placed-argument: de nationale instanties zijn nu eenmaal beter toegerust dan het Hof om een oordeel te geven over het gevaar dat een specifieke persoon voor de openbare orde in het land vormt, zodat het inderdaad het beste lijkt om de noodzaak van het beperken van de bewegingsvrijheid door hen te laten beoordelen.

\section{Subsidiariteit}

Het better placed-argument is nauw verbonden met het internationaalrechtelijke en communautaire beginsel van subsidiariteit, dat (onder andere) impliceert dat internationale rechterlijke instanties zich terughoudend moeten opstellen als zij moeten oordelen over onderwerpen die nauw verband houden met de nationale soevereiniteit. Waar het better placed-argument vooral verband houdt met de beperkingen van het rechterlijk instrumentarium en ook voor de nationale rechter relevant kan zijn, ${ }^{4 s 6}$ leent het subsidiariteitsargument zich dan ook vooral voor toepassing door de internationale rechter.

Uit de jurisprudentie van het Hof over beperkingen van het vrije verkeer blijkt nergens met zoveel woorden dat het zich uit subsidiariteitsoverwegingen terughoudend opstelt, maar uit verschillende uitspraken over de openbare veiligheid kan blijken dat dergelijke overwegingen wel degelijk een rol spelen. ${ }^{457}$ Een illustratie hiervan is te vinden in het arrest Leifer ${ }^{a s 8}$, dat betrekking had op een Duitse vergunningsplicht voor de uitvoer van zogenaamde dual use-goederen - goederen die zowel voor civiele als voor militaire doeleinden kunnen worden aangewend. De Duitse regering beriep zich ter rechtvaardiging van deze vergunningsplicht, waardoor het vrij verkeer van goederen werd belem. merd, op de noodzaak de openbare veiligheid te beschermen. Het Hof stelde het volgende:

"Opgemerkt zij [...] dat, afhankelijk van de omstandigheden, de nationale autoriteiten over
een zekere beoordelingsmarge beschikken bij de vaststelling van de maatregelen die zij ter
bescherming van de openbare veiligheid van een Lid-Staat in de hierboven aangegeven zin
noodzakelijk achten."

Zoals A-G Jacobs in zijn conclusie bij deze uitspraak aangaf bestaat er bij de handel in dual use-goederen direct gevaar voor een verstoring van de externe betrekkingen van een land, hetgeen ernstige consequenties kan hebben voor de nationale veiligheid van de betrokken staat. ${ }^{+\omega}$ Voor een rechter is het buitengewoon moeilijk om een oordeel te

456. Ook op nationaal niveau geldt immers dat de rechter minder goed uitgerust en gelegitimeerd is om over bepaalde onderwerpen te besluiten dan wetgever of bestuur.

457. Vgl. ook De Bürca 1993, p. 127.

458. EHvJ 17 oktober 1995, zaak C-83/94, Jurispr. 1995, 1-3231

459. Punt 35

460. Punt 41 en 42 van A-G Jacobs' conclusie bij de arresten Werner en Leifer, beide gewezen op 17 oktober 1995, zaken C-70/94 en C-83/94, Jurispr. 1995, 1-3189 resp. 1-3231. Zie ook zijn conclusie bij tet 
geven over dit soort overwegingen van buitenlandse politiek, zodat de omvang van zijn toetsing noodzakelijkerwijze vrij beperkt is: de besluitvormende autoriteiten zijn "better placed" om hierover een oordeel te vellen dan de rechter. Voor een internationale of supranationale rechter is het nog minder passend om in te grijpen: door een dergelijk internationaal optreden zou al snel een te vergaande inbreuk worden gemaakt op de nationale soevereiniteit van de betrokken lidstaat. ${ }^{+61}$ Het is dan ook redelijk dat het Hof zich in gevallen als deze terughoudend opstelt. ${ }^{462}$

\section{Gewicht van de nagestreefde doelstelling}

Een vierde factor die van belang blijkt te zijn bij het toekennen van een ruime beoordelingsmarge is het gewicht van het met de belemmerende maatregel nagestreefde belang. Voorbeelden hiervan zijn vooral te vinden in de rechtspraak over de volksge-

arrest Commissie/Griekenland (Macedonië) (EHvJ 19 maart 1996, zaak C-120/94, Jurispr. 1996, I1513), waarin hij inging op de rechterlijke bevoegdheid ten aanzien van maatregelen die in het kader van een directe oorlogsdreiging zijn genomen; daarbij geldt de beperktheid van de rechterlijke taak vanzelfsprekend nog sterker (zie m.n. punt 50 conclusie). Zie in gelijke zin De Búrca 1993, p. 131. Vgl. ook A-G Darmon in zijn conclusie bij het arrest Maclaine Watson (EHvJ 10 mei 1990, zaak C241/87, Jurispr. 1991, I-1797); hij gaf hierin een uitgebreid overzicht van de opvattingen over dit onderwerp, waaruit blijkt dat de rechter zich in alle lidstaten terughoudend zou opstellen (zie punt 55-96 conclusie). Hierdoor is er sprake van een common ground die wijst in de richting van een marginale toetsing door het Hof; vgl. punt 96 conclusie.

461. Punt 43 van de conclusie bij Werner en Leifer, reeds aangehaald.

462. De rechtspraak van het Hof is op dit punt bijzonder genuanceerd en niet altijd even voorspelbaar. Zo bleek uit het arrest Richardt, dat betrekking had op een uit- en doorvoerverbod van strategische goederen, geen bijzonder marginale toetsing, terwijl hierbij de externe veiligheid wel degelijk in het geding kon zijn (EHvJ 4 oktober 1991, zaak C-367/89, Jurispr. 1991, 1-4621); zie ook De Búrca 1993, p. 135. Daarnaast blijkt het Hof in gevallen waarin een beroep wordt gedaan op de openbare veiligheid, maar er geen sprake is van gevaar voor de externe betrekkingen, voor een strikte toetsing te kiezen. Zie bijvoorbeeld de arresten Campus Oil (EHvJ 10 juli 1984, zaak 72/83, Jurispr. 1984, 2727, punt 37), CullevCentre Leclerc (EHvJ 29 januari 1985, zaak 231/83, Jurispr. 1985, 305, punt 32 en 33) en Commissie/Griekenland (aardolie) (EHvJ 13 december 1990, zaak C-347/88, Jurispr. 1990, I-4747, punt 4749); deze arresten hadden betrekking op het verzekeren van voldoende voorraden aardolie om in tijden van crisis aan de vraag te kunnen voldoen. Nu daarbij duidelijk alleen de interne veiligheid in het geding was - en het er bovendien op leek dat economische argumenten de hoofdrol speelden -, stelde het Hof hoge eisen aan het aantonen van de noodzaak om ter bereiking van dit doel handelsbelemmerende maatregelen vast te stellen. Van belang is verder of het Hof reden heeft om te veronderstellen dat niet wordt geprobeerd om de veiligheid te beschermen, maar er andere, minder edele bedoelingen bestaan (vgl. EHvJ 13 juli 2000, zaak C-423/98, Albore, Jurispr. 2000, I-5965); vgl. Tridimas 1999 (I), p. 149150, De Búrca 1993, p. 134 en Craig/De Búrca 1998, p. 600. Ook in andere groepen van gevallen waarin een beroep op deze uitzonderingsgrond werd gedaan voerde het Hof een intensieve toetsing uit, zoals in de gevallen waarin een migrerende werknemer wordt verplicht zich binnen een bepaalde termijn bij de autoriteiten in de lidstaat van verblijf te melden, zodat de lidstaat voldoende controle kan houden over de mensen die zich op een bepaald tijdstip in het betrokken land bevinden en effectief optreden mogelijk maken wanneer de migrant bepaalde regels overtreedt. Weliswaar liet het Hof ruimte voor een dergelijke verplichting, maar uit de rechtspraak blijkt dat de gestelde regels streng op hun evenredigheid worden beoordeeld (bijv. EHvJ 7 juli 1976, zaak 118/75, Watson en Belmann, Jurispr. 1976, 1185 en EHvJ 12 december 1989, zaak C-265/88, Messner, Jurispr. 1989, 4209). Zie tenslotte de conclusie van A-G Jacobs bij het arrest Centro-Com, waarin hij aangaf dat de beoordelingsvrijheid van de staten niet onmiddellijk groter is wanneer er belangen van openbare veiligheid meespelen, maar afhankelijk is van het doel, de tekst en de context van de betrokken maatregel (conclusie bij EHvJ 14 januari 1997, zaak C-124/95, Jurispr. 1997, I-81, punt 43). Het Hof heeft overigens nooit expliciet aandacht besteed aan de verschillende factoren, maar kiest meestal ongemotiveerd voor de toetsingsintensiteit die het in een bepaald geval het meest passend acht. 
zondheid. Interessant is bijvoorbeeld de volgende overweging uit het arrest De Peijper $^{463}$, dat betrekking had op nationale controles van medicijnen:

"[...] onder de in artikel 36 [nu 30, JHG] beschermde goederen of belangen [nemen] de gezondheid en het leven van personen de eerste plaats [in] [...], en [...] het [staat] aan de Lid-Staten $[\ldots]$ om binnen de door het Verdrag gestelde grenzen te beslissen over de mate waarin zij de bescherming daarvan willen waarborgen, met name over de ernst van de te verrichten controles." ${ }^{n+4}$

Juist omdat de volksgezondheid een groot goed is hebben de lidstaten de ruimte gekregen om hoge eisen te stellen aan de kwaliteit van voedingsmiddelen en medicijnen en kunnen zij strenge kwaliteitscontroles verplicht stellen, zelfs als dit een aantasting van het vrije handelsverkeer tussen de lidstaten zou opleveren. ${ }^{465}$ Uit deze benadering van het Hof komt naar voren dat het steeds een afweging zal maken tussen het belang bij het realiseren van een volledig vrij verkeer van goederen en het belang van de volksge. zondheid.

\section{Ernst van de belangenaantasting}

Uit een enkel arrest van het Hof is verder af te leiden dat de ernst van de belangenaantasting van invloed kan zijn op de intensiteit van de toetsing. ${ }^{466}$ Een voorbeeld daarvan is te vinden in het arrest Aragonesa ${ }^{467}$, waarin het Hof een oordeel uitsprak over een Spaans verbod op reclame voor dranken met een alcoholpercentage van meer dan $23 \%$. Volgens het Hof werd hierdoor inbreuk gemaakt op artikel $28 \mathrm{EG}$, omdat een reclameverbod een vermindering van de import van bepaalde producten kan opleveren en de verhandeling van die producten bemoeilijkt. De Spaanse regering beriep zich ter rechtvaardiging van haar verbod op de noodzaak de volksgezondheid te beschermen. Het Hof overwoog daaromtrent het volgende:

"Een nationale maatregel als die waarom het in het hoofdgeding gaat, beperkt slechts in geringe mate de vrijheid van het handelsverkeer, daar hij enkel betrekking heeft op alcoholhoudende dranken met een alcoholgehalte van meer dan $23 \%$. In de strijd tegen het alcoholmisbruik is dit in beginsel geen kennelijk onredelijke maatregel." ${ }^{\text {"4s }}$

Uit de formulering van de bovenstaande overweging ("geen kennelijk onredelijke maatregel") kan worden afgeleid dat het Hof een minder intensieve toetsing uitvoert wanneer er ter bescherming van een zwaarwegend algemeen belang een geringe inbreuk op het beginsel van het vrije verkeer wordt gemaakt. ${ }^{469}$ In dit arrest zal warr-

463. EHvJ 20 mei 1976, zaak 104/75, Jurispr. 1976, 613

464. Punt 15. Een ander voorbeeld is te vinden in EHvJ I februari 2001, zaak C-108/96, MacQuen, Jurispt. $2001,1-837$, waarin het Hof het belang van de doelstelling van de volksgezondheid benadrukte en daarbij wees op het feit dat het verwezenlijken van een hoog niveau van bescherming van de gezondheid éen van de in artikel 3 EG opgenomen centrale doelstellingen van de EG is (punt 29).

465. Dit is overigens slechts een relatieve vrijheid, die wordt begrensd door de vereisten van geschiktheid. noodzakelijkheid en proportionaliteit.

466. De Búrca 1993, p. 141 en 142

467. EHvJ 25 juli 1991, gevoegde zaken C-1/90 en C-176/90, Jurispr. 1990, 1-4151

468. Punt 17

469. Anderzijds lijken er nog hogere eisen dan gebruikelijk aan de rechtvaardiging te worden gesteld watneer er sprake is van een zeer vergaande inbreuk op het beginsel van vrij verkeer; vgl. De Bürca 1993, p. 139 en Slynn 1987, p. 21. Beiden noemen als voorbeeld het arrest Reinheitsgebot, waarin cen striktt 
schijnlijk ook een rol hebben gespeeld dat er op het gebied van reclame voor schadelijke producten nog geen duidelijke eenheid tussen de lidstaten bestond, zodat ook de common ground-factor een rol speelde. Het is waarschijnlijk dat de factor "ernst van de inbreuk" betrekkelijk weinig belang toekomt en dat er slechts ruimte is om op deze grond een marginale toetsing uit te voeren wanneer deze factor ondersteund wordt door andere intensiteitbepalende factoren. ${ }^{470}$

\section{Omstandigheden van het geval}

Hoewel de aanwezigheid van de hiervoor beschreven factoren in zijn algemeenheid een minder strenge toetsing oplevert, zullen in sommige gevallen de omstandigheden van het geval zodanig zijn dat een strikte toets toch op zijn plaats is. Dit kan worden geîllustreerd aan de hand van een uitspraak over het vrij verkeer van goederen, namelijk het arrest Commissie/VK (pluimvee). ${ }^{471}$ In deze zaak was een Engelse importbeperking voor pluimvee in het geding, die volgens de Engelse regering was bedoeld om de pseudovogelpest tegen te gaan. In het licht van de eerder genoemde factoren kan er aanleiding bestaan om daarbij een minder strenge toetsing toe te passen, met name nu er sprake is van het beschermen van zeer zwaarwegende belangen. Het Hof had echter redenen om te veronderstellen dat de maatregel vooral vanuit protectionistische overwegingen was ingesteld: het bleek niet zozeer de bedoeling te zijn om de zwaar besmettelijke ziekte uit te bannen, maar vooral om de import van goedkope kerstkalkoenen uit Frankrijk, waardoor de Engelse productie werd bedreigd, tegen te houden. Onder die omstandigheden lag een intensievere toetsing in de rede: de intensiteitverminderende factoren speelden immers niet écht een rol. Hoewel het Hof zich daarover niet met zoveel woorden uitsprak, kan uit de inhoud van het arrest dan ook worden afgeleid dat het een zeer strenge toetsing uitvoerde. ${ }^{472}$

proportionaliteitstoets werd toegepast omdat er sprake was van een vergaande beperking (EHvJ 12 maart 1987, zaak 178/84, Jurispr. 1987, 1227, punt 47). Een voorbeeld is ook te vinden in een uitspraak over non-discriminatoire beperkingen, waarin het Hof een strenge proportionaliteitstoets toepaste nadat het had vastgesteld dat de nationale maatregel niet slechts een beperking, maar zelfs een ontkenning van het vrije dienstenverkeer vormde: EHvJ 4 december 1986, zaak 205/84, Commissie/Duitsland (verzekeringsmaatschappijen), Jurispr. 1986, 3755, punt 52.

470. Hierbij is opnieuw het lastige probleem van het relatieve gewicht van de betrokken factoren aan de orde. Het Hof spreekt zich daarover helaas niet duidelijk uit.

471. EHvJ 15 juli 1982, zaak 40/82, Jurispr. 1982, 2793, m.n. punt 40 en 41

472. A-G Capotorti gaf in zijn conclusie wel aan wat de reden was voor een strenge toetsing: "de beperkende maatregelen [...] mogen niet in wezen een verborgen andere bedoeling hebben en een dekmantel zijn voor protectionisme of een boycot van produkten uit andere staten" (p. 2845 conclusie). Zie hierover ook De Búrca 1993, p. 131 en 132. Vergelijkbare overwegingen spelen wel vaker een rol: hoewel het dit zelden expliciet stelt, lijkt het Hof strenger te zijn als het het idee heeft dat er bij het treffen van de maatregel ook andere overwegingen zijn betrokken dan uitsluitend het gestelde doel. Dit blijkt bijvoorbeeld uit de eerder besproken jurisprudentie over de bescherming van de nationale veiligheid, waarbij het Hof een strengere toetsing uitvoert wanneer het de regering ervan verdenkt vooral economische belangen te behartigen. Een ander voorbeeld van een intensieve toetsing die werd ingegeven door de specifieke omstandigheden van het geval is te vinden in het arrest Commissie/Duitsland (invoer geneesmiddelen), EHvJ 8 april 1992, zaak C-62/90, Jurispr. 1992, I-2575, punt 10 en 11: in dit arrest was er sprake van een flagrante schending van het gemeenschapsrecht, waarvoor geen overtuigende argumenten waren aangevoerd. Vgl. Tridimas 1999 (I), p. 145 en Sir Gordon Slynn 1987, p. 18. 


\subsubsection{Conclusie}

In het voorgaande is gebleken dat het Hof bij onderscheid op grond van nationaliteit en bij beperkingen van het vrije verkeer in de meeste gevallen een strikte toetsing uitvoert. De reden daarvoor is gelegen in het fundamentele belang van de betrokken verdragsbepalingen voor het gemeenschapsbeleid: het uitbannen van onderscheid en van nietdiscriminatoire belemmeringen van het verkeer tussen de lidstaten is noodzakelijk om de interne markt goed te laten functioneren en een vrij verkeer tussen de lidstaten in een zo hoog mogelijke mate te realiseren. Het aantal gevallen waarin de lidstaten een ruimere beoordelingsmarge wordt toegekend is dan ook vrij beperkt. Gebleken is dat er vooral meer ruimte wordt gelaten wanneer tussen de lidstaten een voldoende mate van eenstemmigheid ontbreekt, zoals het geval blijkt te zijn op gevoelige gebieden als de bescherming van de goede zeden. Interessant is dat het Hof ook een ruimere beoordelingsmarge aan de lidstaten blijkt toe te kennen wanneer er op een ander vlak onvoldoende consensus bestaat, zoals in het geval waarin er over de noodzaak van bepaalde maatregelen wetenschappelijk gezien nog maar weinig eenduidigheid bestaat. Dit is een belangwekkende uitbreiding van het common ground-argument dat zich uitstekend leent voor toepassing door de nationale rechter.

Verder wordt door de rechtspraak over onderscheid op grond van nationaliteit bevestigd dat het argument van subsidiariteit en het better placed-argument voor een terug. houdende opstelling kunnen zorgen. Van belang is tenslotte dat de specifieke omstandigheden van het geval altijd tot een andere toetsingsintensiteit kunnen leiden dan op basis van een loutere afweging van de verschillende toetsingsfactoren verwacht zou kunnen worden, met name wanneer hieruit blijkt dat sommige intensiteitbepalende factoren niet echt een rol spelen.

In de rechtspraak over onderscheid op grond van nationaliteit wordt, net zomin als bij de andere discriminatieverboden, duidelijk aangegeven welk relatief gewicht er aan de verschillende factoren moet worden toegekend. Ook blijft onduidelijk op welke manier en aan de hand van welke criteria de afweging tussen deze factoren moet plaatsvinden. Hoogstens kan worden vastgesteld dat het Hof het belang van het verbod van ongelijke behandeling op grond van nationaliteit zodanig zwaarwegend acht dat er in beginsel steeds een intensieve toetsing moet worden uitgevoerd. De overige factoren, zoals het ontbreken van consensus of de invloed van het subsidiariteitsbeginsel, kunnen slechts zorgen voor een vermindering van de toetsingsintensiteit. Voor de afweging van deze intensiteitverminderende factoren onderling heeft het Hof geen duidelijke criteria vastgesteld. Daardoor is het niet geheel duidelijk wat de uitkomst van deze afweging zou zijn wanneer er, bijvoorbeeld, een geringe inbreuk wordt gemaakt op het gelijkheidsbeginsel op een gebied waarop een duidelijke common ground aanwezig is.

De problemen die het resultaat zijn van het gebrek aan afwegingscriteria en het onduldelijk articuleren van de verschillende intensiteitbepalende factoren komen in de rechtspraak van het Hof duidelijk naar voren. Zo is eerder in deze paragraaf het voorbeeld gegeven van de bescherming van de volksgezondheid, waarbij een ruimere beoordelingsmarge werd toegekend omdat er geen eenduidige wetenschappelijke opvattingen bestonden over het gezondheidsgevaar van bepaalde additieven. In andere arresten over 
hetzelfde onderwerp stelde het Hof hogere eisen aan de bewijslast, waardoor het feitelijk een striktere toetsing toepaste. ${ }^{473}$ Ook in die arresten was het duidelijk dat een consensus op wetenschappelijk niveau ontbrak, hetgeen ook steeds door het Hof werd bevestigd. De oorzaak van de intensievere toetsing kan daarin dan ook niet worden gevonden, maar was waarschijnlijk gelegen in de specifieke aard van de nagestreefde doelstellingen ${ }^{474}$ de mate waarin het vrij verkeer door de maatregel werd beperkt of in de (verborgen) aanwezigheid van protectionistische elementen. ${ }^{475}$ Juist nu de toetsingsintensiteit belangrijke consequenties kan hebben voor de uitkomst van de toetsing is het, vanuit een oogpunt van individuele rechtsbescherming, bezwaarlijk dat in dit soort zaken onvoldoende wordt aangegeven welke factoren en overwegingen precies een rol speelden. Een duidelijke set van intensiteitbepalende factoren en afwegingscriteria zou de voorspelbaarheid en doorzichtigheid van de toetsing in ieder geval zeer ten goede komen.

\section{Conclusies}

\subsection{Conclusies met betrekking tot de toetsingsmethodiek}

\subsection{Consequenties van de achtergrond van het verbod van onderscheid}

De drie hiervoor besproken verboden van onderscheid kenmerken zich door een zeer verschillende achtergrond en functie. ${ }^{476} \mathrm{Zo}$ was het verbod van onderscheid op grond

473. In het eerste arrest over dit onderwerp, Sandoz, stelde het Hof dat de lidstaten de toevoeging daarvan toe moesten staan wanneer daardoor werd voldaan aan een werkelijke behoefte, met name verband houdend met de technologie of de voeding (EHvJ 14 juli 1983, zaak 174/82, Jurispr. 1983, 2445, punt 19). In 1986 herhaalde het Hof deze overweging: zie EHvJ 6 mei 1986, zaak 304/84, Muller, Jurispr. 1986, 1511, punt 22. In een aantal andere arresten stelde het Hof echter dat de lidstaat moesten aantonen dat de verhandeling van het betrokken product een emstig gevaar voor de volksgezondheid opleverde (zie bijv. EHvJ 30 november 1983, zaak 227/82, Van Bennekom, Jurispr. 1983, 3883, punt 40, EHvJ 6 juni 1984, zaak 97/83, Melkunie, Jurispr. 1984, 2367, punt 15 en EHvJ 12 maart 1987, zaak 178/84, Commissie/Duitsland (Reinheitsgebot), Jurispr. 1987, 1227, punt 47). Door dit vereiste werden duidelijk hogere eisen aan het te leveren bewijs gesteld en werd ruimte geschapen voor een verdergaande toetsing door het Hof.

474. Een ander voorbeeld wordt gegeven door De Búrca: zij stelt vast dat het Hof een minder intensieve toetsing uitvoert wanneer een lidstaat zich beroept op een combinatie van gezondheidsbelangen en belangen van openbare orde, dan wanneer alleen gezondheidsbelangen worden ingeroepen. Het Hof spreekt zich hierover niet duidelijk uit, terwijl uit de uitkomsten van de door De Búrca gegeven voorbeelden wel degelijk blijkt dat de intensiteit een bepalende invloed heeft op de uitkomst (1993, p. 137 en 142-145). Zie EHvJ 18 mei 1989, gev. zaken 266 en 267/87, Association of Pharmaceutical Importers, Jurispr. 1989, 1295 (waarin zowel een beroep werd gedaan op de belangen van de volksgezondheid als op de vrijheid van artsen om bepaalde geneesmiddelen voor te kunnen schrijven) en EHvJ 7 februari 1984, zaak 238/82, Duphar, Jurispr. 1984, 523 (waarin de volksgezondheid in het geding was, maar vooral ook een beroep werd gedaan op de noodzaak om te bezuinigen op de uitgaven
voor het ziekenfonds).

475. De Búrca 1993, p. 139 en 141. Daarnaast zullen de omstandigheden van het geval en soms ook pragmatische overwegingen een rol spelen. Zo kan de geringere intensiteit in het hierboven in noot 473 genoemde arrest Muller worden verklaard vanuit het feit dat de betrokken maatregel heel wenselijk was,

476. Zie paragraaf 1.1, waarin diverse verwijzingen naar rechtspraak en literatuur zijn opgenomen.
. 
van geslacht aanvankelijk vooral ingegeven door economische overwegingen, maat heeft het Hof al vroeg aangenomen dat dit verbod tevens een belangrijk fundamenteel grondrechtelijk karakter heeft. Zowel door de rechtspraak van het Hof als door communautaire regelgeving is dit karakter in de loop van de tijd nog versterkt, zodat het Hof in 2000 zelfs de conclusie kon trekken dat het economische karakter ondergeschikt is geworden aan de functie die het verbod als fundamenteel grondrecht heeft. ${ }^{n}$ Het verbod van ongelijke behandeling op het gebied van de landbouw heeft daarentegen weliswaar een functie als beginsel van behoorlijk bestuur, maar het kan nauwelijks worden gezien als een fundamenteel grondrecht. De praktische betekenis van het beginsel blijkt bovendien beperkt te zijn, nu het in het landbouwrecht ondergeschikt wordt geacht aan het realiseren van goede concurrentieverhoudingen en aan het verwezenlijken van de door de gemeenschapsinstellingen vastgestelde beleidsdoelen. Hoewel het in theorie mogelijk is dat maatregelen van de gemeenschapsinstellingen ongeldig worden verklaard wegens schending van artikel 34 lid 2 EG, zal dit dan ook vrijwel uitsluitend voorkomen als er sprake is van een ernstig geval van ongelijkheid waardoor de belangen van de gemeenschappelijke landbouwpolitiek slechts in geringe mate worden gediend. ${ }^{37 x}$ Tenslotte heeft het verbod van onderscheid op grond van nationaliteit niet zozeer een functie als fundamenteel grondrecht of als algemeen beginsel van behoorlijk bestuur, maar eerder als instrument om de belangrijkste doelstellingen van het gemeenschapsrecht te verwezenlijken: het is een nuttig middel bij het tot stand brengen van een interne markt waarbinnen vrije handel mogelijk is en de productiemiddelen zich vrij kunnen verplaatsen. Voor de Europese Unie is het verbod van onderscheid op grond van nationaliteit dan ook van zeer groot belang. ${ }^{479}$

Ondanks deze variatie in achtergrond en functie van de verschillende verboden blijken de modellen die het Hof voor de toetsing hieraan heeft ontwikkeld niet in sterke mate te verschillen. Vooral de toetsingsmodellen die bij onderscheid op grond van geslacht en nationaliteit worden gehanteerd zijn nagenoeg identiek. ${ }^{400}$ Alleen op het gebied van de landbouw heeft het Hof consequent van een iets afwijkende benadering gebruik gemaakt. Anders dan bij de beide andere verboden wordt daarbij veel aandacht besteed aan de vergelijkbaarheidstoets en wordt er bij het uitvoeren van de rechtvaardigings. toets nauwelijks onderscheid gemaakt tussen verschillende toetsingscriteria. Deze af wijkende benadering lijkt echter niet zozeer voort te vloeien uit fundamentele bezwaren tegen de toepassing van het bij de andere gelijkheidsbepalingen gehanteerde model, maar houdt eerder verband met de zojuist geschetste achtergrond en de in het licht daarvan gekozen toetsingsintensiteit: zoals eerder is aangegeven kiest het Hof op het

477. EHvJ 10 februari 2000, zaak C-50/96, Schröder, Jurispr. 2000, 1-743, punt 56 en 57; zie verder partgraaf 1.1 .

478. Zoals eerder is aangegeven heeft het verbod een belangrijkere functie wanneer het gaat om handelingen van de lidstaten. Ook daarbij zijn de doelstellingen van het landbouwbeleid echter van groot ter lang, nu ongelijke behandeling door de lidstaten voor het realiseren van deze doelstellingen vask nado lig is.

479. Daarnaast is eerder in dit hoofdstuk aangegeven dat dit gelijkheidsbeginsel in de loop van de tijd ent meer fundamenteel karakter heeft gekregen, vooral door instellingen als het Unieburgerschap (pangraaf 1.1). In de meeste arresten over dit onderwerp speelt het verwezenlijken van een vrij verkeer tussen de lidstaten echter nog steeds de hoofdrol.

480. Zie de paragrafen 2.1 .1 en 2.1.3. 
gebied van de landbouw in de meeste gevallen een methodiek waardoor het met een minimum aan motivering tot de gewenste uitkomst kan komen. Belangrijk is bovendien dat de toetsingsmethodiek op het gebied van de landbouw minder afwijkt van het bij de andere verboden gehanteerde model dan wellicht zou kunnen worden verondersteld. Zo houdt het ontbreken van de vergelijkbaarheidstoets bij het verbod van ongelijke behandeling op grond van geslacht en nationaliteit vooral verband met het feit dat het toetsingsmodel betrekking heeft op indirect onderscheid: zoals eerder is aangegeven heeft het bij die vorm van onderscheid nauwelijks zin om gebruik te maken van een vergelijkbaarheidstoets. Verder blijkt het in landbouwzaken gehanteerde rechtvaardigingsmodel niet zozeer af te wijken van de bij de beide andere verboden gehanteerde modellen, maar is het vooral minder nauwkeurig uitgewerkt: net als bij de overige verboden van onderscheid onderzoekt het Hof of er een redelijk doel wordt nagestreefd en gaat het na of er aan de keuze voor een bepaalde classificatie willekeurige overwegingen ten grondslag hebben gelegen.

Hoewel de verschillen in achtergrond en functie van een bepaald verbod van ongelijke behandeling een belangrijke invloed kunnen hebben op de uitkomst van de toetsing, kan dan ook worden vastgesteld dat zij niet van doorslaggevende betekenis zijn voor de methodiek die wordt gehanteerd om deze uitkomst te bereiken. ${ }^{481}$ Dit is van bijzonder belang, omdat hierdoor de theoretische veronderstelling wordt bevestigd dat het mogelijk is om een toetsingsmodel te ontwikkelen dat de rechter op uiteenlopende gebieden van het recht houvast kan bieden. Bij deze conclusie moet echter een aantal kanttekeningen worden geplaatst.

Allereerst blijkt de achtergrond van het verbod van ongelijke behandeling wel degelijk van betekenis te kunnen zijn voor de vraag welke doelstellingen als gerechtvaardigd worden geaccepteerd en voor de criteria die bij de beoordeling van die gerechtvaardigdheid worden gehanteerd. Zo is gebleken dat puur economische doelstellingen op het gebied van het vrije verkeer nooit een ongelijke behandeling kunnen rechtvaardigen, terwijl een doelstelling met een economisch karakter bij horizontaal onderscheid op grond van geslacht juist vereist lijkt te zijn. Verder is gebleken dat het Hof voor het vrije dienstenverkeer een criterium heeft ontwikkeld dat is toegesneden op de bijzondere problematiek die daarbij een rol speelt, terwijl het ook bij indirect onderscheid op het gebied van binnenlandse belastingen bijzondere eisen aan de rechtvaardiging blijkt te stellen. ${ }^{42}$ Dergelijke criteria zijn niet voor algemene toepassing vatbaar, maar hebben voor het gebied waarvoor zij ontwikkeld zijn een belangrijke betekenis. Het lijkt dan ook noodzakelijk om in het algemene toetsingsmodel voldoende ruimte te laten voor het gebruik van dit soort criteria. In paragraaf 4.1.4 zal hierop nader worden ingegaan.

Een tweede kanttekening houdt verband met de rechtspraak van het Hof over het in artikel 90 EG neergelegde verbod van onderscheid. Hoewel deze bepaling geen ruimte

481. Wel is het verschil in achtergrond en functie van betekenis voor de intensiteit van de toetsing, waardoor de uitkomst van de toetsing in belangrijke mate wordt bepaald. Hierop zal in paragraaf 4.2 nader worden ingegaan.

482. Zie hiervoor de paragrafen 2.3 .3 en 2.3 .4 , waarin de specifieke problematiek en de daarbij gekozen criteria zijn besproken. 
laat voor de beoordeling van een eventuele rechtvaardiging bij direct onderscheid, heeft het Hof ook hierbij een concept van indirect onderscheid ontwikkeld, waarbij wel een rechtvaardigingsmogelijkheid is aangenomen. Het zou in de lijn der verwachting liggen dat daarbij gebruik zou worden gemaakt van een toetsingsmodel dat in grote lijnen identiek is aan de eerdergenoemde modellen. Dit is op het eerste gezicht ook inderdaad het geval, hoewel het model eerder lijkt op het algemene willekeursmodel dat bij de landbouw wordt gehanteerd dan op het uitgebreide en genuanceerde rechtvaardigingsmodel bij de andere discriminatieverboden. Het Hof blijkt bij de toetsing aan dit model echter een heel andere insteek te kiezen dan bij de overige verboden. Waar normaal gesproken wordt onderzocht of er uit de door de verweerder aangevoerde argumenten een gerechtvaardigd doel kan worden afgeleid, gaat het Hof bij artikel 90 vooral na of het onderscheid is ingegeven door protectionistische overwegingen. Pas als duidelijk is dat dit niet het geval is wordt nagegaan of de door de verwerende regering aangevoerde doelstellingen het onderscheid kunnen rechtvaardigen; daarbij wordt dan een soort algemene willekeurstoets uitgevoerd.

Hoewel de rechtspraak over dit artikel in duidelijkheid veel te wensen overlaat ${ }^{\text {to }}$ en het verschil met het gebruikelijke toetsingsmodel niet bijzonder groot is, wordt door deze afwijkende benadering opnieuw bevestigd dat de specifieke aard van het verbod soms een bijzondere toetsingsmethodiek nodig kan maken. Voor dit soort bijzondere verboden van onderscheid zou in het algemene toetsingsmodel dan ook een afwijkingsmogelijkheid moeten worden geboden. Daarbij dient echter voorop te worden gesteld dat alleen kan worden afgeweken als er sprake is van dwingende omstandigheden en als een dergelijke afwijking voldoende kan worden gemotiveerd: gezien het belang van een eenduidig en helder toetsingsmodel is het van belang dat hiervan niet al te licht wordt afgeweken.

\subsubsection{Horizontale en verticale verhoudingen: gevolgen voor de toetsingsmethodiek}

Uit de bestudeerde rechtspraak is gebleken dat zowel in horizontale als in verticale verhoudingen een beroep kan worden gedaan op het verbod van ongelijke behandeling op grond van geslacht en nationaliteit. ${ }^{44}$ Of dit ook het geval is bij de landbouw is niet geheel duidelijk, omdat het Hof zich hierover tot nu toe nog niet uit heeft hoeven spreken. Aangezien het verbod van ongelijke behandeling in het landbouwrecht vooral een functie heeft als beginsel van behoorlijk bestuur, zal hierop in horizontale verhoudingen ook niet snel een beroep worden gedaan. ${ }^{\text {ss }}$

In het licht van het ontwikkelen van een algemeen bruikbaar toetsingsmodel is het van bijzonder belang dat er in de door het Hof gehanteerde toetsingsmethodiek nawwelijks verschil bestaat tussen de toepassing in horizontale en verticale situaties. Het Hof heeft

483. Zo is er in de literatuur zelfs nog discussie over de vraag welke benadering het Hof nu precies hantert: hoewel de opvatting dat het Hof allereerst nagaat of er sprake is van een protectionistische bedocling het meest voor de hand lijkt te liggen en de beste verklaring vormt voor de (schijnbaar) inconsistente rechtspraak van het Hof, is dit zeker niet de enige mogelijke verklaring. Zie daarover vooral Denus: so/Denton 1990, p. 68-70 en de in paragraaf 2.3.4 genoemde literatuur.

484. Zie paragraaf 1.3 .

485. Bij artikel 90 is horizontale werking zeer onwaarschijnlijk, nu het steeds de overheid zal zijn die vetantwoordelijk is voor het instellen van binnenlandse belastingen. 
impliciet ook aangegeven geen behoefte te hebben aan het maken van een dergelijk onderscheid naar rechtsverhouding: hoewel het zijn toetsingsmodel aanvankelijk heeft ontwikkeld voor onderscheid op grond van nationaliteit (waarbij het meestal gaat om verticale verhoudingen) heeft het ditzelfde model in een later stadium tot uitgangspunt genomen in de rechtspraak over onderscheid op grond van geslacht (waarbij er in de praktijk meestal sprake blijkt te zijn van horizontale verhoudingen) ${ }^{486}$ Kleine verschillen zijn in de rechtspraak over onderscheid op grond van nationaliteit en geslacht hoogstens zichtbaar bij de toetsing van het doel: de criteria die het Hof hanteert voor horizontaal onderscheid zijn daarbij iets anders dan de voor verticaal onderscheid vastgestelde maatstaven. ${ }^{487}$

Hoewel uit het voorgaande kan worden afgeleid dat het niet nodig is om twee aparte toetsingsmodellen op te stellen voor onderscheid in horizontale en verticale verhoudingen, lijkt het zinvol om in het algemene toetsingsmodel ruimte te verschaffen om rekening te houden met de specifieke verschillen tussen de beide verhoudingen. Een dergelijke ruimte voor differentiatie lijkt met name nuttig bij de beantwoording van de vraag naar de aanwezigheid van een gerechtvaardigd doel; hieraan zal in paragraaf 4.1.4 nader aandacht worden besteed.

\subsubsection{Toetsing in de eerste fase: vergelijkbaarheid en benadeling}

\section{Vergelijkbaarheid}

De vergelijkbaarheidstoets wordt door het Hof voornamelijk gebruikt bij de toetsing aan het verbod van ongelijke behandeling op het gebied van de landbouw. Het Hof heeft daarbij een aantal criteria ontwikkeld die dienstig kunnen zijn voor het bepalen van de relevantie van de verschillen tussen de voorgelegde gevallen en die blijken te variëren naar gelang de context van de voorgelegde zaak. Verschillende van deze criteria zijn duidelijk gericht op de specifieke omstandigheden in de landbouw en zijn zodanig van aard dat een toepassing vrijwel altijd zal leiden tot de conclusie dat er sprake is van onvergelijkbare gevallen. ${ }^{488}$ Het is duidelijk dat een dergelijke specifieke invulling van de vergelijkbaarheidstoets zich niet leent voor een toepassing op andere gebieden dan de landbouw. Het Hof heeft echter ook een aantal criteria vastgesteld die zich beter voor een algemene toepassing lenen. In de meeste gevallen neemt het Hof tot uitgangspunt dat bij de beoordeling van de relevantie van verschillen en overeenkomsten het doel van de regeling als vergelijkingsmaatstaf dient. Deze doelstelling wordt bovendien soms inhoudelijk getoetst op zijn objectiviteit en redelijkheid. Ook in de schaarse gevallen waarin het Hof zich in het kader van indirect onderscheid op grond van geslacht en nationaliteit uitspreekt over de vergelijkbaarheid zijn dit de gebruikelijke beoordelingscriteria.

486. Dit blijkt overigens niet zozeer uit de arresten van het Hof zelf als wel uit conclusies van de Advocaten-Generaal; zie bijv. A-G Warner in zijn conclusie bij het arrest Jenkins (EHvJ 31 maart 1981, zaak $96 / 80$, Jurispr. 1981,911, op p. 937). Zie over dit onderwerp paragraaf 1.3 van dit hoofdstuk.

487. Zie paragraaf 2.3.1.

488. Zoals door de cumulatie van de vereisten dat twee producten met elkaar moeten concurreren, dat zij binnen dezelfde marktordening moeten vallen en dat zij bovendien binnen deze marktordening een vergelijkbare functie moeten hebben. 
De beoordeling van de vergelijkbaarheid heeft door de hiervoor geschetste benaderingswijze een vrij objectief karakter en wordt in de meeste gevallen goed gemotiveerd. Toch is het niet wenselijk of noodzakelijk om van de vergelijkbaarheidstoets gebruik te maken. De belangrijkste reden om het gebruik van een vergelijkbaarheidstoets onwen. selijk te achten is inmiddels verschillende malen naar voren gebracht. Het uitvoeren van een vergelijkbaarheidstoets in de eerste fase is bijzonder problematisch wanneer twee gevallen niet vergelijkbaar worden bevonden en uit die onvergelijkbaarheid zonder meer de conclusie wordt getrokken dat het onderscheid toelaatbaar is. Bij een dergelijke benadering wordt alleen gekeken naar de relevantie van de verschillen tussen de gevallen in het licht van het nagestreefde doel; de verhouding tussen dit doel en de door de discriminatoire regeling aangetaste belangen blijft buiten beschouwing. Dit kan in veel gevallen nadelig zijn voor de individuele klager, hetgeen treffend wordt geillustreerd door de jurisprudentie van het Hof. Een goed voorbeeld vormen de eerder besproken Kerstboterzaken ${ }^{4 \mathrm{~s}}$, die betrekking hadden op een bijzondere steunregeling voor boter. Als gevolg van deze regeling konden boterproducenten hun producten in de kerstperiode zeer goedkoop op de markt brengen. Margarine, een in het normale gebruik duidelijk concurrerend product, werd niet gesubsidieerd, waardoor de margarineproducenten een concurrentienadeel ondervonden en bijzonder veel schade leden. Het Hof kwam, onder andere op grond van de indeling van beide producten in verschillende marktordeningen, tot het oordeel dat margarine en boter zich niet in een vergelijkbare positie bevonden, zodat het toelaatbaar was om het ene product wel en het andere niet te subsidiëren. Gezien de omvang van het nadeel dat de margarineproducenten ondervonden lijkt de vraag echter gerechtvaardigd of het onderscheid ook de in het rechtvaardigingsmodel opgenomen proportionaliteitstoets zou hebben doorstaan.

Ook de stelling dat het niet noodzakelijk is om een vergelijkbaarheidstoets uit te voeren kan aan de hand van de jurisprudentie van het Hof worden onderbouwd. Zo blijkt uit de landbouwrechtspraak dat het Hof niet altijd gebruik maakt van de vergelijkbaarheidstoets, ondanks het feit dat deze toets bij dit verbod een vast bestanddeel van de toetsingsmethodiek vormt. ${ }^{40}$ Van belang is verder dat de criteria die het Hof heeft ontwikkeld voor het vaststellen van de vergelijkbaarheid duidelijke overlap vertonen met de verschillende elementen van het rechtvaardigingsmodel: bij beide toetsen wordt immers nagegaan welk doel door de betrokken regeling wordt nagestreefd en wordt beoordeeld of het gemaakte onderscheid in het licht van dit doel relevant is. Hoe sterk deze overlap is kan blijken uit het feit dat er verschillende voorbeelden zijn te vinden van zaken waarbij de Advocaat-Generaal in zijn conclusie gebruik maakte van de vergelijkbaarheidstoets, terwijl het Hof het rechtvaardigingsmodel hanteerde. In deze zaken kwamen zij niet alleen tot dezelfde uitkomst, maar maakten zij ook gebruik van sterk vergelijkbare argumenten. ${ }^{411}$ De vergelijkbaarheidstoets heeft als toetsingsingang dan ook geen bijzondere toegevoegde waarde.

489. EHvJ 11 maart 1987, gev, zaken 279, 280, 285 en 286/84, Walter Rau Lebensmittehwerke, Jurispt. 1987, 1069 en EHvJ 11 maart 1987, zaak 265/85, Van den Bergh e.a., Jurispr. 1987, 1155.

490. In de meeste gevallen waarin de vergelijkbaarheidstoets achterwege wordt gelaten gaat het om zaket waarin een overtuigende rechtvaardiging is aangevoerd en waarbij het relatief gemakkelijk is om vis de rechtvaardigingstoets tot een goed resultaat te komen. Deze benadering van het Hof is bijzonder pratmatisch en methodologisch niet zo fraai.

491. Zie Barents 1994 (II), p. 534-537. Daarbij is overigens van belang dat dit alleen maar mogelijk w3 
Terecht kan worden opgemerkt dat de vergelijkbaarheidstoets op het gebied van de landbouw vaak leidt tot een zorgvuldigere toetsing en een betere motivering dan de toepassing van de rechtvaardigingstoets; daarin zou een argument kunnen worden gevonden voor het uitvoeren van een vergelijkbaarheidstoets. De betere motivering lijkt echter vooral verband te houden met de wijze waarop het Hof aan de rechtvaardigingstoets vorm heeft gegeven: deze toets is veel minder goed uitgewerkt dan de toetsingsmodellen bij andere verboden en komt neer op een nogal grove willekeurstoets. Wanneer het meer gebruikelijke en beter uitgewerkte toetsingsmodel zou worden toegepast, is het waarschijnlijk dat zowel de inhoud als de motivering van de rechtvaardigingstoets een ander uiterlijk zouden krijgen. Uit deze rechtspraak van het Hof kan dan ook zeker niet worden afgeleid dat de vergelijkbaarheidstoets per definitie leidt tot een betere formulering.

Eerder in dit hoofdstuk en in hoofdstuk 2 is gewezen op de belangrijke functie die de vergelijkbaarheidstoets als toetsingsingang kan hebben voor de verdeling van de bewijslast. Pas wanneer de eiser voldoende duidelijk heeft aangetoond dat er sprake is van vergelijkbare situaties, en hij dus recht van klagen heeft, zal van de verwerende partij worden verwacht dat deze het gemaakte onderscheid met inhoudelijke argumenten rechtvaardigt. Wanneer vergelijkbaarheid zonder meer zou worden verondersteld en meteen zou worden overgegaan tot een toetsing van de rechtvaardiging, zou de balans in de bewijsposities van eiser en verweerder worden doorbroken: terwijl de eiser in dat geval alleen maar hoeft te stellen dat er sprake is van een ongelijke behandeling, zal de verweerder steeds inhoudelijke argumenten ter rechtvaardiging aan moeten voeren. Dit zou leiden tot een onredelijk zware bewijspositie voor de verweerder en, naar alle waarschijnlijkheid, tot een problematisch groot aantal rechtszaken over ongelijke behandeling.

Het Hof heeft in zijn rechtspraak echter gebruik gemaakt van één van de in hoofdstuk 2 reeds genoemde alternatieven voor de vergelijkbaarheidstoets: het criterium van benadeling. ${ }^{42}$ De wijze waarop aan dit criterium vorm is gegeven is eerder in dit hoofdstuk uitgebreid besproken en komt er, kort gezegd, op neer dat de eiser aan zal moeten tonen dat hij daadwerkelijk is benadeeld ten opzichte van een andere persoon of groep. ${ }^{493}$ Pas wanneer dit is vastgesteld is het de verplichting van de verwerende partij om argumen-

doordat het Hof bij de toepassing van het rechtvaardigingsmodel in landbouwzaken niet aan vereisten als geschiktheid, noodzakelijkheid en proportionaliteit toetst. Als dit wel het geval zou zijn, zou de uitkomst wellicht een andere zijn geweest.

492. Zie hoofdstuk 2, paragraaf 4.4.4. Het Hof heeft dit benadelingsvereiste vooral toegepast bij indirect onderscheid op grond van nationaliteit en geslacht, maar uit een beperkt aantal arresten op het gebied van de landbouw blijkt dat het ook bij direct onderscheid als alternatief voor de vergelijkbaarheidstoets wordt gekozen.

493. Opvallend is ook dat in de richtlijnen ter uitwerking van artikel 13 EG eveneens gebruik maakt van de benadelingsterminologie en niet van de vergelijkbaarheidstoets. In beide richtlijnen wordt aangegeven dat er sprake is van onderscheid wanneer een bepaalde persoon "minder gunstig" of "ongunstiger" wordt behandeld; deze terminologie wordt zowel bij direct als bij indirect onderscheid gehanteerd. Zie artikel 1 van de algemene kaderrichtlijn (RI. 2000/78/EG van de Raad van 27 november 2000 tot instelling van een algemeen kader voor gelijke behandeling in arbeid en beroep, Pb. EG $2000 \mathrm{~L} \mathrm{303/16)}$ en artikel I van de rassenrichtlijn (RI. 2000/43/EG van de Raad van 29 juni 2000 houdende toepassing van het beginsel van gelijke behandeling van personen ongeacht ras of etnische afstamming, $\mathrm{Pb}$. EG 2000 L 180/22). 
ten ter rechtvaardiging van de benadeling aan te voeren. Het voordeel van dit benadelingsvereiste is dat het een feitelijke en goed controleerbare toetsing blijkt op te leve. ren. Anders dan bij de vergelijkbaarheidstoets bestaat er bovendien maar weinig ruimte om subjectieve overwegingen en ingeslepen vooroordelen mee te laten wegen in de toetsing. Een voordeel van dit criterium is verder dat het bij alle vormen van onderscheid bruikbaar is: hoewel in de rechtspraak van het Hof meestal gebruik van het criterium wordt gemaakt bij indirect onderscheid, blijkt uit enkele arresten over het landbouwrecht en over artikel 12 EG dat het ook toepasbaar is bij direct onderscheid. Bovendien kan het benadelingsvereiste zowel bij materieel als bij formeel onderscheid worden toegepast: de oorzaak van de benadeling is bij beide vormen weliswaar verschillend (een gelijke behandeling bij materieel onderscheid, een ongelijke behandeling bij formeel onderscheid), maar de eiser zal hierbij steeds kunnen (en moeten) aantonen dat hij door de betrokken regeling nadeel heeft ondervonden ten opzichte van een andere persoon of groep.

\section{Definitie van de groepen waartussen een benadeling kan worden vastgesteld}

Een belangrijk probleem dat steeds een rol zal spelen bij de vaststelling van benadeling is reeds aan de orde gekomen in het kader van de bespreking van de vergelijkbaarheidstoets bij artikel 90 EG. ${ }^{94}$ Daarbij is vastgesteld dat de definitie van de groepen waartussen moet worden vergeleken van doorslaggevende betekenis kan zijn voor de uitkomst van de toetsing in de eerste fase. Deze definitie vindt vaak ongemerkt plaats, terwijl het bovendien vaak onduidelijk is welke overwegingen daarbij een rol hebben gespeeld. ${ }^{49}$ Dezelfde problematiek van het definiëren van groepen zal zich voordoen bij het vaststellen van een benadeling, nu daarbij moet worden bepaald of de eiser een nadeliger behandeling ten deel is gevallen dan een andere persoon of groep. ${ }^{4 \%}$ Het Hof heeft zich hierover zelden uitgelaten, zodat het lastig is om aan de hand van de rechtspraak algemene criteria vast te stellen die de rechter bij deze definitie behulpzaam kunnen zijn. ${ }^{47}$ Gezien het belang dat de omschrijving van de groepen heeft voor de uitkomst van de toetsing aan het benadelingsvereiste - en daarmee voor de uitkomst van de procedure -, kan in ieder geval worden vereist dat de rechter duidelijk en overtuigend motiveert op welke manier de relevante groepen dienen te worden gedefinieerd.

494. Zie paragraaf 2.2.4.

495. Meestal zal de rechter zonder meer uitgaan van de definitie zoals die door de eiser is gegeven, tenzij] die uitdrukkelijk door de verwerende partij is betwist.

496. Voorbeelden daarvan zijn in de literatuur regelmatig gegeven bij bespreking van de rechtspraak over onderscheid op grond van geslacht. Interessant is bijvoorbeeld of bij de vraag of door onderscheid op grond van het aantal werkuren vrouwen worden benadeeld ten opzichte van mannen moet worden gekeken naar het relatieve aandeel van in deeltijd werkende vrouwen in een geheel bedrijf, in bepalde afdelingen, in bepaalde beroepssectoren of zelfs op de gehele arbeidsmarkt. Zie hierover 0.a Herbet 1994, p. $122 / 123$.

497. Op de wijze waarop de groepen moeten worden gedefinieerd zal verder niet worden ingegaan, nu het hierbij gaat om een zeer ingewikkelde problematiek die het bestek van dit onderzoek te buiten gat Verwezen kan echter worden naar eerder onderzoek dat over dit onderwerp verricht is en waarin word verwezen naar relevante rechtspraak en literatuur; zie vooral Leenders 1997, p. 292-307. 
Nauw verbonden met de definitieproblematiek is de vraag of in het kader van de benadelingstoets moet worden onderzocht of de betrokken groepen zich in een vergelijkbare positie bevinden. Zoals eerder in dit hoofdstuk is aangegeven heeft het Hof deze eis slechts zelden gesteld. ${ }^{498}$ Een dergelijk onderzoek is ook niet wenselijk, omdat daardoor de aan de vergelijkbaarheidstoets verbonden nadelen toch weer in de toetsing worden ingevoerd. Ook is het gebruik van een vergelijkbaarheidselement niet noodzakelijk voor het bewerkstelligen van evenwicht in de bewijslastverdeling: wanneer een eiser heeft aangetoond dat hij benadeeld wordt ten opzichte van een groep die zich in een duidelijk andere positie bevindt, is het waarschijnlijk erg gemakkelijk om de ongelijke behandeling te rechtvaardigen. ${ }^{49}$ Wanneer de groepen waartussen de benadeling moet worden vastgesteld eenmaal zijn gedefinieerd kan dan ook meteen worden overgegaan tot een rechtvaardigingstoets, zonder dat het nodig is om nader aandacht te besteden aan de vergelijkbaarheid.

\section{Bewijs van benadeling}

Wanneer de relevante groepen voldoende duidelijk zijn gedefinieerd moet worden beoordeeld of er op basis van de aangevoerde gegevens een benadeling kan worden vastgesteld. ${ }^{500}$ Opmerkelijk genoeg heeft het Hof het begrip "benadeling" nooit duidelijk gedefinieerd. Het lijkt er echter op dat een benadeling kan worden aangenomen in alle gevallen waarin kan worden aangetoond dat een persoon of groep op enigerlei wijze is achtergesteld ten opzichte van een andere groep of persoon. Dit lijkt een redelijke benadering, die zowel ruimte laat voor het vaststellen van een duidelijk meetbare benadeling (zoals een verschil in beloning) en van achterstelling op sociaal of economisch vlak, als voor het vaststellen van een minder tastbare, meer moreel getinte benadeling.

De uitkomst van de toetsing aan het benadelingscriterium is in sterke mate afhankelijk van de eisen die aan het bewijs van benadeling worden gesteld. Zoals eerder is aangegeven zijn de door het Hof gestelde eisen vooral bij onderscheid op grond van geslacht bijzonder streng. Een benadeling zal volgens deze rechtspraak steeds moeten worden aangetoond aan de hand van feitelijke, bij voorkeur statistische gegevens. ${ }^{501}$ Er lijkt hierbij geen ruimte te bestaan voor het aantonen van een benadeling aan de hand van feiten van algemene bekendheid of op basis van op logica gebaseerde veronderstellin-

498. Zie paragraaf 2.2.1, waarin het arrest Gruber is besproken (EHvJ 14 september 1999, zaak C-249/97, Jurispr. 1999, 1-5295) en paragraaf 2.2.3, waarin het arrest Commissie/Italie (effectenbemiddelaars) aan de orde is gekomen (EHvJ 6 juni 1996, zaak C-101/94, Jurispr. 1996, 1-296). Ook bij onderscheid op grond van nationaliteit lijkt daarvan een voorbeeld te vinden te zijn, maar bij nauwkeurige bestudering van het arrest kan worden vastgesteld dat het daarin eigenlijk om een benadelingstoets gaat; zie de bespreking van Sotgiu (EHvJ 12 februari 1974, zaak 152/73, Jurispr. 1974, 153) in paragraaf 2.2.3.

499. Dit betekent dat een dergelijke, tamelijk soepele invulling van de benadelingstoets ook niet problematisch is voor de bewijslastverdeling: het zal in dit soort gevallen gemakkelijk zijn om een rechtvaardiging aan te tonen, zodat de bewijslast van de verwerende partij goed is te overzien.

500. In sommige gevallen, wanneer alleen onderscheid op bepaalde gronden is verboden of bij indirect onderscheid, zal bovendien moeten worden aangetoond dat de benadeling op een bepaald differentiatiecriterium is terug te voeren.

501. Waarbij bovendien nog de eis wordt gesteld dat er statistisch gezien "een veel groter" percentage vrouwen dan mannen door de regeling wordt benadeeld. 
gen over de effecten van een bepaalde maatregel. De bij onderscheid op grond van nationaliteit aan het bewijs van benadeling gestelde eisen zijn beduidend minder zwaar. het Hof acht het daarbij meestal al voldoende dat een bepaling een benadelend effect $k a n$ hebben of wanneer kan worden verondersteld dat er van een benadeling sprake is. Het is niet eenvoudig om aan te geven welke benadering het beste is. Het zal in lang niet alle gevallen van onderscheid mogelijk zijn om relevante statistische gegevens te vinden, terwijl bovendien kan worden aangenomen dat dergelijke gegevens niet altijd noodzakelijk zijn om een benadeling aan te tonen: met name in evidente gevallen van benadeling, zoals in gevallen van direct onderscheid, zou het vereisen van statistische gegevens een overbodige en zware bewijslast opleveren. Tegelijkertijd kan het evenwicht in de bewijslastverdeling ook worden verstoord wanneer een benadeling altijd alleen maar hoeft te worden gebaseerd op veronderstellingen en feiten van algemene bekendheid: dit kan al snel leiden tot een subjectief gekleurd en moeilijk controleerbaar oordeel, terwijl dat nu juist vermeden moet worden.

De redenen om bij geslacht strenge eisen te stellen en bij nationaliteit juist niet zijn in de rechtspraak van het Hof nooit duidelijk tot uitdrukking gebracht, zodat het niet mogelijk is om uit deze jurisprudentie aanknopingspunten af te leiden voor het stellen van meer algemeen bruikbare eisen aan het bewijs van benadeling. Op zichzelf kan wel worden gesteld dat de intensiteit van de toetsing hierop enige invloed mag hebben. In hoofdstuk 2 is aangegeven dat een strenge toetsing vooral gerechtvaardigd is wanneer er twijfel zou kunnen bestaan over de zorgvuldigheid van het besluitvormingsproces of over de redelijkheid van de overwegingen die bij het maken van onderscheid een rol hebben gespeeld. Wanneer een dergelijke twijfel gerechtvaardigd is zal het sneller noodzakelijk kunnen worden geacht om de rechtvaardiging voor het onderscheid zorgvuldig te beoordelen, zodat de eisen die in de eerste fase van de toetsing worden gesteld iets minder hoog kunnen zijn. Andersom zal een rechtvaardiging niet te licht mogen worden gevergd wanneer er een marginale toetsing wordt uitgevoerd: in dergelijke gevallen kan in beginsel worden verondersteld dat het gemaakte onderscheid niet onredelijk is. In die gevallen kunnen er dan ook hogere eisen worden gesteld aan het bewijs van benadeling in de eerste fase.

Met die benadering is echter nog geen antwoord gegeven op de vraag aan welke eisen het bewijs van benadeling bij een terughoudende of intensieve toetsing nu precies zou moeten voldoen. Het lijkt er op dat een eenduidig antwoord op die vraag ook niet kan worden gegeven. De middelen om een benadeling aan te tonen zijn daarvoor te zeer afhankelijk van de omstandigheden van het geval: wanneer er sprake is van een verschillende beloning van werknemers in dezelfde functie kan de benadeling al door het verschil in de hoogte van de beloning worden aangetoond, in andere gevallen is het vereisen van statistische gegevens redelijk en (relatief) gemakkelijk, terwijl in gevallen als dat van moreel nadeel een overtuigende argumentatie vaak het enige geschikte bewijsmiddel zal zijn. Voorlopig kan dan ook tot uitgangspunt worden genomen dat er geen vastomlijnde en algemeen geldende eisen aan het bewijs van benadeling kunnen worden gesteld. ${ }^{\mathrm{so2}}$ Dit betekent dat het vooral aan de discretie van de rechter zal moeten

502. Het lijkt er op dat dit ook de mening is van de Europese instellingen. In de toelichting bij haar vourstel voor de algemene kaderrichtlijn ter uitwerking van artikel 13 EG (RI. 2000/78/EG van de Raad van 27 november 2000 tot instelling van een algemeen kader voor gelijke behandeling in arbeid en berocp, Pb. 
worden overgelaten hoe hij het aangedragen bewijs waardeert. ${ }^{\text {sus }}$ Wel moet daarbij worden vereist dat de rechter duidelijk aangeeft welke concrete eisen hij stelt en zijn keuze daarvoor voldoende motiveert. Gezien zijn ruime discretie kan immers alleen op die manier voldoende rechtszekerheid en voorspelbaarheid worden gewaarborgd. Daarnaast kan van de rechter worden verlangd dat hij alle omstandigheden van het geval in zijn oordeel over de aanwezigheid van een benadeling betrekt. Dit betekent dat hij niet alleen rekening zal moeten houden met de nadelen die door de eiser naar voren zijn gebracht, maar ook met eventuele voordelen die dit nadeel compenseren..$^{304}$ Ook in dit opzicht is een goede motivering van bijzonder belang.

\section{Mate van benadeling; relevantie}

Wanneer is aangetoond dat er sprake is van een benadeling is dit volgens het Hof nog niet voldoende om hiervoor een rechtvaardiging te vereisen: de eiser zal daarnaast moeten aantonen dat de benadeling voldoende ernstig is. Zo wordt bij onderscheid op grond van geslacht in de meeste gevallen vereist dat door de betrokken regeling een veel groter percentage vrouwen dan mannen (of mannen dan vrouwen) wordt benadeeld. Hoewel het niet onredelijk lijkt om te vereisen dat een benadeling voldoende ernstig is, kunnen er ook voor de mate waarin daarvan sprake moet zijn geen eenduidige criteria worden vastgesteld. ${ }^{\text {sos }}$ Zeker bij morele benadeling zou het stellen van eisen aan de mate van benadeling bovendien kunnen leiden tot uitspraken die sterk zijn geïnspireerd door subjectieve overwegingen. Ook bij de beoordeling van de benodigde mate van benadeling moet de rechter dan ook de nodige ruimte worden gelaten, waarbij vanzelfsprekend opnieuw de eis geldt dat de gemaakte keuze voldoende wordt gemotiveerd.

Een laatste vereiste dat uit de rechtspraak van het Hof naar voren komt is dat de benadeling daadwerkelijk relevant moet zijn in het licht van het voorwerp van het geschil. ${ }^{\text {.06 }}$ Dit lijkt een redelijk en logisch vereiste te zijn dat zonder meer in het algemene model kan worden opgenomen. Wel kan daarbij worden aangetekend dat het niet altijd noodzakelijk is om uitdrukkelijk aandacht aan dit vereiste te besteden. Gesteld zou kunnen worden, dat dit alleen het geval is wanneer de verweerder aannemelijk weet te maken

EG $2000 \mathrm{~L}$ 303/16) heeft de Commissie aangegeven dat bij het beoordelen of er sprake is van indirect onderscheid gebruik kan worden gemaakt van statistisch bewijsmateriaal "of van elk ander middel dat aantoont dat een bepaling vanwege haar aard zelf nadelig is voor de betrokken perso(o)n(en)" (COM (1999) 565 def, p. 9). Hieruit blijkt dat ook de Commissie de rechter ruimte heeft willen laten om te beoordelen welke eisen in een specifiek geval het meest geschikt zijn.

503. Hierbij moet bovendien ruimte worden gelaten voor een eventuele omkering van de bewijslast in gevallen waarin het voor de eiser moeilijk is om een benadeling aan te tonen, als gevolg van omstandigheden die aan de verwerende partij zijn te verwijten.

504. Vgl. hiervoor het in paragraaf 2.2 .3 besproken arrest Sotgiu, waaruit naar voren komt dat een dergelijke volledige beoordeling van doorslaggevende betekenis kan zijn voor de uitkomst van de benadelingstoets (EHvJ 12 februari 1974, zaak 152/73, Jurispr. 1974, 153).

505. Hetgeen ook door het Hof zelf erkend is: aanvankelijk stelde het steeds de eis dat er sprake moest zijn van benadeling van een "zeer groot percentage" vrouwen, maar later heeft het aangenomen dat ook een minder duidelijk, maar aanhoudend en vrij constant verschil voldoende kan zijn om van een benadeling te kunnen spreken (zie paragraaf 2.2.1).

506. Zie voor een voorbeeld van toepassing van het relevantievereiste paragraaf 2.2 .2 . 
dat voldoende relevantie ontbreekt of wanneer dit uit het voorliggende feitencomplex duidelijk naar voren komt.

\subsubsection{Het doel van het onderscheid}

Het vereiste dat door de regeling een gerechtvaardigd doel moet worden nagestreefd is door het Hof bijzonder nauwkeurig uitgewerkt: om een goede en zoveel mogelijk uni. forme toepassing van dit vereiste te verzekeren, heeft het Hof een groot aantal criteria ontwikkeld die de nationale rechter bij zijn toetsing behulpzaam kunnen zijn. Veel van de in dit hoofdstuk besproken criteria van het Hof kunnen een interessante invulling van het algemene toetsingsmodel opleveren.

\section{Doelstelling mag niet inherent discriminatoir zijn}

Van belang is allereerst het vereiste dat de doelstelling van de maatregel niet inherent discriminatoir mag zijn. Dit betekent dat een persoon die tot een bepaalde groep behoort of bepaalde (persoons)kenmerken vertoont niet uitsluitend vanwege die kenmerken of vanwege zijn behoren tot die specifieke groep mag worden achtergesteld. ${ }^{\text {sn }}$ Door een dergelijke doelstelling wordt namelijk vaak bewust of onbewust uitdrukking gegeven aan stereotypen of vooroordelen jegens een bepaalde groep, waardoor stigmatisering wordt bevorderd en bestaande ongelijkheden in stand worden gehouden. Het is redelijk om te stellen dat dergelijke doelstellingen niet gerechtvaardigd kunnen worden geacht.

Dit criterium is in de praktijk echter niet altijd even gemakkelijk toepasbaar, vooral omdat het in veel gevallen niet zonder meer duidelijk zal zijn dat er aan een regeling discriminatoire overwegingen ten grondslag liggen. De verklaringen die voor een onderscheid worden aangedragen zijn meestal vrij gecompliceerd en hebben vaak verschillende aspecten, terwijl in sommige gevallen bovendien zal worden geprobeerd de discriminatoire bedoelingen te verhullen. ${ }^{\text {sor }}$ Het Hof zelf heeft tot nu toe dan ook alleen toepassing aan dit criterium gegeven in evidente gevallen, waarin geen bijzonder diep. gaand onderzoek naar de achterliggende bedoelingen noodzakelijk was.

In het algemene toetsingsmodel zou tot uitgangspunt kunnen worden genomen dat een classificatie niet gerechtvaardigd is wanneer daaraan uitsluitend of vooral overwegin-

507. Dit betekent bijvoorbeeld dat vrouwen niet mogen worden benadeeld om het enkele feit dat zij vrouw zijn, of dat een allochtoon niet anders mag worden behandeld dan een autochtoon om het enkele feit dat hij allochtoon is. Het zal duidelijk zijn dat in de praktijk de overwegingen die aan een ongelijke be handeling ten grondslag liggen meestal genuanceerder en minder expliciet discriminatoir zijn. Van belang is echter dat het Hof, vooral in de rechtspraak over onderscheid op grond van geslacht, heeft aangegeven dat veel schijnbaar neutrale overwegingen een discriminatoire basis hebben en om die reden geen objectieve rechtvaardiging kunnen opleveren. Zo kan een benadeling van vrouwen niet worden gerechtvaardigd op grond van sociologische of demografische gegevens, zoals het feit dat nu cenmal meer mannen dan vrouwen kostwinner zijn of dat nu eenmaal meer vrouwen dan mannen in deeltijd werken: dergelijke overwegingen houden volgens het Hof rechtstreeks verband met het geslacht van de benadeelde en zijn discriminatoir van aard. Ook onderscheid dat wordt gemotiveerd met een beroep op typisch mannelijke of vrouwelijke eigenschappen wordt vaak inherent discriminatoir geacht.

508. Zeker wanneer de ongelijke behandeling niet zozeer is ingegeven door sociologische, demografische of andere relatief neutrale overwegingen, maar door daadwerkelijk discriminatoire motieven dic een uit. drukking vormen van een bewust vooroordeel jegens een bepaalde groep, zal de verantwoordelijke deze overwegingen in veel gevallen proberen te verhullen. 
gen ten grondslag liggen die rechtstreeks verband houden met de grond van onderscheid. Een ongelijke behandeling waaraan dergelijke overwegingen ten grondslag liggen kan alleen toelaatbaar zijn wanneer er daarnaast voldoende andere, wél gerechtvaardigde, doelstellingen ter rechtvaardiging zijn aangevoerd. ${ }^{500}$ De mate waarin onderzoek kan worden gedaan naar de aanwezigheid van een discriminatoire doelstelling kan worden bepaald door de gekozen toetsingsintensiteit: bij een intensieve toetsing kan een vergaand onderzoek worden ingesteld naar de bedoelingen van de verantwoordelijke voor het onderscheid, terwijl bij een marginale toetsing kan worden volstaan met een minder vergaande benadering. In het laatste geval hoeft alleen nader onderzoek te worden verricht wanneer het bestaan van een discriminatoire doelstelling door de eisende partij voldoende aannemelijk is gemaakt of wanneer dit uit het voorliggende feitencomplex duidelijk naar voren komt.

\section{Onderscheid mag niet gebaseerd zijn op té generaliserende uitspraken}

Een tweede uit de rechtspraak van het Hof voortvloeiend vereiste, dat nauw samenhangt met het vorige, houdt in dat een onderscheid niet gebaseerd mag zijn op te generaliserende uitspraken of op vooroordelen jegens een bepaalde groep. Ook aan dit criterium kan zonder meer een plaats worden gegeven in het algemene toetsingsmodel. Het is echter lastig te beoordelen wanneer van generalisering of vooroordelen sprake is. Ten dele zou dit aan de discretie van de rechter kunnen worden overgelaten, maar wellicht kunnen er ook nog nadere criteria worden gevonden om hieraan invulling te geven. In hoofdstuk $7 \mathrm{zal}$ daarop nader worden teruggekomen.

\section{Discriminatoire regeling moet voorzien in een concrete behoefte}

Volgens een derde criterium dat het Hof heeft ontwikkeld en dat voor algemene toepassing bruikbaar lijkt te zijn moet worden aangetoond dat de discriminatoire regeling voorziet in een concrete behoefte. De precieze inhoud die aan dit criterium moet worden gegeven is afhankelijk van de aard van de rechtsverhouding waarin het onderscheid is gemaakt. Voor onderscheid in horizontale verhoudingen is dit vereiste zonder meer bruikbaar. ${ }^{510} \mathrm{Bij}$ onderscheid dat door een wetgever of een bestuursorgaan is gemaakt moet dit criterium echter iets anders worden geformuleerd. Daarbij kan bijvoorbeeld worden vereist dat wordt aangetoond dat door de maatregel duidelijke en concrete beleidsdoelstellingen worden nagestreefd. ${ }^{\text {s" }}$ Dit lijkt een bruikbaarder criterium te zijn dan het nogal ruime vereiste dat de maatregel moet worden gerechtvaardigd door redenen van algemeen belang.

\section{Voorkomen van ernstigere vormen van onderscheid}

Interessant is tenslotte dat het Hof verschillende malen heeft aangegeven dat het voorkomen van ernstigere, meer of duidelijkere vormen van ongelijke behandeling een gerechtvaardigd doel kan opleveren, net als het waarborgen van fundamentele rechten

509. Het is vanzelfsprekend aan de rechter om in het concrete geval te beoordelen of de overige aangevoerde doelstellingen voldoende zwaarwegend zijn om het onderscheid te rechtvaardigen.

510. Zie voor voorbeelden de in paragraaf 2.3 .1 besproken jurisprudentie.

511. Bovendien moeten deze beleidsdoelstellingen zelf legitiem zijn. Zo mogen zij, zoals eerder gesteld, niet inherent discriminatoir zijn en moeten zij in overeenstemming zijn met het positieve recht. 
en beginselen, zoals de grondrechten of het rechtszekerheidsbeginsel. Beide stellingen kunnen aan het algemene toetsingsmodel worden toegevoegd als voorbeelden van gerechtvaardigde doelstellingen.

\section{Ruimte voor bijzondere criteria}

$\mathrm{Al}$ eerder in deze paragraaf is aangegeven dat de verschillen in achtergrond en functie van de verschillende gelijkheidsbepalingen kunnen leiden tot verschillen in de criteria voor de beoordeling of er een gerechtvaardigd doel wordt nagestreefd. Terwijl de hiervoor beschreven criteria toepasbaar lijken te zijn bij alle vormen van onderscheid, geldt dit zeker niet voor een aantal andere criteria die in dit hoofdstuk aan de orde zijn gekomen. Zo is het criterium dat een maatregel het waarborgen van een verantwoorde dienstverlening tot doel moet hebben zeker bruikbaar bij onderscheid op het gebied van de dienstverlening, maar is dit bepaald niet nuttig bij de beoordeling van een ongelijke behandeling van producten op het gebied van de landbouw. Verder is het criterium dat een maatregel niet mag zijn ingegeven door protectionistische overwegingen zonder meer van belang in de context van het verwezenlijken van een vrije handel, maar is dit meestal irrelevant bij onderscheid op grond van geslacht. Hoewel dergelijke criteria niet in het algemene model kunnen worden opgenomen, moet hieraan wel bijzondere waarde worden gehecht: het gebruik van specifieke criteria kan veelal leiden tot een betere en meer inhoudelijke motivering. Om die reden mag de rechter door het opstellen van een algemeen toetsingsmodel niet de mogelijkheid worden ontnomen om bijzondere criteria te ontwikkelen die kunnen worden gehanteerd als aanvulling op de in het model opgenomen algemene criteria. In het uiteindelijke model zal hiervoor voldoende ruimte moeten worden gelaten.

\section{Minder geschikte criteria}

Het Hof heeft tenslotte een criterium ontwikkeld dat minder geschikt lijkt te zijn voor opneming in het algemene toetsingsmodel. Het gaat daarbij om de stelling dat administratieve overwegingen en budgettaire argumenten een onderscheid niet kunnen rechtvaardigen. Zoals eerder is aangegeven (en bovendien ook blijkt uit de rechtspraak van het Hof) is de vraag of dergelijke overwegingen een gerechtvaardigd doel op kunnen leveren in hoge mate afhankelijk van de omstandigheden van het geval. In beginsel moet er dan ook vanuit worden gegaan dat dergelijke doelstellingen als rechtvaardiging kunnen worden geaccepteerd. Vanzelfsprekend geldt bij dit soort doelstellingen wel dat een goede toetsing aan de vereisten van noodzakelijkheid en proportionaliteit vereist is. $^{512}$

512. Hetzelfde geldt voor de - in dit hoofdstuk niet verder besproken - eis dat beperkingen van het vije verkeer nooit kunnen worden gerechtvaardigd door economische doelstellingen. Zie voor dit vereiste o.a. artikel 2 lid 2 van Richtlijn 64/221/EEG van de Raad van 25 februari 1964 betreffende de coôrdinatie van de voor vreemdelingen geldende bijzondere maatregelen ten aanzien van verplaatsing en ver blijf, die gerechtvaardigd zijn uit hoofde van de openbare orde, de openbare veiligheid en de volksge zondheid, Pb. EG (bijzondere editie) 1963-1964, 117. 


\subsubsection{Mate van fit, geschiktheid, noodzakelijkheid en proportionaliteit}

\section{Geschiktheid, subsidiariteit en noodzakelijkheid}

De rechtspraak van het Hof met betrekking tot de verschillende verboden van onderscheid bevestigt dat de rechter niet alleen moet onderzoeken of met een bepaald onderscheid een gerechtvaardigd doel wordt nagestreefd, maar ook of de getroffen maatregelen een redelijk middel vormen om het gestelde doel te bereiken. De geschiktheidsen subsidiariteitstoets die bij de beoordeling van die redelijkheid worden toegepast heeft, blijkens de rechtspraak van het Hof, een sterk feitelijk karakter: de uitkomst van deze toets wordt sterk bepaald door de omstandigheden van het geval en door de gekozen toetsingsintensiteit. Juist de toepassing op de feiten wordt in een groot aantal van de uitspraken van het Hof echter overgelaten aan de nationale rechter, zodat het niet goed mogelijk is om hieruit aanknopingspunten of criteria af te leiden die in het algemene model kunnen worden opgenomen.

Een uitzondering op het voorgaande wordt gevormd door de jurisprudentie over het vereiste van geschiktheid in de landbouw. Het is op dit gebied vaste rechtspraak van het Hof dat bij de beoordeling van de geschiktheid moet worden uitgegaan van de kennis en de gegevens die beschikbaar waren op het moment dat de litigieuze maatregel werd vastgesteld. ${ }^{13}$ Uit het feit dat later duidelijk is geworden dat het beoogde doel niet met de getroffen maatregel kon worden bereikt, mag volgens het Hof niet zonder meer worden afgeleid dat de maatregel ongeschikt is. Een dergelijk uitgangspunt lijkt wellicht redelijk, maar gesteld kan worden dat juist het feit dat het gestelde doel niet is bereikt aanleiding zou kunnen en moeten vormen voor een goed onderzoek naar de redelijkheid van de maatregel. Wanneer de maatregel achteraf gezien kennelijk niet geschikt is voor het bereiken van het gestelde doel heeft deze immers nog maar één duidelijk effect, namelijk een aantasting van individuele belangen. In een dergelijk geval mag van de regelgever worden verlangd dat hij opnieuw naar de regeling kijkt en beziet of deze niet moet worden ingetrokken. Met name wanneer een regeling aan een striktere toetsing wordt onderworpen, lijkt het redelijk om hoge eisen aan de geschiktheid te stellen en niet alleen te kijken naar de stand van zaken ten tijde van het aannemen van de regeling.

Ook in een ander opzicht is de rechtspraak van het Hof over de redelijkheidstoets van belang. Uit de rechtspraak van het Hof kan worden afgeleid dat het een noodzakelijkheidsbegrip hanteert dat breder is dan het tot nu toe steeds gehanteerde begrip subsidiariteit. Waar bij de subsidiariteitstoets onderzoek moet worden gedaan naar de aanwezigheid van minder belastende alternatieven om de betrokken doelstellingen te bereiken, kan bij de noodzakelijkheidstoets zoals die door het Hof wordt gehanteerd worden volstaan met de beoordeling of de maatregel voor het bereiken van het gestelde doel nodig was. ${ }^{514}$ Dit criterium heeft als belangrijk voordeel boven de subsidiariteitstoets dat de rechter niet hoeft na te gaan welke verschillende alternatieven er bestaan en in welke mate deze de betrokken belangen zouden aantasten, maar alleen een algemeen oordeel hoeft te vellen over het nut van de gekozen maatregel. Hoewel het aangewezen

513. Zie hierover paragraaf $2,4.2$ en de daar vermelde rechtspraak.

514. Zie voor een praktische illustratie van het verschil tussen beide criteria paragraaf 2.4.3. 
lijkt om zowel de noodzakelijkheidstoets als de subsidiariteitstoets in het gekozen mo. del op te nemen, kan het vanwege de tussen de beide toetsen bestaande overlap redelijk zijn om de rechter de mogelijkheid te geven om hiertussen een keuze te maken. Daarbij kan als uitgangspunt worden gehanteerd dat er bij een intensieve toets in beginsel een subsidiariteitstoets moet worden uitgevoerd, terwijl bij een marginale toetsing met de algemenere noodzakelijkheidstoets kan worden volstaan. ${ }^{515}$

\section{Proportionaliteit}

Eerder in dit hoofdstuk is gebleken dat het Hof in zijn rechtspraak over het landbouw. recht een breed proportionaliteitsbegrip hanteert. Onder dit begrip vallen zowel de geschiktheids- als de noodzakelijkheidstoets, maar - opvallend genoeg - niet het vereiste van evenredigheid in strikte zin. Ook bij onderscheid op grond van geslacht maakt een toetsing aan het strikte evenredigheidsbeginsel geen vast onderdeel uit van de beoordeling van het Hof. Hieruit kan echter niet zonder meer worden afgeleid dat het Hof het niet noodzakelijk acht om na te gaan of er sprake is van een redelijke verhouding tussen het door een maatregel nagestreefde doel en de daardoor aangetaste belangen: vooral in de rechtspraak over onderscheid op grond van nationaliteit zijn voorbeelden te vinden van arresten waarin wel degelijk aan het strikte evenredigheidsvereiste wordt getoetst, terwijl ook bij het verbod van onderscheid op grond van geslacht en bij het (zelfstandige) evenredigheidsbeginsel in de landbouw sporadisch toepassing aan dit vereiste wordt gegeven. ${ }^{316}$

Met name de rechtspraak over het zelfstandige proportionaliteitsbeginsel in de landbouw is voor de ontwikkeling van een algemeen toetsingsmodel interessant. Eerder in dit hoofdstuk is reeds vastgesteld dat daaruit blijkt dat de evenredigheid op twee niveaus kan worden getoetst: onderzocht kan worden of er in het concreet aan de rechter voorgelegde geval sprake is van een disproportionele belangenaantasting, maar ook kan worden nagegaan of de maatregel in zijn algemeenheid getuigt van een onzorgvuldige belangenafweging. ${ }^{517}$ Zoals eerder is aangegeven hoeft in de meeste gevallen alleen een toetsing op het tweede niveau, dus een algemene proportionaliteitstoets, te worden uitgevoerd. Een concrete toets is alleen noodzakelijk wanneer de ongelijke behandeling is veroorzaakt door een specifieke, op het individuele geval gerichte regeltoepassing of wanneer de eiser aannemelijk heeft kunnen maken dat zijn individuele belangen door een normatieve classificatie onevenredig zwaar zijn aangetast.

515. Hiermee is niet gezegd dat de subsidiariteitstoets per definitie leidt tot een intensievere toets: ook de noodzakelijkheidstoets kan vrij intensief zijn. Het is echter wel zo dat juist de subsidiariteitstoets etn vrij nauwkeurig onderzoek veronderstelt naar de verschillende mogelijke altematieven en daardoot etf aanzienlijke mate van rechterlijk activisme veronderstelt. Een dergelijke actieve opstelling past duidelijk beter bij een intensieve dan bij een marginale toets.

516. Een reden om deze toets achterwege te laten kan worden gevonden in opvattingen over de staatsrechtelijke positie van de rechter: juist de proportionaliteitstoets vergt een vrij vergaande beoordeling van de afwegingen die door de opsteller van de betrokken regeling zijn gemaakt. Dit verklaart echter nikt het ontbreken van een proportionaliteitstoets in horizontale verhoudingen.

517. Zie paragraaf $2,4.2$. 


\section{Mate van fit}

Het vereiste van een voldoende mate van fit tussen het doel van de maatregel en de reikwijdte van de classificatie komt in geen enkele van de door het Hof ontwikkelde toetsingsmodellen met zoveel woorden voor. Ook in de feitelijke toepassing van de toetsingsmodellen wordt zelden aan dit vereiste getoetst, hoewel eerder in dit hoofdstuk enkele voorbeelden zijn gegeven van arresten waarin dit wel is gebeurd. Juist uit deze schaarse arresten kan blijken dat het toetsingselement in bepaalde gevallen een duidelijke toegevoegde waarde heeft. ${ }^{\text {sIx }}$ Zeker nu er geen overtuigende argumenten in de rechtspraak zijn terug te vinden die pleiten voor het weglaten van dit toetsingselement, is er in deze rechtspraak geen reden te vinden om het theoretische toetsingsmodel op dit punt aan te passen.

\subsection{Conclusies met betrekking tot de toetsingsintensiteit}

\subsubsection{Gradaties of "niveaus" van toetsingsintensiteit}

Bij de verschillende discriminatieverboden lijkt het Hof gebruik te maken van slechts twee gradaties van toetsingsintensiteit: bij onderscheid op grond van geslacht en nationaliteit is de toetsing in beginsel intensief, maar kan deze in bepaalde omstandigheden worden afgezwakt tot een marginale toetsing, terwijl bij onderscheid op het gebied van de landbouw de tegenovergestelde situatie zichtbaar is. In beide gevallen wordt vrijwel nooit expliciet verwezen naar een tussenliggende intensiteit. ${ }^{519}$

Als de verschillende discriminatieverboden in samenhang worden bezien blijkt een tussenvorm echter wel degelijk zichtbaar te zijn. ${ }^{520}$ Het is duidelijk dat er bij onderscheid op grond van nationaliteit en geslacht in beginsel een strikte toetsing wordt toegepast, waarbij de ter rechtvaardiging aangevoerde argumenten zorgvuldig op hun waarde worden onderzocht en waarbij nauwkeurig wordt nagegaan of er een redelijke verhouding tussen doel en middel bestaat. ${ }^{321}$ Daartegenover staat de uiterst marginale toets zoals die wordt uitgevoerd bij ongelijke behandeling op het gebied van de land-

518. Dit geldt zeker ook voor de rechtspraak over ongelijke behandeling op het gebied van de landbouw, nu daarin veelvuldig van het vergelijkbaarheidsvereiste gebruik wordt gemaakt. Wanneer dit vereiste, waarin belangrijke elementen van de toetsing van de mate van fit naar voren komen (zie paragraaf 2.5), wordt vervangen door het vereiste van benadeling, is het wenselijk dat meer waarde wordt gehecht aan het onderzoek naar de over-en underinclusiveness van de betrokken maatregel.

519. Eventueel kan bij onderscheid op grond van geslacht worden gesteld dat er in gevallen van voorkeursbehandeling een toetsing wordt uitgevoerd die noch als bijzonder intensief, noch als bijzonder marginaal kan worden bestempeld. Deze rechtspraak is op dit punt echter verre van duidelijk, met name omdat iedere verwijzing naar de keuze voor een bepaalde toetsingsintensiteit in de rechtspraak vooralsnog ontbreekt.

520. Vanzelfsprekend geldt dat het moeilijk is om een duidelijke grens te trekken tussen de verschillende toetsingsniveaus, omdat daarbij in de praktijk sprake is van een glijdende schaal. Zoals in het theoretische hoofdstuk is aangegeven kan echter wel een aantal ijkpunten worden aangewezen (zie hoofdstuk 2, paragraaf 5.2.1).

521. De rechtspraak over onderscheid op grond van nationaliteit laat nog een intensievere toetsing zien dan de rechtspraak over onderscheid op grond van geslacht: bij dit laatste wordt de toetsing aan elementen als geschiktheid en noodzakelijkheid meestal overgelaten aan de nationale rechter, zodat uit de rechtspraak niet duidelijk blijkt of er een intensieve toetsing wordt uitgevoerd. Uit de aanwijzingen over de gerechtvaardigdheid van het doel, die blijk geven van streng toezicht, kan echter wel degelijk worden afgeleid dat er bij onderscheid op grond van geslacht intensief wordt getoetst. 
bouw. Het Hof voert hierbij een willekeurstoets in de ware zin van het woord uit, waarbij het uitsluitend nagaat of de getroffen maatregelen kennelijk ongeschikt of onredelijk waren en waarbij het veel waarde hecht aan de keuzevrijheid van de gemeenschapsinstellingen: het Hof zal een landbouwmaatregel meestal alleen ongeldig verklaren in de gevallen waarin al op het eerste gezicht duidelijk is dat deze onredelijk belas. tend of evident ongeschikt is. Ook bij onderscheid op grond van geslacht leidt een vermindering van de toetsingsintensiteit, tot een aanzienlijk marginalere toetsing dan bij onderscheid op grond van nationaliteit: op gebieden als de sociale zekerheid blijkt het Hof de aangevoerde doelstellingen vrijwel steeds als gerechtvaardigd te accepteren en stelt het vaak zonder inhoudelijke motivering vast dat de maatregelen ter bereiking van die doelstellingen geschikt en noodzakelijk waren. Bij onderscheid op grond van nationaliteit blijkt de aanwezigheid van intensiteitverminderende factoren niet te leiden tot een dergelijke, zeer marginale benadering. Weliswaar wordt de lidstaten soms een zekere beoordelingsruimte toegekend, maar dit neemt niet weg dat het Hof ook dan zorgvuldig nagaat of aan de vereisten van geschiktheid en noodzakelijkheid wordt voldaan. Er is hierbij weliswaar geen sprake van een intensieve toetsing, maar evenmin van een zeer marginale benadering. Gesteld kan dan ook worden dat de intensiteit van de toetsing door het Hof kan variëren van zeer intensief tot zeer marginaal, met daartussenin de tussenvorm zoals die soms zichtbaar is bij onderscheid op grond van nationaliteit. Deze conclusie stemt overeen met de theoretische veronderstelling dat het voor een rechter praktisch niet goed mogelijk is om gebruik te maken van meer dan drie gradaties van toetsingsintensiteit.

\subsubsection{Factoren die een rol spelen bij de bepaling van de toetsingsintensiteit}

\section{Inleiding}

Bij de keuze voor één van de drie genoemde gradaties spelen verschillende, in paragraaf 3 van dit hoofdstuk uitgebreid besproken factoren een rol. Er bestaat op dit punt een grote mate van overeenstemming tussen de verschillende verboden van ongelijke behandeling. Zo blijkt het bestaan van een common ground vrijwel steeds van invloed te zijn op de toetsingsintensiteit, ${ }^{322}$ spelen het better placed-argument en het internationaalrechtelijke en communautaire subsidiariteitsbeginsel bij alle verboden een rol, en wordt de toetsingsintensiteit beïnvloed door de mate waarin de besluitvormende instellingen beschikken over discretionaire bevoegdheden, door de aard van het betrokken beleidsveld en door de nagestreefde doelstellingen. Bij ongelijke behandeling op het gebied van de landbouw blijken bovendien de aard en ernst van de inbreuk van invloed te zijn op de toetsingsintensiteit en is het bepalend of de inbreuk is veroorzaakt door een lidstaat of een gemeenschapsinstelling. Vrijwel al deze factoren zijn reeds aan de orde gekomen in het theoretische gedeelte of in hoofdstuk 3; alleen de laatste factor, volgens welke de toetsingsintensiteit bepaald wordt door de vraag welk orgaan voor de ongelijke behandeling verantwoordelijk is, is geheel nieuw. Deze factor leent zich echter in mindere mate voor een algemene toepassing, omdat de problematiek waarvan

522. Behalve bij onderscheid op het gebied van de landbouw, waarbij van dit toetsingselement geen melding wordt gemaakt. 
bouw. Het Hof voert hierbij een willekeurstoets in de ware zin van het woord uit, waarbij het uitsluitend nagaat of de getroffen maatregelen kennelijk ongeschikt of onredelijk waren en waarbij het veel waarde hecht aan de keuzevrijheid van de gemeenschapsinstellingen: het Hof zal een landbouwmaatregel meestal alleen ongeldig verklaren in de gevallen waarin al op het eerste gezicht duidelijk is dat deze onredelijk belastend of evident ongeschikt is. Ook bij onderscheid op grond van geslacht leidt een vermindering van de toetsingsintensiteit, tot een aanzienlijk marginalere toetsing dan bij onderscheid op grond van nationaliteit: op gebieden als de sociale zekerheid blijkt het Hof de aangevoerde doelstellingen vrijwel steeds als gerechtvaardigd te accepteren en stelt het vaak zonder inhoudelijke motivering vast dat de maatregelen ter bereiking van die doelstellingen geschikt en noodzakelijk waren. Bij onderscheid op grond van nationaliteit blijkt de aanwezigheid van intensiteitverminderende factoren niet te leiden tot een dergelijke, zeer marginale benadering. Weliswaar wordt de lidstaten soms een zekere beoordelingsruimte toegekend, maar dit neemt niet weg dat het Hof ook dan zorgvuldig nagaat of aan de vereisten van geschiktheid en noodzakelijkheid wordt voldaan. Er is hierbij weliswaar geen sprake van een intensieve toetsing, maar evenmin van een zeer marginale benadering. Gesteld kan dan ook worden dat de intensiteit van de toetsing door het Hof kan variëren van zeer intensief tot zeer marginaal, met daartussenin de tussenvorm zoals die soms zichtbaar is bij onderscheid op grond van nationaliteit. Deze conclusie stemt overeen met de theoretische veronderstelling dat het voor een rechter praktisch niet goed mogelijk is om gebruik te maken van meer dan drie gradaties van toetsingsintensiteit.

\subsubsection{Factoren die een rol spelen bij de bepaling van de toetsingsintensiteit}

\section{Inleiding}

Bij de keuze voor één van de drie genoemde gradaties spelen verschillende, in paragraaf 3 van dit hoofdstuk uitgebreid besproken factoren een rol. Er bestaat op dit punt een grote mate van overeenstemming tussen de verschillende verboden van ongelijke behandeling. Zo blijkt het bestaan van een common ground vrijwel steeds van invloed te zijn op de toetsingsintensiteit, ${ }^{522}$ spelen het better placed-argument en het internationaalrechtelijke en communautaire subsidiariteitsbeginsel bij alle verboden een rol, en wordt de toetsingsintensiteit beïnvloed door de mate waarin de besluitvormende instellingen beschikken over discretionaire bevoegdheden, door de aard van het betrokken beleidsveld en door de nagestreefde doelstellingen. $\mathrm{Bij}$ ongelijke behandeling op het gebied van de landbouw blijken bovendien de aard en ernst van de inbreuk van invloed te zijn op de toetsingsintensiteit en is het bepalend of de inbreuk is veroorzaakt door een lidstaat of een gemeenschapsinstelling. Vrijwel al deze factoren zijn reeds aan de orde gekomen in het theoretische gedeelte of in hoofdstuk 3; alleen de laatste factor, volgens welke de toetsingsintensiteit bepaald wordt door de vraag welk orgaan voor de ongelijke behandeling verantwoordelijk is, is geheel nieuw. Deze factor leent zich echter in mindere mate voor een algemene toepassing, omdat de problematiek waarvan

522. Behalve bij onderscheid op het gebied van de landbouw, waarbij van dit toetsingselement geen melding wordt gemaakt. 


\section{De common ground-factor}

Van bijzonder belang voor het algemene toetsingsmodel is de uitleg die het Hof heeft gegeven aan het common ground-argument. Op het eerste gezicht lijkt dit argument vooral een functie te hebben voor de internationale of supranationale rechter, die de intensiteit van zijn toetsing kan laten afhangen van de mate van overeenstemming die er over een bepaald onderwerp tussen de verschillende verdragsluitende staten bestaat. In het vorige hoofdstuk is echter al gesteld dat kan worden aangenomen dat het ontbreken van binnenlandse overeenstemming over de invulling van begrippen als de "goede zeden" of "de openbare orde" kan leiden tot een minder intensieve toetsing, zodat deze factor ook op nationaal niveau een rol kan spelen. ${ }^{526}$ Dat dit praktisch ook daadwerkelijk zo is wordt bevestigd door de rechtspraak van het Hof. Op het gebied van de volks. gezondheid heeft het Hof de lidstaten bijvoorbeeld een vrij ruime mogelijkheid gegeven om discriminatoire of handelsbelemmerende maatregelen te treffen, nu er op dit gebied nog maar weinig wetenschappelijke consensus bestaat over de noodzaak en wenselijkheid van het verhinderen van, bijvoorbeeld, de toevoeging van additieven aan voedingsmiddelen. Hieruit blijkt niet alleen dat de rechter zich terughoudend op kan stellen wanneer er op nationaal niveau slechts een beperkte overeenstemming over cen bepaald onderwerp bestaat, maar ook dat de consensus zelf een verschillend karakter kan hebben: waar er bij de uitleg van begrippen als de goede zeden sprake is van een (ontbreken van) overeenstemming in (morele) opvattingen, kan het ook gaan om een gebrek aan voldoende wetenschappelijke bewijzen. In het toetsingsmodel moet voor deze verschillende invulling uitdrukkelijk ruimte worden gelaten.

\section{Aard van de nagestreefde doelstellingen}

Bij de bepaling van de toetsingsintensiteit houdt het Hof nauwelijks rekening met de aard van de met het onderscheid nagestreefde doelstellingen. Zoals in paragraaf 3.2.2 is gebleken wordt de toetsingsintensiteit bijvoorbeeld nauwelijks verminderd wanneer et maatregelen in het geding zijn die tot doel hebben bestaande ongelijkheden op te heffen en te komen tot een meer evenredige vertegenwoordiging van bepaalde groepen. Gesteld kan hoogstens worden dat het Hof in dit geval kiest voor een toetsing die ergens tussen een intensieve en een marginale toetsing in ligt. Aangezien de rechtspraak op dit punt nog onvoldoende is uitgekristalliseerd en hierin vrijwel nooit een uitdrukkelijke uitspraak wordt gedaan over de intensiteit van de toetsing, is dit echter moeilijk vast te stellen. Vooralsnog kunnen er aan de benadering van het Hof dan ook geen consequenties worden verbonden voor het algemene toetsingsmodel.

Van belang is verder dat in de rechtspraak van het Hof over onderscheid op grond van nationaliteit verschillende arresten zijn te vinden waarin het Hof een strengere toetsing toepast wanneer het de bevoegde instantie ervan verdenkt andere doelstellingen na te streven dan ter rechtvaardiging zijn aangevoerd. Dit is vooral het geval wanneer er een beroep wordt gedaan op een uitzonderingsgrond waarbij normaal gesproken een minder strenge toetsing geldt - zoals bescherming van de volksgezondheid of van de nationale veiligheid -, terwijl er vooral overwegingen aan een besluit ten grondslag blijken te liggen die een veel strengere toets rechtvaardigen. Dit lijkt een redelijke benadering,

526. Zie hoofdstuk 3, paragraaf 3.2 .2 en 4.2.2. 
die voor veralgemenisering vatbaar is. Problematisch is echter dat een dergelijke vaststelling van de toetsingsintensiteit een onderzoek vergt naar de werkelijke bedoeling van het onderscheid, terwijl juist dit een vrij vergaande vorm van rechterlijke activiteit vergt. Door een dergelijke factor in de toetsing te betrekken dreigen de vaststelling van de toetsingsintensiteit en toetsing van de rechtvaardiging door elkaar te lopen. Het is dan ook niet wenselijk om in het kader van de vaststelling van de toetsingsintensiteit reeds te onderzoeken of er een discrepantie bestaat tussen het gestelde en het werkelijke doel. Alleen wanneer al op het eerste gezicht duidelijk is dat een dergelijke discrepantie anwezig is, kan van de rechter worden verlangd dat hij hiermee rekening houdt bij de bepaling van zijn toetsingsintensiteit. ${ }^{527}$

\section{Gewicht van het aangetaste belang}

In de rechtspraak van het Hof kan een bevestiging worden gevonden van de opvatting dat het gewicht van het belang dat door een ongelijke behandeling wordt aangetast van groot belang is voor de intensiteit van de toetsing. Zowel bij onderscheid op grond van nationaliteit als bij onderscheid op grond van geslacht is de keuze voor de "basisintensiteit", een strikte toets, vooral ingegeven door het feit dat door deze vormen van onderscheid zwaarwegende belangen worden aangetast. Tegelijkertijd is van belang dat bij onderscheid op het gebied van de landbouw vooral een marginale toetsing zal worden uitgevoerd, nu de daardoor aangetaste belangen meestal een beperkt fundamenteel gewicht hebben. ${ }^{328}$

Deze rechtspraak van het Hof is vooral interessant omdat hierin een aantal criteria kan worden gevonden die behulpzaam kunnen zijn bij het bepalen van het gewicht van het angetaste belang. In het hoofdstuk over de rechtspraak van het Europees Hof voor de Rechten van de Mens is al aangegeven dat in dit verband het common ground-argument een belangrijke rol kan spelen: het gewicht van een bepaald recht kan tamelijk objectief worden bepaald aan de hand van de hierover bestaande consensus, zoals die bijvoorbeeld tot uitdrukking komt in verdragen of wetgeving. Aangegeven is echter dat het nadeel van deze benadering is dat de toetsingsintensiteit sterk afhankelijk wordt gesteld van bestaande opvattingen en dus ook van eventuele vooroordelen jegens een bepaalde groep. Dit is in veel mindere mate het geval met de stelling dat voor het bepalen van het fundamentele karakter moet worden nagegaan of door een bepaald onderscheid de menselijke waardigheid wordt aangetast. Ook dit criterium heeft echter belangrijke nadelen: het is niet gemakkelijk toe te passen en bij de interpretatie ervan kunnen sub-

527. Zoals bijvoorbeeld in de in paragraaf 3.4 .2 besproken situatie in de pluimveearresten, waarin de feiten duidelijk een protectionistische bedoeling lieten zien.

528. Het ligt echter in de lijn der verwachting dat het Hof een intensievere toets uit zal voeren wanneer er op het gebied van de landbouw onderscheid zou worden gemaakt waardoor individuele fundamentele rechten worden aangetast of dat is gebaseerd op een verdachte grond. Dit is vooral waarschijnlijk, omdat het Hof een striktere toets uitvoert bij sanctiemaatregelen of benadelende individuele beschikkingen: dergelijke maatregelen leveren naar hun aard een vrij sterke aantasting van individuele rechten en belangen op. Een verhoging van de toetsingsintensiteit bij onderscheid op verdachte gronden of bij de aantasting van fundamentele belangen is bovendien waarschijnlijk tegen de achtergrond van de rechtspraak over de aantasting van grondrechten: de formulering die daarbij door het Hof wordt gehanteerd laat ruimte voor een striktere beoordeling van de aan de inbreuk ten grondslag liggende belangenafwe- 
jectieve overwegingen een belangrijke rol spelen. In de praktijk kan het gebruik van dit criterium echter worden gecombineerd met het gebruik van het common ground-criterium. Bij een goede en zorgvuldige motivering lijkt het daardoor mogelijk om tot een redelijk goede invulling te komen van deze factor.

De rechtspraak van het Hof is bovendien van belang omdat hieruit blijkt dat funda. mentele belangen niet uitsluitend individuele belangen hoeven te zijn. Zo wordt bij onderscheid op grond van nationaliteit niet zozeer een strikte toets uitgevoerd omdat door een dergelijk onderscheid de menselijke waardigheid wordt aangetast of omdat er consensus bestaat over het feit dat nationaliteit een irrelevante onderscheidingsgrond is, maar omdat door onderscheid op deze grond fundamentele communautaire doelstellin. gen worden doorkruist. Hoewel het niet vaak zal voorkomen dat een verbod van onge. lijke behandeling tot doel heeft specifieke maatschappelijke belangen te dienen, is het bij het vaststellen van de toetsingsintensiteit zeker van belang om met deze mogelijk. heid rekening te houden.

\section{Afweging tussen de verschillende factoren}

Zoals hiervoor is angegeven maakt het Hof gebruik van een bepaalde "basisintensiteit": bij onderscheid op grond van geslacht en nationaliteit is dit een strenge toetsing, terwijl bij ongelijke behandeling op het gebied van de landbouw een marginale toets als uitgangspunt wordt gehanteerd. Dit is een belangrijk verschil met de rechtspraak van het Europees Hof voor de Rechten van de Mens, waarin een dergelijke basisintensitet ontbreekt en per geval opnieuw alle verschillende factoren tegen elkaar worden afgewogen. De bepaling van de toetsingsintensiteit is bij het Hof dan ook minder gecompliceerd: omdat de intensiteit in beginsel al vaststaat hoeft alleen nog maar te worden bekeken of er factoren zijn die wijzen in de richting van een vermindering van de toelsingsintensiteit, of, bij de landbouw, in de richting van een verzwaring. Ook hierbij is het echter van belang dat voldoende aandacht wordt besteed aan het relatieve gewicht van de verschillende factoren en aan de wijze waarop deze tegen elkaar moeten worden afgewogen: de diverse besproken factoren kunnen in een concreet geval in andere richtingen wijzen. $\mathrm{Zo}$ is het niet duidelijk wat de consequenties voor een intensieve basistoets zijn als er sprake is van een beperkte belangenaantasting op een gebied warop een duidelijke consensus bestaat, of wanneer een classificatie het verwezenlijken van bepaalde doelstellingen van gemeenschapsrecht ernstig bemoeilijkt op een complex terrein waarop een ruime beoordelingsruimte bestaat. Hoewel het opmerkelijk is dat het Hof hieraan nooit uitdrukkelijk aandacht heeft besteed moet worden toegegeven dat het ook zelden met dergelijke lastige afwegingen te maken heeft gekregen: in vrijwel alle gevallen waarover het Hof tot nu toe heeft geoordeeld was het duidelijk dat de factoren in dezelfde richting wezen. Wanneer het Hof zich in de toekomst met complexere afwegingen bezig moet houden valt het echter te hopen dat het Hof duidelijke afwegingscriteria zal vaststellen. 


\section{De toetsing aan de Equal Protection Clause door het Supreme Court}

\section{$1 \quad$ Inleiding}

\subsection{Achtergrond en reikwijdte van de Equal Protection Clause}

\subsubsection{Totstandkoming en betekenis van het Veertiende Amendement}

Het gelijkheidsbeginsel is in de Verenigde Staten neergelegd in het Veertiende Amendement op de Constitutie. De in dit Amendement opgenomen Equal Protection Clause is als volgt geformuleerd:

"No State shall $[\ldots]$ deny to any person within its jurisdiction the equal protection of the laws."

Rondom deze korte en zeer algemeen geformuleerde bepaling heeft zich een uitgebreide en gecompliceerde rechtspraak ontwikkeld. Voor een goed begrip daarvan is het noodzakelijk om enige kennis te hebben van de achtergrond en ontwikkeling van dit gelijkheidsbeginsel.

Het Veertiende Amendement maakte geen deel uit van de Bill of Rights zoals die in 1791 in de vorm van amendementen aan de Constitutie is toegevoegd; in deze Bill of Rights is zelfs in het geheel geen gelijkheidsbepaling terug te vinden. Over de verklaring daarvoor bestaat onduidelijkheid, maar het is waarschijnlijk dat men het neerleggen van een gelijkheidsbeginsel destijds niet nodig achtte: de staten zelf kenden in de meeste gevallen al wetgeving tegen zogenaamde "special or partial laws" - wetten waardoor een groep voor bijzondere behandeling wordt uitgezonderd.' De werking van dit soort regelgeving strekte zich echter niet uit tot Afro-Amerikanen: zelfs in de staten waar de slavernij al was afgeschaft werden aan deze groep nauwelijks rechten toegekend. In 1856, in de zaak Dred Scott, oordeelde het Supreme Court zelfs dat vrijgelaten of gevluchte slaven niet konden worden gezien als Amerikaanse burgers, hetgeen betekende dat bescherming van de constitutionele grondrechten voor hen niet werd gegarandeerd. ${ }^{2}$ Over het instituut van de slavernij en de precieze rechten van vrijgelatenen bestond echter grote controverse tussen de noordelijke en zuidelijke staten. Zoals be-

1. Saunders 1997 , p. $260 / 261$. Dergelijke bepalingen zijn te zien als uitdrukkingen van het gelijkheidsbeginsel; de rechter die de bepalingen uitlegden stelden dat "partial or special laws" gerechtvaardigd konden worden door doelstellingen van algemeen belang. Overigens vormt dit geen volledige verklaring voor het niet opnemen van een gelijkheidsbeginsel in de Bill of Rights, nu deze zich niet richt tot de staten, maar tot de federale overheid: voor de federale overheid bestond geen regeling waardoor "partial or special laws" werden verboden, zodat het opnemen van een gelijkheidsbepaling wel voor de hand had gelegen.

2. 60 U.S. 393, 405 (1856). Dit arrest riep grote woede bij tegenstanders van de slavernij op, vooral door de redenering van het Supreme Court: dit stelde dat slaven op het moment dat het aangevochten besluit werd genomen moesten worden gezien als een ondergeschikt en lager ras en dat aan hen alleen die rechten toekwamen die hen door de regering uitdrukkelijk waren verleend. 
kend mondde dit conflict uit in de Burgeroorlog, die na een overwinning voor het noorden uiteindelijk leidde tot de afschaffing van de slavernij. ${ }^{3}$ Voor de voormalige slaven leverde dit geen onmiddellijke verbetering op. Met name in de zuidelijke staten werden veel zogenaamde "Black Codes" ingesteld - wetten die sterk leken op de slavernijwetgeving van voor de Burgeroorlog en die de rechten van de voormalige slaven ernstig beperkten. ${ }^{4}$ Deze wetgeving leidde vooral in het noorden tot een bredere discussie over de rechten van Afro-Amerikanen,' waaraan actief werd deelgenomen door het Congres. Het resultaat van deze periode van discussie (beter bekend als de "Reconstruction") was de inwerkingtreding van de eerste Civil Rights Act in 1866. Deze wet bood iedereen, dus ook de voormalige slaven, bescherming tegen aantasting van de meest fundamentele grondrechten en bevatte bovendien een gelijkheidsbepaling. Gezien de opstelling van de zuidelijke staten bestond echter de angst dat deze wet door een toekomstig, politiek anders samengesteld Congres zou worden ingetrokken of ge. wijzigd. ${ }^{6}$ Om die reden werd uiteindelijk het Veertiende Amendement op de Constitutie aangenomen, dat in grote lijnen hetzelfde luidt als de belangrijkste bepaling van de Civil Rights Act en dat ook de hiervoor reeds geciteerde Equal Protection Clause om. vat.

Over de precieze betekenis van de bewoordingen van het Veertiende Amendement en de Equal Protection Clause bestaat veel discussie. Juristen en historici hebben in de loop van de tijd uiteenlopende interpretaties gegeven, alle gebaseerd op een andere waardering en uitleg van de voorgeschiedenis van het Amendement en de in het Congres gevoerde debatten. Op twee punten lijken de commentaren het echter, in grote

3. Hetgeen in 1865 werd bevestigd met het aannemen van het Dertiende Amendement op de Constituic. "Neither slavery nor involuntary servitude, except as a punishment for crime whereof the party shall have been duly convicted, shall exist within the United States, or any place subject to their jurisdiction."

4. Zie nader Burns 1998, p. 282 en Berger 1977, p. 26, die enkele citaten aanhaalt waaruit blijkt dat de opstellers van het Amendement (en de daaraan voorafgaande, sterk vergelijkbare Civil Rights dict 1866) zich uitdrukkelijk tegen deze wetgeving richtten; vgl. ook de opinie van Justice Miller in de Slaughter-house cases, 83 U.S. 36, 70 (1872).

5. Van belang binnen deze discussie was ook de hiervoor genoemde uitspraak in de zaak Dred Scott, diz in de weg stond aan een erkenning van burgerrechten voor Afro-Amerikanen. Zoals in de Slaughterhouse Cases werd aangegeven was Dred Scott nooit "overruled", zodat het arrest ook na de Civil War nog deel uitmaakte van het geldende recht. Dit betekende dat de vrijgelaten slaven niet alleen geen staatsburgers waren of konden worden, maar ook dat zij niet automatisch recht hadden op doot de Constitutie beschermde rechten (83 U.S., op 73). Vgl. Berger 1977, p. 45 en Kelly 1956, p. 1058/1059.

6. Vgl. "Developments" 1969, p. 1068 en Berger 1977, p. 23. Deze vrees bleek overigens gegrond: toen in 1892 een anders samengesteld Congres werd gekozen werden vrijwel alle wetten die de rechten van Afro-Amerikanen beschermden ingetrokken (zie Loevy 1997, p. 4). Bovendien waren verschillende Congresleden ervan overtuigd dat alleen door een aanpassing van de Constitutie de controverse ovet het burgerrecht kon worden beèindigd: Dred Scott was officieel nog steeds geldend recht, en men wilde deze uitspraak definitief "overrulen" door een grondwettelijke bepaling op te nemen waaruit bleek dat ook de voormalige slaven Amerikaanse staatsburgers waren.

7. De volledige tekst van de eerste paragraaf daarvan, die in het licht van dit hoofdstuk het belangrijkst is, luidt als volgt: "All persons born or naturalized in the United States, and subject to the jurisdiction the reof, are citizens of the United States and of the State wherein they reside. No State shall make of etforce any law which shall abridge the privileges or immunities of citizens of the United States; nor shall any State deprive any person of life, liberty, or property, without due process of law; nor deny to any person within its jurisdiction the equal protection of the laws." 
lijnen, eens te zijn. Allereerst wordt algemeen aangenomen dat de opstellers een beperkte reikwijdte voor het Amendement zagen: alleen de meest essentiële burgerrechten zouden door de bepalingen worden beschermd, terwijl meer politiek en sociaal getinte rechten, zoals het recht op onderwijs en het kiesrecht, in ieder geval niet onder

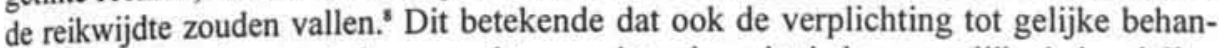
deling zich beperkte tot de burgerrechten en dat zeker niet iedere ongelijke behandeling door de Equal Protection Clause werd verboden. In de tweede plaats staat het vast dat de Equal Protection Clause primair werd aangenomen om onderscheid op grond van ras te bestrijden; de bepaling leek zich aanvankelijk niet tot andere gronden van onderscheid uit te strekken.?

Voor de rechtspraak is deze achtergrond van bijzonder belang, omdat in de VS vaak naar de bedoelingen van de opstellers, de "framers", wordt verwezen bij het geven van uitleg aan constitutionele bepalingen. Op grond van deze bedoelingen heeft het Supreme Court tot lang na het aannemen van het Amendement een beperkte uitleg gegeven aan de Equal Protection Clause. Vooral voor de reikwijdte van deze bepaling heeft dit grote consequenties gehad.

\subsubsection{Uitbreiding van de reikwijdte tot aantasting van alle belangen en rechten}

De belangrijkste beperking van de reikwijdte was gelegen in de opvatting dat het Veertiende Amendement alleen bescherming zou bieden tegen onderscheid waardoor fundamentele burgerrechten werden aangetast. De consequenties van deze interpretatie blijken uit twee arresten die relatief snel na de ratificatie van het Amendement werden gewezen, Strauder $v$. West Virginia ${ }^{10}$ en Plessy v. Ferguson" ${ }^{11}$. Het eerste arrest had betrekking op het recht om zitting te nemen in een jury, een in Amerika fundamenteel geacht recht. ${ }^{12}$ Volgens een wet in West Virginia kwam dit recht niet toe aan AfroAmerikanen. Het Supreme Court verklaarde deze wet in scherpe bewoordingen strijdig

8. Zie Siegel 1997, p. 1120, Berger 1977, p. 170 e.v., Perry 1979, p. 1027 en Lively 1991, p. 497. Tot deze rechten werd blijkens de discussies over de Civil Rights Act, waarop het Veertiende Amendement is gebaseerd, in ieder geval gerekend het recht op "life, liberty and property". De uitsluiting van het stemrecht werd later gecompenseerd door het opnemen van het Vijftiende Amendement, waarin dit recht expliciet aan alle bevolkingsgroepen wordt toegekend. Er bestaan overigens aanwijzingen dat de Civil Rights Act 1866 een bredere reikwijdte had en ook was gericht tegen segregatiewetgeving, hetgeen betekent dat ook de hierop geĭnspireerde tekst van het Veertiende Amendement een ruimer bereik had dan later is aangenomen; zie Kelly 1956, p. 1070 (waarbij moet worden aangetekend dat Kelly's onderzoek niet geheel objectief is: het werd uitgevoerd ten behoeve van een "brief" voor de Supreme Court waarin werd betoogd dat segregatie in de oorspronkelijke bedoeling binnen de reikwijdte van de Equal Protection Clause viel).

9. Vgl. Lively 1991, p. 497. Ook hierover bestaat enige discussie in de literatuur: geopperd is dat het Veertiende Amendement er meer in het algemeen op was gericht om "partial or special laws" te bestrijden, zodat het een algemeen gelijkheidsbeginsel inhield dat zich niet beperkte tot onderscheid op grond van ras. Zie bijv. Saunders 1997, p. 285-286.

10. 100 U.S. 303 (1879)

11. 163 U.S. 537 (1896)

12. Overigens blijkt niet uit de wetsgeschiedenis dat het recht om in een jury te zitten gezien moet worden als een "civil right"; in ieder geval is hierover discussie mogelijk. Dit blijkt bijvoorbeeld uit een citaat van House Chairman Wilson, die stelde dat dit recht, net als het recht op gemeenschappelijk onderwijs, niet kon worden beschouwd als een "civil right" (aangehaald door Berger 1977, p. 27). Zie echter ook
Perry 1979, p. 1028 in noot 26. 


\title{
met de Equal Protection Clause:
}

"The very fact that colored people are singled out and expressly denied by a statute all right to participate in the administration of the law, as jurors, because of their color, though they are citizens, and may be in other respects fully qualified, is practically a brand upon them, affixed by the law, an assertion of their inferiority, and a stimulant to that race prejudice which is an impediment to securing to individuals of the race that equal justice which the law aims to secure to all others."13

Plessy v. Ferguson daarentegen had geen betrekking op een burgerrecht, maar op de segregatie van vervoersmogelijkheden in Louisiana: een donkere man was gearresteerd toen hij weigerde om plaats te nemen in het speciaal voor Afro-Amerikanen bestemde rijtuig van een trein. Hierover stelde het Supreme Court het volgende:

\begin{abstract}
"The object of the amendment [het Veertiende Amendement, JHG] was undoubtedly to enforce the absolute equality of the two races before the law, but in the nature of things it could not have been intended to abolish distinctions based upon color, or to enforce social, as distinguished from political equality, or a commingling of the two races upon terms unsatisfactory to either."14
\end{abstract}

Vervolgens oordeelde het Supreme Court dat de aanwijzing van een speciaal rijtuig voor Afro-Amerikanen niet in strijd was met de Equal Protection Clause. Deze uitspraak vormde de basis voor de separate but equal-doctrine, waardoor de segregatie van talloze voorzieningen lange tijd juridisch werd gesanctioneerd.

Dit aanvankelijk bestaande verschil in benadering is niet uitsluitend te verklaren vanuit de beperkte interpretatie van de reikwijdte van de Equal Protection Clause. Belangrijker was wellicht nog dat er volgens het Supreme Court bij segregatie geen sprake was van een daadwerkelijke aantasting of ontneming van rechten. In Plessy was AfroAmerikanen niet volledig het recht ontnomen om met de trein te reizen: zij werden slechts gedwongen om in een bepaald rijtuig plaats te nemen. ${ }^{\text {is }}$ In Strauder was daarentegen wel degelijk sprake van de volledige ontneming van een (fundamenteel geacht) recht, nu Afro-Amerikanen in West-Virginia geen enkele mogelijkheid hadden om in een jury zitting te nemen. Op grond van dit verschil kon het Supreme Court volhouden dat er in de segregatiezaken geen sprake was van een daadwerkelijke benadeling van Afro-Amerikanen, zodat er ook niet kon worden gesproken van een ontoelaatbaar onderscheid. ${ }^{16}$

\section{100 U.S., op 308}

14. 163 U.S., op 544. Zie ook Siegel 1997, p. 1124, die aangeeft dat, zelfs als de rechters toegang tot het openbaar vervoer al zagen als een fundamenteel recht, zij de toegang tot geỉntegreerde voorzieningen in ieder geval niet beschouwden als een door het Veertiende Amendement beschermd recht. Het fetit dat daardoor een gevoel van inferioriteit werd gecreěerd was niet van belang: de reikwijdte van het Amendement strekte zich eenvoudigweg niet tot dit soort sociale rechten uit (p. 1125).

15. Vgl. Klarman 1991, p. 227. Een verklaring is ook te vinden in de totstandkomingsgeschiedenis van hat Veertiende Amendement. Hoewel er in die tijd al sprake was van segregatie van talrijke voorzieningen, met name van scholen, kan uit de debatten over het Amendement nauwelijks worden afgeleid dat het de bedoeling was om daaraan een einde te maken; zie Berger 1977, p. 118.

16. Zoals in Plessy expliciet werd gesteld: "Laws permitting, and even requiring, their separation in places where they are liable to be brought into contact do not necessarily imply the inferiority of either race to the other, and have been generally, if not universally, recognized as within the competency of the state 
Deze tweedeling in de rechtspraak heeft lang stand gehouden. Pas in 1954, in het arrest Brown v. Board of Education ${ }^{17}$, accepteerde het Supreme Court op basis van sociologische onderzoeken dat segregatie bij gelijkwaardige voorzieningen per definitie benadelend is voor Afro-Amerikanen. In deze zaak werd de reikwijdte van het Veertiende Amendement bovendien uitgebreid naar sociale rechten, zoals het recht op onderwijs. Vanaf dit moment lopen de lijnen in de rechtspraak dan ook weer samen, zodat bij zaken over segregatie dezelfde toetsingsmethodiek kan worden gehanteerd als bij andere vormen van onderscheid. ${ }^{18}$ Van belang is bovendien dat uit Brown en uit het grote aantal latere uitspraken over desegregatie duidelijk blijkt dat ook de tweede beperking in de reikwijdte van de Equal Protection Clause is verdwenen: het is tegenwoordig voldoende om aan te tonen dat er sprake is van een ongelijke behandeling, zonder dat hoeft te worden bewezen dat daardoor essentiële burgerrechten zijn aangetast.

\subsubsection{Uitbreiding van de reikwijdte naar andere gronden van onderscheid}

Ook in een ander opzicht heeft het Supreme Court in de loop van de tijd gekozen voor een uitbreiding van de reikwijdte van de Equal Protection Clause. Zoals al is aangegeven werd het vaststellen van de Equal Protection Clause vooral gemotiveerd door het streven naar gelijkberechtiging van de voormalige slaven. Aangenomen kon dan ook worden dat de reikwijdte van deze bepaling beperkt was tot onderscheid op grond van ras." Aanvankelijk was dit ook de interpretatie van het Supreme Court, zoals blijkt uit de in 1872 gewezen Slaughter-house Cases:20

\footnotetext{
"We doubt very much whether any action of a State not motivated by way of discrimination against the negroes as a class, or on account of their race, will ever be held to come within the purview of this provision."2i
}

Al snel aanvaardde het Supreme Court echter een ruimere reikwijdte voor de Equal Protection Clause. Niet alleen nam het aan het dat de bepaling ook betrekking had op andere raciale groepen dan Afro-Amerikanen ${ }^{22}$, maar ook werden al relatief snel na de Slaughter-house Cases beroepen op de Equal Protection Clause gehonoreerd in eco-

legislatures in the exercise of their police power" (163 U.S., op 544). Uit de verdere rechtspraak blijkt dat het Supreme Court op dit punt ook niet volstrekt onredelijk was: als voorzieningen voor AfroAmerikanen helemaal niet openstonden of van duidelijk inferieure kwaliteit waren, werd in de meeste gevallen wel ingegrepen; zie bijv. McCabe v. Atchison, Topeka and Santa Fe Railway, 235 U.S. I51 (1914) en Missouri ex rel. Gaines v. Canada, 305 U.S. 337 (1938).

17. 347 U.S. 438 (1954)

18. Een recent voorbeeld hiervan is te vinden in United States v. Virginia, 518 U.S. 515 (1997), een zaak die betrekking had op het uitsluitend toelaten van mannen tot een bepaalde school, terwijl er een als "gelijkwaardig" betitelde opleiding voor vrouwen bestond.

19. In die zin ook Perry 1979, p. 1050, Blattner 1981, p. 779 en Lively 1991, p. 497.

20. 83 U.S. $36(1872)$

21. 83 U.S., op 81. Deze stelling was gebaseerd op de achtergrondgeschiedenis van het Veertiende Amendement; zie 83 U.S., op 71. In dezelfde zaak gaf de Supreme Court overigens aan dat het niet ondenkbaar zou zijn dat het Amendement ook op andere groepen dan de voormalige slaven van toepassing was: "We do not say that no one else but the negro can share in this protection" (83 U.S., op 72). Dit betekende echter alleen dat ook andere raciale minderheden een beroep konden doen op het Amendement, niet dat het Amendement op andere gronden dan ras kon worden toegepast.

22. Zie Yick Wo v. Hopkins, 118 U.S. 356 (1886) (waarin een ongelijke behandeling jegens Chinezen in het geding was). 
nomische en belastingzaken. De ruimere reikwijdte werd expliciet erkend in de Rail. road Tax Cases (1882), die betrekking hadden op een verschil tussen particulieren en spoorwegmaatschappijen bij de bepaling van de grondslag voor belastingheffing. Zonder in te gaan op een eventuele beperking van de Equal Protection Clause tot onderscheid op grond van ras oordeelde het Supreme Court als volgt:

"The fourteenth amendment to the constitution, in declaring that no state shall deny to any person within its jurisdiction the equal protection of the laws, imposes a limitation upon the exercise of all the powers of the state which can touch the individual or his property, including among them that of taxation. Whatever the state may do, it cannot deprive any one within its jurisdiction of the equal protection of the laws." ${ }^{24}$

Uit deze overweging blijkt een erkenning van de toepasselijkheid van de Equal Pro. tection Clause op ieder handelen van de overheid dat een ongelijke behandeling tot gevolg heeft; de grond van onderscheid is daarbij niet relevant. Gesteld kan dan ook worden dat de Equal Protection Clause in de interpretatie van het Supreme Court een volledig open karakter heeft: het is niet nodig om aan te tonen dat er onderscheid is gemaakt op bepaalde gronden. ${ }^{25}$

\subsubsection{Materiële of formele gelijkheid; direct en indirect onderscheid}

Materieel onderscheid en de toetsing van overinclusiveness

In de VS wordt geen gebruik gemaakt van het, in Europa welbekende, onderscheid tussen formele en materiële gelijkheid. Dit wil echter niet zeggen dat het verschil tussen deze vormen van gelijke behandeling als zodanig onbekend is en er alleen uitspraak wordt gedaan over formeel onderscheid: er zijn zeker arresten te vinden waarin het Supreme Court een oordeel moest geven over een materieel onderscheid. Een duidelijk voorbeeld hiervan is het arrest Jenness $v$. Fortson, ${ }^{26}$ een zaak die betrekking had op een regeling voor de deelname aan verkiezingen. Voor alle partijen golden dezelfde voorwaarden voor deelname, maar in de praktijk bleek het voor de grote, gevestigde partijen veel gemakkelijker te zijn om daaraan te voldoen dan voor kleine, nieuwe partijen. Het Supreme Court oordeelde hierover als volgt:

23. 13 F. 722 (1882). Daarvóór oordeelde het Supreme Court nog expliciet dat het Veertiende Amendement niet op belastingzaken betrekking had: zie Davidson v. City of New Orleans, 96 U.S. 97, 105 (1877), waarin het Supreme Court over een belastingregeling stelde dat "It may violate some provision of the State Constitution against equal taxation; but the Federal Constitution imposes no restraints on the States in that regard. [...] [W]e know of no provision in the Federal Constitution which forbids this, or which forbids unequal taxation by the States"; vgl. ook Tussman/TenBroek 1949, p. 369.

24. 13 F., op 733; het Supreme Court bevestigde dit door in 1890 een belastingregeling aan de Equel Protection Clause te toetsen: zie Bell's Gap R Co. v. Pennsylvania, 134 U.S. 232 (1890).

25. Vgl. "Note" 1981 , p. 916. Wel moet daaraan worden toegevoegd dat de historische achtergrond van de bepaling steeds van groot belang is gebleken. De rechtspraak over onderscheid op grond van ras en de keuzes voor toetsingsintensiteit en -methodiek die in dat verband zijn gemaakt kunnen zelfs bepalend worden geacht voor de rechtspraak over onderscheid op andere gronden. Zo is de toetsingsintensiteit sterk afhankelijk van de "ernst" van onderscheid op bepaalde gronden, waarbij ras tot ijkpunt word genomen. Zie daarover nader paragraaf 3.3.3.

26. 403 U.S. 431 (1971) 
"Sometimes the grossest discrimination can lie in treating things that are different as though they were exactly alike."27

Uit deze overweging blijkt dat het Supreme Court erkent dat ook materieel onderscheid onder de Equal Protection Clause verboden kan zijn. In recentere rechtspraak heeft het Supreme Court echter aangegeven niet snel bereid te zijn om een beroep op dit concept te honoreren:

"Generally speaking, laws that apply evenhandedly to all 'unquestionably comply' with the Equal Protection Clause."28

Deze terughoudendheid vindt een gedeeltelijke verklaring in de bijzondere toetsingsmethodiek van het Supreme Court, die tot gevolg heeft dat er nauwelijks behoefte bestaat aan een afzonderlijk concept van materieel onderscheid. Blijkens zijn rechtspraak vereist het Supreme Court in de eerste fase van de toetsing namelijk uitsluitend dat er een benadeling wordt aangetoond, waarna het een uitgebreide beoordeling geeft van de hiervoor aangevoerde rechtvaardiging. $\mathrm{Bij}$ deze rechtvaardigingstoets gaat het Supreme Court (anders dan de meeste Europese rechters) in vrijwel alle gevallen na of er sprake is van een voldoende mate van fit. Zoals eerder uiteen is gezet heeft deze toets betrekking op de verhouding tussen het doel en de definitie van de te onderscheiden groep. Wanneer een maatregel een groep uitzondert voor een nadelige behandeling, maar deze groep te ruim definieert (overinclusiveness) zal de maatregel meestal ontoelaatbaar zijn. In dat geval is het namelijk zo dat een bepaalde groep wordt benadeeld, terwijl deze niet over het kenmerk beschikt dat in het licht van het doel van de regeling als relevant moet worden beschouwd. Feitelijk is er in een dergelijk geval sprake van materiële ongelijkheid: een groep die relevant verschilt van een andere groep wordt door de overinclusiveness van de classificatie immers toch op dezelfde manier behandeld. ${ }^{29}$ Dit betekent dat het Supreme Court door de toetsing van de overinclusiveness in vrijwel ieder geval feitelijk kan nagaan of er sprake is van een materiële ongelijkheid. Het gebruik van een afzonderlijk concept van materiële gelijkheid is daardoor overbodig.

\section{Alleen "bedoeld" indirect onderscheid wordt inhoudelijk beoordeeld}

Ook het gebruik van het concept van indirect onderscheid lijkt bij een open bepaling als de Equal Protection Clause niet nodig te zijn: alle ongelijke behandelingen kunnen immers op hun waarde worden beoordeeld, ongeacht de grond van onderscheid. Toch heeft het Supreme Court al in een vroeg stadium van dit concept gebruik gemaakt. Een belangrijke reden daarvoor is dat er bij een aantal "verdachte" gronden van onderscheid

27. 403 U.S., op 442. Zie ook Tigner v. Texas, 310 U.S. 141 (1940): "The Constitution does not require things which are different in fact or opinion to be treated in law as though they were the same" (op 147) en, iets minder expliciet, het recente arrest Tuan Anh Nguyen v. INS, 533 U.S. 53 (2001): " [...]

28. Vacco v. Quill, 521 U.S. 793, 800 (1997); zie ook Geduldig v. Aiello, 417 U.S. 484, 496/497 (1974) en "Developments" 1969, p. 1171.

29. Anderzijds is het mogelijk om door een toetsing van de mate van fit formeel onderscheid te beoordelen: in dat geval is er sprake van een te nauwe definitie, waardoor mensen die feitelijk wel voor een bepaalde behandeling in aanmerking zouden moeten komen hiervan worden uitgesloten (underinclusiveness). In dat geval is er sprake van een formeel ongelijke behandeling, nu mensen die zich in een relevant vergelijkbare situatie bevinden verschillend worden behandeld. 
een bijzonder strenge toetsing wordt uitgevoerd, terwijl de toetsing bij andere gronden zeer terughoudend is. Dit betekent dat het voor de klagende partij nuttig kan zijn om te betogen dat een op een neutrale grond gebaseerd onderscheid tot feitelijk gevolg heeff dat er onderscheid wordt gemaakt op een verdachte grond.

Een eerste uitdrukkelijke erkenning van het concept van indirect onderscheid is te vinden in het arrest Lane v. Wilson, gewezen in $1939 .^{30}$ Deze uitspraak had betrekking op een regeling voor kiezersregistratie in Oklahoma. Aanvankelijk gold er in deze stasat een wet die tot gevolg had dat het kiesrecht vrijwel uitsluitend aan blanken toekwam. Toen deze wet door de Supreme Court onconstitutioneel werd verklaard ontstond de noodzaak om een nieuwe regeling vast te stellen. Daarin werd vastgelegd dat alle mensen die in 1914, het jaar waarin de laatste verkiezingen onder de oude regeling waren gehouden, kiesgerechtigd waren, dat automatisch ook waren op het moment van inwerkingtreding van de nieuwe regeling. Mensen die op die datum nog niet kiesgerechtigd waren moesten zich binnen 12 dagen laten registreren, anders zouden zij het kiesrecht verliezen. Deze regeling, hoewel op het eerste gezicht neutraal van aard, had een bijzonder nadelig effect voor Afro-Amerikanen: niet alleen hadden deze mensen, anders dan de meeste blanken, als gevolg van de oude regeling in 1914 nog geen kiesrecht, maar ook waren zij zich nauwelijks bewust van het belang van de registratie." Nu de registratietermijn ook nog bijzonder kort was had de nieuwe regeling tot resultaat dat Afro-Amerikanen vrijwel volledig van het kiesrecht werden uitgesloten. Het Supreme Court oordeelde als volgt:

"The Amendment nullifies sophisticated as well as simple-minded modes of discrimination. It hits onerous procedural requirements which effectively handicap exercise of the franchise by the colored race although the abstract right to vote may remain unrestricted as to race."12

Ook in latere uitspraken bleek het Supreme Court te aanvaarden dat neutrale maatregelen ontoelaatbaar kunnen zijn vanwege hun negatieve effecten voor minderheids. groeperingen. ${ }^{3}$ Vooral uit recentere rechtspraak komt echter naar voren dat het Supre me Court het concept van indirect onderscheid niet onvoorwaardelijk heeft aanvaard. Dit blijkt bijvoorbeeld uit de volgende overwegingen uit het arrest Personnel Administrator of Massachusetts $v$. Feeney: ${ }^{34}$

"When the basic classification is rationally based, uneven effects upon particular groups within a class are ordinarily of no constitutional concern. The calculus of effects $[\ldots]$ is a legislative and not a judicial responsibility. [...] [It is a] settled rule that the Fourtenth Amendment guarantees equal laws, not equal results." ${ }^{\prime 3}$

30. 307 U.S. 268 (1939)

31. Zoals het Supreme Court uitlegde: "[...] we are dealing with a body of citizens lacking the habits and traditions of political independence and otherwise living in circumstances which do not encourage initiative and enterprise" (307 U.S., op 276).

32. 307 U.S., op 275

33. Zie bijv. Gomillion v. Lightfoot, 364 U.S. 339 (1960) en Village of Arlington Heights v. Metropolian Housing Development Co., 429 U.S. 252 (1977).

34. 442 U.S. $256(1979)$

35. 442 U.S., 271 en 273. Vgl. ook San Antonio School District v. Rodriguez, 411 U.S. 1 (1973): "[...] the Equal Protection Clause does not require absolute equality or precisely equal advantages" (op 24). 
Deze overweging lijkt op het eerste gezicht in strijd te zijn met de uitspraak in Lane $v$. Wilson en met verschillende andere zaken waarin het Supreme Court indirect onderscheid onconstitutioneel verklaarde. Dit verschil kan echter worden verklaard door de specifieke aard van de zaken waarin de eerdere klachten over indirect onderscheid werden gehonoreerd: er was daarbij steeds sprake van gevallen waarin het indirecte onderscheid heel dicht tegen direct onderscheid aanlag. In Lane v. Wilson was het bijvoorbeeld duidelijk dat het benadelende effect van de regeling door de wetgever bewust werd geaccepteerd en daar zelfs specifiek op was gericht: feitelijk was er sprake van een gecamoufleerd direct onderscheid op grond van ras. In 1976, in Washington $v$. Davis, ${ }^{3{ }^{3}}$ gaf het Supreme Court expliciet aan dat uitsluitend dit soort "beoogde effecten" aan een inhoudelijke toetsing kunnen worden onderworpen:

"The central purpose of the Equal Protection Clause of the Fourteenth Amendment is the prevention of official conduct discriminating on the basis of race. [...][O]ur cases have not embraced the proposition that a law or other official act, without regard to whether it reflects a racially discriminatory purpose, is unconstitutional solely because it has a racially disproportionate impact. [...] A purpose to discriminate must be present [...]." ${ }^{\prime 37}$

Onbedoelde effecten, waarvan bijvoorbeeld sprake was in Feeney, behoeven geen uitdrukkelijke rechtvaardiging. Deze keuze om alleen daadwerkelijk bedoelde effecten aan een toetsing te onderwerpen is van bijzonder belang voor de beoordeling van de toetsingsmethodiek van het Supreme Court: niet alleen is het interessant dat hierdoor een ander criterium dan benadeling of vergelijkbaarheid tot toetsingsingang wordt gekozen, maar ook is van belang dat deze benadering tot gevolg heeft dat er bij indirect onderscheid een andere toetsingsingang wordt gehanteerd dan bij direct onderscheid. In de loop van dit hoofdstuk zal dan ook uitgebreid aandacht worden besteed aan de wijze waarop het Supreme Court inhoud heeft gegeven aan het vereiste van een discriminatoir doel en aan de wenselijkheid van de keuze voor dit criterium.

\subsubsection{Toepasselijkheid van de Equal Protection Clause in alle situaties}

Veruit de meeste uitspraken van het Supreme Court hebben betrekking op normatieve classificaties: vrijwel steeds wordt een algemeen en abstract oordeel gegeven over de constitutionaliteit van een algemene regel waardoor een bepaalde groep is uitgezonderd en aan een bijzondere (voordelige of nadelige) behandeling is onderworpen. Opvallend genoeg is er geen rechtspraak te vinden waarin na vaststelling van de constitutionaliteit van een bepaalde classificatie nog wordt nagegaan of er misschien in het concrete geval sprake is van een toepassing die in strijd is met de Equal Protection Clause. ${ }^{38}$ Dit betekent dat er in de rechtspraak van het Supreme Court geen antwoord kan worden gevon-

36. 442 U.S. 229 (1976)

37. 426 U.S., 239 en 242 . Zie voor een heel andere en tegenstrijdige benadering de eerdere arresten United States v. O'Brien, 391 U.S. 367 (1968) (dat primair op vrijheid van meningsuiting betrekking had) en Palmer v. Thompson, 403 U.S. 217 (1971); in beide arresten werd gesteld dat uitsluitend moet worden gekeken naar het effect van een maatregel en niet naar de doelstelling. Het kostte het Supreme Court

38. Zelfs wanneer om aan te tonen dat het in deze gevallen ging om een andere situatie.

naar een klacht naar een klacht over de classificatie als zodanig; zie bijv. Oyama v. California, 332 U.S. 633 (1948). 
den op de vraag of het algemene toetsingsmodel bij concrete toepassing op een andere manier moet worden toegepast dan bij abstracte toetsing.

Het Supreme Court heeft wel verschillende malen uitspraak gedaan over de vraag of de Equal Protection Clause van toepassing is op het handelen van administratieve organen bij de toepassing van een (overigens niet-discriminatoire) algemene regeling. ${ }^{3 "} Z_{0}$ werd er in 1886 geklaagd over de manier waarop een administratief orgaan in San Francisco uitvoering gaf aan een algemene vergunningsregeling voor wasserijen: in de praktijk bleken dergelijke vergunningen nooit te worden toegekend aan Chinezen. Het Supreme Court oordeelde dat de Equal Protection Clause ook in dit soort gevallen bescherming biedt:

"Though the law itself be fair on its face, and impartial in appearance, yet, if it is applied and administered by public authority with an evil eye and an unequal hand, so as practically to make unjust and illegal discriminations between persons in similar circumstances material to their rights, the denial of justice is still within the prohibition of the constitution." "40

Ook uit latere uitspraken blijkt dat het Supreme Court bereid is om administratieve handelingen te beoordelen onder de Equal Protection Clause," Daarbij lijkt het Supreme Court geen andere toetsingsmethodiek te hanteren dan bij normatieve classificaties; alleen de specifiek voor normatieve classificaties ontwikkelde toetsing van de over- of underinclusiveness blijft in dit soort gevallen achterwege. Hierdoor wordt de theoretische veronderstelling bevestigd dat het algemene toetsingsmodel in deze situatie viij. wel ongewijzigd kan worden toegepast.

\subsection{Federale en statelijke verhoudingen}

\subsubsection{Gevolgen van het federale stelsel voor de opstelling van het Supreme Court}

Amerika is een federale staat, waarin aan de federale overheid slechts die bevoegdheden toekomen die in Artikel I, $\S 8$ en andere bepalingen van de Constitutie zijn opgesomd..$^{22}$ Hoewel de bevoegdheden van de federale overheid in de loop van de tijd door optreden door het Congres en door rechterlijke interpretatie ruim zijn uitgelegd, is de positie van de staten nog altijd bijzonder sterk. Dit betekent dat de federale overheid, en daarmee ook federale rechterlijke instanties als het Supreme Court, de vrijheid en de bevoegdheden van de staten zullen moeten respecteren. ${ }^{43}$

Voor de rechtspraak over gelijke behandeling is de verhouding tussen federatie en staten van bijzonder belang. Het Veertiende Amendement richt zich tot de staten en beperkt hun bevoegdheden, maar wordt in laatste instantie geïnterpreteerd en toegepast

39. Zie ook Currie 1985 , p. 386.

40. Yick Wo v. Hopkins, 118 U.S. 356, 373, 374 (1886)

41. Zie bijv. Wayte v. United States, 470 U.S. 598, 608 (1985), Allegheny Pittsburgh Co. v. Webster County, 488 U.S. 336, 345, 346 (1989) en Village of Willowbrook v. Olech, 528 U.S. 562, 464 (2000), vgl. ook Gunther/Sullivan 1997, p. 750.

42. Zie ook het Tiende Amendement: "The powers not delegated to the United States by the Constitution. nor prohibited by it to the States, are reserved to the States respectively, or to the people."

43. Vgl. Maltz 1981, p. 214. 
door het Supreme Court. ${ }^{4}$ Dit betekent dat het Supreme Court zich in een moeilijke positie bevindt: hoewel het gehouden is het Amendement zo goed mogelijk toe te passen, moet het er tegelijkertijd rekening mee houden dat de staten een grote mate van autonomie toekomt en dat zij bovendien over een eigen constitutie met een grondrechtencatalogus beschikken. Het Supreme Court grijpt in de meeste gevallen alleen in in de vrijheid van de staten en de keuzes die zij hebben gemaakt als de bescherming van de Equal Protection Clause alleen op die manier voldoende kan worden gewaarborgd. ts $^{3}$ Voor een goed begrip van de rechtspraak van het Supreme Court is deze achtergrond van groot belang: de verplichting om rekening te houden met federale verhoudingen kan soms een verklaring vormen voor het feit dat aan sommige rechten door het Supreme Court minder aandacht wordt besteed dan in Europese ogen logisch of wenselijk zou zijn en voor het feit dat de rechtspraak over de Equal Protection Clause hier en daar tegenstrijdig lijkt of hiaten vertoont.

\subsubsection{Toepassing van de Equal Protection Clause op de federale overheid}

\section{Zoals gezegd richt het Veertiende Amendement, waarvan de Equal Protection Clause} onderdeel vormt, zich uitsluitend tot de staten. Weliswaar bestaat er een tekstueel vrijwel identieke bepaling die zich tot de federale overheid richt, de Due Process Clause in het Vijfde Amendement, maar deze bevat geen expliciete gelijkheidsbepaling ${ }^{46}$ Vol-

44. De eerste tien amendementen van de Constitutie (de Bill of Rights) zijn niet gericht tot de staten, maar tot de federatie. De gedachte die ten grondslag lag aan het instellen van de Bill of Rights was dat de staten al over een grondwet beschikten die de vrijheid van de burgers beschermde, terwijl de federale overheid niet aan soortgelijke banden was gelegd (vgl. Berger 1977, p. 135/136). Later, na inwerkingtreding van het Veertiende Amendement, heeft het Supreme Court de Bill of Rights geleidelijk aan geincorporeerd in de verschillende clausules van dit Amendement; hierdoor hebben de bepalingen vaak ook betekenis voor de staten. Vanzelfsprekend is de toepasselijkheid van de Bill of Rights op de staten echter niet.

45. Een goed voorbeeld vormen de Civil Rights Cases, 109 U.S. 3, 13/14 (1883), waarin het Supreme Court uitdrukkelijk stelde dat het niet aan het Congres is om wetgeving op het terrein van het Veertiende Amendement in te stellen, tenzij er een noodzaak bestaat voor corrigerend optreden. Positieve regelgeving die niet is ingegeven door de noodzaak tot correctie, zoals het geval was bij enkele bepalingen van de Civil Rights Act, valt in het algemeen niet binnen de bevoegdheden van het Congres, maar binnen die van de staten. Het Supreme Court oordeelde dus feitelijk niet anders dan dat de bevoegdheid moet worden uitgeoefend door degene bij wie deze berust. Een probleem bij deze benadering is wel dat de sociale en politieke realiteit hierdoor soms uit het oog wordt verloren. Zo was het in 1883 nauwelijks denkbaar dat de zuidelijke staten positieve wetgeving zouden instellen, terwijl AfroAmerikanen hiervoor nauwelijks actief konden lobbyen vanwege de alomtegenwoordige discriminatie en de beperkingen van hun politieke rechten (vgl. Lusky/Botein 1975, p. 17). In die omstandigheden lijkt federaal ingrijpen wel degelijk zinvol en wenselijk.

De relevante tekst van het Vijfde Amendement luidt: "No person [...] shall be deprived of life, liberty, or property, without due process of law"; de formulering in het Veertiende Amendement luidt: "[...] nor shall any State deprive any person of life, liberty, or property, without due process of law; nor deny to any person within its jurisdiction the equal protection of the laws". "Due process of law" heeft een dubbele betekenis. Allereerst is er een procedurele betekenis: ieder individu heeft bepaalde procedurele rechten bij, bijvoorbeeld, vrijheidsontneming en onteigening; dit is due process in de eigenlijke zin van het woord. Daarnaast wordt er een betekenis aan de bepaling gegeven die wordt aangeduid als substantive due process. Daarmee wordt gedoeld op het feit dat overheidsmaatregelen waardoor inbreuk wordt gemaakt op individuele rechten voldoende legitiem moeten zijn (zie bijv. Allgeyer v. Louisiana, 165 U.S. 578 (1897), 589/590). Blijkens de rechtspraak van het Supreme Court biedt deze uitleg ruimte voor een rechterlijke toetsing van de redelijkheid en rechtvaardigheid van (wettelijke) regelgeving (zie 
gens enkele vroege uitspraken van het Supreme Court had dit tot consequentie dat het handelen van de federale overheid in beginsel niet aan het gelijkheidsbeginsel is onderworpen: in Detroit Bank v. US (1943) $)^{47}$ stelde het, dat

"[u]nlike the Fourteenth Amendment, the Fifth contains no equal protection clause and it provides no guarantee against discriminatory legislation by Congress."

Ter verzachting van dit verschil stelde het Supreme Court in deze en andere uitspraken wel dat bepaalde gevallen van federale ongelijke behandeling zodanig willekeurig en benadelend kunnen zijn, dat zij zelfstandig een inbreuk opleveren op de Due Process Clause in het Vijfde Amendement. ${ }^{4 y}$ Hierdoor werd echter nog steeds een minder ver. gaande bescherming geboden tegen federaal onderscheid dan tegen ongelijke behandeling door de staten. Het Supreme Court leek dit aanvankelijk niet problematisch te vinden, maar toen er met de zaak Brown v. Board of Education ${ }^{30}$ een einde werd gemaakt aan de segregatie op scholen in de verschillende staten, bleek er opeens toch behoefte te bestaan aan een effectieve bescherming tegen ongelijke behandeling door de federale overheid. Ook in het District of Columbia, dat federaal grondgebied is, bleek namelijk een segregatiebeleid te worden gevoerd; door het ontbreken van een duidelijke verplichting tot gelijke behandeling kon daaraan nauwelijks een einde worden gemaakt. Het Supreme Court reageerde op dit probleem door in Bolling v. Sharpe de eerdere rechtspraak over het Vijfde Amendement aan te scherpen:

"The 'equal protection of the laws' is a more explicit safeguard of prohibited unfairness than 'due process of law,' and, therefore, we do not imply that the two are always interchangeable phrases. But [...] discrimination may be so unjustifiable as to be violative of due process. [...] In view of our decision that the Constitution prohibits the states from

vooral Lochner v. New York, 198 U.S. 45, 56 (1905)). Aangezien de rechter daardoor een vergande vrijheid wordt toegekend ten opzichte van de wetgever is deze uitleg bijzonder controversieel (zien. der paragraaf 3.2). Ondanks de academische controverse wordt de gedachte van substantive due process als zodanig vrij algemeen geaccepteerd; vgl. Cover 1982, p. 1288. Een voordeel van de benadering is namelijk dat deze ruimte laat voor het inlezen van grondwettelijke waarborgen tegen overheis. optreden. Zo kan het inlezen van een gelijkheidsbeginsel in de Due Process Clause van het Vijtiende Amendement worden gezien als een uitvloeisel van de substantive due process-benadering. Daarbij geldt dat het gelijkheidsbeginsel inderdaad gemakkelijk in de Due Process Clause kan worden ondergebracht: zowel bij substantive due process als bij gelijke behandeling moet een inhoudelijk oorded over de gerechtvaardigdheid van een regeling worden uitgesproken, zodat beide beginselen feitelijk dicht tegen elkaar aanliggen. Vgl. Karst 1977, p. 547 en 550 en "Note" 1982, p. 1419.

47. 317 U.S. 329,337 (1943)

48. 317 U.S., op 337

49. Zie m.n. Steward Machine Co. v. Davis, 301 U.S. 548, 584 (1937) (waar de problematiek ontwekth werd door te stellen dat de classificatie gerechtvaardigd zou zijn geweest als deze door een staat was veroorzaakt, en dus a fortiori gesteld kon worden dat deze toelaatbaar was nu de federale overhid hiervoor verantwoordelijk was) en Currin v. Wallace, 306 U.S. 1, 14 (1939). Een iets ruimere formule ring is zichtbaar in Hirabayashi, waarin het Supreme Court stelde dat: "The Fifth Amendment contains to a denial of due process" (320 U.S. 81, 100 (1943)). Zie nader Karst 1977, p. 543/544 en Watterson Jr. 1996, p. 313/314.

50. 347 U.S. $438(1954)$

51. 347 U.S. 497 (1954); deze zaak is op dezelfde dag gewezen als Brown en heeft betrekking op de federale gesegregeerde scholen. 
maintaining racially segregated public schools, it would be unthinkable that the same Constitution would impose a lesser duty on the Federal Government."

Uit latere rechtspraak blijkt dat het Supreme Court deze formulering zag als de definitieve erkenning van het feit dat het gelijkheidsbeginsel ook geldt voor de federale overheid.." In de grote meerderheid van de latere uitspraken wordt het gelijkheidsbeginsel op identieke wijze op de staten en de federale overheid toegepast en wordt vaak niet eens melding gemaakt van het feit dat het gaat om een federale maatregel. ${ }^{\text {st }}$ In $\mathrm{Wein}$ berger $v$. Wiesenfeld stelde het Supreme Court zelfs dat

"[t]his Court's approach to Fifth Amendment equal protection claims has always been precisely the same as to equal protection claims under the Fourteenth Amendment."ss

Aanvankelijk bestonden er echter wel degelijk verschillen tussen beide bepalingen in toetsingsmethodiek en vooral toetsingsintensiteit. Zo gaf het Supreme Court aan dat sommige vormen van onderscheid op federaal niveau toelaatbaar waren, terwijl dat niet het geval zou zijn als het onderscheid door een staat zou zijn gemaakt, ${ }^{56}$ en is het een tijdlang zo geweest dat er minder hoge eisen werden gesteld aan de rechtvaardiging van positieve actie door de federale overheid dan aan voorkeursbeleid dat door de staten werd gevoerd ${ }^{57}{ }^{58}$ Inmiddels lijkt het Supreme Court definitief een einde te hebben ge-

52. 347 U.S., op 499/500. Opvallend is dat dit ook de enige motivering is die voor het inlezen van het gelijkheidsbeginsel in het Vijfde Amendement is gegeven; vgl. Doherty 1989, p. 597 en Karst 1977, p. 546.

53. Hetzelfde geldt voor de commentatoren; zie bijv. Siedziekowski 1978, p. 557. Gezien de voorgeschiedenis is dit niet geheel terecht, al is de formulering in de uitspraak aanmerkelijk scherper dan die in eerdere zaken; in die zin ook Karst 1977, p. 543 en Watterson Jr. 1996, p. 316.

54. Zie bijv. Schlesinger v. Ballard, 419 U.S. 498 (1975). Een andere illustratie voor het feit dat het Supreme Court nauwelijks nog verschil maakt tussen de beide amendementen is te vinden in de omstandigheid dat in rechtspraak over het Veertiende Amendement soms verwezen wordt naar precedenten die betrekking hebben op het Vijfde Amendement; de onderlinge uitwisselbaarheid van de rechtspraak is dus groot; zie bijv. McLaughlin v. Florida, 379 U.S. 184 (1964). In haar opinie in het arrest Adarand, 515 U.S. 200 (1995) gaat Justice O'Connor uitgebreid op dit soort factoren in.

55. 420 U.S. 636,638 , voetnoot 2 (1975)

56. In het arrest Hampton v. Mow Sun Wong stelde de Supreme Court het volgende: "Although both Amendments require the same type of analysis [...], the Court of Appeals correctly stated that the two protections are not always coextensive. Not only does the language of the two Amendments differ, but more importantly, there may be overriding national interests which justify selective federal legislation that would be unacceptable for an individual State" (426 U.S. 88, 100 (1976)); zie hierover Watterson Jr. 1996, p. 323/324. Overigens betekent dit niet dat er bij federaal onderscheid daadwerkelijk een andere toetsingsmethodiek of toetsingsintensiteit wordt toegepast: onafhankelijk van het gekozen model is het mogelijk dat de federatie bepaalde vormen van onderscheid mag maken, terwijl een staat dit niet kan doen omdat een bevoegdheid daartoe ontbreekt. Als deze overweging ook betekent dat in beide situaties een andere toetsingsintensiteit kan worden gehanteerd (hetgeen zou kunnen blijken uit $\mathrm{Ma}$ thews v. Diaz, 426 U.S. 67, 83 (1976), in vergelijking tot Graham v. Richardson, 403 U.S. 365,372 (1971)) is er wel een duidelijk verschil aanwezig; vgl. Levi 1979, p. 1084, Doherty 1989, p. 606 en Siedzikowski 1978, p. 579. Zie nader paragraaf 3.5 .

57. Vgl. Metro Broadcasting v. FCC, 497 U.S. 547, 563, 564 (1990) (voortbordurend op Fullilove v. Klutznick, 448 U.S. 448, 463 (1980)) (waarin het Congres een relatief ruime bevoegdheid werd toegekend om een voorkeursbeleid te voeren), met City of Richmond v. J.A. Croson, 488 U.S. 469, 489, 490 (1989) (waarin uitdrukkelijk werd gesteld dat staten en andere lagere overheidsorganen als gemeenten een dergelijke vrijheid niet hebben). Aan het uiteenlopen van deze rechtspraak werd nadrukkelijk een einde gemaakt in Adarand, 515 U.S. 200, 224 (1995).

Tegen de hiervoor geschetste achtergrond van terughoudendheid tegenover de staten lijkt dit wat 
maakt aan deze verschillen tussen het Veertiende en Vijfde Amendement. In Adarand Constructors, Inc. v. Pena ${ }^{59}$ legde het een drietal grondbeginselen voor de interpretatie van het gelijkheidsbeginsel neer, waartoe ook het beginsel van congruentie behoort. Dit beginsel houdt in, dat

"[e]qual protection analysis in the Fifth Amendment area is the same as that under the Fourteenth Amendment.",

In het hiernavolgende zal er dan ook vanuit worden gegaan dat de toetsingsmethodick en de toetsingsintensiteit bij de toetsing van federale en statelijke ongelijke behandeling identiek zijn. ${ }^{61}$

\subsection{Horizontale werking}

\subsubsection{Het Veertiende Amendement en de noodzaak van state action}

Uit de tekst van het Veertiende Amendement blijkt dat deze bepaling zich primair richt tot de staten en niet uitdrukkelijk betrekking heeft op de verhoudingen tussen burgers onderling. ${ }^{62}$ In de Civil Rights Cases ${ }^{63}$, relatief snel na het aannemen van het Amendement gewezen, werd dit door het Supreme Court bevestigd:

merkwaardig: het zou eerder in de lijn der verwachting liggen als er hogere eisen werden gesteld an de federale overheid. De verklaring hiervoor lijkt in de genoemde gevallen gelegen te zijn in de bijzondere omstandigheden van het geval (zie Siedzikowski 1978, p. 577). Soms houdt het verschil verband met een bevoegdheidskwestie: het immigratiebeleid betreft een van de terreinen waarop de federale bevoegdheden veel omvangrijker zijn dan die van de staten, zodat het redelijk is dat de federale antoriteiten meer ruimte hebben om onderscheid te maken dan de staten. Voor de situatie rondom voorkeursbeleid kan een verklaring worden gevonden in een strijd tussen de rechters van het Suprene Court. Een deel van de rechters was in de relevante periode zeer gekant tegen voorkeursbeleid, terwi] een ander deel juist van mening was dat hiervoor een bijzondere rechtvaardiging bestond; een latste groepje van rechters twijfelde. Daardoor was het mogelijk dat er in de in de vorige noot genoemde us resten, deels betrekking hebbend op statelijk, deels op federaal onderscheid, wisselende meerderheden bestonden. Met name uit de zaak Metro Broadcasting, 497 U.S. 547 (1990), waarin de voorstanders de meerderheid hadden, blijkt een verklaring voor het verschil in benadering van federaal en statelijk of derscheid: in City of Richmond v. J.A. Croson Co., 488 U.S. 469 (1989), was voorkeursbeleid voor de staten vrijwel onmogelijk gemaakt; de enige manier om voorkeursbeleid als instituut te "redden" wa om de ruimte daarvoor in ieder geval voor federale maatregelen veilig te stellen. Op die manier konden staten weliswaar geen voorkeursbeleid voeren, maar de federale overheid kon programma's aannemen die hetzelfde effect sorteerden; vgl. Rutten 1997, p. 609.

59. 515 U.S. 200 (1995)

60. 515 U.S., op 224. Van belang is dat Justice O'Connor, de auteur van de meerderheidsopinie, in eat eerdere passage opmerkt dat afwijkingen van de algemene lijn van onderlinge uitwisselbaarheid, zoals het hiervoor genoemde arrest Hampton v. Mow Sun Wong, onbegrijpelijk zijn (515 U.S., op 217/218).

61. Hoewel het beginsel van congruentie niet wegneemt dat de bevoegdheden van staten en federatis blijven verschillen: ook na Adarand kan een bevoegdheidsuitoefening door de federatie leiden tot een toelaatbaar onderscheid, terwijl dit niet het geval zou zijn wanneer het zou gaan om een bevoegdheids. uitoefening door de staat. Vgl. Doherty 1989, p. 634.

62. Ook hier is discussie mogelijk: er zijn commentatoren die stellen dat uit de debatten die san het annemen van het Amendement vooraf gingen kan worden afgeleid dat er een ruimere reikwijdte werd beoogd dan alleen state action; in ieder geval zou het de bedoeling zijn geweest om het Congres (dat op basis van Section 5 van het Amendement de bevoegdheid heeft "to enforce, by appropriate legistation, the provisions of this article") de mogelijkheid te geven om wetgeving te maken die betrekking heft op ongelijke behandeling in horizontale verhoudingen. Vgl. "Developments" 1969, p. 1070.

63. 109 U.S. 3 (1883) 
"It is State action of a particular character that is prohibited. Individual invasion of individual rights is not the subject-matter of the amendment. [...][C]ivil rights, such as guaranteed by the Constitution against State aggression, cannot be impaired by the wrongful act of individuals, unsupported by State authority in the shape of laws, customs, or judicial or executive proceedings."

Ondanks deze uitspraak is de Equal Protection Clause niet van ieder effect voor horizontale verhoudingen verstoken gebleven: in de loop van de tijd bleek het Supreme Court bereid te zijn een ruime uitleg aan het begrip state action te geven. ${ }^{65}$ Eén van de belangrijkere arresten in dit opzicht is Shelley $v$. Kraemer ${ }^{66}$, een zaak die betrekking had op een convenant dat werd gesloten tussen huiseigenaren in bepaalde wijken, inhoudend dat hun huizen niet verhuurd of verkocht mochten worden aan mensen van het Afro-Amerikaanse of Mongoolse ras. Toen een Afro-Amerikaan toch een koopcontract had gesloten met één van de eigenaren stapten de andere eigenaren naar de rechter om naleving van het convenant af te dwingen; de rechter wees hun eis toe. Aan het Supreme Court werd vervolgens de vraag voorgelegd of er door het verzekeren van de afdwingbaarheid van het convenant door de rechter sprake was van state action. Het Supreme Court gaf een bevestigend antwoord:

"We have no doubt that there has been state action in these cases in the full and complete sense of the phrase. [...] It is clear that but for the active intervention of the state courts, supported by the full panoply of state power, petitioners would have been free to occupy the properties in question without restraint." ${ }^{\prime 6}$

64. 109 U.S., op 11 en 17. Deze uitspraak is vooral zo beperkend gezien het feitencomplex. In het geding was een federale wet die een discriminatieverbod bevatte voor eigenaars van cafés en vergelijkbare gelegenheden. Zoals in voetnoot 62 is aangegeven zou uit het Amendement kunnen worden afgeleid dat dit hiervoor ruimte laat. Deze uitspraak heeft dan ook niet alleen tot consequentie dat horizontaal onderscheid niet rechtstreeks aan het Supreme Court kan worden voorgelegd, maar ook dat er voor het Congres geen mogelijkheid bestaat om via positieve wetgeving een discriminatieverbod in te stellen voor horizontale verhoudingen (vgl, Lusky/Botein 1975, p. 15). De verklaring voor deze uitspraak is te vinden in de beleidsvrijheid van de staten: in zijn motivering merkte het Supreme Court op, dat "[Section 5] does not invest Congress with power to legislate upon subjects which are within the domain of State legislation [...]" (109 U.S., op 11). Hoewel horizontaal onderscheid niet door federale wetgeving kan worden beperkt, kunnen de staten dit soort wetgeving wel zelf tot stand brengen. In latere rechtspraak is de bevoegdheid om corrigerend op te treden wel vrij ruim geïnterpreteerd; zie bijv. Katzenbach v. Morgan, 384 U.S. 641 (1966) en Kimel v. Florida Board of Regents, 528 U.S. 62 (2000).

65. Dit is alleen al het geval doordat het Supreme Court in tal van uitspraken heeft aangegeven dat onder het begrip alle besluiten en handelingen vallen van alle personen die formeel identificeerbaar zijn als een "instrumentality" van de staat, ook al is er sprake van een handeling waaraan geen geldige bevoegdheid ten grondslag lag of die meer in het algemeen door de wet verboden is. Alleen handelingen die kennelijk in de privé-sfeer liggen zijn niet te beschouwen als "state action". Zie "Developments" 1969 , p. 1071 en Lewis 1960 , p. 1086 en de daarin genoemde verwijzingen naar de relevante rechtspraak. Verder kan uit de omstandigheden van het geval soms worden afgeleid dat een particuliere handeling moet worden gezien als handeling van de overheid, zoals in het geval van een huurder die overheidseigendommen exploiteert en daarbij onderscheid maakt op grond van ras (Burton v. Wilmington Parking Authority, 365 U.S. 715, 724, 725 (1961)). Vgl. Lewis 1960, p. 1100, Lusky 1975, p. $228 / 229$ en "Developments" 1969, p. 1071. Tenslotte kan ook het uitoefenen van een publieke functic door een particulier ervoor zorgen dat het Veertiende Amendement van toepassing is ("Developments" 1969 , p. 1071). Zie voor enkele algemene criteria voor het toerekenen van private handelingen aan de overheid Vaugh Dunnigan 1988, p. 359/360.

66. 334 U.S. I (1948)

67. 334 U.S., op 19 
Uit deze overweging blijkt dat het Supreme Court een soort indirecte vorm van hori. zontale werking accepteert: weliswaar kan geen rechtstreeks beroep worden gedaan op de Equal Protection Clause in het geval van ongelijke behandeling door particulieren, maar het is wel mogelijk om deze bepaling in te roepen wanneer een particulier onderscheid door een rechter (of een ander overheidsorgaan ${ }^{(s)}$ ) uitdrukkelijk is goedgekeurd," Van belang is echter dat er in gevallen als deze, en ook in de andere gevallen waarin het Supreme Court de toepasselijkheid van het Veertiende Amendement op een schijp. baar horizontale verhouding heeft geaccepteerd, toch altijd sprake is van het aanvech. ten van een vorm van state action. ${ }^{70}$ Uit de rechtspraak van de Supreme Court over de Equal Protection Clause kunnen dan ook geen aanwijzingen worden afgeleid over de vraag of en, zo ja, hoe de verschillende criteria van het toetsingsmodel kunnen worden toegepast in werkelijk horizontale verhoudingen.

\subsubsection{Horizontale werking: de Civil Rights Act 1964}

Interessante aanwijzingen over de toetsingsmethodiek bij onderscheid in horizontale verhoudingen zijn wel te vinden in de rechtspraak over de Civil Rights Act 1964." Deze federale wet werd ingevoerd omdat verschillende staten niet bereid of in staat bleken om wetgeving in te stellen ter bestrijding van ongelijke behandeling in horizontale verhoudingen en de Equal Protection Clause geen mogelijkheden bood om hen hiertoe te verplichten. ${ }^{12}$ Daardoor verliep het proces van desegregatie, ingezet met de hiervoor besproken zaak Brown v. Board of Education, veel langzamer dan gewenst: in veel staten konden Afro-Amerikanen nauwelijks een baan krijgen en werden zij in ieder geval slechter betaald dan blanken, door convenanten als hierboven besproken konden zij nauwelijks huizen huren of kopen in "blanke" wijken, en veel cafés, restaurants en andere voorzieningen bleven voor hen gesloten. De Civil Rights Act 1964 biedt verschillende mechanismen om dergelijke particuliere vormen van discriminatie aan te pakken: zo bevat de wet een verbod op segregatie in schouwburgen en andere, door particulieren geëxploiteerde, openbare gelegenheden, ${ }^{3}$ een verbod op discriminatie door werkgevers ${ }^{74}$ en een verbod op ongelijke behandeling bij de uitvoering van door de federale overheid gesubsidieerde programma'ss. Van belang is verder dat de reik-

68. De reikwijdte van de formuleringen in Shelley is vrij ruim en beperkt zich duidelijk niet tot de rechterlijke macht: het Supreme Court stelde dat "State action [...] refers to exertions of state power in all forms. And when the effect of that action is to deny rights subject to the protection of the Fourteenth Amendment, it is the obligation of this Court to enforce the constitutional commands" ( 334 U.S., op 20). Vgl. ook Cooper v. Aaron, 358 U.S. 1, 17 (1958).

69. Overigens lijkt de reikwijdte van de uitspraak beperkt te zijn: in latere rechtspraak maakte het Supreme Court verschil tussen het daadwerkelijk afdwingen van een convenant jegens een partij die niet berrid is zich eraan te houden en de erkenning van het recht van een partij om vast te houden aan de voos. waarden van een door hem opgesteld, discriminatoir contract; in het laatste geval is er geen sprake vas state action. Vgl. Lusky 1975, p. 180 en Lewis 1960, p. 1111 en 1121 en de door hem genoemde rechtspraak.

70. Vgl. Winter 1972, p. 52.

71. Zie 42 U.S.C., Chapter 21 ,

72. Vgl. Loevy 1997, p. 18/19.

73. 42 U.S.C. $\$ 2000 \mathrm{a}$

74. 42 U.S.C. $\$ 2000 \mathrm{e}$

75. 42 U.S.C. $\$ 2000 \mathrm{~d}$ 
wijdte van de wet niet beperkt is tot onderscheid op grond van ras of huidskleur: de bepalingen richten zich ook op onderscheid op grond van religie en geslacht. Deze wet vormt dan ook een belangrijk instrument voor de bestrijding van horizontale ongelijke behandeling.

Voor de toetsingsmethodiek is vooral Title VII van de wet interessant. ${ }^{76}$ Deze titel, die specifiek betrekking heeft op onderscheid in arbeidsverhoudingen, heeft geleid tot een uitgebreide rechtspraak waarin gedetailleerde criteria zijn ontwikkeld voor de beoordeling van normatieve classificaties door werkgevers en voor de toetsing van bloot onderscheid. Het accent in deze rechtspraak ligt op de bewijslastverdeling en de wijze waarop kan worden aangetoond dat er van een ongelijke behandeling op bepaalde gronden sprake is. ${ }^{n}$ Hoewel de rechtspraak over Title VII voor het onderzoek op zichzelf interessante elementen bevat, zal hieraan in dit hoofdstuk geen aandacht worden besteed. Een belangrijke reden voor deze keuze is gelegen in het feit dat het Supreme Court zijn maatstaven en criteria specifiek heeft ontwikkeld voor zaken over ongelijke behandeling bij "employment practices". Voor de andere onderdelen van de Civil Rights Act 1964 gelden vaak andere criteria, ${ }^{7 s}$ terwijl er bovendien nauwelijks wisselwerking bestaat tussen de rechtspraak over Title VII en die over de Equal Protection Clause. ${ }^{79}$ De diverse criteria die in de rechtspraak zijn uitgewerkt lenen zich daardoor niet altijd even goed voor een meer algemene toepassing en zijn dan ook minder interessant voor de ontwikkeling van een algemeen bruikbaar toetsingsmodel. Van belang is verder dat deze rechtspraak specifiek betrekking heeft op de bewijslastverdeling en de wijze waarop ongelijke behandeling in horizontale verhoudingen kan worden aangetoond. De ruimte die het Supreme Court heeft voor het vormgeven van een eigen toetsingsmethodiek is aanzienlijk beperkter als het gaat om de rechtvaardigingsfase, die in het onder-

76. 42 U.S.C., Chapter 21 , Subchapter VI ( $\$ 2000$ e e.v.). De belangrijkste bepaling is $\$ 2002 \mathrm{e}-2$.

77. Zie voor de criteria voor de toetsing van bloot onderscheid ("disparate treatment") vooral McDonnell Douglas v. Green, 411 U.S. 792 (1973), Texas Department of Community Affairs v. Burdine, 450 U.S. 248 (1981), Watson v. Fort Worth Bank \& Trust, 487 U.S. 977 (1988) en Price Waterhouse v. Hopkins, 490 U.S. 228 (1989). Voor direct onderscheid in normatieve classificaties door werkgevers bestaat een rechtvaardigingsmogelijkheid onder de Civil Rights Act (42 U.S.C. $\$ 2000 \mathrm{e}-2(\mathrm{e})$ ). Voor indirect onderscheid in horizontale normatieve regelingen ("disparate impact") bestond aanvankelijk geen specifieke wettelijke regeling, hetgeen resulteerde in een uitgebreide rechtspraak waarin diverse toetsingscriteria werden vastgelegd. Belangrijke uitspraken zijn Griggs v. Duke Power Co., 401 U.S. 424 (1971). Watson v. Fort Worth Bank \& Trust, 487 U.S. 977 (1988) en Wards Cove Packing v. Atonio, 490 U.S. 642 (1989). Dit laatste arrest (waarin zodanig beperkende voorwaarden werden neergelegd dat disparate impact vrijwel nooit kon worden aangetoond) kan overigens niet als geldig precedent worden beschouwd: in 1991 is er een nieuwe Civil Rights Act aangenomen waarin criteria voor de toetsing van gevallen van disparate impact zijn neergelegd en waarin is aangegeven dat deze bepalingen alleen mogen worden uitgelegd aan de hand van arresten die vóór Wards Cove zijn gewezen (zie 42 U.S.C. $2000 \mathrm{e}-2(\mathrm{C}))$.

78. Zo bestaat er onder Title VII een mogelijkheid om onbedoeld indirect onderscheid aan te vechten, terwijl voor Title VI (net als voor de Equal Protection Clause, zie daarover paragraaf 1.1.4) uitdrukkelijk is gesteld dat alleen bedoelde effecten onder de reikwijdte vallen; vgl. Alexander v. Sandoval, 69 U.S.L.W. 4250 (2001) en Alexander v. Choate, 469 U.S. 287, 293 (1985),

79. Heel duidelijk stelde het Supreme Court dit in Washington v. Davis, 426 U.S. 229 (1976): "We have never held that the constitutional standard for adjudicating claims of invidious racial discrimination is identical to the standards applicable under Title VII and we decline to do so today" (op 238). 
zoek nu juist centraal staat. ${ }^{\text {*o }}$ Aangezien de keuze is gemaakt om aan de specifieke problematiek van het bewijs geen bijzondere aandacht te besteden is deze rechtspraak dan ook in mindere mate relevant.

\subsection{Werkwijze van het Supreme Court}

\section{"Writ of certiorari"}

Het Supreme Court fungeert meestal als hoger beroepsinstantie, hoewel er voor een beperkt aantal gevallen een bevoegdheid bestaat om als rechter in eerste aanleg op te treden. ${ }^{81}$ De belangrijkste manier waarop hoger beroepszaken het Supreme Court bereiken is die van de writ of certiorari. ${ }^{{ }^{2}}$ Het is in vrijwel alle zaken waarin een vraag over de uitleg van het federale recht een rol speelt mogelijk een verzoek in te dienen tot het verlenen van certiorari, hetgeen kan worden beschouwd als een verzoek om een zaak inhoudelijk te beoordelen. ${ }^{83}$ De verlening van certiorari is een discretionaire bevoegdheid: het is aan het Supreme Court om te bepalen of het verzoek vragen aan de orde stelt die in het licht van de interpretatie en toepassing van het federale recht (met name de Constitutie) van belang zijn. ${ }^{\text {st }}$ Daardoor heeft het Supreme Court de mogelijkheid

80. Vooral de rechtvaardigingsmogelijkheid is sterk ingekaderd door de Civil Rights Act 1964. De belangrijkste rechtvaardigingsmogelijkheid is de "bona fide occupational qualification" (ofwel de BFOQ-verdediging): "[...] it shall not be an unlawful employment practice [...] to hire and employ employees [...] on the basis of his religion, sex, or national origin in those certain instances where religion, sex of national origin is a bona fide occupational qualification reasonably necessary to the normal operation of that particular business or enterprise" (42 U.S.C. $\$ 2002 \mathrm{e}-2$ (e)); deze uitzonderingsmogelijkheid is zeer specifiek en beperkt de mogelijkheid voor het Supreme Court om eigen toetsingscriteria te ontwikkelen. Er bestaan nog enkele andere uitzonderingsbepalingen, maar deze hebben een beperkte reikwijdte (42 U.S.C. $\$ 2002 \mathrm{f}-\mathrm{i}$ ). Van belang is bovendien dat de $B F O Q$-verdediging niet geldt voor onderscheid op grond van ras of huidskleur: onderscheid op deze gronden is nooit gerechtvaardigd Ook in de gevallen waarin de Civil Rights Act geen aanwijzingen gaf voor de rechtvaardiging (zoals bii disparate impact) is de vrijheid van het Supreme Court beperkt: in de praktijk blijkt het Supreme Cour zich te laten leiden door de rechtvaardigingsmogelijkheid zoals die bij direct onderscheid geldt. $z_{0}$ stelde het Supreme Court in Griggs: "the touchstone is business necessity. If an employment practice which operates to exclude Negroes cannot be shown to be related to job performance, the practice is prohibited" (401 U.S., 431). Daarbij is van belang dat Title VII, in reactie op de rechtspraak van hit Supreme Court over de bewijslastverdeling en de manier waarop het bewijs kan worden geleverd, in 1991 ingrijpend is gewijzigd; het Congres was van mening dat de rechtspraak onwenselijke consequenties had en heeft een nauwkeurige bewijsregeling vastgesteld. Hoewel de eerdere rechtspraak intsressante aanwijzingen kan geven over de manier waarop met bewijslast kan worden omgegaan, kunnen de diverse uitspraken dus niet meer worden gezien als geldende precedenten.

81. Zie Artikel III, lid 2 van de Constitutie. Daaruit blijkt dat het Supreme Court alleen "original jurisdicton" heeft "in all cases affecting ambassadors, other public ministers and consuls, and those in which 2 state shall be party". Deze competentie is bovendien ingeperkt door het Elfde Amendement.

82. Een andere mogelijkheid is de "writ of appeal", waarbij aan een procespartij bij wet een automatisch recht is toegekend om hoger beroep in te stellen bij het Supreme Court, dat vervolgens verplicht is ofit een oordeel over de zaak te vellen. Sinds 1988 is deze mogelijkheid echter sterk beperkt (Abrahan 1998, p. 190).

83. Zie 28 U.S.C. $\$ \$ 1254$ en 1257.

84. Freund 1961, p. 12 en Stern/Gressman 1978, p. 36. De factoren die hierbij een rol kunnen spelen zipp neergelegd in Rule 10 van de Rules of the Supreme Court of the U.S. (1999); belangrijke redenen om certiorari te verlenen zijn aanwezig wanneer een uitspraak van een lagere rechter inconsistenties met andere lagere rechtspraak op kan leveren, wanneer er sprake is van een onderwerp waarover het Sypreme Court zich nog niet eerder heeft uitgesproken en wanneer er sprake is van strijd met een uli- 
om alleen de meest controversiële of juridische ingewikkelde vraagstukken te selecteren en daarover een goed doordachte en uitgebreid gemotiveerde uitspraak te doen.

\section{"Stare decisis", "overruling" en "distinguishing"}

Bij de uitleg van de Constitutie is het Supreme Court gebonden aan de regel van stare decisis, waardoor aan precedenten een met geldend recht vergelijkbare status wordt toegekend: deze regel impliceert de verplichting om de in eerdere uitspraken gegeven interpretatie te volgen. ${ }^{85} \mathrm{Om}$ toch een zekere mate van flexibiliteit te creëren en ervoor te zorgen dat er ingegrepen kan worden wanneer een precedent niet meer als juist of wenselijk wordt beschouwd, beschikt het Supreme Court over een tweetal mogelijkheden om deze regel te doorbreken. ${ }^{\$ 6}$ De meest vergaande en directe manier is "overruling" van de eerdere uitspraak, hetgeen betekent dat expliciet wordt gesteld dat een precedent niet meer als geldig mag worden beschouwd. ${ }^{87}$ Dit is echter een vergaand en grof middel, dat bij voorkeur niet wordt gehanteerd. ${ }^{8 s}$ Een tweede, veel subtielere mogelijkheid voor het afwijken van precedenten is "distinguishing". Bij toepassing van deze methode zal het Supreme Court stellen dat de rechtsregel die in het precedent is neergelegd op de voorliggende zaak niet van toepassing kan worden geacht omdat de feiten op relevante punten verschillen. ${ }^{80}$ Omdat twee zaken nooit volledig identiek zijn

spraak van het Supreme Court. Zoals Ulmer aangeeft spelen bij de beslissing om een bepaalde zaak inhoudelijk te beoordelen vooral politieke overwegingen een rol (1981, p. 284). In de praktijk wordt 85 tot $90 \%$ van alle verzoeken om het verlenen van certiorari afgewezen; zie Abraham 1998, p. 194.

85. Vgl. Abraham 1998, p. 189.

86. Voor het constitutionele recht wordt overigens aangenomen dat de regel van stare decisis minder zwaarwegend is dan voor de overige gebieden van het recht. Reden daarvoor is onder andere dat het moeilijk is om de Constitutie te wijzigen om een onwenselijke rechterlijke uitspraak te corrigeren; zie Israel 1975, p. 77-79 en Monaghan 1979, p. 3/4. De laatste geeft bovendien aan dat alleen door af te wijken van de stare decisis-regel ontwikkelingen in het constitutionele recht kunnen bewerkstelligd; het recht zou anders eenvoudigweg stil blijven staan. De stare decisis-regel geldt bij het constitutionele recht dan ook niet zozeer voor de belangrijkste interpretator van de Constitutie (het Supreme Court), maar vooral voor lagere rechters; op die manier wordt voorkomen dat er afbreuk wordt gedaan aan uniformiteit en rechtszekerheid.

87. Een voorbeeld hiervan is te vinden in City of New Orleans v. Dukes, 427 U.S. 297 (1976), waarin Morey v. Doud, 354 U.S. 457 (1957) werd overruled. Beide arresten hadden betrekking op economische regelgeving waarin een "closed class" werd uitgesloten; dit wil zeggen dat een specifieke, bij naam genoemde groep van de werking van een benadelende regeling wordt uitgezonderd. In Morey v. Doud stelde het Supreme Court dat daarbij sprake was van een ongewone vorm van onderscheid die aan een iets strengere toets moest worden onderworpen, en oordeelde dat het ontoelaatbaar was. Daarmee week het Supreme Court af van een lange lijn van rechtspraak waarin onderscheid in economische wetgeving terughoudend benaderd wordt en vrijwel steeds toelaatbaar wordt geacht (zie nader paragraaf 3). In Dukes stelde het Supreme Court het volgende: "[...][T] he reliance on the statute's potential irrationality in Morey v. Doud [...] was a needlessly intrusive judicial infringement on the State's legislative powers, and we have concluded that the equal protection analysis employed in that opinion should no longer be followed. Morey was the only case in the last half century to invalidate a wholly economic regulation solely on equal protection grounds, and we are now satisfied that the decision was erroneous" (427 U.S., op 306). Meestal is het veel moeilijker om te bepalen of er daadwerkelijk sprake is van overruling, omdat dit niet altijd met zoveel woorden wordt aangegeven; vgl. Maltz 1988, p. 384.

88. Israel 1975, p. $75 / 76$ (met verwijzingen): in anderhalve eeuw tijd is in minder dan 100 gevallen sprake geweest van een expliciete overruling van een eerdere uitspraak.

89. ledere uitspraak is in beginsel beperkt tot de feiten van het specifieke geval; er wordt geen abstracte en algemene interpretatie van een bepaalde constitutionele bepaling gegeven. Dit betekent dat, ondanks de precedentwerking, in iedere zaak opnieuw beslist moet worden en bekeken moet worden of de feiten 
is het heel gemakkelijk om van deze methode gebruik te maken, hetgeen in de praktijk dan ook met grote regelmaat gebeurt. Dit heeft tot gevolg gehad dat de rechtspraak van het Supreme Court heel verfijnd en genuanceerd is geworden, zodat er vaak verschil. lende rechtsregels gelden voor op minimale punten verschillende situaties. Ook in de rechtspraak over de Equal Protection Clause is deze verfijning zichtbaar: hoewel er een duidelijke hoofdlijn bestaat, wordt er in een vrij groot aantal specifieke situaties een iets afwijkende toetsingsmethodiek gehanteerd. ${ }^{\text {\% }}$ Soms is dit lastig voor het maken van een goede inschatting van het belang van een bepaalde lijn van uitspraken: het kan gebeuren dat een precedent jarenlang op een bepaalde manier is uitgelegd en toegepast, waarna in een nieuwe uitspraak opeens wordt gesteld dat het precedent slechts betrek. king had op een specifieke feitenconstellatie. Hierdoor kan van een hoofdregel soms opeens een uitzondering worden gemaakt, maar ook het omgekeerde komt voor: een eerder als uitzondering beschouwd precedent kan door middel van distinguishing ook tot hoofdregel verworden." ${ }^{.1}$ De mogelijkheid van distinguishing maakt het vinden van lijnen in de rechtspraak niet eenvoudig. Tegelijkertijd maken de stare decisis-regel en de afwijkingsmogelijkheden het onderzoeken en waarderen van de rechtspraak ook gemakkelijker: uit de manier waarop met precedenten wordt omgegaan kunnen soms interessante conclusies worden afgeleid over de betekenis en het gewicht van bepaalde doctrines, criteria en concepten..$^{22}$

\section{Besluitvorming; "dissenting" en "concurring opinions"}

Nadat certiorari is verleend zal het Supreme Court de zaak inhoudelijk beoordelen. Dit betekent dat er schriftelijke stukken worden uitgewisseld en er een zitting plaatsvindt waarbij de partijen hun standpunt kunnen toelichten. ${ }^{\text {"3 }} \mathrm{Na}$ afloop van de zitting komen de rechters bij elkaar en wordt er gestemd over de gewenste uitkomst van de zaak. Een

een toepassing van een bepaald precedent toelaten; zie Shapiro in Ulmer 1981, p. 310 en $316 / 317$. De kracht van een bepaald precedent is bovendien lang niet altijd even groot: veel is afhankelijk van de formulering van de rechtsregel in het precedent. Als deze uitdrukkelijk is beperkt tot bepaalde feitelijt: omstandigheden kan in een iets andere context gemakkelijk van het precedent worden afgeweken. Ook is het gemakkelijker om een vaag geformuleerd precedent in latere rechtspraak aan te passen dan een heel helder en beperkt geformuleerde rechtsregel: zie Maltz 1988, p. 376/377.

90. Een dergelijke bijzondere benadering is zichtbaar in de hierna nog te bespreken rechtspraak over de toetsingsingang bij indirect onderscheid. Hoewel de hoofdlijn daarbij is dat een discriminatoire bedosling moet worden aangetoond, zijn er bepaalde groepen van gevallen waarin het Supreme Court eet iets andere benadering hanteert. Zie nader paragraaf 2.2.3.

91. Een voorbeeld hiervan is aan de orde gekomen in paragraaf 1.1.4. Daar werd gesteld dat het Suprents Court in de zaak Washington v. Davis, 426 U.S. 229 (1976) uitdrukkelijk vereiste dat er een discriminatoire bedoeling wordt aangetoond, alvorens kan worden overgegaan tot een inhoudelijke beoordeling van de rechtvaardiging. Hoewel dit in eerdere arresten niet uitdrukkelijk werd tegengesproken, gold een dergelijke regeling tot dan toe nog niet; sterker nog, uit eerdere rechtspraak kon worden afgeleid dat het aantonen van een benadelend effect voldoende was.

92. Zoals Maltz aangeeft: de sterkste precedenten zijn die waarin een algemene doctrine wordt neergelegd, iets minder belangrijk zijn precedenten die daarvan een verbijzondering inhouden. Belangrijk is ook zijn conclusie dat de uitkomst van een zaak vaak belangrijker is dan de daaraan ten grondslag liggends redenering. Zelfs als die redenering in een volgend geval niet volledig opgaat kan het toch nog 20 zijn dat de uitkomst wordt overgenomen (1988, p. 382/383).

93. Er zijn juridisch altijd verschillende uitkomsten mogelijk, zoals bevestiging of vernietiging van de uitspraak van de lagere rechter, maar ook herziening of terugverwijzing voor een nieuwe behandeling door een lagere rechter. 
gewone meerderheid van vijf rechters zal daarbij voldoende zijn om de uitkomst van de procedure te bepalen." Wanneer op deze wijze het resultaat is vastgesteld, zal één van de leden van de meerderheid worden gevraagd om de "opinion of the Court", de meerderheidsopinie, te schrijven; in deze opinie wordt de juridische onderbouwing gegeven voor de vastgestelde uitkomst. ${ }^{95}$ Voor de tegenstemmers is het mogelijk om hun opvattingen over de zaak uiteen te zetten in een "dissenting opinion", hetgeen in de praktijk met grote regelmaat gebeurt. Ook voorstemmers kunnen echter een aparte opinie schrijven, een "concurring opinion", als zij het weliswaar eens zijn met de uitkomst die door de meerderheid is bereikt, maar niet met de daaraan ten grondslag liggende redenering; ook van deze mogelijkheid wordt in een groot aantal zaken gebruik gemaakt. ${ }^{96}$

De dissenting en concurring opinions kunnen van groot belang zijn voor de waardering van een uitspraak. Zo neemt de overtuigingskracht van een meerderheidsopinie af wanneer er tegelijkertijd verschillende concurring opinions worden geschreven die een heel andere redenering volgen. Scherp geformuleerde en overtuigende dissenting opinions, zeker in een uitspraak die slechts op een minimale meerderheid steunt, kunnen eveneens afbreuk doen aan de kracht van de meerderheidsopinie. Bij de waardering van de jurisprudentie van het Hof en het zoeken van lijnen daarin moet met de waarde van deze separate opinions dan ook terdege rekening worden gehouden.

\section{Stemgedrag en de gevolgen van ideologische kleur}

Voor een goed begrip van de rechtspraak van het Supreme Court is het tenslotte van belang dat het stemgedrag - en daarmee de uitkomst van een concrete procedure - in hoge mate wordt bepaald door de ideologische kleur van de rechters. Gedeeltelijk houdt dit verband met de aard van de zaken die door het Supreme Court behandeld worden: vaak gaat het hierin om grondrechten waarover veel maatschappelijke en politieke controverse bestaat (zoals de toelaatbaarheid van voorkeursbeleid of de constitu-

94. Abraham geeft aan dat slechts tussen de 20 en $50 \%$ van de uitspraken unaniem gedaan wordt (1998, p. 221); bij de echt belangrijke constitutionele vraagstukken is het aantal unanieme uitspraken nog veel kleiner. Een belangrijke verklaring hiervoor kan worden gevonden in de aard van de zaken die het Supreme Court behandelt. Zoals gezegd heeft het Supreme Court de mogelijkheid om alleen uitspraak te doen over controversiêle en juridisch ingewikkelde onderwerpen; het zal duidelijk zijn dat het bij dat soort onderwerpen vaak moeilijker is om unanimiteit te bereiken dan bij gemakkelijke zaken.

95. Het is mogelijk dat de mening van bepaalde rechters nog verandert nadat de uitspraak eenmaal geschreven is; in sommige gevallen kan het daardoor voorkomen dat er geen meerderheid meer bestaat voor de oorspronkelijk vastgestelde uitkomst en dat de minderheidsopvatting opeens die van de meerderheid wordt. Vanzelfsprekend moet er in een dergelijk geval een nieuwe meerderheidsopinie worden geschreven. Het zal echter maar zelden naar buiten toe blijken dat een dergelijke verschuiving zich heeft voorgedaan; alleen door het bestuderen van interne stukken kan dit aan het licht komen.

96. Lusky 1993, p. 30; hij wijst er bovendien op dat binnen de verschillende opinies zelf een toenemende fragmentarisering optreedt. Het is vrij gebruikelijk geworden om alleen met bepaalde onderdelen van de meerderheidsopinie in te stemmen en voor andere delen een dissenting en/of concurring te schrijven (1993, p. 33/34). Het is ook mogelijk dat er voor geen enkele redenering een meerderheid kan worden gevonden (bijvoorbeeld wanneer er drie redeneringen mogelijk zijn en de verdeling 4-3-2 is), hoewel de rechters het wel eens kunnen worden over de uitspraak die wordt gedaan. In dat geval wordt er gesproken van een "plurality opinion" (vgl. Easterbrook 1982, p. 815/816 en Novak 1980, p. 756). De waarde van dit soort uitspraken als precedent is beperkt: het is moeilijk om op basis van dit soort uitspraken te bepalen wat de geldende uitleg is en hoe de uitspraak in een vergelijkbaar geval moet worden toegepast. 
tionele bescherming van het recht op euthanasie of abortus) ${ }^{97}$, om zaken waarin de gevoelige verhouding van het Supreme Court tot de staten in het geding is, of om zaken waarin wordt gevraagd om een plaatsbepaling van de rechter ten opzichte van demo. cratisch gekozen organen. In dit soort gevallen is het voor de uitkomst van een procedure van groot belang welke visie een rechter heeft op de rol van het Supreme Court en of zijn opvatting over de interpretatie van de Constitutie liberaal of conservatief is." Het belang van de ideologische kleur van de rechters in het Supreme Court wordt nog vergroot door de wijze waarop zij worden benoemd: kandidaten worden voorgedragen door de President, waarna de Senaat deze voordracht al dan niet kan bevestigen." Om. dat het Supreme Court vaak beslist over politiek controversiële onderwerpen en in staat is om federale wetgeving terzijde te stellen, is het voor de President en de Senaat van groot belang dat er een kandidaat wordt benoemd wiens opvattingen nauw bij de eigen politieke belangen aansluiten en die in staat is om zijn politiek-ideologische visie binnen het Supreme Court ook daadwerkelijk te laten gelden. Dit heeft tot gevolg dat er bij de benoeming niet alleen rekening wordt gehouden met de objectieve geschiktheid van een kandidaat als rechter ${ }^{100}$, maar vooral ook met zijn persoonlijke filosofie: de opvattingen die een kandidaat in het verloop van zijn carrière ten toon heeft gespreid zullen nauwkeurig worden bestudeerd, terwijl tijdens de benoemingsprocedure vaak wordt geprobeerd om duidelijkheid te verkrijgen over de wijze waarop de kandidaat als rech. ter om zal gaan met bepaalde controversiële kwesties. ${ }^{101}$ Een dergelijk benoemingspro-

97. De keuze voor politiek controversiële zaken wordt voor een groot deel verklaard door het feit dat het in de VS gebruikelijk is om, ter verkrijging van gelijkberechtiging of grondwettelijke bescherming van een recht, geen gebruik te maken van het politieke proces, maar naar de rechter te stappen (te denken valt aan de juridische procedures die door organisaties als de NAACP of de American Civil Rights and Liberties Union worden bekostigd en begeleid); zie Jacob 1996, p. 73 en Brennan 1987, p. 676. Het Supreme Court acht deze kwesties van bijzonder belang en zal ze vrijwel steeds selecteren voor een in: houdelijke beoordeling, zelfs als het zich daardoor in een politiek wespennest begeeft en gedwongen is om controversiële keuzes te maken. Dit lijkt vooral een ontwikkeling van de laatste vijftig jaar te zjij; vgl. Novak 1980, p. 759.

98. Vgl. Novak 1980, p. 759. Op zijn beurt heeft dit merkwaardige gevolgen: "The changes [in de interpretatie van de Constitutie, JHG] seem to be essentially the result of changes in personnel. [.... [A] watershed in constitutional law is marked not by changes in the constitutional text [...], nor by changes in social conditions that give rise to the problems to which the text is applied [...]" (Kurland 1970,p 265).

99. Abraham 1998, p. 22. De invloed van de Senaat is vrij belangrijk: het komt met enige regelmat voot dat de Senaat een kandidaat afwijst (vgl. de afwijzing van de kandidatuur van Robert Bork in de jaren 80 ), hetgeen kan werken als een rem op de keuze voor erg controversiêle kandidaten (vgl. Stone ca 1996, p. 78).

100. Ervaring als rechter is vooral de laatste jaren belangrijker geworden, maar was dat aanvankelijk nict. Abraham geeft aan dat tot 1922 de meerderheid van de Supreme Court geen jurist was en dat het pts sinds $1957 \mathrm{zo}$ is dat alle rechters juristen zijn. Tegenwoordig is een juridische graad een vereiste, zi] het dat dit nog steeds nergens formeel is vastgelegd $(1998$, p. 55). Ervaring als rechter is evenmin vat groot belang: grote rechters, zoals Warren, Frankfurter en Powell, hadden geen enkele ervaring ats rechter voordat zij in het Supreme Court werden benoemd (Abraham 1998, p. 56). Wel belangrijk is algemene juridische ervaring (bijv. als advocaat) en politieke ervaring; zie Abraham 1998, p. 64-65.

101. Dit geldt zowel voor de door de President gemaakte keuze voor een bepaalde kandidaat, als voor de bevestiging van de benoeming ("confirmation") door de Senaat. Zie voor een voorbeeld Ulmer 1981 , p. 257 e.v., waar een gedeelte van de confirmation hearings van Chief Justice Rehnquist (bij zijn kandidatuur als Associate Justice) is weergegeven. Verder wordt bij de benoeming rekening worden gs houden met de politieke, geografische en religieuze spreiding binnen het Supreme Court en met de vertegenwoordiging van raciale minderheden en vrouwen (Abraham 1998, p. 67, Stone e.a. 1996, p. 78 
ces leidt onvermijdelijk tot een grote invloed van ideologische (en politieke) opvattingen op het stemgedrag van de rechters.

Het feit dat rechters meestal in overeenstemming met hun ideologische kleur oordelen heeft belangrijke consequenties voor de jurisprudentie. Groepen van rechters met vergelijkbare voorkeuren hebben de neiging om elkaar bij de stemming te steunen en vormen daardoor liberale of conservatieve blokken. ${ }^{102}$ Wanneer er een duidelijk afgetekende en sterke conservatieve of liberale meerderheid bestaat zal de ideologische minderheid nauwelijks kans hebben om zijn opvattingen tot die van het Supreme Court te maken. In die situatie is de rechtspraak in het algemeen vrij consistent en voorspelbaar, zij het dat deze vaak sterk ideologisch gekleurd is. Een onzekere situatie ontstaat echter wanneer er geen duidelijke minderheid en meerderheid zijn, maar het Supreme Court bijvoorbeeld is samengesteld uit vier conservatieve en vier liberale rechters en één rechter zonder duidelijke kleur. Soms kan een dergelijke situatie aanleiding vormen voor het zoeken van een compromis, gebaseerd op een gemeenschappelijke basis in de verschillende opvattingen, maar vaak zijn de verschillen tussen conservatieven en liberalen daarvoor te groot. Als dit laatste het geval is zal de stem van de "neutrale" rechter (de swingvote) de uitkomst bepalen, waardoor soms een meer conservatieve en soms een meer liberale uitkomst wordt bereikt. Zeker bij controversiële onderwerpen kan dit leiden tot een onzekere rechtspraak, waarbij de uitspraken als precedent niet altijd betrouwbaar zijn: in een volgende, vergelijkbare zaak kan een anders samengestelde meerderheid door het systeem van distinguishing gemakkelijk een andere uitkomst bereiken. ${ }^{103}$ In dergelijke omstandigheden zijn de dissenting en concurring opinions van groot belang: zij hebben een grote voorspellende waarde voor het stemgedrag van de swingvoter en voor de juridische lijn die zal worden gekozen door een door de swingvote bepaalde meerderheid. ${ }^{104}$ Vooral de laatste twintig jaar is de situatie van een onduidelijke meerderheid en van swingvotes kenmerkend gebleken voor de rechtspraak

en Ulmer 1981, p. 251); ook de persoonlijke integriteit van de rechters kan een belangrijke rol spelen (zie Lazarus p. 193 en 453/454 en Abraham 1998, p. 90). De voorkeur van de kandidaat voor een bepaalde politieke partij (republikeinen of democraten) speelt weliswaar een belangrijke rol bij de benoeming (in de meeste gevallen zal de president een kandidaat willen benoemen die lid of aanhanger is van de regerende partij), maar is lang niet altijd doorslaggevend; vgl. Lazarus 1999, p. 227 en Ulmer 1981 , p. 251. De voorspellende waarde van de politieke achtergrond voor de manier waarop een rechter zal oordelen blijkt namelijk beperkter te zijn dan die van zijn ideologische kleur, hoewel hiertussen een nauwe samenhang kan bestaan; zie nader Jacob 1996, p. 74/75.

102. Adamany 1991, p. 11

103. Een voorbeeld van deze onzekerheid is te vinden in de rechtspraak over voorkeursbeleid, waarbij lange tijd een strijd woedde tussen liberalen en conservatieven over de juiste toetsingsintensiteit. Aanvankelijk had een conservatieve meerderheid gekozen voor een zeer strenge toetsing (City of Richmond $v$. J.A. Croson Co., 488 U.S. 469 (1989)), maar in een zaak die een jaar later speelde was er een liberale meerderheid die - in een net iets andere feitenconstellatie - stelde dat een minder strenge toets aangewezen was (Metro Broadcasting v. FCC, 497 U.S. 547 (1990)). Deze laatste uitspraak werd vervolgens door een conservatieve meerderheid overruled, waarbij voor alle gevallen werd gekozen voor een intensieve toetsing (Adarand Constructors, Inc. v. Pena, 515 U.S. 200 (1995)), In alle zaken bepaalde de stem van Justice O'Connor de uitkomst.

104. Vgl. Rehnquist 1980, p. 978. 
van het Supreme Court; bij de waardering van de verschillende uitspraken moet daar. mee terdege rekening worden gehouden. ${ }^{105}$

\subsection{Toetsingsmethodiek van het Supreme Court en opzet van het hoofdstuk}

In de rechtspraak van het Supreme Court over de Equal Protection Clause bestaat een nauwe samenhang tussen de keuze voor een bepaalde toetsingsintensiteit en de metho. diek die wordt gehanteerd bij de beoordeling van de aangevoerde rechtvaardiging Officieel hanteert het Supreme Court een drietal verschillende tests. ${ }^{166}$ Allereerst is et de rational basis-test, ontwikkeld voor een zeer marginale toetsing; deze test wordt vooral toegepast bij onderscheid op sociaal-economisch gebied en bij belastingwetge. ving. Ook voor een zeer intensieve toetsing is er een aparte test: de strict scrutiny-test. Het Supreme Court ziet echter maar zelden ruimte voor de toepassing van deze test: van strict scrutiny zal uitsluitend sprake zijn bij onderscheid op gronden die als "verdacht" worden aangemerkt (ras, nationaliteit en nationale herkomst), of bij een emstige aantasting van fundamenteel geachte rechten of belangen. Verder is er een test die een middenweg tussen deze uitersten vormt: de intermediate scrutiny-test. Deze test wordt toegepast in gevallen waarin er wel reden is voor een iets zorgvuldigere beoordeling, maar niet voor de zeer strikte toetsing van de strict scrutiny-test. In de praktijk blijkt deze test maar in twee gevallen te worden toegepast, namelijk bij onderscheid op grond van geslacht en bij onderscheid op grond van wettige geboorte. Tenslotte heeft het Supreme Court impliciet een vierde test erkend, die gezien kan worden als een iets minder marginale versie van de rational basis-test; deze test wordt in de literatuur wel aangeduid als de rational basis "with bite"-test.

In het hiernavolgende zal allereerst een korte uiteenzetting worden gegeven van de wijze waarop het Supreme Court inhoud heeft gegeven aan de verschillende tests (paragraaf 2.1). Vervolgens zal nader worden ingegaan op de beoordelingscriteria die de onderscheiden tests gemeenschappelijk hebben. In dat verband zal zowel aandacht worden besteed aan toetsing in de eerste fase (paragraaf 2.2) als aan de toetsing van de rechtvaardiging zelf (paragraaf 2.3 en 2.4). In paragraaf 3 zal daarna worden ingegaan op de wijze waarop het Supreme Court beslist om één van de onderscheiden tests toe te passen, hetgeen feitelijk hetzelfde blijkt te zijn als het maken van een keuze voor een bepaalde toetsingsintensiteit. Tenslotte zal in paragraaf 4 worden bezien in hoeverre er in de besproken rechtspraak van het Supreme Court elementen zijn terug te vinden die bruikbaar zijn voor het ontwikkelen van een algemeen toetsingsmodel.

105. Gemiddeld is bijna 20\% van de zaken in deze periode door een $5-4$ meerderheid beslist (Abrahum 1998, p. 222). In die gevallen is de kans groot dat in een latere, vergelijkbare zaak de meerderheid wis. selt als de rechters die de swingvote houden de andere zijde kiezen. Onder het Burger Court en in de eerste paar jaar van het Rehnquist Court was de verdeling inderdaad 4-4-1, waarbij Justice Powell eth. daama, Justice O'Connor de swingvote hielden (zie over Justice Powell nader Kahn 1987, p. I). Latt is de stemverhouding 4-3-2 geworden in het voordeel van de conservatieven: Justice Kennedy, benoemd in 1988, is nu samen met O'Connor de swingvoter (vgl. Lazarus 1999, p. 515). Doordat er twe relatief neutrale rechters zijn temidden van een ideologisch sterk gepolariseerd Supreme Court is de rechtspraak de laatste jaren alleen nog maar onvoorspelbaarder geworden.

106. Zie voor een duidelijke uiteenzetting van deze drie tests City of Cleburne v. Cleburne Living Center, 473 U.S. 432 (1985) en Clark v. Jeter, 486 U.S. 456, 461 (1988). 
 Toetsingsmethodiek
}

\subsection{Algemeen overzicht van de door het Supreme Court gehanteerde tests}

\subsubsection{De rational basis-test}

De rational basis-test werd als eerste van de vier in paragraaf 1.5 kort omschreven tests ontwikkeld. Al in 1897 gaf het Supreme Court aan dat het wenselijk is om normatieve classificaties op hun redelijkheid te beoordelen en gaf het bovendien inhoud aan deze redelijkheidstoets:

\begin{abstract}
"While good faith and a knowledge of existing conditions on the part of a legislature is to be presumed, yet to carry that presumption to the extent of always holding that there must be some undisclosed and unknown reason for subjecting certain individuals or corporations to hostile and discriminating legislation is to make the protecting clauses of the Fourteenth Amendment a mere rope of sand, in no manner restraining state action. [...] But it is said that it is not within the scope of the Fourteenth Amendment to withhold from the State the power of classification, and that if the law deals alike with all of a certain class it is not obnoxious to the charge of a denial of equal protection. While, as a general proposition, this is undeniably true, yet it is equally true that such classification cannot be made arbitrarily. [...] That must always rest upon some difference which bears a reasonable and just relation to the act in respect to which the classification is proposed, and can never be made arbitrarily and without any such basis."107
\end{abstract}

In een later arrest, Lindsley v. Natural Carbonic Gas Co. ${ }^{108}$ heeft het Supreme Court nader uitwerking gegeven aan de rational basis-test zoals die in het bovengeciteerde arrest is neergelegd:

\footnotetext{
"The rules by which this contention [nl. dat de classificatie willekeurig is, JHG] must be tested $[\ldots]$ are these: 1 . The equal-protection clause of the 14th Amendment does not take from the state the power to classify in the adoption of police laws, but admits of the exercise of a wide scope of discretion in that regard, and avoids what is done only when it is without any reasonable basis, and therefore is purely arbitrary. 2. A classification having some unreasonable basis does not offend against that clause because it is not made with mathematical nicety, or because in practice it results in some unequality. 3 . When the classification in such a law is called in question, if any state of facts reasonably can be conceived that would sustain it, the existence of that state of facts at the time the law was enacted must be assumed. 4 . One who assails the classification in such a law must carry the burden of showing that it does not rest upon any reasonable basis, but is essentially arbitrary."ton
}

107. Gulf, Colorado and Santa Fe Railway Co. v. Ellis, 165 U.S. 150, 154/155 (1897) (cursief toegevoegd). Vgl. Bennett 1979, p. 1052.

108. 220 U.S. 61 (1911). Zie echter ook al het arrest Watson v. State of Maryland, 218 U.S. 173 (1910), waarin nader werd aangegeven welke standaard zou moeten worden gehanteerd: "[...][R] egulations of a particular trade or business essential to the public health and safety are within the legislative capacity of the State in the exercise of its police power, and [...] unless such regulations are so unreasonable and extravagant as to interfere with property and personal rights of citizens, unnecessarily and arbitra-

109. 220 U.S., op $78 / 79$ 
Het model zoals dat in deze overweging wordt uiteengezet gaat uit van een vermoeden van constitutionaliteit en daarmee van een omkering van de bewijslast. Hoewel het normaal gesproken aan de overheid is om aan te tonen dat het onderscheid gerech. vaardigd is wordt hier van de eisende partij geëist dat hij aantoont dat een dergelijke rechtvaardiging ontbreekt. ${ }^{110}$ Dit zal niet eenvoudig zijn: wanneer het redelijkerwijze mogelijk is om een gerechtvaardigd doel voor het maken van onderscheid te bedenken zal deze reden volgens bovenstaand citaat steeds gezien worden als voldoende acceptabel. "' De eiser zal dan ook overtuigend moeten aantonen dat er geen enkel redelijk doel voor het onderscheid denkbaar is, hetgeen vanzelfsprekend vrijwel onmogelijk is. Utt de rechtspraak blijkt verder dat een beroep op het ontbreken van een rationele verhou. ding tussen doel en middel alleen zal worden gehonoreerd wanneer er werkelijk sprake is van een zeer ernstig geval van willekeur. ${ }^{112}$ Dit betekent bijvoorbeeld dat niet alleen moet worden aangetoond dat een onderscheid niet geschikt is om een doelstelling te bereiken, maar ook dat de regelgever redelijkerwijs niet kon denken dat dit het geval was; het bestaan van eventuele alternatieve middelen om het doel te bereiken wordt bij de rational basis-test vrijwel steeds irrelevant geacht. ${ }^{113}$ Een toepassing van dit model zal dan ook vrijwel steeds leiden tot de conclusie dat het onderscheid toelaatbaar is: het aantal gevallen waarin het Supreme Court een schending van het Veertiende Amendement aanwezig achtte bij toepassing van de rational basis-test is minimaal. ${ }^{114}$

Naast de Lindsley-versie van de rational basis-test bestaat er echter nog een tweede, afwijkende formulering van de test, die eveneens als gezaghebbend precedent wordt

110. Zie bijv. ook Central State University v. American Association of University Professors, 526 U.S. 124, 128 (1999): "A State ... has no obligation to produce evidence to sustain the rationality of a statutory classification."

111. Zie nader paragraaf 2.4 .2 .

112. Voorbeelden laten dit duidelijk zien: "[...] the presumption of constitutionality can be overcome only by the most explicit demonstration that a classification is a hostile and oppressive discrimination against particular persons and classes" (Madden v. Kentucky, 309 U.S. 83, 87 (1940)), "The problems of government are practical ones and may justify [...] rough accommodations, - illogical, it may be, and unscientific. [...] Mere errors of government are not subject to our judicial review. It is only plpably arbitrary exercises which can be declared void under the 14th Amendment [...]" (Metropoli Theatre Co. v. City of Chicago, 228 U.S. 61 (1913), "[...] the Due Process Clause [de zaak betrof ent federale classificatie, JHG] can be thought to interpose a bar only if the statute manifests a patently :bitrary classification, utterly lacking in rational justification" (Flemming v. Nestor, 363 U.S. 603 (1960)). Zie voor meer voorbeelden Weinberger v. Salfi, 422 U.S. 749, 768 (1975).

113. Zie Farrell 1992, p. 39 en vgl. Tuan Anh Nguyen v. INS, 533 U.S. 53 (2001) (J. O'Connor, dissenting). Een zelfde terughoudendheid geldt bij de toetsing van de mate van fit: de wetgever heeft ruime mogelijkheden om classificaties te maken die niet perfect zijn toegesneden op het doel van de regeling. Zie daarover paragraaf 2.4.2. Op subsidiariteit en proportionaliteit wordt bij de rational basis-test mart zeer zelden ingegaan: er wordt vanuit gegaan dat de wetgever op dit punt beter in staat is om keuzen te maken dan de rechter. Zie daarvoor paragraaf 2.4 .4 en 2.4.5.

114. Vgl. de dissenting opinion van Justice Marshall bij Massachusetts Board of Retirement v. Murgia, 423 U.S. 307, 320 (1976). Zie ook de meerderheidsopinie van Justice Thomas in FCC v. Beach Commatications, 508 U.S. 307 (1993), waarin hij stelde dat in dit soort gevallen de classificatie "virtually unteviewable" is (op 316). Veelbetekenend is ook het adagium van Gunther: "minimal scrutiny in theory and virtually none in fact" (1972, p. 8). Zie nader Tussman/TenBroek 1949, p. 372, Perry 1979, f 1070 , Bennett 1979, p. 1057, Barrett 1979/1980, p. 860 en Farrell 1992, p. 39. Er zijn overigens verschillende zaken te vinden waarin een beroep op het gelijkheidsbeginsel werd toegewezen, ondanks de toepassing van de rational basis-test; in de meeste gevallen was daarbij impliciet sprake van een vet hoogde toetsingsintensiteit (zie paragraaf 2.1.2). 
beschouwd." ${ }^{115}$ Deze formulering is voor het eerst te vinden in het in 1920 gewezen arrest F.S. Royster Guano v. Virginia ${ }^{116}$ en luidt als volgt:

"[...][T] he classification must be reasonable, not arbitrary, and must rest upon some ground of difference having a fair and substantial relation to the object of the legislation, so that all persons similarly circumstanced shall be treated alike."11?

Opvallend in deze overweging is dat hierin niet wordt gesproken over de bewijslastverdeling. Uit de toepassing van het model in deze en latere uitspraken blijkt echter dat de bewijslast voor het aantonen van een rechtvaardiging van het onderscheid op de overheid rust. Verder wordt volgens deze formulering vereist dat er sprake is van een relevant verschil tussen de gevallen, dat een substantiële relatie vertoont tot het doel dat met de classificatie wordt nagestreefd. Feitelijk betekent dit dat een vergelijkbaarheidstoets bij de Royster-test, anders dan bij de Lindsley-test, inherent is aan de rechtvaardiging van het onderscheid. Opmerkelijk is ook dat de eisen die aan de doel-middel verhouding worden gesteld duidelijk hoger zijn dan de eisen die in Lindsley zijn vastgesteld. ${ }^{\text {"s }}$

In latere rechtspraak ${ }^{119}$ is slechts sporadisch aandacht besteed aan het verschil tussen beide precedenten: meestal wordt eenvoudigweg de keuze gemaakt om één van beide uitspraken te volgen en de andere te negeren. ${ }^{120}$ Wel is het opvallend dat in de grote

115. Vgl. Gunther/Sullivan 1997, p. 636. In een aantal arresten wordt in het geheel niet verwezen naar een van de gebruikelijke modellen, maar wordt er een soort sui generis-benadering gevolgd. Zie bijv. Mathews v. Diaz, 426 U.S. 67 (1976), waarin in het algemeen werd beoordeeld of het onderscheid "invidious" en "wholly irrational" was.

116. 253 U.S. $412(1920)$

117. 253 U.S., op 415

118. Er zijn nog andere verschillen die erop wijzen dat de Royster-test strikter is dan de Lindsley-test: zo lijkt het erop dat bij toepassing van Lindsley veel eerder genoegen wordt genomen met plausibele doelstellingen en dat het Supreme Court sneller bereid is om zelf doeistellingen te bedenken als deze niet uitdrukkelijk zijn aangevoerd. Zie nader Cathey 1983, p. 1506/1507.

119. Ook in de literatuur is weinig aandacht besteed aan het verschil: bij de beschrijving van de test wordt vaak gewezen op de noodzaak om aan te tonen dat er relevante verschillen bestaan tussen de gevallen, zonder dat aandacht wordt besteed aan het feit dat slechts in een klein aantal gevallen van deze vergelijkbaarheidstoets gebruik wordt gemaakt (zie bijv. Ely 1970, p. 1223); een uitzondering is Cathey 1983, p. 1506/1507. Dit is verwarrend vanwege het verschil in bewijslast: auteurs die de Royster-toets als standaardmodel beschouwen stellen dat het aan de overheid is om een redelijke rechtvaardiging aan te voeren (Ely 1970, p. 1229/1230), terwijl dit niet in overeenstemming is met de bewijslastverdeling onder de Lindsley-toets.

120. Een uitzondering waarin het Supreme Court erkende dat er verschil bestaat tussen de benaderingen is United States Railway Retirement Board v. Fritz, 449 U.S. 166 (1980). Het Supreme Court gaf daarin aan dat het gebruik van de Royster-test minder gebruikelijk is (op 174/175). Verder worden beide modellen in een aantal arresten met elkaar gecombineerd, doordat het Supreme Court zowel uitgaat van een vermoeden van constitutionaliteit als van de stelling dat een rational basis moet worden gevonden in een relevant verschil tussen de voorgelegde gevallen; zie bijv. Morey v. Doud, 354 U.S. 457 (1957), Allied Stores v. Bowers, 358 U.S. 522, 527 (1959) en Vacco v. Quill, 521 U.S. 793, 799/800 (1997). Overigens is het gebruik van de rational basis-test meer in het algemeen weinig consistent: er zijn periodes waarin heel vaak van deze test gebruik werd gemaakt om een heel terughoudende toetsing toe te passen, andere periodes laten een complete afwezigheid van de toets zien en in weer andere periodes is een vrij actieve invulling van de test zichtbaar (zie Bennett 1979, p. 1052/1053). In dit hoofdstuk zal vooral de algemene lijn worden gevolgd. 
meerderheid van de zaken een beroep wordt gedaan op het Lindsley-model ${ }^{121}$, terwijl de formulering in Royster slechts in een klein aantal arresten is terug te vinden. ${ }^{12}$ In de laatste twintig jaar is bovendien vaak gebruik gemaakt van de volgende formulering van de rational basis test, die duidelijk op Lindsley is gebaseerd:

"The appropriate standard of review is whether the difference in treatment [...] rationally furthers a legitimate state interest. In general, the Equal Protection Clause is satisfied so long as there is a plausible policy reason for the classification, the legislative facts on which the classification is apparently based may have been considered to be true by the governmental decisionmaker, and the relationship of the classification to its goal is not so attenuated as to render the distinction arbitrary or irrational." 123

Gesteld kan dan ook worden dat niet de vergelijkbaarheidstoets van Royster, maar het rechtvaardigingsmodel van Lindsley op dit moment het heersende toetsingsmodel vormt. ${ }^{124}$ Dit betekent dat de rational basis-test bijzonder terughoudend is, waarbij het voor de eisende partij noodzakelijk is om aan te tonen dat een objectieve rechtvaardiging voor het onderscheid ontbreekt. Op de precieze criteria die het Supreme Court

121. Zie voor voorbeelden van de toepassing van het Lindsley-model of daarop geĩnspireerde modellen Madden v. Kentucky, 309 U.S. 83, 87 (1940), Lassiter v. Northampton County Board of Elections, 360 U.S. 45 (1959), McGowan v. Maryland, 366 U.S. 420, 425 (1961), McDonald v. Board of Election Commissioners of Chicago, 394 U.S. 802, 809 (1969), Lindsey v. Normet, 405 U.S. 56 (1972), Webr v. Aetna, 406 U.S. 164, 172/175 (1972), United States v. Kras, 409 U.S. 434, 446 (1973), Stanton . Stanton, 421 U.S. 7 (1975), Weinberger v. Salfi, 422 U.S. 749, 768 (1975), City of New Orleans v. D. kes, 427 U.S. 297, 303 (1976), Massachusetts Board of Retirement v. Murgia, 427 U.S. 307,314 (1976), Parham v. Hughes, 441 U.S. 347, 352 (1979), Vance v. Bradley, 440 U.S. 93,96 (1979), Harris v. McRae, 448 U.S. 297, 322 (1980), Minnesota v. Clover Leaf Creamery, 449 U.S. 456,463 (1981), Schweiker v. Wilson, 450 U.S. 221 (1981), Zobel v. Williams, 457 U.S. 55,62 (1982), Cily of Cleburne v. Cleburne Living Center, 473 U.S. 432, 440 (1985), Kadrmas v. Dickinson Public Schools, 487 U.S. 450, 463 (1988), Lyng v. Castillo, 477 U.S. 635, 639 (1986), Lyng v. International Union, 485 U.S. 360,370 (1988), Gregory v. Ashcroft, 501 U.S. 452 (1991), Nordlinger v. Hahn, 505 U.S. I, 11 (1992), FCC v. Beach Communications, 508 U.S. 307, 314 (1993), Heller v. Doe, 509 U.S. 312 , 319 (1993) en Central State University v. American Association of University Professors, 526 US. 124,128 (1999).

122. Voorbeelden zijn Louisville Gas \& Electric Company v. Coleman, 227 U.S. 32, 37 (1928), Tigner v. Texas, 310 U.S. 141 (1940), Goesaert v. Cleary, 335 U.S. 464 (1948), Rinaldi v. Yaeger, 384 U.S. 305, 309 (1966), Reed v. Reed, 404 U.S. 71, 76 (1971), Eisenstadt v. Baird, 405 U.S. 438,447 (1972) (waarin overigens eerder een redelijkheidstoets dan een vergelijkbaarheidstoets lijkt te worden uitgevoerd), Johnson v. Robison, 415 U.S. 361, $374 / 375$ (1974), Kahn v. Shevin, 416 U.S. 351 (1974) ten Schlesinger v. Ballard, 419 U.S. 498 (1975). Dat dit het geval is wordt ook bevestigd door het al genoemde arrest United States Railway Retirement Board v. Fritz, 449 U.S. 166 (1980).

123. Nordlinger $v$. Hahn, 505 U.S. 1, 11 (1992). Er bestaat ook een versie die uitdrukking lijkt te vormen van een nog verdergaande rechterlijke terughoudendheid: "On rational-basis review, a classification [...] comes to us bearing a strong presumption of validity, and those attacking the rationality of the legislative classification have the burden 'to negative every conceivable basis which might support i': Moreover, [...] it is entirely irrelevant for constitutional purposes whether the conceived reason for the challenged decision actually motivated the legislature. [...] [A] legislative choice is not subject to courtroom factfinding and may be based on rational speculation unsupported by evidence or empirial data" (FCC v. Beach Communications, 508 U.S. 307 (1993); zie ook de vergelijkbare formulering in Heller v. Doe, 509 U.S. 312, 320/321 (1993)). Het is niet duidelijk wat de verhouding is tussen de verschillende uitspraken: het Supreme Court is de laatste jaren verdeeld over de manier waarop de rational basis-test moet worden ingevuld. Vgl. Farrell 1999, p. 407-409.

124. Vgl. United States Railway Retirement Board v. Fritz, 449 U.S. I66, 175 (1980). 
heeft ontwikkeld ter invulling van deze test zal verderop in deze paragraaf nader worden ingegaan.

\subsubsection{Rational basis "with bite"}

Zoals hiervoor is aangegeven kenmerkt de rational basis-test zich door een bijzondere terughoudende toetsing en door een zware bewijslast voor de eisende partij. Beide kenmerken hebben tot resultaat dat vrijwel geen enkel beroep op de Equal Protection Clause zal slagen als het aan deze test wordt onderworpen. In een relatief groot aantal zaken heeft het Supreme Court echter een alternatieve toepassing gegeven aan deze test, waarbij er formeel gezien weliswaar sprake is van een rational basis-test, maar er feitelijk een toetsing wordt uitgevoerd die meer gemeen heeft met de hierna te bespreken intermediate scrutiny-test. De bewijslast berust in deze uitspraken bij de overheid en er worden relatief strenge eisen gesteld aan de rechtvaardiging. In de literatuur wordt deze toepassing vaak gezien als een aparte, vierde test: gesproken wordt dan van de rational basis-test "with bite". ${ }^{125}$ De reden voor deze bijzondere toepassing van de rational basis-test is gelegen in de beperkte toepassing die het Supreme Court heeft gegeven aan de twee striktere tests: zoals in paragraaf 3 nog nader zal worden toegelicht is de toepassing van de intermediate scrutiny-test beperkt tot onderscheid op grond van geslacht en onwettige geboorte, terwijl de strict scrutiny-test alleen wordt toegepast bij onderscheid op "verdachte" gronden en bij de aantasting van constitutioneel beschermde rechten. Een intensievere toetsing kan echter ook in andere omstandigheden op zijn plaats zijn, bijvoorbeeld wanneer er onderscheid is gemaakt op een quasi-verdachte grond als seksuele geaardheid of wanneer er een ernstige inbreuk is gemaakt op zwaarwegende individuele belangen. ${ }^{126}$ De terughoudende rational basistest biedt in dergelijke gevallen onvoldoende mogelijkheden voor een zorgvuldig on-

125. Ook wel aangeduid als "second order rational-basis review", bijvoorbeeld in de dissenting opinion van Justice Marshall bij City of Cleburne v. Cleburne Living Center, 473 U.S. 432 (1985), op 458; zie ook Rogers 1997, p. 958. Voorbeelden van arresten waarin deze test wordt toegepast zijn Griffin v. Illinois, 351 U.S. 12 (1956), Douglas v. California, 372 U.S. 353 (1963), Levy v. Louisiana, 391 U.S. 68 (1968), Reed v. Reed, 404 U.S. 71 (1971), Eisenstadt v. Baird, 405 U.S. 438 (1972) (zie echter Farrell 1999, p. 364/365), Weber v. Aetna, 406 U.S. 164 (1972), James v. Strange, 407 U.S. 128 (1972), Gomez v. Perez, 409 U.S. 535 (1973), U.S. Department of Agriculture v. Moreno, 413 U.S. 528 (1973), Lubin v. Panish, 415 U.S. 709 (1974), Weinberger v. Wiesenfeld, 420 U.S. 636 (1975), Stanton v. Stanton, 421 U.S. 7 (1975), Hampton v. Mow Sun Wong, 426 U.S. 88 (1976), Trimble v. Gordon, 430 U.S. 762 (1977), Lalli v. Lalli, 439 U.S. 259 (1978), Zobel v. Williams, 457 U.S. 55 (1982), Plyler v. Doe, 457 U.S. 202 (1982), Williams v. Vermont, 472 U.S. 14 (1985), Hooper v. Benallillo, 472 U.S. 612 (1985), City of Cleburne v. Cleburne Living Center, 473 U.S. 432 (1985), Romer v. Evans, 517 U.S. 620 (1996) en M.L.B. v. S.L.J., 519 U.S. 102 (1996); zie voor een uitgebreide bespreking van een aantal van deze arresten Pettynga 1987, p. 787 e.v. en Gunther 1972, p. 25 e.v. Het is opvallend dat het grootste deel van deze arresten is gewezen in de jaren ' 70 , door het Burger Court; waarschijnlijk is dit een reactie geweest op het feit dat het Warren Court in de jaren ' 50 en ' 60 slechts een rational basisen een strict scrutiny-test onderscheidde. Deze rigide tweedeling leidde tot onbevredigende resultaten, vooral bij onderscheid op grond van onwettige geboorte en geslacht. De intermediate scrutiny-test bestond in die tijd nog niet, zodat het strikter toepassen van de rational basis-test de enige oplossing leek; zie Gunther 1972, p. 18/19.

126. Zie voor deze en andere factoren nader paragraaf 3 . 
derzoek, zodat een goed instrument voor beoordeling feitelijk ontbreekt. ${ }^{127}$ De rational basis "with bite"-test lijkt bedoeld te zijn om in dit hiaat te voorzien. ${ }^{12 x}$

Opmerkelijk is dat het Supreme Court de rational basis "with bite"-test nooit als afzonderlijke of officiële test heeft erkend: hoewel het in bepaalde arresten heel duidelijk is dat er geen sprake is van een "gewone" rational basis-test, zijn het vooral de rechtsgeleerde auteurs geweest die hebben aangegeven dat daarbij van een afzonderlijke test kan worden gesproken. ${ }^{129}$ Het ontbreken van een expliciete erkenning door het Supreme Court heeft tot gevolg dat de test binnen de rechtspraak geen duidelijke status heef en dat er geen specifieke criteria zijn ontwikkeld die hieraan invulling geven. ${ }^{130} 0 \mathrm{~m}$ die reden is deze rechtspraak voor de ontwikkeling van het algemene toetsingsmodel niet altijd even bruikbaar. Aan de arresten waarin toepassing is gegeven aan de rational basis "with bite"-test zal in het hiernavolgende dan ook slechts sporadisch aandacht worden besteed.

127. Vgl. Gunther/Sullivan 1997, p. 647.

128. Zie voor een voorbeeld de dissenting opinion van Justice Marshall bij City of Cleburne v. Clebume Living Center, 473 U.S. 432 (1985); hij geeft daarin nauwkeurig aan tot welke conclusies een toepassing van de gewone rational basis-test in dit geval had moeten leiden en in welke opzichten de metrderheidsopinie strengere eisen stelt. Het verschil in benadering is ook zichtbaar in de meerderheidsopinie en de dissenting opinion van Chief Justice Burger in Plyler v. Doe, 457 U.S. 202 (1982). Vgl. ook Gunther 1972, p. 33.

129. Vgl. Meyers 1986, p. 1190. Het Supreme Court gaf uitdrukking aan zijn weigering om een vierde test te erkennen in Rostker v. Goldberg, 453 U.S. 57 (1981): "We do not think that the substantive guarattee of due process or certainty in the law will be advanced by any further 'refinement' in the applicable tests" (op 69). Een impliciete erkenning is wel te vinden in het arrest City of Cleburne v. Cleburne Li. ving Center, 473 U.S. 432 (1985). In deze zaak zette het Supreme Court de drie gebruikelijke tests uilgebreid uiteen; daarna stelde het voor onderscheid op grond van onwettige geboorte het volgende. "[...] official discriminations resting on that characteristic are also subject to somewhat heightened $n$ view. Those restrictions 'will survive equal protection scrutiny to the extent that they are substantially related to a legitimate state interest'“ (op 441). Verder maakte het Supreme Court van deze toetsings. intensiteit melding in Kadrmas v. Dickinson Public Schools, 487 U.S. 450 (1988): "This standard of review [heightened scrutiny, JHG], which is less demanding than 'strict scrutiny' but more than the standard rational basis test, has generally be applied only in cases that involved discriminatory classifi. cations based on sex or illegitimacy. [...] We have not extended this holding beyond the 'unique if cumstances,' that provoked its 'unique confluence of theories and rationales'” (op 459). Hoewel hienit blijkt dat het Supreme Court erkent dat de toets bestaat, blijkt ook uit deze overweging dat de test 1 leen in uitzonderlijke gevallen zal worden toegepast. Van een dergelijk bijzonder geval lijkt sprake te zijn in een arrest als Louisville Gas \& Electric Company v. Coleman, 227 U.S. 32, $37 / 38$ (1928), waarin het Supreme Court stelde dat "discriminations of an unusual character especially suggest careful consideration to determine whether they are obnoxious to the constitutional provision." In Morey w. Doud, 354 U.S. 457, 464 (1957) herhaalde het Supreme Court deze uitspraak. Morey v. Doud werd en. kele jaren later echter uitdrukkelijk overruled (City of New Orleans v. Dukes, 427 U.S. 297, 306 (1976)); sindsdien is er niet meer naar deze rechtspraak verwezen.

130. In de literatuur is op deze benadering veel kritiek geleverd, vooral omdat het Supreme Court niet duidelijk heeft aangegeven in welke omstandigheden het deze test zal toepassen. Zie bijv. Meyers 1986 , p. 1192, Pettynga 1987, p. 801/802, Rutten 1997, p. 592, Rogers 1997, p. 963 en 968 en Farrell 1999 , p. 415. Ook door rechters in het Supreme Court zelf is dit gesteld. Expliciet in zijn kritick was vooral Justice Marshall, die vond dat door deze benadering onvoldoende duidelijkheid wordt verschat aan lagere rechters (City of Cleburne v. Cleburne Living Center, 473 U.S. 432, 459 (1985) (J. Marshall. dissenting)). 


\subsubsection{De strict scrutiny-test}

Algemeen wordt aangenomen dat het arrest Korematsu de basis heeft gevormd voor de ontwikkeling van de meest intensieve test van het Supreme Court - de strict scrutinytest. ${ }^{13}$ Dit arrest, gewezen in 1944, had betrekking op maatregelen die waren getroffen uit angst voor spionage en sabotage door Japan: mensen van Japanse afkomst, zelfs als zij Amerikaans staatsburger waren en ondanks hun eventuele loyaliteit ten opzichte van Amerika, werden gedwongen om bepaalde gebieden aan de oostkust te verlaten. Het Supreme Court begon zijn oordeel over deze maatregel met de volgende overweging:

"It should be noted, $[\ldots]$ that all legal restrictions which curtail the civil rights of a single racial group are immediately suspect. That is not to say that all such restrictions are unconstitutional. It is to say that courts must subject them to the most rigid scrutiny."132

In latere rechtspraak heeft het Supreme Court nader aangegeven wat onder deze "most rigid scrutiny" zou moeten worden verstaan:

"[...] In undertaking this scrutiny, the governmental interest claimed to justify the discrimination is to be carefully examined in order to determine whether that interest is legitimate and substantial, and inquiry must be made whether the means adopted to achieve that goal are necessary and precisely drawn." ${ }^{133}$

Zeer gebruikelijk is ook de volgende formulering van de test:

"[...][A]Il racial classifications [...] must be analyzed [...] under strict scrutiny. In other words, such classifications are constitutional only if they are narrowly tailored measures that further compelling governmental interests."

De test is ook nog op enkele andere manieren gedefinieerd, maar de verschillende formuleringen zijn steeds op dezelfde manier opgebouwd: volgens iedere definitie is het noodzakelijk dat met het onderscheid een zwaarwegende en gerechtvaardigde doelstelling wordt nagestreefd en dat doel en onderscheid nauwkeurig op elkaar zijn afgestemd. ${ }^{135}$ Dit betekent dat de opbouw van deze test vrijwel identiek is aan die van de

131. Toyosaburo Korematsu v. United States, 232 U.S. 214 (1944). Twee jaar eerder, in het arrest Skinner v. Oklahoma, 316 U.S. 535 (1942), werd ook al melding gemaakt van het begrip strict scrutiny, namelijk in het kader van een onderscheid waardoor een fundamenteel recht (het recht op voortplanting) werd aangetast. Het Supreme Court stelde in deze zaak dat "[...] strict scrutiny of the classification which a State makes in a sterilization law is essential [...]" (op 541). Verder blijkt ook uit eerdere rechtspraak dat er een striktere toetsing werd toegepast bij classificaties op grond van ras, maar dit werd in de rechtspraak niet met zoveel woorden gesteld; zie bijv. Strauder v. West-Virginia, 100 U.S. 303 (1879).

132. 232 U.S,, op 216. De maatregelen bleken deze toets overigens wel te kunnen doorstaan: de onmiddellijke oorlogsdreiging vormde een voldoende rechtvaardiging. Vgl. ook Hirabayashi v. United States, 320 U.S. 81 (1943), dat betrekking had op een nachtklok die was ingesteld voor mensen van Japanse afkomst. Ook die maatregel bleek (bij toepassing van de rational basis-test!) toelaatbaar te zijn.

133. Nyquist v. Mauclet, 432 U.S. 1, 7 (1977); idem in Regents of the University of California v. Bakke, 438 U.S. 265,305 (1978)

134. Adarand Constructors, Inc. v. Pena, 515 U.S. 200, 227 (1995); idem in Kramer v. Union Free School District, 395 U.S. 621 (1969), Dunn v. Blumstein, 405 U.S. 330, 342 (1972), Wygant v. Jackson Board of Education, 476 U.S. 267, 274 (1986), Shaw v. Reno, 509 U.S. 630, 643 (1993) en Miller v. Johnson, 515 U.S. 900,904 (1995)

135. Zie bijv. McLaughlin v. Florida, 379 U.S. 184, 192 (1964) ("some overriding statutory purpose requiring the [classification]"), Loving v. Virginia, 388 U.S. 1, 11 (1967) ("necessary to the accomplishment of some permissible state objective", maar ook "legitimate overriding purpose independent of invidi- 
rational basis-test in de Lindsley-formulering; het verschil tussen de tests is gelegen in het feit dat de toetsing aan de verschillende beoordelingscriteria bij de strict scrutim. test aanzienlijk intensiever zal zijn en in het feit dat de bewijslast voor het aantonen van een rechtvaardiging bij de strict scrutiny-test niet bij de eisende partij, maar bij de overheid wordt gelegd. ${ }^{136}$ Dit verschil komt bijvoorbeeld tot uitdrukking in het feit dat er bij de strict scrutiny-test veel hogere eisen worden gesteld aan het bewijs van een redelijke rechtvaardiging voor het onderscheid dan bij de rational basis-test: zo moet het doel niet alleen legitiem zijn, maar moet het ook een substantieel of dwingend $\mathrm{k}$ rakter hebben. ${ }^{137}$ Verder worden er bij de strict scrutiny-test vergaande eisen gesteld aan de verhouding tussen doel en onderscheid: de classificatie moet "necessary" en "narrowly tailored" zijn, waarbij het begrip "narrowly tailored" lijkt te duiden op en toetsing van de mate van fit en het begrip "necessary" op een toetsing van noodzakelijkheid en subsidiariteit. ${ }^{138}$ In de rechtspraak zijn enkele interessante toepassingen van deze vereisten terug te vinden, waarop in het verloop van deze paragraaf nader zal worden ingegaan.

ous racial discrimination"), Shapiro v. Thompson, 394 U.S. 618, 634 (1969) ("necessary to promote I compelling governmental interest"), Bullock v. Carter, 405 U.S. 134 (1972) ("reasonably necessary to the accomplishment of legitimate state objectives"), Bernal v. Fainter, 476 U.S. 216,219 (1984) ("the law must advance a compelling state interest by the least restrictive means available") en Shav $v$. Hian, 517 U.S. 899, 908 (1996) ("the means chosen to accomplish the State's asserted purpose must be spo cifically and narrowly framed to accomplish that purpose").

136. Vgl. "Developments" 1969, p, 1101.

137. Op de betekenis van deze begrippen zal worden ingegaan bij de bespreking van de doeltoets zoals dif door het Supreme Court wordt uitgevoerd (paragraaf 2.3). Interessant is in ieder geval dat het vereiste van een "dwingend" doel vaak een toetsing inhoudt die verder gaat dan een toetsing van de gerecthvaardigdheid: soms impliceert dit vereiste ook dat de maatregel geschikt moet zijn om het doel te bereiken (bijvoorbeeld in Frontiero v. Richardson, 411 U.S. 677, 689 (1973)). Ook blijkt het mogelijk om in dit vereiste een proportionaliteitstoets in te bouwen (vgl. Evans v. Cornman, 398 U.S. 419, 422/423 (1970), waarin doeltoets en doel-middeltoets naadloos in elkaar overvloeien).

138. Vgl. Bice 1977, p. 695. In de praktijk wordt overigens op een onzuivere manier met deze begrippen omgesprongen: bij de noodzakelijkheidstoets wordt vaak ook een toetsing van de geschiktheid, proportionaliteit of de mate van fit uitgevoerd; zie bijv. In re Griffiths, 413 U.S. 717, 725 (1973). In dit : rest was de vraag aan de orde of het redelijk was om alleen mensen met de Amerikaanse nationalitel toe te laten tot de balie. Binnen het kader van de noodzakelijkheidstoets oordeelde het Supreme Cout dat de uitsluiting veel te ruim was om het beoogde doel (waarborgen van loyaliteit) te bereiken; dit is duidelijk een overinclusiveness-argument. Een vergelijkbare situatie is zichtbaar in Bernal v. Fainter, 476 U.S. 216, 219 en 227 (1984). In Dunn v. Blumstein, 405 U.S. 330 (1972) formuleerde het Suprent Court de "necessity"-test zo dat hieronder officieel zelfs de toetsing van de mate van fit, de geschilitheid én de subsidiariteit moeten worden begrepen (op 343). Ook veel voorkomend is het uitvoeren van een geschiktheidstoets onder de noemer van de "necessity"-test; zie bijv. de opinie van Justice Powell in Regents of the University of California v. Bakke, 438 U.S. 265, 311 en 315 (1978). Hieruit blijkt uel dat het begrip "necessity" eerder gebruikt wordt als een soort algemene aanduiding voor de doctmiddeltoets dan als een aanduiding van een noodzakelijkheidstoets in de strikte zin van het woord. Van belang is verder dat het Supreme Court onder de noemer van het "narrowly tailored"-versiste regelmatig een geschiktheids- of noodzakelijkheidstoets toepast. Een voorbeeld van dit door elkar lopen van de criteria is het volgende citaat: "[...] we think that the racial classification would have to rt: alize that goal; the legislative action must, at a minimum, remedy the anticipated violation of achice compliance to be narrowly tailored" (Shaw v. Hunt, 517 U.S. 899, 916 (1996)). Hoewel het begrip "narrowly tailored" normaal gesproken wordt gebruikt om een toetsing van de over- en underinchist. veness aan te duiden, wordt het hier duidelijk gebruikt als een noemer voor een geschiktheidstocts. 
Opmerkelijk is echter dat lang niet in alle arresten aan al deze criteria zorgvuldig aandacht wordt besteed: meestal wordt alleen aan die vereisten getoetst die het Supreme Court het meest interessant vindt, waarbij het bovendien vaak volstaat met een oppervlakkige en weinig overtuigende motivering. De toetsing aan de strict scrutiny-test is inhoudelijk dan ook niet altijd even gestructureerd en doorzichtig. Een verklaring voor deze slordige benadering is te vinden in het feit dat, net als bij de rational basis-test, de uitkomst van de procedure bij de strict scrutiny-test al op voorhand vaststaat: in de praktijk blijkt vrijwel ieder onderscheid dat aan deze test wordt onderworpen onconstitutioneel te worden verklaard. ${ }^{139}$ Tekenend voor deze test is dan ook het veelgebruikte adagium dat deze "strict in theory, but fatal in fact" is. ${ }^{1+0}$ Het lijkt waarschijnlijk dat het Supreme Court het, juist met het oog op de voorspelbaarheid van de uitkomst van deze toets, niet nodig vindt om veel aandacht te besteden aan de inhoudelijke toepassing ervan. Een belangrijke reden om een consistente en consequente toetsing aan een vaste set van toetsingscriteria uit te voeren is immers het bereiken van rechtszekerheid, een doelstelling die door de voorspelbaarheid van het resultaat ook zonder zorgvuldige motivering wel kan worden bereikt. ${ }^{141} \mathrm{De}$ aandacht van het Supreme Court gaat dan ook veel meer uit naar de vraag in welke omstandigheden de test moet worden toegepast dan naar de toetsingsmethodiek als zodanig; in paragraaf 3 zal daaraan nader aandacht worden besteed. ${ }^{142}$

\subsubsection{De intermediate scrutiny-test}

Tussen de rational basis-test en de strict scrutiny-test is lange tijd geen tussenvorm mogelijk geweest: ieder onderscheid dat niet aan een strict scrutiny-test werd onderworpen, dat wil zeggen ieder onderscheid dat niet op ras, afkomst of nationaliteit was gebaseerd en dat niet een select groepje van fundamentele rechten aantastte ${ }^{143}$, werd beoordeeld onder de rational basis-test. ${ }^{144}$ Zoals bij de bespreking van de rational basis "with bite"-test al is aangegeven was dit echter een minder wenselijke situatie, vooral vanwege de zeer voorspelbare uitkomst van deze tests. Problematisch was met name dat er maar weinig ruimte bestond voor het geven van een goed oordeel over quasi-

139. Alleen in het allereerste geval waarin van strict scrutiny werd gesproken (het hiervoor besproken arrest Korematsu) werd een rechtvaardiging aanwezig geacht; zie ook Blattner 1981, p. 781.

140. Gunther 1972, p. 8; vgl. ook Bice 1977, p. 698 en Wunder 1993, p. 517 , die spreekt van een "per se rule", waarmee bedoeld wordt dat onderscheid op grond van ras altijd verboden is en er geen rechtvaardigingsmogelijkheid bestaat.

141. Vgl. Cathey 1983, p. 1501 en Vincent 1978, p. 319. Ook in de Amerikaanse literatuur wordt erkend dat de toetsingsmethodiek slordig is; zo spreekt één commentator van "opaque analysis and mechanical results" ("Note" 1978, p. 772), terwijl een andere (over de intermediate scrutimy-test) stelt dat "the inquiries used [...] lack specificity and are insufficiently objective to be applied as general standards" (Vincent 1978, p. 320).

142. Vgl. Sullivan 1993, p. 242.

143. Zie voor de gevallen waarin de strict scrutiny-test wordt toegepast nader paragraaf 3 .

144. Vgl. Bice 1977 , p. 698 . Een tussenvorm leek lange tijd ook niet echt nodig: tot 1960 werd er nauwelijks een beroep op het gelijkheidsbeginsel gedaan, behalve in zaken over onderscheid op grond van ras. In de jaren ' 50 en ' 60 werd door het Warren Court echter een uitbreiding gegeven aan de reikwijdte van de strict scrutiny-test, waardoor de Equal Protection Clause een aantrekkelijke beroepsgrond begon te worden voor andere groepen dan de raciale minderheden (vgl. Wilkinson 1975, p. 948). Toen men zich dat eenmaal realiseerde werd ook de behoefte aan een test die het grote verschil tussen rational basis en strict scrutiny kon overbruggen groter. Zie Vincent 1978, p. 306. 
verdachte classificaties. ${ }^{145}$ Het bestaande "two tier"-systeem bood doctrinair gezien maar weinig ruimte voor een tussenliggende toetsingsintensiteit, waardoor het Supreme Court een tijdlang heeft geaarzeld over de oplossing van dit probleem: in arresten die betrekking hadden op quasi-verdachte gronden van onderscheid, zoals geslacht of onwettige geboorte, werd soms de hiervoor al besproken rational basis "with bite"-toets uitgevoerd ${ }^{166}$, in één geval werd gekozen voor een toepassing van de strict scrutim. test ${ }^{147}$ en in een aantal andere zaken werd in het geheel niet aangegeven welke test van toepassing was $^{148}$. In 1976 maakte het Supreme Court aan deze onduidelijkheid een einde door een nieuwe test te introduceren: de intermediate scrutiny-test. In het arrest Craig v. Boren ${ }^{149}$ werd deze test als volgt geformuleerd:

145. Vgl. Cathey 1983, p. 1503 en Ginsburg 1983, p. 133. Ook het Supreme Court heeft zich de beperkingen van het "two tier system" in de loop van de tijd gerealiseerd; vgl. Sullivan 1993, p. 244. Deze sterkere gevoeligheid heeft zich echter pas in de loop van de jaren ' 60 ontwikkeld. Voor die tijd werd 00 derscheid op grond van geslacht aan de rational basis-test onderworpen en terughoudend getoetst in 1948 stelde het Supreme Court nog dat, ondanks de veranderingen in de sociale en juridische postit: van vrouwen, er niets aan in de weg stond om scherpe lijnen te trekken tussen mannen en vrouwen; $z$ was het toelaatbaar om, om morele en sociale redenen, vrouwen te verbieden als "bartender" te later werken (Goesaert v. Cleary, 335 U.S. 464, 466 (1948)). Vgl. Hull 1979, p. 645 en Ginsburg 1983, p. 132. Een verhoogde gevoeligheid voor deze problematiek kwam later vooral tot uitdrukking in de tos passing van de iets strengere rational basis-test die in paragraaf 2.1.2 is besproken (rational baris "with bite"). Vooral door het Burger Court is daarvan in de jaren " 70 gebruik gemaakt om de rigit: tweedeling in een rational basis- en een strict scrutimy-test te doorbreken; vgl. Gunther 1972, p. $17 \mathrm{~cm}$ Blattner 1981, p. 785. Deze ontwikkeling in de rechtspraak van het Supreme Court lijkt ook te zjngs inspireerd door de politieke ontwikkelingen op het gebied van de emancipatie van vrouwen. In 1972 werd een Equal Rights Amendment op de Constitutie aangenomen door het Congres, waardoor onderscheid op grond van geslacht verboden werd; dit Amendement, dat overigens niet in werking is gettrden omdat het door onvoldoende staten werd geratificeerd, vormt uitdrukking van het toenemende belang dat er in de jaren ' 70 werd gehecht aan de gelijkberechtiging van vrouwen. Zie nader Tribe 1988, p. $1585 / 1586$.

146. Vgl. Hull 1979 , p. $656 / 657$. Opvallend is dan ook dat in veel van deze gevallen niet zozeer gebriik wordt gemaakt van de Lindsley-formule, maar van de Royster-formule; reden daarvoor zal zijn dat deat laatste test ruimte laat voor het neerleggen van de bewijslast bij de staat. Zie bijv. Reed v. Reed, 404 U.S. 71, 76 (1971) (een arrest waarin gebroken werd met de praktijk om ieder onderscheid op grod van geslacht toelaatbaar te achten, vgl. Ginsburg 1983, p. 133), Stanton v. Stanton, 421 U.S. 7, 13 (1975), Kahn v. Shevin, 416 U.S. 351, 355 (1974) en Schlesinger v. Ballard, 419 U.S. 498 (1975), in de beide laatste arresten werd overigens een zeer terughoudende toetsing uitgevoerd, waarschijplif vanwege het feit dat het in die zaken ging om regeling die in strikt juridische zin niet nadelig was voor vrouwen; vgl. Cathey 1983, p. 1509 en Vincent 1978, p. 314.

147. In een lange, uitgebreid gemotiveerde uitspraak betoogde Justice Brennan dat bij onderscheid op grond van geslacht dezelfde factoren een rol spelen als bij onderscheid op grond van ras en dat om die reden een strict scrutiny-test aangewezen was: Frontiero v. Richardson, 411 U.S. 677 (1973). Opmerking verdient echter dat het hierbij ging om een "plurality opinion", een uitspraak die slechts wordt onder steund door een minderheid en waarvan de precedentiele waarde gering is. In latere uitspraken wordt dan ook alleen naar Frontiero verwezen als precedent voor de noodzaak van een striktere toetsing, niel voor de noodzaak van een toepassing van een strict scrutimy-test; vgl. Hull 1979, p. 655. Zie verder Nowak 1974, p. 1078, die stelt dat de uitspraak zelf ook een minder strikte toetsing inhoudt dan doct de betiteling strict scrutiny wordt geimpliceerd.

148. Bijv. Weinberger v. Wiesenfeld, 420 U.S. 636 (1975); hierin wordt verwezen naar Frontiero (zie vorigs noot), maar er wordt geen strict scrutiny toegepast; ook de gebruikelijke rational basis-formulering ontbreekt echter. Zie ook Wilkinson 1975, p. 952

149. 429 U.S. 190, 197 (1976) 
"To withstand constitutional challenge, [...] classifications by gender must serve important governmental objectives and must be substantially related to achievement of those objectives."150

Net als de beide andere tests gaat ook de intermediate scrutiny-test uit van een tweeledige rechtvaardigingstoets: er wordt zowel gekeken naar het doel van het onderscheid als naar de verhouding tussen doel en middel. Het verschil met de andere tests is opnieuw vooral gelegen in de zorgvuldigheid waarmee wordt beoordeeld of aan deze criteria is voldaan. Van belang is allereerst dat het volgens deze test, anders dan bij de rational basis-test, aan de regering is om een toereikende rechtvaardiging voor het onderscheid aan te dragen. ${ }^{151}$ Verder is het opvallend dat het Supreme Court bij de toepassing van de intermediate scrutiny-test regelmatig nagaat of het ter rechtvaardiging naar voren gebrachte doel ook de werkelijke doelstelling van de classificatie is, terwijl bij rational basis genoegen wordt genomen met iedere enigszins plausibele doelstelling. ${ }^{152}$ Ook wordt er bij de intermediate scrutiny-test vaak een proportionaliteitstoets uitgevoerd, met name als ter rechtvaardiging een beroep is gedaan op administratief gemak. ${ }^{153}$ Tegelijkertijd is de test duidelijk minder streng dan de strict scrutinytest: een rechtvaardiging is zeker mogelijk en onderscheid op grond van geslacht is in verschillende gevallen inderdaad toelaatbaar geacht. ${ }^{154}$ Met name bestaat er bij de intermediate scrutiny-test relatief veel ruimte voor de conclusie dat er geen sprake was

150. 429 U.S., op 19. Opmerkelijk is dat de test niet geheel consequent wordt toegepast: er zijn arresten waarin eerder een beroep lijkt te worden gedaan op de Royster-formule dan op Craig v. Boren; zie bijv. Parham v. Hughes, 441 U.S. 347, 354 (1979). In sommige latere arresten is bovendien de eis gesteld dat de rechtvaardiging "exceedingly persuasive" moet zijn; zie bijv. Personnel Administrator of Massachusetts v. Feeney, 442 U.S. 256, 273 (1979), Kirchberg v. Feenstra, 450 U.S. 455, 460 (1981), Mississippi University of Women v. Hogan, 458 U.S. 718, 723 (1982), Heckler v. Mathews, 465 U.S. 728, 745 (1984), J.E.B. v. Alabama, 511 U.S. 127, 136 (1994) en vooral United States v. Virginia, 518 U.S. 515,533 (1996) (waarin van de verwarrende en niet eerder gebruikte term "skeptical scrutiny" gebruik wordt gemaakt, op 531). Er bestaat discussie over de vraag of deze eis moet worden gezien als een verhoging van de toetsingsintensiteit tot boven het niveau van de gebruikelijke intermediate scrutiny. test. Ook binnen het Supreme Court bestaat daarover onduidelijkheid: zie de dissenting opinion van Justice Scalia bij United States v. Virginia, op 571 e.v. en de concurring opinion van Chief Justice Rehnquist bij dezelfde uitspraak, op 558); zie verder Kovacic-Fleischer 1997, p. 870-874, die stelt dat in United States $v$. Virginia feitelijk een strict scrutiny-test is toegepast. De term lijkt echter vooral te moeten worden gezien als een iets andere benaming van de intermediate scrutiny-test: het gebruik van de term wordt steeds gevolgd door de toetsingselementen van Craig v. Boren en de toetsing die wordt uitgevoerd past binnen het gebruikelijke stramien van de intermediate scrutiny-zaken; vgl. Bowsher 1998 , p. 308 en 330.

151. Dit blijkt uit Wengler v. Druggists Mutual Insurance, 446 U.S. 142, 151 (1980), waarin het Supreme Court stelde dat "the burden [...] is on those defending the discrimination to make out the claimed justification"; zie ook Kirchberg v. Feenstra, 450 U.S. 455 (1981) en United States v. Virginia, 518 U.S. 515,533 (1996) ("the burden of justification is demanding and it rests entirely on the State").

152. Zie nader paragraaf 2.3.1; zie bovendien Tuan Anh Nguyen v. INS, 533 U.S. 53 (2001) (J. O'Connor, dissenting).

153. Zie Blattner 1981, p. 793 en Tuan Anh Nguyen v. INS, 533 U.S. 53 (2001) (J. O'Connor, dissenting). Op deze verschillen zal in paragraaf 2.3 e.v. nader worden ingegaan.

154. Zie bijv. Michael M. v. Superior Court of Sonoma County, 450 U.S. 464 (1981), Rostker v. Goldberg, 453 U.S. 57 (1981), Lehr v. Robertson, 463 U.S. 248 (1983), Heckler v. Mathews, 465 U.S. 728 (1984), Miller v. Albright, 523 U.S. 420 (1998) en Tuan Anh Nguyen v. INS, 533 U.S. 53 (2001). Zie ook Rutten 1997, p. 589, die met betrekking tot de intermediate scrutiny-test spreekt van een "very
flexible tool". 
van minder vergaande alternatieven of van een disproportionele belangenaantasting. Hoewel ook bij strict scrutiny een toetsing van subsidiariteit en proportionaliteit zich. baar is, zal deze daarbij vrijwel nooit leiden tot het oordeel dat aan deze eisen is vol. daan. ${ }^{15 s}$

Van belang is echter dat het Supreme Court voor de toepassing van de intermediate scrutiny-test maar een beperkte reikwijdte blijkt te zien: de test is uitsluitend toegepast op onderscheid op grond van geslacht en onwettige geboorte. ${ }^{156}$ Voor onderscheid op andere gronden, zoals seksuele geaardheid, ${ }^{157}$ leeftijd ${ }^{158}$ of handicap, ${ }^{159}$ is een toepassing steeds afgewezen. ${ }^{160}$ Voor die gevallen geldt dan ook de gebruikelijke rational basistest of, in de meeste gevallen, de informele rational basis "with bite"-test. ${ }^{161}$ op de

155. Vgl. Sullivan 1993, p. 243.

156. Zie Clark v. Jeter, 486 U.S. 456, 461 (1988). Aanvankelijk gold voor onwettige geboorte de intermsdiate scrutiny-test nog helemaal niet, maar werd er een rational basis-test uitgevoerd met een iets ver. hoogde zorgvuldigheid. Zie City of Cleburne v. Cleburne Living Center, 473 U.S. 432, 441 (1985) (waarin gesproken wordt van een "somewhat heightened review") en Farrell 1999, p. 372.

157. Romer v. Evans, 517 U.S. 620, 631 (1996): omdat er geen reden was voor strict scrutiny werd hierbij de rational basis-test toegepast. Wel lijkt er feitelijk sprake te zijn van een iets intensievere toetsing dan gebruikelijk.

158. Massachusetts Board of Retirement v. Murgia, 427 U.S. 307, 314 (1976) ("under the circumstances, it is unnecessary to subject the State's resolution of competing interests in this case to the degree of critical examination that our cases under the Equal Protection Clause recently have characterized as 'srict judicial scrutiny'. We turn then to examine this state classification under the rational basis-test"); zik ook de dissenting opinion van Justice Marshall, die een striktere toetsing bij onderscheid op grond van leeftijd gepast achtte. Zie ook Vance v. Bradley, 440 U.S. 93, 96 (1979) en Gregory v. Ashcroft, 501 U.S. 452, 470 (1991).

159. In ieder geval geldt dit voor onderscheid op grond van een geestelijke handicap: City of Cleburne v. Cleburne Living Center, 473 U.S. 432, 441 (1985) ("To withstand equal protection review, legislation that distinguishes between the mentally retarded and others must be rationally related to a legitimats govemmental purpose"). Over de vraag of ook bij onderscheid op grond van lichamelijke handicap eet rational basis-test moet worden uitgevoerd is tot nu toe nog geen uitspraak gedaan.

160. Hetzelfde geldt voor positieve discriminatie op grond van ras. Er is binnen het Supreme Court lasge tijd discussie gevoerd over de test die daarop zou moeten worden toegepast: een deel van de rechters was van mening dat ook hiervoor de strict scrutiny -test zou moeten gelden, met de daaraan verbonden consequentie dat vrijwel ieder onderscheid ontoelaatbaar is (zie de concurring opinion van Justice Powell bij Fullilove v. Klutznick, 448 U.S. 448, 496 (1980), de meerderheidsopinie van Justice O'Connot in City of Richmond v. J.A. Croson, 488 U.S. 469,489 e.v. (1989) en de dissenting opinion van Justiu O'Connor, Chief Justice Rehnquist en Justices Scalia en Kennedy in Metro Broadcasting v. FCC, 497? U.S. 547, $611(1990)$ ), een ander deel vond dat, gezien de specifieke omstandigheden die bij voorkeursbeleid een rol spelen, een intermediate scrutiny-test aangewezen was (zie m.n. de concurring opinion van Justices Marshall, Brennan en Blackmun bij Fullilove v. Klutznick, 448 U.S. 448, 518 (1980) en hun dissenting opinion bij City of Richmond v. J.A. Croson, 488 U.S. 469, 535 (1989)). Voor bepaalde gevallen van voorkeursbeleid heeft korte tijd inderdaad een intermediate scrutimy-test gegolder zie Metro Broadcasting v. FCC, 497 U.S. 547, 565 (1990). Dit arrest is in 1995 echter overnuld waarbij de intermediate scrutiny-test is vervangen door de strict scrutiny-test; zie Adarand Consins: tors, Inc. v. Pena, 515 U.S. 200, 224 (1995). In de literatuur is gesuggereerd dat daardoor misschice een vijfde test is ontstaan (naast de officieel erkende tests en de rational basis-test "with bite"), zit Rutten 1997, p. 592 en 610 . Vooralsnog lijkt het er echter niet op dat bij voorkeursbehandeling dastwerkelijk een minder strenge toetsing wordt uitgevoerd.

161. Dit soort uitspraken wekt regelmatig verwarring. Het Supreme Court is vaak verdeeld over de keurt voor een bepaalde toetsingsintensiteit (zie Gunther/Sullivan 1997, p. 650-652), hetgeen resultert in onvoldoende gemotiveerde en onduidelijke uitspraken. Daardoor is het mogelijk dat, nadat in een at" rest een geintensiveerde rational basis-test wordt toegepast, in commentaren wordt gesteld dat het St- 
vraag welke criteria de toepasselijkheid van de intermediate scrutiny-test bepalen zal in paragraaf 3 nader worden ingegaan.

\section{Toetsing in de eerste fase: vergelijkbaarheid, benadeling en discriminatoi- re doelstelling}

\subsubsection{Vergelijkbaarheid}

Er zijn verschillende omstandigheden waarin het Supreme Court in zijn rechtspraak gebruik heeft gemaakt van vergelijkbaarheidselementen: voorbeelden hiervan zijn zichtbaar in het kader van de bijzondere separate but equal-doctrine, maar ook bij de toepassing van de rational basis-test en bij de toepassing van de intermediate scrutinytest op onderscheid op grond van geslacht. In het hiernavolgende zal kort op deze verschillende toepassingen worden ingegaan.

\section{Vergelijkbaarheid en de separate but equal-doctrine}

In paragraaf 1.1 .2 is reeds melding gemaakt van het arrest Plessy v. Ferguson ${ }^{162}$, waarin het Supreme Court aangaf dat de Equal Protection Clause niet wordt geschonden wanneer er sprake is van aparte, maar gelijkwaardige voorzieningen voor Afro-Amerikanen en blanken. Inherent aan de toepassing van deze separate but equal-doctrine is het uitvoeren van een vergelijkbaarheidstoets: de rechter diende in ieder concreet geval na te gaan of de voorzieningen voor de verschillende groepen daadwerkelijk gelijkwaardig zijn. Dit element bleek vooral van belang te zijn in de periode waarin het verzet tegen segregatie langzaam groeide, nu het als een instrument kon worden gebruikt om de excessieve gevolgen van het segregatiebeleid te bestrijden. ${ }^{163}$ Interessant is vooral een aantal uit 1950 daterende uitspraken waaruit bleek dat het Supreme Court de gelijkwaardigheid van de betrokken voorzieningen zorgvuldig had onderzocht. ${ }^{164}$ Eén van

preme Court de reikwijdte van de intermediate scrutiny-test (impliciet) heeft uitgebreid (zie bijv. Hutchinson 1982, p. 169 in reactie op Plyler v. Doe, 457 U.S. 202 (1982), waarin het Supreme Court een striktere toets toepaste vanwege de omstandigheden van het geval). Uit de rechtspraak blijkt echter dat de "echte" intermediate scrutiny-test beperkt moet worden geacht tot geslacht en onwettige geboorte, en er in de andere gevallen sprake is van een niet nader benoemde tussenvorm waarvan de toepassing beperkt is tot de omstandigheden van het geval (zie bijv. de bespreking van de na Plyler gewezen uitspraken door Farrell 1999, p. 385/386).

162. 163 U.S. 537 (1896)

163. Aanvankelijk was de gelijkwaardigheidstoets nog niet zo sterk: het Supreme Court oordeelde eigenlijk alleen dat er sprake was van een schending van de Equal Protection Clause wanneer bepaalde voorzieningen helemaal niet open bleken te staan voor Afro-Amerikanen; zie bijv. McCabe v. Alchison, Tope$k a$ and Santa Fe Railway, 235 U.S. 151 (1914).

164. Deze uitspraken hadden betrekking op de gelijkwaardigheid van universitaire voorzieningen. De eerste aanzet tot een strengere benadering werd gegeven in het arrest Missouri ex rel. Gaines v. Canada, 305 U.S. 337 (1938). In deze zaak werden Afro-Amerikaanse studenten niet toegelaten tot de University of Missouri; wel werd hun subsidie gegeven om een zwarte universiteit in een van de aangrenzende staten te bezoeken. Het Supreme Court oordeelde dat er daardoor geen sprake was van gelijkwaardigheid; de afstand tussen woonplaats en universiteit was daarbij de relevante vergelijkingsmaatstaf (op 349/350). In een tweede arrest ging het Supreme Court nog iets verder. De zaak Sweatt v. Painter, 339 U.S. 629 (1950) had betrekking op de gelijkwaardigheid van de blanke rechtenfaculteit van de University of Texas en een (op last van de rechter) speciaal voor Afro-Amerikanen opgezette rechtenfaculteit. Het Supreme Court stelde: “[...] we cannot find substantial equality in the educational opportunities offe- 
deze zaken was McLaurin v. Oklahoma State Regents, een zaak die betrekking had op de toelating van een Afro-Amerikaanse student tot een blanke universitaire instelling.": Hoewel deze student formeel was toegelaten en, anders dan bij veel andere blanke instellingen het geval was, alle vakken mocht volgen, in de bibliotheek mocht zitten en in het cafetaria mocht eten, waren er in alle ruimtes speciale plaatsen voor hem gereserveerd, zodat hij steeds duidelijk apart zat van de andere studenten. Daardoor was er volgens het Supreme Court geen sprake van gelijkwaardigheid:

"The result is that appellant is handicapped in his pursuit of effective graduate instruction. Such restrictions impair and inhibit his ability to study, to engage in discussions and exchange views with other students, and, in general, to learn his profession."

Dit oordeel was voor Amerika zeer vergaand, nu het feitelijk impliceerde dat gesegregeerde voorzieningen vrijwel nooit gelijkwaardig zijn. Het vormde dan ook een belang. rijke stap in de richting van een vermindering van het belang van de separate but equal-doctrine. Zoals eerder al is aangegeven werd deze doctrine in 1954 met Brownv. Board of Education ${ }^{167}$ definitief doorbroken. ${ }^{168}$ Brown heeft echter niet tot gevolg gehad dat de gelijkwaardigheidstoetsing als zodanig volledig uit de rechtspraak is verdwenen: in de rechtspraak over aparte onderwijsinstellingen voor mannen en vrouwen heeft het Supreme Court in de afgelopen twintig jaar verschillende malen onderzocht in hoevere er kwalitatief gelijkwaardige voorzieningen voor het andere geslacht bestonden. ${ }^{100}$

red white and Negro law students by the State. In terms of number of the faculty, variety of course and opportunity for specialization, size of the student body, scope of the library, availability of law ro view and similar activities, the University of Texas Law School is superior. What is more imporanth the University of Texas Law School possesses to a far greater degree those qualities which are inceptble of objective measurement but which make for greatness in a law school" (op 633/634).

165. 339 U.S. 637 (1950)

166. 339 U.S., op 641

167. 347 U.S. 483 (1954)

168. Overigens werd er in deze zaak geen gebruik gemaakt van een gelijkwaardigheidstoets om de doctrits te doorbreken. De zaak was zorgvuldig geselecteerd om de separate but equal-doctrine als zodanig an de orde te stellen: de kwaliteit van de aparte zwarte scholen was minstens zo goed als die van de blan. ke, zodat het Supreme Court de zaak nauwelijks kon afdoen met een beroep op kwaliteitsverschillen (vgl. 346 U.S., op 492). Het Supreme Court stelde, dat "to separate [children] from others of simily age and qualifications solely because of their race generates a feeling of inferiority as to their status in the community that may affect their hearts and minds in a way unlikely ever to be undone [...]. [... Separate educational facilities are inherently unequal" (347 U.S., op 494/495). Het Supreme Cour stelde in dit arrest dus niet dat gesegregeerde voorzieningen nooit gelijkwaardig kunnen zijn, masr dit raciale segregatie altijd in strijd is met de Equal Protection Clause vanwege het gevoel van inferionitil dat daardoor wordt veroorzaakt.

169. Zie bijv. Mississippi University for Women v. Hogan, 458 U.S. 718 (1982) (J. Powell, dissenting) (t.a.v. de uitsluiting van een man van een vrouwenschool redenerend dat er voldoende vergelijktar? onderwijsinstellingen openstonden, zij het dat de man daarvoor iets verder moest reizen - vgl. het hiel: werd geklaagd over het feit dat vrouwen niet werden toegelaten tot een zeer prestigieuze opleiding (hth Virginia Military Institute, VMI); wel bestond er een vergelijkbare opleiding die alleen voor vrouwth opleidingen, waarbij diverse factoren, zoals onderwijskwaliteit en contact met alumni, werden beor"
deeld. De deeld. De conclusie was dat de opleiding niet als een "remedy" kon worden beschouwd die het vethod
op toelating van vrouwen tot VMI kon corrigeren (op 551). Dit oordeel is sterk vergelijkbaar met dat in het genoemde arrest Sweatt v. Painter, waarnaar in de uitspraak ook wordt verwezen (op 554). 
Hoewel deze gelijkwaardigheidstoets sterk lijkt op de gebruikelijke vergelijkbaarheidstoets, gaat het hierbij om een onzuivere toepassing. Normaal gesproken heeft de vergelijkbaarheidstoets betrekking op de vraag of de personen, groepen of gevallen waartussen onderscheid wordt gemaakt op relevante punten van elkaar verschillen. Bij de separate but equal-doctrine gaat het echter niet om verschillen tussen de voorgelegde gevallen, maar alleen om de gelijkwaardigheid van hun behandeling. In essentie is de vraag dan ook niet zozeer of er sprake is van vergelijkbaarheid, maar of er voor de betrokken groepen sprake is van een daadwerkelijk nadeel. In deze zaken is er dan ook feitelijk sprake van een benadelingstoets, ook al wordt deze onder een andere noemer geplaatst.

\section{Vergelijkbaarheid als onderdeel van de rational basis-test}

Een daadwerkelijke toepassing van de vergelijkbaarheidstoets is zichtbaar in de rechtspraak waarin de rational basis-test wordt toegepast. In paragraaf 2.2.1 is al aangegeven dat het Supreme Court op twee verschillende manieren uitwerking heeft gegeven aan deze test, namelijk via het Lindsley-model en het Royster-model. In dit laatste model is een duidelijk element van vergelijkbaarheid terug te vinden:

"[...] the classification must [...] rest upon some ground of difference having a fair and substantial relation to the object of the legislation, so that all persons similarly circumstanced shall be treated alike." ${ }^{170}$

Blijkens deze formule wordt niet van de eisende partij verwacht dat hij aantoont dat er sprake is van relevant vergelijkbare gevallen, maar wordt vereist dat de overheid aantoont dat de gevallen relevant verschillen. Dit betekent dat de vergelijkbaarheidstoets door het Supreme Court niet wordt gehanteerd als een toetsingsingang, zoals in Europa gebruikelijk is, maar veeleer als een manier om de rechtvaardiging te beoordelen. ${ }^{171}$ Zoals eerder al is aangegeven wordt de Royster-test echter slechts toegepast in een zeer beperkt aantal arresten. ${ }^{172}$ In veruit de meeste uitspraken wordt een beroep gedaan op de

170. F.S. Royster Guano v. Virginia, 253 U.S. 412, 415 (1920). Van een vergelijkbare formulering werd overigens al eerder gebruik gemaakt; zie bijv. Gulf, Colorado and Santa Fe Railway Company v. Ellis, 165 U.S. 150 (1897): "[a classification] must always rest upon some difference which bears a reasonable and just relationship to the act in respect to which the classification is proposed [...]." Opmerkelijk is dat ook in het arrest Lindsley gebruik werd gemaakt van de vergelijkbaarheidsterminologie, als een soort samenvatting van de verschillende rechtvaardigingscriteria die in het arrest werden genoemd (" $[\ldots]$ in other words, $[\ldots]$ the classification may rest upon some substantial difference $[\ldots]$ and this difference may afford a reasonable basis for the classification"). In latere rechtspraak ontbreekt echter iedere verwijzing naar dit onderdeel van de uitspraak.

171. Het onderscheid tussen de eerste fase en tweede fase van de toetsing is besproken in hoofdstuk 2 , paragraaf 3.1.2. In de eerste fase dient de eisende partij aannemelijk te maken dat hij daadwerkelijk recht van klagen heeft, bijvoorbeeld door te bewijzen dat er sprake is van een ongelijke behandeling van vergelijkbare gevallen of door aan te tonen dat hij door een classificatie daadwerkelijk is benadeeld. In de tweede fase moet vervolgens een inhoudelijk oordeel worden gegeven over de ongelijke

172. Zie voor een inhoudelijke toepassing van de vergelijkbaarheidstoets echter Lindsley v. Natural Carbonic Gas, 220 U.S. 61, 79 (1911) (opmerkelijk genoeg werd er in dit arrest, waarin de rational basis-test zo uitdrukkelijk werd geformuleerd, een vergelijkbaarheidstoets toegepast), Louisville Gas \& Electric Company v. Coleman, 227 U.S. 32 (1928), Tigner v. Texas, 310 U.S. 141, 146 e.v. (1940), Morey v. Doud, 354 U.S. 457, 466 (1957), Rinaldi v. Yaeger, 384 U.S. 305, 309 (1966), Labine v. Vincent, 401 
Lindsley-test, waarin een vergelijkbaarheidselement ontbreekt. ${ }^{17}$ Bovendien gaat het Supreme Court in de arresten waarin Royster wordt toegepast vrijwel nergens daad. werkelijk in op de vergelijkbaarheid, maar wordt hierin steeds een gewone rechtvaardigingstoets uitgevoerd. Een vergelijkbaarheidstoets is vrijwel uitsluitend zichtbaar in de gevallen waarin onderscheid op grond van geslacht aan de orde was; deze gevallen zullen hierna afzonderlijk worden besproken. Het is dan ook lastig om op basis van de rational basis-rechtspraak een oordeel te geven over de wijze waarop het Supreme Court met de vergelijkbaarheidstoets omgaat.

\section{Vergelijkbaarheid als onderdeel van de intermediate scrutiny-test bij onderscheid op grond van geslacht}

Een vergelijkbaarheidstoets is tenslotte relatief vaak terug te vinden in de rechtspraak over onderscheid op grond van geslacht. Het Supreme Court realiseerde zich in het begin van de jaren " 70 dat bij deze grond van onderscheid een iets strengere toetsing voor de hand lag, maar had daarvoor nog geen duidelijk model in gedachten. De enige mogelijkheid voor een striktere toetsing werd op dat moment geboden door het Royster-model, waarbij de bewijslast voor het aantonen van een rechtvaardiging bij de overheid lag. Kenmerkend voor deze test is echter, zoals hiervoor is gebleken, dat hierbij een vergelijkbaarheidstoets moet worden uitgevoerd. In het arrest Reed v. Reed $(1971)^{174}$ paste het Supreme Court dit model, in een iets aangepaste formulering, toe op onderscheid op grond van geslacht. Uit deze toepassing blijkt duidelijk dat het vergelijkbaarheidselement van belang is:

"[...] this Court has consistently recognized that the Fourteenth Amendment does not deny to States the power to treat different classes of persons in different ways. [...] The question presented by this case, then, is whether a difference in [...] sex [...] bears a reasonable relationship to a state objective that is sought to be advanced [...]."175

U.S. 532 (1971), Johnson v. Robison, 415 U.S. 361,378 e.v. (1974) en Williams v. Vermont, 472 US. 14,24 (1985).

173. Vooral in de laatste vijftien jaar is een beroep op de vergelijkbaarheidstoets uiterst zeldzaam geworden; alleen in 1997 werd nog gebruik gemaakt van de toets ("States must treat like cases alike but may trah unlike cases accordingly"; Vacco v. Quill, 521 U.S. 793, 799 (1997)). Bovendien geldt dat de mests gevallen waarin de test wordt toegepast betrekking hebben op onderscheid op grond van geslacht $0 \mathrm{~m}$. dat er in die arresten sprake is van een verhoogde toetsingsintensiteit die sterk doet denken aan de litter officieel erkende intermediate scrutiny-test, kan daarbij niet worden gesproken van een echte toepss. sing van de rational basis-test. Verder komt het vaak voor dat er in de algemene formulering van de test gebruik wordt gemaakt van de vergelijkbaarheidsterminologie, maar er vervolgens een gevone rechtvaardigingstoets wordt uitgevoerd; zie bijv. Watson v. Maryland, 218 U.S. 173, 180 (1910). Het is ook niet onlogisch dat de vergelijkbaarheidstoets door het Supreme Court niet zo vaak wordt toegepst: zoals verderop nog zal blijken voert het Supreme Court meestal een toets van de mate van fit uit. Dastdoor wordt een belangrijk element van de vergelijkbaarheidstoets vervangen, zodat deze toets gemis. kelijk gemist kan worden.

174. 404 U.S. 71, 76 (1971)

175. 404 U.S., op 76. Uit dit arrest lijkt voort te vloeien dat een "reasonable relationship" bij onderscheid op grond van geslacht alleen aanwezig kan zijn wanneer het onderscheid zijn rechtvaardiging vindt in to levante verschillen tussen mannen en vrouwen. Dit blijkt ook uit het vervolg van de redenering in bst arrest, dat betrekking had op de aanwijzing van de executeur testamentair; volgens de relevante rese ling kreeg een man die in dezelfde graad tot de overledene stond als een vrouw deze functie autom: tisch kreeg toebedeeld. Doel van de regeling was de vermindering van conflicten over de aanwijing 
In de jaren na Reed $v$. Reed bleef het Supreme Court vasthouden aan deze toepassing van de Royster-test. ${ }^{176}$ Opmerkelijk is echter dat het Supreme Court vooral van de test gebruik maakte in gevallen waarin het een rechtvaardiging voor de ongelijke behandeling aanwezig achtte. Zo was er in het arrest Kahn v. Shevin ${ }^{177}$ (1974) een regeling aan de orde die aan weduwen een belastingvoordeel toekende, maar dit aan weduwnaars onthield. De regering had als rechtvaardiging hiervoor aangevoerd dat het voor vrouwen veel moeilijker was om een baan te vinden, omdat zij tijdens hun huwelijk vaak niet hadden gewerkt en de arbeidsmarkt niet kenden; voor mannen gold dit nadeel niet. Het Supreme Court stelde hierover het volgende:
"There can be no dispute that the [...] difficulties confronting the lone woman in Florida or in any other State exceed those facing the man. [...] There can be no doubt, therefore, that Florida's differing treatment of widows and widowers 'rest[s] upon some ground of difference having a fair and substantial relation to the object of the legislation'."17s

Hoewel het Supreme Court in 1976 afstapte van een directe toepassing van de Roystertest door de erkenning van de intermediate scrutiny-test, bleef het ook daarna van de vergelijkbaarheidstoets gebruik maken. ${ }^{179}$ Dit gebeurt vooral door de vergelijkbaarheidstoets te hanteren als controle op de aanwezigheid van een "fair and substantial

bij de rechter, volgens het Supreme Court een gerechtvaardigde doelstelling. Het Supreme Court voegde daaraan echter toe, dat "to give mandatory preference to members of either sex over members of the other, merely to accomplish the elimination of hearings on the merits, is to make the very kind of arbitrary choice forbidden by the Equal Protection Clause of the Fourteenth Amendment [...]" (op 76). Automatische bevoordeling kan dus nooit een "reasonable basis" opleveren: er moet daadwerkelijk sprake zijn van relevante verschillen op grond van geslacht. Hoewel de stelling dat alleen relevante verschillen een voldoende rechtvaardiging kunnen opleveren ook in andere arresten terugkomt (bijv. Parham v. Hughes, 441 U.S. 347, 354 (1979)), blijkt uit andere rechtspraak dat een rechtvaardiging voor onderscheid op grond van geslacht ook kan worden gevonden in andere factoren; zie bijvoorbeeld Caban v. Mohammed, 441 U.S. 380, 390 (1979). Dit is ook logisch, omdat er "exteme" factoren kunnen zijn die een onderscheid kunnen rechtvaardigen. Zo heeft een doelstelling als "administrative convenience" niets van doen met het verschil tussen mannen en vrouwen, maar kan deze soms wel reden vormen voor het maken van onderscheid op grond van geslacht. Het Supreme Court kan er in dat geval eenvoudigweg niet omheen om een rechtvaardigingstoets te gebruiken in plaats van een vergelijkbaarheidstoets.

176. Soms gebeurt dit expliciet, soms meer impliciet; zie bijv. Frontiero v. Richardson, 411 U.S. 677, 690 (1973) (gerechtvaardigd doel, maar geen relevant verschil tussen mannen en vrouwen dat het redelijk kan maken om onderscheid te maken op grond van geslacht).

177. 416 U.S. 351 (1974)

178. 416 U.S., op 353 en 355. Zie ook Schlesinger v. Ballard, 419 U.S. 498, 508 (1975).

179. Bijv. Parham v. Hughes, 441 U.S. 347, 355/356 (1979). Michael M. v. Superior Court of Sonoma County, 450 U.S. 464 (1981), Rostker v, Goldberg, 453 U.S. 57, 78 (1981), Lehr v. Robertson, 463 U.S. 248, $267 / 268$ (1983), Miller v. Albright, 523 U.S. 420, 436 (1998) en Tuan Anh Nguyen v. INS, 533 U.S. 53 (2001). Zie vooral ook United States v. Virginia, 518 U.S. 515 (1996): "Supposed "inherent differences' are no longer accepted as a ground for race or national origin classifications. Physical differences between men and women, however, are enduring. [...] 'Inherent differences' between men and women, we have come to appreciate, remain cause for celebration, but not for denigration of the members of either sex of for artificial constraints on an individual's opportunity" (op 533). KovacicFleischer stelt echter terecht dat verderop in de uitspraak blijkt dat ook fysieke verschillen niet altijd bepalend mogen zijn, met name niet als het vrij gemakkelijk is om aan deze verschillen tegemoet te komen (1997, p. 882). Vgl. verder Stone e.a. 1996, p. 714; zij wijzen erop dat de verschillen niet alleen biologisch van aard kunnen zijn, maar ook juridisch of maatschappelijk. Wel is het de vraag of het redelijk is om ook dergelijke, "kunstmatige" verschillen te accepteren. 
relationship" tussen doel en classificatie. ${ }^{\text {180 }}$ De toepassing die in dat verband aan de vergelijkbaarheidstoets wordt gegeven is in de meeste gevallen nauwelijks te onder. scheiden van een toepassing van het gebruikelijke rechtvaardigingsmodel: in sommige arresten gaat het Supreme Court na of er sprake is van noodzakelijkheid ${ }^{181}$, terwijl in de praktijk het verschil tussen een goede toetsing van de mate van fit en de vergelijkbaar. heid minimaal blijkt te zijn. ${ }^{1{ }^{2} 2}$ Van belang is bovendien dat het Supreme Court in lang niet alle arresten over onderscheid op grond van geslacht verwijst naar de vergelijkbaarheid: in veel gevallen wordt gewoon een rechtvaardigingstoets uitgevoerd. ${ }^{10}$

\section{Conclusie}

Uit het voorgaande kan blijken dat de rechtvaardigings- en vergelijkbaarheidstoets in de rechtspraak van het Supreme Court in sterke mate uitwisselbaar zijn, hetgeen een belangrijke ondersteuning vormt voor de stelling dat het niet noodzakelijk is om van de vergelijkbaarheidstoets gebruik te maken. Verder is het van belang dat het Supreme Court het kennelijk lang niet altijd nodig vindt dat in de eerste fase van de toetsing wordt aangetoond dat de gevallen vergelijkbaar zijn; ook hierin kan een bevestiging worden gevonden van de opvatting dat de toetsing van de vergelijkbaarheid van de voorgelegde gevallen niet onmisbaar is. Wel roept dit vanzelfsprekend de vraag op welke toetsing het Supreme Court als alternatief voor de vergelijkbaarheidstoets in de eerste fase hanteert; in de hiernavolgende subparagrafen zal daarop nader worden inge. gaan.

180. Hoewel de vergelijkbaarheidstoets ook wel eens is gehanteerd als instrument om aan te tonen dat er een "important governmental interest" voor het onderscheid bestaat. Zie bijv. Tuan Anh Nguyen v. INS, 533 U.S. 53 (2001).

181. Zie bijv. Orr v. Orr, 440 U.S. 268, 281/282 (1979).

182. Een duidelijk voorbeeld is het arrest Craig v. Boren, 429 U.S. 190 (1976), waarin voor het eerst do intermediate scrutiny-test werd toegepast. In dit arrest was een maatregel in het geding op grond wart: van de verkoop van licht alcoholische dranken aan minderjarigen werd verboden ter bescherming van de verkeersveiligheid. Omdat vrouwen in de betrokken staat (Oklahoma) meerderjarig werden op 16 jarige leeftijd, terwijl voor mannen 18 als datum voor meerderjarigheid gold, leidde deze maatregel tot een onderscheid op grond van geslacht. In zijn oordeel over de toelaatbaarheid van het onderscheid maakte het Supreme Court gebruik van statistische gegevens over rijden onder invloed bij mannen en vrouwen, waaruit bleek dat $0.18 \%$ van de vrouwen en $2 \%$ van de mannen vanwege deze overtreding werden gearresteerd. Het Supreme Court oordeelde dat " [...] a correlation of $2 \%$ must be considerd an unduly tenuous 'fit'" (op 202). Hoewel de redenering kan worden gezien als een vergelijkbas. heidstoets (bekeken wordt immers of er statistische verschillen bestaan die het onderscheid kunnen rechtvaardigen) kan ook worden gesteld dat het onderscheid ontoelaatbaar werd geacht vanwege zijp overinclusiveness: een groot percentage mannen wordt uitgesloten van alcoholgebruik, terwijl slechts een minimaal percentage het gevaar vormt dat de maatregel beoogt te bestrijden. Vgl. ook de dissen: ting opinion van Justice Rehnquist bij dit arrest, die het oordeel bestrijdt met de overweging dat ent "perfect fit" niet is vereist en de wetgever niet verplicht is om naar alternatieven te zoeken, beide div. delijk overwegingen die in een rechtvaardigingstoets thuis horen.

183. Zie bijv. Caban v. Mohammed, 441 U.S. 380, 390 (1979); dit arrest is een duidelijk voorbeeld van een toepassing van beide elementen. Allereerst wordt nagegaan of de ongelijke behandeling wordt gerechlvaardigd door seksegerelateerde verschillen. Pas als blijkt dat dit niet het geval is wordt nagegaan of et nog andere overwegingen zijn die het onderscheid kunnen rechtvaardigen; daarbij wordt vooral geke ken naar de geschiktheid en de noodzakelijkheid van het onderscheid om het gestelde doel te bereiken. Een dergelijke combinatie is ook terug te vinden in Miller v. Albright, 523 U.S. $420,436 \mathrm{en} 438 \mathrm{ev}$. (1998). Andere voorbeelden zijn Califano v. Webster, 430 U.S. 313 (1977), Califano v. Goldfarb, 430 U.S. 199 (1977) en Wengler v. Druggists Mutual Insurance, 446 U.S. 142 (1980) 


\subsubsection{Direct onderscheid: het bestaan van een classificatie als toetsingsingang}

\section{Veronderstelling van benadeling bij normatieve classificaties}

In de meeste gevallen waarin wordt geklaagd over direct onderscheid zal er sprake zijn van een normatieve classificatie, dus van een regeling waardoor een bepaalde groep wordt uitgezonderd voor een bijzondere behandeling. ${ }^{13}$ Het Supreme Court heeft consequent gesteld dat het enkele bestaan van een dergelijke classificatie voldoende is om een inhoudelijke beoordeling uit te lokken. Dit bleek reeds toen het in 1897 uitspraak moest doen over proceskostenvergoedingen door spoorwegmaatschappijen. ${ }^{\text {iss }}$ Wanneer iemand schade had geleden doordat zijn vee onder een trein was gekomen gold in Texas de regeling dat, als de gedupeerde naar de rechter stapte, de spoorwegmaatschappij verplicht was om hem een bedrag van $\$ 10$ te betalen als proceskostenvergoeding. Voor schade aan vee waarvoor andere bedrijven of particulieren verantwoordelijk waren gold een dergelijke vergoedingsplicht niet. Volgens het Supreme Court hadden de spoorwegmaatschappijen door het enkele bestaan van deze regeling voldoende reden tot klagen:

"The act singles out a certain class of debtors and punishes them when for like delinquencies it punishes no others. They are not treated as other debtors, or equally with other debtors. [...] In the suits [...] to which they are parties they are discriminated against, and are not treated as others. They do not stand equal before the law. They do not receive its equal protection."186

Uit de benadering die in het bovenstaande arrest werd gekozen blijkt dat het in de eerste fase voldoende is wanneer de eiser aantoont dat er sprake is van een normatieve classificatie; het Supreme Court veronderstelt kennelijk dat benadeling daarvan een inherent gevolg is en stelt verder geen eisen aan het bewijs daarvan. ${ }^{187}$ Uit de verdere rechtspraak blijkt dat dit niet alleen geldt bij de rational basis-test ${ }^{1 \mathrm{18}}$, maar ook bij de intermediate scrutiny- en de strict scrutiny-test. ${ }^{18 \%}$ Voor de laatste test blijkt dit bijvoor-

184. Er bestaan overigens uitzonderingen; daarin werd niet geklaagd over normatieve classificaties, maar over administratieve toepassing; zie Allegheny Pittsburgh Coal Co. v. Webster County, 488 U.S. 336 (1989), Nordlinger v. Hahn, 505 U.S. I (1992) en Village of Willowbrook v. Olech, 528 U.S. 562 $(2000)$. In die arresten wordt gebruik gemaakt van een gewone benadelingstoets.

185. Gulf, Colorado and Santa Fe Railway Company v. Ellis, 165 U.S. 150 (1897)

186. 165 U.S., op 153

187. Door Ely is dit model aangeduid als het "disadvantageous decision model" (1970, p. 1228); hij merkt overigens terecht op dat de klager wel moet aantonen dat hij aan de benadelende kant van de classificatie valt, hetzij doordat hij geen deel uitmaakt van een groep die is uitgezonderd voor een voordelige behandeling, hetzij omdat hij deel uitmakt van een groep die is uitgezonderd voor een nadelige behandeling (idem); in die zin ook Brest 1971, p. 107. Het Supreme Court gaat echter alleen in zeldzame gevallen daadwerkelijk na of van een benadeling sprake is; meestal wordt dit eenvoudigweg verondersteld.

188. Hetzelfde geldt voor de rational basis "with bite"-test: zie bijv. Weber v. Aetna Casualty \& Surety Co., 406 U.S. 164, 169 (1972).

189. Eisenberg 1977, p. 62. Bij de intermediate scrutiny-test besteedde het Supreme Court aanvankelijk wel aandacht aan de benadelingskwestie. De vraag was dan vooral of de man dan wel de vrouw nadelig door de regeling werd getroffen; zie bijv. Weinberger $v$. Wiesenfeld, 420 U.S. 636 (1975), Califano $v$. Goldfarb, 430 U.S. 199 (1977) en Wengler v. Druggists Mutual Insurance, 446 U.S. 142, 147 (1980). De reden voor de benadelingstoets zou kunnen zijn dat aanvankelijk niet zonder meer duidelijk was of de intermediate scrutiny test ook van toepassing was bij benadeling van mannen, nu daarbij minder reden zou kunnen bestaan voor een intensivering van de toetsing (zie daarover nader paragraaf 3 ). Nadat 
beeld uit een arrest over een statelijke wet op grond waarvan het verboden was on interraciale huwelijken af te sluiten. ${ }^{190}$ Volgens de verantwoordelijke staat bestond hierbij geen reden voor een inhoudelijke toetsing, omdat het verbod zowel voor Afro. Amerikanen als voor blanken gold: gesteld kon dus niet worden dat één van beide groepen uitdrukkelijk werd benadeeld. Het Supreme Court oordeelde echter anders:

"[...] the Equal Protection Clause requires the consideration of whether the classifications drawn by any statute constitute an arbitrary and invidious discrimination. [...] There can be no question but that Virginia's miscegenation statutes rest solely upon distinctions drawn according to race. The statutes proscribe generally accepted conduct if engaged in by members of different races." 191

Klagers hoefden dus niet aan te tonen dat de regeling voor de ene raciale groep nadeligere effecten had dan voor de andere. Voor een inhoudelijke toetsing was het ook hiet voldoende dat er sprake was van een wettelijke classificatie: het sluiten van interraciale huwelijken werd bestraft, terwijl huwelijken tussen mensen van hetzelfde ras toelaatbaar waren. ${ }^{192}$

\section{Nadere invulling van het classificatievereiste als toetsingsingang}

Het Supreme Court heeft in de loop van de tijd wel nader invulling gegeven aan het vereiste van een normatieve classificatie als toetsingsingang. Zo stelde het in het arrest New York Transit Authority $v$. Beazer ${ }^{193}$ dat een inhoudelijke toetsing alleen nodig is wanneer een regeling daadwerkelijk een bepaalde groep uitzondert voor bijzondere behandeling. De zaak had betrekking op een algemeen verbod op het gebruik van drugs of bepaalde medicijnen door werknemers van de Transit Authority. Volgens het Supreme Court bestond er om die reden geen aanleiding voor het uitvoeren van een in. houdelijke beoordeling:

"General rules that apply evenhandedly to all persons within the jurisdiction unquestionably comply with [the Fourteenth Amendment]. Only when a government unit adopts a rule that

eenmaal duidelijk was dat ook een benadeling van mannen aan een intermediate scrutimy-test moss worden onderworpen, is deze uitgebreidere benadelingstoets niet meer uitgevoerd.

190. Loving v. Virginia, 388 U.S. I (1967)

191. 388 U.S., op 10/11

192. Vgl. Ely 1970, p. 1230. Hoewel het voor de hand liggend lijkt om in dit soort wetgeving een classificatie aanwezig te achten, is dit voor de VS niet het geval. In 1882, relatief snel nadat de Equal Protec tion Clause was aangenomen, was een vergelijkbaar geval aan de Supreme Court voorgelegd. Dezt zaak had betrekking op twee maatregelen die een verbod op overspel bevatten; voor overspel tussen twee mensen van hetzelfde ras gold echter een lagere strafmaat dan voor overspel tussen twee menseh van een verschillend ras. Het Supreme Court volgde in dit arrest een met de separate but equal-test vergelijkbare redenering: "There is in neither section any discrimination against any race. Sect 4184 equally includes the offence when the persons of the two sexes are both white and when they are both black. Sect. 4189 applies the same punishment to both offenders, the white and the black. [...] What ever discrimination is made in the punishment prescribed in the two sections is directed against the of fence designated and not against the person of any particular color or race" (Pace v. Alabama, 106 US. 583, op 584 (1882)). Het Supreme Court oordeelde al in 1964, drie jaar voor Loving, dat in Pace ten onrechte de vraag over het hoofd was gezien of niet juist door de ongelijke behandeling van vethovdingen tussen mensen van gelijk en verschillend ras sprake is van een met de Equal Protection Clast onverenigbare classificatie: McLaughlin v. Florida, 379 U.S. 184, op 190 (1964).

193. 440 U.S. 568 (1979) 
has a special impact on less than all the persons subject to its jurisdiction does the question whether this principle is violated arise,"

Uit latere rechtspraak blijkt verder dat het bestaan van een duidelijke classificatie niet in alle gevallen voldoende is om een rechtvaardigingstoets uit te lokken. In een beperkt antal zaken ging het Supreme Court in de eerste fase van de toetsing toch nader in op de vraag of de classificatie een benadeling had veroorzaakt. Zo werd er in de zaak Jenness $v$. Fortson ${ }^{195}$ geklaagd over de kieswet van de staat Georgia. Deze wet verschafte verschillende mogelijkheden voor de vermelding van een partij op de kieslijst: afhankelijk van het resultaat bij de meest recente verkiezingen werd de naam automatisch vermeld of was het nodig om een bepaald aantal handtekeningen van kiesgerechtigden op te halen. Het Supreme Court stelde daarover het volgende:

"We cannot see how Georgia has violated the Equal Protection Clause of the Fourteenth Amendment by making available these two alternative paths, neither of which can be assumed to be inherently more burdensome than the other." ${ }^{\text {196 }}$

Ook in andere gevallen waarin er reden voor twijfel bestond ging het Supreme Court nader in op de aanwezigheid van een benadeling. Interessant is daarbij dat het in zijn rechtspraak heeft aanvaard dat een benadeling niet altijd tastbaar hoeft te zijn, maar ook gelegen kan zijn in het oproepen van een gevoel van inferioriteit of in de stigmatisering van een bepaalde groepering. Het eerder besproken arrest Brown v. Board of Education $^{197}$ vormt een duidelijke illustratie van deze benadering. In de staat waarop deze zaak betrekking had waren de openbare scholen verplicht gesegregeerd, maar bleken de voorzieningen van volstrekt gelijkwaardige kwaliteit te zijn. Hoewel de betrokken regeling duidelijk onderscheid maakte op basis van ras, kon dan ook, waar het de kwaliteit van het onderwijs betrof, moeilijk worden gesproken van een tastbare benadeling van Afro-Amerikanen. Het Supreme Court stelde echter, dat

\footnotetext{
"To separate them [schoolkinderen in het algemeen, JHG] from others of similar age and qualifications solely because of their race generates a feeling of inferiority $[\ldots] .[\ldots]$ Therefore, we hold that the plaintiffs and others similarly situated $[\ldots]$ are, by reason of the segregation complained of, deprived of the equal protection of the laws guaranteed by the Fourteenth Amendment."
}

Een benadeling hoeft dus niet altijd meetbaar of tastbaar te zijn, in die zin dat de betrokkene door een regeling financieel nadeel lijdt of geen recht heeft op het gebruik van

194. 440 U.S., op 587/588. Overigens werd er in dit arrest niet geklaagd over formeel, maar over materieel onderscheid: de regeling zou ten onrechte betrekking hebben op gebruikers van methadon. Uit de formulering van het Supreme Court blijkt dat ook een materieel onderscheid aan een inhoudelijke toets kan worden onderworpen (gesproken wordt over "special impact" op een bepaalde groep). Het automatisme waarmee normaal gesproken een inhoudelijke toets wordt uitgevoerd valt dan weg: er wordt dan eerst nader onderzoek gedaan naar het daadwerkelijk bestaan van een benadeling en van een discriminatoire bedoeling.

195. 403 U.S. 431 (1971)

196. 403 U.S., op $440 / 441$

197. 347 U.S. 483 (1954)

198. Op 494 en 495 
een bepaalde voorziening: nadeel kan ook moreel of psychisch van aard zijn. ${ }^{1 \text { m }} \mathrm{Van}_{\mathrm{an}}$ zelfsprekend zal het in de praktijk echter moeilijk zijn om vast te stellen wanneer et kan worden gesproken van psychisch nadeel. In dat verband is van belang dat het Sapreme Court in Brown steun voor zijn oordeel vond in sociologisch en psychologisch onderzoek, waaruit bleek dat het gevoel van inferioriteit niet alleen gold voor de indviduele klagers in deze zaak, maar voor vrijwel alle kinderen. Het oordeel over de benadeling van Afro-Amerikaanse kinderen werd daardoor in belangrijke mate ge steund door objectief bewijsmateriaal en was niet alleen gelegen in een persoonlijke en subjectieve waarneming van de betrokken rechters. ${ }^{200}$

Zoals is aangegeven is het echter uitzonderlijk dat het Supreme Court aandacht besteedt aan het bestaan van een (psychische of materiële) benadeling: het feit dat hierop in Jenness v. Fortson en Brown zo nadrukkelijk werd ingegaan houdt vooral verband met het feit dat er in deze zaken duidelijk reden bestond om aan het bestaan van een benadeling te twijfelen. ${ }^{201}$ In veruit de meeste gevallen zal het Supreme Court, zolang

199. Vgl. Lawrence 1987 , p. $350 / 351$ en Pildes/Niemi 1993, p. 506/507, die spreken over "expressic harm". Een ander voorbeeld is de zaak Anderson v. Martin, 375 U.S. 399 (1964), die betrekking had op de in Louisiana geldende regel dat op stembiljetten het ras van de kandidaten moest worden verneld Hoewel niet duidelijk bleek dat dit resulteerde in een kleiner of groter aantal stemmen voor kandidaten van bepaalde raciale groepen, was dit volgens het Supreme Court een problematische regeling: The vice lies not in the resulting injury but in the placing of power of the State behind a racial classifiction that induces prejudice at the polls". Zie ook de zaak United Jewish Organization of Williamsburg 1 Carey, 430 U.S. 144 (1977), die betrekking had op de indeling van New York in kiesdistricten. In her plan was rekening gehouden met de raciale samenstelling van bepaalde wijken, maar hierdoor werl geen enkele groep benadeeld. Daardoor was er sprake van een classificatic op grond van ras, masr "[the] plan represented no racial slur or stigma with respect to whites or any other race, and we discen no discrimination" (op 165). A contrario kan uit Carey worden afgeleid dat een benadeling nomal gesproken wel gelegen kan zijn in stigmatisering of in het creêren van negatieve gevoelens ten op: zichte van raciale groeperingen.

200. Overigens is er in de Amerikaanse literatuur veel kritiek geleverd op de specifieke sociologische bronnen waarnaar het Supreme Court verwees; het bewijsmateriaal zou niet bijzonder overtuigend zijp (zie Gunther/Sullivan 1997, p. 679). Dit neemt echter niet weg dat bewijs van goede kwaliteit een do gelijke basis kan vormen voor de vaststelling van een psychische benadeling.

201. Zie ook Gordon v. Lance, 403 U.S. 1, 5 en 7 (1971), Geduldig v. Aiello, 417 U.S. 484, $496 / 497$ (1974), American Party of Texas v. White, 415 U.S. 767, 781 (1976). United Jewish Organization of Williumt burg v. Carey, 430 U.S. 144 (1977), Caban v. Mohammed, 441 U.S. 380, 387 (1979), Heckler : Mathews, 465 U.S. 728, $743 / 744$ (1984) en Miller v. Albright, 523 U.S. 420 (1998). In uitzonderings: gevallen gaat het Supreme Court zelfs zeer actief op zoek naar de aanwezigheid van een benadeling zelfs bij toepassing van de rational basis-test. Dit gebeurde bijvoorbeeld in het arrest Williams $\mathrm{k}$. Vermont, 472 U.S. 14 (1985), een arrest dat betrekking had op een regeling voor motorrijtuigenbelas. ting, waarin bij het bepalen van de grondslag van belastingheffing onderscheid werd gemaakt naar de plaats van aankoop van de auto. In de regeling leek geen sprake te zijn van een daadwerkelijke bent: deling (vgl. de dissenting opinion van Justice Blackmun). Via cen uitgebreide redenering, warin me. ding werd gemaakt van het werkelijke doel van de regeling en van hypothetische gevallen warop dex van toepassing kon zijn, kwam de meerderheid echter tot de conclusie dat er toch van een benadeling sprake was. Gezien de terughoudendheid waarmee onderscheid in belastingregelingen normal gespro ken wordt beoordeeld is deze uitspraak onbegrijpelijk. Een onderzoek naar het bestaan van een bentdeling blijkt verder te worden uitgevoerd wanneer er sprake is van andere vormen van direct onderscheid dan een normatieve classificatie, zoals in het geval waarin iemand klaagt over een benadeling door administratief optreden. Ook gaat het Supreme Court uitdrukkelijk in op de benadelingstots bi direct onderscheid in zaken waarin wordt geklaagd over de aantasting van een fundamenteel recht tin verschillende arresten blijkt dat het Supreme Court dan vereist dat er sprake is van een daadwerkelijit 
kan worden aangetoond dat er sprake is van een classificatie, eenvoudigweg veronderstellen dat de eisende partij hierdoor is benadeeld. ${ }^{202}$

Dat het bestaan van een daadwerkelijke benadeling meestal niet relevant is kan worden geillustreerd door het arrest Nyquist $v$. Mauclet ${ }^{20.3}$, dat betrekking had op studiebeurzen in de staat New York. Voor de verlening van deze beurzen werd de eis gesteld dat de aanvrager Amerikaans staatsburger was of dat hij in ieder geval blijk had gegeven van de intentie zich te laten naturaliseren. De betrokken staat stelde dat er in dit geval weliswaar sprake was van een onderscheid op grond van staatsburgerschap, maar dat dit nauwelijks benadelende gevolgen had: aan de negatieve effecten van de regeling kon gemakkelijk worden ontkomen door een intentieverklaring af te leggen. Het Supreme Court oordeelde anders:

"The important points are that $\S 661$ (3) is directed at aliens and that only aliens are harmed by it. The fact that the statute is not an absolute bar does not mean that it does not discriminate against the class."

De vermijdbaarheid van een benadeling staat dan ook niet in de weg aan het geven van een inhoudelijk oordeel over de gerechtvaardigdheid ervan. Dit blijkt ook te gelden voor classificaties waardoor vaders van onwettige kinderen worden benadeeld: ook daarbij kan aan de nadelige consequenties vrij gemakkelijk kan worden ontkomen, bijvoorbeeld door het kind te erkennen. ${ }^{205}$ Deze benadering van het Supreme Court is niet meer dan redelijk: het feit dat aan de werking van een classificatie kan worden ontkomen impliceert nog niet dat hierdoor geen onredelijke benadeling wordt gecreeerd. Of dit daadwerkelijk het geval is kan alleen aan de hand van een rechtvaardigingstoets worden onderzocht.

en absolute aantasting van deze rechten; om dit te kunnen vaststellen wordt er een benadelingstoets toegepast. In dat geval gaat het echter om een toetsing in het kader van de (aan de eerste fase nog voorafgaande) vaststelling van de toetsingsintensiteit; als er sprake is van de aantasting van een fundamenteel recht kan er een strict scrutiny-test worden toegepast. Zie bijv. Bullock v. Carter, 405 U.S. 134, 144 (1972) ("real and appreciable impact" op het recht is vereist), San Antonio School District v. Rodriguez, 411 U.S. 1, 19 (1973) en Ross v. Moffitt, 417 U.S. 600, 616 (1974). Deze specifieke toepassing van de benadelingstoets heeft dan ook niets te maken met de toetsing in de eerste fase.

202. Overigens kan een reden voor de geringe aandacht voor de benadelingstoets ook gelegen zijn in het feit dat het Supreme Court meestal optreedt als rechter in laatste instantie en alleen uitspraak doet over de punten die daadwerkelijk in het geding zijn; dit betekent dat het veelal alleen op de benadelingskwestie zal ingaan wanneer daarover tussen de partijen discussie bestaat. Vaak zal hierover al overeenstemming zijn bereikt voor de eerdere rechterlijke instanties, waar waarschijnlijk aandacht zal worden besteed aan de benadelingstoets bij de beoordeling van de ontvankelijkheid van de klacht (bijvoorbeeld in het kader van de beoordeling van het procesbelang van de eiser). Het Supreme Court zal dan niet meer toekomen aan deze toets.

203. 432 U.S. 1 (1977)

204. 432 U.S., op 8; idem in Kirchberg v. Feenstra, 450 U.S. 455, 461 (1981). Het "onontkoombaarheidsargument" speelt wel een belangrijke rol bij de beoordeling van de proportionaliteit van de maatregel; zie bijv. Ambach v. Norwick, 441 U.S. 68, 80 (1979) en Miller v. Albright, 523 U.S. 420, 441 (1998). Zie

205. Zier paragraaf 2.4.5.

have taken Trimble v. Gordon, 430 U.S. 762 (1977) ("By focusing on the steps that an intestate might sential question: the some inheritance for his illegitimate children, the analysis loses sight of the ession law", op 774) constitutionality of discrimination against illegitimates in a state intestate succescent, 401 U.S. 532. Het Supreme Court oordeelde overigens anders in de eerdere zaken Labine v. Vinre zaak: Parham v. Hughes, 441 en Weber v. Aetna, 406 U.S. 164, 170 (1972), maar ook nog in een late- 


\section{Bewijslastverdeling}

Het resultaat van het gebruik van het bestaan van een classificatie als toetsingsingang is een minimale bewijslast voor de eisende partij in de eerste fase. Bij een toepassing van de strict scrutiny-test, en in iets mindere mate ook bij de intermediate scrutiny-test, is dit redelijk: bij een classificatie op verdachte gronden zal er vrijwel steeds sprake zijn van een (eventueel psychische) benadeling, zodat hierbij zonder meer van de verwe. rende partij gevergd mag worden dat hij het onderscheid rechtvaardigt. Bij de rational basis-test ligt het minder voor de hand om zulke lage eisen te stellen aan de bewijslast van de eisende partij. Een dergelijke toetsingsingang heeft immers tot gevolg dat vrijwel iedere classificatie aan een inhoudelijke beoordeling wordt onderworpen, hetgeen onredelijk belastend is voor de betrokken overheidsorganen en niet in overeenstem. ming lijkt te zijn met de zeer terughoudende opstelling van het Supreme Court. Dit probleem is door het Supreme Court opgevangen door de toepassing van de Lindslej. test als rechtvaardigingsmodel. Zoals eerder al is angegeven wordt daarbij uitgegaan van een omkering van de bewijslast in de rechtvaardigingsfase: het Supreme Cout veronderstelt dat het onderscheid gerechtvaardigd is en zal alleen tot een ander oordeel komen wanneer de eisende partij overtuigend aantoont dat een toereikende rechtvaardiging ontbreekt. Hierdoor ligt er toch een zware bewijslast op de klager, terwijl de last van de regering minimaal is. Op de vraag of deze keuze redelijk is, en dient te worden overgenomen in het algemene toetsingsmodel, zal in paragraaf 4.1 nader worden inge. gaan.

\subsubsection{Indirect onderscheid: effect en bedoeling als toetsingsingang}

Tot ver in de jaren 50 was het voor veel staten niet ongebruikelijk om direct onderscheid te maken op grond van ras. Nadat het Supreme Court verschillende arresten had gewezen waarin op dit soort classificaties een strict scrutiny-test werd toegepast en waaruit duidelijk werd dat onderscheid op grond van ras niet langer werd getolereerd, begonnen de staten echter voorzichtiger te worden. Wanneer zij een (raciale) minderheidsgroep in de staat wilden benadelen deden zij dat bij voorkeur niet meer rechtstreeks, maar op een meer verhulde manier. ${ }^{206}$ In deze periode ontstond er bovendien een grotere gevoeligheid voor de negatieve maatschappelijke effecten die veel regelgeving voor minderheidsgroeperingen had, als gevolg van de jarenlange achterstelling van deze groepen. Een toenemend aantal mensen was van mening dat de overheid bij het vaststellen van regels met dit soort effecten rekening zou moeten houden. Het bleek echter lastig te zijn om gecamoufleerde vormen van achterstelling en de maatschappo lijke effecten van regelgeving rechtstreeks aan te vechten: de classificaties die deze effecten veroorzaakten waren meestal neutraal en weinig verdacht, zodat zij alleen aan de zeer marginale rational basis-test konden worden onderworpen. Er werd dan ook een toenemend aantal klachten ingediend waarin werd gesteld dat de neutrale classificaties leidden tot indirect onderscheid op grond van ras. Bij onderscheid op die grond paste het Supreme Court immers wel steeds een strict scrutiny-test toe, waardoot de kans van slagen van deze beroepen aanzienlijk werd vergroot. ${ }^{207}$

206. Vgl. Brest 1983, p. 113/114, Siegel 1997, p. 1143 en Ortiz 1989, p. 1118.

207. Aanvankelijk werd bovendien vooral geklaagd over indirect onderscheid dat eigenlijk gecamoufleerd 
Aanvankelijk stelde het Supreme Court dat iemand die een klacht indiende over indirect onderscheid op grond van ras kon volstaan met het bewijs dat de regeling een disproportionele benadeling opleverde voor een raciale minderheidsgroepering. ${ }^{20 \times}$ Volgens deze rechtspraak vormde de benadelingstoets zelfs de enige wenselijke toetsingsingang: het Supreme Court stond afwijzend tegenover een vaak aangevoerd alternatief, waarbij het zou moeten beoordelen of er sprake was van een op benadeling van een bepaalde raciale groep gerichte bedoeling. ${ }^{209}$ Dit blijkt bijvoorbeeld uit het arrest $\mathrm{Pal}$ mer $v$. Thompson, ${ }^{210}$ dat betrekking had op een besluit tot sluiting van alle zwembaden in een gemeente in Mississippi. De klagers beweerden dat deze maatregel ontoelaatbaar was: hoewel deze geen disproportioneel benadelend effect had voor Afro-Amerikanen, was de sluiting volgens hen ingegeven door ontoelaatbare (want discriminerende) motieven. Inderdaad bleek uit diverse documenten dat de gemeentelijke overheid de baden vooral had gesloten omdat zij grote bezwaren had tegen de gedachte van gedesegregeerde zwembaden. Het Supreme Court stelde echter dat de motieven van de regelge-

direct onderscheid was, zodat het Supreme Court weinig moeilijkheden had bij het vaststellen van een schending van de Equal Protection Clause (vgl. Selmi 1997, p. 298-300). Later werd vaker geklaagd over werkelijk onbedoelde, maatschappelijke effecten; tegenwoordig is dit zelfs de meest voorkomende klacht. Over direct onderscheid wordt eigenlijk alleen nog geklaagd in de context van voorkeursbeleid. Vgl. Binion 1983, p. 400 en Siegel 1997, p. 1131.

208. Zie bijv. Yick Wo v. Hopkins, 118 U.S. 356, 373 (1886) ("Though the law itself be fair on its face, and impartial in appearance, yet, if it is applied and administered by public authority with an evil eye and an unequal hand, so as practically to make unjust and illegal discriminations between persons in similar circumstances, material to their rights, the denial of equal justice is still within the prohibition of the constitution"). Een ander voorbeeld is Gomillion v. Lightfoot, 364 U.S. 339 (1960). Dit arrest had betrekking op de zodanige vormgeving van een gemeentelijk kiesdistrict in Alabama dat alle AfroAmerikaanse kiesgerechtigden werden uitgesloten. De relevante regeling maakte echter niet rechtstreeks onderscheid op grond van ras. Het Supreme Court stelde dat "[i]t is difficult to appreciate what stands in the way of adjudging a statute having this inevitable effect invalid in light of the principles by which this Court must judge, and uniformly has judged, statutes that, howsoever speciously defined, obviously discriminate against colored citizens". Hoewel het Supreme Court later heeft gesteld dat uit dit arrest blijkt dat alleen effecten die kennelijk bedoeld zijn tot een inhoudelijke toetsing kunnen leiden, kan uit deze formulering worden afgeleid dat de toetsing op het benadelend effect is gericht; dit was overigens ook de interpretatie die het Supreme Court zelf aanvankelijk aan het arrest gaf (zie United Siates v. O'Brien, 391 U.S. 367, op 385 (1968)). Een evidente erkenning van de op effect gebaseerde toets is ook te vinden in Hunter v. Erickson, 393 U.S. 385, 391 (1969) en Wright v. Council of City of Emporia, 407 U.S. 451 (1972). Het Supreme Court stelde daarin dat een discriminatoire bedoeling wel een versterking kan vormen voor een klacht, bijvoorbeeld omdat deze de emst van het effect onderstreept (op 461), maar stelde uiteindelijk dat in de rechtspraak "we have focused upon the effect - not the purpose or motivation -", en dat "[t]he existence of a permissible purpose cannot sustain an action that has an impermissible effect" (op 462). Het Supreme Court gaf ook een belangrijke reden aan voor de op effect gebaseerde test: "It is of no consolation to an individual denied the equal protection of the laws that it as done in good faith" (Burton v. Wilmington Parking Authority, 365 U.S. 715, 725 (1961)). Zie ook Perry 1977, p. 546 en Binion 1983, p. 423.

209. Het Supreme Court is overigens nooit geheel consistent geweest in zijn aanvaarding van de benadelingstoets en de afwijzing van de doeltoets. Er zijn ook voor Washington v. Davis (zie verderop) gevallen geweest waarin het Supreme Court een klacht over raciale ongelijkheid afwees omdat er slechts sprake was van een discriminatoir effect, en niet van een discriminatoire bedoeling; zie bijv. Jefferson v. Hackney, 406 U.S. 535,548 (1972). Ook blijkt in de arresten waarin effect tot toetsingsingang wordt gekozen vaak toch een element van een doeltoets zichtbaar te zijn. Vgl. Ely 1970, p. 1211, Brest 1971, p. 100 , Perry 1977 , p. 544 en 547 , Miller 1977, p. 730 , Eisenberg 1977, p. 43 en 109/110, Issacharoff 1982 , p. 330 en Binion 1983, p. 410.

210. 403 U.S. 217 (1971) 
ver in het kader van de toetsing aan de Equal Protection Clause niet relevant konden worden geacht:

"[...][T] $]$ his is not a case where whites are permitted to use public facilities while blacks are denied access. It is not a case where a city is maintaining different sets of facilities for blacks and whites and forcing the races to remain separate in recreational or educational activities. Petitioners have also argued that respondents' action violates the Equal Protection Clause because the decision to close the pools was motivated by a desire to avoid integration of the races. But no case in this Court has held that a legislative act may violate equal protection solely because of the motivations of the men who voted for it. [...] The focus [...] [is] on the actual effect of the enactments, not on the motivation which led the States to behave as they did."

$\mathrm{Nu}$ er in dit geval geen sprake was van een duidelijke benadeling van een specifieke raciale groepering bestond er volgens het Supreme Court geen reden voor een inhou. delijke beoordeling van de maatregel. ${ }^{212}$

Het aantal arresten waarin de benadelingstoets bij indirect onderscheid is toegepast is niet bijzonder groot: aanvankelijk werd er nog niet veel geprocedeerd over indirect onderscheid, terwijl het Supreme Court, zoals hierna nog zal blijken, al in 1976 voor een andere toetsingsingang heeft gekozen. Het Supreme Court heeft bovendien, waarschijnlijk vanwege het aanvankelijk uitzonderlijke karakter van dit soort zaken, mar weinig moeite gedaan om verfijnde criteria te ontwikkelen waaraan een benadeling moet worden getoetst. In de meeste gevallen stelde het eenvoudigweg vast dat een regeling een achterstelling van een bepaalde groep tot effect had, zonder dat nader werd ingegaan op zaken als statistisch bewijs. ${ }^{213}$ Een uitzondering waarin wel aandacht werd

211. 403 U.S., op 223/224 en 225. In die zin ook Wright v. Council of City of Emporia, 407 U.S. 451, 462 (1972). Zie voor een inhoudelijke bestrijding van dit soort argumenten (die ook vaak worden geopperf als het gaat om de uitvoering van een rechtvaardigingstoets) nader hoofdstuk 2 , m.n. paragraaf 3.2 .

212. De benadering in dit arrest is wat kortzichtig. Hiervoor is aangegeven dat een benadeling ook bif gelijkwaardige voorzieningen of bij het ontbreken van een tastbare benadeling kan bestaan in het creb ren van een gevoel van inferioriteit of in stigmatisering. In deze zaak kon daarvan duidelijk gesproken worden, nu het blanke stadsbestuur niet wilde dat Afro-Amerikanen van dezelfde zwembaden gebruk zouden maken als blanken. Hoewel de tastbare benadeling die daardoor ontstond (sluiting van de bs: den) gold voor zowel zwart als blank, zal het duidelijk zijn dat het besluit vooral door Afro Amerikanen als vernederend, pijnlijk en stigmatiserend werd gevoeld. Dat het Supreme Court, dat zich in Brown en de latere segregatiezaken zo gevoelig toonde voor deze vorm van benadeling, dit in deze zaak niet inzag, kan alleen worden verklaard doordat de samenstelling van het Supreme Court vak voor deze zaak veranderde: nadat Chief Justice Warren in 1969 aftrad werd de samenstelling van bet Supreme Court aanzienlijk conservatiever en verzette de nieuwe meerderheid tegen zeer liberale koers die tot dan toe was gevaren.

213. Een uitzondering is het hiervoor reeds besproken arrest New York City Transit Authority v. Beater, 40 U.S. 568 (1979), dat betrekking had op een gemeentelijke regeling die ieder gebruik van verdovents middelen en medicijnen door werknemers van de Transit Authority uitsloot. Volgens de eisers was de reikwijdte van deze regeling onredelijk breed, omdat de maatregel tot gevolg had dat ook het gebrilk van methadon werd uitgesloten. Uit het hierboven gegeven citaat blijkt reeds dat dit soort gevalien vat materieel onderscheid kan worden aangevochten wanneer er sprake is van een "special impact" op eet bepaalde groep. Of daarvan in dit arrest sprake was werd bepaald aan de hand van statistische gefe vens. Dit is overigens een uitzonderlijke werkwijze: in dit arrest waren de gegevens toevallig voortalin den, omdat er ook een toetsing onder Title VII van de Civil Rights Act werd uitgevoerd (waarbij het gs bruik van statistische gegevens regel is). Zie over het gebruik van statistische gegevens bij de benade. 
besteed aan de benadelingstoets is het arrest Keyes v. School District No. 1214, waarin het Supreme Court aangaf hoe een benadeling moet worden vastgesteld als de getroffen groep is samengesteld uit enkele andere, kleinere groepen. In dit arrest was een onderwijsbeleid in het geding dat tot effect had dat er ten nadele van Hispanos (mensen die oorspronkelijk uit Zuid-Amerika afkomstig zijn) en Afro-Amerikanen segregatie optrad. Het probleem was echter dat een lagere rechter het effect voor de raciale groepen apart had beoordeeld en tot de conclusie was gekomen dat er ten aanzien van de afzonderlijke groepen niet kon worden gesproken van een disproportionele benadeling. Het Supreme Court hanteerde een andere redenering:

"We have held that Hispanos constitute an identifiable class for purposes of the Fourteenth Amendment. [...] But there is also much evidence that in the Southwest Hispanos and Negroes have a great many things in common. [...] [T] hough of different origins, Negroes and Hispanos in Denver suffer identical discrimination in treatment when compared with the treatment afforded Anglo students. In that circumstance, we think petitioners are entitled to have schools with a combined predominance of Negroes and Hispanos included in the category of "segregated" schools."215

Belangrijk in deze uitspraak is dat hierin een vergelijkingselement is terug te vinden: als het gaat om de vaststelling van een benadeling van verschillende groepen moet bekeken worden in hoeverre deze groepen zich in dezelfde positie bevinden. Dit lijkt inderdaad de enige manier te zijn om in dit soort gevallen tot een bevredigende uitkomst te komen.

Verder is van belang dat het Supreme Court enige aandacht heeft besteed aan de definitie van de groepen die relevant zijn voor de vaststelling van een disproportionele benadeling. In het arrest Mayor of Philadelphia v. Educational Equality League ${ }^{216}$ werd geklaagd over de wijze waarop de burgemeester van Philadelphia omging met zijn recht om de leden van het Educational Nomination Panel te benoemen. Volgens het City Charter moesten negen van de veertien leden van dit panel afkomstig zijn uit de hogere bestuursregionen van bepaalde categorieën instellingen en organisaties. Het probleem was dat in de periode voorafgaand aan de rechtszaak slechts $15 \%$ van de benoemingen een Afro-Amerikaan betrof, terwijl de bevolking van Philadelphia voor $34 \%$ uit Afro-Amerikanen bestond. Het Supreme Court stelde echter dat deze vergelijking van percentages niet relevant was:

\footnotetext{
"At least with regard to nine seats on the Panel and assuming, arguendo, that percentage comparisons are meaningful in a case involving discretionary appointments, the relevant universe for comparison purposes consists of the highest ranking officers of the categories of organizations and institutions specified in the city charter, not the population at large,"217
}

Uit deze overweging blijkt dat voor het vaststellen van de disproportionaliteit van een

lingstoets ook Jefferson v. Hackney, 406 U.S. 535, 548 (1972) (waaruit blijkt dat statistisch bewijs van disproportionele benadeling niet voldoende is wanneer een discriminatoire doelstelling ontbreekt) en Costaneda y. Partida, 430 U.S. 482,494 (1977).

215. 413 U.S. 189 (1973)

15. 413 U.S., op $197 / 198$

216. 415 U.S. 605 (1974)

217. 415 U.S., op 605 
benadeling alleen mag worden gekeken naar de voor het doel van de regeling relevante groep, niet naar de bevolking als geheel. Hoewel het Supreme Court hiervan in de rechtspraak over de Equal Protection Clause geen verdere voorbeelden heeft gegeven kan dit als een zinvolle invulling van de benadelingstoets worden beschouwd: zoals uit het vorige hoofdstuk al is gebleken is juist het vaststellen van de relevante groepen een kwetsbaar punt van deze toets.

\section{Academische discussie: benadelend effect geen wenselijke toetsingsingang}

Tegen het gebruik van de benadelingstoets werden door veel rechtsgeleerde commentatoren bezwaren geopperd. ${ }^{218}$ Zo waren sommigen van mening dat een op effect gebs. seerde test een te vergaande bemoeienis met het wetgevende beleid opleverde: rechterlijk ingrijpen bij direct onderscheid leidt al snel tot een positieve verplichting voor de wetgever om de ongelijke effecten van zijn optreden op te heffen, hetgeen een onaan. vaardbare doorkruising van zijn vrijheid zou betekenen. ${ }^{21}$ ' Rechterlijk optreden bij benadelende effecten zou bovendien niet in overeenstemming zijn met de Constitutie, die uitsluitend negatieve verplichtingen oplegt aan de overheid (zoals de verplichting om zich te onthouden van het maken van onderscheid op grond van ras). Een positieve verplichting om actief te reageren op maatschappelijk bestaande ongelijkheden kan nit uit de Constitutie worden afgeleid en is daarmee volgens critici dan ook onverenig. baar. ${ }^{220}$ Los van de constitutionele toelaatbaarheid zouden positieve verplichtingen volgens sommige auteurs tot maatschappelijk onwenselijke consequenties kunnen leiden, vooral bij maatregelen die nadelige effecten hebben voor raciale minderheden: het uitgangspunt dat dit soort effecten niet toelaatbaar is zou, tot het uiterste doorgersdeneerd, tot gevolg hebben dat alle maatschappelijke goederen moeten worden gedistribueerd in overeenstemming met de raciale opbouw van de bevolking. Ras is volgens deze auteurs echter zeker niet de enige factor die bij de distributie moet worden betrokken om een rechtvaardige uitkomst te bereiken. ${ }^{21}$

Een op effect gebaseerde toets heeft, als gevolg van de specifieke toetsingsmethodiek van het Supreme Court, nog een tweede nadeel, dat door de critici zeer zwaarwegend werd geacht. Zoals eerder is aangegeven zal bij onderscheid op grond van ras steeds een strict scrutiny-test worden uitgevoerd, die "strict in theory, but fatal in fact" is Wanneer deze test ook wordt toegepast bij indirect onderscheid op grond van ras, 200 dit betekenen dat vrijwel alle maatregelen met negatieve effecten voor raciale minder heden onconstitutioneel zouden worden verklaard. In de VS leidt een dergelijke situatic

\section{Zie Siegel 1997, p. 1133.}

219. Vgl. Selmi 1997, p. 343 en Rosenblum 1979, p. 1383/1384. Deze factoren worden vanzelfsprektend nog versterkt door het element van federale machtsverhoudingen dat voortdurend meespeelt: het of leggen van positieve verplichtingen aan statelijke wetgevers levert niet alleen een doorkruising op var de wetgevende bevoegdheden, maar kan ook de verhouding tussen federale en statelijke overheid ver. storen.

220. Zie Perry 1977, p. 555/556, Ely 1970, p. 1255 en 1260 en Linde 1993, p. 221; vgl. over positien verplichtingen en de Equal Protection Clause ook Freeman 1978, p. 1054 en Ortiz 1989, p. 1142.

221. Zie bijv. Ely 1970, p. 1257-1260, Brest 1971, p. 110 en Eisenberg 1977, p. 42. Bij deze stelling worth voorbijgegaan aan het feit dat niet ieder disproportioneel raciaal effect ontoelaatbaar zal zijn: soms kit het doel van een regeling zwaarder wegen dan zijn benadelende effecten. Bij voldoende mogelijhked tot rechtvaardiging hoeft de consequentie die door deze auteurs wordt gevreesd dus niet te wordert verwerkelijkt. 
tot problematische gevolgen voor de mogelijkheid om regelgeving op sociaaleconomisch terrein vast te stellen. Afro-Amerikanen (en bepaalde andere minderheidsgroeperingen) zijn in dit land jarenlang ernstig achtergesteld, waardoor zij op diverse gebieden een grote achterstand hebben. ${ }^{222}$ Maatregelen op allerlei terreinen zullen daardoor al snel grotere en nadeligere effecten hebben voor raciale minderheidsgroeperingen dan voor de blanke meerderheid. ${ }^{223}$ Tot op zekere hoogte is het redelijk om van de wetgever te verwachten dat hij met dit soort effecten rekening houdt. Wanneer de wetgever op overtuigende en gerechtvaardigde gronden tot de conclusie is gekomen dat de voordelen van een regeling opwegen tegen de nadelige effecten voor een bepaalde minderheid, moet het echter mogelijk zijn om een dergelijke maatregel toch door te voeren. De strict scrutiny-test laat door zijn fatale karakter nauwelijks ruimte voor een dergelijke rechtvaardiging. Een consequente toepassing van deze test zou, gecombineerd met een eenvoudige benadelingstoets, dan ook al snel leiden tot een frustratie van de mogelijkheid om regelgeving tot stand te brengen. ${ }^{224}$

\section{Alternatieve toetsingsingang: de bedoeling van de regelgever}

In het arrest Washington v. Davis ${ }^{225}$, gewezen in 1976, reageerde het Supreme Court op de hiervoor genoemde kritiek door de benadelingstoets voor indirect onderscheid te vervangen door een andere toetsingsingang. Het arrest had betrekking op de toelatingsprocedure voor het Police Department van het District of Columbia, waarvan een test van de actieve en passieve taalbeheersing onderdeel vormde. Voor deze test bleken vier keer zoveel blanken als Afro-Amerikanen te slagen, maar het Supreme Court stelde dat dit effect niet voldoende was om de strict scrutiny-test op de toelatingsprocedure toe te passen:

"[...][O]ur cases have not embraced the proposition that a law or other official act, without regard to whether it reflects a racially discriminatory purpose, is unconstitutional solely because it has a racially disproportionate impact. [...] A purpose to discriminate must be present [...]. Disproportionate impact is not irrelevant, but it is not the sole touchstone of an invidious racial discrimination forbidden by the Constitution. Standing alone, it does not trigger the rule that racial classifications are to be subjected to the strictest scrutiny and are justifiable only by the weightiest of considerations. [...] A rule that a statute designed to serve neutral ends is nevertheless invalid, absent compelling justification, if in practice it benefits or burdens one race more than another, would be far reaching and would raise serious questions about, and perhaps invalidate, a whole range of tax, welfare, public

222. Zie Perry 1977, p. 557 en Aleinikoff 1991, p. 1066. Zo blijkt dat Afro-Amerikanen door de jarenlange segregatie en de daaraan verbonden minder goede scholing minder gemakkelijk toegang verkrijgen tot het universitair onderwijs, dat kleine ondernemingen die worden geleid door Afro-Amerikanen nauwelijks effectief weten mee te dingen naar belangrijke contracten en dat de inkomensverschillen nog steeds groot zijn; zie o.a. Wilson 1984, p. 273.

223. Wilson 1984 , p. 278

224. Vgl. Eisenberg 1977 , p. $69 / 70$, Miller 1977, p. 738 , Bennett 1979, p. 1076 , "Note" 1981, p. 923 en Ortiz 1989, p. 1138. Dit probleem werd ook door het Supreme Court erkend: in Jefferson v. Hackney, 406 U.S. 535 (1972) gaf het aan dat: "The acceptance of appellants' constitutional theory [inhoudend dat disproportionele effecten als toetsingsingang golden, JHG] would render suspect each difference in treatment along the grant classes, however lacking in racial motivation and however otherwise rational the treatment might be. Few legislative efforts to deal with the difficult problems posed by current welfare problems could survive such scrutiny."

225. Washington v. Davis, 426 U.S. 229 (1976) 
service, regulatory, and licensing statutes that may be more burdensome to the poor and to the average black than to the more affluent white." 226

Alleen wanneer de eiser kan aantonen dat de wetgever een maatregel daadwerkelijk heeft aangenomen met het oog op de discriminatoire effecten ervan, zal het Supreme Court blijkens deze overweging een strict scrutiny-test uitvoeren; in alle andere gevallen wordt het gemaakte onderscheid direct toelaatbaar geacht. De bedoeling van de regelgever wordt blijkens deze overweging dan ook gehanteerd als toetsingsingang. In latere rechtspraak heeft het Supreme Court deze toetsingsingang nader uitgewerkt. Een aantal belangrijke verfijningen is terug te vinden in het arrest Village of Arlington Heights v. Metropolitan Housing Co. ${ }^{227}$ In dit arrest besteedde het Supreme Court allereerst aandacht aan het probleem dat een regeling vaak wordt ingegeven door verschillende motieven en doelstellingen: Washington $v$. Davis liet de vraag open of de eiser in een dergelijk geval moet aantonen dat de discriminatoire doelstelling de enige of bepalende reden vormde voor het vaststellen van de regeling. In Arlington Heights gaf het Supreme Court aan dit niet nodig te vinden: het is voldoende als de eiser kan aantonen dat de discriminatoire doelstelling "a motivating factor" in het besluitvormingsproces heeft gevormd. ${ }^{22 x}$ Dit betekent dat de doeltoets niet impliceert dat de klager moet bewijzen dat de regeling niet tot stand zou zijn gekomen als de litigieuze discriminatoirt overwegingen niet zouden hebben meegespeeld. ${ }^{229}$ De bewijslast voor de eiser blijft daardoor relatief beperkt.

Verder ging het Supreme Court in Arlington Heights uitgebreid in op de vraag op welke manier de aanwezigheid van een discriminatoire bedoeling kan worden vastgesteld. Daarbij nam het tot uitgangspunt dat eerst moet worden gekeken naar de effecten van de regeling. Soms is het namelijk zodanig duidelijk dat bepaalde handelingen bepaalde effecten tot gevolg zullen hebben, dat er eigenlijk geen twijfel kan bestaan over de vraag of de effecten beoogd zijn. In dat soort gevallen kan volgens Arlington Heights uit het effect van de regeling een daarop gerichte bedoeling worden afgeleid. ${ }^{20}$ Daarbij

226. 426 U.S., op 239,242 en 245 . De gevolgde redenering is overigens niet zo fraai. Van de in eerder rechtspraak zo benadrukte nadelen van de doeltoets wordt geen melding gemaakt, laat staan dat er een inhoudelijke bestrijding van deze argumenten wordt gegeven. Verder is de stelling dat in eerdere redtspraak de wettelijke bedoeling al tot toetsingsingang werd genomen zonder meer onjuist; uit arreser als Palmer v. Thompson, 403 U.S. 217 (1971) en United States v. O'Brien, 391 U.S. 367 (1968) blije dat het tegendeel waar is. Tenslotte is de keuze voor de doeltoets bepaald niet uitgebreid gemotiveer Gewezen wordt uitsluitend op het risico dat veel matschappelijk wenselijke wetgeving door een op effect gebaseerde toetsingsingang niet meer constitutioneel zou kunnen zijn. Er wordt echter geen woond gewijd aan de alternatieve oplossing daarvoor: een minder strenge of in ieder geval niet steeds "fatale" toetsing. Andere argumenten, zoals het eerder genoemde argument van federalisme, komen niet aan de orde. Vgl. Binion 1983, p. 410 en Eisenberg 1977, p. 47 ("Washington seems to rest more on fear of pure impact test than on the cogency of the standard it adopted").

227. 429 U.S. 252 (1977)

228. 429 U.S., op 266. In die zin ook al eerder Wright v. Council of City of Emporia, 407 U.S. 451, 461 (1972).

229. In dat geval zou er sprake zijn van een "but for"-test; zie daarover hoofdstuk 2, paragraaf 4.4.3. Di" vereiste is wel gesteld voor een specifiek probleem van ongelijke behandeling, namelijk onderscheid op grond van ras bij de herverdeling van kiesdistricten; zie daarover hierna voetnoot 247 . Verder is door verschillende auteurs meer in het algemeen uit de rechtspraak afgeleid dat het "but for"-veris een rol speelt (zie bijv. "Note" 1979, p. 1397); het Supreme Court heeft dit zelf steeds ontkend.

230. Zie bijv. Davis v. Bandemer, 478 U.S. 109, 128 (1986). Vgl. ook Eisenberg 1977, p. 62. 
noemde het Supreme Court als voorbeeld een regeling die tot gevolg heeft dat een specifieke raciale minderheid in zijn geheel wordt uitgesloten van een bepaald voordeel. ${ }^{211}$

In feite impliceert dit oordeel dat het bestaan van een discriminatoire bedoeling kan worden verondersteld in het geval van een indirecte, maar absolute uitsluiting van één specifieke groep. Opmerkelijk is dat deze situatie zich in de praktijk niet zozeer voordoet bij indirect onderscheid op grond van ras, maar vooral bij onderscheid op grond van vermogen. Veel van de uitspraken van het Supreme Court hebben betrekking op regelingen die een betaling vereisen voor het gebruik van bepaalde (vooral procedurele) rechten, zoals door het vereisen van griffiegeld voor het instellen van hoger beroep ${ }^{22}$ of van betaling van de kosten voor een in het kader van een procedure noodzakelijk onderzoek ${ }^{23}$. In beginsel zijn dergelijke regelingen neutraal van aard, maar zij hebben vaak tot praktisch effect dat minvermogenden volledig van het gebruik van bepaalde procedurele rechten worden uitgesloten. Het Supreme Court heeft dan ook steeds aangegeven dat het in dit soort zaken niet nodig is om aan te tonen dat de bedoeling van de regelgever op de benadeling van minvermogenden was gericht. Heel duidelijk bevestigde het dit in een uitspraak uit 1996:

"To comprehend the difference between the case at hand and the cases controlled by Washington v. Davis, one need look no further than this Court's opinion in Williams $v$. Illinois, 399 U.S. 235 (1970) [een zaak die betrekking had op de mogelijkheid om gevangenen die een geldboete moesten betalen langer vast te houden wanneer zij deze boete niet tijdig hadden betaald, JHG]. [...][T]he Williams Court [...] explain[ed] that 'the Illinois statute in operative effect exposes only indigents to the risk of imprisonment beyond the statutory maximum.' Sanctions of the Williams genre [...] are not merely disproportionate in impact. Rather, they are wholly contingent on one's ability to pay, and 'thus visit different consequences on two categories of persons'; they apply to all indigents and do not reach anyone outside that class." ${ }^{\prime 24}$

Bepalend is volgens deze overweging dus de aard van het effect: wordt een bepaalde groep door een neutrale regeling volledig van een bepaald voordeel uitgesloten, dan is

231. Een voorbeeld waar het Supreme Court zelf op wijst is het eerder genoemde arrest Gomillion v. Lightfoot, 364 U.S. 339 (1960), dat betrekking had op een neutrale regeling waarin een kiesdistrict werd vastgesteld. De gevolgen van deze regeling waren zodanig benadelend (door de indeling werden alle Afro-Amerikaanse inwoners van de betrokken gemeente, op vier na, van deelname aan de verkiezingen uitgesloten), dat het niet anders kón zijn dan dat dit effect bedoeld was. Van een vergelijkbare situatie was sprake in Yick Wo v. Hopkins, 118 U.S. 356 (1886), waarin werd geklaagd over het feit dat Chinezen in het geheel niet in aanmerking bleken te komen voor een wasserijvergunning. In deze gevallen was de bedoeling van de verantwoordelijke duidelijk gericht op het discriminatoire effect en werd deze bedoeling slechts bedekt door de dunne camouflage van een neutrale onderscheidingsgrond.

232. Zie bijv. Griffin v. Illinois, 351 U.S. 12 (1956) (betaling van kosten voor een transcript van de procedure is vereist voor het kunnen instellen van hoger beroep) en Ortwein v. Schwab, 410 U.S. 656 (1973) (vereiste van betaling van een waarborgsom van $\$ 2000$ voor het kunnen instellen van hoger beroep in een civiele procedure).

233. Little v. Straeter, 452 U.S. 1 (1981). Ook wanneer het vermogen bepalend is voor de toegang tot nietprocedurele rechten of voordelen, zoals de toegang tot vervoer naar een school, geldt deze regel; zie

Kadrmas v. Dickinson Public School, 487 U.S. 450 (1988).
519 U.S. 102, 126/127 (1996); cursief uit origineel. 
het niet nodig om aan te tonen dat de doelstelling van de regeling ook daadwerkelijk was gericht op het bereiken van dit effect. ${ }^{235}$

Wanneer een maatregel niet leidt tot een volledige uitsluiting van een groep en daardoor geen uitsluitsel geeft over het nagestreefde doel, zal de rechter volgens Arlington Heights moeten kijken naar een groot aantal factoren waaruit de bedoeling van de re. gelgever kan worden afgeleid:

"The historical background of the decision is one evidentiary source, particularly if it reveals a series of official actions taken for invidious purposes. [...] The specific sequence of events leading up to the challenged decision also may shed some light on the decisionmaker's purposes. [...] Departures of the normal procedural sequence also might afford evidence that improper purposes are playing a role. Substantive departures too may be relevant, particularly if the factors usually considered important by the decisionmaker strongly favor a decision contrary to the one reached. The legislative or administrative history may be highly relevant, especially where there are contemporary statements by members of the decisionmaking body, minutes of its meetings, or reports. In some extraordinary instances the members might be called to the stand at trial to testify concerning the purpose of the official action [...]."236

In latere rechtspraak heeft het Supreme Court aangegeven dat een indicatie voor een discriminatoire bedoeling ook kan worden gevonden in een geschiedenis van achterstelling of in de gebrekkige politieke participatie van de getroffen groep, net als in een systematische benadeling van deze groep..$^{237}$

Hoewel het door de grote hoeveelheid mogelijke bronnen waaruit het doel kan worden afgeleid relatief gemakkelijk lijkt om een discriminatoire bedoeling aan te tonen, blijkt uit latere rechtspraak van het Supreme Court dat het in de praktijk bijzonder hoge eisen stelt aan het bewijs. Heel duidelijk blijkt dit uit het arrest Personnel Administrator of

235. Overigens is het de vraag of deze uitspraak stand zal houden. In een scherpe dissenting opinion wezt drie rechters deze motivering volledig van de hand; zij stelden dat ook in deze gevallen het aantonet van een bedoeling is vereist. De toekomst zal moeten uitwijzen of deze minderheid kan uitgrocien tor een meerderheid. Vgl. verder Nelson 1986, p. 353 en Ortiz 1989, p. 1118 en 1139. Overigens blijkt er ook sprake te kunnen zijn van een impliciete bedoeling wanneer er geen sprake is van een volledige uitsluiting, maar slechts van een vrijwel volledige. Wel moet in die gevallen daadwerkelijk naar het ff fect wordt gekeken: enige congruentie tussen de neutrale grond van onderscheid en een andere, nith neutrale grond is niet voldoende (anders: Perry 1977, p. 552/553). Dit blijkt bijvoorbeeld uit Persone? Administrator of Massachusetts v. Feeney, 442 U.S. 256 (1979). In het geding was een regeling in Massachusetts waardoor veteranen werden bevoordeeld. Daarbij was er sprake van een hoge mate vart congruentie met onderscheid op grond van geslacht: $98,2 \%$ van de veteranen was man en slechts 1,8\% vrouw; zoals Binion stelt: "A legislature intent on keeping women out of high official places could find no more efficient surrogate for a men-only policy than a veteran preference" (1983, p. 425). Het $5 \mathrm{~s}$ preme Court stelde echter, dat "this is not a law that can plausibly be explained only as a gender-based classification. [...] Although few women benefit from the preference, the nonveteran class is not substantially all female" (op 275). I.c. profiteerde $1,8 \%$ van de vrouwen van de regeling tegenover $544^{\circ}$ van de mannen. De congruentie bij het effect was dus niet volledig, zoals kennelijk is vereist ont een bepaald effect te kunnen afleiden dat de bedoeling op het bereiken ervan gericht was.

236. 429 U.S., op 267; zie voor een nadere onderbouwing van deze toetsingsmaatstaven Selmi 1997, P $304 / 305$.

237. Deze vereisten zijn terug te vinden in Rogers v. Lodge, 458 U.S. 613, op 623-626 (1982). 
Massachusetts $v$. Feeney ${ }^{23}$, dat betrekking had op een klacht over indirect onderscheid op grond van geslacht. ${ }^{29}$ In het geding was een regeling op grond waarvan veteranen bij benoeming in de openbare dienst voorrang kregen boven niet-veteranen. Doordat er vrijwel uitsluitend mannelijke veteranen waren (voor vrouwen was slechts een beperkt aantal plaatsen in het leger beschikbaar), werkte de regeling in zeer sterke mate in het voordeel van mannen en in het nadeel van vrouwen. Dit effect was duidelijk voorzienbaar op het moment waarop de regeling werd aangenomen en was kennelijk door de regering van Massachusetts geaccepteerd. De vraag was of er in een dergelijk geval kan worden gesproken van een discriminatoire bedoeling. Het Supreme Court beantwoordde deze vraag als volgt:

"Discriminatory purpose [...] implies more than intent as volition or intent as awareness of consequences. It implies that the decisionmaker [...] selected or reaffirmed a particular course of action at least in part 'because of,' not merely 'in spite of,' its adverse effects upon a identifiable group."210

Dit betekent dat de eisende partij in de eerste fase zal moeten aantonen dat de bedoeling van de classificatie uitdrukkelijk was gericht op het verwezenlijken van de benadelende effecten; het bewust aanvaarden van dergelijke consequenties is niet voldoende voor een inhoudelijke toetsing van de regeling. ${ }^{2+1}$

De uit Feeney voortvloeiende, aanzienlijke bewijslast wordt nog verzwaard doordat het Supreme Court heeft aangenomen dat de eisende partij niet kan volstaan met het aantonen van een discriminatoire bedoeling: aangetoond moet ook altijd nog worden dat er sprake is van een benadelend effect. Dit blijkt uit een vlak na Washington v. Davis gewezen arrest, United Jewish Organization of Williamsburgh v. Carey. ${ }^{242}$ Dit arrest had betrekking op een voorstel van de stad New York om de districtsgrenzen voor de plaatselijke verkiezingen aan te passen. In de aanpassingsplannen speelden raciale overwegingen uitdrukkelijk een rol; zo werd hierin voor één district aangegeven dat het de bedoeling was om de representatie van de gekleurde bevolking toe te laten nemen van $61 \%$ tot $65 \%$. Het Supreme Court stelde echter dat een inhoudelijke toetsing ondanks deze discriminatoire doelstelling niet nodig was:

238. 442 U.S. 256 (1979)

239. Hetgeen een opmerkelijke en helaas niet nader toegelichte uitbreiding van Washington $v$. Davis betekent; vgl. "Note" 1981, p. 921 . De toepassing van de Washington-test is te rechtvaardigen bij indirect onderscheid waarbij een strict scrutiny-test moet worden toegepast, op grond van de eerder genoemde overweging dat een op benadelend effect gebaseerde test daarbij kan leiden tot frustratie van regelgeving. Bij onderscheid op grond van geslacht wordt normaal gesproken een intermediate scrutiny-test toegepast, waarbij wel degelijk ruimte bestaat voor een belangenafweging door de wetgever. Daardoor ontbreekt een belangrijke grondslag voor een toepassing van de doeltoets; het is dan ook merkwaardig dat het Supreme Court deze toets gewoon toepast. Nog opmerkelijker is dat de test zonder enige nadere toelichting ook bij indirect onderscheid op niet verdachte gronden is toegepast, zoals in het arrest Schweiker v. Wilson, 450 U.S. 221 (1981), dat betrekking had op indirect onderscheid op grond van geestelijke handicap, en Wayte v. United States, 470 U.S. 598 (1985), dat betrekking had op benadeling van bepaalde dienstweigeraars. Hieruit blijkt dat de waarde van de Equal Protection Clause bij indirect onderscheid minimaal is.

240. 442 U.S., op 279

241. Wel kan de voorzienbaarheid een aanwijzing voor een discriminatoire bedoeling vormen, maar dan moet er ook nog ander bewijsmateriaal worden aangedragen; zie "Note" 1979, p. 1393.

242. 430 U.S. 144 (1977) 
"[...][N]either the Fourteenth nor the Fifteenth Amendment mandates any per se rule against using racial factors in districting and apportionment. [...] There is no doubt that in preparing the 1974 legislation, the State deliberately used race in a purposeful manner. But its plan represented no racial slur or stigma with respect to whites or any other race, and we discern no discrimination violative of the Fourteenth Amendment nor any abridgement of the right to vote on account of race $[\ldots],{ }^{, 243}$

In latere rechtspraak is dit vereiste nog verschillende malen expliciet teruggekomen, maar het Supreme Court heeft hieraan jammer genoeg nauwelijks nader invulling gegeven. ${ }^{24}$ Verondersteld kan echter worden dat voor deze benadeling dezelfde criteria gelden als bij direct onderscheid, hetgeen betekent dat de benadeling ook een immate. rieel, psychisch karakter kan hebben en dat de vermijdbaarheid van een benadeling voor de vaststelling ervan niet relevant is. ${ }^{24}$

Buiten de hierboven besproken algemene criteria heeft het Supreme Court maar weinig duidelijkheid gegeven over de precieze eisen die aan het bewijs van een discriminatoire bedoeling zullen worden gesteld. ${ }^{246}$ De meeste arresten waarin een toetsing van indirect onderscheid wordt uitgevoerd betreffen zeer specifieke onderwerpen waarvoor bijzondere, op het speciale karakter van de classificatie toegespitste vereisten zijn ontwik.

243. 430 U.S., op 161 en 165 . In de literatuur is gesuggereerd dat deze overweging gelezen moet worden als een extra vereiste dat wordt gesteld aan de doelstelling: deze moet niet alleen discriminatoir zijn, mas moet ook zijn gericht op het creëren van een stigma (Miller 1977, p. 759). In het licht van de rest van de uitspraak en de latere jurisprudentie lijkt deze interpretatie echter niet juist; in die zin ook Selni 1997, p. 289.

244. Zie bijv. Davis v. Bandemer, 478 U.S. 109, 127 (1986) en, buiten de context van onderscheid op grond van ras, Schweiker v. Wilson, 450 U.S. 221, 233 (1981). In de latere rechtspraak van het Suprems Court speelt de benadeling geen rol meer. Dit is merkwaardig, omdat herverdeling van kiesdistricten via raciale lijnen niet per se een aantasting van de belangen van blanken oplevert: daarvoor is bijvoorbeeld vereist dat er overeenkomstig raciale lijnen wordt gestemd, hetgeen niet altijd het geval zal zijn (aanvankelijk vond het Supreme Court dit soort raciale bedoelingen zonder nadelig effect dan ook niet in strijd met de Equal Protection Clause; zie United Jewish Organization of Williamsburg v. Carry, 430 U.S. 144, 165 (1977) en Davis v. Bandemer, op 127; zie de dissenting opinion van Justice Whit bij Shaw v. Reno, 509 U.S. 630, 660 en 667 (1992)). Hoogstens kan worden gesteld dat het enkele gr: bruik van ras als differentiatiecriterium een soort abstracte benadeling impliceert (zie PildesNieni 1993 , p. 508/509); op die grond heeft het Supreme Court echter nooit een beroep gedaan. Hoe dan ook is het daadwerkelijk bestaan van een benadeling voor het Supreme Court binnen deze tak van de recti. spraak ondergeschikt aan de doelstelling van de maatregel (zie Miller v. Johnson, op 911 (1995); ten terechte bestrijding is te vinden in de dissenting opinion van Justice Stevens, op 931).

245. Zie nader paragraaf 2.2 .2 .

246. Soms zijn de eisen zelfs met elkaar in strijd. Hoewel uit Washington v. Davis kan worden afgeleid dal een discriminatoire bedoeling moet worden gezocht in het gehele feitencomplex, wordt in het anst Mobile v. Bolden, 446 U.S. 55 (1980) een heel andere benadering gekozen. In dat arrest beoordetld het Supreme Court voor ieder bewijselement afzonderlijk (bijvoorbeeld historische achterstelling, discriminatie op andere terreinen, werking van de in het geding zijnde maatregel) of daaruit een discrimi: natoire bedoeling voor de litigieuze maatregel kon worden afgeleid, zonder dat werd gekeken naar de aanwijzingen voor discriminatie die voortvloeiden uit de totaliteit van dit bewijsmateriaal (vgl. lsstcharoff 1982, p. 335). Ook bleek uit Mobile v. Bolden dat aanwijzingen die in eerdere rechtspratk relo vant waren gebleken, zoals historische achterstelling of gebrekkige politieke participatie, alleen werder gezien als "most tenuous and circumstantial evidence" en als "of limited help" (op 73 en 74). 
keld. $^{2 n}$ Weliswaar zijn deze arresten voor de specifieke gebieden waarom het gaat bijzonder interessant, maar de criteria die hierin zijn ontwikkeld zijn meestal niet voor

247. Bijzondere vereisten zijn in de eerste plaats ontwikkeld voor indirect onderscheid bij de samenstelling van jury's. In de VS wordt bij de samenstelling van een jury eerst een "venire" van een groot aantal juryleden samengesteld door een ambtenaar. Vervolgens mogen de openbare aanklager en de verdediger zonder opgaaf van redenen een aantal juryleden wegsturen die zij niet geschikt vinden ("peremptory challenges"). Deze wijze van samenstelling kan op twee punten benadelend werken voor minderheden. Allereerst kan het zo zijn dat er weinig tot geen minderheidsleden in de venire worden benoemd; in de tweede plaats is het mogelijk dat de peremptory challenges door de openbare aanklager worden gebruikt om alle minderheidsleden weg te sturen, waardoor een "all white" jury ontstaat die vooroordelen zal koesteren tegen verdachten die lid zijn van een minderheidsgroepering. In het arrest Batson $v$. Kentucky, 476 U.S. 79 (1986) oordeelde het Supreme Court dat ook voor de samenstelling van jury's geldt dat er alleen dan reden voor een toetsing onder de Equal Protection Clause bestaat als de uitsluiting van minderheden beoogd is. Het bleek met dit vereiste echter soepeler om te gaan dan op basis van de eerdere rechtspraak kan worden vermoed. Voor de samenstelling van de venire houdt het Supreme Court bijvoorbeeld vast aan de al veel langer geldende "rule of exclusion", die inhoudt dat het in de eerste fase van de toetsing voldoende is als de benadeelde aantoont dat leden van zijn minderheidsgroep substantieel ondervertegenwoordigd zijn en de benoemingsprocedure ruimte voor willekeur bood (zie Norris v. Alabama, 294 U.S. 587, 591 (1935), Hernandez v. Texas, 347 U.S. 475, 480 (1954) en Castaneda v. Partida, 430 U.S. 482, 495/496 (1977); zie ook Nelson 1986, p. 351 en Ortiz 1989, p. 1122 ). Volgens het Supreme Court in Batson zal er in deze gevallen onvermijdelijk sprake zijn van een discriminatoire bedoeling (476 U.S., op 94). Voor de peremptory challenges geldt dat het voor het aantonen van een bedoeling al voldoende is dat er een patroon van "strikes" tegen minderheidsjuryleden bestaat (476 U.S., 96). Dat dit een soepele bewijslast is blijkt wanneer wordt gekeken naar de hoge bewijslast die gold in eerdere zaken, zoals Swain v. Alabama, 380 U.S. 202 (1965): het Supreme Court vereiste hierin dat de klager een systematisch patroon van volledige uitsluiting van minderheidsgroepen aantoonde in alle jury's (dus niet alleen de zijne) (op 223/224; vgl. Vaugh Dunnigan 1988, p. 356/357). In latere rechtspraak zijn deze vereisten verder uitgewerkt; zie bijv. Hernandez $v$. New York, 500 U.S. 352, 362 (1991) en J.E.B. v. Alabama, 511 U.S. 127, 144/145 (1994) (waaruit blijkt dat de Batson-regels ook gelden voor onderscheid op grond van geslacht, tot uitdrukking komend in het wegsturen van alle mannelijke juryleden).

Een tweede belangrijke specificering is te vinden in de rechtspraak over herverdeling van kiesdistricten. Volgens de constitutie is het aantal volksvertegenwoordigers in het Huis van Afgevaardigden per staat afhankelijk van de omvang van de bevolking. ledere tien jaar wordt er een volkstelling uitgevoerd, die kan leiden tot het verlies of juist het winnen van een zetel (U.S. Const. Article I, Section 2). Omdat de staten een districtenstelsel kennen en het volgens rechtspraak van het Supreme Court vereist is dat ieder district een gelijk aantal inwoners heeft (Reynolds v. Sims, 377 U.S. 533, 577 (1964)), verplicht iedere wijziging van het aantal zetels tot het vaststellen van nieuwe kiesdistricten. In de praktijk wordt daarbij met allerlei factoren rekening gehouden, zoals met de politieke kleur van de inwoners (hetgeen volgens het Supreme Court meestal toelaatbaar is, zie Davis v. Bandemer, 478 U.S. 109, 131/132 (1986)), maar ook met de raciale samenstelling. Vaak streven staten naar een grote vertegenwoordiging van minderheden in tenminste één district, waardoor hun stem in dat district doorslaggevend kan zijn; het gaat daarbij dus eigenlijk om een soort voorkeursbeleid. Meestal zal er in dit soort gevallen sprake zijn van indirect onderscheid, omdat in de herverdelingsregeling niet uitdrukkelijk onderscheid wordt gemaakt op grond van ras. Het Supreme Court vereist ook op dit terrein dat er sprake is van een raciale bedoeling, maar net als bij de peremptory challenges zijn hierbij bijzondere, moeilijk veralgemeniseerbare criteria ontwikkeld. Bepalend criterium is of de regeling "unexplainable on grounds other than race" is (Shaw v. Reno, 509 U.S. 630, 643 (1992)); in latere rechtspraak is ook wel gesteld dat moet worden bekeken of "race was the legislature's predominant consideration" (Shaw v. Hunt, 517 U.S. 899, 907 (1996)). In dit opzicht wijkt deze rechtspraak af van Arlington Heights, waarin immers slechts vereist werd dat de raciale motieven een rol speelden, niet dat zij dominant onder andere woren de aanwezigheid van overheersende raciale motieven te kunnen bepalen moet onder andere worden gekeken naar de vormgeving van het district (merkwaardige vormen kunnen erop ties van minderheding bewust gebieden in het district probeert te betrekken waar bepaalde concentraties van minderheden wonen); Shaw v. Reno, 509 U.S. 630, 646/647 (1993)), de mate waarin de vast- 
algemene toepassing vatbaar. Deze lijnen in de rechtspraak zullen dan ook niet nader worden besproken.

\section{Conclusie}

Zoals hiervoor is aangegeven beoordeelt het Supreme Court indirect onderscheid alleen op zijn gerechtvaardigdheid als kan worden aangetoond dat de benadelende effecten uitdrukkelijk bedoeld waren. Het zal voor een individuele klager niet gemakkelijk zijn om te achterhalen welke doelstellingen er precies aan een onderscheid ten grondslag hebben gelegen, ook al heeft het Supreme Court gesteld dat de doelstellingen van een maatregel uit de omstandigheden van het geval kunnen worden afgeleid en direct be wijs voor het bestaan van een discriminatoire bedoeling niet noodzakelijk is. ${ }^{2 a}$ In de praktijk blijken de aan het bewijs gestelde eisen bijzonder hoog te zijn en hebben alleen de zeer zeldzame zaken enige kans van slagen waarin direct bewijs van discriminatie kan worden geleverd of waarin een groep volledig van een bepaald voordeel wordt uitgesloten. ${ }^{249}$ Deze benadering heeft tot resultaat dat veel maatregelen met disproportionele effecten voor minderheden niet aan een inhoudelijke toetsing kunnen worden onderworpen, zelfs niet in gevallen waarin het onredelijk lijkt dat de regelgever met de benadelende effecten geen rekening heeft gehouden. ${ }^{230}$

stelling van het district voldoet aan de daarvoor relevante criteria (Miller v. Johnson, 515 U.S. 900,919 (1995)) en direct bewijs van raciale overwegingen zoals dat naar voren komt uit relevante documenten (Bush v. Vera, 517 U.S. 952, 962 (1996)). Gesteld is wel dat het door het Supreme Court ontwikkelde bewijsmodel nadelig is voor minderheidsgroeperingen: als een regeling voor hen bevoordelend welt wordt deze veel sneller aan een strenge toetsing onderworpen dan wanneer er sprake is van een bentdeling (Selmi 1997, p. 317). Dit kan hoogstens worden verklaard door overwegingen van toetsingsintensiteit: het Supreme Court laat meestal veel ruimte voor statelijk beleid op dit gebied (zie darover nader paragraaf 3 en Issacharoff 1982, p. 345). Recentelijk is het Supreme Court echter ook hogert tsen gaan stellen aan het bewijs van "raciale inspiratie" bij benadeling van blanken: in Hunt v. Cromer tie, 121 S.Ct. 1452 (2001) ging het veel uitgebreider in op diverse bewijsmaterialen dan gebruikelijk. Waar op basis van deze feiten eerder een raciale bedoeling zou zijn worden vastgesteld, oordeclde ent (overigens anders samengestelde!) meerderheid nu dat deze ontbrak.

248. Rogers $v$. Lodge, 458 U.S. 613,618 (1982). Zie over de onredelijkheid van de bewijslastverdeling Karst 1978, p. 1165, Eisenberg 1977, p. 48 en 49, Perry 1979, p. 1038, Nelson 1986, p. 344, Lively 1991 , p. 490 en Siegel 1997, p. 1137 ("[...] the form of discriminatory purpose the Court asked plain. tiffs to prove in Feeney [...] is one that the sociological and psychological studies of racial bias sugest plaintiffs will rarely be able to prove"). In vergelijkbare zin Lawrence 1987, 322/323.

249. Selmi 1997, p. 322 en 334 , Lively 1991, p. 490 en Binion 1983, p. 441

250. Vgl. Eisenberg 1977, p. 47, Binion 1983, p. 441, Nelson 1986, p. 336, Lively 1991, p. 490 en 503 th Siegel 1997, p. 1136. Een illustratie hiervan is City of Memphis v. Greene, 451 U.S. 100 (1981), warin geklaagd werd over de afsluiting van de verbindingsweg tussen een chique volledig blanke burt tn een ten noorden daarvan gelegen volledig zwarte buurt. Niet alleen was deze afsluiting voor de bewoners van de zwarte wijk lastig, maar ook hadden zij redenen om aan te nemen dat de bedoeling van de afsluiting was om Afro-Amerikanen te ontmoedigen om in de blanke buurt te komen. Het Supreme Court oordeelde dat de feiten aan de vermeende bedoeling geen steun gaven en de regeling er vooral op was gericht om verkeershinder te beperken. Uit de dissenting opinion blijkt echter dat bij een zorguldige bestudering van de feiten wel degelijk blijkt dat er een discriminatoire bedoeling bestond, marr dat de autoriteiten van Memphis erg hun best hadden gedaan om deze te verbergen achter neutrale overwegingen. Uit deze zaak blijkt dat het zonder direct bewijs bijzonder moeilijk is om ann te tonet dat er sprake is van een bedoeling die is gericht op benadeling en dat veel afhangt is van de gevoelig heid van een rechterlijke instantie voor de achtergronden van een regeling; vgl. Lively 1991 , p.
Selmi 1997, p. 307. Een bekende problematische toepassing is verder te vinden in MoClesky v. Kemp, 481 U.S. 279 (1987). Hoewel in deze zaak was aangetoond dat in Georgia de doodstraf aanzienlijk vat 
Vooral voor onderscheid op grond van ras heeft de benadering van het Supreme Court problematische consequenties. Van belang is namelijk dat direct onderscheid op grond van ras altijd aan een strict scrutiny-test wordt onderworpen, ook als daardoor, zoals bij voorkeursbeleid, een meerderheidsgroep benadeeld wordt. ${ }^{251} \mathrm{Nu}$ voorkeursbeleid tegenwoordig vrijwel de enige vorm van direct onderscheid op grond van ras lijkt te zijn heeft de benadering van het Supreme Court tot feitelijk gevolg dat nadelige effecten voor meerderheidsgroepen aan een aanzienlijk strengere beoordeling zullen worden onderworpen dan nadelige effecten voor minderheidsgroeperingen: dergelijke effecten zullen immers vaak onbedoeld zijn en zijn daardoor niet voor toetsing vatbaar. ${ }^{252}$ De onbedoelde effecten van neutrale regelgeving voor minderheden zijn echter zeker niet minder ernstig en vragen niet in mindere mate om een rechtvaardiging. ${ }^{253} \mathrm{Om}$ deze en andere redenen ${ }^{24}$ is in de VS veel kritiek geleverd op deze benadering en is er vaak gepleit voor het hanteren van een andere toetsingsingang. ${ }^{235}$ In de rechtspraak van het Supreme Court kan dan ook nauwelijks aanleiding worden gevonden om niet het benadelende effect, maar de doelstelling als ingang voor het algemene toetsingsmodel te kiezen. In paragraaf $4 \mathrm{zal}$ op de wenselijkheid van de keuze voor deze toetsingsingang nog nader worden ingegaan.

ker werd opgelegd bij moorden met een blank dan met een zwart slachtoffer (een duidelijke indicatie voor de willekeurige werking van het systeem), stelde het Supreme Court dat er onvoldoende bewijs was om aan te nemen dat dit effect was beoogd (op 296). De vraag is gerechtvaardigd of een dergelijk effect beoogd moet zijn om een rechtvaardiging uit te lokken: als zodanig zwaarwegende belangen zijn betrokken als bij de oplegging van de doodstraf en het verschil op het eerste gezicht groot én onverklaarbaar is, lijkt het niet meer dan redelijk dat een regering hiervoor een verklaring biedt en, als zij dit niet kan, moeite doet om het verschil uit de wereld te helpen. Vgl. ook Perry 1978, p. 1178 en Lively 1991, p. 504.

251. Zie daarover paragraaf 3 .

252. Chang 1991, p. 790; zie ook Lively 1991, p. 505 en 511, Selmi 1997, p. 344 en Siegel 1997, p. 1141.

253. Dit geldt in de VS nog in het bijzonder voor onderscheid op grond van ras: dit is zeer overheersend aanwezig en beïnvloedt de besluitvorming vaak ook onbewust; bovendien heeft het grote maatschappelijke effecten; vgl. Lawrence 1987, p. 322 en 349.

254. Kritiek is ook geleverd op de theoretische onderbouwing van de test. Zie Ortiz 1989, p. 1118/1119, die stelt dat de doeltoets weliswaar een onderbouwing vindt in een procesgebaseerde theorie (namelijk op de gedachte dat een regeling onconstitutioneel is wanneer deze tot stand is gekomen door een slecht verlopend besluitvormingsproces, bijvoorbeeld wanneer ontoelaatbare doelstellingen in de besluitvorming zijn betrokken), maar dat de uitvoering zo slordig is dat onvoldoende recht wordt gedaan aan de theoretische uitgangspunten.

255. Zie bijv. de voorstellen van Eisenberg 1977, p. 60, Binion 1983, p. 444/445, Lively 1991, p. $520 / 521$ en Lawrence 1987, p. 354. Overigens hebben ook rechters in het Supreme Court zelf aangegeven dat het niet altijd redelijk is om het doel tot toetsingsingang te kiezen. Zo heeft Justice Marshall betoogd dat bij een aantasting van fundamentele rechten met een minder hoge bewijslast voor de eerste fase kan worden volstaan (dissenting opinion bij Mobile v. Bolden, 446 U.S. 55, 114 en 136 (1980)). Zeer kritisch, met name vanwege de manier waarop het SC met het bewijs omspringt, is ook Justice Stevens (zie bijvoorbeeld Rogers v, Lodge, 458 U.S. 613, 643 (1982) (J. Stevens, dissenting)). Ook door lagere rechters zijn verschillende alternatieven aangevoerd, die overigens allemaal een element van een discriminatoire bedoeling bevatten; zie voor een bespreking hiervan Miller 1977, p. 730-736. Zelfs het Congres blijkt een benadelingstoets te prefereren, zoals blijkt uit de wettelijke bepalingen die het heeft vastgesteld in het kader van de Civil Rights Act 1991 (42 U.S.C. 2000e-2) en de Voting Rights Act 1982 (42 U.S.C. $\$ 1973$ ). In beide wetten is uitdrukkelijk een benadelingstoets als toetsingsingang vastgelegd om de nadelige consequenties van de "intent"-rechtspraak te omzeilen; vgl. Nelson 1986, p. 345 en Pildes/Niemi 1993, p. 486. 


\subsection{Toetsing van de aanwezigheid van een gerechtvaardigde doelstelling}

\subsection{Wijze van vaststelling van het doel}

\section{Inleiding}

Zoals eerder is aangegeven is een onderzoek naar de aanwezigheid van een gerechtvaardigd doel een vast bestanddeel van alledrie de tests die door het Supreme Court officieel zijn erkend. In paragraaf 2.1 is echter al vastgesteld dat de tests verschillen in de mate van rechterlijke vrijheid die zij toelaten, hetgeen duidelijk tot uitdrukking komt in de wijze waarop het Supreme Court het doel van een bepaald onderscheid vaststelt: bij de rational basis-test wordt daarbij een zeer terughoudende opstelling gekozen (de conceivable basis-test), terwijl bij de strict scrutiny- en de intermediate scrutiny-test juist actief wordt onderzocht welke redenen de regelgever had voor het vaststellen van een bepaalde classificatie (de actual purpose-test). In het hiernavolgende zal kort op deze twee benaderingen worden ingegaan.

\section{De conceivable basis-test}

De conceivable basis-test vindt zijn basis in het al eerder besproken arrest Lindsley v. Natural Carbonic Gas Co. ${ }^{256}$ In dit arrest werd een aantal criteria geformuleerd voor de toetsing van classificaties in sociaal-economische en belastingwetgeving; één van deze criteria luidt als volgt:

"When [...][a classification] is called in question, if any state of facts reasonably can be conceived that would sustain it, the existence of that state of facts at the time it was enacted must be assumed." 257

Zoals uit dit citaat blijkt zal het Supreme Court bij een toepassing van de conceivable basis-test niet onderzoeken welke overwegingen de regelgever er daadwerkelijk toe hebben gebracht om een bepaalde classificatie vast te stellen. In plaats daarvan bekijkt het uitsluitend of het theoretisch gezien denkbaar is dat er legitieme gronden voor het onderscheid bestonden, waarna het eenvoudigweg veronderstelt dat het deze gronden waren die de regelgever motiveerden tot het vaststellen van de classificatie. ${ }^{288}$ Een on

\section{220 U.S. 61 (1911)}

257220 U.S., op 78. Zie verder Watson v. Maryland, 218 U.S. 173, 180 (1910) (impliciet), Smith v. Cohoon, 283 U.S. 553, 567 (1931), Stanley v. Public Utilities Commission, 295 U.S. 76, 78 (1935), Madden v. Kentucky, 309 U.S. 83, 87 (1940), Kotch v. Board of River Port Pilots, 330 U.S. 552, 563 (1947) (impliciet), Goesaert v. Cleary, 335 U.S. 464, 467 (1948), Railway Express Agency v. New York, 336 U.S. 106, 110 (1949), Williamson v. Lee Optical Co., 348 U.S. 483, 487 (1955), Allied Stores v. Bo wers, 358 U.S. 522, 528/529 (1959), Flemming v. Nestor, 363 U.S. 603, 612 (1960), McGowan v. Mar ryland, 366 U.S. 420, 425 (1961), Ferguson v. Skrupa, 372 U.S. 726, 732 (1963), McDonald v. Boant of Election Commissioners of Chicago, 394 U.S. 802, 809 (1969), Sosna v. Iowa, 419 U.S. 393, 400 (1975) (impliciet), Schweiker v. Wilson, 450 U.S. 221, 235 (1981), Burlington v. Ford, 504 U.S. 648 , 651-653 (1992) (impliciet), Nordlinger v. Hahn, 505 U.S. 1, 12 (1993), Heller v. Doe, 509 U.S. 312 323-326 (1993), FCC v. Beach Communications, 508 U.S. 307,317 (1993) en Vacco v. Quill, 521 US 793,801 (1997).

258. Zie bijv. Tuan Anh Ngryen v. INS, 533 U.S. 53 (2001) (J. O'Connor, dissenting): "This standurt permits a court to hypothesize interests that might support legislative distinctions [....". Zoals Fardl stelt geldt dat hierbij sprake is van een "purely intellectual exercise, limited only by the imagination of the court and the imaginations of the government authorities on whom the court sometimes relies to fashion a purpose" (1992, p. 23). Van belang is dat het hierbij niet eens nodig blijkt te zijn om hat 
derzoek naar de werkelijke bedoeling van het onderscheid lijkt zonder meer uitgesloten te zijn, zoals wordt bevestigd door de volgende overweging uit het arrest FCC v. Beach Communications: ${ }^{259}$

"[...][] $]$ is entirely irrelevant for constitutional purposes whether the conceived reason for the challenged distinction actually motivated the legislature."260

De doelstellingen die het Supreme Court redelijkerwijze voorstelbaar acht zijn dus steeds bepalend voor de toetsing, ook al is het mogelijk of zelfs waarschijnlijk dat er feitelijk andere overwegingen aan het onderscheid ten grondslag hebben gelegen. ${ }^{201}$

Het voordeel van deze conceivable basis-test is dat deze een minimaal rechterlijk onderzoek vergt: aan een inhoudelijke bestudering van wetsgeschiedenis, parlementaire stukken en uitlatingen van congresleden wordt niet toegekomen. ${ }^{262}$ Aangezien het Supreme Court al snel aan blijkt te nemen dat er plausibele redenen aan het onderscheid ten grondslag lagen levert de test in de praktijk bovendien een zeer marginale toetsing op. ${ }^{263}$ Deze wijze van vaststelling van het doel past daardoor goed bij het terughoudende karakter van de rational basis-test.

Een nadeel van de conceivable basis-test is echter de omvang van de bewijslast voor de eisende partij. De test vereist namelijk niet alleen dat de eiser aantoont dat er andere doelstellingen aan het onderscheid liggen dan het Supreme Court veronderstelt of dan

meest waarschijnlijke doel voor de totstandkoming van de regeling te kiezen: iedere denkbare rechtvaardiging volstaat. Zie ook "Developments" 1969, p. 1078, "Note" 1978, p. 798 en Bennett 1979, p. 1057.

259. 508 U.S. 307,317 (1993)

260. 508 U.S., 315. Vgl. ook Goesaert v. Cleary, 335 U.S. 464, 467 (1948), Flemming v. Nestor, 363 U.S. 603, 612 (1960), US Railroad Retirement Board v. Fritz, 449 U.S. 166, 179 (1980) en Heller v. Doe, 509 U.S. 312, 320 (1993)

261. Zie bijv. Goesaert v. Cleary, 335 U.S. 464, 467 (1948), Heller v. Doe, 509 U.S. 312, 323-326 (1993), FCC v. Beach Communications, 508 U.S. 307, 317 (1993) en Vacco v. Quill, 521 U.S. 793, 801 (1997). Interessant is dat het Supreme Court soms ook tot de conclusie komt dat er redelijkerwijze geen relevante doelstellingen voorstelbaar zijn (zie bijv. Gulf v. Ellis, 165 U.S. 150 (1897)), of dat het Supreme Court een doelstelling uitkiest waartoe de regeling duidelijk niet in een redelijke verhouding staat (zoals in Smith v. Cahoon, 283 U.S. 553, 567 (1931)); zie hierover Nagel 1972, p. 133/134. Het aantal gevallen waarin dit gebeurt is echter bijzonder beperkt.

262. Een belangrijke reden voor het hanteren van de conceivable basis-test is het feit dat "this Court has never insisted that a legislative body articulate its reasons for enacting a statute" (Allied Stores v. Bowers, 358 U.S. 522, 528 (1959) en United States Railroad Retirement Board v. Fritz, 449 U.S. 166, 179 (1980)). Aangezien niet wordt vereist dat de doelstellingen uitdrukkelijk worden vastgelegd kan kennelijk niet worden verwacht dat deze in een juridische procedure worden aangevoerd. Op het zelf bedenken van doelstellingen is overigens ook binnen het Supreme Court kritiek geleverd, vooral op de mogelijkheid om doelstellingen te bedenken die lijnrecht ingaan tegen doelstellingen die uit de wetsgeschiedenis of tekst van de wet naar voren komen; zie de dissenting opinion van Justice Brennan bij het genoemde arrest US Railroad Retirement $B^{\prime} d v$. Fritz, op 186; zie bovendien Schweiker v. Wilson, 450 U.S. 221, 244 (1981) (J. Powell, dissenting).

263. Overigens ligt deze terughoudendheid niet voor de hand: het zelf bedenken van doelstellingen impliceert een grote rechterlijke vrijheid, die er in theorie zelfs in kan resulteren dat de rechter alleen doelstellingen voorstelbaar acht die onconstitutioneel zijn. Hoewel de conceivable basis-test in de VS algemeen wordt aanvaard als het summum van terughoudendheid, is dit alleen juist zolang het Supreme Court de test zo toepast als het dit op dit moment doet. Vgl. in deze zin ook "Developments" 1969, p. 
door de wederpartij zijn aangevoerd, maar ook dat hij bewijst dat er geen enkele rede. lijkerwijs denkbare legitieme doelstelling aan het onderscheid ten grondslag had kur. nen liggen: ${ }^{26}$

"The burden is on the one attacking the legislative arrangement to negative every conceivable basis which might support it." ${ }^{265}$

Voor de individuele klager is het vrijwel onmogelijk om aan dit bewijsvereiste te voldoen. ${ }^{266}$ Dit geldt nog temeer daar het Supreme Court bereid is om ook zeer algemene doelstellingen te accepteren, zoals de bescherming van de volksgezondheid of de open. bare veiligheid en het dienen van algemene economische belangen ${ }^{267}$ Feitelijk betekent de conceivable basis-test voor de klager dan ook dat hij met positief bewijsmateriasl zal moeten aantonen dat het onderscheid volkomen willekeurig was en zelfs niet werd ingegeven door vage en heel algemeen geformuleerde, maar op zichzelf legitieme doelstellingen. ${ }^{208}$ Door deze bewijslast valt de mogelijkheid om een onderscheid op geslaagde wijze via de doeltoets aan te vechten in de praktijk vrijwel weg, zodat de kansen op een geslaagd beroep volledig afhankelijk zijn van de vraag of kan worden aangetoond dat er geen redelijke verhouding bestaat tussen de veronderstelde doelstellin. gen en de gekozen classificatie. ${ }^{269}$

Van belang is echter dat de conceivable basis-test niet consequent wordt toegepast. In

264. 508 U.S. 307 (1993). Of, iets anders geformuleerd, dat "the legislative facts on which the classification is apparently based could not reasonably conceived to be true by the governmental decisionmaket, Vance v. Bradley, 440 U.S. 93, 111 (1979).

265. 309 U.S. 83, 87 (1940); idem in Heller v. Doe, 509 U.S. 312, 320 (1993) en FCC v. Beach Communications, 508 U.S. 307,314 (1993).

266. Dit blijkt wanneer het vereiste wordt uitgelegd op de manier waarop een lagere rechter dat deed. " $A$ plaintiff would have to hypothesize all conceivable justifications for a statutory classification and then prove that no legislative body could rationally have believed that the classification served any of tic hypothesized purposes"; zie citaat bij Farrell 1992, p. 39.

267. Een uitstekende illustratie biedt McGowan v. Maryland, 366 U.S. 420 (1961), waarin een regeling in het geding was die voor bepaalde bedrijven een uitzondering maakte op het verbod op zondag goederen te verkopen of diensten aan te bieden. Het Supreme Court stelde dat: "It would seem that a legis. lature could reasonably find that the Sunday sale of the exempted commodities was necessary eitter for the health of the populace or for the enhancement of the recreational atmosphere of the day. [...] The record is barren of any indication that this apparently reasonable basis does not exist, that the sth tutory distinctions are invidious, that local tradition and custom might not rationally call for this legislative treatment. [...] [T]here would appear to be many valid reasons for these exemptions [...] and too reason to dispel them" (op 426/427). Vooral doordat het altijd wel mogelijk is om een regeling th rechtvaardigen met een beroep op een zeer algemene doelstelling zal het moeilijk zijn om aan te tonet dat een redelijke basis voor het onderscheid ontbreekt.

268. Hetgeen in de praktijk onmogelijk lijkt; vgl. Gottlieb 1988, p. 963 en Farrell 1992, p. 23.

269. Dit lijkt ook de bedoeling van de test te zijn. Door het accent te leggen op de verhouding tussen doel ten middel in plaats van op de doelstelling zelf wordt verondersteld dat de rechterlijke toetsing in vet mindere mate ingrijpt in de vrijheid van de wetgever. Zie in deze zin Gunther 1972, p. 43-45; vgl. ook Bhagwat 1997, p. 309. De vraag is echter of dit in alle gevallen wel redelijk is, nu het uitvoeren val een striktere toetsing beperkt is tot een klein aantal gevallen. Daardoor kan deze extreem tenughouderde toets ook worden toegepast op gevallen die eigenlijk om een strengere toetsing zouden vragen. Bovendien zijn classificaties door deze methode nauwelijks nog voor invalidatie vatbaar, de vraag is of de balans daardoor niet te ver doorslaat in de richting van een voordeel voor de wetgever, ten koste van de. individuele rechten en belangen van de burger. Zie voor een kritiek op deze benadering ook Bhagus 1997, p. 309 en de concurring opinion van Justice Stevens bij FCC v. Beach Communications, 508 U.S. 307, 323, voetnoot 3 (1993). 
een relatief groot aantal arresten vereist het Supreme Court in plaats daarvan dat het onderscheid een "legitimate state purpose" dient. ${ }^{270}$ Wanneer deze formule wordt gebruikt zal het Supreme Court niet zelf een doelstelling bedenken, maar zal het nagaan of er een redelijk doel is terug te vinden in de tekst van de wet $^{271}$ of in de wetsgeschiedenis. ${ }^{2 n}$ In een aantal gevallen zoekt het Supreme Court bovendien aansluiting bij het effect dat de regeling sorteert ${ }^{273}$, of gaat het af op een de doelstelling die is geformuleerd door een lagere rechter ${ }^{274}$ of door de procespartijen ${ }^{275}$. $^{276}$ Hoewel het Supreme Court ook in dit soort gevallen niet actief zoekt naar de werkelijke bedoeling van het onderscheid, is deze toetsing beduidend minder terughoudend dan de conceivable basis-test. Het is niet geheel duidelijk welke verklaring hiervoor bestaat: een actievere

270. Zie bijv. Vance v. Bradley, 440 U.S. 93, 97 (1979), Zobel v. Williams, 457 U.S. 55, 60 (1982), City of Cleburne v. Cleburne Living Center, 473 U.S. 432, 440 (1985), Lyng v. Castillo, 477 U.S. 635, 639 (1986), Gregory v. Ashcroft, 501 U.S. 452, 471 (1991) en Central State University v. American Association of University Professors, 526 U.S. 124, 128 (1999). Bovendien komt het voor dat het Supreme Court niet ieder plausibel doel aanvaardt, maar alleen dat doel kiest waarvan het waarschijnlijk is dat het aan de regeling ten grondslag heeft gelegen; zie daarover "Developments" 1969, p. 1079.

271. Zie bijv. US Railroad Retirement Board v. Fritz, 449 U.S. 166 (1980) (waarin het Supreme Court zelfs stelde dat "the plain language of $\$ 231$ (b) marks the beginning and end of our inquiry" (op 175)), Rinaldi v. Yaeger, 384 U.S. 305, 309 (1966) en Johnson v. Robison, 415 U.S. 361, 376 (1974). Gesteld is echter ook dat het maken van een bepaald onderscheid niet mag worden gezien als het enige doel van de classificatie, aangezien dit een tautologie zou opleveren; zie Nordlinger v. Hahn, 505 U.S. 1, 34 (1992) (J. Stevens, dissenting).

272. Vgl. Farrell 1992, p. 27. Een voorbeeld is Mayflower Farms, Inc. v. Ten Eyck, 297 U.S. 266 (1936). Deze zaak had betrekking op een regeling voor de vaststelling van minimumprijzen voor melk - een onderwerp dat duidelijk om een terughoudende toetsing vraagt. Het Supreme Court ging uitgebreid op zoek naar een doelstelling in de wetsgeschiedenis en besteedde aandacht aan de doelstellingen zoals die door lagere rechters waren vastgesteld en door de verdedigende partij waren aangevoerd. De conclusie luidde dat: "The record discloses no reason for the discrimination. [...] In the absence of any such showing, we have no right to conjure up possible situations which might justify the discrimination" (op 273/274). Deze zaak is vooral zo uitzonderlijk omdat het Supreme Court bij een toepassing van de conceivable basis-test juist wel zelf een doelstelling vaststelt. Een verklaring voor deze benadering zou kunnen zijn dat het in deze zaak ging om een zogenaamde "closed class", een regeling die een groep mensen uitsluit door middel van een classificatie die niet is gebaseerd op persoonskenmerken, zoals een datumgrens. Het Supreme Court heeft vaker aangegeven dat dit soort maatregelen een bijzonder en ongebruikelijk karakter heeft (het trekken van een datumgrens is altijd wat willekeurig), hetgeen een verklaring kan vormen voor de iets intensievere toetsing (vgl. Morey v. Doud, 354 U.S. 457, 463 (1957)). Zie echter ook Vance v. Bradley, 440 U.S. 93, 98 e.v. (1979) en Williams v. Vermont, 472 U.S. 14, 25 (1985), waarin het Supreme Court uitgebreid inging op de bedoelingen van de wetgever zonder dat er sprake was van een verhoogde toetsingsintensiteit of een "closed class".

273. Zie Truax $v$. Raich, 239 U.S. 33 (1915): "The purpose of an act must be found in its natural operation and effect" (op 40)

274. Bijv. Zobel v. Williams, 457 U.S. 55, 61 (1982), City of Cleburne v. Cleburne Living Center, 473 U.S. 432, 448 (1985), Hooper v. Bernalillo, 472 U.S. 612, 618/619 (1985), Metropolitan Life Ins. v. Ward, 470 U.S. 869 (1985) en Gregory v. Ashcroft, 501 U.S. 452, 471 (1991).

275. Zie bijv. Heller v. Doe, 509 U.S. 312, 321/322 (1993); het Supreme Court acht de stellingen van partijen en lagere rechters echter niet altijd bepalend: in Kadrmas v. Dickinson Public Schools, 487 U.S. 450 (1988) stelde het dat "[...] we are not bound by explanations of the statute's rationality that may be offered by litigants or other courts" (op 463).

276. Ook wanneer er duidelijke doelstellingen zijn aangevoerd of in een eerder stadium van de procedure zijn vastgesteld verzint het Supreme Court soms zelf nog doelstellingen. Zie bijv. Hooper v. Bernalillo, 472 U.S. 612, 621 (1985), waar het Supreme Court leek vast te houden aan in eerdere fasen van de procedure vastgestelde doelstellingen, maar vervolgens ook de rationaliteit toetste van een doelstelling die in het geheel niet was aangevoerd. 
opstelling wordt soms ook gekozen bij onderwerpen die zeker geen intensievere toet. sing vergen dan de conceivable basis-test toelaat. ${ }^{27}$ Het is waarschijnlijk dat de beschikbaarheid van duidelijke wettelijke doelstellingen bepalend is: is in het procesdos. sier een plausibele doelstelling gemakkelijk te vinden, dan zal het Supreme Court hier. op afgaan; ontbreekt daarentegen een duidelijk doel, dan kan het alleen door zelf etn doelstelling te bedenken voorkomen dat het een vergaand onderzoek van de wetsge. schiedenis of de wettelijke context moet uitvoeren. ${ }^{278}$

Tenslotte kan erop worden gewezen dat het Supreme Court niet alleen bij een toepas. sing van de rational basis-test zelf een doelstelling bedenkt, maar dit in sporadische gevallen ook doet in het kader van een strict scrutiny-test. De functie van de vaststelling is dan een geheel andere: het doel dat wordt vastgesteld is bij deze toets het enig denkbare dat een rechtvaardiging voor het verdachte onderscheid zou kunnen opleve. ren. ${ }^{27 y}$ Een voorbeeld van deze benadering is te vinden in het arrest Skinner v. Oklaho$m a^{230}$, dat betrekking had op de verplichte sterilisatie van misdadigers die een bepaald type misdrijf gepleegd hadden. Het Supreme Court was het met de eisers eens dat de keuze voor de misdrijven waarbij sterilisatie werd toegepast willekeurig was:

"We have not the slightest basis for inferring that that line has any significance in eugenics nor that the inheritability of criminal traits follows the neat legal distinctions which the law has marked between those two offenses."

In feite gaf het Supreme Court met bovenstaande overweging te kennen dat er alletn een rechtvaardiging voor de regeling zou kunnen bestaan wanneer daadwerkelijk zou blijken dat er een erfelijke aanleg bestaat voor het plegen van bepaalde misdrijven, zodat kan worden aangenomen dat met sterilisatie een preventiedoel wordt nagestreefd Impliciet blijkt daaruit dat preventie het enige doel is dat het Supreme Court voor verplichte sterilisatie redelijk acht: een andere rechtvaardiging is niet mogelijk. ${ }^{n}$ Een

277. Vgl. Bennett 1979, p. 1059.

278. Een verdere verklaring kan worden gevonden in de fluctuaties in de samenstelling van het Suprent: Court. De conceivable basis-test werd vooral veel toegepast door het Warren Court in de jaren '60; de rechtspraak van dit Hof kenmerkte zich door een strikte tweedeling in een uitermate terughoudents toets en een zeer intensieve toets, waarbij de nadruk lag op de vraag welke toetsingsintensiteit in een bepaalde zaak moest worden toegepast. Vooral in de jaren '70 en in het begin van de jaren '80, toen het Supreme Court werd voorgezeten door Burger, ontstonden er tussengelegen vormen van toetsing" intensiteit en werd de rational basis-test meer in het algemeen op een minder terughoudende manit toegepast; een actievere benadering bij de vaststelling van het doel past wel in deze rechtsprak Por sinds de jaren ' 90 , bij een overwegend conservatieve samenstelling onder Rehnquist zonder bijzonder sterke liberalen, heeft de rational basis-test weer aan kracht verloren en wordt de conceivable basis. test vaker toegepast.

279. Vgl. Bhagwat 1997 , p. 338 , Nagel 1972, p. 152/153, die spreekt van "mandatory goals" en Green 1998 p. 460 .

280. 316 U.S. 535 (1942)

281. 316 U.S., op 542

282. Andere voorbeelden zijn McLaughlin v. Florida, 379 U.S. 184, 193 (1964), Clark v. Jeter, 486 US. 456,462 (1988) en de rechtspraak over de "public function exception", waardoor onderscheid op groes van nationaliteit toelaatbaar wordt geacht wanneer daarmee de integriteit van de openbare dienst worth beschermd; zie bijv. Foley v. Connelie, 435 U.S. 291, 296 (1978), Cabell v. Chavez-Salido, 454 US 432, 440 (1982) en Bernal v. Fainter, 467 U.S. 216 (1984). Ook in de rechtspraak over kiesrecht th voorkeursbehandeling is deze benadering terug te vinden. Deze methode impliceert een hoge mate vit 
dergelijke benadering vormt uitdrukking van een zeer intensieve toetsing: de rechter stelt zijn oordeel over de doelstellingen die mogen worden nagestreefd in de plaats van dat van de wetgever.

\section{De actual purpose-test}

Terwijl bij de rational basis-test een zeer terughoudende benadering wordt gekozen als het gaat om de vaststelling van het doel, is de benadering bij de intermediate scrutinyen strict scrutiny-test juist zeer intensief: regelmatig gaat het Supreme Court daarbij actief op zoek naar de werkelijke bedoeling van het onderscheid. ${ }^{2 \times 3}$ Recentelijk heeft het Supreme Court hierbij zelfs expliciet gesteld dat alleen het werkelijk doel van de classificatie mag worden onderzocht op zijn redelijkheid: in het arrest United States $v$. Virginia $^{2 \mu}$ stelde het dat:

"The justification must be genuine, not hypothesized or invented post hoc in response to litigation. [...] [A] tenable justification must describe actual state purposes, not rationalizations for actions in fact differently grounded."2zs

Deze eis wordt zowel gesteld bij de intermediate scrutiny-test als bij de strict scrutinytest; het verschil in toetsingsintensiteit tussen beide tests is voor de vaststelling van het doel kennelijk niet relevant. ${ }^{286}$

toetsingsintensiteit: er bestaat hierbij geen ruimte meer voor rechtvaardiging via andere doelstellingen die de regering of wetgever redelijk acht. De reden hiervoor is waarschijnlijk dat het in de betrokken gevallen steeds gaat om beperkingen van essentiële rechten en belangen of om onderscheid op zeer verdachte gronden; vgl. Green 1998, p. 464.

283. Vgl. Bhagwat 1997, p. 330, Blattner 1981, p. $834 / 835$ en Cathey 1983 , p. $1509 / 1510$. Dit is niet altijd het geval: vaak veronderstelt het Supreme Court dat een doelstelling de werkelijke bedoeling voor het onderscheid vormde, omdat het gemakkelijker is te beredeneren dat er geen redelijke verhouding bestaat tussen doel en middel (hetgeen de voorkeur blijkt te hebben: het Supreme Court heeft zeker geen voorliefde voor de toetsing van het doel) (zie bijv. Kramer v. Union Free School District, 395 U.S. 621, 635 (1969) en Police Department of Chicago v. Mosley, 408 U.S. 92, 99 (1972)), of dat het doel ongerechtvaardigd (of onvoldoende "compelling") is (zie bijv. Graham v. Richardson, 403 U.S. 365 (1971), Dunn v. Blumstein, 405 U.S. 330, 355 (1972) en Memorial Hospital v. Maricopa County, 415 U.S. 250 (1974)). Evenmin voert het Supreme Court een nader onderzoek uit wanneer er geen duidelij$\mathrm{ke}$ aanleiding bestaat een discrepantie tussen gesteld en werkelijk doel te veronderstellen; vgl. Stone e.a. 1996, p. 591. Tenslotte is van belang dat het gebruik van de actual purpose-formulering vaak alleen retorisch is: het komt voor dat het Supreme Court zelf doelstellingen vaststelt waarvan het vindt dat deze een goede basis voor toetsing vormen en stelt dat deze de actual purpose vormen, maar dat uit nader onderzoek blijkt dat er discrepantie bestaat tussen deze doelstellingen en de werkelijke doelstelling van het onderscheid. Zie bijv. Tuan Anh Nguyen v. INS, 533 U.S. 53 (2001), en de kritiek op de daarin gekozen benadering in de door drie andere rechters ondersteunde dissenting opinion van Justice O'Connor.

284. 518 U.S. 515 (1996)

285. 518 U.S., op 533 en 535/536. Zie in vergelijkbare zin overigens ook al Schweiker v. Wilson, 450 U.S. 221, 244 (1981) (J. Powell, dissenting) ("[...] the Court should receive with some skepticism post hoc hypotheses about legislative purpose, unsupported by legislative history").

286. Zie ook Weinberger $v$. Wiesenfeld, 420 U.S. 636, 648, voetnoot 16, (1975): "The court need not in equal protection cases accept at face value assertions of legislative purposes, when an examination of the legislative scheme and its history demonstrates that the asserted purpose could not have been a goal of the legislation." Zie voor een voorbeeld van toepassing bij de strict scrutiny-test Bernal v. Fainter. 467 U.S. 216 (1984): "This justification fails because the State fails to advance an actual showing that the unavailability of notaries' testimony [het beweerdelijk te bestrijden risico, JHG] presents a real, as opposed to a merely speculative, problem to the State" (op 227/228). De test komt verder voor bij de 
De actieve wijze waarop het Supreme Court onderzoek verricht naar het werkelijk doet van de regeling wordt geïllustreerd door de zaak Weinberger $v$. Wiesenfeld ${ }^{2 n}$ Dezs zaak had betrekking op een regeling voor uitkeringen na overlijden, waarbij onder. scheid werd gemaakt op grond van geslacht: overleed de mannelijke partner, dan ontvingen zowel zijn kinderen als zijn weduwe een uitkering, terwijl alleen de kindert uitkeringsgerechtigd waren als de vrouwelijke partner overleed. De regering had aar. gevoerd dat het hierdoor voor vrouwen bestaande voordeel bedoeld was als compensatie voor de moeilijkheden die zij - wanneer zij plotseling voor zichzelf en hun familie moesten zorgen - zouden ondervinden als gevolg van langdurige maatschappelijke achterstelling van vrouwen. Een vergelijkbare doelstelling werd door het Supreme Court in een eerdere zaak gerechtvaardigd geacht ${ }^{28 x}$, maar nu stelde het het volgende:

"[...][T] $]$ he mere recitation of a benign, compensatory purpose is not an automatic shield which protects against any inquiry into the actual purpose underlying a statutory scheme. Here, it is apparent from both the statutory scheme and from the legislative history $[\ldots]$ that Congress' purpose in providing benefits to young widows with children was not to provide an income to women who were, because of economic discrimination, unable to provide for themselves. Rather, [...][this provision], linked as it is directly to responsibility for minor children, was intended to permit women to elect not to work and to devote themselves to the care of children." ${ }^{289}$

Het Supreme Court liet zich in deze zaak dus niet afleiden door de doelstelling die door de regering naar voren werd gebracht, maar ging uit eigen beweging op zoek naar het werkelijk doel. In Weinberger $v$. Wiesenfeld vond het Supreme Court het werkelijke doel in de totstandkomingsgeschiedenis van de regeling, ${ }^{200}$ maar het Supreme Cour blijkt bij zijn onderzoek ook gebruik te maken van andere bronnen. Zo heeft het soms op basis van logica geconcludeerd dat een aangevoerde doelstelling niet aan een classificatie ten grondslag kón hebben gelegen, bijvoorbeeld vanwege de zeer evidente ongeschiktheid van de classificatie om dit doel te bereiken, ${ }^{291}$ of kwam het tot deze conclusie op basis van de effecten die een regeling in de praktijk sorteerde ${ }^{2 y_{2}}$. Verder heeft het

rational basis "with bite"-test, maar is daarbij meestal minder expliciet; zie Swierenga 1986, p. 1469. 287. 420 U.S. 636 (1975)

288. Zie Kahn v. Sevin, 416 U.S. 351,353 (1974).

289. 420 U.S., op 648; zie ook "Note" 1978, p. 810. Deze overweging werd gevolgd door een uitgebreil onderzoek van de wetsgeschiedenis. Het Supreme Court heeft een vergelijkbaar oordeel nog versctit. lende keren uitgesproken in zaken die ook op onderscheid op grond van geslacht betrekking hader, zie bijv. Califano v. Goldfarb, 430 U.S. 199, 212 (1977), Califano v. Webster, 430 U.S. 313,318 (1977), Califano v. Westcott, 443 U.S. 76, 87 (1979) en Mississippi University of Women v. Hogen, 458 U.S. 718,729 (1982).

290. Ook in andere zaken was dit het geval; zie bijv. Shapiro v. Thompson, 394 U.S. 6I8, 628 (1969), de it de vorige noot reeds aangehaalde arresten Califano v. Goldfarb, Califano v. Webster en Califano r. Westcott, en U.S. Department of Agriculture v. Moreno, 413 U.S. 528, 534 (1973), Schlesingerv. Bulard, 419 U.S. 498, 515 (1975) (J. Brennan, dissenting), Trimble v. Gordon, 430 U.S. 762,775 (1977) en Shaw v. Hunt, 517 U.S. 899, 910 (1996). Wanneer er geen wettelijke regeling, maar een andert scheid door een administratief orgaan in het geding is, kijkt het Supreme Court eveneens naar de schiedenis van de totstandkoming van het onderscheid, voor zover deze te achterhalen valt; zit bif United States v. Virginia, 518 U.S. 515, 538/539 (1996).

291. Zie bijv. Evans v. Cornman, 398 U.S. 419 (1970) en Eisenstadt v. Baird, 405 U.S. $438,449(1972)$ Vgl. ook Jackson 1997, p. 497, Swierenga 1987, p. 1468 en Rosberg 1977, p. 306/307.

292. Zoals in U.S. Department of Agriculture v. Moreno, 413 U.S. 528, 537 (1973). Zie ook Bemal 
Supreme Court zich in een antal gevallen op de samenhang of de tekst van wettelijke bepalingen gebaseerd. ${ }^{291} 294$

Nu het Supreme Court deze toetsing uit eigen beweging uitvoert en het zelfs niet noodzakelijk is dat de eiser aannemelijk maakt dat er een discrepantie bestaat tussen gesteld en werkelijk doel, is deze actual purpose-test zonder meer zeer intensief te noemen. ${ }^{29 s}$

\subsubsection{Pluraliteit van doelstellingen}

In hoofdstuk 2 is aangegeven dat een regelgever bij het vaststellen van regelgeving slechts zelden één doelstelling nastreeft: in de meeste gevallen zal er een complex van samenhangende doelstellingen aan een normatieve classificatie ten grondslag liggen. Soms zullen deze doelstellingen een gelijk gewicht hebben, maar meestal zal het zo zijn dat er een soort overkoepelende, algemene doelstelling bestaat waaraan specifiekere doelstellingen ondergeschikt zijn. Voor het onderzoek naar de gerechtvaardigdheid van een classificatie is het bestaan van verschillende doelstellingen bijzonder lastig. De

Fainter, 467 U.S. 216, 224 (1984), Lyng v. International Union, 485 U.S. 360, 375/376 (1988) (J. Marshall, dissenting). Ook uit de algemene omstandigheden van het geval kan een "werkelijke" doelstelling soms worden afgeleid. Dit gebeurt vooral in de omstandigheid waarin het doel ook als toetsingsingang wordt gehanteerd en in dat verband al is vastgesteld welke "werkelijke" bedoelingen het onderscheid motiveerden; zie bijv. Miller v. Johnson, 515 U.S. 900, 921 (1995) en Bush v. Vera, 517 U.S. 952,963 e.v. (1996); vgl. ook Cathey 1983, p. 1518/1519.

293. Zie opnieuw U.S. Department of Agriculture v. Moreno, 413 U.S. 528 (1973); vgl, ook Schlesinger v. Ballard, 419 U.S. 498, 514 (1975) (J. Brennan, dissenting). Vergelijkbaar is ook Palmore v. Sidoti, 466 U.S. 429 (1984), waarin het Supreme Court een door een rechterlijke uitspraak veroorzaakt onderscheid moest beoordelen; om het doel te achterhalen bestudeerde het de motivering van deze uitspraak heel zorgvuldig (op 432).

294. Van belang is verder dat er vrij specifieke eisen zijn gesteld aan het bewijs van de doelstelling bij onderscheid dat is gemaakt door administratieve organen van de federale overheid. Daarbij geldt het volgende: "If the agency which promulgates the rule has direct responsibility for fostering or protecting that interest [een belang dat in de procedure als rechtvaardiging is aangevoerd, JHG], it may reasonably be presumed that the asserted interest was the actual predicate for the rule. [...] Altematively, if the rule were expressly mandated by the Congress or the President, we might presume that any interest which might rationally be served by the rule did in fact give rise to its adoption" (Hampton $v$. Mow Sun Wong, 426 U.S. 88, 103 (1976)). Hierdoor lijkt het erop dat er aan de federale overheid minder strenge eisen worden gesteld dan aan de statelijke overheden, ongeacht de toepasselijkheid van een verhoogde toetsingsintensiteit. Zoals eerder is aangegeven is het echter niet geheel duidelijk wat de waarde van dit precedent is, nu in 1995 het principe van congruentie duidelijk is vastgelegd (zie paragraaf 1.2.2); waarschijnlijk zal tegenwoordig ook bij strict scrutiny verdergaand onderzoek worden uitgevoerd naar de werkelijke bedoelingen als het onderscheid onder verantwoordelijkheid van de federale overheid is gemaakt.

295. Vgl. Farrell 1992, p. 37; zie ook Minnesota v. Clover Leaf Creamery, 449 U.S. 456, 463, voetnoot 7 (1981): "In equal protection analysis, this Court will assume that the objectives articulated by the legislature are actual purposes of the statute, unless an examination of the circumstances forces us to conclude that they 'could not have been a goal of the legislation'." Het Supreme Court is ook hier niet altijd even consistent: in sommige gevallen is er sprake van verhoogde toetsingsintensiteit zonder dat er een actual purpose-test wordt uitgevoerd; de doelstellingen worden dan, net als bij de conceivable basis-test, verondersteld. Zie bijv. Schlesinger v. Ballard, 419 U.S. 498, 508 (1975), Michael M. v. Superior Court of Sonoma County, 450 U.S. 464 (1981), Miller v. Albright, 523 U.S. 420, 435 (1998) en Tuan Anh Nguyen v. INS, 533 U.S. 53 (2001); in deze gevallen geldt meer in het algemeen dat de feitelijke toetsing minder streng is dan de intermediate scrutimy-test die formeel wordt toegepast. De zaken kunnen dan ook eerder worden gezien als afwijkingen van de gebruikelijke standaard dan als een aparte lijn van precedenten. 
vraag is bijvoorbeeld of, wanneer één van de doelstellingen ongerechtvaardigd is, het voor de toelaatbaarheid van het onderscheid voldoende is wanneer één of meer andere doelstellingen wél legitiem zijn. Het Supreme Court heeft in het kader van de striktere tests (intermediate scrutiny en strict scrutiny, maar ook rational basis "with bite" regelmatig aandacht besteed aan deze problematiek en heeft daarvoor enkele intertssante oplossingen gevonden.

Opmerkelijk is allereerst dat het Supreme Court geen onderscheid lijkt te willen maken tussen de situatie waarin de doelstellingen een vergelijkbaar gewicht hebben en de situatie waarin er sprake is van een hoofddoelstelling en subdoelstellingen. Als reden daarvoor stelde het in Wright $v$. Council of City of Emporia ${ }^{2 \%}$, dat

"[...] it is difficult or impossible for any court to determine the 'sole' or 'dominant' motivation behind the choices of a group of legislators [...]. [...] [A]n inquiry into the 'dominant' motivation [...] is as irrelevant as it is fruitless."

Dit betekent dat het Supreme Court er steeds vanuit zal gaan dat alle aangevoerde of vastgestelde doelstellingen een nagenoeg gelijk gewicht hebben. ${ }^{288}$ Van belang is verder dat het Supreme Court alle verschillende doelstellingen die zijn aangevoerd of die het zelf heeft vastgesteld afzonderlijk op hun gerechtvaardigdheid onderzoekt: gekeken wordt niet of de doelstellingen in hun onderlinge samenhang een rechtvaardiging kun. nen vormen. ${ }^{2 w}$ In de praktijk blijkt dit onderzoek in vrijwel iedere zaak tot de conclusie te leiden dat geen enkele doelstelling gerechtvaardigd is of dat er geen redelijke ver. houding tussen doelstellingen en middel bestaat: met de problemen die bij pluralitit van doelstellingen bestaan heeft het Supreme Court daardoor bijna nooit te maken."

Een zeldzame uitzondering waarin één van de doelstellingen wel gerechtvaardigd werd geacht is Lyng $v$. International Union. ${ }^{301}$ Deze zaak had betrekking op een voedselprogramma voor minvermogenden, het Food Stamp Program, dat inhield dat iedereen die minder verdiende dan een bepaald minimumbedrag in aanmerking kwam voor en soort voedselbonnen. Mensen die als gevolg van deelname aan een staking onder de inkomensgrens van dit programma terecht waren gekomen hadden volgens $\S 109 \mathrm{vm}$ de regeling echter geen recht op de bonnen. Voor het maken van deze uitzondering was een drietal doelstellingen aangevoerd: het beperken van overheidsuitgaven in het algs meen, het beperken van de uitgifte van bonnen tot die mensen die ze het meest nodig

296. 407 U.S. 451 (1972)

297. 407 U.S., op 462

298. Vgl. Farrell 1992, p. 18.

299. Vgl. Nagel 1972, p. 126/127 en 135, en Bice 1977, p. 700.

300. Voorbeelden van de werkwijze van het Supreme Court in zaken waarin meerdere doelstellingen eanto spelen zijn Richardson v. Ramirez, 418 U.S. 24 (1984), Memorial Hospital v. Maricopa County, 41 ? U.S. 250, 263-269 (1974), Nyquist v. Mauclet, 432 U.S. 1, 9-12 (1977), Regents of the Univerily California v. Bakke, 438 U.S. 265, 305 e.v. (1978), Zobel v. Williams, 457 U.S. 55 (1982), Phler t Doe, 457 U.S. 202, 228-230 (1982), City of Cleburne v. Cleburne Living Center, 473 U.S. 432, 4t 450 (1985) en Hooper v. Bernalillo, 472 U.S. 612, 619-621 (1985). Overigens lost het Supreme coed het probleem van pluraliteit van doelstellingen soms ook op door beide doelstellingen gerechtvaarif te achten; dit blijkt vooral mogelijk bij toepassing van de intermediate scrutiny-test. Zie bijv. Tuen the Nguyen v. INS, 533 U.S. 53 (2001).

301. 485 U.S. 360 (1988) 
hebben en het voorkomen van misbruik van het programma door vakbonden als steun voor het opzetten van stakingen. Het Supreme Court gaf hierover het volgende oordeel:

"We have little trouble in concluding that $\S 109$ is rationally related to the legitimate governmental objective of avoiding undue favoritism to one side or the other in private labor disputes. [...] In view of the foregoing, we need not determine whether either of the other two proferred justifications for $\$ 109$ would alone suffice."302

Uit deze overweging kan worden afgeleid dat het voor de toelaatbaarheid van een classificatie voldoende kan zijn wanneer slechts één van de aangevoerde doelstellingen gerechtvaardigd is. Het lijkt daarbij echter wel vereist te zijn dat deze doelstelling het onderscheid volledig zelfstandig, dus ook zonder de aanwezigheid van de andere doelstellingen, kan dragen. ${ }^{303}$

Dit uitgangspunt is vooral van belang voor de rechtspraak met betrekking tot indirect onderscheid. Zoals hiervoor is aangegeven is het daarbij noodzakelijk is dat de eisende partij aantoont dat het bereiken van een benadelend effect voor een bepaalde (meestal raciale) groep voor de regelgever een factor was bij zijn besluitvorming. ${ }^{304}$ Het zal duidelijk zijn dat de discriminatoire doelstelling als zodanig vrijwel nooit gerechtvaardigd is, zeker niet wanneer deze een basis vindt in afkeer van of vooroordelen jegens de betrokken groep. ${ }^{105}$ In het eerder besproken arrest Arlington Heights ${ }^{306}$ oordeelde het Supreme Court echter dat indirect onderscheid ondanks de aanwezigheid van een dergelijke doelstelling toch nog gerechtvaardigd kan zijn:

\section{485 U.S., op 371 en 373}

303. Zo is i.c. de vraag of de eerste doelstelling, de algemene wens tot beperking van overheidsuitgaven, het onderscheid had kunnen dragen wanneer de andere doelstellingen hadden ontbroken. Hoewel deze doelstelling waarschijnlijk wel gerechtvaardigd zou worden geacht (485 U.S., op 373), is het niet waarschijnlijk dat ook voldaan zou zijn aan de eisen van subsidiariteit en proportionaliteit. Impliciet wordt deze conclusie gesteund door Hampton v. Mow Sun Wong, 426 U.S. 88 (1976). In dit arrest was een groot aantal doelstellingen ter rechtvaardiging aangevoerd, bij het nastreven waarvan volgens het Supreme Court sprake was van détournement de poivoir. Dit bezwaar gold echter niet voor één van de doelstellingen - het vergemakkelijken van de administratieve procedure die in het geding was. Het Supreme Court stelde vervolgens dat dit doel weliswaar gerechtvaardigd was, maar dat niet voldaan was aan het vereiste van subsidiariteit; de doelstelling kon het onderscheid niet zelfstandig dragen. Zie 426 U.S., op 104/105 en 114.

304. In het arrest Arlington Heights oordeelde het Supreme Court dat het niet nodig is om aan te tonen dat de discriminatoire doelstelling de enige of de dominante doelstelling is; voldoende is dat kan worden aangetoond dat de effecten van de maatregel voor het instellen daarvan "a motivating factor" vormden (429 U.S. 252, 265/266 (1977)). Een uitzondering hierop vormen de eerder besproken zaken over de herverdeling van kiesdistricten (zie noot 247). Het Supreme Court heeft daarbij (om onduidelijke redenen) steeds vereist dat de discriminatoire doelstelling dominant is. Dit heeft gevolgen voor de rechtvaardigingsmogelijkheden, zoals blijkt uit Miller $v$. Johnson: "Although a legislature's compliance with 'traditional districting principles such as compactness, contiguity, and respect for political subdivisions' may well suffice to refute a claim of racial gerrymandering, appellants cannot make such a refutation where, as here, those factors were subordinated to racial objectives" (515 U.S. 900, 919 (1995)). In dit geval kon de staat alleen nog proberen aan te tonen dat het gebruik van ras als differentiatiecriterium in dit geval gerechtvaardigd was (i.c. werd bijvoorbeeld gesteld dat een federale wettelijke bepaling vereiste dat met raciale minderheden rekening wordt gehouden), maar het kon niet meer

305. Zoals hierna

kwetsbare nog zal blijken is het vaste rechtspraak van het Supreme Court dat de bedoeling om een

306. 429 U.S. 252 (1977) 
"Proof that the decision [...] was motivated in part by a racially discriminatory purpose would not necessarily have required invalidation of the challenged decision. Such proof would, however, have shifted [...] the burden of establishing that the same decision would have resulted even had the impermissible purpose not been considered. If this were established, the complaining party in a case of this kind no longer fairly could attribute the injury complained of to improper consideration of a discriminatory purpose [...] ${ }^{m 07}$

Heeft de eisende partij dus eenmaal aangetoond dat er een discriminatoire doelstelling aan het onderscheid ten grondslag lag, dan verschuift de bewijslast naar de verdedigen. de partij; deze moet vervolgens aantonen dat met de regeling ook andere, gerechtvaardigde, doelstellingen werden nagestreefd en dat de beslissing ook tot stand zou zjp gekomen wanneer de discriminatoire doelstelling niet zou hebben meegespeeld." Dit betekent dat steeds zal moeten worden nagegaan of de aangevoerde, gerechtvaardigde doelstellingen zelfstandig een rechtvaardiging voor de classificatie kunnen vormen."

\subsubsection{Toetsing van de gerechtvaardigdheid van het doel}

\section{"Important" en "compelling governmental interests"}

Zoals eerder is aangegeven bestaat er een belangrijk verschil tussen de drie tests als het gaat om de eisen die zij stellen aan de belangen die de verdedigende partij ter recht. vaardiging kan aanvoeren. $\mathrm{Bij}$ de rational basis-test is het voldoende dat er een "legitimate governmental purpose" "sı of een "permissible state objective" bestaat, bij de intermediate scrutiny-test moeten "important governmental objectives" 12 worden aan. gevoerd en bij de strict scrutiny-test moet het onderscheid zelfs worden gerechtvardigd door "compelling governmental interests" purpose" aan deze formules: er zijn slechts weinig uitspraken waarin het Supreme Court daadwerkelijk uitlegt wanneer een belang "compelling" of "important" is." Uit de sparrzame rechtspraak over dit onderwerp kan echter worden afgeleid dat deze begrippen niet zozeer betrekking hebben op de inhoud, maar vooral op het gewicht van het nage streefde belang: hoe strikter de toetsing, hoe zwaarwegender het overheidsbelang mott zijn om de classificatie te kunnen rechtvaardigen. ${ }^{316}$ Dit betekent dat het Supreme Cout

307. 429 U.S., voetnoot 21. Idem in Texas v. Lesage, 528 U.S. 18, 20/21 (1999).

308. Vgl. ook Perry 1979, p. 1037.

309. Het Supreme Court heeft deze werkwijze in andere context bevestigd: zie bijv. Mt. Healthy v. Doyle, 429 U.S. 274,287 (1977).

310. Vance v. Bradley, 440 U.S. 93,97 (1979)

311. Parham v. Hughes, 441 U.S. 347, 351 (1979)

312. Craig v. Boren, 429 U.S. 190, 197 (1976)

313. Adarand Constructors, Inc. v. Pena, 515 U.S. 200, 227 (1995)

314. McLaughlin v. Florida, 379 U.S. 184, 192 (1964)

315. Zie Gottlieb 1988, p. 932 en 936; vgl. ook Rosenfeld 1989, p. 1738.

316. Vgl. Bhagwat 1997, p. 311; hij geeft ook nog een andere betekenis aan het begrip, volgens welke ent doelstelling alleen "compelling" kan zijn als deze aansluit bij of ondersteuning biedt aan het gelifkheidsbeginsel zelf (bijvoorbeeld bij voorkeursbeleid, waardoor beoogd wordt een grotere matschap pelijke gelijkheid te creëren) (p. 340). Dit zou een juiste interpretatie kunnen zijn van de rechtsprak maar er zijn te weinig zaken waarin de aanwezigheid van een "compelling interest" inhoudelijk is g" toetst om deze conclusie goed te kunnen onderbouwen; bovendien geeft Bhagwat zelf aan dat ef oli zaken zijn waarin een doelstelling als "compelling" is aanvaard, terwijl deze met gelijke behandelif 
een soort proportionaliteitstoets uitvoert binnen het kader van de toetsing van het doel $\mathrm{I}^{\mathrm{p} 7}$, hetgeen bevestigd wordt door het arrest Richardson $v$. Ramirez: ${ }^{318}$

“'Compelling state interest' is merely a shorthand description of the difficult process of balancing individual and state interests that the Court must embark upon when faced with a classification touching on fundamental rights." 119

Op deze uitleg van het vereiste van een "compelling interest" zal dan ook nader worden ingegaan bij de bespreking van het vereiste van proportionaliteit.

Opmerkelijk is verder de uitleg die het Supreme Court aan het vereiste heeft gegeven in het kader van positieve discriminatie op grond van ras. In Shaw $v$. Hunt ${ }^{320}$ stelde het het volgende:

"A State's interest in remedying the effects of past or present racial discrimination may in the proper case justify a government's use of racial distinctions. For that interest to rise to the level of a compelling state interest, it must satisfy two conditions. First, the discrimination must be 'identified discrimination'. [...] A generalized assertion of past discrimination in a particular industry or region is not adequate because it provides no guidance for a legislative body to determine the precise scope of the injury it seeks to remedy. [...] Second, the institution that makes the racial distinction must have had a strong basis in evidence to conclude that remedial action was necessary [...]."321

niets van doen heeft (bijv. Toyosaburo Korematsu v. United States, 323 U.S. 214 (1944)). Een interessante interpretatie die Korematsu wel kan verklaren is gegeven door Sobelsohn, die stelt dat het voortbestaan van de democratische samenleving als toetssteen wordt genomen (1977, p. 479); ook daarvoor geldt echter dat de interpretatie theoretisch redelijk is, maar hiervoor slechts weinig ondersteuning is te vinden in de rechtspraak. Zie over de intermediate scrutiny-test Cathey 1983, p. 1523: "The threshold factor in the importance inquiry is whether the state's interest is generally adressed to a problem of significant concern." Dit criterium biedt echter niet veel meer duidelijkheid dan dat van het "important governmental interest" zelf.

317. Een aanwijzing daarvoor bieden Shapiro v. Thompson, 394 U.S. 618 (1969), Graham v. Richardson, 403 U.S. 365 (1971) en Memorial Hospital v. Maricopa County, 415 U.S. 250, 263 (1974), waarin werd gesteld dat "fiscal integrity" weliswaar kan worden gezien als een gerechtvaardigd doel, maar dat een onderscheid op grond van ras hierdoor niet kan worden gerechtvaardigd - een duidelijke proportionaliteitsoverweging. In Graham verbindt het Supreme Court hieraan de conclusie dat de doelstelling niet "compelling" is (op 375). Zie verder de opinie van Justice Powell in Board of Regents of the University of California v. Bakke, 438 U.S. 265, 310 (1978): "[...] in some situations a State's interest in facilitating the health care of its citizens is sufficiently compelling to support the use of a suspect classification".

318. 418 U.S. 24 (1974)

319. 418 U.S., op 78. Voor het "important governmental interest" van de intermediate scrutiny-test lijkt iets vergelijkbaars te gelden: zo gaf het Supreme Court in Craig v. Boren een aantal voorbeelden van doelstellingen, "[...] deemed of insufficient importance to sustain use of an overt gender criterion [...]" (429 U.S. 190, $197(1976))$.

320. 517 U.S. 899 (1996)

321. 517 U.S., op 909; vgl, ook Wygant v, Jacksan Board of Education, 476 U.S. 267, 276 (1986) (basis voor onderscheid mag niet "amorphous" zijn), Miller v. Johnson, 515 U.S. 900 (1995) ("strong basis in evidence of the harm being remedied" vereist) en City of Richmond v. Croson, 488 U.S. 469, 505 (1989) (noodzaak van daadwerkelijk aantonen van discriminatie in het verleden). Het vereiste dat een doelstelling een duidelijke basis in de feiten heeft is ook in andere zaken wel genoemd, zie bijv. United States v. Virginia, 518 U.S. 515,544 (1996) (in het kader van het vereiste van een "exceedingly persuasive justification"). 
Deze invulling is zeer specifiek en wordt door het Supreme Court uitsluitend toegepast in de context van positieve discriminatie; veel aanknopingspunten voor de invulling van de formule in andere situaties kunnen hierin niet worden gevonden. Hoogstens kan uit dit citaat worden afgeleid dat er hoge eisen worden gesteld aan het gewicht, de specificiteit en de feitelijke basis van het doel, hetgeen de conclusie ondersteunt dat het vereiste van een "compelling interest" vooral een indicatie geeft van de intensiteit van de toetsing. Concrete aanwijzingen met betrekking tot de inhoud van het begrip kunnen uit dit vereiste en zijn toepassing echter nauwelijks worden afgeleid. ${ }^{322}$

Al heeft het Supreme Court weinig inhoud gegeven aan begrippen als "compelling" en "important", het heeft in de loop van de tijd wel een vrij uitgebreide rechtspraak ontwikkeld over de eisen die aan de gerechtvaardigdheid van het doel moeten worden gesteld. ${ }^{32}$ Het verschil tussen de rational basis-test en de twee intensievere tests komt in deze vereisten duidelijk tot uitdrukking. Bij de rational basis-test is de inhoudelijke toetsing nauwelijks van belang. Vooral wanneer hierbij een conceivable basis-test wordt toegepast zal het Supreme Court aan een inhoudelijke toetsing niet eens toekomen, omdat het de gerechtvaardigdheid van de doelstellingen die het zelf vaststelt als vanzelfsprekend aanvaardt. ${ }^{32}$ Ook wanneer het Supreme Court in het kader van de rational basis-test nagaat of er sprake is van een "legitimate purpose" blijken de gestelde eisen echter te verschillen van die bij de intermediate scrutiny- en strict scrutimtest. ${ }^{325}$ In het hiernavolgende zullen de verschillende eisen en criteria kort worden besproken. Daarbij zal allereerst worden ingegaan op enkele meer algemene toetsingscriteria die door het Hof zijn ontwikkeld, hetzij voor alle tests, hetzij specifiek voor de twee striktere tests. Daarna zal kort aandacht worden besteed aan een tweetal concrete doelstellingen die regelmatig terugkomen en ook in de Europese rechtspraak verschilende malen zijn genoemd: administratieve overwegingen en bescherming van de openbare financiën.

322. De gevallen waarin het Supreme Court wel een "compelling governmental interest" aanwezig actite zijn eveneens zeldzaam en geven weinig aanwijzingen over de inhoud van het begrip. Meestal volstat het Supreme Court met het noemen van een bepaald doel en de opmerking dat dit als "compelling" of "important" kan worden beschouwd; waarom dit zo is wordt niet nader toegelicht. Zie bijv. Dumn $\mathrm{s}$ Blumstein, 405 U.S. 330, 346 (1972), Police Department of the City of Chicago v. Mosley, 408 US. 92, 99 (1972), In Re Griffiths, 413 U.S. 717, 722 (1973), Califano v. Webster, 430 U.S. 313,317 (1977), Caban v. Mohammed, 441 U.S. 380, 391 (1979), Wengler v. Druggists, 446 U.S. I42, 151 (1980), Rostker v. Goldberg, 453 U.S. 57, 70 (1981), Metro Broadcasting v. FCC, 497 U.S. 547, $567 / 568$ (1990) (wel iets uitgebreidere toelichting door verwijzing naar de grondwettelijke bescher:ming van het gediende belang), J.E.B. v. Alabama, 511 U.S. 127, 137 (1994) en Miller v. Albright, 527 U.S. 420 (1998). Verder wordt vaak uitgegaan van de veronderstelling dat een doel "compelling" is, omdat het onderscheid na het ontbreken van een goede doel-middel verhouding met een eenvoudiget motivering ontoelaatbaar kan worden verklaard; zie bijv. Cornman v. Evans, 398 U.S, 419, 422 (1970).

323. Hoewel door enkele auteurs gesteld is dat de criteria voor toetsing zeker niet voldoende zijn ontwil. keld, dat de rechtspraak te zeer een ad hoc-karakter heeft en deze vooral wordt bepaald door polities en sociale overwegingen; vgl. Bhagwat 1997, p. 308 en 319.

324. Vgl. "Developments" 1969, p. 1078.

325. Gesteld is wel dat in het kader van de rational basis-test helemaal geen inhoudelijke toetsing van bat doel wordt uitgevoerd; zie Nagel 1972, p. 131. Dit lijkt niet juist: er zijn wel degelijk arresten terug 15 vinden waarin het Supreme Court daadwerkelijk naging of er sprake is van een "legitimate purpose" ook al zijn de voorbeelden beperkt. 


\section{Verenigbaarheid met hogere regelgeving en vereiste van bevoegdheid}

Het Supreme Court vereist consequent, ongeacht de keuze voor een bepaalde test, dat alle doelstellingen verenigbaar moeten zijn met hogere regelgeving en dat de regelgever bevoegd moet zijn om het gestelde doel na te streven. Aan het eerste vereiste wordt slechts zelden uitdrukkelijk getoetst: meestal zal in dergelijke gevallen rechtstreeks worden getoetst aan de hogere regeling. ${ }^{326} \mathrm{Er}$ zijn echter wel degelijk gevallen te vinden waarin het Supreme Court een doelstelling ongerechtvaardigd verklaarde omdat deze in strijd was met de Constitutie. ${ }^{327}$

Het komt vaker voor dat het Supreme Court nagaat of het nastreven van een bepaalde doelstelling binnen de bevoegdheid van een statelijke overheid lag. Blijkens de rechtspraak betekent dit niet alleen dat staten de grenzen van hun eigen bevoegdheden niet mogen overschrijden ${ }^{328}$, maar ook dat zij hun bevoegdheden zodanig moeten uitoefenen

326. Vgl. Stone e.a. 1996, p. 588. Hiernaar gaat in de praktijk ook de voorkeur van het Supreme Court uit: aanvankelijk werden klachten over onderscheid op grond van vermogen bij de toegang tot bepaalde processuele rechten onder de Equal Protection Clause behandeld (zie bijv. Griffin v. Illinois, 351 U.S. 12 (1956) en Douglas v. California, 372 U.S. 353 (1963)), maar later werden zij, vooral na scherpe kritiek van één van de leden van het Supreme Court (vgl. Williams v. Illinois, 399 U.S. 235, 260 (1970) (J. Harlan, dissenting) meestal behandeld onder de Procedural Due Process Clause van het Veertiende Amendement (zie bijv. Boddie v. Connecticut, 401 U.S. 371 (1971)).

327. Bijv. Memorial Hospital v. Maricopa County, 415 U.S. 250, 263/264 (1974) ("[...] to the extent the purpose of the requirement is to inhibit the immigration of indigents generally, that goal is constitutionally impermissible"). Ook volgens andere rechtspraak is het vereist dat de doelstellingen in overeenstemming zijn met de Constitutie. Zie bijv. In Re Griffiths, 413 U.S. 717, 722 (1973) (vereiste van een "constitutionally permissible and substantial state interest"); vgl. ook Bhagwat 1997, p. 332, "Note" 1978, p. 805 en "Developments" 1969, p. 1081. Het Supreme Court heeft wel een uitzondering op dit vereiste van constitutionaliteit geaccepteerd, namelijk de bescherming van de rechtszekerheid. Soms wordt tijdelijk een regeling ingesteld om gerechtvaardigde verwachtingen, gebaseerd op een eerdere, onconstitutioneel verklaarde wet, te honoreren; nu daarbij vaak sprake zal zijn van een soort tijdelijke voortzetting van de wet is het goed mogelijk dat ook deze onconstitutioneel is. Het feit dat de primaire doeistelling het honoreren van gerechtvaardigde verwachtingen is, kan deze onconstitutionaliteit "repareren". Zie bijv. Heckler v. Mathews, 465 U.S. 728, 745/746 (1984), waarin het Supreme Court stelde dat "[t]he protection of reasonable reliance interests is not only a legitimate governmental objective: it provides 'an exceedingly persuasive justification' for the statute at issue here."

Van belang in dit verband is dat de staat zelf de constitutionaliteit moet controleren van een federale regeling die het nastreven van een bepaalde doelstelling toelaat of zelfs verplicht stelt: het bestaan van dit soort hogere regelgeving levert geen rechtvaardiging op voor een ongelijke behandeling. Impliciet is dit af te leiden uit het arrest Miller v. Johnson, 515 U.S. 900 (1995). Dit arrest had betrekking op een herverdeling van kiesdistricten waarbij ras als factor bij de bepaling van de nieuwe grenzen werd betrokken. De staat deed dit niet vrijwillig, maar in opdracht van een federaal overheidsorgaan dat een bepaling van de federale Voting Rights Act toepaste. Het Supreme Court stelde in dit arrest dat "[... compliance with federal antidiscrimination laws cannot justify race-based districting where the challenged district was not reasonably necessary under a constitutional reading and application of those laws. The congressional plan challenged here was not required by the Voting Rights Act under a correct reading of the statute" (op 920). Vervolgens gaf het Supreme Court een eigen uitleg aan de Voting Rights Act en verklaarde dat het statelijke herverdelingsplan hiermee in strijd was.

328. Vgl. bijv. Stanley v. Public Utilities Commission, 295 U.S. 76 (1935), waarin het Supreme Court stelde dat "there is no ground for concluding that the legislature transgressed the bounds of permissible discretion in this case" (op 78). Expliciet blijkt dit ook uit het arrest Takahashi v. Fish \& Game Commission, 334 U.S. 410, 419 (1948), waarin het Supreme Court stelde dat de staten geen bevoegdheid hebben tot het reguleren van immigratie; het vervolgde met de overweging dat "State laws which impose discriminatory burdens upon the entrance or residence of aliens lawfully within the United States conflict with this constitutionally derived federal power to regulate immigration, and have accordingly been held invalid." Zie verder Johnson v. Robison, 415 U.S. 361, 376 (1974) en Nyquist v. Mauclet, 
dat zij daardoor niet terechtkomen op het (exclusieve) bevoegdheidsterrein van de centrale overheid. ${ }^{329}$ Voorbeelden van deze laatste situatie zijn met name te vinden in het immigratierecht. ${ }^{330}$ Zo was in het arrest Truax v. Raich ${ }^{311}$ een regeling van de staat Arizona in het geding, die inhield dat iedere werkgever met meer dan vijf werknemers verplicht was om ervoor te zorgen dat tenminste $80 \%$ van zijn werknemers in de VS was geboren. Het Supreme Court stelde dat de staat hiermee feitelijk op het bevoegd. heidsterrein van de federale overheid terechtkwam:

"[...][R] easonable classification implies action consistent with the legitimate interests of the State, and it will not be disputed that these cannot be so broadly conceived as to bring them into hostility to exclusive Federal power. The authority to control immigration - to admit or exclude aliens - is vested solely in the Federal Government. [...] The assertion of an authority to deny to aliens the opportunity of earning a livelihood when lawfully admitted to the State would be tantamount to the assertion of the right to deny them entrance and abode. for in ordinary cases they cannot live where they cannot work." ${ }^{312}$

Hoewel het de staat vrijstond om beleid te voeren op het terrein van de werkgelegenheid, was hier toch sprake van een ontoelaatbare bevoegdheidsuitoefening...3

432 U.S. 1, 10 (1977). Ook voor federale overheidsorganen geldt deze regel. Zo stelde het Supremis Court ter motivering van zijn beslissing dat een bevoegdheidsuitoefening door een federaal organ ontoelaatbaar was het volgende: "The only concern of the Civil Service Commission is the promotion of an efficient federal service. [...] With only one exception, the interests which the petitioners have put forth as supporting the Commission regulation at issue in this case are not matters which are properly the business of the Commission" (Hampton v. Mow Sun Wong, 426 U.S. 88, 114 (1976)); zie voor een uitgebreid onderzoek naar de vraag of de nagestreefde doelstellingen binnen de federale bevoegdheid passen ook Fullilove v. Klutznick, 448 U.S. 448, 476-479 (1980). Zie voor andere voorbetden, vooral ook van misbruik van bevoegdheid, Bice 1977, p. 700/701.

329. Hetgeen ook voortvloeit uit de zogenaamde Supremacy Clause van de Constitutie, die implicert dande Constitutie in de weg staat aan statelijke wetgeving die in strijd is met de Constitutie of het voeren van federaal beleid belemmert (Article VI, Clause 2); gesproken wordt dan van "preemption". Dit geld niet alleen voor die beleidsterreinen die volgens de Constitutie tot de exclusieve bevoegdheid vande federale overheid behoren, maar ook voor terreinen die door de Constitutie niet expliciet aan staten of federatie worden toevertrouwd en die het Congres zichzelf volledig heeft toegeceigend. Zie daarvir nader Levi 1979, p. 1070 en Manheim 1995, p. 944 en 959.

330. Vooral omdat het Supreme Court beleid en regelgeving met betrekking tot immigratic ziet als ent federale bevoegdheid, terwijl het al snel voorkomt dat staten regelgeving tot stand brengen die (bedoeld of onbedoeld) de immigratie beĭnvloedt; zie Manheim 1995, p. 958.

331. 239 U.S. 33 (1915)

332. 239 U.S., op 42; vgl. "Note" 1957, p. 1025/1026. Dit geldt ook voor gevallen waarin cen stati can eigen bevoegdheid uitoefent met een doelstelling die is afgestemd op bevoegdheidsuitoefening door de federale overheid, zoals bij het ontzeggen van onderwijs aan illegale kinderen die waarschijnlijk tod wel worden uitgezet. Daardoor kan sprake zijn van een doorkruising van federale bevoegdheden, hel: geen niet toelaatbaar is; vgl. Plyler v. Doe, 457 U.S. 202, 225/226 (1982).

333. Zie Levi 1979, p. 1072. In andere zaken heeft het Supreme Court dit bevestigd. Zo stelde het dat staten immigratie niet indirect mogen beînvloeden door beperkingen te stellen op het recht op bezit van et. gendom (zie Oyama v. California, 332 U.S. 633, $646(1948)$ ), of door buitenlanders geen invaliditeits pensioen toe te kennen (zie Graham v. Richardson, 403 U.S. 365, 378/379 (1971)). Ook oordelde the in Takahashi v. Fish \& Game Commission, 334 U.S. 410, 420 (1948) dat uit het feit dat de federale overheid de bevoegdheid heeft om buitenlanders anders te behandelen dan Amerikaanse staatsburgers niet kan worden afgeleid dat ook de staten dit binnen het kader van hun statelijke bevoegdheden mogeth doen. Een dergelijke bevoegdheidsuitoefening, zo wordt geïmpliceerd, betekent dat zij op ontoelastbs re wijze een federale bevoegdheid uitoefenen. Overigens is het de staten niet altijd verboden om beleid te voeren dat effecten heeft voor het federale immigratiebeleid; de rechtspraak daarover is uitgebrid 
Doelstellingen gebaseerd op vooroordelen, haat of stereotypen zijn nooit gerechtvaardigd

In zijn rechtspraak heeft het Supreme Court verder aangegeven dat een classificatie nooit tot doel mag hebben leden van kwetsbare groep nadelig te behandelen, enkel en alleen vanwege hun lidmaatschap van deze groep. Een voorbeeld hiervan is te vinden in het arrest Gomez v. Perez ${ }^{34}$, dat betrekking had op een benadeling van onwettige kinderen. Het Supreme Court stelde daarover, dat:

“[...] there is no constitutionally sufficient justification for denying [...] an essential right to a child simply because its natural father has not married its mother."

Hetzelfde criterium komt ook tot uitdrukking in de rational basis-jurisprudentie. Zo oordeelde het Supreme Court over een belastingregeling die een voordeel opleverde voor in Alabama gevestigde bedrijven het volgende:

"Alabama's aim to promote domestic industry is purely and completely discriminatory, designed only to favor domestic industry within the State [...]. Alabama's purpose [...] constitutes the very sort of parochial discrimination that the Equal Protection Clause was intended to prevent." ${ }^{\text {"3is }}$

Het aantal gevallen waarin het Supreme Court zonder meer oordeelt dat de doelstelling om een bepaalde groep te benadelen ongerechtvaardigd is, is echter maar klein. Dit is ook logisch, omdat iedere classificatie (impliciet) tot doel zal hebben een bepaalde groep te benadelen. ${ }^{37}$ Problematisch is dit alleen wanneer de benadeling is ingegeven door vooroordelen, afkeer of haat jegens een bepaalde groep, of wanneer de benadeling een stigmatisering of benadrukking van inferioriteit tot gevolg heeft. ${ }^{318}$ Het Supreme Court heeft dit in verschillende arresten uitdrukkelijk erkend. Zo was in het arrest U.S.

en complex. Zo wordt er geen aandacht besteed aan het bevoegdheidsprobleem wanneer buitenlanders worden uitgesloten van openbare functies, de zogenaamde "public function exception", hoewel ook daarbij sprake kan zijn van invloed op het immigratiebeleid (zie Sugarman v. Dougall, 413 U.S. 634 (1973); zie verder Nyquist v. Mauclet, 432 U.S. 1 (1977), Ambach v. Norwick, 441 U.S. 68 (1979), Foley v. Connelie, 435 U.S. 291 (1978), Cabell v. Chavez-Salido, 454 U.S. 432 (1982) en Bernal v. Fainter, 467 U.S. 216 (1984)). Zie voor deze en enkele andere uitzonderingen op het verbod op statelijke regelgeving die de immigratie raakt Manheim 1995, p. 988 e.v.

334. 409 U.S. 535 (1973)

335. 409 U.S., op 538

336. Metropolitan Life Ins. Co. v. Ward, 470 U.S. 869, 878 (1985). Dit oordeel is overigens uitzonderlijk voor een rational basis-test; de zaak wordt in de VS zelf ook wel beschouwd als een (niet geheel verklaarbaar) voorbeeld van toepassing van de rational basis "with bite"-test. Zie in soortgelijke zin de rechtspraak over de zogenaamde "closed class"-regelingen. Daarin wordt de reikwijdte van een bepaalde regeling niet bepaald aan de hand van relevante persoonskenmerken, maar op basis van een willekeurige lijn, zoals een datumgrens; in dat opzicht is er altijd sprake van een classificatie om het classificeren. Hoewel het Supreme Court dit tegenwoordig toelaatbaar acht, heeft het in eerdere arresten gesteld dat juist het ontbreken van een andere doelstelling dan het classificeren ongerechtvaardigd is. Zie bijvoorbeeld Mayflower Farms, Inc. v. Ten Eyck, 297 U.S. 266, 274 (1936), impliciet overruled

337. Vgl. "Developments" 1969, p. 1081 en Farrell 1992, p. 44. Deze benadeling zal niet altijd expliciet
beoogd beoogd zijn, omdat het vaak niet zozeer de bedoeling is om een bepaalde groep te benadelen als wel om een groep te bevoordelen. Een dergelijke bevoordeling impliceert een bedoeling op om de andere groep nict te bevoordelen, d.w.z. te benadelen. p. 45 en Jackson 1997 , p. $493 / 494$. 
Department of Agriculture v. Moreno ${ }^{339}$ het al eerder genoemde Food Stamp Program in het geding. Ditmaal richtte de klacht zich tot de wijze waarop het begrip "huishou. den" in de betrokken wet was geregeld: huishoudens waarin niet-familieleden waren opgenomen kwamen volgens een amendement op de wet niet in aanmerking voor het programma. Het Supreme Court oordeelde met betrekking tot de bewering dat hierdoor een gerechtvaardigd doel werd nagestreefd als volgt:

"The legislative history $[\ldots]$ indicates that that amendment was intended to prevent so-called 'hippies' and 'hippie communes' from participating in the food stamp program. The challenged classification clearly cannot be sustained by reference to this congressional purpose. For if the constitutional conception of 'equal protection of the laws' means anything, it must mean that a bare congressional desire to harm a politically unpopular group cannot constitute a legitimate governmental interest." ${ }^{.340}$

In deze zaak speelden afkeer en antipathie jegens een politiek minder populaire groep een doorslaggevende rol bij de vaststelling van de classificatie, een motivatie die het Supreme Court duidelijk niet toelaatbaar achtte. ${ }^{3+1}$ Een vergelijkbare oordeel heeft het Supreme Court geveld over doelstellingen die een uitdrukking vormen van stereotypen en verouderde noties over de rol van bepaalde groepen in de samenleving ${ }^{3,2}$ In Califa. no $v$. Goldfarb, ${ }^{3+3}$ waarin een federale regeling voor pensioenen in het geding waarin onderscheid werd gemaakt tussen weduwnaars en weduwen, stelde het Supreme Court het volgende:

"[...] the gender-based differentiation created by [the statute] [...] is forbidden by the Constitution, at least when supported by no more substantial justification than 'archaic and overbroad' generalizations, $[\ldots]$ or 'old notions', $[\ldots]$ such as 'assumptions as to depen-

339. 413 U.S. 529 (1973)

340. 413 U.S., op 534. Zie in vergelijkbare zin Yick Wo v. Hopkins, 118 U.S. 356, 374 (1886) ("No resson for [the discrimination] [...] is shown, and the conclusion cannot be resisted that no reason for it exist except hostility to the race and nationality to which the petitioners belong, and which, in the eye of the law, is not justified"), Toyosaburo Korematsu v. United States, 323 U.S. 214, 216 (1944) ("Pressint public necessity may sometimes justify the existence of [...] restrictions; racial antagonism never can"), Kotch v. Board of River Port Pilots, 330 U.S. 552, 556 (1947) ("[A discrimination] might offend that constitutional safeguard [het Veertiende Amendement, JHG] if it rested on grounds wholly irrte vant to achievement of the regulation's objectives. An example would be a law applied to deny apteson a right to earn a living or hold any job because of hostility to his particular race, religion, belicf, of because of any other reason having no rational relationship to the regulated activities"), Loving v. Fir ginia, 388 U.S. 1, 11 (1967), Shapiro v. Thompson, 394 U.S. 618, $631 / 632$ (1969), Weinberger v. Salf h, 422 U.S. 749, 772 (1975), United Jewish Organization of Williamsburg v. Carey, 430 U.S. 144, 165 (1977), City of Cleburne v. Cleburne Living Center, 473 U.S. 432, 448 (1985) ("mere negative atiti des, or fear, unsubstantiated by factors which are properly cognizable [...], are not permissible base for treating a home for the mentally retarded differently from apartment houses, multiple dwellings and the like") en Romer v. Evans, 517 U.S. 620.634 (1996). Van belang is dat deze toetsing ook voorkomt in zaken waarin formeel een rational basis-test wordt toegepast, zoals in het geciteerde arres Moreno. Juist het feit dat er zeer streng wordt geoordeeld over de gerechtvaardigdheid van het doc zorgt ervoor dat commentatoren over deze arresten spreken als toepassingen van de rational besi "with bite"-test (bijv. Bhagwat 1997, p. 327).

341. Vgl. Bhagwat 1997, p. 330 en Tussman/TenBroek 1949, p. 358.

342. Vgl. Meyers 1986, p. 1196.

343. 430 U.S. 199 (1977) 
dency, $[\ldots]$ that are more consistent with 'the role-typing society has long imposed,' [...] than with contemporary reality."

Hetzelfde geldt voor het geval waarin onderscheid is gebaseerd op vooroordelen jegens een bepaalde groep. Dit blijkt bijvoorbeeld uit het arrest Palmore $v$. Sidoti ${ }^{34}$, dat betrekking had op de toewijzing van een kind aan een van haar gescheiden ouders. De rechter wees het kind aan de moeder toe omdat deze, anders dan de vader, een blanke huidskleur had. Op die manier wilde hij het kind beschermen tegen in de Amerikaanse samenleving bestaande vooroordelen jegens Afro-Amerikanen. Het Supreme Court stelde hierover, dat

"[t]he Constitution cannot control such prejudices but neither can it tolerate them. Private biases may be outside the reach of the law, but the law cannot, directly or indirectly, give them effect. [...] The effects of racial prejudice, however real, cannot justify a racial classification $[\ldots]]^{1346}$

Dit betekent dat op zichzelf genomen sympathieke doelstellingen toch ontoelaatbaar zullen zijn, zodra zij rechtstreeks voortvloeien uit het bestaan van vooroordelen. In dergelijke gevallen kan wel de vraag worden gesteld of een onderscheid uitsluitend vanwege het bestaan van een ongerechtvaardigd doel onconstitutioneel mag worden verklaard. Zoals in hoofdstuk 2 al is aangegeven kan het soms zo zijn dat een dergelijk onderscheid wel maatschappelijk wenselijke effecten oplevert, waarin een toereikende rechtvaardiging zou kunnen worden gevonden. ${ }^{347}$ Gesteld zou dan ook kunnen worden dat de rechter in gevallen als Palmore $v$. Sidoti niet mag volstaan met het geven van een oordeel over het nagestreefde doel, maar ook uitdrukkelijk aandacht moet besteden aan eventuele gunstige gevolgen van de regeling.

\section{Algemene vereisten bij de intermediate scrutiny en strict scrutiny-test}

Bij de intermediate scrutiny- en de strict scrutiny-test heeft het Supreme Court nog een aantal verdergaande vereisten voor toelaatbaarheid van onderscheid ontwikkeld. Allereerst wordt vereist dat de doelstelling een voldoende feitelijke onderbouwing heeft.

344. 430 U.S., op 199; vgl. ook Weinberger v. Wiesenfeld, 420 U.S. 636, 645 en 651/652 (1975) (impliciet), Mississippi University of Women v. Hogan, 458 U.S. 718, 725 (1982) ("Care must be taken in ascertaining whether the statutory objective itself reflects archaic and stereotypic notions. Thus, if the statutory objective is to exclude or "protect" members of one gender because they are presumed to suffer from an inherent handicap or to be innately inferior, the objective itself is illegitimate"), Heckler v. Mathews, 465 U.S. 728, 744 (1984), J.E.B. v. Alabama, 511 U.S. 127, 138 (1994) en United States v. Virginia, 518 U.S. 515, 533 (1996). Het Supreme Court heeft dit ook gesteld voor onderscheid op grond van wettige geboorte, zie bijv. Caban v. Mohammed, 441 U.S. 380, 394 (1979), en onderscheid op grond van ras, zie bijv. Metro Broadcasting v. FCC, 497 U.S. 547, 579 (1990). Het Supreme Court accepteert overigens niet altijd zo snel dat een ongelijke behandeling feitelijk is ingegeven door stereotiepe opvattingen, zelfs wanneer dit uit de feiten van het voorgelegde geval duidelijk kan worden afgeleid. De reden daarvoor kan soms vrijwel alleen worden gevonden in het feit dat de opinie is geschreven door de conservatieve meerderheid, die in het algemeen meer nuimte wenst te laten voor de wetgever en zelfs bij intermediate scrutiny vaak een terughoudende opstelling kiest. Zie bijv. Tuan Anh Nguyen v. INS, 533 U.S. 53 (2001), en de, terecht, zeer scherpe kritiek daarop van de vier dissenters, onder leiding van Justice O'Connor.

345. 466 U.S. 429 (1984)

346. 466 U.S., op 433

347. Zie hoofdstuk 2, paragraaf 3.1.3. 
Deze eis is vooral gesteld in gevallen waarin een onderscheid op grond van geslacht wordt gerechtvaardigd met een beroep op maatschappelijke of biologische verschillen tussen mannen en vrouwen. Zo stelde de regering van Missouri in Wengler v. Druge gists $^{3+8}$ ter rechtvaardiging van een voor weduwen voordelige regeling dat vrouwen in de praktijk meestal afhankelijk zijn van mannelijke kostwinners. Het Supreme Cour oordeelde dat voor deze stelling een voldoende feitelijke basis ontbrak:

"It may be that there is empirical support for the proposition that men are more likely to be the principal supporters of their spouses and families, but the bare assertion of this argument falls far short of justifying gender-based discrimination [...]."

Wanneer onderscheid wordt gemaakt om een bepaald probleem op te lossen moet dus voldoende aannemelijk worden gemaakt dat het probleem daadwerkelijk bestaat." In dit verband is ook van belang dat het Supreme Court alleen doelstellingen accepteent die de totstandkoming van een maatregel daadwerkelijk hebben gemotiveerd; rationaliseringen die achteraf worden bedacht zal het vrijwel nooit aanvaarden, net zomin als een beroep op een algemene en vage formule, zoals de stelling dat een regeling bedold is om maatschappelijke ongelijkheid te bestrijden. ${ }^{351}$

Ook verder heeft het Supreme Court in het kader van de strict scrutiny- en de intermediate scrutiny-test enkele algemene eisen gesteld waaraan een doelstelling moet voldoen om gerechtvaardigd te kunnen worden geacht. Zo moet het doel voldoende specifiek $^{32}$ en substantieel ${ }^{33}$ zijn en mag het niet hypothetisch zijn. ${ }^{34}$ Dergelijke eisen lijken bij een verhoogde toetsingsintensiteit volstrekt redelijk te zijn.

348. 446 U.S. $142(1980)$

349. 446 U.S., op 151/152. Zie ook Memorial Hospital v. Maricopa County, 415 U.S. 250, 265 (1974), Bernal v. Fainter, 467 U.S. 216, 227 (1984) en Miller v. Johnson, 515 U.S. 900, 922 (1995); opmetko lijk genoeg is het bestaan van een feitelijke basis ook aan de orde gekomen bij een bijzonder tervglovedende toepassing van de rational basis-test (Heller v. Doe, 509 U.S. 312, 322 (1993); zie echter ook op 326). Deze eis wordt vooral gesteld in de context van voorkeursbehandeling, waarbij ter rechtvardiging vaak wordt gesteld dat het voorkeursbeleid nodig is om ongelijkheden op te lossen die ontstan zijn door achterstelling in het verleden. Het enkele bestaan van maatschappelijke ongelijkheid worth niet gezien als een voldoende basis: voor het aanvaarden van deze doelstelling als gerechtvaarfige moet daadwerkelijk worden aangetoond dat er sprake is van een ongelijkheid (bij voorkeur door middel van statistische gegevens) en dat deze ongelijkheid het gevolg is van discriminatie door de verat. woordelijke organisatie in het verleden, waarbij het Supreme Court het liefste ziet dat de geschiedenit van achterstelling door een rechterlijke instelling formeel is erkend (zie City of Richmond v. JA. Cro son, 488 U.S. 469, $501-504$ (1989)).

350. Het vereiste verschilt dus van het geschiktheidsvereiste: ook daarbij wordt verlangd dat het onderscheid voldoende basis vindt in de feiten, maar dan gaat het niet om het bestaan van een concretp pobleem, maar om de vraag of de classificatie een goed middel is om dit probleem aan te pakken. Toegs geven moet echter worden dat beide vereisten in de praktijk nogal eens overlap vertonen; zie bij. Frontiero v. Richardson, 411 U.S. 677,689 (1973).

351. Deze criteria zijn reeds besproken bij de wijze waarop het Supreme Court het nagestreefde doel vas: stelt; de vaststelling en inhoudelijke toetsing lopen in de rechtspraak van het Supreme Court af en toe in elkaar over.

352. Dit is a contrario af te leiden uit Wygant v. Jackson Board of Education, 476 U.S. 267 (1986), warith het Supreme Court stelde dat er sprake was van een doelstelling die "too amorphous" was als basis voor onderscheid (op 276). Vgl. ook Shaw v. Hunt, 517 U.S. 899, 909 (1996), waarin het Supresst Court stelde dat het opheffen van onderscheid op grond van ras door middel van het gebruik van ras ai onderscheidingscriterium alleen toelaatbaar is wanneer de historische discriminatie "with some speth fity" kan worden vastgesteld. Zie verder Metro Broadcasting v. FCC, 497 U.S. 547, 612 (1990) 
Specifieke vereisten: administratieve overwegingen en openbare financiën

Veel classificaties, met name op het gebied van de sociale zekerheid, hebben mede of uitsluitend tot doel om administratieve procedures te vergemakkelijken. ${ }^{355}$ Het Supreme Court heeft dit soort doelstellingen consequent als gerechtvaardigd aangemerkt. Deze soepele opstelling komt bijvoorbeeld tot uitdrukking in het arrest Weinberger $v$. Salfi. ${ }^{336}$ Deze zaak had betrekking op een federale sociale zekerheidsregeling op grond waarvan weduwen een uitkering ontvingen bij overlijden van hun echtgenoot. Een voorwaarde om in aanmerking te komen voor deze uitkering was echter dat het huwelijk tenminste negen maanden voor het overlijden van de man was gesloten, dit om te voorkomen dat vrouwen met terminaal zieke mannen zouden trouwen om te kunnen profiteren van de uitkering. Eiseres vond deze voorwaarde onredelijk en stelde dat het gemakkelijk genoeg zou zijn om fraude in voorkomende gevallen vast te stellen. Volgens de federale overheid zou dat echter administratief te ingewikkeld zijn. Het Supreme Court oordeelde als volgt:

"[...] The administrative difficulties of individual eligibility determinations are without doubt matters which Congress may consider when determining whether to rely on rules which sweep more broadly than the evils with which they seek to deal. [...] The Constitution does not preclude such policy choices as a price for conducting programs for the distribution of social insurance benefits." 357

Hoewel het Supreme Court deze doelstelling als gerechtvaardigd beschouwt, zal het een onderscheid dat uitsluitend dit doel nastreeft vrijwel nooit constitutioneel achten: in de meeste gevallen concludeert het dat volstaan had kunnen worden met minder vergaande middelen of dat er geen sprake is van proportionaliteit. ${ }^{338}$

O'Connor, dissenting): "An interest capable of justifying race-conscious measures must be sufficiently specific and verifiable, such that it supports only limited and carefully defined uses of racial classifications".

353. Dit vereiste komt in de rechtspraak bijzonder vaak voor (zie voor één voorbeeld uit vele In Re Griffiths, 413 U.S. 717, 722 (1973)). Helaas voegt het inhoudelijk weinig toe, omdat het net als de vereisten "compelling interest" of "important interest" in de rechtspraak niet nader is uitgewerkt en vooral wordt gebruikt als een retorische formule. Waarschijnlijk wordt hiermee eveneens geduid op het gewicht van het nagestreefde doel en wordt op die manier een proportionaliteitsaspect in de doeltoetsing geïntroduceerd.

354. United States v. Virginia, 518 U.S. 515, 533 (1996); idem in Miller v. Albright, 523 U.S. 420, 482 (1998) (J. Breyer, dissenting)

355. Het gaat daarbij om doelstellingen als geldbesparing, het voorkomen van de noodzaak ieder individueel geval apart te bekijken, het voorkomen van overmatig procederen, het voorkomen van fraude en de toepassing van regels op uniforme en consistente wijze; zie Abramson 1984, p. 2.

356. 422 U.S. 749 (1975)

357. 422 U.S., op 784. Zie verder Carrington v. Rash, 380 U.S. 89, 96 (1965), Shapiro v. Thompson, 394 U.S. 618 (1969), Reed v. Reed, 404 U.S. 71, 76 (1971), Frontiero v. Richardson, 411 U.S. 677 (1973), Memorial Hospital v. Maricopa County, 415 U.S. 250, 267 (1974), Hampton v. Mow Sun Wong, 426 U.S. 88, 114 (1976), Mathews v. Lucas, 427 U.S. 495, 509 (1976), Wengler v. Druggists Mutual Insurance, 446 U.S. 142, 152 (1980), Rostker v. Goldberg, 453 U.S. 57, 81 (1981) en, meer impliciet, Tuan Anh Nguyen v. INS, 533 U.S. 53 (2001)

358. Zie Frontiero v, Richardson, 411 U.S. 677 (1973), een zeldzaam geval waarin strict scrutiny werd toegepast op onderscheid op grond van geslacht: "[...] [O]ur prior decisions make clear that, although efficacious administration of govemmental programs is not without some importance, 'the Constitution recognizes higher values than speed and efficiency'. And when we enter the realm of 'strict judicial scrutiny', there can be no doubt that 'administrative convenience' is not a shibboleth, the mere recitati- 
Ook de bescherming van de openbare financiën is door het Supreme Court consequent als gerechtvaardigd doel aangemerkt. ${ }^{35 y}$ Zo stelde het Supreme Court in Shapiro v. Thompson $^{360}$, dat betrekking had op de beperking van bijstandsuitkeringen tot rechthebbenden die langer dan een jaar in de betrokken staat woonden, het volgende:

"We recognize that a State has a valid interest in preserving the fiscal integrity of its programs. It may legitimately attempt to limit its expenditures, whether for public assistance, public education, or any other program."”3.1

Maar, zo voegde het Supreme Court hieraan toe,

"The saving of welfare costs cannot justify an otherwise invidious classification."

Ook voor deze doelstelling geldt dus dat deze in beginsel gerechtvaardigd is, maar dat het Supreme Court bijzondere aandacht zal besteden aan de toetsing van de verhouding tussen deze doelstelling en het aangetaste recht of belang. ${ }^{36}$ Dit betekent dat onderscheid dat uitsluitend een financiële doelstelling nastreeft meestal in strijd zal zijn met de Equal Protection Clause.

\subsection{Toetsing van de verhouding tussen doel en middel}

\subsubsection{Inleiding}

In paragraaf 2.1 is al gebleken dat alle tests die door het Supreme Court worden toege. past een toetsing inhouden van de verhouding tussen het doel van de regeling en de ter bereiking daarvan gekozen classificatie. Het Supreme Court lijkt binnen deze tests niet

on of which dictated constitutionality. On the contrary, any statutory scheme which draws a sharp lins between the sexes, solely for the purpose of achieving administrative convenience, $[\ldots]$ involves te 'very kind of arbitrary legislative choice forbidden by the Constitution..."' (op 690). Zie ook Tuan hit Nguyen v. INS, 533 U.S. 53 (2001) (J. O'Connor, dissenting). Vgl. verder Abramson 1984, p. 3 en IL.

359. Vgl. Abramson 1984, p. 15.

360. 394 U.S. 618 (1969)

361. 394 U.S., op 633. Zie ook Graham v. Richardson, 403 U.S. 365, $374 / 375$ (1971), Geduldig v. Aialla, 417 U.S. 484 (1974), Plyler v. Doe, 457 U.S. 202, 227 (1982), Lyng v. Castillo, 477 U.S. 635, 642 (1986) en Lyng v. International Union, 485 U.S. 360, 373 (1988). Deze doelstelling wordt overigets ook op andere gebieden dan de sociale zekerheid geaccepteerd: zie bijv. Ortwein v. Schwab, 410 US 656, 660 (1973), waarin het Supreme Court stelde dat het vereisen van griffiegeld redelijk is on de kosten van de gerechtelijke procedures voor de staat te drukken.

362. Idem. Zie ook Memorial Hospital v. Maricopa County, 415 U.S. 250, 263 (1974) en Plyler v. Doe, 45? U.S. 202, 227 (1982). Heel duidelijk blijkt dit verder uit Graham v. Richardson, 403 U.S. 365, 375 (1971), waarin het Supreme Court stelde dat het belang bij de bescherming van de openbare financith geen "compelling interest" kon opleveren, hoewel het in beginsel wel ging om een gerechtvaardigl streven. Zie ook Manheim 1995, p. 1006.

363. Zie ook Abramson 1984, p. 16, die aangeeft dat hierbij, net als bij rechtvaardiging op basis van administratieve overwegingen, de keuze voor een bepaalde test meestal bepalend is: bij een rational basir test heeft dit verweer aanzienlijk meer kans van slagen dan bij toepassing van een strict scruting of intermediate scrutiny-test. Dit blijkt ook uit een vereiste dat geldt bij toepassing van de strict schuirip test, inhoudend dat de staat daadwerkelijk zal moeten aantonen dat door het maken van onderschei een financieel voordeel wordt bereikt; zie Frontiero v. Richardson, 411 U.S. 677, 689 (1973) en Mo thews v. Lucas, 427 U.S. 495,510 (1976), waarin het Supreme Court stelde dat de regering bij strict scrutiny moet aantonen dat "the Government's dollar 'lost' to overincluded benefit recipients is to tumed by a dollar 'saved' in administrative expenses avoided." 
expliciet te onderscheiden tussen de toetsingscriteria die in hoofdstuk 2 zijn besproken (mate van fit, geschiktheid, subsidiariteit en proportionaliteit in strikte zin), maar gaat meer in het algemeen na of er sprake is van een "rational relationship" of een "substantial relationship", of van een classificatie die "narrowly tailored" of "necessary" is. Uit een analyse van de rechtspraak blijkt echter dat het Supreme Court bij het toepassen van deze formules wel degelijk gebruik maakt van de criteria die in het theoretische deel zijn genoemd. Dit gebeurt echter niet op een gestructureerde en zuivere manier, in die zin dat zorgvuldig aan alle vier de criteria wordt getoetst. In de meeste gevallen wordt alleen van dat criterium gebruik gemaakt dat het beste past in de motivering en dat goed aansluit bij de door het Supreme Court beoogde uitkomst. Ondanks deze slordige toetsing zijn er in de jurisprudentie van het Supreme Court interessante aanwijzingen te vinden over de wijze waarop in de praktijk met deze criteria kan worden omgegaan. Hierop zal in deze paragraaf worden ingegaan.

\subsubsection{Toetsing van de mate van fit}

\section{Toetsing bij de rational basis-test}

De toetsing van de mate van fit tussen de doelstelling en de wijze waarop de classificatie is gedefinieerd vormt een belangrijk element in de toetsing door het Supreme Court en komt in alle onderscheiden tests terug. Naar gelang de toepasselijke test zijn er echter verschillen zichtbaar in de wijze waarop met het vereiste wordt omgegaan. ${ }^{364} \mathrm{Zo}$ heeft het Supreme Court bij de rational basis-test consequent aangegeven geen hoge eisen aan de mate van fit te stellen. Heel duidelijk blijkt dit uit het al eerder besproken arrest Lindsley v. Natural Carbonic Gas ${ }^{365}$, waarin het Supreme Court voor het eerst duidelijk inhoud gaf aan de rational basis-test. Eén van de criteria die het in dit arrest ontwikkelde luidt als volgt:

"A classification having some unreasonable basis does not offend against that clause [the Equal Protection Clause, JHG] because it is not made with mathematical nicety, or because in practice it results in some unequality."366

In latere rechtspraak heeft het Supreme Court nader uitgelegd wat het met deze uitspraak precies bedoelde. ${ }^{367}$ Een belangrijke verduidelijking wordt geboden door het

364. Vgl. Kelso 1994, p. 1279.

365. 220 U.S. 61 (1911)

366. 220 U.S., op 78. Zie ook Missouri v. May, 194 U.S. 267, 270 (1904), waarin het Supreme Court een andere beroemde formule neerlegde: "Some play must be allowed for the joints of the machine [...]." Idem in Bain Peamut Co. of Texas v. Pinson, 282 U.S. 499, 501 (1931). Zie kritisch over deze formule "Note" 1978, p. 788.

367. Daarbij is het opmerkelijk dat meestal geklaagd wordt over underinclusiveness: vrijwel steeds stellen eisers dat zij ten onrechte niet onder een voordelige regeling of uitzondering vallen. Een voorbeeld waarin overinclusiveness een rol speelde is Mathews v. Lucas, 427 U.S. 495 (1976). In dit arrest was sprake van een generalisering die het gemak van de administratie diende, maar tot gevolg had dat een bepaalde groep ten onrechte werd benadeeld. Het Supreme Court acht dit soort generaliseringen toelaatbaar "so long as the lack of precise equivalence does not exceed the bounds of substantiality tolerated by the applicable level of scrutiny" (op 509). Daaraan voegde het toe dat bij een toepassing van de rational basis-test de verhouding tussen definitie van de classificatie en het doel van de regeling niet "scientifically substantiated" hoeft te zijn (op 510). Ook hierbij geldt dus een terughoudende toetsing. Dit blijkt ook uit Foley v. Connelie, 435 U.S. 291 (1978) en uit Dandridge v. Williams, 397 U.S. 471 , 
arrest Railway Express Agency, Inc. v. New York. ${ }^{368}$ Dit arrest had betrekking op een regeling in New York die het eigenaars van vrachtwagens verbood om reclame voor andere bedrijven op hun vrachtwagens te plaatsen. Volgens het stadsbestuur was deze regeling gericht op de bescherming van de verkeersveiligheid: verkeersdeelnemer zouden door de reclames gemakkelijk kunnen worden afgeleid. De eisers stelden echter dat de regeling, gelet op deze doelstelling, in ernstige mate underinclusive was: niet alleen was het wel toegestaan om reclame van het eigen bedrijf op de vrachtwagens te voeren, maar ook werd er geen verbod gesteld op de grote advertenties op reclamezuj. len en muren. Volgens eisers zouden verkeersdeelnemers door dergelijke reclames net zo goed worden afgeleid. Het Supreme Court stelde het volgende:

"The local authorities may well have concluded that those who advertised their own wares on their trucks do not present the same traffic problem in view of the nature or extent of the advertising which they use. [...] We cannot say that that judgment is not an allowable one. [...] And the fact that New York City sees fit to eliminate from traffic this kind of distraction but does not touch what may be even greater ones in a different category, such as the vivid displays on Times Square, is immaterial. It is no requirement of equal protection that all evils of the same genus be eradicated or non at all." ${ }^{\text {369 }}$

Deze benadering is typisch voor een toepassing van de rational basis-test: de overheid heeft een grote vrijheid om de groep te definiëren die door de classificatie zal worden geraakt. ${ }^{370}$ Dat er in werkelijkheid nauwelijks enig verband bestaat tussen de definitie en het doel dat wordt nagestreefd is niet relevant: volgens het Supreme Court is het niet aan de rechter om de wijsheid van een wettelijke definitie te betwisten. Zoals uit het gegeven voorbeeld blijkt leidt dit ertoe dat de Equal Protection Clause nauwelijks nog bescherming biedt tegen onderscheid, zelfs niet wanneer dit onlogisch of willekeurig is. ${ }^{371}$ Het lijkt niet wenselijk om de rechterlijke terughoudendheid zo ver door te voeren: het gelijkheidsbeginsel verliest hierdoor iedere kracht.

484 (1970), waarin het Supreme Court stelde dat bij de rational basis-test "the concept of 'overts ching' has no place".

368. 336 U.S. 106 (1949)

369. 336 U.S., op 110. Dit oordeel stuitte overigens op felle kritiek van Justice Jackson, die in zijn conar. ring opinion stelde dat "nothing opens the door to arbitrary action so effectively as to allow those offcials to pick and choose only a few to whom they will apply legislation and thus to escape the politial retribution that might be visited upon them if larger numbers were affected" (op 111). Een goed voorbeeld van de benadering van het Supreme Court is ook Patsone v. Pennsylvania, 232 U.S. 138, 144 (1914). In het geding was een regeling waardoor aan buitenlanders werd verboden om wild te schicth. dit ter bescherming van de fauna in de staat. Nog los van het feit dat het gestelde doel hier waarschijplijk niet het werkelijke doel was (het lijkt eerder de bedoeling om buitenlanders te benadelen en hent: ontmoedigen in de staat te blijven), kan worden gesteld dat hierbij sprake was van een ontoclatbar: mate van misfit. Het Supreme Court stelde echter dat "The State "may direct its law against what it deems the evil as it actually exists without covering the whole field of possible abuses." Voorbeeldent van de terughoudende toetsing van de mate van fit zijn ook te vinden in Flemming $v$. Nestor, 363 US 603, 612 (1960), City of New Orleans v. Dukes, 427 U.S. 297, 303 (1976) ("rational distinctions min) be made with substantially less than mathematical exactitude"), Massachusetts Board of Retirement 8 Murgia, 427 U.S. 307,314 (1976), Lalli v. Lalli, 439 U.S. 259, 274 (1978), New York Ciry Transil Authority v. Beazer, 440 U.S. 568, 594 (1979), Vance v. Bradley, 440 U.S. 93, 108 (1979), Lyng v. in ternational Union, 485 U.S. 360, 372 (1988), Gregory v. Ashcroft, 501 U.S. 452, 473 (1991), Burtings ton v. Ford, 504 U.S. 648, 653 (1992) en FCC v. Beach Communications, 508 U.S. 307,316 (1993).

370. Vgl. ook Pettynga 1987, p. 783.

371. Of, zoals Tussman en TenBroek de benadering bij deze test tekenend omschrijven: " $[\ldots][$ T] he Court'. 
Interessant is wel een specifieke motivering die in sommige arresten over de rational basis-test is gegeven voor de keuze voor een terughoudende toetsing van de mate van fit. Het Supreme Court heeft deze redengeving uitgewerkt in het arrest Williamson $v$. Lee Optical Co. ${ }^{372}$, dat betrekking had op een verbod an opticiens om de sterkte van brillen te bepalen of de aard van de benodigde lenzen vast te stellen: dit soort handelingen mocht alleen door oogspecialisten en optometristen worden verricht. De verkopers van "ready-to-wear"-brillen waren echter van dit verbod uitgezonderd, waardoor er volgens eisers sprake was van underinclusiveness. Het Supreme Court stelde het volgende:

"Evils in the same field may be of different dimensions and proportions, requiring different remedies. Or so the legislature may think. Or the reform may take one step at a time, addressing itself to the phase of the problem which seems most acute to the legislative mind. The legislature may select one phase of one field and apply a remedy there, neglecting the others." "13

Inderdaad is het zo dat de wetgever, zeker op het terrein van sociale of economische wetgeving, vaak met gecompliceerde problemen te maken krijgt, waarbij het niet mogelijk of beleidsmatig gezien niet wenselijk is om alle facetten ineens te bestrijken. Het lijkt terecht dat het Supreme Court in deze gevallen voor een zekere mate van underinclusiveness ruimte laat: wanneer het in dergelijke gevallen een "perfect fit" zou vereisen, zou een te grote inbreuk worden gemaakt op de beleidsvrijheid van de regelgever. ${ }^{37}$ Het is in dit soort gevallen echter noodzakelijk dat steeds wordt nagegaan of er daadwerkelijk vervolgwetgeving is gepland: is dit niet het geval, dan kan een regelge-

use of the equal protection clause can only be described as an abandonment of it" (1949, p. 368). Er zijn overigens enkele arresten waarin het Supreme Court op een zorgvuldigere manier omgaat met de test of iets hogere eisen aan de mate van fit stelt; zie bijv. Morey v. Doud, 354 U.S. 457, 467 (1957), Weinberger v. Salfi, 422 U.S. 749, 777 (1975) en Rinaldi v. Yaeger, 384 U.S. 305, 310 (1966). Het gaat daarbij echter om uitzonderingen, waarbij de grotere aandacht voor de mate van fit deels worden verklaard doordat er een iets intensievere toetsing wordt uitgevoerd dan gebruikelijk. Verder zal er meestal zorgvuldiger naar de mate van fit worden gekeken wanneer er een rational basis "with bite".test wordt uitgevoerd; dit ligt ook voor de hand, omdat er in die gevallen over de hele linie sprake is van een iets intensievere toetsing. Zie impliciet bijv. Romer v. Evans, 517 U.S. 620, 635 (1996) en, meer expliciet, Eisenstadt v. Baird, 405 U.S. 438, 450/451 (1972), City of Cleburne v. Cleburne Living Center, 473 U.S. 432, 449 (1985), Hooper v. Bernalillo, 472 U.S. 612, 621 (1985) en Williams v. Vermont, 472 U.S. 14, 25/26(1985).

372. 348 U.S. 483 (1955)

373. 348 U.S., op 489. Idem in McDonald v. Board of Election Commissioners of Chicago, 394 U.S. 802, 809 (1969), Dandridge v. Williams, 397 U.S. 471, $486 / 487$ (1970) Geduldig v. Aiello, 417 U.S. 484, 495 (1974), City of New Orleans v. Dukes, 427 U.S. 297, 303 en 305 (1976), Minnesota v. Clover Leaf Creamery, 449 U.S. 456, 466 (1981) en Heller v. Doe, 509 U.S. 312, 321 (1993).

374. Vgl. "Developments" 1969, p. 1084/1085, waarin dit vereiste nader wordt toegelicht. Gesteld wordt daarbij dat van de wetgever niet verwacht kan worden dat hij met de oplossing van een facet van een bepaald probleem wacht tot hij voldoende (financièle) middelen heeft om ook de andere facetten aan te pakken. Ook kan het soms alleen politiek haalbaar zijn om op één punt regelgeving tot stand te brengen, zodat met de rest gewacht moet worden totdat er een andere meerderheid bestaat. Zie in vergelijkbare zin Tussman/TenBroek 1949, p. 349. Van belang is wel dat in deze gevallen een goede proportionaliteitstoets moet worden uitgevoerd. Het is altijd de vraag of de belangenaantasting die de gedeeltelijke aanpak van een probleem heeft opgeleverd niet ernstiger is dan het voordeel dat deze aanpak voor andere belangen heeft: de vrijheid van de staat om te experimenteren mag niet ten koste gaan van individuele rechten en belangen. In die zin ook Stone e.a. 1996, p. 569. 
ver zijn onzorgvuldige definitie niet op deze grond verdedigen. ${ }^{375}$ Een dergelijk onderzoek wordt door het Supreme Court echter vrijwel steeds achterwege gelaten, hetgeen er opnieuw wijst op het tandeloze karakter van de rational basis-test. ${ }^{376}$

\section{Toetsing bij de strict scrutiny-test}

Bij de strict scrutiny-test zijn de eisen die worden gesteld aan de mate van fit juist bij. zonder streng. Dit blijkt reeds uit de definitie van deze test, die vereist dat de classifi. catie "narrowly tailored" is. ${ }^{3 n}$ In de praktijk blijkt dat een maatregel bij toepassing van deze test inderdaad al snel onaanvaardbaar over- of underinclusive zal worden ge. acht. ${ }^{378}$ Een duidelijk voorbeeld hiervan is te vinden in het arrest Dunn v. Blumstein. ${ }^{\text {In }}$ In het geding in deze zaak was een regeling van de staat Tennessee die het recht om deel te nemen aan de statelijke verkiezingen alleen toekende aan mensen die langer dan een jaar in de staat resideerden. Eén van de redenen die ter rechtvaardiging van deze beperking waren aangevoerd luidde dat burgers pas na een jaar voldoende ingeburgerd konden worden geacht om hun stem op een intelligente manier te gebruiken. Het Supreme Court sprak hierover een vernietigend oordeel uit:

"[...][T]he durational residence requirements in this case founder because of their crudeness as a device for achieving the articulated state goal [...]. The classifications created by durational residence requirements obviously permit any longtime resident to vote regardless of his knowledge of the issues - and obviously many longtime residents do not have any. On the other hand, the classifications bar from the franchise many other, admittedly new, residents who have become at least minimally, and often fully, informed about the issues. [...] Given modern communications, and given the clear indication that campaign spending and voter education occur largely during the month before an election, the State cannot seriously maintain that it is 'necessary' to reside for a year in the State [...] in order to be knowledgeable about congressional, state, or even purely local elections." ${ }^{\text {ina }}$

375. Vgl. "Note" 1978, p. 790.

376. Het Supreme Court herhaalt de formule van Lee Optical vaak, maar geeft in geen van de voorbelden aan waarom er reden is om te veronderstellen dat er vervolgwetgeving tot stand zal worden gebratt waardoor de underinclusiveness zal worden opgeheven. Vgl. Tussman/TenBroek 1949, p. 348.

377. Zie bijv. Fullilove v. Klutznick, 448 U.S. 448,480 (1980). In de rechtspraak zijn ook andere formuls ringen van deze toets terug te vinden. Zo vereiste het Supreme Court in Sugarman v. Dougall, 413 US 634,643 (1973) dat "the means the State employs must be precisely drawn in light of the acknowlotged purpose."

378. Bovendien blijkt veel vaker een oordeel te worden uitgesproken over de overinclusiveness dan bij en toepassing van de rational basis-test. Het is niet waarschijnlijk dat daaraan een theoretische motivering ten grondslag ligt: eerder is het zo dat de eiser bij strict scrutiny meestal klaagt over het feit dat hij ton onrechte is opgenomen in een groep die wordt benadeeld, terwijl bij rational basis veelal wordt g5 klaagd over het feit dat de eiser niet tot een bevoordeelde groep behoort. Anders dan soms wordt ver ondersteld hoeft er bij overinclusiveness dus niet automatisch een strengere toetsing te worden uthos voerd omdat dit "ernstiger" zou zijn dan underinchusiveness (zie Tussman/TenBroek 1949, p. 352).

379. 405 U.S. 330 (1972)

380. 305 U.S., 358. Zie verder Kramer v. Union Free School District, 395 U.S. 621, 632 (1969), Palia Department of the City of Chicago v. Mosley, 408 U.S. 92, 102 (1972), Shapiro v. Thompson, 394 US 618, 631 (1969), Bullock v. Carter, 405 U.S. 134, 146 (1972), In re Griffiths, 413 U.S. 717, 727 (1973), Sugarman v. Dougall, 413 U.S. 634, 643 (1973), Memorial Hospital v. Maricopa Count), 415 U.S. 250, 264 (1974) en Bernal v. Fainter, 467 U.S. 216 (1984). Overigens wordt zelfs bij toepassing van de strict scrutiny-test niet altijd geconcludeerd tot het ontbreken van een voldoende mate valt fif zie bijv. Korematsu v. United States, 323 U.S. 214, 219 (1944) en Reynolds v. Sims, 377 U.S. 533,56 
Een dergelijk oordeel is typerend voor de strict scrutiny-test en zou bij een toepassing van de rational basis-test nooit zijn uitgesproken: zoals hiervoor is gebleken werden verschillende classificaties onder de rational basis-test zonder meer aanvaard, terwijl zij een minder zorgvuldige mate van fit lieten zien dan de regeling in Dunn v. Blumstein. Opmerkelijk daarbij is dat het verschil in benadering tussen de tests niet zozeer lijkt te zijn gelegen in de mate van zorgvuldigheid waarmee het Supreme Court de over- of underinclusiveness beoordeelt (ook in het bovenstaande citaat wordt immers eerder afgegaan op feiten van algemene bekendheid en gezond verstand dan op daadwerkelijk bewijsmateriaal), maar vooral in de bereidheid om het oordeel van de regelgever over de redelijkheid van de definitie te accepteren en in de mate van misfit waarmee genoegen wordt genomen.

\section{Toetsing bij de intermediate scrutiny-test}

Tenslotte speelt de toetsing van de mate van fit ook bij de intermediate scrutiny-test een belangrijke rol. Vooral bij onderscheid op grond van geslacht voert het Supreme Court een intensievere toetsing uit, omdat dit soort onderscheid vaak is gebaseerd op "overbroad generalizations", dat wil zeggen op stereotiepe opvattingen over de rol van mannen en vrouwen. ${ }^{331}$ Dit soort generaliseringen leidt al snel tot over- en underinclusiveness, zoals wordt geilllustreerd door het arrest Caban $v$. Mohammed. ${ }^{3 \times 2}$ Deze zaak had betrekking op een toestemmingsvereiste in een adoptieregeling ("Section 111"): in het geval van adoptie van een onwettig kind hoefde alleen de moeder - niet de natuurlijke vader - hiervoor toestemming te geven. Dit onderscheid was gebaseerd op de veronderstelling dat de band tussen moeder en kind hechter is dan die tussen het kind en zijn natuurlijke vader. Het Supreme Court stelde hierover het volgende:

"[...] [W]e believe that Section 111 is another example of 'overbroad generalizations' in gender-based classifications. [...] Section 111 both excludes some loving fathers from full participation in the decision whether their children will be adopted and, at the same time, enables some alienated mothers arbitrarily to cut off the paternal rights of fathers."

(1964). In dit laatste arrest stelde het Supreme Court zelfs voor de strict scrutiny-test dat "mathematical nicety is not a constitutional requisite", een formule die eerder past bij een rational basis-test. In latere zaken is van deze formule geen gebruik meer gemaakt, zodat de precedentiele waarde van het arrest gering kan worden geacht. Een iets soepelere toetsing is ook te vinden in de vroege rechtspraak over voorkeursbeleid van de federale overheid. Voorkeursbeleid is vrijwel altijd over-en underinclusive, in die zin dat het zelden alle achtergestelde groepen helpt, en tegelijkertijd ook mensen steunt die deze steun niet nodig hebben. Het Supreme Court heeft in Fullilove v. Klutznick, 448 U.S. 448, 485/486 (1980) gesteld dat een dergelijk gebrek in de mate van fit niet problematisch is; de toetsing van de mate van fit was echter wel heel zorgvuldig, waarmee deze afwijkt van de oppervlakkige beoordeling zoals die bij de rational basis-test plaatsvindt. Verder wordt in arresten over voorkeursbehandeling een soepele toetsing van de mate van fit vaak gecompenseerd met een strikte proportionaliteitstoets; zie paragraaf 2.4.5.

381. Zie hierover nader paragraaf 3 .

382. 441 U.S. 380 (1979)

383. 441 U.S., op 394. Voorbeelden zijn ook Orr v. Orr, 440 U.S. 268, 282/283 (1979), Califano v. Westcott, 443 U.S. 76, 88/89 (1979), Michael M. v. Superior Court of Sonoma County, 450 U.S. 464, 472 (1981) en Heckler v. Mathews, 465 U.S. 728, 750 (1984); in beide laatste arresten achtte het Supreme Court een voldoende mate van fit aanwezig, maar motiveerde het zijn oordeel zorgvuldiger dan bij een rational basis-test het geval zou zijn. 
Omdat een vrij groot aantal ongelijke behandelingen op grond van geslacht is gebs. seerd op stereotypen, vormt de toetsing van over- en/of underinclusiveness een belang. rijk onderdeel van de intermediate scrutimy-test. Deze toets wordt bovendien met grote zorgvuldigheid uitgevoerd. ${ }^{384}$ Dit betekent dat de intermediate scrutiny-test en de strict scrutiny-test wat betreft de toetsingsmethodiek sterk vergelijkbaar zijn; het verschil tussen de twee tests is vooral gelegen in het feit dat bij intermediate scrutiny een zekere mate van misfit door de vingers wordt gezien, terwijl daarvoor bij de strict scrutiny-test nauwelijks ruimte bestaat.

\subsubsection{Toetsing van de geschiktheid}

Ook het vereiste van geschiktheid is terug te vinden in de toepassing van alle door het Supreme Court onderscheiden tests, hoewel het niet vaak expliciet wordt genoemd. Opvallend is dat bij de rational basis-test relatief vaak aan dit vereiste wordt getoetst; de beoordeling van geschiktheid lijkt hierbij zelfs de kern te vormen van de toetsing van de redelijkheid van de verhouding tussen doel en classificatie. ${ }^{386}$ Het geschiktheidsvereiste zal echter weinig inhoudelijke betekenis hebben wanneer er een conceivable basis-test wordt uitgevoerd: daarbij bedenkt het Supreme Court immers zelf een rede.

384. Bovendien accepteert het Supreme Court minder snel het verweer dat de wetgever slechts én aspect van een probleem wilde aanpakken. Dit blijkt bijvoorbeeld uit Califano v. Westcott, 443 U.S. 76 (1979), waarin het Supreme Court stelde dat '[...] Congress may not legislate 'one step at a time' when that step is drawn along the line of gender, and the consequence is to exclude one group of fanilies altogether from badly needed subsistence benefits" (op 89).

385. Opmerkelijk is bovendien dat in de rechtspraak van het Supreme Court het oordeel over de mate vanfit en de geschiktheid regelmatig samenvallen. Dit komt vooral voor in het geval waarin een maatregd een grote mate van over of- underinclusiveness vertoont: aangezien in dit geval een grote groep voor het doel relevante gevallen door de classificatie niet wordt geraakt, is de kans klein dat de doelstelling door de classificatie zal worden bereikt (vgl. Stone e.a. 1996, p. 568 en 569). Bovendien wordt te overlap bevorderd door de specifieke redengeving die het Supreme Court in zijn rechtspraak heet ge geven voor het terughoudend toetsen van de mate van fit: de wetgever hoeft een probleem niet in then keer volledig te bestrijken. In veel rechtspraak heeft deze redengeving tot gevolg dat het Suprente Court genoegen neemt met onvolledige classificaties, die gemakkelijk een grote mate van underinch siveness kunnen vertonen. Het lijkt erop dat het Supreme Court hiermee soms ook bedoelt dat etn orderscheid niet volledig geschikt hoeft te zijn om een gesignaleerd probleem op te lossen. Zie bijvoofbeeld City of New Orleans v. Dukes, 427 U.S. 297, 303 (1976): "Legislatures may implement thit program step by step in such economic areas, adopting regulations that only partially ameliorate a per. ceived evil and deferring complete elimination of the evil to future regulations." De overlap tussen mate van fit en geschiktheid was in deze zaak groot. Het ging om een regeling waardoor alle stralk venters, behalve een kleine groep die al vanaf een bepaalde datum actief was, van het drijven van hat: del in het "Vieux Carré" van de stad werden uitgesloten, dit om het ouderwetse en gezellige kardtet van de stadswijk te beschermen. Niet alleen lijdt deze regeling aan underinclusiveness (gezien het doel van de regeling was het uitsluiten van straatventers op basis van een datumgrens niet erg relevant? maar ook aan ongeschiktheid: doordat niet alle straatventers buiten de wijk werden gehouden, kon hat doel slechts gedeeltelijk worden verwezenlijkt. Het weergegeven citaat lijkt op beide aspecten betrekking te hebben, hetgeen niet bevorderlijk is voor de duidelijkheid van de uitspraak.

386. Dit blijkt ook uit de wijze waarop deze test vaak wordt geformuleerd: een classificatie moet "rationaly related to furthering a legitimate state interest" zijn (Vance v. Bradley, 440 U.S. 93,97 (1979), cursiff toegevoegd), of mag niet "[...] wholly irrelevant to the achievement of [any legitimate govemments] objective" zijn (Harris v. McRae, 448 U.S. 297, 322 (1980), cursief toegevoegd). Een classificalic moet zijn doelstelling dus redelijkerwijze kunnen bereiken, een vereiste dat op een marginale causalteitstoets duidt. 
lijke doelstelling voor het onderscheid, waarbij het vanzelfsprekend steeds voor een doelstelling zal kiezen waarbij een voldoende causaal verband tussen doel en middel aanwezig is. ${ }^{367}$ Wanneer het Supreme Court een iets strengere toetsing uitvoert en vereist dat het onderscheid in een redelijke verhouding staat tot een "legitimate governmental purpose" is het geschiktheidsvereiste regelmatig terug te vinden. Ook dan blijkt het Supreme Court de aanwezigheid van een causaal verband echter terughoudend te toetsen, zoals tot uitdrukking komt in een formulering als de volgende:

"The question is whether Congress, its concern having been reasonably aroused by the possibility of an abuse which it legitimately desired to avoid, could rationally have concluded $[\ldots]$ that a particular limitation or qualification would protect against its occurrence [...].,"3ss

Bij de beantwoording van een dergelijke vraag gaat het Supreme Court vervolgens alleen na of de wetgever redelijkerwijze van het bestaan van een causaal verband kon uitgaan; het feit dat een dergelijk verband in de praktijk blijkt te ontbreken of geen steun vindt in wetenschappelijk of empirisch bewijsmateriaal is niet relevant. ${ }^{3 \times y}$ Heel duidelijk blijkt dit uit het arrest Minnesota $v$. Clover Leaf Creamery. ${ }^{390}$ Dit arrest had betrekking op een wet die, met het oog op milieubescherming en afvalvermindering, de verkoop van melk in plastic wegwerpflessen verbood. De verkoop van melk in kartonnen verpakkingen, evenmin recyclebaar of navulbaar, was wel toegestaan. De eisers betoogden aan de hand van wetenschappelijk bewijs dat de maatregel door deze uitzondering zijn doel niet kon bereiken en zelfs contraproductief zou werken. Het Supreme Court stelde echter dat dit bewijs niet relevant was in het kader van de toetsing aan de Equal Protection Clause:

\footnotetext{
"Where there was evidence before the legislature reasonably supporting the classification, litigants may not procure invalidation of the legislation merely by tendering evidence in court that the legislature was mistaken. [...] Whether in fact the Act will promote more environmentally desirable milk packaging is not the question: the Equal Protection Clause is satisfied by our conclusion that the Minnesota Legislature could rationally have decided that its ban on plastic nonreturnable milk jugs might foster greater use of environmentally desirable alternatives."
}

Het feit dat het theoretisch gezien denkbaar is dat een classificatie een zinvol middel is om een doel te bereiken is dus voldoende voor het aantonen van geschiktheid, ook al blijkt (achteraf) uit empirische en wetenschappelijke gegevens duidelijk iets anders. Deze benadering is in overeenstemming met de voor de rational basis-test kenmerkende terughoudendheid, maar het is de vraag of hierdoor altijd voldoende recht wordt gedaan aan de belangen van de benadeelde groep.

387. Vgl. Bennett 1979, p. 1059.

388. Weinberger $v$. Salfi, 422 U.S. 749,777 (1975). Zie voor een vergelijkbare terughoudendheid Vance v. Bradley, 440 U.S. 93, 101 (1979) (zie vooral ook de dissenting opinion van Justice Marshall, die betoogde dat er onvoldoende causaal verband bestond tussen de grond van onderscheid en het doel dat werd nagestreefd, op 121/122) en Harris v. McRae, 448 U.S. 297, 324 (1980).

389. $\mathrm{Vgl}$. Swierenga 1986 , p. 1460.

390. 449 U.S. 456 (1981)

391. 449 U.S., op $463 / 464$; cursief uit origineel. Vgl. ook reeds Powell v. Pennsylvania, 127 U.S. 678 (1888). 
Het Supreme Court lijkt ook niet geheel blind te zijn voor deze belangen. Zoals eerder is aangegeven heeft het zich in een aantal zaken bereid getoond om een intensievere rational basis-test uit te voeren - de rational basis "with bite"-test. Deze intensivering blijkt vooral de waarde van de geschiktheidstoets sterk te vergroten: in gevallen waarin de rational basis "with bite"-test wordt toegepast heeft het Supreme Court verschillende malen vastgesteld dat een toereikend causaal verband ontbrak. Een voorbeeld hiervan is te vinden in het arrest Eisenstadt v. Baird ${ }^{32}$, waarin geklaagd werd over ten statelijke wet die tot doel had om seksueel contact voor of buiten het huwelijk te voor. komen. Op grond van deze wet mochten middelen ter voorkoming van zwangerschap uitsluitend aan gehuwden ter beschikking worden gesteld. Wanneer de middelen alleen zouden worden gebruikt als preventie voor seksueel overdraagbare aandoeningen mochten zij echter ook aan ongehuwden worden verstrekt. Met het oog op deze uitzondering stelde het Supreme Court het volgende over de geschiktheid van de regeling om zijn doel te verwezenlijken:

"[...][1]t is abundantly clear that the effect of the ban on distribution of contraceptives to unmarried persons has at best a marginal relation to the proffered objective. [...] The rationality of this justification is dubious, particularly in the light of the admitted widespread availability to all persons [...], unmarried as well as married, of birth-control devices for the prevention of disease, as distinguished from the prevention of conception." ${ }^{39}$

Uit dit citaat, maar ook uit een groot aantal andere arresten waarin de geschiktheid inhoudelijk werd getoetst, blijkt dat het Supreme Court bij zijn beoordeling vooral gebruik maakt van gezond verstand en logisch redeneervermogen: het komt slechts zeer zelden voor dat in het kader van deze toetsing gebruik wordt gemaakt van wetenschappelijk bewijs. Hetzelfde geldt voor de rechtspraak over de strict scrutiny-en de intermediate scrutiny-test, waarin eveneens regelmatig een geschiktheidstoets is terug te vinden; nu de toetsing die daarbij wordt uitgevoerd nagenoeg identiek is aan die bij een toepassing van de rational basis "with bite"-test zal deze rechtspraak niet afzorderlijk worden besproken. ${ }^{34}$

\section{405 U.S. 438 (1972)}

393. 405 U.S., op 448/449. Van belang is overigens dat het Supreme Court uit het ontbreken van geschilt. heid tussen doel en het onderscheid concludeerde dat er een discrepantie moet bestaan tussen gestell en werkelijk doel. In dit geval leidde het ontbreken van geschiktheid dus niet tot de conclusie dat bet onderscheid ontoelaatbaar was, maar slechts tot een nader onderzoek naar andere mogelijke doelstellingen voor het onderscheid. Daaruit blijkt dat er in dit arrest niet gesproken kan worden van een rational basis-test, maar eerder van rational basis "with bite". Andere voorbeelden waarbij het Suprearit Court in het kader van een rational basis "with bite"-test inging op de geschiktheid zijn U.S. Department of Agriculture v. Moreno, 413 U.S. 528, 537 (1973) (".... in practical effect, the challenged dis sification simply does not operate so as rationally to further the prevention of fraud"), Lubin v. Panish 415 U.S. 709, 717 (1974), Zobel v. Williams, 457 U.S. 55, 63 (1982) (" [...] the State's interest is not it any way served by [the classification][...]"), Hooper v. Bernalillo, 472 U.S. 612,619 (1985) ("The lo gislature cannot plausibly encourage veterans to move into the State by passing such [...] legislation" en Plyler v. Doe, 457 U.S. 202, 228 (1982) (waarin de classificatie werd beschreven als en "luoficrously ineffectual attempt" om het doel te bereiken). Voor al deze gevallen geldt dat niet duidelijk w de uitspraak blijkt dat de ongeschiktheid met wetenschappelijk bewijsmateriaal is aangetoond; vetect is het zo dat het Supreme Court op basis van logica en eigen redeneervermogen tot de conclusie kwir dat een causaal verband ontbrak.

394. Zie voor een toepassing bij de strict scrutiny-test bijv. Bullock v. Carter, 405 U.S. 134, 145 (1972) (waarin het Supreme Court tot de conclusie kwam dat de maatregel geschikt was ter bereiking van the 


\subsubsection{Toetsing van noodzakelijkheid en subsidiariteit}

Het Supreme Court heeft zich verschillende malen uitgesproken over de plaats die het vereiste van subsidiariteit bij de toetsing aan de Equal Protection Clause zou moeten innemen. Bij de toepassing van de rational basis-test heeft het consequent aangenomen dat de gekozen classificatie niet het beste of minst belastende alternatief hoeft te zijn om het gestelde doel te verwezenlijken. ${ }^{395}$ Dit blijkt bijvoorbeeld uit het arrest San Antonio School District v. Rodriguez $z^{3 \%}$, dat betrekking had op een ingewikkeld financieringssysteem voor het lager onderwijs in Texas. Het Supreme Court stelde in dit arrest, dat

"[...] [T]he financing system [must] not fail because, as appellees suggest, other methods of satisfying the State's interest, which occasion 'less drastic' disparities in expenditures, might be conceived. Only where state action impinges on the exercise of fundamental constitutional rights or liberties must it be found to have chosen the least restrictive alternative, ${ }^{\text {,397 }}$

gestelde doel), Frontiero v. Richardson, 411 U.S. 677, 689 (1973) (hoewel daarbij kan worden betoogd dat de redenering van het Supreme Court betrekking heeft op de vraag of de doelstelling van de regeling een voldoende basis in de feiten vond) en Memorial Hospital v. Maricopa County, 415 U.S. 250, 268/269 (1974); heel duidelijk is ook Shaw v. Hunt, 517 U.S. 899, 915 (1996): "[...][W]e have always expected that the legislative action would substantially address, if not achieve, the avowed purpose" (waaraan overigens in een voetnoot werd toegevoegd dat het niet noodzakelijk was dat de doelstelling volledig verwezenlijkt zou worden: zie voetnoot 7). Bij de intermediate scrutiny-test komt de geschiktheidstoets zelden voor, meestal omdat de zaak daarbij gemakkelijker via de toetsing van de mate van fit kan worden afgedaan. Een voorbeeld waarin de geschiktheid wel nauwkeurig werd onderzocht (en waarin uitzonderlijk genoeg ook gebruik werd gemaakt van (wetenschappelijk) bewijs dat was aangevoerd door de procespartijen) is Metro Broadcasting v. FCC, 497 U.S. 547, 569 (1990); in deze zaak werd de intermediate scrutiny toegepast op een geval van voorkeursbeleid op grond van ras, een context die de grote zorgvuldigheid in de toetsing kan verklaren. Ook wanneer (impliciet of expliciet) een strict scrutiny-test wordt toegepast worden er hoge eisen gesteld aan het bestaan van een causaal verband; zie bijv. Justice Powell opinie in Regents of the University of California v. Bakke, 438 U.S. 265, 311 en 315 (1978). Een bijzondere toepassing is tenslotte te zien in Tuan Anh Nguyen v. INS, 533 U.S. 53 (2001). In dit arrest was formeel gezien sprake van een intermediate scrutiny-test, maar werd feitelijk van een zeer terughoudende toetsing uitgevoerd. Deze terughoudendheid kwam vooral tot uitdrukking in het feit dat de meerderheid de doelstellingen van het onderscheid zodanig koos dat er gemakkelijk een causaal verband kon worden aangetoond; de meerderheid had daardoor weinig woorden nodig om hierover een oordeel te geven. De dissenters, die een echte intermediate scrutiny-test uitvoerden, toetsten aan de hand van het werkelijk doel van de regeling en kwamen daarbij tot de conclusie dat een toereikend causaal verband ontbrak (zie J. O'Connor, dissenting). Zie over de toepassing bij de intermediate scrutiny-test verder Cathey 1983, p. 1511.

395. Vgl. Bastress 1974, p. 996.

396. 411 U.S. 1 (1973)

397. 411 U.S., op 51. Vgl. ook Massachusetts Board of Retirement v. Murgia, 427 U.S. 307, 315 (1976), Lalli v. Lalli, 439 U.S. 259, 274 (1978) (" [...] it is not the function of a court 'to hypothesize independently on the desirability or feasability of any possible [alternatives]' to the statutory scheme"), Vance v. Bradley, 440 U.S. 93, 109 (1970) ("Whether we [...] think Congress was unwise in not choosing a means more precisely related to its primary purpose is irrelevant") en Heller v. Doe, 509 U.S. 312, 330 (1993) ("We do not require Kentucky to have chosen the least restrictive means of achieving its legislative end. $[\ldots][W]$ e must disregard the existence of every alternative method of furthering the objective that we, as individuals, perhaps would have preferred"). Een uitzondering is Hampton v. Mow Sun Wong, 426 U.S. 88 (1976), waarin gesteld werd dat er een alternatief bestond dat gevolgd had moeten worden (op 114); het lijkt er echter op dat in deze zaak geen gewone rational basis-test, maar een striktere toetsing werd toegepast. Opmerkelijk is ook Gregory v. Ashcroft, 501 U.S. 452 (1991), waarin 
Bij een toepassing van de rational basis-test acht het Supreme Court een toetsing van subsidiariteit duidelijk niet wenselijk: hoewel het dit niet nader motiveert is het kenne. lijk van mening dat een dergelijke toets een te grote inbreuk op de beleidsvrijheid van de wetgever zou inhouden. ${ }^{39}$ Zoals uit het weergegeven citaat blijkt ziet het Supreme Court in andere omstandigheden echter wel ruimte voor een beoordeling van de subsj. diariteit. Dit is niet alleen het geval wanneer door het onderscheid fundamentele con. stitutionele rechten zijn aangetast, zoals het citaat suggereert, maar ook wanneer er sprake is van een classificatie op verdachte gronden, bij een toepassing van de interme. diate scrutiny-test en soms ook bij de rational basis "with bite"-test. In die gevallen maakt het Supreme Court impliciet onderscheid tussen een vereiste van noodzakelijk. heid en een vereiste van subsidiariteit. Een toetsing aan het noodzakelijkheidsvereiste houdt in dat meer in het algemeen wordt nagegaan of het doel niet ook had kunnen worden bereikt zonder het maken van onderscheid; de bestudering van het bestaan van alternatieven, zo typerend voor de subsidiariteitstoets, wordt dan achterwege gelaten." Het aantal voorbeelden waarin een toetsing aan dit vereiste wordt uitgevoerd is echter beperkt: in veruit de meeste gevallen onderzoekt het Supreme Court daadwerkelijk of er alternatieve, minder belastende oplossingen denkbaar waren geweest. ${ }^{400}$ Uit het amest Dunn v. Blumstein ${ }^{\text {tol }}$, dat betrekking had op een beperking van het kiesrecht, blijkt zelfs dat het een dergelijk onderzoek essentieel acht:

"In pursuing [an] [...] important interest, the State cannot choose means that unnecessarily burden or restrict constitutionally protected activity. [...] If there are other, reasonable ways to achieve those goals with a lesser burden [...], a State may not choose the way of greater interference. If it acts at all, it must choose less drastic means." ${ }^{\text {\$102 }}$

het Supreme Court in het kader van een echte rational basis-test verschillende alternatieven besprak th verwierp (op 472); in het licht van de eerdere rechtspraak is deze uitspraak onverklaarbaar.

398. Dit blijkt uit Weinberger v. Salfi, 422 U.S. 749 (1975), waarin het Supreme Court de suggestie vands lagere rechter om te kijken naar minder vergaande altematieven afwees, op grond van het bezwar dil "[t]his would represent a degree of judicial involvement in the legislative function which we have 6 . chewed except in the most unusual circumstances [...]"; zie in vergelijkbare zin Rostker v, Goldbers 453 U.S. 57,70 en $71 / 72$ (1981).

399. Vgl. Bastress 1974, p. 999 en Wormuth/Mirkin 1964, 257

400. Zie voor voorbeelden van de noodzakelijkheidstoets Toyosaburo Korematsu v. United States, 323 US 214 (1944) (impliciet; onderscheid op grond van nationaliteit) en In re Griffiths, 413 U.S. 717, 724 (1973) (onderscheid op grond van nationaliteit: "[...] the Committee simply has not established that th must exclude all aliens from the practice of law in order to vindicate its undoubted interest in high professional standards" - uit deze overweging blijkt overigens dat het noodzakelijkheidsvereiste dicht to gen het verbod van een te grote mate van overinclusiveness aanligt), Weber v. Aetna Casualy \& Surtit) Co., 406 U.S. 164, 175 (1972), Lubin v. Panish, 415 U.S. 709, 718 (1974) (aantasting kiesrectit), Co. ban v. Mohammed, 441 U.S. 380, 392 (1979), Mississippi University of Women v. Hogan, 458 US. 718,731 (1982) (onderscheid op grond van geslacht: "In sum, the record in this case is flatly inconsis? tent with the claim that excluding men from the School of Nursing is necessary to reach any of MUW? educational goals"), Clark v. Jeter, 486 U.S. 456, 465 (1988) (onderscheid op grond van wettige ge boorte), United States v. Virginia, 518 U.S. 515,541 (1996) (impliciet) en Tuan Anh Nguyen v. NS. 533 U.S. 53 (2001) (J. O'Connor, dissenting) (impliciet).

401. 405 U.S. 330 (1972)

402. 405 U.S., 344. Zie verder Hunter v. Erickson, 393 U.S. 385, 391 en voetnoot 7 (1969) (kiesredtil) Shapiro v. Thompson, 394 U.S. 618, 637 (1969) (recht op interstatelijk reizen), Bullock v. Carter, 405 U.S. 134, 146 (1972) (kiesrecht), Eisenstadt v. Baird, 405 U.S. 438, 452 (1972) (privacy), Memorid Hospital v. Maricopa County, 415 U.S. 250, 267 en 268 (1974) (recht op interstatelijk reizen), Amert- 
In veruit de meeste zaken waarin een intermediate scrutiny- of een strict scrutiny-test wordt toegepast en het Supreme Court toekomt aan een beoordeling van de verhouding tussen doel en onderscheid wordt dan ook een expliciet oordeel gegeven over de subsidiariteit. Daarbij is van belang dat het Supreme Court niet met ieder alternatief genoegen neemt: bekeken moet altijd worden of de doelstellingen van de regeling

"[...] cannot be served equally well in significantly less burdensome ways." "403

Het is dus niet voldoende dat er andere mogelijkheden bestaan: vereist is ook dat deze zeker zo geschikt zijn om het beoogde doel te bereiken. ${ }^{404}$ Door bovendien te vereisen dat het alternatief duidelijk minder belastend is, voorkomt het Supreme Court dat te gemakkelijk wordt ingegrepen in de keuzevrijheid van de regelgever.

Interessant is verder dat in de rechtspraak over de subsidiariteitstoets relatief veel openheid wordt gegeven over de wijze waarop het bestaan van alternatieve oplossingen kan worden achterhaald. In veel gevallen blijkt het Supreme Court af te gaan op de algemene kennis die bij de rechters aanwezig is en op eigen onderzoek ${ }^{405}$, maar vaak baseert het zich ook op stellingen van de procespartijen, op uitspraken van eerdere rechters in dezelfde zaak of op juridische adviezen die door buitenstaanders aan het Supreme Court zijn verschaft, de zogenaamde amicus briefs $s^{406} .^{407}$ Van belang is verder

can Party of Texas v. White, 415 U.S. 767, 781 (1974) (kiesrecht), Trimble v. Gordon, 430 U.S. 762, 771 (1977) (onderscheid op grond van wettige geboorte), Orr v. Orr, 440 U.S. 268, 283 (1979) (onderscheid op grond van geslacht), Bernal v. Fainter, 467 U.S. 216, 227 (1984) (onderscheid op grond van nationaliteit) en Wygant $v$. Jackson Board of Education, 476 U.S. 267, 283/284 (1986) (voorkeursbehandeling op grond van ras).

403. American Party of Texas v. White, 415 U.S. 767, 781 (1974)

404. Vgl. ook "Developments" 1969, p. 1102; gesteld wordt daarin dat het alternatief administratief en financieel haalbaar moet zijn. Zie verder Tuan Anh Nguyen v. INS, 533 U.S. 53 (2001), waaruit blijkt dat het alternatief zelf niet tot feitelijk effect mag hebben dat er nog steeds onderscheid wordt gemaakt. Dit kan bijvoorbeeld het geval zijn als het alternatief een classificatie op een neutrale grond is, die disproportionele effecten voor de betrokken groep zal opleveren.

405. Zo beriep Justice Brennan zich in Shapiro $v$. Thompson op het bestaan van een alternatieve regeling die in een andere staat was getroffen voor een vergelijkbaar probleem, zonder te verwijzen naar de processtukken (394 U.S, op 637, noot 18); zie voor een vergelijkbare benadering Memorial Hospital v. Maricopa County, 415 U.S. 250, 267 en 268 en noten 27-30 (1974).

406. Zie bijv. Dunn v. Blumstein, 405 U.S. 330, 347 en 348 (1972), waarin Justice Marshall de staat erop wees dat deze tijdens de procedure zelf had aangegeven dat het gemaakte onderscheid niet echt nodig was ter bereiking van één van de doelstellingen die het naar voren had gebracht; zie verder Eisenstadt v. Baird, 405 U.S. 438,452 (1972), waar het oordeel over alternatieve oplossingen lijkt te zijn gebaseerd op de uitspraak die een lagere rechter in de zaak had gedaan. Een voorbeeld waarin het Supreme Court zich in belangrijke mate baseerde op een amicus brief is het arrest Regents of the University of California v, Bakke, 438 U.S. 265, 317 (1978).

407. Het Supreme Court is overigens niet altijd zo zorgvuldig: er zijn ook gevallen waarin het Supreme Court vermoedt of veronderstelt dat er alternatieven bestaan en met die conclusie volstaat. Zie bijv. Bullock v. Carter, 405 U.S. 134, 146 (1972), waarin het Supreme Court eenvoudigweg concludeerde dat "other means to protect those valid interests are available", zonder enige indicatie te geven van de inhoud van deze altematieven en zonder aan te geven op welke bron het dit oordeel baseerde. Zo ook in Wengler v. Druggists Mutual Insurance, 446 U.S. 142, 151 (1980), waarin een bronvermelding ontbrak en vooral op vermoedens en veronderstellingen werd afgegaan; idem in Bernal v. Fainter, 467 U.S. 216, 227 (1984), Wygant v. Jackson Board of Education, 476 U.S. 267, 283/284 (1986) en City of Richmond v. J.A. Croson Co., 488 U.S. 469, 507 (1989). Vooral in gevallen als de laatste twee, waarin sprake was van voorkeursbeleid, is het ontbreken van een duidelijke bron voor de aanwezigheid van 
dat alternatieven vaak worden ontleend aan een onderzoek van regelingen in andere staten, counties (een soort provincies), gemeenten of zelfs universiteiten: vaak zijn vergelijkbare problemen daar op een iets andere, voor het individu minder belastende manier opgelost. ${ }^{\text {as }}$ Een dergelijke methode van rechtsvergelijking kan zeker gezien worden als een interessante en objectieve invulling van het subsidiariteitscriterium. Opmerkelijk is tenslotte dat er bij de inhoudelijke beoordeling van de subsidiariteit opnieuw nauwelijks verschil bestaat tussen de intermediate scrutiny- en de strict schtiny-test: in beide gevallen is de aard van de toetsing hetzelfde. Het verschil tussen beide toetsen is, net als bij de toetsing van de mate van fit, vooral gelegen in de uif. komst van de toets: bij een intermediate scrutiny-test leidt een onderzoek van verge lijkbare inhoud en intensiteit als bij een strict scrutiny-test aanmerkelijk vaker tot de conclusie dat er geen geschikte alternatieven bestonden. ${ }^{\text {to9 }}$

\subsubsection{Toetsing van de proportionaliteit in strikte zin}

Tenslotte is ook een proportionaliteitstoets in strikte zin soms terug te vinden in de rechtspraak van het Supreme Court. Ook hierbij geldt echter dat de rational basis-tes voor een dergelijke toets geen ruimte biedt. Heel duidelijk blijkt dit uit het arrest Harris v. McRae ${ }^{410}$, dat betrekking had op een vergoedingsregeling voor medische kosten. Volgens deze regeling werd geen kostenvergoeding gegeven voor abortus in nietlevensbedreigende situaties, maar wel voor de kosten die verbonden zijn aan het voldragen van een zwangerschap. Een lagere rechter had geoordeeld dat dit onderscheid ongerechtvaardigd was, aangezien hieraan een onjuiste afweging ten grondslag lag van het overheidsbelang bij de bescherming van het ongeboren kind tegen het individuele

alternatieven problematisch: in dit soort gevallen is extra zorgvuldigheid vereist om een in beginsel po sitieve maatregel onconstitutioneel te verklaren. Vgl. ook Bastress 1974, p. 998.

408. Een fraai voorbeeld hiervan biedt het arrest Regents of the University of California v. Bakke, 438 US 265 (1978). Dit arrest had betrekking op het toelatingsbeleid van een van de faculteiten van de Univer sity of Califomia, waarbij ervoor was gezorgd dat een raciaal gevarieerde studentenpopulatic verzeked was. Hiervoor was een voorkeursbeleid gehanteerd dat erg belastend was voor blanke kandidaten, omdat het werkte met een soort quotum. Justice Powell stelde hierover het volgende (in een opinie dic behalve wat betreft zijn uitkomst, overigens niet werd ondersteund door een meerderheid van het So preme Court): "[...] [P]etitioner's argument that this is the only effective means of serving the interst of diversity is seriously flawed. [...] The experience of other university admission programs, which th ke race into account in achieving the educational diversity valued by the First Amendment, demonstrates that the assignment of a fixed number of places to a minority group is not a necessary meass toward that end. An illuminating example is found in the Harvard College program [...])" (op 315 316). Daama beschreef Powell uitgebreid de merites van het Harvard program, waama het concludert de dat dit een veel beter en minder belastend alternatief vormde; een kopie van het Harvard progrth werd zelfs als appendix aan de opinie gehecht.

409. Een uitzondering waarin het Supreme Court bij de intermediate scrutiny-test daadwerkelijk een minde intensieve subsidiariteitstoets uitvoerde en het, net als bij de rational basis-test, aan de wetgever ovetliet om altematieven te onderzoeken en daartussen een keuze te maken is Rostker v. Goldberg, 45 ? U.S. 57, 70 en 71/72 (1981). Het Supreme Court had in deze zaak moeite met de keuze voor een good toetsingsintensiteit, omdat er weliswaar onderscheid werd gemaakt op grond van geslacht, maar dif beurde op het terrein van nationale veiligheid en defensie. Het Supreme Court weigerde daarom af etiket op de gehanteerde toetsingsintensiteit te plakken en voerde een terughoudendere toetsing uil div. gebruikelijk. Deze subsidiariteitstoets moet voor de intermediate scrutimy-rechtspraak dan ook als istrepresentatief worden beschouwd.

410. 448 U.S. 297 (1980) 
belang bij de (fysieke én mentale) gezondheid van de moeder. Het Supreme Court achtte een dergelijk oordeel in het kader van een rational basis-test niet toelaatbaar:

"In making an independent appraisal of the competing interests involved here, the District Court went beyond the judicial function. Such decisions are entrusted under the Constitution to Congress, not to the courts. It is the role of the courts only to ensure that congressional decisions comport with the Constitution."

De rational basis-rechtspraak is ten aanzien van de proportionaliteitstoets niet geheel consequent: in een aantal gevallen is wel degelijk een toetsing van de belangenafweging van wetgever of administratie zichtbaar. ${ }^{412}$ Het is echter duidelijk dat de proportionaliteitstoets in strikte zin maar een zeer geringe plaats inneemt in de rechtspraak: in veruit de meeste zaken wordt de aanwezigheid van een rational basis uitsluitend beoordeeld op basis van een geschiktheidstoets of met toepassing van een over- of underinclusiveness-test.

Bij de intermediate scrutiny-test en de strict scrutiny-test is vaker een element van proportionaliteit terug te vinden. ${ }^{43}$ Opmerkelijk is daarbij dat de evenredigheidstoets zelden wordt gezien als onderdeel van de doel-middeltoets, maar vooral als een aspect van de doeltoets. Zoals eerder is aangegeven komt dit ook tot uitdrukking in de typische formulering van deze tests: bij de strict scrutiny-test wordt vereist dat het onderscheid wordt gerechtvaardigd door "compelling interests", terwijl bij de intermediate

411. 448 U.S., op 326

412. Zie bijv. Weinberger v. Salfi, 422 U.S. 749, 777 (1975), waarin het Supreme Court stelde dat "The question is whether Congress [...] could rationally have concluded [...] that the expense and other difficulties of individual determinations justified the inherent imprecision of a prophylactic rule." Hoewel het Supreme Court in het vervolg van dit arrest eigenlijk geen antwoord gaf op deze vraag, lijkt deze op de mogelijkheid van een proportionaliteitstoets te duiden. Impliciet komt een proportionaliteitstoets ook naar voren bij onderscheid dat administratieve of financięle doelstellingen dient. Zo stelde het Supreme Court in Lyng v. International Union, 485 U.S. 360 (1988), dat "[...] protecting the fiscal integrity of governmental programs, and of the Government as a whole, is a legitimate concern of the state. This does not mean that Congress can pursue the objective of saving money by discriminating against individuals or groups. But our review of distinctions that Congress draws in order to make allocations from a finite pool of resources must be deferential [...]". Hieruit blijkt dat het wel degelijk noodzakelijk kan zijn om de door de overheid gemaakte belangenafweging te controleren, zij het dat dit op een zeer terughoudende manier moet gebeuren. Zie in deze zin ook Allegheny Pittsburgh Coal v. Webster County, 488 U.S. 336, 344 (1989) ("A State may divide different kinds of property into classes and assign to each class a different tax burden so long as those divisions and burdens are reasonable"), Burlington v. Ford, 504 U.S. 648, 652 (1992) ("Montana could thus have decided that a nonresident defendant's interest in convenience is too slight to outweigh the plaintiff's interest [...]") en Central State University v. American Association of University Professors, 526 U.S. 124, 128 (1999).

413. Zie voor de strict scrutiny-test "Developments" 1969 , p. 1103 en voor de intermediate scrutiny-test Vincent 1978, p. 316. Een proportionaliteitstoets is overigens pas zichtbaar sinds 1935; daarvoor werd bij de toetsing aan de Constitutie nauwelijks gewerkt met een idee van belangenafweging of toetsing daarvan (zie nader Aleinikoff 1987, p. 949-953). Ook hier bestaat inhoudelijk nauwelijks verschil tussen de strict scrutiny-en de intermediate scrutiny-test, maar is vooral de uitkomst van de toetsing verschillend: in gevallen waarin een strict scrutiny-test wordt toegepast weegt het aangetaste belang vrijwel steeds zwaarder dan het nagestreefde belang (behalve in gevallen van voorkeursbeleid), terwijl het bij de intermediate scrutiny-test mogelijk is dat het Supreme Court tot het oordeel komt dat het overheidsbelang zwaarder weegt; zie ook daarover Aleinikoff 1987, p. 970. Volgens Sullivan kan er bij de strict scrutiny-test vanwege het vooraf vaststaan van de uitkomst niet echt worden gesproken van een proportionaliteitstoets (1993, p. 243). 
scrutiny-test rechtvaardiging door "important governmental purposes" wordt verlangd. ${ }^{114}$ De adjectieven in deze formules wijzen erop dat de nagestreefde doelstellingen een zeker gewicht moeten hebben om het onderscheid en de daaraan verbonden belan. genaantasting te kunnen rechtvaardigen. De toepassing van deze formules leidt echter maar zelden tot een volledige belangenafweging: in de meeste gevallen beoordeelt het Supreme Court alleen het gewicht van de nagestreefde doelstelling, zonder het aangetaste belang daartegenover te plaatsen. ${ }^{415}$ Slechts in een beperkt aantal gevallen is het oordeel over de proportionaliteit volledig. Dit blijkt met name het geval te zijn wanneer door een regeling (vrij) zwaarwegende individuele belangen worden aangetast, terwij] daarmee slechts een administratief of financieel overheidsbelang wordt gediend." Een voorbeeld hiervan is het arrest Memorial Hospital v. Maricopa County. ${ }^{417}$ Dit arrest had betrekking op een vergoedingsregeling voor ziektekosten in Arizona, op grond warvan bepaalde ziekenhuiskosten alleen werden vergoed wanneer de rechthebbende tenminste een jaar in deze staat had gewoond. De staat had ter rechtvaardiging van deze beper. king aangevoerd dat deze nodig was om de fiscale integriteit van het vergoedingsprogramma te bewaken. Het Supreme Court oordeelde daarover als volgt:

"[...] [A] State may not protect the public fisc by drawing an invidious distinction between classes of its citizens, so appellees must do more than show that denying free medical care to new residents saves money. The conservation of the taxpayers' purse is simply not a sufficient state interest to sustain a durational residence requirement which, in effect, severely penalizes exercise of the right to freely migrate and settle in another State."

Ook bij voorkeursbeleid wordt vrijwel steeds een volledige proportionaliteitstoets uilgevoerd. De reden daarvoor is gelegen in het feit dat voorkeursbeleid vaak negatieve gevolgen heeft voor derden, namelijk voor die mensen die door het bestaan van dergo lijk beleid nadeel ondervinden bij het verkrijgen van banen, contracten, opleidings. plaatsen etc. Het Supreme Court gaat in vrijwel al zijn arresten over dit onderwerp zorgvuldig na of belangen van deze mensen niet onevenredig zwaar zijn aangetast:"

414. Zie nader paragraaf 2.4 .4 .

415. Zie bijv. Kadrmas v. Dickinson Public Schools, 387 U.S. 450 (1988) (J. Marshall, dissenting), th andere gevallen wordt alleen gewezen op het gewicht van de aangetaste belangen, zonder dat et duswerkelijk een oordeel wordt gegeven over de verhouding tussen deze belangen en het nagestrefli: doel; zie bijv. Tuan Anh Nguyen v. INS, 533 U.S. 53 (2001).

416. Vgl. Aleinikoff 1987, p. 969.

417. 415 U.S. 250 (1974)

418. 415 U.S., op 263. Zie ook Clark v. Jeter, 486 U.S. 456, 463/464 (1988), Shapiro v. Thompson, 34 U.S. 618, 633 (1969), Graham v. Richardson, 403 U.S. 365, 375 (1971) en Frontiero v. Richarders 411 U.S. 677,690 (1973). Overigens voert het Supreme Court bij doelstellingen van administratiere of fiscale aard soms ook een proportionaliteitstoets uit in de context van de doel-middeltoets. Zie biy. James v. Strange, 407 U.S. 128, 141/142 (1972) en M.L.B. v. S.L.J., 519 U.S. 102 (1996), wamin voor het oordeel over een onderscheid op grond van vermogen doorslaggevend was dat "[ ...] the staks fir petitioner M.L.B. [...] are large, more substantial than mere loss of money", terwij! "[...][t]he counte" vailing governmental interest [...] is financial".

419. De reden voor het in deze gevallen uitvoeren van een zorgvuldige proportionaliteitstoets werd gegetel door Powell in zijn opinie bij Regents of the University of California v. Bakke, 438 U.S. 265 (1978): [...] there is a measure of inequity in forcing innocent persons [...] to bear the burdens of redresing grievances not of their making". 
"[...] [A] congressional mandated, benign, race-conscious program that is substantially related to the achievement of an important governmental interest is consistent with equal protection principles so long as it does not impose undue burdens on nonminorities." 220

Uit zijn rechtspraak blijkt dat het Supreme Court bij deze beoordeling diverse overwegingen betrekt: de aard van het gekozen voorkeursbeleidd ${ }^{421}$, de tijdelijkheid van het beleid $^{m}$, de aanwezigheid van uitzonderingsmogelijkheden of hardheidsclausules ${ }^{43}$ en het bestaan van gerechtvaardigde verwachtingen ${ }^{424}$. Deze factoren zijn specifiek verbonden aan de context van voorkeursbeleid en kunnen daardoor nauwelijks dienen als invulling van het algemene toetsingsmodel. Interessant is echter wel dat uit uitspraken als deze blijkt dat het Supreme Court, ondanks het feit dat de proportionaliteitstoets meestal maar een beperkte plaats inneemt in de beoordeling, hier in bepaalde contexten toch niet buiten blijkt te kunnen.

Ook los van de doeltoets en buiten de context van doelstellingen van administratieve of financiële aard of van voorkeursbeleid wordt in een beperkt aantal gevallen een volledige belangenafweging uitgevoerd. Daarbij geldt echter dat de overwegingen van het Supreme Court meestal vrij ondoorzichtig en impliciet zijn. Een typerend voorbeeld is het arrest Lalli $v$. Lalli ${ }^{425}$, waarin een regeling werd aangevochten die het recht voor onwettige kinderen om van hun natuurlijke vader te erven beperkte tot die gevallen waarin het vaderschap door middel van een door de rechter afgegeven vaderschapsverklaring kon worden aangetoond. Het Supreme Court stelde allereerst vast dat deze regeling een aanzienlijk belang diende:

420. Metro Broadcasting v. FCC, 497 U.S. 547, 596/597 (1990) (cursief in origineel); vgl. ook Fullilove v. Klutznick, 448 U.S. 448, 484 (1980). De term "undue" kan ook op subsidiariteit duiden, maar uit de nadere uitwerking die het Supreme Court aan deze overweging geeft blijkt dat hiermee vooral op proportionaliteit in strikte zin wordt gedoeld.

42L. Wanneer bijvoorbeeld wordt vastgesteld dat een bepaald aantal arbeidsplaatsen binnen een organisatie ingenomen moet worden door Afro-Amerikanen, levert dit voor blanke kandidaten een grotere benadeling op dan wanneer voor alle plaatsen de regel geldt dat bij gelijke geschiktheid de AfroAmerikaanse kandidaat voorrang krijgt; in het laatste geval komen blanken wel voor de plaatsen in aanmerking, terwijl dit in het eerste geval niet zo is. Zie bijv. Wygant v. Jackson Board of Education, 476 U.S. 267, 282 (1986), Metro Broadcasting v. FCC, 497 U.S. 547, 599 (1990), Johnson v. Transportation Agency, 480 U.S. 616, 638 (1987) (een arrest met betrekking tot voorkeursbeleid onder Title VII; de criteria die het Supreme Court in dit arrest vastlegde zijn echter algemeen bruikbaar en lijken de rechtspraak over voorkeursbeleid onder de Equal Protection Clause te hebben geinspireerd) en City of Richmond v. J.A. Croson Co, 488 U.S. 469, 548/549 (1989) (J. Marshall, dissenting)

422. Johnson v. Transportation Agency, 480 U.S. 616, 639/640 (1987); iets meer impliciet ook in Wygant v. Jackson Board of Education, 476 U.S. 267, 275 (1986) en City of Richmond v. J.A. Croson Co. 488 U.S. 469, 498 (1989) (zie ook J. Marshall, dissenting, op 548); in beide arresten was vooral problematisch dat het voorkeursbeleid geen "logical stopping point" had en ook kon worden voortgezet als de doelstellingen eenmaal waren verwezenlijkt.

423. Metro Broadcasting v. FCC, 497 U.S. 547,599 (1990)

424. Wygant v. Jackson Board of Education, 476 U.S. 267, 283 (1986), Metro Broadcasting v. FCC, 497 U.S. 547,597 (1990) en Johnson v. Transportation Agency, 480 U.S. 616, 638 (1987); zie kritisch met 439 U.S. 259 (1978) 
"The primary state goal underlying the challenged aspects of $\$ 4-1.2$ is to provide for the just and orderly disposal of property at death. We long have recognized that this is an area with which the States have an interest of considerable magnitude." 426

Enkele bladzijden verderop besprak het vervolgens kort het door de eisers geleden nadeel:

"Inheritance is barred only where there has been a failure to secure evidence of paternity during the father's lifetime in the manner prescribed by the State. This is not a requirement that inevitably disqualifies an unnecessarily large number of children born out of wedlock." "\$2?

Het door de overheid gediende belang werd dus als zwaarwegend beschouwd, terwijlet geen sprake was van een onontkoombare en vergaande aantasting van individuele be langen. In combinatie leidden deze twee elementen tot het oordeel dat de maatregel niet onevenredig was, hoewel het Supreme Court dit oordeel niet expliciet uitsprak. Dit arrest is typerend voor de werkwijze van het Supreme Court bij het uitvoeren van een proportionaliteitstoets: de afzonderlijke elementen worden de lezer aangereikt, maar deze zal hieruit zelf zijn conclusies moeten trekken. ${ }^{428}$

De in Lalli $v$. Lalli gevolgde werkwijze is echter nog om een andere reden interessant. Uit het tweede citaat blijkt namelijk dat het Supreme Court de belangenaantasting vooral als minder ernstig beschouwde omdat het relatief eenvoudig was om aan de benadeling te ontkomen: door het aanvragen van een vaderschapsverklaring kon het erfrecht voor onwettige kinderen gemakkelijk veilig worden gesteld. Ook uit andere arresten blijkt dat het Supreme Court een belangenaantasting minder zwaarwegend acht wanneer het uit de ongelijke behandeling voortvloeiende nadeel gemakkelijk kan worden omzeild. ${ }^{429}$ Het lijkt echter niet juist om automatisch te stellen dat het bestaan van een ontsnappingsmogelijkheid de belangenaantasting minder ernstig maakt. Het gevaar

426. 439 U.S., op 268

427. 439 U.S., op 273

428. Soortgelijke impliciete oordelen over de proportionaliteit zijn terug te vinden in andere uitspraken. Zie bijvoorbeeld Craig v. Boren, 429 U.S. 190 (1976), waarin een verschil tussen mannen en vrouwen in de minimumleeftijd voor het kopen van alcohol werd gebaseerd op het feit dat slechts $0,18 \%$ van de vrouwen tegenover $2 \%$ van de mannen in de relevante leeftijdsgroep werd aangehouden wegens rijdan onder invloed. Het Supreme Court achtte dit verschil (en daarmee het belang bij het voorkomen vit rijden onder invloed) niet zwaarwegend genoeg om het verschil in behandeling en de daardoor veroorzaakte belangenaantasting te kunnen rechtvaardigen: "While such a disparity is not trivial in a statistical sense, it hardly can form the basis for employment of a gender line as a classifying device" (op 201). Ook dit is een proportionaliteitsoordeel, maar dit werd niet met zoveel woorden gezegd; opnievin is het aan de lezer om de conclusie zelf uit de overwegingen af te leiden. Vgl. iets meer explicie Palmore v. Sidoti, 466 U.S. 429, 433 (1984).

429. Voorbeelden zijn Labine v. Vincent, 401 U.S. 532, 546 (1971) (nadeel door onwettig vaderschap km gemakkelijk worden opgeheven door erkenning van het kind), Weber v. Aetna Casualty \& Surety Ca. 406 U.S. 164, 171 (1972) (waarin juist de tegenovergestelde conclusie werd getrokken: "The burdes of illegitimacy, already weighty, become doubly so when neither parent nor child can legally lighten them"), Parham v. Hughes, 441 U.S. 347, 353 (1979) (het feit dat de vader verantwoordelijk is vort verwekking en niet-erkenning van een onwettig kind rechtvaardigt dat de maatschappij daarover $\mathrm{jin}_{\mathrm{A}}$ veroordeling uitspreekt door hem het recht te ontnemen een civiele procedure te starten wanneer his kind door de schuld van een derde om het leven is gekomen) en Miller v. Albright, 523 U.S. 420 (1998) (waarin aandacht werd besteed aan het feit dat klager 21 jaar de tijd had gehad om de benater ling te vermijden). 
dat hieraan kleeft wordt bijvoorbeeld geilllustreerd door een dissenting opinion bij het arrest Nyquist $v$. Mauclet ${ }^{40}$, waarin geklaagd werd over een regeling die buitenlanders benadeelde bij de toekenning van studiebeurzen. Aan deze benadeling kon de buitenlandse student gemakkelijk ontsnappen door een verklaring te tekenen waarin hij zijn bereidheid aangaf de Amerikaanse nationaliteit aan te nemen. De dissenters achtten deze mogelijkheid bijzonder relevant voor de beoordeling van het onderscheid, ${ }^{211}$ maar hielden daarbij geen rekening met het feit dat verlies van de eigen nationaliteit voor veel mensen ook een identiteitsverlies kan betekenen. ${ }^{432}$ In dit soort omstandigheden levert het bestaan van een ontsnappingsmogelijkheid een moeilijk persoonlijk dilemma op en kan zeker niet worden gesteld dat er sprake is van een minder ernstige belangenaantasting. Belangrijk is bovendien dat de vermijdbaarheid van een bepaald nadeel niet altijd zoveel zegt over de ernst van het nadeel als zodanig: wanneer bijvoorbeeld een zeer hoge straf wordt opgelegd voor het plegen van een klein vergrijp kan dit niet zonder meer worden gerechtvaardigd door te stellen dat de straf vermeden had kunnen worden door het vergrijp niet te plegen. ${ }^{43}$ Het is dan ook zeker niet wenselijk om de vermijdbaarheid van de belangenaantasting bij de proportionaliteitstoets een belangrijke rol te laten spelen; wel zou deze factor eventueel een rol kunnen spelen bij de bepaling van de intensiteit bij de toetsing. In de volgende paragraaf zal daarop nog worden teruggekomen.

\section{Toetsingsintensiteit}

\subsection{Inleiding}

In paragraaf 2 is duidelijk geworden dat het Supreme Court een drietal officiële tests heeft ontwikkeld voor de toetsing aan de Equal Protection Clause, de rational basistest, de intermediate scrutiny-test en de strict scrutiny-test, waaraan in de praktijk nog een vierde, officieuze, test is toegevoegd: de rational basis "with bite"-test. Zoals de in de vorige paragraaf gegeven beschrijving laat zien verschillen deze tests niet zozeer in

430. 432 U.S. 1 (1977)

431. Overigens gaven zij dit oordeel in een iets andere context; zij betoogden dat er in dit geval geen reden bestond voor een verhoogde toetsingsintensiteit, omdat gemakkelijk aan het onderscheid kon worden ontkomen. Dezelfde argumenten kunnen echter gemakkelijk in het kader van een proportionaliteitstoets worden geplaatst. Een meerderheid van het Supreme Court heeft een vergelijkbaar oordeel overigens omhelsd in Ambach v. Norwick, 441 U.S. 68, 80 (1979), waar gesteld werd dat buitenlanders die worden benadeeld hier in feite zelf voor hebben gekozen, zodat er geen sprake is van een ernstige belangenaantasting.

432. Vgl. Rosberg 1977, p. 302. Van een zelfde dilemma kan sprake zijn bij benadeling wegens politieke overtuiging of godsdienst: een dergelijke benadeling is niet onontkoombaar door te veranderen van overtuiging of godsdienst, maar het bestaan van deze mogelijkheid mag niet worden gezien als een reden om de belangenaantasting minder ernstig te achten.

433. Dit bezwaar is ook door het Supreme Court zelf opgeworpen: in Trimble v, Gordon, 430 U.S. 762 (1977) stelde het dat "by focusing on the steps that an intestate might have taken to assure some inheritance for his illegimitate children, the analysis loses sight of the essential question: the constitutionality of discrimination against illegitimates in an intestate succession law. [...] Hard questions cannot be avoided by a hypothetical reshuffling of the facts" (op 774). 
de toetsingselementen die zij omvatten, maar vooral in de verdeling van de bewijslas, de zorgvuldigheid waarmee aan de verschillende criteria wordt getoetst en in de uif. komst van deze toetsing. Gesteld kan dan ook worden dat de tests verschillende grads. ties van toetsingsintensiteit representeren, waardoor de benadering van het Supreme Court verwantschap lijkt te vertonen met het in hoofdstuk 2 beschreven theoretische model.

De benadering van het Supreme Court wijkt echter op een belangrijk punt van het theoretische model af. Weliswaar maakt ook het theoretische model gebruik van drie of vier "gradaties" van toetsingsintensiteit, maar het gebruikt deze vooral als ijkpunten op een glijdende schaal. ${ }^{\text {s4 }}$ Dergelijke ijkpunten verschaffen de rechter duidelijkheid en een houvast bij zijn toetsing, maar zijn niet absoluut: vereist een bepaald geval een tussenliggende toetsingsintensiteit, dan bestaat ook daarvoor ruimte. De door het Supreme Court gevolgde benadering mist deze flexibiliteit. In zijn rechtspraak heeft het Supreme Court de toepasselijkheid van de meest intensieve tests, de intermediate scrutimy-ende strict scrutiny-test, slechts toegepast op een beperkt aantal ongelijke behandelingen. $D_{e}$ overige zaken worden steeds beoordeeld op basis van de minst intensieve test, de rati. onal basis-test, ongeacht de aanwezigheid van factoren die een verhoging van de toetsingsintensiteit zouden kunnen rechtvaardigen. Deze werkwijze laat, anders dan het theoretische model, nauwelijks ruimte voor de afweging van intensiteitbepalende factoren of voor het gebruik van een tussenliggende toetsingsintensiteit.

Het gevolg van de benadering van het Supreme Court is een zeer voorspelbare en dul. delijke toetsing, die zich tegelijkertijd kenmerkt door een grote mate van inflexibilitet en rigiditeit. Het model laat geen ruimte voor het toepassen van een striktere of just meer terughoudende benadering wanneer het concrete geval daartoe aanleiding geeth, en geeft evenmin de mogelijkheid om het gewicht van de aanwezige intensiteitbepalende factoren per geval te beoordelen. Het Supreme Court lijkt dit probleem overigens wel te hebben onderkend, en heeft dit (deels) opgevangen door het creëren van de mogelijkheid van een verhoging van de minst intensieve toetsing tot rational basis "with bite".

De uitgebreide rechtspraak van het Supreme Court over de intensiteit van de toetsing is bijzonder interessant voor de verdere ontwikkeling en verfijning van het algement toetsingsmodel. In de rechtspraak over de intermediate scrutiny- en strict scrutiny-test heeft het Supreme Court zeer uitgebreid aangegeven welke factoren een rol spelen bij de keuze voor een van deze tests. In het hiernavolgende zullen de belangrijkste van deze factoren worden besproken. Daarbij zal vooral aandacht worden besteed aan twee groepen factoren die aanleiding blijken te kunnen vormen voor een toepassing va intermediate of strict scrutiny; het gaat daarbij om factoren die het onderscheid zelf betreffen (paragraaf 3.3) en factoren die betrekking hebben op het aangetaste rectit (paragraaf 3.4). Vervolgens zal kort worden ingegaan op enkele andere intensiteibepalende factoren die in de rechtspraak over de rational basis-test naar voren zijn gekomen en die een rechtvaardiging voor een terughoudende opstelling kunnen opleveren (paragraaf 3.5). Allereerst zal echter worden ingegaan op de algemene onderbouwing die het Supreme Court in zijn rechtspraak heeft gegeven voor de mogelijkheid van

434. Zie hoofdstuk 2, paragraaf 5.2.1. 
differentiatie in de intensiteit van de toetsing, nu deze voor de ontwikkeling van een algemeen toetsingsmodel van bijzonder belang kan worden geacht (paragraaf 3.2).

\section{2 \\ Theoretische onderbouwing van de variatie in toetsingsintensiteit}

Het Supreme Court heeft de keuze voor een intensivering van zijn toetsing steeds bijzonder goed gemotiveerd. De belangrijkste reden daarvoor is gelegen in de afkeer die in de VS wordt gevoeld tegen een vergaande rechterlijke toetsing van wettelijke maatregelen. Deze afkeer komt niet alleen voort uit rechtstheoretische opvattingen over machtenscheiding en het rechterlijk gebrek aan democratische legitimatie, maar houdt vooral ook verband met de negatieve ervaringen die in de VS zijn opgedaan met intensieve toetsing door de rechter. In de periode 1905-1937, het zogenaamde Lochnertijdperk $^{31}$, werd de rechtspraak van het Supreme Court bepaald door een meerderheid van rechters met een bijzonder activistische instelling. Gedurende deze periode lazen zij verschillende "nieuwe" rechten in de Constitutie in, zoals het recht op "substantive due process" (inhoudend dat wetgeving niet op ongerechtvaardigde wijze de individuele vrijheid mag aantasten) ${ }^{436}$ en een vergaand recht op contractsvrijheid. ${ }^{437}$ Hierdoor werd een aanzienlijke ruimte geschapen voor het beoordelen van de redelijkheid van wetgeving, hetgeen in de praktijk tot gevolg had dat een groot aantal maatschappelijk wenselijke wetten op sociaal-economisch terrein onconstitutioneel werd verklaard. In de crisisjaren na 1930 dreigde het activisme van het Supreme Court zelfs te leiden tot een mislukking van Roosevelts New Dealpolitiek. ${ }^{438}$ Pas in 1937 ontstond er een meer gematigde meerderheid en kwam er een einde aan het Lochner-tijdperk.

De nieuwe meerderheid was, met de meeste rechtsgeleerde auteurs, van mening dat er een andere benadering moest worden gekozen om de geloofwaardigheid van het Supreme Court en het vertrouwen in zijn rechters te herstellen. Het was duidelijk dat rechterlijke terughoudendheid daarbij als uitgangspunt zou moeten gelden. ${ }^{39}$ Allereerst vond het Supreme Court dit nodig vanwege de plaats die het zelf inneemt binnen het staatsrechtelijk systeem:

435. Zo genoemd naar één van de eerste arresten waarin het Supreme Court een wet in strijd met de grondwet verklaarde omdat deze inhoudelijk onredelijk zou zijn: Lochner v. New York, 198 U.S. 45 (1905).

436. Zie bijv. Allgeyer v. Louisiana, 165 U.S. 578 (1897)

437. Controversieel is vooral het inlezen van een recht op "substantive due process" in de Due Process Clause van het Veertiende Amendement. Dit recht houdt in dat wetten inhoudelijk gerechtvaardigd moeten zijn, hetgeen onder andere duidt op een toetsing van proportionaliteit en noodzakelijkheid: "In every case that comes before this court [...] the question necessarily arises: Is this a fair, reasonable and appropriate exercise of police power of the States, or is it an unreasonable, unnecessary and arbitrary interference with the right of the individual [...]?" (198 U.S., op 56). In de Lochner-periode leidde cen toetsing aan dit recht er regelmatig toe dat het Supreme Court de belangenafweging die aan de regeling ten grondslag lag zorgvuldig zelf overdeed en zijn eigen oordeel voor dat van de wetgever in de plaats stelde. Problematisch was verder dat het Supreme Court een essentieel geacht grondrecht in de Constitutie inlas: het recht op contractsvrijheid. Wetgeving die hiermee in strijd was, hetgeen vooral bij sociale wetgeving al snel het geval bleek, werd onvermijdelijk onconstitutioneel verklaard; een voorbeeld daarvan is het arrest Lochner zelf.

438. Vgl. Lusky 1975, p. 102.

439. Vgl. Lusky 1975 , p. 103. 
"The Congress is a coequal branch of government whose Members take the same oath we do to uphold the Constitution of the United States. [...][W] must have due regard to the fact that this Court is not exercising a primary judgment but is sitting in judgment upon those who also have taken the oath to observe the Constitution and who have the responsibility for carrying on government. The customary deference accorded the judgments of Congress is certainly appropriate when [...] Congress specifically considered the question of the Act's constitutionality." 440

Verder nam het Supreme Court tot uitgangspunt dat het politieke systeem in beginsel voldoende in staat is om fouten te herstellen. Zolang dit zelfcorrigerend vermogen goed functioneert bestaat er geen reden tot rechterlijk ingrijpen:

"[...] [A] Court is not free under the aegis of the Equal Protection Clause to substitute its judgment for the will of the people of a State as expressed in the laws passed by their popularly elected legislatures. The Constitution presumes that, absent some reason to infer antipathy, even improvident decisions will eventually be rectified by the democratic process and that judicial intervention is generally unwarranted no matter how unwisely we may think a political branch has acted."

Overwegingen als deze hebben ervoor gezorgd dat een zeer terughoudende toetsing, zoals die bijvoorbeeld zichtbaar is bij de rational basis-test, het uitgangspunt is gaan vormen bij de toetsing aan de Equal Protection Clause.

Al in 1937 bestond echter het besef dat een terughoudende rechterlijke opstelling niet altijd wenselijk is: de op grote schaal door de staten geïnstitutionaliseerde achterstelling van Afro-Amerikanen kon daardoor bijvoorbeeld nauwelijks worden bestreden, net zomin als vergaande inbreuken op individuele rechten en vrijheden. ${ }^{42}$ Het leek dan ook noodzakelijk om criteria te ontwikkelen waardoor in bepaalde gevallen een intensievere toetsing mogelijk werd, zonder dat afbreuk werd gedaan aan het uitgangspunt van terughoudendheid en de theoretische veronderstellingen die dit uitgangspunt ondersteunden. ${ }^{+33}$ In 1938 werd daarvoor in een verder relatief onbelangrijk arrest, United States v. Carolene Products Co.t4, de basis gelegd. In een voetnoot in dit arrest werd een aantal gronden neergelegd die een verhoging van de toetsingsintensiteit zouden kunnen rechtvaardigen. ${ }^{45}$ De tekst van deze voetnoot luidt als volgt:

440. Rostker v. Goldberg, 453 U.S. 57, 64 (1981). Zie ook reeds (meer impliciet) Powell v. Pennyshunia, 127 U.S. 678 (1888) (nog vóór het Lochner-tijdperk!) en Schweiker v. Wilson, 450 U.S. 221, 20 (1981). Ook jegens de wetgever van de verschillende staten hoort het Supreme Court zich terughoodend op te stellen; zie bijv. Ferguson v. Skrupa, 372 U.S. 726, 730/731 (1963).

441. Parham v. Hughes, 441 U.S. 347, 351 (1979); idem in Personnel Administrator of Massachusetls: Feeney, 442 U.S. 256 (1979), Vance v. Bradley, 440 U.S. 93, 97 (1979) en FCC v. Beach Communicetions, 508 U.S. 307,314 (1993). Vgl. ook Williamson v. Lee Optical Co., 348 U.S. 483,488 (1955) "For protection against abuses by legislatures the people must resort to the polls, not to the courts."

442. Vgl. Lusky 1982, p. 1095. Ook de opkomst van de totalitaire regimes in Europa en de rassenhatit dis daaruit voortvloeide riep destijds twijfel op over de juiste werking van het democratisch proces: veth mensen stelden zichzelf de vraag of het echt altijd wenselijk is om belangrijke keuzes an dit proco over te laten. Vgl. Cover 1982, p. 1293/1294.

443. Vgl. Ackerman 1985, p. 714.

444. 304 U.S, 144 (1938)

445. De voetnoot was bedoeld om academische discussie uit te lokken, vandaar dat deze is geformuleerd in de vorm van veronderstellingen en vragen; zie Lusky 1982, p. 1098/1099 en Powell 1982, p. 1090. 
"There may be narrower scope for operation of the presumption of constitutionality when legislation appears on its face to be within a specific prohibition of the Constitution, such as those of the first ten amendments, which are deemed equally specific when held to be embraced within the Fourteenth.

It is unnecessary to consider now whether legislation which restricts those political processes which can ordinarily be expected to bring about repeal of undesirable legislation, is to be subjected to more exacting judicial scrutiny under the general prohibitions of the Fourteenth Amendment than are most other types of legislation. [...] [volgt een opsomming van een aantal voorbeelden van politieke rechten, zoals kiesrecht en rechten van politieke partijen, die niet expliciet door de Constitutie worden beschermd, JHG].

Nor need we enquire whether similar considerations enter into the review of statutes directed at particular religious, or national, or racial minorities: whether prejudice against discrete and insular minorities may be a special condition, which tends seriously to curtail the operation of those political processes ordinarily to be relied upon to protect minorities, and which may call for a correspondingly more searching judicial inquiry." ${ }^{146}$

Voor de rechtspraak over de Equal Protection Clause is vooral de derde alinea van deze voetnoot van bijzonder belang. ${ }^{47}$ De criteria die hierin zijn opgenomen zijn zelden als zodanig in de latere rechtspraak van het Supreme Court terug te vinden; het criterium van de "discrete and insular minority" wordt bijvoorbeeld slechts in een beperkt aantal uitspraken expliciet genoemd. ${ }^{448}$ Van groot belang is echter dat deze alinea een algemene theoretische basis vormt waarop een verhoging van de toetsingsintensiteit kan worden gegrond: wanneer de rechten van bepaalde minderheden zijn aangetast en deze aantasting is ingegeven door vooroordelen, is het waarschijnlijk dat het democratisch proces niet op deugdelijke en betrouwbare wijze heeft gefunctioneerd. ${ }^{4+9}$ In die

446. 304 U.S., op 152, voetnoot 4; de uitgebreide verwijzingen naar relevante rechtspraak zijn weggelaten.

447. Ook de eerste twee alinea's hebben echter betekenis voor de gelijke behandelingsrechtspraak; zie daarover paragraaf 3.4. Zie over de betekenis van en de onderlinge verhouding tussen de verschillende alinea's Ball 1974, p. 1064.

448. Gordon v. Lance, 403 U.S. 1 (1971) is het eerste arrest waarin het criterium expliciet genoemd wordt, gevolgd door de niet erg verhelderende uitleg dat het moet gaan om een "independently identifiable group" (op 5). Daarna heeft het Supreme Court het criterium enkele malen ingeroepen ter rechtvaardiging van de toepassing van de strict scrutiny-test op buitenlanders, evenwel zonder uit te leggen waarom deze groep als "discrete and insular" moet worden beschouwd: zie Graham v. Richardson, 403 U.S. 365, 372 (1971), In re Griffiths, 413 U.S. 717, 721 (1973), Sugarman v. Dougall, 413 U.S. 634, 642 (1973) en Hampton v. Mow Sun Wong, 426 U.S. 88, 102 (1976); zie ook Levi 1979, p. 1074 en Rosberg 1977, p. 299. Later heeft het Supreme Court geen gebruik meer gemaakt van het criterium om de verdachtheid van een grond van onderscheid te rechtvaardigen.

449. Vgl. New York Transit Authority v. Beazer, 440 U.S. 568, 593 (1979). Zie ook Ball 1974, p. 1063, Lusky 1975, p. 110 en Ely 1980, p. 103 en 135. Op het probleem dat de meerderheid vaak niet in staat is om de belangen van de minderheid te beschermen en alleen zijn eigen ideeěn en vooroordelen na zal streven werd overigens al gewezen door eén van de Framers van de Amerikaanse constitutie, Madison; het probleem werd dus al veel eerder erkend dan in Carolene Products. Madison droeg voor dit probleem een andere oplossing aan dan het Supreme Court: volgens hem was de oplossing gelegen in het kiezen van een groter aantal volksvertegenwoordigers in een grotere staat; de gedachte lijkt te zijn dat daardoor het idee van pluralisme beter kan functioneren. Zie The Federalist No. 10 (Madison) (in Rossiter 1999 (red.), p. 47, 49 en 51). De rationale in Carolene Products is juist op de gedachte gebaseerd dat zelfs het democratische, pluralistische systeem niet altijd een deugdelijke oplossing voor het probleem van de benadeling van minderheden oplevert; deze gedachte wordt ondersteund door een andere Framer-Hamilton: zie The Federalist No. 78 (Hamilton) (in Rossiter 1999 (red.), p. 437). Vgl. ook Ball 1974, p. 1069 en Ely 1980, p. 80/81. Van belang is tenslotte dat de Carolene Productsrechtvaardiging ook een intensievere toetsing kan opleveren bij indirect onderscheid, hoewel vooroor- 
situatie vallen de eerdergenoemde redenen voor rechterlijke terughoudendheid weg: kennelijk is de wetgever in dit soort gevallen onvoldoende in staat om de Constitutie te waarborgen, terwijl bovendien de vrees gerechtvaardigd is dat het zelfcorrigerend ver. mogen van het democratisch systeem niet naar behoren functioneert. De rechter heeff dan tot taak om als een soort vangnet te fungeren door ervoor te zorgen dat de ge. maakte fouten worden gecorrigeerd en recht wordt gedaan aan de constitutionele bepalingen. ${ }^{450}$

Dit fraaie theoretische systeem is in de loop van bijna 65 jaar in diverse zaken verder uitgewerkt en beter bruikbaar gemaakt voor de rechterlijke toetsingspraktijk. Met name heeft het Supreme Court in verschillende arresten factoren genoemd die kunnen duiden op fouten in het functioneren van het politieke proces en die een rechtvaardiging kun. nen vormen voor een intensievere rechterlijke toetsing. In het hiernavolgende zullen de belangrijkste van deze concrete factoren nader worden besproken.

\subsection{Factoren die betrekking hebben op de ongelijke behandeling}

\subsubsection{Factoren met betrekking tot de benadeelde groep}

\section{Vereiste van duidelijke bepaalbaarheid van de benadeelde groep}

Zoals hiervoor al is aangegeven wordt het vereiste van een "discrete and insular minority" zelden met zoveel woorden door het Supreme Court genoemd. ${ }^{\text {sI }}$ In de rechtsprak is echter wel een factor terug te vinden die als een uitwerking van dit criterium kan worden gezien. Het Supreme Court heeft in een aantal gevallen vastgesteld dat er at leen reden zal bestaan voor een verhoogde toetsingsintensiteit wanneer de benadeelde groep voldoende duidelijk kan worden afgebakend. Een reden hiervoor gaf het in het arrest City of Cleburne v. Cleburne Living Center ${ }^{452}$, waarin het zich uit moest spreken over de constitutionaliteit van een onderscheid op grond van geestelijke handicap. Het Supreme Court koos daarbij voor een terughoudende toetsing. Onderdeel van de moti-

delen jegens een bepaalde groep daarbij afwezig lijken te zijn. In veel gevallen wordt een disproportio neel effect echter veroorzaakt door het bewust accepteren van dit soort gevolgen, hetgeen goed gets seerd kan zijn op vooroordelen. Ook wanneer de gevolgen niet bewust zijn geaccepteerd kan er bovendien sprake zijn van een vorm van "prejudice based indifference" jegens de benadeelde groep (vg. Sherry 1984, p. 105). Hoewel dit moeilijker is aan te tonen, bestaat er in dit soort gevallen wel deglip reden voor een verhoging van de toetsingsintensiteit.

450. Vgl. Schweiker v. Wilson, 450 U.S. 221, 230 (1981) en (meer impliciet) Mathews v. Lucas, 427 US. 495, 506 (1976).

451. De term "insular" duidt erop dat een bepaalde groep een geisoleerde positie in de maatschappij inneent en daardoor niet genoeg "bondgenoten" kan vinden om een benadeling ongedaan te maken (vgl. Corr 1982, p. 1299 en Ely 1980, p. 151). Uit de rechtspraak blijkt echter niet dat dit een hard vereiste is bij onderscheid op grond van ras en geslacht is consequent een strikte toetsing toegepast, terwijl Afivo Amerikanen noch vrouwen tegenwoordig nog als een in matschappelijk isolement verkerende groff kunnen worden beschouwd. Andersom geldt voor sommige religieuze minderheden en voor homosessuelen een dergelijk isolement wel, maar is voor hun geval de noodzaak van een intensieve toeting nooit erkend. Om die reden is volgens Ackerman het vereiste van "discrete and insular minoritio" achterhaald (1985, p. $718 / 719$ en 724). Ball geeft echter aan dat dit vereiste ook niet het belangrijkst it binnen de rationale: de politieke machteloosheid en het bestaan van vooroordelen zijn van veel grotet belang, omdat vooral daaruit de onbetrouwbare of verkeerde werking van het politieke proces lat worden afgeleid (1974, p. 1080); vgl. in die zin ook Ely 1980, p. 151.

452. 473 U.S. 432 (1985) 
vering daarvoor vormde de volgende overweging:

"How this large and diversified group is to be treated under the law is a difficult and often a technical matter, very much a task for legislators guided by qualified professionals and not by the perhaps ill-informed opinions of the judiciary."

Het Supreme Court lijkt meestal echter geen hoge eisen te stellen aan de duidelijkheid warmee de benadeelde groep kan worden bepaald: wanneer een groep gemakkelijk is te onderscheiden, bijvoorbeeld door de aanwezigheid van een duidelijk groepskenmerk als ras, geslacht of nationaliteit, zal dit in de meeste gevallen al voldoende zijn. ${ }^{454}$

\section{Historische en/of sociale achterstelling van de benadeelde groep}

Een tweede factor die bepalend is voor de verhoging van de toetsingsintensiteit en die verband lijkt te houden met het vereiste van een "discrete and insular minority" betreft de sociale en/of historische achterstelling van de benadeelde groep. ${ }^{45}$ Het belang van deze factor blijkt bijvoorbeeld uit het arrest Frontiero $v$. Richardson ${ }^{456}$, dat betrekking had op een benadeling van vrouwen. Het Supreme Court motiveerde in dit arrest uitgebreid waarom hierbij een intensieve toetsing moest worden uitgevoerd. ${ }^{457}$ Eén van de redenen daarvoor was de volgende:

"There can be no doubt that our Nation has a long and unfortunate history of sex discrimination. [...] [I]ndeed, throughout much of the 19th century the position of women in our society was, in many respects, comparable to that of blacks under the pre-Civil War slave codes. Neither slaves nor women could hold office, serve on juries, or bring suit in

453. 473 U.S., op 442/443; in de uitspraak werd uiteindelijk vanwege de aanwezigheid van een aantal andere, intensiteitverhogende factoren een rational basis "with bite"-test toegepast. Zie ook San Antonio School Disctrict v. Rodriguez, 411 U.S. 1, 19 en 22 (1973) (de klasse van onvermogenden is "a large, diverse and amorphous group"), Schweiker v. Wilson, 450 U.S. 221, 231 (1981) ("The statute does not isolate the mentally ill or subject them, as a discrete group, to special or subordinate treatment"), Lyng v. Castillo, 477 U.S. 635, 638 (1986) (bloedverwanten kunnen niet gezien worden als een "discrete group") en City of Cleburne v. Cleburne Living Center, 473 U.S. 432 (1985) (het feit dat geestelijk gehandicapten een "large and diversified group" vormen lijkt invloed te hebben op de toetsingsintensiteit), In het genoemde arrest Lyng v. Castillo vereiste het Supreme Court dat de benadeelde groep daadwerkelijk een minderheid is, maar van dit vereiste lijkt later afstand te zijn gedaan: bij voorkeursbeleid vormt het feit dat hierdoor geen minderheid, maar juist een meerderheid wordt benadeeld in ieder geval geen belemmering voor het toepassen van de strict scrutiny-test.

454. Zo wordt de groep van legaal in het land residerende buitenlanders meestal gezien als een duidelijk afgebakende groep. Zie bijv. Nyquist v. Mauclet, 432 U.S. 1, 8 (1977), waarin werd betoogd dat het bij buitenlanders gaat om een "heterogeneous class", maar waarin het Supreme Court stelde dat dit niet relevant is: " $\$ 66 \mathrm{I}(3)$ is directed at aliens and only aliens are harmed by it": het feit dat onderscheid is gemaakt op grond van een duidelijk groepskenmerk, al gaat het dan om een heterogene groep, is dus voldoende voor toepassing van strict scrutimy. Zie ook Graham v. Richardson, 403 U.S. 365, 372 (1971). Alleen in Mathews v. Diaz, 426 U.S. 67, 79/80 (1976) vond het Supreme Court de groep buitenlanders te amorf voor de toepassing van een sirict scrutiny-test.

455. Vgl. Sobelsohn 1977, p. 472.

456. 411 U.S. 677 (1973)

457. Dit oordeel werd slechis

conclusie van dezechts ondersteund door vier rechters (plurality opinion) en in latere uitspraken is de conclusie in het a zaak (strict scrutiny) teruggedraaid. Niettemin wordt de onderbouwing van deze rechtspraak verwezen. 
their own names, and married women traditionally were denied the legal capacity to hold of convey property or to serve as legal guardians of their own children.'Nss

Deze factor is ook aanwezig in andere gevallen waarin het Hof een strikte toetsing heeft aanvaard. Met name is het duidelijk dat veel raciale groepen historisch gezien ernstig zijn achtergesteld en ook nu nog een maatschappelijk moeilijke positie hebben. Ook voor onwettige kinderen en buitenlanders heeft het Supreme Court aangenomen dat zij als groep nadeel ondervinden van historische en sociale achterstelling. ${ }^{\text {s? }}$

In de meeste gevallen lijkt het oordeel van het Supreme Court over deze achtergrond vooral te zijn gebaseerd op algemene veronderstellingen: veelal ontbreekt daadwerkelijk onderzoek naar de aanwezigheid en de ernst van de achterstelling. ${ }^{+6}$ Een dergelijk onderzoek lijkt meestal ook niet nodig te zijn: voor het beperkte aantal gevallen waarin een intermediate scrutiny- of strict scrutiny-test is aanvaard is het zonder meer duids. lijk dat de betrokken groep nadeel ondervindt van een consequente sociale en historische benadeling, ${ }^{461}$

\section{Aanwezigheid van vooroordelen of stereotypen jegens een bepaalde groep}

Nauw aan de factor van historische en sociale achterstelling verwant is een derde factor: er blijkt alleen reden te bestaan voor een intensievere toetsing, wanneer er in de samenleving vooroordelen bestaan jegens een bepaalde groep of wanneer er sprake is van vergaande en onterechte stereotyperingen. ${ }^{462}$ Zo stelde het Supreme Court in het arrest Massachusetts Board of Retirement v. Murgia ${ }^{463}$ dat een verhoging van de toetsingsintensiteit gerechtvaardigd is wanneer een groep:

"[...][has] been subjected to unique disabilities on the basis of stereotyped characteristics $[\ldots] ., " 464$

458. 411 U.S., op 684/685. De factor werd ook genoemd in J.E.B. v. Alabama, 511 U.S. 127, 135 (1994) en United States v. Virginia, 518 U.S. 515, 531 (1996), beide met betrekking tot onderscheid op grond van geslacht.

459. Zie Mathews v. Lucas, 427 U.S. 495, 506 (1976) (onderscheid op grond van onwettige geboonte) th Hampton v. Mow Sun Wong, 426 U.S. 88, 102 (1976) ("[...][Aliens] are already subject to disadvatt: ges not shared by the remainder of the community. Aliens [...] are often handicapped by a lack of to miliarity with our language and customs"). In In re Griffiths, 413 U.S. 717, 722 (1973) gaf het Supte me Court aan dat in het geval van buitenlanders een hogere toetsingsintensiteit op zijn plaats is ondir zij worden achtergesteld, terwijl zij wel een bijdrage leveren aan de samenleving door het betalen van belastingen en het nemen van dienst in het leger. Hierdoor wordt de sociale achterstelling van exh groep die dit niet verdient feitelijk nog benadrukt. Vergelijkbare overweging gelden voor onderschil op grond van wettige geboorte: zie Levy v. Louisiana, 391 U.S. 68, 71 (1968).

460. Vgl. Wilkinson 1975 , p. 981.

461. Het Supreme Court heeft ook in andere gevallen op deze factor gewezen, vooral om aan te geven tht een historische of sociale achterstelling ontbreekt. ledere nadere onderbouwing van dit oordeel onfbreekt echter. Zie bijv. San Antonio School District v. Rodriguez, 411 U.S. I, 28 (1973) (onvernogetr den kenmerken zich als groep niet door "a history of purposeful unequal treatment"), Massachuseth Board of Retirement v. Murgia, 427 U.S. 307 (1976) (de groep van mensen ouder dan 50 is geth slachtoffer geweest van historische achterstelling) en Lyng v. Castillo, 477 U.S. 635, 638 (1986) (bloedverwanten kenmerken zich niet door historische achterstelling).

462. Vgl. Sherry 1984, p. 110.

463. 427 U.S. 307 (1976)

464. 427 U.S., op 313; het citaat vervolgt met de stelling dat het moet gaan om kenmerken, "not ruly indicative of their abilities". Dit is weggelaten, omdat dit vooral betrekking heeft op de grond van on- 
Deze factor rechtvaardigde aanvankelijk vooral een striktere toetsing bij een benadeling van raciale minderheden ${ }^{465}$, maar vormde ook een belangrijke reden voor het aanvaarden van een intensieve toetsing bij benadeling van vrouwen. ${ }^{+66}$ In andere gevallen waarin een intensieve toetsing is aanvaard heeft het Supreme Court minder aandacht besteed aan deze factor. Het lijkt echter duidelijk dat vooroordelen en stereotypen ook bij een benadeling van onwettige kinderen, buitenlanders of mensen met een bepaalde etnische afkomst vaak een belangrijke rol zullen spelen.

Jammer genoeg heeft het Supreme Court weinig moeite gedaan om nader inhoud te geven aan deze factor, bijvoorbeeld door aan te geven in welke gevallen de conclusie gerechtvaardigd is dat er vooroordelen of stereotypen over een bepaalde groep bestaan. ${ }^{47}$ Het is echter waarschijnlijk dat het oordeel over het bestaan van vooroordelen nauw samenhangt met de hiervoor besproken factor van sociale en historische achterstelling: wanneer daarvan sprake is (hetgeen relatief gemakkelijk en objectief vaststelbaar is) kan in veel gevallen worden verondersteld dat vooroordelen en stereotypen daarbij een belangrijke rol hebben gespeeld.

derscheid en daardoor verwarring zou kunnen scheppen; over de relevantie van bepaalde onderscheidingskenmerken als zodanig zal in paragraaf 3.2.3 nader worden ingegaan. Zie voor een voorbeeld ook San Antonio School District v. Rodriguez, 411 U.S. 1, 28 (1973), waarin dezelfde formule, zonder de betrokken toevoeging, wordt gehanteerd. Vgl. verder J.E.B. v. Alabama, 511 U.S. 127 (1994) (waarin wordt gesproken over "prejudicial attitudes toward women"). Een belangrijk bezwaar tegen deze factor is naar voren gebracht door Justice Powell in zijn opinie in Regents of the University of California v. Bakke, 438 U.S. 265 (1978): "[...][T] he white 'majority' itself is composed of various minority groups, most of which can lay claim to a history of prior discrimination at the hands of the State and private individuals. [...] There is no principled basis for deciding which groups would merit 'heightened judicial solicitude' and which would not." Vanzelfsprekend geldt dit bezwaar niet voor gevallen waarin een duidelijke meerderheid en minderheid duidelijker aanwijsbaar zijn, zoals bij onderscheid op grond van geslacht.

465. Dit blijkt al uit het arrest Strauder v. West Virginia, 100 U.S. 303, 308 (1879), waarin het Supreme Court concludeerde dat de benadeling van raciale minderheden verwerpelijk is omdat het hierdoor de veronderstelde inferioriteit van de groep wordt benadrukt en vooroordelen jegens deze groep worden gestimuleerd; vgl. ook Brown v. Board of Education, 347 U.S. 483, 494/495 (1954). In beide arresten speelde deze factor overigens niet zozeer een rol bij de vaststelling van de toetsingsintensiteit (waarover in beide arresten niet wordt gesproken), maar leidde deze wel tot de conclusie dat het onderscheid ontoelaatbaar was; ongetwijfeld betekent dit dat de gepercipicerde inferioriteit van een bepaalde groep ook relevant zou zijn geweest wanneer de vraag was gesteld of een strengere toetsing aangewezen was.

466. "Traditionally, [...] [sex] discrimination was rationalized by an attitude of 'romantic paternalism' which, in practical effect, put women, not on a pedestal, but in a cage. [...] As a result of notions such as these, our statute books gradually became laden with gross, stereotyped distinctions between the sexes"; Frontiero v. Richardson, 411 U.S., op 684/685. Deze factor lijkt ook een rol te spelen bij het toepassen van een iets verhoogde toetsingsintensiteit bij onderscheid op grond van homoseksualiteit, waarbij het Supreme Court heeft aangegeven dat "laws of the kind now before us raise the inevitable inference that the disadvantage imposed is born of animosity toward the class of persons affected" (Romer v. Evans, 517 U.S. 620 (1996)); het Supreme Court zag hierin echter geen reden voor de toepassing van een intermediate of strict scrutiny-test.

467. Zie ook Sherry 1984, p. 111. In de gevallen waarin het Supreme Court onderzoekt of een regeling is gebaseerd op vooroordelen of stereotypen gebeurt dit, vooral bij onderscheid op grond van geslacht, meestal niet bij de vaststelling van de toetsingsintensiteit (zoals volgens Carolene Products is vereist), maar bij de toetsing van het doel. Zie daarover de bespreking van de gerechtvaardigdheid van het doel in paragraaf 2.3.3. Een onderzoek naar de reden voor onderscheid is in deze gevallen ook echt nodig, omdat onderscheid op grond van geslacht niet in ieder concreet geval ingegeven zal zijn door verouderde opvattingen of stereotypen (Perry 1979, p. 1052). 


\section{Gebrek aan politieke invloed bij de benadeelde groep}

Tenslotte is het volgens de rechtspraak van het Supreme Court voor de verhoging van de toetsingsintensiteit van belang dat een bepaalde groep een gebrekkige politieke invloed heeft. Wanneer een benadeelde groep geen kiesrecht heeft, zoals lange tijd gold voor Afro-Amerikanen en vrouwen en nog steeds het geval is voor buitenlanders" ontbreekt voor deze groep immers de mogelijkheid om een benadeling via politieke wegen te voorkomen of te herstellen. In die situatie is het bovendien relatief gemakkelijk mogelijk om de belangen van deze groepen in het politieke proces over het hoofd te zien. Volgens Carolene Products is juist dit een belangrijke reden voor ingrijpen door de rechter. Ook in latere arresten heeft het Supreme Court regelmatig aangegeven dat het gebrek aan mogelijkheden van politieke participatie reden kan vormen voor het toepassen van strict of intermediate scrutiny. ${ }^{49}$ Een duidelijk voorbeeld is het amest Foley $v$. Connelie ${ }^{470}$, dat betrekking had op de uitsluiting van buitenlanders van be. paalde politiefuncties. Het Supreme Court stelde hierin het volgende:

"[...][T] he Court has treated certain restrictions on aliens with "heightened judicial solicitude,' a treatment deemed necessary since aliens - pending their eligibility for citizenship - have no direct voice in the political processes." 147

Ook wanneer een groep wel kiesrecht heeft kan er echter sprake zijn van een gebrek aan politieke invloed: een groep kan onvoldoende in staat zijn om te onderhandelen of coalities met andere minderheden te sluiten en kan daardoor een permanente verliezz zijn als het gaat om belangenbehartiging. Vanzelfsprekend is het inherent aan een democratisch systeem dat er minderheidsgroepen zijn die verliezen. Normaal gesproken zal het pluralisme dat binnen een goed werkende democratie aanwezig is er voldoende toe bijdragen dat er in andere omstandigheden een meerderheid ontstaat die wel weer recht doet aan hun belangen. ${ }^{472}$ Lang niet iedere classificatie waardoor een politieke minderheid wordt benadeeld kan dan ook een intensievere toetsing rechtvaardigen; zou dit wel zo zijn, dan zou feitelijk in iedere zaak een intensieve toetsing moeten worden uitgevoerd.

De situatie is echter anders wanneer er sprake is van een combinatie van factoren, namelijk wanneer een bepaalde groep een regelmatige verliezer blijkt te zijn binnen het politieke systeem en bovendien het slachtoffer is van historische of sociale achterstel.

468. Zie Rosberg 1977, p. 304/305.

469. Vgl. ook Ball 1974, p. 1080 en Sherry 1984, p. 109. Deze factor blijkt ook tot een intensivering van de rational basis-test te kunnen leiden. Zo is het opmerkelijk dat de benadeelden in een aantal zaken waarin sprake was van rational basis "with bite" geen van allen enige invloed konden uitoefenen of de betrokken regelgeving; zie Williams v. Vermont, 472 U.S. 14 (1985), Hooper v. Bermalillo Count) Assessor, 472 U.S. 612 (1985) en Metropolitan Life Insurance v. Ward, 470 U.S. 869 (1985); over do ze arresten nader Swierenga 1986, p. 1478/1479.

470. 435 U.S. 291 (1978)

471. 435 U.S., op 294. Zie verder Lane v. Wilson, 307 U.S. 268 (1939) (impliciet), Hampton v. Mow Sin Wong, 426 U.S. 88, 102 (1976) ("aliens are not entitled to vote"), San Antonio School District v. Ratriguez, 411 U.S. 1, 28 (1973) (de klasse van onvermogenden is niet "relegated to such a position of political powerlessness as to command extraordinary protection from the majoritarian political pro cess") en Massachusetts Board of Retirement v. Murgia, 427 U.S. 307, 313 (1976) (ouderen kennen dis groep geen geschiedenis van politieke machteloosheid). Zie kritisch over deze benadering "Develop" ments" 1969 , p. 1126.

472. Vgl. Ackerman 1985, p. 718 en 720; zo ook Rosberg 1977, p. 301. 
ling en van het bestaan van vooroordelen. In dat geval is de kans groot dat de gebrekkige politieke invloed met die vooroordelen of achterstelling verband houdt en een goede werking van het pluralistische systeem wordt verhinderd. ${ }^{473}$ Op basis van de Carolene Products-rationale bestaat er in dit soort omstandigheden zeker reden voor een intensievere toetsing door de rechter.

Hoewel dit aanvankelijk ook het uitgangspunt leek te zijn van het Supreme Court, heeft het later een interpretatie aan deze factor gegeven die aan de waarde van de doctrinaire grondslag afbreuk doet. Dit blijkt uit het arrest City of Cleburne v. Cleburne Living Center $^{174}$, dat betrekking had op een benadeling van geestelijk gehandicapten. Klagers hadden gesteld dat een verhoogde toetsingsintensiteit hierbij op zijn plaats was, nu deze mensen meestal geen stemrecht hebben. Het Supreme Court ontkende echter dat er een noodzaak bestond voor een striktere toetsing, vooral omdat er in de jaren voorafgaand aan de uitspraak veel voor deze groep positieve wetgeving tot stand was gekomen:

"[...][T]he legislative response, which could hardly have occurred and survived without public support, negates any claim that the mentally retarded are politically powerless in the sense that they have no ability to attract the attention of the lawmakers. Any minority can be said to be powerless to assert direct control over the legislature, but if that were a criterion for higher level scrutiny by the courts, much economic and social legislation would now be suspect." 4 's

Wanneer er sprake is van een voor de betrokken minderheidsgroep positief beleid, acht het Supreme Court het blijkens deze overweging niet nodig dat de betrokken groep rechtstreeks invloed kan uitoefenen op de totstandkoming van het beleid; dit geldt zelfs wanneer de groep door gebrek aan actief kiesrecht geen invloed heeft op de wijze waarop hun belangen in het politieke proces worden vertegenwoordigd. ${ }^{476}$ Dit lijkt geen geheel redelijke benadering te zijn. Ook wetgeving die in de ogen van de politieke meerderheid positief is kan immers zijn ingegeven door vooroordelen en stereotypen en kan door de betrokken minderheid soms zelfs als zeer negatief worden ervaren. ${ }^{47}$ Door

473. Vgl. Cover 1982, p. 1296. Ackerman bestrijdt dit: hij geeft aan dat wanneer minderheden politieke invloed hebben, het niet van belang is dat bij de meerderheid vooroordelen jegens deze minderheid bestaan: ook de minderheid zal immers vooroordelen hebben, die in een pluralistisch stelsel een zekere uitwerking kunnen hebben $(1985$, p. 734$)$. Het is echter twijfelachtig dat het pluralistische model bij het bestaan van grootschalige vooroordelen en stereotypen goed functioneert en de minderheid voldoende gelegenheid heeft om zijn eigen vooroordelen in het politieke systeem tot uitdrukking te brengen. Op zijn minst is het in die gevallen dan ook wenselijk de rechter de mogelijkheid te geven nader te kijken naar de beweegredenen en alternatieven voor een benadeling van de achtergestelde groep.

474. 473 U.S. 432 (1985)

475. 473 U.S., op 444

476. Deze gedachte lijkt gegrond te zijn op de theorie van "virtual representation"; zie daarover nader Ely 1980 , p. $83 / 84$. Ely geeft aan dat deze theorie, die ervan uitgaat dat iemands belangen ook door iemand anders behartigd kunnen worden, niet altijd effectief is: wanneer de belangenbehartiger zelf een permanente verliezer in het politieke proces is of de belangen niet op de gewenste wijze behartigt, is er alsnog sprake van politieke machteloosheid (op p. 86). Weliswaar was van een dergelijke situatie i.c. geen sprake (de belangenbehartiging vond kennelijk op een goede manier plaats), maar de overweging is in zodanig brede termen gesteld dat deze een verhoogde toetsingsintensiteit ook bij een verkeerde of ongewenste vorm van belangenbehartiging bemoeilijkt. Zie ook Wunder 1986, p. 251,

477. $\mathrm{Z} 0$ is het de vraag of veel "beschermende" wetgeving voor vrouwen die in de negentiende eeuw werd ingesteld (bijvoorbeeld verbod van nachtarbeid) ook door vrouwen zelf als wenselijk en noodzakelijk 
het ontbreken van voldoende politieke kracht zal een dergelijke minderheid vaak niet in staat zijn om deze wetgeving tegen te houden, zodat er wel degelijk sprake is van poli. tiek verlies. Het zou dan ook beter zijn wanneer het Supreme Court primair aandacht zou besteden aan de factoren die het eerder als relevant heeft erkend. De vraag is dan of er sprake is van wijdverbreide vooroordelen en stereotypen jegens een bepaalde groep, die sterk bepalend zijn voor hun werkelijke invloed binnen het politieke systeem. Het bestaan van positieve wetgeving zal zeker een indicatie kunnen vormen voor een negatieve beantwoording van deze vraag, maar kan, anders dan het Supreme Court in Cle. burne veronderstelt, voor de vaststelling van de toetsingsintensiteit niet direct doorslaggevend worden geacht.

\section{Irrelevantie van bovengenoemde factoren na Adarand?}

Alle bovengenoemde factoren lijken zich zonder meer te lenen voor een meer algemene toepassing en kunnen een nuttige invulling geven aan het algemene toetsingsmodel. Het Supreme Court zelf heeft echter aangegeven dat deze factoren voor een tweetal differentiatiecriteria niet relevant kunnen worden geacht. Zowel bij onderscheid op grond van ras als bij onderscheid op grond van geslacht heeft het verschillende malen expliciet gesteld dat het niet van belang is welke groep door het onderscheid wort benadeeld: doorslaggevend is slechts of er sprake is van onderscheid op een (quasi-) verdachte grond. ${ }^{477}$ Dit is een subtiel, maar zeer belangrijk verschil in benadering. Voor onderscheid op grond van geslacht betekent dit bijvoorbeeld dat onderscheid dat bensdelend is voor vrouwen even strikt zal worden getoetst als onderscheid dat nadelig is voor mannen, ondanks het feit dat mannen niet bloot hebben gestaan aan enige vom van historische of maatschappelijke achterstelling en politiek altijd dominant zijn geweest. ${ }^{47}$ Dit zou echter nog niet geheel onredelijk kunnen worden geacht: vrouwen zjpn tegenwoordig zeker niet meer politiek invloedloos, terwijl mannen evengoed als vrouwen regelmatig het slachtoffer zijn van stereotypen en opvattingen over rolpatronen. Werkelijk problematische consequenties heeft deze accentverschuiving vooral voor onderscheid op grond van ras, en dan met name voor positieve discriminatie. Wanneet de historische en sociale achterstelling of stigmatisering van een groep een bepalende factor vormt voor de vaststelling van de toetsingsintensiteit, dan betekent dit in de VS

werd ervaren (het "gouden kooi"-effect); daarover kon nooit duidelijkheid worden verkregen, nth vrouwen geen mogelijkheden hadden tot actieve participatie in de politiek.

478. Vgl. Sobelsohn 1977, p. 477 en Sherry 1984, p. 106/107; de laatste geeft aan dat het Supreme Court lang verdeeld is geweest over de vraag of alleen groepsbepaalde factoren of de grond van ondersckidi als zodanig de toetsingsintensiteit bij ras en geslacht bepalen.

479. Dit blijkt al uit Craig v. Boren, 429 U.S. 190 (1976) (het arrest waarin het Supreme Court voor het eerst de intermediate scrutiny-test toepaste): in dit arrest was sprake van een benadeling van mannen Het Supreme Court legde overigens niet uit waarom ook in dit geval een striktere toetsing zou moter gelden; zie daarover kritisch de dissenting opinion van Justice Rehnquist, die stelde dat een strikter toetsing bij benadeling van mannen niet nodig is omdat zij historisch gezien nooit zijn achtergesteld of structureel zijn gediscrimineerd (op 219) (overigens is deze dissenting opmerkelijk, nu Rehnquist in latere opinies vurig heeft verdedigd dat bij ras steeds een strikte toetsing moet worden uitgevoerd, ongedacht de benadeelde groep). Overigens is het niet ondenkbaar dat ook mannen soms lijden onder be paalde rollenpatronen of stereotypen over typische kwaliteiten of gebreken: zo kan de gedachte dur vrouwen een betere band hebben met hun kind mannen soms benadelen in hun rechten ten opzidhe van hun kinderen (zie voor een voorbeeld Miller v. Albright, 523 U.S. 420, 443 (1998)). Vgl, ook Perm 1979, p. 1053 en Sobelsohn 1977, p. 478. 
dat ieder onderscheid jegens Afro-Amerikanen (en enkele andere raciale minderheidsgroepen) moet worden onderworpen aan de fatale strict scrutiny-test. Tegelijkertijd zou dit tot gevolg hebben dat bij positieve discriminatie een minder strenge toetsing zou moeten worden toegepast: door voorkeursbeleid wordt immers uitsluitend de blanke meerderheid benadeeld, die nooit heeft geleden onder achterstelling of stigmatisering en die de politiek steeds heeft gedomineerd. ${ }^{480}$ Een dergelijke vermindering van de toetsingsintensiteit bij voorkeursbeleid kan zeker als positief worden beschouwd, omdat een toepassing van de strict scrutiny-test het voeren van een dergelijk beleid vrijwel onmogelijk zou maken. Door niet de benadeelde groep, maar de grond van onderscheid tot uitgangspunt te nemen heeft het Supreme Court deze mogelijkheid van een verschil in toetsingsintensiteit echter volledig weggenomen. In 1995 gaf het hiervoor de volgende motivering:

"[...][T] he basic principle [is] that the Fifth and the Fourteenth Amendment to the Constitution protect persons, not groups. It follows from that principle that all governmental action based on race - a group classification long recognized as in most circumstances irrelevant and therefore prohibited - should be subject to detailed judicial inquiry to ensure that the personal right to equal protection of the laws has not been infringed. [...][A] free people whose institutions are founded upon the doctrine of equality should tolerate no retreat from the principle that government may treat people differently because of their race only for the most compelling reasons. Accordingly, we hold today that all racial classifications, imposed by whatever federal, state, or local governmental actor, must be analyzed by a reviewing court under strict scrutiny." ${ }^{\text {sis }}$

Met deze overweging verplaatst het Supreme Court het accent van de bescherming van een individu als lid van een groep naar de bescherming van het individu als zodanig. Los van de vraag of hiermee een juiste interpretatie wordt gegeven aan het gelijkheidsbeginsel, kan worden opgemerkt dat door een dergelijke accentverschuiving in sterke mate afbreuk wordt gedaan aan de waarde van de Carolene Products-rationale als rechtvaardiging voor een verhoogde toetsingsintensiteit. Deze rationale is gebaseerd op de gedachte dat de wetgever altijd zal classificeren op basis van groepskenmerken en op het gevaar dat aan dergelijke classificaties inherent is. ${ }^{482}$ Duidelijk is immers dat de

480. Vgl. Ely 1980, p. 170/171. Volgens een drietal rechters binnen het Supreme Court (Justices Brennan, Marshall en Blackmun) was dit verschil inderdaad relevant; zij stelden in hun opinies consequent dat om deze reden geen strict scrutiny test moet worden toegepast. Zie hun partly concurring, partly dissenting opinion bij Regents of the University of California v. Bakke, 438 U.S. 265, 357 (1978) en hun concurring opinion bij Fullilove v, Klutznick, 448 U.S. 448, 518 (1980).

481. Adarand Constructors, Inc. v. Pena, 515 U.S. 200, 227 (1995). Een vergelijkbaar oordeel, maar dan alleen voor onderscheid door de staten, gaf het Supreme Court in City of Richmond v. J.A. Croson Co., 488 U.S. 469, 493 (1989). De gedachte daarbij leek te zijn dat iedere classificatie op grond van ras verdacht is en een stigmatiserend effect kan hebben. Ook in 1986 oordeelde het Supreme Court dat " [...] the level of scrutiny does not change merely because the challenged classification operates against a group that historically has not been subject to governmental discrimination" (Wygant v. Jackson Board of Education, 476 U.S. 267 (1986)), maar deze opinie werd toen niet door een meerderheid ondersteund. Hetzelfde gebrek aan steun gold voor Justice Powells opinie in Regents of the University of California v. Bakke, 438 U.S. 265,294 (1978), waarin hij stelde dat "it is far too late to argue that the guarantee of equal protection to all persons permits the recognition of special wards entitled to a dregree of protection greater than that accorded others." Zie verder Shaw v. Reno, 509 U.S, 630, 643 (1993) en Miller v. Johnson, 515 U.S. 900, 904 (1995).

482. Vgl. Sherry 1984, p. 94. 
wetgever beïnvloed zal worden door maatschappelijke opvattingen, stereotypen en vooroordelen over de groepen waartussen hij onderscheid maakt, hetgeen tot gevolg kan hebben dat zijn oordeel niet objectief is. ${ }^{43}$ Juist dit gebrek aan objectiviteit zal voor de rechter reden kunnen zijn om het individu extra bescherming te bieden. Een dergelijke bescherming is in veel mindere mate nodig wanneer de kans klein is dat het 00 o. deel van de wetgever is ingekleurd door vooroordelen of wanneer een groep zelf over voldoende mogelijkheden beschikt om het politieke proces te beïnvloeden. ${ }^{\text {at }}$ Volgens de redenering in Adarand is echter niet de invloed van vooroordelen op de besluitvorming of het vermoeden van een verstoring van het politieke proces reden voor een striktere toetsing, maar het enkele feit dat iemand is benadeeld op grond van een groepskenmerk dat irrelevant is voor zijn functioneren als individu. ${ }^{\text {tes }}$ Op zichzelf lijkt deze benadering wel binnen de Carolene Products-rationale te passen: het feit dat er onderscheid is gemaakt op een irrelevant persoonskenmerk kan immers een vermoeden doen rijzen dat het politieke proces niet op een betrouwbare en objectieve manier heeft gefunctioneerd. ${ }^{4 \$ 6}$ Het Supreme Court heeft dan ook, zoals hierna nog zal blijken, in een uitgebreide rechtspraak aandacht besteed aan de irrelevantie en verdachtheid van bepaalde onderscheidingskenmerken. Van belang is echter dat de verdachtheid van de grond van onderscheid in de eerdere rechtspraak slechts één factor is die twijfel kan doen ontstaan over de juiste werking van het politieke proces. Wanneer er andere factoren in een zaak naar voren komen die deze twijfel kunnen wegnemen (bijvoorbeeld in het geval waarin de benadeelde groep nooit slachtoffer is geweest van het bestaan van massale vooroordelen en stigmatisering en het politieke proces voldoende heeft kunnen beïnvloeden) bestaat er volgens deze lijn van rechtspraak geen aanleiding voor het uitvoeren van een intensieve rechterlijke toetsing. Door Adarand wordt juist deze afwegingsmogelijkheid weggenomen, zodat een strikte rechterlijke toetsing ook mogelijk is wanneer er geen reden bestaat om te twijfelen aan de juiste werking van het politieke proces.

Helaas heeft het Supreme Court geen aandacht besteed aan dit gevolg van de verandering in de grondslag voor verhoogde toetsingsintensiteit. Problematisch is bovendien dat het Supreme Court sinds 1995 weinig zaken in behandeling heeft genomen waaruit kan blijken of het bereid is deze nieuwe rationale voor toepassing van een verhoogde

483. Zie Ely 1974, p. 732, die dit beschrijft als het verschil tussen de "they-they"-generalisering en de "w5 they"-generalisering. Meestal zal de wetgever classificeren op basis van algemene veronderstellingen over twee groepen waarvan de parlementariërs zelf geen deel uitmaken, bijvoorbeeld bij onderscheid tussen optometristen en opticiens (een "they-they"-situatic). Wanneer er onderscheid wordt gemaskt of grond van ras (of geslacht) zal er echter al snel een vergelijking worden gemaakt tussen "we" en "they", in de zin dat "They [Blacks] differ from us [Whites] in certain respects that we find sufficier on balance to justify the decision to classify on this basis." Ely toont aan dat in het geval van een "ve they"-generalisering de invloed van positieve oordelen over de eigen groep en negatieve oordelen over de andere groep wordt versterkt, waardoor het risico bestaat dat de "they"-groep sterket wordt ben deeld dan het geval zou zijn in een "they-they"-situatie (op p. 733). Zie ook "Note" 1974, A $1250 / 1251$.

484. Vgl. ook hier Ely 1974, p. 735 en 736 : "a we-they classification that favors the 'they's' does not merit 'special scrutiny',"

485. Zie over het verschil tussen de benadering waarin gelijke behandeling wordt gezien als individuet of als groepsrecht ook "Developments" 1969, p. 1111/1112.

486. In ieder geval bestaat hiervoor altijd een risico; vgl. "Developments" 1969, p. 1115. 
toetsingsintensiteit ook toe te passen bij andere gronden. ${ }^{487}$ Vooralsnog is dan ook onduidelijk of de Carolene Products-rationale daadwerkelijk is verlaten.

\subsubsection{Factoren met betrekking tot de grond van onderscheid}

Irrelevantie van het onderscheidingskenmerk voor het maatschappelijk functioneren In zijn rechtspraak heeft het Supreme Court verschillende factoren ontwikkeld die kunnen duiden op de verdachtheid van bepaalde differentiatiecriteria. De belangrijkste reden om een onderscheidingsgrond als verdacht aan te merken blijkt daarbij de irrelevantie van een groepskenmerk voor het (maatschappelijk) functioneren van het individu te zijn. Dit blijkt duidelijk uit het al eerder genoemde arrest Frontiero $v$. Richardson $^{\text {iss: }}$ :

"[...][W] hat differentiates sex from such nonsuspect statuses as intelligence or physical disability, and aligns it with the recognized suspect criteria, is that the sex characteristic frequently bears no relation to ability to perform or contribute to society."

Vanzelfsprekend geldt een vergelijkbare overweging ook voor onderscheid op grond van ras, etnische afkomst en nationaliteit, terwijl het Supreme Court dit ook bij onderscheid op grond van wettige geboorte als een intensiteitverhogende factor heeft geaccepteerd. ${ }^{4 \infty}$ De irrelevantie van het differentiatiecriterium lijkt ook inderdaad een zinvol

487. Hoogstens kunnen enige aanwijzingen worden afgeleid uit Romer v. Evans, 517 U.S. 620 (1996), een zaak die betrekking had op onderscheid op grond van seksuele geaardheid. Hoewel het Supreme Court zich niet waagde aan een uitgebreid oordeel over de intensiteit van de toetsing en een gewone rational basis-test toepaste, wordt er vanuit gegaan dat in de uitspraak een verhoogde toetsingsintensiteit werd toegepast. Een belangrijke reden daarvoor was de ernst van de inbreuk (zie daarover paragraaf 3.4.4), maar van belang leek ook te zijn dat "the disadvantage imposed is born of animosity toward the class of persons affected". Het gaat hierbij duidelijk om één van de hiervoor genoemde factoren; de bezwaren daartegen lijken dan ook minder principieel te zijn dan uit Adarand zou kunnen blijken.

488. 411 U.S. 677 (1973)

489. 411 U.S., op 686; vgl. ook City of Cleburne v. Cleburne Living Center, 473 U.S. 432, 441 (1985). De "recognized suspect criteria" genoemd in het citaat zijn ras en nationaliteit. Bij deze gronden wordt slechts zelden aangegeven dat zij irrelevant zijn voor het maatschappelijk functioneren, waarschijnlijk omdat dit evident is; zie echter Hirabayashi v. United States, 320 U.S. 81, 100 (1943) ("racial discriminations are in most circumstances irrelevant") en Adarand Constructors, Inc. v. Pena. 515 U.S. 200, 227 (1995). Nationaliteit kan overigens wel degelijk relevant zijn voor het maatschappelijk functioneren; het Supreme Court heeft dit ook erkend: in verschillende arresten heeft het een "public function exception" aanvaard die is gebaseerd op de gedachte dat bij mensen van een andere nationaliteit de loyaliteit en de band met het lad die is vereist voor het goed vervullen van een ambtelijke functie wel eens kunnen ontbreken (deze arresten zijn reeds genoemd, supra noot 367). In dergelijke gevallen wordt een minder intensieve toetsing uitgevoerd, hoewel normaal gesproken een strict scrutiny-test wordt toegepast.

490. Zie bijv. Mathews v. Lucas, 427 U.S. 495, 505 (1976) ("“...] the legal status of illegitimacy [...] bears no relation to the individual's ability to participate in and contribute to society") en City of Cleburne v. Cleburne Living Center, 473 U.S. 432, 441 (1985). Overigens heeft het Supreme Court ook bij onderscheid op grond van onvermogendheid soms een verhoogde toetsingsintensiteit toegepast vanwege de irrelevantie van dit kenmerk. Een voorbeeld is Harper v. Virginia Board of Elections, 383 U.S. 663 (1966): "Wealth, like race, creed, or color, is not germane to one's ability to participate intelligently in the electoral process" (op 668). In andere context kan vermogen echter wel degelijk relevant zijn; de grond wordt dan ook niet altijd als verdacht aangemerkt (zie bijv. Maher v. Roe, 432 U.S. 464, 470/471 (1977) en Harris v. McRae, 448 U.S. 297, 323 (1980)). De factor is tenslotte soms genoemd om aan te geven dat een kenmerk juist wel relevant is en er dus geen reden bestaat voor een intensievere toetsing; 
criterium voor de bepaling van de verdachtheid te zijn: het is niet eenvoudig om een persoonskenmerk te bedenken dat voor het maatschappelijk functioneren niet relevant is en dat tegelijkertijd een grond van onderscheid kan vormen die geen vragen oproept over de objectiviteit en neutraliteit van de regelgever. ${ }^{491}$

\section{Onveranderlijkheid van het onderscheidingskenmerk}

Een tweede factor die een rol blijkt te spelen bij het aanmerken van een onderschei. dingskenmerk als verdacht betreft de onveranderlijkheid van dit kenmerk. Deze factor heeft er in belangrijke mate toe bijgedragen dat bij onderscheid op grond van onwettige geboorte een verhoogde toetsingsintensiteit wordt gehanteerd. Zo stelde het Supreme Court in Mathews $v$. Lucas ${ }^{42}$, dat

"It is true, of course, that the legal status of illegitimacy, however defined, is, like race or national origin, a characteristic determined by causes not within the control of the illegitimate individual."

Het zal echter duidelijk zijn dat de onveranderlijkheid van het onderscheidingsken. merk, anders dan de relevantie daarvan voor het maatschappelijk functioneren, niet altijd doorslaggevend kan zijn voor het aanmerken van een bepaalde grond als verdacht. Kenmerken waaraan een mens niet of moeilijk iets kan veranderen worden im. mers regelmatig als aanvaardbare gronden voor onderscheid beschouwd, zoals het geval is bij intelligentie, talent of handicap. Andersom worden kenmerken die relatief gemakkelijk te veranderen zijn, zoals nationaliteit (door middel van naturalisatie),

zie bijv. Massachusetts Board of Retirement v. Murgia, 427 U.S. 307, 313 (1976) (ouderen worden niet achtergesteld op basis van kenmerken "not truly indicative of their abilities").

491. Meer in het algemeen is het moeilijk voorstelbaar dat bepaalde gronden van onderscheid nooit relevat zijn voor het maatschappelijk functioneren. Zo kan worden gesteld dat in een land waar een racile minderheid zeer lang is achtergesteld, het ras relevant kan zijn voor het bepalen van economische act. terstand en achterstand op het gebied van scholing. Dit kan vervolgens een rechtvaardiging vomen voor het uitvoeren van een minder intensieve toetsing van beleid dat op positieve wijze met dit soct achterstand rekening houdt. Zie "Developments" 1969, p. 1112. Ook heeft het Supreme Court onderscheid op grond van schijnbaar irrelevante kenmerken (zoals het zijn van familie van een gids, is Kotch v. Board of River Board Pilot Commissioners for Port of New Orleans, 330 U.S. 552 (1947) niet als verdacht aangemerkt, omdat dit kenmerk in het licht van het doel van de regeling wel degelip. relevant kon worden geacht. Bij het gebruik van een factor als die van irrelevantie van het differentilit tiecriterium, zonder daarbij andere factoren (zoals het bestaan van vooroordelen) te betrekken, kuntan dan ook onwenselijke conclusies worden bereikt. Vgl. Sherry 1984, p. 112. Perry stelt dat er on dez reden beter over "morele irrelevantie" dan over "maatschappelijke relevantie" kan worden gesprokan $(1979$, p. 1050); een daadwerkelijke verduidelijking lijkt dit echter niet echt op te leveren.

492. 427 U.S. 495,505 (1976)

493. 427 U.S., op 505. Vgl. ook Parham v. Hughes, 441 U.S. 347, 351 (1979) (geen reden voor terughoodendheid bij onderscheid op grond van "immutable human attributes"), Weber v. Aetna Casually \& S. rety Co., 406 U.S. 164, 175 (1972) (waarbij dit argument vooral een rol speelde bij de beoordeling vas de proportionaliteit), Plyler v. Doe, 457 U.S. 202, 220 (1982) (impliciet verhoogde toetsingsintensitith bij benadeling illegale kinderen, omdat deze groep "can neither affect their parents' conduct nor their own status"), Lyng v. Castillo, 477 U.S. 635, 638 (1986) ("Close relatives [...] do not exhibit [...] im. mutable [...] characteristics"(!)) en City of Cleburne v. Cleburne Living Center, 473 U.S. 432, 41 (1985) (verhoogde toetsingsintensiteit omdat "illegitimacy is beyond the individuals control"). In bat laatste arrest paste het Supreme Court overigens een verhoogde toetsingsintensiteit bij onderscheid an grond van geestelijke handicap, o.a. vanwege de onveranderlijkheid van dat onderscheidingskenmer. Zie ook Sobelsohn 1977, p. 473. 
volgens vaste rechtspraak van het Supreme Court wel degelijk als verdacht aangemerkt.

\section{Zichtbaarheid van het onderscheidingskenmerk}

Relevant voor de verdachtheid van een bepaald differentiatiecriterium is tenslotte de zichtbaarheid van het onderscheidingskenmerk. Deze factor wordt door het Supreme Court slechts zelden genoemd, hetgeen ook wel begrijpelijk is: (quasi-)verdachte kenmerken zijn vaak niet kenbaar, zoals het geval is bij onderscheid op grond van onwettige geboorte en nationaliteit, terwijl veel niet-verdachte kenmerken, zoals lichamelijke handicap, juist duidelijk zichtbaar zijn. Als deze factor al wordt genoemd wordt deze dan ook vaak gecombineerd met een andere factor, zoals sociale achterstelling. Een voorbeeld hiervan is opnieuw te vinden in Frontiero $v$. Richardson ${ }^{44}$, waarin het Supreme Court stelde dat

"[...][]t can hardly be doubted that, in part because of the high visibility of the sex characteristic, women still face pervasive, although at times more subtle, discrimination $[\ldots]$, , 995

\subsubsection{Afweging van de factoren met betrekking tot het onderscheid als zodanig}

Elk van de in paragraaf 3.3.1 en 3.3.2 genoemde factoren kan bijdragen aan de keuze voor een verhoging van de toetsingsintensiteit. Het is echter duidelijk dat bepaalde factoren zwaarder zullen wegen dan andere: zo zal de zichtbaarheid van een bepaald kenmerk minder belangrijk zijn dan de irrelevantie voor het maatschappelijk functioneren, terwijl de duidelijke bepaalbaarheid van een groep minder relevant is dan de aanwezigheid van een sociale of historische achterstelling. Van belang is verder dat sommige van de genoemde factoren alleen in combinatie met andere kunnen leiden tot een verhoging van de toetsingsintensiteit, zoals het geval is bij de onveranderlijkheid van een bepaald kenmerk. Voor de factoren die in paragraaf 3.3.1 zijn besproken en die betrekking hebben op de politieke invloed en het bestaan van vooroordelen jegens een bepaalde groep geldt zelfs dat een verhoging van de toetsingsintensiteit alleen gerechtvaardigd is als deze factoren inderdaad in combinatie voorkomen: het enkele bestaan van vooroordelen of de enkele aanwezigheid van een historische achterstelling verschaft onvoldoende basis voor een strengere toetsing. De vraag kan dan ook rijzen op welke manier het Supreme Court met deze verschillende (groepen van) factoren omgaat wanneer het daadwerkelijk een keuze moet maken voor een bepaalde toetsingsintensiteit.

Van belang is hierbij dat het Supreme Court onderscheid op grond van ras beschouwt als een soort ijkpunt. Het ziet deze grond voor onderscheid niet alleen als inherent verdacht, maar zelfs als "invidious" (letterlijk: aanstootgevend) ${ }^{4 \%}$ Een belangrijke

494. 411 U.S. 677 (1973)

495. 411 U.S., op 686

496. Vgl. Lusky 1975, p. 246 en Wilkinson 1975, p. 978, die spreekt van een "super-suspect classification". Een uitgebreide definitie van het begrip "invidious" is gegeven door Michelman 1969, p. 20; daaruit 
reden daarvoor is dat bij deze grond aan alle genoemde factoren voor verdachtheid is voldaan: ras is een zichtbaar en onveranderlijk persoonskenmerk, dat bovendien irrels. vant is voor het maatschappelijk functioneren. ${ }^{497}$ Een betekenisvolle factor lijkt verder de historische achtergrond van onderscheid op grond van ras te zijn. Dit blijkt bijvoorbeeld uit het arrest McLaughlin v. Florida ${ }^{98}$, waarin een wet in het geding was die ongetrouwd samenwonen van gemengde koppels zwaarder bestrafte dan samenwonen van personen van hetzelfde ras. Ten aanzien van de toetsingsintensiteit stelde het Su. preme Court het volgende:

" $[\ldots][W]$ e deal here with a classification based upon the race of the participants, which must be viewed in light of the historical fact that the central purpose of the Fourteenth Amendment was to eliminate racial discrimination emanating from official sources in the States. This strong policy renders racial classifications constitutionally suspect, and subject to the most rigid scrutiny."

Een verdere rechtvaardiging voor de kwalificatie als verdachte grond is terug te vinden in Miller v. Johnson ${ }^{500}$, waarin het Supreme Court over het betrekken van ras als factor bij het vaststellen van kiesdistricten het volgende stelde:

"Race-based assignments embody stereotypes that treat individuals as the product of their race, evaluating their thoughts and efforts -- their very worth as citizens -- according to a criterion barred to the Government by history and the Constitution. They also cause society serious harm. $[\ldots]$ Racial gerrymandering, even for remedial purposes, may balkanize us into competing racial factions $[\ldots] .$, ."30t

blijkt dat het begrip impliceert dat alle hiervoor genoemde factoren die de verdachtheid van een grool van onderscheid bepalen aanwezig zijn.

497. De eerste twee factoren worden vrijwel nooit genoemd; van de irrelevantie wordt wel vaak melding gemaakt. Zie bijv. Adarand Constructors, Inc. v. Pena, 515 U.S. 200, 227 (1995). Vgl. ook Aleiniloff 1991, p. 1063.

498. 379 U.S. 184 (1964)

499. 379 U.S., op 191/192; zie ook Miller v. Johnson, 515 U.S. 900,904 (1995). Andere redenen om onder scheid op grond van ras als inherent verdacht aan te merken zijn genoemd in het arrest Strander : West Virginia, 100 U.S. 303, 309 (1897), waarin het Supreme Court stelde dat het ontnemen van bo paalde rechten aan Afro-Amerikanen vanwege hun huidskleur "is practically a brand upon them, at fixed by the law, an assertion of their inferiority, and a stimulant to that race prejudice which is an int pediment to securing to individuals of the race that equal justice which the law aims to secure to $\mathrm{al}^{-}$ others." Vgl. ook "Developments" 1969, p. 1125. Aantoonbaar is dat de opstellers van het Veertient Amendement weliswaar het oog hadden op de uitbanning van onderscheid op grond van ras, maar zith daarbij uitsluitend concentreerden op benadeling van de voormalige slaven. Voor de "color blind" if terpretatie biedt de totstandkomingsgeschiedenis minder ruimte dan vaak wordt verondersteld. $Z$ is Sherry 1984, p. 92/93.

500. 515 U.S. 900 (1995)

501. 515, op 912. Zie ook City of Richmond v. J.A. Croson Co., 488 U.S. 469, 493 (1989). Vgl. ook Ciyed Cleburne v. Cleburne Living Center, 473 U.S. 432, 440 (1985): “[...][R]ace, alienage, or national of gin [...] are so seldom relevant to the achievement of any legitimate state interest that laws groundd in such considerations are deemed to reflect prejudice and antipathy [...]." Vgl. ook Posner 1979, p. 177. die stelt dat alle vormen van onderscheid op grond van ras, ongeacht de benadeelde groep, zjin gobo seerd op een gelijke vorm van stereotypering. Vgl. ook Perry 1979, p. I031, die zich vooral verzet lo gen het uitgangspunt van morele inferioriteit dat ten grondslag ligt aan onderscheid op deze grond ae steld kan echter worden dat deze benadering van "color blindness" in theorie heel fraai en juist is, nIII dat een dergelijke benadering in de praktijk tot gevolg kan hebben dat de vooroordelen en stigna'sjo gens raciale groepen worden versterkt. Een "race conscious approach", waarbij ras soms wel gejiet 
Om bij andere onderscheidingskenmerken te kunnen bepalen of er reden bestaat voor de toepassing van een strict scrutiny-test zal het Supreme Court steeds bekijken of ze de vergelijking met onderscheid op grond van ras kunnen doorstaan. ${ }^{302}$ De hiervoor genoemde factoren lijken daarbij van belang te zijn als objectieve punten van vergelijking: hoe meer factoren er aanwezig zijn, des te meer "lijkt" een onderscheidingskenmerk op ras en des te groter is de kans dat er een strict scrutiny-test zal worden toegepast. In de praktijk heeft deze benadering tot gevolg gehad dat naast ras slechts een tweetal onderscheidingskenmerken als werkelijk verdacht zijn aangemerkt; het gaat daarbij om nationaliteit ("alienage") ${ }^{503}$ en nationale origine ("ancestry") ${ }^{504} .{ }^{505} \mathrm{Bij}$ onderscheid op grond van nationaliteit heeft het Supreme Court in latere rechtspraak bovendien nog aangegeven dat een strict scrutiny-test niet altijd nodig is. ${ }^{306}$

Aanvankelijk bleek het Supreme Court, zij het in een plurality opinion, ook bereid te zijn om onderscheid op grond van geslacht te rekenen tot de gevallen waarop de strict scrutiny-test moet worden toegepast. ${ }^{507}$ In latere rechtspraak kwam het hier echter op

wordt als een relevante factor, kan volgens verschillende auteurs veel positievere effecten hebben voor het bereiken van een werkelijke gelijkberechtiging. Vgl. bijv. Aleinikoff 1991, p. 1081 en "Developments" 1969, p. 1113.

502. Vgl. Ely 1980 , p. 149.

503. Dit werd voor het eerst uitdrukkelijk erkend in Graham v. Richardson, 403 U.S. 365, 372 (1971). Met dit begrip wordt overigens alleen gedoeld op buitenlanders die op legale wijze permanent in het land wonen, niet op illegalen of mensen die slechts tijdelijk in het land verblijven; zie Rosberg 1977, p. 304.

504. Zie Hirabayashi v. United States, 320 U.S. 81, 100 (1943); het ging in dit arrest om een benadeling van Amerikanen van Japanse afkomst; zie verder Oyama v. California, 332 U.S. 633 (1948). Ook in het arrest Yick Wo v. Hopkins, 118 U.S. 356 (1886) paste het Supreme Court impliciet een strikte toetsing toe op de benadeling van (vaak tot Amerikaan genaturaliseerde) Chinezen. Inderdaad is het verschil tussen ras en nationale origine niet bijzonder groot.

505. In een drietal arresten is ook voor andere gronden een strict scrutiny-test aanvaard, maar in beide gevallen is het Supreme Court daarvan vrijwel meteen teruggekomen. Bekend is het voorbeeld van Frontiero v. Richardson, 411 U.S. 677, 682 (1974) met betrekking tot onderscheid op grond van geslacht, maar ook heeft het Supreme Court dit een keer geïmpliceerd bij onderscheid op grond van vermogendheid: "[...][A] careful examination on our part is especially warranted where lines are drawn on the basis of wealth or race, [...] two factors which would independently render a classification highly suspect and thereby demand a more exacting judicial scrutiny" (McDonald v. Board of Election Commissioners of Chicago, 394 U.S. 802, 807 (1969); cursief toegevoegd); vgl. ook Harper v. Virginia Board of Elections, 383 U.S. 663, 668 (1966) en Michelman 1969, p. 26/27. In latere arresten heeft het Supreme Court deze stelling niet herhaald, en heeft het aangegeven dat een onderscheid op deze grond alleen in combinatie met de aantasting van een belangrijk recht tot verhoogde toetsingsintensiteit kan leiden; zie daarover paragraaf 3.4.4. Verder heeft het Supreme Court in een opsomming van verdachte gronden onderscheid op grond van religie soms als verdacht aangemerkt (City of New Orleans v. Dukes, 427 U.S. 297, 303 (1976)). Deze kwalificatie sluit aan bij Carolene Products, waarin religieuze minderheden expliciet genoemd worden als kwetsbare groep; het Supreme Court heeft echter nooit nader aangegeven waarom deze grond als zodanig (d.w.z. los van de aangetaste groep) verdacht zou zijn.

506. Het gaat hierbij om de zogenaamde "public function exception", die inhoudt dat een minder strikte toetsing zal worden uitgevoerd wanneer er onderscheid op grond van nationaliteit wordt gemaakt bij het bekleden van bepaalde ambtelijke functies. Deze rechtspraak is reeds kort besproken; zie nader paragraaf 3.5.2.

507. Frontiero v. Richardson, 411 U.S. 677, 682 (1974). Opmerkelijk is dat in deze zaak uitvoerig werd gemotiveerd waarom een intensievere toetsing moest worden toegepast bij onderscheid waardoor vrouwen werden benadeeld, maar dat het Supreme Court nooit expliciet heeft aangegeven waarop dit ook geldt bij benadeling van mannen. Duidelijk is wel dat alle "verdachtmakende" factoren bij deze 
terug, waarschijnlijk niet zozeer omdat de besproken intensiteitverhogende factoren in onvoldoende mate aanwezig waren of omdat deze grond van onderscheid achteraf gezien als minder ernstig werd beschouwd $\mathrm{d}^{\mathrm{sos}}$, maar vooral vanwege de maatschappelij. ke consequenties die de keuze voor de strict scrutiny-test zou hebben. ${ }^{\text {(n) }}$ Zoals in part. graaf 2 is aangegeven heeft deze test een fataal karakter: ongelijke behandelingen die hieraan worden onderworpen zullen feitelijk steeds onconstitutioneel worden verklaard. $\mathrm{Bij}$ onderscheid op grond van geslacht is een dergelijke fataliteit niet wenselijk: onderscheid tussen mannen en vrouwen zal relatief vaak gerechtvaardigd zijn en is in som. mige gevallen zelfs heel zinvol. Om de fatale gevolgen van de strict scrutiny-test te vermijden en toch een zorgvuldige toetsing uit te kunnen voeren, accepteerde het Supreme Court dan ook een tussenliggende gradatie van toetsingsintensiteit: intermediale scrutiny. Opmerkelijk is dat onderscheid op grond van geslacht vervolgens als ijkpunt ging dienen voor het aanmerken van andere onderscheidingskenmerken als quasiverdacht, op vergelijkbare wijze als ras een ijkpunt voor de strict scrutiny-test vormt:" Tot nu toe heeft slechts één onderscheidingskenmerk de vergelijking met onderscheid op grond van geslacht doorstaan: in 1988, in het arrest Clark v. Jeter "sil, oordeelde het Supreme Court dat bij onderscheid op grond van onwettige geboorte een intermediate scrutiny-test moet worden toegepast. ${ }^{512}$

grond van onderscheid aanwezig zijn: niet alleen is geslacht duidelijk zichtbaar en onveranderili. maar ook gaat het om een grond die in de meeste gevallen niet relevant is voor het maatschappelig functioneren.

508. Het tegendeel blijkt uit J.E.B. v. Alabama, 511 U.S. 127 (1994), waarin het Supreme Court ns ent geslacht tot gelijk stelde, al erkende het dat er verschillen bestaan in de aard en ernst van de voorortdelen jegens de benadeelde groepen.

509. Er zijn ook andere factoren die kunnen verklaren waarom het Supreme Court bij onderscheid op grosd van geslacht niet heeft gekozen voor een toepassing van de strict scrutiny-test. De intensivering van de toetsing bij deze grond was voor een belangrijk deel ingegeven door de politieke ontwikkelingen op het gebied van gelijkberechtiging van vrouwen, die bijvoorbeeld tot uitdrukking kwamen in het umnemen van een Equal Rights Amendment op de Constitutie: door dit Amendement zou onderscheid op grond van geslacht grondwettelijk expliciet worden verboden. Dit Amendement stuitte na aannening door het Congres echter op bezwaren bij de staten: deze namen algemeen aan dat onderscheid op gmond van geslacht minder ernstig is dan onderscheid op grond van ras, zodat het niet nodig zou zijp om $\mathrm{g}$ voorzien in een uitdrukkelijk verbod. Het Amendement werd dan ook niet geratificeerd en is nooit in werking getreden. Het is goed mogelijk dat het Supreme Court zich aan de opvatting van de stater heeft geconformeerd door weliswaar te kiezen voor een verhoogde toetsingsintensiteit, maar niet root een toepassing van de fatale, voor ras geldende strict scrutiny-test.

510. Zie voor een voorbeeld van de manier waarop het Supreme Court "ijkt" Mathews v. Lucas, 427 US. 495,506 (1976).

511. 486 U.S. 456,461 (1988)

512. Het Supreme Court heeft lang geaarzeld over de juiste toetsingsintensiteit bij onwettige getoonte Aanvankelijk oordeelde het zelfs, dat " $[. .$.$] this discrimination against illegitimates has never appro-$ ched the severity or pervasiveness of the historic legal and political discrimination against women an Negroes", zodat "the Act's discrimination between individuals on the basis of their illegitimacy der not 'command extraordinary protection from the majoritarian political process'" (Mathers $v$. Lueve. 427 U.S. 495, 506 (1976)). In verschillende arresten paste het dan ook een rational basis-test toe (bij) in het genoemde arrest Mathews v. Lucas, maar ook in Labine v. Vincent, 401 U.S. 532 (1971) en Par ham v. Hughes, 441 U.S. 347 (1979)). In eerdere rechtspraak was echter ook sprake van een vehtooget toetsingsintensiteit, door een toepassing van de rational basis "with bite"-test (bijv. Levy v. Louisiant 391 U.S. 68 (1968), Weber v. Aetna Casualty \& Surety Co., 406 U.S. 164 (1972) en Trimble v. Gor don, 430 U.S. 762 (1977)). In enkele gevallen werd zelfs gebruik gemaakt van een terminologie die th aan intermediate scrutiny deed denken (bijv. Lalli v. Lalli, 439 U.S. 259, 265 (1978), warin werd tel 
Voor de overige onderscheidingskenmerken heeft het Supreme Court nooit willen erkennen dat zij het niveau van onderscheid op grond van geslacht of onwettige geboorte, en zeker niet dat van ras of nationale afkomst, benaderen. Dit geldt zelfs wanneer alle of een groot aantal van de hiervoor genoemde factoren met betrekking tot de grond van onderscheid en de benadeling van een bepaalde groep aanwezig zijn..$^{513}$ Dit blijkt bijvoorbeeld uit het arrest City of Cleburne v. Cleburne Living Center, ${ }^{\text {sit }}$ waarin werd geklaagd over een benadeling van geestelijk gehandicapten. Omdat hierbij een groot aantal van de hiervoor genoemde factoren aanwezig zijn, had de lagere rechter het onderscheid aan een intermediate scrutiny-toets onderworpen. Hoewel ook het Supreme Court inzag dat er reden zou kunnen bestaan voor verhoging van de toetsingsintensiteit, oordeelde het anders:

"[...] [1]f the large and amorphous class of the mentally retarded were deemed quasi-suspect for the reasons given by the Court of Appeals, it would be difficult to find a principled way to distinguish a variety of other groups who have perhaps immutable disabilities setting them off from others, who cannot themselves mandate the desired legislative responses, and who can claim some degree of prejudice from at least part of the public at large. One need mention in this respect only the aging, the disabled, the mentally ill, and the infirm. We are reluctant to set out on that course, and we decline to do so."

Deze overweging maakt duidelijk dat zeker niet ieder onderscheid dat voldoet aan een bepaald aantal kenmerken automatisch wordt onderworpen aan één van de expliciet erkende hogere toetsingsniveaus: de angst voor een te groot aantal gevallen waarin afstand moet worden gedaan van de terughoudende toetsing staat hieraan in de weg. Deze vrees voor het creëren van een hellend vlak lijkt niet geheel terecht: de factoren die zijn ontwikkeld lijken voldoende ruimte te laten om in relevante gevallen vast te stellen dat er geen reden bestaat voor een verhoogde toetsingsintensiteit. Bovendien levert een hellend vlak-argument geen overtuigende rechtvaardiging op voor terughoudendheid wanneer objectieve factoren laten zien dat er daadwerkelijk een goede reden bestaat om de toetsing te intensiveren. De argumentatie van het Supreme Court kan dan ook niet leiden tot verwerping van de theoretische stelling dat in ieder afzonderlijk

eist dat het onderscheid "substantially related to permissible state interests" was). De keuze voor intermediate scrutiny is opmerkelijk, omdat onderscheid op grond van onwettige geboorte aan alle criteria voor toepasselijkheid van strict scrutiny voldoet en er, anders dan bij geslacht, geen goede maatschappelijke redenen voor onderscheid bestaan. De reden om in dit geval toch niet te kiezen voor strict scrutiny kan alleen gelegen zijn in een verschil in gepercipieerde ernst tussen ras, nationaliteit en nationale afkomst enerzijds en onwettige geboorte anderzijds; het is opmerkelijk dat het Supreme Court zich daarover nooit heeft uitgesproken. Vgl. ook Perry 1979, p. 1056/1057.

513. Zie impliciet Romer v. Evans, 517 U.S. 620 (1996), waarin een rational basis-test werd toegepast ondanks het feit dat seksuele geaardheid onveranderlijk en irrelevant is en onderscheid op deze grond (voor alle benadeelden) stigmatiserend kan werken. Alleen een historische afkeuring van onderscheid op deze grond ontbreekt, hetgeen het Supreme Court kennelijk doorslaggevend achtte.

514. 473 U.S. 432 (1985). Dit arrest werd gewezen voordat het Supreme Court aannam dat alleen de grond van onderscheid van belang is voor de verhoging van de toetsingsintensiteit; groepsgerelateerde factoren konden in dit arrest dan ook een belangrijke rol spelen.

515. 473 U.S., op 445/446; vgl. ook Wunder 1986, p. 252. Het Supreme Court probeerde de conclusie van een verhoogde toetsingsintensiteit overigens te ontwijken door te beredeneren dat niet alle intensiteitbepalende factoren met betrekking tot de benadeelde groep aanwezig waren. 
geval van ongelijke behandeling een degelijke afweging van intensiteitbepalende factioren moet worden gemaakt.

\title{
3.4 Strict scrutiny bij aantasting van fundamentele rechten
}

\subsubsection{Erkenning van individuele grondrechten als rechtvaardiging voor strict scrutiny}

Hiervoor is aangegeven dat het bestaan van een verdachte grond van onderscheid een rechtvaardiging vormt voor het toepassen van een strict scrutiny-test. In 1942, in het arrest Skinner v. Oklahoma ${ }^{516}$ stelde het Supreme Court echter dat een dergelijke recht. vaardiging ook bestaat wanneer door het onderscheid fundamentele rechten zijn aasgetast. Deze zaak betrof een regeling die inhield dat mensen die voor de derde keer werden veroordeeld voor een misdrijf "involving moral turpitude" verplicht moesten worden gesteriliseerd. Alvorens in te gaan op de rechtvaardiging die Oklahoma had aangevoerd voor het nogal willekeurig aanmerken van misdrijven als moreel verwer. pelijk, stelde het Supreme Court het volgende:

\begin{abstract}
"We are dealing here with legislation which involves one of the basic civil rights of man Marriage and procreation are fundamental to the very existence and survival of the race. The power to sterilize, if exercised, may have subtle, farreaching and devastating effects. [...] There is no redemption for the individual whom the law touches. [...] He is forever deprived of a basic liberty. We advert [to these matters] [...] in emphasis of our view that strict scrutiny of the classification which a State makes in a sterilization law is essential, lest unwittingly or otherwise invidious discriminations are made against groups or types of individuals in violation of the constitutional guaranty of just and equal laws." ${ }^{\text {s12 }}$
\end{abstract}

De basis voor deze verhoging van de toetsingsintensiteit is opnieuw te vinden in de in paragraaf 3.2 weergegeven Carolene Products-voetnoot. Relevant is nu echter niet de derde alinea (die betrekking heeft op benadeling van minderheidsgroepen), maar de eerste. Volgens deze alinea kan er reden zijn voor verhoging van de toetsingsintensiteit, wanneer er rechtstreeks inbreuk is gemaakt op een door de Constitutie en de Bill of Rights beschermd recht. ${ }^{\text {sis }}$ Hoewel het Supreme Court daarvoor geen reden noemde, was het duidelijk van mening dat de rechter een bijzondere functie heeft bij de bescherming van de individuele grondrechten; in die bijzondere functie vond het boverdien een rechtvaardiging voor een intensieve toetsing. ${ }^{519}$

Hoewel in Carolene Products alleen is gewezen op de aantasting van expliciet door de Constitutie en de Bill of Rights beschermde rechten, heeft het Supreme Court ook voor

\section{316 U.S. 535 (1942)}

517. 316 U.S., op 541. In deze overweging speelt niet alleen het fundamentele karakter van het rectr eet rol, maar ook de ernst en de onomkeerbaarheid van de aantasting van dit recht. Deze laatste factor lijt echter geen afzonderlijke betekenis te hebben voor het toepassen van een strict scrutimy-test bij de aantasting van fundamentele rechten. De factor blijkt wel in andere omstandigheden intensiteitvetho gend te kunnen werken, zie nader paragraaf 3.4.4.

518. Vgl. Cover 1982, p. 1291.

519. Zie Lusky 1975 , p. 110/110, die uitlegt dat de eerste paragraaf op instigatie van een andere rectiter werd toegevoegd en hieraan een andere theoretische basis ten grondslag ligt dan aan de beide andert paragrafen: niet de bescherming tegen zwakheden van het politieke proces vormt de basis, mar de go dachte dat bepaalde rechten belangrijker zijn dan andere en de rechter tot taak heeft deze te bewaken 
een intensieve toetsing gekozen bij daarin niet opgenomen, maar toch fundamenteel geachte rechten. Het geciteerde arrest Skinner v. Oklahoma, waarin een fundamenteel recht op voortplanting werd erkend, vormt daarvan een goed voorbeeld. Opmerkelijk is dat het Supreme Court in deze zaak slechts summier aangaf waarom het dit recht zo belangrijk achtte: het stelde uitsluitend dat het hierbij gaat om een basaal burgerlijk recht dat is terug te voeren op een essentiële bestaansvoorwaarde voor het menselijk ras. Deze rechtvaardiging heeft een vrij algemeen karakter en kan een basis verschaffen voor een verhoogde toetsingsintensiteit bij een aantasting van andere rechten. ${ }^{520}$ Door deze uitspraak creëerde het Supreme Court dan ook een aanzienlijke ruimte voor een verhoging van de toetsingsintensiteit bij de aantasting van fundamentele rechten. ${ }^{521}$

Pas in de jaren 60, de periode waarin Chief Justice Warren zorgde voor een actieve bescherming van individuele rechten, is het Supreme Court daadwerkelijk gebruik gaan maken van de door Skinner v. Oklahoma gecreëerde ruimte. Zo stelde het in 1969, in de zaak Shapiro $v$. Thompson, ${ }^{522}$ dat het niet constitutioneel beschermde recht op interstatelijk verkeer een fundamenteel karakter heeft en dat een aantasting van dit recht aan een strict scrutiny-test moet worden onderworpen:

"The Court long ago recognized that the nature of our Federal Union and our constitutional concepts of personal liberty unite to require that all citizens be free to travel throughout the length and breadth of our land [...]. [...] Since the classification here touches on the fundamental right of interstate movement, its constitutionality must be judged by the stricter standard of whether it promotes a compelling state interest." ${ }^{\text {"23 }}$

Net als in Skinner v. Oklahoma vond het Supreme Court ook hier het fundamentele karakter van dit recht in vage en algemene beginselen, zoals de aard van het federale systeem en een concept van persoonlijke vrijheid. ${ }^{324}$ Iedere specifieke verwijzing naar

520. In Eisenstadt v. Baird, 405 U.S. 438, 452 (1972) borduurde het Supreme Court bijvoorbeeld voort op Skimner door het recht op privacy en het daaruit voortvloeiende recht op vrijheid tot geboorteplanning essentieel te achten. Overigens paste het Supreme Court in deze zaak verder geen strict scrutimy toe, maar slechts rational basis "with bite"; de reden daarvoor is onduidelijk.

521. Dit is ook een belangrijk bezwaar tegen deze paragraaf van Carolene Products, dat niet geldt voor de overige twee paragrafen. Zie daarover Lusky 1975, p. $111 / 112$.

522. 394 U.S. 618 (1969)

523. 394, op 630 en 637. Zie ook Dunn v. Blumstein, 405 U.S. 330, 338 (1972). Het Supreme Court achtte het recht op interstatelijk verkeer al eerder fundamenteel in de context van andere constitutionele bepalingen; zie bijv. Edwards v. California, 314 U.S. 160, $173 / 174$ (1941) m.b.t. de Commerce Clanuse, Zic ook Porter 1992, p. 824.

524. Vgl. Lusky 1975 , p. 252 en 266 . Een nadere motivering gaf het Supreme Court in een eerdere zaak, die betrekking had op de Due Process Clause: "In Anglo-Saxon law that right was emerging at least as early as the Magna Carta. [...] Freedom of movement across frontiers in either direction, and inside frontiers as well, was part of our heritage. Travel abroad, like travel within the country, may be necessary for a livelihood. It may be as close to the heart of the individual as the choice of what he eats, wears, or reads, Freedom of movement is basic in our scheme of values. [...] Freedom of movement also has large social values. [...] Freedom to travel is, indeed, an important aspect of the individual's 'liberty" (Kent v. Dulles, 357 U.S. 116, 125-127 (1958)). Hieruit blijkt dat de redenering van het Supreme Court iets preciezer is dan die in Shapiro en dat er meer elementen in het oordeel worden betrokken. Ook deze motivering is echter nog tamelijk vaag in zijn verwijzingen naar de historische, individuele en sociale betekenis van het grondrecht, waardoor er relatief veel ruimte open wordt gelaten voor de erkenning van andere rechten als fundamenteel. 
de Constitutie zelf of de daarin expliciet erkende rechten, volgens Carolene Products de enige basis voor verhoging van de toetsingsintensiteit, ontbrak in deze uitspraak. ${ }^{\text {.5 }}$

\subsubsection{Erkenning van politieke rechten als rechtvaardiging voor strict scrutiny}

In dezelfde periode ging het Supreme Court ook de tweede alinea van de Carolene Products-voetnoot als basis voor intensivering van de toetsing gebruiken. Volgens deze tweede alinea kan een striktere toetsing noodzakelijk zijn wanneer door een regeling fundamentele politieke rechten worden aangetast. De grondslag hiervoor vormt, net als bij de derde alinea, de opvatting dat een intensieve rechterlijke toetsing nodig is warl. neer er twijfel bestaat over het deugdelijk functioneren van het politieke proces of wanneer dit functioneren door een bepaalde maatregel in gevaar wordt gebracht. ${ }^{\mathrm{s}}$ In deze rationale vond het Hof bijvoorbeeld een rechtvaardiging voor het uitvoeren van een strict scrutiny-test bij aantastingen van het kiesrecht. Dit blijkt onder andere uithet in 1969 gewezen arrest Kramer v. Union Free School District ${ }^{527}$, dat betrekking had op de uitsluiting van een bepaalde groep kiesgerechtigden van verkiezingen voor het be stuur van een schooldistrict. Het Supreme Court stelde hierover, dat

"[...] in this case, we must give the statute a close and exacting examination. Since the right to exercise the franchise in a free and unimpaired manner is preservative of other basic civil and political rights, any alleged infringement of the right of citizens to vote must be carefully and meticulously scrutinized. This careful examination is necessary because statutes distributing the franchise constitute the foundation of our representative society. Any unjustified discrimination in determining who may participate in political affairs or in the selection of public officials undermines the legitimacy of representative government [...] The presumption of constitutionality and the approval given 'rational' classifications in other types of enactments are based on the assumption that the institutions of state governments are structured so as to represent fairly all the people. However, when the challenge to the statute is in effect a challenge of this basic assumption, the assumption can no longer serve as the basis for presuming constitutionality."

Het Supreme Court gaf met deze overweging een algemene rechtvaardiging voor verhoging van de toetsingsintensiteit bij politieke rechten: een aantasting van deze rechten levert automatisch een inbreuk op het zelfcorrigerend vermogen van het democratisch

525. Deze doctrine van het Supreme Court is (wat betreft de Equal Protection Clause) beperkt gebleven at erkenning van het recht op interstatelijk verkeer en het recht op voortplanting. Andere rechten zijp nooit als fundamenteel erkend, waarschijnlijk omdat Chief Justice Burger al vrij snel na Shapiro zorb de voor een nieuwe lijn in de rechtspraak van het Supreme Court. Gesteld is wel dat ook processule rechten door het Warren Court als fundamenteel zijn erkend (zie bijv. Bice 1977, p. 697), mas dil heeft in ieder geval nooit strict scrutiny opgeleverd. Bovendien is het waarschijnlijk dat hierbij nict zw. zeer het fundamentele belang van deze rechten als wel een combinatie van factoren tot verhoogde whsingsintensiteit heeft geleid. Zie nader paragraaf 3.4.4.

526. Vgl. Cover 1982, p. 1291/1292.

527. 395 U.S. 621 (1969)

528. 395 U.S., op 626. Overigens paste het Warren Court om vergelijkbare redenen al eerder een srict scrutiny-test toe wegens aantasting van een fundamenteel recht; zie Reynold v. Sims, 377 U.S. 533, 562 (1964). Zie verder Carrington v. Rash, 380 U.S. 89 (1965), Harper v. Virginia Board of Elections, 383 U.S. 663, 668 (1966) (meer impliciet), McDonald v. Board of Election Commissioners of Chicago, 394 U.S. 802, 806 (1969), Evans v. Cornman, 398 U.S. 419, 422 (1970), Dunn v. Blumstein, 405 U.S. 300 (1972) en Burdick v. Takushi, 504 U.S. 428, 433 (1992). Zie hierover ook Ely 1980, p. 117 en 120. 
proces op. ${ }^{529}$ Wanneer een groep een politiek recht wordt ontnomen is deze groep immers niet meer in staat om een dergelijk besluit met gebruik van dit recht weer ongedaan te maken. ${ }^{530}$ Deze redenering kan niet alleen de basis vormen voor een strict scrutiny-test bij onderscheid waardoor het kiesrecht wordt aangetast, maar in principe ook voor een strikte toetsing bij een aantasting van andere politieke rechten, zoals het recht om politieke partijen op te richten of het recht op demonstratievrijheid. ${ }^{331}$ Deze basis voor verhoging van de toetsingsintensiteit is echter veel minder vergaand dan die is vervat in de eerste alinea van de strict scrutiny-test: de rechter zal alleen strikter mogen toetsen wanneer kan worden aangetoond dat het deugdelijk functioneren van het politieke proces door de maatregel daadwerkelijk in gevaar is gebracht. ${ }^{532}$

\subsubsection{Verandering van rechtspraak: constitutionele rechten als basis voor intensive- ring van de toetsing}

Al tijdens het voorzitterschap van Chief Justice Warren bestond er veel kritiek op de hierboven besproken rechtspraak. De consequenties van de benadering van het Warren Court waren volgens velen wel positief, maar tegelijkertijd riep de benadering herinneringen aan het Lochner-tijdperk op. ${ }^{533}$ Veel auteurs hadden bezwaar tegen de wijze waarop het Supreme Court uit algemene beginselen als de individuele vrijheid, het functioneren van het democratisch stelsel of de menselijke waardigheid "nieuwe" fundamentele rechten afleidde en deze vervolgens hanteerde als basis voor een intensieve rechterlijke toetsing. ${ }^{534}$ Toen Warren terugtrad en werd opgevolgd door de veel conservatievere Burger bestond dan ook de hoop dat hij een einde zou maken aan deze vergaande rechtspraak, en inderdaad heeft Supreme Court onder zijn voorzitterschap belangrijke doctrinaire veranderingen teweeggebracht. Met name beperkte het Burger Court al snel de mogelijkheid om fundamentele rechten te erkennen als basis voor strict scrutiny. ${ }^{535}$ De belangrijkste uitspraak in dit verband is San Antonio School District v.

529. Vgl. Ball 1974, p. 1061.

530. Vgl. Lusky 1975, p. 110 en Ely 1980, p. 103, die de grondslag voor verhoging van de toetsingsintensiteit kemachtig samenvat als de situatie waarin "the ins are choking off the channels of political change to ensure that they will stay in and the outs will stay out".

531. Het Supreme Court is niet scheutig geweest met het erkennen van politieke rechten: eigenlijk is alleen het kiesrecht als zodanig erkend. Zoals hierna in paragraaf 3.4 .3 nog zal blijken heeft het Supreme Court niet erkend dat rechten die rechtstreeks van belang zijn voor het goed uitoefenen van het kiesrecht, zoals het recht op onderwijs, tot een strict scrutiny-test kunnen leiden.

532. Dit vormt ook een rechtvaardiging voor de latere rechtspraak, waarin niet zozeer het aantasten van een politiek recht, maar de ernst van de aantasting bepalend is. Zie nader paragraaf 3.4.4

533. Enthousiast ontvangen werd vooral het streven naar meer gelijkheid: pas door het Warren Court is daadwerkelijk invulling gegeven aan de Equal Protection Clause door uitspraken als Brown v. Board of Education, 347 U.S. 483 (1954) en door de strikte toetsing van onderscheid op grond van ras. Vgl. Wilkinson 1975 , p. $947 / 948$.

534. Zie bijv. de dissenting opinion van Justice Harlan bij Shapiro v. Thompson, 394 U.S. 618 (1969): hij stelde dat deze rechtspraak "creates an exception which threatens to swallow the standard equal pro-

535. Het gaat hierbij om de erkenning van rechten als basis voor toepassing van een strict scrutiny-test bij
He de toepassing van de Equal Protection Clause. Het Burger Court zag wel ruimte voor de erkenning van nieuwe rechten in de Due Process-clause van het Veertiende Amendement: zoals bekend erkende het bijv. in 1973 dat hierin een recht op abortus is opgenomen (Roe v. Wade, 410 U.S. 113 (1973)). Ook kan niet worden gezegd dat het Burger Court in belangrijke mate afbreuk heeft gedaan aan het egalita- 
Rodriguez. ${ }^{536}$ Dit arrest had betrekking op een ingewikkelde financieringsregeling voor scholen in Texas, die tot gevolg had dat schooldistricten waarin de bevolking relatief arm was aanzienlijk minder geld te besteden hadden dan schooldistricten met een rela. tief rijke bevolking. De eisers betoogden in deze zaak dat het recht op onderwijs was aangetast en dat er daarom reden bestond voor de toepassing van een strict scrutimtest. Volgens hen was dit recht namelijk essentieel voor een goede individuele ontplooiing en was het van minstens zo groot belang als het in Shapiro v. Thompson erkende recht op interstatelijk verkeer. Zoals eerder is gebleken zijn dit argumenten dit door het Warren Court hoogstwaarschijnlijk inderdaad als reden voor verhoging van de toetsingsintensiteit zouden zijn aanvaard. Het Burger Court oordeelde echter als volgt:

"In Brown v. Board of Education (1954), a unanimous Court recognized that education is perhaps the most important function of state and local governments. [...] But the importance of a service performed by the State does not determine whether it must be regarded as fundamental for purposes of examination under the Equal Protection Clause. [...] It is not the province of this Court to create substantive constitutional rights in the name of guaranteeing equal protection of the laws. Thus, the key to discovering whether education is "fundamental" is not to be found in comparisons of the relative societal significance of education as opposed to subsistence or housing. Nor is it to be found by weighing whether education is as important as the right to travel. Rather, the answer lies in assessing whether there is a right to education explicitly or implicitly recognized by the Constitution.,"517

Uit deze overweging blijkt duidelijk dat het volgens de nieuwe doctrine niet zo gemak. kelijk is om een reden voor strict scrutiny te vinden in de aantasting van fundamentele rechten, aangezien het niet meer mogelijk is om de grondslag voor het fundamentele karakter van een recht te vinden in een algemeen grondbeginsel of in het maatschappslijk belang van dit recht: alleen de expliciete of impliciete erkenning van het recht door de Constitutie kan de basis vormen voor een verhoging van de toetsingsintensiteit. ${ }^{5 .}$

Op het eerste gezicht lijkt deze formule nog een aanzienlijke ruimte te laten voor verhoging van de toetsingsintensiteit: veel fundamentele rechten zouden immers implicit in de Constitutie aanwezig kunnen worden geacht. Zo zou kunnen worden aangenomen dat het recht op onderwijs door de Constitutie wordt beschermd, aangezien het een zeet nauw verband vertoont met expliciet erkende rechten, zoals het recht op vrijheid van meningsuiting en het (overigens zelf alleen impliciet in de Constitutie aanwezige) kis. recht. In het geciteerde arrest gaf het Supreme Court echter aan voor een dergelijke

ristische streven van het Warren Court: zo is tijdens Burgers voorzitterschap de intermediate scruting test aanvaard en is de rechtspraak zoals die was ontwikkeld onder Warren zoveel mogelijk in stand gs houden.

536. 411 U.S. 1 (1973)

537. 411 U.S., op 31 en 33 (cursief uit origineel). In een eerdere zaak ontkende het Supreme Court al op vergelijkbare gronden dat er reden was voor een strict scrutiny-test bij aantasting van het rectr of huisvesting: "We do not denigrate the importance of decent, safe, and sanitary housing. But the Cornstitution does not provide judicial remedies for every social and economic ill. We are unable to perter ve in that document any constitutional guarantee of access to dwellings of a particular quality, of 3 il recognition of the right of a tenant to occupy the real property of his landlord beyond the term of this lease without the payment of rent or otherwise contrary to the terms of the relevant agreement" (Limsey v. Normet, 405 U.S. 56, 74 (1972)); hetzelfde gold voor het recht om failliet te kunnen gaan: Uivted States v. Kras, 409 U.S. 434, 446 (1973). Vgl. Wilkinson 1975, p. 949.

538. Vgl. Bice 1977, p. 697. 
"nexus theory" geen ruimte te zien: deze theorie zou volgens de meerderheidsopinie tot gevolg hebben dat een te groot aantal rechten als fundamenteel zouden moeten worden anvaard. ${ }^{599}$ Duidelijk is dan ook dat een strict scrutiny-test op basis van San Antonio alleen gerechtvaardigd kan worden geacht wanneer het aangetaste recht daadwerkelijk door de Constitutie wordt beschermd. ${ }^{\text {sto }}$

Deze verandering in de rechtspraak heeft tot gevolg gehad dat het Supreme Court, naast de door het Warren Court reeds als fundamenteel aanvaarde ${ }^{5+1}$ en de expliciet in de Constitutie opgenomen rechten, ${ }^{542}$ geen nieuwe rechten heeft erkend die een strict scrutiny-test rechtvaardigen. ${ }^{5+3}$ Bovendien is van belang dat zelfs een inbreuk op de reeds als fundamenteel erkende rechten volgens de recentere rechtspraak niet automa-

539. Kritisch hierover is Justice Marshall in zijn dissenting opinion bij deze zaak; hij stelt terecht dat het hellende vlak dat door de meerderheid werd waargenomen niet per se hoeft te gelden. Voor de "nexus theory" geldt namelijk dat, hoe nauwer het verband is met een wel erkend recht, des te groter de rechtvaardiging is voor een striktere rechterlijke toetsing (411 U.S., op 102/103). Via die redenering is onderwijs wel een fundamenteel recht (op 112/113), maar hoeft dit voor andere rechten niet te gelden.

540. In latere rechtspraak heeft het Supreme Court de nog vrij ruime formulering "explicitly or implicitly recognized" dan ook weggelaten. Zo stelde het in 1980, dat "It is well settled that where a statutory classification does not itself impinge on a right or liberty protected by the Constitution, the validity of the classification must be sustained unless the classification rests on grounds wholly irrelevant to the achievement of [any legitimate governmental] objective]" (Harris v. McRae, 448 U.S. 297, 322 (1980))

541. Dat het Supreme Court bij kiesrecht een strict scrutiny-test is blijven erkennen blijkt uit Dunn v. Blumstein, 405 U.S. 330, 336 (1972). Uit dit arrest blijkt bovendien dat ook een inbreuk op het recht op interstatelijk verkeer nog steeds wordt gezien als een reden voor strict scrutiny (op 338). Wel bleek het Supreme Court voor beide rechten verschillende eisen te stellen voor de toepasselijkheid van strict scrutiny; zie paragraaf 3.4.4. Verder erkende het Supreme Court ook het in Skinner v. Oklahoma, 316 U.S. 535, 541 (1942) vastgestelde recht op huwelijk en voortplanting en verbond daaraan een recht op vrijheid van geboorteplanning (Eisenstadt v. Baird, 405 U.S. 438, 452 (1972)). Deze erkenning leidde echter niet tot een strict scrutiny-test, maar slechts tot rational basis "with bite".

542. Bij aantasting van constitutioneel erkende rechten door een ongelijke behandeling heeft het Supreme Court wel consequent een strict scrutiny-test toegepast. Zie bijv. Police Department of the City of Chicago v. Mosley, 408 U.S. 92 (1972), waarin het Supreme Court een strict scrutiny-test toepaste op een onderscheid waardoor de vrijheid van meningsuiting (beschermd door het Eerste Amendement) werd aangetast. In de meeste van dit soort gevallen zal overigens een rechtstreeks beroep op het aangetaste constitutionele recht mogelijk zijn (vgl. Perry 1979, p. 1078/1079); dit verklaart waarom het aantal voorbeelden van strict scrutiny wegens aantasting van fundamentele rechten na 1973 zeer klein is.

543. Bovendien heeft het bestaande rechten terughoudend geïnterpreteerd. Zo erkende het Supreme Court in 1973 dat in de Due Process Clause van het Veertiende Amendement een recht op abortus kan worden gelezen (Roe v. Wade, 410 U.S. 113 (1973)). Een strict scrutiny-test lijkt dan ook op zijn plaats wanneer dit recht door een ongelijke behandeling wordt aangetast. In het arrest Maher v. Roe, 432 U.S. 464 (1977) stelde het Supreme Court echter dat "Roe did not declare an unqualified constitutional right to abortion". Om die reden was er geen sprake van een aantasting van een fundamenteel recht, zodat een rational basis-test kon worden toegepast; idem in Harris v. McRae, 448 U.S. 297, 322/323 (1980). Recentelijk heeft het Supreme Court toch weer een strengere test geaccepteerd bij een niet expliciet constitioneel beschermd recht: in M.L.B. v. S.L.J., 519 U.S. 102, 116/117 (1996) stelde het dat "choices about marriage, family life, and the upbringing of children are among associational rights this Court has ranked as 'of basic importance in our society'. [...] M.L.B.'s case, involving the State's authority to sever permanently a parent-child bond, demands the close consideration the Court has long required when a family association so undeniably important is at stake." De benadering sluit wel nog steeds aan bij de in San Antonio gestelde vereisten, nu het recht impliciet in de Constitutie was terug te vinden: "[...] the interest of parents in their relationship with their children is sufficiently fundamental to come within the finite class of liberty interests protected by the Fourteenth Amendment" (op 120). 
tisch een toepassing van de strict scrutiny-test impliceert; dit is alleen nog het geval wanneer hierop een ernstige inbreuk is gemaakt. ${ }^{544}$

\subsubsection{Ernst van de aantasting}

Het Burger Court heeft, naast de beperking van de fundamental rights-doctrine, nog een tweede belangrijke verandering in de rechtspraak aangebracht. In de rechtspraak van het Warren Court lijkt iedere aantasting van een fundamenteel recht, hoe gering ook, automatisch tot een strict scrutiny-test te leiden. ${ }^{545}$ Vanaf de jaren 70 is het echter zo dat ook de ernst van de aantasting een rol speelt bij de bepaling van de toetsingsintensiteit. Heel duidelijk is dit bij onderscheid waardoor het kiesrecht wordt aangetast. ${ }^{3}$ In Burdick v. Takushi ${ }^{547}$ zette het Supreme Court uiteen op welke manier kan worden beoordeeld welk niveau van toetsingsintensiteit daarbij moet worden gekozen:

" $[\ldots][T]$ he rigorousness of our inquiry into the propriety of a state election law depends upon the extent to which a challenged regulation burdens First and Fourteenth Amendment rights. Thus, $[\ldots]$ when these rights are subjected to severe restrictions, the regulation must be narrowly drawn to advance a state interest of compelling importance. But when a state election law provision imposes only reasonable, nondiscriminatory restrictions upon the First and Fourteenth Amendment rights of voters, the State's important regulatory interests are generally sufficient to justify the restrictions." 448

Deze benadering lijkt niet onredelijk: in het kader van de organisatie van verkiezingen worden talrijke beslissingen genomen en keuzes gemaakt, waarbij een risico voor verstoring van het democratische proces - de Carolene Products-rationale voor een intensievere toetsing - lang niet altijd zal bestaan. Problematisch is hoogstens dat de rechter

544. Zie bijv. Bullock v. Carter, 405 U.S. 134, 142 (1972). Overigens lijkt ook de rechtspraak van het Warren-Court zelf dit al te impliceren: voor toepassing van strict scrutiny vereiste het Supreme Cout al in McDonald v. Board of Election Commissioners of Chicago, 394 U.S. 802, 807/808 (1969) datet sprake was van een daadwerkelijke aantasting van het kiesrecht. Daarbij zou het er echter op kunnen lijken dat niet de ernst van de aantasting bepalend was, maar eerder de vraag of er überhaupt wel var een inbreuk op het kiesrecht kon worden gesproken.

545. Vgl. Simson 1977, p. 673.

546. Zie reeds Bullock v. Carter, 405 U.S. 134, 143 (1972) en O'Brien v. Skinner, 414 U.S. 524, 530 (1974) ("The New York statutes [...] operate as restriction which is so severe as itself to constitute an unconstitutionally onerous burden on the ... exercise of the franchise"). Een vergelijkbare benadering is gsvolgd bij het recht op interstatelijk verkeer. Waar het Supreme Court het in Shapiro v. Thompson 394 U.S. 618,628 (1969)) nog voldoende achtte dat mensen werden ontmoedigd om gebruik te maken van hun recht op interstatelijk verkeer (er moest sprake zijn van een "penalty", vgl. McCoy 1975, p. 1002). vereiste het in latere rechtspraak dat mensen er door het vooruitzicht van een ongelijke behandeling daadwerkelijk werden weerhouden van het gebruik van hun recht op interstatelijk verkeer. Daabij stelde het Supreme Court onder andere dat de ongelijke behandeling betrekking moest hebben op ect belangrijk recht of belang, zoals het recht op levensonderhoud of het recht op ziekenzorg (Memorial Hospital v. Maricopa County, 415 U.S. 250, 259 (1974)) en vereiste het dat door de ongelijke belindeling iemand volledig van dit recht of belang zou worden uitgesloten (Sosna v. Iowa, 419 U.S. 393, 406 (1975) en Martinez v. Bymum, 461 U.S. 321, 328/329 (1983)).

547. 504 U.S. 428 (1992)

548. 504 U.S., op 433. Zie ook Lubin v. Panish, 415 U.S. 709 (1974), waarin sprake was van rational barit "with bite" omdat het passief kiesrecht vrijwel volledig afhankelijk werd gesteld van het vermoget van de kandidaat om een "filing fee" te betalen. Volgens het Supreme Court werd hierdoor het kiesrecht ernstig aangetast, aangezien minvermogende kandidaten door het vereiste nauwelijks in aannerking kwamen voor deelname aan de verkiezingen. 
met een beoordeling als deze enigszins vooruitloopt op de inhoudelijke toetsing: normaal gesproken wordt het gewicht van de aangetaste belangen immers pas bepaald in het kader van de proportionaliteitstoets. Bijzonder ernstig is dit echter niet, nu het voor het vaststellen van het gewicht van de belangen, anders dan voor de beoordeling van de belangenafweging als zodanig, niet noodzakelijk is dat de toetsingsintensiteit al is vastgesteld: het oordeel over het gewicht van de belangen zal niet anders uitvallen wanneer er een strikte toetsing wordt uitgevoerd dan wanneer er terughoudend wordt getoest.

Van belang is verder dat deze factor in de loop van de tijd ook buiten de specifieke context van de rechtvaardiging van strict scrutiny betekenis heeft gekregen. Een ernstige aantasting van een belangrijk, maar niet fundamenteel individueel recht blijkt in de praktijk namelijk een rechtvaardiging te kunnen vormen voor een rational basis "with bite"-test." ${ }^{\text {"4 }}$ Dit wordt geilllustreerd door het arrest Plyler $v$. Doe, waarin een regeling in het geding was (\$21.031) die illegale kinderen uitsloot van deelname aan het onderwijs. ${ }^{50}$ Het Supreme Court gaf het volgende oordeel over de intensiteit waarmee deze uitsluiting zou moeten worden beoordeeld:

"Undocumented aliens cannot be treated as a suspect class because their presence in this country in violation of federal law is not a 'constitutional irrelevancy'. Nor is education a fundamental right. But more is involved [...]. \$21.031 imposes a lifetime hardship on a discrete class of children not accountable for their disabling status. The stigma of illiteracy will mark them for the rest of their lives. By denying these children a basic education, we deny them the ability to live within the structure of our civic institutions [...]. [T] discrimination contained in $\$ 21.031$ can hardly be considered rational unless it furthers some substantial goal of the State." $\$ 51$

In dit geval lijkt het oordeel over de ernst van de aantasting en de daaraan verbonden verhoogde toetsingsintensiteit te zijn ingegeven door de combinatie van de aanwezigheid van een belangrijke voorziening en de vrijwel volledige uitsluiting van het individu op gronden waaraan het zelf niets kan veranderen. Het is niet duidelijk of een dergelijke combinatie van omstandigheden noodzakelijk is voor een verhoging van de

549. Zie kritisch over deze benadering McCoy 1975, p. 995.

550. 457 U.S. 202 (1982)

551. 457 U.S., op 223/224; vgl. ook Hutchinson 1982, p. 181. Van belang is dat het Supreme Court in een aantal gevallen heeft aangegeven het relevant te achten of de ongelijke behandeling is ontstaan door het opleggen van een last aan een bepaalde groep of door het niet toekennen van een voordeel. Dit blijkt uit het al eerder genoemde arrest San Antonio School District v. Rodriguez, 411 U.S. 1 (1974), waarin het Supreme Court stelde dat "Each of our prior cases 'deprived', 'infringed', or 'interfered' with the free exercise of some such fundamental personal right or liberty. [...] A critical distinction between those cases and the one now before us lies in what Texas is endeavoring to do with respect to education. [...] This is not a complaint that Congress ... has unconstitutionally denied or diluted anyone's right [...] but rather that Congress violated the Constitution by not extending the relief effected [to others similarly situated]'. [...] [T] he thrust of the Texan system is affirmative and reformatory and, therefore, should be scrutinized under judicial principles sensitive to the nature of the State's efforts and to the rights reserved to the States under the constitution" (op 38; vgl. ook Sobelsohn 1977, p. 501). Het is echter de vraag of het wel redelijk is om de intensiteit van de toetsing afhankelijk te stellen van de vraag of er een daadwerkelijke inbreuk op een recht is gemaakt. Het gaat immers om een nuanceverschil: iedere weigering om aan groep een bepaald voordeel toe te kennen kan worden beschreven als een aantasting van een recht en andersom. Het Supreme Court heeft deze factor in latere rechtspraak niet meer genoemd. 
toetsingsintensiteit, maar de gevallen waarin tot nu toe een rational basis "with bite". test is toegepast wijzen daar wel op: vrijwel steeds gaat het daarbij om een emstige aantasting van zwaarwegende belangen of om een volledige uitsluiting van het genot van belangrijke voorzieningen. ${ }^{552}$

\subsection{Overige factoren die de toetsingsintensiteit beïnvloeden}

\subsubsection{Inleiding}

In het voorgaande zijn de belangrijkste factoren besproken die de toepassing van etn strict scrutiny- of intermediate scrutiny-test kunnen rechtvaardigen en die rechtstreeks betrekking hebben op de grond van onderscheid, de benadeelde groep, het gewicht van het aangetaste belang en de ernst van de belangenaantasting. In de rechtspraak zijn daarnaast nog verschillende andere factoren terug te vinden die de intensiteit van de toetsing kunnen beïnvloeden en die soms een intensivering, maar soms ook een vermindering van de toetsingsintensiteit kunnen opleveren. Dit is mogelijk doordat de drie officieel erkende tests soms minder rigide zijn dan door het Supreme Court wordt gesteld: niet alleen bestaat er de mogelijkheid van een intensievere rational basis-test, maar ook blijkt in sommige gevallen een minder intensieve toetsing te worden uitge voerd in gevallen waarin formeel gezien een strict scrutiny-test zou moeten gelden. In deze laatste paragraaf zal kort op deze intensiteitbepalende factoren worden ingegaan.

552. Deze benadering is consequent gevolgd wanneer door een regeling (indirect) onderscheid wordt gs: maakt op grond van vermogen bij belangrijke processuele rechten. Voor het uitoefenen van bepalle. processuele rechten worden vaak financièle eisen gesteld, zoals betaling van griffierecht of het over leggen van een kostbaar transcript van de procedure in eerste aanleg voor het kunnen instellen van ho ger beroep. Door dit soort eisen worden minvermogenden soms volledig uitgesloten van processuct rechten. Weliswaar is er dan geen sprake van een verdachte grond van onderscheid en evenmin van eat fundamenteel en constitutioneel beschermd belang, maar er is wel degelijk sprake van een entsis aantasting van belangrijke rechten. Om die reden heeft het Supreme Court in dit soort gevallen conss: quent, zij het meestal niet expliciet, een striktere toetsing toegepast; in de meeste gevallen kan zeler worden gesproken van rational basis "with bite". Zie bijv. Griffin v. Illinois, 351 U.S. 12 (1956), Douglas v. California, 372 U.S. 353 (1963), James v. Strange, 407 U.S. 128 (1972) en M.L. B. . S.L. 519 U.S. 102 (1996); vgl. ook Williams v. Illinois, 399 U.S. 235 (1970), dat overigens geen betreklite had op een procedureel recht maar op een verlenging van detentie voor mensen die een deel van de kosten voor het strafproces niet aan de overheid konden terugbetalen. Een verhoogde toetsingsintersiteit wordt overigens niet toegepast als het niet gaat om een strafproces, maar om een civiele procedirt, kennelijk vindt het Supreme Court dat er in dat geval sprake is van een minder ernstige belangenaw. tasting. Zie bijv. United States v. Kras, 409 U.S. 434 (1973) en Ortwein v. Schwab, 410 U.S 656 (1973), beide met betrekking tot faillissementsprocedures. Zie nader "Developments" 1969, P. $1122 / 1123$ en 1130 , Lusky 1975 , p. $254 / 255$ en Clune 1975 , p. 296 . Een ander voorbeeld warin eat verhoogde toetsingsintensiteit werd toegepast vanwege een emstige aantasting van een belangrijk redit is Romer v. Evans, 517 U.S. 620 (1996). In deze zaak was een amendement op de constitutie van Cilfornia in het geding dat inhield dat er geen wetgeving tot stand kon worden gebracht of kon worden li gedwongen waardoor ongelijke behandeling op grond van seksuele geaardheid werd verboden. Hel amendement had volgens het Supreme Court tot gevolg dat homoseksuelen iedere juridische bestrer ming tegen ongelijke behandeling werd ontnomen. Deze ernstige consequenties voor de rechsto scherming van deze groep leidden tot een toepassing van een rational basis "with bite"-test. Zie wor" enkele andere voorbeelden waarin de combinatie van deze factoren tot een verhoogde toetsingsititur siteit leidde Pettynga 1987, p. 800/801. 


\subsubsection{Aanwezigheid van beleidsvrijheid, aard van het beleidsterrein en het better placed-argument}

Zoals eerder is aangegeven hanteert het Supreme Court een marginale toets als uitgangspunt; de keuze daarvoor wordt in de meeste gevallen dan ook niet nader toegelicht. Toch heeft het Supreme Court in een aantal arresten aangegeven waarom het een bijzondere terughoudendheid geboden achtte. Een belangrijke factor daarbij blijkt vooral de aanwezigheid van een ruime mate van beleidsvrijheid voor de regelgever te zijn. Een dergelijke beleidsvrijheid kan voortvloeien uit bijzondere omstandigheden van het geval, bijvoorbeeld in het geval van een noodtoestand waarin snel moet worden opgetreden ${ }^{53}$, maar is meestal verbonden aan een bepaald beleidsterrein, zoals dat van het fiscale recht ${ }^{54}$, de nationale veiligheid ${ }^{555}$ of de sociale zekerheid ${ }^{556}$. 587 De klachten over ongelijke behandeling op dit soort gebieden hebben vaak betrekking op zeer complexe regelgeving, waarbij de relevante politieke en economische omstandigheden en inzichten snel kunnen veranderen. ${ }^{558}$ Het Supreme Court heeft verschillende malen aangegeven dat het als rechter onvoldoende inzicht en expertise heeft om de wenselijkheid van de getroffen maatregelen op deze gebieden voldoende te kunnen beoordelen..$^{559}$

553. Zie bijv. Hirabayashi v. United States, 320 U.S. 81 (1943), een zaak die betrekking had op onderscheid op grond van ras om tegemoet te komen aan een acuut gevaar van spionage en verraad in een oorlogssituatie. Hoewel het Supreme Court stelde dat onderscheid op grond van ras altijd verdacht en zeer ernstig is, paste het hier een terughoudende toetsing toe vanwege de urgentie waarmee maatregelen moesten worden getroffen en vanwege de bijzondere oorlogsomstandigheden.

554. F.S. Royster Guano Co. v. Virginia, 253 U.S. 412, 415 (1920), Madden v. Kentucky, 309 U.S. 83 , $87 / 88$ (1940), Allied Stores v. Bowers, 358 U.S. 522, 526 (1959), Kahn v. Shevin, 416 U.S. 351, 355 (1974), Williams v. Vermont, 472 U.S. 14, 21 (1985) (waarin om onduidelijke redenen toch een rational basis-test "with bite" werd toegepast), Allegheny Pittsburgh Coal v. Webster County, 488 U.S. 336, 344 (1989) en Nordlinger v. Hahn, 505 U.S. 1, 11 (1992).

555. Rostker v. Goldberg, 453 U.S. 57, 64/65 (1981); in dit arrest moest deze intensiteitverlagende factor het opnemen tegen het feit dat bij onderscheid op grond van geslacht normaal gesproken een intermediate scrutiny-test wordt toegepast. Het Supreme Court weigerde aan te geven of er daadwerkelijk sprake was van een verminderde toetsingsintensiteit, maar uit de uitspraak blijkt duidelijk dat er een minder strenge toetsing werd uitgevoerd dan bij intermediate scrutiny gebruikelijk is. Vgl. meer impliciet ook Schlesinger v. Ballard, 419 U.S. 498, 510 (1975).

556. Zie bijv. Geduldig v. Aiello, 417 U.S. 484, 495 (1974) en voor de federale overheid Flemming v. Nestor, 363 U.S. 603, 611 (1960) en Weinberger v. Salfi, 422 U.S. 749, 768 (1975). Een vergelijkbare ruime beleidsvrijheid geldt voor het gebied van de volksgezondheid; zie Watson $v$. State of Maryland, 218 U.S. 173,178 (1910).

557. Het Supreme Court beschreef het gebied waarop een ruime beleidsvrijheid geldt als "the area of economics and social welfare" (Dandridge v. Williams, 397 U.S. 471 (1970), United States v. Kras, 409 U.S. 434, 446 (1973) en United States Railway Retirement Board v. Fritz, 449 U.S. 166, 174 (1980); vgl. ook Ferguson v. Skrupa, 372 U.S. 726 (1963)). Een ruime beleidsvrijheid is buiten deze context erkend op het gebied van de vaststelling van straffen voor statelijke misdrijven (Williams v. Illinois, 399 U.S. 235, 241 (1970)) en de organisatie van verkiezingen (Lassiter v. Northampton County Board of Elections, 360 U.S. 45, 50 (1959) en McDonald v. Board of Election Commissioners of Chicago, 394 U.S. 802, 807 (1969)), hoewel daarbij een strict scrutiny-test kan worden toegepast als er sprake is

558. Zie voor de enstige aantasting (zie paragraaf 3.4.4).

San Antonio School District vijv. Jefferson v. Hackney, 406 U.S. 535 (1972); zie voor belastingen o.a.

559. Zie San Antonio School District vodriguez, 411 U.S. 1, 42 (1973)

gelden bij andere bijzool District v. Rodriguez, 411 U.S. 1, $41 / 42$ (1973). Vergelijkbare argumenten v. United States, voerd bij de beoordeling. 598, 607/608 (1985) dat een terughoudende toetsing moest worden uitgevoerd bij de beoordeling van de keuzen die de openbare aanklager makt bij het vervolgen van mis- 
Dit geldt nog in het bijzonder wanneer het gaat om maatregelen die specifiek zijn toen gesneden op de situatie in een bepaalde staat of stad: voor een goede beoordeling daar. van ontbreekt het het Supreme Court aan voldoende kennis van de plaatselijke omstan. digheden. ${ }^{360}$ Eén en ander impliceert dat zowel de aard van het beleidsterrein als het better placed-argument in de Amerikaanse rechtspraak een belangrijke rol speelt bij de keuze voor een terughoudende opstelling. ${ }^{561}$ Deze factoren zijn ook in de voorgande hoofdstukken reeds aan de orde gekomen; het gebruik hiervan door het Supreme Cour bevestigt vooral dat zij algemeen toepasbaar zijn.

Interessant is dat deze factoren soms ook intensiteitverhogend blijken te kunnen werken. Wanneer een staat slechts een zeer beperkte beleidsvrijheid heeft om op een bepaald terrein op te treden zal een strengere toetsing bijvoorbeeld al snel gerechtvaardigd zijn. Zo was in Takahashiv. Fish \& Game Commission ${ }^{562}$ een wet in het geding op grond waarvan het verboden was visvergunningen af te geven aan buitenlanders. Nu deze wet buitenlanders de mogelijkheid ontnam om door middel van visvangst een inkomen te verwerven, was het Supreme Court van mening dat deze regeling de immi. gratie kon beïnvloeden. De regulering van immigratie is echter toevertrouwd an de federale overheid, zodat het kon stellen dat

"[...] the power of a state to apply its laws exclusively to its alien inhabitants as a class is confined within narrow limits."

Deze overweging had in dit arrest betrekking op de toelaatbaarheid van de bevoegd. heidsuitoefening, maar in latere rechtspraak is deze vooral geciteerd als de rechtvaardiging van de toepassing van strict scrutiny op onderscheid op grond van nationaliteit." Hieruit blijkt duidelijk dat de mate van beleidsvrijheid, gekoppeld aan de bevoegdheidsomvang en het betrokken beleidsterrein, zeker van invloed kunnen zijn op de intensiteit van de toetsing.

\subsubsection{Context van het onderscheid}

Belangrijk is verder dat ook het Supreme Court aanneemt dat de context waarin onderscheid wordt gemaakt van doorslaggevende betekenis kan zijn voor de intensiteit van de toetsing. Dit wordt vooral geillustreerd door de rechtspraak over onderscheid op grond van nationaliteit. Normaal gesproken wordt daarbij, zoals eerder is aangegeven,

drijven; daarbij achtte het relevant dat bij deze keuzen een groot aantal voor de rechter moeilijk te tohsen factoren meespeelt en dat een vergaande controle ondermijnend kan werken voor het vervolging beleid.

560. Zie Patsone v. Pennsylvania, 232 U.S. 138, 144/145 (1914), Madden v. Kentucky, 309 U.S. 83, 80 (1940), Railway Express Agency, Inc. v. New York, 336 U.S. 106, 109 (1949), San Antonio Schred District v. Rodriguez, 411 U.S. I, 41 (1973), City of New Orleans v. Dukes, 427 U.S. 297, 303 (1976) en Lalli v. Lalli, 439 U.S. 259, 274 (1978).

561. Vgl. "Developments" 1969, p. 1128.

562. 334 U.S. 410 (1948)

563. 334 U.S., op 420

564. Zie Graham v. Richardson, 403 U.S. 365, 372 (1971). Vgl. ook Plyler v. Doe, 457 U.S. 202, 22522 (1982), waarin dit argument ook een rol lijkt te spelen voor de verhoging van de toetsingsintensiter van rational basis naar rational basis "with bite". 
een strict scrutiny-test toegepast. ${ }^{365}$ Het Supreme Court heeft echter een terughoudende toetsing aanvaard wanneer op deze grond onderscheid wordt gemaakt in de specifieke context van benoeming van bepaalde ambtenaren. In het arrest Sugarman v. Dougall ${ }^{\text {s6o }}$ motiveerde het deze uitzondering als volgt:

"[...] Each State has the power to prescribe the qualifications of its officers and the manner in which they shall be chosen. [...] Such power inheres in the State by virtue of its obligation $[\ldots]$ to preserve the basic conception of a political community. And this power and responsibility of the State applies, not only to the qualifications of voters, but also to persons holding state elective or important nonelective executive, legislative, and judicial positions, for officers who participate directly in the formulation, execution, or review of broad public policy perform functions that go to the heart of representative government. [...] We have held, of course, that such state action [...] is not wholly immune from scrutiny under the Equal Protection Clause. [...] But our scrutiny will not be so demanding where we deal with matters resting firmly within a State's constitutional prerogatives." 1567

Bij de benoeming van ambtenaren die functies zullen bekleden die essentieel zijn voor een representatieve democratie is er kennelijk sprake van een beleidsvrijheid van de staten die zodanig zwaarwegend is dat hierdoor de rechtvaardiging voor het toepassen van een strict scrutiny-test wordt doorbroken. ${ }^{\text {sos }}$ Op zichzelf lijkt dit niet onredelijk, nu vrij algemeen wordt aangenomen dat onderscheid op grond van nationaliteit niet altijd als even verdacht kan worden aangemerkt. ${ }^{56 y}$ Wanneer dit anders zou zijn zou het, gezien de fataliteit van de strict scrutiny-test, bovendien vrijwel onmogelijk worden om een immigratiebeleid te voeren. ${ }^{570}$ Juist dat is niet de bedoeling, zo blijkt uit Mathews $v$.

565. Zie voor het eerst Graham v. Richardson, 403 U.S. 365, 372 (1971). Op deze keuze is veel kritiek geleverd, aangezien het niet praktisch is om bij een grond die in veel gevallen een volstrekt toelaatbare basis voor onderscheid vormt een rechtvaardiging vrijwel onmogelijk te maken; zie bijv. Miller/Steele 1975, p. 3, Levi 1979, p. 1074 en Manheim 1995, p. 943.

566. 413 U.S. 634 (1973)

567. 413 U.S., op 647/648. Interessant is dat deze uitzondering goed aansluit bij de rationale die in Carolene Products is gegeven voor verhoging van de toetsingsintensiteit. Hoewel het nodig is om intensief te toetsen wanneer inbreuk wordt gemaakt op de goede werking van het politieke systeem, is terughoudendheid aangewezen bij maatregelen die redelijkerwijze bedoeld zijn om het systeem beter te laten functioneren. De toepassing van de uitzondering lijkt echter niet altijd even fraai aan te sluiten bij zijn rechtvaardiging. De uitzondering is bedoeld om ruimte te laten voor een minder strenge toetsing bij essentiele overheidsbenoemingen, zoals die van topambtenaren, rechters of openbare aanklagers. Het Supreme Court heeft echter ook een rational basis-test uitgevoerd bij benoemingen van politieagenten (Foley v. Connelie, 435 U.S. 291, 297 (1978)), "probation officers" (Cabell v. Chavez-Salido, 454 U.S. $432,447(1982)$ ) en zelfs van leraren op openbare scholen (Ambach v. Norwick, 441 U.S. 68 (1979)); in die gevallen is een directe relatie met het goed functioneren van een democratie zeker niet duidelijk aanwezig. Het Supreme Court is overigens niet altijd zo terughoudend: vgl. Bernal v. Fainter, 467 U.S. 216 (1984), waarin het aangaf dat de "public function exception" niet geldt voor notarissen.

568. Dit betekent dus niet dat nationaliteit als grond voor onderscheid in die gevallen niet verdacht is, maar alleen dat er andere, zwaarwegendere redenen kunnen bestaan voor terughoudendheid. Vgl. (kritisch) Manheim 1995, p. 1012/1013.

569. Vgl. bijv. Miller/Steele 1975, p. 15 en 16 en Rosberg 1977, p. 276.

570. Hoewel dit vanwege het Amerikaanse begrip "alienage" een minder relevante rechtvaardiging voor terughoudendheid lijkt te zijn: gedoeld wordt alleen op buitenlanders die legaal en permanent in het land woonachtig zijn en daardoor nauwelijks zijn te onderscheiden van staatsburgers. Onderscheid op grond van "alienage" is om die reden niet relevant voor het immigratiebeleid. Dit is anders voor onderscheid op buitenlanderschap in zijn algemeenheid. In die zin Rosberg 1977, p. 337. 
Diaz"1:

"In the exercise of its broad power over naturalization and immigration, Congress regularly makes rules that would be unacceptable if applied to citizens. [...] The fact that an Act of Congress treats aliens differently from citizens does not in itself imply that such dispanate treatment is 'invidious'. [...] Since decisions in these matters may implicate our relations with foreign powers, and since a wide variety of classifications must be defined in the light of changing political and economic circumstances, such decisions are frequently of a character more appropriate to either the Legislature or the Executive than to the Judiciary." $\$ 72$

In veruit de meeste gevallen is de context echter niet of nauwelijks relevant: wanneer eenmaal is vastgesteld dat een grond verdacht of quasi-verdacht is geldt dit altijd, ongeacht de omstandigheden van het geval. ${ }^{573}$ Niettemin kan uit de gegeven voorbeelden een bevestiging worden gevonden van de stelling dat enkele bestaan van een verdachte grond niet noodzakelijkerwijze een strict scrutiny-test kan opleveren: een afweging tegen andere relevante intensiteitbepalende factoren is, om ongewenste resultaten te voorkomen, in ieder concreet geval vereist.

\subsubsection{Verhouding tussen staten en federale overheid; subsidiariteitsargument}

Zoals eerder al is aangegeven zijn de vijftig staten die deel uitmaken van de VS autonoom op alle beleidsterreinen die door de Constitutie niet uitdrukkelijk ter regeling an de federale overheid zijn toegewezen. ${ }^{574}$ Deze autonomie blijkt voor het Supremt Court, dat een federale instelling is, soms een belangrijke reden te vormen voor tengs houdendheid. ${ }^{575}$ Dit blijkt bijvoorbeeld uit het arrest Labine v. Vincent ${ }^{57}$, dat betrekking had op het erfrecht in Louisiana. Het Supreme Court paste hierop een rational basis: test toe nadat het had geoordeeld dat

571. 426 U.S. 67 (1976)

572. 426 U.S., op $79 / 80$ en 81 . Dit arrest is niet geheel verenigbaar met de overige rechtspraak, die metr in het algemeen onduidelijk is. In een op dezelfde dag gewezen arrest was bijvoorbeeld eveneens etn to nadeling van buitenlanders door de federale overheid in het geding (zij het dat het ging om een spetfiek orgaan waaraan bevoegdheden waren gedelegeerd), waarin het Supreme Court geen melifin makte van de terughoudendheid die het in Mathews $v$. Diaz zo belangrijk leek te vinden, en zelfseen intensieve toetsing toepaste vanwege de grond van onderscheid; zie Hampton v. Mow Sun Wong, 426 U.S. 88, 103 (1976). Vgl. Levi 1979, p. 1086 en 1088 (die overigens aangeeft dat de test in Hanplonn feitelijk minder streng is dan een strict scrutiny-test zou doen verwachten en om die reden minder val Mathews v. Diaz afwijkt dan kan worden verondersteld; vgl. ook voetnoot 21 in Hampton, waarin wezen wordt op de ruime beleidsvrijheid op dit terrein en daaraan gekoppelde rechterlijke terughowdendheid). Zie echter ook Rosberg 1977, p. 286, die het verschil "perplexing" noemt.

573. In ieder geval heeft het Supreme Court nooit expliciet willen aangeven dat het in sommige omstandf heden een minder strenge toetsing uitvoert. Uit het arrest Rostker v. Goldberg, 453 U.S. 57 (1981), du betrekking had op onderscheid op grond van geslacht bij militaire aangelegenheden, kan echter worden afgeleid dat in de praktijk een vermindering van de toetsingsintensiteit wel degelijk mogelijk is. In dit arrest gaf het Supreme Court aan dat er op dit beleidsterrein normaal gesproken een zeer terughoudet: de toetsing wordt uitgevoerd, waarna het vervolgens een toetsing uitvoerde die zeker niet als interntrdiate scrutiny kan worden aangemerkt.

574. Zie paragraaf 1.2.1.

575. Vgl. San Antonio School District v. Rodriguez, 411 U.S. 1, 44 (1973)

576. 401 U.S. 532 (1971) 
"[... the choices reflected by the intestate succession statute are choices which it is within the power of the State to make. The Federal Constitution does not give this Court the power to overturn the State's choice under the guise of constitutional interpretation because the Justices of this Court believe that they can provide better rules." 577

Terughoudendheid is volgens het Supreme Court in het bijzonder vereist als het gaat om de toetsing van bepalingen in de statelijke constituties ${ }^{578}$ of om bepalingen die een centrale plaats in het rechtssysteem van de staat innemen ${ }^{579}$. Het internationaalrechtelijke principe van subsidiariteit, dat een zo belangrijke rol speelt voor de intensiteit van de toetsing door de Europese Hoven, blijkt dus ook binnen de VS van belang te zijn.

Er zijn echter ook gebieden waarop de bevoegdheid tot regeling zowel aan de federale als aan de statelijke overheden toekomt. Soms is de beleidsvrijheid voor de staten daarbij minder groot dan die van de federale overheid, hetgeen kan leiden tot een verschil in toetsingsintensiteit bij federale en statelijke maatregelen. ${ }^{5 \mathrm{x}_{0}}$ Een voorbeeld hiervan is het verschil in toetsingsintensiteit dat korte tijd werd gehandhaafd bij positieve discriminatie: in Metro Broadcasting v. FCC ${ }^{\text {ss }}$ stelde het Supreme Court dat voorkeursbeleid dat was ontworpen door het Congres aan een intermediate scrutiny-test moest worden onderworpen, terwijl een jaar eerder, in City of Richmond v. J.A. Croson Co., ${ }^{582}$ was vastgesteld dat op positieve discriminatie door de staten een strict scrutiny-test moest worden toegepast. Reden voor dit verschil was volgens het Supreme Court dat het Congres volgens het Veertiende Amendement een bijzondere bevoegdheid heeft om positieve maatregelen te treffen ter implementatie van de Equal Protection Clause. ${ }^{533}$ Staten hebben deze bijzondere bevoegdheid niet, zodat zij slechts voorkeursbeleid mogen voeren zolang de Equal Protection Clause daardoor niet wordt aangetast; dit betekent dat hiervoor dezelfde maatstaven gelden als voor iedere andere vorm van statelijk onderscheid. ${ }^{s * 4}$ Dit verschil in toetsingsintensiteit is echter al enkele jaren na

577. 401 U.S., op 532. Zie ook Weber v. Aetna Casualty \& Surety Co., 406 U.S. 164, 169 (1972) (waarin uiteindelijk een striktere toetsing werd toegepast vanwege de grond van onderscheid (onwettige geboorte)), San Antonio School District v. Rodriguez, 411 U.S. 1, 40 en 44 (1974) (waarin gewezen werd op het feit dat belastingwetgeving traditioneel een taak van de staten is; de factoren beleidsvrijheid en subsidiariteit lopen daarbij samen), Mayor of Philadelphia v. Educational Equality League, 415 U.S. 605 (1974) (waarin meer in het algemeen werd gewezen op de gevoelige federale verhoudingen) en Lalli v. Lalli, 439 U.S. 259, 268 (1978) (waarin het erfrecht aan de orde was).

578. Gregory v. Ashcroft, 501 U.S. 452,471 (1991)

579. McClesky v. Kemp, 481 U.S. 279, 296 (1987)

580. De hiervoor reeds besproken rechtspraak over immigratierecht kan een voorbeeld vormen: de federale overheid heeft daarbij een grote vrijheid, die blijkens Mathews v. Diaz, 426 U.S. 67 (1976) tot een terughoudende toetsing kan leiden. Voor de staten, die op dit gebied minder bevoegdheden hebben, geldt een dergelijke terughoudendheid niet maar wordt (op de hiervoor besproken "public function exception" na) een strict scrutimy-test toegepast. Vgl. Rosberg 1977, p. 288 en Perry 1979, p. 1062.

581. 497 U.S. 547 (1990). Deze rechtvaardiging blijkt impliciet ook uit Fullilove v. Klutznick, 448 U.S. 448 , 463 en 477 (1980); het Supreme Court onthield zich in deze uitspraak echter van een oordeel over de toetsingsintensiteit.

582. 488 U.S. 469 (1989)

583. Namelijk op grond van Section 5: "The Congress shall have power to enforce, by appropriate legislation, the provisions of this article."

584. 497 U.S., op 563-565. Expliciet blijkt deze onderbouwing ook uit Croson: "Congress, unlike any State or political subdivision, has a specific constitutional mandate to enforce the dictates of the Fourteenth Amendment. [...] That Congress may identify and redress the effects of society-wide discrimination does not mean that, a fortiori, the States and their political subdivisions are free to decide that such re- 
deze uitspraken doorbroken: in Adarand Constructors Inc. v. Pena $a^{55}$ stelde het Supreme Court vast dat het voor de intensiteit van de toetsing van positieve actie niet van belang is of de federale dan wel de statelijke overheid voor het voorkeursbeleid ver. antwoordelijk is. ${ }^{\mathrm{s} 6} \mathrm{Het}$ is echter onwaarschijnlijk dat dit oordeel een algemene reik. wijdte heeft, in die zin dat er bij concurrerende bevoegdheden altijd sprake is van een identieke toetsingsintensiteit voor maatregelen van de staten en maatregelen van de federale overheid; de concrete omstandigheden van het geval zullen daarvoor meestal bepalend zijn.

\subsubsection{Ongewoon karakter van het onderscheid}

Tenslotte is in de rechtspraak van het Supreme Court nog enkele malen een bijzondere intensiteitverhogende factor terug te vinden: wanneer er sprake is van onderscheid met een ongewoon karakter zal het Supreme Court een zorgvuldiger onderzoek naar de rechtvaardiging daarvan uitvoeren. Een goed voorbeeld van het gebruik van deze factor is het arrest Morey $v$. Doud ${ }^{587}$, dat betrekking had op de regulering van bepaalde financiële handelingen in Illinois. Voor de verkoop van zogenaamde "money orders" was volgens de relevante regeling een vergunning vereist. Bijzonder was daarbij dat de American Express Company expliciet en als enige van deze vergunningsplicht was uitgezonderd. Het Supreme Court paste op dit onderscheid een rational basis-test toe, maar stelde daarbij dat

"[...] we add the caution that discriminations of an unusual character especially suggest careful consideration to determine whether they are obnoxious to the constitutional provision." $\$ 8 x$

Het in een algemene regeling uitzonderen van één specifiek, bij naam genoemd bedriff moet kennelijk als een dergelijk ongewoon onderscheid worden gekwalificeerd. Hoewel het Supreme Court de noodzaak van verhoogde zorgvuldigheid bij ongewoon onderscheid verschillende malen heeft genoemd, heeft het nooit nader uitgelegd wanneet een onderscheid als "ongewoon" moet worden beschouwd. Na 1957 komt het vereiste bovendien niet meer voor, zodat het niet duidelijk is of deze factor nog steeds als relevant kan worden beschouwd. ${ }^{589}$ Juist door het ontbreken van een nadere uitwerking is het lastig om een oordeel te geven over de algemene bruikbaarheid van deze factor.

medies are appropriate. Section 1 of the Fourteenth Amendment is an explicit constraint on state power, and the States must undertake any remedial efforts in accordance with that provision" (488 U.S. op 490 ).

585. 515 U.S. $200(1995)$

586. De belangrijkste reden daarvoor leek te zijn dat het "would be unthinkable that the same Constitution would impose a lesser duty on the Federal Government than it does on a State to afford equal protection" (515 U.S., op 225). Terecht stelde de dissenting opinion bij deze zaak dat daarmee onvoldoende is gemotiveerd waarom het verschil in bevoegdheid tussen staten en federale overheid in het Veertiends Amendement niet relevant is (515 U.S., op 253 (J. Stevens, dissenting)).

587. 354 U.S. 457 (1957)

588. 354 U.S., op 463. Idem in Bell's Gap R. Co. v. Commonwealth of Pennsylvania, 134 U.S. 232, 237 (1890), Louisville Gas \& Electric Company v. Coleman, 227 U.S. 32, $37 / 38$ (1928) en Hartfords Harrison, 301 U.S. 459, 462 (1937).

589. Dit is niet zeer waarschijnlijk, nu het Supreme Court in City of New Orleans v. Dukes, 427 U.S. 29? (1976) te maken had met een closed class en daarbij niet alleen een zeer terughoudende rational basib- 


\section{Conclusies}

\subsection{Conclusies met betrekking tot de toetsingsmethodiek}

\section{I.I Inleiding}

Zoals hiervoor is aangegeven hanteert het Supreme Court één officieuze en drie officiele tests: de rational basis-test, soms informeel geïntensiveerd tot een rational basistest "with bite", de intermediate scrutiny-test en de strict scrutiny-test. Duidelijk is geworden dat deze tests wat betreft de gehanteerde toetsingsmethodiek in de rechtvaardigingsfase nauwelijks verschillen: in alle gevallen wordt onderzocht of het onderscheid een gerechtvaardigd doel dient en wordt nagegaan of er een redelijke verhouding bestaat tussen doel en onderscheid. De feitelijke toepassing van deze tests, net als de keuze voor een bepaalde toetsingsingang, verschilt echter wel degelijk. Op de meest opvallende kenmerken van de tests en hun implicaties voor het algemene toetsingsmodel zal in deze laatste paragraaf worden ingegaan.

\subsubsection{Toetsing in de eerste fase: vergelijkbaarheid, benadeling en discriminatoire bedoeling}

\section{Vergelijkbaarheid}

In paragraaf 2.2 is duidelijk geworden dat de toetsing van de vergelijkbaarheid in de rechtspraak van het Supreme Court een ondergeschikte rol speelt. Van deze toets leek aanvankelijk nog wel gebruik te worden gemaakt bij de toetsing van de gelijkwaardigheid van voorzieningen in het kader van de separate but equal-doctrine, maar daarbij is aangegeven dat het Supreme Court eerder een soort benadelingstoets uitvoerde: het Supreme Court ging steeds na of de voorzieningen voor de eisende partij van slechtere kwaliteit waren, waardoor feitelijk werd onderzocht of de eiser daadwerkelijk werd benadeeld. Van de gelijkwaardigheidstest wordt tegenwoordig nauwelijks nog gebruik gemaakt, zodat de relevantie hiervan voor de Amerikaanse rechtspraak beperkt moet worden geacht.

Bij de rational basis- en de intermediate scrutiny-test wordt wel relatief vaak gebruik gemaakt van een vergelijkbaarheidstoets. Daarbij is echter opmerkelijk dat de toetsing die het Supreme Court uitvoert nauwelijks afwijkt van de toetsing aan het rechtvaardigingsmodel. Van belang is vooral dat het Supreme Court de vergelijkbaarheidstoets zelf niet ziet als een toetsingsingang: van de eisende partij wordt niet verwacht dat hij in de eerste fase van de toetsing aantoont dat er sprake is van vergelijkbare gevallen. In plaats daarvan hanteert het Supreme Court de toets vooral als invulling van de tweede fase, waarbij deze een vergelijkbare functie lijkt te vervullen als het rechtvaardigingsmodel. Daarbij is van belang dat het Supreme Court, om vast te kunnen stellen of er sprake is van vergelijkbare gevallen, eerst zoekt naar een geschikte vergelijkingsmaatstaf, hetgeen in de praktijk betekent dat het doel van de maatregel wordt vastgesteld;

test toepaste, maar Morey $v$. Doud zelfs expliciet terzijde schoof als een "needlessly intrusive judicial infringement on the State's legislative powers" (op 306). 
de relevante verschillen het gemaakte onderscheid voldoende kunnen rechtvaardigen. De werkwijze die het Supreme Court hanteert bij de toetsing aan de vergelijkbaar. heidstoets is daarmee vrijwel identiek aan de wijze waarop het aan het rechtvaardigingsmodel toetst. In de loop van de tijd zijn beide toetsen bovendien steeds meer door elkaar gaan lopen en maakt het Supreme Court hiertussen nauwelijks nog onderscheid. Bij de rational basis-test wordt de laatste twintig jaar zelfs in het geheel geen gebruik meer gemaakt van de vergelijkbaarheidstoets en is deze volledig vervangen door een toetsing aan het rechtvaardigingsmodel. Bij de intermediate scrutimy-test word de vergelijkbaarheidstoets wel nog gehanteerd, maar heeft dit gebruik vooral retorische waarde: inhoudelijk gezien kan het in de verschillende zaken bereikte resultaat even gemakkelijk worden gerealiseerd door een toepassing van het rechtvaardigingsmodel. Dit wordt nog benadrukt door het feit dat het Supreme Court niet in iedere intermediate scrutiny-zaak gebruik maakt van de vergelijkbaarheidsterminologie: alleen wanneer dit goed past in de redenering en een vergelijkbaarheidselement het beoogde toetsingsesultaat krachtig ondersteunt is deze toets in de uitspraken terug te vinden.

Juist doordat het Supreme Court de vergelijkbaarheidstoets op een sterk met het rechvaardigingsmodel vergelijkbare manier toepast, zijn er in de rechtspraak weinig uit. spraken terug te vinden die duidelijk pleiten tegen de toepassing van de vergelijkbaarheidstoets. Anderzijds biedt de rechtspraak evenmin overtuigende argumenten voor het verkiezen van de vergelijkbaarheidstoets boven het rechtvaardigingsmodel: er bestaat geen enkele uitspraak waarin een vergelijkbaarheidstoets tot een andere en duidelijk betere uitkomst zou hebben geleid. Van belang is verder dat het gebruik van beide toetsen veel verwarring oplevert: in de Amerikaanse juridische literatur bestaat hierdoor bijvoorbeeld weinig duidelijkheid over de vraag welke criteria er nu precies mosten worden toegepast bij een toetsing aan de rational basis-test. Het lijkt dan ook werselijk om beide tests in ieder geval niet door elkaar heen toe te passen, maar een duidelijke keuze te maken voor een bepaalde toetsingsmethodiek. De keuze voor het rechtvaardigingsmodel lijkt daarbij het meest voor de hand te liggen: zoals uit hoofdstuk 2 is gebleken is dit model theoretisch gezien het meest aantrekkelijk, terwijl de rechtspraak van het Supreme Court geen duidelijke argumenten biedt voor een vervanging van deze toets door de vergelijkbaarheidstoets.

\section{Benadeling en discriminatoire doelstelling}

In de meeste gevallen heeft het Supreme Court te maken met klachten over direct onderscheid door normatieve classificaties: vrijwel steeds wordt er geklaagd over algemene regelingen waardoor een specifieke groep wordt uitgezonderd voor een bijzondere behandeling. Dergelijke classificaties leveren consequent een benadeling op, hetzi] doordat een groep wordt uitgezonderd voor een benadelende behandeling, hetzij doosdat er een groep juist niet voor een voordelige behandeling in aanmerking komt. Om die reden gaat het Supreme Court bij de toetsing van normatieve classificaties in beginsel uit van de veronderstelling dat er sprake is van een benadeling van de eisende partij, zonder nadere eisen te stellen aan het bewijs daarvan. Slechts wanneer er twijfel bestaal over de vraag of er daadwerkelijk sprake is van een nadelige behandeling blijkt het Supreme Court hiernaar nader onderzoek te verrichten. Dit is bijvoorbeeld het geval 
wanneer er wordt geklaagd over een morele benadeling, die kan ontstaan door het benadrukken van de inferioriteit van een bepaalde groep of door stigmatisering. Op zichzelf wordt het bestaan van een mentale benadeling door het Supreme Court gezien als voldoende reden om de classificatie op zijn gerechtvaardigdheid te toetsen, maar de eisende partij zal dan wel voldoende aannemelijk moeten maken dat hij daadwerkelijk is benadeeld, liefst door middel van psychologisch of sociologisch bewijsmateriaal. Ook in andere gevallen waarin twijfel mogelijk is, bijvoorbeeld omdat het nadeel door het bestaan van een andere regeling wordt gecompenseerd, wordt in de meeste gevallen nader aandacht besteed aan het benadelingsvereiste.

Omdat het nagenoeg onvermijdelijk is dat directe, normatieve classificaties leiden tot de benadeling van een bepaalde groep, is het veronderstellen van een benadeling (behalve in gevallen van twijfel) daarbij zeker niet onredelijk. Een dergelijke veronderstelling kan in beginsel dan ook een zinvol uitgangspunt vormen voor het algemene toetsingsmodel. Een nadeel hiervan zou echter kunnen zijn dat hierdoor een relatief lichte bewijslast voor de eisende partij ontstaat, tegenover een zware bewijslast voor de verweerder; dit zou bovendien kunnen leiden tot een grote hoeveelheid klachten waartegen de regelgever zich ten onrechte inhoudelijk moet verweren.

Wanneer er sprake is van direct onderscheid waarbij om enigerlei reden een strikte toets wordt toegepast, lijkt een dergelijke bewijslastverdeling niet onredelijk te zijn. De toepassing van een intensieve toetsing wijst er immers op dat de kans dat de eisende partij ten onrechte ongelijk is behandeld relatief groot is, zodat het redelijk is om al snel van de verwerende partij te verwachten dat hij ter rechtvaardiging van het onderscheid overtuigende argumenten aanvoert. Ook wanneer een terughoudende toetsing wordt toegepast hoeft het veronderstellen van een benadeling echter niet te leiden tot een onevenredige bewijslastverdeling. Het Supreme Court zelf hanteert bij de rational basis-test als uitgangspunt dat de bewijslast moet worden omgekeerd, waardoor de eisende partij aan moet tonen dat iedere mogelijke rechtvaardiging voor het onderscheid ontbreekt. Hoewel hierdoor de bewijslast van de overheid inderdaad sterk wordt verminderd, lijkt dit toch geen redelijke bewijslastverdeling te zijn. Met name is het problematisch dat door deze methodiek een bijzonder zware bewijslast aan de eisende partij wordt opgelegd, terwijl het juist voor een individuele klager vaak moeilijk zal zijn om bewijsmateriaal te vergaren waaruit kan blijken dat een onderscheid ongerechtvaardigd is. Het is ook niet nodig om van een dergelijke zware bewijslast gebruik te maken om een redelijk evenwicht te creëren. Daarvoor kan het al voldoende zijn wanneer van de eiser wordt gevergd dat hij aannemelijk maakt dat de door de verdedigende partij aangevoerde rechtvaardiging op bepaalde punten tekortschiet, bijvoorbeeld omdat het gestelde doel niet het werkelijke doel van het onderscheid is of omdat er alternatieve mogelijkheden bestonden om het nagestreefde doel te verwezenlijken. De bewijslast voor de eiser wordt daardoor enigszins verzwaard, terwijl die van de overheid juist lichter wordt. Wordt van een dergelijke bewijslastverdeling gebruik gemaakt, dan kan, ook bij een terughoudende toetsing, in de eerste toetsingsfase worden volstaan met de beoordeling of er sprake is van een benadelende classificatie.

Zoals eerder is aangegeven zal er lang niet altijd sprake zijn van klachten over direct onderscheid door normatieve classificaties. Het komt regelmatig voor dat wordt aange- 
voerd dat een maatregel een indirect onderscheid op een (quasi-)verdachte grond, zoals ras of geslacht, tot gevolg heeft. Ook in die gevallen kan een benadelingstoets als toet. singsingang worden gekozen: vereist kan bijvoorbeeld worden dat de eisende partij aantoont dat een neutrale classificatie een disproportioneel benadelend effect heeft voor de groep waarvan hij deel uitmaakt. Hoewel dit de benadering is die aanvankelijk door het Supreme Court werd gevolgd, heeft de benadelingstoets als toetsingsingang bij indirect onderscheid al in 1976 plaats moeten maken voor het vereiste van een discriminatoire bedoeling. Aan deze benadering kleven echter belangrijke bezwaren. Allereerst wordt er door de hoge eisen die het Supreme Court stelt aan het aantonen van een discriminatoire doelstelling een zeer zware bewijslast op de eisende partij gelegd: het is voor een individuele klager in het algemeen al relatief moeilijk om te achterhalen welke doeleinden een wetgever met een classificatie nastreefde, maar dit geldt nog in het bijzonder wanneer moet worden aangetoond dat deze doelstellingen discriminatoir waren. Een wetgever die doelstellingen nastreeft waarvan hij weet dat zij in strijd zijn met hogere regelgeving, zal deze immers maar hoogst zelden expliciet in de toelichting bij de classificatie vermelden. Door de hoge bewijslast zal het dan ook vaak onmogelijk zijn om discriminatoire gevolgen op een effectieve manier aan te vechten.

Van belang is echter vooral dat indirecte effecten, bedoeld of onbedoeld, voor de ge troffen groeperingen niet minder ernstig zullen zijn dan die van classificaties waardoor zij rechtstreeks worden benadeeld. Wanneer er sprake is van een duidelijk disproportioneel benadelend effect voor een bepaalde groep kan dan ook zeker van de overheid worden verlangd dat zij redenen aanvoert die kunnen rechtvaardigen dat dit effect is getolereerd. In veel gevallen zal een dergelijke rechtvaardiging inderdaad bestaan, bijvoorbeeld wanneer het met de maatregel nagestreefde algemene belang zwarder weegt dan het benadelende effect hiervan. Het Supreme Court laat echter nauwelijks ruimte voor een dergelijke rechtvaardiging, althans bij een toepassing van de strict scrutiny-test: zoals bekend heeft deze test een fataal karakter, waardoor een rechtvaardiging vrijwel onmogelijk is. Een toepassing van deze test op indirect onderscheid zou dan ook tot gevolg kunnen hebben dat regelgeving op sociaal-economisch terrein vij. wel onmogelijk wordt: juist door de jarenlange achterstelling van raciale minderheden zullen vrijwel alle maatregelen op dit gebied ongelijke effecten opleveren, waardoor deze regelgeving in strijd met het Veertiende Amendement zou zijn. Het is echter niet nodig om dit probleem op te lossen door een zo beperkende toetsingsingang als de discriminatoire bedoeling te kiezen: het is evengoed mogelijk om de strict scrutiny-test zijn fatale karakter te ontnemen, waardoor er ruimte ontstaat voor de rechtvaardiging van ongelijke effecten. Waarom het Supreme Court dit alternatief nooit heeft gekozen is niet geheel duidelijk. ${ }^{500}$

De rechtspraak van het Supreme Court bevestigt dat de keuze voor een benadelingstoets als toetsingsingang de meest wenselijke is, zowel bij direct als bij indirect

590. In Adarand Constructors, Inc. v. Pena, 515 U.S. 200 (1995) stelde het Supreme Court echter dat de test niet altijd een fataal karakter hoeft te hebben. Het is nog niet geheel duidelijk wat het Supreme Cour hiermee precies bedoelt, maar wanneer dit uiteindelijk leidt tot een grotere mogelijkheid van rechvaardiging wordt hiermee de belangrijkste reden voor de keuze voor de doelstelling als toetsingsingun? weggenomen. De vraag is of het Supreme Court nog lang op gerechtvaardigde wijze aan deze tolt singsingang vast zal kunnen blijven houden. 
onderscheid. Niet alleen levert deze toetsingsingang een redelijke bewijslastverdeling op, althans zolang er bij de bewijslastverdeling in de tweede fase voldoende rekening wordt gehouden met de gekozen toetsingsintensiteit, maar ook laat een benadelingstoets ruimte voor het bestrijden van maatschappelijke ongelijkheden. Vereist is vanzelfsprekend wel dat er goede eisen worden gesteld aan het bewijs van benadeling. Dergelijke eisen zijn in de rechtspraak van het Supreme Court over de Equal Protection Clause nauwelijks uitgewerkt, nu het Supreme Court zich bij indirect onderscheid concentreert op het bewijs van een discriminatoire bedoeling en het bij direct onderscheid het bestaan van een benadeling eenvoudigweg veronderstelt. Gewezen kan hoogstens worden op een tweetal bruikbare aanwijzingen. Allereerst heeft het Supreme Court in zijn rechtspraak aangegeven dat het disproportionele effect van een benadeling kan worden beoordeeld aan de hand van statistisch bewijs dat relatieve verschillen in het aandeel van de relevante groepen laat zien; uit absolute verschillen kunnen geen conclusies worden afgeleid. Verder is van belang dat het Supreme Court voor het vaststellen van een disproportionele benadeling in beginsel niet zal kijken naar het aandeel van een groep in de samenleving in zijn algemeenheid, maar naar het aandeel in een groep die in het licht van de regeling relevant is. Daarbij is het echter wel mogelijk om het relatieve aandeel van afzonderlijke minderheidsgroepen bij elkaar op te tellen, zolang deze groepen zich met betrekking tot het doel van de regeling in een vergelijkbare positie bevinden. Deze aanwijzingen zijn in principe algemeen bruikbaar en kunnen, in samenhang met enkele criteria die in de voorgaande hoofdstukken reeds zijn besproken en die in hoofdstuk 6 nog aan de orde zullen komen, een zinvolle aanvulling vormen voor het algemene toetsingsmodel.

\section{I.3 Toetsing van het doel}

\section{Vaststelling}

Zoals hiervoor is gebleken is het verschil tussen de rational basis-test en de verschillende striktere toetsen duidelijk zichtbaar bij de vaststelling van het doel. Waar bij de striktere tests vrijwel steeds ambtshalve wordt gezocht naar het werkelijk doel (actual purpose-test), stelt het Supreme Court bij de rational basis-test alleen een hypothetisch doel vast, waarbij het niet noodzakelijk is dat dit ook de werkelijke of zelfs de meest waarschijnlijke doelstelling van het onderscheid is (conceivable basis-test). Deze laatste benadering levert een grote mate van terughoudendheid op, maar laat tegelijkertijd veel ruimte voor rechterlijke willekeur. Zolang de rechter doelstellingen kiest die plausibel zijn en het onderscheid kunnen rechtvaardigen, zal het inderdaad zo zijn dat de conceivable basis-test een goede balans creëert in de verhouding tussen rechter en wetgever. Het is echter evengoed denkbaar dat de rechter een doelstelling vaststelt die duidelijk onredelijk is, en vervolgens tot de conclusie komt dat het onderscheid onconstitutioneel is. Een dergelijke benadering is vooral problematisch wanneer er wel degelijk goede redenen zijn te bedenken om het onderscheid te rechtvaardigen. ${ }^{391}$ Het ver-

591. In de rechtspraak van het Supreme Court zijn hiervan op verschillende plaatsen voorbeelden zichtbaar.

Zo vond het Supreme Court in Gulf. Colorado and Santa Fe Railway Company v. Ellis, 165 U.S. 150

(1897) dat er geen gerechtvaardigde doelstellingen voor het onderscheid konden worden bedacht en dit dus in strijd was met de Equal Protection Clause, terwijl de dissenters wel degelijk een plausibele rechtvaardiging voor het onderscheid konden bedenken. Zie voor andere voorbeelden waarin het Su- 
eiste dat primair wordt afgegaan op de doelstellingen zoals die door de wederpartij naar voren worden gebracht lijkt dan toch een grotere waarborg te bieden tegen rechterlijke subjectiviteit.

Een bijkomend probleem is opnieuw dat de door het Supreme Court gehanteerde com. ceivable basis-test bijzonder hoge eisen stelt aan de bewijslast van de eisende partij, nu deze volgens de rechtspraak moet aantonen dat er geen enkele plausibele doelstelling aan het onderscheid ten grondslag kon hebben gelegen. Deze eis maakt het nagenoeg onmogelijk om een effectieve klacht over ongelijke behandeling in te dienen en zorgt ervoor dat de Equal Protection Clause voor alle gebieden waarvoor geen verhoogde toetsingsintensiteit geldt een vrijwel zinloze waarborg is geworden. Dit is niet redelijk: een individu moet ook worden beschermd tegen onredelijk of willekeurig overheids. optreden wanneer de overheid een grote mate van beleidsvrijheid heeft. Deze benade. ring verdient dan ook zeker geen navolging.

Bij de intermediate scrutiny- en de strict scrutiny-test heeft het Supreme Court voor een veel actievere benadering gekozen, waarbij het in veel gevallen uit eigen beweging nagaat wat het werkelijke doel van het onderscheid is. Bij strict scrutiny is dit redelijk: een vergaand onderzoek naar de toelaatbaarheid van het onderscheid wordt daarbij gerechtvaardigd door de redenen die ook tot verhoging van de toetsingsintensiteit hebben geleid. Bij de intermediate scrutiny-test ligt een intensief onderzoek echter minder voor de hand, hetgeen door het Supreme Court ook is erkend: bij de toepassing van deze test wordt blijkens de rechtspraak alleen een nader onderzoek ingesteld wanneer de feiten twijfel oproepen over de vraag of het gestelde doel ook het werkelijke doel van het onderscheid was. Voor een dergelijk onderzoek zal vooral ruimte bestan als het onderscheid duidelijk ongeschikt is om het gestelde doel te bereiken, als het aangevoerde doel zeer vaag is of wanneer duidelijk is dat de doelstelling speciaal voor de procedure naar voren is geschoven. Een dergelijke benadering maakt een verschil in intensiteit tussen de twee striktere tests mogelijk en lijkt zeer bruikbaar te zijn voor de ontwikkeling van een algemeen toetsingsmodel.

\section{Inhoudelijke toetsing}

Het is opmerkelijk dat het aantal gevallen waarin het Supreme Court daadwerkelijk toekomt aan een inhoudelijke toetsing van het doel relatief gering is: zelfs wanneer een strict scrutiny- of intermediate scrutiny-test wordt uitgevoerd wordt de gerechtvarrdigdheid verondersteld, zodra het Supreme Court via een andere redenering gemakkelijker en sneller tot de gewenste uitkomst kan komen. In de rechtspraak van het Supreme Court kunnen dan ook niet veel nieuwe elementen worden teruggevonden die behulpzaam kunnen zijn bij de beoordeling van de gerechtvaardigdheid van het doel. Van belang is echter dat de rechtspraak wel een bevestiging vormt van de bruikbaarheid van bepaalde, in eerdere hoofdstukken reeds genoemde, criteria. Zo is het duidelijk dat doelstellingen die in strijd zijn met hogere regelgeving of die niet kunnen worden nagestreefd zonder bevoegdheidsoverschrijving niet toelaatbaar zijn, net zomin als inherent discriminatoire doelstellingen. Verder is het interessant dat het Supreme Court bij de

preme Court geen redelijke doelstelling kon bedenken Smith v. Cahoon, 283 U.S. 553 (1931) en Mar flower Farms, Inc. v. Ten Eyck, 297 U.S. 266 (1936). 
strict scrutiny-test en de intermediate scrutiny-test heeft gesteld dat het onderscheid een voldoende feitelijke basis moet hebben: wanneer de wetgever door middel van een classificatie een bepaald probleem wil oplossen, moet het duidelijk zijn dat dit probleem ook daadwerkelijk bestaat. Dit criterium, dat nauw verwant is aan het Europeesrechtelijke criterium van de werkelijke behoefte, kan zeker een nuttige invulling van het algemene toetsingsmodel vormen. Van belang is verder dat het Supreme Court heeft aanvaard dat administratieve en financiële doelstellingen in beginsel gerechtvaardigd kunnen zijn. Zoals uit zijn rechtspraak blijkt zullen dergelijke doelstellingen in veel gevallen echter onvoldoende zwaar wegen om het onderscheid daadwerkelijk te kunnen rechtvaardigen: de classificatie zal dan sneuvelen op het vereiste van proportionaliteit, hoewel het de toetsing aan het vereiste van een gerechtvaardigd doel heeft doorstaan. Dit is een redelijke benadering die meer recht doet aan de realiteit dan de benadering van het Europees Hof van Justitie, dat deze doelstellingen in het geheel niet gerechtvaardigd acht.

\subsubsection{Beoordeling van de verhouding tussen doel en middel}

Over- en underinclusiveness

Het Supreme Court gaat in een groot aantal zaken na of een classificatie in het licht van zijn doelstelling voldoende specifiek is gedefinieerd. Dit is een bijzonder zinvolle toetsing, nu deze een element van de verhouding tussen doel en middel betreft dat moeilijk kan worden beoordeeld door toetsing aan meer traditionele criteria als geschiktheid, subsidiariteit of proportionaliteit. Juist vanwege het belang van dit criterium binnen de toetsing van het Supreme Court is het opmerkelijk dat het hieraan nauwelijks uitwerking heeft gegeven: in de meeste gevallen wordt slechts vastgesteld dat een regeling al dan niet over- of underinclusive is, zonder dat dit nader wordt toegelicht. Dit probleem is vooral aanwezig bij de rational basis-test, waarbij vrijwel iedere misfit, hoe vergaand en willekeurig ook, toelaatbaar blijkt te zijn. De enige rechtvaardiging die het Supreme Court daarvoor heeft gegeven luidt dat de wetgever niet ieder probleem ineens en volledig hoeft aan te pakken, zeker niet op gebieden waar hij een grote mate van beleidsvrijheid heeft. Underinclusiveness en zeker ook overinclusiveness zijn echter lang niet altijd het gevolg van partiële wetgeving, maar vaak ook van slordigheid of kortzichtigheid van de wetgever. Op zichzelf is terughoudendheid bij een marginale toets als de rational basis-test wenselijk en redelijk, maar deze mag er niet toe leiden dat duidelijke onvolkomenheden worden getolereerd. Is dit wel het geval, dan wordt daardoor immers een belangrijke waarborg tegen ongelijke benadeling weggenomen. In dit opzicht verdient de benadering van het Supreme Court dan ook geen navolging: op zijn minst mag van de rechter worden vereist dat hij nagaat welke oorzaken er bestonden voor een bepaalde misfit, waarna hij kan beoordelen of deze hiervoor een voldoende rechtvaardiging vormen.

Bij intermediate scrutiny en strict scrutiny concludeert het Supreme Court aanzienlijk vaker tot het ontbreken van een voldoende mate van fit, maar ook hierbij ontbreekt een goede en duidelijke inhoudelijke toetsing. Geconcludeerd kan dan ook worden dat de rechtspraak van het Supreme Court weliswaar het belang van de toetsing van de overen underinclusiveness onderstreept en illustreert dat deze toets praktisch bruikbaar is, 
maar dat hieruit nauwelijks aanknopingspunten voor de precieze invulling van dit crite. rium kunnen worden afgeleid.

\section{Geschiktheid, subsidiariteit en proportionaliteit}

Ook de drie meer klassieke criteria voor de toetsing van de verhouding tussen doel en classificatie - geschiktheid, subsidiariteit en proportionaliteit - zijn in de rechtspraak van het Supreme Court regelmatig terug te vinden. Het Supreme Court gaat echter niet op een zorgvuldige en structurele manier na of aan deze criteria is voldaan: meestal besteedt het alleen aandacht aan dat criterium waaraan een onderscheid duidelijk wel of niet voldoet. De toetsing is daardoor erg onduidelijk en niet altijd even overtuigend: vaak blijft de vraag in de lucht hangen of een bepaalde uitspraak ook zou zijn gedaan als er wel een proportionaliteitstoets was uitgevoerd of als zorgvuldiger was nagegaan of er bruikbare alternatieven voor de classificatie bestonden. Voor de doorzichtigheid van de toetsing zou het dan ook beter zijn wanneer het Supreme Court in iedere uitspraak aandacht zou besteden aan alle verschillende elementen van het rechtvaardgingsmodel.

Voor de toepassing van de geschiktheidstoets geldt dat het Supreme Court bij de rational basis-test nauwelijks waarde hecht aan wetenschappelijk en empirisch bewijs: als de regelgever op het moment dat de regeling tot stand kwam redelijkerwijze kon veronderstellen dat deze geschikt was om het beoogde doel te bereiken is dat voldoende, ook als tijdens de procedure blijkt dat ieder causaal verband feitelijk ontbreekt. Dit betekent dat het Supreme Court altijd ex tunc toetst: het uitgangspunt is het vermoeden van causaliteit op het moment van totstandkoming van de regeling, niet de feitelijke geschiktheid van de maatregel zoals die uit de werking van de regeling naar voren komt. Hoewel een terughoudende opstelling bij beleidsvrijheid gepast is, lijkt deze benadering geen wenselijke consequenties te hebben. Een wetgever, zelfs wanneer deze de beste bedoelingen heeft, kan de praktische uitwerking van zijn regelgeving lang niet altijd overzien. Wanneer kan worden aangetoond dat de regeling evident ongeschikt is om zijn doelstellingen te bereiken, maar hierdoor wel individuele belangen worden aangetast, kan echter redelijkerwijze van de regelgever worden verwacht dat hij de regeling herziet en eventueel vervangt of aanpast. Wanneer de rechter hem daartoe niet zou kunnen dwingen zou het vereiste van geschiktheid zijn nut verliezen en zou het gelijkheidsbeginsel een aanzienlijk minder effectieve bescherming bieden. De invulling die het Supreme Court bij de rational basis-test aan het geschiktheidsvereiste geeft lijkt dan ook niet navolgenswaardig te zijn. Of het Supreme Court een andere benadering kiest bij de toetsing aan de striktere tests is niet geheel duidelijk: het antal uitspraken waarin daarbij een toetsing aan het geschiktheidsvereiste wordt uitgevoerd is zo beperkt dat daaruit nauwelijks conclusies zijn af te leiden.

De noodzakelijkheidstoets, die een zo belangrijke plaats inneemt in het Europese recht, blijkt ook in de rechtspraak van het Supreme Court voor te komen als afzonderlijk toetsingscriterium. De toets heeft echter zeker geen vaste plaats verworven: het antal gevallen waarin in het algemeen wordt nagegaan of er daadwerkelijk behoefte bestond aan het onderscheid is beperkt. Veel groter is het aantal gevallen waarin een klassieke 
subsidiariteitstoets wordt uitgevoerd en waarin wordt bekeken of de doelstellingen van de regeling niet door minder belastende middelen hadden kunnen worden bereikt. Aangegeven is echter al dat deze test bij de rational basis-test volledig ontbreekt. Dit wordt door het Supreme Court gemotiveerd met de stelling dat door een toetsing aan het subsidiariteitsvereiste afbreuk zou worden gedaan aan de keuzevrijheid die inherent is aan het voeren van beleid. Op zichzelf is dit juist, maar dit betekent nog niet dat de wetgever ook een voor de individuele burger nadelige keuze mag maken wanneer er minder belastende middelen voorhanden waren. Het lijkt bovendien goed mogelijk om een subsidiariteitstoets uit te voeren zonder al teveel afbreuk te doen aan de beleidsvrijheid van de regelgever, bijvoorbeeld door van de eisende partij te vereisen dat deze voldoende aannemelijk maakt dat er geschikte alternatieven bestonden. Zonder nadere argumenten die pleiten voor een volledige afwijzing van deze test kan op basis van de rechtspraak van het Supreme Court dan ook niet worden aangenomen dat het criterium uit het algemene toetsingsmodel moet worden verwijderd.

Bij de toepassing van de strict scrutiny-test en de intermediate scrutiny-test gaat het Supreme Court wel regelmatig na of de regelgever voor het verwezenlijken van zijn doelstellingen niet met minder belastende middelen had kunnen volstaan. Interessant is daarbij dat het vaak gebruik maakt van zelf verworven of bij de partijen aanwezige kennis over de oplossingen die in andere staten, steden, counties, etc, voor vergelijkbare problemen zijn gevonden. Er wordt daardoor een soort interne rechtsvergelijking uitgevoerd, hetgeen in de praktijk een bijzonder effectieve benadering blijkt te zijn die op een objectieve manier leidt tot het vinden van interessante en bruikbare alternatieven. Het Supreme Court is bovendien tegemoet gekomen aan het bezwaar tegen te snel rechterlijk ingrijpen door te vereisen dat de gevonden alternatieven net zo geschikt moeten zijn om het beoogde doel te bereiken als door de gekozen classificatie; bovendien heeft het steeds vereist dat het alternatief duidelijk minder belastend moeten zijn voor de betrokken individuele belangen. Het enkele bestaan van alternatieve mogelijkheden is dus nog niet voldoende om een onderscheid onconstitutioneel te achten. Juist nu deze invulling een goede balans lijkt te creëren tussen de beleidsvrijheid van de regelgever en de bescherming van de belangen van het individu kan hierbij zonder meer aansluiting worden gezocht bij het opstellen van het algemene toetsingsmodel.

Tenslotte kan worden opgemerkt dat de proportionaliteitstoets in strikte zin in de praktijk geen belangrijk onderdeel vormt van de toetsing door het Supreme Court. Dit wordt verklaard door het feit dat het Supreme Court in de meeste gevallen al door een toepassing van de andere toetsingscriteria tot de conclusie komt dat het onderscheid ontoelaatbaar is, zodat het slechts zelden zal toekomen aan de vraag of er een evenredige verhouding bestaat tussen doel en classificatie. Zoals eerder is gebleken zijn er echter enkele gevallen te vinden waarin, vaak impliciet, wel degelijk een proportionaliteitstoets wordt uitgevoerd. Met name is dit het geval wanneer administratieve of financiële overwegingen als rechtvaardiging worden aangevoerd: het Supreme Court gaat dan na of deze overwegingen voldoende "important" of "compelling" zijn. Deze toetsing is echter zelden volledig: meestal wordt alleen het gewicht van het nagestreefde doel vastgesteld, zonder dat het aangetaste belang daartegenover wordt geplaatst. In dit opzicht is de benadering van het Supreme Court dan ook zeker niet bijzonder fraai 
of zorgvuldig te noemen. Deze toepassing bevestigt echter wel dat de proportionali. teitstoets in strikte zin ook binnen de rechtspraak van het Supreme Court gezien kan worden als een afzonderlijk toetsingselement met een eigen betekenis.

Voor de sporadische gevallen waarin een daadwerkelijke toetsing van de proportionaliteit wordt uitgevoerd is aangegeven dat het Supreme Court hierbij soms rekening houdt met de vermijdbaarheid van de belangenaantasting: in een dergelijk geval wordt de aantasting als minder ernstig beschouwd. In sommige gevallen is deze benadering terecht, maar meestal is deze problematisch: zoals eerder is aangegeven mag lang niet altijd worden verwacht dat iemand een belangenaantasting vermijdt, zoals in het geval waarin het daarvoor nodig zou zijn om afstand te doen van belangrijke persoonlijke waarden. Gesteld is bovendien dat de vermijdbaarheid van de aantasting niet altijd afdoet aan het gewicht van het aangetaste belang als zodanig. Om die reden lijkt het dan ook beter om bij de bepaling van de proportionaliteit slechts in beperkte mate rekening te houden met deze factor.

\subsection{Conclusies met betrekking tot de toetsingsintensiteit}

\subsubsection{Niveaus van toetsingsintensiteit}

Zoals in paragraaf 2 en 3 is beschreven heeft het Supreme Court in zijn rechtspraak drie officiële gradaties van toetsingsintensiteit erkend, zodat de rechtspraak in dat opzicht goed aansluit bij de benadering die in het theoretische hoofdstuk is gekozen. De toetsingsmethodiek van het Supreme Court wijkt echter in twee belangrijke opzichten van de theoretische benadering af. In de eerste plaats hebben de minst en de meest intensieve test een zeer sterke voorspellende waarde voor de uitkomst van de toetsing: wanneer een rational basis-test wordt toegepast is het nagenoeg zeker dat het onderscheid in stand zal worden gelaten, terwijl een toepassing van de strict scrutiny-test vrijwel steeds leidt tot de conclusie dat het onderscheid onconstitutioneel is. In de tweede plaats is de toepassing van de intermediate scrutiny- en de strict scrutiny-test beperks tot een limitatief aantal gevallen, waardoor alle andere vormen van onderscheid aan een rational basis-test zullen worden onderworpen. Van een dergelijke voorspellende waarde en van een gesloten karakter van de toetsingsniveaus is in het theoretische model geen sprake..$^{5 / 2}$

De strict scrutiny-test met zijn fatale karakter lijkt op het eerste gezicht sympathiek, nu deze test een voorspelbare toetsing oplevert en duidelijk uitdrukking geeft aan de onwenselijkheid van bepaalde classificaties. Zeker in de tijd dat er in de VS op grote schaal sprake was van rechtstreeks onderscheid op grond van ras bewees deze test goede diensten: de zeer strenge toetsing heeft in belangrijke mate bijgedragen aan het opheffen van directe achterstelling van raciale minderheden. Inmiddels vormen de (vaak onbedoelde) discriminatoire effecten van regelgeving echter een veel groter probleem en heeft de rigide strict scrutiny-test problematische consequenties gekregen. De test vormt voor het aanpakken van deze effecten een veel te zwaar middel, omdat hel fatale karakter tot gevolg heeft dat ook neutrale en sociaal wenselijke wetgeving met 
toevallige disproportionele effecten vrijwel per definitie ontoelaatbaar zal worden verklaard. Weliswaar heeft het Supreme Court geprobeerd dit probleem op te lossen door een andere toetsingsingang te kiezen, maar zoals eerder is aangegeven leidt dit niet tot bevredigende resultaten. Een bezwaar tegen de strict scrutiny-test is bovendien dat deze een log en onhanteerbaar toetsingsinstrument verschaft. Eigenlijk is de test alleen zinvol voor de gevallen waarin onderscheid nooit gerechtvaardigd is, terwijl dit soort gevallen zich in de praktijk nauwelijks nog voordoet. Voor de praktijk zou de waarde van de strict scrutiny-test dan ook veel groter zijn wanneer de test meer mogelijkheden liet voor de rechtvaardiging van ongelijke behandeling.

Juist vanwege de logheid en de praktische onbruikbaarheid van de strict scrutiny-test heeft Supreme Court een tweede niveau van toetsingsintensiteit ontwikkeld, de intermediate scrutiny-test. Deze test heeft als voordeel dat een zorgvuldige toetsing mogelijk is, terwijl de uitkomst niet op voorhand vaststaat. Ieder geval kan daardoor op zijn merites worden beoordeeld, zodat alleen onderscheid onconstitutioneel wordt verklaard waarvoor een deugdelijke rechtvaardiging daadwerkelijk ontbreekt. Het Supreme Court heeft deze toets echter alleen van toepassing geacht op twee gronden van onderscheid geslacht en onwettige geboorte. De praktische waarde van de test is daardoor beperkt, zodat vrijwel alle gevallen van onderscheid moeten worden beoordeeld onder de rational basis-test. Deze laatste test heeft echter opnieuw als kenmerk dat de uitkomst van de toetsing al op voorhand vaststaat, waardoor veel onredelijke of willekeurige gevallen van ongelijke behandeling constitutioneel zullen worden geacht.

Het Supreme Court vond uiteindelijk een uitweg uit deze beperkingen en problemen door het impliciet erkennen van een vierde test, die niet beperkt is tot een specifiek aantal gronden en die dezelfde flexibiliteit vertoont als de intermediate scrutiny-test: de rational basis-test "with bite". Jammer genoeg is het tot nu toe onduidelijk gebleven in welke gevallen deze test precies zal worden toegepast: juist omdat deze niet uitdrukkelijk is erkend heeft het Supreme Court zich nooit genoodzaakt gevoeld om criteria te ontwikkelen voor de toepasselijkheid ervan. Een dergelijke benadering is zeker niet bevorderlijk voor de voorspelbaarheid van de rechtspraak.

Het voorgaande noopt tot de conclusie dat het niet wenselijk is om de benadering van het Supreme Court ten aanzien van de toetsingsintensiteit volledig over te nemen als invulling van het algemene toetsingsmodel. Aan de beperking van de intensievere tests tot een klein aantal gronden van onderscheid zijn belangrijke bezwaren verbonden, terwijl, los van de reikwijdte van de verschillende tests, bovendien kan worden gesteld dat het niet wenselijk is om de verschillende tests een te grote voorspellende waarde te geven. Van belang is immers dat de benadering van het Supreme Court tot gevolg heeft dat de factoren die de intensiteit van de toetsing bepalen direct doorslaggevend zijn voor de uitkomst van de procedure. Dit is problematisch, omdat de uitkomst van de toetsing dan wordt bepaald door factoren die eigenlijk niet relevant zijn voor de beoordeling van een rechtvaardiging, zoals de beleidsvrijheid van de wetgever of de onveranderlijkheid van het onderscheidingscriterium. Voor een zinvol en inhoudelijk onderzoek van de doelstelling en de verhouding tussen doel en classificatie biedt een dergelijke test nauwelijks ruimte.

Verder is het belangrijk dat gevallen van onderscheid die aan de rechter worden voor- 
gelegd sterk kunnen verschillen in karakter en verschijningsvorm. Dit betekent dat een goed toetsingsmodel niet alleen tot redelijke resultaten moet kunnen leiden bij norma. tieve classificaties, maar bijvoorbeeld ook bij onbedoeld, indirect onderscheid. Wanneer de toepassing van een bepaalde test rechtstreeks bepalend is voor de uitkomst van de toetsing ontbreekt daarvoor de nodige flexibiliteit. Zoals eerder is aangegeven wordt dit probleem geîllustreerd door de problematiek rond de keuze voor de juiste toetsingsingang: juist omdat de strict scrutiny-test bij ieder onbedoeld benadelend effect op grond van ras leidde tot onconstitutionaliteit heeft het Supreme Court ervoor gekozen om deze test alleen toe te passen op bedoeld onderscheid. Onbedoelde ongelijke behandelingen, maatschappelijk gezien een belangrijk probleem, kunnen hierdoor ten onrechte niet meer aan een toetsing aan de Equal Protection Clause worden onderworpen.

Van belang is tenslotte dat het bij een model waarin de tests geen voorspellende waarde hebben niet nodig is om te werken met een vierde niveau van toetsingsintensiteit: het Supreme Court heeft de vierde test alleen onderscheiden om te voorkomen dat iedere ongelijke behandeling toelaatbaar zou zijn die niet aan een intermediate of strict scr. tiny-test werd onderworpen. Nu dit vierde niveau in de praktijk leidt tot een toetsing die vrijwel identiek is aan de intermediate scrutiny-test, voegt het inhoudelijk slechts weinig toe aan de drie "officiële" tests. Bovendien is het moeilijk om objectieve factoren te ontwikkelen die de rechter tot houvast kunnen zijn bij de keuze tussen intermediate scrutiny en rational basis "with bite". In de rechtspraak van het Supreme Court kan dan ook geen aanleiding worden gevonden om een uit vier toetsingsniveaus bestaand toetsingsmodel te ontwikkelen.

\subsubsection{De intensiteitbepalende factoren}

\section{Inleiding}

Zoals in paragraaf 3 is gebleken baseert het Supreme Court zich op het uitgangspunt dat de toetsing aan de Equal Protection Clause terughoudend moet zijn: alleen wanneer er een toereikende rechtvaardiging bestaat voor een intensivering van de toetsing zal daarvoor worden gekozen. In zijn rechtspraak heeft het Supreme Court hiervoor een tweetal theoretische grondslagen ontwikkeld. Allereerst is van belang dat het Supreme Court zich verantwoordelijk voelt voor een goede bescherming van de individuele grondrechten die in de Constitutie zijn opgenomen. Wanneer een ongelijke behandeling leidt tot een aantasting van deze rechten acht het een intensievere toetsing dan ook aangewezen. In de tweede plaats acht het Supreme Court zich bevoegd om in te grijpen wanneer er reden bestaat om te veronderstellen dat het democratische proces niet goed heeft gefunctioneerd of wanneer er maatregelen zijn getroffen die tot obstructie van dif proces kunnen leiden. Deze uitgangspunten zijn gebaseerd op overwegingen die ook voor de ontwikkeling van het theoretische model van belang zijn geweest; de praktische uitwerking die het Supreme Court hieraan heeft gegeven is dan ook bijzonder interessant.

Factoren met betrekking tot het onderscheid als zodanig

Hiervoor is reeds aangegeven dat het Supreme Court een aantal concrete factoren heefl ontwikkeld die bij de vaststelling van de toetsingsintensiteit dienstig kunnen zijn. Zoaks 
is angegeven heeft een aantal van deze factoren betrekking op het onderscheid als zodanig. Deze factoren zijn voor een nadere invulling van het algemene toetsingsmodel zonder meer bruikbaar, maar dit is alleen het geval wanneer daarvan een ander gebruik wordt gemaakt dan het Supreme Court in de praktijk blijkt te doen. Van belang is bijvoorbeeld dat het Supreme Court een verhoging van de toetsingsintensiteit redelijk acht in alle gevallen waarin er wordt geklaagd over onderscheid op grond van enkele specifieke (quasi-)verdachte differentiatiecriteria, ongeacht de vraag of het concrete geval van onderscheid daadwerkelijk twijfel doet ontstaan over de goede werking van het democratische proces. Met deze benadering doet het Supreme Court geen recht aan de rechtvaardiging van een intensievere toetsing die het zelf in Carolene Products heeft gegeven. Het theoretische en door het Supreme Court uitdrukkelijk erkende uitgangspunt is immers dat de wetgever de Constitutie in beginsel zeker zo goed kan waarborgen als de rechter en dat het democratisch proces in principe voldoende in staat moet worden geacht om eventuele fouten te corrigeren. In de meeste gevallen kan er dan ook van worden uitgegaan dat de wetgever bij het maken van onderscheid objectief en onbevooroordeeld te werk gaat, zodat er geen bijzondere reden bestaat voor rechterlijk ingrijpen. Zoals hiervoor al is gesteld kan er in het concrete geval echter sprake zijn van omstandigheden die twijfel oproepen aan de objectiviteit van de wetgever of aan de goede werking van het democratisch proces. Dit is bijvoorbeeld het geval wanneer er in de samenleving grote vooroordelen jegens een bepaalde groep bestaan, die naar alle waarschijnlijkheid hun weerslag op de wetgeving niet hebben gemist. In die omstandigheden is het redelijk dat een onpartijdige en objectieve derde, de rechter, het gemaakte onderscheid aan een nauwkeurig onderzoek onderwerpt en dat deze zorgvuldig nagaat of hiervoor een overtuigende en objectieve rechtvaardiging bestaat.

Wanneer onderscheid is gemaakt op grond van enkele specifieke persoonskenmerken zal er al snel reden bestaan om te vrezen dat de wetgever op een onjuiste manier met zijn bevoegdheden is omgesprongen. Dit zal vooral het geval zijn wanneer het gaat om onderscheid dat is gebaseerd op kenmerken die irrelevant zijn voor het maatschappelijk functioneren, terwijl het maken van onderscheid op grond van deze kenmerken bovendien historisch en ethisch gezien afkeurenswaardig is. Niet ieder onderscheid op een dergelijke "verdachte" grond roept echter twijfel op over de objectiviteit en onbevooroordeeldheid van de wetgever, zoals wordt geilllustreerd door het voorbeeld van voorkeursbehandeling. Of er inderdaad reden bestaat voor een striktere toetsing moet dan ook altijd worden bepaald aan de hand van een aantal andere factoren die het Supreme Court in de loop van de tijd heeft ontwikkeld: het onderscheid moet betrekking hebben op een duidelijk kenbare groep die het slachtoffer is van historische of sociale achterstelling en van wijdverspreide stereotypen of vooroordelen, en (daardoor) onvoldoende in staat is om zijn belangen in het politieke proces met enig succes te (laten) vertegenwoordigen. Wanneer geen waarde wordt gehecht aan dergelijke factoren valt de bodem onder de rechtvaardiging van een strikte toetsing volledig weg.

Zoals in paragraaf 3 reeds duidelijk werd lijkt het Supreme Court in Adarand ${ }^{53}$ echter te hebben gekozen voor een eenvormige benadering, waarin uitsluitend de verdachtheid van de grond van onderscheid bepalend is voor de toepasselijkheid van strict scrutiny.

593. 515 U.S. 200 (1995) 
Ook uit eerdere rechtspraak blijkt echter dat de genoemde "groepsgebonden" factoren niet altijd even relevant zijn voor de vaststelling van de toetsingsintensiteit. In paragraaf 3.3.3 is aangegeven dat de keuze voor een bepaalde test vooral wordt ingegeven door de vergelijkbaarheid van een concreet differentiatiecriterium met onderscheid op grond van ras (voor toepassing van de strict scrutiny-test) of geslacht (voor toepassing van de intermediate scrutiny-test). Dit heeft tot gevolg dat bij een beperkt aantal gronden altijd een intermediate scrutiny- of strict scrutiny-test wordt toegepast, terwijl dit voor andere gronden nooit mogelijk is. Deze rigiditeit strookt niet met de hiervoor beschreven Carolene Products-rationale voor de verhoging van de toetsingsintensiteit: iedere ruimte om daadwerkelijk rekening te houden met het bestaan van twijfels over het deugdelijk functioneren van het democratisch proces ontbreekt hierdoor immers. Het is dan ook opmerkelijk dat het Supreme Court nooit aandacht heeft besteed aan de onverenigbaarheid van zijn werkwijze met de gekozen rationale. Gezien de problemen die aan de huidige benadering van het Supreme Court verbonden zijn kan echter worden vastgesteld dat het beter is om vast te houden aan de originele rechtvaardiging voor de verhoging van de toetsingsintensiteit en de factoren die zijn ontwikkeld voor de invulling daarvan, zonder gebruik te maken van de methodiek die het Supreme Court in de praktijk hanteert bij het maken van de keuze voor de toepasselijkheid van rational basis, intermediate scrutiny of strict scrutiny.

Ruimte voor een meer flexibele benadering bestaat in beperkte mate ook in de rechtspraak van het Supreme Court: zoals eerder al is aangegeven heeft het Supreme Court hiervoor de mogelijkheid geschapen door de toepassing van de rational basis "with bite"-test. Onder deze categorie lijken al die gevallen te worden geschaard waarin er weliswaar reden bestaat voor een verhoging van de toetsingsintensiteit, maar waarin geen onderscheid is gemaakt op een van de erkende (quasi-)verdachte gronden. Juist vanwege deze grotere flexibiliteit zou de toepassing van deze test interessante informatie kunnen bieden over de wijze waarop verschillende factoren tegen elkaar worden afgewogen. Helaas blijkt dit in de praktijk niet het geval te zijn: het Supreme Court heeft nooit precies aangegeven welke factoren tot een toepassing van rational basis "with bite" kunnen leiden. Duidelijk is alleen dat hierbij vaak een algemene afweging wordt gemaakt van diverse factoren, waarbij zowel intensiteitverminderende factoren (zoals het better placed-argument en het subsidiariteitsargument), als intensiteitverhogende factoren (zoals het belang van het aangetaste recht en de ernst van de aantasting) een rol kunnen spelen. Welk gewicht aan deze factoren moet worden toegekend en welke factoren doorslaggevend zijn voor de bepaling van de toetsingsintensiteit blijft onduidelijk: de intensivering van de toetsing lijkt meestal niet zozeer op objectieve argumenten te zijn gebaseerd, als wel op de persoonlijke voorkeur van de auteur van de opinie.

\section{Factoren met betrekking tot de aantasting van fundamentele belangen}

Zoals eerder is aangegeven heeft het Supreme Court erkend dat ook de aantasting var fundamentele rechten tot een intensivering van de toetsing kan leiden. Van belang daarbij is vooral de rechtspraak over de politieke grondrechten. Het Supreme Court heeft in zijn rechtspraak voorop gesteld dat een ernstige aantasting van het kiesrecht 
een rechtvaardiging voor een striktere toetsing kan opleveren. Wanneer dit recht aan een bepaalde groep wordt ontnomen of wanneer de uitoefening van dit recht ernstig wordt bemoeilijkt, kan dit een goede werking van het democratisch systeem immers in gevaar brengen. Minder ernstige aantastingen, bijvoorbeeld veroorzaakt door regels die de organisatie van de verkiezingen betreffen, rechtvaardigen een strikte toetsing niet. Het Supreme Court heeft echter maar weinig concrete aanwijzingen gegeven over de vraag hoe ernstig een aantasting van het kiesrecht moet zijn voor de toepassing van een strict scrutiny-test: kennelijk wordt de rechter in staat geacht om hierover in een concreet geval een redelijk oordeel te vellen.

Het Supreme Court heeft slechts sporadisch uitspraak gedaan over de antasting van individuele, niet-politieke grondrechten als intensiteitverhogende factor. Opmerkelijk is dat het de "nexustheorie" voor deze rechten uitdrukkelijk heeft verworpen: constitutioneel beschermde rechten kunnen een strikte toetsing rechtvaardigen, maar hiervoor bestaat geen mogelijkheid bij de aantasting van niet door de Constitutie beschermde rechten die met dergelijke rechten nauw verband houden of die voor een goede uitoefening van de constitutionele rechten essentieel zijn. De reden voor dit beperkte gebruik van deze intensiteitverhogende factor is waarschijnlijk gelegen in het feit dat er bij nietconstitutionele rechten een minder sterke legitimatie bestaat voor verhoging van de toetsingsintensiteit. Bij rechten die uitdrukkelijk door de Constitutie worden genoemd kan nog worden gesteld dat de rechter een bijzondere taak heeft om deze aan de burger te garanderen, maar voor andere rechten en belangen geldt dat de wetgever hiertoe voldoende in staat moet worden geacht. Een nadeel van deze benadering is dat de burger voor de bescherming van zijn belangen sterk afhankelijk is van de opsomming van rechten in de Constitutie. Vooral nu de Bill of Rights uit 1791 stamt en hieraan sindsdien slechts sporadisch rechten zijn toegevoegd, kan het voorkomen dat bepaalde, tegenwoordig fundamenteel geachte rechten hierin niet zijn opgenomen. In die situatie is het niet zonder meer redelijk om geen intensieve toetsing uit te voeren omdat een recht niet in de Constitutie zelf is opgenomen. Het Supreme Court lijkt dit ook wel te hebben onderkend en heeft aanvaard dat een aantasting van belangrijke rechten in sommige gevallen aanleiding kan vormen voor een verhoging van de toetsingsintensiteit (rational basis "with bite"). Deze benadering van het Supreme Court lijkt redelijk en doet zowel recht aan de belangen van het individu als aan de beleidsvrijheid van de regelgever; deze benadering kan dan ook zeker een plaats krijgen binnen het algemene toetsingsmodel. Een nadeel van deze benadering is wel dat het niet altijd duidelijk is wanneer een recht "belangrijk" is en wanneer kan worden gesproken van een "ernstige aantasting". Om te voorkomen dat er op een willekeurige manier met deze factor wordt omgegaan is het noodzakelijk om hiervoor verdere criteria te ontwikkelen. 



\section{Toetsing aan het gelijkheidsbeginsel in Nederland}

\section{$1 \quad$ Algemeen}

\subsection{Gelijkheidsbepalingen in het Nederlandse recht}

\subsubsection{Inleiding}

Het Nederlandse recht kent een grote variatie aan gelijke behandelingsnormen, ieder met een andere inhoud en een ander toepassingsbereik. ${ }^{.}$Sommige van deze bepalingen geven een limitatieve opsomming van verboden onderscheidingsgronden en kennen een gesloten stelsel van uitzonderingsbepalingen, andere zijn heel open geformuleerd en laten de rechter een aanzienlijke beoordelingsruimte, en weer andere bepalingen zijn weliswaar open van karakter, maar richten zich slechts tot een beperkt aantal situaties van ongelijke behandeling. Hierdoor is de Nederlandse situatie van toetsing aan het gelijkheidsbeginsel bijzonder complex: anders dan in de hiervoor besproken stelsels is het mogelijk dat er op één feitenconstellatie verschillende gelijkheidsbepalingen van toepassing zijn, waardoor het voor de rechter niet altijd eenvoudig is om de juiste toetsingsmethodiek te bepalen. Alvorens nader in te gaan op de wijze van toetsing van de verschillende rechterlijke instanties die bevoegd zijn tot toetsing aan het gelijkheidsbeginsel', lijkt het dan ook zinvol om aandacht te besteden aan de diverse gelijkheidsbepalingen en de plaats die zij innemen in het Nederlandse recht.

\subsubsection{Artikel 1 Grondwet}

Een belangrijke gelijkheidsbepaling voor het Nederlandse recht is allereerst neergelegd in artikel 1 van de Nederlandse Grondwet:

\footnotetext{
"Allen die zich in Nederland bevinden, worden in gelijke gevallen gelijk behandeld. Discriminatie wegens godsdienst, levensovertuiging, politieke gezindheid, ras, geslacht of welke grond dan ook, is niet toegestaan."
}

1. Vgl. Asscher-Vonk 1998, p. 112.

2. Ook op dit punt is de situatie aanzienlijk gecompliceerder dan in de eerder besproken stelsels: in Nederland zijn verschillende rechterlijke instanties in laatste instantie bevoegd tot het interpreteren en toepassen van verschillende gelijkheidsbepalingen, namelijk de Centrale Raad van Beroep, de Afdeling Bestuursrechtspraak van de Raad van State en de Hoge Raad. Daarnaast is er nog de Commissie Gelijke Behandeling, die op basis van artikelen 11 en 12 Algemene wet gelijke behandeling bevoegd is om deze wet uit te leggen. Hoewel deze uitleg niet bindend is voor andere rechterlijke instanties, is deze wel gezaghebbend (zie HR 13 november 1987, NJ 1989/698 (St. Bavo/Gielen)).

Deze bepaling is pas in 1983 aan de Grondwet toegevoegd. Voorheen was er geen duidelijke gelijkin het oude artike Grondwet terug te vinden; hoogstens kan een gelijkheidsbeginsel worden gelezen hebben gelijke aanspraak 4 Grot, luidende: "Allen die zich op het grondgebied van het Rijk bevinden, eerste en de tweede zin op bescherming van persoon en goederen". Over de verhouding tussen de sie betreft vooral de vraan het huidige artikel bestaat in de literatuur enige onduidelijkheid. De discusmoet worden te vraag of er aan het gelijke behandelingsgebod in de eerste zin een andere betekenis 
Deze bepaling heeft een open karakter: de opsomming van verboden discriminatiegronden is niet limitatief en de bepaling is in zijn reikwijdte niet beperkt tot specifieke gevallen van ongelijke behandeling. Van belang is verder dat in deze bepaling geen criteria zijn opgenomen voor de beoordeling van de gerechtvaardigdheid of toelaatbaarheid van een concreet geval van onderscheid, hetgeen betekent dat de bepaling veel ruimte laat voor het ontwikkelen van een eigen toetsingsmethodiek door de rechter. Ondanks zijn ruime formulering en prominente plaats in de Grondwet blijkt artikel I in de praktijk nauwelijks betekenis te hebben voor de toetsing door de Nederlandse rechter. Deels is dit te verklaren vanuit het in artikel 120 Grondwet neergelegde toetsings. verbod: formele wetgeving kan door de rechter niet aan de Grondwet worden getoetst, zodat daarin neergelegde classificaties ook niet op hun verenigbaarheid met artikel 1 kunnen beoordeeld. ${ }^{4}$ Het toetsingsverbod geldt echter niet voor lagere regelgeving, noch voor ongelijkheden die voortkomen uit een ongelijke bevoegdheidsuitoefening door bestuursorganen. Inderdaad toetsen de Nederlandse rechterlijke instanties in dergelijke gevallen soms aan artikel $1^{5}$, maar een dergelijke toetsing is relatief zeldzaam: de rechterlijke instanties geven vaak de voorkeur aan een toetsing aan het gelijkheidsbeginsel als algemeen rechtsbeginsel of aan het gelijkheidsbeginsel zoals dat is neergelegd in artikel 26 IVBPR. $^{6}$

\subsubsection{Gelijkheidsbepalingen in internationale verdragen}

Artikel 26 IVBPR vormt voor Nederland feitelijk de belangrijkste weerslag van het gelijkheidsbeginsel. Dit houdt in belangrijke mate verband met de algemene formulering van artikel 26 IVBPR:

natie te beschouwen als een "ernstige" vorm van ongerechtvaardigd onderscheid, zodat het discrimin? tieverbod een duidelijkere toegevoegde waarde heeft). Voor de toetsingsmethodiek is deze discussie niet bijzonder interessant: de rechter blijkt in de praktijk een zo ruime interpretatie van gelijkheidsboginsel en discriminatieverbod te hanteren dat deze elkaar vrijwel overlappen. Om die reden zal op dezs discussie niet worden ingegaan; zie echter Van der Hoeven 1983, p. 190/191, Den Boer 1987, p. 133

en Kroes 1998 , p. 16 e.v.
4ie bijv. HR 20 januari 1995 , NJ 1995/326 (verjaringstermijn vaderschapsactie): "het beroep op strijy met art. $1 \mathrm{Grw}$. faalt reeds omdat het de rechter niet vrijstaat in de beoordeling van de grondwettigheid van de wet te treden." Zie ook Loenen 1992, p. 130 en Happé 1999, p. 12.

5. Zie bijv. HR 6 november 1990 (strafkamer), NJ 1991/218 (tippelverbod), HR 20 september 1995 (belastingkamer), BNB 1995/315 (afvalwater), ARRS 18 maart 1988, AB 1988/342 (Humanististh Vormingsonderwijs Oldebroek), ABRS 19 december 1996, AB 1997/414 (Hervormde Jeugdrad Hoogblokland), ABRS 10 februari 1997, JB 1997/85 (Parkeerbeleid Leiden) en CRvB 5 juli 2000, JB 2000/257.

6. Vgl. Vis 1988, p. 51 en Van Male 1988 (II), p. 367 . In veel gevallen waarin een beroep wordt gedan op artikel I wordt (voor alle zekerheid) ook een beroep gedaan op het algemene gelijkheidsbeginst, artikel 26 IVPBR en artikel 14 EVRM. De rechter is dan vaak geneigd om in algemene temen over toetsing aan "het gelijkheidsbeginsel" te spreken, in plaats van aan ieder van deze bepalingen afzon derlijk te toetsen en hiervoor een aparte toetsingsmethodiek te ontwikkelen. Zie bijv. HR 20 janum 1995, NJ 1995/326 (verjaringstermijn vaderschapsactic), HR 7 november 1997, NJ 1998/399 (204, vi/Zaanwerk), ARRS 23 augustus 1993, AB 1994/111 (parkeervergunningen), ABRS 3 maan (AAW. AB 1995/85 (leeftijdscriterium woonruimtevordering) en CRvB 29 april 1993, RSV 1993/307 (Atilenaanspraak na 65 ste jaar). Het voordeel van deze benadering is dat er bij de toetsing an de verchilid vain de bepalingen een vergelijkbare toetsingsmethodiek wordt gehanteerd, waardoor de duidelijkhcid wa de toetsing wordt vergroot. 
"Allen zijn gelijk voor de wet en hebben zonder discriminatie aanspraak op gelijke bescherming door de wet. In dit verband verbiedt de wet discriminatie van welke aard ook en garandeert een ieder gelijke en doelmatige bescherming tegen discriminatie op welke grond ook, zoals ras, huidskleur, geslacht, taal, godsdienst, politieke of andere overtuiging, nationale of matschappelijke afkomst, eigendom, geboorte of andere status."

Net als artikel 1 is deze bepaling bijzonder ruim geformuleerd: de verboden differentiatiegronden zijn niet limitatief opgesomd, de bepaling is in zijn reikwijdte niet beperkt tot specifieke gevallen van ongelijke behandeling en er worden geen bijzondere uitzonderingssituaties genoemd. ${ }^{8}$ Een belangrijk verschil met artikel 1 Grondwet is echter dat ook formele wetten aan een toetsing aan artikel 26 IVBPR kunnen worden onderworpen: de verschillende Nederlandse rechterlijke instanties hebben al vrij snel na de inwerkingtreding van het IVBPR" erkend dat artikel 26 directe werking heeft, zodat hiermee strijdige bepalingen van nationaal recht ingevolge de artikelen 93 en 94 Grondwet buiten toepassing moeten worden gelaten. ${ }^{10}$ Gecombineerd met de ruime toetsingsmogelijkheden die het artikel biedt maakt dit het voor procespartijen bijzonder aantrekkelijk om op artikel 26 een beroep te doen.

Opgemerkt moet echter worden dat de directe werking en de daaraan verbonden voorrang niet altijd worden aanvaard. De civiele kamer van de Hoge Raad is slechts zelden bereid om artikel 26 te laten prevaleren boven een formele wet, ook al is in die wet een classificatie opgenomen die overduidelijk ongerechtvaardigd is. De reden daarvoor is dat een ongelijke behandeling vaak op verschillende manieren ongedaan kan worden gemaakt. Het maken van een keuze daartussen gaat volgens de Hoge Raad de rechts-

7. Internationaal Verdrag inzake burgerrechten en politieke rechten, New York 19 december 1966, Trb. 1969,99 ,

8. Vgl. Heringa 1993, p. 147 en Gribnau 2000, p. 906/907. Het feit dat er in de bepaling geen uitzonderingsgronden zijn opgenomen betekent niet dat geen enkele ongelijke behandeling toelaatbaar is: net als bij artikel 14 EVRM betekent dit veeleer dat er een algemene rechtvaardigingsmogelijkheid bestaat. Dit blijkt uit de uitleg die aan artikel 26 is gegeven door het Human Rights Committee, dat ingevolge artikel 1 jo. 7 van het Facultatieve Protocol bij het IVBPR bevoegd is om een oordeel te geven over individuele klachten met betrekking tot een schending van het IVBPR: "The right to equality before the law and to equal protection of the law without any discrimination does not make all differences of treatment discriminatory. A differentiation based on reasonable and objective criteria does not amount to prohibited discrimination within the meaning of article 26" (Human Rights Committee 9 april 1987, Communication No. 172/1984 (Broeks $v$. The Netherlands), CCPR/C/29/D/192/1984, \$13).

9. Voor Nederland trad het Verdrag in werking op 11 maart 1979.

10. De Afdeling Rechtspraak erkende, bij monde van zijn voorzitter, de rechtstreekse werking al in 1979: Vz. ARRS 10 mei 1979, AB 1979/472 (woonruimteverordening Valkenburg). Ook de Hoge Raad erkende de rechtstreekse werking al vroeg, zonder overigens te motiveren waarom hij dit deed: HR 8 oktober 1980, NJ 1981/308 (kiesregister). De Centrale Raad van Beroep wachtte het langste met het erkennen van de rechtstreekse werking: aanvankelijk was hij van mening dat aan artikel 26 geen rechtstreekse werking kon toekomen op het gebied van de sociale rechten (CRvB 1 november 1983, RSV 1984/147-150; zie over deze zaak nader Woltjer 2002, p. 184, Heringa 1994 (II), p. 857 en Riphagen/Smitskam 1990, p. 403). Pas toen het Human Rights Committee in de hiervoor in noot 8 aangehaalde zaak Broeks uitdrukkelijk had aangegeven dat sociale zekerheidsregelgeving wel degelijk onder de reikwijdte van artikel 26 valt, erkende ook de Centrale Raad de directe werking (CRvB 14 mei 1987, RSV 1987/246). Opmerkelijk is dat de Raad daarbij aangaf dat deze rechtstreekse werking pas vanaf 23 december 1984 zou gelden: in zaken waarin het voor die datum geldende recht in het geding was kan meestal geen geslaagd beroep op artikel 26 worden gedaan (uitzonderingen zijn mogelijk: zie CRvB 5 januari 1988, RSV 1988/198). Zie over deze wat merkwaardige "overgangstermijn" nader Heringa 1993, p. 163-165. 
vormende taak van de rechter te buiten: het maken van een dergelijke keuze is typisch een aangelegenheid voor de wetgever. Een reden voor terughoudendheid is volgens de Hoge Raad nog in het bijzonder aanwezig wanneer de wetgever al bezig blijkt te zijn met het voorbereiden van een wet waardoor het onderscheid zal worden weggenomen." In dergelijke gevallen laat de Hoge Raad in het midden of artikel 26 geschonden is of wijst hij, na geoordeeld te hebben dat er sprake is van een schending, een beroep op deze bepaling eenvoudigweg af. ${ }^{12}$ De rol die artikel 26 potentieel zou kunnen spelen bij de toetsing van formele wetten aan het gelijkheidsbeginsel is daardoor in het civiele recht beperkt.

De bestuursrechters vertonen op dit punt iets minder scrupules. ${ }^{13}$ Zo blijkt de Centrale Raad een in beginsel voor honorering vatbaar beroep op artikel 26 alleen af te wijzen met een beroep op zijn beperkte rechtsvormende taak, wanneer de wetgever al bezig is met de voorbereiding van een wet die aan de ongelijke behandeling een einde maakt: de Raad is van mening dat rechterlijk optreden in een dergelijk geval zou leiden tot een inhoudelijke en organisatorische verstoring van het wetgevingsproces. ${ }^{14}$ Wanneer van een dergelijke situatie geen sprake is ziet de Raad geen reden om een beroep op artikel 26 af te wijzen, zelfs niet wanneer honorering van het beroep tot gevolg heeft dat de Raad zelf een oplossing voor het daardoor ontstaande rechtsvacuüm moet zoeken." De belastingkamer van de Hoge Raad gaat zelfs nog verder: uit zijn rechtspraak blijkt dat hij de rechtstreekse werking van artikel 26 vrijwel steeds accepteert en ook met enige

11. Voorbeelden van zaken waarin de civiele kamer van de Hoge Raad een schending van artikel 26 in het midden liet vanwege de beperkte omvang van zijn rechterlijke taak zijn HR 12 oktober 1984, N 1985/230 (Optierecht), HR 23 september 1988, NJ $1989 / 740$ (Naamrecht), HR 24 februari 1995, NJ 1995/468 (Brieven van wettiging), HR 17 januari 1997, NJ 1997/483 (Erfenis onwettig kind) en HR 5 september 1997, NJ 1998/686 (Adoptie door lesbisch paar). Zie verder Heringa 1994 (II), p. 859 en Den Boer 1995, p. 1028/1029.

12. Dit is niet gemakkelijk verenigbaar met artikel $93 / 94$ Grondwet; hoogstens zou kunnen worden gettlll dat in dit soort gevallen geen rechtstreekse werking aan artikel 26 tockomt, maar het is twijfelachtig of het inderdaad mogelijk is om een bepaling in het ene geval rechtstreekse werking toe te kennen en dext daaraan in een volgend geval te ontzeggen. Zie nader Van Dijk 1988, p. 200/201 en Alkema 1987, p 96/97.

13. Alleen de Afdeling Rechtspraak en de Afdeling Bestuursrechtspraak lijken een met die van de Hogs Raad vergelijkbare benadering te kiezen, hoewel dit niet eenvoudig te bepalen is: beide instellingen hebben zelden uitspraak gedaan over de verenigbaarheid van formele wetgeving met artikel 26 IVBPR Zie echter Vz. ABRS 26 september 1997, AB 1998/140 (Loting geneeskundestudie).

14. Voorbeelden zijn te vinden in enkele uitspraken met betrekking tot een in de AWW vervat onderscheid op grond van burgerlijke staat: CRvB 5 juni 1991, RSV 1992/18 en CRvB 9 januari 1992, RSV $1992 / 282$. Uit de laatste zaak blijkt overigens dat, zelfs wanneer de Centrale Raad opzij stapt voor de wetgever, daarbij in ieder geval de nodige voorbehouden worden gemaakt: hoewel de Centrale Rud een schending om de genoemde redenen aanvankelijk niet aanwezig achtte, gaf de hij in de tweede go noemde zaak aan dat wél tot ingrijpen zou worden overgegaan (d.w.z. uitdrukkelijk zou worden geoordeeld dat artikel 26 is geschonden), wanneer de wetgever te traag zou zijn bij het opstellen van eall nieuwe wet waardoor het onderscheid zou worden weggenomen; zie hierover nader Woltjer 2002, $\mathrm{P}$ 220. Dit bleek overigens retoriek: hoewel het nog tot eind 1995 duurde voordat de Algemene nabestaandenwet werd aangenomen, heeft de Centrale Raad zijn dreigement nooit uitgevoerd (zie bij. CRvB 18 oktober 1995, AB 1996/77 en CRvB 10 december 1997, JB 1998/58).

15. Bekend is CRvB 7 december 1988, RSV 1989/67 (AWW), waarin de Centrale Raad de in de Algente ne Weduwen- en Wezenwet vervatte beperking tot uitkeringen aan vrouwen in strijd achtte met artike 26. 
regelmaat beroepen op deze bepaling honoreert. ${ }^{16}$ Het feit dat dit de belastingkamer er soms toe dwingt zelf met een vervangende regeling te komen, iets waarvan de civiele kamer vindt dat het zijn rechtsvormende taak ver te buiten gaat, vormt daarvoor kennelijk geen belemmering. ${ }^{17}$ In het belastingrecht is artikel 26 daardoor een belangrijke toetsingsmaatstaf waarop regelmatig een beroep wordt gedaan. ${ }^{18}$

Een tweede belangrijke internationale gelijkheidsbepaling die rechtstreeks doorwerkt in de Nederlandse rechtsorde is het in hoofdstuk 3 uitgebreid besproken artikel 14 EVRM. Deze bepaling is voor de Nederlandse rechtspraak over gelijke behandeling echter van minder groot belang dan artikel 26 IVBPR, ondanks het feit dat de bepalingen inhoudelijk gezien sterk op elkaar lijken. ${ }^{19}$ De reden daarvoor is gelegen in het accessoire karakter van artikel 14: een beroep op deze bepaling kan alleen slagen wanneer wordt aangetoond dat de feitenconstellatie ook onder de reikwijdte van één van de materiële verdragsbepalingen valt ${ }^{20}$ Met name in het Nederlandse sociale zekerheidsrecht en het belastingrecht blijkt dit vereiste vaak in de weg te staan aan een geslaagd beroep op artikel 14: zowel de belastingkamer als de Centrale Raad hebben maar in een beperkt aantal gevallen aangenomen dat een koppeling met een bepaling als artikel 1 Eerste Protocol (bescherming van het eigendomsrecht) of met een andere EVRM-bepaling aanwezig is. ${ }^{21} \mathrm{Nu}$ artikel 14 inhoudelijk niet méér waarborgen geeft dan het zelfstandi-

16. Een bekend voorbeeld waarin de belastingkamer een formele wet buiten toepassing liet wegens strijd met artikel 26 IVBPR betrof het arbeidskostenforfait (HR 12 mei 1999 (belastingkamer), FBR 1999, p. 2115). Andere voorbeelden zijn HR 17 augustus 1998 (belastingkamer), JB 1998/196 (Grijs kenteken), HR 15 juli 1998 (belastingkamer), NJ 2000/168, BNB 1998/293 (Autokostenforfait), HR 17 november 1993 (belastingkamer), BNB 1994/36 (Studeerkamerkosten), HR 30 september 1992 (belastingkamer), NJ 1994/495 (Griffiegeld) en HR 27 september 1989 (belastingkamer), BNB 1990/449 (Tandartsvrouw). Zie voor een nadere bespreking van deze arresten nader Happé 2000, p. 153 e.v. Uit een door Happé verricht onderzoek blijkt overigens dat ook de belastingkamer soms een schending in het midden laat (Happé 1999, p. 23); helaas geeft hij geen verwijzingen naar deze arresten. Zie echter HR 27 september 1990 (belastingkamer), NJ 1990/449 (Samentelling inkomens gehuwden) en HR 12 mei 1999 (belastingkamer), FBR 1999, 2115 (Arbeidskostenforfait).

17. In HR 12 mei 1999 (belastingkamer), FBR 1999, p. 2115 (Arbeidskostenforfait) heeft de belastingkamer hierbij wel nadere eisen gesteld. Voorwaarde is bijvoorbeeld dat zich uit het stelsel van de wet of de wetsgeschiedenis voldoende duidelijke oplossingen laten afleiden. Als een keuze tussen verschillende oplossingen mogelijk is en deze keuze sterk afhankelijk is van rechtspolitieke opvattingen of overwegingen van algemeen beleid moet bovendien worden gekozen voor een terughoudende opstelling (r.0.3.15).

18. Deze beroepen slagen overigens lang niet altijd, nu de belastingkamer bereid is de wetgever een aanzienlijke beleidsvrijheid toe te kennen. Uit een door Happé verricht onderzoek blijkt bijvoorbeeld dat in de periode 1993-1998 68 arresten werden gewezen over 26 IVBPR, waarvan in slechts 6 gevallen het beroep op deze bepaling werden gehonoreerd (Happé 1999, p. 21).

19. Weliswaar is de formulering van de artikelen verschillend, maar beide bepalingen komen er in de kem op neer dat zij ongelijke behandeling verbieden wanneer daarvoor geen voldoende rechtvaardiging bestaat. Beide bepalingen hebben daardoor een open karakter en laten de rechter veel vrijheid bij de be-

20. Zie hoofdstuk ongelijke behandeling toelaatbaar is.

21. Voorbeelden 3, paragraaf 1.1 ; vgl. ook Heringa 1994, p. 16.

pas te vinden nadat het Eassing van artikel 14 zijn in de rechtspraak van de Centrale Raad eigenlijk september 1996, Reports 1996-IV) Hof voor de Rechten van de Mens in de zaak Gaygusuz (EHRM 16 ale zekerheidswetgeving. Ook J) had geoordeeld dat artikel 14 een rol kan spelen in zaken over sociCRvB 11 april 1997, AB 1997/242 (ijn de voorbeelden van toepassing echter beperkt; zie slechts kering ongehuwden AAW), CR (Inkomenseis AAW), CRvB 10 december 1997, JB 1998/58 (Uit- 
ge artikel 26 IVBPR, is het niet verbazend dat procespartijen slechts zelden (uitsluj. tend) op dit artikel een beroep doen.

Naast de genoemde twee bepalingen bestaat er op internationaal niveau nog een groot aantal andere normen die ongerechtvaardigd onderscheid verbieden. Te denken valt aan specifieke anti-discriminatieverdragen als het Verdrag ter bestrijding van Rassendiscriminatie (IVRD) $)^{22}$ en het Vrouwenverdrag ${ }^{23}$, maar ook aan andere, meer algemene, verdragen waarin gelijkheidsbepalingen zijn opgenomen, zoals het IVESCR ${ }^{24}$ en het Verdrag inzake de rechten van het kind ${ }^{25}{ }^{26}$ Tot nu toe is echter aangenomen dat de gelijkheidsbepalingen in deze verdragen niet een ieder verbindend zijn, zodat de mo. gelijkheid ontbreekt om nationale regelgeving wegens strijd met dergelijke bepalingen buiten toepassing te laten. Voor de beoordeling van de rechterlijke toetsingsmethodiek zijn de genoemde verdragen dan ook nauwelijks relevant. Van belang is wel dat deze verdragen soms als inspiratiebron dienen bij de beoordeling van een beroep op andere, wel rechtstreeks werkende gelijkheidsbepalingen: zo kan het feit dat een bepaald on-

november 1998, JB 1998/258 (Wet van Otterloo), CRvB 19 juli 2000, JB 2000/259 (Zwitserse hooffwerktuigkundige) en CRvB 4 oktober 2000, RSV 2001/19 (Overgangsregeling Anw). Ook bij de belastingkamer van de Hoge Raad wordt zelden een beroep gedaan op artikel 14, hoewel de frequentie de laatste jaren lijkt toe te nemen; meestal wordt daarbij een verbinding gelegd met artikel 1 Eerste Proticol. Zie bijv. HR 30 september 1992 (belastingkamer), NJ 1994/495 (Griffiegeld; hierbij werd ten koppeling gezocht met artikel 6 EVRM), HR 12 november 1997 (belastingkamer), BNB 199822 (Reiskosten als studiekosten), HR 17 augustus 1998 (belastingkamer), JB 1998/196 (Grijs kentekn), HR 20 januari 1999 (belastingkamer), BNB 1999/80 (Levensonderhoud verwanten), HR 12 mei 1999 (belastingkamer), FBR 1999, p. 2115 (Arbeidskostenforfait), HR 16 juni 1999 (belastingkamer), BNB 1999/286 (Vakantiebonnen), HR 23 juni 1999 (belastingkamer), BNB 1999/292 (Autokostenfictic) all HR 19 april 2000 (belastingkamer), BNB 2000/192 (Autokostenforfait); zie ook Gribnau 2000, p. 907. Ook bij de Afdeling is het aantal beroepen op artikel 14 gering, hetgeen zich laat verklaren door het feit dat de Afdeling zelden klachten over normatieve classificaties te behandelen krijgt, maar vooral is maken heeft met beroepen op het gelijkheidsbeginsel als algemeen beginsel van behoorlijk besturt. Tenslotte is bij de civiele kamer en de strafkamer van de Hoge Raad evenmin een groot aantal beros. pen op artikel 14 zichtbaar: meestal wordt ook hier een beroep op artikel 26 gedaan. In de uitzonderingsgevallen waarin wel wordt getoetst aan artikel 14 gaat het vaak om beroepen die vergelijkbar zjp met door het Europees Hof voor de Rechten van de Mens reeds beoordeelde klachten (HR 18 janumi 1980, NJ 1980/463 (Onwettige geboorte), HR 22 februari 1985, NJ 1985/604 (Omgangsrecht met onwettig kind) en HR 21 maart 1986, NJ 1986/585 (Ouderlijke macht voor ongehuwden), of om klachten over ongelijke behandeling die werden ingesteld voordat het IVBPR voor Nederland in werking tod (HR 7 januari 1975 (strafkamer), NJ 1975/206 (Onderscheid op grond van nationaliteit)).

22. Internationaal Verdrag inzake de uitbanning van alle vormen van rassendiscriminatie, New York ? maart 1966, Trb. 1966, 237; zie vooral artikel 1 en 5. Ten aanzien van dit laatste artikel heeft de Affer ling uitdrukkelijk geoordeeld dat hieraan geen rechtstreekse werking toekomt; zie ARRS 11 jantari 1985, AB 1986/92 (Koopkrachtuitkering echte minima).

23. Verdrag inzake de uitbanning van alle vormen van discriminatie van vrouwen, New York 18 december 1979, Trb. 1980, 146; zie vooral artikel 1.

24. Internationaal Verdrag inzake economische, sociale en culturele rechten, New York 19 december 1966. Trb. 1969, 100; zie vooral artikel 2 lid 2 en artikel 7. Van deze laatste bepaling heeft de HR vastgestell dat deze niet een ieder verbindend is: HR 20 april 1990, NJ 1992/636 (Hoogenraad/NWO).

25. Verdrag inzake de rechten van het kind, New York 20 november 1989, Trb. 1990, 46, m.n. artikel2.

26. Zie voor een nader overzicht "Gelijk in de praktijk" 1990, p. 16; een overzicht van de eventuele rechtstreekse werking van deze bepalingen is te vinden op p. 101/102. 
derscheid door een specifieke verdragsbepaling is verboden tot gevolg hebben dat de aangevoerde rechtvaardiging strikter wordt beoordeeld. ${ }^{27}$

\subsubsection{Gelijkheidsbepalingen in het Europese recht}

Van groot belang voor het Nederlandse recht zijn verder de Europeesrechtelijke gelijkheidsbepalingen, waarvan de belangrijkste in hoofdstuk 4 zijn besproken. Deze bepalingen werken in het algemeen rechtstreeks door in de Nederlandse rechtsorde, hetzij omdat zij zijn neergelegd in richtlijnen die zijn omgezet in Nederlandse wetgeving, hetzij omdat het gaat om bepalingen van het EG-Verdrag of van verordeningen waaraan burgers direct rechten kunnen ontlenen ${ }^{28}$; bovendien kan aan niet-rechtstreeks toepasselijk Europees recht soms een met rechtstreekse werking vergelijkbare toepassing worden gegeven, zoals bijvoorbeeld het geval is bij richtlijnen die niet tijdig, niet of niet juist in nationaal recht zijn omgezet. ${ }^{29}$ Dit betekent dat burgers op deze bepalingen

27. Zie bijv. HR 7 mei 1993, RvdW 1993/101 (Ongehuwde onderwijzeressen). Ook kan een internationaal verdrag soms helpen bij de uitleg van een onduidelijke nationale bepaling (zo legde de Hoge Raad artikel 429 quater Sr. uit in overeenstemming met het IVRD (HR 13 december 1991, NJ 1993/363 (NBBS/Akel)) of bij de interpretatie van de Awgb (zie bijv. Oordeel 01-06 (Kappers)). Vgl. ook Rodrigues 1992, p. 505.

28. Dit is niet voor alle bepalingen van gemeenschapsrecht het geval: blijkens Van Gend \& Loos moet het gaan om duidelijke en onvoorwaardelijke bepalingen die zich er naar hun aard toe lenen onmiddellijk effect te krijgen in de rechtsbetrekkingen tussen een lidstaat en zijn onderdanen (EHvJ 5 februari 1963 , zaak 26/62, Jurispr. 1963,4). Is aan die voorwaarde voldaan, dan kunnen burgers zich voor de rechter op deze bepalingen beroepen; deze moet aan het Europese recht voorrang geven boven het nationale recht (zie EHvJ 15 juli 1964, zaak 6/64, Costa/ENEL, Jurispr. 1964, 1202, op 1210). In de praktijk wordt voor alle belangrijke verdragsbepalingen waarin een gelijkheidsbepaling is terug te vinden (zoals genoemd en besproken in hoofdstuk 4) aangenomen dat hieraan rechtstreekse werking toekomt. Vgl. Heringa 1993, p. 158 en Craig/De Búrca 1998, p. 168/169.

29. Vereist is dan wel dat de relevante bepalingen aan bepaalde voorwaarden voldoen. Bovendien kunnen de bepalingen in deze situatie alleen worden ingeroepen jegens de overheid, d.w.z. niet in horizontale verhoudingen. Zie voor een uitstekend overzicht van alle rechtspraak op dit punt en de belangrijkste toepassingsvoorwaarden het arrest Paola Facchini Dori, EHvJ 14 juli 1994, zaak C-91/92, Jurispr. 1994, 1-3325. Belangrijk voor Nederland zijn vooral de sociale zekerheidsrichtlijnen, met name de zogenaamde Derde Richtlijn (RI. 79/7/EEG van de Raad van 9 februari 1978 betreffende de geleidelijke tenuitvoerlegging van het beginsel van gelijke behandeling van mannen en vrouwen op het gebied van de sociale zekerheid, Pb. EG 1979 L 6/24), en de zogenaamde bewijsrichtlijn (RI. 97/80/EG van de Raad van 15 december 1997 inzake de bewijslast in gevallen van discriminatie op grond van het geslacht, Pb. EG 1998 L 14/6). Deze en andere relevante richtlijnen zijn vaak op zodanige wijze omgezet in Nederlands recht dat de oorspronkelijke richtlijn nauwelijks nog te herkennen valt; het verschil tussen EG-recht en nationaal recht is daardoor niet altijd even duidelijk. De herkomst blijft echter van belang voor de uitleg van de bepalingen, die in overeenstemming moet zijn met de rechtspraak van het Europees Hof van Justitie.

Van belang is dat op grond van artikel 13 EG nog enkele nieuwe richtlijnen tot stand zijn gekomen die van belang zullen zijn voor het Nederlandse gelijke behandelingsrecht; zie RI. 2000/43/EG van de Raad van 29 juni 2000 houdende toepassing van het beginsel van gelijke behandeling van personen ongeacht ras of etnische afstamming ( $\mathrm{Pb}$. EG $2000 \mathrm{~L} \mathrm{180/22)}$ ), die in juli 2003 moet zijn omgezet in nationaal recht, en Richtlijn 2000/78/EG van de Raad van 27 november 2000 tot instelling van een algemeen kader voor gelijke behandeling in arbeid en beroep (Pb. EG $2000 \mathrm{~L} \mathrm{303/16).} \mathrm{Deze} \mathrm{laatste}$ richtijin is een algemene kaderrichtlijn ter bestrijding van ongelijke behandeling op een aantal gronden, namelijk leeftijd, handicap, godsdienst of overtuiging en seksuele geaardheid. Zie nader Holtmaat 2001, p. 110-112 en, voor een nader overzicht van de wijze waarop de verschillende Europese richtlijnen in Nederland zijn of worden geîmplementeerd, Wentholt 2000 (1), p. 286. 
bij de verschillende Nederlandse rechterlijke instanties een beroep kunnen doen, waar. na de rechter hieraan een interpretatie moet geven die met het Europese recht verenig. baar is of, als dit niet mogelijk is, het nationale recht buiten toepassing moet laten." In de praktijk wordt vooral door de Centrale Raad van Beroep regelmatig aan de Europese gelijkheidsbepalingen getoetst: de invloed van het gemeenschapsrecht op het sociale zekerheidsrecht is groot." Van belang is daarbij dat de Centrale Raad minder vrijheid heeft bij de uitleg en toepassing van deze bepalingen dan bijvoorbeeld het geval is bij de toepassing van artikel 26 IVPBR. Weliswaar laten sommige communautaire bepalingen veel ruimte voor het beoordelen van de aanwezigheid van een objectieve en redelijke rechtvaardiging, maar deze ruimte is beperkt door de uitleg die het Europees Hof van Justitie hieraan heeft gegeven: in de praktijk hebben de nationale rechterlijke instanties nauwelijks ruimte om af te wijken van de door dit Hof ontwik. kelde toetsingsmethodiek. ${ }^{32}$ Als gevolg hiervan vertonen de criteria die de Centrale Raad hanteert bij de toepassing van het communautaire recht grote gelijkenis met die van het Hof van Justitie. ${ }^{33}$

30. Zie EHvJ 9 maart 1978, zaak 106/77, Simmenthal, Jurispr. 1978, 629, punt 21.

31. Een verklaring voor het feit dat andere instanties zelden expliciet aan het gemeenschapsrecht toetsen is niet gemakkelijk te geven. Waarschijnlijk worden zij minder vaak met dit soort beroepen geconfon: teerd of zijn de beroepen op Europese gelijkheidsbepalingen minder zichtbaar doordat een beroep wordt gedaan op nationaalrechtelijke implementatiebepalingen (zoals de Wet gelijke behandeling vai mannen en vrouwen of bepaalde artikelen die ter implementatie van een richtlijn zijn ingevoegd in hat Burgerlijk Wetboek, zoals art. 7:646 EG; zie nader Heringa 1994, p. 17). Overigens komt het wel vour dat een beroep op het Europese recht als zodanig herkenbaar is; zie bijv. HR 6 november 1998, RvolW 1998/206 (Bos/KLM; beroep op art. 141 EG (art. 119 oud), HR 13 februari 1998, NJ 1999/58, in s menhang met HR 31 maart 2000, JB 2000/133 (Scholingsbesluit bijstandsgerechtigden, prejudicitle vragen na beroep op art. 4 lid 1 RI. 97/7/EEG), HR 13 september 1991, NJ 1992/225 (Dekker/VIV; toepassing RI. 76/207/EEG na beantwoording prejudiciēle vragen door EHvJ) en HR 25 november 1988, NJ 1989/730 (Stichting Centrum voor Onderwijsbegeleiding/Pot; beroep op art. 7A:1637ij BW (oud, nu art. 7:646 BW)). Door de Afdeling is soms uitspraak gedaan over het algemene verbod vin discriminatie op grond van nationaliteit zoals dat is terug te vinden in art. 12 EG (ABRS 4 augustis 1998, AB 1998/377 (Loting geneeskunde)) en artikel 28 EG (ABRS 25 juli 1996, AB 1996/425 (Uilvoer bedrijfsafvalstoffen)).

32. Zo blijkt uit het arrest Von Colson en Kamann dat het nationale recht zoveel mogelijk in overeenstem. ming met de Europese richtlijnen moet worden uitgelegd en toegepast (EHvJ 10 april 1984, ass 14/83, Jurispr. 1984, 1892, punt 26). Ingevolge artikel 234 EG moeten instanties als de Centrale Rav bovendien prejudiciele vragen stellen als zij niet zeker zijn van de juiste uitleg of toepassing van en (van oorsprong) communautaire bepaling. De uitleg die door het Hof wordt gegeven moet vervolgens op het concreet voorliggende geval worden toegepast, waarbij slechts ruimte voor eigen uitleg bestar voor zover het Hof die uitdrukkelijk heeft toegekend. Zie bijv. CRvB 19 april 1990, RSV 1990323 (Teuling-Worms), waarin het Hof de beantwoording van de vraag of de bepaling in kwestie geschilte en noodzakelijk was overliet aan de Centrale Raad, en CRvB 15 mei 1996, RSV 1996/170 (Posthumb Van Damme), waarin de Centrale Raad naar aanleiding van een prejudiciéle beslissing van het Hofin het geheel geen eigen interpretatie- of toepassingsruimte meer zag. Het gevolg hiervan is dat de redh terlijke instanties geneigd zijn om de methodiek van het Hof ook te volgen bij zaken waarin geen pre judiciēle vragen zijn gesteld; zie bijv. CRvB 9 april 1991, RSV 1991/247 (Drie-uit-vijf-eis). CRvB 25 mei 1991, RSV 1991/257 (Overgang AAW-AWW), CRvB 23 juni 1992, RSV 1992/317 (Inkomensels AAW), CRvB 18 juni 1993, RSV 1994/68 (Samenloop AAW-uitkeringen), CRvB 20 september 1998 AB 1996/20 (Kostwinnerscriterium ZFW), CRvB 29 april 1996, RSV 1996/247 (WW huishoudelif) personeel), CRvB 12 augustus 1999, RSV 2000/73 (Inkomensvereiste thuiswerkers) en CRvB 21 sep tember 2000, JB 2000/313 (Scholierenregeling).

Op de precieze uitwerking die de Centrale Raad hieraan heeft gegeven zal verderop in dit hoofdstith worden ingegaan. 
Interessant is verder dat de Centrale Raad heeft aangenomen dat de uitleg die wordt gegeven aan de communautaire bepalingen ook geldt voor de uitleg van eventuele andere gelijkheidsbepalingen waarop in een concreet geval een beroep is gedaan. ${ }^{34}$ Wanneer bijvoorbeeld al is vastgesteld dat een nationale maatregel in overeenstemming is met een bepaling van Europees recht, kan een subsidiair beroep op artikel 26 IVBPR of artikel 14 EVRM niet meer leiden tot een ander oordeel. ${ }^{35}$ Andersom kan een bepaling die in strijd wordt geacht met een specifieke communautaire norm niet worden gesauveerd met een beroep op de (soms ruimere) rechtvaardigingsmogelijkheden die het internationale recht biedt. ${ }^{36}$ Deze benadering heeft tot gevolg dat het Europese recht boven het internationale recht wordt geplaatst. Dit is niet onredelijk, omdat het alleen op die manier mogelijk is om de door het Hof van Justitie vereiste volledige en nuttige werking aan het Europese recht toe te kennen. Niettemin is de vraag gerechtvaardigd of het niet toch mogelijk moet zijn om artikel 26 zelfstandig toe te passen, wanneer dit tot een verdergaande bescherming zou leiden dan een toepassing van het Europese recht. ${ }^{37}$

\subsubsection{Gelijkheidsbepalingen in de Nederlandse wetgeving}

Van belang is verder dat een aantal gelijkheidsbepalingen uitdrukkelijk in Nederlandse formele wetgeving is neergelegd, hetzij ter implementatie van Europees recht, hetzij als nadere uitwerking van artikel 1 Grondwet. De Algemene wet gelijke behandeling is hiervan het belangrijkste voorbeeld. ${ }^{18}$ In deze wet, die in zijn reikwijdte beperkt is tot een aantal horizontale en enkele (semi-)verticale rechtsverhoudingen ${ }^{39}$, is direct onderscheid op enkele specifieke gronden verboden, tenzij een beroep kan worden gedaan op een in de wet opgenomen uitzonderingsgrond. ${ }^{40}$ In dat opzicht laat de Awgb de rechter aanzienlijk minder vrijheid in het beoordelen van de toelaatbaarheid van een ongelijke

34. Dit blijkt ook al uit het feit dat de Centrale Raad voor de "ingangsdatum" van de rechtstreekse werking van artikel 26 IVBPR de datum heeft gekozen waarop RI. 79/7/EEG had moeten worden omgezet in nationaal recht (en, bij gebreke van tijdige omzetting, op grond van de hiervoor in noot 31 besproken doctrine rechtstreeks inroepbaar werd); zie CRvB 14 mei 1987, RSV 1987/246. Volgens het rapport Gelijk in de praktijk vormt het beginsel van de lex specialis de grondslag voor deze benadering (1990, p. 41). Dit betekent dat het internationale recht kan prevaleren in gevallen waarin het een specifiekere regeling biedt dan het Europese recht.

35. Zie bijv. CRvB 19 april 1990, RSV 1990/323 (Teuling-Worms), CRvB 23 mei 1991, RSV 1991/257 (Overgang AAW-AWW), CRvB 23 juni 1992, RSV 1992/317 (Inkomenseis AAW), CRvB 20 september 1995, AB 1996/20 (Kostwinnerscriterium ZFW), CRvB 29 april 1996, RSV 1996/249 (WW huishoudelijk personeel) en CRvB 15 mei 1996, RSV 1996/170 (Posthuma-Van Damme).

36. Weliswaar zijn van deze laatste situatie geen voorbeelden in de rechtspraak van de Centrale Raad terug te vinden, maar het is onwaarschijnlijk dat deze een andere benadering zou kiezen.

37. Zie hierover nader Woltjer 2002, p. 236/237 en 239.

38. De Awgb is opgezet als uitwerking van artikel 1 van de Grondwet en is vooral ook bedoeld als oplossing voor de problematiek van botsing van het gelijkheidsbeginsel met andere grondrechten, zoals de vrijheid van godsdienst (zie MvT, TK 1990-1991, 22 014, nr. 3, p. 5/6 en vgl. Cremers-Hartman 1999, p. 51, Koekkoek 1991, p. 29 en Heringa 1991, p. 8). Het heeft lang geduurd voordat deze wet tot stand kwam: een eerste voorontwerp werd al in 1981 ingediend, terwijl de wet uiteindelijk pas in 1994 in werking trad. Zie nader Heringa 1991, p. 3 en, specifiek met betrekking tot het voorontwerp, Fase/Van der Heijden 1982, p. 84 en Bergamin 1983, p. 529.

39. Zie artikelen 5,6 en 7 Awgb.

geslacht is direct onderscheid op grond van godsdienst, levensovertuiging, politieke gezindheid, ras, b). De uitzonderingt, hetero- of homoseksuele gerichtheid of burgerlijke staat (zie artikel 1 lid 1 sub ). De uitzonderingsgronden zijn opgenomen in artikel 2 en artikel 5 lid 2 en 7 lid 2. 
behandeling dan artikel 1 van de Grondwet of de hiervoor besproken verdragsbepalip. gen. Interessant is echter artikel 2 lid 1 van deze wet:

"Het in deze wet neergelegde verbod van onderscheid geldt niet ten aanzien van indiret onderscheid dat objectief gerechtvaardigd is."

Deze bepaling is in de wet verder niet uitgewerkt, hetgeen tot gevolg heeft dat de rechter een ruime mate van vrijheid heeft om criteria te ontwikkelen voor de beoorde. ling van de aangevoerde objectieve rechtvaardiging. Van belang is wel dat deze viij. heid in belangrijke mate is ingeperkt doordat in de wetsgeschiedenis uitvoerige aanwij. zingen worden gegeven over de wijze waarop de bepalingen moeten worden uitgelegd.

Voorbeelden van toetsing aan de Algemene wet gelijke behandeling zijn met name te vinden in uitspraken van lagere rechterlijke instanties: opmerkelijk is dat de civicle kamer van de Hoge Raad vrijwel nooit aan deze wet toetst. ${ }^{41}$ Het is dan ook niet gemakkelijk om op basis van uitspraken van de Hoge Raad af te leiden welke criteria moeten worden gehanteerd bij de toepassing van artikel 2 lid $1 \mathrm{Awgb}$. Van groot belang voor de interpretatie van de Awgb zijn wel de oordelen van de Commissie Gelijke Behandeling, een semi-rechterlijke instantie die bevoegd is een oordeel te geven over klachten met betrekking tot schending van de Awgb. ${ }^{42}$ In deze oordelen heeft de Commissie een uitgebreid en genuanceerd toetsingsmodel ontwikkeld voor de beoordeling van indirect onderscheid. Hoewel de oordelen van de Commissie niet binden, zijn zij toch in het onderzoek betrokken vanwege het belang van de door haar gehanterde methodiek voor de ontwikkeling van een algemeen toetsingsmodel.

Naast de Algemene wet gelijke behandeling, die betrekking heeft op een groot antal verschillende gronden van onderscheid, bestaan er enkele wetten die ongelijke behandeling op specifieke gronden verbieden. ${ }^{4}$ Zo bestaat er sinds 1996 een Wet onderscheid arbeidsduur, op grond waarvan ongelijke behandeling op basis van arbeidsduur verboden is wanneer daarvoor geen objectieve rechtvaardiging bestaat. ${ }^{44}$ Inmiddels bestat ef een aanzienlijke hoeveelheid rechtspraak met betrekking tot deze wet, waarvan de Oordelen van de Commissie Gelijke Behandeling een belangrijk onderdeel vormen ${ }^{6}$ Van belang zijn verder de Wet gelijke behandeling voor mannen en vrouwen (WGB) en artikel 7:646 BW. ${ }^{+6}$ Deze wetgeving is bedoeld als implementatie van Europese

41. De uitspraken van lagere rechterlijke instanties zijn niet onderzocht.

42. Zie artikelen 11 en 12 Awgb; de Commissie kan overigens ook uit eigen beweging een onderzoki instellen. Verder kunnen "gewone" rechters om een oordeel verzoeken als zij uitspraak moeten doet over een zaak waarin de Awgb een rol speelt (artikel 12 lid 2 sub c Awgb); van deze mogelijkheil wordt in de praktijk nauwelijks gebruik gemaakt.

43. Bovendien zijn er recentelijk wetsvoorstellen ingediend met betrekking tot onderscheid op grond val leeftijd en handicap: zie TK 2001-2002, 28 170, nr. 1-2 (Wet gelijke behandeling op grond van leetiji bij de arbeid) en TK 2001-2002, 28 169, nr. 1-2 (Wet gelijke behandeling op grond van handicap of chronische ziekte).

44. De bepalingen van deze wet zijn terug te vinden in artikel 7:648 BW en artikel 125g Ambtenarenwel.

Op grond van artikel 6:248 lid 4 BW en artikel 125g lid 3 Ambtenarenwet is de Commissie op gelijke wijze als bij de Awgb bevoegd om een oordeel te geven over klachten met betrekking tot schending van de WOA.

46. Er zijn nog andere belangrijke gelijkheidsnormen in het civiele recht terug te vinden, maar ondat 2 il 
regelgeving en heeft betrekking op ongelijke behandeling op het gebied van het arbeidsrecht. ${ }^{47}$ Net als de Awgb verbieden de WGB en artikel 7:646 BW direct onderscheid op grond van geslacht, tenzij daarvoor één van de limitatief opgesomde rechtvaardigingen bestaat. Ook deze wetgeving laat dus nauwelijks ruimte voor het ontwikkelen van een eigen model door de rechter. Opnieuw is het echter zo dat in deze wetgeving een algemene rechtvaardigingsmogelijkheid is opgenomen voor gevallen van indirect onderscheid. ${ }^{\text {ss }}$ Aan deze rechtvaardigingsmogelijkheid is vooral vorm gegeven door de voorganger van de huidige Commissie Gelijke Behandeling, de Commissie Gelijke Behandeling van mannen en vrouwen bij de arbeid. In het hiernavolgende zal af en toe dan ook melding worden gemaakt van de oordelen van de CGB m/v.

Niet alleen in het civiele recht, maar ook in het strafrecht zijn enkele bijzondere discriminatieverboden terug te vinden. Belangrijk is vooral artikel 429 quater Wetboek van Strafrecht, op grond waarvan discriminatie in de uitoefening van ambt, beroep of bedrijf strafbaar is gesteld. ${ }^{49}$ In het algemeen zal op deze bepaling alleen beroep worden gedaan in situaties van bloot onderscheid, bijvoorbeeld in het geval waarin een portier van een discotheek iemand op raciale gronden niet heeft binnengelaten. ${ }^{50}$ In hoofdstuk 2 is al aangegeven dat in dergelijke gevallen het toetsingsmodel in mindere mate relevant is, zodat in het verloop van dit hoofdstuk slechts sporadisch aandacht zal worden besteed aan deze bepaling.

\subsubsection{Het gelijkheidsbeginsel als algemeen beginsel van behoorlijk bestuur}

Tenslotte is van belang dat het gelijkheidsbeginsel in veel rechterlijke uitspraken is terug te vinden als algemeen beginsel van behoorlijk bestuur. Als zodanig is het gelijkheidsbeginsel vooral van belang wanneer een bestuursorgaan een bevoegdheid zodanig heeft uitgeoefend dat een ongelijke behandeling hiervan het resultaat is." Met dit soort beroepen op het gelijkheidsbeginsel krijgen vooral bestuursrechters (Centrale Raad, Afdeling en Belastingkamer) te maken ${ }^{52}$, maar ook de strafrechter kan hiermee worden

minder algemeen zijn en niet onder de bevoegdheid van de Commissie vallen zullen zij hier niet worden behandeld. Te denken valt aan artikel 7:670 BW (ontslagverbod gedurende zwangerschap) en artikel 2I WOR (bescherming leden ondernemingsraad tegen benadeling binnen de onderneming). Zie nader Asscher-Vonk 1998, p. 113.

47. Vgl. Asscher-Vonk 1995, p. 617 en 619

48. Zie artikel 7:646 lid 5 en 6 BW en artikel 6 WGB

49. Deze bepaling luidt als volgt: "Hij die in de uitoefening van een ambt, beroep of bedrijf personen discrimineert wegens hun ras, hun godsdienst, hun levensovertuiging, hun geslacht of hun hetero- of homoseksuele gerichtheid wordt gestraft met hechtenis van ten hoogste twee maanden of geldboete van de derde categorie." De bepaling moet worden gelezen in samenhang met artikel 90 quater $\mathrm{Sr}$, waarin een definitie van het begrip "discriminatie" wordt gegeven. Opzettelijke discriminatie is apart strafbaar gesteld in artikel $137 \mathrm{~g} \mathrm{Sr}$.

51. Zie voor voorbeelden van deze rechtspraak nader Hoens 1981, p. 261/262

51. De voorbeelden daarvan zijn legio, variërend van het in én geval wel en in het andere geval niet verlenen van een vergunning tot het ongelijk waarderen van huizen ten behoeve van de vaststelling van De bestume zaakbelasting. Zie nader Duk 1975, p. 859/860 en Addink 1999, p. 154/155.

Zie bijv. CRvB 8 hebben rechtstreekse beroepen op het gelijkheidsbeginsel al vroeg gehonoreerd. (Dakkapellen) 8 april 1964, ARB 1964/872 (Postume gelijkheid), ARRS 5 april 1977, AB 1977/309 beider). De civiele kart 1979 (belastingkamer), BNB 1979/140 (Navorderingsaanslag grensar- 
geconfronteerd: in strafzaken wordt met enige regelmaat gesteld dat een vervolging in strijd is met het gelijkheidsbeginsel omdat in eerdere gevallen niet tot vervolging is overgegaan..$^{31}$

Opgemerkt moet echter worden dat de bestuursrechters en de strafkamer van de Hoge Raad niet altijd rechtstreeks toetsen aan het gelijkheidsbeginsel als algemeen beginsel van behoorlijk bestuur, ook al is er in een concreet geval duidelijk sprake van een ongelijke behandeling. In plaats daarvan wordt vaak gesteld dat de motivering van het bestuursbesluit niet deugdelijk is", dat er sprake is van onzorgvuldig handelen"s of dat het verbod van willekeur is geschonden ${ }^{6.57}$. Door die werkwijze is het voor de rechter mogelijk om de soms lastige beoordeling van de redelijkheid van een ongelijke behar. deling te vermijden en toch recht te doen aan de belangen van de benadeelde. Dit betekent echter niet dat het gelijkheidsbeginsel als algemeen beginsel van behoorlijk be stuur in het geheel geen betekenis heeft: in een groot aantal gevallen wordt rechtstreeks aan dit beginsel getoetst, ook al levert dit in de praktijk slechts zelden een voor de be. langhebbende positief resultaat op. ${ }^{\mathrm{sx}}$

len van de overheid rechtstreeks (dus niet via een toetsing aan het verbod van willekeur) aan het as lijkheidsbeginsel kan worden getoetst (HR 27 maart 1987, NJ 1987/727 (Amsterdam/lkon)).

53. Het gelijkheidsbeginsel dient dan als een algemeen beginsel van behoorlijk strafprocesrecht: zie bijvoorbeeld HR 13 januari 1998 (strafkamer), NJ 1998/407 (Gedoogbeleid Delfzijl). Een beroep hierop wordt maar zelden gehonoreerd: algemeen aanvaard is dat ongelijkheid bij de vervolging min of meet is geïnstitutionaliseerd (zie Corstens 1995, p. 65). Zie bijv. HR 10 februari 1987 (strafkamer), N 1987/950 (Vechtpartij zigeuners), HR 20 oktober 1987 (strafkamer), NJ 1988/473 (Valsheid in gs: schrifte), HR 13 januari 1998 (strafkamer), NJ 1998/407 (Gedoogbeleid Delfzijl), HR 2 februari l999 (strafkamer), NJ 1999/664 (Transactievoorstel) en HR 18 mei 1999 (strafkamer), NJ 1999/578 (Ridtlijn Handhaving Arbeidsomstandigheden). Toch is het denkbaar dat een werkelijk willekeurige ongelijke behandeling tot niet-ontvankelijkheid van het OM leidt: het is eerder zo dat de eisen die worden gesteld aan de rechtvaardiging buitengewoon laag zijn, dan dat het gelijkheidsbeginsel voor het sraf: procesrecht geen rol speelt. Corstens geeft enkele voorbeelden van situaties waarin een beroep op het gelijkheidsbeginsel wel kans van slagen zou hebben (1995, p. 65).

54. Zie bijv. HR 23 juni 1982 (belastingkamer), AB 1983/2 (Onroerendgoedbelasting Scheemda II), ARRS 1 augustus 1983, AB 1984/532 (Humanistisch vormingsonderwijs), ARRS 15 augustus 1983, AB 1983/539 (Servicestation), ARRS 2 september 1987, AB 1988/303 (Humanistisch vormingsondenvips 1998, AB 1999/100 (Pensioenuitkering KNIL-militairen II) en ABRS 9 mei 2000, JB 2000/179 (Das. kapellen).

55. Bijv. ARRS 22 april 1991, AB 1991/603 (Tegemoetkoming scholingskosten) en ARRS 21 oktober 1993, AB 1994/357 (Begeleidingssubsidie vrije school).

56. Zie bijv. HR 21 juni 1988 (strafkamer), NJ 1988/1021, HR 25 april 1980, NJ 1981/416 (Sogut) (niel zozeer toetsing aan het verbod van willekeur, maar eerder een algemene redelijkheidstoets), HR 13 maart 1981, AB 1981/396 (Robbe/Van Beveren) (eveneens een algemene redelijkheidstoets), ARRS 6 november 1984, AB 1985/417 (Verhuis- en herinrichtingskostenvergoeding), ABRS 26 mei 1994, AB 1995/179 (Medewerkersovereenkomst AWBZ), CRvB 13 oktober 1987, RSV 1988/118 (Referentic voeding) (algemene redelijkheidstoets) en CRvB 28 mei 1998, AB 1998/244 (Malusbeschikkingent Wet Amber). Zie over de verhouding tussen het verbod van willekeur en het gelijkheidsbeginsel Dul 1975 , p. 862.

57. Zie voor een groot aantal voorbeelden uit de rechtspraak van de Afdeling en een verklaring daarvoor Versteden 1985, p. 69-72.

58. In de literatuur is wel gesteld dat het niet nodig is om het gelijkheidsbeginsel als afzonderlijk algemeen beginsel van behoorlijk bestuur te beschouwen, omdat het op kan gaan in beginselen als het evenredie. heidsbeginsel, het verbod van willekeur, het vertrouwensbeginsel of het rechtszekerheidsbeginsel (zk Versteden 1985, p. $62 / 63$ en Addink 1999, p. 159/160). Het gelijkheidsbeginsel verdient echter zelet de aparte plaats die het in de praktijk blijkt te hebben: het heeft wel degelijk een bijzondere betekenti 
Van belang is nog dat de rechter bij de beoordeling van beroepen op het gelijkheidsbeginsel als algemeen beginsel van behoorlijk bestuur te maken kan krijgen met de bijzondere problematiek van de contra legem-werking. Het kan voorkomen dat een bestuursorgaan in een concreet geval een besluit heeft genomen (of een beleid heeft gevoerd) dat niet in overeenstemming is met de wet waaraan hij zijn bevoegdheid ontleent. Een ongelijke behandeling kan ontstaan wanneer het bestuursorgaan in een later geval een besluit neemt dat wel in overeenstemming is met de wet, maar afwijkt van het eerder genomen besluit (of het eerder gevolgde beleid). In een dergelijke situatie heeft het honoreren van een beroep op het gelijkheidsbeginsel tot gevolg dat het bestuursorgaan gedwongen is om een handelen in strijd met de wet voort te zetten. Bestuursrechters hebben deze problematiek op sterk verschillende wijze benaderd: de Afdeling heeft aangegeven dat de noodzaak van contra legem-werking altijd in de weg staat aan een geslaagd beroep op het gelijkheidsbeginsel ${ }^{59}$, de Centrale Raad en de civiele kamer van de Hoge Raad voeren een genuanceerd beleid waarbij zij, afhankelijk van de omstandigheden van het geval, een contra legem-beroep honoreren ${ }^{(1)}$ en de belastingkamer van de Hoge Raad heeft een fraai en gedetailleerd model ontwikkeld,

als specificering van een bepaald algemeen beginsel (het verbod van ongerechtvaardigde ongelijke behandeling is te zien als een specialis van het verbod van willekeur) of als veralgemenisering van een specifieker beginsel (zo kan het gelijkheidsbeginsel een functie hebben waar er geen sprake is van opgewekt vertrouwen, maar wel van een ongelijke behandeling). In die zin ook Versteden 1985, p. 63 en Duk 1975, p. 862.

59. Zie recentelijk nog ABRS 15 september 2000, AB 2001/154 (Kapvergunning Medemblik); zie ook Addink 1999, p. 163. Opmerkelijk is overigens dat een voorganger van de Afdeling, de Afdeling Rechtspraak in enkele apert onredelijke gevallen van onderscheid heeft geconcludeerd tot contra legem-werking; zij deed daarbij echter geen rechtstreeks beroep op het gelijkheidsbeginsel, maar redeneerde via het verbod van willekeur; zie bijv. ARRS 6 november 1984, AB 1985/417 (Verhuis- en herinrichtingskostenvergoeding). Versteden besteedt hieraan uitgebreid aandacht: 1985, p. 70. Verder is er een beperkt aantal gevallen waaruit kan worden afgeleid dat de Afdeling Rechtspraak bereid zou kunnen zijn om een beroep op contra legem-werking te honoreren als er in het eerdere geval duidelijk sprake was van een bewuste en beoogde afwijking van de wet: zie ARRS 2 januari 1989, AB 1989/392 (Rietkerk-uitkering).

60. De Hoge Raad heeft de mogelijkheid van contra legem-werking voor algemene beginselen van behoorlijk bestuur in zijn algemeenheid erkend, maar hij kiest hierbij een terughoudende opstelling: per geval wordt een afweging gemaakt en wordt beoordeeld of het gelijkheidsbeginsel voorrang moet krijgen boven het legaliteitsbeginsel. Een belangrijk voorbeeld waarin aan het gelijkheidsbeginsel voorrang werd gegeven is het Deltaschade-arrest (HR 15 juli 1988, NJ 1989/714); daaruit bleek onder andere dat een duidelijk tegenwettelijk beleid wel, maar een incidenteel afwijken van de wet niet kan leiden tot contra legem-werking van het gelijkheidsbeginsel. Met deze benadering lijkt de civiele kamer zich enigszins aan te sluiten bij de uitgebreide rechtspraak van de belastingkamer, hoewel de civiele kamer enkele voorwaarden heeft aangenomen die de belastingrechter niet hanteert (zie Van Wijk/Konijnenbelt 1999, p. 407/408). Ook de Centrale Raad honoreert in sommige gevallen een beroep op het gelijkheidsbeginsel, namelijk als het eerdere besluit voortvloeide uit een tegenwettelijk beleid of als er spra$k e$ is van een zeer groot aantal van de wet afwijkende gevallen (bijv. CRvB 11 juni 1981, AB 1981/458 (Salarisindeling artsen)). Contra legem-werking is volgens de Centrale Raad bovendien mogelijk in de uitzonderlijke situatie waarin er ook nog sprake is van onzorgvuldigheid in de voorbereiding van het besluit (CRvB 6 september 2000, JB 2000/311 (Korting uitkering wegens verwijtbare werkloosheid)). Als in het eerdere geval sprake was van een incidentele, onjuiste wetsafwijking, zal een beroep op het gelijkheidsbeginsel door de Centrale Raad echter niet worden gehonoreerd (zie bijv. CRvB 22 november 1994, RSV 1995/107 (WW-uitkering leraren), CRvB 7 januari 1997, RSV 1997/115 (Achterstand bij heronderzoeken ABW), CRvB 2 juni 1998, RSV 1998/230 (Bijstand opleidingskosten) en CRvB 26 oktober 1999, RSV 2000/22 (WW-uitkering musicus)). Vgl. ook Addink 1999, p. 163. 
waarbij contra legem-werking relatief gemakkelijk wordt aanvaard ${ }^{6}$. Enkele aspecten van deze problematiek zullen nader aan de orde komen bij de bespreking van de toetsingsmethodiek zoals die door de verschillende instanties wordt gehanteerd.

\subsection{Situaties van onderscheid}

Voor de beoordeling van de toetsingsmethodiek van de Nederlandse rechterlijke instanties is van belang dat er verschillende situaties bestaan waarin onderscheid kan worden gemaakt. $^{62}$ Allereerst kan een ongelijke behandeling het gevolg zijn van etn zogenaamde normatieve classificatie. Het gaat daarbij om onderscheid dat is neergelegd in of dat voortvloeit uit een algemene regeling; of het daarbij gaat om een formele wet, een beleidsregel of een regeling die binnen een onderneming is vastgesteld is niet van belang. In Nederland hebben alle rechterlijke instanties (impliciet) aanvaard dat normatieve classificaties kunnen worden beoordeeld op hun verenigbaarheid met het gelijkheidsbeginsel. $^{63}$

In de tweede plaats kan een ongelijke behandeling het resultaat zijn van de ongelijke toepassing van een algemene regeling in een concreet geval. Het kan immers zo zijn dat een wettelijke regeling of een (ongeschreven) beleidsregel, die op zichzelf heel redelijk is en niet in strijd is met het gelijkheidsbeginsel, op zodanige wijze wordt toegepast dat daardoor toch sprake is van een ongerechtvaardigd onderscheid. De bestudeerde Nederlandse rechterlijke instanties lijken allemaal bereid te zijn om niet alleen de redelijkheid van een classificatie als zodanig te beoordelen, maar ook te kijken narr de concrete toepassing daarvan. Voor de ontwikkeling van een algemeen toetsingsmodel is dit bijzonder interessant: de vraag is immers of in deze situatie hetzelfde toetsingsmodel kan worden gehanteerd als bij normatieve classificaties.

Tenslotte bestaat er nog het geval van bloot onderscheid. Daarvan is sprake wanneer een individu een beslissing neemt waarvan een ongelijke behandeling het resultaat is (bijvoorbeeld in het geval waarin een huisarts weigert een allochtone patiënt te behan.

61. De belastingkamer aanvaardde de contra legem-werking van het gelijkheidsbeginsel voor het cerst in 1979 (HR 6 juni 1979 (belastingkamer), BNB 1979/211 (Buitengewone lasten pensionprijs)), en hetf daama in een lange reeks van uitspraken aangegeven in welke omstandigheden een beroep hierop bu worden gehonoreerd.

62. Zie nader hoofdstuk 2, paragraaf 2.3 .

63. Dit geldt zelfs wanneer er sprake is van een normatieve classificatie in horizontale gevallen; zie dur. over nader paragraaf 1.4. Een uitzondering moet worden gemaakt voor de bestuursrechter, die ingevol. ge art. 8:2 sub a Algemene wet bestuursrecht niet rechtstreeks algemeen verbindende voorschritten (et daarin opgenomen normatieve classificaties) mag beoordelen. Dit verbod is echter gemakkelijk te ontzeilen door een concreet besluit aan te vechten op de grond dat de wettelijke regeling warop het be sluit is gebaseerd niet deugdelijk is (beroep bij wege van exceptie); de rechter kan ook ambtshalve de deugdelijkheid van de wettelijke grondslag van de bevoegdheidsuitoefening toetsen. Vgl. Van Mals 1988 (II), p. 285 en Mok 1984, p. 58. Van belang is dat er enige twijfel mogelijk is over de valag of artikel 26 IVBPR wel betrekking heeft op normatieve classificaties, dus op gelijkheid in de wet; wit en onderzoek van Govers naar de totstandkomingsgeschiedenis blijkt dat dit waarschijnlijk niet de bedocling van de verdragspartijen is geweest (Govers 1985, p. 366-370). Ook bij de totstandkoming van lat huidige artikel 1 Grondwet is intensief gediscussieerd over de vraag of dit alleen betrekking zou mos" ten hebben op wetstoepassing, of ook op de inhoud van de wet: vgl. Burkens 1982, p. 51/52. Inmiddels is echter algemeen aanvaard, ook door de rechterlijke macht, dat normatieve classificaties an deze be palingen kunnen worden getoetst. 
delen) of wanneer een bestuursorgaan in twee gevallen verschillende besluiten neemt zonder dat daaraan een duidelijk beleid of een algemene regeling ten grondslag ligt ${ }^{\text {ts }}$ : dit is de in hoofdstuk 2 beschreven situatie 3 . Opgemerkt is daar al dat bloot onderscheid niet in het onderzoek zal worden betrokken. ${ }^{65}$ Ook in dit hoofdstuk zal hieraan geen bijzondere aandacht worden besteed, hetgeen betekent dat niet zal worden ingegaan op arbeidsrechtelijke vraagstukken als gelijke beloning of onredelijk ontslag of op de strafrechtelijke problematiek rond discriminatie door particulieren. ${ }^{66}$

\subsection{Direct en indirect onderscheid; materieel en formeel onderscheid}

\subsubsection{Formeel en materieel onderscheid}

$\mathrm{Nu}$ de in Nederland geldende gelijkheidsbepalingen qua inhoud sterk uiteenlopen en er verschillende instanties bevoegd zijn om hierover een oordeel uit te spreken, is het niet eenvoudig om in zijn algemeenheid vast te stellen of het concept van materieel onderscheid (het gelijk behandelen van onvergelijkbare gevallen) in Nederland wordt geaccepteerd. ${ }^{\text {t }}$ Toch kan uit de beschikbare rechtspraak worden afgeleid dat de meeste van de onderzochte instanties (Hoge Raad, Afdeling Bestuursrechtspraak, Centrale Raad en Commissie Gelijke Behandeling) aanvaarden dat ook materieel onderscheid op zijn redelijkheid kan worden beoordeeld, ongeacht de aard en inhoud van de betrokken gelijkheidsbepaling. De meest expliciete erkenning daarvan is te vinden in een uitspraak van de belastingkamer van de Hoge Raad. In een zaak waarin gesteld werd dat voor alleenstaanden ten onrechte dezelfde belastingvrije som gold als voor tweeverdieners oordeelde hij dat,

"voor zover [...] uit een oogpunt van draagkracht sprake is van een gelijke behandeling van ongelijke gevallen, $[\ldots]$ de wetgever in redelijkheid [heeft] kunnen oordelen dat voor die

64. Handelen door een bestuursorgaan dat leidt tot bloot onderscheid is zeldzaam. Wanneer daarvan al sprake is zal in de meeste gevallen geen beroep worden gedaan op het gelijkheidsbeginsel, maar op het legaliteitsbeginsel, het verbod van détournement de pouvoir of het verbod van willekeur. Een geval waarin van bloot onderscheid door bestuurshandelen sprake zou kunnen zijn is het gebruik van de bestuursdwangbevoegdheid die is neergelegd in artikel 125 Gemeentewet (een bepaling die volgens Klap is aan te merken als omvattend een "niet nader omschreven bevoegdheid" (1996, p. 246)). Deze bevoegdheid is zodanig algemeen geformuleerd dat, wanneer er geen nadere beleidsregels zijn vastgesteld voor de toepassing, het hanteren ervan kan leiden tot een bloot onderscheid. Het onderscheid met de tweede situatie is in dit soort gevallen dun.

65. Zie paragraaf 2.3 van hoofdstuk 2 : hoewel het toetsingsmodel ook op deze situatie kan worden toegepast, zij het met enige aanpassingen, is de bewijsproblematiek bij bloot onderscheid zo specifiek dat aan de rechtvaardigingstoets vrijwel nooit wordt toegekomen.

66. Dit geldt vanzelfsprekend niet als er sprake is van een normatieve classificatie op horizontaal niveau, bijvoorbeeld in het geval waarin de ongelijke beloning voortvloeit uit een algemeen binnen het bedrijf geldende beloningsregeling of $\mathrm{CAO}$ of wanneer een ongelijke behandeling het resultaat is van een algemeen beleid van een onderneming. Verder geldt voor het meeste bestuursrechtelijk handelen dat daarbij sprake zal zijn van situatie twee, namelijk van een algemeen beleid dat op verschillende wijze wijze is uitgest of van een uit de wet voortvloeiende en gereguleerde bevoegdheid die op ongelijke

67. In ieder uitgeoefend.

formeel, geval blijkt uit geen van de hiervoor besproken gelijkheidsbepalingen expliciet dat, naast formeel, ook materieel onderscheid onder hun reikwijdte valt. 
behandeling de uitvoerbaarheid van de wetgeving een objectieve en redelijke recht. vaardiging biedt."

Het aantal gevallen waarin de belastingkamer met materieel onderscheid te maken heeft gekregen is echter beperkt: in veruit de meeste zaken wordt geklaagd over een formeel ongelijke behandeling. ${ }^{69}$ Hetzelfde geldt voor de civiele kamer: uit het onderzoek is slechts één geval naar voren gekomen waarin werd geklaagd over een gelijke behandeling van ongelijke gevallen. In dat geval sprak de Hoge Raad bovendien geen eigen oordeel uit over de rechtvaardiging, maar verwees hij daarvoor naar de motivering van de lagere rechter. ${ }^{70}$ Hoewel de civiele kamer het concept van materieel onderscheid daarmee impliciet leek te erkennen, moet een geval waarin dit uitdrukkelijk wordt bevestigd nog worden afgewacht. Ook voor de strafkamer geldt dat het aantal zaken over materieel onderscheid feitelijk zo gering is dat daaruit geen conclusies kun. nen worden getrokken."

De rechtspraak van de Afdeling en de Centrale Raad is evenmin bijzonder duidelijk op het punt van materieel onderscheid. In de sporadische gevallen waarin wordt geklaagd over een gelijke behandeling van ongelijke gevallen wordt meestal wel inhoudelijk getoetst aan een relevante gelijkheidsbepaling, maar een uitdrukkelijke erkenning van het concept is nergens terug te vinden. ${ }^{n}$

68. HR 21 oktober 1992, BNB 1993/29 (Belastingvrije som alleenstaanden); het ging in dit geval om ete beroep op artikel 26 IVBPR. Vgl. ook Van Leijenhorst 1997, p. 1115.

69. Zie echter HR 20 september 2000 (belastingkamer), BNB 2000/380 (OZB woonschepen).

70. HR 30 maart 2001, NJ 2001/292 (Stichting Pensioenfonds Medisch Specialisten)

71. Uit de enige zaak die in het onderzoek naar voren is gekomen kan worden afgeleid dat de straftaner uitgaat van een sterk formele benadering. Deze zaak (HR 8 mei 1984, NJ 1985/429 (Benadeling werkloze)) had betrekking op het verrichten van herstelwerkzaamheden aan televisietoestellen door een werkloze, zonder dat hij in het bezit was van de daarvoor vereiste vergunning. Verdachte stelde dit werklozen door het vergunningsvereiste feitelijk werden benadeeld, nu zij in het bijzonder werden belemmerd in het vinden van werk. De HR wees deze stelling af met de volgende motivering. "[... de [...] verbodsbepaling richt zich gelijkelijk tegen een ieder die een elektrotechnisch bedrijf wenst uitt: oefenen, terwijl in genoemde Wet of Besluit in geen enkel opzicht [...] enig verschil wordt gemalt tussen werklozen en niet werklozen."

72. Impliciet erkende de Centrale Raad het concept van materieel onderscheid in CRvB 26 juni 2001, IB 2001/184 (Koppelingswet). In het geding in deze zaak was een in 1998 geîntroduceerde bepaling, of grond waarvan vreemdelingen die niet rechtmatig in Nederland verbleven geen recht hadden op eat bijstandsuitkering. Deze bepaling gold niet alleen voor vreemdelingen die na 1998 naar Nederiant kwamen en niet in aanmerking kwamen voor een geldige verblijfstitel, maar ook voor vreemdelingen die al voor 1998 in Nederland verbleven en een uitkering ontvingen, maar later hun verblijfstitel kwij: raakten. De Centrale Raad stelde dat het onredelijk was om de gevolgen van de Koppelingswet ookte laten gelden voor deze tweede groep, nu deze zich in een duidelijk andere situatie bevonden; dit 00 . deel wijst duidelijk op een erkenning van het concept van materieel onderscheid. Andere voorbeliden van impliciete erkenning zijn te vinden in CRvB 14 november 2000, RSV 2001/32 (Bijzondere bi): stand Breukelen) en CRvB 13 oktober 1988, RSV 1988/118 (Referentievoeding). Hoewel de Centrik Raad soms een meer formele benadering heeft gekozen (zie bijv. CRvB 10 augustus 1988, RSV 1989/94 (Overgangsregeling WAO)), staat het daardoor vast dat materieel onderscheid een inhoudelip beoordeling behoeft. Hetzelfde geldt voor de rechtspraak van de Afdeling. Met name haar voorgangeh, de Afdeling Rechtspraak, heeft verschillende malen een inhoudelijk oordeel uitgesproken in een Wlatt die betrekking had op een gelijke behandeling van ongelijke gevallen; zie bijv. ARRS 15 september 1986, AB 1987/280 (Zendtijd Humanistisch Verbond: gesteld werd dat de Stichting Turks Islamitisthe Culturele Federatie evenveel zendtijd had gekregen, terwijl zij minder leden had en dus in een ander? situatie verkeerde). ARRS 2 september 1987, AB 1988/303 (Humanistisch Vormingsonderwijs Valkenswaard; de gemeente weigerde subsidie voor vormingsonderwijs voor openbare scholen om op dit 
Voor de oordelen van de Commissie Gelijke Behandeling geldt tenslotte dat het onderscheid tussen materieel en formeel onderscheid niet zichtbaar is. De verklaring daarvoor is gelegen in het feit dat de Commissie geen vergelijkbaarheidstoets, maar een benadelingstoets als toetsingsingang hanteert. Bij de beoordeling of er sprake is van een benadeling is het niet van belang of deze het resultaat is van een gelijke behandeling van onvergelijkbare gevallen of van een ongelijke behandeling van vergelijkbare gevallen."

Een en ander betekent dat het nauwelijks mogelijk is om uit de Nederlandse rechtspraak af te leiden welke toetsingsmethodiek bij materieel onderscheid moet worden gehanteerd. Hoogstens kan worden opgemerkt dat de oordelen van de Commissie Gelijke Behandeling de theoretische veronderstelling bevestigen dat het niet nodig is om onderscheid te maken tussen formeel en materieel onderscheid, wanneer niet de vergelijkbaarheidstoets, maar de benadelingstoets tot uitgangspunt wordt genomen.

\subsubsection{Direct en indirect onderscheid}

Over het concept van indirect onderscheid bestaat, anders dan over materieel onderscheid, in Nederland een zeer uitgebreide jurisprudentie. Dit houdt verband met het feit dat dit concept in verschillende gelijkheidsbepalingen (of in de uitleg die daaraan door een hogere instantie is gegeven) uitdrukkelijk is terug te vinden. Eerder is bijvoorbeeld aangegeven dat artikel 2 lid $1 \mathrm{Awgb}$ een verbod bevat van ongerechtvaardigd indirect onderscheid. ${ }^{4}$ Indirect onderscheid wordt in deze wet als volgt gedefinieerd:

manier bijzonder en openbaar onderwijs gelijk te behandelen, waarbij eiser de vraag opwierp of daardoor geen onvergelijkbare gevallen gelijk werden behandeld) en ARRS 18 maart 1988, AB 1988/342 (Humanistisch Vormingsonderwijs Oldebroek).

73. Zie infra paragraaf 2.1 .5 en 2.2.3. Een uitzonderlijk geval waarin wel van het concept gebruik werd gemaakt is Oordeel $99-10$ (Leeftijdseis Raio-opleiding). Het verzoek in deze zaak had betrekking op de leeftijdsgrens van (maximaal) 31 jaar bij de toelating tot de opleiding voor de rechterlijke macht. Voor deze leeftijdsgrens bestond een ontheffingsmogelijkheid, waarvan echter geen gebruik kon worden gemaakt bij kandidaten die als gevolg van zwangerschap en kinderzorg niet aan de leeftijdseis voldeden. Anders dan gezien de vaste rechtspraak te verwachten was, oordeelde de Commissie niet dat dit gebruik van de uitzonderingsregeling leidde tot een indirect onderscheid op grond van geslacht. In plaats daarvan stelde de Commissie, dat er "[...] eveneens sprake kan zijn van discriminatie wanneer dezelfde regel wordt toegepast op verschillende situaties. Dit kan met name het geval zijn als het toepassingsbeleid dermate 'gendered' is dat vrouwspecifieke omstandigheden geheel ontbreken bij de beoordeling of kandidaten in aanmerking komen voor ontheffing van de leeftijdsgrens. In die gevallen worden mannen en vrouwen als ongelijke gevallen gelijk behandeld in een mate die de grenzen van de gelijke behandelingsvoorschriften overschrijdt" (r.o. 4.8). Zowel eerder als later is niet van een vergelijkbare benadering gebruik gemaakt.

74. Hetzelfde geldt voor de WGB en voor artikel 7:646 BW: ook daarin is expliciet een verbod van ongerechtvaardigd indirect onderscheid opgenomen (zie artikel 6 WGB en art. 7:646 lid 6 BW); vgl. Wentholt 1999 (II), p. 105. Hierover bestaat een uitgebreide jurisprudentie waarin nadere invulling is gegeven aan het begrip indirect onderscheid en aan de rechtvaardigingsmogelijkheid, ook van de Hoge Raad; zie bijv. HR 24 april 1992, NJ 1992/689 (KLM/Bouma), HR 3 januari 1997, NJ 1997/435 (Zorggroep Oost-Gelderland/Gerrits) en HR 31 maart 2000, JB 2000/133 (Scholingsbesluit bijstandgerechtigden). De WOA (uitgewerkt in art. 7:648 BW en art. $125 \mathrm{~g}$ Ambtenarenwet) verbiedt niet expliciet indirect onderscheid, maar een dergelijk verbod kan in deze ruim geformuleerde bepaling wel worden gelezen; zie Burri 1996, p. 21 en Asscher-Vonk 1997, p. 391/392. 
"indirect onderscheid: onderscheid op grond van andere hoedanigheden of gedragingen dan die bedoeld in onderdeel b [waarin direct onderscheid op een aantal specifieke gronden verboden is gesteld, JHG], dat direct onderscheid tot gevolg heeft."'s

Gezien het feit dat de Awgb slechts direct onderscheid op een limitatief opgesond aantal gronden verbiedt, is dit verbod van indirect onderscheid van groot belang: de civiele rechter, maar vooral ook de Commissie Gelijke Behandeling, zijn hierdoor in staat om onderscheid te beoordelen dat weliswaar gebaseerd is op een neutraal, niet rechtstreeks verboden differentiatiecriterium, maar dat een onderscheid op één van de verboden gronden tot resultaat heeft. ${ }^{76}$ Over de vraag wanneer er sprake is van indirect onderscheid heeft de Commissie Gelijke Behandeling een uitgebreide jurisprudentie ontwikkeld. Interessant is daarbij dat de Commissie goed gebruik heeft gemaakt van haar toetsingsruimte door het ontwikkelen van verschillende nauwkeurig uitgewerkte criteria voor het beoordelen van de aangevoerde rechtvaardiging. In het verloop van dit hoofdstuk zal daaraan dan ook uitgebreid aandacht worden besteed.

\section{Artikel 1, aanhef en sub c Awgb}

76. Voor de praktijk is dit een voordeel, omdat het niet altijd wenselijk is dat direct onderscheid op eten van de limitatief opgesomde gronden per definitie verboden is gesteld. De voorbeelden zijn legio: het kan voor banken of andere bedrijven redelijk zijn om bij krediet- of dienstverlening bij klanten met een be perkte verblijfsvergunning om een borgstelling te vragen (waardoor feitelijk sprake is van een diret onderscheid op de verboden grond van nationaliteit - mensen met een verblijfsvergunning zijn per de finitie geen Nederlanders -, maar waarbij de Commissie koos voor een constructie via indirect onderscheid: Oordeel 97-97 (Paspoortvereiste mobiele telefoon), Oordeel 98-07 (Acceptatiebeleid kreditbank), Oordeel 99-98 (Apparatuurverhuur niet-Nederlanders), Oordeel 00-28 (Acceptatievereiste mobiel telefoonabonnement) en Oordeel 01-26 (Acceptatiebeleid mobiel telefoonabonnement)); voor ect bedrijf kan het wenselijk zijn maatregelen op te leggen aan een werknemer die bij voortduring klanten confronteert met godsdienstige mededelingen en liederen (waarbij gesproken kan worden van cen ofi. rect onderscheid op grond van godsdienstige overtuiging, maar waarover de CGB oordeelde dat dit soort maatregelen feitelijk het gevolg zijn van klachten van klanten en patienten en er dus sprake is van indirect onderscheid: Oordeel 97-148 (Hinderlijke geloofsuitingen) en Oordeel 99-19 (Christelijke fivsiotherapeut)); voor scholen kan het nodig zijn om hoofddoeken of lange mouwen tijdens de gymas: tiekles te verbieden om daardoor de veiligheid van de leerlingen te beschermen (waarbij eveneens gesproken kan worden van een directe benadeling van mensen met een bepaalde godsdienstige oventivi: ging, maar de Commissie aannam dat de benadeling gebaseerd was op veiligheidsoverwegingen (0or deel 97-149 (Hoofddoek tijdens gymles) en Oordeel 98-79 (Lange mouwen bij gymles)); en wort bloedbanken kan het nodig zijn om homoseksuelen als HIV-risicogroep van het doneren van bloed uit te sluiten (de Commissie stelde dat de benadeling was gebaseerd op seksueel risicovol gedrag: Oorded 98-137 (Homoseksuele bloeddonoren)) (vgl. ook Wentholt 2000 (II), p. 110/111). Door de construtic via indirect onderscheid creeterde de Commissie in deze gevallen een mogelijkheid om het absolitit verbod van direct onderscheid te omzeilen. Deze soepelheid kent overigens zijn grenzen: zo wordt onderscheid op grond van zwangerschap steeds aangemerkt als verboden onderscheid op grond van g* slacht, zelfs wanneer voor het maken van een dergelijk onderscheid een zwaarwegende en overtuigtr de rechtvaardiging bestaat. Gezien de wat gewrongen aandoende constructies die de Commissie sons heeft gekozen en gezien de hardheid van de gevolgen die het verbod van direct onderscheid in conctht situaties kan hebben, is door verschillende auteurs gepleit voor een versoepeling van het "gesloten" stelsel (bijv. Wentholt 1999 (II), m.n. p. 127-130 en Vegter 2000 (1), p. 120/121). De Commissie zeff stelde in haar evaluatierapport in 1999 echter dat het voor de rechtszekerheid wenselijk is het gesloter systeem te handhaven. Wel zij gaf toe dat het mogelijk moet zijn de wet buiten toepassing te laten in gevallen waarin wetstoepassing zou leiden tot absoluut onaanvaardbare resultaten (Evaluatierappunt 2000 , p. 24/25; kritisch hierover Vegter 2000 (1), p. 124). 
Van belang is verder dat in de meeste Europeesrechtelijke bepalingen die in de Nederlandse rechtsorde doorwerken of die zijn omgezet in Nederlands recht een verbod van ongerechtvaardigd indirect onderscheid besloten ligt: zoals in hoofdstuk 4 is angegeven vormt dit één van de vaste uitgangspunten van de Europese jurisprudentie. ${ }^{7} \mathrm{Nu}$ de Nederlandse rechter gehouden is om de uitleg van het Hof te volgen ${ }^{78}$, is het concept van indirect onderscheid regelmatig in de Nederlandse jurisprudentie over de Europeesrechtelijke gelijkheidsbepalingen terug te vinden. ${ }^{79}$

Van belang is daarbij dat het Europeesrechtelijke concept van indirect onderscheid veel vrijheid laat bij het vaststellen van de aanwezigheid van een benadelend effect en bij het beoordelen van de aangevoerde rechtvaardiging. Op nationaal niveau is deze ruimte enigszins beperkt doordat de rechter gebruik dient te maken van de door het Europees Hof ontwikkelde criteria: een volledig eigen toetsingsmethodiek kan hij daardoor niet

77. Zie paragraaf 1.2 .1 van hoofdstuk 4 .

78. Zie hiervoor paragraaf 1.1.4.

79. Vgl. Dierx/Siegers 1990, p. 554 en Goldschmidt/Jaspers/Loenen 1990, p. 279. Van belang is vooral de rechtspraak van de Centrale Raad van Beroep: zoals in paragraaf 1.1.4 is gebleken wordt vooral in zaken over de sociale zekerheid regelmatig een beroep gedaan op gelijkheidsbepalingen van Europeesrechtelijke afkomst. Zie bijv. CRvB 28 september 1989, RSV 1990/235 (Medeverzekering ZFW), CRvB 19 april 1990, RSV 1990/323 (Teuling-Worms), CRvB 9 april 1991, RSV 1991/247 (Drie-uitvijf-eis), CRvB 15 mei 1991, RSV 1991/158 (Pensioenopbouw buitenlandse werknemer), CRvB 23 mei 1991, RSV 1991/257 (Overgang AAW naar AWW), CRvB 23 juni 1992, RSV 1992/317 (Inkomenseis AAW), CRvB 18 juni 1993, RSV 1994/68 (Samenloop AAW-uitkeringen), CRvB 20 september 1995, AB 1996/20 (Kostwinnerscriterium ZFW), CRvB 29 april 1996, RSV 1996/247 (WWuitkering huishoudelijk personeel), CRvB 17 oktober 1996, RSV 1997/235 (Rariteitenbesluit WAO), CRvB 16 januari 1998, RSV 1998/160 (Inkomensvereiste AAW), CRvB 12 augustus 1999, RSV $2000 / 73$ (Inkomensvereiste thuiswerkers), CRvB 4 januari 2000, RSV 2000/79 (Noodzakelijke scholing Abw) en CRvB 21 september 2000, JB 2000/313 (Scholierenregeling). Ook in de rechtspraak van de andere rechterlijke instanties zijn voorbeelden te vinden. Zie HR 25 november 1988, NJ 1989/730 (Stichting Centrum voor Onderwijsbegeleiding/Pot), HR 4 november 1992 (belastingkamer), BNB 1993/102 (Inkomstentoerekening bij gehuwden) en ABRS 4 augustus 1998, AB 1998/377 (Loting geneeskunde). Overigens was de Afdeling aanvankelijk weigerachtig bij het erkennen van het concept van indirect onderscheid. Dit wordt geillustreerd door ABRS 5 juli 1994, AB 1995/180 (Vrijlatingsregeling), een zaak die betrekking had op een beperking van de werking van de zogenaamde vrijlatingsregeling (op grond waarvan eigen inkomsten niet volledig op de bijstandsuitkering werden gekort) tot gevallen waarin iemand door individuele omstandigheden geen volledig dienstverband heeft. Door deze regeling werd onderscheid naar arbeidsduur gemaakt, hetgeen volgens vaste rechtspraak van het Europese Hof vrijwel per definitie een indirect onderscheid op grond van geslacht oplevert. Door appellant werd dan ook een beroep op het Europese recht gedaan. De Afdeling leek echter niet op de hoogte te zijn van de Europese rechtspraak en oordeelde als volgt: "De Afdeling Bestuursrechtspraak is van oordeel dat de in het geschil zijnde beèindiging van de vrijlatingsfaciliteit niet een direct of indirect discriminerend resultaat ten opzichte van appellant heeft dan in het geval van een vrouw die in een soortgelijke situatie als die van appellant een volledige dienstbetrekking met inkomsten op het voor die situatie geldende minimumloon-niveau zou verwerven." Met deze overweging stelde de Afdeling alleen vast dat er geen direct onderscheid op grond van geslacht was gemaakt - over de klacht dat het gehanteerde onderscheidingscriterium zelf discriminatoire effecten zou hebben werd niet gerept; zie in vergelijkbare zin de noot van Holtmaat bij deze uitspraak. Ook de Centrale Raad blijkt in sporadische gevallen niet bereid te zijn om onderzoek te verrichten naar de effecten van een bepaald onderscheid. Zie bijv. CRvB 24 november 1992, RSV 1993/147 (Werkloze zeelieden), dat betrekking had op het in de $A K W$ vervatte eis van ingezetenschap; de $C R v B$ was niet geneigd om uit eigen beweging na te gaan of door deze eis wellicht indirect onderscheid op grond van geslacht werd gemaakt, zoals door het Europees Hof toch regelmatig wordt aangenomen (zie hoofdstuk 4, paragraaf 2.2.3). 
meer ontwikkelen. ${ }^{80}$ In hoofdstuk 4 is echter al aangegeven dat de antwoorden van het Hof op prejudiciële vragen zelden erg gedetailleerd zijn. In veruit de meeste gevallen wordt de beoordeling van belangrijke elementen als noodzakelijkheid en geschiktheid overgelaten aan de nationale rechter. ${ }^{81}$ Daardoor is deze in de gelegenheid om een nade. re invulling te geven aan de door het Hof vastgestelde criteria, hetgeen voor de ontwikkeling van een algemeen toetsingsmodel van bijzonder belang kan zijn. Aan deze rechtspraak zal in het verloop van dit hoofdstuk dan ook bijzondere aandacht worden besteed.

Uit de tekst van de overige gelijkheidsbepalingen die van belang zijn voor het Nederlandse recht (artikel 1 Grondwet, artikel 14 EVRM en artikel 26 IVBPR) is niet duide. lijk af te leiden of ook indirect onderscheid onder hun reikwijdte kan worden gebracht. Het is bij deze bepalingen ook niet noodzakelijk om gebruik te maken van dit concept. de opsommingen van de verboden differentiatiecriteria zijn in geen van de genoemde bepalingen limitatief. Dit betekent dat voor iedere ongelijke behandeling kan worden nagegaan of er een objectieve rechtvaardiging bestaat, ongeacht de grond van onderscheid. In de rechtspraak van de Hoge Raad en de Afdeling, die het meest met deze bepalingen te maken hebben, is het concept van indirect onderscheid hierdoor zelden terug te vinden. ${ }^{82}$

80. Zie paragraaf 1.1.4.

81. Dit geldt vooral voor de uitspraken die betrekking hebben op ongelijke behandeling op grond val geslacht: zie paragraaf 1.4 en 2.4 .I van hoofdstuk 4 .

82. Vgl. "Gelijk in de praktijk 1990", p. 26. De Centrale Raad gaf zelfs expliciet aan dat de vrag of er indirect of direct onderscheid gemaakt werd bij artikel 26 IVBPR niet interessant was, omdat en rechtvaardiging hierbij toch altijd moet worden aangetoond; zie CRvB 12 februari 1997, RSV $1997 / 227$. Sporadische voorbeelden van toetsing van indirect onderscheid bestaan wel, maar daarbij is niet altijd duidelijk waarom er nu eigenlijk met het concept gewerkt wordt. Meestal kan dit alleen wor den verklaard doordat partijen een beroep op het concept hebben gedaan in de hoop dat dit een ander toetsing oplevert of omdat bekend is dat onderscheid op een bepaalde grond niet snel gerechtvaardigy. wordt geacht. Zie bijv. HR 13 januari 1995, NJ 1995/430 (Codfried/ISS), CRvB 30 augustus 1999, RSV 1990/92 (Onderhoudsbijdrage AKW), CRvB 9 mei 1990, RSV 1990/383 (AWW-uitkering bij huwelijk met gepensioneerde), CRvB 17 maart 1992, AB 1992/419 (Wooneis AAW I), CRvB 14 april 1992, RSV 1993/42 (Intrekking arbeidsongeschiktheidsuitkering), CRvB 3 november 1992, RSV 1994/114 (Wooneis AAW II), CRvB 19 april 1994, RSV 1994/225 (Wooneis AAW III), CRvB 21 juni 1994, AB 1995/106 (Wooneis AAW IV) en CRvB 16 januari 1998, RSV 1998/160 (Inkomensvereists AAW). Ook de Afdeling krijgt soms te maken met een expliciet beroep op het concept van indiret of derscheid. Zij lijkt dan echter niet geheel te begrijpen welke betekenis dit concept heeft. Hiervoor is daarvan al een voorbeeld gegeven voor het Europese recht (zie noot 79), maar ook daarbuiten kotill soms een vreemde benadering naar voren, zoals in ABRS 28 februari 1995, AB 1995/439 (Tertitoritliteitsbeginsel IOAW). In deze zaak stelde eiser dat een indirect onderscheid werd veroorzaakt doortse
feit dat bij de bepaling van de hoogte van een IOAW-uitkering alleen rekening werd gehouden met zinsleden die in één van de lidstaten van de EU woonden. De Afdeling stelde hierover slechts dat vin - indirecte - discriminatie naar nationaliteit, zoals appellant stelt, [geen sprake is] [...], mede geter op het feit dat art. 5, tweede lid IOAW gelijkelijk geldt voor Nederlanders en vreemdelingen [...]". Op. nieuw zag de Afdeling over het hoofd dat er bij indirect onderscheid niet gekeken moet worden nard classificatie als zodanig, maar naar de discriminatoire effecten ervan; vgl. de noot van Holtmast bij to ze uitspraak. Van belang is overigens dat de Afdeling in ieder geval wel aanvaardde dat ook indirat onderscheid onder de reikwijdte van artikel 26 IVBPR valt, getuige de tussenvoeging "indirect onderscheid" in de geciteerde overweging. 


\subsection{Horizontale en verticale werking}

Net als voor de erkenning van de concepten van materieel en indirect onderscheid, geldt voor de erkenning van horizontale werking dat deze in sterke mate afhankelijk is van de aard van de betrokken gelijkheidsbepaling. Voor artikel 1 van de Grondwet geldt bijvoorbeeld dat niet vaststaat of deze bepaling kan worden ingeroepen in verhoudingen tussen burgers onderling. ${ }^{\mathrm{s}}$ Weliswaar is daar bij de discussies over de vormgeving van de Grondwet wel voor gepleit, maar het is niet geheel duidelijk geworden welke opvatting de grondwetgever hier nu precies over koesterde. ${ }^{44}$ Voor de internationale verdragsbepalingen is de situatie wel duidelijk: zij richten zich uitsluitend tot de overheid en niet tot burgers onderling. Zoals in hoofdstuk 3 is beschreven is dit voor artikel 14 zelfs uitdrukkelijk door het Europees Hof voor de Rechten van de Mens vastgesteld. ${ }^{\text {.s }}$ Van belang is echter dat de civiele kamer van de Hoge Raad zich bereid heeft getoond enige horizontale werking aan deze bepalingen toe te kennen, bijvoorbeeld door het hierin tot uitdrukking komende algemene gelijkheidsbeginsel te kwalificeren als algemeen beginsel van privaatrecht $t^{86}$ of door het in te lezen in andere privaatrechtelijke beginselen, zoals de redelijkheid en billijkheid ${ }^{87}{ }^{8 x}$ Dit betekent dat de burger die is geconfronteerd met een normatieve classificatie in een horizontale verhouding (bijvoorbeeld een discriminatoire beloningsregel of een huisregel van een discotheek op grond waarvan allochtonen van toegang worden uitgesloten) of met bloot

83. De bepaling kan wel worden ingeroepen in verhoudingen waarbij de overheid partij is: algemeen wordt aanvaard dat de overheid ook als privaatrechtelijke actor aan de grondrechten gebonden is. $\mathrm{Vgl}$. Burkens 1989 (I), p. 173/174.

84. Gesteld is wel dat de grondwetgever horizontale werking impliciet aanvaardde door te verwijzen naar de zogenaamde glijdende schaal. Dit betekent dat de mate van horizontale werking afhankelijk is van het karakter van de betrokken grondrechtelijke bepaling (zie Burkens 1989 (I), p. 171). Voor het gelijkheidsbeginsel is niet nader aangegeven welke gradatie van horizontale werking hieraan toekomt; vgl. Vis 1988, p. 50. Deze onduidelijkheid heeft tot gevolg dat er ook in de literatuur verschillende opvattingen zijn terug te vinden. Door sommigen is aangenomen dat artikel 1 Grondwet niet rechtstreeks in horizontale verhoudingen inroepbaar is (zie de conclusie van A-G Leijten bij HR 9 januari 1987, $1987 / 928$ (Bespiede bijstandsmoeder)), of dat alleen de tweede zin (het discriminatieverbod) horizontale werking heeft (vgl. Van der Hoeven 1983, p. 198/199). Meer algemeen aanvaard is de gedachte dat de rechter moet beoordelen in hoeverre de bepaling in strikt horizontale verhoudingen kan worden toegepast en op welke manier dit moet gebeuren; bijv. Van der Grinten 1984, p. 15.

85. Zie paragraaf 1.4 van hoofdstuk 3 . Zie over het ontbreken van horizontale werking bij artikel 26 nader Alkema 1987, p. 82. De Nederlandse regering heeft op vergelijkbare wijze als bij de Grondwet aangegeven dat doorwerking in horizontale verhoudingen bij deze bepaling niet ondenkbaar is; de vraag op welke manier en in welke mate dit mogelijk is heeft zij niet beantwoord. Zie de Memorie van Toelichting bij de goedkeuringswet, TK 1975-1976, 13932 (R 1037), nrs. 1-6, p. 35

86. Zie bijv. HR 10 december 1982, NJ 1983/687 (Binderen/Kaya). De Hoge Raad stelde in dit geval overigens niet met zoveel woorden dat het gelijkheidsbeginsel een algemeen beginsel van privaatrecht vormt. Wel komt deze kwalificatie uitdrukkelijk naar voren in het oordeel van de president van de Rechtbank in deze zaak.

87. Zie bijv. HR 8 april 1994, NJ 1994/704 (Agfa); vgl. Leenders 1997, p. 143.

88. De civiele kamer van de Hoge Raad past het gelijkheidsbeginsel vaak toe in horizontale verhoudingen, zonder zich nader uit te spreken over de exacte grondslag daarvoor. Zie bijv. HR 30 maart 1984, NJCM 1984, 253 (Suikerfeest), HR 7 mei 1993, RvdW 1993/101 (Ongehuwde onderwijzeressen), HR 13 januari 1995, NJ 1995/430 (Codfried/ISS), HR 3 januari 1997, NJ 1997/435 (Zorggroep OostGelderland/Gerrits) en HR 7 november 1997, NJ 1998/399 (Levi/Zaanwerk). Vgl. Heringa 1994, p. 862 en Van Bijsterveld 2000, p. 69. 
onderscheid (bijvoorbeeld afwijzing van een sollicitante vanwege het dragen van een hoofddoek), een redelijke kans maakt dat de Hoge Raad de ongelijke behandeling inhoudelijk zal beoordelen.

Duidelijk is de situatie ook voor het Europese recht en voor de gelijkheidsbepalingen die in formele wetgeving zijn neergelegd, zoals de Awgb en de WOA. Voor het Europese recht is al in hoofdstuk 4 aangegeven dat de relevante bepalingen niet alleen betrekking hebben op de verhouding tussen overheid en burger, maar ook op de verhou. ding tussen burgers onderling. ${ }^{89}$ Met name op het gebied van het arbeidsrecht is de Europese regelgeving met betrekking tot gelijke beloning, voorkeursbeleid en arbeidsvoorwaarden van groot belang; hierop wordt bij de civiele rechter dan ook regelmatig een beroep gedaan.

Voor de Awgb en andere specifieke gelijke behandelingswetten als de WGB en de WOA geldt dat hun reikwijdte zelfs beperkt is tot horizontale verhoudingen: deze wetgeving kan niet worden ingeroepen bij handelen van de overheid, tenzij deze optreedt in zijn hoedanigheid als werkgever ${ }^{* 0}$ of anderszins als privaatrechtelijke actor is te beschouwen ${ }^{11} .{ }^{12}$ Op regelingen van sociaal recht, bestemmingsplannen of subsidiever.

89. Zie paragraaf 1.3 van hoofdstuk 4. Voor de doorwerking van het Europese recht in de nationale rectisorde kan daarover enige twijfel bestaan, vooral wanneer gelijkheidsbepalingen zijn neergelegd in richtlijnen. Wanneer deze niet, niet tijdig of onjuist worden omgezet kan hieraan wel een met dircte toepasselijkheid vergelijkbare werking worden toegekend, maar deze geldt alleen voor verticale ver: houdingen. Zelfs wanneer een richtlijn uitdrukkelijk bedoeld is om in horizontale verhoudingen rect. ten te scheppen of verplichtingen op te leggen, kan deze werking hieraan ontbreken wanneer de richl. lijn niet, zoals vereist, goed in nationaal recht is omgezet. Zie nader EHvJ 14 juli 1994, zaak C.9192, Paola Facchini Dori, Jurispr. 1994, 1-3325. Uit dit arrest blijkt wel dat de rechter in dit soort gevallan moet proberen de nationale regelgeving zoveel mogelijk uit te leggen in overeenstemming met de bs trokken richtlijn, waardoor soms toch een vorm van horizontale werking kan worden gecreterd.

90. Zoals blijkt uit artikel $125 \mathrm{~g}$ Ambtenarenwet, waarin onderscheid op grond van arbeidsduur door \& overheid als werkgever uitdrukkelijk verboden is gesteld. Een soortgelijke bepaling is terug te vinden in artikel 5 lid 1 sub c Awgb. Dit is ook logisch, omdat het bij arbeidsvoorwaarden feitelijk niet va belang is of de werkgever een particulier is of een overheidsorgaan (zie de Memorie van Toeliching bij de Awgb, TK 1990-1991, 22 014, nr. 3, p. 16-17)

91. Klassieke voorbeelden zijn die waarin een overheidsorgaan overgaat tot de aanschaf van apparaturur of wanneer het optreedt als pachter van woningen. Zie expliciet artikel 7 lid 1 sub b Awgb: "Onderscheid is verboden bij het aanbieden van goederen of diensten en bij het sluiten, uitvoeren of beeindigen van overeenkomsten ter zake, alsmede bij het geven van school- of beroepskeuze, indien dit geschiedt [. b. door de openbare dienst [...]". Zie hierover nader de MvT, TK 1990-1991, 22 014, nr. 3, p. 20 en 21 en de MvA, TK 1991-1992, 22 014, nr. 5, p. 88: reden voor het verbod is dat de overheid zich ook in horizontale verhoudingen moet onthouden van discriminatie. De "openbare dienst" is blijkens de wetsgeschiedenis een ruim begrip: hieronder vallen niet alleen openbare lichamen als de staat, de provincie en de gemeenten, maar ook door hen beheerde ondernemingen, zoals energie- en spoorwegbedrijeti Dit is vooral van belang omdat het niet geheel voor de hand ligt dat handelen van de overheid op privaatrechtelijk vlak rechtstreeks op zijn verenigbaarheid met het gelijkheidsbeginsel kan worden beoverdeeld: tot 1987 nam de Hoge Raad consequent aan dat toetsing aan dit beginsel slechts via het vetbod van willekeur mogelijk was (in het arrest Amsterdam/lkon ging de Hoge Raad om: HR 27 maart 1987? NJ 1987/727; zie verder voor een rechtstreekse toetsing HR 22 maart 1991, NJ 1994/170 (Amster dam/Ikon II) en, meer impliciet, HR 26 maart 1999, NJ 1999/446 (Erfpachters Den Haag)).

Ditzelfde lijkt te gelden voor de strafrechtelijke discriminatieverboden, zoals artikel 429 quater Sr. ool deze bepaling richt zich alleen tot horizontale situaties en niet tot de overheid. Zie Van der Neut 1986 p. 42 , die overigens aangeeft dat onduidelijk is of deze opvatting verenigbaar is met het IVRD, wavive de bepaling is gestoeld. Artikel $137 \mathrm{~g} \mathrm{Sr}$, waarin opzettelijke discriminatie strafbaar is gesteld, nith 
lening zijn deze bepalingen dan ook niet van toepassing, zodat klachten over dergelijke regelingen of handelingen zullen worden afgewezen. ${ }^{.3} \mathrm{Om}$ tegen overheidshandelen in puur verticale situaties op te kunnen komen zal de burger naar de bestuursrechter moeten stappen en een beroep moeten doen op een bepaling als artikel 26 IVBPR of op het gelijkheidsbeginsel als algemeen beginsel van behoorlijk bestuur.

\subsection{Verschillen tussen de tot toetsing bevoegde instanties; opzet van het hoofdstuk}

Zoals uit het voorgaande reeds is gebleken is in het kader van dit onderzoek gekeken naar de uitspraken van verschillende rechterlijke instanties. Onderzocht is de rechtspraak van de Hoge Raad, waarbij aandacht is besteed aan de rechtspraak van de civiele kamer, de belastingkamer en de strafkamer, de rechtspraak van de Centrale Raad van Beroep, van de Afdeling Bestuursrechtspraak van de Raad van State en van de Commissie Gelijke Behandeling. ${ }^{4}$ De toetsingsmethodiek van deze instanties blijkt sterk uiteen te lopen, zelfs wanneer zij een oordeel moeten uitspreken over identieke

zich daarentegen wel op discriminatie door ambtenaren, zodat gesteld kan worden dat hieraan enige verticale werking toekomt. In een dergelijk geval zal echter steeds de individuele ambtenaar en niet het bestuursorgaan of -lichaam worden vervolgd.

93. Hetgeen overigens niet betekent dat de Awgb nooit van toepassing kan zijn op normatieve classificaties die zijn neergelegd in formele wetgeving, algemene maatregelen van bestuur, ministeriële regelingen of andere van de overheid afkomstige algemeen verbindende voorschriften: een toepassing is denkbaar wanneer dergelijke maatregelen betrekking hebben op het werkingsgebied van de Awgb, doordat zij arbeids- of salarisvoorwaarden regelen of een algemene regeling geven voor het verlenen van diensten. Zie bijv. Oordeel 466-93-34 (Anciěnniteit deeltijdrechters) (met betrekking tot de benoemingsregeling in de Wet RO), Oordeel 531-93-47 (Inverdienregeling) (met betrekking tot een soort studiefinancieringsregeling voor huisartsen), Oordeel 97-06 (Kostenbijdrage maaltijden militairen), Oordeel 97-84 (Pas 65), Oordeel 97-112 (Termijnen vliegbevoegdheid), Oordelen 97-127 V/m 130 (Diacritische tekens), Oordeel 98-73 (Verklaring van geen bezwaar), Oordeel 98-124 (Registratie echtgenoten als aandeelhouder), Oordeel 00-39 (Overgangsregeling Gezondheidszorgpsychologen) en Oordeel 00-90 (Vaccinatieprogramma Hepatitis B). Ook interessant zijn de oordelen met betrekking tot de Abp-wet, zoals Oordeel 97-145 (Pensioenopbouw vervangster voortgezet onderwijs), Oordeel 99-02 (Pensioenopbouw vervangster basisonderwijs) en Oordeel 00-06 (Pensioenopbouw oproepkracht), de verschillende oordelen over de interimuitkering ziektekosten voor ambtenaren (Oordeel 95-27 en 28 (IRZK 1982) en Oordeel 97-140 (ZKOO-regeling)), en de diverse oordelen over de voor het openbaar onderwijs geldende beloningsregelingen (o.a. Oordelen $348 \mathrm{t} / \mathrm{m}$ 351-92-61 t/m 64, Oordeel 358-92-65, Oordeel 367-92-66, Oordeel 364-92-71, Oordeel 171-92-71, Oordeel 95-17 (BBRa'84 en Rbpo), Oordeel 96-07 en 08 (Rpbo), Oordeel 96-71, Oordeel 97-54 en 55, Oordeel 98-28, Oordeel 00-99 (HOSregeling) en Oordeel 01-20 (Rpbo)).

94. Dit betekent dat geen onderzoek is verricht naar de rechtspraak van bijzondere bestuursrechtelijke instanties, zoals het College van Beroep voor het Bedrijfsleven en het College van Beroep voor de Studiefinanciering, hoewel ook zij interessante uitspraken hebben gedaan; zo heeft het CBB veel te maken gekregen met beroepen op het Europeesrechtelijke verbod van discriminatie op grond van nationaliteit, waarmee de onderzochte rechterlijke instanties slechts bij uitzondering in aanraking komen. Ook is niet gekeken naar de rechtspraak van lagere rechters, zoals de kantongerechten (die veel zaken over ongelijke behandeling in het arbeidsrecht behandelen) of de Ondernemingskamer (die veel met Europees recht te maken heeft). De reden daarvoor is uitsluitend gelegen in de noodzaak tot beperking van de reikwijdte van het onderzoek, om op die manier de hoeveelheid te bestuderen rechtspraak en de beschrijving daarvan overzichtelijk te houden. Gekozen is daarom voor een beperking tot de belangrijkste en meest representatieve rechterlijke instanties; de oordelen van de Commissie Gelijke Behandeling zijn bestudeerd omdat deze instantie zich specifiek met toetsing van ongelijke behandeling bezig 
gelijkheidsbepalingen. Gewezen is al op de benadering die wordt gekozen bij het buj. ten toepassing laten van een wettelijke classificatie wegens strijd met artikel 26 IVBPR: waar de civiele kamer van de Hoge Raad hiertoe niet vaak overgaat vanwege vermeende beperkingen in de omvang van de rechterlijke taak, hebben de belastingka. mer en de Centrale Raad van Beroep een veel minder terughoudende opstelling geko. zen. Ook is gewezen op de contra legem-werking van het gelijkheidsbeginsel, die door de belastingrechter heel gemakkelijk en door de Afdeling vrijwel nooit wordt geaccepteerd. Belangrijke verschillen zijn echter ook op andere punten aanwezig. Interessant is bijvoorbeeld dat de strafkamer van de Hoge Raad en de Centrale Raad hebben gesteld dat alleen onderscheid op grond van persoonskenmerken is verboden; onderscheid op grond van andere kenmerken zou niet onder de reikwijdte van het gelijkheidsbeginsel vallen en hoeft dus ook niet op zijn redelijkheid te worden beoordeeld. ${ }^{55}$ In de rechtspraak van de andere rechterlijke instanties is dit nooit als uitdrukkelijk vereiste gesteld; zo heeft de belastingrechter consequent aanvaard dat onderscheid ook aan een rechtvaardigingstoets moet worden onderworpen als dit is gebaseerd op volstrekt niet persoonsgebonden gronden, zoals de waarde van onroerende zaken of de hoeveetheid afval die in een riool wordt gestort."

Ook hierna, bij de bespreking van de toetsingsmethodiek, zal blijken dat er weinig eenheid bestaat in de methodiek die de instanties volgens hun rechtspraak hebben gekozen: bij vrijwel alle onderdelen van de toetsing zijn verschillen zichtbaar, variërend van het belang dat aan de vergelijkbaarheidstoets wordt gehecht tot de noodzaak van het uitvoeren van een geschiktheidstoets.

Voor een belangrijk deel zijn deze verschillen in benadering te verklaren vanuit bijzondere kenmerken van de instanties zelf. Voor de Commissie Gelijke Behandeling geldt bijvoorbeeld dat zij is ontworpen als een laagdrempelige instantie die op gespeciallseerde wijze ongelijke behandelingen kan beoordelen en daarbij rekening houdt met de vaak kwetsbare positie van de benadeelden. ${ }^{.7}$ Dit heeft onder andere tot resultaat dat de Commissie zich in de meeste zaken actief opstelt, bijvoorbeeld door zelf onderzoek te verrichten naar de aanwezigheid van een indirect onderscheid of door nauwkeurig nate gaan of de doelstelling van de ongelijke behandeling ook op een andere, minder belastende manier kon worden bereikt. ${ }^{9 k}$ Bestuursrechters kiezen daarentegen meestal voor een grotere mate van terughoudendheid, waarbij meer activiteit wordt gevraagd van de partijen en waarbij al snel wordt aanvaard dat daarvoor een rechtvaardiging bestaat. Dit

95. Zie HR 10 maart 1981 (strafkamer), NJ 1981/385 (Antenne-inrichting Nozema) en CRvB 4 juni 1987, SV 1988/1016 (Korting WUV-uitkering). Bij de strafkamer kan deze benadering worden verkland door het feit dat in deze zaak artikel 14 EVRM werd toegepast; in hoofdstuk 3, paragraf 1.2, is al vastgesteld dat het Europees Hof voor de Rechten van de Mens heeft aangenomen dat alleen onder. scheid op grond van persoonskenmerken verboden is. Dit verklaart ook waarom in dit soort gevallen later aan het ongeschreven gelijkheidsbeginsel (en dus niet meer aan het EVRM) is getoetst, zie bijy. HR 13 januari 1987 (strafkamer), NJ 1987/917 (Klein geel kenteken), waarin de Hoge Raad een in. houdelijke beoordeling gaf van een regeling met betrekking tot de maat van het kenteken op auto's.

96. Zie bijv. HR 24 september 1980 (belastingkamer), AB 1983/1 (Onroerendgoedbelasting Scheemda I) en HR 20 september 1995 (belastingkamer), BNB 1995/315 (Afvalwater).

97. Zie Van Vleuten/Willems 1999, p. 245.

98. Vgl. Evaluatierapport 2000, p. 43/44, Leenders 2000, p. 80, Goldschmidt 1998, p. 50 en Van Vletrten/Willems 1999, p. 235 en 261. 
vindt een verklaring in een klassieke opvatting over de scheiding der machten, waarbij wordt aangenomen dat de rechter niet te actief mag zijn bij het toetsen van wetgeving of bestuurshandelen. Een zelfstandig onderzoek naar de aanwezigheid van een ongelijke behandeling zou in die visie niet goed passen, net zomin als een vergaande toetsing van de aangevoerde rechtvaardiging. ${ }^{99}$ Van belang is wel dat in het bestuursrecht een viij soepele bewijsregeling geldt, waarbij de rechter de mogelijkheid heeft om zelf onderzoek te verrichten als dit nodig mocht zijn. ${ }^{100}$ Vooral de Centrale Raad lijkt daarvan nog wel eens gebruik te willen maken, hetgeen soms resulteert in een vrij actieve opstelling. ${ }^{101}$ De civiele rechtspraak kenmerkt zich tenslotte door lijdelijkheid van de rechter, hetgeen betekent dat de partijen zelf volledig verantwoordelijk zijn voor het aandragen van de feiten en rechtsgronden die de basis voor de beslissing vormen. ${ }^{112}$ In gelijke behandelingszaken levert deze lijdelijkheid soms problemen op: een benadeelde werknemer zal bijvoorbeeld niet altijd in staat zijn om voldoende statistische gegevens te verzamelen om een indirect onderscheid door zijn werkgever aan te tonen. Dit heeft tot gevolg dat klachten bij de civiele rechter vaak maar een kleine kans van slagen hebben. ${ }^{103}$

Met dit soort typische kenmerken moet, evenals met de bijzondere toetsingseisen die voortvloeien uit de specifieke gelijkheidsbepalingen, terdege rekening worden gehouden bij de analyse en beoordeling van de toetsingsmethodiek van de verschillende rechters: vaak kan juist hierin een verklaring worden gevonden voor opvallende afwijkingen van een door andere rechters gevolgde lijn.

99. Verschillen tussen de bestuursrechters onderling zijn niet altijd zo gemakkelijk te verklaren. Zo is het niet duidelijk waarom de belastingrechter contra legem-werking zoveel sneller erkent dan de Afdeling: voor beide rechters is het legaliteitsbeginsel van bijzonder belang (voor het belastingrecht is dit beginsel zelfs expliciet in de Grondwet opgenomen: zie artikel 104), terwijl zij beide te maken hebben met de problematische consequentie dat een tegenwettelijk beleid mogelijk in een groot aantal gevallen moet worden voortgezet.

100. Het gaat hierbij om de zogenaamde vrij-bewijsleer: er bestaan in het bestuursrecht vrijwel geen materieel bewijsrechtelijke regels, waardoor de bestuursrechter grote vrijheid heeft bij het verdelen van de bewijslast, het bepalen van de toelaatbaarheid van bewijsmiddelen en het waarderen van de bewijskracht (Van Wijk/Konijnenbelt 1999, p. 574); verder blijkt uit artikel 8:69 lid 3 Algemene wet bestuursrecht blijkt dat de bestuursrechter ambtshalve bevoegd is de feiten aan te vullen, waardoor in beginsel ruimte wordt gecreëerd voor een actieve rechterlijke rol. Zie nader Leenders 1997, p. 30 en Burkens/Kummeling 1991, p. 13.

101. Een voorbeeld van een dergelijk eigen onderzoek is te vinden in CRvB 21 maart 1990, RSV 1990/320 (Vakantiebonnen): de Centrale Raad vergeleek in deze zaak, om tot een oordeel te kunnen komen over het bestaan van een ongelijke behandeling, de gedingstukken met die van een andere, op dat moment eveneens aanhangige, zaak over hetzelfde onderwerp.

102. Zie Van den Oord 1990, p. 227, Leenders 1997, p. 14/15 en Burkens/Kummeling 1991, p. 12; de laatsten geven wel aan dat de rechter via het concept van redelijkheid en billijkheid nog wel eens corrigerend kan optreden en de bewijslast kan verschuiven. Een actief eigen onderzoek lijkt echter niet binnen de mogelijkheden te liggen. Overigens is het mogelijk dat er in deze voor klagers nadelige situatie verandering komt door implementatie van de eerdergenoemde RI. 2000/78/EG van de Raad van 27 november 2000 tot instelling van een algemeen kader voor gelijke behandeling in arbeid en beroep $(\mathrm{Pb}$. EG 2000 L 303/16). Deze richtlijn verbiedt onderscheid op een groot aantal gronden en bevat een aantal bepalingen over bewijslastverdeling die de bewijspositie van de individuele klager iets lijken te verlichten; zie Leenders 2000 , p. 82 . Ook deze bepalingen zullen er echter niet automatisch voor zorgen dat de rechter zich zelf actiever opstelt; het gevolg voor het civiele recht zal uitsluitend zijn dat de

103. $\mathrm{Vgl}, \mathrm{Van}$ in sommige gevallen van eiser/klager verschuift naar de verwerende partij. 
In het hiernavolgende zal worden nagegaan op welke manier de verschillende Neder. landse instanties hun toetsing aan het gelijkheidsbeginsel vorm hebben gegeven. Daar. bij zal een vergelijkbare werkwijze worden gekozen als in de eerdere rechtsvergelij. kende hoofdstukken. Dit betekent dat allereerst een overzicht zal worden gegeven van de algemene toetsingsmethodiek die door de verschillende instanties wordt gekozen (paragraaf 2.1). Vervolgens zal nader worden ingegaan op de verschillende onderdelen van de toetsing, waarbij het theoretische toetsingsmodel dat in hoofdstuk 2 is ontwikkeld tot uitgangspunt wordt genomen: nagegaan wordt in hoeverre de toetsing door de Nederlandse rechters daarmee overeenstemt en op welke punten de rechtspraak afwijkingen laat zien (paragraaf 2.2 tot en met 2.4). Daarna zal in paragraaf 3 aandacht worden besteed aan de intensiteit van de toetsing; ook voor Nederland is immers de vraag in hoeverre de intensiteit varieert en welke factoren daarbij een rol spelen. Tenslotte zullen in hoofdstuk 4 enkele algemene bevindingen worden neergelegd met betrekking tot de toetsingsmethodiek in Nederland en de consequenties daarvan voor het ontwikkelen van een algemeen toetsingsmodel.

\section{Toetsingsmethodiek}

\subsection{Algemene beschrijving van de methodiek van de verschillende instanties}

\subsubsection{Toetsingsmethodiek van de Hoge Raad - civiele en strafkamer}

\section{Inleiding}

In veruit de meeste zaken over gelijke behandeling waarmee de civiele en strafkamer van de Hoge Raad te maken hebben wordt geklaagd over een normatieve classificatie. Weliswaar wordt in een enkel geval uitsluitend de concrete toepassing van een algemene regeling door een bestuursorgaan (zoals ook het $\mathrm{OM}$ ) aan de orde gesteld, maar het gaat daarbij om een zo beperkt aantal uitspraken dat het lastig is om uit die rechtspraak algemene conclusies af te leiden met betrekking tot de gehanteerde methodiek. ${ }^{10}$ Dezz rechtspraak zal in het hiernavolgende dan ook grotendeels buiten beschouwing blijven.

104. Het gaat daarbij om zaken waarin de onderliggende algemene regeling zelf niet op zijn waarde word onderzocht, maar waarbij alleen wordt gekeken naar de redelijkheid van de bevoegdheidsuitoefening Zie bijv. (voor de civiele kamer) HR 25 april 1980, NJ 1981/416 (Sogut/Staat), HR 15 juli 1988, N 1989/7 14 (Deltaschade), HR 7 april 1995, AB 1995/608 (Bakir/Staat) en HR 28 mei 1999, NJ 1999/816 (Nassy-Tseng/Eilandgebied Curaçao). Bij de strafkamer komt dit soort klachten iets vaket voor. omdat daar nogal eens wordt geklaagd over het feit dat in het in geding zijnde geval wel is ver: volgd, terwijl dit in eerdere of andere gevallen niet is gebeurd: zie bijv. HR 10 februari 1987, N 1987/950 (Vechtpartij zigeuners), HR 20 oktober 1987, NJ 1988/473 (Ongelijke behandeling bij ver. volging), HR 21 juni 1988, NJ 1988/1021 (Folderverspreiding Centrumpartij), HR 21 mei 1991, N 1991/728 (Strafkorting bijstandsuitkering), HR 2 februari 1999, NJ 1999/664 (Transactievoorstel) of HR 18 mei 1999. NJ 1999/578. Veelal wordt in dit soort gevallen niet zozeer getoetst aan het gelfis heidsbeginsel, maar wordt bekeken of er sprake was van willekeur en wordt nagegaan of er oncigenty ke of niet op de bewijsmogelijkheden betrekking hebbende motieven in het vervolgingsbesluit zjn trokken. Voor zover relevant zullen deze zaken alleen aan de orde komen bij de bespreking van de ver gelijkbaarheidstoets (paragraaf 2.2.2). 
Voor de toetsing van normatieve classificaties aan één van de in paragraaf 1 beschreven gelijkheidsbepalingen geldt dat een duidelijk omlijnd toetsingsmodel in de rechtspraak van de Hoge Raad nauwelijks kan worden teruggevonden. De oorzaak hiervan is vooral gelegen in de zeer summiere en vaak ondoorzichtige motivering van de arresten: de Hoge Raad expliciteert hoogst zelden de criteria die worden gehanteerd en volstaat vaak met een kort en tamelijk cryptisch oordeel, waarin lang niet altijd duidelijk wordt welke overwegingen nu precies tot het bereikte resultaat hebben geleid. Bij bestudering van de rechtspraak kan daardoor een beeld van verwarring en inconsistentie rijzen: nu eens wordt een vergelijkbaarheidstoets als toetsingsingang gehanteerd ${ }^{105}$, dan weer een benadelingstoets ${ }^{106}$, in sommige gevallen blijkt de Hoge Raad de vergelijkbaarheidstoets als rechtvaardigingstoets te beschouwen ${ }^{107}$, terwijl in andere gevallen een motivering is te vinden die meer in overeenstemming is met het theoretische toetsingsmodel ${ }^{105}$ en soms wordt zorgvuldig nagegaan of een onderscheid voldoet aan eisen als geschiktheid of noodzakelijkheid ${ }^{109}$, terwijl in andere gevallen een nadere uitwerking van de rechtvaardigingstoets ontbreekt. ${ }^{100}$ Alvorens in te gaan op enkele specifieke toetsingscriteria is het dan ook zinvol om enig algemeen inzicht te verschaffen in de methodiek die de Hoge Raad hanteert.

\section{Toetsing in de eerste fase}

Van belang is allereerst dat de Hoge Raad in veel gevallen geen toetsing uitvoert in de eerste fase, hetgeen betekent dat zelden uitdrukkelijk wordt nagegaan of er eigenlijk wel sprake is van een voor toetsing vatbaar onderscheid." ${ }^{\text {" }}$ Er zijn verschillende verklaringen te geven voor deze omissie. In de eerste plaats is van belang dat de Hoge Raad een cassatierechter is en daardoor slechts beschikt over beperkte toetsingsmogelijkheden. De Hoge Raad heeft bijvoorbeeld geen ruimte om de feiten zelfstandig te beoordelen: hij mag slechts onderzoeken of door de lagere rechters juiste maatstaven zijn aangelegd bij de vaststelling van een ongelijke behandeling. Daardoor zal er minder ruimte bestaan voor een toetsing in de eerste fase, nu deze vaak zeer feitelijk van aard is." ${ }^{\text {II }}$ Van belang is verder dat de Hoge Raad bij zijn toetsing gebonden is aan de middelen die door de procespartijen zijn voorgesteld. Wanneer deze zich alleen richten op een toetsing van de rechtvaardiging van het onderscheid, is het voor de Hoge Raad niet mogelijk om ambtshalve aandacht te besteden aan de aanwezigheid van een ongelijke behandeling. ${ }^{13}$ Tenslotte is het bestaan van een ongelijke behandeling bij veel klachten

\section{HR 6 november 1998, RvdW $1998 / 206$ (Bos/KLM)}

106. HR 10 december 1982, NJ 1983/687 (Binderen/Kaya)

107. HR 13 november 1992, NJ 1993/502 (El Hammouti/Staat)

108. HR 7 mei 1993, RvdW 1993/101 (Ongehuwde onderwijzeressen)

109. HR 31 maart 2000, JB 2000/133 (Scholingsbesluit bijstandsgerechtigden)

110. HR 26 maart 1999, NJ 1999/446 (Erfpachters Den Haag)

111. Zie over de onderverdeling in fasen nader paragraaf 1.2 en hoofdstuk 2, paragraaf 3.1.2.

112. In veel gevallen gaat de Hoge Raad daarom af op de beoordeling door de lagere instantie en geeft hij geen zelfstandig oordeel over de aanwezigheid van een ongelijke behandeling. Zie bijv. HR 13 januari 1995, NJ 1995/430 (Codfried/ISS), waarin de Hoge Raad zich baseerde op de ongelijke behandeling zoals die was vastgesteld door de Rechtbank.

113. Een voor de Hoge Raad typerende werkwijze is zichtbaar in HR 31 december 1993, NJ 1994/436 (Van den Berge/Verenigde Bootlieden). De Hoge Raad herhaalde daarin kort de overwegingen van het Hof met betrekking tot de voorliggende ongelijke behandeling en stelde vervolgens: "Aldus begrepen, geeft 
over normatieve classificaties evident: meestal komt deze duidelijk naar voren bij een zorgvuldige lezing van de tekst van de betrokken wet of algemene regeling. Waar. schijnlijk acht de Hoge Raad het om die reden vaak niet noodzakelijk om uitdrukkelijk op de aanwezigheid van een ongelijke behandeling in te gaan, ook al zou het de moge. lijkheid daartoe hebben. ${ }^{1+4}$

In een enkele gevallen heeft de Hoge Raad echter wel degelijk onderscheid gemaaks tussen een eerste en een tweede toetsingsfase. Daarbij lijkt als regel te gelden dat er in de eerste fase een vergelijkbaarheidstoets wordt uitgevoerd" ${ }^{115}$, hoewel er ook een relatief groot aantal gevallen is terug te vinden waarin een benadelingstoets als toetsingsingang werd gehanteerd. ${ }^{116}$ Dit laatste is met name het geval bij uitspraken waarin geklaagd wordt over indirect onderscheid op het gebied van het Europese recht, nu daar. bij de benadering van het Europese Hof van Justitie moet worden gevolgd. Ook buiten het Europese recht om zijn er echter voorbeelden te vinden waarin een benadelingstoets als toetsingsingang wordt gebruikt, zowel bij indirect als bij direct onderscheid.

Een duidelijke verklaring voor het feit dat soms de vergelijkbaarheidstoets, dan weer de benadelingstoets als toetsingsingang wordt gekozen is, behoudens de gevallen warin Europees recht wordt toegepast, eigenlijk niet te geven. Waarschijnlijk is de keuze afhankelijk van subjectieve factoren, zoals de voorkeur van de rechter, de stellingen

's hofs oordeel [...] niet blijk van een onjuiste rechtsoverweging. Met name heeft het hof bij zijn be oordeling van de vraag of een rechtvaardiging als evenbedoeld kon worden gevonden in de bijzonder omstandigheden van het gegeven geval, niet een verkeerde maatstaf aangelegd"' (r.0. 4.3.1).

114. Een voorbeeld hiervan is een zaak uit 1990, waarin werd geklaagd over de (toen nog bestaande) onnogelijkheid voor personen van gelijk geslacht om met elkaar te trouwen: HR 19 oktober 1990, N] 1992/129 (Homohuwelijk). De Hoge Raad besteedde in zijn uitspraak eerst uitgebreid aandacht an de interpretatie van de betrokken wettelijke bepaling en stelde vast dat deze inderdaad zo moest worder uitgelegd dat alleen personen van verschillend geslacht een burgerlijk huwelijk konden sluiten. Vervolgens toetste hij aan de gelijkheidsbepalingen van artikel 14 EVRM en artikel 26 IVBPR en voente daarbij een redelijkheidstoets uit. Een expliciete toetsing in de eerste fase bleef achterwege: gesteld werd slechts dat de wettelijke regeling onderscheid maakt, zonder dat dit nader werd toegelicht. Eent dergelijke toetsing was in dit geval echter ook niet nodig, nu de ongelijke behandeling duidelijk bleck uit de door de Hoge Raad aan de betrokken bepaling gegeven interpretatic. Soortgelijke gevallen waarin de ongelijke behandeling automatisch voortvloeit uit een zorgvuldige lezing van de betrolken normatieve regeling zijn HR 18 januari 1980, NJ 1980/463 (Onwettige geboorte), HR 22 februri 1985, NJ 1986/3 (Omgangsregeling met onwettig kind III), HR 13 november 1992, NJ 1993/502 (E) Hammouti/Staat), HR 8 mei 1998, NJ 1998/496 (Leeftijdsgrens voor commissarissen), HR 7 januar 1975 (strafkamer), NJ 1975/206 (Strafbaarheid in het buitenland), HR 13 november 1979 (strafkaner). NJ 1980/171 (Nederlandstalige oproeping aan Fries), HR 18 december 1984 (strafkamer), NJ 1985/356 (Heren- en dameskappers), HR 22 januari 1985 (strafkamer), NJ 1986/24 (Vervangende dienstplicht gewetensbezwaarden II), HR 6 november 1990, NJ 1991/218 (Tippelverbod Heerlen) en HR 6 juni 1995 (strafkamer), NJ 1995/645 (Wederrechtelijk verkregen voordeel).

115. Zie bijv. HR 30 maart 1984, NJCM 1984, 253 (Suikerfeest), HR 14 april 1989, NJ 1990/412 (Bijstandsverhaal), HR 30 maart 1990, NJ 1991/644 (Busvervoer Lelystad), HR 22 maart 1991, N 1994/170 (Amsterdam/lkon II), HR 10 augustus 1994, NJ 1995/58 (General Accident) en HR 6 november 1998, RvdW 1998/206 (Bos/KLM).

116. Zie bijv. HR 10 december 1982, NJ 1983/687 (Binderen/Kaya), HR 21 maart 1986, NJ 1986/585 (Ouderlijke macht voor ongehuwden), HR 25 november 1988, NJ 1989/730 (Centrum voor Onderwijs" begeleiding/Pot), HR 30 maar 1990, NJ 1991/644 (Busvervoer Lelystad), HR 13 december 1991, N 1993/363 (NBBS/Akel), HR 24 april 1992, NJ 1992/689 (Bouma/KLM), HR 15 oktober 1996 (straf kamer), NJ 1997/199 (Doodslag in het verkeer; impliciet), HR 3 januari 1997, NJ 1997/435 (Zorgeroep Oost-Gelderland/Gerrits), HR 27 mei 1997, NJ 1997/577 (Cassatie bij verstekvonnis) en HR 31 mast 2000, JB 2000/133 (Scholingsbesluit bijstandsgerechtigden). 
van partijen of de keuze van de rechters voor de meest efficiënte motivering. Deze situatie komt de duidelijkheid van de rechtspraak van de Hoge Raad niet ten goede.

Helderheid bestaat wel over de consequenties van de toetsing in de eerste fase, ongeacht de methode die daarbij wordt gehanteerd. Uit de rechtspraak blijkt dat, wanneer een benadeling voldoende vast is komen te staan of wanneer voldoende duidelijk is geworden dat er sprake is van een ongelijke behandeling van vergelijkbare gevallen, in de regel zal worden nagegaan of daarvoor een rechtvaardiging bestaat. Is een benadeling niet aangetoond of zijn de gevallen niet vergelijkbaar, dan betekent dit dat het onderscheid niet in strijd is met één van de gelijkheidsbepalingen: een verdergaande toetsing acht de Hoge Raad in dat geval niet nodig. ${ }^{117}$ Dit is een wat merkwaardige benadering, vooral wanneer de vergelijkbaarheidstoets als toetsingsingang wordt gehanteerd: zoals eerder is aangegeven is het wel degelijk denkbaar dat een ongelijke behandeling van onvergelijkbare gevallen in strijd is met het gelijkheidsbeginsel, bijvoorbeeld wegens het ontbreken van geschiktheid of proportionaliteit.

\section{Toetsing in de tweede fase}

Bij de inhoudelijke toetsing van de rechtvaardiging voor het onderscheid (de tweede fase), is opnieuw variatie in de gehanteerde toetsingsmethodiek zichtbaar. Grofweg kunnen er drie toetsingsmethoden worden onderscheiden. In de eerste plaats zijn er gevallen waarin de Hoge Raad deze fase volledig invult door een vergelijkbaarheidstoets. De rechtvaardiging voor een onderscheid wordt dan geacht gelegen te zijn in relevante verschillen tussen de gevallen. Een voorbeeld van deze benadering is zichtbaar in het arrest El Hammouti. ${ }^{\text {I8 }}$ In deze zaak was een bepaling van de Vreemdelingencirculaire in het geding, op grond waarvan in het kader van gezinshereniging een verblijfsvergunning kon worden toegekend aan minderjarige vreemdelingen die al langer dan een jaar in Nederland verbleven. Voorwaarde daarvoor was wel dat de minderjarige in ieder geval een jaar bij het gezin zou blijven waarin hij of zij thuishoorde. Bij een huwelijk van de betrokkene in dit eerste jaar werd verondersteld dat aan deze voorwaarde niet werd voldaan en werd de verblijfsvergunning ingetrokken. Voor andere vreemdelingen gold een dergelijke beperkende voorwaarde niet, hetgeen volgens het aangevoerde middel een ongerechtvaardigde ongelijke behandeling tot gevolg had. Het oordeel van de Hoge Raad hierover luidde als volgt:

117. Zie bijv. HR 14 april 1989, NJ 1990/412 (Bijstandsverhaal) (geen vergelijkbaarheid), HR 20 december 1991, NJ 1992/180 (Steijnen/Staat)(geen vergelijkbaarheid), HR 30 maart 1990, NJ 1991/644 (Busvervoer Lelystad) en HR 21 mei 1991 (strafkamer), NJ 1991/728 (Strafkorting bijstandsuitkering). Een uitzondering is het Suikerfeest-arrest (HR 30 maart 1984, NJCM 1984, 253), waarin de Hoge Raad oordeelde dat de voorgelegde gevallen onvergelijkbaar waren, maar toch een soort proportionaliteitstoets uitvoerde; een volledig ongelijke behandeling van de voorgelegde gevallen zou kennelijk onredelijk zijn. Een vergelijkbare benadering is terug te vinden in HR 18 juni 1985 (strafkamer), NJ 1986/25 (Vervangende dienstplicht gewetensbezwaarden), waarin de HR overwoog dat het oordeel van het Hof dat het verschil in behandeling "in het onderhavige geval in een redelijke verhouding staat tot het verschil in inconvenienten", niet onredelijk was. Van een vaste en consequente proportionaliteitstoets is echter zeker geen sprake.

118. HR 13 november 1992 , NJ $1993 / 502$ 
"Tussen het geval van toelating voor gezinshereniging en dat van toelating op andere gronden bestaan relevante verschillen welke een verschillend beleid [...] kunnen rechtvaardigen." 119

Deze overweging laat een versmelting zien van de vergelijkbaarheidstoets en de rechlivaardigingstoets: gekeken werd niet zozeer naar de vraag of er sprake was van een gerechtvaardigd doel of naar de vraag of er tussen doel en onderscheid een redelijke verhouding bestond, maar gesteld werd uitsluitend dat er relevante verschillen beston. den (welke dit zijn werd aan de fantasie van de rechtzoekende overgelaten) en dat daarin een rechtvaardiging kon worden gevonden voor het gemaakte onderscheid. ${ }^{\text {m }}$

Een tweede toetsingsmogelijkheid is het uitvoeren van een rechtvaardigingstoets, waarin de vergelijkbaarheid een zelfstandig element vormt. Deze situatie lijkt sterk op de eerste, maar kenmerkt zich door een uitgebreidere motivering. Van belang is dat in deze gevallen steeds wordt vastgesteld welk doel er met het gemaakte onderscheid werd nagestreefd en dat consequent aandacht wordt besteed aan de verhouding tussen doel en middel. Een voorbeeld van deze benadering is te vinden in een arrest uit 1995 met betrekking tot verjaringstermijnen in het familierecht. Op grond van de toen geldende regeling verjaarde een vordering tot vaststelling van het vaderschap vijf jaar na de geboorte van het kind. Na verjaring was het niet meer mogelijk een vordering tegen de vermeende vader in te stellen tot betaling van een bijdrage in de verzorging en opvoeding van het kind. Een dergelijke temporele beperking van alimentatievorderingen gold niet voor gehuwde vaders of ongehuwde vaders waarvan het vaderschap juridisch vaststond. Volgens eiseres had dit een ongeoorloofd onderscheid tot gevolg. De Hoge Raad was een andere mening toegedaan:

"Een zodanige rechtsvordering [een vordering tot vaststelling van vaderschap, JHG] verschilt van een rechtsvordering, ingesteld tegen een vader die tot het kind in familierechtelijke betrekking staat en waarvan het - hier juridisch - vaderschap reeds vaststaat op grond van huwelijk of erkenning. Dit verschil kan ook een verschil in behandeling van beide soorten rechtsvorderingen op het punt van de verjaring rechtvaardigen in dier voege dat voor de eerstbedoelde rechtsvordering een kortere verjaringstermijn dan voor de tweede noodzakelijk kan worden geacht met het oog op de rechtszekerheid en de bescherming van de rechten van hen tegen wie de aan die termijn onderworpen rechtsvordering zich richt."121

Hoewel de onvergelijkbaarheid van de voorgelegde gevallen in deze overweging een belangrijke rol speelt, is hierin ook een rechtvaardigingsaspect zichtbaar: gesteld wordt immers dat het verschil in behandeling voortkwam uit de doelstelling de rechtszeker-

119. R.o. 3.4 .

120. Een ander voorbeeld van deze benadering is te vinden in HR 4 november 1977, NJ 1978/418 (0mir gangsregeling na echtscheiding), waarin werd gesteld dat juist de vergelijkbaarheid van gevallen een rechtvaardiging kon vormen voor een gelijke behandeling; het ging in dit geval om een (implicieti) klacht over materieel onderscheid. Zie ook HR 10 december 1982, NJ 1983/4II (Omgangsregeline met onwettig kind; idem), HR 23 november 1984 (kort geding), RvdW 1984/200 (Touijri), HR 22 jp nuari 1985 (strafkamer), NJ 1986/24 (Vervangende dienstplicht gewetensbezwaarden II) en HR 6 juri 1995 (strafkamer), NJ 1995/645 (Wederrechtelijk verkregen voordeel). Vgl. verder Van Hoof/Jaspers 1986, p. 159.

121. R.o. 3.2. 
heid te beschermen en dat de ongelijke behandeling ter verwezenlijking van dat doel noodzakelijk was. ${ }^{122}$

Tenslotte voert de Hoge Raad in een meerderheid van gevallen een rechtvaardigingstoets uit die verwantschap vertoont met het theoretische rechtvaardigingsmodel. De exacte vormgeving van de toetsing is daarbij sterk afhankelijk van de toepasselijke gelijkheidsbepaling. Wordt er bijvoorbeeld een beroep gedaan op een uit het Europese recht stammende regeling, dan is de Hoge Raad genoodzaakt de toetsingscriteria toe te passen die het Europese Hof van Justitie heeft ontwikkeld. Concreet betekent dit dat de Hoge Raad dan nauwkeurig moet nagaan of in een bepaald geval een legitiem doel wordt nagestreefd en of het gekozen middel (het gemaakte onderscheid) geschikt en noodzakelijk is om dit doel te bereiken. ${ }^{123}$ Wordt er getoetst aan het EVRM of het IVBPR, dan kiest de Hoge Raad voor een eigen, iets andere formulering van het rechtvaardigingsmodel. Dit model werd voor het eerst gedefinieerd in een zaak met betrekking tot de beloning van onderwijzeressen op Aruba. ${ }^{124}$ Geklaagd werd daarin over het feit dat ongehuwden onderwijzeressen een beduidend lager salaris ontvingen dan hun gehuwde collega's. De Hoge Raad nam bij de beoordeling van de redelijkheid van dit onderscheid het volgende tot uitgangspunt:

\begin{abstract}
"Uit art. 26 IVBP, dat een verbod behelst van discriminatie wegens onder meer 'status' (waaronder begrepen het al of niet gehuwd zijn), vloeit voort dat een hogere salariëring van gehuwden die hetzelfde werk verrichten als hun ongehuwde collega's, slechts geoorloofd is, indien daarvoor een redelijke en objectieve rechtvaardiging kan worden aangewezen. [...] Om te kunnen vaststellen of voor het omstreden verschil in beloning een redelijke en objectieve rechtvaardiging voorhanden is, moet worden nagegaan of met het gemaakte onderscheid een legitiem doel wordt nagestreefd en of dit onderscheid kan worden aangemerkt als een passend middel om dat doel te bereiken." 25
\end{abstract}

De rechtvaardigingstoets zoals in deze overwegingen geformuleerd bestaat uit slechts twee onderdelen: de toetsing van de legitimiteit van het nagestreefde doel en de beoor-

122. Zie voor een soortgelijke toetsing HR 27 april 1987 (strafkamer), NJ 1984/513 (Onbekwame getuige), HR 18 december 1984 (strafkamer), NJ 1985/356 (Dames- en herenkappers) en HR 18 juni 1985 (strafkamer), NJ 1986/25 (Vervangende dienstplicht gewetensbezwaarden IV). Een andere wijze waarop de vergelijkbaarheidstoets een functie kan krijgen binnen de rechtvaardigingstoets is te vinden in HR 16 februari 2001, JB 2001/106 (Kiesrecht Antillen). In geding was het feit dat op de Antillen nietingezetenen niet mochten deelnemen aan de verkiezingen. De Hoge Raad stemde in met het oordeel van het Gemeenschappelijk Hof, "dat [niet kan worden volgehouden dat] ingezetenen en nietingezetenen door de verbeterde communicatiemiddelen zich in dit verband in geheel gelijke positie bevinden [...]" (zie r.o. 4.14 van het arrest van het Gemeenschappelijk Hof). Deze overweging vormde onderdeel van uitgebreide overwegingen met betrekking tot de doelstellingen van de uitsluiting van niet-ingezetenen en van de redelijkheid van de verhouding tussen doel en uitsluiting, waardoor het vergelijkbaarheidselement als het ware werd ingebed in een rechtvaardigingstoets.

123. Zie bijv. HR 25 november 1988, NJ $1989 / 730$ (Centrum voor Onderwijsbegeleiding/Pot) en vooral HR 31 maart 2000, JB 2000/133 (Scholingsbesluit Bijstandsgerechtigden); in een daaraan voorafgaande uitspraak (HR 13 februari 1998, JB 1998/90) had de Hoge Raad de zaak zelfs terugverwezen naar het gerechtshof om antwoord te krijgen op de vraag welk doel met het Scholingsbesluit werd nagestreefd en of de in het besluit gehanteerde middelen geschikt en noodzakelijk waren om het gestelde doel te 124.

125. R 7 mei 1993, RvdW 1993/101 (Ongehuwde onderwijzeressen) 
deling van de "passendheid" van het middel om deze doelstelling te bereiken. Met "passendheid" lijkt daarbij gedoeld te worden op de geschiktheid van het middel om het gestelde doel te bereiken. Hierop zal nader worden ingegaan bij de bespreking van de gehanteerde toetsingsmaatstaven in paragraaf 2.4.2; ook zal verderop nader aan. dacht worden besteed aan de methodiek bij de vaststelling en inhoudelijke beoordeling van het nagestreefde doel.

De hiervoor geciteerde formule behoort tot de vaste rechtspraak van de Hoge Raad: behalve in de gevallen waarin van de hiervoor besproken vergelijkbaarheidsoverwe. gingen gebruik wordt gemaakt, vormt deze steeds de invulling van de rechtvaardigingstoets. ${ }^{126}$ Wel moet worden opgemerkt dat de toetsing aan de verschillende criteria lang niet altijd zorgvuldig is: in veel uitspraken ontbreekt één van de genoemde criteria $^{127}$ of wordt slechts zeer in zijn algemeenheid vastgesteld dat er een objectieve rectrvaardiging voor het onderscheid bestaat ${ }^{128}$. De doorzichtigheid en voorspelbaarheid van de uitspraken worden daardoor duidelijk niet bevorderd.

\subsubsection{Toetsingsmethodiek van de Hoge Raad - belastingkamer}

\section{Toetsing van normatieve classificaties: inleiding}

Anders dan de civiele kamer en de strafkamer krijgt de belastingkamer ongeveer net 20 vaak te maken met klachten over normatieve classificaties als met klachten over ongelijke toepassing van een algemene regeling in concrete gevallen (zoals in het geval waarin een inspecteur in één geval wel aftrek heeft toegelaten, maar in een ander geval niet). Bij normatieve classificaties hanteert de belastingkamer in het algemeen een toetsingsmethodiek die verwantschap vertoont met die van de civiele en de strafkamer. Dit blijkt uit de vaste definitie van de toets die bij klachten over normatieve classificaties wordt toegepast:

"Bij de beantwoording van de vraag of toepassing van voornoemde wetsbepalingen een door het IVBP verboden ongelijke behandeling oplevert [...] moet worden vooropgesteld dat het Verdrag niet iedere ongelijke behandeling van gelijke gevallen verbiedt, maar alleen die

126. Zie expliciet HR 7 november 1997, NJ 1998/399 (Levi/Zaanwerk), HR 8 mei 1998, NJ 1998496 (Leeftijdsgrens commissarissen) en HR 24 november 2000, NJ 2001/376 (Landsverordening Toelating en Uitzetting). Wel wordt de formule soms iets anders geformuleerd, waardoor aansluiting wordt ver kregen bij het model van het Europees Hof voor de Rechten van de Mens (zie bijv. HR 16 februari 2001, JB 2001/106 (Kiesrecht Antillen), waarin het Gemeenschappelijk Hof (naar wiens formulering de HR verwees) stelde dat "niet gezegd kan worden dat het [onderscheid] geen legitiem doel dient cin dat proportionaliteit tussen doel en middelen ontbreekt" (r.o. 4.17)) of bij dat van het Europees Hof van Justitie (zie bijv. HR 6 november 1990 (strafkamer), NJ 1991/218 (Tippelverbod Heerlen)). Bovendien wordt vaak melding gemaakt van de noodzaak van een objectieve en redelijke rechtvaardiging, zonder dat de bij de beoordeling daarvan te hanteren toetsingscriteria worden opgesomd; zie HR 31 decenter 1993, NJ 1994/436 (Van den Berge/Verenigde Bootlieden), HR 22 december 1995, AB 1996/295 (IBG/Groenhart), HR 26 maart 1999, NJ 1999/446 (Erfpachters Den Haag) en HR 7 januari 1973 (strafkamer), NJ 1975/206 (Strafbaarheid in het buitenland).

127. Bijv. HR 7 november 1997, NJ 1998/399 (Levi/Zaanwerk) (passendheidstoets ontbreekt).

128. Zie bijv. HR 19 oktober 1990. NJ 1992/129 (Homohuwelijk), HR 31 december 1993, NJ 1994/436 (Van den Berge/Verenigde Bootlieden), HR 22 april 1994, NJ 1994/560 (Theves), HR 22 december 1995, AB 1996/295 (IBG/Groenhart) en HR 26 maart 1999, NJ 1999/446 (Erfpachters Den Haag). 
ongelijke behandeling welke als discriminatie moet worden beschouwd omdat een objectieve en redelijke rechtvaardiging hiervoor ontbreekt."

Uit deze overweging blijkt dat een inhoudelijke rechtvaardigingstoets zal worden toegepast wanneer vast is komen te staan dat er sprake is van een ongelijke behandeling van vergelijkbare gevallen. ${ }^{130}$ Dit betekent dat de belastingkamer in de eerste fase van de toetsing een vergelijkbaarheidstoets zal moeten uitvoeren. ${ }^{\text {"I }}$ Een daadwerkelijke toetsing in de eerste fase wordt echter in een vrij groot aantal gevallen achterwege gelaten. De verklaring daarvoor kan, net als bij de civiele en de strafkamer, worden gevonden in het sterk feitelijke karakter van deze toets: als cassatierechter zal de Hoge Raad niet altijd in staat zijn om over de vergelijkbaarheid een eigen oordeel te geven. Bovendien zal niet uitdrukkelijk op de vergelijkbaarheid kunnen worden ingegaan wanneer de aangevoerde middelen voor een dergelijke toetsing geen ruimte laten.

Opmerkelijk is verder dat in sommige zaken wel een toetsing in de eerste fase wordt uitgevoerd, maar de belastingkamer daarbij niet ingaat op de vergelijkbaarheid. In die gevallen wordt de eerste fase vooral gebruikt voor een nadere verduidelijking van de litigieuze classificatie of om vast te stellen of de classificatie daadwerkelijk een benadeling van de betrokken belastingplichtige tot gevolg heeft. Wanneer voor een dergelijk gebruik gekozen wordt betekent dit dat feitelijk wordt gekozen voor een benade-

129. HR 27 september 1989 (belastingkamer), NJ 1990/449 (Samentelling inkomens ongehuwden)

130. Vgl. Happé 1990, p. 392 en Happé 1991, p. 300. Zie ook HR 6 juni 1990 (belastingkamer), BNB 1990/299 (Zorgrelatie buiten familieverband), HR 30 september 1992 (belastingkamer), NJ 1994/495 (Griffiegeld), HR 16 juli 1993 (belastingkamer), BNB 1993/299 (Uitzendtoelage ambtenaren), HR 17 november 1993 (belastingkamer), BNB $1994 / 36$ (Koffiegeld en studeerkamerkosten), HR 4 mei 1994 (belastingkamer), BNB 1994/195 (Studeerkamerkosten), HR 1 februari 1995 (belastingkamer), BNB 1995/81 (Sollicitatiekosten), HR 14 juni 1995 (belastingkamer), AB 1995/609 (Gebroken boekjaar), HR 13 december 1995 (belastingkamer), BNB 1996/90 (Kinderopvang II), HR 8 januari 1997 (belastingkamer), BNB 1997/64 (PTT Telecom), HR 26 maart 1997 (belastingkamer), BNB $1997 / 186$ (Waardering landbouwgrond), HR 27 augustus 1997 (belastingkamer), BNB 1998/109 (Huurwaardeforfait bij kamerverhuur), HR 24 september 1997 (belastingkamer), BNB 1997/400 (Kledingkosten presentatrice), HR 12 november 1997 (belastingkamer), BNB 1998/22 (Reiskosten als studiekosten), HR 15 juli 1998 (belastingkamer), BNB 1998/293 (Autokostenforfait), HR 17 augustus 1998 (belastingkamer), JB 1998/196, HR 20 januari 1999 (belastingkamer), BNB 1999/80 (Levensonderhoud verwanten), HR 3 maart 1999 (belastingkamer), BNB 1999/202 (Leeftijdsgrens zelfstandigenaftrek II), HR 12 mei 1999 (belastingkamer), BFR 1999, p. 2115 (Arbeidskostenforfait), HR 11 augustus 2000 (belastingkamer), BNB 2000/334 (Aftrek studiekosten) en HR 6 december 2000 (belastingkamer), BNB 2001/144 (Studiekostenaftrek uitwonende/thuiswonende studenten).

131. Zie bijv. HR 22 juni 1988 (belastingkamer), BNB 1988/259 (Koffiegeld en reiskosten), HR 6 juni 1990 (belastingkamer), BNB 1990/212 (Leeftijdsgrens zelfstandigenaftrek), HR 21 oktober 1992 (belastingkamer), BNB 1993/28 (Middelingsregeling), HR 7 april 1993 (belastingkamer), BNB 1993/172 (35\%regeling), HR 22 maart 1994 (belastingkamer), BNB 1994/112 (OV-verklaring), HR 8 februari 1995 (belastingkamer), BNB 1995/83 (Aftrekbaarheid studiekosten en studiefinanciering), HR 20 september 1995, BNB 1995/315 (Afvalwater), HR 13 december 1995 (belastingkamer), BNB 1996/72 (Vee als bedrijfsmiddel), HR 9 augustus 1996 (belastingkamer), BNB 1996/336 (Aftopping reiskostenforfait), HR 13 november 1996 (belastingkamer), BNB 1997/54 (Belasting aanmerkelijk belang), HR 1 oktober 1997 (belastingkamer), BNB 1997/391 (Vergoeding vervolgingsslachtoffers), HR 15 oktober 1997 (belastingkamer), BNB 1997/380 (Kosten kinderopvang), HR 16 juni 1999 (belastingkamer), BNB 1999/286 (Vakantiegeld en vakantiebonnen), HR 23 juni 1999 (belastingkamer), BNB 1999/292 (Autokostenfictie), HR 10 november 1999 (belastingkamer), BNB 2000/125 (Nedeco-regeling), HR 19 april 2000 (belastingkamer), BNB 2000/192 (Rentevrijstelling werknemersspaarregelingen) en HR 21 februari 2001 (belastingkamer), BNB 2001/163 (Peildatumsysteem). Vgl. ook Happé 1990, p. $395 / 396$. 
lingstoets als toetsingsingang: vergelijkbaarheid wordt dan immers verondersteld, terwijl uitdrukkelijk wordt nagegaan of de classificatie een nadeliger positie voor etn bepaalde groep tot gevolg heeft. ${ }^{12}$ Deze werkwijze bevestigt de veronderstelling dat de benadelingstoets een toereikende en zinvolle toetsingsingang kan opleveren.

\section{Toetsing van normatieve classificaties: vergelijkbaarheidstoets als toetsingsingang}

Zoals hiervoor al is aangegeven hoeft de belastingkamer blijkens de definitie van zijn toetsingsmodel alleen een rechtvaardigingstoets uit te voeren wanneer is gebleken dat de gevallen voldoende vergelijkbaar zijn: een ongelijke behandeling van onvergelijkba. re gevallen hoeft kennelijk niet aan een nadere toetsing te worden onderworpen." In een beperkt aantal gevallen heeft de belastingkamer echter geoordeeld dat de constatering dat de voorgelegde gevallen onvergelijkbaar zijn niet onmiddellijk leidt tot afwij. zing van het beroep op het gelijkheidsbeginsel. Dit kan bijvoorbeeld blijken uit een arrest met betrekking tot de belastingvrije som: voor alleenstaanden werd deze som niet verhoogd, terwijl dit wel het geval was bij alleenstaande verzorgende ouders en alleenverdieners. ${ }^{134}$ De Hoge Raad merkte hierover het volgende op:

"Voor alleenstaande verzorgende ouders en alleenverdieners brengt de aanwezigheid van gezinsleden financiële lasten mee, welke alleenstaanden niet hebben. Op grond hiervan kon de wetgever in redelijkheid oordelen dat uit een oogpunt van draagkracht een verschil in belastingvrije sommen gerechtvaardigd is. De klacht dat de wetgever aan alleenstande verzorgende ouders en alleenverdieners, vergeleken met alleenstaanden, een zodanig hoge belastingvrije som heeft toegekend dat, hoewel niet sprake is van gelijke gevallen, niettemin zich een door artikel 26 IVBPR verboden discriminatie voordoet, faalt evenzeer. Discriminatie op de grond dat ongelijke gevallen onevenredig ongelijk worden behandeld, doet zich slechts voor bij een overduidelijke onevenredigheid. Daarvan is hier geen sprake [...]."135

Uit deze overweging blijkt duidelijk dat de belastingkamer ruimte laat voor een beoordeling van de redelijkheid van een ongelijke behandeling van onvergelijkbare gevallen. ${ }^{136}$ In dat opzicht wijkt zijn rechtspraak af van die van de beide andere kamers van

132. Voorbeelden zijn HR 8 juli 1988 (belastingkamer), NJ 1990/448 (Studeerkameraftrek I), HR 16 sep. tember 1992 (belastingkamer), BNB 1993/21 (Interimuitkering ziektekosten), HR 17 november 1999 (belastingkamer), BNB 1994/36 (Koffiegeld en studeerkamerkosten), HR 15 juli 1997 (belastinglamer), BNB 1997/325 (Koffiegeld en representatiekosten), HR 15 december 1999 (belastingkamer), BNB 2000/57 (Belastingvrije som gehuwden/ongehuwden) en HR 28 februari 2001 (belastingkamer). BNB 2001/169 (Alleenstaande ouder-aftrek).

133. Een beroep op het gelijkheidsbeginsel wordt in die gevallen meestal meteen afgewezen. Zie bijv. HR \& juli 1988 (belastingkamer), NJ 1990/448 (Studeerkameraftrek I), HR 27 september 1989 (belastingta mer), NJ 1990/449 (Tandartsvrouw; m.b.t. het onderscheid op grond van burgerlijke staat), HR 16 september 1992 (belastingkamer), BNB 1992/21 (Interimregeling ziektekosten), HR 19 mei 1993 (b6lastingkamer), BNB 1993/341 (Successiebelasting ongehuwden), HR 1 februari 1995 (belastingkanet), BNB 1995/81 (Sollicitatiekosten), HR 27 augustus 1997 (belastingkamer), BNB 1998/109 (Huurwar. deforfait bij kamerverhuur), HR 20 januari 1999 (belastingkamer), BNB 1999/80 (Levensondethoud deforfait bij kamerverhuur), HR 20 januari 1999 (belastingkamer), BNB 1999/80 (Levensondenafid
verwanten) en HR 3 maart 1999 (belastingkamer), BNB 1999/202 (Leeftijdsgrens zelfstandigenufret
II).

134. HR 21 oktober 1992 (belastingkamer), BNB 1993/29 (Belastingvrije som voor alleenstaanden)

135. R.o. 3.2; cursief toegevoegd.

136. Zie ook HR 19 mei 1993, BNB 1993/242 (Uitvoeringsbeschikking Loonbelasting), HR 16 juni $199 \%$ (belastingkamer), BNB 1999/286 (Vakantiegeld en vakantiebonnen; zie oordeel Hof, de Hoge Rar 
de Hoge Raad, waarin een dergelijke toetsing niet is terug te vinden. Ook bij de belastingkamer is het aantal voorbeelden van de "overduidelijke onevenredigheidstoets" echter beperkt: in veruit de meeste gevallen leidt de conclusie van onvergelijkbaarheid automatisch tot afwijzing van het beroep op het gelijkheidsbeginsel. Waarschijnlijk zal een verdergaande toetsing alleen worden uitgevoerd wanneer in het middel uitdrukkelijk een beroep op de proportionaliteitstoets wordt gedaan. Duidelijk is dit jammer genoeg niet, nu de belastingkamer nooit heeft aangegeven in welke gevallen precies een beroep op deze doctrine kan worden gedaan.

\title{
Toetsing van normatieve classificaties: rechtvaardigingstoets in tweede toetsingsfase
} Wanneer de belastingkamer toekomt aan een toetsing in de tweede fase zal hij, zoals gezegd, een rechtvaardigingstoets uitvoeren. Deze toets wordt soms echter, net zoals het geval is in de rechtspraak van de civiele en de strafkamer, enigszins vertroebeld door vergelijkbaarheidselementen. Dit gebeurt echter slechts zelden ${ }^{137}$; veel vaker komt het voor dat de rechtvaardigingstoets in zuivere vorm wordt toegepast.

De rechtvaardigingstoets van de belastingkamer bestaat in principe uit twee onderdelen: de beoordeling van de legitimiteit van het nagestreefde doel en de toetsing van de redelijkheid van de verhouding tussen doel en middel. Anders dan de eerder besproken kamers maakt de belastingkamer geen gebruik van het "passendheidscriterium". De vaste formulering luidt als volgt:

\begin{abstract}
"Een ongelijke behandeling van gelijke gevallen wordt door artikel 14 EVRM en artikel 26 IVBPR verboden als daarvoor niet een objectieve en redelijke rechtvaardiging bestaat, of anders gezegd, indien daarmee niet een gerechtvaardigd doel wordt nagestreefd of indien er niet een redelijke verhouding bestaat tussen de ongelijke behandeling en het doel dat wordt nagestreefd."13s
\end{abstract}

Opnieuw is het opmerkelijk dat de redelijkheidstoets niet nader wordt uitgewerkt in specifieke toetsingscriteria: de geciteerde formule lijkt uitsluitend een algemene willekeurs- of redelijkheidstoets toe te laten. Bij nauwkeurige bestudering van de rechtspraak blijkt echter dat in de praktijk wel degelijk gebruik wordt gemaakt van criteria als de mate van fit, geschiktheid en noodzakelijkheid, met name wanneer er een iets intensievere toets dan gebruikelijk wordt uitgevoerd. Op de verschillende elementen van het model en de wijze waarop hiermee door de belastingkamer wordt omgegaan zal in het vervolg van dit hoofdstuk nader worden ingegaan.

stelde dat ten onrechte van deze toets gebruik werd gemaakt), HR 15 december 1999, BNB 2000/57 (Belastingvrije som gehuwden/ongehuwden; impliciet) en HR 28 februari 2001 (belastingkamer), BNB 2001/172 (OZB winkelpand). Vgl. Happé 1996, p. 301 en 380/381.

137. Zie bijv. HR 1 oktober 1997 (belastingkamer), BNB 1997/391 (Vergoeding vervolgingsslachtoffers) ("Het verschil in de aard van de uitkeringen vormt een voldoende objectieve en redelijke rechtvaardiging voor het onderscheid [...]", r.o. 3.7), HR 15 december 1999 (belastingkamer), BNB 2000/57

(Belastingvrije som ongehuwden) en HR 2 mei 2001 (belastingkamer), BNB 2001/276 (Wubo 1940-
1945).

138.

HR 23 november 1997 (belastingkamer), BNB 1998/22 (Reiskosten als studiekosten), r.o. 3.8. Idem in HR 23 juni 1999 (belastingkamer), BNB 1999/292. 


\section{Toetsing van concrete bevoegdheidsuitoefening: voorrangsregels}

Voor de situatie waarin er geklaagd wordt over een ongelijke toepassing van een rege. ling in een concreet geval heeft de belastingkamer een andere toetsingsmethodiek ontwikkeld dan voor de beoordeling van normatieve classificaties. Van belang is dat deze methodiek specifiek is ontwikkeld voor het geval van contra legem-werking van het gelijkheidsbeginsel. In het belastingrecht blijkt zich relatief vaak de situatie voor te doen dat de fiscus, in strijd met de wet, in een aantal gevallen gunstige beslissingen heeft genomen, maar in het geval van de betrokken belastingplichtige van die lijn is afgeweken door in overeenstemming met de wet te handelen. ${ }^{139}$ Een geslaagd beroep op het gelijkheidsbeginsel zou in een dergelijk geval noodzaken tot het voortzetten van het met de wet strijdige handelen. ${ }^{140} \mathrm{Om}$ een dergelijke vergaande conclusie te bereiken dient volgens de belastingkamer een goede afweging plaats te vinden van het belang bij een gelijke behandeling voor de belanghebbende tegen het belang van (be stuurs)handelen in overeenstemming met de wet. ${ }^{14}$ Binnen het theoretische toetsingsmodel zoals dat in hoofdstuk 2 is ontwikkeld en zoals dat, in grote lijnen, ook door de belastingkamer wordt gevolgd, komt de rechter aan deze afweging pas toe wanneer hij al een oordeel heeft uitgesproken over enkele andere elementen, zoals de aanwezigheid van een benadeling, het bestaan van een gerechtvaardigd doel en de geschiktheid en noodzakelijkheid van het gemaakte onderscheid. Door de belastingrechter is bij contra legem-werking echter een andere benadering gekozen, waarbij de proportionaliteitstoets feitelijk is verplaatst naar de eerste fase van de toetsing. Daarbij is de daadwerkelijke, concrete beoordeling van de belangenafweging bovendien vervangen door een aantal nauwkeurig omschreven "voorrangsregels". ${ }^{1+2}$ Zorgvuldige toepassing van deze regels leidt automatisch tot een conclusie over het beginsel dat in het concrete geval voorrang moet krijgen. ${ }^{143}$

Uitgangspunt van dit stelsel van voorrangsregels is dat de belastingrechter moet nagan of er in de eerdere gevallen sprake was van een tegenwettelijk, voor de belastingplichtigen begunstigend beleid. Dit blijkt duidelijk uit het eerste arrest met betrekking tot de

139. Vgl. Gribnau 2001, p. 12; hij geeft aan dat de mogelijkheid voor de fiscus om van de wet af te wijkat vrij algemeen wordt geaccepteerd, zelfs als de wettelijke regeling zelf tamelijk gedetailleerd is.

140. Vgl. Geppaart 1983, p. 12.

141. In HR 6 juni 1979, BNB 1979/211 (Buitengewone lasten pensionprijs I) overwoog de belastingkante dat "onder omstandigheden strikte toepassing van de wet [...] in die mate in strijd kan komen met ean of meer beginselen van behoorlijk bestuur, dat die toepassing achterwege moet blijven, dat in het 1 gemeen de vraag onder welke omstandigheden dit laatste zich voordoet van geval tot geval moet worden beantwoord door afweging van het beginsel dat de wet moet worden toegepast tegen een of metr in aanmerking komende beginselen van behoorlijk bestuur [en] dat het een in het algemeen rechstbwustzijn levend beginsel van behoorlijk bestuur is dat de administratie gelijke gevallen gelijk belist:delt." Dit is een vergaande stelling, vooral nu het legaliteitsbeginsel voor het belastingrecht (anders tan voor de meeste andere rechtsgebieden) uitdrukkelijk in de Grondwet verankerd is (zie artikel 104). Eor doorkruising van dit beginsel moet daarom goed worden gemotiveerd. Zie ook Happé 1996, p. 287288 en Gribnau 2001, p. 9.

142. De term is van Happé (0.a. 1996, p. 288).

143. Vgl. Happé 1993, p. 146, die aangeeft dat hiermee de feitelijke afweging van beginselen is geconcretlseerd tot een rechtstreeks toepasbare rechtsregel. Kenmerk daarvan is dat bij toepassing van een rechtsregel de vraag of hieraan voldaan is eenvoudigweg met ja of nee kan worden beantwoord, terwijl voor beginselen als het legaliteitsbeginsel en het gelijkheidsbeginsel geldt dat zij echt tegen elkaar afgeno. gen moeten worden, waarbij per geval een andere uitkomst kan worden bereikt. 
contra legem-werking van het gelijkheidsbeginsel. ${ }^{144}$ Nadat de Hoge Raad had vastgesteld dat een afweging van het legaliteitsbeginsel tegen het gelijkheidsbeginsel in dit soort gevallen noodzakelijk is, oordeelde hij in deze uitspraak,

"dat aan dit beginsel [het gelijkheidsbeginsel, JHG] bij een afweging als voormeld doorslaggevende betekenis moet worden toegekend in gevallen waarin de fiscus ten aanzien van bepaalde belastingplichtigen [...] een hen begunstigend beleid heeft gevoerd; [...] dat niet blijkt dat is aangevoerd dat er redenen zouden zijn om niet te aanvaarden dat de overige belanghebbenden [...] zich op dit stuk in een gelijke positie bevinden;

dat mitsdien $[\ldots]$ dat beleid ook ten aanzien van de overige bewoners moet worden gevolgd."145

Uit deze overwegingen kan worden afgeleid dat het gelijkheidsbeginsel prevaleert boven het legaliteitsbeginsel, zodra wordt aangetoond dat er sprake is van een afwijking van een tegenwettelijk, begunstigend beleid. ${ }^{1+6}$ Hoogstens kan de fiscus nog stellen dat een beroep op het gelijkheidsbeginsel niet opgaat omdat de afwijking werd ingegeven door een verschil in feitencomplex (hetgeen een vergelijkbaarheidstoets impliceert $^{117}$ of omdat de gevallen waarnaar de belastingplichtige verwijst niet onder de bevoegdheid van dezelfde inspecteur vielen: wanneer de ongelijke behandeling het resultaat is van het optreden van verschillende inspecteurs zal een beroep op het gelijkheidsbeginsel in het algemeen niet kunnen slagen, tenzij er een landelijk, coördinerend beleid bestond. ${ }^{14}$ Een verdere inhoudelijke toetsing is niet mogelijk: het bestaan van de

144. HR 6 juni 1979 (belastingkamer), BNB 1979/211 (Buitengewone lasten pensionprijs)

145. Zie ook HR 25 juni 1980 (belastingkamer), BNB 1980/277 (Berekening vloeroppervlakte), HR 24 september 1980 (belastingkamer), AB 1983/1 (Onroerendgoedbelasting Scheemda 1), HR 19 januari 1983 (belastingkamer), BNB 1983/132 (Onroerendgoedbelasting Hengelo), HR 27 augustus 1986 (belastingkamer), BNB 1986/317 (Besparing vakantiereis), HR 23 september 1998 (belastingkamer), BNB 1999/3 (FIOD-onderzoek) en HR 27 juli 1999 (belastingkamer), BNB 1999/403 (Huurwaardeforfait).

146. Vgl. Van den Berge 1999, p. 102, die stelt dat in dit soort gevallen de fiscus zijn recht op een juiste wetstoepassing verwerkt heeft. Over de vraag wanneer er sprake is van "beleid" is discussie mogelijk. Aanvankelijk was de Hoge Raad van oordeel dat dit een feitelijke vaststelling is, waarover hij als cassatierechter geen oordeel mocht vellen (HR 18 juni 1980, BNB 1980/223 (Buitengewone lasten pensionprijs II)), maar later heeft hij hierover wel enige aanwijzingen gegeven; zo blijkt er van een tegenwettelijk beleid in ieder geval geen sprake te zijn als de wetsafwijking het gevolg was van een incidentele fout of vergissing: HR 25 juni 1980, BNB 1980/277 (Berekening vloeroppervlakte). Zie nader Harlaar 1983, p. 78, Van Leijenhorst 1997, p. 1116 en Kavelaars-Niekoop 1999, p. 759-761. De bewijslast om aan te tonen of er sprake is van een beleid berust bij de belastingplichtige (HR 19 januari 1983 (belastingkamer), BNB 1983/132 (Onroerendgoedbelasting Hengelo)), maar de rechter lijkt hem hierbij soms te hulp te schieten (zie Harlaar 1983, p. 79). Verder is de bewijslast in de loop van de tijd iets verlicht, doordat de fiscus de verplichting is opgelegd om gegevens te verschaffen over het gevoerde beleid (Gladpootjes 1988, p. 1256/1257). Ook een antwoord op de vraag wanneer er sprake is van een begunstigend beleid is niet gemakkelijk te geven; zo is niet geheel duidelijk of er sprake moet zijn van een op begunstiging gericht oogmerk. Zie hierover Harlaar 1983, p. 80, Happé 1993, p. 148 en 152, Van Leijenhorst 1997, p. 1117 en Kavelaars-Niekoop 1999, p. 761.

147. Zie voor de specifieke toepassing in het belastingrecht nader Harlaar 1983, p. 80/81, Gladpootjes 1988 , p. 1259/1260, Happé 1993, p. 147, Van Leijenhorst 1997, p. 1113/1114 en Kavelaars-Niekoop 1999, p.

148. Dit geldt ook voor de hierna te bespreken meerderheidsregel. Zie HR 27 augustus 1986 (belastingka-
mer), BNB $1986 / 7$. mer), BNB 1986/317 (Besparing vakantiereis), HR 23 september 1998 (belastingkamer), BNB 1999/3 (FIOD-onderzoek), HR 16 december 1998, JB 1999/44 (Autokostenforfait) en HR 21 april 1999 (belastingkamer), BNB 1999/310 (CDK-spaarbiljetten). Zie ook Kavelaars-Niekoop 1999, p. 764/765. 
voorrangsregel impliceert dat niet aan het rechtvaardigingsmodel kan worden getoets en dat er geen ruimte bestaat voor een afweging van belangen in het concrete geval."."

Kan een begunstigend contra legem-beleid niet worden aangetoond, dan betekent dit nog niet dat het legaliteitsbeginsel altijd zal prevaleren. De Hoge Raad heeft namelijk aanvaard dat het legaliteitsbeginsel ook moet wijken wanneer er weliswaar geen sprake was van een begunstigend beleid, maar wel van een individuele wetsafwijking waarbij het oogmerk uitdrukkelijk op de begunstiging van de betrokken belanghebbende was gericht. ${ }^{150}$ In 1992 heeft de belastingkamer bovendien nog een tweede criterium onkwikkeld voor gevallen waarin een begunstigend beleid niet kan worden aangetoondde zogenaamde meerderheidsregel. ${ }^{151}$ Deze regel luidt als volgt:

"[...] buiten evenbedoelde gevallen [het geval waarin er geen sprake was van een begunstigend beleid of een oogmerk van begunstiging in een individueel geval, JHG] dient bij de afweging van het beginsel dat de wet moet worden toegepast, tegen het beginsel dat de administratie gelijke gevallen gelijk moet behandelen, aan laatstgenoemd beginsel doorslaggevende betekenis te worden toegekend wanneer in een meerderheid van de met het geval van de betrokken belastingplichtige vergelijkbare gevallen een juiste wetstoepassing achterwege is gebleven, met dien verstande dat hierbij niet in aanmerking mogen worden genomen gevallen zoals die waarin een juiste wetstoepassing achterwege is gebleven vanwege het geringe financiêle belang of de aanslag niet overeenkomstig de wet is vastgesteld ten gevolg van tik- of schrijffouten of daarmee gelijk te stellen vergissingen." ${ }^{138}$

149. Overigens zijn sporadische gevallen zichtbaar waarin wél een rechtvaardigingstoets wordt uitgevoerd en waarin bovendien een toetsing van de belangenafweging mogelijk blijkt. Zie bijv. HR 27 mant 1985 (belastingkamer), BNB 1985/164 (Reiskostenforfait): "waar de Inspecteur aldus een redelijp grond had voor de door belanghebbende gewraakte verschillende behandeling [...] diende zulks voot het Hof voldoende te zijn om niet in belanghebbendes geval een naar 's Hofs oordeel juiste wetstovpassing te laten wijken voor toepassing van het gelijkheidsbeginsel." Verder is in de literatuur gewezn op een algemene uitzonderingsmogelijkheid voor die gevallen waarin de afwijkende behandeling vat de belastingplichtige werd ingegeven door eisen van een doelmatige belastingheffing (zie bijv. HR 23 oktober 1985 (belastingkamer), BNB 1986/158 (Fooien taxichauffeurs) en HR 22 mart 2000 (belsstingkamer), BNB 2001/173 (Juridisch eigendom zonder economisch belang)); zie nader Schutte 2000, p. 6 en Engwerda 1999, p. 49. In het arrest met betrekking tot het juridisch eigendom stelde de Hoge Raad echter dat "dit beleid werd ingegeven door overwegingen van een doelmatige belastingheffing th een niet-begunstigend karakter heeft" (r.o. 3.2). Uit deze overweging lijkt eerder te kunnen worden al: geleid dat in een dergelijk geval niet aan de voorwaarden voor voorrang van het gelijkheidsbeginsel is voldaan (namelijk de eis dat het beleid een begunstigend karakter moet hebben), dan dat er een apatt: rechtvaardigingsmogelijkheid wordt gecreěerd. In die zin ook Happé 1996, p. 305.

150. HR 28 maart 1984 (belastingkamer), BNB 1984/196 (Ongelijke belasting aandeelhouders). Dit antsi had betrekking op twee gevallen, waarbij in het ene geval was afgeweken van de wet en in het andert niet. In die situatie is het niet mogelijk om een begunstigend beleid aan te tonen, nu daarvoor meet toe passingsgevallen vereist zijn. De belastingkamer stelde echter het volgende criterium vast: "[...] vot toepassing van het gelijkheidsbeginsel in een geval als het onderhavige [is] nodig [...] dat de ongelijkt behandeling voortkomt uit een oogmerk van begunstiging, waarvoor niet voldoende is dat een onge lijkheid in behandeling tussen twee belastingplichtigen welbewust - nog - niet is gecorrigeerd." Vpl Gladpootjes 1988, p. 1258, Happé 1993, p. 149 en Van Leijenhorst 1997, p. 1118.

151. HR 17 juni 1992, BNB 1992/295 (Benelux-Merkenbureau). Eerder erkende de Hoge Raad deze rege nog niet, hetgeen tot onredelijke gevolgen kon leiden als de gedaagde over onvoldoende gegevens te schikte om een beleid aan te kunnen tonen, maar er in een groot aantal gevallen op begunstigende wi] ze van de wet was afgeweken. Zie bijvoorbeeld HR 19 januari 1983, BNB 1983/132 (Onrocrendgecel belasting Hengelo).

152. R.o. 3.9. Zie voor een vergelijkbare weergave van de toets HR 17 juni 1992 (belastingkamer), $B N B$ 
Ook deze regel functioneert als voorrangsregel: is er in een meerderheid van gevallen sprake geweest van een wetsafwijking, dan moet een juiste wetstoepassing wijken voor de werking van het gelijkheidsbeginsel. Voor een concrete belangenafweging of een nadere beoordeling van een eventuele rechtvaardiging bestaat bij de toepassing van deze regel opnieuw geen ruimte. ${ }^{153}$

Door de ontwikkeling van deze voorrangsregels voert de belastingrechter als enige van de bestudeerde rechterlijke instanties een toetsing uit die volledig afwijkt van het theoretische model. Een belangrijk verschil is vooral dat het bij deze toetsing niet relevant is waaróm in het geval van de belanghebbende is gekozen voor een andere behandeling dan in eerdere gevallen: van belang is slechts dát er is gekozen voor een andere behandeling. Bovendien bestaat er, anders dan bij het theoretische model, geen mogelijkheid van een concrete belangenafweging: de voorrangsregels hebben een absoluut karakter en laten weinig ruimte voor flexibiliteit.

Juist door zijn bijzondere en absolute karakter leent dit model zich niet voor algemene toepassing. De ontwikkelde voorrangsregels zijn specifiek bedoeld voor de situatie waarin verschillende besluiten zijn genomen in een opeenvolging van concrete gevallen, waarbij bovendien sprake is van tegenwettelijk handelen. Op zichzelf zou het model nog wel toepassing kunnen krijgen buiten de specifieke situatie van contra legembeleid. Wanneer bijvoorbeeld in een reeks van gevallen consequent en in overeenstemming met de wet een vergunning is verleend, terwijl dit in één geval is geweigerd, kan zeker gebruik worden gemaakt van de regel met betrekking tot begunstigend beleid

1992/294 (Taxatie onroerend goed), HR 16 december 1998 (belastingkamer), JB 1999/44 (Autokostenforfait), HR 21 april 1999 (belastingkamer), BNB 1999/310 (CDK-spaarbiljetten) en HR 15 maart 2000 (belastingkamer), BNB 2000/278 (Bedrijfskosten meewerkende kinderen). Uit HR 22 maart 2000 (belastingkamer), BNB 2000/173 (Juridisch eigendom zonder economisch belang) blijkt duidelijk dat de meerderheidsregel pas van toepassing zal zijn wanneer niet kan worden aangetoond dat er sprake was van een begunstigend beleid. Daardoor zijn enige onduidelijkheden opgelost die voorheen golden met betrekking tot de verhouding tussen de verschillende voorrangsregels, hoewel de verhouding tussen de meerderheidsregel en de eerdergenoemde regel van het oogmerk van begunstiging nog steeds onduidelijk is (vgl. Happé 1993, p. 151).

153. Vgl. Happé 1996, p. 339. Zoals uit de geciteerde overweging al blijkt bestaat wel de mogelijkheid om aan te tonen dat er feitelijk geen sprake was van vergelijkbare gevallen en dat de ongelijke behandeling in werkelijkheid uitsluitend daarmee verband houdt. Zie bijv. HR 17 juni 1992, BNB 1992/294 (Taxatie onroerend goed). Ook verder zijn in de rechtspraak de nodige eisen gesteld. Zo geldt, net als bij de regeling van het begunstigende beleid, ook bij de meerderheidsregel dat geen beroep kan worden gedaan op gevallen waarover door een inspecteur in een ander ambtsgebied is beslist (HR 24 april 1996 (belastingkamer), BNB 1996/210 (Bijzondere verbruiksbelasting personenauto's), HR 16 december 1998, JB 1999/44 (Autokostenforfait) en HR 21 april 1999, BNB 1999/310 (CDK-spaarbiljetten I)). Uit de geciteerde overweging blijkt bovendien dat geen beroep kan worden gedaan op gevallen waarin de wetsafwijking het gevolg was van een kennelijke fout of verschrijving; dat dit niet betekent dat in alle gevallen waarin fouten zijn gemaakt sprake is van voorrang voor het legaliteitsbeginsel blijkt echter uit HR 27 juli 1999 (belastingkamer), BNB 1999/403 (Huurwaardeforfait). Verder geldt de eis dat altijd moet worden verwezen naar méér gevallen: een referentie aan slechts één vergelijkbaar geval is niet voldoende (HR 28 juni 1995 (belastingkamer), BNB 1995/281 (Bonusregeling), HR 24 april 1996 (belastingkamer), BNB 1996/210 (Bijzondere verbruiksbelasting personenauto's), HR 24 september 1997 (belastingkamer), BNB 1998/20 (Aan- en verkoop woningen) en HR 16 december 1998, BNB ligt: hoe (Overbedeling na echtscheiding)). Interessant is overigens de vraag waar daarbij de grens vergelijking moet de groep zijn waarbinnen de wetsafwijking heeft plaatsgevonden om een relevante deze vraag gegeven. 
en van de meerderheidsregel. ${ }^{154}$ Voor andere gevallen van ongelijke behandeling, zoals de normatieve classificaties, is het stelsel van voorrangsregels echter duidelijk onge. schikt; zoals hiervoor is gebleken hanteert de belastingkamer in die gevallen ook zeff een methodiek die meer met het theoretische model overeenstemt. Het is echter juist de bedoeling om een toetsingsmodel te ontwikkelen dat geschikt is voor de beoordeling van alle vormen van ongelijke behandeling, inclusief de normatieve classificaties. Voor het onderzoek is de benadering van de belastingkamer, hoe fraai ook uitgewerkt, dan ook niet bijzonder relevant. Om die reden zal aan de voorrangsregels in het vervolg van dit hoofdstuk slechts in beperkte mate aandacht worden besteed. Op enkele lastige problemen die bij deze regels spelen zal daarbij niet nader worden ingegaan. ${ }^{\text {ss }}$

\subsubsection{Toetsingsmethodiek van de Afdeling Bestuursrechtspraak}

\section{Inleiding}

Als bestuursrechter krijgt de Afdeling Bestuursrechtspraak feitelijk alleen te maken met het gelijkheidsbeginsel in gevallen waarin een bestuursorgaan een verschillend gebruik heeft gemaakt van zijn bevoegdheid: een rechtstreeks beroep tegen algemeen verbindende voorschriften en de daarin opgenomen classificaties is blijkens de Algemene wet bestuursrecht vooralsnog niet mogelijk. ${ }^{156}$ Het is echter niet ongebruikelijk dat één van de partijen stelt dat de concreet voorgelegde ongelijke behandeling het

154. Dan is echter de vraag, die overigens ook bij de contra legem-gevallen kan worden gesteld, of niet todh een rechtvaardigingsmogelijkheid moet worden geboden: de voorrangsregels laten daarvoor gert ruimte, terwijl het bij een bredere toepassing toch redelijk kan zijn om in bepaalde gevallen een mogs: lijkheid open te laten voor een ongelijke behandeling.

155. Lastig is allereerst de verdeling van de bewijslast. Zo blijken de stelplicht en de bewijslast vam het bestaan van een begunstigend beleid bij de belanghebbende te liggen (HR 19 januari 1983 (belasting kamer), BNB 1983/132 (Onroerendgoedbelasting Hengelo) en HR 21 april 1999 (belastingkamer) BNB 1999/310 (CDK-spaarbiljetten)), terwijl het aan de fiscus is om aan te tonen dat er geen spres: was van vergelijkbare gevallen (HR 22 juni 1983 (belastingkamer), BNB 1983/240 (Onroerendgoedbelasting Schiedam II)). Bij de meerderheidsregel is het zo dat de belastingplichtige aannemelijk moet maken dat in een meerderheid van gevallen die met de zijne vergelijkbaar zijn een juiste wetstoeps. sing achterwege is gebleven; daarbij mag hij alleen melding maken van vergelijkbare gevallen dic ke betrokken bestuursorgaan uit hoofde van zijn bevoegdheid bekend zijn (HR 16 december 1998 (belstingkamer), JB 1999/44 (Autokostenforfait)). Zie nader Gladpootjes 1988, p. 1256/1257, Happó 1993 p. 152/153, Van Leijenhorst 1997, p. 1115 en Schutte 2000, p. 6. Verder is het de vraag wanneer eregenlijk sprake is van begunstigend beleid (zie nader Harlaar 1983, p. 80, Happé 1996, p. 305 en Kaire laars-Niekoop 1999, p. 761/762), wat er gebeurt bij overlap tussen de meerderheidsregel en de andert voorrangsregels (zie Happé 1993, p. 151 en Happé 1996, p. 341-343), hoe de groep moet worden be paald waarbinnen een meerderheid kan worden vastgesteld (zie Happé 1993, p. 153/154 en Happe 1996 , p. 330-333) en welke consequenties er moeten worden verbonden aan een tegenwettelijk hande len dat voortvloeit uit een onjuiste interpretatie van de wet. Vooral de laatste kwestie is interessant omdat bij onjuiste wetsinterpretatie het gelijkheidsbeginsel kennelijk niet automatisch kan prevalert boven het legaliteitsbeginsel. Zie daarvoor HR 5 februari 1997 (belastingkamer), BNB 1997/16 (Dienstauto bewindslieden), waarin de HR stelde dat "wanneer beleid, dat berust op een onjulis rechtsopvatting, naar zijn bedoeling slechts wordt gevoerd ten aanzien van een zeer beperkte groc belastingplichtigen en aannemelijk is dat het zonder die onjuiste rechtsopvatting achterwege zou zif gebleven, kunnen belastingplichtigen die niet tot de beperkte groep behoren niet met vrucht berof doen op toepassing van het gelijkheidsbeginsel als algemeen beginsel van behoorlijk bestuur zolang onjuistheid van die rechtsopvatting niet is gebleken"; zie ook HR 24 januari 2001, BNB 200129\%. (Dienstauto bewindslieden II). Zie nader Van Leijenhorst 1997, p. 1127/1128.

156. Zie artikel 8:2 Awb. 
rechtstreekse resultaat is van een ongerechtvaardigde classificatie in een algemeen verbindend voorschrift. In dergelijke gevallen zal de Afdeling Bestuursrechtspraak via een exceptieve toetsing kunnen controleren of deze classificatie in overeenstemming is met het algemene gelijkheidsbeginsel zoals dat is neergelegd in de Grondwet, het Europese recht of de internationale verdragen. Een beoordeling van normatieve classificaties is in de rechtspraak van de Afdeling dan ook vrij regelmatig terug te vinden.

\title{
Rechtvaardigingstoets in de tweede toetsingsfase
}

Anders dan de belastingkamer heeft de Afdeling geen verschillende toetsingsmodellen ontwikkeld voor de toetsing van ongelijke bevoegdheidsuitoefening en de toetsing van normatieve classificaties: in beide situaties wordt een identieke toetsingsmethodiek gehanteerd. Daarbij geldt volgens vaste rechtspraak dat in de tweede fase van de toetsing een rechtvaardigingstoets moet worden uitgevoerd. Deze toets wordt in verschillende uitspraken soms iets anders gedefinieerd, maar zeer gebruikelijk is een formulering als de volgende:

\begin{abstract}
"De gemeentelijke wetgever heeft [...] op toereikende, de grenzen van de redelijkheid niet overschrijdende, gronden geoordeeld, dat voor het onderscheid een objectieve en redelijke rechtvaardiging bestaat. Waar aldus met dit onderscheid een legitiem doel kan worden nagestreefd en het kan worden aangemerkt als een passend middel om dat doel te bereiken, is geen sprake van een ongerechtvaardigd onderscheid als bedoeld in artikel 26 IVBPR."157
\end{abstract}

Hieruit valt af te leiden dat in de tweede fase een toetsing wordt uitgevoerd die slechts bestaat uit twee onderdelen: een toetsing van het doel en een algemene toetsing van de verhouding tussen doel en middel. In dit opzicht is het model vergelijkbaar met dat van de Hoge Raad. Deze gelijkenis wordt nog versterkt door het gebruik van het "passendheidscriterium", dat ook is terug te vinden in de rechtspraak van de civiele kamer van de Hoge Raad. ${ }^{13 x}$ In het verloop van dit hoofdstuk zal aan deze uitwerking van de rechtvaardigingstoets nader aandacht worden besteed.

157. ABRS 18 januari 2000, JB 2000/53 (Koffieshop-beleid Leiden). Zie voor vergelijkbare omschrijvingen ABRS 3 maart 1994, AB 1995/85 (Leeftijdscriterium woonruimteverordening; onderscheid moet gebaseerd zijn op "zakelijk en rechtens relevante gronden"), ABRS 2 september 1994, AB 1995/146 (Medewerkersovereenkomst met 65-plusser), ABRS 21 februari 1995, AB 1996/222 (Vererving adeldom in vrouwelijke lijn), ABRS 28 februari 1995, AB 1995/439 (Territorialiteitsbeginsel IOAW), ABRS 15 januari 1996, AB 1999/185 (Hoger beroep vreemdelingenzaken), ABRS 25 juli 1996, AB 1996/425 (Uitvoer bedrijfsafvalstoffen; hier vond een iets afwijkende toetsing plaats omdat moest worden getoetst aan het EG-Verdrag), ABRS 10 februari 1997, JB 1997/85 (Parkeerbeleid Leiden), ABRS 24 april 1997, JB 1997/149 (Pensioenuitkering KNIL-militairen), ABRS 12 juni 1997, JB 1997/189 (Stichting Silicose Oud-Mijnwerkers II), ABRS 9 december 1997, JB 1998/10 (Pensioenuitkering weduwe KNIL-militair), ABRS 5 november 1998, AB 1999/100 (Pensioenuitkering KNIL-militairen II), ABRS 19 maart 1999, JB 1999/103 (Vervangend rijbewijs) en ABRS 27 april 2000, AB 2000/243 (Afgifte rijbewijs). De Afdeling Rechtspraak heeft een vergelijkbare definitie gegeven: zie bijv, ARRS 5 juli 1979, AB 1980/414 (Economische gebondenheid Zaanstad) (" [...] de voorwaarden van ingezetenschap en economische gebondenheid [...] zijn aan te merken als objectief en redelijkerwijs te rechtvaardigen middelen welke passen bij het met de Woonruimtewet beoogde doel"), ARRS 15 januari 1982, AB 1982/332 (Economische binding Wamel), ARRS 2 januari 1986, AB 1986/443 (Woonwa-

158. Overigens wordt lang niet in alle gevallen melding gemaakt van dit criterium: in de meeste van de in
de vorige de vorige noot genoemde gevallen volstond de Afdeling met een algemene redelijkheidstoets, en maakte zij geen gebruik van specifieke toetsingscriteria zoals passendheid of proportionaliteit. 


\section{Vergelijkbaarheidstoets in de eerste toetsingsfase}

In de meeste gevallen zal de Afdeling echter niet toekomen aan deze tweede, inhoude. lijke, toetsingsfase. De oorzaak daarvan is gelegen in het feit dat de Afdeling in dz eerste fase consequent een strenge vergelijkbaarheidstoets uitvoert, zowel in de geval. len waarin een oordeel moet worden uitgesproken over een normatieve classificatie als in de gevallen waarin een concrete bevoegdheidsuitoefening wordt beoordeeld." Vooral in de laatste situatie blijkt de vergelijkbaarheidstoets een vrijwel absolute barrière op te leveren voor een geslaagd beroep op het gelijkheidsbeginsel: het aantal go vallen waarin de Afdeling heeft aanvaard dat de gevallen voldoende vergelijkbar zijn is minimaal. ${ }^{160}$ Verder ziet de Afdeling, anders dan de belastingkamer, geen ruimte voor een nadere redelijkheidstoets wanneer eenmaal is vastgesteld dat de gevallen onverge. lijkbaar zijn. Zelfs wanneer er sprake lijkt te zijn van een grove onevenredigheid tussen de gesignaleerde verschillen en het verschil in behandeling zal een beroep op het gelijkheidsbeginsel geen uitkomst bieden: vaststelling van onvergelijkbaarheid betekent automatisch dat het beroep op het gelijkheidsbeginsel wordt afgewezen. ${ }^{161}$

159. Zie bijv. ABRS 3 november 1994, AB 1995/13 (Beleid bij autokeuringen), ABRS 28 december 1995, AB 1996/206 (Sluiting veemarkt), ABRS 26 september 1996, AB 1996/483 (Uitstallingsbeleid Bos th Lommer), ABRS 10 oktober 1996, AB 1996/482 (Betonnen casco bij woonboot; impliciet), ABRS 19 december 1996, AB 1997/414 (Hervormde Jeugdraad Blokland), ABRS 5 juni 1998, AB 1998286 (Woonschipbeleid Amsterdam), ABRS 20 juli 1998, AB 1998/406 (Ligplaats Omzigt), ABRS $17 \mathrm{mci}$ 1999, AB 1999/294 (Bekostiging opleiding verpleeghuisarts), ABRS 11 december 1998, AB 199915 (Opslag caravans), ABRS 29 februari 2000, AB 2001/1 (Vermindering bedden verpleeghuis) en ABRS 13 februari 2001, JB 2001/109 (Bijdrage premiederving). Eerder is al opgemerkt (zie paragraf 122) dat de Afdeling zelfs bij klachten over indirect onderscheid gebruik maakt van een vergelijkbarmheidstoets, waarbij bovendien wordt uitgegaan van een zeer formele benadering. Voor de gedachted ook een gelijke behandeling van ongelijke gevallen (waarvan feitelijk sprake is bij indiret onder scheid, zie hoofdstuk 2, paragraaf 1.2.2) tot een ongerechtvaardigd onderscheid kan leiden lijkt gert ruimte te bestaan; zie ABRS 5 juli 1994, AB 1995/180 (Vrijlatingsregeling). Een uitzonderlijk gend waarin een benadelingstoets werd toegepast is ABRS 4 augustus 1998, AB 1998/377 (Loting genety kunde); hierin was echter een klacht over schending van het Europese recht aan de orde, waardoor de Afdeling zich moest conformeren aan de rechtspraak van het Europees Hof van Justitie.

160. Zie echter 9 december 1997, JB 1998/10 (Pensioenuitkering weduwe KNIL-militair, in deze zak gff de Afdeling geen oordeel over de vergelijkbaarheid, maar veronderstelde zij deze om op die maniet ds rechtvaardiging te kunnen beoordelen), ABRS 15 november 1999, JB 2000/8 (Huursubsidic; in dez zaak ontbrak een toetsing in de eerste fase - vergelijkbaarheid werd kennelijk verondersteld) en ABRS 9 mei 2000, JB 2001/179 (Dakkapellen). Daamaast is het in een aantal gevallen niet helemaal duidelifi of het beroep werd afgewezen wegens onvergelijkbaarheid van de gevallen of vanwege een voot hes onderscheid bestaande rechtvaardiging. Zie bijv. ABRS 27 juni 1996, AB 1998/50 (Bouwverguning woonwagens): appellant had geen bouwvergunning gekregen voor het bouwen van een soort woonis gen-chalet, terwijl er op het woonwagencentrum verschillende vergelijkbare woonwagens waren ge plaatst zonder dat B\&W daartegen waren opgetreden. De Afdeling meende dat foto's lieten zien ditl b verschillende woonwagens qua omvang en constructie erg op elkaar leken. Vervolgens stelde zij ectiter dat B\&W ook van plan waren tegen de nieuwe woonwagens op te treden, maar dit nog niet gedaris hadden omdat de betrokken woonwagenbewoners zich bereid hadden getoond om te verhuizen. Hetiu niet duidelijk of dit laatste argument moet worden gezien als onderdeel van de vergelijkbaarheidstich (er bestaat immers verschil tussen de gevallen in die zin dat appellant niet en de andere woonhas bewoners wel verhuizingsbereid waren) of als rechtvaardigingsargument. Zie voor een vergelf 5 hybride benadering ABRS 2 juni 1994, AB 1994/629 (Ligplaatsenverordening Friesland), $A B$, 1999, AB vember 1998, AB 1999/100 (Pensioenuitkering KNIL-militairen II) en ABRS 1 juni 199, A 1999/313 (Zeilschool).

161. Zie bijv. ABRS 28 december 1995, AB 1996/206 (Sluiting veemarkt), ABRS 26 september 1996, $A B$ 1996/483 (Uitstallingsbeleid Bos en Lommer), ABRS 19 december 1996, AB 1997 (Hervomot 
Opmerkelijk is overigens dat ook in de sporadische gevallen waarin is vastgesteld dat de gevallen wél vergelijkbaar zijn, een toetsing van de aangedragen rechtvaardiging vaak ontbreekt: de Afdeling heeft verschillende uitspraken gedaan waarin in dit soort gevallen direct werd geconcludeerd tot schending van het gelijkheidsbeginsel, zonder dat eerst een redelijkheidstoets werd uitgevoerd. ${ }^{162}$ Dit betekent dat zij in dergelijke gevallen niet zal toekomen aan de vraag of er een objectieve en redelijke rechtvaardiging bestaat die buiten het onderscheid zelf is gelegen. ${ }^{163}$ De benadering van de Afdeling is daarmee in overeenstemming met de in hoofdstuk 2, paragraaf 4.3 .1 beschreven situatie, waarbij de vergelijkbaarheidstoets altijd, ongeacht de uitkomst, bepalend is voor de uitkomst van de procedure. Juist omdat in hoofdstuk 2 al is aangegeven dat deze benadering in theorie de minst wenselijke is, is het de moeite waard om aan deze rechtspraak nader aandacht te besteden. In paragraaf 2.2 zal hierop dan ook uitgebreid worden ingegaan.

\subsubsection{Toetsingsmethodiek van de Centrale Raad van Beroep}

\section{Toetsing bij toepasselijkheid van het Europese recht}

De Centrale Raad van Beroep blijkt in de praktijk vooral te maken te hebben met klachten over normatieve classificaties. ${ }^{164}$ De methodiek die de Centrale Raad bij de beoordeling daarvan hanteert wordt in sterke mate bepaald door de toepasselijke gelijkheidsbepaling. Eerder is bijvoorbeeld al opgemerkt dat de Centrale Raad regelmatig uitspraak moet doen over klachten over de schending van het Europese recht. In zijn rechtspraak blijkt de Centrale Raad de methodiek van het Europees Hof van Justitie nauwgezet te volgen. Wanneer er geklaagd wordt over indirect onderscheid betekent dit dat de Centrale Raad meestal uitgaat van een formule als de volgende:

Jeugdraad Blokland), ABRS 5 juni 1998, AB 1998/286 (Woonschipbeleid Amsterdam), ABRS 17 mei 1999, AB 1999/294 (Verpleeghuisarts), ABRS 17 mei 1999, AB 1999/294, ABRS 29 februari 2000. AB 2001// (Vermindering bedden verpleeghuis) en ABRS 13 februari 2001, JB 2001/109 (Bijdrage premiederving).

162. Hiervan zijn nauwelijks voorbeelden te vinden in de rechtspraak van de Afdeling Bestuursrechtspraak, maar wel in de uitspraken van de Afdeling Rechtspraak; het is niet erg waarschijnlijk dat de Afdeling Bestuursrechtspraak hierin een radicaal andere benadering zal kiezen. In veel van dit soort gevallen werd overigens geen strijd met het gelijkheidsbeginsel, maar met een ander algemeen beginsel van behoorlijk bestuur aangenomen, zoals het motiveringsbeginsel of het zorgvuldigheidsbeginsel. Zie bijv. ARRS I augustus 1983, AB 1984/532 (Humanistisch vormingsonderwijs Haarlem; strijd met het motiveringsbeginsel), ARRS 6 november 1984, AB 1985/417 (Verhuis- en herinrichtingskostenvergoeding; strijd met verbod van willekeur), ARRS 2 september 1987, AB 1988/303 (Humanistisch Vormingsonderwijs Valkenswaard; strijd met motiveringsbeginsel) en ABRS 9 mei 2000, JB 2001/179 (Dakkapellen; strijd met het motiveringsbeginsel). Van een rechtstreekse toepassing van het gelijkheidsbeginsel was sprake in ARRS 1 augustus 1980, AB 1981/5 (Maatbouw/Weststellingswerf), ARRS 7 november 1980, AB 1981/346 (Leijtens/Van Waalwijk), ARRS 15 augustus 1985, AB 1986/250 (Pensioentoeslag ambtenaren Antillen), ARRS 27 juli 1990, AB 1991/595 (Terugploegexperiment), ARRS 27 augustus 1991, AB 1992/313 (Speelautomatenhal) en ARRS 2 maart 1993, AB 1993/364 (Wooncomplex Florence Nightingale-straat)

163. Een dergelijke rechtvaardiging zal vooral kunnen worden gevonden in administratieve of financiele argumenten: deze houden vrijwel nooit verband met kenmerken van de gevallen waartussen wordt on-

164. Wel zal den, zodat zij niet goed kunnen worden ingevoegd in de vergelijkbaarheidstoets.

duele beslissin altijd sprake zijn van een indirect beroep: het beroep zal zijn gericht tegen een indiviwordt door de eraarbij gesteld wordt dat de ongerechtvaardigdheid van die beslissing veroorzaakt 
"Van een dergelijke discriminatie [indirecte discriminatie op grond van geslacht, JHG] kan sprake zijn als een regeling die op zichzelf sexe-neutraal is, door verwijzing naas bijvoorbeeld de echtelijke staat of de gezinssituatie een aanmerkelijk groter deel van hetzi de vrouwen, hetzij de mannen in vergelijking met de leden van het andere geslacht nadelig treft, terwijl daarvoor geen rechtvaardiging bestaat."

Blijkens deze definitie moet er in de eerste fase een benadelingstoets worden uitge. voerd, waarbij moet worden gekeken naar de effecten van de maatregel voor bepaalde, door het Europese recht in het bijzonder beschermde groepen. In navolging van het Hof van Justitie acht de Centrale Raad het daarbij niet van belang of het oogmerk van de regelgever op het bereiken van dit benadelende effect was gericht: voldoende is dat uit feitelijke gegevens blijkt dat een dergelijk effect in de praktijk aanwezig is. ${ }^{106}$

Wanneer voldoende vaststaat dat er sprake is van indirect onderscheid zal de Centrale Raad, zoals uit bovenstaand citaat blijkt, een rechtvaardigingstoets uitvoeren. Ook daarbij volgt de Raad de rechtspraak van het Europese Hof van Justitie:

"Indien zou moeten worden uitgegaan van de veronderstelling dat genoemde nationaalrechtelijke bepalingen [...] een aanmerkelijk groter aantal vrouwen dan mannen treffen, zodat in beginsel zou moeten worden gesproken van een vermoeden van indirecte discriminatie van vrouwen, rijst de vraag of deze bepalingen worden gerechtvaardigd door objectieve factoren die geen verband houden met discriminatie op grond van geslacht. Volgens de rechtspraak van het EG-Hof van Justitie [...] is dit het geval, wanneer de gekozen middelen beantwoorden aan een legitieme doelstelling van het sociaal beleid van de Lid-Staat waarvan de wettelijke regeling in het geding is, en zij ter bereiking van dat docl geschikt en noodzakelijk zijn."167

Op de invulling die de Centrale Raad aan deze toetsingscriteria heeft gegeven zal in paragraaf 2.3 en 2.4 nader worden ingegaan.

165. CRvB 23 mei 1991, RSV 1991/257 (Overgang AAW-AWW II), r.o. 2.2. Idem in CRvB 23 juni 1992 , RSV 1992/317 (Inkomenseis AAW), CRvB 9 april 1991, RSV 1991/247 (Drie-uit-vijf-eis), CRvB 23 mei 1991, RSV 1991/257 (Overgang AAW-AWW II), CRvB 18 juni 1993, RSV 1994/68 (Samenloop AAW-uitkeringen), CRvB 20 september 1995, AB 1996/20 (Kostwinnerscriterium medeverzekering ziekenfonds), CRvB 29 april 1996, RSV 1996/247 (WW-uitkering huishoudelijk personeel), CRvB 1f oktober 1996, RSV 1997/235 (Inkomenseis Rariteitenbesluit WAO), CRvB 4 november 1998, IB 1998/285 (Wet Van Otterloo) en CRvB 21 september 2000, JB 2000/313 (Scholierenregeling; onderscheid op grond van nationaliteit).

166. Zie bijv. CRvB 28 september 1989, RSV 1990/235 (Medeverzekering ZFW, waarin overigens onvoldoende statistisch bewijs aanwezig geacht werd om een indirect onderscheid aan te kunnen nemen) CRvB 9 april 1991, RSV 1991/247 (Drie-uit-vijf-eis, waarin het criterium van "aanmerkelijke benats ling" nader wordt uitgewerkt), CRvB 23 mei 1991, RSV 1991/257 (Overgang AAW-AWW II; getruil van feiten van algemene bekendheid), CRvB 25 juli 1991, RSV 1992/77 (Verhouding AAW-AOW. gebruik van feiten van algemene bekendheid) en CRvB 17 oktober 1996, RSV 1997/235 (Inkomensel Rariteitenbesluit WAO; gebruik van statistische gegevens). In sommige gevallen voert de Centrals Raad zelf geen benadelingstoets uit, maar gaat hij af op de stellingen van partijen; zie bijv. CRvB 12 augustus 1999, RSV 2000/73 (Inkomensvereiste thuiswerkers).

167. CRvB 20 september 1995, AB 1996/20 (Kostwinnerscriterium medeverzekering ZFW). Zie ook CRvB 19 april 1990. RSV 1990/323 (Teuling-Worms), CRvB 23 juni 1992, RSV 1992/317 (Inkomensil AAW), CRvB 20 september 1995, AB 1996/20 (Kostwinnerscriterium medeverzekering ziekenfonds) CRvB 29 april 1996, RSV 1996/247 (WW-uitkering huishoudelijk personeel) en CRvB 21 sepplenter 2000 , JB 2000/313 (Scholierenregeling; onderscheid op grond van nationaliteit). 
Toetsing bij toepasselijkheid van andere gelijkheidsbepalingen

Interessant is verder de methodiek die de Centrale Raad hanteert bij de toetsing aan artikel 26 IVBPR en artikel 14 EVRM. Deze wordt in belangrijke mate bepaald door de vraag of er in de voorgelegde zaak ook een Europeesrechtelijk element meespeelt. Is dat het geval, dan zal altijd eerst aan het Europese recht worden getoetst. Een beroep op artikel 26 IVBPR of artikel 14 EVRM kan dan, volgens vaste rechtspraak, niet meer leiden tot een ander resultaat, ook al is er aanleiding om te veronderstellen dat die artikelen in het voorliggende geval meer bescherming bieden. ${ }^{16 s}$ De toetsingsmethodiek bij het Europese recht wordt daardoor min of meer geïncorporeerd in de toetsing aan de andere internationale gelijkheidsbepalingen.

Wanneer uitsluitend op één van de internationale gelijkheidsbepalingen een beroep wordt gedaan past de Centrale Raad wel een eigen toetsingsmodel toe. Dit model is geïnspireerd door uitspraken van het Human Rights Committee (het orgaan dat toezicht houdt op de naleving van het IVBPR en in dat verband ook individuele klachten kan behandelen) ${ }^{169}$ en het Europees Hof voor de Rechten van de Mens ${ }^{170} .{ }^{171}$ De meest gangbare definitie van het toetsingsmodel is hierbij de volgende:

"[Niet iedere] [...] in de nationale regelingen op het gebied van de sociale zekerheid voorkomende ongelijke behandeling [is] discriminatoir van aard [...] te achten. Zo heeft art. 26 van het BP-Verdrag, gelet op de aard en strekking ervan, niet het oog op die ongelijke behandeling welke op redelijke en objectieve gronden, waaraan iedere gedachte van discriminatie vreemd is, kan worden gerechtvaardigd." 172

168. Zie CRvB 23 juni 1992, RSV 1992/217 (Inkomenseis AAW), CRvB 15 mei 1996, RSV 1996/170 (Posthuma-Van Damme), CRvB 11 april 1997, AB 1997/242 (Inkomenseis AAW), CRvB 16 januari 1998, RSV 1998/160 (Inkomenseis AAW II) en CRvB 4 november 1998, JB 1998/285 (Wet Van Otterloo).

169. De Centrale Raad verwijst soms naar uitspraken van het Human Rights Committee ter ondersteuning van de eigen motivering. Zie bijv. CRvB 28 september 1989, RSV 1990/235 (Medeverzekering ZFW). CRvB 28 februari 1990, RSV 1990/295 (AWW-uitkering ongehuwde partner) en CRvB 10 juli 1991, RSV 1992/76 (Samenwonende bloedverwanten AOW). Zie ook Riphagen/Smitskam 1990, p. 406.

170. Zie CRvB 11 april 1997, AB 1997/242 (Inkomenseis AAW), CRvB 16 januari 1998, RSV 1998/160 (Inkomenseis AAW II) en CRvB 4 november 1998, JB 1998/285 (Wet Van Otterloo).

171. Ook is soms een met de toetsing aan het Europese recht vergelijkbare benadering zichtbaar. Zie bijv. CRvB 30 augustus 1989, RSV 1990/92 (Onderhoudsbijdrage AKW), waarin de Centrale Raad in het kader van een toetsing aan artikel 26 IVBPR stelde dat "ook indien het feitelijk effect van het hanteren van het onderhoudscriterium zou zijn dat buitenlandse werknemers in overwegende mate geen aanspraak zouden kunnen maken op kinderbijslag [...] vindt dit zijn oorzaak in factoren die geen verband houden met discriminatie op grond van nationaliteit of herkomst." Zo ook in CRvB 4 januari 2000, RSV 2000/79 (Noodzakelijke scholing Abw).

172. CRvB 5 januari 1988, RSV 1988/198 (Overgangsrecht AAW), CRvB 25 mei 1989, RSV 1989/275 (Weduwenuitkering bij concubinaat), CRvB 9 mei 1990, RSV 1990/383 (AWW-uitkering bij huwelijk met gepensioneerde), CRvB 12 december 1990, RSV 1991/264 (Leeftijdsgrens AWW), CRvB 23 mei 1991, RSV 1991/257 (Overgang AAW-AWW II), CRvB 10 juli 1991, RSV 1992/21 (Overgangsregeling AOW; impliciet), CRvB 17 maart 1992, AB 1992/419 (Wooneis AAW), CRvB 14 april 1992, RSV 1993/24 (Wezenpensioen als eigen inkomen kind), CRvB 26 mei 1992, RSV 1993/44 (ADLassistentie), CRvB 1 oktober 1992, RSV 1993/14 (Eigen bijdrageregeling AWBZ), CRvB 29 april 1993, RSV 1993/307 (AAW-aanspraak na 65ste jaar), CRvB 24 mei 1993, RSV 1994/43 (Leeftijdscriterium AWW), CRvB 20 juli 1993, RSV 1994/45 (Leeftijdscriterium eigen bijdrage AWBZ), CRvB 3 november 1993, AB 1994/94 (Leeftijdseis AAW), CRvB 4 november 1993, AB 1994/213 (Van 
In deze definitie ontbreken aanwijzingen over de toetsing in de eerste fase: het is nitt. duidelijk of daarin een vergelijkbaarheidstoets of een andere toets moet worden uitgevoerd. ${ }^{173}$ In de praktijk blijkt echter dat in veel gevallen een vergelijkbaarheidstoets wordt toegepast; opvallend is bovendien dat in deze vergelijkbaarheid regelmatig meteen een rechtvaardiging wordt gezien. Een voorbeeld van deze benadering is te vinden in de uitgebreide rechtspraak over het feit dat bepaalde uitkeringen aan sommi. ge samenwonende bloedverwanten werden toegekend, terwijl zij aan andere werden onthouden: zo kwamen minderjarige kinderen die met hun ouders samenwoonden na overlijden van één van de ouders ingevolge de AOW wel in aanmerking voor eat

Maarseveen), CRvB 21 januari 1994, RSV 1994/192 (Verplichte verzekering WTZ), CRvB 3 mei 1994, AB 1994/667 (Beperking eigen bijdrage AWBZ), CRvB 21 oktober 1994, AB 1995/341 (0ver. gangsregeling AOW), CRvB 30 juni 1995, RSV 1996/206 (Samenleving aanverwanten), CRvB if september 1996, RSV 1997/154 (Verlenging kinderbijslag JWG), CRvB 16 oktober 1996, AB 1997/140 (Referte-eis AAW), CRvB 12 februari 1997, RSV 1997/227 (WW-uitkering vreemdelingen), CRvB 14 januari 1998, RSV 1998/179 (Onderhoudsbijdrage AKW), CRvB 1 april 1998, RSV 1998/187 (AOW voor gehuwden), CRvB 4 november 1998, JB 1998/285 (Wet Van Otterloo), CRvB 24 november 1998, AB 1999/77 (Gezamenlijke huishouding met broer), CRvB 23 februari 1999, RSV 1999/1 19 (Aanvangsdatum fictief arbeidsverleden), CRvB 22 oktober 1999, AB 2000/289 (Persoons. gebonden budget thuiszorg), CRvB 26 november 1999, RSV 2000/50 (Verlaging eigen bijdrage zrak. zinnigen), CRvB 5 juli 2000, JB 2000/257 (Referte-eis seizoensmedewerkers), CRvB 4 oktober 2000, RSV 2001/19 (Overgangsregeling Anw) en CRvB 26 juni 2001, JB 2001/184 (Koppelingswet) in sommige gevallen wordt voor een iets andere benadering gekozen, waarbij een rechtvaardiging wout gevonden in verschillen tussen de gevallen; zie CRvB 16 april 1991, RSV 1991/212 (Uitlooptemijp) en CRvB 10 juli 1991, RSV 1992/76 (Samenwonende bloedverwanten AOW) (en in dezelfde lijn ny een hele serie arresten: CRvB 26 november 1991, RSV 1992/144, CRvB 2 mei 1995, AB 1996190 CRvB 30 juni 1995, RSV 1996/206, CRvB 17 juli 1996, AB 1996/518) en CRvB 13 augustus 19\%, AB 1996/461 (Uitzondering inkomenseis AAW)).

173. Soms wordt wel aandacht aan de eerste fase besteed, met name ter verduidelijking van de normatien classificatie. Deze toetsing komt vaak neer op een benadelingstoets, nu hierbij niet wordt nagegan of er sprake is van onvergelijkbare gevallen, maar of er sprake is van een ongelijke (nadelige) behandeling voor een bepaalde groep ten opzichte van een andere groep. Zie bijv. CRvB 25 mei 1989, RSV 1989/275 (Weduwenuitkering bij concubinaat), CRvB 5 oktober 1989, RSV 1990/132 (Weduviant. pensioen Wbp '40-'45), CRvB 23 mei 1991, RSV 1991/257 (Overgang AAW-AWW II), CRvB 26 me 1992, RSV 1993/44 (ADL-assistentie), CRvB 20 juli 1993, RSV 1994/45 (Leeftijdscriterium eigen bijdrage AWBZ), CRvB 21 januari 1994, RSV 1994/192 (Verplichte verzekering WTZ), CRvB 2 oktober 1994, AB 1995/341 (Overgangsregeling AOW), CRvB 16 oktober 1996, AB 19971140 (Re ferte-eis AAW), CRvB 1 april 1998, RSV 1998/187 (AOW voor gehuwden), CRvB 4 november 1948 JB 1998/285 (Wet Van Otterloo), CRvB 26 november 1999, JB 2000/14 (Penisprothese) en CRvB2 januari 2001, RSV 2001/138 (Inkomensafhankelijkheid Anw). Ook komt het voor dat wordt gekekt of er in het concreet voorgelegde geval wel sprake was van een benadeling (CRvB 23 mei 1991, RS) 1991/256 (Overgang AAW-AWW 1), CRvB 14 april 1992, RSV 1993/42 (Intrekking arbeidsonge schiktheidsuitkering)); de ontkoombaarheid van het nadeel lijkt daarbij een rol te spelen (CRvB 6 fo bruari 1992, RSV 1993/6 (Verloskundige zorg door huisarts). Ook wordt er een toetsing in de eess. fase uitgevoerd in gevallen van indirect onderscheid; zie bijv. CRvB 17 maart 1992, AB 1992419 (Wooneis AAW). In een enkel geval wordt er tenslotte een vergelijkbaarheidstoets uitgevoerd; zie bijy CRvB 6 september 1989, RSV 1990/150 (Pleegouderschap), CRvB 10 juli 1991, RSV 199276 (52 menwonende bloedverwanten AOW; in deze zaak lopen eerste en tweede fase overigens erg doorest Zie over hetzelfde onderwerp ook CRvB 26 november 1991, RSV 1992/144, CRvB 2 mei 1995, A 1996/190, CRvB 30 juni 1995, RSV 1996/206, CRvB 17 juli 1996, AB 1996/518; verder zjon relenal CRvB 23 februari 1994, RSV 1994/219 (Uitzondering inkomenseis AAW), CRvB 23 november 199 RSV 2000/28 (Gezamenlijke huishouding zusters) en CRvB 6 september 2000, JB 2000/31! (Korting uitkering wegens verwijtbare werkloosheid). 
overlijdensuitkering, terwijl dit niet het geval was wanneer de kinderen meerderjarig waren. De Centrale Raad oordeelde over dit onderscheid als volgt:

"[...] de wettelijke zorg-en onderhoudsverplichting voor minderjarige kinderen doet hen in een zodanig andere positie verkeren dan meerderjarige kinderen, dat daarin een redelijke en objectieve rechtvaardiging voor het door de wetgever gemaakte onderscheid kan worden gevonden."

In deze overweging is een soort fusie zichtbaar van de vergelijkbaarheidstoets en de rechtvaardigingstoets, waardoor het onderscheid tussen de eerste en tweede toetsingsfase wordt vertroebeld. Hoewel er in de rechtspraak van de Centrale Raad ook voorbeelden te vinden zijn waarin dit onderscheid scherper wordt gemaakt, ${ }^{175}$ blijkt deze versmelting eerder regel dan uitzondering te zijn. Opnieuw is hierbij de kritiek op zijn plaats dat de motivering hierdoor erg ondoorzichtig en onduidelijk wordt.

Toetsing van concrete bevoegdheidsuitoefening: vergelijkbaarheidstoets als toetsingsingang

Tenslotte is het mogelijk dat de Centrale Raad geen oordeel hoeft uit te spreken over de verenigbaarheid van normatieve classificaties met het gelijkheidsbeginsel, maar de voorgelegde zaak betrekking heeft op een concrete bevoegdheidsuitoefening. In die gevallen kiest de Centrale Raad een iets andere benadering dan bij de toetsing van normatieve classificaties. Een afwijking is vooral terug te vinden in de eerste fase: waar bij normatieve classificaties vaak van een benadelingstoets gebruik wordt gemaakt, de toetsing in de eerste fase eenvoudigweg achterwege wordt gelaten of een versmelting zichtbaar is van de eerste en tweede fase, past de Centrale Raad bij concrete bevoegdheidsuitoefening vrij consequent een afzonderlijke vergelijkbaarheidstoets toe. ${ }^{176}$ In dat

174. CRvB 17 juli 1996, AB 1996/518 (AOW-uitkering bloedverwanten). Zie ook CRvB 16 april 1991, RSV 1991/212 (Uitlooptermijn bij vervallen arbeidsongeschiktheid), CRvB 23 februari 1994, RSV 1994/219 (Uitzondering inkomenseis AAW), CRvB 30 juni 1995, RSV 1996/206 (Samenleving aanverwanten) en CRvB 29 november 2000, RSV 2001/54 (Zigeunerhuwelijk). Verder zijn er gevallen waarin wellicht geen sprake is van een volledige versmelting, maar het onderscheid tussen de eerste en de tweede fase evenmin erg zuiver was; zie bijv. CRvB 26 november 1999, RSV 2000/50 (Verlaging eigen bijdrage zwakzinnigen).

175. Bijv. CRvB 24 november 1998, AB $1999 / 77$ (Gezamenlijke huishouding met broer). Er zijn bovendien gevallen waarin de Centrale Raad vaststelde dat er geen gelijke gevallen waren en er dus geen sprake was van een ontoelaatbare ongelijke behandeling: zie bijv. CRvB 26 november 1991, RSV 1992/44 (Samenwonende bloedverwanten AAW), CRvB 2 mei 1995, AB 1996/190 (Samenwonende bloedverwanten) en CRvB 5 september 2001, USZ 2001/271 (Onverzekerbaar risico Anw).

176. Zie bijv. CRvB 26 april 1977, AB 1978/46 (Overwerkuren), CRvB 11 juni 1981, AB 1981/458 (Salarisindeling artsen), CRvB 10 augustus 1988, RSV 1988/94 (Overgangsregeling WAO), CRvB 16 november 1988, RSV 1988/64 (Premievaststelling fysiotherapeuten I), CRvB 14 juni 1989, AB 1991/418 (Premievaststelling fysiotherapeuten II), CRvB 19 juli 1989, RSV 1989/126 (Premievaststelling fysiotherapeuten III), CRvB 21 maart 1990, RSV 1990/320 (Vakantiebonnen), CRvB 22 november 1994, RSV 1995/107 (WW-uitkering leraren), CRvB 20 maart 1995, RSV 1995/244 (Toepassing WWdagloon), CRvB 8 augustus 1995, RSV 1996/4 (Subjecttoets WW), CRvB 24 december 1996, JB 1997/30 (Premieplicht Leergang Bedrijfskunde), CRvB 27 november 1997, RSV 1998/56 (Verzeke7 november 2000 -managers), CRvB 2 juni 1998, RSV 1998/230 (Bijstand kosten opleiding) en CRvB heid leek 2000, RSV 2001/22 (TOG-regeling). Zie voor een uitzondering waarin de vergelijkbaarWWV). 
opzicht vertoont de methodiek van de Centrale Raad overeenkomsten met die van de Afdeling. Opvallend is vooral dat het resultaat van de vergelijkbaarheidstoets ook bij de Centrale Raad vrijwel steeds rechtstreeks bepalend is voor de uitkomst van de procedure: als geconcludeerd wordt dat de gevallen niet voldoende vergelijkbaar zijn be. staat er nauwelijks nog ruimte voor een beoordeling van de redelijkheid of proportionaliteit van de ongelijke behandeling. ${ }^{m}$ Belangrijk is echter dat de Centrale Raad gemakkelijker dan de Afdeling lijkt aan te nemen dat de gevallen vergelijkbaar zijn en dat de Raad kiest voor een iets lichtere bewijslast voor de belanghebbende. Op de benadering van de Centrale Raad bij de toepassing van de vergelijkbaarheidstoets zal in de volgende paragrafen nader worden ingegaan.

\subsubsection{Toetsingsmethodiek van de Commissie Gelijke Behandeling}

\section{Inleiding}

Zoals in paragraaf 1.1.5 is aangegeven laat de Algemene wet gelijke behandeling (Awgb) niet veel ruimte voor de ontwikkeling van een eigen toetsingsmethodiek; bij direct onderscheid op de limitatief opgesomde gronden mag uitsluitend worden getoetst aan de nauwkeurig in de wet omschreven uitzonderingsmogelijkheden. Van belang is echter dat de Awgb wel ruimte laat voor de ontwikkeling van een eigen toetsingsmethodiek bij de beoordeling van indirect onderscheid: artikel 2 lid 1 stelt daarover slechts dat dit onderscheid toelaatbaar is als daarvoor een objectieve rechtvaardiging bestaat, zonder dat nadere aanwijzingen worden gegeven over de vraag wanneer van een dergelijke rechtvaardiging sprake is. ${ }^{178} \mathrm{De}$ in deze bepaling besloten liggende toetsings ruimte is echter op verschillende manieren ingeperkt.

Allereerst blijkt de Commissie haar eigen toetsingsmethodiek te hebben afgestemd op het toetsingsmodel dat door haar voorgangster, de Commissie Gelijke Behandeling van mannen en vrouwen bij de arbeid (hierna $\mathrm{CGB} \mathrm{m} / \mathrm{v}$ ) is ontwikkeld. ${ }^{\text {nv }} \mathrm{De}$ CGB m/v was specifiek bevoegd tot uitleg en toepassing van de WGB. Zoals eerder aangegeven is deze wet bedoeld als implementatie van verschillende Europeesrechtelijke regelingen, zodat de CGB m/v zich aan de rechtspraak van het Europees Hof van Justitie diende te conformeren. Het door de CGB m/v gehanteerde model en de daarop gebaseerde methodiek van de Commissie vertonen dan ook grote gelijkenis met het toetsingsmodel van het Europese Hof. ${ }^{1 * 0}$ Van belang is verder dat de Commissie soms rechtstreks gehouden is het Europese recht te volgen, bijvoorbeeld wanneer zij aan de WGB toets of wanneer zij een oordeel moet geven over een onderwerp waarover veel Europese rechtspraak bestaat, zoals het geval is bij onderscheid op grond van arbeidsduur en op

177. Zie bijv. CRvB 16 november 1988, RSV 1988/64 (Premievaststelling fysiotherapeuten) en CRvB \& augustus 1995, RSV 1996/4 (Subjecttoets WW). Een rechtvaardiging blijkt wel nodig te zijn ats ef sprake is van een ongelijke behandeling van vergelijkbare gevallen; zie bijv. CRvB 24 december 1996 JB 1997/30 (Premieplicht Leergang Bedrijfskunde) en CRvB 27 november 1997, RSV 1998/56 (Verzekeringsplicht interim-managers).

178. Vgl. Wentholt 1999 (II), p. 106.

179. Zie bijv. Oordeel 96-32 (Deeltijdwerk leerkrachten basisonderwijs), Oordeel 96-36 (Kinderoppas) en Oordeel 99-31 (Voorkeursbeleid allochtonen; deze zaak had betrekking op direct onderscheid op grond van geslacht).

180. Vgl. ook Wentholt 2000 (II), p. 287. 
het gebied van pensioenen. ${ }^{181}$ Ook dan bestaat er dus relatief weinig ruimte om een geheel eigen invulling te geven aan de toetsing van indirect onderscheid. Een laatste beperking van de vrijheid van de Commissie om een geheel eigen model te ontwikkelen is gelegen in de wetsgeschiedenis. Bij de totstandkoming van de Awgb en de Wet onderscheid arbeidsduur (WOA) is uitgebreid aandacht besteed aan de wijze waarop de rechter en de Commissie zouden moeten vaststellen of er van indirect onderscheid sprake is; ook zijn in de wetsgeschiedenis aanwijzingen gegeven over de criteria waaraan de aangevoerde rechtvaardiging vervolgens zou moeten voldoen. ${ }^{182}$ Het toetsingsmodel werd daardoor al min of meer vastgelegd, hetgeen tot gevolg heeft gehad dat de Commissie dit model alleen nog nader kon uitwerken en toepassen. In de praktijk heeft de Commissie van die mogelijkheid gebruik gemaakt door de verschillende criteria nader te expliciteren en te nuanceren, zoals in het hiernavolgende nog zal blijken. Deze nadere uitwerking is vaak bijzonder interessant, nu de Commissie verschillende elementen heeft uitgewerkt die behulpzaam kunnen zijn bij de ontwikkeling van een algemeen toetsingsmodel.

\section{Toetsing in de eerste fase: benadelingstoets}

Vooral bij indirect onderscheid is de toetsing in de eerste fase bij uitstek van belang, nu hierbij niet geklaagd wordt over de formele classificatie als zodanig (waarbij meestal gemakkelijk is vast te stellen dat er sprake is van een ongelijke behandeling), maar over de effecten die een classificatie voor een bepaalde groep teweegbrengt. Volgens de definitie van indirect onderscheid die in de Awgb is gegeven moeten deze effecten zodanig zijn dat er feitelijk direct onderscheid wordt gemaakt op één van de in deze wet expliciet verboden gronden. ${ }^{183}$ Om vast te kunnen stellen of er van dergelijke effecten sprake is maakt de Commissie gebruik van een toetsing die een sterke gelijkenis vertoont met de benadering van het Europees Hof van Justitie. ${ }^{184}$ Dit blijkt duidelijk uit de volgende, in vrijwel iedere uitspraak terugkomende, formulering:

\footnotetext{
"Van indirect onderscheid is sprake indien door toepassing van bovengenoemd criterium [i.c. werd onderscheid gemaakt op grond van anciënniteit, JHG] in overwegende mate personen van één geslacht worden getroffen. Teneinde vast te stellen of daarvan sprake is, gaat de Commissie na of de toepassing van dit criterium binnen de kring van werknemers van de wederpartij in overwegende mate voor personen van één geslacht een nadelig effect heeft. De Commissie hanteert hierbij relatieve cijfers, aangezien daardoor rekening wordt gehouden met het aandeel dat mannen respectievelijk vrouwen hebben in het personeels-
}

181. Zie voor expliciete verwijzingen o.a. Oordeel 95-19 (Uitsluiting deeltijdwerkers van pensioenfonds), Oordeel 95-20 (Uitsluiting deeltijdwerkers van pensioenreglement bibliotheek), Oordeel 97-72 (Overuren deeltijdwerkers), Oordeel 97-93 (Werkervaring gemeenteambtenaar), Oordeel 97-140 (Tegemoetkoming ziektekosten onderwijspersoneel), Oordeel 97-144 (Ouderenregeling openbare bibliotheek), Oordeel 98-04 (Deeltijders in OR), Oordeel 98-41 (Pensioenregeling montagelaborante), Oordeel 9866 (Anciênniteit bij afvloeiingsregeling), Oordeel 98-102 (Meenemen ervaring bij inschaling) en Oor-

182. deel 99-10 (Leeftijdseis raio-opleiding).

de

183. Zi Memorie van Toelichting, TK 1995-1996, 24 498, nr. 3, p. 8 en 9. Vgl. Wentholt 1999 (II), p. 106.

184. En dartikel I aanhef en onder c Awgb.

ciet ciet naar de rechtspraak van het Hof. 
bestand van de wederpartij. Bij een bestand waarin mannen en vrouwen niet een ongeveer gelijk aandeel hebben, zouden absolute aantallen een vertekend beeld kunnen geven."is

Uit deze overweging blijkt dat de Commissie in de eerste fase van de toetsing een be nadelingstoets toepast: eerst wordt vastgesteld of de in het geding zijnde regeling of handeling een nadeel oplevert voor een bepaalde groep, waarna vervolgens wordt gecontroleerd of deze groep in overwegende mate bestaat uit personen die zich onderscheiden door een in de Awgb expliciet genoemd persoonskenmerk (zoals geslacht, nationaliteit of seksuele geaardheid). ${ }^{126}$ Zoals blijkt uit de geciteerde overweging kan bij deze beoordeling gebruik worden gemaakt van statistische gegevens, terwijl uit andere oordelen blijkt dat hierbij ook feiten van algemene bekendheid of veronderstellingen en aannemelijkheden betrokken kunnen worden. De wijze van vaststelling van de benads ling is voor het onderwerp van onderzoek bijzonder interessant; in paragraaf $2.2 .2 \mathrm{zal}$ hieraan dan ook uitgebreid aandacht worden besteed.

De Commissie hanteert ook bij direct onderscheid consequent een benadelingstoets. Dit blijkt vooral uit de oordelen die zijn uitgesproken over de WOA. Deze wet verbiedt direct onderscheid op grond van arbeidsduur, tenzij daarvoor een objectieve rechtvar. diging kan worden gevonden. Net als de bepalingen in de Awgb met betrekking tot indirect onderscheid laat deze wet dus enige ruimte voor het vormgeven van een eigen toetsingsmodel, zij het dat deze ruimte enigszins is ingeperkt door de rechtspraak van het Europese Hof en door de wetsgeschiedenis. De vaste formule waarmee de Commissie invulling heeft gegeven aan de eerste fase van de toetsing aan de WOA luidt als volgt:

"Volgens de MvT is van onderscheid pas sprake indien een handelwijze benadeling van werknemers op grond van hun arbeidsduur impliceert. Voorts wordt in de MvT opgemerkt dat het van de aard en strekking van de betrokken arbeidsvoorwaarde afhangt of toekenning naar rato van het aantal arbeidsuren, dan wel een identieke behandeling, dan wel nog een andere handelwijze in overeenstemming is met het beginsel van gelijke behandeling.

185. Oordeel 98-66 (Anciënniteit bij afvloeiingsregeling), r.o. 4.4 (voetnoten zijn weggelaten). Dit is d meest voorkomende definitie; de Commissie en haar voorgangster (de CGB m/v) hebben ook van wdere formuleringen gebruik gemaakt. Een benadeling wordt bijvoorbeeld aanwezig geacht als ent be paalde regeling hoofdzakelijk in het voordeel van één geslacht uitvalt (Oordeel 704-94-38), als de to geling een relatief of onevenredig nadelig effect heeft voor personen van éen bijzondere groep $(0.2$ Oordeel 94-01 (Ontslag wegens ouderschapsverlof), Oordeel 95-33 (Gratificatieregeling ambtjubile um), Oordeel 96-56 (Studieverlof bedrijfsartsen), Oordeel 97-06 (Kostenbijdrage maaltijden militur ren), Oordeel 98-13 (Partner als medewerker), Oordeel 99-49 (Bidden op het werk) en Oordeel 0022. (Werkervaring bij dienstverlening gehandicapten)), of als de regeling onevenredig meer, significar vaker of vooral personen van één bijzondere groep treft (bijv. Oordeel 96-85 (Hoofddock en veliff heidsvoorschriften), Oordeel 97-04 (Inschaling stewardessen), Oordeel 98-05 (Inschrijvingsvoorwalden videotheek), Oordeel 99-50 (Zangdocenten) en Oordeel 00-90 (Vaccinatieprogramma Hepatitio B)).

186. In uitzonderlijke gevallen wordt gebruik gemaakt van een vergelijkbaarheidstoets in de eerste fase d wordt een element van vergelijkbaarheid verweven in de benadelingstoets (zie Oordeel 97-27 (Dasts paar van gelijk geslacht), Oordeel 98-43 (Inconveniëntietoeslag toneelmeester), Oordeel 98-50 (G: Games), Oordeel 98-106 (Inconvenientietoeslag hulpkrachten winkels), Oordeel 00-04 (IVFinstellingen) en Oordeel 00-12 (Éloignement en duurtetaeslag militairen)); de reden waarom dil of beurt is niet duidelijk. Het aantal gevallen waarin deze toets is toegepast is bovendien zodanig bepelit ten opzichte van de zaken waarin een benadelingstoets wordt uitgevoerd dat hieraan verder geen dacht zal worden besteed. 
Per arbeidsvoorwaardelijke regeling zal derhalve in het licht van aard en strekking van de betreffende arbeidsvoorwaarde, bezien moeten worden welke gedragslijn uitgangspunt behoort te zijn."

Met deze overweging benadrukt de Commissie de beperking van haar vrijheid om de toetsing in de eerste fase vorm te geven: de Memorie van Toelichting bevat een duidelijk omschreven methodiek, waaraan de Commissie zich in de praktijk zal conformeren. $^{\text {in }}$ Van belang is daarbij dat het model van de MvT uitdrukkelijk een benadelingstoets bevat, zodat de Commissie steeds moet nagaan of een arbeidsvoorwaardelijke regeling een daadwerkelijke benadeling op grond van arbeidsduur oplevert. ${ }^{\text {Is9 }}$ In de praktijk blijkt dat de Commissie op een heel feitelijke manier vorm heeft gegeven aan dit vereiste: per geval gaat zij nauwkeurig na welke aard de arbeidsvoorwaarde heeft, waarna zij vervolgens beoordeelt of een toekenning daarvan naar rato van arbeidsduur een benadeling oplevert. ${ }^{190}$

\section{Toetsing in de tweede fase: het rechtvaardigingsmodel}

Wanneer vast is komen te staan dat er sprake is van een daadwerkelijke benadeling die kan worden teruggevoerd op één van de door de Awgb (of de WOA) expliciet verboden gronden, ontstaat er volgens de vaste rechtspraak van de Commissie een vermoeden van indirect onderscheid. ${ }^{191} \mathrm{Om}$ te kunnen beoordelen of dit onderscheid werkelijk in strijd is met de Awgb, zal de Commissie nagaan of hiervoor een objectieve rechtvaardiging bestaat. ${ }^{192} \mathrm{Bij}$ de ontwikkeling van een model voor de beoordeling van de aanwezigheid van een dergelijke rechtvaardiging kon de Commissie putten uit de criteria die in de wetsgeschiedenis van de Awgb zijn neergelegd. De basis voor die criteria werd gevormd door de uitgebreide hoeveelheid oordelen die de CGB m/v inmiddels had uitgesproken over de WGB. Belangrijk was vooral een set van criteria waaraan een rechtvaardiging voor indirect onderscheid getoetst zou moeten worden, die door de $\mathrm{CGB} \mathrm{m} / \mathrm{v}$ in 1989 werd geformuleerd:

187. Oordeel $98-49$ (EHBO-cursus), r.o. 4.4 (voetnoten zijn weggelaten)

188. Zie ook (onder andere) Oordeel 97-140 (Tegemoetkoming ziektekosten onderwijspersoneel), Oordeel 98-18 (Nivra-opleidingskosten), Oordeel 98-43 (Inconvenie̋tietoeslag toneelmeester), Oordeel 98-44 (EHBO-cursus), Oordeel 98-67 (Pensioenopbouw ABP) en Oordeel 99-101 (Dienstauto deeltijdwerker).

189. Dit geldt ook voor andere bevoegde instanties die hierover uitspraak moeten doen, zoals de Centrale Raad, een rechtbank of een kantonrechter.

190. Zie 0.a. Oordeel 95-27 (Interimuitkering ziektekosten), Oordeel 97-140 (Tegemoetkoming ziektekosten onderwijspersoneel), Oordeel 98-18 (Nivra-opleidingskosten), Oordeel 98-43 (Inconveniêntietoeslag toneelmeester), Oordeel 98-49 (EHBO-cursus), Oordeel 98-67 (Pensioenopbouw ABP), Oordeel 98-106 (Inconveniëntietoeslag hulpkrachten winkels), Oordeel 98-150 (ADV Ministerie van Defensie), Oordeel 99-07 (Feestdagenregeling CAO), Oordeel 99-24 (Inroostering onregelmatige diensten), Oordeel 99-101 (Dienstauto deeltijdwerker), Oordeel 99-40 (WTV-opbouw deeltijdwerkers) en Oordee! 00-70 (Alfahulpen).

191. Zie voor een willekeurig voorbeeld Oordeel 95-14 (Toepassing anciénniteitsbeginsel bij ontslag). Opmerkelijk is overigens dat in een beperkt aantal gevallen wordt verondersteld dat er sprake is van een benadeling, terwijl er eigenlijk onvoldoende gegevens beschikbaar zijn om dat vast te kunnen stellen. Zie bijv. Oordeel 94-19 (Doorstroombeleid accountancy- en adviesorganisatie) en Oordeel 00-

39 (Overgangsregeling Gezondheidszorgpsychologen).
singssystematiek geldt dat de benadelingstoets een vermoeden van direct onderscheid oplevert; de toetsingssystematiek is verder hetzelfde. 
"Het vermoeden van door de wet verboden onderscheid kan pas worden weggenomen wanneer degene die het onderscheid teweegbrengt aantoont

- dat het onderscheid werd gemaakt om een objectief gerechtvaardigd doel te dienen

- dat de middelen die hij/zij heeft gekozen om dit doel te bereiken (en waardoor het onderscheid teweeg wordt gebracht) geschikt en noodzakelijk zijn om dit doel te bereiken. Het op zich eventueel gerechtvaardigde doel moet niet evenzeer op en andere manier te bereiken zijn, waarbij geen onderscheid naar geslacht teweeg zou worden gebracht."

Deze criteria zijn duidelijk gebaseerd op het door het Europees Hof van Justitie ontwikkelde en in hoofdstuk 4 besproken rechtvaardigingsmodel. ${ }^{194}$ Een opmerkelijke toevoeging is de subsidiariteitstoets: volgens de weergegeven formule is het voor het accepteren van een rechtvaardiging noodzakelijk dat er geen andere, minder benade. lende maatregelen bestonden waardoor het beoogde doel ook had kunnen worden gerealiseerd. Deze subsidiariteitstoets vormt geen vast onderdeel van de formule van het Europese Hof en kan dan ook worden gezien als een door de CGB m/v zelf ontwikkeld criterium.

Ook de Commissie Gelijke Behandeling heeft deze criteria tot uitgangspunt genomen: in nagenoeg al haar oordelen over indirect onderscheid komt deze vrijwel letterlijk terug. Wel heeft zij de rechtvaardigingsformule enigszins aangepast en genuanceerd. Meestal wordt deze weergegeven als volgt:

"De Commissie toetst bij de vraag of er sprake is van een objectieve rechtvaardigingsgrond [...] aan de volgende criteria:

- $\quad$ aan het nagestreefde doel moet iedere discriminatie vreemd zijn;

- de middelen die gekozen worden om het nagestreefde doel te bereiken dienen te beantwoorden aan een werkelijke behoefte van de bedrijfssector en

- deze moeten geschikt en noodzakelijk zijn om dat doel te bereiken."195

Deze definitie wijkt met name af van die van de CGB m/v doordat er een nadere ulwerking is gegeven aan het vereiste van een gerechtvaardigd doel: dit mag niet inherent discriminatoir zijn (in die zin dat de classificatie niet uitdrukkelijk gericht mag zijn op het bereiken van discriminatoire effecten) en het moet verband houden met een werkelijke behoefte van degene die voor het onderscheid verantwoordelijk is. ${ }^{19}$ Opmerkelijk

193. Oordeel 3068-89-1 (Verbreking samenwerkingsrelatie fysiotherapeuten)

194. De CGB m/v verwees in zijn oordeel naar enkele zaken van het Hof die het als bron van zijn model had gehanteerd, namelijk Bilka (EHvJ 13 mei 1986, zaak 170/84, Jurispr. 1986, 1607) en Rinner-Kioln (EHvJ 13 juli 1989, zaak 171/88, Jurispr. 1989, 2743); zie r.o. 4.7 in fine.

195. Oordeel 00-15 (Taalvereiste glastuinbouw), r.o. 4.8 (voetnoten zijn weggelaten); deze formulering stemt overeen met het model dat de regering in de Memorie van Toelichting bij de Awgb voorstelde, zie TK 1990-1991, 22 014, nr. 3, p. 14. Ook hierbij zijn afwijkingen zichtbaar waarbij een iets andart formulering is gekozen. Zie bijv. Oordeel 99-87 (Taalbeleid sportcentrum: de doelstelling moet eth zakelijk karakter hebben), Oordeel 95-22 (Studie- en beroepskeuzevoorlichting christelijke organistik de doelstelling moet beantwoorden aan het criterium van "het kader van een normale bedrijfsvoering"? Oordeel 98-16 (Pensioenregeling huishoudelijk personeel: toetsing aan het criterium van een "objectiel gerechtvaardigde economische reden"), Oordeel 98-22 (Pensioenregeling belastingadvieskantoor. idem), Oordeel 98-24 (Duobaan: idem) en Oordeel 98-04 (Deeltijders in OR: er moet sprake zijn valt een doelstelling van sociale politiek).

196. Opnieuw blijkt de rechtspraak van het Europees Hof van Justitie een belangrijke inspiratiebron te 2 ijp geweest: de genoemde criteria komen daarin uitdrukkelijk terug. Zie hoofdstuk 4, m.n. paragraf 23. 
is verder dat de expliciete verwijzing naar de subsidiariteitstoets in deze formule ontbreekt. In het verloop van dit hoofdstuk zal echter blijken dat de Commissie in de praktijk vaak wel degelijk een subsidiariteitstoets uitvoert.

Van belang is tenslotte dat de Commissie bij de toetsing aan de WOA gebruik maakt van een iets ander rechtvaardigingsmodel. Dit is nodig omdat de WOA een verbod bevat van direct onderscheid. Het in het hiervoor geciteerde model opgenomen vereiste van het ontbreken van een inherent discriminatoire doelstelling kan daarbij niet goed worden gebruikt: direct onderscheid is per definitie gericht op het maken van onderscheid op een bepaalde grond, zodat een rechtvaardiging bij toepassing van het hierboven geciteerde model altijd geacht moet worden te ontbreken. Bij direct onderscheid op grond van arbeidsduur luidt het model als volgt:

"[...] [B]ij het onderscheid op grond van arbeidsduur [moet] getoetst [...] worden aan de volgende criteria:

- het met de betreffende handelwijze nagestreefde doel moet zwaarwegend en legitiem zijn;

de middelen die gekozen worden, moeten geschikt (doelmatig) en noodzakelijk (proportioneel) zijn om het doel te bereiken." ${ }^{197}$

Zoals uit deze formulering blijkt moet de doelstelling bij direct onderscheid voldoen aan andere eisen: zij moet zwaarwegend en legitiem zijn. ${ }^{19 \%}$ Voor het overige is het model identiek aan het bij indirect onderscheid gehanteerde model; in het hiernavolgende zal dit model dan ook samen met het model voor indirect onderscheid worden besproken.

\subsection{Vergelijkbaarheid en benadeling in de Nederlandse rechtspraak}

\subsection{Inleiding}

Zoals uit de vorige paragraaf is gebleken laat de Nederlandse rechtspraak over gelijke behandeling een inconsistent patroon zien wanneer het gaat om de eerste fase van de toetsing aan het gelijkheidsbeginsel: sommige instanties besteden vrijwel geen aandacht aan de eerste fase, andere hanteren consequent een strenge vergelijkbaarheidstoets en weer andere maken vrijwel uitsluitend gebruik van een benadelingstoets. In het hiernavolgende zal allereerst worden ingegaan op de rechtspraak waarin een vergelijkbaarheidstoets tot uitgangspunt wordt gekozen (paragraaf 2.2.2). Daarbij zal

197. Oordeel 97-114 (Afvloeiingsregeling basisschool), r.o. 4.4.

198. Idem in Oordeel 97-140 (Tegemoetkoming ziektekosten overheidspersoneel), Oordeel 97-144 (Ouderenregeling openbare bibliotheek), Oordeel 98-04 (Deeltijders in OR), Oordeel 98-18 (Nivraopleidingskosten), Oordeel 98-49 (EHBO-cursus), Oordeel 98-132 (Werkindeling psychiatrische inrichting), Oordeel 98-151 (Wisselwerk-regeling II), Oordeel 99-07 (Feestdagenregeling CAO), Oordeel 99-24 (Inroostering onregelmatige diensten), Oordeel 99-94 (Overgang CAO indicatieorgaan), Oordeel 00-24 (Ureneis ADV bij onderzoeksbureau), Oordeel 00-48 (Ondernemings-CAO voor financieel concern) en Oordeel 00-70 (Alfahulpen). Opmerkelijk zijn enkele zaken waarin, ondanks het feit dat er sprake was van direct onderscheid op grond van arbeidsduur, toch werd getoetst aan het vereiste van een non-discriminatoire doelstelling; zie bijv. Oordeel 98-96 (Seniorenregeling CAO NOB), Oordeel 98-150 (ADV Ministerie van Defensie), Oordeel 99-78 (CAO Thuiszorg) en Oordeel 00-93 (Assistent Analist Landstrijdkrachten). 
vooral aandacht worden besteed aan de werkwijze die de verschillende rechterlijke instanties daarbij kiezen: alleen aan de hand van een nauwkeurige beschrijving daarvan is het mogelijk om conclusies te trekken over de wenselijkheid van het gebruik van deze toets in de eerste fase. In paragraaf 2.2.3 zal vervolgens worden ingegaan op de benadelingstoets. Daarbij zal met name aandacht worden besteed aan de rechtspraak van de Centrale Raad en aan de oordelen van de Commissie Gelijke Behandeling, waarin enkele interessante criteria zijn terug te vinden waardoor nader vorm en inhoud aan deze toets wordt gegeven.

\subsubsection{De vergelijkbaarheidstoets als toetsingsingang}

Relevantie van de verschillen; noodzaak van vaststelling van een vergelijkingsmaatstuf Bij normatieve classificaties betekent een vergelijkbaarheidstoets in de eerste fase dat er een vergelijking wordt gemaakt tussen de groep waaraan op grond van de algemene regeling of het gevoerde beleid een bepaald voordeel is ontzegd en de groep die wel voor dit voordeel in aanmerking komt. Bij concrete bevoegdheidstoepassing heef de vergelijkbaarheidstoets een iets andere inhoud: beoordeeld moet dan worden of de gevallen waarin de bevoegdheid op een bepaalde manier is toegepast vergelijkbaar zijn met het geval waarin de bevoegdheid niet of op een andere manier is aangewend. Zoals in hoofdstuk 2 is aangegeven kan de vergelijking in beide gevallen alleen goed plaats. vinden wanneer de rechter een maatstaf vaststelt aan de hand waarvan hij kan bepalen of de verschillen en overeenkomsten tussen de gevallen voldoende relevant zijn. Uit de rechtspraak blijkt dat dit ook de benadering is die door de Nederlandse rechterlijke instanties wordt gekozen. ${ }^{199}$ Dit blijkt bijvoorbeeld uit een uitspraak van de belasting. kamer met betrekking tot de aftrekbaarheid van de kosten van een studeerkamer." Wanneer de belastingplichtige het huis huurde mocht hij volgens de betreffende regeling een groter bedrag aftrekken dan wanneer hij eigenaar was van de woning. De belastingkamer stelde hierover het volgende:

"Deze ongelijke behandeling kan er niet op worden gegrond dat sprake is van verschillende gevallen. Redelijkerwijs kan niet worden volgehouden dat op het punt van de inrichtingskosten e.d. enig relevant verschil bestaat tussen de eigenaar-bewoner en de huurder-bewoner."201

199. Alleen de Afdeling Bestuursrechtspraak lijkt dit niet tot uitgangspunt te nemen: hoewel zij soms andacht besteedt aan de relevantie van de verschillen en overeenkomsten tussen gevallen, gebeurt dit tigenlijk alleen bij de toetsing van concrete bevoegdheidsuitoefening, niet bij normatieve classificaties een uitzondering vormt ABRS 17 mei 1999, AB 1999/294 (Bekostiging opleiding verpleeghuisats) Ook bij andere rechterlijke instanties ontbreekt regelmatig een inhoudelijke motivering of een verwijzing naar een vergelijkingsmaatstaf en wordt eenvoudigweg opgemerkt dat de gevallen vergelijhbur of juist onvergelijkbaar zijn. Zie bijv. HR 8 juli 1988 (belastingkamer), BNB 1990/448 (Studertkameraftrek I) en HR 11 augustus 2000 (belastingkamer), BNB 2000/334 (Aftrek studiekosten).

200. HR 17 december 1993, BNB 1994/36 (Koffiegeld en studeerkamerkosten)

201. R.o. 3.5; zie ook HR 17 augustus 1998 (belastingkamer), JB 1998/196 (Grijs kenteken). In de mest: gevallen wordt het vereiste van relevantie niet expliciet genoemd, maar blijkt dit impliciet wel uit de beoordeling. Zie bijv. HR 19 mei 1993 (belastingkamer), BNB 1993/24I (Successiebelasting ongehuwden), HR 9 april 1997 (belastingkamer), BNB 1997/188 (Nedeco-regeling), HR 12 november 1997 (belastingkamer), BNB 1998/22 (Reiskosten als studiekosten), HR 15 juli 1998 (belastingkamet), NN 2000/168 (Autokostenforfait) en HR 28 februari 2001 (belastingkamer), BNB 2001/172 (OZB winkel- 
Uit deze overweging blijkt dat de belastingkamer voor het aannemen van vergelijkbaarheid vereist dat de voorgelegde gevallen relevante overeenkomsten vertonen. Bovendien werd in dit geval een duidelijk vergelijkbaarheidsmaatstaf vastgesteld (namelijk de kosten van de studeerkamer) die kon dienen om de relevantie van de verschillen en overeenkomsten vast te stellen. ${ }^{202}$

\section{Wijze van vaststelling van de vergelijkingsmaatstaf}

Gezien het feit dat de noodzaak van het vaststellen van een vergelijkingsmaatstaf door alle rechterlijke instanties wordt erkend, is het opmerkelijk dat er in de rechtspraak nauwelijks aanwijzingen zijn terug te vinden over de wijze waarop deze vaststelling plaats zou moeten vinden. In de grote meerderheid van gevallen geven de bestudeerde instanties weliswaar aan wat volgens hen de vergelijkingsmaatstaf zou moeten zijn (zoals ook het geval was in de hiervoor geciteerde overweging) ${ }^{203}$, maar blijft het onduidelijk wat daarvan de bron is. ${ }^{204}$ Dit is problematisch, omdat de toetsing daardoor in

pand, zie ook de noot van Van Leijenhorst bij dit arrest). Opmerkelijk is verder HR 27 september 1990 (belastingkamer), NJ 1990/449 (Samentelling inkomens gehuwden), waarin de belastingkamer stelde dat de wetgever in redelijkheid kon oordelen dat "gehuwden en ongehuwd samenwonenden niet als in alle opzichten gelijk vielen te beschouwen" (г.o. 7.2, cursief toegevoegd); het lijkt waarschijnlijk dat het hierbij om een verschrijving gaat, nu het vanzelfsprekend te ver zou gaan om te verwachten dat gevallen niet alleen in alle relevante opzichten, maar zelfs in alle opzichten gelijk zijn.

202. Ook in de rechtspraak van de Centrale Raad is dit uitgangspunt terug te vinden, zoals blijkt uit een uitspraak met betrekking tot de verlaging van de eigen bijdrage voor zwakzinnigen die in gezinsvervangende tehuizen wonen (CRvB 26 november 1999, RSV 2000/50); zwakzinnigen die woonden in zogenaamde socio-woningen kwamen voor dit voordeel niet in aanmerking. De Centrale Raad stelde hiefover het volgende: "Hoewel er tussen bewoners van socio-woningen en bewoners van gezinsvervangende tehuizen in zijn algemeenheid nauwelijks verschillen wat betreft de mate van sociale redzaamheid bestaan terwijl deze woonvormen ook qua doelstelling in hoge mate vergelijkbaar zijn, moet anderzijds worden vastgesteld dat er tussen beide categorieën enkele in dit kader relevante verschillen bestaan [volgt een opsomming van de verschillen waaruit blijkt dat de verschillen aanzienlijk relevanter zijn dan de overeenkomsten]." Blijkens deze overweging heeft de Centrale Raad zich gerealiseerd dat alle gevallen zowel overeenkomsten en verschillen vertonen en dat het er bij de vaststelling van vergelijkbaarheid om gaat te bepalen welke daarvan voor het geding relevant zijn. Vgl. ook CRvB 26 april 1977, AB 1978/46 (Overwerkuren), CRvB 6 september 1989, RSV 1990/150 (Pleegouderschap), CRvB 1 oktober 1992, RSV 1993/14 (Eigen bijdrageregeling AWBZ) en CRvB 7 november 2000, RSV 2001/22 (TOG-regeling). Ook de andere rechterlijke instanties hebben ervan blijk gegeven te erkennen dat het bij het uitvoeren van een vergelijkbaarheidstoets noodzakelijk is om te beoordelen of de tussen de gevallen bestaande verschillen en overeenkomsten voldoende relevant zijn. Dit blijkt meestal echter alleen uit de argumentatie die rondom de vergelijkbaarheidstoets wordt opgebouwd. Zie bijv. HR 25 april 1980, NJ 1981/416 (Sogut/Staat) en HR 10 augustus 1994, NJ 1995/58 (General Accident/Staat)

203. Hoewel soms iedere nadere onderbouwing van het oordeel over vergelijkbaarheid ontbreekt; zie bijv. CRvB 24 mei 1993, RSV 1994/43 (Leeftijdscriterium AWW).

204. Dit blijkt al uit de eerder weergegeven overwegingen van de belastingkamer van de Hoge Raad en de Centrale Raad, maar het aantal voorbeelden is veel groter. Zie bijv. HR 21 oktober 1992 (belastingkamer), BNB 1993/29 (Belastingvrije som voor alleenstaanden) (waarin een vage verwijzing naar de wetgever voorkomt, maar niet blijkt of de gekozen vergelijkingsmaatstaf inderdaad aan de wetsgeschiedenis is ontleend), HR 16 juli 1993 (belastingkamer), BNB 1993/299 (Uitzendtoelage ambtenaren) (waarin de belastingkamer verwees naar feitelijke overeenkomsten die door het Hof waren vastgesteld, maar geen basis leken te vinden in het doel van de regeling of in de wetsgeschiedenis), HR 13 december 1995 (belastingkamer), BNB 1996/72 (Vee als bedrijfsmiddel), HR 13 december 1995, BNB 1996/90 (Kinderopvang II), HR 8 januari 1997 (belastingkamer), BNB 1997/64 (PTT Telecom), HR 15 oktober 1997, BNB 1997/380 (Kinderopvang III), HR 16 juni 1999 (belastingkamer), BNB 1999/286 
hoge mate subjectief en ondoorzichtig wordt: het is niet of nauwelijks controleerbaar welke objectieve grondslag de rechter heeft gehanteerd bij het vaststellen van de ver. gelijkbaarheid. Zeker nu de vergelijkbaarheid in de meeste gevallen direct bepalend is voor de uitkomst van de toetsing is dit een onbevredigende situatie.

Er zijn echter gevallen waarin de bron van de gehanteerde vergelijkingsmaatstaf wel wordt geëxpliciteerd. Meestal wordt de vergelijkingsmaatstaf in die uitspraken ont. leend aan de totstandkomingsgeschiedenis van de regeling. Een voorbeeld hiervan is een uitspraak van de belastingkamer over de problematiek rondom het zogenaamde grijze kenteken. ${ }^{205}$ In 1994 werd over dit onderwerp een nieuwe wet ingevoerd, waarin het begrip "personenauto" via allerlei technische eisen werd verruimd. Deze verniming had tot gevolg dat minder auto's in aanmerking kwamen voor de gunstige grijs kenteken-regeling. In de regeling werd een uitzondering gemaakt voor eigenaars van grote wagenparken: zij bleven in aanmerking komen voor de gunstige regeling, $00 \mathrm{k}$ al ging het om wagenparken die bestonden uit gewone personenauto's. Over de vergelijk. baarheid van eigenaars van grote wagenparken en eigenaars van een gewone personenauto stelde de belastingkamer, na een uitgebreide bespreking van de wetsgeschiedenis, het volgende:

"[...] met de verruiming van het begrip personenauto per 1 januari 1994 [werd] beoogd het particuliere gebruik van auto's met een grijs kenteken terug te dringen door [...] dit soort auto's door hun inrichting en uiterlijk minder aantrekkelijk te maken voor particulieren, en was een voorname reden voor deze aanpak, dat in geval van een keuze voor het toepassen van gebruikscriteria de uitvoering van de regels voor alle betrokkenen in een onevenredige mate zou worden gecompliceerd, en impliceert deze keuze dat het voor particulieren nog steeds mogelijk is dergelijke auto's aan te schaffen. [...] [De] financiële consequenties [van deze regeling] golden voor alle gevallen in gelijke mate. De wetgever heeft dan ook in redelijkheid de houders van een omvangrijk wagenpark niet als ongelijk kunnen beschouwen aan de overige houders."

(Vakantiegeld en vakantiebonnen), HR 21 februari 2001 (belastingkamer), BNB 2001/176 (Drempetbedrag aftrekbaarheid kinderopvang) en HR 28 februari 2001 (belastingkamer), BNB 2001/181 (hnv? lidenparkeerkaart). Ook de andere onderzochte rechterlijke instanties stellen relatief vaak een vergeli.; kingsmaatstaf vast zonder de bron daarvan te vermelden. Zie bijv. HR 30 maart 1984, NJCM 1984 253 (Suikerfeest), HR 14 april 1989, NJ 1990/412 (Bijstandsverhaal), HR 6 november 1998, Rvdl 1998/206 (Bos/KLM), CRvB 1 oktober 1992, RSV 1993/14 (Eigen bijdrageregeling AWBZ), CRvB 23 februari 1994, RSV 1994/219 (Uitzondering inkomenseis AAW), CRvB 30 juni 1995, RSV 1996/206 (Samenleving aanverwanten), CRvB 17 juli 1996, AB 1996/518 (AOW-uitkering bloctret wanten), CRvB 13 augustus 1996, AB 1996/461 (Uitzondering inkomenseis AAW), CRvB 23 novent ber 1999, RSV 2000/28 (Gezamenlijke huishouding zusters), CRvB 26 november 1999, JB 2000/14 (Penisprothese (waarin overigens niet de gelijkheid van de gevallen, maar van de aanspraken in het go ding was)), CRvB 29 november 2000, RSV 2001/54 (Zigeunerhuwelijk) en ABRS 2 februari 1998, Al 1998/181 (Horsman).

205. HR 17 augustus 1998 (belastingkamer), JB 1998/196 (Grijs kenteken)

206. R.o. 3.6.2. Zie voor een vergelijkbare benadering HR 26 maart 1997 (belastingkamer), BNB 1997/18 (Waardering landbouwgrond), HR 20 januari 1999 (belastingkamer), BNB 1999/80 (Levensonderthos broer partner), HR 3 maart 1999 (belastingkamer), BNB 1999/202 (Leeftijdsgrens zelfstandigenaflech II), HR 12 mei 1999 (belastingkamer), FBR 1999/2115 (Arbeidskostenforfait), HR 20 september 2001 (belastingkamer), BNB 2000/380 (OZB woonschepen), HR 28 februari 2001 (belastingkamer), $\mathrm{BN}$ 2001/172 (OZB winkelpand) en HR 2 mei 2001 (belastingkamer), BNB 2001/276 (Wubo 1940-1955) Zie verder HR 18 december 1984 (strafkamer), NJ 1985/356 (Dames- en herenkappers), CRvB 24 av vember 1998, AB 1999/77 (Gezamenlijke huishouding met broer), CRvB 4 oktober 2000, RS 
Uit deze overweging blijkt dat het doel van de regeling werd ontleend aan de wetsgeschiedenis en dat dit doel vervolgens functioneerde als vergelijkingsmaatstaf. Zoals is aangegeven is het aantal gevallen waarin deze benadering wordt gekozen zeldzaam: in veruit de meeste gevallen kiest de rechter voor een maatstaf die hij zelf redelijk vindt, zonder uitdrukkelijk te verwijzen naar de wetsgeschiedenis of het doel van de regeling.

\section{Vaststelling van de vergelijkingsmaatstaf bij concrete bevoegdheidsuitoefening} Wanneer er geklaagd wordt over een concrete bevoegdheidsuitoefening waarvan een ongelijke behandeling het resultaat is, blijkt het voor de rechter niet altijd gemakkelijk te zijn om de juiste vergelijkingsmaatstaf vast te stellen. Ook in deze gevallen kan het doel van het onderscheid tot uitgangspunt worden genomen. In de meeste gevallen zal de bevoegdheidsuitoefening immers gebonden zijn aan wettelijke regels, waaruit ook de doelstellingen kunnen worden afgeleid ter realisering waarvan de bevoegdheid is verleend. ${ }^{20 s}$ Ook wanneer een duidelijke bevoegdheidsgrondslag ontbreekt of wanneer deze grondslag bijzonder vaag of algemeen is geformuleerd, kan worden gesteld dat het

2001/19 (Overgangsregeling Anw) en CRvB 2 mei 2001, RSV 2001/164 (Inkomensafhankelijkheid AOW). In een groot aantal gevallen wordt niet expliciet een vergelijkingsmaatstaf vastgesteld, maar wordt voor het oordeel over de vergelijkbaarheid meer in het algemeen terugverwezen naar de wetsgeschiedenis. Zie bijv. HR 19 mei 1993 (belastingkamer), BNB 1993/241 (Successiebelasting ongehuwden), waarin de belastingkamer stelde: "[...] uit de geschiedenis van totstandkoming van de Wet [...] blijkt dat de wetgever de relatie tussen gehuwden enerzijds en die tussen ongehuwd samenwonenden anderzijds voor de heffing van het recht van successie niet als gelijke gevallen heeft beschouwd" (r.o. 3.3). Vgl. ook HR 30 september 1992 (belastingkamer), NJ 1994/495 (Griffiegeld), HR 12 november 1997 (belastingkamer), BNB 1998/22 (Reiskosten als studiekosten), HR 15 juli 1998 (belastingkamer), NJ 2000/168 (Autokostenforfait) en HR 19 april 2000 (belastingkamer), BNB 2000/192 (Rentevrijstelling werknemersspaarregelingen). Zie verder HR 29 april 1994, NJ 1994/625 (Alimentatie bij homofiel concubinaat), HR 22 januari 1985 (strafkamer), NJ 1986/24 (Vervangende dienstplicht gewetensbezwaarden), CRvB 10 juli 1991, RSV 1992/76 (Samenwonende bloedverwanten) en CRvB 23 november 1999, RSV 2000/28 (Gezamenlijke huishouding zusters). Verder wordt soms verwezen naar de context van de wettelijke regeling of wordt vooruit gekeken naar een wetswijziging; zie bijv. HR 27 september 1989 (belastingkamer), NJ 1990/449 (Samentelling inkomens ongehuwden), waarin de belastingkamer bij de vaststelling van verschillen tussen gehuwden en ongehuwden verwees naar de in het BW opgenomen verplichtingen voor de huwelijkse staat, en ARRS I augustus 1983, AB 1984/532 (Humanistisch Vormingsonderwijs Haarlem), waarin de Afdeling als basis voor haar vergelijkbaarheidsoordeel verwees naar een nieuwe wet waarin levensbeschouwelijk onderwijs op één lijn werd gesteld met godsdienstonderwijs; idem in ARRS 21 maart 1985, AB 1986/16 (Humanistisch Vormingsonderwijs Putten).

207. Tenslotte kiest de belastingkamer een bijzondere benadering bij de toepassing van de in paragraaf 2.1 .2 besproken meerderheidsregel. Om de vergelijkbaarheid te kunnen beoordelen moet daarbij volgens de belastingkamer worden gekeken naar de kenmerken ten aanzien waarvan in de eerdere gevallen een fout is gemaakt of een afwijking van de wet zichtbaar is geworden, waarna vervolgens moet worden bezien of ten aanzien van dat kenmerk sprake is van vergelijkbaarheid van de gevallen waarin de wet gewoon is toegepast. Zie bijv. HR 17 juni 1992, BNB 1992/294 (Taxatie onroerend goed). Zoals uit deze formulering al blijkt leent deze benadering zich alleen voor de contra legem-toets waarvoor zij bedoeld is: in lang niet alle gevallen van ongelijke behandeling zal sprake zijn van een "fout" in het eerdere concrete geval.

208. De Afdeling verwijst soms naar de wettelijke basis van de regeling. Zie bijv. ABRS 5 juni 1998, AB 1998/286 (Woonschipbeleid Amsterdam) en ABRS 29 februari 2000, AB 2001/1 (Vermindering bedden verpleeghuis). Vgl. ook Versteden 1985, p. 65, die in dit verband spreekt van "wettelijke beleidsmaatstaven", 
voor de beoordeling van de vergelijkbaarheid bepalend is met welk doel de bevoegd. heid normaal gesproken wordt uitgeoefend. Van een bestuursorgaan mag op zijn minst worden verwacht dat het enig beleid aan zijn handelen ten grondslag legt en niet volles dig naar willekeur handelt. ${ }^{209}$ Aan de hand van de doelstelling van het bestuurshandelen kan vervolgens worden bepaald of de voorgelegde gevallen inderdaad relevante ver. schillen vertoonden. ${ }^{210}$

Bij de vaststelling van een vergelijkingsmaatstaf blijken de Nederlandse rechterlijke instanties echter lang niet altijd rekening te houden met relevante juridische kaders." In de meeste gevallen wordt niet zozeer gekeken naar de bevoegdheidsgrondslag of de doelstelling die aan het beleid van een bestuursorgaan ten grondslag lag, maar veeleet naar feitelijke overeenkomsten en verschillen tussen de ongelijk behandelde gevallen." De relevantie daarvan lijkt meestal door de rechter zelf te worden bepaald, zonder dat een uitdrukkelijke verwijzing naar het juridisch kader in de uitspraak is terug te virden. ${ }^{213}$ Dit levert een vrij actieve rechterlijke opstelling op, waarbij de rechter an de hand van de processtukken de feiten beoordeelt en nagaat of de gevallen naar zijn mening voldoende overeenstemming vertonen. Een dergelijke feitelijke beoordeling, waarmee niet altijd recht wordt gedaan aan de beleids- en beoordelingsvrijheid van de bevoegde organen, is niet wenselijk en ook niet nodig. Het is beter wanneer de bestuursrechter uitsluitend nagaat welke maatstaf het bestuursorgaan heeft gehanteerd (dat wil zeggen welke reden het orgaan zelf heeft aangevoerd) voor de verschillende behandeling. Hij hoeft dan slechts te beoordelen of deze reden of maatstaf zelf redelijk is, zonder een nader oordeel uit te spreken over de feitelijk tussen de gevallen bestande verschillen. ${ }^{214}$

209. Vgl. Versteden 1985 , p. 69 , die in dit verband spreekt van "bestuurlijke beleidsmaatstaven".

210. Vgl. ook Leijenhorst 1997, p. 1113/1114.

211. Vanzelfsprekend zijn er gevallen te vinden waarin de toetsing wél op zorgvuldige wijze plaatsvindt met name in de rechtspraak van de Centrale Raad; vaak wordt dan afgegaan op de stellingen van partijen of op externe adviezen en documenten waaruit de vergelijkbaarheid kan blijken. Zie bijvoorbelt CRvB 16 november 1988, RSV 1989/64 (Premievaststelling fysiotherapeuten), CRvB 19 februar 1993, RSV 1993/263 (Daad van verzet), CRvB 22 november 1994, RSV 1995/107 (WW-uitkering lo raren), CRvB 8 augustus 1995, RSV 1996/4 (Subjecttoets WW), CRvB 6 september 2000, IB 2000/311 (Verwijtbare werkloosheid), CRvB 4 oktober 2000, RSV 2001/19 (Overgangsregeling Anv/ en CRvB 7 november 2000, RSV 2001/22 (TOG-regeling).

212. Vgl. bijv. ABRS 9 mei 2000, JB 2000/179 (Dakkapellen). Ook in de rechtspraak van een voorgange van de Afdeling Bestuursrechtspraak, de Afdeling Rechtspraak, zijn veel van dit soort feitelijke verge lijkbaarheidsoordelen terug te vinden. Deze oordelen kenmerken zich in het algemeen door het actert wege blijven van een expliciet oordeel over de vergelijkingsmaatstaf en door het zoeken van een bai voor het vergelijkbaarheidsoordeel in door de partijen aangevoerde feiten en omstandigheden. Zie bin? ARRS 1 augustus 1980, AB 1981/5 (Maatbouw/Weststellingswerf), ARRS 7 november 1980, At 1981/346 (Leijtens/Van Waalwijk), ARRS 6 november 1984, AB 1984/417 (Verhuis- en herinith tingskostenvergoeding), ARRS 15 augustus 1985, AB 1986/250 (Gepensioneerde ambtenaren Antiflen), ARRS 27 augustus 1991, AB 1992/313 (Speelautomatenhal) en ARRS 2 maart 1993, Al 1993/364 (Smale e.a.).

213. Zie bijv. CRvB 16 april 1991, RSV 1991/212 (Uitlooptermijn bij vervallen arbeidsongeschiktheid. CRvB 27 november 1997, RSV 1998/56 (Verzekeringsplicht interim-managers), ABRS 27 jurii 19\%. AB 1998/50 (Bouwvergunning woonwagens) en ABRS 19 december 1996, AB 1997/414 (Hervorme Jeugdraad Hoogblokland). Ook Versteden geeft aan dat in veel gevallen niet verwezen wordt nas he bestaande stelsel van gelijkheidsmaatstaven, maar alleen feitelijke objecten of activiteiten met elksir worden vergeleken $(1985$, p. 79$)$.

214. Deze benadering wordt door de belastingkamer soms gehanteerd. Zie bijv. HR 9 juni 1982 (belastint 
Toetsing van de redelijkheid van de vergelijkingsmaatstaf

In de gevallen waarin een vergelijkingsmaatstaf wél is vastgesteld blijken de bestudeerde rechterlijke instanties zelden geneigd om deze maatstaf inhoudelijk op zijn redelijkheid te beoordelen. ${ }^{215}$ Wanneer de rechter zelf een maatstaf of doelstelling voor het onderscheid bedacht heeft, is dit niet meer dan logisch: de rechter zal ongetwijfeld alleen een maatstaf kiezen die hij zelf redelijk acht, zodat een afzonderlijke rechtvaardigingstoets overbodig is. Als de maatstaf ontleend wordt aan de wetsgeschiedenis of aan de stellingen van de verwerende partij ligt het veel minder voor de hand om de redelijkheid te veronderstellen. Een dergelijke benadering kan tot gevolg hebben dat zelfs een kennelijk discriminatoire maatstaf zonder meer toelaatbaar wordt geacht. Dit probleem kan worden geïllustreerd aan de hand van een arrest waarin de civiele kamer van de Hoge Raad een vergelijkbaarheidstoets uitvoerde. ${ }^{216}$ Dit arrest had betrekking op een (inmiddels gewijzigde) regeling in het Burgerlijk Wetboek met betrekking tot omgangsregelingen: volgens de betrokken bepaling kon aan de natuurlijke vader van een onwetting kind geen omgangsregeling worden toegekend. De benadeelde stelde echter dat wettige en natuurlijke vaders in belangrijke opzichten zodanig vergelijkbaar zijn dat ook aan natuurlijke vaders een omgangsregeling moest kunnen worden toegekend. De Hoge Raad oordeelde hierover als volgt:

"Weliswaar kunnen er zich gevallen voordoen die met de situatie waarvoor de art. 161 lid 5 en 170 lid 4 zijn geschreven zoveel gelijkenis vertonen dat het gerechtvaardigd is daarop die bepalingen mede van toepassing te achten, maar van een dergelijke gelijkenis is geen sprake indien de man die de omgangsregeling verzoekt noch de wettige vader van het kind is noch het kind heeft erkend. De overwegingen die de wetgever ertoe hebben gebracht, de mogelijkheid voor een man om een kind te erkennen waarvan hij stelt de verwekker te zijn, te beperken, staan er eveneens aan in de weg de relatie tussen verwekker en kind buiten het geval van erkenning op één lijn te stellen met die waarop de bepalingen $[\ldots]$ betrekking hebben."217

kamer), BNB 1982/215 (Onroerendgoedbelasting Schiedam). Vgl. ook Duk 1975, p. 860.

215. De belastingkamer vormt hierbij een uitzondering: meestal voert hij een redelijkheidstoets uit, zij het dat deze zeer algemeen en vaag is. Zie bijv. HR 19 mei 1993 (belastingkamer), BNB 1993/241 (Successiebelasting ongehuwden), waarin de belastingkamer onder verwijzing naar de conclusie van de advocaat-generaal het volgende vaststelde: "Op grond van de daarvoor gegeven argumenten zoals die zijn vermeld in de [conclusie van] [...] de Advocaat-Generaal [...] kon de wetgever in redelijkheid oordelen dat evenvermelde gevallen voor de toepassing van artikel 26 IVBPR niet als gelijk hoefden te worden beschouwd" (r.o. 3.3; cursief toegevoegd). Idem in HR 27 september 1989 (belastingkamer), BNB 1990/449 (Samentelling inkomens ongehuwden), HR 21 oktober 1992 (belastingkamer), BNB 1993/29 (Belastingvrije som voor alleenstaanden) en HR 13 december 1995, BNB 1996/72 (Vee als bedrijfsmiddel). Slechts in sporadische gevallen wordt tot de conclusie gekomen dat het oordeel van de wetgever over de vergelijkbaarheid niet als redelijk kan worden aangemerkt: zie bijv. HR 15 juli 1998 (belastingkamer), NJ 2000/168 (Autokostenforfait). Een inhoudelijke toetsing is ook terug te vinden in de rechtspraak van andere rechters. Zie bijv. HR 29 april 1994, NJ 1994/625 (Alimentatie bij concubinaat), HR 6 november 1998, RvdW 1998/206 (Bos/KLM) en HR 18 december 1984 (strafkamer), NJ 1985/356 (Dames- en herenkappers). Deze toetsing is meestal zeer marginaal (zie bijv. CRvB 6 september 1989, RSV 1990/150 (Pleegouderschap) en CRvB 4 oktober 2000, RSV 2001/19 (Overgangsregeling Anw)) of minder overtuigend (bijv. CRvB 10 juli 1991, RSV 1992/76 (Samenwonende bloedverwanten; zie ook de noot van Feenstra onder deze uitspraak)).

216. HR 10 december 1982, NJ $1983 / 411$ (Omgangsregeling met onwettig kind)
217. R.o. 3.2. Op vergelijkbare wijze werd een inhoudelijke beoordeling van de vergelijkingsmaatstaf of de
basis van het onders basis van het onderscheid volledig achterwege gelaten in CRvB 23 november 1999, RSV 2000/28 (Ge- 
Deze overweging bevat een ontkenning van de vergelijkbaarheid van enerzijds natuur. lijke vaders en anderzijds wettige vaders of vaders die hun kind hebben erkend. Het is echter de vraag of het door de Hoge Raad gehanteerde, in de wet opgenomen onder. scheidingscriterium van wettig vaderschap wel gerechtvaardigd was: drie jaar voordat dit arrest werd gewezen had het Europees Hof voor de Rechten van de Mens al met nadruk gesteld dat wettigheid een steeds minder geaccepteerd criterium voor onderscheid is en dat er zeer zwaarwegende redenen moeten bestaan om het gebruik van dit criterium te rechtvaardigen. ${ }^{218}$ Het gemak waarmee de Hoge Raad overwoog dat de gevallen niet op één lijn konden worden gesteld en de magere motivering die daarvoor werd gegeven is in dat verband niet te rechtvaardigen: op zijn minst had de Hoge Raad moeten nagaan of de door de wetgever gehanteerde maatstaf wel in overeenstemming was met het EVRM.

Gelukkig wordt dit soort dubieuze vergelijkingsmaatstaven niet altijd zo gemakkelijk geaccepteerd: vaak wordt in ieder geval een algemene redelijkheidstoets uitgevoerd. Op de eisen die daarbij worden gesteld zal nader worden ingegaan in paragraaf 23 , waarin de toetsing van het doel zal worden besproken.

\section{Overige bijzonderheden met betrekking tot de vergelijkbaarheid}

Interessant is tenslotte dat de verschillende bestudeerde instanties voor een aantal om. standigheden hebben gesteld dat er nooit sprake kan zijn van vergelijkbaarheid. In de eerste plaats is dit het geval wanneer de ongelijkheid het gevolg is van een verschil in rechtspositie dat is ontstaan doordat op de voorgelegde gevallen verschillende (wette lijke) regelingen van toepassing zijn. Een voorbeeld daarvan is een uitspraak van de belastingkamer met betrekking tot de aftrekbaarheid van kledingkosten voor presentatoren. ${ }^{219}$ Volgens de wet op de inkomstenbelasting kunnen dergelijke kosten wel worden afgetrokken door belastingplichtigen die als presentator optreden in de uitoefening van hun onderneming of zelfstandig beroep, maar niet door belastingplichtigen die deze functie in dienstbetrekking uitoefenen. De belastingkamer oordeelde hierover als volgt:

"De klacht dat niet valt in te zien waarin [...] voor de belastingplichtige die in de uitoefening van zijn onderneming of zelfstandig beroep optreedt als presentator etn uitzondering is gemaakt op de niet-aftrekbaarheid van kledingkosten, terwijl voor de presentator in dienstbetrekking een dergelijke bepaling ontbreekt, is op zichzelf terecht. Tot cassatie kan dit echter niet leiden. De berekening van winst uit onderneming en van zuivere inkomsten uit arbeid is nu eenmaal in de wet zo principieel verschillend geregeld dat niet kan worden gezegd dat hier sprake is van gelijke gevallen." ${ }^{220}$

zamenlijke huishouding zusters).

218. Zie daarover nader hoofdstuk 3, paragraaf 3.3.2 en het daar besproken arrest Marckx (EHRM 13 jiti 1979, Series A, vol. 31). Overigens erkende de Hoge Raad dit enkele jaren later ook: in 1985 kwam lim terug van de geciteerde opvatting en gaf hij aan dat de regeling niet in overeenstemming was met afikel 14 EVRM: zie HR 22 februari 1985, NJ 1986/3 (Omgangsrecht met onwettig kind).

219. HR 24 september 1997 (belastingkamer), BNB 1997/400 (Kledingkosten presentatrice)

220. R.o. 3.3. Zie ook HR 4 mei 1994 (belastingkamer), BNB 1994/195 (Studeerkamerkosten), HR I fs bruari 1995 (belastingkamer), BNB 1995/81 (Sollicitatiekosten) en HR 27 augustus 1997 (belasting kamer), BNB 1998/109 (Huurwaardeforfait bij kamerverhuur). Ook andere rechterlijke instanties his teren dit uitgangspunt. Zie bijv. HR 6 juni 1995 (strafkamer), NJ 1995/645 (Vervangende hechtenis bi 
Daarnaast wordt in het algemeen geen vergelijkbaarheid aangenomen wanneer de ongelijke behandeling het resultaat is van een concrete bevoegdheidsuitoefening door twee of meer verschillende bestuursorganen. Een opmerkelijk voorbeeld daarvan is te vinden in de rechtspraak van de Afdeling Bestuursrechtspraak. In 1996 diende de Afdeling zich uit te spreken over het "uitstallingsbeleid" in Amsterdam: in een gemeentelijke verordening was een algemeen verbod opgenomen om goederen te plaatsen op de openbare weg, tenzij daarvoor een ontheffing was verkregen. ${ }^{221}$ Appellant klaagde over het feit dat aan hem geen ontheffing was verleend, terwijl de eigenaar van de bloemenzaak aan de overkant van dezelfde straat zijn bloemen en planten wel op het trottoir mocht uitstallen. De Afdeling stelde hierover het volgende:

"[...][K]rachtens art. 28 Verordening op de stadsdeelraden [zijn] vrijwel alle bevoegdheden van de gemeente Amsterdam [...] overgedragen aan de stadsdeelbesturen, voor zover het aangelegenheden van hun grondgebied betreft. Daarbij is de mogelijkheid gecreëerd dat stadsdelen een eigen beleid voeren, zodat beter kan worden ingespeeld op de plaatselijke situatie. Gebleken is dat de Jan van Galenstraat de grens vormt tussen twee stadsdelen, warbij de winkel van appellant is gelegen in het stadsdeel Bos en Lommer, terwijl de bloemenzaak aan de overzijde van de Jan van Galenstraat is gelegen in het stadsdeel de Baarsjes. [...] Voor zover appellant er op heeft gewezen dat deze eigenaar de richtlijnen van het stadsdeel de Baarsjes overschrijdt, terwijl hiertegen niet wordt opgetreden, overweegt de Afdeling dat de door appellant gestelde overschrijding van deze richtlijnen een aangelegenheid betreft van het dagelijks bestuur van stadsdeel de Baarsjes, [...] en mitsdien niet kan worden tegengeworpen aan het dagelijks bestuur van Bos en Lommer."222

Hoewel de Afdeling strak aan deze regel vasthoudt, hebben andere instanties hierop soms uitzonderingen aanvaard. Zo heeft de belastingkamer uitdrukkelijk gesteld dat vergelijkbaarheid wel aanwezig kan zijn in gevallen waarin weliswaar meerdere inspecteurs bevoegd zijn, maar zij zich hebben te houden aan een landelijk, gecoördineerd beleid. ${ }^{23}$ Dit is ook logisch, omdat in deze situatie de ratio van de onvergelijk-

ontneming wederrechtelijk verkregen voordeel), CRvB 6 februari 1992, RSV 1993/6 (Verloskundige zorg Zfw), CRvB 26 november 1999, JB 2000/14 (Penisprothese) en ABRS 13 februari 2001, JB $2001 / 109$ (Bijdrage premiederving). Belangrijk is echter dat een rechtspositioneel verschil niet altijd leidt tot de conclusie van onvergelijkbaarheid: in sommige gevallen laat de belastingkamer de feitelijke vergelijkbaarheid van de gevallen (door hemzelf vastgesteld!) zwaarder wegen; zie bijv. HR 9 april 1997 (belastingkamer), BNB 1997/188 (Nedeco-regeling). Verder voert de belastingkamer soms een gewone rechtvaardigingstoets uit, ook al is de ongelijke behandeling het gevolg van het bestaan van verschillende regelingen; zie HR 22 juni 1988 (belastingkamer), BNB 1988/259 (Koffiegeld en reiskosten) en HR 11 augustus 2000, BNB 2000/334 (Aftrek studiekosten). Zie voor enkele voorbeelden uit de rechtspraak van de Afdeling Rechtspraak ook Versteden 1985, p. 77.

22I. ABRS 26 september 1996, AB 1996/483 (Uitstallingsbeleid Bos en Lommer)

222. Zie ook ABRS 8 mei 1995, AB 1995/401 (Recreatiewoningen Ameland), CRvB 9 juli 1985, SV 1985/111 (Werkloosheidsuitkering bij alternatieve straf), CRvB 9 maart 1988, RSV 1988/269 (Dagloon musici), HR 26 oktober 1990, NJ 1991/231 (Huisman/Vries), HR 20 november 1985 (belastingkamer), BNB 1986/17 (Autokostenfictie), HR 16 april 1986 (belastingkamer), BNB 1986/236 (Strijkgelden), HR 16 september 1992 (belastingkamer), BNB 1992/371 (Veeverbetering) en HR 21 april 1999 (belastingkamer), BNB 1999/310 (CDK-biljetten). Interessant in dit verband is ook HR I november 1995, BNB 1996/37 (Omzetbelasting manege), waaruit blijkt dat voor de vraag of er sprake is van een ongelijke behandeling door verschillende bestuursorganen moet worden gekeken naar verschillende relevante beslismomenten. Vgl. Addink 1999, p. 164 en Koekkoek 1992, p. 43.

223. Zie Happé 1996, p. 310/311 en Schutte 2000, p. 9/10. 
baarheid ontbreekt: van een daadwerkelijke, eigen beleidsvrijheid voor de verschillen. de organen is bij een gecoördineerd beleid geen sprake. ${ }^{224}$

Op het eerste gezicht lijkt het vanzelfsprekend dat in de hierboven beschreven omstandigheden een beroep op het gelijkheidsbeginsel niet opgaat. Een andere benadering zou tot gevolg kunnen hebben dat deconcentratie en decentralisatie zinloos worden, ondat de verschillende bestuursorganen dan verplicht zijn om één en hetzelfde, gecentrali. seerde, beleid te voeren. Bovendien kan door een andere benadering nauwelijks worden ingespeeld op de concrete omstandigheden van het geval. Niettemin is het de vraag of een rigide benadering op dit punt wenselijk is. Het is niet vanzelfsprekend dat het feit dat twee situaties in twee verschillende wetten geregeld zijn steeds tot de conclusie leidt dat er sprake is van onvergelijkbaarheid. Zou dit wel zo zijn, dan is het voor de wetgever wel erg gemakkelijk om de werking van het gelijkheidsbeginsel te omzeilen: een verschillende behandeling op ontoelaatbare gronden kan dan eenvoudig worden gerealiseerd door het treffen van afzonderlijke regelingen. Van belang is verder dat de belangenaantasting die wordt veroorzaakt door een ongelijke behandeling niet groter of kleiner zal zijn doordat deze wordt veroorzaakt door één of door meerdere wettelijke regelingen. Wanneer het minimaliseren van belangenaantastingen door ongelijke be handeling tot uitgangspunt van de gelijkheidstoets wordt genomen (zoals in hoofdsuk 2 is bepleit), betekent dit dat de precieze herkomst van de ongelijke behandeling geen belemmering mag vormen voor een geslaagd beroep op het gelijkheidsbeginsel. Dit betekent dat de rechter de wetgever een positieve verplichting moet kunnen opleggen om de verschillende wettelijke regelingen meer met elkaar in overeenstemming ti brengen. Op vergelijkbare wijze kan in sommige gevallen een verplichting worden opgelegd tot overleg over de wijze waarop een bevoegdheid moet worden uitgeofend of tot het formuleren van specifiekere beleidsregels op een hoger niveau. ${ }^{25}$ of en in welke mate dergelijke positieve verplichtingen in een concreet geval inderdaad kunnen worden opgelegd moet worden beoordeeld aan de hand van de omstandigheden van het geval, waarbij met name rekening moet worden gehouden met de ernst van de door de ongelijkheid aangetaste belangen en andere factoren die bepalend kunnen zijn voor de intensiteit van de toetsing. ${ }^{26}$ Een dergelijk genuanceerd model is beter dan een stritgente benadering zoals die hiervoor is omschreven. Het is dan ook niet wenselijk om de

224. Vgl. ook CRvB 6 september 2000, JB 200/311 (Verwijtbare werkloosheid), waarin de Centrale Ravo vergelijkbaarheid accepteerde in een geval waarin de ongelijke behandeling weliswaar werd veroor zaakt door twee verschillende districtskantoren van het GAK, maar deze kantoren handelden in mat: daat. Dit betekent dat zij geen eigen bevoegdheid uitoefenden en zich hadden te houden aan de be leidslijnen die door het GAK zelf waren uitgezet.

225. Dit blijkt door de Nederlandse rechterlijke instanties ook wel te worden erkend. Zie bijv. ARRS 2 april 1991, AB 1991/ 603 (Tegemoetkoming scholingskosten), waarin de Afdeling stelde: "Weliswar worden de beleidsplannen, bedoeld in de regeling, per afzonderlijk GAB vastgesteld en wordt in eesse instantie door de directeuren der onderscheidende GAB's op de desbetreffende aanvragen beschilt maar een en ander betekent niet dat verweerder, wanneer hij wordt geroepen om als hoger adninistrt tief orgaan toe te zien op de juiste toepassing van deze regeling, niet zou behoeven na te gasn hos ifi vergelijkbare gevallen elders aan deze regeling toepassing is gegeven". Zie verder HR 23 septembe 1998 (belastingkamer), BNB 1999/3 (FIOD-onderzoek).

226. Zie nader paragraaf 3. 
door de Nederlandse rechter op dit punt gehanteerde benadering zonder meer in het algemene toetsingsmodel op te nemen.

\title{
2.2.3 De benadelingstoets als toetsingsingang
}

\section{Inleiding}

De benadelingstoets wordt door de Nederlandse rechterlijke instanties vooral als toetsingsingang gekozen bij indirect onderscheid: hoewel er gevallen zijn waarin deze toets ook wordt uitgevoerd bij direct onderscheid, is het aantal voorbeelden daarvan beperkt. ${ }^{2}$ Aan de benadelingstoets wordt door de instanties die hiervan gebruik maken op eenduidige wijze invulling gegeven. De Centrale Raad van Beroep definieert de toets, in navolging van het Europese Hof van Justitie, als volgt:
"[...] met indirecte discriminatie [wordt] in het algemeen [...] aangeduid een situatie waarin een (ogenschijnlijk) sexe-neutrale norm in de praktijk in het overgrote merendeel van de gevallen uitpakt ten nadele van - hetzij de vrouw hetzij de man [...]."22s

De Commissie Gelijke Behandeling kiest voor een vergelijkbare formulering:

\begin{abstract}
"[...] de vraag [rijst] of er gezien het effect van [...] het voornoemde criterium sprake is van indirect onderscheid. Hiervan is sprake wanneer door het hanteren van een op zichzelf sexeneutraal criterium in overwegende mate personen van een bepaald geslacht worden getroffen $[\ldots]$...229
\end{abstract}

Uit deze citaten blijkt dat aan verschillende eisen moet zijn voldaan om te kunnen spreken van een zodanige benadeling dat een (vermoeden van) indirect onderscheid kan worden vastgesteld. Allereerst moet de benadeling het gevolg zijn van direct onderscheid op een neutrale (dat wil zeggen niet door het de Awgb of een andere gelijkheidsbepaling rechtstreeks verboden) grond van onderscheid. Daarnaast moet vaststaan dat de regeling zodanige effecten teweeg brengt dat er feitelijk toch onderscheid op één van de verboden gronden is gemaakt. Dit is het geval wanneer de door het directe onderscheid veroorzaakte benadeling in overwegende of disproportionele mate één van de groepen raakt die door de relevante gelijkheidsbepaling uitdrukkelijk worden beschermd.

In het hiernavolgende zal worden nagegaan op welke manier in de Nederlandse rechtspraak met deze vereisten wordt omgegaan. De nadruk zal daarbij liggen op de oordelen van de Commissie Gelijke Behandeling en de uitspraken van de Centrale Raad, maar er zal ook aandacht worden besteed aan uitspraken van andere rechterlijke instanties waaruit een afwijkende of anderszins interessante benadering naar voren komt.

\section{Aanwezigheid van een daadwerkelijke en voldoende ernstige benadeling}

Zoals hiervoor is aangegeven moet, alvorens kan worden vastgesteld of een regeling een bepaalde groep in het bijzonder treft, worden nagegaan of de effecten van de nor-

\footnotetext{
227. Een bekend voorbeeld is HR 10 december 1982, NJ 1983/687 (Binderen/Kaya). Ook zijn er verschillende voorbeelden van een benadelingstoets bij direct onderscheid te vinden in de oordelen van de

228. CRvissie over (direct) onderscheid op grond van arbeidsduur.

229. CvB 28 september 1989, RSV 1990/235 (Meeverzekering ongehuwde partner)

Dordeel 95-17 (BBRS'84 en Rbpo)
} 
matieve classificatie als zodanig inderdaad een benadelend karakter hebben. Is dit niet het geval, dan bestaat er geen reden tot klagen en kan een inhoudelijke beoordeling achterwege blijven. In de meeste gevallen is het benadelende karakter van een regeling evident en wordt hieraan door de onderzochte instanties geen aandacht besteed. ${ }^{20}$ Soms blijkt echter dat het wel degelijk noodzakelijk is om deze toets daadwerkelijk uit to voeren. Voor die gevallen hebben de betrokken instanties enkele criteria ontwikkeld om te kunnen beoordelen of er sprake is van een benadeling. Van belang is daarbij dra door de Commissie Gelijke Behandeling vrij consequent is aangenomen dat er alleen ruimte bestaat voor een geslaagd beroep op de Awgb als er sprake is van een benadeling in het concrete geval. Dit betekent dat de verzoeker daadwerkelijk persoonlijk nadeel van de regeling moet hebben ondervonden: zijn verzoek mag niet slechts betrekking hebben op abstracte, voor hem niet nadelige, consequenties van de regeling."II

Een eerste criterium dat door de verschillende instanties is ontwikkeld betreft de aard van het ondervonden nadeel. Uit de rechtspraak blijkt dat het niet relevant is of het nadeel financieel van aard is of dat er een feitelijk voordeel is ontzegd, zolang het ondervonden nadeel maar voldoende "meetbaar" is. Zo blijkt de Commissie duidelijk niet bereid te zijn om een inhoudelijke toetsing uit te voeren wanneer er uitsluitend sprake is van psychisch nadeel dat in sterke mate subjectief van aard is: het is vaste rechtspraak dat het nadeel in ieder geval een rechtens relevant belang moet treffen." ${ }^{21}$ it vereiste kan worden geïllustreerd aan de hand van een oordeel met betrekking tot d? registratie van een besloten vennootschap van een echtpaar. ${ }^{23}$ Volgens de geldend? wetsbepalingen kon slechts één van de echtgenoten worden ingeschreven als enig aandeelhouder; de andere echtgenoot kon alleen worden vermeld als "alleen/zelfstandif bevoegd bestuurder". Verzoekster was van mening dat door deze regeling onderscheil op grond van burgerlijke staat en geslacht werd gemaakt. De Commissie oordeelde hierover als volgt:

"De Commissie stelt vast dat verzoekster de wijze van registratie door de wederpartij als onjuist ervaart $[\ldots]$ maar dat zij door de huidige registratie niet in haar functioneren als

230. Hetzelfde is eerder al gesignaleerd voor de toetsing in de eerste fase bij direct onderscheid door it Hoge Raad; zie paragraaf 2.1.1 en 2.1.2.

231. Een voorbeeld is Oordeel 96-36 (Kinderoppas), waarin de Commissie weliswaar vaststelde dal de in een bedrijf geldende kinderopvangregeling benadelende effecten had voor mannen, maar de verzoelit zelf geen concreet nadeel had ondervonden. Een uitzondering op deze regel is te vinden in Oordeelos07 (Feestdagenregeling CAO): de Commissie voerde in dit oordeel een inhoudelijke toetsing uit, nats zij had vastgesteld dat de betrokken regeling in het concrete geval geen nadeel voor de verzocker by opgeleverd. Eenzelfde benadering wordt gevolgd door de Centrale Raad: zie bijv. CRvB 23 mei $196 \mathrm{l}$, RSV 1991/256 (Overgang AAW-AWW 1). Overigens blijkt het vereiste van concreet nadeel niet s betekenen dat de benadeelde zelf deel moet uitmaken van de groep die in overwegende mate door te regeling wordt geraakt, hoewel de uitspraken daarover niet geheel eenduidig zijn (niet geheel verent; baar met de gebruikelijke benadering is bijv. Oordeel 97-127 (Diacritische tekens)). In het algenten kan uit de oordelen worden afgeleid dat een verzoek van een man die is getroffen door een regelith waardoor in overwegende mate vrouwen worden benadeeld kan worden toegewezen; zie Oordeel 35\% 92-40 (ADV-regeling onderwijs), Oordeel 96-36 (Kinderoppas) en Oordeel 99-50 (Zangdocente).

232. De Centrale Raad heeft zich hierover nooit uitgelaten, maar heeft hiertoe ook nooit aanleiding gate gen: in alle gevallen waarin de benadeling is toegepast is duidelijk sprake van een concreet finacist of feitelijk nadeel.

233. Oordeel 98-124 (Registratic echtgenoten als aandeelhouder) 
directeur van de onderneming wordt belemmerd. Verzoekster is weliswaar van mening dat het feit dat uitsluitend haar echtgenoot als enig aandeelhouder staat ingeschreven [...] haar status ondermijnt. Ter zitting heeft zij echter aangegeven door de wijze van registratie niet concreet benadeeld te worden. [...] Op grond van deze feiten en omstandigheden stelt de Commissie vast dat het handelen van de wederpartij in het onderhavige geval niet is te beschouwen als onderscheid zoals bedoeld in de wet, omdat verzoekster door het bestreden handelen niet een nadeel ondervindt in een door het recht beschermd belang."234

Uit deze overweging blijkt dat een subjectief ervaren nadeel niet voldoende is voor een geslaagd beroep op het gelijkheidsbeginsel. Dit hoeft echter niet te betekenen dat psychisch nadeel nooit tot een inhoudelijke toetsing van de ongelijke behandeling kan leiden: wanneer het nadeel voldoende objectiveerbaar is en is terug te brengen tot rechtens beschermde belangen (zoals het geval kan zijn bij "separate-but-equal"-achtige maatregelen) laat de formulering van de Commissie op zichzelf voldoende ruimte voor een geslaagd beroep op het gelijkheidsbeginsel.

Verder is het algemeen geaccepteerd dat er voor een geslaagd beroep op het gelijkheidsbeginsel sprake moet zijn van een werkelijk nadeel. Daarvan zal geen sprake zijn wanneer het nadeel wordt gecompenseerd door een voordeel dat door een andere regeling teweeg wordt gebracht ${ }^{235}$, wanneer uit de gegevens niet kan worden afgeleid dat de betrokken groep inderdaad benadeeld wordt ${ }^{236}$ of wanneer er andere feiten en omstandigheden zijn waaruit blijkt dat er van een werkelijk nadeel geen sprake is ${ }^{237}$. Dit laatste

234. R.0. 4.3. Zie bijv. ook Oordeel 95-54 (Naamsvermelding Eurocheques), Oordeel 96-03 (Ouderschapsverlofregeling) en Oordeel 01-143 (Directiesecretaresse).

235. Uit verschillende oordelen blijkt dat de Commissie onderzoekt of bepaalde compenserende maatregelen een zodanig karakter hebben dat zij de benadeling wegnemen. Diverse voorbeelden zijn te vinden in de oordelen over beloningsregelingen voor het openbaar onderwijs (zie o.a. Oordeel 96-07, Oordeel 96-08, Oordeel 96-71, Oordeel 97-54, Oordeel 97-55, Oordeel 98-27, Oordeel 98-28 en Oordeel 0099); de Commissie kwam in deze oordelen overigens steeds tot de conclusie dat het door de litigieuze regelingen berokkende nadeel niet voldoende of niet op relevante wijze werd gecompenseerd door de toegekende voordelen. Ook verder blijkt Commissie te kiezen voor een vrij soepele benadering; zie bijv. Oordeel 94-01 (Ontslag wegens beroep op ouderschapsverlof) (waarin een inhoudelijke toets werd uitgevoerd terwijl de wederpartij al tegemoet was gekomen aan verzoekers eisen, waardoor de benadeling was weggenomen), Oordeel 97-119 (Levering wasmachine op woonwagenterrein) (waarin een inhoudelijke toetsing werd uitgevoerd terwijl aan verzoeker een gelijkwaardig alternatief was aangeboden voor de dienst die hem op discriminatoire wijze was ontzegd) en Oordeel 99-07 (Feestdagenregeling) (waarin een benadeling werd geaccepteerd bij een regeling die zowel voordelige als nadelige effecten had). Eén van de weinige gevallen waarin een gelijkwaardige compensatie voor een nadeel wel aanwezig werd geacht is Oordeel 99-101 (Dienstauto deeltijdwerker), waarin aan deeltijdwerkers in plaats van een dienstauto een financiēle vergoeding werd toegekend. Zie verder, zij het slechts op een klein onderdeel van het verzoek, Oordeel 00-48 (Ondernemings-CAO voor financieel concem). Ook andere rechterlijke instanties nemen het daadwerkelijk bestaan van een ongecompenseerde benadeling tot uitgangspunt. Zie bijv. HR 31 maart 2000, JB 2000/133 (Scholingsbesluit bijstandsgerechtigden), waarin de Hoge Raad bij zijn oordeelsvorming uitdrukkelijk aandacht besteedde aan de mogelijkheid voor appellante om het aan haar ontzegde voordeel via andere wegen te verkrijgen (zie r.o. 3.1 onder b en 3.2). Zie verder HR 15 oktober 1996 (strafkamer), NJ 1997/199 (Doodslag in het verkeer).

236. Zie CRvB 23 mei 1991, RSV 1991/257 (Overgang AAW-AWW II) en CRvB 14 april 1992, RSV 1993/42 (Intrekking arbeidsongeschiktheidsuitkering)

237. Zie bijv. ABRS 1 juni 1999, AB 1999/313 (Aanwijzing examenbevoegde zeilschool). Deze zaak had betrekking op het ontzeggen van examenbevoegdheid aan een zeilschool. Volgens de Afdeling was daarbij geen sprake van een benadeling, omdat de school wel onderwijs kon aanbieden en de leerlingen 
betekent dat bij de vaststelling van een benadeling zorgvuldig moet worden gekeken naar de specifieke omstandigheden van het geval. Dit speelt vooral een rol bij zaken over onderscheid op grond van arbeidsduur. In veel gevallen zal er namelijk geen spro. ke zijn van een benadeling op grond van het aantal gewerkte uren als een voordeel nasat rato van de werktijd wordt toegekend, ook al betekent dit dat deeltijdwerkers in absolute zin een minder groot voordeel ontvangen dan voltijdwerkers. $\mathrm{Z}_{0}$ is er geen benadeling wanneer blijkt dat het salaris volledig is afgestemd op het aantal gewerkte uren (hetgeen bijvoorbeeld kan blijken uit het feit dat het uurloon voor voltijd- en deeltijdwerkers gelijk is) of als datzelfde geldt voor loonbestanddelen of de opbouw van vakantiedagen. ${ }^{23 x}$ Sommige voordelen hebben echter een zodanig karakter dat een toekenning naar rato van arbeidsduur niet redelijk is, bijvoorbeeld omdat zij niets te maken hebben met het aantal gewerkte uren. ${ }^{29}$ Wanneer in die gevallen toch een variatie nass werktijd zichtbaar is kan worden gesproken van een benadeling. Dit betekent dat van geval tot geval zorgvuldig moet worden nagegaan om welk type arbeidsvoorwaarde het gaat om vast te kunnen stellen of er sprake is van een benadeling op grond van arbeids. duur. ${ }^{2+0}$

\section{Vaststelling van het benadelend effect}

Bij klachten over direct onderscheid kan, zoals hiervoor is gebleken, meestal volstan worden met de eenvoudige vaststelling van het feitelijk of financieel nadeel dat de betrokkene heeft ondervonden. Voor het ontstaan van een vermoeden van indiret onderscheid is het daarnaast echter noodzakelijk dat het directe onderscheid zodanige effecten heeft dat er feitelijk sprake is van onderscheid op één van de door de Awgbof door andere gelijkheidsbepalingen verboden gronden. Dit betekent dat de rechter zal moeten onderzoeken op welke manier de door de betrokken regeling benadeelde groep precies is samengesteld: de vraag is of personen die over een bepaald, door de Awg verboden kenmerk beschikken, van deze groep in overwegende mate deel uitmaken. Zo $\mathrm{zal}$ er sprake zijn van een problematisch effect wanneer de benadeelde groep voor de overgrote meerderheid uit mensen van een bepaald geloof bestaat, wanneer overwe gend vrouwen door de regeling worden getroffen of wanneer allochtonen binnen de benadeelde groep sterk oververtegenwoordigd zijn. In een dergelijk geval is de betrok-

in staat kon stellen om de benodigde examens af te leggen, zij het op een andere plek. Zie verder 000 . deel 01-84 (Erkenning buitenlands diploma), waarin gesteld werd dat het beweerde nadeel eerder fast literend dan belemmerend van aard was, zodat niet kon worden gesteld dat er sprake was van een wat: kelijke benadeling.

238. Zie nader de Memorie van Toelichting bij de WOA, TK 1995-1996, 24 498, nr. 3, p. 9/10.

239. Een voorbeeld is een reiskostenvergoeding: als iemand vijf dagen per week vier uur werkt heeft hij nt zoveel reiskosten hebben als iemand die vijf dagen per week acht uur werkt. Wanneer in een dergeri geval de vergoeding afhankelijk wordt gesteld van het aantal werkuren leidt dit tot een benadeling op grond van arbeidsduur.

240. Hoe moeilijk dit soms is blijkt uit het feit dat verschillende rechterlijke instanties soms een afwijkente interpretatie hebben gegeven van een arbeidsvoorwaarde. Een voorbeeld is de tegemoetkoming in ts ziektekosten van overheidspersoneel. In Oordeel 97-140 (Tegemoetkoming ziektekosten onderwijspts: soneel) stelde de Commissie dat dit een voordeel is dat niet afhankelijk kan worden gesteld van \% beidsduur; een toekenning naar rato leverde volgens de Commissie een benadeling op. De Centrle Raad dacht over ditzelfde onderwerp anders: in 1999 oordeelde hij dat de tegemoetkoming wel dese lijk gerelateerd kon worden aan het aantal gewerkte uren (CRvB 25 november 1999, JB $1999 / 307$ (10 gemoetkoming ziektekosten $-\mathrm{Btzr}$ )), zodat een pro rata toekenning niet benadelend was. 
ken regeling alleen acceptabel wanneer daarvoor een objectieve en redelijke rechtvaardiging bestaat.

De Commissie Gelijke Behandeling en, in mindere mate, de Centrale Raad hebben een uitgebreide rechtspraak ontwikkeld over dit vereiste van een disproportionele benadeling. In het hiernavolgende zal aan twee aspecten van deze rechtspraak in het bijzonder aandacht worden besteed. Allereerst zullen de gegevens en factoren worden bezien die de Commissie van belang heeft geacht bij het vaststellen van de effecten van een maatregel. Vervolgens zal gekeken worden naar de criteria die de Commissie en de Centrale Raad hanteren bij de vaststelling van de "disproportionaliteit" van de effecten: de vraag is immers wanneer een bepaalde groep zodanig is vertegenwoordigd dat de effecten van de regeling problematisch moeten worden geacht.

\section{Bronnen voor de vaststelling van het benadelend effect: statistisch bewijs}

De Commissie Gelijke Behandeling heeft in de loop van enkele jaren (voortbouwend op de al bestaande rechtspraak van haar voorgangsters) een zorgvuldig uitgewerkt stelsel van bronnen ontwikkeld voor de vaststelling van het benadelend effect van een matregel of handeling. De belangrijkste van deze bronnen wordt gevormd door statistische gegevens: aan de hand van cijfermatig bewijsmateriaal kan nauwkeurig en objectief worden vastgesteld op welke manier de benadeelde groep is samengesteld. ${ }^{241}$ Fraaie illustraties van het gebruik van statistische gegevens zijn vooral zichtbaar in de periode waarin de WOA nog niet in werking was getreden. In veel gevallen werd toen door benadeelde deeltijdwerkers geklaagd over indirect onderscheid op grond van geslacht: de groep van deeltijdwerkers bestond (en bestaat) in overwegende mate uit vrouwen. Een goede illustratie van de benadering die de Commissie in dit soort zaken koos is te vinden in haar oordeel over een studieverlofregeling van een gemeentelijke bedrijfsgezondheidsdienst. ${ }^{242}$ Op grond van deze regeling werd aan bedrijfsartsen die minder dan 19 uur werkten geen studieverlof toegekend, terwijl ook aan bedrijfsartsen die meer dan 19, maar minder dan 32 uur werkten slechts de helft van het verlof voor voltijdwerkers werd toegekend. De Commissie onderzocht enkele gegevens van het Centraal Bureau voor de Statistiek met betrekking tot het aantal bedrijfsartsen in dienst van gezondheidsdiensten en concludeerde daaruit het volgende:

"Uit deze gegevens vloeit voort dat in 1986 in totaal $93 \%$ van de mannen fulltime werkten en $7 \%$ parttime. Bij de vrouwen werkte $45 \%$ fulltime en $55 \%$ parttime. [Volgt een vergelijkbare opsomming voor 1988 en 1990, JHG] [...] Met andere woorden, in 1986, 1988 en 1990 waren er dus relatief $(55: 7=) \quad 7,8$ respectievelijk relatief $(60: 7=)$ 8,5 en relatief $(56: 10=) 5,6$ keer zoveel vrouwelijke parttimers als mannelijke." ${ }^{243}$

Op basis van deze gegevens kon de Commissie gemakkelijk tot de conclusie komen dat er sprake was van een overwegende benadeling van vrouwen en daarmee van een vermoeden van indirect onderscheid.

241. Vgl. Heringa 1994 (I), p. 43

242. Oordeel 96-56 (Studieverlof bedrijfsartsen)
243. R. 0.4 .8 
De geciteerde overweging is met name interessant omdat hieruit blijkt dat de Commissie gebruik makt van relatieve cijfers om het aandeel van personen met een bepaald kenmerk (in dit geval geslacht) in de volledige benadeelde groep (in dit geval deeltijd. werkers) te berekenen: naar absolute gegevens wordt in de oordelen vrijwel nooit verwezen. ${ }^{2+}$ De reden daarvoor is gelegen in het feit dat absolute gegevens een vertekend beeld van de verhoudingen kunnen opleveren. De Commissie illustreert dit in een in vrijwel ieder oordeel terugkerende voetnoot als volgt:

"Een voorbeeld: een onderneming waarin 10 vrouwen en 1000 mannen werken. Van de vrouwen werken er 9 in deeltijd, van de mannen ook. Stel dat de deeltijders een lager uurloon ontvangen dan voltijdwerkers. Indien men alleen maar kijkt naar de aantallen (dus absolute getallen) werkt onderscheid ten nadele van deeltijders gelijk uit naar geslacht; er zijn immers 9 vrouwen en 9 mannen die benadeeld worden. Toch zal duidelijk zijn dat met name vrouwen nadelig worden getroffen: immers 9 van de 10 vrouwen tegenover 9 van 1000 mannen worden nadelig getroffen." 245

Hoewel relatieve statistische cijfers op het eerste gezicht een goed en objectief instrtment vormen voor de beoordeling van de effecten van een regeling, blijken hieraan in de praktijk de nodige problemen te kleven. Allereerst kan het lastig zijn om de referentiegroepen goed te definiëren. In beginsel zal de Commissie de kleinst mogelijke groep als referentiegroep kiezen, dat wil zeggen dat in het algemeen alleen zal worden gekeken naar de verhoudingen binnen de groep die rechtstreeks door de betrokken regeling wordt benadeeld. ${ }^{246}$ Als de benadeelde groep bijzonder klein is, zoals in het geval van een kleine onderneming waarin maar weinig mensen werken, is het echter lastig om daarbinnen een representatieve benadelingstoets uit te voeren: kleine verschillen in absolute getallen leiden in dit soort gevallen al snel tot grote afwijkingen in de relatieve

244. Er zijn enkele sporadische uitzonderingen: zie Oordeel 339-91-16 (Ouderschapsverlofregeling Am hem) van de CGB m/v en Oordeel 97-71 (VUT- en spaarloonregeling grafisch bedrijf). Soms wort the een soort ondersteuning van het oordeel over de relatieve gegevens bovendien gesteld dat dezelfit: conclusie zou worden bereikt wanneer alleen naar absolute getallen zou worden gekeken; zie bij. Oordeel 374-92-04 (VUT-regeling afroepkracht).

245. Oordeel 97-04 (Inschaling stewardessen), voetnoot 1. Deze benadering werd al gehanteerd door de voorgangster van de Commissie, de CGB m/v; zie bijv. Oordeel 1-90-10 (Overwerkregeling bedrits: CAO). De Commissie weet zich in deze benadering gesteund door rechtspraak van de Hoge Rad (vel. HR 10 december 1982, NJ 1983/687 (Binderen/Kaya)) en door "een redelijke wetsuitleg" (zie hict il genoemde Oordeel 1-90-10 en Oordeel 419-92-67 (Snackindustrie)).

246. Ook dan is er vaak twijfel mogelijk over de keuze van de referentiegroep. Zo blijt het onduidelikin hoeverre het mogelijk is om binnen een bedrijf waarin zeer diverse functies bestaan een representatif oordeel te vellen over de verhoudingen: moet worden gekeken naar het personeelsbestand in zijn gs" heel of alleen naar de verhoudingen binnen de relevante functiegroepen? Aan dit soort lechnistrstatistische problemen zal in het bestek van dit proefschrift geen aandacht worden besteed. In de prak tijk kan dit voor rechters echter een complicerende factor vormen bij oordelen over ongelijke behundring; nader onderzoek naar de vaststelling van referentiekaders is dan ook nodig. Zie voor illustratis instantie als de Commissie ondervindt Oordeel 96-51 (Pensioenten die zelfs een gewardessen), Oordeel $98-43$ (Inconvenientietoeslag toneelmeester), Oordeel 98-106 (Incon (Éloignement en duurtetoeslag uitgezonden militairen); zie ook Oordeel 553 , 555 en (Ontslag wegens reorganisatie), Oordeel 551-93-16 (Ontslagen wegens reorganisatie), Oodedewerkest. 22 (Doorbetaling arbeidsongeschiktheid) en Oordeel 669-94-06 t/m 21 (Ontslag log 1994, p. 44 Zie verder Dierx/Siegers 1990, p. 558, Burkens/Kummeling 1991, p. 21 en Heringa 1994, p. 
verhoudingen. ${ }^{27}$ De Commissie lost dit probleem op door in die gevallen steun te zoeken in andere informatie over de verhoudingen van de relevante groepen, bijvoorbeeld in gegevens over de gehele bedrijfssector of zelfs in landelijke gegevens ${ }^{248}$, of door meer in het algemeen te kijken naar de verhoudingen binnen een grotere groep dan de groep die daadwerkelijk door de regeling is benadeeld ${ }^{249}$. Ook wordt soms steun gezocht in feiten van algemene bekendheid, een factor waarop hierna nog zal worden ingegaan. ${ }^{20}$ Wanneer van een dergelijke werkwijze gebruik wordt gemaakt acht de Commissie het overigens noodzakelijk om na te gaan of deze gegevens ook relevant zijn voor het voorliggende geval.

Een tweede probleem betreft het achterhalen van relevante gegevens. Een moeilijke situatie ontstaat bijvoorbeeld wanneer de betrokken wederpartij niet beschikt over de cijfermatige gegevens die voor het specifieke geval van belang zijn of wanneer de cijfers zodanig zijn verouderd dat zij niet meer indicatief kunnen worden geacht ${ }^{231}$; problematisch is ook de situatie waarin beide partijen gegevens hebben aangevoerd, maar de resultaten hiervan verschillen ${ }^{252}$. In dergelijke omstandigheden blijkt de Commissie vaak bereid te zijn om zelf naar andere cijfers op zoek te gaan; pas wanneer er echt geen geschikte cijfers kunnen worden gevonden of wanneer blijkt dat geen van de

247. Bovendien kunnen verhoudingen binnen een kleine organisatie afwijken van de situatie binnen de arbeidsmarkt in het algemeen of de bedrijfssector, waardoor de bedrijfsgegevens minder representatief zijn voor de vaststelling van een benadeling. Ook daarom is het goed om in dit soort gevallen (ook) een benadelingstoets uit te voeren met een ruimer referentiekader. Vgl. Evenhuis 1991, p. 42 en Dierx 1992, p. $116 / 117$.

248. Vgl. Burkens/Kummeling 1991, p. 20. Dergelijke gegevens kunnen afkomstig zijn van het CBS, maar ook van andere onderzoeksinstanties (zie bijv. Oordeel 398-92-40 (ADV-regeling onderwijs) en Oordeel 445-93-09 (Leeftijdseis opleiding belastinginspecteur)). De Commissie heeft ook de bevoegdheid om zelf statistische gegevens te verzamelen, maar dit gebeurt slechts in uitzonderlijke gevallen. Een voorbeeld is een onderzoek naar de benadeling van oudere deeltijdwerkers door regelingen in bedrijven die medewerkers met een (relatief) groot dienstverband de kans geven om bij behoud van loon minder te gaan werken; zie Oordeel 99-78 (Seniorenregeling). Zie voor voorbeelden van een beroep op algemene gegevens verder Oordeel 96-15 (Pensioenregeling zeefdrukkerij), Oordeel 97-45 (Vakantieregeling), Oordeel 97-71 (VUT- en spaarloonregeling grafisch bedrijf), Oordeel 98-22 (Pensioenregeling belastingadvieskantoor), Oordeel 98-119 (Pensioenregeling zwembad) en Oordeel 99-20 (Uitsluiting deeltijdwerkers van pensioenregeling). Tenslotte is van belang dat de Commissie in het algemeen landelijke gegevens doorslaggevend acht wanneer de gegevens in een kleine referentiegroep duidelijk afwijken van het landelijke beeld; zie Oordeel 00-60 (Fulltime werkende oproepkracht). Overigens ziet de Commissie de kleine omvang van de benadeelde groep niet steeds als een belemmering voor het hanteren van relatieve cijfers en wordt ook niet altijd gekeken naar een ruimere referentiegroep. Zie bijv. Oordeel 94-05 (Arbeidstijdvermindering oudere werknemers) en Oordeel 98-66 (Anciênniteit bij afvloeiingsregeling). Hierop is wel kritiek geleverd, net als op de keuze van de Commissie om alleen naar een ruimer referentiekader te kijken wanneer de gegevens van het bedrijf zelf beperkt zijn; het zou volgens de betrokken auteurs beter zijn wanneer een ruimer referentiekader in alle gevallen in ogenschouw werd genomen. Zie Loenen 1996, p. 839 en Evenhuis 1991, p. 42.

249. Bijv. Oordeel 96-117 (Korter dienstverband 55-plussers)

250. Bijv. Oordeel 98-13 (Partner als medewerker), Oordeel 98-119 (Pensioenregeling zwembad) en Oordeel 99-20 (Uitsluiting deeltijdwerkers van pensioenregeling).

251. Bijv. Oordeel 98-93 (Pensioenregeling gehuwden met groot leeftijdsverschil) en Oordeel 98-118 (Pensioenopbouw vervangende leerkrachten); dat de gegevens voldoende recent moeten zijn om indicatief te kunnen worden geacht blijkt ook uit Oordeel 00-60 (Fulltime werkende oproepkracht).

252. Zie bijv. Oordeel 463A-94-02 (Bijzondere uren supermarktsector). 
gevonden gegevens voldoende representatief zijn voor het voorgelegde geval, zal zij tot de conclusie komen dat een benadeling ontbreekt. ${ }^{25 s}$

Uit het voorgaande blijkt dat de Commissie bij het achterhalen en waarderen van sta. tistische gegevens een actieve rol speelt. Haar uitgangspunt bij de beoordeling van verzoeken om een oordeel is weliswaar dat de verzoekende partij aannemelijk moot maken dat er sprake is van een benadeling, maar de eisen die aan deze bewijslast worden gesteld zijn in de praktijk minimaal. Het is bijvoorbeeld al snel zo dat de Commissie aan de verweerder vraagt of hij nadere, cijfermatige, gegevens kan verschaffen op grond waarvan een benadeling objectief kan worden vastgesteld. ${ }^{24}$ Als dit niet mogelijk blijkt, terwijl de Commissie een benadeling niet onaannemelijk acht, is zij bovendien vaak bereid om zelfstandig onderzoek te verrichten naar het bestaan van relevant sta. tistisch bewijsmateriaal.

Ook de andere rechterlijke instanties maken regelmatig gebruik van statistische gegevens als bron voor de vaststelling van een benadeling: in de rechtspraak van zowel de Centrale Raad als de Hoge Raad zijn hiervan verschillende voorbeelden terug te vinden. ${ }^{25 s}$ Beide instanties blijken echter in veel mindere mate dan de Commissie geneigd tot het uitvoeren van een eigen onderzoek en zijn niet bereid om zich bezig te houden met de problemen die bij het waarderen van statistische bewijsmateriaal een rol kunnen spelen. Heel duidelijk blijkt dit uit een uitspraak van de Centrale Raad over een klactit met betrekking tot indirect onderscheid op grond van geslacht:

"Om in een geval als het onderhavige tot die conclusie te komen [namelijk die van een benadelend effect, JHG] dient men echter te beschikken over meer statistische gegevens dan thans beschikbaar zijn. Bovendien rijst ook hier de vraag, zoals zo dikwijls bij statistische

253. Zie bijv. Oordeel 94-19 (Doorstroombeleid accountancy-en adviesorganisatie), Oordeel 95-43 (Affes: tieve relatie met collega), Oordeel 96-27 (Pensioen arbeidsongeschikte), Oordeel 96-71 (Rbpo), 00deel 97-88 (Vrijwilligers ontwikkelingslanden), Oordeel 98-13 (Partner als medewerker), Oordec 9878 (Project Wisselwerk), Oordeel 98-118 (Pensioenopbouw vervangende leerkrachten), Oordeel 00-39 (Overgangsregeling gezondheidszorgpsychologen) en Oordeel 00-81 (Kinderopvangregeling UM Overigens verricht de Commissie niet in alle genoemde gevallen eigen onderzoek, vooral niet wannert de benadeling zo specifiek is voor een bepaald bedrijf dat het verder zoeken naar gegevens opeen igemener niveau niet echt zinvol zou zijn. Wanneer de Commissie ambtshalve op zoek gaat naar rekvante gegevens ligt het overigens op de weg van de verwerende partij om aan te tonen dat deze cijtes niet representatief zijn voor zijn situatie; zie bijv. Oordeel 98-93 (Pensioenregeling gehuwden mat groot leeftijdsverschil). Ook dan blijkt de Commissie zich overigens vaak zelf een oordeel te vormen over de relevantie van de cijfers, zodat de bewijslast voor de wederpartij ook weer niet bijzonder groul is. Zie bijv. Oordeel 96-56 (Studieverlof bedrijfsartsen), Oordeel 97-92 (Ouderschapsverlof bij beizlnestation), Oordeel 97-102 (Ouderschapsverlof maatschappelijk werkster), Oordeel 97-106 (Leeffij. grenzen NWO-subsidies), Oordeel 98-16 (Pensioenregeling huishoudelijk personeel) en Oordeel 0056 (Uitruil nabestaandenpensioen).

254. Dit gebeurt vooral als de benadelende regeling erg ondoorzichtig is; vgl. Wentholt 1999 (II), p. 106.

255. Zie bijv. HR 10 december 1982, NJ 1983/687 (Binderen/Kaya): "Overigens verzet geen rechistro" zich ertegen dat de rechter cijfermatige, statistische verschillen als de onderhavige aanmerkt als wol doende motivering van de stelling dat er gediscrimineerd is, noch dat hij aan dergelijke verschillen tel (zwaarwegend) vermoeden voor discriminatie ontleent en enkel op grond van dat vermoeden op de ris discriminatie betichte de last legt aan te tonen dat de hem verweten achterstelling berust op rechiss aanvaardbare gronden"; zie ook (meer impliciet) HR 3 januari 1997, NJ 1997/435 (Zorggroep 0est Gelderland/Gerrits). Zie ook Burkens/Kummeling 1991, p. 12. 
verwerkingen, wat precies moet worden geteld, van welke categoriee̊n moet worden uitgegaan, wat met wat moet worden vergeleken, etc. [...] De Raad is tot de conclusie gekomen, dat er te veel redenering met te veel arbitraire keuzemomenten nodig is om met voldoende duidelijkheid als vaststaand aan te nemen dat [de betrokken bepaling] [...] (indirecte) discriminatie naar geslacht inhoudt."256

Deze terughoudendheid staat in schril contrast met de actieve houding van de Commissie. Een belangrijk verschil tussen de Commissie en de Centrale Raad is echter dat de Commissie een gespecialiseerd orgaan is met een grote mate van expertise op dit gebied: voor haar is het aanzienlijk gemakkelijker om ingewikkelde statistische gegevens te achterhalen en te waarderen dan voor een rechterlijke instantie die met de onderhavige problematiek niet dagelijks geconfronteerd wordt. ${ }^{257}$ Dit wil echter nog niet zeggen dat de benadering van de Centrale Raad ook tegenwoordig nog noodzakelijk is: de Awgb geeft rechterlijke instanties de mogelijkheid om bij onduidelijkheid over de uitleg van deze wet (waaronder ook de vraag of er in een concreet geval spaken is van een indirect onderscheid) hulp te vragen aan de Commissie. ${ }^{25 k}$ Door het bestaan van een dergelijke mogelijkheid staat er ook voor andere instanties nauwelijks iets in de weg aan het gebruik en de beoordeling van statistisch bewijsmateriaal.

\section{Bronnen voor de vaststelling van het benadelend effect: feiten van algemene bekend- heid}

Een tweede bron voor het vaststellen van benadelende effecten blijkt de Commissie te vinden in de zogenaamde feiten van algemene bekendheid. Illustratief voor het gebruik van deze bron is een oordeel waarin geklaagd werd over de weigering door een werkgever om een deeltijdfunctie voor verzoekster te creëren. ${ }^{259}$ Over de vraag of deze weigering indirect onderscheid op grond van geslacht opleverde oordeelde de Commissie als volgt:

"Het is een feit van algemene bekendheid dat met name vrouwen in deze maatschappij in deeltijdbanen (willen) werken aangezien zij het betaald werk veelal combineren met zorgtaken. Daarnaast blijkt uit 'Het Gezinsrapport', een verkennende studie naar het gezin in een veranderende samenleving [...] dat onder vrouwen met een voltijdbaan de behoefte aan een kortere werkweek groter is dan bij mannen. Dit rechtvaardigt de conclusie dat het

256. CRvB 28 september 1989, RSV 1990/235 (Meeverzekering ongehuwde partner). In sommige uitspraken blijkt de Centrale Raad overigens iets actiever te zijn: zo ontleent hij soms gegevens aan relevante wetsgeschiedenis (bijv, CRvB 9 april 1991, RSV 1991/247 (Drie-uit-vijf-eis)) of aan uitspraken van het Europees Hof (CRvB 23 juni 1992, RSV $1992 / 317$ (Inkomenseis AAW)). Veelal wordt echter alleen verwezen naar de door partijen aangevoerde gegevens (CRvB 18 juni 1993, RSV 1994/68 (Samenloop AAW-uitkeringen) en CRvB 12 augustus 1999, RSV 2000/73 (Inkomensvereiste thuiswerkers)) of naar de vaststellingen van de rechter in eerste aanleg (CRvB 17 oktober 1996, RSV 1997/235 (Inkomenseis Rariteitenbesluit WAO)). Uit laatstgenoemde uitspraak blijkt ook dat de Centrale Raad, zelfs als hij van mening is dat de verschafte gegevens weinig relevante informatie bevatten, niet bereid

257.

dat literatuur is ook wel als bezwaar tegen het gebruik van statistische bewijsmateriaal aangevoerd fouten wiermee in het algemeen niet op een goede en kritische manier omgaan, waardoor veel fouten worden gemaakt; zie bijv. Dierx/Siegers 1990, p. 554. De benadering van de Centrale Raad is

258. Zisschien nog niet eens onredelijk, nu dergelijke fouten daardoor kunnen worden voorkomen.

259. Oordeel $98-56$ lid 2 onder c Awgb.

Oordeel 98-56 (Deeltijdwerk productmanager) 
weigeren om in deeltijd te werken relatief meer vrouwen dan mannen zal treffen, en dat et derhalve sprake is van indirect onderscheid naar geslacht."260

Feiten van algemene bekendheid blijken maar zelden een zelfstandige bron te vormen waaruit de Commissie het bestaan van benadelende effecten afleidt: hierop wordt feite. lijk alleen teruggevallen wanneer niet uitsluitend gebruik kan worden gemaakt van sterkere gegevens (zoals statistisch bewijs of duidelijke onderzoeksresultaten), terwij] het vrij evident is dat er sprake is van een indirect onderscheid. ${ }^{261}$ Het geciteerde oor. deel vormt hiervan een illustratie. In het geding was niet een normatieve classificatie waardoor een volledige groep werd benadeeld, maar de individuele beslissing van een werkgever om iemand geen deeltijdbaan te gunnen. In een dergelijk geval kan geen gebruik worden gemaakt van statistisch bewijs, nu het hierbij niet mogelijk is om het aandeel van vrouwen in een grotere benadeelde groep te bepalen. De Commissie moest dan ook andere methoden zoeken om indirect onderscheid op grond van geslacht aante tonen. ${ }^{262}$ Feiten van algemene bekendheid, ondersteund door een verwijzing naar algemene statistische of onderzoeksgegevens, kunnen daarbij behulpzaam zijn. ${ }^{203}$

Van belang is verder dat feiten van algemene bekendheid een belangrijke ondersteu. ning kunnen vormen wanneer de gevonden statistische gegevens niet bijzonder relevant of overtuigend zijn. Een voorbeeld hiervan is een oordeel waarin een benadeling moest worden vastgesteld binnen een groep die uit slechts 13 personen bestond. ${ }^{26}$ Zoals eerder is opgemerkt is het daarbij moeilijk om uitsluitend van statistische gegevens go bruik te maken, zelfs wanneer met relatieve cijfers wordt gewerkt. Na vaststelling van de statistische verhoudingen oordeelde de Commissie dan ook nog het volgende:

"Vorenstaande cijfers zijn in overeenstemming met het feit van algemene bekendheid dat ef meer vrouwen dan mannen in deeltijd werken." 265

260. R.o. 4.3

261. Dit was reeds vaste rechtspraak van de CGB m/v; zie bijv. Oordeel 374-92-04 (VUT-regeling affoet kracht), Oordeel 466-93-34 (Anciënniteit deeltijdrechters) en Oordeel 529-93-43 (Rangorde ontslag ch overplaatsing). Zie verder Oordeel 95-20 (Pensioenregeling bibliotheek) en Oordeel 96-111 (Publiatievereiste onderzoeksschool).

262. Overigens wordt niet alleen in deze situatie van feiten van algemene bekendheid gebruik gemust: maar ook wanneer er bij een normatieve classificatie te weinig cijfermatige gegevens te vinden zijn on een zinvolle conclusie over de benadeling te bereiken. De in de vorige noot genoemde zaken van de Commissie geven daarvan een voorbeeld.

263. Wanneer steun wordt gevonden in algemeen toegankelijke gegevens wordt de kwalificatie van fitten als "algemeen bekend" objectiever en overtuigender. Deze steun kan worden gezocht in openbare tf algemene rapporten (zoals in het aangehaalde geval en in Oordeel 96-90 (Berekening inkomenssdrde), Oordeel 98-78 (Project Wisselwerk), Oordeel 98-126 (Werktijdenregeling slachterij)), maar ook int andere bronnen, zoals uitspraken van andere rechterlijke instanties of de Nationale ombudsman (oij. Oordeel 95-30 (Taaleis kamermeisje), of in de wetsgeschiedenis (bijv. Oordeel 01-90 (Woonruitst? verdelingssysteem)).

264. Oordeel 94-05 (Arbeidstijdvermindering oudere werknemers)

265. R.o. 4.3. Zie ook Oordeel 95-19 (Uitsluiting deeltijdwerkers van pensioenfonds), Oordeel $98-41$ (fatr sioenregeling montagelaborante), Oordeel 98-119 (Pensioenregeling zwembad) en Oordeel 99-20 (tilsluiting deeltijders van pensioenregeling). Soms wordt een tegenovergestelde volgorde gekozen, wath bij eerst wordt vastgesteld dat een feit van algemene bekendheid wijst in de richting van een bensts ling, waarna wordt nagegaan of deze conclusie wordt ondersteund door de concrete cijfers in het worgelegde geval; zie bijv. Oordeel 98-66 (Anciënniteit bij afvloeiingsregeling). 
Het is ook redelijk dat aan feiten van algemene bekendheid slechts een ondersteunende functie wordt toegekend: het gebruik van dit soort feiten is vaak arbitrair en subjectief, terwijl het oordeel van de leden van de Commissie over wat "algemeen bekend" is bovendien anders kan zijn dan dat van de gemiddelde burger. Een voorzichtige benadering als die van de Commissie, waarbij aan feiten van algemene bekendheid alleen een ondersteunende functie wordt toegekend, vormt echter een zinvolle aanvulling op de "harde" statistische gegevens als bron voor de vaststelling van een benadeling. ${ }^{2.66}$

\title{
Bronnen voor de vaststelling van het benadelend effect: evidentie
}

In een groot aantal gevallen acht de Commissie het tenslotte niet nodig om gebruik te maken van statistische gegevens of feiten van algemene bekendheid, omdat het evident is dat het gebruik van een bepaald onderscheidingscriterium indirect onderscheid op een ontoelaatbare grond oplevert. ${ }^{267}$ Zo moet de Commissie zich regelmatig uitspreken over taalvereisten die in functieomschrijvingen worden gesteld. Op de vraag of het vereiste van het spreken van accentloos Nederlands een indirect onderscheid op grond van nationaliteit oplevert gaf zij het volgende antwoord:

\begin{abstract}
"Niet ontkend wordt dat daardoor [door het taalvereiste, JHG] ook kandidaten van autochtone afkomst vanwege hun uitspraak door de wederpartij afgewezen kunnen worden. Een dergelijke functie-eis treft echter merendeels diegenen die niet vanaf hun eerste kinderjaren in Nederland hebben gewoond. Dit zijn in overwegende mate personen van nietNederlandse etnische of nationale afstamming, of niet-Nederlandse nationaliteit. In zoverre heeft de gestelde functie-eis indirect onderscheid naar ras of nationaliteit tot gevolg.,"268
\end{abstract}

Inderdaad kan het in dit geval zodanig vanzelfsprekend worden geacht dat overwegend allochtonen door de regeling werden benadeeld, dat een verdergaand onderzoek naar statistische gegevens overbodig was. Hetzelfde geldt voor andere, niet rechtstreeks verboden onderscheidingscriteria, zoals het hebben van een verblijfsvergunning ${ }^{2(6)}$, het

266. Door de Centrale Raad en de andere bestudeerde instanties wordt geen gebruik gemaakt van feiten van algemene bekendheid als bron voor het oordeel over de benadeling. De reden daarvoor is niet geheel duidelijk, maar is waarschijnlijk gelegen in het feit dat de Centrale Raad meestal kiest voor een terughoudende opstelling: wanneer niet duidelijk uit de feiten blijkt dat er sprake is van een benadeling, zal de Raad daardoor minder snel dan de Commissie geneigd zijn om deze benadeling te zoeken in tamelijk vage feiten van algemene bekendheid.

267. Ook de Centrale Raad en de Afdeling maken soms gebruik van "aannemelijkheden" of veronderstellingen bij de beoordeling van indirect onderscheid. Zie bijv. CRvB 15 mei 1991, RSV 1992/158 (Pensioenopbouw buitenlandse werknemers), CRvB 29 april 1996, RSV 1996/247, CRvB 21 september 2000, JB 2000/313 (Scholierenregeling) en ABRS 4 augustus 1998, AB 1998/377 (Loting geneeskun-

268. Oordeel 96-101 (Taalvereiste receptioniste), r.o. 5.7. Zie ook Oordeel 96-29 (Taaleis schoonmaakster), Oordeel 96-55 (Taalvereisten strijksters), Oordeel 96-75 (Taalvereiste administratief werk), Oordeel 97-43 (Taalvereiste schoonmaakfunctie), Oordeel 98-19 (Taalvereiste boekverkoper), Oordeel 00-15 (Taalvereiste glastuinbouw), Oordeel 00-36 (Iraans accent peuterleidster) en Oordeel 01-12 (Taalvereiste peuterleidster). Zie voor een vergelijkbare benadering in een iets andere context Oordeel 97-96 (Nederlands op de werkplek), Oordeel 97-127 (Diakritische tekens) en Oordeel 99-87 (Taalbeleid
sportcentrum).

269. Zie bijv. Oordeel 95-69 (Acceptatievoorwaarden kredietbank), Oordeel 96-12 (Kredietverlening vreemdelingen), Oordeel 96-60 (Mobiele telefoon), Oordeel 97-97 (Paspoortvereiste bij mobiele telefoonaansluiting), Oordeel 97-117 (Afwijzing wegens verblijfstitel), Oordeel 98-05 (Inschrijvingsvoorwaarden videotheek), Oordeel 98-07 (Acceptatiebeleid kredietbank), Oordeel 99-98 (Verhuur appara- 
geboren zijn in de regio ${ }^{270}$ of het voldoen aan bepaalde kledingregels (die bijvoorbeeld niet toelaten dat een chador of een hoofddoek gedragen wordt) ${ }^{27}$ : ook daarbij is het uit de aard van het onderscheidingscriterium duidelijk dat door de Awgb beschermde groepen of personen sneller zullen worden getroffen dan andere. ${ }^{2 n}$ Deze toetsingsme. thodiek is bijzonder bruikbaar, aangezien op een snelle en duidelijke manier een bena. deling van een bepaalde groep kan worden vastgesteld. Wel is een goede motivering steeds noodzakelijk: er zijn zeker gevallen denkbaar waarin het minder evident is dat direct onderscheid op de ene grond een indirect onderscheid op een andere grond to weegbrengt. ${ }^{273}$

tuur aan niet-Nederlanders), Oordeel 00-28 (Acceptatievereisten mobiel telefoonabonnement) en $0 \mathrm{or}$ deel 01-26 (Acceptatiebeleid mobiel telefoonabonnement). Zie ook Oordeel 01-69 (Accommodrik asielzoekers), waarin de Commissie stelde dat asielzoekers per definitie niet-Nederlanders zullen zjn.

270. Oordeel 96-05 (Sollicitatie politiekorps).

271. Bijv. Oordeel 96-85 (Hoofddoek en veiligheidsvoorschriften), Oordeel 96-109 (Hoofddoek en lengteeis), Oordeel 97-24 (Kledingvereiste Sikh), Oordeel 97-149 (Hoofddoek tijdens gymles), Oordeel \$79 (Lange mouwen bij bewegingsonderwijs), Oordeel 00-63 (Chador) en Oordeel 01-53 (Hoofdook griffier). Ook verder zijn er veel zaken terug te vinden waarin onderscheid op grond van praktische overwegingen onvermijdelijk tot gevolg heeft dat er indirect onderscheid wordt gemaakt op grond vin godsdienst. Dit is bijvoorbeeld het geval wanneer bepaalde geloofsuitingen leiden tot klachten van klanten of patiènten en juist deze klachten (dus niet zozeer het geloof van de betrokkene als zodarig) de grond voor een benadeling vormen (zie bijv. Oordeel 96-59 (Jehova's getuige als bankmedewetster), Oordeel 97-148 (Hinderlijke geloofsuitingen) en Oordeel 99-19 (Christelijke fysiotherapeut). Zie verder Oordeel 97-23 (Bidden op de werkplek), Oordeel 97-46 (Jehova's getuige als verplecghurdige) en Oordeel 99-49 (Bidden op het werk).

272. Overigens kan deze benadering van de Commissie leiden tot een minimalisering van het verscil tussen direct en indirect onderscheid. Wanneer bijvoorbeeld houders van een verblijfsvergunning van een bepaalde dienst worden uitgesloten, is het duidelijk dat hierdoor nooit mensen met de Nederlaniss nationaliteit zullen worden geraakt. De neutrale grond (het hebben van een verblijfsvergunning) ver toont dan een zodanige mate van overlap met de verboden grond (nationaliteit), dat feitelijk sprake is van direct onderscheid. Door dan toch te kiezen voor een constructie via indirect onderscheid (wartif, anders dan bij direct onderscheid, een rechtvaardiging mogelijk is) wordt in de hand gewerkt dat mat. sen hun eigenlijke beweegredenen en differentiatiecriteria verhullen achter de façade van een neurrde onderscheidingsgrond. Voor de Commissie is deze constructie echter de enige manier om te ontkonen aan de knellende banden van het gesloten stelsel van de Awgb, dat weinig rechtvaardigingsmogelis. heden laat voor direct onderscheid. Dit systeem is vooral zo beperkend, nu direct onderscheid sams ook buiten de limitatief opgesomde gronden om redelijk kan worden geacht (zie voor enkele voorbet. den voetnoot 75). Dit is bijvoorbeeld het geval bij het verbieden van het dragen van een tulband, onop die manier hygiěne te garanderen. Het is evident dat de groep van dragers van tulbanden vrijwel vole dig zal bestaan uit mensen die een tulband dragen als uitdrukking van hun religieuze overtuiging, mar de Commissie neemt in dit soort gevallen geen direct onderscheid aan: alleen door uit te gaan van de stelling dat het onderscheid niet op geloofsovertuiging, maar op overwegingen van hygiene is geto seerd is immers een rechtvaardiging mogelijk (zie voor dit voorbeeld nader Oordeel 97-24 (Kledingte reisten Sikh)). Op deze benadering is in de literatuur kritiek geleverd, omdat hierdoor het wettelijk ver bod van direct onderscheid wordt omzeild en de toetsing zelf door deze benadering bepaald niet dorr zichtiger wordt. Zie o.a. Wentholt 1999 (II), p. 110 en Veldman 1998, p. 3.

273. Zo is het niet altijd duidelijk dat het vereiste van accentloos Nederlands, hiervoor al genoemd, ovents gend buitenlanders raakt: er zijn ook veel Nederlanders die een sterk accent hebben. In gevallen warih het minder evident is dat er sprake is van een benadeling op een verboden grond verwijst de Corminis sie ter ondersteuning van haar oordeel soms naar secundaire gegevens, zoals rechtspraak van het Euvpees Hof van Justitie waarin in een vergelijkbaar geval een benadeling is vastgesteld; zie bijv. Oordecl 01-17 (Creditcard als borg), waarin een onderscheid op grond van een vaste woon- of verblijplast in Nederland in het geding was. 
Vereiste van een "overwegende benadeling"

Hiervoor zijn enkele instrumenten besproken aan de hand waarvan kan worden vastgesteld of er binnen de door een regeling benadeelde groep één specifieke groep in overwegende mate wordt getroffen. De vraag is echter wanneer er van een dergelijke "overwegende benadeling" sprake is. In veel gevallen besteedt de Commissie daaraan geen aandacht, vooral niet wanneer het evident is dat een onderscheid op een bepaalde grond een indirect onderscheid op een verboden grond tot effect heeft. Wanneer het benadelende effect minder voor de hand ligt en er gewerkt wordt met statistische gegevens stelt de Commissie echter strengere eisen: vereist wordt dan dat het verschil tussen de benadeelde groepen substantieel of significant is. ${ }^{274}$ In een oordeel uit 1997 heeft de Commissie dit vereiste nader geconcretiseerd. ${ }^{275}$ In het geding was toen een vakantieregeling op grond waarvan ouders (gehuwd of ongehuwd) met schoolgaande kinderen voorrang kregen bij het aangeven van een periode waarin zij hun vakantie wilden plannen. Volgens verzoeker werd daardoor indirect onderscheid gemaakt op grond van burgerlijke staat, omdat ongehuwden zonder kinderen door deze regeling benadeeld werden. De Commissie becijferde dat van de gehuwden binnen het bedrijf $55,2 \%$ geen kinderen had en dus door de regeling werd benadeeld, terwijl van de ongehuwden $66,7 \%$ niet voor de gunstige regeling in aanmerking kwam. Uit deze berekening trok zij de volgende conclusie:

"Dit betekent dat de ongehuwde werknemers uit verzoekers functiegroep 1,2 keer $(66,7: 55,2=1,21)$ vaker worden getroffen door de vakantievoorrangsregeling voor werknemers met leerplichtige kinderen. Een vermoeden van indirect onderscheid zou kunnen worden geconstateerd als sprake is van een benadeling met een factor van ongeveer 1,5 of meer. De benadeling van 1,2 op zichzelf is te gering om te concluderen tot indirect onderscheid op grond van burgerlijke staat." 276

Het is jammer dat een verdere motivering voor deze overweging ontbreekt: onduidelijk is waarom precies deze factor als minimum is gekozen. Het lijkt echter niet onredelijk om in gevallen waarin een bepaalde groep anderhalf maal zo sterk wordt getroffen door een benadelende regeling in ieder geval een nader onderzoek uit te voeren naar de rechtvaardiging voor de regeling. In de praktijk blijkt bovendien dat de Commissie met grensgevallen zorgvuldig omgaat. Wanneer een groep precies 1,5 maal zo vaak geraakt wordt door de regeling zal zij bijvoorbeeld naar ondersteunende gegevens zoeken, zoals landelijke cijfermatige gegevens, terwijl in dit soort gevallen ook vaak een beroep wordt gedaan op feiten van algemene bekendheid. ${ }^{27}$ Door deze zorgvuldige en genuan-

274. Zie bijv. Oordeel 96-95 (Ziekmelding en aftrek verlofdagen), Oordeel 96-109 (Hoofddoek en lengtecis), Oordeel 98-01 (Diplomavereiste), Oordeel 98-66 (Anciënniteit bij afvloeiingsregeling) en Oordeel 00-99 (HOS-regeling). De Centrale Raad stelt vergelijkbare eisen: zie CRvB 9 april 1991, RSV 1991/247 (Drie-uit-vijf-eis); er moet sprake zijn van "duidelijke verschillen") en CRvB 23 mei 1991, RSV 1991/257 (Overgang AAW naar AWW II: het nadeel moet "aanmerkelijk meer" vrouwen dan mannen of (mannen dan vrouwen) treffen).

275. Oordeel 97-45 (Vakantievoorrangsregeling)

276. R.0. 4.6

277. Dit gebeurde ook in het geciteerde Oordeel 97-45. Zie verder Oordeel 94-06 (Reorganisatieplan universiteit; nadere toetsing bij een factor van 1,5), Oordeel 96-117 (Seniorenregeling thuiszorg; factor van 1,3), Oordeel 97-196 (Leeftijdsgrenzen NWO-subsidies; factor van 1,5 t.a.v. oio's) en Oordeel 98- 
ceerde werkwijze lijkt voldoende te worden bewerkstelligd dat "verdachte" benadelin. gen inhoudelijk kunnen worden beoordeeld, terwijl tegelijkertijd wordt vermeden dat voor regelingen die nauwelijks een benadelend effect hebben een inhoudelijke rechti. vaardiging moet worden aangevoerd.

\subsection{Toetsing van het doel}

\subsubsection{Inleiding}

Wanneer eenmaal is vastgesteld dat er sprake is van een benadeling of van een ongeliij: ke behandeling van vergelijkbare gevallen, dan zullen de onderzochte rechterlijke in. stanties in de meeste gevallen een rechtvaardigingstoets uitvoeren. Zoals is gebleken in paragraaf 2.1 is het daarbij vaste rechtspraak dat met het onderscheid een legitiem of toelaatbaar doel moet worden nagestreefd: alle rechterlijke instanties hebben dit vereiste meer of minder expliciet in hun rechtspraak genoemd. In deze paragraaf zal nader worden onderzocht op welke manier de verschillende instanties aan deze toetsing vorm hebben gegeven. Daarbij wordt allereerst aandacht besteed aan de wijze waarop wort vastgesteld welk doel met het onderscheid wordt nagestreefd. In dat verband wordt bovendien bekeken of en in hoeverre de Nederlandse rechter bereid is om zelf te of derzoeken of er in werkelijkheid een andere doelstelling wordt nagestreefd dan door de verwerende partij naar voren is gebracht. Verder zal kort worden ingegaan op de sittu. tie waarin gelijktijdig verschillende doelstellingen worden nagestreefd. Tenslotte zal worden gekeken naar de toetsing van de gerechtvaardigdheid van het vastgestelde docl, waarbij met name aandacht zal worden besteed aan de verschillende criteria die in de rechtspraak voor de beoordeling daarvan zijn ontwikkeld.

\subsubsection{Vaststelling van het doel}

Bronnen voor het vaststellen van het doel van het onderscheid; onderzoek naar het werkelijk doel

In de meeste gevallen waarin de onderzochte rechterlijke instanties toekomen aan ten inhoudelijke toetsing van de rechtvaardiging is er sprake van een klacht over een normatieve classificatie. Vaak zijn deze classificaties neergelegd in algemene regelgeving, zoals formele wetgeving of algemene maatregelen van bestuur. Het blijkt daarbij voor de Nederlandse rechterlijke instanties relatief gemakkelijk te zijn om vast te stellen welk doel met de regeling wordt nagestreefd: meestal kunnen zij dit eenvoudig affeiden uit de totstandkomingsgeschiedenis van de regeling. Uit de rechtspraak van de Hoge Raad, de Centrale Raad en de Afdeling dan ook dat dit een veel gehanteerde bron is voor de vaststelling van het doel van het onderscheid: in een groot aantal zaken onderzoeken deze instanties zelf de wetsgeschiedenis en komen zij op grond daarvan tot een conclusie over het nagestreefde doel. ${ }^{278}$ In andere zaken blijkt een uitgebreid onderzees

119 (Pensioenregeling zwembad; in 1992 factor van 1,5). Kritisch over deze grens zijn Waldijk/Hendriks 2000, p. 49/50.

278. Zie voor de civiele kamer bijv. HR 21 maart 1986, NJ 1986/585 (Ouderlijke macht voor ongchuwden) HR 4 maart 1988, NJ 1989/875 (Toescheidingsovereenkomst Suriname), HR 29 mei 1996, JB 1996/185 (Wessels), HR 27 mei 1997, NJ $1997 / 577$ (Cassatie bij verstekvonnis), HR 8 mei 1998, N 
al uitgevoerd te zijn door de lagere rechter of, bij zaken voor de Hoge Raad, door de advocaat-generaal; in die gevallen volstaat de rechter vaak met een verwijzing naar de door hen vastgestelde doelstelling. ${ }^{27 y}$ Ook dan is het echter duidelijk dat de wetsgeschiedenis de bron is voor het vaststellen van het doel.

Het is opmerkelijk hoe weinig moeilijkheden de rechterlijke instanties in deze zaken lijken te ondervinden bij het vaststellen van het doel. Uit de theoretische literatuur, zoals besproken in hoofdstuk 2, zou kunnen worden geconcludeerd dat het voor rechters bijzonder lastig is om een eenduidige doelstelling uit de totstandkomingsgeschiedenis af te leiden, al was het maar omdat zoiets als de "wil van de wetgever" niet bestaat. Uit de Nederlandse rechtspraktijk blijkt echter dat rechters wel degelijk in staat zijn om de algemene beweegredenen en motieven te achterhalen die aan een wettelijke

1998/496 (Leeftijdsgrens commissarissen), HR 31 maart 2000, JB 2000/133 (Scholingsbesluit bijstandsgerechtigden) en HR 10 november 2000, NJ 2001/187 (Komdeur/Eilandgebied Curaçao). Ook de strafkamer maakt van deze methode gebruik, zij het minder vaak; zie HR 18 december 1984 (strafkamer), NJ 1984/356 (Dames- en herenkappers) en HR 22 januari 1985 (strafkamer), NJ 1986/24 (Vervangende dienstplicht gewetensbezwaarden). De belastingkamer maakt juist heel vaak gebruik van deze werkwijze; twee recente voorbeelden uit vele zijn HR 19 april 2000 (belastingkamer), BNB 2000/192 (Rentevrijstelling werknemersspaarregelingen) en HR 11 augustus 2000 (belastingkamer), BNB 2000/334 (Aftrek studiekosten). Zie ook Happé 1990, p. 393, die aangeeft dat de belastingkamer soms niet volstaat met een onderzoek van de wetgeving, maar de daarin gevonden doelstellingen ook wel eens herformuleert en corrigeert om tot een betere uitkomst te komen; een dergelijke benadering impliceert wel een heel vergaande mate van rechterlijk activisme. Tenslotte maken de Afdeling Bestuursrechtspraak en de Centrale Raad eveneens vaak gebruik van deze methode. Zie bijv. ABRS 28 februari 1995, AB 1995/439 (Territorialiteitsbeginsel IOAW), ABRS 25 juli 1996, AB 1996/425 (Uitvoer bedrijfsafvalstoffen), ABRS 24 april 1997, JB 1997/149 (Pensioenuitkering KNIL-militairen), ABRS 4 augustus 1998, AB 1998/377 (Loting geneeskunde), ABRS 5 november 1998, AB 1999/100 (Pensioenuitkering KNIL-militairen II), ABRS 16 maart 1999, JB 1999/102 (Inschrijving filiatieregister), ABRS 19 maart 1999, JB 1999/I03 (Vervangend rijbewijs), ABRS 27 april 2000, AB 2000/243 (Afgifte rijbewijs) en o.a. CRvB 9 mei 1990, RSV 1990/383 (AWW-uitkering bij huwelijk met gepensioneerde), CRvB 23 juni 1992, RSV 1992/317 (Inkomenseis AAW), CRvB 24 mei 1993, RSV 1994/43 (Leeftijdscriterium AWW), CRvB 20 juli 1993, RSV 1994/45 (Leeftijdscriterium eigen bijdrage AWBZ), CRvB 3 november 1993, RSV 1994/94 (Leeftijdseis AAW), CRvB 16 oktober 1996, AB 1996/140 (Referte-eis AAW), CRvB 4 november 1998, RSV 1999/38 (Wet Van Otterloo), CRvB 22 oktober 1999, AB 2000/289 (Persoonsgebonden budget thuiszorg), CRvB 4 januari 2000, RSV $2000 / 79$ (Noodzakelijke scholing Abw), CRvB 4 oktober 2000, RSV 2001/19 (Overgangsregeling Anw) en CRvB 24 januari 2001, RSV 2001/138 (Inkomensafhankelijkheid Anw).

279. Zie bijv. HR 8 oktober 1980, NJ 1981/308 (Kiesregister; overigens ontbreekt hierin een uitdrukkelijke verwijzing, maar de door de Hoge Raad geaccepteerde doelstelling en de doelstelling die A-G Franx afleidde uit de wetsgeschiedenis corresponderen zodanig dat kan worden verondersteld dat de Hoge Raad zijn oordeel op de conclusie van Franx heeft gebaseerd), HR 13 januari 1987 (strafkamer), NJ 1987/917 (Klein geel kenteken), HR 4 november 1992 (belastingkamer), BNB 1993/102 (Inkomstenberekening gehuwden), HR 19 mei 1993 (belastingkamer), BNB 1993/241 (Successiebelasting ongehuwden), HR 17 november 1993 (belastingkamer), BNB 1994/36 (Koffiegeld en studeerkamerkosten) en HR 16 juni 1999 (belastingkamer), BNB 1999/286 (Vakantiegeld en vakantiebonnenregeling). Zie verder CRvB 12 december 1990, RSV 1991/264 (Leeftijdsgrens AWW) en CRvB 20 september 1995, AB 1996/20 (Kostwinnerscriterium medeverzekering ziektekosten). Opmerkelijk is tenslotte HR 28 februari 2001 (belastingkamer), BNB 2001/169 (Alleenstaande ouderaftrek): voor de regeling in kwestie bestond geen duidelijk doel, maar uit de wetsgeschiedenis bij een andere, vergelijkbare regeling kon een doeistelling wel worden afgeleid. Op basis van de wettelijke regels stelde de Hoge Raad vast dat voor de regeling in kwestie dezelfde doelstelling gold. Een dergelijke creatieve benadering getuigt van een grote bereidheid om een ongelijke behandeling in stand te laten. De toetsing is daardoor tegelijkertijd actief én terughoudend, nu de Hoge Raad door zijn werkwijze uitdrukking geeft aan de wens aan de beleidsvrijheid van de wetgever tegemoet te komen. 
regeling en de daarin opgenomen classificatie ten grondslag liggen, zelfs als de doelstellingen niet met zoveel woorden in de wet of de considerans zijn opgenomen. Warr het misschien lastig kan zijn om heel specifieke doelstellingen te achterhalen, is har kennelijk veel minder moeilijk om de algemene achtergrond te raden. ${ }^{20}$ Dergelijke algemene doelstellingen kunnen meestal ook wel een voldoende basis vormen voor de toetsing van het onderscheid.

Wanneer er reden zou zijn om te veronderstellen dat de gevonden algemene doelsterling niet de werkelijke achtergrond voor de classificatie heeft gevormd, zou een verdergaand onderzoek naar de specifieke doelstellingen wel kunnen worden verwacht. Afgaande op de rechtspraak van de onderzochte instanties lijkt die situatie zich echter maar sporadisch voor te doen: een eigen onderzoek naar een van de totstandkomingsgeschiedenis afwijkende, "werkelijke", doelstelling is in geen van de onderzochte uilspraken terug te vinden. ${ }^{281}$

Een tweede veelgebruikte bron voor het achterhalen van het doel van het onderscheid zijn de stellingen van partijen en het verhandelde ter zitting. ${ }^{2 \times 2}$ Vooral de Commissie Gelijke Behandeling maakt van deze bron vaak gebruik. Uit haar oordelen blijkt zelfs zelden van een eigen onderzoek naar het nagestreefde doel: vrijwel steeds volstaat 2 ij met een eenvoudige verwijzing naar de doelstelling zoals die door partijen naar voren is gebracht. ${ }^{283}$ Op zichzelf is dit een praktische methode, waarbij de Commissie zelf

280. Een voorbeeld is CRvB 21 januari 1994, RSV 1994/192 (Verplichte verzekering WTZ); de Centale Raad verwees daarin niet naar een passage uit de wetsgeschiedenis, maar leidde meer in het algentra uit de regeling en de wetsgeschiedenis af wat de "kennelijke bedoeling" van de wetgever moest zijp geweest.

281. Dit geldt zelfs voor de oordelen van de Commissie Gelijke Behandeling: hoewel zij soms angeet is betwijfelen dat de aangevoerde doelstelling daadwerkelijk aan het onderscheid ten grondslag lag, pat zij eigenlijk nooit na welke redenen dan wél de basis vormden voor het onderscheid. Zie bijv. Oorket 96-15 (Pensioenregeling zeefdrukkerij) en Oordeel 97-102 (Ouderschapsverlof maatschappelijk wet. ster), Een zeldzaam geval waarin de Commissie wel vermoedens uitsprak over de werkelijke acitstgrond van een benadeling is Oordeel 98-126 (Werktijdenregeling slachterij). Van belang is wel da 2 ij soms een onderzoek naar het werkelijk doel "inbouwt" in de benadelingstoets. Dit gebeurt voonl in zaken waarin twijfel bestaat over de vraag of er sprake is van direct of indirect onderscheid: in ditgs: vallen is het vaak nodig om te achterhalen of het onderscheid daadwerkelijk was gebaseerd op eenver: boden grond (zoals het verbieden van een geloofsuiting) of op een neutrale overweging (bijy, hetvel: bieden van het dragen van een hoofddoek uit veiligheidsoverwegingen). Zie voor een voorbeld $0 \mathrm{r}$ deel 97-149 (Hoofddoek tijdens gymles).

282. Zie bijv. HR 24 april 1992, NJ 1992/689 (Bouma/KLM), HR 20 oktober 1987 (strafkamer), N 1988/473 (Ongelijke behandeling bij vervolging), HR 13 januari 1998 (strafkamer), NJ 1998/407 (Go doogbeleid Delfzijl), HR 27 maart 1985 (belastingkamer), BNB 1985/164 (Reiskostenforfait) en HR 20 maart 1996 (belastingkamer), BNB 1996/178 (Woningbouwvereniging). Ook de Afdeling nualt van deze bron gebruik, waarbij vaak wordt verwezen naar "het verhandelde ter zitting"; zie bijv, ABRS 2 juni 1994, AB 1994/629 (Ligplaatsverordening Friesland), ABRS 9 december 1997, JB 199810 (Pensioenuitkering weduwe KNIL-militair), ABRS 4 augustus 1998, AB 1998/377 (Loting geneeturde), ABRS 17 mei 1999, AB 1999/294 (Verpleeghuisarts), ABRS 1 juni 1999, AB 1999/313 (Exanterle bevoegde zeilschool) en ABRS 18 januari 2000, JB 2000/53 (Koffieshops Leiden). Hetzelfic feld voor de Centrale Raad; zie bijv. CRvB 8 augustus 1995, RSV 1996/4 (Subjecttoets WW), CRvB 24 december 1996, JB 1997/30 (Premieplicht leergang bedrijfskunde) en CRvB 21 september 2000, 18 2000/313 (Scholierenregeling).

283. Wanneer de wederpartij geen duidelijke doelstelling naar voren heeft gebracht veronderstelt de Care missie dat een gerechtvaardigd doel ontbreekt: een eigen onderzoek naar een eventucle redelifk doctstelling wordt niet uitgevoerd. Zie bijv. Oordeel 01-12 (Taalvereiste peuterleidster). Er zijn enkel ull 
nauwelijks activiteit hoeft te betonen. Voor de Commissie deze werkwijze bovendien vaak noodzakelijk, omdat zij in veel gevallen een oordeel moet uitspreken over gevallen van horizontaal onderscheid. Anders dan de wetgever zal een bedrijf of organisatie zelden een schriftelijke toelichting geven bij een algemene regeling over arbeidsvoorwaarden of een algemeen beleid voor het aanbieden van diensten, zodat het vrijwel nooit mogelijk is om uit totstandkomingsgegevens af te leiden welke overwegingen er aan de regeling precies ten grondslag lagen. ${ }^{284}$ Een inhoudelijk, eigen onderzoek naar het doel van de regeling blijft echter ook achterwege als er wél objectieve, niet direct door partijen verschafte, gegevens voorhanden zijn. ${ }^{285}$ Bovendien valt bij een bestudering van de oordelen van de Commissie op dat zij wel al snel bereid is de stelling van de wederpartij over het door hem nagestreefde doel te accepteren, zonder dat nader onderzoek wordt verricht naar de vraag of dit ook de werkelijke doelstelling van het onderscheid is. De Commissie geeft er wel blijk van dit soort doelstellingen te doorzien, maar doet dit zelden via de stelling dat het aangevoerde doel niet het werkelijk doel is: vaak wordt in plaats daarvan gesteld dat het doel niet gerechtvaardigd is, omdat het geen zakelijk karakter draagt. Een illustratie daarvan is te vinden in een oordeel waarin geklaagd werd over een in een sportkantine geldende verplichting om Nederlands te spreken. ${ }^{266}$ Als rechtvaardiging hiervoor had de wederpartij gesteld dat "een vrouw alleen" zich ongemakkelijk zou kunnen voelen als er een andere taal werd gesproken en dat moest worden voorkomen dat de barman zou worden uitgesloten van het gesprek. Dit is een nogal geforceerde beweegreden, waarmee discriminatoire doelstellingen lijken te worden verhuld. De Commissie stelde echter niet dat het aangevoerde doel niet het werkelijke doel was, maar oordeelde dat het aangevoerde doel niet zakelijk en daarom niet gerechtvaardigd was. De vraag is echter of een dergelijke conclusie bij subtieler verhulde doelstellingen ook zo gemakkelijk te trekken is.

Tenslotte moet worden opgemerkt dat in de rechtspraak van de Hoge Raad, de Afdeling en de Centrale Raad regelmatig iedere vermelding van een vindplaats van het vastgestelde doel ontbreekt: vaak wordt eenvoudigweg een doelstelling vastgesteld waarvan de rechterlijke instantie het waarschijnlijk acht dat deze an het onderscheid ten grondslag heeft gelegen. ${ }^{287}$ Deze benadering is weinig overtuigend en leidt tot een ver-

zonderingen waarin de Commissie wel verwees naar de totstandkomingsgeschiedenis of de considerans bij een regeling; zie bijv. Oordeel 95-27 (Interimuitkering ziektekosten), Oordeel 98-137 (Homoseksuele bloeddonoren) en Oordeel 00-81 (Kinderopvangregeling UM).

284. Dit verklaart het relatief frequente gebruik van deze bron door de bestuursrechter. Bij gevallen van ongelijke behandeling die ontstaan door een verschillende bevoegdheidsuitoefening in het concrete geval zal een neutrale toelichting (zoals een memorie van toelichting) veelal ontbreken; hoogstens kan een beleidsregel dienen als bron voor het achterhalen van de doelstelling. In de meeste gevallen moet de rechter dan ook, bij gebreke van objectieve gegevens, gebruik maken van de verklaringen van het

285. Dit is vooral het geval wanneer geklaagd wordt over een normatieve classificatie; zie bijv. Oordeel 00 -
39 (Overganger 39 (Overgangsregeling Gezondheidszorgpsychologen).

286. Oordeel $99-87$ (Taalbeleid sportcentrum)

287. Zie HR 22 april 1994, NJ 1994/560 (Ther

vaderschap), HR 16 februari 2001, JBeves), HR 20 januari 1995, NJ 1995/326 (Verjaringstermijn vaak de bron van het onderscheid, JB 2001/106 (Kiesrecht Antillen). Ook de belastingkamer noemt BNB 1986/158 het onderscheid vaak niet expliciet; zie bijv. HR 23 oktober 1985 (belastingkamer), geld en reiskosten), taxichauffeurs), HR 22 juni 1988 (belastingkamer), BNB 1988/259 (Koffie- 
mindering van de waarde van de toetsing aan het gelijkheidsbeginsel. In de meerder. heid van de gevallen waarin de rechter zelf een doeistelling vaststelt lijkt dit namelijk te gebeuren om op die manier gemakkelijker tot de conclusie te kunnen komen dat het onderscheid gerechtvaardigd is. ${ }^{28 x}$ Een daadwerkelijk onderzoek naar het nagestreefde doel zou soms tot een andere conclusie kunnen leiden, waardoor aan de belangen van de individuele rechthebbende meer recht zou worden gedaan. ${ }^{2 s y}$ Het lijkt dan ook nitt wenselijk om een benadering als deze over te nemen in het algemene toetsingsmodel.

\section{Pluraliteit van doelstellingen}

Zoals hiervoor is aangegeven gaat de Nederlandse rechter bij het vaststellen van het doel van het onderscheid globaal te werk: in de meeste gevallen wordt aan de totstandkomingsgeschiedenis van een regeling of aan de stellingen van partijen één algemene doelstelling ontleend die de belangrijkste beweegreden heeft gevormd voor het vaststellen van een classificatie of het maken van onderscheid in een concreet geval. Dit betekent dat het slechts zelden voorkomt dat de rechter tot de conclusie komt dat er ann het onderscheid meerdere overwegingen van gelijke waarde ten grondslag hebben gelegen, of dat met een maatregel niet alleen een algemene hoofddoelstelling, maar ook nog verschillende subdoelstellingen worden nagestreefd. ${ }^{200}$ De problematiek van de

band), HR 16 september 1992 (belastingkamer), BNB 1993/21 (Interimregeling ziektekosten ambten: ren), HR 12 november 1997 (belastingkamer), BNB 1998/22 (Reiskosten als studiekosten) en HR 10 augustus 2001 (belastingkamer), BNB 2001/400 (Fictiebepaling Successiewet). Zie ook ABRS $3 \mathrm{~mm}$ 1994, AB 1995/85 (Leeftijdscriterium woonruimteverdeling), ABRS 10 februari 1997, JB 1997/25 (Parkeerbeleid Leiden) en CRvB 23 mei 1991, RSV 1991/257 (Overgang AAW naar AWW), CRvB10 juli 1991, RSV 1992/21 (Overgangsregeling AOW), CRvB 17 maart 1992, AB 1992/419 (Wooneis AAW), CRvB 1 oktober 1992, RSV 1993/14 (Eigen bijdrageregeling AWBZ), CRvB 29 april 1993 , RSV 1993/307 (AAW-aanspraak na 65ste jaar), CRvB 4 november 1993, AB 1994/213 (Van Maaseveen), CRvB 11 februari 1994, RSV 1994/217 (Nederlandervereiste AOW/AWW) en CRvB 3 mei 1994, AB 1994/667 (Beperking eigen bijdrage AWBZ).

288. De belastingkamer blijkt in sommige gevallen zelfs bereid te zijn om, nadat hij heeft vastgesteld dar de in de wetsgeschiedenis genoemde doelstelling het gemaakte onderscheid onvoldoende kan dragen, na te gaan of er buiten de wetsgeschiedenis nog overtuigende doelstellingen voor het onderscheid kunnth worden gevonden. In vergelijking tot de benadeelde krijgt de wetgever hierdoor wel heel veel krediet. de belastingkamer doet alle moeite om het onderscheid gerechtvaardigd te kunnen achten. Dit getuig (ondanks het feit dat een eigen onderzoek naar andere doelstellingen duidt op grote rechterlijke activiteit) van een zeer terughoudende toetsing aan het gelijkheidsbeginsel. Zie bijv. HR 17 augustus 1998 (belastingkamer), JB 1998/196 (Grijs kenteken); zie ook ABRS 19 maart 1999, JB 1999/103 (Vervagend rijbewijs). Overigens wordt niet in alle gevallen voor een dergelijke actieve opstelling gekozent er zijn ook gevallen waarin de rechter vaststelt dat het onderscheid niet gerechtvaardigd is wannet er geen overtuigende reden voor het maken van dit onderscheid is aangevoerd. Vooral de rechtsprakk vit de civiele kamer biedt daarvan voorbeelden; zie HR 12 december 1990 (belastingkamer), BNB 1991/76 (Kosten kinderopvang), HR 30 september 1992 (belastingkamer), NJ 1994/495 (Griffiegelid) en HR 16 juli 1993, BNB 1993/321 (Herinrichtingskosten). Zie verder ABRS 5 november 1998, AB 1999/100 (Pensioenuitkering KNIL-militairen II).

289. Een voorbeeld is CRvB 3 mei 1994, AB 1994/667 (Beperking eigen bijdrage AWBZ). De Centrale Raad gaf daarin enkele vage overwegingen met betrekking tot het eventuele doel van de regeling, num verwees niet naar de wetsgeschiedenis. Dit is problematisch, omdat in het arrest financiele overwegingen een belangrijke rol speelden. Zoals hierna nog zal blijken worden dergelijke overwegingen in hel algemeen niet als een sterke rechtvaardiging gezien. Een nauwkeuriger onderzoek naar het doel van of regeling had in dit geval tot een andere uitkomst kunnen leiden.

290. Voorbeelden waarin van een dergelijke vaststelling wel sprake was zijn ABRS 28 februari 1995, AB 1995/439 (Territorialiteitsbeginsel IOAW), CRvB 19 april 1990, RSV 1990/323 (Teuling-Worns). 
pluraliteit van doelstellingen is in de Nederlandse rechtspraak dan ook vrijwel niet terug te vinden. ${ }^{291}$ De enige instantie die wel met enige regelmaat met een pluraliteit van doelstellingen geconfronteerd blijkt te worden is de Commissie Gelijke Behandeling. De Commissie heeft met een dergelijke situatie meestal weinig moeite: in gevallen waarin de verwerende partij verschillende argumenten ter rechtvaardiging aanvoert bestudeert zij al deze argumenten op hun eigen waarde, waarbij zij vervolgens beoordeelt of tenminste één van de argumenten het gemaakte onderscheid voldoende kan dragen..$^{22}$ Een iets afwijkende benadering wordt alleen gekozen wanneer één van de aangevoerde argumenten financieel van aard is, bijvoorbeeld wanneer is gesteld dat aan het maken van onderscheid bezuinigingsoverwegingen ten grondslag hebben gelegen. Van dergelijke argumenten heeft de Commissie in een vaste lijn van oordelen aangegeven dat zij nooit als zodanig een rechtvaardiging voor een ongelijke behandeling kunnen vormen: zij moeten altijd ondersteund worden door andere argumenten. ${ }^{293}$ Interessant is daarbij de vraag of deze aanvullende argumenten een zodanig karakter moeten hebben dat zij een zelfstandige rechtvaardiging voor het gemaakte onderscheid kunnen

CRvB 23 juni 1992, RSV 1992/317 (Inkomenseis AAW) en CRvB 4 november 1993, AB 1994/213 (Van Maarseveen).

291. In de uitzonderlijke gevallen waarin meer dan één doelstelling is vastgesteld (zie de vorige voetnoot) wordt een gevarieerde benadering gekozen. In de uitspraak met betrekking tot de IOAW toetste de Afdeling alleen de doelstellingen die een specifieke verklaring voor het onderscheid vormden, maar gaf zij geen oordeel over de algemene doelstelling die aan de betrokken wettelijke regeling ten grondslag lag. In Teuling-Worms beoordeelde de Centrale Raad bij de redelijkheidstoets zowel de verhouding tussen middel en hoofddoelstelling als die tussen middel en nevenoogmerk en kwam hij tot de conclusie dat het middel in een redelijke verhouding stond tot de beide doelstellingen (vgl. Van Male 1988 (II), p. 383). Bij de toetsing van de inkomenseis in de AAW toetste de Centrale Raad alle gevonden motieven afzonderlijk op hun gerechtvaardigdheid en voerde hij ten aanzien van alle doelstellingen een afzonderlijke doel-middeltoets uit. Daaruit bleek dat geen van de doelstellingen zelfstandig het gemaakte onderscheid konden dragen; gekeken werd niet of zij in combinatie beschouwd misschien wel een toereikende rechtvaardiging zouden opleveren. In de zaak Van Maarseveen werd tenslotte een pluraliteit van motieven vastgesteld, die in combinatie op hun redelijkheid en "draagkracht" werden beoordeeld. Iedere eenduidigheid in de toetsing ontbreekt dus.

292. Zie bijv. Oordeel 98-93 (Pensioenregeling gehuwden met groot leeftijdsverschil); in dit geval kon overigens in geen van beide aangevoerde argumenten een toereikende rechtvaardiging worden gevonden. Voorbeelden zijn verder te vinden in de oordelen van de CGB m/v; zie Oordeel 150-91-19 (Lengte-eis bedrijfsassistenten), Oordeel 374-92-04 (VUT-regeling afroepkracht) en Oordeel 614-9357 (Deeltijdwerk accountantsbedrijf).

293. Zie bijv. Oordeel 97-88: "Ingevolge de jurisprudentie van de Commissie zijn financiêle overwegingen op zichzelf niet voldoende voor het aannemen van een objectieve rechtvaardigingsgrond. Het enkele feit dat de kosten voor verzoekster zullen toenemen wanneer men het onderscheid bij werving en selectie laat varen, is derhalve niet voldoende om de handelwijze te rechtvaardigen" (r.0. 4.11, voetnoot is weggelaten). Van belang is verder Oordeel $01-44$ (35\%-Regeling), één van de weinige oordelen waarin de Commissie aannam dat er sprake was van voldoende bijkomende argumenten. Basis voor deze oordelen vormen de rechtspraak van het Europees Hof van Justitie en de oordelen van de CGB $\mathrm{m} / \mathrm{v}$, zoals blijkt uit Oordeel 96-07 (Rpbo) en Oordeel 35-90-138 (VUT-regeling levensmiddelen$\mathrm{CAO}$ ). De Commissie blijkt financiële belangen overigens wel als een zelfstandige rechtvaardiging te beschouwen wanneer er sprake is van een extreme situatie waarbij deze belangen daadwerkelijk heel zwaarwegend kunnen worden geacht; zie Oordeel 97-114 (Afvloeiingsregeling basisschool). De Commissie zal een beroep op deze uitzondering echter niet snel honoreren: er moet echt al sprake zijn van een dreigend faillissement of van een voor de voortzetting van het bedrijf absoluut noodzakelijke bezuiniging (zie voor een voorbeeld Oordeel 613-93-55 (Reorganisatie schoonmaakdienst)). Kritisch over deze benadering is De Wolff 2001, p. 54, die van mening is dat deze uitzonderingsmogelijkheid zorgt voor rechtsonzekerheid. 
vormen, of dat zij ook in combinatie met het financiële argument kunnen worden be. schouwd. ${ }^{294}$ Een duidelijk oordeel daarover heeft de Commissie nooit gegeven..$^{23}$ Een variatie op de problematiek van de pluraliteit van doelstellingen is te vinden in een specifieke benadering van de Commissie. In een aantal oordelen blijkt zij verschil te maken tussen, enerzijds, het doel dat met een algemene regeling wordt nagestreefd en, anderzijds, de specifieke beweegreden voor het onderscheid dat in deze regeling is opgenomen. Ten aanzien van het eerste, algemene, doel wordt dan vastgesteld of het legitiem en niet-discriminatoir is, terwijl ten aanzien van het tweede doel alleen wordt beoordeeld of het "beantwoordt aan een werkelijke behoefte van de onderneming". Ook komt het voor dat het tweede doel in het geheel niet op zijn gerechtvaardigdheid wordt beoordeeld, maar dat ten aanzien hiervan alleen een doel-middeltoets wordt uitgevoerd. Een voorbeeld hiervan is te vinden in een oordeel met betrekking tot de leeftijdsgrenzen in enkele subsidieprogramma's voor wetenschappelijk onderzoek." De Commissie stelde met betrekking tot het doel van de subsidieregeling het volgende:

"Het doel van de wederpartij is om fundamenteel en toegepast onderzoek te stimuleren. Gesteld kan worden dat aan dit doel iedere discriminatie vreemd is, terwijl het beantwoord aan een werkelijke behoefte van de wederpartij. ${ }^{.297}$

Vervolgens onderzocht de Commissie of er sprake was van een redelijke verhouding tussen doel en onderscheid. Daarbij zou het hiervoor genoemde doel tot uitgangspunt moeten worden genomen, maar de Commissie bleek de beoordeling uit te voeren aan de hand van een iets andere doelstelling, namelijk de specifieke doelstelling die ten grondslag lag aan de in de subsidieregeling opgenomen leeftijdsgrenzen:

"Het middel dat is gekozen om dit doel te bereiken, is een leeftijdsgrens te hanteren [.... Aan de keuze van dit middel liggen wetenschappelijke, maatschappelijke en economische motieven ten grondslag." ${ }^{298}$

Over de gerechtvaardigdheid van deze motieven werd echter geen oordeel uitgesproken: beoordeeld werd alleen of zij in een redelijke verhouding stonden tot het gekozen middel. ${ }^{2 \%}$ Het effect van een dergelijke benadering zou kunnen zijn dat er een doelmiddeltoets wordt uitgevoerd ten aanzien van een ongerechtvaardigde of discriminatoire doelstelling. Vanzelfsprekend is dat geen wenselijke situatie, nu onredelijke vormen van ongelijke behandeling daardoor in overeenstemming met de Awgb kunnen worden bevonden. ${ }^{300}$ In de praktijk blijkt dit risico overigens minimaal te zijn: wanneer duidelijk is dat de doelstelling van het onderscheid ongerechtvaardigd is lijkt de genoemde

294. De idee in de laatstgenoemde situatie is dat twee op zichzelf minder zwaarwegende argumenten etn toereikende rechtvaardiging kunnen vormen wanneer zij in combinatie worden beschouwd.

295. Er zijn enkele oordelen van de Commissie waaruit zou kunnen blijken dat een dergelijke combinatie als rechtvaardiging volstaat, maar volledige duidelijkheid ontbreekt. Zie bijv. Oordeel $97-13$ (Aziatische scheepsgezellen) en Oordeel 00-48 (Ondernemings-CAO voor financieel concerm).

296. Oordeel $97-106$ (Leeftijdsgrenzen NWO)

297. R.o. 4.6.

298. R.0. 4.6.

299. Zie voor een vergelijkbare benadering Oordeel 96-56 (Studieverlof bedrijfsartsen), Oordeel 98-49 (EHBO-cursus) en Oordeel 00-22 (Werkervaring bij dienstverlening gehandicapten).

300. Het gekozen middel kan immers perfect geschikt en noodzakelijk zijn om het gestelde, ongerechrvat digde, doel te bereiken en bovendien voldoen aan de eisen van fitness en proportionaliteit. 
methode door de Commissie niet te worden gehanteerd. Het zal echter duidelijk zijn dat het niet wenselijk is om deze methodiek over te nemen in het algemene toetsingsmodel.

\subsubsection{Toetsing van de gerechtvaardigdheid van het doel}

\section{Algemeen}

Wanneer de rechter het doel van de ongelijke behandeling eenmaal heeft vastgesteld is het van belang dat hij beoordeelt of dit doel gerechtvaardigd is: een onderscheid is niet toelaatbaar wanneer de nagestreefde doelstelling in strijd is met het positieve recht of wanneer de ongelijke behandeling uitsluitend is gericht op de achterstelling van een kwetsbare groep. Dit blijkt ook het uitgangspunt te zijn van de onderzochte rechterlijke instanties: uit de in paragraaf 2.1 weergegeven definities van het rechtvaardigingsmodel blijkt dat zij voor toelaatbaarheid van het onderscheid vereisen dat het met het onderscheid nagestreefde doel "redelijk" of "legitiem" is. ${ }^{301}$ Het is echter opmerkelijk dat in de grote meerderheid van de uitspraken een inhoudelijk oordeel over het doel achterwege wordt gelaten, net als het geval is bij de toetsing van de vergelijkbaarheidsmaatstaf in de eerste fase. ${ }^{302}$ Als er al een toetsing van het doel wordt uitgevoerd wordt deze bovendien vaak verweven met de toetsing van de verhouding tussen doel en middel, bijvoorbeeld doordat in zijn algemeenheid wordt nagegaan of er sprake is van een "objectieve en redelijke rechtvaardiging" voor het onderscheid. ${ }^{303}$

301. De Commissie Gelijke Behandeling heeft zelfs nog een uitgebreider stelsel van eisen voor de toetsing van het doel geformuleerd. Vaste rechtspraak bij de beoordeling van indirect onderscheid is dat aan het nagestreefde doel iedere discriminatie vreemd moet zijn en dat het moet beantwoorden aan een werkelijke behoefte van de wederpartij (zie bijv. Oordeel 00-90 (Vaccinatieprogramma Hepatitis B)). Bij direct onderscheid is voor een iets andere benadering gekozen: daarbij wordt vereist dat het doel legitiem en zwaarwegend moet zijn (zie bijv. Oordeel 00-70 (Alfahulpen)). Op de verschillende criteria zal verderop in deze paragraaf worden ingegaan.

302. Enkele voorbeelden zijn HR 27 april 1984, NJ 1984/513 (Getuigenverhoor), HR 29 mei 1996, JB 1996/185 (Wessels), HR 13 januari 1987 (strafkamer), NJ 1987/917 (Klein geel kenteken), HR 6 november 1990 (strafkamer), NJ 1991/218 (Tippelverbod), HR 23 oktober 1985 (belastingkamer), BNB 1986/158 (Fooien taxichauffeurs), HR 27 september 1988 (belastingkamer), NJ 1990/449 (Samentelling inkomens gehuwden), HR 13 november 1996 (belastingkamer), BNB 1997/54 (Belasting aanmerkelijk belang in buitenland), ABRS 10 februari 1997, JB 1997/85 (Parkeerbeleid Leiden), ABRS 24 april I997, JB $1997 / 149$ (Pensioenuitkering KNIL-militairen), ABRS 1 juni 1999, AB 1999/313 (Zeilschool), CRvB 29 april 1993, RSV 1993/307 (AAW-aanspraak na 65ste jaar), CRvB 21 oktober 1994, AB 1995/341 (Overgangsregeling WAO) en CRvB 23 februari 1999, RSV 1999/1 19 (Aanvangsdatum fictief arbeidsverleden). Soms wordt een inhoudelijk oordeel achterwege gelaten omdat uit de aard van de nagestreefde doelstelling al blijkt dat deze gerechtvaardigd is; zie bijv. HR 20 januari 1995, NJ 1995/326 (Verjaringstermijn vaderschapsactie; rechtszekerheid en bescherming van rechten van derden als doelstelling) en HR 14 mei 1996 (strafkamer), NJ 1996/644 (Onpartijdige rechter; integere en doelmatige rechtspleging als doelstelling). In het verleden waren ook de CGB $\mathrm{m} / \mathrm{v}$ en de Commissie nog wel eens geneigd om een inhoudelijke toetsing van het doel achterwege te laten, maar de laatste jaren wordt een rechtvaardigingstoets consequent uitgevoerd. Zie voor voorbeelden van de eerdere benadering Oordeel 163-91-13 (Ouderschapsverlofregeling Rotterdam), Oordeel 331-91-40 (Deeltijders Raad van State), Oordeel 467-92-68 (ADV bij wisseldienstroosters), Oordeel 623-93-46 (Seniorenregeling Uden), Oordeel 463A-94-02 (Bijzondere uren supermarktsector) en Oordeel 94-05 (Arbeidstijdvermindering oudere werknemers).

Opmerkelijk zijn HR 4 maart 1988, NJ 1989/875 (Toescheidingsovereenkomst Suriname), HR 7 januari 1975 (strafkamer), NJ 1975/206 (Onderscheid nationaliteit), HR 21 oktober 1992 (belastingkamer), BNB 1993/29 (Belastingvrije som alleenstaanden), HR 8 juni 1996 (belastingkamer), BNB 
Een verklaring voor het ontbreken van een specifieke doeltoets of het uitvoeren van een soort algemene redelijkheidstoets is waarschijnlijk gelegen in overwegingen van effici. ency. Wanneer een doelstelling niet evident onredelijk of ontoelaatbaar is, achten de rechterlijke instanties het overbodig om hieraan expliciet aandacht te besteden. Vanuit het oogpunt van machtenscheiding zullen zij deze toetsing bovendien graag vermijden, nu een inhoudelijk oordeel over de redelijkheid van het doel ook een oordeel over de juistheid of de wenselijkheid van het handelen van de wetgever of het bestuursorgaan impliceert. In dat verband is van belang dat een inhoudelijke toetsing wel degelijk is terug te vinden wanneer er duidelijk twijfel mogelijk is over de redelijkheid van het nagestreefde doel of wanneer er een strengere toetsing wordt uitgevoerd. ${ }^{304}$ Voor de beoordeling van de redelijkheid van het doel hebben de verschillende instanties bovendien interessante toetsingscriteria ontwikkeld, waarbij hun rechtspraak een grote mate van overeenstemming vertoont. In het hiernavolgende zal aan de belangrijkste van dezz criteria nader aandacht worden besteed.

\section{Legitimiteit: geen strijd met hogere regelgeving}

Een belangrijk vereiste voor gerechtvaardigdheid van het doel is allereerst legitimiteit. Het is vaste rechtspraak van alle bestudeerde instanties dat een doelstelling niet in strijd mag zijn met hogere regelgeving. ${ }^{305}$ In de praktijk blijkt vooral de toetsing aan verdragen en de daaraan door internationale rechterlijke instanties gegeven uitleg van belang te zijn: het komt vrij regelmatig voor dat een wettelijke classificatie met internationale of supranationale bepalingen of rechtspraak in strijd wordt geacht. ${ }^{306}$ Voor normatieve classificaties in lagere regelgeving of in regelingen van bedrijven (bijvoorbeeld een

1996/336 (Aftopping reiskostenforfait), HR 15 juli 1997 (belastingkamer), BNB 1997/325 (Studetrkamer en AOW), HR 19 april 2000 (belastingkamer), BNB 2000/192 (Rentevrijstelling werknemersspaarregelingen), HR 6 december 2000 (belastingkamer), BNB 2001/144 (Uitwonende/thuiswonents studenten), ABRS 3 maart 1994, AB 1995/85 (Leeftijdscriterium woonruimteverdeling), ABRS 2 jumi 1994, AB 1994/629 (Ligplaatsenverordening Friesland), ABRS 28 februari 1995, AB 1995/439 (Tetritorialiteitsbeginsel IOAW), CRvB 17 maart 1992, AB 1992/419 (Wooneis AAW) en CRvB 16 oktober 1996, AB 1997/140 (Referte-eis AAW).

304. Zie nader paragraaf 3.

305. Vgl. Van Male 1988 (II), p. 373 en 374

306. Zie bijv. HR 18 januari 1980, NJ 1980/463 (Bloedverwantschap onwettig kind), waarin de Hoge Rud een ongelijke behandeling toetste an artikel 14 EVRM en de uitleg die het Europees Hof voor de Rechten van de Mens daaraan heeft gegeven, HR 13 december 1991, NJ 1993/363 (NBBS/Akel), waarin getoetst werd aan het internationale stelsel van luchtvaartafspraken, en HR 18 april 1995 (stral. kamer), NJ 1995/611 (Dienstplicht Jehova's getuigen), waarin de strafkamer een ongelijke behandeling toetste aan een oordeel dat het Human Rights Committee over hetzelfde onderwerp had uitgesproket Zie verder ABRS 25 juli 1996/425 (Uitvoer bedrijfsafvalstoffen; toetsing aan het Europese recht). D. Afdeling Bestuursrechtspraak en zijn voorganger, de Afdeling Rechtspraak, tonen overigens minder belangstelling voor de internationale verdragen dan de Hoge Raad. Nog in 1985 (ruim 6 jaar nadat het Straatsburgse Hof had geoordeeld dat onderscheid op grond van wettige geboorte verdacht is en din alleen zwaarwegende redenen als rechtvaardiging kunnen dienen) oordeelde de Afdeling Rechtsprsis zonder enige motivering dat het uitsluiten van onwettige nakomelingen van adellijke ouders vart is adeldom niet als discriminatie kon worden aangemerkt: ARRS 9 september 1985, AB 1986/83 6 juni tieregister I). Zie verder (impliciet) CRvB 11 oktober 1995, AB 1996/72 (Roks) en CRvB 26 jalk 2001, JB 2001/184 (Koppelingswet); de CRvB heeft bovendien aangegeven dat kan worden gelde naar de doelstellingen van andere sociale zekerheidswetgeving, dus naar het gehele stelsel val 193, RSV ving: CRvB 12 december 1990, RSV 1991/264 (Leeftijdsgrens AWW) en CRvB 29 april 199, 1993/307 (AAW-aanspraak na 65ste jaar). 
Een verklaring voor het ontbreken van een specifieke doeltoets of het uitvoeren van een soort algemene redelijkheidstoets is waarschijnlijk gelegen in overwegingen van efficiency. Wanneer een doelstelling niet evident onredelijk of ontoelaatbaar is, achten de rechterlijke instanties het overbodig om hieraan expliciet aandacht te besteden. Vanuit het oogpunt van machtenscheiding zullen zij deze toetsing bovendien graag vermijden, nu een inhoudelijk oordeel over de redelijkheid van het doel ook een oordeel over de juistheid of de wenselijkheid van het handelen van de wetgever of het bestuursorgaan impliceert. In dat verband is van belang dat een inhoudelijke toetsing wel degelijk is terug te vinden wanneer er duidelijk twijfel mogelijk is over de redelijkheid van het nagestreefde doel of wanneer er een strengere toetsing wordt uitgevoerd. ${ }^{\text {jor }}$ Voor de beoordeling van de redelijkheid van het doel hebben de verschillende instanties bovendien interessante toetsingscriteria ontwikkeld, waarbij hun rechtspraak een grote mate van overeenstemming vertoont. In het hiernavolgende zal aan de belangrijkste van deze criteria nader aandacht worden besteed.

\section{Legitimiteit: geen strijd met hogere regelgeving}

Een belangrijk vereiste voor gerechtvaardigdheid van het doel is allereerst legitimitet. Het is vaste rechtspraak van alle bestudeerde instanties dat een doelstelling niet in strijd mag zijn met hogere regelgeving. ${ }^{305}$ In de praktijk blijkt vooral de toetsing aan verdragen en de daaraan door internationale rechterlijke instanties gegeven uitleg van belang te zijn: het komt vrij regelmatig voor dat een wettelijke classificatie met internationale of supranationale bepalingen of rechtspraak in strijd wordt geacht. ${ }^{306}$ Voor normatieve classificaties in lagere regelgeving of in regelingen van bedrijven (bijvoorbeeld een

1996/336 (Aftopping reiskostenforfait), HR 15 juli 1997 (belastingkamer), BNB 1997/325 (Studerkamer en AOW), HR 19 april 2000 (belastingkamer), BNB 2000/192 (Rentevrijstelling werknemers. spaarregelingen), HR 6 december 2000 (belastingkamer), BNB 2001/144 (Uitwonende/thuiswonende studenten), ABRS 3 maart 1994, AB 1995/85 (Leeftijdscriterium woonruimteverdeling), ABRS 2 jumi 1994, AB 1994/629 (Ligplaatsenverordening Friesland), ABRS 28 februari 1995, AB 1995/439 (Ter. ritorialiteitsbeginsel IOAW), CRvB 17 maart 1992, AB 1992/419 (Wooneis AAW) en CRvB 16 oktober 1996, AB 1997/140 (Referte-eis AAW).

304. Zie nader paragraaf 3 .

305. Vgl. Van Male 1988 (II), p. 373 en 374.

306. Zie bijv. HR 18 januari 1980, NJ 1980/463 (Bloedverwantschap onwettig kind), waarin de Hoge Rad een ongelijke behandeling toetste aan artikel 14 EVRM en de uitleg die het Europees Hof voor de Rechten van de Mens daaraan heeft gegeven, HR 13 december 1991, NJ 1993/363 (NBBS/Akel), waarin getoetst werd aan het internationale stelsel van luchtvaartafspraken, en HR 18 april 1995 (stralkamer), NJ 1995/611 (Dienstplicht Jehova's getuigen), waarin de strafkamer een ongelijke behandeling toetste aan een oordeel dat het Human Rights Committee over hetzelfde onderwerp had uitgesproket Zie verder ABRS 25 juli 1996/425 (Uitvoer bedrijfsafvalstoffen; toetsing aan het Europese recht). De Afdeling Bestuursrechtspraak en zijn voorganger, de Afdeling Rechtspraak, tonen overigens mindat belangstelling voor de internationale verdragen dan de Hoge Raad. Nog in 1985 (ruim 6 jaar nadat hel Straatsburgse Hof had geoordeeld dat onderscheid op grond van wettige geboorte verdacht is en dil alleen zwaarwegende redenen als rechtvaardiging kunnen dienen) oordeelde de Afdeling Rechtspras zonder enige motivering dat het uitsluiten van onwettige nakomelingen van adellijke ouders var hidie adeldom niet als discriminatie kon worden aangemerkt: ARRS 9 september 1985, AB 1986/83 6 juil tieregister 1). Zie verder (impliciet) CRvB 11 oktober 1995, AB 1996/72 (Roks) en CRvB 2001, JB 2001/184 (Koppelingswet); de CRvB heeft bovendien aangegeven dat kan worden geket. naar de doelstellingen van andere sociale zekerheidswetgeving, dus naar het gehele stelsel vai 1993, RSV ving: CRvB 12 december 1990, RSV 1991/264 (Leeftijdsgrens AWW) en CRvB 29 april 1993, 1993/307 (AAW-aanspraak na 65ste jaar). 
Commissie geen rechtvaardiging op. ${ }^{310}$ Dit betekent dat bedrijven steeds zelf zallen moeten nagaan of de regelingen die zij willen uitvoeren of die zij analoog willen toe. passen in overeenstemming zijn met de Algemene wet gelijke behandeling of met andere hogere regelgeving. Op zichzelf is dit een goede benadering, maar deze kent ook zijn grenzen: vooral in horizontale situaties mag niet méér van de eigen verantwoordelijkheid van partijen worden verwacht dan redelijk is. De Commissie heeft dan ook aangenomen dat er bijzondere omstandigheden kunnen zijn waarin een beroep op een hogere regeling toch als disculpatiegrond kan gelden. ${ }^{31 t}$ Tot nu toe is zij echter zeet terughoudend geweest bij het toepassen van deze uitzonderingsmogelijkheid." ${ }^{\prime \prime}$

\section{Doelstelling mag niet inherent discriminatoir zijn}

De onderzochte rechterlijke instanties lijken het erover eens te zijn dat de doelstelling van het onderscheid niet inherent discriminatoir mag zijn, dat wil zeggen dat het onderscheid niet uitsluitend mag zijn ingegeven door de wens een bepaalde groep te benadelen. ${ }^{313}$ In de praktijk blijkt dit criterium echter de nodige moeilijkheden op te leveren.

310. Zie reeds Oordeel 95-14 (Anciènniteitsbeginsel bij ontslag) en Oordeel $95-20$ (Pensioenregeling bibliotheek). Meer recentelijk ook Oordeel 99-20 (Uitsluiting deeltijders van pensioenregeling) en Oordecl 01-53 (Hoofddoek griffier).

311. Oordeel 97-81 (Melkert II-regeling)

312. Hetgeen niet altijd redelijk lijkt te zijn, zoals kan blijken uit Oordeel 99-20. De wederpartij in deze zaak was een instantie die voor $100 \%$ werd gesubsidieerd door de gemeente Amsterdam en die verplicht was de voorwaarden van deze gemeenten na te leven. In verband met die voorwaarden had de wederpartij deeltijders uitgesloten van een pensioenregeling; voor de Commissie beriep zij zich dan ook op overmacht. De Commissie stelde echter dat "de wederpartij als werkgever een eigen verntwoordelijkheid draagt voor de naleving van de gelijke behandelingswetgeving. Het feit dat de wederpartij voor $100 \%$ wordt gesubsidieerd en derhalve niet over eigen financiele middelen beschikt kan dim ook niet als objectieve rechtvaardiging dienen" (r.o. 4.12). Toch kan worden gesteld dat in dit geval de ongelijke behandeling echt niet aan de instantie kon worden tegengeworpen, ook al is het vervelend voor verzoekster dat zij het slachtoffer werd van de in het geding zijnde constructie als in het geding. een eigen verantwoordelijkheid van verweerder was afwezig. Een voorbeeld waarin wel een disculpstiegrond aanwezig werd geacht is Oordeel 97-131 (Schoolinformatie voor gescheiden vader): de ongelijke behandeling was daarbij het gevolg van een rechterlijk gebod dat de wederpartij niet op zijn redelijkheid kon toetsen.

313. Vgl. (impliciet) HR 24 april 1992, NJ 1992/689 (Bouma/KLM), HR 4 november 1992 (belastingtamer), BNB 1993/102 (Inkomstentoerekening bij gehuwden), CRvB 30 augustus 1989, RSV 19909 ? (Onderhoudsbijdrage AKW), CRvB 23 juni 1992, RSV 1992/317 (Inkomenseis AAW), CRvB 11 oktober 1995, AB 1996/72 (Overgangsregeling AAW) en CRvB 12 augustus 1999, RSV 2000/73 (Intomensvereiste thuiswerkers). Het vereiste wordt overigens niet door alle rechters consequent toegepst Vooral de rechtspraak van de Afdeling laat voorbeelden zien van zaken waarin inherent discriminatioit doelstellingen worden geaccepteerd. Opmerkelijk is ABRS 28 februari 1995, AB 1995/439 (Territorialiteitsbeginsel IOAW). Geklaagd werd daarin over het feit dat voor het verkrijgen van een inkomens voorziening op basis van de IOAW een woonplaats in Nederland vereist was: volgens appellant wert daardoor (direct of indirect) onderscheid op grond van nationaliteit gemaakt. De Afdeling constaterts op basis van de wetsgeschiedenis dat het onderscheid gebaseerd was op het territorialiteitsbeginsel, ceth beginsel dat onderscheid op grond van nationaliteit impliceert en daarmee inherent discriminatoir is is plaats van verder te kijken of er nog andere, niets met nationaliteit te maken hebbende, doelstellingen voor het onderscheid waren aangevoerd oordeelde de Afdeling als volgt: "Het territorialiteitsbeginsel, waarbij de rechtsplicht van de overheid zich beperkt tot diegenen aan wie het is toegestan in Neder land te verblijven [...] veronderstelt een zekere binding met de Nederlandse rechtssfeer. Vanuit dezt benadering en mede vanuit een oogpunt van praktische hanteerbaarheid, is de Afdeling bestuurstectlspraak van oordeel dat het hebben van een woonplaats in Nederland als voorwaarde voor het recht op een uitkering, op redelijke en objectieve gronden berust." Het is duidelijk dat via deze redenering ean 
Commissie geen rechtvaardiging op. ${ }^{310}$ Dit betekent dat bedrijven steeds zelf zullen moeten nagaan of de regelingen die zij willen uitvoeren of die zij analoog willen toe. passen in overeenstemming zijn met de Algemene wet gelijke behandeling of met an. dere hogere regelgeving. Op zichzelf is dit een goede benadering, maar deze kent ook zijn grenzen: vooral in horizontale situaties mag niet méér van de eigen verantwoorde. lijkheid van partijen worden verwacht dan redelijk is. De Commissie heeft dan ook aangenomen dat er bijzondere omstandigheden kunnen zijn waarin een beroep op een hogere regeling toch als disculpatiegrond kan gelden. ${ }^{311}$ Tot nu toe is zij echter zeer terughoudend geweest bij het toepassen van deze uitzonderingsmogelijkheid."

\section{Doelstelling mag niet inherent discriminatoir zijn}

De onderzochte rechterlijke instanties lijken het erover eens te zijn dat de doelstelling van het onderscheid niet inherent discriminatoir mag zijn, dat wil zeggen dat het onderscheid niet uitsluitend mag zijn ingegeven door de wens een bepaalde groep te bena. delen. ${ }^{313}$ In de praktijk blijkt dit criterium echter de nodige moeilijkheden op te leveren.

310. Zie reeds Oordeel 95-14 (Anciënniteitsbeginsel bij ontslag) en Oordeel 95-20 (Pensioenregeling bibli. otheek). Meer recentelijk ook Oordeel 99-20 (Uitsluiting deeltijders van pensioenregeling) en Oordecl 01-53 (Hoofddoek griffier).

311. Oordeel 97-81 (Melkert II-regeling)

312. Hetgeen niet altijd redelijk lijkt te zijn, zoals kan blijken uit Oordeel 99-20. De wederpartij in deze zaak was een instantie die voor $100 \%$ werd gesubsidieerd door de gemeente Amsterdam en die verplicht was de voorwaarden van deze gemeenten na te leven. In verband met die voorwaarden had de wederpartij deeltijders uitgesloten van een pensioenregeling; voor de Commissie beriep zij zich dan ook op overmacht. De Commissie stelde echter dat "de wederpartij als werkgever een eigen veratl. woordelijkheid draagt voor de naleving van de gelijke behandelingswetgeving. Het feit dat de wederpartij voor $100 \%$ wordt gesubsidieerd en derhalve niet over eigen financièle middelen beschikt kan dan ook niet als objectieve rechtvaardiging dienen" (r.o. 4.12). Toch kan worden gesteld dat in dit geval de ongelijke behandeling echt niet aan de instantie kon worden tegengeworpen, ook al is het vervelend voor verzoekster dat zij het slachtoffer werd van de in het geding zijnde constructie als in het geding een eigen verantwoordelijkheid van verweerder was afwezig. Een voorbeeld waarin wel een disculpatiegrond aanwezig werd geacht is Oordeel 97-131 (Schoolinformatie voor gescheiden vader): de ongelijke behandeling was daarbij het gevolg van een rechterlijk gebod dat de wederpartij niet op zijn redelijkheid kon toetsen.

313. Vgl. (impliciet) HR 24 april 1992, NJ 1992/689 (Bouma/KLM), HR 4 november 1992 (belastinglamer), BNB 1993/102 (Inkomstentoerekening bij gehuwden), CRvB 30 augustus 1989, RSV 199092 (Onderhoudsbijdrage AKW), CRvB 23 juni 1992, RSV $1992 / 317$ (Inkomenseis AAW), CRvB II dktober 1995, AB 1996/72 (Overgangsregeling AAW) en CRvB 12 augustus 1999, RSV $2000 / 73$ (inkomensvereiste thuiswerkers). Het vereiste wordt overigens niet door alle rechters consequent toegepst. Vooral de rechtspraak van de Afdeling laat voorbeelden zien van zaken waarin inherent discriminatoirt doelstellingen worden geaccepteerd. Opmerkelijk is ABRS 28 februari 1995, AB 1995/439 (Teritorialiteitsbeginsel IOAW). Geklaagd werd daarin over het feit dat voor het verkrijgen van een inkometse voorziening op basis van de IOAW een woonplaats in Nederland vereist was: volgens appellant werd daardoor (direct of indirect) onderscheid op grond van nationaliteit gemaakt. De Afdeling constaterde op basis van de wetsgeschiedenis dat het onderscheid gebaseerd was op het territorialiteitsbeginset, etan beginsel dat onderscheid op grond van nationaliteit impliceert en daarmee inherent discriminatoir is. In plaats van verder te kijken of er nog andere, niets met nationaliteit te maken hebbende, doelstellingan voor het onderscheid waren aangevoerd oordeelde de Afdeling als volgt: "Het territorialiteitsbeginsch. waarbij de rechtsplicht van de overheid zich beperkt tot diegenen aan wie het is toegestaan in Neder. land te verblijven [...] veronderstelt een zekere binding met de Nederlandse rechtssfeer. Vanuit dest benadering en mede vanuit een oogpunt van praktische hanteerbaarheid, is de Afdeling bestuurstectrspraak van oordeel dat het hebben van een woonplaats in Nederland als voorwaarde voor het rectr op een uitkering, op redelijke en objectieve gronden berust." Het is duidelijk dat via deze redenering eat 
laatbaar moet worden geacht. ${ }^{316}$ Gedacht kan bijvoorbeeld worden aan een regeling die is ingegeven door vooroordelen of door de welbewuste wens om een kwetsbare groep achter te stellen. Duidelijk is echter dat het verbod van een inherent discriminatoir doel vooral van betekenis is voor indirect onderscheid. Het is namelijk mogelijk dat een regeling feitelijk is gericht op het realiseren van een verboden classificatie, maar dat deze doelstelling door de verantwoordelijke wordt verborgen achter de façade van een neutrale onderscheidingsgrond. Zo kan een werkgever die zo min mogelijk islamitische vrouwen in dienst wil nemen zijn doel eenvoudig realiseren door een algemeen verbod te stellen op het dragen van hoofdbedekking tijdens het werk. Als hij vervolgens aangeeft dat dit verbod is gericht op het bevorderen van de veiligheid op de werkvloer, dan is nauwelijks zichtbaar dat het verbod eigenlijk is ingegeven door een persoonlijk vooroordeel jegens mensen met de islamitische geloofsovertuiging. De Commissie is niet snel geneigd om door dit soort façades heen te prikken, net zomin als zij, zoals eerder is gebleken, bereid is om een onderzoek uit te voeren naar het werkelijk doel van de regeling. ${ }^{117}$ Het gevolg hiervan is dat het verbod van de inherent discriminatoire doelstelling in de praktijk maar weinig betekenis heeft, ondanks het feit dat de Commissie in ieder oordeel een toetsing aan dit verbod uitvoert: slechts in uitzonderlijke gevallen komt de Commissie tot de conclusie dat het werkelijk niet anders kon dan dat de bedoeling van de betrokkene op de verwezenlijking van een ontoelaatbaar onderscheid was gericht. Deze conclusie blijkt vooral te worden bereikt wanneer de verantwoordelijke onderscheid heeft gemaakt op grond van een neutraal criterium waarbij het evident is dat dit ontoelaatbare effecten heeft. In dergelijke gevallen acht de Commissie de doelstelling mede gericht te zijn op het verwezenlijken van de nadelige effecten, zodat vaststaat dat de bedoeling inherent discriminatoir is. Een voorbeeld van deze benadering is te vinden in een zaak waarin geklaagd werd over het feit dat een werkgever voor zijn werknemers een pensioenregeling had getroffen, maar het huishoudelijk personeel en deeltijdwerkers hiervan had uitgesloten. ${ }^{318}$ De wederpartij voerde als rechtvaardiging hiervoor aan dat de regeling bedoeld was om de concurrentiepositie van het bedrijf te verbeteren en dat, gezien dat doel, alleen personeel dat een wezenlijke bijdrage leverde aan zijn onderneming voor de regeling in aanmerking kwam. De Commissie oordeelde als volgt:
"Het is een feit van algemene bekendheid dat zowel huishoudelijk personeel als deeltijders in meerderheid vrouwen zijn. Onder die omstandigheden komt de Commissie tot het oordeel dat het doel van de regeling door het uitsluiten van huishoudelijk personeel en deeltijders van deelname aan de pensioenregeling, niet vreemd is van iedere discriminatie."'19

316. Vgl. ook Asscher-Vonk/Konijn 2000, p. 42.

317. Dit is vanuit bewijstechnisch oogpunt ook wel redelijk: het is moeilijk om harde bewijzen te leveren voor de stelling dat de bedoelingen van een individu discriminatoir waren. Hoewel hiervoor soms anwijzingen kunnen bestaan, is het niet vreemd dat de Commissie in dit soort gevallen liever terugvalt op een strengere doel-middeltoetsing: daardoor kan een vergelijkbare uitkomst vaak op een objectievert manier worden bereikt. Met deze methode moet echter voorzichtig worden omgegaan: het is lang niet altijd zo dat de toetsing van de verhouding tussen doel en middel tot een bevredigende uitkomst leidt Het gekozen middel kan immers geschikt en noodzakelijk zijn om een duidelijk ontoelaatbare doetstelling te verwezenlijken; in een dergelijk geval is het noodzakelijk om de toetsing op de gerechtvats digdheid van het doel toe te spitsen.

318. Oordeel 98-16 (Pensioenregeling huishoudelijk personeel)

319. R.o. 4.6. Zie voor een vergelijkbare benadering Oordeel 98-22 (Pensioenregeling belastingadvieskan: 
Deze benadering van de Commissie kan in beginsel gelden voor alle gevallen waarin zij heeft aanvaard dat het evident is dat de keuze voor een bepaald, neutraal, onderscheidingscriterium discriminatoire effecten heeft. Zo kan ook in het hiervoor gegeven voorbeeld van het verbod op hoofdbedekking tijdens het werk worden aangenomen dat het oogmerk van de werkgever was gericht op het benadelen van islamitische vrouwen: bij de keuze voor het betrokken onderscheidingscriterium is het immers duidelijk dat met name die groep zal worden benadeeld. Die consequentie heeft de Commissie echter (nog) niet willen aanvaarden. De conclusie dat het oogmerk inherent discriminatoir is wordt vooralsnog uitsluitend bereikt wanneer er, naast de benadeling van een bepaalde groep, geen andere, neutrale en doorslaggevende argumenten voor het onderscheid zijn aangevoerd: alleen wanneer de inherent discriminatoire doelstelling de belangrijkste of overwegende reden voor het onderscheid is, zal het onderscheid ontoelaatbaar worden geacht. ${ }^{320}$ Deze benadering lijkt ook niet onredelijk: zou een andere invalshoek worden gekozen, dan kan een op zichzelf maatschappelijk wenselijke regeling uitsluitend ontoelaatbaar worden verklaard vanwege het bestaan van een discriminatoir nevendoel. ${ }^{321}$ Vanzelfsprekend is een zorgvuldige rechterlijke toetsing in dit soort gevallen wel vereist: wanneer duidelijk is dat een regeling overwegend benadelende effecten heeft voor één bepaalde groep en de bedoeling van de regelgever ook nog op die benadeling was gericht, dan zal de rechter nauwkeurig en grondig moeten nagaan of de aangevoerde "neutrale" rechtvaardiging voldoende overtuigend is. Met name zal in dit soort gevallen een goede subsidiariteitstoets moeten worden uitgevoerd, waarbij zorgvuldig wordt nagegaan of het maatschappelijk wenselijke doel niet met maatregelen kon worden bereikt die in mindere mate discriminatoire effecten teweeg zouden brengen.

\section{Doelstelling moet beantwoorden aan een werkelijke behoefte}

In navolging van de rechtspraak van het Europese Hof van Justitie heeft de Commissie Gelijke Behandeling als vast onderdeel van zijn doeltoets gesteld dat het doel moet beantwoorden aan een werkelijke behoefte van de wederpartij. ${ }^{122}$ De wijze waarop aan dit criterium invulling moet worden gegeven is in het Europese recht enigszins onduidelijk gebleven: het Hof heeft de uitwerking van het criterium overgelaten aan de nationale rechter. ${ }^{32}$ Bij bestudering van de oordelen van de Commissie blijkt echter dat ook zij niet precies weet welke betekenis aan het vereiste moet worden gegeven: uit haar

toor), Oordeel 98-102 (Meenemen ervaring bij inschaling) en Oordeel 00-66 (Uitruil nabestaandenpensioen),

320. Hetgeen wordt geillustreerd door het oordeel waaraan het voorbeeld van de hoofdbedekking is ontleend. De Commissie accepteerde hierin dat het verbod primair gericht was op het voorkomen van ongelukken en voerde een uitgebreide doel-middeltoets uit; Oordeel 96-85 (Hoofddoek en veiligheidsvoorschriften).

321. Waarbij bovendien geldt dat in sommige gevallen het doel wordt "geconstrueerd", zoals in het geval waarin gesteld wordt dat de effecten zo voorspelbaar zijn dat het oogmerk geacht moet worden mede niet relevant.

322. In een enkel geval is bovendien gesteld dat het moet gaan om een "zwaarwegende" behoefte, maar deze toevoeging lijkt geen bijzondere toegevoegde waarde te hebben. Zie Oordeel 97-24 (Kledingvereisten Sikh).

323. Zie hoofdstuk 4, paragraaf 2.3 .1 . 
oordelen blijkt nergens wat er onder een "werkelijke behoefte" moet worden verstaan en wanneer een bepaald onderscheid daarin voorziet. ${ }^{324}$ De Commissie blijkt het criterium bovendien vaak zodanig toe te passen dat er sprake is van een samenloop met het vereiste van noodzakelijkheid: in veel gevallen gaat zij bij de toetsing aan dit criterium na of het voor de wederpartij echt nodig was om het litigieuze onderscheid te maken, hetgeen betekent dat zij beoordeelt of het gebruik van het gekozen middel voor de wederpartij noodzakelijk was. Een illustratie van deze benadering wordt gevormd door een oordeel over het verbod van een school op het dragen van een chador, een sluier die het gezicht van de leerling vrijwel volledig bedekt. ${ }^{325}$ Doel van dit verbod was volgens de school de optimalisering van de didactische omstandigheden. Het lijkt duidelijk dat dit doel beantwoordt aan een werkelijke behoefte: voor een school is het van. zelfsprekend van belang dat de onderwijsomstandigheden zo goed mogelijk zijn. De Commissie oordeelde echter het volgende:

"Door verzoeker is ter zitting aangegeven dat door de docenten van de school verschillend wordt gedacht over de behoefte aan het kledingvoorschrift. [...] Het is niet aan de Commissie om de merites van de didactische argumenten inhoudelijk te beoordelen. Nu hier evenwel door docenten verschillend over kan worden gedacht en ook niet is gebleken dat het onderwijs aan getuige in de periode dat zij een chador droeg is bemoeilijkt, is het door de wederpartij niet aannemelijk gemaakt dat het kledingvoorschrift in een werkelijke behoefle voorziet." ${ }^{1326}$

De Commissie beoordeelt in deze overweging dus of het gekozen middel (het verbod op het dragen van een chador) voorziet in een werkelijke behoefte van de school. Dit lijkt een oneigenlijk gebruik van het criterium te zijn. De bedoeling van het criterium zoals dat door het Europese Hof is ontwikkeld lijkt namelijk niet zozeer dat de nationale rechter nagaat of het middel voldoet aan een werkelijke behoefte (daarvoor is immers de noodzakelijkheidstoets bedoeld), maar vooral of het voor de wederpartij inderdaad nuttig is om het gestelde doel na te streven. ${ }^{327}$ Juist deze toepassing wordt door de Commissie niet altijd aan het criterium gegeven. ${ }^{338}$

324. Bovendien is het aantal gevallen waarin de Commissie tot de conclusie komt dat het onderscheid niet beantwoordt aan een werkelijke behoefte gering: uit het onderzoek zijn slechts enkele voorbeelden nair voren gekomen. Zie bijv. Oordeel 99-02 (Pensioenopbouw vervangster basisonderwijs), warin als rechtvaardiging voor het uitzondering van vervangers in het onderwijs van een pensioenregeling was aangevoerd dat dit administratieve problemen zou opleveren. Gezien het feit dat computers gebruikt konden worden om de administratie bij te houden, stelde de Commissie dat zij er niet van was overtuigd was dat het gehanteerde middel voorzag in een werkelijke behoefte. Zie verder Oordeel 98.18 (Nivra-opleidingskosten), Oordeel 00-63 (Chador), Oordeel 01-24 (Nabestaandenpensioen bij grool leeftijdsverschil) en Oordeel 0I-53 (Hoofddoek griffier).

325. Oordeel 00-63 (Chador)

326. R.o, 4.9

327. Overigens lijkt de Commissie dit ook te beseffen. Dit blijkt opnieuw uit een uitspraak over kleding. voorschriften, ditmaal in een hotel. De Commissie oordeelde als volgt: "Het middel dat in het voodi gende geval gehanteerd is, is het schorsen/wegsturen van een medewerker die niet voldoet aan de klo dingvoorschriften. Daarbij dient aan de orde te komen of er sprake is van een werkelijke, zwaarwegende, behoefte van de organisatie, ter realisering waarvan het gekozen middel geschikt en noodzakelijin. is. De Commissie neemt hiema bij de beoordeling of aan deze aspecten is voldaan beide criteria tetzmen $\mathrm{en}$ beschouwt ze in onderling verband. Immers, de geschiktheid en noodzaak van een middel bangen ten nauwste samen met de mate van de zwaarwegendheid van de behoefte om dat middel te kis zen" (Oordeel 97-24 (Kledingvereisten Sikh), r.o. 4.6). Hoewel de Commissie zich kennelijk realiseert 
Betekenis van maatschappelijke ontwikkelingen en veranderde rechtsopvattingen Een doelstelling die aanvankelijk, ten tijde van de inwerkingtreding van een regeling, gerechtvaardigd kon worden geacht, kan die gerechtvaardigdheid na verloop van tijd verliezen: maatschappelijke omstandigheden en opvattingen kunnen soms zodanig veranderen dat de aanvankelijke beweegredenen een onderscheid op een bepaald moment niet meer kunnen dragen. Zo werd het maken van onderscheid tussen gehuwden en (duurzaam) ongehuwd samenwonenden aanvankelijk volstrekt toelaatbaar geacht, terwijl daar tegenwoordig heel anders over wordt gedacht.

Over de vraag in hoeverre de rechter bij de toetsing van de redelijkheid van het doel rekening moet houden met veranderde rechtsopvattingen bestaat in Nederland maar weinig duidelijkheid. De Hoge Raad heeft uitdrukkelijk erkend dat maatschappelijke ontwikkelingen van invloed kunnen zijn op het oordeel over de toelaatbaarheid. Dit blijkt bijvoorbeeld uit een arrest uit 1980 over onderscheid tussen wettige en onwettige kinderen. ${ }^{39}$ Onder verwijzing naar het Marckx-arrest ${ }^{300}$ van het Europees Hof voor de Rechten van de Mens oordeelde de Hoge Raad het volgende:

dat de gekozen uitleg van het criterium van de werkelijke behoefte overlapt met het vereiste van geschiktheid en noodzakelijkheid, concludeert zij daaruit niet dat wellicht een verkeerde betekenis aan het criterium wordt gegeven.

328. Hoewel het aantal voorbeelden toch nog altijd vrij groot is; zie Oordeel 95-69 (Acceptatievoorwaarden kredietbank), Oordeel 96-12 (Kredietverlening vreemdelingen), Oordeel 96-29 (Taaleis schoonmaakster), Oordeel 96-55 (Taalvereiste strijksters), Oordeel 96-59 (Jehova's getuige als bankmedewerkster), Oordeel 96-60 (Mobiele telefoon), Oordeel 96-71 (Rpbo), Oordeel 96-75 (Taalvereiste administratief werk), Oordeel 96-81 (Ontsiag wegens reorganisatie), Oordeel 96-87 (CAO Thuiszorg), Oordeel 96101 (Taalvereiste receptioniste), Oordeel 96-111 (Publicatievereiste onderzoeksschool), Oordeel 97-96 (Eis Nederlands spreken op de werkplek), Oordeel 97-97 (Paspoortvereiste bij mobiele telefoonaansluiting), Oordeel 97-106 (Leeftijdsgrenzen NWO-subsidies), Oordeel 97-110 (Praktijkproef stukadoorsbedrijf), Oordeel 97-117 (Afwijzing wegens verblijfstitel), Oordeel 97-119 (Levering wasmachine op woonwagenterrein), Oordeel 98-05 (Inschrijvingsvoorwaarden videotheek), Oordeel 98-07 (Acceptatiebeleid kredietbank), Oordeel 98-96 (Seniorenregeling CAO NOB), Oordeel 98-152 (Diplomavereisten APK-keuring), Oordeel 99-22 (Verandering werktijden), Oordeel 99-98 (Verhuur apparatuur aan niet-Nederlanders), Oordeel 00-15 (Taalvereiste glastuinbouw), Oordeel 00-28 (Acceptatievereisten mobiel telefoonabonnement), Oordeel 00-36 (Iraans accent peuterleidster), Oordeel 00-93 (Assistent Analist Landstrijdkrachten), Oordeel 01-17 (Creditcard als borg), Oordeel 01-20 (Rpbo), Oordeel 01-26 (Acceptatiebeleid mobiel telefoonabonnement), Oordeel 01-44 (35\%-Regeling), Oordeel 01-53 (Hoofddoek griffier), Oordeel 01-97 (Nederlands in café) en Oordeel 01-141 (Kappersmodel).

329. HR 18 januari 1980, NJ 1980/463 (Bloedverwantschap onwettig kind). Een voldoende vergaande rechtsontwikkeling werd niet erkend in HR 19 oktober 1990, NJ 1992/129 (Homohuwelijk), waarin de vraag aan de orde was of het niet openstellen van het huwelijk voor paren van gelijk geslacht in strijd was met artikel 26. De Hoge Raad stelde, zonder te verwijzen naar kenbare bronnen, dat de rechtsovertuiging daarvoor nog niet ver genoeg ontwikkeld was. Een vergelijkbaar oordeel gaf het in 1994: HR 29 april 1994, NJ 1994/625 (Alimentatiebeëindiging bij homofiele concubinaatsverhouding). Van belang is verder dat de belastingkamer heeft aangenomen dat in het algemeen ex tunc getoetst moet worden: de huidige opvattingen over de redelijkheid van een normatieve classificatie kunnen volgens de belastingkamer geen betekenis hebben voor de rechtvaardiging van een (concreet) onderscheid dat veel eerder gemaakt is, dat wil zeggen onder heerschappij van andere opvattingen. Toen de Hoge Raad in 1989 geroepen werd om uitspraak te doen over de toepassing van een in 1985 gewijzigde wet over de periode 1973-1984 hield hij alleen rekening met de rechtsopvattingen zoals hij die veronderstelde te gelden in de periode tot 1985 (HR 27 september 1989 (belastingkamer), NJ 1990/449 (Samentelling inkomens gehuwden). Hoewel dit op zichzelf een redelijke benadering is, kan deze ook voor problemen zorgen: het zal niet eenvoudig zijn om vast te stellen hoe de heersende rechtsopvattingen tien of vijftien jaar geleden waren. Een oplossing voor dit probleem is in de Nederlandse rechtspraak niet terug te vinden. 
"De opvattingen over de vraag of het gerechtvaardigd is aan het onderscheid tussen wettige en natuurlijke kinderen belangrijke rechtsgevolgen te verbinden, hebben in recente tijd sterke wijzigingen ondergaan. [...] Welke betekenis aan bedoelde ontwikkeling, mede in verband met deze uitspraak van het Europese Hof, bij de bepaling en de uitleg van het bestaande Nederlandse recht door de rechter moet worden gehecht, zal voor ieder voorschrift waarin het bedoelde onderscheid een rol speelt, afzonderlijk moeten worden nagaan $[\ldots]$."

Vervolgens gaf de Hoge Raad aan dat in het voorgelegde geval de wettelijke regeling zodanig moest worden uitgelegd dat het daarin gemaakte onderscheid op grond van wettige geboorte werd weggenomen. Belangrijk in deze uitspraak is de invloed van het internationale recht: door de uitspraak van het Straatsburgse Hof was het duidelijk dat de maatschappelijke opvattingen zodanig waren veranderd dat onderscheid op grond van wettige geboorte niet langer toelaatbaar kon worden geacht.

Steun voor het oordeel over de verandering in de heersende rechtsovertuiging blijkt daarnaast soms te worden gevonden in het nationale recht: zo heeft de Centrale Raad zich met enige regelmaat gebaseerd op voorstellen voor verandering van wetgeving als basis voor het oordeel over veranderde opvattingen. ${ }^{331}$

Meestal lijken de onderzochte instanties echter nogal huiverachtig te zijn om juridische consequenties te verbinden aan veranderde rechtsopvattingen, zeker wanneer er geen duidelijke nationale of internationale consensus bestaat die aan hun oordeel steun kan bieden. In de grote meerderheid van gevallen wordt gesteld dat de rechtsopvattingen nog niet overtuigend genoeg zijn veranderd of wordt het aan de wetgever of "de politiek" overgelaten om maatschappelijke veranderingen te signaleren en daarop te reageren. Een goed voorbeeld van deze benadering is te vinden in het oordeel van de Centrale Raad in de zaak Van Maarseveen, die betrekking had op de verplichte pensionering op 65-jarige leeftijd. ${ }^{32}$ Van Maarseveen had gesteld dat hierdoor ongerechtvardigd onderscheid op grond van leeftijd werd gemaakt. Nadat de Centrale Raad enkele motieven en redenen voor de keuze voor het verplichte pensioen op deze leeftijd uiteen had gezet, oordeelde hij als volgt:

"Een en ander sluit niet uit, dat stemmen opgaan die bepleiten de leeftijd van 65 jaar hetzij te wijzigen hetzij een flexibeler karakter te geven waardoor meer ruimte voor een indi-

\section{EHRM 13 juni 1979, Marckx, Series A, vol. 31}

331. Zie CRvB 7 december 1988, RSV 1989/67 (AWW). Anderzijds heeft de Centrale Raad ook de volgende uitspraak gedaan, waaruit blijkt dat verandering van wetgeving lang niet altijd doorslaggevend is: "Dat de wetgever inmiddels op een toenemend aantal gebieden [...] de gelijkstelling van gehuwden die niet duurzaam gescheiden leven, en niet-gehuwden die duurzaam een gezamenlijke huishouding voe ren [...] wel heeft gerealiseerd, brengt niet zonder meer met zich mee dat specifieke wetgeving, 2015 de AWW, waarbinnen de gelijkstelling nog niet is gerealiseerd, zich niet verdraagt met het in art. 26 IVBPR neergelegde discriminatieverbod. Het staat de wetgever vrij om, ook waar er geen sprake is van (verboden) discriminatie, bestaande wetgeving te wijzigen en daarin een gelijke behandeling van tevoren onderscheiden groepen te realiseren" (CRvB 16 oktober 1991, RSV 1992/138 (Onderscheid but: gerlijke staat AWW)). Zie ook CRvB 18 juni 1993, RSV 1994/68 (Samenloop AAW-uitkeringen). Ook de Commissie Gelijke Behandeling verwijst bij de toetsing van het doel soms naar recente rechtsontwikkelingen; zij vindt de basis dan vooral in feiten van algemene bekendheid waaruit de verandering zou blijken (zie bijv. Oordeel 01-53 (Hoofddoek griffier). Anders dan de andere rechterlijke instantics neemt de Commissie bij gewijzigde opvattingen niet aan dat het doel niet meer gerechtvaardigd is, maar stelt zij dat het niet langer beantwoordt aan een werkelijke behoefte van de wederpartij.

332. CRvB 4 november 1993, AB 1994/213 (Van Maarseveen) 
viduele benadering wordt geschapen. Dit evenwel zijn betogen, welke op zich in alle redelijkheid kunnen worden gehouden doch die op het terrein van politiek en wetgeving liggen; ze vertegenwoordigen (nog) niet een zo overheersende rechtsovertuiging dat rechterlijke rechtsvinding haar zou moeten volgen [...]." 333

In dit verband kan ook worden gewezen op een benadering van Afdeling Bestuursrechtspraak. In 1999 moest zij zich uitspreken over de inschrijving in het filiatieregister voor de adel. Op basis van een uit 1815 stammende wet kon de adeldom alleen via afstamming van een mannelijke lijn worden verworven. ${ }^{334}$ Volgens appellante werd hierdoor ongerechtvaardigd onderscheid op grond van geslacht gemaakt. De Afdeling oordeelde als volgt:

[...] voor het handhaven van onderscheid tussen afstamming via mannen en afstamming via vrouwen [bestaat] een objectieve en redelijke grond, gelegen in de omstandigheid dat het om een historisch instituut gaat dat zijn bestaansrecht uitsluitend ontleent aan dat historische karakter en zich daarom niet leent voor aanpassing aan recentere opvattingen over gelijke behandeling."

Hiermee gaf de Afdeling aan geen ruimte te zien voor een toetsing van het onderscheid aan recente rechtsopvattingen, ook al blijkt uit de rechtspraak van het Europees Hof voor de Rechten van de Mens en van de Hoge Raad dat onderscheid op grond van wettige geboorte eigenlijk niet meer toelaatbaar kan worden geacht. Reden voor deze benadering bleek vooral de aard van de betrokken regeling te zijn: deze was zodanig dat nieuwe ontwikkelingen hierop geen invloed hadden. ${ }^{336}$ Deze uitspraak illustreert dat

333. De discussie met betrekking tot de heersende rechtsovertuiging over de noodzaak of wenselijkheid van verplicht pensioen bij het bereiken van de leeftijd van 65 jaar speelt overigens ook bij de Hoge Raad en de Afdeling Bestuursrechtspraak. De Hoge Raad heeft hierbij opgemerkt dat juist het bestaan van controverse en onduidelijkheid noopt tot terughoudendheid, zodat niet kan worden gesteld dat de doelstellingen die vroeger voor het instellen van deze pensioenleeftijd golden daaraan nu zijn ontvallen; zie HR 13 januari 1995, NJ 1995/430 (Codfried/ISS). In een op dit punt nauwelijks inhoudelijk gemotiveerde uitspraak herhaalde de Hoge Raad dit in 1998: HR 8 mei 1998, NJ 1998/496 (Leeftijdsgrens voor commissarissen). Zie voor de benadering van de Afdeling ABRS 2 september 1994, AB 1995/146 (Medewerkersovereenkomst met 65 plusser). De Centrale Raad heeft ook voor andere gronden van onderscheid een met Van Maarseveen vergelijkbaar oordeel uitgesproken; zie bijv. CRvB 28 februari 1990, RSV 1990/295 (AWW-uitkering ongehuwde partner), waarin de Centrale Raad oordeelde dat naar de omstandigheden ten tijde van inwerkingtreding van de wet ongehuwden en gehuwden niet op eén lijn konden worden gesteld. Zie kritisch daarover Riphagen/Smitskam 1990, p. 419/420: de CRvB baseerde zich bij dit oordeel op een uitspraak van het Human Rights Committee die op dat moment al verouderd geacht kon worden. Opmerkelijk is dat de Centrale Raad deze lijn heeft vastgehouden tot ver in de jaren 90: zie bijv. CRvB 10 december 1997, JB 1998/58 (Uitkering ongehuwden AWW). Ook recentelijk gaf de Centrale Raad aan er niet veel voor te voelen om rekening te houden met recente rechtsontwikkelingen: zie CRvB 29 november 2000, RSV 2001/54 (Zigeunerhuwelijk), waarin de Centrale Raad stelde dat "aan het feit dat de maatschappelijke opvattingen ten aanzien van andere samenlevingsvormen inmiddels zijn gewijzigd [...] blijkens vaste rechtspraak van de Raad voor de toepassing van de AWW geen betekenis toe[komt],"

334. ABRS 16 maart 1999, JB 1999/102 (Filiatieregister III)

335. R.o. 2.3. Idem in ABRS 21 februari 1995, AB 1996/222 (Filiatieregister II).

336. Of dit erg overtuigend is blijft de vraag: ook historische instrumenten kunnen op een bepaald moment in strijd worden geacht met internationaal recht en intemationale ontwikkelingen. Traditie en geschiedenis zijn geen sterke argumenten wanneer er sprake is van onderscheid op een verdachte en eigenlijk onaanvaardbare grond. Het beroep dat de Afdeling in deze zaak deed op het feit dat de wetgever in 1994 had geoordeeld dat het systeem in stand hoorde te blijven vormt in dat verband eerder cen auto- 
de mate waarin veranderde rechtsopvattingen consequenties kunnen hebben voor het oordeel over de gerechtvaardigdheid van een ongelijke behandeling van afhankelijk is van diverse factoren. Van belang is niet alleen de precieze ontwikkeling van de rechtsopvattingen en het bestaan van rechtspraak van internationale organisaties, maar ook de aard van de betrokken regeling. Onduidelijk is echter welk gewicht precies aan deze factoren moet worden toegekend en of er wellicht nog andere factoren zijn die een rol kunnen spelen: de Nederlandse rechterlijke instanties hebben zich daarover tot nu toe nauwelijks uitgesproken. ${ }^{37}$ Zeker in vergelijking tot de andere bestudeerde stelsels, waarin toch vrij precieze criteria voor dit onderwerp zijn ontwikkeld, schiet de Nederlandse rechtspraak op dit punt tekort.

\section{Doelstelling moet zwaarwegend zijn}

Wanneer er sprake is van direct onderscheid op grond van arbeidsduur stelt de Commissie Gelijke Behandeling consequent dat gekeken moet worden of het nagestreefde doel zwaarwegend is. ${ }^{338}$ Ook andere rechterlijke instanties hebben dit af en toe als vereiste gesteld, zij het dat dit veel minder vaak voorkomt. ${ }^{339}$ De beoordeling van de zwaarwegendheid van een doelstelling hoort echter niet thuis bij de beoordeling van de redelijkheid van het nagestreefde doel: het is eerder een element dat moet worden be trokken bij de beoordeling van de proportionaliteit. ${ }^{300} \mathrm{Bij}$ de beoordeling van de zwaarwegendheid wordt immers niet zozeer de inhoudelijke gerechtvaardigdheid getoetst, maar vooral het gewicht van het nagestreefde doel: het feit dat een doelstelling niet zwaarwegend is betekent nog niet dat het nastreven ervan niet toelaatbaar is. Een beoordeling van het gewicht van het nagestreefde doel zal echter pas in het laatste stadium van de toetsing plaatsvinden: het al verwerken van proportionaliteitsaspecten in de doeltoets kan de overzichtelijkheid van de toetsing verstoren. Het lijkt dan ook niet wenselijk om in het kader van de redelijkheidstoets rekening te houden met het gewicht van het nagestreefde doel.

\section{Overige eisen: zakelijkheid, objectiviteit, redelijkheid, specificiteit en actualiteit}

In de rechtspraak zijn tenslotte nog enkele criteria terug te vinden, waarvan in zijn algemeenheid zou kunnen worden gesteld dat zij zo vaag zijn dat zij nauwelijks prakti-

riteitsargument dan een inhoudelijke ondersteuning voor het onderscheid. In ieder geval schiet de uitspraak in motivering tekort.

337. Bovendien wordt in sommige gevallen geen motivering gegeven voor het oordeel over de verandering in rechtsopvattingen, zelfs wanneer dit oordeel voor de procedure bepalend is. Zie bijv. CRvB 25 mei 1989, RSV 1989/275 (Weduwenuitkering WUV bij concubinaat) en CRvB 9 januari 1992, RSV 1992/282 (Benadeling mannen door WUV). De Nederlandse benadering is des te opmerkelijker, daar in de hiervoor besproken rechtstelsels wel soms criteria zijn ontwikkeld voor het "meten" van rechtsontwikkelingen. Weliswaar gaat het daarbij vaak om factoren die bij de bepaling van de toetsingsintensiteit een rol spelen, maar deze kunnen ook betekenis hebben voor de toetsing van het doel.

338. Zie bijv. Oordeel 97-140 (Tegemoetkoming ziektekosten overheidspersoneel). Het element komt recentelijk ook vaker terug bij indirect onderscheid op andere gronden; zie bijv. Oordeel 97-106 (Leeftijdsgrenzen NWO-subsidies), Oordeel 01-90 (Woonruimteverdelingssysteem), Oordeel $01-91$ (Acceptatiebeleid consumentenkrediet) en Oordeel 01-109 (Woonruimteverdeling Haarlem).

339. Zie bijv. ABRS 1 juni 1999, AB 1999/313 (Zeilschool).

340. Ook de Commissie concludeert soms pas dat de doelstelling niet zwaarwegend is als zij al een inhoudelijke doel-middeltoets heeft uitgevoerd. Zie bijv. Oordeel 98-132 (Werkindeling psychiatrische inrichting) en Oordeel 00-70 (Alfahulpen). 
sche aanknopingspunten bieden voor de rechterlijke toetsing. De vraag is dan ook of er in de Nederlandse rechtspraak een toepassing is gegeven aan deze criteria, waardoor het nut ervan toch vast komt te staan.

Interessant is allereerst het vereiste van redelijkheid. Dit vereiste speelt vooral een rol in het bestuursrecht en wordt meestal gebruikt bij een terughoudende toetsing van discretionaire bevoegdheidsuitoefeningen. Een typisch voorbeeld van toepassing van dit vereiste is terug te vinden in een uitspraak van de Afdeling Bestuursrechtspraak over het koffieshopbeleid in Leiden. ${ }^{341}$ Op basis van dit beleid was het gebied waarin koffieshops gedoogd werden beperkt tot het centrum binnen de Leidse singels. Deze geografische beperking was ingegeven door overwegingen van handhaving en controle. De Afdeling oordeelde hierover als volgt:

"De gemeentelijke wetgever heeft [...] op toereikende, de grenzen van de redelijkheid niet overschrijdende, gronden geoordeeld, dat voor het onderscheid een objectieve en redelijke rechtvaardiging bestaat." ${ }^{\text {42 }}$

Jammer genoeg blijkt uit deze overweging, en overigens evenmin uit de andere uitspraken van de Afdeling, niet duidelijk wat er nu precies onder de "grenzen van de redelijkheid" moet worden verstaan. Problematisch is vooral dat de formule niet alleen lijkt te duiden op de redelijkheid van de doelstelling, maar op de redelijkheid van het onderscheid als zodanig. De geciteerde formule biedt verder slechts weinig aanknopingspunten voor een goede en zorgvuldige motivering van de gelijkheidstoets, waardoor deze eigenlijk uitsluitend geschikt is voor een zeer marginale en niet nader uitgewerkte willekeurstoets. ${ }^{34}$ Juist vanwege zijn zeer evidente en algemene karakter lijkt het dan ook niet erg zinvol om dit vereiste als zodanig in het algemene toetsingsmodel op te nemen.

Een tweede vaak terugkerend vereiste is dat van objectiviteit, dat deel uitmaakt van de vaste formule van de rechtvaardigingstoets. De verschillende rechterlijke instanties hebben slechts zelden een rechtvaardiging ontoelaatbaar geacht omdat de nodige objectiviteit hieraan zou ontbreken. Een voorbeeld van toepassing is te vinden in een oordeel van de voorgangster van de Commissie Gelijke Behandeling, de CGB m/v. Zij moest in 1993 een oordeel uitspreken over de deeltijdregeling van een accountantskantoor, op grond waarvan het werken in deeltijd slechts onder zeer restrictieve voorwaarden werd toegestaan. ${ }^{34}$ Ter rechtvaardiging van deze beperkingen stelde het kantoor dat het binnen de branche waarin het werkzaam was niet gebruikelijk was dat personeel in deeltijd werkt en dat zij met het huidige beleid al veel risico's nam. De $\mathrm{CGB} \mathrm{m} / \mathrm{v}$ stelde hierover het volgende:

341. ABRS 18 januari 2000, JB 2000/53 (Koffieshopbeleid Leiden)
342. R.0.2.4

. In dit opzicht wijkt de "redelijkheidstoets" van de Nederlandse bestuursrechter af van die van het autorikaanse Supreme Court: wanneer daar een rational basis-test wordt toegepast betekent dit vrijwel voorspelbat dat onderscheid toelaatbaar is, terwijl de uitkomst bij de Nederlandse toets veel minder waarin de bir is. Dit blikt wel uit het feit dat er in de Nederlandse rechtspraak zaken te vinden zijn trokken bestuursrechter vaststelt dat het onderscheid onredelijk is, zelfs in gevallen waarin het be-

344. Oordeel 614-93-rgaan een ruimte mate van beleidsvrijheid toekwam. 
"De Commissie onderkent dat deeltijdwerk niet in alle branches gebruikelijk is, en dat in dit licht bezien, het huidige beleid van de wederpartij zeer vooruitstrevend is. Ook begrijpt zij dat een eventueel verdergaand deeltijdbeleid de nodige tijd zal vergen alvorens dit door alle betrokkenen geaccepteerd wordt. [...] Aangezien hier van de kant van de wederpartij sprake is van een subjectief argument, voldoet dit [echter] niet aan de [...] vereisten." ${ }^{\text {mas }}$

Zolang een argument in de sfeer blijft van een subjectief ervaren overmacht is dit ken. nelijk niet voldoende om het als objectieve rechtvaardiging te accepteren. Veel aan. knopingspunten voor toepassing van het objectiviteitscriterium biedt deze uitspraak echter niet, terwijl andere interpretaties of toepassingen van het vereiste in de rechtspraak niet of nauwelijks zijn terug te vinden. Het is dan ook de vraag of dit criterium eigenlijk wel zelfstandige betekenis toekomt naast de hiervoor reeds besproken vereisten. ${ }^{366}$ Dat dit wellicht toch het geval is kan hoogstens blijken uit de rechtspraak van de Commissie over het vereiste van zakelijkheid, een sterk op objectiviteit lijkend criterium dat in diverse formuleringen van de rechtvaardigingstoets terugkeert. ${ }^{37}$ Op dit vereiste werd door de Commissie een beroep gedaan in een geval waarin een houder van een sportschool als regel had gesteld dat er in de kantine alleen Nederlands mocht worden gesproken. ${ }^{34}$ Als rechtvaardiging daarvoor werd gesteld dat de barman zich anders uitgesloten zou voelen en voorkomen moest worden dat een vrouw alleen zich in de kantine ongemakkelijk zou voelen. De Commissie oordeelde hierover als volgt:

"De Commissie is van oordeel dat hier geen sprake is van een zakelijk doel. Een kantine is een plek waar mensen komen voor een consumptie. Zij mogen daarbij vrijelijk met elkar verkeren en communiceren. Een beperking in de taal dient daarbij geen enkel zakelijk doel." 149

In deze zaak lijkt duidelijk dat het taalvereiste, en daarmee het indirecte onderscheid op grond van nationaliteit, was ingegeven door puur discriminatoire overwegingen: de aangevoerde argumenten waren zodanig zwak dat de façade van de aangevoerde, nelltrale, doelstellingen gemakkelijk kon worden doorgeprikt. Zoals eerder is aangegeven is de Commissie weinig geneigd een onderzoek naar het werkelijk doel van de regeling uit te voeren. Het vereiste van zakelijkheid of objectiviteit blijkt in dit soort gevallen een handig criterium te zijn om een rechtvaardiging toch ontoereikend te kunnen bevinden. Wordt een beter onderzoek uitgevoerd naar het werkelijk doel van de regeling, dan heeft dit vereiste maar een beperkte, vooral retorische waarde.

Verder heeft de Commissie Gelijke Behandeling aangegeven geen genoegen te nemen met erg algemene of vage doelstellingen, hetgeen tot uitdrukking komt in het vereiste van specificiteit. Dit vereiste werd bijvoorbeeld toegepast in een oordeel dat betrekking had op de uitsluiting van deeltijdwerkers uit een pensioenregeling:

\section{R.o. 4.4}

346. De Commissie gebruikt het criterium na 1995 ook niet meer: in haar vaste formule van de rechtvardit:gingstoets maakt zij uitsluitend nog melding van het vereiste dat de doelstelling niet inherent discriminatoir mag zijn en moet voldoen aan een werkelijke behoefte.

347. Zie bijv. ARRS 21 oktober 1993, AB 1994/357 (Begeleidingssubsidie vrije school) en ABRS 3 mant 1994, AB 1995/85 (Leeftijdscriterium woonruimteverdeling).

348. Oordeel 99-87 (Taalvereiste sportschool)

349. R.o. 4.8. Idem in Oordeel 01-97 (Nederlands in café). 
"De wederpartij heeft geen specifieke rechtvaardigingsgronden aangevoerd doch slechts de algemene rechtvaardiging dat de uitsluiting van deeltijdwerkers paste in het toenmalige tijdsgewricht. [...] Deze argumenten kunnen niet als objectieve rechtvaardigingsgronden dienen $[. .$.$] ."1so$

De Commissie stelt ook weer geen erg hoge eisen aan de specificiteit van het doel: uit haar oordelen blijkt dat zij ook heel algemeen geformuleerde doelstellingen, zoals de bescherming van bedrijfsbelangen of de bevordering van werkgelegenheid, als gerechtvaardigd accepteert. Alleen wanneer de rechtvaardiging, zoals in het geciteerde oordeel, zodanig vaag en abstract is dat een concrete doel-middeltoets bijna niet is uit te voeren, zal de Commissie het doel onaanvaardbaar achten. ${ }^{351}$

Tenslotte is ook het vereiste van actualiteit praktisch bruikbaar bij de beoordeling van een rechtvaardiging. Dit vereiste houdt in dat het doel van het onderscheid moet corresponderen met een werkelijk bestaande situatie of met een werkelijk bestaand probleem. Wanneer het onderscheid kennelijk alleen beantwoordt aan een fictieve problematiek kan de belangenaantasting die hiervan het resultaat is nooit gerechtvaardigd zijn. Een voorbeeld van toetsing aan dit vereiste is terug te vinden in een oordeel van de Commissie Gelijke Behandeling uit 1995 over de weigering van een werkgever om het voor verzoekster mogelijk te maken om haar baan in deeltijd te vervullen. ${ }^{352} \mathrm{De}$ werkgever voerde als rechtvaardiging voor zijn weigering aan dat het organisatorisch niet mogelijk was om de werkzaamheden in deeltijd te vervullen, onder andere omdat het werk moeilijk overdraagbaar zou zijn en de goede communicatie en interne samenwerking door het werken in deeltijd in gevaar zouden worden gebracht. De Commissie stelde het volgende:

\begin{abstract}
"Op zichzelf kunnen deze doelen als gerechtvaardigd worden aangemerkt, mits aangetoond is dat dergelijke problemen zich feitelijk voordoen. [Volgt een onderzoek van de feitelijke omstandigheden, JHG]. De Commissie acht derhalve niet aangetoond dat de functie van Junior Systeemontwerper niet in deeltijd uitgeoefend kan worden, zodat dit niet als objectieve rechtvaardiging kan gelden." 353
\end{abstract}

Hoewel deze toepassing van dit criterium enige overlap lijkt te vertonen met het noodzakelijkheidsvereiste, verschilt het daarvan toch duidelijk. In dit geval wordt immers gekeken of het doel een feitelijke basis heeft, terwijl bij de noodzakelijkheidstoets wordt nagegaan of het gekozen middel noodzakelijk was om dit doel te bereiken. Opgemerkt kan echter worden dat dit vereiste vrijwel volledig samenvalt met het eerder besproken criterium van de werkelijke behoefte: ook dat is immers gericht op het toetsen van de noodzaak van het nastreven van een bepaald doel. In de latere oordelen van

350. Oordeel 95-20 (Pensioenregeling bibliotheek), r.o. 4.11

351. Zie bijv. Oordeel $95-19$ (Uitsluiting deeltijdwerkers van pensioenfonds) (bedrijfseconomische redenen en maatschappelijke opvattingen), Oordeel 97-106 (Leeftijdseisen NWO-subsidies) (streven naar evenwichtige leeftijdsopbouw als doel; niet nader is gespecificeerd wat dit dan zou moeten inhouden), Oordeel 98-41 (Pensioenregeling montagelaborante) (algemene bedrijfseconomische belangen en maatschappelijke opvattingen als rechtvaardiging, zonder enige nadere uitwerking) en Oordeel 99-20 (Uitsluiting deeltijders van pensioenregeling) (bedrijfseconomische redenen en maatschappelijke op-
vattingen).

353. R.o. 4.3 en-32 (Junior Systeemontwerper) 
de Commissie wordt ook vooral van dat criterium gebruik gemaakt, zodat gesteld kan worden dat het actualiteitscriterium weinig toegevoegde waarde heeft.

\subsection{Toetsing van de verhouding tussen doel en onderscheid}

\subsubsection{Mate van fit (over- en underinclusiveness) en toetsing van de relevante proxy}

\section{Toepassing en invulling van de toetsing van de mate van fit}

Wanneer eenmaal is vastgesteld dat met een regeling of beleid een gerechtvaardigde doelstelling wordt nagestreefd, moet worden beoordeeld of het gemaakte onderscheid een redelijke manier is om dit doel te bereiken. In hoofdstuk 2 is aangegeven dat daar. voor allereerst is vereist dat de definitie van de groep die door de regeling wordt geraakt zo nauwkeurig mogelijk is geformuleerd: er moet een voldoende mate van aansluiting (ofwel van "fit") bestaan tussen de definitie en het nagestreefde doel. Is de reikwijdte van de regeling zodanig gedefinieerd dat bepaalde gevallen of personen ten onrechte van een bepaalde regeling worden uitgesloten, dan is er sprake van underinclusiveness. Is de definitie daarentegen juist zo geformuleerd dat personen of groepen ten onrechte onder de reikwijdte van een (benadelende) regeling vallen, dan is er sprake van overinclusiveness. Zoals in het theoretische hoofdstuk al is aangegeven is het onvermijdelijk dat een regeling een bepaalde mate van over- en underinclusiveness vertoont: het is bijna niet mogelijk om een classificatie zo nauwkeurig te formuleren dat met alle individuele verschillen tussen personen of gevallen rekening wordt gehouden. De vraag in ieder concreet geval is dan ook niet of er een perfecte ansluiting bestaat tussen doel en classificatie, maar vooral of er sprake is van een toelaatbare mate van misfit.

In de Nederlandse rechtspraak is het vereiste van een redelijke mate van fit slechts zelden terug te vinden: in veruit de meeste gevallen gaan de onderzochte rechterlijke instanties na de toetsing van het doel meteen over tot een beoordeling van geschiktheid, noodzakelijkheid en (soms) proportionaliteit, of voeren zij een algemene redelijk heidstoets uit. Het ontbreken van een toetsing van de mate van fit is ook wel verklarbaar, aangezien in de meeste gevallen in de eerste fase van de toetsing een vergelijk. baarheidstoets wordt uitgevoerd. Als wordt toegekomen aan de tweede fase van de toetsing (de rechtvaardigingstoets), betekent dit dat in de eerste fase de conclusie moet zijn bereikt dat er sprake is van een ongelijke behandeling van vergelijkbare gevallen of van een gelijke behandeling van onvergelijkbare gevallen. Door een dergelijk vergelijkbaarheidsoordeel is er feitelijk al een oordeel over de mate van fit van de regeling gegeven. Wanneer er bijvoorbeeld sprake is van een ongelijke behandeling van vergelijkbare gevallen, vertoont de regeling onvermijdelijk ook een zekere mate van underinclusiveness: de regeling is dan zodanig eng geformuleerd dat gevallen of personen die gezien het doel van de regeling onder haar reikwijdte hadden moeten vallen, hier toch buiten zijn gebleven. Andersom zal er bij een gelijke behandeling van onvergelijkbare gevallen onvermijdelijk sprake zijn van overinclusiveness. Als in de eerste fase 
al een dergelijke conclusie is bereikt is het niet verrassend dat er in de tweede fase geen behoefte meer bestaat aan een afzonderlijke toetsing van de mate van fit $^{34}$

Wanneer in de eerste fase een benadelingstoets wordt uitgevoerd is de noodzaak voor het uitvoeren van een toetsing van de mate van fit in de tweede fase wel nog aanwezig: in de eerste fase is dan immers nog geen oordeel gegeven over de definitie of reikwijdte van de regeling. ${ }^{355}$ In Nederland wordt de benadelingstoets echter vrijwel uitsluitend toegepast in gevallen van indirect onderscheid, waarbij een toetsing van de mate van fit meestal minder relevant is. Deze toetsing zou zich in dit soort gevallen moeten richten op de beoordeling van de definitie van de classificatie op de neutrale onderscheidingsgrond, terwijl een dergelijke toetsing nauwelijks interessant is: in het geding is immers niet de redelijkheid van de neutrale classificatie als zodanig, maar de gerechtvaardigdheid van de effecten die daardoor teweeg zijn gebracht. Een toetsing van de mate van fit zal dan ook vrijwel alleen worden uitgevoerd wanneer de constructie via indirect onderscheid uitsluitend wordt gebruikt om op die manier het directe onderscheid op zijn redelijkheid te kunnen beoordelen. Deze benadering wordt in Nederland vooral door de Commissie Gelijke Behandeling gevolgd: zij construeert soms een indirect onderscheid om te ontkomen aan het gesloten systeem van uitzonderingsgronden van de Awgb, zodat zij een eigen toetsing van de redelijkheid van het onderscheid kan uitvoeren. Opmerkelijk is echter dat de Commissie de mate van fit niet beschouwt als een afzonderlijk toetsingscriterium, maar de toetsing hiervan steeds uitvoert in de context van de beoordeling van de noodzakelijkheid van het gekozen middel. . $^{\text {sk }}$ Een illustratie van deze werkwijze is te vinden in een oordeel over een winkel die

354. Daar komt nog bij dat sommige rechters fundamentele bezwaren lijken te hebben tegen een toetsing van de mate van fit. Zo stelde de appellant in ABRS 2 januari 1989, AB 1989/392 (Rietkerk-uitkering) dat zijn situatie ten onrechte niet onder de reikwijdte van het zogenaamde Rietkerk-Besluit was gebracht. De Afdeling oordeelde dat "de tekst van het Besluit bepalend is; het staat haar niet vrij om de innerlijke waarde van het Besluit te beoordelen, nu dat een algemeen verbindend voorschrift is." Dit oordeel is opmerkelijk, nu is gebleken dat een oordeel over de redelijkheid van de reikwijdte van de regeling ook kan worden bereikt via een vergelijkbaarheidstoets. Tegen een dergelijke toets koestert de Afdeling geen bezwaren.

355. Ook dan wordt er niet altijd een toetsing van de mate van fit uitgevoerd. Een voorbeeld is cen arrest over het tippelverbod in Heerlen (HR 6 november 1990 (strafkamer), NJ 1991/218 (Tippelverbod)): aan prostitué(e)s was bij verordening een verbod opgelegd om tijdens bepaalde uren in Heerlen te tippelen, om zo de veroorzaakte overlast op te heffen. Gesteld kan worden dat deze bepaling duidelijk underinclusive is, nu ook de klanten van de prostitué(e)s verantwoordelijk zijn voor de overlast die het tippelen oplevert. De Hoge Raad besteedde geen aandacht aan deze tekortkoming in de definitie van het verbod, maar stelde alleen dat de regeling op zichzelf een geschikt en noodzakelijk middel opleverde om het gestelde doel te bereiken. Daarmee voorkwam hij dat hij het, wellicht merkwaardige, oordeel moest uitspreken dat de reikwijdte van het verbod moest worden uitgebreid. Vanuit een oogpunt van gelijke behandeling is de redenering van de Hoge Raad echter wat beperkt. Vgl. Serrarens/Spronken 1991, p. 7. Er zijn overigens ook gevallen te vinden waarin in een vergelijkbare situatie wel degelijk een toetsing van de mate van fit werd uitgevoerd, ook al werd dit daarbij meestal niet met zoveel woorden gesteld; zie bijv, CRvB 4 november 1998, RSV 1999/38 (Wet Van Otterloo) en CRvB 26 juni 2001, JB 2001/184 (Koppelingswet). Zie ook Happé 1990, p. 394, die verwijst naar een voorbeeld uit de belastingrechtspraak. Happé geeft in een later artikel bovendien aan dat de belastingkamer soms feitelijk gebruik maakt van een underinclusiveness-test, maar deze meestal wordt verpakt in een

356. Er zijn echter gevallen waarin een zuivere toepassing van het fitness-vereiste aanwezig is en waarbij de
verwijzing verwijzing naar geschiktheid en noodzakelijkheid alleen lijkt te zijn ingegeven door de daartoe op grond van Europees recht bestaande verplichting; zie bijv. Oordeel 96-101 (Taalvereiste receptioniste), 
als algemeen beleid hanteerde dat geen meubels werden bezorgd op woonwagencom. plexen. ${ }^{357}$ De reden hiervoor was dat in het verleden ernstige incidenten hadden plaats. gevonden bij het afleveren van de goederen; de winkel wilde zijn leveranciers daartegen in de toekomst beschermen. De Commissie oordeelde hierover het volgende;

"Ten aanzien van het in geding zijnde woonwagencomplex overweegt de Commissie dat dit een klein complex betreft en dat het gelegen is in een woonwijk. Verder overweegt de Commissie dat bij de regionale politie niet bekend is dat er problemen zijn bij het afleveren van goederen bij dit woonwagencomplex. Gelet op deze feiten en omstandigheden is de Commissie van oordeel dat het onverkort toepassen van het beleid, dat niet geleverd wordt an een woonwagencomplex, een te grofmazig middel is. Dit beleid kan in het onderhavige geval dan ook niet als een noodzakelijk middel worden gekwalificeerd om het gestelde doel te bereiken. ${ }^{\text {"3ss }}$

Het is duidelijk dat het beleid van de meubelwinkel overinclusive was: gezien het doel van het beleid was het niet redelijk om ook woonwagenkampen van levering uit te sluiten waar het risico voor de leveranciers afwezig was. In de geciteerde overweging wordt het oordeel over de mate van fit echter verweven met het vereiste van noodzakelijkheid. Een dergelijke benadering is niet geheel zuiver. Op zichzelf kan er immers van worden uitgegaan dat het beleid van de winkel noodzakelijk was om het gestelde doel (in zijn algemeenheid) te bereiken. De tekortkoming betrof in dit geval niet zozeer de noodzakelijkheid van het beleid, maar vooral de onzorgvuldigheid van de formulering daarvan. Een afzonderlijke toetsing van de mate van fit zou kunnen leiden tot een vergroting van de doorzichtigheid van de motivering.

Van belang is echter dat uit de bovengeciteerde overweging blijkt dat de Commissie het criterium van de mate van fit erkent, ook al wordt het gezien als een onderdeel van de noodzakelijkheidstoets. De Commissie heeft in verschillende oordelen nader invulling heeft gegeven aan de wijze van beoordeling van de mate van fit van een classifica. tie. Een algemeen uitgangspunt is daarbij dat de classificatie voldoende genuanceerd en zorgvuldig moet zijn: hoe preciezer de definitie is toegesneden op het doel van de regeling, hoe groter de kans is dat het onderscheid aanvaardbaar is. ${ }^{359}$ Het trekken van een

Oordeel 97-04 (Inschaling stewardessen), Oordeel 97-43 (Taalvereiste schoonmaakfunctie) en Oordeel 97-131 (Schoolinformatie voor gescheiden vader). Een verwijzing naar de noodzakelijkheidstoets is zelfs geheel afwezig in Oordeel 01-17 (Creditcard als borg).

357. Oordeel 99-65 (Aflevering meubels in woonwagenkamp)

358. R.o. 4.7. Ook in andere gevallen is overlap zichtbaar: regelmatig stelt de Commissic vast dat een classificatie "verder gaat dan voor het bereiken van het doel noodzakelijk is", waarbij zij lijkt te doelen op een onvoldoende zorgvuldigheid in de formulering van de reikwijdte van de regeling; zie bijv. Ootdeel 95-69 (Acceptatievoorwaarden kredietbank 1), Oordeel 96-60 (Mobiele telefoon), Oordeel 96-75 (Taalvereiste administratief werk), Oordeel 97-97 (Paspoortvereiste bij mobiele telefoonaansluiting), Oordeel 01-26 (Acceptatiebeleid mobiel telefoonabonnement) en Oordeel 01-91 (Acceptatiebeleic consumentenkrediet; waarin ook werd verwezen naar het vereiste van proportionaliteit). Overigens is deze benadering soms ook zichtbaar in de rechtspraak van de andere onderzochte instanties; zie biy. ABRS 10 februari 1997, JB 1997/85 (Parkeerbeleid Leiden).

359. Dit wordt geillustreerd door een reeks oordelen over krediet- en andere dienstverienende instantics Dergelijke instanties stellen voor het verlenen van een dienst vaak beperkende voorwaarden om then kredietrisico te beperken: zo vragen banken bij het verstrekken van een lening soms dat iemand zich garant stelt, terwijl bedrijven die goederen verhuren vaak een borgsom vragen. In de gevallen die ast de Commissie werden voorgelegd was het steeds zo dat de beperkende voorwaarden in het bijzonder 
willekeurige grens tussen groepen van gevallen is blijkens de oordelen van de Commissie in ieder geval nooit toelaatbaar: op zijn minst is vereist dat de definitie van de classificatie is gebaseerd op objectieve gegevens of op enig onderzoek naar de relatie tussen het onderscheid en het nagestreefde doel. ${ }^{360}$ Dit kan worden geïllustreerd aan de hand van een oordeel over een zogenaamde seniorenregeling - een regeling waardoor oudere werknemers met behoud van salaris minder kunnen gaan werken. In de litigieuze regeling werd de toepasselijkheid van dit voordeel afhankelijk gesteld van de omvang van het dienstverband: werknemers met kleinere deeltijdbanen kwamen niet voor de seniorenregeling in aanmerking. De reden daarvoor was dat de seniorenregeling erop gericht was het ziekteverzuim onder oudere werknemers terug te dringen en, meer in het algemeen, hen enigszins te ontlasten. De betrokken werkgever veronderstelde dat kleinere deeltijdbanen een minder grote belasting opleveren, zodat deeltijdwerkers niet onder de reikwijdte van de regeling hoefden te worden gebracht. De Commissie oordeelde hierover als volgt:

"De Commissie is van oordeel dat de problemen die bestaan bij de vaststelling van een belastbaarheidsgrens van oudere werknemers, een werkgever niet ontslaan van de verplichting om in zijn onderneming een poging te doen een dergelijke grens zo objectief mogelijk vast te stellen dan wel te benaderen. De Commissie stelt vast dat de wederpartij een dergelijke poging niet heeft gedaan."

golden voor kortdurend in Nederland verblijvende vreemdelingen. Om de duur van het verblijf te kunnen bepalen werd daarbij naar het verblijfsdocument gekeken. Eenzelfde verblijfsdocument kan echter op verschillende situaties betrekking hebben. Zo kon het onder de oude Vreemdelingenwet zo zijn dat een bezitter van een D-document inderdaad slechts voor korte tijd in Nederland mocht verblijven (hetgeen een kredietrisico kon opleveren), maar het was ook mogelijk dat de houder een "C-status" had; deze laatste status impliceerde dat de betrokkene feitelijk permanent in Nederland kon verblijven, zodat er geen bijzonder kredietrisico bestond. Wanneer de dienstverlener met deze verschillen in status onvoldoende rekening hield en aan iedere houder van een D-document dezelfde beperkende voorwaarden stelde, achtte de Commissie het beleid overinclusive (zie bijv. Oordeel 95-69 (Acceptatievoorwaarden kredietbank I), Oordeel 96-12 (Kredietverlening vreemdelingen), Oordeel 96-60 (Mobiele telefoon), Oordeel 97-97 (Paspoortvereiste bij mobiele telefoon), Oordeel 98-07 (Acceptatiebeleid kredietbank II), Oordeel 01-26 (Acceptatiebeleid mobiel telefoonabonnement) en Oordeel 01-91 (Acceptatiebeleid consumentenkrediet)). Hoe preciezer het beleid werd geformuleerd, hoe groter de kans was dat het toelaatbaar werd geacht. Dit blijkt bijvoorbeeld uit Oordeel 99-98 (Verhuur aan nietNederianders), waarin de Commissie een beleid in stand hield waarbij de dienstverlener niet alleen keek naar het verblijfsdocument, maar ook naar de verblijfsstatus. Zie ook Oordeel 00-28 (Acceptatiebeleid mobiele telefoon) en, voor de nieuwe Vreemdelingenwet, Oordeel 01-26 (Acceptatiebeleid mobiel telefoonabonnement). Het uitgangspunt dat de regeling zo genuanceerd en precies mogelijk moet zijn komt ook naar voren in de rechtspraak van andere instanties; zie bijv. CRvB 12 februari 1997, RSV 1997/227 (WW-uitkering vreemdelingen)

360. Vgl. Oordeel 01-36 (Regeling wachtdiensten). De Centrale Raad blijkt hierover overigens iets anders te denken wanneer het gaat om klachten over overgangsrecht: hij stelde in CRvB 21 oktober 1994, AB 1995/341 (Overgangsregeling WAO) wordt gesteld dat overgangsregelingen vanwege het inherente tijdsaspect onvermijdelijk arbitraire elementen bevatten. Dit lijkt ook de enige mogelijke en redelijke uitzondering die tot nu toe is erkend.

361. Oordeel 98-96 (Seniorenregeling CAO NOB), r.o. 4.4. Zie verder Oordeel 99-78 (CAO Ziekenhuiswezen), waarin de Commissie aangaf dat de veronderstelling dat de werkbelasting toeneemt met de omvang van het dienstverband niet werd ondersteund door duidelijke onderzoeksgegevens en dat het gemaakte onderscheid daardoor enigszins willekeurig was. De Commissie voerde in deze zaak zelf een onderzoek uit naar de verhouding tussen werkbelasting, leeftijd en omvang van het dienstverband, waaruit bleek dat de oorzaak-gevolgrelaties in dit opzicht niet steeds duidelijk waren. Zie in dezelfde 
Inderdaad lijkt het redelijk om van de opsteller van een regeling te verwachten dat hij bij het formuleren van een regeling zorgvuldig te werk gaat en zich niet uitsluitend baseert op vage veronderstellingen. Gezien de praktische bruikbaarheid van dit criteri. um is het zeker wenselijk om dit als nuancering van de fitness-toets te verwerken in het algemene toetsingsmodel.

Van belang is tenslotte dat de Commissie in enkele oordelen heeft aangegeven dat een op het oog tekortschietende mate van fit toelaatbaar kan zijn wanneer de regeling is gericht op het objectiveren en veralgemeniseren van bepaalde individuele omstandig. heden. Hoewel het gelijkheidsbeginsel eigenlijk verlangt dat zoveel mogelijk met individuele, persoonlijke omstandigheden rekening wordt gehouden, kan het namelijk zo zijn dat dit in een concreet geval niet wenselijk of mogelijk is, bijvoorbeeld omdat dit zou leiden tot een te grote inbreuk op de privacy van de betrokkenen ${ }^{362}$ of tot ernstige problemen bij de uitvoerbaarheid van de regeling. ${ }^{363} \mathrm{Op}$ zichzelf is deze benadering niet onredelijk, maar in dit soort gevallen moet wel steeds een zorgvuldige proportionaliteitstoets worden uitgevoerd: in ieder geval moet worden nagegaan of de administratieve overwegingen daadwerkelijk zwaarder konden wegen dan het belang dat wordt gediend door rekening te houden met individuele omstandigheden. De Commissie heeft bovendien gesteld dat de objectivering er niet toe mag leiden dat er feitelijk sprake is van een door de Awgb verboden ongelijke behandeling, bijvoorbeeld doordat er bij de objectivering gebruik wordt gemaakt van een criterium dat inherent discriminatoire consequenties heeft (zoals het anciënniteitsbeginsel). ${ }^{364}$

\section{Toetsing van de relevante proxy}

Hiervoor is aangegeven dat de Nederlandse rechterlijke instanties in veel gevallen geen expliciet oordeel geven over de mate van fit van een classificatie. Wel blijken zij vaak gebruik te maken van een iets ander, aan de fitness-toets verwant, toetsingscriterium: de beoordeling van hetgeen met een Amerikaanse term kan worden aangeduid als de "proxy". In veel uitspraken wordt, nadat is vastgesteld welk doel met de regeling wordt nagestreefd, gekeken naar de wijze waarop aan de litigieuze classificatie vorm is gege-

lijn, steeds met een meer of minder expliciet oordeel over de mate van fit, Oordeel 94-05 (Arbeidstijd. vermindering oudere werknemers), Oordeel 95-06 (Seniorenregeling thuiszorg), Oordeel 96-117 (Korter dienstverband 55-plussers in thuiszorg) en Oordeel 97-144 (Ouderenregeling openbare bibliotheek).

362. Dit is overigens een rechtvaardiging voor een tekortschietende mate van fit die niet zozeer door de Commissie, maar door de belastingkamer is bedacht; zie HR 6 juni 1990 (belastingkamer), BNB 1990/299 (Zorgrelatie buiten familieverband). In vergelijkbare zin ook de civiele kamer: HR 13 januar 1995, NJ 1995/430 (Codfried/ISS).

363. De Commissie aanvaardt een dergelijke objectivering, maar stelt hieraan wel grenzen: de objectivering mag niet zelf leiden tot een ongelijke behandeling. Zie bijv. Oordeel 96-07 (Rpbo), Oordeel 96-71 (Rpbo II), Oordeel 98-102 (Meenemen ervaring bij inschaling) en Oordeel 01-20 (Rpbo). Ook de be lastingkamer heeft geoordeeld dat overwegingen van uitvoerbaarheid en doelmatigheid een zeker mate van "ruwheid" van de definitie kunnen rechtvaardigen: HR 15 december 1999 (belastingkamer) BNB 2000/57 (Belastingvrije som gehuwden/ongehuwden) en HR 28 februari 2001 (belastingkamer) BNB 2001/169 (Alleenstaande ouder-aftrek). Zie in vergelijkbare zin CRvB 23 februari 1999, RSI 1999/119 (Aanvangsdatum fictief arbeidsverleden), CRvB 26 november 1999, RSV 2000/50 (Veria ging eigen bijdrage zwakzinnigen) en CRvB 4 oktober 2000, RSV 2001/19 (Overgangsregeling Anw).

364. Dit vereiste komt naar voren in elk van de in de vorige noot genoemde oordelen van de Commissic. 
ven. Van belang is daarbij dat de definitie van de onderscheiden groep zal worden bepaald door een groepskenmerk dat voor het bereiken van het gestelde doel essentieel wordt geacht. Zo zal het bestaan van een goede onderlinge verhouding tussen de ouders een belangrijk criterium zijn voor het toekennen van de ouderlijke macht, en kan vakkennis soms worden gezien als een relevante factor bij het vaststellen van de hoogte van het salaris. Voor de regelgever kan het echter bezwaarlijk zijn om dergelijke criteria daadwerkelijk tot uitgangspunt van de classificatie te nemen: vaak zijn deze wel bepalend voor de definitie van de te onderscheiden groep, maar lenen zij zich minder goed voor toepassing door het bevoegde uitvoeringsorgaan. ${ }^{365}$ In die gevallen zal de regelgever zijn onderscheid vaak baseren op een ander, beter toepasbaar criterium, dat sterk verband houdt met het eigenlijk gewenste onderscheidingscriterium. Dit ruimere criterium wordt dan als de proxy aangeduid. In het geval van de toekenning van ouderlijke macht merkte de wetgever bijvoorbeeld een tijdlang het bestaan van een huwelijk aan als proxy voor het bestaan van een goede onderlinge verhouding tussen de partners $^{36}$, terwijl vakkennis door werkgevers vaak gelijk wordt gesteld met het gevolgd hebben van een bepaalde opleiding of het bezitten van een bepaald diploma ${ }^{367}$.

Op zichzelf is het gebruik van een proxy bijzonder praktisch: degene die tot uitvoering van de regeling bevoegd is (vaak een bestuursorgaan, maar soms ook een rechter of een werkgever) zal immers niet zelf hoeven te beoordelen welke uitleg aan een onderscheidingscriterium moet worden gegeven, maar kan gewoon de wettelijke invulling van het criterium overnemen. De keuze van regelgevers voor deze benadering kan echter ook tot problemen leiden, nu niet iedere proxy een goede benadering van het eigenlijke onderscheidingscriterium is. ${ }^{368}$ De Nederlandse rechter blijkt daarom vaak te onderzoeken of door de keuze voor een bepaalde proxy (vrijwel) dezelfde groep wordt uitgezonderd als wanneer gekozen zou zijn voor het eigenlijke differentiatiecriterium. ${ }^{369}$ Een voorbeeld van deze toetsing is te vinden in een uitspraak van de Hoge Raad over een verschil in het salaris van gehuwde en ongehuwde onderwijzeressen op de Nederlandse Antillen. ${ }^{300}$ Het betrokken schoolbestuur had als rechtvaardiging hiervoor aangevoerd dat gehuwde onderwijzeressen in het algemeen hogere onderhoudsverplichtingen hebben. Hieruit blijkt dat het bestuur het bestaan van een huwelijk beschouwde als een

365. Zo kan worden gesteld dat de genoemde criteria wel erg veel beoordelingsruimte aan de uitvoeringsinstelling laten: de rechter moet in het eerste voorbeeld zelf bepalen of er sprake is van een zodanige verhouding tussen de ouders dat de ouderlijke macht aan hen kan worden toegekend, terwijl in het tweede voorbeeld de werkgever moet beoordelen wat vakkennis precies inhoudt en wanneer aan dat vereiste is voldaan.

366. Zie HR 21 maart 1986, NJ 1986/585 (Ouderlijke macht voor ongehuwden).

367. Zie HR 3 januari 1997, NJ 1997/435 (Zorggroep Oost-Gelderiand/Gerrits).

368. Zo oordeelde HR in het genoemde arrest over ouderlijke macht voor ongehuwden dat "de in de wet tussen ouderlijke macht en gehuwd zijn gelegde band niet van juridische, doch slechts van feitelijke aard is en berust op een feitelijke veronderstelling die in elk geval thans niet juist is" (r.o. 3.3). Vgl. HR 17 maart 1999, BNB 1999/348 (35\%-regeling II).

369. Voor deze beoordeling is vanzelfsprekend noodzakelijk dat duidelijk is dat er sprake is van een proxy. Soms blijkt dit uit de regeling zelf of uit de toelichting daarop, maar in veel gevallen zal de rechter zelf moeten achterhalen of het waarschijnlijk is dat het gehanteerde criterium dient als een benadering van een ander, preciezer, onderscheidingscriterium. In de praktijk blijkt dit nauwelijks tot problemen te lei-

370. HR 7 mei 1993, RvdW 1993/101 (Ongehuwde onderwijzeressen) 
goede proxy voor het eigenlijke onderscheidingscriterium: het bestaan van onderhoudsverplichtingen. De Hoge Raad oordeelde anders:

"De maatschappelijke ontwikkelingen in zowel de Nederlandse Antillen als Nederland hebben [...] meegebracht dat het al dan niet bestaan van een huwelijk een te onbetrouwbare aanwijzing vormt voor het al dan niet aanwezig zijn van onderhoudsverplichtingen om de enkele omstandigheid dat een werknemer gehuwd is, te kunnen aanmerken als een voldoende grond voor het betalen van een hoger salaris voor gelijke arbeid." ${ }^{371}$

Wanneer op deze manier invulling wordt gegeven aan dit toetsingscriterium, kan dit een zinvolle aanvulling vormen op de reeds eerder genoemde criteria. Wanneer al duidelijk is dat het gehanteerde onderscheidingscriterium niet relevant is, staat immers meteen vast dat het onderscheid niet precies genoeg is geformuleerd. In die gevallen hoeft niet meer te worden nagegaan of er sprake is van een voldoende mate van fit en kan ook de beoordeling van geschiktheid, noodzakelijkheid en proportionaliteit achterwege blijven. Het verdient echter opmerking dat de toetsing van de relevantie van de gehanteerde proxy niet mag worden gezien als een vervanging van de toetsing van de mate van fit. Wanneer is vastgesteld dat het gehanteerde criterium een redelijke benadering is van een ander onderscheidingscriterium, moet ook nog worden nagegaan of de definitie die op basis van dit criterium is geformuleerd voldoende aansluit bij het nagestreefde doel: het is mogelijk dat ook het originele criterium zodanig slecht is gekozen dat een relevante groep personen of gevallen ten onrechte buiten de reikwijdte van de regeling blijft of hier juist ten onrechte binnen valt. Zolang een dergelijke toetsing zorgvuldig wordt uitgevoerd, is het echter zeker de moeite waard het criterium van de relevante proxy toe te voegen aan het algemene toetsingsmodel.

\subsubsection{Geschiktheid}

Zoals eerder is aangegeven voeren veel rechterlijke instanties de rechtvaardigingstoets op zodanige wijze uit dat nauwelijks verschil zichtbaar is tussen de verschillende criteria zoals die in het theoretische model zijn uiteengezet: in de grote meerderheid van gevallen wordt eenvoudigweg een soort algemene redelijkheidstoets uitgevoerd, warrbij in zijn algemeenheid wordt beoordeeld of er sprake is van een "objectieve en reder

371. R.o. 3.4; cursief toegevoegd. Maatschappelijke ontwikkelingen spelen in deze en andere uitsprakea waarin de proxy niet relevant werd geacht overigens een belangrijke rol: kennelijk zijn deze niet alleen van belang voor de toetsing van de redelijkheid van het nagestreefde doel, maar ook voor de beoordo ling van de relevantie van de gehanteerde toetsingscriteria. Zie verder HR 21 maart 1986, NJ 1986/585 (Ouderlijke macht voor ongehuwden), HR 29 mei 1996, JB 1996/185 (Wessels), HR 16 februari 2001, JB 2001/106 (Kiesrecht Antillen). Voorbeelden van arresten waarin de proxy wel relevant werd geachi zijn HR 18 december 1984 (strafkamer), NJ 1985/356 (Dames- en herenkappers), HR 4 maart 1988, NN1989/875 (Toescheidingsovereenkomst Suriname), HR 21 oktober 1992 (belastingkamer), BNB 1993/28 (Middelingsregeling) en HR 16 februari 2001, JB 2001/106 (Kiesrecht Antillen). Ook door andere rechterlijke instanties is van deze benadering gebruik gemaakt; zie bijv. ABRS 2 september 1994, AB 1995/146 (Medewerkersovereenkomst met 65-plusser) en ABRS 10 februari 1997, JB 1997/85 (Parkeerbeleid Leiden; waarin het overigens nog maar de vraag is of er sprake was van een it delijke proxy), en verder CRvB 24 mei 1993, RSV 1994/43 (Leeftijdscriterium AWW), CRvB 3 no vember 1993, RSV 1994/94 (Leeftijdsgrens AAW) en CRvB 23 februari 1999, RSV 1999/119 (Aamvangsdatum fictief arbeidsverleden). Zie tenslotte Oordeel 96-06 (Bootpas Terschelling), Oordeel 96 111 (Publicatievereiste onderzoeksschool), Oordeel 97-06 (Kostenbijdrage maaltijden militairen) en Oordeel 97-106 (Leeftijdsgrenzen NWO). 
lijke rechtvaardiging". Niettemin is in een aantal uitspraken een nadere uitwerking van de doel-middeltoets terug te vinden waarin verschillende toetsingscriteria worden onderscheiden. Uit de definities van de rechtvaardigingstoets zoals die in paragraaf 2.1 zijn weergegeven blijkt bijvoorbeeld dat het vereiste van geschiktheid (door de Hoge Raad, de Afdeling en de Centrale Raad ook wel aangeduid als het vereiste van "passendheid") ${ }^{3 n}$ vrijwel steeds als een zelfstandig onderdeel van deze toets wordt beschouwd. Met dit vereiste lijkt dan te worden gedoeld op het bestaan van een causaal verband tussen het nagestreefde doel en het gemaakte onderscheid. Is het evident dat het gestelde doel niet door de gekozen classificatie kan worden bereikt, dan zal het onderscheid meteen ontoelaatbaar worden geacht. ${ }^{373}$ Een daadwerkelijke beoordeling van de geschiktheid of passendheid is echter maar zelden in de rechtspraak terug te vinden. In de schaarse gevallen waarin van een inhoudelijke toetsing sprake is, is de motivering bovendien vaak zodanig summier dat hieruit nauwelijks conclusies zijn af te leiden over de gehanteerde methodiek. ${ }^{374}$ Een consequent en goed gemotiveerd gebruik van het geschiktheidscriterium is eigenlijk uitsluitend terug te vinden in de oordelen van de Commissie Gelijke Behandeling, die dit criterium als essentieel onderdeel van de rechtvaardigingstoets beschouwt. In het hiernavolgende zal de aandacht dan ook op deze rechtspraak worden geconcentreerd.

Bij de toetsing van de geschiktheid is het uitgangspunt van de Commissie dat aannemelijk moet zijn dat het gemaakte onderscheid daadwerkelijk bijdraagt aan het bereiken van het nagestreefde doel. ${ }^{375}$ Om na te gaan of van een dergelijk causaal verband sprake is maakt de Commissie gebruik van diverse instrumenten. Zo verwijst zij regelmatig naar objectieve gegevens die door de partijen beschikbaar zijn gesteld of die zij

372. Bijv. HR 7 mei 1993, RvdW 1993/101 (Ongehuwde onderwijzeressen), HR 7 november 1997, NJ 1998/399 (Levi/Zaanwerk; in dit arrest werd een toepassing aan dit vereiste gegeven, maar slechts in die zin dat de HR oordeelde dat er te weinig gegevens waren om te kunnen concluderen dat het doel niet met het gemaakte onderscheid zou kunnen worden bereikt), HR 8 mei 1998, NJ 1998/496 (Leeftijdsgrens commissarissen), HR 24 november 2000, NJ 2001/376 (Landsverordening Toelating en Uitzetting), ABRS 18 januari 2000, JB 2000/53 (Koffieshopbeleid Leiden), ABRS 27 april 2000, AB 2000/243 (Afgifte rijbewijs), CRvB 20 september 1995, AB 1996/20 (Kostwinnerscriterium medeverzekering ziekenfonds), CRvB 12 februari 1997, RSV 1997/227 (WW-uitkering vreemdelingen; in deze uitspraak werd met "passendheid" vooral op de mate van fit van het onderscheid geduid) en CRvB 4 januari 2000, RSV 2000/79 (Noodzakelijke scholing Abw).

373. Voorbeelden van toepassing van dit criterium zijn (buiten de oordelen van de Commissie) vooral te vinden in arresten waarin de rechtspraak van het Europees Hof van Justitie wordt gevolgd; zie bijv. HR 31 maart 2000, JB 2000/133 (Scholingsbesluit bijstandsgerechtigden), CRvB 19 april 1990, RSV 1990/323 (Teuling-Worms), CRvB 23 juni 1992, RSV 1992/317 (Inkomenseis AAW; waarin de geschiktheidstoets sterk lijkt op een noodzakelijkheidstoets) en CRvB 20 september 1995, AB 1996/20

374. Zie bijv. (impliciet) HR 30 mei 2001 (belastingkamer), BNB 2001/302 (Korting 35\%-regeling), HR 8 mei 1998, NJ 1998/496 (Leeftijdsgrens commissarissen), HR 6 november 1990 (strafkamer), NJ 1991/218 (Tippelverbod), ABRS 18 januari 2000, JB 2000/53 (Koffieshopbeleid Leiden) en CRvB 1 april 1998, RSV 1998/187 (AOW voor gehuwden); wat betreft motivering iets zorgvuldiger zijn ABRS 27 april 2000, AB 2000/243 (Afgifte rijbewijs), CRvB 26 mei 1992, RSV 1993/44 (Vergoeding ADLassistentie), CRvB 4 november 1998, RSV 1999/38 (Wet van Otterloo) en CRvB 26 november 1999,

375. Zie voor deze formulering Oordeel 96-34 (Positieve discriminatie bij kinderopvang), Oordeel 97-110
(Praktijkproef stuker (Praktijkproef stukadoorsbedrijf), Oordeel 98-93 (Pensioenregeling gehuwden met groot leeftijdsverschil), Oordeel 99-22 (Verandering werktijden) en Oordeel 00-36 (Iraans accent peuterleidster). 
zelf heeft achterhaald; een belangrijke bron vormen dan vooral statistische en andere onderzoeksgegevens waaruit de effectiviteit van het onderscheid kan worden afgeleid, net als door de wederpartij opgestelde evaluatieverslagen en rapporten over de effecten van een regeling. ${ }^{376}$ Daarnaast houdt de Commissie rekening met feiten van algemene bekendheid die wijzen op de geschiktheid van bepaalde instrumenten om een doelstelling te bereiken, hoewel zij daarbij enigszins terughoudend is: voor het gebruik van deze bron moet in ieder geval voldoende vaststaan dat de feiten van algemene bekendheid representatief zijn voor de situatie bij de wederpartij. ${ }^{3 n}$ Het bestaan van objectieve gegevens is voor de Commissie essentieel om een regeling ongeschikt te kunnen bevinden: alleen als anderszins evident is dat de ongelijke behandeling geschikt is om het gestelde doel te bereiken, kan het ontbreken van voldoende gegevens tot een andere conclusie leiden. ${ }^{378}$

Wanneer er wel voldoende informatie aanwezig is om een zinvol oordeel te kunnen geven over de geschiktheid, voert de Commissie een onderzoek uit naar de directheid van het verband tussen doel en onderscheid. ${ }^{379}$ Daarbij kiest zij meestal een kritische opstelling, met name wanneer blijkt dat er, naast het gemaakte onderscheid, nog andere factoren zijn die op relevante wijze hebben bijgedragen aan het verwezenlijken van het gestelde doel. Om het onderscheid nog te kunnen redden zal de wederpartij in die ge. vallen overtuigend aannemelijk moeten maken dat het gestelde doel zonder het gemakte onderscheid echt niet kon worden bereikt. ${ }^{380}$

Waardevol in de benadering van de Commissie is dat haar benadering zowel ruimte biedt voor een intensieve als voor een meer terughoudende toetsing. De eisen die worden gesteld aan de directheid van het causale verband laten voldoende ruimte voor differentiatie, waardoor rekening kan worden gehouden met de aanwezige mate van

376. Zie o.a. Oordeel 98-137 (Homoseksuele bloeddonoren), Oordeel 98-144 (Kinderopvangregeling Har. lemmermeer), Oordeel 99-102 (Dierenparkbezoek op zondag) en Oordeel 00-36 (Iraans accent peuter. leidster). De Commissie blijkt soms ook bereid te zijn om deze gegevens zelf te achterhalen, zoals blijkt uit Oordeel 99-78 (CAO Ziekenhuiswezen). Het ging in dit oordeel overigens om een bijzonder geval, waarin uitspraak moest worden gedaan over een situatie van ongelijke behandeling die zich rs: gelmatig voordeed, maar waarin weinig duidelijkheid bestond over de causaliteit en noodzakelijkheid van het gekozen middel.

377. Bijv. Oordeel 97-35 (Kinderopvangregeling Algemene Rekenkamer), Oordeel 97-75 (Kinderopvang ziekenhuis) en Oordeel 00-65 (Kinderopvangregeling regionale politie).

378. Zie bijv, Oordeel 00-04 (IVF-instellingen), waaruit een gedifferentieerde benadering naar voren kont: soms kunnen onvoldoende gegevens over het bestaan van causaliteit leiden tot de conclusie dat het gemaakte onderscheid ontoelaatbaar is, maar het ontbreken van goede gegevens kan in andere gevallen juist worden gezien als een reden om onderscheid te maken. Zie verder Oordeel 97-84 (Pas 65), 0or. deel 98-144 (Kinderopvangregeling Haarlemmermeer), Oordeel 00-65 (Kinderopvangregeling regionale politie) en Oordeel 00-70 (Alfahulpen). Hetzelfde geldt wanneer het anderszins evident is dat hel middel niet geschikt is om het doel te bereiken; zie Oordeel 00-24 (Ureneis ADV bij onderzocksbovreau) en Oordeel 00-66 (Uitruil nabestaandenpensioen).

379. Dit blijkt niet altijd te gebeuren: in sommige gevallen blijkt uit de feiten al meteen dat het onderscheid al dan niet geschikt is om het doel te bereiken, zodat een nader onderzoek naar het verband tussen doe en onderscheid achterwege kan blijven.

380. Vgl, Oordeel 99-78 (CAO Ziekenhuiswezen), Oordeel 00-66 (Uitruil nabestaandenpensioen) en Oordeel 00-81 (Kinderopvangregeling UM). Soms krijgt de wederpartij daarvoor niet eens de kans, man wordt het onderscheid direct ongeschikt bevonden; zie Oordeel 98-93 (Pensioenregeling gehuwder met groot leeftijdsverschil). 
beleidsvrijheid of andere factoren die de intensiteit van de toetsing bepalen. Het zou wenselijk zijn wanneer de andere rechterlijke instanties op een vergelijkbare manier met het vereiste van causaliteit tussen doel en onderscheid zouden omgaan: van enige zorgvuldigheid in de geschiktheidstoets is in hun rechtspraak op dit moment geen sprake.

\subsubsection{Noodzakelijkheid en subsidiariteit}

Zoals is gebleken bij de beschrijving van de andere rechtsstelsels wordt er in de praktijk onderscheid gemaakt tussen de vereisten van noodzakelijkheid en subsidiariteit. ${ }^{\text {Ist }}$ Beide vereisten zijn inhoudelijk sterk aan elkaar verwant. Bij de toetsing van noodzakelijkheid wordt in het algemeen beoordeeld of het gestelde doel ook had kunnen worden bereikt zonder onderscheid te maken, dat wil zeggen dat wordt nagegaan of er daadwerkelijk behoefte bestond aan het gemaakte onderscheid. Bij de toetsing aan het vereiste van subsidiariteit wordt specifiek nagegaan of er andere, minder belastende middelen beschikbaar waren waardoor het doel evenzeer kon worden bereikt als met het gekozen middel. Deze toetsing is aanzienlijk uitgebreider dan de noodzakelijkheidstoets, omdat hierbij niet alleen moet worden gekeken naar het nut van het gekozen middel, maar ook naar eventueel bestaande alternatieven.

Net als voor het vereiste van geschiktheid geldt ook voor de vereisten van noodzakelijkheid en subsidiariteit dat hieraan in de rechtspraak van de Hoge Raad, de Centrale Raad van Beroep en de Afdeling Bestuursrechtspraak slechts zelden afzonderlijk wordt getoetst: in de meeste gevallen wordt deze toetsing vervangen door een algemene redelijkheidstoets. Een expliciete toetsing aan het vereiste van noodzakelijkheid is vrijwel uitsluitend terug te vinden in uitspraken waarin de toetsing wordt afgestemd op de rechtspraak van het Europese Hof van Justitie. ${ }^{3 \times 2}$ Net als voor het geschiktheidsvereiste geldt daarbij dat de toetsing zelden goed wordt gemotiveerd, zodat het niet gemakkelijk is om op basis van deze rechtspraak vast te stellen welke methodiek nu precies wordt gehanteerd. Ook aan het specifiekere vereiste van subsidiariteit blijkt slechts zelden te worden getoetst. Dit is ook wel begrijpelijk, aangezien de onderzochte instanties meestal een terughoudende toetsing uitvoeren en bovendien niet allemaal bevoegd zijn de feiten te onderzoeken: de mogelijkheid om alternatieven te achterhalen en te beoordelen op hun redelijkheid wordt daardoor sterk beperkt. In de sporadische gevallen waarin een subsidiariteitstoets wel zichtbaar is blijkt deze overigens opvallend zorgvuldig te zijn: nagegaan wordt dan welke alternatieve mogelijkheden er bestonden (waarbij de stellingen van partijen of de wetsgeschiedenis vaak als bron worden gehanteerd), waarna vrij nauwkeurig wordt onderzocht of tegen deze alternatieven zoda-

381. Zie voor het EHRM hoofdstuk 3, paragraaf 2.6, voor het Europese recht, waarin dit onderscheid zeer uitgesproken naar voren komt, hoofdstuk 4, (vooral) paragraaf 2.4.3, en voor het Amerikaanse recht hoofdstuk 5, paragaaf 2.4 .4 .

382. Zie bijv. HR 31 maart 2000, JB 2000/133 (Scholingsbesluit bijstandsgerechtigden), CRvB 23 juni 1992, RSV 1992/317 (Inkomenseis AAW), CRvB 29 april 1996, RSV 1996/247 (WW-uitkering huishoudelijk personeel), CRvB 12 augustus 1999, RSV 2000/73 (Inkomensvereiste thuiswerkers) en CRvB 21 september 2000, JB 2000/313 (Scholierenregeling). Zie voor voorbeelden buiten de context van het Europese recht HR 20 januari 1995, NJ 1995/326 (Verjaringstermijn vaderschapsactie), HR 26 maart 1997, BNB 1997/186 (Waardering landbouwgrond), (impliciet) HR 13 januari 1998 (strafkamer), NJ 1998/407 (Gedoogbeleid Delfziji) en CRvB 26 juni 2001, JB 2001/184 (Koppelingswet). 
nige bezwaren bestaan dat de keuze voor het litigieuze onderscheid voldoende redelijk kan worden geacht. ${ }^{383}$ Deze uitspraken bevestigen dat het uitvoeren van een subsidiari. teitstoets praktisch mogelijk is, zelfs bij een terughoudende toetsing, en dat rechterlijke instanties voldoende in staat zijn om op objectieve wijze alternatieve mogelijkheden vast te stellen.

Zijn voorbeelden van een expliciete toepassing van de noodzakelijkheids- of subsidiariteitsvereisten in de rechtspraak van Hoge Raad, Centrale Raad en Afdeling vrij zeldzaam, voor de Commissie Gelijke Behandeling geldt dat zij aan deze vereisten in vrij. wel ieder oordeel aandacht besteedt. Aanvankelijk bleek de Commissie de vereisten van subsidiariteit en noodzakelijkheid te zien als aparte toetsingscriteria, waaraan afzonderlijk moest worden getoetst. Dit blijkt duidelijk uit de definitie van de rechtvaardigingstoets zoals die in veel van de oordelen is terug te vinden:

"Onder een objectieve rechtvaardigingsgrond wordt verstaan dat [...] middelen zijn gekozen die geschikt en noodzakelijk zijn om [het] doel te bereiken, terwijl dit doel niet is te bereiken op andere wijze waarbij geen indirect onderscheid [...] wordt gemaakt." ${ }^{\text {isi }}$

In latere oordelen is dit onderscheid tussen de noodzakelijkheids- en de subsidiariteits. toets vervaagd. Op dit moment wordt volgens de vaste formulering van de rechtvaardigingstoets zelfs uitsluitend nog een noodzakelijkheidstoets uitgevoerd. ${ }^{385}$ Deze verandering in definitie heeft echter niet tot gevolg gehad dat de subsidiariteitstoets volledig uit de oordelen van de Commissie is verdwenen: nog steeds zijn er oordelen te vinden waarin een onderscheid ontoelaatbaar wordt geacht omdat er minder vergaande alternatieven bestonden. ${ }^{386}$ Gesteld kan dan ook eerder worden dat de subsidiariteitstoets tegenwoordig wordt gezien als een instrument bij de beoordeling van noodzakelijkheid,

383. Zie bijv. HR 16 september 1992 (belastingkamer), BNB 1993/21 (Interimregeling ziektekosten ambtenaren en vakantiebonnen), r.o. 3.12., HR 14 juni 1995 (belastingkamer), AB 1995/609 (Gebroken boekjaar), r.o. 3.4.5, HR 10 november 2000, NJ 2001/187 (Komdeur/Eilandgebied Curacao), to. 2.8/2.9 en, vrij impliciet, HR 21 februari 2001 (belastingkamer), BNB 2001/176 (Drempelbedrag aff. trekbaarheid kinderopvang), r.o. 3.4. Zie verder ABRS 10 februari 1997, JB 1997/85 (Parkeerbeleid Leiden), ABRS 4 augustus 1998, AB 1998/377 (Loting geneeskunde; zij het dat de afwijzing van bet alternatief hierin niet echt goed werd gemotiveerd) en CRvB 23 mei 1991, RSV 1991/257 (Overgang AAW naar AWW).

384. Oordeel 94-01 (Ontslag wegens beroep op ouderschapsverlof), r.o. 4.5. Zie ook Oordeel 94-06 (Arbeidstijdvermindering oudere werknemers), Oordeel 94-19 (Doorstroombeleid accountancy-an adviesorganisatie), Oordeel 95-22 (Studie- en beroepskeuzevoorlichting) en Oordeel 95-32 (Junior Systeemontwerper). $\mathrm{Na} 1995$ verdween de formulering een hele tijd uit de oordelen van de Commissic, maar sinds 1998 is deze toch weer terug te vinden: zie Oordeel 98-41 (Pensioenregeling montagelaborante) en Oordeel 00-18 (Partner Kaapverdiaan als bloeddonor). Een verklaring voor deze terugket wordt in deze oordelen niet gegeven, maar is waarschijnlijk gelegen in het feit dat het subsidiariteitsvereiste soms toch waardevol blijkt te zijn.

385. Zie bijv, Oordeel 00-05 (Salarisregeling OK-assistenten), waarin het rechtvaardigingsdeel van de toets als volgt werd geformuleerd: "[...] deze middelen moeten geschikt en noodzakelijk zijn om het gestelde doel te bereiken." De voor de eerdere formule kenmerkende zinsnede dat er "geen andere, minder vergaande middelen mogen hebben bestaan" is hierin weggevallen.

386. Zie bijv. Oordeel 96-56 (Studieverlof bedrijfsartsen), Oordeel 97-114 (Afvloeiingsregeling basis. school), Oordeel 98-137 (Homoseksuele bloeddonoren), Oordeel 99-102 (Dierenparkbezoek op 2005dag), Oordeel 01-53 (Hoofddoek griffier) en Oordeel 01-140 (Pensioenopbouw taalschool). 
dan dat de subsidiariteitstoets zijn belang voor de oordelen van de Commissie volledig heeft verloren.

Bij de beoordeling van de noodzakelijkheid gaat de Commissie, net als de andere onderzochte instanties, in zijn algemeenheid na of er daadwerkelijk behoefte bestond aan het specifiek gemaakte onderscheid. ${ }^{387}$ De benadering van de Commissie onderscheidt zich echter door een grotere mate van zorgvuldigheid: net als bij de beoordeling van geschiktheid houdt de Commissie bij de toetsing van noodzakelijkheid rekening met onderzoek dat op het betrokken terrein is verricht, met verklaringen van getuigedeskundigen en met algemeen bekende feiten en omstandigheden. ${ }^{38 s}$ Voor het overige zijn er nauwelijks toetsingscriteria in de oordelen terug te vinden die voor algemene toepassing bruikbaar zijn: de beoordeling van noodzakelijkheid is bij uitstek feitelijk van aard, zodat de toetsing primair wordt bepaald door de concrete omstandigheden van het geval. Hoogstens zijn in enkele specifieke oordelen elementen zichtbaar die zich lenen voor een ruimere toepassing. Zo blijkt dat een maatregel niet noodzakelijk wordt geacht wanneer het probleem waarop het zich richt zich in de praktijk slechts sporadisch voordoet, of wanneer uit feitelijk onderzoek blijkt dat de maatregel niet consequent of consistent wordt toegepast. ${ }^{3 \times 9}$ Voor inpassing in het algemene toetsingsmodel vatbaar is verder de stelling dat het oordeel over de noodzakelijkheid van een onderscheid in de loop van de tijd kan veranderen, bijvoorbeeld doordat er nieuwe beleidsmatige of wetenschappelijke inzichten ontstaan over de noodzaak om gebruik te maken van bepaalde middelen. ${ }^{30}$ Natuurlijk is een dergelijke ontwikkeling niet altijd even gemakkelijk vast te stellen; deskundigenrapporten of andere onderzoeksgegevens kunnen hierbij uitkomst bieden.

Tenslotte kan er volgens de Commissie twijfel bestaan over de noodzaak van een bepaald onderscheid wanneer de discriminatoire regeling inmiddels is vervangen door

387. Dit criterium is in de oordelen niet expliciet terug te vinden (zie echter Oordeel 98-93 (Pensioenregeling gehuwden met groot leeftijdsverschil), r.o. 4.16), maar uit de toepassing kan worden afgeleid dat dit de uitleg is die de Commissie hieraan geeft; zie bijv. Oordeel 96-81 (Ontslag wegens reorganisatie), Oordeel 96-85 (Hoofddoek en veiligheidsvoorschriften), Oordeel 97-24 (Kledingvereisten Sikh), Oordeel 97-30 (Medewerkster pastorale dienst), Oordeel 97-88 (Vrijwilligers ontwikkelingslanden), Oordeel 97-92 (Ouderschapsverlof benzinestation), Oordeel 97-112 (Termijn vliegbevoegdheid), Oordeel 98-126 (Werktijdenregeling slachterij), Oordeel 99-02 (Pensioenopbouw vervangster basisonderwijs), Oordeel 00-06 (Pensioenopbouw oproepkracht) en Oordeel 00-63 (Chador).

388. Zie bijv. Oordeel 97-149 (Hoofddoek tijdens gymles). Wanneer er onvoldoende gegevens zijn waarop een inhoudelijk oordeel over de noodzakelijkheid kan worden gebaseerd, stelt de Commissie vast dat het onderscheid deze toetsing niet kan doorstaan. Zie bijv. Oordeel 98-132 (Werkindeling psychiatrische inrichting).

389. Zie Oordeel 00-24 (Ureneis ADV bij onderzoeksbureau) en Oordeel 00-63 (Chador); een voorbeeld van inconsistente toepassing is Oordeel 98-07 (Acceptaticbeleid kredietbank). Het criterium van sporadische of inconsistente toepassing komt ook naar voren in de rechtspraak van andere onderzochte instanties: zie bijv. HR 27 maart 1997 (belastingkamer), BNB 1997/186 (Waardering landbouwgrond) en in vergelijkbare zin (zij het niet in het directe kader van een noodzakelijkheidstoets, maar in dat van een algemene redelijkheidstoets) en HR 22 maart 1991, NJ 1994/170 (Amsterdam/lkon II). Dit criterium kan overigens gemakkelijk overlap kan vertonen met het vereiste van actualiteit dat naar voren is

390. Zie bijv. Oordeel 97-144 (Ouderenregeling openbare bibliotheek) en Oordeel 00-63 (Chador). Deze
benadering benadering wordt ondersteund door rechtspraak van de Hoge Raad, zij het dat deze minder expliciet is; vgl. HR 24 april 1992, NJ 1992/689 (Bouma/KLM). 
een andere regeling, waarin het litigieuze onderscheid niet meer wordt gemaakt. Dit blijkt bijvoorbeeld uit een oordeel over de uitsluiting van oproepkrachten van de pensioenvoorziening van een bepaald bedrijf. ${ }^{391} \mathrm{Bij}$ de beoordeling van de noodzaak van deze uitsluiting achtte de Commissie onder andere het volgende van belang:

"De Commissie constateert dat vanaf 1994 de oproepkrachten van de arbeidspool wèl in de pensioenregeling van de wederpartij deelnemen, zodat bovengenoemde verweren van de wederpartij na deze datum blijkbaar niet meer golden." ${ }^{312}$

Dit argument bleek echter niet het enige te zijn dat wees op een gebrek aan noodzakelijkheid: de Commissie wees daarnaast nog op andere factoren, waardoor eveneens twijfel aan de noodzaak werd opgeroepen. Het criterium van vervanging van de be. trokken regeling is ook terug te vinden in de andere stelsels die in het onderzoek betrokken zijn, maar daar wordt er vaak op een minder genuanceerde manier gebruik van gemaakt: het Europees Hof van Justitie leidt een gebrek aan noodzakelijkheid vaak al af uit het enkele feit dat een regeling inmiddels is ingetrokken. ${ }^{3{ }^{31}}$ Een dergelijk automatisme gaat duidelijk te ver, nu er redenen ten grondslag kunnen liggen aan de wijziging of intrekking van een wet die met de noodzaak van het daarin opgenomen onderscheid niets van doen hebben. Reden voor twijfel aan de noodzaak kan eigenlijk alleen bestaan wanneer een wet wordt ingetrokken met het doel het daarin gemaakte onderscheid op te heffen, of wanneer er meteen een nieuwe regeling wordt ingevoerd die op alle punten identiek is, maar waarin de litigieuze classificatie ontbreekt. Ook dan kan echter niet méér worden geoordeeld dan dat het onderscheid op het moment van wijziging of intrekking kennelijk niet meer noodzakelijk was: uit de wetswijziging kan niet worden afgeleid dat het onderscheid al op een eerder moment overbodig was. De benadering van de Commissie laat voor deze nuancering voldoende ruimte, nu zij de aanwezigheid van een nieuwe regeling slechts blijkt te zien als een aanwijzing voor het ontbreken van noodzakelijkheid en hieruit slechts conclusies afleidt voor de direct aan de wijziging voorafgaande periode. In een dergelijke genuanceerde vorm kan het criterium zeker in het algemene toetsingsmodel worden opgenomen.

Zoals eerder is aangegeven is het bij de beoordeling van subsidiariteit nodig dat wordt onderzocht of er bruikbare alternatieven voor het gemaakte onderscheid bestaan die een minder grote belangenaantasting tot gevolg zouden hebben. Dit wordt in het algemeen beschouwd als een lastige toets, omdat hierbij niet alleen moet worden gezocht naar alternatieven, maar ook moet worden beoordeeld of het gebruik daarvan inderdaad tot een minder grote belangenaantasting zou leiden; ook moet worden nagegaan of de alternatieven zelf voldoende geschikt zijn om het gestelde doel te bereiken.

391. Oordeel 00-06 (Pensioenopbouw oproepkracht)

392. Zie ook Oordeel 99-07 (Feestdagenregeling CAO) en Oordeel 01-109 (Woonruimteverdeling Hartlem); in deze gevallen bereikte de Commissie de conclusie dat het onderscheid kennelijk niet geschilk was. Enigszins vergelijkbaar is de situatie waarin een werkgever stelt dat een bepaalde ongelijke bchandeling voor hem noodzakelijk is, terwijl uit de feiten blijkt dat hij gedurende een bepaalde periods een oplossing voor het probleem heeft gevonden waarbij geen onderscheid is gemaakt, zie bijv. Oordeel 98-56 (Deeltijdwerk productmanager).

393. Dit geldt vooral voor het Europese recht; zie nader hoofdstuk 4, paragraaf 2.4.3. 
Met het vinden van minder belastende alternatieven heeft de Commissie in het algemeen weinig moeite. Soms wordt het bestaan hiervan afgeleid uit stellingen van partij$\mathrm{en}^{39}$, in andere gevallen onderzoekt de Commissie ambtshalve of er andere mogelijkheden bestonden ${ }^{395}$ en in een laatste groep van oordelen wordt een toetsing uitgevoerd aan de hand van theoretische, kennelijk door de Commissie zelf bedachte, alternatieven. De laatste methode, die weinig objectief en controleerbaar is, lijkt echter alleen te worden gekozen wanneer het bestaan van deze alternatieven zodanig voor de hand ligt dat nader onderzoek overbodig is. Een voorbeeld hiervan is te vinden in een oordeel met betrekking tot de toelating van senior-onderzoekers tot een onderzoeksschool. ${ }^{396}$ Voor deze toelating was vereist dat de kandidaat tenminste vijf internationale publicaties had uitgebracht, een vereiste dat vooral voor in deeltijd werkende onderzoekers een hoge barrière bleek op te leveren. De Commissie overwoog in het kader van haar subsidiariteitstoets het volgende:

"Wat [...] de kwantitatieve aspecten van de publicatie-eis betreft kan de wederpartij het nagestreefde doel van gewenst publicatiegedrag op andere wijze bereiken, bijvoorbeeld door de termijn waarbinnen die publicaties moeten zijn verricht aan te passen naar evenredigheid van de omvang van het dienstverband. Mogelijk is dat daarbij een bepaalde noodzakelijke ondergrens wat betreft het aantal publicaties wordt aangehouden." ${ }^{397}$

Inderdaad lag dit alternatief voor de hand, zodat het ontbreken van een goede onderbouwing minder ernstig is.

Wordt niet van deze theoretische methode gebruik gemaakt, maar voert de Commissie daadwerkelijk onderzoek uit naar eventuele alternatieven, dan zoekt zij zoveel mogelijk naar objectieve bronnen: gekeken wordt bijvoorbeeld naar oplossingen die andere bedrijven voor hetzelfde probleem hebben gevonden ${ }^{398}$, naar onderzoek dat is verricht door deskundigen ${ }^{399}$ of naar algemene regelingen of CAO's die op het onderwerp betrekking hebben ${ }^{400}$. Deze werkwijze is zeker navolgenswaardig en verdient de voorkeur boven de beschreven "theoretische" methode.

394. Bijv. Oordeel 96-109 (Lengte-eis), Oordeel 97-23 (Bidden op de werkplek), Oordeel 98-132 (Werkindeling psychiatrische inrichting), Oordeel 00-35 (Deeltijdwerkers psychiatrische inrichting) en Oordeel 00-37 (Deeltijdpensioenen). Het kan soms zelfs zo zijn dat de Commissie van de wederpartij eist dat deze aannemelijk maakt dat er geen alternatieven voor het gemaakte onderscheid bestonden. Kan dit niet worden aangetoond, terwijl de Commissie vermoedt dat er wel degelijk altematieven mogelijk waren, dan zal het onderscheid niet noodzakelijk worden geacht. Zie bijv. Oordeel 96-55 (Taalvereiste strijksters) en Oordeel 98-56 (Deeltijdwerk productmanager).

395. Bijv. Oordeel 96-07 (Rpbo), Oordeel 96-56 (Studieverlof bedrijfsartsen), Oordeel 99-102 (Dierenparkbezoek op zondag) en Oordeel 00-05 (Salarisregeling OK-assistenten),

396. Oordeel 96-111 (Publicatievereiste onderzoeksschool)

397. R.0. 4.8. Zie verder Oordeel 96-51 (Pensioenregeling havenbedrijf), Oordeel 96-87 (CAO Thuiszorg), Oordeel 98-04 (Deeltijders in OR), Oordeel 98-126 (Werktijdenregeling slachterij), Oordeel 99-58 (Voordeelkrant supermarkt), Oordeel 99-94 (Overgang CAO indicatieorgaan), Oordeel 00-93 (Assistent Analist Landstrijdkrachten), Oordeel 00-97 (Meerurenvergoeding) en Oordeel 01-53 (Hoofddoek griffier).

398. Of andere afdelingen binnen hetzelfde bedrijf: zie Oordeel 98-132 (Werkindeling psychiatrische inrichting).

399. Zie bijv. Oordeel 98-137 (Homoseksuele bloeddonoren).

400. Bijv. Oordeel 96-07 (Rpbo), Oordeel 96-56 (Studieverlof bedrijfsartsen) en Oordeel 00-05 (Salarisregeling $\mathrm{OK}$-assistenten). 
Wanneer eenmaal is vastgesteld dat er minder belastende alternatieven voor het onder. scheid bestaan gaat de Commissie na of een keuze voor die alternatieven van de we. derpartij verwacht had mogen worden; beoordeeld wordt dan eigenlijk of de alternatie. ven geschikt zijn om het nagestreefde doel te bereiken en of zij praktisch bruikbaar zijn. ${ }^{\text {tai }}$ De wijze waarop de Commissie deze toetsing uitvoert blijkt afhankelijk te zijn van de gekozen toetsingsintensiteit en van de omstandigheden van het geval. In een beperkt aantal gevallen waarin een intensieve toetsing werd uitgevoerd vereiste de Commissie bijvoorbeeld dat de wederpartij aannemelijk maakte dat de keuze voor het alternatief feitelijk onmogelijk was of zou hebben geleid tot onoverkomelijke problemen of onaanvaardbare consequenties. ${ }^{+02}$ Dit is een zware bewijslast, die alleen aanvaardbaar is wanneer er goede redenen bestaan om te twijfelen aan de juistheid van de keuze die door de wederpartij is gemaakt en wanneer er aanleiding bestaat voor het uitvoeren van een strikte toetsing.

Een iets andere benadering wordt gekozen wanneer de toetsing weliswaar terughoudend is, maar dit vooral het geval is omdat door de litigieuze regeling essentiële individuele belangen worden beschermd. Een voorbeeld daarvan is te vinden in een aantal oordelen over bloedbanken die homoseksuelen en andere risicogroepen volledig van het geven van bloed uitsloten om het risico van besmetting van het bloed met het HIV. virus te minimaliseren. ${ }^{403}$ Hoewel in een dergelijk geval meestal wordt volstaan met een marginale toets, werd het in deze zaak niet aan de wederpartij overgelaten om aan te tonen dat de bestaande alternatieven ontoereikend waren: de Commissie bleek bereid te zijn om zelf onderzoek uit te voeren en hierbij zelfs de hulp van deskundigen in te roepen. ${ }^{404}$ Deze benadering is echter uitzonderlijk en wordt vrijwel uitsluitend gehanteerd wanneer een ongelijke behandeling weliswaar de belangen van een groep aantast,

401. In sommige oordelen ontbreekt een dergelijke uitspraak, zonder dat daarvoor duidelijke redenen an te wijzen zijn (hoewel het opvallend is dat het hierbij overwegend om de zaken gaat waarin de Commissie zelf een alternatief bedenkt; wellicht gaat zij er dan van uit dat dit alternatief geschikt is). Zeket wanneer er geen of nauwelijks andere argumenten zijn die het oordeel over de gerechtvaardigdheid ondersteunen is dit geen wenselijke benadering. Zie bijv. Oordeel 96-51 (Pensioenregeling havenbedrijf) Oordeel 96-87 (CAO Thuiszorg), Oordeel 99-58 (Voordeelkrant supermarkt), Oordeel 99-94 (Overgang $\mathrm{CAO}$ indictieorgaan), Oordeel 00-05 (Salarisregeling OK-assistenten) en Oordeel 00-97 (Meeturenvergoeding).

402. Vgl. Oordeel 95-32 (Junior Systeemontwerper), Oordeel 96-32 (Deeltijdwerk leerkrachten basisonderwijs), Oordeel 97-88 (Vrijwilligers ontwikkelingslanden), Oordeel 96-56 (Studieverlof bedrijfsartsen), Oordeel 96-111 (Publicatievereiste onderzoeksschool), Oordeel 97-92 (Ouderschapsverlof bij benzinestation), Oordeel 98-93 (Pensioenregeling gehuwden met groot leeftijdsverschil), Oordeel 98126 (Werktijdenregeling slachterij), Oordeel 00-37 (Deeltijdpensioenen) en Oordeel 00-70 (Alfahulpen). De Commissie voerde voor deze benadering als rechtvaardiging aan dat "om te voorkomen dat de norm van gelijke behandeling van mannen en vrouwen wordt uitgehold, niet al te gemakkelijk mas worden aangenomen dat bepaalde oplossingen niet mogelijk zijn" (Oordeel 98-126 (Werktijdenregeling slachterij), r.o. 4.7). De bewijslast wordt in sommige gevallen nog iets verzwaard doordat vereist wordt dat alternatieven alleen kunnen worden verworpen op grond van knelpunten die zich daadwerkelijk voordoen, hetgeen bijvoorbeeld moet blijken uit onderzoeksgegevens: zie Oordeel 95-32 (Junior Systeemontwerper) en Oordeel 00-70 (Alfahulpen).

403. Zie Oordeel 98-137 (Homoseksuele bloeddonoren) en Oordeel 00-18 (Partner Kaapverdiaan als bloeddonor)). lets vergelijkbaars geldt voor spermadonoren: zie Oordeel 98-139 (Homoseksuele spermadonoren).

404. Zie opnieuw vooral Oordeel 97-137 (Homoseksuele bloeddonoren). 
maar tegelijkertijd bedoeld is om zeer zwaarwegende belangen van derden te bescher-

men.

Wanneer de toetsing tenslotte om enigerlei reden minder intensief is, wordt het meestal aan de verzoeker overgelaten om aannemelijk te maken dat de alternatieven praktisch bruikbaar waren of wordt een oppervlakkige eigen toetsing uitgevoerd. ${ }^{405}$ Ook dit is een redelijke benadering: een beoordeling van subsidiariteit is hierdoor wel mogelijk, maar een (te) actieve rechterlijke opstelling wordt vermeden.

Deze genuanceerde benadering van de Commissie laat zien dat het praktisch mogelijk is om een subsidiariteitstoets uit te voeren en dit te doen op een manier die voldoende aansluit bij de in een bepaald geval meest passende mate van toetsingsintensiteit. Bovendien blijkt uit de oordelen van de Commissie dat er nauwelijks gevaar hoeft te bestaan voor subjectiviteit of overmatig rechterlijk activisme: het aanvoeren en betwisten van geschikte alternatieven wordt meestal aan de partijen overgelaten, zodat het alleen nodig is om ambtshalve onderzoek uit te voeren wanneer de feiten en de intensiteit van de toetsing daartoe aanleiding geven. Het oordeel kan daarbij worden gebaseerd op objectieve onderzoeksgegevens, waardoor het risico voor een subjectief gekleurd rechterlijk oordeel wordt verminderd. Eén en ander impliceert dat het mogelijk is om de subsidiariteitstoets in het algemene toetsingsmodel te verwerken en dat het wenselijk is om hieraan een op de oordelen van de Commissie gebaseerde invulling te geven.

\subsubsection{Proportionaliteit in strikte zin}

\section{Inleiding}

Een belangrijk element van de toetsing van de verhouding tussen doel en middel is tenslotte de beoordeling van de proportionaliteit in strikte zin. Zelfs wanneer is gebleken dat de definitie van de onderscheiden groep zorgvuldig is geformuleerd, dat het onderscheid een geschikt en noodzakelijk middel is om het gestelde doel te bereiken en dat het doel niet met minder vergaande middelen kon worden bereikt, is het immers altijd nog mogelijk dat een onderscheid een zo zware belangenaantasting oplevert dat het toch als ontoelaatbaar moet worden aangemerkt. De proportionaliteitstoets vormt daarmee het sluitstuk van de toetsing van de verhouding tussen doel en middel: aan deze toets zal alleen worden toegekomen als het onderscheid de toetsing aan alle eerdere criteria heeft doorstaan.

Opvallend genoeg blijkt de proportionaliteitstoets in de Nederlandse rechtspraak slechts zelden te worden aangemerkt als afzonderlijk toetsingselement: in de definities van het rechtvaardigingsmodel is deze toets vrijwel nergens expliciet terug te vinden. ${ }^{406}$

405. Zie 0.a. Oordeel 94-06 (Reorganisatieplan universiteit), Oordeel 97-23 (Bidden op de werkplek), Oordeel 98-93 (Pensioenregeling gehuwden met groot leeftijdsverschil), Oordeel 99-22 (Verandering werktijden) en Oordeel 00-90 (Vaccinatieprogramma Hepatitis B). Interessant is ook Oordeel 99-102 (Dierenparkbezoek op zondag), waarin de wederpartij weliswaar moest aantonen dat zijn keuze de beste was, maar de Commissie ook zelf beoordeelde of de door verzoeker aangevoerde alternatieven leidden tot een disproportionele belangenaantasting voor de wederpartij. De keuze voor een bepaald

406. Zie echter HR 24 november 2000, NJ 2001/376 (Landsverordening Toelating en Uitzetting), HR 21 oktober 1992 (belastingkamer), BNB 1993/29 (Belastingvrije som ongehuwden), HR 20 september 1995, BNB 1995/315 (Afvalwater), ABRS 15 januari 1996, AB 1999/185 (Hoger beroep vreemdelin- 
Uit een nauwkeurig onderzoek van de rechtspraak van de verschillende instanties blijkt echter dat de proportionaliteitstoets wel degelijk een rol speelt: er is een aanzienlijk aantal uitspraken waarin een oordeel wordt uitgesproken over het gewicht van de betrokken belangen of over de afweging daarvan. In het hiernavolgende zal op deze uitspraken nader worden ingegaan. Daarbij zal allereerst aandacht worden besteed aan de vaststelling van het gewicht van de betrokken belangen, waarbij het accent zal liggen op enkele factoren die dit gewicht blijken te bepalen. Vervolgens zal worden ingegaan op de mate waarin en de wijze waarop de belangenafweging door de Nederlandse rechter wordt beoordeeld.

\section{Vaststelling van het gewicht van de betrokken belangen}

Om een oordeel te kunnen geven over de redelijkheid van de gemaakte afweging is het noodzakelijk om het relatieve gewicht van de in het geschil betrokken belangen te bepalen. Hoewel dit theoretisch gezien een lastige onderneming lijkt te zijn, blijken de onderzochte rechterlijke instanties hiermee in de praktijk niet bijzonder veel moeite te hebben. Belangrijk is daarbij dat de verschillende instanties zelden proberen om het gewicht van de betrokken belangen exact vast te stellen, hetgeen inderdaad ondoenlijk zou zijn, maar vooral kijken naar enkele in het oog springende kenmerken. Het gewicht van het aangetaste individuele belang blijkt bijvoorbeeld vooral te worden bepaald door de ernst van de belangenaantasting, die op zijn beurt weer wordt bepaald door een aantal specifieke factoren. Zo acht de Commissie Gelijke Behandeling onder andere de duur van de aantasting van belang: is de ongelijke behandeling slechts van korte duur, dan zal de daaruit resulterende belangenaantasting vermoedelijk minder ernstig zjjn dan wanneer de regeling een langdurige benadeling oplevert. ${ }^{407}$ De duur van de belan-

genzaken), CRvB 1 april 1998, RSV 1998/187 (AOW voor gehuwden) en CRvB 4 november 1998, RSV 1998/38 (Wet Van Otterloo); zie bovendien de rechtspraak van de belastingkamer over de "overduidelijke onevenredigheid" in het kader van de vergelijkbaarheidstoets (besproken in paragraaf 2.1.2). De Commissie Gelijke Behandeling maakt in haar oordelen wel vrij regelmatig expliciet melding van het vereiste. Dit gebeurt vooral in de context van voorkeursbeleid (zie bijv. Oordeel 95-35 (Voorkeurs beleid aio's wijsbegeerte) en, voor een recenter voorbeeld, Oordeel 00-65 (Kinderopvangregeling regionale politie)), maar soms ook bij de toetsing van indirect onderscheid of bij direct onderscheid op grond van arbeidsduur (zie Oordeel 95-22 (Studie- en beroepskeuze), Oordeel 96-59 (Jehova's getuigs bij bank), Oordeel 97-24 (Kledingvereiste Sikh), Oordeel 97-131 (Schoolinformatie gescheiden vader), Oordeel 99-78 (CAO Ziekenhuiswezen), Oordeel 00-15 (Taalvereiste glastuinbouw), Oordeel 00-11 (Partner Kaapverdiaan als bloeddonor), Oordeel 00-40 (WTV-opbouw deeltijdwerkers), Oordeel $01-05$ (Winstdeling bij meerwerk), Oordeel 01-16 (Arbeidsvoorwaarden topambtenaren), Oordeel 01-53 (Hoofddoek griffier), Oordeel 01-68 (Stageverlenging advocatuur) en Oordeel 01-91 (Acceptaticbeleic consumentenkrediet; waarin het vereiste werd genoemd als onderdeel van het noodzakelijkheidsver. eiste)). Zoals eerder is aangegeven speelt het vereiste van proportionaliteit in de oordelen van de Commissie soms ook een rol bij de beoordeling van de zwaarwegendheid van het doel; zie voor eet interessante toepassing Oordeel 00-70 (Alfahulpen). Tenslotte wordt het vereiste van proportionalite' soms wel met zoveel woorden genoemd, maar wordt daarmee kennelijk gedoeld op proportionaliteir in ruime zin (dus op de redelijkheid van de verhouding tussen doel en middel in zijn algemeenheid, niled
op de specifieke verhouding tussen aangetast en bescherms belang). Zie bijv. HR 16 februari 2001,JB 2001/106 (Kiesrecht Antillen).

407. Zie bijv. Oordeel 95-22 (Studie- en beroepskeuzevoorlichting), Oordeel 95-35 (Voorkeursbeleid aio ? wijsbegeerte) en Oordeel 00-48 (Ondernemings-CAO voor financieel concern). Deze factor wordt 004 door de belastingkamer en de civiele kamer van de Hoge Raad relevant geacht, zoals blijkt uit HR 2: juni 1995, AB 1995/609 (Gebroken boekjaar) en HR 24 april 1992, NJ 1992/689 (Bouma/KLM). 
genaantasting kan echter zeker niet volledig bepalend worden geacht voor de ernst ervan: ook een eenmalige rechtshandeling (zoals ontslag of het intrekken van een vergunning) kan zwaarwegende gevolgen hebben voor het individu. De Commissie heeft dit erkend en heeft gesteld dat er eveneens sprake zal zijn van een ernstige belangenantasting wanneer de gevolgen van het onderscheid eenmalig, onherroepelijk en onherstelbaar zijn. ${ }^{408}$ Verder is duidelijk dat er van een ernstige belangenaantasting sprake is wanneer het onderscheid tot gevolg heeft dat een bepaalde groep volledig en onvoorwaardelijk wordt uitgesloten van een belangrijk voordeel. ${ }^{400}$

Anderzijds kunnen er factoren worden gevonden die wijzen op een minder zware belangenaantasting..$^{40}$ Eén van die factoren is het bestaan van een hardheidsclausule, waardoor voldoende ruimte ontstaat voor het maken van uitzonderingen in het individuele geval." Verder wordt door de meeste instanties aangenomen dat het bestaan van alternatieven voor de benadeelde of de mogelijkheid van compensatie voor het geleden nadeel betekent dat er sprake is van een minder ernstige belangenaantasting. Een voorbeeld hiervan is te vinden in een oordeel van de Commissie met betrekking tot het afsluiten van mobiele telefoonabonnementen. ${ }^{412} \mathrm{Om}$ het risico te beperken dat de abonnementskosten en telefoon niet op de klant konden worden verhaald, weigerde het betrokken bedrijf abonnementen af te geven aan vreemdelingen die blijkens hun verblijfsdocument slechts één jaar in Nederland mochten verblijven. De Commissie oordeelde in deze zaak het volgende:

408. Zoals bijv. het geval is bij de vaststelling van de ontslagvolgorde bij een reorganisatie: zie Oordeel 99 50 (Zangdocenten), r.0. 4.7.

409. Bijv, Oordeel 96-44 (Kinderopvang VROM), Oordeel 97-35 (Kinderopvangregeling Algemene Rekenkamer) en Oordeel 97-88 (Vrijwilligers ontwikkelingslanden). Daarentegen zal er sprake zijn van een minder ernstige belangenaantasting als de uitsluiting van het voordeel niet volledig is: zie bijv. Oordeel 01-90 (Woonruimteverdelingssysteem). De CRvB heeft gesteld dat hierbij rekening moet worden gehouden met de aard van de groep: wanneer deze zich onderscheidt door een "verdacht" persoonskenmerk, zoals geslacht, dan zal proportionaliteit minder snel aanwezig zijn (CRvB 5 oktober 1989, RSV 1990/132 (Weduwnaarspensioen Wbp 1940-1945)). Deze benadering duidt echter eerder op een verhoogde toetsingsintensiteit dan op het toekennen van meer gewicht aan het aangetaste belang.

410. Naast de hierna te noemen factoren zijn er nog andere factoren te vinden die soms worden gehanteerd om vast te stellen dat er van een minder vergaande belangenaantasting sprake is. Zo stelde de belastingkamer in HR 4 november 1992, BNB 1993/102 (Inkomstentoerekening bij gehuwden) dat er sprake was van een minder ernstige belangenaantasting omdat het nadeel zich slechts in sporadische gevallen voordeed. Deze factor kan echter alleen in het oordeel worden betrokken wanneer er een abstracte proportionaliteitstoets wordt uitgevoerd, waarbij in zijn algemeenheid wordt nagegaan of er sprake is van een redelijke verhouding tussen aangetast en beschermd belang: wanneer wordt uitgegaan van een concrete toets is het niet relevant dat de belangen van het individu slechts sporadisch worden aangetast, nu daarbij uitsluitend moet worden nagegaan of de concrete belangenaantasting redelijk was. Hetzelfde geldt voor het in HR 12 november 1997 (belastingkamer), BNB 1998/22 (Reiskosten als studiekosten) gegeven oordeel dat bij de beoordeling van het gewicht van het aangetaste belang niet gekeken moet worden naar het concreet aangetaste belang, maar naar een soort "gemiddelde" belangenaantasting, d.w.z. naar de belangenaantasting die in het doorsnee-geval door de regeling zal worden veroorzaakt.

411. Zie bijv. Oordeel 96-34 (Positieve discriminatie bij kinderopvang) en Oordeel 01-68 (Stageverlenging advocatur). Interessant is ook Oordeel 00-39 (Overgangsregeling gezondheidszorgpsychologen), waarin de belangenaantasting minder emstig werd geacht omdat de betrokken regeling zodanig was ingericht dat ieder individueel geval afzonderlijk werd beoordeeld en met diverse persoonlijke factoren rekening kon worden gehouden. Vgl, ook Van Male 1988 (II), p. 385

4I2. Oordeel 00-28 (Acceptatievereisten mobiel telefoonabonnement) 
"Daarbij [bij de beoordeling van de redelijkheid, JHG] speelt een rol dat voor deze groepen andere faciliteiten ter beschikking staan om mobiel te kunnen bellen (de zogenoemde prepaid toestellen). De Commissie acht de uitsluiting een geschikt en noodzakelijk middel om het bedrijfsrisico te beperken." 113

Hoewel de betrokken groep vreemdelingen door de regeling werd benadeeld, achtte de Commissie deze benadeling niet zo ernstig: er was een bruikbaar en redelijk altematief voor de gewenste voorziening voorhanden. Deze factor kan worden gezien als een variatie op het in de Amerikaanse rechtspraak ontwikkelde "vermijdbaarheidscriterium", dat inhoudt dat de belangenaantasting minder ernstig is wanneer de benadeling gemak. kelijk is te vermijden. ${ }^{414} \mathrm{Bij}$ de bespreking hiervan in hoofdstuk 5 is echter gesteld dat dit een wat problematisch criterium is, dat slechts in beperkte omstandigheden in het oordeel mag worden betrokken: niet alleen moet vaststaan dat de bestaande alternatie. ven voor het individu voldoende toegankelijk en bruikbaar zijn, maar ook moet duidelijk zijn dat de verwijzing naar deze alternatieven niet zelf een belangenaantasting tot gevolg heeft. ${ }^{415}$ Hoewel het op zichzelf genomen zeker redelijk kan zijn om het bestaan van alternatieven of de vermijdbaarheid van het nadeel een rol te laten spelen bij de proportionaliteitstoets, moet met deze factor dus op een terughoudende en voorzichtige manier worden omgegaan. In Nederland lijkt van een dergelijke zorgvuldigheid wel sprake te zijn, doordat niet zozeer naar de vermijdbaarheid wordt verwezen, maar vooral naar het bestaan van alternatieven of naar een compensatiemogelijkheid; de geciterde overweging van de Commissie verschaft daarvan een goed voorbeeld. In die geval. len bestaat er weinig risico dat iemand door het vermijden van het ene nadeel wordt getroffen door het andere. In deze vorm kan het criterium zeker voor algemene toepassing bruikbaar worden geacht.

Voor de beoordeling van de proportionaliteit is vanzelfsprekend niet alleen het aangetaste belang relevant, maar ook het nagestreefde doel. Op dit punt zijn er in de rechtspraak minder algemene criteria te vinden dan voor het bepalen van de ernst van de belangenaantasting. ${ }^{416}$ Hoogstens hebben de verschillende bestudeerde instanties aanwijzingen gegeven voor het meten van het gewicht van enkele specifieke doelstellingen. Zo hebben alle rechterlijke instanties aangenomen dat puur financiële doelstellin-

413. R.o. 4.10. Zie ook HR 13 januari 1995, NJ 1995/430 (Codfried/ISS), HR 22 december 1995, AB 1996/295 (IBG/Groenhart), HR 8 mei 1998, NJ 1998/496 (Leeftijdsgrens commissarissen), CRvB 20 april 1996, RSV 1996/247 (WW-uitkering), (meer impliciet) CRvB 22 oktober 1999, AB 2000/289 (Persoonsgeboden budget thuiszorg) en Oordeel 97-131 (Schoolinformatie gescheiden vader). Verge lijkbaar hiermee is een oordeel waarin de Commissie een belangenaantasting minder emstig achtt: omdat het nadeel snel kon worden weggewerkt: Oordeel 00-22 (Werkervaring bij dienstverlening ge handicapten).

414. Zie nader hoofdstuk 5, paragraaf 2.4.5.

415. Gewezen is op het voorbeeld waarin gesteld werd dat een onderscheid op grond van nationaliteit riet erg was, aangezien er een mogelijkheid tot naturalisatie bestond. Naturalisatie kan echter voor velet een onaantrekkelijk alternatief vormen, nu daardoor de eigen nationaliteit en daarmee een onderdect van de eigen identiteit wordt aangetast; zie hoofdstuk 5, paragraaf 2.4.5.

416. Hoewel ook hier soms wordt verwezen naar criteria die vergelijkbaar zijn met die voor de vaststelling van het gewicht van het aangetaste belang: zie bijv. Oordeel 97-114 (Afvloeiingsregeling basisschool). waarin een maatregel werd vastgesteld om een tijdelijk problematische situatie op te heffen. Gezien do tijdelijkheid van het probleem achtte de Commissie dit belang niet erg zwaarwegend. 
gen slechts een beperkt gewicht hebben: om op te kunnen wegen tegen de individuele belangen die door het onderscheid worden angetast moet er bij deze doelstellingen ofwel sprake zijn van een ondersteuning of aanvulling door andere, wél zwaarwegende belangen, ofwel van zodanige bijzondere en uitzonderlijke omstandigheden dat het gewicht van de financiële belangen feitelijk wordt vergroot. ${ }^{417}$

Minder eenstemmigheid bestaat er over het gewicht van een tweede doelstelling die vaak wordt aangevoerd: het bevorderen van doelmatigheid, administratief gemak of een goede uitvoerbaarheid van regelgeving. ${ }^{418}$ De Commissie Gelijke Behandeling heeft gesteld dat dergelijke belangen, net als puur financiële belangen, in beginsel minder zwaarwegend moeten worden geacht. ${ }^{419}$ De belastingkamer blijkt daarover anders te denken: in de meeste gevallen ziet hij de uitvoerbaarheid van regelgeving of het belang bij een goede administratie als zwaarwegende belangen, die zonder meer kunnen opwegen tegen de aangetaste individuele belangen. ${ }^{420}$ Het is moeilijk om in abstracto aan te geven welke benadering de beste is: voor administratieve en uitvoeringsbelangen

417. Zie HR 24 april 1992, NJ 1992/689 (Bouma/KLM), HR 14 juni 1995 (belastingkamer), AB 1995/609 (Gebroken boekjaar), ABRS 24 april 1997, JB 1997/149 (Pensioenuitkering KNIL-militairen) en o.a. Oordeel 00-99 (HOS-regeling) en Oordeel 01-44 (35\%-Regeling). Zie impliciet ook HR 17 november 1993 (belastingkamer), BNB 1994/36 (Koffiegeld en studeerkamerkosten). De Centrale Raad blijkt financielle doelstellingen soms wel gerechtvaardigd en voldoende zwaarwegend te achten; zie bijv. CRvB 22 oktober 1999, AB 2000/289 (Persoonsgebonden budget thuiszorg). Verder blijkt de Hoge Raad onderscheid te maken tussen financiêle en economische doelstellingen; de laatste zijn blijkens HR 24 november 2000, NJ 2001/376 (Landsverordening Toelating en Uitzetting) voldoende zwaarwegend. Vgl. ook Van Male 1988 (II), p. 384, Burkens/Kummeling 1991, p. 23, Wentholt 1993, p. 162 en Happé 1999, p. 33/34.

418. Vgl. Van Male 1988 (II), p. 383.

419. Zie vooral Oordeel 01-05 (Winstdeling bij meerwerk); zie verder Oordeel 96-71 (Rpbo), Oordeel 99 02 (Pensioenopbouw vervangster basisonderwijs) en impliciet Oordeel 00-06 (Pensioenopbouw oproepkracht). Zie ook (bij uitvoering gemeenschapsrecht!) CRvB 12 augustus 1999, RSV 2000/73 (Inkomensvereiste thuiswerkers) en CRvB 21 september 2000, JB 2000/313 (Scholierenregeling). Uitzonderingen zijn ook bij de Commissie mogelijk: wanneer de uitvoeringsproblemen heel groot zijn zullen zij toch als zwaarwegend worden beschouwd; zie Oordeel 00-37 (Deeltijdpensioenen).

420. Zie (naast vele andere uitspraken waarin de proportionaliteitstoets in het geheel niet aan de orde komt) HR 23 oktober 1985 (belastingkamer), BNB 1986/158 (Fooien taxichauffeurs), HR 12 november 1997 (belastingkamer), BNB 1998/22 (Reiskosten als studiekosten) en HR 6 december 2000 (belastingkamer), BNB 2001/144 (Uitwonende/thuiswonende studenten). Zie nader Van Leijenhorst 1997, p. 1119/1120, die er op wijst dat doelmatigheid niet altijd een voldoende rechtvaardiging vormt: in het concrete geval moet steeds een afweging plaatsvinden tegen het individueel geraakte belang (vgl. ook zijn kritische noot bij HR 14 februari 2001 (belastingkamer), BNB 2001/134 (Toeristenbelasting Waterland)); zie in die zin ook Simon in zijn noot bij HR 17 augustus 1998 (belastingkamer), JB 1998/196 (Grijs kenteken). Voorbeelden waarin van een dergelijke concrete belangenafweging sprake was zijn HR 12 november 1997, BNB 1998/22 (Reiskosten als studiekosten) en HR 15 juli 1998, BNB 1998/293 (Autokostenforfait), Ook voor de civiele kamer geldt dat hij administratieve doelstellingen meestal zwaar laat wegen: zo blijkt uit HR 26 maart 1999, NJ 1999/446 (Erfpachters Den Haag) dat capaciteitsproblemen bij het bestuursorgaan een voldoende zwaarwegend belang kunnen vormen; van belang voor dit oordeel zal echter ook zijn geweest dat tegenover dit doel geen bijzonder zwaarwegende individuele belangen stonden. Zie verder HR 8 oktober 1980, NJ 1981/308 (Kiesregister), waarin het belang bij een goed verloop van de verkiezingen zeer zwaarwegend werd geacht. Voorbeelden waarin de rechter groot gewicht toekende aan administratieve belangen zijn tenslotte terug te vinden in ABRS 9 december 1997, JB 1998/10 (Pensioenuitkering weduwe KNIL-militair), ABRS 4 augustus 1998, AB 1998/377 (Loting geneeskundestudenten), CRvB 23 februari 1999, RSV 1999/119 (Aanvangsdatum fictief arbeidsverleden) en CRvB 29 november 2000, RSV 2001/54 (Zigeunerhuwelijk). 
geldt bij uitstek dat het gewicht sterk afhankelijk is van de omstandigheden van het geval, zoals het betrokken beleidsveld.

Verder wordt vrij vaak gesteld dat een regeling bedoeld is om de belangen van derden te beschermen. ${ }^{421}$ In het algemeen blijken de bestudeerde rechterlijke instanties geneigd te zijn om dergelijke belangen hoog te waarderen, maar ook hiervoor geldt dat het concrete gewicht in sterke mate wordt bepaald door de specifieke omstandigheden van het geval.

Tenslotte doet het bestuursorgaan regelmatig een beroep op het legaliteitsbeginsel, vooral in zaken waarin het honoreren van een beroep op het gelijkheidsbeginsel zou leiden tot een verplichting tot contra legem-handelen. ${ }^{42}$ Dit beginsel wordt door alle bestudeerde rechters van groot belang geacht $\mathrm{t}^{123}$, maar het precieze gewicht dat hieraan wordt toegekend blijkt sterk te verschillen. De Afdeling Bestuursrechtspraak heef bijvoorbeeld aangegeven het legaliteitsbeginsel van zodanig essentieel belang te achten dat de door de ongelijke behandeling aangetaste belangen hiertegen nooit kunnen opwegen ${ }^{424}$, terwijl de belastingkamer van de Hoge Raad heeft aangenomen dat een afweging van het legaliteitsbeginsel tegen het gelijkheidsbeginsel soms ook kan uitvallen in het voordeel van de belangen van het individu: het legaliteitsbeginsel weegt weliswar zwaar, maar dit wil volgens de belastingkamer nog niet zeggen dat het altijd moet prevaleren boven rechtsgelijkheid ${ }^{425}$. Ook de civiele kamer van de Hoge Raad en de Centrale Raad van Beroep hanteren een genuanceerde benadering: hoewel deze instanties

421. Waarbij dit soms in nogal abstracte zin gebeurt, bijvoorbeeld door de stelling dat een regeling dient on de rechtszekerheid te dienen of om een andere ongelijke behandeling te voorkomen. Zie bijv. Oorded 97-04 (Inschaling stewardessen; rechtszekerheid, overigens niet in de context van een echte proportio naliteitstoets), Oordeel 97-35 (Kinderopvangregeling Algemene Rekenkamer; rechtszekerheid), Oordeel 97-81 (Melkert II-regeling; voorkomen ongelijke behandeling), Oordeel 00-06 (Pensioenopbour oproepkracht; rechtszekerheid) en Oordeel 00-48 (Ondernemings-CAO voor financieel concern; voos: komen ongelijke behandeling). Zie in dezelfde zin HR 31 december 1993, NJ 1994/436 (Van den Berge/Verenigde Bootlieden; voorkomen ernstigere ongelijke behandeling) en HR 20 januari 1995, N 1995/326 (Verjaringstermijn vaderschapsactie; bescherming rechtszekerheid). Concreter zijn de zike waarin rechtstreeks verwezen wordt naar de belangen van derden: zie Oordeel 97-30 (Medewerkste pastorale dienst; belangen van patiěnten), Oordeel 98-137 (Homoseksuele bloeddonoren; bescherming ontvangers van bloed tegen HIV, overigens vooral in de context van een subsidiariteitstoets), Oordet 00-04 (IVF-instellingen; bescherming belangen van het kind) en Oordeel 00-36 (Iraans accent peuterleidster; optimale ontwikkeling peuters).

422. Dit beginsel beschermt in zichzelf een aantal essentiěle rechtsstatelijke belangen, zoals rechtszekeheid, voorspelbaarheid van regelgeving, democratische legitimatie van inbreuken op de individuet vrijheid en (wanneer het maken van een algemene regel beschouwd wordt als een garantie voor gelijk behandeling van een bepaalde groep gevallen of personen) rechtsgelijkheid. Vgl. Klap 1994, p. 32:35 en Gribnau 2001, p. 11.

423. Althans die rechters die met beroepen op het legaliteitsbeginsel zijn geconfronteerd: voor de Commin sie geldt dat zij zich nooit uitdrukkelijk uit heeft hoeven spreken over het gewicht van dit beginsh. noch over de afweging daarvan tegen het gelijkheidsbeginsel.

424. Vgl. ABRS 15 september 2000, AB 2001/154 (Kapvergunning Medemblik); zie nader Addink 1999, 163 en Geppaart 1983, p. 12. Overigens wordt deze beperking van de werking van het gelijkheidsber ginsel in sommige gevallen omzeild met de stelling dat weliswaar het gelijkheidsbeginsel niet is " schonden, maar dat er wel sprake is van willekeur. Zie voor een ouder voorbeeld ARRS 6 november 1984, AB 1985/417 (Verhuis- en herinrichtingskostenvergoeding).

425. Zie vooral HR 6 juni 1979 (belastingkamer), BNB 1979/211 (Buitengewone lasten pensionprijs), recenter voorbeeld van toepassing van deze voorrangsregels is HR 22 maart 2000, BNB 2000/173 (b th ridisch eigendom zonder economisch belang). Zie nader Happé 1988, p. 1256 en Happé 1993, p. 146. 
hebben aangegeven het legaliteitsbeginsel van groot belang te achten, zijn zij blijkens hun rechtspraak van mening dat de omstandigheden zodanig kunnen zijn dat het individuele belang toch zwaarder moet wegen. ${ }^{426}$

Inderdaad lijkt het redelijk om ruimte te laten voor een concrete afweging van het gelijkheidsbeginsel tegen het legaliteitsbeginsel: het is duidelijk dat een strikte wetstoepassing in bepaalde gevallen tot zodanig onredelijke gevolgen kan leiden dat deze onaanvaardbaar moet worden geacht. Zolang dit uitgangspunt maar wordt gehanteerd kan het vervolgens aan de betrokken rechterlijke instantie worden overgelaten welke benadering hij kiest: hij kan ervoor kiezen de toetsing van de afweging voorafgaand in te kaderen door het vaststellen van bepaalde voorrangsregels (zolang deze althans voldoende ruimte laten om rekening te houden met concrete omstandigheden van het ge-

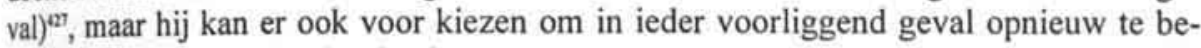
palen welk van beide beginselen het zwaarste weegt.

\section{De afweging van belangen}

Nadat het relatieve gewicht van de verschillende belangen is vastgesteld kan de rechter beoordelen of de verwerende partij deze belangen op een redelijke manier tegen elkaar heeft afgewogen. Voor rechters is dit een lastige beoordeling: de belangenafweging is het centrale punt van de besluitvorming, zodat de rechter door een eigen oordeel hierover al snel in de beleidsvrijheid van wetgever, bestuur of particulier treedt. ${ }^{428}$ Waarschijnlijk kan hierin een verklaring worden gevonden voor het feit dat een daadwerkelijke beoordeling van de belangenafweging in de bestudeerde uitspraken slechts sporadisch is terug te vinden. ${ }^{42}$ In veruit de meeste gevallen volstaan de rechters met de vaststelling dat er een bepaald belang is aangetast of dat er met het onderscheid juist een (gewichtig) algemeen belang gediend wordt: de andere belangen die in de zaak betrokken zijn worden meestal onvermeld gelaten. Kenmerkend is een overweging als de volgende, afkomstig uit een uitspraak van de Afdeling Bestuursrechtspraak:

"De uitsluiting van hoger beroep in procedures op grond van de Vreemdelingenwet is gemotiveerd met een beroep op de noodzaak zo spoedig mogelijk tot een eindbeslissing te komen. De wetgever heeft zich naar het oordeel van de Afdeling op het standpunt kunnen stellen dat die noodzaak in verband staat met een - blijkbaar ongewenste - inburgering van vreemdelingen die geen aanspraak op een verblijfstitel hebben. Het uitsluiten dat wel nietinvoeren, van hoger beroep dienst aldus een redelijk doel. Van onevenredigheid tussen dat doel en het middel (het niet-invoeren van hoger beroep) is geen sprake." ${ }^{\text {1.10 }}$

426. Zie bijv. HR 15 juli 1988, NJ 1989/714 (Deltaschade) en CRvB 11 juni 1981, AB 1981/458 (Salarisindeling artsen). Vgl. Van Wijk/Konijnenbelt 1999, p. 407/408. Zie ook de voetnoten bij paragraaf 1.1.6.

427. Een dergelijke benadering wordt bijv. gehanteerd door de belastingkamer; zie nader paragraaf 2.1 .2

428. Vgl. Klap 1996, p. 244.

429. Zelfs wanneer de rechter uitdrukkelijk stelt dat er een proportionaliteitstoets moet worden uitgevoerd ontbreekt een beoordeling van het gewicht van de betrokken belangen én van de gemaakte belangenafweging soms volledig: HR 21 oktober 1992 (belastingkamer), BNB 1993/29 (Belastingvrije som voor alleenstaanden).

430. ABRS 15 januari 1996, AB 1999/185 (Hoger beroep vreemdelingenzaken); zie ook ABRS 1 juni 1999, AB 1999/313 (Zeilschool; idem). Soms ontbreekt bovendien iedere inhoudelijke motivering voor het oordeel over proportionaliteit, terwijl het vereiste wel met zoveel woorden wordt genoemd; zie bijv. CRvB 1 april 1998, RSV 1998/187 (AOW voor gehuwden) en CRvB 4 november 1998, RSV 1998/38 (Wet Van Otterloo). 
In deze overweging wordt uitsluitend melding gemaakt van het door de regeling ge. diende belang: het individuele belang dat hierdoor werd aangetast wordt niet nader genoemd. Toch stelt de Afdeling vast dat er sprake is van evenredigheid, een oordeel dat voor de lezer moeilijk controleerbaar is.

Ook een andere benadering wordt gehanteerd: soms worden de verschillende betrokken belangen en het relatieve gewicht daarvan vastgesteld, waarna vervolgens zonder veel omhaal wordt geconcludeerd dat de verwerende partij redelijkerwijze kon menen dat het gediende belang zwaarder woog dan het aangetaste belang. Deze benadering kan worden geillustreerd aan de hand van de volgende overweging uit een arrest van de civiele kamer van de Hoge Raad over een ongelijke behandeling van aandeelhouders:

"[...] de bijzondere, in [...] 's hofs arrest geschetste omstandigheden - met name de omstandigheid [...] dat het ging om het opheffen van voor vier aandeelhouders nadelige fiscale ongelijkheid, door maatregelen welke voor de andere aandeelhouders slechts een relatief geringe daling van hun belang meebrachten - vormen een zodanige [redelijke en objectieve] rechtvaardiging."

In dit geval werd een volledige proportionaliteitstoets uitgevoerd, waarbij het relatieve gewicht van de belangen werd vastgesteld en een (impliciet) oordeel werd uitgesproken over de redelijkheid van de daartussen bestaande afweging. De toets is echter minimaal gemotiveerd en kenmerkt zich door een grote mate van terughoudendheid.

Het aantal gevallen waarin de rechter tot de conclusie komt dat de verwerende partij een verkeerde afweging heeft gemaakt is minimaal. Dit is ook niet anders te verwachten, omdat een duidelijk disproportioneel onderscheid in het algemeen de toetsing aan de andere vereisten van het rechtvaardigingsmodel, zoals die van het gerechtvaardigd doel of van noodzakelijkheid, al niet zal doorstaan. Bovendien blijken de onderzochte Nederlandse instanties in de meeste gevallen een terughoudende toetsing uit te voeren: het ligt daarbij voor de hand dat de conclusie van disproportionaliteit slechts in evidente gevallen van onredelijkheid zal worden bereikt. ${ }^{42}$ Wanneer een intensievere toets wordt uitgevoerd blijkt deze situatie iets anders te liggen. Vooral de Commissie Gelijke Behandeling, die een vrij strikte toets als uitgangspunt heeft genomen, komt vrij regelmatig tot de conclusie dat een voldoende mate van proportionaliteit ontbreekt." Deze conclusie wordt met name bereikt wanneer de nagestreefde doelstellingen niet echt

431. HR 31 december 1993, NJ 1994/436 (Van den Berge/Verenigde Bootlieden, r.o. 4.2.2, sub 3); cen vergelijkbare benadering is terug te vinden in HR 23 oktober 1985 (belastingkamer), BNB 19861158 (Fooien taxichauffeurs). Zie impliciet en in het kader van een toetsing van de mate van fit ook CRvB 26 november 1999, RSV 2000/50 (Verlaging eigen bijdrage zwakzinnigen). Soms blijkt de rechter ook rekening te houden met andere dan de direct betrokken belangen. Zo bleek in HR 29 april 1994, NJ 1994/625 (Alimentatie bij homofiele concubinaatsverhouding) dat de Hoge Raad bij de belangenafueging doorslaggevend achtte dat een gelijkstelling zoals door de eisende partij werd verlangd voor hem feitelijk nog negatievere consequenties zou hebben dan het directe nadeel dat uit de ongelijke behandeling voortvloeide.

432. Daarvan was bijvoorbeeld sprake in HR 20 september 1995 (belastingkamer), BNB 1995/315 (Afvalwater). Zie over de rechterlijke terughoudendheid en de factoren die daarbij een rol spelen nader parngraaf 3.

433. Zie bijv. Oordeel 96-59 (Jehova's getuige als bankmedewerkster), Oordeel 97-106 (Leeftijdsgrenten NWO), Oordeel 97-110 (Praktijkproef stukadoorsbedrijf) en Oordeel 99-50 (Zangdocenten). Zic overgens ook CRvB 24 december 1996, JB 1997/30 (Premieplicht Leergang Bedrijfskunde). 
zwaarwegend zijn, zoals in het geval waarin deze puur financieel of administratief van aard zijn. Overigens stelt de Commissie in dergelijke gevallen meestal niet dat er sprake is van disproportionaliteit, maar oordeelt het dat het onderscheid niet noodzakelijk is. ${ }^{\text {B4 }}$ Dit impliceert een onzuivere toepassing van de noodzakelijkheidstoets: in dit soort gevallen zal vaak wel duidelijk zijn dat de doelstellingen zonder het gemaakte onderscheid niet konden worden bereikt, maar is het probleem vooral dat deze doelstellingen niet opwegen tegen de door het onderscheid veroorzaakte belangenaantasting.

Uit het voorgaande kan worden afgeleid dat de proportionaliteitstoets, hoewel deze zelden met zoveel woorden wordt genoemd, een vrij belangrijke rol speelt in de $\mathrm{Ne}$ derlandse rechtspraak. Bovendien blijkt uit de bestudeerde rechtspraak dat de problemen die zijn verbonden aan de rechterlijke beoordeling van proportionaliteit niet onoverkomelijk zijn. Zo is duidelijk dat er voldoende factoren bestaan aan de hand waarvan het relatieve gewicht van de betrokken belangen kan worden vastgesteld en blijkt de toetsing van de belangenafweging nauwelijks praktische problemen op te leveren: door goed gebruik te maken van de mogelijkheden van de marginale toetsing kunnen rechterlijke inbreuken op de beleidsvrijheid van de verwerende partij gemakkelijk worden voorkomen. Op grond van deze rechtspraak kan dan ook worden gesteld dat het vereiste van proportionaliteit in strikte zin niet uit het algemene toetsingsmodel hoeft te worden weggelaten.

\section{Toetsingsintentensiteit}

\subsection{Variatie in de toetsingsintensiteit in Nederland}

Net als in de hiervoor besproken rechtsstelsels blijkt ook in Nederland enige variatie in de toetsingsintensiteit mogelijk te zijn: in de rechtspraak van vrijwel alle bestudeerde rechterlijke instanties zijn overwegingen terug te vinden waaruit blijkt dat in een voorgelegd geval een toetsing wordt uitgevoerd die strikter of juist terughoudender is dan gebruikelijk. ${ }^{43}$ Het uitgangspunt van de meeste rechterlijke instanties is een tamelijk terughoudende toetsing, waarbij de discretie van wetgever of bestuur zoveel mogelijk wordt gerespecteerd. Deze toetsing kenmerkt zich door het feit dat de rechter zich weinig actief opstelt en zich bij zijn oordeelsvorming vooral baseert op de stellingen van

434. Ook in de definitie van de rechtvaardigingstoets worden noodzakelijkheid en proportionaliteit soms gelijkgesteld; zie bijv. Oordeel 98-04 (Deeltijders in OR) en Oordeel 98-96 (Seniorenregeling CAO NOB).

435. In de rechtspraak van de civiele en de belastingkamer van de Hoge Raad ontbreekt een uitdrukkelijke overweging waaruit blijkt dat variatie in de toetsingsintensiteit mogelijk is. Hoogstens is in de rechtspraak van de strafkamer een uitspraak te vinden waaruit blijkt dat er variatie mogelijk is tussen een "volledige" toetsing en een "marginale" toetsing: zie HR 13 januari 1998 (strafkamer), NJ 1998/407 (Gedoogbeleid Delfzijl); op dit onderscheid in begrippen zal in paragraaf 3.2.2 nader worden ingegaan. Ook is een variatiemogelijkheid in de toetsingsintensiteit expliciet erkend in de rechtspraak van de Centrale Raad van Beroep: zie CRvB 4 november 1993, AB 1993/213 (Van Maarseveen). Vgl. verder CRvB 16 januari 1998, RSV 1998/160 (Inkomensvereiste AAW) en CRvB 4 november 1998, RSV 1999/38 (Wet Van Otterloo). 
partijen en de gegevens die zij hebben overgelegd. Het komt hierbij regelmatig voor dat er een oppervlakkige vergelijkbaarheidstoets wordt uitgevoerd of dat in zijn algemeenheid wordt nagegaan of er sprake is van een redelijke verhouding tussen doel en onderscheid, zonder dat nader wordt onderscheiden tussen verschillende toetsingscriteria. ${ }^{436}$ Niet alle bestudeerde instanties nemen echter een terughoudende toetsing tot uitgangspunt: de oordelen van de Commissie Gelijke Behandeling vormen hierop een uitzondering. De "basisintensiteit" van de Commissie is tamelijk intensief, zoals blijkt uit het feit dat zij in vrijwel alle oordelen een zorgvuldige en uitgebreide toetsing van de aangedragen rechtvaardiging uitvoert. ${ }^{437}$ Van belang daarbij is dat de Commissie vrijwel steeds bereid blijkt te zijn tot het uitvoeren van een subsidiariteitstoets en een inhoudelijke toetsing van het doel, terwijl deze toetsen - vanwege de rechterlijke activiteit die zij vergen - bij een terughoudende toetsing meestal achterwege worden gela. ten. ${ }^{438}$

Beide uitgangspunten, zowel die van terughoudendheid als die van intensiteit, blijken in bepaalde omstandigheden te worden verlaten. In een groot aantal gevallen, vooral bij de toetsing van bestuurshandelen en bij de beoordeling van belastingwetgeving of wetgeving op het terrein van de sociale zekerheid, wordt een werkelijk marginale toetsing uitgevoerd, die nog terughoudender is dan gebruikelijk. ${ }^{49}$ Deze marginale toetsing

436. Zie bijv. HR 22 december 1995, AB 1996/295 (IBG/Groenhart): hierin voerde de Hoge Raad cent redelijkheidstoets uit die werd aangevuld met een oppervlakkig onderzoek naar de gerechtvaardigdheid van de gronden en van de belangenaantasting. Hetzelfde geldt voor HR 14 april 1989, NJ 19901412 (Bijstandsverhaal), HR 13 januari 1995, NJ 1995/430 (Codfried/1SS) en HR 24 november 2000, N 2001/376 (Landsverordening Toelating en Uitzetting). Ook de belastingkamer kiest een dergelijke ts rughoudende toetsing, waarbij toch de nodige zorgvuldigheid wordt betracht, tot uitgangspunt. Zis bijv. HR 27 september 1989 (belastingkamer), NJ 1990/449 (Samentelling inkomens gehuwden), HR 19 mei 1993 (belastingkamer), BNB 1993/24I (Successiebelasting ongehuwden), HR 14 juni 1995 (belastingkamer), AB 1995/609 (Gebroken boekjaar), HR 15 juli 1998 (belastingkamer), BNB 1998/293 (Autokostenforfait; uit dit arrest blijkt overigens dat ook een terughoudende toetsing soms tot ontoelaatbaarverklaring van het onderscheid kan leiden. Zoals uit de noot van Wattel bij dit arrest blijkt kan daardoor de vraag rijzen of hier van een "gewone" terughoudende toetsing sprake is, of eerder van een iets verhoogde toetsingsintensiteit), HR 19 april 2000 (belastingkamer), BNB 2000/192 (Renterii). stelling werknemersspaarregelingen) en HR 28 februari 2001 (belastingkamer), BNB 2001/169 (Alleenstaande ouder-aftrek). Ook de Afdeling hanteert dit uitgangspunt, hoewel het onderscheid tussen een gewone terughoudende toetsing en een zeer marginale toetsing in haar rechtspraak niet duidelijk is te herkennen. Typische voorbeelden van de benadering van de Afdeling zijn ABRS 2 juni 1994, AB 1994/629 (Ligplaatsverordening Friesland), ABRS 26 mei 1994, AB 1995/179 (Medewerkersovereenkomst AWBZ), ABRS 15 januari 1996, AB 1999/185 (Hoger beroep in vreemdelingenzaken) th ABRS 18 januari 2000, JB 2000/53 (Koffieshops Leiden). Zie verder de rechtspraak van de Centrale Raad, bijv, CRvB 12 augustus 1999, RSV 2000/73 (Inkomensvereiste thuiswerkers).

437. Zie bovendien Oordeel 96-06 (Bootpas Terschelling), waarin de Commissie de door haar gehanteede vereisten zelf als "strikt" aanmerkte (r.o. 4.9, laatste alinea), en enkele oordelen van de oude CGB miv, waarin werd gesteld dat het bestaan van een objectieve rechtvaardiging "niet te lichtvaardig mag worden aangenomen": Oordeel 3068-89-1 (Verbreking samenwerkingsrelatie fysiotherapeuten), Oordet 429-93-06 (Netto-uurloon uitzendkrachten) en Oordeel 667-94-05 (Minimum dienstverband reisorg:nisatie); vgl. ook Oordeel 01-140 (Pensioenopbouw taalschool).

438. Vgl. Oordeel 01-140 (Pensioenopbouw taalschool).

439. Zelfs de Commissie blijkt soms bereid haar toetsing enigszins af te zwakken: zie (impliciet) Oordect 00-39 (Overgangsregeling gezondheidszorgpsychologen). Dit gebeurt soms ook wanneer een mani wordt benadeeld door een onderscheid dat normaal gesproken overwegend vrouwen treft (zic Oordect 96-36 (Kinderoppas)) en bij onderscheid in functie-eisen voor een bepaald bedrijf (zie bijv. Oorjet 
impliceert een soort willekeurstoets, waarbij slechts wordt nagegaan of de wetgever of het bevoegde bestuursorgaan in redelijkheid tot het gemaakte onderscheid kon komen of waarbij alleen wordt beoordeeld of er duidelijk sprake is van strijd met een hogere regeling. ${ }^{+0}$ Enkele karakteristieken van deze marginale toetsing blijken uit de volgende overweging van de Centrale Raad:

"[...] wanneer het gaat om rechtspositionele regelingen terzake van bijv. financiële en andere aanspraken en faciliteiten, welke aan de ene categorie van personen wel en aan de andere niet worden toegekend en waarbij de meest uiteenlopende beleidsnormen en -doelen als onderscheidend criterium worden gehanteerd, de genoemde objectieve en redelijke gronden reeds aanwezig geacht worden wanneer sprake is van beleidskeuzen waarvan met een nog marginalere toetsing dan gebruikelijk kan worden gezegd dat ze binnen redelijkheidsgrenzen liggen. Daarbij ligt het ook in de rede [...] in meerdere mate van de ambtenaar [dat wil zeggen degene die over het onderscheid klaagt, JGH] te vergen de aanwezigheid van discriminatie dus de afwezigheid van redelijke en objectieve gronden hard te maken $[\ldots]$...4t

96-75 (Taalvereiste administratief werk) en Oordeel 96-118 (Christelijke identiteit keukenhulp)). Vgl. over de mogelijkheid verschil te maken tussen een terughoudende en een werkelijk marginale toetsing nader Van Wijk/Konijnenbelt 1999, p. 383.

440. Zie voor de begripsbepaling ook De Lange 1991, p. 46/47. Zie verder HR 10 november 2000, NJ 2001/187 (Komdeur/Eilandgebied Curaçao) en HR 30 maart 2001, NJ 2001/292 (Stichting Pensioenfonds Medisch Specialisten/V): in beide gevallen volstond de Hoge Raad met een redelijkheidstoets en werd niet nader verwezen naar elementen als de gerechtvaardigdheid van het doel of de proportionaliteit. In HR 13 november 1992, NJ 1993/502 (EI Hammouti/Staat) werd een oppervlakkige vergelijkbaarheidstoets uitgevoerd en werd gesteld dat er bij de in het geding zijnde maatregel geen sprake was van een "willekeurige" maatstaf. Ook de strafkamer heeft aangegeven dat in gevallen van grote beleidsvrijheid voor het OM uitsluitend sprake kan zijn van een "uiterst marginale toetsing": HR 20 oktober 1987 (strafkamer), NJ 1988/473 (Ongelijke behandeling bij vervolging) en HR 2I juni 1988 (strafkamer), NJ 1988/1021 (Folderverspreiding Centrumpartij). Uit HR 13 januari 1998, NJ 1998/407 (Gedoogbeleid Delfzijl) blijkt echter dat de rechter zich ten volle bevoegd acht om de vervolgingsbeslissing te toetsen aan het recht en aan beginselen van een behoorlijke procesorde. Het gaat dan echter om de toetsing van de legaliteit van de beslissing, niet om de beoordeling van de redelijkheid daarvan (dat wil zeggen de vraag of het nuttig of wenselijk was om tot vervolging over te gaan). Ten aanzien van dit laatste aspect is een grote mate van beleidsvrijheid aanwezig en moet een terughoudende toetsing worden uitgevoerd. Zie hierover nader paragraaf 3.2.2. De belastingkamer maakt in zijn rechtspraak niet expliciet melding van een toetsing die terughoudender is dan gebruikelijk. Voorbeelden hiervan zijn echter toch wel te vinden: enkele zaken kenmerken zich door een zeer summiere motivering waarin het verweer van de Staatssecretaris volledig wordt overgenomen en gebruik wordt gemaakt van voor de wederpartij gunstige veronderstellingen over overwegingen van de wetgever: zie bijv. HR 8 februari 1995 (belastingkamer), BNB 1995/83 (Aftrekbaarheid studiekosten en studiefinanciering), HR 15 juli 1997 (belastingkamer), BNB 1997/325 (Studeerkamer en AOW-uitkering), HR 23 juni 1999, BNB 1999/292 (Autokostenfictie) en HR 6 december 2000 (belastingkamer), BNB 2001/144 (Uitwonende/thuiswonende studenten). Zoals in noot 436 al is aangegeven is het verschil tussen een zeer marginale en de gebruikelijke terughoudende toets bij de rechtspraak van de Afdeling minder goed zichtbaar; uit haar rechtspraak blijkt dat zij meer in het algemeen een zeer terughoudende toets uitvoert. Zie verder ook de rechtspraak van de Centrale Raad van Beroep: CRvB 15 mei 1996, RSV 1996/170 (Posthuma-Van Damme), waarin de Raad stelde dat bij wetten in formele zin alleen kan worden getoetst op verenigbaarheid van de wet met rechtsnormen van supranationale of internationale aard. Op zichzelf zegt dit nog niet zoveel, omdat ook artikel 26 IVBPR een bepaling van internationale aard is. Het is echter duidelijk dat de Centrale Raad hiermee aangeeft bij doelmatigheidsaspecten een terughoudende toetsing uit te zullen voeren.

441. CRvB 4 november 1993, AB 1994/213 (Van Maarseveen); zie in dezelfde zin CRvB 22 oktober 1999. AB 2000/289 (Persoonsgebonden budget thuiszorg) en CRvB 26 november 1999, RSV 2000/50 (Ver- 
Alleen in zeer evidente gevallen van onredelijkheid, willekeur of misbruik van bevoegdheid zal een dergelijke toetsing leiden tot een ontoelaatbaarverklaring van de ongelijke behandeling. Voorbeelden van een geslaagd beroep op het gelijkheidsbeginsel zijn bij toepassing van deze marginale toets dan ook schaars. ${ }^{42}$

Ook de intensieve toets van de Commissie blijkt soms te worden afgezwakt, maar deze toetsing is dan niet echt als marginaal aan te duiden. De afzwakking betekent eerder dat een toetsing wordt uitgevoerd die met de normale, terughoudende toetsing van de andere instanties te vergelijken is. Ook in deze gevallen geldt echter dat de beoordeling steeds vrij nauwkeurig blijft en dat aan alle criteria van het model, zij het op terughoudende wijze, wordt getoetst. ${ }^{43}$ Dit is vanuit een oogpunt van zorgvuldigheid en controleerbaarheid zonder meer een wenselijke benadering.

Tenslotte blijkt in een beperkt aantal gevallen de terughoudendheid plaats te maken voor een intensievere toets. ${ }^{4+4}$ De verhoogde intensiteit van de toetsing komt dan vooral tot uitdrukking in een zorgvuldigere beoordeling van de gerechtvaardigdheid van het doel en een scherpere toetsing van de door wetgever of bestuursorgaan gemaakte belangenafweging. ${ }^{45}$ De Centrale Raad heeft daarnaast aangegeven dat hij in dit soort gevallen hogere eisen zal stellen aan de motivering van het onderscheid, hetgeen betekent dat de aangevoerde argumenten een grote overtuigingskracht zullen moeten hebben om als rechtvaardiging te kunnen dienen. Ook heeft de Centrale Raad gesteld dat de bewijslast van de wederpartij bij een intensieve toets aanzienlijk verzwaard dient te worden, terwijl minder hoge eisen zullen worden gesteld aan de bewijslast van de ei$\operatorname{ser}^{4+6}$

laging eigen bijdrage zwakzinnigen). De beoordeling in de laatstgenoemde uitspraak getuigt echter van een tamelijk grote zorgvuldigheid, hoewel de opvattingen van de wetgever werden gerespecteerd.

442. Zie echter HR 21 juni 1988 (strafkamer), NJ 1988/1021 (Folderverspreiding Centrumpartij).

443. Zie bijv. Oordeel 96-36 (Kinderoppas) en Oordeel 96-75 (Taalvereiste administratief werk).

444. Zie bijv. HR 18 januari 1980, NJ 1980/463 (Bloedverwantschap onwettig kind); weliswaar werd hierin niet uitdrukkelijk aangegeven dat er een intensievere toets werd uitgevoerd, maar uit de scherpe beoordeling van de betrokken wettelijke bepaling blijkt dat de toetsing aanzienlijk minder terughoudend was dan voor de civiele kamer gebruikelijk is: van belang is vooral dat de Hoge Raad zelf het enige doel vaststelde dat als een voldoende rechtvaardiging voor het gemaakte onderscheid zou kunnen fungeren, waardoor hij nauwelijks ruimte overliet voor de wetgever om nog andere doelstellingen an te voeren. Vgl. ook HR 7 mei 1993, RvdW 1993/101 (Ongehuwde onderwijzeressen), waarin de Hoge Raad stelde dat het met de internationale rechtsontwikkelingen "[...] niet [zou] stroken om al te snel aan te ne. men dat voor een beloningsverschil dat het uitgangspunt van een gelijke beloning voor gelijke arbeid doorkruist, een redelijke en objectieve rechtvaardiging voorhanden is" (r.o. 3.4). De rechtspraak van de belastingkamer laat nauwelijks voorbeelden van een strikte toetsing zien: hij werkt vrijwel steeds met de redelijkheidsformule. Een vrij intensieve toetsing is wel soms zichtbaar wanneer de belastingkamer zijn eigen oordeel over de redelijkheid in de plaats stelt van dat van de fiscus; voorbeelden daarvan zijn HR 17 november 1993 (belastingkamer), BNB 1994/36 (Koffiegeld en studeerkamerkosten), HR 15 oktober 1997 (belastingkamer), BNB 1997/380 (Kinderopvang III) en HR 17 augustus 1998 (belatingkamer), JB 1998/196 (Grijs kenteken). Zie verder (zij het meer impliciet) CRvB 5 oktober RSV 1990/132 (Weduwnaarspensioen Wbp 1940-1945). In paragraaf 3.2 .2 en
ingegaan op de factoren die bepalend zijn voor de intensivering van de toetsing.

445. Deze intensieve toets mag overigens niet worden verward met de zogenaamde "integrale" toets zoals die in de literatuur over de toetsing door de bestuursrechter wordt onderscheiden; zie hierna paragraf 3.2.2.

446. Zie CRvB 4 november 1993, AB 1994/213 (Van Maarseveen). Overigens geeft de Centrale Rad hierbij (terecht) aan dat er slechts een gradueel verschil bestaat tussen de intensieve toetsing en de hiervoor beschreven marginale toetsing. 
De Commissie Gelijke Behandeling maakt eveneens soms melding van een intensieve toetsing, maar dit is vrijwel uitsluitend het geval bij klachten over direct onderscheid op grond van geslacht, meer specifiek bij voorkeursbehandeling. ${ }^{47}$ Omdat de betreffende bepalingen vrijwel steeds een uitwerking vormen van Europees recht moet de Commissie daarbij de jurisprudentie van het Europese Hof volgen, waaruit blijkt dat uitzonderingen op het gelijkheidsbeginsel strikt moeten worden getoetst. ${ }^{43}$ In de praktijk blijkt deze strikte toets echter nauwelijks te verschillen van de gebruikelijke, toch al behoorlijk intensieve, toets. ${ }^{49}$ Hoogstens kan uit de betreffende uitspraken worden afgeleid dat er hogere eisen worden gesteld aan het onderzoek van de wederpartij naar de effectiviteit van het gemaakte onderscheid of naar mogelijke alternatieven; ook kan worden vastgesteld dat de proportionaliteitstoets een belangrijker onderdeel vormt dan gebruikelijk. ${ }^{400}$ Opmerkelijk is tenslotte dat de Commissie in een aantal gevallen weliswaar niet uitdrukkelijk aangeeft dat de intensiteit van de toetsing wordt verhoogd, maar dat uit de beoordeling zelf blijkt dat dit wel degelijk het geval is. Eerder is bijvoorbeeld gebleken dat in dergelijke gevallen vaak hogere eisen worden gesteld aan de bewijslast van de verwerende partij als het gaat om het bestrijden van bruikbare alternatieven, en dat de Commissie in die gevallen bereid is om een intensief eigen onderzoek naar de subsidiariteit te verrichten. ${ }^{451}$

Uit het voorgaande kan blijken dat ook in Nederland onderscheid wordt gemaakt tussen tenminste drie gradaties van toetsingsintensiteit: een zeer marginale toets, een "gewone", enigszins terughoudende toets en een strikte toets. ${ }^{452}$ Alleen de benadering van de Commissie lijkt hiervan iets af te wijken, hetgeen een verklaring kan vinden in het bijzondere karakter van deze instelling: de Commissie is geen gewone rechterlijke instantie, maar een instelling waarvan de taken en werkwijze primair gericht zijn op het

447. Een uitzondering is Oordeel 99-50 (Zangdocenten), waarin een verhoogde toetsingsintensiteit werd gehanteerd vanwege de ingrijpendheid van de maatregel (zie r.o. 4.7).

448. Zie bijv. Oordeel 97-75 (Kinderopvang ziekenhuis), Oordeel 98-144 (Kinderopvangregeling Haarlemmermeer), Oordeel 99-57 (Voorkeursbeleid Gelderland) en Oordeel 00-65 (Kinderopvangregeling regionale politie). Hetzelfde geldt voor onderscheid op grond van nationaliteit: zie bijv. Oordeel 99-31 (Voorkeursbeleid allochtonen). Dat deze factor in uitspraken van de Centrale Raad en de andere instanties die Europees recht toepassen nauwelijks is terug te vinden, kan worden verklaard door het feit dat de voorgelegde zaken vaak betrekking hebben op sociaal recht en beleid: daarbij heeft ook het Europees Hof een ruime beleidsvrijheid toegekend. Zie nader hoofdstuk 4, paragraaf 3.2.2.

449. Dit lijkt ook een bewuste keuze van de Commissie te zijn: een strikte toetsing van voorkeursbeleid zou in de praktijk het streven naar werkelijke gelijkheid kunnen bemoeilijken. Zoals de Commissie in Oordeel 99-31 (Voorkeursbeleid allochtonen) stelde: "Vast uitgangspunt van de Commissie is dat uitzonderingen op het gebod van gelijke behandeling restrictief moeten worden uitgelegd. Dat neemt niet weg dat een dergelijke uitleg niet dermate strikt mag worden dat deze op gespannen voet komt te staan met de met de uitzondering beoogde doeleinden terzake van de feitelijke gelijkheid van de in de wet genoemde bevolkingsgroepen" (r.0.4.8).

450. Dit laatste blijkt bijvoorbeeld uit Oordeel 00-65 (Kinderopvangregeling regionale politie), r.0. 4.10, Dat van de wederpartij zelf wordt verwacht dat hij voldoende onderzoek verricht naar de geschiktheid en subsidiariteit kan blijken uit Oordeel 98-126 (Werktijdenregeling slachterij) en Oordeel 98-144 (Kinderopvangregeling Haarlemmermeer).

451. Zie paragraaf 2.4 .3

452. Waarbij moet worden opgemerkt dat de grenzen tussen de gradaties van toetsingsintensiteit niet altijd duidelijk zijn; met name de terughoudende en de werkelijk marginale toets zijn niet altijd goed van elkaar te onderscheiden. 
waarborgen van gelijke behandeling. Het spreekt vanzelf dat de toetsing van ongelijke behandelingen daardoor vrij intensief is.

In algemene zin bevestigt de Nederlandse rechtspraak hiermee de veronderstelling die in hoofdstuk 2 is uitgesproken, namelijk dat het mogelijk is om variatie in de striktheid van de toetsing aan te brengen. Belangrijk is ook dat hieruit blijkt dat het praktisch haalbaar is om drie gradaties van toetsingsintensiteit te onderscheiden.

\subsection{Factoren die de intensiteit van de toetsing bepalen}

\subsubsection{Inleiding}

Zoals hiervoor is aangegeven is er in de Nederlandse rechtspraak duidelijk variatie in de intensiteit van de toetsing zichtbaar. Voor deze differentiatie wordt slechts zelden een inhoudelijke motivering gegeven: in de meeste gevallen wordt eenvoudigweg volstaan met de stelling dat er een toetsing op redelijkheid of juist een strikte toetsing zal worden uitgevoerd. Het is dan ook niet eenvoudig om puur op basis van de jurisprudentie conclusies te trekken over de wijze waarop de Nederlandse rechters de intensiteit van hun toetsing bepalen. Niettemin blijkt bij zorgvuldig onderzoek van de rechtspraak dat er enkele factoren zijn die regelmatig bij de vaststelling van de toetsingsintensiteit worden betrokken. In het hiernavolgende zal aan de belangrijkste van deze factoren aandacht worden besteed. Daarbij zal allereerst een tweetal factoren worden besproken die betrekking hebben op de bevoegdheidsverdeling tussen rechter, wetgever en bestuur, nu deze factoren in de rechtspraak het vaakst naar voren komen (paragraaf 3.2.2). Vervolgens zal worden ingegaan op enkele andere factoren die soms van invloed blijken te zijn voor de intensiteit van de toetsing, namelijk de grond van onderscheid en het bestaan van een common ground, de aard en het gewicht van de nagestreefde en aangetaste belangen en het karakter van het onderscheid (paragraaf 3.2.3). Deze paragraaf zal worden afgesloten met een bespreking van de wijze waarop de rechterlijke instanties de verschillende factoren tegen elkaar afwegen (paragraaf 3.2.4).

\subsubsection{Factoren die verband houden met de bevoegdheidsverdeling}

Toetsing van wetmatigheid of van doelmatigheid; formulering van de bevoegdheidsgrondslag

Voor een goed begrip van de intensiteit van de toetsing is het van belang dat in Nederland vaak onderscheid wordt gemaakt tussen de wetmatigheidsaspecten van een ongelijke behandeling en de doelmatigheidsaspecten ervan. ${ }^{453} \mathrm{Bij}$ de toetsing van de doelmatigheidsaspecten van de ongelijke behandeling moet de rechter beoordelen of het in

453. Zie bijv. Steenbeek 1961 , p. 150 en (voor de precieze betekenis) p. $167 / 168$, Jue 1985, p. 442 en het Rapport ABAR 1984, p. 384. Er worden nog diverse andere onderscheidingen gemaakt met betrekking tot de bevoegdheid van de rechter om bestuurs- of normatief handelen te toetsen, maar het is dit onderscheid dat in de rechtspraak het meest ingang lijkt te hebben gevonden (hoewel discussie over de procieze betekenis ervan voor de toetsingsintensiteit mogelijk is; zie reeds Steenbeek 1961, p. 161-163). De andere onderscheidingen (zoals die tussen gebonden en vrije bevoegdheden, beoordelings- en beleidsvrijheid, beoordelingsruimte en beoordelingsvrijheid, macro- en microbestuur en heldere en vage normen) hebben, hoe belangrijk zij voor de rechtstheorie ook zijn, weinig praktische betekenis voor de toetsing van ongelijke behandelingen; zij zullen in deze paragraaf dan ook niet aan de orde komen. 
het concrete geval wenselijk of opportuun was om een bepaald besluit te nemen of om een normatieve classificatie vast te stellen. Wanneer een bestuursorgaan of regelgever de nodige discretie heeft is het primair aan dit orgaan om daarover een oordeel te geven: de rechter zal zich terughoudend moeten opstellen en de beleidsvrijheid van het betrokken orgaan moeten respecteren. Heel duidelijk blijkt dit uit een uitspraak van de strafkamer over de toetsing van ongelijke behandelingen in het vervolgingsbeleid van het openbaar ministerie:

"Het in het eerste en tweede lid van art. $167 \mathrm{~Sv}$ neergelegde opportuniteitsbeginsel houdt in, dat de officier van justitie bevoegd is op gronden aan het algemeen belang ontleend af te zien van vervolging. Beslist de officier van justitie dat hij tot vervolging overgaat, dan staat die beslissing in het algemeen niet ter beoordeling van de rechter. [...] De rechter dient in geval van wel (verder) vervolgen, de op grond van het opportuniteitsbeginsel aan het openbaar ministerie toekomende beleidsvrijheid te respecteren." ${ }^{\text {s4 }}$

Uit deze overweging blijkt dat de vervolgingsbevoegdheid van het openbaar ministerie een grote mate van beleidsvrijheid impliceert, in die zin dat het aan het OM is om te beslissen in welke gevallen al dan niet een vervolging zal worden ingesteld. De rechter dient deze vrijheid te respecteren, hetgeen automatisch een minder strenge toetsing van elementen als noodzakelijkheid, subsidiariteit en vooral proportionaliteit tot gevolg heeft. ${ }^{\text {ss }}$ Ook de verschillende bestuursrechters beschouwen het bestaan van een discretionaire bevoegdheid als uitgangspunt voor het bepalen van hun toetsingsintensiteit: wanneer blijkt dat het bestuursorgaan bij het nemen van zijn besluit over een aanzienlijke mate van discretie beschikte, zal bij de beoordeling van de doelmatigheid in het algemeen voor een terughoudende toetsing worden gekozen. ${ }^{466}$

Bij de beoordeling van doelmatigheidsaspecten van een door een bestuursorgaan veroorzaakt onderscheid is een nog verdergaande differentiatie in de toetsingsintensiteit mogelijk is wanneer de rechter ook rekening houdt met de precieze formulering van de bevoegdheidsgrondslag. ${ }^{457}$ In zijn algemeenheid kan worden vastgesteld dat de vrijheid van de rechter om een oordeel uit te spreken over de doelmatigheid beperkter is naarmate de bevoegdheid van het bestuur ruimer is geformuleerd. Dit betekent dat een bestuursrechter een onderscheid dat het gevolg is van de ongelijke toepassing van een gebonden bevoegdheid strikter kan beoordelen dan een ongelijke behandeling die het resultaat is van de uitoefening van een volledig beleidsvrije bevoegdheid. ${ }^{4 s}$ Voorbeel-

454. HR 13 januari 1998 (strafkamer), NJ 1998/407 (Gedoogbeleid Delfzijl), r.o. 6.2 en 6.3.

455. Dit is te zien in HR 2 februari 1999 (strafkamer), NJ 1999/554 (Transactievoorstel) en HR 30 maart 2001, NJ 2001/292 (Stichting Pensioenfonds Medisch Specialisten/V.).

456. Zie nader Klap 1996, p. 249. Hetzelfde geldt voor wetgeving: zoals Duk heeft aangegeven beschikt $00 k$ de wetgever over een grote mate van vrijheid bij het tot stand brengen van regelgeving (1988, p. 156). Dit wordt vooral door de belastingkamer tot uitgangspunt van zijn toetsing genomen; zie de in het volgende onderdeel van deze subparagraaf genoemde voorbeelden.

457. Vanzelfsprekend speelt dit onderscheid geen rol bij de toetsing van formeel-wettelijke classificaties: de wetgever beschikt immers over een originaire bevoegdheid. Algemeen wordt aangenomen dat deze bevoegdheid ruim is, zodat er in beginsel een terughoudende opstelling kan worden gekozen. Zie bijv. HR 10 november 2000, NJ 2001/187 (Komdeur/Eilandgebied Curaçao) en CRvB 15 mei 1996, RSV

458. Handzame definities van de gebonden en beleidsvrije bevoegdheid zijn terug te vinden bij Helder/Jue
1987, p. 1987, p. 30. De consequenties van de wettelijke definitie voor de mate van discretie komen vooral tot 
den van dit verschil in toetsingsintensiteit zijn in de uitspraken over het gelijkheidsbeginsel zeldzaam. Een verklaring daarvoor is wellicht te vinden in het feit dat bij de toepassing van gebonden bevoegdheden slechts zelden een ongelijke behandeling wordt veroorzaakt. Gebeurt dit wel, dan zal eerder rechtstreeks worden getoetst aan de wet of aan het verbod van détournement de pouvoir dan aan het algemene gelijkheids. beginsel. ${ }^{49}$ Verder is het mogelijk dat klachten over ongelijke behandeling bij gebonden bevoegdheden niet zozeer voortvloeien uit de bevoegdheidsuitoefening als zodanig, maar het rechtstreekse gevolg zijn van een betwistbare classificatie in de bevoegdheidstoedelende bepaling. In die gevallen is het de wettelijke regeling zelf die (indirect) zal worden aangevochten, waarbij alleen rekening hoeft te worden gehouden met de discretie die de wetgever toekomt: de beleidsvrijheid van het bestuursorgaan is voor de vaststelling van de toetsingsintensiteit dan niet relevant.

Zoals is aangegeven worden in Nederland naast doelmatigheidsaspecten ook wetmatig. heidsaspecten onderscheiden. ${ }^{460}$ Wanneer de rechter deze aspecten van het onderscheid toetst zal hij nagaan of de ongelijke behandeling verenigbaar is met hogere regelgeving en algemene rechtsbeginselen. De toetsing van een besluit of een regeling aan hogere regelgeving is bij uitstek een taak voor de rechter en zeker geen typisch bestuurlijke activiteit. ${ }^{41}$ Nederlandse rechterlijke instanties hebben dan ook aangenomen dat zij de wetmatigheidsaspecten van een ongelijke behandeling steeds "ten volle" of "integraa" mogen beoordelen, hetgeen betekent dat zij het bestuursorgaan of de regelgever geen ruimte hoeven te laten om een eigen oordeel over de verenigbaarheid met hogere regelgeving te geven. ${ }^{462}$ Dit blijkt bijvoorbeeld uit de volgende overweging van de Hoge

uitdrukking in de rechtspraak van één van de voorgangers van de Afdeling Bestuursrechtspraak, de Afdeling Rechtspraak. In ARRS 18 november 1985, AB 1986/293 (Stichting Humanistisch Vormingsonderwijs) oordeelde zij het volgende: "De Afd. overweegt dat geen wettelijk voorschrift verweetuer verplicht om subsidie te verlenen [...]. Daaruit volgt dat aan verweerder een grote mate van beleids. vrijheid toekomt". Zie voor een vergelijkbaar oordeel ARRS 20 februari 1986, AB 1986/438 (Van Geleuken/Noordoostpolder) en ARRS 18 maart 1988, AB 1988/342 (Humanistisch Vormingsonderwijs Oldebroek). Overigens geldt de variatie in toetsingsintensiteit zowel wanneer het bestuur beschikt over beleidsvrijheid als wanneer het bestuur beschikt over beoordelingsvrijheid (zie voor een korte definitie van deze vrijheden Duk 1988, p. 157). Beide vrijheden impliceren immers een gradatie van be. stuurlijke discretie, hoewel zij op verschillende facetten daarvan betrekking hebben (zie Helder/ue 1987 , p. 31). Het onderscheid tussen de vrijheden kan dan ook als zodanig geen invloed hebben op de toetsing: het is niet zo dat beoordelingsvrijheid tot een minder grote mate van toetsingsintensiteit noodzaakt dan beleidsvrijheid (zie Klap 1996, p. 246).

459. Vgl. Versteden 1985, p. 87.

460. Het onderscheid tussen wetmatigheid en rechtmatigheid zal niet altijd even scherp kunnen worden getrokken. Vooral bij de uitleg en invulling van vage normen in wetgeving kunnen deze twee facetten in elkaar overlopen, omdat bij de uitleg van deze begrippen soms verschillende interpretaties rechtens juist kunnen zijn (vgl. Klap 1994, p. 36). In dergelijke gevallen kan wel soms worden onderscheiden tussen de vaststelling en de kwalificatie van feiten. Daarbij geldt dat de rechter volledig bevoegd is tot een beoordeling van de vastgestelde feiten (bijv. door na te gaan of een fabriek inderdaad zoveel uit stoot als door het bestuursorgaan is beweerd), maar dat er een terughoudende toetsing moet worden uitgevoerd wanneer deze feiten door het bestuur zijn beoordeeld (bijv. als de uitstoot als "ernstig" wordt aangemerkt). Zie Duk 1988, p. 161 en De Lange 1991, p. 48. Aan Klap moet echter worden tocgegeven dat de grens tussen kwalificatie en vaststelling evenmin altijd duidelijk is (1994, p. 36).

461. Vgl. Duk 1988, p. 163.

462. Vgl. ook Klap 1996, p. 250/251 en Duk 1988, p. 163. 
Raad over een besluit tot vaststelling van een pensioenpremie door het bestuur van het Pensioenfonds voor medisch specialisten:

"Weliswaar komt [...] aan de rechter slechts een beperkte bevoegdheid toe tot toetsing van een besluit als het onderhavige, maar die beperking gaat niet zover dat de rechter bij de beoordeling van het onderhavige besluit van het bestuur zich niet zou mogen begeven in de beantwoording van de [...] aan de orde gestelde vraag of het bestuur bij het nemen van dit besluit $[\ldots]$ in strijd heeft gehandeld met een zo fundamenteel beginsel als het gelijkheidsbeginsel."

De integrale toetsing van wetmatigheidsaspecten mag niet worden verward met een intensieve toetsing van doelmatigheidsaspecten. Het onderscheiden van wetmatigheidsaspecten en doelmatigheidsaspecten is vooral bedoeld om tot een zinvolle competentieverdeling tussen bestuur en rechter te komen: het is de taak van de rechter om vast te stellen of een bepaalde regeling of een bepaald besluit verenigbaar is met hoger recht, terwijl het (bij beleidsvrijheid) primair aan het bestuur is om te beoordelen of het wenselijk of opportuun is om een bepaald besluit te nemen. ${ }^{464}$ Tot de toetsing van wetmatigheid is de rechter altijd ten volle bevoegd; de variatie van de toetsingsintensiteit speelt daarbij geen enkele rol. ${ }^{465}$ De toetsing van doelmatigheid is een andere kwestie: de rechter mag zich daarover wel uitspreken ${ }^{\star 66}$, maar de vraag in hoeverre hij het bestuur kan controleren en corrigeren is afhankelijk van de toelaatbare intensiteit van de toetsing. Dit betekent dat het mogelijk is dat de toetsing van een ongelijke behandeling zowel integraal als marginaal is: de rechter kan zich bijvoorbeeld terughoudend opstellen bij het vaststellen van het doel van de regeling, terwijl hij wel ten volle kan beoordelen of het vastgestelde doel verenigbaar is met hogere regelgeving en rechtsbeginselen. Voor de toetsing van de verhouding tussen doel en onderscheid blijkt het verschil tussen wetmatigheid en doelmatigheid geen rol te spelen: bij de beoordeling van de mate van fit, de geschiktheid, de noodzakelijkheid en vooral de proportionaliteit zal steeds sprake zijn van een doelmatigheidstoets, zodat een integrale toetsing van wetmatigheidsaspecten niet aan de orde is.

\section{Onderscheid door bestuur of wetgever?}

Een tweede factor die in de Nederlandse rechtspraak, en dan vooral in de jurisprudentie van de belastingkamer, een rol blijkt te spelen betreft de verantwoordelijkheid voor het gemaakte onderscheid. ${ }^{467}$ Wanneer geklaagd wordt over een normatieve classificatie

463. HR 30 maart 2001, NJ 2001/292 (Stichting Pensioenfonds Medisch Specialisten/V.), r.o. 3.7. Zie verder HR 13 januari 1998 (strafkamer), NJ 1998/407 (Gedoogbeleid Delfzijl: aan het hierboven gegeven citaat voegde de strafkamer hierin nog toe dat "in het kader van de beoordeling van de ontvankelijkheid [...] de rechter evenwel de beslissing om tot vervolging over te gaan ten volle [mag] toetsen aan beginselen van een goede procesorde" (r.o. 6.3)) en CRvB 15 mei 1996, RSV 1996/170 (Posthuma/Van Damme). Vanzelfsprekend zal bij de "volle" toetsing aan het gelijkheidsbeginsel wel rekening moeten worden gehouden met de beleidsvrijheid als het gaat om de beoordeling van de doelmatigheidsaspecten die een rol hebben gespeeld: daarbij speelt de toetsingsintensiteit wel weer een belangrijke rol.

464. Vgl. ook Koopmans 1991 , p. $87 / 88$.

465. Vgl. Van Wijk/Konijnenbelt 1999, p. 185.

466. Zie Duk 1988, p. 158.

467. Zie ook de noot van Rijkers bij HR 15 juli 1997, BNB 1997/326 (Studeerkamer en WAO-uitkering) en de noot van Wattèl bij HR 12 november 1997, BNB 1998/22 (Reiskosten als studiekosten). 
waarvoor de formele wetgever verantwoordelijk is, voegt de belastingkamer (in het bijzonder bij de toetsing aan artikel 26 IVBPR) steevast een overweging als de volgende in:

"[...] het Verdrag verbiedt [niet] iedere ongelijke behandeling van gelijke gevallen [...]. Hierbij verdient opmerking dat de wetgever een zekere beoordelingsvrijheid toekomt bij het beantwoorden van de vraag of gevallen voor de toepassing van het Verdrag als gelijk moeten worden beschouwd." ${ }^{\circ 68}$

Deze erkenning van de discretie van de wetgever bij het beoordelen van de noodzaak van normatieve classificaties impliceert dat de belastingkamer een terughoudende toetsing zal uitvoeren..$^{49}$ In de praktijk komt deze terughoudendheid vooral tot uitdrukking in een minder scherpe toetsing van de verhouding tussen doel en onderscheid: meestal volstaat de belastingkamer met de stelling dat de wetgever in redelijkheid tot het $00 \mathrm{r}$ deel kon komen dat er een objectieve rechtvaardiging voor het onderscheid aanwezig was.

Wanneer wordt geklaagd over een door een bestuursorgaan veroorzaakte ongelijke behandeling (hetzij in een concreet geval, hetzij in de vorm van een beleidsregel) blijkt de toetsing aanzienlijk intensiever te zijn. Deze verhoging van de toetsingsintensiteit is niet expliciet in de uitspraken van de belastingkamer terug te vinden, maar het is opmerkelijk dat in dit soort gevallen de motivering aanzienlijk uitgebreider is, dat de belastingkamer vaak bereid is om een actief onderzoek naar de achtergronden en doelstellingen van de bevoegdheidsgrondslag uit te voeren en dat hij regelmatig zijn eigen waardering van de redelijkheid van de ongelijke behandeling in de plaats stelt van die van het bestuursorgaan. Opvallend is bovendien bij de toetsing van concrete bevoegdheidsuitoefening geen enkele verwijzing is te vinden naar de beoordelingsvrijheid die uit artikel 26 IVBPR zou voortvloeien, terwijl deze verwijzing bij de toetsing van wetgeving steeds aanwezig is. Ook ontbreken in dit soort zaken de gebruikelijke formuleringen waaruit terughoudendheid kan blijken. ${ }^{400}$

Andere rechterlijke instanties lijken in veel mindere mate waarde te hechten an de vraag of het onderscheid tot de verantwoordelijkheid van de wetgever of het bestuur behoort. Het is ook niet vanzelfsprekend dat de wetgever in het algemeen over een

468. HR 27 september 1989 (belastingkamer), NJ 1990/449 (Samentelling inkomens gehuwden), r.0. 4.5; zie ook de noot van Scheltens bij deze uitspraak. Zie verder HR 14 juni 1995 (belastingkamer), $A B$ 1995/609 (Gebroken boekjaar), HR 13 december 1995, BNB 1996/72 (Vee als bedrijfsmiddel), HR 12 november 1997 (belastingkamer), BNB 1998/22 (Reiskosten als studiekosten), HR 15 juli 1998 (belas. tingkamer), BNB 1998/293 (Autokostenforfait) en HR 23 juni 1999 (belastingkamer), BNB 1999/292 (Autokostenfictie). Opmerkelijk is ook HR $12 \mathrm{mei}$ 1999, FBR 1999, 2115 (Arbeidskostenforfait), waarin de belastingkamer (overigens in het kader van de derde fase van de toetsing, dus bij de beoor. deling van de consequenties van het oordeel over de ongelijke behandeling) oordeelde dat "[...] in de gegeven staatsrechtelijke verhoudingen de rechter bij zulk ingrijpen in een wettelijke regeling een terughoudende opstelling past" (r.o. 3.14).

469. Zie ook Wattèl 1993, p. 1723/1724 en Van Leijenhorst 1997, p. 112. De belastingkamer wordt zelfs bekritiseerd vanwege het feit dat hij een té terughoudende toetsing zou uitvoeren. Zie bijv. Happé 1990, p. 391.

470. Belangrijk is verder dat de belastingkamer de wetgever soms toestaat om een bepaald onderscheid te maken, terwijl een vergelijkbaar onderscheid dat door het bestuur in een beleidsregel is gemaakt nicl toelaatbaar wordt geacht. Zie nader de noot van Wattel bij HR 12 november 1997, BNB 199822 (Reiskosten als studiekosten). 
grotere mate van beoordelingsvrijheid zou beschikken dan het bestuur en dat de rechter daarmee bij de bepaling van zijn toetsingsintensiteit rekening zou moeten houden. ${ }^{471}$ Zoals eerder is aangegeven is de aanwezigheid van beoordelings- of beleidsvrijheid voor het bestuur geen eenduidig gegeven: de mate waarin een orgaan over deze vrijheid beschikt is sterk afhankelijk van de formulering van de bevoegdheidsgrondslag. In sommige gevallen zal deze vrijheid net zo groot zijn als die van de wetgever (zoals in gevallen waarin voor bestuurshandelen geen wettelijke grondslag is vereist of alleen een zeer algemene grondslag beschikbaar is), terwijl deze in andere gevallen inderdaad minimaal kan zijn. Tegelijkertijd kan ook voor de wetgever worden gesteld dat deze niet in zijn algemeenheid beschikt over een grotere mate van vrijheid dan het bestuur: de mate waarin die vrijheid aanwezig is, is steeds afhankelijk van factoren als het betrokken beleidsterrein of de aard van de nagestreefde doelstellingen. Of bij de beoordeling van formele wetgeving een terughoudender toetsing moet worden toegepast dan bij de beoordeling van beleidsregels van bestuursorganen is dan ook een vraag die niet in zijn algemeenheid kan worden beantwoord: de intensiteit van de toetsing is daarvoor te zeer afhankelijk van een groot aantal andere factoren. Hoewel de aanwezigheid van democratische legitimatie enige rol zou kunnen spelen bij de vaststelling van de toetsingsintensiteit, is het dan ook niet wenselijk om hieraan doorslaggevende betekenis toe te kennen. ${ }^{42}$

\subsubsection{Andere factoren die de toetsingsintensiteit kunnen beïnvloeden}

\section{Grond van het onderscheid en de common ground-factor}

Hoewel de intensiteit van de toetsing in Nederland primair wordt bepaald door de bevoegdheidsgrondslag, zijn er verschillende arresten waaruit blijkt dat andere factoren soms een rol kunnen spelen. Van belang is allereerst dat enkele van de bestudeerde instanties hebben aangenomen dat de grond van onderscheid van belang kan zijn voor de bepaling van de toetsingsintensiteit. ${ }^{477}$ De rechtspraak daarover is echter veel minder uitgebreid en genuanceerd dan het geval is bij het Supreme Court en het Europees Hof voor de Rechten van de Mens. Het is bijvoorbeeld niet duidelijk welke gronden volgens de onderzochte instanties als "verdacht" moeten worden beschouwd, terwijl er evenmin een helder antwoord is gegeven op de vraag in welke omstandigheden onderscheid op een bepaalde "verdachte" grond intensiever moet worden getoetst. De enige rechterlijke instantie die aan deze kwestie expliciet aandacht heeft besteed is de Cen-

471. Van Leijenhorst stelt dat dit verschil vooral is ingegeven door het feit dat er bij wettelijke classificaties sprake is van een directe democratische legitimatie, terwijl dit niet het geval is bij handelingen van het bestuur, hij stelt dan ook dat naarmate de democratische legitimatie minder direct is, er een intensievere toetsing kan worden toegepast (1997, p. 1124). Dit lijkt echter, gelet op het in de hoofdtekst gestelde, geen overtuigend argument om de verantwoordelijkheid als doorslaggevende intensiteitbepalende factor te beschouwen. Weliswaar kan de aanwezigheid van democratische legitimatie een reden vormen voor een terughoudende opstelling, maar het ontbreken daarvan hoeft niet te betekenen dat kan worden gekozen voor een striktere toetsing.

472. Zie ook Wattel, die aangeeft dat het voor de benadeelde in het algemeen geen verschil maakt of de benadeling is veroorzaakt door de wetgever of door de administratie (noot bij HR 12 november I997, BNB 1998/22 (Reiskosten als studiekosten)).

473. Hoewel dit toch tamelijk zeldzaam is; vgl. Loenen 2000, p. 296. 
trale Raad van Beroep. In een uitspraak over onderscheid op grond van leeftijd oordeelde hij als volgt:

"[...] het [gaat] hier niet [...] om één van de differentiatiecriteria, welke in de genoende artikelen [namelijk artikel 1 Grondwet en artikel 26 IVBPR, JHG] met zoveel woorden zijn vermeld doch om discriminatie 'op welke grond ook' zoals in die artikelen aangegeven. Zonder aan dit laatste een al te grote betekenis toe te kennen en met afwijzing van een te ver reikende leerstelligheid op dit punt, ligt hierin naar 's raads oordeel toch enig waardeverschil besloten hetgeen tot uiting kan komen in de toetsing van het concrete geval, in de eisen waaraan de genoemde redelijke en objectieve rechtvaardiging moet voldoen en ook enigszins in datgene wat van de verschillende partijen ten aanzien van de motivering van hun stellingen mag worden gevergd." ${ }^{\text {M7t }}$

Uit het feit dat bepaalde onderscheidingscriteria door de verdragsluitende staten bij het IVBPR en door de grondwetgever expliciet zijn verboden kunnen volgens de Raad dus aanwijzingen worden afgeleid over de verdachtheid van deze criteria. Dit criterium houdt verband met de common ground-factor: kennelijk bestond er bij het afsluiten van het IVBPR en het vaststellen van de Grondwet bij de verdragsluitende staten en binnen regering en parlement overeenstemming over de onwenselijkheid van het maken van onderscheid op deze gronden. Zoals de Raad zelf ook al aangeeft moet met deze benadering echter voorzichtig worden omgesprongen. Het IVBPR bestaat inmiddels 35 jaar en ook artikel 1 van de Grondwet is alweer bijna 20 jaar oud. Zoals in hoofdstuk 2 is aangegeven zijn de opvattingen over de toelaatbaarheid en wenselijkheid van bepaalde onderscheidingscriteria voortdurend in beweging: het kan zijn dat onderscheid op bepaalde gronden in de loop van de tijd minder ernstig gevonden wordt, terwijl tegelijkertijd de overtuiging kan ontstaan dat andere, tot dan toe geoorloofd geachte gronden geen redelijke basis voor onderscheid meer vormen. Wanneer het door de Centrale Raad gehanteerde uitgangspunt gekozen wordt, moet met deze veranderingen terdege rekening worden gehouden: het is altijd mogelijk dat gronden waarbij de verdragsluitende staten enkele decennia geleden nog niet stilstonden tegenwoordig als verdacht worden aangemerkt. ${ }^{45} \mathrm{Bij}$ de vaststelling van de toetsingsintensiteit is het dan ook verstandig om niet alleen te kijken naar de common ground zoals die kan worden afgeleid uit de opsomming van gronden in verdragen en grondwettelijke teksten, maar ook naar de consensus zoals die naar voren komt uit recentere rechtspraak en wetswijzigingen. Uit de Nederlandse rechtspraak blijkt dat dit sporadisch ook wel gebeurt. Met name de Hoge Raad en, in iets mindere mate, de Commissie Gelijke Behandeling hebben een strengere toetsing toegepast wanneer uit uitspraken van het Europees Hof voor

474. CRvB 4 november 1993, AB 1994/213 (Van Maarseveen)

475. Vgl. Loenen 2000 , p. 298. Zo kunnen enige kanttekeningen worden geplaatst bij het oordeel van de Centrale Raad dat nationaliteit niet uitdrukkelijk in artikel 26 IVBPR is opgenomen en een verhoogde toetsingsintensiteit daarbij dus niet is vereist (CRvB 11 februari 1994, RSV 1994/217 (Nederlandenve reiste $\mathrm{AOW} / \mathrm{AWW})$ ). Los van het feit dat nationale afkomst wel degelijk expliciet in artikel $26 \mathrm{ge}$ noemd staat, blijkt uit de rechtspraak van het Europees Hof voor de Rechten van de Mens (bijv. EHRM 16 september 1996, Gaygusuz, Reports 1996-IV) en van het Europees Hof van Justitie (zie hoofdstuk 4, paragraaf 3.4.1), maar ook uit de oordelen van de Commissie, dat er bij deze grond zeker reden be staat voor een intensievere toetsing. Met Loenen kan bovendien worden opgemerkt dat er ook binnen de opsomming van artikel 26 IVBPR en artikel I Grondwet onderscheid kan worden gemaakt tussen meer en minder verdachte gronden (2000, p. 298). 
de Rechten van de Mens of van het Europees Hof van Justitie bleek dat een bepaalde grond in Europa als verdacht wordt aangemerkt. ${ }^{476}$ Van een proactieve benadering op dit punt blijkt echter geen sprake te zijn: de beide instanties volgen slechts de internationale rechtspraak en lijken niet bereid te zijn om zelf nieuwe rechtsopvattingen te signaleren die zouden noodzaken tot een strengere toetsing. ${ }^{477}$

Waar de Hoge Raad, de Centrale Raad en de Commissie soms nog bereid zijn om bepaalde gronden als verdacht aan te merken en een strikte toetsing uit te voeren, blijkt deze bereidheid bij de Afdeling volledig te ontbreken. Dat dit tot problematische consequenties kan leiden blijkt uit een al iets oudere uitspraak van één van de voorgangers van de Afdeling, de Afdeling Rechtspraak, over de inschrijving in het filiatieregister voor de adel. ${ }^{\text {77 }}$ Volgens een uit 1815 stammende wet kunnen alleen wettig geboren kinderen in dit register worden ingeschreven, zodat onwettige kinderen niet in aanmerking komen voor een adellijke titel. De Afdeling Rechtspraak deed hierover in 1985 uitspraak, ruim zes jaar nadat het Europees Hof voor de Rechten van de Mens, op basis van het bestaan van een duidelijke Europese common ground, had vastgesteld dat onderscheid op grond van wettige geboorte als verdacht moet worden aangemerkt. ${ }^{479} \mathrm{De}$ Afdeling oordeelde in deze zaak als volgt:

476. Zie bijv. HR 18 januari 1980, NJ 1980/463 (Bloedverwantschap onwettig kind), waarin de Hoge Raad verwees naar de rechtspraak van het Europees Hof voor de Rechten van de Mens; op zichzelf sprak de Hoge Raad zich in dit arrest niet expliciet uit over de intensiteit van de toetsing, maar uit het feit dat hij zelf vaststelde welke doelstellingen het onderscheid zou moeten nastreven om toelaatbaar te kunnen zijn kan worden afgeleid dat hij een intensievere toetsing dan normaal uitvoerde. Uit HR 13 januari 1995, NJ 1995/430 (Codfried/ISS) blijkt verder dat het ontbreken van een common ground een reden kan zijn voor een terughoudende toetsing, zelfs wanneer er wel een openbare discussie bestaat over de wenselijkheid van onderscheid op bepaalde gronden. Dit wordt bevestigd door de rechtspraak van de Centrale Raad, die uit de jurisprudentie van het Europees Hof van Justitie heeft afgeleid dat bij de "huidige stand van het gemeenschapsrecht" bij de beoordeling van de noodzaak van maatregelen van sociaal beleid een zekere discretie bestaat; zie CRvB 12 augustus 1999, RSV 2000/73 (Inkomensvereiste thuiswerkers). Ook de veelgenoemde reden voor de intensievere toetsing door de Commissie ("voorkomen dat de norm van gelijke behandeling van mannen en vrouwen wordt uitgehold") lijkt op internationale consensus te zijn gebaseerd; zie bijv. Oordeel 95-32 (Junior Systeemontwerper), Oordeel 96-32 (Deeltijdwerk leerkrachten basisonderwijs), Oordeel 98-126 (Werktijdenregeling slachterij) (waarin expliciet werd verwezen naar enkele internationale instrumenten, zie voetnoot 4) en Oordeel 99-57 (Voorkeursbeleid Gelderland). De Commissie verwijst als rechtvaardiging voor een strikte toetsing vaak naar de rechtspraak van het Europees Hof van Justitie; zie bijv. Oordeel 97-75 (Kinderopvang ziekenhuis), Oordeel 98-144 (Kinderopvangregeling Haarlemmermeer) en Oordeel 00-65 (Kinderopvangregeling regionale politie).

477. Dit geldt nog sterker voor de Centrale Raad: ook hij lijkt slechts bereid te zijn om internationale aanwijzingen te volgen, niet om zelf een actieve benadering te kiezen. Heel duidelijk blijkt dit uit een serie uitspraken over de benadeling van ongehuwden ten opzichte van gehuwden. In een uitspraak over dit onderscheid had het Human Rights Committee gesteld dat artikel 26 IVBPR niet noodzaakt tot een gelijkstelling van gehuwden en ongehuwden (Human Rights Committee 9 april 1987, Communication No. 180/1984 (Danning $v$. The Netherlands), CCPR/C/29/D/180/1984, \$ 14), terwijl zeker in jaren '90 duidelijk werd dat het onderscheid tussen deze groepen nauwelijks nog maatschappelijk draagvlak heeft. Toch bleef de Centrale Raad tot ver in de jaren " 90 vasthouden aan de uitspraak van het HRC, zonder zelf te oordelen dat het hier ging om een verdachte grond die tot een strikte toetsing van wetgeving noodzaakt. Zie bijv. CRvB 2 mei 1995, AB 1996/190 (Samenwonende bloedverwanten) en CRvB 17 juli 1996, AB 1996/518 (AOW-uitkering bloedverwanten).

478. ARRS 9 september 1985, AB 1986/83 (Inschrijving filiatieregister)

479. Zie EHRM 13 juni 1979, Marckx, Series A, vol. 31 
"De Afd. is niet gebleken dat het bepaalde in [de betrokken wet, JHG] [...] een onderscheid naar wettigheid dan wel anderszins zou maken dat als discriminatie en derhalve als ongeoorloofd zou moeten worden beschouwd. Voor zover onderscheid is gemaakt, is niet gebleken dat zou worden gehandeld in strijd met hetzij door appellante in dit verband genoemde verdragsbepalingen, hetzij met de Grondwet."

De motivering van dit oordeel schiet ernstig tekort, vooral omdat de Afdeling nalaat om in navolging van het Straatsburgse Hof onwettige geboorte als verdachte grond aan te merken. Zou dit wel gebeurd zijn, dan had de Afdeling haar oordeel over de rechtvaardiging veel uitgebreider moeten motiveren en had zij vooral meer aandacht moeten besteden aan de vraag of er sprake was van een voldoende mate van proportionaliteit tussen het nagestreefde doel en de belangen van onwettige kinderen. Ook in andere gevallen heeft de Afdeling nagelaten om gronden als verdacht aan te merken en een striktere toetsing uit te voeren. Met name blijkt dit uit een aantal zaken over onderscheid op grond van geslacht, een grond die zowel in de rechtspraak van het Straatsburgse Hof als in de jurisprudentie van het Europees Hof van Justitie consequent als verdacht is aangemerkt. ${ }^{481}$ De Afdeling blijkt in haar uitspraken over deze vorm van onderscheid een net zo marginale toets uit te voeren als gebruikelijk, zonder enige reden te geven voor het niet verhogen van de toetsingsintensiteit. ${ }^{422}$ Het is duidelijk dat deze benadering, zeker gezien het gebrek aan motivering, niet navolgenswaardig is.

In vergelijking tot de jurisprudentie van de in eerdere hoofdstukken bestudeerde rechterlijke instanties kan worden gesteld dat de Nederlandse rechtspraak over de onderscheidingsgrond als intensiteitbepalende factor teleurstellend is: behalve het slechts beperkt bruikbare "opsommingscriterium" van de Centrale Raad hebben de Nederlandse rechterlijke instanties nauwelijks aanwijzingen gegeven voor de beantwoording van de vraag wanneer een grond als verdacht moet worden gekwalificeerd. Het zou goed zijn wanneer de verschillende instanties aan deze factor meer aandacht zouden besteden, vooral nu uit de rechtspraak in de eerder besproken stelsels kan worden afgeleid dat de grond van onderscheid een belangrijke factor kan vormen bij de bepaling van de toetsingsintensiteit.

\section{Aard en gewicht van de aangetaste belangen}

Ook voor de aard en het gewicht van de aangetaste rechten of belangen geldt dat hiervan soms enige invloed uitgaat op de intensiteit van de toetsing, maar dat het aantal voorbeelden van toepassing van deze factor minimaal is. Alleen de Hoge Raad heeft van deze factor met enige regelmaat gebruik gemaakt. ${ }^{483}$ Een voorbeeld hiervan vormt

480. Zie ook CRvB 22 oktober 1999, AB 2000/289 (Persoonsgebonden budget thuiszorg) en CRvB 26 november 1999, RSV 2000/50 (Verlaging eigen bijdrage zwakzinnigen).

481. Zie daarover nader hoofdstuk 3, paragraaf 3.3.2 en hoofdstuk 4, paragraaf 3.2.6.

482. M.n. ABRS 21 februari 1995, AB 996/222 (Vererving adeldom via vrouwelijke lijn) en ABRS 16 maart 1999, JB 1999/102 (Vererving adeldom via vrouwelijke lijn II).

483. Opgemerkt moet echter worden dat ook de Commissie soms rekening houdt met de belangenaantasting; zij kijkt dan niet zozeer naar de aard of het gewicht van de aangetaste rechten of belangen, mas vooral naar de emst van de belangenaantasting. Zo leek zij in Oordeel 99-50 (Zangdocenten) een iets striktere toetsing dan gebruikelijk toe te passen vanwege het onherstelbare en definitieve karakter vali de belangenaantasting. 
het al eerder besproken arrest over ongehuwde onderwijzeressen die een aanmerkelijk lager salaris ontvingen dan hun gehuwde collega's. ${ }^{4+} \mathrm{Bij}$ de beoordeling van de rechtvaardiging voor dit onderscheid verwees de Hoge Raad naar artikel 7 IVESCR, waarin gesteld wordt dat de staten een gelijke beloning voor werk van gelijke waarde moeten warborgen, zonder onderscheid van welke aard dan ook. Vervolgens oordeelde de Hoge Raad als volgt:

-Weliswaar mist deze bepaling rechtstreekse werking [...] maar de waarborg van een gelijke beloning voor gelijke arbeid in het IVESC is wel een doelstelling waarnaar gestreefd dient te worden. Hiermee zou niet stroken om al te snel aan te nemen dat voor een beloningsverschil dat het uitgangspunt van een gelijke beloning voor gelijke arbeid doorkruist, een redelijke en objectieve rechtvaardiging voorhanden is."

Uit deze overweging kan worden afgeleid dat een strengere toetsing zal worden uitgevoerd wanneer objectief kan worden vastgesteld dat het aangetaste recht of belang van bijzonder gewicht is. Interessant is daarbij dat de bron voor het bepalen van het gewicht van het recht in deze zaak werd gevonden in internationale bepalingen. Een dergelijk objectief aanknopingspunt is zeer waardevol bij de bepaling van het gewicht van individuele rechten, met name wanneer hiermee op een relatief soepele manier wordt omgesprongen: zoals de Hoge Raad zelf aangeeft kunnen niet alleen rechtstreeks werkende verdragen richtinggevend zijn, maar kan hetzelfde gelden voor andere, minder "harde" verdragsverplichtingen. Een bevestiging van het gewicht van een bepaald recht of belang kan bijvoorbeeld worden gevonden in resoluties en aanbevelingen van internationale organisaties (soft law) of in een common ground die kan worden afgeleid uit wetgeving en rechtspraak van andere staten.

\section{Aard en gewicht van de beschermde belangen}

In het theoretische hoofdstuk is aangegeven dat het gewicht van het nagestreefde doel een rol zou kunnen spelen bij de bepaling van de toetsingsintensiteit. In Nederland wordt deze factor duidelijk van ondergeschikt belang geacht. Alleen de Commissie Gelijke Behandeling heeft hieraan in een enkel geval impliciet aandacht besteed. Een voorbeeld van het gebruik van deze factor is te vinden in haar oordeel over de uitsluiting van homoseksuele mannen van het geven van bloed. ${ }^{46}$ Door deze uitsluiting werden zeer zwaarwegende belangen gediend, te weten de bescherming van ontvangers van het bloed tegen het levensbedreigende HIV-virus. Met het oog op deze belangen voerde de Commissie een aanzienlijk minder veeleisende toetsing uit dan gebruikelijk: niet alleen werd de vrij grote mate van overinclusiveness, waarvan in de betrokken

484. HR 7 mei 1993, RvdW 1993/101 (Ongehuwde onderwijzeressen)

485. R.o. 3.4. Impliciet blijkt een soortgelijke benadering uit HR 30 september 1992 (belastingkamer), NJ 1994/495 (Griffiegeld), waarin het door artikel 6 EVRM beschermde recht op toegang tot de rechter was aangetast; vgl. ook de noot van Alkema bij dit arrest en Happé 1999, p. 32. Zie verder ARRS 21 maart 1985, AB 1986/16 (Stichting Humanistisch Vormingsonderwijs II), waarin het door de Grondwet beschermde recht op vrijheid van godsdienst werd beperkt.

486. Oordeel 98-137 (Homoseksuele bloeddonoren). Eenzelfde benadering werd gevolgd in een oordeel waarin het niet ging om homoseksuelen, maar om de uitsluiting van een andere risicogroep; daardoor werd onderscheid op grond van nationaliteit veroorzaakt: Oordeel 00-18 (Partner Kaapverdiaan als bloeddonor). Interessant is ook een oordeel waarin homoseksuelen werden uitgesloten als spermadonoren: Oordeel 98-139 (Homoseksuele spermadonoren). 
regeling overduidelijk sprake was, getolereerd, maar ook werd bij de beoordeling van de subsidiariteit een geheel eigen, door deskundigen ondersteund, onderzoek uitgevoerd naar de geschiktheid van de alternatieven om het doel te bereiken. ${ }^{43}$ In deze en andere oordelen van de Commissie zijn jammer genoeg geen nadere aanknopingspunten terug te vinden voor de beoordeling wanneer de nagestreefde belangen zodanig van aard zijn dat de toetsing moet worden geïntensiveerd of juist een marginaler karakter moet krijgen. Gesteld kan hoogstens worden dat in deze oordelen een bevestiging is te vinden van de stelling dat aard en gewicht van de nagestreefde doelstellingen een rol kunnen spelen bij de bepaling van de toetsingsintensiteit.

\section{Direct of indirect onderscheid}

Tenslotte is van belang dat de Centrale Raad in een aantal uitspraken heeft gesteld dat indirect onderscheid terughoudender moet worden getoetst dan direct onderscheid, zelfs wanneer er sprake is van indirect onderscheid op een verdachte grond. De aanleding voor dit oordeel was een zaak waarin geklaagd werd over schending van artikel 14 EVRM. Appellant had daarbij een beroep gedaan op het arrest Van Raalte, waarin het Europees Hof voor de Rechten van de Mens had geoordeeld dat bij onderscheid "exclusively based" op het geslacht van de betrokkene een very weighty reasons-test moet worden uitgevoerd. Volgens appellant moest ook de Centrale Raad deze zeer strikte en voor het onderscheid vrijwel steeds fatale toets toepassen, hetgeen ongetwijfeld tot gevolg zou hebben dat het aangevochten onderscheid als ontoelaatbaar zou worden aangemerkt. De Centrale Raad oordeelde anders:

"In casu gaat het [...] niet om een onderscheid dat uitsluitend op geslacht is gebaseerd, maar op het al dan niet verworven hebben van arbeidsinkomen. Ook al kan dat onderscheid tot op zekere hoogte in verband worden gebracht met verschil in geslacht, de Raad ziet geen grond om in het kader van de toetsing aan artikel 14 EVRM de door het Hof onder meer in het arrest Van Raalte gehanteerde, specifieke, maatstaf van toepassing te achten." ${ }^{\text {"ss }}$

Het is onwaarschijnlijk dat deze uitleg van het arrest Van Raalte (nog steeds) verenig. baar is met de bedoeling van het Hof: de stelling dat het onderscheid "exclusively based" moet zijn op een verdachte grond is in lang niet alle uitspraken terug te vinden en ontbreekt in recentere uitspraken zelfs volledig. ${ }^{4 \times y}$ Zou de interpretatie van de Centrale

487. In dit laatste geval lijkt er van een intensieve toetsing sprake te zijn, maar deze wijkt sterk af van hat gebruikelijke patroon dat door de Commissie wordt gevolgd: in paragraaf 2.4.3 is aangegeven dat zij] normaal gesproken van de wederpartij verlangt dat hij aantoont dat de alternatieven niet bruikbaar waren, een benadering die tot gevolg heeft dat veel sneller tot de conclusie wordt gekomen dat niet is voldaan aan het vereiste van subsidiariteit. In dit geval vergde de toetsing weliswaar een aanzienlijke malc van rechterlijke activiteit, maar is zou dat de conclusie dat het onderscheid niet gerechtvaardigd was niet snel zijn bereikt. Ook een terughoudende rechterlijke toetsing kan soms dus een zekere mate vail activisme vereisen.

488. CRvB 16 januari 1998, RSV 1998/160 (Inkomensvereiste). Idem in CRvB 4 november 1998, RSV 1999/38 (Wet Van Otterloo). Andersom heeft de Centrale Raad aangenomen dat bij direct onderscheid dat uitsluitend is gebaseerd op geslacht een intensievere toetsing moet worden uitgevoerd; zie bijr. CRvB 5 oktober 1989, RSV 1990/132 (Weduwnaarspensioen Wbp 1940-1945).

489. Dit geldt in ieder geval voor de meest recente uitspraken over onderscheid op grond van onvetige geboorte, zoals EHRM 1 februari 2000, Mazurek, EHRC 2000/25, EHRM 3 oktober 2000, Camp and Bourimi, EHRC 2000/82 en EHRM 11 oktober 2001, Sahin, EHRC 2001/81. Ook bij onderscheid op grond van geslacht komt de formule zoals door de Centrale Raad geciteerd niet altijd terug. Dit blijt 
Raad al juist zijn, dan is het bovendien de vraag of het directe of indirecte karakter van het onderscheid inderdaad grote invloed zou mogen hebben op de intensiteit van de toetsing. Vanuit het oogpunt van individuele rechtsbescherming is eerder betoogd dat dit niet het geval zou mogen zijn. ${ }^{4 \%}$ Het uitgangspunt van een goede toetsing is steeds de belangenaantasting van het individu, waarbij het geen verschil maakt of deze aantasting het directe of slechts het indirecte gevolg is van een bepaalde regeling of classificatie. Het zou ook al te gemakkelijk worden om een intensieve toetsing te vermijden, bijvoorbeeld door het onderscheidingscriterium zodanig te kiezen dat er geen direct onderscheid op een verdachte grond wordt gemaakt, maar de regeling een dergelijk onderscheid wel tot effect heeft. Het verdient dan ook geen aanbeveling om deze benadering in het algemene toetsingsmodel op te nemen.

\subsubsection{Afweging van de verschillende factoren}

Uit het voorgaande is gebleken dat bij de bepaling van de toetsingsintensiteit verschillende factoren een rol kunnen spelen, ook al worden enkele van deze factoren slechts zelden uitdrukkelijk genoemd. De vraag kan dan ook rijzen op welke manier de onderzochte instanties deze factoren tegen elkaar afwegen: het is immers denkbaar dat een bestuursorgaan een ruime mate van beleidsvrijheid heeft, maar dat hij deze heeft aangewend om onderscheid te maken op een verdachte grond, of dat de wetgever door een classificatie bepaalde individuele belangen ernstig aantast.

Net als voor de eerder besproken stelsels geldt ook voor Nederland dat alle instanties een bepaalde "basisintensiteit" hanteren, die zij toepassen wanneer er geen factoren aanwezig zijn die tot een striktere of juist marginalere toetsing noodzaken. Zoals in paragraaf 3.1 is aangegeven is deze basisintensiteit voor de Hoge Raad, de Centrale Raad van Beroep en de Afdeling terughoudend, terwijl deze voor de Commissie Gelijke Behandeling tamelijk intensief is. In veruit de meeste gevallen blijkt de basisintensiteit inderdaad te worden toegepast, zodat een nadere motivering van de gehanteerde intensiteit nauwelijks nodig is. Ook wanneer er sprake is van een intensivering of juist van een afzwakking van de toetsingsintensiteit komt het echter regelmatig voor dat een motivering ontbreekt: soms wordt nog wel melding gemaakt van de factoren die een rol hebben gespeeld, maar het relatieve gewicht daarvan wordt vrijwel nooit vastgesteld, laat staan dat er sprake is van een inzichtelijke afweging. In gevallen waarin de toetsingsintensiteit verandert wordt bovendien slechts zelden meer dan één intensiteitbepalende factor genoemd; de genoemde factor wordt daarbij meteen doorslaggevend geacht voor de intensiteit van de toetsing. Wanneer de Centrale Raad bijvoorbeeld signaleert dat een grond niet is opgenomen in de opsomming van artikel 26 IVBPR, zal hij onmiddellijk concluderen tot een marginale toetsing. Op dezelfde manier is de aanwezigheid van een duidelijke common ground voor de Hoge Raad een doorslaggevende factor om de intensiteit te verhogen. Aan het eventueel bestaan van andere factoren

bijvoorbeeld uit EHRM 27 maart 1998, Petrovic, Reports 1998-II. Weliswaar koos het Hof hierin uiteindelijk voor een terughoudende toetsing, maar het citeerde ook de very weighty reasons-test. Daarbij gaf het echter niet aan dat deze alleen van toepassing zou zijn bij onderscheid "exclusively based" op geslacht (zie \& 37).

490. Zie hoofdstuk 2, paragraaf 5.3.2. 
wordt door geen van beide instanties aandacht besteed. ${ }^{49}$ Deze benadering is onbevredigend. Bij de bestudering van andere stelsels is gebleken dat in vrijwel alle gevallen van ongelijke behandeling meer dan één intensiteitbepalende factor een rol speelt. Het is onwaarschijnlijk dat dit in Nederland anders zou zijn: ook hier zal het vaak genoeg voorkomen dat er onderscheid wordt gemaakt op grond van een verdacht differentiatiecriterium, terwijl het gaat om een onderwerp waarbij een grote mate van beleidsvrijheid bestaat, of dat er zwaarwegende belangen worden aangetast door de toepassing van een discretionaire bevoegdheid. Een motivering waarin slechts één factor uitdrukkelijk wordt genoemd schiet in dit soort gevallen duidelijk tekort. Terwijl het onvermijdelijk is dat er bij de bepaling van de toetsingsintensiteit tussen de verschillende factoren een afweging is gemaakt, blijft dit onderdeel van de rechterlijke oordeelsvorming impliciet. Daardoor is het voor de rechthebbende vrijwel onmogelijk om te bepalen waarom de rechter de genoemde factor doorslaggevend heeft geacht en kan hij nauwelijks beoordelen of de door de rechter gemaakte afweging redelijk is. Dit heeft tot gevolg dat de controleerbaarheid en doorzichtigheid van de uitspraken veel te wensen overlaat. Gesteld kan dan ook worden dat het eerder de moeite waard is wanneer de Nederlandse rechter meer rekening zou houden met de factoren die in het algemene toetsingsmodel uiteen zullen worden gezet, dan dat in de Nederlandse rechtspraak aanknopingspunten kunnen worden gevonden voor het aanvullen en nuanceren van dit model.

\section{Conclusies}

\subsection{Conclusies met betrekking tot de toetsingsmethodiek}

\subsubsection{Toetsing in de eerste fase: vergelijkbaarheid en benadeling}

Vergelijkbaarheid of benadeling als toetsingsingang?

Zoals in paragraaf 2.2 is vastgesteld voeren de Hoge Raad, de Centrale Raad van Beroep en de Afdeling Bestuursrechtspraak in de eerste fase in beginsel een vergelijk. baarheidstoets uit, terwijl de Commissie Gelijke Behandeling (en in gevallen van indirect onderscheid ook de Centrale Raad) een benadelingstoets tot toetsingsingang kiest. De uitvoering van de vergelijkbaarheidstoets laat in de meeste gevallen aan zorgvuldigheid en doorzichtigheid te wensen over. In een groot aantal gevallen wordt niet uitdrukkelijk een vergelijkingsmaatstaf vastgesteld; gebeurt dit wel, dan wordt meestal niet aangegeven waarin de basis van deze maatstaf is gelegen. Een dergelijke benadering is niet wenselijk: het is hierdoor nauwelijks na te gaan welke redenering de rechter heeft gevolgd bij het bereiken van zijn conclusie over de vergelijkbaarheid van de voorgelegde gevallen. Dit is vooral problematisch omdat het ontbreken van vergelijk-

491. Opmerkelijk is overigens dat vooral in het bestuursrecht nauwelijks oog bestaat voor andere intensiteitbepalende factoren dan de mate van beleids- of beoordelingsvrijheid die in de bevoegdheidstoedelende bepaling is terug te vinden. Dit getuigt van een zeer beperkte blik op de variatie van toetsingsittensiteit: duidelijk zal inmiddels zijn dat ook andere factoren bepalend kunnen zijn voor de toetsings. intensiteit, zoals de grond van onderscheid en de aard van de aangetaste en nagestreefde belangen. in het licht van de genuanceerde en uitgebreide benaderingen zoals die in eerdere hoofdstukken naar voren zijn gekomen moet deze typisch Nederlandse beperking dan ook van de hand worden gewezen. 
baarheid bij verschillende instanties automatisch tot gevolg heeft dat het onderscheid toelaatbaar is. Het eindoordeel is hierdoor voor de belanghebbende vrijwel oncontroleerbaar en zal door hem niet zelden als willekeurig worden beschouwd.

Uit de bestudeerde rechtspraak is het verder gebleken dat de vergelijkingsmaatstaf slechts zelden op zijn toelaatbaarheid wordt beoordeeld. Ook dit is geen wenselijke benadering, nu hierdoor ongelijke behandelingen in stand kunnen worden gehouden die evident in strijd zijn met het EVRM of met andere nationale of internationaalrechtelijke regelgeving. Enkele voorbeelden van de problemen die daardoor kunnen ontstaan zijn in paragraaf 2.2 gegeven.

Ook overigens kunnen er bezwaren naar voren worden gebracht tegen de wijze waarop de vergelijkbaarheidstoets in Nederland wordt gehanteerd. Zoals gezegd achten verschillende rechterlijke instanties de uitkomst van de vergelijkbaarheidstoets direct doorslaggevend voor de uitkomst van de procedure. Wanneer de voorgelegde gevallen in de ogen van de betrokken instantie voldoende vergelijkbaar zijn, leidt dit regelmatig tot de conclusie dat het gemaakte onderscheid in strijd is met het gelijkheidsbeginsel. Een dergelijke benadering is niet wenselijk, ook om andere redenen dan de hiervoor genoemde oncontroleerbaarheid. Het is namelijk denkbaar dat er voor een ongelijke behandeling van vergelijkbare gevallen een rechtvaardiging is te vinden, die is gelegen in overwegingen die met de vergelijkbaarheid zelf niets van doen hebben ${ }^{492}$ Door de meeste rechterlijke instanties wordt dit erkend: alleen de Afdeling Bestuursrechtspraak blijkt ook in deze omstandigheden slechts zelden een rechtvaardigingstoets uit te voeren. ${ }^{40}$ In Nederland wordt verder vrij algemeen aanvaard dat, wanneer is vastgesteld dat de voorgelegde gevallen onvergelijkbaar zijn, het gemaakte onderscheid zonder meer toelaatbaar is. Deze opvatting wordt aangehangen door de Centrale Raad, de Afdeling en de civiele kamer van de Hoge Raad, maar tot nu toe heeft geen van deze instanties in zijn rechtspraak aangegeven welke argumenten pleiten voor het automatisme van deze conclusie. Het is zeker niet vanzelfsprekend dat ieder onderscheid tussen onvergelijkbare gevallen de toetsing aan het gelijkheidsbeginsel kan doorstaan: niet alleen is het mogelijk dat er in dit soort gevallen geen sprake is van geschiktheid of noodzakelijkheid van het gekozen middel, maar ook is het denkbaar dat er sprake is van een onredelijke verhouding tussen de mate waarin de gevallen van elkaar verschillen en de mate waarin zij ongelijk worden behandeld. Dit is in Nederland alleen erkend

492. Vaak is het mogelijk dat de rechtvaardiging zo wordt ingekleed dat ook gesteld kan worden dat de gevallen eigenlijk niet vergelijkbaar zijn. Wanneer bijvoorbeeld als rechtvaardiging voor een voorkeursbehandeling wordt aangevoerd dat de achterstandspositie van een bepaalde groep moet worden opgeheven, kan evengoed worden gesteld dat uit het oogpunt van achterstandspositie de betrokken groepen niet vergelijkbaar zijn. Er zijn echter ook rechtvaardigingen voor onderscheid te bedenken die met de eigenschappen van de groepen waartussen wordt onderscheiden geen enkel verband houden. Dit is vooral het geval wanneer een tussen twee groepen is onderscheiden om administratieve of praktische redenen (zoals wanneer wordt besloten een bepaalde uitkering om praktische redenen alleen te verlenen aan musici die na 1980 werkloos zijn geworden; de datum die in dit geval bepalend is voor het onderscheid heeft ongetwijfeld niets van doen met eigenschappen van musici die relevant zijn voor hun werkloosheid). In het belastingrecht en in het sociale zekerheidsrecht wordt dit soort onderscheidingen vaak zeer acceptabel geacht, ook al zijn de betrokken groepen voor het overige volledig vergelijkbaar. Zie nader hoofdstuk 2, paragraaf 4.4.2.

493. Zie nader paragraaf 2.1 .3 . 
door de belastingkamer, die heeft aangegeven bereid te zijn om een schending van het gelijkheidsbeginsel te constateren in gevallen van "overduidelijke onevenredigheid" tussen de ongelijke behandeling en de ongelijkheid van de gevallen. Zeker nu in de rechtspraak goede argumenten ontbreken die pleiten tegen het uitvoeren van een (op zijn minst oppervlakkige en tot evenredigheid beperkte) rechtvaardigingstoets bij gebleken onvergelijkbaarheid, kan worden vastgesteld dat het wenselijk is dat een dergelijke evenredigheidstoets consequent wordt uitgevoerd.

Ondanks het gebrek in eenduidigheid bevestigt de Nederlandse rechtspraak de theoretische veronderstelling dat het - wanneer in de eerste fase van de toetsing een vergelijkbaarheidstoets wordt uitgevoerd - noodzakelijk is om een rechtvaardigingstoets uit te voeren om een redelijke en bevredigende uitkomst te kunnen bereiken. Wordt vastgesteld dat de gevallen vergelijkbaar zijn, dan is een rechtvaardigingstoets nodig omdat er argumenten voor het onderscheid kunnen bestaan die met de vergelijkbaarheid als zodanig niets van doen hebben. Wordt vastgesteld dat de gevallen niet vergelijkbaar zijn, dan is een rechtvaardigingstoets aangewezen om te kunnen beoordelen of de belangen van de benadeelde groep niet al te ernstig zijn aangetast. In dit licht is de vraag gerechtvaardigd of de vergelijkbaarheidstoets een nuttige toetsingsingang vormt: de toets heeft maar weinig onderscheidend vermogen, in die zin dat, ongeacht de conclusie in de eerste fase, een rechtvaardigingstoets moet worden uitgevoerd.

Wanneer wordt gekeken naar het alternatief voor de vergelijkbaarheidstoets, de benadelingstoets, ligt het des te meer voor de hand om de vergelijkbaarheidstoets als toetsingsingang terzijde te stellen. Vooral de Commissie Gelijke Behandeling, maar in mindere mate ook de Centrale Raad van Beroep en de Hoge Raad, hanteren de benadelingstoets als toetsingsingang. De Centrale Raad en de Commissie gebruiken de toets vooral in gevallen van indirect onderscheid: het is vaste rechtspraak van beide instanties dat een rechtvaardigingstoets moet worden uitgevoerd wanneer de effecten van een ongelijke behandeling één bepaalde groep in overwegende of onevenredige mate raken. De toets leent zich echter ook goed als toetsingsingang bij de beoordeling van direct onderscheid: ook daarbij kunnen de nadelige effecten van een bepaalde handeling of regeling een bepaalde persoon of groep in bijzondere mate treffen.

De voordelen van deze toetsingsingang boven de vergelijkbaarheidstoets worden vooral duidelijk bij bestudering van de oordelen van de Commissie Gelijke Behandeling. De Commissie blijkt in staat te zijn om een benadeling op objectieve wijze vast te stellen, doordat rekening wordt gehouden met feitelijke gegevens die door de partijen zijn overgelegd of die zij zelf heeft achterhaald. Hoewel er in sommige gevallen twiffel mogelijk is over de juistheid van de conclusies die de Commissie uit cijfermatig bewijsmateriaal afleidt, is haar redenering in vrijwel alle oordelen duidelijk, doorzichtig en voldoende controleerbaar. Het geven van een zorgvuldige motivering voor het oordeel is bij de keuze voor de benadelingstoets als toetsingsingang ook vrijwel onvermijdelijk: het is niet mogelijk om een benadeling vast te stellen, anders dan door uitdrukkelijke verwijzing naar gegevens die door partijen zijn overgelegd of door de betrokken instantie zijn vastgesteld. In dit opzicht biedt de benadelingstoets belangrijke voordelen boven de vergelijkbaarheidstoets: uit het voorgaande is gebleken dat deze toets de rechter geen enkele prikkel geeft tot het geven van een goede en doorzichtige motive- 
ring. Belangrijk is verder dat de benadelingstoets zoals die wordt uitgevoerd door de Commissie Gelijke Behandeling en de Centrale Raad aanzienlijk meer onderscheidend vermogen heeft dan de vergelijkbaarheidstoets: alleen wanneer is vastgesteld dat er daadwerkelijk sprake is van een (voldoende ernstige) benadeling is het nodig om een rechtvaardigingstoets uit te voeren, terwijl in alle andere gevallen duidelijk is dat het gelijkheidsbeginsel niet is geschonden. Daardoor is de benadelingstoets als toetsingsingang aanzienlijk zinvoller dan de vergelijkbaarheidstoets, waarbij een goed gebruik altijd noodzaakt tot het uitvoeren van een rechtvaardigingstoets.

\section{De benadelingstoets als toetsingsingang}

Wanneer de benadelingstoets tot toetsingsingang wordt gekozen moet deze op een zorgvuldige manier wordt uitgevoerd. Voor de wijze waarop aan deze toets invulling kan worden gegeven zijn aanwijzingen te vinden in de oordelen van de Commissie Gelijke Behandeling. In beginsel leidt de Commissie het bestaan van een benadeling af uit cijfermatige gegevens die zijn overgelegd door de partijen of die uit eigen onderzoek naar voren zijn gekomen. $\mathrm{Zij}$ heeft daarbij een uitgebreide rechtspraak ontwikkeld over de vraag hoe de betrokken referentiegroepen moeten worden gedefinieerd en welke eisen er moeten worden gesteld aan de representativiteit van statisch bewijsmateriaal. ${ }^{\text {ts }}$ Ontbreekt cijfermatig bewijs of is dit niet bijzonder sterk, dan leidt de Commissie een benadeling af uit feiten van algemene bekendheid of doet zij een beroep op logica of evidentie. Deze werkwijze van de Commissie vertoont overeenstemming met die van het Europees Hof van Justitie: ook het Hof maakt veel gebruik van cijfermatig bewijsmateriaal en waardeert dit op vergelijkbare wijze. Wanneer de diverse elementen van de toetsing door Hof en Commissie met elkaar worden gecombineerd kan dan ook een zinvolle invulling worden gegeven aan de benadelingstoets. In hoofdstuk $7 \mathrm{zal}$ worden getracht een dergelijke combinatie tot stand te brengen.

Interessant is verder dat de Commissie in een vaste lijn van rechtspraak heeft aangenomen dat de benadeling een concreet karakter moet hebben, dat wil zeggen dat er sprake moet zijn van een benadeling waardoor de betrokkene in een rechtens beschermd belang wordt getroffen. Ook dit lijkt een redelijke benadering, waardoor de wederpartij niet de moeite hoeft te nemen om een objectieve rechtvaardiging aan te voeren wanneer er slechts sprake is van louter subjectief ervaren nadeel. Het door de Commissie gebruikte criterium laat tegelijkertijd wel voldoende ruimte voor het vereisen van een rechtvaardiging bij objectief vaststelbaar psychisch nadeel, zoals bij een ernstige belediging wegens nationaliteit of godsdienst of in gevallen waarin objectief gezien een gevoel van inferioriteit bij de betrokkene kon worden opgeroepen. Dit criterium kan dan ook worden overgenomen in het algemene toetsingsmodel. Hetzelfde geldt voor het vereiste dat er sprake moet zijn van een werkelijk nadeel: de Commissie verlangt dat de betrokkene daadwerkelijk persoonlijk is geraakt door de betrokken regeling, terwijl het niet zo mag zijn dan het ondervonden nadeel op de één of andere manier wordt gecompenseerd. Inderdaad is het niet redelijk om van de wederpartij te verwachten dat hij een rechtvaardiging aanvoert in een geval waarin er feitelijk geen sprake is van een belangenaantasting. Door het gebruik van dit soort criteria wordt de

494. Zie paragraaf 2.2 .3 . 
benadelingstoets iets aangescherpt, waardoor deze ook voor gevallen van direct onder. scheid beter bruikbaar wordt.

Ook een laatste door de Commissie ontwikkelde toetsingscriterium - het vereiste dat er sprake moet zijn van een "overwegende" benadeling - is vatbaar voor invoeging in het algemene toetsingsmodel. ${ }^{45}$ Dit criterium is ontwikkeld voor gevallen van indirect onderscheid, waarbij moet worden aangetoond dat onderscheid op grond van een neutraal criterium een ongelijke behandeling op een "verdachte" grond tot gevolg heef. Om dit te kunnen bewijzen is het nodig dat het effect van een handeling of regeling in verband kan worden gebracht met een bepaalde grond van onderscheid, zoals geslacht of godsdienst. Dit is alleen te bepalen door te kijken naar de verhoudingen binnen de benadeelde groep: om te kunnen spreken van een benadeling die is gebaseerd op religie moet bijvoorbeeld duidelijk zijn dat mensen die het betrokken geloof aanhangen inderdaad vaker nadeel ondervinden van de regeling dan anderen. Deze benadering kan ook worden gehanteerd wanneer er wordt geklaagd over direct onderscheid dat op een specifiek onderscheidingscriterium is gebaseerd: ook dan moet immers worden aangetoond dat er verband bestaat tussen het nadeel en het genoemde criterium. Alleen wanneer in het algemeen wordt gesteld dat er sprake is van een benadeling, zonder dat een bijzondere onderscheidingsgrond wordt genoemd, is het niet nodig (en ook niet mogelijk) om na te gaan of een bijzondere groep in onevenredige mate door het onderscheid wordt getroffen: voldoende is dan dat wordt beoordeeld of de betrokken klager inderdaad aan een nadeliger behandeling is onderworpen dan anderen.

\subsubsection{Toetsing in de tweede fase: de rechtvaardigingstoets}

\section{Algemeen}

De Nederlandse rechterlijke instanties, met uitzondering van de Commissie Gelijke Behandeling, blijken slechts zelden toe te komen aan een rechtvaardigingstoets: het feit dat de vergelijkbaarheidstoets in de meeste gevallen de uitkomst van de toetsing bepaalt staat daaraan in de weg. Wanneer er wél een rechtvaardigingstoets wordt uitgevoerd is deze vaak erg oppervlakkig en algemeen: de onderzochte instanties onderscheiden slechts zelden tussen verschillende toetsingscriteria en voeren in veruit de meeste gevallen alleen een soort algemene redelijkheidstoets uit. De betrokken instanties lijken zelf van mening te zijn dat alleen door een dergelijke benadering recht kan worden gedaan an het vereiste van rechterlijke terughoudendheid. Terughoudendheid hoeft echter niet gelijk te staan aan een onzorgvuldige toetsing: het is zeker mogelijk om een oordeel te geven over elementen als geschiktheid, noodzakelijkheid en evenredigheid, zonder dat hierbij een (te) ingrijpende toetsing wordt uitgevoerd. Vooral door het hanteren van een soepele bewijslastverdeling (waarbij bijvoorbeeld genoegen wordt genomen met een geringe mate van bewijs voor de geschiktheid van het onderscheid of waarbij aan de benadeelde wordt gevraagd om annemelijk te maken dat het onderscheid niet noodzakelijk is) en een terughoudende toetsing van de gemaakte belangenafweging kan voldoende tegemoet worden gekomen aan de noodzaak van terughou-

495. Zie voor dit criterium en de modaliteiten ervan, in het bijzonder voor de vraag wanneer een benadeling een groep in "overwegende mate" treft, nader paragraaf 2.2.3. 
dendheid, terwijl tegelijkertijd een goed gemotiveerd en overtuigend oordeel over de angedragen rechtvaardiging wordt gewaarborgd.

\section{Toetsing van het doel}

In het beperkte aantal gevallen waarin een zorgvuldige rechtvaardigingstoets wordt uitgevoerd blijken de verschillende rechterlijke instanties vooral aandacht te hebben voor de toetsing van het nagestreefde doel. Daarbij blijken zij weinig moeite te hebben met het achterhalen van dit doel: in de meeste gevallen blijken de algemene doelstellingen van het onderscheid relatief gemakkelijk te kunnen worden afgeleid uit de totstandkomingsgeschiedenis van de betrokken regeling of uit de stellingen van partijen en het verhandelde ter zitting. Een onderzoek naar het "werkelijke" doel van de regeling (waarvoor aanleiding kan bestaan wanneer het aangevoerde of op basis van de wetsgeschiedenis vastgestelde doel erg algemeen of weinig overtuigend is) blijkt hoogst zelden te worden uitgevoerd. Gezien het feit dat de Nederlandse rechters meestal een terughoudende toetsing uitvoeren is dit ook niet verrassend: het zoeken naar een andere doelstelling dan uit de totstandkomingsgeschiedenis of de stellingen van partijen naar voren komt vergt een zo vergaande rechterlijke activiteit dat daarvoor eigenlijk alleen ruimte bestaat bij een intensieve toetsing, of wanneer de feiten daadwerkelijk tot een dergelijk onderzoek aanleiding geven. Ook in die omstandigheden blijft een onderzoek naar het werkelijk doel veelal regelmatig achterwege, zoals blijkt uit de oordelen van de Commissie Gelijke Behandeling. De oorzaak daarvoor lijkt gelegen te zijn in het feit dat het in concrete gevallen niet altijd gemakkelijk is om voldoende bewijs te vinden voor het bestaan van een onoirbare werkelijke doelstelling. Inderdaad is het in die gevallen vrijwel onvermijdelijk om een rechtvaardigingstoets uit te voeren aan de hand van het door de verwerende partij angevoerde doel. Zeker bij een intensieve toetsing is het noodzakelijk dat hierbij een bijzonder grote mate van zorgvuldigheid en nauwkeurigheid aan de dag wordt gelegd.

Wanneer het doel van het onderscheid eenmaal is vastgesteld moet dit op zijn redelijkheid worden beoordeeld. Het volledig achterwege laten van de redelijkheidstoets, zoals in sommige rechterlijke uitspraken zichtbaar is, is niet wenselijk. Op zichzelf is het inderdaad mogelijk dat een onderscheid dat is ingegeven door ongerechtvaardigde overwegingen toelaatbaar is, bijvoorbeeld wanneer duidelijk is dat door de betrokken regeling maatschappelijk wenselijke effecten worden bereikt of wanneer er nog andere, zwaarwegende en legitieme overwegingen zijn die het onderscheid ondersteunen. In de meeste gevallen zal een regeling waarvan de doelstelling ongerechtvaardigd is echter niet in stand kunnen blijven: het kan niet redelijk worden geacht dat individuele belangen worden aangetast, zonder dat daarvoor een overtuigende en legitieme reden bestaat.

In de meeste uitspraken van de onderzochte instanties komt dit uitgangspunt inderdaad tot uitdrukking, doordat een uitdrukkelijk (zij het vaak niet of zeer summier gemotiveerd) oordeel wordt uitgesproken over de redelijkheid van het nagestreefde doel. Voor de ontwikkeling van een algemeen toetsingsmodel is het vooral interessant om te bezien aan welke criteria de doelstellingen daarbij worden getoetst. Vanzelfsprekend vereisen alle verschillende instanties dat het doel in overeenstemming is met hogere 
regelgeving en, in gevallen van concrete bevoegdheidsuitoefening, dat er geen sprake is van détournement de pouvoir. Verder is in de rechtspraak regelmatig de stelling te vinden dat het nagestreefde doel niet inherent discriminatoir mag zijn, in die zin dat het onderscheid niet mag zijn ingegeven door overwegingen die rechtstreeks betrekking hebben op de betrokken onderscheidingsgrond. De betekenis van dit criterium is in de Nederlandse rechtspraak minder groot dan in de rechtspraak van de in eerdere hoofdstukken besproken instanties, nu het vrijwel alleen wordt gehanteerd bij indirect onderscheid. Bovendien blijkt een doelstelling in de praktijk bijna nooit inherent discriminatoir te worden geacht: die conclusie wordt eigenlijk alleen bereikt wanneer het voor de verantwoordelijke duidelijk moet zijn geweest dat het door hem gemaakte onderscheid een ongelijke behandeling op een "verdachte" grond tot gevolg zou hebben. Hoewel deze invulling van het criterium zeer bruikbaar is, is zij wat beperkt: ook direct onderscheid kan zijn ingegeven door de bewuste wens een bepaalde groep achter te stellen, waarbij die wens is gebaseerd op ongegronde stereotypen of vooroordelen.

Ook overigens laat de Nederlandse rechtspraak over de toetsing van het doel weinig bijzonderheden zien: het vereiste van beantwoording aan een werkelijke behoefte van de wederpartij (ofwel het vereiste van actualiteit) en de vereisten van zwaarwegendheid, zakelijkheid, objectiviteit, redelijkheid en specificiteit zijn ook in de andere bestudeerde stelsels in enigerlei vorm terug te vinden. De verschillende vereisten kunnen dan ook zeker in het algemene toetsingsmodel worden verwerkt, met uitzondering van het vereiste van zwaarwegendheid: zoals eerder is aangegeven wordt door toetsing aan dit vereiste zodanig vooruitgelopen op de evenredigheidstoets dat de duidelijkheid van de redenering daardoor in gevaar kan komen.

Tenslotte is in de Nederlandse rechtspraak vrij algemeen aangenomen dat het oordeel over de gerechtvaardigdheid van een bepaalde doelstelling kan veranderen als gevolg van maatschappelijke ontwikkelingen en veranderde rechtsopvattingen. Dit lijkt een juiste benadering te zijn: wanneer de redelijkheid van een belangenaantasting maatschappelijk niet langer wordt aanvaard, kunnen er vraagtekens worden geplaatst bij de juridische toelaatbaarheid van die aantasting. Zoals de Nederlandse instanties hebben aangegeven moet met deze factor op zorgvuldige en terughoudende wijze worden omgesprongen: er is slechts plaats voor ontoelaatbaarverklaring van het doel wanneer de verandering in de opvattingen duidelijk vaststaat (zoals bijvoorbeeld kan blijken uit het bestaan van een internationale consensus of uit rechtspraak van internationale rechterlijke instanties) en dat de wetgever onvoldoende in staat is (of niet bereid blijkt te zijn) om hierop voldoende snel en adequaat te reageren. Wanneer die uitgangspunten als randvoorwaarden worden gesteld, is het mogelijk om dit toetsingscriterium in het algemene toetsingsmodel op te nemen.

\section{Toetsing van de verhouding tussen doel en onderscheid}

De toetsing van de verhouding tussen doel en onderscheid is in Nederland meestal uiterst summier: in veruit de meeste gevallen gaat de rechter alleen in zijn algemeenheid na of de verhouding "redelijk" is, zonder dat aandacht wordt besteed aan de afzonderlijke vereisten van fit, geschiktheid, noodzakelijkheid of subsidiariteit, en evenredigheid. In paragraaf 2.4 is echter duidelijk geworden dat de genoemde criteria allemaal in enigerlei vorm in de Nederlandse rechtspraak zijn terug te vinden; duidelijke en 
overtuigende argumenten voor weglating van één of meer van de theoretische criteria zijn in ieder geval niet genoemd.

Aan verschillende criteria is in Nederland een invulling gegeven die zich leent voor inpassing in het algemene toetsingsmodel. Van belang is vooral het in paragraaf 2.4.1 besproken proxy-element. Wanneer de rechter op basis van stellingen van partijen of eigen onderzoek signaleert dat het gehanteerde onderscheidingscriterium beschouwd moet worden als een benadering of proxy voor een ander, specifieker criterium, dan moet hij nagaan of door het gebruik van de proxy (vrijwel) dezelfde groep wordt uitgezonderd als het geval zou zijn geweest wanneer het eigenlijke criterium was gehanteerd. Daarbij geldt hetzelfde als bij de toetsing van de mate van fit: van een perfecte aansluiting tussen beide onderscheidingscriteria zal nooit sprake zijn, maar vereist kan wel worden dat de aansluiting zo goed mogelijk is. De precieze eisen die daarbij kunnen worden gesteld zullen vooral afhankelijk zijn van de intensiteit van de uitgevoerde toetsing. Ontbreekt een voldoende aansluiting tussen het werkelijke onderscheidingscriterium en de proxy, dan kan het onderscheid meteen ontoelaatbaar worden verklaard: de classificatie is dan zodanig slecht gedefinieerd dat de daardoor veroorzaakte belangenaantasting onredelijk moet worden geacht. Is er wel sprake van een voldoende aansluiting, dan betekent dit echter nog niet dat de classificatie onmiddellijk als voldoende zorgvuldig moet worden aangemerkt. De toetsing van de relevante proxy en die van de mate van fit vallen niet volledig samen: zoals in paragraaf 2.4.1 is opgemerkt is het denkbaar dat ook het eigenlijke toetsingscriterium zodanig ongelukkig is gekozen dat een bepaalde groep, ten onrechte voor een bijzondere behandeling wordt uitgezonderd. De toetsing van de proxy moet dan ook als apart toetsingselement worden toegevoegd an het algemene toetsingsmodel; de toetsing hieraan moet voorafgaan aan de toetsing van de over- of underinclusiveness van het onderscheid.

In de paragrafen 2.4 .2 en 2.4 .3 is duidelijk geworden dat alleen de oordelen van de Commissie Gelijke Behandeling een interessante toepassing van de vereisten van geschiktheid, noodzakelijkheid en subsidiariteit laten zien. Wat betreft de geschiktheid komt de toetsingsmethodiek van de Commissie sterk overeen met het theoretische model: de Commissie gaat na of er sprake is van een toereikende mate van causaliteit tussen doelstelling en onderscheid, waarbij het oordeel hierover gemotiveerd wordt aan de hand van objectieve en feitelijke gegevens die aan de Commissie zijn voorgelegd. Nadere bijzonderheden die kunnen dienen als aanvulling op het theoretische model kunnen in deze rechtspraak niet worden gevonden.

Voor de toetsing van subsidiariteit en noodzakelijkheid geldt dat de Commissie een vrij scherp onderscheid maakt tussen deze twee vereisten, ook al is dit blijkens haar definitie van de rechtvaardigingstoets niet het geval. In de praktijk blijkt zij vooral aan het vereiste van subsidiariteit te toetsen wanneer er voldoende gegevens voorhanden zijn om een zinvol oordeel uit te kunnen spreken over eventuele alternatieven voor het onderscheid; ontbreken die gegevens, dan zal meestal in zijn algemeenheid worden nagegaan of het onderscheid noodzakelijk was om het doel te bereiken. Een subsidiariteitstoets wordt verder vooral toegepast wanneer het onderscheid als verdacht wordt aangemerkt; in die gevallen verlangt de Commissie zelfs van de wederpartij dat hij 
aannemelijk maakt dat er geen minder benadelende mogelijkheden bestonden om het gestelde doel te bereiken. Op deze manier wordt zeker recht gedaan aan het graduele verschil tussen de beide toetsen. Het lijkt daarom zinvol om ook voor het algemene toetsingsmodel te stellen dat in beginsel een algemene noodzakelijkheidstoets wordt uitgevoerd, tenzij de toetsing zo intensief is dat een subsidiariteitstoets is aangewezen. Bovendien kan in zijn algemeenheid worden gesteld dat er ruimte bestaat voor een subsidiariteitstoets wanneer de benadeelde partij aan de hand van feiten aannemelijk heeft gemaakt dat er minder vergaande alternatieven bestonden of wanneer dit duidelijk blijkt uit de omstandigheden van het geval.

Ook wat betreft de praktische toepassing van de subsidiariteitstoets verschaffen de oordelen van de Commissie waardevolle aanknopingspunten voor het algemene toetsingsmodel. Belangrijk is bijvoorbeeld dat de Commissie een goed gebruik maakt van de mogelijkheden die deskundigenrapporten en onderzoeksgegevens bieden en dat zij nauwkeurig kijkt naar de gegevens die door de partijen zijn aangedragen. Aan de hand van dergelijke gegevens kunnen objectieve conclusies worden getrokken over de vraag of er minder belastende alternatieven bestonden.

Voor de situatie waarin is gebleken dat er inderdaad minder vergaande mogelijkheden bestonden leveren de oordelen van de Commissie eveneens interessante aanwijzingen op. Volgens de Commissie moet bij de beoordeling of het in deze situatie toch redelijk was dat de wederpartij voor het gemaakte onderscheid koos, rekening worden gehouden met de intensiteit van de toetsing ${ }^{4 \%}$ Dit is ook terecht, nu het maken van keuzen tussen verschillende middelen om een bepaalde doelstelling te bereiken normaal gesproken aan de verantwoordelijke moet worden overgelaten, met name wanneer deze over een ruime mate van discretie beschikt. Is de toetsing terughoudend, dan laat de Commissie het meestal aan de benadeelde over om aannemelijk te maken dat de wederpartij voor de minder vergaande alternatieven had moeten kiezen. Voor de benadeelde zal dit geen gemakkelijke opdracht zijn, zodat het onderscheid de toetsing an het vereiste van subsidiariteit in deze omstandigheden gemakkelijk zal kunnen doorstaan. Is de toetsing intensief, dan is het juist de wederpartij die moet aantonen dat de minder vergaande alternatieven niet geschikt of bruikbaar waren voor het bereiken van het gestelde doel. Een dergelijke genuanceerde benadering kan worden gezien als een zinvolle invulling van het algemene toetsingsmodel.

Tenslotte is in paragraaf 2.4.4 ten aanzien van de proportionaliteitstoets opgemerkt dat deze in Nederland een minder belangrijke rol speelt: in de definities van de rechtvaardigingstoets van de verschillende instanties is dit element zelfs in het geheel niet terug te vinden. Gebleken is echter dat de toets in de praktijk wel degelijk een rol speelt. Het accent ligt daarbij niet zozeer op de beoordeling van de gemaakte belangenafweging (daaraan staat de terughoudendheid van de toetsing meestal in de weg), maar vooral op de vaststelling van het gewicht van de aangetaste en nagestreefde belangen. De conclusie over de proportionaliteit vloeit uit die vaststelling vrijwel automatisch voort.

496. Daarbij geldt dat bij een terughoudende toetsing eigenlijk een algemene noodzakelijkheidstoets word uitgevoerd. Zoals hiervoor is aangegeven kan het echter ook zo zijn dat er een subsidiariteitstoets wordt uitgevoerd omdat de benadeelde aannemelijk heeft gemaakt dat er goede alternatieven bestonden of omdat dit uit de feiten zelf al bleek. 
Zoals in paragraaf 2.4.4 is aangegeven bevat de Nederlandse rechtspraak maar weinig algemeen bruikbare aanknopingspunten voor het vaststellen van het gewicht van de betrokken belangen. Het zijn voornamelijk de duur van de benadeling, het onherroepelijk karakter daarvan en het onvoorwaardelijke karakter van de uitsluiting van een bepaald recht of voordeel, die invloed zullen hebben op het oordeel over het gewicht van het aangetaste belang. Factoren als deze zijn ook bij de bespreking van andere stelsels naar voren gekomen en kunnen zeker een rol spelen in het algemene toetsingsmodel. Verder bevestigt de rechtspraak van de verschillende Nederlandse instanties dat financiële overwegingen in het algemeen minder belangrijk zijn als rechtvaardiging voor een ongelijke behandeling. Ten aanzien van administratieve belangen bestaat er minder eenduidigheid: de waarde van dit soort belangen blijkt sterk afhankelijk te zijn van de aard van de betrokken zaken en van de omstandigheden van het geval. Dit is geen onredelijke benadering, die de voorkeur verdient boven de stelling van het Europese Hof van Justitie dat administratieve overwegingen vrijwel nooit een voldoende rechtvaardiging kunnen opleveren: door die opvatting wordt te weinig rekening gehouden met het belang dat administratieve overwegingen in de praktijk kunnen hebben.

Interessant is verder dat de door het legaliteitsbeginsel beschermde belangen steeds als bijzonder gewichtig worden beschouwd: het honoreren van een beroep op het gelijkheidsbeginsel zal alleen tot een doorbreking van het legaliteitsbeginsel (contra legemwerking) kunnen leiden als de door het onderscheid aangetaste belangen op hun beurt eveneens zeer zwaarwegend zijn. Tenslotte geldt voor de bescherming van de belangen van derden (ook als het gaat om abstracte belangen, zoals de bescherming van rechtszekerheid) dat dit als een zwaarwegend doel wordt aangemerkt. In het algemeen sluit deze rechtspraak aan bij hetgeen in hoofdstuk 2 is opgemerkt over het gewicht van de nagestreefde belangen.

\subsection{Conclusies met betrekking tot de toetsingsintensiteit}

\subsubsection{Variatie in de toetsingsintensiteit}

Zoals in paragraaf 3 van dit hoofdstuk is gebleken biedt de Nederlandse rechtspraak weinig nieuwe gezichtspunten als het gaat om de vaststelling van de toetsingsintensiteit. De rechtspraak bevestigt slechts dat het praktisch mogelijk is om onderscheid te maken tussen verschillende gradaties van toetsingsintensiteit, namelijk tussen een zeer marginale, een terughoudende en een intensieve toets of, in het geval van de Commissie Gelijke Behandeling, tussen een terughoudende, een intensieve en een zeer intensieve toets. Verder wordt door de Nederlandse rechtspraak het vermoeden bevestigd dat rechters een bepaalde "basisintensiteit" hanteren, die als gevolg van de aanwezigheid van bepaalde factoren kan worden geïntensiveerd of juist kan worden afgezwakt. Bijzonder is wel dat de basisintensiteit in Nederland, afhankelijk van het karakter van de betrokken instantie, terughoudend dan wel intensief is. Het is dus niet zo dat alle rechterlijke instanties vanzelf een terughoudende toets tot uitgangspunt nemen, zoals op basis van de in de voorgaande hoofdstukken besproken rechtspraak wellicht zou kunnen worden verondersteld. Het is ook niet problematisch om een andere dan een terughoudende toetsing tot basisintensiteit te kiezen, maar het is belangrijk dat de betrokken instantie motiveert waarom zij deze intensiteit tot uitgangspunt neemt en daar- 
bij aangeeft welke consequenties die intensiteit heeft voor de toetsingsmethodiek en de bewijslastverdeling. In Nederland heeft tot nu toe alleen de Centrale Raad van Beroep in de in paragraaf 3.1 besproken Van Maarseveen-zaak ${ }^{4 y 7}$ een dergelijke motivering gegeven.

\subsubsection{Intensiteitbepalende factoren}

Met betrekking tot de factoren die een rol kunnen spelen bij de vaststelling van de toetsingsintensiteit is de Nederlandse rechtspraak teleurstellend. De discussie over de intensiteit van de rechterlijke toetsing wordt in Nederland bepaald door sterk theoretische onderscheidingen tussen doelmatigheids- en wetmatigheidsaspecten, tussen beleids- en beoordelingsvrijheid, tussen vage normen en duidelijk geformuleerde bevoegdheidsgrondslagen, tussen macro- en microbestuursniveau, etc. Deze onderscheidingen spelen vooral een rol bij de toetsing van bestuurshandelen, dus bij de beoorde. ling van onderscheid dat het gevolg is van een concrete bevoegdheidsuitoefening (zoals een subsidieverlening of het opleggen van een bestuurlijke boete). Bij de toetsing van normatieve classificaties die zijn neergelegd in (formele of materiële) wetgeving of in regelingen op horizontaal niveau (beloningsregelingen in bedrijven, CAO's, etc.) spelen de genoemde begrippen nauwelijks een rol en ontbreekt ieder duidelijk inzicht in de wijze waarop de intensiteit van de toetsing wordt bepaald. Hoogstens kan ook hierbij het vaak gemaakte onderscheid tussen wetmatigheids- en doelmatigheidsfactoren van belang zijn. Dit onderscheid impliceert dat de variatie in toetsingsintensiteit niet geldt voor de toetsing aan alle criteria van het rechtvaardigingsmodel: de beoordeling van de legitimiteit van het doel zal altijd "integraal" zijn en kan geen marginaal of intensief karakter hebben, nu het eenvoudigweg niet mogelijk is om "strikt" of "minder strikt" te controleren of de doelstelling van het onderscheid in overeenstemming is met hogere regelgeving. Voor alle overige onderdelen van de toetsing, dus voor het vaststellen van het doel en het onderzoek naar de redelijkheid van het doel buiten de beperkte context van de legitimiteit (bijvoorbeeld bij de toetsing aan veranderde opvattingen of de beoordeling van de actualiteit), geldt dat de vrijheid van de wederpartij in beginsel moet worden gerespecteerd, zodat de intensiteit van de toetsing daarbij kan variëren.

De andere factoren die sporadisch zijn terug te vinden, zoals de aanwezigheid van een common ground, de grond van onderscheid, de aard en het gewicht van het aangetaste en nagestreefde belang en het karakter van het onderscheid, zijn in de Nederlandse rechtspraak weinig uitgewerkt en bieden nauwelijks nieuwe gezichtspunten. De rechtspraak op dit punt bevestigt vooral de in hoofdstuk 2 geuite veronderstelling dat deze factoren praktisch bruikbaar zijn. Meer in het algemeen kan worden gesteld dat de Nederlandse rechterlijke instanties zich er nauwelijks van bewust zijn dat er bij ieder geval van ongelijke behandeling verschillende factoren een rol zullen spelen, die ieder voor zich een bepaalde invloed kunnen hebben op de intensiteit van de toetsing. In dit opzicht staan de Nederlandse belangstelling voor de toetsingsintensiteit en de kwaliteit van de rechtspraak over dit onderwerp in schril contrast met de aandacht die daaraan in andere stelsels wordt besteed. De Nederlandse jurisprudentie over ongelijke behande- 
ling zal dan ook maar een beperkte invloed kunnen hebben op de ontwikkeling van een afwegingsmodel voor de vaststelling van de toetsingsintensiteit. 



\section{Conclusie: naar een algemeen toetsingsmodel}

\section{$1 \quad$ Inleiding}

In hoofdstuk 1 van dit proefschrift werd aangegeven dat het van groot belang is dat rechters hun oordeel over een ongelijke behandeling zorgvuldig en overtuigend motiveren: alleen op die manier kan de voorspelbaarheid en controleerbaarheid van de rechtsprak over het gelijkheidsbeginsel worden gewaarborgd. Bovendien kan het stellen van hoge eisen aan de motivering leiden tot een vermindering van de invloed van subjectieve elementen op de rechterlijke oordeelsvorming en wordt een redelijke toetsingsuitkomst hierdoor zoveel mogelijk gegarandeerd. Uit de voorgaande hoofdstukken is echter gebleken dat rechters hun oordeel in de praktijk lang niet altijd op een goede manier onderbouwen. Weliswaar hebben alle onderzochte rechterlijke instanties criteria ontwikkeld voor de beoordeling van onderscheid, maar hun "toetsingsmodellen" blijken lang niet altijd even precies en genuanceerd te zijn uitgewerkt. Zo bestaat het rechtvaardigingsmodel van het Europees Hof voor de Rechten van de Mens officieel uit maar twee onderdelen (een doeltoets en een toetsing van de proportionaliteit in rume zin), terwijl ook de Nederlandse rechter uitsluitend nagaat of het onderscheid een "passend" middel is om een legitiem doel te bereiken.' Het Europees Hof van Justitie geeft in landbouwzaken evenmin een uitgebreide motivering: het Hof maakt in deze zaken gebruik van een nauwelijks uitgewerkt model en is bij de toepassing daarvan niet altijd consequent. Juist door het gebrek aan een goed toetsingsmodel laat de motivering van de uitspraken van deze instanties te wensen over: in veel gevallen beoordelen zij slechts of het onderscheid in zijn algemeenheid als "redelijk" kan worden beschouwd, zonder dat zij duidelijkheid verschaffen over de criteria die zij in deze beoordeling betrekken.

Wanneer een nauwkeurig en genuanceerd uitgewerkt model wel voorhanden is, blijkt dit evenmin altijd een waarborg te verschaffen voor een redelijke toetsing. Het Amerikaanse Supreme Court heeft bijvoorbeeld een drietal uitgebreide en duidelijke toetsingsmodellen ontwikkeld (de rational basis-test, de intermediate scrutiny-test en de strict scrutiny-test), maar de inhoud van deze modellen en de wijze waarop daarmee wordt omgegaan blijken in de praktijk vaak onbevredigende uitkomsten op te leveren. ${ }^{2}$ Van belang is bijvoorbeeld dat het Supreme Court soms zodanige toetsingscriteria in zijn oordeel betrekt, dat maatschappelijk onwenselijke uitkomsten nauwelijks kunnen worden vermeden. ${ }^{3}$ Bovendien kenmerken de Amerikaanse modellen zich door een

1. Zie voor het toetsingsmodel van het Europees Hof voor de Rechten van de Mens hoofdstuk 2 par. 2.1. De Nederlandse toetsingsmethodiek is besproken in hoofdstuk 6 par. 2. Alleen de Commissie Gelijke Behandeling, een semi-rechterlijke instantie, blijkt een aanzienlijk beter uitgewerkt model te hanteren en consequent een goede motivering voor haar oordeel te geven.

2. Zie hoofdstuk 5 par. 2. Alleen bij de intermediate scrutiny-test en de (formeel niet erkende) rational basis "with bite"-test is de motivering vaak beter, maar dan is de keuze voor de test ook niet automatisch bepalend voor de uitkomst. Zie nader hoofdstuk 5 par. 2.1.2 en 2.1.3.

3. Dit is vooral het geval bij de strict scrutimy-test, waarbij een doeltoets als toetsingsingang wordt gekozen. Op de daaraan verbonden problemen zal hierna, in paragraaf 2.3 , nog nader worden ingegaan. Zie 
grote mate van rigiditeit, waardoor het lang niet altijd mogelijk is om rekening te houden met de individuele omstandigheden van het geval en een voor de benadeelde partij
vaak onredelijk hoge bewijslast wordt gecreëerd.

Het voorgaande laat zien dat het voor een goede motivering van een oordeel over gelijke behandeling nodig is dat de rechter beschikt over een uitgewerkt toetsingsmodel, maar dat het enkele bestaan daarvan nog niet voldoende is. Een toetsingsmodel kan alleen een waarborg verschaffen voor een overtuigende motivering en een redelijke toetsingsuitkomst, wanneer de daarin opgenomen beoordelingscriteria de rechter noodzaken tot een inhoudelijk beoordeling van alle relevante aspecten van het voorgelegde onderscheid. Het model moet de rechter bovendien voldoende ruimte verschaffen om rekening te kunnen houden met de concrete omstandigheden van het geval, terwijl het tenslotte van groot belang is dat door de vormgeving van het model een redelijke bewijslastverdeling wordt gecreëerd.

In hoofdstuk 2 is een theoretische aanzet gegeven voor de ontwikkeling van een model dat aan deze voorwaarden tegemoet komt. Het uitgangspunt van dit model is dat de rechterlijke toetsing uit drie fasen bestaat." In de eerste fase van zijn toetsing zal de rechter moeten nagaan of de eisende partij, die stelt dat hij het slachtoffer is van een ongelijke behandeling, voldoende recht van klagen heeft. Anders gezegd: in deze fase moet de rechter vaststellen of er eigenlijk wel sprake is van een ongelijke behandeling die rechtvaardiging behoeft. Pas als dit voldoende vaststaat zal de rechter toe kunnen komen aan de tweede fase van de toetsing, waarin hij moet nagaan of er voor het gesignaleerde onderscheid een objectieve en redelijke rechtvaardiging bestaat. In deze fase moet hij het onderscheid toetsen aan een aantal beoordelingscriteria, die samen het rechtvaardigingsmodel vormen. Wanneer de rechter heeft vastgesteld of aan deze eisen is voldaan kan hij tenslotte toekomen aan de derde en laatste toetsingsfase: het vaststellen van de consequenties van het oordeel over de toelaatbaarheid van het onderscheid. ${ }^{6}$

Voor de eerste twee fasen van de toetsing is in hoofdstuk 2 een aantal theoretische beoordelingscriteria ontwikkeld. Aangegeven is daarbij dat het om verschillende redenen niet wenselijk of nodig is om in de eerste fase van de toetsing na te gaan of er sprake is van een ongelijke behandeling van vergelijkbare gevallen of van een gelijke behandeling van onvergelijkbare gevallen, zoals in de literatuur vaak wordt verondersteld. Voor de kwaliteit van de motivering is het beter dat de rechter gebruik maakt van

ook hoofdstuk 5 par. 2.2.3. Aan de werkwijze van het Supreme Court zijn nog andere bezwaren ver. bonden, zoals het rigide karakter van de indeling in toetsen en de grote voorspellende waarde van de keuze voor één van deze toetsen.

4. Zie daarover nader hoofdstuk 5 par. 2.2 .3 en 4.2.1; zie ook hierna par. 4.1.

5. Ook in de praktijk blijkt van deze onderverdeling in fasen gebruik te worden gemaakt, hoewel dit niet altijd even expliciet gebeurt; zie steeds par. 2.1 van de rechtsvergelijkende hoofdstukken. Overigens kan worden gesteld dat aan deze fasen nog een vierde fase voorafgaat: in deze "voorfase" stelt de rechter vast hoe intensief hij het onderscheid zal beoordelen. Deze fase wordt hierna in paragraaf 4 besproken.

6. Deze toetsingsfase is niet in het onderzoek betrokken. Zie nader hoofdstuk 2 par. 3.1.2. 
een andere toetsingsingang, zoals een benadelingstoets. ${ }^{7}$ Verder is in hoofdstuk 2 een hypothetisch rechtvaardigingsmodel geformuleerd voor de toetsing in de tweede fase, dat bestaat uit een vijftal algemene toetsingscriteria. Daarbij is aangegeven dat een nadere invulling en nuancering van de verschillende criteria is vereist om dit model daadwerkelijk bruikbaar te laten zijn voor toepassing door de rechter. Bovendien is ten anzien van enkele van de criteria gesteld dat zij niet in alle gevallen van ongelijke behandeling kunnen worden toegepast.

Om die reden is in het rechtsvergelijkende gedeelte van dit boek onderzocht hoe enkele belangrijke rechterlijke instanties in de praktijk met de toetsing aan het gelijkheidsbeginsel omgaan; de resultaten van dit onderzoek zijn in de hoofdstukken 3 tot en met 6 neergelegd. Een belangrijke conclusie die uit dit onderzoek kan worden afgeleid is dat in alle onderzochte stelsels één of meer nuttige aanvullingen en nuanceringen op het theoretische rechtvaardigingsmodel kunnen worden gevonden, zoals criteria voor de invulling van de eerste fase van de toetsing, maatstaven voor de beoordeling van de gerechtvaardigdheid van het nagestreefde doel, een alternatief voor de subsidiariteitstoets (de noodzakelijkheidstoets) en een aanvulling op de toetsing van de mate van fit (de toetsing van de gehanteerde proxy). Door toevoeging van dergelijke praktische criteria aan het theoretische model kan een voor de praktijk goed bruikbaar toetsingsmodel worden gecreëerd. Wanneer de rechter daaraan op een consequente en zorgvuldige manier toetst, kan een goede en doorzichtige motivering worden bewerkstelligd; bovendien kan een redelijke toetsingsuitkomst hierdoor zoveel mogelijk worden gegarandeerd.

Van belang is verder dat in hoofdstuk 2 is aangegeven dat de rechterlijke beoordeling zich steeds zal kenmerken door een bepaalde, consequent volgehouden toetsingsintensiteit: een ongelijke behandeling kan strikt worden getoetst, maar de beoordeling kan ook gematigd terughoudend of zelfs zeer marginaal zijn. Voorafgaand aan zijn beoordeling van het onderscheid zal de rechter dan ook moeten vaststellen met welke intensiteit hij deze beoordeling uit zal voeren. Om dit te kunnen doen zal de rechter moeten vaststellen welke intensiteitbepalende factoren er in een zaak aanwezig zijn en zal hij deze tegen elkaar moeten afwegen. Gezien het belang van de toetsingsintensiteit voor de uitkomst van de procedure is het essentieel dat de rechter deze afweging in zijn motivering expliciet tot uitdrukking brengt en zijn keuze voor een bepaalde intensiteit voldoende onderbouwt.

Ook voor de vaststelling van de toetsingsintensiteit zijn in hoofdstuk 2 enkele theoretische aanknopingspunten verschaft, maar opnieuw werd daarbij benadrukt dat de verschillende factoren een voorlopig en hypothetisch karakter hebben. In de rechtsvergelijkende hoofdstukken is nagegaan op welke manier rechters de intensiteit van hun toetsing in de praktijk bepalen. Net als bij het onderzoek naar de toetsingsmethodiek is ook hierbij een aantal interessante en bruikbare factoren en criteria gevonden, die een belangrijke aanvulling op en nuancering van het theoretische model verschaffen.

Het doel van dit laatste hoofdstuk is om de verschillende theoretische en praktische criteria en factoren, zoals die uit de voorgaande hoofdstukken naar voren zijn gekomen,

7. Zie hoofdstuk 2 par. 4. 
op zodanige wijze met elkaar te combineren dat er een werkbaar toetsingsmodel ontstaat. Daarbij is van belang dat van dit model gebruik moet kunnen worden gemaakt in alle situaties van ongelijke behandeling die in hoofdstuk 2 zijn onderscheiden. Dit betekent dat het model niet alleen van toepassing moet zijn op onderscheid in algemene regelgeving (normatieve classificaties), maar ook moet kunnen worden gebruikt bij de beoordeling van onderscheid dat is veroorzaakt door een concrete bevoegdheidsuitoefening (bijvoorbeeld in het geval waarin een bestuursorgaan in twee gevallen van een bepaalde bevoegdheid een verschillend gebruik heeft gemaakt). ${ }^{x}$ Bovendien mag het voor de toepasselijkheid van het model niet van belang zijn of het onderscheid is veroorzaakt door de overheid (een verticale verhouding) of door een individu of een onderneming (een horizontale verhouding) 9 en moet de rechter niet alleen met het model kunnen werken in gevallen van formeel of direct onderscheid, maar ook in gevallen van materieel of indirect onderscheid..$^{10}$ Tenslotte is van belang dat het model moet kunnen worden toegepast bij alle mogelijke gronden van onderscheid en in iedere denkbare context.

In het hiernavolgende zal allereerst worden ingegaan op de toetsing in de eerste fase, waarbij zal worden aangegeven welk toetsingscriterium daarbij het beste kan worden gehanteerd en op welke manier daarvan gebruik moet worden gemaakt (paragraaf 2). Vervolgens zal de inhoud van het rechtvaardigingsmodel aan de orde komen: vastgesteld zal worden welke criteria daarin moeten worden opgenomen en op welke wijze daaraan invulling moet worden gegeven (paragraaf 3 ). In paragraaf $4 \mathrm{zal}$ worden ingegaan op de vaststelling van de toetsingsintensiteit, waarbij vooral aandacht zal worden besteed aan de diverse factoren die bij deze vaststelling een rol kunnen spelen en aan de manier waarop deze factoren tegen elkaar moeten worden afgewogen. Dit hoofdstuk zal worden afgesloten met een korte, overzichtelijke weergave van het algemene toetsingsmodel (paragraaf 5); daarbij zal blijken dat dit op enkele punten daadwerkelijk afwijkt van het in hoofdstuk 2 ontwikkelde theoretische toetsingsmodel.

\section{Toetsing in de eerste fase: benadeling als toetsingsingang}

\section{$2.1 \quad$ Inleiding}

Zoals in het voorgaande is aangegeven zal de rechter, alvorens over te gaan tot een beoordeling van de aangevoerde rechtvaardiging, steeds moeten vaststellen of er eigenlijk wel sprake is van een ongelijke behandeling. Deze vaststelling is vooral van belang voor de verdeling van de bewijslast. Algemeen geaccepteerd is namelijk dat het een verantwoordelijkheid van de verwerende partij is om aan te tonen dat er een toereikende rechtvaardiging bestaat voor het door hem gemaakte onderscheid." De hierdoor

8. Zie nader hoofdstuk 2 par. 2.3 .

9. Zie nader hoofdstuk 2 par. 2.6.

10. Zie nader hoofdstuk 2 par. 2.4 .

11. Een uitzondering is het Supreme Court, die bij een toepassing van de rational basis-toets vereist dat de klager aantoont dat er geen rechtvaardiging voor het onderscheid bestaat. In hoofdstuk 5 is aangegevel dat dit om verschillende redenen geen wenselijke benadering is; bovendien wordt deze bijzondere be- 
voor de verwerende partij gecreëerde bewijslast is aanzienlijk, zodat het onredelijk is om deze ook op te leggen wanneer er twijfel zou bestaan over de aanwezigheid van een ongelijke behandeling. Belangrijk is bovendien dat het voor de verwerende partij duidelijk moet zijn waarop hij zijn rechtvaardiging precies moet richten. Een dergelijk richtpunt kan alleen ontstaan als de klager duidelijk aangeeft waarin het onderscheid volgens hem is gelegen.

De onderzochte rechterlijke instanties blijken op een zeer verschillende manier om te gaan met de toetsing in de eerste fase, waarbij het vooral opmerkelijk is dat zij bij direct onderscheid vaak een andere toetsingsingang kiezen dan bij indirect onderscheid. Zo voert het Europees Hof van Justitie bij direct onderscheid meestal een vergelijkbaarheidstoets uit, terwijl het bij indirect onderscheid consequent gebruik maakt van een benadelingstoets, en kiest het Supreme Court bij direct onderscheid voor een benadelingstoets, terwijl het bij indirect onderscheid een soort doeltoets uitvoert. ${ }^{12}$ Een dergelijke variatie is alleen nodig wanneer een andere dan de benadelingstoets tot uitgangspunt wordt gekozen: de benadelingstoets zelf vormt zowel bij direct als bij indirect onderscheid een bruikbare toetsingsingang. In deze paragraaf zal nader worden ingegaan op de wenselijkheid van de keuze voor deze toets. Eerst zal echter enige aandacht worden besteed aan de twee alternatieven voor deze toets die in de praktijk het meest gehanteerd blijken te worden: de vergelijkbaarheidstoets en de doeltoets. Daarbij zal aan de hand van de in de voorafgaande hoofdstukken bereikte conclusies worden aangegeven waarom het niet wenselijk is om van deze alternatieven gebruik te maken.

\subsection{De vergelijkbaarheidstoets als toetsingsingang}

De precieze inhoud en betekenis van de vergelijkbaarheidstoets zijn in hoofdstuk 2 uitgebreid besproken. Voor een goede beoordeling van deze toetsingsingang lijkt het echter nuttig om hierop nogmaals kort in te gaan. De vergelijkbaarheidstoets impliceert dat de rechter in de eerste fase van de toetsing beoordeelt of er sprake is van een ongelijke behandeling van vergelijkbare gevallen of, in het geval van materieel onderscheid, van een gelijke behandeling van onvergelijkbare gevallen. De rechter mag daarbij niet willekeurig te werk gaan en zonder nadere motivering vaststellen dat de gevallen al dan niet vergelijkbaar zijn: hij zal steeds zorgvuldig moeten nagaan welke overeenkomsten en verschillen de voorgelegde gevallen vertonen en zal moeten beoordelen welke van deze overeenkomsten en verschillen voor het geschil relevant zijn. ${ }^{13}$ Voor deze beoordeling is het noodzakelijk dat de rechter een bruikbare en redelijke vergelijkingsmaatstaf kiest, waarbij hij zich moet laten leiden door het juridisch kader van het voorgeleg-

wijslastverdeling ook door het Supreme Court niet consequent gehanteerd. Zie hoofdstuk 5 par. 2.3.I en 4.1.2.

12. Zie hoofdstuk 4 par. 2.2 en hoofdstuk 5 par. 2.2 .2 en 2.2 .3 .

13. Overigens trekken rechters zich daar in de praktijk niet altijd veel van aan: zoals uit het rechtsvergelijkend deel is gebleken hebben vooral het Europees Hof voor de Rechten van de Mens en de Nederlandse Afdeling Bestuursrechtspraak de neiging om hun oordeel over de vergelijkbaarheid niet of zeer cryptisch te motiveren. Het spreekt vanzelf dat door een dergelijke benadering de controleerbaarheid van de uitspraak niet wordt vergroot. Alleen het Europees Hof van Justitie blijkt tamelijk zorgvuldig om te gaan met de vergelijkbaarheidstoets; zie hoofdstuk 4 par. 2.2.2. 
de geval: de rechter mag zeker niet subjectief te werk gaan en een maatstaf kiezen die hij zelf redelijk vindt. Een goede vergelijkingsmaatstaf kan meestal gevonden kunnen worden in het doel van het betrokken onderscheid. ${ }^{14}$

De vergelijkbaarheid van de voorgelegde gevallen kan aan de hand van de hiervoor genoemde criteria relatief gemakkelijk worden vastgesteld. Enkele problemen zijn echter inherent aan deze toets. Zo blijkt het niet altijd eenvoudig te zijn om het precieze doel van de regeling te achterhalen en is het regelmatig zo dat met een regeling verschillende doelstellingen worden nagestreefd; in dat geval is het moeilijk te bepalen aan de hand van welke doelstelling de vergelijkbaarheid moet worden bepaald. Lastig is echter vooral dat uit de vaststelling van de vergelijkbaarheid van de voorgelegde gevallen niet meteen kan worden afgeleid of er inderdaad een toetsing in de tweede fase moet worden uitgevoerd: dit blijkt afhankelijk te zijn van de toetsingsmethodiek die de rechter in het concrete geval hanteert. Zoals in hoofdstuk 2 is weergegeven zijn er hierbij theoretisch vier mogelijkheden denkbaar; van drie van deze mogelijkheden blijkt in de praktijk ook daadwerkelijk gebruik te worden gemaakt.

Een eerste mogelijke benadering houdt in dat de uitkomst van de vergelijkbaarheidstoets bepalend is voor de uitkomst van de procedure. Dit betekent dat een ongelijke behandeling nooit toelaatbaar is wanneer wordt geconcludeerd dat de gevallen vergelijkbaar zijn: gelijke gevallen moeten volgens deze benadering altijd gelijk worden behandeld. Wordt daarentegen geconcludeerd dat de gevallen niet vergelijkbaar zijn, dan is het steeds toelaatbaar om hen ongelijk te behandelen.

In hoofdstuk 2 is aangegeven dat deze benadering zich kenmerkt door een ernstig gebrek aan nuanceringsmogelijkheden: niet alleen bestaat er in deze benadering geen ruimte om te beoordelen of een ongelijke behandeling van ongelijke gevallen ongeschikt of onevenredig is (zelfs niet wanneer de verschillen tussen de gevallen maar heel beperkt zijn, terwijl de ongelijke behandeling zeer vergaand is), maar ook ontbreekt de mogelijkheid om na te gaan of er voor een ongelijke behandeling van gelijke gevallen een overtuigende en objectieve rechtvaardiging bestaat. Gezien deze nadelen wordt in de praktijk vrijwel nooit gebruik gemaakt van deze variant: uit het rechtsvergelijkend onderzoek is naar voren gekomen dat alleen de Afdeling Bestuursrechtspraak deze tot uitgangspunt kiest. Zij heeft haar keuze voor deze werkwijze echter nooit uitdrukkelijk gemotiveerd, zodat niet duidelijk is welke argumenten de Afdeling hiervoor hanteert. Duidelijk is echter dat de benadering van de Afdeling leidt tot een zeer ondoorzichtige en onvoorspelbare rechtspraak, waarbij nauwelijks inzicht wordt verschaft in de rechterlijke oordeelsvorming. De keuze voor deze eerste benadering verdient dan ook geen navolging.

De tweede en derde mogelijke benadering van de vergelijkbaarheidstoets vormen een variatie op de eerste. Volgens de tweede benadering is alleen de constatering van ver-

14. Dit blijkt in de praktijk lang niet altijd te gebeuren: zowel in de rechtspraak van het Europees Hof voor de Rechten van de Mens als in die van de Nederlandse rechterlijke instanties wordt de vergelijkbars heid regelmatig vastgesteld zonder dat daarbij een duidelijke maatstaf wordt vastgesteld. Is er wel een vergelijkbaarheidsmaatstaf vastgesteld, dan blijft vaak onduidelijk waaraan deze wordt ontleend en wordt meestal niet nagegaan of de maatstaf inhoudelijk redelijk is. Zie nader hoofdstuk 3 par. $22.1 \mathrm{en}$ hoofdstuk 6 par. 2.2.2. 
gelijkbaarheid direct doorslaggevend voor de uitkomst. Dit betekent dat een ongelijke behandeling van vergelijkbare gevallen steeds ontoelaatbaar zal zijn, ongeacht het eventuele bestaan van een rechtvaardiging. Worden er relevante verschillen tussen de gevallen gesignaleerd, dan zal de rechter echter niet meteen kunnen concluderen dat deze ongelijk kunnen worden behandeld: om deze conclusie te kunnen bereiken zal hij eerst nog moeten nagaan of de ongelijke behandeling wel in een redelijke verhouding staat tot de geconstateerde verschillen. Deze tweede benadering wordt door geen van de bestudeerde rechterlijke instanties gehanteerd; kennelijk vinden zij het geen van alle redelijk wanneer een ongelijke behandeling van vergelijkbare gevallen nooit gerechtvaardigd zou kunnen worden.

De derde benadering wordt aanzienlijk vaker gekozen, waarschijnlijk omdat daarbij als uitgangspunt geldt dat de constatering dat de gevallen vergelijkbaar zijn, niet rechtstreeks bepalend is voor de uitkomst van de procedure: volgens deze benadering moet de rechter steeds beoordelen of er niet toch een rechtvaardiging kan worden gevonden voor het gemaakte onderscheid. Stelt de rechter daarentegen vast dat de gevallen ongelijk zijn, dan wordt het gemaakte onderscheid toelaatbaar geacht: anders dan bij de tweede benadering is het niet nodig dat de rechter nog nagaat of er sprake is van evenredigheid tussen de ongelijkheid in behandeling en de verschillen tussen de gevallen. Deze derde variant blijkt de voorkeur te hebben van de meeste van de onderzochte rechterlijke instanties: niet alleen het Europees Hof voor de Rechten van de Mens maakt hiervan gebruik, maar ook het Europees Hof van Justitie (bij direct onderscheid), de Centrale Raad van Beroep (eveneens alleen bij direct onderscheid) en de civiele kamer van de Hoge Raad. Ook deze benadering staat echter open voor kritiek, juist nu hierbij de mogelijkheid ontbreekt om een ongelijke behandeling van onvergelijkbare gevallen op haar redelijkheid te beoordelen. Frappante voorbeelden van de problemen die daardoor kunnen ontstaan zijn gegeven in de rechtsvergelijkende hoofdstukken. Gewezen werd daar bijvoorbeeld op een evident ongeschikt onderscheid, dat volgens het Europees Hof voor de Rechten van de Mens toch toelaatbaar was, omdat de gevallen waartussen werd onderscheiden relevante verschillen vertoonden. Ook is melding gemaakt van een onderscheid dat niet in verhouding leek te staan tot de gesignaleerde verschillen, maar door het Europees Hof van Justitie toch toelaatbaar werd geacht. ${ }^{\text {15 }}$ Hoewel deze derde benadering redelijker is dan de eerste, die in het geheel geen ruimte laat voor een rechtvaardigingstoets, is het niet wenselijk om deze als toetsingsingang voor het algemene toetsingsmodel te hanteren.

Tenslotte is de vierde benadering het meest open van karakter. Volgens deze benadering is vergelijkbaarheid noch onvergelijkbaarheid direct doorslaggevend voor de uitkomst van de procedure. Wanneer wordt vastgesteld dat de voorgelegde gevallen in relevante opzichten vergelijkbaar zijn, dan moet volgens deze benadering worden nagegaan of er voor de ongelijke behandeling een rechtvaardiging bestaat. Wordt daarentegen de conclusie bereikt dat de gevallen relevante verschillen vertonen, dan moet de rechter controleren of de ongelijke behandeling tot deze verschillen in een evenredi-

15. Het gaan om de zaak Observer and Guardian (Spycatcher) van het Europees Hof voor de Rechten van de Mens (besproken in hoofdstuk 3 par. 4.1.2) en om de Kerstboterzaken van het Europees Hof van Justitie (besproken in hoofdstuk 4 par. 4.1.3). 
ge verhouding staat en of het gemaakte onderscheid voldoet aan de overige vereisten van het rechtvaardigingsmodel. Voorbeelden van deze benadering zijn vooral zichtbaar in de rechtspraak van de belastingkamer van de Hoge Raad. Deze kamer blijkt consequent een rechtvaardigingstoets uit te voeren wanneer is vastgesteld dat er onderscheid is gemaakt tussen vergelijkbare gevallen, terwijl uit een aantal uitspraken blijkt dat een ongelijke behandeling van onvergelijkbare gevallen ontoelaatbaar is, wanneer er sprake is van een overduidelijke mate van onevenredigheid. ${ }^{16}$

Met deze vierde variant wordt tegemoet gekomen aan de kritiek op de eerste drie benaderingen. Niettemin leidt deze nauwelijks tot een zinvolle invulling van de eerste fase van de toetsing. Problematisch is vooral dat deze benadering als toetsingsingang onvoldoende selecterend vermogen heeft. Zoals is aangegeven zal de wederpartij altijd een rechtvaardiging aan moeten voeren voor het gemaakte onderscheid, ongeacht de uitkomst van de vaststelling van de vergelijkbaarheid. Wanneer kan worden aangetoond dat de gevallen voldoende vergelijkbaar zijn, dan zal de wederpartij moeten aantonen dat er toch een rechtvaardiging voor het onderscheid bestond; neemt de rechter daarentegen aan dat de gevallen relevant verschillen, dan zal de wederpartij moeten aantonen dat de ongelijkheid in behandeling een doelmatig, noodzakelijk en evenredig middel vormde om het doel te bereiken. De toetsing in de eerste fase ontleent zijn waarde echter juist aan zijn selecterende functie: zaken waarin een rechtvaardiging niet nodig is moeten direct opzij kunnen worden geschoven, zodat de wederpartij alleen een rechtvaardiging aan hoeft te voeren in die gevallen waarin dit echt de moeite waard is. $\mathrm{Nu}$ de vierde (en meest redelijke) variant van de vergelijkbaarheidstoets onvoldoende recht doet aan deze functie, is het niet wenselijk om deze toets tot uitgangspunt van het algemene toetsingsmodel te nemen.

Ook verder zijn er in de rechtspraak van de verschillende onderzochte instanties redenen te vinden om de vergelijkbaarheidstoets een minder geschikt te achten. Allereerst blijken veel instanties het uitvoeren van deze toets in bepaalde gevallen niet nodig te vinden, omdat de vergelijkbaarheid van de gevallen evident is; dit blijkt vooral het geval te zijn bij onderscheid op verdachte differentiatiegronden, zoals ras of onwettige geboorte. Ook wordt een vergelijkbaarheidstoets soms achterwege gelaten omdat elementen die van belang zijn voor de vaststelling van de vergelijkbaarheid, zoals het bepalen van het nagestreefde doel, ook bij de beoordeling van de rechtvaardiging aan de orde kunnen komen. ${ }^{17}$ Daaruit kan worden afgeleid dat de praktische behoefte aan deze toets niet altijd even groot is.

Belangrijk is verder dat het gebruik van de vergelijkbaarheidstoets in de eerste fase vaak leidt tot een ondoorzichtige toetsing. Deze ondoorzichtigheid wordt veroorzakt door het feit dat het voor een goede vaststelling van de vergelijkbaarheid noodzakelijk is om het doel van het onderscheid al in de eerste fase vast te stellen en op zijn rede-

16. Zie hoofdstuk 6 par. 2.1.2.

17. Voorbeelden hiervan zijn zichtbaar in de rechtspraak van het Europees Hof voor de Rechten van de Mens: in hoofdstuk 3 is gebleken dat het Hof bij de toetsing van verdachte classificaties slechts zelden een vergelijkbaarheidstoets uitvoert, terwijl het deze toets ook in veel andere gevallen achterwege last (paragraaf 2.2.2). Ook het Europees Hof van Justitie blijkt bij direct onderscheid, waar officieet een vergelijkbaarheidstoets moet worden uitgevoerd, niet altijd van deze toetsingsingang gebruik te maken, zie hoofdstuk 4 par. 4.1.3. 
lijkheid te beoordelen. In de tweede fase is dit opnieuw nodig, ditmaal om te kunnen beoordelen of het onderscheid gerechtvaardigd is. Om de daardoor gecreëerde overlap te voorkomen worden de beide toetsen in veel gevallen min of meer samengevoegd, waardoor het onderscheid tussen de eerste en de tweede toetsingsfase vervaagt. Bovendien wordt de vergelijkbaarheidstoets zowel in de rechtspraak van het Supreme Court als in de jurisprudentie van de Nederlandse rechters regelmatig gezien als een onderdeel van de rechtvaardigingstoets, waardoor eveneens een soort fusie zichtbaar is. ${ }^{18}$ De vervaging tussen de toetsingsfasen die hierdoor wordt veroorzaakt is niet alleen problematisch omdat de motivering hierdoor al snel ondoorzichtig wordt, maar ook omdat deze kan leiden tot onduidelijkheid over de verdeling van de bewijslast: de partijen weten vaak niet wie verantwoordelijk is voor het aanvoeren van bewijs met betrekking tot het aangevoerde doel, de vergelijkbaarheid van de gevallen en de rechtvaardiging van het onderscheid. ${ }^{19}$ Ook om die reden is het beter om gebruik te maken van een andere toetsingsingang dan de vergelijkbaarheidstoets, waarbij minder overlap bestaat met de tweede fase van de toetsing en waardoor heldere aanknopingspunten worden verschaft voor de verdeling van de bewijslast.

\subsection{De doeltoets als toetsingsingang}

Zoals in paragraaf 2.1 is aangegeven zijn er in de rechtspraak van de onderzochte rechterlijke instanties verschillende alternatieven te vinden voor de vergelijkbaarheidstoets. Alvorens nader in te gaan op de meest bruikbare toetsingsingang - de benadelingstoets - is het interessant om kort aandacht te besteden aan een toetsingscriterium dat in de Amerikaanse rechtspraak over indirect onderscheid is terug te vinden. Volgens het Supreme Court is het bij indirect onderscheid nodig dat de klager aantoont dat een regeling disproportioneel zware consequenties heeft voor een bepaalde groep, zoals in het geval waarin vrijwel uitsluitend een raciale minderheid nadelig wordt getroffen door de gevolgen van een bepaalde maatregel. Het bestaan van een dergelijke disproportionele benadeling is volgens het Supreme Court echter nog niet voldoende om toe te kunnen komen aan een toetsing in de tweede fase: de klager zal daarvoor ook moeten bewijzen dat de bedoeling van de regelgever (mede) was gericht op het bereiken van deze consequenties. De keuze voor deze "doeltoets" als toetsingsingang heeft als voordeel dat de wederpartij niet steeds een rechtvaardiging hoeft aan te voeren wanneer een maatregel nadelige gevolgen heeft voor een kwetsbare groep. Zeker in de Verenigde

18. Voorbeelden van overlap zijn zichtbaar in de intermediate scrutimy-rechtspraak van het Supreme Court, waarin de vergelijkbaarheidstoets vaak naadloos overloopt in de rechtvaardigingstoets. Zie daarover nader hoofdstuk 5 par. 2.2.1. Zie voor voorbeelden uit de Nederlandse rechtspraak hoofdstuk 6 par. 2.1.

19. Normaal gesproken is de wederpartij verantwoordelijk voor het aanvoeren van een gerechtvaardigd doel voor het onderscheid, nu dit een onderdeel vormt van het rechtvaardigingsmodel in de tweede fase; in de eerste fase is het aan de klager om aan te tonen dat de gevallen niet vergelijkbaar zijn. Door het bestaan van overlap kan het echter gebeuren dat de klager in de eerste fase bewijs moet leveren met betrekking tot het nagestreefde doel, of dat in de eerste fase een bewijsplicht aan de wederpartij wordt opgelegd. Andersom is het mogelijk dat de klager door de verweving van de vergelijkbaarheidstoets met de rechtvaardigingstoets in de tweede fase een bewijsplicht heeft (het is immers zijn taak om de 'ergelijkbaarheid aan te tonen), terwijl het eigenlijk aan de wederpartij is om aan te tonen dat er een htvaardiging bestaat, Daardoor kan onnodig veel verwarring ontstaan. 
Staten is dit een voordeel: door historische en sociale oorzaken lijkt haast iedere sociaal-economische maatregel in dit land disproportionele consequenties te hebben voor bepaalde etnische of raciale minderheden. Omdat (direct of indirect) onderscheid op raciale of etnische gronden aan de zeer strenge, voor het onderscheid vrijwel steeds fatale strict scrutiny-test moet worden onderworpen, zou de keuze voor een puur op benadelend effect gebaseerde toets er al snel toe leiden dat vrijwel iedere maatregel ontoelaatbaar zou worden verklaard. Het verbaast dan ook niet dat het Supreme Court heeft geprobeerd deze onwenselijke consequenties te voorkomen door in de eerste fase een strenge toetsing uit te voeren.

Aan de benadering van het Supreme Court zijn echter zodanig grote nadelen verbonden dat de keuze hiervoor onwenselijk moet worden geacht. Problematisch is allereerst dat deze doeltoets een zeer hoge bewijslast voor de klager oplevert. Aangegeven is al dat de klager moet aantonen dat de bedoeling van de regelgever op het creëren van benadelende effecten voor een bepaalde groep was gericht. In de praktijk komt dit erop neer dat hij zal moet bewijzen dat de regelgever bewust probeerde een raciale, etnische of andere minderheidsgroep achter te stellen. Voor een individuele klager zal het niet eenvoudig zijn om de doelstelling van een maatregel te achterhalen; het is niet voor niets dat de bewijslast voor het aantonen van een gerechtvaardigd doel in de tweede fase bij de wederpartij rust. Het leveren van bewijs van een discriminatoire doelstelling is nog veel moeilijker: de verwerende partij zal dit soort doelstellingen onvermijdelijk zoveel mogelijk proberen te verhullen. Omdat de klager vaak niet over middelen beschikt om diepgaand onderzoek te verrichten naar de motieven van de wederpartij, zal het voor hem nagenoeg onmogelijk zijn om aan zijn bewijslast te voldoen. Een belangrijk vereiste waaraan een goede toetsingsingang moet voldoen - het creëren van een redelijke bewijslastverdeling - wordt door de doeltoets dan ook niet vervuld.

Het is ook niet nodig om van deze toetsingsingang gebruik te maken. Zoals eerder is aangegeven heeft het Supreme Court zijn doeltoets vooral ontwikkeld omdat de strict scrutiny-test het in de praktijk onmogelijk maakt om een ongelijke behandeling op een verdachte grond te rechtvaardigen. Om te voorkomen dat alle maatregelen met disproportionele consequenties voor minderheden in strijd worden verklaard met het Veertiende Amendement, achtte het Supreme Court het noodzakelijk om de toepassing van deze toets te beperken tot apert onredelijke gevallen van ongelijke behandeling. Het uitgangspunt is in dit hoofdstuk echter niet een rigide en fatale strict scrutiny-test, maar een flexibel toetsingsmodel. Dit model laat zonder meer ruimte voor een rechtvaardging van disproportioneel benadelende maatregelen, zij het dat de aangevoerde argumenten in dit soort gevallen strikt zullen worden getoetst. In de eerste fase kan dan ook worden volstaan met een minder strikt toetsingscriterium dan de Amerikaanse doeltoets.

Tenslotte is een belangrijk bezwaar tegen de keuze voor een doeltoets als toetsingsingang gelegen in het feit dat direct onderscheid daardoor minder snel toelaatbaar zal worden geacht dan indirect onderscheid. Bij direct onderscheid geldt in de VS namelijk dat een benadelingstoets tot toetsingsingang wordt gekozen. Aan het vereiste van een nadelig effect zal veel sneller zijn voldaan dan aan het vereiste van een discriminatoire doelstelling, waardoor de strenge strict scrutiny-test bij direct onderscheid anzienlijk 
vaker zal worden toegepast dan bij indirect onderscheid: daarbij geldt immers de strenge doeltoets. De grens tussen direct en indirect onderscheid kan echter niet altijd scherp worden getrokken. Het is relatief gemakkelijk om een neutraal en volstrekt redelijk differentiatiecriterium tot uitgangspunt van een onderscheid te kiezen, waarbij het duidelijk is dat een benadeling van een specifieke groep hiervan het resultaat zal zijn. Gewezen is bijvoorbeeld al op het voorbeeld van uitsluiting van analfabeten van het kiesrecht, omdat een zekere mate van geletterdheid nodig zou zijn om een goed gebruik van dit recht te maken. Het effect van deze "neutrale" classificatie was dat vrijwel alle Afro-Amerikanen van het kiesrecht werden uitgesloten, omdat zij als gevolg van jarenlange discriminatie en achterstelling over aanzienlijk minder goede scholingsmogelijkheden beschikten dan de meeste blanken. De consequenties van een dergelijk indirect onderscheid zullen niet anders of minder ernstig zijn dan wanneer er rechtstreeks onderscheid zou zijn gemaakt op grond van huidskleur. Het is dan ook niet redelijk om bij indirect onderscheid veel scherpere eisen aan de bewijslast te stellen dan bij direct onderscheid.

\subsection{De benadelingstoets als toetsingsingang}

\subsubsection{De benadelingstoets als toetsingsingang voor het algemene toetsingsmodel}

De hiervoor genoemde bezwaren tegen de vergelijkbaarheidstoets en de doeltoets gelden niet voor een derde toetsingsingang: de benadelingstoets. Deze toets is in alle bestudeerde stelsels terug te vinden, ook wanneer hij niet officieel als toetsingsingang wordt gehanteerd. ${ }^{20}$ Interessant is daarbij dat de toets zowel blijkt te worden gehanteerd bij direct als bij indirect onderscheid. Zo neemt het Supreme Court, maar soms ook de Nederlandse Hoge Raad en het Europees Hof voor de Rechten van de Mens, een benadelingstoets tot uitgangspunt bij de toetsing van direct onderscheid. Daarbij veronderstellen deze instanties in beginsel dat één van de onderscheiden groepen bij een directe classificatie wordt benadeeld ten opzichte van de andere. Verder zijn er in de rechtspraak van het Europees Hof van Justitie en de Centrale Raad van Beroep en in de oordelen van de Commissie Gelijke Behandeling interessante voorbeelden te vinden van de toepassing van de benadelingstoets in gevallen van indirect onderscheid. Daarbij vertoont deze toets overeenstemming met de benadelingstoets die wordt toegepast bij direct onderscheid, zij het dat de toetsing bij indirect onderscheid op enkele punten iets uitgebreider is.

Deze ruime toepasbaarheid van de benadelingstoets maakt hem aanzienlijk bruikbaarder dan de vergelijkbaarheidstoets, die in gevallen van indirect onderscheid minder geschikt blijkt te zijn. ${ }^{21}$ Bovendien komt de benadelingstoets tegemoet aan het vereiste

20. Zo maken het Europees Hof voor de Rechten van de Mens en de civiele kamer van de Hoge Raad in de eerste fase officieel gebruik van een vergelijkbaarheidstoets, maar blijken zij in de praktijk soms een benadelingstoets uit te voeren. Zie nader hoofdstuk 3 par. 2.2.3 en hoofdstuk 6 par. 2.1.1.

21. Dit wordt geillustreerd door het feit dat geen van de onderzochte rechterlijke instanties bij indirect onderscheid gebruik maakt van deze toets, ook al nemen zij een vergelijkbaarheidstoets tot toetsingsingang bij direct onderscheid. Hoogstens komt het voor dat een vergelijkbaarheidsaspect in de benadelingstoets wordt betrokken, bijvoorbeeld doordat wordt nagegaan of de groep waarnaar de klager verwijst zich in een relevant vergelijkbare positie bevindt. Het gebruik van dergelijke vergelijkbaarheidsaspecten is echter niet nodig en kan tot verwarring leiden. Zie nader hoofdstuk 4 par. 2.2 .1 en 2.2 .3$. 
dat er geen andere en aanzienlijk hogere eisen mogen worden gesteld bij indirect onderscheid dan bij direct onderscheid: hoewel de toets voor beide vormen van onderscheid een iets andere uitwerking zal krijgen, zal de bewijslast hierbij niet heel sterk verschillen.

Een voordeel van het gebruik van de benadelingstoets is verder dat deze relatief gemakkelijk toepasbaar is en een aanzienlijke mate van objectiviteit garandeert. Bij de vergelijkbaarheidstoets blijkt het relatief vaak voor te komen dat de rechter zelf een vergelijkingsmaatstaf vaststelt, zonder te verwijzen naar het juridisch kader of het doel van de regeling, en gebeurt het zelfs regelmatig dat de rechter zonder enige nadere motivering vaststelt dat de voorgelegde gevallen al of niet vergelijkbaar zijn; vooral in de Nederlandse rechtspraak en de rechtspraak van het Europees Hof voor de Rechten van de Mens zijn daarvan voorbeelden te vinden. ${ }^{22} \mathrm{Bij}$ de benadelingstoets is het nauwelijks mogelijk om een dergelijk subjectief en ongemotiveerd oordeel te geven: een benadeling kan nauwelijks worden vastgesteld zonder verwijzing naar objectieve en controleerbare gegevens. ${ }^{23}$

Tenslotte is van belang dat de benadelingstoets, anders dan de vergelijkbaarheidstoets, een goed onderscheidend vermogen heeft. Zoals hierna nog zal blijken kunnen er zodanige eisen worden gesteld aan het bewijs van benadeling dat de wederpartij alleen een rechtvaardiging hoeft aan te voeren wanneer daarvoor daadwerkelijk reden bestaat. Belangrijk is bovendien dat de bewijsvereisten, anders dan bij de Amerikaanse doeltoets, ook weer niet zodanig streng zijn dat het voor de klager nagenoeg onmogelijk wordt om een ongelijke behandeling effectief aan te vechten. Ook in dat opzicht verdient de benadelingstoets de voorkeur boven de eerder besproken alternatieven.

\subsubsection{Vormgeving van de benadelingstoets}

\section{Vereisten bij direct onderscheid}

Zoals hiervoor is aangegeven is de benadelingstoets als toetsingsingang zowel geschikt voor de vaststelling van direct onderscheid als voor de vaststelling van indirect onderscheid. De precieze vormgeving van de toets zal echter iets verschillen, om op die manier recht te doen aan de specifieke kenmerken van de beide vormen van ongelijke behandeling.

Wanneer wordt geklaagd over een direct onderscheid in een algemene regeling (een normatieve classificatie) zal het nadeel meestal meteen kunnen blijken uit de effecten van de regeling. Bij normatieve classificaties zal het immers steeds zo zijn dat er één groep van personen of gevallen wordt uitgezonderd voor een bijzondere behandeling, terwijl deze behandeling alle andere personen of gevallen niet ten deel valt. In dergelijke gevallen zal er vrijwel altijd sprake zijn van een benadeling, hetzij van de uitgezonderde groep, hetzij van de groep die juist niet wordt uitgezonderd. Of de benadeling het gevolg is van een formeel ongelijke behandeling (waarbij, om in termen van vergelijkbaarheid te spreken, gelijke gevallen ongelijk worden behandeld) of van een materieel

22. Zie hoofdstuk 6 par. 2.2 .2 en hoofdstuk 3 par. 2.2.1.

23. Overigens bestaat voor het gebruik van "vage" bronnen soms wel ruimte bij de vaststelling van indiret onderscheid; daarop zal hierna worden teruggekomen. 
onderscheid (waarbij ongelijke gevallen gelijk worden behandeld) is bij deze toetsingsingang niet van belang: doorslaggevend is uitsluitend het feit dat er een nadeel wordt gecreëerd voor de groep waarvan de klager deel uitmaakt, terwijl dit nadeel een andere groep niet ten deel valt.

De rechter kan bij zijn toetsing in de eerste fase echter niet volstaan met de enkele vaststelling dat er sprake is van een normatieve classificatie en de conclusie dat er dús ook sprake zal zijn van een benadeling. Uit de toepassing door de verschillende onderzochte instanties blijkt dat er bij direct onderscheid nog enkele aanvullende eisen worden gesteld aan het bewijs van benadeling: het zou anders wel erg gemakkelijk zijn om een benadeling aan te tonen, waardoor een rechtvaardiging al snel wordt vereist en de toetsing in de eerste fase zijn selecterende karakter verliest.

Een zinvol en algemeen geaccepteerd aanvullend vereiste is allereerst dat de klager door de betrokken classificatie daadwerkelijk en aantoonbaar in zijn belangen moet zijn geraakt. Dit zal niet het geval zijn wanneer de benadeling wordt gecompenseerd door een voordeel dat is vervat in een andere regeling of bepaling, ${ }^{24}$ of wanneer er op het eerste gezicht wel sprake lijkt te zijn van een benadeling, maar uit de feiten en omstandigheden van het geval kan worden afgeleid dat daarvan geen sprake is. ${ }^{25}$ Een toetsing in de tweede fase kan bovendien achterwege blijven wanneer het door de classificatie veroorzaakte nadeel niet voldoende objectiveerbaar is of wanneer dit geen betrekking heeft op rechtens beschermde belangen: het zou te ver gaan om ook in dit soort gevallen van de wederpartij te verwachten dat hij een rechtvaardiging voor het gemaakte onderscheid aanvoert. ${ }^{26}$ Van belang is wel dat in sommige gevallen ook immaterieel of psychisch nadeel een rechtens beschermd belang kan raken en een objectiveerbaar karakter kan hebben; dit zal bijvoorbeeld het geval kunnen zijn bij onderscheid met een stigmatiserend karakter of bij een classificatie die objectief gezien een gevoel van inferioriteit bij de benadeelde kan oproepen. ${ }^{27} \mathrm{Bij}$ een benadeling van deze aard, waarbij de objectiviteit van het getroffen belang niet gemakkelijk is vast te stellen, zullen hoge eisen moeten worden gesteld aan de rechterlijke motivering. De rechter zal zijn oordeel

24. Een voorbeeld hiervan is gegeven in hoofdstuk 4 par. 2.2.3; het Hof telde in het betrokken geval de voor- en nadelen van de voor de klager geldende regeling bij elkaar op, net als de voor- en nadelen van de regeling die gold voor de groep ten opzichte waarvan de klager zich benadeeld voelde. Uit deze optelsom bleek dat de andere regeling minstens zo nadelig was en dat de klager zelfs voordeel van zijn situatie ondervond, ook al kon dit op het eerste gezicht anders lijken.

25. Dit wordt geillustreerd door het in hoofdstuk 6 gegeven voorbeeld van een regeling binnen een bedrijf waarin bepaalde loonbestanddelen naar rato van werktijd worden toegekend. Dit leidt in absolute zin tot een benadeling van deeltijdwerkers, doordat zij een lager salaris zullen ontvangen. Van een daadwerkelijk nadeel is echter geen sprake wanneer wordt gekeken naar het loon per eenheid gewerkte tijd: dit zal voor deeltijd- en voltijdwerkers identiek zijn. Zie nader hoofdstuk 6 par. 2.2.3. Een ander voorbeeld is gegeven in hoofdstuk 3 par. 2.2.3: het Europees Hof voor de Rechten van de Mens nam geen benadeling aan in een geval waarin de klaagster door een bepaalde regeling weliswaar juridisch werd benadeeld, maar waarin feitelijk geen sprake bleek te zijn van een belangenaantasting.

26. Dit vereiste is ontwikkeld door de Commissie Gelijke Behandeling; zie voor de uitwerking hiervan en voor een voorbeeld van subjectief ervaren nadeel hoofdstuk 6 par. 2.2.3.

27. Een extreem voorbeeld is te vinden in de Amerikaanse rechtspraak ten tijde van de segregatie. In de zaak Pace v. Alabama werd geklaagd over een regeling die interraciale huwelijken verbood (106 U.S. $583(1882)$ ). Hoewel daarbij geen rechtstreeks onderscheid werd gemaakt op grond van ras (het verbod gold zowel voor Afro-Amerikanen als voor blanken), kan worden gesteld dat van dit verbod een zodanige stigmatisering van interraciale relaties uitgaat dat beide groepen emstig worden benadeeld. 
in dit soort gevallen bij voorkeur moeten onderbouwen aan de hand van psychologisch of sociologisch bewijsmateriaal, waaruit duidelijk blijkt dat er in het concrete geval sprake is van een voldoende objectiveerbaar belang. ${ }^{28}$

Hiervoor is gesproken over het aantonen van een benadeling bij een normatieve classificatie, dat wil zeggen bij een ongelijke behandeling die in een algemene regeling is neergelegd. Eerder is echter al aangegeven dat een direct onderscheid ook kan worden veroorzaakt door een concrete bevoegdheidsuitoefening, zoals die zich bijvoorbeeld voordoet wanneer een bestuursorgaan aan één bedrijf wel subsidie heeft verleend, maar aan een ander bedrijf niet. Ook in dit soort gevallen vormt een benadelingstoets een goede toetsingsingang. De klager kan dan meestal volstaan met het bewijs dat hij als gevolg van het verschil in bevoegdheidsuitoefening in een feitelijk of financieel minder gunstige positie is komen te verkeren dan degene naar wiens situatie hij verwijst. Van belang is wel dat de rechter ook bij concrete bevoegdheidstoepassing moet nagaan of de klager in een rechtens beschermd, voldoende objectiveerbaar belang is getroffen; bovendien geldt opnieuw dat een rechtvaardiging alleen van de wederpartij gevergd kan worden wanneer er sprake is van een daadwerkelijk bestaand en niet gecompenseerd nadeel.

\section{Vereisten bij indirect onderscheid}

Bij indirect onderscheid zal het vaststellen van een benadeling gecompliceerder zijn dan bij direct onderscheid. Vereist is in dit soort gevallen niet alleen dat de klager aantoont dat een bepaalde regeling of handeling een benadeling tot gevolg heeft - waarbij dezelfde eisen gelden als bij direct onderscheid -, maar ook dat hij aantoont dat deze benadeling een specifieke groep in disproportionele mate raakt. Wanneer een klager bijvoorbeeld wil aantonen dat een bijzondere beloningsregeling voor deeltijdwerkers een indirect onderscheid op grond van geslacht veroorzaakt, dan zal hij niet alleen moeten aantonen dat deze regeling daadwerkelijk nadelige effecten heeft voor deeltijdwerkers, maar ook dat de groep van deeltijdwerkers in overwegende mate uit vrouwen bestaat.

Dit extra vereiste levert voor de rechter een aantal motiveringsverplichtingen op die niet gelden bij het aantonen van direct onderscheid. Allereerst is de bepaalbaarheid van de benadeelde groep bij indirect onderscheid van groot belang: alleen wanneer deze groep voldoende precies kan worden afgebakend is het mogelijk om te bepalen hoe groot het aandeel van een specifieke groep hierin is. ${ }^{20}$ De rechter zal dan ook zorgvuldig moeten aangeven op welke manier de groep die tot uitgangspunt wordt genomen bij het vaststellen van het indirecte onderscheid moet worden gedefinieerd. Verder moet de rechter steeds bepalen welk aandeel de specifiek te onderscheiden groep (zoals een raciale of godsdienstige minderheidsgroep) binnen de gehele benadeelde groep heeft. Tenslotte moet hij beoordelen of er in het voorgelegde geval inderdaad sprake is van een benadeling met een disproportioneel karakter, hetgeen betekent dat hij moet nagaan

28. Zie voor een illustratie uit het Amerikaanse recht hoofdstuk 5 par. 2.2.2.

29. Bij direct onderscheid is de afbakening van deze groep niet nodig. Noor het vereisen van een rechtvaardiging is het daarbij voldoende dat een groep is benadeeld ten opzichte van een andere groep: $d c$ precieze samenstelling en definitie van de groepen is verder niet van belang. 
of het aandeel van deze groep in de benadeelde groep zodanig groot is dat een rechtvaardiging daadwerkelijk is vereist.

Deze extra motiveringsvereisten hebben tot gevolg dat er bij indirect onderscheid veelal gebruik zal worden gemaakt van een specifiek soort bewijsmateriaal. ${ }^{30}$ In de meeste gevallen van indirect onderscheid zal de rechter kunnen verwijzen naar statistisch en ander cijfermatig bewijsmateriaal dat door de partijen is verschaft of door de rechter zelf is achterhaald. Het gebruik van dit soort materiaal heeft het grote voordeel dat de conclusies die op basis hiervan worden bereikt goed controleerbaar zijn. Bovendien is statistisch bewijsmateriaal relatief gemakkelijk verkrijgbaar en heeft het een objectief karakter. Het gebruik van cijfermatige gegevens als basis voor de vaststelling van een disproportionele benadeling verdient daarom de voorkeur boven het gebruik van andere bronnen die door de verschillende onderzochte rechterlijke instanties wel worden gehanteerd, zoals feiten van algemene bekendheid, algemene onderzoeksgegevens of het (op logica of evidentie gebaseerde) oordeel dat de disproportioneel benadelende effecten onvermijdelijk en voorspelbaar voortvloeiden uit de keuze voor een bepaald differentiatiecriterium. ${ }^{31}$ Dit betekent overigens niet dat van dergelijke bronnen in het geheel geen gebruik mag worden gemaakt: de onderzochte rechtspraak laat zien dat daarvoor soms wel degelijk ruimte bestaat. Vooral wanneer cijfermatig bewijsmateriaal niet of in mindere mate voorhanden is of wanneer daaruit geen duidelijke of overtuigende conclusies kunnen worden afgeleid, kunnen feiten van algemene bekendheid of nietcijfermatige onderzoeksgegevens een belangrijke aanvullende of ondersteunende rol spelen. De rechter zal bovendien kunnen terugvallen op feiten van algemene bekendheid of op evidentie en logica wanneer ieder statistisch of ander objectief controleerbaar bewijs voor de aanwezigheid van een benadeling ontbreekt. Wel moeten er in een dergelijk geval hoge eisen worden gesteld aan de motivering.

Hoewel het gebruik van cijfermatig bewijsmateriaal bij het vaststellen van een disproportionele benadeling bijzonder waardevol is, kan dit ook problemen met zich meebrengen. Zoals in hoofdstuk 2 is aangegeven is in het kader van dit proefschrift geen bijzondere aandacht besteed aan de bewijstechnische problematiek die hierbij een rol speelt. Niettemin is het van belang om de aandacht te vestigen op enkele hoofdpunten, waarmee de rechter in zijn motivering rekening zal moeten houden.

Allereerst kan worden gewezen op het in de onderzochte stelsels algemeen aanvaarde uitgangspunt dat de rechter bij het gebruik van cijfermatig bewijsmateriaal zoveel mogelijk gebruik zal moeten maken van relatieve gegevens (percentages): het gebruik van absolute gegevens kan een vertekend beeld geven van de verhoudingen binnen de be-

30. Dit bewijsmateriaal zal anders zijn dan bij direct onderscheid, waarbij niet nodig is om gegevens aan te voeren waardoor de omvang van de benadeelde groep kan worden bepaald en waaruit het relatieve aandeel van een specifieke groep kan worden afgeleid. Bij indirect onderscheid zal het bewijs zich vooral richten op het bestaan van een objectief bepaalbaar nadeel voor een specifiek gedefinieerde groep.

31. Een voorbeeld van dit laatste is het maken van onderscheid op grond van het hebben van een verblijfsvergunning: het is onvermijdelijk en voorspelbaar dat de benadelende effecten van het onderscheid op deze grond uitsluitend buitenlanders zullen treffen, nu alleen zij over een verblijfsvergunning zullen beschikken. 
nadeelde groep. ${ }^{32}$ Verder moet de rechter zorgvuldig omgaan met het vaststellen van referentiekaders. Wanneer de volledige benadeelde groep erg klein is, zoals het geval is bij een arbeidsvoorwaardenregeling van een onderneming met slechts 15 medewerkers, kan het wenselijk zijn om de motivering niet te beperken tot het bepalen van het aandeel van een bepaalde groep binnen de volledige groep: het is dan waardevol om ook nog te kijken naar een ruimer referentiekader, bijvoorbeeld door rekening te houden met de verhoudingen binnen de volledige bedrijfstak.

Vanzelfsprekend geldt verder dat de rechter zorgvuldig om zal moeten gaan met het vaststellen en waarderen van statistisch bewijsmateriaal, in die zin dat hij alleen genoegen mag nemen met gegevens die daadwerkelijk relevant zijn voor de voorgelegde zaak en die voldoende recent zijn. Het is bijvoorbeeld riskant om, bij gebrek aan specifieke bedrijfsgegevens, zonder nadere toelichting te wijzen op statistische gegevens over de verhoudingen in een andere organisatie of bedrijfstak: bekeken zal moeten worden of dergelijke gegevens voor het voorgelegde geval daadwerkelijk relevant zijn.

Een bijzondere problematiek betreft tenslotte de waardering van het aandeel van de specifiek onderzochte groep binnen de gehele benadeelde groep. Vooral de Commissie Gelijke Behandeling blijkt hieraan veel aandacht te besteden; de andere rechterlijke instanties hebben minder oog voor deze problematiek. ${ }^{33}$ Volgens de Commissie kan, wanneer wordt gewerkt met cijfermatig bewijsmateriaal, het bestaan van een disproportionele benadeling worden verondersteld wanneer de onderzochte groep meer dan 1,5 maal vaker door een regeling wordt benadeeld dan andere groepen. Ten aanzien van dit getal heeft de Commissie echter zelf al aangegeven dat het slechts een richtlijn vormt en dat bij grensgevallen ook moet worden gekeken naar andere gegevens, zoals algemene onderzoeksgegevens of feiten van algemene bekendheid. Verder moet in dit verband worden gewezen op een uitspraak van het Europees Hof van Justitie, waarin het aangaf dat een daadwerkelijk disproportioneel aandeel niet altijd noodzakelijk is: het kan soms al voldoende zijn wanneer de betrokken groep gedurende langere tijd consequent nadeel heeft ondervonden. Ook dan is er reden om van de regelgever te verwachten dat deze meer aandacht besteedt aan de effecten van zijn regelgeving, zodat een inhoudelijke rechtvaardiging redelijkerwijze kan worden verlangd. De rechter zal bij zijn oordeelsvorming dan ook zeker rekening moeten houden met deze mogelijkheid.

Lastig is de vaststelling van het aandeel van de benadeelde groep vooral wanneer statistisch bewijsmateriaal niet voorhanden is en er uitsluitend wordt gewerkt met algemene feitelijke gegevens. In dergelijke gevallen kan de disproportionaliteit van de benadeling eigenlijk alleen op basis van gezond verstand worden vastgesteld, hetgeen kan leiden tot subjectieve en moeilijk controleerbare uitspraken. Als er dus al gebruik wordt gemaakt van een dergelijke benadering, dan is het essentieel dat de rechter zijn

32. Ter illustratie kan worden verwezen naar de bespreking van het gebruik van statistisch bewijsmaterial door de Commissie Gelijke Behandeling: zie hoofdstuk 6 par. 2.2.3.

Overigens gaat dit voor het Supreme Court niet volledig op: weliswaar wordt er in de onderzochte rechtspraak over het Veertiende Amendement maar weinig aandacht besteed aan de omvang van het aandeel van de onderzochte groep, in de rechtspraak met betrekking tot Title VII van de Civil Rights Act is dit onderwerp des te beter uitgewerkt. Deze rechtspraak is echter niet onderzocht, nu deze minder interessant is waar het de rechtvaardigingstoets zelf betreft. Zie nader hoofdstuk 5 par. 1.32 
oordeel goed motiveert en daarbij zoveel mogelijk verwijst naar de concrete omstandigheden van het geval.

\section{Toetsing in de tweede fase: het rechtvaardigingsmodel}

\subsection{Toetsing van het doel}

\subsubsection{Inleiding}

Wanneer eenmaal is vastgesteld dat er sprake is van een daadwerkelijke en objectiveerbare benadeling, dan moet de rechter beoordelen of hiervoor een overtuigende rechtvaardiging bestaat. Zoals uit het theoretische toetsingsmodel is gebleken en zoals ook voortvloeit uit de werkwijze van de verschillende onderzochte rechterlijke instanties, is het daarbij vereist dat de rechter allereerst nagaat of met het onderscheid een gerechtvaardigd doel wordt nagestreefd. ${ }^{34}$ In dat verband moet de rechter vaststellen welke overwegingen of doelstellingen aan het maken van onderscheid ten grondslag hebben gelegen. Eerder is aangegeven dat dit bijzonder lastig kan zijn: niet alleen is het vaak moeilijk om de doelstellingen van een ongelijke behandeling te achterhalen, maar ook zal er soms een discrepantie bestaan tussen de doelstellingen die de wederpartij naar voren heeft gebracht en de overwegingen die in werkelijkheid aan het maken van het onderscheid ten grondslag lagen. Daarnaast worden er, vooral bij classificaties in wetgeving, vaak verschillende doelstellingen tegelijkertijd nagestreefd. Ook dat kan voor de rechter een lastige situatie opleveren, bijvoorbeeld wanneer slechts één van deze doelstellingen ongerechtvaardigd is; de vraag is dan of hij het onderscheid al op die grond ontoelaatbaar kan verklaren. In paragraaf $3.1 .2 \mathrm{zal}$ op deze aspecten van de doeltoets nader worden ingegaan.

Heeft de rechter eenmaal vastgesteld welke doelstelling(en) er aan het onderscheid ten grondslag liggen, dan zal hij vervolgens na moeten gaan of deze doelstelling gerechtvaardigd is. In de toetsingspraktijk van de verschillende onderzochte instanties blijkt voor die beoordeling een groot aantal criteria te zijn ontwikkeld die goede aanknopingspunten bieden voor de invulling van het algemene toetsingsmodel. Ook aan deze toetsingscriteria zal aandacht worden besteed: in paragraaf 3.1 .3 zullen de meest bruikbare criteria worden opgesomd en zal hun inhoud kort worden besproken.

\subsubsection{Vaststelling van het doel van het onderscheid}

\section{Achterhalen van het nagestreefde doel - werkelijk doel van het onderscheid}

Zoals eerder is aangegeven berust de bewijslast voor het aantonen van een objectieve en redelijke rechtvaardiging in de tweede toetsingsfase in beginsel bij de wederpartij. Het is dan ook primair aan deze partij om aan te geven welke overwegingen er aan het maken van onderscheid ten grondslag hebben gelegen. In hoofdstuk 2 is vastgesteld dat de rechter zijn rechtvaardigingstoets meestal op deze doelstellingen kan afstemmen: de

34. Bij indirect onderscheid moet worden nagegaan of er met de regeling waardoor het disproportioneel benadelende effect is veroorzaakt een gerechtvaardigd doel wordt nagestreefd; dit blijkt ook de werkwijze van de onderzochte rechterlijke instanties te zijn. 
wederpartij zal zelf het beste op de hoogte zijn van de door hem nagestreefde doelstellingen. Gesteld is daarbij echter dat er soms redenen kunnen bestaan om te bekijken of er nog andere doelstellingen aan het onderscheid ten grondslag lagen dan door de wederpartij naar voren zijn gebracht. ${ }^{3 s}$ Dergelijke redenen kunnen bijvoorbeeld aanwezig zijn wanneer de klager het bestaan van andere doelstellingen op overtuigende wijze aannemelijk maakt of wanneer de aanwezigheid van dergelijke doelstellingen uit de feiten en omstandigheden van het geval kan worden afgeleid.

In de rechtspraktijk blijkt dit theoretische uitgangspunt regelmatig te worden gevolgd: de meeste van de onderzochte rechters beschouwen de stellingen van de wederpartij als vertrekpunt voor hun toetsing en voeren alleen een verdergaand onderzoek uit wanneer daartoe daadwerkelijk reden bestaat. Voorbeelden van deze werkwijze zijn vooral te vinden in de rechtspraak van het Europees Hof voor de Rechten van de Mens, dat in de regel slechts een verdergaand onderzoek uitvoert wanneer door de klager aannemelijk is gemaakt dat er andere, minder gemakkelijk te rechtvaardigen, overwegingen aan het onderscheid ten grondslag lagen dan door de wederpartij is gesteld. ${ }^{36}$

De snelheid waarmee tot een nader onderzoek van het doel wordt overgegaan blijkt in de praktijk vooral te worden bepaald door de gekozen toetsingsintensiteit, terwijl bovendien een zeker pragmatisme een rol speelt. De meeste onderzochte instanties blijken alleen bij een intensieve toetsing bereid te zijn om na te gaan of er andere redenen bestonden voor het maken van onderscheid dan door de wederpartij naar voren zjn gebracht. Het Amerikaanse Supreme Court heeft bij de toepassing van een intermediate scrutiny- of strict scrutiny-test bijvoorbeeld stelselmatig aangenomen dat een doelstelling alleen zal worden geaccepteerd wanneer deze kan worden gezien als het "actual purpose" van het onderscheid. ${ }^{37}$ Voert het Supreme Court een terughoudende toetsing uit, dan blijkt het aanzienlijk sneller af te gaan op de doelstellingen die door de wederpartij naar voren zijn gebracht.

Opmerkelijk is echter dat het Supreme Court ook bij een terughoudende toetsing sons bereid blijkt te zijn om zelf in de totstandkomingsgeschiedenis te zoeken naar het doel van de regeling. Hetzelfde geldt voor de Nederlandse Hoge Raad, ondanks het feit dat deze normaal gesproken eveneens een terughoudende toetsing uitvoert. ${ }^{3 k}$ Een dergelijk

35. Een dergelijk nader onderzoek kan tot uitdrukking komen in een bestudering van de wetsgeschiedenis en, bij een vergaand onderzoek, van de politieke en sociale omstandigheden op het moment van otstandkoming van de regeling. Ook kan gekeken worden naar de samenhang van de regeling met antere regelgeving. Het Supreme Court heeft soms ook gebruik gemaakt van logica, in die zin dat het vaststelde dat een bepaalde doelstelling logischerwijze niet aan het onderscheid ten grondslag kón hetben gelegen; deze methode lijkt echter niet wenselijk gezien het hierbij bestaande risico van subjectivitit
van het rechterlijk oordeel (zie nader hoofdstuk 6 par. 2.3.1). Naar de wijze waarop het werkelijk doel van het rechterlijk oordeel (zie nader hoofdstuk 6 par. 2.3.1). Naar de wijze waarop het werkelijk doel
door de rechter precies kan worden achterhaald, vooral ook in gevallen van concrete bevoegdheidsoepassing, is nader onderzoek nodig.

36. Zie hoofdstuk 3 par. 2.3.1.

37. Een uitzondering op deze werkwijze is te vinden in de oordelen van de Commissie Gelijke Behandeling die bij een intensieve toetsing uitsluitend blijkt af te gaan op de doelstellingen van de wederpurtij. Opmerkelijk is dat zij dit ook doet wanneer het vrij evident is dat er een discrepantie bestaat tussen het gestelde en het werkelijke doel van het onderscheid. Zie voor deze benadering en de kritick darop hoofdstuk 6 par. 2.3.2.

38. Overigens is het Supreme Court in dit soort gevallen, in het kader van de conceivable basis-test, bereid om zelf hypothetische doelstellingen voor het onderscheid te bedenken en de toetsing aan de tand 
eigen onderzoek lijkt echter alleen plaats te vinden wanneer de doelstellingen gemakkelijk zijn te achterhalen: een vergaand en actief rechterlijk onderzoek is dan niet vereist, zodat toch recht wordt gedaan aan de eisen van terughoudendheid. Aan deze keuze voor een eigen onderzoek lijken vooral overwegingen van proceseconomie ten grondslag te liggen: het is waarschijnlijk dat de rechters een andere benadering kiezen wanneer de doelstellingen minder gemakkelijk uit de totstandkomingsgeschiedenis zijn af te leiden.

Ook in het algemene toetsingsmodel kan tot uitgangspunt worden genomen dat de rechter zijn oordeel over de gerechtvaardigdheid van het onderscheid kan baseren op de doelstellingen die door de wederpartij naar voren zijn gebracht. Daarnaast kan rechter ook zelf nagaan welk (algemeen) doel er aan de regeling ten grondslag ligt, vooral wanneer dit op basis van de voorgelegde stukken gemakkelijk mogelijk is. Wordt er een daadwerkelijk marginale toetsing uitgevoerd, dan kan de rechter in de meeste gevallen met één van deze methoden volstaan: het zal dan alleen nodig zijn om een verdergaand onderzoek uit te voeren, wanneer de klager op overtuigende wijze aannemelijk weet te maken dat de stellingen van de wederpartij met betrekking tot het doel niet juist of onvolledig zijn.

In normale omstandigheden, dus bij een "neutrale" toetsingsintensiteit, kan een dergelijk onderzoek iets sneller worden verlangd. Een zorgvuldigere vaststelling van de overwegingen die aan het onderscheid ten grondslag liggen zal dan niet alleen voor de hand liggen wanneer de klager aannemelijk maakt dat er een discrepantie bestaat tussen het gestelde en het werkelijke doel van het onderscheid, maar ook wanneer er in de feiten en omstandigheden van het voorliggende geval aanleiding kan worden gevonden voor een nader onderzoek. Dit zal met name het geval zijn wanneer de door de wederpartij aangevoerde doelstellingen een algemeen en oppervlakkig karakter hebben; gebeurt dit niet, dan zou het al te gemakkelijk worden om een ongerechtvaardigde doelstelling te verhullen.

Tenslotte is het bij een intensieve toetsing altijd nodig om een eigen onderzoek uit te voeren naar het werkelijk doel van de regeling: in de omstandigheden waarin voor een dergelijke toetsing gekozen wordt zal er steeds reden zijn om te betwijfelen of de wederpartij de door hem werkelijk nagestreefde doelstellingen naar voren heeft gebracht."

\section{Maatschappelijke effecten van het onderscheid}

In hoofdstuk 2 is aangegeven dat het denkbaar is dat een maatregel weliswaar is ingegeven door ongerechtvaardigde overwegingen, maar deze wel maatschappelijk wenselijke effecten blijkt te sorteren. Het lijkt onredelijk wanneer een dergelijke regeling uitsluitend vanwege zijn doelstellingen ontoelaatbaar zou worden geacht. Dit betekent dat de rechter, wanneer hij tot de conclusie is gekomen dat de nagestreefde doelstellin-

daarvan uit te voeren. Ook Nederlandse rechters lijken sporadisch voor deze benadering te kiezen. Deze werkwijze kan echter niet wenselijk worden geacht; zie nader hoofdstuk 5 par. 2.3 .1 en 4.1 .3 en hoofdstuk 6 par. 2.3.2.

39. Een intensieve toetsing zal namelijk vooral worden uitgevoerd wanneer er doelbewust onderscheid is gemaakt op een verdachte grond of jegens een kwetsbare groep. In veel gevallen is een dergelijk onderscheid niet door gerechtvaardigde overwegingen ingegeven, zodat de wederpartij zal proberen deze achter beter verdedigbare doelstellingen te verhullen; zie vooral ook hoofdstuk 5 par. 3.2 
gen ongerechtvaardigd zijn, altijd moet nagaan of de maatregel zodanig wenselijke effecten sorteert dat het onderscheid toch gerechtvaardigd moet worden geacht." In de rechterlijke toetsingspraktijk zijn helaas geen voorbeelden terug te vinden waarin van een dergelijke beoordeling sprake is: wanneer rechters tot de conclusie komen dat het doel van het onderscheid ongerechtvaardigd is, blijken zij het onderscheid steeds in strijd met het gelijkheidsbeginsel te achten. Er is echter evenmin ooit een oordeel uitgesproken waarin werd aangegeven dat met de maatschappelijke effecten van een ongelijke behandeling geen rekening mag worden gehouden, of waarin hiertegen overtujgende argumenten zijn aangevoerd. Het is op basis van de onderzochte rechtspraak dan ook niet mogelijk om te bepalen of het wenselijk is om deze nuancering in het algemene toetsingsmodel op te nemen. Gezien de theoretische argumenten voor het gebruik hiervan kan er echter van worden uitgegaan dat de rechter, voor zover in het concrete geval gewenst, inderdaad rekening kan houden met de effecten van een regeling. Ujteraard zal de rechter voor een dergelijk oordeel wel een bijzonder zorgvuldige motivering moeten geven.

\section{Pluraliteit van doelstellingen}

In veel gevallen zal er meer dan één reden bestaan voor de instelling van een maatregel of voor het op een bepaalde manier uitoefenen van een bevoegdheid. Het kan daarbij zo zijn dat er verschillende doelstellingen van gelijke waarde worden nagestreefd, maar meestal zal er sprake zijn van één of meer hoofddoelstellingen, waaraan enkele bijko. mende, minder belangrijke subdoelstellingen zijn toegevoegd.

De onderzochte rechterlijke instanties blijken op uiteenlopende wijze te reageren op het bestaan van verschillende doelstellingen. De Nederlandse rechterlijke instanties kiezen meestal voor een eenvoudige oplossing: zij stellen slechts vast welke doelstelling het meest belangrijk of relevant is en stemmen daarop vervolgens hun rechtvaardigingstoets af. De overige doelstellingen worden dan buiten beschouwing gelaten. Wanneer een terughoudende toetsing wordt uitgevoerd lijkt dit een redelijke benadering te zijn, nu het hierdoor niet nodig is om een uitgebreid onderzoek uit te voeren en alle aangevoerde doelstellingen afzonderlijk op hun redelijkheid te beoordelen.

Wordt er een intensievere toetsing uitgevoerd, dan wordt vaak gekozen voor een iets andere benadering; deze is vooral zichtbaar in de oordelen van de Commissie Gelijke Behandeling en in de strict scrutiny- en intermediate scrutiny-rechtspraak van het Amerikaanse Supreme Court. De verschillende doelstellingen worden in deze rechtspraak zorgvuldig onderscheiden, waarna voor iedere doelstelling afzonderlijk wordt nagegaan of deze gerechtvaardigd is en of het gemaakte onderscheid tot de doelstelling in een redelijke verhouding staat. In de rechtspraak blijft echter onduidelijk welke gevolgen moeten worden verbonden aan de conclusie dat één van de onderscheiden doelstellingen ongerechtvaardigd is, of aan de conclusie dat er geen redelijke verhouding bestaat tussen een doelstelling en het onderscheid: soms wordt meteen aangenomen dat

40. Zie hierover nader hoofdstuk 2 par. 3.1.3. Doorslaggevend hierbij is het argument van "futility". wanneer de rechter een regeling louter vanwege zijn ongerechtvaardigde doelstellingen ongerechtvastdigd zou achten, dan zou het voor de regelgever relatief gemakkelijk zijn om de regeling oprieuw in te voeren, ditmaal met een motivering die beter is afgestemd op de maatschappelijk wenselijke effecten die de regeling sorteert. De rechterlijke toetsing levert in een dergelijk geval slechts een onnodige be lemmering voor de regelgever op: een duidelijk meetbaar verschil in resultaat zal er niet zijn. 
het onderscheid niet toelaatbaar is, maar in andere gevallen wordt nagegaan of de overblijvende, wél gerechtvaardigde doelstellingen misschien nog een voldoende rechtvaardiging voor het onderscheid kunnen vormen. Deze laatste benadering, die vooral door het Europees Hof voor de Rechten van de Mens wordt gehanteerd, lijkt de meest wenselijke te zijn. Het enkele feit dat één van de doelstellingen niet redelijk is, wil immers nog niet zeggen dat het onderscheid niet kan worden gerechtvaardigd: dit is in sterke mate afhankelijk van de vraag of de ongerechtvaardigde doelstelling een hoofddoelstelling of een minder belangrijke subdoelstelling was, terwijl ook het gewicht en belang van de overige doelstellingen relevant zijn.

Op grond van het voorgaande kan worden gesteld dat het bij een terughoudende toetsing in beginsel niet nodig is om nader onderzoek te verrichten naar het bestaan van verschillende doelstellingen. Het is daarbij meestal voldoende wanneer de rechter alleen de belangrijkste of meest relevante doelstelling vaststelt en zijn rechtvaardigingstoets daarop afstemt. Is de toetsing intensiever, dan is een zorgvuldig onderzoek wel steeds vereist. Wanneer de rechter bij een dergelijke toetsing tot de conclusie komt dat er sprake is van meerdere doelstellingen, dan moet hij al deze doelstellingen op hun redelijkheid beoordelen. Voor het bereiken van de conclusie dat het onderscheid niet toelaatbaar is, is het daarbij niet voldoende dat de rechter één van de onderscheiden doelstellingen ongerechtvaardigd acht: deze conclusie kan pas worden bereikt wanneer ook de overige doelstellingen zijn getoetst aan de hand van de verschillende, hierna nog te bespreken criteria van het rechtvaardigingsmodel en wanneer daarbij is vastgesteld dat zij noch afzonderlijk, noch gezamenlijk een voldoende overtuigende rechtvaardiging vormen.

\subsubsection{Beoordeling van de gerechtvaardigdheid van het doel}

Wanneer de rechter eenmaal heeft vastgesteld welke doelstellingen er ten grondslag liggen aan een ongelijke behandeling, zal hij vervolgens moeten bepalen of deze doelstellingen gerechtvaardigd zijn. In het theoretische model zijn met betrekking tot deze toets slechts enkele aanwijzingen gegeven: gesteld is alleen dat het doel moet worden getoetst aan het geschreven recht en dat soms rekening mag worden gehouden met veranderende maatschappelijke opvattingen." Deze criteria kunnen ook in de rechtspraak van de onderzochte instanties worden teruggevonden. Daarnaast hebben de verschillende instanties nog enkele andere maatstaven ontwikkeld, die behulpzaam kunnen zijn bij de beoordeling van de gerechtvaardigdheid van het nagestreefde doel en in het algemene toetsingsmodel kunnen worden opgenomen. De belangrijkste van deze beoordelingsmaatstaven zullen hier kort worden besproken.

\section{Legitimiteit}

In hoofdstuk 2 is aangegeven dat het nagestreefde doel verenigbaar moet zijn met het positieve recht en de algemene rechtsbeginselen. Wanneer het doel wordt getoetst aan hogere regelgeving, zal de rechter bovendien rekening moeten houden met de uitleg die daaraan door de bevoegde rechterlijke instanties is gegeven. Zoals hiervoor is aangege-

41. Zie hoofdstuk 2 par. 3.2.4 
ven wordt door de onderzochte rechterlijke instanties regelmatig van deze maatstaf gebruik gemaakt. Uit de bestudeerde rechtspraak blijkt bovendien dat de rechter integraal aan dit criterium zal kunnen toetsen, ongeacht de toetsingsintensiteit die hij heeft gekozen. De beoordeling van de rechtmatigheid van een doelstelling is namelijk, an. ders dan de beoordeling van de doelmatigheid, een primair rechterlijke taak, zodat de rechter bij zijn oordeelsvorming geen rekening hoeft te houden met het eventuele bestaan van beleidsvrijheid of met factoren als het (internationaalrechtelijke) beginsel van subsidiariteit. ${ }^{42}$

Met betrekking tot dit criterium is verder van belang dat een ongelijke behandeling soms is gebaseerd op of rechtstreeks voortvloeit uit een hogere regeling die zelf onrechtmatig is of die een ongerechtvaardigd onderscheid bevat. Het beroep op een dergelijke regeling kan in beginsel niet dienen als disculpatiegrond: zoals de Nederlandse Commissie Gelijke Behandeling in haar oordelen terecht heeft aangegeven, is het de verantwoordelijkheid van de wederpartij om na te gaan of het door hem gemaakte onderscheid gerechtvaardigd is. Uitzonderingen op dit uitgangspunt zijn echter mogelijk, bijvoorbeeld in het geval waarin het voor de wederpartij feitelijk of juridisch niet mogelijk is om van de hogere regeling af te wijken.

\section{Geen overschrijding van bevoegdheden}

Nauw verwant aan het vereiste van legitimiteit is het vereiste dat de wederpartij bij het maken van het litigieuze onderscheid binnen de grenzen van zijn bevoegdheden moet blijven. Dit vereiste is vooral van belang bij de beoordeling van onderscheid dat het gevolg is van een concrete bevoegdheidsuitoefening, maar kan ook relevant zijn bij federale of gedecentraliseerde regelgeving. Ook voor dit vereiste geldt dat het bij de toepassing niet nodig is om verschil te maken tussen een intensieve, een neutrale en een terughoudende toetsing: de rechter kan steeds integraal toetsen of er in het concrete geval sprake is van een bevoegdheidsoverschrijding.

\section{Geen inherent discriminatoire doelstelling}

Alle onderzochte rechterlijke instanties blijken tot uitgangspunt te nemen dat een doelstelling met een inherent discriminatoir karakter niet gerechtvaardigd is. Van belang is daarbij dat niet iedere bedoeling die is gericht op het maken van onderscheid ongerechtvaardigd zal zijn. Aangenomen kan immers worden dat een (impliciete) bedoeling om onderscheid te maken aan iedere ongelijke behandeling ten grondslag zal liggen." Van een inherent discriminatoire (en dus ontoelaatbare) maatregel of handeling zal alleen sprake zijn wanneer de wederpartij daadwerkelijk tot doel had een bepaalde groep te benadelen of achter te stellen en deze doelstelling werd ingegeven door anti-

42. Zie hierover nader hoofdstuk 6 par. 3.2.2. Andere rechterlijke instanties hebben dit minder explicid aangegeven dan de Nederlandse rechter, maar ook uit hun rechtspraak kan blijken dat de rechtmatig. heid altijd volledig wordt beoordeeld.

43. De reden daarvoor is gelegen in het feit dat iedere regeling een beperking in zijn reikwijdte zal kennen, hetgeen automatisch tot consequentie zal hebben dat twee groepen verschillend worden behandeld. $D e$ beperking van de reikwijdte zal steeds bewust plaatsvinden, zodat aangenomen kan worden dat er ook steeds een bedoeling aanwezig is die is gericht op het maken van onderscheid. Duidelijk is echter dat deze bedoeling niet altijd wordt uitgesproken. 
pathie of subjectieve haatgevoelens jegens die groep. Daarnaast kan soms worden gesproken van een inherent discriminatoire doelstelling wanneer de wens om een groep achter te stellen niet bewust aanwezig was: volgens de onderzochte rechtspraak is het daarvoor voldoende als de basis voor het onderscheid wordt gevormd door overmatig generaliserende uitspraken, verouderde of stereotiepe noties of in de samenleving algemeen bestaande vooroordelen jegens een bepaalde groep.

Anders dan bij de hiervoor besproken criteria is de intensiteit van de toetsing voor de toepassing van dit criterium van belang. Bij dit vereiste wordt immers een aanzienlijke activiteit van de rechter gevergd: een vrij vergaand onderzoek naar de motieven van de wederpartij en naar de in de samenleving heersende opvattingen, vooroordelen en stereotypen is voor een goede toepassing vereist. In de praktijk blijkt dan ook vooral aan dit vereiste te worden getoetst bij een intensieve toetsing, en dan nog met name wanneer het onderscheid is gebaseerd op verdachte gronden, zoals ras of geslacht. Gezien het gekozen differentiatiecriterium bestaat er in die gevallen reden om te vermoeden dat discriminatoire overwegingen bij de besluitvorming een rol hebben gespeeld, zodat een nauwkeurig en actief rechterlijk onderzoek gerechtvaardigd is.

\section{Actualiteit}

Een vierde vereiste dat in de onderzochte rechtspraak steeds terugkeert is het vereiste van actualiteit. Dit vereiste houdt in dat het nagestreefde doel moet voorzien in een werkelijke behoefte van de wederpartij of moet beantwoorden aan een daadwerkelijk bestaande situatie: wanneer een (discriminatoire) regeling is getroffen om een bepaald probleem op te lossen, dan moet duidelijk zijn dat het hierbij niet gaat om een puur theoretisch of hypothetisch probleem. Wanneer de klacht betrekking heeft op een normatieve classificatie, dan blijkt in dit verband te worden vereist dat de nagestreefde doelstellingen passen binnen het relevante, bredere beleidskader; zo heeft het Europees Hof van Justitie op het gebied van de sociale zekerheid consequent gesteld dat het onderscheid moet beantwoorden aan een "doelstelling van sociaal beleid".4

Dit beoordelingscriterium kan bij alle niveaus van toetsingsintensiteit worden toegepast, maar de rechter zal meer mogelijkheden hebben om onderzoek te verrichten naar de achtergronden van een ongelijke behandeling naarmate de toetsing intensiever is. Bij een marginale toetsing zal de rechter al snel kunnen aannemen dat de wederpartij goede redenen had om een bepaald doel na te streven, terwijl bij een intensieve toetsing kan worden gevergd dat de wederpartij aantoont dat het realiseren van bepaalde doelstellingen voor hem daadwerkelijk van belang was.

\section{Specificiteit}

Interessant is verder het vereiste van specificiteit, dat eveneens in veel van de bestudeerde uitspraken is terug te vinden. Dit vereiste houdt in dat doelstellingen die zeer abstract, vaag of algemeen zijn geformuleerd in de regel geen toereikende rechtvaardiging vormen. Het is echter alleen bij een intensieve toetsing redelijk om van dit criterium gebruik te maken, nu daarbij hoge eisen kunnen worden gesteld aan de kwaliteit en de formulering van de doelstellingen. $\mathrm{Bij}$ een minder intensieve toetsing kunnen vage

44. Zie nader hoofdstuk 4 par. 2.3.1. 
of abstracte doelstellingen wel degelijk worden geaccepteerd: een gebrek aan specificiteit staat als zodanig niet in de weg aan de redelijkheid van een doelstelling. Hoog. stens zal in dergelijke gevallen iets zorgvuldiger moeten worden gekeken naar de proportionaliteit: de vraag is steeds of de vage of algemeen geformuleerde doelstellingen inderdaad zwaarwegender kunnen worden geacht dan de concrete belangen die door het onderscheid zijn aangetast.

\section{Gerechtvaardigd doel: bescherming van rechten en belangen van derden}

Volgens de rechtspraak van de onderzochte instanties zal het vrijwel steeds gerechtvaardigd zijn om de rechten en belangen van derden te beschermen. Het kan daarbij gaan om een bescherming van concrete en fundamentele belangen, zoals grondrechten, maar ook om meer abstracte belangen, zoals de rechtszekerheid of het voorkomen van ernstigere vormen van ongelijke behandeling. ${ }^{45} \mathrm{Bij}$ de toepassing van dit criterium zal de rechter moeten onderzoeken of de bescherming van de (abstracte) belangen van derden beantwoordt aan een werkelijke behoefte van de wederpartij en moet, bij een intensievere toetsing, zorgvuldig worden nagegaan of er niet nog andere, minder gerechtvaardigde doelstellingen aan het onderscheid ten grondslag lagen.

\section{Maatschappelijke opvattingen en ontwikkelingen}

Tenslotte kan de rechter bij de beoordeling van de gerechtvaardigdheid van het doel soms rekening houden met veranderingen in maatschappelijke opvattingen. In sommige gevallen wordt er namelijk geklaagd over een regeling die lange tijd redelijk heeft geleken, maar die inmiddels zijn maatschappelijk draagvlak heeft verloren. Dergelijke gevallen van ongelijke behandeling zullen veelal ongerechtvaardigd worden geacht op basis van de eerder besproken criteria. De rechter kan bijvoorbeeld oordelen dat de gedateerde doelstellingen niet meer verenigbaar zijn met internationale verdragen of rechtspraak of dat de doelstellingen zijn gebaseerd op verouderde noties of stereotypen en dus inherent discriminatoir zijn. In de praktijk blijkt dan ook maar zelden gebruik te worden gemaakt van de mogelijkheid om een onderscheid ongerechtvaardigd te achten vanwege het ontbreken van maatschappelijk draagvlak. Daarbij speelt vanzelfsprekend ook een rol dat het volgens de bestudeerde instanties niet aan de rechter, maar aan de wetgever is om gehoor te geven aan veranderingen in maatschappelijke opvattingen.

Gesteld kan worden dat de rechter alleen bij een intensieve toetsing gebruik kan maken van deze beoordelingsmaatstaf; bij een terughoudende toetsing bestaat geen ruimte voor een zo actieve rechterlijke opstelling als hierbij is vereist. Bovendien zal de rechter alleen een beroep op deze maatstaf mogen doen wanneer de opvattingen zich voldoende duidelijk in een bepaalde richting ontwikkelen en wanneer de democratisch gekozen instellingen onvoldoende bereid of in staat zijn om aan deze ontwikkelingen te beantwoorden. 
Toetsing van de gehanteerde proxy en van de mate van fit

\subsubsection{Inleiding}

Als eenmaal vaststaat dat er met het onderscheid een gerechtvaardigd doel wordt nagestreefd, zal de rechter vervolgens moeten beoordelen of er tussen deze doelstelling en het gemaakte onderscheid een redelijke verhouding bestaat. In hoofdstuk 2 is al aangegeven dat deze beoordeling iets verschillend zal zijn voor de toetsing van normatieve classificaties (onderscheid in algemene regelgeving) en voor de toetsing van individuele gevallen van onderscheid (ontstaan door een ongelijke bevoegdheidsuitoefening). Wanneer een normatieve classificatie wordt getoetst is het mogelijk (en noodzakelijk) om te beoordelen of de definitie van de classificatie voldoende aansluit op het nagestreefde doel. Dit betekent dat de rechter na moet gaan of de groep die is uitgezonderd voor een nadelige behandeling te ruim is gedefinieerd (overinclusiveness) of dat er juist een te kleine groep is uitgezonderd voor een voordelige behandeling (underinclusiveness). Een dergelijke beoordeling is bij een individueel geval van ongelijke behandeling vanzelfsprekend niet mogelijk. Wordt de rechter met een klacht over een individueel geval van ongelijke behandeling geconfronteerd, dan is het dus ook niet nodig om aan dit tweede onderdeel van het algemene toetsingsmodel te toetsen: de rechter kan dan meteen overgaan tot een beoordeling van de geschiktheid (zie paragraaf 3.3).

De wenselijkheid van een toetsing van de mate van fit wordt door de toetsingspraktijk bevestigd, ook al maken de onderzochte instanties zelden gebruik van de hier gehanteerde terminologie. Opmerkelijk is bovendien dat veel rechters de reikwijdte van de definitie al beoordelen in de eerste fase van de toetsing, namelijk bij het uitvoeren van een vergelijkbaarheidstoets. In het kader van die toets wordt beoordeeld of er, in het licht van het met de regeling nagestreefde doel, gesproken kan worden van een ongelijke behandeling van vergelijkbare gevallen (hetgeen betekent dat een relevante groep ten onrechte niet in de uitgezonderde groep is betrokken: underinclusiveness) of van een gelijke behandeling van onvergelijkbare gevallen (hetgeen betekent dat een niet relevante groep ten onrechte in de uitgezonderde groep is betrokken: overinclusiveness). ${ }^{\text {t6 }}$ Wanneer een dergelijke toetsing in de eerste fase is uitgevoerd, dan ligt het voor de hand dat hieraan in de tweede fase niet nogmaals aandacht wordt besteed.

Wordt in de eerste fase een benadelingstoets uitgevoerd, dan is een beoordeling van de definitie van de classificatie in de tweede fase wel regelmatig terug te vinden; in alle rechtsvergelijkende hoofdstukken is gewezen op enkele voorbeelden daarvan. ${ }^{47}$ Van belang is echter dat deze toepassing op enkele punten te wensen overlaat: de toetsing wordt niet consequent uitgevoerd en wordt vaak ondergebracht bij toetsingsonderdelen waar zij niet thuishoort. Zo heeft de Commissie Gelijke Behandeling uit het ontbreken van een toereikende mate van fit soms afgeleid dat het onderscheid niet noodzakelijk was, terwijl het Europees Hof voor de Rechten van de Mens hieruit in een enkel geval heeft geconcludeerd dat een gerechtvaardigd doel ontbrak. ${ }^{4 x}$ Een dergelijke onzuivere

\footnotetext{
46. Zie met name hoofdstuk 2 par. 4.2.4; ook in de verschillende rechtsvergelijkende hoofdstukken is hieraan aandacht besteed.

47. Zie hoofdstuk 3 par. 2.8, hoofdstuk 4 par. 2.5, hoofdstuk 5 par. 2.4.2 en hoofdstuk 6 par. 2.4.1.

48. Zie hoofdstuk 6 par. 2.4.1 en hoofdstuk 3 par. 4.1.3. Opmerkelijk is verder de benadering van het
} 
toepassing kan leiden tot een verwarrende en ondoorzichtige motivering. Het is dan ook beter om de toetsing van de definitie van de classificatie een afzonderlijke plats te geven binnen de rechterlijke toetsing.

\subsubsection{Toetsing van de proxy}

Anders dan in hoofdstuk 2 is verondersteld blijkt de toetsing van de redelijkheid van de definitie uit twee onderdelen te kunnen bestaan. Uit de Nederlandse rechtspraak, be sproken in hoofdstuk 6, is gebleken dat de rechter niet alleen een oordeel kan uitspreken over de mate van fit (de hiervoor al besproken toetsing van over- of underinclusiveness), maar ook over de relevantie van de gehanteerde proxy." Het is van belang om dit tweede vereiste te onderscheiden, omdat de regelgever bij het definiëren van een classificatie vaak rekening zal houden met de toepassings- of interpretatieproblemen die het gebruik van een bepaald differentiatiecriterium met zich mee kan brengen. Wanneer de wetgever een bepaalde uitkering bijvoorbeeld alleen wil toekennen aan mensen die daaraan werkelijk behoefte hebben, dan moet hij de classificatie eigenlijk zodanig formuleren dat "behoefte" het centrale onderscheidingscriterium vormt. Een dergelijke formulering zal echter ongetwijfeld leiden tot uitvoeringsproblemen: het is voor een uitvoeringsinstantie moeilijk te bepalen in welke gevallen aan dit criterium is voldaan, hetgeen kan leiden tot onzekerheid en wellicht zelfs tot willekeurige toepassingen. Daarom zal de regelgever in dit soort gevallen vaak een ander, specifieker, criterium bedenken, waardoor aan het eigenlijk beoogde differentiatiecriterium nader invulling wordt gegeven: de proxy. Zo kan de wetgever in het gegeven voorbeeld aangeven welke groepen van personen volgens hem behoeftig moeten worden geacht, waardoor niet meer de behoefte als zodanig, maar de categorisering van de wetgever bepalend is voor de reikwijdte van de regeling.

In hoofdstuk 6 is aangegeven dat deze wetgevingstechniek bijzonder praktisch is, maar dat deze ook tot problemen kan leiden: niet iedere proxy blijkt een goede of relevante benadering te vormen van het eigenlijk gewenste onderscheidingscriterium..$^{50}$ Om die reden is het wenselijk dat de rechter onderzoekt of door het hanteren van de proxy (nagenoeg) dezelfde groep wordt uitgezonderd als het geval zou zijn geweest wanneer het eigenlijke differentiatiecriterium was gehanteerd.

Het is niet in alle gevallen noodzakelijk dat de rechter beoordeelt of er sprake is van het gebruik van een proxy: een dergelijke toetsing hoeft alleen te worden uitgevoerd wanneer de rechter een intensieve toetsing heeft gekozen of wanneer de feiten van het voorgelegde geval twijfel oproepen over de aansluiting tussen de proxy en het eigenlijke differentiatiecriterium. Bij een marginale toetsing kan het bestaan van een voldoende mate van aansluiting in beginsel aanwezig worden geacht en is een toetsing van de proxy alleen nodig wanneer de klager aannemelijk maakt dat het gebruik hiervan niet redelijk is. Wordt de proxy niet getoetst, dan zal de rechter wel nog moeten nagaan of er sprake is van een voldoende mate van fit (zie paragraaf 3.2.3).

Europees Hof van Justitie, dat in één geval van toepassing concludeerde dat er geen sprake was van evenredigheid (zie hoofdstuk 4 par. 2.5).

49. Zie hoofdstuk 6 par. 2.4.1.

50. Zie hoofdstuk 6 par. 2.4.1. 
Besluit de rechter om wél een toetsing van de proxy uit te voeren, dan zal hij allereerst moeten vaststellen of er inderdaad van een proxy sprake is: het is immers denkbaar dat de regelgever het eigenlijke toetsingscriterium tot uitgangspunt heeft genomen. Vervolgens dient de rechter, op basis van de stellingen van de wederpartij of op basis van eigen onderzoek, vast te stellen welk differentiatiecriterium de regelgever eigenlijk voor ogen stond. Pas daarna kan hij beoordelen of de beide criteria voldoende op elkaar aansluiten. Daarbij moet worden opgemerkt dat de aansluiting tussen de proxy en het eigenlijke differentiatiecriterium nooit volledig zal zijn: er zal altijd een groep zijn die wel onder de reikwijdte van de classificatie zou vallen wanneer het originele criterium was gekozen, terwijl dit niet het geval is bij de keuze voor de proxy. ${ }^{\text {s1 }}$ De rechter zal dan ook moeten beoordelen of de overeenstemming tussen beide criteria toereikend kan worden geacht. De eisen die daarbij kunnen worden gesteld zijn afhankelijk van de gekozen toetsingsintensiteit: bij een marginale toetsing zal vaak al genoegen kunnen worden genomen met een matige overeenstemming, terwijl er bij een intensieve toetsing veel hogere eisen kunnen worden gesteld.

\subsubsection{Toetsing van de mate van fit}

Ontbreekt een toereikende aansluiting tussen het eigenlijke differentiatiecriterium en de proxy, dan kan de rechter het onderscheid ontoelaatbaar verklaren. Komt de rechter daarentegen tot de conclusie dat de criteria voldoende overeenstemmen, dan is zijn oordeel over de definitie van de classificatie nog niet volledig. Het is dan noodzakelijk dat wordt vastgesteld of er een voldoende mate van aansluiting bestaat tussen de definitie van de classificatie en het nagestreefde doel. Zowel de proxy als het originele differentiatiecriterium kunnen in het licht van het nagestreefde doel namelijk zodanig ongelukkig zijn gekozen dat een bepaalde groep ten onrechte onder de reikwijdte van de classificatie valt of hier juist ten onrechte buiten blijft.

Uit het rechtsvergelijkende gedeelte is gebleken dat de verschillende rechterlijke instanties vrij regelmatig een oordeel uitspreken over de mate van fit, maar in hun rechtspraak nauwelijks criteria hebben ontwikkeld die nader inhoud geven aan deze toets. Duidelijk is alleen dat er hogere eisen worden gesteld aan de zorgvuldigheid van de definitie naarmate de toetsing intensiever is: waar bij een verdacht onderscheid een nagenoeg perfecte fit wordt verlangd, blijkt bij een marginale toetsing vaak al genoegen te worden genomen met een matige aansluiting. ${ }^{32}$ Het stellen van lage eisen aan de mate van fit bij een terughoudende toetsing geldt nog sterker wanneer de wederpartij goede redenen voor de tekortkoming heeft aangevoerd. Zo kan het relevant zijn dat de regeling slechts een onderdeel vormt van uitgebreidere regelgeving die nog tot stand moet komen (waardoor een betere mate van fit in een later stadium zal worden bereikt), ${ }^{\text {s" }}$ of dat het gaat om een noodmaatregel die slechts een tijdelijk karakter heeft. Bij een te-

51. Het tegenovergestelde kan eveneens het geval zijn: het is mogelijk dat een groep wel onder de reikwijdte van een classificatie valt door het gebruik van een bepaalde proxy, terwijl dit niet het geval zou zijn geweest als het eigenlijke differentiatiecriterium zou zijn gekozen. Dit is vooral problematisch wanneer de uitgezonderde groep een nadelige behandeling ten deel valt.

52. Zie voor deze verschillen vooral hoofdstuk 5 par. 2.4.2.

53. Zie voor een illustratie hoofdstuk 5 par. 2.4.2. 
rughoudende toetsing kan een vrij grote mate van misfit bovendien redelijk worden geacht wanneer de wederpartij om redenen van uitvoerbaarheid of privacybescherming streeft naar een objectivering of veralgemenisering van individuele omstandigheden." Accepteert de rechter een dergelijke rechtvaardiging voor een gebrekkige mate van fit, dan zal hij in het vervolg van zijn toets wel steeds een zorgvuldige proportionaliteits. toets moeten uitvoeren: het is immers mogelijk dat juist door de misfit een ernstige belangenaantasting wordt veroorzaakt. Belangrijk is bovendien dat de rechter ook bij een marginale toetsing geen genoegen mag nemen met een willekeurig getrokken lijn tussen twee groepen van gevallen: vereist is steeds dat de definitie van de classificatie is gebaseerd op objectieve gegevens of op enig onderzoek naar de relatie tussen het onderscheid en het nagestreefde doel..$^{s s}$

Komt de rechter tot de conclusie dat er om enigerlei reden geen sprake is van een toereikende mate van fit, dan moet hij het onderscheid ontoelaatbaar verklaren. Oordeelt hij daarentegen dat de classificatie voldoende zorgvuldig is gedefinieerd, dan betekent dit nog niet dat het onderscheid gerechtvaardigd is: om dit oordeel te kunnen geven zal de rechter nog moeten toetsen aan de hierna te bespreken onderdelen van het rechtvaardigingsmodel.

\subsection{Geschiktheid}

In hoofdstuk 2 is opgemerkt dat het niet redelijk is om een maatregel in stand te houden die weliswaar zorgvuldig is gedefinieerd en waaraan gerechtvaardigde overwegingen ten grondslag liggen, maar die een ongeschikt middel blijkt te zijn om de nagestreefde doelstellingen te verwezenlijken. ${ }^{56}$ In die omstandigheden worden er immers individuele belangen aangetast, zonder dat daar feitelijk iets tegenover staat. Volgens het theoretische toetsingsmodel zal de rechter dan ook steeds moeten onderzoeken of er een toereikend causaal verband bestaat tussen het gemaakte onderscheid en het gestelde doel.

Uit de rechtspraak van de onderzochte instanties blijkt dat het geschiktheidsvereiste ook in de rechtspraktijk een belangrijk onderdeel van de toetsing vormt. Weliswar hebben niet alle instanties het geschiktheidsvereiste expliciet in hun toetsingsmodel opgenomen, maar uit de rechtsvergelijkende hoofdstukken is gebleken dat ook deze instanties regelmatig een causaliteitstoets uitvoeren. ${ }^{57}$ In de diverse uitspraken kan daardoor interessante informatie worden gevonden, waardoor nader inhoud kan worden gegeven aan het geschiktheidsvereiste.

Bij het uitvoeren van een geschiktheidstoets zal de rechter allereerst moeten bepalen of hij rekening houdt met de situatie ten tijde van het rechtsgeding (een ex munc-

54. Zie nader hoofdstuk 6 par. 2.4.1.

55. Zie nader hoofdstuk 6 par. 2.4.1.

56. Zie hoofdstuk 2 par. 3.3.3.

57. Zie voor voorbeelden hoofdstuk 3 par. 2.5. Het ontbreken van een expliciete geschiktheidseis lijkt verband te houden met het feit dat de betrokken instanties nauwelijks onderscheid maken tussen de verschillende onderdelen van de doel-middeltoets, maar meer in het algemeen beoordelen of er een $t^{\circ}$ delijke verhouding bestaat tussen doel en middel. 
benadering), dan wel uitsluitend kijkt naar de verwachtingen die de wederpartij op het moment van de besluitvorming kon hebben ten aanzien van de effecten van het onderscheid (een ex tunc-benadering). Het Supreme Court en het Europees Hof van Justitie blijken bij een marginale toetsing uit te gaan van de tweede benadering, nu deze nauwelijks rechterlijke activiteit vergt: de rechter kan hierbij de redelijkheid van de stellingen van de wederpartij tot uitgangspunt nemen en hoeft zelf geen onderzoek te verrichten naar de feitelijke effecten van het onderscheid..5x Van belang is echter dat deze benadering tot gevolg kan hebben dat een ineffectieve maatregel in stand wordt gehouden. Juist omdat een dergelijke maatregel voor een bepaalde groep benadelende consequenties zal hebben, is dit niet redelijk. Het is dan ook wenselijker om een ex nuncbenadering te hanteren, waarbij juist naar de daadwerkelijk bereikte resultaten wordt gekeken. Eventuele problemen die door deze benadering (vooral bij een marginale of neutrale toetsing) kunnen rijzen, zijn relatief gemakkelijk op te lossen door een soepele bewijslastverdeling te kiezen. Bij een neutrale toetsing kan voorop worden gesteld dat de wederpartij weliswaar moet aantonen dat de maatregel effectief is, maar dat hij daarvoor geen hard bewijsmateriaal, zoals wetenschappelijke gegevens, hoeft aan te voeren; meestal kan hij volstaan met een overtuigende redenering, waaruit de geschiktheid kan worden afgeleid. ${ }^{59} \mathrm{Bij}$ een marginale toetsing kan een nog verdergaand uitgangspunt worden gekozen: daarbij kan worden verondersteld dat de gekozen maatregel geschikt is, tenzij de klager aannemelijk maakt dat dit niet het geval is, of tenzij de ongeschiktheid uit de feiten van het voorliggende geval duidelijk blijkt. Bovendien kan bij een marginale toetsing sneller genoegen worden genomen met een maatregel die op het eerste gezicht niet bijzonder effectief lijkt; de rechter kan bijvoorbeeld aannemen dat aan het geschiktheidsvereiste is voldaan als blijkt dat de doelstellingen slechts ten dele zijn verwezenlijkt of wanneer de doelstellingen wel zijn gerealiseerd, maar het waarschijnlijk is dat de litigieuze maatregel daaraan maar een beperkte bijdrage heeft geleverd.

Wordt er een intensieve toetsing uitgevoerd, dan zal de rechter hogere eisen kunnen stellen aan de effectiviteit van het onderscheid. Net zoals het geval is bij de oordelen van de Commissie Gelijke Behandeling, kan de bewijslast in dit geval primair berusten bij de wederpartij. Dit betekent dat deze verantwoordelijk is voor het aandragen van objectieve gegevens, zoals cijfermateriaal of evaluatieverslagen, waaruit de effectiviteit van het gemaakte onderscheid kan worden afgeleid. Is dergelijk materiaal niet voorhanden en is de effectiviteit ook anderszins niet evident, dan kan de rechter concluderen dat het onderscheid niet toelaatbaar is. Wanneer er wel voldoende gegevens voorhanden zijn, zal de rechter aan de hand van deze gegevens moeten beoordelen of de maatregel een wezenlijke bijdrage levert aan het realiseren van het gestelde doel. De rechter zal kunnen aannemen dat het onderscheid niet geschikt is om het gestelde doel te bereiken, wanneer duidelijk is dat van een dergelijke bijdrage geen sprake is; in dat geval is het onderscheid in strijd met het gelijkheidsbeginsel. Komt de rechter daarentegen tot de conclusie dat het onderscheid een geschikt middel vormt, dan kan hij daar-

58. Zie voor de werkwijze van het Supreme Court hoofdstuk 5 par. 2.4.3. Voor het Europese recht geldt

59. Wanneer feitelijke gegevens beschikbaar zijn is het wenselijk dat deze ook daadwerkelijk naar voren worden gebracht. 
uit nog niet afleiden dat het voldoende gerechtvaardigd is: daarvoor is vereist dat het onderscheid ook de toetsing doorstaat aan de hierna te bespreken vereisten van noodzakelijkheid en proportionaliteit.

\subsection{Subsidiariteit en noodzakelijkheid}

Volgens het theoretische toetsingsmodel is een ongelijke behandeling niet toelaatbaar wanneer er alternatieve oplossingen of maatregelen voorhanden waren waarmee het nagestreefde doel ook kon worden bereikt, maar waardoor de individuele belangen minder ernstig zouden zijn aangetast. In hoofdstuk 2 is aangegeven dat de verplichting tot het uitvoeren van een dergelijke subsidiariteitstoets problematisch kan zijn: het is voor de rechter niet altijd gemakkelijk om na te gaan welke andere mogelijkheden er voorhanden waren en het kan lastig zijn om vast te stellen of deze mogelijkheden net zo effectief zouden zijn als het gekozen middel. ${ }^{60}$ Uit de onderzochte rechtspraak zijn bovendien enkele andere bezwaren tegen deze toets naar voren gekomen. Belangrijk is vooral dat verschillende rechterlijke instanties hebben aangegeven dat zij een subsidiariteitstoets niet verenigbaar achten met de beperkingen van de rechterlijke taakomvang, omdat de keuze tussen verschillende alternatieven primair behoort tot de discretie van de wetgever of het bestuur. ${ }^{61}$

Van belang is echter dat uit de rechtspraak van de verschillende bestudeerde instanties een goed alternatief voor de subsidiariteitstoets kan worden afgeleid. Wanneer er een minder intensieve toetsing wordt uitgevoerd voeren de meeste instanties geen subsidiariteitstoets uit, maar kiezen zij voor de algemenere noodzakelijkheidstoets. In het kader van deze toets wordt in algemene zin nagegaan of het gemaakte onderscheid zinvol (of, bij een strikte toetsing, onmisbaar) kan worden geacht voor het bereiken van het nagestreefde doel.

De noodzakelijkheidstoets heeft een bij uitstek feitelijk karakter, hetgeen betekent dat de toepassing primair wordt bepaald door de omstandigheden van het geval. In de rechtspraak zijn dan ook niet veel algemene maatstaven terug te vinden die de rechter bij het uitvoeren van deze toets behulpzaam kunnen zijn. Hoogstens kan uit de oordelen van de Commissie Gelijke Behandeling en uit de rechtspraak van het Supreme Court en het Europees Hof van Justitie een tweetal relevante aanwijzingen worden afgeleid.

Allereerst blijkt uit deze rechtspraak dat de noodzaak voor het maken van onderscheid minder duidelijk aanwezig is wanneer het probleem waarop de maatregel zich richt zich in de praktijk slechts sporadisch voordoet, of wanneer blijkt dat de maatregel niet consequent of consistent wordt toegepast. Het gemaakte onderscheid lijkt dan niet onmisbaar te zijn of zou op zijn minst genuanceerder of beperkter kunnen worden ge-

60. Zie hoofdstuk 2 par. 3.3.4.

61. Dit is ook het bezwaar dat door het Supreme Court en door het Europees Hof voor de Rechten van de Mens tegen deze toets naar voren is gebracht; beide instanties voeren, althans bij een terughoudende toetsing, dan ook nooit een toetsing van eventuele alternatieven uit. Zie hoofdstuk 5 par. 2.44 en hoofdstuk 3 par. 2.6 . 
formuleerd. In die omstandigheden kan al snel worden aangenomen dat het niet noodzakelijk is. ${ }^{62}$

In de tweede plaats kan er twijfel ontstaan over de noodzaak van het onderscheid wanneer de betrokken maatregel inmiddels is vervangen door een andere regeling, waarin het litigieuze onderscheid ontbreekt. Hoewel deze maatstaf praktisch goed bruikbaar lijkt en ook regelmatig wordt toegepast, moet worden benadrukt dat hiermee voorzichtig moet worden omgegaan. Heeft de klacht bijvoorbeeld betrekking op een periode die al iets verder in het verleden ligt, dan kunnen uit het intrekken van de regeling niet automatisch conclusies worden getrokken over de onmisbaarheid van een daarin opgenomen classificatie: het is goed mogelijk dat er op het relevante tijdstip wel degelijk behoefte bestond aan het gemaakte onderscheid. Ook meer in het algemeen kan uit het intrekken van een regeling echter niet onmiddellijk worden afgeleid dat de daarin vervatte classificatie noodzakelijk was: aan het intrekken van een regeling kunnen diverse overwegingen en redenen ten grondslag liggen, die met het gemaakte onderscheid weinig van doen hebben. Eigenlijk kan er alleen van worden uitgegaan dat het onderscheid kennelijk niet meer noodzakelijk was, wanneer na de intrekking een nieuwe, nagenoeg identieke regeling is ingevoerd, waarin de litigieuze classificatie niet meer is terug te vinden. In andere gevallen kan een intrekking hoogstens een indicatie vormen van een gebrek aan noodzakelijkheid: voor het rechterlijk oordeel over de toelaatbaarheid van het onderscheid zal deze niet als zodanig doorslaggevend kunnen zijn.

Hiervoor is al aangegeven dat de algemene noodzakelijkheidstoets een alternatief voor de subsidiariteitstoets kan vormen bij een marginale of neutrale toetsing. Wordt er intensief getoetst, dan kan echter wel degelijk worden gesteld dat het onderscheid alleen toelaatbaar is wanneer er geen andere, minder belastende mogelijkheden bestonden om het nagestreefde doel te realiseren. Bij een intensieve toetsing bestaan er namelijk goede redenen om te vereisen dat de wederpartij kiest voor de minst belastende of vergaande oplossing: meestal gaat het in dit soort gevallen om "verdacht" onderscheid of onderscheid waardoor fundamentele belangen worden aangetast. Ook bij een minder intensieve toetsing kan echter een subsidiariteitstoets worden uitgevoerd, bijvoorbeeld in gevallen waarin het bestaan van minder vergaande mogelijkheden evident of voor de hand liggend is, of wanneer de klager aannemelijk heeft gemaakt dat er goede alternatieven beschikbaar waren.

Bij het uitvoeren van de subsidiariteitstoets moet de rechter allereerst nagaan welke alternatieven er voor het gemaakte onderscheid voorhanden waren. Uit de bestudeerde rechtspraak is gebleken dat hij daarbij gebruik kan maken van een groot aantal verschillende bronnen. Zo kan de rechter een soort vergelijkend onderzoek uitvoeren en nagaan of er elders (bijvoorbeeld in een ander rechtsstelsel, of, afhankelijk van de omstandigheden van het geval, in een ander bedrijf of een andere regio) andere oplossingen zijn gevonden voor een vergelijkbaar probleem. Verder kan hij gebruik maken van

62. Overigens moet bij het gebruik van dit criterium overlap met de toetsing van het doel worden vermeden: het is mogelijk dat het gekozen middel noodzakelijk is, maar dat het nastreven van het gestelde doel niet voldoet aan een werkelijke behoefte. Dit kan het geval zijn wanneer het probleem waarop de maatregel zich richt zich slechts sporadisch voordoet: de vraag is dan vaak niet zozeer of het maken van onderscheid nodig was om de oplossing voor dit probleem te verwezenlijken, maar of het eigenlijk wel nodig was om voor dit probleem een oplossing te bedenken. 
onderzoek dat is verricht door deskundigen en van informatie die door de partijen naar voren is gebracht of die in de totstandkomingsgeschiedenis van het onderscheid is terug te vinden. Ook kan hij soms terugvallen op zijn eigen kennis en inzicht, hoewel dit, gezien het subjectieve karakter daarvan, in het algemeen niet de voorkeur verdient. Aan de hand van de geschikte alternatieven zal de rechter vervolgens moeten beoordelen of een keuze daarvoor van de wederpartij verwacht had mogen worden. Bij deze beoordeling kan de intensiteit van de toetsing een belangrijke rol spelen. Zoals wordt geîllustreerd door de oordelen van de Commissie Gelijke Behandeling kan bij een intensieve toetsing van de wederpartij worden verwacht dat hij aannemelijk maakt dat de keuze voor het alternatief feitelijk onmogelijk was, of dat deze zou leiden tot onoverkomelijke problemen of onaanvaardbare consequenties. Ook uit de rechtspraak van het Supreme Court kan een dergelijke strenge benadering worden afgeleid. ${ }^{3}$ Als aan deze bewijslast niet wordt voldaan, dan kan worden aangenomen dat het onderscheid niet toelaatbaar is. Bij de minder strenge, "neutrale" subsidiariteitstoets kan de rechter zelf een oppervlakkige beoordeling geven van de geschiktheid van de alternatieven, terwijl bij een marginale toetsing van de klager kan worden verwacht dat hij zelf aannemelijk maakt dat de gevonden mogelijkheden net zo bruikbaar waren als het gekozen middel; de rechter zal er daarbij relatief snel vanuit kunnen gaan dat dit niet het geval is.

Voor het uitvoeren van een noodzakelijkheids- of subsidiariteitstoets geldt verder hetzelfde als voor de eerder besproken toetsingselementen: is het onderscheid niet noodzakelijk of zijn er minder vergaande en geschikte alternatieven voorhanden, dan kan het zonder meer ontoelaatbaar worden geacht. Doorstaat het onderscheid deze toetsing, dan kan echter nog niet worden aangenomen dat het voldoende gerechtvaardigd is: daarvoor is het noodzakelijk dat het ook voldoet aan het laatste rechtvaardigingsvereiste - dat van een redelijke mate van proportionaliteit.

\subsection{Proportionaliteit}

\subsubsection{Abstracte of concrete toetsing?}

Zoals hiervoor is aangegeven is het voor de toelaatbaarheid van een ongelijke behandeling niet voldoende dat hiermee een gerechtvaardigd doel wordt nagestreefd, dat de classificatie zorgvuldig is geformuleerd en dat het onderscheid een geschikt en noodzakelijk middel vormt om het gestelde doel te realiseren: het is altijd denkbaar dat de aan het onderscheid ten grondslag liggende belangenafweging zodanig onredelijk is, dat het onderscheid onaanvaardbaar is. Een ongelijke behandeling zal dus alleen gerechtvaardigd kunnen zijn wanneer er een evenredige verhouding bestaat tussen de belangen die met het onderscheid worden gediend en de belangen die hierdoor zijn aangetast. ${ }^{6}$

63. Zie hoofdstuk 6 par. 2.4 .3 en hoofdstuk 5 par. 2.4.4.

64. Hoewel de instanties de verplichting van het uitvoeren van een proportionaliteitstoets lang niet allemaal uitdrukkelijk erkennen, hechten zij blijkens hun rechtspraak veel belang aan deze toets: in cen groot aantal uitspraken van de onderzochte instanties zijn proportionaliteitsoverwegingen terug te vín den. Zie hoofdstuk 3 par. 2.7, hoofdstuk 4 par. 2.4, hoofdstuk 5 par. 2.4 .5 en hoofdstuk 6 par. 2.4.4. 
De belangenafweging kan op verschillende manieren worden getoetst, afhankelijk van de aard van het aan de rechter voorgelegde geval. Bij de beoordeling van een normatieve classificatie zal de rechter meestal in zijn algemeenheid nagaan of er sprake is van een redelijke verhouding tussen de aangetaste en de nagestreefde belangen; er is dan sprake van een abstracte toetsing. Het is echter ook denkbaar dat de rechter beoordeelt of er door de toepassing van de betrokken regeling in het voorliggende geval sprake is van een onevenredig zware belangenaantasting: de toetsing heeft dan een concreet karakter. Van een dergelijke concrete toetsing zal ook steeds sprake zijn bij de beoordeling van een onderscheid dat het gevolg is van een ongelijke bevoegdheidsuitoefening: in dat geval is het niet anders mogelijk dan dat de rechter een oordeel geeft over de verhouding tussen het nagestreefde doel en het nadeel dat daardoor in het concrete geval is veroorzaakt.

Dit onderscheid tussen een abstracte en een concrete proportionaliteitstoets is ook terug te vinden in de praktische toepassing van het gelijkheidsbeginsel door de onderzochte rechterlijke instanties. De meeste rechters blijken daarbij aan te nemen dat bij normatieve classificaties zowel een abstracte als een concrete toets mogelijk is. Afwijkingen van dit uitgangspunt zijn echter zichtbaar: het Europees Hof voor de Rechten van de Mens geeft slechts zelden een abstract oordeel over de evenredigheid van een algemene regeling, terwijl het Europees Hof van Justitie (in landbouwoordelen) juist niet bereid is om een concreet oordeel uit te spreken over de proportionaliteit. In de relevante hoofdstukken is echter aangegeven dat beide instanties niet erg consequent zijn in hun benadering: in de rechtspraak van het Straatsburgse Hof zijn wel degelijk voorbeelden van een abstracte toetsing terug te vinden, terwijl de jurisprudentie van het Hof van Justitie soms toepassingen laat zien van een concrete proportionaliteitstoets. ${ }^{63}$ Bovendien is in de relevante hoofdstukken duidelijk geworden dat er noch tegen de abstracte, noch tegen de concrete toetsing van regelgeving overtuigende bezwaren bestaan. Het is dan ook mogelijk om in het algemene toetsingsmodel tot uitgangspunt te nemen dat beide benaderingen bij de toetsing van normatieve classificaties kunnen worden gevolgd. Het meest zorgvuldig is dan een combinatie van de twee toetsen, waarbij de rechter eerst een abstract oordeel geeft over de verhouding tussen de verschillende belangen en vervolgens vaststelt of er in het concrete geval tot een ander oordeel moet worden gekomen." $\mathrm{Bij}$ die benadering kunnen alle relevante aspecten van de ongelijke behandeling voldoende worden beoordeeld.

\subsubsection{Opbouw van het proportionaliteitsoordeel; vaststelling van belangen}

Voor het oordeel over de belangenafweging is het van belang dat de rechter in eerdere fasen van zijn toetsing al heeft bepaald welke belangen in het voorliggende geval een rol spelen: in de eerste fase van de toetsing heeft de rechter vastgesteld dat de klager een benadeling heeft ondervonden en daardoor in bepaalde belangen is aangetast, terwijl hij in de tweede fase bij de vaststelling van het doel heeft bepaald welke belangen

65. Zie nader hoofdstuk 3 par. 2.7 en hoofdstuk 4 par. 2.4.2; op andere terreinen dan de landbouw blijkt het Hof van Justitie overigens minder huiverig te zijn voor een concrete toetsing.

66. Het is mogelijk om bij een grote mate van terughoudendheid alleen een concrete toetsing uit te voeren wanneer de klager voldoende aannemelijk heeft gemaakt dat zijn individuele belangen onevenredig zwaar zijn aangetast; zie nader hoofdstuk 4 par. 2.4.2. 
door het gemaakte onderscheid gediend worden. Bij de beoordeling van de proportionaliteit komt het er vooral op aan deze belangen tegenover elkaar te plaatsen en te beoordelen of de wederpartij hiertussen een redelijke afweging heeft gemaakt. Van belang is daarbij dat de redelijkheid van de afweging pas kan worden beoordeeld wanneer uitspraak is gedaan over het gewicht van de betrokken belangen: alleen dan kan worden vastgesteld of het redelijk was het nagestreefde belang zwaarder te laten wegen dan het aangetaste belang.

In het rechtsvergelijkend gedeelte is gebleken dat de rechterlijke instanties bij het uitvoeren van een proportionaliteitstoets tamelijk onzorgvuldig te werk gaan. Het is zeldzaam dat alle betrokken belangen daadwerkelijk worden vastgesteld en op hun gewicht worden beoordeeld: in veruit de meeste gevallen geven de onderzochte instanties alleen een oordeel over de zwaarte van de nagestreefde belangen of volstaan zij met een uitspraak over het gewicht van het aangetaste belang. ${ }^{67}$ De toetsing van de proportionaliteit is daardoor vaak ondoorzichtig en moeilijk controleerbaar. De verschillende rechterlijke instanties zouden hierin dan ook een zorgvuldigere benadering moeten kiezen. De ondoorzichtigheid van de motivering wordt nog vergroot doordat de proportionaliteitstoets vaak niet afzonderlijk en als laatste onderdeel van de toetsing wordt uitgevoerd, maar wordt verweven met de toetsing aan de eerder besproken toetsingscriteria. Het komt regelmatig voor dat een oordeel over het gewicht van het nagestreefde doel wordt gegeven in het kader van de doeltoets, vooral wanneer er een intensieve toetsing wordt uitgevoerd: vrijwel alle onderzochte instanties vereisen bij een strikte toetsing dat er met het onderscheid een zwaarwegend of dwingend doel wordt nagestreefd." Een dergelijke benadering is echter niet wenselijk, niet alleen omdat de proportionaliteitstoets daardoor in een te vroeg stadium van de toetsing wordt uitgevoerd, maar vooral ook omdat deze toets erg eenzijdig is: er wordt hierbij wel een oordeel gegeven over het gewicht van het nagestreefde doel, maar het gewicht van het aangetaste belang wordt hier niet tegenover geplaatst. Het oordeel over het zwaarwegende karakter van het doel blijft daardoor vaak in de lucht hangen, hetgeen leidt tot een onvolledige en onbevredigende motivering. Het verdient dan ook de voorkeur om de "zwaarwegendheid" niet te betrekken bij de beoordeling van de gerechtvaardigdheid van het doel, maar in plaats daarvan een zorgvuldige proportionaliteitstoets uit te voeren.

\subsubsection{Gewicht van de betrokken belangen}

Hoe onzorgvuldig en onvolledig de motivering van de verschillende onderzochte instanties vaak ook is, in diverse uitspraken zijn wel enkele interessante maatstaven terug te vinden voor de beoordeling van de proportionaliteit. Belangrijke aanwijzingen betreffen vooral de vaststelling van het gewicht van de betrokken belangen.

67. Zie vooral hoofdstuk 5 par. 2.4.5 en 4.1.4 en hoofdstuk 6 par. 2.4.4.

68. In de rechtspraak van het Europees Hof voor de Rechten van de Mens komt dit tot uitdrukking in het vereiste van het aanvoeren van very weighty reasons, dat wordt gesteld bij een strikte toetsing (zic hoofdstuk 3 par. 2.7); in de rechtspraak van het Supreme Court komt dit terug in het vereiste van een "important governmental objective" bij intermediate scrutiny en in dat van een "compelling governmental interest" of een "overriding statutory purpose" bij strict scrutiny (zie hoofdstuk 5 par. 2.4.5). 
Gewicht van het aangetaste belang

Belangrijk is allereerst dat het gewicht van de aangetaste belangen in sterke mate blijkt te worden bepaald door de ernst en de aard van de belangenaantasting. Zo hebben vrijwel alle instanties aangenomen dat een absolute en onomkeerbare belangenaantasting moeilijk is te rechtvaardigen, net als een benadeling waardoor individuele belangen in de kern worden geraakt. ${ }^{69}$ Van een minder ernstige belangenaantasting zal daarentegen sprake zijn wanneer de aantasting slechts een beperkt of een tijdelijk karakter heeft, of wanneer er een hardheidsclausule bestaat die de gevolgen van een maatregel in het voorgelegde geval verzacht. ${ }^{70}$

Van belang is verder dat zowel de Nederlandse rechters als het Supreme Court hebben aangenomen dat een belangenaantasting minder ernstig is wanneer er voor de benadeelde goede alternatieven voorhanden zijn, of wanneer het voor hem gemakkelijk is om aan de belangenaantasting te ontkomen. In hoofdstuk 5 en 6 is echter aangegeven dat de rechter met deze factoren voorzichtig om moet gaan." Vooral de "vermijdbaarheidsfactor" moet op terughoudende wijze worden gehanteerd: de rechter zal hierop alleen een beroep mogen doen wanneer duidelijk is dat het vermijden van het nadeel niet leidt tot een onredelijk grote belasting voor de betrokkene. Ook de eventuele alternatieven voor een voordeel dat aan de klager is onthouden moeten steeds zorgvuldig worden onderzocht: het bestaan hiervan mag alleen invloed hebben op het oordeel over de proportionaliteit wanneer duidelijk is dat de alternatieven voldoende bruikbaar of geschikt zijn en wanneer vaststaat dat van de klager verwacht kon worden dat hij hiervan gebruik zou maken.

Het gewicht van het aangetaste belang blijkt echter niet alleen te worden bepaald door de ernst en de aard van de aantasting. Vooral uit de rechtspraak van het Europees Hof voor de Rechten van de Mens en - in mindere mate - van het Europees Hof van Justitie blijkt dat daarnaast de aard van het aangetaste recht of belang van belang zijn. Is er sprake van een aantasting van een fundamenteel recht of een "kernrecht" (een recht dat binnen een democratische samenleving van bepalend belang is of dat essentieel is voor de menselijke waardigheid of de individuele ontplooiing), dan is het gewicht dat hieraan moet worden toegekend veel groter dan wanneer het aangetaste recht slechts als "perifeer" kan worden gekwalificeerd. Op deze factor zal in de volgende paragraaf nog nader worden ingegaan (paragraaf 4.2.3), nu deze ook van belang is voor de vaststelling van de toetsingsintensiteit.

\section{Gewicht van de nagestreefde belangen}

Voor de vaststelling van het gewicht van het nagestreefde doel zijn in de rechtspraak van de onderzochte instanties maar weinig algemeen bruikbare aanwijzingen te vinden. Belangrijk is echter dat ten aanzien van enkele specifieke doelstellingen, die in de praktijk vaak als rechtvaardiging worden aangevoerd, vrij duidelijk is welke waarde hieraan moet worden gehecht. Zo blijken alle rechterlijke instanties te aanvaarden dat puur financiële of budgettaire doelstellingen maar een beperkt gewicht hebben: als een

\footnotetext{
69. Zie bijv. hoofdstuk 4 par. 2.4.2 en hoofdstuk 6 par. 2.4.4

70. Zie bijv. hoofdstuk 5 par. 2.4 .5 en hoofdstuk 6 par. 2.4.4.

71. Zie hoofdstuk 5 par. 2.4 .5 en hoofdstuk 6 par. 2.4.4.
} 
ongelijke behandeling uitsluitend wordt gerechtvaardigd met een beroep op een dergelijke doelstelling, dan wordt het onderscheid vrijwel steeds ontoelaatbaar geacht." Opgemerkt moet echter worden dat de precieze waarde van een financiële doelstelling afhankelijk is van de context waarin hierop een beroep wordt gedaan: in bijzondere omstandigheden, bijvoorbeeld bij een dreigend faillissement, kan hieraan een groter gewicht worden toegekend dan gebruikelijk. ${ }^{3}$

Deze contextafhankelijkheid geldt in nog sterkere mate voor doelstellingen van administratieve aard. Deze doelstellingen hebben een uiteenlopend karakter: zij kunnen variëren van de uitvoerbaarheid van regelgeving en het vereenvoudigen van bureaucratische procedures tot het voorkomen van fraude. Door de verschillende instanties wordt aangenomen dat deze doelstellingen in principe niet zwaarwegend zijn. ${ }^{74}$ Gezien het diverse karakter van deze doelstellingen geldt echter dat de omstandigheden van het geval een ander oordeel kunnen rechtvaardigen.

Van belang is tenslotte dat vrijwel alle rechters grote waarde hechten aan onderscheid dat erop is gericht de belangen van derden te beschermen. Het kan daarbij gaan om specifieke belangen of rechten (zoals de bescherming van de gezondheid of de godsdienstvrijheid), maar ook om meer abstracte belangen, zoals de rechtszekerheid of de legaliteit van het overheidshandelen. Dit laatste belang blijkt vooral in de Nederlandse rechtspraak bijzondere betekenis te hebben: de verschillende Nederlandse rechters aanvaarden niet gemakkelijk dat een beroep op het gelijkheidsbeginsel leidt tot een handelen (of tot het voortzetten van een handelen) in strijd met de wet. ${ }^{\text {s }}$ Een algemeen en abstract oordeel over het gewicht van het legaliteitsbeginsel is echter niet mogelijk: de waarde van dit beginsel, in relatie tot de belangen die zijn aangetast, moet in ieder concreet geval opnieuw worden bepaald. Het is dan ook niet redelijk om het legaliteitsbeginsel altijd van groter gewicht te achten dan het gelijkheidsbeginsel.

\subsubsection{Toetsing van de belangenafweging}

$\mathrm{Na}$ vaststelling van het relatieve gewicht van de verschillende belangen, moet de rechter tenslotte beoordelen of de wederpartij hiertussen een redelijke afweging heeft gemaakt. Met deze toetsing zal de rechter op een zorgvuldige manier moeten omgaan. De

72. Het Europees Hof van Justitie gaat er zelfs van uit dat financiēle doelstellingen een ongelijke behandeling op grond van geslacht of nationaliteit nooit kunnen rechtvaardigen. Deze benadering gaat te ver, zoals in hoofdstuk 4 is opgemerkt: de omstandigheden van het geval kunnen soms zodanig zijn dat dergelijke doelstellingen wel degelijk een rechtvaardiging vormen. Zie nader hoofdstuk 4 par. 23.1. Een genuanceerdere benadering wordt vooral gekozen door het Supreme Court (hoofdstuk 5 par. 2.4.5) en de Nederlandse rechter (hoofdstuk 6 par. 2.4.4.)

73. Zie voor enkele voorbeelden vooral de rechtspraak van de Commissie Gelijke Behandeling, waamar is verwezen in hoofdstuk 6 par. 2.4.4.

74. Ook bij deze doelstelling heeft het Europees Hof van Justitie de meest vergaande benadering gekozen: bij de beoordeling van onderscheid op grond van nationaliteit heeft het consequent aangenomen dat overwegingen van administratieve aard nooit voldoende zwaarwegend kunnen zijn om een ongelijke behandeling te rechtvaardigen. Opnieuw geldt hierbij dat deze stelling te absoluut is: het oordeel over de evenredigheid en het gewicht van de administratieve doelstellingen is afhankelijk van de concrete omstandigheden van het geval en kan niet algemeen en abstract worden vastgesteld. Zie hoofdstuk 4 par. 2.3.3. Een genuanceerdere benadering is vooral zichtbaar in de rechtspraak van het Supreme Court (hoofdstuk 5 par. 2.4.5) en in de jurisprudentie van de Nederlandse rechters (hoofdstuk 6 par. 2.4.4).

75. Zie nader hoofdstuk 6 par. 2.4.4. 
belangenafweging is veelal het centrale punt in de besluitvorming, zodat de rechter door het geven van een eigen oordeel hierover al snel in de discretie van regelgever, bestuur of particulier treedt. In de praktijk blijken de verschillende rechterlijke instanties zich bij deze toetsing dan ook terughoudend op te stellen: vaak gaan zij uitsluitend na of de wederpartij, gezien het gewicht van de betrokken belangen, een zodanige afweging heeft gemaakt dat er sprake is van willekeur. Het zal duidelijk zijn dat een dergelijk geval zich in de praktijk vrijwel nooit voor zal doen.

Wordt er geen marginale, maar een neutrale toetsing uitgevoerd, dan blijkt er in de praktijk van een vergelijkbare benadering sprake zijn. De eisen die worden gesteld aan de belangenafweging zijn bij deze intensiteit echter iets hoger: er mag niet alleen geen sprake zijn van willekeur, maar er moet daadwerkelijk van een redelijke belangenafweging kunnen worden gesproken. Het verschil tussen de marginale en de neutrale toetsing blijkt in de praktijk echter slechts gradueel van aard te zijn.

Tenslotte blijken de onderzochte rechterlijke instanties bij een intensieve toetsing vrijwel nooit aan de toetsing van de belangenafweging toe te komen: classificaties die aan een strikte toetsing worden onderworpen zijn meestal in een eerder stadium van de toetsing al gesneuveld. Wanneer er wel een proportionaliteitstoets wordt uitgevoerd, dan is het verschil met een marginale toetsing vooral gelegen in de verdeling van de bewijslast: bij een intensieve toetsing blijkt de rechter aan te nemen dat er sprake is van een disproportionele belangenaantasting, tenzij de wederpartij overtuigend aannemelijk maakt dat de nagestreefde belangen zwaarder wogen. ${ }^{76}$ Dit betekent dat de rechter ook bij een intensieve toets geen eigen belangenafweging maakt en dat hij zijn oordeel niet in plaats stelt van dat van de wederpartij; hij zal slechts kritisch onderzoeken of de door de wederpartij aangevoerde argumenten voldoende overtuigend zijn.

Wanneer de rechter tot de conclusie komt dat de door de wederpartij gemaakte belangenafweging (in abstracte en/of concrete zin) niet redelijk kan worden geacht, dan moet hij concluderen dat het onderscheid ontoelaatbaar is. Komt hij daarentegen tot de slotsom dat er een voldoende mate van evenredigheid bestaat tussen de nagestreefde en de angetaste belangen, dan zal hij kunnen vaststellen dat het onderscheid voldoende gerechtvaardigd is, zodat het verenigbaar is met het gelijkheidsbeginsel.

\section{Toetsingsintensiteit}

\subsection{Inleiding: niveaus van toetsingsintensiteit}

Uit het voorgaande is gebleken dat de intensiteit waarmee de rechter een ongelijke behandeling beoordeelt van groot belang is voor de uitkomst van de procedure. De rechter zal immers aanzienlijk sneller een schending van het gelijkheidsbeginsel kunnen aannemen wanneer hij een intensieve toetsing tot uitgangspunt neemt, dan wanneer hij een neutrale of marginale toetsing uitvoert. Om die reden is het van belang dat de

76. Zie bijvoorbeeld hoofdstuk 5 par. 2.3.3: volgens de rechtspraak van het Supreme Court moet het overheidsbelang, om te kunnen dienen als overtuigende rechtvaardiging, zwaarwegender zijn naarmate de toetsing intensiever is. 
rechter, alvorens over te gaan tot een benadelingstoets en een beoordeling van de rechtvaardiging, bepaalt hoe intensief zijn toetsing zal zijn. Aan de gekozen intensiteit dient hij vervolgens consequent vast te houden, op de manier die in de voorgaande paragrafen is omschreven.

Hiervoor is steeds tot uitgangspunt genomen dat er drie niveaus van toetsingsintensiteit denkbaar zijn: een marginale, een neutrale en een intensieve toets. In hoofdstuk 2 is aangegeven dat de intensiteit van de toetsing vaak wordt gezien als een glijdende schaal, die loopt van zeer intensief tot zeer marginaal. ${ }^{\text {" }}$ Gesteld is daarbij echter dat het glijdende schaal-model in de praktijk tot problemen kan leiden: voor de duidelijkheid en helderheid van de rechterlijke motivering is het beter om te werken met drie (of hoogstens vier) duidelijke ijkpunten. De keuze voor een dergelijk ijkpunt kan goed worden onderbouwd aan de hand van objectieve factoren, en de toetsingsmethodiek is gemakkelijker te bepalen op basis van drie duidelijke meetpunten dan door middel van een glijdende schaal.

De rechtspraktijk in de onderzochte stelsels sluit goed aan bij deze theoretische benadering. Hoewel niet alle rechters gebruik maken van duidelijke ijkpunten, is in de onderzochte jurisprudentie wel steeds verschil zichtbaar tussen twee uitersten (marginaal en intensief) en een tussenvorm (neutraal); belangrijk is dat deze tussenvorm in de meeste gevallen de "basisintensiteit" vormt." De overgangen tussen deze drie gradaties van toetsingsintensiteit zijn in de praktijk veelal vloeiend, hetgeen onvermijdelijk lijkt te zijn: het is praktisch onmogelijk om te voorkomen dat een neutrale toets in bepaalde gevallen iets intensiever of marginaler is dan gebruikelijk, of dat een intensieve toetsing soms iets terughoudender is dan verwacht zou kunnen worden. Dit neemt echter niet weg dat het gebruik van drie gradaties of "niveaus" duidelijkheid schept in de rechterlijke motivering, zodat het zinvol is om deze onderverdeling in het algemene toetsingsmodel te verwerken.

Een uitgangspunt van het algemene toetsingsmodel moet verder zijn dat de toepassing van de "hogere" niveaus van toetsingsintensiteit niet beperkt is tot nauw omschreven groepen van gevallen. Dit betekent dat de benadering zoals die in de VS wordt gehanteerd in dit model niet wordt overgenomen." Volgens de rechtspraak van het Supreme Court moet in beginsel een rational basis-test worden gehanteerd, tenzij er reden bestaat om een intermediate scrutiny- of strict scrutiny-test uit te voeren. Met deze onderverdeling, die op het eerste gezicht goed aansluit bij het hiervoor beschreven algemene uitgangspunt, blijkt het Supreme Court in de praktijk zeer inflexibel om te gaan,

77. Zie hoofdstuk 2 par. 5.2.1.

78. Overigens wordt de tussenvorm niet altijd als uitgangspunt gehanteerd. In de VS wordt juist een marginale toets tot uitgangspunt gekozen (zie hoofdstuk 5 par. 3.1), terwijl het Europees Hof van Justitie (bij onderscheid op grond van geslacht en nationaliteit) en de Commissie Gelijke Behandeling een (vrij) intensieve toetsing tot uitgangspunt nemen (zie hoofdstuk 4 par. 3.2.2 en 3.4 .1 en hoofustuk 5 par. 3.1). Ook dan is een verdeling in drie niveaus van toetsingsintensiteit echter zichtbaar. het VS kiest voor een onderverdeling in een rational basis-test, een intermediate scrutimy-test en een strict scrutiny-test en de rechtspraak van het Europese Hof van Justitie en de Commissie Gelijke Behandeling laat soms een vermindering van de toetsingsintensiteit zien, maar soms ook een nog verdergande intensivering.

79. Zie voor een uitgebreide bespreking van dit model hoofdstuk 5 , in het bijzonder par, 3.1 en $4.2,1$. 
in die zin dat de beide intensievere tests slechts in een beperkt aantal gevallen worden toegepast. ${ }^{30}$ Van belang is bovendien dat de rational basis-test een sterk voorspelbaar en zeer marginaal karakter heeft: een toetsing aan de hand van deze test leidt vrijwel steeds tot de conclusie dat het gemaakte onderscheid toelaatbaar is. Deze werkwijze heeft onwenselijke consequenties, nu het lang niet altijd wenselijk is om een zo marginale toetsing uit te voeren in alle gevallen waarin toepassing van de intermediate scrutimy-test of de strict scrutiny-test niet mogelijk is. De praktische onwerkbaarheid van dit model heeft in de VS dan ook tot noodgrepen geleid, zoals de ontwikkeling van de informele rational basis "with bite"-test. Deze test is iets intensiever dan de rational basis-test en wordt toegepast in vrijwel alle gevallen waarin een striktere toetsing weliswaar is aangewezen, maar niet is voldaan aan de toepassingsvoorwaarden van de beide striktere tests. De voorwaarden waaronder de rational basis "with bite"-test kan worden toegepast zijn echter niet duidelijk omschreven, net zomin als de precieze consequenties van deze test voor de toetsingsmethodiek. Daardoor is de Amerikaanse rechtspraak over het gelijkheidsbeginsel vaak ondoorzichtig en onduidelijk, hetgeen in de rechtswetenschappelijke literatuur heeft geleid tot scherpe kritiek. Het is dan ook niet wenselijk om de Amerikaanse benadering tot uitgangspunt van het algemene toetsingsmodel te nemen.

Het alternatief voor de benadering van het Supreme Court is een flexibel afwegingsmodel, waarbij in ieder concreet geval opnieuw wordt bepaald welke intensiteitbepalende factoren een rol spelen en op welke manier deze tegen elkaar moeten worden afgewogen. Aan de hand van deze afweging kan worden bepaald of er een neutrale toetsing kan worden uitgevoerd of dat er juist aanleiding bestaat om de toetsing te intensiveren of verder af te zwakken. Een dergelijke soepele benadering blijkt ook in de praktijk veel te worden gevolgd: deze vormt het uitgangspunt van de gelijke behandelingsrechtspraak van de Nederlandse rechter, het Europees Hof van Justitie en het Europees Hof voor de Rechten van de Mens. ${ }^{\mathrm{si}}$

Om van dit afwegingsmodel zinvol gebruik te kunnen maken moet duidelijk zijn op welke manier de verschillende intensiteitbepalende factoren in een concreet geval tegen elkaar moeten worden afgewogen. Jammer genoeg verschaft de rechtspraak van de onderzochte instanties daarover maar weinig duidelijkheid: hoewel regelmatig wordt aangegeven welke factoren in het voorgelegde geval een rol spelen, wordt slechts zelden geëxpliciteerd welk gewicht er aan deze factoren kan worden toegekend en wordt vrijwel nooit aangegeven waarom bepaalde factoren voor de vaststelling van de toetsingsintensiteit bepalend zijn. Een behulpzaam criterium voor de afweging van de intensiteitbepalende factoren kan echter worden gevonden in de rechtspraak van het Supreme Court. Belangrijk is in dit verband de in het Carolene Products-arrest ontwikkelde rationale voor de intensivering van de rechterlijke toetsing. ${ }^{\mathrm{x} 2}$

80. Zie daarvoor hoofdstuk 5 par. 3.3.3.

81. Zie hoofdstuk 3 par. 3.2.8, waarin is opgemerkt dat het Europees Hof voor de Rechten van de Mens als enige van de onderzochte instanties geen duidelijke basisintensiteit kent, hoewel ook uit zijn rechtspraak lijkt te kunnen worden afgeleid dat een tussenvorm het meest gebruikelijk is. Zie ook hoofdstuk

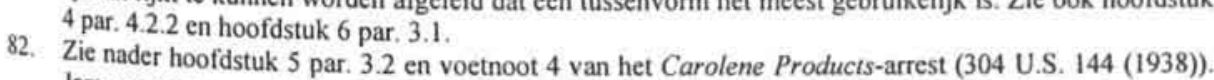
Jammer genoeg maakt het Supreme Court zelf de laatste tijd nauwelijks zinvol gebruik van deze ratio- 
De basis van de Carolene Products-rationale is gelegen in de gedachte dat de wetgever, gezien zijn democratische legitimatie, de meest geëigende instantie is om regelgeving tot stand te brengen en de belangen van individuele burgers te behartigen. Verder is de rationale gebaseerd op de gedachte dat een goed functionerend democratisch systeem zich kenmerkt door een zelfcorrigerend vermogen: worden de belangen van een bepaalde groep door een wettelijke regeling aangetast, dan is het mogelijk dat deze regeling na de volgende verkiezingen, wanneer de betrokken groep meer steun heeft weten te verwerven, wordt veranderd. In Carolene Products gaf het Supreme Court echter aan dat het democratisch systeem soms zodanige gebreken vertoont dat niet meer aan deze uitgangspunten wordt beantwoord. In het arrest werd een drietal situaties onderscheiden waarin van een gebrekkig functioneren van het systeem sprake zal zijn.

Allereerst kan volgens het Supreme Court worden vastgesteld dat het democratisch systeem disfunctioneert, wanneer er sprake is van een beperking van fundamentele politieke rechten, zoals het kiesrecht of het recht om politieke partijen te vormen. Door een dergelijke beperking wordt het zelfcorrigerend vermogen van het democratisch proces in essentie aangetast, nu de politieke rechten juist door deze beperking niet meer kunnen worden gehanteerd om de beperking ongedaan te maken. In de tweede plats kan er volgens Carolene Products twijfel bestaan over het deugdelijk functioneren van het democratisch proces, wanneer er maatregelen zijn getroffen waardoor fundamentele individuele rechten worden aangetast die rechtstreeks verband houden met de menselijke waardigheid of de individuele ontplooiing. Tenslotte kan er reden zijn om te twijfelen aan de goede werking van het systeem wanneer er sprake is van een aantasting van de belangen van groepen die het slachtoffer zijn of zijn geweest van maatschappelijke achterstelling of waarover in het algemeen vooroordelen of stigma's bestann: in die gevallen is het waarschijnlijk dat deze groepen, als gevolg van hun achterstelling, hun belangen in het politieke proces onvoldoende hebben kunnen behartigen, zodat geen recht is gedaan aan de hierboven beschreven uitgangspunten.

In alle in Carolene Products omschreven gevallen zal er een gegronde reden bestaan om minder vertrouwen te stellen in de goede werking van het democratisch systeem. De resultaten van de democratische besluitvorming en de argumenten die voor het bereiken van deze resultaten zijn aangevoerd moeten in die omstandigheden met bijzondere argwaan worden bekeken. Hoewel het normaal gesproken wenselijk kan worden geacht dat de rechter zich terughoudend opstelt, kan in deze gevallen een zorgvuldiger en uitgebreider rechterlijk onderzoek worden verwacht: een intensieve toetsing is dan gerechtvaardigd.

Van belang is dat de hiervoor besproken rationale zich specifiek richt op de goede werking van het democratisch proces en dus eigenlijk alleen houvast biedt bij de toetsing van classificaties die door een democratisch gekozen orgaan tot stand zijn gebracht. Bij onderscheid dat door bestuursorganen of door particulieren is gemaakt kan echter gebruik worden gemaakt van een maatstaf die op de Carolene Products. rationale is geïnspireerd. Doorslaggevend bij de keuze voor een intensievere toetsing is

nale; zie nader hoofdstuk 5 par. 3.3.1. Belangrijk is dat deze rationale impliciet ook is terug te vinder in de rechtspraak van het Europees Hof voor de Rechten yan de Mens, dat tot uitgangspunt neemt dal maatregelen waardoor essentięle politieke en fundamentele rechten worden geraakt strikt moeten worden getoetst; zie nader hoofdstuk 3 par, 3.2.6. 
dan vooral het bestaan van het vermoeden dat een bevoegdheid op oneigenlijke wijze is gebruikt of, bij particulieren, van het vermoeden dat er bij het handelen ongeoorloofde overwegingen hebben meegespeeld.

Het voorgaande betekent dat de rechter steeds zal moeten beoordelen of er sprake is van een zodanige combinatie van factoren dat er objectief gezien twijfel kan bestaan over het goed functioneren van het democratisch proces of dat het vermoeden kan rijzen dat er bij de besluitvorming oneigenlijke of ongeoorloofde overwegingen hebben meegespeeld. Is daarvan sprake, dan zal er steeds een intensieve toetsing moeten worden uitgevoerd. Ontbreekt een dergelijk vermoeden, dan zal de rechter moeten beoordelen of er in het concrete geval een neutrale toetsing kan worden uitgevoerd, of dat deze tot een marginale toets moet worden afgezwakt. Deze keuze is afhankelijk van de omstandigheden van het geval: de rechter zal moeten nagaan of er in het voorliggende geval zodanige factoren aanwezig zijn dat een bijzondere terughoudendheid aangewezen is.

Het voorgaande betekent dat de vaststelling van intensiteitbepalende factoren van groot belang is. Uit de aanwezigheid van bepaalde factoren kan immers worden afgeleid dat er reden bestaat voor intensivering van de toetsing (op basis van de Carolene Productsrationale), maar ook kan aan de hand van deze factoren een keuze worden gemaakt tussen een neutrale en een terughoudende toetsing. Om die reden zullen de belangrijkste intensiteitbepalende factoren hierna kort worden besproken. Daarbij zal een onderverdeling worden gemaakt in een drietal groepen. De eerste twee groepen omvatten enkele factoren die bepalend zijn voor de intensivering van de toetsing. Bekeken moet steeds worden of er een zodanige combinatie van deze factoren aanwezig is, dat er objectief gezien twijfel mogelijk is over de deugdelijkheid van de besluitvorming; is dit het geval, dan is een intensieve toetsing noodzakelijk (zie paragraaf 4.2.1 en 4.2.2). De derde groep factoren is relevant als er geen reden is om de toetsing te intensiveren. Deze groep omvat namelijk enkele factoren die bepalend zijn voor de keuze tussen een neutrale en een terughoudende toetsing (paragraaf 4.2.3).

\subsection{De intensiteitbepalende factoren}

\subsubsection{Groep 1. Factoren die het onderscheid als zodanig betreffen}

\section{a. Factoren die betrekking hebben op de grond van onderscheid}

Belangrijk is allereerst dat de keuze voor een bepaald differentiatiecriterium in sommige gevallen twijfel kan oproepen over de deugdelijkheid van de besluitvormingsprocedure: sommige gronden kunnen objectief gezien zodanig "verdacht" worden geacht dat een hierop gebaseerd onderscheid vrijwel nooit gerechtvaardigd zal zijn. Een bijzondere mate van zorgvuldigheid is bij de beoordeling van een dergelijk onderscheid gewenst.

Of er van een dergelijk verdacht differentiatiecriterium sprake is kan blijkens de rechtspraak van de verschillende instanties aan de hand van een aantal factoren worden bepaald. 
Aanwezigheid van een common ground die het gebruik van het differentiatiecriterium veroordeelt

Het Europees Hof voor de Rechten van de Mens heeft consequent geoordeeld dat er reden bestaat om een grond als verdacht aan te merken (en een daarop gebaseerd onderscheid strikt te toetsen), wanneer er een algemene consensus of common ground bestaat over de verwerpelijkheid van het maken van onderscheid op deze grond. ${ }^{x}$ Deze factor kan op verschillende manieren worden toegepast. Zo voert het Hof regelmatig een rechtsvergelijkend onderzoek uit naar de regelgeving en rechtspraak van de omrin. gende landen, waarbij het nagaat of er een consensus bestaat over de afkeurenswaardigheid van het gebruik van een bepaald onderscheidingskenmerk. Voor het bestaan van een common ground blijkt het daarbij niet nodig te zijn dat er in de verschillende onderzochte stelsels volstrekte eenstemmigheid zichtbaar is: meestal is het voldoende dat er een algemene tendens kan worden gesignaleerd die strekt in de richting van verdachtheid."

Verder blijkt het Hof de aanwezigheid van een common ground vaak af te leiden uit het bestaan van internationale regelgeving en rechtspraak. Ook deze methode is voor andere rechters goed bruikbaar. De nationale rechter kan bijvoorbeeld uit rechtspraak van het Europees Hof voor de Rechten van de Mens of uit het bestaan van internationale verdragen afleiden dat het maken van onderscheid op een bepaalde grond niet (langer) acceptabel is. ${ }^{85}$ Belangrijk is hierbij dat het Hof, maar ook andere rechters die van deze benadering gebruik maken, op een flexibele manier met deze factor omgaan: een common ground wordt soms ook afgeleid uit niet-bindende regelgeving, zoals resoluties van internationale organisaties ("soft law"), terwijl het evenmin vereist is dat een bepaald verdrag door een meerderheid van staten is geratificeerd."

Tenslotte is een algemeen bruikbare toepassing van de common ground-factor gegeven door het Europees Hof van Justitie. In een aantal arresten heeft dit Hof aangegeven dat kan worden nagegaan of er binnen de betrokken staat zelf eigenlijk wel overeenstemming bestaat over de wenselijkheid van het gebruik van een bepaald differentiatiecriterium. ${ }^{\text {77 }}$ Daarbij kunnen belangrijke aanwijzingen worden gevonden in bestaande regelgeving, zoals in een opsomming van "verboden" gronden in de nationale constitutie, maar soms ook in wetenschappelijke rapporten of andere objectieve informatie." Van belang is hierbij wel dat de geldende regelgeving niet altijd doorslaggevend mag zijn: rekening moet worden gehouden met het feit dat de opvattingen over de verdachtheid van bepaalde differentiatiecriteria in de loop van de tijd kunnen veranderen.

83. Zie voor een bespreking van de rechtspraak van het Europees Hof voor de Rechten van de Mens hoofdstuk 3 par. 3.2.2. Ook het Europese Hof van Justitie en, in mindere mate, de Hoge Raad hebben onder verwijzing naar deze factor soms een strengere toetsing uitgevoerd dan gebruikelijk; deze rechtspraak is besproken in hoofdstuk 4 par. $3.2 .1,3.2 .3$ en 3.2 .4 en hoofdstuk 6 par. 3.2 .3 .

84. Zie nader hoofdstuk 3 par. 3.2 .2 onder a.

85. Door de Nederlandse rechter wordt deze techniek wel eens gebruikt. Zie nader hoofdstuk 6 par. 323.

86. Zie hoofdstuk 3 par. 3.2 .2 onder b. Een toepassing hiervan is ook te vinden in de Nederlandse rechtspraak; zie hoofdstuk 6 par. 3.2.3.

87. Zie hoofdstuk 4 par, 3.4 .2 en 4.2 .2 .

88. Dit is een werkwijze die ook in Nederland wel wordt gevolgd; zie bijv. hoofdstuk 6 par. 3.2 .3 . 
Onveranderlijkheid en zichtbaarheid van het onderscheidingscriterium

Voor de bepaling van de verdachtheid van een differentiatiecriterium kan het verder relevant zijn of het criterium een onveranderlijk persoonskenmerk betreft, zoals ras of huidskleur." Daarbij is van belang dat de onveranderlijkheid ruim moet worden opgevat, in die zin dat het hierbij ook kan gaan om persoonskenmerken die in theorie veranderlijk zijn, maar waarbij een verandering niet van de betrokkene kan of mag worden verwacht. Door een dergelijke ruime uitleg kunnen ook kenmerken als godsdienst of politieke overtuiging als onveranderlijk worden gekwalificeerd.

In het rechtsvergelijkend gedeelte is echter aangegeven dat deze factor bij de bepaling van verdachtheid nooit doorslaggevend mag worden geacht. Niet alle onveranderlijke kenmerken zijn immers onmiddellijk verdacht, zoals de voorbeelden van onderscheid op grond van talent of intelligentie laten zien. Om een rechtvaardiging te kunnen vormen voor een intensieve toets moet deze factor dan ook altijd met andere intensiteitverhogende factoren worden gecombineerd.

Hetzelfde geldt voor een derde factor: de zichtbaarheid van het onderscheidingskenmerk. Deze factor, die overigens alleen door het Supreme Court is genoemd, impliceert dat het maken van onderscheid op grond van zichtbare persoonskenmerken, zoals geslacht of huidskleur, al snel verdacht is. ${ }^{90}$ Veel verdachte kenmerken zullen echter niet zichtbaar zijn (zoals politieke overtuiging), terwijl niet-verdachte kenmerken wel degelijk naar buiten toe kenbaar kunnen zijn (zoals leeftijd). Om die reden zal deze factor nooit zelfstandig mogen worden gebruikt, maar kan deze alleen dienen ter ondersteuning van een primair op andere factoren gebaseerde verhoging van de toetsingsintensiteit.

\section{Irrelevantie van het onderscheidingskenmerk voor het maatschappelijk functioneren}

Een laatste factor die van belang is voor het bepalen van de verdachtheid van een differentiatiecriterium betreft de irrelevantie van het onderscheidingskenmerk voor het matschappelijk functioneren." Deze factor wordt in het algemeen van bijzonder belang geacht, hoewel ook hiervoor geldt dat deze de keuze voor een intensivering van de toetsing nooit zelfstandig kan rechtvaardigen. Inderdaad zal het in de meeste gevallen zo zijn dat het maken van onderscheid op grond van kenmerken die in het dagelijks leven niet relevant zijn twijfel kan oproepen over de objectiviteit van de besluitvorming. Bij sommige factoren is het belang voor het maatschappelijk functioneren echter moeilijk vast te stellen. Zo kan geslacht, dat in het algemeen wordt gezien als een verdachte grond van onderscheid, in sommige gevallen wel degelijk van invloed zijn voor het functioneren. Een combinatie met andere factoren zal dan ook nodig zijn om de verdachtheid van een irrelevant kenmerk te onderstrepen en een intensieve toetsing te rechtvaardigen.

89. Dit criterium komt vooral naar voren in de rechtspraak van het Supreme Court; zie hoofdstuk 5 par. 3.3.2.

90. Zie hoofdstuk 5 par. 3.3 .2 .

91. Zie nader hoofdstuk 5 par. 3.3 .2 . 


\section{b. Factoren die betrekking hebben op de benadeelde groep}

Zoals hiervoor is aangegeven kan de rechter aan de hand van een aantal factoren bepa. len of er in een concreet geval sprake is van een verdacht differentiatiecriterium. De enkele vaststelling van verdachtheid kan echter niet automatisch leiden tot de conclusie dat er een intensieve toets moet worden uitgevoerd. ${ }^{92}$ Zo wordt er in gevallen van voorkeursbehandeling vaak wel onderscheid gemaakt op een verdachte grond, zoals etnische afkomst of geslacht, maar zal een strikte toetsing daarbij lang niet altijd nodig zijn. Bepalend is, zoals in paragraaf 4.1 werd aangegeven, of er zodanige omstandigheden zijn dat twijfel over de goede werking van het democratisch proces mogelijk is of, in het geval van onderscheid door bestuursorganen of particulieren, dat er twijfel kan bestaan over de redelijkheid of objectiviteit van de besluitvorming. De hierna te noemen factoren kunnen de rechter behulpzaam zijn bij de beantwoording van de vraag of een dergelijke twijfel gerechtvaardigd is.

\section{Bestaan van historische of sociale achterstelling van de betrokken groep}

Bijzondere aanleiding om een onderscheid zorgvuldig te beoordelen zal allereerst aanwezig zijn wanneer de benadeelde groep lange tijd het slachtoffer is geweest van achterstelling, of wanneer deze groep in de samenleving een sociaal moeilijke of zwakke positie inneemt. ${ }^{y 3}$ In dergelijke omstandigheden is het namelijk waarschijnlijk dat de groep onvoldoende in staat is zijn belangen in het politieke proces voldoende te behartigen, en is de mogelijkheid aanwezig dat er zodanige vooroordelen tegen deze groep bestaan dat de besluitvorming daardoor negatief is beïnvloed. Is van een dergelijke achterstelling geen sprake, zoals het geval kan zijn in gevallen van voorkeursbeleid, dan is het enkele feit dat er sprake is van een verdachte grond van onderscheid meestal niet voldoende om een intensieve toets te rechtvaardigen.

\section{Bestaan van vooroordelen, stereotypen of antipathie jegens de benadeelde groep}

Ook het bestaan van vooroordelen, haatgevoelens of stereotypen jegens een bepaalde groep zal in de meeste gevallen een overtuigende rechtvaardiging opleveren voor een intensivering van de toetsing. De kans dat dergelijke opvattingen of gevoelens invloed hebben gehad op de totstandkoming van het onderscheid is namelijk aanzienlijk, zodat er twijfel kan bestaan over de objectiviteit van de besluitvorming."

\section{Ontbreken van politieke invloed}

Een derde reden voor een striktere beoordeling van het onderscheid zal aanwezig zijn wanneer de benadeelde groep nauwelijks beschikt over relevante politieke invloed." Het zelfcorrigerend vermogen van het democratisch systeem, één van de redenen voor een terughoudende opstelling van de rechter zal dan immers niet of onvoldoende func-

92. De conclusie dat er geen sprake is van een verdacht onderscheidingskenmerk kan overigens niet zonder meer een keuze voor een neutrale of marginale toetsing rechtvaardigen: ook hiervoor geldt dat een in. tensieve toetsing aangewezen kan zijn wanneer de hierna te bespreken factoren twijfel doen rijzen over de deugdelijkheid en objectiviteit van de besluitvorming.

93. Zie voor een nadere onderbouwing van deze factor paragraaf hoofdstuk 5 par. 3.3.1.

94. Zie nader hoofdstuk 5 par. 3.3.1.

95. Zie nader hoofdstuk 5 par. 3.3.1. 
tioneren, nu de betrokken groep niet in staat is om nadelige beslissingen terug te draaien of te verzachten.

Van belang is dat de conclusie dat politieke invloed ontbreekt niet uitsluitend kan worden bereikt wanneer een bepaalde groepering niet beschikt over kiesrecht of over andere essentiële politieke rechten. Een reden voor intensivering van de toetsing kan ook aanwezig zijn wanneer de groep een "permanente verliezer" is binnen het politieke systeem, in die zin dat de groep consequent niet in staat blijkt te zijn om zijn belangen binnen het democratische proces op de door hem gewenste manier te behartigen of om op adequate wijze in de besluitvorming te participeren. Vooral wanneer ook nog één van de hiervoor besproken factoren aanwezig is (het bestaan van vooroordelen of van matschappelijke of historische achterstelling) kan in een dergelijk geval het vermoeden rijzen dat het democratisch systeem niet geheel naar wens functioneert, zodat een zorgvuldige beoordeling van de rechtvaardiging van een achterstelling aangewezen is.

\subsubsection{Groep 2. Factoren met betrekking tot de belangenaantasting}

Hiervoor is gebleken dat een intensieve toetsing aangewezen zal zijn als het onderscheid is gebaseerd op verdachte gronden en er een kwetsbare groep wordt aangetast. Wanneer daarvan geen sprake is, is het echter niet meteen zo dat de rechter een minder intensieve toetsing kan uitvoeren. Het is namelijk mogelijk dat zich andere omstandigheden voordoen die aanleiding kunnen vormen voor een zorgvuldiger onderzoek van de angedragen rechtvaardiging dan gebruikelijk is. Een dergelijke aanleiding zal vooral aanwezig zijn wanneer door het onderscheid fundamentele rechten worden aangetast of wanneer er anderszins sprake is van een ernstige belangenaantasting: zoals in Carolene Products werd aangegeven kan ook daardoor het vermoeden ontstaan dat de besluitvorming niet op deugdelijke wijze heeft plaatsgevonden. In dit verband zal de rechter vooral aandacht kunnen besteden aan de volgende factoren:

\section{a. Factoren met betrekking tot de aard en het gewicht van het aangetaste recht}

Allereerst is het mogelijk dat door het onderscheid fundamentele rechten of belangen worden aangetast. Uit de rechtspraak van alle verschillende instanties blijkt dat er in dat geval reden bestaat om hogere eisen te stellen aan de argumenten die ter rechtvaardiging van deze aantasting zijn aangevoerd. Een dergelijke intensievere toetsing past ook goed in de in paragraaf 4.1 besproken Carolene Products-rationale. Het is echter moeilijk te bepalen of er in een concreet geval sprake is van een recht of belang dat als fundamenteel moet worden gekwalificeerd. Wel zijn er in de onderzochte rechtspraak enige aanknopingspunten te vinden die de rechter hierbij behulpzaam kunnen zijn.

\section{Belang van het recht voor het functioneren van het democratisch systeem (bij politieke rechten)}

Verschillende van de onderzochte instanties hebben aangenomen dat er ruimte bestaat voor een intensieve toetsing wanneer door het onderscheid rechten worden aangetast die essentieel zijn voor een goed functioneren van het democratisch systeem.* Deze

96. Zie hoofdstuk 5 par. 3.4.2. Zoals in hoofdstuk 4 is opgemerkt is het overigens mogelijk dat bepaalde rechten niet zozeer van belang zijn voor het functioneren van het democratisch systeem, maar wel voor 
factor past goed in de rationale voor intensivering van de toetsing: zoals hiervoor is aangegeven wordt juist door een aantasting van essentiële democratische en politieke rechten het zelfcorrigerend vermogen van het democratisch systeem aangetast, zodat het niet meer dan redelijk is dat de houdbaarheid van de hiervoor aangevoerde rechtvaardiging zorgvuldig wordt beoordeeld.

Bij een aantal politieke rechten is het democratisch karakter en het belang voor de politieke participatie evident, zoals bij het kiesrecht, de demonstratievrijheid of het recht om politieke partijen op te richten. Ook bij andere rechten kan een verband met de werking van het democratisch systeem echter worden angetoond, al is dit minder rechtstreeks. Een goed voorbeeld is de vrijheid van meningsuiting: hoewel het hierbij niet gaat om een direct als politiek te kwalificeren recht, is het duidelijk dat een democratisch bestel zonder vrijheid van meningsuiting niet goed kan functioneren. Het is moeilijk om in zijn algemeenheid aan te geven welke rechten een zo direct verband tonen met politieke rechten dat een intensieve toetsing is vereist, en bij welke rechten het verband met de politieke rechten daarvoor al te ver verwijderd is. Gesteld kan slechts worden dat er minder reden bestaat voor het uitvoeren van een intensieve toetsing naarmate de relatie tussen de duidelijk fundamentele politieke rechten en de "afgeleide" rechten verder is verwijderd; de rechter zal in ieder concreet geval moeten beoordelen of het getroffen belang nog kan worden gerekend tot de kern van een bepaald politiek recht, of dat het een meer "perifeer" karakter heeft."

\section{Belang van het recht voor de menselijke waardigheid of zelfontplooiing}

Ook wanneer het getroffen recht of belang geen politiek karakter heeft kan een intensieve toetsing aangewezen zijn. Dit zal het geval zijn wanneer door de ongelijke behandeling een recht of belang is aangetast dat direct is verbonden met de menselijke waardigheid of met het recht op individuele ontplooiing; vooral bij rechten als dat van godsdienstvrijheid of bescherming van privacy zal daarvan sprake zijn. ${ }^{98}$ Ook bij deze factor geldt dat er onderscheid moet worden gemaakt tussen kernrechten (waarbij het objectieve belang voor het individu evident is) en meer perifere rechten." Opnieuw is hierbij sprake van een glijdende schaal: het is niet goed mogelijk om een duidelijke scheidslijn te trekken tussen de rechten waarbij een neutrale toetsing mogelijk is en de rechten waarbij een intensieve toetsing is aangewezen. Hoogstens kunnen aanwijzingen voor het fundamentele karakter van een recht worden gevonden in de grondwettelijke bescherming van het betrokken recht of in het bestaan van een common ground met

het algemene functioneren van het systeem waarin het gelijkheidsbeginsel is ingebed. Zo is het verbod van onderscheid op grond van nationaliteit voor het Europese recht essentieel, omdat dit verbod het mogelijk maakt de doelstellingen van het Verdrag te verwezenlijken. Zie hoofdstuk 4 par. 3.4.1.

97. Deze benadering is terug te vinden in de rechtspraak van het Europees Hof voor de Rechten var de Mens; zie hoofdstuk 3 par. 3.2.6.

98. Zie bijv. de oude benadering van het Supreme Court; nader hoofdstuk 5 par. 3.4.1. Overigens zien sommige rechterlijke instanties het recht op gelijke behandeling bij bepaalde gronden (zoals geslachr) als een zelfstandig fundamenteel recht (zoals het Europees Hof van Justitie; zie hoofdstuk 4 par. 3.2.2). Wordt dat uitgangspunt gehanteerd, dan vloeien de in par. 4.2.1 besproken groep en de hier besproken factoren feitelijk samen.

99. Zie opnieuw hoofdstuk 3 par. 3.2.6. 
betrekking tot de waarde van dit recht. ${ }^{100}$ Het ligt voor de hand dat de rechter bij de motivering van een intensieve toetsing naar dergelijke bronnen verwijst.

\section{b. Factoren met betrekking tot de aard en de ernst van de belangenaantasting}

Zoals hiervoor is aangegeven wordt door een ongelijke behandeling in veel gevallen geen kernrecht, maar een minder belangrijk, perifeer recht aangetast. Hoewel een minder intensieve toetsing in die gevallen redelijk kan zijn, mag uit het feit dat er geen kernrecht is aangetast niet automatisch worden afgeleid dat een neutrale of marginale toetsing gerechtvaardigd is. Het is namelijk mogelijk dat het betrokken recht zodanig ernstig is aangetast dat een zorgvuldigere beoordeling van de aangevoerde rechtvaardiging toch is aangewezen. Bij de bepaling van de ernst van de aantasting blijken in de praktijk verschillende factoren relevant te zijn.

\section{Onomkeerbaar karakter van de belangenaantasting}

Van belang is allereerst of de belangenaantasting een onomkeerbaar en definitief karakter heeft, dat wil zeggen dat de effecten van de maatregel niet of moeilijk ongedaan kunnen worden gemaakt. Is dit het geval, dan zal een intensievere toetsing meestal zijn aangewezen, zelfs wanneer de belangenaantasting geen fundamenteel recht betreft.

\section{Mate van uitsluiting van een bepaald voordeel; aanwezigheid van een hardheidsclau- sule}

Wanneer een ongelijke behandeling tot gevolg heeft dat een bepaalde groep volledig wordt uitgesloten van het gebruik van een maatschappelijk belangrijk geachte voorziening, zal een zorgvuldige beoordeling van de rechtvaardiging in het algemeen aangewezen zijn. ${ }^{101}$ In hoofdstuk 5 is ter illustratie van deze factor gewezen op een bijzondere voorwaarde voor het instellen van hoger beroep in strafzaken, inhoudend dat de appellant een (kostbaar) transcript van de procedure in eerste aanleg moest overleggen; een tegemoetkoming in de kosten hiervan was niet voorhanden. ${ }^{112}$ Minvermogenden werden door deze regeling nagenoeg volledig uitgesloten van de mogelijkheid van hoger beroep. Het Supreme Court achtte het redelijk om de rechtvaardiging voor deze uitsluiting aan een zorgvuldige toetsing te onderwerpen. Kon er een hardheids- of ontsnappingsclausule worden toegepast, dan zou er echter sprake zijn geweest van een minder ernstige belangenaantasting: de nadelige gevolgen van de regeling zouden daardoor zijn verzacht. Een minder strenge toetsing ligt in dat geval voor de hand.

\section{Vermijdbaarheid van de belangenaantasting; bestaan van alternatieven}

Een benadeling wordt in het algemeen minder ernstig geacht wanneer de belangenaantasting vermijdbaar is of wanneer er geschikte en bruikbare alternatieven bestonden voor het ontzegde voordeel. Deze factor, die ook al is genoemd bij de bespreking van de proportionaliteitstoets, zal met de nodige voorzichtigheid moeten worden gehan-

100. Deze benadering wordt tegenwoordig vooral gehanteerd door het Supreme Court (zie hoofdstuk 5 par. 3.4.3) en door de Nederlandse rechter (zie hoofdstuk 6 par. 3.2.3).

101. Zie bijvoorbeeid hoofdstuk 5 par. 3.4.4.

102. Hoofdstuk 5 par. 3.4.4, in noot 552. Zie voor andere voorbeelden hoofdstuk 3 par. 3.2 .7 en hoofdstuk 4 par. 3.4.2. 
teerd. Van belang is vooral dat de rechter niet al te gemakkelijk mag aannemen dat een belangenaantasting kan worden vermeden: nagegaan moet worden of het ontwijken van de aantasting niet zelf leidt tot een benadeling. Ook bij de beschikbaarheid van alternatieven moet steeds worden beoordeeld of deze daadwerkelijk bruikbaar waren en of van de klager mocht worden verwacht dat hij op deze alternatieven terug zou vallen.

\section{Preventieve of repressieve, punitieve of reparatoire belangenaantasting}

Een laatste factor die een rol kan spelen bij de bepaling van de ernst van de belangenaantasting betreft het karakter van de betrokken maatregel. Zo heeft het Europees Hof voor de Rechten van de Mens aangenomen dat preventieve beperkingen van grondrechten strikter moeten worden getoetst dan repressieve beperkingen, omdat preventieve beperkingen het gebruik van het recht volledig onmogelijk maken en daardoor een grotere belangenaantasting opleveren. ${ }^{103}$ Deze factor is zeker voor algemene toepassing vatbaar, hoewel de context zich hiervoor vanzelfsprekend niet altijd leent.

Van belang is verder dat het Europees Hof van Justitie heeft aangenomen dat er in het algemeen een striktere toetsing kan worden toegepast wanneer een maatregel een punitief karakter heeft, dan wanneer er sprake is van een reparatoire maatregel: een punitieve maatregel levert in beginsel een aanzienlijk verdergaande inbreuk op de individuele vrijheid op en veroorzaakt daarmee een aanzienlijke belangenaantasting. ${ }^{104}$ Ook deze factor is voor algemene toepassing vatbaar, maar opnieuw geldt dat de omstandigheden van het geval zich niet altijd voor deze toepassing zullen lenen.

\subsubsection{Groep 3. Factoren met betrekking tot het nagestreefde belang, het beleidsveld en de positie van de wederpartij}

De factoren die hiervoor zijn besproken hadden steeds betrekking op het maken van een keuze tussen een neutrale en een intensieve toets. De verschillende factoren kunnen echter ook relevant zijn voor de keuze tussen een neutrale en een marginale toets. Wanneer er sprake is van een ernstige aantasting van een minder belangrijk recht, zal er bijvoorbeeld niet altijd reden bestaan om een intensieve toetsing uit te voeren, maar zal een zorgvuldige beoordeling soms toch zijn aangewezen; een marginale toets ligt dan minder voor de hand. De keuze tussen een marginale of een neutrale toetsing wordt echter ook bepaald door een derde groep van factoren. Voor deze factoren geldt opnieuw dat de rechter in ieder concreet geval zal moeten vaststellen of zij een rol spelen, waarna hij moet beoordelen welke factoren het zwaarste wegen; aan de hand van deze afweging kan vervolgens de keuze voor een neutrale of marginale toetsing worden bepaald. Een goede motivering van de afweging is vanzelfsprekend een vereiste.

\section{a. Factoren met betrekking tot de nagestreefde belangen en de aard van het beleidsveld}

Van belang is allereerst dat er sprake kan zijn van een zodanig beleidsterrein of van het nastreven van zodanige belangen dat een bijzondere mate van rechterlijke terughou- 
dendheid redelijk moet worden geacht. Uit de onderzochte rechtspraak blijkt dat de volgende factoren relevant zijn bij de beantwoording van de vraag of dit het geval is.

\section{Het "better placed"-argument}

In sommige omstandigheden zal de wederpartij (regelgever, bestuursorgaan of particulier) beter dan de rechter in staat zijn om een oordeel te geven over de gerechtvaardigdheid van het treffen van een bepaalde maatregel. ${ }^{105}$ Dit geldt vooral wanneer er onderscheid is gemaakt op een beleidsterrein dat zich kenmerkt door het bestaan van complexe regelgeving, snel veranderende beleidsopvattingen of politiek gevoelige onderwerpen. Voor dit soort gebieden geldt namelijk dat de rechter meestal niet beschikt over de expertise en het beleidsmatig inzicht dat noodzakelijk is om een oordeel te kunnen geven over de doelmatigheid of de noodzakelijkheid van het gemaakte onderscheid. ${ }^{\text {Iue }}$

Verder zal de wederpartij in het algemeen beter in staat zijn tot oordeelsvorming dan de rechter, wanneer het treffen van een maatregel kennis en inzicht verlangt in plaatselijke of persoonlijke omstandigheden (zoals het geval is bij de beoordeling van gemeentelijke verordeningen, maar ook bij de beoordeling van de redelijkheid van een ongelijke beloning of van de plaatsing van een kind in een pleeggezin). Ook dergelijke omstandigheden kunnen voor de rechter aanleiding vormen om te kiezen voor een terughoudende opstelling.

\section{Aard van de nagestreefde belangen}

Een andere belangrijke factor betreft de aard van de nagestreefde belangen. Wanneer de betrokken maatregel of handeling bedoeld is om gevoelige en zwaarwegende belangen te beschermen, zoals de nationale veiligheid, de volksgezondheid of de goede zeden, blijken de onderzochte instanties de wederpartij in het algemeen een aanzienlijke vrijheid toe te kennen om vast te stellen welke maatregelen ter bescherming van deze belangen nodig zijn. ${ }^{107}$ In dit verband blijkt ook de common ground-factor weer van belang te zijn. Wanneer er een grote mate van duidelijkheid bestaat over de wenselijkheid van het nastreven van bepaalde doelstellingen of over de wijze waarop deze doelstellingen kunnen worden gerealiseerd, dan blijken de onderzochte rechterlijke instanties in het algemeen namelijk meer ruimte te zien voor een actieve rechterlijke opstelling dan wanneer een dergelijke consensus ontbreekt. ${ }^{\text {tox }}$ Dit is ook redelijk, omdat de rechter in het laatste geval nauwelijks houvast heeft voor het geven van een oordeel over de gerechtvaardigdheid van het doel en de redelijkheid van het gekozen middel. De keuze van de wederpartij zal dan niet beter of slechter zijn dan de keuze die de rechter zou maken, zodat een terughoudende rechterlijke opstelling aangewezen is.

\section{b. Factoren met betrekking tot de positie van de wederpartij en van de rechter} Een tweede set factoren, die met de hiervoor besproken factoren nauw samenhangt,

\footnotetext{
105. Zie voor toepassingen van deze factor hoofdstuk 3 par. 3.1 .2 en 3.2.3, hoofdstuk 4 par. $3.2 .2,3.3 .2$ en 3.4 .2 en hoofdstuk 5 par. 3.5.2.

106. Zie ook hoofdstuk 3 par. 3.1.2. en 3.2.3.

107. Zie voor voorbeelden hoofdstuk 3 par. 3.2 .4 en hoofdstuk 6 par. 3.2.3.

108. Zie hoofdstuk 4 par, 3.4.2.
} 
houdt verband met de bevoegdheidsomvang van de wederpartij en de taakopvatting van de rechter. Van belang zijn hierbij vooral de volgende factoren:

\section{Mate van beleidsvrijheid of beoordelingsvrijheid die de wederpartij is toegekend}

In de rechtspraak van de verschillende bestudeerde instanties blijkt tot uitgangspunt te worden genomen dat er minder ruimte bestaat voor een actieve rechterlijke opstelling naarmate de wederpartij beschikt over een grotere beleids- of beoordelingsvrijheid. in Deze factor is vooral van belang bij de beoordeling van onderscheid dat het gevolg is van een bevoegdheidsuitoefening door een bestuursorgaan. Is daarbij sprake van een gebonden bevoegdheid, dan zal de rechter bij de beoordeling van de redelijkheid van het onderscheid beschikken over duidelijke, in de bevoegdheidstoedelende regeling vervatte normen. In dit soort gevallen bestaat er dan ook nauwelijks aanleiding voor een terughoudende rechterlijke opstelling. Is er echter sprake van een ruim geformuleerde bevoegdheid, dan betekent dit dat het bestuursorgaan over een aanzienlijke mate van discretie beschikt bij het beoordelen van de noodzaak en de geschiktheid van het gemaakte onderscheid en bij de afweging van de betrokken belangen. Juist omdat deze vrijheid zo uitdrukkelijk aan het bestuursorgaan is toegekend, zal de rechter zich bij de beoordeling van een dergelijke bevoegdheidsuitoefening terughoudend moeten opstellen.

Ook in andere gevallen kan de omvang van de beleidsvrijheid van de wederpartij van belang zijn. Zo wordt algemeen aangenomen dat de wetgever een grote mate van vrijheid toekomt, waarmee de rechter rekening moet houden. Of er daadwerkelijk reden bestaat voor een terughoudende toetsing is echter afhankelijk van de ruimte die de wetgever in het concrete geval toekomt. Zo zal er in een federaal of gedecentraliseerd stelsel sprake zijn van een zekere bevoegdheidsverdeling tussen de centrale of federale organen en de decentrale of statelijke overheden. Afhankelijk van de precieze bevoegdheidsverdeling zal de vrijheid van de wetgever om bepaalde maatregelen te treffen daardoor soms beperkter zijn dan anders. Zo is met betrekking tot het Europese recht het voorbeeld gegeven van de beperkte vrijheid van de nationale overheden om zelfstandig maatregelen te treffen op het gebied van het gemeenschappelijk landbouwbeleid. ${ }^{110}$

Ook in deze situatie geldt dat de rechter zich bij nauwkeurig ingekaderde bevoegdheden minder terughoudend op zal kunnen stellen dan wanneer de regelgever een over primaire, geheel vrije bevoegdheid beschikt. Het Europese Hof blijkt bij de beoordeling van de nationale landbouwmaatregelen bijvoorbeeld steevast een vrij intensieve toetsing uit te voeren, terwijl op andere gebieden, waarbij de nationale autoriteiten over veel grotere bevoegdheden beschikken, juist voor een terughoudende opstelling wordt gekozen. ${ }^{\prime \prime \prime}$

109. Zie bijv. hoofdstuk 4 par. 3.2 .2 en 3.3.2, en vooral hoofdstuk 6 par. 3.2.2: in Nederland speell deze factor een belangrijke rol.

110. Zie hoofdstuk 4 par. 3.3.2. Een soortgelijke problematiek is in het Amerikaanse recht terug te vinden: zie hoofdstuk 5 par. 3.5 .5 .

111. Een voorbeeld hiervan is het sociale zekerheidsrecht: op dat terrein bestaat nauwelijks specificke Europese regelgeving, zodat er voor de Europese rechter maar weinig aanknopingspunten bestaan om de nationale maatregelen te toetsen. Het Hof kiest hierbij meestal een terughoudende opstelling. 
(Internationaalrechtelijk) beginsel van subsidiariteit

Een tweede relevante factor, die met de voorgaande nauw verband houdt, betreft het internationaalrechtelijke beginsel van subsidiariteit. In de praktijk houden vooral internationale en supranationale rechters hiermee rekening, maar het beginsel blijkt ook een rol te spelen in federale stelsels waarin de staten aanzienlijke bevoegdheden hebben. ${ }^{112}$ Het subsidiariteitsbeginsel impliceert dat regelgeving tot stand moet worden gebracht op een zo laag mogelijk niveau, hetgeen betekent dat de verantwoordelijkheid om te voldoen aan verdragsverplichtingen primair bij de staten ligt. ${ }^{13}$ Voor de "hogere" instanties zal er alleen ruimte bestaan om in te grijpen wanneer dit werkelijk noodzakelijk is, bijvoorbeeld wanneer de staten zelf niet of onvoldoende in staat zijn om tot actie over te gaan of wanneer zij op een verkeerde of inefficiënte manier van hun bevoegdheden gebruik maken. Dit subsidiariteitsbeginsel geldt ook voor de rechter, hetgeen betekent dat deze bij de toetsing van de regelgeving van de staten in beginsel een terughoudende opstelling moet kiezen. ${ }^{\mathrm{It}}$

\section{c. Factoren met betrekking tot de context van het onderscheid}

Tenslotte kan ook de context van het onderscheid nog van belang zijn voor de keuze voor een bepaalde toetsingsintensiteit. Zelfs wanneer er in bepaald geval een combinatie van factoren aanwezig is die een specifiek niveau van toetsingsintensiteit rechtvaardigt, kunnen de omstandigheden van het geval zodanig zijn dat een andere keuze geraden is.

\section{Aanwezigheid van een noodtoestand of andere situatie die snel ingrijpen noodzakelijk maakt}

In de praktijk blijken rechters allereerst te kiezen voor een terughoudender opstelling dan gebruikelijk, wanneer blijkt dat het litigieuze onderscheid is gemaakt in de context van een noodtoestand of in andere omstandigheden waarin snel en efficiënt optreden vereist is. ${ }^{115}$ In die omstandigheden zal de rechter enige consideratie tonen voor het feit dat er bij het maken van onderscheid wellicht andere overwegingen hebben meegespeeld dan gebruikelijk en dat ook de belangenafweging op een andere manier plaats heeft gevonden. Van belang is bovendien dat in dit soort gevallen sneller genoegen kan worden genomen met een zekere mate van misfit.

112. Zie voor voorbeelden van toepassing hoofdstuk 3 par. 3.1.2 en hoofdstuk 4 par. 3.2 .2 en 3.4.2. Een nationale toepassing van dit beginsel is zichtbaar in het Amerikaanse recht; zie hoofdstuk 5 par. 3.5.4.

113. Op federaal niveau betekent het beginsel vooral dat de verantwoordelijkheid om bij "gedeelde" bevoegdheden besluiten te nemen primair bij de staten rust. In federale stelsels zal het subsidiariteitsbeginsel soms een minder grote rol spelen, vooral wanneer er een nauwkeurige bevoegdheidsverdeling in de constitutie is neergelegd. Op gebieden waarin de bevoegdheidsverdeling tekort schiet blijkt hiervan echter wel degelijk gebruik te worden gemaakt. Daarnaast acht het Supreme Court het beginsel van bijzonder belang bij de uitleg van de Constitutie. Zie hierover kort hoofdstuk 5 par. 1.2.1.

114. Dit geldt overigens alleen wanneer de bevoegdheden van de staten niet door het internationale of supranationale recht zijn ingeperkt of door internationale instellingen zijn overgenomen: zoals hiervoor is gebleken is ook de omvang van de bevoegdheden van belang voor de vaststelling van de toetsingsintensiteit.

115. Zie voor een voorbeeld hoofdstuk 5 par. 3.5.2. 


\section{Aanwezigheid van een situatie die afwijkt van het "normale" leven}

Uit de onderzochte rechtspraak is verder gebleken dat een afgezwakte toetsingsintensiteit wordt gekozen wanneer het onderscheid een situatie betreft die afwijkt van het "normale" leven. Zo blijken beperkende maatregelen sneller toelaatbaar te worden geacht wanneer zij worden getroffen in de context van een gevangenissituatie of wanneer zij uitsluitend bedoeld zijn voor het leger. ${ }^{\mathrm{H}}{ }^{6}$

\section{Onderscheid op grond van nationaliteit: immigratiebeleid of ander beleidsterrein?}

Een laatste contextueel bepaalde variatie in toetsingsintensiteit blijkt zich voor te doen bij onderscheid op grond van nationaliteit. Vrijwel alle onderzochte rechterlijke instanties hebben expliciet aangegeven dat nationaliteit moet worden aangemerkt als een verdacht differentiatiecriterium. Onderscheid dat op deze grond is gebaseerd blijkt in de praktijk echter niet altijd even intensief te worden getoetst. Algemeen erkend is namelijk dat onderscheid op grond van nationaliteit in de context van het immigratieof vreemdelingenbeleid relatief snel toelaatbaar kan worden geacht en dat de rechter de keuzes die de regelgever hierbij maakt terughoudend moet toetsen. Vooral internationale en supranationale instanties blijken voor een dergelijke terughoudendheid te kiezen, nu het immigratiebeleid nauw raakt aan de soevereiniteit van de staten. ${ }^{117}$

Wordt daarentegen onderscheid op grond van nationaliteit gemaakt op andere beleidsterreinen, zoals de sociale zekerheid of het arbeidsrecht, dan speelt de nationale soevereiniteit een minder belangrijke rol en kan daarin geen reden worden gevonden om te kiezen voor een terughoudende opstelling. In die omstandigheden blijkt dan ook meestal te worden gekozen voor een neutrale of zelfs een intensieve toetsing.

\section{$5 \quad$ Korte weergave van het toetsingsmodel}

\section{Voorfase: vaststelling van de toetsingsintensiteit}

Er kunnen drie "niveaus" van toetsingsintensiteit worden onderscheiden:

- marginaal (de meest terughoudende toets)

- neutraal (het uitgangspunt, een tussenliggende vorm)

- intensief (de meest strikte toetsing)

De rechter zal in beginsel een neutrale toetsing uitvoeren, tenzij er in het concrete geval sprake is van zodanige omstandigheden dat een keuze voor een marginale of een intensieve toetsing gerechtvaardigd is. $\mathrm{Bij}$ de keuze voor een intensivering van de toetsing zal de rechter moeten bekijken welke van de factoren uit de groepen 1 en 2 aanwezig zijn. Bepalend is of op basis van deze factoren moet worden aangenomen dat het besluitvormingsproces dat aan het onderscheid ligt is beïnvloed door ondeugdelijke overwegingen. Is dit het geval, dan zal er een intensieve toetsing moeten worden uitgevoerd. Ontbreekt een reden om een intensieve toetsing uit te voeren, dan moet de rechter beslissen of er redenen aanwezig zijn om de toetsing verder af te zwakken tot een

117. Zie bijvoorbeeld hoofdstuk 3 par. 3.2.5. 
marginale toetsing. Ook daarbij kunnen factoren uit groep 1 en 2 een rol spelen, maar de factoren uit groep 3 zullen hierbij meestal bepalend zijn. Ontbreken dergelijke redenen, dan moet een neutrale toetsing worden uitgevoerd.

Groep 1. Factoren die het onderscheid als zodanig betreffen

a. Factoren die betrekking hebben op de grond van onderscheid (verdachtheid):

- aanwezigheid van een common ground die het gebruik van de grond veroordeelt;

- onveranderlijkheid van het onderscheidingskenmerk;

- irrelevantie van het onderscheidingskenmerk voor het maatschappelijk functioneren van het individu;

- zichtbaarheid van het onderscheidingskenmerk (minder relevant; alleen in combinatie met voorgaande factoren);

b. Factoren die betrekking hebben op de benadeelde groep:

- bestaan van historische en/of sociale achterstelling van de benadeelde groep;

- bestaan van vooroordelen, stereotypen of antipathie jegens de benadeelde groep;

- gebrekkige politieke invloed van de benadeelde groep.

\section{Groep 2. Factoren met betrekking tot de belangenaantasting}

a. Factoren met betrekking tot aard en gewicht van het aangetaste recht:

- belang van het recht voor het functioneren van het democratisch systeem (politieke grondrechten);

- belang van het recht voor de menselijke waardigheid of zelfontplooiing (overige grondrechten);

- kernaspect of perifeer aspect van het betrokken fundamentele recht of belang;

- bestaan van een common ground met betrekking tot de waarde van het belang of recht.

b. Factoren met betrekking tot de aard en ernst van de belangenaantasting:

- onomkeerbaar karakter van de belangenaantasting;

- mate van uitsluiting van een bepaald voordeel (volledig of gedeeltelijk; langdurig of tijdelijk); aanwezigheid van een hardheidsclausule;

- vermijdbaarheid van de aantasting; beschikbaarheid van alternatieven;

- preventieve of repressieve, punitieve of reparatoire belangenaantasting.

Groep 3. Factoren met betrekking tot het nagestreefde belang, het beleidsveld en de positie van de wederpartij

a. Factoren met betrekking tot de aard van het beleidsveld en de nagestreefde belangen:

- "better placed"-argument;

- betekenis van snel veranderende beleidsinzichten; complexiteit beleidsterrein;

- aard van de nagestreefde belangen: bestaan van een common ground met betrekking tot het nagestreefde belang; gevoeligheid en belang van het betrokken onderwerp (nationale veiligheid, goede zeden).

b. Factoren met betrekking tot de positie van de wederpartij: 
- mate van beleidsvrijheid/beoordelingsvrijheid die de wederpartij is toegekend;

- (internationaalrechtelijk) beginsel van subsidiariteit.

c. Factoren met betrekking tot de context van het onderscheid:

- noodtoestand of andere situatie die snel ingrijpen noodzakelijk maakte;

- aanwezigheid van een situatie die afwijkt van het "normale" leven (omstandigheden in het leger, de openbare dienst, een gevangenis);

- bij onderscheid op grond van nationaliteit: immigratiebeleid of ander beleidsterrein?

De op basis van deze factoren vastgestelde toetsingsintensiteit moet in het vervolg van de toetsing consequent worden vastgehouden.

\section{Eerste fase: vaststelling van benadeling}

\section{Direct onderscheid:}

1. Is de klager ten opzichte van een andere persoon of groep daadwerkelijk benadeeld?

2. Is er hierbij sprake van een aantasting van een rechtens beschermd, objectiveerbaar belang?

Zijn deze vragen positief beantwoord, dan is een rechtvaardigingstoets vereist (zie tweede fase). Is één van beide vragen negatief beantwoord (of luidt het antwoord op beide vragen ontkennend), dan is er geen sprake van een ongelijke behandeling waarvoor een rechtvaardiging is vereist.

\section{Indirect onderscheid:}

1. Is er sprake van een direct onderscheid (zie hierboven)?

2. Hoe kan de benadeelde groep worden gedefinieerd?

3. Welk aandeel heeft de groep waarop de klacht betrekking heeft (en die zich onderscheidt door een specifiek kenmerk, zoals ras, geslacht of nationaliteit) binnen de gehele benadeelde groep?

4. Kan gezien het aandeel van de groep waarop de klacht betrekking heeft worden gesproken van een disproportionele benadeling, althans van een zodanige benadeling dat het vereisen van een rechtvaardiging redelijk is?

Zijn vraag 1 en 4 beide positief beantwoord, dan moet de rechter een rechtvaardigingstoets uitvoeren (zie tweede fase). Is één van deze twee vragen negatief beantwoord, dan is een rechtvaardiging niet vereist en is er geen sprake van een ontoelaatbare inbreuk op het gelijkheidsbeginsel.

\section{Tweede fase: beoordeling van de rechtvaardiging}

Het rechtvaardigingsmodel is op een logische manier opgebouwd, in die zin dat de rechter alleen aan een volgend toetsingscriterium toe zal komen wanneer hij heeft vastgesteld dat de rechtvaardiging de toetsing aan het voorgaande criterium kan doorstaan. Zoals uit het voorgaande is gebleken is het altijd nodig dat de rechter vaststelt of er 
sprake is van een gerechtvaardigd doel: zonder deze vaststelling is het niet mogelijk om te beoordelen of er een redelijke verhouding bestaat tussen doel en middel. Voor de toetsing van de redelijkheid van het gekozen middel zelf geldt dat de volgorde die hierna is aangegeven de meest wenselijke is, maar dat het niet per se noodzakelijk is om deze aan te houden. De hierna gekozen volgorde is ingegeven door het feit dat vereisten als die van geschiktheid, noodzakelijkheid, subsidiariteit en proportionaliteit een vrij actieve rechterlijke toetsing vergen, terwijl dit in mindere mate het geval is voor de toetsing van de mate van fit. Wanneer de rechter door een relatief terughoudende toetsing al kan vaststellen dat een toereikende mate van fit ontbreekt, is het niet meer nodig om aan de overige criteria te toetsen; dit komt de terughoudendheid van de toetsing zeker ten goede. Kan de rechter relatief gemakkelijk vaststellen dat er in het concrete geval geen sprake is van noodzakelijkheid of geschiktheid, dan is het mogelijk om die toetsing meteen na de toetsing van het doel plaats te laten vinden. Een afzonderlijke toetsing van de mate van fit is dan niet nodig. Ook de geschiktheids-, noodzakelijkheids- of proportionaliteitstoets kunnen eventueel van plaats wisselen als dit een betere onderbouwing van het rechterlijk oordeel tot gevolg heeft.

\section{Aanwezigheid van een gerechtvaardigd doel}

\section{Vaststelling van het doel}

Uitgangspunt van de toetsing zijn de doelstellingen die door de wederpartij zijn aangevoerd of die door lagere rechterlijke instanties zijn vastgesteld.

- Marginale toetsing: de gestelde doelstellingen vormen de basis van de rechtvaardigingstoets, tenzij de klager op overtuigende wijze aannemelijk kan maken dat er (ook) andere, niet genoemde doelstellingen aan het onderscheid ten grondslag liggen. Alleen in het laatste geval is verdergaand rechterlijk onderzoek aangewezen.

- Neutrale toetsing: hierbij geldt hetzelfde uitgangspunt als bij een marginale toets, maar kan een onderzoek naar andere doelstellingen eerder worden ingesteld, bijvoorbeeld ook wanneer de klager aannemelijk maakt dat er andere doelstellingen bestonden dan zijn aangevoerd of wanneer de rechter het bestaan van andere doelstellingen vermoedt op basis van de feiten of omstandigheden van het geval.

- Intensieve toetsing: de rechter dient steeds te onderzoeken of de gestelde doelstellingen overeenkomen met de daadwerkelijke beweegredenen voor het maken van onderscheid.

\section{Beoordeling van het doel op zijn gerechtvaardigdheid}

De gerechtvaardigdheid van het doel kan worden beoordeeld aan de hand van de volgende criteria:

- Het nagestreefde doel moet in overeenstemming zijn met het positieve recht en de uitleg die daaraan door de relevante rechterlijke instanties is gegeven;

- Het gestelde doel moet kunnen worden nagestreefd zonder dat de wederpartij daarbij zijn bevoegdheden overschrijdt;

De doelstelling mag niet inherent discriminatoir zijn;

Het gestelde doel moet voorzien in een werkelijke behoefte (actualiteitsvereiste);

De gerechtvaardigdheid van het doel kan soms mede worden beoordeeld aan de hand van maatschappelijke en in het recht geldende opvattingen; 
- Het doel moet voldoende specifiek zijn (specificiteitsvereiste) (alleen bij intensieve
toetsing);

- Een doelstelling die ertoe strekt de rechten en belangen van derden te beschermen zal meestal gerechtvaardigd zijn (maar: de eisen van legaliteit gelden steeds!).

De bovenstaande criteria zijn niet limitatief: het mogelijk dat de rechter aanvullende toetsingscriteria ontwikkelt die beter aansluiten bij het bijzondere beleidsterrein of bij de specifieke gelijkheidsbepaling waaraan hij moet toetsen.

\section{Vaststelling van de consequenties van het oordeel over de gerechtvaardigdheid}

- Is het doel gerechtvaardigd, dan moet de rechter beoordelen of het gemaakte onderscheid in een redelijke verhouding staat tot dit doel. Toetsing aan de overige criteria van het toetsingsmodel is dan vereist.

- Is het doel niet gerechtvaardigd, dan kan de rechter beoordelen of er maatschappelijke effecten met het onderscheid worden bereikt die als zodanig een voldoende rechtvaardiging kunnen opleveren. Deze beoordeling is echter controversieel en zal overtuigend moeten worden gemotiveerd.

- Zijn er meerdere doelstellingen vastgesteld, waarvan er één of meer ongerechtvaardigd zijn, dan zal ten aanzien van de overige doelstellingen moeten worden nagegaan of het onderscheid hiertoe in een redelijke verhouding staat. Toetsing aan de overige vereisten van het rechtvaardigingsmodel is hierbij vereist. Ten aanzien van de proportionaliteitstoets in strikte zin (zie hierna onder 5) moet worden beoordeeld of de gerechtvaardigde doelstellingen gezamenlijk het gemaakte onderscheid kunnen dragen.

\section{Zorgvuldigheid van de definitie van de classificatie (mate van fit, relevante proxy)}

Aan het tweede toetsingscriterium zal alleen worden getoetst bij klachten over normatieve classificaties. Bij klachten over individuele gevallen van onderscheid kan meteen worden overgegaan tot een toetsing van de geschiktheid (zie onder 3 ).

De toetsing van de zorgvuldigheid van de definitie bestaat uit twee onderdelen:

\section{a. Onderzoek van de proxy}

- Is er aanleiding om te veronderstellen dat het in de regeling gehanteerde differentiatiecriterium een proxy vormt?

Dit kan blijken uit de feiten of omstandigheden van het voorgelegde geval of uit de stellingen van de klager. Bij intensieve toetsing zal er sneller aanleiding bestaan om hiernaar
onderzoek te verrichten dan bij een marginale toetsing. Is er geen sprake van een proxy, dan hoeven de overige vragen niet te worden beantwoord en kan meteen worden overgegaan naar de toetsing van de mate van fit.

- Hoe moet het eigenlijk gewenste differentiatiecriterium worden geformuleerd?

- Wordt door het gebruik van de proxy nagenoeg dezelfde groep uitgezonderd voor een bijzondere behandeling als het geval zou zijn geweest wanneer het eigenlijke differentiatiecriterium zou zijn gehanteerd? 
Ontbreekt een voldoende mate van aansluiting, dan is het onderscheid ontoelaatbaar. Is een voldoende mate van aansluiting wel aanwezig of is hiernaar geen onderzoek verricht, dan moet de rechter de mate van fit beoordelen.

\section{b. Onderzoek van de mate van fit}

Gekeken moet worden naar de wijze waarop de classificatie is gedefinieerd in relatie tot het doel van het onderscheid. Is de groep die voor een bijzondere behandeling wordt uitgezonderd in relatie tot het nagestreefde doel te ruim gedefinieerd, dan is er sprake van overinclusiveness. Is de voor een bijzondere behandeling uitgezonderde groep te eng gedefinieerd in verhouding tot het nagestreefde doel, dan is er sprake van underinclusiveness.

De eisen die kunnen worden gesteld aan de mate van fit zijn afhankelijk van de gekozen toetsingsintensiteit:

- Intensieve toetsing: er zal sprake moeten zijn van een nagenoeg perfecte fit;

- Neutrale of marginale toetsing: genoegen kan worden genomen met een zekere mate van misfit. Dit geldt in het bijzonder wanneer voor de misfit goede redenen bestaan, bijvoorbeeld omdat er sprake is van partiële regelgeving of tijdelijke (nood)wetgeving.

Ontbreekt een toereikende mate van fit, dan is het onderscheid ontoelaatbaar. Is een voldoende mate van fit wel aanwezig, dan moet de rechter het onderscheid toetsen aan de volgende criteria van het toetsingsmodel.

\section{Geschiktheid}

Onderzocht moet worden of het gemaakte onderscheid (of in het geval van indirect onderscheid: de betrokken regeling of handeling) een effectief middel vormt voor het realiseren van het nagestreefde doel. Het uitgangspunt bij de beoordeling van de geschiktheid zijn de feiten en omstandigheden op het moment van het rechtsgeding. De modaliteiten van toetsing zijn afhankelijk van de toetsingsintensiteit:

- Marginale toetsing: de effectiviteit kan worden verondersteld, tenzij het evident is dat het gekozen middel niet geschikt is, of de klager aannemelijk maakt dat de maatregel ongeschikt is;

- Neutrale toetsing: de wederpartij moet feiten en omstandigheden aanvoeren waaruit de geschiktheid kan blijken, maar hard bewijsmateriaal is niet vereist. Het oordeel van de rechter kan op deze feiten worden gebaseerd, maar kan ook gegrond worden op logica en gezond verstand;

- Intensieve toetsing: de wederpartij moet concrete en controleerbare gegevens overleggen waaruit de effectiviteit van het onderscheid kan blijken. Ontbreken deze gegevens, dan moet de ongeschiktheid van het onderscheid worden verondersteld.

Wordt tot de conclusie gekomen dat het onderscheid geen geschikt middel vormt, dan is het ontoelaatbaar. Acht de rechter het onderscheid wel effectief, dan moet hij verder gaan met een toetsing aan het vierde onderdeel van het rechtvaardigingsmodel. 
4. Subsidiariteit en noodzakelijkheid

De keuze voor het uitvoeren van een subsidiariteitstoets of een noodzakelijkheidstoets is afhankelijk van de omstandigheden van het geval en van de gekozen toetsingsintensiteit. $\mathrm{Bij}$ een intensieve toetsing moet steeds een subsidiariteitstoets worden uitgevoerd, bij een marginale of neutrale toetsing kan ook een noodzakelijkheidstoets worden gekozen.

\section{Noodzakelijkheid}

Beoordeeld moet worden of het maken van onderscheid in zijn algemeenheid kan worden beschouwd als een noodzakelijk of onmisbaar middel om het gestelde doel te verwezenlijken. Anders gezegd: nagegaan moet worden of het doel niet zonder het maken van onderscheid kon worden bereikt.

\section{Subsidiariteit}

- Beoordeeld moet worden of er minder belastende alternatieven voorhanden waren. Daarbij kan de rechter aanknopingspunten vinden in vergelijkend onderzoek (zijn er elders, bijvoorbeeld in een ander rechtsstelsel, in een ander bedrijf of in een andere gemeente, goede oplossingen gevonden voor een vergelijkbaar probleem?), maar ook in de stellingen van partijen, in de totstandkomingsgeschiedenis, in deskundigenrapporten, etc.

- Beoordeeld moet worden of de keuze voor één van deze alternatieven van de wederpartij verwacht kon worden. De inhoud van deze beoordeling zal worden bepaald door de toetsingsintensiteit:

- Intensieve toetsing: de wederpartij moet aannemelijk maken dat de keuze voor het alternatief feitelijk onmogelijk was of dat deze keuze zou leiden tot onoverkomelijke problemen of onaanvaardbare consequenties. Wordt an deze bewijslast niet voldaan, dan is het onderscheid niet toelaatbaar;

- Neutrale toetsing: de rechter zal op basis van de voorliggende gegevens zelf een oppervlakkig oordeel kunnen geven over de geschiktheid van de alternatieven;

- Marginale toetsing: van de klager kan worden verwacht dat hij aannemelijk maakt dat de alternatieven net zo geschikt waren om het gestelde doel te bereiken als het gekozen middel.

Komt de rechter tot de conclusie dat het onderscheid niet noodzakelijk was of dat er minder vergaande en geschikte alternatieven bestonden, dan is het onderscheid niet toelaatbaar. Wordt de tegenovergestelde conclusie bereikt, dan moet tenslotte worden beoordeeld of er sprake is van een voldoende mate van proportionaliteit.

\section{Proportionaliteit}

De rechter moet beoordelen of er sprake is van een redelijke afweging van de belangen die met het onderscheid worden gediend (het nagestreefde doel) en de belangen die door dit onderscheid worden aangetast. De toetsing kan daarbij iets verschillen naar gelang de omstandigheden van het geval:

- Bij normatieve classificaties zal in beginsel een abstracte toetsing worden uitge- 
voerd. Als daaruit blijkt dat de belangenafweging redelijk is kan eventueel nog worden nagegaan of er bij de toepassing in het individuele geval sprake was van een onevenredig zware belangenaantasting (concrete toetsing);

Bij concrete bevoegdheidstoepassing zal er steeds sprake zijn van een concrete toetsing, waarbij uitsluitend wordt nagegaan of er in het voorgelegde geval sprake was van een redelijke belangenafweging.

De (abstracte of concrete) proportionaliteitstoets bestaat uit verschillende onderdelen:

Vaststelling van de betrokken belangen: hierbij kan gebruik worden gemaakt van de vaststelling van het ondervonden nadeel in de eerste fase en van het doel dat in de tweede fase van de toetsing is gevonden.

Bepaling van het gewicht van de betrokken belangen; relevant hierbij zijn de volgende criteria:

- Ernst van de belangenaantasting: is het belang of recht in de kern aangetast? Is er sprake van een onomkeerbare belangenaantasting? Is de aantasting tijdelijk of permanent? Is de aantasting vermijdbaar of zijn er geschikte alternatieven voorhanden, waarvan gebruik kan worden gemaakt zonder dat dit als zodanig een belangenaantasting oplevert? Is er een relevante hardheids- of ontsnappingsclausule?

- Aard en gewicht van het aangetaste recht of belang: gaat het om een kernrecht (essentieel voor het goed functioneren van de democratie of voor de menselijke waardigheid of zelfontplooiing) of om een perifeer recht?

- De bescherming van belangen van derden (concreet of abstract) geldt in het algemeen als een zwaarwegend belang.

- Budgettaire, puur financiële of administratieve belangen gelden in het algemeen niet als zwaarwegend belang; de omstandigheden van het geval zijn hierbij echter bepalend.

- Beoordeling van de door de wederpartij gemaakte belangenafweging; de intensiteit van de toetsing is hierbij bepalend:

- Marginale toetsing: is er door de gemaakte belangenafweging sprake van willekeur?

- Neutrale toetsing: kan de belangenafweging als redelijk worden aangemerkt?

- Intensieve toetsing: zijn de door de wederpartij aangevoerde belangen zodanig overtuigend en gewichtig dat deze het gemaakte onderscheid kunnen dragen?

Komt de rechter tot de conclusie dat er een redelijke belangenafweging (in abstracte en/of concrete zin) aan het onderscheid ten grondslag ligt, dan is het voldoende gerechtvaardigd en kan het verenigbaar worden geacht met het gelijkheidsbeginsel. Is er geen sprake van een voldoende mate van proportionaliteit, dan moet het onderscheid ontoelaatbaar worden geacht en moet worden geconcludeerd tot een schending van het gelijkheidsbeginsel. 



\section{Summary}

The principle of equality is valued by all of us. Unfortunately, application of this principle is not always possible and violations are inevitable. Each statute or regulation will impose special burdens upon or grant special benefits to groups or classes of individuals, while in daily life it can hardly be expected that each individual treat all others in the same way. In some instances, differential treatment is reasonable, but not always. If someone is deprived of opportunities as a result of prejudice or gross stereotyping, or if unequal treatment results in disproportionate impairment of interests, this cannot be considered permissible. It is therefore essential that each classification or distinction can be objectively and reasonably justified.

In practice, courts and tribunals are often presented with cases of unequal treatment, which they must test against the general principle of equality. The judicial application of this principle must be as predictable, objective and thorough as possible: only then can justice be done to the principle's significance.

The existence of clear, general rules increases the predictability and objectivity of judicial review. In many legal systems, however, such rules are lacking: mostly, equality provisions apply exclusively to a number of specific cases or are designed to prohibit discrimination on specific grounds, such as gender or race. Furthermore, many legal provisions elaborating on the principle of equality lack clarity and precision. As a consequence, the courts find little support in legal texts in deciding on complaints about unequal treatment. Mostly, they must rely on broadly formulated provisions laid down in constitutions or international treaties or have to apply the general, unwritten principle of equality. As a result, the courts enjoy a large degree of discretion in interpreting and applying the principle of equality. It is possible, therefore, that in concrete cases judges employ disparate standards of review, which may result in a lack of predictability and legal certainty. An additional problem is that, due to this lack of clear, predefined testing standards, prejudices and personal views may influence the court's judgment.

To prevent such problems, it is necessary to set high standards for the reasoning of the judgment. Well-structured and comprehensive judicial reasoning may bring out the angle and personal perspective on which the court has premised its decision. This enables the parties, the general public, and possibly a superior court, to probe the decision properly. Furthermore, a well-reasoned judgment, in which a number of fixed and clear standards of review have been taken into account, will greatly enhance outcome predictability and legal clarity.

The above factors have led to the conclusion that there is a need for a decision model, which can be used in applying the general, unwritten principle of equality. Such a model may aid judges in reaching a decision and provide a framework for judicial reasoning. The aim of this dissertation has been to develop such a model. The research has been premised on the idea that judicial application of the principle of equality is conducted in three phases. In the first phase, the court must establish whether there is indeed a case of unequal treatment. The burden of proof primarily rests with the appli- 
cant, who must demonstrate that there are genuine grounds for his complaint. When a case of unequal treatment has been established, the court proceeds to the second phase, in which a justification test is applied. In this phase, the court has to ascertain whether there are convincing and appropriate grounds for the distinction, while the defendant must adduce evidence to demonstrate that the distinction is justified. If the court establishes that the distinction is not sufficiently justified - and therefore incompatible with the principle of equality - it will have to determine the consequences of that conclusion in the third and final testing phase. It may decide, for instance, to annul the litigious decision, to declare the discriminatory rule not binding, or to award damages.

Judicial review in equality cases is always characterised by a certain degree of intensity: unequal treatment can be strictly scrutinised, but it is also possible to use a neutral or even a marginal test. The court, prior to the assessment of the distinction itself, will therefore have to select the factors that determine the level of scrutiny and ascertain which of the factors it deems decisive in opting for a specific intensity. As the intensity of the review may be of great importance for the outcome of the proceedings, it is essential that the court expressly state its choice for a particular level of scrutiny and provide well-founded arguments for this choice.

In this study, a number of theoretical standards have been developed, both for judicial application of the principle of equal treatment and determination of the level of scrutiny. On the basis of theoretical literature, a number of elements were identified which the court should ideally involve in its review in order to arrive at a just decision. In addition to this, research was conducted into the factors that ought to play a role in optimally determining the level of scrutiny. The research produced a hypothetical decision model, containing several standards of review, and various standards for balancing the factors that determine the level of scrutiny. However, the theoretical research also made clear that the various criteria and factors required further defining and refining in order to be of practical use.

For this reason, an examination has been made of the methods and criteria that are presently used by a number of important judicial bodies in applying the principle of equality. An analysis was made of the case law of the European Court of Human Rights, the European Court of Justice, the US Supreme Court and several Dutch (semi) judicial bodies. The analysis served to study the standards of review employed by the different courts during the first and second phase, as evidenced by their reasoning. The factors used in determining the level of scrutiny and the ways in which these factors are balanced were also examined.

On the basis of a combination of the theoretical decision model and the criteria and factors involved in practice in judicial review, a general model has been created for assessing cases of unequal treatment. This model can be employed in all cases in which the court has to apply the general, unwritten principle of equality. This means that it is not only applicable to distinctions contained in general rules ("regulatory classifica. tions"), but that it may also be used in assessing distinctions brought about by the exercise of authority (as in the case in which a tax exemption has been granted to person A, but not to person B). In addition, it makes no difference as to the applicability of the 
model whether the distinction was made by the government (vertical relation) or by an individual or enterprise (horizontal relation). Moreover, the court can employ the model not only in case of "formal" and direct distinctions, but also in case of substantive and indirect distinctions. Finally, it is important to note that the model may be used for all grounds of distinction and in all conceivable contexts.

According to the general decision model, the court must determine the strictness of its review before proceeding to the assessment of the distinction presented to it. Three "levels" of strictness can be distinguished: a marginal test (the variant in which the court uses the most restraint), a neutral test (an intermediate form of review) and an intensive test (or "strict scrutiny": the most intensive form). The court will have to administer a neutral test, unless there are circumstances in the case in hand justifying the choice for either a marginal or an intensive test. The intensive test can only be chosen when, on the basis of a number of factors relating to either the distinction as such or the impairment of interests inflicted by it, it can be suspected that the decisionmaking process leading to the distinction was affected by inappropriate considerations, e.g. inherently discriminatory or prejudicial considerations. This will often be the case if the distinction is based on a "suspect" ground, such as race or skin colour; several factors and criteria have been identified to determine "suspectness", such as the societal irrelevance and immutability of the personal trait on which the distinction is based. There will also be reason to doubt the fairness of the decision-making process if it is probable that the distinction is based on prejudice or prompted by antipathy towards a socially underprivileged and politically insignificant group, or if fundamental rights of the group in question have been seriously violated.

If there are no arguments in favour of strict scrutiny, the court must subsequently decide whether a neutral test can be applied, or whether there are reasons for administering a marginal test. Again, this choice depends on the presence of various factors. In the first place, factors relating to the seriousness of the impairment and the context within which the distinction was made, may tip the scales towards either a neutral or a restrained test. There may be reasons to conduct a marginal test rather than a neutral one, if the injurious act has no serious consequences for the applicant, for instance, because he has feasible alternatives. Good reasons for a more restrained form of review will also obtain if the decision-making organ enjoys a large degree of discretionary freedom or if it is in a better position than the court to judge the necessity of the measure. Finally, the court may wish to exercise restraint if the distinction has been made within the context of an emergency situation or in a situation outside "ordinary life" (e.g. a classification in a prison regulation).

When, based on the factors discussed briefly above, the court has determined the level of scrutiny, it will have to hold on to this level for the remainder of the review,

As discussed above, the court must proceed to the first testing phase after having established the level of scrutiny. In this first phase, it will have to ascertain whether there is a case of unequal treatment, which in effect warrants justification. From studying the theoretical literature and as a result of case law analysis, it was found that, in this first testing phase, regular use is made of the test of comparability. In applying this test, the 
court examines whether comparable cases have been treated differently ("formal" unequal treatment) or whether incomparable cases have been treated in the same way (substantive unequal treatment). A close study has revealed, however, that comparability is not an appropriate standard of review for a number of reasons. In the first place, judicial bodies prove to have great difficulty in finding an appropriate criterion for determining the relevance of the differences and similarities present in concrete cases of unequal treatment. Secondly, the relevant case law in the legal systems under study reveals that the courts do not always exercise prudence in determining such relevance. This creates the risk that considerations of a subjective nature slip in and have a major impact on the decision of the case. A third drawback of the comparability test is that its application often results in a lack of transparency in the judicial reasoning. This is mainly due to the fact that the test inevitably overlaps the justification test used in the second testing phase. When comparability is established, the purpose of the distinction is often already taken into account as a standard of comparison, whereas the purpose test, as will be seen below, also forms an important part of the justification test. Such overlap may cause confusion, as a result of which an important objective of the general decision model, namely the guarantee of transparent and objective testing, can hardly be achieved. A final reason not to opt for the comparability test as a standard in the first testing phase is its flawed selective function. The conclusion that two cases are comparable does not automatically entail that their unequal treatment is not permissible: to reach this outcome, it must first be established whether such treatment can be objectively justified. The same applies to the opposite conclusion, namely that the cases at issue are not sufficiently comparable. Whereas it would seem to be logical that unequal treatment of unequal cases is permissible, this will not always be the case: the difference in treatment may not stand in a rational or proportional relationship to the differences between the cases, or the classification may be an unnecessary or ineffective means to achieve the aims pursued by the defendant. If the comparability test is chosen as a standard in the first phase, it is therefore always necessary to investigate the justification advanced for the difference in treatment. First-phase testing, however, derives its value precisely from its selective function: the test applied must make it possible to dismiss cases in which there is no need for justification, so that the burden of demonstrating arguments in defence of the distinction may only be demanded of the defendant in genuine cases. The comparability test therefore cannot be regarded as a suitable standard of review in the first phase of testing.

In this regard, it is of importance that the analysis of the case law of various judicial bodies produced an appropriate alternative to the comparability test: the disadvantageous treatment test. This test implies that the court must ascertain whether the applicant has been disadvantaged as compared to another person (or group of persons). The applicant's interests must have been actually impaired by the unequal treatment, and the interest impaired must be objectifiable (i.e. a legally relevant interest). In the case of direct unequal treatment, the disadvantage can usually be directly inferred from the effects of the regulation or action: what has to be ascertained is merely whether the applicant has suffered actual disadvantage, such as not experienced by another person of group of persons. In the case of indirect unequal treatment, determining possible disadvantage is somewhat more complicated. In these cases, the applicant must not 
only prove that a specific regulation or action has led to an impairment of interests or rights, but he must also demonstrate that such disadvantage disproportionately affects a clearly definable group of persons. If, for instance, the applicant wishes to demonstrate that a remuneration scheme for part-time workers constitutes indirect differentiation on the ground of sex, he must not only demonstrate that the scheme disadvantages parttime workers, but also that the group of part-time workers consists predominantly of men or women.

If it has been established that there is a case of direct or indirect disadvantage (i.e. a prima facie violation of the principle of equal treatment), the court will have to proceed by applying the second-phase justification test. If no disadvantage has been established, it should reject the claim.

Assessment as to whether a classification or distinction is objectively and reasonably justified must take place on the basis of five criteria. First, the courts must establish whether the distinction was made in pursuit of a legitimate aim. Point of departure for this test are the objectives put forward by the applicant. Only in specific circumstances (e.g. in cases of strict scrutiny), should the court investigate of its own motion whether there are reasons for the distinction other than those put forward by the defendant. After having determined the objectives underlying the classification, the court must render judgement on their legitimacy. In so doing, it must assess, among other things, whether the aim is consistent with national and international law (as construed by the courts); whether it could be pursued without exceeding powers; whether it was inherently discriminatory, and whether its pursuance fulfilled a genuine need of the defendant. Apart from these and a number of other criteria developed in the dissertation, the courts themselves may develop other standards, specifically relevant to the policy area in question or a particular equal treatment provision.

If the court concludes that the aim is not legitimate, it will, in principle, have to decide that the classification or distinction is not consistent with the principle of equal treatment. However, in many cases more than one aim is pursued. If, in such cases, one of the aims that have been put forward is considered illegitimate, the court cannot automatically draw the conclusion that the distinction is not permissible. In such cases it is conclusive whether the classification or distinction can be sufficiently supported by the remaining, legitimate, aims, even when no account is taken of the illegitimate objectives.

Once the court has established that a legitimate aim is pursued, it must assess the relation between the aim and the means elected in pursuing the aim, i.e. the distinction made. This relation may be tested on the basis of four criteria. Preferably, these criteria are to be tested in the order given below, but it is not necessary to adhere to this order when this would prove to be impractical or undesirable in the case at issue.

The first criterion for the assessment of the relation between aim and means can only be used in cases in which the complaint is directed at a regulatory classification (i.e. a classification contained in regulatory mechanisms, such as statutes, municipal regula- 
tions or pension schemes in enterprises). The criterion is meant to be used in assessing the precision with which the classification has been defined.

In this context, the court must first investigate whether the lawmaker has made use of a "proxy". In creating laws or regulations, the lawmaker, for reasons of implementability, sometimes opts for another, more concrete, differentiation criterion than would be actually desirable. For example, in social security cases the proxy "breadwinner" has often been used to replace the broader, more appropriate criterion "need". The criterion selected in such instances is an approximation, a "proxy", for the actual criterion of differentiation. If the lawmaker has made use of such a proxy, the court will have to assess whether virtually the same group has been selected by using the proxy, as would have been the case if the actual criterion had been employed. The distinction is not permissible, if the court reaches the conclusion that the criteria in question lack sufficient similarity.

The existence of a reasonable proxy is not sufficient, however, to conclude that the distinction has been formulated with adequate precision. To do this, the court will also have to examine how the classification has been defined in relation to its purpose. Classifications can both be "overinclusive", namely if the group has been defined too broadly in relation to the aim pursued, and "underinclusive", namely if the group has been defined too narrowly. Both over- and underinclusiveness can be problematic. In case of overinclusiveness, some persons or groups will be disadvantaged, while they, with regard to the aim pursued, should not receive such disadvantageous treatment. Underinclusiveness is also undesirable, as it has the consequence of denying favourable treatment to persons or groups who, with regard to the aim of the regulation, should have been afforded such treatment. However, it is clear that a perfect fit between the definition of the classification and the aim pursued by it can never be reached: a certain measure of misfit must be allowed. The degree of either under- or overinclusiveness deemed permissible must be contingent on the level of scrutiny: in cases in which a strict test is applied, there should be an almost perfect fit, whereas in cases in which the judge applies a neutral or marginal test, a relatively large misfit can be allowed. If an intolerable measure of misfit appears to be present, the classification must be deemed to be in violation of the principle of equal treatment.

If the court considers the distinction to be defined with sufficient precision, it will have to assess the appropriateness of the distinction. This criterion implies that the court has to investigate whether the distinction constitutes an effective means to achieve the aim pursued. The precise modalities of this test are mainly contingent on the level of scrutiny. In cases in which a marginal test is used, the effectiveness of the measure may be presumed, unless it is evident that the means chosen is not suitable, or the applicant convincingly demonstrates its inappropriateness. On the other hand, if strict scrutiny is applied, the defendant may be expected to submit concrete and controllable facts from which effectiveness can be objectively inferred. In the absence of such information, the court may assume that the distinction was not appropriate and that, in consequence, the principle of equality was violated. 
If the court deems the distinction to be an appropriate means to achieve the aim pursued, it must proceed to the next component of the model: the test of necessity or subsidiarity. The circumstances of the case and the level of scrutiny determine whether either a subsidiarity test or a test of necessity must be applied: in case of strict scrutiny, the distinction must be tested against the subsidiarity criterion, whereas in cases in which a marginal or neutral test is chosen, it is also possible to make use of the necessity test. In applying the necessity test, the court must determine whether the distinction may be generally regarded as a necessary or indispensable means to attain the aim pursued. If, on the other hand, a subsidiarity test is applied, the court must investigate the availability of less burdensome alternatives to the distinction made and ascertain whether the defendant could have been expected to opt for one of the alternatives.

If the court decides that the distinction is not necessary, or that suitable, less drastic, alternatives exist, the distinction is not permitted.

Upon having scrutinised the distinction on the basis of the above criteria, what remains for the court to be done is to assess whether the distinction meets the proportionality requirement. In so doing, it must ascertain whether the defendant has reasonably balanced the interests that are served by the distinction, i.e. the aim pursued, against the interests that are impaired by the distinction. This test will consist of several elements. First, the court must determine which interests are at stake. To this end, it can rely on the disadvantage suffered by the applicant, as established in the first testing phase, and on the aim of the distinction, as established in the second phase. Subsequently, the court has to determine the weight of these interests, taking into account such criteria as the seriousness of the impairment and the objective weight of the interest affected (by examining, for instance, whether a fundamental right has been infringed). Finally, the court will have to assess whether the defendant's balance of interests is to be regarded as sufficiently reasonable. For this assessment, the intensity of the review is once more decisive. When applying a marginal test the court may, for instance, only determine whether the weighing of interests is essentially arbitrary or evidently unreasonable, whereas in strict scrutiny cases, the court must ascertain whether the interests adduced by the defendant are sufficiently convincing and weighty to support the impairment of interests caused by the distinction. Only if the court reaches the conclusion that the distinction was based on a reasonable balance of the interests involved, can the distinction be deemed sufficiently justified and compatible with the principle of equality. If no sufficient degree of proportionality is found, the court's conclusion must be that the principle of equality has been violated. 



\section{Jurisprudentie}

\section{Human Rights Committee}

9 april $1987 \quad$ No. $172 / 1984$

Broeks v. The Netherlands

9 april 1987

No. $180 / 1984$

Danning $v$. The Netherlands

CCPR/C/29/D/192/1984

CCPR/C/29/D/180/1984

\section{Europees Hof voor de Rechten van de Mens}

\begin{tabular}{|c|c|c|}
\hline A.D.T. v. UK & 31 juli 2000 & EHRC 2000/69 \\
\hline A.0.v. Italy & 30 mei 2000 & EHRC $2000 / 58$ \\
\hline Abdulaziz, Cabales en Balkandali & 28 mei 1985 & Series A, vol. 94 \\
\hline Ahmed and Others & 2 september 1998 & Reports 1998-VI \\
\hline Airey & 9 oktober 1979 & Series A, vol. 32 \\
\hline Almeida Garrett & 11 januari 2000 & EHRC $2000 / 20$ \\
\hline Andreas Wabl & 21 maart 2000 & EHRC 2000/36 \\
\hline Annoni di Gussola & 14 november 2000 & EHRC $2001 / 4$ \\
\hline Association Ekin & 17 juli 2001 & EHRC 2001/66 \\
\hline Autronic AG & 24 april 1990 & Series A, vol. 178 \\
\hline B. v. UK & 26 mei 1987 & Series A, vol. 121-B \\
\hline Baranowski & 28 maart 2000 & EHRC 2000/38 \\
\hline Barthold & 25 februari 1985 & Series A, vol. 90 \\
\hline Beldjoudi & 26 februari 1992 & Series A, vol. 234-A \\
\hline Belgische Taal & 23 juli 1968 & Series A, vol. 6 \\
\hline Bergens Tidende & 2 mei 2000 & EHRC 2000/52 \\
\hline Berrehab & 21 juni 1988 & Series A, vol. 138 \\
\hline Beyeler & 5 januari 2000 & EHRC $2000 / 18$ \\
\hline Botta & 24 februari 1998 & Reports 1998-I \\
\hline Bouamar & 29 februari 1988 & Series A, vol. 129 \\
\hline Boyle en Rice & 27 april 1988 & Series A, vol. 131 \\
\hline Buckley & 25 september 1996 & Reports 1996-IV \\
\hline Building Societies & 23 oktober 1997 & Reports 1997-VII \\
\hline Burghartz & 22 februari 1994 & Series A, vol. 280-B \\
\hline C. v. Belgiě & 7 augustus 1996 & Reports 1996-III \\
\hline Camp and Bourimi & 3 oktober 2000 & EHRC 2000/82 \\
\hline Campbell & 28 februari 1988 & Series A, vol. 233 \\
\hline Campbell and Cosans & 29 januari 1982 & Series A, vol. 48 \\
\hline Canea Catholic Church & 16 december 1997 & Reports 1997-VIII \\
\hline Casado Coca & 26 januari 1994 & Series A, vol. 285-A \\
\hline Castells & 26 maart 1992 & Series A, vol. 236 \\
\hline Ceylan & 8 juli 1999 & Reports 1999-IV \\
\hline Chapman & 18 januari 2001 & n.n.g. \\
\hline Chassagnou & 29 april 1999 & Reports 1999-III \\
\hline Ciliz & 11 juli 2000 & EHRC 2000/72 \\
\hline Cossey & 27 september 1990 & Series A, vol. 184 \\
\hline Darby & 23 oktober 1990 & Series A, vol. 187 \\
\hline De Jong, Baljet and Van den Brink & 22 mei 1984 & Series A, vol. 77 \\
\hline Dudgeon & 22 oktober 1981 & Series A, vol. 45 \\
\hline
\end{tabular}


E.P. v. Italy

Église Métropolitaine de Bessarabie

Elsholz

Engel and Others

Eriksson

F. v, Switzerland

Fey

Fogarty

Fredin

Freedom and Democracy Party (ÖZDEP)

Fuentes Bobo

G.L. v. Italy

García Manibardo

Gaygusuz

Gerger

Gillow

Golder

Gustafsson

Hadjianastassiou

Handyside

Hertel

Hoffmann

Holy Monasteries

Immobiliare Saffi

Incal

Informationsverein Lentia

Inze

Ireland v. United Kingdom (IRA-case)

James and Others

Jane Smith

Janowski

Jerusalem

Jewish Liturgical Association Cha'are Shalom Ve Tsedek

Johnston

$\mathrm{K}$. and T. v. Finland

Kamasinsky

Karlheinz Schmidt

Kelly

Kjeldsen, Busk Madsen and Pedersen

Klass

Kokkinakis

L. v. Finland

Larkos

Leander

Lingens

Lithgow and Others

Lustig-Prean and Beckett

Magee

Manoussakis
16 november 1999

13 december 2001

13 juli 2000

8 juni 1976

23 mei 1989

27 november 1987

24 februari 1993

21 november 2001

18 februari 1991

8 december 1999

29 februari 2000

3 augustus 2000

15 februari 2000

16 september 1996

8 juli 1999

24 november 1986

21 februari 1975

25 april 1996

23 november 1992

12 december 1976

25 augustus 1998

23 juni 1993

21 november 1994

28 juli 1999

9 juni 1998

28 oktober 1993

28 oktober 1987

18 januari 1978

21 februari 1989

18 januari 2001

21 januari 1999

27 februari 2001

27 juni 2000

18 december 1986

27 april 2000

19 december 1989

18 juli 1994

4 mei 2001

7 december 1976

6 september 1978

25 mei 1993

27 april 2000

18 februari 1999

26 maart 1987

8 juli 1986

22 mei 1984

27 september 1999

6 juni 2000

26 september 1996
EHRC 2000/9

EHRC 2001/9

EHRC 2000/73

Series A, vol. 22

Series A, vol. 156

Series A, vol. 128

Series A, vol. 255-A

EHRC 2001/7

Series A, vol. 192

EHRC 2000/12

EHRC 2000/34

EHRC 2000/76

EHRC 2000/30

Reports 1996-IV

n.n.g.

Series A, vol. 109

Series A, vol. 18

Reports 1996-II

Series A, vol. 252

Series A, vol. 24

Reports 1998-VI

Series A, vol. 255-C

Series A, vol. 301-A

Reports 1999-V

Reports 1998-IV

Series A, vol. 276

Series A, vol. 126

Series A, vol. 25

Series A, vol. 98

EHRC 2001/19

JB 1999/40

EHRC 2001/27

EHRC 2000/66

Series A, vol. 112

EHRC 2000/49

Series A, vol. 168

Series A, vol. 291-B

EHRC 2001/40

Series A, vol. 23

Series A, vol. 28

Series A, vol. 260-A

n.n.g.

Reports 1999-1

Series A, vol. 116

Series A, vol. 103

Series A, vol. 102

EHRC 1999/2

EHRC 2000/63

Reports 1996-I 
Marckx

Markt intern Verlag GmbH

Mazurek

McMichael

Mellacher

Messina (No. 2)

Monnell and Morris

Moustaquim

Mutlu and Yildiz

National Union of Belgian Police

News Verlags GmbH and Co KG

Nilsen and Johnsen

Observer and Guardian (Spycatcher)

Olsson

Otto Preminger-Institut

P.M. v. Italy

Petrovic

Pine Valley Developments

Prince Hans-Adam II of Liechtenstein

R. v. UK

Rasmussen

Rekvényi

Sahin

Salgueiro da Silva Mouta

Schmidt and Dahlstrőm

Schuler-Zgraggen

Serif

Sheffield and Horsham

Sibson

Silver

Spadea and Scalabrino

Sporrong and Lönnroth

Stankov

Stjerna

Stubbings

Sunday Times (2)

Sunday Times I

Swedish Engine Drivers' Union

Tammer

Thlimmenos

Tyrer

United Communist Party of Turkey

V.v. UK

Van der Mussele

Van Raalte

Velikova

Vereniging Weekblad Bluf?

Vermeire

VGT Verein gegen Tierfabriken

W. v. UK
13 juni 1979

25 oktober 1989

1 februari 2000

24 februari 1995

19 december 1989

28 september 2000

2 maart 1987

18 februari 1991

17 oktober 2000

27 oktober 1975

11 januari 2000

25 november 1999

26 november 1991

24 maart 1988

20 september 1994

11 januari 2001

27 maart 1998

29 november 1991

12 juli 2001

26 mei 1987

28 november 1984

20 mei 1999

11 oktober 2001

21 december 1999

6 februari 1976

24 juni 1993

14 december 1999

30 juni 1998

20 april 1993

25 februari 1983

28 september 1995

23 september 1982

2 oktober 2001

25 november 1994

22 oktober 1996

26 november 1991

26 april 1979

6 februari 1976

6 februari 2001

6 april 2000

24 april 1978

30 januari 1998

16 december 1999

23 november 1983

21 februari 1997

18 mei 2000

9 februari 1995

29 november 1991

28 juni 2001

25 mei 1987
Series A, vol. 31

Series A, vol. 165

EHRC 2000/25

Series A, vol. 307-B

Series A, vol. 169

EHRC 2000/80

Series A, vol. 115

Series A, vol. 193

n.n.g.

Series A, vol. 19

EHRC 2000/21

EHRC 2000/10

Series A, vol. 216

Series A, vol. 130

Series A, vol. 295-A

n.n.g.

Reports 1998-II

Series A, vol. 222

EHRC 2001/64

Series A, vol. 121-C

Series A, vol. 87

Reports 1999-III

EHRC 2001/81

EHRC 2000/16

Series A, vol. 21

Series A, vol. 263

EHRC 2000/14

Reports 1998-V

Series A, vol. 258-A

Series A, vol. 61

Series A, vol. 315-B

Series A, vol. 52

EHRC 2001/84

Series A, vol. 299-B

Reports 1996-IV

Series A, vol. 217

Series A, vol. 30

Series A, vol. 20

EHRC 2001/20

EHRC 2000/45

Series A, vol. 26

Reports 1998-1

EHRC 2000/15

Series A, vol. 70

Reports 1997-I

EHRC 2000/57

Series A, vol. 306-A

Series A, vol. 214-C

EHRC 2001/55

Series A, vol. 121-A 
Weeks

Wessels-Bergervoet

Wille

Willis

Z. v. Finland
27 januari 1987

4 juni 2002

28 oktober 1999

11 juni 2002

25 februari 1997
Series A, vol. 114

EHRC 2002/60

EHRC 1999/7

EHRC 2002/62

Reports 1997-1

\section{Hof van Justitie van de EG en Gerecht van Eerste Aanleg van de EG}

21 december 1954

23 april 1956

29 november 1956

21 juni 1958

17 juli 1959

17 december 1959

10 mei 1960

12 juli 1962

13 juli 1962

5 februari 1963

17 juli 1963

15 juni 1964

15 oktober 1969

17 december 1970

17 december 1970

27 oktober 1971

6 juni 1972

\section{4 oktober 1973}

24 oktober 1973

13 november 1973

12 februari 1974

2 juli 1974

11 juli 1974

11 juli 1974

3 december 1974

4 december 1974

12 december 1974

17 juni 1975

17 februari 1976

8 april 1976
Zaak 1/54

Gev. zaken 7 en

9/54

Zaak 9/55

Zaak 13/57

Gev. zaken 32$33 / 58$

Zaak $14 / 59$

Gev. zaken 3-18, Barbara Erzbergbau 25 en $26-58$

Zaak 16/61

Gev. zaken 17 en 20/61

Zaak 26/62

Zaak $13 / 63$

Zaak 6/64

Zaak $15 / 69$

Zaak 11/70

Zaak 34/70

Zaak 6/71

Zaak 94/71

Zaak 5/73

Zaak 43/72

Gev. zaken 63-

69/72

Zaak 152/73

Zaak 153/73

Zaak 8/74

Zaak 11/74

Zaak 33/74

Zaak $41 / 74$

Zaak 36/74

Zaak 7/75

Zaak 45/75

Zaak 43/75
Frankrijk/Hoge Autoriteit

Groupement des Industries J J

Sidégurgiques

Kolenmijnen van

Beeringen

Wirtschafsvereinigung

Eisen- und Stahlindustrie

SNUPAT

Pont-à-Mousson

Accaierie Ferriere e

Fonderie di Modena

Klöckner

Van Gend \& Loos

Italiè/Commissie

Costa/E.N.E.L.

Ugliogla

Internationale

Handelsgesellschaft

Syndicat national céréales

Rheinmühlen Düsseldorf

Schlüter \& Maack

Balkan-Import-Export

Merkur

Wilhem Werhahn

Hansamühle

Sotgiu

Holtz \& Willemsen

Dassonville

Union des Minotiers de la

Champagne

Van Binsbergen

Van Duyn

Walrave en Koch

Echtelieden $\mathrm{F}$.

Rewe-Zentrale

Defrenne (II)
Jurispr. 1954-55, 1

Jurispr. 1954-56, 86

Jurispr. 1954-56, 311

Jurispr. 1957-58, 285

Jurispr. 1958-9, 305

Jurispr. 1959, 215

Jurispr. 1960, 381

Jurispr. 1962, 579

Jurispr. 1962, 643

Jurispr. 1963, 4

Jurispr. 1963, 375

Jurispr. 1964, 1202

Jurispr. 1969, 363

Jurispr. 1970, 1125

Jurispr. 1970, 1233

Jurispr. 1971, 823

Jurispr. 1972, 307

Jurispr. 1973, 1091

Jurispr. 1973, 1055

Jurispr. 1973, 1229

Jurispr. 1974, 153

Jurispr. 1974, 675

Jurispr. 1974, 837

Jurispr. 1974, 877

Jurispr. 1974, 1299

Jurispr. 1974, 1337

Jurispr. 1974, 1405

Jurispr. 1975, 679

Jurispr. 1976, 181

Jurispr. 1976, 455 


\begin{tabular}{|c|c|c|c|}
\hline 20 mei 1976 & Zaak 104/75 & De Peijper & Jurispr. 1976, 613 \\
\hline 7 juli 1976 & Zaak 118/75 & Watson en Belmann & Jurispr. 1976, 1185 \\
\hline 28 oktober 1976 & Zaak 36/75 & Rutili & Jurispr. 1975, 1219 \\
\hline 5 juli 1977 & Zaak 114/76 & Bela-Mühle & Jurispr. 1977, 1211 \\
\hline 12 juli 1977 & Zaak 2/77 & Hoffmann's Stărkefabriken & Jurispr. 1977,1375 \\
\hline 19 oktober 1977 & $\begin{array}{l}\text { Gev. zaken } \\
117 / 76 \text { en } 16 / 77\end{array}$ & Ruckdeschel & Jurispr. 1977,1753 \\
\hline 27 oktober 1977 & Zaak 30/77 & Bouchereau & Jurispr. 1977, 1999 \\
\hline 9 maart 1978 & Zaak $106 / 77$ & Simmenthal & Jurispr. 1978, 629 \\
\hline 13 juni 1978 & Zaak 139/77 & Denkavit Füttermittel & Jurispr. 1978, 1317 \\
\hline 15 juni 1978 & Zaak 149/77 & Defrenne (III) & Jurispr. 1978, 1365 \\
\hline 13 juli 1978 & Zaak $8 / 78$ & Milac & Jurispr. 1978, 1721 \\
\hline 10 oktober 1978 & Zaak 148/77 & Hansen \& Balle & Jurispr. 1978, 1787 \\
\hline 25 oktober 1978 & $\begin{array}{l}\text { Gev. zaken } 103 \\
\text { en } 145 / 77\end{array}$ & $\begin{array}{l}\text { Royal Scholten-Honig } \\
\text { (Isoglucose) }\end{array}$ & Jurispr. 1978, 2037 \\
\hline 18 januari 1979 & $\begin{array}{l}\text { Gev. zaken } 110 \\
\text { en } 111 / 78\end{array}$ & Van Wesemael e.a. & Jurispr. 1979, 35 \\
\hline 20 februari 1979 & Zaak 122/78 & Buitoni & Jurispr. 1979, 677 \\
\hline 21 februari 1979 & Zaak 138/78 & Stölting & Jurispr. 1979, 713 \\
\hline 28 maart 1979 & Zaak 90/78 & Granaria & Jurispr. 1979, 1081 \\
\hline 21 juni 1979 & Zaak 240/78 & Atalanta & Jurispr. 1979, 2137 \\
\hline 28 juni 1979 & $\begin{array}{l}\text { Gev. zaken } 233 \text {, } \\
234 \text { en } 235 / 78\end{array}$ & Lentes & Jurispr. 1979, 2305 \\
\hline 12 juli 1979 & Zaak $237 / 78$ & CRAM/Toia & Jurispr. 1979, 2645 \\
\hline 12 juli 1979 & Zaak 166/78 & Italië/Raad & Jurispr. 1979, 2575 \\
\hline 27 september 1979 & Zaak 230/78 & Eridania (I) & Jurispr. 1979, 2749 \\
\hline 13 december 1979 & Zaak 44/79 & Hauer & Jurispr. 1979, 3727 \\
\hline 14 december 1979 & Zaak 34/79 & Henn en Darby & Jurispr. 1979, 3795 \\
\hline 8 januari 1980 & Zaak 21/79 & $\begin{array}{l}\text { Commissie/Italië } \\
\text { (geregenereerde } \\
\text { aardolieproducten) }\end{array}$ & Jurispr. 1980, I \\
\hline 27 februari 1980 & Zaak 168/78 & $\begin{array}{l}\text { Commissie/Frankrijk } \\
\text { (belastingregeling } \\
\text { gedistilleerde dranken) }\end{array}$ & Jurispr. 1980, 347 \\
\hline 18 maart 1980 & Zaak 52/79 & Debauve & Jurispr. 1980, 833 \\
\hline 29 oktober 1980 & Zaak 22/80 & Boussac & Jurispr. 1980, 3427 \\
\hline 29 oktober 1980 & Zaak 139/79 & Maizena & Jurispr. 1980, 3393 \\
\hline 14 januari 1981 & Zaak 140/79 & Chemial Farmaceutici & Jurispr. 1981, 1 \\
\hline 14 januari 1981 & Zaak 35/80 & Denkavit Nederland BV & Jurispr. 1981, 45 \\
\hline 14 januari 1981 & Zaak $46 / 80$ & Vinal & Jurispr. 1981, 77 \\
\hline 5 februari 1981 & Zaak 53/80 & $\begin{array}{l}\text { Koninklijke Kaasfabriek } \\
\text { Eyssen }\end{array}$ & Jurispr. 1981, 409 \\
\hline 31 maart 1981 & Zaak 96/80 & Jenkins & Jurispr. 1981, 911 \\
\hline 16 oktober 1981 & Zaak 147/79 & Hochstrass & Jurispr. 1981, 3005 \\
\hline 3 februari 1982 & $\begin{array}{l}\text { Gev. zaken } 62 \text { - } \\
63 / 81\end{array}$ & Seco & Jurispr. 1982, 223 \\
\hline $\begin{array}{l}18 \text { mei } 1982 \\
15 \text { juli } 1982\end{array}$ & Zaak 293/83 & Gravier & Jurispr. 1985, 593 \\
\hline 15 juli 1982 & Zaak 40/82 & $\begin{array}{l}\text { Commissie/VK en Noord- } \\
\text { lerland (pluimvee) }\end{array}$ & Jurispr. 1982, 2793 \\
\hline 15 juli 1982 & Zaak 245/81 & Edeka & Jurispr. 1982, 2745 \\
\hline
\end{tabular}


15 september 1982
28 oktober 1982

23 februari 1983

12 juli 1983

14 juli 1983

30 november 1983

7 februari 1984

10 april 1984

6 juni 1984

10 juli 1984

12 juli 1984

6 november 1984

6 december 1984

13 december 1984

13 december 1984

29 januari 1985

9 mei 1985

11 juli 1985

4 maart 1986

4 maart 1986

11 maart 1986

18 maart 1986

18 maart 1986

17 april 1986

6 mei 1986

13 mei 1986

15 mei 1986

1 juli 1986

27 november 1986

4 december 1986

16 december 1986

12 februari 1987

11 maart 1987

11 maart 1987

12 maart 1987
Zaak 106/81

Gev, zaken 292- Loiret \& Haentjens 293/81

\section{Zaak $8 / 82$}

Zaak 170/78

Zaak 174/82

Zaak 227/82

Zaak 238/82

Zaak 14/83

Zaak 97/83

Zaak $72 / 83$

Zaak 184/83

Zaak $182 / 83$

Zaak 59/83

Zaak 251/83

Zaak 106/83

Zaak 231/83

Zaak 112/84

Zaak 278/83

Zaak 106/84

Zaak 243/84

Zaak 121/85

Zaak 179/84

Zaak 244/83

Zaak 59/85

Zaak 304/84

Zaak 170/84

Zaak 222/84

Zaak 237/85

Zaak 21/85

Zaak 205/84

Zaak 200/85

Zaak 221/85

Zaak 265/85

Gev. zaken 279 -

280, 285-286/84

Zaak 178/84

Julius Kind

Wagner/BALM

Commissie/VK

wijn)

Sandoz

Van Bennekom

Duphar

Melkunie

Campus Oil

Hofmann

Fearon

Biovilac

Haug-Adrion

Sermide

Cullet

Humblot

(belasting op

vruchtenwijnen)

John Walker

Conegate

Bozzetti

Meggle

Reed

Muller

Bilka-Kaufhaus

Johnston

Rummler

Maas \& Co.

pijen)

dieselauto's)

Commissie/België gen)

Van den Bergh

Walter Rau

Lebensmittelwerke (belastingregeling voor

Van Colson en Kamann

Commissie/Italiě (belasting Jurispr. 1985, 2503 op mousserende wijnen)

Commissie/Denemarken Jurispr. 1986, 833

Commissie/Duitsland

(verzekeringsmaatschap-

Commissie/Italië (BTW op Jurispr. 1986, 3953

(laboratoriumverstrekkin-

Commissie/Duitsland

(Reinheitsgebot)
Jurispr. 1987, 719

Jurispr. 1982, 2885

Jurispr. 1982, 3887

Jurispr. 1983, 371

Jurispr. 1983, 2265

Jurispr. 1983, 2445

Jurispr. 1983, 3883

Jurispr. 1984, 523

Jurispr. 1984, 1892

Jurispr. 1984, 2367

Jurispr. 1984, 2727

Jurispr. 1984, 3047

Jurispr. 1984, 3677

Jurispr. 1984, 4057

Jurispr. 1984, 4277

Jurispr. 1984, 4209

Jurispr. 1985, 305

Jurispr. 1985, 1367

Jurispr. 1986, 2013

Jurispr. 1986, 1007

Jurispr. 1986, 2301

Jurispr. 1986, 1101

Jurispr. 1986, 1283

Jurispr. 1986, 1511

Jurispr. 1986, 1607

Jurispr. 1986, 165 I

Jurispr. 1986, 2101

Jurispr. 1986, 3537

Jurispr. 1986, 3755

Jurispr. 1987, 1155

Jurispr. 1987, 1069

Jurispr. 1987, 1227 


\begin{tabular}{|c|c|c|c|}
\hline 7 mei 1987 & Zaak 184/85 & $\begin{array}{l}\text { Commissie/Italiẽ } \\
\text { (verbruiksbelasting op } \\
\text { bananen) }\end{array}$ & Jurispr. 1987, 2013 \\
\hline 11 juni 1987 & Zaak 30/85 & Teuling & Jurispr. 1987, 2497 \\
\hline 16 juni 1987 & Zaak 225/85 & $\begin{array}{l}\text { Commissie/Italië } \\
\text { (bezoldiging ambtenaren) }\end{array}$ & Jurispr. 1987, 2625 \\
\hline 17 september 1987 & Zaak $433 / 85$ & Feldain & Jurispr. 1987, 3536 \\
\hline 17 mei 1988 & Zaak $84 / 87$ & Erpelding & Jurispr. 1988, 2665 \\
\hline 7juli 1988 & Zaak 143/87 & Stanton & Jurispr. 1988, 3877 \\
\hline 7 juli 1988 & $\begin{array}{l}\text { Gev. zaken } 154- \\
155 / 87\end{array}$ & Wolf & Jurispr. 1988, 3897 \\
\hline 2 februari 1989 & Zaak 186/87 & Cowan & Jurispr. 1989, 195 \\
\hline 18 mei 1989 & $\begin{array}{l}\text { Gev. zaken 266- } \\
267 / 87\end{array}$ & $\begin{array}{l}\text { Association of } \\
\text { Pharmaceutical Importers }\end{array}$ & Jurispr. 1989,1295 \\
\hline 18 mei 1989 & Zaak 249/86 & $\begin{array}{l}\text { Commissie/Duitsland } \\
\text { (behoorlijke huisvesting) }\end{array}$ & Jurispr. 1988, 1263 \\
\hline 30 mei 1989 & Zaak 33/88 & Allué (I) & Jurispr. 1989, 1591 \\
\hline 11 juli 1989 & Zaak $265 / 87$ & Schräder & Jurispr. 1989, 2237 \\
\hline 13 juli 1989 & Zaak 171/88 & Rinner-Kühn & Jurispr. 1989, 2743 \\
\hline 13 juli 1989 & Zaak 5/88 & Wachauf & Jurispr. 1989, 2609 \\
\hline 17 oktober 1989 & Zaak 109/88 & Danfoss & Jurispr. 1989, 3199 \\
\hline 28 november 1989 & Zaak C-379/87 & Groener & Jurispr. 1989, 3967 \\
\hline 5 december 1989 & Zaak C-3/88 & $\begin{array}{l}\text { Commissie/Italië } \\
\text { (overheidsopdrachten } \\
\text { automatisering) }\end{array}$ & Jurispr. 1989, 4035 \\
\hline 12 december 1989 & Zaak C-265/88 & Messner & Jurispr. 1989,4209 \\
\hline 13 december 1989 & $\begin{array}{l}\text { Gev. zaken C- } \\
181-182,218 / 88\end{array}$ & Deschamps & Jurispr. 1989, 4381 \\
\hline 13 december 1989 & Zaak C-204/88 & Paris & Jurispr. 1989,4361 \\
\hline 13 december 1989 & Zaak C-102/88 & Ruzius-Wilbrink & Jurispr. 1989,4311 \\
\hline 21 februari 1990 & $\begin{array}{l}\text { Gev. zaken C- } \\
267 / 88 \mathrm{t} / \mathrm{m} \mathrm{C} \text { - } \\
285 / 88\end{array}$ & Wuidart & Jurispr. 1990, I-435 \\
\hline 5 april 1990 & Zaak C-132/88 & $\begin{array}{l}\text { Commissie/Griekenland } \\
\text { (motorvoertuigenbelasting) }\end{array}$ & Jurispr. 1990, I-1567 \\
\hline 8 mei 1990 & Zaak C-175/88 & Biehl & Jurispr. 1990, I-1779 \\
\hline 10 mei 1990 & Zaak C-241/87 & Maclaine Watson & Jurispr. 1990, I-1797 \\
\hline 14 juni 1990 & Zaak C-37/89 & Weiser & Jurispr. 1990, I-2395 \\
\hline 27 juni 1990 & Zaak C-33/89 & Kowalska & Jurispr. 1991, 1-2591 \\
\hline 30 november 1990 & Zaak C-331/88 & Fedesa & Jurispr. 1990, I-4023 \\
\hline 13 december 1990 & Zaak C-347/88 & $\begin{array}{l}\text { Commissie/Griekenland } \\
\text { (aardolie) }\end{array}$ & Jurispr. 1990, I-4747 \\
\hline 24 januari 1991 & Zaak C-27/90 & SITPA & Jurispr. 1991, I-133 \\
\hline 5 februari 1991 & Zaak C-363/89 & Roux & Jurispr. 1991, I-273 \\
\hline 7 februari 1991 & Zaak C-184/89 & Nimz & Jurispr. 1991, I-297 \\
\hline 26 februari 1991 & Zaak C-154/89 & $\begin{array}{l}\text { Commissie/Frankrijk } \\
\text { (toeristengidsen) }\end{array}$ & Jurispr. 1991, 1-659 \\
\hline 26 februari 1991 & Zaak C-198/89 & $\begin{array}{l}\text { Commissie/Griekenland } \\
\text { (toeristengidsen) }\end{array}$ & Jurispr. 1991, I-727 \\
\hline
\end{tabular}




\begin{tabular}{|c|c|c|}
\hline 7 mei 1991 & Zaak C-229/89 & $\begin{array}{l}\text { Commissie/België } \\
\text { (werkloosheidsuitkeringen) }\end{array}$ \\
\hline 7 mei 1991 & Zaak C-340/89 & Vlassopoulou \\
\hline 18 juni 1991 & Zaak C-260/89 & ERT \\
\hline 25 juli 1991 & $\begin{array}{l}\text { Gev. zaken C- } \\
1 / 90 \text { en C- } 176 / 90\end{array}$ & Aragonesa \\
\hline 25 juli 1991 & Zaak C-288/89 & Gouda \\
\hline 4 oktober 1991 & Zaak C-159/90 & Grogan \\
\hline 4 oktober 1991 & Zaak C-349/87 & Parashi \\
\hline 4 oktober 1991 & Zaak C-367/89 & Richardt \\
\hline 10 januari 1992 & Zaak C-177/90 & Kühn \\
\hline 28 januari 1992 & Zaak C-204/90 & Bachmann \\
\hline 28 januari 1992 & Zaak C-300/90 & $\begin{array}{l}\text { Commissie/België } \\
\text { (levensverzekeringen) }\end{array}$ \\
\hline 19 maart 1992 & Zaak C-311/90 & Hierl \\
\hline 8 april 1992 & Zaak C-62/90 & $\begin{array}{l}\text { Commissie/Duitsland } \\
\text { (invoer geneesmiddelen) }\end{array}$ \\
\hline 8 april 1992 & Zaak C-256/90 & Mignini \\
\hline 4 juni 1992 & Zaak C-360/90 & Bötel \\
\hline
\end{tabular}

Jurispr. 1991, 1-2205

Jurispr. 1991, 1-2357

Jurispr. 1991, 2925

Jurispr. 1991, I-4151

Jurispr. 1991, 1-4007

Jurispr. 1991, 1-4685

Jurispr. 1991, 1-4501

Jurispr. 1991, I-621

Jurispr. 1992, I-35

Jurispr. 1992, I-249

Jurispr. 1992, I-305

Jurispr. 1992, 1-2061

Jurispr. 1992, I-2575

Jurispr. 1992, I-2651

Jurispr. 1992, 1-3589

Commissie/VK en Noord- Jurispr. 1992, I-5785

17 november 1992 Zaak C-279/89

19 november 1992

14 januari 1993

10 maart 1993

30 maart 1993

30 maart 1993

7 juli 1993

13 juli 1993

2 augustus 1993

2 augustus 1993

20 oktober 1993

20 oktober 1993
27 oktober 1993
9 november 1993
30 november 1993
10 februari 1994
28 februari 1994
18 mei 1994
14 juli 1994
5 oktober 1994

5 oktober 1994
Zaak C-226/91

Zaak C-190/91

Zaak C-111/91

Zaak C-168/91

Zaak C-328/91

Zaak C-217/91

Zaak C-330/91

Gev, zaken C.

259/91, C-331/91

en $\mathrm{C}-332 / 91$

Zaak C-87/92

Gev. zaken C-

92/92 en C.

326/92

\section{Zaak C-272/92}

Zaak C-127/92

Zaak C-132/92

Zaak C-189/91

Zaak C-398/92

Zaak C-343/92

Zaak C-309/89

Zaak C-91/92

Gev, zaken C-

133/93, C-300/93

en $\mathrm{C}-362 / 93$

Zaak C-280/93
Ierland

(visserijvergunningen)

Molenbroek

Lante

Commissie/Luxemburg

(geboortetoelagen)

Konstantinidis

Thomas

Spanje/Commissie

Commerzbank AG

Allué (II)

Hoche

Phil Collins

Spotti

Enderby

Birds Eye Walls

Kirsammer-Hack

Mund \& Fester

Roks

Codorníu

Paola Facchini Dori

Crispoltoni

Jurispr. 1992, 1-5943

Jurispr. 1993, I-67

Jurispr. 1993, I-817

Jurispr. 1993, 1-119]

Jurispr. 1993, I-1247

Jurispr. 1993, I-3923

Jurispr. 1993, I-4017

Jurispr. 1993, 1-4309

Jurispr. 1993, 1-4623

Jurispr. 1993, I-5145

Jurispr. 1993, I-5185

Jurispr. 1993, I-5535

Jurispr. 1993, I-5579

Jurispr. 1993, 1-6185

Jurispr. 1994, 1-467

Jurispr. 1994, I-57I

Jurispr. 1994, I-1853

Jurispr. 1994, 1-3325

Jurispr. 1994, 1-4863

Jurispr. 1994, 1-4973

Duitsland/Raad

(bananen I) 


14 februari 1995
31 mei 1995
29 juni 1995
11 augustus 1995
17 oktober 1995
17 oktober 1995
17 oktober 1995
14 december 1995
1 februari 1996
6 februari 1996
8 februari 1996
13 februari 1996
29 februari 1996

7 maart 1996
19 maart 1996
28 maart 1996
30 april 1996
23 mei 1996
6 juni 1996
27 juni 1996
4 juli 1996
4 juli 1996
12 september 1996
26 september 1996
12 november 1996
14 januari 1997
23 januari 1997
20 maart 1997
17 juni 1997

26 juni 1997

17 juli 1997

\section{2 oktober 1997 \\ 23 oktober 1997 \\ 11 november 1997 \\ 20 november 1997 \\ 27 november 1997 \\ 15 januari 1998}

17 februari 1998
Zaak C-279/93

Zaak C-400/93

Zaak C-56/94

Zaak C-80/94

Zaak C-450/93

Zaak C-83/94

Zaak C-70/94

Zaak C-317/93

Zaak C-280/94

Zaak C-457/93

Zaak C-8/94

Zaak C-342/93

Gevoegde zaken

C-296/93 en C. $307 / 93$

Zaak C-278/93

Zaak C-120/94

Zaak C-299/94

Zaak C-13/94

Zaak C-237/94

Zaak C-101/94

Zaak C-107/94

Zaak C-295/94

Zaak C-296/94

Zaak C-278/94

Zaak C-43/95

Zaak C-84/94

Zaak C-124/95

Zaak C-29/95

Zaak C-323/95

Gev, zaken C-

65/95 en C.

$111 / 95$

Zaak C-368/95

Gev, zaken C-

248/95 en C-

249/95

Zaak C-1/95

Zaak C-150/95

Zaak C-409/95

Zaak C-90/96

Zaak C-57/96

Zaak C-15/96

Zaak C-249/96
Schumacker

Royal Copenhagen

SCAC

Wielockx

Kalanke

Leifer

Werner

Nolte

Posthuma

Lewark

Laperre

Gillespie

Frankrijk en

Ierland/Commissie

Freers en Speckmann

Commissie/Griekenland

(Macedoniē)

Anglo Irish Beef

Processors

P. tegen S.

O'Flynn

Commissie/Italie

(effectenbemiddelaars)

Asscher

Hüpeden

Pietsch

Commissie/België (jonge werklozen)

Data Delecta (organisatie arbeidstijd)

Centro-Com

Pastoors en Trans-Cap

Hayes

Shingara en Radiom

Heinrich Bauer Verlag

SAM Schiffahrt

Gerster

Portugal/Commissie

Marschall

Petrie

Meints

Schöning-

Kougebetopoulou

Grant
Jurispr. 1997, I-3689
Jurispr. 1997, I-4475

Jurispr. 1997, I-3689
Jurispr. 1997, I-4475

Jurispr. 1995, I-225

Jurispr, 1995, I-1275

Jurispr. 1995, I-1769

Jurispr. 1995, I-2493

Jurispr. 1995, 1-3051

Jurispr. 1995, I-3235

Jurispr. 1995, I-3189

Jurispr. 1995, I-4625

Jurispr. 1996, I-179

Jurispr. 1996, I-243

Jurispr. 1996, I-273

Jurispr. 1996, I-475

Jurispr. 1996, I-795

Jurispr. 1996, I-1165

Jurispr. 1996, I-1513

Jurispr. 1996, I-1925

Jurispr. 1996, I-2143

Jurispr. 1996, 1-2617

Jurispr. 1996, 2691

Jurispr. 1996, I-3089

Jurispr. 1996, 1-3375

Jurispr. 1996, I-3409

Jurispr. 1996, I-4307

Jurispr. 1996, I-4661

Jurispr. 1996, 1-5755

Jurispr. 1997, I-81

Jurispr. 1997, I-285

Jurispr. 1997, 1-1711

Jurispr. 1997, I-3343

Jurispr. 1997, I-5253

Jurispr. 1997, I-5863

Jurispr. 1997, I-6363

Jurispr. 1997, I-6529

Jurispr. 1997, I-6689

Jurispr. 1998, I-47

Jurispr. 1998, 1-621 
10 maart 1998

12 maart 1998

28 april 1998

30 april 1998

7 mei 1998

17 juni 1998

22 oktober 1998

27 oktober 1998

19 november 1998

26 januari 1999

9 februari 1999

14 september 1999

26 oktober 1999

11 januari 2000

10 februari 2000

28 maart 2000

6 april 2000

13 april 2000

13 april 2000

11 mei 2000

16 mei 2000

6 juni 2000

6 juni 2000

6 juli 2000

6 juli 2000

6 juli 2000

13 juli 2000

13 juli 2000

21 september 2000

3 oktober 2000

3 oktober 2000

7 december 2000

1 februari 2001

8 maart 2001

20 maart 2001

31 mei 2001

26 juni 2001

26 juni 2001

5 juli 2001

12 juli 2001
Zaak C-122/95

Zaak C-187/96

Zaak C-120/95

Zaak C-136/95

Zaak C-350/96

Zaak C-243/95

Gev. zaken C-

9/97 en C-118/97

Zaak C-411/96

Zaak C-66/96

Zaak C-18/95

Zaak C-167/97

Zaak C-249/97

Zaak C-273/97

Zaak C-285/98

Zaak C-50/96

Zaak C-158/97

Zaak C-226/98

Zaak C-251/98

Zaak C-292/97

Zaak C-56/99

Zaak C-87/99

Zaak C-281/98

Zaak C-35/98

Zaak C-289/97

Zaak C-407/98

Zaak C-356/97

Zaak C-423/98

Zaak C-117/99

Zaak C-124/99

Zaak C-58/98

Zaak C-411/98

Zaak C-79/99

Zaak C-108/96

Gev. zaken C-

$397 / 98$ en C-

$410 / 98$

Zaak T-52/99

Gev. zaken C-

122/99P en C-

125/99 P

Zaak C-381/99

Zaak C-212/99

Zaak C-100/99

T. Port

D./Raad

Brunnhofer

Commissie/Italië (lectoren)

Italië/Raad en Commissie

(agromonetair stelsel voor euro)

Zaak C-189/01 Jippes
Jurispr. 1998, I-973

Jurispr. 1998, I-1095

Jurispr. 1998, 1-1831

Jurispr. 1998, I-011

Jurispr. 1998, I-2521

Jurispr. 1998, 1-3739

Jurispr. 1998, I-6267

Jurispr. 1998, I-6401

Jurispr. 1998, I-7327

Jurispr. 1999, I-345

Jurispr. 1999, 1-623

Jurispr. 1999, I-5295

Jurispr. 1999, 1-7403

Jurispr. 2000, 1-69

Jurispr. 2000, 1-743

Jurispr. 2000, 1-1875

Jurispr. 2000, I-2447

Jurispr. 2000, I-2787

Jurispr. 2000, 1-2737

Jurispr. 2000, I-3079

Jurispr. 2000, 1-3337

Jurispr. 2000, I-4139

Jurispr. 2000, I-4071

Jurispr. 2000, I-5409

Jurispr. 2000, I-5539

Jurispr. 2000, 1-5461

Jurispr. 2000, I-5965

Jurispr. 2000, I-6077

Jurispr. 2000, I-7293

Jurispr. 2000, 1-7919

Jurispr. 2000, I-8081

Jurispr. 2000, I-10997

Jurispr. 2001, 1-837

Jurispr. 2001, I-1727

Jurispr. 2001, II-981

Jurispr. 2001, I-4319

Jurispr. 2001, 1-4961

Jurispr. 2001, I-4923

Jurispr. 2001, I-5217

Jurispr. 2001, I-5689 


$\begin{array}{llll}25 \text { oktober 2001 } & \text { Zaak C-493/99 } & \begin{array}{l}\text { Commissie/Duitsland } \\ \text { (bouwondernemingen) }\end{array} & \text { Jurispr. 2001, 1-8163 } \\ \text { 25 oktober 2001 } & \begin{array}{l}\text { Gev. zaken C- } \\ \text { 49/98, C-50/98, }\end{array} & \text { Finalarte } & \text { Jurispr. 2001, 1-7831 } \\ & \begin{array}{l}\text { C-52/98 t/m C- } \\ 54 / 98 \text { en C-68/98 }\end{array} & & \\ & \text { t/m C-71/98 } & & \\ 8 \text { januari 2002 } & \text { Zaak C-507/99 } & \begin{array}{l}\text { Denkavit Nederland BV } \\ \text { (II) }\end{array} & \text { n.n.g. } \\ 19 \text { maart 2002 } & \text { Zaak C-476/99 } & \text { Lommers } & \text { n.n.g. }\end{array}$

\section{Supreme Court of the United States}

Adarand Constructors, inc. v. Pena

515 U.S. 200 (1995)

Alexander v, Choate

469 U.S. 287 (1985)

Alexander v. Sandoval

69 U.S.L.W. 4250 (2001)

Allegheny Pittsburgh Coal Co. v. Webster County

488 U.S. 336 (1989)

Allgeyer v. Louisiana

Allied Stores v. Bowers

165 U.S. 578 (1897)

358 U.S. 522 (1959)

Ambach v. Norwick

American Party of Texas v. White

441 U.S. 68 (1979)

415 U.S. 767 (1974)

375 U.S. 399 (1964)

Anderson v. Martin

282 U.S. 499 (1931)

476 U.S. 79 (1986)

134 U.S. 232 (1890)

467 U.S. $216(1984)$

401 U.S. 371 (1971)

347 U.S. 497 (1954)

404 U.S. 226 (1971)

347 U.S. 483 (1954)

405 U.S. 134 (1972)

504 U.S. 428 (1992)

504 U.S. 648 (1992)

365 U.S. 715 (1961)

517 U.S. 952 (1996)

441 U.S. 380 (1979)

454 U.S. 432 (1982)

430 U.S. 199 (1977)

430 U.S. 313 (1977)

443 U.S. 76 (1979)

380 U.S. 89 (1965)

430 U.S. 482 (1977)

526 U.S. 124 (1999)

473 U.S. 432 (1985)

451 U.S. 100 (1981)

427 U.S. 297 (1976)

488 U.S. 469 (1989)

I09 U.S. 3 (1883) 
Clark v. Jeter

Cooper v. Aaron

Craig v. Boren

Currin v. Wallace

Dandridge $v$. Williams

Davidson v. City of New Orleans

Davis v. Bandemer

Douglas v. California

Dunn v. Blumstein

Edwards v. California

Eisenstadt v. Baird

Evans v. Cornman

F.S. Royster Guano Co. v. Virginia

FCC v. Beach Communications

Ferguson v. Skrupa

Flemming v. Nestor

Foley v. Connelie

Frontiero v. Richardson

Fullilove v. Klutznick

Geduldig v. Aiello

Goesaert v. Cleary

Gomez v. Perez

Gomillion v. Lightfoot

Gordon v. Lance

Graham v. Richardson

Gregory v. Ashcroft

Griffin v. Illinois

Griggs v. Duke Power Company

Gulf, Colorado \& Santa Fe Railway Co. v. Ellis

Hampton v. Mow Sun Wong

Harper v, Virginia State Bd. of Elections

Harris v. McRae

Hartford v. Harrison

Heckler v. Mathews

Heller v. Doe

Hernandez v. New York

Hernandez v. Texas

Hirabayashi v. United States

Hooper v. Bernalillo County Assessor

Hunter v. Erickson

In re Griffiths

J.E.B. v. Alabama

James v. Strange

Jefferson v. Hackney

Jenness v. Fortson

Johnson v. Robinson

Johnson v. Transportation Agency

Kadrmas v. Dickinson Public Schools

Kahn v, Sevin

Katzenbach v. Morgan

486 U.S. 456 (1988)

358 U.S. 1 (1958)

429 U.S. 190 (1976)

306 U.S. 1 (1939)

397 U.S. 471 (1970)

96 U.S. 97 (1877)

478 U.S. 109 (1986)

372 U.S. 353 (1963)

405 U.S. 330 (1972)

314 U.S. 160 (1941)

405 U.S. 438 (1972)

398 U.S. 419 (1970)

253 U.S. 412 (1920)

508 U.S. 307 (1993)

372 U.S. 726 (1963)

363 U.S. 603 (1960)

435 U.S. 291 (1977)

411 U.S. 677 (1973)

448 U.S. 448 (1980)

417 U.S. 484 (1974)

335 U.S. 464 (1948)

409 U.S. 535 (1973)

364 U.S. 339 (1960)

403 U.S. 1 (1971)

403 U.S. 365 (1971)

501 U.S. 452 (1991)

351 U.S. 12 (1956)

401 U.S. 424 (1971)

165 U.S. 150 (1897)

426 U.S. 88 (1976)

383 U.S. 663 (1966)

448 U.S. 297 (1980)

301 U.S. 459 (1937)

465 U.S. 728 (1984)

113 S.Ct. 2637 (1993)

500 U.S. 352 (1991)

347 U.S. 475 (1954)

320 U.S. 81 (1943)

472 U.S. 612 (1985)

393 U.S. 385 (1969)

413 U.S. 717 (1973)

511 U.S. 127 (1994)

407 U.S. 128 (1972)

406 U.S. 535 (1972)

403 U.S. 431 (1971)

415 U.S. 361 (1974)

480 U.S. 616 (1987)

487 U.S. 450 (1988)

416 U.S. 351 (1974)

384 U.S. 641 (1966) 
Kent v. Dulles

Keyes v. School District No. 1

Kimel v. Florida Bd. of Regents

Kirchberg v. Feenstra

Kotch v. Board of River Port Pilot Commissioners for Port of New Orleans

Kramer v. Union Free School District

Labine v. Vincent

Lalli v. Lalli

Lane v. Wilson

Lassiter v. Northampton County Board of Elections

Lehr v. Robertson

Levy v. Louisiana

Lindsey v. Normet

Lindsley v. Natural Carbonic Gas Co.

Little v. Straeter

Lochner v. New York

Louisville Gas Co. v. Coleman

Loving $v$. Virginia

Lubin v. Panish

Lyng v. Castillo

Lyng v. International Union, United Automobile, Aerospace \& Agricultural Implement Workers

M.L.B.v. S.L.J.

Madden v. Kentucky

Maher v. Roe

Martinez v. Bynum

Massachusetts Bd. of Retirement v. Murgia

Mathews v. Lucas

Mayflower Farms, Inc. v. Ten Eyck

Mayor of Philadelphia v. Educational Equality League

McCabe v. Atchison, Topeka and Santa Fe Railway

McClesky v. Kemp

McDonald v. Board of Election

McDonnell Douglas v, Green

McGowan v. Maryland

McLaughlin v. Florida

Memorial Hospital v. Maricopa County

Memphis v. Greene

Metro Broadcasting Inc. v. FCC

Metropolis Theatre Co. v. Chicago

Metropolitan Life Ins. Co. v. Ward

Michael M. v. Sonoma County Superior Court

Miller v, Allbright

Miller v. Johnson

Minnesota v. Cover Leaf Creamery

Mississippi University for Women v. Hogan

Missouri ex rel. Gaines v. Canada

Missouri, K. \& T. Ry. v. May

Mobile v. Bolden
357 U.S. $116(1958)$

413 U.S. 189 (1973)

528 U.S. 62 (2000)

450 U.S. 455 (1981)

330 U.S. 552 (1947)

395 U.S. 621 (1969)

401 U.S. 532 (1971)

439 U.S. 259 (1978)

307 U.S. 268 (1939)

360 U.S. 45 (1959)

463 U.S. 248 (1983)

391 U.S. 68 (1968)

405 U.S. 56 (1972)

220 U.S. 61 (1911)

452 U.S. 1 (1981)

198 U.S. 45 (1905)

277 U.S. 32 (1928)

388 U.S. 1 (1967)

415 U.S. 709 (1974)

477 U.S. 635 (1986)

485 U.S. 360 (1988)

519 U.S. 102 (1996)

309 U.S. 83 (1940)

432 U.S. 464 (1977)

461 U.S. 321 (1983)

427 U.S. 307 (1976)

427 U.S. 495 (1976)

297 U.S. 266 (1936)

415 U.S. 605 (1974)

235 U.S. 151 (1914)

481 U.S. 279 (1987)

394 U.S. 802 (1969)

411 U.S. 792 (1973)

366 U.S. 420 (1961)

379 U.S. 184 (1964)

415 U.S. 250 (1974)

434 U.S. 1026 (1978)

497 U.S. 547 (1990)

228 U.S. 61 (1913)

470 U.S. 869 (1985)

450 U.S. 464 (1981)

523 U.S. 420 (1998)

515 U.S. 900 (1995)

449 U.S. 456 (1981)

458 U.S. 718 (1982)

305 U.S. 337 (1938)

194 U.S. 267 (1904)

446 U.S. 55 (1980) 
Morey v. Doud

Mount Healthy Bd. of Educ. v. Doyle

354 U.S. 457 (1957)

New York Transit Authority v. Beazer

429 U.S. 274 (1977)

440 U.S. 568 (1979)

Nordlinger v. Hahn

Norris v. Alabama

Nyquist v. Mauclet

O'Brien v. Skinner

Orr v. Orr

Ortwein v. Schwab

Oyama v. California

Pace v. Alabama

Palmer v. Thompson

Palmore v. Sidoti

Parham v. Hughes

Patsone v. Pennsylvania

Personnel Administrator of Massachusetts v. Feeney

Plessy v. Ferguson

Plyler v. Doe

Police Department of Chicago v. Mosley

Powell v. Pennsylvania

Railway Express Agency Inc. v. New York

Reed v. Reed

Reynolds v. Sims

Richardson v. Ramirez

Rinaldi v. Yeager

Roe v. Wade

Rogers v. Lodge

Romer v. Evans

Rosario v. Rockefeller

Ross v. Moffitt

Rotsker v. Goldberg

San Antonio Independent School District v. Rodriguez

Schlesinger v. Ballard

Schweiker v. Wilson

505 U.S. 1 (1992)

294 U.S. 587 (1935)

432 U.S. 1 (1977)

414 U.S. 524 (1974)

440 U.S. 268 (1979)

410 U.S. 656 (1973)

332 U.S. 633 (1948)

106 U.S. 583 (1882)

403 U.S. 217 (1971)

466 U.S. 429 (1984)

441 U.S. 347 (1979)

232 U.S. 138 (1914)

442 U.S. 256 (1979)

163 U.S. 537 (1896)

457 U.S. 202 (1982)

408 U.S. 92 (1972)

127 U.S. 678 (1888)

336 U.S. 106 (1949)

404 U.S. 71 (1971)

377 U.S. 533 (1964)

418 U.S. 24 (1974)

384 U.S. 305 (1966)

410 U.S. 113 (1974)

458 U.S. 613 (1982)

517 U.S. 620 (1996)

410 U.S. 752 (1973)

417 U.S. 600 (1974)

453 U.S. 57 (1981)

411 U.S. 1 (1973)

419 U.S. 498 (1975)

450 U.S. 221 (1981)

394 U.S. 618 (1969)

Shapiro v. Thompson

517 U.S. 899 (1996)

Shaw v. Hunt

509 U.S. 630 (1993)

Shaw v. Reno

Shelley v. Kraemer

Sherbert v. Verner

Skinner v. Oklahoma

334 U.S. 1 (1948)

374 U.S. 398 (1963)

316 U.S. 535 (1942)

Smith v. Cahoon

283 U.S. 553 (1931)

Sosna v. Iowa

Stanley v. Public Utilities Commission

419 U.S. 393 (1975)

295 U.S. 76 (1935)

421 U.S. 7 (1975)

Stanton v. Stanton

301 U.S. 548 (1937)

Steward Machine Co. v. Davis

100 U.S. 303 (1879)

Strauder v. West Virginia

Sugarman v. Dougall

413 U.S. 634 (1973)

Swain v. Alabama

380 U.S. 202 (1965)

Sweatt v. Painter

Takahashi v. Fish \& Game Comm'n 
Texas Dept. of Community Affairs v. Burdine

Texas v. Lesage

The Railroad Tax Cases

The Slaughter-House Cases

Tigner $v$. Texas

Toyosaburo Korematsu v. United States

Trimble v. Gordon

Truax v. Raich

Tuan Anh Nguyen et al. v. INS

U.S. Railroad Retirement Bd. v. Fritz

U.S. v. Kras

United Jewish Organization of Williamsburg v. Carey

United States Department of Agriculture v. Moreno

United States v. Carolene Products

United States v. O'Brien

United States v. Virginia

University of California Regents v. Bakke

Vacco v. Quill

Vance v. Bradley

Village of Arlington Heights v. Metropolitan Housing Dev.

Corp.

Village of Willowbrook v. Olech

Wards Cove Packing v. Atonio

Washington v. Davis

Watson v. Fort Worth Bank \& Trust

Watson v. Maryland

Wayte v. United States

Weber v. Aetna Casualty \& Surety Co.

Weinberger $v$. Salfi

Weinberger $v$. Wiesenfeld

Wengler v. Druggist's Mutual Ins. Co.

Williams v. Illinois

Williams v. Vermont

Williamson v. Lee Optical

Wright v. Council of City of Emporia

Wygant v. Jackson Bd. of Education

Yick Wo v. Hopkins

Zobel v. Williams
450 U.S. 248 (1981)

528 U.S. 18 (1999)

13 Fed. 722 (1882)

83 U.S. 36 (1873)

310 U.S. 141 (1940)

323 U.S. 214 (1944)

430 U.S. 762 (1977)

239 U.S. 33 (1915)

533 U.S. 53 (2001)

449 U.S. $166(1980)$

409 U.S. 434 (1973)

430 U.S. 144 (1979)

413 U.S. 528 (1973)

304 U.S. 144 (1938)

391 U.S. 367 (1968)

518 U.S. 515 (1996)

438 U.S. 265 (1978)

521 U.S. 793 (1997)

440 U.S. 93 (1979)

429 U.S. 252 (1977)

528 U.S. $562(2000)$

490 U.S. 642 (1989)

426 U.S. 229 (1976)

487 U.S. 977 (1988)

218 U.S. $173(1910)$

470 U.S. 598 (1985)

406 U.S. 164 (1972)

422 U.S. 749 (1975)

420 U.S. 636 (1975)

446 U.S. $142(1980)$

399 U.S. 235 (1970)

472 U.S. 14 (1985)

348 U.S. 483 (1955)

407 U.S. 451 (1972)

476 U.S. 267 (1986)

118 U.S. 356 (1886)

457 U.S. 55 (1982)

\section{Hoge Raad}

\section{Belastingkamer}

14 maart 1979

6 juni 1979

18 juni 1980

25 juni 1980

24 september 1980

9 juni 1982
BNB 1979/140

BNB 1979/211

BNB 1980/223

BNB 1980/277

AB 1983/1

BNB 1982/215
Navorderingsaanslag grensarbeider

Buitengewone lasten pensionprijs I

Buitengewone lasten pensionprijs II

Berekening vloeroppervlakte

Onroerendgoedbelasting Scheemda 1

Onroerendgoedbelasting Schiedam I 
23 juni 1982

19 januari 1983

22 juni 1983

28 maart 1984

27 maart 1985

23 oktober 1985

20 november 1985

16 april 1986

27 augustus 1986

22 juni 1988

8 juli 1988

27 september 1989

21 maart 1990

6 juni 1990

6 juni 1990

12 december 1990

17 juni 1992

17 juni 1992

16 september 1992

16 september 1992

30 september 1992

21 oktober 1992

21 oktober 1992

4 november 1992

7 april 1993

19 mei 1993

19 mei 1993

16 juli 1993

16 juli 1993

17 november 1993

22 maart 1994

4 mei 1994

1 februari 1995

8 februari 1995

14 juni 1995

28 juni 1995

20 september 1995

1 november 1995

13 december 1995

13 december 1995

20 maart 1996

24 april 1996

9 augustus 1996

13 november 1996

8 januari 1997

5 februari 1997

26 maart 1997

9 april 1997

15 juli 1997
AB 1983/2

BNB 1983/132

BNB 1983/240

BNB 1984/196

BNB 1985/164

BNB 1986/158

BNB 1986/17

BNB 1986/236

BNB 1986/317

BNB 1988/259

NJ 1990/448

NJ 1990/449

BNB 1990/179

BNB 1990/212

BNB 1990/299

BNB 1991/76

BNB 1992/294

BNB 1992/295

BNB 1992/21

BNB 1992/371

NJ 1994/495

BNB 1993/28

BNB 1993/29

BNB 1992/102

BNB 1993/172

BNB 1993/241

BNB 1993/242

BNB 1993/299

BNB 1993/321

BNB 1994/36

BNB 1994/112

BNB 1994/195

BNB 1995/81

BNB 1995/83

AB 1995/609

BNB 1995/281

BNB 1995/315

BNB 1996/37

BNB 1996/72

BNB 1996/90

BNB 1996/178

BNB 1996/210

BNB 1996/336

BNB 1997/54

BNB 1997/64

BNB 1997/160

BNB 1997/186

BNB 1997/188

BNB 1997/325
Onroerendgoedbelasting Scheemda II

Onroerendgoedbelasting Hengelo

Onroerendgoedbelasting Schiedam II

Ongelijke behandeling aandeelhouders

Reiskostenforfait

Fooien taxichauffeurs

Autokostenfictie

Strijkgelden

Besparing vakantiereis

Koffiegeld en reiskosten

Studeerkameraftrek I

Samentelling inkomens gehuwden (tandartsvrouw)

Vrijstelling motorrijtuigenbelasting

Leeftijdsgrens voor zelfstandigenaftrek I

Zorgrelatie buiten familieverband

Kosten kinderopvang

Taxatie onroerend goed

Belasting uitkering ineens

Interimregeling ziektekosten ambtenaren

Veeverbetering

Griffiegeld

Middelingsregeling

Belastingvrije som alleenstaanden

Inkomstentoerekening bij gehuwden

$35 \%$-regeling

Successiebelasting ongehuwden

Uitvoeringsbeschikking Loonbelasting

Uitzendtoelage ambtenaren

Herinrichtingskosten

Koffiegeld en studeerkamerkosten

Openbaar vervoer-verklaring

Studeerkamerkosten

Sollicitatiekosten

Aftrekbaarheid studiekosten en studiefinanciering

Gebroken boekjaar

Bonusregeling

Afvalwater

Omzetbelasting manege

Vee als bedrijfsmiddel

Kinderopvang II

Woningbouwvereniging

Bijzondere verbruiksbelasting personenauto's

Aftopping reiskostenforfait

Belasting aanmerkelijk belang in buitenland

PTT Telecom

Dienstauto bewindslieden

Waardering landbouwgrond

Nedeco-regeling

Koffiegeld en representatiekosten 
27 augustus 1997

24 september 1997

24 september 1997

I oktober 1997

15 oktober 1997

12 november 1997

15 juli 1998

17 augustus 1998

23 september 1998

16 december 1998

16 december 1998

20 januari 1999

3 maart 1999

17 maart 1999

21 april 1999

12 mei 1999

16 juni 1999

23 juni 1999

27 juli 1999

10 november 1999

15 december 1999

15 maart 2000

22 maart 2000

19 april 2000

11 augustus 2000

20 september 2000

6 december 2000

24 januari 2001

14 februari 2001

21 februari 2001

21 februari 2001

28 februari 2001

28 februari 2001

28 februari 2001

2 mei 2001

30 mei 2001

10 augustus 2001

\section{Strafkamer}

7 januari 1975

13 november 1979

10 maart 1981

18 december 1984

22 januari 1985
BNB 1998/109

BNB 1998/20

BNB 1997/400

BNB 1997/391

BNB 1997/380

BNB 1998/22

NJ 2000/168

BNB 1998/293

JB 1998/196

BNB 1999/3

JB 1999/44

BNB 1999/166

BNB 1999/80

BNB 1999/202

BNB 1999/348

BNB 1999/310

FBR 1999, p.

2115

BNB 1999/286

BNB 1999/292

BNB 1999/403

BNB 2000/125

BNB 2000/57

BNB 2000/278

BNB 2000/173

BNB 2000/192

BNB 2000/334

BNB 2000/380

BNB 2001/144

BNB 2001/292

BNB 2001/134

BNB 2001/163

BNB 2001/176

BNB 2001/169

BNB 2001/172

BNB 2001/181

BNB 2001/276

BNB 2001/302

BNB 2001/400
Huurwaardeforfait bij kamerverhuur door ondernemer

Ongelijke behandeling één vergelijkbaar geval

Kledingkosten presentatrice

Vergoeding vervolgingsslachtoffers

Kosten kinderopvang

Reiskosten als studiekosten

Autokostenforfait

Grijs kenteken

FIOD-onderzoek

Autokostenforfait

Overbedeling na echtscheiding

Levensonderhoud verwanten

Leeftijdsgrens zelfstandigenaftrek II

35\%-regeling II

CDK-spaarbiljetten

Arbeidskostenforfait

Vakantiegeld en vakantiebonnen

Autokostenfictie

Huurwaardeforfait

Nedeco-regeling

Belastingvrije som gehuwden/ongehuwden

Bedrijfskosten meewerkende kinderen

Juridische eigendom zonder economisch belang

Arbeidskostenforfait en rentevrijstelling

werknemersspaarregelingen

Aftrek studiekosten

OZB woonschepen

Studiekostenaftrek uitwonende/thuiswonende

studenten

Dienstauto bewindslieden II

Toeristenbelasting Waterland

Waardebepaling via peildatumsysteem

Drempelbedrag aftrekbaarheid kinderopvang

Alleenstaande-ouderaftrek

$\mathrm{OZB}$ winkelpand

Invalidenparkeerkaart

Wubo 1940-1945

Korting 35\%-regeling

Fictiebepaling Successiewet
NJ $1975 / 206$

NJ $1980 / 171$

NJ $1981 / 385$

NJ $1984 / 356$

NJ 1986/24
Onderscheid op grond van nationaliteit

Nederlandstalige oproeping van Friese verdachte

Antenne-inrichting Nozema

Heren- en dameskappers

Vervangende dienstplicht gewetensbezwaarden III 
18 juni 1985

13 januari 1987

10 februari 1987

20 oktober 1987

21 juni 1988

6 november 1990

21 mei 1991

18 april 1995

6 juni 1995

14 mei 1996

13 januari 1998

2 februari 1999

18 mei 1999

\section{Civiele kamer}

4 november 1977

18 januari 1980

25 april 1980

8 oktober 1980

13 maart 1981

10 december 1982

10 december 1982

30 maart 1984

27 april 1984

12 oktober 1984

23 november 1984

22 februari 1985

21 maart 1986

9 januari 1987

27 maart 1987

13 november 1987

4 maart 1988

24 juni 1988

15 juli 1988

23 september 1988

25 november 1988

14 april 1989

20 april 1990

30 maart 1990

19 oktober 1990

26 oktober 1990

22 maart 1991

13 september 1991
NJ $1986 / 25$

NJ $1987 / 917$

NJ $1987 / 950$

NJ $1988 / 473$

NJ $1988 / 1021$

NJ 1991/218

NJ $1991 / 728$

NJ $1995 / 611$

NJ 1995/645

NJ 1996/644

NJ $1998 / 407$

NJ $1999 / 664$

NJ $1999 / 578$
Vervangende dienstplicht gewetensbezwarden IV

Klein geel kenteken

Vechtpartij zigeuners

Ongelijke behandeling bij vervolging

Folderverspreiding Centrumpartij

Tippelverbod

Strafkorting bijstandsuitkering

Vrijstelling dienstplicht Jehova's getuigen

Vervangende hechtenis bij wederrechtelij!

verkregen voordeel

Onpartijdige rechter

Gedoogbeleid Delfzijl

Transactievoorstel

Richtlijn Handhaving Arbeidsomstandighrden
NJ $1978 / 418$

NJ $1980 / 463$

NJ $1981 / 416$

NJ $1981 / 308$

AB 1981/396

NJ $1981 / 346$

NJ 1983/411

NJ $1983 / 687$

NJCM 1984, 253

NJ $1984 / 513$

NJ $1985 / 230$

RvdW 1984/200

NJ $1985 / 604$

NJ $1986 / 3$

NJ $1986 / 585$

NJ $1987 / 928$

NJ $1987 / 727$

NJ 1989/698

RVR 1992, nr.

215

NJ $1989 / 875$

NJ $1988 / 1002$

NJ $1989 / 714$

NJ $1989 / 740$

NJ $1989 / 730$

NJ 1990/412

NJ 1992/636

NJ 1991/644

RvdW 1990/176

NJ 1992/129

NJ 1991/231

NJ 1994/170

NJ 1992/225
Omgangsregeling na echtscheiding

Onderscheid op grond van onwettige gebrorte

Sogut/Staat

Registratie kiesregister

Den Haag/Van Beveren

Omgangsrecht met onwettig kind

Binderen/Kaya

Suikerfeest

Getuigenverhoor

Optierecht

Touijri/Staat

Omgangsrecht met onwettig kind III

Ouderlijke macht voor ongehuwden

Bespiede bijstandsmoeder Edam

Amsterdam/lkon

St. Bavo/Gielen

Toescheidingsovereenkomst

Dekker/VJV I

Deltaschade

Naamrecht (Van Veen)

Definitie indirecte discriminatie

Bijstandsverhaal

Hoogenraad/NWO

Lelystad/Staat

Huwelijk lesbiěnnes

Huisman/Vries

Amsterdam/Ikon II

Dekker/VJV II 
13 december 1991

20 december 1991

24 april 1992

13 november 1992

7 mei 1993

31 december 1993

8 april 1994

15 april 1994

22 april 1994

29 april 1994

10 augustus 1994

13 januari 1995

20 januari 1995

24 februari 1995

7 april 1995

22 december 1995

29 mei 1996

3 januari 1997

17 januari 1997

27 mei 1997

5 september 1997

7 november 1997

13 februari 1998

8 mei 1998

6 november 1998

26 maart 1999

28 mei 1999

10 november 2000

24 november 2000

31 maart 2000

16 februari 2001

30 maart 2001
NJ 1993/363

NJ 1992/180

JAR 1992/14

RN 1992/255

NJ 1992/689

NJ 1993/502

RvdW 1993/101

NJCM 1993, 694

NJ 1995/259

NJ 1994/436

NJ 1994/704

NJ 1994/608

NJ 1994/560

NJ 1994/625

NJ 1995/58

NJ 1995/430

NJCM 1995/344

NJ 1995/326

NJ 1995/468

AB 1995/608

NJ 1996/580

NJ 1998/217

AB 1996/295

JB 1996/185

NJ 1997/435

NJ $1997 / 483$

NJ 1997/577

NJ 1998/686

NJ 1998/399

AB 1998/281

JB 1998/90

AB 1998/106

RvdW 1998/206

NJ 1999/446

NJ 1999/816

NJ 2001/187

NJ 2001/376

JB 2000/133

JB 2001/106

NJ 2001/292
NBBS/Akel

Steijnen/Staat

Bouma/KLM

El Hammouti/Staat

Ongehuwde onderwijzeressen

Van den Berge/Verenigde Bootlieden BV

Agfa

Valkenhorst

Theves

Alimentatiebeëindiging bij homofiele

concubinaatsverhouding

General Accident/Staat

Codfried/ISS

Verjaringstermijn vaderschapsactie

Brieven van wettiging

Bakir/Staat

IBG/Groenhart

Wessels

Zorggroep Oost-Gelderland/Gerrits

Erfenis onwettig kind

Cassatie bij verstekvonnis

Adoptie door lesbisch paar

Levi/Zaanwerk

Scholingsbesluit bijstandsgerechtigden

Leeftijdsgrens voor commissarissen

Bos/KLM

Belangenbehartiging Erfpachters Den Haag/Den

Haag

Nassy-Tseng/Eilandgebied Curaçao

Komdeur/Eilandbestuur Curaçao

Landsverordening Toelating en Uitzetting

Scholingsbesluit bijstandsgerechtigden

Kiesrecht Antillen

Stichting Pensioenfonds Medische Specialisten/V

\section{Afdeling Rechtspraak Raad van State}

\section{S april 1977}

5juli 1979

1 augustus 1980

Inovember 1980
AB 1977/309
Dakkapellen
AB 1980/414
AB $1981 / 5$
AB 1981/346
Economische gebondenheid Zaanstad
Maatbouw/Weststellingswerf
Leijtens/Van Waalwijk 


\section{5 januari 1982}

1 augustus 1983

15 augustus 1983

6 november 1984

11 januari 1985

21 maart 1985

15 augustus 1985

9 september 1985

18 november 1985

2 januari 1986

14 januari 1986

20 februari 1986

15 september 1986

30 juni 1987

2 september 1987

18 maart 1988

2 januari 1989

20 juli 1990

14 april 1991

22 april 1991

27 augustus 1991

2 maart 1993

23 augustus 1993

21 oktober 1993

Vz. ARRS $10 \mathrm{mei}$ 1979
AB 1982/332

AB 1984/532

NJCM 1983/166

AB 1983/539

AB 1985/417

AB 1986/92

AB 1986/16

AB 1986/250

AB 1986/83

AB 1986/293

AB 1986/443

AB 1986/519

AB 1986/438

AB 1987/280

AB 1988/207

AB 1988/303

AB 1988/342

AB 1989/392

AB 1991/595

AB 1991/625

AB 1991/603

AB 1992/313

AB 1993/364

AB 1994/111

AB 1994/357

AB 1979/472
Economische binding Wamel

Humanistisch vormonderwijs

\section{Servicestation}

Verhuis- en herinrichtingskostenvergoeding

Subsidiëring vervanging bij ziekte

Humanistisch vormingsonderwijs Putten

Pensioentoeslag ambtenaren Antillen II

Inschrijving filiatieregister

Stichting Humanistisch Vormingsonderwijs III

Woonwagenwetvergunning

Subsidiëring rijvereniging

Van Geleuken/Noordoostpolder

Zendtijd Humanistisch Verbond

Benadeling gewetensbezwaarden t.o.v. dienstplichtigen

Humanistisch Vormingsonderwijs Valkenswaard

Humanistisch Vormingsonderwijs Oldebroek

Rietkerk-uitkering

Terugploegexperiment

Verblijfsvergunning broers

Tegemoetkoming scholingskosten

Speelautomatenhal

Verschil bij bevoegdheidsuitoefening

Parkeervergunningen

Begeleidingssubsidie vrije school

Directe werking art. 26 Bupo

\section{Afdeling Bestuursrechtspraak Raad van State}

3 maart 1994

26 mei 1994

2 juni 1994

5 juli 1994

2 september 1994

3 november 1994

21 februari 1995

28 februari 1995

8 mei 1995

28 december 1995

15 januari 1996

27 juni 1996

25 juli 1996

26 september 1996

10 oktober 1996

19 december 1996

10 februari 1997

24 april 1997
AB 1995/85

AB 1995/179

AB 1994/629

AB 1995/180

AB 1995/146

AB 1995/13

AB 1996/222

AB 1995/439

AB 1995/401

AB 1996/206

AB 1999/185

AB $1998 / 50$

AB 1996/425

AB $1996 / 483$

AB 1996/482

AB 1997/414

JB 1997/85

JB 1997/149
Leeftijdscriterium woonruimteverdeling

Medewerkersovereenkomst AWBZ

Ligplaatsenverordening Friesland

Vrijlatingsregeling

Medewerkersovereenkomst met 65-plusser

Beleid bij autokeuringen

Verwerving adeldom in vrouwelijke lijn

Territorialiteitsbeginsel IOAW

Recreatiewoningen Ameland

Sluiting veemarkt

Hoger beroep vreemdelingenzaken

Bouwvergunning woonwagens

Uitvoer bedrijfsafvalstoffen

Uitstallingsbeleid Bos en Lommer

Betonnen casco bij woonboot

Hervormde jeugdraad Blokland

Parkeerbeleid Leiden

Pensioenuitkering KNIL-militairen 


12 juni 1997
9 december 1997
2 februari 1998
5 juni 1998
20 juli 1998
4 augustus 1998
5 november 1998
11 december 1998
16 maart 1999
19 maart 1999
17 mei 1999
1 juni 1999
15 november 1999
18 januari 2000
29 februari 2000
27 april 2000
9 mei 2000
15 september 2000
13 februari 2001
Vz. ABRS 26
september 1997

JB $1997 / 189$

JB $1998 / 10$

AB 1998/181

AB 1998286

AB 1998/406

AB 1998/377

AB 1999/100

JB 1999/15

JB $1999 / 102$

JB $1999 / 103$

AB 1999/294

AB 1999/313

JB 2000/8

JB 2000/53

AB 2001/1

AB 2000/243

JB 2000/179

AB 2001/154

JB 2001/109

AB 1998/140
Stichting Silicose Oud-Mijnwerkers II

Pensioenuitkering weduwe KNIL-militair

Faas en Deen/Lisse

Woonschipbeleid Amsterdam

Ligplaats Omzigt

Loting geneeskunde II

Pensioenuitkering KNIL-militairen II

Opslag caravans

Vererving adeldom via vrouwelijke lijn II

Vervangend rijbewijs

Verpleeghuisarts

Aanwijzing examenbevoegde zeilschool

Huursubsidie en nabetaling

Koffieshops

Vermindering bedden verpleeghuis

Afgifte rijbewijs

Dakkapellen

Kapvergunning Medemblik

Bijdrage premiederving

Loting geneeskunde

\section{Centrale Raad van Beroep}

8 april 1964
26 april 1977
11 juni 1981
I november 1983
9 juli 1985
14 mei 1987
4 juni 1987
13 oktober 1988
5 januari 1988

9 maart 1988

10 augustus 1988

16 november 1988

7 december 1988

25 mei 1989

14 juni 1989

19 juli 1989

30 augustus 1989

6 september 1989

28 september 1989

5 oktober 1989

28 februari 1990
ARB 1964/872

AB 1978/46

AB 1981/458

RSV 1984/147-

150

SV $1985 / 111$

RSV $1987 / 246$

SV $1988 / 1016$

RSV 1988/118

RSV 1988/198,

199 en 200

AB 1988/252

RSV 1988/269

RSV 1989/94

RSV 1989/64

RSV 1989/67

AB 1989/10

RSV 1989/275

AB 1991/418

RSV 1989/126

RSV 1990/92

RSV 1990/150

RSV 1990/235

RSV 1990/132

RSV 1990/295
Posthume gelijkheid

Overwerkuren bij ziekengeld

Salarisindeling artsen

Directe werking art. 26 IVBPR I

Werkloosheidsuitkering bij alternatieve straf

Directe werking art. 26 IVBPR II

Korting uitkering WUV 1940-1945

Referentievoeding

Overgangsrecht AAW

Dagloon musici

Overgangsregeling WAO

Premievaststelling fysiotherapeuten AWW

Weduwenuitkering WUV bij concubinaat

Premievaststelling fysiotherapeuten II

Premievaststelling fysiotherapeuten III

Onderhoudsbijdrage AKW

Pleegouderschap

Medeverzekering ongehuwde partner ZFW

Weduwnaarspensioen Wbp 1940-1945

AWW-uitkering ongehuwde partner 
21 maart 1990

19 april 1990

9 mei 1990

12 december 1990

9 april 1991

16 april 1991

15 mei 1991

23 mei 1991

23 mei 1991

5 juni 1991

10 juli 1991

10 juli 1991

25 juli 1991

16 oktober 1991

26 november 1991

9 januari 1992

6 februari 1992

17 maart 1992

14 april 1992

14 april 1992

26 mei 1992

23 juni 1992

1 oktober 1992

3 november 1992

24 november 1992

19 februari 1993

29 april 1993

24 mei 1993

18 juni 1993

20 juli 1993

3 november 1993

4 november 1993

21 januari 1994

11 februari 1994

22 februari 1994

23 februari 1994

19 april 1994

3 mei 1994

21 juni 1994

21 oktober 1994

22 november 1994

20 maart 1995

2 mei 1995

30 juni 1995

8 augustus 1995

20 september 1995

11 oktober 1995

18 oktober 1995
RSV $1990 / 320$

RSV 1990/323

RSV 1990/383

RSV 1991/264

RSV 1991/247

RSV 1991/212

RSV 1991/158

RSV 1991/256

RSV 1991/257

RSV 1992/18

RSV 1992/21

RSV 1992/76

RSV 1992/77

RSV 1992/138

RSV 1992/144

AB 1992/344

RSV 1992/282

RSV 1993/6

AB 1992/419

RSV 1993/24

RSV 1993/42

RSV 1993/44

RSV 1992/317

RSV 1993/14

RSV 1994/114

RSV 1993/147

RSV 1993/263

RSV 1993/307

RSV 1994/43

RSV 1994/68

RSV 1994/45

RSV 1994/94

AB 1994/213

RSV 1994/192

RSV 1994/217

RSV 1994/198

RSV 1994/219

RSV 1994/225

AB 1994/667

AB 1995/106

AB 1995/341

RSV 1995/107

RSV 1995/244

AB 1996/190

RSV 1996/206

RSV 1996/4

AB 1996/20

AB 1996/72

AB 1996/77
Vakantiebonnen

Teuling-Worms

AWW-uitkering bij huwelijk met gepensioneerde

Leeftijdsgrens AWW

Drie-uit-vijf-eis WW

Uitlooptermijn bij vervallen arbeidsongeschiktheid

Pensioenopbouw buitenlandse werknemers

Overgang van AAW naar AWW-uitkering

Overgang van AAW naar AWW-uitkering

Onderscheid burgerlijke staat AWW

Overgangsregeling AOW

Samenwonende bloedverwanten AOW

Verhouding AOW-AAW

Onderscheid burgerlijke staat AWW

Gezamenlijke huishouding bloedverwanten AAW

Benadeelde WUV-mannen

Verloskundige zorg door huisarts bij Zfw

Wooneis AAW

Wezenpensioen als eigen inkomen kind

Intrekking arbeidsongeschiktheidsuitkering

ADL-assistentie

Inkomenseis AAW

Eigen bijdrageregeling AWBZ

Identiek aan CRvB 17 maart 1992; zie daar.

Werkloze zeelieden

Daad van verzet Wbp 1940-1945

AAW-aanspraak na $65^{\text {ste }}$ levensjaar

Leeftijdscriterium AWW

Samenloop AAW-uitkeringen

Leeftijdscriterium eigen bijdrage AWBZ

Leeftijdseis AAW

Van Maarseveen

Verplichte verzekering WTZ

Nederlandervereiste AWW/AOW

Kostwinnersvereiste WWV

Uitzondering inkomenseis AAW

Wooneis AAW III

Beperking eigen bijdrage $A W B Z$

Wooneis AAW

Overgangsregeling AOW

WW-uitkering leraren

Toepassing WW-dagloon

Samenwonende bloedverwanten

Samenleving aanverwanten

Subjecttoets WW-uitkering tijdens opleiding

Kostwinnerscriterium medeverzekering

ziekenfonds

Overgangsregeling AAW

AWW-uitkering voor ongehuwden 
29 april 1996

15 mei 1996

17 juli 1996

13 augustus 1996

18 september 1996

16 oktober 1996

17 oktober 1996

24 december 1996

7 januari 1997

12 februari 1997

II april 1997

27 november 1997

10 december 1997

14 januari 1998

16 januari 1998

I april 1998

28 mei 1998

2 juni 1998

4 november 1998

24 november 1998

23 februari 1999

12 augustus 1999

22 oktober 1999

26 oktober 1999

23 november 1999

25 november 1999

26 november 1999

26 november 1999

4 januari 2000

5 juli 2000

19 juli 2000

6 september 2000

21 september 2000

4 oktober 2000

7 november 2000

14 november 2000

29 november 2000

24 januari 2001

2 mei 2001

26 juni 2001

5 september 2001
RSV 1996/247

RSV 1996/170

AB 1996/518

AB 1996/461

RSV 1997/154

AB 1997/140

RSV 1997/235

JB 1997/30

RSV 1997/115

RSV 1997/227

AB 1997/242

RSV 1998/56

JB 1998/58

RSV 1998/179

RSV 1998/160

RSV 1998/187

AB 1998/244

RSV 1998/230

JB 1998/285

RSV 1998/38

AB 1999/77

RSV 1999/119

RSV $2000 / 73$

AB 2000/289

RSV $2000 / 22$

RSV $2000 / 28$

JB 1999/307

JB 2000/14

RSV $2000 / 50$

RSV $2000 / 79$

JB 2000/257

JB 2000/259

JB 2000/311

JB 2000/313

RSV 2001/19

RSV 2001/22

RSV 2001/32

RSV 2001/54

RSV $2001 / 138$

RSV 2001/164

JB 2001/184

USZ 2001/271
WW-uitkering huishoudelijk personeel

Posthuma-van Damme

AOW-uitkering bloedverwanten

Uitzondering inkomenseis AAW

Verlenging kinderbijslag JWG

Referte-eis AAW

Inkomenseis Rariteitenbesluit WAO

Premieplicht Leergang Bedrijfskunde

Achterstand bij heronderzoeken $\mathrm{ABW}$

WW-uitkering vreemdelingen

Inkomenseis AAW

Verzekeringsplicht interim-managers

Uitkering ongehuwden AWW

Onderhoudsbijdrage AKW

Inkomensvereiste AAW

AOW voor gehuwden

Malusbeschikkingen Wet Amber

Bijstand kosten opleiding

Wet Van Otterloo

Gezamenlijke huishouding met broer

Aanvangsdatum fictief arbeidsverleden

Inkomensvereiste thuiswerkers

Persoonsgebonden budget thuiszorg

WW-uitkering musicus

Gezamenlijke huishouding zusters; AOW

Tegemoetkoming ziektekosten (Btzr)

Penisprothese

Verlaging eigen bijdrage zwakzinnigen.

Noodzakelijke scholing Abw

Referte-eis seizoensmedewerkers

WW-uitkering Zwitserse hoofdwerktuigkundige

Korting uitkering wegens verwijtbare

werkloosheid

Scholierenregeling

Overgangsregeling Anw

TOG-regeling

Bijzondere bijstand Breukelen

Zigeunerhuwelijk

Inkomensafhankelijkheid Anw

Inkomensafhankelijkheid AOW

Koppelingswet

Onverzekerbaar risico Anw

\section{Commissie gelijke behandeling van mannen en vrouwen bij de arbeid}

$\begin{array}{lll}\text { Oordeel 3068-89-1 } & 18 \text { oktober } 1989 & \begin{array}{l}\text { Verbreking samenwerkingsrelatie } \\ \text { fysiotherapeuten } \\ \text { Overwerkregeling bedrijfs-CAO }\end{array}\end{array}$


Oordeel 35-90-138

Oordeel 163-91-13

Oordeel 150-91-19

Oordeel 331-91-40

Oordeel 374-92-04

Oordeel 398-92-40

Oordeel 467-92-68

Oordeel 429-93-06

Oordeel 445-93-09

Oordeel 553, 555 en 556-93-10 t/m 12

Oordeel 551-93-16

Oordeel 439-93-22

Oordeel 466-93-34

Oordeel 529-93-43

Oordeel 623-93-46

Oordeel 531-93-47

Oordeel 613-93-55

Oordeel 614-93-57

Oordeel 513-93-58

Oordeel 463A-94-02

Oordeel 667-94-05

Oordeel 669-94-06 $\mathrm{t} / \mathrm{m} 21$

Oordeel 704-94-38
15 november 1990

10 april 1991

8 april 1991

24 juni 1991

4 februari 1992

14 juli 1992

22 december 1992

26 januari 1993

3 maart 1993

23 maart 1993

20 april 1993

7 juni 1993

30 september 1993

5 november 1993

23 november 1993

1 december 1993

29 december 1993

31 december 1994

31 december 1993

12 januari 1994

26 januari 1994

26 januari 1994

24 mei 1994
VUT-regeling CAO levensmiddelensector

Ouderschapsverlofregeling Rotterdam

Lengte-eis bedrijfsassistenten

Deeltijdwerk Raad van State

VUT-regeling afroepkracht

ADV-regeling onderwijs

$A D V$ bij wisseldienstroosters

Netto-uurloon uitzendkrachten

Leeftijdseis opleiding belastinginspecteur

Ontslag wegens reorganisatie

Ontslagen wegens reorganisatie

Doorbetaling arbeidsongeschiktheid

Anciënniteit deeltijdrechters

Rangorde ontslag en overplaatsing

Seniorenregeling Uden

Inverdienregeling

Reorganisatie schoonmaakdienst

Deeltijdwerk accountantsbedrijf

Minimum dienstomvang verpleegkundigen

Bijzondere uren supermarktsector

Minimum dienstverband reisorganisatie

Ontslag loodsmedewerkers

Afvloeiingsregeling kostwinners

\section{Commissie Gelijke Behandeling}

Oordeel 94-01

Oordeel 94-05

Oordeel 94-06

Oordeel 94-19

Oordeel 95-06

Oordeel 95-14

Oordeel 95-17

Oordeel 95-19

Oordeel 95-20

Oordeel 95-22

Oordeel 95-27

Oordeel 95-30

Oordeel 95-32

Oordeel 95-33

Oordeel 95-35

Oordeel 95-43
1 december 1994

21 december 1994

30 december 1994

30 december 1994

\section{7 maart 1995}

9 mei 1995

30 mei 1995

30 mei 1995

7 juni 1995

30 juli 1995

18 juli 1995

18 juli 1995

10 augustus 1995

23 augustus 1995

25 augustus 1995

30 oktober 1995
Ontslag wegens beroep op ouderschapsverlof Arbeidstijdvermindering oudere werknemers Reorganisatieplan universiteit

Doorstroombeleid accountancy- en adviesorganisatie

Arbeidstijdvermindering oudere werknemers thuiszorg

Toepassing anciënniteitsbeginsel bij ontslag

BBRA'84 en Rbpo

Uitsluiting deeltijdwerkers van pensioenfonds

Uitsluiting deeltijders van pensioenreglement bibliotheek

Studie- en beroepskeuzevoorlichting bij

christelijke organisatie

Interimuitkering ziektekosten

Taaleis kamermeisje

Vereiste om voltijds te werken

Gratificatieregeling ambtsjubileum

Voorkeursbeleid aio's wijsbegeerte

Affectieve relatie met collega 
Oordeel 95-54

Oordeel 95-69

Oordeel 96-03

Oordeel 96-05

Oordeel 96-06

Dordeel 96-07

Oordeel 96-12

Oordeel 96-15

Oordecl 96-27

Oordeel 96-29

Oordeel 96-32

Oordeel 96-34

Oordeel 96-36

Oordeel 96-44

Oordeel 96-51

Oordeel 96-55

Oordeel 96-56

Oordeel 96-59

Dordeel 96-60

Oordeel 96-68

Oordeel 96-71

Oordeel 96-75

Oordeel 96-81

Oordeel 96-85

Oordeel 96-87

Oordeel 96-90

Oordeel 96-95

Oordeel 96-101

Oordeel 96-109

Oordeel 96-111

Oordeel 96-117

Oordeel 96-118

Oordeel 97-04

Oordeel 97-06

Oordeel $97-13$

Oordeel $97-23$

Oordeel 97-24

Oordeel 97-30

Oordeel 97.35

Oordeel 97-43

Oordeel 97.45

Oordeel $97-46$

Oordeel 97-61

Oordeel 97-67

Oordeel 97.71

Oordeel $97-72$

Oordeel $97-75$
27 november 1995

2 december 1995

18 januari 1996

30 januari 1996

1 februari 1996

6 februari 1996

6 maart 1996

18 maart 1996

26 maart 1996

2 mei 1996

9 mei 1996

14 mei 1996

23 mei 1996

28 mei 1996

20 juni 1996

1 juli 1996

14 mei 1996

15 juli 1996

15 juli 1996

29 juli 1996

30 juli 1996

27 september 1996

15 oktober 1996

17 oktober 1996

24 oktober 1996

5 november 1996

13 november 1996

19 november 1996

25 november 1996

26 november 1996

19 december 1996

23 december 1996

15 januari 1997

7 januari 1997

4 februari 1997

21 maart 1997

26 maart 1997

3 april 1997

8 april 1997

18 april 1997

23 april 1997

23 april 1997

3 juni 1997

11 juni 1997

17 juni 1997

18 juni 1997

25 juni 1997
Naamsvermelding eurocheques

Acceptatievoorwaarden kredietbank I

Ouderschapsverlofregeling

Sollicitatie politiekorps

Bootpas Terschelling

Rechtspositiebesluit onderwijspersoneel

Kredietverlening vreemdelingen

Pensioenregeling zeefdrukkerij

Pensioen arbeidsongeschikte

Taaleis schoonmaakster

Deeltijdwerk leerkrachten basisonderwijs

Positieve discriminatie bij kinderopvang

Kinderoppas

Kinderopvang VROM

Pensioenregeling havenbedrijf

Taalvereiste strijksters

Studieverlof bedrijfsartsen

Jehova's getuige als bankmedewerkster

Mobiele telefoon

Praktiserend christen

Rechtspositiebesluit Onderwijspersoneel

(RPBO) II

Taalvereiste administratief werk

Ontslag wegens reorganisatie

Hoofddoek in strijd met

veiligheidsvoorschriften

$\mathrm{CAO}$ thuiszorg

Berekening inkomensschade

Ziekmelding en aftrek verlofdagen

Taalvereiste receptioniste

Hoofddoek uitzendbureau

Publicatievereiste onderzoeksschool

Korter dienstverband 55-plussers in thuiszorg

Christelijke identiteit keukenhulp

Inschaling stewardessen

Kostenbijdrage maaltijden militairen

Aziatische scheepsgezellen

Bidden op de werkplek

Kledingvereisten Sikh

Medewerkster pastorale dienst

Kinderopvangregeling Algemene

Rekenkamer

Taalvereiste schoonmaakfunctie

Vakantieregeling

Jehovah's Getuige als verpleegkundige

Ouderdoms- en nabestaandenpensioen

Kinderopvangregeling vleessector

VUT- en spaarloonregeling grafisch bedrijf

Overuren deeltijdwerkers

Kinderopvang ziekenhuis 
Oordeel 97-81

Oordeel 97-84

Oordeel 97-88

Oordeel 97-92

Oordeel 97-93

Oordeel 97-96

Oordeel 97-97

Oordeel 97-102

Oordeel 97-106

Oordeel 97-110

Oordeel 97-112

Oordeel 97-114

Oordeel 97-117

Oordeel 97-119

Oordeel 97-127 $\mathrm{t} / \mathrm{m} 130$

Oordeel 97-131

Oordeel 97-140

Oordeel 97-144

Oordeel 97-145

Oordeel 97-148

Oordeel 97-149

Oordeel 98-01

Oordeel 98-04

Oordeel 98-05

Oordeel 98-07

Oordeel 98-13

Oordeel 98-16

Oordeel 98-18

Oordeel 98-19

Oordeel 98-22

Oordeel 98-24

Oordeel 98-41

Oordeel 98-43

Oordeel 98-49

Oordeel 98-50

Oordeel 98-56

Oordeel 98-66

Oordeel 98-67

Oordeel 98-68

Oordeel 98-73

Oordeel 98-78

Oordeel 98-79

Oordeel 98-93

Oordeel 98-96

Oordeel 98-102

Oordeel 98-106
3 juli 1997

14 juli 1997

15 juli 1997

13 augustus 1997

3 september 1997

9 september 1997

9 september 1997

25 augustus 1997

13 oktober 1997

29 oktober 1997

4 november 1997

10 november 1997

20 november 1997

27 november 1997

11 december 1997

22 december 1997

22 december 1997

22 december 1997

23 december 1997

23 december 1997

24 december 1997

13 januari 1997

22 januari 1997

21 januari 1998

22 januari 1998

16 februari 1998

25 februari 1998

5 maart 1998

9 maart 1998

13 maart 1998

16 maart 1998

28 april 1997

27 april 1998

12 mei 1998

28 april 1998

25 mei 1998

8 juni 1998

8 juni 1998

11 juni 1998

29 juni 1998

6 juli 1998

6 juli 1998

25 augustus 1998

2 september 1998

16 september 1998

9 september 1998
Melkert II-regeling

Pas 65

Vrijwilligers ontwikkelingslanden

Ouderschapsverlof bij benzinestation

Werkervaring gemeenteambtenaar

Eis Nederlands spreken op de werkplek

Paspoortvereiste bij mobiele

telefoonaansluiting

Ouderschapsverlof maatschappelijk werkster

Leeftijdsgrenzen NWO-subsidies

Praktijkproef stukadoorsbedrijf

Termijnen vliegbevoegdheid

Afvloeiingsregeling basisschool

Afwijzing wegens verblijfstitel

Levering wasmachine op woonwagenterrein

Diacritische tekens

Schoolinformatie voor gescheiden vader

Tegemoetkoming ziektekosten

onderwijspersoneel

Ouderenregeling openbare bibliotheek

Pensioenopbouw vervangster onderwijs

Hinderlijke geloofsuitingen

Hoofddoek tijdens gymles

Diplomavereiste

Deeltijders in OR

Inschrijvingsvoorwaarden videotheek

Acceptatiebeleid kredietbank

Partner als medewerker

Pensioenregeling huishoudelijk personeel

Nivra-opleidingskosten

Taalvereiste boekverkoper

Pensioenregeling belastingadvieskantoor

Duobaan

Pensioenregeling montagelaborante

Inconveniëntietoeslag toneelmeester

EHBO-cursus

Gay Games

Deeltijdwerk productmanager

Anciěnniteit bij afvloeiingsregeling.

Pensioenopbouw ABP

Taalvaardigheidseis automatisering

Verklaring van geen bezwaar

Project Wisselwerk

Lange mouwen bij bewegingsonderwijs

Pensioenregeling gehuwden met groot

leeftijdsverschil

Seniorenregeling $\mathrm{CAO}$ NOB

Meenemen ervaring bij inschaling

Inconveniëntietoeslag hulpkrachten winkels 
Oordeel 98-118 Oordeel 98-119 oordeel 98-124 Oordeel 98-126 Oordeel 98-132 Oordeel 98-137 Oordeel 98-139 Oordeel 98-144 Oordeel 98-150 Dordeel 98-151 Oordeel 98-152 Oordeel $99-02$ Oordeel 99-07 Dordeel 99-10 Oordeel 99-19 Oordeel 99-20 Dordeel 99-22 Oordeel 99-24 Oordeel 99-28 Oordeel 99-31 Oordeel 99-49 Oordeel 99-50 Oordeel 99-57 Oordeel 99-58 Oordeel 99-65 Oordeel 99-87 Oordeel 99-94 Oordeel 99-98 Oordeel 99-101 Oordeel 99-102 Oordeel 00-04 Oordeel 00-05 Oordeel 00-06 Oordeel 00-12

Oordeel $00-15$

Oordeel 00-18

Oordeel 00-22

Oordeel 00-24

Oordeel 00-28

Oordeel 00-35

Oordeel 00-36

Oordeel 00-37

Oordeel 00-39

Oordeel 00-40

Oordeel 00-48

Oordeel 00-60
27 oktober 1998

3 november 1998

16 november 1998

19 november 1998

8 december 1998

15 december 1998

15 december 1998

21 december 1998

24 december 1998

24 december 1998

24 december 1998

19 januari 1999

28 januari 1999

2 februari 1999

11 februari 1999

11 februari 1999

24 februari 1999

23 maart 1999

26 maart 1999

19 april 1999

1 juni 1999

9 juni 1999

8 juni 1999

21 juni 1999

6 juli 1999

12 november 1999

7 december 1999

13 december 1999

16 december 1999

22 december 1999

7 februari 2000

8 februari 2000

9 februari 2000

21 maart 2000

28 maart 2000

5 april 2000

6 april 2000

4 mei 2000

19 mei 2000

6 juni 2000

13 juni 2000

14 juni 2000

30 juni 2000

3 juli 2000

4 juli 2000

31 augustus 2000
Pensioenopbouw vervangende leerkrachten

Pensioenregeling zwembad

Registratie echtgenoten als aandeelhouder

Werktijdenregeling slachterij

Werkindeling psychiatrische inrichting

Homoseksuele bloeddonoren

Homoseksuele spermadonoren

Kinderopvangregeling Haarlemmermeer

ADV Ministerie van Defensie

Wisselwerk-regeling II

Diplomavereisten APK-keuring

Pensioenopbouw vervangster basisonderwijs

Feestdagenregeling $\mathrm{CAO}$

Leeftijdseis raio-opleiding

Christelijke fysiotherapeut.

Uitsluiting deeltijders van pensioenregeling

Verandering werktijden

Inroostering onregelmatige diensten

Verlofregeling Randstad Noord

Voorkeursbeleid allochtonen

Bidden op het werk

Zangdocenten

Voorkeursbeleid Gelderland

Voordeelkrant supermarkt

Aflevering meubels in woonwagenkamp

Taalbeleid sportcentrum

Overgang $\mathrm{CAO}$ indicatieorgaan

Verhuur apparatuur aan niet-Nederlanders

Dienstauto deeltijdwerker

Dierenparkbezoek op zondag

IVF-instellingen

Salarisregeling $\mathrm{OK}$-assistenten

Pensioenopbouw oproepkracht

Éloignement en duurtetoeslag uitgezonden

militairen

Taalvereiste glastuinbouw

Partner Kaapverdiaan als bloeddonor

Werkervaring bij dienstverlening

gehandicapten

Ureneis ADV bij onderzoeksbureau

Acceptatievereisten mobiel

telefoonabonnement

Deeltijdwerkers psychiatrische inrichting

Iraans accent peuterleidster

Deeltijdpensioenen

Overgangsregeling

Gezondheidszorgpsychologen

WTV-opbouw deeltijdwerkers

Ondernemings- $\mathrm{CAO}$ voor financieel concern

Fulltime werkende oproepkracht 
Oordeel 00-63

Oordeel 00-65

Oordeel 00-66

Oordeel 00-70

Oordeel 00-81

Oordeel 00-90

Oordeel 00-93

Oordeel 00-97

Oordeel 00-99

Oordeel 01-05

Oordeel 01-06

Oordeel 01-12

Oordeel 01-16

Oordeel 01-17

Oordeel 01-20

Oordeel 01-24

Oordeel 01-26

Oordeel 01-36

Oordeel 01-44

Oordeel 01-53

Oordeel 01-68

Oordeel 01-69

Oordeel 01-84

Oordeel 01-90

Oordeel 01-91

Oordeel 01-97

Oordeel 01-109

Oordeel 01-140

Oordeel 01-141

Oordeel 01-143
6 september 2000

19 september 2000

28 september 2000

31 oktober 2000

11 december 2000

18 december 2000

22 december 2000

29 december 2000

29 december 2000

16 januari 2001

16 januari 2001

31 januari 2001

22 februari 2001

31 januari 2001

28 februari 2001

13 maart 2001

13 maart 2001

26 april 2001

31 mei 2001

22 juni 2001

27 juli 2001

31 juli 2001

21 augustus 2001

2 oktober 2001

11 oktober 2001

5 november 2001

26 november 2001

18 december 2001

18 december 2001

20 december 2001
Chador

Kinderopvangregeling regionale politie

Uitruil nabestaandenpensioen

Alfahulpen

Kinderopvangregeling UM

Hepatitis B vaccinatieprogramma

Assistent Analist Landstrijdkrachten

Meerurenvergoeding

HOS-regeling

Winstdeling bij meerwerk

Kappers

Taalvereiste peuterleidster

Arbeidsvoorwaarden topambtenaren

Creditcard als borg

Rpbo

Nabestaandenpensioen bij groot

leeftijdsverschil

Acceptatiebeleid mobiel telefoonabonnement

Regeling wachtdiensten

$35 \%$-Regeling

Hoofddoek griffier

Stageverlenging advocatuur

Accommodatie asielzoekers

Erkenning buitenlands diploma

Woonruimteverdelingssysteem

Acceptatiebeleid consumentenkrediet

Nederlands in café

Woonruimteverdeling Haarlem

Pensioenopbouw taalschool

Kappersmodel

Directiesecretaresse 


\section{Literatuur}

Abraham 1998: H.J. Abraham, The Judicial Process. An Introductory Analysis of the Courts of the United States, England, and France, Seventh Edition, Oxford University Press, New York, Oxford, 1998

Abramson 1984: L.W.Abramson, "Equal Protection and Administrative Convenience", 52 Tennessee Law Review 1 (1984)

Ackerman 1985: B. Ackerman, "Beyond Carolene Products", 98 Harvard Law Review 713 (1985)

Adamany 1991: D. Adamany, "The Supreme Court", in: Gates, J.B. en Johnson, Ch.A. (red.), The American Courts. A Critical Assessment, CQ Press, Washington 1991

Addink 1999: G.H. Addink, De algemene beginselen van behoorlijk bestuur, Kluwer, Deventer 1999

Aleinikoff 1987: T.A. Aleinikoff, "Constitutional Law in the Age of Balancing", 96 Yale Law Review 943 (1987)

Aleinikoff 1991: T.A. Aleinikoff, "A Case for Race-Consciousness", 91 Columbia Law Review 1060 (1991)

Alexander 1978: L.A. Alexander, "Introduction: Motivation and Constitutionality", 15 San Diego Law Review 925 (1978)

Alexander 1992: L.A. Alexander, "What Makes Wrongful Discrimination Wrong? Biases, Preferences, Stereotypes, and Proxies" 141 University of Pennsylvania Law Review 149 (1992)

Alexy 1985: R. Alexy, Theorie der Grundrechte, editie Suhrkamp taschenbuch wissenschaft, oorspronkelijk 1985

Alkema 1975: E.A. Alkema, "Rechterlijk toezicht en de Europese vrijheidsrechten. Enige 'Europese' kanttekeningen naar aanleiding van de marginale toetsing", in: Vrijheid en recht. Opstellen aangeboden aan Prof. $m r$ E.H. s'Jacob, W.E.J. Tjeenk Willink, Zwolle 1975, p. 1-26

Alkema 1978: E.A. Alkema, Studies over Europese grondrechten. De invloed van de Europese Conventie op het Nederlandse recht (Diss. Leiden), Kluwer, Deventer 1978

Alkema 1985: E.A. Alkema, "Rechter en mensenrechtenbeleid", in: Rechter en mensenrechtenbeleid: 10 jaar NJCM, Stichting NJCM-Boekerij, Leiden 1985, p. 15-27

Alkema 1987: E.A. Alkema, "Het internationale gelijkheidsbeginsel en de Nederlandse staatsrechtelijke verhoudingen. Wie leidt de wals van het gelijkheidsbeginsel?", in: Staatsrecht, buitenlandse betrekkingen en de internationale rechtsorde, Staatsrechtconferentie 1987, Ars Aequi Libri, Nijmegen 1987, p. 64-105

Alkema 1995: E.A. Alkema, "De reikwijdte van fundamentele rechten - de nationale en internationale dimensies", Handelingen NJV, $125^{e}$ Jaargang, 1995-I, p. 3-129

Anderman 1996: S. Anderman, "Constitutional Law and Labour Law Dimensions of Article 119: The Case of Justification for Indirect Discrimination", in: Dine, J. en Watt, B., Discrimination Law: Concepts, Limitations and Justifications, Longman, Londen, New York 1996

Aristoteles - Ethica: Aristoteles, The Nicomachean Ethics, vertaald in het Engels door D. Ross, Oxford University Press, Oxford, Londen 1980

Aristoteles - Politics: Aristoteles, Politics, vertaald in het Engels door B. Jowett, Clarendon Press, Oxford 1905

Arnull 1990: A. Amull, The General Principles of EEC Law and the Individual, Leicester University Press, London, Leicester 1990

Asscher-Vonk 1995: I.P. Asscher-Vonk, "De Algemene wet gelijke behandeling en de Wet gelijke behandeling mannen en vrouwen", SMA 1995, p. 617-628

Asscher-Vonk 1997: I.P. Asscher-Vonk, "Het verbod van onderscheid op grond van een verschil in arbeidsduur in art. 7:648 BW", SMA 1997, p. 387-400 
Asscher-Vonk/Konijn 2000: I.P. Asscher-Vonk en Y. Konijn, "Geslacht en arbeidsduur", in: T Loenen (red.), Gelijke behandeling: oordelen en commentaar 1999, Kluwer, Deventer 2000, p. Asscher-Vonk/Konijn 2001: I.P. Asscher-Vonk en Y. Konijn, "Geslacht", in: T. Loenen (red.), Gelijke behandeling: oordelen en commentaar 2000, Kluwer, Deventer 2001, p. 27-43 Baker 1980: C.E. Baker, "Neutrality, Process and Rationality: Flawed Interpretations of Equal
Protection", 58 Texas Law Review 1029 (1980)

Ball 1974: M.S. Ball, "Judicial Protection of Powerless Minorities", 59 lowa Law Review 1059 (1974)

Banton 1999: M. Banton, "Discrimination Entails Comparison", in: Loenen, T., en Rodrigues, P.R., Non-Discrimination Law: Comparative Perspectives, Kluwer Law International, Den Haag/Boston/Londen 1999, p. 107-117

Barents 1983: R. Barents, "Artikel 95 en de gemeenschappelijke markt", $S E W$ 1983, p. 438-482

Barents 1985: R. Barents, "The System of Deposits in Community Agricultural Law: Efficiency v. Proportionality", European Law Review 1985, p. 239-249

Barents 1986: R. Barents, "Recent Case-Law on the Prohibition of Fiscal Discrimination under Article 95", Common Market Law Review 1986, p. 641-660

Barents 1989: R. Barents, "Common agricultural law and the Court's case law in 1986-1988", Common Market Law Review 1989, 391-421

Barents 1994 (I): R. Barents, The Agricultural Law of the EC. An Inquiry into the Administrative Law of the European Community in the Field of Agriculture, Kluwer, Deventer 1994, p. 331-352

Barents 1994 (II): R. Barents, "The Significance of the Non-Discrimination Principle for the Common Agricultural Policy: Between Competition and Intervention", in: Curtin, D., en Heukels, T. (red.), Institutional Dynamics of European Integration. Essays in Honour of Henry G. Schermers, Volume II, Martinus Nijhoff, Dordrecht, Boston, London 1994, p. 527-548

Barents 1997: R. Barents, "Recent developments in Community case law in the field of agriculture", Common Market Law Review 1997, p. 811-843

Barnard 1996 (I): C. Barnard, "Gender and Commercial Discrimination", in: Dine, J. en Watt, B., Discrimination Law: Concepts, Limitations and Justifications, Longman, Londen, New York 1996, p. 63-76

Barnard 1996 (II): C. Barnard, "The economic objectives of Article 119", in: Hervey, T.K. en O'Keeffe, D., Sex Equality Law in the European Union, John Wiley \& Sons, Chistester 1996, p. 321-334

Barnard 1998: C. Barnard, "The principle of equality in the Community context: $P$, Grant, Kalanke and Marschall: four uneasy bedfellows?", Cambridge Law Journal 1998, p. 352-373

Barrett 1980: E.L. Barrett, "The Rational Basis Standard for Equal Protection Review of Ordinary Legislative Classifications", 68 Kentucky Law Journal 845 (1980)

Bastress 1974: R.M. Bastress, "The Less Restrictive Alternative in Constitutional Adjudication: An Analysis, A Justification, and Some Criteria", 27 Vanderbilt Law Review 971 (1974)

Bedau 1967: H.A. Bedau, "Egalitarianism and the Idea of Equality", in: Pennock en Chapman (red.), Nomos IX. Equality, Yearbook of the American Society for Political and Legal Philosophy, Atherton Press, New York 1967, p. 3-27

Van den Berge 1999: J.W. van den Berge, "Het gelijkheidsbeginsel", in: Gribnau (red.), Belastingrecht en ethiek in debat, Fed, Deventer 1999, p. 101-105

Van den Berge 2000: J.W. van den Berge, "Gelijkheid, de toepassing van het nondiscriminatiebeginsel (art. 14 EVRM en art. 26 IVBPR)", Weekblad voor Fiscaal Recht 2000, p. 895-901 
Bernard 1996 (I): N. Bernard, "What are the purposes of EC Discrimination Law?", in: Dine \& Watt, Discrimination Law: Concepts, Limitations and Justifications, Longman, Londen, New York 1996, p. 77- 99

Bernard 1996 (II): N. Bernard, "The future of European Economic Law in the Light of de the Principle of Subsidiarity", Common Market Law Review 1996, p. 633-666

Bell 1999: M. Bell, "The New Article 13 EC Treaty: A Sound Basis for European AntiDiscrimination Law?, Maastricht Journal of European and Comparative Law 1999, p. 5-23

Bennett 1979: R.W. Bennett, "'Mere' Rationality in Constitutional Law: Judicial Review and Democratic Theory", 67 California Law Review 1049 (1979)

Benn/Peters 1969: S.I. Benn en R.S. Peters, "Justice and Equality", in: Blackstone (red.), The Concept of Equality, Burgess Publishing Company, Minneapolis 1969, p. 54-81

Bergamin 1983: Bergamin, "Grondrechtelijke conflicten en gelijke behandeling", NJB 1983, p. $529-536$

Berger 1977: R. Berger, Government by Judiciary. The Transformation of the Fourteenth Amendment, Harvard University Press, Cambridge, Mass. and London 1977

Berlin 1969: I. Berlin, "Equality", in: Blackstone, W.T. (red.), The Concept of Equality, Burgess Publishing Company, Minneapolis 1969, p. 14-34

Bezzenberger 1996: T. Bezzenberger, "Ethnische Diskriminierung, Gleichheit und Sittenordnung im bürgerlichen Recht", Archiv für die civilistische Praxis 196 (1996), b.z. 395-434

Bhagwat 1997: A. Bhagwat, "Purpose Scrutiny in Constitutional Analysis", 85 California Law Review 297 (1997)

Bice 1977: S.H. Bice, "Standards of Judicial Review Under the Equal Protection and Due Process Clauses", 50 Southern California Law Review 689 (1977)

Bickel 1962: A.M. Bickel, The Least Dangerous Branch. The Supreme Court at the Bar of Politics, Bobs-Merrill Company Inc., Indianapolis, New York 1962

Bieback 1994: K.-J. Bieback, "Comment", in: McCrudden (red.), Equality of Treatment between Women and Men in Social Security, Butterworths, London, Dublin, Edinburgh 1994, p. 45-49

Van Bijsterveld 2000: S.C. van Bijsterveld, "Artikel 1", in: Koekkoek (red.), de Grondwet. Een systematisch en artikelsgewijs commentaar, W.E.J. Tjeenk Willink, Zwolle 2000, p. 63-74

Binion 1983: G. Binion, "'Intent' and Equal Protection: A Reconsideration”, 9 Supreme Court Review 397 (1983)

Blackstone 1969: W.T. Blackstone, "On The Meaning and Justification of Equality Principle", in: Blackstone (red.), The Concept of Equality, Burgess Publishing Company, Minneapolis 1969, p. 117-133

Blattner 1981: J.H. Blattner, "The Supreme Court's 'Intermediate' Equal Protection Decisions: Five Imperfect Models of Constitutional Equality”, 8 Hastings Constitutional Law Quarterly 777 (1981)

Bleckmann 1979: A. Bleckmann, "Der Beurteilungsspielraum im Europa- und im Vőlkerrecht", Europäische Grundrechte-Zeitschrift 1979, p. 485-495

De Boer 1995: J. De Boer, "De broedende kip in EVRM-zaken", NJB 1995, p. 1027-1034

Den Boer 1987: M.M. den Boer, "Artikel 1 Grondwet: gelijke behandeling en nondiscriminatie", AAe 1987, p. 132-138

Boest 1984: R. Boest, Die Agrarmärkte im Recht der EWG, Nomos, Baden-Baden 1984

Bossuyt 1976: M. Bossuyt, L'Interdiction de la discrimination dans le droit international des droits de l'homme, Bruylant, Brussel 1976

Bourn 1996: C. Bourn, "Equal treatment and managerial prerogatives", in: Dine \& Watt, Discrimination Law: Concepts, Limitations and Justifications, Longman, Londen, New York 1996, p. $37-48$

Bowsher 1998: D.K. Bowsher, "Cracking the Code of United States v. Virginia", 48 Duke Law Journal 305 (1998) 
Brennan 1987: Brennan, "The Equality Principle: A Foundation of American Law", 20 U.C.
Davis Law Review 673 (1987)

Brest 1971: P. Brest, "Palmer v. Thompson: An Approach to the Problem of Unconstitutional Legislative Motive", Supreme Court Review 1971, p. 95-146

Brest 1983: P. Brest, "Race Discrimination", in: Blasi (red.), The Burger Court. A CounterRevolution That Wasn't, Yale University Press, New Haven/Londen 1983, p. 113-131

Bronkhorst 1987 (I): H.J. Bronkhorst, "Het Hof van Justitie en het communautaire landbouwbeleid in 1981-1985", SEW 1987, p. 27-51

Bronkhorst 1987 (II): H.J. Bronkhorst, "National discretionary powers in the field of agricultural policy and their limits under the EEC Treaty", in: Schwarze (red.), Discretionary Powers of the Member States in the Field of Economic Policies and their Limits under the EEC Treaty, Nomos Verlagsgesellschaft, Baden-Baden 1987, p. 121-127

Brownstein 1994: A. Brownstein, "How Rights Are Infringed: The Role of Undue Burden Analysis in Constitutional Law", 45 Hastings Law Journal 867 (1994)

Bruinsma 1997: F. Bruinsma, "De kaasschaaf van de Commissie Gelijke Behandeling", NJB 1997, p. 854

De Búrca 1993: G. de Búrca, "The Principle of Proportionality and its Application in EC Law", Yearbook of European Law 1993, p. 105-150

De Búrca 1997: G. de Búrca, "The Role of Equality in European Community Law", in: Dashwood \& O'Leary (red.), The Principle of Equal Treatment in E.C. Law. A Collection of Papers by the Centre for European Studies (Cambridge), Sweet \& Maxwell, London, Dublin, Hong Kong 1997, p. 13-34

De Búrca 1998: G. de Búrca, "The Principle of Subsidiarity and the Court of Justice as an Institutional Actor", Journal of Common Market Studies 1998, p. 217-235

Burke 1981: K.C. Burke, "Note: Secret Surveillance and the European Convention on Human Rights", Stanford Law Review 1981, p. 1113-1140

Burkens 1969: M.C. Burkens, Gelijkheid voor de wet, Openbare les, Samson, Alphen a/d Rijn 1969

Burkens 1982: M.C. Burkens, "Gelijke behandeling", in: A.K. Koekkoek e.a. (red.), Grondrechten: Commentaar op hoofdstuk I van de herziene Grondwet: aangeboden aan mr. H.J.M. Jeukens in verband met zijn afscheid als hoogleraar aan de Katholieke Hogeschool Tilburg, Ars Aequi Libri, Nijmegen 1982, p. 49-65

Burkens 1989 (I): M.C. Burkens, Algemene leerstukken van grondrechten naar Nederlands constitutioneel recht, W.E.J. Tjeenk Willink, Zwolle 1989

Burkens 1989 (II): M.C. Burkens, "Problemen van de rechtsstaat", in: J.W.M. Engels e.a. (red.), De rechtsstaat herdacht, W.E.J. Tjeenk Willink 1989, p. 63-71

Burkens/Kummeling 1991: M.C. Burkens en H.R.B.M. Kummeling, "Het bewijs van discriminatie", NJCM-Bulletin 1991, p. 3-27

Burns 1998: W.H. Burns, "Law and Race in Early America", in: Kairys (red.), The Politics of Law. A Progressive Critique, Third Edition, Basis Books 1998, p. 278-284

Burri 1996: S. Burri, "Gelijke behandeling en arbeidsduur. Het wetsvoorstel tot verbod van onderscheid tussen voltijd- en deeltijdwerknemers", Nemesis 1996, p. 18-26

Callewaert 1993: J. Callewaert, "The Judgments of the Court: Background and Content", Macdonald, Matscher \& Petzold (red.), The European System for the Protection of Human Rights, Martinus Nijhoff Publishers, Dordrecht, Boston, Londen 1993, p. 713-731

Carozza 1998: P.G. Carozza, "Propter honoris respectum: uses and misuses of comparative law in international human rights: some reflections on the jurisprudence of the European Court of Human Rights", Notre Dame Law Review 1998, p. 1217-1237 
Cathey 1983: K.C. Cathey, "Note: Refining the Methods of Middle-Tier Scrutiny: A New Proposal for Equal Protection", 61 Texas Law Review 1501 (1983)

Chang 1991: D. Chang, "Discriminatory Impact, Affirmative Action and Innocent Victims: Judicial Conservatism or Conservative Judges", 91 Columbia Law Review 790 (1991)

Charpentier 1998: L. Charpentier, "The European Court of Justice and the Rhetoric of Affirmative Action", European Law Journal 1998, p. 167-195

Chemerinsky 1983: Chemerinsky, "In Defense of Equality: A Reply to Professor Westen", 81Michigan Law Review 575 (1983)

Clark 1978: J.M. Clark, "Legislative Motivation and Fundamental Rights in Constitutional Law", 15 San Diego Law Review 953 (1978)

Clune 1975: W.H. Clune III, "The Supreme Court's Treatment of Wealth Discriminations under the Fourteenth Amendment", 1975 Supreme Court Review 289

Coffin 1988: F.M. Coffin, "Judicial Balancing: The Protean Scales of Justice", 63 New York University Law Review 16 (1988)

Corstens 1995: G.J.M. Corstens, "Het Nederlands strafprocesrecht", Gouda Quint, Amhem 1995 Cover 1982: R.M. Cover, "The Origins of Judicial Activism in the Protection of Minorities", 91 Yale Law Journal 1287 (1982)

Cox 1966: A. Cox, "The Supreme Court, 1965 Term -- Foreword: Constitutional Adjudication and the Promotion of Human Rights", 80 Harvard Law Review 91 (1966)

Craig/De Búrca 1998: P. Craig \& G. de Búrca, EU Law. Text, Cases and Materials, Tweede druk, Oxford University Press 1998

Crombag/De Wijkerslooth/Cohen 1977: H.F.M. Crombag, J.L. de Wijkerslooth \& M.J. Cohen, Een theorie over rechterlijke beslissingen, H.D. Tjeenk Willink, Groningen 1977

Currie 1985: D.P. Currie, The Constitution in the Supreme Court. The First Hundred Years 1789-1888, The University of Chicago Press, Chicago, London 1985

Danusso/Denton 1990: M. Danusso en R. Denton, "Does the European Court of Justice look for a protectionist motive under Article 95?", European Issues of Legal Integration 1990, p. 67-120 Developments 1969: "Developments in the Law -- Equal Protection", 82 Harvard Law Review 1065 (1969)

Dewost 1987: J.-L. Dewost, "Les pouvoirs discrétionnaires du Conseil des ministres", in: Schwarze (red.), Discretionary Powers of the Member States in the Field of Economic Policies and their Limits under the EEC Treaty, Nomos Verlagsgesellschaft, Baden-Baden 1987, p. 165172

Dierx/Siegers 1990: J.R. Dierx en J.J. Siegers, "Indirecte discriminatie van deeltijdwerkers. Statistisch bewijs en objectieve rechtvaardiging", NJB 1990, p. 554-560

Dierx 1992: J.R. Dierx, "Indirecte discriminatie: oplossing of obstakel?", in: Kraamwinkel, Schippers \& Siegers (red.), De toekomst van de aanvullende pensioenen, W.E.J. Tjeenk Willink, Zwolle 1992, p. 110-127

Van Dijk 1988: P. van Dijk, "De houding van de Hoge Raad jegens de verdragen inzake de rechten van de mens", in: De plaats van de Hoge Raad in het huidige staatsbestel. De veranderingen in de rol van de Hoge Raad als rechtsvormer, W.E.J. Tjeenk Willink, Zwolle 1988, p. $173-209$

Van Dijk/Van Hoof 1997: P. van Dijk en G.J.H. van Hoof, Theory and Practice of the European Convention on Human Rights, Derde druk, Kluwer, Deventer, Boston 1997

Doherty 1989: E. Doherty, "Equal Protection Under the Fifth and Fourteenth Amendments: Patterns of Congruence, Divergence and Judicial Deference", 16 Ohio Northern University Law Review 591 (1989)

Drijber/Prechal 1997: B.J. Drijber en S. Prechal, "Gelijke behandeling van mannen en vrouwen in horizontaal perspectief', SEW 1997, p. 122-167 
Duk 1975: W. Duk, "Het gelijkheidsbeginsel", NJB 1975, p. 858-863

Duk 1988: W. Duk, "Beoordelingsvrijheid en beleidsvrijheid", RMThemis 1988, p. 156-169

Dworkin 1985: R. Dworkin, A Matter of Principle, Harvard University Press, Cambridge, Mas-
sachusetts 1985 Dworkin 1996: R. Dworkin, Freedom's Law, Harvard University Press, Cambridge, Massachu-
setts 1996

Dworkin 1997: R. Dworkin, "Comment", in: Scalia, A. (red.: Gutmann, A.), A Matter of Interpretation. Federal Courts and the Law, Princeton University Press, Princeton, New Jersey 1997,
p. 115-127

Easterbrook 1982: F.H. Easterbrook, "Ways of Criticizing the Court", 95 Harvard Law Review 802 (1982)

Eisenberg 1977: Th. Eisenberg, "Disproportionate Impact and Illicit Motive: Theories of Constitutional Adjudication, 52 New York University Law Review 36 (1977)

Eissen 1968: M.-A. Eissen, "l" Autonomie" de l'Article 14 de la Convention Européenne des Droits de l'Homme dans la jurisprudence de la Commission", in: Pedone (red.), Mélanges Offerts à Polys Modinos. Problèmes des Droits de l'Homme et de l'Unification Européenne, Parijs 1968, p. $122-145$

Emiliou 1996: N. Emiliou, The Principle of Proportionality in European Law. A Comparative Study, Kluwer, Londen, Den Haag, Boston 1996

Ellis 1991: E. Ellis, European Community Sex Equality Law, Clarendon Press, Oxford 1991

Ellis 1996: E. Ellis, "Gender Discrimination Law in the European Community", in: Dine \& Wath, Discrimination Law: Concepts, Limitations and Justifications, Longman, Londen, New York 1996, p. 14-30

Ellis 1997: E. Ellis, "The Principle of Equal Treatment of Opportunity Irrespective of Sex: Some Reflections on the Present State of European Community Law and its Future Development", in: Dashwood \& O'Leary (red.), The Principle of Equal Treatment in E.C. Law. A Collection of Papers by the Centre for European Studies (Cambridge), Sweet \& Maxwell, Londen, Dublin, Hong Kong 1997, p. 172-188

Ellis 1998: E. Ellis, "Recent Developments in European Community Sex Equality Law", Common Market Law Review 1998, p. 379-408

Ellis 2000: E. Ellis, "The Recent Jurisprudence of the Court of Justice in the Field of Sex Equality", Common Market Law Review 2000, p. 1403-1426

Ely 1970: J.H. Ely, "Legislative And Administrative Motivation In Constitutional Law", 79 Yale Law Journal 1205 (1970)

Ely 1974: J.H. Ely, "The Constitutionality of Reverse Racial Discrimination", 41 University of Chicago Law Review 723 (1974)

Ely 1980: J.H. Ely, Democracy and Distrust. A Theory of Judicial Review, Harvard University Press, Cambridge, Mass. en Londen 1980

Engwerda 1999: C.P. Engwerda, Beginselen van behoorlijk bestuur in het belastingrecht, SDU, Amersfoort 1999

Evaluatierapport CGB 2000: Commissie Gelijke Behandeling, Gelijke behandeling in beweging: Evaluatie van vijf jaar Algemene wet gelijke behandeling 1994-1999, Utrecht 2000

Evenhuis 1991: C.H.S. Evenhuis, "Referentiekaders: meer dan alleen een kwestie van rekenen", in: Goldschmidt, Heringa \& Van Vliet (red.), De zij-kant van het gelijk. Het recht als instrument ter verbetering van de kansen op gelijke posities voor vrouwen, W.E.J. Tjeenk Willink, Zwolle 1991 , p. $39-45$

Fallon 1993: R.H. Fallon, "Individual Rights and the Powers of Government", 27 Georgia Law Review 343 (1993) 
Farrell 1992: R.C. Farrell, "Legislative Purpose and Equal Protection's Rationality Review", 37 Villanova Law Review 1 (1992)

Farrell 1999: R.C. Farrell, "Successful Rational Basis Claims in the Supreme Court from the 1971 Term through Romer v. Evans", 32 Indiana Law Review 357 (1999)

Fase/Van der Heijden 1982: W.J.P.M. Fase en Van der Heijden, "Gelijke behandeling in behandeling", SMA 1982, p. 84-100

Fenwick/Hervey 1995: H. Fenwick en T.K. Hervey, "Sex Equality in the Single Market: New Directions for the European Court of Justice", Common Market Law Review 1995, p. 443-470

Fitzmaurice 1983: G. Fitzmaurice, "Some reflections on the European Convention on Human Rights - and on Human Rights", in: Bernhardt, Geck, Jaenicke \& Steinberger (red.), Völkerrecht als rechtsordnung. Internationale Gerichtsbarkeit. Menschenrechte. Festschrift für Hermann Mosler, Springer-Verlag, Berlin, Heidelberg, New York 1983, p. 203-219

Flathman 1967: R.E. Flathman, "Equality and Generalization, A Formal Analysis", in: Pennock \& Chapman (red.), Nomos IX. Equality, Yearbook of the American Society for Political and Legal Philosophy, Atherton Press, New York, 1967, p. 38-60

Florijn 1996: N. Florijn, "Rechtsvergelijking in de bestudering van het publiekrecht. Een stilistische benadering", Preadvies voor de Nederlandse Vereniging voor Rechtsvergelijking, Kluwer, Deventer 1996, p. 81-112

Flynn 1999: L. Flynn, "The implications of Article 13 EC - After Amsterdam, will some forms of discrimination be more equal than others?", Common Market Law Review 1999, p. 1127-1152

Freeman 1978: A.D. Freeman, "Legitimizing Racial Discrimination Through Antidiscrimination Law: A Critical Review of Supreme Court Doctrine", 62 Minnesota Law Review 1049 (1978)

Fried 1990: Ch. Fried, "The Supreme Court, 1989 Term: Comment: Metro Broadcasting, Inc., v. FCC: Two Concepts of Equality", 104 Harvard Law Review 107 (1990)

Frowein/Peukert 1996: J.A. Frowein en W. Peukert, Europäische MenschenRechtsKonvention. EMRK-Kommentar, Tweede druk, N.P. Engel Verlag, Kehl, Straatsburg, Arlington 1996

Fuss 1959: E.-W. Fuss, "Gleichheitssatz und Richtermacht", Juristenzeitung nr. 11/12, 1959, p. 1959 e.v.

Garvey/Aleinikoff 1999: J.H. Garvey en T.A. Aleinikoff, Modern Constitutional Theory: A Reader, Vierde druk, West Group, St. Paul, Minnesota 1999

Gelijk in de praktijk 1990: Gelijk in de praktijk, Rapport van de interdepartementale juridische werkgroep gelijkheidsbeginsel (IWEG), Ministerie van Justitie, Den Haag 1990

Geppaart 1983: Ch.P.A. Geppaart, "De betrekkelijk waarde van het gelijkheidsbeginsel", in: Quod Licet Jovi. Opstellen aangeboden aan Prof. dr. D. Brüll, FED 1983, p. 9-14

Van Gerven 1973: W. van Gerven, Het beleid van de rechter, Standaard Wetenschappelijke Uitgeverij, Antwerpen 1973

Van Gerven 1981: W. van Gerven, "De taak van de rechter in een democratisch bestel", in: Van Gerven \& Leijten, Theorie en pratijk van de rechtsvinding, Tjeenk Willink, Zwolle 1981

Ginsburg 1983: R.B. Ginsburg, "The Burger Court's Grapplings with Sex Discrimination", in: Blasi (red.), The Burger Court. The Counter-Revolution That Wasn't, Yale University Press, New Haven, Londen 1983, p. 132-156

Gladpootjes 1988: T.A. Gladpootjes, "De opmars van het gelijkheidsbeginsel in het belastingrecht", WFR 1988, p. 1253-

Goldschmidt 1989: J.E. Goldschmidt, "Staats- en bestuursrechtelijke aspecten van positieve actie", Preadvies NJV 1989, p. 59-117

Goldschmidt/Jaspers/Loenen 1990: J.E. Goldschmidt, A.Ph.C.M. Jaspers en T. Loenen, "Referentiekaders voor gelijke behandeling uit en thuis. Verschillen in inhoud van gelijke behandeling tussen het sociaal recht en het familierecht", Beleid \& Maatschappij 1990, p. 277-287 
Goldschmidt 1998: J.E. Goldschmidt, "Geschillenbeslechting door de Commissie gelijke behandeling: een alternatief?", in: Polak (red.), Geschillenbeslechting naar behoren: algemene Kluwer, Deventer 1998, p. 47-57

Gomien/Harris/Zwaak 1996: D. Gomien, D. Harris en L. Zwaak, Law and practice of the European Convention on Human Rights and the European Social Charter, Council of Europe Govers 1985: A.W. Govers, "Gelijke behandeling in de sociale zekerheid; wat doet de rechter?", NJCM-Bulletin 1985, p. 365-378

Gottlieb 1988: S.E. Gottlieb, "Compelling Governmental Interests: An Essential But Unana. lyzed Term in Constitutional Adjudication", 68 Boston University Law Review 917 (1988)

Götz 1986: V. Götz, "Probleme des Verwaltungsrechtes auf dem Gebiet des gemeinsamen Agrarmarktes”, Europarecht 1986, p. 29-51

Green 1998: R.L. Green, "Interest Definition in Equal Protection: A Study of Judicial Technique”, 108 Yale Law Journal 439 (1998)

Greenawalt 1983: K. Greenawalt, "How Empty is the Idea of Equality?", Columbia Law Review 1983, p. $1167-1185$

Gribnau 2000: J.L.M. Gribnau, "Perspectieven op het gelijkheidsbeginsel", WFR 2000, p. 902912

Gribnau 2001: J.L.M. Gribnau, "Legaliteit en legitimiteit. Fiscale rechtsvorming in de democratische rechtsstaat", NTB 2001 p. 9-19

Van der Grinten 1984: W.C.L. van der Grinten, Discriminatie en burgerlijk recht, W.E.J. Tjeenk Willink, Zwolle 1984

Groenendijk 1988: C.A. Groenendijk, "Ouderenrecht, funktionele rechtsgebieden en discriminatie. Mobilisatie van recht door ouderen of mobilisatie van ouderen door het recht?", AAe 1988, p. 615-626

Gunther 1972: G. Gunther, "Foreword: In Search of Evolving Doctrine on a Changing Court: A Model for a Newer Equal Protection", Harvard Law Review 1972, p. 1-48

Gunther/Sullivan 1997: G. Gunther en K.M. Sullivan, Constitutional Law, Dertiende druk, University Casebook Series, Foundation Press, Westbury, New York 1997

Hall 1991: S. Hall, "The European Convention on Human Rights and Public Policy Exceptions to the Free Movement of Workers under the EEC Treaty", European Law Review 1991, p. 466488

Happé 1990: R.H. Happé, “Artikel 26 Bupo-Verdrag, ofwel hoe het belastingrecht de maat wordt genomen", WFR 1990, p. 387-402

Happé 1991: R.H. Happé, "Gelijkheid: een kwestie van standpunt", WFR 1991, p. 298-308

Happé 1993: R.H. Happé, "De opmars van het gelijkheidsbeginsel voltooid?", WFR 1993, p. 145-158

Happé 1996: R.H. Happé, Drie beginselen van fiscale rechtsbescherming, Diss. Leiden, Kluwer, Deventer 1996

Happé 1999: R.H. Happé, Schuivende machten. Over trias politica en het gelijkheidsbeginsel in het belastingrecht, Inaugurale rede KUB, Kluwer, Deventer 1999

Happé 2000: R.H. Happé, "Toetssteen of steen des aanstoots. Over het gelijkheidsbeginsel en de kwaliteit van belastingwetgeving", RegelMaat 2000, p. 151-161

Harlaar 1983: A. Harlaar, "Reikwijdte en praktische toepassing van het gelijkheidsbeginsel in het belastingrecht", Losbladig Fiscaal Weekblad FED, Beschouwingen: 76

Harris/O'Boyle/Warbrick 1995: D.J. Harris, M. O'Boyle en C. Warbrick, Law of the European Convention on Human Rights, Butterworths, Londen, Dublin, Edinburgh 1995 
Hartley 1998: T.C. Hartley, The Foundations of European Community Law. An Introduction to the Constitutional and Administrative Law of the European Community, Vierde druk, Oxford University Press 1998

Helder/Jue 1987: E. Helder en R.J. Jue, "Belangenafweging in het bestuursrecht", Bestuurswetenschappen 1987, p. 25-41

Helfer 1990: L.R. Helfer, "Note: Finding a consensus on equality: the homosexual age of consent and the European Convention on Human Rights", New York University Law Review 1990, p. 1044 e.v.

Helfer 1993: L.R. Helfer, "Consensus, Coherence and the European Convention on Human Rights", Cornell International Law Journal 1993, p. 133-166

Hepple 1997: B. Hepple, "The Principle of Equal Treatment in Article 119 EC and the Possibilities for Reform", in: Dashwood en O'Leary (red.), The Principle of Equal Treatment in EC Law, A Collection of Papers by the Centre for European Studies (Cambridge), Sweet \& Maxwell, Londen, Dublin, Hong Kong 1997, p. 137-152

Herbert 1994: F. Herbert, "Social Security and Indirect Discrimination", in: McCrudden, Ch. (red.), Equality of Treatment between Women and Men in Social Security, Butterworths, London, Dublin, Edinburgh 1994, p. 117-142

Herdegen 1985: M. Herdegen, "The relation between the principles of equality and proportionality", Common Market Law Review 1985, p. 683-696

Heringa 1984: A.W. Heringa, "Tippelen of recreëren. De gemeentelijke wetgever met de billen bloot?", NJB 1984, p. 781-785

Heringa 1985: A.W. Heringa, "Rechter en gelijkheid. Recente jurisprudentie over de mogelijkheden van de rechter en de inhoud van het gelijkheidsbeginsel respectievelijk discriminatieverbod", NJCM-Bulletin 1985 , p. $290-302$

Heringa 1989: A.W. Heringa, Sociale Grondrechten. Hun plaats in de gereedschapskist van de rechter, Diss. Leiden 1989

Heringa 1991: A.W. Heringa, "De Algemene wet gelijke behandeling. Is iets beter dan niets of is zelfs het iets al te veel?", in: Gelijk behandelen, commentaren op het wetsvoorstel Algemene wet gelijke behandeling, W.E.J. Tjeenk Willink, Zwolle 1991, p. 1-29

Heringa 1992: A.W. Heringa, "Onderscheid en discriminatie", NJCM-Bulletin 1992, p. 12-14

Heringa 1993: A.W. Heringa, "Judicial Enforcement of Article 26 of the International Covenant on Civil and Political Rights in the Netherlands", Netherlands Yearbook of International Law 1993, p. 139-182

Heringa 1994 (I): A.W. Heringa, Algemene wet gelijke behandeling, Kluwer, Deventer 1994 Heringa 1994 (II): A.W. Heringa, "De toepassing van artikel 26 IVBPR door de Nederlandse rechter", NJCM-Bulletin 1994, p. 855-864

Heringa 1996: A.W. Heringa, "Artikel 14 EVRM: een achtergestelde waarborg?", in: Heringa \& Myer (red.), 45 Jaar Europees Verdrag voor de Rechten van de Mens, NJCM-Bulletin, Leiden 1996

Heringa/Woltjer 1997: A.W. Heringa en A. Woltjer, "Gelijke behandeling in het sociale zekerheidsrecht: "Straatsburg" scherpt de eisen aan!", NJB 1997, p. 1710-1715

Heringa 1998: A.W. Heringa, "Discriminatieverbod", in: Heringa, Schokkenbroek, \& Van der Velde, EVRM Rechtspraak en Commentaar, Koninklijke Vermande, aanvulling 2, juli 1998, p. $3.14-1 \cdot 14$

Heringa 1999: A.W. Heringa, "Standards of Review for Discrimination. The Scope of Review by the Courts", in: Loenen en Rodrigues, Non-Discrimination Law: Comparative Perspectives, Kluwer Law International, Den Haag/Boston/Londen 1999, p. 25-37

Hervey 1991: T.K. Hervey, "Justification for indirect sex discrimination in employment: European Community and United Kingdom law compared", International and Comparative Law Quarterly 1991, p. 807-826 
Hervey 1993: T.K. Hervey, Justifications for Sex Discrimination in Employment, Butterworths,
Londen, Dublin, Edinburgh, Brussels 1993 Hervey 1998: T.K. Hervey, "Sex Equality in Social Protection: New Institutionalist Perspectives on Allocation of Competence", European Law Journal 1998, p. 196-219

Hilson 1999: Ch. Hilson, "Discrimination in Community free movement law", European Law Review 1999 , p. $445-462$

Hoens 1981: J. Hoens, "Rassendiscriminatie en het wetsontwerp tot wijziging van artikel 429 quater Wetboek van Strafrecht", NJB 1981, p. 259-265

Van der Hoeven 1983: J. van der Hoeven, Botsing van grondrechten, Mededelingen der KNAW, Deel 46, No. 7, Noord-Hollandsche Uitgeversmaatschappij, Amsterdam/Oxford/New York 1983

Van der Hoeven 1989: J. van der Hoeven, "De rechtsstaat herdacht", in: J.W.M. Engels e.a. (red.), De rechtsstaat herdacht, W.E.J. Tjeenk Willink, Zwolle 1989, p. 1-9

Van der Hoeven 1992: J. van der Hoeven, "Handhaving van grondrechten", RM Themis 1992, p. $102-112$

Holtmaat 2001: R. Holtmaat, "Uit de keuken van de Europese Unie: De gelijke behandelingsrichtlijnen op grond van artikel 13 EG-Verdrag", in: Loenen (red.), Gelijke behandeling: oordelen en commentaar 2000, Kluwer, Deventer 2001, p. 105-124

Van Hoof/Jaspers 1986: G.J.H. van Hoof en A.Ph. Jaspers, "Over gelijkheid: enige aspecten van rechterlijke toetsing aan het gelijkheidsbeginsel", in: Ten Berge e.a. (red.), Recht als norm en als aspiratie, Ars Aequi Libri, Nijmegen 1986, p. 136-162

Hull 1979: E.A. Hull, "Sex Discrimination and the Equal Protection Clause: An Analysis of Kahn v. Shevin and Orr v. Orr", 30 Syracuse Law Review 639 (1979)

Hutchinson 1982: D.J. Hutchinson, "More Substantive Equal Protection? A Note on Plyler v. Doe", 1982 Supreme Court Review 167 (1982)

Israel 1975: J.H. Israel, "Gideon v. Wainwright: The Art of Overruling", in: Kurland (red.), The Supreme Court and the Judicial Function, The University of Chicago Press, Chicago en Londen 1975 , p. $73-143$

Issacharoff 1982: S. Issacharoff, "Note: Making the Violation Fit the Remedy: The Intent Standard and Equal Protection Law", 92 Yale Law Journal 328 (1982)

Jacob 1996: H. Jacob, "Courts and Politics in the United States", in: Jacob e.a., (red.), Courts, Law \& Politics in Comparative Perspective, Yale University Press, New Haven, Londen 1996, p. $16-80$

Jacobs 1999: F.G. Jacobs, "Recent Developments in the Principle of Proportionality in European Community Law", in: Ellis (red.), The Principle of Proportionality in the Laws of Europe, Oxford 1999, p. 1-21

Jackson 1997: J.S. Jackson, "Persons of Equal Worth: Romer v. Evans and the Politics of Equal

Protection", 45 UCLA Law Review 453 (1997)
Jacqué 1985: J.-P. Jacqué, "The Principle of equality in economic law", Common Market Law Review 1985, p. 135-142

Jones 1995: T.H. Jones, "The Devaluation of Human Rights Under the European Convention", Public Law 1995, p. 430-449

De Jong 1975: De Jong, "De motieven van de rechter en de motivering van het vonnis", NJB 1975, p. 541-547

Jørgensen 1996: E.B. Jørgensen, Union Citizens. Free movement and non-discrimination, Juristog Økonomforbundets Forlag, 1996

Jue 1985: R.J. Jue, "Rechterlijke terugtred bij de beoordeling van bestuurlijke beslissingen", Bestuurswetenschappen 1985, p. 440-465 
Kahn 1987: P.W. Kahn, "The Court, the Community and the Judicial Balance: The Jurisprudence of Justice Powell", 97 Yale Law Journal 1 (1987)

Karst 1977: K.L. Karst, "Foreword: Equal Citizenship Under the Fourteenth Amendment", 91 Harvard Law Review I (1977)

Karst 1978: K.L. Karst, "The Costs of Motive-Centered Inquiry", 15 San Diego Law Review $1163(1978)$

Kavelaars-Niekoop 1999: R.M. Kavelaars-Niekoop, "Hoe het gelijkheidsbeginsel ongelijkheid creëert!", WFR 1999, p. 753766

Kelly 1956: A.H. Kelly, "The Fourteenth Amendment Reconsidered. The Segregation Question", 54 Michigan Law Review 1049 (1956)

Kelso 1994: R.R. Kelso, "Considerations of Legislative Fit under Equal Protection, Substantive Due Process, and Free Speech Doctrine: Separating Questions of Advancement, Relationship and Burden", 28 University of Richmond Law Review 1279 (1994)

Kerdel 2001: K. Kerdel, "Meer gelijkheid in de bescherming tegen discriminatie? Protocol 12 bij het EVRM", Nemesis 2001, p. 37-46

Kewenig 1972: W. Kewenig, Der Grundsatz der Nichtdiskriminierung im Völkerrecht der internationalen Handelsbeziehungen. Band 1: Der Begriff der Diskriminierung, Athenăum Verlag, Frankfurt am Main 1972

Khol 1970: A. Khol, "Zur Diskriminierung im Erziehungswesen", Zeitschrift für ausländisches offentliches Recht und Volkerrecht 1970, p. 263-301

Klap 1994: A. Klap, Vage normen in het bestuursrecht, W.E.J. Tjeenk Willink, Zwolle 1994

Klap 1996: A. Klap, "Bestuurlijke vrijheid en rechterlijke toetsing", Bestuurswetenschappen 1996, p. 242-258

Klarman 1991: M. Klarman, "An Interpretive History of Equal Protection", 90 Michigan Law Review 213 (1991)

Klein 1975: E. Klein, "The Principle of Equality and its Protection in the Federal Republic of Germany", Koopmans (red.), Constitutional Protection of Equality, A.W. Sijthoff, Leiden 1975, p. $69-125$

Klerk 1995: Y.S. Klerk, Het ECRM-toezichtmechanisme. Verleden, heden, toekomst, Ars Aequi Libri, Nijmegen 1995

Koekkoek 1991: A.K. Koekkoek, "Grenzen aan grondrechten. Aantekeningen bij het voorstel voor een Algemene wet gelijke behandeling”, in: Gelijk behandelen, commentaren op het wetsvoorstel Algemene wet gelijke behandeling, W.E.J. Tjeenk Willink, Zwolle 1991, p. 29-54

Koopmans 1981: T. Koopmans, "Juridische dialectiek. Rede uitgesproken tijdens de vergadering, 12 oktober 1981", Mededelingen der Koninklijke Nederlandse Akademie van Wetenschappen, Amsterdam, 1982, opgenomen in: Juridisch Stippelwerk, Kluwer, Deventer 1991, p. 77-95

Koopmans 1986: T. Koopmans, "Understanding Political Systems: A Comment on Methods of Comparative Research", 17 Georgia Journal of International and Comparative Law 261 (1986), opgenomen in: Juridisch Stippelwerk, Kluwer, Deventer 1991, p. 350-362

Koopmans 1989: T. Koopmans, "Equal protection - The social Dimension of European community law", Michigan Journal of International Law 1989, p. 1-10

Koopmans 1994: T. Koopmans, "The Quest for Subsidiarity", in: Curtin \& Heukels, Institutional Dynamics of European Integration. Essays in Honour of Henry G. Schermers, Volume II, Martinus Nijhoff Publishers, Dordrecht, Boston, London 1994, p. 43-57

Kovacic-Fleischer 1997: C.S. Kovacic-Fleischer, "United States v. Virginia's New Gender Equal Protection Analysis with Ramifications for Pregnancy, Parenting and Title VII", 50 Vanderbilt Law Review 845 (1997)

Kroes 1998: M. Kroes, Werking en doorwerking van grondrechten, Diss. Leiden 1998

Kuiper 1987: M.J. Kuiper, "Gemeenschappelijk landbouwbeleid: rationalisering of renationalisering?", SEW 1987, p. 611-621 

Kurland 1970: Ph.B. Kurland, Egalitarianism and The Warren Court", 68 Michigan Law Re-
view 629 (1970) De Lange 1991: R. de Lange, Publiekrechtelijke rechtsvinding, W.E.J. Tjeenk Willink, Zwolle
1991

Laski 1969: H. Laski, "Liberty and Equality", in: Blackstone (red.), The Concept of Equality, Burgess Publishing Company, Minneapolis 1969, p. 165-174

Lawrence 1987: Ch.R. Lawrence III, "The Id, the Ego and Equal Protection: Reckoning with Unconscious Racism”, 39 Stanford Law Review 317 (1987)

Lazarus 1999: E. Lazarus, Closed Chambers. The Rise, Fall, and Future of the Modern Supreme Court, Penguin Books 1999

Leenders 1997: M.A.J. Leenders, Bewijsrecht en discriminatie bij de arbeid, W.E.J. Tjeenk Willink, Deventer 1997

Leenders 2000: M.A.J. Leenders, "Procesrecht en handhaving van de AWGB", in: Loenen (red.), Gelijke behandeling: oordelen en commentaar 1999, Kluwer, Deventer 2000, p. 69-87

Van Leijenhorst 1997: G.J. van Leijenhorst, "Gelijke kabouters, gelijke puntmutsen", WFR 1997, p. 1111-1128

Leijten 1981: J.C.M. Leijten, "Rechtspraak en topiek", in: Van Gerven \& Leijten, Theorie en praktijk van de rechtsvinding, Tjeenk Willink, Zwolle 1981

Lenaerts 1991: K. Lenaerts, "L'égalité de traitement en droit communautaire. Un principe unique aux apparences mutiples", Cahiers de Droit Européen 1991, p. 3-41

Lenaerts/Foubert 2001, K. Lenaerts en P. Foubert, "Social Rights in the Case-Law of the European Court of Justice. The Impact of the Charter of Fundamental Rights of the European Union on Standing Case-Law", 28 Legal Issues of Economic Integration 2001, p. 267-296

Levi 1979: D.F. Levi, "Note: The Equal Treatment of Aliens: Preemption or Equal Protection?", 31 Stanford Law Review 1069 (1979)

Lewis 1960: Lewis, "The Meaning of State Action", 60 Columbia Law Review 1083 (1960)

Linde 1976: H.A. Linde, "Due Process of Lawmaking", 55 Nebraska Law Review 197 (1976)

Linde 1993: H.A. Linde, "Who Must Know What, When, and How: The Systemic Incoherence of 'Interest' Scrutiny", in: Gottlieb (ed.), Public Values in Constitutional Law, The University of Michigan Press, Ann Arbor 1993, p. 219-240

Lively 1991: D.E. Lively, "Equal Protection and Moral Circumstance: Accounting for Constitutional Basics", 59 Fordham Law Review 485 (1991)

Llewellyn 1960: K.N. Llewellyn, The Common Law Tradition. On Deciding Appeals, Little, Brown and Company, Boston, Toronto 1960

Loenen 1992: T. Loenen, Verschil in gelijkheid. De conceptualisering van het gelijkheidsbeginsel met betrekking tot vrouwen en mannen in Nederland en de Verenigde Staten, diss. Leiden 1992

Loenen 1996: T. Loenen, "Overzicht oordelen Commissie Gelijke Behandeling, april 1994-april 1996”, NJCM-Bulletin 1996, p. 838850

Loenen 1998: T. Loenen, Het gelijkheidsbeginsel, Ars Aequi Libri, Nijmegen 1998

Loenen 1999: T. Loenen, "Indirect Discrimination: Oscillating Between Containment and Revolution", in: Loenen \& Rodrigues, Non-Discrimination Law: Comparative Perspectives, Kluwer Law International, Den Haag/Boston/Londen 1999, p. 195-211

Loenen 2000: T. Loenen, "Leeftijdsdiscriminatie", in: Van der Burg, Van Buuren \& Van der Veen (red.), AB Klassiek. Standaarduitspraken Bestuursrecht, opnieuw geannoteerd, vierde druk, W.E.J. Tjeenk Willink, Deventer 2000, p. 292-299

Loevy 1997: R.D. Loevy, The Civil Rights Act of 1964. The Passage of the Law That Ended Racial Segregation, State University of New York Press, Alabany 1997 
Loucaides 1995: L.G. Loucaides, Essays on the Developing Law of Human Rights, Martinus Nijhoff Publishers, Dordrecht, Boston, London 1995, p. 179-218

Lusky/Botein 1975: L. Lusky en M. Botein, "The Law of Equality in the United States", in: Koopmans (red.), Constitutional Protection of Equality, A.W. Sijthoff, Leiden 1975, p. 11-55

Lusky 1982: L. Lusky, "Footnote Redux: A Carolene Products Reminiscence", 82 Columbia Law Review 1093 (1982)

Lusky 1993: L. Lusky, Our Nine Tribunes. The Supreme Court in Modern America, Praeger, Westport, London 1993

Van Maarseveen 1990: H. van Maarseveen, Discriminatie. Opmerkingen inzake juridische theorie en praktijk in Nederland, Coornhertpublicatie nr. 6, Samson H.D. Tjeenk Willink, Alphen a/d Rijn 1990

MacCallum 1966: G.C. MacCallum, "Legislative Intent", 75 Yale Law Journal 754 (1966)

Macdonald 1993: R.St.J. Macdonald, "The Margin of Appreciation", in: Macdonald, Matscher \& Petzold (red.), The European System for the Protection of Human Rights, Martinus Nijhoff Publishers, Dordrecht, Boston, London 1993, p. 83-124

Mahoney 1990: P. Mahoney, "Judicial activism and judicial self restraint in the European Court of Human Rights: two sides of the same coin", Human Rights Law Journal 1990, p. 57-88

Van Male 1988 (I): R. van Male, "Beredeneerd besluiten. Plaats, functie en betekenis van het motiveringsbeginsel in het Nederlandse bestuursrecht", NTB 1988, p. 73-79

Van Male 1988 (II): R. van Male, Rechter en Bestuurswetgeving. Beroep tegen door bestuursorganen vastgestelde algemeen verbindende voorschriften en toetsing daarvan aan ongeschreven recht in rechtsvergelijkend perspectief, W.E.J. Tjeenk Willink, Zwolle 1988

Maltz 1981: E.M. Maltz, "Federalism and the Fourteenth Amendment: A Comment on Democracy and Distrust", 42 Ohio State Law Journal 209 (1981)

Maltz 1988: E.M. Maltz, "The Nature of Precedent", 66 North Carolina Law Review 367 (1988) Mancini/O'Leary 1999: G.F. Mancini en S. O'Leary, "The new frontiers of sex equality law in the European Union", European Law Review 1999, p. 331-353

Manheim 1995: K. Manheim, "State Immigration Laws and Federal Supremacy", 22 Hastings Constitutional Law Quarterly 939 (1995)

Manolkidis 1997: S. Manolkidis, "The Principle of Equal Treatment from a Comparative Constitutional Perspective: Lessons for the EU", in: Dashwood \& O'Leary (red.), The Principle of Equal Treatment in E.C. Law. A Collection of Papers by the Centre for European Studies (Cambridge), Sweet \& Maxwell, London, Dublin, Hong Kong 1997, p. 80-104

Maris 1985: C.W. Maris, "Gelijkheid en bestuursrecht", NJB 1985, p. 1293-1301

Maris 1988: C.W. Maris, "Gelijkheid en recht filosofisch beschouwd", in: C.W. Maris (red.), gelijkheid en recht, W.E.J. Tjeenk Willink, Deventer 1988, p. 35-68

Matscher 1980: F. Matscher, "Betrachtungen über das Diskriminierungsverbot (Art. 14 EMRK) nach der neueren Praxis der Straßburger Instanzen", in: Adamovich en Pernthaler (red.), Auf dem Weg zur Menschenwürde und Gerechtigkeit. Festschrift für Hans R. Klecatsky, Deel II, Wilhelm Braumuller, Wenen 1980, p. 627-639

Matscher 1993: F. Matscher, "Methods of Interpretation of the Convention", in: Macdonald, Matscher, \& Petzold (red.), The European System for the Protection of Human Rights, Martinus Nijhoff Publishers, Dordrecht, Boston, London 1993, p. 63-81

McCoy 1975: Th.R. McCoy, "Recent Equal Protection Decisions - Fundamental Right to Travel or "Newcomers" as a Suspect Class?", 28 Vanderbilt Law Review 987 (1975) McKean 1985: McKean, Equality and Discrimination under international law, Clarendon Press

Merrills 1993: J.G. Merrills, The development of international law by the European Court of Human Rights, Manchester University Press 1993, p. 168-176 
Meyers 1986: M.E. Meyers, "Note: Impermissible Purposes and the Equal Protection Clause", 86 Columbia Law Review 1184

Michelman 1969: F.I. Michelman, "Foreword: On Protecting the Poor Through the Fourteenth Amendment", 83 Harvard Law Review 7 (1969)

Miller 1977: B.A. Miller, "Proof of Racially Discriminatory Purpose Under the Equal Protection Clause: Washington v. Davis, Arlington Heights, Mt. Healthy, and Williamsburg, 12 Harvard Civil Rights and Civil Liberties Law Review 725 (1977)

Minow 1990: M. Minow, Making All the Difference. Inclusion, Exclusion and American Law, Cornell University Press, Ithaca, London 1990, p. 19-97

Mok 1984: M.R. Mok, "Rechterlijke toetsing van wetgeving", in: Recht op scherp. Beschouwingen over handhaving van publiekrecht, aangeboden aan Prof. Mr. W. Duk, W.E.J. Tjeenk Willink, Zwolle 1984, p. 55-74

Monaghan 1979: H.P. Monaghan, "Taking Supreme Court Opinions Seriously", 39 Maryland Law Review 1 (1979)

De Moor-van Vlugt 1995: A. de Moor-van Vlugt, Maten en gewichten. Het evenredigheidsbeginsel in Europees perspectief, W.E.J. Tjeenk Willink, Zwolle 1995

More 1999: G. More, "The Principle of Equal Treatment: From Market Unifier to Fundamental Right?", in: Craig \& De Bùrca (red.), The Evolution of EU Law, Oxford University Press 1999, p. $517-553$

Mulder 1987: L. Mulder, "Het gelijkheidsbeginsel: half ei of lege dop", in: Staatsrecht, buitenlandse betrekkingen en de internationale rechtsorde, Staatsrechtconferentie 1987, Ars Aequi Libri, Nijmegen 1987, p. 106-120

Nelson 1986: R. Nelson, "Note: To Infer or Not to Infer a Discriminatory Purpose: Rethinking Equal Protection Doctrine", 61 New York University Law Review 334 (1986)

Van der Neut 1986: J.L. Van der Neut, Discriminatie en strafrecht, Gouda Quint, Amhem 1986 Nieuwenhuis 1976: Nieuwenhuis, "Legitimatie en heuristiek van het rechterlijk oordeel", RMThemis 1976, p. 494-515

"Note" 1957: "Note: Constitutionality of Restrictions on Aliens' Right to Work", 57 Columbia Law Review 1012 (1957)

"Note" 1970: "Note: Legislative Purpose and Federal Constitutional Adjudication", 83 Harvard Law Review 1887 (1970)

"Note" 1972: "Note: Legislative Purpose, Rationality, and Equal Protection", 82 Yale Law Journal 123 (1972)

"Note" 1974: "Note: The Irrebuttable Presumption Doctrine in the Supreme Court", 87 Harvard Law Review 1534 (1974)

"Note" 1978: "Note: Equal Protection: A Closer Look at Closer Scrutiny", 76 Michigan Law Review 771 (1978)

"Note" 1981: "Note: Quasi-Suspect Classes and Proof of Discriminatory Intent: A New Model", 90 Yale Law Journal 912 (1981)

"Note" 1982: "Note: A Madisonian Interpretation of the Equal Protection Doctrine", 91 Yale Law Journal 1403 (1982)

Novak 1980: L. Novak, "The Precedential Value of Supreme Court Plurality Opinions", 80 Columbia Law Review 756 (1980)

Nowak 1974: J.E. Nowak, "Realining the Standards of Review Under the Equal Protection Guarantee - Prohibited, Neutral, and Permissive Classifications", 62 Georgetown Law Journal $1071(1974)$ 
0'Donnell 1982: Th.A. O'Donnell, "The Margin of Appreciation Doctrine: Standards in the Jurisprudence of the European Court of Human Rights", Human Rights Quarterly 1982, p. 474496

0'Fallon 1979: J.M. O'Fallon, "Adjudication and Contested Concepts: The Case of Equal Protection", 54 New York University Law Review 19 (1979)

Van den Oord 1990: J.W.J. van den Oord, "Wat heet wijs bij bewijs? De bewijslastverdeling en de Wet gelijk loon en de Wet gelijke behandeling", Nemesis 1990, p. 226-238

Van den Oord 1994: J.W.J. van den Oord, "Speuren naar sporen van de ander in de wet van de ene", in: Van Vleuten (red.), In Concreto. Bijdragen over rechtsvorming gelijke behandeling, Ministerie van Sociale Zaken en Werkgelegenheid 1994, p. 39-54

Ortiz 1989: D.R. Ortiz, "The Myth of Intent in Equal Protection", 41 Stanford Law Review 1105 (1989)

Partsch 1993: K.J. Partsch, "Discrimination", in: Macdonald, Matscher en Petzold (red.), The European System for the Protection of Human Rights, Martinus Nijhoff Publishers, Dordrecht, Boston, Londen 1993, p. 571-592

Partsch 1995: K.J. Partsch, "Wertet die neuere Strassbuger Judikatur das Diskriminierungsverbot auf?", in: Due, Lutter \& Schwarze (red.), Festschrift fur Ulrich Everling, Band II, Nomos Verlagsgesellschaft, Baden-Baden 1995, 1049-1056

Pels Rijcken 1979: L.D. Pels Rijcken, "Rechtszekerheid: Assepoester onder de rechtsvindingstheorieên", in: Non Sine Causa. Opstellen aangeboden aan Prof. Mr. G.J. Scholten, W.E.J. Tjeenk Willink, Zwolle 1979, p. 311-318

Perelman 1963: Ch. Perelman, The Idea of Justice and the Problem of Argument, Translated from the French by J. Petrie, Routledge \& Kegan Paul, Londen 1963

Perry 1977: M.J. Perry, The Disproportionate Impact Theory of Racial Discrimination", 125 University of Pennsylvania Law Review 540 (1977)

Perry 1978: M.J. Perry, "A Brief Comment on Motivation and Impact", 15 San Diego Law Review 1173 (1978)

Perry 1979: M.J. Perry, "Modern Equal Protection: A Conceptualization and Appraisal", 79 Columbia Law Review 1023 (1979)

Peters 1981: J.A. Peters, Het primaat van de vrijheid van meningsuiting. Vergelijkende aspecten Nederland-Amerika, Ars Aequi Libri, Nijmegen 1981, p. 87 e.v.

Pettynga 1987: G.L. Pettynga, "Note: Rational Basis With Bite: Intermediate Scrutiny By Any Other Name", 62 Indiana Law Journal 779 (1987)

Petzold 1993: H. Petzold, "The Convention and the Principle of Subsidiarity", Macdonald, Matscher en Petzold (red.), The European System for the Protection of Human Rights, Martinus Nijhoff Publishers, Dordrecht, Boston, Londen 1993, p. 41-62

Pildes/Niemi 1993: R.H. Pildes en R.G. Niemi, 'Expressive Harms, 'Bizarre Districts,' and Voting Rights: Evaluating Election-District Appearances After Shaw v. Reno", 92 Michigan Law Review 483 (1993)

Piso 1998: I.Y. Piso, De rechter klem tussen discriminatie en rechtvaardiging, SDU Uitgevers, Den Haag 1998

Plamenatz 1967: J.P. Plamenatz, "Diversity of Rights and Kinds of Equality", in: Pennock en Chapman (red.), Nomos IX. Equality, Yearbook of the American Society for Political and Legal Philosophy, Atherton Press, New York, 1967, p. 79-98

Plamenatz 1969: J.P. Plamenatz, "Equality of Opportunity", in: W.T. Blackstone (red.), The Concept of Equality, Burgess Publishing Company, Minneapolis 1969, p. 82-96

Porter 1992: A.C. Porter, "Toward a Constitutional Analysis of the Right to Interstate Travel", 86 Northwestern University Law Review 820 (1992) 
Posner 1979: R.A. Posner, "The Bakke Case and the Future of Affirmative Action", 67 Califor-
nia Law Review 171 (1979) Powell 1982: L.F. Powell, "Carolene Products Revisited”, 82 Columbia Law Review 1087 (1982)

Prechal 1988: S. Prechal, "Gelijke behandeling retrospectief", SEW 1988, p. 78-105

Prechal/Burrows 1990: S. Prechal en N. Burrows, Gender Discrimination Law of the European Community, Dartmouth 1990

Prechal 1993: S. Prechal, "Combatting Indirect Discrimination in Community Law Context", Legal Issues of European Integration 1993, p. 81-97

Priebe 1988: R. Priebe, "Le Droit Communautaire des Structures Agricoles", Cahiers de Droit Européen 1988, p. 3-38

Rapport ABAR 1984: Algemene bepalingen van administratief recht, Rapport van de commissie inzake algemene bepalingen van administratief recht, Samson H.D. Tjeenk Willink, Alphen a/d Rijn 1984

Rehnquist 1980: W.H. Rehnquist, “'All Discord, Harmony not Understood', 22 Arizona Law Review 973 (1980)

Ress 1983: G. Ress, "Die 'Einzelfallbezogenheit' in der Rechtsprechung des Europäischen Gerichtshofs für Menschenrechte”, in: Bernhardt, Geck, Jaenicke \& Steinberger (red.), Völkerrecht als rechtsordnung. Internationale Gerichtsbarkeit. Menschenrechte. Festschrift für Hermann Mosler, Springer-Verlag, Berlin, Heidelberg, New York 1983, p. 719-744

Riphagen/Smitskam 1990: J. Riphagen en C.J. Smitskam, "De betekenis van artikel 26 IVPBR voor de sociale verzekeringsrechtspraak", NJCM-Bulletin 1990, p. 401-428

Robertson/Merrills 1993: A.H. Robertson en J.G. Merrills, Human Rights in Europe. A study of the European Convention on Human Rights, Derde druk, Manchester University Press, Manchester en New York, 1993

Rodrigues 1992: P.R. Rodrigues, "Onderscheid naar nationaliteit en achterstelling in privaatrechtelijke rechtsverhoudingen, NJCM-Bulletin 1992, p. 503-517

Rogers 1997: J.W. Rogers, "Romer v. Evans: Heightened Scrutiny Has Found a Rational Basis", 45 Kansas Law Review 953 (1997)

Rosberg 1977: G.M. Rosberg, "The Protection of Aliens from Discriminatory Treatment by the National Government", 1977 Supreme Court Review 275

Rosenblum 1979: B.E. Rosenblum, "Note: Discriminatory Purpose and Disproportionate Impact: An Assessment After Feeney", 79 Columbia Law Review 1376 (1979)

Rosenfeld 1989: M. Rosenfeld, "Decoding Richmond: Affirmative Action and the Elusive Meaning of Equality", 87 Michigan Law Review 1729 (1989)

Ross 1958: A. Ross, On Law and Justice, University of California Press, Berkeley en Los Angeles 1958

Rossiter 1999: C. Rossiter (red.), The Federalist Papers, Mentor 1999

Ruiter 1985: D.W.P. Ruiter, Het ongrijpbare gelijkheidsbeginsel, Preadvies voor de Vereniging van Administratief Recht, Geschriften van de VAR XCIII, Alphen a/d Rijn 1985

Rutten 1997: J.C. Rutten, "Elasticity in Constitutional Standards of Review: Adarand Constructors Inc. v. Pena and Continuing Uncertainty in the Supreme Court's Equal Protection Jurisprudence", 70 Southern California Law Review 591 (1997)

Scalia 1997: A. Scalia, A Matter of Interpretation. Federal Courts and the Law, Princeton University Press, Princeton, New Jersey 1997

Scheltema 1989 (I): M. Scheltema, "Wie stelt de wet: de wetgever of de rechter?", in: Van Dijk (red.), De relatie tussen wetgever en rechter in een tijd van rechterlijk activisme, Mededelingen der KNAW 1989, p. 85-94 
Scheltema 1989 (II): M. Scheltema, "De rechtsstaat", in: J.W.M. Engels e.a. (red.), De rechtsstaat herdacht, W.E.J. Tjeenk Willink, Zwolle 1989, p. 11-25

Schiek 1998: D. Schiek, "Sex Equality Law After Kalanke and Marschall", European Law Journal 1998, p. 148-166

Schiek 1999: D. Schiek, "Freedom of Contract and a Non-Discrimination Principle - Irreconcilable Antonyms?", in: Loenen, T., en Rodrigues, P.R., Non-Discrimination Law: Comparative Perspectives, Kluwer Law International, Den Haag/Boston/Londen 1999, p. 77-89

Schmitthoff 1977: C.M. Schmitthoff, "The Doctrines of Proportionality and NonDiscrimination", European Law Review 1977, p. 329-334

Schokkenbroek 1995: J.G.C. Schokkenbroek, "Judicial review by the European Court of Human Rights: constitutionalism at European level”, in: Bakker, Heringa \& Stroink, Judicial Control. Comparative essays on judicial review, Maklu, Antwerpen 1995, p. 153-165

Schokkenbroek 1996: J.G.C. Schokkenbroek, Toetsing aan de vrijheidsrechten van het Europees verdrag tot Bescherming van de Rechten van de Mens, diss. Leiden 1996

Schokkenbroek 1998: J.G.C. Schokkenbroek, "The Prohibition of Discrimination in Article 14 of the Convention and the Margin of Appreciation", Human Rights Law Journal 1998, vol. 19, no. 1, p. 20-23

Schoordijk 1972: H.C.F. Schoordijk, Oordelen en vooroordelen, Kluwer, Deventer 1972

Schutte 2000: N.J. Schutte, "Toepassing van het gelijkheidsbeginsel", Tijdschift voor Formeel Belastingrecht 2000, afl. 11-12, p. 4-10

Schwarze 1992: Schwarze, J., European Administrative Law, Office for Official Publications of the EC, Sweet and Maxwell, 1992

Sedemund 1987: J. Sedemund, "Statement in the concept of the free movement of goods and the reservation for national action under Art. 36 EEC Treaty", in: Schwarze (red.), Discretionary Powers of the Member States in the Field of Economic Policies and their Limits under the EEC Treaty, Nomos Verlagsgesellschaft, Baden-Baden 1987, p. 25-36

Selmi 1997: M. Selmi, "Proving Intentional Discrimination: The Reality of Supreme Court Rhetoric", 86 Georgetown Law Journal 279 (1997)

Serrarens/Spronken 1991: J. Serrarens en T. Spronken, "Tippelen in Heerlen. Het Heerlense tippelverbod en het gelijkheidsbeginsel", Nemesis 1991, p. 4-9

Shapiro 1987: D.L. Shapiro, "In Defense of Judicial Candor", 100 Harvard Law Review 731 (1987)

Sherry 1984: S. Sherry, "Selective Judicial Activism in the Equal Protection Context: Democracy, Distrust, and Deconstruction", 73 Georgetown Law Review 89 (1984)

Siedzikowski 1978: H. Siedzikowski, "Comment: Federalism and a New Equal Protection", 24 Villanova Law Review 557 (1978)

Siegel 1997: R. Siegel, "The Critical Use of History: Why Equal Protection No Longer Protects: The Evolving Forms of Status-Enforcing State Action", 49 Stanford Law Review 1111 (1997)

Simon 1994: H.J. Simon, "De verkeerde kant van het gelijkheidsbeginsel", Sociaal Recht, 1994, p. $39-49$

Simons 1985: K. Simons, "Equality as a Comparative Right", 65 Boston University Law Review 387 (1985)

Simson 1977: G.J. Simson, "A Method for Analyzing Discriminatory Effects Under the Equal Protection Clause", 29 Stanford Law Review 663 (1977)

Sjerps 1999: I. Sjerps, "Effects and Justifications, Or how to Establish a Prima Facie Case of Indirect Sex Discrimination", in: Loenen \& Rodrigues (red.), Non-Discrimination Law: Comparative Perspectives, Kluwer Law International, Den Haag/Boston/Londen 1999, p. 237-247

Sloot 1986: B.P. Sloot, Positieve discriminatie. Maatschappelijke ongelijkheid en rechtsontwikkeling in de Verenigde Staten en in Nederland, W.E.J. Tjeenk Willink, Zwolle 1986 
Sloot 1989: B.P. Sloot, "Over positieve actie en positieve discriminatie", Preadviezen NJV 1989, p. 2-56

Slynn 1987: Sir Gordon Slynn, "The concept of the free movement of goods and the reservation for national action under Article 36 EEC Treaty", in: Schwarze (red.), Discretionary Powers of the Member States in the Field of Economic Policies and their Limits under the EEC Treaty, Nomos Verlagsgesellschaft, Baden-Baden 1987, p. 17-24

Sobelsohn 1977: D.Ch. Sobelsohn, "Note: Of Interests, Fundamental and Compelling: The Emerging Constitutional Balance", 57 Boston University Law Review 462 (1977)

Somek 1999: A. Somek, "A Constitution for Antidiscrimination: Exploring the Vanguard Moment of Community Law", European Law Journal 1999, p. 243-271

Van der Steen 2001: I. van der Steen, "Horizontale werking van de vier vrijheden en van het discriminatieverbod van artikel 12 EG", NTER 2001, p. 4-9

Steenbeek 1961: J.G. Steenbeek, "Rechtmatigheid en doelmatigheid", RMThemis 1961, p. 150176

Steiner 1996: J. Steiner, "The Principle of Equal Treatment for Men and Women in Social Security", in: Hervey \& O'Keeffe (red.), Sex Equality Law in the European Union, John Wiley \& Sons, Chichester, New York, Brisbane, Toronto, Singapore 1996, p. 111-136

Stern/Gressman 1978: R.L. Stern en E. Gressman, Supreme Court Practice, Fifth Edition, BNA Books, Washington D.C. 1978

Stoter 1996: W.S.R. Stoter, "Rechtvaardigingsgronden voor ongelijke behandeling van vrouwen en mannen in het gemeenschapsrecht", NJB 1996, p. 1811-1815

Strasser 1996: W. Strasser, "Remedies against racial discrimination and other forms of racism, xenophobia or intolerance under the ECHR", in: Woltjer \& De Beer, Juridische middelen ter bestrijding van rassendiscriminatie en raciaal gemotiveerde geweldpleging, Stichting NJCMBoekerij, Leiden 1996, p. 39-50

Stroink 1987: F.A.M. Stroink, "De toepassing van het internationale recht door de Nederlandse (administratieve) rechter", in: Staatsrecht, buitenlandse betrekkingen en de internationale rechtsorde, Staatsrechtconferentie 1987, Ars Aequi Libri, Nijmegen 1987, p. 30-52

Sullivan 1993: K.M. Sullivan, "Categorization, Balancing and Governmental Interests", in: Gottlieb (red.), Public Values in Constitutional Law, The University of Michigan Press, Ann Arbor 1993, p. 241-266

Sundberg-Weitman 1977: B. Sundberg-Weitman, Discrimination on grounds of nationality. Free movement of Workers and Freedom of Establishment under the EEC Treaty, North-Holland Publishing Company, Amsterdam, New York, Oxford 1977

Sundberg-Weitman 1980: B. Sundberg-Weitman, "Legal tests for applying the European Convention on Human Rights and Freedoms in adjudicating on alleged discrimination", Nordisk Tidsskrift for International Ret 1980, p. 31-58

Timmermans 1982: C.W.A. Timmermans, "Verboden discriminatie of (geboden) differentiatie?", SEW 1982, p. 426-460

Thomson 1969: D. Thomson, "The Problem of Equality", in: Blackstone (red.), The Concept of Equality, Burgess Publlishing Company, Minneapolis 1969, p. 2-13

Tobler 2001: Ch. Tobler, "Rechtvaardiging van direct onderscheid in het EG-recht", Nemesis 2001, p. 121-127

Tomuschat 1992: C. Tomuschat, "Europe - A common constitutional space", in: De Witte en Forder (red.), The Common Law of Europe and the future of legal education, Kluwer, Deventer 1992, p. 133-147

Tribe 1980: L.H. Tribe, "The Puzzling Persistence of Process-Based Constitutional Theories", 89 Yale Law Journal 1063 (1980) 
Tribe 1988: L.H. Tribe, American Constitutional Law, tweede druk, The Foundation Press, Mineaola, New York 1988

Tribe 1997: L.H. Tribe, "Comment", in: Scalia (red.: Gutmann), A Matter of Interpretation. Federal Courts and the Law, Princeton University Press, Princeton, New Jersey 1997, p. 65-94

Tridimas 1997: T. Tridimas, "The Application of the Principle of Equality to Community Measures", in: Dashwood \& O'Leary (red.), The Principle of Equal Treatment in EC Law, A Collection of Papers by the Centre for European Studies (Cambridge), Sweet \& Maxwell, London, Dublin, Hong Kong 1997, p. 214-242

Tridimas 1999 (I): T. Tridimas, The General Principles of EC Law, Oxford University Press, Oxford 1999

Tridimas 1999 (II): T. Tridimas, "Proportionality in Community Law: Searching for the Appropriate Standard of Scrutiny", in: Ellis (red.), The Principle of Proportionality in the Laws of Europe, Oxford 1999, p. 65-84

Tussman en TenBroek 1949: J. Tussman en J. TenBroek, "The Equal Protection of the Laws", California Law Review 1949, p. 341-381

Tuytenschaever 1999: F. Tuytenschaever, Differentiation in European Union Law, Hart Publishing, Oxford 1999

Ulmer 1981: S.S. Ulmer, Courts, Law, and Judicial Processes, The Free Press, New York 1981

Vaugh Dunnigan 1988: E. Vaugh Dunnigan, "Note: Discrimination by the Defense: Peremptory Challenges after Batson v. Kentucky", 88 Columbia Law Review 355 (1988)

Velaers 1991: J. Velaers, De beperkingen van de vrijheid van meningsuiting, Deel I en II, Maklu, Antwerpen, Aperdoorn 1991

Vegter 2000 (I): M.S.A. Vegter, "Wijziging arbeidsduur en gelijke behandeling $\mathrm{m} / \mathrm{v}$ : de stand van zaken", ArbeidsRecht 2000 , p. $30-34$

Vegter 2000 (II): M.S.A. Vegter, "Zwangerschap en discriminatie. De pijnpunten van het gesloten discriminatiestelsel", Nemesis 2000, p. 118-125

Veldman 1998: A. Veldman, "Het homoseksuele paar, hun treinkaartjes en het recht. Juridische beoordeling van (indirect) onderscheid op meerdere discriminatiegronden tegelijk", Nemesis 1998, p. 1-4

Versteden 1985: C.J.N. Versteden, Het falende gelijkheidsbeginsel, Preadvies voor de Vereniging van Administratief Recht, Geschriften van de VAR XCIII, Samson H.D. Tjeenk Willink, Alphen a/d Rijn 1985

Vierdag 1973: E.W. Vierdag, The concept of discrimination in international law, Martinus Nijhoff, Den Haag 1973

Viljanen 1994: V.-P. Viljanen, "Abstention or Involvement? The Nature of State Obligations under Different Categories of Rights”, in: Drzewicki, K., Krause, C. en Rosas, A. (red.), Social Rights as Human Rights. A European Challenge, Åbo Akademi University 1994, p. 43-66

Vincent 1978: J.K. Vincent, "Equal Protection and the "Middle-Tier": The Impact on Women and Illegitimates", 54 Notre Dame Lawyer 303 (1978)

Vis 1988: J.J. Vis, "Gelijkheid en non-discriminatie: Art. 1 Grondwet", in: Boon e.a. (red.), Opstellen over grondrechten, Wolters-Noordhoff, Groningen 1988, p. 47-89

Van Vleuten/Willems 1999: C.E. van Vleuten en L. Willems, "Commissie Gelijke Behandeling in de AWGB", in: Asscher-Vonk \& Groenendijk (red.), Gelijke behandeling: regels en realiteit. Een juridische en rechtssociologische analyse van de gelijke behandelingswetgeving, Sdu, Den Haag 1999, p. 235-299

Vogenauer 1997: S. Vogenauer, "What is the Proper Role of Legislative Intention in Judicial Interpretation?”, 18 Statute Law Review 235 (1997) 
Waaldijk/Hendriks 2000: C. Waaldijk en A.C. Hendriks, "Hetero- of homoseksuele gerichtheid en burgerlijke staat", in: Loenen, T. (red.), Gelijke behandeling: oordelen en commentaar 1999, Kluwer, Deventer 2000, p. 45-59

Waddington/Bell 2001: L. Waddington en M. Bell, "More Equal than Others: Distinguishing European Union Equality Directives", Common Market Law Review 2001, 587-611.

Walzer 1983: M. Walzer, Spheres of Justice, Basic Books Publishers, New York 1983

Watson 1995: Ph. Watson, "Equality of Treatment: A Variable Concept?", Industrial Law Journal 1995, p. 33-48

Wattèl 1993: P.J. Wattel, "Het ongelijkheidsbeginsel", WFR 1993, p. 1723-1724

Watterson Jr. 1996: R.N. Watterson Jr., "Adarand Constructors v. Pena: Madisionian Construction as a Justification for Lesser Constitutional Scrutiny of Federal Race-Conscious Legislation”, 1996 Brigham Young University Law Review 301 (1996)

Weidmann 1985: K.W. Weidmann, Der Europäische Gerichtshof für Menschenrechte auf dem Weg zu einem europäische verfassungsgerichtshof, Lang, Frankfurt am Main, Nern, New York 1985

Wentholt 1990: K. Wentholt, Arbeid en zorg. Een verkenning vamuit het gelijkheidsbeginsel van de rechtspositie van werknemers met gezinsverantwoordelijkheid, Thesis Publishers, Amsterdam 1990

Wentholt 1999 (I): K. Wentholt, "Formal and Substantive Equal Treatment: the Limitations and the Potential of the Legal Concept of Equality", in: Loenen en Rodrigues, Non-Discrimination Law: Comparative Perspectives, Kluwer Law International, Den Haag/Boston/Londen 1999, p. 53-64

Wentholt 1999 (II): K. Wentholt, "Het verbod om onderscheid te maken (art. 1 en 2 lid 1 AWGB)", in: Asscher-Vonk en Groenendijk (red.), Gelijke behandeling: regels en realiteit. Een juridische en rechtssociologische analyse van de gelijke behandelings-wetgeving, Sdu, Den Haag 1999 , p. $89-130$

Wentholt 2000 (I): K. Wentholt, "Direct en indirect onderscheid en het verschil in toetsingsmethodiek", in: Loenen (red.), Gelijke behandeling: oordelen en commentaar 1999, Kluwer, Deventer 2000 , p. $105-118$

Wentholt 2000 (II): K. Wentholt, "De EG-dimensie van de gelijke behandeling van mannen en vrouwen", SMA 2000, p. 285-291

Westen 1982 (I): P. Westen, "The Empty Idea of Equality", 95 Harvard Law Review 537 (1981/1982)

Westen 1982 (II): P. Westen, "On 'Confusing Ideas': Reply", 91 Yale Law Journal 1982/1983, p. $1153-1165$

Westen 1983 (I): P. Westen, "The Meaning of Equality in Law, Science, Math and Morals: A Reply”, 81 Michigan Law Review 604 (1983)

Westen 1983 (II): P. Westen, "To Lure the Tarantula from Its Hole: A Response", 83 Columbia Law Review 1983, p. 1186-1208

Westen 1990: P. Westen, Speaking of Equality. An Analysis of the Rhetorical Force of "Equality" in Moral and Legal Discourse, Princeton University Press, New Jersey 1990

Wiarda 1986: G.J. Wiarda, Rechterlijke voortvarendheid en rechterlijke terughouding bij de toepassing van de Europese Conventie tot bescherming van de rechten van de mens, Vuga, Den Haag 1986

Wiarda 1999: G.J. Wiarda., 3 Typen van rechtsvinding, Bewerkt en van een nabeschouwing voorzien door T. Koopmans, Vierde druk, W.E.J. Tjeenk Willink, Deventer 1999

Wiggers 1991: J.H. Wiggers, Recht doen aan gelijkheid. Een beschouwing over voorkeursbehandeling en de betekenis van het gelijkheidsbeginsel in het grensgebied van recht en sociaalpolitieke ethiek, Ars Aequi Libri, Nijmegen 1991 
Van Wijk/Konijnenbelt 1999: H.D. van Wijk (herzien door W. Konijnenbelt en R.M. van Male), Hoofdstukken van bestuursrecht, Dertiende druk, Elsevier, Den Haag 1999

Wilkinson 1975: J.H. Wilkinson III, "The Supreme Court, the Equal Protection Clause, and the Three Faces of Constitutional Equality", 61 Virginia Law Review 945 (1975)

Wilkinson 1995: B. Wilkinson, "Towards European Citizenship? Nationality, Discrimination and Free Movement of Workers in the European Union", European Public Law 1995, p. 417-437 Wilson 1984: W.J. Wilson, "Race-Specific Policies and the Truly Disadvantaged", 2 Yale Law \& Public Policy Review 272 (1984)

Winter 1972: R.K. Winter, "Poverty, Economic Equality, and the Equal Protection Clause", 1972 Supreme Court Review 41

De Wolff 2001: D.J.B. de Wolff, "Arbeidsduur", in: Loenen (red.), Gelijke behandeling: oordelen en commentaar 2000, Kluwer, Deventer 2001, p. 45-54

Woltjer 2002: A. Woltjer, Wetgever, rechter en het primaat van de gelijkheid. Over primaten in het recht (Diss. Utrecht 2002), Boom Juridische Uitgevers, Den Haag 2002

Wormuth/Mirkin 1964: F.D. Wormuth en H.G. Mirkin, "The Doctrine of the Reasonable Alternative", 9 Utah Law Review 254 (1964)

Wright 1980: S.J. Wright, "Judicial Review and the Equal Protection Clause", 15 Harvard Civil Rights and Civil Liberties Law Review 1 (1980)

Wunder 1986: M.V. Wunder, "Equal Protection and the Mentally Retarded: A Denial of QuasiSuspect Status in City of Cleburne v. Cleburne Living Center", 71 lowa Law Review 241 (1986)

Zwart 1999: T. Zwart, "De juridische bescherming van minderheden door de Raad van Europa", NJCM-Bulletin 1999, p. 336-357 



\section{Zakenregister}

Aansluiting onderscheid op doelstelling - zie mate van fit

Abstracte toetsing

$19,21-23,56,118-120,296,694-695$

Accessoir karakter

$103-109,517-518$

Achterstelling - zie benadeling

Actualiteitsvereiste - zie doelstelling

Actual purpose-test

$429-431$

Administratieve doelstellingen - zie doelstelling

Afgeleide rechten

$96,186-191,485-486,511,708$

Afweging intensiteitbepalende factoren - zie toetsingsintensiteit

Algemeen toetsingsmodel (opbouw)

714-722

Algemene beginselen van behoorlijk bestuur

$523-526,548-552,640$

Algemene belangen als doelstelling - zie doelstelling

Algemene wet gelijke behandeling

$521-523$

Alternatieven voor onderscheid - zie subsidiariteitsvereiste

Ambtshalve toetsing

$260,429-430,581-583$

Begripsbepaling

9-16

Begunstigend beleid

548-549

Belangenaantasting - zie proportionaliteitsvereiste of gewicht betrokken belangen of benadelingstoets

Belangenafweging - zie proportionaliteitsvereiste

Beleidsmarge - zie toetsingsintensiteit

Beleidsterrein

98-99, 309-310

Beleidsvrijheid - zie toetsingsintensiteit

Benadeelde groep, gevolgen van definitie van voor toetsingsintensiteit

Benadelingstoets

als toetsingsingang

inhoud

$77,135-137,246-248,259-261,405-414,575,653-654,674-679$

selecterend vermogen

$78,653-654,674$

bewijs en verdeling bewijslast

$77-79,246-248,259-260,349-351$. $410,498-500,581-583,674$

definitie/afbakening benadeelde groep

criteria voor vaststelling

77-79, 134-137, 245, 256-257, 258-266, 347-348, $399-401,405-415,498-501,545-546,556,561-563$.

$575-588,652-654,673-679$

algemene verwachtingen/evidentie/logica

bestaan van classificatie

concrete/abstracte benadeling

daadwerkelijke benadeling

disproportionele/overwegende benadeling

feitelijke benadeling

feiten van algemene bekendheid

herleidbaarheid tot verboden grond

$348-349,413,501,578-579,580,676,678$

246-248

$259-260,349-350,585-586,677$

$405-406,498-499,540,545-546,674-675$

576,653

$262,406-407,499,563,577,653,675-676$

$246,248,351,500,562,575,578-579$.

$587-588,654,676,678$

$246-247,577,675$

$260,349,583-585,677$

$246,561-562,575,654$ 
materiële benadeling

$78,350,407,576,578$

$576-577,675$

meetbaar/objectiveerbaar nadeel

morele/geestelijke benadeling

rechtens relevant belang

relatieve/absolute gegevens

$78,350,407-408,499,576,675$
$576-577,653,675-676$

$562,580,677-678$

relevante benadeling

$247,351,501$

576,653

voldoende ernstige benadeling

statistisch/feitelijk/cijfermatig bewijsmateriaal

246-247, 259, 349, 579-583.

$653,677-678$

subjectief ervaren benadeling

577,675

vermijdbaarheid

409

betekenis vergelijkbaarheid voor -

- in combinatie met doelstelling als toetsingsingang

$78-79,248-250,262-264,349,399-401,413$

invloed toetsingsintensiteit op -

$419-422$

bij formeel/materieel onderscheid

bij indirect onderscheid

$78,348,674-675$

$246,248,258,348,411-423,556,561-563$,

$579-588,673,676-679$

bij direct onderscheid

$264-266,348,405-410,540,545-546,562,673,674-676$

bij separate but equal-doctrine

399-401

384

Benoeming rechters

Beoogd onderscheid

$23,369-371,415-423$

Beoordelingscriteria - zie toetsingsmodel

Beoordelingsruimte

$166-168$

zie ook margin of appreciation-doctrine

Beoordelingsvrijheid - zie toetsingsintensiteit

Bepaalbaarheid benadeelde groep

$466-467$

Beslissingsmodel - zie toetsingsmodel

Better placed-argument - zie toetsingsintensiteit

Bevoegdheidsomvang - zie doelstelling of toetsingsintensiteit

Bevoegdheidsuitoefening, onderscheid door -

$19-20,48-49,372,526,544,548-552$, $552,573-574,642-643,666,712$

Bewijsfunctie vergelijkbaarheidstoets - zie vergelijkbaarheid

Bewijslastverdeling

$27-28,37,73-79,82-83,129,246-248,259-260$, $362,349-351,388-389,394,410,415-423,425-426$, $434,462,498-501,502,581-583,666-667,671,672,691$

Bewijsrecht

537

Bill of Rights

$363,482,485-488,511$

Binnenlandse belasting

$266-268,281-284$

Bloot onderscheid - zie onderscheid

Bronnen voor vaststelling doel - zie doelstelling

Budgettaire overwegingen als doelstelling - zie doelstelling

"But for"-criterium

Carolene Products-rationale

Casuïstisch karakter rechtspraak

Causaliteit - zie geschiktheid

Cijfermatig bewijsmateriaal - zie benadelingstoets (statistisch bewijs)

Civil Rights Act 1866
$464-466,472-475,482,488,508-510,701-703,707$

$118-120,126,140-143,240,278,299$ 


\section{Classificatie}

betekenis begrip -

normatieve -

$18-19,498-501,526,544,546-547,555,641-643,666,674-675$ als toetsingsingang - zie toetsingsingang

Common ground- of consensusfactor

$170-179,199-207,218,310,332-334,360$, $644-646,704,708,711$

Conceivable basis-test $424-429,450-451,501$

Concreet onderscheid - zie onderscheid

Concrete bevoegdheidsuitoefening - zie bevoegdheidsuitoefening

Concrete toetsing

$19,21-22,56,118-120,296-297,694-695$

Concurrentieverhoudingen

$242,252,254,266-268,342$

Concurring opinions

Congruent/discongruent onderscheid

91-92n

Congruentiebeginsel

Context onderscheid - zie toetsingsintensiteit

Contra legem-werking

$56,525-526,536,548-552,630-631,659,698$

Coördinerend beleid

$549,573-574$

Decentralisatie

574

Deconcentratie

Definitie onderscheid - zie mate van fit of proxy

Democratie, zelfcorrigerend vermogen -

$464-466,470-472,484-485,509,702,707$

Demonstratievrijheid - zie politieke rechten

Derdenbelangen - zie gewicht betrokken belangen

Diensten, vrij verkeer van -

$280-281,302$

Differentiatie

betekenis begrip -

noodzaak van -

Differentiatiegrond/-criterium - zie grond van onderscheid

Differentiatie in toetsingsintensiteit - zie toetsingsintensiteit

Direct onderscheid - zie onderscheid

Directe belastingen

263-264

Directe werking

Discrepantie tussen gesteld en werkelijk doel - zie doelstelling (werkelijke -)

Discrete and insular minority

Discretionaire bevoegdheid - zie toetsingsintensiteit

Discriminatie

betekenis begrip -

verbodsbepalingen

Discriminatoire doelstelling - zie doelstelling

Disproportionele benadeling - zie benadelingstoets

Dissenting opinions

Distinguishing

Distributie van rechten

Doelmatigheidsaspecten

$638-641,660,684$

Doel-middeltoets - zie verhouding doel-middel 
Doelstelling

noodzaak van toetsing van -

$32-34,63-65,254,655$

als intensiteitbepalende factor - zie toetsingsintensiteit

als toetsingsingang

$74-75,411-412,415-423,500,671-673$

bewijs discriminatoire doelstelling

$416-422,500-501,672$

effect maatregel is gelijk aan doelstelling

$416-418$

bronnen ter bepaling van discriminatoire doelstelling

418

overige bewijsvereisten

$419-422$

als vergelijkingsmaatstaf

vaststelling van -

$35-39,137-140,424-431,568-570,588-592,655,668,679-681$

effect van de wet als bron

$35-39,427,430$

eigen fantasie rechter als bron

$424-429,569,591-592$

lagere rechtspraak als bron

427,589

logica/evidentie als bron

430

samenhang van de wet als bron

$35-39,431$
$655,680-681$

stellingen partijen als bron

tekst van de wet als bron

totstandkomingsgeschiedenis als bron

waarschijnlijkheid als bron

$137,427,590-591,655,680-681$

$35-39,427,569$

bewijslast

werkelijke -

$35-39,427,430,568-569,588,655,680$

591

$425-426,434,502,655,679$

conceivable basis-test

$35-39,138-140,214,270-271,282,284-285$,

$429-430,590-591,594,600,655,680-681$

actual purpose-test

pluraliteit van -

$424-429,501-502$

$429-431,680$

proportionaliteitstoets bij toetsing -

noodzakelijkheidstoets bij toetsing -

toetsing bij very weighty reasons-test

toetsing in horizontale/verticale verhoudingen

gerechtvaardigdheid -

$40-42,271,416,431-434,592-595,682-683$ $142-143,213,434-436,457-459,505,606,656$

602

$142-144$

$272-274,344-345$

$42,140-144,213,254-246,269-285,345$.

$427,595-596,655-656,683-686$

criteria/factoren voor toetsing gerechtvaardigdheid/vaststelling gewicht -

actualiteit

administratieve doelstellingen

algemeen belang

algemene en abstracte doelstellingen

beantwoorden aan reële situatie

begrenzing bevoegdheid

bescherming gebruikers van diensten

budgettaire/financiële overwegingen

compelling governmental interest

common ground- of consensusfactor

détournement de pouvoir

derdenbelangen

discriminatoire motieven

doelmatigheid

economische doelstelling

feitelijke grondslag
$144,353,441-442,503,601-602,609,656,585$

$279-280,354,443,503,505,629,659,698$

278

143,272

$144,272-274,353,441-442,601-602$

$437-438,684$

280-281

$274-275,354,444,503,505,628-629,659,697$

$434-435$

711

$284 \mathrm{n}, 437-438,597,656,684$ $277-278,630,647,686,698$

$30-31,269,279,284,352-353,598-601,656,684-685$

$279-280,354,443,503,505,629$

282-283

$144,271,441-442,503,656,685$ 
important governmental objective

434-435

generalisatie als basis

$271,353,685$

$441-442$

hypothetisch

legaliteitsbeginsel

$548,630-631,659,698$

legitimiteit

maatschappelijke opvattingen

$603-606,656,686$

noodzakelijke doelstelling sociaal beleid

$273-274,685$
$607-608$
272
$282-284$
$277-278,630,686$
607

objectiviteit

$273-274,685$
$607-608$
272
$282-284$
$277-278,630,686$
607

onderzoeksverplichting wederpartij

$273-274,685$
$607-608$
272
$282-284$
$277-278,630,686$
607

protectionistische bedoeling

$273-274,685$
$607-608$
272
$282-284$
$277-278,630,686$
607

rechtszekerheid

$273-274,685$
$607-608$
272
$282-284$
$277-278,630,686$
607

redelijkheid

$273-274,685$
$607-608$
272
$282-284$
$277-278,630,686$
607

vooroordelen/stereotypen als basis

specificiteit

substantieel

$284,437-438,596-598,655-656,683-684$

$143,269,272,439-451,684-685$

$143,271-272,441-442,608-609,685$

441-442

629-630

603-606

veranderde rechtsopvattingen

verenigbaarheid met positief recht

voorkeursbehandeling

$284,437-438,596-598,655-656$,
$4883-684$
$435-436$

281

voorkomen dubbele belasting

$277,353-354,686$

werkelijke behoefte

zakelijkheid

$272-273,353,503,594,601-602,656,685$

zwaarwegendheid

608

doelcriteria

ruimte voor bijzondere criteria

$142-144,434-436,606,656$ $141-142,213,275-276$

$284-285,354$

Dominante groep, aantasting rechten van - zie toetsingsintensiteit

en voorkeursbehandeling

Drittwirkung - zie horizontale verhouding

Dubbele belasting

280-281, 302

Due Process Clause

373-376

Dwingende redenen van algemeen belang

Economisch recht, gelijkheidsbeginsel als -

$222-225,331,342$

Eerste fase - zie toetsingsfasen

Effect

- als doelstelling

benadelend/discriminatoir zie ook benadelingstoets

maatschappelijk -

$30-31,410,441,681-682$

Effectiviteit - zie geschiktheid

Eigendomsrecht

$149-150,327$

Equal Protection Clause

totstandkomingsgeschiedenis

363-365

interpretatie

364-368

reikwijdte

$365-368,373-376$

Erga omnes-werking

118-120

Ernst belangenaantasting - zie gewicht betrokken belangen 
Evenredigheid - zie proportionaliteitsvereiste

Evenredigheidsbeginsel als zelfstandig beginsel

$290-291,295-297$

Evenwicht in bewijslastverdeling - zie bewijslastverdeling

Evidente onredelijkheid

Ex tunclex nunc-toetsing

$292-292,355,451,504,690-691$

Fair balance

$149-150$

Fasen van toetsing - zie toetsingsfasen

Fataal karakter strict scrutiny-test - zie strict scrutiny-test

Federale verhoudingen

$372-376,494-496,712$

Feitelijk handelen

Feiten van algemene bekendheid - zie benadelingstoets

Financiële overwegingen als doelstelling - zie doelstelling

Fiscale integriteit - zie doelstelling of gewicht aangetast belang

Fitness - zie mate van fit

Formeel onderscheid - zie onderscheid

Formulering onderscheid - zie mate van fit of proxy

Fundamenteel recht, gelijkheidsbeginsel als -

$222-225,308-309,342$

Fundamentele rechten/belangen - zie gewicht betrokken belangen

Fundamentele rechtsbeginselen, toetsing aan - zie rechterlijke toetsing

Gebonden bevoegdheid

$639-640,712$

Gecoördineerd beleid

$549,573-574$

Gebrekkig functioneren democratie - zie democratie (zelfcorrigerend vermogen)

Gelijkheid door de wet

$3,18-19$

Gelijkheidsbeginsel

betekenis

$4-5,9-11,342-343$

als abbb

523-526

als algemeen rechtsbeginsel

514

als economisch recht

$222-225,327,342-343,359$

als fundamenteel recht

$222-225,342-343,359$

Gelijkheid in resultaat - zie materiële gelijkheid

Gelijkheid van kansen

Gelijkheid voor de wet

Gelijkheidsbepalingen (open en gesloten)

Gelijksoortigheid

$16-18,111-113,225-226,367-368,513-526$

Gelijkwaardigheid voorzieningen - zie separate but equal-doctrine

Gemeenschappelijk landbouwbeleid

266-268

Gerechtvaardigd doel - zie doelstelling

Gerechtvaardigde verwachtingen

$239,251-254,275-276,319-322,342-343$

Geschiktheidsvereiste

inhoud geschiktheidstoets

$49,151-154,215,286-287,291-293,299$, $355,450-452,617,657$

passendheidsvereiste

$543-544,547,553,617$

toetsing ex tunc/ex nunc

rechterlijke bevoegdheid tot toetsing

$292,355,451,504,690-691$

bewijs en bewijslastverdeling

$50-51,215$

toetsingscriteria

$451,504,691$

$617-619,657-658,691$ 
gevolgen toetsingsintensiteit voor toetsing

verhouding tot andere toetsingscriteria

Geschreven recht, toetsing aan -

Geslacht - zie grond van onderscheid

Gesloten gelijkheidsbepalingen

Gewicht betrokken belangen

wijze van vaststelling

objectieve/subjectieve vaststelling

gewicht aangetast belang

afgeleide rechten

common ground

constitutioneel/verdragsrechtelijk beschermd recht

derdenbelangen

economische/financiële rechten/belangen

kernrecht/perifeer recht

minderheidsrechten/-belangen

ontplooiingsrechten

politiek-procedurele (grond)rechten

voorkeursbehandeling

ernst belangenaantasting

bestaan van alternatieven/compensatie

duur benadeling

eenmalig/onherroepelijk/onherstelbaar nadeel

hardheidsclausules, invloed van -

individuele beschikking/algemene maatregel

preventieve/repressieve aantasting

punitief/reparatoir karakter aantasting

vermijdbaarheid nadeel

volledige/onvoorwaardelijke uitsluiting

gerechtvaardigde verwachtingen, invloed van -

gewicht nagestreefd belang

zie verder doelstelling
$287,451-452,691$

153-154

$42-46$

$16,225-226,367-368,513-526$

94-96, 186-191, 361-362, 482-490, 626-631

$94-95,186-191,647$

96-97, 160-161, 186-191, 296, 327-328, 331, $360-361,458-459,482-490,624,697,707-709$

$96,186-191,485-486,511,708$

647,708

$485-488,647,708$

624

327,331

186-191, 361, 697, 708

465-466

$95,186-191,309,361,482-484,697,708$

$95,186-191,484-485,697,707-708$

$315-318,360,458-459$

191-192, 326, 338-339, 460-461. $488-490,626-628,659,709-710$

$627-628,697,709$ 626,697

$627,697,709$

$459,627,697,709$

326

191,710

326,710

$460-461,506,628,697,709$

$489,627,709$

459

invloed op proportionaliteitstoets - zie proportionaliteitsvereiste

invloed op toetsingsintensiteit - zie toetsingsintensiteit

zie ook benadelingstoets

Godsdienst - zie grond van onderscheid

Godsdienstvrijheid - zie ontplooiingsrechten

Gradaties van toetsingsintensiteit - zie toetsingsintensiteit

Groepskenmerk, onderscheid op grond van

$466-475$

Grond van onderscheid

als intensiteitbepalende factor

groeps-/persoonskenmerk

$85-91,197-207,308-309,329-332,475-482$

noodzaak van toetsing ongeacht -

$111-112,466-475$

25,666

toetsing bij limitatieve opsomming toetsing bij niet-limitatieve opsomming verdachtheid -

97-98, 160-161, 313, 337-338, 431-432, 443-444, $458-460,505,628-630,659,697-698,710-711$ 


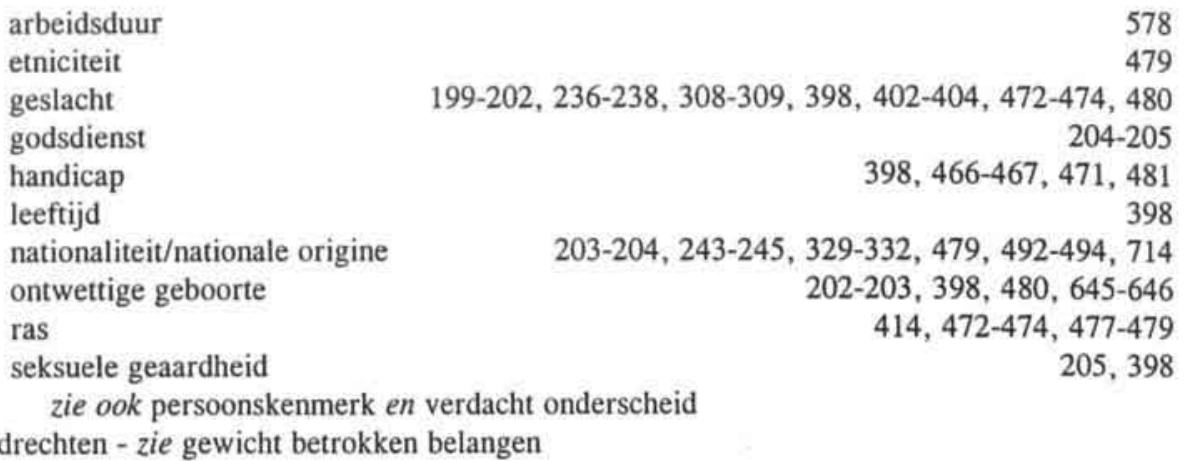
Grondrechten - zie gewicht betrokken belangen

Hardheidsclausule - zie gewicht betrokken belangen

Heightened review - zie rational basis "with bite"-test

Hoofd-/nevendoelstelling - zie doelstelling (pluraliteit)

Horizontale werking gelijkheidsbeginsel

$20,26-28,116-118,230-232,314$, $344-345,346-380,533-535,666$

Ideologische kleur rechters

383-386

Immigratiebeleid

$184,494,714$

519-520

Implementatie

$117-118,377-378$

Indirecte horizontale werking

Indirect onderscheid - zie onderscheid

Individuele belangen - zie gewicht aangetast belang

Individuele toepassing algemene regeling - zie concrete toetsing

Inferioriteit

$408,439-441$

Inherent discriminatoire doelstelling - zie doelstelling

Instrumentele functie gelijkheidsbeginsel

223

Integrale toetsing

$638-641,660,684$

Intensieve toetsing - zie toetsingsintensiteit

Intensiteitbepalende factoren - zie toetsingsintensiteit

Intermediate scrutiny-test

opbouw toetsingsmodel

397

consequenties van toepassing

verband met toetsingsintensiteit

$397,449-450,454,462$

factoren die toepassing verklaren - zie toetsingsintensiteit

vergelijkbaarheidstoets

$397,454,462,506-508$

actual purpose-test

402-404

429-431

important governmental objective

Interne markt

222-224, 242

Irrelevantie grond van onderscheid - zie persoonskenmerk of verdacht onderscheid

Kernrecht/perifeer recht - zie gewicht betrokken belangen

Kiesrecht - zie politieke rechten

Koppelingsvereiste

$103-109,517-518$

Landbouwproducten 
Legaliteitsbeginsel

$548-549,630-631,659,698$

Legitimiteit doelstelling - zie doelstelling

Lindsley-model

$387-388,390,401-402,410,424$

Lochner-rechtspraak

500-501

Maatschappelijke ongelijkheid zie ook onderscheid (materieel/indirect)

Maatschappelijke opvattingen consequenties voor toetsing $43-45,603-606,656,686$ als intensiteitbepalende factor vaststelling van -

Maatstaf - zie vergelijkingsmaatstaf

$604,656,686$

Machtenscheiding

$463-464,536-537$

Marginale toetsing - zie toetsingsintensiteit

Margin of appreciation-doctrine

betekenis voor toetsingsintensiteit

inhoud

$129-132,145-148,154-155,159-160,168-169$

grondslagen

$165,169-170$

$166-168$

very weighty reasons-test - zie very weighty reasons-test

factoren ter bepaling van omvang margin of appreciation

aard/gewicht nagestreefd belang

181-183

aard/ernst beperkingsmaatregel

191-192

better placed-argument

common ground- of consensusfactor

$179-181,219$

context maatregel

$170-179,197-207,218$

gewicht aangetast belang

184-186

186-191

kernrecht/perifeer recht

186-191

afweging van factoren

$192-197$

Marktordening

$252-253,275-276,319-320$

Mate van fit

inhoud vereiste

$46-49,161,304,445-450,610,687$

toetsingsmaatstaven

$613-614,689-690$

over- en underinclusiveness

perfect fit

$46-49,162-163,215,305,368,445-450,503,612,687$

447,689

misfit

$447,450,503,614$

partiële regelgeving

$447,503,689$

proxy - zie proxy

rechterlijke toetsing van -

gevolgen van toetsingsintensiteit voor -

$48-49,162,215,305,357,445-450,503,610-614$

$444-450,503,689$

bij materieel onderscheid

bij indirect onderscheid

verhouding tot vergelijkbaarheidstoets

$65-66,162,610-611,687$

verhouding tot gerechtvaardigd doel

215,687

verhouding tot noodzakelijkheidstoets

$611-612,687$

verhouding tot subsidiariteitstoets

$52-53$

verhouding tot proportionaliteitstoets

Materieel onderscheid - zie onderscheid

Materiële benadeling - zie benadeling 
Materiële gelijkheid

Mededinging - zie concurrentieverhoudingen

Meerderheidsopinie

383-383

Meerderheidsregel (belastingrecht)

550-551

Menselijke waardigheid - zie ontplooiingsrechten

Minderheden, aantasting rechten van -

$465-472,500,702,706-707$

Morele/geestelijke benadeling - zie benadeling

Motieftoets - zie doelstelling

Motiveringsbeginsel

Motivering, belang goede -

$3-5,61-62,663$

Nadeel - zie benadelingstoets of gewicht betrokken belangen

Narrowly tailored-vereiste

Nationale veiligheid

185,313

Nationaliteit - zie grond van onderscheid

Negatief effect - zie benadelingstoets

Neutrale toetsing - zie toetsingsintensiteit

Neven-/hoofddoelstelling - zie doelstelling (pluraliteit)

Nexustheorie

$96,186-191,485-486,511,708$

Nietigheidsberoep

Niet-nakomingsprocedure

Niveaus van toetsingsintensiteit - zie toetsingsintensiteit

Noodzakelijke doelstelling van sociaal beleid - zie doelstelling

Noodzakelijkheidsvereiste
inhoud
$154,157,287,300-302,454,621,692-693$
toetsingscriteria
$621-622,692-693$
bij inmiddels totstandgekomen nieuwe regeling
$159,622,693$
verhouding tot vereiste gerechtvaardigd doel
602
verhouding tot mate van fit
610-611

verhouding tot subsidiariteitsvereiste

$154-156,214,300-301,355-356,454,504$, $619-620,657-658,692$

verhouding tot proportionaliteitsvereiste

633

Normatieve classificatie

betekenis begrip

18-19

toetsing van -

$372,498-501,526,539,544,546-548,555,641-643,666,674-675$

Objectieve en redelijke rechtvaardiging - zie rechtvaardiging

Objectieve/subjectieve vaststelling aangetast belang - zie benadelingstoets of gewicht betrokken belangen

Objectiviteit rechterlijk oordeel - zie rechterlijke toetsing

Omkering bewijslast

$248,362,388,434,499$

Onbedoeld onderscheid - zie onderscheid

Onderscheid

absoluut/relatief

bedoeld/onbedoeld

$23,369-371,415-423$

betekenis begrip

bloot

$20,27-29,526-527$

concreet 
congruent/discongruent

direct/indirect

formeel/materieel

grond van - zie grond van onderscheid

juridisch/feitelijk

kwalitatief/kwantitatief

normatief - zie normatieve classificatie

procedureel

symmetrisch/asymmetrisch

verdachtheid - zie verdacht onderscheid 91-92n

$13-14,22-24,113-115,225-228,239,244$, 264-265, 282, 369-371, 410, 499-501, $529-530,556,585-586,648-649,666,672$

$12,22-24,115-117,228-230,368-369$. $527-529,666,674-675$

Onderscheidingskenmerk - zie grond van onderscheid of verdacht onderscheid

Ongeschreven recht, toetsing aan -

Ongewoon karakter onderscheid - zie toetsingsintensiteit

Ontkoombaarheid - zie benadelingstoets of proportionaliteitsvereiste of toetsingsintensiteit

Ontplooiingsrechten

Ontvankelijkheidsvereisten EHRM

$95,186-191,309,482-484,486,702,708$

$103-109,112-113,116-118$

Ontvankelijkheidsvereisten Supreme Court

$365-368$

Onveranderlijk persoonskenmerk - zie persoonskenmerk

Onwettige geboorte - zie grond van onderscheid

Openbare financiën als doelstelling - zie doelstelling

Open gelijkheidsbepalingen

$16-18,111-113,225-226,239,367-368,513-526$

Overheidsinstantie, begrip -

$117,377-378$

Overinclusiveness - zie mate van fit

Overruling

381

Overwegende benadeling - zie benadelingstoets

Participatie (politiek en sociaal)

$46,90,95-96,467-468,470-472,484-485,706-707$

Particulieren, onderscheid door -

zie horizontale werking gelijkheidsbeginsel

Partiële wetgeving - zie mate van fit

Passendheid - zie geschiktheid

Patroon van benadeling/bevoordeling

92(n)

Perifeer recht/kernrecht - zie gewicht betrokken belangen

"Permanente verliezer" - zie participatie

Persoonskenmerk

irrelevantie voor maatschappelijk functioneren

onveranderlijkheid van -

zichtbaarheid van -

vereiste van onderscheid gebaseerd op

verdachtheid van onderscheid op - zie verdacht onderscheid

Persoonlijke vrijheid - zie ontplooiingsrechten of gewicht betrokken belang

Pluralistisch syteem

$464-466,470-472,707$

Pluraliteit van doelstellingen - zie doelstelling

Plurality opinions 
Politieke participatie - zie participatie

Politieke rechten

Positieve discriminatie - zie voorkeursbehandeling

Positieve verplichtingen

Precedentwerking

Prejudiciële procedure

Pressing social need

Privaatrecht - zie horizontale werking gelijkheidsbeginsel

Privé-leven - zie ontplooiingsrechten

Procedurele gelijkheid

Producten, gelijke behandeling van -

Proportionaliteitsvereiste

inhoud

concrete/abstracte toetsing

in ruime/strikte zin

volledige/onvolledige toetsing belangenafweging

vaststelling betrokken belangen

gewicht aangetast/nagestreefd belang

$53-54,56-57,159-160,216,288-289,294-295,302-304$, $356,458-461,625,631-633,658-659,694$

$56,159-160,296-297,356,694-695$

$144-145,290-291,296$

$458-461,505-506,631-632,696$

$56-57,458-460,505,626-631,659,696-696$

$57,160-161,296,458-460,505,549,606$,

$626-631,659,697$

zie verder gewicht betrokken belangen en doelstelling

ernst belangenaantasting

zie verder gewicht betrokken belangen

rechterlijke bevoegdheid tot toetsing

gevolgen toetsingsintensiteit voor

bij verdacht onderscheid

als zelfstandig beginsel

contra legem-werking

voorrangsregels

verhouding tot andere toetsingscriteria

verhouding tot vergelijkbaarheidstoets

Protectionisme

Protocol 12 EVRM

Proxy

betekenis

nut gebruik proxy

noodzaak toetsing proxy

toetsingscriteria

verhouding tot mate van fit

Psychisch nadeel - zie benadelingstoets

Rassendiscriminatie - zie grond van onderscheid

Rassensegregatie - zie segregatie

Rational basis-test

opbouw toetsingsmodel

bewijslastverdeling
$297-298,460,627-628,659,697$

$55,456-457,505,631,699$ $296,456-461,632-633$

$160-161,458$

290-291, 295-297

$56,548-552,630-631$

548-552

$54-55,142-143,434-435,457-458$,

$606,614,633,656$

$68-69,546-547,652,669-670$

$222,282-283,344$

110,117

$614-616,657,687-689$

$614-615,688$

615,688

688

$615-616,657,689$

$616,657,688,689$ 
Lindsley-model

$387-388,390,401-402,410$

Royster-model

$389,401-402$

consequentie van toepassing

$388,447,454,462$

factoren die toepassing verklaren - zie toetsingsintensiteit

verband met toetsingsintensiteit

vergelijkbaarheidstoets

$388,390,445-448,454,457,462,506-508$

conceivable basis-test

401-402

$424-429,450-451,501$

Rational basis "with bite"-test

$391-392,452,461-462,489-490,507,701$

Rechterlijke toetsing

aan fundamentele rechtsbeginselen

43,45

aan geschreven/ongeschreven recht

$42-46$

concreet/abstract - zie concrete of abstracte toetsing

veranderde maatschappelijke/rechtsopvattingen

$43-45,603-606$

fasen van - zie toetsingsfasen

formele wetgeving

gevolgen van grond van onderscheid voor -

gevolgen van situatie van onderscheid voor -

20-22, 371-372

in horizontale verhoudingen

$26-28,314$

interpretatieruimte

$4,16-18,531-532$

machtenscheiding

$463-464,536-537$

$2-3,23-24$

noodzaak voor

$5-6,62,128,268,568,625,674$

objectiviteit/subjectiviteit

4

politiek karakter

rechtsvormende taak

$516-517,536$

terughoudend/intensief - zie toetsingsintensiteit

toetsingsverbod

van maatschappelijke effecten - zie effect

van doel-middelverhouding - zie verhouding doel-middel

Rechtmatigheidsaspecten - zie wetmatigheidsaspecten

Rechtspositioneel verschil

Rechtstreekse werking - zie directe werking

Rechtszekerheid

$4,277-278,395$

Rechtvaardiging

keuze voor rechtvaardigingsmodel

$69-72,346-347,404,498$

noodzaak voor -

$1-3,22-24$

objectieve en redelijke -

$17,121,237,240$

wijze van beoordeling - zie toetsingsmodel

Redelijkheid en billijkheid

Redelijkheidstoets - zie toetsingsmodel of verhouding doel/middel

Relevant and sufficient

Relevante verschillen - zie vergelijkingsmaatstaf

Royster-model

$389-390,401-402$

Segregatie

$366-367,378,399-401$

Separate but equal-doctrine

$366,399-401,497$

Seksuele geaardheid - zie grond van onderscheid

Situaties van onderscheid

$18-22,371-372,526-527,666$

Sociaal beleid

$273-274,309-310$ 
Sociale participatie - zie participatie

Sociologisch bewijsmateriaal

Special or partial laws

Specificiteitsvereiste - zie doelstelling

Stare decisis

State action

Statistisch bewijsmateriaal - zie benadelingstoets (statistisch bewijs)

Stemgedrag rechters

Stereotypen als basis voor onderscheid als reden voor intensieve toetsing

$143,269,272,439-441,684-685$

383-386

Stigmatisering

Strict scrutiny-test

opbouw toetsingsmodel

bewijsvereisten/bewijslastverdeling

consequentie toepassing (fataal karakter -)

$202,468-469,706$

$88-90,408,439-441,468-469$

verband met toetsingsintensiteit

factoren die toepassing verklaren - zie toetsingsintensiteit

actual purpose-test

393-394

394,500

compelling governmental interest

narrowly tailored-vereiste

Subjectiviteit rechterlijk oordeel - zie rechterlijke toetsing

Subsidiariteitsbeginsel, internationaal-/Europeesrechtelijk -

Subsidiariteitsvereiste

betekenis subsidiariteitsvereiste

$51-53,155,157-158,301,454-456,505,693-694$

rechterlijke bevoegdheid tot toetsing van -

gevolgen van toetsingsintensiteit voor toetsing

$51-52,155-158,214,293,453-454,505$

$294,453-454,505,619,624-625$,

$658,693-694$

verhouding tot noodzakelijkheidsvereiste

155-156, 214, 300-301, 355-356, $454,619-620,657-658,693$

wijze van vaststelling alternatieven

$158-159,214,301,455-456,505,619$, $623,658,693-694$

eisen aan mogelijke alternatieven

bij inmiddels totstandgekomen nieuwe regeling

$455,505,619,624,658,694$

Swingvote

159,622

385-386

Symmetrisch/asymmetrisch onderscheid

$92 n$

Tegenwettelijk beleid - zie contra legem-werking

Territoriaal onderscheid

276

Terughoudende toetsing - zie toetsingsintensiteit

Title VII

$379-380$

Toetsing - zie rechterlijke toetsing

Toetsing ex tunc - zie ex tunc-toetsing

Toetsingscriteria - zie toetsingsmodel

Toetsingsfasen

28-29, 66-69, 73-79, 100-102, 403-404, 497-499, 539-544, $565,610-611,664,671$ 
Toetsingsingang

bewijsfunctie

selecterend vermogen

$73,248,410,666-667$

geen gebruik van -

benadelingstoets als -

$539-540,545$

77-79, 134-137, 246-251, 256-257, 258-266,

$347-348,405-415,545-546,556,561-563$, $575-588,652-654,673-679$

zie verder benadelingstoets

classificatie als -

$405-406,498-499,540,545,674-675$

doelstelling of motief als -

$74-75,415-423,500-501,671-673$

bewijs discriminatoire doelstelling

$416-422,500-501,672$

effect maatregel is gelijk aan doelstelling

$416-418$

bronnen ter bepaling van discriminatoire doelstelling

418

overige bewijsvereisten

$419-422$

selecterend vermogen

671-672

effect als -

410-415

vergelijkbaarheidstoets als -

$67-74,122,129-134,251-256,265-268$, $345-347,399-404,497-498,540-541,545$,

$554-555,558-560,650-651,667-671$

Toetsingsintensiteit

noodzaak van differentiatie in -

vaststelling - als voorfase

gevolgen van differentiatie voor toetsing

$79-81,168,217,463-466,639-641$

$82,100-101,665,704$

$37,51,82-84,129-132,145-148$, $154-155,159-160,168-169,287,294,296$, $321-322,330,424-431,445-461,462,547$, $635,637,647,681,684,685,699$

gevolgen van differentiatie voor bewijslast(verdeling)

$322,387-399,445-446,462,635$, $637,647-648,691$

gradaties/niveaus van -

glijdende schaal-model

basisintensiteit

rigide/flexibel model

integrale/gedifferentieerde toetsing

voorspellende waarde voor uitkomst

neutrale toets

intensieve/strikte toets -

marginale/terughoudende/willekeurstoets -

margin of appreciation-doctrine -

zie margin of appreciation-doctrine

rational basis-test - zie rational basis-test

intermediate scrutiny - zie intermediate scrutiny-test

strict scrutiny - zie strict scrutiny-test

very weighty reasons-test - zie very weighty reasons-test

afweging intensiteitbepalende factoren

90-91, 96-97, 99-100, 192-197, 313, 318-319, $340,359,361,477-482,490,649-650,701-703,707$

gewicht intensiteitbepalende factoren
$81-84,217,307-308,357-358,461-462,507-508$, $634-638,659-660,704$

$81-82,217,704$

$308,328,330,357,633-637,649,659,704$ $462,472-475,477-482,507-508,700-701$ $639-641,660,684$

$161,198,388,395,414-415,447-449,454$, $456,462,500-501,506,508,636,672,701$

$82,358,700$

$82,308,330,357,636-637,659,700$

$81-82,321-322,358,547,634-636,659,700$ 
Carolene Products-rationale $464-466,472-475,482,488,508-510,701-703,707$

intensiteitbepalende factoren aantasting minderheidsbelangen

$465-475,706-707$

aard handeling waardoor onderscheid is gemaakt

beleidsterrein

beleidsvrijheid/beoordelingsvrijheid

bepaalbaarheid benadeelde groep

better placed-argument

$166,179-181,219,311,323-324,335-336,491-492,711$

common ground- of consensusfactor

$170-179,218,310,332-334,360,644-646$.

97-99, 191-192, 324-326, 496, 711 $219,309-310,320-321,491-492,711$ $320-321,491-492,495,639,660,712$

466-468

congruent/discongruent onderscheid

704,711

constitutionele prerogatieven

$91-92 \mathrm{n}$

context

493

direct/indirect onderscheid

$184-186,339,492-494,713-714$

discrete and insular minority

$92-93,314-315,648-649$

$465,466-467$

discretionaire bevoegdheid

$320-321,639$

doelmatigheid/wetmatigheid

$638-639,660$

ernst belangenaantasting

zie ook gewicht betrokken belangen

federale verhoudingen

$494-496,712$

formulering bevoegdheidsgrondslag

$639-640,712$

fundamentele/zwaarwegende belangen, aantasting van - $94-97$ 308-309, 327, 329-332,

$361,482-488,511,646-647,707-709$

zie ook gewicht betrokken belangen

gebonden bevoegdheid

$639-640,712$

gewicht/aard nagestreefd belang

$97-98,181-183,313,324-325,337-338,360$,

$710-711$

zie ook gewicht betrokken belangen

grond van onderscheid

85-91, 96-97, 197-207, 308-309, 329-332, $475-482,506-507,643-646,703-705$

historische/sociale achterstelling

$467-468,706$

horizontale/verticale verhouding

314

kwetsbare groep

706-707

immigratiebeleid

$184,494,714$

irrelevantie onderscheidingskenmerk

$87,202,475-476,705$

maatschappelijke opvattingen

$86-87,645$

omstandigheden van het geval

$339,713-714$
496

ongewoon karakter onderscheid

$339,713-714$
496

onveranderlijkheid onderscheidingskenmerk

$87-88,476-477,705$

491,713

noodsituatie

politieke participatie

$470-472,706-707$

$186-186,714$

situatie die afwijkt van het normale leven

$166-168,312,336-337,713$

subsidiariteitsbeginsel (internationaal-/Europeesrechtelijk)

symmetrisch/asymmetrisch onderscheid

$92 n$

verantwoordelijkheid voor besluitvorming

$324-325,641-642$

verdacht onderscheid

$85-91,327-328,466-472,643-646,648,703-705$

zie ook verdacht onderscheid

voorkeursbehandeling

$315-318,473-474,495-496,637$ 
vooroordelen/stereotypen/haat/stigmatisering

$88-90,202,468-469,706$

wetenschappelijke eenduidigheid

334

wetmatigheid/doelmatigheid

$638-639,660$

zichtbaarheid onderscheidingskenmerk

477,705

Toetsingsmodel

noodzaak voor -

algemeen (opbouw)

theoretisch (opbouw)

$5,17-18,663-664$

$673-699,714-721$

EHRM (opbouw)

29-32, 46, 100-102, 664-665

EHvJ (opbouw)

$120-126,207$

236-245

Supreme Court (opbouw)

387-399

Hoge Raad - civiele en strafkamer (opbouw)

538-544

Hoge Raad - belastingkamer (opbouw)

$544-552$

Afdeling Bestuursrechtspraak (opbouw)

$552-555$

Centrale Raad van Beroep (opbouw)

$555-560$

Commissie Gelijke Behandeling (opbouw)

$561-565$

toepassingsbereik

$16-27$

toetsingscriteria

$30-31,100-102,120-126,237-238,243,244-245,387-399$,

$444-445,538-565,664-665,673-699$

verhouding tussen toetsingscriteria

29-32, 49-50, 52-53, 120-126, 238, 240-241, 243,

$245,388,389,403-404,444-445,539,547,687$

verhouding tot toetsingsintensiteit

$386,395,414-415,665,681$

bij concrete bevoegdheidsuitoefening

voorrangsregels bij contra legem-werking

$21,48-49,372,526,548-552,552-555,666,676$

in horizontale/verticale verhoudingen

$548-552,630-631$

in eerste/tweede fase - zie toetsingsfasen

$27,232,344-345$

Toetsingsverbod

$514-515$

Traditionele opvattingen - zie stereotypen

Twaalfde Protocol EVRM

110,117

Tweede fase - zie toetsingsfasen

Uitzonderingsmogelijkheden

$16-18,225-228,243-244$

Underinclusiveness - zie mate van fit

Veertiende Amendement - zie Equal Protection Clause

Veranderde rechtsopvattingen - zie doelstelling en toetsingsintensiteit

Verdacht onderscheid

gevolgen voor toetsingsmethodiek

$129-132,142-144,370,509-510$

zie ook strict scrutiny-test

common ground m.b.t. -

$197-207,644-646,704$

constitutionele/verdragsrechtelijke erkenning

644,646

discrete and insular minority

$466-467$

historische/sociale achterstelling

$467-468$

irrelevantie onderscheidingskenmerk

$87,202,475-476,705$
$86-87$

maatschappelijke opvattingen

$87,202,475-476,705$
$86-87$

onveranderlijkheid onderscheidingskenmerk

$87-88,476,705$

$477-479$

ras/nationaliteit/etniciteit

$88-90,202,468-469$

stigmatisering/stereotypen/vooroordelen 
zichtbaarheid van onderscheidingskenmerk zie ook toetsingsintensiteit

\section{Vergelijkbaarheid}

betekenis begrip

9-10, 57

vaststelling van -

$10,57-64,126-129,251-256,266-268$, $399-404,497-498,566-575,667$

modaliteiten van toetsing

vergelijkbaarheidstoets als toetsingsingang

$66-72,668-670$

$57-58,66-74,122-126,208-213,228-229$. 240-241, 250-256, 265-266, 266-268, $345-346,399-404,497-498,540,545$, $554-555,558-560,566-575,650-651$ 240-241, 403-404, 497-498, $541-542,547,559$

vergelijkbaarheidstoets als rechtvaardigingstoets $66-68,123,250,258,346,541,546-547$. $554-555,560,650-651,668-670$ $73-74,134-136,346,652,670$

$73-74,129$

selecterend vermogen

bewijsfunctie

binnen benadelingstoets

bij indirect onderscheid

$248-250,261-264,349,413$

$248-250,264,673$

bij onderscheid door verschillende organen/instanties

573-574

bij onderscheid door verschillende regelingen

572

ontbreken van - in rechtspraak

alternatieven voor -

$129-134,211-212,539,670$

mate van fit en -

$65-66,162,610-611,687$

proportionaliteitstoets en -

$67-69,346,546,651-652,669$

separate but equal-doctrine

399-401

Vergelijkingsmaatstaf

doelstelling onderscheid als zie ook doelstelling

feitelijke verschillen als -

gelijksoortigheid

266,268

gelijkwaardigheid voorzieningen - zie separate but equal-doctrine

gerechtvaardigdheid van -

$63-65,254,256,345,571-572,651$

onderlinge uitwisselbaarheid gevallen

251-252, 267 vaststelling van -

$60-61,126-128,251-253,255,566-570,667$

Verhoogde toetsingsintensiteit - zie toetsingsintensiteit

Verhouding doel-middel

$46-57,144-150,214-216,286-306,355-357$, $444-461,503-506,610-633,656-659,687-699$

Vermoeden van onderscheid - zie toetsingsingang

Vermijdbaarheid - zie benadelingstoets of gewicht betrokken belangen

Verschijningsvormen van onderscheid - zie onderscheid

Verticale werking gelijkheidsbeginsel

Vervangbaarheid

$116-118,230-232,314,344-345$, $376-378,533-535,666$

Very weighty reasons-test

Voorfase

$142-144,160-161,197-207$

100-101

Voorkeursbehandeling

Vooroordelen

$32,315-318,422-423,435-436,458-459,473,637$ 
gevolg voor toetsingsintensiteit

als basis voor onderscheid

Voorrang internationaal/Europees recht

Voorrangsregels bij contra legem-werking

Volledige belangenafweging - zie proportionaliteitsvereiste

Volledige toetsing

Vreemdelingenbeleid

Vrijheid van meningsuiting/vereniging - zie politieke rechten

Vrij verkeer

$222-223,243-245,280-281,302,329-330,342$

Werkelijke behoefte onderneming - zie doelstelling

Werkelijk doel onderscheid - zie doelstelling

Wet gelijke behandeling mannen en vrouwen

Wetmatigheidsaspecten

Wet Onderscheid Arbeidsduur

Wetsafwijking - zie contra legem-werking

Wettige geboorte - zie grond van onderscheid

Willekeur, verbod van -

Willekeurstoets - zie toetsingsintensiteit

Writ of certiorari

Zelfcorrigerend vermogen democratie

Zelfstandig discriminatieverbod EVRM

$464-466,470-472,484-485,509,702,707$

Zwaarwegendheid doelstelling - zie doelstelling of gewicht betrokken belangen of proportionaliteit
$240,242,321,524,570$

$380-381$

$88-90,202,468-469,706$

$143,439-441,684-685$

$515,519-521,557$

548-552, 630-631

$640-641,660,684$

184

$522,562-563$

$522-523$

110 



\section{Dankwoord}

Het schrijven van een proefschrift is een fascinerend proces. Het is bijzonder hoeveel kennis je kunt verwerven door je lange tijd in een onderwerp te verdiepen en om te ervaren dat je die kennis uiteindelijk kunt verwerken tot een nog niet eerder geschreven boek. Ik heb de gelijke behandelingsproblematiek steeds heel boeiend gevonden en het was uitdagend om erover na te denken. Veel mensen hebben bijgedragen aan het plezier dat ik bij het schrijven van het proefschrift heb ondervonden; hen wil ik dan ook graag bedanken.

Aalt Willem, mijn promotor en begeleider, heeft me veel ruimte gelaten om het onderzoek vorm en inhoud te geven; daarvoor ben ik hem zeer erkentelijk. Tegelijkertijd was er altijd tijd om gezamenlijk te piekeren over de uitgangspunten en de structuur van het boek. Zijn enthousiasme voor het onderwerp werkte aanstekelijk en ik heb veel inspiratie ondervonden van zijn prikkelende opmerkingen en verrassende oplossingen.

De leescommissie, Luc Verhey, Bruno de Witte, Lisa Waddington, Ben Sloot en Jenny Goldschmidt, wil ik bedanken voor de aandacht waarmee ze het dikke manuscript hebben bestudeerd.

Verder dank ik de Onderzoeksschool Ius Commune en de Wetenschapscommissie, die het financieel mogelijk hebben gemaakt om gedurende vier maanden in Amerika onderzoek te doen. Als research scholar bij de University of Michigan Law School kreeg ik de gelegenheid om inzicht te verwerven in het Amerikaanse denken over gelijke behandeling en over de rol van de rechter. De vier maanden in de VS hebben als een katalysator gefungeerd voor mijn denken over gelijke behandeling. Daarvoor dank ik ook Virginia Gordan en Stephanie Wiederhold, die mijn verblijf vanuit Amerika hebben geregeld, en Mark Rosenbaum, wiens leerzame en inspirerende "Fourteenth Amendment"-classes ik mocht bijwonen.

Het schrijven van een proefschrift vereist een inspirerende en academische omgeving, waar tegelijkertijd ruimte moet bestaan voor relativering en ontspanning. Een dergelijke omgeving is aanwezig binnen de rechtenfaculteit van de Universiteit Maastricht, en zeker binnen de Capaciteitsgroep Publiekrecht. Heleen Janssen wil ik in het bijzonder bedanken. Samen hebben we het redactiesecretariaat van European Human Rights Cases vorm gegeven en we hebben heel wat vrijdagmiddagen zitten praten over grondrechten, over de leuke en lastige kanten van het schrijven van een proefschrift, en over heel veel andere dingen. Bregtje Schwenke wil ik bedanken voor het camera ready maken van dit proefschrift: het is erg leuk om een stuk waaraan je jaren hebt gewerkt opeens tot een boek te zien verworden.

Ook buiten de faculteit zijn er veel mensen die de tijd waarin dit proefschrift is geschreven tot een bijzondere periode hebben gemaakt. Kathelijne, Karlijn, Ellen, Teske, Anja, Barbara, Anneke, Manon: de wandelingen, de lunches en logeerpartijen, de kopjes thee na ballet, maar vooral de leuke gesprekken over vanalles en nog wat zorgden voor veel gezelligheid en ontspanning. Joska, mijn beste vriendin, bedank ik in het bijzonder. Onze lange telefoongesprekken en weekendjes zijn me dierbaar en ik ben 
blij dat ik haar, net als Kathelijne, bij mijn promotie als paranimf in de buurt zal weten. Jos en Giny tenslotte bedank ik voor hun nooit aflatende steun en voor een bijzondere vriendschap, die de afgelopen periode tot een fijne en onvergetelijke tijd heeft gemaakt. 


\section{Curriculum vitae}

Janneke Gerards werd geboren op 12 januari 1976 te Schaesberg. In 1994 behaalde zij haar gymnasiumdiploma (alpha) aan het Trichter College te Maastricht en begon zij met haar studie Nederlands recht aan de Universiteit Maastricht. In oktober 1998 studeerde zij cum laude af, waarna zij eerst als aio en vanaf juni 2000 als junior onderzoeker werkzaam was bij de capaciteitsgroep publiekrecht van de Universiteit Maastricht. In 2001 verbleef zij als research scholar bij de University of Michigan Law School enkele maanden in de Verenigde Staten. Sinds april 2002 is zij als universitair docent staatsrecht verbonden aan de capaciteitsgroep publiekrecht van de Universiteit Maastricht. 
In deze studie wordt een algemeen bruikbaar toetsingsmodel ontwikkeld voor rechters die te maken krijgen met klachten over ongelijke behandeling. In de praktijk blijkt aan zo'n toetsingsmodel grote behoefte te bestaan, nu de grondwettelijke en wettelijke bepalingen met betrekking tot gelijke behandeling de rechter vaak weinig houvast bieden. Dit gebrek aan houvast leidt tot uiteenlopende uitkomsten in vergelijkbare zaken, hetgeen de rechtsgelijkheid en de rechtszekerheid niet ten goede komt. Het gebruik van het toetsingsmodel zal de duidelijkheid van de rechterlijke motivering en de legitimiteit van de uitspraken vergroten.

Het algemene toetsingsmodel is gebaseerd op een theoretisch onderzoek naar de maatstaven en normen die bij de beoordeling van een ongelijke behandeling betrokken moeten worden. Daarnaast is onderzoek gedaan naar de criteria waaraan rechters in de praktijk toetsen, aan de hand van een uitgebreide analyse van de gelijke behandelingsrechtspraak van het Europees Hof voor de Rechten van de Mens, het Europees Hof van Justitie, het Amerikaanse Supreme Court en verschillende Nederlandse rechterlijke instanties. Uiteindelijk is het theoretische model op basis van de rechtsvergelijkende conclusies aangevuld en verfijnd, waardoor het toetsingsmodel voor de rechtspraktijk bruikbaar is.

Janneke Gerards (1976) is als universitair docent staatsrecht verbonden aan de capaciteitsgroep Publiekrecht van de Universiteit Maastricht. 